\title{
GEWÄSSER IN DER MITTELEUROPÄISCHEN KULTURLANDSCHAFT.
}

Ein Beitrag der Historischen Geographie zur Gewässergeschichte und regionalen Verbreitung anthropogener Gewässerformen der Wasserhaltung und der Wässerung unter besonderer Berücksichtigung der Teichwirtschaft.

\author{
Dissertation \\ zur Erlangung des Doktorgrades \\ der Mathematisch-Naturwissenschaftlichen Fakultäten \\ der Georg-August-Universität zu Göttingen \\ vorgelegt von \\ Diplom-Geograph \\ Bernd Brühöfner \\ aus Herford
}

Göttingen, November 2004 
D 7

Referent: Prof. Dr. Dietrich Denecke

Korreferent: Prof. Dr. Karl-Heinz Pörtge

Tag der mündlichen Prüfung: 6.12.2004 
„Wir kehren immer zum Wasser zurück.“

[John von DÜFFEL 1998] 


\section{Danksagung}

Meinem hochverehrten Lehrer, Prof. Dr. Dietrich Denecke, der mich nach langer Zeit des Umherirrens in verschiedenen geographischen Fachdisziplinen in meinem eigentlichen Interessengebiet - der Historischen Geographie - mit meinem Vorhaben in Göttingen aufgenommen hat, gilt mein erster Dank. Ihm verdanke ich das grundständige Thema und die entscheidenden Weichenstellungen sowohl während seiner aktiven Zeit als Lehrstuhlinhaber für Kulturgeographie an der Universität Göttingen als auch über die Zeit nach seiner Emeritierung hinaus. Für die langjährige Geduld und seine persönliche und wissenschaftliche Begleitung während des gesamten Zeitraums der Erstellung gebührt ihm meine besondere Anerkennung.

Dank sei hier auch in besonderer Ausdrücklichkeit an Herrn Prof. Dr. Karl-Heinz Pörtge gerichtet, der spontan die Aufgabe des Koreferenten übernommen hat, und ebenso an Prof. Dr. Bernd Herrmann und an Prof. Dr. Peter Tobias Stoll für ihre Bereitschaft in den Fachgebieten Umweltgeschichte und Umweltrecht prüfend zur Verfügung zu stehen.

Ein großer Dank geht auch an Herrn Prof. Dr. Klaus Fehn, der mich noch zu seiner Zeit als Direktor des Historisch-Geographischen Seminars im historisch-geographischen Kolloquium in Bonn als Gasthörer aufgenommen hat, für seine konstruktiven, kritischen Anregungen und Unterhaltungen und tatkräftige Hilfsbereitschaft.

Ebenso gilt mein Dank seinem Nachfolger auf dem Lehrstuhl, Herr Prof. Dr. Winfried Schenk, der mich seit seiner „Antrittsvorlesung“ im kleinen Kreis der Historischen Geographen in den intimen „Katakomben“ des früheren Historisch-Geographischen Seminars hoch über dem Rheinufer mit seinen Ausführungen immer wieder begeistert hat. Ihm verdanke ich zahlreiche Hinweise und seine Integration eines aus beruflichen Gründen in das Rheinland gezogenen „Wahl-Niedersachsen“, vor allem in den von mir unvergessenen Gasthaussitzungen.

Dank auch an mein Elternhaus und meine Schwester Doris-Marie, die in Ruhe die Jahre abgewartet und nicht nur, aber schon allein dadurch, wesentlich geholfen haben. Dank auch an die dortige erlebbare historische Landschaft des Sollings - und des „Derentals“ im Besonderen -, für die notwendige Spiritualität zum Erinnern an vergangene Zeiten und an mein im Laufe der Beschäftigung mit dem Thema alt gewordenes Hündchen Senta, die mich als Große Münsterländerin immer wieder zur Natur- und Kulturwahrnehmung geführt hat.

Schließlich gilt meine ganze Dankbarkeit meiner Frau Julia, für entbehrungsreiche Jahre im Dienste dieser nebenberuflich geschriebenen Arbeit, die sie mit Geduld und großem Zuspruch getragen hat.

Für ihre Ausdauer und Hilfe beim Korrekturlesen danke ich meinem Freund Dipl.-Geogr. Achim Hendrichs, der mir einige wertvolle Hinweise gab und Dr. Swen Wagner, der die Arbeit mit großer Begeisterung für das Thema gebändigt hat.

Die Arbeit entstand zum wesentlichen Teil berufsbegleitend. Periodische Berufswechsel, bedingt durch den existenziell-motivierten Wunsch nach einer (ansprechenden) Tätigkeit oder durch zeitlich befristete Arbeitsverträge, erzwangen zudem eine immer wiederkehrende berufliche Einarbeitung - zumindest bzw. verstärkt während der Probezeit - und ließen für diesen Zeitraum die wissenschaftliche Arbeit ruhen bzw. in den Hintergrund geraten. Zudem nahm eine alternierende Bewerbungsoffensive, mit dem Bemühen eine Standardisierung zu umgehen, wertvolle Zeit in Anspruch.

Dennoch hoffe ich, dass die Ausführungen zur Geschichte der Gewässer in unserer Kulturlandschaft zu einem umfassenden und zusammenhängenden kulturhistorischen Verständnis führen. Eine Berücksichtigung bei zukünftigen Planungsprozessen und in der Gesetzgebung wird dabei ausdrücklich beabsichtigt. 


\section{Inhaltsverzeichnis}

Inhaltsverzeichnis I

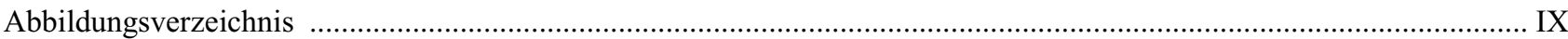

Tabellenverzeichnis

Prolegomena

0 Vertrocknung und Vernässung in gegenwärtiger und früherer Zeit......

1 Thematische Einführung und Zielsetzung ...ris.

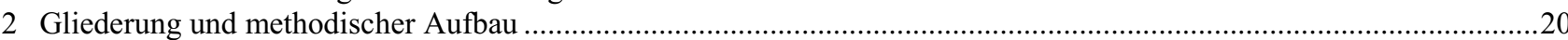

A FRAGESTELLUNGEN UND FORSCHUNGSANSÄTZE EINER „ANWENDUNGSORIENTIERTEN HISTORISCHGEOGRAPHISCHEN GEWÄSSERFORSCHUNG“

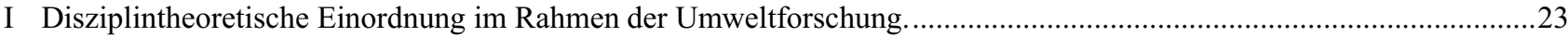

1 Die „Geographie” im Disziplingebäude der ,,allgemeinen Umweltforschung” .....................................................23

a Die Geographie als Geosystemlehre und integrative Umweltwissenschaft .....................................................23

b Perspektiven und Ansätze der „Umweltwissenschaften“ und Fragestellungen der „Umweltforschung“. ..............28

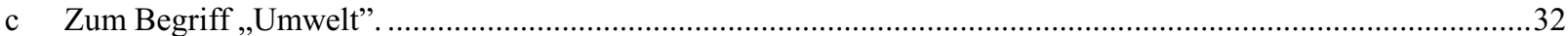

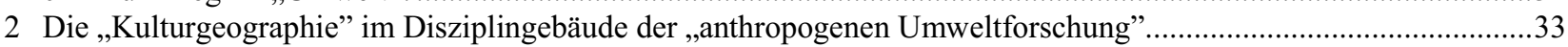

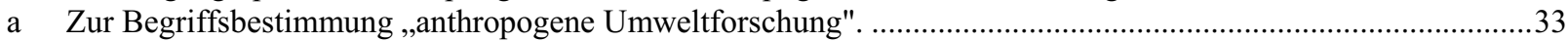

b Zur Stellung der Kulturgeographie in der anthropogenen Umweltforschung...................................................34

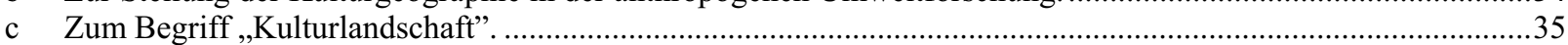

3 Die „historische Kulturgeographie“ im Disziplingebäude der „historischen Umweltforschung“. ..............................43

a Stellung und Aufgaben der ,historischen Kulturgeographie“ innerhalb der Geographie. ..................................43

b Die zeitgeschichtliche und zukünftige Entwicklung der „historischen Kulturgeographie“.................................51

c Zur Begriffsbestimmung und Stellung der „historischen Umweltforschung“ bzw. „Umweltgeschichte”...............59

d „Historische Kulturgeographie“ als ,historisch-geographische Umweltforschung“...........................................77

e Probleme und Chancen der Interdisziplinarität historisch-geographischer Umweltforschung. .............................83

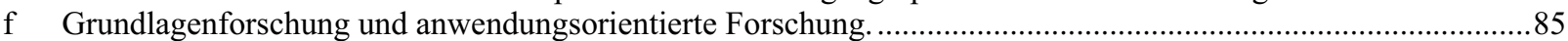

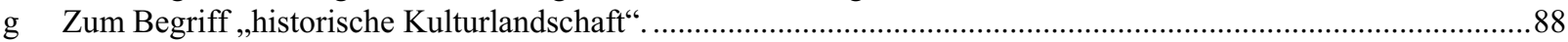

4 Die ,anwendungsorientierte historisch-geographische Forschung“ im Disziplingebäude der historischen

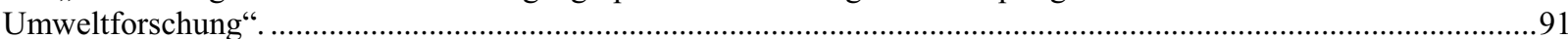

a Zur wissenschaftlichen Grundlegung eines neuen Forschungsansatzes umwelthistorischer Forschung in der historischen Geographie

b Die methodische Ausgestaltung des anwendungsbezogenen Forschungsansatzes umwelthistorischer

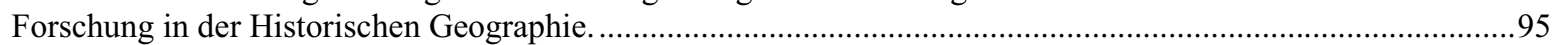

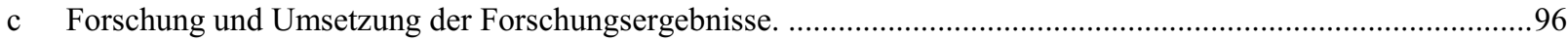

5 Die ,anwendungsorientierte historisch-geographische Gewässerforschung“ im Disziplingebäude der ,,angewandten

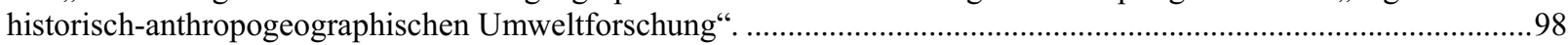

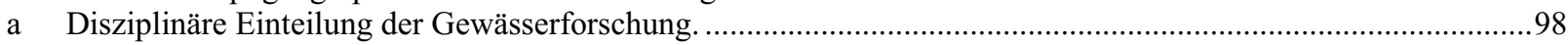

b Betrachtungsansatz der ,anwendungsorientierten historisch-geographischen Gewässerforschung“..................100

c Aufgabenfelder einer, ,anwendungsorientierten historisch-geographischen Gewässerforschung “......................104

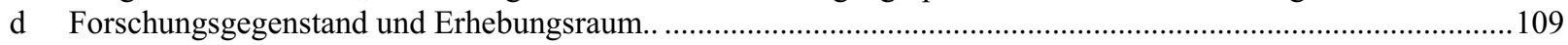

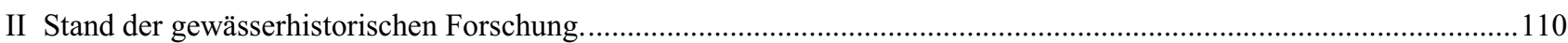

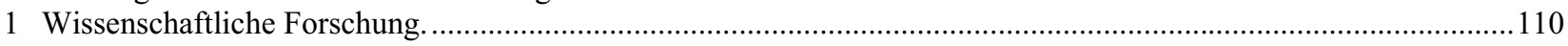

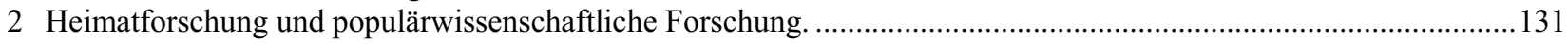

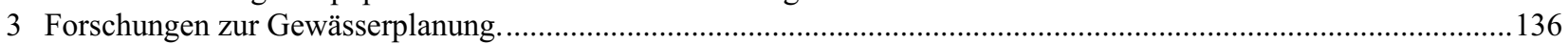

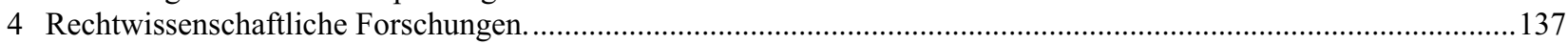

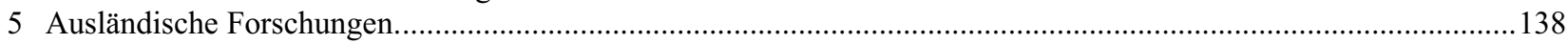

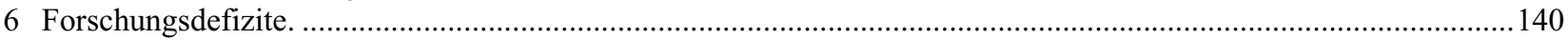




\section{B METHODISCHER TEIL}

III Quellen, Methoden und Kartenwerke der historisch-geographischen Gewässerforschung. ......................................143

1 Quellen.

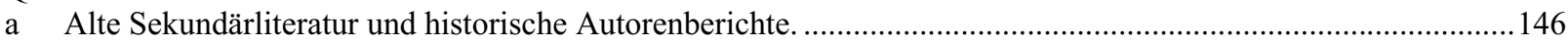

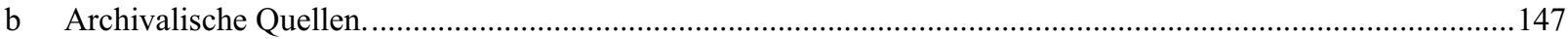

c Lyrik.

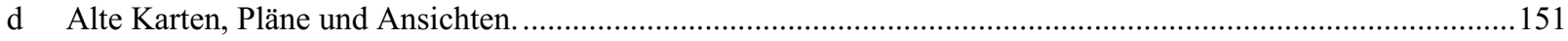

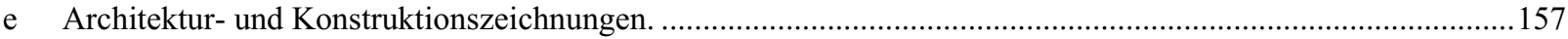

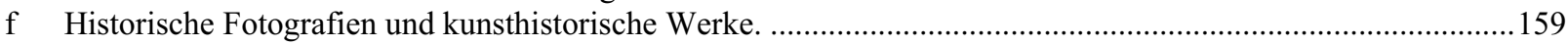

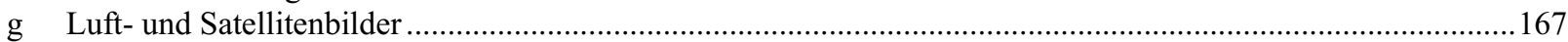

h Aquatische Flur- und Ortsbezeichnungen, Fluss- und Gewässernamen. .................................................. 168

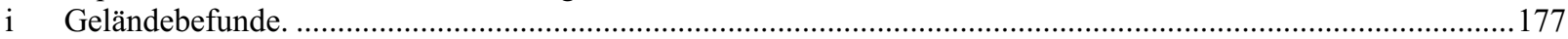

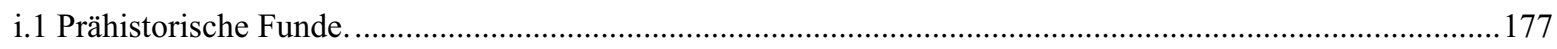

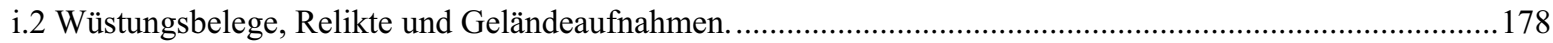

2 Methoden.

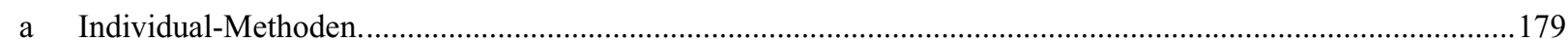

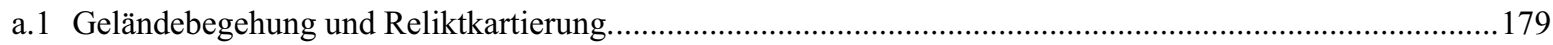

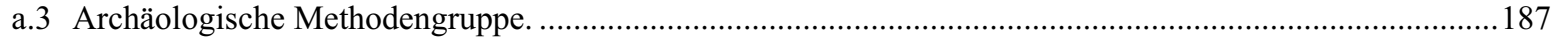

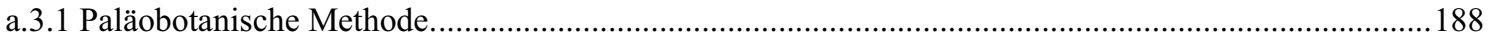

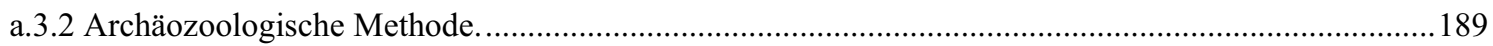

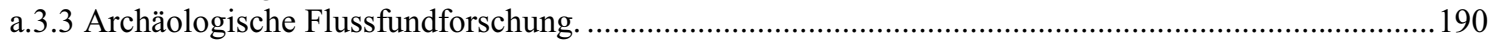

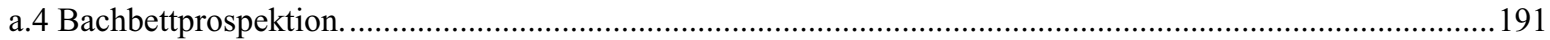

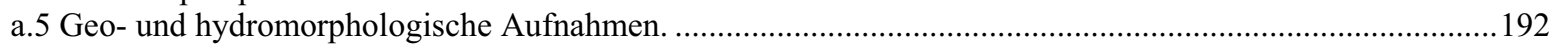

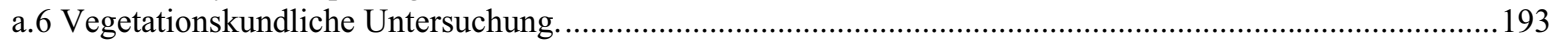

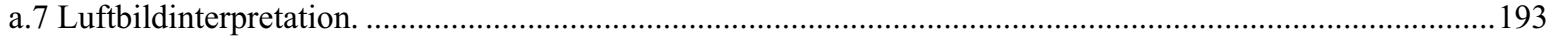

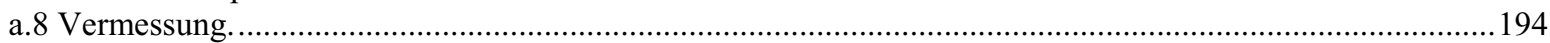

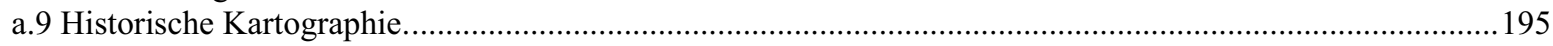

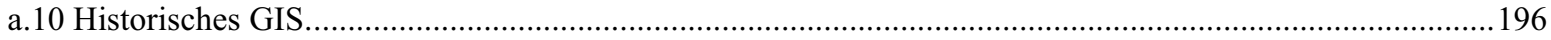

a.11 „Oral history“

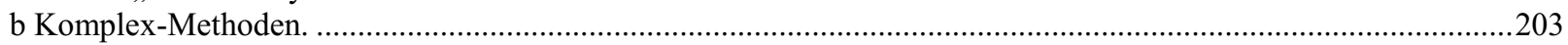

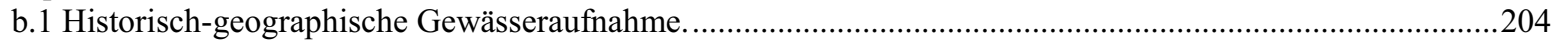

b.1.1 Historische Gewässerlandschaftsanalyse............................................................................204

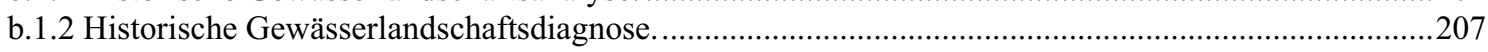

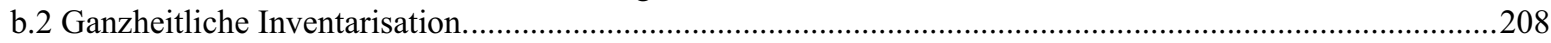

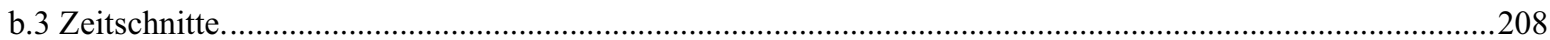

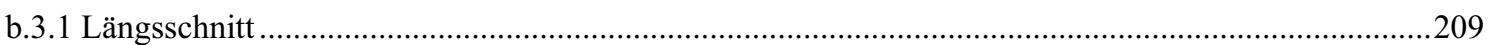

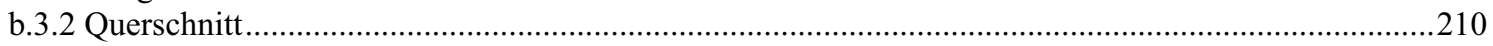

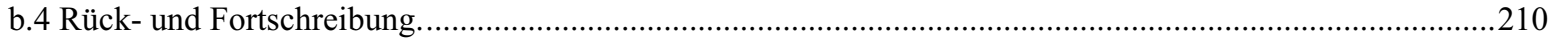

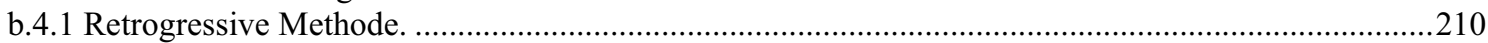

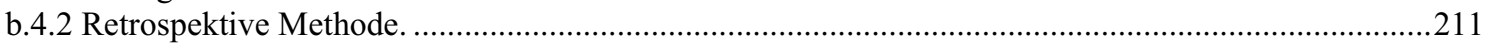

3 Kartenwerke.

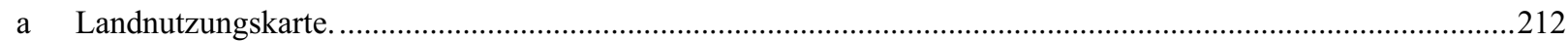

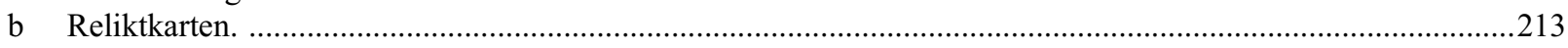

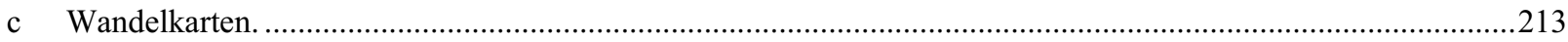

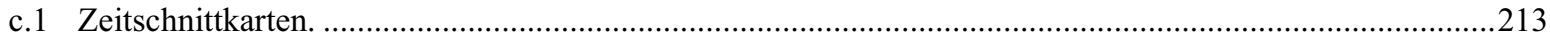

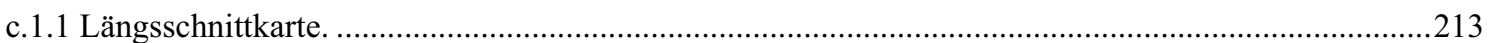

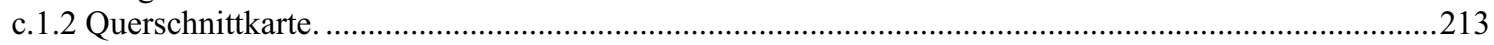

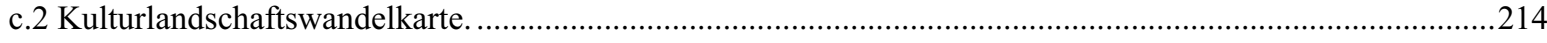

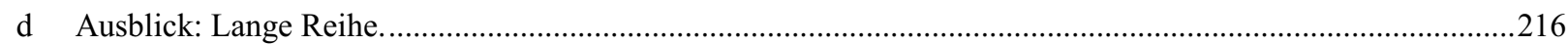




\section{ALLGEMEINER TEIL.}

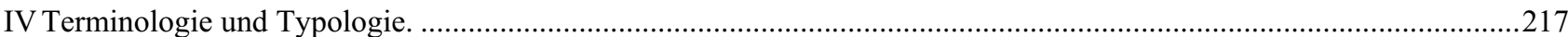

1 Terminologie und Typologie bisheriger Gewässersystematik. .......................................................................217

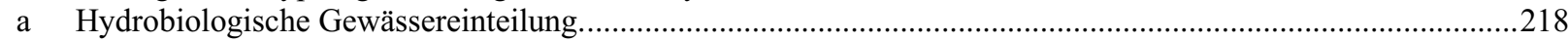

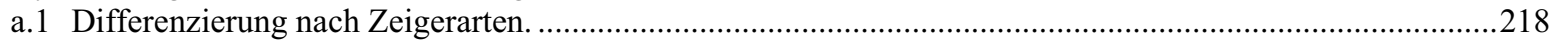

a.2 Differenzierung nach zönökologischen Fließgewässerregionen. .........................................................219

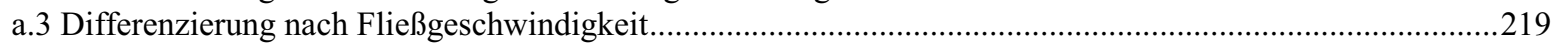

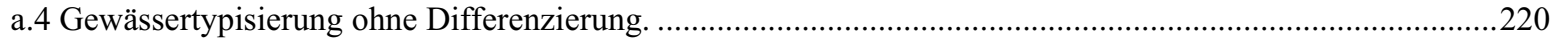

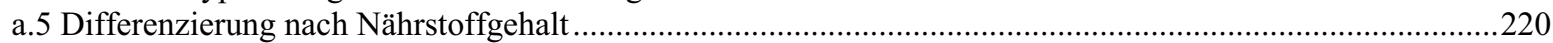

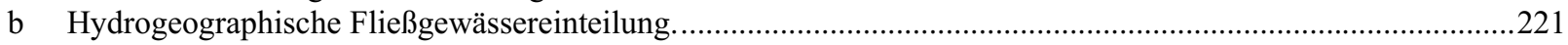

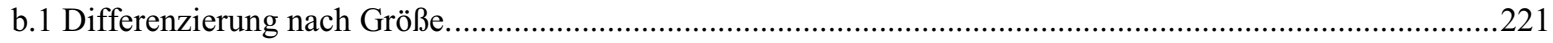

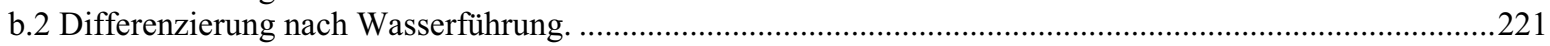

b.3 Unterscheidung nach Art des Wasseraustritts. ..............................................................................222

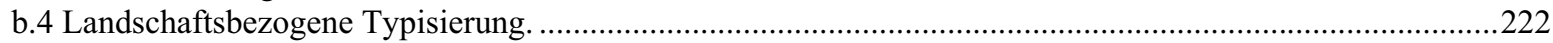

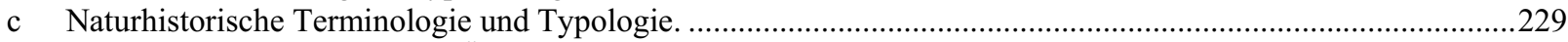

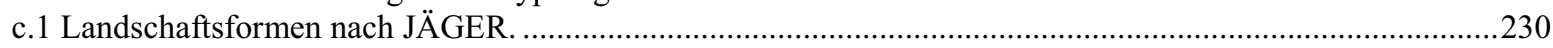

c.2 Landschaftsformationen nach ELLENBERG. ................................................................................231

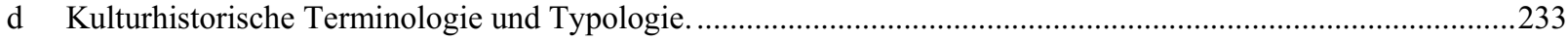

2 Historisch-geographische Terminologie und Typologie neuerer Gewässersystematik...........................................2236

a Differenzierung von Gewässern nach ihrer zeitgeschichtlich-formalen Erscheinung.....................................236

b Differenzierung von Gewässern nach ihrer Entstehungs- und Nutzungsgeschichte. .....................................239

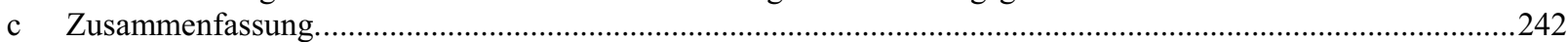

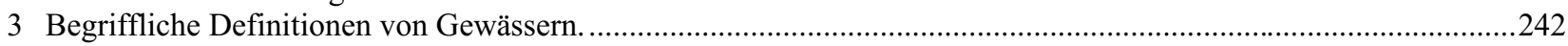

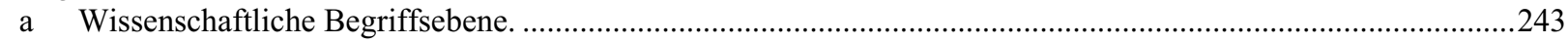

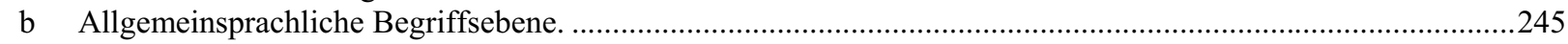

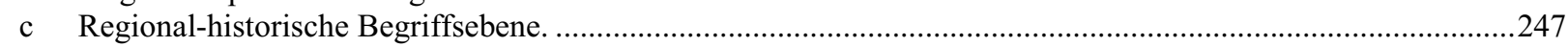

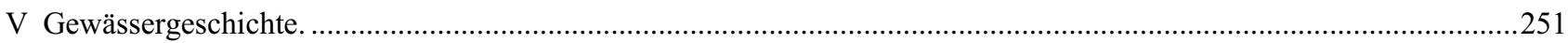

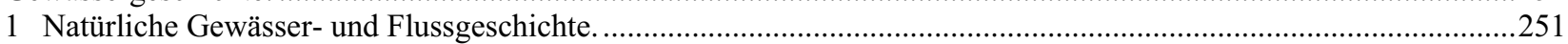

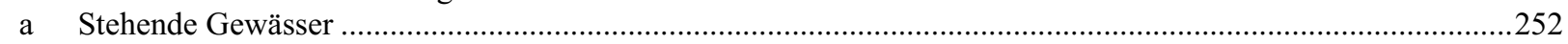

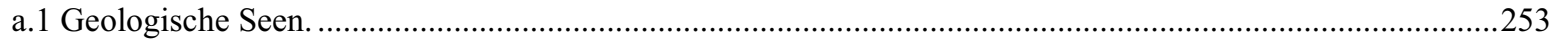

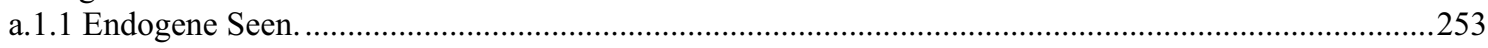

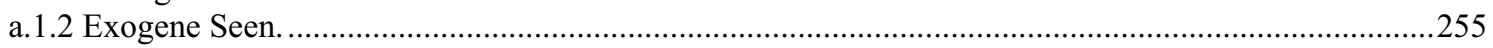

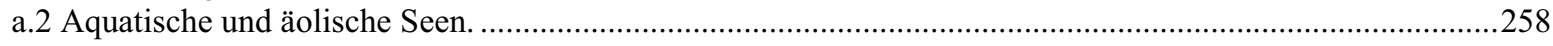

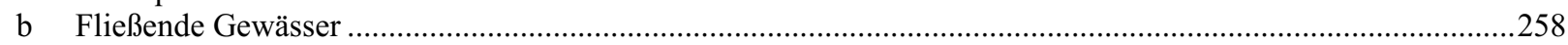

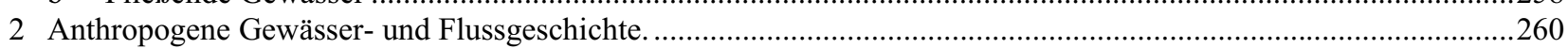

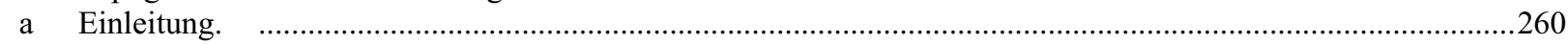

b Die hydrologisch-topographische Lage als Siedlungsvoraussetzung.........................................................261

c Der hydrologisch-topographische Lagewert und sein Wandel .............................................................267

d Die hydrologisch-topographische Lage der Wohnplätze und Siedlungen. ...................................................2270

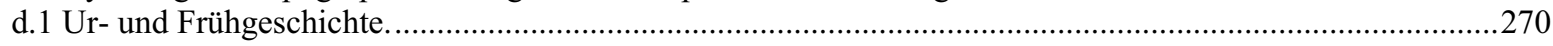

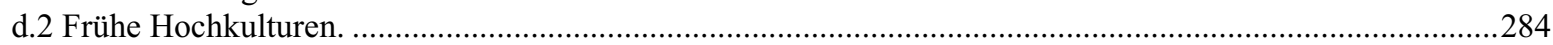

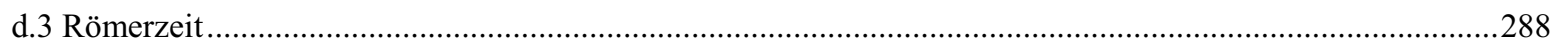

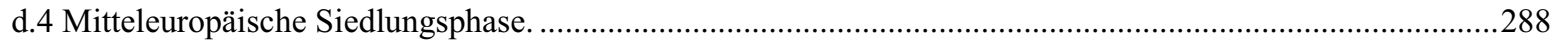

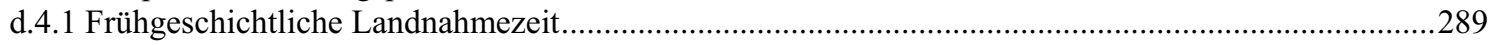

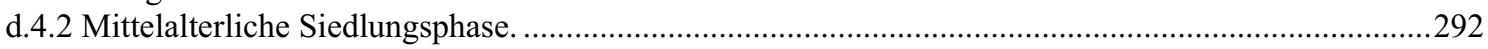

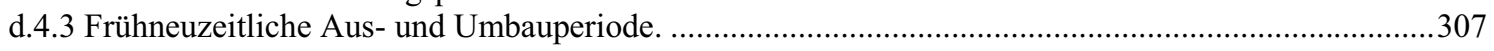

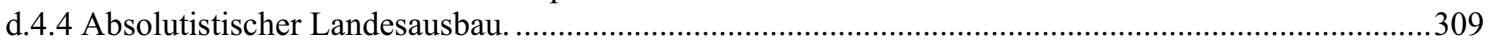

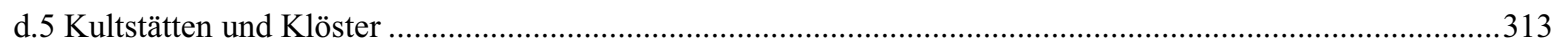

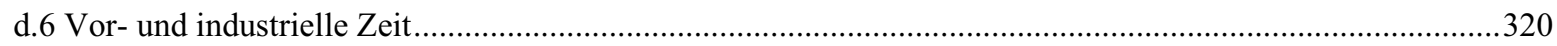

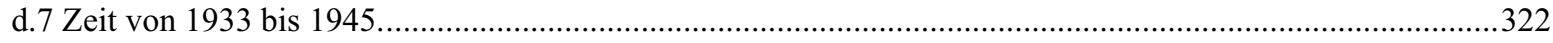

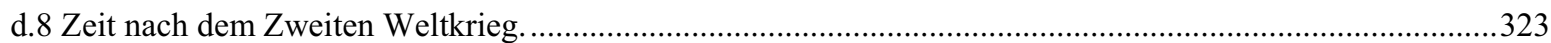

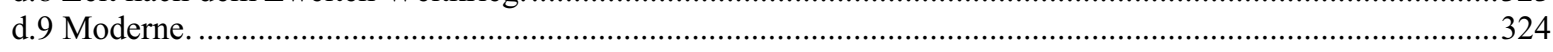

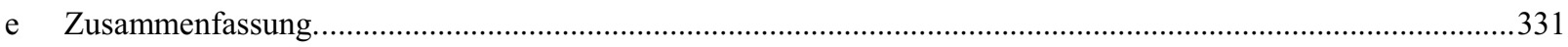




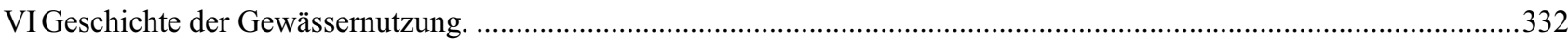

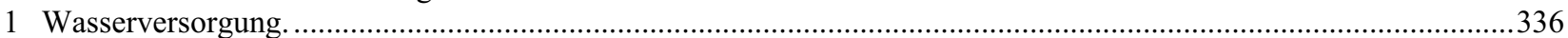

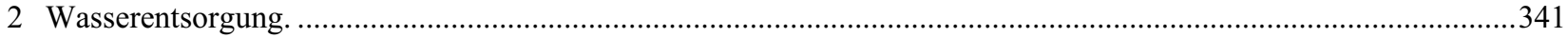

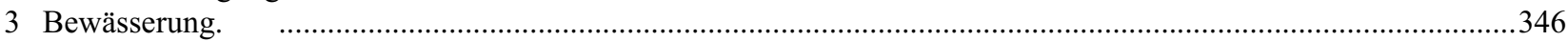

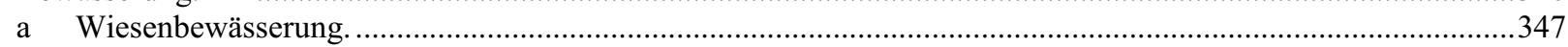

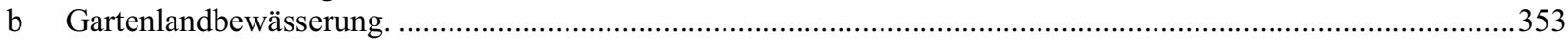

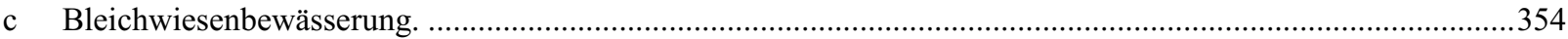

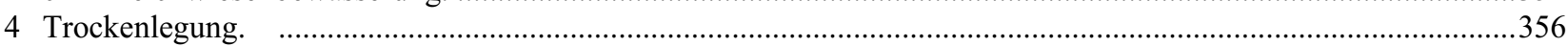

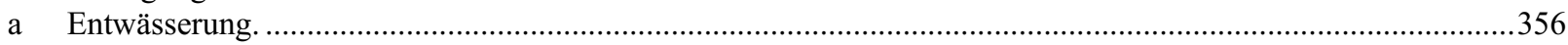

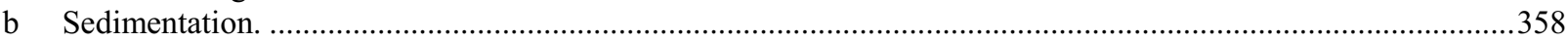

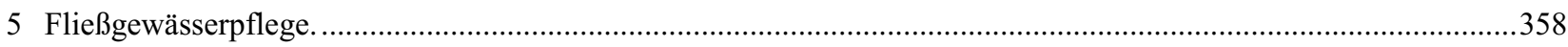

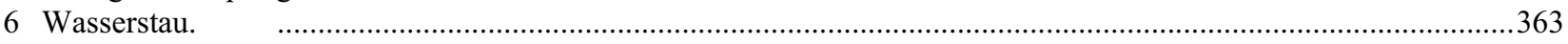

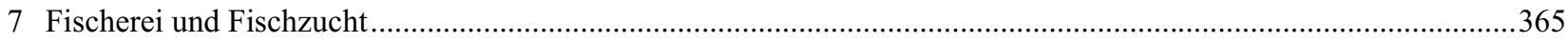

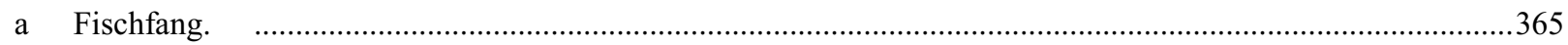

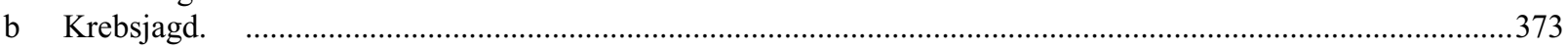

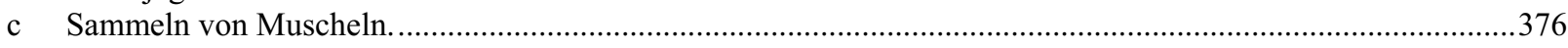

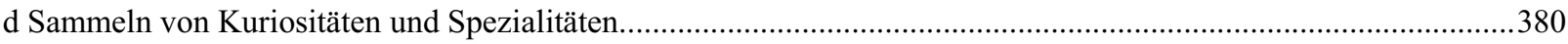

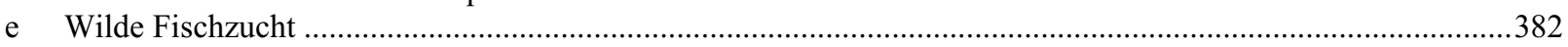

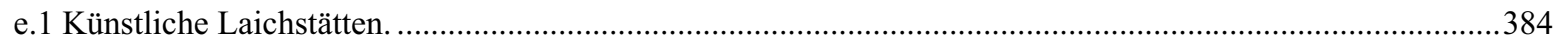

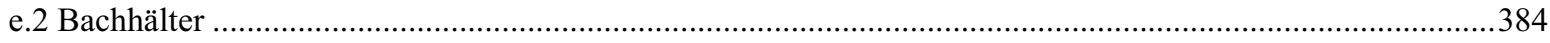

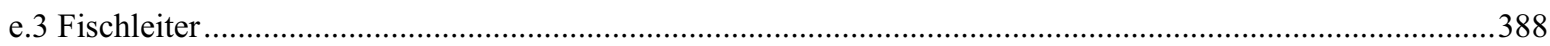

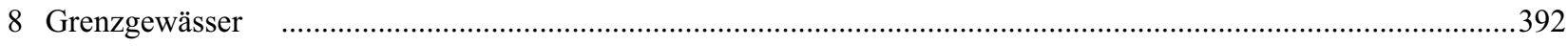

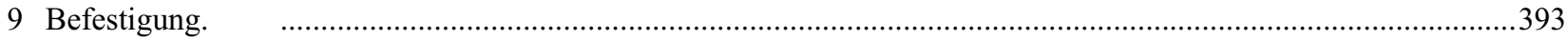

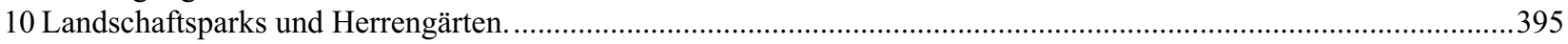

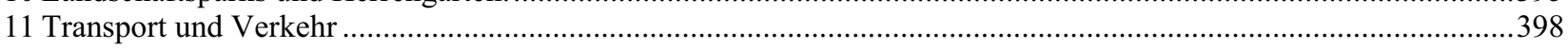

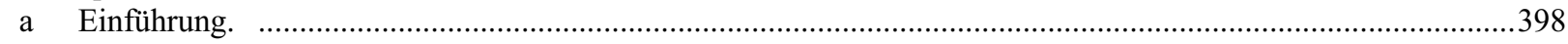

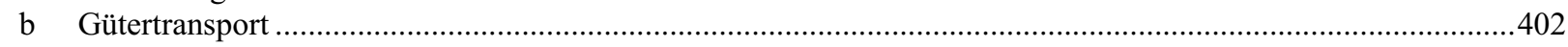

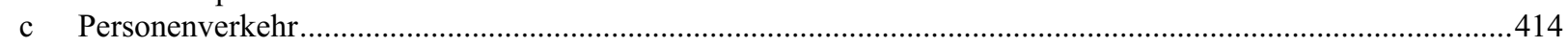

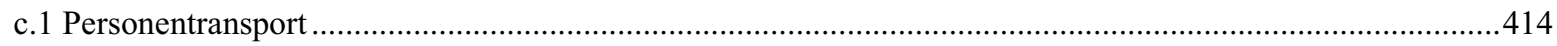

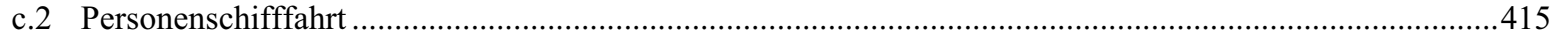

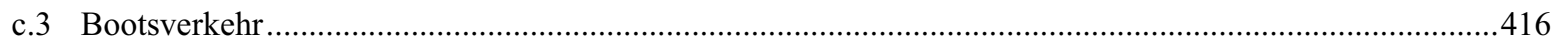

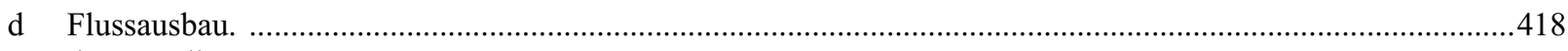

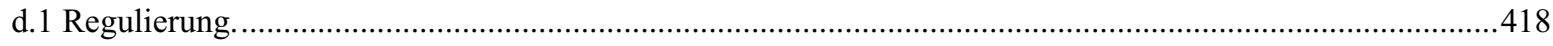

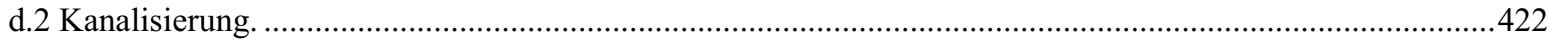

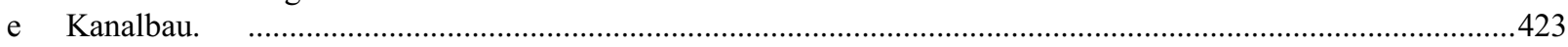

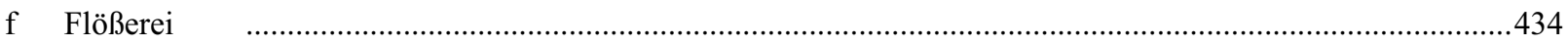

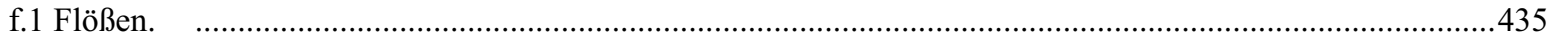

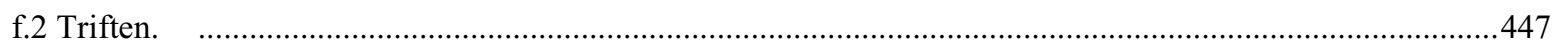

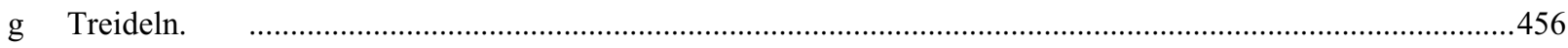

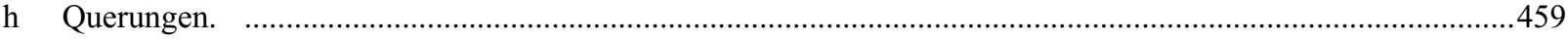

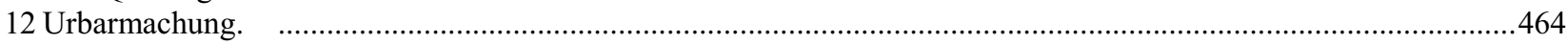

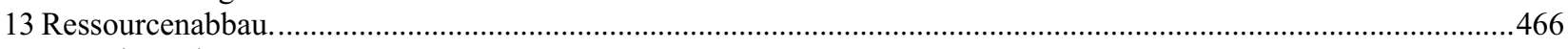

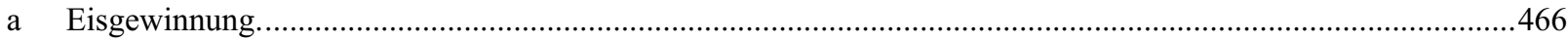

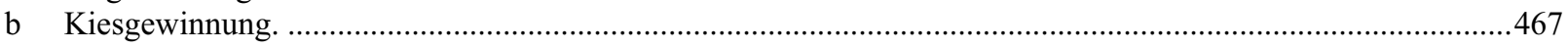

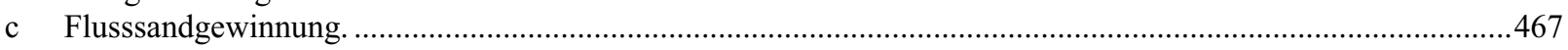

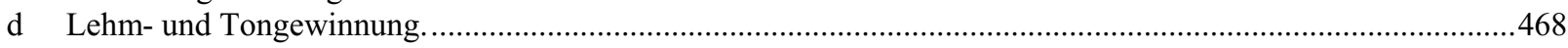

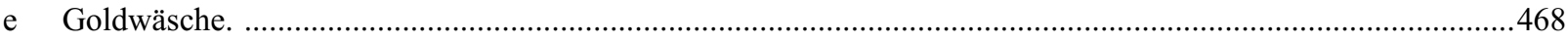

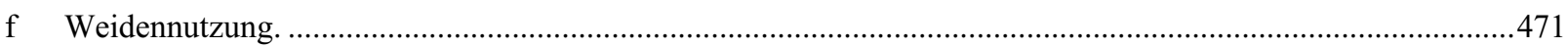

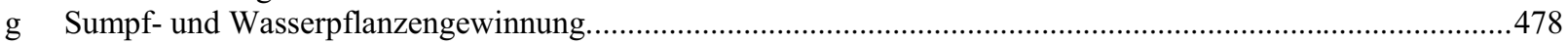

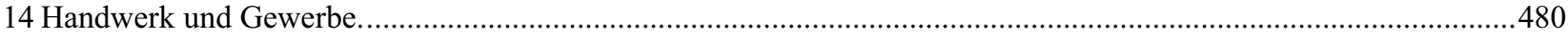

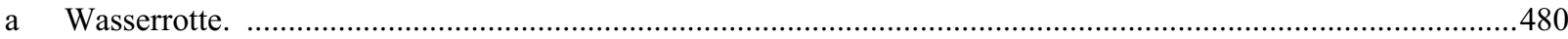

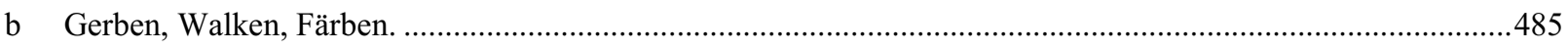

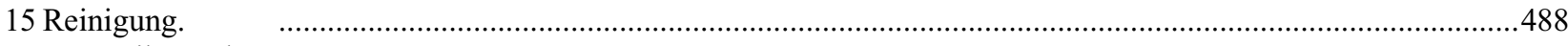

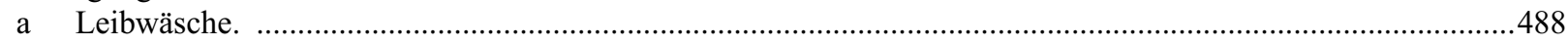

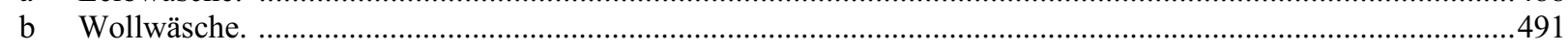

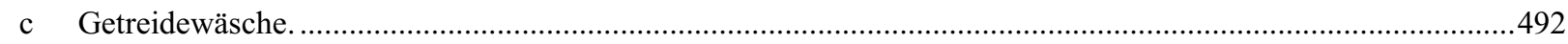




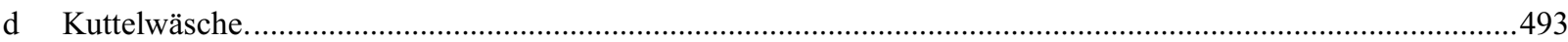

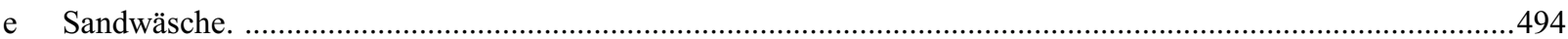

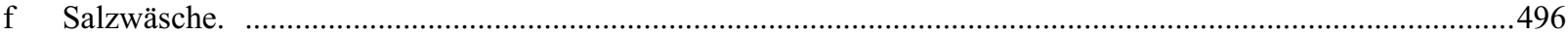

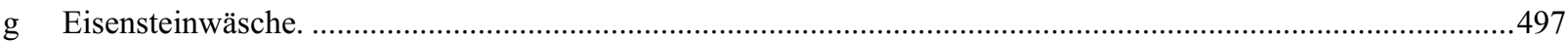

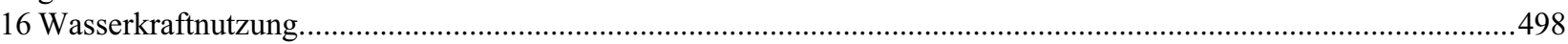

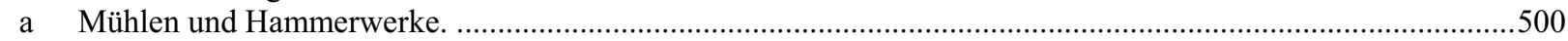

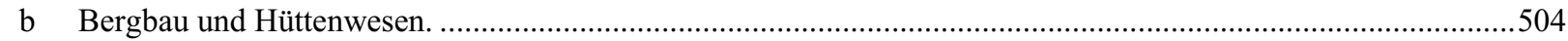

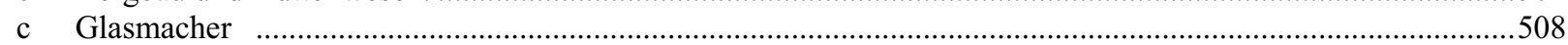

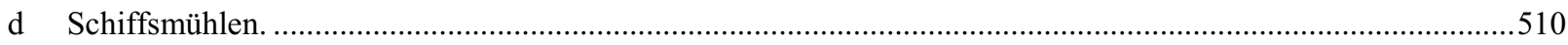

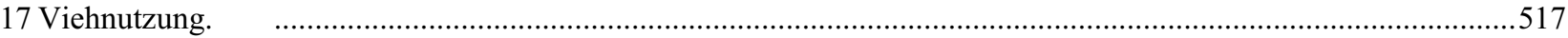

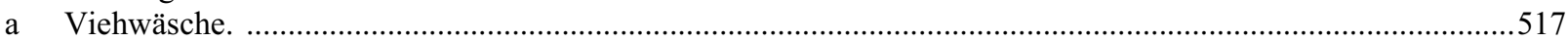

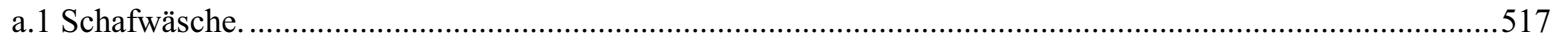

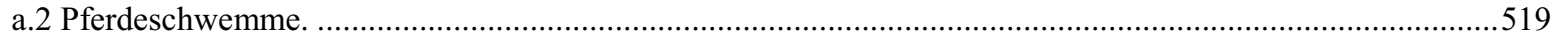

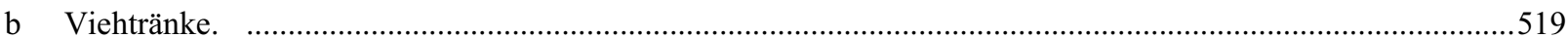

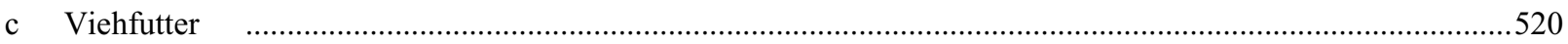

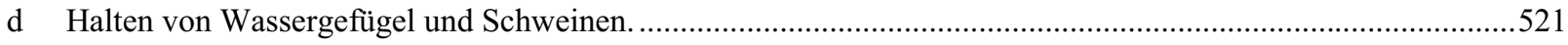

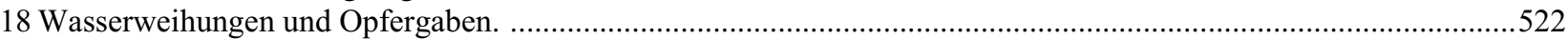

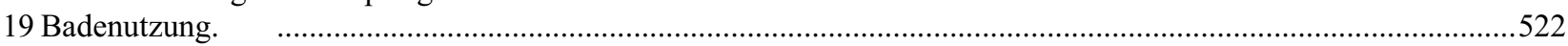

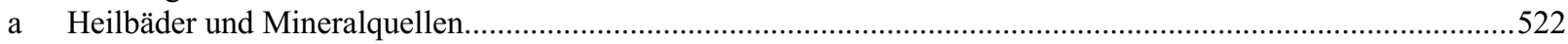

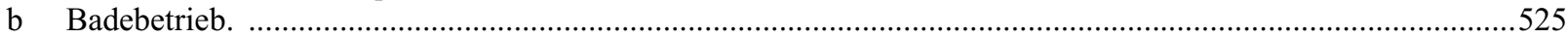

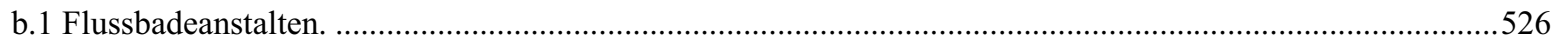

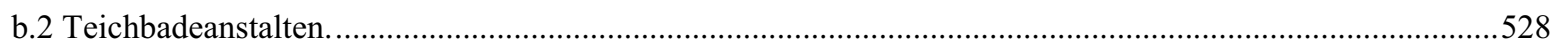

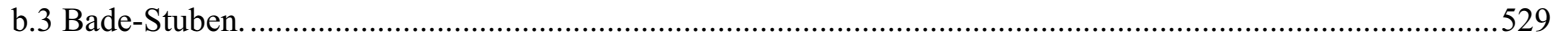

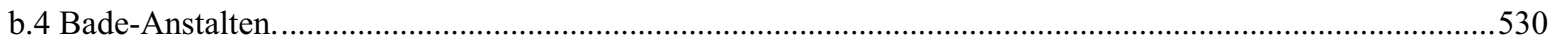

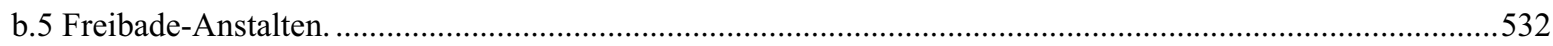

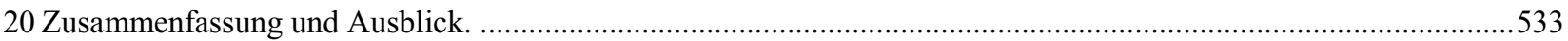

VII Ausgewählte Anlagen und Elemente anthropogener Gewässernutzung. …...........................................................535

1 Teiche.

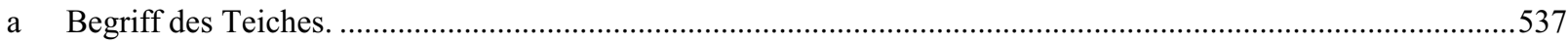

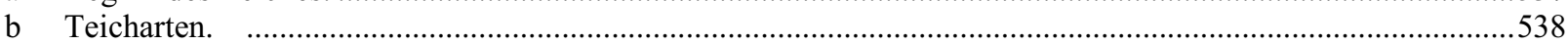

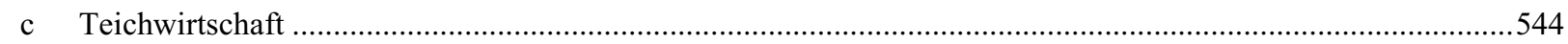

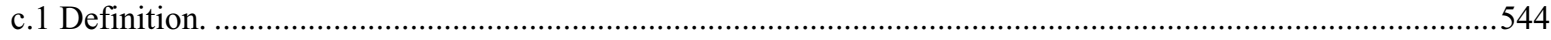

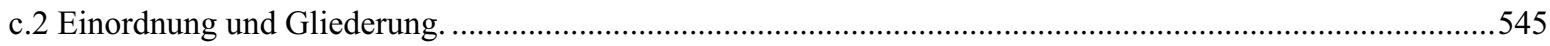

2 Fischteiche.

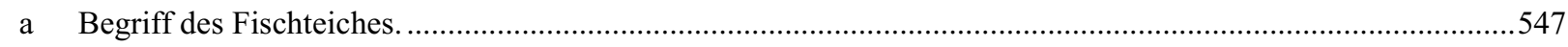

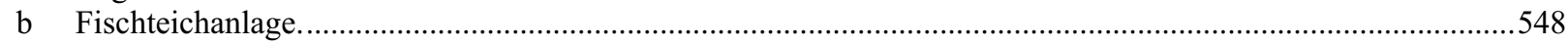

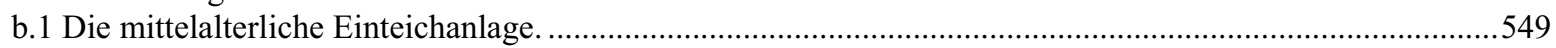

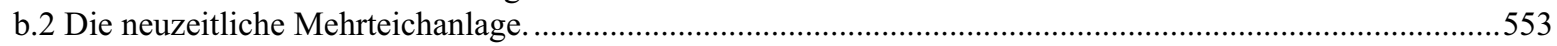

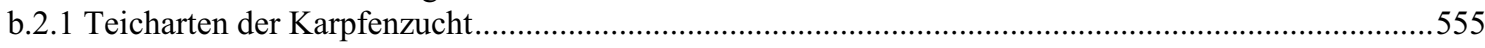

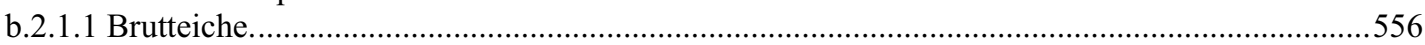

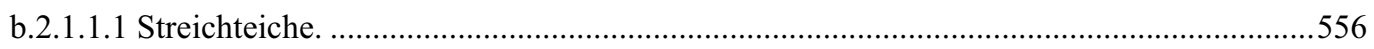

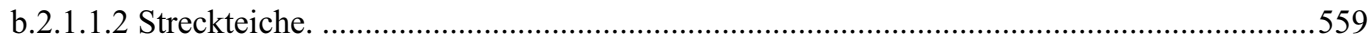

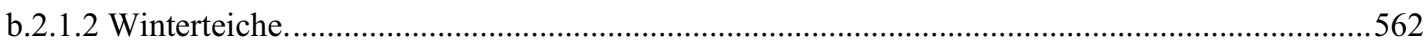

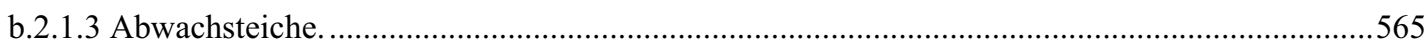

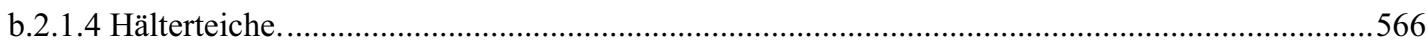

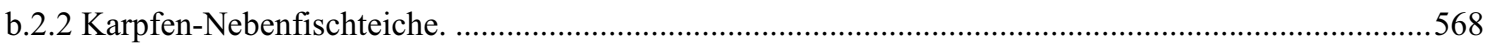

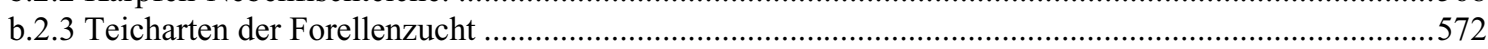

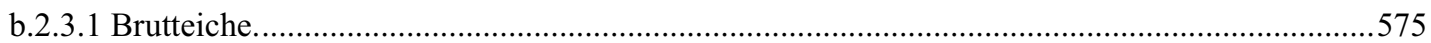

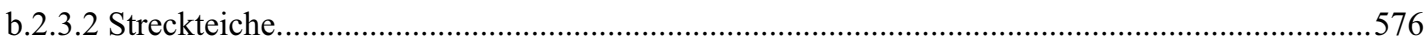

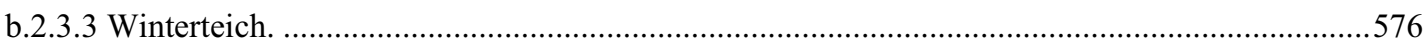

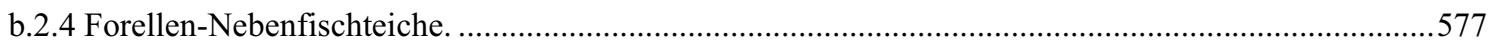

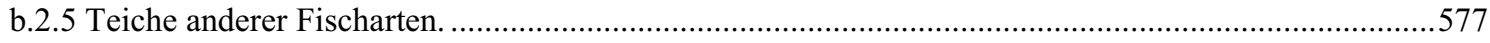

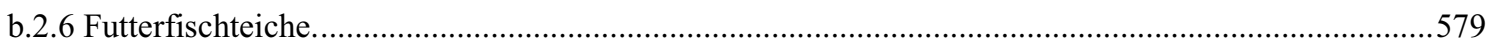

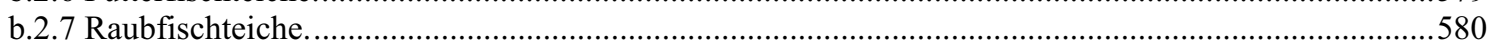

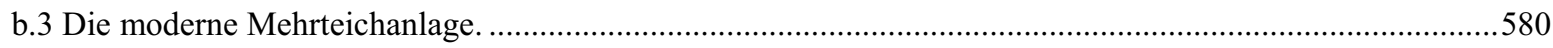




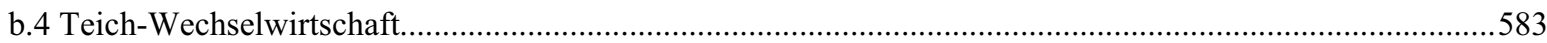

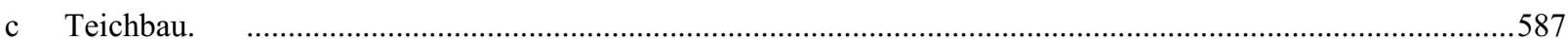

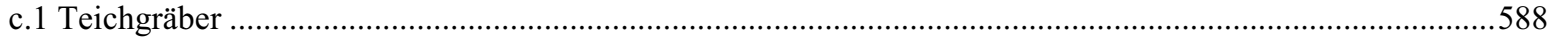

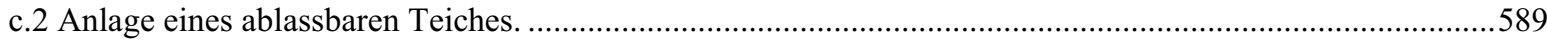

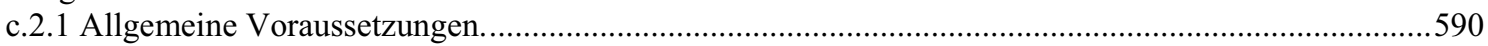

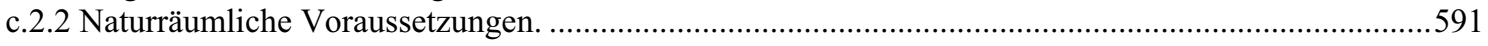

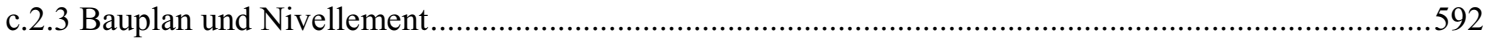

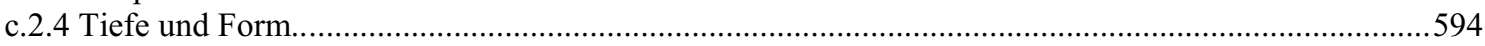

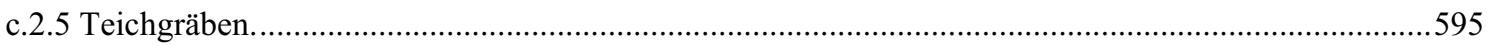

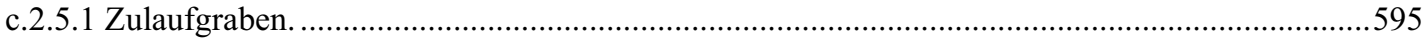

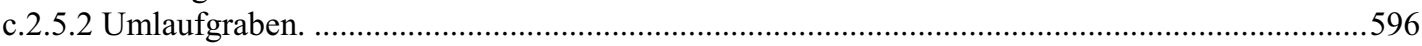

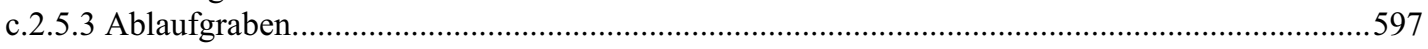

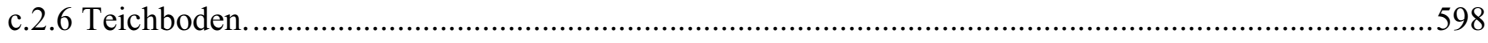

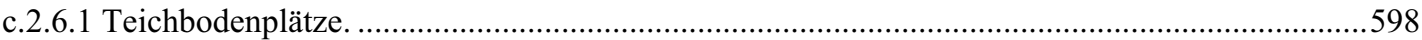

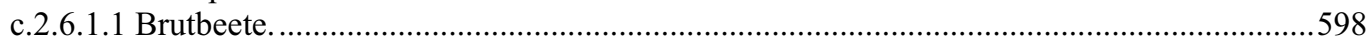

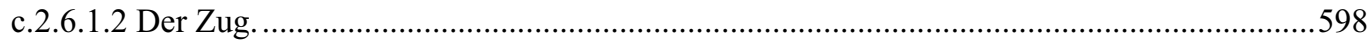

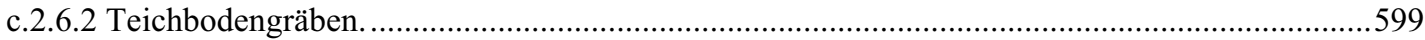

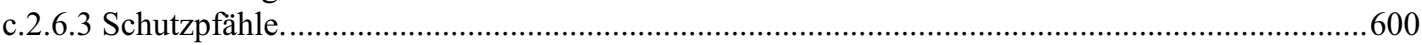

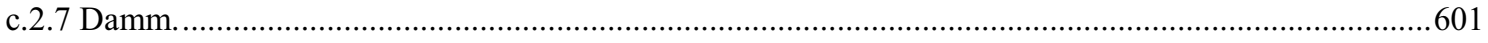

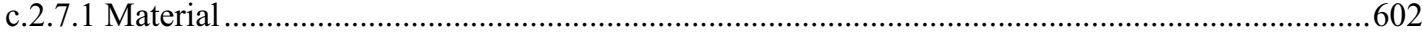

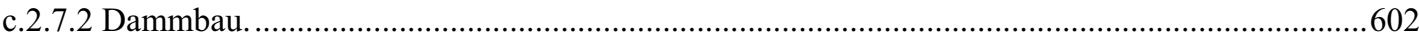

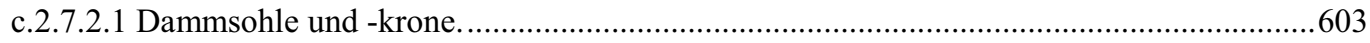

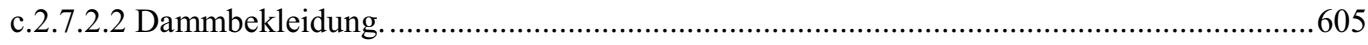

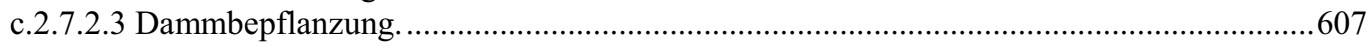

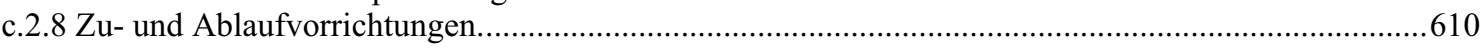

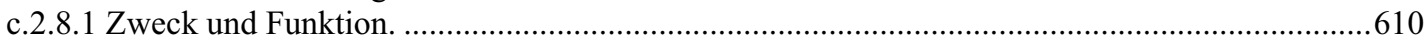

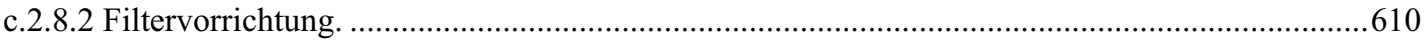

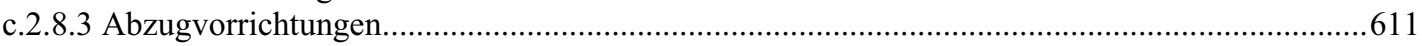

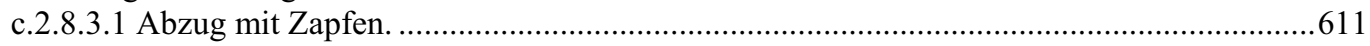

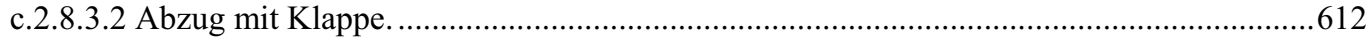

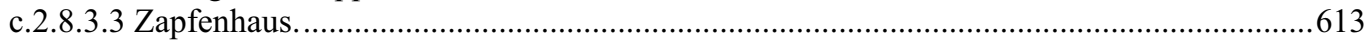

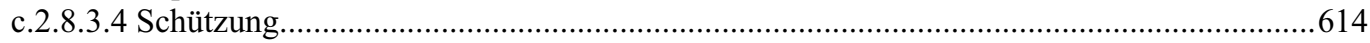

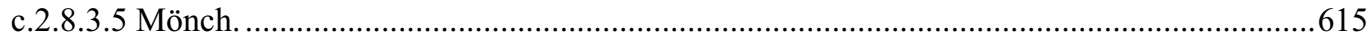

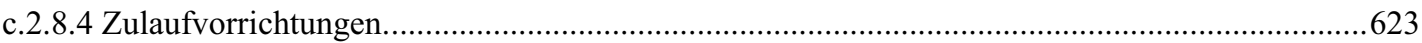

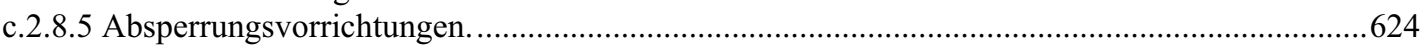

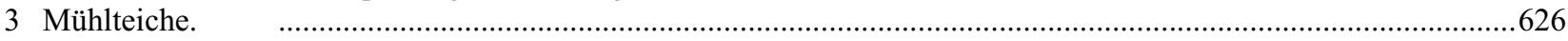

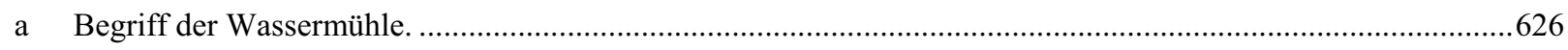

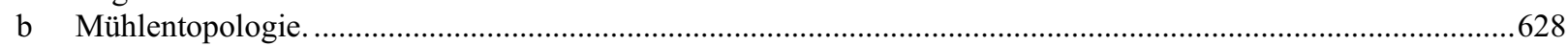

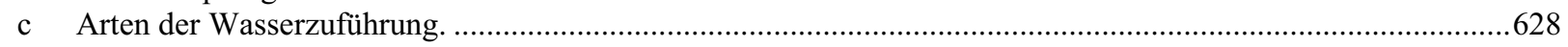

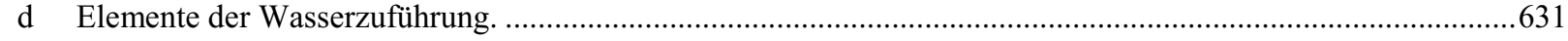

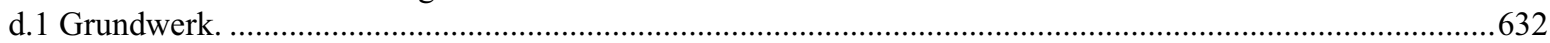

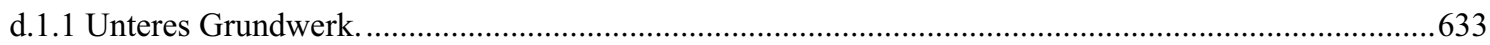

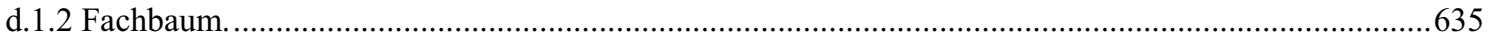

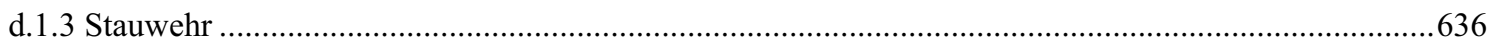

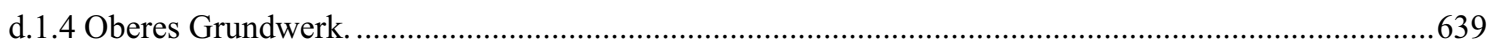

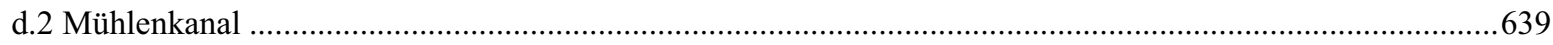

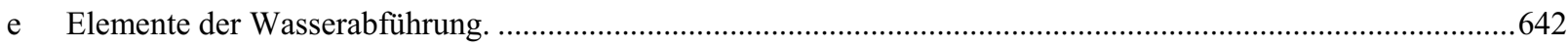

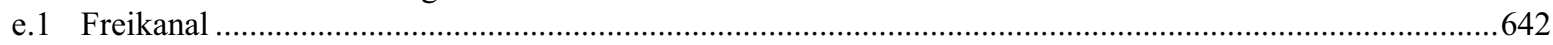

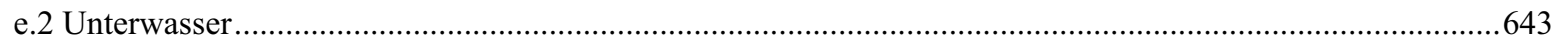

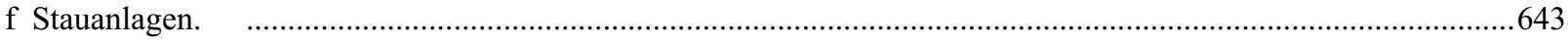

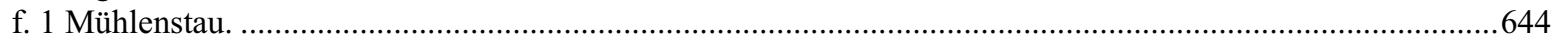

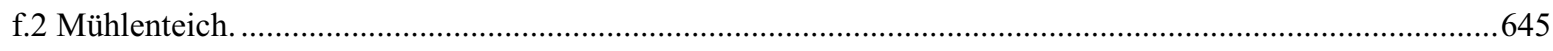

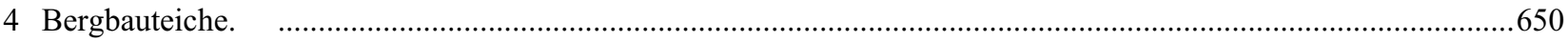

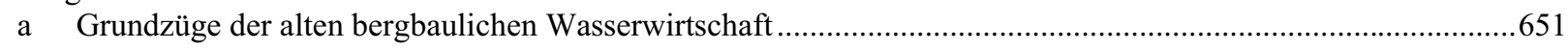

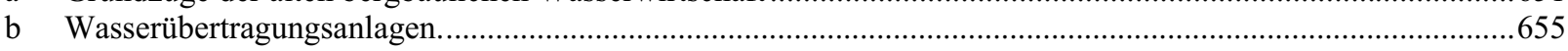

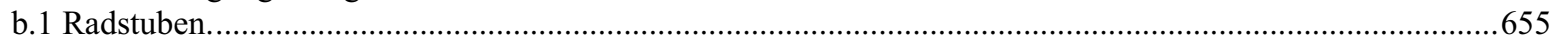




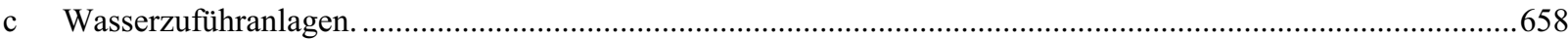

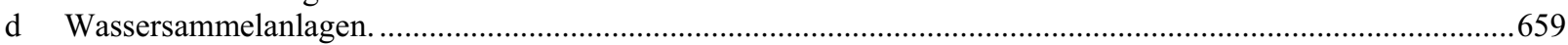

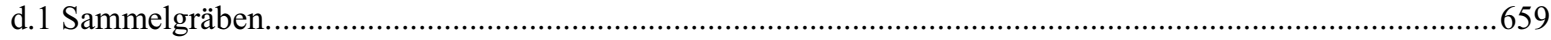

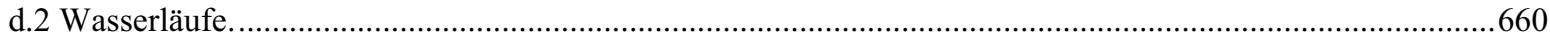

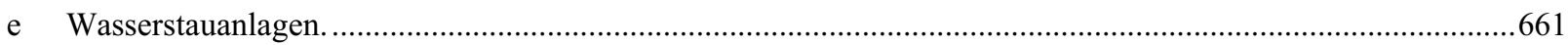

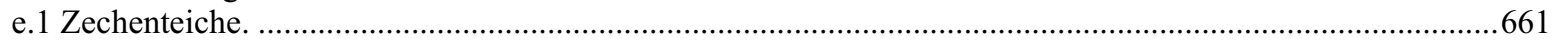

e.1.1 Dammbau.

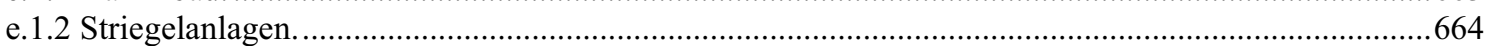

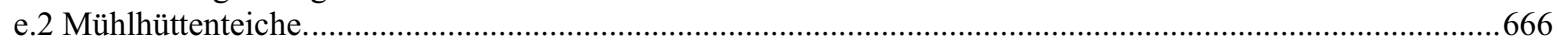

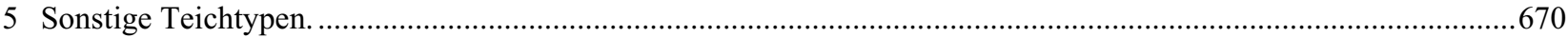

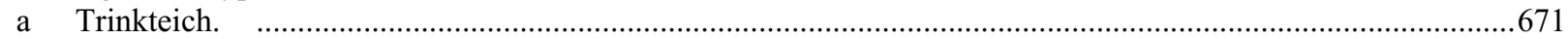

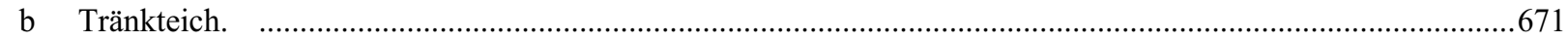

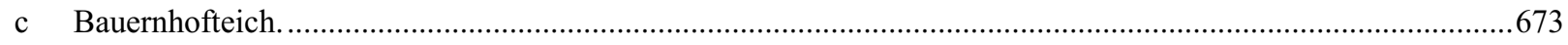

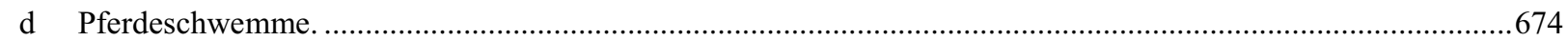

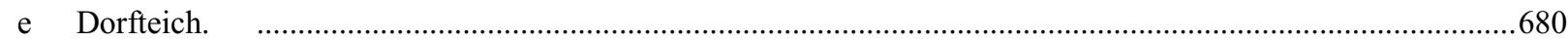

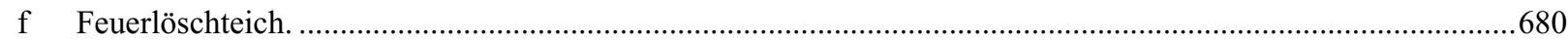

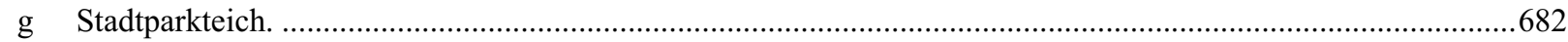

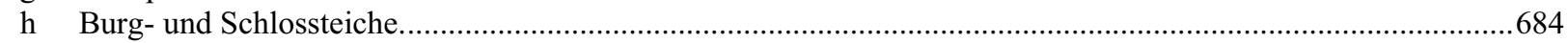

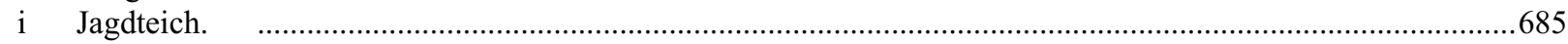

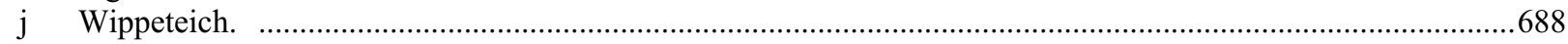

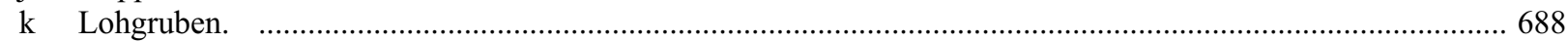

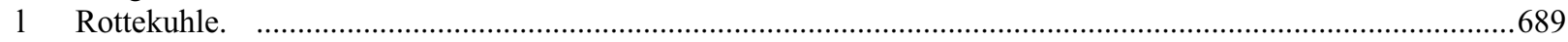

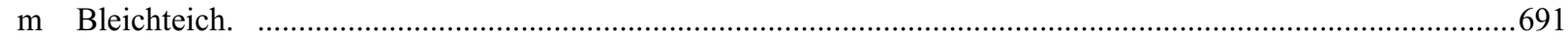

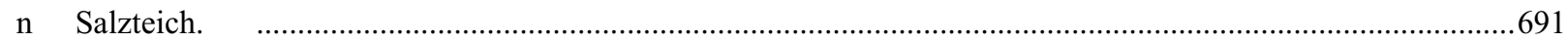

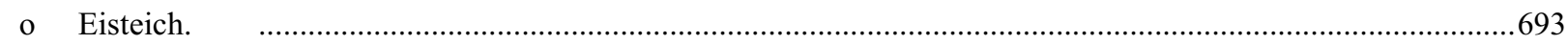

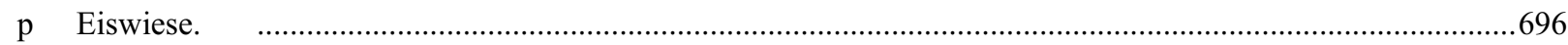

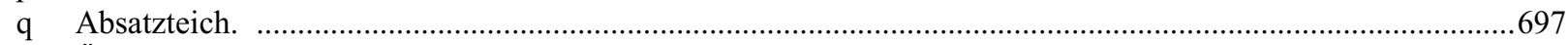

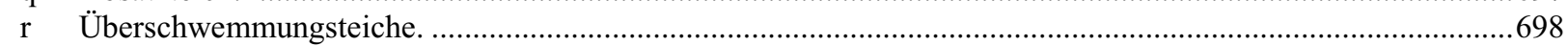

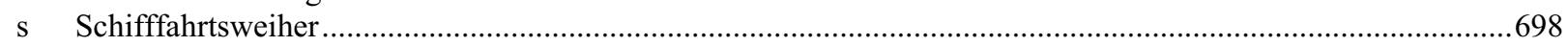

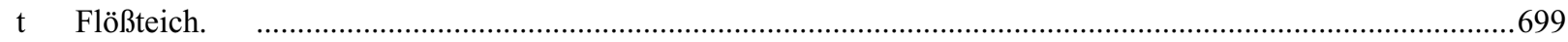

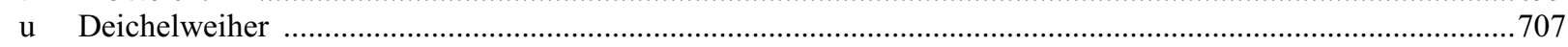

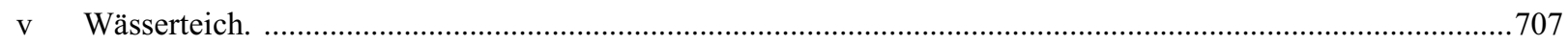

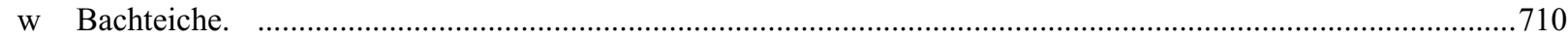

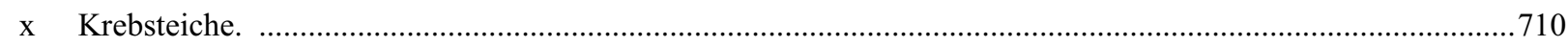

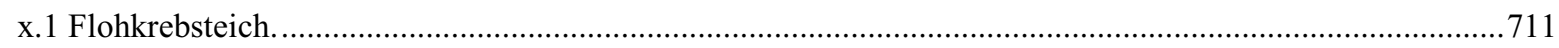

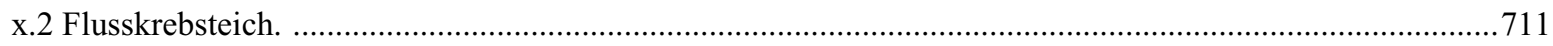

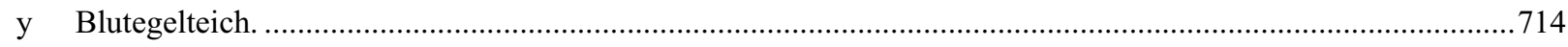

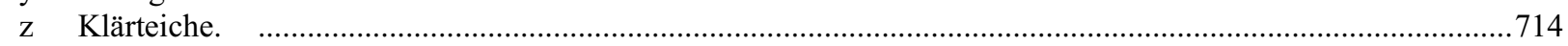

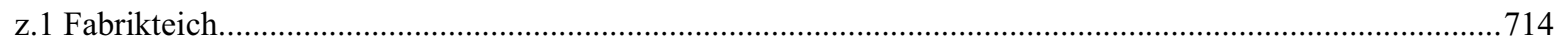

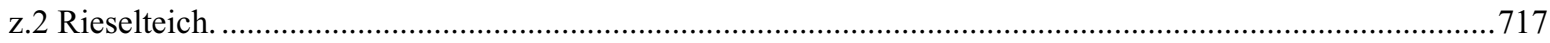

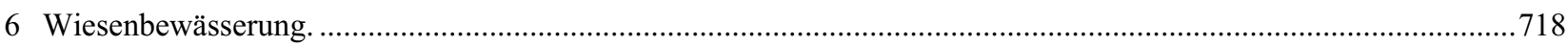

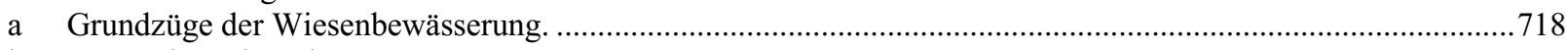

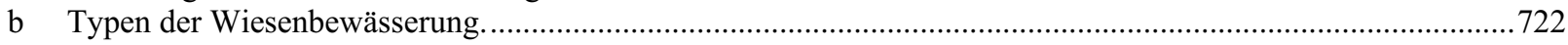

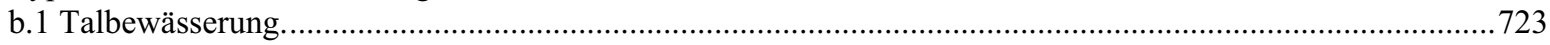

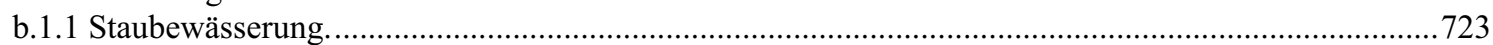

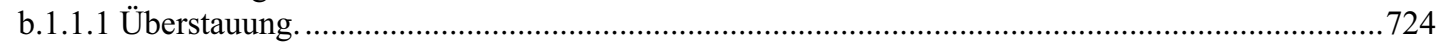

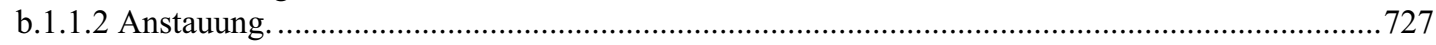

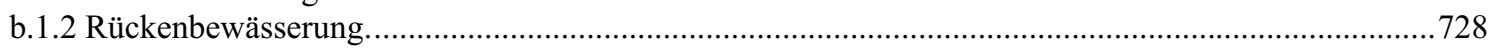

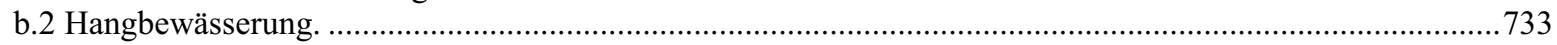

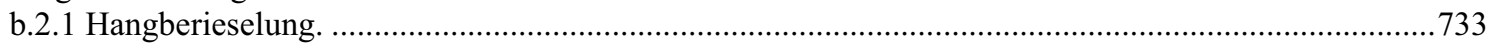

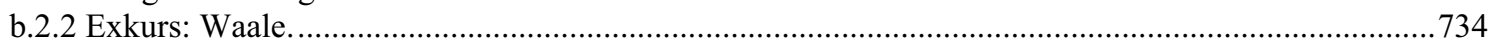

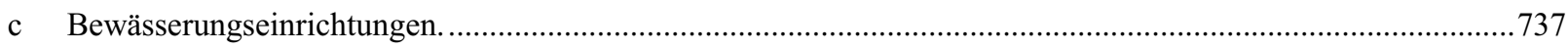

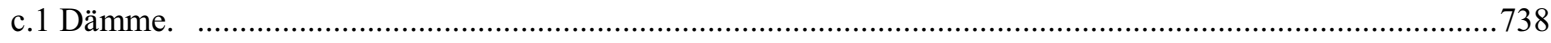

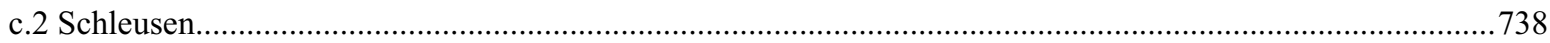

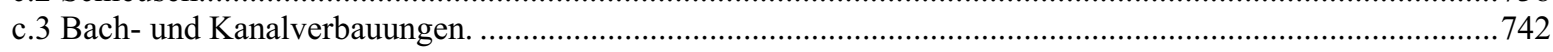

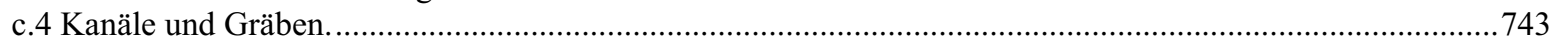




\section{REGIONALER TEIL}

VIII. Historische Wassernutzungen in ihrem Landschaftsbezug: geographisch-großräumige Verbreitungen und

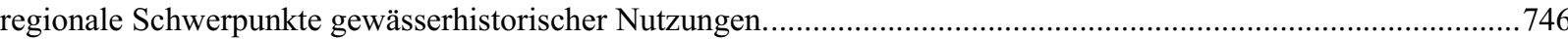

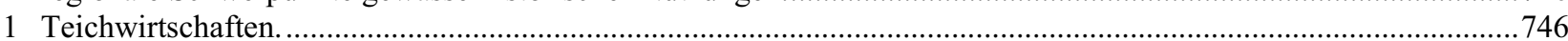

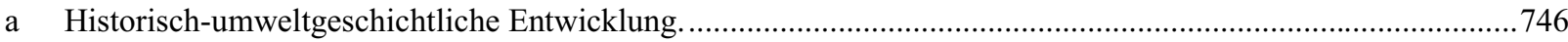

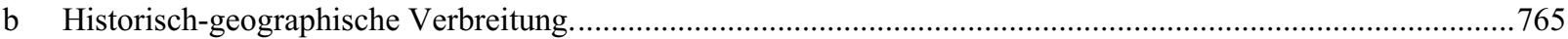

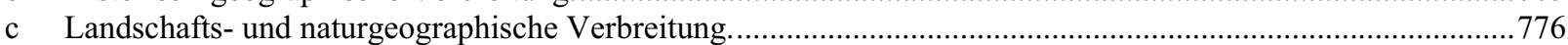

c.1 Die Bedeutung der Topographie und Pedologie für die Lage und Anlage von Teichen. .............................777

c.2 Die Bedeutung des Wassers für die Lage und Anlage von Teichen...................................................... 778

c.3 Die Bedeutung des Klimas für die Lage und Anlage von Teichen. ...............................................................779

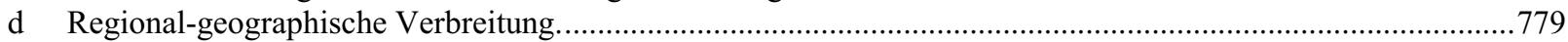

d.1 Unterscheidung der Teichwirtschaft nach Größe und Betriebsform..................................................780

d.2 Verbreitung der Teichwirtschaft nach Größe und Betriebsform. ...............................................................782

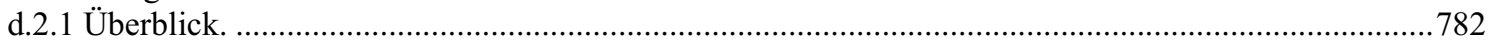

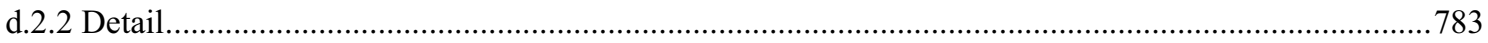

d.2.2.1 Tiefland

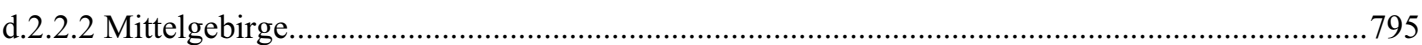

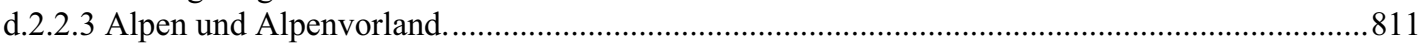

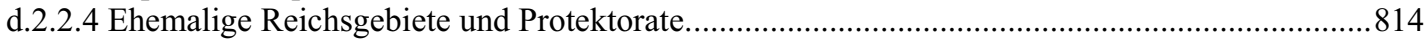

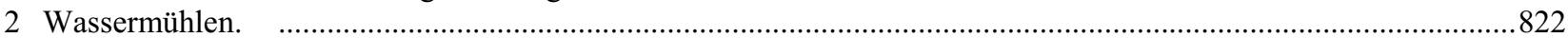

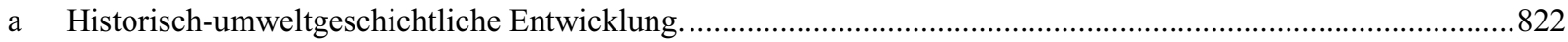

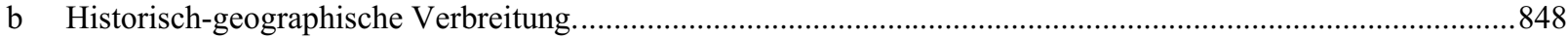

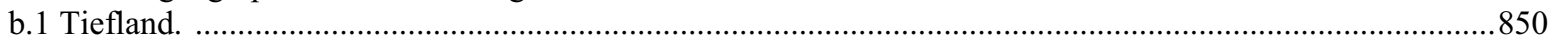

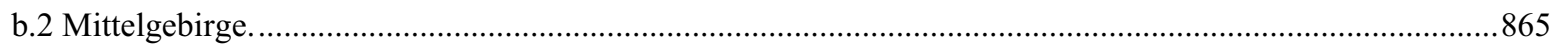

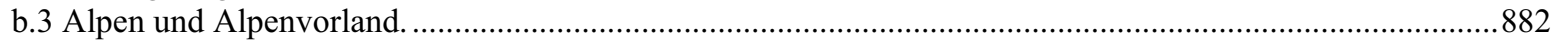

3 Bergbau.

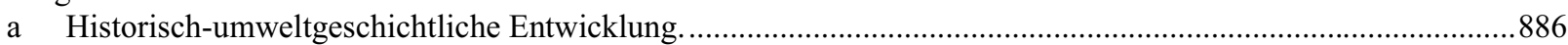

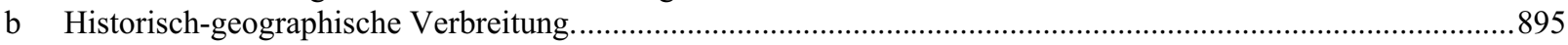

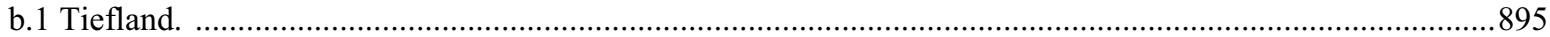

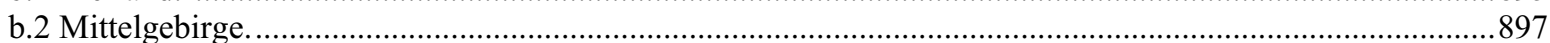

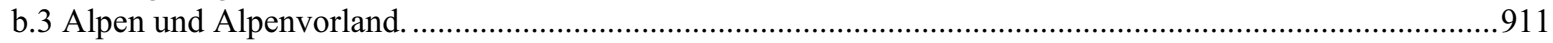

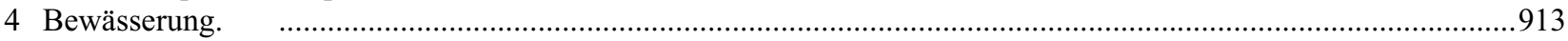

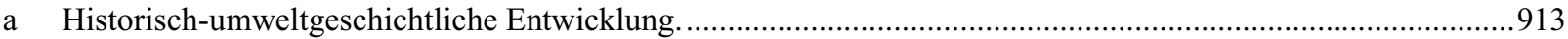

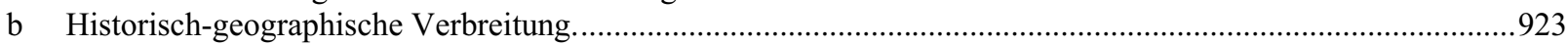

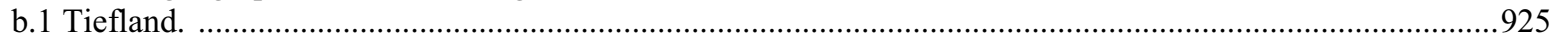

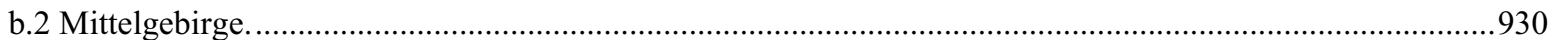

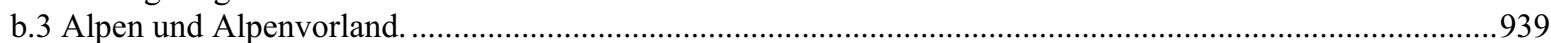

\section{E ANWENDUNGSBEZOGENER TEIL}

IX Berücksichtigung gewässerhistorischer Kulturlandschaftselemente in der Praxis..........................................947

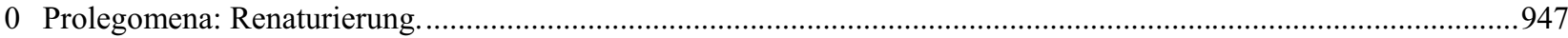

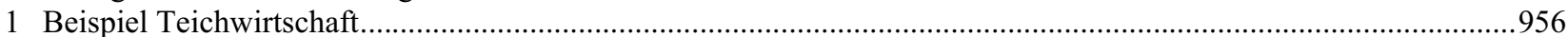

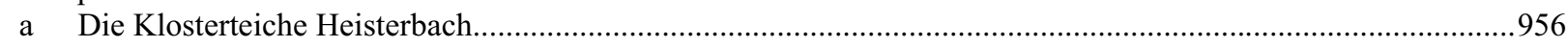

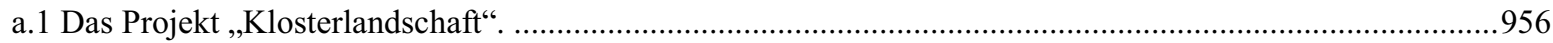

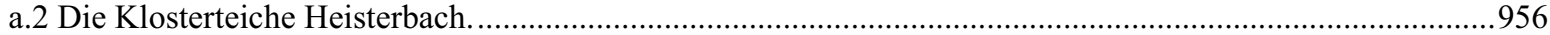

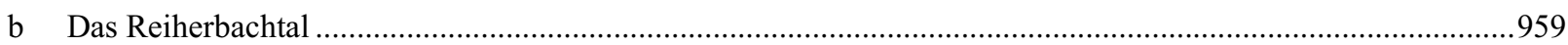

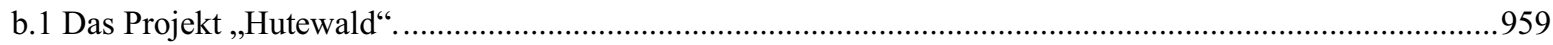

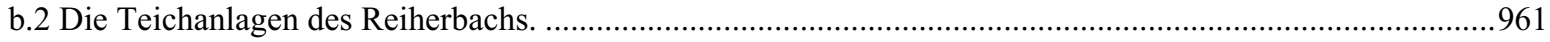

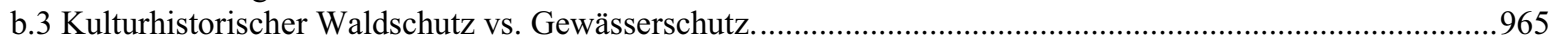

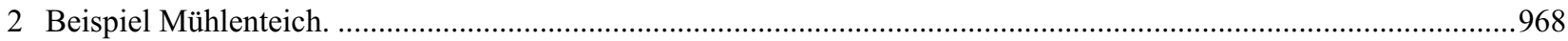

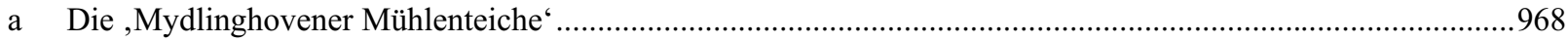

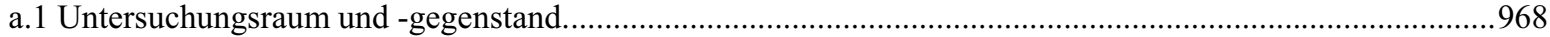

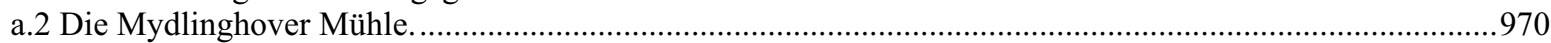

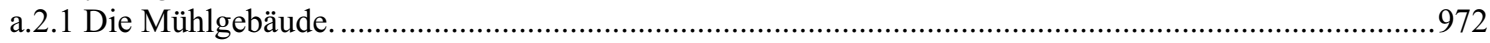




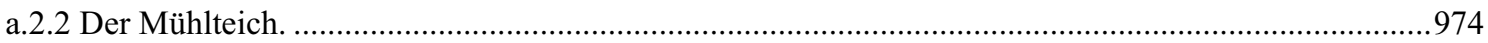

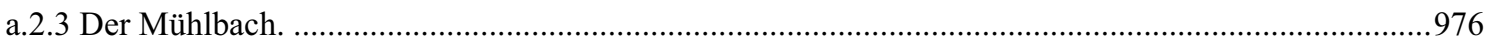

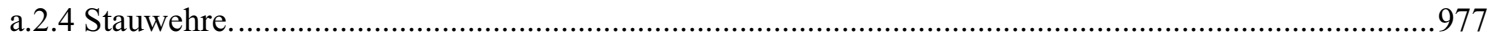

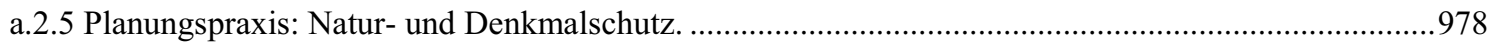

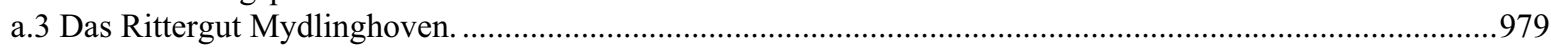

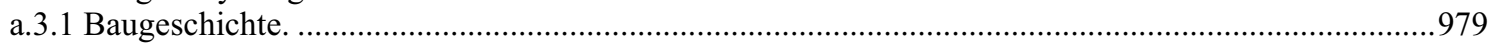

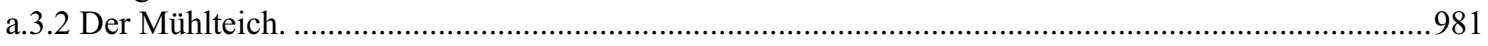

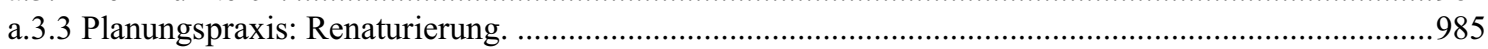

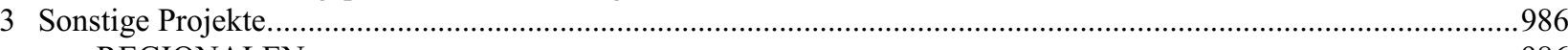

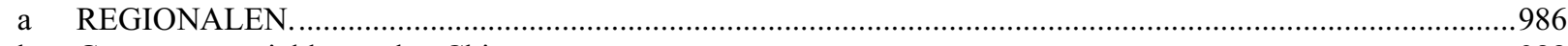

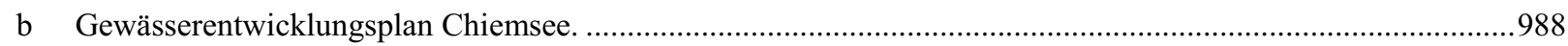

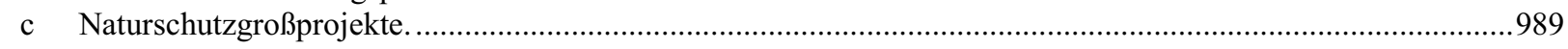

c.1 Naturschutzgroßprojekt „,Teichgebiete Niederspree-Hammerstadt““.....................................................990

c.2 Naturschutzgroßprojekt „Waldnaab-Aue“. .....................................................................................994

X Ausblick: Der Beitrag der historisch-geographischen Gewässerforschung zu den drängenden Gegenwartsfragen.........995

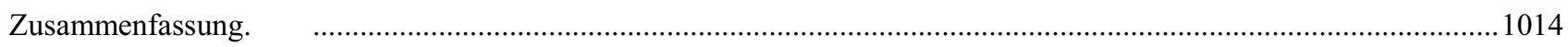

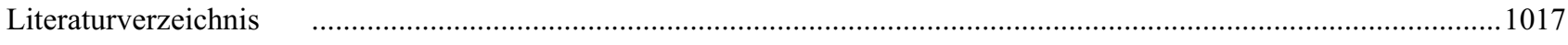

Anhang 


\section{Abbildungsverzeichnis}

Abb. 0-1:

Abb. 0-2:

Abb. 0-3:

Abb. 0-4:

Abb. 0-5:

Abb. 0-6:

Abb. 0-7:

Abb. 0-8:

Abb. 0-9:

Abb. 0-10:

Abb. 0-11:

Abb. I-1:

Abb. I-2:

Abb. I-3:

Abb. I-4:

Abb. I-5:

Abb. I-6:

Abb. I-7:

Abb. III-1:

Abb. III-2:

Abb. III-3:

Abb. III-4:

Abb. III-5:

Abb. III-6:

Abb. III-7:

Abb. III-8:

Abb. III-9:

Abb. III-10:

Abb. III-11:

Abb. III-12:

Abb. III-13:

Abb. III-14:

Abb. III-15:

Abb. III-16:

Abb. III-17:

Abb. IV-1:

Abb. IV-2:

Abb. IV-3:

Abb. IV-4:

Abb. IV-5:

Abb. V-1:

Abb. V-2:

Abb. V-3:

Abb. V-4:

Abb. V-5:

Abb. V-6:

Abb. V-7:

Abb. V-8:

Abb. V-9:

Abb. V-10:

Abb. V-11:

Abb. V-12:

Abb. V-13:

Abb. V-14:
Zeitschnittartige und stark generalisierte Entwicklung einer Flusstal-Landschaft im Mittellauf.....................1

Zentrale landwirtschaftliche Wasserentnahmestelle in Derental im Solling.............................................2

„Vertrocknung“ einer Flussauen-Landschaft vor und nach den Flusskorrektionen des 19. Jh.......................3

Die unterschiedliche Bedrohung großer und kleiner Gewässer. ...........................................................4

Wassergefüllte Wagenspuren auf unbefestigtem Landweg in Priozersk/Ostkarelien...................................5

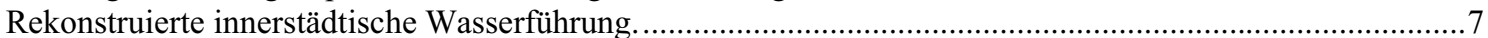

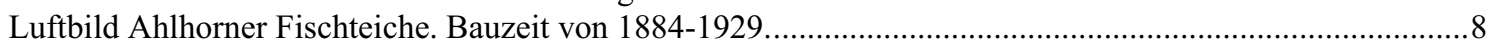

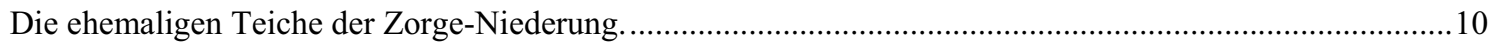

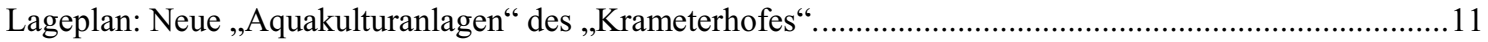

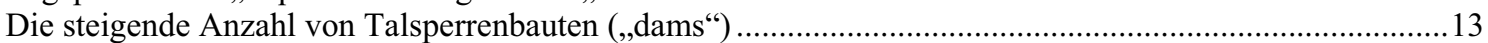

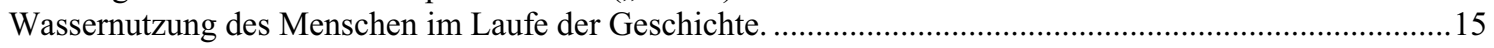

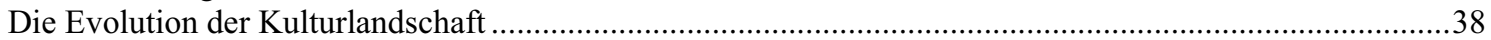

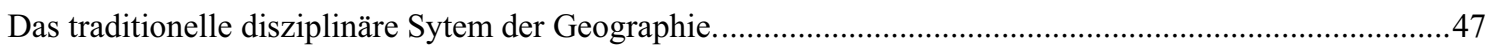

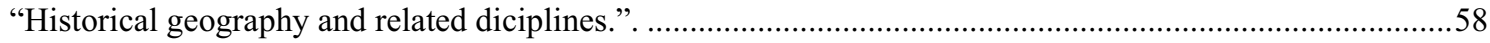

Von Eingriffen des Menschen betroffene Geoelemente. …............................................................. 81

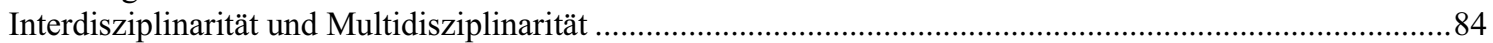

Periodischer „Werdegang“ der Angewandten Geographie und entsprechende Ausrichtungen.....................86

Städtebauliche Integration eines kleinen Gewässerlaufes in der Stadt ...............................................108

Ausschnitt aus einer Planungskarte der Oderbruchregion. ............................................................. 152

Der Neckar zwischen Aldingen und Neckargröningen (nicht maßstabsgerecht) ......................................155

„Wehr-Schützen zum Mühlgraben-Einlauf für die Stadt Nordhausen“.................................................. 158

Modell eines großen Aufziehwehres an einem breiten Fluss..............................................................159

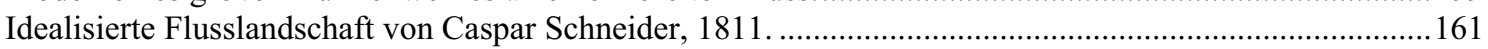

Die Mainzer Schiffbrücke mit Blick auf Kastel von Caspar Schneider, um 1807....................................162

Wassermühle am Berg. Tusche-Bleistift-Zeichnung von Goethe um 1780 ...........................................163

„Westfälische Wassermühle” von Andreas Achenbach.......................................................................... 164

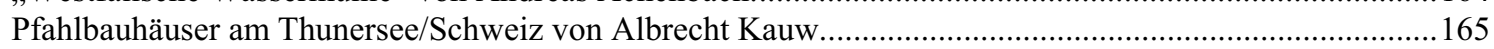

Etymologisch rekonstruierte Teichflächen des Gutes Bothkamp/Schleswig-Holstein. .............................175

Relikte von Hangbewässerungswiesen im Bachtal von Hagendorf/Extertal ..........................................183

Vermessungstechnische Aufnahme eines Teilstücks des Dammbachs................................................... 195

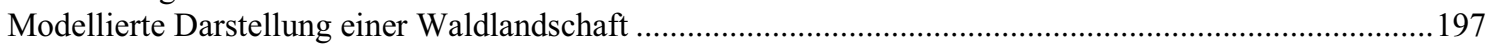

Mögliche Datenquellen für ein kulturhistorisches GIS.................................................................... 198

Mögliche Themenbereiche als Ergebnis des KLEKs.........................................................................202

Maßstabsebenen und Elemente der historisch-geographischen Kulturlandschaftsanalyse. ........................205

Schema einer Kulturlandschaftswandelkartierung mit Gewässerbezug............................................... 214

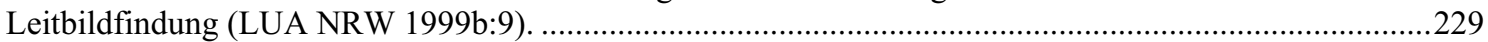

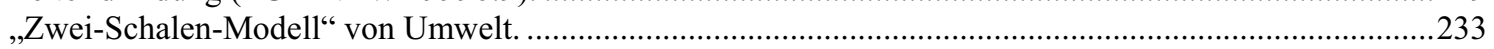

Kennzeichen der „kultürlichen Umwelt“ im Gegensatz zur „,natürlichen Umwelt““.................................234

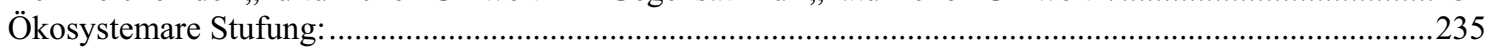

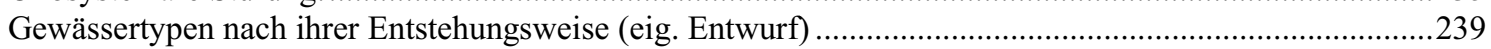

Schematische Darstellung eines durch Salzablaugung hervorgerufenen Erdfalls.....................................253

Erdfallsee bei Bad Pyrmont, nördlich des Ortsteiles Holzhausen..........................................................254

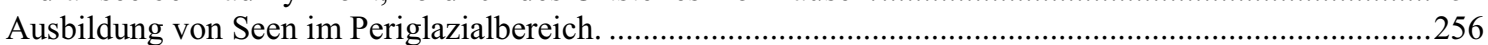

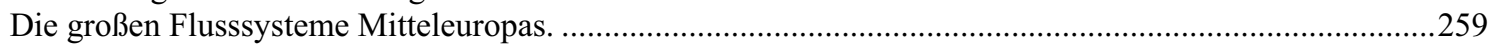

Oase Tadmor mit den Ruinen von Palmyra im Hintergrund der Bildmitte. .............................................265

Jungsteinzeitliche Siedlungsstätte einer „Flusskultur“ in Priozersk/Ostkarelien........................................274

Halbfertige, kuppelförmige mesolithische Hütte. Rekonstruktion. .........................................................2. 275

Pfahlbauer-Kolonie. „Pfahlbaudorf aus der Jungsteinzeit““ (1867) .......................................................280

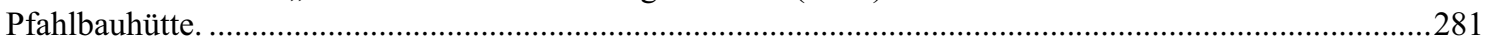

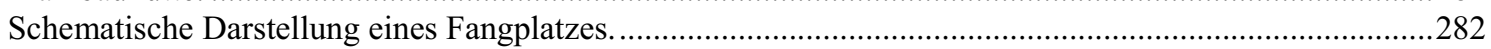

Die Waldhufendörfer Kunzendorf (Miedzna) und Heinwald (Grzawa) ................................................293

Pollhagen (Schaumburg/Lippe) als aufgesiedelte hochmittelalterliche Hagenhufensiedlung. .....................294

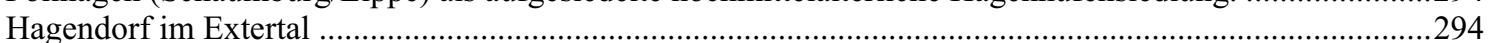

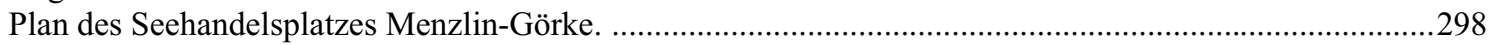


Abb. V-15: Abb. V-16: Abb. V-17: Abb. V-18: Abb. V-19: Abb. V-20: Abb. V-21: Abb. V-22: Abb. V-23: Abb. V-24:

Abb. V-25:

Abb. V-26:

Abb. V-27:

Abb. V-28:

Abb. VI-1:

Abb. VI-2:

Abb. VI-3:

Abb. VI-4:

Abb. VI-5:

Abb. VI-6:

Abb. VI-7:

Abb. VI-8:

Abb. VI-9:

Abb. VI-10:

Abb. VI-11:

Abb. VI-12:

Abb. VI-13:

Abb. VI-14:

Abb. VI-15:

Abb. VI-16:

Abb. VI-17:

Abb. VI-18:

Abb. VI-19:

Abb. VI-20:

Abb. VI-21:

Abb. VI-22:

Abb. VI-23:

Abb. VI-24:

Abb. VI-25:

Abb. VI-26:

Abb. VI-27:

Abb. VI-28:

Abb. VI-29:

Abb. VI-30:

Abb. VI-31:

Abb. VI-32

Abb. VI-33.

Abb. VI-34:

Abb. VI-35:

Abb. VI-36:

Abb. VI-37:

Abb. VI-38:

Abb. VI-39:

Abb. VI-40:

Abb. VI-41:

Abb. VI-42:
Aus der Darstellung ist die Spornlage an der Alsterschleife gut sichtbar ..................................................304

Motte Zoppesmur: Bächlein, das die Motte um- bzw. durchfließt .............................................................306

Schematischer Lageplan Burg Vischering. Rekonstruktion nach dem Urkataster...................................307

Die ehemalige Wüstung Falkenhagen/Südniedersachsen nach einer Karte von 1880/81 ............................309

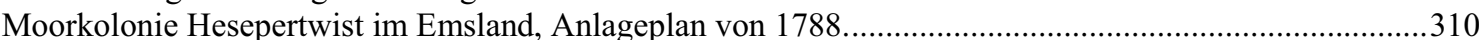

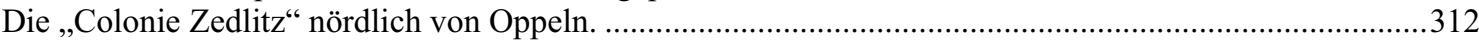

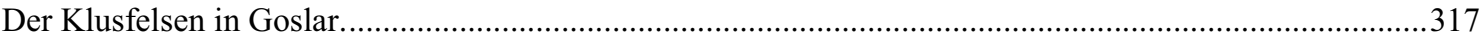

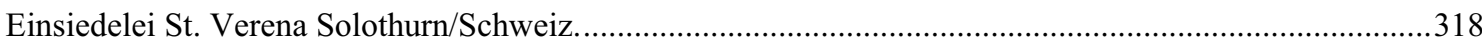

Luftbild Eremitenklause und Schloss „Lichtenberg“/Saalfelden...........................................................319

Mächtiges Wasserrad der Kammgarnspinnerei Bedworth bei Coventry um 1800 ..................................320

Zeitungsausschnitt, der die Aktualität des Themas „Wohnen am Wasser“ widerspiegelt............................3326

Lageplan und Ansicht Hotel Pallafitte, Monruz/Schweiz. ........................................................................329

Fa. B!otop: Plan und Unternehmenszentrale mit Empfangs- und Kommunikationsbereich........................329

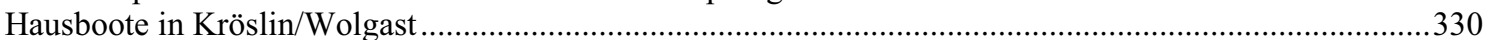

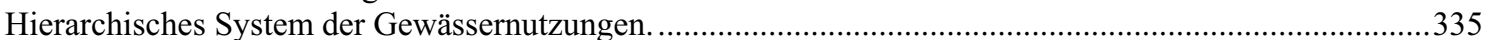

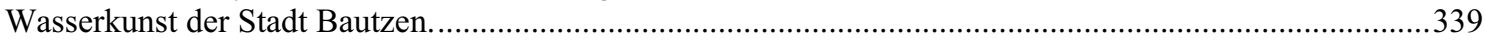

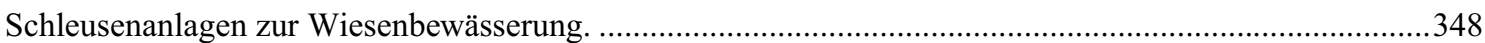

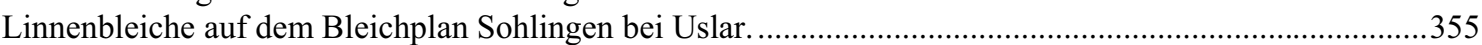

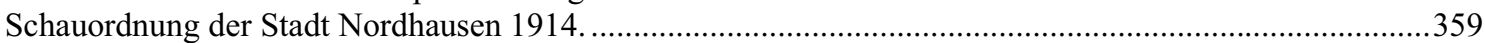

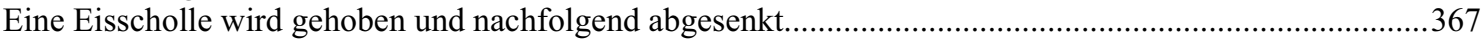

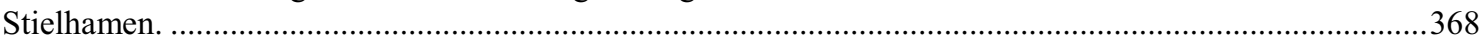

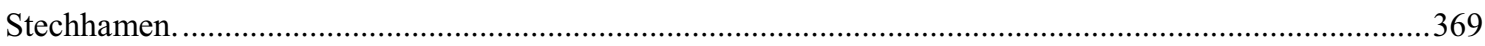

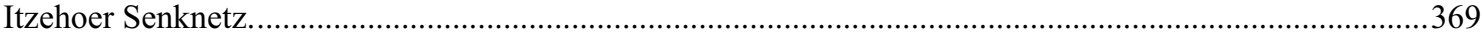

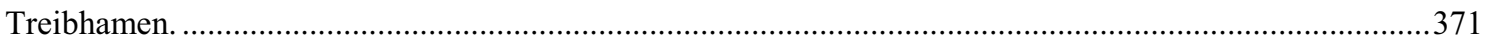

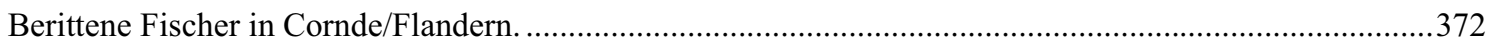

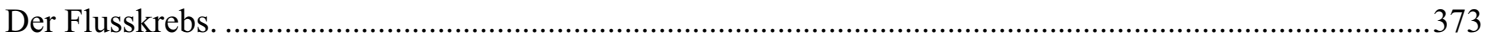

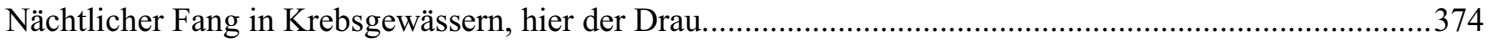

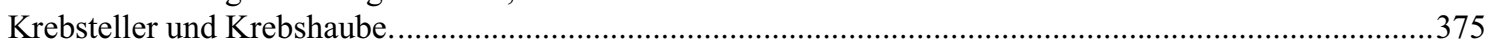

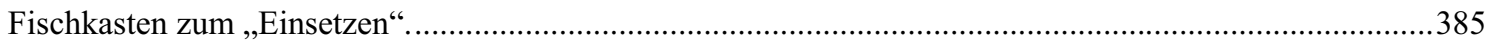

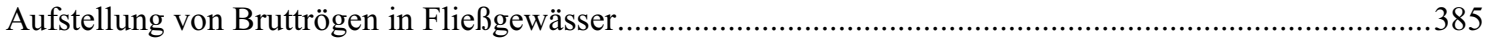

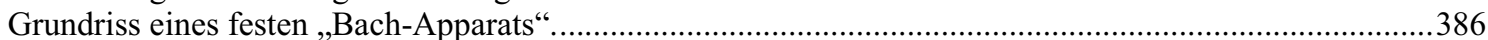

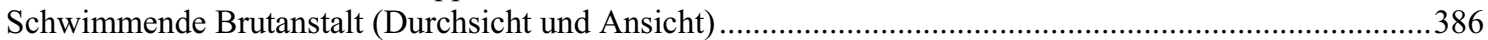

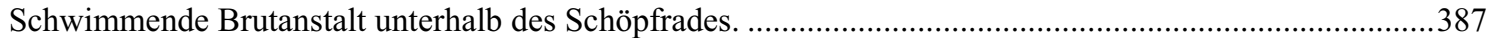

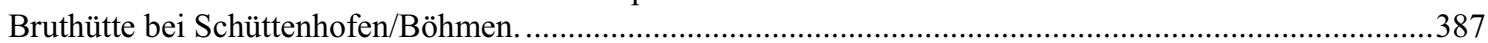

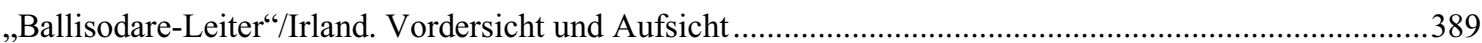

Längsschnitt der Fischtreppe im „Ellermühlenwehr“ mit den einzelnen Aufstiegszellen. ..........................389

„Diagonalpass“, auf einem geneigten Wehr angebracht. Beispiel: Bransford/Teme.................................390

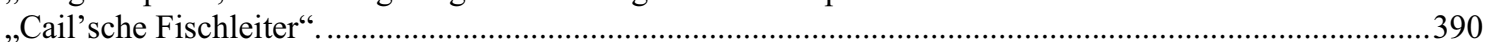

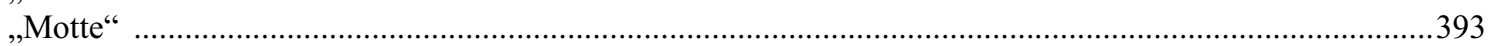

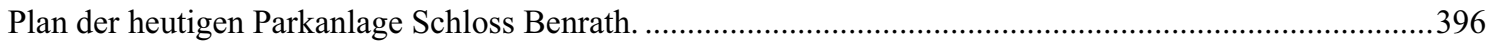

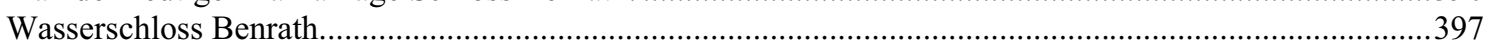

Wasserlandschaft im Landschaftsgarten Schloss Branitz/Cottbus..........................................................398

Stecknitzkahn, vergleichbar mit der Emspünte, mit Spritsegel vor dem Vossberg bei Mölln.....................401

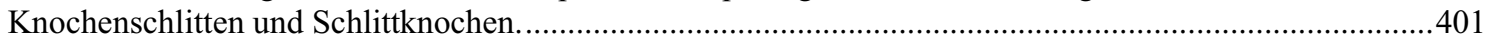

Anlandung von Weinfässern vor der Weinhandlung Gebr. Köster in Quakenbrück, ...................................405

Andernach mit Kranen-Verladung von Mühlsteinen auf Schiffe..........................................................408

Prinzipskizze eines Kettendampfers und Lage der Kette in der Elbe bei Dresden. ..................................413

Gebiete, in denen holl. Ingenieure in Urbarmachung von Feuchtgebieten involviert waren. .......................415

Bootsverkehr auf dem sog. Kunstgraben im Kurpark des Kurbades Salzuflen, um 1900. .........................416

„Gondelteich“ der Heidberger Mühle im Ittertal zwischen Solingen und Haan. ......................................417

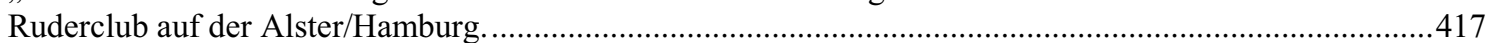

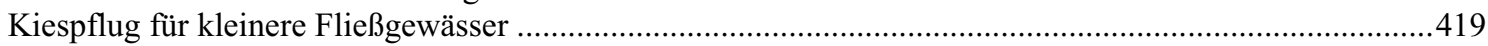

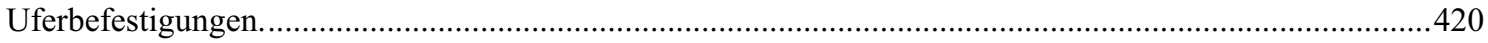

Buhnen an der Weser mit Blick auf Glashütte bei Hannoversch Münden....................................................422

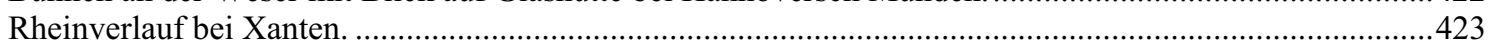

Kennzeichnung der geographischen Lage des „Fossa“ zwischen Donau und Main..................................425 
Abb. VI-43: Der Dorfweiher von Graben als Teil des „Fossatum magnum“.............................................................425

Abb. VI-44: Norddeutsche Wasserstraßen und das Jahr ihrer Inbetriebnahme.......................................................427

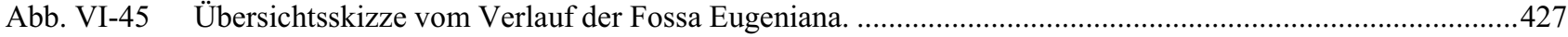

Abb. VI-46: Schleusenrelikt des Diemelkanals in Trendelburg. .........................................................................428

Abb. VI-47: Erztransport auf der ,,schiffbaren Wasserstrecke“. ...........................................................................429

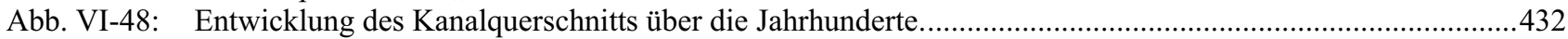

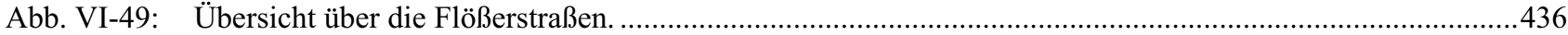

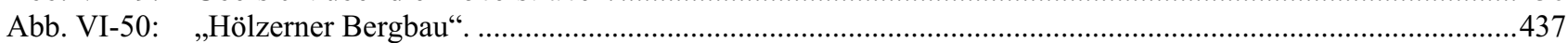

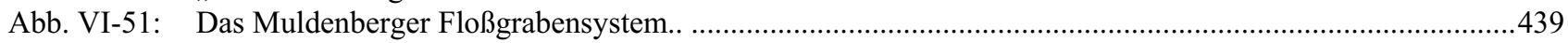

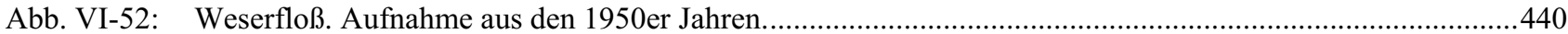

Abb. VI-53: Flößerei („timber raft“) von gebundenem Holz auf einem Wildbach...................................................441

Abb. VI-54: Flößholzrechen, -wehre und Flößbahnen in der Zwickauer Mulde und Malgraben mit Holzanger ..............446

Abb. VI-55: Skizze von Stauschleusen bzw. Wehren in einem Flusslauf mit Floßteich. ............................................447

Abb. VI-56: Triftbach im Solling, von zwei aufgestauten Flößteichen in seiner Wasserkraft unterstützt .......................447

Abb. VI-57: Darstellung des Feuersetzens in einem Holzschnitt aus AGRICOLA (1556)..........................................449

Abb. VI-58: Schematische Darstellung eines Flößplatzes an der Bode. .................................................................451

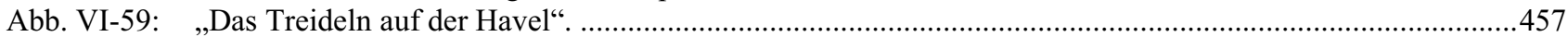

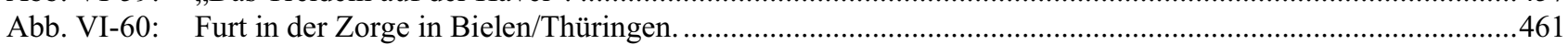

Abb. VI-61: Goldwaschen im Raurisertal/Maria Alm (Österreich) ...................................................................469

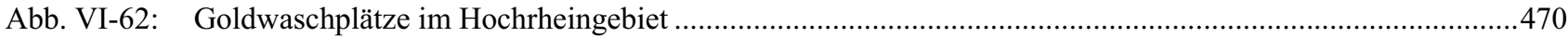

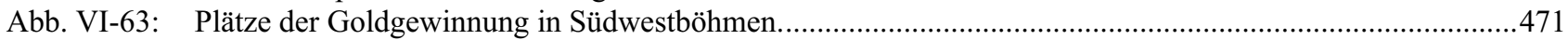

Abb. VI-64: Korbwagen mit Pferdeanspannung für Holzkohlentransporte. ...........................................................472

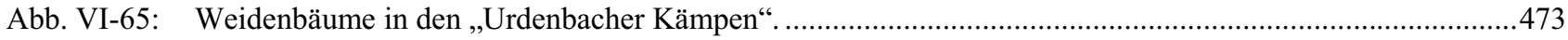

Abb. VI-66: Weidenanpflanzungen am Fährhaus an der Leine. ...........................................................................474

Abb. VI-67: Wiedendrehplatz zum gewerblichen Wiedendrehen im nördlichen Schwarzwald, um 1900 .....................477

Abb. VI-68: Einbringen der Wasserbunde in die Rottekuhle, Wibbecke um 1910.................................................482

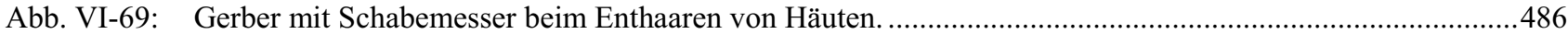

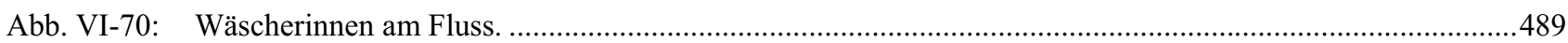

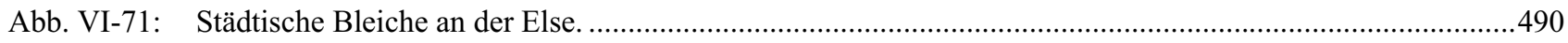

Abb. VI-72: $\quad$ Reinigung der Getreidekörner nach Fausto VERANZIO (ca. 1616) ................................................492

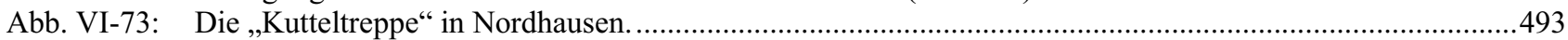

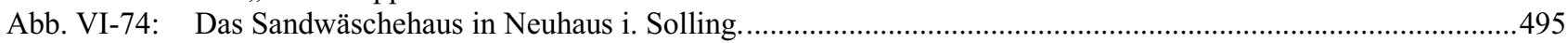

Abb. VI-75: Sandwaschvorgang und Rekonstruktion des Innenraums der abgegangenen Sandwäschehütte...................495

Abb. VI-76: Solegraben - Ableitung in Bad Sooden. .......................................................................................497

Abb. VI-77: Das berühmte „Mühlenhäuser-Aquädukt“ von Arles. .........................................................................499

Abb. VI-78: Drahtziehmühle: Drahtzug mit Hilfe der Wasserkraft ......................................................................501

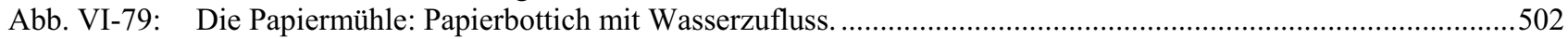

Abb. VI-80: Grubenentwässerung (,Wasserhebung“) mit Kehrrad und Bulgen..........................................................505

Abb. VI-81: Glasschlieferkotten im Ort Polier am Reiherbach unterhalb des Jagdschlosses. .....................................510

Abb. VI-82: Schiffmühle in bzw. an der Ilmenau bei Bienenbüttel. ......................................................................511

Abb. VI-83: Ausschnitt aus der Preußischen Landesaufnahme von 1898 ................................................................512

Abb. VI-84: „Weiset die Beschaffenheit einer Schiff-Mühle, nach ihren Grund- und Aufrissen.“ ................................514

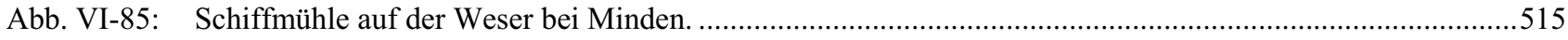

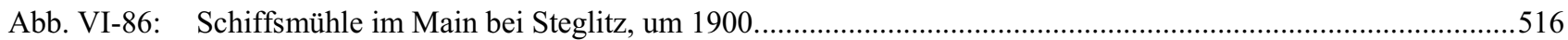

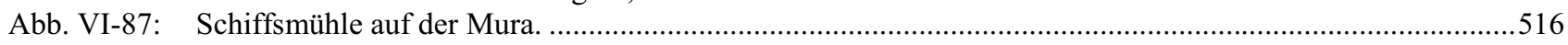

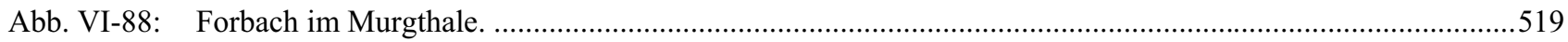

Abb. VI-89: Heinrich Neppel (1874 - 1936): „Landschaft mit Kühen an einem kleinen Weiher“..................................520

Abb. VI-90: Badende in der Pleisse am Dölitzer Wehr, um 1900 .........................................................................526

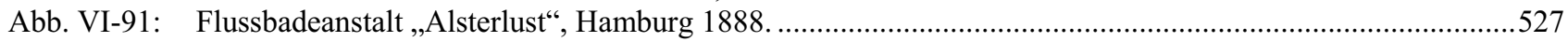

Abb. VI-92: Badeteich der Forellenzucht „Bögerhof“ bei Rinteln. ...................................................................528

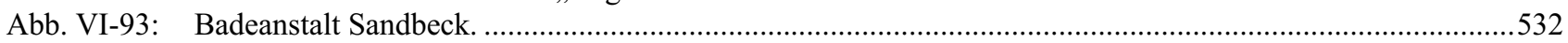

Abb. VII-1: Schematische Darstellung der Teichtypen einer Karpfenaufzucht im 3jährigen Umtrieb. ..........................549

Abb. VII-2: $\quad$ Kombinierte Forellen- und Karpfenzucht Sarlhusen-Papiermühle/Schleswig-Holstein..............................554

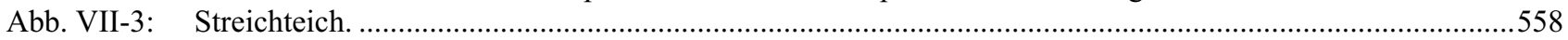

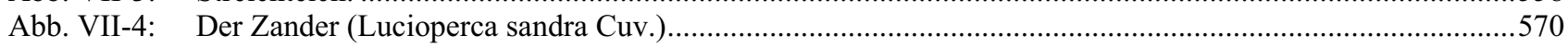

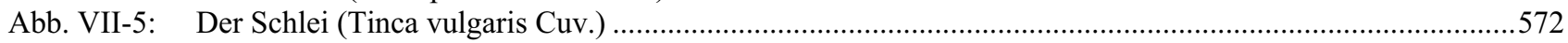




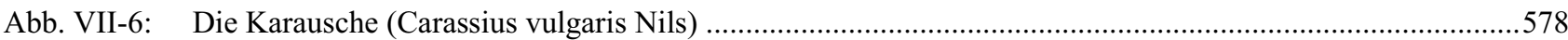

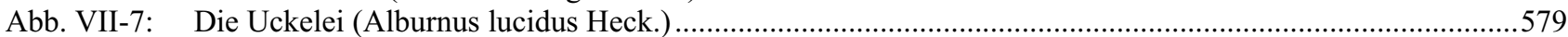

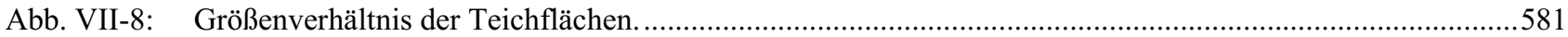

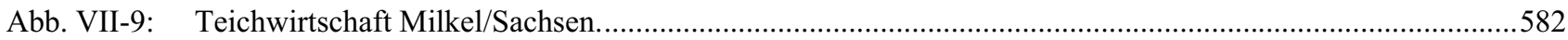

Abb. VII-10: „Situations-Plan einer Teichwirthschaft verbunden mit Wiesenwachs.“..................................................586

Abb. VII-11: Talmulde mit Bezeichnung der zur Anlage von Dämmen geeigneten Stellen.........................................591

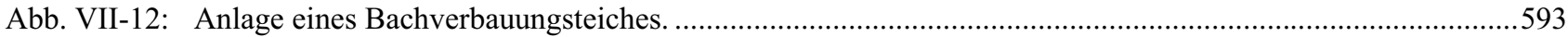

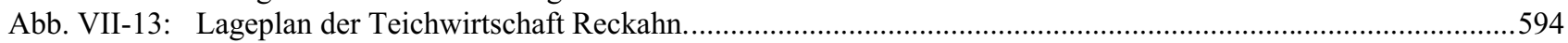

Abb. VII-14: Teiche in einem flachen Wiesenterrain mit Umlaufgraben oder Bachlauf ..............................................596

Abb. VII-15: Boden des Teiches mit Fischgrube (,Zug“") und Gräben. …..............................................................599

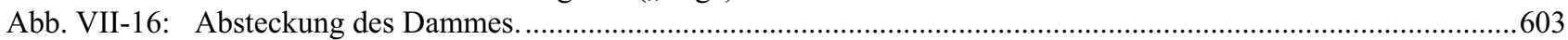

Abb. VII-17: Höhe des Dammes, Größe des Teiches, Dammbreite ...........................................................................605

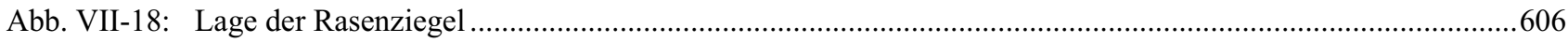

Abb. VII-19: Durchschnitt des Dammes: Dammbekleidung mit Weidenpflanzung. .....................................................606

Abb. VII-20: Weideschafe auf dem Areal der Teichwirtschaft , Timmerhorner Teiche'..................................................608

Abb. VII-21: Aufgelassener Teich (,Seelzer Teich“) im Reinhardswald..................................................................609

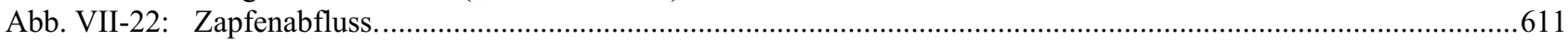

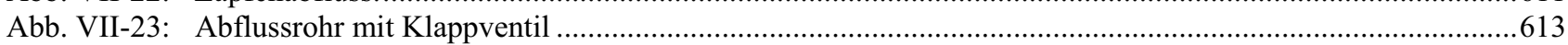

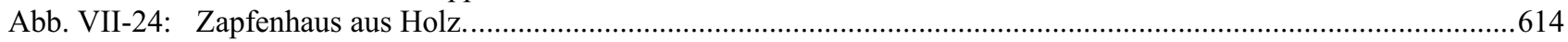

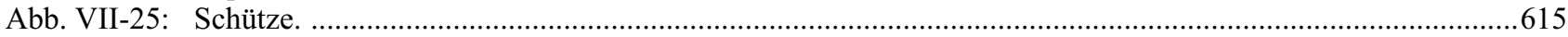

Abb. VII-26: Perspektivische Ansicht eines hölzernen Mönches mit Staubrettern. ....................................................616

Abb. VII-27: Querschnitt durch einen Teichdamm mit eingebauten Mönchabfluss. .....................................................617

Abb. VII-28: Ablassvorrichtung (Teichmönch) mit Rechen (R) und Staubrettchen (S) ...........................................620

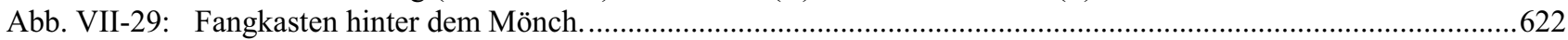

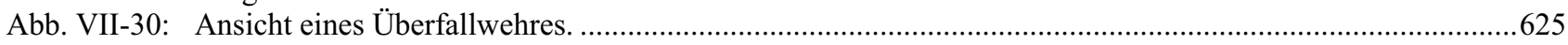

Abb. VII-31: Ansicht des Dammes mit Wehr, Rechen und Schwimmbalken.............................................................626

Abb. VII-32: Typen von Wasserrad-Antrieben: 1. unter-, 2. mittel-, 3. oberschlächtig. ...............................................629

Abb. VII-33: Modellskizze einer unterschlächtigen Mühle mit Strauberrad..............................................................630

Abb. VII-34: Modellskizze einer oberschlächtigen Mühle mit Strauberrad...........................................................630

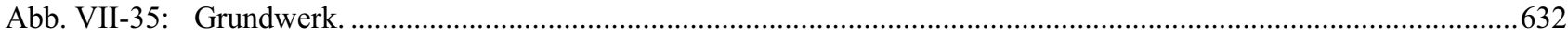

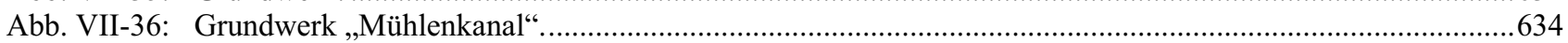

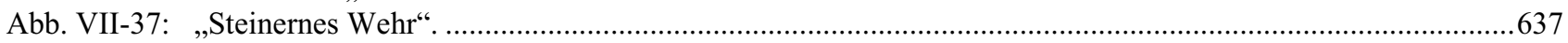

Abb. VII-38: Aufziehwehr der Ellemühle in Nordhausen mit Steg ...................................................................638

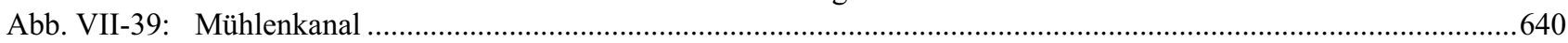

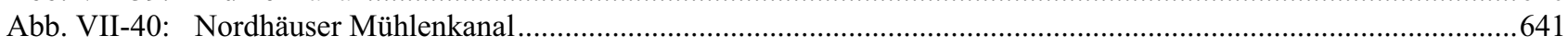

Abb. VII-41: Stelzenkanal der Wassermühle Ruschkamp (am Ruschkamp) in Scharmbeckstotel ................................642

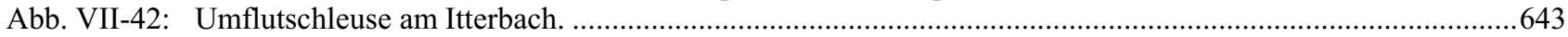

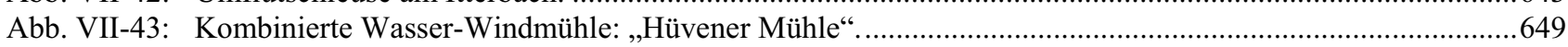

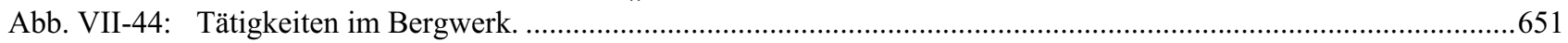

Abb. VII-45: Gewässerhistorische Elemente des montanen Wasserbaus...............................................................655

Abb. VII-46: Funktionsprinzip einer Harzer Fahrkunst mit ihren Wasserrädern. ........................................................657

Abb. VII-47: Grabenabdeckung: Formen der Winterabdeckung (,Beheckung“") der Gräben........................................660

Abb. VII-48: Oberharzer Bergwerksteich mit früher typischem geständertem Striegelhäuschen. .................................662

Abb. VII-49: Bergwerksteich und sein wasserbauliches System...........................................................................662

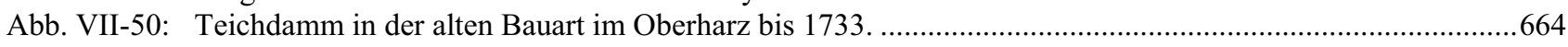

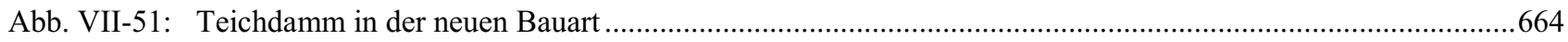

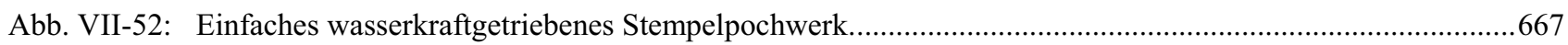

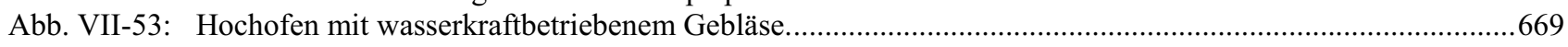

Abb. VII-54: Hammerhüttenbetrieb mit Rennwerk und Rauchabzug. 1. Hälfte des 16. Jahrhunderts............................670

Abb. VII-55: Darstellung einer frühen Form einer Hammerhütte des 16. Jahrhunderts...........................................671

Abb. VII-56: „Traditionelle Wasserversorgung einer Warft“.............................................................................673

Abb. VII-57: Tränkteich unterhalb der "Schwalbenwand” zwischen Maria Alm und Zell a. See/Österreich.....................674

Abb. VII-58: Außerhalb des Innenhofes gelegener Bauernhofteich beim Hof Flee, Hilden........................................675

Abb. VII-59: Pferdeschwemmteich des ehemaligen Gutes Hoisbüttel, Großgemeinde Ammersbek...............................676

Abb. VII-60: Pferdeschwemmteich auf dem Vorhof des adeligen Rittergutes Meinbrexen“ um 1800............................678

Abb. VII-61: Das Beispiel der Pferdeschwemme unterhalb der Sababurg...........................................................679 
Abb. VII-62: Löschteich in Hellental, Landkreis Holzminden...............................................................................682

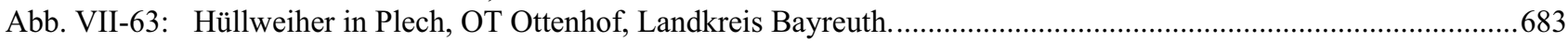

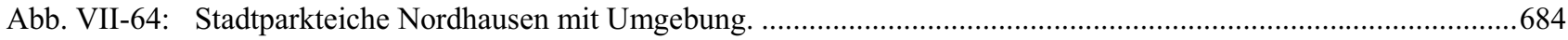

Abb. VII-65: Burggräben als Reminiszenz um das Schloss Anhold bei Isselburg......................................................686

Abb. VII-66: Wasserjagd in einem Teich bei Kloster Michaelstein. .........................................................................687

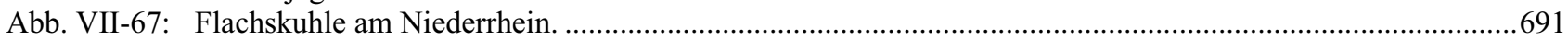

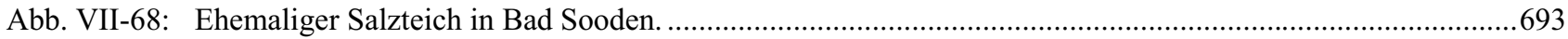

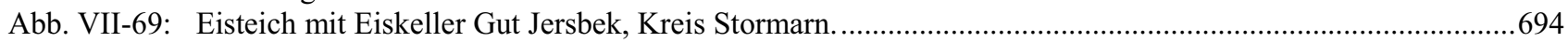

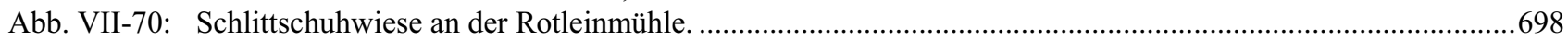

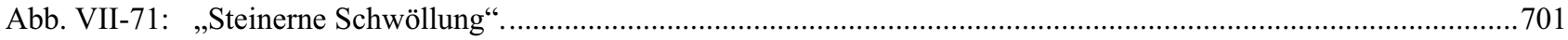

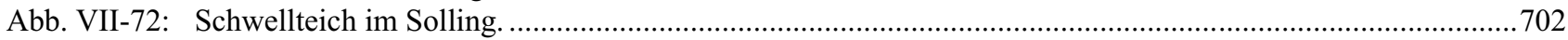

Abb. VII-73: Lageplan und Längsschnitt der Flößschleusen im Radauborn. .................................................................704

Abb. VII-74: Der Große Juliusstau im Okertal nach einem Riss von 1573 .......................................................... 706

Abb. VII-75: Plan von 1792 für einen neuen Holzgarten beim Schloss Gottesaue/Karlsruhe. .......................................708

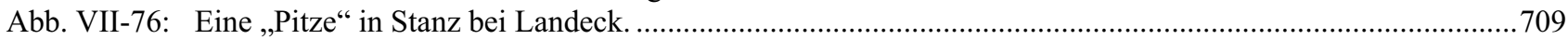

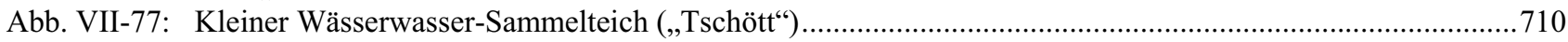

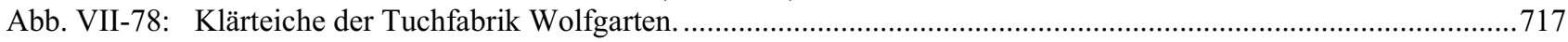

Abb. VII-79: Rieselfelder Münster.

Abb. VII-80: Verschiedene Formen der zum Gräbenstechen und -nachziehen benutzten Wiesenäxte............................723

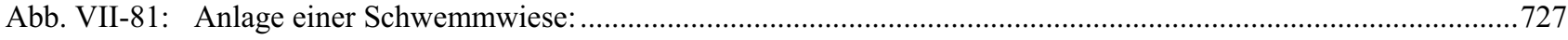

Abb. VII-82: System der Anstauung mit Zu- und Abflussgraben sowie Verteilungsgräben............................................728

Abb. VII-82: Schematische Darstellung einer Rückenbewässerung. .................................................................729

Abb. VII-83: Schematische Darstellung des natürlichen Rückenbaus bzw. der Grippenbewässerung. …….....................730

Abb. VII-84: Abgesetzter Rücken des natürlichen Rückenbaus im Profil ....................................................................730

Abb. VII-85: Unreguläre, wenig schematische Anlage; d. h. ,natürlicher Bewässerungsbau““.........................................731

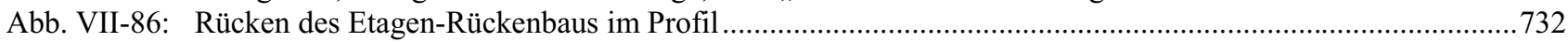

Abb. VII-87: Aufsicht und Längsschnitt des schmalen Rückenbaus...............................................................732

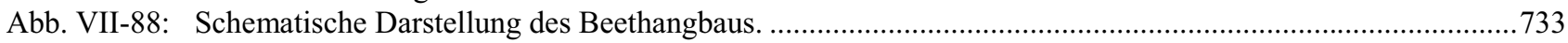

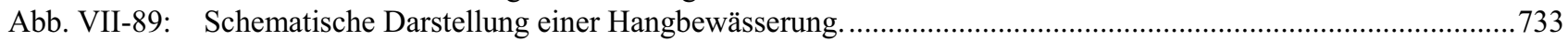

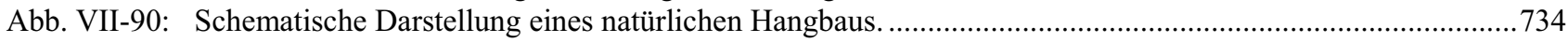

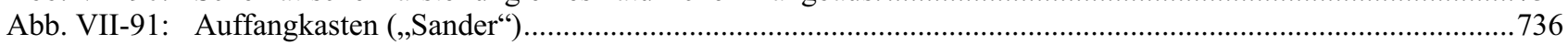

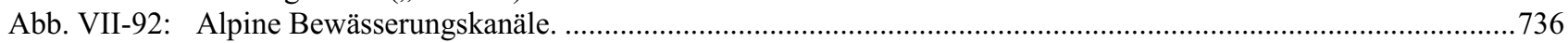

Abb. VII-93: „Schadensmelder“ in einem alpinen Bewässerungssystem................................................................737

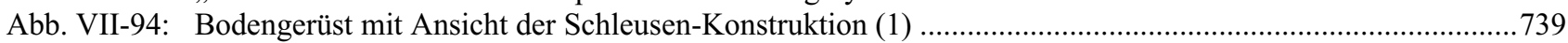

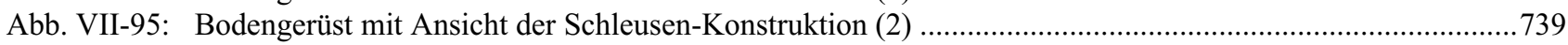

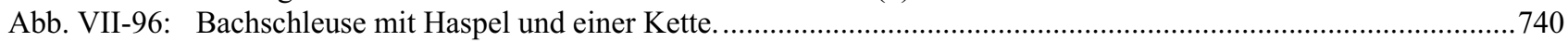

Abb. VII-97: Bachschleuse wie in Abb. VII-102, aber mit Gewinde und Drehschraube............................................740

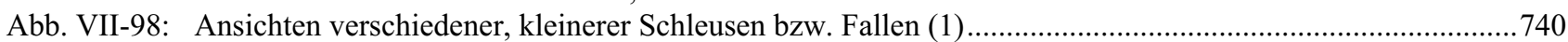

Abb. VII-99: Ansichten verschiedener, kleinerer Schleusen bzw. Fallen (2) ........................................................... 741

Abb. VII-100: Ansichten verschiedener, kleinerer Schleusen bzw. Fallen (3) ...........................................................741

Abb. VII-101: Ansicht einer stabil eingebauten Schleusenkonstruktion. .....................................................................742

Abb. VII-102: Ausführungen zur Stabilisierung der Grabenbette vor Schleuseneinrichtungen.....................................743

Abb. VII-103: Ausführungen zur Beuferung von Bewässerungsgräben. ............................................................. 743

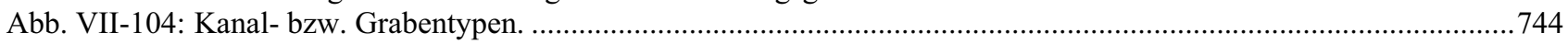

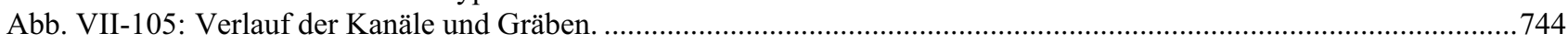

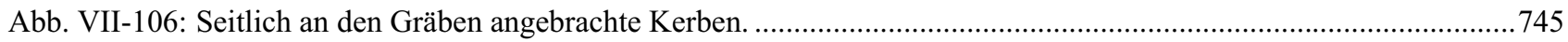

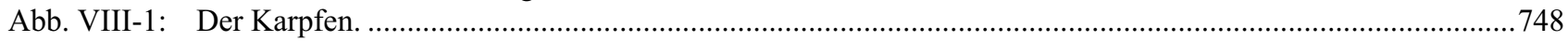

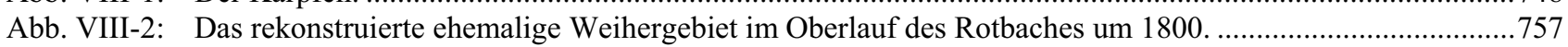

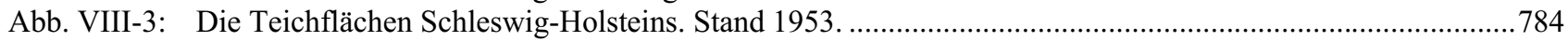

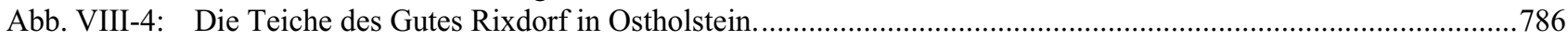

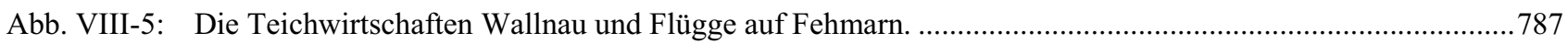

Abb. VIII-6: Karte der Staatlichen Teichwirtschaft Ahlhorn 1:10.000 (um 1930) ......................................................789

Abb. VIII-7: „Ungepflegter“, nicht mehr bewirtschafteter Teich der Teichwirtschaft Ahlhorn.....................................790

Abb. VIII-8: Karte des Meißendorfer Teichgebietes in seinen Schutzgebietsgrenzen (punktierte Linie). .......................793

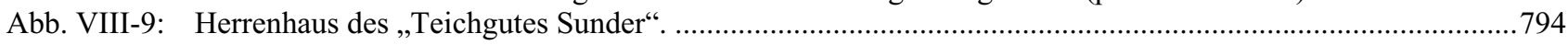

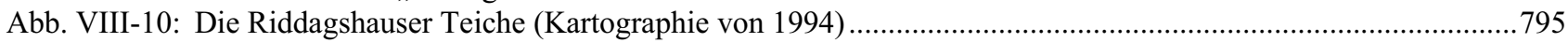


Abb. VIII-11: „Central-Fischzucht-Anstalt zu Kloster Michaelstein“ bei Blankenburg im Harz......................................798

Abb. VIII-12: Zentrale Fischzuchtanstalt Kloster Michaelstein (1883) ..................................................................798

Abb. VIII-13: Ausschnitt aus der TK25 mit Darstellung von kleinen Mehrteich-Teichwirtschaften. ...............................800

Abb. VIII-14: Räumliche Abgrenzung des Aischgründer Karpfengebietes..................................................................8 801

Abb. VIII-15: Bodennutzung dem zum Kloster Ebrach gehörenden „Guet Winckhel““ 1694. .........................................805

Abb. VIII-16: Teichwirtschaft der „Büschlebmühle“ an der Wipper in Worbis..............................................................808

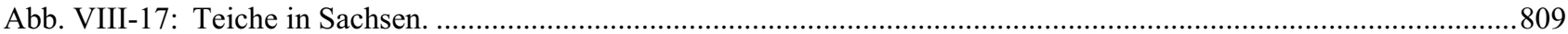

Abb. VIII-18: Übersichtskarte des „Biosphärenreservat Oberlausitzer Heide- und Teichlandschaft“ ...............................810

Abb. VIII-19: Übersichtsplan der Teiche in der Wielenbacher Anlage. .................................................................813

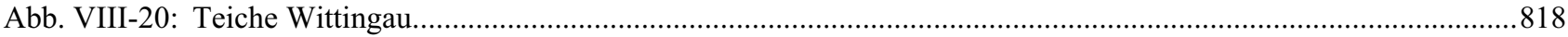

Abb. VIII-21: Die Hauptteichgebiete Deutschlands in seinen Grenzen bis 1945 (Stand 1925). ....................................820

Abb. VIII-22: Die wichtigsten Teichwirtschaften Deutschlands im Jahr 1915. .....................................................821

Abb. VIII-23: Die ortsfesten Wassermühlen vom 9. - 19. Jahrhundert................................................................. 827

Abb. VIII-24: Karte über die zur ehemaligen Eisenhütte „Pfeilhammer“, Pöhla, gehörenden Teiche..............................828

Abb. VIII-25: Die heutige Nutzung der ehemaligen Wassermühlen. .........................................................................842

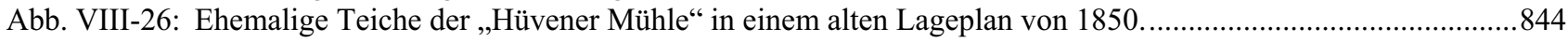

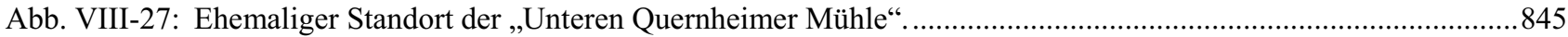

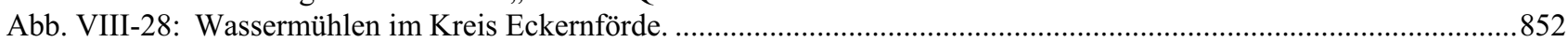

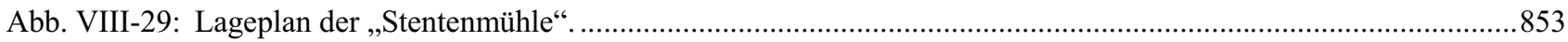

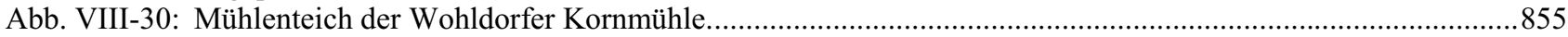

Abb. VIII-31: Die Standorte der Wasser- und Windmühlen im Landkreis Harburg. ....................................................856

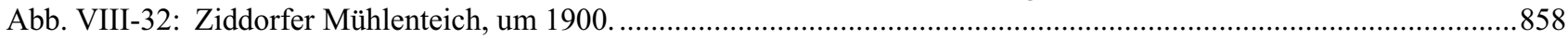

Abb. VIII-33: Wasser- und Windmühlen im Hannoverschen Wendland, einschließlich ihrer Wasserläufe. ......................861

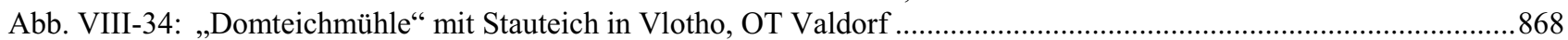

Abb. VIII-35: Lageskizze der zum ehemaligen Kloster Gräfrath gehörenden Klosterteiche. ..........................................871

Abb. VIII-36: Ausschnitt aus einer 1790 vermessenen „Situations-Charte“ der Bausmühle. ..........................................872

Abb. VIII-37: Zieleskotten mit Teich und Kindern am Wehr. Nach einer Postkarte um 1900_....................................873

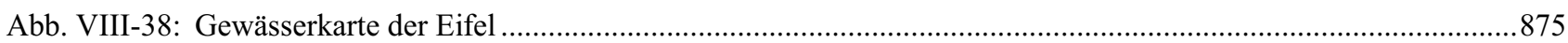

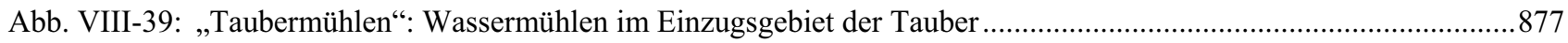

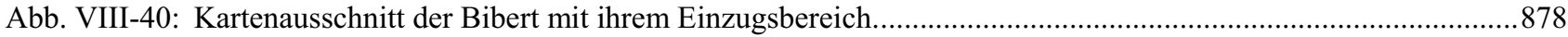

Abb. VIII-41: Teich des Höllhammers an der Elsava, Gemarkung Heimbuchenthal .....................................................880

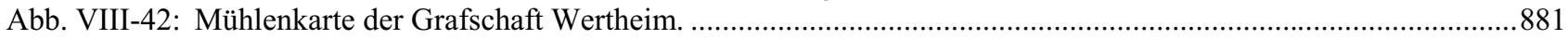

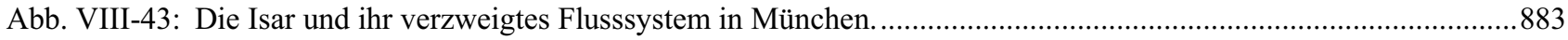

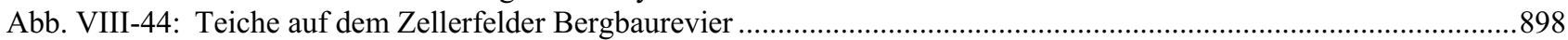

Abb. VIII-45: „Wiesenteiche“ auf der Buntenbocker Höhenfläche südlich Clausthal ..................................................899

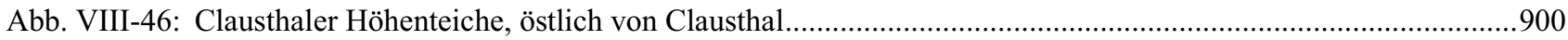

Abb. VIII-47: Bergbaulich genutzte Teiche im Gebiet um Hahnenklee-Bockswiese..................................................901

Abb. VIII-48: Übersicht über das Oberharzer Wassersystem mit seinen Teichen.........................................................902

Abb. VIII-49: Bergbauteiche und andere Bestandteile der alten bergmännischen Wasserwirtschaft (1) ..........................906

Abb. VIII-50: Bergbauteiche und andere Bestandteile der alten bergmännischen Wasserwirtschaft (2) ...........................907

Abb. VIII-51: Hammer- und Eisenhütten des Erzgebirges und Vogtlandes 12. bis 19. Jahrhundert...............................908

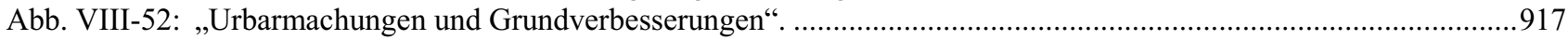

Abb. VIII-53: Rieselwiesen in Mitteleuropa für das Gebiet Deutschlands in seinen Grenzen bis 1945 ...........................924

Abb. VIII-54: Plan einer künstlichen Wiesen-Bewässerung beim Gute Koselau in Holstein“..........................................926

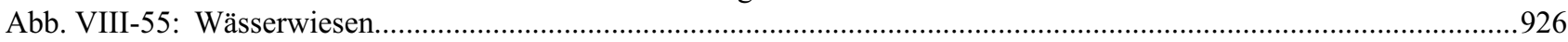

Abb. VIII-56: Das Meliorationsgebiet im Huntetal mit einem vergrößerten Ausschnitt ...............................................927

Abb. VIII-57: „Charte von den geschwemmten Wiesen an der Meisse in der Amtsvoigtey Bergen“..............................929

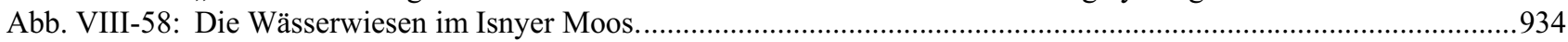

Abb. VIII-59: Ehemalige Wiesenbewässerungsanlagen im Einzugsbereich der Donau in Württemberg. .........................935

Abb. VIII-60: Verschiedene Bewässerungseinrichtungen entlang der Schmiech..................................................936

Abb. VIII-61: Bewässerungsanlage an Dürnach und Saubach bei Baltringen............................................................9936

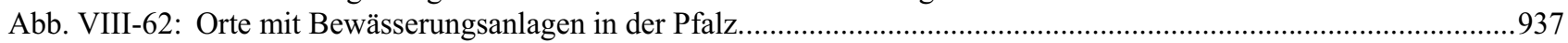

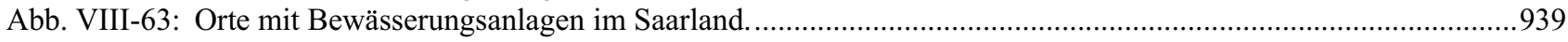

Abb. VIII-64: Wässermatten in den Tälern von Langete und Rot .....................................................................9941

Abb. VIII-65: Vollständige Wässermattenlandschaft (Grabennetz) im Tal von Langete und Bodebach. ...........................9942

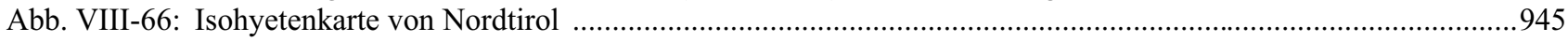


Abb. IX-1: Gegenüberstellung eines ,natürlichen“ und eines kanalisierten Bachlaufs...............................................947

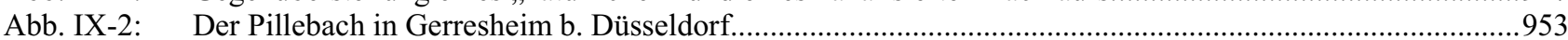

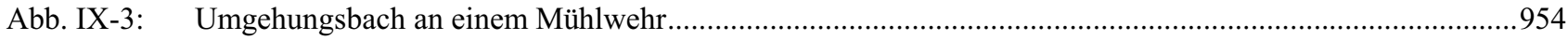

Abb. IX-4: $\quad$ Fischweiher am Kloster Heisterbach nach dem Lageplan von Minzenbach 1804.....................................957

Abb. IX-5: $\quad$ Fischweiher im Heisterbachtal nach Preußischer Uraufnahme von 1843...............................................958

Abb. IX-6: Ausschnitt aus der Kurhannoverschen Landesaufnahme des 18. Jahrhunderts (1784) ..............................961

Abb. IX-7: Ausschnitt aus dem Topographischen Atlas des Königreichs Hannover ..............................................962

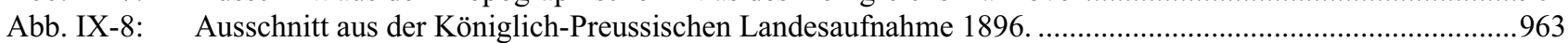

Abb. IX-9: $\quad$ Ausschnitt aus der Topographischen Karte 1:25.000, Blatt 4323 Uslar ...............................................963

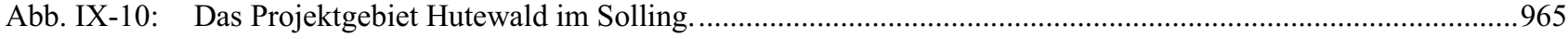

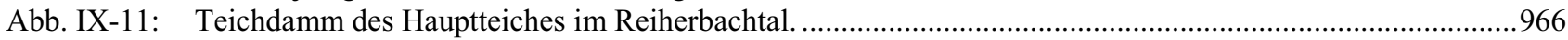

Abb. IX-12: Ausschnitt aus der DGK 5 „Hubbelrath, Dorp West“...........................................................................969

Abb. IX-13: Ausschnitt aus der topographischen Aufnahme des „Nördlichen Bergischen Landes“..............................971

Abb. IX-14: Blick auf den ehemaligen Standort der „Mydlinghovener Wassermühle“..............................................972

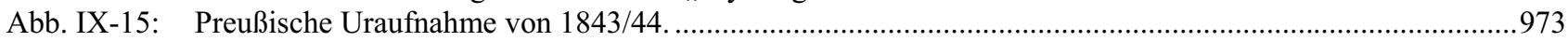

Abb. IX-16: „General-Karte der Bürgermeisterey Hubbelrath [...]“ (1851/1869) ..................................................973

Abb. IX-17: ,Mydlinghovener Mühlenteich’ im stark reliktären Stadium...........................................................974

Abb. IX-18: Fischteich in Bachtal mit Fischgräben, abgeleitetem Umlauf, Teichmönch mit Teichdamm........................975

Abb. IX-19: Trockengefallener Teich südlich der ehemaligen Mydlinghovener Mühle. .............................................975

Abb. IX-20: Kanalisierter, linear verlaufender Mühlenkanal im Mydlinghovener Bachtal ........................................976

Abb. IX-21: Übertrag des Mühlenteiches [1], der Mühlengebäude [2] und des Mühlengrabens [3] .............................977

Abb. IX-22: $\quad$ Rest einer ehemaligen Staustufe am Ende des linearen Mühlenkanals...................................................9978

Abb. IX-23: Lagepläne: „Rittergut Mydlinghoven“ im Jahr 1912 und „Rittergut Mydlinghoven“ 1931........................980

Abb. IX-24: Panoramaaufnahme des Gestüt Mydlinghoven um 1920/30..................................................................982

Abb. IX-25: Bodensenke vor den Gutsgebäuden, wahrscheinliche Restfläche eines ehemaligen Teiches.......................982

Abb. IX-26: Lageplan zum Neubau eines Einfamilienhauses auf Rittergut Mydlinghoven. ...........................................983

Abb. IX-27: Gestüt mit gefasstem Wasserbecken, Aufnahme aus dem Jahr 1978. ...............................................984

Abb. IX-28: Die Urkatasterkarte von 1830 mit der „Mühlingkovermühle“.............................................................995

Abb. IX-29: Lage des Projektgebietes „Teichgebiete Niederspree-Hammerstadt“..................................................991

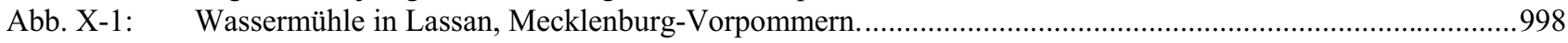

Abb. A-1: Künstliche Gewässerlandschaften durch Nassauskiesung in der Weserniederung........................................1

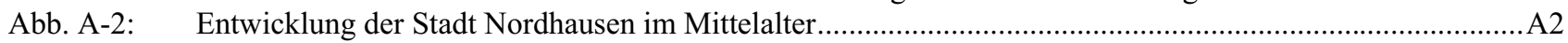




\section{Tabellenverzeichnis}

Tab. III-1: $\quad$ Kartierschlüssel zur Untersuchung aufgelassener Wasserwege (Kanäle) ...............................................185

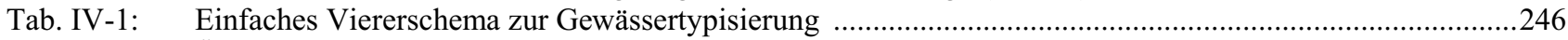

Tab. VI-1: $\quad$ Übersicht über an die Gewässer des Kreises Nordhausen gebundene Gewerbe .........................................333

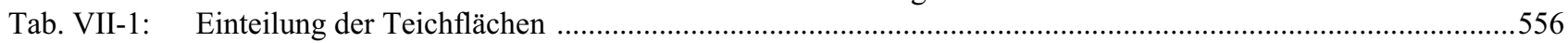

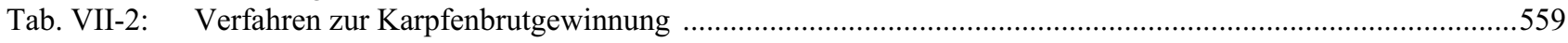

Tab. VIII-1: „Herrschaftliche Weiher und Seen“ im Besitz des Kloster Ebrach ...........................................................804

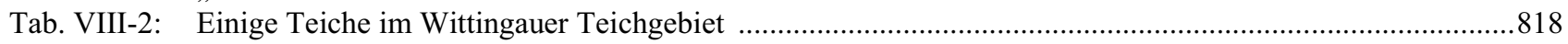

Tab. VIII-3: Bewässerungskanäle und bewässerte Flächen in Südtirol im Jahr 1935 ............................................944

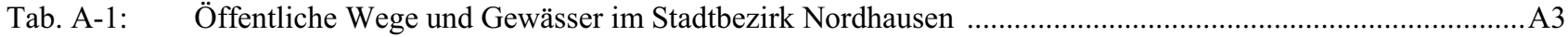

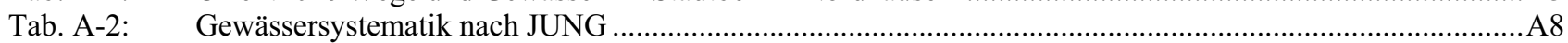

Tab. A-3: $\quad$ Verzeichnis der bergbaulich genutzten Sammelteiche in den Oberharzer Revieren ....................................A9 


\section{Prolegomena}

\section{$0 \quad$ Vertrocknung und Vernässung in gegenwärtiger und früherer Zeit}

Vertrocknung [in gegenwärtiger Zeit]

Fließende und stehende Kleingewässer des ländlichen und städtischen Raumes sind durch eine Vielzahl anthropogener Faktoren in ihrer physischen Existenz bedroht.

Zahlreiche Bächlein und Weiher verschwanden im 20. Jahrhundert von der Landoberfläche: Durch flächenhaften Landschaftsverbrauch als Folge ,postrurbaner"1 Urbanisierungs- und Industrialisierungsprozesse, durch Eutrophierung infolge landwirtschaftlichen Düngereintrages und der dadurch beschleunigend einsetzenden Verlandungsprozesse, durch Gewässerverschmutzung nach Einleitung wasserverunreinigender Stoffe sowie durch den Schwebstoffeintrag von belasteten Aeorosolen, die das Interesse an einer weiteren Nutzbarmachung reduzieren bzw. gänzlich verbieten. Aber auch durch den Niedergang traditioneller Wasser- und Wiesenbewirtschaftungsweisen, getragen zum einen vom sog. agrarstrukturellen Wandel, der auch als „Technisierung des ländlichen Raumes“ (KNAUSS 1998) beschrieben wird, und zum anderen von der Aufgabe fischereiwirtschaftlicher Kleinbetriebe. Angesichts schon seit Jahren unbefriedigender Erzeugerpreise und steigender Produktionskosten lohnt sich beispielsweise die Arbeit der Teichwirte kaum noch. Hinzu kommt die Einflussnahme der Konkurrenz aus dem Ausland wie das Beispiel des Speisekarpfenmarktes (HUBERT 1991:18) und der Forellenzucht zeigt. Aber auch die Interessenkonflikte zwischen Teichwirtschaft und Naturschutz haben beim Offenlassen der Nutzung unausweichlich die Verlandung der Stillgewässer zur Folge. Zudem erschweren Naturschutz-vorschriften, so sinnvoll sie auch sein mögen, die konstante Kultivierung von Altgewässern.

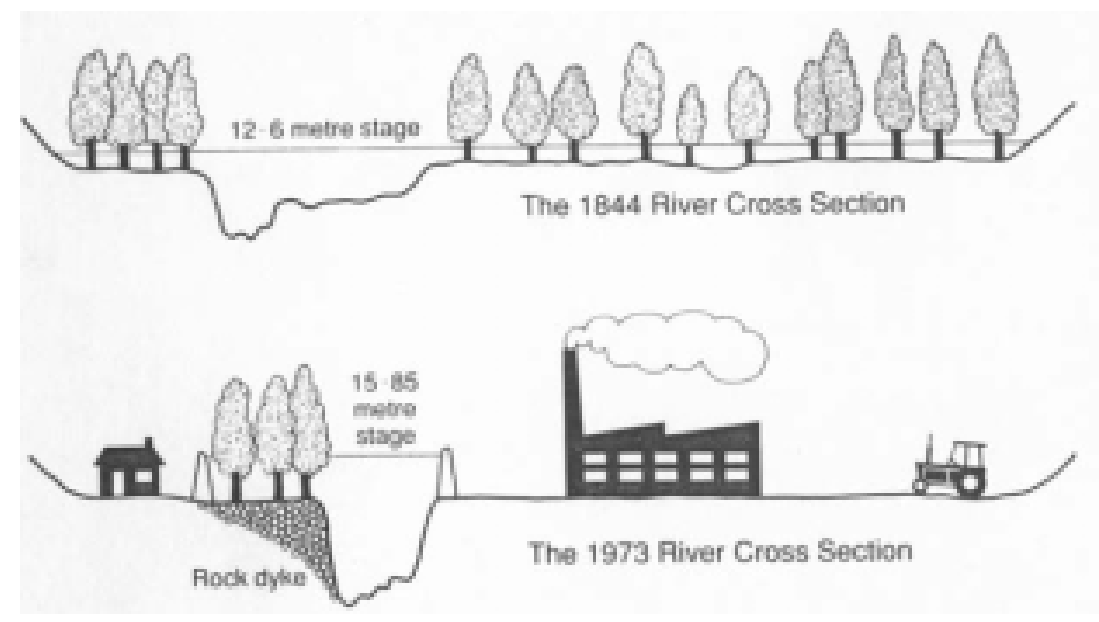

Abb. 0-1: Zeitschnittartige und stark generalisierte Entwicklung einer Flusstal-Landschaft im Mittellauf bei Zunahme von Entwaldung, Entwässerung, Erosion, Deichbau, Auelehmbildung und Urbanisierung (Gewerbeflächenansiedlung). Das hier dargestellte Flussquerschnittprofil stellt das Beispiel des „Mississippi River“ dar. Es lässt sich in seiner prinzipiellen Aussage aber auf mitteleuropäische und kleinere Flusstal-Landschaften übertragen mit dem Hinweis der zeitlichen Vorverschiebung: die Umgestaltung von Flussläufen (Flusskorrekturen, Entwaldung) zum Beispiel setzte hier bereits vor und im zweiten Drittel des 19. Jahrhunderts verstärkt ein (nach PETTS 1990:19).

Die damit verbundenen Folgen der Umwandlung ruraler Wasserläufe in urbane Gewässer, der künstlichen Desertifikationsprozesse, des Brachfallens von Kleingewässernutzungen, des Umbruchs von Feucht- und Hangwiesen durch Melioration und Drainage sowie der Anzapfung von juvenilen Wasservorräten und der Fassung von Fließen zur zentralen Wasserversorgung mit verstärkter Intermittierung als Folge, mögen beispielhaft die Eingriffe verdeutlichen, die in neuerer Zeit zur „Austrocknung“ unserer Landschaft führen.

\footnotetext{
${ }^{1}$ Die künstliche Wortzusammenstellung aus „rural“ und „urban“ wurde vom amerikanischen Geographieprofessor Dr. Harley JOHANSEN 1992 gewählt, um die Verstädterungstendenzen des ländlichen Raumes zu beschreiben.
} 
Ich war erstaunt darüber, wie viele der kleineren Gewässer, die noch auf Messtischblättern der 1970er Jahre verzeichnet sind, im Laufe der letzten Jahre beseitigt wurden; obgleich es bereits etwa schon seit den 1930er Jahren im kulturbautechnischen Denken fast nur noch darum ging, „Wasser so schnell wie möglich loszuwerden." (GROTTIAN 2001:28) Auf Kartenwerken des 20. Jahrhunderts sind kleine Bäche, obwohl sie nachweislich schon im Mittelalter Mühlen antrieben, als Mühlengewässer oftmals schon nicht mehr aufgeführt.

Gerade die Teich- und Flusslandschaften gehören zu den wichtigen Lebensräumen unserer Landschaft, nachdem der Mensch die natürlichen Feuchtbiotope nach und nach trockengelegt hat. Die postglazialen Verbreitungsstrukturen von limnischen und aquatischen Arealen des norddeutschen und voralpinen Raumes wurden bereits in historischer Zeit, vor allem durch die gegenwärtig stattfindende intensive Landnutzung anthropogen überformt. Auch die Waldbienenwirtschaft, auch „Zeitlerei“ oder „Beutnerei“ genannt, hat durch die flächenhafte Rodung von Auen- und Niederungswäldern und deren eventuelle Trockenlegung noch bis in die 70er Jahre sog. „Bienenweiden“ geschaffen, damit die Bienen bei der Nektarsuche auf Blütenpflanzen trafen. Ich selbst weiß gar von einer in den 1990er Jahren praktizierten Umwandlung feuchter Auenbereiche in durchblumte Wiesentalböden für die kleingewerbliche Honigproduktion, die durch Forstprogramme auch noch fiskalisch gefördert wurden ${ }^{2}$. Überhaupt trägt der Wiesenbau erheblich zum Gewässerschwund bei, da das Wasser in den kleinen Bachläufen oftmals von den Wiesen der Täler aufgesogen wird (TEICH 1995:7). Ebenso bindet der intensivierte Ackerbau und die mit hohen Großvieheinheiten besetzten Weiden mehr Wasser als früher, das für den Abfluss nicht mehr zur Verfügung steht. Hang-Wiesenbewässerungen, auch wenn sie noch praktiziert werden wollten, könnten oftmals nicht mehr durchgeführt werden, weil die Gewässer und deren Uferstreifen durch Milchkuh- und Rinderhaltung zu sehr angezapft werden (siehe Abb. 0-2).

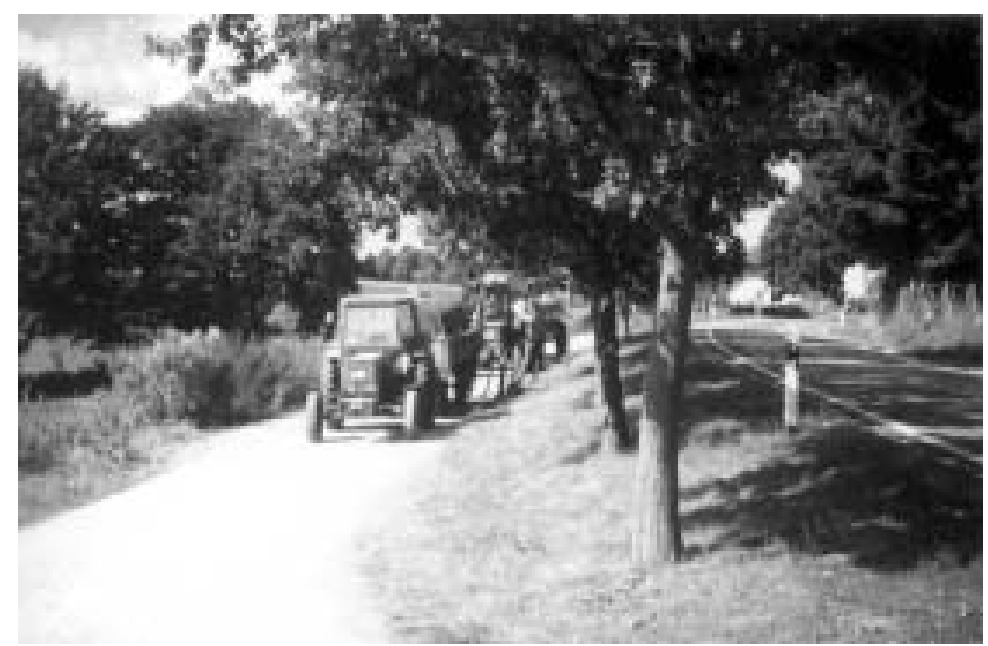

Abb. 0-2: Zentrale landwirtschaftliche Wasserentnahmestelle in Derental im Solling.

Sie darf von den Bauern kostenfrei und unbegrenzt benutzt werden. Die Füllung der Wassertanks wird notwendig aufgrund der Beweidung der trockenen Hangwiesen wie auch der feuchten Talwiesen, weil der ursprünglich am Talhang verlaufende Höxterborn kein Wasser mehr führt. Dies ist u. a. Folge der zusätzlich zu den Wassertanks angebrachten Tränkpumpen auf den Hangweiden, die in trockenen Sommermonaten aber auch kein Wasser mehr aus den unterhalb liegenden feuchten Talbereich saugen können, dem proportional zur Fließgewässermenge hohen Viehbesatz pro Flächeneinheit auf den Talwiesen und einer kleineren, oberhalb liegenden Einteichforellenzucht, die frühzeitig dem Lauf Frischwasser entnimmt (eig. Aufnahme 2003).

Die geringe Wasserführung der kleinen Bäche in den Lößbörden, Geesthochflächen und Mittelgebirgstälern im Vergleich zu früheren Jahrhunderten ist zur Hauptsache auf die Veränderung der hydrographischen Verhältnisse durch den Menschen zurückzuführen.

Viele Gräben und Teiche des ehemaligen wassergebundenen Bergbaus, wie zum Beispiel auch die - im Vergleich zur Oberharzer - weniger bekannte Unterharzer Wasserwirtschaft, sind, nachdem sie funktionslos geworden waren, trockengelegt oder sogar zugeschüttet worden (LIESSMANN 1997:263).

\footnotetext{
${ }^{2}$ Im Tal des „Dörnhofer Forstes“, Landkreis Bayreuth, entstand eine private standortfeste Bienenzucht mit angeschlossenem Holzhaus. Die ehemals feucht-nassen Wiesenböden wurden mit Blumensamen bestreut und teilweise drainiert.
} 
Die Vertrocknung der Landschaft durch die „Fällung“ von Weihern setzte besonders durch das große Mühlensterben ein, das in den 60er und 70er Jahren des 20. Jahrhunderts folgte und das sich noch bis in heutige Zeit fortsetzt. DENZER (1996:178) berichtet von der letzten tätigen Mahlmühle im südwestlichen Spessart, die am Ortsausgang von Heimbuchenthal nach Mespelbrunn gelegen war, im Jahre 1993 stillgelegt und dann abgerissen worden ist. Ich persönlich kann von einer Getreidewassermühle im ehemalige Stiftsort Quernheim/Kreis Herford berichten, die im Zuge eines Bundesstraßenneubaus im Jahr 1974 abgerissen und deren Mühlenteich zugeschüttet worden ist. In der Stilllegung der wasserradbetriebenen Hammerwerke in der zweiten Hälfte des 19. Jahrhunderts findet der Niedergang von historischen Wirtschaftsteichen ihre Fortsetzung. Durch die Mühlgrabentrockenlegungen sowie durch die massive Zuschüttung von Teichen, wie die Hammerteiche des Hobbacher Hammerwerkes im Spessart im Jahre 1954 (:182), wurde das ehemalige Gewässerbild nachhaltig verändert.

Des Weiteren wurden alte Nebenarme zugefüllt, überbaut, verrohrt oder mit Steinplatten abgedeckt und verschwanden genau wie die Teiche und feuchten Niederungsteile. Sie wurden künstlich aufgeschüttet, um Bauland zu gewinnen (SCHÜTTE 1989:243) oder um in die ackerbaulichen Nutzflächen mit einbezogen zu werden. TEICH (1995:6) berichtet vom Modschiedelbach/Schüttenitz-Böhmen: „Heute ist der Bach leider nur noch ein Schatten seiner selbst. [...] Noch bis zum Beginn dieses Jahrhunderts aber plätscherte er [...] dahin." Und wurden diese Niederungen nicht durch direkte Eingriffe entwässert, so führten die Regulierungsmaßnahmen der Flüsse zu einem häufigeren Übertreten und schadeten dadurch „,vor allem durch Versandung der Talwiesen“ (HAGEL 1988:16), die aber erst mit den Meliorationsmaßnahmen der Auen entstanden waren.

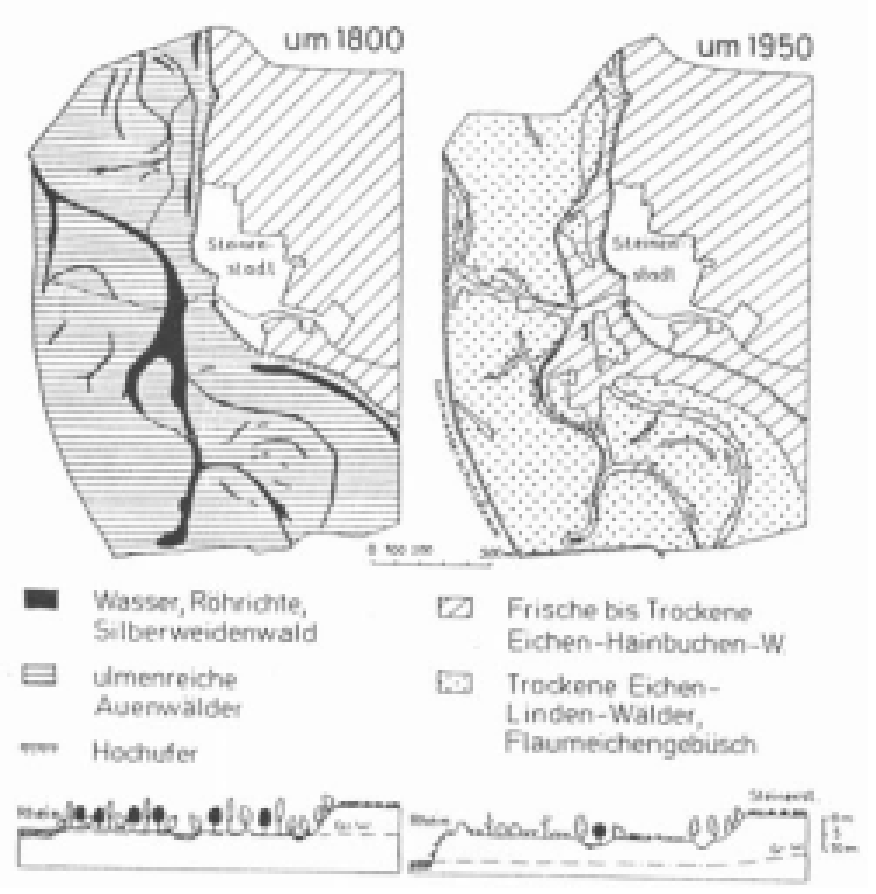

Abb. 0-3: „Vertrocknung“ einer Flussauen-Landschaft vor und nach den Flusskorrektionen des 19. Jahrhunderts.

Dieses Beispiel aus der Oberrhein-Ebene mit seinen Folgen der Grundwasserabsenkung lässt sich auch auf kleine Gewässerläufe übertragen. Das Ausmaß der Wassersenkung wird hier aber noch aufgefangen mit einer Vegetationsveränderung in Richtung trockenheitsertragende Eichen-Lindenmischwälder. In vielen Fällen kam es zu einer vollständigen Beseitigung der Vegetation durch Überplanung (aus: ELLENBERG 1986:65, Abb. 31).

Feuchte Mikrostandorte, wie zum Beispiel die kleinen Gräben und Rinnen, die das Wässerwasser auf die Beetrücken in den Wiesentälern geleitet haben, sind ebenso verschwunden; in viel stärkerem Ausmaße hingegen als die Hauptgewässer, wie LEIBUNDGUT 1986 am Beispiel der Emme (Zollbrück/Schweiz) nachweist. Dabei besitzen sie einen hohen biologischen Wert: Ein Großteil der heimischen Frosch- und Schwanzlurche ist auf Kleingewässer mit einem Wasserkörper, der nicht zu früh austrocknet, angewiesen. Die größten Feinde für Laich und Kaulquappen, die Fische, gibt es hier kaum; sie können das regelmäßige Trockenfallen der Gewässer nicht überleben (MÜLLER 1988:17). 


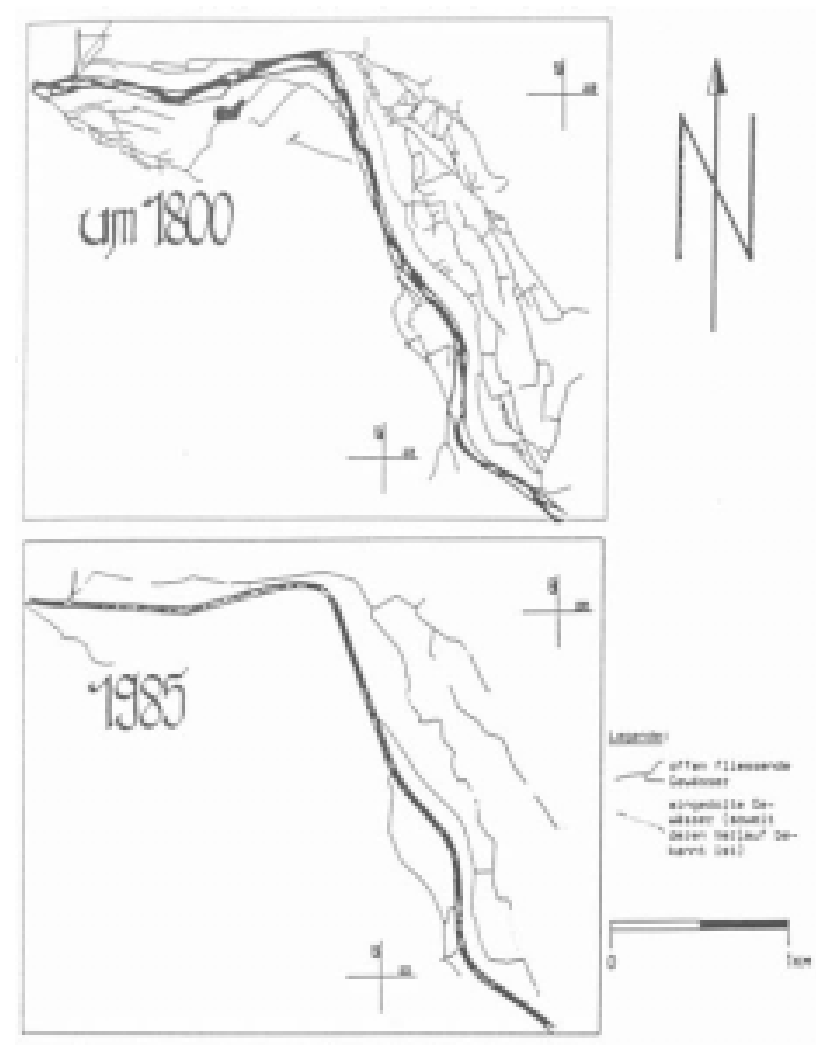

Abb. 0-4: Die unterschiedliche Bedrohung großer und kleiner Gewässer.

Die hier in einem Ausschnitt dargestellte Emme bei Zollbrück wird kanalisiert, bleibt aber in ihrem Lauf erhalten. Die Nebengewässer hingegen sind im gleichen Zeitraum großteils verschwunden (nach MÜHLETHALER 1985, aus: LEIBUNDGUT 1986:155).

Aber nicht nur Kleingewässer, darunter oft natürliche Senken oder von Menschen geschaffene obertägige, wassergefüllte Pingen und eingestürzte, mit Wasser gefüllte Stollenmundköcher sowie Bombentrichter, sind eingeebnet oder zugeschüttet worden, sondern auch ephemere ${ }^{3}$ Kleinstgewässer, wie wassergefüllte Huftritte (MÜLLER 1988:17), Ackerspuren oder Wagenspuren, nach FELDMANN (1974:17) bedeutende Laichplätze für Molche und Mollusken, Pfützen und sogar Suhlen, von SEEL (1996:248) als „Verzweiflungsbiotope“ bezeichnet, sind nicht mehr vorhanden. Dennoch besitzen sie eine große Bedeutung für die speziell an diese kurzlebigen Biotope angepassten Pflanzen und Tiere: Eine kurze Entwicklungszeit und ein Austrocknungsschutz durch Trockenstarre im Gewässerboden besitzen zum Beispiel zahlreiche Insektenlarven von Schwimmkäfer und Wasserläufer, von Plattbauchlibelle sowie Fadenwürmer und die Eier niederer Krebse (MÜLLER 1988:17).

Temporäre Gewässerkleinformen gehörten in regenreicher Zeit als Rückbleibsel von Wagenspuren zum alltäglichen mittelalterlichen Landschaftsbild und waren noch so lange vorhanden, wie der Transport mit Pferde- oder Ochsgespannen durchgeführt wurde. Die Fern- und Haupthandelsstraßen waren in früheren Jahren noch ungepflastert. Wie ein breiter festgefahrener Feldweg, mit mehreren nebeneinander herlaufenden Wagengleisen, hier und da tiefe Löcher hatte, „,in denen die meiste Zeit des Jahres Wasser stand“ (HEINE o. J.:185), so präsentierte sich das damalige Wegenetz. Erst ,gegen Ende des 18. Jahrhunderts fing man an, die wichtigsten Straßen zu pflastern" (:185). Mikrogewässer, sog. Telmen und Senken existierten bis zur endgültigen Durchführung agrarstruktureller Flurbereinigungsverfahren im bewegten, schwieriger zu beackernden Gelände.

\footnotetext{
3 ,Ephemere Bäche' ,sind Fließgewässer, ihre Bachbetten sind als solche zu erhalten, auch wenn sie nur in kurzen Intervallen durchgehend Wasser führen. Lokale Quellaustritte im Bachbett sind besonders wertvoll für die Besiedlung. Ihr Erscheinen und die Dauer ihrer Quellschüttung ist abhängig von der Füllung des Karstaquifers und kann von Jahr zu Jahr schwanken. Massive Wasserentnahme im Einzugsgebiet führt zum Versiegen solcher Quellaustritte." (LUA NRW 1999b:83).
} 


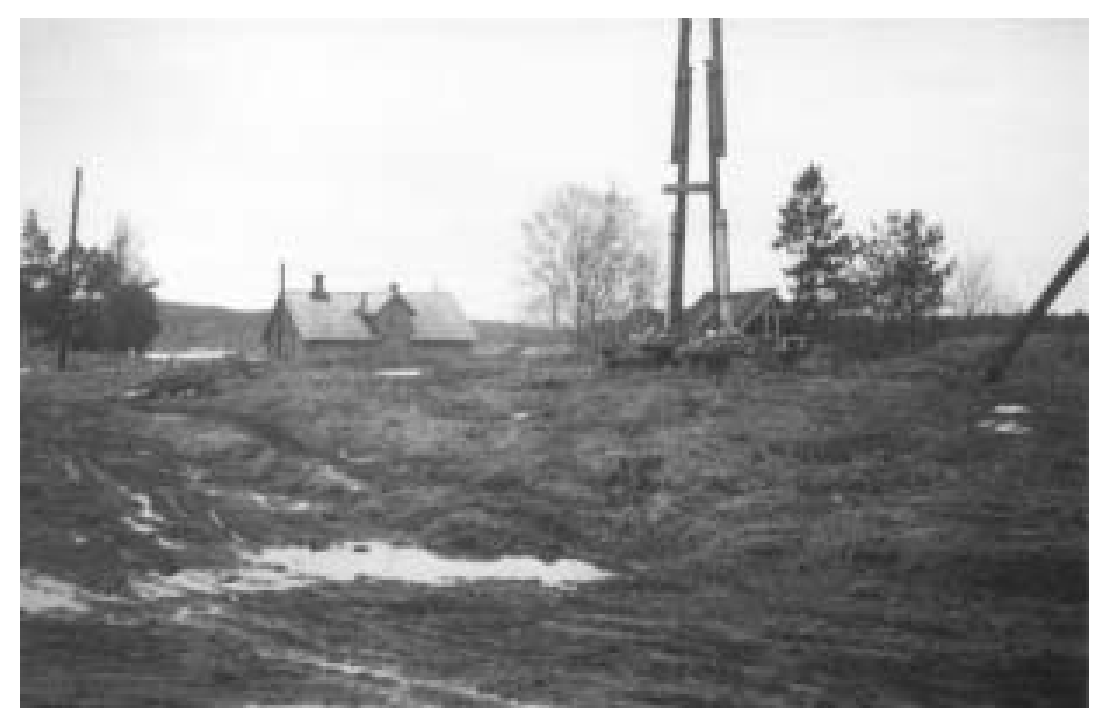

Abb. 0-5: Wassergefüllte Wagenspuren auf unbefestigtem Landweg in Priozersk/Ostkarelien.

So muss man sich die Wegeverbindung in den zentralen mitteleuropäischen Ländern vor Beginn des gepflasterten Chausseebaus vorstellen (eig. Aufnahme 1992).

Zugleich haben sich auch die Wassermengen verändert. Der Übergang zur öffentlichen Wasserversorgung und der gewaltig angestiegene Wasserverbrauch in den Haushalten und in der Industrie haben vielerorts zur Absenkung des Grundwasserspiegels geführt. „Die Folge war, daß mancher Mühlenbach zu einem Rinnsal verkam oder gar ganz trockenfiel“(VOGT 1998:19).

Dramatisch wirkte sich die Grundwasserabsenkung auf das Gewässerbild in Feuchtgebieten aus, wie Quellmooren, Niedermooren, Auen, stehenden und fließenden Gewässer (EBHARDT 1992:197ff.), insbesondere aber auch auf Landschaften, die von Natur aus relativ arm an natürlichen Gewässern waren. Die Ursachen der Beeinträchtigung liegen beispielsweise in dem direkten Wasserentzug, zum Beispiel durch Ableitung von Quellwasser für die Wasserversorgung sowie in der Absenkung des Grundwasserspiegels durch Tieferlegung der Vorflut durch Drainage und Grundwasserentnahmen durch Brunnen oder andere Entnahmeeinrichtungen (:200). Als Beispiel sei die Lüneburger Heide, die durch die Grundwasserentnahme für das Hamburger Stadtgebiet nahezu völlig ausgetrocknet ist, und das Emsland genannt. Viele der ehemaligen, auf natürliche Weise entstandenen Heide- und Moorseen liefen durch Grundwasserabsenkung leer oder waren so stark in ihrem Wasserstand herabgesetzt, dass sie leichter eutrophierten und schließlich verlandeten. So etwa hat die allgemeine Grundwasserabsenkung beispielsweise das Theikenmeer bei Ostenwalde/Kreis Emsland, „das sich noch vor 20 Jahren als eine ca. $400 \mathrm{~m}$ breite und $800 \mathrm{~m}$ lange offene Wasserfläche ausdehnte, heute in eine vollständig trockengefallene Binsen-Wüste (mit Juncus effesus) verwandelt" (WEBER 1992:95).

Das Beispiel der „Schlatts“ zeigt eine solche Entwicklungsgeschichte für das Gebiet um Ganderkesee auf einem Geestrücken zwischen den Flüssen Delme und Hunte. Auch diese zu- und abflusslosen, natürlicherweise durch Auswehungen in Dünengebieten des Geestrandes entstandenen kleinen und flachen Tümpel, die die tieferen Bodensenken der Geestlandschaft früher so zahlreich ausgefüllt haben, verschwanden aufgrund ihres nur geringen Wasserstandes, der in Abhängigkeit zu den jährlichen starken Wasserspiegelschwankungen stand.

Im Zuge der fortschreitenden Technisierung wurden die weiträumigen Hochflächen der Geest zwischenzeitlich systematisch entwässert und die ehemals kleinräumige Gewässerlandschaft aufgehoben. Das Entwässerungsnetz wurde schließlich immer engmaschiger gelegt und die Drainierung der Flächen fortgesetzt, um eine intensivere land- oder forstwirtschaftliche Nutzung zu ermöglichen. Wo die Entwässerungsmaßnahmen nicht ausreichten, um das Schlatt trocken zu legen, wurde die nässende Bodesenke zugeschüttet und eingeebnet.

Die kulturhistorische Nutzung dieser natürlichen Kleingewässer als Viehtränke wandelte sich zu einer Nutzung als Weidefläche oder in eine Waldnutzung um. 
Eine im Frühjahr 1978 von JAGUSCH (1980:106) vorgenommene Kartierung von insgesamt 26 untersuchten Schlattflächen ergab, dass lediglich ein (!) Schlatt in seiner Ursprünglichkeit erhalten geblieben ist. Sein Fazit: „Die Existenz der Schlatts als typische Kleingewässer unserer Landschaft ist damit in der Gemeinde Ganderkesee erloschen.“

Vor allem die Veränderung durch Düngerzuflüsse führte des Weiteren zu einer immer stärkeren Eutrophierung, im extremen Fall zu einer Hypertrophierung mit den genannten Folgen. „Erst in unserem Jahrhundert“, stellt WEBER (1992:98) fest, „hat die allgemeine und flächendeckende agrarstruktrurell bedingte Landschaftseutrophierung auch die letzten natürlichen Klargewässer so mit Nährstoffen angereichert, daß der ursprünglich oligotrophe Charakter verloren gegangen ist.“ „Fast alle“ diese durch natürliche Prozesse entstandenen biogenen Gewässer ,wurden trockengelegt und in landwirtschaftliche Nutzflächen umgewandelt“ und sind „,bis zur Gegenwart weitgehend vernichtet worden“ (:95). Mit einem „Blick auf ältere amtliche Karten“ zeigt uns WEBER (:95), dass „die westniedersächsische Landschaft um die Jahrhundertwende immerhin noch um ein Vielfaches reicher an natürlichen Seen als heute war.“

In den offenen Tagebauen der großen rheinischen und sächsischen Braunkohlenreviere wurden mit Beginn der großflächigen Abräumung Mitte des 19. Jahrhunderts (z. B. Döbern 1867, Schönfließ bei Eisenhüttenstadt 1859) - bedingt zum einen durch die Absenkung des Grundwasserspiegels und zum anderen durch den sukzessiven Entfall der Einleitung von eher Hochwasser produzierendem Sümpfungswasser durch Wanderung des Braunkohlentagebaus - ehemals wasserführende Fließgewässer zu Flüsschen degradiert oder fallen vollkommen trocken (vgl. auch VOGT 1998:19). Gleichermaßen ergeht es den punktuellen gewässerhistorischen Kulturdenkmalen: Der ehemalige Hofverband Glesch und heutiger Ortsteil des Landkreises Bergheim-Erft beispielsweise, der nach 1287 zum Oberhof Paffendorf gehörte, umfasste mehr als 30 Unterhöfe am Ort und 29 außerhalb sowie eine Wassermühle an der Erft. Im Zuge des fortschreitenden Braunkohlenabbaus mussten 1963 der Glescher Mühlenteich und die Mühle dem neuen Erftflutkanal weichen (LANDKREIS BERGHEIM-ERFT 2001).

Doch nicht nur im ländlichen, sondern auch im urbanen Raum lässt sich der Gewässerschwund nachzeichnen: Die früher kaum überschaubare und ehemals das Weichbild einer jeden Stadt prägende Ansammlung von Mühl-, Bewässerungs-, Gewerbe- und Entsorgungskanälen innerhalb der Städte hat sich aufgelöst. Die alten Mauerringe mit ihren wassergefüllten Wehrgräben und die Stadtweiher wurden - bis auf geringfügige Reste - verfüllt, wie die Beispiele der Städte Nordhausen, Euskirchen, Saarlouis, Höxter, Minden usw. demonstrieren. Im Zuge allgemeiner Straßenregulierungen verschwanden ebenso „Entenpfuhle“ (KREINER 1996:214 am Bsp. Euskirchen) und „Pferdeschwemmen“ weitgehend aus dem Stadt- und Dorfbild. Und auch stadtnahe „Restseen“ ehemaliger Retentionsflächen mussten weichen, wie zum Beispiel der „Diepold“, ein See gleich hinter der Dessauer Muldebrücke in Dessau gelegen, der bereits 1937 beim Bau des Autobahnzubringers zugeschüttet wurde (HUHN 1992:49). Dabei verfügten sogar die Ortsgründungen des 7./8. Jahrhunderts im Zentrum der trockenen Lößbörden über ,winzige Wasserläufe“. „Einige von diesen Wasserläufen lassen sich heutzutage nur noch durch Trockenrinnen im Gelände rekonstruieren“(KREINER 1996b:77). 


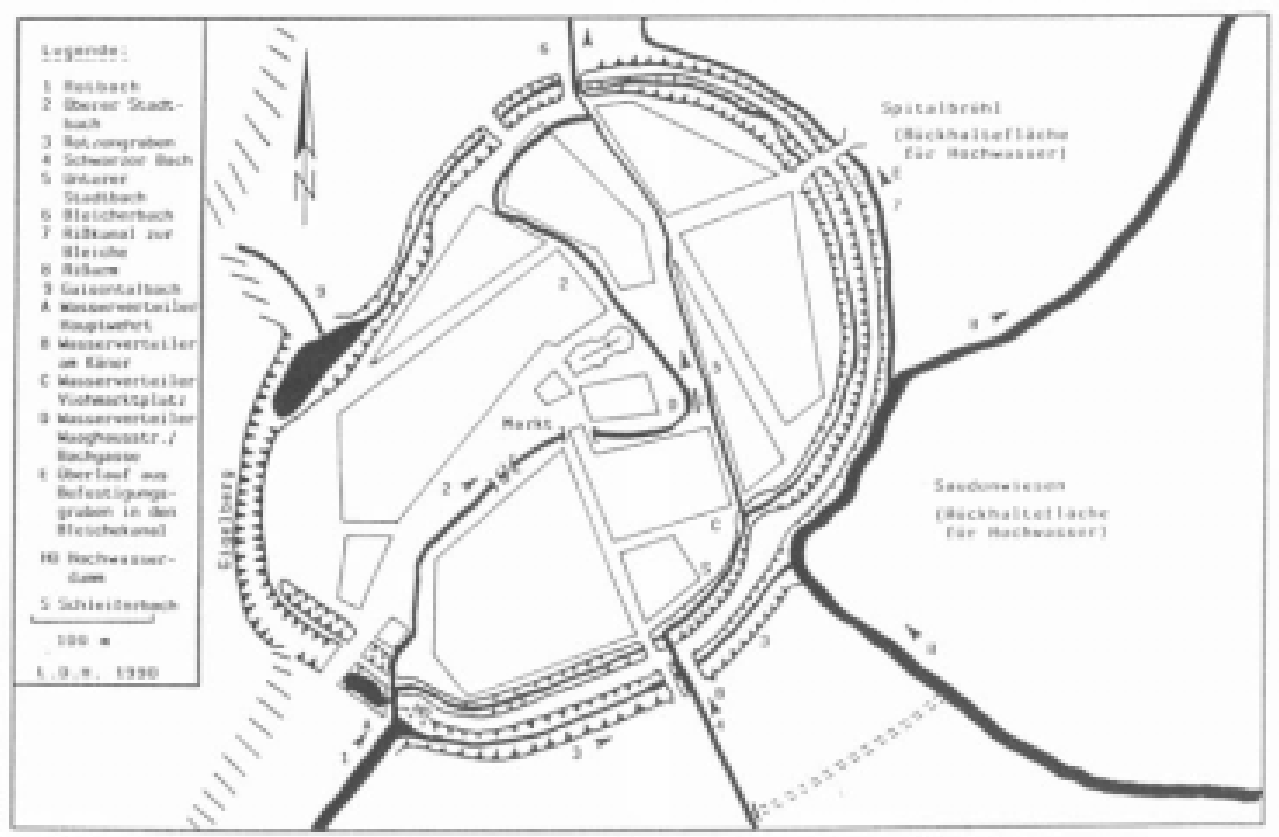

Abb. 0-6: Rekonstruierte innerstädtische Wasserführung (aus: HERBST 1992:10, Abb. 27)

Verwässerung [in früherer Zeit]

Dem „Trend“ der Trockenlegung von natürlich und anthropogen entstandenen Gewässern stand auf der anderen Seite die Schaffung neuer Gewässer gegenüber: Menschen schufen Ausgrabungen entweder primär, um künstliche Gewässerstauungen zu erreichen, wie bei der Anlage von Fischteichen (siehe Abb. 0-7), oder sekundär. Das heißt, das Ziel war es nicht, wassergefüllte Gruben zu wasserwirtschaftlichen Zwecken zu schaffen, sondern sie stellten sich als Folge des Ressourcenabbaus, aus wasserbaulichen bzw. schifffahrtstechnischen Erwägungen, wie die Buhnenteiche an der Weser, die infolge der Erzielung höherer Fließgeschwindigkeiten aus dem Buhnenbau hervorgegangen sind, aus anderen nicht-gewässerbezogenen Gründen ein.

Das Beispiel der Heidetümpel zeigt diese anthropogeographische Entstehungsursache deutlich auf: Nach Degradierung der natürlichen Eichen-Birkenwälder durch die Waldweidenutzung und verstärkte Holzentnahme waren hier - wie auch anderswo - gegen Ende des 16. Jahrhunderts großflächige Sandheiden entstanden. Die intensive Schafbeweidung und Plaggenentnahme durch die Markgenossenschaften vollendete vielerorts das Werk der Zerstörung bis hin zur totalen Vegetationsvernichtung. Die so bloßgelegten Sandböden gerieten wieder in Bewegung, so dass einige der Heidetümpel durchaus erst im 16. - 17. Jahrhundert entstanden sein können (HORST et al. 1980:71ff.). Diese, durch menschliche Einflüsse entstandenen, wassergefüllten Heidesand- und Moorstichgruben schufen ein mosaikartiges Stillgewässernetz. Fast überall gab es beispielsweise im Emsland Moor- und Heidegewässer, stellenweise sogar ausgeprägte „Seenplatten“, wie etwa in der Wulfenauer Mark bei Quakenbrück mit mehr als 30 Seen teils mit bis zu über $300 \mathrm{~m}$ Durchmesser, oder ähnlich im Welplager Moor bei Hunte (WEBER 1992:95).

Das Beispiel der „Fleuthkuhlen“ zeigt eine ähnliche Entwicklungsgeschichte für die niederrheinische Region auf: Hierbei handelt es sich um eine Reihe ehemaliger und wassergefüllter kleinerer und größerer Torfstiche (HEIN 1985:2), die aufgrund ihres Vorkommens am Niederrhein „Fleuthkuhlen“ genannt werden oder die niederdeutschen Namen „Kuhlen“, „Kullen“ und „Kaulen“ tragen (:9). Diese im 18. und 19. Jahrhundert und selbst noch im 20. Jahrhundert, in den Jahren der Brennstoffknappheit nach dem Ersten Weltkrieg noch stellenweise, durch Torfstich entstandenen Fleuthkuhlen setzten sich aus 45 einzelnen kleineren und größeren Gewässern zusammen und erstreckten sich von Sevelen bis Geldern/Kapellen über eine Länge von 12 Kilometern Luftlinie $^{4}$ (:7ff.). An den ergiebigsten Standorten war der Torf bereits um 1800 so großflächig

\footnotetext{
${ }^{4}$ Die von HEIN (1985:7ff.) untersuchten Fleuthkuhlen liegen geographisch im Kreis Kleve in Nordrhein-Westfalen (Reg.-Bez. Düsseldorf) und gehören in landschaftsgeographischer Gliederung zu dem nördlichen Teil der „Niederrheinlande“, der als „Niederrheinisches Tiefland“ bezeichnet wird. In naturräumlicher Hinsicht befinden sich die Fleuthkuhlen im Bereich der naturräumlichen Haupteinheit „Niersniederung“ innerhalb der „Fleuthniederung“. Das charakteristische Element der naturräumlichen Untereinheit „Fleuthniederung“ ist das gewundene Talsystem der Fleuth mit seinen mäanderartigen Schlingen. Innerhalb dieses
} 
gestochen, dass deshalb ein großer Teil der Fleuthkuhlen schon zu dieser Zeit existierte. Anhand älterer Flurkarten kann festgestellt werden, dass manche Kuhlen eine Größe von $87.000 \mathrm{~m}^{2}$ erreichten; kleinere Kuhlen dagegen nur einige $\mathrm{m}^{2}$ groß waren $(: 11)$. Die meisten Kuhlen findet man an den Prallufern der frühen Mäander der Niers und der Fleuth. Diese Lage der Kuhlen erklärt sich dadurch, dass an den Steilufern der Mäander das bessere Material gefunden wurde, nämlich immer dort, wo die Verlandung wegen der größeren Tiefe weniger durch die harten Uferpflanzen als durch Laub und die eigentlichen Wasserpflanzen erfolgte (:11). Die Torflöcher füllten sich schnell mit Grundwasser. Weil die Torfschichten stark durchfeuchtet und zum Teil schlammig waren, betrieb man die Torfgewinnung sogar von einem Kahn, dem sog. Nachen, aus. Darüber hinaus wurden die Kuhlen an verschiedenen Stellen über das Torfstechen hinaus vertieft, um die sog. „Grieserde“ abzubauen, die sich unter dem Torf befindet. Es handelt sich bei der Grieserde um den schlammigen nahrungsreichen Untergrund, der von den Flüssen im Holozän und Pleistozän abgelagert wurde. Als die Torflöcher sich dann mit Wasser füllten, wurde die Grieserde dieser großen Teiche mit Schleppnetzen in die Nachen gefüllt und anschließend auf die Äcker gebracht (:11). Es galt ,die kleinen Wassertümpel, Torflöcher usw., die niemand als Fischwässer betrachtete, zu Nutzung heranzuziehen.“ (SKOWRONNEK 1904:143).

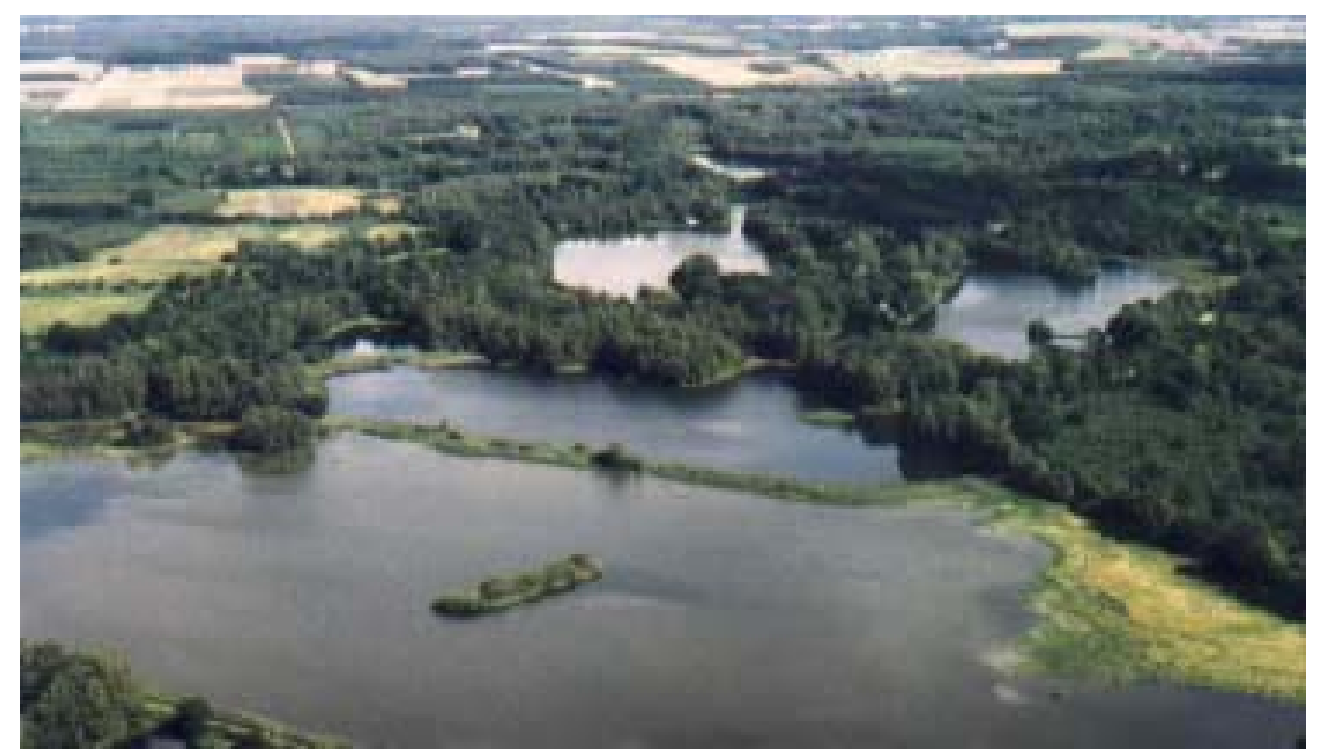

Abb. 0-7: Luftbild Ahlhorner Fischteiche. Bauzeit von 1884-1929.

$\mathrm{Zu}$ Wasserflächen sekundärer Entstehung, d. h. zu den infolge einer primären Nutzung mit Wasser vollgelaufenen Hohlformen, gehören auch sog. Töpferteiche. In der Stadt Nordhausen beispielsweise hieß der zentrale und größte Platz der Stadt, der heutige ,Neumarkt' mit einer Fläche von etwa 2,5 ha, früher ,Töpferteich' und wird auch heute vielfach in der Bevölkerung noch so genannt. Er war im Laufe der Zeit dadurch entstanden, dass die Töpfer der Stadt von hier ihren Ton holten. Nachdem im Jahr 1824 die letzten Töpfer die Tongruben nutzten (JUNKER 1992:18), wurde im Sommer des Jahres 1835 die sumpfige Ausgrabung teilweise trocken gelegt und in Ackerland verwandelt, das im November desselben Jahres auf 6 Jahre zur Verpachtung vergeben wurde. Dann diente der Teich längere Zeit als Schuttabladeplatz, bis er ausgefüllt und geebnet wurde. In den neunziger Jahren des 20. Jahrhunderts wurde er auf der Süd- und Ostseite mit einer 4geschossigen Zeilenbebauung bebaut, so dass er jetzt ringsum von Häusern eingeschlossen ist. Auf ihm werden Jahrmärkte und Schaustellungen abgehalten (HEINE o. J.:92; SCHROETER 1991:101,103).

Weitaus zahlreicher bildeten sich Ziegelteiche in der Nähe der Ziegeleien vor den Toren der Stadt, da seit den verheerenden Stadtbränden, wie beispielsweise im Jahre 1284 in Hamburg, die Stadträte in sämtlichen Städten die Verwendung von Backsteinen anstelle von Fachwerk bei allen Bürgerhäusern förderten. Obschon der Fachwerkbau weiterhin vorherrschte, wurden sukzessive und vor allem primär zunächst jene Häuser mit Ziegelmauern errichtet, die wegen der in ihnen gelagerten Waren hinreichend brandfest zu sein hatten, also die Dielenhäuser und viele der Hofspeicher. 
Im ländlichen Bereich war der Anbau von Waid eine arbeitsintensive Sonderkultur und diente zur Gewinnung von blauem Farbstoff, bis sich dieser durch die Einfuhr von indischem Indigo seit dem 16. Jahrhundert nicht mehr rentierte. Diese Sonderkultur ist im Kontext der mittelalterlichen bis neuzeitlichen Leinen- und Tuchherstellung zu betrachten und ebenso wie der Flachsanbau mit den Flachsrösten hat der Anbau von Färberwaid indirekt Hohlformen in der Kulturlandschaft hinterlassen, und zwar in Form von Mergelgruben. Die Mergelung ist ein indirekter Hinweis auf Waidanbau, denn das für die feldbauliche Düngung benötigte Sedimentgestein bestand aus Ton und kohlensaurem Kalk und wurde im Schachtbau gewonnen, da es in den unteren Bodenschichten vorkam. Die Schächte sind dann später eingestürzt und nunmehr als sanfte, wassergefüllte Einmuldungen im Gelände sichtbar. Das Westmünsterland im Raum Dülmen beispielsweise war früher von Tausenden solcher kleinen Mergelgruben mosaikiert ${ }^{5}$.

Neben den wassergefüllten Hohlformen mit rein anthropogener Entstehungsgeschichte bildeten sich in früherer Zeit auch solche natürlicher Art. Die Dynamik der Wasserführung, der deutlich höher liegende Grundwasserspiegel (SCHENK 1998:252), der mäandrierende Gewässerlauf sowie die Frachten von leicht erodier- und sedimentierbarem Material führten früher - vor den Meliorationen und in Abhängigkeit der variierenden Speichermöglichkeiten des Untergrundes -, sommers wie winters vor allem in den Überschwemmungsebenen von Tieflandflüssen zur Bildung einer großen Zahl von kurzlebigen und regelmäßig überformten Wasserkörpern in der Flussaue. Insbesondere die Hochwasserwellen hinterließen beim Rückzug wassergefüllte Ausgleichsbecken, die einen zusammenhängenden Retentionsraum bildeten. In allen Überschwemmungsgebieten waren solche ephemeren Flussseen vorhanden. So besaß die Oder in ihrem Verlauf seenartige Abschnitte, teich- und tümpelähnliche Stillgewässer und stellte eine Kombination von Mittellauf, See- und Teich-Biotop dar (HERRMANN 1997:29). In diesen periodisch entstandenen Tümpeln und Teichen in der Aue war im 12. Jahrhundert auch den Untergebenen die sog. Hamenfischerei erlaubt; dies war für die Versorgung der „einfachen“ Bevölkerung besonders wichtig, da sie am Fließgewässer keine Fischereirechte besaßen.

Vertrocknung [in früherer Zeit]

Dieser unter anderem durch Mühlenbaue, Wiesenbewässerung und Flussverlagerungen getragenen Vernässung weiter Gebiete der Niederung stand auf der anderen Seite die Entnässung, d. h. die Melioration eben dieser Flächen entgegen: Be- und Entwässerungsgräben durchzogen die Überflutungsbereiche, Deich und Staudämme wurden gebaut und Flussregulierungen durchgeführt.

Bereits im Mittelalter begann der Bau von Entwässerungsgräben zur Erschließung der Flussmarschen, beispielsweise in der Wesermarsch. Die Gräben wurden etwa parallel zu den die Marsch durchziehenden Flussläufen angelegt, die nunmehr als Vorfluter dienten. Binnenwärts endeten die Gräben, die aus dem Binnenland kommendes Wasser aufhalten sollten, achterdeichs. „Angestrebt wurde der Idealfall eines parallelen Verlaufes von Vorfluter und Achterdeich. Hierzu war oft die Verlegung von Flußläufen erforderlich.“ (BORN 1977:54). Doch nicht nur kleine Fließgewässer waren betroffen. Von den etwa 10.000 Jahre alten Glazialseen der letzten Vereisung ist ,allenfalls noch die Hälfte erhalten, wobei neben der natürlichen Verlandung vor allem im 19. Jahrhundert Entwässerungsmaßnahmen der Landwirtschaft zum Verlust von Seen geführt haben.“(KLAPPER 1999:211).

Auch von den küstennahen oder binnenländischen Hochmoorkolken, Moorteichen oder sog. „Pütten“ sind kaum mehr als Restflächen verblieben. Selbst die quasi-natürlichen Entwässerungssysteme, zu Anfang des vorigen Jahrhunderts „flache, muldenförmige bis tief eingeschnittene Rüllen“, die das überschüssige Oberflächenwasser aus dem Moor in den Lagg führte, der als Vernässungszone das Moor umgab, gibt es heute nicht mehr (PREISING et al. 1990:48). Da auch die meisten Kuhlen Ende des 19. Jahrhunderts und Anfang des 20 Jahrhunderts nach Beendigung des Torf- und Grieserdeabbaus sich selbst überlassen wurden, ist ein großer Teil der kleineren Gewässer heute wieder verlandet oder zugeschüttet worden. Die Verlandung wurde in den letzten Jahrzehnten stark durch die künstliche Grundwasserabsenkung und zusätzliche Nährstoffzufuhr vorangetrieben, so dass aus diesem Grunde viele flachgründige Kuhlen innerhalb weniger Jahre verschwanden und sich zu Flachmooren verwandelten. Lediglich die größeren Kuhlen sind heute noch als offene Gewässer vorhanden (HEIN 1985:11). So ist ein großer Teil der Fleuthkuhlen heute nicht mehr als offene Wasserfläche ersichtlich. Nur ,auf topographischen Karten sind auch heute noch deutliche Dämme

\footnotetext{
${ }^{5}$ Rudolf BERGMANN, Westfälisches Amt für Denkmalpflege; mündl. 18.09.2003
} 
zwischen den einzelnen Kuhlen zu erkennen. Hierbei handelt es sich um Verlandungsstreifen, die man beim Torfstechen aussparte, um darüber den Torf leichter mit Karren abzufahren und um einen Wegübergang zum anderen Ufer zu erhalten." (:11)

Zuvor wurden nach der Säkularisation ,zahlreiche Weiher aus Rentabilitätsgründen aufgelassen“ (HERBST 1992:128), „um bereits eingeleitete Meliorationsmaßnahmen in großem Umfang beschleunigen zu können.“ (:145). Dies führte in Deutschland vor allem in den Jahren 1802/03 zum Verlust einer Vielzahl von Weihern (:36). Gleichwohl handelte es sich bei dem Wegfall von Klosterteichen um einen prozessualen Vorgang, bei dem sich periodische Vertrocknung und Rekultivierung vor dem Hintergrund zeitgeschichtlicher Geschehnisse abwechselten - bis hin zur endgültigen Auflassung.

Ein Wegfall von Teichen ist ebenfalls bzw. vor allem innerhalb des Stadtraumes zu verzeichnen. Bevor das Flussbett der Zorge im 19. Jahrhundert vollständig reguliert wurde, war der Teil der Stadt Nordhausen unterhalb der westlichen Stadtmauer im Niederungsbereich „erfüllt von Rinnsalen und pfuhlähnlichen Teichen, zwischen denen kleine buschbewachsene Inseln lagen“ (ALLGEMEINER ANZEIGER 1997). Die Überflutungen der Zorge hinterließen hier, so vermutet man, ihre Spuren und nach ihrem Rückzug diese Teiche. Diese natürlich entstandenen, aber - davon ist allein aufgrund ihrer Namensgebung auszugehen anthropogen genutzten Teichlandschaften sind auf einem Stadtplan kartographisch rekonstruiert und dokumentiert (siehe Abb. 0-8).

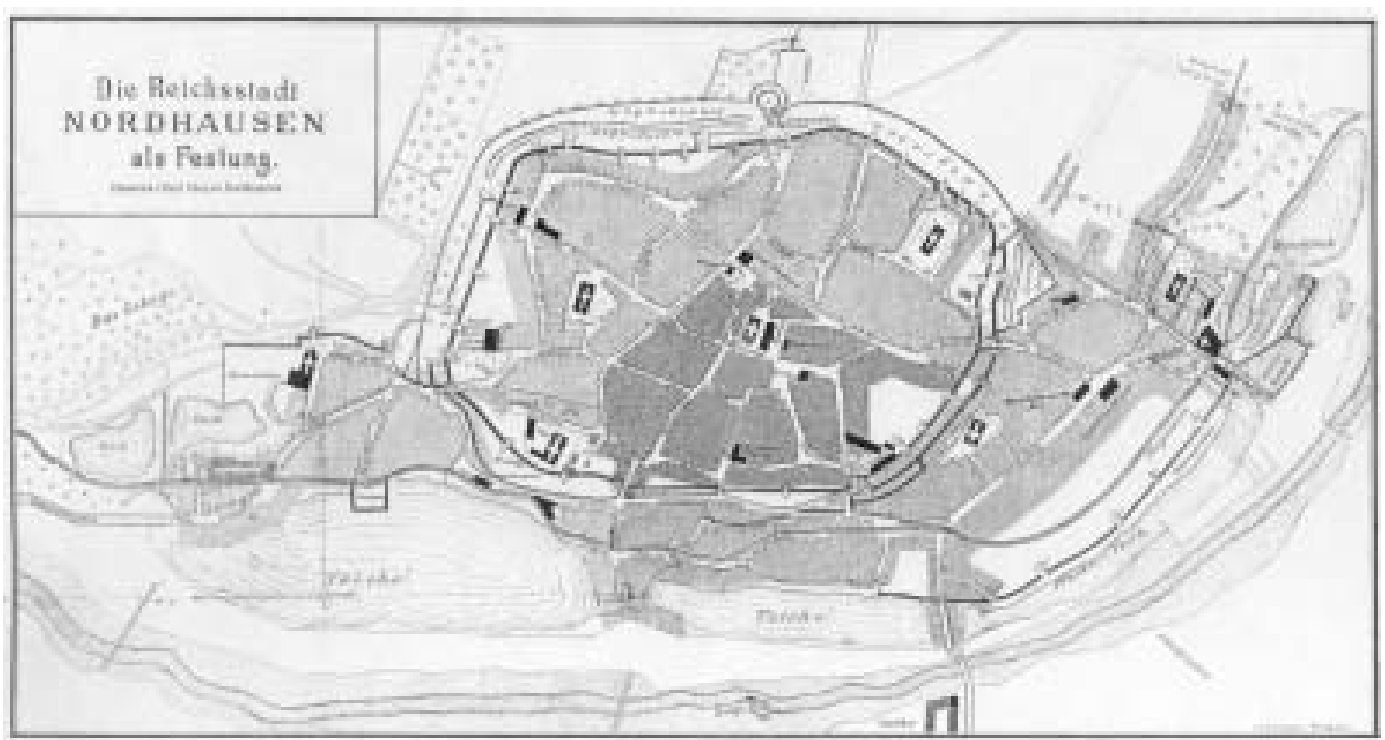

Abb. 0-8: Die ehemaligen Teiche der Zorge-Niederung

in der spätmittelalterlichen Reichsstadt Nordhausen nach einem Entwurf von Karl Meyer (1888).

Es gibt darüber hinaus die Darstellung der Stadt von O. August (siehe Anhang), in denen der Verlauf der Zorge zum Zeitpunkt des 12. und 13. Jahrhunderts noch stärker verästelt erscheint und auch die Teiche aus mehreren kleineren Teichen bestehen, die infolgedessen auch in ihrer Form von den dargestellten „Großteichen“ abweichen. Mir erscheint aber die Rekonstruktion begrenzter und teilweise mit Dämmen gefasster Teiche (siehe z. B. die beiden Teiche beim Eintrag „Nonnenkloster“ im linken Kartenrand) aus Gründen der zu diesem Zeitpunkt bestehenden geordneten Inwertsetzung als Mühl-, Fischteich oder als „Entenpfuhl“ (siehe Eintrag beim linken Großteich) bzw. als „Pferdeteich“ realistischer, zumal hier auch die mögliche Einbeziehung der Teiche als Festungsgräben bzw. die mitunter erst aus dieser fortifikatorischen Absicht entstandene Situation deutlich wird. In einem „Grundriss der Stadt Nordhausen“ von 1849 sind die abgebildeten Teiche bis auf den „Pferdeteich“, dieser ist im Gegensatz dazu erheblich geschrumpft, trockengefallen und die Flächen mit einer Wiesen- bzw. Baumsignatur belegt (siehe Anhang).

Des Weiteren wurden bereits in früherer Zeit durch anthropogene Einflüsse des Bergbaus nicht nur Teiche und lineare Oberflächenwasser geschaffen, sondern auch ein Trockenfallen von Standgewässern erreicht. Der Mansfeldische Kupferbergbau des 19. Jahrhunderts musste für den Abbau in größerer Tiefe immer mehr Grundwasser fördern. Der Absenkungstrichter erreichte das Gebiet des 900 ha großen „Salzigen Sees“ bei Halle. Erdfälle und Spalten führten das salzige Seewasser in die Grubengebäude, einige Schächte mussten durch die Abflüsse aufgegeben werden. Im Mai 1892 versiegte der Oberflächenabfluss des Sees, bis November 1892 war der Seespiegel um 2 m gefallen. Schließlich wurde das Seebecken über 100 Jahre lang über Pumpstationen trocken gehalten und landwirtschaftlich genutzt. Erst nach Stilllegung des Mansfelder Reviers nach der Wende wird jetzt das Wiederentstehen des „Salzigen Sees“ durchgeführt. 
Infolge natürlicher Verlandungsprozesse, ausgelöst durch menschliche Entscheidungen und unterstützt mit Hilfe menschlicher Technik, sind auch im Kreis UECKERMÜNDE zahlreiche stehende Gewässer bereits schon zu früherer Zeit verschwunden: 1775 wurde der 1216 urkundlich erwähnte ,Karpin See' entwässert, um 1700 war schon der ,Blader See' verlandet, der ,Große Kartsch See' wurde 1850/87 trocken gelegt. Verschwunden sind ferner der 1278 urkundlich erwähnte, Warnicker See', der ,Schwichten See', der ,Zarow See' und der See ,Deest', in der Nähe von Altwarp und schon in den 1930er Jahren Bruchgelände. Des Weiteren wird größeres Bruchgelände in den Amtsakten genannt, das früher einmal eine Seefläche gewesen sein muss (BOSSE 1962:82).

Die Stillgewässer West-Niedersachsens wurden zumeist in der ersten Hälfte des 20. Jahrhunderts systematisch in landwirtschaftliche Nutzflächen umgewandelt (WEBER 1992:95). Vor allem die mit der Verkoppelung durchgeführten Meliorationsmaßnahmen und die dadurch hervorgerufenen Wasserstandsschwankungen bzw. Grundwasserstandsabsenkungen bewirkten hier wie auch anderswo den Untergang dieser den Heide-Landschaftsraum prägenden gewässerbezogenen Kulturlandschaftsrelikte. Darüber hinaus wurde das den Tümpel umgebende Grünland - oftmals sogar erst ab den 70er Jahren des 20. Jahrhunderts in Ackerfläche umgebrochen. Mit der Folge eines erhöhten Düngereintrags, der den Prozess der Eutrophierung des Stillwassers und damit den Verlandungsprozess zusätzlich beschleunigte. Aber auch die Trittschäden durch Vieheintrieb sowie das Einbringen von Erdaushub trugen zum Niedergang der Stillgewässer maßgeblich bei.

Verwässerung [in gegenwärtiger Zeit]

Demgegenüber stehen technische Maßnahmen, die zur verstärkten Bildung von Oberflächenwasser in industrieller und postindustrieller Zeit geführt haben. Dieser Prozess der „Verwässerung“ wird geführt durch den Bau von großen Wasserspeichern (Trinkwassertalsperren, Hochwasserschutzbecken, Flutwasserspeicher, Energiewasserspeicher), durch den Bau künstlicher Wasserstraßen und in besonders großem Umfang durch die Schaffung von künstlichen Seen durch Nassauskiesung (siehe Abb. A-1 im Anhang) und der Wiederauffüllung ehemaliger Braunkohlentageabbaue mit Wasser (Abgrabungsrestgewässer, Bergbausenkungsgewässer) sowie aus fischereilichen und jagdlichen Gründen tiefer gebaggerte oder an alten oder neuen Standorten neu geschaffene Fisch- und Jagdteiche (vgl. auch POTT/REMY 2000:29; GRÜNEWALD 1997:279ff.; HEIN 1989:11; KLAPPER 1999:212).

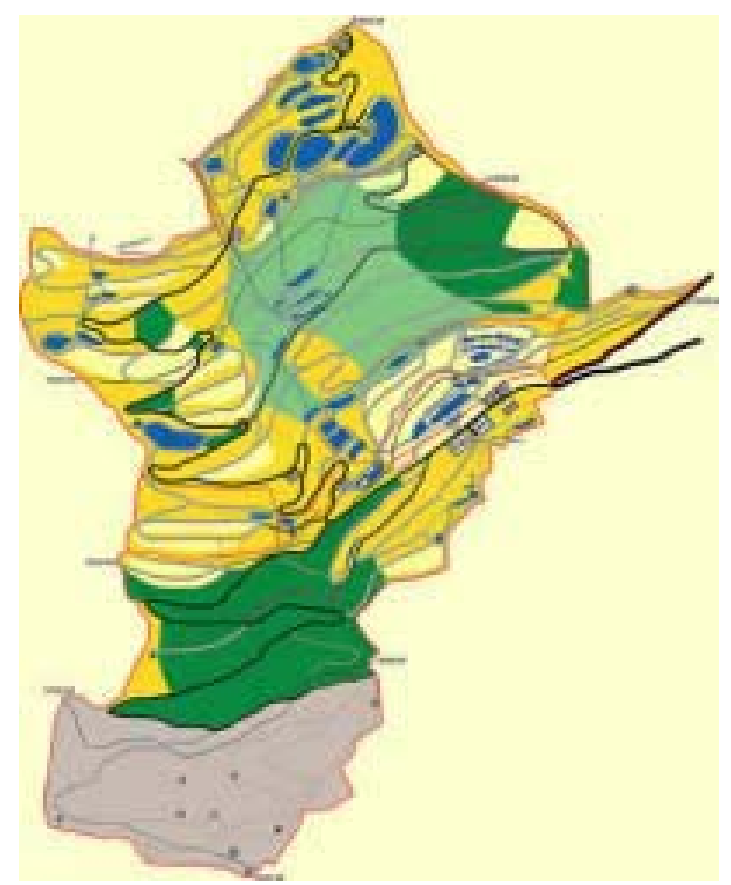

Abb. 0-9: Lageplan: Neue „Aquakulturanlagen“ des „Krameterhofes“.

Am Südhang des Schwarzenberges in Ramingstein (Lungau) erstreckt sich der durch Funk und Fernsehen bekannt gewordenen Krameterhof über eine Fläche von 45 Hektar von 1100 bis 1500 Metern Seehöhe. Die alpine „Wasserlandschaft“ am Krameterhof besteht aus über 70 Teichen und Feuchtbiotopen, in denen auf nachhaltiger Basis nicht nur die Zucht von Fischen, Krebsen und Pflanzen betrieben wird, sondern ebenso die Stromerzeugung durch eigene Wasserkraftwerke. 
Vor allem in den weniger dicht besiedelten Gebieten außerhalb Europas - dies sei hier eingeflochten wurden Talsperren mit gigantischen Ausmaßen errichtet, ganze Flüsse wurden in neuerer Zeit für die Energiegewinnung zu Talsperrenkaskaden ausgebaut, zum Beispiel die Wolga, der Dnjepr, Tennessee, Parana, vor kurzem der Tschang Tse, und der armenische Sewansee treibt über den Rasdan-Fluss eine fünfstufige Kraftwerkskaskade an (KLAPPER 1999:213). Mit teilweise nicht prognostizierten Nebenwirkungen: Erdbeben am Kariba-Damm, Ausbleiben des düngenden Nilschlammes unterhalb des AssuanDammes, ethnologische Probleme durch Gebietszerschneidungen an der $565 \mathrm{~km}$ langen Talsperre Bratsk an der Angara. Einige Landschaften der Erde werden gar von Dämmen, Kanälen und Staueinrichtungen regelrecht geprägt. Das wahrscheinlich eindrucksvollste Beispiel ist die Landschaft der „Schwemmteiche“ im Südosten Indiens, wo man unzählige kleine Wasserläufe und überflutete Flächen durch kleine Erdwälle aufstaute, die SPATE und LEARMONTH mit einer „Oberfläche riesiger, sich überlappender Fischschuppen“verglichen (Zitat aus GOUDIE 1994:207).

Zwar existieren historische Talsperren in den Alpen, sog. „Gletschersperrseen“, die die austretenden Wassermassen nach Gletscherausbrüchen auffangen, bereits seit 1745 (VOGEL 1994:232). Heute jedoch, wo die natürlichen Gletscherseen durch die Eisschmelze zum einen austrocknen, die Wassermassen der Gletscher jedoch aufgefangen werden müssen, werden große gemauerte Staubauwerke errichtet. Und auch die anthropogene „Verwässerung“ der Mittelgebirgslandschaft mit Stauseen setzte großflächig bereits zu Anfang des 18. Jahrhunderts ein. So entstand im Harz 1714 - 1718 die erste größere Talsperre Europas, der Oderteich bei St. Andreasberg mit 1,668 Mio. $\mathrm{m}^{3}$ Stauraum (NIEMEYER-LÜLLWITZ/ZUCCHI 1985:91f.). Desgleichen gab es Wasserauskiesungen bereits in vorindustrieller Zeit (siehe VI 13.b). Betrachtet man jedoch die Dimensionen des heutigen Kies- und Sandabbaus, wird die nach HANSEN (2000:58) ,abseits des Publikumsinteresses stattfindende Landschafts- und Denkmalzerstörung“ deutlich: In Deutschland wurden 1995 etwa 450 Millionen Tonnen Kies und Sand gewonnen (während 200 Millionen Tonnen Braunkohle abgebaut wurden). Der damit verbundene Flächenbedarf betrug 1995 etwa $45 \mathrm{~km}^{2}$. Gegenwärtig verschlingt der Kies- und Sandabbau im Rheinland mit 3,6 km² mehr Fläche als der Braunkohlenabbau. „Die gegenüber dem Braunkohlenabbau relativ hohe öffentliche Akzeptanz für diesen Flächenverbrauch erklärt sich vermutlich zu einem gewissen Teil mit der Aussicht, dass Baggerlöcher häufig zu mehr oder minder idyllischen Badeseen umgewandelt werden." (:58) So soll sich beispielsweise der bergbaubedingte Restraum des Tagebaues bei Hammerstadt-Niederspree nach der Rekultivierung langfristig zu einem See mit der Fläche von ca. 1.490 ha entwickeln, wobei die Endstauhöhe bei +130 m HN liegt (BfN et al. 2000:A-21f.).

Durch den Bau von Talsperren oder Stauseen und die Stauregulierung von Schifffahrtsstraßen werden weiterhin Fließgewässerstrecken in kurzer Zeit hydrologisch umgeformt und in vorwiegend stehende Wasserkörper überführt. Die möglichen Effekte der großflächigen Evaporation der vielen neuen Gewässerflächen auf den Klimahaushalt werden kontrovers diskutiert, von herrschender Meinung aber seit Jahren wissenschaftlich bestätigt (BACH 1982; FLOHN 1985; ENDLICHER 1991; HUBER, 1991; RAPP/SCHÖNWIESE 1995). Auf jeden Fall aber ist die damit verbundene Umgestaltung der Gewässer- und Kulturlandschaft tiefgreifend. 

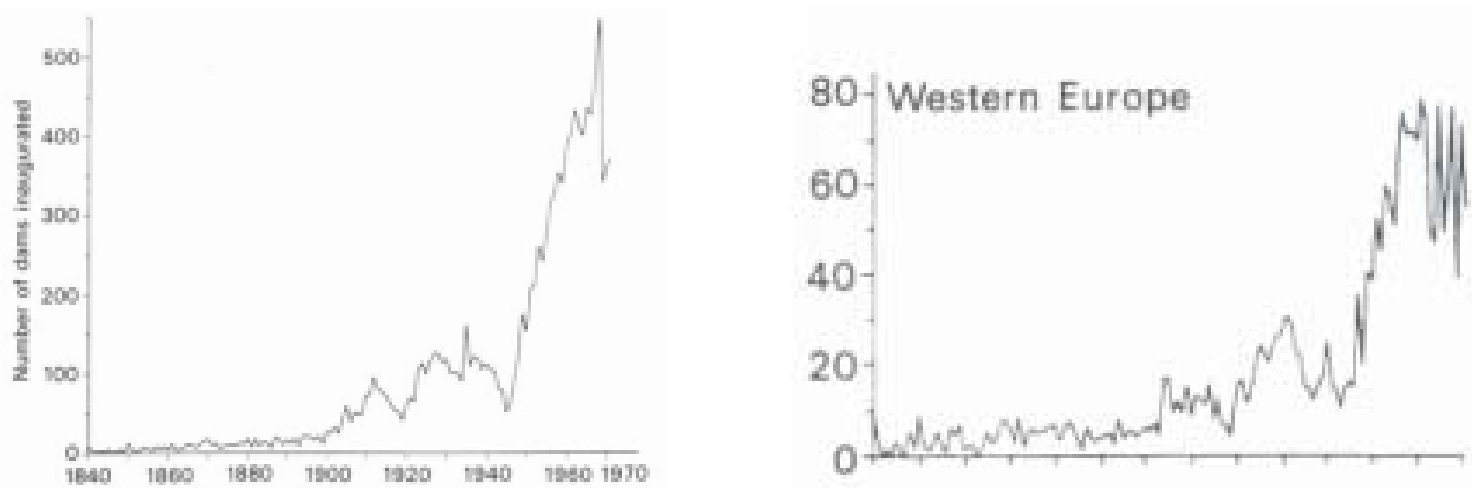

Abb. 0-10: Die steigende Anzahl von Talsperrenbauten (,dams“)

li.: weltweit, re.: in Westeuropa (aus: GOUDIE 1981:141)

Aber auch kleine Bausteine tragen zu dieser Entwicklung der Verwässerung in neuer Zeit maßgeblich bei: Neben den Zierteichen auf Golfplätzen, die mittlerweile als „Anziehungspunkt für Fischotter“ eine naturschutzfachlich positive Bewertung erfahren (KRANZ 2000:10) und den „Mini-Biotopen“ in den Privatgärten, die die postindustriellen suburbanen Wohnlandschaften prägen, werden zunehmend Regenwassersammelanlagen in Wohngebieten als „naturnahe Teichanlage“ in eine Grün- und Spielfläche integriert. Diese Teichflächen nehmen vor allem darum eine so große Dimension ein, da oftmals diese Teiche auch dem Spielen am und im Wasser dienen sollen und deshalb nach DIN-Vorschrift 18034 eine maximale Anstauhöhe von 0,40 m in Ausnahmefällen eine Aufstauhöhe von $0,60 \mathrm{~m}$ besitzen dürfen, aber aufgrund einer bestimmten Regenmenge ein entsprechendes Volumen vorweisen müssen (OTTO 2003:32; OSTERMEYER 2002:33).

Des Weiteren hat die Zahl der Schwimmteiche, auch Kleinbadeteiche oder Bioteiche genannt, in den letzten zehn Jahren in Deutschland deutlich zugenommen (HOFFMANN 2003:35). Im Jahr 2001 fand sogar der erste internationale Kongress für naturnahe Badegewässer statt.

Im August 2002 gab es in Deutschland bereits 34 öffentlich zugängliche Schwimm- und Badeteiche, bis Ende 2003 kommen noch sieben Anlagen hinzu und „es ist zu erwarten, dass diese Entwicklung anhält und in Zukunft in großer Zahl weitere öffentliche Schwimm- und Badeteichanlagen gebaut werden." (GÖRING et al. 2003:42) Obgleich es sich hierbei in Einzelfällen nicht immer um Neuanlagen, sondern auch um Umgestaltungen konventionell betriebener Freibäder handelt, wie zum Beispiel beim Schwimm- und Badeteich in Lauenstein/Landkreis Hameln-Pyrmont (:42).

Schließlich legen Naturschützer Laichgewässer für den Laubfrosch (Hyla arborea) an, um den Bestand dieser vom Aussterben bedrohten Amphibienart anzuheben. So schuf die Ortsgruppe des Naturschutzverbandes Südpfalz im Jahr 2001 in der Gemarkung Minfeld im Kreis Germersheim eine Flachwasserzone in der Größe von rund 900 Quadratmetern: „Es entstand ein ideales Laichgewässer für den kleinsten einheimischen Frosch“ um „das einstige Verbreitungsgebiet des Laubfrosches durch die Schaffung vernetzter Biotope wieder zu beleben“ (HOCK 2001). Unter der Regie des Verbandes entstanden seit den 1990er Jahren 25 größere Feuchtgebiete mit ausgedehnten Flachwasserzonen (HOCK 2001).

Aufklärung und nicht naiv-romantisierende Darstellung

Ohne Frage bedeuteten auch die vorangestellten historischen Arbeitsweisen einen schweren Eingriff in den Naturhaushalt und trugen teilweise zur Gewässerverschmutzung nachweislich erheblich bei: Künstliche Wasserleitungen aus mehreren Kilometern weit entfernten wasserreichen Gebieten in wasserarme, teilweise mit Tunnelung von Gebirgen (Beispiel: Wallis in Tirol), Reliefveränderungen von Flussauen, Schädigungen der Uferbereiche beim Triftflößen, Anlage künstlicher Stauhaltungen, exkrementale Sinkstoffe vom überhöhten Fischbesatz und die Einleitungen aus den zuvor beschriebenen mühlenbetriebenen Produktionsverfahren sowie den bäuerlichen und volkstümlichen Anbau- und Haushaltsmethoden veranschaulichen die Veränderungen der naturnahen Umwelten mit Beginn nachhaltiger Einwirkungen durch den Menschen. 
Natürlich hinterließen die schmalen Speichenräder der Post- und Frachtwagen, die sich tief in den Boden einschnitten, „messerscharfe Wunden“ (SEEDORF/MEYER 1996:592), beispielsweise in der Gras- und Heidevegetation der Geest, ,die dann unter den Huftritten von Pferden, Ochsen und Schafen weiter aufgerissen wurden. Flächenhafte Sandverwehungen waren die Folge, die besonders im Emsland und in der Lüneburger Heide manche Äcker, Wiesen und Weiden für immer unter sich begraben haben. “(:592) Zudem stellten die schlechten Straßenbedingungen - Auswaschungen, Spurrillen, Huckel und Löcher - hohe Anforderungen an Menschen, Zugtiere und Transportwagen (ALTMANN 1999:124). Der mühsame Landverkehr bis zum Beginn der Industrialisierung vollzog sich fast ausschließlich auf unbefestigten Wegen. Tiefgründige Moore und Sümpfe mussten entweder mühsam umfahren werden, oder sie wurden nicht ohne Risiko auf schmalen, hölzernen Bohlenwegen durchquert.

$\mathrm{Zu}$ Idealisierungen besteht auch hinsichtlich der Vielzahl an heute idyllisch gelegenen Bergbauteichen kein Anlass, „denn irreversibel waren die Folgen der Erzgewinnung und -verarbeitung selbst“ (BARTELS 2000:48). Bergbau bedeutete „vom Anfang seiner Geschichte an massive und irreversible Eingriffe in die Naturhaushalte“ (:49), denn Bergbau und Hüttenwesen benötigten große Mengen an ständig verfügbarer Energie. Hier gab es lange Zeit nur die Wasserkraft, mit deren Erschließung beispielsweise im Oberharz „tiefgreifend in den Naturhaushalt eingegriffen wurde“ (TRUNZ 2000:V).

Durch den frühen landesherrlichen Steinkohlenbergbau im niedersächsischen Berg- und Hügelland versickerten und versiegten Bäche, Brunnen trockneten aus (NEUBER 2002:5). Da der Untergrund vom Bergbau stark zerklüftet war, entstanden durch Senkungen „,selbst in bisher undurchlässigen Schichten vertikale wasserableitenden Klüfte" (:211f.). Durch diese schwerwiegenden bergbaulichen Eingriff in die hydrologischen Verhältnisse wurde hier beispielsweise im ersten Drittel des 17. Jahrhunderts Wassermühlen das Wasser genommen, Wasser zum Bewässern der Wiesen, zum Bleichen und Waschen sowie das Löschwasser stand nicht mehr zur Verfügung, von den metallhaltigen Verunreinigungen und dessen Folgen, die zur Aufgabe des Viehtränkens bzw. sogar zum Viehsterben führen konnten, ganz zu schweigen (:212ff.).

Der große Komplex von Bergbau und Verhüttung, Mühlen und Hammerwerken, Teichwirtschaften und Wiesenbewässerungen wirkte nachhaltig auf die Umwelt ein und hat der Natur bleibende Narben zugefügt. Nicht immer wurde behutsam mit ihr umgegangen. Höhlungen und das weitläufige Netz der Untertageanlagen wurden über Tage durch zahlreiche Baulichkeiten ergänzt. Wassergefüllte alte Schürfstellen und Einsturzmulden, Relikte und Reste alter Betriebsanlagen künden in den meisten Bergorten von Traditionen, von bergmännischer Kultur in Landschaften, in denen der Bergbau weitgehend erloschen ist. Doch in historischer Zeit, wenn es Kunde von reichen Silbererzvorkommen gab, wurde der ganze Berg aufgewühlt, ohne dass es zu eigentlichem Tiefbau kam. So entstanden nebeneinander massenweise Löcher und Gruben, „Hohlen“ oder „Pingen“ genannt. So entstanden ganze Pingenfelder (CZAYA 1990:20).

Des Weiteren hat der historische Mensch nicht nur die großen Ströme reguliert und Sumpfgebiete entwässert, sondern bereits in vorindustrieller Zeit auch in die kleineren Wasserläufe eingegriffen und so künstliche Stauteiche zur Wasserkraftgewinnung, zur Fischzucht, zur Rohrkolbengewinnung, zum Grünlandanbau, zur Leinenbearbeitung usw. geschaffen und Wiesen zur Bleichung, Sandwäsche und Düngung geflutet und morphologisch durch Terrassierung verändert. Und schließlich formte in den Flusstälern die Flößerei die historische Kulturlandschaft, die als wirtschaftlich einträglichstes Gewerbe bis in das 20. Jahrhundert hinein die Gestalt der Flüsse und Quellläufe unter anderem durch Stauung von „Schwöllungen“ in ganz spezifischer Weise formte (GUNZELMANN 2003:4).

Die stärker werdende Umgestaltung der Flusssysteme durch den Menschen - verbunden mit der Zerstörung, Auffüllung und Bebauung von Weihern, Kanälen - führte zu einer nachhaltigen Veränderung der natürlichen Umgebung, vergrößerte die Flutmenge (HERBST 1992:71) und trug zu einer „Vernässung“ erheblich bei: Infolge des Baus von Stauwehren, deren nachfolgender sukzessiven Erhöhung durch in Verbindung mit erhöhter, durch erosive Kräfte verursachte Sedimentation entstandene Erhöhung des Flussbettes, kam es zu einem anthropogenen Wasserstau, der aber aufgrund seiner Regulierung und Kanalisierung keine Brüche und Niederungsbereiche entstehen ließ. Die Fließgeschwindigkeit der Flüsse verringerte sich durch die vielen Stauwehre und die Temperatur des Wassers erhöhte sich. Diese neuen Bedingungen verdrängten die kälteliebenden Wanderfische wie den Stör und den Lachs, der wärmeliebende Karpfen profitierte jedoch von dieser Entwicklung (LAMPEN 2000:136f.). Die Teichwirtschaft schuf durch Rodung von Auenwäldern und Gewässeraufstau zum Teil mehrere Hektar große Teichlandschaften und die wachsenden Städte durch die 
Anlage von geringgründigen Rieselfeldern, ehemals der städtischen Fäkalienreinigung dienend und heute zum Teil als Vogelzugreservat unter Naturschutz stehend, ausgedehnte Reinigungsteichflächen. Auf der anderen Seite waren mit der Wasserlieferung für die Teichwirtschaften Veränderungen der Wasserqualität und der Durchflussmenge (Verdunstungsverlust) verbunden (BfN et al. 2000:D-10).

Die technische Nutzbarmachung des Wassers, zum einen durch Wassermangel oder sogar Wassernot, zum anderen durch den Überfluss an Wasser hervorgerufen, lässt sich dabei bis in frühgeschichtliche Zeit zurückverfolgen.

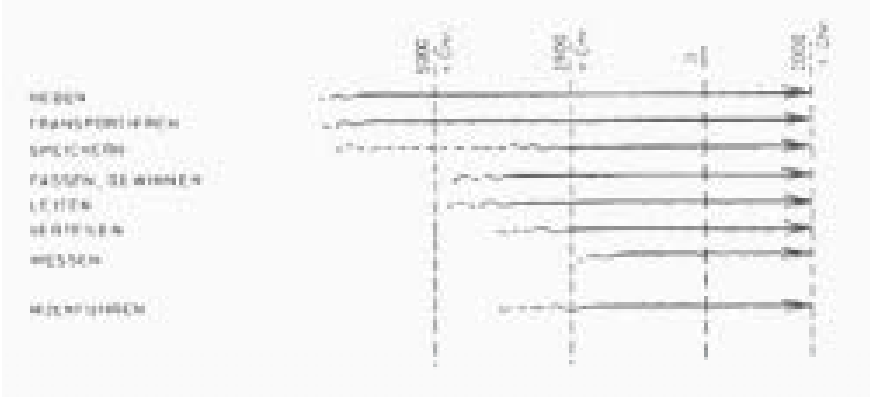

Abb. 0-11: Wassernutzung des Menschen im Laufe der Geschichte (nach GARBRECHT 1985: 43, veränd.)

„Wassersünden“66, d. h. naturwidrige Eingriffe in den Wasserhaushalt, in Wasservorrat und Wassergüte, wurden demnach seit langer Zeit begangen. Obschon, dies sei hier angemerkt, ein präökologisches Bewusstsein auch schon früher, vor allem mit Beginn der durch Industrialisierung einsetzenden Verschmutzung, erwachte (WALTER 1996:75).

Auch kam es in früherer Zeit zu „Wässerstilllegungen“ und „Wässerschwünden“. So sind auch schon zu Anfang des 18. Jahrhunderts Speicherteiche des Bergbaus, „nach der Zeit, weil er kein Wasser halten wollte, wieder abgegangen und zu Wieswachs gemacht worden.“ (HAASE 1961:87; am Beispiel des „Bährner Teichs“ / St. Andreasberg, Harz) Vor allem dann, wenn eine Grube stillgelegt wurde, verfiel der Teich (:88; am Beispiel der Grube „Engelsburg“ im Jahre 1765).

Auf der anderen Seite entstanden nicht nur „Stillgewässer“, sondern auch - beispielsweise durch forsthistorische Tätigkeiten - neue kleine Fließgewässer. So bildete sich wahrscheinlich der Bachlauf der Blochschleife, einem Nebenbach des Kellwassers im Hochharz, „aus einer Schleifrinne, [...] beim Abtransport von Holzblochen - den Stammabschnitten gefällter Bäume - aus.“ (HAASE 1961:19) Zu Gewässerneubildungen kam es auch durch Rodung der noch im 19. Jahrhundert zahlreichen verstreut liegenden Waldparzellen; der Wasserabfluss wurde beschleunigt und Abflusswege bildeten sich neu.

Der gegensätzliche Prozess der Vertrocknung ist ebenfalls nicht auf die aktuelle Zeitrechnung begrenzt und lässt sich auch in früheren Zeiten datieren: Im Hochmittelalter zum Beispiel wurden auch an kleinsten Gewässern Mühlen betrieben, die dann in der frühen Neuzeit, spätestens im 18. Jahrhundert, aus Wassermangel aufgegeben werden mussten. Die spannende Frage für weitergehende Forschungen ist nur: Warum? Zu zahlreich, so ist meistens zu lesen, seien die Mühlen im Laufe der Zeit geworden, zu anspruchsvoll die stetig steigenden Produktionsziele für die zur Verfügung stehende Wassermenge, zu erheblich und zu oft die für Wässerungszwecke abgeleiteten Wassermengen.

Die Versuchung ist sicher groß, auf der Suche nach Gegenmodellen zur postindustriellen und virtuellen Gesellschaft die alten handwerklichen und bäuerlichen Produktionsformen zu mystifizieren - und dabei zu vergessen, dass diese Produktionsformen auch mit zahlreichen Risiken und Umwelteingriffen zusammenhingen (WALTER 1996:13).

Kulturlandschaftsgeschichtlicher Bedeutungsverlust

Zugleich beeindruckt das Ausmaß historischer landschaftsgestalterischer Prozesse für das Gewässerbild. Die im 18. Jahrhundert aufkommenden Entwürfe englischer Gartenkunst und deren nachfolgende Umsetzung in

\footnotetext{
${ }^{6}$ Ein aus dem Biblischen entlehnter Begriff nach THIENEMANN (1955:133f.)
} 
Deutschland sind auf das Engste mit der anthropogenen Ausformung von Oberflächengewässern verbunden. Wasser galt als Gestaltungsmittel, als „die wichtigste Komponente“ der vier Elemente (UERSCHELN/KALUSOK 2003:264). Auf mehrere Hektar großen Arealen im Schlossbereich wurden - als charakteristische Merkmale für Gärten englischen Typs - ganze Seenfolgen mit natürlich wirkenden Uferkonturen, verborgene sog. „Aha-Gräben“, Quellanlagen, Brunnen, Wasserbecken, künstliche Wasserfälle, Kaskaden, Kanäle, Wasserspiele geschaffen. Um dieses zu erreichen, wurde massiv in die benachbarten oder auch entfernt liegenden Gewässerläufe eingegriffen. Als bekannte Beispiele dafür seien die Fürst-Pückler-Parklandschaften auf Schloss Branitz bei Cottbus (hier die Spree) und seiner Standesherrschaft Muskau (hier die Neiße) sowie das Dessau-Wörlitzer Gartenreich (hier die Oder) genannt.

Einige der früheren anthropogenen Kleingewässerformen haben sich den Nivellierungsversuchen widersetzt und bis in die Gegenwart erhalten können. Dazu zählen bspw. die fischereiwirtschaftlichen Teichflächen. Aber auch die Teichwirtschaft war früher weiter verbreitet als heute und betrug etwa das Dreifache der Teichfläche zum Nachkriegsvergleichsjahr 1950 (RUST 1956:35). Viele mittelalterliche und frühneuzeitliche Teiche wurden jedoch durch die Drainage seit Mitte des vorigen Jahrhunderts trocken gelegt und unkenntlich gemacht. Hier und da zeugen verfallene Dammanlagen von dem einst so umfangreichen Wirtschaftszweig. Sie sind überwiegend Reste alter klösterlicher und gutsherrlicher Anlagen (:34).

Selbst mit den in dieser Arbeit aufgeführten methodischen Hilfsmitteln lassen sich nicht sämtliche ehemaligen Teiche ermitteln. Die Kulturlandschaft hat eine so durchgreifende Veränderung durchgemacht, dass sich viele wüste Teiche, deren Grenzen sogar urkundlich belegt sind, nicht mehr im Gelände auffinden lassen (RUST 1952:35).

Das Bild eines stagnierenden, immobilen Mittelalters und einer frühen Neuzeit ist demzufolge falsch und, was zur zwingenden Berücksichtigung im Wasserbau führt: Der ungeheure Wandlungsprozess bestimmt bis heute noch weitgehend die Verteilung von Gewässern (STROMER 2000:151).

Kulturhistorischer Bedeutungsverlust

Gleichwohl ist aber mit der topographischen und hydroökologischen Veränderung unserer Gewässer- und Flusslandschaften der kulturhistorische Bedeutungsverlust ebenso zu beklagen. Die zahlreichen mit dem Wasser verbundenen Handwerke und Berufe zur naturnahen Inwertsetzung des existentiell wichtigsten Geoelementes sind vielfach in Vergessenheit geraten: Die Kunst des Flachsröstens zuerst in Bachläufen, dann in speziellen hofnahen Rösteteichen zur Leinenherstellung, die Triftflößerei von Scheithölzern auf den gefluteten Mittelgebirgsbächen als Baumaterial für den städtischen Fachwerkbau, die kleingewerbliche Flussfischerei mit ihren Fanganlagen und Fangmethoden der Boot- und Landfischerei, die mit wachsender Industrialisierung wegen der Verunreinigung der großen Flüsse aufgegeben werden musste (MARCINEK/ROSENKRANZ 1996:282), die daraufhin verstärkt einsetzende Teichwirtschaft, die zum Beispiel in Form der Feld-Teichwechselwirtschaft den Wechsel von Fischzucht und Getreideanbau auf den abgelassenen Teichböden praktizierte, die klösterliche Subsistenz- und Grangienwirtschaft, die insbesondere zur Versorgung der bischöflichen Residenzen eine Vielzahl von Teichen zur Karpfen- und Forellenzucht und zur Brunnenkressegewinnung anlegte und so vielfach ganze Teichlandschaften schuf (Beispiel: Niederlausitzer Teichlandschaft bei Bautzen), die anfänglich den Adeligen vorbehaltene Zucht und Gewinnung von Flussperlmuscheln und Flusskrebsen, das Mahlen von Getreide und ölhaltigen Faserpflanzen und die Produktion von Metallen und Glas durch Anlagen der Wasserkraft, die verschiedensten Arten der Wiesenbewässerung als Mittel der natürlichen Düngung, des Frostschutzes, der Bodenreinigung, der Abwässerfiltration, der Auflandung etc. und schließlich sogar die Nutzung der Flussauen als Wäschewiesen zum Bleichen und zur Sandwäsche für die Porzellanherstellung (Beispiel: Neuhaus im Solling für das Fürstenberger Porzellan). Als sichtbares Kennzeichen einer ehemaligen Wirtschaftsweise sind ebenso alte, offen gelassene und wassergefüllte Lehmgruben auf Altarmverschwenkungen, ,wie sie in vergangenen Zeiten zur Fertigung von Ziegeln gelegentlich ausgehoben“ wurden (LIEPELT 1992:57), lediglich als Geländerelikte verblieben.

Die einleitende umwelthistorisch-geographische Darstellung gewässerbezogener Kulturlandschaftsgeschichte mit ihren wechselseitig ablaufenden Prozessen der Vernässung und Vertrocknung in vergangener und gegenwärtiger Zeit, vermag in dieser Zusammenschau Konsistenz und Wandel in ihren räumlichen, hydrologischen und volkskundlichen Ausprägungen widerzuspiegeln und die Probleme anzureißen, mit 
denen sich diese Veröffentlichung näher beschäftigt. Der sich daraus ergebende Zukunftsbeitrag wird am Ende dieser Arbeit diskutiert.

\section{Thematische Einführung und Zielsetzung}

Von entscheidender Relevanz im Zusammenhang des hier vorgelegten Arbeitsansatzes einer anwendungsorientierten umwelthistorischen Gewässerforschung mit anthropogeographischem Schwerpunkt ist die Annahme, dass sämtliche natürlich entstandenen Gewässer im menschlichen Einflussbereich einer vielgestaltigen Nutzung im Rahmen der Siedlungs-, Rodungs- und Bergbautätigkeit zugeführt wurden und die verbleibenden zu diesem Zwecke künstlich errichtet worden sind. Dies bedeutet folglich, dass auch kleinere Wasserläufe einer speziellen kleinräumlichen anthropogenen Entwicklungs- und Nutzungsgeschichte unterlagen bzw. - in rudimentärer Form - noch unterliegen. Diese Kleingewässerentwicklungsund -nutzungsgeschichte zusammenzutragen und exemplarisch offen zu legen, steht im Blickpunkt meiner gewässerhistorischen Betrachtung. Sie will einen Einblick in die Geschichte der Gewässernutzung in Mitteleuropa vermitteln und kann deshalb und aus Gründen des Systemzusammenhangs an einigen Stellen nicht auf die Darstellung größerer Gewässer verzichten.

Die Darstellung früherer Wassernutzungen beinhaltet die Frage, auf welche Art und Weise die Gewässer genutzt wurden. Die Vielzahl von Wassernutzungen auch an kleineren Fließgewässern bezieht sich aber nicht nur auf die allgemein bekannte Versorgung mit Trink- und Brauchwasser. Hier ist auch keine allein an Abwassereinleitungen orientierte „Verschmutzungsgeschichte“ beabsichtigt und auch keine Geschichte der Wasserkraftnutzung, sondern die Darstellung der früheren Nutzung des Wassers in seiner gesamten Bandbreite - dies ist ein wesentlicher Anspruch der Arbeit, von der aufgrund der Bandbreite der Betrachtung jedoch keine Vollständigkeit erwartet werden darf, die aber um sie bemüht ist und das Ziel einer möglichst intensiven Darstellung ehemaliger gewässerbezogener Wirtschaftsweisen verfolgt. Aus den Einzelbausteinen dieser Betrachtung soll vor allem eine möglichst flächendeckende anthropogene Umweltgeschichte kleinerer Fließgewässer möglich sein. Zugleich zeigt sich bei diesem Thema der Umgang des Menschen mit der aquatischen bzw. amphibischen Natur. Insofern also ist es ein Beitrag zur Umweltgeschichte.

Zeitlich grenze ich dabei das Aufgabenfeld bewusst nicht ein, denn Gewässernutzungsgeschichte geht von den Anfängen der Menschheitsgeschichte bis in unsere heutige Zeit hinein und eine zeitliche Gruppierung würde zudem die Erkennung des Zusammenhanges erschweren. Die Vielzahl der möglichen Aspekte birgt hingegen die Gefahr einer Sichtweise in sich, die letztlich alles mit allem in Verbindung setzt. Die große Menge und Unterschiedlichkeit möglicher Nutzungen zwingt zu einer Auswahl und unterstreicht, dass es immer nur um einen individuellen Ausschnitt und nicht um eine generalisierte Umweltgeschichte gehen kann (vgl. DIX 1997:31).

Bisher wurde in der Literatur das gesamte Spektrum der Wassernutzung noch nicht zusammenhängend dargestellt, obgleich es mittlerweile einige lesenswerte Arbeiten zu diesem Themenbereich der Umweltgeschichte gibt, die auch speziell die historisch-gewässergeographische Ebene umfasst. Wenn auch nur ein Bruchteil der vielfältigen fachspezifischen sowie allgemeingültigen Literatur herangezogen werden kann, so „soll aber nicht verkannt werden, dass auch der Ansatz einer systematischen Zusammenführung und Analyse der stetig zunehmenden Dichte von Einzelbefunden durch individuelle Forschungsarbeit [...] zu siedlungsräumlichen Forschungsergebnissen führt.“ (DENECKE 2001:283) Insofern ist es auch ein Beitrag zur Literatur- und Forschungsgeschichte, die in ihrer Zusammenfügung durchaus zu den von DENECKE angeführten Ergebnissen führen kann; mit der Ausnahme, dass in diesem Fall der Forschungsansatz eine gewässerhistorische Ergebnisorientierung besitzt.

Ziel dieses Beitrages soll es neben der Darstellung des Nutzungsspektrums weiterhin sein, den kulturlandschaftlichen Ausformungen historischer Nutzungen kleinerer Gewässer ein besonderes „Denkmal“ zu setzen. Zahlreiche Wassernutzungen und viele technische Wasserbauten der Vergangenheit, die der Nutzbarmachung des Wassers dienen sollten, sind heute kaum mehr sichtbar und gänzlich dem Bewusstsein entrückt. Mit der systematischen Auswahl an Gewässernutzungen soll, wie oben genannt, zum einen der intensive Ge- und Verbrauch des Mediums Fließgewässer in früherer Zeit beschrieben werden; mit den daraus erwachsenden anthropogenen Morphologien der Wasserhaltung und der Wässerung zum anderen die kulturlandschaftlichen Auswirkungen dieser Benutzungen auf die Oberflächengestalt der Landschaft 
dargestellt werden: Gewässer und deren Nutzungsformen als Elemente der Kulturlandschaft aus dem Zusammenfluss historischer Mensch-Umwelt-Beziehungen. Insofern ist dies ein Beitrag zur historischgeographischen Kulturlandschaftsgeschichte.

Beginnend mit den Anfängen der menschlichen Siedlungen und deren engem topologischen Bezug zur Gewässerlage und folgend der weiteren Siedlungsentwicklung bis hin zum modernen Städtebau wird die Thematik der Siedlungsgeschichte in ihrer Verbindung zum Wasser skizziert. Insofern ist es ein Beitrag zur genetischen Siedlungsgeographie.

Im Mittelpunkt meiner gewässerhistorischen Untersuchungen stehen, wie bereits gesagt, die aus den menschlichen Nutzungen resultierenden Landschaftsveränderungen und deren Ergebnis: künstliche Anlagen der Wasserhaltung, des Wasserstaues und des Wasserüberfalles. Die Formen und Typen der künstlichen Wasserbespannung werden dabei, ihrer kulturhistorischen Bedeutung entsprechend, in diesem Kontext besonders hervorgehoben. Doch um zum einen den ökologisch gewollten Fortgang der natürlichen Sukzession von Gewässern zu verlandetem Feuchtgrünland durch gewässerwirtschaftliche Rekultivierungsmaßnahmen anzuhalten und dadurch eine kulturhistorische Gewässerlandschaft zu bewahren bzw. wiederherzustellen und um zum anderen eine historische Gewässerbewirtschaftung zu belegen, die beispielsweise im Rahmen der Museumspädagogik oder der Kulturlandschaftspflege ihre Anwendung finden könnte, sollen aufgrund dieser Intention alte teich- und fischereiwirtschaftliche Arbeitstechniken beschrieben werden. Die Einbeziehung der Wiesenbewässerung in diesen Kontext geschieht hier aus der Zielsetzung heraus, unmittelbar oder mittelbar mit kleineren Gewässern in Verbindung stehende Bewirtschaftungsformen zu dokumentieren ${ }^{7}$. Insofern ist es hier zweierlei: ein praktischer Beitrag zur Erhaltung historischer Wasserund Bewässerungswirtschaft im Rahmen historisch-geographischer Kulturlandschaftspflege wie auch ein Beitrag der Historischen Geographie zur musealen bzw. umweltpädagogischen Anwendung.

Die traditionelle geographische Komponente ist die Frage nach der räumlichen Entwicklung und Verteilung von Formen der Wassernutzung. „Die Orientierung an räumlichen Maßstäben dürfte“, wie DIX (1997:37) meint, ,ein umfassenderes Bild der Gewässernutzung zeichnen, auch im Hinblick auf den Informationsgehalt einzelner Elemente“. Zur Gewinnung neuer Einsichten lässt sich daraus die Forderung ableiten, den jeweils landschaftlichen und wirtschaftlichen Zusammenhang der Verbreitung von Gewässernutzungen sowie ihren daraus resultierenden Formen auch auf großräumlicher Maßstabsebene darzustellen. Denn „,der Anteil an noch landschaftsprägenden alten Strukturen, an Kulturlandschaftswandel oder gravierenden Umgestaltungen wie letztlich auch an Kulturlandschaftsrelikten kann sehr unterschiedlich sein, was regionalisierend zu erfassen und zu typisieren ist." (DENECKE 2000:204f.). Dieser für die Historische Geographie allgemeingültigen Aufgabenstellung DENECKEs möchte ich nachkommen mit einer regional differenzierten, großmaßstäblichen Übersicht ausgesuchter historischer Wassernutzungen. Sie wird von ihm (2001:283) als Forschungsdesiderat beschrieben: „Weitgehend nebeneinanderstehend und in den Ergebnissen auf sich bezogen ist es bisher noch kaum zu einer vergleichenden Analyse der Erkenntnisse, der Defizite, der weiterführenden und noch offenen Fragen und vor allem zur großräumigeren Bedeutung und Aussage der regionalen Exempel gekommen." Eine detailgetreue Schilderung der räumlichen Schwerpunkte an Beispielen aller Gegenden Deutschlands bzw. Mitteleuropas zu verdeutlichen würde mehrere Bände füllen und solche Karten mit den Einträgen aller gewässerbezogenen Objekte und Relikte der Wasserhaltung (Fischteiche, Bergbauteich, Kanäle, Pumpwerke) wären unübersichtlich und im Rahmen einer Einzelarbeit nicht leistbar. Deshalb gilt mein Augenmerk, um dennoch eine genügend anschauliche überblickartige Darstellung zu erreichen, vor allem den zurück gebliebenen flächenhaften und räumlich zusammenhängenden Oberflächenformen der Wasserhaltung und des Wasserstaus im deutschsprachigen Raum; doch richtet es sich zuweilen auch darüber hinaus. Insofern ist dies ein Beitrag zur deutschen (bzw. deutschsprachigen) Landeskunde.

Die Begrenzung auf eine nur dem reinen Naturschutz unterliegende Konservierungskonzeption soll nach dem hier zugrunde liegenden historisch-geographischen Leitbild durchbrochen, eine Erhaltung durch Wiederbelebung vielmehr angestrebt werden. Ob die räumliche Planung aber überhaupt auch den Beitrag der

\footnotetext{
${ }^{7}$ Wenn der Geobotaniker Heinz ELLENBERG (1986:332) sagt: „Nur soweit überhaupt Überschwemmungen reichen, rechnen wir die Pflanzengesellschaften und Böden zur Flussaue.“, so können in einer kulturlandschaftlichen Auslegung auch die vom gelenkten Flusswasser überschwemmten Wiesen (,Rieselwiesen“) im weiteren Sinne zum Auenbereich und somit zum Fließgewässer gezählt werden.
} 
Historischen Geographie und in diesem Kontext, speziell die historischen Gewässerelemente in ihre zeichnerischen und textlichen Festsetzungen mit aufnimmt, mögen einige Beispiele aus der Planungspraxis zeigen. Unter Einbeziehung vorhandener Untersuchungs- und Forschungsergebnisse werden am Beispiel von kleinen Gewässerläufen verschiedener Landschaftsräume - in der Planungspraxis aus zumeist finanzpolitischen und siedlungsstrukturellen Gründen bezogen auf Gewässerabschnitte und nicht ausgehend von der Quelle bis hin zur Einmündung - die durchgeführten und projektierten Gewässerplanungen und Renaturierungsmaßnahmen beschrieben. Dem gegenübergestellt werden die vielgestaltigen früheren anthropogenen Nutzungen und Eingriffe in Fließen und deren morphogenetische Formen, die das politische und naturwissenschaftlich begründete Leitbild einer naturnahen Gewässergestaltung in Richtung kulturhistorisches Erbe verschieben. Dieses $\mathrm{zu}$ eruieren wie auch die erhaltungswürdigen Kulturlandschaftselemente der Gewässer- und Flusslandschaften im Rahmen einer Gewässerplanung zu inventarisieren, stellt einen Beitrag zur Angewandten Historischen Geographie, hier einer anwendungsorientierten historisch-geographischen Gewässerplanung dar.

Die graphische Darstellung ehemaliger Nutzungsformen an Wasserläufen und deren aquatischen Einflussbereichen kann anhand computergestützter Geographischer Informationssysteme (GIS) erfolgen, mit deren Einsatz im Bereich der Historischen Geographie sich erst seit wenigen Jahren sowohl die Lehre ${ }^{8}$ als auch die Forschung ${ }^{9}$ beschäftigt. Zuvor erfolgte die punkt-, flächen- und linienhafte Aufnahme der Gewässerrelikte im Gelände; dies mag auch unter Zuhilfenahme der Vermessungstechnik geschehen. Dass sich eine auch anwendungsorientierte historisch-geographische Gewässerforschung niemals nur auf ein methodisches Konstrukt, sondern auf eine auch aus den Nachbarwissenschaften rezipierte Methoden- und Quellenvielfalt stützen muss, um zu hinreichenden Ergebnissen zu gelangen, ist bekannt und wird von führender Seite immer wieder hervorgehoben (siehe Kap. III), liegt aber in nur unvollständiger Form vor. Die für eine historisch-geographische Gewässerforschung bedeutsamen Quellen und Methoden seien deshalb in einem Zusammenschnitt vorgestellt. Insofern ist dies auch ein Beitrag zur modernen, das heißt methodisch um digitale und geodätische Arbeitstechniken erweiterten, Methodischen Historischen Geographie.

Neben den methodischen Rahmenbedingungen setzt die Aufnahme von historisch-anthropogenen Gewässerelementen im Rahmen historisch-geographisch orientierter Landschafts-, Gewässer- oder Stadtplanung eine Bewertung voraus, die wiederum aber erst nach eingehender Beschreibung erfolgen kann. Um dies zu erreichen, muss deshalb Folgendes gewährleistet sein: „Eine Charakterisierung, Typisierung und Abgrenzung von Kulturlandschaftseinheiten (Kulturökotopen), die vornehmlich persistent (traditionelle Landschaften, alte Landschaften, stagnierende Landschaften) oder in jüngerer Zeit neu gestaltet sind (neue rekultivierte Landschaften) - auf unterschiedlichen Maßstabsebenen, zugerichtet auf planerische und pflegerische Instrumentarien.“ (DENECKE 2000:200) Diese Typisierung und Gruppierung stellt einen Beitrag zur historisch-geographischen Terminologie und Typologiefindung dar. Eine terminologische Sicherheit konnte nämlich bislang nicht festgestellt werden. Auf der anderen Seite sind die bisherigen Begrifflichkeiten $\mathrm{zu}$ verwoben und $\mathrm{zu}$ fest gefügt, wobei vor allem biologische Klassifizierungen und Termini Zugang in den allgemeinen Sprachgebrauch gefunden haben.

Zusammengefasst verstehe ich meine Arbeit im disziplingeschichtlichen Kontext im weiteren Sinne als Beitrag zur ,interdisziplinären anwendungsorientierten historisch-geographischen Umweltforschung“ nach DENECKE (1996). Im engeren Sinne geht es hier um geographische Kulturlandschaftsforschung mit Gewässerschwerpunkt. Bei den Gewässerreliktformen handelt es sich

a. um historische, potentiell-natürliche Gewässer mit anthropogener Nutzung und

b. um anthropogen entstandene historische Gewässertypen,

die beide erst durch Einflüsse der Land-, Wald- und Forstwirtschaft, des Handwerks und Handels auf das Gewässersystem entstanden sind. Sie sind damit Ausdruck verschiedener Denk- und Wirtschaftsweisen

\footnotetext{
${ }^{8}$ Das Seminar „Historische Geographie“ in Bonn z. B. praktiziert lt. Vorlesungsverzeichnis seit SS 1999 die Vermittlung von GISTechniken.

${ }^{9}$ Die 2002 abgeschlossene Dissertation von Rolf PLÖGER sowie die 2001 beendete Magisterarbeit von Beate LANGE, beide wissenschaftlicher Mitarbeiter am Seminar für „Historische Geographie“ in Bonn mögen als Beispiele benannt werden.
} 
sowie technischer und kultureller Standards und vermitteln ein Bild über die Umweltgeschichte vergangener Epochen.

Die vielgestaltige Inwertsetzung des Wassers durch technische Kunst- und Kulturbauten der Wasserhaltung und des Wasserstaus zu dokumentieren und in den anthropogeographischen Zusammenhang des MenschNatur-Verhaltens (HAMBLOCH 1986) in früherer Zeit zu stellen, ist die zentrale Aufgabe dieser Arbeit. Die daraus abgeleiteten, künstlich geschaffenen Nutzungsformen werden als Ausdruck historischer Arbeitsweisen angesehen und hinsichtlich ihrer Bedeutung als historische Bestände unserer Kulturlandschaft beschrieben. Die Kombination aus Umweltgeschichte und Historischer Geographie einschließlich deren Nachbarwissenschaften soll einen Einblick in die Anwendbarkeit der historisch-geographischen Umweltforschung am Beispiel des Forschungsgegenstandes „Gewässergeschichte“ ermöglichen.

Aus diesem Grund beschäftigte ich mich auch eingehend mit der sequentiellen Definition dieses neuartigen Betrachtungsansatzes. Insofern ist es deshalb schließlich auch ein Beitrag zur Theoretischen Geographie.

Eine solche Abhandlung besteht bisher für das hier vorgestellte Gewässerthema nicht und für andere Untersuchungsbereiche in zu geringer Zahl, wie auch DENECKE (2000:200) findet:

„Eine historisch-geographische wie auch umweltgeschichtliche Ausarbeitung der Nutzungsgeschichte und historischer Wirtschaftsformen unter besonderer Berücksichtigung der raumwirksamen Maßnahmen einer Bewirtschaftung und früheren Strukturveränderung mit ihren jeweiligen groß- und kleinräumigen Auswirkungen. Diese Fragestellungen sind in der auf eine Kulturlandschaftspflege ausgerichteten Historischen Geographie bisher zu wenig behandelt worden, obgleich gerade von hier aus der Weg zur Landschaftspflege des Naturschutzes am direktesten gegeben ist."

\section{Gliederung und methodischer Aufbau}

Einführend möchte ich im ersten Kapitel meiner Arbeit einen disziplingeschichtlichen Überblick und eine fachliche Einordnung der historisch-geographischen Umweltforschung geben und meinen eigenen Betrachtungsansatz der historisch-geographischen Gewässerforschung verdeutlichen.

Nachfolgend soll im zweiten Kapitel der Stand der historisch-geographischen Gewässerforschung in Deutschland beleuchtet werden. Den bisherigen Veröffentlichungen gegenübergestellt wird die Historische Geographie des englischsprachigen Auslandes nach ihren Ansätzen zur historischen Gewässerforschung befragt.

Die für die gewässerhistorische Forschung zur Verfügung stehenden Quellen und Methoden werden im dritten Kapitel benannt. Neben dem klassischen Quellenstudium werden insbesondere auch solche methodischen Instrumentarien beschrieben, die zum einen für die Historische Geographie allgemein betrachtet eher neuartig sind und zum anderen speziell für die historisch-geographische Gewässerforschung eine besondere Rolle einnehmen können.

In einem vierten Kapitel möchte ich auf die Terminologie und Typologie bislang in der Literatur verwendeter Gewässersystematik hinweisen und das Beispiel einer Gewässerterminologie unter stärkerer Berücksichtigung der historisch-geographischen Perspektive formulieren.

Die Geschichte der Gewässernutzung, beginnend mit einem Abriss der natürlichen Gewässerentstehung, folgend mit der siedlungsgeschichtlichen Inanspruchnahme von Gewässern in periodischen Epochen und anschließend mit den anthropogenen Arten der Gewässernutzung wird im fünften und sechsten Kapitel dargestellt, deren bedeutendste landschaftsräumliche Wirkung unter gewässerhistorischer Perspektive die künstliche Anlage von Teichen war.

Aus diesem Grund werden in einem siebten Kapitel ausgewählte Anlagen und Elemente der historischen Gewässernutzung (Fischteiche, Mühlteiche, Bergbauteiche, sonstige Teichtypen und Wasserstauanlagen 
einschließlich Bewässerung) dargestellt. Vor allem die historische Teichwirtschaft wird umfassend beschrieben: Die nur diffus und singulär vorliegenden Erkenntnisse zur Teichwirtschaft werden zusammengefasst und strukturiert, die Teiche und ihre Varianten begrifflich gefestigt, ihre Anlagen und ihr Aufbau beschrieben. Zugleich wird mit der Darstellung der geordneten Wechselhaftigkeit bei der Fischteichbewirtschaftung mit dem tradierten Vorurteil der landwirtschaftlichen Eindimensionalität in der Teichwirtschaft aufgeräumt.

In einem regionalen Teil werden im achten Kapitel die aus den historischen Wassernutzungsarten abgeleiteten Wasserstau- und Bewässerungsformen in ihrer schwerpunktartigen landschaftsräumlichen Verbreitung dargestellt, die nach ihrer Massierung als Gewässergroßlandschaften zu bezeichnen sind: Die in diesen Landschaftsräumen liegenden Kleingewässer bzw. die an kleinen Wasserläufen liegenden Oberflächenformen, wie Fischteiche, Mühlteiche, Bergbauteiche und Bewässerungsanlagen, werden in unterschiedlichen Regionen Mitteleuropas nachgewiesen und ihre Nutzungs- und Entwicklungsgeschichte beschrieben.

Im anwendungsbezogenen Teil, dem neunten Kapitel, wird die Berücksichtigung historischer Gewässerelemente in der Planungspraxis untersucht. Es wird hier der Frage nachgegangen, ob diese Elemente bereits Eingang in die räumliche, naturschutzfachliche Planungspraxis und sonstige Projektarbeit gefunden haben. Überprüft wird diese Frage anhand verschiedener Planungsbeispiele aus unterschiedlichen Fachplanungsebenen. Bei Negierung des historisch-geographischen Betrachtungsansatzes werden in der Art einer vergleichenden Feldstudie kulturhistorische Gewässerelemente in diesen Planungsräumen aufgezeigt und die aus der jeweiligen früheren Gewässernutzung resultierenden Formen und Elemente inventarisiert.

Als Finis steht im zehnten Kapitel die Zukunftsperspektive des im Vorausgehenden skizzierten gewässerhistorischen Ansatzes: Der Beitrag einer historischen-geographischen Teildisziplin und eines ,zentralen umwelthistorischen ,Brückenfaches'““ (SCHENK 2003:145) zu den drängenden Gegenwartsfragen. 


\section{A FRAGESTELLUNGEN UND FORSCHUNGSANSÄTZE EINER „ANWENDUNGS- ORIENTIERTEN HISTORISCH-GEOGRAPHISCHEN GEWÄSSERFORSCHUNG“}

\section{Disziplintheoretische Einordnung im Rahmen der Umweltforschung}

„Die Geographie hat wiederholt versucht, sich ihre Geschichte zu schreiben, im Grunde aber fehlt sie noch. Das ist verständlich aus ihrer besonderen Situation; denn sie ist eine totalisierende Wissenschaft; in ihr strömen Geologie, Paläontologie, Bodenkunde, Geomorphologie, Botanik, Zoologie, Anthropologie, Soziologie, ja sämtliche Geisteswissenschaften bis hinein in die Religionswissenschaften zusammen.", schreibt Martin SCHWIND 1964 (b:29) und diese Aussage hat nichts an Aktualität eingebüßt. Wie man an den zahlreichen publizierten Theoriediskursen ablesen kann, wäre die Aufzählung vielmehr um einige weitere Fächer zu ergänzen.

Die stete Auseinandersetzung mit der theoretischen Geographie ist eng mit der - vielleicht manchmal etwas nervenden - disziplinimmanenten Diskussion über Richtung, Stellenwert und Raumbezug der Geographie verbunden. Diese Standortbestimmung halte ich dennoch für überaus wichtig im Sinne einer „Theorie als Basis der ,eigentlichen' Arbeit“ (BOESCH 1989:11) und erst recht dann, will man sich an der disziplintheoretischen Diskussion zur Einordnung eines neuen Forschungsfeldes beteiligen.

DENECKE erhebt gar in seinem 1999 gehaltenenen und 2001 veröffentlichten forschungsgeschichtlichen Rückblick auf 25 Jahre „Arbeitskreis für genetische Siedlungsforschung in Mitteleuropa” schwere Vorwürfe gegen die nicht stattfindende Durchführung solcher Diskussionen, für ihn umso unverständlicher vor dem Hintergrund des bereits länger währenden gemeinsamen disziplinären Austausches: „Interdisziplinäre Diskussion und breit angelegte Information auf dem Gebiet der genetischen Siedlungs- und Kulturlandschaftsforschung haben vielfältige Forschungsrichtungen angeregt, gefördert und geprägt, frei und sachbezogen, allerdings auch weitgehend ohne eine Verfolgung wissenschaftstheoretischer Paradigmen und Diskurse.“ (:272) Die Notwendigkeit einer solchen Theoriediskussion besteht nach seiner Ansicht im internationalen Vergleich umso dringender, als dass „eine theoretische Grundlegung historischgeographischer Betrachtungsansätze [...] in Deutschland - im Vergleich zur englischen und amerikanischen Historischen Geographie - nur in wenigen Ansätzen vertreten und kaum paradigmatisch wirksam“ ist (:292). Aus diesem Grund werden in diesem Kapitel des Theoriediskurses auch gerade anglo-amerikanische Aussagen zur theoretischen Fundamentierung hinzugezogen, die, um Sprachverzerrungen zu vermeiden, im Original wiedergegeben werden. Aus dieser Situation jedenfalls zieht DENECKE (:291) das für die weitere Entwicklung dunkle Resümee, dass ,die Historische Geographie [...] in bezug auf ihre Stellung im eigenen Fach wie auch im Rahmen der interdisziplinären Partnerschaft in eine Zwickmühle geraten [ist], aus der nur sehr schwer Auswege zu erkennen sind.“

Um den Beitrag einer "historisch-geographischen Gewässerforschung" innerhalb des Faches der Historischen Geographie und ihr Selbstverständnis sowohl in der Lehre als auch in der Anwendungpraxis zu verstehen und für einen disziplinären Teilbereich einen perspektivischen Lösungsweg aus der scheinbar ausweglosen, zumindest aber bedrohlichen Positionierung aufzuzeigen, ist deshalb eine Auseinandersetzung mit der disziplingeschichtlichen Stellung innerhalb der Geographie zwingend notwendig. Dies bedingt zunächst auch den Versuch, eine Einordnung der historischen Gewässergeographie in das übergeordnete Wissenschaftsprinzip vorzunehmen, ohne sich in wissenschaftstheoretische Überlegungen allzu sehr zu verlieren.

\section{Die „Geographie” im Disziplingebäude der ,allgemeinen Umweltforschung”}

\section{a Die Geographie als Geosystemlehre und integrative Umweltwissenschaft}

„Der Geograph”, so die häufig vorgetragene Kritik und andauerndes Vorurteil, ,ist bis heute zu sehr der wörtlichen Bedeutung seines Faches ${ }^{[1]}$ verbunden geblieben: Er beschreibt mit Vorliebe Zustände und

\footnotetext{
${ }^{1}$ Griech. geo = Erde; graphein $=$ schreiben
} 
analysiert die Gründe, die zu einem Zustand geführt haben. Der spekulative Gedanke, der allein in die Zukunft weisen kann, wird vernachlässigt”, so MÄDER 1986 (:416). Ebenso zu hören anlässlich eines telefonischen Vorstellungsgespräches mit dem Leiter des Sachgebietes Stadtentwicklung bei der Stadt Freiburg im Breisgau im Jahr 2002; vor dem Hintergrund meiner dort eingegangenen Bewerbung, die aus diesem Grund nicht zu einer persönlichen Einladung geführt hat.

Doch wie sähe ein solches Zukunftsszenario aus, in einer Welt, in der „Umwelt- und Landschaftszerstörung und die Schwächung der Qualität der scheinbar nur äußeren Heimat Folgen für die Innenwelt des Menschen - für seine innere Heimat hat” und „räumliche Orientierungslosigkeit, das Vernachlässigen und Vergessen von Bezugsräumen [...] sichtbar und unüberhörbar zu innerer Orientierungslosigkeit und geistiger Heimatlosigkeit” führt? (RIEDEL 1987:562). Doch welche (Umwelt-) Veränderung bewirkt denn eine ,auf Mutmaßungen beruhende Erwartung“, wie Zukunftsprognosen definiert werden - weist sie wirklich in die Zukunft oder zerstört sie nur voreilig Geschichte? Sollten auch Spekulationen, in philosophischer Hinsicht verstanden als „Vernunftstreben nach Erkenntnis jenseits der Sinnenwelt“ (DUDEN, Bd. 1), innerhalb der Geographie nicht Spekulation bleiben, solange man beispielsweise Kulturlandschaft in statu nascendi noch beobachten und sinnlich erfahren kann?

Auf der anderen Seite habe ich in meiner Diplomarbeit verschiedene prognostische Szenarien suburbaner Entwicklung am Beispiel des Verdichtungsraumes Halle-Merseburg-Leipzig aufgezeigt (BRÜHÖFNER 1992) und sehe mittlerweile die Spekulation gewordene Realität.

Interessant ist vor diesem Hintergrund der divergierenden Rezepte - bodenständige Analytik versus Zukunftsforschung - die seit vielen Jahren wiederkehrend gestellte und niemals zufriedenstellend beantwortete wissenschaftstheoretische Frage, "what kind of geography matters"? (MASSEY et al. 1999:12, Hervorhebung im Original) Beispielsweise eine Inventarisierung von historischen Kulturlandschaftselementen als Beitrag eines präventiven Kulturlandschaftsschutzes oder eine perspektivische Zustandsbeschreibung vermutlich hässlicher Zukunftswelten? - Anders formuliert: Naturalistische Landschaftsmalerei versus abstrakte Moderne? Wer von beiden liefert aufrüttelnde Einsichten und bewirkt ein Umdenken zur kulturlandschaftlichen Nachhaltigkeit und lebensräumlichen Prävention?

Fest steht zunächst: „Die Geographie ist eine beschreibende, darüber hinaus aber auch analysierende und erklärende Wissenschaft." (DENECKE 1989c:51) und vereint damit beide "Kunstrichtungen”. Die geographischen Fragestellungen erfordern nach TREPL (1978:52) für die Zukunftsforschung geradezu Beschreibungen und Klassifikationen, denn diese Beschreibungen und Klassifikationen bilden nach seiner Meinung die Grundlage für Versuche erklärender Theorien bzw. Beschreibungen vermuteter Prozessabläufe aus der Perspektive der Beziehung des Menschen zu seiner natürlichen Umgebung. Die traditionelle und traditionsreiche Geographie als Erd- und Landschaftsbeschreibung ist aber eben auch und heute gar zunehmend „Schilderung von Landschaftszerstörung” sowie eines ,allmählichen Kulturlandschaftswandels” (RIEDEL 1987:561) und verschließt sich damit, den Wandel weitergedacht, auch nicht der Prognostik.

Doch vielleicht liegt die zukünftige Bedeutung des Faches Geographie auch dazwischen oder, um mit EISEL/SCHULTZ (1997:9) zu sprechen: „Die Tiefe des geographischen Denkens liegt in der Widerspruchsbindung zwischen Wissenschaft und Ästhetik, zwischen Modernismus und Antimodernismus, zwischen Kontemplation und Planung, zwischen Verstehen und Erklären, zwischen Raum und Gesetz, Begriff und Bild, zwischen Physiognomie und Funktion". Geographen, so mein Selbstverständnis in Überstimmung mit Doreen MASSEY (1999:17), ,are by no means the only group responsible for constructing either hegemonic or critical geographical imaginations [...]. It is one element of the responsibility of being a geographer."

Die Schwierigkeiten dieser umfassenden Sichtweise und Platzbeanspruchung konnte auch die Konstituierung der Geographie als eigenständige Disziplin, die in den letzten Jahrzehnten des 18. Jahrhunderts ihren Anfang nahm, im Laufe ihres Daseins nicht auflösen. „Statt im Zuge der allgemeinen Ausdifferenzierung der Wissenschaften den Gegenstandsbereich des Faches zu begrenzen und den Erfolg in der Selbstbeschränkung der Problemstellung zu suchen, beschritt die Geographie den umgekehrten Weg, der sie immer wieder in Versuchung führte, über alle Spezialisierungen hinweg das ,Ganze', die ,Totalität' des Verhältnisses von Natur und Menschenleben aufzeigen zu wollen - mit der Konsequenz, daß sie gegenüber den anderen 
Disziplinen dazu neigte, eine superiore Rolle zu beanspruchen." (SCHULTZ 1997:188), was, nach HARD (1982), zu einer Geographie als „diffuse Disziplin” führte.

Im Zentrum des geographischen Interesses stand und steht hingegen das "materiell-physische Substrat" der Gesellschaft. Dieses umfasst zunächst die „Natur” und die „menschlichen Artefacte” (WERLEN 1986: Kap. 4.5.3). „Diese Perspektive”, so BAHRENBERG (1987:235) ironisch wehmütig, „scheint offenbar nicht ,ausrottbar' zu sein".

Der Verfasser dieser Arbeit hegt - im Gegensatz zu Vertretern der „,modernen kritischen Geographie” - nicht „die Lust an der Destruktion liebgewordener Lösungen” (EISEL/SCHULTZ 1997:10) und versteht die Geographie im Sinne von DENECKE (1997:37) als "raum- und landschaftsbezogene Wissenschaft"; wobei bereits CAROL (1967:486) eindeutig die „Geographie als Wissenschaft von der Landschaft" beschrieben hat. Denn, wie anglo-amerikanische Forscher pragmatisch erkannt haben: "geographers can take some comfort from the fact that other disciplines are at least recognizing the spatiality of human society." (DANIELS et al. 2001:2)

Diese klassische Sichtweise definiert die Geographie als ,chorologische Wissenschaft' (NORTON 1984:18). Das heißt als eine Wissenschaft, welche beliebige Dinge unter einem räumlichen Aspekt ordnet ${ }^{2}$. Da sich die Geographie mit der „Klärung räumlicher Zusammenhänge” (WIRTH 1969:184) beschäftigt, ist sie auf die Erforschung von Räumen festgelegt. Geographie ist Raumwissenschaft (NORTON 1984:17) oder wie JOHNSTON (JOHNSTON et al. 1986:175) es ausdrückt: Geographie ist ,the study of the earth's surface as the space within the human population lives." Dieses ,innergeographisch tradierte Raumverständnis“ (KÖCK 1987:179) sieht die Geosphäre als das "Realobjekt der Geographie” (KÖCK 1987:189, Hervorhebung im Original).

Die Geographie ist aber nicht nur Raumwissenschaft im Sinne von örtlicher Verteilung, Verbreitung, Anordnung der verschiedenen Objekte auf der Erdoberfläche, sondern auch die Wissenschaft von der Erfüllung der Räume. Prägnant gesagt: „Sie ist Raumwissenschaft, wie die Geschichte Zeitwissenschaft ist” (HETTNER 1927:124,125; aus BAHRENBERG 1987:227, Hervorhebung im Original). Der Raum und die räumliche Ausprägung sozio-ökonomischer Prozesse sind ,das eigentliche Forschungsobjekt der Geographie” (MÜCKE 1988:96). Der Raum wird dabei gesehen als das „Produkt menschlicher Handlungen” $(: 98)$.

Wenn auch der die Disziplin identifizierende „Gegenstand“ der Geographie nunmehr verortet zu sein scheint, so sind aufgrund der Komplexität des Raumes die Betrachtungsebenen vielschichtig und erschweren eine generelle disziplinäre Klammerung, denn ,geography occupies a puzzling position within the traditional organizations of knowledge. It is neither a purely natural science nor a purely social science." (JOHNSTON et al. 1986:175) In dieser Zwitterstellung der Geographie sieht COONES (1992:74) gar ,its identity as a distinct, coherent and unified discipline, addressing itself to the interaction of communities and environments as manifested in the character of places."

Aus diesem Zusammenspiel von Raum, Natur- und Sozial- bzw. Kulturwissenschaften fasst JOHNSTON (JOHNSTON et al. 1986:176), ,three essential geographical characteristics” zusammen:

"1. The first characteristic is an emphasis on location. Geography is concerned with the locational or spatial variation in both physical and human phenomena and the Earth's surface.

2. A second characteristic is geography's ecological emphasis on society-land relations. Here the stress is on the interrelations of phenomena, the links between aspects of the natural environment of a particular area and the human population occupying or modifying it.

3. A third characteristic of geography is regional analysis in which the spatial and ecological approaches described under (1) and (2) are fused."

\footnotetext{
${ }^{2}$ Zur Geographie-Diskussion siehe auch die Beiträge in Geographica Helvitica, Nr. 4/1981 und Nr. 1/1982
} 
Zusammengefasst kennzeichnen also der regionalwissenschaftliche Ansatz, als der den natur- und kulturräumlichen sowie den umweltökologischen und umwelthistorischen Ansatz vereinende anspruchvollste geographische Betrachtungsansatz, wie aber auch die einzelnen aufgezählten Ansätze für sich genommen, den Charakter der Geographie: Die Geographie ist demnach nicht nur eine singuläre Raumwissenschaft, sondern vielmehr eine „Geosystemlehre” (HAMBLOCH 1986:7), d. h. die Lehre von den „zwischen den Systemelementen bestehenden Übertragungs-, Austausch- und Wechselbeziehungen, die den Prinzipien von Ursache und Wirkung, Reiz und Reaktion sowie Signal und Antwort folgen." (:8f.). So kann auch ein so klassisches geographisches Arbeitsfeld wie das Werden der Kulturlandschaft nur in einem Systemzusammenhang betrachtet werden (FEHN 1997:17). Aber auch die Fragen nach den Veränderungen des Naturhaushalts durch den Menschen ergeben sich erst im geosystemaren Zusammenhang (HAGEL 1988:131).

Für den Geographen ist es deshalb wichtig, unabhängig von den verfolgten Ansätzen, ,das Zusammenwirken [...] vieler solcher Kräfte, die Überlagerungen verschiedenster Prozesse - kurz die Wechselwirkungen und die Wirkgefüge im Raum zu erkennen.” (HAMBLOCH 1986:9). Denn „wenn der Geograph“, wie HAMBLOCH (:12) argumentiert, ,sich mit der räumlichen Struktur und den raumwirksamen Prozessen im globalen Ökosystem und seinen regionalen Subsystemen beschäftigt, kann er den Menschen nicht ausklammern", weil, wie auch JÄGER (1994:11) ausführt, in unserer realen Welt die anthropogenen Faktoren eng mit den natürlichen interferieren.

Es müssen daraus folgernd in der Geographie, so NIEMEIER (1977:13) mit seiner noch immer aktuellen Einweisung in das Fach, ,die gestaltenden Kräfte erkannt werden, der motorische Hintergrund, der sich aus dem komplizierten Kräftespiel von geographischer Lage, naturräumlicher Ausstattung, Funktionen und Genese ergibt. Dazu gehören auch Wirkungszusammenhänge". Es ist folglich eine eigenständige, von anderen Disziplinen zu unterscheidende geographische Betrachtungsrichtung, ,wo der Mensch nicht nur das erkennende Subjekt, sondern zugleich das in seinem Handeln zu erkennende Objekt ist" (HAMBLOCH 1986:10).

Dabei kann man die disziplintheoretische Entscheidung, ob Geographie denn nun zu den Natur- oder zu den Geisteswissenschaften zählt, "für zweitrangig, wenn nicht gar für falsch" halten "gegenüber der Feststellung, daß sie vor allem eine Systemwissenschaft ist" (HAMBLOCH 1986:7,12). Wichtig sind vielmehr in diesem Zusammenhang "die Probleme, nicht die inhaltlichen und methodologischen Abgrenzungsversuche eines Faches" (:12).

Bereits für BANSE (1953:93) ging es „,fernerhin nicht mehr an, den geographischen Gesamtstoff in einen naturgeographischen (physiogeographischen) und menschengeographischen (anthropogeographischen) Teil aufzuspalten, sondern der Stoff muß einheitlich um zwei Brennpunkte gruppiert werden, Landschaft und Volkheit, deren jeder sowohl natur- wie geisteswissenschaftliche Erscheinungen umfaßt und verarbeitet. Nur so verstanden, erhält die Geographie ganzheitlichen Charakter und darf es wagen, sich im System der Wissenschaften ebenbürtig neben die Philosophie zu stellen.“, und nennt sie deshalb eine ,universale Wissenschaft" (obschon er zu diesem Zeitpunkt der Geographie zwar zwischen einer Wirtschaftsgeographie, Siedlungs-, Kultur-, Politischen und sogar einer Wehrgeographie differenziert, aber eine Historische Geographie nicht kennt; höchstwahrscheinlich, weil diese zu dem Zeitpunkt die maßgebende inhaltliche Ausrichtung der Kulturgeographie und ihrer Teildisziplinen schlechthin war [vgl. SCHWIND 1964a:15].

Die langjährige Dichotomie der Geographie, die Trennung zwischen Physischer Geographie und Kulturgeographie und darin der einzelnen physisch- oder kulturgeographischen Teildisziplinen, erscheint zudem auch vor dem Hintergrund der realen Umweltentwicklung obsolet, denn ,angesichts der aktuellen Umweltsituation" müsste in allen Disziplinen "die Interdisziplinarität [...] hohe Priorität genießen" (ANDERSEN 1993:680f.) und nicht „,monodisziplinäre Lösungsansätze” (MÜLLER-HOHENSTEIN 1995:271) verfolgt werden; obgleich auch der Ruf nach Interdisziplinarität innerhalb der Geographie in neuerer Zeit nicht überall uneingeschränkt Zustimmung findet und diese für die Weiterentwicklung der eigenen Disziplin bestehenden Gefahren durchaus vorhanden sind.

Als Anlass der geographischen „Reformation“ hin zu einer interdisziplinären Betrachtungsweise führt BÄTZING die Umweltbewegung an, die bereits zu Anfang der 70er Jahre als Reaktion auf die weltweite 
Umweltzerstörung entstanden ist. In diesem Zusammenhang wurde erstmals deutlich, „dass die analytische Zergliederung der Natur und des Menschen eine zentrale Voraussetzung der heutigen Umweltzerstörung darstellt, weil dadurch die existierenden ,Vernetzungen' nicht wahrgenommen werden können" (BÄTZING 1991:105). In der Folge entstanden Ansätze für ,integrative, holistische oder ganzheitliche Theorien, die der ,Vernetztheit' von Natur, Umwelt und Gesellschaft gerecht zu werden suchten" (:105), da es vor dem Hintergrund der zunehmenden Spezialisierung und der Umweltzerstörung ein „Bedürfnis nach integrativen Wissenschaftskonzepten” gab (:106) und dies noch immer besteht. Denn wenn Wissenschaft als ,engagierte Wissenschaft" (BOESCH 1990) nicht ihren Sinn und Zweck in sich selbst, sondern als einen Beitrag zur Lösung der Umweltprobleme unserer Welt leisten soll, „dann werden integrative Konzepte erforderlich, die die Segmentierungen und Spezialisierungen der Einzelanalyse überwinden” (BÄTZING 1991:106).

BÄTZING entwickelte aus dieser Sichtweise daraufhin das Konzept der „Geographie als integrative Umweltwissenschaft“. Gegenstand der Geographie als integrative Umweltwissenschaft ist nach seiner Meinung „die Analyse der Wechselwirkungen zwischen Mensch und Natur in ihrer räumlichen Interaktion. Dabei kommt der Verbindung zwischen Physischer und Kulturgeographie als Brückenschlag zwischen Natur- und Sozialwissenschaften die fundamentale Bedeutung zu" (1991:107), die nicht nur nach Auffassung des Verfassers dieser Arbeit lange Zeit unterbrochen schien und auch noch anhält (siehe auch DENECKE 2001:289). Denn erst, so BÄTZING (1991:108), „wenn die Geographie [...] die extreme Spezialisierung ihrer Teildisziplinen durch bewußte Einbindung in diesen Rahmen aus ihrer Vereinzelung löst, dann kann die Geographie als integrative Umweltwissenschaft eine wichtige Aufgabe bei der Lösung der gegenwärtigen Umweltprobleme übernehmen."

EGLI sieht die geographische Positionierung in ähnlicher Weise in die Umweltfächer integriert, wenn er ausführt: die „Geographie als prozeßorientierte Umwelt-Wissenschaft beschäftigt sich mit der physischmateriellen Umwelt des Menschen, deren Untersuchung unter einer doppelten Perspektive erfolgt: als Voraussetzung und Beschränkung des Menschen und seiner kulturellen Entwicklung und als Produkt und Ergebnis wirtschaftlicher, sozialer und politischer Prozesse.” (1997:64)

Bei dieser über die Einbindung als Umwelt-Wissenschaft funktionierenden Hinwendung zu einer, wie MÜLLER-HOHENSTEIN (1995:271) es formuliert, ,problemorientierten Umweltforschung” wird deutlich, „daß die Geographie [...] zu aktuellen Umweltproblemen eine wichtige, von keiner anderen Disziplin zu übernehmende Rolle spielt." (1995:271).

„Doch die Geographie ist nicht zur Leitdisziplin der modernen Wissenschaftsentwicklung geworden” (BECKER 1998:34); stattdessen ist die Ökologie zur ,'Leitwissenschaft' von Umweltforschung und Ökologiebewegung aufgestiegen“ (TREPL 1987:226, zitiert aus BECKER 1998:34) und so bleibt der Wunsch MÜLLER-HOHENSTEINs bislang unerfüllt.

Damit die Geographie „zu den wichtigsten Wissenschaftsbereichen für die Lösung von Umweltproblemen” (MÜLLER-HOHENSTEIN 1995:275) aufsteigt, muss der Geographie als Geosystemlehre und integrative Umweltwissenschaft eine phänomenologisch-hermeneutische Theorie zugrunde liegen. Sie darf sich nicht als eine in sich geschlossene, isolierte Fachrichtung betrachten, sondern als eine offene Umweltwissenschaft, die eine disziplinüberbrückende Funktion übernimmt. „Im Rahmen eines solchen Verständnisses von Umweltwissenschaft könnte auch die Geographie eine neue gesellschaftliche Aufgabe und Bedeutung erhalten: [...] ,Raum' als den Bereich, in dem Mensch und Natur, besser: naturräumliche Dynamik und menschliche Handlungen aufeinander treffen und sich wechselseitig beeinflussen und verändern." (BÄTZING 1991:107)

Gegenstand der Geographie als integrative Umweltwissenschaft und Geosystemlehre wäre also die Deskription und Analyse der Wechselwirkungen zwischen Mensch und Natur in ihrer räumlichen Interaktion. Dabei käme der Verbindung zwischen Physischer, Kultureller und Historischer Geographie als Brückenschlag zwischen Natur-, Sozial- und Geschichtswissenschaften eine fundamentale Bedeutung zu, denn die Geographie ,mit ihrem ganzheitlichen, Gesellschaft und Natur umschließenden Forschungsansatz und Theorienanspruch” (SCHOLZ 1995:269) besitzt hier ihr ,zentrales Forschungsfeld” (:269). 
Mit dieser disziplinären Manifestation wird am Ende dieses Kapitels die Anfangsfrage nach der Zukunftsfähigkeit der Geographie wieder aufgegriffen und mit den Worten DANIELS' selbstbewusst beantwortet: "geography in its broader definition provides a unique interface between the human and the natural worlds. Without being too pompous, we would argue that geography is the discipline for the twentyfirst century, because many of the challenges that face humankind are at that interface between human societies and natural environments." (DANIELS et al. 2001:2, Hervorhebung im Original)

\section{b Perspektiven und Ansätze der „Umweltwissenschaften“ und Fragestellungen der „Umweltforschung“}

All die Fachbereiche, die sich aus Sicht der Umweltforschung und des Umweltschutzes sowie der Umweltpolitik und der Umweltplanung mit den Zusammenhängen der Umwelt aus disziplinärer Sicht separativ und integrativ beschäftigen, werden unter dem Fach „Umweltwissenschaften“ subsumiert. Oder, wie BECKER (1998:33) es einfach in Auflösung des Wortstammes ausdrückt: „Die Umweltforschung will die Umwelt des Menschen erforschen".

Das Fach Umweltwissenschaften umfasst dabei ,alle Wissenschaften, die sich mit unserer physikalischen und organischen Umwelt beschäftigen, und reicht von der Geographie und der Geologie bis zur Ökologie und der Evolutionstheorie.” (BOWLER 1997:V) und „wie in anderen Wissenschaftsbereichen auch können umweltwissenschaftliche Ansätze prinzipiell deskriptiv, analytisch und normativ geprägt sein." (BRANDT 2000:58)

Die Aufgabenstellung der Umweltwissenschaften wird begründet ,in den Anforderungen der unmittelbaren täglichen Praxis: umweltgerechtes Wirtschaften, Setzen und Durchsetzen von Rechtsnormen des Umweltschutzes, Umweltbildung für die Menschen [...]” (STAMM 2000:33). „Die Umweltwissenschaften sollen helfen”, so STAMM (2000:17) mit hohem Anspruch an anderer Stelle weiter, ,die Umweltkrise zu meistern."

Aber „die Definition dessen, woraus die Umweltwissenschaften eigentlich bestehen, muß noch genauer erarbeitet werden." (O'RIORDAN 1996:3). AMELUNG (2000:35) beispielsweise möchte zwar den Begriff Umweltwissenschaften klären und widmet dem ein ganzes gleichlautendes Kapitel in seinem Aufsatz „Einsichten aus der Geschichte der Umweltwissenschaften zum Problem des interdisziplinären Arbeitens”, doch wird eine konkrete Beschreibung nicht gegeben.

Ein sich anbietender Ausgangspunkt, um die Umweltwissenschaften auf anderem Wege als dem einer Definition zu beschreiben, ist die Darstellung der Aktivitäten und Institutionen auf dem Gebiet der Umweltforschung. Die Durchsicht der Aufgaben und Aktivitäten der Deutschen Forschungsgemeinschaft (DFG) lässt zumindest die Schwerpunkte der Umweltforschung sichtbar werden. Die hier dokumentierte deutsche akademische Umweltforschung wird durch verschiedenste wissenschaftliche Disziplinen bestritten. Die historische Dimension der durch die DFG geförderten Umweltforschung wird in Punkt II 1 ,Forschungsstand' beschrieben.

Angesichts dieser Vielzahl an unterschiedlichen Umweltforschung betreibenden Umweltwissenschaften ist „unser gegenwärtiges Verlangen, eine einheitliche Gruppierung der Umweltwissenschaften zu entwickeln“ (BOWLER 1997:2) zur Aussichtslosigkeit bestimmt. „Das heißt”, um mit BÄTZINGs Worten zu sprechen (1991:106, Hervorhebung im Original), ,es gibt nicht die Umweltwissenschaft als ökologische Super- oder Metawissenschaft, sondern eine Reihe von umweltrelevanten Wissenschaften, die auf integrative Weise jeweils unterschiedliche Teilbereiche der Ganzheit thematisieren und die formal alle nebeneinander stehen, weil die Ganzheit als Ganzes nicht wissenschaftlich analysierbar ist."

In gewisser Weise sind die Umweltwissenschaften deshalb „eine künstliche Kategorie - eine Ansammlung verschiedener Spezialgebiete, die nur über die öffentliche Sorge um die Umwelt verbunden sind." (BOWLER 1997:VI) Die Einheit der Umweltwissenschaften entsteht aber „nicht in den Wissenschaften selbst” (:1). Sie ist vielmehr, so BOWLER (:1) kritisch, ,erzwungen, weil das öffentliche Bewußtsein wächst, daß wir die Umwelt durch unsere eigenen Aktivitäten gefährden." 
Es wird dabei unterstellt, dass Fachgebiete, welche sich als Angehörige der Umweltwissenschaften bezeichnen, von einem holistischen, ökologischen Ansatz ausgehen, der sowohl den Grundsätzen der Landschaftsökologie, der Umweltethik, der ökologischen Planung als auch der ökologisch-orientierten Politik Rechnung trägt. Es kann weiterhin als dessen Selbstverständnis angenommen werden, dass Umweltwissenschaftler Umweltforschung betreiben und dementsprechend ausgerichtete Arbeiten in die Forschung einbringen. Auch ,die Rekonstruktion der Ursprünge der Umweltforschung ist nicht nur Gegenstand der Wissenschaftsgeschichte und damit der Fach- oder Wissenschaftshistoriker, sondern gehört ebenso zum Forschungsgegenstand der Umweltwissenschaftler.” (DASCHKEIT 1998:51)

Der Begriff "Umweltforschung" ist jedoch in der Fachliteratur nicht klar definiert. Er präsentiert sich vielmehr ebenso wie der Begriff "Umweltwissenschaften" als eine etwas unscharfe Bezeichnung für unterschiedlichste Forschungsrichtungen fast aller Fachbereiche und -disziplinen, die sich mit der biotischen und abiotischen Umwelt, insbesondere der Umwelt des Menschen, der Umweltbeeinflussung und den daraus resultierenden ökologischen, ökonomischen und sozialen Folgen aus zeitlich differenter Perspektive (historischer, gegenwärtiger und zukünftiger) beschäftigen. „Immer noch gibt es zuviel ,Natur'- und ,Umwelt'-Tagungen, die in Wirklichkeit kein Thema haben, und wo jeder das, was er eh und je gemacht hat, zur ,Umweltforschung' deklariert.” (RADKAU 1994:20).

Die Bezeichnung „Umweltforschung“ geht ursprünglich zurück, so ist allgemein zu lesen, auf den Vegetationskundler und Botaniker Jacob VON UEXKÜLL, der in den 1930er Jahren in Hamburg das Institut für Umweltforschung gründete und die erstmalige Namensgebung für sich in Anspruch nehmen darf. Den Ansatz einer Umweltforschung reduzierte UEXKÜLL aber auf die Erkundung tierpsychologischer Umweltwahrnehmung (zum Begriff „Umwelt” siehe 1c), während die Bausteine der modernen Umweltforschung mehrheitlich einen ökosystemaren Hintergrund haben. Die eigentliche Herkunft und Bedeutung des Wortes „Umweltforschung“ aber wurde - es ist anzunehmen, aufgrund seiner zeitgemäßen Brillanz und inhaltlichen Schwere - ökologisch aufgeweitet, zugleich aufgeweicht, bisweilen missbraucht, vereinnahmt und auch vergessen.

So sieht MERKEL (1998:VII) beispielsweise, aus nicht näher erläuterten Gründen, die Konzeption einer Umweltforschung im Jahr 1978 entstanden. Die Idee der Umweltforschung beruht nach ihrer Auffassung „,neben einem ökologischen Bewertungssystem auf folgenden sich wechselseitig ergänzenden Bausteinen eines ökologischen Informationssystems: der grundlagenorientierten Ökosystemforschung und der planungsorientierten ökologischen Umweltbeobachtung einschließlich der Umweltprobenbank".

Wie diese Begriffsbestimmung, was Umweltforschung erforscht bzw. beinhaltet, zeigt, besitzt die Struktur einer solchen Umweltforschung zum einen eine ,grundlagenbezogene, überwiegend naturwissenschaftlichökologische Orientierung” (SCHRÖDER/DASCHKEIT 1998:1). Sie ist aus der Geschichte des „Global Change" hervorgegangen, das die Rahmung der Umweltdebatte in den 1970er Jahren darstellte (BECHMANN/FREDERICHS 1998:13). Die naturwissenschaftliche Umweltforschung unterstellt dabei, die menschliche Gesellschaft ließe sich aus der Perspektive der natürlichen Systeme beobachten: die Menschen und ihre Gesellschaften als Umwelt der natürlichen Systeme (BECKER 1998:45). „Doch die natürlichen Systeme", so BECKER (:45) in Umkehr der mehrheitlich anzutreffenden naturzentrischen Sichtweise, „beobachten nicht die Gesellschaft, sondern die Gesellschaft beobachtet die natürlichen Systeme beispielsweise mit den Mitteln der Ökosystemforschung”.

Diese beiden unterschiedlichen, geschichtlich gewachsenen Positionen des Natur-Mensch-Systems innerhalb der Umweltforschung werden auch in einer disziplintheoretischen bzw. -methodischen Zweiteilung von MÜLLER-HOHENSTEIN deutlich:

MÜLLER-HOHENSTEIN (1995:274) differenziert zwischen „Umweltforschung im weiteren Sinn“ und „Umweltforschung im engeren Sinn” und beschreibt die beiden Gruppierungen anhand von symbolhaften Personen. Als Forscherpersönlichkeiten der weiteren Umweltforschung sieht er beispielsweise Alexander von Humboldt, der „,von den beschreibenden Ansätzen der Geographie zu weiterführenden erklärenden Aussagen” gelangte, „Zusammenhänge sah” und „Gesetzmäßigkeiten erkannte” und den Vergleich zu einer wichtigen Methode erhob (:272). Und nachfolgend Carl Troll, der an einem, ,integrierenden, möglichst 
umfassenden Ansatz" (:272) festhielt und zeitliche sowie räumliche Abfolgen (Sukzessionen) miteinander verknüpfte.

Die engere Umweltforschung dagegen schließt ,den Menschen Ökosystem-verändernd und -belastend in die Untersuchungen" ein (MÜLLER-HOHENSTEIN 1995:274). Als Vertreter dieser interdisziplinären Ökosystemforschung nennt er Karl-Friedrich SCHREIBER, Professor für Landschaftsökologie und ehemaliger Direktor des Instituts für Geographie an der Universität Münster und eigentlich Agrarwissenschaftler der Universität Hohenheim, ,als wegweisenden, mit der Geographie bzw. Landschaftsökologie beschäftigten Forscher” (:273). Er sieht die neuere (im Sinne von „engere“) Umweltforschung als „nicht teilbaren festen Verbund von biotischen und abiotischen Kompartimenten" (:276) und bezieht damit eine eindeutig kulturökologisch-zentrierte Position der Umweltforschung, die in ihrem ökologisch fundierten Systemansatz den Menschen nicht ausklammert.

Im Gegensatz dazu steht die hier abzulehnende Auffassung von DASCHKEIT (1998:51), Gegenstand der „Umweltforschung im eigentlichen Sinne” sei „die natürliche Umwelt des Menschen, teils mit, teils ohne Einschluß der wirtschaftenden Tätigkeiten des Menschen". Einen großen Teil der begrifflichen Konfusionen in der Umweltforschung glaubte man dadurch auflösen zu können, dass zwischen einer Natur- und einer Anthroposphäre unterschieden wird (BECKER 1998:46). Eine Umweltforschung, welche die strikte Trennung der Sphären des Natürlichen und des Gesellschaftlichen verfolgt, kann die tatsächliche Umwelt der Menschen und ihrer Gesellschaften nicht untersuchen. Für die Umweltforschung in dem hier verstandenen Sinne stellt sich deshalb nicht nur die Aufgabe, ökologische, sondern auch soziale und ökonomische Sachverhalte in ihrem Zusammenhang zu erforschen (BECHMANN/FREDERICHS 1998:7,8).

Dies zwingt nach BECHMANN/FREDERICHS (1998:8) ,zu einem interdisziplinären und integrativen Ansatz in der Forschung”, den SCHRÖDER/DASCHKEIT (1998:1) auf ihrem Buchtitel als ,integrative Umweltforschung" bezeichnen und damit als eigenen Forschungsansatz deklarieren.

Zwei Wesensmerkmale „einer sich heute neu formierenden Umweltforschung“ stellen BECHMANN/ FREDERICHS (1998:8) in diesem Zusammenhang heraus:

1. Umweltprobleme müssen in globaler Perspektive thematisiert werden und verweisen somit auf einen integrativen, interdisziplinären Ansatz.

2. Die Natur wird nicht mehr als etwas von der Gesellschaft Getrenntes angesehen, sondern die Art des Umgangs mit ihr stellt eine gesellschaftliche Entscheidung dar.

Während der zweite Punkt die Quintessenz des zuvor Gesagten bedeutet, wird hier mit der ersten Aussage die ökologisch determinierte Disziplinausrichtung der Umweltforschung aufgebrochen und interdisziplinär erweitert. Die Autoren verstehen unter Interdisziplinarität „,nichts anderes [...] als die Koordination von Entscheidungsprozessen zur Organisation und Integration von Wissensbeständen und Forschungsaktivitäten.” (BECHMANN/FREDERICHS 1998:10) In Bezug auf die hier anzusprechenden Fächer begrenzt hingegen DASCHKEIT (1998:51) die fachliche Auswahl und versteht „unter Interdisziplinarität in der Umweltforschung die Kommunikation und Kooperation von Natur- und Sozialwissenschaften“. Auch BECKER (1998:31) sieht „eine integrative, Natur- und Sozialwissenschaften umgreifende Umweltforschung“.

Es ist für DASCHKEIT (1998:51) ,charakteristisch, daß die Begriffe ,Umweltforschung' und ,Interdisziplinarität' zumeist in einem Atemzug genannt werden. Das hat seinen - historischen - Grund in der frühzeitigen Erkenntnis, daß man dem Gegenstand der Umweltforschung [...] mit einer isolierten Betrachtungsweise nicht näher kommt." Die Forderung nach Interdisziplinarität ist nach BECHMANN/ FREDERICHS (1998:12) sogar ein Eingeständnis dafür, „daß das Erfolgsprinzip der neuzeitlichen Wissenschaft, nämlich Leistungssteigerung durch disziplinäre Arbeitsteilung, gegenüber den neuen Problemthemen versagt" hat. Die bestehende Disziplinenvielfalt - „die ja durchaus Vorteile mit sich bringt” (DASCHKEIT 1998:55), differenzierte sich im Zuge des Wachstums der Wissenschaft und des Wissenschaftssystem insgesamt immer weiter aus, „was zu der heute kaum noch überblickbaren Fülle von Einzel- und Subdisziplinen geführt hat." (:54) 
All die integrativ konzipierten Einzelwissenschaften gehen von der Komplexität der Gegenwart bzw. ihres Untersuchungsgegenstandes aus, um dann daraus schwergewichtig spezifische Teilbereiche zu thematisieren, „ohne aber die übrigen Beziehungen total auszublenden” (BÄTZING 1991:107), denn natürlich hat die zunehmende Spezialisierung in allen Disziplinen dazu geführt, dass jeweils nur Teilsysteme untersucht werden können (MÜLLER-HOHENSTEIN 1995:276). Doch auch eine partielle bzw. sektorielle Umweltforschung beinhaltet immer das Diktat der Geosystemlehre: die Unteilbarkeit (:275). So ist es das Ziel integrativer Umweltforschung „Komplementarität von Disziplinarität und Interdisziplinarität“ zu erreichen (DASCHKEIT 1998:55).

Interdisziplinarität lässt sich dabei als ein „Schlüsselwort gegenwärtiger und zukünftiger Umweltforschung“ begreifen (BRANDT 2000:52): „Mit Hilfe dieses Begriffs sollen Grenzen und Abgrenzungen zwischen Institutionen, Fachbereichen und Disziplinen überwunden werden und dies mit der ohne weiteres einsichtigen Begründung, daß auch in der realen Umwelt alle Disziplinen miteinander verwoben sind und komplexe, nichtlineare Problemlösungen benötigt werden."

Interdisziplinarität ist aber „nicht nur eine Frage der Integration” (O’RIORDAN 1996:4), „,nicht nur eine Sache verstärkt integrierender Theorien und größerer Verschmelzung der Disziplinen” (:8). Sie ist „die Basis für einen neuen Weg, Umweltprobleme zu erkennen, zu charakterisieren, zu interpretieren, zu analysieren und zu lösen." (:4)

Denn sie umfasst nicht nur wissenschaftliche Forschung, „sondern auch eine fruchtbare Beziehung zwischen denen, die eigenverantwortlich handeln und entscheiden müssen, und jenen, die auf der Basis verschiedener Forschungsmethoden Entscheidungsgrundlagen aufbereiten und ihren Rat anbieten." (O'RIORDAN 1996:4) Sie zielt ,auf einen praktisch ausgerichteten Forschungsstil, der seine Themen umfassender diskutiert und mehr Beteiligung zuläßt.” (:8) Dieser, die Anwender und Praktiker in die Interdisziplinarität einbeziehende Betrachtungsansatz, trifft auch für die Umweltforschung zu. Denn Umweltforschung hat nicht nur die komplexe Beziehung zwischen gesellschaftlicher Entwicklung und Umweltveränderung zu erforschen, sondern es stellt sich ihr auch „das Problem, dieses Wissen in die Entscheidungsprozesse einzubringen." (BECHMANN/FREDERICHS 1998:9) Umweltwissen ist also „für politische Entscheidungsträger unter der Perspektive einer dauerhaften und umweltgerechten Entwicklung zu bündeln und entscheidungsbezogen zu präsentieren.” (:7f.) Diese „Rückbindung an Politik oder andere wichtige Handlungsbereiche macht sie zu einer problemorientierten, praxisbezogenen Wissenschaft" (:9). Bei Berücksichtigung dieses interdisziplinären anwendungsorientierten Ansatzes „erhält Umweltforschung einen zentralen Stellenwert im Zusammenhang mit der Modernisierung der Gesellschaft." (:9)

Doch, so fragt DASCHKEIT (1998:69) berechtigt: „Was nützt eine breit gefächerte Ausbildung, solange überwiegend Spezialisten gesucht werden und die ,Interdisziplinären' als ,All-Round-Dilettanten' verspottet werden?", wie dies beispielsweise oft von Geographen erfahren wird.

Da dem zur Zeit so ist, entstehen zukünftig "nicht nur interdisziplinäre, sondern eben auch „'transdisziplinäre' Forschungsteams, [...] die sich nicht mehr innerhalb der wissenschaftlichen disziplinären Struktur beschreiben lassen, die in Zusammenarbeit mit gesellschaftlichen Gruppen wissensbasierte Lösungen entwickeln" (BECHMANN/FREDERICHS 1996:16). Für die Entwicklung eines solchen Wissenschaftssystems ,wird zunehmend das Verhältnis zu anderen gesellschaftlichen Teilbereichen relevant, was sich in der interdisziplinären Umweltforschung als verstärkter transdisziplinärer Bezug (auch: Anwendungsbezug) bezeichnen läßt.” (DASCHKEIT 1998:56)

Zusammenfassend lässt sich sagen: "Im Bereich interdisziplinärer Umweltforschung sind Grundlagenforschung, problemorientierte Forschung und anwendungsbezogene Forschung als eng miteinander verzahnt zu betrachten." (DASCHKEIT 1998:56). Wegen der großen Komplexität der Umwelt und den zahlreichen möglichen Betrachtungsperspektiven wird in der Umweltforschung ein integrativer Denkansatz angestrebt. Dieser methodisch wie auch institutionell prägende Anspruch der interdisziplinären Verknüpfung fachlicher Disziplinen wird als „ein Hauptanliegen der Umweltforschung" bezeichnet (VON LERSNER/HUCKE 1992:553). Dieses Primat, eben das der Vernetztheit der wissenschaftlichen Disziplinen, stellt sich aber auch gleichzeitig als herrschendes Problem dar, da Forschung zumeist fachspezifisch organisiert ist und deshalb 
oft auch fachlich eingegrenzt erfolgt. Aus forschungspraktischen wie aus methodischen Gründen kann Interdisziplinarität meist nur selten verwirklicht werden (:553).

Die Ursache dieses schwierigen interdisziplinären Gedankenaustausches und seiner praktischen Umsetzung liegt möglicherweise in den Interpretationsschwierigkeiten des Begriffes „Umweltforschung“ und lässt sich vermutlich aus der Bedeutungsvielfalt des Wortstammes „Umwelt-“ ableiten. Denn „Umwelt“ ist „die Klammer für alle Disziplinen der Umweltforschung” (MÜLLER-HOHENSTEIN 1995:276).

\section{c Zum Begriff „Umwelt”}

Im biologischen Sinne wurde der Begriff „Umwelt” erstmals von dem Zoologen und Verhaltensforscher Jacob Johann Baron VON UEXKÜLL (1864 - 1944) im Jahr 1921 gebraucht (SCHÄFER 1997:165) für „die ein Lebewesen umgebende Außenwelt, soweit sie von den Merk- und Wirkorganismen erfaßt wird und diese zu einem bestimmten Verhalten veranlaßt“" (ILLIES 1973:16).

VON UEXKÜLL liefert also für ökologische Fragestellungen zwei Interpretationen von „Umwelt“ (SCHÄFER 1997:165):

1. die "Merkwelt"; als Summe der Sinneswahrnehmungen oder die subjektiv wahrnehmbare Umwelt eines Organismus und

2. die "Wirkwelt"; als Summe aller auf einen Organismus einwirkenden Faktoren oder die objektiv vorhandene Umwelt.

Seine Perspektive bezieht sich dabei auf Organismen, genauer: auf Tiere. Er versteht unter deren „Umwelt“ die gesamte von ihnen sinnlich wahrnehmbare und aktiv erschließbare Welt. UEXKÜLL erweiterte das damalige Spektrum der Umweltbeziehungen insofern, als dass zu den Wirkungszusammenhängen noch Wahrnehmungszusammenhänge hinzu kamen oder, mit der VON UEXKÜLLschen wahrnehmungsphilosophischen Terminologie gesprochen: Eine 'Wirkwelt' verschränkt sich mit einer 'Merkwelt' (BECKER 1998:46). Der damit zustande gekommene „Funktionskreis“ (UEXKÜLL 1921:218f.) bedeutet, „daß eine in sich geschlossene Kette von Wirkungen bei jeder tierischen Handlung Subjekt und Objekt aneinander bindet” (:45f.), dass also ,ein jedes Tier eng mit seiner Umwelt verbunden” ist (:45f.).

Nach dieser Vorstellung gibt es prinzipiell für jeden Organismus eine eigene Umwelt, die sich - dies ist allein aus dem Wortzusatz ,-welt” zu begründen - VON UEXKÜLL räumlich denkt. Ein jedes Tier bildet den Mittelpunkt seiner Umwelt, der es als selbständiges Subjekt gegenübertritt. „Jede Umwelt eines Tieres bildet einen sowohl räumlich als auch zeitlich wie inhaltlich abgegrenzten Teil aus der Erscheinungswelt des Beobachters" (UEXKÜLL 1921:218f.).

Diese faunistische Auslegung des Umweltbegriffs hat bis in die Jetztzeit fortbestanden. Der ehemalige Leiter des Umweltbundesamtes in Berlin, LERSNER (1994: Stichwort Umwelt, Umweltaspekte), gebraucht die Bezeichnung „Umwelt" - ,in Anlehnung an den kleinsten gemeinsamen Nenner” - als „komplexe Lebensumwelt von Organismen“. In ebensolcher biologischer Ausrichtung definiert die ANL (1994) „Umwelt”: „der räumliche und funktionale Lebensbereich von Organismen und ihren Gemeinschaften mit der Gesamtheit der auf sie einwirkenden Einflüsse”.

Dieser Raum - als Bestandteil des Umweltbegriffs im VON UEXKÜLLschen Sinne - fällt aber nicht mit den verschiedenen geographischen Räumen des Menschen zusammen und "es bleibt dann das Problem, wie das jeweilige Verhältnis zwischen den verschiedenen Räumen zu denken ist, wie sich beispielsweise ein subjektiver Umweltraum in eine Landschaft eintragen läßt" (BECKER 1998:47), in eine Umwelt als "die Geo- und Kulturbasis, auf der sich äußere und innere Heimatbildung vollzieht.” (RIEDEL 1987:562)

Dieser bodenständige, heimatbezogene Begriffsinhalt von „Umwelt“ lag vermutlich der ursprünglichen Bedeutung zugrunde, die dem etymologischen Herkunftswörterbuch (Duden 1989) zu entnehmen ist: Demnach ist ,das seit 1800 bezeugte Wort [...] eine Lehnübersetzung von dän. Omverden 'umgebendes 
Land; umgebende Welt'. In der 2. Hälfte des 19. Jh.s wurde 'Umwelt' als Ersatzwort für frz. Milieu gebräuchlich."

Umwelt stellt sich aus humanpsychologischer Sicht aber "nicht als eine vorgegebene Realität dar, sondern als ein flexibler Wahrnehmungs- und Handlungsraum, dessen Merkmale erst durch das im sozialen und kulturellen Kontext sich vollziehende Handeln des Menschen entstehen und verändern." (FASSHEBER 1989:259) Der Umweltbegriff darf des Weiteren auch nicht die Fähigkeiten des Menschen ausschließen, sich durch Hilfsmittel einen indirekten Zugang zu der von seinen Sinnesorganen nicht wahrnehmbaren Umwelt $\mathrm{zu}$ verschaffen. Diese Art der Umwelt wird als technisch erfassbare Umwelt bezeichnet (SCHÄFER 1997:165).

Die Umwelt des Menschen besteht zusammenfassend "außer der physisch-materiellen Umwelt aus seiner psychisch-intellektuellen und seiner sozial-ökonomischen Umwelt". (SCHÄFER 1997:165). Der Umweltbegriff ist also eigentlich ein Beziehungsbegriff.

Auch wenn hier eine verschiedene Umwelten berücksichtigende Definition gefunden wurde, so sind diese Begriffsumschreibungen dennoch zum einen sehr weich und lassen durch ihre weitgefasste Definition erhebliche Spielräume zu, so dass JÄGER (1994:2f.) die seit Beginn der 70er Jahre ganz erhebliche Ausweitung des Gebrauchs des Wortes „Umwelt" konstatiert, die diesen Begriff seiner Meinung nach in Bezug auf die von UEXKÜLLsche Definition zu einer Leerformel hat verkommen lassen. Zum anderen resultieren die Definitionsprobleme aus der jeweiligen Betrachtungsebene, die die betreffende umweltbezogene Wissenschaftsrichtung verfolgt: Umwelt als gegenständlicher Natur- und Lebensraum, als Biotop oder als "black box" im Sinne der Wahrnehmungsgeographie. Der Begriffsinhalt ergibt sich für JÄGER deshalb ganz pragmatisch letztlich aus dem Zusammenhang. Und BRÜGGEMEIER (1992:13) umgeht diese diversen Standpunkte, indem er - im Gegensatz zur schwierigen biologisierten bzw. humanisierten Diskussion eine simple anthropozentrische Begriffsdefinition vorlegt: Danach bezeichnet Umwelt „,ie gesamte den Menschen umgebende Welt”.

Als gemeinsame Basis kann jedoch die Feststellung getroffen werden, dass Umwelt ohne Raum nicht denkbar ist. Umwelt ist der die jeweiligen Lebenseinheiten umgebende Raum.

\section{Die „Kulturgeographie” im Disziplingebäude der ,anthropogenen Umweltforschung”}

\section{a Zur Begriffsbestimmung ,anthropogene Umweltforschung"}

Als Konklusion der o. g. Ausführungen lässt sich resümieren: die Umweltforschung der Umweltwissenschaften beschäftigt sich mit der Analyse lebensräumlicher Einheiten - und dazu gehört auch und insbesondere der gestaltende Mensch. Gemeinsames Ziel der Umweltforschung ist daher neben der Erkenntnis vom Funktionieren der Umwelt, Gefahren für die Umwelt zu erkennen und Abwehrmaßnahmen auszuarbeiten, auch Normen und Wertevorstellungen zu entwickeln, die der Umwelt als Lebensraum des Menschen gerecht werden. Eine als Menschheitsschutz so verstandene Umweltforschung schließt auch die Umweltethik, das heißt die Diskussion von Verhaltensweisen des Menschen in der Umwelt mit ein. Nach diesem erklärten Selbstverständnis „will die Umweltforschung die Umwelt der Menschen und ihrer Gesellschaft untersuchen.” (BECKER 1998:34)

In Reduktion der ursprünglich weiter zu fassenden Bedeutung des Begriffes „Umwelt“ und im Gegensatz zur noch immer dominierenden naturwissenschaftlich-ökologisch orientierten Betrachtungsrichtung beziehe ich mich deshalb im Folgenden auf einen Teilaspekt: der „menschlichen Umwelt“. Sie erfasst „alle für den Menschen relevanten Teile der Außenwelt" und beschreibt damit den Betrachtungsansatz der ,,anthropozentrischen Umweltforschung“, wobei hier definitionsgemäß die „Veränderungen dieser Außenwelt durch natürliche und menschliche Einflüsse und ihre Rückwirkungen auf den Menschen im Vordergrund“" stehen (LERSNER/HUCKE 1992:552).

Anthropologie - als institutionelle Einheit und zugleich adjektivisches Merkmal der hier vorgetragenen anthropogenen Umweltforschung - heißt, Wissenschaft vom Menschen'. Die anthropologische Forschung 
betrachtet den Menschen nach zwei Hauptaspekten - als Naturwesen und als Kulturwesen -, die sich wiederum nicht voneinander trennen lassen. Modern ausgedrückt: Der Mensch ist ein Lebewesen, zu dessen Natur die Kultur gehört. Das Kennzeichen der Anthropologie ist demnach, „daß sie ganz spezifisch nach dem Gesamtbild vom Menschen fragt, nach dem Menschenbild oder, wie man früher gesagt hätte, nach dem Wesen des Menschen. Sie bündelt alle zur Beantwortung dieser Fragestellung geeigneten Fakten aus den Wissenschaften zu einem Paket, das einen Überblick über das Wesen des Menschen ermöglicht und vor allem, das zur Orientierung in der Praxis dienen kann. [...] Anthropologie will die Menschenbilder bewußt machen; sie will über den Menschen aufklären." (STAMM 2000:18) Die Anthropologie nutzt dabei - im Sinne der Interdisziplinarität - ,die Beobachtungen der Fachwissenschaften und das umfassende Nachdenken der Philosophie." (:18)

Die von BECHMANN/FREDERICHS (1998:15) vorgetragene Kritik der „Anthropologenisierung“ in der Umweltforschung muss jedoch insofern geteilt werden, als „,daß die relevanten gesellschaftlichen Fragen, zu denen das Mensch-Umwelt Problem [...] in besonderer Weise gehört, eben nicht aus fachspezifischer Enge so wichtig die Detailforschung und Detailkenntnisse auch sind -, sondern nur aus der Berücksichtigung des komplexen Zusammenwirkens einer Vielzahl von Faktoren der natürlichen und kultürlichen Umwelt zu verstehen und letztlich zu beantworten sind" (SCHOLZ 1995:269).

Das von der anthropozentrischen Umweltforschung studierte Wechselgefüge zwischen Außenwelt und Mensch wird infolgedessen in diesem Betrachtungsansatz gedanklich verknüpft mit dem Konzept der Ökosysteme und erreicht somit wieder den ursprünglich holistischen Ganzheitsanspruch einer integrativen Umweltforschung.

Um dennoch die Bedeutung des Menschen als maßgebliche Einflussgröße der Umwelt herauszustellen, ist die Frage zu klären: „Ist die Umweltforschung eine Natur- oder eine Sozialwissenschaft, oder beides, oder keines von beiden? Solche Fragen müssen beantwortet werden, wenn eine integrative Umweltforschung mehr sein will als ein schönes Versprechen.” (BECKER 1998:34) Und in diesem schwierigen wissenschaftstheoretischen Rahmen ist die Positionierung der Geographie als kulturgeographische Umweltforschung zu ermitteln.

\section{b Zur Stellung der Kulturgeographie in der anthropogenen Umweltforschung}

Manche, wie beispielsweise MÜLLER-HOHENSTEIN (1995:271), verstehen Geographie noch heute als eine Umweltforschung im Sinne einer ,umfassenden Ökosystemforschung”. Nicht in Kontradiktion zu einer solchen vom naturwissenschaftlichen Verständnis geprägten physisch-geographischen Umweltforschung, vielmehr in einer den ökologischen Ansatz integrierenden, aber nicht hervorhebenden Weise, steht bei anderen ,Umweltforschern' wiederum die Geographie als anthropogene bzw. kulturelle Geographie im Zentrum der Umweltforschung. Doch nicht als eigenständiger Disziplin, sondern als Betrachtungsansatz. Die theoretische Grundlegung dieses Betrachtungsansatzes liegt für SCHOLZ (1995:269) in der Thematik ,Mensch-Umwelt'. Sie „,ist originär geographisch, Gegenstand und Programm geographischer Wissenschaft an sich". Oder wie DANIELS et al. (2001:3, Hervorhebung im Original) zwingend ausführen: "geographers must [...] accept that all descriptions of the world are culturally determined, often politically motivated, and always contested."

In Fortführung der Betrachtung von Geographie als Raumwissenschaft (siehe 1a) stehen nach DENECKE (1989c:51) ,die Betrachtung räumlicher Verhältnisse sowie das Verhältnis des Menschen zum Raum und zu seiner natürlichen, gebauten wie auch sozialen Umwelt [...] im Vordergrund der Untersuchungen der Anthropo- oder Kulturgeographie.” "Cultural geography” so in gleicher Sichtweise JOHNSTON et al. (1986:86, Hervorhebung im Original), "focuses on the impact of human CULTURE [...] upon the natural environment and the human organisation of SPACE." "Dabei ist der wirtschaftende, nutzende und gestaltende Mensch“, um zu DENECKEs (2000:212) Argumentationsstrang zurückzukehren, „mit der sich daraus ergebenden Kulturlandschaft ein wesentlicher Ausgangs- und Zielpunkt der Betrachtung wie auch der Maßnahmen.” Kulturgeographie wird demgemäß als die „geographische Forschung an der vom Menschen gestalteten Landschaft" definiert (PFEIFER 1982:329). 
Bezeichnet man die Geographie also ,als ganzheitliche, komplexe Landschaftsforschung“ (DENECKE 2000:198) und steht der Mensch im Mittelpunkt der Betrachtung, so hat sie auch dementsprechende spezielle Aufgaben wahrzunehmen: „A classic concern of cultural geography is”, wie NORTON (2000:2) das zentrale Anliegen ausdrückt, ,to decribe and explain the visible material landscapes that different groups of people have fashioned from the physical geographic environment that they occupy."

„Cultural geographers”, so NORTON (2000:2) weiter in seiner Aufgabenbeschreibung, „try to make sense of the visible and material landscapes that are associated with cultural groups". Beschreibung und Erklärung der „visible landscape" nach NORTON, dessen Auffassung hier uneingeschränkt gefolgt wird, ist eine der wichtigen, doch oftmals unterbewerteten Aufgaben der Kulturgeographen.

Der Einfluss der ,cultural groups', der Betrachtungsgegenstand der, visible landscape' sowie die Deskription und Analytik als klassisches Aufgabenfeld machen es notwendig, Kulturgeographie innerhalb der anthropogenen Umweltforschung in diesem Sinne als Landschaftsforschung bzw. - da der Mensch seit Beginn die Landschaft gestaltete - besserhin als Kulturlandschaftsforschung zu verstehen. Landschaft bzw. Kulturlandschaft stellt somit das zentrale Forschungsobjekt innerhalb der Kulturgeographie dar.

\section{c Zum Begriff „Kulturlandschaft”}

Der Begriff Kulturlandschaft, so FEHN bereits 1975 (1975a:51,52) unter Hervorhebung der räumlichen Abgrenzung und seiner anthropogenen geschichtlichen Ausgestaltung „könnte [...] von der Historischen Geographie als Bezeichnung für eine geographische Einheit mit einer ausgeprägten individuellen Geschichte übernommen werden." Man weiß nicht, ob der langjährige Direktor des Bonner Seminars für Historische Geographie vor nunmehr fast 30 Jahren den anstehenden Siegeszug, SCHENK (2003:mündl.) spricht von einer „Karriere” des Begriffs, dieses eine ganze geographische Teildisziplin prägenden und identifikationsstiftenden Terminus geahnt hat. Zu vermuten ist hingegen, daß FEHN keine Vorstellung davon besaß, wie lange dieser Begriff für etymologische Beschäftigung sorgte und inhaltlich noch immer für Unruhe sorgt.

Dies zeigen aktuell solche begrifflichen Erweiterungen und räumlichen Übertragungen wie „Urbane Kulturlandschaft" ${ }^{\text {*3 }}$ (BROERMANN 2003) und „Suburbane Kulturlandschaft"“4 (LANGE 2003) aus dem traditionell ländlichen Raum heraus und es gipfelt in der Aussage, „das Sonnborner Autobahnkreuz“ als „kulturlandschaftliches Element der Gegenwart“ zu bezeichnen (DINNEBIER 2002:7).

Über den Landschaftsbegriff herrscht - vielleicht auch neu angeregt aufgrund der in jüngster Zeit vorgenommenen Erweiterung - noch immer ,innerhalb der Disziplinen, die sich mit Natur und Landschaft beschäftigen, aber auch außerhalb in der Öffentlichkeit, eine babylonische Sprachverwirrung." (BURGGRAAFF 1997:237) und ,a number of different - and debated - definitions” (BAKER 1992:6). Ohne an dieser Stelle auf den Landschaftsbegriff tiefgründig eingehen zu können ${ }^{5}$, sollen dennoch einige zum Verständnis beitragene Erklärungsversuche gemacht werden, denn ,es ist dringlich geboten, die heute vielseitige und oft unklar angewendete Bedeutung des Begriffes ,Kulturlandschaft' zu verifizieren und dabei zugleich das Objekt wie den Betrachtungsansatz auf die jeweilige Fragestellung bezogen zu definieren.“

\footnotetext{
${ }^{3}$ Johannes B. BROERMANN/Hamburg hat sich in seiner Diplomarbeit der „urbane[n] Kulturlandschaft als Forschungsgegenstand“ (2003:V,5ff.) angenommenen und mit einer methodischen Erfassung urbaner Freiflächen, d. h. unbebauter Flächen, die allgemeine Defnition von „Kulturlandschaft“ auf den urbanen Kontext übertragen.

${ }^{4}$ Das Beispiel des Dissertationsvorhabens von Beate LANGE/Bonn, vorgestellt auf dem Historisch-Geographischen Forum 2003 an der Universität Bonn unter dem Vortragstitel "Suburbaner Raum als Kulturlandschaft?" [!] und am 02.07.2003 mit dem Vortragstitel „Junge Kulturlandschaft suburbaner Raum?” [!] anlässlich der Fachtagung "Kulturlandschaften in Deutschland” der KonradAdenauer-Stiftung auf Schloss Eichholz, widmet sich dem bisher am stärksten vernachlässigten Anwendungsbereich der Kulturlandschaftsforschung, lässt aber gleichzeitig Unsicherheit dadurch erkennbar werden, dass sie die Übertragung des Begriffs auf den suburbanen Raum in Frage stellt - symbolisiert durch ein Fragezeichen.

${ }^{5}$ Mit den Fragen „Was ist Landschaft“ (18ff.), „Was sind historische Kulturlandschaften“ (25ff.) hat sich JOB (19991) in seiner Dissertation ausführlich beschäftigt. Antworten über die Schlüsselbegriffe „Landschaft“, „Kulturlandschaft“, „historische Kulturlandschaft“ gibt ebenso GUNZELMANN (1987:30ff, 41ff.; ib.: 1999a:5). Zur spannenden Geschichte der Schlüsselbegriffe „Landschaft“ und „Kulturlandschaft“ und ihrer aktuellen Verwendung und Stellung siehe SCHENK (2003a:6-13). Zu den begrifflichen und sachlichen Gemeinsamkeiten zwischen Heimat und Kulturlandschaft siehe GUNZELMANN (2003:2-7).
} 
(DENECKE 1997:35) Die von DENECKE erfolgte Aufforderung wie auch die von BURGGRAAFF beschriebene terminologische Situation wurde neben der (bevorstehenden) Einbeziehung der urbanen und suburbanen Räume in Kulturlandschaften in neuer Zeit in anderer Hinsicht - pragmatisch - gelöst:

Einen noch weitergehenden pragmatischen respektive anwendungs- und politikorientierten Umgang mit dem „Kulturlandschaftsbegriff“ verfolgt BURGGRAAFF (2003). Der Begriff der Kulturlandschaft sei entsprechend mit dem jeweiligen Auftraggebern und den Bürgern gemeinsam zusammenzutragen. Es müsse eine inhaltliche Anpassung des theoretischen Begriffs zur Praxis je nach Auftraggeber und gemeinsam mit dem Bürger erfolgen. Eine begriffliche Festlegung abseits der akademischen Diskurse fordert ebenso KALESSE (2003). Um den Kulturlandschaftsbegriff umsetzbar zu machen, muss er eingeengt werden, eingeschränkt in Bezug auf den Auftrag, um Kulturlandschaft zum Beispiel für eine Denkmalpflege operationalisierbar zu machen. GUNZELMANN (1999a:5) sieht zwar auch „ein grundsätzliches Problem im Umgang mit der Kulturlandschaft“ im terminologischen Bereich, sieht jedoch „die inhaltliche Definition dessen, was unter Kulturlandschaft zu verstehen ist [...] jeweils fachintern festgelegt“", beschränkt damit die Variabilität der begrifflichen Festlegung, verhindert aber so eine zu starke individuelle Begriffsauslegung abseits der fachspezifischen Diskussion, die mit der übertriebenen Bürgerfreundlichkeit am Beispiel der Stadtplanung und Stadtentwicklung zu einer mancherorts weitgehenden Aufgabe der fachlich versierten Lenkung als Hoheitsaufgabe geführt hat.

Hinsichtlich der Aufgabe, den Terminus „Kulturlandschaft” aufzudecken, gibt es dabei unterschiedliche Vorgehensweisen: entweder über den Wortstamm „Kultur” oder den der „Landschaft”. Die Entscheidung darüber ist eher von theoretischer Natur, sind doch beide miteinander unzertrennlich verbunden, wie die weiter unten stehenden Ausführungen zeigen. Dennoch sei hier nicht der Sicht Herbert MÜCKEs (1988:152) gefolgt, es sei "wenig erfolgversprechend, dem Inhalt von Kulturlandschaft über den Begriff der Landschaft näher kommen zu wollen.“ „Im geschlossenen System der Landschaft”, so seine Begründung, „laufen Prozesse $a b$, die für den Kontaktbereich Mensch-Umwelt nur in der Form wirksam sind, in welcher sie vom Menschen wahrgenommen und bewertet werden." (:152). Daher seien "Beziehungen und Wirkungsfelder offenzulegen" (:152), die erst eine Auseinandersetzung mit der Kategorie Kultur innerhalb der Geographie und der Historischen Geographie ermöglichen. Dieselbe Auslegung ist bei NORTON (2000:15) anzutreffen: "the single most important cultural geographic idea derived from the cultural studies tradition is a concept of cultures as maps of meaning". Auch CRANG (1998:6) sieht als "the guiding principle [...] that cultures are sets of beliefs or values that give meaning to ways of life and produce (and are reproduced through) material and symbolic forms."

Was spricht gegen eine solche eher sozialwissenschaftlich und wahrnehmungsgeographisch fundierte primäre Annäherung an den Begriff Kulturlandschaft über den Begriff „Kultur“"?:

„Kultur“ („,culture“), so sagt zunächst MITCHELL (2000:13) auf der Suche nach dem Wortinhalt, ,,is an incredibly complex word” (:13), meint ,a lot of things" (:13) und scheint „thus something of a muddle” (:14; ebenso CRANG 1998:1). ,'Culture”, so sein vorläufiges Resümee, ,seems to mean everything. Or maybe it is so broad a term it means nothing - or at least not anything analytically useful." (MITCHELL 2000:15). Der Kulturbegriff scheint nach seiner Auffassung ,to be both a nebulous 'structure of feeling' [...] that defines the life of people (or perhaps is constructed out of the lives of peoples) and a set of productions (like art) that reflect upon, speak to, or attempt to mold that 'structure of feeling' through various strategies of representation" (Hervorhebung im Original).

Des Weiteren sei der Term 'Kultur' negativ besetzt. „'Culture' was becoming a term to differentiate the good from the bad, the cultivated from the unruly." (MITCHELL 2000:15, Hervorhebung im Original) und MITCHELL (:14) fährt in seiner anti-kulturellen Argumentation fort, dass: „the idea of culture often indicates a hierarchical ordering of all these processes, activities, ways of life, and culture production" 
Schließlich und am wichtigsten für die Entscheidung ist die rein etymologische Bedeutung, auf die man sich hier zurückziehen kann: Das Wort „Kultur“ entstammt dem lateinischen „cultura”, bedeutet in der Verbform colere $=[$ das Land] bebauen und deshalb ist die Übersetzung klar: Doch was bedeutet (dann) „Landschaft”?

Ist es nicht so, wie VAN DEN HÖVEL (2001:36) es sagt: „Eine Landschaft ohne Kultur ist somit eine Kultur ohne Landschaft"?

Einfach wäre es auch, den Begriff - ähnlich wie den der negativ getönten „Kultur“ - zu diskreditieren, wie Friedmar APEL, Professor für Vergleichende Literaturwissenschaft in Paderborn, es beispielsweise versucht, indem er der Frage nachgeht, ,warum die Landschaftsdarstellung seit dem 18. Jahrhundert gerade in Deutschland die reichste und eigentümlichste Tradition ausgebildet hat" (APEL 1998:27). Nach seiner Auffassung „lassen sich insbesondere am Landschaftsverständnis bedenkliche Züge des deutschen Wesens entziffern“ (:13) und er gibt angesichts der Ganzheitlichkeit von Landschaft zu bedenken, „daß solche Ganzheitsvorstellung in gefährliche Nähe zu totalitärer Ideologie geraten kann“(:13).

Die „3. Reich-Keule“ greift aber nur bei einer symbolischen Evidenz von Landschaft, aber nicht, wenn sie als wirklicher Raum möglichen Handelns begriffen wird. Die Zeugnisse „sind die Buchstaben, Worte und Sätze in einer Geschichte, die Menschen vor langer Zeit zu schreiben begonnen haben und an der andere unablässig weiterformulieren“ (SCHUMACHER/STRAUSS 1998:9).

Das Wort „Landschaft” hat also eine mehr als 60jährige Geschichte, eine Historie, die sich bis in das Mittelalter zurückverfolgen lässt, und verschiedene Bedeutungen besessen:

1. Landschaft als Personenkollektiv: Im 12. Jahrhundert bezeichnete 'Landschaft' die Bevölkerung, eine Personengruppe eines Landes, der Begriff wurde später auf die politisch handlungsfähigen Bewohnerinnen und Bewohner, d. h. für die Versammlung der politischen Vertreter eines solchen Raumes (z. B. die Ständeversammlung der Ritterschaft eines Landes) eingeengt. Heute würde man dafür eher das Wort 'Landstände' verwenden.

2. Landschaft als Region: Das althochdeutsche 'lantscaf' bezeichnete einen größeren Siedlungsraum mit gewissen einheitlichen rechtlichen und sozialen Normen (provincia, regio). Diese Bedeutung dominierte in der Hochsprache bis ins späte 18. Jahrhundert. Als Synonym für diese Landschaft als einen politisch-rechtlich abgegrenzten Raum könnte das Wort Region stehen.

3. Landschaft als Kunst: Die heutige alltagssprachliche Bedeutung von Landschaft stammt aus dem späten Mittelalter und der Zeit der Renaissance, als unter Landschaft die gemalte Darstellung des Ausschnitts einer Gegend verstanden wurde. Dabei handelte es sich aber nicht nur um eine möglichst wirklichkeitsgetreue Darstellung, sondern auch um die bewusste Komposition von Ideallandschaften. Diese Bedeutung wurde im 16. und 17. Jahrhundert auf die Vorlage des gemalten Landschaftsbildes - also auf das, was wir heute alltagssprachlich unter Landschaft verstehen - ausgedehnt, aber nur von Künstlern und Kunsttheoretikern verwendet.

4. Landschaft als Gegenstand der Geographie: Eine spezielle Form der Landschaft ist die "geographische Landschaft", die zu Beginn des 20. Jahrhunderts als ein Amalgam aus der alltagssprachlichen Landschaft und der Bedeutung von Landschaft als Region entstand. Die alltagssprachliche Landschaft wird also um eine räumliche, regionale und materielle Komponente ergänzt (AMANN 1999:32; NEUMANN 1989:65). Es handelt sich ,aus Sicht der Geographie - um einen wissenschaftlichen Grundbegriff [...], auch wenn keine allgemein anerkannte Landschaftsdefinition existiert” (AMANN 1999:33). Dies ist umso verwunderlicher, „da das Entscheidende für den Landschaftsbegriff die konkrete Gestaltung der Erdoberfläche ist" (FEHN 1975a:51). „Sie ist nämlich das Konkreteste, was wir haben auf der Welt.” (EISEL 1997:41)

\footnotetext{
${ }^{6}$ Im Gegensatz zur wörtlichen Übersetzung aus dem lateinischen bezeichnet „,cultura“ - in der Auslegung von TÖLLEKASTENBEIN (1990:8) „ursprünglich die Gesamtheit der Bestrebungen einer Gemeinschaft, den Grundbedürfnissen der menschlichen Natur nachzukommen." Diese Übersetzung in seiner allumfassenden, auch die Bestrebungen abseits der Wertevorstellungen integrierenden Form, kann nach meiner Aufassung jedoch nicht überzeugen.
} 
Auch wenn es keine Legaldefinition von 'Landschaft' und so unterschiedliche Begriffsbestimmungen gibt, so können dennoch Übereinstimmungen mehrheitlich festgestellt werden, die die Herkunft der Landschaft zur Grundlage haben:

Landschaft ist Kulturlandschaft, das heißt vom Menschen überformte, gestaltete und kultivierte Landschaft (KRAUSMANN/WEISZ 1999:49; SUSKE 1999:112), und ,galt und gilt auch heute noch als ein Korrelat landschaftlicher und menschlicher Elemente.” (MÜCKE 1988:152f.) „Die Kulturlandschaft”, so schrieb bereits KRENZLIN (1969:1) in ihrer Einleitung zu ihrer Dissertation 1931 über das hannoversche Wendland, ,ist das durch menschliche Tätigkeit umgestaltete Landschaftsbild”. Pathetischer drückt es SCHWIND (1964a:3) aus, wenn er von Kulturlandschaft ,als ein Werk des Menschen“ spricht, indem also „objektivierter Geist [...] in der Landschaft dauernde Form gewonnen habe.“ Ein Geist, der „objektive Werte schafft und sich in diesen ausdrückt." Es handelt sich also nicht um ein Erleben bzw. eine Seele des Menschen, sondern es gilt in interpretatorischer und analytischer Sicht aus den „Objekten“, eben den Kulturlandschaften, „herauszuholen, was von den Schaffenden hineingelegt wurde.“(:6). Die menschliche Ideengeschichte und Gedankenwelt als Konstrukteur betont auch DENECKE (1992:306), wenn er hervorhebt, dass ,the shaping and changing of the countryside and of settlement patterns are initiated by human thought.”. In gleicher, aber allgemeinerer Weise ist für FEHN (1989:2) die Kulturlandschaft „das Ergebnis der raumwirksamen Tätigkeit des Menschen.“

Ebenso wird von KISTEMANN (1997:377) Kulturlandschaft ,als anthropogen beeinflußte physische Lebensumwelt verstanden”. Auch GUNZELMANN (2002:93) meint: „die Kulturlandschaft ist das Ergebnis der Wechselwirkung zwischen naturräumlichen Gegebenheiten und menschlicher Einflussnahme im Verlauf der Geschichte.“ Und diese unterliegt einem fortwährenden Wandel und ist niemals statisch. „Kulturlandschaft ist also ein System der permanenten Veränderung bei gleichzeitiger Übernahme älterer Strukturen, die angepasst oder aber auch unverändert, zum Teil sogar funktionslos, weitertradiert werden können.“(:4)

Auch für den anglo-amerikanischen Sprachraum sahen bereits in den 1960er Jahren WAGNER und MIKESELL „cultural landscape“ als ,a concrete and characteristic product of the complicated interplay between a given human community, embodying certain cultural preferences and potentials, and a particular set of natural circumstances. It is a heritage of many eras of natural evolution and of many generations of human effort" (WAGNER/MIKESELL 1962; aus: JOHNSTON et al. 1986:90). Mit gleicher inhaltlicher Aussage definieren CRUMLEY/MARQUARDT (1987; aus CRUMLEY 1994:6) Landschaften ,as the material manifestion of the relation between humans and the environment.", wie auch KNOWLES (1985:21) der Ansicht ist: „Landscapes reflect the societies that create them, their values and priorities, their social distinctions, and their stage of economic and social development." Und der bekannte US-amerikanische Kulturgeograph Carl Ortwin SAUER (1889 - 1975) (1963:343; aus: MITCHELL 2000:27) schrieb zum Ende seiner wissenschaftlichen Laufbahn: „The cultural landscape is fashioned from a natural landscape by a culture group". Eine Einsicht, die er bereits inmitten seines Forscherdaseins mit seiner oft zitierten Trilogie (z. B. in JOHNSTON et al. 1986:87) äußerte: „Culture”, so schrieb er 1925 (:46) in „einem seiner einflußreichen Aufsätze” (LEXIKON DER GEOGRAPHIE, Bd. 3:180), „,is the agent, the natural area is the medium, the cultural landscape the result". Und weiter an gleicher Stelle formuliert er hinsichtlich der wechselseitigen, doch klar abgegrenzten Bedeutung von Natur und Kultur: „The unnatural landscape is of course of fundamental importance, for it supplies the materials out of which the cultural landscape is formed. The shaping force, however, lies in the culture itself."

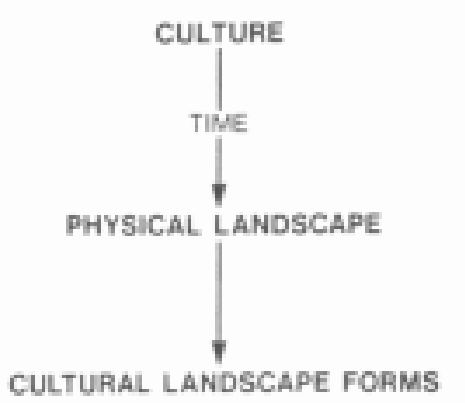

Abb. I-1: Die Evolution der Kulturlandschaft nach Carl O. SAUER (1926) (aus: NORTON 1984:32) 
Diese "culture" hingegen ist es, die in ihren verschiedenartigen Ausprägungen zu einem räumlich differenzierten Landschaftsbild führt: ,a landscape [...] needs to be situated within ist own natural and cultural history - ist own ancestry and upbringing - if it is to be properly understood." (BAKER 1992:2) Der "way of seeing" Landschaften bei den meisten traditionellen Kultur- und Historischen Geographen hingegen, kritisiert BAKER (:7f.) seine Kollegen, „focussed their attentions upon landscape expressions of material culture and tended to ignore, or at least to neglect, the mentalité of the people who created them." (:7f., Hervorhebung im Original) Mentalitäten sind die Kräfte, die hinter den Landschaftenformungen und -ausprägungen stehen und die es nach seiner Auffassung gilt, stärker in den Vordergrund zu bringen: „A landscape is a resultant of attitudes and actions; but to the extent that actions are themselves outcomes of attitudes the latter deserve - but have by no means always been granted - a privileged status over the former in historico-geographical studies." (:2)

Wenn auch all diese Definitionen Kulturlandschaft in ihrer räumlichen Umgrenzung und hinsichtlich der menschlichen Einflussgröße richtig und verständlich umschreiben, geben sie doch nur eine bekannte inhaltliche Form wieder. Der Begriff "Landschaft", so beschrieb Alan BAKER (1992:6) Anfang der 1990er Jahre die Situation ,has been most usually employed to refer to the impression conveyed by an area, to the objects producing that impression, and to the area itself'. Während also zur Dekodierung von Landschaften die anthropogenen Interaktionen in ihrem räumlichen Niederschlag gewöhnlich erkannt wurden, blieben als Schwerpunkt der Begriffserklärung noch immer die starren natürlichen Gegebenheiten bzw. die kulturellen Faktoren bestehen und andere Inhalte weitgehend unbeobachtet. Doch „more frequently, however," führte BAKER (1992:9, Hervorhebung im Original) fort, „Landscape is being likened to a written document to be read critically as a 'deeply-layered text'. [...]. Its common metapher currently in use in landscape studies is that of a Landscape as a message which has to be decoded." In neuerer Zeit nimmt SEYMOUR (2000:214) für den anglo-amerikanischen Raum diesen Gedanken wieder auf und meint, ,landscape [...] needs to be understood as enmeshed within the processes which shape how the world is organised, experienced and understood, rather than read as its end product."

In gleicher Weise sieht die deutsche Geographie - hier sei stellvertretend LENZ (2000:193) zitiert „Landschaft als Wandel und nicht als planbares Fertigprodukt.” Er will damit aufzeigen, „daß Kulturlandschaft weder ewig ist noch das soeben Vergangene, sondern lediglich eine historische Momentaufnahme. Im Gegensatz zu Architektur im Sinne 'geronnener Zeit' ist Kulturlandschaft 'fließende Zeit'“ (:193) Und ebenso bleibt es für DENECKE (2001:279) „,bei der bleibenden Tatsache, dass die Kulturlandschaft ein Kontinuum von gestaltenden, umgestaltenden und nutzenden Eingriffen und Maßnahmen ist, mit einem weitgehend historisch gewordenen Substrat.“

„Von einer historischen Kulturlandschaft zu reden,“ stellen SCHUMACHER/STRAUSS (1998:9) für Österreich ebenso die Wandelbarkeit heraus, „klingt wie Ewigkeit, als handele es sich um einen lange währenden, unveränderlich dauerhaften Bestand. Je öfter der Begriff benutzt wird und je mehr er sich im Sprachschatz etabliert, desto stärker glaubt man daran. Dabei ist das Gegenteil richtig: Kulturlandschaft befindet sich in einem Prozeß des Werdens, der unablässigen Veränderung. Fortwährende Entwicklung ist ihr ureigenes Wesen, Dauer verleiht ihr nur der Wandel.“ Die Definition, die im Rahmen eines Forschungsschwerpunktes vom österreichischen Wissenschaftsministeriums erarbeitet wurde, berücksichtigt und erweitert diese Sichtweise und beschreibt ,Kulturlandschaft' als „ein vom Menschen als Einheit wahrgenommenes räumliches Wirkungsgefüge von natürlichen Gegebenheiten und menschlichen Einwirkungen. Kulturlandschaften entwickeln und verändern sich über die Zeit als Ergebnis des Zusammenwirkens sozio-ökonomischer, kultureller und naturräumlicher Faktoren” (AMANN 1999:34).

Die von AMANN angesprochene besondere Bedeutung der Interdependenzen bei der Wahrnehmung von Kulturlandschaften hebt LENZ (2000:191) hervor. Nach ihm ist es „charakteristisch für Kulturlandschaften, daß sich sowohl deren Physiognomie realiter verändert als auch die Sichtweise des Begehers der Landschaft im Kontext der jeweiligen Zeit wandelt, das Abbild der Landschaft also durch kulturelle Dispositionen determiniert wird“".

Eine die menschliche Tätigkeit und Wahrnehmung in den Mittelpunkt stellende und in Bezug auf die Tatsächlichkeit von Kulturlandschaft „tolerante“ Definition von Kulturlandschaft, die die einführende 
Aufweiterung des Begriffs aufnimmt, ist die von DENECKE (2000:201), indem er ausführt: „Die geographische Kulturlandschaft ist die vom Menschen geschaffene dingliche und strukturelle Erfüllung der Landschaft, aber auch ihre Wahrnehmung, Darstellung, Rezeption und Reflexion auf geisteswissenschaftlicher Grundlage, ohne eine Einschränkung auf kulturell oder ästhetisch herausragende, besonders wertvolle oder schutzwürdige Landschaftsbereiche.” „Sie kann”, dies bestätigt SUSKE (1999:112), „ausgeräumt sein, eben oder hügelig, mit und ohne Wiesen, mit geraden Schachbrettwegen oder mit gewundenen Wegführungen ausgestattet sein. Kulturlandschaft trägt immer ein Gesicht unserer Gesellschaft. Not, Reichtum, Macht, Streit, Harmonie, Kreativität, Phantasielosigkeit."

Landschaften sind Kulturlandschaften, wie aus DENECKEs Definition und auch zuvor zu lesen war. Kulturlandschaft ist nicht länger der komplementäre Begriff zu Naturlandschaft, wie er noch bei MÜCKE (1988:153f.) in Zusammenfassung der früheren Literaturquellen nachzulesen war bzw. zur Unterscheidung auch heute noch im Amerikanischen von MITCHELL (2000:14f.): „culture is the opposite of nature” verwendet wird.

Die besondere historisch wertvolle Komponente hingegen enthalten sie nicht, diese wird erst in der „Historischen Kulturlandschaft“ deutlich (siehe 3g). Ausnahmen davon gibt es aber auch: „The "natural' landscapes of proceeding generations", resümiert FAEGRI (1998:2) unter Gleichschaltung von Natur- und Kulturlandschaften als historische Landschaften, ,are now understood for what they really are: relicts of earlier types of land-use, which were maintained by extensive methods demanding little machinery and much manpower and which therefore became uneconomical." Und auch für WHITNEY (1994:2) ist die Landschaft "a historical document, a cumulative record of man's impact on the natural world".

Aus diesen unterschiedlichen Definitionen und Sichtweisen zum Begriff „Kulturlandschaft” hat MÜCKE (1988:156) - in Anlehnung an HARD (1977), der 13 Bedeutungen bzw. Deutungen für „Landschaft” aufgestellt hat -10 Begriffsumschreibungen herausgefiltert bzw. zusammengestellt, die auch auf den Begriff Kulturlandschaft zutreffen und Kulturlandschaft ausmachen ${ }^{7}$ :

1. Kulturlandschaft als erlebtes Landschaftsbild

2. Kulturlandschaft als Physiognomie eines Erdraumes

3. Kulturlandschaft als Landschaftsraum (Erdraum mit einheitlichem physiognomischem Charakter)

4. Kulturlandschaft als Erdraum mit seiner gesamten dinglichen Erfüllung

5. Kulturlandschaft als Region

6. Kulturlandschaft als räumliche Ordnungsstruktur

7. Kulturlandschaft als Ausdruck der historischen Konstanten eines Raumes

8. Kulturlandschaft als Raum mit charakteristischen historischen Konstanten

9. Kulturlandschaft als räumlich begrenztes Interaktionssystem

10. Kulturlandschaft in einer metaphorischen Verwendung als Phänomengesamtheit beliebiger Art

Neben der physisch durch den Menschen gestalteten Landschaft, der Definition von Landschaft als räumlich abgegrenztem Raum und weiteren durchaus zutreffenden dinglichen Unterscheidungkriterien dieser Aufzählung ist Kulturlandschaft - und hier wird die an erster Stelle gesetzte Umschreibung wieder aufgegriffen und in ihrer besonderen Bedeutung herausgestellt - ,auch erlebbare, erlebte Landschaft und Lebensumfeld, deren ästhetische und sinnlich wahrnehmbare Qualität [...] Ein emotionaler und intellektueller Landschaftsbezug wird hergestellt durch Wahrnehmung und Perzeption der Landschaft" (DENECKE 2000:203). Erst mit

\footnotetext{
${ }^{7}$ Die UNESCO nimmt einige Aspekte einer so verstandenen, differenzierten Kulturlandschaftsbestimmung auf und unterscheidet drei verschiedene Typen „Kulturlandschaften“: 1. gestaltete Kulturlandschaft (Parks, Gärten, ...), 2. assoziative Kulturlandschaft (religiöse, politisch-historische, ästhetische Aspekte) und 3. organisch gewachsene Kulturlandschaften, die wiederum sowohl a. fossile (Lüneburger Heide) und b. lebende (Mittelrheintal) Kulturlandschaften umfassen.

Zum Kulturlandschaftsbegriff in Gesetzen und Konventionen siehe BURGGRAAFF/KLEEFELD (2003:hier:16-19) in dem Sonderheft „Kulturlandschaftsforschung“ in der Reihe „Petermanns Geographische Mitteilungen“. Siehe dazu auch HÖNES (1991:402; 2003:257ff.) und GUMMLICH-WAGNER (2003:96ff.).
} 
dieser Perspektive wird „die Kulturlandschaft als Identifikations- und Erlebnisraum” (:203) betrachtet. Die Erforschung der Veränderungen in der Wahrnehmung der Umwelt ist auch für WALTER (1996:210), „sicherlich einer der vielversprechendsten Bereiche der Mentalitäts- und Ideengeschichte.“ (:210)

HARD stellte in ebensolcher Ansicht die sauber reduzierte These auf, dass Landschaft (und alles, was ihr im Denken der Geographen strategisch entspricht) nicht ein Objekt, sondern eine ästhetische Idee ist (aus: EISEL 1997:39). „Zweifellos gibt es” nach Ulrich EISEL (1997:39, Hervorhebung im Original),,jene Landschaften und zwar genau in der Weise, wie die Geographen sie wesensmäßig konzipierten”, doch „nur für den, der jener Idee, die sich ästhetisch ergibt, fähig ist."

Landschaftswahrnehmung also als ein Produkt der Natur- bzw. Kulturempfindung, die bei manchen halt einfach nicht ausgebildet (worden) ist, sondern nur bei "Landschaftsliebhabern"

„Was wir Geographen als Harmonie der Landschaft empfinden,” so drückt es EISEL (1997:42, Hervorhebung im Original) gemeinschaftlich aus, ist „eine spezifische Errungenschaft der neueren wissenschaftlichen Geographie. Diese Harmonie erschließt sich keineswegs jedem, und auch den geschulten Geographen nicht auf den ersten Blick, auch nicht bei der Feststellung der einzelnen charakteristischen Erscheinungen, vielmehr erst dann, wenn die unerläßliche Frage nach den Ursachen der Erscheinungen die Brücke schlägt einer Erscheinungsreihe zur anderen. [...] Das Gefühl der Harmonie wächst daher auch an Stärke und Reinheit, je deutlicher die Zusammenhänge und Abhängigkeiten in Erscheinung treten." Die Genese der Landschaft ist zu eruieren, so lässt sich die Quintessenz dieser Aussage sogar eines Vertreters der „,neueren Geographie” zusammenfassen, wenn Landschaft erfahr- und wahrnehmbar werden soll. Womit die Verbindung - mit hoher Wahrscheinlichkeit von EISEL unbeabsichtigt, da sich in seinem Werk keine Anhaltspunkte dafür finden lassen - zur klassischen siedlungsgenetischen Kulturlandschaftsforschung hergestellt ist.

Landschaftsgeographie ist deshalb nach COONES (1992:74) zunächst weiterhin der Versuch „to explain why landscapes are as they are”. Doch mit den Mitteln der Landschaftswahrnehmung und -empfindung: ,,and indeed in recent years the very subjectivity of landscape has been hailed as an asset for constructing a geography in which human values, symbols and aesthetic concerns replace the quantifiable, value-free, abstract and unreal worlds of the spatial scientists and their allegedly objective appraisals of 'rational man'." $(: 70)$

Der Landschaftsbegriff, ob physiognomisch oder perzeptorisch verstanden, wurde - auch aus den ,eigenen Reihen" - heftig als gegenwartsfremd kritisiert: ,Landschaft', so der bereits zitierte EISEL (1987:91), richte sich „strukturell gegen die Anerkennung der Industrie (und der ,Moderne') im Namen einer Einheit von Mensch und Natur [und ...] alles, was aus der Unterwerfung unter das Wertgesetz mit Einsetzen der industriellen Produktionsweise an Realität folgt, ist irrelevant für diesen Blick". Auch TREPL war 1978 (:235) in fast gleichlautender Formulierung der Überzeugung, da alles „nach der Umformung der Natur aufgrund der Unterwerfung unter die Gesetzmäßigkeiten der industriellen Produktion irrelevant für diesen Blick" sei und sieht dadurch gar den Untergang einer geographischen Disziplin in die Bedeutungslosigkeit: „Darum werden aber zwangsläufig die Interpretationen der Landschaftskunde auch irrelevant für die Realität der Industriegesellschaft, und indem die Landschaftskunde von deren Abstraktion abstrahiert, abstrahiert sie vom Wesen ihrer eigenen Marginalisierung” (TREPL 1978:235). Diese „alte Geographie” war zu diesem Zeitpunkt, Ende der 1970er Jahre, tatsächlich „,in Nischen abgedrängt, quasi zu Geschichte geworden.” (WIRTHS 2001:48) TREPLs Prognose der Bedeutungslosigkeit und der Geschichtswerdung ist nicht eingetreten, Landschaftsgeographie als disziplinäres Nischenprodukt hingegen geblieben ${ }^{9}$.

Das Wesen der Landschaft und damit der Kulturlandschaftskunde ist jedoch im Gegensatz zu dem Vorwurf der Ausklammerung moderner Landschaften und in der Schlussbetrachtung ein ganz anderes. Es geht ,nicht um die Verherrlichung einer ,guten alten Zeit', die auch ihre unangenehmen Seiten gehabt hat." (SUSKE 1999:113) Landschaft ist nach heutigem Betrachtungsansatz erkannt worden als „eine soziale Konstruktion”

\footnotetext{
${ }^{8}$ Begriff wurde gefunden bei Ulrich EISEL (1997:112).

${ }^{9}$ Landschaftsgeographie bzw. Kulturgeographie wird heute als „Historische Geographie“ bezeichnet; zur weiteren Diskussion siehe dazu 4.b.
} 
(LENZ 2000:191) und aufgrund der landschaftsprägenden, aber dennoch veränderlichen gesellschaftlichen Einflüsse „fossilierter Rest von Lebenssituationen” (SIEFERLE 1997:12). Solche geschichtlich gewachsenen Kulturlandschaften ,geben Zeugnis vom Umgang früherer Generationen mit Natur und Landschaft und vermitteln ein anschauliches und ungekünsteltes Bild vom Lebensstil unserer Vorfahren, ihren Möglichkeiten und Bedürfnissen.” (AURIG 1999a:7)

Doch nur „bei entsprechend erlebbarer Kontinuität sind sie ein wichtiger Bestandteil unserer Heimat und Voraussetzung von lokaler Identität.” (AURIG 1999a:7) Deshalb ist „,von größerer Bedeutung bei der geographischen Betrachtung der aktuellen Kulturlandschaft [...] der Aspekt der Konstanz und Persistenz. Sind die erhaltenen älteren Elemente in der heutigen Kulturlandschaft zunächst ein wesentliches Element der erklärenden Funktion im Rahmen der kulturlandschaftsgenetischen Analyse und Fragestellungen wie auch ein sichtbares Dokument älterer Landschaftszustände, so bekommen die überdauerten Reste und Landschaftsstrukturen im Zuge der Landschaftspflege und erhaltenden Weiterentwicklung den Charakter eines zu schützenden und weiterhin zu tradierenden kulturlandschaftsgeschichtlichen Erbes bzw. die Bedeutung besonderer historisch bedingter Eigenart, die zur Vielfalt der Landschaft und Umwelt wesentlich beizutragen vermag." (DENECKE 1997:41)

„Die hermeneutische klassische Landschaftskunde" konnte es sich noch leisten, die Landschaft als „objektivierten Geist” zu untersuchen, zu einer Zeit, ,,als die ,idiographischen', ,einzigartigen' Landschaften noch entstanden und nicht nur als Relikte fortexistierten" (TREPL 1978:235). Gegenstand der heutigen geographischen Kulturlandschaftsforschung ist die Untersuchung der einzelnen ,,̈̈berdauerten Reste und Landschaftsstrukturen". Und obgleich DENECKE (2000:201) mahnt, die ganzheitliche Sicht im Blickfeld: „Objekt der geographischen Kulturlandschaftsbetrachtung und -analyse sind die zusammenhängenden kompletten und komplexen Kulturlandschaften und nicht nur einzelne Landschaftselemente oder spezielle Landschaftsteile.”, und auch COONES (1992:73, Hervorhebung im Original) der Meinung ist: „there is a crucial difference between the analysis of bits and pieces in the landscape and the embracing of the landscape itself“, so bleiben doch nur „Landschaftsbausteine" ${ }^{10}$ in der Gegenwart als Forschungsobjekte übrig.

Kulturlandschaften also lediglich als ,kulturlandschaftliche Mosaikstücke' als kulturgeographisches Gegenstück nach dem Prinzip der ,Biotopverbundsteine, ${ }^{\text {, }}$, als „sog. persistente Phänomene, wozu die gesamte Kulturlandschaft zu rechnen ist" (FEHN 1997:541), wenn sie auch nur in räumlich-dispersen Restbeständen bilanziert werden kann?

So verwundert es nicht, dass ,die Wahrnehmung von Landschaft [...] das Resultat einer Verlusterfahrung zu sein [scheint], das heißt, wir entdecken immer das als Landschaft und in Folge als schützenswert, was gerade im Verschwinden begriffen ist" (BURCKHARDT 1994; aus: LENZ 2000:190f.). Kulturlandschaft demzufolge reduziert auf Geschichts- bzw. Reliktlandschaft, als „Idealbegriff einer schönen, naturnahen, kleingekammerten, offenen, ländlichen Kulturlandschaft"? (SCHENK 2003; mündl.) Es ist hier, um die Fragen zu beantworten, die Anfangskritik der Zukunftsverweigerung wiederaufzunehmen und vehement der Aussage zu widersprechen, „die Erinnerung daran dient nur jenen als willkommene Ausrede, die ohnehin kein Interesse (mehr) haben, die heutige Zeit aktiv und vor allem kreativ mitzugestalten" (SUSKE 1999:113). Ganz im Gegenteil will man die kulturell geformte Landschaft zumindest in ihren Restbestandteilen der Nachwelt erhalten. Das geschichtliche Erbe auch als Bestandteil in der heutigen posturbanen Landschaft zu bewahren, ist gegenwärtige und zukünftige Aufgabe einer - sich der disziplingeschichtlichen Vergangenheit bewussten - Kulturgeographie.

Dabei ist es gleichgültig, ob es sich dabei um einen urbanen oder suburbanen Ausschnitt aus einer aktuellen Kulturlandschaft oder um eine organisch gewachsene oder gestaltete Kulturlandschaft, wie die Grundsätze der UNESCO es vorsehen, handelt, wesentlich sind die kulturhistorischen Bestandteile. Denn ,jede Zeit [hat] typische Prägungen hinterlassen, gute wie schlechte, geistreiche wie primitive, anmutige wie hässliche, bewahrenswerte und auch solche, die es nicht sind." (SCHUMACHER/STRAUSS 1998:9). So ist Kultur-

\footnotetext{
${ }^{10}$ Begriff nach W. SUSKE (1999:114)

11 In Anlehung an den klassischen, von JESCHKE 1990 geprägten Begriff aus der Angewandten Landschaftsökologie: „Biotopverbundsysteme“.
} 
landschaft nicht immer nur „Herrschaftlandschaft“ (ONGYERTH 2003), aber auch nicht jede anthropogen überformte Landschaft ist eine Kulturlandschaft.

Der sich in der gegenwärtigen Kulturlandschaft darstellende historische Anteil sollte streng genommen als „traditionelle Kulturlandschaft“ (lat.: überkommene Kulturlandschaft) bezeichnet werden (EWALD 1978; aus: SCHERER-HALL 1998:363) und in diesem Sinne von einer „historischen Kulturgeographie“ vertreten werden, die, vergleichbar der kulturlandschaftlichen Übereinkunft, als „traditionelle Kulturgeographie“ bezeichnet werden kann. Im Folgenden wird es daher „kaum zu vermeiden sein, den Begriff , historische Kulturlandschaft' synonym zu ,traditionelle Kulturlandschaft' zu verwenden.“(:363)

Und noch eins hat die Diskussion um den Landschaftsbegriff gebracht. Eine neue Perspektive, vielmehr ein Paradigma hat sich auch in der Naturphilosophie etabliert: „Nature is no longer perceived merely as the correlate of theoretical knowledge but increasingly as the object of human practice and, above all, of [...] technology.” (BAYERTZ 1997:364)

\section{Die „historische Kulturgeographie“ im Disziplingebäude der „historischen Umweltforschung“}

„[...] Geography without History seemeth as a carcass without Motion, so History without Geography wandereth as a Vagrant without a certaine habitation." [John SMITH 1624] ${ }^{12}$

Der Terminus „historische Kulturgeographie“ wurde nach meiner Kenntnis erstmalig von PFEIFER (1982:330) verwendet, der jedoch eine nähere Begriffsbestimmung schuldig blieb. Der Begriff als disziplinärer Terminus - eingeordnet in das übergeordnete Schema der historischen Umweltforschung - soll hier aber wieder aufgegriffen werden, um die anthropogene Determinante als zentrales Merkmal innerhalb des Faches einer historischen Kulturlandschaftsforschung zu verdeutlichen. Synonym und häufiger wird der Begriff „Historische Geographie” als Fachbezeichnung verwendet.

„Über das, was unter Historischer Geographie zu verstehen sei, ist viel Widersprüchliches formuliert worden. Es in allen Nuancen nachzeichnen zu wollen, wäre müßig." (BECKER 1998:15) Da dem nur beizupflichten ist und diese Aufgabe an dieser Stelle unlösbar erscheint, aber auf der anderen Seite in Ermangelung einer begrifflichen Festlegung und disziplinären Einordnung einer „historischen Kulturgeographie" in das interdisziplinäre Wissenschaftsgebäude der historischen Umweltforschung Klärungsbedarf besteht, wird in vier Erklärungsschritten $(\mathrm{a}-\mathrm{d})$ versucht, diesen theoretischen Ansatz zu verdeutlichen. Dabei ist eine Beschäftigung mit der Wort- und Disziplingeschichte unumgänglich.

\section{a Stellung und Aufgaben der, „historischen Kulturgeographie“ innerhalb der Geographie}

„Die Historische Geographie hat innerhalb des Faches Geographie in Deutschland eine lange und bedeutende Tradition.” (BECKER 2001:6) und „die Betrachtung der heutigen Kulturlandschaft ist undenkbar ohne die Hilfe der historischen Geographie." (SCHWIND 1964b:15, Hervorhebung im Original) .

Umso verwunderlicher, dass sie sich gegen Ende der 1990er Jahre in ,einer noch immer nicht ganz gefestigten Begriffs- und Standortbestimmung” (BECKER 1998:15) befindet. Den Grund dafür liefert FEHN (1997:542): „Bedauerlicherweise fehlt in Deutschland eine Plattform für einen kontinuierlichen Gedankenaustausch zwischen den historisch orientierten Geographen bzw. Historischen Geographen, unabhängig von ihren räumlichen Schwerpunkten. Deshalb findet auch nicht [...] eine intensive Diskussion über die theoretischen Grundpositionen der Historischen Geographie statt." Ob dies noch immer so ist, vermag der Verfasser nicht abschließend zu beurteilen. Die Inhalte der stattfindenden Seminare, Tagungen, Kongresse und Kolloquien jedenfalls lassen nach meiner Einschätzung den wissenschaftstheoretischen Diskurs vermissen zumal auch der Trend zur Anwendungsbezogenheit innerhalb der Geographie allgemein diese Tendenz zu verstärken scheint. Die - auf der anderen Seite - Vielzahl an publizierten, auch in den Anfangskapiteln einer nahezu jeden historisch-geographischen Arbeit dargestellten

\footnotetext{
${ }^{12}$ John SMITH [1579 - 1631], engl. Abenteurer und Seefahrer; (aus VILEISIS 1997:11)
} 
wissenschaftstheoretischen Ansichten zu Stellung und Aufgaben der Historischen Geographie im Wissenschaftsbild der betreffenden historischen und geographischen Disziplin, lassen eine eindeutige Positionierung nicht erkennen bzw. erschweren diese; auch aus Gründen fehlender Unterschiedlichkeit durch Rezeption immer gleicher Autorenzitate. „Als erstes ist die Frage zu stellen, ob die Historische Geographie eine selbständige Disziplin neben der Geographie oder eine Teildisziplin sei?" (EGLI 1997:64); denn „Historische Geographen werden weiterhin lediglich als Lieferanten und nicht als zuständige Fachdisziplin anerkannt.” (BURGGRAAFF 1997:236) Oder ob es lediglich nur ein anderer Name für die ,alte“ Kulturgeographie ist? (vgl. BECKER 2001:6)

Der ehemalige Ordinarius Helmut JÄGER (1997:345) sieht in einem seiner letzten Aufsätze die „Funktion der Historischen Geographie als Hilfswissenschaft für alle historisch-landeskundlich ausgerichteten Fächer und einzelne Naturwissenschaften" und weist damit der Historischen Geographie keinen eigenen institutionellen Wissenschaftsrahmen, sondern lediglich eine Art ,Zulieferfunktion' zu, wie sie BURGGRAAFF bemängelt. Das alte WESTERMANN-LEXIKON DER GEOGRAPHIE (1973:417) definiert die Historische Geographie gar lediglich als „ein geographisches Studium der historisch belegten Vergangenheit“. Nach dieser ,ältlichen“ Auffassung besitzt die Historische Geographie gar keinen disziplinären Charakter, sondern ist nur einfacher Bestandteil des allgemeinen Geographiestudiums. Darüber hinaus besteht nach dieser Definition gar kein Gegenwarts- bzw. Zukunftsbezug, wie er für die Kulturgeographie zuvor festgelegt worden war.

Historische Geographie, stellt Robert A. BUTLIN (1993:51) zunächst grundlegend fest, ,is essentially a geographical subject. Its excitements and intellectual possibilities and challenges largely derive from that fact, and it follows logically therefore that space, place, time and scale are critical components of the historical geographer's thinking and practice."

Dieser durch die Inhalte bedingten geographischen Zugehörigkeit stimmt auch Paul COONES (1992:75) zu, da nach seiner Ansicht nur wenige ,subjects are so innately geographical in their content, significance and ramifications as the study of landscape, involving the physical and the human, the past and the present, the reality of the environment and the realm of ideas, and, not least, in this period of concern with 'relevance', the pure and the applied."

DENECKE (2001) ordnet an mehreren Stellen die Historische Geographie als „Teildisziplin“ (:291) resp. „Teilbereich der Geographie“ (:282) bzw. „der geographischen Wissenschaft“ (:275,292) zu.

Die wissenschaftstheoretische Standortbestimmung der Historischen Geographie als Teilbereich der Geographie stellt Klaus FEHN (1975a:49) unter eine „Wenn-Dann”-Bedingung und beantwortet die Eingangsfrage diplomatisch: „Die Historische Geographie ist eine selbständige Wissenschaft, die sowohl für die Gegenwartsgeographie als auch für die Geschichtswissenschaft eine wichtige Hilfswissenschaft darstellt. Falls der Geographie nicht nur die Aufgabe zugewiesen wird, die Verhältnisse der Gegenwart zu erforschen, kann die Historische Geographie auch als ein Teil der Gesamtgeographie bezeichnet werden. Die Historische Geographie ist dementsprechend Geographie im umfassenden Sinne, die sich im Gegensatz zur Gegenwartsgeographie nur nicht mit der Gegenwart, sondern mit der Vergangenheit beschäftigt. [...] Ebenso wie die Gegenwartsgeographie läßt sich die Historische Geographie in eine (Historische) Landschafts- und Länderkunde und eine (Historische) Allgemeine Geographie unterteilen.”

Für FEHN gebührt der Historischen Geographie der Rang einer selbständigen Wissenschaft, die aber zugleich für die sog. Gegenwartsgeographie und die Geschichtswissenschaft die Rolle einer jeweils wichtigen Hilfswissenschaft übernimmt. Einschränkend formuliert er: Falls sich die Geographie nicht nur als gegenwartsorientierte Wissenschaft verstehe, könne die Historische Geographie Teil der Gesamtgeographie sein (und sei dann nicht mehr eigenständige Wissenschaft). Diese disziplinäre Separierung unter gleichzeitiger hilfsweiser Zuteilung zur Geographie und zur Geschichtswissenschaft oder, bei Vorliegen bestimmter Voraussetzungen nur zur Geographie, ist unter heutigem Gesichtspunkt schwer zu verstehen, weil sie viele Optionen offenhält; doch vor dem Hintergrund der damaligen institutionellen Situation des einzigen Historischen Seminars in Deutschland, das der Philosophischen Fakultät Bonn zugeordnet war und erst mit der Verschmelzung mit dem Geographischen Institut im Jahr 2002 eine eindeutige geographische 
Eingliederung erfahren hat, durchaus verständlich ${ }^{13}$; verständlich auch vor dem allgemeinen zeitgeschichtlichen Hintergrund, dass sich der siedlungsgenetische Zweig an allen Geographischen Lehrstätten, vor allem nach der 1968er Zeit, auflöste. In der Generation der 68er Bewegung, so die These eines CDU-Papiers ${ }^{14}$ sei die Pflege des deutschen Kultur-Erbes ausgesetzt, gar demontiert worden. Und der Zerfallsprozess hält bis heute an.

Bei seiner weiteren Ausdifferenzierung zur disziplinären Stellung setzt FEHN beim zeitgeschichtlichen Bezug an, der ihn zu einer inhaltlichen Zweiteilung veranlasst. So ist „,von der Historischen Geographie im engeren Sinne zu trennen [...] die Genetische (Kultur-) Geographie“(1975a:50). An anderer, späterer, Stelle vereint er deutlich diese beiden Grundrichtungen unter einem gemeinsamen Haupt und füllt diese Begriffe mit Inhalt. Danach umfasst die Historische Geographie ,sowohl die Historische Geographie im engeren Sinne (d. h. ohne Gegenwartsbezug) als auch die Genetische Siedlungsgeographie mit direktem Bezug zu den gegenwärtigen Verhältnissen“"(1998:11). FEHN unterscheidet also deutlich zwischen eigentlicher Historischer und Genetischer Geographie.

Dies macht er fest anhand der unterschiedlichen Fragestellung bei der Historischen und der Genetischen Geographie. Die Genetische Geographie - im Gegensatz zur Historischen Geographie - „untersucht zur Bewertung eines einzelnen in der Vergangenheit entstandenen Elementes das Gesamtgefüge der betreffenden Zeit, greift zur Erklärung der heutigen Kulturlandschaft weit in historische Zeiten aus. [...] Es werden dabei nur die Fakten aus der Vergangenheit verwertet, die für die Gegenwart von Bedeutung sind." (FEHN 1975a:50) Die Anwendungsorientierung und gleichzeitige Aufsplittung der Historischen Geographie in eine Angewandte und eine ,pure“, d. h. rein auf die wissenschaftliche Lehre bezogene, nicht pragmatische und nicht so sehr politikorientierte Historische Geographie wird schon hier deutlich.

MÜCKE (1988:15) entscheidet sich sowohl für eine anwendungsbezogene als auch für eine geographische Sichtweise. Für ihn ,stellt sich die Historische Geographie als Teilaspekt einer gegenwartsbezogenen Allgemeinen Geographie dar.“ Er sieht dies vor allem „durch die starken Affinitäten zur genetischen Siedlungsforschung“, die „ein Kernbereich“ der historisch-geographischen Arbeit auszeichnet. Er nähert sich damit der FEHNschen Sichtweise an, die sich unter der Prämisse der "Falls-Dann"-Bedingung ergibt, d. h. wenn die Geographie auch ein Geschichtsbewusstsein besitzt, ist die Historische Geographie Mitglied dieses Faches, setzt den Schwerpunkt aber eindeutig auf die Verbindung an die moderne, praxisbezogene Geographie. Während er in dieser Definition die Zusammenlegung mit dem Fach Geographie aus disziplingeschichtlichen Gründen zwar eindeutig präferiert, sieht MÜCKE an anderer Stelle (1988:9; ebenso:20) dennoch die „Eigenständigkeit einer Historischen Geographie als Grenzwissenschaft zwischen Geographie und Geschichtswissenschaft” bewahrt. Er geht „damit von einer Definition von Historischer Geographie aus, welche Historische Geographie als Wissenschaft zwischen Geographie und Geschichtswissenschaft auffaßt.“ (:8)

Auch für SONNABEND (1999d:219) ist die Historische Geographie „sowohl für die Geographie als auch für die Geschichtswissenschaft eine Zweigdisziplin." Hierbei bleibt aber unklar, ob eine eigenständige Lösung erkannt wird, die sich nur thematisch zwischen beiden Disziplinen ansiedelt, oder ob damit eine Unterabteilung des jeweiligen Faches gemeint ist.

Eine ebensolche Sichtweise für den anglo-amerikanischen Raum vertritt früh GOLDENBERG (1972:421, zitiert aus NORTON 1984:38), wenn er die Historische Geographie positioniert als ,a unified historical geography (both ,geographical' and ,historical') as an independent scientific discipline located in the transition zone between geography and history". Der institutionelle Standort bzw. Zugehörigkeit einer solchen „unabhängigen wissenschaftlichen Disziplin“ wird auch hier nicht geklärt.

BUTLIN andererseits erkennt die Historische Geographie als Mitglied der Geographie und übernimmt das bekannte hierarchische Disziplingebäude der Geographie. Er bezeichnet die Historische Geographie als -

\footnotetext{
13 Die wissenschaftsgeschichtliche und wissenschaftstheoretische Aufarbeitung zu Definitionen und zum Verständnis der „Historischen Geographie“ innerhalb der Geographie und der Geschichtswissenschaft bis 1974 ist nachzulesen bei Klaus FEHN 1975a, vor allem auf den Seiten 31-44.

${ }^{14}$ Rheinische Post v. 25.Mai 2002, Nr. 119, 0483
} 
eine von vielen - „subdisciplines“ der Geographie. Er begründet das damit, „that the properties and relations of time and space are the unique prerogative of geography in general, and thus also of subdisciplines such as [...] historical geography." (1993:51) In gleicher Hinsicht sieht PACIONE (1987:IX) die Historische Geographie als eine von anderen „sub-branches of geography“. NORTON (1984:VI) spricht gar nur von „the historical as being one approach to geography".

BECKER ist in der Festlegung der disziplinären Stellung selbstbewusster und geht einen Schritt weiter als die vorherigen (anglo-)amerikanischen und deutschen Positionen, die die Historische Geographie nur als einen Teil der Geographie sehen, aber in der genauen Positionierung vage bleiben. Für ihn handelt es sich „um einen übergreifenden Teil des Gesamtfaches, der - zumindest nach der formalen Systematik gleichberechtigt neben der gegenwartsorientierten Geographie steht.“ (1998:16)

UHLIG ordnete bereits 1967 (:130) die Historische Geographie in seinem Gliederungsschema als eigenständiges Teilfach parallel zur Natur- und Kulturgeographie ein, weil sie sowohl Teilgebiete als auch das Gesamtgebiet der Geographie behandelt.

Ist die Historische Geographie eine eigenständige Wissenschaftsdisziplin neben Physischer und Anthropogener Geographie, so können darunter weitere „Sub-Disziplinen“ subsumiert werden. BECKER (1998:15) betrachtet beispielsweise die Historische Agrargeographie als Teil der Historischen Geographie. Im weiteren Verlauf seiner Abhandlung differenziert er das geographische Strukturmodell: Danach gehört die Historische Agrargeographie ,als Teil der Historischen Kulturgeographie [...] zu den allgemein-geographischen Unterdisziplinen der Historischen Geographie.“(:17).

Diese Einordnung in das Strukturschema haben in neuerer Zeit NAGEL/SCHENK (2001:4) bestätigt, aber auch vereinfacht: Sie sehen die Historische Geographie unterhalb des Daches der Allgemeinen Geographie und verstehen sie als thematisch und auch in der Forschungspraxis eng verwandten Forschungsansatz der Kulturgeographie. BECKER und NAGEL/SCHENK setzten hier also Historische Geographie mit Kulturgeographie näherungsweise gleich. Insofern ist sie eine "historische Kulturgeographie".

Unberücksichtigt bei diesem Modell bleibt der physiogeographische Zweig, der bis heute den einen Teil des dualen Ansatzes der Allgemeinen Geographie (Kulturgeographie - Physische Geographie) beschreibt. Und auch die historisch-physiogeographische Komponente wird unter das Dach der Historischen Kulturgeographie subsumiert, nach der Vorstellung des oben skizzierten Landschaftsmodells, nachdem die heutige scheinbare Naturlandschaft eine anthropogen überformte Kunstlandschaft darstellt.

Geht man aber von einem Strukturmodell aus, bei dem neben der Historischen Kulturgeographie, gleichsam der grundlegenden fachlichen Differenzierung zwischen Natur- und Kulturgeographie, ,,auch eine historische Naturgeographie [...] möglich“ ist (WESTERMANN-LEXIKON DER GEOGRAPHIE 1973:418), so müsste schließlich das wissenschaftstheoretische Geographiemodell wie folgt aussehen: 


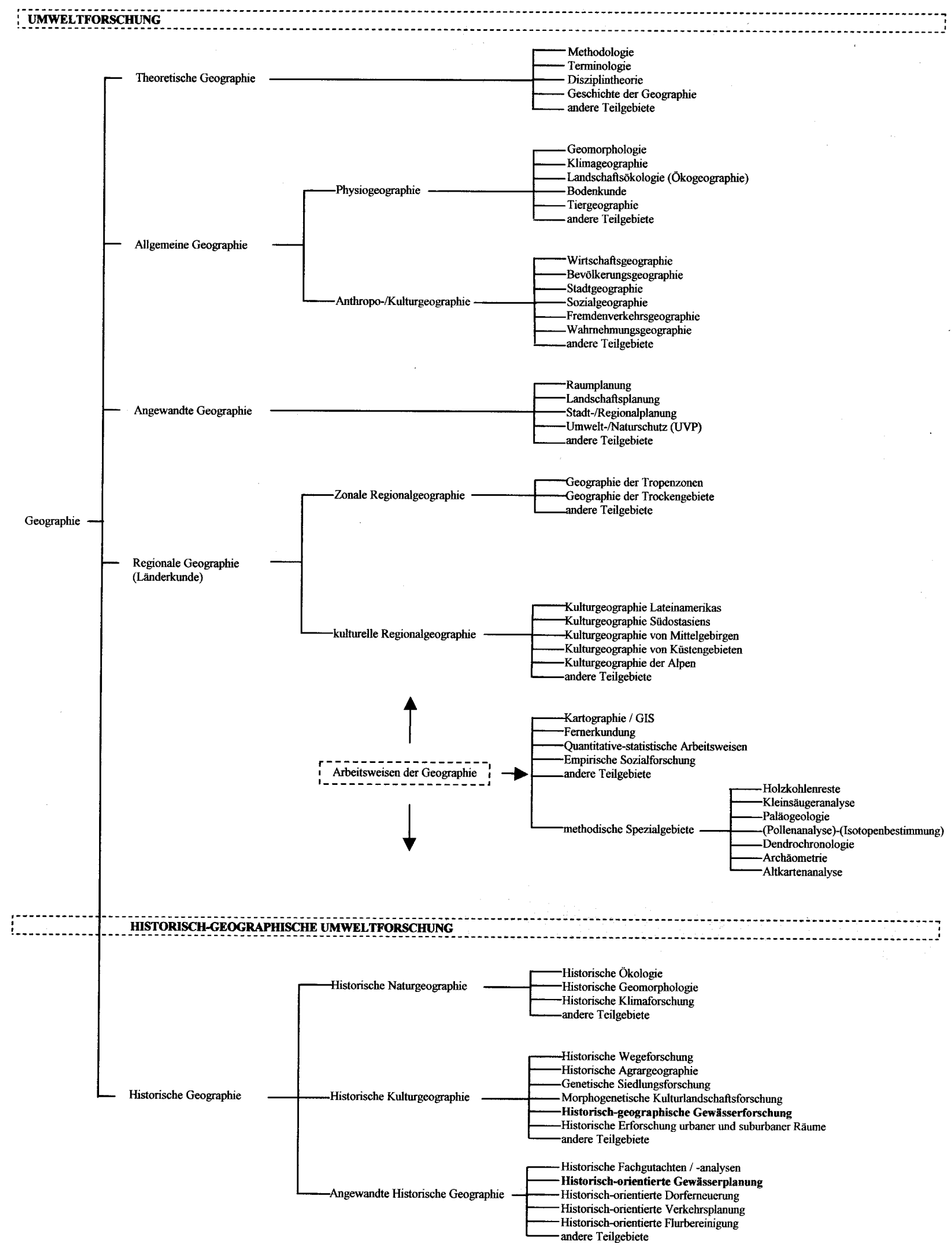

Abb. I-2: Das traditionelle disziplinäre Sytem der Geographie eingebunden in den wissenschaftlichen Überbau der Umweltforschung. Hier ist die Historische Geographie eine selbstständige Teildisziplin innerhalb der Geographie, nicht Teildisziplin der Allgemeinen Kulturgeographie. Die historisch-geographische Gewässerforschung ist als wissenschaftliche Unterdisziplin der Historischen Kulturgeographie zugeordnet, die historisch-geographische Gewässerplanung der Angewandten Historischen Geographie. Die Arbeitsweisen können - deshalb grafisch herausgestellt - allen Teildisziplinen zugeordnet werden; wenn auch unter Verschiebung der Fragestellungen es spezielle Methoden sind, die nur in der Historischen Geographie zur Anwendung kommen (nach LESER 1980: 26 stark verändert; Grundschema basierend auf P. Haggett 1975). 
Die Historische Geographie ist demnach als eigenständiger Bestandteil der Gesamtgeographie zu betrachten. Unterhalb dieser eigenen Fachrichtung existiert wie bei der Allgemeinen Geographie die Aufspaltung einer Historischen Geographie in die Zweige , historische Naturgeographie' und , historische Kulturgeographie'. So leistet die Historische Geographie nach NASH/GRAHAM (2000:3) auch ,a work of reconstructing past environments and understanding processes of landscape change within physical geography”. „Dabei untersucht sie im Bereich der Naturgeographie nur die für den Menschen wichtigen Gegebenheiten, vor allem die Unterschiede zu heute und ihre verschiedene Bewertung im Laufe der Zeiten." (FEHN 1975a:49)

Resümierend lässt sich die Einordnung von FEHN (1975a:31) übernehmen, der die „Historische Geographie als Hilfswissenschaft der Geschichte und als Teilwissenschaft der Geographie" einordnet. Sie ist überzeugend, weil erstens die Historische Geographie aufgrund ihres geschichtlichen Bezuges eine historische Wissenschaft darstellt und zweitens aufgrund ihres Raumbezuges als selbständiger Teil des institutionellen Faches „Geographie“ angesehen werden muss.

Um diese (end-)gültige Positionsbestimmung der Historischen Geographie bzw. Historischen Kulturgeographie $\mathrm{zu}$ begründen, erscheint es notwendig, die Frage nach den zentralen Untersuchungsobjekten, den Inhalten, zu stellen:

Historische Geographie ist, wie JOHNSTON et al. (1986:194) es plakativ ausdrücken: „The geography of the past”. Doch ist die Historische Geographie ,im Rahmen der immer wieder zu stellenden Frage“ (DENECKE 2001:279) deshalb eine geographische Geschichtswissenschaft? Oder wie DENECKE (:279) die Frage formuliert: „Die Historische Geographie - ein historischer oder ein geographischer Forschungsund Betrachtungsansatz?“

MÜCKE (1998:20) beantwortet sie wie folgt: „Eine Historische Geographie als eigenständige Wissenschaft im Grenzbereich Geographie/Geschichtswissenschaft muß nicht nur beide wissenschaftstheoretischen Standorte verbinden, sondern auch einen produktiven Beitrag zur Forschung leisten, der darin liegt, Gegenstände und Fragestellungen von Geographie und Geschichtswissenschaft zu verbinden, in Beziehung zu setzen und drittens somit etwas zu leisten, zu dem Geographen und Historiker in der Regel nicht in der Lage sind." Dies ist die historische, natur- und kulturgeographische Erforschung des Raumes, d. h. der Landschaft. Den zeitgeschichtlichen Anspruch berücksichtigend, besitzt die Historische Geographie die „Raum-Zeit-Kompetenz“ (FEHN 1997:539).

Diese grenzwissenschaftliche Stellung begründet auch PACIONE (1987:IX) mit „the fact that historical geography studies both space (chorography) and time (chronology) [...], but in contrast to other subbranches of geography, it is defined not by concentration on a particular area or theme but by its focus on the fourth dimension - that of time.” Die Betonung der Dimension „Zeit“ bringen auch DENECKE/FEHN (1989:8) zum Ausdruck, wenn sie sagen: „Die historische Geographie ist eine Forschungsrichtung, die von der Fragestellung her der historischen Disziplin und besonders der Landesgeschichte schon immer sehr nahegestanden hat."

Der Schwerpunkt aber, befragt man stellvertretend das in dieser Hinsicht noch immer aktuelle WESTERMANN-LEXIKON DER GEOGRAPHIE (1973:417, lexikalische Abkürzungen ausgeschrieben), liegt auf Geographie, denn ,wenn sich die Historische Geographie auch mit der Geschichte befaßt, so stehen doch im Vordergrund die Untersuchungen über die Wirkungen der Landesnatur und der anthropogenen Kräfte auf die kulturgeographische Substanz, die Einwirkungen des Menschen auf die Erdoberfläche und die Veränderung der Landschaften und Länder als räumliche Gebilde.“ Die Historische Geographie „umfaßt das Werden der Landschaften und Länder als geographisch-räumliche Gebilde in geschichtlicher Zeit, [...] das ein besseres Verständnis der Gegenwart mit ihren in der Vergangenheit entstandenen Formen und Verhältnissen erstrebt." Als Gegenstand der Historischen Geographie erscheint somit, wie JÄGER (1969:33) es ausdrückt, „die anthropogene Veränderung der Geomorphologie“.

Die anthropogeographische Betonung der Genese wird bei FEHN (1982:277) noch deutlicher. Er sieht als „eine der wichtigsten Aufgaben der Historischen Geographie als einer historischen Raumwissenschaft [...] die Erforschung der allmählichen Umwandlung der Naturlandschaft in die gegenwärtige Kulturlandschaft.“ 
Auch DENECKE (1997:43) ist der Meinung, ,die historische Geographie verfolgt als eine ihrer wesentlichen Aufgaben die Zielsetzung, ältere Landschaftszustände zu rekonstruieren“. Nach seinem Betrachtungsansatz ,stehen für eine historisch-geographische Betrachtung die Primärform, die Abfolge historischer Sekundärformen wie auch der formale Entwicklungsprozeß der Vergangenheit im Vordergrund des Interesses" (:43). Wie zugleich NAGEL/SCHENK (2001:3) diese Auffassung vertreten, indem sie sagen: „Historisch-arbeitende Geographen sahen und sehen ihre Hauptaufgabe [...] in der Rekonstruktion vergangener Raumgefüge zu bestimmten Zeitschnitten.“

In der englischsprachigen Geographie wird auch die Ansicht vertreten, „the description and interpretation of Landscapes has been a long and honourable tradition within geography“ (BAKER 1992:6). Für Alan BAKER (:6) steht die Landschaftsbeschreibung und -interpretation gleichberechtigt neben ,the main ,deviations' from geography's central concern with regions, places and areas." Dergleichen auch POWELL (2000:169, Hervorhebung im Original) für die amerikanische Geographie: „One of historical geography’s most venerable traditions focuses on reconstructions of past physical environments" und erinnert damit glücklicherweise nochmals an die Bedeutung des physiogeographischen Bereiches für die Rekonstruktionsaufgabe der Historischen Geographie.

In Zusammenfassung des Aufgabenfeldes einer „Historischen Kulturgeographie“ besitzt noch immer die nunmehr fast 30jährige Aussage von FEHN (1975a:49) Gültigkeit, die Historische Geographie ,,untersucht die Wirkungen der Landesnatur und der anthropogeographischen Kräfte auf die kulturgeographische Substanz, die Einwirkungen des Menschen auf die Erdoberfläche und die Veränderung der Landschaften und Länder als räumliche Gebilde.“ „Die Untersuchung der physiognomisch-strukturellen Landschaften und der funktionalen Räume der Vergangenheit einschließlich der Geschichtslandschaften im oben definierten Sinne wäre also die Aufgabe der Historischen Geographie" (:52). Die Historische Geographie erforscht, wie FEHN (:51) den historisch-räumlichen Forschungsauftrag zusammenfasst, „primär Struktur und Wandel historischer Räume“.

Durch historische Konstanten, also Traditionen und Überreste, versucht die Historische Geographie dabei die Entwicklung von Kulturlandschaft zu erklären. „Persistente Strukturen und Elemente ${ }^{15}$ sind im Konzept der Kulturlandschaft ein objektivierter Bestandteil der raumzeitlichen Analyse, welche Kulturlandschaftsgeschichte in Begriffen der Veränderungen, des Beharrens und der Dauer untersucht.“ (MÜCKE 1988:155f.) „Ihr [der Historischen Geographie] ist abgesehen von verbalen [...] und archäologischen Zeugnissen der Vergangenheit der landschaftliche Rahmen historischer Ereignisse die zentrale Quelle.“, hebt ebenso SONNABEND (1999d:219) die historisch-räumlichen Komponenten als primäre Bestandteile des historisch-kulturgeographischen Forschungsansatzes hervor. Auch nach NORTON (1984:33) hat die Historische Geographie ,insights into the character of past landscapes“ zu liefern, „offered by the present landscape“. Sein griffiger Slogan hierfür lautet: „The past in the present".

Diese klassische Sichtweise hat sich im deutschen und weitgehend auch im anglo-amerikanischen Sprachraum bis heute erhalten. Historische Kulturgeographie nach heutigem Maßstab, so BECKER (1998:15, ebenso: 16) allgemein, beschäftigt sich mit der „Erforschung allgemein-geographischer oder landes- und länderkundlicher geographischer Sachverhalte in der Vergangenheit“, der entsprechend arbeitende Historische Geograph, so BURGGRAAFF (1997:235) ein Aufgabengebiet herausgreifend, ,mit vergangenen Kulturlandschafts- bzw. Siedlungsphasen“, die ebenfalls durch ihre jeweiligen räumlichen Korrespondenzen sichtbar und deshalb erfassbar sind.

Hinsichtlich der Zeitfrage, d. h. mit welchen Vergangenheitsepochen oder -perioden sich der Historische Geograph auseinandersetzen sollte, bestehen divergierende Auffassungen bzw. Auslegungen. JÄGER (1987:106) sieht die Erforschung der historischen Kulturlandschaft auf die Zeit vor den 1940er Jahren begrenzt. Für BECKER (1998:16) ist es ,,prinzipiell gleichgültig, ob die gewählte historische Situation in frühgeschichtlicher Zeit oder etwa im 19. Jahrhundert liegt“. „Diese Position“, stellt BECKER (:16) in seiner Arbeit allgemeingültig fest, „hat sich heute [...] weitgehend durchgesetzt.“ Dennoch werden hinsichtlich der Zeiten für die Historische Geographie bestimmte Schwerpunkte von FEHN (1975a:50) empfohlen: „Obwohl

\footnotetext{
${ }^{15}$ Persistente Elemente und Strukturen sind "in historischen Epochen gebildete, heute noch in verschiedenen Stadien erhaltene und damit auch weiter zu pflegende und zu gestaltende Teile heutiger Kulturlandschaften" (KLEEFELD/BURGGRAAFF: 36,37).
} 
die Historische Geographie sich auch mit der eigentlichen Vorgeschichte bis zur Steinzeit zurück beschäftigen sollte, ist für den mitteleuropäischen Raum die Zeit nach der Landnahme besonders wichtig."

Der Frage der zeitliche Dimension der historischen Kulturlandschaft nimmt sich auch DENZER (1996:19) in ihrer Arbeit an und ist dort der Meinung: „Sie kann in ihrer Komplexität nur schwerlich von einer bestimmten Jahreszahl begrenzt werden, schon gar nicht von dem so häufig gewählten Zeitraum des Beginns der Industrialisierung um das Jahr 1850, da sie vom Ursprung des jeweiligen Elementes oder Reliktes her bestimmt wird. Konkret heißt das, daß als Bestandteile einer historischen Kulturlandschaft alle Objekte erfaßt werden, die unter den gegenwärtigen Bedingungen nicht mehr in der ihnen typischen Form erstellt werden. Die Relikte der Wiesenbewässerung, die zum Teil erst in den 60er Jahren dieses Jahrhunderts zu solchen geworden sind, zählen ebenso dazu wie die Triftrelikte oder Grenzsteine, die noch heute in ihrer aufwendig gearbeiteten Form Rechtsgültigkeit besitzen.“

Einen sehr logischen und zugleich pragmatischen Lösungsansatz geben NAGEL/SCHENK (2001:4) am Beispiel der Genetischen Kulturlandschaftsforschung: Die Erklärung gegenwärtiger räumlicher Strukturen und Prozesse aus der Vergangenheit heraus kann dabei nur so weit in die Geschichte zurückgehen, als noch Bezüge zur Gegenwart bestehen.

Bezüglich des Betrachtungsraumes wird der ganzheitliche Zusammenhang als besonderes Merkmal (historisch-) geographischer Forschung hervorgehoben: „Die Historische Geographie versucht immer den gesamten Siedlungsraum bzw. die ganze Siedlung zu sehen. Sie bietet dadurch einen Grobraster, in den viele wichtige Einzelergebnisse der Realienkunde eingeordnet werden können, wodurch diese häufig eine wesentlich größere Aussagekraft bekommen.“ (FEHN 1989:3) „Die Historische Geographie hat [...] die kulturlandschaftliche Entwicklung in größeren geographischen Gebieten zusammenhängend darzustellen“ (:4). Für BÄTZING (1991:107) jedoch spielt hinsichtlich des Betrachtungsgegenstandes „gerade [...] die kleinräumige Fülle und Vielfalt der konkreten ,Landschaft' (von der die traditionelle Geographie noch sehr viel wußte) die entscheidende Rolle“.

Die beiden Maßstabsebenen fasst FEHN (1989:3) schließlich zusammen, indem er sagt: „Die Historische Geographie ist mehr als andere Wissenschaften in der Lage, die räumlich funktionalen Verflechtungen innerhalb historischer Lebensräume aufzudecken und dadurch Voraussetzungen für eine optimale Verknüpfung von Einzelbefunden und ihre Einfügung in größere Zusammenhänge zu schaffen.“ Erst „die genaue historisch-geographische Interpretation der früheren Kulturlandschaftszustände erlaubt tiefgreifende Einblicke in die fortwährende Auseinandersetzung des Menschen mit der Natur und die allmähliche Umformung der Naturlandschaft zur Kulturlandschaft.“ (:8)

Aus dem bisher Gesagten können vier primäre Aufgabenfelder der traditionellen Historischen Geographie abgeleitet werden (EGLI 1997:64, in Anlehnung an FEHN 1985:378):

1. die genetische Erklärung gegenwärtiger Strukturen und Prozesse,

2. die Geschichte der Landschaften und Länder als räumliche Gebilde,

3. die Erforschung der räumlichen Elemente und raumrelevanten Prozesse der Vergangenheit und ihrer Veränderung in der Zeit und

4. die Beschreibung eines Geosphärenteils zu einer bestimmten, mehr oder weniger weit zurückliegenden Zeit.

Um den Beweis dieses Leistungsspektrums auch für den anglo-amerikanischen Sprachraum zu bringen, sei hier zunächst NORTON (1984:VI) zitiert. Nach seiner Auffassung ist „,historical geography [...] interpreted as being primarily concerned with geographical change through time, the development of landscape and the evolution of spatial form." Diese Einordnung teilt auch BUTLIN (1993:IX, ähnlich:1) in seiner Definition, auf die in - und aufgrund - ihrer Vollständigkeit an dieser Stelle nicht verzichtet werden soll: „Historical geography is the study of the geographies of past times, involving the imaginative reconstruction of a wide range of phenomena and processes central to our geographical understanding of the dynamism of human affairs, such as change in the evaluation and uses of human and natural resources, in the form and functions of human settlements and built environments, in the advances in the amount and forms of geographical 
knowledge, and in the exercising of power and control over territories and peoples." Das Hauptziel der historisch-geographischen Forschung ist dabei ,geographical or environmental information to the study of the chronology and major political and social experiences of peoples, states, empires, frontiers, and civilizations" zu liefern (:IX).

Die Historische Geographie resp. Historische Kulturgeographie kann, dies kann abschließend nach diesen Ausführungen gesagt werden, als eine eigenständige Fachrichtung innerhalb der Gesamtgeographie positioniert werden. Sie widmet sich primär kulturhistorischen als auch naturhistorischen räumlichen Erscheinungen, die allgemein keiner zeitlichen Begrenzung unterliegen. Dabei ist der tatsächliche institutionelle Aufenthalt je nach fakultativer Verankerung ein anderer. Sie ist gleichzeitig eine Hilfswissenschaft insbesondere für die Geschichtswissenschaft, hält aber Kontakt zu allen umwelthistorischen Fächern.

\section{b Die zeitgeschichtliche und zukünftige Entwicklung der „historischen Kulturgeographie“}

Historische Geographie ist im Laufe der Disziplingeschichte und von verschiedenen Vertretern der historischen Geographie sehr verschieden aufgefasst worden: „Historische Geographie als Entdeckungsgeschichte; als Geschichte der kartographischen Erschließung der Erde; als umfassende Geschichte der Reisen, der Kenntnis bzw. der wissenschaftlichen Erschließung der Erdoberfläche; als Geschichte der Veränderung der politischen Einheiten und Grenzen; als Studium der Rolle, welche ,der geographische Faktor' bzw. ,die physisch-geographischen Bedingungen' in der Geschichte gespielt haben (, die geographischen Grundlagen der Geschichte'); als Studium des Wandels der physisch-geographischen Bedingungen in historischer Zeit; als Studium der historisch variablen Art und Weise, in der sich die menschlichen Gruppen an bestimmten Erdstellen, in bestimmten Regionen mit der physisch-biotischen Umwelt auseinandergesetzt haben; als Beschreibung und genetische Erklärung der Transformation von Natur- und Kulturlandschaft, oder schließlich umfassend als ,Rekonstruktion vergangener Geographien' - sei es als historische Länderkunde, historische Landschaftskunde (Kulturlandschaftsentwicklung) oder als historische Sozial- und Wirtschaftsgeographie. Es versteht sich, daß jede Art, die historische Geographie zu betreiben, auf's engste verbunden war mit der Art, wie der betreffende historische Geograph die Geographie insgesamt verstanden hat und wie die zeitgenössische Geographie insgesamt betrieben wurde." (HARD 1973:273f.)

Innerhalb der „Allgemeinen Anthropogeographie“ war der frühere Schwerpunkt der historisch-geographischen Komponente in den 60er Jahren des 19. Jh. in der Siedlungs- und Kulturlandschaftsforschung verankert. Die historische Geographie wurde hierin - auch von der anglo-amerikanischen Disziplin - als kennzeichnender und fester Bestandteil der Geographie angesehen: „Historical geography has been recognized as a distinctive and substantive component of geography throughout the twentieth century." (NORTON 1984:27) Ebenso, aber in etwas abgeschwächter in der Positionierung, BUTLIN (1993:IX): „Historical geography has been an important aspect of the study of geography“.

Wenn auch, im Gegensatz zur anglo-amerikanischen und zur französischen Historischen Geographie, die Historische Geographie in Deutschland den sozialwissenschaftlich orientierten Weg nicht mitgegangen ist (vgl. DENECKE 2001:278), ,,wozu vor allem auch die bleibende Landschaftsbindung des Arbeitskreises [für genetische Siedlungsforschung in Mitteleuropa] beigetragen hat" (:278), so waren und sind dennoch zumindest die Bewertungen zum disziplintheoretischen Wissenschaftsbild der Historischen Geographie in ähnlicher Form vorgenommen worden, wie auch im Folgenden zu sehen ist.

Als Schwerpunkt und Betrachtungsansatz innerhalb der Kulturgeographie kristallisierte sich in Deutschland, Skandinavien sowie in den Niederlanden die Siedlungsgenese bzw. Kulturlandschaftsgenese heraus (DENECKE 2001:278). Im Mittelpunkt ,stand die Frage nach der Entstehung und Entwicklung von Erscheinungsformen in der Kulturlandschaft im Mittelpunkt der Anthropogeographie.“ (BECKER 2001:6) Der morphogenetische Betrachtungsansatz, d. h. die Ausweisung primärer Formtypen und ihre siedlungsgeschichtliche Erklärung war mit der deutschen historisch-siedlungsgeographischen Forschung lange Zeit verbunden (DENECKE 2001:278). Die genetische Siedlungsgeographie suchte das Werden der ländlichen Siedlungsformen zu erforschen und ,galt lange Zeit als unbestrittene Krönung der Kulturgeographie. Sie war fest eingebunden in eine regional angelegte genetische Kulturlandschaftsforschung." (BECKER 2001:6) 
„Dabei gilt, daß der Schwerpunkt des geographischen Arbeitens sich vor allem auf jene Sachverhalte der Vergangenheit konzentriert[e], die bis zur Gegenwart nachwirken bzw. die der Erklärung gegenwärtiger Erscheinungen aus der Vergangenheit dienen können.“ (:15) Dieser Schwerpunkt kulturlandschaftsgenetischer Betrachtungsweise galt bis in die 1960er Jahre. Dieses Arbeitsfeld, so DENECKE 1994 (:433) konsterniert, wird aber „heute nur noch selten bestellt, die Blütezeit dieses Forschungsansatzes gehört in die [19]60er Jahre." und ist mit klangvollen Namen wie GRADMANN, SCHLÜTER und KRENZLIN verbunden.

„Seit den 1970er Jahren“, fasst DENECKE (2001:289) die weitere Entwicklung bezüglich Stand und Aufgaben der siedlungs- und kulturlandschaftsgeschichtlichen Forschung zusammen, „hat sich - ganz besonders in Deutschland - die allgemeine Kulturgeographie nicht nur von der konkreten Siedlungs- und Landschaftsanalyse zunehmend entfernt, sondern ganz speziell auch von dem genetischen Erklärungsansatz, bezogen auf Siedlung und Landschaft. Forschungsbereich und Forschungsansatz wurden einer sich verselbständigenden Historischen Geographie überlassen, die einen Zusammenhalt und eine Stärkung in einer interdisziplinären Arbeit suchte, vor allem mit der heranwachsenden Siedlungsarchäologie." In die Mitte der 1970er Jahre fällt also ,auch [...] in der siedlungs- und kulturlandschaftsgenetischen Forschung die Durchsetzung des interdisziplinären Arbeitsansatzes. Zu den bereits vielfältigen Teilbereichen der kulturlandschaftsgeschichtlichen Forschung“, beschreibt DENECKE (:276) das erweiterte Aufgabenspektrum und den nur schwierig durchzusetzenden Anspruch, ,kamen weitere hinzu, die zusammengenommen eine äußerst komplexe und facettenreiche Kooperation und Zusammenschau verlangten, wenn ein integratives Ziel in der Synthese einer Kulturlandschaftsentwicklung angestrebt werden sollte.“ „War dieser Weg in vieler Hinsicht für beide Seiten auch außerordentlich fruchtbar“, summiert er (:289) den teuer erkauften Vorteil auf, „,so ging doch gleichzeitig der Zusammenhang mit der eigenen geographischen Disziplin zunehmend verloren." (zur Gefahr bzw. zum Problem von ,Interdisziplinarität" siehe 3e). In gleicher Weise findet KRINGS (2001:49), ,in dem Maße, wie sich ein großer Teil der Geographen von der traditionellen genetischen Kulturlandschaftsforschung abwandte, wurde der Begriff von anderen Fächern adaptiert. Damit ging aber beispielsweise die Möglichkeit verloren, selbst Kenntnisse der physisch-geographischen Grundlagen einzubringen bzw. sich mit Hilfe innerfachlicher Kontakte [sic] zu verschaffen. Diese Entwicklung ist fachpolitisch betrachtet eine selbstverschuldete Schwächung.“

Mit der Loslösung von der genetisch orientierten Kulturgeographie und der Durchsetzung einer interdisziplinären Arbeitsweise folgte zudem seit der 2. Hälfte des 20. Jh. die „Hinwendung zur einer ,vorrangig aktualistisch orientierten’ Kulturgeographie“ (BECKER 2001:6). „Als Folge dieser Entwicklung hat sich die Situation in der Kulturgeographie vollkommen gewandelt. Nicht mehr historisch-geographische Fragenkreise bestimmen die Forschung der meisten Kollegen, sondern aktual-geographische Ansätze in den genannten neuen Teildisziplinen ${ }^{16}$. Unter derartigen Umständen hat natürlich die Historische Geographie ihre einst so beherrschende Stellung längst eingebüßt; sie ist zu einem unter zahlreichen anderen Teilgebieten des Faches geworden.“(:7). „Den Paradigmata der klassischen Kulturgeographie“, so DENECKE (2001:279) im Rückblick, „gingen im Laufe der letzten 30 Jahre die bis dahin vorherrschenden entwicklungsgeschichtlichen Perspektiven und Erklärungsansätze verloren“.

Aufgrund dieser Entwicklung sieht ebenso BECKER (2001:7) einen Paradigmenwechsel ,innerhalb der hier zu behandelnden Teildisziplin“: „War noch vor rund 35 Jahren [1965] historisch-geographische Forschung in erster Linie eine genetische Kulturlandschaftsforschung mit dem Ziel, die Entwicklung der heutigen Kulturlandschaft zu erklären, so besteht heute das Anliegen dieser Teildisziplin des Faches vor allem darin, geographische Sachverhalte in der Vergangenheit zu erschließen.”, und beschreibt damit die Unterschiede zwischen neuerer historischer Geographie und früherer Kulturgeographie hinsichtlich des Anwendungsbezuges, die beispielsweise in der Katastrierung aller möglichen historischen Erscheinungen liegt: „Es geht also nicht - zumindest nicht primär - um die Deutung der Wurzeln des heutigen Landschaftsbildes, sondern um das Erkunden und Erschließen von geographischen Verhältnissen in der Vergangenheit.“(:7)

Zusammenfassend lässt sich zu dem Werdegang der Historischen Geographie sagen, dass seit Mitte der 1960er Jahre, vor allem aber der 1970er Jahre. die Loslösung der allgemeinen Siedlungs- und Kultur-

16 Neue Teildisziplinen nach BECKER: moderne Stadtgeographie, Bevölkerungsgeographie, Industriegeographie, Fremdenverkehrsgeographie, moderne Sozialgeographie 
geographie vom genetischen Forschungs- und Erklärungsansatz und die Entwicklung der „Historischen Geographie“ zu einer eigenständigen Teildisziplin erfolgte (DENECKE 2001:277) und daraus folgend eine Verselbständigung der historischen Geographie innerhalb der Geographie unter gleichzeitigem „Ausbau [...] in einem interdisziplinären Zusammenhang" (:273). Ab diesem Zeitraum folgte sowohl in der deutschen als auch - neben der besonderen Zuwendung zu sozialwissenschaftlichen Fragestellungen - in der angloamerikanischen und frankophilen historischen Kulturgeographie - die stärkere Verbindung und interdisziplinäre Hinwendung zur Siedlungsarchäologie und Siedlungsgeschichte und „historical geography in its proto-modern form evolved as a branch of history“ (BUTLIN 1993:IX) und führte in England zur Entwicklung der „New Historical Geography“ (DENECKE 2001:273), wie wir bereits an der Stellung der Geographie innerhalb eines Teils des heute noch gültigen Wissenschaftsbildes gesehen haben.

Eine Ursache dafür mag in dem mangelnden Nexus dieses Forschungsansatzes liegen, dessen Fehlen man glaubte erkannt zu haben. „Historisch-genetische Erklärungen“, stimmte Ludwig TREPL (1978:55) in die ,Rücktrittsforderungen' mit ein, haben ,überwiegend den Charakter von Chronologien oder Genealogien, $d$. h. von Beschreibungen eines Wandels, und nur an einigen Stellen wird tatsächlich kausal erklärt.“

Einen weiteren Grund liefert TREPL mit der These der prognostischen Inkompetenz, die uns als Vorwurf schon früher einmal begegnet ist (siehe 1a). Historische Ereignisse, so TREPL (1978:55) unter Einschränkung bzw. teilweiser Rücknahme des vorhergehenden Kausalitätsproblems, ,lassen sich wohl kausal erklären, aber nicht aus der Kenntnis einer Ausgangssituation prognostizieren, denn die Ausgangssituation liefert die zwischen ihr und dem zu prognostizierenden Ereignis liegenden ,neuen' [...] Randbedingungen nicht mit“. Es genüge ,also nicht, eine Ausgangsituation zu erkennen, aus der heraus sich die Erklärung (Prognose) konstruieren ließe“, wie es der historisch-genetischen Forschung eigen ist (:55). Jedoch: „Wenn ,Erklären’ in der Geschichte wie anderswo nicht bloß die Ableitung eines Ereignisses aus einem anderen, sondern die Herleitung historischer Prozesse aus relativ dauerhaften Gegebenheiten mit verallgemeinerbarer Logik bedeutet, dann", so die gegenteilige und die eine Zukunftsfähigkeit bejahende Position RADKAUs (2002:46), ,stehen historisch-genetische Erklärungsmuster in vielen Fällen nicht ganz schlecht dar. Ähnliches gilt, wenn ,Erklären' die Herleitung aus einer Ursachenebene meint, hinter die man mit historischer Empirie nicht zurückgelangt.“

Parallel zu England und Nordamerika, in denen der Schwerpunkt auf sozialhistorischen Ansätzen lag, entwickelte sich die Anthropo- bzw. Kulturgeographie gleichzeitig zur Kulturlandschaftsforschung insbesondere seit den 70er Jahren zu einer Sozialgeographie. Als Beispiel sei hier die Münchner sozialgeographische Schule um RUPPERT, MAIER und POPP (1977) genannt, die durch Verteilung der Lehrstühle in den Folgejahren bis nach Passau und Bayreuth fortwirkte und beispielsweise auch im skandinavischen Raum große Beachtung fand ${ }^{17}$. Weiterhin ,..wandte sich die allgemeine Siedlungs- und Stadtgeographie gezielt jüngeren und jüngsten Entwicklungsprozessen zu, um damit letztlich auch zu einer planungsbezogenen Anwendung zu gelangen.“ (DENECKE 2001:277) Dies hingegen „war nur einer der Aspekte heraufkommender Spannungen oder Trennungsbewegungen innerhalb der allgemeinen Kulturgeographie.“ (:277). Mit dem Festhalten an der siedlungs- und kulturlandschaftsgenetischen Forschung, „verstärkt vor allem durch den Verbund mit der Siedlungsarchäologie“, analysiert DENECKE (:289) die Ursachen und kritisiert zugleich die disziplinäre ,Neuorientierung', „hat die Historische Geographie - ganz speziell in Deutschland - nicht den Weg zu einer modernen Sozialgeographie wie auch zur modernen Sozialgeschichte gefunden. Dies hat sie losgelöst von der Entwicklung der allgemeinen Kulturgeographie im eigenen Fach, zugleich aber auch von der internationalen Entwicklung der Historischen Geographie selbst.“

Im Gegensatz zur deutschen Geographie, die zunehmend die landschaftskundliche Seite vernachlässigte, bildete sich nämlich in Amerika in den 1990er Jahren vergleichbar zur früheren deutschen Kulturlandschaftsgeographie eine Gruppe von „Landscape historians“ aus, die es hier in der Form vorher gar nicht gegeben hat (,an important field of history that has been far too long neglected“, SAUER 1996:236) und sich als Aufgabe gesetzt hat, ,the impacts of settlement and its accompanying land use changes“ (:236) festzustellen. SAUER

\footnotetext{
${ }^{17}$ Als Beispiel sei Perttu VARTIAINEN, Direktor des Instituts für Geographie und Regionalplanung der Universität Joensuu /Finnland genannt, der sich - da auch die deutsche Sozialgeographie in ihrer Weiterentwicklung in den 1990er Jahren eingebrochen ist -, der sozialkritischen, zuweilen marxistisch-orientierten anglo-amerikanischen Geographie zugewandt hat.
} 
(:236) beschreibt die Arbeit dergestalt, dass „landscape historians do the valuable hard work of documenting from the widely scattered and often quite obscure sources the stories of how we have altered our lands."

Die Entwicklung lässt sich für die gesamtsprachliche Historische Geographie wie folgt zusammenfassen: ,a variety of different historical geographies has developed in different periods and places, reflecting different intellectual, political, and moral contexts.” (BUTLIN 1993:2) und gleichzeitig haben „different and changing traditions and contexts of and for historical geography developed elsewhere, in the United States, Germany and France, for example, and these traditions continue, with varied degrees of modification, to the present day" (:IX).

Die spezifische Situation in Deutschland sieht dabei wie folgt aus: „Die H.[istorische] G.[eographie] wird heutzutage im wesentlichen von zwei Forschungsrichtungen bestritten: Die eine Forschungsrichtung der H.[istorischen] G.[eographie] führt auf den Kulturgeographen Otto Schlüter (1872-1959) zurück und begreift sich als Angewandte H.[istorische] G.[eographie], deren hauptsächliches Anliegen die historische Begründung und Ableitung aktueller Landschafts- und Siedlungsplanung ist. Die andere Forschungsrichtung der H.[istorischen] G.[eographie] führt auf die Anfänge der abendländischen Wissenschaft zurück, wo sich etwa bei Hekataios von Milet natur- und geisteswissenschaftliche Fragestellungen und Methoden noch als Einheit begreifen lassen.“ (SONNABEND 1999d:219)

Die Historische Geographie war und ist zwar ,auch heute noch“, befindet DENECKE (2001:279), „weitgehend der landschaftsräumlichen Analyse und Synthese verpflichtet, [...] viele Stränge“ hingegen, „die bis in die [19]70er Jahre gebündelt leitend gewesen sind,“ haben „heute an Tragkraft verloren“. Diese, natur- und geisteswissenschaftliche Fragestellungen verbindende, Historische Geographie, die ,andere Forschungsrichtung" nach SONNABEND, ist im Rückzug begriffen.

Die „historische Kulturlandschaftsforschung“, die das Aufgabenfeld und das Selbstverständnis der historischen Geographie heute maßgeblich trägt und, dies lässt sich ohne Übertreibung feststellen, mittlerweile das Grundgerüst der historisch-geographischen Disziplin darstellt, beschäftigt sich heute weniger mit der Siedlungs- und Landschaftsgenese, sondern schwerpunktmäßig mit der „Erfassung, Dokumentation, Erforschung sowie mit dem Schutz und der Pflege von Relikten, Elementen und Landschaften“ (AURIG/VOGELMANN 1996:9); obschon auch diese erstgenannte Forschungsrichtung einen alten Zweig der Historischen Geographie repräsentierte, stellt der anwendungsbezogene Betrachtungsansatz heute die maßgebliche Forschungsrichtung dar. Die von SONNABEND als zweite Forschungsrichtung deklarierte rein scientistische Ausprägung wird dagegen zunehmend weniger verfolgt.

Im Mittelpunkt der heutigen Landschaftsforschung stehen die sichtbaren Bestandteile, die sich gut umweltgeschichtlich auswerten lassen: die 'historischen Kulturlandschaftselemente'. Diesen in der Regel persistenten Strukturen und Phänomenen wird bei der Behandlung von Kulturlandschaftswandel eine besondere Aufmerksamkeit geschenkt. „Persistenzen unterschiedlicher historischer Tiefe,“ sind ,als Indikatoren und Relikte der Gestaltung und Nutzung vergangener Epochen ein wesentliches Element historisch-geographischer Betrachtung“ (DENECKE 2001:292). Es handelt sich dabei um Elemente oder Strukturen, die im Wandlungsprozess übrig geblieben sind, das heißt trotz neuer Ansprüche ihre Form, aber in der Regel nicht ihre Funktion, weitgehend behielten (in Anlehnung an MÜCKE 1988:160). Sie ,geben Zeugnis ab vom Umgang früherer Generationen mit Natur und Landschaft und vermitteln ein anschauliches und ungekünsteltes Bild vom Lebensstil unserer Vorfahren, ihrer Möglichkeiten und Bedürfnisse“" (AURIG/VOGELMANN 1996:9). Vor diesem Hintergrund spricht Luise GRUNDMANN (1996:7) auch von „identitätsstiftenden Kulturlandschaftsstrukturen und -elementen“. Es sind nach ihrer Definition ,alle in der Landschaft sichtbaren Objekte, die wesentliche landeskundliche Zusammenhänge erkennen lassen und im Bewußtsein des Menschen geläufig sind“" (:7).

PRINCE (1969:113) vertritt - insbesondere angesichts der frühen Zeit der Aussage - eine sehr moderne und aktuelle Auffassung, wie bei der „Kulturlandschafts-Diskussion“ deutlich wurde (siehe 2.c), wenn er sagt: „This study [landscape history] also includes studies of relict features in the contemporary landscape without any direct concern for the relevant former landscapes." Nach seiner Auffassung ,all features in present landscapes are relict features according to one interpretation.": 113; aus: NORTON 1984:34). Die Bedeutung persistenter, d. h. sichtbarer Strukturen und Elemente für die Erforschung der Kulturlandschaft auch für die 
angelsächsische Geographie wird deutlich, wenn BAKER (1992:3) sagt: „historical studies of landscapes must be grounded in an analysis of material structures: they are properly concerned with tangible, visible expressions of different modes of production, with hedgerows and filed systems, with canals and factory systems."

Als Beispiele von historischen Kulturlandschaftselementen können Torfkanäle als fossiles Verkehrssystem aus der Zeit des Spätmittelalters und der frühen Neuzeit, Mühlräder als oberschlächtiger Wasserantrieb oder Dorfbrunnen als zentraler Wasserversorgungsplatz der Dorfgemeinschaft genannt werden. Als Beispiele von Kulturlandschaftsrelikten außerhalb der unmittelbaren Gewässerthematik können beispielsweise Goldseifenanlagen als Relikte der Goldgewinnung in Südböhmen, Glashüttenrelikte im mittleren Erzgebirge (Öfen, Abfallhalden, Lehmgruben) oder typische Reliktformen des historischen Tonbergbaues (sog. Glockenschachtfelder ${ }^{18}$ ) und sog. Kannenbäckerstraßen (Erd- bzw. Tonwege) genannt werden.

Diese Fokussierung der Historischen Geographen auf die Erforschung der Kulturlandschaftsgeschichte anhand von landschaftlichen Elementen und ihre Aufnahme in Form einer taxonomischen Ordnung hat aber auch Kritiker gefunden. Für TREPL (1978:232) „erscheint ihre Arbeit als ein regelloses Auflisten, als bloße Inventarisierung“.

Doch gibt es hinsichtlich der zukünftigen Entwicklung neben der zur Zeit „modernen“, doch nichtsdestotrotz notwendigen, Beschäftigung mit historischen Kulturlandschaftelementen weitere Inhalte. Die zukünftigen und gegenwärtigen Aufgabenfelder bzw. Forschungsthemen der historischen Kulturgeographie skizzieren NITZ (1998a,b), DENECKE (2001) und KRINGS (2001) an verschiedenen Stellen ihrer Veröffentlichungen, die sich wie folgt zusammenstellen lassen. Es ist dabei ein Konglomerat aus ,alten“ und „neuen“ Zielsetzungen und deckt ein breites Spektrum bestehender und zukünftiger historisch-geographischer Forschung ab:

1. Die Historische Geographie sollte „die Entstehung und den Werdegang historischer Kulturlandschaftsstrukturen, ihre Funktion in früheren Gesellschaften und deren Lebens- und Wirtschaftsraum vermitteln und bewußt machen." (NITZ 1998b:416). Der historisch arbeitende Geograph sollte in dieser Hinsicht dazu beitragen, das öffentliche Bewusstsein für die Bedeutung historischer Strukturen zu wecken und zu fördern. „Seine Aufgabe liegt dabei [...] vor allem in der ,wissenschaftlichen Aufklärung', das heißt in der Vermittlung von Wissen über die örtlichen historischen Strukturen" (:416). Dafür ist ein profundes Fachwissen erforderlich, denn „die Erforschung der historischen Wurzeln oder Ursprünge der gegenwärtigen Muster und Strukturen, der persistenten historischen Elemente also, ist unabdingbar, wenn wir diese vollständig verstehen und erklären wollen." (NITZ 1998:125) Für die Anwendung der Vermittlung und der Bewusstbarmachung gibt es nach KRINGS (2001:49, Hervorhebung im Original) zwei große Aufgabengebiete: neben der Beschäftigung mit der Stadt als einem der beiden großen Aufgabengebiete der Historischen Geographie ist das andere „mit dem Begriff Kulturlandschaft etikettiert.“: Beide Untersuchungsbereiche - Städte ebenso wie Kulturlandschaften - „können [...] in ihrem heutigen Erscheinungsbild als Palimpsest betrachtet werden. Ein Palimpsest ist ein wertvolles Pergament, das immer wieder für neue Botschaften benutzt worden ist. Nur die jüngsten Einträge sind ohne weiteres erkennbar, die älteren aus einer mehr oder weniger fernen Vergangenheit müssen erst sichtbar gemacht werden, um lesbar zu sein. Genau dies entspricht dem, was die Historische Geographie leisten kann. Anders ausgedrückt, jede wisenschaftliche Beschäftigung mit heutigen kulturlandschaftlichen Zuständen steht vor der Herausforderung, Elemente und Strukturen erklären zu müssen, die aus der Vergangenheit in die Gegenwart hineinreichen.“ (:49) Dieser Weg, so NITZ, sei außerdem der „einzige Weg“ für die Historische Geographie „Argumente für den Schutz und den Erhalt von historischen Raumstrukturen zu finden.“ (NITZ 1998:125,126)

2. Um dieses Ziel der Wissensvermittlung und Sensibilisierung überhaupt erst zu ermöglichen, besteht eine wichtige Aufgabe der Historischen Geographie in der landes- und landschaftsgeschichtlichen Erforschung. „Nur eine Historische Geographie bietet die Möglichkeit, langandauernde Prozesse zu studieren, durch die Raumstrukturen geschaffen, transformiert, konsolidiert, zurückgebildet oder

\footnotetext{
${ }^{18}$ Es handelt sich dabei um glockenförmige Schachterweiterungen mit Durchmessern am Schachtanfang von $\varnothing=1,5 \mathrm{~m}$ und bis zu $\varnothing$

$=10 \mathrm{~m}$ in der Tiefe, die $10-20 \mathrm{~m}$ beträgt.
} 
ausgelöscht wurden, wobei zugleich die Kräfte, Akteure und Interessen hinter diesen Wandlungen erfaßt werden.” (NITZ 1998:126) Auch DENECKE (2001:292) betont, dass die historisch-geographische Betrachtung ,auf Langzeitentwicklungen gerichtet“ ist, sieht aber auch „das Nacheinander von Epochen in einer Verknüpfung mit der Gegenwart.“ Inhaltlich ist diese „rückblickende Erschließung, Analyse und Dokumentation der raum-zeitlichen Prozesse [...] auf den Wandel gerichtet, auf Transformationsvorgänge, auf Sukzessionen oder Umnutzungen, die in den früheren Epochen langzeitig in jüngere Zeit hineinführend auch recht kurzfristig ablaufen können.“(:292)

3. Die Historische Geographie sollte die Einstellungen, das Verhalten und Handeln früherer Generationen gegenüber dem historischen Erbe in der Kulturlandschaft untersuchen: Die heutige Generation könnte aus den gemachten Fehlern, aber auch aus dem konstruktiv-bewahrenden Verhalten in der Vergangenheit lernen (vgl. NITZ 1998b:416).

4. Der historisch arbeitende Geograph sollte bei der erhaltenden Stadt- und Dorferneuerung mitwirken. Nicht nur bei der Bestandsaufnahme historischer Kulturlandschaftsstrukturen, sondern auch bei der Aufstellung von Bewertungskriterien, die zugrunde gelegt werden müssen, wenn es zu Entscheidungen über Erhalten oder Nichterhalten kommt (vgl. NITZ 1998b:416).

5. Aber es gilt auch den Fortbestand der Landeskunde zu sichern. Die Historische Geographie sollte die geographischen Verhältnisse der Vergangenheit einer Region um ihrer selbst willen erforschen, aus einem wissenschaftlichen Interesse heraus, um die räumlichen Muster und Prozesse einer vergangenen Gesellschaft kennenzulernen. „Diese stehen uns in der zeitlichen Dimension so fern wie etwa eine räumlich weit entfernte fremde Gesellschaft in der heutigen Welt.“(NITZ 1998:126)

6. Deshalb besteht eine besondere Verantwortung der Historischen Geographie hinsichtlich der räumlichen Verortung. „Im Kontinuum von Raum und Zeit ist der Blick auf den Ort, vor allem aber auf größere Räume der Landschaft gerichtet, auf Ort und Raum sind Betrachtungen und Analysen bezogen, im theoretischen wie auch im praktischen Ansatz, in den Fragestellungen wie auch in der Wahrnehmung von Ort und Raum.“ (DENECKE 2001:292) Diesen Raumbezug als zentrales Element der Historischen Geographie hebt auch PÖRTGE (2004) hervor: „Kern der Historischen Geographie ist das Gewinnen von Einsichten in die Regelhaftigkeiten im Verhältnis von Mensch und Umwelt in historischer Zeit. Gegenstand der Untersuchungen sind u. a. raumrelevante Prozesse, raumprägende Strukturen und die Umgestaltung der Naturlandschaft zur Kulturlandschaft durch den handelnden Menschen. Dazu müssen ehemalige Landschaftszustände rekonstruiert und die raumzeitliche Entwicklung zum heutigen Landschaftszustand erklärt werden.“

Diese sechs Themenbereiche spiegeln das gegenwärtige Selbstverständnis der Historischen Geographie wider, das auch in der aktuellen Definition von NAGEL/SCHENK (2001:4, Hervorhebung im Original) deutlich wird:

„Anliegen der Historischen Geographie ist der Gewinn von Einsichten in die Regelhaftigkeiten im Verhältnis von Mensch und Umwelt in historischer Zeit (SPERLING 1982). Als historische Raumwissenschaft beschäftigt sie sich in diesem Sinne mit den raumrelevanten Prozessen, den raumprägenden Strukturen und der konkreten Umgestaltung der Natur- zur Kulturlandschaft durch das Wirken des Menschen vom Beginn der menschlichen Geschichte bis in die Gegenwart herein. Das setzt die Erfassung, Beschreibung und Erklärung der Qualität und Quantität kulturgeographischer Prozesse in der raumzeitlichen Differenzierung voraus und schließt die Rekonstruktion von Landschaftszuständen zu einer bestimmten mehr oder weniger weit zurückliegenden Zeit (Querschnittverfahren) und die Geschichte von Regionen (Längsschnittverfahren) ein. All das dient als Hintergrund und Ursachenerklärung für wirtschaftliche, soziale, demographische, ökologische und mentale Prozesse und Zustände in Vergangenheit und Gegenwart. Es geht darüber hinaus um eine Verlängerung des Beobachtungszeitraums in die Vergangenheit, damit um eine Erweiterung des Merkmals- und Erkenntnisraums, welcher die Spannbreite natürlicher und menschlicher Entwicklungen verdeutlicht. Die Vergangenheit ist in diesem Sinne ein Modellraum, der aktuelle und vergangene Strukturen und Prozesse durch die wechselseitige Erhellung interpretieren hilft. Die Erarbeitung raumzeitlicher Modelle im Sinne der Formulierung allgemeingültiger Prinzipien räumlicher Differenzierung sowie regelhafter Abläufe raumrelevanter Prozesse und 
dahinterstehende Kräfte für die Vergangenheit ist damit eng verbunden; die Ausweisung von Siedlungsräumen steht in diesem Kontext. “

Beachtenswerte neue Ansätze einer vor allem die interdisziplinäre Ausrichtung verfolgende „contemporary historical geography“ (BUTLIN 1993:XI) bzw. einer zeitlich jüngeren ,historical geography of modernity“ (NASH 2000:22) [Hervorhebungen im Original] kommen aus dem anglo-amerikanischen Sprachraum. Die Historische Geographie sei, so beispielsweise die Kritik, ,apparently blind to the significances of studies of subject positions, such as class, gender, race and sexuality [...] in cultural understandings of landscape" (SEYMOUR 2000:213).

Der Ansatz einer „historical geography of modernity“ bzw. „modern historical geography“ geht über die hautpsächlich rein interdisziplinäre Forderung der gegenwärtigen „contemporary historical geography“ hinaus, ohne die Interdisziplinarität zu vergessen. Sie bezieht darüber hinaus in den modernen Kanon die Substanz klassischer historischer Geographie mit ein und legt sich auch zeitgeschichtlich fest, aber orientiert sich weiterhin an ihre sozialgeographischen Wurzeln. Dies ist ein interessanter Aspekt, der sich bei der Analyse der zukünftigen Entwicklung der anglo-amerikanischen Historischen Geographie ergibt; dass auch in der aktuellen Literatur weiterhin der traditionelle Grundkonsens besonders herausgestellt wird: „The geographical processes which have shaped the modern world and the ways in which the past is understood and culturally represented in the present are central concerns within the historical geography." (NASH 2000:15).

Dennoch musste dafür ein neuer Begriff gefunden werden, den NASH/GRAHAM (2000:1) wie folgt begründen: „First, it denotes our concern with contemporary or new approaches, perspectives and themes within historical geography at the turn of the twenty-first century. Secondly, [...] the title here alludes to the time period of the 'modern', usually divided into the early modern of the sixteenth and seventeenth century, the modern eighteenth and nineteenth centuries, and the (post)modern twentieth century." Dabei ist es "not [a ...] call for a "new historical geography', a label which would diminish what historical geography is and has been.” (:4) „Modern Historical Geographies” im Sinne von NASH/GRAHAM (:5), ,is meant to be less an agenda, or a programmatic statement for a "new historical geography', than a reflection of already current interests, new developments and continuities of concern within historical geography."

Das im Wesentlichen Neue ist, dass „historical geographies of modernity map complex and specific interconnections between places and between different processes.” (NASH 2000:22, ebenso:2): „Pursuing both an interdisciplinary perspective and the long traditions of historical geography shaped by agricultural change, urbanisation, industrialisation, transport and the lives, deaths and migrations recorded in the statistics of demography" (NASH/GRAHAM 2000:1). "Modern Historical Geographies extends this tradition of considering the interconnections between places - for example, within modern networks of communication, transport or trade that connected Europe and its imperial sphere of influence - by analysing the kinds of geographical discourses and practices which have structured the ways in which the relationships between places or regions are understood." (:1f.)

Und wenn die britische Theoretische Geographie von „historischer Geographie“ spricht, dann subsumiert sie auch die ,postcolonial geographies“ darunter (SHURMER-SMITH 2002); ein Themenfeld, das in der (neueren) deutschen Geographie bislang nicht bearbeitet wird. Mitunter dadurch, weil sie betrachtet wird als „a shameful episode“ (:67). Dies hindert aber die angelsächsische Geographie nicht daran, sich mit ihr zu beschäftigen, denn, so die Argumentation, ,all postcolonial cultural geography has a broadly similar, antiimperialist, perspective.“(:67)

Auch in der deutschsprachigen Historischen Geographie sind seit einigen Jahren Bestrebungen im Gange, neue inhaltliche Aussagen zu gewinnen und die Zukunftsfähigkeit zu gewährleisten. Hierbei ist primär das Bemühen erkennbar, sich zukünftig den anderen Bereiche der Geographie zu nähern bzw. diese wieder näher zusammen zu führen. „Eine stärkere Zusammenarbeit der Historischen Geographie mit der Naturgeographie, [...] wird gegenwärtig vor allem durch die Bedeutung der Umweltgeschichte für die Historische Geographie nahegelegt.“ (JÄGER 1997:343). JÄGER sieht darin eine der „wichtigsten Aufgaben der Historischen Geographie für heute und morgen“ (:344). Da sich „seit einigen Jahren auch die physische Geographie 
intensiv mit Landschafts- und Umweltgeschichte befaßt, sollte die gelockerte, wenn nicht abgebrochene Zusammenarbeit mit jener intensiviert werden.“(:344)

Eine rein 'Historische Physische Geographie' kann hingegen als gewisses Problem angesehen werden, weil aus der Forschungstradition und der allgemeinen Auffassung bisher überwiegend eine "Historische Kulturgeographie" praktiziert wird. Es gibt nach BECKER (1998:17) jedoch eine hinreichend große Zahl historisch-physisch-geographischer Arbeiten, die ,einen theoretisch abgeleiteten Anspruch auf eine ,historische Gesamtgeographie' auch für den Bereich der Physischen Geographie empirisch" bestätigen. Als Beispiele können in Ergänzung an BECKERs Aufzählung genannt werden: die Erforschung der Klimaschwankungen in geschichtlicher Zeit, anthropogene Oberflächenformung (Auenlehmfrage, Bodenerosion, Tilkenproblematik, Binnendünen-Diskussion u. Ä.), Erfassung und Datierung historischer Flussverlagerungen, tierhistorische Fragestellungen usw.

Zwar ausgehend von einer mehr kulturgeographischen Perspektive, aber in ähnlicher gesamtheitlicher Betrachtungsweise fordert DENECKE (1994:432), an die Historische Geographie gerichtet, nicht nur "wieder eine festere Bindung an die Fortentwicklung der allgemeinen Anthropo- und Sozialgeographie zu erreichen", sondern auch darüber hinaus den „historisch-genetische Betrachtungsansatz [...] vielmehr weiterführend in einen integrativen, vielseitigen Zusammenhang zu stellen, im Rahmen einer Kulturgeographie, in der das langzeitig wirksame Beziehungsgefüge zwischen Mensch und Natur eine führende Problemstellung ausmacht“ (:432). „Geistes- und sozialwissenschaftliche Forschungsansätze”, so fährt er in seinen Überlegungen fort, sind dabei ,in einem neuen Zusammenhang mit den natürlichen Ressourcen und Verhältnissen zu verfolgen“" (:432).

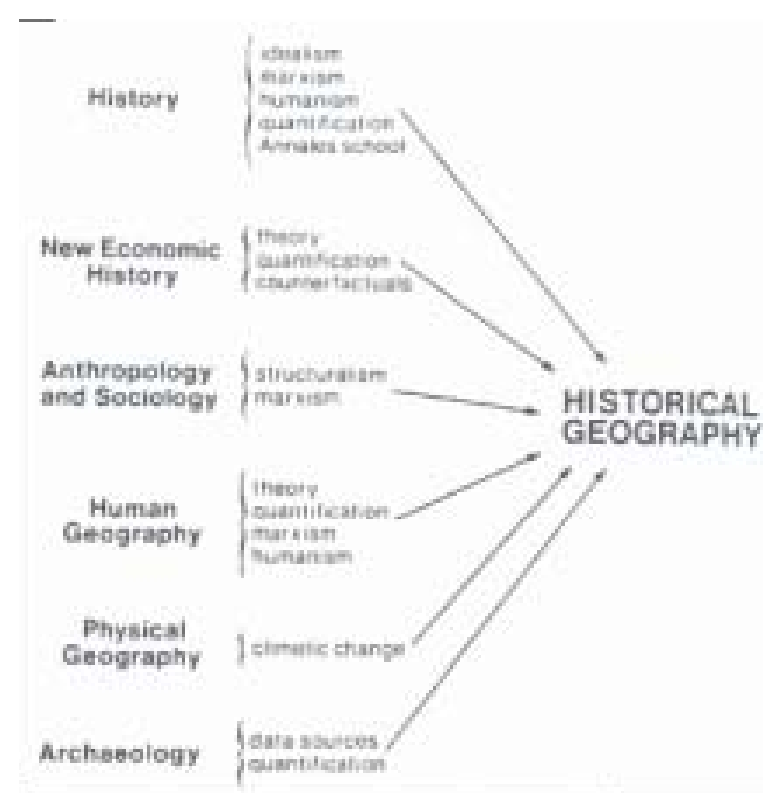

Abb. I-3: "Historical geography and related diciplines."

Vorschläge ("suggests") von "some of the possible impacts of these related disciplines." (aus: NORTON 1984:38)

Die Stärkung der Historischen Geographie durch Befreiuung aus der (zu) engen Klammer der Kulturgeographie, obgleich die Sichtweise des anthropogenen Hintergrundes der "Naturlandschaft“ selbstverständlich weiterhin Gültigkeit besitzt, und die Re-Integration physischer bzw. naturhistorischer Forschungselemente, könnte den Weg aufzeigen von einer historischen Raumwissenschaft zu einer integrativen historisch-geographischen Umweltwissenschaft.

Doch Vorsicht ist geboten. Um mit BUTLINs (1993:X) Worten zu sprechen: „There is more than one way of uncovering the geography of the past, [...] and claims to the superiority of any one approach, together with attempts to encapsulate this myriad of approaches into a single definition or ideological framework, must therefore be viewed with caution, if not with suspicion." BUTLIN sieht die Historische Geographie vielmehr als eine „multi-faceted and complex hybrid discipline”(:2) und dies entspricht auch dem Leitbild einer integrativen historisch-geographischen Umweltwissenschaft. 
Hier wurden bereits die grundlegenden Komponenten des umwelthistorischen Ansatzes innerhalb der (Kultur-) Geographie deutlich, der in den nachfolgenden Absätzen eine weitere Konkretisierung und seine endgültige Ausgestaltung erfährt. Deutlich ist geworden, dass die zukünftige Entwicklung geprägt ist von einer Historischen Geographie als interdisziplinäres umwelthistorisches Fach. Gleichzeitig steht der traditionelle Forschungsgegenstand „Kulturlandschaft“ weiter im Zentrum der Betrachtung unter stärkerer Beachtung der physiogeographischen Aspekte.

\section{c Zur Begriffsbestimmung und Stellung der „historischen Umweltforschung“ bzw. „Umweltgeschichte”}

„History”, skizziert WORSTER (1993b:311) die unbefriedigende, zu ,klinisch-saubere', theorieschwangere Situation bis zu Beginn der 1970er und die positive Entwicklung danach, ,increasingly became an archival pursuit, carried on by urban scholars; there was less and less dirt on it. [...] A growing number of scholars, consequently, have begun to talk about something called 'environmental history'. In 1972 the Pacific Historical Review devoted an entire issue to this new inquiry, and three years later the American Society for Environmental History formed to promote the study in earnest." Ob diese Wandlung einer sterilen Geschichtswissenschaft zu einer Geschichte der Umwelt in all seinen, auch ,schmutzigen' Facetten zu diesem Zeitpunkt auch in Deutschland einsetzte und ob dies eine eigenständige oder zeitgleiche bzw. sogar globale Entwicklung oder eine schlichte Adaption des amerikanischen Betrachtungsansatzes darstellt, lässt sich aus der von mir recherchierten Literatur zur Umweltgeschichte nicht beantworten. Fest steht nur, dass sie einsetzte; unter synonymer Verwendung des VON UEXKÜLLschen „Umwelt“-Begriffs, mit dem „die heutige Ökologie [...] nichts anfangen“ kann; „aber für die historische Umweltforschung paßt er gut.“ (RADKAU 2002:40)

Die ,historische Umweltforschung' wird im deutschen Schrifttum oftmals mit dem Begriff ,Umweltgeschichte' gleichgesetzt (z. B. von REITH 1998:15). Im anglo-amerikanischen Sprachraum wird dafür der Name ,environmental history' oder , history of environment" gebraucht (BLASCHKE 1990:68).

Historische Umweltforschung bzw. Umweltgeschichte wurde institutionell schon vor rund einer Dekade als - zumindest in Deutschland - noch junge Teildisziplin der allgemeinen Geschichtswissenschaft verstanden und diesem Disziplinbereich untergeordnet (so von ISENBERG/MÖLICH 1992:7; SIEFERLE 1984:496). Der Umwelthistoriker RADKAU (1994:21) wollte diese Verbindung noch fördern und forderte, ohne Zuordnung in ein Disziplingebäude, jedoch mit einer disziplinären Verengung, „daß die Umwelthistorie einen engen Konnex mit den Hauptströmungen der Geschichtswissenschaft anstreben sollte." Glaubt man HAUPTMEYER/FROHNER (2000:7), ist sie dort auch angekommen, denn ,in den letzten beiden Jahrzehnten hat sich die Umweltgeschichte als ein eigenständiger Zweig der Geschichtswissenschaft etabliert.“

Obgleich die historische Komponente tragend für das Selbstverständnis der Geschichtswissenschaften ist, kann die hier vorgenommene Einordnung nicht überzeugen. Sie verkörpert vielmehr das Produkt des Bestrebens nach einer fachbezogenen Aufwertung durch eine selbstverständliche Eingliederung sämtlicher historisierender Elemente in das Fach Geschichte. Die ,historische Umweltforschung' erscheint hier als untergeordnete Disziplin der allgemeinen Geschichte innerhalb der Gesamtdisziplin Geschichtswissenschaft.

Im Gegensatz zu der geschichtswissenschaftlichen Untergruppierung ist für LEHMANN (1976:21) vielmehr „der naturwissenschaftlichen Grundlagenforschung und der Technik im Rahmen der gesamten Umweltforschung eine entscheidende Bedeutung beizumessen“. FUCHSLOCH (1996:6) stützt die ,technokratische“ Sichtweise, indem er den Platz des Ersten in Anspruch nimmt: „Umweltgeschichte faßte in der Technikgeschichte Fuß, da sich im deutschen Sprachraum eine größere Anzahl der Arbeiten mit den 'Folgewirkungen technischer Innovationen' auseinander gesetzt hat und so Umweltgeschichte als eine Form historischer Technikfolgenabschätzung interpretiert. In dieser Form konkretisiert sie sich häufig als eine Geschichte der Umweltverschmutzung und -vernutzung.“ 
RADKAU (2002:41) verfolgt in seinem disziplingeschichtlichem Rückblick den gleichen Standpunkt. Nach ihm ,läßt sich die Umwelthistorie auf eine Philosophie der ökologischen Nische gründen.“ Danach hat sich die Historische Umweltforschung ,zunächst - und das war für den Anfang eine vernünftige Strategie - im Wissenschaftsbetrieb ihre ökologische Nische gesucht, die noch von keinem Establishment besetzt war. Daraus und aus dem aktuellen Impetus erklärt sich die Konzentration auf die industrielle Wasser- und Luftverschmutzung, eine bis in die [19]70er Jahre kaum bearbeitete Außenzone der Industrie- und Technikgeschichte“ (:12). Auch DIX (1997:273) ist noch der Meinung: „Die Industrialisierung und ihre Auswirkungen auf die natürliche Umwelt des Menschen sind ein zentrales Thema der Umweltgeschichte.“ Innerhalb dieses Bereichs deuten sich nach GROHMANN et al. (2000:10) zwei Schwerpunkte an: „Der eine könnte mit dem Begriff ,Städtehygiene' zusammengefaßt werden, der andere mit ,industrieller Umweltverschmutzung', wobei letztere allerdings häufig gerade in Städten als in den industriellen Zentren auftrat und daher Überschneidungen unvermeidlich sind.“

ABELSHAUSEN (1994b:7) hingegen ordnet Umweltgeschichte als ,junge, potentiell neue Teildisziplin der Historischen Sozialwissenschaften“ ein und reduziert Umweltgeschichte auf „die Frage, was Historische Sozialwissenschaft zu einer umweltverträglichen Gestaltung der Wirtschaft beitragen kann.“ Wiederum andere sehen in der Disziplingeschichte der historischen Umweltforschung, „die aus dem Bewußtsein gegenwärtiger Umweltprobleme hervorgegangen ist“ (RADKAU 1994:21) und ,vor dem Hintergrund der globalen Umweltkrise [...]" entstand (BAYERL et al. 1996:Vorwort), die Grundlage der Unterordnung unter das Diktat der Ökologie. „Environmental problems”, so BLASCHKE (1990:68), ,initiate the development of environmental history.” Ebenso ist DIX (1997:18) der Ansicht, dass die ursprüngliche Intention ,im Hinblick auf die aktuelle Diskussion nach Vorbildern der heutigen in weiten Bereichen als krisenhaft angesehenen Situation zu suchen“ ist.

Zum aktuellen Themenspektrum der Umweltgeschichte und seiner disziplinären Stellung verweise ich auf den von Wolfram SIEMANN 2003 herausgegebenen Band und den darin enthaltenen Einzelbeiträgen. Weitere Beschäftigung mit dem disziplintheoretischen Diskurs zu „Umweltwissenschaften“, deren Stellung und Inhalten erlauben die Beiträge in dem von Edmund BRANDT (2000) herausgegebenen und aus einer gleichnamigen Ringvorlesung hervorgegangenen Band zu „Perspektiven der Umweltwissenschaften“. Einen frühen Überblick über die verschiedenen Fragestellungen und Probleme der an der Umweltforschung in historischer Sicht beteiligten Fachdisziplinen gibt der Band 7 der ,Rundgespräche der Kommission für Ökologie' (1993) mit seinen gedruckten Beiträgen. Hier wird - im gleichen Verfahren wie zur oftmaligen geschichtswissenschaftlichen Einengung der historischen Umweltforschung - die Schwerpunktsetzung auf rein naturwissenschaftliche und ökologische Themen gelegt. Gleichzeitig wird aber auch und insbesondere die Interdisziplinarität der Umweltforschung deutlich hervorgehoben: „Ein Hauptproblem, mit dem sich alle Umwelthistoriker beschäftigen (müssen)" (ANDERSEN 1993:680).

Mit großer Weitsicht geht WORSTER (1993) bereits in etwa zur gleichen Zeit wie die zu diesem Zeitpunkt noch in starren disziplinären Grenzen denkenden ISENBERG/MÖLICH (1992) und ABELSHAUSEN (1994b) sogar so weit und definiert „the new academic field of environmental history; which can be defined as the interdisciplinary study of the relations of culture, technology, and the nature through time." (WORSTER 1993:VIII). Selbstverständlich hingegen dehnt sich diese interdisziplinäre Zusammenarbeit nicht auf jedes Fach aus und die Verbindungen der , new history' fokussieren sich ,with such natural sciences as ecology and with such fields as anthropology and geography." (:VIII)

Die als ,geschichtswissenschaftliche Interdisziplinarität' zu bezeichnende Fächerverbindung betonen auch HAUPTMEYER/FROHNER (2000:7) und heben die daraus resultierende umweltgeschichtliche Methodensymbiose hervor: „Um die Lösung umweltgeschichtlicher Fragestellungen bemühen sich die verschiedenen historischen Fächer, Archäologie beispielsweise ebenso wie die historische Anthropologie. Methodenvielfalt ist daher ein Charakteristikum der Umweltgeschichte.” „Darüber hinaus“, begründen sie einen Aktualitätsund Anwendungsbezug, ,werden offensichtlich in größerem Umfang als in anderen historischen Arbeitsgebieten Verknüpfungen zwischen wissenschaftlicher Forschung sowie aktuellen Anwendungen in Politik, Kultur und Planung hergestellt.“ (:7)

Während die Interdisziplinärität, als ein wesentliches Element der Umweltforschung, für die ökologischfundamentierte Umweltgeschichte als Bezugsrahmen erkannt wird, ist aber für das klassische Grundlagen- 
fach - der Geschichtswissenschaft - „die interdisziplinäre Zusammenarbeit in der historischen Umweltforschung, wie sie die Archäologie [und Siedlungsforschung; auf gleicher Seite weiter oben] bereits praktiziert, derzeit noch ein Desiderat", beschreibt gegensätzlich LEIDINGER (1991:503), ein Befürworter der überfachlichen Zusammenarbeit, die deutsche Situation Anfang der 1990er Jahre.

LEIDINGER (1991:506) sieht neben der „Einzelfaktorenanalyse“ ebenfalls die „,interdisziplinäre Systembetrachtung“ als die historische Umweltforschung konstituierenden Faktor. In diesem Sinne plädiert er „statt des Begriffs ,Historische Umweltforschung' für den einer ,Historischen Ökologie' [...], weil er über die vielen möglichen Einzelaspekte historischer Umweltforschung hinweg von seinem Ansatz her stärker auf die Gesamtheit des Wirkungsgefüges von Naturgegebenheiten und kulturell-zivilisatorischer Tätigkeit des Menschen gerichtet ist."

Die Historische Ökologie nach LEIDINGERs Definition (1987:14) ist also keine rein biogene Umweltgeschichte, sondern „, fragt nach dem Verhältnis des Menschen zu seiner jeweiligen Umwelt in der Vergangenheit. Es geht ihr dabei [...] um die Bewußtmachung der gesamten Lebenszusammenhangs, in dem Menschen der verschiedensten Zeiten, Kulturen und Schichten zu ihrer Umwelt gestanden haben." Die Historische Ökologie, so führt er weiter aus, ,,ist jedoch nicht nur auf die anthropogenen Verhältnisse und Veränderungen im Zusammenhang mit der Natur gerichtet, sondern muß auch die Auswirkungen natürlicher Veränderungen der Lebenswelt des Menschen [...] in die Betrachtung einbeziehen.” (:14)

Um also „den Charakter des Mensch-Natur-Verhältnisses im Sinne einer ,histoire totale' zu beschreiben, wird gelegentlich der Begriff, Historische Ökologie' dem der Historischen Umweltforschung oder Umweltgeschichte vorgezogen", dessen Stellvertreter LEIDINGER ist (DIX 1997:19). Dieses umfassende Konzept wird der bisherigen ,Historischen Umweltforschung' gegenübergestellt (:19). RADKAU (2002:15) ist mit dem Gesamtheitsanspruch etwas vorsichtiger und begreift „Umweltgeschichte nicht als Spezialität, sondern als integralen Bestandteil einer ,histoire totale”". Dann, so fährt er fort, „lernt man all das andere, was bei Umweltkonflikten mitspielt, besser zu schätzen.“

„The basic goal of the historical ecologist”, beschreibt der Amerikaner WHITNEY (1994:8) die Zielsetzung, , is to document the environment changes of the past and to determine the factors responsible for their occurrence." Diese prägnante Aufgabenbeschreibung ist insofern von Bedeutung, als dass das Berufsbild des Historischen Ökologen in Amerika entstanden sein soll.

Der Begriff ,Historical Ecology' entstand nach Auffassung von Carole CRUMLEY (1994:XIII) aus zwei Seminaren, die sie als Lektorin gegeben hat: Dem Seminar ,Environmental Studies' und einem Kurs in ,ecology'). Da die Unterschiede schwierig herauszuarbeiten waren, so CRUMLEY:XIII), richtete sie einen neuen Kurs ein, mit der Bezeichnung ,Historical Ecology' und dem Ziel, ,to address the important work of environmental historians, anthropologists, geographers, and others who seek to combine evidence of the human past with evidence about the environment by studying the evolution of landscapes." Leider hat sie in ihrem Rückblick nicht das Semester ihrer erstmaligen Lehrveranstaltung genannt.

Auch HOMMEL (1992:4-6) beispielsweise vergleicht in einem Aufsatz die deutsche historische Umweltforschung, synonym bezeichnet er sie auch in traditionellem geographischem Gebrauch als „,historische Umweltkunde“, mit der - nach seiner Aufassung aus dem Niederländischen stammenden „Historischen Ökologie“, die er schlicht „,als die Ökologie der Vergangenheit“ definiert (:4). Die historische ökologische Forschung befasst sich nach seiner Auffassung „besonders mit Systemen, die jetzt verschwunden oder degeneriert sind und nicht mehr mit den üblichen ökologischen Methoden erforscht werden können“ (:4). Dabei wird entweder eine „Rekonstruktion einer historischen Lage oder einer Erklärung der heutigen Lage aus der Sicht der Vergangenheit" verfolgt (:5) und entspricht damit dem Querschnittverfahren bzw. der retrospektiven Methode der Historischen Geographie (siehe III 2 b3.2 und b4.2). Als Schwerpunkt der Untersuchungen sieht er die Landschaft und hier den Komplex biotischer und abiotischer Faktoren (:4ff.). Eine ebenfalls die biologische mit der anthropogenen Kulturlandschaftsgeschichte verknüpfende, aber stärker die Anwendungsmöglichkeit in den Vordergrund stellende Definition liegt von BRANDE et al. (1987:197) vor. Danach beruht die Arbeitsweise der Historischen Ökologie ,,auf dem Grundprinzip von Datierung, ökologischer Deutung und Rekonstruktion landschaftsabhängiger Lebensgemeinschaften und ihrer Teile“. 
Ein weiterer Vertreter der von ihm auch als „Ökogeschichte“ bezeichneten „Geschichte der Umwelt" ist der Geschichtswissenschaftler Jean-François WALTER (1996:10). „Eine solche Umweltgeschichte untersucht die Beziehung der Menschen zu ihrer Umgebung, ihrer Umwelt über lange Zeiträume hinweg. “ Man könnte sie deshalb nach seiner Auffassung auch „Öko-Geohistorie“ nennen. „Der Vorteil dieser Bezeichnung besteht darin, dass sie eine im heutigen Sinne ökologische Sichtweise mit der großen Tradition der Erdgeschichte [...] verbindet. Die Ökogeschichte gibt Antwort auf drei Fragenkomplexe: Wie bilden Gesellschaften und Ökosysteme ein geschlossenes Ganzes? Wie entsteht die Erkenntnis, dass der Mensch Teil der Erde ist, die er nicht ohne weiteres nutzen und ausbeuten kann? Welche Formen nimmt die Beziehung zur Umwelt in verschiedenen Gesellschaften zu unterschiedlichen Zeiten an?“ (:9)

Die sich aus den Fragen ergebende Aufgabe einer „Geschichte der Ökologie als Wissenschaft“ ist, „das Verhältnis früherer Gesellschaften zur Natur“ zu erforschen: „Eines der vorrangigen Ziele der Umweltgeschichte“ und „einer der gewaltigen Herausforderungen“ der Geschichtswissenschaft sei deshalb, „die Entwicklung des Wissens über die Umwelt und des Umgangs mit der Natur zu untersuchen.“ (WALTER 1996:10) Um dies zu verstehen, müsse sich die Geschichtsschreibung den Ergebnissen der interdisziplinären Untersuchungen zuwenden, als da sind die Klimatologie, Botanik, Physik und Geologie. Dazu sind „die verschiedensten Zeitebenen, jene der Natur und jene der Menschen, darzustellen.“ (:12)

Die Geschichte untersucht insofern also „nicht mehr nur den zeitlichen Ablauf der Wechselbeziehungen zwischen Gesellschaft und Umwelt, sondern analysiert die Veränderungen sowohl innerhalb der Gesellschaft als auch der Umwelt und erforscht die Rückwirkungen dieser Veränderungen auf die Beziehung zwischen den Menschen und ihrer Umwelt.“ (WALTER 1996:14) Als Beispiele nennt er die Abholzung, durch die nicht nur bewaldete Hänge zerstört, sondern auch die Zusammensetzung der Waldgesellschaft verändert werden.

WALTER nimmt damit eine derartig erweiterte Position auf, die nach meiner Auffassung die Geschichte als Disziplin auflöst, zumindest aber inhaltlich und ausbildungsmäßig sprengt.

Um dieses Forschungsfeld zusammenzufassen, kann - in Anlehnung an HOMMEL, BRANDE und WALTER - eine Unterteilung der historischen Ökologie in fünf Arbeitsfelder unternommen werden:

1. Abiotische Umwelt in der VergangenheitBeispielsweise die Erforschung der historischen Verbreitung von Hochmooren

2. Biotische Umwelt der Vergangenheit (Fauna und Flora) Beispielsweise die Geschichte der Einführung nichteinheimischer Waldpflanzen und deren Folgen

3. Historische Bodennutzungssysteme

Beispielsweise die Erforschung ökologischer Aspekte der Agrargeschichte (z. B. Feld-TeichWechselwirtschaft)

4. Umweltqualität von Boden, Luft und Wasser

Beispielsweise die Lokalisierung von Arealen für Altlastensanierung

5. Historische Rekonstruktionen

Beispielsweise die Lokalisierung und Datierung fossiler Lebensgemeinschaften

Als Quellen zur Ergründung dieser Arbeitsbereiche nennt HOMMEL alte Karten, Archivalien, Toponyme, Pflanzen- und Tierreste sowie fossile Bodenmerkmale (1992:4ff.).

CRUMLEY (1994:6) ordnet Umweltgeschichte in gleicher landschaftsbetonender Weise wie HOMMEL ein, wenn sie sagt: „Historical ecology or landscape history is the study of past ecosystems by charting the change in landscapes over time." Darüber hinaus wählt sie diesen Begriff als disziplinären Oberbau, unter den sich andere Fächer zusammenfügen: „The practice of globally relevant archaeology, ethnohistory, ethnography, and related disciplines can be termed historical ecology." (:7, Hervorhebung im Original) 
Für BLASCHKE (1990:68) hingegen, ,the term ,ecological history' would be too limiting. Here, we are not only concerned with nature, but with the whole system, consisting of nature, society, and culture." Eine alternative Bezeichnung bietet er aber nicht an.

Ulrich TROITZSCH (1981:177) hat zwar auch keine reine Begriffsdefinition gegeben, doch einleitend Forschungsstand und Forschungsaufgaben einer „Historischen Umweltforschung“ umrissen und hätte damit eigentlich diese Bezeichnung präferiert. Demnach geht es TROITZSCH zwar generell um ,eine stärkere Beachtung der historischen Ökologie im Rahmen der historischen Wissenschaften." Doch auch er beschreibt in seinem Aufsatz den Weg von der historischen Umweltforschung zu einer Historischen Ökologie, die auf den Gesamtzusammenhang der natürlichen und anthropogenen Faktoren einer Gesellschaft gerichtet ist, ohne jedoch dem Begriff selbst beizutreten.

Ökologisch orientiert ist auch die Definition von BRÜGGEMEIER (1992:13), der als Umweltgeschichte „die Untersuchung des Bodens und der freien Natur als elementare, von der Geschichtsschreibung bisher vernachlässigte Faktoren“ ansieht. Auch nach REITH (1998:16, Hervorhebung im Original) sind „Gegenstand der Diskussion [...] vor allem die Umweltmedien Boden, Wasser und Luft, sowie Themen wie die Erschöpfung der Ressourcen, Energie, Klima, Bevölkerungsentwicklung, Seuchen, Verkehr und Städtewachstum." SIEFERLE (1984:496) grenzt den Untersuchungsbereich ein und sieht das spezielle Thema ,Umweltschäden' als „weites Arbeitsfeld historischer Umweltforschung“. Er definiert Umweltschäden in umwelthistorischer Sichtweise ,als zumindest langfristige Folge ertragswirtschaftlichen Handelns des Menschen, [...] die sich von frühen Gesellschaften über bäuerlich-gewerblich organisierte bis zu industriellen der Gegenwart verschärften, zugleich aber auch Natur- und Landschaftsschutz, Denkmalpflege in zunehmender Weise auf den Platz riefen" (:496). Mit dieser, wenn auch zeitlich weiter gespannten thematischen Aufgabenbeschreibung wäre die annähernd zu Beginn des Abschnitts wiedergegebene Auffassung von Historischer Umweltforschung wieder erreicht.

„Umweltgeschichte kann sich aber nicht auf eine Geschichte der Umweltverschmutzung beschränken. Eine derart selbstkasteite Disziplin Umweltgeschichte hätte sicherlich für einige Zeit genügend Themenstellungen durchzuarbeiten. Dennoch ist die Anzahl der Produktionsverfahren begrenzt, ebenso wie die mit historischen Methoden faßbaren wasser-, boden- und luftverunreinigenden Stoffe." (FUCHSLOCH 1996:7) In gleicher Weise sieht WALTER (1996:13) eine Beschränkung darin, wenn er sagt, dass ein Umwelthistoriker zwar punktuell unser Gewissen beruhigen könne, ,indem er darauf hinweist, dass vor hundert Jahren das Wasser des Rheins [...] bestimmt stärker verschmutzt war als heute.“ Er könnte auch ,auf mehrere Fälle gravierender Wasser- und Luftverschmutzungen in den Jahren 1870-1880 aufmerksam machen.“ Aber ,die Erkenntnis, dass die Umwelt eine Geschichte hat, hat leider oft dazu geführt, daß in der Vergangenheit nach Ähnlichkeiten mit unserer Gegenwart gesucht und so das Neue an den heutigen ökologischen Krisen verharmlost wurde.“ (:12) Nach seiner Auffassung müssen wir uns gar „davor hüten, die Vergangenheit zu verharmlosen, auch wenn dies oft von der Geschichte erwartet wird.“ (:12), denn „,die Geschichtsschreibung muss die Verhältnisse stets in ihrer besonderen zeitlichen und sozialen Eigentümlichkeit rekonstruieren." $(: 13)$

Neben diesem Ansatz, Umweltgeschichte als Geschichte der Umwelt-Verschmutzung zu betrachten, steht die Aufforderung von HERMAND, Umweltgeschichte als Umwelt- und Ressourcen-Verbrauch zu begreifen: „Aus der bisherigen Umweltgeschichte, die lediglich die Gefahren für den Menschen auflistet und diesen vorzubeugen versucht, müßte also endlich eine konsequente Mitweltgeschichte werden, welche vor allem jene Prozesse in den Vordergrund rückt, durch die sich die Menschen [...] auf Kosten anderer Lebewesen auf Erden alle Naturprodukte in einer grenzenlosen Machtdemonstration an sich reißen und zu ihrem Nutzen ausschlachten.” (1996:304) „Sie sollte zeigen, wie sich die Geschichte der letzten drei- bis vierhundert Jahre im Hinblick auf die Wildtiere, Wildpflanzen, Naturschätze und menschlichen Ureinwohner abgespielt hat, das heißt wie Industriestaaten der Ersten Welt erst ihre eigenen natürlichen Ressourcen und dann die Ressourcen der restlichen Welt erbarmungslos ausgeplündert haben.“ (:304f.) „Eine solche Mitweltgeschichte wäre demnach beides: eine Mord- und eine Selbstmordgeschichte.“(:305)

Ähnlich formuliert Arne ANDERSEN (1992:6), Umweltgeschichte sollte sich „mit dem Mensch-NaturVerhältnis, der gesellschaftlichen Naturaneignung, beschäftigen. Dies schließt Produktions- und Reproduktionsverhältnisse ebenso ein wie deren mentale und kulturelle Verarbeitung." Martina KAUP 
(1996:111) versteht „Umweltgeschichte“ in verwandter Wortwahl „als Untersuchung der langfristigen Entwicklung der menschlichen Lebens- und Reproduktionsbedingungen." Und auch PFISTER (1993:17) nennt als eine der Zielsetzungen von Umweltgeschichte „die Untersuchung der Steuerungselemente des Mensch-Umwelt-Verhältnisses in der Vergangenheit.“ (aus: GROHMANN 2000:63; 56, Anmerkung 8)

Dabei spielt die bereits von ANDERSEN angesprochene „mentale“ Ebene nach Auffassung von WALTER (1996:16) eine bedeutende Rolle: Umwelthistoriker „müssen intellektuelle und emotionale Voraussetzungen verstehen lernen, kontemplative (Bewunderung, Zurückhaltung, Furcht) und voluntaristische Haltungen (Veränderung, Verteidigung oder Schutz) entschlüsseln. Nebst der materiellen Beschaffenheit der Umwelt gilt es auch das Bild zu berücksichtigen, das wir uns von ihr machen und mit dem wir einen inneren Plan und eine Geschichte zuschreiben. Im gesellschaftlichen Kontext kommt der Umwelt auch eine symbolische und wirtschaftliche Funktion zu. Der sich wandelnden Nutzung der Natur entspricht auch eine veränderte Wahrnehmung der Umwelt.“

Ludwig TREPL (1978:26) hingegen verwendet den Begriff "historische Umweltforschung" nicht, sondern spricht von einer "Naturgeschichte”, bleibt aber eine nähere Beschreibung schuldig: „Was Naturgeschichte war bzw. in einem bestimmten Verständnis ist, läßt sich nicht in wenigen Worten sagen.“ „Oft wird unter Naturgeschichte ein wahl- bzw. theorieloses Sammeln und Beschreiben von Gegenständen verstanden, ein Anhäufen von Kenntnissen ohne jedes Selektionskriterium” (:43). Er charakterisiert sie, „zur vorläufigen Orientierung, ganz grob als ,faktensammelnde' und ,beschreibende' Naturwissenschaft [...]. In ihr, ,einer beschreibenden Wissenschaft [...] hat sich offenbar etwas vom kontemplativen Wesen der antiken Wissenschaft erhalten, das den Gegenstand ,ganz' und ,unversehrt' ließ.“ (:26) Für die „historischen Wissenschaften [...] verschwindet das Besondere [...] nicht in allgemeinen Formeln, sondern ihr Interesse ist [...] auf das Besondere, das Historische, Einmalige gerichtet.“ (:26f.). „Eben die gilt für die Naturgeschichte auch. Sie beschreibt Besonderes, ist ,Ereignis-', nicht ,Gesetzeswissenschaft'. Sie lehrt nicht, ,was immer ist', sondern ,was einmal war' oder als Einmaliges ist.“ (:27)

Die Ansätze der historischen Umweltforschung in den 1980er und noch zu Beginn der 1990er Jahre, dies lässt sich zusammenfassend sagen, knüpften weniger an ältere umwelthistorische Arbeiten an, sondern waren ,zumeist von der aktuellen ökologischen Problemsituation der Gegenwart inspiriert, die in ihrer vielschichtigen historischen Dimension befragt“ wurde, „um zum Problemverständnis der Gegenwart beizutragen.“ (SIEFERLE 1984:496) „Die historische Umweltforschung”, schreibt RADKAU (2002:11), ,,ist ein Abkömmling der Umweltbewegung.“ Und auch DIX (1997:15) ist der Meinung: „Die Umweltgeschichte ist ein Kind der aktuellen Umweltdiskussion."

Dies liegt wahrscheinlich darin begründet, dass einige Autoren die historische Umweltforschung stark an dem ökologisch geprägten Wort „Umwelt“ festmachen, wie beispielsweise SIEFERLE, „der eine nichtanthropozentrische Geschichtsschreibung als höchstes Ideal begreift“ (RADKAU 1994:17).

Demgegenüber steht die anthropozentrisch ausgerichtete Sichtweise. Als Beispiel dafür sei - man könnte beinahe aufgrund seiner tatsächlichen fachlichen Ausrichtung sagen natürlicherweise - der Anthropologe Bernd HERRMANN aus Göttingen, genannt, der ,richtungsweisend für die allgemeine Umweltgeschichte [...] in den 1980er Jahren [...] zwei [...] Aufsatzsammlungen" herausgegeben hat ${ }^{19}$ (GROHMANN et al. 2000:9) und darin ausführt: „Aus der Sicht der Historischen Anthropologie fragt die Umweltgeschichte nach individueller Lebensweise, nach kollektiven Lebensbedingungen und nach den übergreifenden Prinzipien (Determinanten), unter denen Bevölkerungsentwicklungen in großen geographischen Arealen wie in globalem Maßstab der Geschichte abgelaufen sind." In einer solchen Sichtweise sind nach seiner Auffassung „auch kulturelle Leistungen eingeschlossen“ (HERRMANN 1989:146).

Auch FUCHSLOCH (1996:6) begreift Umweltgeschichte als Menschheitsgeschichte. Nach ihm erscheint Umweltgeschichte ,im weitesten Sinne als Geschichte des menschlichen Handelns zur Nutzung und Umgestaltung der Welt, der diesbezüglichen Ideologien und Motivationen, der Wahrnehmung der Veränderungen und der Reaktionen darauf.“ In gleicher Weise ist BLASCHKE (1990:69) der Meinung:

\footnotetext{
19 1. Bernd HERRMANN (Hg.): Mensch und Umwelt im Mittelalter. - Stuttgart, 1987; 2. ib. (Hg.): Umwelt in der Geschichte. Göttingen, 1989
} 
„environmental history must begin when the natural landscape changed to a cultural one, i. e., when human actions began to transform the environment." Konsequenterweise grenzt er einige Fächer aus der disziplinären umwelthistorischen Zusammenarbeit aus, wenn er sagt: „Palaeontology and all other palaeosciences are not included in the field of interest of environmental history." (:69)

Einen Ansatz, die institutionellen Pfadzuweisungen zu verlassen, ohne die naturökologische Orientierung aufzugeben und gleichzeitig die begriffliche Diskussion unter Berücksichtigung der anthropogenen Komponente zu konkretisieren, vermittelt die Aufgabenbeschreibung von HERRMANN aus dem Jahr 1989 (:Vorwort): „Nutzung und Gestaltung, viel mehr noch Aneignung und Ausbeutung kennzeichnen die Beziehungen des Menschen zur natürlichen Umwelt, seit er gelernt hat, durch kulturelle Leistungen zusätzliche Ressourcen zu erschließen. Die damit verbundenen Handlungen, ihre Folgen und Nebenfolgen in der Vergangenheit sind Themen der Umweltgeschichte, welche die Wechselwirkungen zwischen Mensch und Natur in der Geschichte untersucht. Umweltgeschichte vermittelt dabei grundsätzliche Einsichten in die Langzeitwirkungen menschlicher Handlungen. Sie macht anschaulich, welche Folgen umweltrelevante Entscheidungen über Generationen oder Jahrhunderte hinweg haben können.“

Die historische Naturveränderung durch den Menschen vor dem Hintergrund der nahen ökologischen Katastrophe bildet seinen Handlungsrahmen, den er wie folgt beschreibt: „Das Ausmaß der Umweltbedrohung durch den Menschen berührt am heutigen Ende der Evolution das gesamte Artenspektrum der Biosphäre. Den Weg zu beschreiben und zu analysieren, den der Mensch dabei in seiner Beziehung zur (natürlichen wie anthropogen veränderten) Umwelt zurückgelegt hat, ist Gegenstand der Umweltgeschichte. Sie fragt nach den Wechselwirkungen zwischen Mensch und Natur in der Geschichte. Sie betrachtet die Handlungen des Menschen, ihre Folgen und Nebenfolgen ebenso wie die Voraussetzungen, die ihrerseits ,Natur' und ,Umwelt' beeinflussen (chemische und physikalische Faktoren).“ (HERRMANN 1989:146)

Während in den Ausführungen von Ende der 1980er Jahre noch eine starke naturgeschichtliche Prägung erkennbar ist, wird von HERRMANN in seiner aktuellen Umschreibung des Faches Umweltgeschichte aus dem Jahr 2002 dem kulturgeschichtlichen Hintergrund von ,Umwelt' ein deutlicheres Gewicht beigemessen Umweltgeschichte ist auch nicht mehr „Kernstück“, sondern ,nur noch' „Teil einer ökologischen Grundbildung“: „Umweltgeschichte (UWG) behandelt die Beschaffenheit von Umwelt im historischen Wandel. Sie fragt insbesondere nach den Lebensbedingungen und Problemen des Menschen in seinen Beziehungen zu den natürlichen und anthropogenen Gegebenheiten des Lebensraumes und systematisiert die Lösungen, die er gefunden hat. Die historischen Voraussetzungen von Umweltzuständen beruhen nicht nur auf den natürlichen Bedingungen, sondern auch auf menschlichen Handlungen und Normen. Auf diesen Wechselbezug hinzuweisen und diesen in seinen ursächlichen Zusammenhängen zu ergründen, ist Aufgabe der UWG. Indem sie Natur als kulturbeeinflußt analysiert macht sie Natur als Kulturaufgabe bewußt.“20

Zwei weitere anthropologisch orientierte Definitionen vom Aufgabengebiet der Umweltgeschichte liegen vor und sollen nicht vorenthalten werden. Nach einem Definitionsversuch von Joachim RADKAU ordnet sich die historische Umweltforschung ,ein in die Erforschung der langfristigen Entwicklung der menschlichen Lebens- und Reproduktionsbedingungen. Sie untersucht, wie der Mensch diese Bedingungen selber beeinflußte und auf Störungen reagierte. Dabei gilt ihre spezifische Aufmerksamkeit unbeabsichtigten Langzeitwirkungen menschlichen Handelns, bei denen synergetische Effekte und Kettenreaktionen mit Naturprozessen zum Tragen kommen.” (RADKAU 1994:20). Die Definition soll nach seiner Aussage „zum Ausdruck bringen, daß Umweltgeschichte es zwar stets mit menschlichen Interessen zu tun hat, dabei aber keineswegs ein bloßer Reflex menschlicher Aktionen und Intentionen ist.“ (:20) Während die eigene Erklärung seiner Definition nach meiner Auffassung unklar ist und nicht den wirklich bedeutsamen Kern trifft, sind die „synergetischen Effekte und Kettenreaktionen“ in den Mittelpunkt zu stellen und besonders beachtenswertes Kennzeichen des Verständnisses von historischer Umweltforschung nach RADKAU: Die Vernetzung menschlicher Handlungen in ihrer zeitlichen Wirkung.

Eine diplomatische, zwischen historisch-ökologischer und -anthropologischer Position stehende Sichtweise nehmen NEUBER et al. (2000:9) ein. Zwar untersucht Umweltgeschichte nach ihrer Auffassung ,die Wechselbeziehungen von Gesellschaften mit ihrer natürlichen Umwelt.“ „Allerdings”, fügen sie

${ }^{20}$ Homepage des AK Umweltgeschichte: http://www.anthro.uni-goettingen.de/s_umweltgeschichte.html; abgerufen am 20.01.2002 
einschränkend hinzu, „ist der Begriff ,natürliche Umwelt' problematisch, da Umwelt gemeinhin nicht simplifizierend mit Natur gleichzusetzen ist. Hinzuzufügen wäre daher auch die gestaltete Umwelt.“

„Es ist nicht schwer zu erkennen,” urteilt RADKAU (2002:14) über die beiden scheinbar gegensätzlichen Positionen, „daß es sich bei Frontstellung, nichtanthropozentrische gegen anthropozentrische Umweltgeschichte' um einen bloßen Schaukampf handelt.“ „We debate what is ,natural' and what is not, what is ,cultural',in the landscape and what is not, [...] how much was wilderness and how much was the white pioneer's mythology or fetish." kritisiert WORSTER (1993:VIII) die gleichartig in Amerika geführte paradigmatische Debatte. „The cultural history of Nature”, beschreibt WORSTER (:X) vor dem Hintergrund des geführten Disputs prägnant den disziplintheoretischen Dissens weiter und hebelt ihn damit aus, ,is as significant as the ecological history of culture. That may be the core message of environmental history“.

„Die umweltgeschichtliche Forschung“, fasst DENECKE (2001:290) die Situation zusammen, „besteht aus zwei Hauptrichtungen:

1. Einer Umweltgeschichte, die auf das Beziehungsgefüge Mensch-Natur gerichtet ist, auf den langzeitigen Wandel ökologischer Bedingungen und den Eingriff des Menschen in das Naturpotential: Paläoethnobotanik, Klimageschichte, Historische Ökologie [...].

2. Einer Umweltgeschichte, die der Technik- und Sozialgeschichte nahesteht und damit sehr wesentlich an die Stadt- und Industriegeschichte des 19. und frühen 20. Jahrhunderts gebunden ist. Sie wird vornehmlich von Stadt- und Wirtschaftshistorikern getragen [...]“.

Nach DIX (1997:18f.) haben sich ,ausgehend von der heutigen Umweltkrise” ebenfalls ,zwei Stränge der geschichtswissenschaftlichen Beschäftigung mit der Umwelt herausgebildet, die sich auf völlig unterschiedlichen Ebenen bewegen"; aber die DIX - im Gegensatz zu DENECKEs thematisch und zeitgeschichtlich orientierter Zuordnung - stark wissenschaftstheoretisch bzw. methodologisch begründet gruppiert:

1. der geisteswissenschaftliche Zugang

Dieser Zugang operiert mit abstrakter philosophischer Begrifflichkeit und versucht möglichst grundsätzliche und globale Zusammenhänge des Mensch-Natur- bzw. Mensch-UmweltVerhältnisses aufzuklären. Die Gefahr dieses Ansatzes besteht nach DIX darin, auf der abstrakten Ebene zu verbleiben.

2. der empirische Ansatz

Dieser geht von konkreten, in den Archiven fassbaren Fallbeispielen historischer anthropogener Umweltbelastung aus. Die negative Tendenz dieses Ansatzes besteht darin, auf der Ebene einer „einzelfallorientierten Ereignisgeschichte” zu verbleiben, „ohne Aussagen machen zu können, wie Veränderungen in der Umwelt quantitativ oder qualitativ einzuordnen sind“ (DIX 1997:18f.).

Nach NEUBER et al. (2000:9) lassen sich hingegen ,in der gegenwärtigen Umweltgeschichtsforschung [...] im wesentlichen vier bedeutende Ansätze voneinander unterscheiden“:

1. sog. umwelthygienischer Ansatz

Stellvertretend für diesen Ansatz werden die Autoren Franz-Josef BRÜGGEMEIER und Arne ANDERSEN genannt, anhand derer der Betrachtungsansatz personalisiert beschrieben wird: „Sie richten ihr Augenmerk auf Störungen im Mensch-Natur-Verhältnis, untersuchen die gesellschaftliche Wahrnehmung und den Umgang mit Umweltzerstörungen durch betroffene Gruppen sowie deren Reaktionen zur Vermeidung, Sanierung oder finanziellen Kompensation der Schäden. Dies schließt die Frage ein, wie sich Gesetze und Rechtsprechung wandelten, welche Lösungsansätze entwickelt wurden und welche Alternativen bestanden." (NEUBER et al. 2000:9)

Dem umwelthygienischen Ansatz, ist sich ABELSHAUSEN (1994b:9) sicher und formuliert noch einmal die Zielsetzung und das Aufgabenfeld in einem Beitrag, ,verdanken wir bei weitem die meisten konkreten Studien zur Umweltgeschichte.“ Es geht ihm um die „Analyse von Störungen des Mensch-Umwelt-Verständnisses durch Übernutzung oder - seltener - Unternutzung biologischer 
Kreisläufe durch den Menschen und die von ihm hervorgebrachte Zivilisation." Dabei werden beispielsweise Fragen aufgegriffen, ,wie sich die Wahrnehmung solcher Störungen durch die Betroffenen im Zeitablauf ändert, wie hoch die Reaktionsschwelle liegt, die überwunden werden muß, bevor Umweltprobleme von der Gesellschaft oder ihren Teilen als Herausforderung begriffen und thematisiert werden und welche Sanierungsmaßnahmen zu welchen Ergebnissen führten“ (:9) .

2. sog. holistischer Ansatz

Dieser aus der Ökosystemforschung abgeleitete Ansatz (NEUBER et al. 2000:9) untersucht „die grundlegenden Veränderungen im Mensch-Umwelt-Verhältnis auf der Grundlage der ihnen zugrundeliegenden stofflich-energetischen Prozesse.“ Dabei richtet er seinen Blick bei „der Untersuchung von Gesellschaften insbesondere auf die Energie als Motor aller biologischen und gewerblichen Prozesse.“ (:9f.) Als Vertreter dieses Ansatzes wird - allen voran - Rolf Peter SIEFERLE genannt.

3. sog. pragmatischer Ansatz

Es hat sich nach Einschätzung von GROHMANN/HAUPTMEYER/NEUBER unterhalb der theoretischen Diskussion über die ,ideale“ Umweltgeschichte und ihre möglichen einzelnen Richtungen eine eher pragmatische umweltgeschichtliche Ebene entwickelt. Die ,pragmatische Umweltgeschichte“ (NEUBER et al. 2000:10) umfasst verschiedene Bereiche, „die einst wenig miteinander verbunden schienen, heute aber mit der Umweltschutzproblematik in Verbindung gebracht werden, z. B. Natur- und Heimatschutz, Stadthygiene, Reinhaltung von Wasser, Luft und Boden, technische Sicherheit oder Arbeitsschutz und Ressourcennutzung.” (:10)

4. sog. umweltökonomischer Ansatz

Der ökonomische Umweltansatz sucht „nach ganzheitlichen und prinzipiellen Lösungsmöglichkeiten für das Umweltproblem“ und rückt „die globale Problematik in den Vordergrund.“ (ABELSHAUSEN 1994b:9). Er ist „,bisher kaum explizit verfolgt worden.“ (:9)

Die Schwierigkeit nun liegt darin, eventuelle Gemeinsamkeiten der verschiedenen Beschäftigungsfelder der umweltgeschichtlichen Forschung festzustellen, um eine geeignete Darstellung einer alle Beschäftigungsfelder umfassenden Umweltgeschichte zusammenzustellen und daraus die zukünftigen Schwerpunktaufgaben abzuleiten.

Während die ersten beiden Ansätze - umwelthygenischer und holistischer Ansatz - der ersten ökologisch orientierten Hauptrichtung DENECKEs entsprechend eingeordnet werden können und auch der ,geisteswissenschaftliche Zugang' nach DIX unter der Rubrik ,Mensch-Natur-Verhältnis' zu subsumieren ist, fällt das für die übrigen Ansätze schwerer.

Mitunter lassen sich hinsichtlich seiner anwendungsorientierten Ausrichtung noch der „empirische Ansatz“ nach DIX und der „pragmatische Ansatz“ von NEUBER miteinander vergleichen. Aber isoliert verbleiben zum einen die zweite Hauptrichtung einer technik- und sozialgeschichtlich geprägten "Stadt- und Industriegeschichte“ nach DENECKE und der „umweltökonomische Ansatz“ von NEUBER. Da ich der Meinung bin, dass die jeweiligen Arbeitsmethoden, ob empirisch, philosophisch oder pragmatisch genannt, methodisch betrachtet in allen Ansätzen ihre Berechtigung haben, lassen sich drei Schwerpunkte umwelthistorischer Forschung herausstellen:

1. der ökologische Ansatz (Mensch-Natur- bzw. Mensch-Umwelt-Verhältnis)

2. der anthropogene Ansatz (Technik- und Sozialgeschichte bzw. Stadt- und Industriegeschichte)

3. der ökonomische Ansatz

Die Zusammenstellung der verschiedenen Ansätze, so notwendig sie auch als Ausgangspunkt für eine strukturierte Beschäftigung mit dem Thema „Umwelt“ sind und eine allgemeine fachliche Zuordnung erst ermöglichen, lässt aber eines unbeantwortet: die allgemeine Frage nach den zukünftigen Aufgaben umwelthistorischer Forschung. Denn „das ist überhaupt ein Manko vieler umwelthistorischer Überblicke: 
daß sie die riesigen Wissenslücken verschleiern. Die historische Umweltforschung kommt jedoch nur dadurch voran, daß sie die offenen Fragen erst einmal eingesteht und präzisiert.“ (RADKAU 2002:47)

Zukunftsaufgaben

Ein nur wenig progressiv anmutendes, weil altbekanntes, umwelthistorisches Gewässerthema sei an den Anfang zukünftiger umweltgeschichtlicher Fragen gestellt: „Städtische Ver- und Entsorgung“ sieht GROHMANN (2000:56) ,als umwelthistorisches Thema“. Dieser Untersuchungsgegenstand bietet, so seine Begründung, „die Möglichkeit, aufgrund seiner räumlichen Begrenztheit alle Aspekte der Wasserver- und Abwasserentsorgung [sic] im städtischen Zusammenhang zu erfassen." Wenn auch der Gegenstand der gewässerbezogenen Ver- und Entsorgung durchaus von großer Bedeutung für die umweltgeschichtliche Forschung ist und Fragen beispielsweise nach der Quantität und Qualität einbezogenen oder abgeführten Wassers unter umwelthistorischen Gesichtspunkten eine aktualitäts- und anwendungsbezogene Brisanz besitzen (Altlastenuntersuchung), so ist dieses Thema bislang nur unzureichend ausgebaut worden. Mitunter mag das damit zu begründen sein, dass dieser Aspekt ziemlich am Anfang der umweltgeschichtlichen Forschungsgeschichte steht und deshalb anscheinend in seinen klassischen Fragestellungen hinreichend bearbeitet worden ist. Fragen nach der großräumlichen Entfernung und Verbreitung von Wasserzu- und ableitungen und der Wasserfiltration in Rieselfeldern sind ebenso zu stellen wie die nach den Folgen des Tiefbrunnens zur Versorgung nicht nur der städtischen, sondern auch ländlichen Bevölkerung und des Viehs und auch die Auswirkungen der flächenhaften Abführung ungefilterten Brauchwassers auf die schwindende Sauberkeit des Fließgewässers zu beantworten sind. Generell aber behandelt dieser Untersuchungsgegenstand nur einen Teilaspekt umweltgeschichtlicher Forschung.

Umfassender ist hier die Aufgabenbeschreibung von HAUPTMEYER/FROHNER (2000:7). Das Themenspektrum der Umweltgeschichte reicht nach ihrer Meinung „von der Umgestaltung der Kulturlandschaft durch die Menschen über die Verschmutzungsdebatten bis zu Problemen der Neunutzung von Industrieflächen." Sie übernehmen damit weitgehend den umfassenden Betrachtungsansatz, der sich aus der Berücksichtigung aller drei Hauptbeschäftigungsfelder ergibt.

Gegenstandsbereich einer solchen ökologischen Umweltgeschichte ist die „Untersuchung der Wechselbeziehungen des Menschen mit den natürlichen Umweltfaktoren.“ Ein Ordnungskriterium stellt dabei „das Ausmaß der vom Menschen ausgelösten, also anthropogenen Beeinflussung" dar (DIX 1997:17). Somit handelt Umweltgeschichte „vorrangig von ,sozial konstituierter' Natur“ (BÜSCHENFELD 2000:82). „Its essential purpose”, beschreibt WORSTER (1993a:20) den Lösungsweg der Umweltgeschichte, ,,is to put nature back onto historical studies, or, defined more elaborately, to explore the ways in which the biophysical world has influenced the course of human history and the ways in which people have thought about and tried to transform their surroundings."

In diesem Zusammenhang lautet nach BÜSCHENFELD „die entscheidende Frage: Wann sind die Grenzen von Lebensfreundlichkeit und Lebenstauglichkeit erreicht?“ (2000:82) Eine ökologisch motivierte Umweltgeschichte wirft Fragen auf, „etwa dahingehend, welche Natur wir eigentlich haben wollen und welche Gruppen, Institutionen und wissenschaftlichen Disziplinen sich an dieser gesellschaftlichen Diskussion beteiligen sollten.“(:103) Darüber muss Umweltgeschichte nach seiner Ansicht (:103) Auskunft geben.

Des Weiteren lässt sich mit Hilfe der Umweltgeschichte aus einer faktischen Vergangenheit eine prognostische Vorhersage auf der Grundlage von Wahrnehmung und Handlung ableiten. Mit ihren Erkenntnissen kann ,aufgezeigt werden, daß längst vorhandene Ergebnisse so lange nicht oder nur wenig beachtet worden sind, wie keine schwerwiegenden Problemfelder entstanden bzw. deutlich sichtbar geworden sind.“ (BÜSCHENFELD 2000:103)

Zukunftsaufgaben zu benennen ist für eine disziplinäre Fortentwicklung notwendig, ebenso unabdingbar ist das Aufzeigen von Forschungsdefiziten, deren Behebung erst zur Lösung der Zukunftsaufgaben führt: „Was ist mit dem ländlichen Raum?", fragen, angesichts der jahrzehntelangen Beschäftigung mit diesem Thema, erstaunlicherweise GROHMANN et al. (2000:10) und bezeichnen die „Forschungslage hierzu recht dünn.“ (:10): „Über die teilweise erhebliche Umwandlung der Kulturlandschaft des ländlichen Raumes insbesondere in den letzten zwei Jahrhunderten fehlt es an neueren Arbeiten.” (:11) Lediglich „einige Untersuchungen 
liegen zur Landschaftsveränderung und Umweltschädigung [...] durch die Montanwirtschaft“ nach ihrer Ansicht vor und sie nennen als Beispiel den Harz (:11).

Ebenso besteht nach ihrer Auffassung ,auf dem Sektor der Erforschung der vorindustriellen urbanen Umwelt noch ein erhebliches Defizit" (GROHMANN et al. 2000:10) und so zeigen sie damit für beide räumlichen Bereiche, den ländlichen wie den urbanen, ein Forschungsdesiderat auf.

Auch für RADKAU hat „auch die zeitbewußte Umwelthistorie [...] ihre Scheuklappen“ (2002:12). „Leider“, so sein Vorwurf, „besteht zwischen den traditionellen ökologischen Nischen der Umweltgeschichte [industrielle Wasser- und Luftverschmutzung, Geschichte der Naturideen] fast gar kein Zusammenhang." (:12) „Vor allem aber“, so setzt er fort, wurden „Kernbereiche der historischen Mensch-Umwelt-Beziehung wie die Agrar- und Forstgeschichte, die Geschichte der Bevölkerungsbewegungen und der Epidemien [...] eher gemieden.“ „Sie waren schon”, so RADKAU entschuldigend und begründend zugleich, ,anderweitig besetzt und Neulingen nicht ganz leicht zugänglich, und die dort etablierten Wissenschaftstraditionen besitzen einen für die Öko-Bewegung suspekten Beigeschmack. Wenn die Umweltgeschichte jedoch zur Weltgeschichte werden will,“ gibt er zu bedenken und gleichzeitig die Zielrichtung vor, „muß sie genau in diese Richtung vorstoßen.“ (:12)

Bei näherer Betrachtung seiner beispielhaft aufgezählten Themenbereiche entfernt sich RADKAU von dem hehren, aber nur schwer verwirklichbaren Ziel einer interdisziplinären Zusammenarbeit zwischen den mit umweltgeschichtlichen Fragestellungen konfrontierten Fächern. Vielmehr fordert er von einer umweltgeschichtlichen Forschung der Zukunft eine Intradisziplinarität ein, die - zumindest mit den genannten umweltgeschichtlichen Themenbereichen - traditionell in der (Historischen) Geographie verankert ist und solche längst vergessenen bzw. nur sporadisch bearbeiteten Arbeitsbereiche wie die Medizinische Geographie oder die Migrationsgeographie anspricht.

WORSTER geht über die Forderungen RADKAUS zum Studium der bislang nur randlich besetzten historischen Umweltthemen hinaus (die ja eigentlich geographische sind) und will die Umweltgeschichte wirklich betrieben wissen; greift damit aber auch in die bewährte methodische ,Schatztruhe' der Geographie (die aber mitunter in ihrer zunehmend einseitig anwendungsbezogenen Ausrichtung den von im Folgenden kritisierten Feld- bzw. Realitätsbezug verloren hat, den die anderen Fächer erst noch erlernen müssen): „The new environmental historians", beschreibt er (1993a:20) den Grund des Forschungsdefizit in der Umweltgeschichte, ,are busy reading books and papers written by scientists in ecology, physical geography, soil chemistry, climatology, plant gentics, parasitology, reproductive biology, and groundwater hydrology. [...] Apparently, to do environmental history really well, one must have some familiarity with, if not advanced training in, more scientific fields than many scientists would adventure to acquire." An anderer Stelle wird er diesbezüglich konkreter: „Historians seemed to have forgotten completely that, until very recently, almost all people lived as intimately with other species and with the wind and weather as they did with their own kind. To ignore that long intimacy was to distort history. Writing history ist, to be sure, always an act of distortion, imposing on the past the experience and outlook of the present." (:VII)

„Ein arger Stolperstein der Umwelthistorie ist”, nach Auffassung von RADKAU (2002:13,) „,auch die Forderung der Öko-Fundamentalisten nach einer Art von Geschichte, in der nicht der Mensch, sondern die Natur im Mittelpunkt steht und nicht aus dem Blickwinkel menschlicher Interessen ins Visier genommen wird. In dieser Geschichte würde das jahrtausendelange menschliche Mühen, sich mit den natürlichen Ressourcen zu arrangieren, nur als Störfaktor auftauchen: als der ewige Versuch des Menschen, sich die Natur dienstbar zu machen.“ „Das Ideal der ,unberührten Natur”, beschreibt RADKAU (:14) die noch heute „,aus Unkenntnis” (:42) fälschlicherweise vertretene Ansicht, ,ist ein Phantom, ein Produkt des Kultus der Virginität.” „In der Umwelthistorie”, formuliert er verschärfend die Tragweite dieser kulturnegierenden Sichtweise für die Ausgestaltung eines zukunftsgerichteten umweltgeschichtlichen Ansatzes, „hat das Leitbild ,Wildnis' die fatale Wirkung, daß es das Interesse von der Verbesserung der vom Menschen gestalteten Umwelt ablenkt.“ (:14). „Eine Umwelthistorie, die auf die ,Umwelt als solche” eingeschworen ist, “ benennt RADKAU die daraus erwachsenden weiteren Nachteile, „legt sich zwangsläufig Scheuklappen gegen die anderweitigen Kontexte der historischen Quellen an [...] und neigt zur Selbsttäuschung." (:15) „Denn der Artentransfer und die Weide sind seit Jahrtausenden Hauptfaktoren der Umweltveränderung.“ 
(:33), „weshalb die historische Umweltforschung sich nicht auf die Moderne beschränken darf; denn dann bekäme sie das elementarste Problem der Umweltgeschichte gar nicht in vollem Umfang ins Visier.“(:23)

Aber, so fragt sich RADKAU angesichts der Vormachtstellung einer naturbezogenen Umweltgeschichte: „Gibt es nicht doch ein großes und sehr einfaches Leitmotiv, das die gesamte Umweltgeschichte seit Beginn des Ackerbaus durchzieht: der unaufhaltsame Niedergang der Natur, je mehr ihre Unterwerfung durch den Menschen voranschreitet?”(2002:22f., Hervorhebung im Original) „Das Gros der populären Öko-Literatur”, befindet er (:23) nach Durchsicht der Veröffentlichungen, „legt diese Schlußfolgerung nahe: Umweltgeschichte als Geschichte eines Sündenfalls und seiner nicht endenden Folgen.“

"Eine unbefangene Umwelthistorie" hingegen handelt seiner Ansicht nach „,nicht davon, wie der Mensch die reine Natur schändete, sondern handelt von Organisations-, Selbstorganisations- und Dekompositionsprozessen in hybriden Mensch-Natur-Kombinationen.“ (RADKAU 2002:14) „Einfache Antworten im Sinne eines simplen Schwarz-Weiß-Schemas von böswilligen Verschmutzern und gutwilligen Beschützern läßt die Umweltgeschichte [...] jedenfalls nicht zu.” (BÜSCHENFELD 2000:103) „Daher sollte sie nicht zu moralisch werden - kein endloses Sündenbekenntnis.“ (RADKAU 2002:41), denn ,in die Umweltgeschichte stets eine Moral hineinzulegen, kann in die Irre führen und eine unvoreingenommene Beobachtung unerwarteter Entwicklungen verhindern.“ (:41)

Doch nicht nur die ,Moralkeule', ,auch eine allzu große Furcht vor dem unter Sozialwissenschaftlern beliebten Vorwurf des ,Biologismus' legt dem Denken Scheuklappen an.“, ist RADKAU (2002:16) der Meinung und tritt einer anthropozentrisch verengten Sichtweise entgegen; zumal ,vieles [...] für die Existenz einer dem Menschen angeborenen ,Biophilie' spricht.” (:29). Vor diesem Hintergrund, fährt er in seinen Überlegungen fort, ,handelt eine Umweltgeschichte, die diesen Namen verdient, nicht nur von Menschen und ihren Werken, sondern auch von Schafen und Kamelen, von Sümpfen und Brachländern. Man muß merken, daß die Natur ihr Eigenleben hat und keineswegs nur Komponente menschlicher Handlungen, Zitat menschlicher Diskurse ist.“ (:15) „Aus der Ökologie wissen wir seit langem, daß man sich unter ,Natur’ keine stabile, in steter Harmonie befindliche organische Einheit vorstellen darf, sondern daß sich die Natur auch ohne menschliches Zutun ständig wandelt.“(:33)

Die nicht nur die kulturlandschaftliche Wirkung, sondern die auch vorindustriegeschichtliche Bedeutung von Weide- und Nutztieren ist ein interessanter und bislang weitgehend unberücksichtigt gebliebener Aspekt umweltgeschichtlicher Forschung, den RADKAU am Beispiel der Verbreitung des Schafes aufzeigt. Denn ,auch für die deutsche Wirtschaft und Landschaft war es - was man heute leicht vergißt - einst von größter Bedeutung." Noch 1860 galt die Wolle ,als stärkste Bastion auf dem Textilsektor gegenüber England und Frankreich [...] - damals gab es in Deutschland noch 28 Millionen Schafe, fast so viele wie Menschen." (2002:37) „Mitunter scheint man die banale Tatsache vergessen zu haben, daß das Schaf nicht nur frißt, sondern zugleich den Boden düngt, auf dem es weidet.“, bezieht RADKAU (:38) Position wider des Vergessens kulturhistorischer Kreisläufe.

Dass Schafe durch ihre ständige Nutzung nicht nur Kulturlandschaft geschaffen haben (Lüneburger Heide, Wacholderhaine in Lingen und Haselünne) und durch die kulturhistorische Bewirtschaftungsweise des gesteuerten und von den Landwirten an die Schäfer bezahlten Schafauftriebs zur Düngung der Felder und damit, infolge der erweiterten Fruchtbarkeit, zu höheren Erträgen geführt hat, die wiederum die Versorgung einer größeren Bevölkerung gewährleistete, sei an dieser vom Verfasser ergänzt. Der sich auf die Verwebung von Schafwolle spezialisierte Mühlenbau mit seinen Auswirkungen auf den Gewässerstau sei in Erweiterung erwähnt.

Überhaupt sollten bei den umweltgeschichtlichen Forschungen, folgt man RADKAU, die „Kulturflächen“ nicht vergessen werden, die dem Betrachter als „Naturflächen“ erscheinen, wie er am Beispiel des ,Kulturgraslandes' betont: „Der Umwelthistoriker hätte allen Grund, neben den Wäldern auch die Wiesen zu würdigen, die bislang von der Geschichtsforschung arg vernachlässigt wurden. ${ }^{21}$ An Artenreichtum sind die

\footnotetext{
${ }^{21}$ Im Gegensatz dazu ist von den Biologen Hartmut DIERSCHKE und Gottfried BRIEMLE das Fachbuch „Kulturgrasland“ (2002) erschienen, das sich dem Thema aus geobotanischer Sicht nähert (Stuttgart: Ulmer-Verl. [Reihe ,Ökosysteme Mitteleuropas aus geobotanischer Sicht']).
} 
Wiesen vielen Wäldern überlegen; und sie waren und sind überdies als menschlich-tierischer Lebensraum von großer Bedeutung.“ (:35)

Es ist also die Verbindung zwischen der anthropologischen und der zooökologischen Landschaftsbildung, die RADKAU in seinem Werk betont. „Umweltgeschichte wird nur dann zur Geschichte großen Stils,” stellt er in Aussicht, nachdem er zuvor die Behandlung der ,Kernbereiche der Mensch-Umwelt-Beziehung' von der weiteren Entwicklung einer Umwelt- zur Weltgeschichte abhängig gemacht hat, "wenn sie nicht nur von den ökologischen Folgen menschlichen Tuns handelt, sondern die Ökologie auch als Erklärung historischer Verläufe einführt.“ (RADKAU 2002:41, Hervorhebung im Original) „Gerade unbeabsichtigte Wirkungsketten menschlichen Handelns, bei denen sich Naturzusammenhänge bemerkbar machen, verdienen besondere Aufmerksamkeit.“ (:15): „Erst dann wird die Natur gleichsam zum historischen Akteur.“ Doch, so Vorwurf, Ausblick und Zukunftsaufgabe zugleich: „die Umwelthistorie hat die in der Historisierung der Ökologie enthaltene Chance jedoch bislang merkwürdig wenig wahrgenommen.“ (:39)

Und schließlich, „um mit den Scheuklappen abzuschließen“, wie RADKAU es nennt, könnte sich nach seiner Auffassung die Umwelthistorie ,,auch dadurch verklemmen, daß sie unter dem Eindruck der ÖkoDiskurse zu exquisit sein will und zu wenig Sinn für das Triviale entwickelt. Misthaufen und Jauchegruben“, exemplifiziert RADKAU die Gegenstände einer trivialen Betrachtung, ,sind große Themen einer realistischen Umweltgeschichte; denn an ihnen hing die Erhaltung der Fruchtbarkeit der Äcker.“ (2002:16) „Eine allzu kopflastige Umwelthistorie ignoriert,” fügt er hinzu, „daß sich Entscheidendes auf und unterhalb der Gürtellinie abspielt.“ (:16)

Umweltgeschichte, so erfährt man, „erschöpft sich nicht in einer einmaligen Kausalität.“ (RADKAU 2002: 43) und erweckt den Eindruck eines losen resp. ungeordneten, eventuell sogar zusammenhanglosen Fächerverbundes. Die innere Einheit der Umwelthistorie, die sich in Zusammenfassung des Gesagten als „buntes Themen-Potpourri“ (:16) präsentiert, „ist letztlich dadurch garantiert, daß zwischen der äußeren Natur und der Natur im Menschen intime Zusammenhänge bestehen und der Mensch dies stets gespürt hat.“ $(: 16)$

,Natur' lässt sich dabei ,als Norm und als philosophische Kategorie mühelos auseinandernehmen”, wie sich gezeigt hat. „Rätselhaft nur“, plädiert RADKAU (2002:31) für eine Auseinandersetzung mit diesem Begriff, „wie dieses Ideal nie totzukriegen ist und wie der Naturbegriff aus jedem Strudel von Konfusionen wieder emportaucht und zu ursprünglichen Bedeutungen zurückkehrt. Dieses Phänomen scheint noch nie angemessen gewürdigt worden zu sein. Irgendeinen Lebenssinn, ob symbolisch oder praktisch, muß der Begriff wohl besitzen und über die Jahrtausende bewahrt haben.“

Die Bedeutung des Terminus ist gewiss aus einer Erfahrung heraus geboren, dem ,alltägliche[n] Sicheinfügen der meisten Menschen in die natürlichen Bedingungen" stellt RADKAU (2002:31, Hervorhebung im Original) erste Vermutungen über die Herkunft des Natur-Begriffs an, „daß unser eigenes Wohlbefinden auf vielerlei Art mit dem Gedeihen von Tier- und Pflanzenwelt zusammenhängt, und eine Ahnung, daß alles dies bestimmten Regeln unterliegt, gegen die man nicht willkürlich verstoßen darf. Längst nicht immer ist die Wirksamkeit des Naturideals an den Begriff Natur gebunden."

„Ihre Vitalität”, begründet RADKAU in einer zweiten Überlegung Dauerhaftigkeit und Überlebensfähigkeit des Begriffs, „bewies ,Natur' immer wieder als Gegenpol gegen künstliche, von Menschen erfundene Ordnungen und Zwänge. Daher verweist ,Natur' nicht so sehr auf eine Ur-Harmonie - die hätte einer solchen Artikulation nicht bedurft -, sondern auf sehr alte Gefahrenzonen des menschlichen Daseins." (2002:32). Eine "non-environmental history", schreibt WORSTER (1993:IX) prägnant und stützt diese These, ,commonly ignores that material reality."

Umweltgeschichte, lässt sich daraus auch folgern, besitzt - trotz des Naturbegriffs - eine ,,anthropologische Basis“ (RADKAU 2002:29). Und man sieht mit dem geschichtlichen ,background,, „daß man die Modernität heutiger Probleme und Problemwahrnehmungen nicht überschätzen darf.“ (:30)

Da die Festlegung auf eine Definition von Umweltgeschichte aufgrund der verschiedenen Betrachtungsansätze sich, wie man sehen konnte, als schwierig erweist und drei Unterschungsbereiche anscheinend keine 
hinreichende Ausgestaltung der Aufgabenstellungen ermöglichen, schlägt von BORRIES (1989:353ff.) einen 6-Punkte-Katalog vor, mit dem sich umweltgeschichtliche Forschung beschäftigen sollte und der hier unkommentiert aufgelistet werden soll:

1. Menschenunabhängige Naturgeschichte der Umwelt

2. Gesellschaftliche Relevanz von Umwelt

3. Menschengemachte Veränderungen der Umwelt

4. Menschliche Wahrnehmung von Umwelt und Umweltveränderung

5. Gesellschaftliche Handlungen zur Umweltverbesserung

6. Menschliche Kulturerzeugnisse als Umwelt

Genauso different wie die Definition bzw. Aufgabenbeschreibung, wird der Zeitraum, auf den sich die Erforschung der historischen Umwelt bezieht, unterschiedlich gesehen.

Nach NEUBER et al. (2000:10) hat sich ,als wichtigster Bereich der umweltgeschichtlichen Forschung [...] in den letzten Jahren vor allem das 19. und frühe 20. Jahrhundert herauskristallisiert, als mit Industrialisierung und Urbanisierung das scheinbar idyllische Mensch-Natur-Verhältnis aus dem Gefüge geriet und die Zusammenballung von Menschen und Betrieben zu bislang unbekannten Dimensionen von Luft- und Wasserverschmutzung führte.“

„Als die historische Umweltforschung über die essayistischen Präliminarien hinauskam und solider wurde,” begründet RADKAU (2002:27) den zeitgeschichtlichen Schwerpunkt, „beschränkte sie sich ganz überwiegend auf das Industriezeitalter, in dem die Emissionen zum drängendsten Umweltproblem geworden sind." GROHMANN et al. (2000:11) geben eine rein pragmatische Begründung der zeitlichen Fokussierung: „Aufgrund der überlieferten Quellen“ verwundert es sie nicht, „daß die von Historikern betriebene historische Umweltforschung schwerpunktmäßig die neuere Zeit behandelt, während die Umweltgeschichte vorangegangener Zeiten in das Metier von Archäologen und Anthropologen fällt." „Aber diese Blickverengung unter dem Eindruck der Aktualität ist historisch borniert.“, konstatiert RADKAU (2002:27).

Nach HOMMEL (1992:4ff.) beginnt die historische Umweltforschung mit der christlichen Zeitrechnung und endet 1945. Für HERRMANN (1989:146) hat sie ,einen Schwerpunkt in der Zeit des Mittelalters, das für viele Bereiche die unmittelbaren strukturierenden Voraussetzungen für unsere heutige Umwelt in Europa geliefert hat.” Darüber hinaus ist für HERRMANN (:146) „,neben den Folgen kultureller Leistungen für die Umwelt [...] in der historischen Umweltforschung auch Platz für Fragestellungen, in denen der Mensch unmittelbar nicht vorkommt (etwa bei der Frage nach der Klimaentwicklung der letzten 100000 Jahre)." „Am Ende“, wiederholt und begründet er an anderer Stelle seine Vorstellung, „kann eine UWG [Umweltgeschichte] auch ohne den Menschen geschrieben werden. Schließlich wäre es eine Illusion zu glauben, daß die Herausnahme des Menschen aus der Natur einen bestimmten, definierbaren Klimaxzustand der Natur/Erde/Umwelt zur Folge hätte, bzw. Organismen mit hohem Eingriffspotential damit für alle Zeiten von der Erde verbannt seien." (1996:22) Dementsprechend bedeutet für HERRMANN historische Umweltforschung auch Erd- bzw. Naturgeschichte, doch „wegen der Quellenlage konzentriert sie sich auf den Zeitabschnitt seit Beginn der "neolithischen Revolution."

Im Rahmen des Betrachtungsansatzes von Jost HERMAND (1996:304f.) Umweltgeschichte als „Mitweltgeschichte“ zu verstehen, sollte sich zeigen, „wie sich die Geschichte der letzten drei- bis vierhundert Jahre im Hinblick auf die Wildtiere, Wildpflanzen, Naturschätze und menschlichen Ureinwohner abgespielt hat, das heißt wie Industriestaaten der Ersten Welt erst ihre eigenen natürlichen Ressourcen und dann die Ressourcen der restlichen Welt erbarmungslos ausgeplündert haben”.

Es lässt sich aus dem Gesagten festhalten, dass das Konzept Umweltgeschichte „keineswegs eindeutig“ ist (BORRIES 1996:317), und auch die Vorstellungen von den Aufgaben der Umweltgeschichte lassen sich „keineswegs auf einen Nenner bringen.” (REITH 1998:18) 
„Sofern eine generelle Grenzziehung in thematischer Perspektive überhaupt möglich ist,“ schreibt auch MEYER (1996:328) unsicher, „verläuft diese zwischen einer Umweltgeschichtsschreibung, die das MenschNatur-Verhältnis in seiner historischen Totalität untersucht und einem Ansatz, der Umweltgeschichte primär als Naturvernutzungsgeschichte versteht und daher fixiert ist auf die Geschichte des Industrialisierungsvorganges in Europa. Weitere Feinunterscheidungen lassen sich dann durch die primäre wissenschaftliche Sozialisation bestimmen - von der Ideen- und Politikgeschichte bis hin zur Wirtschaftsund Technikgeschichte."

Des Weiteren gehen die Meinungen und Überlegungen zum disziplinären Charakter der Umweltgeschichte weit auseinander, wie die vorhergehenden Zuweisungen gezeigt haben:

Eine Position versucht die Fragen der Umweltgeschichte in den jeweiligen Disziplinen zu behandeln und mehr als bisher einzubeziehen. Für diese Gruppe handelt es sich im Grunde nur um eine zusätzliche Facette herkömmlicher Technik- und Wirtschaftsgeschichte besonders der letzten Jahrhunderte und Jahrzehnte (vgl. BORRIES 1996:317).

- Eine weitere Position versteht Umweltgeschichte als neue Subdisziplin mit einem gesicherten theoretischen Forschungskonzept (vgl. MEYER 1996:325; BLASCHKE 1990:68), das allerdings noch weitgehend fehlt ${ }^{22}$ und ,zum größten Teil zwischen Fortschritts- und Entfremdungsparadigma angesiedelt ist.“ (MEYER 1996:328)

- Eine dritte Position erhebt die Forderung nach einer Umweltgeschichte mit ,integrierter Multidisziplinarität“" (vgl. REITH 1998:16).

- Und für eine vierte ist Umweltgeschichte „more a clustering of interests than a discipline, and it has never had a unique, discrete paradigm to work with.” (WORSTER 1993b:41)

Während also die historische Umweltforschung von den vorhergehenden Autoren als eine von verschiedenen Fragestellungen innerhalb der Disziplin betrachtet oder als eine Subdisziplin der Geschichtswissenschaften, der Sozialwissenschaften, der Ökologie etc. angesehen wird, erhält sie von anderen Autoren einen mehr interdisziplinären Stellenwert und wird dem jeweiligen Fach (Geschichte, Sozialwissenschaften, Ökologie) mindestens gleichgesetzt oder sogar übergeordnet und damit als eigene Fachrichtung innerhalb des Faches institutionalisiert.

Die Zwischenbilanz von REITH (1998:20) hinsichtlich eines einheitlichen disziplinären Zusammenhangs fällt denn auch dementsprechend schlecht aus: „Die Meinungen, ob die Umweltgeschichte eine übergreifende, integrative Disziplin, ob sie eine Subdisziplin sei, oder ob sie eine Erweiterung der Geschichtswissenschaft bringe, gehen ebenso weit auseinander wie die Fragestellungen, Themen und Methoden. Auch hinsichtlich der Aufgaben, Perspektiven sowie der zeitlichen Schwerpunkte ist kein Konsens abzusehen".

Betrachtet man dieses Konglomerat, so könnte man die Auffassung von MEINECKE (1996:285, Hervorhebung im Original) teilen, dass es so wenig wie es ,die Umweltwissenschaft in meinem Verständnis gibt oder geben wird, so wenig glaube ich an die Umweltgeschichte” oder personifiziert ausgedrückt: „Es gibt den Umwelthistoriker ebenso wenig wie den Umweltwissenschaftler.“

Und auch FUCHSLOCH (1996:12) ist sich unsicher, wenn er fragt: „Was ist charakteristisch für Umweltgeschichte? Die Untersuchung der Wechselwirkungen zwischen gesellschaftlichen und technischen Entwicklungen und der Umwelt und somit eine Aufhebung der thematischen Fixierung auf den Menschen als Mittelpunkt aller Dinge, oder die Zusammenführung von Kenntnissen und Methoden diverser Fachrichtungen? Oder etwas anderes? Oder etwa nichts?"

Schließlich erwächst jedoch zur Beantwortung dieses Unsicherheitsmomentes eine weitere Gruppe, die die historische Umweltforschung als „eine neue Disziplin“ (BRÜGGEMEIER 1992:Untertitel) mit einem

${ }^{22}$ Eine Ausnahme bildet das an der Universität Göttingen als Wahlfach zugelassene Fach „Umweltgeschichte“; siehe nächste Seite 
eigenen interdisziplinär zusammengesetzten wissenschaftlichen Unterbau betrachtet und die zunehmend die disziplinäre Neuordnung bestimmt. Genauso wie es dann eine Historische Geographie unterhalb des interdisziplinären Daches der historischen Umweltwissenschaften gibt, gibt es dann auch eine Historische Anthropologie, Technikgeschichte etc. und jede hat ihre eigene Definition von Umweltgeschichte, begründet in der Disziplingeschichte des eigenen Faches, wo sie auch weiterhin institutionell verbleibt. Denn „eine kompetente Auswertung einer Quelle bedarf des disziplinären Rückgriffs.“ (HERRMANN 1996:26)

Diese Konzepte weisen der Umweltgeschichte eine Schlüsselstellung in der Umweltdebatte zu und sehen Umweltgeschichte als interdisziplinäre ,'Integrations'- und vor allem als ,Überlebenswissenschaft'“ (REITH 1998:18; ebenso BORRIES 1996:317) mit anthropogenem Betrachtungsansatz. Schon FEHN zog 1982 aus den Schädigungen von Boden, Luft, Gewässern und Meeren seit der Industrialisierung die Folgerung, sowohl für eine entschiedene Umweltpolitik wie für die Weiterentwicklung der Naturökologie zu einer interdisziplinären Humanökologie und historischen Umweltforschung zu sorgen. Der Begriff , historische Umweltforschung' wird hier in Zusammenhang mit einer humanökologischen Betrachtungsweise gesetzt, da er die Integration der menschlichen Aktivitäten in alle die Umwelt entscheidend prägenden Prozesse ausdrückt. Auch nach HERRMANN (1996:24) ordnet sich ,die historische Umweltforschung [...] ein in die Erforschung der Themenfelder der Humanökologie. Diese muß nach Regeln, Konstanten, Universalien o. ä. suchen."

Wie sich die weitere Entwicklung vollzieht, bleibt abzuwarten, denn eine letzte Option steht noch offen: Historische Umweltforschung als eigenes institutionelles Fach. Schon jetzt gibt es - einmalig in Deutschland - an der Universität Göttingen die Möglichkeit das Fach Umweltgeschichte als Nebenfach zu studieren. Wenn dies auch einen ersten Schritt einer institutionellen Prägung bedeutet, so hat sich „,bisher [...] die umweltgeschichtliche Forschung in Niedersachsen nicht mit landesweit wirkenden Institutionen etablieren können." (GROHMANN et al. 2000:9) Die in den 1990er Jahren von Franz-Josef BRÜGGEMEIER besetzte Professur für Umwelt- und Technikgeschichte an der Universität Hannover ist den Sparzwängen zum Opfer gefallen. Es ist zu fragen, wie es zukünftig mit dem 'Arbeitskreis Wirtschafts- und Sozialgeschichte der Historischen Kommission für Niedersachsen und Bremen' und dem 'Niedersächsischen Institut für Historische Regionalforschung e.V.' weitergeht.

So ist denn auch mit dieser Perspektive die pessimistische Prognose RADKAUs (1994:19) sowohl abzulehnen wie gleichzeitig hinsichtlich der thematischen Zusammensetzung zuzustimmen, es sei „,vermutlich aussichtslos, die Umweltgeschichte als Spezialdisziplin im vollen Sinne mit eigenem Stoffbereich und eigener Methodik etablieren zu wollen; denn ihre Spannweite reicht von der Agrar- bis zur Verkehrs- und von der Medizin- bis zur Siedlungsgeschichte.“ In die gleiche Richtung argumentiert DIX (1997:17f.): „Auch wenn damit der Gegenstandsbereich der Umweltgeschichte wenigstens benannt ist, so verwundert es doch nicht, daß Umweltgeschichte als eigenständige Disziplin bisher nicht existiert, da das potentielle Feld der zu untersuchenden Faktoren und ihrer Wechselwirkungen unübersehbar groß ist.“

Gemeingut bei der derzeitigen standörtlichen Betrachtung der neueren historischen Umweltforschung ist die Feststellung, und hier ist REITH (1998:20) zuzustimmen, dass ,sich eine [solche] disziplinäre Abgrenzung [...] kaum theoretisch begründen ließe.“ Denn ,am Ende hilft uns eine festgestellte Zuständigkeit der Disziplinen nicht von der Stelle, weil wir die Unmöglichkeit erkennen müssen, die Fortsetzung des Drehbuches zu diesem Film disziplinär zu schreiben.“ (HERRMANN 1996:23)

„Die Zukunft umwelthistorischer Forschung“, dessen ist sich REITH (1998:20f.) sicher, „kann sicherlich nicht (nur) in einer disziplinären Ausrichtung liegen, zumal die Anstöße für umwelthistorische Forschungen aus sehr unterschiedlichen Disziplinen kommen, und die Umweltgeschichte interdisziplinäre Zusammenarbeit einfordert.“ Denn es "handelt [...] sich hierbei um das Gesamtergebnis des Zusammenwirkens aller Einflußfaktoren” (HERRMANN 1996:26, Hervorhebung im Original).

Für RADKAU (1994:22f.) beispielsweise ist die „Verbindung zur Agrargeschichte für die historische Umweltforschung essentiell“ und auch ,eine Querverbindung zwischen Umwelt- und Medizingeschichte erscheint vielversprechend.“ (:23) Aber auch über diese grob skizierten Verbindungen hinaus „sollte es offen bleiben, ob sich durch den Forschungsproze $ß$ nicht doch das eine oder andere Forschungsgebiet - und mit 
diesem auch weitere methodische Ansätze - als interessant und relevant für die Umweltgeschichte erweist.“ (REITH 1996:13).

Der szientistische Grund der Einforderung von Interdisziplinarität liegt darin begründet, dass Umweltgeschichte der historischen Empirie bedarf: „Die Empirie der Umweltgeschichte beruht zunächst sowohl auf den Ergebnissen einzelner historisch orientierter Naturwissenschaften als auch historischer Geisteswissenschaften. Hinzu kommen Ergebnisse solcher Fächer, welche die Grundlagen der raumzeitlichen Verteilung von Leben auf der Erde behandeln. Schließlich bedarf der Fächerkanon fachwissenschaftlicher Ergänzung durch eine historische Materialkunde zur materiellen Analyse von Artefakten und technischen Innovationen.“ (HERRMANN 1989:146)

Die Einbindung der verschiedenen fachlichen Beiträge in den Bezug umwelthistorischer Entwürfe bedarf einer erfahrenen, vernetzten Sichtweise. Zu dieser können naturwissenschaftliche wie kulturwissenschaftliche Zugänge führen, die Bestandteil umwelthistorischer Lehrinhalte sind. „UWG [Umweltgeschichte] ist ein Paradebeispiel für das diskursive Gespräch, an dem viele teilhaben und in dessen Verlauf sich durch ständige Verbesserung das Richtige ergibt." (HERRMANN 1996:26) Aus den vielen einzelwissenschaftlichen Ansätzen „zu einer synthetischen Betrachtungsweise zu finden und diese zum Paradigma des Forschungsansatzes $\mathrm{zu}$ machen, ist eine zentrale Aufgabe der historischen Umweltforschung." (HERRMANN 1989:146) Aus diesem Grund kann es „,die Disziplin nicht geben [...]. Nur mit einem umwelthistorischen integrativen Ansatz des Miteinander von Natur- und Kulturwissenschaften wird es dies geben können.“ (HERRMANN 1996:26)

Wenn also „die Umweltgeschichte schon keine stoffliche Einheit hat, so braucht sie doch eine Einheit der Fragestellungen, des Erkenntnisinteresses.“ (RADKAU 1994:20) Es sollte deshalb das grundsätzliche Ziel sein „der UWG [Umweltgeschichte] eine adäquate disziplinübergreifende erkenntnistheoretische Grundlage zu geben, die keinem der klassischen Wissenschaftsansätze (Naturwissenschaften und Kulturwissenschaften) verpflichtet ist, sondern in einem systemtheoretischen Ansatz ihren angemessenen Standort findet, um die komplexen Sachverhalte zu verbinden.“ (HERRMANN 1996:27) Und dies bedeutet, „daß historische Umweltforschung als empirische Wissenschaft mit abgrenzbarem Gegenstandsbereich problemorientiert sein muß.” (RADKAU 1994:21) Es ist, um mit HERRMANNs Worten zu sprechen, die „Relevanzfrage“ (1989:151) zu stellen: „kann die historische Betrachtung [...] zu einem besonders verantwortungsvollen Umgang mit ,Umwelt' führen”? (:152) Bislang, ist WORSTER (1993:VIII) der Ansicht, „environmental history ought to have a few ideas to offer the public, and those ideas ought to have a little conviction in them as well as reason and evidence."

Deshalb bedarf es einiger „Beispiele für die Sinnfälligkeit historischer Umweltforschung. Der bloße Hinweis auf allgemeine Berechtigung jeder historischen Forschung kann als alleinige Begründung nicht ausreichen. Es wäre dem Verdacht der modischen Attitüde ausgesetzt. Es sollten weitere Gründe für eine historische Umweltforschung sprechen, womöglich sogar im Hinblick auf die (nicht immer angebrachte) Relevanzfrage.“ (HERRMANN 1989:151)

Mit dieser Darstellung skizziert HERRMANN (1989:Vorwort) gleichzeitig auch den zukunftsgerichteten Aufgabenbereich der Umweltgeschichte: „Naturbewahrung“ ist nach seiner Auffassung als die künftige zentrale Kulturaufgabe anzusehen. „An dieser Aufgabe wirkt die Umweltgeschichte mit. Sie schult durch die Betrachtung historischer Prozesse das für ökologische Fragen wesentliche Denken in Zusammenhängen. Damit ist sie ein Kernstück der ,ökologischen Grundbildung' “ Um dieses zu erreichen, muss Umweltgeschichte ,aber im Kern eine vergleichende Geschichte sein und als Geschichte für sich wohl am ehesten in Anspruch nehmen dürfen, Lehren bereitzuhalten.“ (HERRMANN 1996:24, Hervorhebung im Original)

Den Sinn einer ,Historischen Umweltforschung' sieht TROITZSCH (1981:177) angesichts der Umweltprobleme der Gegenwart und der ausgesprochenen Ahistorizität der wachsenden ökologisch orientierten Literatur darin, durch „die Kenntnis des Vergangenen [...] insofern [...] einen Beitrag zur Bewältigung künftiger Aufgaben zu leisten, als durch die Freilegung und kritische Analyse von Wurzeln, Wegen, Irr- und Umwegen historischer Prozesse Hinweise und Entstehungshilfen für die Lösung vor uns liegender Probleme gewonnen werden können.“ Die Diskussion über Umweltfragen soll damit auf „solide historische Fundamente“ gestellt und versachlicht werden, denn ,die Wiederherstellung eines ursprünglichen 
[...] Zustandes ist nur möglich, wenn hinter die Umschlagsituation zurückgegangen wird. Hierzu ist eine historische Betrachtung unerläßlich.“ (HERRMANN 1989:152)

„Die Intensivierung historischer Umweltforschung ist ein Weg der zukunftsorientierten Umweltforschung.“ (HERRMANN 1989:152), denn es ist unstrittig: „The present problem of environment is the result of historical development." (BLASCHKE 1990:69).

Als Beispiele einer solchen zukunftsorientierten historischen Umweltforschung nennt HERRMANN (1989:152f.) „Langzeitversuche unter natürlichen Bedingungen“. Die Auswertung dieser ,Langzeitversuche’ „sollte helfen, die Modellierung komplexer Umweltverhältnisse zur Lösung der Zukunftsaufgaben wesentlich zu verbessern.” (:152f.) „Die Aufdeckung der Gesetze, nach denen sich die Prozesse der Umweltgestaltung vollziehen, wird durch den historischen Aspekt wesentlich erleichtert", stellte schon LEHMANN 1976 (:20) fest. Unter historischem Aspekt würde „das grundlegend veränderte Verhältnis des Menschen zu seiner Umwelt in der Gegenwart [...] besonders deutlich“, begründet er (:21) seine Sichtweise. „Heutzutage”, ergänzt GROHMANN et al. (2000:13) den Zukunftsbeitrag historischer Umweltforschung, „werden Erkenntnisse der Umweltgeschichte zunehmend mit dem Konzept der Nachhaltigkeit in Beziehung gesetzt, so daß die Umweltgeschichte zur Realisierung zukunftsorientierter Ziele auf dem Umweltsektor beitragen kann.“

„Es geht“, so die immer noch aktuelle Philosophie LEHMANNs (1976:21), „um einen grundsätzlich neuen, durch die Berücksichtigung der Ergebnisse naturwissenschaftlichen und technischen Denkens in den Gesellschafts- und Wirtschaftswissenschaften sich entscheidend auswirkenden Weg, die Natur und die Gesellschaft unter den gegebenen lokalen oder regionalen Umständen optimal zu verändern.“ „Die Analyse der Umweltbedingungen ohne den historischen Bezug ist auch im Hinblick auf prognostische Aussagen unzureichend, weil Aufgaben der Umweltgestaltung eng mit den gesellschaftlichen Zielen verbunden sind und nicht selten mit grundstürzenden Veränderungen der Wirtschafts- und Sozialstruktur parallel laufen.“ (LEHMANN 1976:20). Daraus ergibt sich, dass "Umweltgeschichte nicht nur materielle Phänomene, nicht nur erfahrungswissenschaftliche Fragen, sondern auch Normen und Handlungsanweisungen thematisiert einschließlich deren Folgen.“ (HERRMANN 1996:21, Hervorhebung im Original)

BLASCHKE (1990:69) fasst dieses Erkenntnisinteresse (,There is a twofold interest of history in regard to environmental questions“) in zwei Punkten zusammen:

1. the exploration of environmental behaviour in history; and

2. the discovery of the roots of the present environmental problem in history.

Bei Beachtung dieser Aufgabenbereiche hätte die historische Umweltgeschichte dann, um hierauf ein Zitat HERRMANNs (1989:153) anzuwenden, „den Schritt von einer Betrachtungsweise mit Erklärungscharakter zu einer akademischen Disziplin vollzogen.“

Abschließend lassen sich einige gemeinsame Grundzüge umwelthistorischer Forschung herausarbeiten:

1. Juvenalität

„Die Umweltgeschichte zählt zu den jüngsten historischen Subdisziplinen.“ (vgl. BAYERL et al. 1996: Vorwort) Mit dieser Feststellung zu erklären sind auch die Vielzahl an Definitionsversuchen und disziplinären Richtungskämpfen; obwohl auch hier zunehmende Übereinstimmung zu den Wesenszügen festzustellen ist, die zu einem grundsätzlichen Verständnis von Historischer Umweltforschung führt, wie die Zusammenstellung der folgenden Punkte noch einmal zeigt.

2. Geschichtlichkeit

Für eine Umweltgeschichte ist „eine historische Dimension, die über eine kurzfristige und kurzsichtige Perspektive hinausgeht, zwingend.“ (REITH 1996:14) Die Langzeitlichkeit, die auch eine Nachhaltigkeit beinhaltet, ermöglicht erst den Aufbau einer geschichtlichen Reihe mit der Fortsetzung zu einer Prognose.

3. Anthropologie

„Der Gedanke, daß die Natur kein vorgegebenes Faktum, sondern ein kulturelles Konstrukt sei, wird 
mehr und mehr zum Gemeingut der Diskussion." (RADKAU 1994:11) Dieses, vom Umwelthistoriker RADKAU als „erste[r] umwelthistorische[r] Lernschritt” bezeichnete, Grundkonstrukt „besteht gewöhnlich darin, daß man sich die romantische Vorstellung einer noch bis in die Moderne ziemlich unberührten, erst durch die Industrialisierung beschädigten Natur aus dem Kopf schlägt. Die Naturidyllen, die uns als Ideallandschaften vorschweben, sind gewöhnlich unter menschlichem Einfluß entstanden." (:12). Und an jüngerer Stelle wiederholt er diese Einsicht, dass es ,auf dem heutigen Forschungsstand [...] großflächige Landschaftsveränderungen durch den Menschen schon seit Jahrtausenden gibt.“ (2002:27f.) und dass „ein ,nichtanthropozentrisches' Konzept von Umweltgeschichte [...] die realen Zusammenhänge zu verschleiern“ droht (:17). „The recognition that Homo sapiens is a major agent of environmental change is a basic tenet of the new field of environmental history", schreibt auch WHITNEY (1994:3).

4. Interdisziplinarität

Historische Umweltforschung ist eine interdisziplinäre historische Erforschung der Umwelt. In der dadurch möglichen und zwingenden Aufnahme eines weit- und tiefverzeigten Fächerkanons liegt allgemein "the perceived worth and therefore the longevity of disciplines and sub-disciplines". Sie „partly depends upon a capacity to adapt to autonomous (or internal) interests and pressures and external demands and potentialities." (POWELL 2000:180)

\section{d „Historische Kulturgeographie“ als „historisch-geographische Umweltforschung“}

Während die genannten Umwelthistoriker immer die Geschichte der Menschheit, ihrer umweltschädlichen Handlungen, ihrer Aktionen und Reaktionen, ihrer ideologischen Verarbeitung von Wirklichkeit etc. behandeln, blieb bislang die räumlich-geographische Dimension einer interdisziplinären historischen Umweltforschung vielfach unbeachtet.

Verständlich, wie DENECKE (1998:25) in einem englischsprachigen Beitrag findet, denn „,no doubt, historical geographers should have played a leading role within this movement, but instead they occupied more secondary positions rather than taking over the leadership." Die an die eigene Disziplin gerichtete Kritik DENECKEs erscheint umso unverständlicher als dass, wie POWELL (2000:186) findet, „historical geography made a deliberate investment in the investigation of environmental change long before the stimulus of the environmental movement intensified the kinds of converging inter-disciplinary research". Diese „Führungs- bzw. Vorreiterrolle” gilt es erneut zu beleben und und in einem umwelthistorischen Kontext weiter zu entwickeln:

Im Folgenden soll deshalb das eigenständige Profil einer Historischen (Kultur-)Geographie als historischgeographische Umweltforschung herausgefiltert werden, um aus dieser Ausrichtung die Zukunftsfähigkeit bzw. den Zukunftsbeitrag der Historischen Geographie herauszustellen. Dazu erscheint es notwendig die Grenzen zu anderen historischen Fächern und die Unterschiede bzw. Erweiterungen zur ,traditionellen' Historischen Geographie, wie aber auch deren gemeinsame Ansätze zu verdeutlichen.

Hinsichtlich der anthropogenen Komponente, ,there is no glaring or defining difference between environmental history and historical geography in the weight given to the 'society' component of the naturesociety equation." (POWELL 2000:180) Der Unterschied in der historisch-geographischen Betrachtungsweise $\mathrm{zu}$ der allein geschichtlichen Umweltbetrachtung liegt darin, dass „environmental historians have chronicled the massive environmental changes resulting from capitalist and colonial settlement and the agricultural systems” (NASH 2000:15) sowie „the early growth of conservation movements.“ (POWELL 2000:180) Eine Historische Geographie „concerned with environmental issues“ im Gegensatz dazu, „illustrates a persistent emphasis on the interpretation of environmental change.“ (:178)

Ausgangspunkt historisch-geographischer Interpretationen ,sind - im Gegensatz zu denen aus der sozialund wirtschaftshistorisch fundierten Umweltgeschichte (siehe z. B. BRÜGGEMEIER 1996, RADKAU 1994, 1997, BAYERL 1999) - in der Regel heute noch sichtbare Raumstrukturen. [...] Ziel ist dabei meist die genetische Erklärung der sichtbaren Elemente und Strukturen in der gegenwärtigen Landschaft. Das“, stellen NAGEL/SCHENK (2001:3) klar, „war schon immer ein bedeutsames Arbeitsfeld der gesamten Geographie." 
Diese beiden Betrachtungsebenen, visuell wahrnehmbare historische Raumelemente und -strukturen und deren Erklärung, hebt auch POWELL (2000:178) hervor, wenn er sagt, dass ,'classical' historical geography typically concentrated on presenting characterisations of landscape elements as scientific evidence" und dass „that stress was prominently, if not exclusively, directed towards landscape reconstructions.” (:178) Die sich aus der Landschaftsrekonstruktion anhand von Kulturlandschaftselementen ergebende ,landscape biography" beschreibt in die gleiche Richtung gehend MARCUCCI (2000:68) als Zielsetzung. Das Aufgabengebiet dieses Forschungsansatzes, ,is to explain the temporal context of the current landscape.”

Der "Raum-Zeit"-Begriff ist - wie in der Geographie generell (siehe 1a) - das Wesensmerkmal der Historischen Geographie: „Raum hat [...] in historisch-geographischem Sinne im wesentlichen die Bedeutung: Siedlungs- und Kulturlandschaft in ihrer historischen Entwicklung, gestalteter und zu gestaltender Siedlungsraum, Aktionsraum in historischen Epochen sowie abstrakter Raum von Systemen und Beziehungsgefügen.” (DENECKE/FEHN 1989:8)

So wie die Geographie Raumwissenschaft, so ist die Historische Geographie historische Raumwissenschaft. Ihr Aufgabenfeld ist von FEHN/BURGGRAAFF (1993:11) klar definiert worden. Danach beschäftigt sich die Historische Geographie als historische Raumwissenschaft mit „den raumrelevanten Prozessen, den raumprägenden Strukturen und der konkreten Umgestaltung der Naturlandschaft durch das Wirken des Menschen vom Beginn der menschlichen Geschichte bis an die Gegenwart heran." Die Historische Geographie versucht dabei vor allem, folgende zentrale Fragen zu beantworten:

1. Auf welche Weise hat sich der Mensch an die bestehenden unterschiedlichen natürlichen Gegebenheiten angepasst? (z. B. durch die Wahl bestimmter Siedlungs- bzw. Wohnlagen und Ackerflächen)

2. Auf welche Weise hat er diese natürlichen Gegebenheiten gemäß seinen Bedürfnissen umgestaltet? (z. B. durch Entwässerung der Anbaugebiete, Umlegung bzw. Anlage von Gewässern) (in Anlehnung an FEHN 1989b:13)

„Diese beiden Aspekte“, so FEHN (1989b:13), „lassen sich zwar theoretisch unterscheiden, sie dürfen aber in der praktischen Arbeit nicht getrennt werden.“ Deutlich wird aber aus den beiden Aspekten „Mensch als Darwinist" und „Mensch als Gestalter“, sind sie auch in ihrer Wirkung unzertrennlich miteinander verbunden, die Weiterentwicklung des historisch-geographischen Ansatzes von einer statischbeschreibenden zur dynamisch-interpretativen Wissenschaft. Die Historische Geographie blieb nach Aussage von DENECKE (1989c:51) bis Anfang der 1990er Jahre bei der Beantwortung der Fragen ,in ihrer Beschreibung, aber auch in ihrer Analyse und Erklärung räumlicher Verhältnisse, räumlicher Gliederungen oder räumlicher Anordnungsmuster [...] in ihrer Betrachtungsrichtung vornehmlich statisch, das heißt auf Zustände gerichtet.“ „Im Mittelpunkt des Interesses der Historischen Geographie“ stehen jedoch „heute weniger die Formen und die Strukturen, sondern die Funktionen, die Prozesse und die dahinterstehenden Kräfte.“ (FEHN 1989b:17) Eine solche „dynamische Betrachtung und Analyse“ untersucht „räumliche Systeme, Beziehungsgefüge und Prozesse in ihren funktionalen, ökonomischen, politischen und sozialen Zusammenhängen [...]. Diese dynamisch-funktionale Betrachtungsweise [...] gewinnt heute mehr und mehr an Bedeutung. Mit ihr verschieben sich die Untersuchungen auch immer mehr von der vorhandenen, gewordenen oder gestalteten Landschaft hin zu den raumgestaltenden Aktionen, den raumwirksamen Aktivitäten und ihren steuernden Faktoren.“ Dies bedeutet, „daß sich die historische Geographie heute stärker als zuvor historischen, das heißt auf den Menschen und sein Handeln gerichteten Betrachtungen zuwendet. Eng verknüpft ist eine entwicklungsgeschichtliche Analyse besonders bei der Betrachtung geographischen Wandels, bei Veränderungen in der Landschaft, im Raumgefüge oder seiner Gestaltung." (DENECKE 1989c:51) „Historical geographies of landscape“ ist auch nach SEYMOUR (2000:214) „,an approach which treats landscape as a cultural process rather than an artefact.“

Es ist also zum einen, dies geht aus den Aussagen zur stärkeren Betonung der anthropogenen Komponente hervor, ein Wandel historischer Geographie zu einer historischen Kulturgeographie feststellbar. Dies betont auch SCHÖLLER (1989:82f.) unter Wahrung der traditionellen Forschungsrichtungen: „Lange Zeit hat die Historische Geographie ihre Hauptaufgabe in der Rekonstruktion relevanter historischer Raumgefüge gesehen, dem Erkennen und Herausarbeiten horizontaler Querschnittsbilder. [...] So soll für verschiedene 
zeitliche Querschnitte ein Bild der Kulturlandschaft erworben werden, um die äußeren Zustände des Lebens jener Zeiten richtig zu erfassen. Diese Aufgabe bleibt wichtig auch für die Zukunft. Doch hat sich die Historische Geographie längst daran gewöhnt, nicht nur Querschnittsbilder zu zeichnen, sondern auch Prozesse und Entwicklungen bis zur Gegenwart zu verfolgen, heutige Raummuster und Raumkonzeptionen in ihrer Wirksamkeit zu historischen Zeiten zu untersuchen und Persistenz und Wandelbarkeit funktionaler Raumbeziehungen zu untersuchen.“

Doch auch „historical geographers are well advised to acknowledge the necessity for a closer engagement with intra- and inter-disciplinary adjustments.”, lautet der Ratschlag von POWELL (2000:187). Erst aus dieser intra- und interdisziplinären Zusammenarbeit erwächst der Wandel einer historischen Geographie zu einer historisch-geographischen Umweltforschung, der in dem Terminus zu Ausdruck kommt. So unterscheidet NITZ (1998:11) ,immer deutlich zwischen der ,Historisch-genetischen Siedlungsgeographie' und dem interdisziplinären Sammelbegriff ,Historisch-genetische bzw. Genetische Siedlungsforschung'.“

JÄGER (1997:343) subsumiert Forschungsrichtungen wie die Landschaftsgeschichte oder die genetische Kulturlandschaftsforschung unter dem Begriff „historisch-geographische Umweltforschung“, ohne sich den Hinweis zu verkneifen, dass eine historisch-geographische Umweltforschung bekanntlich ,auf eine bis ins 19. Jahrhundert zurückreichende Tradition zurückblicken“ kann, ,auch wenn die Arbeiten andere Namen, wie Landschaftsgeschichte oder genetische Kulturlandschaftsforschung getragen haben." Doch ist, außer einer neuen Namensgebung wirklich kein inhaltlicher Unterschied vorhanden?

POWELL (2000:169f.) nennt die Disziplin „historical geographies of the environment” und ordnet sie als Bestandteil des interdisziplinären Faches „environmental history“ ein. Als Untersuchungsebenen zählt er in thematischer Hinsicht auf:

- The woods

- The waters

- Grassland

- Soil, climate and fire

Es wird deutlich, dass es sich hier um die natürlichen Lebensbedingungen handelt, die im Mittelpunkt seiner historisch-geographischen Umweltforschung stehen. Es ist anzunehmen, da nach seiner Ansicht, wie zuvor beschrieben, primär ,Landschaftsrekonstruktion' von der ,klassischen' Historischen Geographie betrieben wurde, dass vor allem die anthropogene Veränderung der Wälder, Gewässer, Wiesen und Weiden, des Bodens, der Klimate und die Auswirkungen des Feuers Gegenstand der Untersuchungen historischgeographischer Umweltforschung sind.

Einschränkend von diesen ,natürlichen' Untersuchungsobjekten einer amerikanischen ,historischen Geographie der Umwelt', sollte die deutschsprachige historisch-geographische Umweltforschung - in Anlehnung an die neuere Historische Geographie - einen wesentlichen Schritt weitergehen. Denn sie stellt „nicht mehr die angeblich unveränderlichen Naturgrundlagen der geschichtlichen Entwicklung gegenüber. Sie begnügt sich auch nicht mit den Untersuchungen über die Veränderungen der natürlichen Umwelt in all ihren Teilbereichen." (FEHN 1989b:13), sondern bezieht auch die baulich-physische Umwelt in ihre Überlegungen mit ein - doch dazu später mehr. Deshalb betont FEHN (1997:18), ,nochmals ausdrücklich [...], daß die Historische Geographie nicht den in der Ökologie entwickelten Begriff der ,Kulturlandschaft' verwendet, der auf die relativ naturnahe Agrarlandschaft des vorindustriellen Zeitalters abzielt und andere vom Menschen gestaltete Landschaften mit Bezeichnungen wie ,Industrielandschaft', ,Zivilisationslandschaften', ,Technotope' ausklammert. Die Bewertung einer Landschaft oder eines Landschaftsteils erfolgt nicht oder zumindest nicht primär nach der Naturnähe, sondern nach kulturlandschaftsgeschichtlichen Kriterien.“

Auch MÜCKE (1988:303) hebt in seiner Konzeption einer umweltgeschichtlichen Geographie die Beachtung von Umwelt als kulturellem Wert hervor. Er verwendet zwar den Begriff historisch- 
geographische Umweltforschung nicht direkt, sondern spricht in seinem Konzept von einer „lebensweltlichen Historischen Geographie“, die sich beide zwar inhaltlich nicht wesentlich voneinander unterscheiden und somit synonym verwendet werden können, sich aber vom Denkansatz der ökologisch-orientierten Umweltgeschichte prägnant abheben: „Eine lebensweltliche Historische Geographie als Umweltforschung unterscheidet sich mithin von Umweltgeschichte durch zwei Kriterien (:303):

\section{Methodisch durch die Beachtung ökologischer Methodologien und}

2. objektsprachlich durch die Behandlung von Umwelt als kulturelles Phänomen.

"Historische Geographie kann Phänomene nicht für sich behandeln, ohne sie dem Raum zuzuordnen", stellt MÜCKE (1988:302) den Raum als disziplinäres Bindeglied dar. „Sie kann aber auch nicht Phänomene behandeln, ohne die kulturellen Folgewirkungen miteinzubeziehen.", arbeitet er (:302) die Wechselwirkungen heraus und resümiert: „Hieraus wird deutlich, daß Historische Geographie [...] eine Beziehungswissenschaft darstellt.“ (:302). Umwelt besteht demnach für eine ,lebensweltliche Historische Geographie' resp. ,historisch-geographische Umweltforschung' „aus räumlichen Phänomenen, die durch kulturelle Prozesse beschrieben werden. Umwelt ist nicht die Anhäufung gegenständlicher Tatbestände, sondern Prozeßfeld kultureller Sachverhalte.“ (:303) Eine historisch-geographische Umweltforschung hat demzufolge auch den kulturellen Aspekt nicht zu vernachlässigen (vgl.:304).

Für eine historisch-umweltgeographische Betrachtung, folgt man MÜCKE (1988:304) in seiner Begründung, „sind nicht allein die naturwissenschaftlich oder ingenieurwissenschaftlich meßbaren Veränderungen von Bedeutung, sondern vielmehr die Einflüsse auf die Lebensweise der Menschen und ihr Verhältnis zur Natur. So bedeutet Flußverschmutzung mehr als die Verringerung des Sauerstoffgehalts und damit Algenbildung, Absenken der Fließgeschwindigkeit usw., sondern den Verlust an Kultur, z. B. durch die Aufgabe von Flußbadeanstalten, die dann auf synthetisierte Art und Weise mit viel Aufwand an anderer Stelle errichtet werden." Es handelt sich also auch um eine kulturelle Verarmung, die sich flächenhaft auswirkt.

Diese raumgreifenden Auswirkungen kulturellen Niedergangs, der sich in dem Verlust historischgeographischer Kultur(landschafts)elemente widerspiegelt, werden von DENECKE aufgegriffen. Nach der Definition von DENECKE ist es „u. a. die Aufgabe gerade der heutigen historischen Umweltforschung, die großräumigen langzeitlichen Veränderungen quantitativ genauer zu erfassen, sie regional zu differenzieren, sie zeitlich zuzuordnen, sie in ihren Ursachen zu erklären sowie Trends einer Weiterentwicklung oder Regeneration der Eingriffe zu erkennen. Vor allem ist dabei herauszuarbeiten, in welchem Ausmaß die menschlichen Eingriffe in die Landschaft auslösend und an Veränderungsprozessen beteiligt waren, um damit auch beleuchten zu können, in welchem Maße heute erkannte ,Umweltschäden' schon auf weit zurückliegende Eingriffe zurückgehen.” (1989b:203) Diese die räumliche differenzierte, kulturlandschaftsgeschichtliche Entwicklung in den Vordergrund stellende Aufgabenbeschreibung von historischer Umweltforschung präsentiert das Selbstverständnis einer historisch-geographischen Umweltforschung und sollte nach der Auffassung DENECKEs einen wesentlichen Bestandteil der historischen Umweltforschung im Allgemeinen darstellen.

„Eine historisch-geographische Umweltforschung soll“ nach Ansicht von DENECKE (1989b:204) „dazu beitragen, Eingriffe und Folgeprozesse in der Landschaft über längere Zeiträume hin und damit auch in die Zukunft hinein besser zu erkennen und zu beurteilen.” Dabei ist FEHN (1989b:18) zuzustimmen, „daß auch in Zukunft von der Historischen Geographie nicht nur Modelle erarbeitet werden und nach allgemeingültigen Prinzipien räumlicher Differenzierung, regelhaften Abläufen raumrelevanter Prozesse und dahinter stehenden Kräften gesucht wird, sondern auch die Erforschung des Realen, Einmalig-Individuellen in Raum und Zeit nicht vernachlässigt wird." Dies soll auch für eine historisch-geographische Umweltforschung gelten.

HAGEL (1988:131) beschreibt als „Aufgabe der historisch-geographischen Umweltforschung“, Veränderungen des Naturhaushalts durch den Menschen nachzugehen. Die historisch-geographische Umweltforschung fragt nach seiner Ansicht nach den Motiven, das heißt aus welchen Gründen es zu Eingriffen in den Naturhaushalt kam, und sucht nach den Trägern der Umwelteinwirkungen. Darüber hinaus jedoch sieht er die Aufdeckung komplexer Beziehungsfüge als Wesensmerkmal einer speziell geographisch orientierten 
historischen Umweltforschung und als Forschungsgegenstände sieht er konsequenterweise die von Eingriffen des Menschen betroffenen zahlreichen Geoelemente (siehe Abb. I-4):

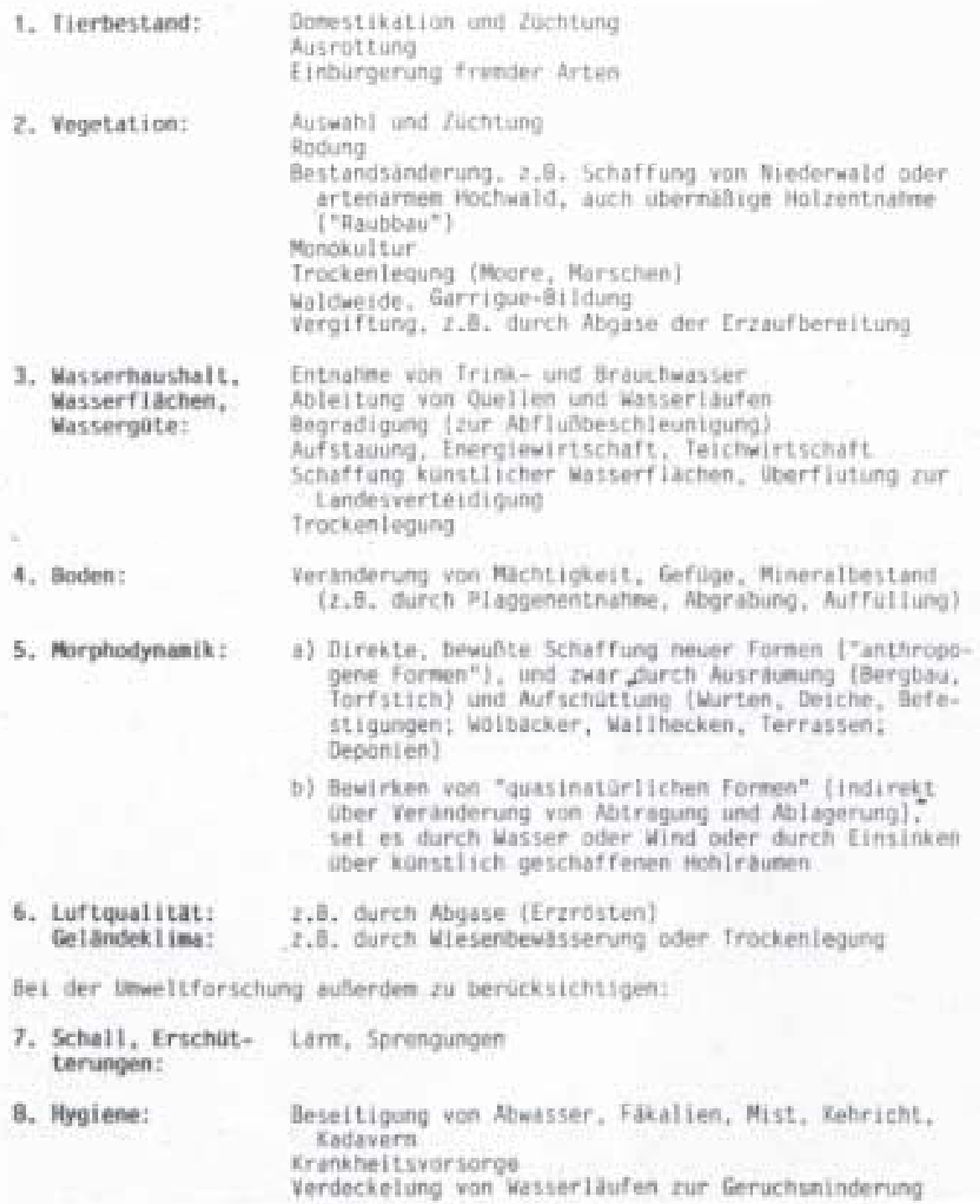

Abb. I-4: Von Eingriffen des Menschen betroffene Geoelemente (aus: HAGEL 1988:130)

Der spezifisch historisch-geographische Beitrag zur Naturbewahrung liegt in der erhaltenden Kulturlandschaftsentwicklung, ausgehend von dem Grundverständnis, dass die bestehende Naturlandschaft eine vom Menschen direkt oder indirekt gestaltete bzw. beeinflusste Kulturlandschaft ist. Dabei bezieht sich der Beitrag insbesonders auf den Erhalt der historischen Kulturlandschaft

Es ergeht also die Forderung und es erwachsen auch seit einigen Jahren die Bemühungen nach einer Weiterentwicklung des traditionsreichen kulturhistorischen Betrachtungsansatzes und nach Integration in einen vielseitigen umwelthistorisch-geographischen Zusammenhang. Ziel einer solchen historischgeographischen Umweltforschung als Fachrichtung ist die Rekonstruktion historischer Umwelteinflüsse sowie die Kennzeichnung aktueller Schutz- wie aber auch Nutzungsmöglichkeiten verschiedener Sachbereiche (vgl. KLEEFELD/BURGGRAAFF 1997:36).

Die zukünftige Ausgestaltung einer Historischen Geographie als eine historisch-geographische Umweltforschung kann jedoch, dies wird bei Betrachtung der zahlreichen Untersuchungsgegenstände deutlich, nur aus einer interdisziplinären Zusammenarbeit bestehen ohne ihr eigentliches charakteristisches Spezialgebiet zu vernachlässigen: die kulturbeeinflusste geschichtliche Umwelt in ihrem Raumbezug. Hinsichtlich der disziplinären Beteiligung und Positionierung hingegen gibt es sowohl noch Abgrenzungs- als auch Auflösungsversuche. 
Nach FEHN (1989:4) „bleibt es [...] die Aufgabe der Historischen Geographie, in Zusammenarbeit mit den historisch orientierten Naturwissenschaften flächenhafte Vorstellungen über die früheren Umwelten zu erarbeiten.“ Während FEHN hier die interdisziplinäre Beteiligung auf die „historisch-orientierten Naturwissenschaften“ beschränkt, spricht er an anderer Stelle davon, die Historische Geographie sei „bestrebt, ältere Landschaftszustände unter koordinierender Verarbeitung der Ergebnisse vieler Naturwissenschaften zu erfassen und dadurch die grundlegenden Veränderungen der räumlichen Wirkungsgefüge im Laufe der Menschheitsgeschichte kennenzulernen." (:3) . Hervorgehoben sei hier auch die Einschätzung von SCHENK (2003b:145) zur Historischen Geographie als „umwelthistorisches Brückenfach zwischen Geschichte und Geographie“, ,an der Schnittstelle verschiedener natur- und kulturwissenschaftlicher Disziplinen“ (:145) und seiner Darstellung der Positionierung dieses Faches in der Wissenschaftslandschaft.

Für SONNABEND (1999d:219) handelt es sich bei der Historischen Geographie „um eine Wissenschaftsdisziplin, die ihre inhaltlich bestimmten Forschungsanliegen - schlagwortartig formuliert: die Wechselwirkungen von Mensch und Landschaft - in engster Kooperation mit anderen Disziplinen gewinnt"; und bezieht damit eine eindeutig breitere interdisziplinäre Position, denn, wie COSGROVE (1990:1) diesen Vorteil formuliert: „Each essay is a self-sufficient study but together they point to common themes and common questions."

Sind die Untersuchungs- und Gegenstandsbereiche einer historisch-geographischen Umweltforschung auf der Grundlage der Historischen Geographie klar definiert und feststehend, so lässt sich behaupten, „daß die optimale Erforschung historischer Kulturlandschaften und Siedlungsräume heute nur noch interdisziplinär geschehen kann.“ (FEHN 1989:16) Da aber die Fächerwahl unterschiedlich gesehen wird bzw. unscharf bleibt, ist auch die Aufgabenverteilung innerhalb einer historisch-geographischen Umweltforschung unklar:

Nach FEHN (1989:16) „,kommt es nicht darauf an, welches Fach [aus den Naturwissenschaften] welche Aufgabe übernimmt“". Er verlässt hiermit die institutionellen Fächergrenzen und kommt damit in die Nähe des früheren, simplifizierenden Slogans „Geography is what geographers do.“

In abgeschwächter Form, aber in der Grundaussage gleichwertig, beschreiben DENECKE/FEHN (1989:8) gemeinsam die Historische Geographie als „ein Forschungsfeld, das sich von den eigenen Betrachtungen und Fragestellungen her definiert, die über die traditionellen Fächergrenzen hinweggehen." Im Gegensatz zur völligen Auflösung des disziplinären Gegenstandsbezuges, machen sie aber noch einmal deutlich, dass die Historische Geographie ausgeht ,von der Untersuchung raum-zeitlicher Verhältnisse, Entwicklungen und Prozesse, die im Raum abgelaufen, die raumwirksam und raumgestaltend sind.“

Aus diesem originär geographischen Untersuchungsbereich verbunden mit einer interdisziplinären Ausrichtung sieht POWELL (2000:1986) die zukünftige Ausgestaltung einer historisch-geographischen Umweltforschung: „If academic geography benefits from being as committed to the elevation of environmental sensibilities as it is to the appreciation of environmental processes, and as much to place-making as to the description and interpretation of places, then multifaceted historical geographies of environmental change surely provide a pivotal relevance." POWELL spricht hier die Relevanzfrage an, die Wolfgang ZORN bereits Ende der 1970er mit der „Frage nach der Stellung des Faches Historische Geographie, insbesondere der ländlichen Siedlungsforschung, zur Umweltkrise der Gegenwart" gestellt hat. POWELL hat die Antwort in Form einer „multiorientierten Historischen Geographie der Umweltveränderungen“ gefunden.

Die ,Historische Geographie' ist also nach diesem Verständnis mehr als ,interdisziplinäre umwelthistorische Geographie' zu bezeichnen bzw., wenn mit einem Forschungsauftrag verbunden, als ,historischgeographische Umweltforschung' zu verstehen und, wenn die Planungspraxis im Vordergrund steht, als ,anwendungsorientierte historisch-geographische Umweltforschung' bzw. als ,historisch-geographische Umweltplanung'. 


\section{e Probleme und Chancen der Interdisziplinarität historisch-geographischer Umweltforschung}

„Ich stand, gleich mehreren, eine Zeitlang in dem Wahn, meine Wissenschaft geheim zu halten, allein ich wurde anders Sinnes, und entschloß mich, nichts für mich zu behalten, sondern ohne allen Hinterhalt öffentlich an den Tag zu legen, was zum gemeinen Vortheil dienlich und nützlich sey.“ [STURM 1815:Vorbericht]

Die charakterliche Wandlung Leonhard Christoph STURMs, doch noch eine wasserbautechnische Abhandlung zu verfassen, beschreibt recht anschaulich die primäre Voraussetzung interdisziplinärer Forschung: die der Öffnung und Weitergabe von Wissen, um überhaupt zu einem Erkenntnisgewinn zu gelangen. In einem das Fachwissen mehrerer Disziplinen umfassenden Wissenschaftsgebäude erweitert sich zwar die monographische Darstellung des Einzelfaches zu einem durch gegenseitigen Austausch geprägten Mehrwert, doch die Einbindung fachübergreifender Ergebnisse führt mitunter $\mathrm{zu}$ einem Verlust der eigenen Charakteristik. Im interdisziplinären Rahmen, betont DENECKE (2001:282), geht es dabei zwar „stets auch um den Beitrag im gemeinsamen Zusammenspiel, zugleich aber auch um die Forderung des Stellenwertes im Kontext des eigenen Faches und seiner Teildisziplinen.“

Dieser mögliche Identitätsverlust bzw. der nicht mögliche Identitätsgewinn betrifft vor allem „die Umweltgeschichte, die als Forschungsfeld und wissenschaftliches Paradigma seit den 1970er Jahren zunehmend an Interesse und Bedeutung gewann [und ...] eine große Zahl von kultur- und naturwissenschaftlichen Fächern“ anspricht (DENECKE 2001:290). Zu den „Forschungsdisziplinen, die seit langem und manchmal sehr öffentlichkeitswirksam Umweltgeschichte betreiben” gehören „die Ethnologie, Anthropologie und die Prähistorie unter Einschluß der Paläobotanik.“ (RADKAU 2002:15) sowie „ganz besonders auch die Siedlungs- und Landschaftsarchäologie, die Landschaftsgeschichte und, übergreifend, die historischgenetische Kulturlandschaftsgeographie“ (DENECKE 2001:290).

In Deutschland waren die neueren Ansätze der Umweltgeschichte förmlich geprägt vom Bestreben zur Interdisziplinarität: „The prevalent view in Germany has seen it as closely tied to a wide variety of disciplines and hence an area of interdisciplinary work." (NORTON 1984:38) Doch, trotz dieser Bemühungen, „bislang wissen diese Disziplinen und die Umweltforschung der Historiker fast nichts voneinander.”, schreibt RADKAU (2002:15). „Viel hängt davon ab“, so seine verheißungsvolle Forderung, „diese Kluft zu überbrücken.“ Auch nach Auffassung von DIX (1997:18) wird zwar „,immer wieder betont, daß eine Historische Umweltforschung nur interdisziplinär betrieben werden kann. Allerdings", so das ernüchternde Urteil, ,ist diese neue Bezeichnung häufig nur auf die bereits innerhalb der Fächer betriebene Forschung angewandt worden, ohne daß neue Fragestellungen oder Theorien formuliert worden wären.“(:18)

Das Streben zu Interdisziplinarität als Allheilmittel birgt auch Gefahren in sich. Die interdizplinäre Ausrichtung seit Mitte der 1970er Jahre hat nämlich, dies bringt DENECKE (2001:276) kritisch hervor, „,die Forschungsansätze in spezifische Bahnen gelenkt [...], die für das Beziehungsgefüge in der jeweils eigenen Disziplin separierende Folgen gehabt haben, ganz besonders in der Geographie.“

„Die archäologische und die zugehörige naturwissenschaftliche Forschung erweiterte“ aufgrund dieser eigenen Fehlentwicklung ,ihren Betrachtungsansatz in eine historisch-geographische Kulturlandschaftsforschung (Kulturlandschaftsentwicklung) hinein, auf der Basis ihrer selbst erarbeiteten Befunde." (DENECKE 2001:277) und führte zum Verlust eines Themas traditionell kulturgeographischen Ursprungs.

Das Wissenschaftsgebäude einer „,contemporary historical geography“ nach BUTLIN (1993:XI) hingegen sieht die neuerdings beschworene Gefahr der Interdisziplinarität nüchtern, denn nach seiner Ansicht bestand dieser wissenschaftliche Austausch auch schon in der Vergangenheit und auch die Historische Geographie hätte von anderen Einflüssen partizipiert.

Dies sehen auch NASH/GRAHAM (2000:4) so: „The tendency to bemoan the erosion of historical geography by other subdisciplines within the subject, or its dilution through the influences of other disciplines, belies the way in which historical geography has always been in some respects an interdisciplinary endeavour, drawing on economic and social history, ecology, social theory, just as it draws 
on feminism, environmental history, post-colonialism and cultural history today. Thus those who berate the contemporary 'colonisation' of historical geography by other theoretical frameworks forget the always hybrid and interdisciplinary richness of its past, one shaped, unsurprisingly, by influences that were simply different from those which apply today."

Der Interdisziplinarität, die mit dem zuvor erhobenen und nachfolgend verworfenen Vorwurf lebt, womöglich die eigene Disziplin zu verwässern und zudem in der Praxis nur schlecht durchführbar zu sein, wird als alternativer Lösungsweg die Multidisziplinarität gegenübergestellt, aber in dem direkten Vergleich für schlechter befunden, wie die Gegenüberstellung von O’RIORDAN (1996) zeigt: „Die Interdisziplinarität unterscheidet sich von der Multidisziplinarität darin, daß sie auf gemeinsame Themen der Prozesse und Entwicklungen abzielt, die sowohl physikalische als auch soziale Systeme umfassen. [...] Multidisziplinarität setzt dagegen auf Informationen, Analyse und Verständnis durch eine Vielzahl an Disziplinen, strebt aber kein breiteres und integriertes Verständnis des ,Was?' und ,Warum?' an. Sie ist verwaltungstechnisch einfacher zu verwirklichen und weniger vom guten Willen und der Toleranz der Praktiker abhängig.“ (:3) „Interdisziplinarität bezieht sich also auf eine machbare oder eine öffentliche Wissenschaft und umfaßt außerdem multidisziplinare Ansätze.“ (:4)

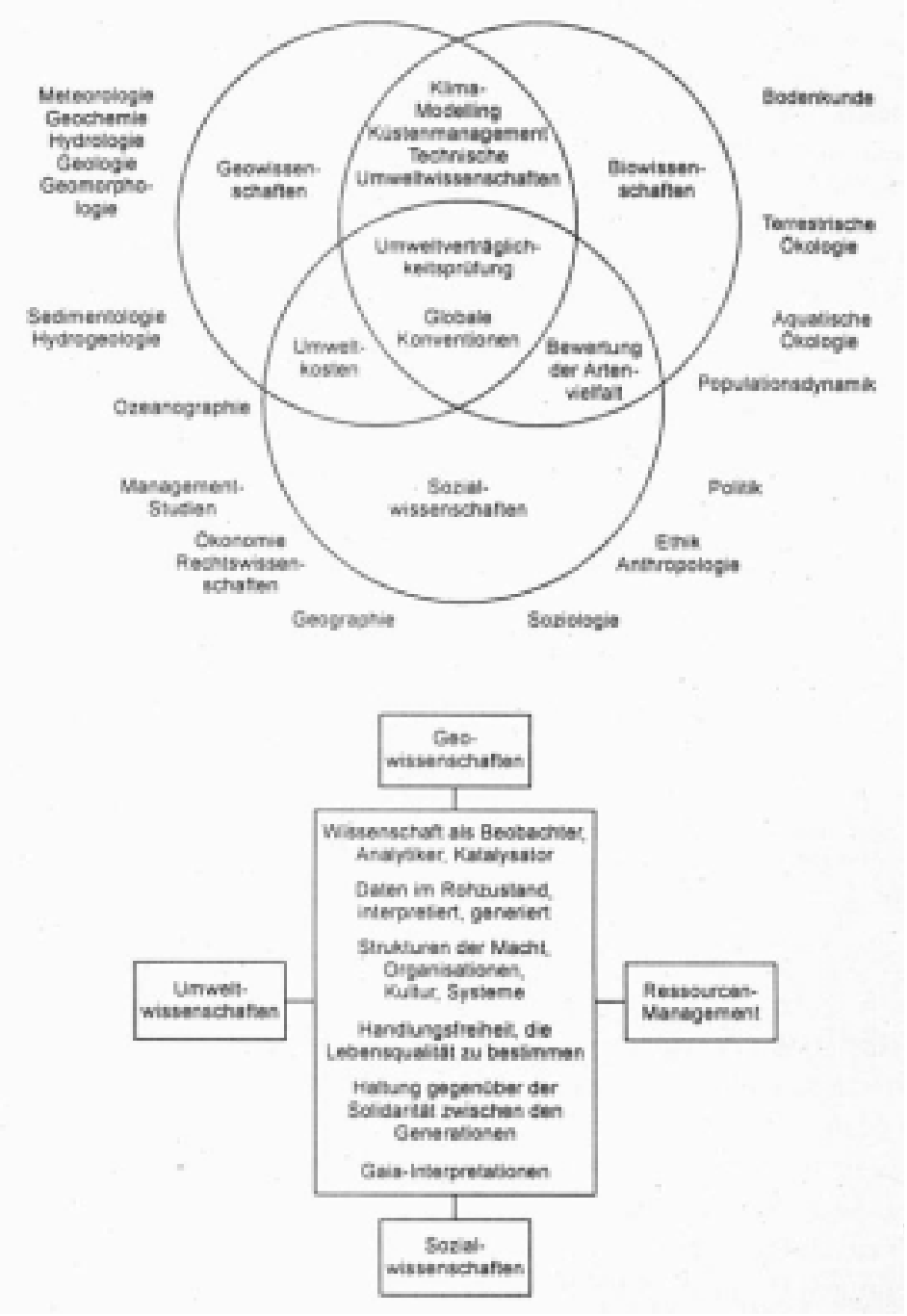

Abb. I-5: Interdisziplinarität und Multidisziplinarität (aus O'RIORDAN 1996:5)

Die zwei Diagramme beschreiben in stark vereinfachter Weise den Unterschied zwischen Interdisziplinarität und Multidisziplinarität. Im Fall der Interdisziplinarität beeinflussen sich die drei Wissenschaftszweige, namentlich die Geowissenschaften, Biowissenschaften und Sozialwissenschaften nur selten. Jede von ihnen 
hat ihre eigenen Entfaltungsbereiche und die Forschungsbereiche finden sich keineswegs nur innerhalb der Überlappungsbereiche der Einzeldisziplinen.

Als weiterer Begriff fachlicher Zusammenarbeit, als Folge zunehmender und schon nicht mehr ausreichender Interdisziplinarität wird als dritter Begriff der der Transdisziplinarität genannt: Die Erkenntnis der „Dynamik interdisziplinärer Beziehungsgefüge und die zunehmende Fokussierung der Wissenschaft und Forschung auf Aufgabenstellungen und Anforderungen in einer übergeordneten disziplinären Komplexität", führt DENECKE (2001:280) den Grund an, „führt zu der wissenschaftstheoretischen Forderung einer Transdisziplinarität, die sich allerdings in ihrer reinen Form niemals einstellen wird.“

Die verschiedenen Entwürfe einer Interdisziplinarität, ihre Vorteile, aber auch ihre vorher genannten Probleme, münden ein in einen Definitionsvorschlag von DENECKE, der als Maßstab für die hier zu vertretende interdisziplinäre historisch-geographische Umweltforschung gelten soll und seinen Ansporn aus eben diesem interdisziplinären Fächerverbund bezieht ohne seine eigenständige Geschichte aufzugeben: „Progression in den Nachbarfächern ist zugleich Herausforderung im eigenen Fach. Dabei geht es nicht um disziplingebundene Abgrenzung oder fachlichen Vorrang, sondern um fachspezifische Arbeitsmethoden, Forschungsansätze und Fragestellungen, die in einen interdisziplinären Zusammenhang einzubringen sind." (DENECKE 2001:281) „Zukünftig wird es vermehrt darauf ankommen,“ so auch die Quintessenz DIX” (1997:18), „Forschungsperspektiven unterschiedlicher Bereiche miteinander zu verknüpfen.“

Daraus ergeben sich drei Forderungen an eine historisch-geographische Umweltforschung:

1. Innerhalb der interdisziplinären Zusammenarbeit hat der Beitrag der Historischen Geographie ,auf spezifische Methoden, auf eine Systematisierung und Typologisierung, auf eine Raumerfassung und Regionalisierung [...] in einem engen Bezug zu historischen Epochen und Prozessen in der Vergangenheit" zu liegen (DENECKE 2001:291).

2. Innerhalb der eigenen geographischen Disziplin sind ,im Rahmen einer Historischen Geographie Verbindungen zu suchen auf dem Gebiet der physischen wie auch der Kulturgeographie [...], bei einem retrospektiven Ansatz.“ (DENECKE 2001:291)

3. Die historisch-geographischen Methoden und Ansätze müssen ,in den Teildisziplinen und in der allgemeinen geographischen Ausbildung integriert sein [...]. Einerseits weil sich bei zahlreichen Fragestellungen eine Zusammenarbeit aufdrängt und weil andererseits die Gefahr besteht, daß sich die Ausbildung noch stärker in naturwissenschaftliche und historisch-geisteswissenschaftliche Bereiche spaltet"“ (EGLI 1997:64f.)

In der vorliegenden Arbeit wird versucht, die hier genannten Anforderungen an eine historischgeographische Umweltforschung - mit Ausnahme des letzten Punktes, der sich auf die eher didaktische Vermittlung umwelthistorisch-geographischer Aspekte bezieht - beispielhaft zu verwirklichen.

\section{f Grundlagenforschung und anwendungsorientierte Forschung}

Wissenschaftliche Grundlagenforschung und anwendungsorientierte Forschung in Verbindung mit einem fächerübergreifenden Gedankenaustausch sind gemeinsamer Bestandteil der Geographie oder, wie POWELL (2000:169) es ausdrückt: „The discipline has always displayed both ,pure' and ,applied' motivations and potentialities, together with a wide range of intra- and inter-disciplinary engagements."

Darüber hinaus bedingen Grundlagenforschung und Anwendungsbezug einander. Es existiert keine „dichotomy between pure and applied geography, which are more correctly seen as two sides of the same coin.” (PACIONE 1999c:6) Denn, ,will die Geographie den notwendigen Spielraum für eine unabhängige und kontinuierliche Forschung erhalten, so muss sie ihre Resultate umsetzen, so dass sie für den Planer, den Politiker und die Öffentlichkeit verwendbar und verständlich sind.“ (RUPP 1986:420)

Es lassen sich dennoch Unterschiede feststellen: „The critical difference [...] between 'pure' and 'applied' science is [...] that applied science couches its questions in terms that are both normative and prescriptive, whereas in pure science the normative element may be present but not the prescriptive." (SANT 1982:1; 
ebenso:137, Hervorhebung im Original) Um diesen Zusammenhang wie auch die Gegensätze zu verdeutlichen, ,applied research in any discipline is best understood in contrast with basic, or pure, research.“(PALM/BRAZEL 1992:342; aus: PACIONE 1999c:6)

So ist beispielsweise ein politisches Ziel des Schwerpunktes „Kulturlandschaftsforschung“ des österreichischen Bundesministeriums für Wissenschaft und Verkehr, wissenschaftliche Grundlagen für die nachhaltige Nutzung der Kulturlandschaften in Österreich zu schaffen, d. h. für den sorgsamen Umgang mit Rohstoffen und Energieträgern, Natur- und Kulturwerten Voraussetzungen zu schaffen - unter größtmöglicher Berücksichtigung der Belange der Bevölkerung (BEGUSCH-PFEFFERKORN/SMOLINER 1999:100).

An diesem Beispiel wird deutlich: „Policy making and the monitoring of problems and plans have been at the heart of applied science." (SANT 1982:2) Deshalb bezeichnet SANT (:3) als ,the scope of applied geography $[\ldots]$ : the sense of problem, the contribution to decision making and policy, the monitoring of actions and the evaluation of plans."

Auf der Grundlage politischer Entscheidungsprozesse, die infolge einer Problemlage oder eines Forschungsdesiderats ausgelöst werden, wird Grundlagenforschung betrieben. Die Ergebnisse der Grundlagenforschung wiederum schaffen die Voraussetzungen für die wissenschaftlich fundierte Durchführung bzw. Anwendung umweltrelevanter Verhaltensweisen, oder, wie PALM/BRAZEL (1992:342; aus: PACIONE 1999c:6) die Unterscheidung am Beispiel der Geographie ausdrücken: „In geography, basic research aims to develop new theory and methods that help explain the processes through which the spatial organisation of physical or human environments evolves. In contrast, applied research uses existing geographic theory or techniques to understand and solve specific empirical problems." Dieser Anwendungsbezug im eigentlichen Sinne besteht bereits nicht erst seit neuerer Zeit (siehe Abb. I-6).

\begin{tabular}{|c|c|}
\hline Alsined & Characteristics \\
\hline Firat appled peried (laie nineteerth century) & 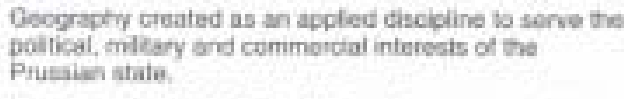 \\
\hline Finst pure period (earty twentieth oentury) & 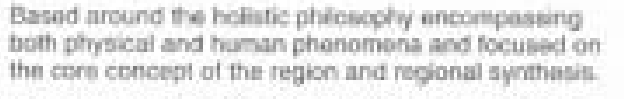 \\
\hline Socond appled period finter-war) & $\begin{array}{l}\text { A period of war, followad by the Doprassion and war } \\
\text { egain, demanded that goography demonswain its } \\
\text { usefuiness in Selds such as kand-use plorring. }\end{array}$ \\
\hline Socond pure period (post. 1945 boom) & 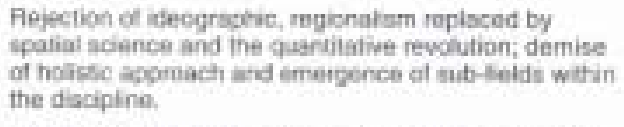 \\
\hline Third appised period (mid-1900s) & 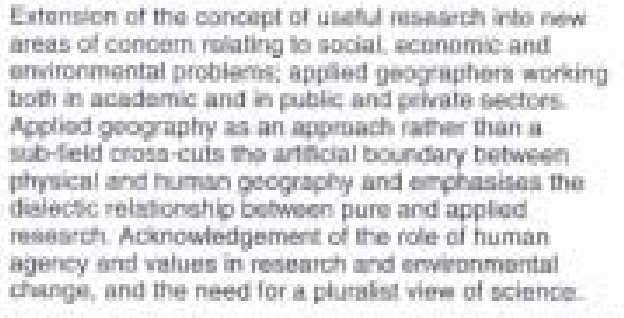 \\
\hline Thint pure ocriod (?) & 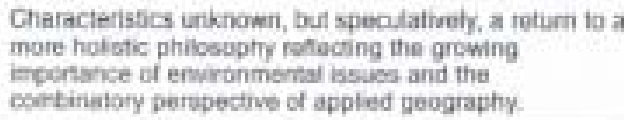 \\
\hline
\end{tabular}

Abb. I-6: Periodischer „Werdegang“ der Angewandten Geographie und seine entsprechenden Ausrichtungen (aus: PACIONE 1999:36)

Im Gegensatz zur wertfreien Grundlagenforschung steht bei der anwendungsorientierten Forschung (fast) immer der Anwendungsnutzen im Vordergrund: „Applied geography is an approach whose relation is based on the particular philosophy of relevance or social usefulness and which focuses on the application of geographical knowledge and skills to advance the resolution of real-world social, economic and environmental problems." (PACIONE 1999c:17) PACIONE (1999:XXV) bezeichnet die Angewandte Geographie deshalb auch als ,problem-orientated research“. In gleicher Form ist für JOHNSTON et al. 
(1986:17) Angewandte Geographie ,the application of geographical knowledge and skills to the solution of economic and social problems.“

Die Rolle als Problemlöser rückt auch SANT in den Vordergrund einer Aufgabenbeschreibung, doch betont er darüber hinaus die Funktion als 'Informationslieferant für Entscheidungsträger', in dem Sinne, ,that applied geographers should be sensitive to problems, whatever their sources, and that their concern should be in ensuring that the information that they have to offer is in a form that is useful to, and usable by, those who need that information, whether they are pressure groups looking for a more equitable share of resources or government departments seeking more efficient operations." (1982:3)

Der gesellschaftliche Nutzen stellt den Kern im Denkansatz einer Angewandten Geographie dar, nicht ein theoretisches Modell. „For applied geography, the unifying concept is not a specific model or theory, but the fundamental philosophy of relevance or usefulness to society." (PACIONE 1999c:4) Dieser anwendungsorientierte Nutzen kennzeichnet die Unterschiede beider Forschungsrichtungen. „The applied researcher has a greater interest than the pure researcher“" um noch einmal diesen Vergleich zu bemühen, ,in taking the investigation beyond analysis into the realms of application of results" (:7).

An dieser Stelle muss eingefügt werden, dass die Relevanzfrage nicht immer am Anfang der Überlegungen steht. Es ist nämlich auch zu beachten, „that academics have beliefs, values and ideologies of their own, it is inevitable that a wide range of needs will be perceived and that much research that is motivated by the researcher's own sense of a problem will not be influential because it is not seen by others to be important or relevant. But that is the price of independence." (SANT 1982:4)

$\mathrm{Ob}$ aber selbstmotiviert oder fremdbeauftragt, es sollen mit einer anwendungsorientierten Forschung ,appropriate responses” (PACIONE 1999:XXVI) gefunden werden, ,concerned about the quality of present and future living conditions and environments on planet Earth.” (1999c:17)

Mit dieser Aufgabenbeschreibung erhält die Angewandte Forschung einen Wert zur Lösung der umweltrelevanten Zukunftsaufgaben, der zwischen Ethik und Pragmatismus pendelt.

Nach JOHNSTON et al. (1986:18) ist Angewandte Geographie „,characterized by a pragmatic approach to particular problems”. Den Grund sieht er darin, dass ,applied geography has not developed a corpus of literature and a central theoretical core. Instead, it comprises ad hoc decisions regarding what is seen to be relevant to a particular issue at a given time".

Auch PACIONE erkennt die Theorieschwäche und führte dazu bereits weiter oben aus, dass diese Grundlagen eben aus der Grundlagenforschung zu beziehen sind. Doch im Gegensatz zu JOHNSTON betrachtet er die Notwendigkeit zur Übernahme von verschiedenen Theorien, Konzepten und Techniken, die als relevant hinsichtlich der Anwendbarkeit angesehen werden, als besondere Chance: ,,applied geographers would content that the identification and application of relevant theory, concepts and techniques both from within geography and across disciplinary boundaries is a positive strength, not a weakness, of the applied geography approach.“(1999c:4)

Intra- und Interdisziplinarität kann also als ein weiteres Merkmal des angewandten Ansatzes gesehen werden (PACIONE 1999:XXV). Angewandte Geographie ist nach PACIONE (1999c:4) „,best viewed as an approach that can bring together researchers from across the range of sub-fields in geography", ein Ansatz, der ,across the traditional human-physical geography divide” vermittelt (1999c:17; ähnlich 1999:XXV).

Doch wie ist es, neben all der Multidisziplinarität innerhalb und außerhalb der Disziplin möglich, „to identify the place of applied geography within the discipline" (PACIONE 1999:XXVI)?

Angewandte Geographie, dieses lässt sich in dieser Hinsicht als Begründung noch einmal festhalten, „refers to an approach that cross-cuts artificial disciplinary boundaries to involve problem-oriented research in both human and physical geography." (PACIONE 1999:XXVI, Hervorhebung im Original) Aus diesem Grund halten es manche Autoren nicht für sinnvoll, Angewandte Geographie ,as a (distinct) branch or sub-field of geography“ einzuordnen (:XXVI). Auch SANT (1982:136) ist der Ansicht, dass ,applied geography is not a 
sub-discipline;" denn wie PACIONE (1999:XXVI, XXVII) begründet, ist "one of the strength of the applied geographical approach [...] that it rejects artificial academic boundaries and highlights linkages between different geographical phenomena."

Aber auch innerhalb der Angewandten Geographie solle es keine „sub-areas“ geben (PACIONE 1999: XXVI): „To do so would be to ignore the complexity of real-world problems, evident in the role of human agency in landscape modification" und zudem ,applied work may draw on existing skills and information in any of the discipline's subfields." (JOHNSTON et al. 1986:18)

Doch eine Auflösung der disziplinären Bindung kann es, wenn man es auch wollte, kaum geben, denn, wie SANT (1982:136) die ,fatale' Situation ausdrückt, ,the crux of applied geography is [...] fundamentally it is about geography. That is, it deals with human and physical landscapes; their structure and composition, their internal dynamic, the forces that shape them, the choices that exist in the way they can be used." Diese Informationen sind es, die Geographen für den Anwendungsbezug qualifizieren. Es resultiert „out of the traditional interests of the discipline - human and physical environments and spatial relationships." (:7)

„Finally, it is unimportant whether or not applied geography achieves the 'formal' status of a subdiscipline. It will continue to function as long as there are challenging problems in the way that landscapes and environments are used." (SANT 1982:137).

Neben all den unbefriedigenden Versuchen zur Definition und disziplinären Einordnungen, trifft - man kann sagen als kleinster gemeinsamer Nenner - die Aussage EGLIs (1997:68) zu: „Angewandte Forschung kann jedoch erst als solche bezeichnet werden, wenn sie in der Praxis auch tatsächlich umgesetzt wird.” „Die Zielorientierung angewandter Forschung ist deshalb eine zwingende Voraussetzung, wenn sie erfolgreich sein will." (:67)

„Most applied geography in capitalist countries”, sind JOHNSTON et al. (1986:17, Großschreibung im Original) der Ansicht, „has been undertaken in the public sector, especially in the realms of PLANNING.” „More generally“, so resümieren sie (:18) aufgrund der einseitigen Zielsetzung angewandter geographischer Forschung, ,applied geography is the study of national and local planning." „Allerdings“, gibt RUPP (1986:419) zu bedenken, ,angewandte und praxisorientierte Geographie kann und soll nicht das oberste und einzige Ziel des Faches sein."

Denn die Orientierung eines anwendungsbezogenen geographischen Studiums an die Planungspraxis, die nicht abzustreiten ist, bedeutet nicht gleichzeitig - wie es im anglo-amerikanischen heißt - 'the application of geographical knowledge' im eigentlichen Sinne. „Of course, most planners do not 'apply' in a strict sense, either. Their role is to provide the intelligence for those who have the formal responsibility to make decisions. [...] In this situation the academic applied geographer is left with a difficult role unless he is content either to remain right outside the system or else to become so much a part of it that his work is determined by his “clients'.” (SANT 1982:4)

So erhält das Wort , angewandt' bzw. ,applied' mittlerweile eine negative Bedeutung dadurch, „that it describes a course that is somehow meant to be linked with the perceived needs of an industry in which students might eventually be employed. If these suspicions are true then we are doing a disservice to our students and to our discipline." (SANT 1982:136)

Doch trotz der Vorbehalte ist sich SANT (1982:136) sicher: „Ultimately, it is about the creation of new geographies."

\section{g Zum Begriff ,historische Kulturlandschaft““}

Vieles, was zum Begriff ,Kulturlandschaft' gesagt worden ist, trifft auch auf den enger zu fassenden Spezialbegriff der ,historischen Kulturlandschaft' $\mathrm{zu}^{23}$. Vielfach wird sogar der Begriff synonym gebraucht.

\footnotetext{
${ }^{23}$ Siehe 2c; beispielsweise die Nr.1-3, 7 und 8 des 10-Punkte-Schemas von MÜCKE. Allgemein ist hier die kulturelle Deposition von „Kulturlandschaft“ hervorzuheben.
} 
Die historische Geographin von den DRIESCH (1997:272) beispielsweise versteht unter Kulturlandschaft „die seit menschlicher Nutzung veränderte, gewachsene Landschaft mit der Vielfalt historischer Elemente.“

Auch SCHENK (2000:223) versteht unter Kulturlandschaften „vor allem die historisch gewachsenen Kulturlandschaften [...], welche sich durch einen relativ hohen Anteil von aus der Vergangenheit überkommenen Elementen und Strukturen auszeichnen.“ und „weil sie“, so seine weitere Begründung, „Formen extensiver Landnutzungsweisen repräsentieren“ (:227). Er grenzt mit dieser Definition aber auch andere (aktuelle) Kulturlandschaften nicht aus.

Ebenso hebt MÜCKE (1988:151) den historischen Bedeutungsinhalt hervor: „Für die Historische Geographie beschreibt der Begriff Kulturlandschaft den Kontaktbereich, welcher stets die historische und menschliche Komponente einschließt.“

Entsteht hieraus der Eindruck einer synonymischen Wortwahl, entspricht dies aber nicht der Differenziertheit des Begriffs. Es sind Ergänzungen notwendig, die die Geschichtlichkeit einer historischen Landschaft herausstellen. Die notwendige Beschäftigung mit dem differenzierten Begriff der , historischen Kulturlandschaft' tritt umso augenscheinlicher in das Bewusstsein, wenn ihm als Gegensatz korrekterweise der Terminus der ,modernen Kulturlandschaft' bzw. der ,aktuellen Kulturlandschaft' gegenübergestellt wird. Historische Kulturlandschaft wird demnach nach der aktualwissenschaftlichen Sichtweise nur als ,ein Teil der Kulturlandschaft' angesehen. Auch die heutige ,urbane' und ,suburbane Kulturlandschaft', so die Begründung, sei per se zunächst einmal auch ,Kulturlandschaft'.

Bereits das altbewährte WESTERMANN-LEXIKON DER GEOGRAPHIE (1973:420) verwendet den Begriff einer „Historischen Landschaft oder Geschichtslandschaft“ und beschreibt diese als „Teil der Erdoberfläche mit einer ausgeprägten, individuellen Geschichte“. Es handelt sich bei einer ,historischen Landschaft' demnach um einen räumlichen Teilausschnitt im Sinne einer ,gewachsenen Kulturlandschaft' nach von den DRIESCH. Eine interpretatorische Einengung auf reine Vorzugsräume des ländlichen Raumes lässt hingegen auch das alte lexikalische Standardwerk nicht zu.

Eine ,Exegese' im Sinne einer dynamischen, ,wachsenden Kulturlandschaft” ermöglicht die modernere Definition von AURIG/VOGELMANN (1996:9). Die (historische) Kulturlandschaft wird dabei verstanden als ein „Prozeß der Umformung und Einrichtung des Naturraumes durch den Menschen, der sich aus der Vergangenheit bis in die Gegenwart hinein erstreckt und sich auch in Zukunft fortsetzen wird". Wobei unter kulturhistorisch von den Autoren ,alle jene Erscheinungen verstanden werden, die zwar noch räumlich wahrnehmbar sind, aber keiner Bewirtschaftung mehr unterliegen. Nicht mehr räumlich wahrnehmbare Erscheinungen sind nach dem [ihrem] Verständnis Historischer Geographie der Archäologie zuzuordnen.“Dies ist eine Definition, die zum einen hinsichtlich der prozessualen Entstehens und des dynamischen Wandels von Kulturlandschaft überzeugt, aber zum anderen auch Unstimmigkeiten enthält und eine Eindeutigkeit vermissen lässt. Dass historische Kulturlandschaften keiner Bewirtschaftungsweise mehr unterliegen, ist schlichtweg falsch, wie die Beispiele der bewirtschafteten, bereits im Mittelalter angelegten Teichlandschaften in Franken oder in der Oberlausitz beweisen. Zudem entspricht die Vorstellung einer fossilierten Landschaft als exklusivem Themenbereich der Archäologie nicht dem Bild des gestuften Aufbaus historisch-geographischer Kulturlandschaftselemente (siehe IV 1d) und der praktizierten historischgeographischen Landschaftsaufnahme, die sehr wohl räumlich nicht mehr wahrnehmbare Strukturen in ihrern Kartierungskatalog mit aufnehmen.

Sinn ergibt eine Reduzierung auf ,räumlich wahrnehmbare Erscheinungen' aber bei der Betrachtung der Bedingungen, an die eine mögliche denkmalpflegerische Unterschutzstellung verknüpft ist. „Für die Denkmalpflege ist die historische Kulturlandschaft einerseits das Umfeld, also der materielle und gedankliche Wirkungsbezugsraum des einzelnen Baudenkmals. Andererseits entfaltet die historische Kulturlandschaft als Träger materieller geschichtlicher Überlieferung oftmals eine eigene Wertigkeit im Sinne einer Denkmalbedeutung. Wesentlich dafür sind ablesbare und substantiell greifbare Elemente und Strukturen in der Landschaft, welchen man erhebliche geschichtliche Bedeutung zumessen kann. Zudem 
muß die Erhaltung von Teilen der historischen Kulturlandschaft oder eines gesamten Kulturlandschaftsausschnittes im Interesse der Allgemeinheit liegen. “24

Von der Denkmalpflege wird auch der Begriff der ,historischen Kulturlandschaft" operationalisierbar gemacht, in dem die teilräumliche ,Exklusivität', der räumliche Bezug und die Geschichtlichkeit präziser hervorgehoben werden ${ }^{25}$ : „Die historische Kulturlandschaft ist ein Ausschnitt aus der aktuellen Kulturlandschaft, der sehr stark durch historische Elemente und Strukturen geprägt wird. Ebenso wie in einem Baudenkmal können in der historischen Kulturlandschaft Elemente aus unterschiedlichen zeitlichen Schichten nebeneinander und in Wechselwirkung miteinander vorkommen. Strukturen und Elemente einer Kulturlandschaft sind dann historisch, wenn sie in der heutigen Zeit aus wirtschaftlichen, sozialen, politischen oder ästhetischen Gründen nicht mehr in der vorgefundenen Weise geschaffen würden, sie also aus einer abgeschlossenen Geschichtsepoche stammen." (GUNZELMANN 2002:93)

Das heißt, ,Historische Kulturlandschaft' ist, wie KLEEFELD/BURGGRRAAF (1997:36) ausführen, „einerseits eine Landschaft, die in der Vergangenheit bestand (z. B. die mittelalterliche Kulturlandschaft), und andererseits ein Ausschnitt aus der heutigen Kulturlandschaft, der besonders viele historische Elemente und Strukturen aufweist.“

Die historischen Kulturlandschaftselemente und -strukturen als die Charakteristika einer historischen Kulturlandschaft, über die sich erst eine solche Landschaft definieren lässt, stellen besonders auch SCHUMACHER/STRAUSS (1998:10) in den Mittelpunkt: „Die sie prägenden Objekte, ob einzeln oder zu einer langen Reihe addiert, sind nicht die Geschichte selber, wohl aber die notwendigen Elemente, durch die der Kontext sich erschließt.“

Eine eindeutige begriffliche Festlegung von ,Historischen Kulturlandschaften' gestaltet sich - zusammenfassend betrachtet - aus der Literatur heraus als äußerst schwierig, da historische Kulturlandschaften ,äußerst komplex strukturierte Gebilde“ sind (SCHUMACHER/STRAUSS 1998:10). Sowohl was die Festlegung der Quantität („Vielfalt“ [von den DRIESCH]; „relativ hoher Anteil“ [SCHENK], ,sehr stark geprägt“ [Denkmalpflege]; „besonders viele“ [KLEEFELD/BURGGRRAAF]), die Räumlichkeit (,Ausschnitt aus der aktuellen bzw. heutigen Kulturlandschaft" [Denkmalpflege; KLEEFELD/BURGGRRAAF]) als auch die Organik (,gewachsene Landschaft" [von den DRIESCH]; „gewachsene Kulturlandschaft“" [SCHENK]) angeht.

Erleichtert wird dies auch nicht durch die oftmalige Gleichsetzung mit „einfachen“Kulturlandschaften. Auch eine terminologische Gegenüberstellung mit neueren Definitionen von Kulturlandschaften (,modern', ,aktuell', ,urban', ,suburban') führt zwar zu der Einsicht der Notwendigkeit einer eindeutigeren Neufassung des um eine historische Perspektive erweiterten Kulturlandschaftsbegriffs, doch liegt eine solche bislang nicht vor.

Das historisierende Element einer Kulturlandschaft wird auch im Raumordnungsgesetz (ROG) deutlich: Demnach werden solche Kulturlandschaften im Grundsatz als erhaltenswert eingestuft, bei denen es sich um „gewachsene Kulturlandschaften“ handelt. Eingeschlossen in den Schutz sind ihre „prägenden Merkmale“ sowie ihre Kultur- und Naturdenkmäler ROG 1998 § 2 Abs. 2 Nr. 13).

Auch das Naturschutzrecht (BNatSchG $2002 \S 2$ Abs. 1 Nr. 14) übernimmt die qualitative Leistungsbeschreibung einer "historischen Kulturlandschaft"in ihre Legaldefinition. Das BNatSchG stellt als erhaltenswert historische Kulturlandschaften und -landschaftsteile heraus, die von „besonderer Eigenart“ sind, ,einschließlich solcher von besonderer Bedeutung für die Eigenart oder Schönheit geschützter oder schützenswerter Kultur-, Bau- und Bodendenkmäler"; obgleich allein die Aufnahme als Grundsatz des Naturschutzes und der Landschaftspflege wie der Raumordnung eine besondere rechtliche Verankerung bedeutet, die für Verfahren der Raumplanung zu beachten ist.

\footnotetext{
24 „Kulturlandschaft“ - Grundsatzpapier. Aufgestellt bei der Tagung der Vereinigung der Landesdenkmalpfleger in Kiel, 1996; siehe auch gleichlautend GUNZELMANN (2002:93).

${ }^{25}$ Siehe Fußnote 23
} 
Neben diesen Versuchen der Quantifizierbarkeit und der besonderen Hervorhebung der schon im Wort „historische Kulturlandschaft“ innewohnenden Geschichtlichkeit, möchte ich als Ausblick und Selbstverständnis die subjektive Imagination an den Schluss dieser Ausführung stellen: Wenn ,Landschaft' „bedeutet des Menschen Wahrnehmung seiner Umgebung - eine Mischung aus Wirklichkeit und Vorstellungskraft.“ und wir unsere Umgebung wahrnehmen ,wie [...] durch das Filter unseres Gedächtnisses und unserer Sehnsucht nach dem Paradies“ (WILKIE 1988:7), so ist auch eine ,historische Landschaft' nicht mathematisch quantifizierbar, d. h. sie unterliegt keiner statischen Größe bezüglich Menge und Historismus.

Die historisch-baulichen Symbole und kulturellen Assoziationen, die unsere Städte und ländlichen Gebiete noch - durchdringen, sind „so subtil und kompliziert wie Sprache.“ (WILKIE 1998:7) und erschließen sich dadurch in ihrer geschichtlichen Bedeutung nur dem Wissenden, der allein auch eine Quantifizierung vornehmen kann. Aber dies schließt die pure, und wenn man so will, unwissende Wahrnehmung und Bewertung von Landschaft als besonderes „Gefühl“ von Ästhetik und Wohlsein nicht aus.

So muss ein heuristischer Ansatz zu einer vielschichtigen Analyse des Mensch-Umwelt-Verhältnisses gefunden werden.

\section{Die ,anwendungsorientierte historisch-geographische Forschung“ im Disziplingebäude der „angewandten historischen Umweltforschung“}

Während innerhalb des disziplinären Überbaus der Allgemeinen Geographie eine deutliche Schwerpunktverschiebung zugunsten einer auf die Planungspraxis ausgerichteten preskriptiven Forschung und Lehre schon seit vielen Jahren erkennbar wird und die Grundzüge einer deskriptiven klassischen geographischen Grundforschung und -bildung zunehmend verschwimmen, ist diese Abkehr bei der Historischen Geographie noch nicht so fortgeschritten, aber bereits sich seit einigen Jahren abzeichnend. Diese allmähliche Schwerpunktverlagerung entwickelte sich in der Historischen Geographie ,seit Ende der 1970er und Anfang der 1980er Jahre” (BECKER 2001:7). In diesem Zeitrahmen haben ,erstmals in der Geschichte unseres Faches [...] junge Geographen Resultate der historisch-geographischen Forschung für die Praxis aufbereitet und verfügbar gemacht." (:7) Welche Position die praxisbezogene Ausrichtung seitdem erreicht hat, wird an der Aussage FEHNs (1998:22) deutlich, der von „dem neuen, immer wichtiger werdenden Feld der planungsbezogenen Historischen Geographie" spricht. Der verstorbene Göttinger Emeritus NITZ (1998:123) als Vertreter des historisch-siedlungsgenetischen Ansatzes ließ sich letztlich sogar dazu hinreißen, die Historische Geographie als einen „relevanter Zweig der Angewandten Geographie“ zu bezeichnen.

Die historische Kulturgeographie spaltet sich also allmählich auf in eine Sektion, die wissenschaftliche Grundlagenforschung betreibt, und in eine, die ein historisch-geographisches Thema auf ihren Anwendungsbezug hin überprüft. Als Beispiel dieser dualen Entwicklung kann der ,Arbeitskreis für genetische Siedlungsforschung in Mitteleuropa' und die Arbeitsgruppe ,Angewandte Historische Geographie' gesehen werden. Während der Arbeitskreis wissenschaftliche Forschungsleistungen erbringt, steht für die Arbeitsgruppe die praxisorientierte Umsetzung dieser Ergebnisse und die Entwicklung planungspraktischer Standards im Vordergrund.

Angesichts dieser Separierung darf aber nicht außer Acht gelassen werden, dass im wissenschaftlichen Arbeitsansatz der Kulturlandschaftsforschung und besonders der historischen Geographie ,auch von vornherein eine Anwendungsorientierung gegeben ist,“ obgleich dies „erst in jüngster Zeit der Fall” ist, wie DENECKE (1997:46) die bereits vor einigen Jahren begonnende Entwicklung chronikalisch vermerkt und „weshalb sich eine angewandte Forschung zunächst auch zum Teil bewußt als eine anwendungsorientierte Grundlagenforschung verstanden hat.“ „Ein Beitrag in diesem Sinne“, beschreibt DENECKE (:46) den in die Zukunft führenden gemeinsamen Weg, ,wird für die praktische erhaltende Landschaftsplanung auch stets ihre [sic] Bedeutung behalten, wenn die Geographie mit den ihr eigenen wissenschaftlichen Ansätzen weiterführende Erkenntnisse zu liefern vermag.“

Grundsätzlich wird hieraus deutlich, dass die Historische Geographie sich zunehmend dem Anwendungsbezug öffnet, weil der Erhalt der Kulturlandschaft und der in ihnen verankerten Elemente sich eben auch und 
insbesondere auf der Planungsebene manifestiert (siehe dazu Teil E). So „wächst der Angewandten Historischen Geographie mehr und mehr eine tragende Rolle bei der Erstellung von Grundlagenuntersuchungen und der Erarbeitung von Erhaltungs- und Entwicklungskonzepten zu.“ (FEHN 1997:17) Diese Öffnung sollte demnach, diese Schlussfolgerung lässt in gleicher Weise die Aussage DENECKEs $\mathrm{zu}$, basierend auf ihrem traditionellen Wissensfundament (beispielsweise der genetischen Siedlungsgeographie) erfolgen, ohne ihre eigene wissenschaftsgeschichtliche Identität aufzugeben. Daraus lässt sich der zukünftige Anwendungsbezug ableiten.

Und so wird mit diesem Begriff des Anwendungsbezugs zu Beginn dieses Kapitels - in disziplinär erweiterter Form - die Anfangsfrage wieder aufgenommen und zu beantworten sein: nach der Antworten des Faches einer ,Anwendungsorientierten Historischen Geographie' zur Umweltkrise der Gegenwart und damit als Bestandteil einer, angewandten historischen Umweltforschung'.

Angewandte Historische Geographie, so die Definition von PFEIFER (1982:331f.), ist, „was neben dem Ertrag an wissenschaftlicher Erkenntnis die Beschäftigung mit den Problemen der historischen Kulturlandschaft als eine Art von Ethik in die gegenwartsbezogene Geographie einbringen sollte, insbesondere wenn sie zur Anwendung, zur Planung vorschreitet.“

Eine solche Verankerung kulturhistorischen Gewissens in den politikorientierten Planungsebenen und -instrumenten böte den Weg zur wissenschaftlichen Grundlegung eines neuen Forschungsansatzes umwelthistorischer Forschung in der historischen Geographie.

Doch um zu hohen moralischen und ethischen Erwartungen vorzubeugen und die Gefahren nicht zu bedenken, aber gleichzeitig die besonderen Chancen einer anwendungsorientierten historisch-geographischen Umweltforschung innerhalb des Disziplingebäudes der Umweltwissenschaften zu verdeutlichen, sei ein Zitat von Arne ANDERSEN (1993:681) an dieser Stelle vorangeführt, der auf die Schwäche und die Diskrepanz umwelthistorischer Forschung aufmerksam macht: „Sehr schnell werden Umwelthistoriker [...] auf die gesellschaftliche Relevanz angesprochen. So falsch es mir scheint als (Umwelt-)Historiker aktuelle Lösungsvorschläge anzubieten, so problematisch, wenn nicht unmöglich, ist der Rückzug in den wissenschaftlichen Elfenbeinturm.“

\section{a Zur wissenschaftlichen Grundlegung eines neuen Forschungsansatzes umwelthistorischer Forschung in der historischen Geographie}

Historische Umweltforschung im bisherigen Sinn untersucht „,in ihrer fachlichen Tradition Nutzungs-, Gestaltungs- und Aneignungsprozesse von Wasser, Boden und Luft, die ihnen zugrunde liegenden grundsätzlichen Motivationen und Handlungsoptionen sowie deren Folgen und unbeabsichtigte Nebenfolgen“" (HERRMANN 1989a:5).

LENZ (2000:181f.) hingegen sieht die „,Pflichten' Historischer Umweltforschung in aktuellen Prozessen der Raumgestaltung“ und beschreibt damit die Aufgaben zukünftiger historischer Umweltforschung. „Kulturelle Dispositionen der Wahrnehmung wie Gestaltung von Landschaft, die über eine klassische umwelthistorische Analyse von Luft, Boden und Wasser hinausgehen müssen“, verdeutlicht LENZ (:182) beispielhaft das aktuelle duale Verständnis umwelthistorischer Forschung, ,bedürfen einer ergänzenden kulturellen Dekodierung wie auch Vermittlung im Gestaltungs- und Planungsprozeß“.

Auf der anderen Seite stellte bereits 1975 FEHN (1975a:50) fest, dass ,auch für die Angewandte Geographie [...] die Genetische Geographie mehr und mehr an Bedeutung“ gewinnt, „da die Prognose um so zuverlässiger sein wird, je genauer der Trend durch die Erforschung vorhergehender Zeiträume bekannt ist." Moderne anwendungsorientierte Forschung und traditionelle Grundlagenforschung suchten also schon Mitte der 1970er Jahre eine Symbiose einzugehen. Die Realität hingegen sieht anders aus und verkehrt sich ins Gegenteil: „Die Grundlagenforschung ist aufgelöst in einzelne Themenstellungen, auf der Suche nach anwendungsbezogenen Aufgaben, neuen Arbeitsmethoden und aktuellen Fragestellungen.“ (DENECKE 2001:279) 
Den Lösungsweg, die Irrigationen und Separierungen zu verhindern, zeigt nach meiner Auffassung das wissenschaftstheoretische Konzept eines ,historische Umweltforschung,, ,Historische Geographie' und ,Angewandte Forschung' zusammenführenden Betrachtungsansatzes: einer auf historisch-geographischer Substanz aufbauenden Umweltforschung mit Anwendungsorientierung nach DENECKE. Er hat mit dem von ihm in den 1990er Jahren formulierten Forschungsansatz einer Grundlagen- und Zweckforschung verbindenden „anwendungsorientierten historisch-geographischen Umweltforschung“ das Fundament zur Bildung eines eigenen theoretischen Betrachtungsansatzes innerhalb der Historischen Geographie und damit auch innerhalb der sich formierenden interdisziplinären Umweltforschung gelegt.

„Im Zuge einer historisch-geographischen Umweltforschung“, gibt DENECKE (2001:289) jedoch zu bedenken, ,ist vornehmlich eine Verfolgung und Integration dessen zu erkennen, was die naturwissenschaftlichen Nachbarfächer der Archäologie an Fragestellungen und Beiträgen geleistet haben, während gemeinsame Arbeitsziele im eigenen Fach mit der aktuellen Umweltforschung und Ökologie sehr deutlich zu wünschen übrig lassen. Auch hier wirkt sich nach seiner Ansicht „die schon lange währende Herauslösung der Historischen Geographie negativ aus.“

Umweltgeschichte im Sinne einer Technik- und Sozialgeschichte sowie Umweltgeschichte im Sinne einer Mensch-Naturgeschichte, „,beide Richtungen sind unmittelbar in eine interdisziplinäre kulturlandschaftsgenetische Forschung einzufügen“, weist DENECKE (2001:290) den Weg zur wissenschaftlichen Grundlegung eines neuen Forschungsansatzes umwelthistorischer Forschung in der historischen Geographie und fordert: „Als führendes Paradigma kulturlandschaftsgenetischer Forschung auf internationaler Ebene und nicht zuletzt auch vor allem in der Gesamtdisziplin der Geographie und gerade auch bei einer sehr direkten Beteiligung der Archäologie und Geschichtswissenschaft sollte der umweltgeschichtlichen Fragestellung weiterführend ein besonderes Gewicht in der wissenschaftlichen Diskussion [...] eingeräumt werden.“ (:290) Zusammenfassend ausgedrückt sind ,andere kulturlandschaftsgenetische Themenstellungen [...] vermehrt und gezielt in umweltgeschichtliche Problemzusammenhänge zu stellen."(:290)

DENECKE (1994:434) besteht in seinem umwelthistorischen Ansatz zunächst darauf, „die Grundlegung der allgemeinen Umweltforschung durch die Kenntnis vorangegangener Entwicklungsprozesse [...] zunehmend auch als Erklärungsansatz zu fordern." Dabei bewirkt das geographische Element erst in Zusammenhang mit der anwendungsbezogenen Komponente einen Bedeutungszuwachs innerhalb der Umweltforschung, denn erst ,aus den unterschiedlichen anthropogeographisch-historischen Beiträgen im Rahmen einer anwendungsorientierten Forschung wird der Umweltforschung ein besonderer Stellenwert beigemessen (:434). Aus diesem Zugewinnverhältnis, der historisch-praxisorientierten Geographie auf der einen und allgemeinen Umweltforschung auf der anderen Seite, muss nach DENECKE (:434), als ein wesentlicher Forschungs- und Betrachtungsansatz, der in die anwendungsorientierte historische Geographie neu und vermehrt hineinzunehmen ist, [...] die historisch-geographische Umweltforschung genannt werden.“

Dabei ist hier nach meiner Interpretation und eigenen Sichtweise nicht die einfache Übernahme der historisch-geographischen Umweltforschung in die anwendungsorientierte historische Geographie gemeint, sondern die Eigenständigkeit des umwelthistorischen Forschungsansatz innerhalb der historischen Geographie wird damit zum Ausdruck gebracht und mit folgender Formel belegt: die , historischgeographische anwendungsorientierte Umweltforschung' als eigener Wissenschaftszweig innerhalb der Historischen Geographie mit dem besonderen Kennzeichen einer vernetzten und ganzheitlichen Perspektive. Auf dieser Ebene werden die Ergebnisse verschiedener Fächer gebündelt. In diesem Kontext ist auch die vorliegende Arbeit zu verstehen.

Die einzelnen Elemente bzw. Objekte der Kulturlandschaft und deren Inventarisation auf verschiedenen Ebenen bleiben dabei aber - als disziplingeschichtliches Standbein der Historischen Geographie - erhalten (vgl. DENECKE 1994:434). Denn die Erfassung und Beschreibung der flächigen oder auch punkthaft auftretenden Kulturlandschaftselemente geben der Historischen Geographie ihr eigenes Grundprofil und verleihen ihr disziplingeschichtlich betrachtet eine eigene Identität und erst die Anwendungslegitimation: „Hier wurde ein Arbeitsansatz und konkreter Beitrag geschaffen, vor allem auf den Gebieten der Inventarisation der Kulturlandschaft, der erhaltenden und nachhaltigen Kulturlandschaftspflege wie auch der Dorferneuerung“ (DENECKE 2001:290f.). 
Diesem Selbstverständnis folgend nimmt beispielsweise die Aufnahme gewässergebundener Kulturlandschaftselemente einen besonderen - zweifachen - Stellenwert ein. Zum einen bedeutet die Inventarisation die Grundlegung einer historisch-geographischen Wissensvermittlung, zum anderen vermittelt sie den Übergang zum Anwendungsbezug und damit zur Praxisrelevanz.

Daraus ergibt sich die Zielsetzung der angewandten historischen Geographie als ein - wesentlicher - Teil einer anwendungsorientierten historisch-geographischen Umweltforschung. „Der Angewandten Historischen Geographie fällt [...] die Aufgabe zu, raum-zeitliche Entwicklungen zu erforschen, entsprechende Kenntnisse zu vermitteln und planerische Umsetzungsempfehlungen zu entwickeln. Dies geschieht auf einer Maßstabsebene, die über das einzelne Bauwerk oder ein beliebiges anderes Einzelelement der Kulturlandschaft hinausgeht, die andererseits unterhalb großräumiger, $\mathrm{zu}$ starker Vereinfachung und Generalisierung zwingender Ansätze bleibt.“ (KRINGS 2001:46)

Darüber hinaus hingegen darf eine solche geographische Forschungsrichtung die - historisch motivierte Umweltforschung nicht außer Betracht lassen: „Der Geographie ist in diesem Zusammenhang besonders die Aufgabe gestellt, die Nutzungsweisen und Nutzungsansprüche von Landschaft und Boden in ihrer Entwicklung und Auswirkung analytisch gewichtend und wertend $\mathrm{zu}$ untersuchen und für praktische Umsetzungen aufzubereiten. Es geht dabei um möglichst schonend erhaltende, nachhaltige Weiterentwicklung von Landschaftsstrukturen, Flächennutzungen und Sukzessionen auf der Grundlage einer geographisch-landschaftsgeschichtlichen Aufarbeitung der Nutzungsentwicklung und deren jeweilige Auswirkungen in unterschiedlichen Landschaftsräumen und Landschaftsteilen.“ (DENECKE 2000:199)

Eine solche in Zusammenhang mit Kulturlandschaftspflege stehende Angewandte Geographie bezeichnet DENECKE (2000:199) auch als , anwendungsorientierte historisch-kulturlandschaftliche Forschung der Geographie' bzw. als , anwendungsorientierte geographische Kulturlandschaftsforschung'. Sie stellt ein wesentliches Forschungsgebiet innerhalb einer anwendungsorientierten historisch-geographischen Umweltforschung dar und ist die Antwort auf die Relevanzfrage.

Die geographische Zielsetzung in Zusammenhang mit der Kulturlandschaftspflege besteht in der „Ausrichtung auf eine erhaltende Kulturlandschaftsentwicklung [...] und führt zu einer integrativen erhaltenden und pflegenden Weiterentwicklung der Landschaft.“ (DENECKE 1997:38) Die Reste ehemaliger Eingriffe in die Landschaft, sog. Kulturdenkmale und Altlandschaftsrelikte, müssen im Rahmen einer erhaltenden und pflegenden Kulturlandschaftsentwicklung kulturlandschaftsgeschichtlich untersucht und ausgewertet werden (vgl. DENECKE 1989b:204). Bis hierhin ist dies im traditionellen Gepräge Aufgabe einer auf Grundlagenforschung ausgerichteten Historischen Geographie.

„Die Kulturlandschaft“ aber, dies ist der zentrale Ansatz der Anwendungsorientierung einer historischgeographischen Forschung, ,ist zu bewahren, aber auch zu nutzen.“ (DENECKE 1997:38). Diese Nutzungskonzeptionen zu entwerfen mit der Option der planerischen Umsetzung ist Aufgabe der anwendungsorientierten historisch-geographischen Forschung: „Lösungen und Maßnahmen einer Erhaltung und Pflege werden im Rahmen einer anwendungsorientierten historisch-geographischen Forschung auf der Grundlage entwicklungsgeschichtlicher Kenntnisse und Bewertungen eingebracht." (:37)

Die geographischen Ansätze in der aktuellen und zukünftigen Umweltforschung liegen darin, dass sich „Grundlagenforschung und Praxisorientierung“ ergänzen müssen (MÜLLER-HOHENSTEIN 1995:278). Die anwendungsorientierte Ausrichtung umwelthistorischer Forschung ist deshalb die weitere Entwicklung des historisch-geographischen Ansatzes. ,Anwendungsorientierte Forschung' kann definiert werden als Forschung, die das Planungskonzept und die konkrete Ausführung der Planung steuert; zugleich aber auch die Aussagekraft der Landschaft durch eine wissenschaftlich fundierte Erläuterung nahebringt. So soll eine stärker anwendungsorientierte umwelthistorisch-geographische Forschung den Anspruch einer wissenschaftlichen und kulturlandschaftsgenetischen Dokumentation bewahren. Es ist eben nur eine andere Interpretationsform aus einer anderen Perspektive unter Berücksichtigung anderer Forschungsansätze, jedoch weiterhin gerichtet auf das Objekt der Landschaft und der Kulturlandschaftselemente.

Historisch-geographische Forschung in diesem Sinne bedeutet die Erweiterung „um die Dimension der Kulturgeschichte, aus ihrem Kenntnisstand heraus Prozesse einer reflexiven Gestaltung initiieren, begleiten 
und unterstützen, historisierender Inszenierung den Rücken kehren und eine Schneise schlagen zwischen Rückbau und Denkmalschutz hin zu einer emanzipatorischen und reflexiven Nutzung der Landschaft“ (LENZ 2000:192). "Hierfür ist ein historisch-geographisches Raumverständnis unabdingbar, in dem die Elemente und Strukturen in ihrem Zusammenhang betrachtet werden müssen." (BURGGRAAFF/ KLEEFELD 1997:28)

Bei der, anwendungsorientierten historisch-geographischen Umweltforschung' geht es zusammenfassend also um eine Erweiterung und Vertiefung der umwelthistorischen Fragestellungen in Richtung einer auf Grundlagenforschung basierenden Praxisorientierung. Ihr Untersuchungsgegenstand ist die Kulturlandschaft und die in ihr erhalten gebliebenen Elemente und Strukturen.

Diese eindeutige Positionsbestimmung erscheint umso wichtiger, als die Zahl der an der historischen Umweltforschung beteiligten Fächer proportional in dem gleichen Maße steigt, wie die eigene Disziplin die (historische) Landeskunde und Landschaftsforschung aus ihrem Wissenschaftsgebäude verbannt. Die sog. Nachbarfächer haben keine Identifikationsschwierigkeiten mit der Beschäftigung der von der ,modernen raumlosen Geographie' abgelehnten Landschaftsgenese und dies im Gegenteil, so scheint es, umso stärker intensiviert, als die traditionelle Bindung dieser Fachrichtung an die Geographie von derselben aufgekündigt wird. Ein Transport notwendiger neuer Blickrichtungen und Fragestellungen in die Historische Geographie hinein wird damit gleichzeitig unterbunden, die Spaltung anstelle der Integration gefördert. Und dies vor dem Hintergrund einer gerade in der historischen Umweltforschung notwendigen Forderung nach Interdisziplinarität unter Bewahrung der disziplinären Eigenständigkeit. Denn wie im vorigen Kapitel deutlich wurde, definiert sich die Angewandte Geographie nicht über die Zugehörigkeit zu einer starren disziplinären Einbindung, da ihr Kennzeichen gerade die Überwindung intra- und interdisziplinären Grenzen ist, sondern über ihre Aufgabe. Und diese liegt in der anwendungsorientierten historisch-geographischen Umweltforschung in der Erhaltung historischer Kulturlandschaftselemente und Kulturlandschaften in Raumordnung und Planung.

\section{b Die methodische Ausgestaltung des anwendungsbezogenen Forschungsansatzes umwelthistorischer Forschung in der Historischen Geographie}

„Wir müssen vordringlich“, so die Mahnung MÜLLER-HOHENSTEINs (1995:281) angesichts drohender Umweltprobleme, ,auf den bestehenden theoretischen Grundlagen aufbauend praxisorientiert arbeiten. Wir können uns nicht vor Aufgaben drücken, die in unseren Kompetenzbereich fallen, auch wenn theoretische Probleme nicht endgültig gelöst sind." Dies gilt ebenso für die methodische Ausgestaltung des anwendungsbezogenen Forschungsansatzes umwelthistorischer Forschung in der Historischen Geographie.

Die Methoden aber „einer derartigen Angewandten Historischen Geographie sind mittlerweile ausgereift und weitgehend standardisiert. So ist eine Inventarisierung historischer Kulturlandschaftselemente heute durchweg der erste Schritt zu einer historisch-geographisch begründeten Landschaftsbewertung, deren Ergebnisse wiederum in Planungsvorhaben integriert werden.“ (BECKER 2001:7) Das bedeutet, es wird bei einer anwendungsorientierten Arbeitsweise primär auf bestehende Methodiken zurückgegriffen; sollten diese jedoch noch nicht verfügbar bzw. entwickelt sein, so sind die anstehenden Aufgaben dennoch pragmatisch, insbesondere vor dem Hintergrund der Umweltrelevanz, auszuführen. Diese unkonventionelle Vorgehensweise, d. h. eine Anpassung bzw. Umformung erprobter Anwendungen auf eine neuartige Fragestellung, entspricht der von MÜLLER-HOHENSTEIN angesichts der prekären Umweltsituation geforderten Handlungsfähigkeit und der täglichen Berufspraxis.

Die ,anwendungsorientierte historisch-geographische Forschung' verfolgt die praktische Anwendung eigener theoretischer Grundlagen und bedient sich dabei erprobter Werkzeuge. Liegen entsprechende, aufgabenbezogene Instrumente nicht vor, werden sie zumeist im Rahmen einer Auftragsarbeit oder wissenschaftlichen Arbeit erarbeitet.

Das methodische Rückgrat einer planungsorientierten historisch-geographischen Forschung bildet, wie BECKER hervorhob, die Inventarisation der kulturlandschaftlichen Inventare. Auf der Basis empirischer, detaillierter quellenbezogener Datengrundlage soll eine möglichst erschöpfende kulturlandschaftsgeschicht- 
liche Inventarisation und Landesaufnahme erfolgen. Die additionale Erfassung in Form der Gelände- und Feldaufnahme schließt die umwelthistorisch-geographische Arbeitsmethode ab. Den Erfassungsrahmen in der Praxis bilden dabei konkret umsetzbare Inventarisationsarbeiten, denen eine besondere Erfassungssystematik zugrunde liegt.

So beinhaltet beispielsweise die Inventarisationssystematik die Gruppierung älterer Kulturlandschaftselemente nach Struktur, Alter und Zustand, die Dokumentation und die grafische Darstellung dieser in Spezialkarten aufgrund von Kartierungen, die Ausarbeitung allgemeiner sowie spezieller Erhebungsmuster und schließlich die Herausgabe von konkreten Gutachten mit Plänen, die einen direkten Bezug zu praktischen Projekten haben. Dies setzt die Herausarbeitung und Fundierung von (projektbezogenen) Bewertungskriterien und -maßstäben voraus, um die Ergebnisse in Form einer eventuellen Schutzwürdigkeit für Entscheidungsträger nachvollziehbar zu gestalten.

Doch, so fragt WIRTHS (2001:231) angesichts der derzeitigen Methodenpraxis in seiner Skizzierung der „gegenwärtigen Zukunft“ einer Historischen Geographie: „Kommt nun die neuzeitliche GeoGraphie [sic] als Inventarisierung der Erde [...]? Die, zu der Auffassung könnte man gelangen, in der Gefahr steht, über die detailgetreue Reliktaufnahme hinaus, ähnlich dem naturwissenschaftlichen Forscherdrang im Verlauf des 19. Jh. alles nur erfassbar Pflanzliche zu herbarisieren und alles Tierische zu präparieren und somit der Nachwelt $\mathrm{zu}$ entziehen, die wesentliche Zielsetzung der Inwertsetzung einer anwendungsorientierten historischgeographischen Forschung aus dem Auge zu verlieren.“

Als fundamentale Aufgabe bleibt deshalb die siedlungs- und kulturlandschaftsgenetische Forschung am Beispiel regionaler Fallstudien bestehen. Sie umfasst die Rekonstruktion der Siedlungslandschaft für historische Epochen, die den Prozess der Kulturlandschaftsentwicklung durch die Herausarbeitung spezifischer Phasen darstellt.

Um aber die eingeforderte und notwendige Interdisziplinarität umwelthistorischer Forschung zu gewährleisten, bedarf es einer „Verbindung von kultur-, sozial- und naturwissenschaftlichen Methoden.“ (FEHN 1997:539) Erst die Methodenkombination erfüllt die methodischen Voraussetzungen an eine interdisziplinäre umwelthistorische Forschung. Diese werden, speziell bezogen auf die gewässerhistorische Forschung, im methodischen Teil B vorgestellt.

\section{c Forschung und Umsetzung der Forschungsergebnisse}

DENECKE (1985:18) sieht als Beitrag der anwendungsorientierten historischen Geographie vor allem die Inventarisation als Beitrag der Grundlagenforschung zur Landschaftsplanung, für Altstadtsanierungen und zur erhaltenden Dorfentwicklung. Auch EGLI (1997:66) erscheint die „Inventarisierung als anwendungsorientierter Forschungsbereich“ und ,[...] als selbständigen Forschungsbeitrag“.

Für BURGGRAAFF (1997:235) trifft man ,als Angewandter Historischer Geograph [...] prognostische Aussagen über die Zukunft des heutigen Kulturlandschaftszustandes, indem die unterschiedlich erhaltenen und manchmal überformten Elemente und Strukturen erfaßt, beschrieben sowie bewertet werden." „Zielorientierte Analyse und Bewertung stehen für die Angewandte Historische Geographie im Vordergrund.“ (EGLI 1997:70) Auch FEHN (1989b:15) sieht als eine „wichtige neue Aufgabe“ der Historischen Geographie „die Mitwirkung am räumlichen Kulturschutz durch die Bewertung der einzelnen Kulturlandschaftselemente.“ „Dies wird vor allem analysiert, um Kulturlandschaften sowie ihre Teile in Wert zu setzen und um den historischen Gehalt der Kulturlandschaft und ihrer Teile in zukünftigen Entwicklungen durch abgestufte Kulturlandschaftspflegemaßnahmen, die von Rekonstruktion, Erhaltung, behutsamen Umgang bis zur Zerstörung [...] reichen können, zu retten. Diese Vorgehensweise könnte insbesondere in die Raumordnung und in die Planung [...] eingebracht werden." (BURGGRAAFF 1997:235)

Nach FEHN (1997:18) stellt sich die Angewandte Historische Geographie ebenfalls ,..der Aufgabe, konkrete prognostische Angaben zur weiteren Zukunft der erfaßten und bewerteten Gebiete früherer Kulturlandschaften und der landschaftsprägenden Muster und Strukturen zu machen." Hier gilt es nach seiner Meinung, ,praktikable Vorschläge zu erarbeiten [...], [...], die, beginnend bei der klassischen 
Unterschutzstellung über die Wiederherstellung bzw. den Rückbau eventuell zu musealen Zwecken und die substanzschonende moderne Nutzung, bis zur Aufgabe nach eingehender Dokumentation in ganz verschiedene Richtung gehen können.“

Vor allem aber wird ,über die Möglichkeiten einer erhaltenden Integration des Überkommenen in die moderne Kulturlandschaft und über zukunftsorientierte Nutzungskonzepte diskutiert“ (FEHN 1997:19). Hier sieht FEHN für die Angewandte Historische Geographie „eine wichtige Aufgabe, für deren Lösung sie [...] besonders qualifiziert ist.“, da sie sowohl planungs- als auch landschaftsorientiert ausgerichtet ist.

FEHN stellt in Zusammenarbeit mit SCHENK (1993:481) diesen Ansatz noch einmal heraus, indem sie sagen: Die Angewandte Historische Geographie hat „die Aufgabe, im Hinblick auf die in den einzelnen Kulturlandschaften enthaltenen historischen Strukturen, Muster und Elemente, Entwicklungsleitbilder aufzustellen, die keineswegs nur auf den Schutz der persistenten Elemente und Strukturen ausgerichtet sind, sondern auch Pflege-, Nutzungs- und Gestaltungsvorschläge enthalten müssen." Nutzungsvorschläge und Festlegungen von Maßnahmen zielen dabei in Richtung, „die historischen Nutzungen, wie belegte Beweidungsformen und forst- sowie landwirtschaftliche Bewirtschaftungsformen unter Beachtung der wirtschaftlichen Möglichkeiten leicht modifiziert wiederzubeleben“ (BURGGRAAFF/KLEEFELD 1997: 25). Dies stellt auch „einen neuen Tätigkeitsbereich der Angewandten Historischen Geographie“ dar (:25).

Als ein Erfolg dieser Diskussion ist zu werten, dass die „konzeptionelle Federführung zur Planung von umfassenden kulturlandschaftspflegerischen Maßnahmen immer häufiger dem Seminar für Historische Geographie übertragen wird.“, so FEHN (1997:540) zu der anwendungsorientierten Neuaurichtung des Faches.

Doch mit der Hinwendung zu einer anwendungsorientierten Forschung, die sich auch den Bedingungen der Planungspraxis unterwerfen muss, bleibt nicht mehr viel von der romantischen Note einer Historischen Geographie übrig. „Mit anderen Worten: Die Formulierung hehrer Konzeptionen und Ziele einer Angewandten Historischen Geographie ist inzwischen profaner Tagesarbeit gewichen." (BECKER 1998:296) Denn ,tatsächlich handelt es sich mittlerweile aber häufig um ,knochentrockene’ objekt- und problembezogene Auftragsarbeit, deren Intensität und Fragestellung sich zunehmend von den Aufgaben und Zielen einer wissenschaftlichen Kulturlandschaftsforschung entfernen.“(:296) So „steht für Gutachten und andere angewandte Projekte oft nur wenig Zeit zur Verfügung, vielfach ist der Abschluß vertraglich auf einen bestimmten Termin festgelegt. Der schriftliche Bericht sollte kurz, allgemein verständlich und in einer möglichst ansprechenden Form vorgelegt werden “ (EGLI 1997:67).

Der planerische Prozess verläuft dabei in folgenden Schritten (nach NAGEL/SCHENK 2001:6f.):

1. Erfassung, Beschreibung, Erklärung kulturlandschaftlicher Strukturen und Elemente durch Bestandserfassungen und Inventarisierungen.

2. Deren Bewertung orientiert sich wegen der Komplexität von Kulturlandschaft an einem Wertekomplex aus Maßstäben des Naturschutzes, der Denkmalpflege und der Raum- und Regionalplanung. Der Wert einer Landschaft ergibt sich dabei aus der spezifischen und historisch einmaligen Kombination von wertvollen Strukturen und Elementen der Natur- und Kulturgeschichte.

3. Die Ableitung von pflegerischen Maßnahmen orientiert sich an der Einsicht, dass eine Konservierung von historisch überkommenen Landschaftsstrukturen nur auf kleinen Flächen oder für einzelne Objekte möglich ist. Kulturlandschaftspflege akzeptiert daher aus der Erkenntnis des steten Wandels als Grundprinzip von Kulturlandschaften deren Weiterentwicklung, sofern dabei nicht Potentiale für zukünftige Entwicklungen im Sinne nachhaltiger Entwicklung zerstört werden.

EGLI (1997) entgeht dieser ,Praxisfalle', indem er sein Augenmerk auf Bildung und Aufklärung setzt, die gleichzeitig erst die Voraussetzung für eine (An-) Erkennung historischer Merkmale in der Landschaft sind: Die Forderung zum Einbezug der Historischen Geographie in den räumlichen Planungsprozess basiert nach seiner Ansicht ,auf der Annahme, daß gewisse materielle Elemente und Strukturen als Ergebnis gesell- 
schaftlicher, wirtschaftlicher, politisch-rechtlicher und kultureller Entwicklungen zwingend erhalten werden müßten. Diese Forderung setzt die Auffassung voraus, daß die Einmaligkeit und die Geschichtlichkeit eines Objektes schützenswert seien.“ Diese Voraussetzung ist nach seiner Meinung ,aber offensichtlich vielfach nicht gegeben bzw. wird von vielen Leuten nicht anerkannt." (:66). Die Beispiele aus der Stadt- und Landschaftsplanung sowie der Flurbereinigung zeigen dieses Manko sehr anschaulich und seien als Argumentationshilfe eingefügt. „In Kenntnis dieser Voraussetzungen steht der Bildungsauftrag und die damit verbundene Öffentlichkeitsarbeit am Anfang der angewandten historisch-geographischen Forschung.", lautet EGLIs (:66) Priorität. „Denn nur“, so sein Credo, „wenn der kulturgenetische Ansatz [...] als Grundlage zum Verständnis der Gegenwart und als Potential für die zukünftige räumliche Entwicklung von einer breiteren Öffentlichkeit und insbesondere von Politikern und Planern anerkannt wird, kann die Historische Geographie einen anwendungsorientierten Beitrag leisten.“(:66)

Als Fazit am Ende der Diskussion zur Ausgestaltung eines ,anwendungsorientierten historischgeographischen Forschungsansatzes' im Wissenschaftsgebäude der ,historischen Umweltforschung' steht, dass die einfache, aus der klassischen Definition zur Angewandten Geographie entlehnte eindimensionale 'Zulieferfunktion', vorgetragen beispielsweise von BECKER (1998:297), nach dem die Angewandte Historische Geographie die Aufgabe hat, ,Erkenntnisse der Historischen Geographie für die Praxis verfügbar zu machen", bei diesem Ansatz nicht mehr greift.

Aufklärung, Öffentlichkeitsarbeit, Lobbyismus, Mitwirkung an und bei der Raumplanung zum Schutze und zum Erhalt der Kulturlandschaft einschließlich ihrer historisch-konformen Weiterentwicklung, um nur einige zu nennen, sind selbständige Bausteine einer historisch-geographischen Umweltforschung, die auf ein eigenes methodisches Instrumentarium zurückgreifen kann. Sie erhält deshalb das Prädikat der „Anwendungsorientierung“.

In ihrer interdisziplinären Ausformung und vor dem Hintergrund einer ethischen Wertevorstellung kann sie als Umweltforschung bezeichnet werden, die aufgrund ihres räumlichen und geschichtlichen Bezuges über eine historisch-geographische Ausrichtung verfügt.

\section{Die ,anwendungsorientierte historisch-geographische Gewässerforschung“ im Disziplingebäude der ,angewandten historisch-anthropogeographischen Umweltforschung“}

Auf Basis des oben skizzierten Betrachtungsansatzes und der disziplinären Einordnung in das Wissenschaftsgebäude einer, anwendungsorientierten historisch-geographischen Umweltforschung' wird im Folgenden das ,neue' geographische Forschungsfeld der historisch-geographischen Gewässerforschung unter besonderer Berücksichtigung des Anwendungsbezuges beschrieben.

\section{a Disziplinäre Einteilung der Gewässerforschung}

Die geographische Gewässerkunde oder auch Hydrogeographie galt bislang als Zweig der allgemeinen Gewässerkunde (Hydrographie bzw. Hydrologie), aber gleichzeitig auch als „Kernbereich der Wasserforschung“ (HERRMANN 1977:11) und wurde beschrieben als die „Lehre von den Erscheinungsformen, dem Vorkommen und der Verbreitung des Wassers über und auf der Erdoberfläche“ im Gegensatz zur Hydrologie, die sich - als disziplinärer Oberbau - als Geowissenschaft mit dem Wasser auch ,unter der Erdoberfläche nach Menge und Güte beschäftigt." (:11)

Inhaltlich beschäftigt sich die Hydrogeographie vor allem mit den Binnengewässern. Als Binnengewässer werden dabei die auf dem Festland fließenden und stehenden Gewässer mit Ausnahme des Küstenmeeres bezeichnet. Als Verzweigungen der Gewässerkunde haben sich dabei - unter Anwendung der Fließdynamik als Differenzierungskriterium (HERRMANN 1977:129) - herausgebildet:

1. Flusskunde (Potamologie ${ }^{26}$ )

${ }^{26}$ griechisch: ,p potamos“ $=$ der Fluss 
2. Seenkunde (Limnologie ${ }^{27}$ )

Als Teilbereich der Gewässerkunde werden diese zumeist der Biologie zugeschrieben (vgl. HERRMANN 1977:11), frühere geographische Schriften weisen die Fluss- und Seenkunde jedoch auch der Geographie als Forschungszweige zu.

Innerhalb der Limnologie wird unterschieden zwischen:

a. theoretischer Limnologie und

b. angewandter Limnologie.

Während die theoretische Limnologie der Ökosystemforschung zugerechnet wird, untersucht die angewandte Limnologie die fisch- und wasserwirtschaftliche Nutzung, darunter auch die Stauhaltung der Gewässer.

Die Limnologie aber , ist ein Teilgebiet der Hydrobiologie, sie befasst sich mit den Süßgewässern und deren Organismen. Sie untersucht die Binnengewässer und hier insbesondere die Ökosysteme, mit deren Struktur, Stoff- und Energiehaushalt. Sie untersucht stehende Gewässer, Fließgewässer und als Spezialfall auch das Grundwasser. Es werden die klimatischen, physikalischen, chemischen und biologischen Faktoren am Gewässer in der Zusammenarbeit mit den dafür zuständigen naturwissenschaftlichen Disziplinen in der Limnologie zusammengeführt.“ (HANSEN 2002/03)

Die Aufgabe der Limnologie ,,ist es, die Systemeigenschaften der Gewässer zu bearbeiten. Neben der reinen oder theoretischen Limnologie sind die Themen der angewandten Limnologie und Hydrobiologie die Abwasserreinigung, Wasseraufbereitung, Gewässerverunreinigung, Gewässerschutz und Gewässerpflege. Praxisorientierte hydrobiologische und fischereibiologische Untersuchungen am Gewässer (Küsten- und Binnengewässer) ergänzen die Limnologie als die Lehre von den Binnengewässern." (HANSEN 2002/03)

Als weitere Ausrichtungen der Hydrologie, die zumeist der Geologie und Geomorphologie sowie Geoökologie zuzurechnen sind, sind zu nennen:

3. Quellen- und Grundwasserkunde (Hydrogeologie)

4. Hydrogeomorphologie (Geschiebebewegung und Geröllverfrachtung durch Wasserkraft)

5. Gletscherkunde (Glazialogie)

6. Meereskunde (Ozeanographie)

7. Hydrobotanik und-zoologie

Neben einer hydrobiologisch, -geologisch und -geographisch ausgerichteten Gewässerforschung innerhalb des jeweiligen Faches Biologie, Geologie und Geographie, existiert eine historisch-geographische Gewässerforschung - mit oder ohne Anwendungsbezug - als Forschungsfeld jedoch noch nicht. Es gibt zwar eine Fülle von Einzelarbeiten zu verschiedenen historisch-gewässergeographischen Themenkomplexen und einige interessante und bedeutende Beiträge zu der Thematik (siehe Pkt. II), doch ein disziplinäres Dach fehlt diesen Arbeiten oftmals. Eine umfassende Konzeption eines entsprechenden Lehrgebäudes fehlt noch. Dies wird zum Beispiel erkennbar daran, dass keine geschlossene lehrbuchartige Darstellung der Historischen Gewässergeographie als Lehr- oder Studienbuch vorliegt.

Disziplinär ist eine historisch-geographische Gewässerforschung als ein eigenständiger historischgeographischer Zweig innerhalb der Geographie und als Teildisziplin der Historischen Geographie zu betrachten - eingebunden in das Wissenschaftsgebäude der historischen Umweltforschung. So wie eine historische Siedlungs- und Stadtgeographie, eine historische Agrargeographie, historische Industrie- und Verkehrsgeographie, eine historische Bevölkerungsgeographie oder eine historisch-geographische Landschaftskunde gehört die historische Gewässergeographie ,als Teil der Historischen Kulturgeographie [...] zu den allgemein-geographischen Unterdisziplinen der Historischen Geographie.“ (BECKER 1998:17)

\footnotetext{
${ }^{27}$ griechisch: „limne“ $=$ See, Teich
} 
Die Einordnung in die Historische Geographie soll den Raumbezug als geographisches Erkennungskriterium zum Ausdruck bringen, die Integration unter das „ethische“ Dach der Umweltforschung die Interdisziplinarität kennzeichnen. Denn aus dem Vorhergegangenen ist deutlich geworden, dass „die optimale Erforschung historischer Kulturlandschaften" - und darunter sind auch die Elemente und Strukturen historischer Gewässer zu verstehen - „heute nur noch interdisziplinär möglich“ ist (FEHN 1989b:19).

Doch die weitergehende, die disziplinären Grenzen auflösende, Sichtweise, es komme dabei ,nicht so sehr darauf an, welches Fach welche Aufgabe übernimmt, sondern es müssen alle wichtigen Problembereiche berücksichtigt und die vorhandenen Quellen sachgerecht ausgewertet werden“ (FEHN 1989b:19), kann nach meiner Auffassung hinsichtlich der pragmatischen Fächerwahl nicht überzeugen; der methodischen Ambivalenz (Berücksichtigung aller wichtigen Problembereiche und Quellen) ist hingegen zuzustimmen. Kulturlandschaftsbezogene gewässerhistorische Forschung ist Bestandteil historischer Raumwissenschaft, da es sich um vergangene, sichtbare oder nicht mehr sichtbare Elemente und Strukturen der Gegenwartslandschaft handelt. Sie sind Gegenstand historisch-geographischer Forschung.

Die nicht einfache Aufgabenbestimmung soll - um es deutlicher werden zu lassen - einer von JÄGER gegebenen Definition der Historischen Geographie entlehnt werden, die umgeformt lautet: Die Historische Gewässergeographie untersucht gewässergeographische Sachverhalte in vergangenen Zeitschnitten unter Verwendung aktual-geographischer Fragestellungen.

Nichtsdestotrotz handelt es sich um eine integrative, interdisziplinäre Fachrichtung, die alle Fachrichtungen in ihre Überlegungen miteinbezieht, soweit sie die historische Gewässererforschung befruchten können. Diese Zusammenarbeit soll insbesondere vor dem Hintergrund, da „eine unmittelbare Zusammenarbeit in Forschung und Lehre [...] bei den starren Grenzen der Disziplinen auch heute noch unterwickelt" ist, wie DENECKE/FEHN 1989 (:8) in noch ungebrochener Aktualität schreiben, elementarer Bestandteil dieser historisch-geographischen Sub-Disziplin sein. Sie soll durch den dadurch möglichen methodischen und theoretischen Zugewinn geradezu das Charakteristikum des Faches werden.

Ein Fach, welches sich mit der Erforschung von Gewässern aus historisch-naturwissenschaftlicher Sicht beschäftigt und die Ergebnisse für historisch-geographische Gewässerforschung liefern könnte, ist beispielsweise die ,Paläolimnologie'. Diese Forschungsrichtung, ein disziplinärer Zusammenschluss paläontologischer und limnologischer Fachbereiche, untersucht die Geschichte eines Gewässers aufgrund von Sedimentuntersuchungen und in diesen nach Tierspuren und organischen Resten. Forschungsergebnisse der o. g. Fachrichtungen und darüber hinaus auch solcher, die in keinem offensichtlichen Zusammenhang mit dem Fachgebiet stehen, können für die historisch-geographische Gewässerforschung sinnvoll verwendet werden, wie das Beispiel dieser Arbeit zu zeigen vermag.

Nach dem Sinn einer eigenständigen anwendungsorientierten historischen Gewässergeographie zu fragen oder die Teildisziplin als solche sogar in Frage zu stellen, mag an dieser Stelle durchaus legitim sein. Die Historische Gewässergeographie jedoch kann Erkenntnisse erzielen, die die Aktual-Geographie nicht zu liefern vermag: Die Einflüsse ehemaliger Gewässernutzungen und -veränderungen auf die heutige Gewässerstruktur und -verteilung, die durch Fließgewässer und deren künstliche Ableitung vorgegebene Anordnung und Verteilung von mittelalterlichen und frühneuzeitlichen Siedlungen und Teichen oder die frühere Vielfalt von Nutzungen an kleinen Bachläufen, dessen Brauch einen kulturgeschichtlichen Wert darstellt, mögen als Beispiele dienen, die in der Schlussbetrachtung der Arbeit eine weitergehende Ausformulierung erfahren.

Die Historische Gewässergeographie bietet also eine erhebliche sachliche Verbreiterung des allgemeingeographischen Erkenntnisrahmens und eine Intensivierung der Historischen Geographie durch die Fokussierung auf einen Forschungsgegenstand - die Gewässer.

\section{b Betrachtungsansatz der ,anwendungsorientierten historisch-geographischen Gewässerforschung“}

In den Veröffentlichungen zum aktuellen Umweltthema Wasser wird oftmals das Wasser als Lebenselement hervorgehoben mit der Intention „daß jeder nach der Lektüre behutsamer als vorher und voller Sorgen mit 
Wasser umgeht und daß aus diesen Sorgen ein Bewußtsein entsteht, das entsprechendes Handeln provoziert.“ (WASSER IM FLUSS 1992:4) Ebenso besteht eine Umweltgeschichtsschreibung mit kritischem Anspruch „häufig aus einer vorwurfsvollen Waldabholzungs- und Flußverschmutzungsgeschichte, zwischen deren Zeilen ein ständiges ,Wie konnten sie nur ...?' zu vernehmen ist.“" (RADKAU 1994:17). Doch sie ist vielmehr: „Flußgeschichte unter dem Gesichtspunkt einer Umweltgeschichte ist ein neu zu entwickelnder, komplexer und regional-spezifischer Betrachtungsansatz.“(DENECKE 1994:247)

Dieser Satz DENECKEs verdeutlicht die besonderen Merkmale dieser Forschungsrichtung, die sich aus drei Aspekten zusammensetzt: Neuartigkeit, Komplexität sowie regionaler Raumbezug, und damit über den traditionellen Ansatz der ,Umweltgeschichtsschreibung' hinausgeht. Der Forschungsansatz einer so verstandenen Flussgeschichte ist, trotz der bereits 1994 verfassten Ansicht, wenn auch nicht mehr im Entwicklungs-, so doch noch im Anfangsstadium (siehe die Ausführungen zur disziplinären Einteilung in 5a; sowie dazu Kap. II: Stand der gewässerhistorischen Forschung). Der Rückgriff beispielsweise auf Untersuchungen, die sich unter dem Forschungsgebäude einer historisch-orientierten Gewässer- oder Flussforschung zusammengefunden haben, ist noch nicht möglich, bzw. sie liegen als Puzzle vor, zusammengefügt aus verschiedensten disziplinären Blickrichtungen.

Die Vielschichtig- und Zusammenhanglosigkeit wird durch die - durch den Betrachtungsgegenstand bedingte - Zugehörigkeit zur Umweltwissenschaft, zur Geschichtswissenschaft und zur Gewässerkunde deutlich, die sich allein durch die Wortstämme ergeben und dessen Inter- und Intradisziplinarität im Vorfeld dargelegt worden sind. Denn wie vorher für die Historische Geographie im Allgemeinen, gilt für die historisch-geographische Gewässerforschung im Besonderen: „Für den Bereich einer umfassenden Bestandsaufnahme historischer Kulturlandschaftselemente ist interdisziplinäres Vorgehen eine Grundvoraussetzung. Für Denkmäler des Wasserbaus bedeutet dies eine Zusammenarbeit von Denkmalpflegern, Geographen, Landschaftsplanern, Kulturtechnikern und Technikhistorikern, um nur die wichtigsten zu nennen." (VON DEN DRIESCH 1997:274)

Die disziplinäre Vielgestaltigkeit wird jedoch in ihrer Komplexität erhöht durch die geschichtliche, anthropogene Physiognomie mitteleuropäischer Gewässerläufe. „Von Menschenhand geschaffene Geländeelemente sind vielfach so mit der natürlichen Umgebung verwachsen, daß ihr künstlicher Ursprung kaum noch bewußt wird.“ (MEYNEN 1997:281) MEYNEN denkt hierbei an die Höherlegung von Bächen, ,,damit die Bachströmung von möglichst vielen Mühlen genutzt werden konnte." Derartige für das Stadt- und Landschaftsbild wichtige Kulturelemente „sind von historischen Geographen noch aufzuspüren und zu bearbeiten.“ (:281)

Mit der Bemerkung, dass eigentlich sämtliche Gewässer Mitteleuropas anthropogen überprägte Lebensräume seien und es daher keine, natürlichen' Bäche in unserer Kulturlandschaft mehr gäbe, weist TÖNSMANN (1990:25) ebenfalls auf eine notwendigerweise die anthropogene Komponente berücksichtigende gewässerhistorische Forschung hin und entspricht damit der Ansicht SCHENKs (2003), der in Zusammenhang mit der gesamten Kulturlandschaft fragt, ob es sich nicht um eine Tautologie handelt, da ganz Mitteleuropa vom Menschen überformt ist?

Selbst RADKAU (2002:21f.), als Vertreter eines eher historisch-ökologischen Diskurses, sieht, dass man dort, „wo die Gefahr der Überschwemmung das Denken beherrscht, [...] nicht die mißlichen Folgen einer drastischen Absenkung des Grundwasserspiegels im Zuge der Flußregulierung" beachtet.

Flusshistorie ist deshalb als ein neuer geographischer Ansatz im Gefüge ,Mensch und Wasser in der Geschichte' zu betrachten. Täler mit ihren Flüssen und Bächen sind in ganz Mitteleuropa Teil von in Jahrhunderten entstandenen Kulturlandschaften. Keines der das nördliche Mitteleuropa und das Alpenvorland durchziehenden und die Landschaften prägenden Gewässer hat heute noch seinen ursprünglichen Zustand. Gewässer sind also nicht Inbegriff von Natur, sondern auch - im gleichen Maße wie der Wald - ein Erzeugnis der Kultur, der Menschen, die sie durch ihre Bewirtschaftung prägten, pflegten, formten und missbrauchten. Flussgeschichte ist deshalb ein anthropogen-geographischer Ansatz.

Die Historische Gewässergeographie liefert Grundaussagen und zahlreiche Informationen über die Beherrschung und Nutzung eines natürlichen Wasserlaufs im historischen Kontext: „Bei detaillierter Forschung bietet der Wasserlauf zahlreiche Informationen über Gefährdung einer großen Ansiedlung durch 
die Naturgewalt des Flusses, die seit dem Mittelalter getroffenen Maßnahmen zur Sicherung vor Hochwasserkatastrophen und die seit dem Mittelalter getroffenen Maßnahmen zur vielfältigen Nutzung der Wasserkraft, die Bewältigung der Fundierungsschwierigkeiten, die gewerbliche Nutzung des Wassers, die Nutzung der Flußaue für Zwecke des allgemeinen Nutzen in ihrer historischen Entwicklung, die Nutzung des Wassers für Verteidigungszwecke, die Problematik der historischen Wasserversorgung, die Inwertsetzung einer Flußaue für Zwecke der Schiffahrt, den Bedarf an öffentlicher Freifläche und die gewählten Gestaltungssatzungen, die Landschaftsbewertung zu unterschiedlichen Zeitpunkten, schließlich die Gesamtheit ökologischer Aussagen, wie auch den eigentlichen ökologischen Wert, die technische Entwicklung und viele andere mehr. Es wird deutlich, daß wasserbauliche Anlagen einen hohen Demonstrationswert für zahlreiche Fragestellungen bieten." (VON DEN DRIESCH 1997:268)

Fluss- bzw. Gewässergeschichte ist demnach bis hierhin eigentlich nichts anderes als eine Form der Siedlungs- und Landschaftsgeschichte, nur mit anderem Betrachtungsgegenstand und eines methodologisch darauf ausgerichteten Quellen- und Feldstudiums. In Substitution des von DENECKE (1994:434) definierten Aufgabenbereiches der Siedlungs- und Landschaftsgeschichte soll Gewässergeschichte „das Bild und den Zustand auch und gerade der heutigen Gewässerlandschaft erklären sowie die Ursachen und Entwicklungsprozesse herausarbeiten, die zu den heutigen Verhältnissen geführt haben." Es wird in der gewässerhistorischen Kulturlandschaftsgeographie nicht nach dem rein historischen, sondern nach dem landeskundlichen Prinzip verfahren: „Erdgeschichtliche und historische Abläufe werden unter dem Gegenwartsaspekt gesehen. Mit anderen Worten, sie werden nur in den Teilen berücksichtigt, die für die Gegenwart von Bedeutung sind. Entweder können sie im Raum des Landes [...] heute noch unmittelbar flächenwirksam sein, oder ihre Behandlung ist für die Erklärung der heutigen Raumstruktur erforderlich; denn die Gegenwart ist etwas Gewordenes mit vielen gegenwartsrelevanten Hinterlassenschaften aus vergangenen Epochen.“ (SEEDORF/MEYER 1996:7) Des Weiteren erfolgt die thematische Schwerpunktsetzung nach diesem Verständnis dahingehend, als der Systemzusammenhang Natur-Technik-Gesellschaft nicht allein im Sinne der geographischen Realität, das heißt der baulichen Manifestierung in der Kulturlandschaft behandelt werden soll, sondern eine verstärkt humanökologische Betrachtungsperspektive eröffnet werden soll, die dem Wirken des Menschen und seinen landschaftsräumlichen Niederschlagungen einen breiteren Stellenwert gibt. Dieser genetische kulturlandschaftliche Erklärungsansatz soll als klassische Aufgabe einer in dieser Arbeit neu angelegten, anwendungsorientierten historisch-geographischen Gewässerforschung' inhaltlich übernommen werden. Es bleibt somit weiterhin das Anliegen der Historischen Geographie erhalten, das gegenwärtige Rauminventar und dessen historische Entwicklung im Wirtschafts- und Kulturraum zu verdeutlichen.

Demnach wird der kulturlandschaftsgeographische Ansatz methodisch aktualisiert u.a. um den Einsatz digitaler Geographischer Informationssysteme (GIS), disziplinär erweitert um den Betrachtungsansatz der historischen Umweltforschung resp. der Umweltgeschichte, ergänzt um die praxisbezogene Anwendungsorientierung, beispielsweise hinsichtlich der Aufnahme planungsbestimmender Inventare und thematisch erweitert um einen bislang vernachlässigten Themenkreis: die historische Gewässerkunde.

Anwendungsorientierte historisch-anthropogeographische Gewässerforschung bedeutet also interdisziplinäre Forschung zur Landschaftsgeschichte im Sinne der Erforschung und Erläuterung verschiedenster Lebensräume und ehemals traditioneller Nutzungsformen in der Kulturlandschaft unter Zuhilfenahme neuerer computerunterstützter Arbeitsmethoden und besteht in der Applikation von - auf die Bedürfnisse der Gewässererhebung angepassten - erprobten Planungsverfahren und Planungstechniken. Die vordringlich kulturhistorische Betrachtungsweise schließt dabei naturgemäß naturhistorische Apekte mit ein.

Damit verbleibt schließlich der dritte Aspekt, der die Flussgeschichte zu einem originär geographischen Forschungsfeld macht - der spezifische Raumbezug. Er dient zur Aufdeckung der regionalen Unterschiedlichkeit, beispielsweise von gewässerbezogenen Bewirtschaftungsformen.

Eine historisch-gewässergeographische Betrachtung führt ausgehend von einer Analyse des Einzelobjektes (hier: Dorfteich, Stauwehr) hin zu einem landschaftsgebundenen Zusammenhang in der Auswahllandschaft bzw. dem Untersuchungsraum (hier: Flusslauf bzw. Flussabschnitt); und letztlich weiter hinaus zur historischen Entwicklung der realen Nutzungs- und Gewässerlandschaft der gesamten Region (hier: Stadt bzw. Siedlung am Fluss). 
Die grundsätzliche Bedeutung des umweltgeographischen Ansatzes liegt gerade in der speziell geographischen Sicht komplexer funktionaler und räumlich-landschaftlicher Zusammenhänge. Die bisherigen Themenbereiche historisch-geographischer Forschung behandelten beispielsweise die historischen Siedlungs- und Flurformen bzw. ihre Typen in ihrer räumlichen Verbreitung und ihrer Bedingtheit; oder auch die historisch-bauliche Struktur von Haus- und Hofformen sowie Konstanz und Wandel der Baulichkeiten als sichtbares Abbild der Transformation neuer Lebens- und Arbeitswelten.

Historisch-geographische Gewässerforschung beinhaltet in diesem Sinne die Aufnahme umfangreicher gewässer- und landschaftsgeschichtlicher Untersuchungen innerhalb eines ausgesuchten Raumes, um aus einer breiten Kenntnis des Flusseinzugsgebietes heraus charakteristische historische Gewässerelemente zu erkennen und Gewässertypen festzustellen. „Ohne Zweifel muß es“, so NAGEL/SCHENK (2001:13) „,in einem ersten Schritt darum gehen, wissenschaftlich fundierte Basisinformationen über den Wert noch sichtbarer Strukturen aus der Vergangenheit bereitzustellen.“ Denn „die Historische Geographie sieht auch heute noch in der Erforschung der natürlichen Umwelt des früheren Menschen und seiner Veränderungen im Laufe der Geschichte eine wichtige Aufgabe“ (FEHN 1989b:13). Erst aufbauend auf der Grundlage einer so gebildeten breiten und tiefgehenden Kenntnis steht die eigentliche ,historisch-geographische Gewässerkunde'.

Hierbei geht es darum, ausgehend von einem Ausschnitt einer historischen Gewässerlandschaft oder einer umfangreichen monographischen Aufnahme, eine - zumeist teilräumliche - gewässergebundene Siedlungsund Kulturlandschaft nachzubilden und deren siedlungsräumlichen, wirtschafts- und sozialgeschichtlichen Zusammenhang zu analysieren.

Gewässernutzungsgeschichte kann folglich definiert werden als eine komplexe Kulturlandschaftsgeschichte eines größeren Raumes, entweder den Wasserlauf von der Quelle bis zur Mündung, das heißt in Form einer Monographie, betrachtend oder auch, unterteilt in Gewässerabschnitte, einzelne Gewässererscheinungen herausgreifend. Da die Veränderungen in der Gewässerlandschaft aber auch die ökologischen Verhältnisse in historischer Zeit widerspiegeln, ist Gewässernutzungsgeschichte gleichzeitig auch eine anspruchsvolle hydroökologische Umweltgeschichte.

Historisch-geographische Gewässerforschung lässt sich zusammengefasst als die Untersuchung der physiognomisch-strukturellen Gewässerlandschaften, ihrer Strukturen und einzelnen Elemente als funktionale Räume der Vergangenheit hinsichtlich ihrer Geschichtlichkeit betrachten, ergänzt um die anwendungsorientierte Komponente einer erneuten bzw. fortdauernden Inwertsetzung einschließlich der Benutzung moderner Erfassungs- und Analysemethoden sowie unter Verwendung fachübergreifender Informationen.

Ihre real- und humanökologischen Ziele entsprechen denen der historisch-geographischen Kulturlandschaftsforschung und liegen in der „Abmilderung der Folgen der gegenwärtigen Transformationsprozesse in städtischen und ländlichen Räumen, da sonst irreversible Verluste eintreten, vor allem hinsichtlich Biodiversität, der landschaftlichen Ästhetik, des Geschichtswertes (,Landschaft als Archivalie'), der regionalen Identität, welche oftmals an historische Landnutzungsformen und -zustände gebunden sind.“ (NAGEL/SCHENK 2001:6)

Anwendungsorientierte Zielsetzung - in Anlehnung an die allgemeine Zielsetzung Historischer Geographie von NITZ (1998:123) - ist die Erhaltung und Wiederherstellung von persistenten gewässerhistorischen Strukturen.

Steht die erhaltende Weiterentwicklung des gesamten historischen Erbes in unseren Landschaften im Mittelpunkt angewandter historisch-geographischer Forschung, spricht man von Kulturlandschaftspflege (SCHENK et al. 1997); handelt es sich um einen Teilbereich des historischen Erbes, den der Gewässer, so kann man von kulturhistorischer Gewässerlandschaftspflege sprechen. Sie versteht sich als ein übergreifendes Konzept zum planerischen Umgang mit räumlichen gewässerhistorischen Werten im Sinne einer Querschnitts- und Daueraufgabe und als Baustein in einem ganzheitlichen, nachhaltigen und zukunftsorientierten Konzept der Umweltsicherung. Das besondere Augenmerk wird dabei auf die aus der 
Vergangenheit überkommenen kulturhistorischen gewässerbezogenen Strukturen und Elemente gelegt (in Anlehnung an NAGEL/SCHENK [2001:6] zum Begriff „Kulturlandschaftspflege“). Es handelt sich hierbei um „Reste ehemaliger Eingriffe“, die heute ,anschauliche und bedeutsame Kulturdenkmale und Altlandschaftsrelikte" darstellen. Sie sollen im Rahmen einer anwendungsorientierten historischgeographischen Umweltforschung „kulturlandschaftsgeschichtlich untersucht und ausgewertet werden“ und „sind als Kulturlandschaftsdenkmale oder im Rahmen von Kulturschutzgebieten oder Altlandschaftsgebieten zu erhalten und zu pflegen.“ (DENECKE 1989b:204)

Steht die Wiederherstellung an, muss in logischer Konsequenz von einer Kulturlandschaftsrekonstruktion gesprochen werden. Sie lässt sich ungleich schwerer durchsetzen, weil sie kostenintensiver ist in Forschung und Durchführung. Dennoch stellt sich die Frage: Wenn es eine Naturierung von Gewässern gibt, warum nicht auch eine „Kulturierung“?

Hinsichtlich des Untersuchungszeitraumes einer historischen Gewässerforschung und planung soll der Zeitrückblick sowohl den methodischen und zeitlichen Bedürfnissen der Anwendungsorientierung entsprechen als auch das Alter der die heutige Geschichtslandschaft prägenden Relikte berücksichtigen. Und letztlich geht es auch um die Schließung einer Forschungslücke: „Der Landschaftszustand des 19. und frühen 20. Jahrhunderts, der für die Charakterisierung der historischen Restlandschaften im Zuge einer erhaltenden Landschaftspflege im Mittelpunkt steht, ist in der Geographie bisher nicht von besonderem Interesse gewesen.", schreibt DENECKE (1997:45) und beschreibt damit den für die angewandte historischgeographische Gewässerforschung zu beachtenden primären Zeitrahmen.

Zusammenfassend betrachtet verbindet eine Gewässerlandschaftspflege und -restaurierung Methoden und Befunde der historisch-genetischen Kulturlandschaftsforschung mit den Anliegen der Angewandten Geographie und dem moralischen Überbau der Umweltforschung (in Anlehnung an NAGEL/SCHENK 2001:6). Kulturlandschaftspflege versteht sich dabei als ein sektoral „übergreifendes Konzept zum planerischen Umgang mit räumlichen kulturhistorischen Werten.“ (SCHENK 2000:230)

Die Größenordnung einer durchzuführenden Erhaltung, Pflege und auch Wiederherstellung von historischen Gewässerelementen und -strukturen unterliegt jedoch dem Realismus. SCHENK (2000:230) ,geht davon aus, dass eine Konservierung ,unter der Käseglocke' von aus der Vergangenheit in unsere heutigen Landschaften überkommenen, weitgehend dysfunktionalen Einzelelementen oder Strukturen nur auf kleinen Flächen möglich ist." FAEGRI (1988:4) geht ebenfalls davon aus, dass "the old landscape of ecological economy cannot be saved entirely. Only small parts can be maintained, preserved and restored.“ „In Entlehnung des Begriffes der ,Trittsteinbiotope' aus dem Planungsarsenal der achtziger Jahre, die ein erster Schritt zur Biotopvernetzung sein sollte", bezeichnet LENZ (2000:193) Kulturlandschaftselemente als „kulturelle Trittsteine“, „als erste Knoten im Netz gegen eine ausschließliche ,Ware Landschaft' im Kopf.“ $(: 193)$

„Für einen Schutz und für eine landschaftspflegerische Integration historisch geprägter Restlandschaften und ihrer einst landschaftsprägenden Kulturelemente“, gibt DENECKE (1997:45) die anstehenden Arbeiten vor, „sind nun [...] die Reste traditioneller und oft auch regionaltypischer Wirtschaftslandschaften nicht nur als solche zu erkennen und zu erfassen, sondern auch die Rekonstruktion des ehemaligen Gesamtbildes in den Zusammenhang des einstigen Landschaftsbildes wie auch der zeitgenössischen Wirtschaftsweisen zu stellen."

Um aber überhaupt diese Zielsetzung zu erreichen, ist es notwendig, "through a thorough study of this economy, understand how the landscape functions and know the interactions of the multiple techniques in the day-to-day work in the field. They may look simple, but they embody millenia of experience." (FAEGRI 1988:4)

\title{
c Aufgabenfelder einer, ,anwendungsorientierten historisch-geographischen Gewässerforschung“
}

\author{
„Die Historische Geographie kann, von ihrem Selbstverständnis aus, wesentliche Beiträge zur \\ Inventarisation wasserwirtschaftlicher Anlagen liefern, so durch die Bestandsaufnahme, die
}


sozialgeschichtliche Einordnung, die Auswertung von historischen Karten, um Aussagen über die historischen Standortbedingungen wie auch über Häufigkeit und Verteilung der Denkmäler zu erbringen. Im Bereich der wünschenswerten und notwendigen Öffentlichkeitsarbiet muß die Historische Geographie die Sachinformationen liefern, die für eine Perzeption der Objekte als Denkmäler erforderlich sind. Zur Zeit scheint ein wachsendes Interesse breiter Schichten an historisch-nostalgischen Objekten eine günstige Ausgangsposition zu schaffen, über den nostalgischen Wert hinaus auch auf die eigentliche Bedeutung der Objekte, und damit ihren Denkmalcharakter hinzuweisen. Wichtig erscheint mir, die inhärenten Möglichkeiten des erweiterten Denkmalbegriffs zu nutzen, nämlich nicht länger die Elemente isoliert zu betrachten, sondern in ihrem landschaftlichen Kontext. Gerade für Denkmäler des Wasserbaus ist dies unabdingbar. Zum getreidelten Flußbetrieb gehören die Leinpfade, gehören die Stationen für den Pferdewechsel, gehören Umladeplätze, Brücken, Mühlen-, Fischteiche. Kanal mit Schleuse, Walkmühlen, Auenwald. Zahlreiche weitere Beispiele ließen sich anfügen, wie die komplex angelegten Zisterzienserklöster mit ihren gestaffelten Fisch-, Mühlenteichen, ihren Wasserzuleitungen für handwerkliche Nutzung, ihren häufig gut geplanten Abwasserkanälen. Diesen Zusammenhang aufzuzeigen und damit auf die in den Gesetzen genannten Schutzbegründungen hinzuweisen, sollte eine Aufgabe der angewandten Historischen Geographie sein. “ (von den DRIESCH 1997:274)

Diese an den Anfang gestellte Darstellung von von den DRIESCH beschreibt in vortrefflicher Weise mögliche Aufgabenfelder einer anwendungsbezogenen historisch-geographischen Gewässerforschung, und einige von diesen Aufgabenfeldern - wie z. B. die Zisterzienserklöster - werden auch bereits seit kürzerer Zeit von historisch-geographischer Seite bearbeitet sowie projektleitend begleitet, wie das Modellprojekt der „Klosterlandschaft Heisterbachtal“ im Siebengebirge zeigt. In diesem wird die kartographische Rekonstruktion der ehemaligen Klosterteiche der Zisterzienser verfolgt und auch die landschaftsräumliche Rekonstruktion zumindest eines Teiches von den ehemals vielzähligen Teichfolgen diskutiert (siehe Teil E).

Ein weiteres interessantes Aufgabenfeld historisch-geographischer Gewässerforschung kommt aus der amerikanischen historischen Umweltforschung, die sich bereits in den 1970er Jahren mit Fließgewässern in der Alten Welt beschäftigt hat (HAMMERTON 1972; BUTZER 1976) und die WORSTER in den 1990er Jahren wieder aufgreift. Am Beispiel des Nils, „the oldest river in terms of sustained human use”, lässt sich nach seiner Auffasung ,the natural history of that usage from its earliest times (about 5000 B.C.) to the present" aufzeigen. Die Epoche ist gekennzeichnet durch ,an extraordinarily long symbiosis between people and river, a recent set of catalysmic environmental changes, a persistent tendency toward concentrated political power based on water management, a rich accumulation of river lore given to Egyptian life. Beginning in the time of the pharaoh Menes (about 3200 B.C.), the valley farmers constructed a series of ditches and dikes to direct the annual floods to their fields." Mit diesen Worten beschreibt WORSTER (1993c:126) die Symbiose in früherer Zeit, ,to what Karl Wittvogel has called a ,hydraulic society'“, und die anthropogenen Eingriffe in den mächtigen Gewässerlauf in jüngerer Vergangenheit zum Zwecke der Bewässerung und zum Schutz vor Hochwasser. Er versucht sich dabei, und dies ist sein eigentlich neuer Ansatz, der hinter diesem Beschäftigungsfeld steht, dem Thema zu nähern, indem er das - spirituell klingende - Prinzip des „Thinking like a River“ verfolgt (:125). Dabei vergisst er nicht die wirklichen Umstände zu benennen, die zu diesen Errungenschaften geführt haben: „In the ancient Egyptian world, the energy for water manipulation came from corvees, immense legions of peasents drafted by the government to build and maintain works, impelled by the whip when they got tired." (:128) Dies steht im Gegensatz beispielsweise zu der oftmals verklärten Aufarbeitung klösterlichen Schaffens.

Auch RADKAU (2002:8) sieht, „daß es an der Zeit ist, konsequenter als bisher Erfahrungen aus der Alten Welt in die Umwelthistorie einzubringen: statt des Kultes der, Wildnis' die Frage nach der Nachhaltigkeit in alten Kulturlandschaften. “ Diese Sichtweise jedoch, das Einbringen aus anderen Kulturkreisen und der damit verbundene wissenschaftstheoretische Austausch fehlt meines Erachtens zur Zeit; unter anderem bedingt durch eine mangelhafte institutionelle Personal- und Lehrkörperausstattung.

Ein weiteres Aufgabenfeld gewässerhistorisch-geographischer Forschung könnte das der Abwässer sein, das eher „als Thema der Umweltgeschichte“ (BÜSCHENFELD 2000:80) bekannt geworden ist. Die ,historische Abwasserforschung" (:80) als disziplinäres Forschungsgebiet innerhalb der historischen Umweltforschung 
beschäftigt sich hauptsächlich mit dem „historischen Gewässerschutz“, beispielsweise der Abwässer aus der Kaliindustrie und ist nach Meinung von BÜSCHENFELD (:103) ein „historisch komplexes Problemfeld“.

Doch ist dies wirklich „ein Thema, das die schon bislang gut untersuchten ,Wassernöte' im Industrialisierungs- und Urbanisierungsprozeß [...] erweitert?“, wie BÜSCHENFELD (2000:82) dies am Beispiel der Kaliabwässer sieht; und gewinnt so seine Legitimation Gegenstand historisch-geographischer Forschung zu sein?

Zum einen aufgrund „der historischen Wahrnehmung der Gewässerbelastung im 19. Jahrhundert“ (BÜSCHENFELD 2000:82), die ich nicht auf diese Zeitperiode beschränken möchte, erhebt sich der Anspruch auf eine weitergehende geographisch ausgerichtete Untersuchung mit diesem Themenfeld zum Beispiel im Rahmen einer ,Historischen Wahrnehmungsgeographie': Die Perzeption von ,natürlichen' Gewässerlandschaften beispielsweise prägt noch heute den fälschlichen Gewässerbegriff und es wäre planungstechnisch von großer Bedeutsamkeit, dieses kulturhistorisch inkorrekte Zerrbild in einen geschichtskonformen Gewässerbau zu überführen. Die „historische Wahrnehmung“ von Veränderungen des Gewässerchemismus kann sich insofern nachteilig für eine kulturhistorisch orientierte Planungspraxis auswirken, als sie im Rahmen beispielsweise des praktizierten Gewässerschutzes, der einen möglichst natürlichen Gewässerlauf als Ideal zur filtrierenden Reinigung betrachtet, den kulturhistorischen Vergleich außer Acht lässt, obgleich vielleicht das ökologische Klimaxstadium erst zu einem bestimmten Zeitpunkt eingetreten ist, als der Mensch durch direkte und indirekte Einleitungen für ein Pflanzenwachstum gesorgt hat. Hat die historische Umweltwahrnehmung, so stellt sich des Weiteren die Frage, z. B. aufgrund der ungeregelten und zum Teil sogar gesetzlich genehmigten Wassereinleitungen nur ein sorgloses „Früher haben die Menschen viel stärker die Flüsse verunreinigt" zur Folge und ermöglicht eventuell Aufschlüsse über die mangelnde Fürsorge und Beachtung von Gewässern in Teilen der Gesellschaft, die sich erst im Zuge von Aufklärung und ökologischer Bewusstseinsbildung gewandelt hat?

Doch aufgrund ihrer nur schwer empirisch und quellenmethodisch zu erbringenden Beweislast - auch insichtlich ihrer Raumwirksamkeit - sind dies eher nur Randplätze einer historisch-geographischen und schon gar angewandten historisch-geographischen Gewässerforschung. Soll diese Forschungsrichtung einen „Beitrag zur Geographie in der Praxis“ liefern, wie DENECKE (2001:291) es fordert, so „kommen folgende Aufgaben hinzu, die für den Schutz historischer Kulturlandschaftselemente von grundlegender Bedeutung sind: Erhaltung kennzeichnender und landschaftsprägender Merkmale, Erfassung gewachsener Strukturen in ihren raum-zeitlichen Prozessen, Bestandsaufnahmen und Bewertung persistenter Elemente." (DRIESCH 1997:274)

„Die planungsorientierte historisch-geographische Dokumentation und Systematisierung historischer Kulturlandschaftszustände und Landschaftselemente" (DENECKE 2001:288) steht also auch im Mittelpunkt einer praxisbezogenen historisch-geographischen Gewässerforschung. Dieses Aufgabenfeld hat sich bewährt, denn bei der „Kulturlandschaftsforschung mit ihrem angewandten Zweig, der Kulturlandschaftspflege“ handelt es sich ,um die konsequente Fortführung eines wissenschaftlichen Ansatzes, der seine Bewährungsprobe in der Praxis bestanden hat. Die historisch-geographische Kulturlandschaftsinventarisation ist zu einem Standardinstrument geworden." (KRINGS 2001:49).

Des Weiteren sind die Langzeitveränderungen und irreversiblen Störungen durch Eingriffe des Menschen in die Landschaft zu erforschen und in der Planung, beispielsweise bei Renaturierungsmaßnahmen, aber eigentlich in der gesamten Raumplanung zu berücksichtigen. Dazu zählen die „Einengung der Flußbetten durch Stromkorrekturen, die Verfüllung und Trockenlegung kleiner abflußloser Hohlformen“ etc. (DENECKE 1989b:203). Dies ,sind großräumige Veränderungen im natürlichen Landschaftshaushalt, deren Ausmaße im Verlauf der Menschheitsgeschichte noch keineswegs recht erfaßt sind.“ (:203)

Es konnte bislang kein flächendeckendes Bild der historischen Entwicklung von Gewässern entstehen. Um die räumlichen und zeitlichen Lücken in der Kenntnis früherer Umwelten weiter zu füllen, müsste im nächsten Schritt etwa „eine umfassende historische Hydrogeographie einer Region wie der des Rheinlandes“, wie es DIX (1997:280) forderte, erstellt werden oder aber die historische Entwicklung auch der kleinen einzelnen Gewässerläufe detailreich geschildert werden. 
Als mögliche Aufgabenbereiche einer weiter zu entwickelnden historisch-geographischen Gewässerforschung können die folgenden Beschäftigungs- bzw. Forschungsfelder genannt werden. Dabei handelt es sich zum einen um eine Zusammenstellung bereits vorhandener Tätigkeitsbereiche im gewässerhistorischen Forschungsfeld, zum anderen sollen hier Denkanstöße skizziert werden. Die verschiedenen Untersuchungsbereiche sind hierbei nicht singulär zu betrachten, sondern bedingen einander.

1. Darstellung der Veränderung der Gewässeroberfläche im Laufe der Geschichte

Die Erforschung der gewässerbezogenen Linien-, Punkt- und Flächenelemente und ihrer Veränderung (Auflösung, Vermehrung, Verschiebung) in historischer Zeit fällt in diese Kategorie. Dabei gilt es nicht nur die Gewässer zu einer bestimmten, mehr oder weniger weit zurückliegenden Zeit zu rekonstruieren, sondern auch die Geschichte der Gewässer bezüglich der mit ihnen verbundenen Landschaftsveränderungen nachzuzeichnen.

Hier ist beispielsweise der siedlungs- und wirtschaftsgeschichtliche Zusammenhang zwischen Flussbegradigung, Waldrodung und Ackerbau einerseits und Auelehmbildung andererseits im zeitlichen Ablauf zu rekonstruieren. Hierbei sind langfristige, historische Bodenbewegungen und Flusslaufkorrekturen zu betrachten, die sich durch den Auf- und Abtrag zur Füllung der Talböden mit Wald- und Auelehm und mit anmoorigem Humus verantwortlich zeichnen. Ein solcher Beitrag hat im Wesentlichen umweltgeschichtliche Bedeutung bei der Rekonstruktion der Vergangenheit.

\section{Großräumige Verbreitung}

Diese Aufgabe baut auf die Darstellung der Gewässerveränderung in quantitativer Hinsicht auf. Die makrogeographische Verbreitung von Gewässerläufen und ihre historisch-anthropogenen Gewässerformen gilt es hier festzustellen (Stichwort: Gewässergroßlandschaften). Dies ist nicht nur ein wichtiger Beitrag zur Umwelt- und Kulturgeschichte, sondern leitet über zur Inventarisierung als im Wesentlichen anwendungsbezogene Aufgabe zum Schutze der Kulturlandschaften.

\section{Die lokale Rekonstruktion der historischen Gewässer}

Die allgemeine, großräumliche Darstellung der historischen Veränderung von Gewässern ist hier auf einer maßstäblich größeren Ebene durchzuführen. Am Beispiel von räumlich abgegrenzten Untersuchungsgebieten sind auf der Grundlage von Geländestudien Lokalisierungen im Gelände durchzuführen. Ehemalige Teich- und Bewässerungsanlagen heben sich beispielsweise durch Reliefierung, Expositionen und durch verschiedene Bodenverhältnisse bzw. Bodenverfärbungen im Gelände ab. In Zusammenarbeit mit flächendeckenden Detailkartierungen (siehe Nr. 4) führt dies zu Aussagen z. B. über die ehemalige Gewässer- und Wasserflächenzusammensetzung in einem begrenzten Untersuchungsraum und ergibt ein Abbild ehemaliger amphibischer Landschaftsverhältnisse.

\section{Oberflächige Geländeaufnahmen von Gewässerlandschaftsrelikten}

Im Wesentlichen ist diese Aufgabe mit der zuvor genannten Aufgabe identisch, mit der Ausnahme, dass es sich hier um den reinen Nachweis beispielsweise zum Bestandsschutz handelt, während eine Rekonstruktion eine ungleich größere Aufgabe ist, die z.B. eine Auswertung verschiedener Zeitschnitte notwendig macht. Alle an einem Gewässerlauf lokalisierbaren und das Wasser in historischer Weise nutzenden Einrichtungen und Anlagen sollen hier kleinräumig erfasst werden. Zur Bearbeitung dieser Aufgabenfelder bedarf es verschiedener methodischer Geländeuntersuchungen und Kartierungen im jeweiligen Untersuchungsraum.

Die klassische kartographische Nachweisaufnahme der Verbreitungsstrukturen und Einzelfunde im Feld gehört ebenso zur oberirdischen Geländeaufnahme dazu wie das Desktop Mapping auf der Grundlage (historisch-)kartographischer Planvorlagen sowie Luftbildaufnahmen und deren photogrammetrische Interpretation. Die in der historischen Kulturlandschaft vorhandenen alten Gewässerlandschaftsrelikte (Bewässerungsterrassen, Flutungsgräben, die Fischerhütten etc.) sollen erfasst, dokumentiert und bewertet, d. h. mit einer Zustandsbeschreibung versehen werden und in ihrer ehemaligen Funktionalität erklärt werden. 
5. Genetische Erklärung von Gewässerlandschaftsrelikten oder anthropogenen Kleinformen

Dies betrifft die genetische Erklärung gegenwärtiger Gewässerstrukturen und -prozesse am Beispiel von gewässerhistorischen Punktobjekten. Die gewässergenetische Forschung dient der Erklärung und Herleitung der gegenwärtigen Gewässersituation. Insbesondere für weiter zurück liegende Zeiten können Gewässer (oder nur ihre Relikte) durch die Persistenz ihrer materiellen Gestalt zu einer wichtigen Geschichtsquelle werden, zu einer Quelle für frühere wirtschaftliche und soziale Lebensverhältnisse und Lebensbedingungen. Diese wiederum kann zu einem bewussterem Umgang mit dem Medium Wasser führen: als Lebensmittel oder in seiner morphologischen Form.

6. Typologie der anthropogenen Kleinformen

Verschiedene Gewässerkleinformen müssen typologisch herausgearbeitet und in einen Typenkatalog aufgenommen werden, damit bei anstehenden Kartierungsarbeiten, die in der Regel einen biologischen Schwerpunkt besitzen, der kulturhistorische Aspekt eine entsprechende Berücksichtigung erfährt.

7. Mitwirkung bei der erhaltenden räumlichen Planung

Dieser Aufgabenbereich der Angewandten Historischen Geographie beschäftigt sich mit der Mitwirkung an der räumlichen Planung, beispielsweise der agrarstrukturellen Vorplanung, Flurbereinigungsplanung, wasserwirtschaftliche Rahmenplanung, der Stadt- und Landschaftsplanung etc. Im Rahmen der Planungsaufgaben sollen gewässerhistorische Erscheinungen eine spezielle Berücksichtigung bzw. Aufnahme erfahren. Dies beinhaltet auch die Erarbeitung von Flusslaufstudien und der Mitwirkung bei der Ausbauplanung, die unter Berücksichtigung des historischen Bestandes ausgeführt werden sollte.

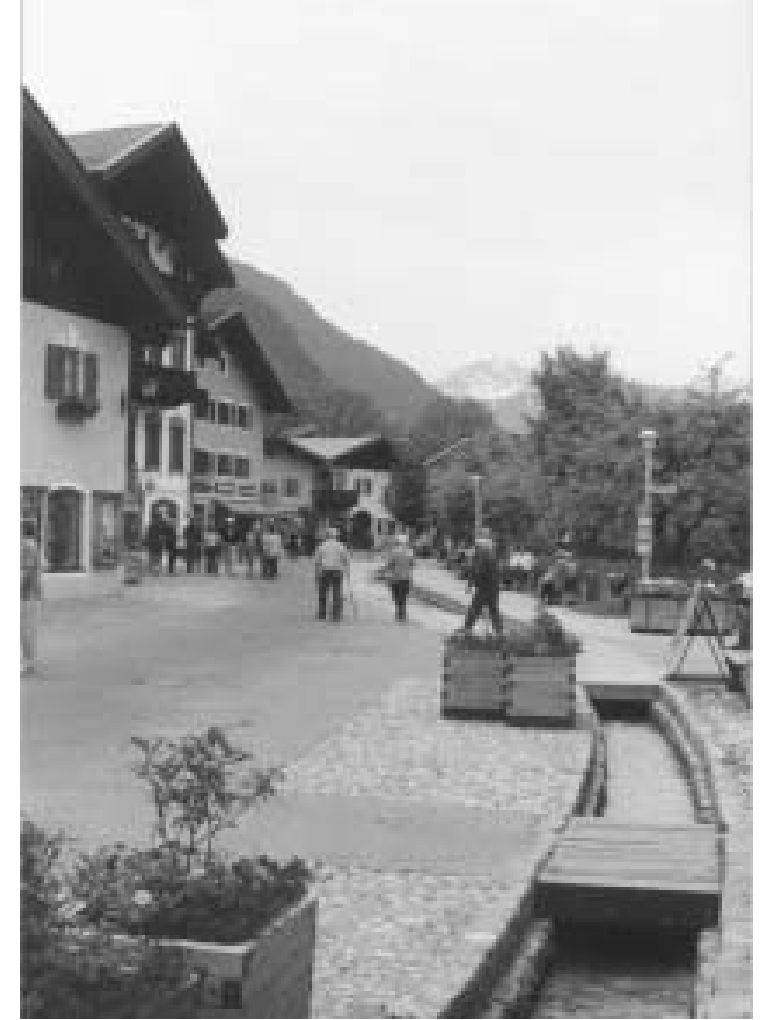

Abb. I-7: Städtebauliche Integration eines kleinen Gewässerlaufes in der Stadt

Imitation bzw. Rekonstruktion der früheren Bedeutung als offener Mühlenkanal in Mittenwald. Ähnliche Beispiele wurden im Rahmen der städtebaulichen Erneuerung verfolgt in Höxter oder auch in Bad Segeberg, hier als integrales Element in einer kleinen innenstädtischen Wohnneubebauung (eig. Aufnahme 2002).

8. Politikorientierte und gesetzgeberische Mitwirkung

Einen weiteren Aspekt einer möglichen Einflussnahme bzw. Mitwirkung stellt die politikorientierte Mitarbeit bei der Gesetzgebung und bei der Vergabe von Fördermitteln dar. 
9. Geschichte der Gewässerkultur

Bei diesem Beschäftigungsfeld geht es um die Mitwirkung bei der so wichtigen Aufgabe der Bewahrung des kulturhistorischen Landschaftserbes durch historisch-geographische Aufklärung und Sensibilisierung. Für den Gewässerbereich bedeutet dies beispielsweise die Darstellung der Kulturgeschichte der Gewässernutzungen und schließt medizinhistorische Aspekte wie z. B. die Geschichte der Heilquellen mit ein.

10. Darstellung der Nutzungsgeschichte

Die vielgestaltigen wirtschaftsgeschichtlichen Nutzungen und Benutzungen von Gewässern stehen hier im Mittelpunkt. Der Lernbereich aus dieser Thematik ist ähnlich dem der rein kulturellen Vermittlung von Gewässergeschichte, legt aber seinen Schwerpunkt auf die Darstellung der Wirtschaftsgeschichte (Transport und Verkehr, Fischerei etc.).

\section{d Forschungsgegenstand und Erhebungsraum}

Forschungsgegenstand und Erhebungsraum einer mitteleuropäischen historisch-geographischen Gewässerforschung sind die persistenten, reliktären wie auch fossilen Fließ- und Stillgewässer und die aus ihnen resultierenden künstlichen Gewässerformentypen und Gewässerbauelemente in verschiedenen naturräumlichen Einheiten Deutschlands und seiner Nachbarländer. Der Verfasser hält es für erforderlich, wenn die gewässerhistorischen Elemente schon nicht mehr in der Landschaft zu sehen sind, dass sie dann wenigstens nachzulesen sein müssen (vgl. SEEDORF/MEYER 1996:7). Damit ist die Hoffnung verbunden, dass sie nicht endgültig in Vergessenheit geraten - die Elemente ehemaliger Wirtschaftsweisen.

In Veränderung der wüstungsgeographischen Definition von BORN (1977:23) ${ }^{28}$, strebt die historischgeographische Gewässerforschung die systematische Erfassung von Gewässerrelikten an, die die Rekonstruktion von Fluss- und Kulturlandschaften früherer Zeiten gestatten; sie achtet so nicht nur auf die Spuren teichwirtschaftlicher, d. h. landwirtschaftlicher Nutzflächen und gewässergebundener Wohnplätze, sondern kartiert auch die Reste alter Teiche, Gräben und Kanäle und verschwundener oder nicht mehr genutzter fischereiwirtschaftlicher Einrichtungen. Im Zuge des Flurbereinigungsverfahrens beispielsweise sind „Graben- und Bewässerungssysteme [..] verfallen und zugeschüttet“ (DENECKE 1989b:203f.) und verdienen ier historisch-geographische Aufmerksamkeit. Aber auch „Schlackenplätze ehemaliger Hütten sind letztlich Altlasten, ,stoffliche Einträge' oder Ablagerungen von Fremdstoffen, die bei der Nutzung durchfließender Gewässer Beachtung finden müssen.“ (:203) und gehören zum, wenn auch eher randlichen, Forschungsspektrum einer gewässerhistorischen Umweltforschung.

Als vorteilhafte Untersuchungsgebiete gelten Gebiete regressiver, peripherer Altlandschaften oder Traditionslandschaften (Begriff nach DENECKE 2000:210), in denen gewässerhistorische Elemente noch vorhanden sind: „Zu diesen Landschaftsbereichen mit hervortretender kulturhistorischer Bedeutung“ gehören „Wässermatten, Teichlandschaften“ (:211) und weitere gewässerbezogene Landschaften wie beispielsweise alte Schifffahrtskanäle mit ihren Treidelpfaden, Weidenkulturen in Auenbereichen usw.

Dennoch bieten auch siedlungsstruktrurell überformte Untersuchungsgebiete noch Gelegenheit zur gewässerhistorischen Forschung und sind aufgrund ihrer besonders komplexen, nur noch rudimentären Situation von besonderem planerischen Reiz und Interesse; veranschaulichen gerade sie in besonderer Weise die sukzessive, wenn auch in wesentlichen Teilen gar überstürzende Überformung unserer Landschaft: „Ziel im Rahmen einer historisch-geographischen Kulturlandschaftspflege ist die Herausstellung der funktionalen wie auch ökologischen Einheit in ihrer historischen Tiefe, auch und gerade wenn es zu einer Aufgabe und Umnutzung kommt.“(DENECKE 2000:210)

\footnotetext{
${ }^{28}$ BORN hat nach eigener Aussage (1977:23) seine Definition in Anlehnung an DENECKE 1969 und DÜSTERLOH 1967 geschrieben, die aber, um es nicht unübersichtlich werden zu lassen, hier der Vollständigkeit halber nur als Fußnote erwähnt werden.
} 
„Um einem eventuellen Mißverständnis vorzubeugen: Die methodische Reflexion über den Forschungsstand und die verwendeten Begriffe sind substantiell.“

[REITH 1996:13]

\section{Stand der gewässerhistorischen Forschung}

In diesem Kapitel soll ein Literaturüberblick über die Beschäftigung mit dem Umweltmedium Wasser in historischer Sicht gegeben werden. Dabei wird kategorisch unterschieden in die folgenden Teilbereiche:

1. wissenschaftliche Forschung, mit der hauptsächlich die Grundlagenforschung und die Geländeforschung gemeint sind,

2. Heimatforschung und populärwissenschaftliche Forschung, die bisweilen auf so hohem Niveau arbeitet, dass eine Zuteilung schwer fällt und nur deshalb in diese Kategorie vorgenommen werden muss, weil sie nicht institutionell verankert ist,

3. Forschungen zur Landschaftsplanung. Hierunter sind Beispiele aus der Planungspraxis zu verstehen,

4. rechtswissenschaftliche Forschungen. Sie betreffen juristisch deklarierte Arbeiten auf dem Gebiet des kulturhistorischen Gewässerschutzes und der Gewässerpflege,

5. Beiträge aus dem Ausland zur historischen Gewässerforschung.

Innerhalb dieser Kategorien wird nach thematischer Schwerpunktsetzung klassifiziert, um eine Vorstellung von der Bandbreite der Forschung zu bekommen. Die regionalen Schwerpunkte der Forschung ergeben sich aus den jeweiligen thematischen Literaturnennungen. Eine gesonderte regionale Gruppierung würde eine Wiederholung dieser Literaturbeispiele lediglich unter einem anderem Gliederungspunkt bedeuten.

Es kann hier unter anderem aus Zeit- und Platzgründen nicht „eine Reflektion der Gesamtentwicklung“ der gewässerbezogenen Forschung, ,in Deutschland wie auch in Europa“ anhand von Publikationen unternommen werden, wie es DENECKE (2001:272) in seiner Darstellung der siedlungs- und kulturlandschaftsgenetischen Forschung getan hat. Allein aufgrund des Themenspektrums können nicht alle für die gewässerhistorische Forschung bedeutsamen Untersuchungen und Abhandlungen vorgestellt werden.

Hier kann es nur um einen Ausschnitt aus der zu diesem Themenbereich vorliegenden Publikationen gehen. Und dieser Querschnitt soll - dies ist der Anspruch - aus den nach Meinung des Verfassers essentiellen Arbeiten zu diesem Forschungsgebiet bestehen. Gleichzeitig wird daraus das breite Spektrum der Beschäftigung mit dem Thema „Gewässer aus historischer Sicht“ deutlich. Die Zusammenstellung und Kommentierung der vorliegenden Arbeiten kann gleichzeitig „als Grundlage für einen forschungsgeschichtlichen Überblick“ dienen (DENECKE 2001:285).

Es geht, zusammenfassend betrachtet, ,um eine strukturierende Information“ (DENECKE 2001:272) der beteiligten Fächer und Themenfelder im Bereich der gewässerbezogenen Kulturlandschaftsforschung. Erst aus der Vielzahl der unterschiedlichen Betrachtungsperspektiven und Fragestellungen wird das breite Spektrum der historischen Gewässerforschung deutlich.

\section{Wissenschaftliche Forschung}

Alle populären Hand- und Lehrbücher, die eine Einführung in die Problematik „Wasser“ geben sollen, dies sei vorausgeschickt, lassen die historische Dimension vermissen. Kann dies bei der von KELLER bereits 1961 verfassten Einführung in die Hydrogeographie „Gewässer und Wasserhaushalt des Festlandes“ aufgrund der $\mathrm{zu}$ diesem Zeitpunkt noch nicht aktuellen Problematik auch nachvollzogen werden, so schließen weder das von Hans Reiner BÖHM und Michael DENECKE 1992 herausgegebene Werk „Wasser: eine Einführung in die Umweltwissenschaften“, noch in dem von FRIMMEL 1999 herausgegebenen Handbuch „Wasser und Gewässer“ diese Lücke. 
Positiv fällt da ein biologisches Bestimmungsbuch auf, das - entgegen des Bandtitels, aber in Erwartung der Mitherausgeberschaft - eben nicht nur „Biologisches“ beinhaltet. In dem von HUTTER/KONOLD/ SCHREINER 1996 herausgegebenen Band „Quellen, Bäche, Flüsse und andere Fließgewässer: Biotope erkennen, bestimmen, schützen" der Reihe Biotop-Bestimmungsbücher informiert über die natur- und kulturgeschichtliche Bedeutung der Fließgewässer, schildert die Wassernutzung und Wasserbauten in früheren Jahrhunderten und beschreibt die zahlreichen Fließgewässer-Biotoptypen, ihre Verbreitung und ihre ökologische Bedeutung. Maßnahmen für den Schutz werden aufgezeigt. In gleicher, die kulturhistorische Komponente berücksichtigenden Weise tat dies auch der zuvor von nahezu identischer Autorenschaft in der gleichen Reihe erschienene Band zu den nicht fließenden Gewässern (HUTTER/KAPFER/KONOLD „Seen, Teiche, Tümpel und andere Stillgewässer“, 1993).

Natürliche Flussgeschichte

Ganz weit zurück in erdgeschichtlicher Zeit geht René HANDTKE mit seiner „Flußgeschichte Mitteleuropas“, in der er sich an ausgewählten Beispielen ,großer mitteleuropäischer Flußsysteme“ (1993:V) mit der erd-, vegetations- und klimageschichtlichen Entstehungsgeschichte von Flussläufen der letzten 40 Millionen Jahre befasst. Frühe Abhandlungen zu diesem Thema haben Carl-Wilhelm SCHMIDT (1918) und Robert GRADMANN (1932), dieser mit einem Beitrag zu den „Flußtälern im Urzustand“, geliefert.

Während sich die drei genannten mit den Fließgewässern beschäftigt haben, beschreibt JUNG (1990) die natürliche, d. h. vom Menschen unbeeinflusste, Landschaftsgeschichte der Seen. Mit den spät- und postglazialen Flussaktivitäten im Bereich - vor allem des mittleren und südlichen - Schwarzwaldes und des Oberrheintales setzt sich MÄCKEL $(1991,1992)$ auseinander.

Flusslaufveränderungen

Weitere Forschungsansätze stehen im Zusammenhang mit anthropogen-morphogenetischer Flussgeschichte, d. h. wie der Mensch die Natur - in diesem Sinne die Gewässer - im Laufe der Zeit geformt hat. Es geht hierbei in der vorliegenden gewässerhistorischen Literatur vordergründig um historisch fluviale, also geomorphologische Flussbettveränderungen und die daraus erwachsenden Fließformen, die zum größten Teil anthropogener Natur sind.

KÜHNERT hat 1936 im Rahmen seiner Dissertation den Versuch unternommen, die morphogenetische Entwicklungsgeschichte der mittleren Saale zu beschreiben. JÄGER beschäftigte sich 1951 mit den mittelalterlichen Veränderungen der Auen- und Flussbetthöhen aus anthropogen verursachten Sedimentationsauftragungen am Beispiel des Werragebietes. Von HEINE liegt eine an der Universität Bonn 1968 abgefasste und 1970 veröffentlichte Dissertation zur geomorphologischen „Fluß- und Talgeschichte“ des Marburger Raumes vor.

Die Untersuchungen zu historischen Stromverläufen und -verlagerungen wurde Mitte der 1990er Jahre in der ingenieurwissenschaftlichen Disziplin wieder aufgegriffen (KERN 1996), nachdem sich Renate GERLACH (1990) in ihrer historisch-anthropogeographischen Monographie mit den flussdynamischen Veränderungen des großen Mainlaufs unter der Einwirkung des Menschen befasste.

Die Veränderungen eines Rheinabschnitts in historischer Zeit, den zwischen Wupper- und Düsselmündung, hat eindrucksvoll Rudolf STRASSER $(1989,1992,1993)$ für den Zeitraum seit der Römerzeit beschrieben. Zur Genese der Rheinauen liegen dazu Arbeiten von GALLUSSER/ SCHENKER (1992) und DETTEN (1994) vor.

Auch die Auswirkungen technischer Maßnahmen durch Flusskorrektionen auf die Pflanzendecke wurden von REICHELT (1996) am Oberrhein nachgewiesen.

Frühere Zustände der Rheinniederung für drei Stromabschnitte zwischen Karlsruhe und Speyer anhand von Rheinstromaltkarten aus den Jahren 1595, 1700, 1817 und 1880 legte Heinz MUSALL 1969 in einer umfangreichen geographisch-morphologischen Untersuchung vor. Ebenso wirkte MUSALL an einer Ende der 1980er Jahre durchgeführten Ausstellung der Badischen Landesbibliothek mit, die den „Neckar in alten Landkarten" thematisiert hatte (RÖMER 1988). 
Die Bedeutung der Kartographie für die gewässerhistorische Rekonstruktion und Forschung verdeutlichen auch andere Veröffentlichungen: Der 1990 aus einer Museumsausstellung hervorgegangene, von MEYER herausgegebene und von HARMS verfasste (1990) Band „Oldenburg und das Wasser“ enthält historische, kommentierte Karten, die die Küste und Flüsse dieses Gebietes betreffen. Dabei werden vergleichende Veränderungen dargestellt. „Auch Hochwasserschutz- und Flußschiffahrtsbelange sind berücksichtigt, ebenso die Kanäle und Moore“ (Klappentext). In ähnlicher Weise dokumentiert der vom Magistrat der Stadt Wien herausgegebene und von MOHILLA/MICHLMAYR (1996) verfasste "Donauatlas Wien“ die „Geschichte der Donauregulierung auf Karten und Plänen aus vier Jahrhunderten“

Einen Abriss der geschichtlichen Fischerei am Oberrhein bis zur Tulla'schen Rheinkorrektur sowie einen umweltgeschichtlichen Beitrag zur „Umgestaltung der hydrologischen Verhältnisse durch die Rheinkorrektion und ihre Auswirkungen auf die Fischerei einschließlich einer Darstellung der „Flussbaumaßnahmen am Oberrhein im 20. Jahrhundert" gibt KUHN in seiner Abhandlung, die als Heft 83 in der Schriftenreihe der Universität Hohenheim 1976 erschienen ist. Neben der historischen Entwicklung gibt er aber auch eine „Analyse der gegenwärtigen Lage der Fischerei“ (KUHN 1976:7). Es folgen Untersuchungen über die Ursachen der kontinuierlichen Gewässerverschmutzung sowie über die Aalschockerfischerei ${ }^{1}$. Eine weitere, aus einer Museumsausstellung hervorgegangene, Arbeit zur Rheinregulierung liegt von BERGMEISTER/LEIPOLD-SCHNEIDER (2000) vor, die den Eingriff des Durchstichs auf einem Teilbereich von 1900 bis heute dokumentieren.

Ein der Literatur über Flussmorphologie und -korrekturen bzw. -regulierungen vergleichbares Schrifttum über die kulturhistorische Morphologie kleinerer Fließgewässer gab es noch vor 10 Jahren nicht (vgl. auch die Aussage der FORSCHUNGSGRUPPE FLIESSGEW ÄSSER 1993:25f.).

Ausnahmen bildeten GARLEFF (1985), der „Untersuchungen zur vorzeitlichen Bodenerosion im Einzugsgebiet des Ellerbaches östlich von Bamberg" vorgenommen hat, MÜHLETHALER (1985; siehe Abb. 1 aus LEIBUNDGUT 1986:155), der sich mit der zeitgeschichtlichen Zerstörung von kleinen Nebengewässer in der Schweiz beschäftigte, indem er methodisch einen Zeitschnitt am Beispiel der mittleren Emme zwischen Zollbrück und der Einmündung des Fännersmülibaches anlegte, und SCHWEINFURTH (1990), der die ,anthropogene Geomorphologie“ am Beispiel der Murg im Nordschwarzwald untersuchte.

Mittlerweile hat sich die Situation weiter verbessert, insbesondere die kulturhistorische Nutzung der Fließgewässer betreffend: $\mathrm{Zu}$ nennen sind ONGYERTH (1995) mit seiner historisch-geographischen und freilandmuseumsdidaktischen Betrachtung der Würm, SCHNEIDER (2000) mit seiner Dissertation zu „Landschafts- und Umweltgeschichte im Einzugsgebiet der Elz“, JUSCHUS (2002), ,zur Flussgeschichte der Dahme“ und SEILER (2002) mit seiner Untersuchung der ,historischen Laufentwicklung der Aller zwischen Müden und Celle“.

Entsorgung

In der Historischen Umweltforschung hingegen stehen oft die historische Gewässerverschmutzung und die Abwasserfrage im Vordergrund.

Neben einem vom Anthropologen Bernd HERRMANN 1989 herausgegebenen Band ist ein Aufsatz von Johann PAUL (1989:55-78) hervorzuheben, in dem an einem Fallbeispiel die Flussverschmutzungen am Beispiel der Sieg im 19. und 20 Jahrhundert vorgestellt werden. PAUL veröffentlichte im Übrigen weitere Fälle von historischer Wasserverschmutzung (1992, 1994, 1999). Dies taten ebenso SIMSON (1978) und RADKAU (1986).

\footnotetext{
${ }^{1}$ Die Aalschocker sind massive Schiffe ohne eigenen Antrieb. Im Frühjahr wurden sie von Schleppern auf ihre Fangplätze bezogen, die sie in der Regel die ganze Saison über beibehielten. Die Fischerei mit dem Schockernetz nutzte die Tatsache aus, dass sich die auf der Laichreise zum Meer befindlichen Aale in der stärksten Strömung flussabwärts treiben lassen. Besonders stark ist die Strömung dort, wo die Fahrrinne nahe an das Ufer kommt und in einem Bogen wieder der Strommitte zustrebt. An diesen Stellen befanden sich auch die Fangplätze der Schocker. Das trichterförmige, etwa $30 \mathrm{~m}$ lange Schockernetz wurde durch eine am Mast angebrachte Haltevorrichtung seitlich in den Strom eingelassen. Von einem Nachen aus wurde die Beute dem Schlusssack entnommen (KUHN 1976:79).
} 
Ebenso verdient der Beitrag von Tim ARNOLD (1987) die Aufnahme in diese Aufzählung. Obwohl im Rahmen eines Schülerwettbewerbes „Umwelt hat Geschichte“ entstanden, stellt er in seiner beispielhaften Studie die Nutzung der Wupper im Kaiserreich als Trink-, Brauch- und Abwasserkanal dar.

1992 haben Franz-Josef BRÜGGEMEIER und Thomas ROMMELSPACHER eine Geschichte der Umwelt im Ruhrgebiet vorgelegt. Die fast ausschließliche Behandlung industrieller Emissionen wird jedoch dem Anspruch des Buches, eine Umweltgeschichte des Ruhrgebietes darzustellen, nicht gerecht, fehlen doch monographische Arbeiten zur Gewässerverschmutzung in diesem Band völlig.

Das historische Entsorgungsverhalten ist aber einem von der STADTENTWÄSSERUNG ZÜRICH 1992 herausgegebenen Band „,von der Schîssgruob zur modernen Stadtentwässerung“ zu entnehmen. In dieser reichhaltigen, allgemeinverständlichen Abhandlung über den Werdegang des Wassers im Dienste des Menschen bietet zudem einen umfassenden, ins Altertum zurückreichenden historischen Exkurs.

Am Beispiel der häuslichen Wäschepflege des 18. Jahrhunderts belegt Barbara ORLAND (1991) die ökologische Krise, die die Wascharbeit am und im Gewässer für dieses Medium verursacht hat. Ebenso beschreiben verschiedene Autoren „Die Große Wäsche im Rhein“. Als eher volkskundliche Aufsätze innerhalb eines Bandes anlässlich einer Ausstellung des Landschaftsverbandes 1988 zum gleichnamigen Thema zeigen sie die verschiedenen Arbeitsverfahren der Wäsche und des Bleichens. Während der Waschvorgang im Fluss bzw. am Flussufer geschah, wurde anschließend die Wäsche zum Weißen auf der nahen Uferwiese ausgebreitet.

Die Vielzahl an Publikationen zur frühen Gewässerverschmutzung legen den Verdacht nahe, es wäre in Gewässer nur emittiert, Wasser nur ver- und entsorgt sowie anderweitig benutzt worden. Aus dem Betrachtungsansatz der historischen Ökologie liegt dazu eine Gegendarstellung vor. Eine inhaltsreiche Monographie von Leopold und Roma SCHUA (1981) über die Geschichte des Gewässerschutzes seit der Antike.

Neben der eher geschichtswissenschaftlichen bzw. volkskundlichen Umweltanalyse von Gewässern anhand schriftlicher Belegquellen wurden historische Gewässerforschungen mit dem methodischen Instrumentarium der Physischen Geographie durchgeführt: So wurden beispielsweise als Forschungsmethode für ein Forschungsvorhaben am Göttinger Geographischen Institut zur Ermittlung von historischen und neuzeitlichen Umwelteinwirkungen durch den ehemaligen Harzer Bergbau und die Nordharzer Hüttenindustrie in Fließgewässerökosystemen, die „Feinstratigraphie der Gewässerauensedimente mittels Auelehmprofile“ bestimmt und das Ergebnis durch pollenanalytische Datierungen erhärtet (NIEHOFF/PÖRTGE 1993; NIEHOFF 1996).

Versorgung

Ein weiterer umfangreicher Themenkomplex zur Gewässergeschichte behandelt die Wasserversorgung.

Eine andere Ausstellung des Landschaftsverbandes Rheinland beschäftigte sich 1991 nicht mit der „niederen“ Wassernutzung infolge häuslicher Pflegearbeit und der dadurch bedingten Gewässerverschmutzung wie oben vorgestellt, sondern mit der ,höheren“ Inwertsetzung als Mineralquelle und als Heilbad, die als „Wasserlust“ empfunden wurde.

In ökologisch-kritischer Sicht betrachten KLUGE/SCHRAMM (1986) in ihrem Buch „Wassernöte“ die Abfolge der Trinkwasserversorgung von der Brunnenversorgung der frühen Neuzeit bis zu den zentralen Wasserversorgungstechniken der Gegenwart.

Hochwasser

Nöte bestanden aber auch in anderer Hinsicht: nicht ein Zuwenig, sondern ein Zuviel stellte in früherer Zeit ein ebenso großes Problem dar.

Dem Thema „Historische Hochwasser“ hat sich - im Vergleich zu den zumeist erst später veröffentlichten Arbeiten von DEUTSCH und PÖRTGE (siehe unten) - Ulrich HENKE (1997/98) in seiner von DENECKE betreuten Diplomarbeit gewidmet. Unter dem Titel „Hochwassermarken an der Weser und ihre historischumweltgeographische Interpretation“ hat er nicht nur die historischen Pegelstände entlang der Weser 
untersucht und eine Vielzahl von statistischen Messdaten bzw. -reihen, zum Beispiel der Wasserwirtschaftsämter, ausgewertet und mit den Pegelmarken abgeglichen, sondern auch die kulturhistorischen gewässerbezogenen Elemente der Hochwassermarkierungen (Pegelmarken, -pfähle und türme) in seiner Untersuchung mit dargestellt. Im Jahr 1997 ist auch die anwendungsorientierte Analyse von Andreas GEES „historischer und seltener Hochwasser in der Schweiz“ erschienen. Ein Jahr später veröffentlichte GLASER (1998), aufbauend auf der ,Historischen Klimadatenbank Deutschland (HISKLID)' zum Thema der „historischen Hochwässer im Maingebiet““.

Eine von der VDG [VEREINIGUNG DEUTSCHER GEWÄSSERSCHUTZ] 2003 herausgegebene Broschüre beschäftigt sich vor dem Hintergrund der Ereignisse im Sommer 2002 an Elbe, Moldau, Mulde und Donau mit dem „Hochwasser - Naturereignis oder Menschenwerk?“ In der Broschüre werden die „vielfältigen Faktoren und Zusammenhänge, die bei der Entstehung von Hochwasser eine Rolle spielen“ (:3), behandelt. In Kapitel 3 wird einem „Rückblick - Hochwasser früher“ beleuchtet.

Historische Hochwässer sind vor allem das Spezialthema von Karl-Heinz PÖRTGE, Professor für Physische Geographie an der Universität Göttingen. In zahlreichen Veröffentlichungen, zumeist in Zusammenarbeit mit Mathias DEUTSCH, hat er historische Hochwasserereignisse, schwerpunktmäßig in Thüringen, untersucht (z. B. 2001a,b; 2002a,b,c). PÖRTGE hat sich dem historischen Thema aus der länderkundlichen Bearbeitung von Hochwässern in außereuropäischen Ländern angenähert, während DEUTSCH als Projektmitarbeiter im Rahmen des BMBF-Projektes „Klimavariabilität und Signalerkennung“ die „Untersuchung Historischer Hochwasser in Deutschland (1500-1900)“ an dem Geographischen Institut der Universität Erfurt durchführte. Ziel der Erfurter Forschungen war es, mit Hilfe historischer Quellen Aussagen zum Hochwassergeschehen im Zeitraum 1500-1900 zu gewinnen, um Daten für die Klimaforschung, für die Wasserwirtschaft - insbesondere zur Abschätzung von Hochwasserrisiken (u. a. Einbeziehung historischer Daten für mathematisch-statistische Modelle zur Berechnung der Eintrittswahrscheinlichkeit außergewöhnlicher bzw. katastrophaler Hochwasser) -, zur Ermittlung verbürgter historischer Überschwemmungsbereiche, für den Katastrophenschutz (Krisenmanagement) sowie für sozialgeschichtliche Untersuchungen (Umgang des Menschen bzw. der Gesellschaft mit derartigen Naturkatastrophen, Aktions-Reaktionsmuster) zu gewinnen.

Weitere Betrachtungen zum Thema „Hochwasser als historisches Phänomen“, vor allem in Zusammenhang mit den darauf folgenden Maßnahmen zum Hochwasserschutz, liegen von Martin SCHMIDT vor (2000, 2002).

Unter dem Leitthema „Fluß und Lebensraum“ wurde in der Veröffentlichung zur gleichnamigen Jahrestagung des DVWK des Jahres 1984 an drei großen Stromgebieten - Rhein, Donau und Nil - ,das Zusammenwirken von Mensch und Fluß im Laufe der Jahrhunderte und Jahrtausende mit seinen positiven und negativen Aspekten dargestellt." (DVWK 1984:V) Dabei reicht die Spanne von historischen Hochwässern bis hin zu Flusskorrektionen. Hieraus sind für den mitteleuropäischen Raum folgende Beiträge hervorzuheben: Im Beitrag von BINDER mit dem Titel „Der Lech zwischen Landsberg und Augsburg Umgestaltung einer süddeutschen Flusslandschaft in den letzten 100 Jahren" wird am Beispiel des süddeutschen Alpen- und Donauzuflusses Lech im kurzen Kapitel „Lechkorrektion“, die Korrektion im Laufe des 19. Jahrhunderts und ihre ökologisch nachteiligen Folgen beschrieben und er bezieht in seinen Ausführungen ausdrücklich die Aue mit ein (:26). KRESSER zeigt im Kapitel seiner Ausführungen zur Donau als Verkehrsweg den historischen Weg „Vom Floß zum Dampfschiff“ (Kap. 3.1:123-134) auf und beschäftigt sich in einem weiteren Beitrag mit dem „Ausbau zu europäischen Wasserstraße“ seit dem ersten Drittel des 19. Jahrhunderts (Kap. 3.2:134-142). Und schließlich setzt sich der Beitrag von HEYENBROCK mit dem „Hochwasserschutz bayerischer Städte“ zunächst auch aus geschichtlicher Sicht auseinander: in Kapitel 2 „Die Flusskorrektionen des 19. Jahrhunderts“ (:187-190) und in dem thematisch interessanten Kapitel $3 \mathrm{zu}$ den „Anfängen des Hochwasserschutzes in der Landeshauptstadt München“ (:190-192). Insgesamt aber handelt es sich nur um sehr kurze Darstellungen und sie sind insofern hier nur erwähnenswert, als dass es sich um eine „frühe“ Integration gewässerhistorischer Thematik in eine Fachtagung handelt.

Ein in gewässerhistorischer Sicht besonderes Werk ist die von REINHARDT (1984) herausgegebene Veröffentlichung über die „erschreckliche Wasser-Fluth“ des Jahres 1634 im nordfriesischen Küstengebiet, 
zusammengetragen aus zeitgenössischen Berichten und Dokumenten, um „dem interessierten Leser mit den Worten der Chronisten jener Jahre [...] die Empfindungen und Beobachtungen der damaligen Zeitgenossen vor Augen zu führen“ (:7). Neben zwei zeitgenössischen Berichten ist darin der Beitrag von ZITSCHER (:149-202) hervorzuheben, in dem er die Auswirkungen der Sturmflut auf das unmittelbare Erlebnis des Einzelnen, auf die Prägung des Menschen, beschreibt und seine daraus hervorgehenden Bestrebungen und bautechnische Erkenntnisse hinsichtlich Bedeichung, um so den Bedrohungen des Küstenraumes zu begegnen (:153ff.). Das „dominierende Motiv“ seiner Arbeit stützt sich „,auf das durch die Sturmfluten seit Beginn des 17. Jahrhunderts bestimmte Geschehen:“ Dafür bedient er sich auch bildhaften Materials (149; siehe III 1.f).

Dem Thema „Sturmflut“ in norddeutschen Küstengebieten hat sich ebenso JAKUBOWSKI-TIESSEN in einigen Veröffentlichungen gewidmet $(1992,1999)$. Sowohl die Erfahrungen mit der Sturmflut von 1717 als auch mit der von 1825 hat er hinsichtlich ihrer Wahrnehmung und Deutung untersucht und damit einen interessanten Beitrag zur gewässerbezogenen Katastrophenforschung geleistet.

In diesen Zusammenhang passt vielleicht auch das Buch von UPHOFF „Die Deicher“ (1995). „Dieses Buch beschäftigt sich mit den Deichern der frühen Neuzeit. Der arbeitende Mensch steht dabei im Vordergrund. Analysiert werden die Grundlagen massenhafter Deicharbeit, die Arbeitsorganisation und die Lebensbedingungen der Arbeiter am Deich. Ihr Widerstand gegen die Mißstände auf den Deichbaustellen ist neben ihrem Selbstverständnis das Untersuchungsthema des Autors. Es entsteht eine vergleichende Sozialgeschichte der Deicharbeit in der Region zwischen Weser und Ems während des 17. und 18. Jahrhunderts.“ (Verlagsbeschreibung), die hier aufgrund ihres einer wissenschaftlichen Fragestellung genügenden sozialhistorischen Ansatzes diesem Bereich zugeordnet werden kann.

Wasserwirtschaft/Wasserbau

Rolf MEURER, ehemals Abteilungsdirektor bei der Bezirksregierung Trier, versucht, ,das große Gebiet des Wasserbaus und der Wasserwirtschaft in Deutschland von seinen geschichtlich halbwegs gesicherten Anfängen bis in unsere Tage darzustellen“ (2000:Vorwort). Beginnend in der Römerzeit wird die Nutzung des Wassers durch den Menschen als lebenserhaltendes Element ebenso behandelt wie der nie endende Kampf gegen bedrohliche Erscheinungsformen: Sturmflut und Hochwasser. Auch dem Wasser als Verkehrsweg und Energiespender wird breiter Raum gewidmet.

Eine fundierte landesgeschichtliche Darstellung der historischen Entwicklung der Wasserwirtschaft und des Wasserbaus in Bayern hat das dortige Amt für Wasserwirtschaft in Zusammenarbeit mit der Technischen Universität München 1981 herausgegeben.

Der unter einem irreführenden Namen veröffentlichte Sammelband zur Natur- und Umweltgeschichte der Stadt Osnabrück thematisiert unter systematischer Auswertung zahlreicher zeitgenössischer Zeitungsartikel unter anderem die Geschichte der Gewässer dieser Stadt (BECKER 1991).

Aus Berlin liegt eine Geschichte der Wasserversorgung vor, die Hilmar BÄRTHEL 1997 im Auftrag der Berliner Wasser-Betriebe verfasst hat. Aus gewässerhistorischer Sicht ist vor allem im ersten Drittel seines Buches die Darstellung der frühen Wassergewinnung und -versorgung interessant.

Alte Welt/Antike

Unter gleicher Thematik hat Albrecht HOFFMANN (1995) hat eine Aufsatzsammlung zur ,,antiken und mittelalterlichen Wasserversorgung in Mitteleuropa“ herausgegeben. Zur antiken Wassergeschichte der semiariden Mittelmeerräume liegen weitere interessante Veröffentlichungen vor, wie die kulturgeschichtliche Untersuchung von dem Finnen SALONEN (1970) zur „Fischerei im alten Mesopotamien“ oder die noch im VEB Verlag für Bauwesen erschienene Schrift von WÖLFEL zum „Wasserbau in den alten Reichen“. Hier liegt eine mit zahlreichen Zeichnungen versehene ingenieurorientierte Studie über Wasserbau bei den Chinesen, im Vorderen Orient und Ägypten sowie bei Griechen und Römern vor, die Darstellungen zu Brücken, Kanälen, Häfen, Stauanlagen und zur Wasserversorgung umfasst.

Die Archäologin Renate TÖLLE-KASTENBEIN (1990) stellt in ihrem Band „Antike Wasserkultur“ die Methoden, mit denen griechisch-römische Ingenieure eine funktionierende Wasserversorgung und entsorgung der antiken Städte planten. Neben Quellen, Brunnen und Leitungen stellt sie auch Vorrats- und 
Verteileranlagen, mit Wasserkraft betriebene Instrumente und Maschinen, Wasserarchitektur und symbolträchtige Wasserbauten vor. Sie möchte mit ihrer Arbeit vermitteln, wie Griechen und Römer mit dem Kulturgut Wasser umgingen. Sie behandelt das ,tägliche Wasser in der Antike', wie sie schreibt. „Nicht behandelt werden Wasserverkehr, Wassertransport, Schiffahrt und Häfen, Wasser- und Flußregulierungen, Wassertiere, Fischzucht und Landwirtschaft, Wassersport, Piscinae, Bäder oder Thermen und auch nicht die dem Wasser zugeschriebenen Heilkräfte“ (:9). Ihre Studie bezieht sich „vor allem auf die Kultivierung von Trink- und Brauchwasser, auf deren An- und Verwendung, auf Einsatz und Schutz, auf Ansehen und Einschätzung des Wassers“(:9) innerhalb der griechisch-römischen Kulturepoche.

Marga WEBER, Lehrbeauftragte am Archäologischen Institut der Universität Frankfurt, zeigt den von TÖLLE-KASTENBEIN ausgesparten Aspekt der klassischen Antike: die Badekultur der männlichen und weiblichen (!) Griechen und Römer auf, die bei diesen Kulturen eine unterschiedliche Bedeutung hatten: bei den Griechen als sportliche Trainingsstätte, bei den Römer eher als Vergnügungsstätte (1996:10).

Dass das Element „Wasser“ in den Mythologien und Religionen der meisten Kulturen - auch noch bis in die Mitte des 19. Jh. in Europa, als dieses Denken ein Ende fand - von zentraler Bedeutung war, und Gewässer, vor allem als Quellen, als Heiligtum verehrt wurden, beschreibt die „Symbolforscherin“ Sybille SELBMANN (1995) in ihrem Buch von der „Symbolik und Kulturgeschichte“ des Wassers. Nicht auf die heutige gefährdete Situation des Wassers konzentriert sich diese Untersuchung, sondern auf dessen „uralte und dennoch ungebrochen aktuelle symbolische Bedeutung“ (:7). „Die vorliegende Untersuchung spannt einen Bogen vom Wasser als Ursprung des Lebens, vom Lebens- und Todeswasser, vom Wasser als Sinnbild der Wiedergeburt, als Mittel und Symbol der Reinigung und Heilung, als Zeichen des Kreislaufs und der Vergänglichkeit über das Wasser als Symbol des menschlichen Lebens, der Seele und der Liebe bis hin zum Wasser als Quell der Weisheit und der schöpferischen Tätigkeit“ (:7). „Erstmals im deutschen Sprachraum wird versucht, interdisziplinär in so breitem Spektrum die symbolische Bedeutung des Wassers in Mythen, Märchen und Träumen, in Religion, Dichtung, Kunst und Musik sowie in Volksbräuchen und Redensarten darzustellen.“(:7)

Zur Rheinmythologie sind die Museumsbände von GASSEN und HOLECZEK (1992) erschienen und die mythologische Bedeutung des Rheins hat auch SMETS (1998) beschrieben.

Technikgeschichte

Zurück in die Gewässerneuzeit der „Neuen Welt“: Hier wird vor allem die mehr technische Nutzungsgeschichte rezipiert. Aus technikgeschichtlicher Sicht haben FÖHL und HAMM (1985) dazu die „Industriegeschichte des Wassers“ vorgelegt. Es handelt sich dabei um eine populäre, aber ingenieurtechnisch-ästhetisierende Gesamtdarstellung der Geschichte der Industrialisierung der Wassernutzung.

Lars U. SCHOLL (1985) hat sich einem technik- und wirtschaftsgeschichtlich faszinierenden und bisher kaum beachteten Thema gewidmet: der „Geschichte der Ketten- und Seilschleppschiffahrt auf dem Rhein“, einer „Art Eisenbahn mit beweglicher Schiene im Wasser“ (:8). Eine thematisch gleichartige Arbeit liegt für die Elbe vor. Es ist eigentlich eine vom Lauenburger Schifffahrtsmuseum herausgegebene und in enger Zusammenarbeit mit dem Verkehrsmuseum und der Technischen Universität Dresden sowie verschiedenen Archiven entstandene Biographie Dr. Ing. h. c. Ewald Bellingraths (1838-1903), Initiator und Leiter der Aktiengesellschaft "Kettenschleppschiffahrt der Oberelbe". Zugleich ist es aber auch eine Aufzeichnung der Schifffahrtsgeschichte auf der Elbe in der zweiten Hälfte des 19. Jahrhunderts, die sich in einem Hauptteil mit der „Kettenschiffahrt“ unter Bellingrath auf der Elbe beschäftigt (ZESEWITZ et al. 2003). Die geschichtliche und technische Entwicklung dieser besonderen heute kaum vorstellbaren Schifffahrtsart wird in dem neuen Buch anhand von umfangreichen ausgewerteten Quellen und Bildmaterial beschrieben.

„Die Geschichte der Wasserkraftnutzung“ beschreiben mehrere Autoren in einem von Martin ECKHOLDT et al. herausgegebenen Berichtsband zur gleichnamigen Tagung, die im April 1982 in Koblenz stattfand.

Historischer Bergbau

Friedrich BALCK beschäftigt sich in seiner an der TU Clausthal vorgelegten und 1999 erschienenen Habilitationsschrift mit den „Wasserkraftmaschinen für den Bergbau im Harz”. „Diese Arbeit“, so stellt er seine Zielsetzung dar, „soll den Endzustand und die Entwicklung dieser über lange Zeit wirkenden 
segensreichen Wasserkraftnutzung beschreiben [...]. Aus dem komplexen Gebiet der Wasserwirtschaft und ihrer Nutzung im Harzer Bergbau werden die technischen Unterschiede der Wasserräder und ihrer Gebäude (Radstuben) durch Konstruktion und Entwicklung herausgearbeitet und das Ergebnis systematisch dargestellt.“ (:4) Des Weiteren verfolgt BALCK ein archivalisches Anliegen. Sein Fokus aber liegt auf der technischen Darstellung der Wasserkraftmaschinen: Wasserräder (Kehr- und Kunsträder) als Antriebe im Bergbau sowie sog. Radstuben, die Gebäude und Einrichtungen für die darin befindlichen Räder sowie auch deren. Sein Zugang zu diesem Thema ist technikgeschichtlicher Art, d. h. er beschäftigt sich mit der Technik der hier verwendeten Maschinen. Der Oberharzer Wasserwirtschaft hingegen widmet er zwar ein eigenes Kapitel, beschränkt die Darstellungen aber auf 2 Seiten.

Die Dissertation von Hugo HAASE (1961) hingegen tritt nicht so sehr durch die Beschäftigung mit den technischen Details der bergbaulichen Wasserkraftmaschinen hervor, sondern durch ihre räumliche Darstellung insbesondere der Bergbauteiche im Oberharz auf der Hochfläche zwischen Clausthal und Zellerfeld. Damit steht sie, Umfang und Thema betreffend, nach nunmehr über 40 Jahren noch immer allein dar.

\section{Talsperren}

Ein bislang in der (historischen) Geographie fast unberücksichtigt gebliebenes kulturlandschaftliches Gewässerelement in Deutschland ist die Talsperre. Einen interessanten frühen „umwelthistorischen“ Beitrag, um das in der Geographie ,weitverbreitete Vorurteil zu überwinden, daß Stauseen unwichtige, also zu vernachlässigende Angelegenheiten sind“ und aufzuzeigen, „welch bedeutende geographische Erscheinungen die Stauseen schon rein flächenmäßig sind, und welche Fülle von Problemen sich an sie knüpft", hat der Münchner Geographieprofessor Edwin FELS 1973 (:131) verfasst. Nach seiner Auffassung - und daraus lässt sich der Auftrag an das Fach ableiten - besteht „die Problematik der Stauseen in der völligen Umwandlung der Naturlandschaft [...], wodurch die unbelebte und belebte Natur sozusagen auf den Kopf gestellt wird." (: 138). Die ersten dieser Art in Deutschland können bereits als persistentes Flächenrelikt der Gegenwart bezeichnet werden. Christiane WEISER hat im Rahmen einer historischgeographischen Prozessanalyse, ,die Talsperren in den Einzugsgebieten der Wupper und der Ruhr als funktionales Element in der Kulturlandschaft in ihrer Entwicklung bis 1945“ untersucht und 1991 der Universität Bonn als Dissertation vorgelegt.

Etwas anders sieht die Situation für die Talsperren der Antike aus. Das von FIETZ 1966 veröffentlichte Werk „Vom Aquädukt zum Staudamm“ bietet einen historische Längsschnittstudie zum diesem speziellen Gebiet des Wasserbaus, der Wasserversorgung. Zu dem Thema liegen aus den 1990er Jahren mehrere Bände der vom Deutschen Verband für Wasserwirtschaft und Kulturbau e. V. (DVWK) herausgegebenen und von Günther Garbrecht bearbeiteten Reihe HISTORISCHE TALSPERREN vor. Der DVWK hat es im Rahmen historischer Arbeiten der Internationalen Kommission für Be- und Entwässerung (ICID) unternommen, an Beispielen geschichtlicher Talsperren Planung, Entwurf, Bau und Betrieb dieser Speicheranlagen darzustellen, technologische Entwicklungen nachzuzeichnen und soweit wie möglich auch politische, soziologische und wirtschaftliche Aspekte aufzuzeigen. In einem 1987 erschienenen ersten Band haben 15 Autoren in 20 Beiträgen herausragende Einzelprojekte dokumentiert, Entwicklungen in einzelnen Ländern und Regionen skizziert und die Entwicklungsgeschichte der verschiedenen Sperrentypen nachgezeichnet. Geographisch wurden dabei hauptsächlich Talsperren in Europa und aus dem Nahen Osten behandelt. In einem zweiten, 1991 veröffentlichten Band wird - neben weiteren Bauwerken von Wasserreservoiren in diesen Ländern - vor allem über die Entwicklung des Talsperrenbaus in den mittelamerikanischen Staaten, im Fernen Osten, in Australien und Japan berichtet. Dass die Behandlung von Talsperren in Deutschland unter umwelthistorischen bzw. historisch-geographischen Gesichtspunkten nach meinem Kenntnisstand bislang ausgeblieben ist, verwundert umso mehr, als dass der Zusammenhang zwischen Bevölkerungsexplosion und Wasserverschmutzung bei gleichzeitiger Sicherung des Trinkwasservorrats mit der Industrialisierung evident ist.

Aus dem Rahmen der in diesem Band zusammengeführten Talsperrengeschichte heraus, als zugleich einziger Beitrag aus dem deutschen Raum, fällt ein Beitrag von Werner KONOLD (1991a:352-369), der sich mit den „mittelalterlichen Weiher und Dämmen in Oberschwaben“ beschäftigt. Ebenfalls hat KONOLD 1994 einen vom DVWK herausgegebenen, sehr interessanten Band über die „Historische Wasserwirtschaft im Alpenraum und an der Donau“" bearbeitet, in dem er und mehrere andere Autoren das Thema der 
historischen Wasserbewirtschaftung und Wassernutzung umfassend darstellen: Am Beispiel der Be- und Entwässerung, der Flusskorrektionen und -regulierungen, von Holztriften und von Meliorationen in den Ländern Österreich, der Schweiz und Deutschland. Einige Beiträge aus diesem Band werden in den entsprechenden Themenbereichen vorgestellt.

Überhaupt ist mit dem Namen KONOLD die historische Gewässerforschung eng verbunden. Als Agraringenieur und Inhaber des Lehrstuhls für Landespflege an der Forstwissenschaftlichen Fakultät der Universität Freiburg hat er sich in mannigfachen Schriften mit diesem Thema auseinandergesetzt, von denen einige im Weiteren zu erwähnen sind. An dieser Stelle hervorzuheben ist seine 1988 verfasste Habilitationsschrift, in der er „Kulturhistorische, vegetationskundliche und limnologische Untersuchungen an oberschwäbischen Stillgewässern“ durchgeführt hat.

Zur Geschichte und Kultur von Weihern, insbesondere des oberschwäbischen Raumes, liegen von ihm weitere Veröffentlichungen vor (1987a,b; 1991a,b). Hervorzuheben ist sein Aufsatz (KONOLD 1987:6-19) über die „Weiher im Alltag der oberschwäbischen Bauern“. Diese Abhandlung ist erschienen in dem als Heft 3 der „Wolfegger Blätter“ herausgegebenen Band, der unter dem Aspekt des „Arbeiten und Wohnens auf dem Lande“ die „Gewässer in Oberschwaben und ihre Nutzung in früherer Zeit" beinhaltet. Wobei hier thematisch drei Aufsätze zu nennen sind: Neben dem genannten von KONOLD die beiden von HERBST (1987a, b) über die historische Wiesenbewässerung (doch zu diesem speziellen Gebiet der Wassernutzung siehe unten).

Dass Dorfteiche und andere Kleingewässer „schutzwürdige Lebensräume der Kulturlandschaft“ sind, stellt KREMER (1992) fest, und auch KNAUSS beschäftigt mit einer in der Schriftenreihe des Agrar- und Freilichtmuseums Schloss Blankenhain veröffentlichten Schrift mit Weiher und Teich als Beispiel von Kleingewässern in der Kulturlandschaft. Über die Anlage von Stauanlagen hinaus geht die archäologischhistorische Dissertation von HAASIS-BERNER (1999/2001) über „Wasserkünste, Hangkanäle und Staudämme im Mittelalter“ am Beispiel des ,Urgrabens' im Schwarzwald. Des Weiteren haben HAASISBERNER et al. (1999) in einem Beitrag die „Wassernutzung von vorgeschichtlicher Zeit bis ins Mittelalter“ behandelt.

Kanäle/Kanalisierung

Im Gegensatz zu den Stauelementen der Wasservorratshaltung widmeten sich einige Autoren mehr der Nutzung des Wassers als Transportweg und schenkten insbesondere den frühen künstlichen Kanalprojekten ihre Aufmerksamkeit, so zum Beispiel KOPPE (2004) mit seiner Arbeit zur Lippe und zum LippeSeitenkanal oder TIBORSKI (1998), der „Kanalbauprojekte in Westfalen im 19. Jahrhundert“ vorstellt.

RÖTTCHER (1995) überarbeitete und ergänzte die Ergebnisse eines Seminars zur nordhessischen Wasserbaugeschichte an der Universität GH Kassel und fasste sie unter dem Titel „Der Kanal des Landgrafen Carl in topographischen Karten“ zusammen. Dieses nie vollendete Kanalprojekt eines ,RheinWeser-Canals' im frühen 18. Jh. war schon zu Zeit der Ausführung historisch, da es niemals vollendet wurde. Umso interessanter sind daher die Arbeiten dieser Studentengruppe, die die nur noch reliktär vorhandenen morphologischen und technischen Kulturlandschaftselemente des Wasserwegeausbaus an der Diemel im Feld lokalisieren.

In der gleichen Reihe der ,Kasseler Wasserbau-Mitteilungen’ erschien 1995 der Band „Zur Geschichte der Wasserstraßen insbesondere in Hessen“. Als Begleitheft zur Ausstellung „100 Jahre Hafen Kassel“ des Stadtmuseums Kassel erschienen, hat Herausgeber Frank TÖNSMANN, Professor im Fachgebiet Wasserbau und Wasserwirtschaft der Universität Kassel, insgesamt 18 Beiträge zusammengestellt. Von diesen sei beispielsweise der von Klaus GREWE zu „frühen Schiffahrtskanälen am Rhein“ oder der von Bettina COMPART zum „Kanalprojekt Fulda-Werra“ hervorgehoben. Des Weiteren werden natürlich aufgrund der räumlichen Verbundenheit auch die Werra und die (Ober-) Weser behandelt, wobei GREWE (1987) auch als Herausgeber des Bandes „Canal d“ Entreroches“ mit anderen Autoren den „Bau eines Schiffahrtsweges von der Nordsee bis zum Mittelmeer im 17. Jahrhundert" nachzeichnet und als Spezialist für den historischen Kanalbau gelten kann. Ein anderer Name in Zusammenhang mit der Geschichte von auch kleinen Flüssen und Kanälen als Schifffahrtswege ist der von Martin ECKOLDT, der hier nicht fehlen darf (z. B. 1980, 1981, 1995, 1998). 
In neuerer Zeit hat Monika RULLE (2001:171-178) eine historisch-geographische Untersuchung über den Isebek-Kanal in Hamburg vorgelegt. Sie beschäftigt sich in ihrer kurzen Abhandlung mit den Kanalisierungsmaßnahmen des Baches Isebek in den westlichen Hamburger Stadtteilen Eimsbüttel und Harvestehude ab 1873. Die Kanalisierung dieses kleinen Baches, die bereits vor 1873 einsetzte und damals schon bis zur Eppendorfer Chaussee reichte, lässt sie dabei außer Acht. Sie legt ihren Betrachtungsschwerpunkt deshalb auch nicht so sehr auf die Funktion des Kanals als Transportweg, sondern sieht diesen innerstädtischen Wasserweg als bedeutendes stadtgestaltendes Element und zeichnet die Bauphasen des Isebek-Kanals und die Gründe für den Bau des Kanals nach.

Eine lesens- und sehenswerte Bilanz über die zehnjährige Bauzeit der landschaftlichen Neugestaltung des Main-Donau-Kanals als - so der Untertitel - „Ersatzlandschaft im Altmühltal“ zieht der Herausgeber Michael BRIX, Professor für Kunstgeschichte an der Fachhochschule München. „Das Buch“, so BRIX (1988:6) in seinem Vorwort „bietet Anschauungsmaterial zur Unterscheidung der Ersatzlandschaften von den letzten Resten naturnaher Landschaften." Zeitschnittartige Foto-Serien dokumentieren die ursprüngliche und die umgebaute Altmühl im Beitrag von KÖNIG (:79-107) und zeigen die einschneidenden kulturlandschaftlichen Veränderungen auf. Dieses für historische Buchveröffentlichungen übliche „Damals Heute" in Bildern findet man zwar in zahlreichen Städteführern, jedoch nicht bei einer Gewässerdarstellung, die zudem einen Planungsbezug herstellt. In einem angewandten Teil nämlich werden die Planungen für die anschließenden Täler, deren Umbau, und Möglichkeiten einer landschaftsgerechten Einbindung der Wasserstraße vorgestellt. Ein Beitrag vom Herausgeber in dieser Publikation (:7-36) widmet sich schließlich im Übrigen auch dem alten Ludwigskanal einschließlich seiner Schleusen, Wehre und Wärterhäusern. Eine ähnlich ausführliche Foto-Dokumentation der historischen Vorläufer des modernen Rhein-Main-DonauKanals, ist die von BADER (1982). Es handelt sich um eine Beschreibung dieses Wasserstraßenprojektes, die mit vielen Fotos historischer Schleusenbauwerke ergänzt wird, die heute zum Teil beseitigt sind.

Andere historisch-geographische Arbeiten, die den Aspekt der Denkmalpflege betonen, sind die Untersuchungen ,zur Entwicklung von Schleusen an norddeutschen Binnenkanälen“ von GOLDAMMER (1999), einem Spezialist für historische Kanalbauten, insbesondere des norddeutschen Raumes (siehe unten) und die von ONGYERTH (1999), der für den Münchner Norden das „Schleißheimer Kanalsystem“ dargestellt hat.

Besonderer Erwähnung hinsichtlich der Darstellung historischer Wasserwege bedarf die hervorragende „Altersarbeit“ von Eckhard BREMER (2001) zur „Nutzung des Wasserweges zur Versorgung der römischen Militärlager an der Lippe“. Zu schiff- und flößbaren Gewässern und zum Wassertransport für Zeit des Mittelalters bis zur Frühen Neuzeit im Alpenraum liegen vom Schweizer BRÖNNIMANN (1997) einige Abhandlungen vor. Da die Ansprache und Klassifizierung als Verkehrsweg erfolgt, lässt sich der Zusammenhang zum großen Schweizer Projekt des historischen Verkehrswegekatasters herstellen. Gewässerhistorische Beiträge zur „Erschließung des Alpenraumes für den Verkehr im Mittelalter und der Frühen Neuzeit" liegen auch in einem von RIEDENAUER (1996) herausgegebenen Band vor. Wie Heilige, Mönche und Laien im frühen Mittelalter mit Schiffen und Booten unterwegs waren, hat ZETTLER (2000), mit zahlreichen Bildern untermalt, für den Bodensee beschrieben.

Die „See- und Flußwege in Südskandinavien aus der Sicht der Archäologie“ und deren massivste Nutzung, beispielsweise durch den Rinder- und Viehtransport durch das zum Teil vermoorte Gelände des heutigen Schleswig-Holsteins, hat Brigitte HARDH (1986) in einem interessanten Beitrag dargestellt. Die „Land- und Seewege im Bereich der Schleswiger Landenge" vom 5. bis zum 11. Jahrhundert beschrieb auch SCHIETZEL (1984).

Aber all diese gewässerbezogenen historischen linearen, punkthaften oder flächenhaften Landschaftselemente und Artefacte benötigen für ihren Erhalt bzw. ihre Dokumentation eine Geländeaufnahme - eine Inventarisation. 
Methodik

Von der (Angewandten) Historischen Geographie sind bereits Verfahren zur Inventarisierung gewässerhistorischer Kulturlandschaftselemente entwickelt und Kriterien für eine planungsbezogene Bewertung erarbeitet worden, wenn auch nicht explizit.

Im Bereich der Inventarisation der Historischen Kulturlandschaft hat GUNZELMANN (1987) verschiedene Elementtypologien unterschiedlicher Funktionsbereiche untersucht. Neben den Elementen aus dem Funktionsbereich ,Siedlung' hat er diejenigen aus dem Bereich ,Landwirtschaft' erfasst. Innerhalb der „flächenhafte Elemente aus dem Funktionsbereich Landwirtschaft“ unterscheidet er die verschiedenen Bewässerungssysteme: Wiesenbewässerungsanlagen mit Rückenbewässerung, mit Hangbewässerung, im Grabenstau, mit Wasserschöpfrädern (:77-80). Als ,linienhafte Elemente aus dem Funktionsbereich Gewerbe“ nennt er „Wassergräben“, die „häufig im Zusammenhang mit den bergbaulichen Teichanlagen“ auftreten (:101). In dem „Funktionsbereich Verkehr“" behandelt er unter anderem jene historischen Kulturlandschaftselemente, die als Anlagen des Binnenschifffahrtsverkehrs klassifiziert werden können: Kanal und Treidelpfad (:111) sowie Anlagen des Floßverkehrs (:113).

„Die methodische Untersuchung aufgelassener Wasserwege gehört jedoch zu denjenigen Teilbereichen der gewässerbezogenen Kulturlandschaftsforschung, die bisher jedoch noch wenig in Angriff genommen worden sind“. Diese Aussage von NAGEL (1988:160), der in einem kurzen Aufsatz die „Verkehrsweg-Wüstungen in der Kulturlandschaft" beleuchtet und sich als Teilaspekt in seiner Abhandlung auch mit der „Untersuchung aufgelassener Wasserwege (Kanäle)“ befasst, besitzt noch immer Gültigkeit, wenn auch einige andere Arbeiten genannt werden können.

In einer grundlegenden und immer wieder zitierten Arbeit hatte bereits GRÜTZBACHER (1985) zwei Kartierschlüssel zur methodischen Untersuchung aufgelassener Binnenwasserstraßen entworfen: Kartierschlüssel 1 zur ,Kanalstrasse“ und Kartierschlüssel 2 zu den ,Kanalbetriebsgebäuden“. Beide Schlüssel erfassen die verschiedenen Elemente des stillgelegten Wasserwegs unter den Aspekten ,Maße, Zustand' und ,gegenwärtige Nutzung'.

Als besonderes Beispiel historisch-geographischer Gewässerforschung hinsichtlich der Erforschung historischer Binnenkanäle sei die 1997 als Dissertation vorgelegte Studie von Götz GOLDAMMER hervorgehoben, die er selbst „,methodisch als Beitrag zur Historischen Geographie, speziell der angewandten Historischen Verkehrsgeographie“ (:26) einstuft. Sie erschien unter dem Titel „Historisch-geographische Untersuchungen zur Entwicklung von Binnenkanälen zwischen Elbe und Ostsee - unter besonderer Berücksichtigung der Kanalbauten und ihrer Relikte im Schaalseegebiet von der Frühen Neuzeit bis zur Gegenwart“, der leider anlässlich der Veröffentlichung als Band der Geographischen Gesellschaft Hamburg um seine geographische Dimension auf der Titelseite beraubt wurde. Nichtsdestotrotz handelt es sich hier um eine sehr lesenswerte historisch-geographische Feld- und Geländeaufnahme historischer Wasserwege in Norddeutschland. Die Reliktkartierung wurde dabei mit Hilfe eines speziellen Kartierschlüssels vorgenommen. Die damals noch analog vorgenommenen Kartierungsmaßnahmen hat GOLDAMMER zwischenzeitlich methodisch weitergeführt und instrumental in ein Geographisches Informationssystem (GIS) überführt. Im Rahmen eines musealen Forschungsauftrages hat er 2001 seine „Vorarbeiten zu einem Kanallandschaftskataster“ am Beispiel der Stecknitz-Delvenau-Senke veröffentlicht. In diesem Beitrag versucht er (2001:153) ,erstmals, die wenigen erhaltenen Relikte des Stecknitzkanals übersichtlich in tabellarischer und kartographischer Form darzustellen. Dieses Kataster einer historischen Kanallandschaft verdeutlicht den starken Rückgang der Kanalbauwerke der Stecknitzfahrt. Das Kataster soll den entsprechenden zukünftigen Planwerken (z. B. Landschaftsplänen od. Umweltverträglichkeitsprüfungen) dazu dienen, den vollständigen Verlust dieser ehemals so bedeutsamen Wasserstraße zu verhindern." Seine „,industriearchäologischen Arbeitstechniken im Bereich einer historisch gewachsenen Wasserstraße”, so der Untertitel, verfolgen also eine anwendungsbezogene Ausrichtung vor der kulturhistorischen Zielsetzung zum langfristigen Erhalt der historisch gewachsenen Kanallandschaft zwischen Lübeck und Lauenburg.

Neben den Veröffentlichungen zu künstlich angelegten Schifffahrtswegen gibt es eine Reihe von wissenschaftlichen Publikationen zur Gewässergeschichte einzelner Fließgewässer. 
Für die Mosel dissertiert Horst-Dietmar SETTLER bei Klaus FEHN am Historischen Geographischen Seminar in Bonn mit einem Thema zur „Moselkanalisation“. Eine Vorveröffentlichung ist als Kurzbeitrag erschienen (2001:209-212).

Zur historischen Nutzung kleinerer Fließgewässer gibt es mittlerweile ebenfalls eine - zwar im Vergleich mit den bedeutsamen Flüssen und Strömen wesentlich kleinere -, aber dennoch beachtenswerte Anzahl an Veröffentlichungen: HAGEL (1988), KONOLD (1991, 1994) sowie die Dissertation von HERBST (1992), und seine darauf aufbauenden Vorveröffentlichungen (1983, 1987a,b, 1993), die weiter unten vorgestellt werden.

Aus den vorliegenden historischen Fließgewässeruntersuchungen ist vor allem auch die Erft herauszustellen, die von verschiedenen Fachdisziplinen untersucht worden ist.

Die von Andreas DIX 1997 veröffentlichte und im Rahmen des Forschungsprojektes zur „Reaktivierung der Tuchfabrik Müller als Außenstelle des Rheinischen Industriemuseums“ bearbeitete Untersuchung (DIX 1997:38) ist die gekürzte Fassung seiner Ende 1993 an der Universität Bonn im Fach Historische Geographie eingereichten Dissertation und stellt dieses kleinere Fließgewässer als umweltgeschichtliches Thema für die Zeit der Industrialisierung vor. Genau genommen ist es jedoch „die Untersuchung einer einzelnen Fabrik als umweltgeschichtliche Quelle“ (:5), die zunächst im Vordergrund steht, und nicht ein Gewässerlauf. Eine Tuchfabrik wird als umweltgeschichtliche Quelle verwertet und darin erst werden gewässerbezogene Themen eingebunden. Im Mittelpunkt der Untersuchung stehen dabei zwei Fragen: „Wie und unter welchen Rahmenbedingungen wurde Wasser als Ressource genutzt? Welche Rolle spielten Gewässer im Gefolge der Industrialisierung und wie wurden sie dabei verändert?“ (:25). Es ist, schreibt DIX (:5) weiter, „ein Versuch, [...] neue Fragen an ein altes Objekt zu stellen." Neuartig insofern, als dass mit dem Inventar der Tuchfabrik als Sachquelle und der Herstellung des Zusammenhangs zwischen Tuchproduktion und Wasserkraft eine besondere gewässerhistorische Sichtweise eingenommen werden kann. Es ist ,ein neuer methodischer Ansatzpunkt [...] umweltgeschichtliche Fragestellungen mit einem konkreten Objekt zu verknüpfen.“ (:24): in diesem Fall die Tuchfabrik Ludwig Müller als umweltgeschichtliches Quellenensemble (:274). Aus diesem Quellenfundus ergeben sich Kapitel, die Namen tragen wie „Zustand der Fließgewässer im 19. und zu Beginn des 20. Jahrhunderts“ sowie in einem nächsten Kapitel „Mühlen und Wiesenbewässerung am Erftmühlenbach“. Hier beleuchtet DIX am Beispiel einer Tuchfabrik die Konkurrenzsituation um knappes Wasser und die sich widersprechenden Ansprüche der Wasserversorgung auf der einen und dem Abwasser der Tuchindustrie (Gewässerverschmutzung) auf der anderen Seite. „Die vorliegende Untersuchung handelt also von der Tuchindustrie, besonders aber von ihren wasserintensiven Veredlungsarbeitsgängen, der Färberei und der Naßappretur.“(:29)

Eine Studie aus dem gleichen Untersuchungsraum, der Erft, konnte DIX zum Zeitpunkt der Verfassung seiner Dissertation noch nicht kennen: die von dem Historiker Ralf KREINER 1995 am Lehrstuhl für Mittlere Geschichte der Philosophischen Fakultät abgegebene und ein Jahr später publizierte Gewässergeschichte der Erft, in der er nach eigenen Aussagen ,die menschlichen (anthropogenen) Eingriffe in ein Gewässersystem“ analysiert (1996:48). Die Vorgabe für die vorliegende Studie lautete, „die Geschichte des vorindustriellen mechanisierten Mühlenwesens der Städte des Erftgebietes in ihrer Komplexität darzustellen, in einer Form, die auch sachfremden Lesern verständlich sein sollte." (:53) und bewegt sich damit in einem Grenzgebiet wissenschaftlich orientierter Forschung und eröffnet mit dieser Sichtweise Spielraum für den wissenschaftstheoretischen Diskurs. Ausgehend von einer naturräumlichen und historischen Darstellung des Erftgebietes erarbeitet er die „molinologischen Grundlagen“ der Erft und beschreibt nachfolgend die „Städte und Mühlen“ sowohl am Ober-, Mittel- und Unterlauf der Erft einschließlich Mündungsgebiet als auch die Städte an deren kleineren Zuläufen (Veybach, Swist, Rinbach, Rotbach, Neffel). Sein Beitrag ist hier vor allem aus dem Grund von Interesse, da er sich um die Kleinstädte an kleinen Nebenflüssen der Erft verdient macht und da das Forschungsfeld Kleinstadt auch von der molinologischen Seite her bislang wenig Aufmerksamkeit gefunden hat.

Die Erft stand bald darauf wiederum im Mittelpunkt gewässerhistorischer Betrachtungen. Doch diesmal wurden in dem von Johannes PAUL 1998 vorgelegten und ein Jahr später erschienenen Band in der Reihe ,Ortstermine' speziell der Bergbau und die Landwirtschaft und nicht die Tuchfabrikation oder das gesamte Mühlenwesen hinsichtlich der Umweltwirksamkeit auf eine Flusslandschaft beleuchtet. „Auf der Grundlage 
in breitem Umfang ausgewerteter Archivmaterialien wird erstmals die Wassernutzung der Erft und ihrer Zuläufe in den vergangenen rund 300 Jahren zusammenhängend dargestellt", so die Professoren BERS/KLÖCKER/WEBER in ihrem Geleitwort zum Buch und ähnlich auch der Autor selbst ohne jeden Anlauf von Understatement (PAUL 1999:10).

PAUL beschäftigt sich ,in der vorliegenden Arbeit mit der Frage, welchen gewerblich-industriellen und landwirtschaftlichen Einwirkungen ein [...] mittelgroßer rheinischer Fluß - die Erft - in den vergangenen rund 300 Jahren ausgesetzt war.“ (1999:9) „Eingebettet in die Hauptphasen der Umweltgeschichte“, so PAUL (:Geleitwort), „wird detailliert die Nutzung des Wassers beschrieben - einschließlich der verhängnisvollen Folgen:“ Dabei schälen sich nach seiner Recherche ,im Geflecht der Nutznießer und der Einwirkungen auf die Wasserläufe und Flusslandschaft“ unter anderem folgende Hauptfaktoren heraus: „der Bleibergbau [...], Wasserbau (Wassermühlen und Flußbegradigungen), Intensivierung und Wandel der landwirtschaftlichen Bodennutzung, industrielle und kommunale Abwässer, der Braunkohlenbergbau.“ (:Geleitwort). Hier wird also eine Umweltgeschichte der Erft-Landschaft, ,in welcher der industrielle Fortschritt und seine ökologischen Risiken sehr genau im Blick auf die Räume und Orte, Nutznießer und Eingriffe konturiert werden.“ (:Geleitwort) „Im Mittelpunkt der Untersuchung stehen handlungsgeschichtliche Aspekte, d. h. anhand der zur Verfügung stehenden Quellen werden sowohl die ökonomisch-technisch bedingten Einwirkungen auf die Gewässer als auch die sich daraus entwickelnden Konflikte zwischen den verschiedenen Wasserbenutzern, der früher oder später entstehende staatliche Regelungsbedarf und schließlich die angestrebten Konfliktlösungen und ihre Ergebnisse beschrieben. Geographische, biologische und andere naturwissenschaftliche Fragen werden dabei nur insoweit behandelt, wie es zum besseren Verständnis dieser Nutzungs- und Konfliktgeschichte notwendig erscheint.“ (:9)

PAUL hat sich auf mittelgroße rheinische Flüsse spezialisiert. In seinen früheren umweltgeschichtlichen Veröffentlichungen über die Sieg (1992) sowie die Rur und Inde (1994) behandelt er aus ähnlicher Perspektive das Thema. So hat er dort die Abwassergeschichte der Sieg im Industriezeitalter dargestellt und anschließend in weiteren Studien Umweltbelastungen und Sanierungsversuche an den Flüssen Rur und Inde rekonstruiert und analysiert.

Eine der vorliegenden Arbeit nahe kommende, aber dennoch durch ihre biologische Schwerpunktsetzung andersartige Untersuchung über „zivilisatorische Nutzungsformen“ der Saale innerhalb der letzten Jahrhunderte legt Stefan SCHUBERT (2001) mit seiner Dissertation vor. Einige ausgewählte anthropogene Nutzungsformen wie Flößerei, Schifffahrt, Talsperrenbau, Fischerei sowie Wehre und Schleusen werden in einem Teilabschnitt dargestellt und hinsichtlich ihrer biologischen Auswirkungen auf das Flussökosystem der Saale beschrieben. In weiteren Kapiteln werden „der biologisch-limnologische Wandel“ sowie „die Abwasserbelastung und Gewässergüte der Saale“ behandelt. Mit einem interessanten „Ausblick auf neue Renaturierungskonzepte für die Saale“ beendet er seine historisch-biologischen Ausführungen, die methodisch auf einem rein literarischen Quellenstudium aufbauen und die primär nach biologischen Gesichtspunkten ausgewertet wurden. „Das vorliegende Buch“, charakterisiert SCHUBERT (:9) selbst sein Werk, ,stellt einen Versuch dar, Charakteristika und die Geschichte der Saale in einer zusammenfassenden Literaturstudie aufzuarbeiten.“ Des Weiteren „wurden die Unterlagen nach primär biologischen Gesichtspunkten ausgewertet.“ (:9) Ein besonderes Gewicht seiner Arbeit stellt nach meiner Auffassung die limnologische und fischereibiologische Bewertung der Folgen historisch anthropogener Fließgewässernutzung, z. B. der Flößerei auf das Ökosystem, z. B. auf die Fische, dar. Das heißt, welchen Einfluss die mannigfaltigen historischen Nutzungen auf das Ökosystem eines Flusses gehabt haben.

Lutz Dietrich HERBST dienen ,ausgebaute Fließgewässer des Mittelalters und der frühen Neuzeit in Oberschwaben“ als Lernfelder der Historischen Geographie. In seiner Dissertation von 1992 an der Pädagogischen Hochschule Weingarten zeigt er auf eindrucksvolle Weise die Folgen von Eingriffen in ein historisches Gewässersystem, das bereits im frühen Mittelalter entstanden ist. Die Hochwassergefahren belegt HERBST nicht nur als Folge einer falsch verstandenen und sich eher ins Gegenteilige auswirkenden Hochwasserschutzpolitik (Flusslaufbegradigungen, Entwässerungen, Erhöhung, Verstärkung und Verbreiterung der Wehre und Dämme, etc.), sondern auch als Ursache eines die historische Komponente negierenden Siedlungs- und Gewässerbaus. Mit dem Wegfall historischer Nutzungen, beispielsweise mit dem Niedergang des spätmittelalterlichen und frühneuzeitlichen Wasserwirtschaftssystems, und dem Verlust an Auffangkapazitäten durch Auflassung und Überbauung von Teichflächen, wurde eine Hochwassergefahr 
vorprogrammiert. Die Diskussion hat aktualpolitische Brisanz, wie die Hochwässer an der Oder und an kleinen Gewässerläufen im Thüringischen der letzten Jahre gezeigt haben. Doch setzt die Fehlentwicklung zeitgeschichtlich bereits viel früher ein und resultierte zum Beispiel im frühen 19. Jh. in der landesweiten Flutkatastrophe von 1817. Die von HERBST vorgelegte Arbeit demonstriert dies anhand einer Bestandsaufnahme und Interpretation von drei künstlich ausgebauten Bachsystemen innerhalb des oberschwäbischen Rißtales, der Rottumtäler sowie des Schussetales. An diesen Gewässerbeispielen rekonstruiert er die Veränderungen der Wasserführung, der Gewässersituation sowie die Wasserzuleitung und Kanalisation. Der Rotbach und seine Nebenbäche dienen ihm als Beispiel für den Aus- und Umbau natürlicher Fließgewässer im Mittelalter. Anhand unterschiedlicher Verlaufsdarstellungen, der Darstellung früher wasserwirtschaftlicher Maßnahmen sowie von Bachausbauten zeigt er die Veränderungen auf. Krummbach und Hungerbach dienen als Beispiel für die Erschließung und Nutzung ergiebiger Quellhorizonte. An diesen am Ursprung des Fließgewässers ansetzenden wasserwirtschaftlichen Nutzungsformen zeigt er die Veränderung durch Wasserzuleitung und Kanalisation auf. Der Stille Bach schließlich dient als Beispiel für die künstliche Vernetzung verschiedener Wassereinzugsgebiete v. a. zum Zwecke des Bewässerungswiesenbaus. Seine Untersuchungen gelten insbesondere den historischen Wasserbauten zur Energie- und Fischereiwirtschaft von Kloster und Adel. Anhand von ausgewählten Gewässerausbauten des Mittelalters und der frühen Neuzeit im Einzugsbereich ehemals bedeutsamer Klöster, konkret der Klosterkanalsysteme der Benediktinerabteien Ochsenhausen und Weingarten in Oberschwaben, möchte HERBST (:1),,am Beispiel des historischen Wasserbaus zeigen, wie der Mensch das regionale Potential des natürlichen Landschaftshaushaltes über Jahrhunderte hinweg optimal zu nutzen versucht hat, ohne es zu zerstören.“

Weiterhin liegen Detailanalysen der Umgestaltung von Gewässersystemen durch Klöster im Mittelalter und in der Frühen Neuzeit durch SCHENK (1988:241-256) vor.

\section{Stadtgeschichte}

Werner KOHL (1969) hat zwar in seiner rechtswissenschaftlichen Dissertation die historischen Rechtsverhältnisse der Münchener Stadtmühlen betrachtet. Der Wesenskern der Arbeit besitzt jedoch auch einen stadtgeschichtlichen Schwerpunkt, indem er die Entwicklung des Stadtbachsystems beschreibt. Interessant ist in dem anderen thematischen Zusammenhang einer gewässerbezogenen Umweltgeschichte vor allem das 4. Kapitel über „die Entwicklung des Stadtbachsystems" (:45-49), in welchem er „verschiedene Entwicklungslinien in der Geschichte der Stadtbäche” Münchens darstellt. Hier stellt er den Bau von wasserbetriebenen Mühlenwerken in Zusammenhang mit den Bachläufen und zeigt deren spätere Umwandlung in Anpassung an den erweiterten Mühlenbau im Verlauf der Geschichte auf, als das Gefälle der Stadtbäche zum Wasserwerkeantrieb erschöpft war und die Errichtung weiterer Betriebe mit gespannter Wasserkraft mit einem ,nicht unwesentlichen Eingriff in das Bachsystem“:47) begleitet wurde.

In einem aktuellen Aufsatz, erschienen in der Zeitschrift „Neue Ufer“, beschäftigt sich Mustafa HAIKAL (2001) mit der Geschichte einer Flusslandschaft am Beispiel der Pleiße in Leipzig. Dabei behandelt er in einigen kurzen Kapiteln „die Anfänge der Besiedlung“ am kleinen Fluss Pleiße die „Fischerei“ auf dem Flusswasser einschließlich der Erwähnung der Teichwirtschaften im unteren und mittleren Pleißegebiet (um Connewitz/Lößnig, Haselbach/Regis-Breitingen, Wilchwitz), die Mühlen im Flussgebiet mit den Mühlgräben, die Pleißeflößerei, die Eingriffe in den Fluss durch diverse Flussbauten (Brücken, Stege, Furten, Viadukte) und Flussverlegungen, die Einflüsse der Industrialisierung, die modernen Stauanlagen (Talsperren) bis zur Wasserverschmutzung.

Wiesenbewässerung

Zum Themenbereich historische Gewässerforschung gehört auch das Thema Wiesenbewässerung, zumindest insofern, als in Fließgewässern zur Berieselung von Wiesen dergestalt eingegriffen wurde, um den Wasserfluss zur Wässerung auf Wiesen umzuleiten. Neben den Wässerwiesen als Flächenelement sind Bewässerungsgräben und -kanäle sowie die ,Fallen' und ,Schleusen' zur Wasserregulierung wichtige historische Kulturlandschaftsdokumente einer ehemaligen landwirtschaftlichen Fließgewässernutzung.

$\mathrm{Zu}$ diesem Themenbereich liegen aus dem deutschsprachigen Bereich eine Reihe von - auch frühen geowissenschaftlichen, historischen und wirtschaftskundlichen Studien vor, die nicht annähernd alle erfasst werden können (z. B. MÜLLER 1837; LAUTER 1851; MONHEIM 1943; ENDRISS 1943/1950; KRAUSE 1956; HARDTKE 1957; SEHORZ 1964; FIEDLER 1965; KLAPP 1971; WEBER 1971; weitere sind dem Literaturverzeichnis zu entnehmen). Einige neuere Veröffentlichungen sollen dennoch erwähnt sein: 
KONOLD gilt nicht nur als „Weiher-Spezialist“, sondern auch der heutige Spezialist in Sachen Wiesenwässerung. Er hat zahlreiche Veröffentlichungen zum Thema Wässerwiesen, insbesondere für den Raum Baden-Württemberg verfasst und herausgegeben (z. B. 1991, 1994, 1997).

Hervorzuheben hinsichtlich seiner Aktualität und umfangreichen Darstellungsweise ist das Heft von HASSLER et al. (1995) über die „Geschichte, Technik und Ökologie der bewässerten Wiesen, Bäche und Gräben“ im baden-württembergischen Kraichgau, Hardt und Bruhrain.

Nicht berücksichtigt werden oftmals diejenigen Darstellungen, die sich in einer Veröffentlichung mit einem anders lautenden Arbeitstitel ,verstecken“. Vera DENZER (1996) beispielsweise widmet ein Kapitel ihrer historisch-geographischen Arbeit (:134ff.) der Inventarisierung von Relikten der Wiesenbewässerung am Beispiel des Dammbachtales und Heimbuchenthales der Gemeinde Mespelbrunn im südwestlichen Spessart.

Nicht zuletzt ist zum Thema Bewässerungswiesen in Deutschland Katrin SCHWINEKÖPER zu nennen, die in einem im Jahr 2001 publizierten Beitrag und im Jahr zuvor gehaltenen Vortrag sich mit den Wässerwiesen in Süddeutschland beschäftigt hat, aber sich bereits seit Mitte der 1990er Jahre mit Untersuchungen zum Wässerungswesen beschäftigt (SCHWINEKÖPER et al 1995/96).

Was KONOLD für den (süd)deutschen Raum, ist LEIBUNDGUT für die Schweiz. Seine Bemühungen vor allem für das Langetental haben sogar eine Unterschutzstellung bewirkt. LEIBUNDGUT dokumentiert in seinen Untersuchungen das subalpine Bewässerungssystem des Langetentals mit Hilfe von Luftbildaufnahmen im Dezember 1978, die aber erst 1993 publiziert wurden. Seine Arbeit entstand „im Bestreben, die Wiesenbewässerungslandschaft in ihren Grundlagen, dem Bewässerungssystem mit dem Mikrorelief festzuhalten“.

Bezüglich Arbeiten zu Wässermatten aus der Schweiz sind auch jene in den 1970er und 80er Jahren entstandenen Untersuchungen von Valentin BINGGELI zu erwähnen. Er beschäftigte sich z. B. in einer 1986 als Festschrift veröffentlichten Untersuchung mit dem Kulturlandschaftswandel der Oberaargauer Wässermatten. Die hydro- und kulturgeographischen Untersuchungen dieses Bewässerungsgebietes wurden dabei seit 1961 betrieben (BINGGELI 1986:123). Doch ihn interessiert nicht nur der Zerfall des subalpinen Bewässerungssystems, sondern auch die Möglichkeiten des Wiederaufbaus. Dies macht seine Untersuchungen $\mathrm{zu}$ einer wertvollen anwendungsorientierten kulturhistorischen Arbeit über die als „naturnahe Kulturlandsysteme“ (:123) eingestufte Wässerwiesen.

Weitere Beiträge in dem Festschriftband sind zum Teil gekürzte Fassungen früherer Beiträge (z. B. FURRER/FREUND: Bewässerung im Kanton Graubünden, erschienen in Geographica Helvetica, H. 4 1974:153-165) oder Reprints alter Literatur (z. B. BLOTNITZKI: Über die Bewässerungskanäle in den Walliser Alpen - Bern 1871 oder STUDER: Die Bewässerungsanlagen von Visperterminen. Walliser Jahrbuch 1934) und verdienen eine ebensolche Beachtung.

Wie die Wässerungswiesen, so sind auch die den Einflussbereich des Gewässerlaufs kennzeichnenden Flussauenlandschaften Betrachtungsgegenstand gewässerhistorischer Forschung. Bei einem Bruch bzw. einer Aue handelt es sich um einen „feuchten Wiesengrund, der beweidet und betreten werden kann“ (GRIMMSCHES WÖRTERBUCH). Es ist jedoch schon eine „die dem Strom durch Dämme abgewonnene Niederung“.

Flussregulierung

Martina KAUP (2000) hat in einem Beitrag die Melioration und Umweltveränderung vom 18. bis 20. Jahrhundert am Beispiel des Oderbruchs geschildert. Mit ihrer Zuarbeit entstand auch HERRMANNs 1997 publizierte umweltgeschichtliche „Geschichte der Eindeichung und Melioration des Oderbruchs, einer urstromtal-geführten Flußauenlandschaft in den Jahren 1747-1753“, die in besonderer Weise die Veränderung eines Gewässerlaufes durch Kolonistentum beschreibt.

Mühlen

Wassermühlen beschreiben, dies lässt sich wohl so sagen, das wichtige bauliche und technische Artefakt, das an Fließgewässer gebunden ist und die Umgestaltung der Flussgewässerlandschaft (Stichwort: Mühlgraben, 
Mühlenteich) seit dem frühen Mittelalter in Mitteleuropa sowie später das vorindustrielle Wachstum entlang des Gewässers (Stichwort: Mühlenhammer) maßgeblich mitbestimmt hat. Eine großräumliche wissenschaftliche historisch-geographische Untersuchung zu diesem interessanten Themenbereich liegt meines Wissens hingegen noch nicht vor.

„Historische Wasserkraftanlagen im Münsterland“ hat Harald WESTBELT in einer am Geographischen Institut der Universität Münster als Diplomarbeit Mitte der 1980er Jahre angenommenen Untersuchung beschrieben.

Einen regionalen Teilausschnitt präsentiert Stefanie UECKER. Sie möchte mit ihrer 1999 veröffentlichten Staatsarbeit „auf die Vielfalt der jahrhundertelangen Wasserkraftnutzung in der Grafschaft Wertheim hinweisen" (:7) Die geographische Eingrenzung der ehemaligen Grafschaft Wertheim erfolgt dabei auf einer Grafschaftskarte aus dem Jahre 1796. Innerhalb dieses räumlichen Abgrenzungsbereiches erfasst sie „den Wassermühlenbestand [...] und gibt gleichzeitig eine Vorstellung von der Vielfalt der Anwendungsmöglichkeiten der Wasserkraft.“ Aufgenommen wurden dabei ,alle Mühlen, die in der Grafschaft Wertheim bestanden und auch historisch belegt sind (:8). Bei den Wassermühlen der ehemaligen Grafschaft Wertheim handelt es sich nach Ihrer Recherche ,um ein nahezu gänzlich unerforschtes Gebiet fränkischer Kulturgeschichte. Bislang sind nur einzelne Mühlen dieser Gegend ausführlich untersucht worden. Ein Überblick fehlte.“ (:43) Die „Inventarisierung der Wassermühlen“ soll deshalb gleichzeitig „ein Grundstock für weitere Untersuchungen zu diesem Thema sein" (:43). Die Anordnung der „Bestandsaufnahme der Wasserkraftwerke der Region“ erfolgt dabei nach Wasserläufen (:45-76). Sie beginnt „mit dem nördlichsten Nebenfluß des Mains im Gebiet der Grafschaft“ und geht ,jeweils von der Quelle bis zur Mündung vor." (UECKER 1999:45). Ein interessanter methodischer Ansatz, einen Flusslauf in seinem gesamten linearen Verlauf, und nicht in Teilausschnitten, zu betrachten.

Die meisten Veröffentlichungen hingegen, die den Zusammenhang Wasser-Wasserkraft-Wassermühle herstellen, werden seitens der Heimatliteratur verfasst und daher später aufgegriffen.

Siedlungsgeographie

Eine vom Ansatz zu beachtende, den historisch-siedlungsgeographischen Zusammenhang aufzeigende Darstellung verfolgt GLAUSER (1991) in seinem Aufsatz zur engen Beziehung zwischen „Fluß und Siedlung" am Beispiel der Schweiz. In Aufweitung des Betrachtungsgegenstandes haben zuvor FEHN und OBERBECK (1997), „vorindustrielle Verkehrssiedlungen am Wasser“ in einem Beitrag beleuchtet, der dem Thema der 5. Arbeitstagung des Arbeitskreises für genetische Siedlungsforschung in Mitteleuropa in Wilhelmshaven gewidmet ist. Das Thema "Stadt und Wasser aus historisch-geographischer Sicht" hat KRINGS (2001) in einem Beitrag am Beispiel der Stadt Bamberg beleuchtet und einen Exkursionsführer zu den jeweiligen Stätten geschrieben.

In neuerer Zeit gibt es - parallel zur wachsenden Bedeutung dieses städtebaulichen Planungsansatzes - eine steigende Zahl von Veröffentlichungen, die sich mit der Beziehung zum Wasser in der Gegenwart auseinandersetzen und Vorschläge zu ihrer Umsetzung darbieten. Beispielhaft dafür ist die Veröffentlichung von Christian STRAUSS (2002), der sich in seiner in Buchform veröffentlichten Diplomarbeit mit der „amphibischen Stadtentwicklung“ und der Frage der „Integration des Wassers des Wassers in die Stadtentwicklung“ beschäftigt. „Urbane Gewässer“ und ihre auch planungsbezogene Beachtung und Behandlung stellen ebenso SCHUHMACHER/THIESMEIER (1991) in den Mittelpunkt ihres Buches.

Wald

Doch zurück zur Historie: Dass das Stammholz der Wälder, insbesondere der Mittelgebirge, in großen Mengen für den expansiven Siedlungsbau benötigt wurden, ist allein an der Vielzahl von Fachwerkstädten erkennbar und im Allgemeinen bekannt. Aber dass besondere Gewässernutzungsarten als Folge waldwirtschaftlicher Nutzungen entstanden sind, ist, so scheint es, weniger im Bewusstsein und bislang von wissenschaftlicher Seite in neuerer Zeit - im Verhältnis zur Bedeutung dieses ehemaligen Gewerbes und seiner umwelthistorischen Ausprägung - nur in geringem Umfang umfassend erforscht worden, obschon es eine Vielzahl an kleineren Beiträgen zur Flößerei gibt. Eine Ausnahme bildet Winfried SCHENK, der sich in seiner 1992 verfassten und 1996 publizierten Habilitation unter anderem mit der historischen Flößerei als Teilbereich seiner Untersuchung zum Waldgewerbe des Mittelgebirges am Beispiel Mainfrankens und Nordhessens beschäftigt hat. 
Exoten

Doch nicht nur die traditionellen Bewirtschaftungsformen sind Gegenstand gewässerhistorischer kulturlandschaftlicher Betrachtungen.

„Mit der Erholungslandschaft als einem Teil der maritimen Kulturlandschaft“ befasst sich Susanne SCHUMACHER-GORNY (1997) in ihrer Untersuchung, in der sie sich aber darauf beschränkt „Ansätze für weitere Untersuchungen vorzustellen und eine Diskussion anzuregen“ (:314). Sie sieht nämlich „die maritime Kulturlandschaft im Wandel“ und den „Übergang zu einer ,pseudomaritimen Kulturlandschaft' im Bereich der Erholungslandschaft", so der gleichnamige Haupt- und Untertitel ihrer angewandt historischgeographischen Arbeit. Während SCHUMACHER-GORNY für den Bereich Travemünde ihre Aussagen getroffen hat, untersuchte Rolf PLÖGER (1997) „die maritime Kulturlandschaft der Kieler Förde in historisch-geographischer Sicht.

Diese dem Küstenbereich zugewiesene Thematik berührt scheinbar zunächst nicht primär den hier thematisch eingeschränkten Untersuchungsraum der binnenländischen Fließgewässernutzung, zählt aber zu dennoch im weiteren Sinne zum Untersuchungsgegenstand gewässerhistorischer Forschungen. Die maritime Kulturlandschaft umfasst - nach der von WESTERDAHL (1986:7) übernommenen Definition - „das gesamte Netz alter und neuer Schiffahrtswege samt Häfen an der Küste und die zu diesem Komplex gehörenden Anlagen und Spuren menschlicher Aktivitäten“. Da sie mit diesen Überlegungen nach eigenen Aussagen ein „neues Forschungsfeld“ erschließt (SCHUMACHER-GORNY 1997:308) und die Terminologie neuartig erscheint, soll die Entstehungsgeschichte dieser postmodernen, zwar der See zugewandten, aber auf dem Festland stationierten gewässerorientierten Kulturlandschaftsform kurz nachgezeichnet werden:

Nach der Umwandlung maritimer (Natur-) Landschaften in maritime Kulturlandschaften „entstehen, bedingt durch konsumorientierte, gesellschaftliche Triebkräfte ,pseudomaritime Kulturlandschaften'“. (SCHUMACHER-GORNY 1997:307). Dabei definiert die Autorin ,pseudomaritime Kulturlandschaft' ,als eine Form der Kulturlandschaft, welche in maritimer Lage entweder räumlich und zeitlich einer maritimen Kulturlandschaft nachfolgt, oder eigenständig, Aspekte maritimer Kulturlandschaft als Gestaltungselement vortäuschend, geschaffen wird“" (:311). Als Triebfeder für die Entstehung ,pseudomaritimer Kulturlandschaft' und ihrer einzelnen Elemente sind dabei „Nutzungsumwandlungen aufgrund geänderter Nachfrage und die Nachfrage nach einer speziell ,gestylten' maritimen Erholungslandschaft zu nennen.“ In beiden Fällen ist nach ihrer Auffassung ,der Mensch, der ,Homo consumens' [...] der Auslöser einer Veränderung in der Landschaft.“ (:311f.). Die Erholungslandschaft droht infolgedessen ,einziger, dominierender Aspekt der maritimen Kulturlandschaft zu werden". Und sie ist es nach Meinung von SCHUMACHER-GORNY (:312) auch, die die maritime Kulturlandschaft „zu einer ,pseudomaritimen Kulturlandschaft' werden läßt.“

Mit der in diesen Untersuchungsgegenstand passenden Fragestellung der „Umnutzung und Wiederbelebung alter Hafen- und Uferbereiche in deutschen Städten" hat sich Dirk BORCHARD in seiner Diplomarbeit (1996/97) beschäftigt und vor allem die großen „Flusshäfen“ untersucht (Bremen, Hamburg). Eine Untersuchung der alten, wirklich kleinen Flusshäfen des Mittelalters, die nicht mehr vorhanden sind (z. B. der Hafen „Schiphorst“ in Quakenbrück) oder die bis in die industrielle Phase noch bestehenden (Rinteln, Vlotho) verharren jedoch einer umwelthistorisch-kulturgeographischen Untersuchung. Einer solchen Forderung am nächsten kommt vielleicht BLUMENBERG (1999), der die vergessene „oldenburgische Seehafenstadt" Elsfleeth an der Weser in Erinnerung ruft. Sie spielte zusammen mit Brake eine lange Zeit bedeutende Rolle in der Konkurrenz zu Bremen. Der oldenburgische Großherzog gründete hier eine der ersten Seefahrtsschulen, die heutige Fachhochschule Seefahrt. Im gleichen Verlag, in dem auch die stadthistorische Monographie BLUMENBERGs veröffentlicht wurde, im Isensee-Verlag, erschien auch eine Darstellung der Seehafenstadt Brake an der Unterweser. Im Gegensatz zu Elsfleeth ist Brake hingegen heute noch ein bedeutender Hafen für den Import von Futtermitteln für das Südoldenburger Land (ECKHARDT / GÜNTHER / SCHAER et al. 1981).

In diesem Zusammenhang nicht zu vergessen ist das Sammelwerk von STOOB (1986) mit Beiträgen zur Geschichte verschiedener Hafen- und Kaianlagen, der Arbeit bei der Schiffsbeladung und weiteren Aspekten der Schifffahrt vom Hochmittelalter bis zur Industrialisierung. 
Einen direkt mit historischer Gewässernutzung in Verbindung stehenden „Beitrag zur Kulturlandschaftsforschung und Industriearchäologie“ hat Stephan LÜTGERT 2000 vorgelegt. Er hat die „Eiskeller, Eiswerke und Kühlhäuser in Schleswig-Holstein und Hamburg“ untersucht, in denen in der Vorzeit aggregat- und strombetriebener Kühlschränke in der Winterzeit gestochenes Eis gelagert wurde. Zur Frischhaltung von nicht gepökeltem Frischfleisch bzw. ungesalzenem Fisch, denn Salz war zwar die erste Möglichkeit Lebensmittel haltbar zu machen, doch deshalb auch kostbar und teuer, auch weil es zum Teil von den Salinen von weither von Salzträgern und Fuhr- und Schifffahrtsleuten transportiert werden musste. Der Gewässerbezug wird vor allem dann offensichtlich, wenn man weiß, dass das Eis auf künstlichen Eisteichen oder auf zugefrorenen Fließgewässern zu diesen Zwecken gestochen wurde (siehe V 16.13a und VII 5o).

Im Rahmen von Tagungen

Dass Gewässer als ein Forschungsbereich der (Angewandten) Historischen Geographie in neuester Zeit (wieder-)entdeckt worden sind, belegt die im März 2000 durchgeführte Jahrestagung der „Arbeitsgruppe für Angewandte Historische Geographie“, die zum zentralen Thema die „Flusslandschaften zwischen Persistenz und Überformung“ gewählt hatte. Das daraus im Jahr 2001 entstandene Themenheft, das zugleich als Jahresheft der Zeitschrift „Koblenzer Geographisches Kolloquium“ erschien, demonstriert in seinen Beiträgen die Vielseitigkeit gewässerhistorischer Forschung, obgleich sich nicht alle Vorträge explizit mit dem Fluss als Gewässerlauf beschäftigen. Als weitere Einschränkung mag gelten, dass sich die Jahrestagung „nur“ mit den historisch gewachsenen Landschaften beschäftigt hat, „die durch ein großes Fließgewässer charakterisiert sind" (KLEEFELD 2001:7) und die durch kleinere Gewässer charakterisierten Flach- und Gebirgslandschaften unberücksichtigt blieben. Dennoch: die Beschäftigung mit historischen Flusslandschaften unter der Zielsetzung des Anwendungsbezuges innerhalb der Historischen Geographie verdient angesichts der aktualpolitischen Diskussion (EU-Wasserrahmenrichtlinie) besondere Beachtung.

Innerhalb der Jahrestagungen des Arbeitskreises wurde das Thema „Gewässergeschichte“ bislang dreimal in den Mittelpunkt gestellt bzw. berührt: Die 5. Tagung fand 1978 in Wilhelmshafen statt und stand unter dem Motto „Vorindustrielle Verkehrssiedlungen am Wasser“. Im 14. Treffen im Jahr 1987 wurden „Frühe Umwelten“ behandelt und bei der 15. Tagung stand die „Siedlungs- und Kulturlandschaftsentwicklung am Unterlauf großer Ströme am Beispiel des Rhein-Maas-Deltas“ am Tagungsort in Wageningen/Niederlande 1988 auf dem Programm. Fließgewässer als Bestandteil der Kulturlandschaft waren auch Thema einer Fachtagung des Landschaftsverbandes Rheinland (LVR) im September 1999.

Im Rahmen von Graduiertenkollegs

Im Rahmen von zwei Graduiertenkollegs werden gegenwärtig gewässerhistorische Themen bearbeitet.

Zum einen geschieht dies an der Universität Freiburg im Graduiertenkolleg „Gegenwartsbezogene Landschaftsgenese“, dessen erste Phase von April 2001-März 2004 ging. Korinna THIEM bearbeitet am dortigen Institut für Landespflege unter Betreuung von Prof. Dr. KONOLD das Thema „Veränderungen an Gewässern durch historische Nutzungen im Südschwarzwald - Möglichkeiten einer Rekonstruktion, Erfassung und Bewertung". Am Beispiel des Flusses Neumagen, einem kleinen Mittelgebirgsfluss im südlichen Schwarzwald werden von ihr „Veränderungen an Gewässern durch historische Nutzungen“ untersucht. Ziel der Arbeit ist es, nicht nur die Auswirkungen historischer Gewässernutzung auf den ökomorphologischen Zustand der Fließgewässer aufzuzeigen (Struktur und Abflussverhältnisse), sondern auch auf die Talentwicklung und das Landschaftsbild, denn, so THIEM ${ }^{2}$,..der natürliche Charakter v. a. der Mittelgebirgsflüsse ist uns weitgehend unbekannt.“ Darüber hinaus „soll diese Forschung einen Beitrag zur besseren Kenntnis des Umgangs der Gesellschaft mit Wasser als Lebensgrundlage, Transport- und Antriebsmittel und der Beständigkeit menschlicher Eingriffe leisten. Die Ergebnisse können verschiedenen Fachbereichen (Naturschutz und Denkmalpflege) ein anwendungsorientiertes Hintergrundwissen liefern und helfen, die stark auseinanderklaffenden Schutzziele zu vereinen. Für spezifische Lebensräume, die erst durch menschliche Eingriffe entstanden sind, fehlen bisher Kriterien zur Bewertungen und Erhaltung. Durch eine Verknüpfung der verschiedenen Fachbereiche können Möglichkeiten zum Erhalt und Pflege dieser kulturhistorischen Zeugnisse entwickelt werden.“

\footnotetext{
${ }^{2}$ Dissertationsbeschreibung unter URL= http://www.geographie.uni-freiburg.de/ipg/gkgl/diss/kothi/Index.htm; Stand: 24.03.2004
} 
In der Phase 2 des Graduiertenkollegs, die inhaltlich und/oder methodisch an die erste anknüpft, wird in gewässerhistorischer Sicht das Dissertationsthema (II-A2) „Parapotamische, nachhaltige Nutzungssysteme: Wiesenbewässerung zwischen Freiburg und Kaiserstuhl“" unter Betreuung von KONOLD am Institut für Landespflege bearbeitet.

In dem Landschaftsraum zwischen Freiburg und dem Kaiserstuhl, in dem in erheblichem Umfang Wiesenbewässerungsanlagen angelegt wurden, gilt es zum einen die Einflüsse dieser Wirtschaftsform bis auf den heutigen Tag zu klären (Gegenwartsbezug) sowie zum anderen die politische und soziale Dimension, die Organisation über die territorialen Grenzen im Untersuchungsgebiet hinweg zu verifizieren. „Aus all dem ergibt sich eine Fragestellung, die einerseits eine agrartechnische -Bewässerungsverfahren und -technik, Rekonstruktion der Systeme, Status quo, Relikte und deren Zustand - und eine landschaftsökologische Komponente - Ausmaß der Kolmatierung, Beeinflussung des Wasser- und Nährstoffhaushalts - und andererseits eine agrar- und sozialhistorische Komponente besitzt. Die Bewertung der Relikte lässt darüber hinaus denkmalpflegerische Aussagen zu.“

Zum anderen wird seit dem 1.7.2004 das vom „Arbeitskreis Umweltgeschichte“ der Universität Göttingen initiierte (Prof. Dr. HERRMANN) und von der Universität Göttingen und der DFG geförderte und zunächst auf 4,5 Jahre festgelegte Graduiertenkolleg „Interdisziplinäre Umweltgeschichte: Naturale Umwelt und gesellschaftliches Handeln in Mitteleuropa“" seine Arbeit aufnehmen ${ }^{3}$.

Ein Projektbereich betrifft die „Eindämmung von Natur: Flussregulierung von der Frühaufklärung bis zur Mitte des 20. Jahrhunderts" die von Prof. Dr. PÖRTGE, Institut für Geographie, mit dem Thema „Wasserbauliche Maßnahmen an Fließgewässern und ihre Folgen von Anfang des 18. bis Mitte des 20. Jahrhunderts unter besonderer Berücksichtigung des Wertewandels wasserbaulicher Maßnahmen" vorgegeben ist. Im Rahmen des Projektbereichs sollen von Seiten der Geographie wasserbauliche Maßnahmen an Fließgewässern (in Thüringen) und ihre Folgen von Anfang des 18. bis Mitte des 20. Jahrhunderts untersucht werden. Besondere Berücksichtigung wird der Wertewandel wasserbaulicher Maßnahmen in dieser Zeit finden. Zudem sollen Bezüge zur Klimageschichte und zur Kulturlandschaftsentwicklung hergestellt werden. Die Auswirkungen der Flussregulierungen und Auenlandschaftsveränderungen werden auf die Gegenstandsbereiche der anderen Projekte im Teilbereich fokussiert.

Die wesentlichen Fragestellungen und Aussagen des Projektteils sind:

1. Welche wasserbaulichen Maßnahmen wurden im Zeitraum von ca. 1700 bis um 1950 an den Fließgewässern durchgeführt?

2. Warum wurden diese Maßnahmen überhaupt durchgeführt?

3. Welche Folgewirkungen hatten diese Maßnahmen?

Forschungsstand zur historischen Fischerei und Teichwirtschaft

Schließlich gehört zum Anwendungsbereich historisch-geographischer Gewässerforschung die historische Teichwirtschaft als Zweig der Binnenfischerei. Und dieses Forschungsgebiet, die Fischerei und erst recht die Teichwirtschaft des Mittelalters und der frühen Neuzeit, wurde lange Zeit fast gänzlich vernachlässigt und findet sich heute noch nicht in den Themen der Graduiertenkollegs wieder; hier liegt der Fokus auf Fließgewässern. Für den Bereich der mediävistischen Fischerei hat dies auch AMACHER (1996:16) nach seiner Literaturrecherche bestätigt: „Symptomatisch scheint mir dabei die Behandlung im mehrbändigen ,Lexikon des Mittelalter'; der Fischerei wird zwar ein Artikel über mehrere Spalten gewidmet, er befasst sich jedoch nur mit der Hochseefischerei und der doch recht speziellen Fischerei in Oberitalien."

Angesichts der Forschungslage bleibt die nunmehr 120 Jahre alte Quintessenz von FRIEDEL (1884:5) aktuell: ,und in der That giebt es auch bis jetzt noch keine erschöpfende Urgeschichte und Vorgeschichte der Fischerei. Dieser wissenschaftliche Zweig ist nur wenig kultivirt [...]. Vor allem fehlt es an einer einigermaßen vollständigen Zusammenstellung der ziemlich zahlreichen, aber überaus vertreuten Materialien einer Darstellung des ur- und vorgeschichtlichen Fischwesens". Wie die Fischereigeschichte war auch die Teichwirtschaft in Deutschland zu diesem Zeitpunkt nur selten Thema grundlegender historischer

\footnotetext{
${ }^{3}$ Entnommen aus URL = http://www.uni-goettingen.de/de/sh/1134.html; 24.03.2004
} 
Untersuchungen. Die älteren Arbeiten aus der ersten Hälfte dieses Jahrhunderts sind nicht als solche anzuerkennen, da sie sich ausschließlich mit zu dem Zeitpunkt aktuellen und regionalen Fragestellungen beschäftigt haben. So z. B. BENECKE 1881 für Ost- und Westpreußen, BESTEHORN 1913 für die märkischen Gebiete, HÄRTWIG 1917 für Sachsen und SCHÜTT 1927 für Schleswig-Holstein.

Auffällig aber ist, dass die mittelalterliche Fischerei im letzten Jahrhundert und am Beginn unseres Jahrhunderts sehr viel intensiver in der Forschung diskutiert wurde. „Ein fokussierendes Zentrum der Fischereigeschichte, das sich jedoch nicht auf die mittelalterliche Geschichte beschränkte“" (LAMPEN 2000:15), existierte in dem von Emil UHLES initiierten ,Archiv für Fischereigeschichte ${ }^{4}$. Das 1913 in Berlin gegründete Forschungsunternehmen basierte ausschließlich auf der Person des Herausgebers, der die Forschungen in eigener Verantwortung herausbrachte. Dementsprechend endete 1917 mit dem Tod Uhles, abgesehen von einer kurzen Wiederaufnahme, die Reihe, „die bis heute für die Geschichte des Fischereiwesens herangezogen werden muß.“ (LAMPEN 2000:15) Als weiteres wichtiges Sammelwerk aus den zwanziger Jahren ist das ,Handbuch zur Binnenfischerei Mitteleuropas', herausgegeben von den Biologen DEMOLL und MAIER, anzusehen, das einen „enzyklopädischen und bereits interdisziplinären Ansatz" verfolgt (LAMPEN 2000:15).

In der zurückliegenden Zeit waren im deutschsprachigen Bereich kaum Publikationen zur Fischereigeschichte erschienen. Lange konnte nur auf die Dissertation des Göttinger Wirtschaftswissenschaftlers Herbert HITZBLECK (1971) zurückgegriffen werden, „der jedoch überwiegend die ältere Forschung rezipiert.“(LAMPEN 2000:16)

Erst in den letzten Jahren wurde auch dieser Bereich der mittelalterlichen Alltags- und Wirtschaftsgeschichte neu entdeckt und es entstanden einige bzw. einzelne Untersuchungen, die diese Forschungslücke aufgegriffen haben, wie der von MEHL (1999) herausgegebene Band über die „Geschichte der Fischerei in Schleswig-Holstein“.

Die Dissertation von dem Schweizer Urs AMACHER (1996) befasst sich mit der „Fischerei im Gebiet des heutigen Kantons Zürich“ (:17) und dies „,mit dem Ziel, ein möglichst genaues Bild von den mittelalterlichen Fischern zu gewinnen“ (:19). Zeitlich liegt der Schwerpunkt seiner Arbeit auf dem 15. Jahrhundert (:17) und gliedert sich in drei Hauptteile: Im ersten Teil ,wird die mittelalterliche Fischerei-Technik erläutert: Beschrieben werden die Geräte, Einrichtungen und Methoden zum Fischfang, aber auch zur Fischzucht und zur Haltung.“ (:15). Der zweite Teil behandelt die Frage, ,welche Bedeutung die Fischerei im Mittelalter hat" (:15). Zusammen mit dem realienkundlichen Themenblock (Speisezettel, Fastenspeise, Konservierung) bildet dieser Abschnitt das Fundament für den dritten Hauptteil. Der „befasst sich mit den sozialgeschichtlichen Aspekten der Fischerei, behandelt also die Fischer als Berufsleute und als Angehörige einer sozialen Gruppe“ (:15) und versucht beispielsweise die eher historisch-juristische Fragestellung zu klären: „,wer hatte das Recht zu fischen“?

Zuletzt hat Angelika LAMPEN den Mangel in der fischereigeschichtlichen Forschung aufgegriffen. Doch auch sie benannte die Situation zur Fischereigeschichte als „Forschungsdesiderat“ (2000:140) und zeichnet ein vernichtendes Bild über die „magere Forschungslage zu diesem Thema“.

Auszufüllen versucht hat sie diese Lücke mit ihrer 1997 an der Universität GH Kassel abgeschlossenen und im Jahr 2000 publizierten Arbeit über „Fischerei und Fischhandel im Mittelalter“. Anhand wirtschafts- und sozialgeschichtlicher Untersuchungen ,nach urkundlichen und archäologischen Quellen des 6. bis 14. Jahrhunderts im Gebiet des deutschen Reiches“ ist es ihr gelungen, „die Bedeutung der Fischerei für die mittelalterliche Ernährung“ (:9) nachzuweisen und zwar am Beispiel jener Arten, „die in der Wirtschaft des Mittelalters und der frühen Neuzeit allgemein gesehen die größte Bedeutung besaßen.“ (:9): Hering, Kabeljau (Stockfisch), Lachs, Hecht und Stör.

\footnotetext{
${ }^{4}$ Insgesamt entstanden bis zu dem Tod Emil UHLES im Jahr 1917 neun Bände von unterschiedlichem wissenschaftlichem Wert. Seit 1926 erschien im Auftrag des Deutschen Fischereivereins eine neue Reihe unter dem Herausgeber Wilhelm KOCH, die jedoch in den 30er Jahren eingestellt wurde (zitiert nach LAMPEN 2000:Anm. 25).
} 
Aber neben dem mittelalterlichen internationalen Fischhandel der Hanse behandelt LAMPEN nur in einem einzigen Kapitel auch die Binnenfischerei. Umso unverständlicher, als LAMPEN (2000:10) selbst formuliert, dass „,selbst ein Zentrum des internationalen Handels wie Lübeck die eigene lokale Fischerei nie vernachlässigte, sie im Gegenteil immer weiter forcierte und ausbaute.“

Doch dieses Kapitel über Teichwirtschaft bezeichnet selbst LAMPEN nur als „Exkurs“ (2000:140) und sie ging dabei „von der Frage aus, wer als Träger der Fischzucht anzusprechen ist.“ (:140). In der Argumentation wurde vor allem die Verbindung zwischen Mühlen und Fischteichen hervorgehoben.“

Die oben skizzierten Fragen wurden vor allem anhand urkundlicher Überlieferung beantwortet. In einer Fleißarbeit hat sie insgesamt über 2000 Urkunden untersucht, ,die sich - in unterschiedlicher Intensität - mit den Fischereiverhältnissen beschäftigen “ (LAMPEN 2000:21): Urkunden (Diplome), klösterliche Haushaltsverzeichnisse (Urbare), frühe Rechnungen adeliger Haushalte, Urkundenregesten des Königs- und Hofgerichts bis 1451 usw. Eine Aufnahme historisch-landschaftsgeographischer Wesensmerkmale der Teichwirtschaft fehlt jedoch in dieser Arbeit völlig. Es handelt sich um eine rein auf archivalischer Quellengrundlage fußende sozial-, wirtschaftshistorische und oecotrophologische Arbeit der Fischereigeschichte.

Doch wenn zur historischen und hier mittelalterlichen Fischerei in neuerer Zeit aus dem deutschsprachigen Raum mit AMACHER und LAMPEN zwei geschichtswissenschaftliche Werke vorlegt wurden, die sich zumindest in Abschnitten mit der Fischzucht in Teichen beschäftigen, so fehlen diese für den Bereich der historisch-geographischen Teichwirtschaftsforschung völlig.

Der Wirtschaftsgeograph HUBERT (1991) hat in seiner empirischen Arbeit „Die Aischgründer Karpfenteichwirtschaft“" mit der historischen Teichwirtschaft und Teichpflege wirklich nur am Rande beschäftigt. Die historische Entwicklung der Karpfenteichwirtschaft im fränkischen Aischgrund wird bei ihm nur in einem Kapitel, d. h. vielmehr auf einer knappen Seite behandelt. In seiner später beendeten Dissertation steht die Wirtschaftlichkeit der Teichwirtschaftsbetriebe deutlich im Vordergrund.

Ein negatives Beispiel für regionale Untersuchungen aus jüngster Zeit stellt der Aufsatz von Wolfgang MÜCK (1990/91) dar. MÜCK rekonstruiert eine frühmittelalterliche Teichwirtschaft im Aischgrund ausschließlich aus den Hinweisen des Capitulare de Villis und der Aussage, im Aischgrund habe es viele Königsgüter gegeben.

Eine unbedingt zu erwähnende Schrift zur historischen Teichwirtschaft ist vielmehr die von Lydia BRÜNGER (1996) zum „historischen Fischereiwesen in Lippe“, in der sie sich, da dort die künstliche Fischzucht erfunden worden ist, mit der Teichwirtschaft beschäftigt. In der ersten Hälfte ihrer Publikation behandelt sie weitgehend die biologischen Verhältnissen der Gewässer im Kreis Lippe, im zweiten Teil dann die historische Teichwirtschaft und Fischzucht in Westfalen-Lippe.

Wenn auch nicht die historische Teichwirtschaft, sondern die historische Fischerei behandelnd, darf die historisch-geographische Untersuchung von Haik Thomas PORADA an dieser Stelle nicht unterschlagen werden, der ,historisch-geographische Aspekte der Fischerei auf dem Stettiner Haff in der Frühen Neuzeit“ aufdeckt. Dabei wird, wenn auch mit Schwerpunkt auf die frühe Meeresfischerei, auch die Flussbezogenheit der Fischerei in Pommern anhand historischer Quellen belegt. Gerade die Bedeutung der Nebengewässer, dies ist ein wesentliches Ergebnis der Untersuchung, führten zu der Namensgebung als Großfischereigebiet: dem Unterlauf der Oder sowie den drei Ausmündungen, Peenestrom mit Achterwasser und Krumminer Wiek, Swine und Dievenow mit der Maade (2001:54).

In der vom Bayerischen Landesverein für Heimatpflege verlegten Zeitschrift „'Schönere Heimat': Erbe und Auftrag“ der Ausgabe 2/2004 sind zwei Abhandlungen erschienen, die sich mit der Kulturlandschaftsinventarisation im direkten Umfeld des Zisterzienserklosters Langheim befassen. Entstanden aus einer 1995 im Rahmen des Dorfentwicklungsplanes vergebenen Auftragsarbeit werden dabei von Wolfgang THIEM (2004:93ff.) auch die klosterzeitlichen Teichanlagen und deren Elemente und Relikte inventarisiert. Steffen SIMMLER (2004:101ff.) übernimmt dabei die computergestützte Rekonstruktion der 
Klosterlandschaft auf der Grundlage des Klosteratlasses von 1741/42 mit der Darstellung auch der unmittelbaren Teichlandschaften in einer umgezeichneten Gesamtkarte.

Archäologie

Archäologisch dokumentierte Grabungen zum mittelalterlichen Teichwesen fehlten im deutschen Sprachraum bislang völlig. Einzige Ausnahme bildet die vom Rheinischen Landesdenkmalamt im Rahmen des Modellprojektes „Klosterlandschaft Heisterbach“ unternommene Sondierung eines ehemaligen, auf Altkarten noch nachzuweisenden, aber im Gelände nur noch schwer erkennbaren Klosterteiches. Die Prospektion eines Schnittes, um den Teichdamm im Gelände nachzuweisen, misslang jedoch. Er brach völlig in sich zusammen (ANDRIKOPOULOU-STRACK et al. 2002).

\section{Heimatforschung und populärwissenschaftliche Forschung}

Mühlen

Institutionell getragene wissenschaftliche Untersuchungen zur - auch regionalisierenden - Mühlengeschichte, die die Veränderung des Gewässersystems mit dem Aufkommen seit dem 8./9. Jh. und insbesondere seit dem 13./14. Jh. entscheidend mitgetragen hat, liegen wie oben dargestellt bislang nur vereinzelt vor (DIX 1997; UECKER 1999). Diese Leistung wird vor allem seitens der Heimatforschung erbracht, und dies dann auch in unüberschaubarer Vielfalt. Einige bemerkenswerte Beispiele seien im Folgenden vorgestellt:

Eine umfangreiche Lokalisation und Mühlenbiographie unternimmt da beispielsweise der ehemalige Krefelder Kulturdezernent Dr. Hans VOGT (1998) mit seinem 594 Seiten starken „Niederrheinischen Wassermühlenführer“, der eine Ergänzung und Aktualisierung seines bereits schon 1989 in 2. Auflage erschienenen Standardwerks für diesen Raum darstellt. In mühevoller Kleinarbeit wurden dort sämtliche Wassermühlen im Stromgebiet zwischen Rhein und Issel inventarisiert und anhand sekundärer Quellen porträtiert. Bei den Illustrationen zu den einzelnen Mühlenbiographien hingegen hat er sich weitgehend für ein aktuelles Bild der Wassermühlen entschieden; der frühere Zustand bleibt in den meisten Fällen verborgen; ebenso werden leider keinen Aussagen zu Mühlenteichen getroffen, nur vereinzelt werden sie an manchen Stellen erwähnt.

Ein von der Systematik her interessantes Werk ist dasjenige von Erich MERTES (1995) über die „Mühlen in der Eifel". Er hat die Eifelmühlen streng nach den von hier entwässernden Fluss- und Bachabläufen angeordnet (:49) und nicht beispielsweise nach Regionen, wie es z. B. BENDAL für Franken und MÖHLSTEDT für Ostwestfalen getan haben. „Die Mühlenfolge“, schreibt MERTES (:49), „folgt dem Wasserlauf von der Quelle bis zur Mündung. Eine Anzahl von Nebenbächen wird dort eingeschaltet, wo sie in das Gewässer einfließen." Aber, so schränkt er das Untersuchungsvolumen ein, "vor allem von den Nebengewässern konnten [...] nicht alle Mühlen aufgezählt werden.” (:49) Bei seiner Auflistung von Mühlen nach ausgewählten Gewässern ging es aber auch ,nicht um die Perfektion der Erfassung aller Mühlen, die Mühlenverzeichnisse aus dem 20. Jh. kommen dem viel näher.“ Es ging ihm vielmehr ,um die Übersicht der wichtigsten Mühlengewässer, an denen die meisten Wassermühlen in der Eifel standen.“ (:49).

Leider aber ist seine Arbeit besitzgeschichtlich aufgebaut und erwähnt ebenso nur selten ehemalige oder noch bestehende Mühlteiche. Dieses Manko teilen jedoch sämtliche Untersuchungen. Mühlteiche bleiben vielfach unberücksichtigt und werden, wenn überhaupt, nur beiläufig erwähnt, wenn es sie im Gelände zum Mühlenensemble noch gibt. Ein vollständiges Mühlenkataster wie auch ein „Mühlenatlas“, mit dem die „Erfassung bestehender und verschwundener Mühlen“ betrieben wird (FRITZ 1988), müsste zwingend diese wichtigen Kulturlandschaftselemente mit aufnehmen.

Einem anderen gewichtigen mühlen- und gewässerhistorischen Landschaftselement hat sich Elke JANSSENSCHNABEL (1998) in einem Beitrag angenommen und „Mühlengräben in der Ruraue“ beschrieben.

Mit ähnlichem Aufbau wie die Arbeit von MERTES ist beim Landschaftsverband Rheinland 1990 ein von Ludwig LUNKENHEIMER bearbeitetes Arbeitsheft erschienen, das in einer gründlichen Zusammenstellung über die „Schleifkotten, Mühlen und Hämmer an den Solinger Bächen” berichtet. Hier ist von LUNKENHEIMER, einem 1903 geborenen, ehemaligen Mitarbeiter des Rheinisch-Westfälischen- 
Elektrizitätswerkes in Solingen, der Versuch gemacht worden „alle Wassertriebwerke an den einzelnen Bachläufen [...] zusammen zu tragen.” (:10), mit dem Vorteil der aus dem Alter erwachsenden eigenen Anschauung. Ausgenommen wurden die Schleifkotten an der Wupper, denn diese wurden bereits 1922 von Franz HENDRICHS in „Die Schleifkotten an der Wupper” bearbeitet. Die Arbeit von LUNKENHEIMER hat es sich vielmehr ,zur Aufgabe gemacht, eine Übersicht über die verschiedenen Anlagen an den Solinger Bachläufen zu geben”, ausgehend „,von der Quelle bis zur Mündung” (:10).

Der vielzitierte, von Konrad BEDAL 1992 in 2. Auflage im Auftrag des Fränkischen Freilichtmuseums Bad Windsheim herausgegebene Band „Mühlen und Müller in Franken“ behandelt im engeren Sinne „wassergetriebene Getreidemühlen in Franken und ihre Müller” (:9). Vor allem wird hier Grundwissen über Mühlentechnik, Müller und auch die Getreidesorten vermittelt (BEDAL 1992). Eine Beschäftigung mit den Gewässern fehlt indessen in diesem Buch.

Diese Details, über die Wasserläufe und Lage der Mühlen in der Fränkischen Schweiz, sind eher der Veröffentlichung von Johann-Bernhard HAVERSATH (1987) „Mühlen in der Fränkischen Schweiz“ zu entnehmen.

Nicht nur aus dem Berg- und Hügelland, als vermeintlichen Schwerpunktraum der Verbreitung von Wassermühlen, sondern auch aus dem Tiefland liegen dazu Publikationen vor. Hermann TERHALLE (1991) beispielsweise berichtet in seiner auf archivalische Quellen beruhenden Arbeit über die Geschichte der Wind- und Wassermühlen im Vredener Land und auch von den Wassermühlen in den darin befindlichen Städten. Entgegen den anderen Sammeldarstellungen, die die Mühlen eines einzigen Gewässers bzw. einschließlich deren Zuflüssen behandeln, geht TERHALLE regionalisierend vor, was diese Arbeit hinsichtlich der Frage zur geographischen Verbreitung zwar hervorhebt, die Rekonstruktion einer gewässerbezogenen Mühlengeschichte aber wird mit dieser Methodik nicht ermöglicht.

Historischer Bergbau

Eine andere Möglichkeit über gewässerhistorische Zusammenhänge zu informieren und über ein Sichtbarmachen der Anlagen hoffentlich auch zu ihrer Erhaltung beizutragen, stellt die museale Variante des Freilichtmuseums dar. Die Harzwasserwerke haben 22 „WasserWanderWege“ einrichten lassen, die in ihrer Gesamtheit das „Freilichtmuseum Kulturdenkmal Oberharzer Wasserregal“ bilden. Martin SCHMIDT, ehemaliger Direktor der Harzwasserwerke, hat in einem dazu erschienenen Exkursionsführer (1997) die mit dem Bergbau verbundenen Einrichtungen und Anlagen der alten Oberharzer Wasserwirtschaft, wie zum Beispiel die zahlreichen Kulturdenkmale des „Oberharzer Wasserregal“ zusammengestellt. Es zeigt die wichtigsten Relikte seiner Energieversorgung des ehemals großen europäischen Industriegebiete auf der Basis von Wasserkraft und umfasst die von den Bergleuten für die Wasserkrafterzeugung gebauten technischen Artefakte und Landschaftselemente: Holzrinnen, Gräben, Wasserläufe, Teiche, sog. Radstuben, das sind Kraftwerke, in denen sich hölzerne Wasserräder drehen, Flößeranlagen wie Flößerteiche und wehre, Flößgräben usw. Aber auch in anderen zahlreichen Veröffentlichungen hat er „die Wasserwirtschaft des Oberharzer Bergbaus“" dargestellt (z. B. SCHMIDT 1992).

Flüsse

Eine ungeheure Vielzahl an heimatkundlichen Veröffentlichungen liegt zu den dem breiten Publikum bekannten Fließgewässern vor. Selbstverständlich sind da zunächst die Monographien zu den großen deutschen Flüssen und Strömen Mitteleuropas. Neben diesen - zumeist populärwissenschaftlichen und touristisch gefärbten - Flussmonographien, sind in letzter Zeit zu einigen größeren Flüssen Monographien bzw. Ausstellungskataloge erschienen, die sich im weitgespannten Rahmen auch mit der Beeinflussung der Gewässer durch den Menschen aus historischer Sicht beschäftigen:

Hans BOLDT (1988) hat „eine außerordentlich vielseitige Dokumentation über den guten alten 'Vater Rhein' "verfasst. Von Mythen, Rheinromantik, Denkmalen, Naturlandschaften über Geschichte und Politik bis hin zu Themen wie Wirtschaft, Ökologie und Verstädterung soll dieser Band ,ein umfassendes Bild des deutschen Schicksalstromes“ bieten (Verlagsbeschreibung). Des Weiteren hat Horst-Johannes TÜMMERS (1994) in acht Jahren nicht nur den Rhein erwandert, sondern beiläufig auch aus allen Wissensgebieten Informationen zusammengetragen, „um die Geschichte eines europäischen Flusses von der Quelle bis zur Mündung“ zu schreiben (:11). 
Das LANDESMUSEUM KOBLENZ (1991) begleitet mit ihrem Band „2000 Jahre Rheinschiffahrt“ die gleichnamige Ausstellung, und das LANDESAMT FÜR DENKMALPFLEGE RHEINLAND-PFALZ (2002) hat das opulente Werk „Das Rheintal von Bingen und Rüdesheim bis Koblenz. Eine europäische Kulturlandschaft" herausgegeben.

Auch für „Die Elbe“ (1992) wird in einem umfangreichen und reich illustrierten Ausstellungskatalog ihr „Lebenslauf" beschrieben. Der Elbstrom wird in all seinen Formen und seiner Vielfalt dargestellt. Schwerpunkte dieser Darstellung sind unter anderen die Kategorien Binnenschifffahrt, Deich- und Wasserbau sowie der Brückenbau. Weitere populärwissenschaftliche Veröffentlichungen unter anderem zur Geschichte des Elbeflusses liegen z. B. von RIEDEL-LORJE/GAUMERT (1982), JÜNGEL (1993), THIELCKE (1999) sowie NEUSCHULZ et al. (2002) vor. Die Geschichte der Donau kann beispielsweise WEITHMANN (2000) entnommen werden.

Für die Weser hat Karl LÖBE, ehemals Jurist in der Bremer Seehafenverwaltung und Vorsitzender des Weserbundes, 1968 das gut recherchierte „Weserbuch“ in erster Auflage veröffentlicht. Es trägt den Untertitel „Roman eines Flusses“, um damit an die literarischen Romanhelden der Geschichte zu erinnern: an Glück und Unglück, an Schicksale und Irrtümer. Der Fluss ,als Objekt von Intrige und Unrecht, als Träger von Segen und Fluch, geliebt und verachtet, umsorgt und verlassen“ steht bei LÖBE (1969:10) im Mittelpunkt. Mit diesem Betrachtungsansatz ist es insofern beachtenswert, als dass es das in Mode kommende Thema der „Spiritualität“ auf den Fluss überträgt, inhaltlich betrachtet ist es hingegen weniger eine Erwähnung wert.

Beachtenswerter für die gewässerhistorische Weserforschung ist vielmehr das opulente dreibändige Werk „Die Weser - Ein Fluss in Europa“, das als Begleitband zur Ausstellung im Museum Hameln vom 17.06.10.09.2000 entstanden ist. Es widmet sich den kulturellen und geschichtlichen Entwicklungen von drei Epochen: Mittelalter, Renaissance und Neuzeit. Dabei steht der Fluss als verbindendes Element und Lebensader der Region im Mittelpunkt. Aus Band 1, der einen Gesamtüberblick auf geistiges und wirtschaftliches Leben in der Weserregion gibt, ist vor allem der Beitrag von ADAMECK und SCHWEEN (:8-24) hervorzuheben, in dem sie im Anschluss an ihre Darstellungen zu den großräumigen Kulturkontakten an der Weser in der Vor- und Frühgeschichte „Überlegungen zur Weserschiffahrt und zum Landverkehr“ anstellen. Der Schwerpunkt der „Wesergeschichte“ ist in dem 2. Band „Aufbruch in die Neuzeit“ zu sehen und behandelt unter anderem die Themenschwerpunkte „Der Fluß“: „Der Fluß als Naturgewalt" und „Der Fluß und die Politik“ sowie „Das Schiff“: z. B. „Schiffe auf der Weser in der Frühen Neuzeit“ (KORINTH), „Schiffe auf der Weser im 18. Jahrhundert“ (HEIL) und „Güter auf dem Fluß“ (KORINTH). Band 3 beschäftigt sich nahezu ausschließlich mit der Entwicklung der Tabakindustrie als Beispiel für das Fortschreiten internationaler Handelsbeziehungen in der Neuzeit mit Ausnahme des Artikels von GROSSJOHANN über die Weser als „wilder Fluß und Linienzieher“, d. h. unter anderem als Treidelstrecke.

„Die schönsten Flüsse und Seen Deutschlands“ werden in einem vom Kunth-Verlag 2004 aufgelegten Band porträtiert. Vom Rhein, dem majestätischen ,,deutschen Strom“, zu den ursprünglichen Auenlandschaften der Spree und der Oder, vom stillen Lauf der Ems zu den felsigen Klüften des Donaudurchbruchs, von den „weinseligen“ Landschaften an Main und Mosel zu den „märchenhaften“ Ufern der Weser, um mit der romantischen Sprache des Verlagstextes zu sprechen, geht dieser „Flüsse-Potpourri“ und bezieht auch die Seenwelten der Norddeutschen Tiefebene zu jener der Voraplen und Alpen.

Zwar liegt das Schwergewicht der Veröffentlichungen auch im populärwissenschaftlichen und heimatkundlichen Bereich auf größeren Wasserläufen, doch neben den zahlreichen Darstellungen der „Wasserschifffahrtsstraßen“ und großen Ströme Mitteleuropas, die in diesem Rahmen nicht weiter gelistet werden sollen, gibt es aber auch eine kleine (aber feine) Anzahl von Studien zu den mittelgroßen Gewässerläufen und zu den aus heutiger Sicht eher kleinen „Flüsschen“, von denen einige stellvertretend genannt seien:

Zunächst einmal Manfred BREMBACHs (2000) unter geschichtlichem Aspekt sehr gut recherchiertes Buch über die Bedeutung und Nutzung der Trave im Raum zwischen Lübeck und Bad Segeberg. 
Natürlich, würde man meinen, ist der Alsterlauf - neben der weniger bekannten Bille, für die jedoch eine Beschreibung ihres Wandels vorliegt (HINRICHSEN 1983) - Gegenstand zahlreicher kulturhistorischer Betrachtungen im norddeutschen Raum. Doch dem ist nicht so. Umso erfreulicher ist daher, dass aus der Freien und Hansestadt Hamburg ein reich bebildertes und aufwendig verarbeitetes Buch zur Alsterregulierung unter Einbeziehung der Siedlungsentwicklung und der Gartenbaukunst vorliegt. In der von Jens BECK und Ralf G. VOSS (1999) bearbeiteten Auflage ,werden der zuletzt kanalisierte Abschnitt der Alster zwischen Winterhude und Fuhlsbüttel“", dessen Arbeiten 1914 begannen und sich bis in die 20er Jahre hinein zogen, und das dort entstandene Wohngebiet untersucht(:9). Das vorliegende Buch basiert auf einer Studienarbeit, die die Autoren 1991-1994 unter dem Titel „Kanalisierung der Alster zwischen Winterhude und Fuhlsbüttel“ am Institut für Grünplanung und Gartenarchitektur der Universität Hannover abgegeben haben.

VOLLRATH und LAMMEL (1993) zeichnen mit ihrem Band „Die Havel - Geschichte eines Flusses“ ein „farbiges Mosaik voller landeskundlicher und kulturhistorischer Informationen, ein Panorama von Geschichte und Geschichten, von Dörfern und Schicksalen." (Verlagsbeschreibung). Da die Havel auch eine bedeutende Wasserstraße von hoher geschichtlicher Bedeutung in Berlin ist, ist die Beachtung kulturhistorischer Werte bei dem Gewässerausbau von besonderer Bedeutung.

In dem von der SPARKASSE GIFHORN-WOLFSBURG 1988 herausgegebenen Buch „Reizvolle Fluß- und Seenlandschaften im Raum Gifhorn-Wolfsburg" haben zahlreiche Autoren wie DEFLS, KRATZ, SCHRÖDER und WÄCHTLER Beiträge zu den hier verlaufenden Bächen, den Still- und Kleingewässern und Mühlen verfasst.

Remmer AKKERMANN (1994) von der Biologischen Schutzgemeinschaft Hunte hat in dem Band „Die Hunte - Porträt eines nordwestdeutschen Flusses" mehrere Autoren vereinigt, die sich hauptsächlich aber leider nur mit der Natur und der Ökologie dieses bedeutenden und kulturhistorisch noch wenig erforschten Flusslaufes des norddeutschen Tieflandes zwischen Wiehengebirge und Oldenburg beschäftigen.

Karsten ALTHÖFER-WESTENHOFF und Bernd Josef WAGNER (1997:7) haben eine Umweltgeschichte der westfälisch-ravensbergischen Flüsse „Else und Werre im 19. und 20. Jahrhundert“ geschrieben. Sie haben sich dabei auf eine bestimmte Baumaßnahme in einem begrenzten Abschnitt der beiden Flüsse konzentriert und zeigen daran beispielhaft die Veränderungen an den Flussläufen auf. In einem ersten Abschnitt behandeln sie die Werre-Kanalisierung zwischen Salzuflen und der Stadt Herford sowie die Renovierung von wichtigen Stauwehren am Ende des 18. Jahrhunderts. Im zweiten Abschnitt steht der Flusslauf der Else in seiner konfliktreichen Funktion als Vorfluter für die Abwässer der Stadt Bünde im Mittelpunkt des Interesses.

Ein heimatgeschichtliches Buch über die Emmer und ihre begleitenden Ortschaften und Herrensitze, von ihrer Quelle im Eggegebirge bei Altenbeken über das Egge-Vorland, das Steinheimer Becken, das Emmerthal bei Bad Pyrmont und schließlich zur Mündung in die Weser, hat Johannes WALDHOFF (1996) verfasst. Doch es ist keine Fluss-Monographie, sondern auch die zahlreichen kleinen Nebenbächen im Emmer-Einzugsgebiet werden zumindest mit einer Kurzbeschreibung aufgenommen, wie die für den Ortsfremden unbekannten Fischbach, Heubach, Napte, Diestel oder Niese.

Auch aus dem Rheinland werden „Geschichte und Geschichten“ des namensgebenden Flusslaufs der nordrhein-westfälischen Landeshauptstadt in einer Publikation von mehreren Autoren in allgemeinverständlicher, aber dennoch sachkundiger, Form erzählt. Entstanden 1998 als Begleitband zur gleichnamigen Ausstellung im Düsseldorfer Stadtmuseum ist sie - vergleichbar mit der Situation zur Alster - eine der wenigen Veröffentlichungen zur Geschichte der Düssel. Die Düssel wird dabei aus unterschiedlichen Perspektiven betrachtet: angefangen beim Heimatforscher (SCHMITZ-PORTEN:25-35) und Wanderer (KNÜBEL:8-14), der seine Eindrücke und Gefühle während eines Spaziergangs von der Quelle bis zur Mündung beschreibt, über den Stadtplaner und Wasserbauingenieur (SPOHR:45-53), die sie unter städteplanerischer bzw. hydrographischer Sicht behandeln, bis hin zur Kunsthistorikerin. Selbst Vertreter der Wirtschaft- und Technikgeschichte setzten sich mit den bislang kaum beachteten und früher zahlreichen Mühlen an der Düssel auseinander (WIEMER:79-92). 
Die mitteldeutsche Unstrut haben SCHLENKER und LAUBNER (2002) porträtiert.

Den aus dem Bayerischen Wald kommenden und namensgebend in Regensburg in die Donau einfließenden Gewässerlauf des Regen hat KLEINDORFER-MARX (1996) in ihrer Flussmonographie nicht nur hinsichtlich seiner ökologischen Bedeutung, sondern auch seines kulturhistorischen Wertes beschrieben.

Nach dem bekannten Schema „,von der Quelle bis zur Mündung“ haben WEIS und FLORIAN (2001) die Kupfer begleitet, die durch das Hohenloher Land im Raum Schwäbisch Hall fließt.

Den Schwarzwaldfluss Kinzig hat KLEIN (2002) als Mittelpunkt bzw. Leitfigur für seine volkskundlichen Lebensbeschreibungen ausgesucht. Das $52 \mathrm{~km}$ lange Flüsschen Alb, das bei Bad Herrenalb im Nordschwarzwald entspringt und bei Karlsruhe in den Rhein mündet, haben die beiden Autoren KIRCHBAUER und WARDA (2001) in einem Bildband dokumentiert. Auch hier wird eine kulturgeschichtliche Reise unternommen, die im Wesentlichen leider nur die Geschichte der Orte und Örtlichkeiten entlang des Ufers nachzeichnet. Der Band versammelt Sagen, Gedichte von Heimatschriftstellern oder Augenzeugenberichte von Hochwasserkatastrophen ebenso wie Dokumente der Industrialisierung, beispielsweise der Papierindustrie Buhl bei Ettlingen, die nur dank der Wasserenergie der Alb und des geringen Härtegrades ihres Wassers entstehen konnte.

Die Isar als vermeintlichen „Wildfluss in der Kulturlandschaft“ haben MAGERL und RABE (1999) als Herausgeber entdeckt und Carmen ROHRBACH (2002) unternimmt „eine Wanderung von der Quelle bis zur Mündung“.

Das von den Autorinnen BERCHTOLD-OGRIS, ENTNER und VERDEL verfasste und vom Slowenischen Kulturverbund 2001 herausgegebene und zweisprachig (deutsch/slowenisch) verfasste Buch „Die Drau ist eine eigene Frau“" handelt von dem Fluss, der auf einer Länge von 748 km vier Länder durchließt (Südtirol, Kärnten, Slowenien, Kroatien) und einen fünften tangiert, indem sie entlang der ungarischen Grenze bis nach Osijek fließt, wo sie schließlich in die Donau mündet. Im Vordergrund steht dabei die Nutzung der Drau (slow. Drava) als Nahrungsquelle, Verbindungsweg, Wasserquelle und Abwasserträgerin, Flößerei und als Antriebskraft. Aber auch die Drau in der Mythologie und in der Literatur wird behandelt, ebenso wie auch Regulierungsmaßnahmen dargestellt werden, die durch das Eigenleben des Flusses, wie das Verschieben von Flussarmen und die Bedrohung durch Hochwasser, angestoßen wurden und $\mathrm{zu}$ dem Ausspruch im Volksmund führten: die Drau sei eine ,eigene Frau“(BERCHTOLD-OGRIS et al. 2001:6f.).

Aus dem Bereich der Gewässermonographien kleinerer Flüsse ist die von Wolfgang HONSINGERLENBURG und Gabriele WIESER 1997 herausgegebene Schrift „Die Gurk und ihre Seitengewässer“ zu erwähnen. Die Publikation setzt die Reihe der gewässerökologischen Bearbeitung von ganzen Fließgewässereinzugsgebieten in Kärnten fort, die im Vorjahr mit der Herausgabe eines Büchleins über die Gewässer des Lavanttales begonnen hatte. Bei der Untersuchung der Gurk, nach der Drau der zweitlängste Fluss Kärntens, wurde jedoch neben den benthischen Organismen, den Fischen und hydrologischgeologischen Grundlagendaten, der gewässerbegleitenden Vegetation und der Avifauna auch auf die Siedlungsgeschichte des Gurktales eingegangen (:15-17) und die Fischereigeschichte der Gurk und ihrer Seitengewässer (Glan) dargestellt $(: 119,133)$.

Volkskunde

Neben den Flussmonographien, die sich der Geschichte des Flusses aus unterschiedlichen Blickwinkeln nähern, gibt es auch Beiträge, die aus volkskundlicher Betrachtung bestimmte Aspekte des Lebens mit, vom oder am Wasser beleuchten.

Den Fluss als Existenzgrundlage für bestimmte Berufssparten beschreibt BAUMANN (1977) in seinem sozialhistorisch-volkskundlichen Buch und berichtet vom Tagwerk der Fährleute, Schiffer und Fischer.

Die Stätten historischer, gewässerbezogener Wirtschaftsweisen des früh- und vorindustriellen Zeitalters zwischen Wupper und Sieg wird in einem vom NETZWERK INDUSTRIEKULTUR BERGISCHES LAND e.V. (2000) herausgegebenen „Reisebuch“ beschrieben. Das NETZWERK, eine seit 1997 bestehende Arbeitsgemeinschaft von Museen, Landschaftsverbänden und Einzelpersonen zur Förderung der Geschichte 
und Gegenwart des Bergischen Landes als einer alten Industrie- und Kulturlandschaft, präsentiert hierin 72 Stätten der Industriekultur im Bergischen Land sowie im angrenzenden Märkischen und Siegerland. Die als Themenrouten zusammengestellten Informationen zeigen in dem Kapitel „Wasser und Energie“ die Zusammenhänge der Industrialisierung mit der Entwicklung der Wassernutzung und der Energieerzeugung in dem durch zahlreiche Fluss- und Bachtäler geprägten Land auf.

Die vom Verein NETWERK INDUSTRIEKULTUR BERGISCHES LAND 2001 beschriebenen „Themenrouten zur Industriekultur zwischen Wupper und Sieg“ stellen die Ergänzung zu dem oben beschriebenen Band dar. Die Routen folgen den Spuren der Montanindustrie und führen zu Stätten der Kleineisenindustrie. Sie beleuchten die Geschichte der Textilproduktion und zeigen die Zusammenhänge der Industrialisierung mit der Entwicklung der Wassernutzung und der Energieerzeugung auf, die wiederum auch in engstem Verbund mit der Inwertsetzung von Wasser steht.

Flößerei

Jenem Berufsstand, den BAUMANN hingegen in seine Veröffentlichung nicht mit aufgenommen hat, widmet sich Hans-Walter KEWELOH (1985). Der Flößerei gilt sein Hauptaugenmerk und er hat die Geschichte dieser Kombination aus Fluss- und Waldarbeit in lesenswerter Form zusammengefasst, zum einen als Herausgeber und Mitautor einer Aufsatzsammlung (1985) zu verschiedenen Flößerthemen und Flüssen in Deutschland und zum anderen in Zusammenarbeit mit seiner Frau Nicola BORGER-KEWELOH, beide Mitarbeiter des See- und Schifffahrtsmuseums in Bremen, in Form der 1991 erschienenen Monographie zur „Flößerei im Weserraum“. Darüber hinaus gibt es eine Vielzahl von Schriften, die sich diesem Thema in früherer Zeit angenommen haben (BARTH 1885; GOTHEIN 1889; LUTTENBERGER 1904; RENNER 1928; BÄRTLE 1933; KNÖSEL 1934; HOHL 1942; DELFS 1952; HERRMANN et al. 1960; WILSDORF 1979; SCHREIBER/WALTER 1987; ROMMEL 1990; JAUERNIG-HOFMANN/ HOFMANN et al. 1993).

Spiritualität/Symbolik

$\mathrm{Zu}$ dem Themenbereich der Sagen und der erzählerischen Symbolik, die sich um Flüsse ranken, sind in einer Taschenbuchreihe der Knaur Verlagsanstalt Gewässermonographien über „Mythen, Märchen und Erzählungen" die Elbe, Donau und den Rhein betreffend erschienen. In gleicher Reihe erschien auch ein Band über „Alte Mühlen in Mythen, Märchen und Erzählungen”. Bei den Gewässerbänden handelt es sich um 'Heimat-Lesebücher' ,über den Fluß und seine Geschichte von der Quelle bis zur Mündung”. Sie haben die Form ,poetischer Wanderungen” von Malern und Dichtern ,an seinem Flußlauf von der Quelle bis zur Mündung", so die Buchbeschreibungen zu den jeweiligen Titeln (SCHLENDER 1988:350ff.). In dem Mühlen-Band ist speziell das 5. Kapitel den Wassermühlen gewidmet (:198-271).

Wiesenbewässerung

Bewässerungswiesen, die vor allem mit Wasser abgeleiteter und gestauter Flüsse benetzt wurden, sind auch Gegenstand heimatkundlicher Forschungen. Im Zuge der Aufnahme archäologischer Bodendenkmale und historisch-geographischer Kulturlandschaftsrelikte im Gebiet um den südniedersächsischen Flecken Adelebsen bei Uslar wurden vom Ehepaar Gertraude und Eckart SCHRÖDER 1979 und 1984 Reste aufgelassener Anlagen für die Wiesenbewässerung kartiert.

Gartengestaltung

Dass der „umfassende Humanismus der Landschaftsbewegung [...] den gesamten Uferraum der Themse“ mit einbezog, „mit ihren Villen und Kirchen, ihren Schlössern und fernen Hügeln ebenso wie mit ihren Booten und geschäftigen Anlegestellen“ und dass die Gewässer als ,integraler Bestandteil der Landschaft“ aus der englischen Landschaftsbewegung in die deutsche Gedankenwelt übertragen wurde, verdeutlichen SCHUMACHER/STRAUSS (WILKIE 1988:7) mit ihrem zweisprachigen Band am Beispiel der Havel (Parklandschaft „Potsdamer Havelseen“) und Elbe (Dessau-Wörlitzer Gartenreich). Generell aber kann die kultur- und umwelthistorische Darstellung von Gewässern in bzw. durch herrschaftliche Landschaftsgärten als ein Desiderat bezeichnet werden.

\section{Forschungen zur Gewässerplanung}

Ein frühes Beispiel einer Auseinandersetzung mit der Thematik „Historische Gewässer in der Planung“ ist der Beitrag von KONOLD/WOLF (1987). Am Beispiel der Gemarkung Bad Wurzach - Seibranz (Kreis 
Ravensburg) unternehmen sie „kulturhistorische und landschaftsökologische Untersuchungen als Grundlage für die Feuchtgebietsplanung“".

Dem „Kulturgüterschutz an Gewässer[n] und Auen“ sowohl in Landschaftsplanung als auch in den Rechtsbereichen der Denkmal- und Landschaftsgesetze widmet sich HEUSCH-ALTENSTEIN (1999) in einem Beitrag. In dem gleichen Band „Fließgewässer in der Kulturlandschaft“ sind noch weitere Beiträge zu diesem Themenbereich zu nennen: Das Statement von SPITTLER (1999) bezüglich „Forderungen zur Berücksichtigung kulturlandschaftlicher Belange bei Planung und Unterhaltung von Fließgewässern und Auen aus der Sicht des Naturschutzes“" und das von ZANGER (1999), in dem sie die Berücksichtigung kulturlandschaftlicher Belange aus Sicht der Denkmalpflege fordert.

Die physiogeographische Dissertation von NIEHOFF (1996), die vom Geographischen Institut der Universität Göttingen begleitet wurde, leitet Bewertungskriterien hinsichtlich der Gewässerrenaturierung insbesondere am Beispiel der Oker im Harz ab. In gleiche Richtung zielen die Überlegungen von JAX (1994).

In dem 2000 in der Reihe Seminarberichte veröffentlichten Band 5 der Natur- und Umweltschutz-Akademie des Landes Nordrhein-Westfalen (NUA) sind 15 Fachbeiträge einer Fachtagung vom September 1998 aufgearbeitet worden, die sich mit der Ökologie, dem Management und Schutz „temporärer Gewässer“ beschäftigen. Mit dem Band wird - erstmals für den deutschsprachigen Raum - nicht nur eine aktuelle Zusammenstellung des Kenntnisstandes zu den von Seiten des Naturschutzes noch recht wenig beachteten „temporären Gewässern“ gegeben, sondern der Band wird abgerundet durch Zielvorgaben und Handlungsempfehlungen zu Schutz und Entwicklung temporärer Gewässer und erhebt damit einen Planungsbezug. „Gewässer ohne Wasser“, so der Titel dieser Veröffentlichung in Anspielung auf das ihr zeitweise fehlende Element, hat ihr Ziel, diesen zeitweiligen Gewässern eine stärkere Beachtung aus Sicht des Naturschutzes zu geben, erreicht, aber eine eingehende Betrachtung aus kulturhistorischer Sicht fehlt hingegen - noch immer.

Im Gegensatz zu den Kleinstgewässern beschäftigt sich die AKADEMIE FÜR RAUMFORSCHUNG UND LANDESPLANUNG (1997) als Herausgeber mit den Großschutzgebieten. Diskutiert werden Chancen und Konflikte im Rahmen einer integrierten Regionalentwicklung am Beispiel insbesondere auch der Flusslandschaft Elbe.

\section{Rechtwissenschaftliche Forschungen}

Aktuelles Recht

Die Historische Geographin Ursula von den DRIESCH geht der - in einer der wenigen Arbeiten zu diesem Thema überhaupt - gestellten juristischen Frage nach, ob „wasserbauliche Elemente [...] als Denkmale schutzwürdig?“" sind. Ziel ihres Beitrages ist es, „einen Überblick über gültige Rechtsvorschriften in der Bundesrepublik Deutschland bis $1986 \mathrm{zu}$ geben, die Schutz und Pflege wasserbaulicher Elemente ermöglichen.“ (von den DRIESCH 1997:265). Der 1997 veröffentlichte Artikel basiert auf einem Vortrag, der 1989 in Breslau anlässlich der polnischen Jahrestagung für Denkmalpflege und Wasserwirtschaft gehalten wurde. Er stellt einige Aspekte der Dissertation vor, die 1988 am Seminar für Historische Geographie der Universität Bonn erschienen ist (von den DRIESCH 1997:265).

Leider hat von den DRIESCH in der gekürzten Wiedergabe ihrer Dissertation nur „die Literatur [...] bis 1986 ausgewertet“", wie sie selbst einräumt (von den DRIESCH 1997:265) und damit den Forschungsstand bis Mitte der 80er Jahre rezipiert. Dennoch ist es der uneingeschränkte Verdienst von Ursula VON DEN DRIESCH, sich bereits in ihrer Dissertation mit dem Titel „Historisch-geographische Inventarisation von persistenten Kulturlandschaftselementen des ländlichen Raumes als Beitrag zur erhaltenden Planung" mit der Rechtslage zum Schutz gewässerhistorischer Kulturlandschaftselemente auseinandergesetzt zu haben. Diese für den Erhalt historischer Wasserbauten so wichtige Thematik ist bislang leider nicht wieder aufgegriffen worden.

Historisches Recht

Werner KOHL (1970) hat die historischen Rechtsverhältnisse der Münchner Stadtmühlen betrachtet und in einem zweiten Teil auch die Entwicklung des verzweigten Stadtbachsystems beschrieben. Seine Arbeit 
versucht deshalb auch, so KOHL (:2) in seiner Einleitung, „die Rechtsgeschichte zu beleuchten und die Grundzüge der Münchner Mühlengeschichte darzustellen.” „Recht und Geschichte [...] der sog. „Stadtmühlen”, sind für ihn „das eigentliche Thema der Arbeit.” (:8)

Den Aspekt des historischen Wasserrechts unter dem Aspekt der Wassernutzung behandelt auch MINKENBERG (1999) in ihrer Dissertation am Beispiel des Aachener Reichsstromes. Hierbei geht es um die Auseinandersetzungen zwischen der Reichsstadt und dem Marienstift im Hoch- und Spätmittelalter.

\section{Ausländische Forschungen}

Am Anfang dieser Übersicht zu den Beiträgen gewässerhistorischer Forschungen aus dem Ausland steht eine deutschsprachige Ausgabe von amerikanischen Originalaufsätzen. Rolf Peter SIEFERLE stellt acht Aufsätze „der weiter fortgeschrittenen amerikanischen Umweltforschung“ (LEIDINGER 1991:506) zum Thema historische Ökologie durch Übersetzung für den nicht fremdsprachlichen deutschen Leser zusammen und gibt damit und durch die Erscheinung auf dem deutschen Buchmarkt den aus Amerika stammenden Beiträgen eine größere Verbreitungsmöglichkeit. In dem Sammelband fällt nur ein gewässerhistorischer Beitrag auf, der die industrielle Umgehensweise mit der Natur am Beispiel der Stadt London mit ihren Abwässern um die Mitte des 19. Jahrhunderts thematisiert (DINGLE 1988). Doch diese Thematik hat auch die deutsche Umweltforschung in zahlreichen Beiträgen aufgenommen, wenn sie nicht gar diese Forschungsrichtung für einen gewissen Zeitraum geprägt hat.

Einen meines Erachtens interessanteren, weil neuartigen und aktualwissenschaftlich bedeutsamen Beitrag liefert da eher Adrian MC DONALD. Das Entstehen der „water industry“ vor dem geschichtlichen Ablauf der steigenden Wasserinanspruchnahme und Wasserabhängigkeit in England zeichnet MC DONALD (1999) in einem Aufsatz nach und teilt diese Entwicklung in vier Zeitphasen ein (,,pre-1850“, „1850-1974“, „197489“ und „post-1989“). Dabei fällt insbesondere die lange Zeitspanne von 1850-1974 auf, die er mit dem Ansteigen des Städtewachstums begründet und damit, dass in dieser Zeit die Städte ihr eigenes Wasserreservoirsystem aufbauten - ,independently from the resource development of adjacent cities“ (MC DONALD 1999:138). Erst danach entstanden die überregionalen, mächtigen Wasserwerkunternehmen, die keine hundertfachen lokalen Wasserreservoire mehr betrieben oder anlegten, sondern die zentrale Wasserversorgung anstrebten.

Einen interessanten Aspekt greift er mit der Wasserbehandlung bzw. -aufbereitung auf, die in dieser Zeit ihren Anfang nimmt. In dieser Periode des ,set of independent unlinked source-sink resource exploitation systems“ fällt "the use of chlorination“. Die Problematik der Desinfektion von Trinkwasser wird hier also aufgegriffen, denn Trihalomethane werden bei der Generierung freigesetzt, die zwar nicht gesundheitsschädlich sind, aber zumindest auch nicht gesundheitsförderlich sind - und dies bereits seit Jahrzehnten über das Wasserhaushaltsnetz.

Weiter in die Vergangenheit der Wasserversorgung zurück geht ein ins Englische übersetzter türkischer Beitrag. Der Autor Ünal ÖZIS (1996:347; ebenso auch mit einem Beitrag 1987 und einem Schriftquellenverzeichnis 1994) nimmt sich, dies wundert aufgrund der Abstammung und der Bedeutung, die diese Einrichtung für sein Land hatte, nicht, der „Historical Water Schemes in Turkey“ an. Er behandelt die „ancient waterworks“, d. h. die „hydraulic structures in Anatolia“ in den letzten 4000 Jahren ,at the crossroads of civilization“, wie ÖZIS (1996:347) sein Forschungsgebiet umreißt. Da einige dieser frühen Wasserwerke noch in Gebrauch sind, wird mit der Erfassung der persistenten türkischen Kanal- und Dammsysteme eine (unbewusste?) Forschungsbrücke zu der angewandten historischen Geographie geschlagen und damit den Ansatz der fortdauernden Inwertsetzung von ,several thousand years old water engineering tradition of Turkey, [...], which will also be appraised in the future“ (:347) verfolgt. Da auf diesem Forschungsgebiet aber auch einige bekannte deutsche Wasserbauer vorher veröffentlicht haben (GARBRECHT 1981; SCHNITTER 1979, ALZINGER 1987, BAUR 1991), scheint unklar, von welcher Seite die Initialisierung zur Bearbeitung dieses Forschungsthemas ausging.

Überraschend ist das oben dargelegte deutschsprachige Forschungsdesiderat zur historischen Teichwirtschaft innerhalb der deutschen Geschichts- und geographischen Wissenschaften und das Defizit der deutschen 
Forschung zur Fischerei und Fischereiwirtschaft des Binnenlandes allgemein, wenn man die Situation mit der in England vergleicht: In England existieren mittlerweile sowohl zahlreiche Einzeluntersuchungen als auch vergleichende Arbeiten über die mittelalterliche Teich- und Fischkultur, wobei zahlreiche Arbeiten sowohl archäologische als auch schriftliche Quellen nutzen.

So hat MC DONNELL (1981) in seiner Arbeit die Teichsysteme verschiedener Klöster in Yorkshire, besonders die Anlagen in der Abtei von Byland untersucht. CURRIE $(1991,1992)$ hingegen überrascht durch ausführliche Grabungsergebnisse, die in Teilen Rekonstruktionen zur mittelalterlichen Fischartenzusammensetzung ermöglichen. In dem von ASTON 1988 herausgegebenen Sammelband sind zahlreiche Aufsätze über regionale Bestandsaufnahmen mittelalterlicher Teichanlagen enthalten. Schon der Titel des Sammelbandes „Medieval Fish, Fisheries and Fishponds in England“ verdeutlicht das weit angelegte Spektrum dieser Publikation, die ausgehend von der Archäologie zahlreiche historische Beiträge präsentiert.

Auch der Sammelband „Fish and Archaeology“, herausgegeben von BRINKHUIZEN (1989), hat diese Forschungsrichtung, die in England durch eine Zusammenarbeit von Archäologie und Geschichtswissenschaft geprägt ist, entscheidend gefördert.

Aus der amerikanischen Literatur ist in dieser Hinsicht ferner die deutsche Taschenbuchausgabe von Mark KURLANSKYs Biographie über den Kabeljau zu nennen (1997/2000), wie der gesalzene Hering genannt wird, und wie er allmählich zum Konkurrenzprodukt der Teichfische aufstieg.

Die amerikanische interdisziplinär zusammengesetzte Fraktion der „landscape historians“ hat Mitte der 90er Jahre einige interessante Arbeiten zum Thema Gewässergeschichte veröffentlicht (ANDERSEN et. al. 1996; HEDEEN 1994). Am Beispiel von Flussläufen und deren Einzugsbereichen wird die Veränderung der Umwelt dokumentiert. Es werden die Faktoren dargestellt, die als Verursacher des „environmental change“ in der Vergangenheit angesehen werden können. Darüber wird ein Rahmen der Periodisierung gelegt, der die Verursacher der Umweltveränderungen benennt: natives, logger, farmer, urbans.

„An environmental history of the upper Mississipi River“ legt P.V. SCARPINO (1985:3) mit seiner Dissertation vor. Die Studie „examines the evolving relationship between the river and the people who lived along its shores, focusing on the period from 1890 to 1950 “(:1) und geht dabei von der Annahme aus, ,that in modern urban, industrial societies, [...] people have increasingly transformed the natural environment into a human artifact.“ (:1) Die Analyse stellt dabei ,three questions that focus on the dynamic interaction between people and the river: How did various groups try to understand and explain their developing relationship with the river? Why did they attempt to alter or control the river? How did they respond to the often unanticipated consequences of man-induced environmental change?" (:3). Die Antworten versucht er an verschiedenen Beispielen, wie der Wasserenergienutzung (waterpower projects), der Flößerei (timberrafts) und der Kanalisierung zu finden.

Die Benutzung des Flusses als Verkehrssystem in historischer Zeit stellen LAMB (1996) wie auch ROLLE (1996) in den Mittelpunkt ihrer Untersuchungen, wenn auch mit jeweils unterschiedlichen Zeitschnitten. Letzterer Autor belegt z. B. in interessanter Weise die Transformation von Drainage- und Wassertransporttechniken zweier deutscher Auswanderer nach Kalifornien und deren Tätigkeit als maßgebliche "cultivators“. Die amerikanische historische Landschaftsforschung ist also stark sozialgeographisch orientiert und verfolgt das menschliche Wirken mit seinen landschaftsstrukturellen Folgen.

Eine mehrere Aspekte umfassende „historical geographies of the environment“ hat J. M. POWELL (2000:174) geschrieben und ein Abschnitt gilt „The Waters“. Vor dem Hintergrund „on the less direct but undeniable hydrological consequences of the removal of tree cover“", beobachtet er ,the desirable interventions, including afforestration, the drainage of lakes and swamps, and the ,rescue ' of land from the sea." Dabei erhebt POWELL (:174) den Anspruch: Research into the transformation of wetland environments constituted another major thrust in the early evolution of historical geography."

Gordon G. WHITNEY (1994) grenzt seine „History of Environmental Change“ räumlich und zeitlich genau ein. Whitney befasst sich mit den Umweltveränderungen ,in Temperate North America 1500 to the Present“ 
und versucht den Werdegang der Landschaft „from Coastal Wilderness to Fruited Plain“ zu rekonstruieren. Er greift dabei auf Berichte aus der Literatur, journalistische Berichte und Berichte von frühen Geographen zurück. Danach bestand „the whole Country“ vor Ankunft der Europäer aus Waldflächen und Sümpfen, die „full of Cripple \& Brush" waren, und der Boden war nicht ackerbaulich umgebrochen. Ein besonderer Aspekt gilt der Veränderung der hydrologischen Situation, die er als „hydrological cycle“ bezeichnet: „deforestration“, „,wetland drainage“ und „land use“ haben die Landschaft nachhaltig verändert (:271). Vor diesem Hintergrund schenkt WHITNEY vor allem dem durch Abholzung behinderten „streamflow“ und seinen Folgen Beachtung, denn „large accumulations of fallen trees and driftwood in many of the rivers of the Midwest compounded the drainage problem“ (:272). Wie groß dieses Problem gewesen sein muss, wird mit folgender Aussage deutlich: „Clearing the downed trees from North America's rivers and streams was a major undertaking which spannend several centuries.“ (:273)

Doch der Anfang einer modernen geosystemaren Betrachtungsweise, die auch die Gewässerhistorie nicht außer Acht lässt, gebührt im anglo-amerikanischen wahrscheinlich Andrew GOUDIE. Er beschrieb bereits 1981 in einem Kapitel seines Buches die nach seiner Auffassung sechs Einflussbereiche des Menschen ,in environmental change“, und die heißen: vegetation, animals, soil, geomorphology, climate - und schließlich: „the human impact on the waters". Er meint damit die Veränderung von Flüssen und Strömen in quantitativer und qualitativer Hinsicht: durch Kanalisierung, Dammbau, Urbanisierung, Pollution usw.

Im Bereich der historischen Gewässerforschung sind in den 80er Jahren in England wie später auch in Deutschland einige Untersuchungen zum Thema wüster Kanäle erschienen (RUSSEL 1982; SHERIFF 1996). Diese Beiträge stehen jedoch - im Gegensatz zu den deutschen Untersuchungen - weniger unter dem Aspekt der geographischen Kulturlandschaftsforschung als unter dem der Verkehrsgeschichte oder der Industriearchäologie.

In einer englischsprachigen Ausgabe ist auch die Beschreibung eines Wasserbauprojektes, dem seit 1667 erbauten und bis heute in Betrieb befindlichen Kanals zwischen Atlantik und Mittelmeer in Frankreich, dem Canal du Midi, von BLANCOTTE (1991) erschienen. Dieses über viele Jahre wirtschaftlich bedeutende Projekt führte zu neuen Erkenntnissen der Wasserbautechnik, und BLANCOTTE stellt sie dar: Schleusenbauten, Schleusentreppe, Kanalüberführungen etc.

Historische Aufnahmen und Beschreibungen des englischen Kanalsystems, das bis in die 60er Jahre des 20. Jahrhunderts noch in Betrieb war, sind in der Veröffentlichung von WARE (1990) zu finden. Vorgestellt werden auch die zwar nur 1,8 m breiten, aber über eine Ladekapazität von 20 bis $60 \mathrm{t}($ !) verfügenden Schiffe, die diese Kanäle befuhren. Von verkehrshistorisch großer Bedeutung sind die vielen alten Fotos aus dem 19. Jahrhundert und der ersten Hälfte des 20. Jahrhunderts.

Das Interesse, das Kanäle in den Darstellungen erfahren, mag sich mit dessen Nutzungen für Wassersport und Tourismus erklären.

Nicht die künstlichen Fließgewässer, sondern „the natural history of lakes”, ihre Entstehungs- und Wandlungsprozesse, stehen im Mittelpunkt der Betrachtung von BURGIS et al. (1987).

Eine in eine interessante umweltgeschichtliche Fragestellung umzuwandelnde Thematik haben LINDBERG/TODD (2002) mit ihrer Geschichte des Einflusses der Geographie „on naval warfare, 1861 to the present" vorgegeben. Die Marineschifffahrt und der Flottenbau auch zu Zwecken der Entdeckungsfahrten als Wegbereiter umfangreicher Hafenanlagen und des Kanalwegebaus sowie des Flößholztransportes und des Holzeinschlags einschließlich der weitreichenden geographischen Verbindungen (z. B. Kartoffel) ist bislang nicht entsprechend ausgearbeitet worden.

\section{Forschungsdefizite}

Verschiedentlich sind bereits bei den Buchbesprechungen Forschungsdefizite angesprochen worden. An dieser Stelle soll noch einmal übergreifend auf Forschungslücken gewässerhistorischer Forschung hingewiesen und Anregungen zu weiterer Beschäftigung gegeben werden. 
1. „Die über die Verschmutzung hinausgehenden räumlichen Auswirkungen des gesamten Feldes ,Gewässergeschichte', etwa der Wassernutzung auf den Natur- und Landschaftsraum sind vernachlässigt worden. [...] Systematische regional flächendeckende Untersuchungen zum früheren Zustand der Gewässer wurden bisher nicht durchgeführt.“ Diese Aussage von DIX (1997:273f.) besitzt weitestgehend noch immer Gültigkeit; wenn seine Arbeit auch exemplarisch eine Antwort darauf gegeben hat und die Ergebnisse der oben beschriebenen Graduiertenkollege eine positive Wende schon jetzt erkennen lassen.

2. Weiterhin besteht ein erhebliches regionales Forschungsdefizit vor allem der historischen, der archäologischen und historisch-geographischen Forschung im Bereich der Geschichte der Wassernutzung und der Wasserbauten. Andererseits sind aber schon eine Menge an interdisziplinären Ergebnissen zur Hand, die eine weitgehend objektive und umfassende Darstellung und Bewertung der früheren Wassernutzung und ihrer Bauten zulassen. Diese Zeugnisse und Forschungsresultate wasserwirtschaftlicher Zusammenhänge müssen aber noch vernetzt und zusammenhängend aufgearbeitet werden, so wie es beispielsweise ELLENBERG (1990) mit seinem Standardwerk zur Bauernhaus- und Siedlungsgeschichte getan hat.

3. Wissenschaftliche Untersuchungen zum Aus- und Umbau natürlicher Fließgewässer im urbanen und suburbanen Raum einer mittelalterlichen, neuzeitlichen und modernen Stadt fehlen bislang. So könnten beispielsweise zeitschnittartige Einblicke Ergebnisse einer lang andauernden und wechselhaften Umgestaltung eines wirtschaftsgeschichtlich und siedlungsgeographisch beeinflussten städtischen Nahraums liefern, die als Planungsgrundlage für den aus gewässerhistorischer Sicht vernachlässigten Vorverstädterungsraum dienen könnten.

4. Tradierte Nutzungs- und Handwerkstechniken der Gewässerbewirtschaftung und hier vor allem die Kulturlandschaftselemente (Stichwort: Teichmönch) sowie die räumlichen Ausprägungen auf die Kulturlandschaft sind von der Historischen Geographie noch nicht intensiv aufgegriffen worden (Stichwort: Teichwirtschaft). Dazu zählt nicht so sehr die besser abgedeckte volkskundliche Betrachtung, sondern vor allem die historische Raum- und Umweltwirksamkeit, die teilweise bis in die Gegenwart hinein wirkt.

5. Man entdeckt zahlreiche Veröffentlichungen, die sich mit den Wassermühlen allgemein oder weitaus häufiger - auf eine bestimmte Region beziehen. Dabei widmet man sich hauptsächlich der Entwicklungsgeschichte, den verschiedenen Mühlentypen, der Mühlenordnung und der volkskundlichen Seite der Wassermühle (z. B. JÜTTEMANN 1990). Bei der Darstellung der verschiedenen Nutzungsarten der Wasserkraft bleiben aber die Stauteiche und die Stauanlagen zumeist außerhalb der Betrachtung. Die Sammelteiche werden nur randlich erwähnt, eine Darstellung der Mühlenteiche in verschiedenen räumlichen Maßstäben fehlt in der neueren deutschsprachigen Literatur vollständig.

6. Das Schwergewicht der Forschungen ,liegt [...] bisher eindeutig auf größeren Wasserläufen. Kleinere Fließgewässer sind hingegen vernachlässigt worden“. Diese Einschätzung von DIX aus dem Jahr 1997 (:26) kann auch für die Historische Umweltforschung nicht mehr ganz geteilt werden. Wenngleich z. B. von landschaftsökologischer und biologischer Seite viel zahlreicher auch kleine Bachläufe Gegenstand von beispielsweise pflanzensoziologischen und aquafaunistischen Untersuchungen sind (vielleicht, weil diese noch vereinzelt den vermeintlichen Ursprungszustand widerspiegeln), lassen die historischen Disziplinen Beiträge zu Kleingewässern zwar weiterhin vermissen, doch existiert auch ein Forschungsdesiderat hinsichtlich großer Wasserläufe, z. B. von wissenschaftlichen Ansprüchen gerecht werdenden Flussmonographien.

7. Großräumigere, flächenhafte Untersuchungen, die nach Größe und Beschaffenheit (Wassermenge, Fließgeschwindigkeit) der jeweiligen Fließgewässer differenzieren und die Verteilung an diesen erfassen, gibt es noch nicht. Dieser traditionell geographische Ansatz könnte beispielsweise unter dem aktuellen Aspekt Wasser als Ressource, deren ausreichende Menge und Qualität für die Produktion von erheblicher Bedeutung war und ist (Wasser zur Energiegewinnung, Wasser als Produktionsmittel), Aussagen treffen zur weiträumigen historischen Umgestaltung der Gewässerlandschaft zu Zwecken der frühen Inwertsetzung, eventuell sogar beteiligt sein an Aussagen zur Klimageschichte (erhöhte oder niedrigere Evapotranspiration durch Gewässeraus- und 
-neubau oder Gewässerzuschüttung bereits im frühen Mittelalter), die wiederum weiter zur Siedlungsgeschichte und Wüstungsforschung führen. Das Aussterben der Jahrtausende währenden Maya-Kulturen beispielsweise führt man nach neuesten Aussagen auf das Ausbleiben von Niederschlag über mehrere Jahre zurück. Dies ist, da es Zuflüsse in den hochgelegenen Tempelorten nicht gab, in Betracht der alleinigen Wasserversorgung durch Wasserspeicherung in großen ausgemeißelten Steinbecken eine durchaus realistische Annahme.

8. Planerische Konzepte zum Umgang mit Gewässern in Form kleinerer Bach- und Flussläufe und ihrer Elemente als wichtige historische Kulturlandschaftsstrukturen und Bestandteil der ländlichen und städtischen Kulturlandschaft fehlen bislang. Der moderne Wasserbau z. B. beruht auf Regelwerken, die dem technischen Ausbau gewidmet sind; gewässerhistorische Beachtungselemente fehlen in den Regelvorschriften. Die Landschaftsplanung ist hingegen weitgehend verhaftet in der ökologischorientierten Gewässerplanung.

9. Des Weiteren sollte die vielgescholtene Wasserverschmutzungsgeschichte von der Historischen Geographie neu aufbereitet werden. Zwar sind diese Auswirkungen aufgrund ihrer fluviatilen Ausprägung im Allgemeinen heute nicht mehr in Form noch sichtbarer persistenter Kulturlandschaftselemente nachvollziehbar, dennoch, wie DIX (1997:27) schreibt, „war die Wasserverschmutzung [...] augenfälligstes Beispiel für die Umweltbeeinflussung durch den Menschen " Durch mittelalterliche und industrielle Produktion wurden Stoffe in die Gewässer eingetragen und abgeleitet. Diesem ging Ansiedlung von Betrieben voraus und die Flucht der Wohnstätten hernach und damit hatte es siedlungsgenetische Veränderungen zur Folge; ein insofern beachtenswertes Faktum, als dass dies Rückwirkungen auf die weitere Nutzung der Gewässer und deren Randbereiche hatte. Die Abfolge und die Zusammenhänge wären genauer zu analysieren. Gewässerhygienische Notwendigkeiten waren es auch, die besondere Formen der Abwässerklärung (Absetzbecken, Klärteiche, Rieselfelder) entstehen ließen, die heute als Vogelreservate eine neue Inwertsetzung gefunden haben. Eine solche mögliche kombinierte oder nachfolgende Nutzung könnte auch Gegenstand einer Diskussion eines zukünftigen Klärwerkbaues sein. Im Hausbereich werden Filterungsteiche beispielsweise schon seit längerer Zeit eingesetzt (Bsp. Hof Möhr/Schneverdingen, Sitz der Niedersächsischen Naturschutzakademie).

10. Es mangelt zuletzt auch noch an einer Beteiligung am aktuellen Thema „Kataster“: Vom Niedersächsischen Heimatbund e. V. wird eine landesweite Erfassung der kulturlandschaftlichen Relikte angestrebt (GROHMANN/HAUPTMEYER/NEUBER 2000:11). Das Gleiche versucht das Land Nordrhein-Westfalen, d. h. der Landschaftsverband Westfalen-Lippe und der Landschaftsverband Rheinland. Hier gilt es, das „alte“ Thema „Gewässerkataster“ anzugliedern und um die historische Komponente zu erweitern, um eine GIS-gestützte Bestandsdokumentation historischer Gewässer und ihrer Bauten und Elemente zu erhalten. Diese können beispielsweise in die denkmalpflegerischen Karteien aufgenommen bzw. mit den bestehenden abgeglichen werden. 


\title{
B METHODISCHER TEIL
}

\section{Quellen, Methoden und Kartenwerke der historisch-geographischen Gewässerforschung}

\author{
Ohne eine solide Kenntnis des Raumes und seiner Geschichte, \\ ohne eigene Archiv- und Feldarbeit \\ und ohne gründliche Auswertung der Karten und Luftbilder \\ ist es nicht möglich, \\ der komplexen Realität einer historisch gewachsenen Kulturlandschaft \\ gerecht zu werden.“ \\ [FLIEDNER 2001:387]
}

Die Historische Geographie „bewegt sich in einem interdisziplinären Spannungsfeld und bedarf daher der Anwendung ganz verschiedener Forschungsmethoden“" (SONNABEND 1999d:219f.), die in zahlreicher Form auch zur Verfügung stehen:

Durch die Feldforschung werden ,gegenständliche Relikte früherer Kulturlandschaften sowie die naturgeographischen Gegebenheiten und durch die Archivforschung schriftliche, kartografische oder bildliche Zeugnisse für die früheren Zustände ausgewertet" (FEHN 1975a 1975:49). Darüber hinaus bezieht sie wesentliche Elemente ihrer Forschungsergebnisse von den verschiedensten Disziplinen der geistes-, natur- und auch ingenieurwissenschaftlichen Bereiche ein (vgl. SONNABEND 1999d:220). Insbesondere müssen häufig Nachbarwissenschaften wie die Archäologie, die Bodenforschung oder die Orts- und Flurnamenkunde herangezogen werden (vgl. FEHN 1975a:49): „Mithilfe spezifischer Verfahrensweisen verarbeitet sie die von diesen Wissenschaftsdisziplinen zugelieferten inhaltlichen wie methodischen Elemente zu eigenen Forschungsergebnissen. Solche Verfahrensweisen haben das Ziel, eine bestimmte historische Landschaftsgestaltung zu rekonstruieren" (SONNABEND 1999d:220). Die Zusammenführung von extradisziplinären Erkenntnissen und Methoden gilt auch für die Rekonstruktion einer Gewässerlandschaft.

Für die Historische Geographie, und damit auch für eine historisch-geographische Gewässerforschung, sind in dieser Hinsicht zwei gegensätzliche, doch beide für sich genommen nachteilige, Entwicklungen zu beobachten:

1. „Ein zunehmend größerer Teil der für historisch-geographische Untersuchungen heranzuziehenden Quellen“, darauf weist DENECKE (2001:293) hin, ,ist von anderer Seite erarbeitet“. Diese sollten nach seiner Ansicht einerseits zwar noch „gezielter genutzt werden“, was andererseits ,aber gerade die geographische Forschung auch von der primären Quellenarbeit wegführen muss.“ (:293) Ein solches methodisch differenziertes Bewusstsein, denke ich, äußert DENECKE vor dem Hintergrund, da das Quellenstudium insbesondere von der , anderen Seite' (z. B. den Geschichtswissenschaften) zur Weiterverarbeitung zur Verfügung gestellt und als primär erkenntnisleitendes Medium genutzt wird und insofern keinen disziplinären Wiedererkennungswert für die Geographie besitzt.

2. „Im interdisziplinären Zusammenhang ist weniger eine Übernahme von Arbeitsmethoden anderer Disziplinen gegeben als vielmehr ein zunehmendes Überlassen, was sich ganz besonders in der Geographie eingestellt hat.“ (DENECKE 2001:293) Es ist demgemäß nicht allein die - wie unter Pkt. 1 dargestellt - Adaption von Quellen und Methoden, die sich im Übrigen noch vermehrt einstellen muss, negativ zu betrachten, sondern die Aufgabe resp. Übergabe ureigener Quellen- und Methodenansätze an die „Fachkonkurrenz“.

Einen Lösungsweg aus dieser, bei weiterem Voranschreiten sukzessiven Aufgabe des fachlichen Stellenwertes bzw. letztendlich sogar der disziplinären Daseinsberechtigung innerhalb des interdisziplinären Verbundes zeigt DENECKE (2001:293) ebenfalls auf: Hierzu „sind bewusst die in der Geographie gegebenen und auch weiter zu entwickelnden methodischen Praktiken von der Historischen Geographie mit der Geographie aufzugreifen und interdisziplinär einzubringen, wozu besonders die spezifische Geländeforschung, die Altkartenanalyse, die Luftbild- und Satellitenbild- 
auswertung, der Entwurf historisch-thematischer Karten, die EDV historischer Daten wie auch die Geographischen Informationssysteme (GIS) gehören, aber auch die Nutzung naturwissenschaftlicher Analysen, die mit den physisch-geographischen Laboreinrichtungen im eigenen Haus gegeben sind.“

Das Einbringen originär geographischer Praktiken wird aber dadurch schwierig, als dass vom umweltgeschichtlichen Überbau ebenfalls die Forderung ergeht: „Umweltgeschichte kann sich nicht allein auf schriftliche Quellen stützen, sondern muß archäologische Zeugnisse und historische Sachüberreste mit einbeziehen." (GROHMANN et al. 2000:11) Mit der Aufnahme von historischen Kulturlandschaftselementen, und nicht anders übersetze ich ,historische Sachüberreste', in die geschichtswissenschaftlich orientierte Umweltgeschichte würde damit ein weiteres wesentliches Standbein der Historischen Geographie aus dem Quellen- und Methodenfundus wegfallen.

Einen Ausweg bietet nach meinem Dafürhalten erstens die ,sture' Beibehaltung historisch-geographischer sowie die vermehrte Einbindung allgemein-geographischer Praktiken, wie sie DENECKE genannt hat, und zweitens, die - nach Prüfung der Sinnhaftigkeit und Anwendbarkeit, die je nach Fragestellung unterschiedlich ausfallen kann - ungehemmte Übernahme von Methoden anderer Fächer. Personifizierte Beispiele dafür gibt es bereits heute: Richard POTT, ehemaliger Privat-Dozent an der Universität Münster und heute Professor für Geobotanik ist eigentlich Geograph und hat sich bereits während seines Studiums der Labore der Biologischen Fakultät zur $\mathrm{C}_{14}$-Isotopen-Bestimmung bedient, ebenso der am Geographischen Institut der Universität Münster ansässige Lehrstuhl für Klimatologie, der zur Bestimmung von Bodenversauerungen mikrobiologische Organismen in biologischen Laborstätten analysiert hat. Und nicht zu vergessen Marie-Luise HILLEBRECHT (1982), die in ihrer Dissertation am Geographischen Institut der Universität Göttingen anhand von Kohlenresten ehemalige Meilerplätze lokalisiert hat.

Methodisch überschreitet also die historisch-geographische Umweltforschung deutlich die klassischen Verfahren der historiographischen und geographischen Fächer. Naturwissenschaftliche Auswertungsmethoden (Pollenanalyse, Dendrochronologie, Bodenuntersuchungen), archäologische Befunde (Siedlungsfunde, Ortskerngrabungen, Wüstungsforschung, Industriedenkmäler), ikonographische und kartographische Quellen spielen eine ungewohnt große Rolle. Die Folge: „Der multimethodische und interdisziplinäre Zugang droht Lehrende und Lernende zu überfordern.“(BORRIES 1996:320)

Aus diesem Grund bestimmt, wie bereits oben angedeutet, „,bei der möglichen Vielfalt der Methoden [...] die Zielsetzung der Untersuchung die Wahl des Arbeitsverfahrens.“ (BORN 1977:18) Neben der Aufgabenstellung und dem Untersuchungsgegenstand kann einzig der Anwendungsbezug, so scheint es jedenfalls, diese Informations- und Verfahrensflut aufgrund seiner strengeren zeitlichen Vorgaben kanalisieren und beschränken. Bei der Zielsetzung der Anwendungsorientierung muss sich die Wahl eines Arbeitsverfahrens zwar nach den Besonderheiten des Untersuchungsobjektes wie auch der Beschaffenheit der Arbeitsmittel richten, sich aber vor allem dem speziellen Zweck der Praxisanwendung unterordnen. Des Weiteren ermöglicht allein die Konzentration auf das methodisch erprobte Handwerkszeug der historisch-geographischen Kulturlandschaftsforschung - einschließlich der Erweiterung um ausgewählte methodische Neuerungen - fachlich fundierte Ergebnisse zur historischen Gewässerforschung vorzulegen.

Es gibt, dies lässt sich indessen vorausschicken, keine dominierenden oder allgemeingültigen Arbeitsmittel zur Untersuchung historischer Gewässer: „Will man die älteren gewässerkundlichen Verhältnisse rekonstruieren, so führt - wie häufig bei landeskundlichen Arbeiten - die kombinierte Auswertung der verschiedensten Zeugnisse zum Ziel.“ (JÄGER 1965:411). Dies trifft für die Historische Geographie im Allgemeinen zu, wohingegen der Anwendungsbezug besondere Bedingungen erfordert: „Historisch-geographischen Forschungen ist die Quellenkombination eigen, die Zusammenführung einer Geländeaufnahme von Erscheinungen und Relikten im Gelände, einer Auswertung von Altkarten sowie von Verbreitungskarten flächenhaft verortbarer Daten und Indikatoren archivalischer Quellen. Die Quellenbasis ist dabei im Maßstab der Fragestellung und der Größe des Arbeitsgebietes stets anzupassen, wobei im anwendungsbezogenen Bereich die Notwendigkeit einer Selektion und Generalisierung von den Zielsetzungen einer wissenschaftlichen Forschung wegführt.“ (DENECKE 2001:293) 
Die Methodenwahl ist bei der historisch-geographischen Gewässerforschung, will sie dem Praxisanspruch genügen, insofern keine leichte, da hier, wie bereits betont, die Berücksichtigung des Praxisbezuges gewährleistet bleiben muss. Das bedeutet eine Methodenauswahl, die es, obgleich keine rein wissenschaftliche Zielsetzung verfolgt wird, neben dem szientistischen Anspruch nach einer auf präzise und umfangreiche Analysen aufbauenden Untersuchung ermöglicht, dem in der Planungspraxis geforderten relativ schnellen Zugriff auf Quellenmaterial hinreichend zu entsprechen. Dazu gehört auch die Durchführbarkeit in einem angegebenen Zeitrahmen. Deshalb bieten sich die nachfolgend beschriebenen Methoden zur Lokalisation, Inventarisation und Rekonstruktion von historischen Gewässern und deren Elementen unter Beachtung des Anwendungsbezuges an. Es muss aber an dieser Stelle auch hervorgehoben werden, dass eine auch angewandt ausgerichtete historischgeographische Forschung, d. h. eine historisch-geographische Gewässerplanung mit ihrem Anspruch und in ihren insbesondere textlichen Ausführungen - vorbehaltlich der Aufgabenstellung - nicht mit einer „gewöhnlichen“ Stadt- oder auch Landschaftsplanung hinsichtlich Quellenwahl und Methodik vergleichbar ist. Dies beweisen allein die verschiedenen Fachgutachten von BURGGRAAFF und KLEEFELD (1997, 1998, 1999, 2000) zu unterschiedlichen Landschaftsräumen sowie die noch näher zu betrachtende Projektarbeit zur „Klosterlandschaft Heisterbachtal“ $(2001,2002)$ (siehe hierzu Kap. IX 1a).

Die Arbeitsweisen einer so verstandenen historischen Gewässerforschung entsprechen dabei zunächst einmal in etwa der bei der Erforschung historischer Wasserwege angewandten methodischen Quellenerfassung, die wiederum sich bei der methodischen Vorgehensweise auf die historischgeographische Untersuchung des Landwegenetzes stützt (GOLDAMMER 1997:29; DENECKE 1969:24). Sie erfolgt in klassischer Form durch die Zusammenstellung und Auswertung schriftlicher und kartographischer Aufzeichnungen (historische Sekundärliteratur, Archivalien, Itinerare, alte Karten), von Flur- und Gewässernamen, von Luftbildern und prähistorischen Funden und verfolgt das Ziel eines sicheren und topographisch genauen Nachweises von historischen Gewässerelementen im Gelände.

Zur Erreichung dieser Zielsetzung gilt als klassisches methodisches Referenzmittel der Historischen Geographie nach wie vor und insbesondere die Geländearbeit zur Bestandsaufnahme und Katastrierung von Gewässerrelikten. FEHN (1989:10) bezeichnet gesamthaft „die wichtigste Voraussetzung für die Erforschung der Entwicklung von Kulturlandschaften [...] die historisch-geographische Landesaufnahme der Relikte im Gelände verbunden mit der Auswertung von schriftlichen und kartographischen Quellen.”

Des Weiteren werden zunehmend in der Historischen Geographie zur computergestützten graphischen Analyse und Verwaltung von Sachdaten Geographische Informationssysteme (GIS) eingesetzt.

Schließlich können aber auch eher nonkonforme Methoden zur Anwendung gelangen, wie die Betrachtung und Auswertung kunsthistorischer Werke, die - leider sehr aufwendige - Paläobotanik und -zoologie sowie die tachymetrische Vermessung und sogar auch, insbesondere bei unzureichender Quellenlage, das mündliche Gespräch mit Zeitzeugen („,oral history“).

Ebenso gilt es die quellenkundliche Analyse nicht auf ein- oder zweidimensionale Quellengattungen zu beschränken, wie es KALESSE (1987:202) vorsieht, wenn er auch die Bedeutung richtig hervorhebt: „Mit Hilfe der quellenkundlichen Analyse, d. h. des Auswertens von Schrift- und Bildquellen zur Genese eines Kulturlandschaftsausschnittes, kann der vom Menschen beeinflusste historische Entwicklungsverlauf zeitlich und flächenhaft relativ präzise rekonstruiert werden.“

Zusammenfassend lässt sich vorausschauend folgende Diagnose stellen:

Der historisch-geographische Befund stützt sich auf eine Reihe von Methoden. Zur Erfassung von historischen Gewässerrelikten bedarf es vielfältiger Hilfsmittel und Arbeitsverfahren, und es wird „die kombinierende Auswertung einer möglichst großen Zahl von Quellen unterschiedlicher Art notwendig." (SCHENK 2002:112f.) Die Historische Geographie gleicht damit in ihrer methodischen Betrachtungsweise naturgemäß der in der Geschichtswissenschaft, Ur- und Frühgeschichte und 
Archäologie angewendeten kritischen Auswertung aller Arten von schriftlichen Quellen, von kulturlandschaftlichen Relikten im Gelände, Grabungsfunden sowie älteren Karten. Aufgrunddessen erhält der abseits aller Disziplinkämpfe und Methodendiskussionen stehende Ausblick DENECKEs (2001:293) seine Mut machende Bestimmung am Ende dieser Überlegungen: „Eine Vielfalt Historischer Geographien ist [...] vor allem auch durch die Forschungsmethoden und Arbeitsansätze“ gegeben. Diese lassen sich grob in Quellen und Methoden einteilen.

\section{Quellen}

„....scheint die Umwelthistorie mitunter in der Kunst zu bestehen, sich um die Misere herumzumogeln, daß wir nur eine Handvoll Quellen haben, deren Aussagekraft obendrein unsicher ist." [RADKAU 2002:46f.]

Die anwendungsorientierte historisch geographische Gewässerforschung hat zum Ziel, ehemalige Gewässerformen, -arten und -nutzungen im Gelände mit Hilfe der im Folgenden benannten Quellengruppen zu erfassen, zu dokumentieren und zu analysieren. „The data and information sources on which such reconstructions are based", so fasst R. A. BUTLIN (1993:IX) nach umfangreichen Quellengrundlagen historisch-geographischer Forschung im Gegensatz zur quellenkundlich schwachen Umweltgeschichte (siehe Zitat RADKAU) allgemein zusammen, ,are extensive, from precensus and census population data to paintings and written accounts, official and personal, of placelocated experiences and processes. [...] They are not sources uniquely employed by historical geographers,” so stellt er zwar fest, „but are examined, repaired, analysed, and deconstructed with reference to senses and ideologies of space and place." Diese für die historisch-raumwissenschaftliche Gewässerforschung nutzbaren und notwendigen Quellengruppen finden im Folgenden ihre Erwähnung.

\section{a Alte Sekundärliteratur und historische Autorenberichte}

„Gewiß,“ beschreibt RADKAU (2002:47) die Situation richtigerweise, „die Literaturtitel werden mehr und mehr; aber man kann immer neue Literaturmassen durchackern, ohne festen Boden zu finden. Wer mit Literatur und Quellen kritisch umgeht, muß durch eine Phase des Agnostizimus hindurch.“

Gewässerhistorisch-geographische Arbeiten, wollen sie der Praxisrelevanz und Aktualität vor dem Hintergrund von Zeit, Verfügbarkeit und Zugänglichkeit entsprechen, bedürfen meist der Heranziehung von jüngeren Forschungsergebnissen der Ur- und Frühgeschichte, der Siedlungs-, Wirtschafts-, Sozial- und Landesgeschichte, der Volkskunde etc., die in zahlreichen Veröffentlichungen erscheinen.

Es gilt jedoch hier, abseits der Sekundärliteratur eine neue Quellengruppe zu erschließen, die als , alte Sekundärliteratur' bezeichnet werden kann, aber oftmals auch Aspekte primärer Quellen erfüllt. Es sind jene frühen Arbeiten auszuwerten, die eigentlich keinen geschichtlichen Bezug haben, sondern einfach in damaliger Zeit verfasst worden sind.

Auf die Bedeutung der zeitgenössischen Fachliteratur für die Einschätzung und Behandlung der Wassernutzung, insbesondere der technischen Fachliteratur zum Wasserbau, sei besonders hingewiesen. Es ist z. B. sehr aufschlussreich, wie in der Mühlen- und Teichwirtschaftsliteratur oder in den landwirtschaftlichen Bewässerungsanweisungen Wasserinanspruchnahme und Gewässerumgestaltung behandelt werden. Ähnliche Erkenntnisse lassen sich bei der Auswertung der entsprechenden zeitgenössischen Fachzeitschriften erzielen, die ab Mitte des 19. Jh. in einer großen Fülle erschienen sind (siehe Literaturverzeichnis zu den entsprechenden Abschnitten).

Da in dem genannten Beispiel zum historischen Teichbau, der Teichbewirtschaftung oder auch zur Technik der Wiesenbewässerung nur eine unzureichende primäre Quellenlage existiert, die zudem in 
den meisten Fällen nur in sehr beschränktem Maße zu geeigneten Zeiten öffentlich zugänglich ist ${ }^{1}$, ist man bei der Rekonstruktion historischer Wirtschaftsweisen auf die Vielzahl geschichtlicher Nachrichten und Berichte frühneuzeitlicher Autoren sowie auf die Fachliteratur hauptsächlich des 19. und 20. Jahrhunderts, teilweise sogar, wie beim Bergbau, auf Übersetzungen von Werken des 16. bis 18 Jh. (z. B. von AGRICOLA) angewiesen.

Sie bilden zweifellos eine hervorragende Grundlage für die Ermittlung der allgemeinen Wasserwirtschaft in früherer Zeit, insbesondere wenn davon ausgegangen wird, dass sich Arbeitsweisen bis zur Industrialisierungswende am Ende des 19. Jh. und noch bis zl Anfang der 1950er Jahre in ländlichen Gebieten nicht wesentlich verändert hatten und zum Teil noch heute als tradierte Formen vorliegen. Aus diesem Grund vermögen in dieser Zeit verfasste Bücher und Beiträge sogar auch die spätmittelalterliche und frühneuzeitliche Wasserbewirtschaftung zu veranschaulichen. Obgleich das vielfach bei fehlenden Quellen angewandte Analogieverfahren, „mit [dem] von Bekanntem auf Unbekanntes geschlossen wird“ (LIENAU 1995:160), nur mit größter Vorsicht verwendbar ist; etwa wenn vom Teichbau und von der beschriebenen Teichbewirtschaftungsweise des 19. Jahrhunderts auf dieselbe Entstehungsgeschichte der mittelalterlichen Teiche und zudem in einer anderen Region geschlossen werden soll.

Doch gerade bei dem Beispiel der landwirtschaftlichen Teichwirtschaft bestehen sogar hinsichtlich der Auffindung von sekundärer Alt-Literatur große Schwierigkeiten. Die unbefriedigende Quellen- und Forschungslage ist für die Vergangenheit teilweise dadurch bedingt, daß z. B. die Instandhaltung der Teichböden sowie der Teichbau ,in der Regel die Sache derer war, die sie bearbeiteten, und nicht staatlicher Instanzen, die schriftliche Quellen und Forschungsergebnisse produzierten." (RADKAU 2002:47). Durch die schriftlichen Quellen sieht sich der Historische Geograph, „,sofern er eine Ahnung von Quellenkritik hat, stets auf den Blickwinkel jener Interessen beschränkt, die diese Quellen produzierten und tradierten.“ (:14) Die Realität der Wassernutzungen aus (sekundären) Literaturquellen zu erarbeiten ist deshalb nicht ganz unproblematisch.

Man darf jedoch - bei aller Kritik bei der Anwendung von jüngeren Fachbeiträgen der Jahrhundertwende - nicht übersehen, dass es zur Auswertung schriftlicher Überlieferungen des Mittelalters fast immer des geschulten Historikers bedarf (BORN 1977:25). Dieser aber ist zum einen nicht immer in Planungsbüros vorhanden und zum anderen ist die dafür notwendige Zeit auch einfach nicht gegeben. Trotzdem, und weil historische Originalüberlieferungen die einzige wirklich originäre Quellengrundlage darstellen, seien sie im Folgenden genannt.

\section{b Archivalische Quellen}

Als zweite wichtige Quellengruppe für die Erforschung historischer Gewässer können die Schriftzeugnisse genannt werden.

Schriftliche Aufzeichnungen, Urkunden und Aktenvorgänge, die als Quellen bezeichnet werden (BOSSE 1991:11), bedeuten eine „für den Historiker ,klassische' Gattung [...], die sowohl in gedruckter als in ungedruckter Form vorliegen“ (KREINER 1996b:51). Der größte Teil der bisher veröffentlichten gewässerhistorischen Untersuchungen basiert auf der Auswertung ungedruckten Quellenmaterials aus staatlichen, kommunalen oder privaten Archiven (stellvertretend KREINER 1996b, DIX 1997).

„Je größer der Umfang des Quellenangebotes ist,“ so lautet die Faustregel, „,umso sicherer sind Untersuchungsergebnisse, Rückschlüsse und Aussagen in ihrer Wertigkeit" (BOSSE 1991:11). Aber ob sie uns ,unbestechliche objektive Aussagen [...] liefern“ (:11), mag angezweifelt werden, angesichts oftmals als Fälschung vorliegender Regesten und der subjektiven Darstellung in der Geschichtsschreibung. „Vergangenheit aufzuhellen und Historisches zu entdecken ist [jedenfalls]

\footnotetext{
${ }^{1}$ Eine Ausnahme von den begrenzten Öffnungszeiten von Staatsarchiven und erst recht von Stadt- und Privatarchiven bildet z. B. die Stadt Nordheim, die bereits 1998 einige ihrer Quellen online zur Verfügung gestellt hat.
} 
immer nur über ein Quellenstudium denkbar. Es ist ein mühsamer Weg, der nur schrittweise Erfolge zeitigt und oft auch stagniert." (:11)

Wissenschaftliche Grundlage für die Bestandsaufnahme historischer Gewässerelemente bildet also neben dem Literatur- und Quellenstudium verschiedener Zugänglichkeit und Wissenschaftsbereiche insbesondere die Auswertung unveröffentlichter Archivalien und Schriften, denn historisch-genetische Analysen von Gewässern können erst durch Heranziehung archivalischer Quellen wesentlich differenzierter durchgeführt werden.

Gleichwohl haben Arbeitsmethoden, wie z. B. die Rückschreibung gezeigt, dass Katasterkarten und Archivalien als wichtigste Hilfsmittel genetischer Kulturlandschaftsforschung nur sehr bedingt direkte Hinweise zur vorangegangenen Landschafts- und Siedlungsentwicklung liefern (z. B. bei KRENZLIN 1961). Sie spiegeln oft nur Augenblickszustände wider und bedürfen deshalb der sorgfältigen und meist mühevollen wissenschaftlichen Aufbereitung und Interpretation (vgl. BORN 1977:17). Dies gestaltet sich umso schwieriger und aufwendiger angesichts der früher üblichen Schrift sowohl in Kalligraphie als auch im Wort.

Die Urkundensprache des frühen und hohen Mittelalters ist das Lateinische und dies gilt auch für gewässerrelevante Quellen wie zum Beispiel für Gerichtsakten. Erst seit der Mitte des 13. Jh. vollzog sich ein Wandel: Akten und Urkunden wurden zunehmend in der Volkssprache abgefasst (KREINER 1996b:52). Die Kanzleien vieler Klöster und Stifte hielten dagegen bis in das 16. Jh. am Latein als Urkundensprache fest (:52). Erst ab Mitte des 16. Jh. löste das Hochdeutsche das Lateinische als Schriftsprache ab.

Völlig unverzichtbar sind aber die Urkundenbücher und andere Quelleneditionen der großen Klöster und Stifte, wovon einige nicht nur mittelalterliches, sondern auch frühneuzeitliches Quellenmaterial präsentieren. Bereits in den Urkunden des 14. Jh. tauchen Fischteiche auf, werden hier aber noch allgemein „piscinae“ genannt. In gleicher Bedeutung kommen auch „stagnum“ und „aqua“ vor. Vielfach bezeichnen stagnum und aqua allerdings auch andere stehende und fließende Gewässer.

Eine andere wichtige archivalische Quelle zur Erforschung von mittelalterlichen und frühneuzeitlichen Teichanlagen und anderen Gewässernutzungsarten gibt es in den sog. Urbarien. Als Urbarium (= Sachbuch) bezeichnet man das seit dem Mittelalter für die Wirtschaftsführung angelegte Güter- und Einkünfteverzeichnis der Grundherrschaften (Klöster, Bistümer, weltliche Landesherren) (vgl. LIENAU 1995:159).

Als eine spezielle Form der Archivalie sind des Weiteren die Teichbücher zu nennen, die die Klöster, wie z. B. das Würzburger Hochstift, geführt haben. In ihnen war der höchstmögliche Fischbesatz eines jeden Teiches festgelegt. Auch die Abfischergebnisse wurden in die Teichbücher eingetragen. Dadurch ließ sich die Ertragsfähigkeit der Teiche ständig kontrollieren. RUST (1952:29) verweist auf die Bücher aus dem 16. Jh., die er in seinem vergleichenden Abschnitt seiner Untersuchungen zur holsteinischen Teichwirtschaft zu Hilfe zieht, um Rückschlüsse daraus auf Stückzahl und Gesamtgewicht des Fischbesatzes und der Teichformen mittelalterlicher Teichwirtschaft zu ziehen.

Eine Untersuchung der Rentabilität der mittelalterlichen Teichwirtschaft auf der Grundlage exakten Urkundenmaterials würde zum Beispiel einen interessanten Beitrag zur Kenntnis früherer Betriebsmethoden in der Fischzucht liefern. Eine Untersuchung über den Fischbesatz auf der Grundlage der Teichbücher würde Aussagen über Menge und Nahrungsanteil an Fisch ermöglichen.

Alte Mühlenverzeichnisse, sog. Mühlenkataster, können als weitere gewässerhistorische Quellenedition herangezogen werden. Die preußische Regierung führte 1817 für die Mühlen eine staatliche Gewerbesteuer ein. Soweit nicht vorhanden, sollte in jeder Gemeinde ein Kataster angelegt werden, in dem sämtliche Mühlen mit Anzahl der Wasserräder und Mahlgänge erfasst wurden. In den verschiedenen Rubriken waren die Gemeinde, der Name der Mühle und der Name des Müllers sowie des Wassers eingetragen. Die nächste Spalte war vorgesehen für Angaben der Anzahl von Mahlgängen, Ölpressen und anderen Einrichtungen, sowie Angaben über Anzahl der Wasserräder, ob 
ober- oder unterschlächtig und ob ein Sammelteich vorhanden war. In der nächsten Spalte wurden Angaben gemacht über die Wasserverhältnisse, dem Mahlgutmangel wegen der vielen Mühlen und der weiteren Entfernung. Die Angaben wurden von dem Polizeidiener sowie dem Inhaber der Mühle bestätigt. Anschließend war die Gewerbesteuer eingetragen. In vielen kleinen Herrschaften und Kondominaten haben sich zudem Rechtsaufzeichnungen erhalten, die man Weistümer nennt. Viele dieser Weistümer enthalten detaillierte Bestimmungen über die Mühlen. Seit dem 14. Jh. wurden diese Rechtsweisungen, d. h. die Rechte und Pflichten von Müllern und Mahlgästen, an vielen Orten schriftlich fixiert (siehe auch FN 132).

Eine annähernd vollständige Aufarbeitung aller gewässerrelevanten Quellenbestände liegt außerhalb aller zeitlichen Möglichkeiten anwendungsbezogener Gewässerforschung. Vor allem betrifft dies die schwer zugänglichen Privatarchive (Adelsarchive etc.), die oftmals in einer angewandten Arbeitsweise nicht berücksichtigt werden können. Das sich aber eine Vielzahl, vor allem der bedeutendsten, Wassermühlen in landesherrlicher oder geistlicher Hand befanden, findet sich der größte Teil der uneditierten Quellen in den jeweiligen Landesarchiven, die mit längeren und geregelten Öffnungszeiten und Kopierdiensten aufwarten.

Bislang einzigartig und erstmalig für die Darstellung einer Wassernutzungsgeschichte wurde von DIX (1997:33) der Quellenbestand eines Firmenarchivs herangezogen. D. h. „Archivalien, in denen die Geschäftstätigkeit der Fabrik für die Zeit von 1894 bis 1961 verfolgt werden kann.“ (DIX 1997:33): „Ein wesentlicher Teilbestand sind Geschäftsbücher, im kaufmännischen Bereich also Hauptbücher, Einkaufs- und Verkaufsbücher, Journale und spezielle Kassenbücher. Weitere Bestände bilden Bücher im Bereich der Produktionsplanung und -kontrolle. Dazu gehören Lagerbücher für die Kontrolle des Rohstoff- und Halbfabrikatebestandes, beispielsweise im Woll- und Garnlager, Partiebücher zur Zusammenstellung einzelner Produktionspartien wie im Bereich der Spinnerei oder Färberei und schließlich Stückbücher (Rohschaubücher, Walkbücher, Fertigstückbücher), in denen Produktionsdaten (z. B. Länge, Breite, Farbe, Kettfaden- und Schußzahl) zu einzelnen fertig gewebten Stücken als Information für nachfolgende Arbeitsprozesse eingetragen wurden. Eine Hauptquelle bildeten die Einkaufsbücher, in denen für den gesamten Zeitraum alle Einkäufe von Rohstoffen, Hilfsmitteln, Maschinen, Ersatzteilen und auch Reparaturen dokumentiert sind.“ (DIX 1997:33). Der Schriftwechsel mit den Behördenkunden wurde von DIX (:33) „besonders beachtet, da diese detaillierte Vorschriften über die Produktion und die Qualität der abzuliefernden Tuche erließen, die Aufschlüsse über Technik und Produktionsabläufe ermöglichen.“

Eine weitere wichtige Quellengruppe sind alte Statistiken. Mit Hilfe der von Fischerei-Statistiken entnommenen Strukturkennziffern lassen sich Auf- und Abschwungphasen der Fischerei- und Teichwirtschaft erkennen, umweltgeschichtliche Rückschlüsse von Gewässerverschmutzung anhand zurückgehender Fangquoten vornehmen, die wiederum auf vermehrten Teichbau schließen lassen, oder, durch Ableitung der Fangquoten im Jahresvergleich, der (veränderte) Verbrauch von Fisch in der Bevölkerung feststellen.

Eine gewichtige Quellengrundlage für die lokalhistorische statistische Gewässerforschung sind die Gemeindeberichte und gemeindlichen Zeitungslegungen. Aus dem Untersuchungsbeispiel der Stadt Nordhausen sind hier die „Zeitungs- und Jahresberichte des Magistrats der Stadt Nordhausen im 19. und beginnenden $20 \mathrm{Jh}$. “ zu nennen (STADTARCHIV NORDHAUSEN, Akten DA I/62-I/70, Ziff. IV). Sie umfassen Rechenschaftslegungen resp. Berichterstattungen und vermitteln wichtige Kenntnisse über Betrachtungsgebiet und Berichtszeitraum. Die hier in den Sachzusammenhang gestellten Fakten entstammen dem Bericht aus dem Jahr 1859, unterzeichnet im Original vom damaligen Landrat Eduard Wieprecht Leopold von Davier $(1818$ - 1885). 1863 erschien eine statistische Publikation über den Kreis Nordhausen (STATISTISCHE DARSTELLUNG DES KREISES NORDHAUSEN 1863: 219), die teilweise auf diesen Bericht aufbaut.

Alte Flurbücher (Katasterbücher) beispielsweise sind Ergänzungen zur Flurkarte mit Verzeichnis von Größe, Nutzungsarten, Wertzahlen (Bodenwertzahlen) und anderem der in einer Gemarkung gelegenen Grundstücke (vgl. LIENAU 1995:159) und geben dort, wo sie namentlich verzeichnet sind, Hinweise über die Gewässergröße und -anzahl, Besitzverhältnisse usw. Bei günstiger Quellenlage, 
d. h. beispielsweise nur bei genauen und ausführlichen Angaben in den Katasterbüchern, können sogar sog. Rückschreibungen vorgenommen werden (vgl. BORN 1977:20; siehe Pkt. 2.b.4).

Aus dem Lagerbuch (Grundbuch) der Stadt Nordhausen von 1910 können Informationen zu „öffentlichen Wegen und Gewässern im Stadtbezirk Nordhausen“" zusammengestellt werden (siehe Tab. A-1 im Anhang). Aus der Spalte „Kulturart der Liegenschaften und Gattung der Gewässer“ beispielsweise können parzellenscharfe Angaben zur Größe und Art der Gewässer (Fluss, Bach, Graben) oder der Wegeverbindungen (Furt, Uferweg) entnommen werden.

\section{c Lyrik}

Stünde sie in der wissenschaftlichen Betrachtung neben der Quellenforschung, so würde die Lyrik zunächst als Quelle gewässerhistorischer Erkenntnisse belächelt. In Gedicht- oder Reimform sind manche dieser Verse jedoch ein Hort verbliebener Quellen historischer Gewässerforschung und vermitteln ein, wenn auch prosaisches Bild von dem Aussehen ehemaliger Bachlandschaften, von gewässerbezogenen Bewirtschaftungsweisen und auch von der Einstellung und Wahrnehmung dieser zu einer bestimmten Zeit.

Als erste Gattung in dieser Hinsicht sei die ,Mühlenlyrik' genannt. „Die erste bedeutende und bleibende Mühlenlyrik [...] stammt von Johann Wolfgang von Goethe, der im Spätsommer des Jahres 1797 seinem aus Italien zurückkehrenden Freunde, dem Kunstmaler Heinrich Meyer, in die Schweiz entgegenreiste und auf dem Weg durch die süddeutsche Landschaft zahlreiche Wassermühlen erblickte." (MAGER et al. 1989:178) Seit diesem Jahr und in den darauf folgenden Jahren erfolgte die Dichtung eines Mühlenliederzyklus, aus dem eigentlich eine Operette entstehen sollte. Der Gedichtzyklus besteht aus vier einzelnen Liedern. Von den vier Liedern ist das zweite Lied, ,Der Junggesell und der Mühlbach', ,wohl das ,mühlenspezifischste', das am schönsten die Einbindung der Menschen [...] in die mitsprechende Natur des Mühlenmilieus bezeugt", (:178), so dass ich hier den Anfang des Zwiegesprächs zitieren möchte (aus MAGER et al. 1989:179).

Gesell

Wo willst du klares Bächlein hin,

So munter?

Du eilst mit frohem, leichtem Sinn

Hinunter.

Was suchst du eilig in dem Tal?

So höre doch und sprich einmal!

Bach

Ich war ein Bächlein, Junggesell;

Sie haben

Mich so gefaßt, damit ich schnell,

Im Graben,

Zur Mühle dort hinunter soll,

Und immer bin ich rasch und voll.

Auch der Schriftsteller Arno SCHMIDT [1914 - 1979] hat eine Mühle mit dem dazugehörigen Mühlenteiche immer wieder beschrieben: Die ,Cordinger Mühle' in Benefeld, Gemeinde Bomlitz, Landkreis Soltau-Fallingbostel ist damit in die Literatur eingegangen. Schmidt war in den Nachkriegsjahren, von 1946 bis 1950 als Flüchtling in unmittelbarer Nähe der Mühle, in dem ehemaligen Gutshaus, untergebracht. Genauer gesagt, er bewohnte ein Zimmer des Cordinger Mühlengutes: „Wenn Schmidt aus dem Fenster seines Zimmers schaute, dann sah er den Mühlenteich. Er hat ihn fast zärtlich beschrieben: ,Schöner Teich zur rechten, mit letztem Abendgold getäfelt.'، (ERLER/MATTHIESEN 1989:32) 
Aus diesen Jahren stammt eine Reihe von Werken von ihm, die sich direkt oder mittelbar auf die Cordinger Mühle und besonders den Mühlenteich Teich beziehen (vgl. ERLER/MATTHIESEN 1989:32), beispielsweise in den Büchern ,Brand's Haide', ,Leviathan', ,Aus dem Leben eines Fauns' und in dem Roman ,Das steinerne Herz'.

Heute ist in der renovierten Mühle in Cordingen die „Arno-Schmidt-Stiftung“ untergebracht. Das Gutshaus, als eigentliche Wohnstätte, wurde in den Nachkriegsjahren abgebrochen und an seiner Stelle befindet sich der Besucherparkplatz.

Theodor STORMs Werk, Westermühlen' gibt nicht nur eine Vorstellung von dem schweren Transport von Korn zur am Bachlauf gelegenen Wassermühle, sondern beschreibt in seiner Heimataussage zugleich den gefährlichen Weg durch eine Furt, die der Bauer vom steilen und sandigen Flussufer(terrasse) hinunter nehmen musste.

Der Maler, Zeichner, Dichter und Humorist Wilhelm BUSCH [1832 - 1908] beschrieb die schönste Zeit seines Lebens auf der ,Bachmannschen Herrenmühle' seines Schulfreundes in seinen Erinnerungen, mittlerweile 43jährig, 1875 rückblickend so:

„Ich verbrachte die letzten Tage in einer alten Mühle, die mich seit Kinderzeiten immer freundlich aufgenommen. Da schlief sich's gut. Das Bett wackelte noch wie früher beim Getriebe der Räder, und das herabstürzende Wasser rauschte durch meine Träume. "

Insofern können aus den lyrischen Beschreibungen nicht nur Umwelten früherer Gewässerlagen rekonstruiert werden, sondern auch die Art der Wahrnehmung des die Mühlen unmittelbar umgebenden Wassers.

Auch das Bild der Flößerei wird durch deutsche Prosa gegenwärtig. GOETHE schreibt am 19. März 1818 in einem Brief an Carl Friedrich Zelter über die (Scheitholz-) Flößerei:

„Ich stehe wieder auf meiner Zinne über dem rauschenden Brückenbogen, die tüchtigen Holzflöße, Stamm an Stamm, in zwey Gelenken, fahren mit Besonnenheit durch und glücklich hinab, Ein Mann versieht das Amt hinreichend, der zweyte ist nur wie zur Gesellschaft [...]. Die Scheite Brennholz dilettantisieren hinterdrein. einige kommen auch hinab. wo Gott will. andere werden im Wirbel umgetrieben. andere interimistisch auf Kies und Sandbank aufgeschoben. Morgen wächst vielleicht das Wasser. hebt sie alle und führt sie Meilen weit zu ihrer Bestimmung. zum Feuerherd. “

\section{d Alte Karten, Pläne und Ansichten}

„Auf die Möglichkeit, die Umweltproblematik aus historischer Sicht zu beleuchten und dabei auch insbesondere anhand von Karten den Landschaftswandel in Moor und Geest, Wald und Flur nachzuvollziehen sowie vergangene Übernutzungen der natürlichen Ressourcen $\mathrm{zu}$ untersuchen, hat in geographisch-landeskundlicher Sichtweise SEEDORF bereits 1987 hingewiesen.“, schreiben GROHMANN et al. (2000:11). Dabei haben SEEDORF und auch GROHMANN et al. augenscheinlich die Untersuchung des Landschaftswandels in Bach- und Flusstälern anhand kartographischer Erzeugnisse in ihrer Aufzählung unberücksichtigt gelassen, obgleich gerade hier die Anwendung kartographischen Materials relativ neuartig gewesen wäre, denn die Analyse des Kulturlandschaftswandels anhand von Karten gehört schon seit Jahrzehnten zum methodischen Repertoire von Geographen.

Auch bei der derzeitigen Leitbildbestimmung von kleineren Fließgewässern wird im Allgemeinen der naturnahe und kein historischer Zustand verfolgt und aus diesen Gründen somit auch kein historisches Quellenmaterial herangezogen (siehe E ,Anwendungsbezogener Teil'). Doch Änderungen sind in Sicht und verfolgen ein auch planungsbezogenes Ziel: Von RASPER (2001:13) hingegen wird für die 
Leitbildbestimmung, wenn auch aus methodischen Gründen beschränkt auf große Fließgewässer, kartographisches Material herangezogen: „Für große Fließgewässer lässt sich das Leitbild unter Zuhilfenahme von historischen Karten meist relativ gut festlegen. Laufverlegungen und Begradigungen lassen sich bei den großen Gewässern, im Gegensatz zu den kleineren, auf diesen Karten gut erkennen." Dennoch wird auch in RASPERs Ausführungen der grundlegende ökologische Ansatz deutlich, wenn nach seinen Worten „allerdings zu berücksichtigen“ ist, „dass die Gewässer zum Kartierzeitpunkt der historischen Karten teilweise schon verbaut waren“ (:13). Damit legt er wiederum den allgegenwärtigen Maßstab der Natürlichkeit an und bedient sich der Historischen Kartenwerke nur als Hilfsmittel zur Bestimmung eines möglichst naturnahen Zustandes.

Ein weiteres Beispiel der Verwendung der originär geographischen Quellengattung, Altkarten' zur Rekonstruktion eines Zustandes biologischer Vielfalt sei hier genannt: In einem Vorhaben des BIOLOG Schwerpunktprogramms, gefördert durch das Bundesministerium für Bildung und Forschung (BMBF), untersuchen Wissenschaftler der Abteilung Anthropologie und Humanökologie der Universität Göttingen zur Zeit, unter welchen Voraussetzungen und in welchem Umfang sich die historische Biodiversität in einer Region mit archivalischen Mitteln rekonstruieren lässt (HERRMANN et al. 2002:54). Bisher nämlich ,wurden Archivbestände für die Biodiversitätsforschung selten herangezogen" (:55).

Die Fallstudie zur Umweltgeschichtsforschung wird an der zwischen 1747 und 1753 meliorierten Oderflussaue durchgeführt, in dem Abschnitt zwischen den Städten Letschin und Bad Freienwalde, das sog. Niedere Oderbruch (HERRMANN et al. 2002:54). Für die „Rekonstruktion früherer Naturzustände“, d. h. den „rekonstruierenden Naturschutz“ oder für die „Pflege von Kultur-Altlandschaften“ (:55) werden neben Aktenbeständen der ehemaligen preußischen Staatsarchive in Potsdam und BerlinDahlem vor allem Altkarten herangezogen, und dies aus folgendem Grund: Rekonstruktionen der Pflanzenbestände sind ,ungleich komplexer [...] als bei den Tierbeständen [...]. Mitteilungen über die Flora einer Region lassen sich nur aufwendig aus sehr unterschiedlichen Quellengattungen ermitteln.“ (:55) Als „,sehr informativ“ erwiesen sich „vor allem Planungskarten [...] mit differenzierten Legenden sowie zeitgenössische Beschreibungen lokaler Landschaftsprospekte.“ (:56; siehe Abb. III-1)

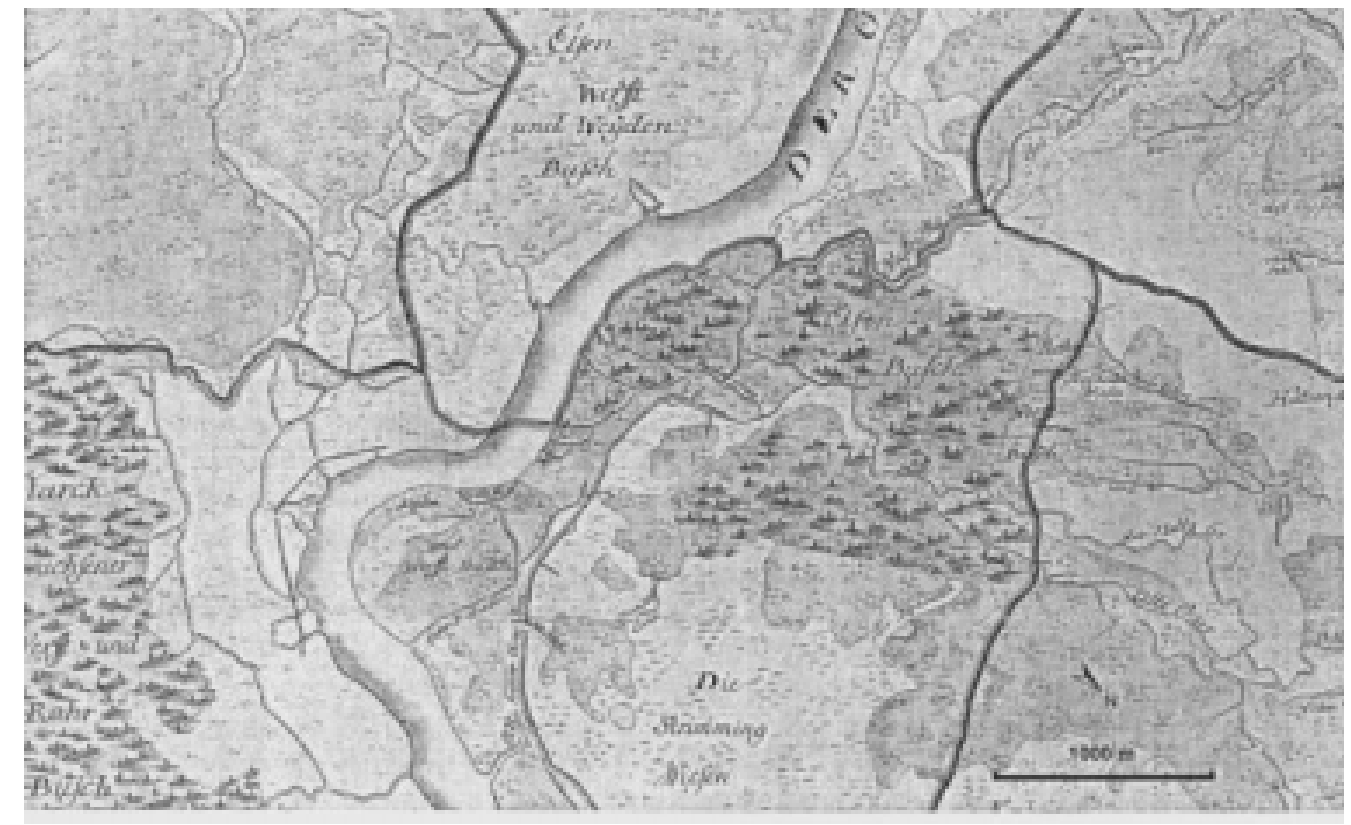

Abb. III-1: Ausschnitt aus einer Planungskarte der Oderbruchregion

Sie zeigt den Zustand vor der Melioration (ca. 1746) (aus: HERRMANN et al. 2002:56).

„Die Eintragungen über Nutzung und Vegetationszustände sind so detailliert, dass eine Rekonstruktion der Pflanzengesellschaften möglich wird.“(HERRMANN et al. 2002:56)

Die anwendungsbezogene Verwendung von Altkarten wird in dem Beispiel der sog. Matrikelkarten der schwedischen Landesaufnahme in Pommern gegen Ende des 17. Jh. im Maßstab von ca. 1:8.300 
deutlich, die vom Geographischen Institut der Universität Greifswald aufbereitet worden sind. Die große Bedeutung dieser Gemarkungskarten resultiert aus der Vielzahl aufgenommener Informationen, die von einzelnen Gebäuden und Wegen, Äckern, Ödäckern, Wäldern und Wiesen reichen und auch Flüsse, Bäche und Mühlen beinhalten. „In Verbindung mit den dazugehörigen Beschreibungsbänden und Ausrechnungsbüchern [...] bildet das Matrikelwerk eine bedeutende historische Quelle zur Erforschung des Landschaftsbildes zu jener Zeit - eine Epoche, die noch nicht durch Gewässerregulierung [...] verändert wurde. Heute stellen diese großmaßstäbigen Karten eine wesentliche Grundlage für Renaturierungsmaßnahmen (z. B. Trebeltal) dar.“(ZÖLITZ-MÖLLER 2003)

Maßgeblich durch Auswertung der Schwedischen Matrikelkarten und der dazu gehörenden Ausrechnungsbücher beispielsweise hat Florian JANSEN (2004) in seiner Dissertation die historische Landschaft des Talmoores der Trebel rekonstruiert und bilanziert. Die Matrikelkarten erwiesen sich als reichhaltige Quelle landschaftökologischer Informationen, dessen Einsatz aber nicht nur zur Interpretation des historischen Landschaftszustandes, sondern auch zur Bilanzierung der aktuellen Landschaftsveränderung eingesetzt werden können. Veränderungen zum Beispiel hinsichtlich Wasserhaushalt (Reduktion der Vernässungsstellen), landwirtschaftlicher Störungsgrade (Agrarintensität), Anteil an anthropogen geförderten Kulturpflanzen usw.

Die anwendungsbezogene Auswertung von alten wasserwirtschaftlichen Kartenbeständen aus dem Zeitraum von 1700-1945 für die Renaturierung von Fließgewässern und aktuelle Bauplanungen heben auch DEUTSCH/PÖRTGE (2002) hervor.

Eine Analyse historischer Karten führte auch zur Rekonstruktion des vom Bundesamt für Naturschutz (BfN) beförderten Pflege- und Entwicklungsplanung (PEP) ,Teichgebiete Niederspree-Hammerstadt' (siehe IX 3c1). Der zeitschnittartige Vergleich der Messtischblätter von 1823, 1889 und 1911 ergab, dass ,die ehemaligen Teichflächen zwischen der Daubitzer und der Quolsdorfer Teichgruppe und ebenso das Terrain östlich der Hirschwiese beackert" wurden (BfN 2000:D-7).

Ausgangspunkt und wichtigstes Hilfsmittel einer historisch-genetisch arbeitenden Gewässergeographie sind demnach Kartenwerke unterschiedlicher Art, die bei der historischen Gewässerforschung herangezogen werden müssen, um das ehemalige Kulturlandschaftsbild zu rekonstruieren und zu Planungsaussagen zu gelangen. HAGEL ${ }^{2}$ (1988) beispielsweise zeichnet anhand alter Karten ein lebendiges Bild der Flussgeschichte des Neckars. Dabei lenkt er das Augenmerk besonders auf den Flusslauf, die Veränderungen der Ufer und die daraus entstehenden Folgen: Hochwasser und Eisgang. Des Weiteren werden Wasserbauwerke, wie z. B. Wehre und Floßgassen in ihrer Bedeutung für die Wasserhaltung der Mühlen, für die Flößerei und die Treidelschiffahrt, aus verschiedenen Kartenarten herausgelesen, die heute den Standard darstellen und unverzichtbar für eine historisch-geographische Gewässerforschung sind:

Flurkarten (=Katasterkarten) sind Karten in den Maßstäben 1:500 bis 1:5.000 mit Angaben über Grundstücksgrenzen, Abmarkungen, Nummern der Flurstücke und Bodenwertzahlen. Aber sie enthalten auch Informationen über Nutzungsarten wie Wald, Grünland, Ackerland, Moor und über Gewässer sowie Gebäude. „Im 19. Jh. für die Grundsteuererhebung geschaffen“ (LIENAU 1995:159f.), bilden sie zusammen mit den Katasterbüchern das Liegenschaftskataster und werden bis heute in nahezu unveränderter Form weitergeführt. Seit den 1990er Jahren liegen sie sogar in digitalisierter Form vor (ALK, ALB), so dass Zeitschnittvergleiche insbesondere auf dieser Quellengrundlage durchgeführt werden.

Da differenzierte Gebäudedarstellungen auf den Katasterkarten enthalten sind, bieten besonders alte Flurkarten ,eine große Hilfe bei der Standortfeststellung der untergegangenen Hämmer, Kotten und Mühlen“ (LUNKENHEIMER 1990:10). Dies gilt, das sei hier hinzugefügt, ebenso für die Inhalte von sog. Messtischblättern. Von besonderem Interesse ist deshalb hierbei vor allem das Urkataster. „Als

\footnotetext{
2 Die Karteninterpretation bzw. geographische Analyse sowie der Umgang mit topographischen Karten hinsichtlich gewässerkundlicher und gewässerhistorischer Fragestellungen ist dem Studienbuch von HAGEL 1998:44-45, 69-74) zu entnehmen.
} 
Urkataster bezeichnet man die ersten, in Deutschland zumeist in der ersten Hälfte des 19. Jh. entstandenen, modernen Katasterkarten“. (LIENAU 1995:160) Dieser Zeitraum dürfte im Regelfall auch für eine historische Gewässerbestimmung ausreichen, da die in den heutigen Fluren sich abzeichnenden alten Gewässer ,freilich meist auch aus frühneuzeitlichen Flurkarten zu ersehen“ sind (BORN 1977:22).

Die Rekonstruktion, beispielsweise von wüsten Teichflächen mittels einer alten Flurkarte, setzt dort ein, wo sie urkundlich nicht belegt sind. Es ist zwar fraglich, ob mit dieser Rückdatierung auf mittelalterliche Teichanlagen geschlossen werden darf, da die meisten Flurkarten dem 18. - 19. Jh. entstammen, wie RUST (1952:34) kritisch anmerkt, doch zumindest für den Zeitraum der Neuzeit können daraus wertvolle Ergebnisse gewonnen werden. Auch den auf diesen Flurkarten als Bruchwald oder feuchte Wiese eingetragenen Flurstücken können Hinweise auf ehemalige Teichanlagen entnommen werden. Schließlich hilft der Vergleich mit den Höhenlinien des Messtischblattes vielfach weiter.

Es muss jedoch folgende Einschränkung bei der Karteninterpretation beachtet werden: „Die Katasterkarten in den Maßstäben 1:2.000 bis 1:10.000 erreichten im 17. und 18. Jahrhundert durchweg noch nicht denselben Grad von Genauigkeit und Abstraktion wie die topographischen Karten." (FEHN 1989:13) Das Fehlen einer genauen Vermessungsgrundlage aber „wird zumindest vom Standpunkt des Historischen Geographen mehr als ausgeglichen durch den großen Reichtum an kulturlandschaftsgeschichtlich auswertbaren Details und die flächendeckende Darstellung vieler Sachverhalte, die in den schriftlichen Quellen meist nur sehr bruckstückhaft sind." (:12)

Seit der Landesaufnahme unter Kaiser Wilhelm I. wurden die Katasterkarten bis in die Gegenwart ständig fortgeführt. Durch Verkleinerung stellt man aus ihnen das Kartenwerk im Maßstab 1:25.000, das sog. Messtischblatt [TK 25] her. Einen guten Überblick über die ehemalige Verbreitung von Wässerungseinrichtungen und Mühlengräben in einem Untersuchungsgebiet beispielsweise erhält man bei der Durchsicht der Erstausgabe der Topographischen Karten 1:25.000, in der z. B. Stauschleusen mit einer eigenen Signatur versehen sind (SCHRÖDER/SCHRÖDER 1997:9).

Des gleichen Kartenwerkes bedient sich auch GRIES (1999:10) zur Auffindung der Lage ehemaliger Wassermühlen und des Verlaufs von Mühlgräben in Oberschwaben: „Wie ältere Meßtischblätter aus den zwanziger Jahren noch erkennen lassen, war der Bieberbach etwa 1,5 km oberhalb der Mühle durch einen künstlich abgelegten Graben aus seinem ursprünglichen Bette im Wiesengrund an den östlichen Rand des flachen Tälchens verlegt und zur Mühle hingeleitet worden.”

Aus dem Messtischblatt wurde beispielsweise der Topographische Atlas des Königreichs Württemberg mit dem Maßstab 1:50.000 entwickelt. Er ist erstmals 1840 herausgekommen. (HAGEL 1988:16, 18) „Diese Karte bezeichnet deutlich die Fähren [...]; die Mühle [...]“ und es ist „ein Stück weit der Treidelpfad erkennbar, der sonst nicht besonders dargestellt ist.“ (:18)

Des Weiteren ist die Analyse und der Vergleich alter topographischer Landesaufnahmen wesentlicher Bestandteil gewässerhistorischer Forschung. Für das 19. und 20. Jahrhundert stehen mit den ,modernen' genauen topographischen Karten „unentbehrliche Hilfsmittel“ zur Verfügung (FEHN 1997:17) und bilden immer das Zentrum einer historisch-geographischen Rückschreibung (FEHN 1989:11; siehe Pkt. 2.b.4). Die topographisch-kartographische Darstellung gibt Aufschlüsse über vorgenommene Meliorationen (z. B. Trockenlegungen) sowie über die vielfache Beseitigung kleiner Gewässer. Das heißt, mit Hilfe der historisch-kartographischen Geländewiedergabe kann über die groß- oder kleinräumige Verbreitung bzw. Abräumung oberflächiger Gewässer befunden werden.

HAGEL (1988:16) zieht für seine flusshistorischen Rekonstruktionen die amtliche Landesaufnahme von Baden-Württemberg 1818 heran: „Hinter dem Wehr von Neckargröningen haben sich zwei Inseln gebildet; die eine ist mit Gebüsch bestanden, die andere eine Kiesinsel. Weiter nördlich ist auch am linken Ufer eine Kiesfläche erkennbar. Die östliche Insel ist durch eine Steinzeile mit dem Wehr verbunden und flußabwärts durch eine Steinzeile verlängert [...]. Auch in der Rems liegt eine kleine Insel. Die Flußaue ist nicht immer scharf abgegrenzt, weil eine Kennzeichnung des Reliefs fehlt; 
lediglich an den Bezeichnungen, Wiesen' und, Wasen' kann man in etwa erkennen, wie weit sich die Aue erstreckt.“ (:16) Die Schwierigkeit der Geländeabgrenzung wird vor dem Hintergrund deutlich, dass man erst gegen Ende des 19. Jh. zur Einzeichnung von Höhenlinien überging. Da die Kartographie des frühen 19. Jh. noch keine Höhenlinien (Isohypsen) kannte, sind auch aktuelle topographische Karten ein unverzichtbares Arbeitsmittel. Diese liegen in vielen Fällen bereits digital vor oder und können mit den digitalisierten Altkarten übereinander gelegt werden (siehe Pkt. 2.a.10 ,GIS'). Im Einzelfall kann auch die Deutsche Grundkarte 1:5.000 (DGK 5) herangezogen werden.

Altkarten

Grundsätzlich anders ist die Situation für diejenigen früheren Zeiten, die wegen der fehlenden Quellen (dies betrifft auch die Karten an sich) nicht in derselben Intensität erkundet werden können (vgl. FEHN 1997:17). „Nach den frühen modernen Katasterkarten und topographischen Karten des 19. Jahrhunderts, neben den großmaßstäbigen Karten des 19. und 20. Jahrhunderts und vor den gedruckten Karten der Zeit vor 1800 stellen die Altkarten die wichtigste kartographische Quellengruppe für die Rekonstruktion der Kulturlandschaft früherer Zeiten dar.“ (FEHN 1989:10) „Die Bedeutung der Altkarten als wichtigste Quelle für die Altlandschaftsforschung neben den Kulturlandschaftsrelikten selbst", hebt FEHN (1989:11; auch FEHN 1975a:51) besonders hervor. Es sind dies handgezeichnete Karten einer Mitte des 16. bis Anfang des 19. Jh. reichenden Periode (FEHN 1989:12).

In diese Kategorie lässt sich wahrscheinlich auch die „Übersichtskarte“ des Neckargebietes um 1800 einordnen, die nach HAGEL (1988:15) einige Hinweise auf die Gewässernutzung gibt: Mühlen sind in dieser Karte an der Rems bei Neckarrems sowie am Neckar bei Neckargröningen durch ein Wasserrad gekennzeichnet. Fähren sind nicht markiert, sie lassen sich jedoch aus dem Wegenetz erschließen, nämlich bei Aldingen und Neckargröningen.

Eine Kartenquelle der besonderen Art, speziell der etwas größeren Fließgewässer, sind die sog. Strombzw. Flusskarten, die zur Regulierung in Auftrag gegeben worden sind. Von 1831 bis 1833 entstand beispielsweise die erste maßstabsgetreue Stromkarte, in der die Ausbaumaßnahmen der Weser enthalten waren (vgl. HENCKEL 1988:49). Die erste genaue Aufnahme des Neckars wurde im Auftrag des Herzogs von Württemberg im Jahre 1598 ebenfalls vor dem Hintergrund gemacht, zu untersuchen, wie der Fluss schiffbar gemacht werden könnte. Da es um die Frage nach der Beschiffbarkeit ging, mussten Wehre und Mühlen mit aufgenommen werden (vgl. HAGEL 1988:7).

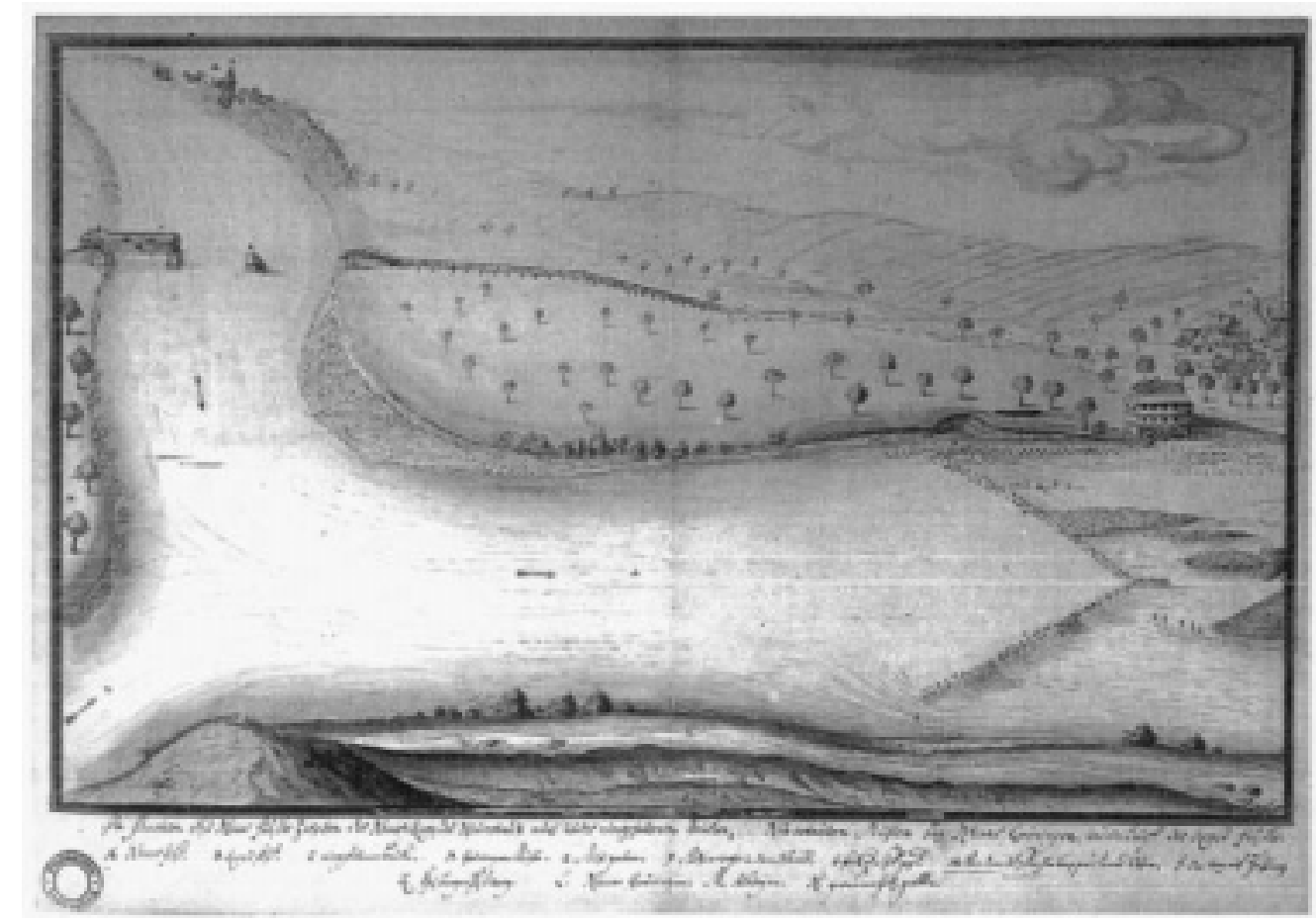

Abb. III-2: Der Neckar zwischen Aldingen und Neckargröningen (nicht maßstabsgerecht) von S. G. Schweiger, um 1734. 
Am rechten Bildrand ist Neckargröningen eingezeichnet. Davor sieht man eine Wassermühle mit vier Wasserrädern und von links einen schmalen Wasserarm zu dem Stellwehr der Mühle führend. Davor wiederum ist eine Pfahlreihe verzeichnet, die die Begrenzung des Mühlkanals bildete. Von ihrem linken Ende verläuft eine weitere Pfahlreihe, die ein Wehr markiert, zur Mitte des Neckarsund weiter bis kurz vor das vordere (rechte) Ufer. Die enge Stelle zwischen Wehr und Ufer war als Floß- und Schiffsgasse offengelassen worden (aus: HAGEL/ PFIZENMAYER 1988:13).

Eines dieser eingezeichneten Wehre ist mit der Bezeichnung „Mül“ versehen. „An dieser Staustelle verbreiteter sich der Fluß, und unterhalb des Wehres hatten sich mehrere Kiesinseln gebildet, wie dies auch von anderen Staustellen des Neckars durchaus bekannt ist. Eben unterhalb dieser Inseln befand sich das ,Fargenhäußle' bzw. die ,far' (Fähre).“ (HAGEL 1988:9) Weiterhin erkennt man ,unterhalb von Neckargröningen [...] zwischen dem linken Ufer und der Kiesinseln ein ,fach’; es handelt sich um ein Fischerfach, einen keilartigen Rechen für den Fischfang. Mühle und Fähre sind hier nicht vermerkt. Ein Stückchen weiter flußabwärts hat sich eine weitere Insel gebildet." (:9) Die Darstellung von Flusskrümmungen und Talmäandern, darauf weist HAGEL (:11) hin, sind dabei nicht immer naturgetreu wiedergegeben.

Auch GREVE bedient sich zur Darstellung der historischen Regulierungsarbeiten an der Sude, der Rögnitz und der Krainke, deren Flussgebiet sich im Urstromtal der Elbe befindet, der „Lusius'schen Generalkarte“ aus dem Jahre 1789 (GREVE 1999:49). Seine Vermutung: „Offenbar hat der schlechte Entwässerungszustand der Niederung die kurfürstlich-hannoversche und die herzoglich-mecklenburgische Regierung zu gemeinsamem Handeln veranlasst, so daß der ,curfürstliche IngenieurLieutenant' Lusius mit dem Regulierungsentwurf betraut wurde.“ (:49)

Weitgehend unberücksichtigt in der gewässerhistorischen Forschung blieben bislang auch frühe thematische Karten der Flussfischerei. Als Beispiel sei 1. die ichthnologische Karte von Deutschland in 25 Blättern nach STIELER und 2. die Rau'sche hydrographische Karte von Preußen genannt. „Auf den Karten sind die Verbreitungsbezirke der leitenden Fischarten, der Wanderfische, die unübersteiglichen oder besonders schwer passirbaren Wehre und andere Hindernisse, sowie die Fischleitern durch Farben bezeichnet.“(BORNE 1886:295)

Weiterhin kann für einen ersten Hinweis, ob es sich eventuell um künstliche oder natürlich entstandene Stillgewässer handelt, die Geologische Karte und die Bodenkarte im Maßstab 1:25.000 und 1:50.000 benutzt werden. In ihnen sind Gesteinsarten und pedologische Schichtungen eingetragen, die z. B. eine wasserundurchlässige Schicht kennzeichnen.

Für die Rekonstruktion alter Mühl- und Hammerstandorte und der entsprechenden Wasserkanäle ist neben den historischen Karten - der frühere Bestand in Plänen, wie beispielsweise in den Liquidationsplänen festgehalten (siehe DENZER 1996:179, Abb. 17 und 51).

Stadtpläne dokumentieren, betrachtet man sie in der Zeitfolge ihres Entstehens, eindrucksvoll die kurzzeitige topographische Entwicklung nicht nur der städtischen Siedlungen, sondern auch die der Gewässerläufe. Für die geographische Gewässergeschichtsforschung besitzen sie nicht zuletzt deshalb erhebliche Aussagekraft.

Der Nordhäuser Stadtplan von 1834 und seine Nachfolgeblätter zum Beispiel vermitteln, wenn sie in der Reihenfolge ihrer zeitlichen Entstehung betrachtet werden, ein zeitschnittartiges Bild auch von der gewässerbezogenen Entwicklung des Stadtgebietes von Nordhausen während der vergangenen rund 165 Jahre. Sie sind ein wichtiges zeitgenössisches Dokument und eine sachbezogene, aussagekräftige historisch-gewässerkundliche Quelle für die Umwelt- und Siedlungsgeschichte der Stadt. Dennoch bleibt, auch wenn sich aus der Abfolge historischer Stadtpläne vieles herauslesen oder ableiten lässt (wie z. B. die sukzessive Umwandlung von Gewässerflächen in Bauland), manches nur Vermutung (z. B. der genaue Zeitpunkt der Wandlung bzw. die Vorgänge, die zu dieser Vertrocknung geführt haben).

Neben Altkarten können auch alte Ansichten als Quellengrundlage verwendet werden, denn ,in der früheren Kartographie sind die Übergänge von der Ansicht zur Karte fließend.“ (FEHN 1989:12) Der gewässerkundliche Historiker muss gar in verstärktem Maß zeitgenössische Stadt- und 
Landschaftsansichten des 16. bis 19. Jh. als kartographisches Quellenmaterial verwerten, auch um eine dreidimensionale, zumindest aber aufrissmäßige Vorstellung von Siedlungen und ihrer Gewässer in früherer Zeit zu gewinnen. Erinnert sei an die Stadtansichten z. B. von Matthäus Merian d. Ä. (1593 1650) und sein Schüler Wenzel Hollar (1607 - 1667), die bestrebt waren, möglichst topographisch genaue Ansichten der Städte wiederzugeben. Die Topographie der Städte und Landschaften wird in ihren Darstellungen stets auf nur wenige typische Erkennungsmerkmale reduziert. In diesem Zusammenhang wurden teilweise auch die vor den Toren der Städte liegenden Gewässer und ihre Nutzungen mit aufgenommen.

Gesamtüberblick

Zusammenfassend lassen sich sieben Arten von Karten hervorheben, die für eine Analyse historischer Wasserläufe und Gewässersituationen herangezogen werden können:

1. Katasterkarten (Flurkarten, Urkataster)

2. Topographische Kartenwerke (Messtischblatt, Topographischer Atlas, Topographische Landesaufnahmen), die in vielen Blättern größere Gebiete einheitlich darstellen und ab etwa 1800 auch in Einzelheiten der Darstellung genau sind.

3. Altkarten (alte Übersichtskarten) des 16. und 17. Jh. für größere Gebiete, die künstlerisch ansprechend gestaltet sind und eine hohe Aussagekraft besitzen.

4. Flusskarten (Stromkarten) aus den Jahren des 16. - 19. Jh. von schon früh großer Genauigkeit.

5. „Fischkarten“

6. Alte Geologische Karten und alte Bodenkarten

7. Spezielle Pläne (Stadtpläne), Ansichten oder Skizzen in großem Maßstab mit zugehörigen Akten v. a. des 18. und 19. Jh.

\section{e Architektur- und Konstruktionszeichnungen}

Die genaue Form und eventuell auch die Maße von historischen, insbesondere technischen Artefakten zu rekonstruieren, die nicht mehr an der Örtlichkeit vorhanden sind, ermöglichen alte Architektur- und Konstruktionszeichnungen, wie beispielsweise von Stau- und Überfallwehren (siehe Abb. III-3). Sie sind Spiegelbild technisch-orientierter historischer Wasserbaumaßnahmen und Flusskorrekturen und geben somit eine technikgeschichtliche Dokumentation der früheren Eingriffe in den Gewässerverlauf wieder. 

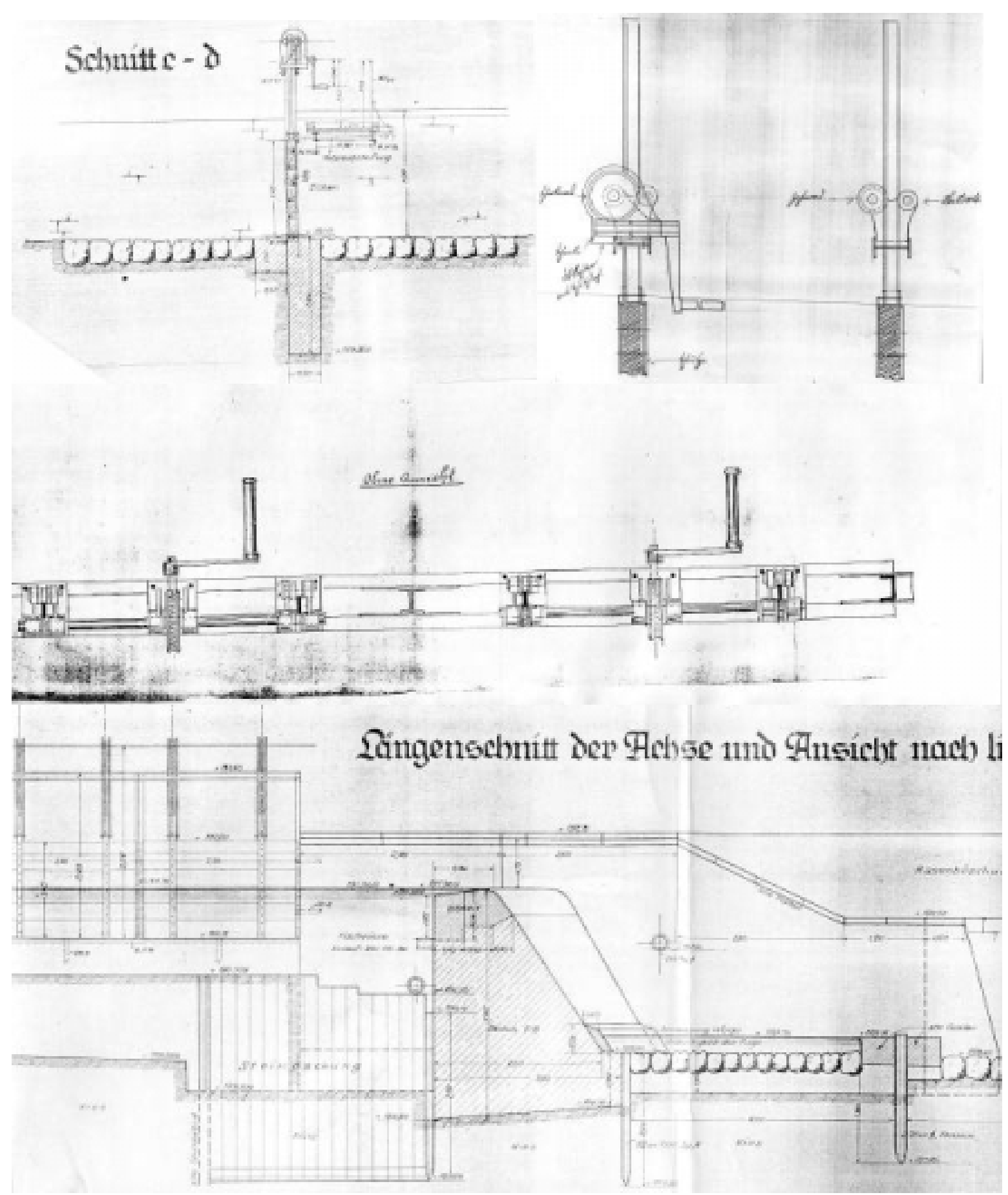

Abb. III-3: „Wehr-Schützen zum Mühlgraben-Einlauf für die Stadt Nordhausen“

Konstruktionszeichnung der Nordhäuser Maschinenfabrik Schmidt, Kramer \& Co. 1906. Verschiedene Ansichten: o. li.: Querschnitt, oben Mitte/re.: Detailzeichnung „Schneckenradantrieb f.[ür] die Schütze z.[um] Mühlgrabeneinlauf", Mitte: Ansicht von oben, unten: Längsschnitt (Ausschnitt) mit Ansicht nach links (Stadtarchiv Nordhausen).

Insbesondere können technische Zeichnungen als Rekonstruktionsvorlagen dienen, wenn ein wasserbauhistorisches Element am Flusslauf oder am Teich nicht mehr vorhanden ist, aber eine Wiederherstellung der ursprünglichen Form gewünscht wird.

LEUPOLD hat in seinem Werk zur „Mühlen-Bau-Kunst“ von 1735 sehr detaillierte „Grund- und AufRisse“ von Mühlengewerken, unter anderem auch von Wehren dargestellt, die für so eine IdealRekonstruktion herangezogen werden können. 
In der nachfolgenden Abbildung III-4 beispielsweise ist ein Aufziehwehr in seinen baulichen Bestandteilen in einer Konstruktionszeichnung beschrieben: „Heerd“, „Fluth-Bette“ (Fig. 3, g), „Fachbaum“ (Fig. 3, h) und „Grießwerk“ (Fig. 4) (LEUPOLD 1735:16; siehe bauliche Beschreibung unter Pkt. VII 3d.1.3).

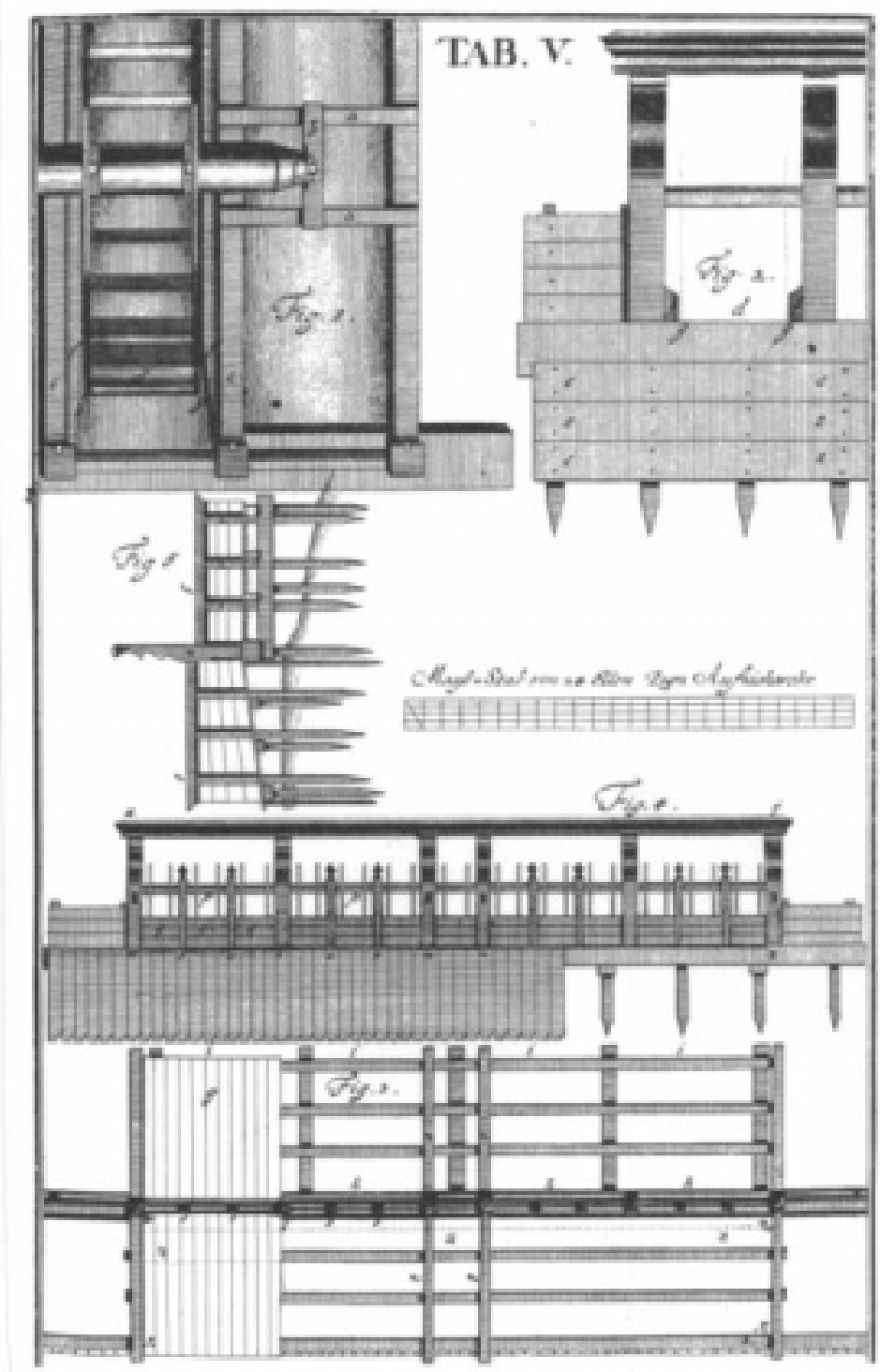

Abb. III-4: Modell eines großen Aufziehwehres an einem breiten Fluss (aus: LEUPOLD 1735:18).

\section{f Historische Fotografien und kunsthistorische Werke}

Die Nutzung von Bildquellen, stellt REITH (1996:18) fest, „ist für umweltgeschichtliche Fragestellungen ertragreich“ und argumentiert: „Durch Einbezug von Bildquellen kann [...]auf einen breiten Fundus [...] zurückgegriffen und zudem ein höheres Maß an Anschaulichkeit erreicht werden.“ (:18f.)

Auch nach Erfahrung von BALCK (1999:5) „liefern Bildquellen einen erheblichen Teil der Informationen.“ Für kulturhistorische Analysen lassen sich diese „zum Teil durch Textstellen sowie durch im Gelände noch vorhandene Spuren und durch Vergleiche mit anderen Bildquellen sichern und nachprüfen.“(:5)

Schließlich vertritt KLAUBE (1995:111) die Auffassung, dass ,als Geschichtsquelle [...] die zeitgenössische Abbildung seit langem von der Forschung beachtet und geschätzt" wird. So bedienen sich BRAUN/KONOLD (1998) zahlreicher Bildquellen (alter Stiche und Gemälde), die Darstellungen von 
Kopfweiden zeigen, da daraus ,auf eine regional gehäuftes Vorkommen geschlossen werden kann“ (:45). Und auch ZITSCHER vermittelt bildhafte Eindrücke über das Geschehen und Erleben einer Sturmflut im nordfriesischen Lebensraum und will sie ,durch Gemälde schleswig-holsteinischer Maler lebendig werden lassen.“(1984:149)

Mit den ,natural forms“ der Landschaft in der Malerei des 19. Jahrhunderts setzt sich auch Peter FULLER (1988:11-31) auseinander. Natur, so führt er für diese Zeit der "Modernen Maler" aus, „was little more than a synonym for the handiwork of God." (:17) In den zahlreichen künstlerischen Werken „kommt die immense Vorstellungskraft, die sich aus der Natur nährte, zum Ausdruck. In ihrem symbolischen und mythischen Gehalt liegt einer der Schlüsse zum Verständnis unserer Beziehung zur Umwelt.“(WALTER 1996:208).

Wenn diese Aussage auch für die geschichtswissenschaftliche Forschung ungeprüft hier so stehen gelassen werden soll, bleibt dennoch die Frage bestehen: Können Bildquellen in einem (angewandten) historisch-geographischen Beitrag als Vorbilder für zum Beispiel Renaturierungen von Flüssen und Bachläufen herangezogen werden und in welchem Umfang geschieht dies bereits schon?

Unter den Sammelbegriff „Bildquellen“ sind Zeitbilder in Öl, in Holzschnitt, Kupferstich, Lithographie oder Stahlstich, aquarellierte Handzeichnungen, kolorierte Federzeichnungen bis zur Momentaufnahme der seit einigen Jahrzehnten dominierenden Lichtbildtechnik zu verstehen. Hinsichtlich gewässerhistorischer Aspekte fallen darunter alte fotografische Aufnahmen und auf zeichnerischer Grundlage beruhende Abbildungen (Gemälde, alte Stiche) ehemaliger oder heute noch bestehender aquatischer Einrichtungen und Anlagen, die dem Leser eine bildhafte Vorstellung von den mit der Gewässernutzung in Beziehung stehenden Kulturlandschaftselementen vermitteln können. Die Auswertung solcher kunsthistorischen Werke, seien es die Gemälde bekannter oder unbekannter Künstler, vermögen ein anschauliches und aussagekräftiges oder auch je nach Stilepoche subjektiv und ideal gefärbtes Bild von Gewässern, Flusslandschaften und historischen Wirtschaftsweisen zu zeichnen. Um den Filter der Objektivität über die Bildquelle laufen zu lassen und damit das Reale bzw. das tatsächlich Mögliche zu erkennen, ist dafür jedoch die Kenntnis der Intention des Malers bzw. der Malepoche zu Zeiten der Entstehung notwendig.

Einige der malerischen Ansichten im 17., 18. Jh. und insbesondere des 19. Jh. in der Kunstepoche des Biedermeiers, zeigen ,Flussidyllen' und spiegeln die romantischen, d. h. „,em Natureindruck weitgehend folgenden“" (FIEDLER-BENDER 1998:7) Empfindungen des Menschen (und auch der Maler) zu dieser Zeit wider. Mit dem in Windungen fließenden Strom mit seinen ruhig dahin fließenden Schiffen sind sie, wie FIEDLER-BENDER (:7) es ausdrückt „auf der Suche nach ihrem ,Arkadien' ${ }^{3}$, nach der idealen Landschaft, jener Idylle, die Vergil in seinen Bucolica schildert.“

Und diese ,Traumlandschaft', ,Sinnbild einer paradiesischen Welt, in der die Menschen mit der Natur in Einklang leben“ (MERTENS 1998:39), setzten die Kunstakademien Dresden, München, Berlin und Düsseldorf motivhaft als Flusslandschaft meisterhaft um. Stille und fließende Gewässer sowie sprudelnde Quellen waren Kennzeichen dieser aquatischen Ideallandschaften und des Ausdrucks des Künstlers. Sie malten manchen schönen Gewässerausschnitt aber „wohl auch, weil sich Käufer dafür finden ließen.“ (FIEDLER-BENDER 1998:7) Die „Ausbeutung eines Landschaftsmotivs“ deutet nämlich auf eine „Nachfrage des Kunstmarktes hin“" (SUHR 1998:55), das Motiv entsprach einfach dem bürgerlichen Kunstgeschmack.

Der Barock „mit seinen [...]idealisierten und komponierten Landschaften“ kann dabei ,als ein Vorläufer der romantischen Landschaftsmalerei angesehen werden“ (FIEDLER-BENDER 1998:7). Die Vertreter des 17. Jh. malten Flusslandschaften als kulissenartig durch Felsmassive verengte Flusstäler.

\footnotetext{
3 Arkadien: „die zentrale Landschaft der Peleponnes, Heimat des Hirtengottes Pan, Schauplatz antiker und barocker Schäferszenen“ (FIEDLER-BENDER 1998:7). „Mit dem Begriff Arkadien ist seit den Hirtenidyllen Vergils eine verlorene pastorale Traumwelt verbunden, der Inbegriff vergänglichen Glücks. Vergil prägte den Begriff Arkadien, bei dem es sich ursprünglich um ein in der Peloponnes gelegenes Bergland handelt.“" (MERTENS 1998:39).
} 
Zumeist aber ,handelt es sich um nicht lokalisierbare Landschaftspanoramen, in die phantasievolle, oft aber auch eindeutig zu identifizierende Architekturen [...] eingefügt werden.“(MERTENS 1998:34)

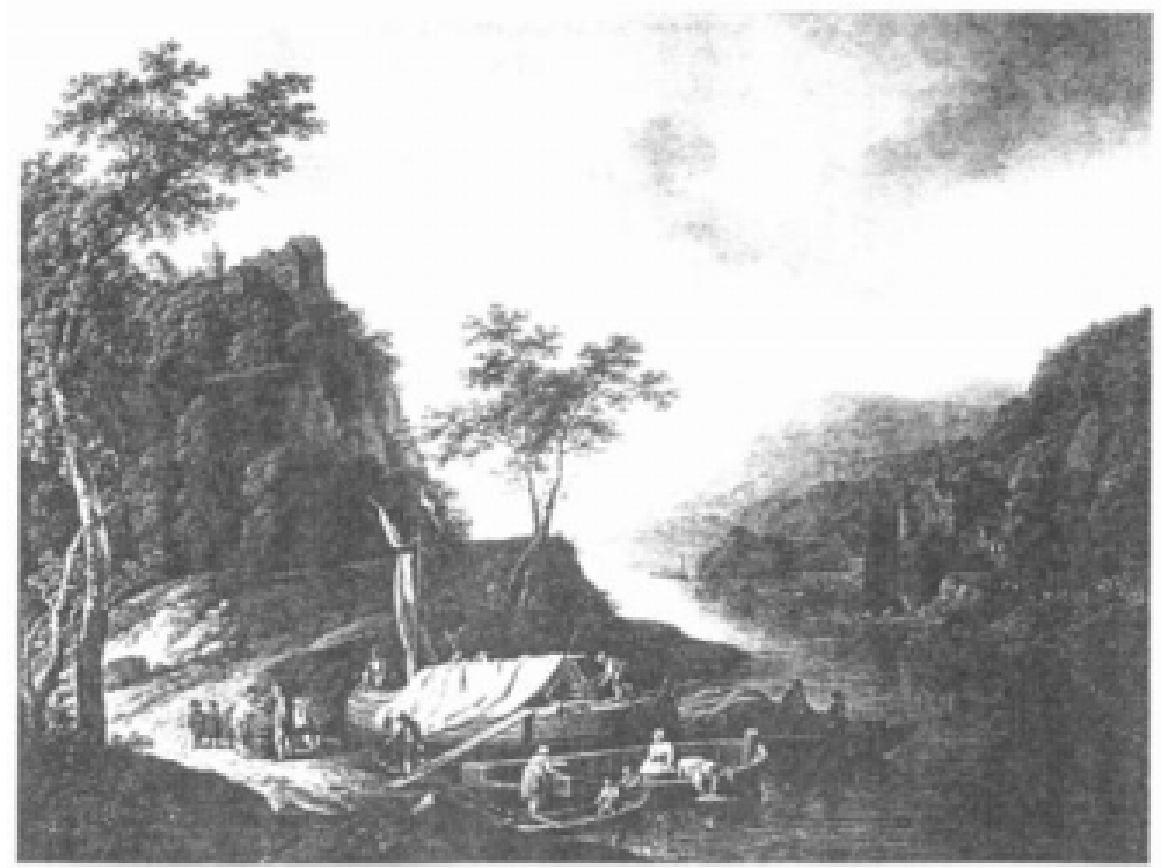

Abb. III-5: Idealisierte Flusslandschaft von Caspar Schneider, 1811

Landesmuseum Mainz (aus: MERTENS 1998:34). Der Betrachter blickt von einem leicht erhöhten Standort in eine weites, gewundenes Flusstal. In einer Bucht (Naturhafen) im Vordergrund haben mehrere Kähne und Transportschiffe angelegt, auf die gerade Fässer geladen werden. Davor gehen Wäschefrauen von einem Boot aus (!) ihrer Arbeit nach. „Die Flußlandschaft gibt den Charakter des Rheintals wieder, ohne auf eine bestimmte topographische Situation Bezug zu nehmen“(:54).

Die meisten barocken Landschaften haben deshalb ,jeden Anspruch auf topographische Genauigkeit verloren. Es sind eher Visionen von Flußlandschaften“ (MERTENS 1998:34). Der Charakter der Flusstäler wird z. B. durch zahlreiche Flusswindungen und durch „die verwirrende Fülle und ungeordnete Vielfalt einzelner Bildelemente“ (:34) entfremdet und lässt die Szene „unwirklich und pittoresk“ (:34) erscheinen.

„Ungeniert bedienen sich auch noch im 18. Jahrhundert die Maler aus diesem reichhaltigen Motivvorrat.“ (MERTENS 1998:34) und setzen „die Tradition der idealen Landschaftsmalerei fort“ (:36). „Beeinflußt durch die romantische Bewegung, begannen die Künstler, sich der Geschichte und Landschaft ihrer Heimat bewußt zu werden.“ (LANDSCHULZ 1998:22). Mit dem in der Landschaftskunst des 18. Jh. ,neuerwachten Naturverständnisses verband sich die Vorstellung von ,Naturwahrheit'“, die zugleich eine Abkehr von den erstarrten höfischen Formen des Barock und Rokoko bedeutete.“ (MERTENS 1998:39). Die ,naturnahe' Landschaftsmalerei wurde nach 1800 (nach der Historien- und Schlachtenmalerei) allmählich ,die führende Bildgattung“ (LANDSCHULZ 1998:22).

Bis in die zweite Hälfte des 18. Jahrhunderts hinein galt hingegen ,die frei komponierte Ideallandschaft - im Gegensatz zur bloßen Wirklichkeitsnachahmung der holländischen Malerei - als eigentliche künstlerische Leistung.“ (MERTENS 1998:34,36) In dieser Zeit „verklärt sich die Wirklichkeit zu einem schönen, idyllisch überhöhten Abbild.“ (:40) „Durch die im 18. Jahrhundert in ganz Europa verbreitete Vorliebe für die holländische Malerei des 17. Jahrhunderts hatte man ein besonderes Interesse an diesen idealisierten und phantastischen Flußlandschaften." (LANDSCHULZ 1998:23). Diese „erfundenen“, „frei komponierbaren Ideallandschaften“ (:24) waren gekennzeichnet durch Darstellungen mit Wasserfällen, Mühlenstimmungen und Quellen, wie sie in den niederländischen Wasserszenen wiedergegeben waren. Wasser- und Flusslandschaften als „phantastische Landschaftsprospekte“ (MERTENS 1998:34), als Ideallandschaften, die letztlich reine „Phantasielandschaften“ sind (:39). 
Die Landbevölkerung, Fischer und Schiffer verrichteten in diesen „fiktiven Landschaftsräumen“ (MERTENS 1998:43) ihre Arbeit am oder im Fluss. „Oft haben diese sogenannten Staffagefiguren auch die Funktion von romantischen Stimmungsträgern.“ (LANDSCHULZ 1998:23) „Als ein typisches romantisches Motiv findet man zuweilen Einsiedler und Mönche inmitten der Natur in beschaulicher Einsamkeit. Sie wurden innerhalb der deutschen Romantik zu Symbolträgern der neuen Einsamkeit [...] in nachbarocker Zeit.“ (:23). „Menschen und Tiere stehen in harmonischem Einklang mit der Natur und erwecken Erinnerungen an Arkadien.“ (MERTENS 1998:39). Mit „dem am Ufer stiller Gewässer lagernden Vieh korrespondieren schlafende oder Flöte spielende Hirten.“ (:39)

Dieses Kompositionsschema fand seine Anwendung bei allen romantischen Flussabschnitten und Gewässern Mitteleuropas, „auch bei den Landschaften der rheinischen Nebenflüsse.“ (LANDSCHULZ 1998:23) „Die Ideallandschaften boten dem Menschen des ausgehenden 18. Jahrhunderts die Möglichkeit zur Rückbesinnung auf eine nicht zerstörte Natur.“ (MERTENS 1998:43) - Wasserlandschaften als ,poetisches“ Landschaftsbild (SUHR 1998:54), umgesetzt mit den Mitteln der Malerei.

Ab der zweiten Hälfte des 18. Jh. dann entsteht eine Kontroverse zwischen Ideal und Wirklichkeit. Die Maler „lösten sich von den Vorstellungen einer dem Barock verpflichteten ,Ideallandschaft', einer [...] komponierten ,Weltlandschaft', und orientierten sich mehr an der ,realen' Landschaft.“ (LANDSCHULZ 1998:23), ohne die andere Darstellungsform gänzlich aufzugeben. Es wird „die Verbindung von exakter Naturnachahmung und idealisierter Naturdarstellung“ (MERTENS 1998:36) versucht zu erreichen. Es ist die Kombination zwischen der realistischen Naturschilderung und einer aus idealen Elementen zusammengesetzten Landschaft oder, anders ausgedrückt, einer Landschaft zwischen Ideal und Wirklichkeit: eine „realistische Idylle“ (SUHR 1998:54).

Die Zielstellung bei dieser malerischen „Vermischung von Ideallandschaft und realistischer Vedute“ (MERTENS 1998:36) lautete, „topographische Dokumentation und Idealisierung der Natur sollten nicht miteinander konkurrieren, sondern sich zu einem ,Idealrealismus' vereinen.“ (:36) Es sollte ein Spannungsverhältnis „Zwischen Phantasieschilderung und topographischer Bestandsaufnahme“ (:37) aufgebaut werden Durch die Aufnahme charakteristischer, ,echter' Kulturlandschaftselemente in die Kunstlandschaft beispielsweise sollte der Maler dies erreichen als eine ,virtuelle' Landschaft, die sich auf der einen Seite durch künstliche Merkmale wie Klarheit des Wassers, anmutige Darstellungen der Ufer und der Auen des Stromes auszeichnete. Auf der anderen Seite waren „topographisch getreue Versatzstücke in seine Ideallandschaften eingebunden.“ (:36) Als topographisch eindeutig zu identifizieren ist am Beispiel des Rheins z. B. die Darstellung Caspar Schneiders mit dem Blick auf Mainz. Mit „den im Fluß verankerten Mühlen erweist sich Schneider als exakter Schilderer topographischer Gegebenheiten.“ (:40)

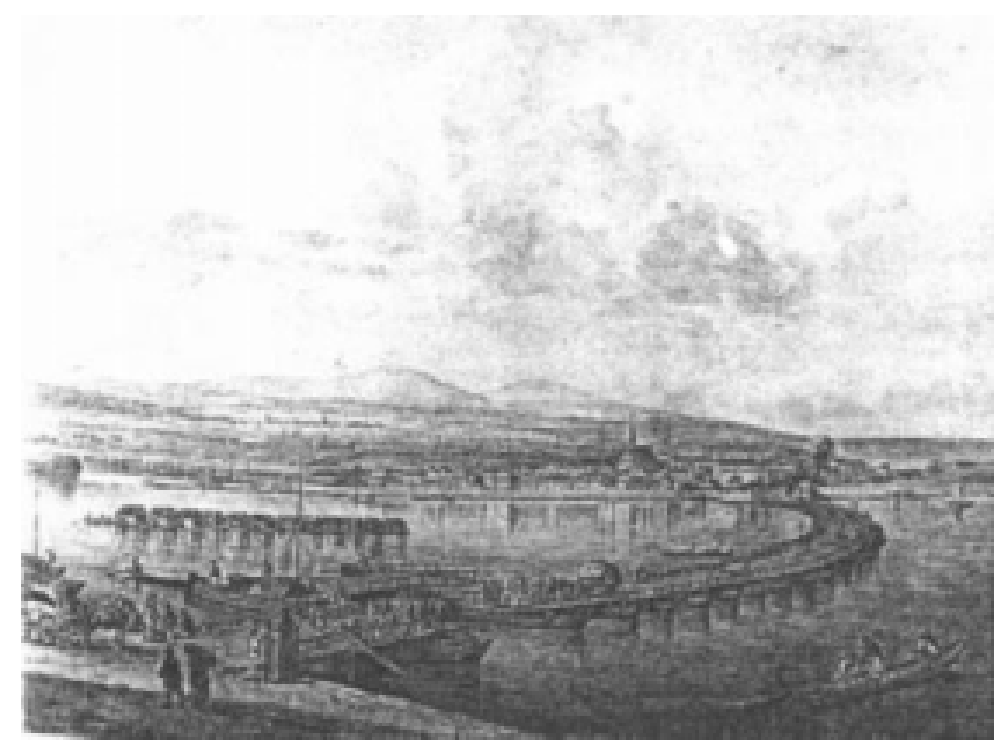

Abb. III-6: Die Mainzer Schiffbrücke mit Blick auf Kastel von Caspar Schneider, um 1807 
Sammlung der Staatlichen Schlösser und Gärten Rheinland-Pfalz, Burg Sooneck. (aus: MERTENS 1988:115) In der Mitte des Flusses vor der Schiffbrücke befinden sich zwölf im Wasser verankerte und mit einander verbundene Schiffsmühlen. Diese Mühlen werden urkundlich erstmalig um 1112 erwähnt, bis sie gegen Ende des 19. Jahrhunderts unter anderen im Zuge der Industrialisierung funktionslos wurden (NEBELING 1995:134).

Innerhalb der Darstellung von Flusslandschaften spielt die Wassermühle eine besondere und wechselhafte Rolle.

Während in den idealisierten Darstellungen sogar „das Herzstück einer Mühle, das Rad mit den stürzenden Wassern“ (LEHMANN 1998:66) in der Landschaftsmalerei zu Anfang des 18. Jh. völlig zurücktrat, obschon der Typus bis etwa zur Mitte des 19. Jahrhunderts weitergeführt wurde, wird die Wassermühle mit ihren wasserbautechnischen Einrichtungen erst später, um 1800, als eigenständiges Bildmotiv entdeckt (:66). Die ,idyllische Natur wird hier durch die Eingriffe des Menschen - Mühle und Wasserrinne statt Wasserfall - zur nutzbar gemachten Landschaft." (SUHR 1998:54) In diesen „realistisch geprägten Landschaften ohne romantische Stimmungsträger“ (LANDSCHULZ 1998:24) sind mit Wasserrad betriebene Wassermühlen wiedergegeben, von denen im 19. Jahrhundert noch zahlreiche in Betrieb, aber einige bereits auch schon niedergegangen waren. Diese vereinzelten malerischen Ruinen der Wassermühlen waren dann oftmals „Anziehungspunkt für Künstler, die der Romantik des Verfalls ländlicher Kultur nachspürten.” (ERLER/MATTHIESEN 1989:74) und die dieses Gewässermotiv, wie bereits angedeutet, noch lange für sich entdeckten.

GOETHE beispielsweise näherte sich dem Mühlenmotiv nicht nur als Verfasser von Lyrik. „Es gibt von seiner Hand, die ja oft zu Pinsel oder Stift gegriffen hat, eine sehr genaue und zugleich schon von romantischer Ahnung erfüllte Bleistift-Tuschzeichnung einer oberschlächtigen Wassermühle mit Kandeln und Schützanlagen, die zwischen 1776 und 1786 nach der Realität in der Umgebung Weimars entstand.“(MAGER et al. 1989:178)

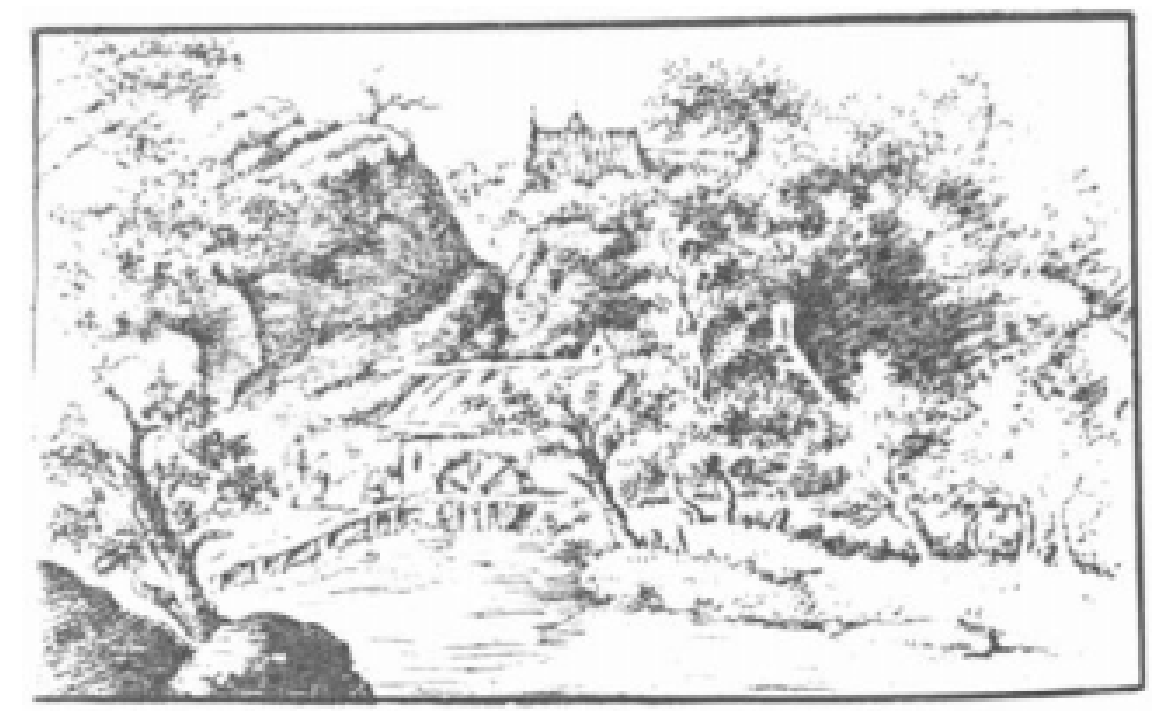

Abb. III-7: Wassermühle am Berg. Tusche-Bleistift-Zeichnung von Goethe um 1780

Nationale Forschungs- und Gedenkstätten der klassischen deutschen Literatur in Weimar, Goethemuseum (aus: MAGER et al. 1989:178).

Auch von Matthäus MERIAN ist auf einem Stich der Burg- und Schlossanlage Hodenhagen die ,Hudemühle' abgebildet. Das Bild von 1648 zeigt eine kleine Wassermühle mit einigen Nebengebäuden.

Zahlreiche andere Maler und Zeichner haben die Wassermühle und ihre dazugehörigen Kulturelemente aufs Papier gebracht: Andreas ACHENBACH (1815 - 1910) eine unterschlächtige ,Westfälische Wassermühle', eine mit zwei Wasserrädern ausgestattete ,Alte Westfälische Mühle' oder die ,Erftmühle' (1866), Albrecht DÜRER (1471 - 1528) die ,Drahtziehmühle an der Pegnitz' und die ,Weidenmühle', Wilhelm HASEMANN (1850 - 1913) ,Eine Mühle in Gutach', Ludwig 
RICHTER (1803 - 1884) ,Die Wassermühle' und Jacob VAN RUISDAL (1628/29 - 1682) ,Zwei Wassermühlen an einer geöffneten Schleuse' (um 1652).

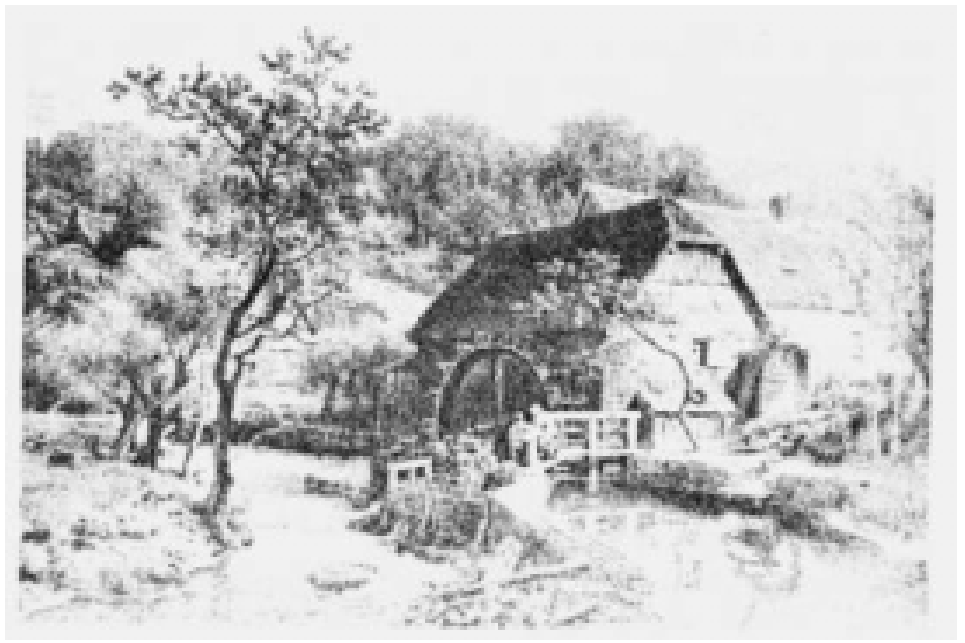

Abb. III-8: „Westfälische Wassermühle” von Andreas Achenbach

$\mathrm{Zu}$ erkennen ist ein Aufziehwehr mit einem unterschlächtig betriebenen Wasserrad und ein durch Mauerwerk eingefasster Flussstau. (aus: SCHLENDER 1988:50)

UNVERFEHERT (1989) hat an einigen Werken der Landschaftsmalerei dieses Quellenmaterial zur Auswertung herangezogen: „Salomon van Ruysdaels Landschaft mit Reisewagen (1660 [...]) läßt die Transportschwierigkeiten im von Flüssen, Bächen und Tümpeln durchzogenen Schwemmland erahnen“ (:52) und „Jan van Goyens Kanallandschaft (1641 [...]) vermittelt einen Eindruck von der intensiven Nutzung der Wasserwege" (:52).

KLAUBE (1995:111ff.) stellt die Fuldaschifffahrt in Kassel auf alten Abbildungen dar. Die bildlichen Darstellungen veranschaulichen nach seiner Überzeugung die Fuldaschifffahrt des 16. bis 19. Jahrhunderts. Das bedeutet eine Zeit, in der ohne Motorantrieb die Lasten mit schwerem körperlichen Einsatz und vor der umfangreichen Regulierung mit stark wechselnden Wasserständen aus und vom Landgrafensitz befördert werden mussten.

Auch HERRMANN erwähnt die Bedeutung von Bildern für die Erforschung des früheren Kulturlandschaftsbildes der Oder bzw. des Oderbruchs, v. a. wenn historisch-kartographische und vermessungstechnische Grundlagen fehlen: „Vom Zustand des Oderbruches vor der Melioration existieren nur wenige authentische Darstellungen, denen auch dokumentierende Qualitäten abgewonnen werden könnten. Hierzu zählen die Vermessungskarten, die Planungsgrundlagen der Wasserbau-, Deichbauund Meliorationsarbeiten waren [...]. Zeitgenössische Prospekte der Landschaft sind hingegen kaum bekannt oder erhalten. Gerade diese könnten hilfreich bei der Such [sic] nach der ,verlorenen' Landschaft sein. Hier sind vor allem (vielleicht auch ausschließlich) zu nennen Arbeiten von Antoine Pesne, Charles Sylva Dubois und Georg Wenzelslaus von Knobelsdorff. Im August 1745 unternahmen die drei Künstler eine gemeinsame Reise in das Oderbruch, wobei zumindest Knobelsdorff das Bruchland bereits früher besucht hatte. Die Exkursion schlägt sich in Landschaftsbildern von Pesne und Dubois nieder.“(HERRMANN 1997:32)

Zur Diskussion und Verifizierung der frühen Pfahlbauhypothese des Züricher Altertumsforschers und Pfahlbaupioniers Ferdinand KELLER $(1800$ - 1881), dass jungsteinzeitliche und bronzezeitliche Bauernbevölkerungen ihre Wohnungen auf Pfähle am Rande der Seen des schweizerischen Mittellandes errichteten, woraus er auf ausgedehnte Pfahlfelder, ja ganze Wasserbaupfahldörfer schloss, bedient sich BANDI (1986:448) ebenfalls der Malerei und liefert damit ein weiteres Beispiel zur wissenschaftlichen Akzeptanz der Landschaftsmalerei in der wissenschaftlichen Forschung. Er verweist auf ein Ölbild von Schloss Oberhofen am Thunersee, das Albrecht Kauw (1621-1681) um 1671 gemalt hat und im Historischen Museum Bern ausgestellt ist. Die Ergebnisse der Pfahlbauforschung stimmt genau mit dem überein, „was Kauw vor dreihundert Jahren an Ort und Stelle gesehen hat" (:451). 


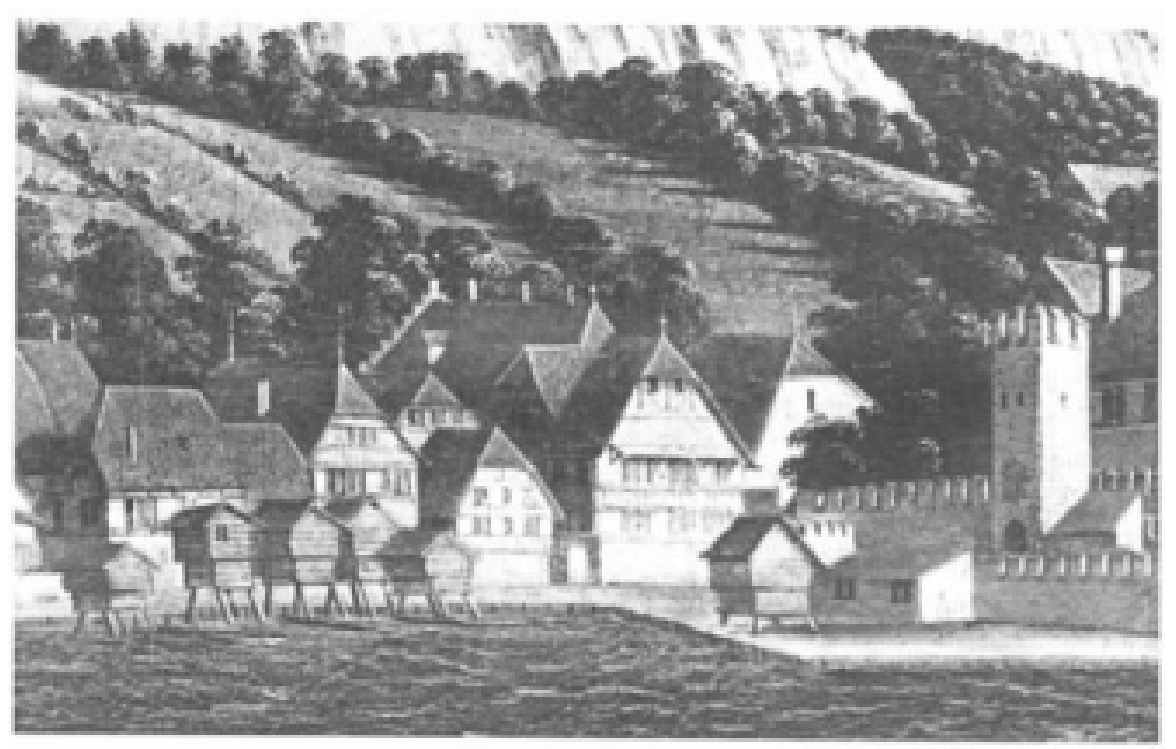

Abb. III-9: Pfahlbauhäuser am Thunersee/Schweiz von Albrecht Kauw

Historisches Museum Bern. Vergrößerter Ausschnitt (aus: BANDI 1986).

Die Interpretation von Bildquellen ist jedoch keineswegs einfach. Zu beachten sind zum Beispiel Symbolik, Authentizität, Originalität etc., aber vor allem Subjektivität (REITH 1996:18). REITH bezeichnet es als „Phänomen, daß man im Bild nur das sieht, was man sehen will bzw. was man kennt“(:19).

Aus diesen Gründen bleibt auch eine abschließende Beurteilung, Landschaftsmalerei als Quelle gewässerhistorisch-geographischer Forschungen vorzunehmen, eine Zwiegespaltene: So reicht die Spanne der Landschaften von topographisch getreuen Ansichten bis hin zu idealisierten Landschaftsfantasien, d. h. idealen Flusslandschaften. In diesem Fall hieß das Ziel nicht Natur- bzw. Wirklichkeitsnachahmung, sondern Naturschöpfung. Die Künstler wählten keinen realen Landschaftsausschnitt, sondern setzten „einzelne fiktive Bildelemente zu einem ausgewogenen, harmonischen Ganzen zusammen.“(MERTENS 1998:34)

Die klassischen Idealdarstellungen dürfen trotzdem nicht vergessen lassen, dass die „,ideale Landschaft [...] von intensivem Naturstudium begleitet" wurde (SUHR 1998:51), um eine ,auf mehrere Einzelstudien aus unterschiedlichen Richtungen basierende Komposition zu einer perspektivischen Einheit werden zu lassen.“ (:52) Dies ist Kennzeichen akademischer Malschulen.

Weiß man um diese Schwächen, so bietet sich auch diese Landschaftsmalerei auf Öl und Leinwand zur Heranziehung beispielsweise ehemaliger Gewässerlandschaftszustände und historischer Wassernutzungen an.

Die Arbeiten auf Papier sind dabei „durchweg von größerer topographischer Treue als die oft nicht näher lokalisierbaren Gemälde, d. h. sie hängen enger mit dem Entstehungsprozess, der Bestandsaufnahme an Ort und Stelle, zusammen" (SUHR 1998:49). Anders als in den Ölgemälden begegnen uns in Zeichnung, Aquarell und Gouache fantastische Flusslandschaften nur ausnahmsweise (vgl.:49). Damit gehörten sie aber zur damaligen Zeit „einem niedrigeren Rang an als die idealisierten Landschaften.“ (:49), wohingegen sie heute für kulturlandschaftsgeschichtliche Interpretationen einen höheren Wert besitzen.

Von großem Wert sind Skizzenbücher. Diese an Ort und Stelle gefertigten Zeichnungen von Gewässerlandschaften und -bauten besitzen weniger eine große Detailtreue, dafür aber eine realistisch geprägte erste Landschaftsaufnahme, die zumeist erst später im Atelier vom Künstler entfremdet und idealisiert wurde (vgl. SUHR 1998:49).

Des Weiteren sind montane Illustrationen zum Beispiel für bergbaubezogene Gewässerrekonstruktionen zu beachten. Von den für den bergmännischen Betrieb notwendigen wasserbetriebenen 
Poch- und Stampfwerken des 13. und 14. Jh. ist nichts mehr erhalten, dafür aber Bildmaterial, das im 16. Jh. einsetzt. Dies darf zwar auch nicht zur Illustration älterer Zeiten unbedenklich herangezogen werden, doch soweit es sich um offenkundige Neuerungen der Agricola-Zeit (1450 - 1618) handelt, die einen großen technischen Aufschwung brachte, spiegeln sie mögliche Änderungen, zum Beispiel hinsichtlich der Intensivierung der Gewässernutzung wider (ALTMANN 1999:25).

In der von MAGER et al. 1989 verfassten „Kulturgeschichte der Mühlen“ benennen die Autoren im letzten Kapitel „Die Mühle in der bildenden Kunst”) „Maler, Zeichner und Graphiker [...] als Kronzeugen der Geschichte" (:203) und brechen damit eine Lanze für diese Quellengattung. Sie erweitern aber auch den Kreis der „Kronzeugen“ um einen bislang weitgehend unbeachteten Personenkreis. „Zu ihnen gehören als bildende Künstler im weitesten Sinne auch die Kunstmeister, Mühlenbauer und -theoretiker, die seit dem 16. Jahrhundert als sachverständige Konstrukteure in ihren zahlreichen kommentierten Rissen und Stichen oft eine über das Technische hinausgehende, bildmäßig verdichtete Zeichenkunst bewiesen.“ (:203) Aus ihren Bauanleitungen und Entwürfen, „,die der großen Schar der Maler und Graphiker als Anschauungsmaterial vor Augen stand" (:203) entstanden oftmals erst die großen bekannten Gemälde. „Ihre damals übliche Charakteristik als ,Künstler’ bestand also zu Recht.“, stellen MAGER et al. (:203) fest.

In der 2. Hälfte des 19. Jh. ging die Zeit zu Ende, in der Künstler Ansichten zeichneten und in Stichen und Lithografien vervielfältigen ließen. An ihre Stelle traten Fotografen, die durch technische Verbesserungen in die Lage versetzt wurden, ihre Ateliers $\mathrm{zu}$ verlassen. Es entstanden Außenaufnahmen, um davon fotografische Abzüge oder im Autotypie-Verfahren oder Kupfertiefdruck hergestellte Ansichtskarten dem Publikum anzubieten. Diese historischen Fotos sind für die Dokumentation „besonders wertvoll“ (MÖRSTEDT 1995:10). Dies trifft besonders auch für die Beweisführung der Veränderungen von Gewässern und der ehemaligen Nutzung dieser zu.

Bei der Fotografie wird der schnelle Verfall der noch vor kurzem sichtbaren Kulturlandschaft und dessen Bestandteile für den Betrachter deutlich. Fotografische Aufnahmen decken dabei einen relativ kurzen Zeitrahmen ab. Erste fototechnische Aufnahmen wurden erstmals um die Wende zum 20. Jahrhundert durchgeführt. Doch schon die zahlreichen „Früher - Heute“ bzw. „Vor vielen Jahren“Bildbände, deren Aufnahmen zumeist aus der Zeit vor dem Ersten bzw. Zweiten Weltkrieg bzw. sogar erst aus den 1950er Jahren stammen, verdeutlichen die Rasanz der Entwicklung.

Historische Fotografien üben aber auf viele Menschen nicht nur eine magische Anziehungskraft aus, sondern liefern einen bedeutenden umweltgeschichtlichen und historisch-orientierten planerischen Beitrag. Der Vergleich von Aufnahmen aus Serien mit verschiedenen Zeitpunkten der Aufnahmen „kann Aufschluß geben über die planerischen Absichten, deren Ausführung und ihre tatsächliche Wirkungen auf Natur und Landschaft.“ (KÖNIG 1988:79) „Dabei liefern die Bilder jedoch lediglich die Informationen für eine Meinungsbildung. Die Bewertung, ob Erfolg oder Mißerfolg, ist vom Standpunkt des Betrachters, von seinem Engagement oder seiner Gleichgültigkeit abhängig. [...] Sie können eine eigene Anschauung [...] nur ergänzen, sie aber nicht ersetzen.“ (:79) Aber gerade deshalb sind sie damit weitgehend objektiv einsetzbares Dokumentationsmaterial. Denn ,auf der anderen Seite sind Erinnerungsbilder durch die persönlichen Vorstellungen, Stimmungen und das unterschiedlich ausgebildete visuelle Gedächtnis mehr oder weniger stark verändert. Solche individuell veränderten Bilder können verbal jedoch nicht vermittelt werden, und da alle Argumentation auf dem Hintergrund dieser subjektiven Bilderinnerungen abläuft, kann eine dokumentierende Fotografie hier zu einer Objektivierung beitragen.“ (:79) In einer Diskussion können die Aufnahmen zudem einen unterschiedlichen Informationsstand der Teilnehmer angleichen helfen und der Diskussion Bezugspunkte bieten.

Ein weiteres, eher pragmatisches Kriterium spricht für diese Quellengattung: „Weil die Fotografie in der Lage ist, mit relativ einfachen Mitteln maßstäblich verkleinerte Abbildungen von Gegenständen mit hoher Auflösung und Informationsdichte herzustellen, ist sie ein besonders geeignetes Medium der Dokumentation.“ (KÖNIG 1988:79) 
Eines gilt es jedoch bei dem Einsatz historischer Fotografien zu berücksichtigen, wenn man zu „Früher-heute“-Aussagen gelangen will: Um die Forderung nach Vergleichbarkeit der Aufnahmen erfüllen zu können, sollten der Standpunkt, die Aufnahmerichtung und die Bildwinkel für jede Serie möglichst identisch sein (KÖNIG 1988:79f.)

Zum Stellenwert des vernachlässigten Ansatzes, kunsthistorische Aufnahmen in die gewässerhistorische Forschung einzubinden, muss an dieser Stelle die englische Historische Geographie zitiert werden, die hierzu in einem Beitrag von Joan M. SCHWARTZ (1996:30) fordert: „We must explore more fully the larger documentary context of written and visual representations for the ways in which photographs complement and supplement, confirm and contest other evidentary sources". Und weiter: „Geographers must learn to approach photographs [...] as an integral part of geographical inquiry.“

In jüngerer Zeit hat in der deutschen Historischen Geographie SCHUMACHER-GORNY (1997:309) diese Quellengruppe erwähnt: Sie listet für die Untersuchung und Inventarisierung ,pseudomaritimer Kulturlandschaften“ am Beispiel des Seebades Travemünde als „Sondergruppe“ im Bereich der Quellen- und Arbeitsmethoden „Fotos vergangener Jahrzehnte“ auf: „Auch sie geben Aufschluß über die Kulturlandschaft und ihre Veränderungen, indem sie besonders die Bebauung eines Ortes dokumentieren, aber auch Aufschluß über die Einwohner und Besucher geben“.

Eine Dokumentation der Gewässerlandschaftsveränderung am Beispiel der Altmühl hat KÖNIG (1988:79) vorgelegt. Die Arbeit erfasst die gesamte Kanalstrecke im Altmühltal von Kelheim bis Dietfurt und darüber hinaus auch das Ottmaringer Tal und das Sulztal. Die Aufnahmen halten die Zustände vor und während des Fortganges der Bauarbeiten am Kanal fest.

Wahrheitsgehalt und Verwendbarkeit von Fotos als zulässiges Quellenmaterial für historische Untersuchungen hat auch BALCK 1999b:12) für die Erforschung eines alten Harzer Grubenfeldes herangezogen. „Fotos“, so seine Erfahrung unter Zuhilfenahme technischer Hilfsmittel, „bieten [...]bei näherem Hinsehen (Vergrößerungsglas), manchmal erstaunliche Einzelheiten“ (BALCK 1999:5).

Zusammenfassend lässt sich feststellen: Der methodische Ansatz einer (vergleichenden) Betrachtung und Auswertung von Fotografien wie auch der Landschaftsmalerei wird nach meinem Kenntnisstand bislang in der deutschsprachigen Historischen Geographie noch nicht genügend verfolgt. Hier scheint ein meiner Meinung nach großes Betätigungsfeld $\mathrm{zu}$ liegen, beachtet man die geringen Einschränkungen, denen diese Quellenarten bei der Interpretation im Vergleich zu den Kartenwerken unterliegen.

\section{g Luft- und Satellitenbilder}

Für das 19. und 20. Jahrhundert stehen, wie wir gesehen haben, mit den topographischen Karten „unentbehrliche Hilfsmittel“ (FEHN 1997:17) für die überblicksartige Darstellung zur Verfügung. Für die ,allerjüngste Vergangenheit können die außerordentlich aussagekräftigen Satellitenbilder herangezogen werden.“(:17)

Beispielsweise zur Ermittlung von Relikten alter Teichanlagen und anderer flächen- und netzhafter Gewässerformen leistet das Luftbild wertvolle Dienste. Neben den Schatten von kleinen Unebenheiten im Mikrorelief lässt es auch Bodenverfärbungen erkennen (BORN 1977:22), die wiederum Hinweise auf ehemalige Anlagen der Teichwirtschaft geben können.

Die archäologische Photogrammetrie (Luftbildarchäometrie) bedient sich sehr erfolgreich diesem Hilfsmittel, um mittels stereoskopischer Auswertungen Veränderungen des Landschaftsbildes anhand ihrer Reliefierung erkennen zu können, die beispielsweise Anhaltspunkte für einen ehemaligen flussmorphologischen Verlauf liefern. Auf aktuellen Luftbildern lassen sich so mittlerweile versiegte Quellen und Wasserläufe erkennen, wie JÄGER (1965:411) feststellt: „Bei genügend kräftiger, wenn auch episodischer Wasserführung und entsprechender Zufuhr von Felsschutt werden im Felde in der 
Linienführung ehemaliger Wasserläufe schmale Schotterstreifen abgelagert, die sich auf sommerlichen Luftbildern durch hellere Färbung des Bodens oder des reifen Getreides abzeichnen.“

Ebenso erlaubt die vergleichende photogrammetrische Interpretation von Luft- und Satellitenbildern Rückschlüsse auf Gewässerhäufigkeit und -verteilung in neuester und jüngerer Zeit. Mit Beginn der flächendeckenden Luftbildbefliegung seit Anfang der 60er Jahre des 20. Jahrhunderts können die Veränderungen des Landschafts- und Stadtbildes aff einer Zeitachse gut dokumentiert werden. Die vor diesem Zeitpunkt aufgenommen militärischen Aufnahmen des Zweiten Weltkrieges stehen mittlerweile ebenfalls, wenn auch begrenzt, zur Verfügung und können somit für eine gewässerhistorische Auswertung herangezogen werden. Naturparkverwaltungen, wie die zum Beispiel der Hainich in Thüringen, verwenden seit Mitte der 1990er Jahre diese Bildquelle zur Waldrekonstruktion und um den Nachweis ehemaliger militärischer Nutzungen und dem von ihr ausgehenden Gefahrenpotential zu erbringen.

Aus Luftbildern lassen sich ebenso auffällige Hinweise für eine gewässerhistorische Analyse erkennen. Stereoskopische Merkmale dafür sind:

- linienhafte Schatten (Schattenmerkmale),

- Verfärbungen des Bodens in Form bestimmter Figuren (Bodenmerkmale),

- Anomalien in der Farbe und im Wuchs der Vegetation (Bewuchsmerkmale).

\section{h Aquatische Flur- und Ortsbezeichnungen, Fluss- und Gewässernamen}

„Der Mensch macht sich seine Umwelt zu eigen, indem er ihr Namen gibt. [...] was er findet, sucht er zu benennen, um es wiederzufinden, um seinen Gefährten davon erzählen zu können und sie zum Mitsuchen anzuleiten. [...] Er gebraucht Wörter als Namen, um bekannte Begriffe auf Unbekanntes, Neuentdecktes anwenden zu können. Er benennt den neu gefundenen Bach, um ihn von anderen Bächen zu unterscheiden“ - so weit BERGER (1993:9) zu den anthropologischen Ursachen der Namensgebung von gewässerbezogenen Umwelten, die eine methodische Überlegung nach sich zieht:

Man kann selbstverständlich mit schwierigen Prospektionen im Rahmen archäologischer Untersuchungen sowohl die Zeit der Entstehung als auch die mikrogeographische Lage einer Lokalität hinreichend genau festlegen. Weitere Anhaltspunkte jedoch, die sich ohne aufwendige Grabungsuntersuchungen allein aus dem Quellenstudium historischer Überlieferungen, sprachwissenschaftlicher Deutung und geographischer Analyse ergeben (NIEMEIER 1977:171) und ein klassisches historischgeographisches Arbeitswerkzeug darstellen bzw. angesichts der heute vernachlässigten Methodengattung vielmehr darstellten, vermitteln uns zum einen Gelände- und Ortsnamen: Sie bieten ,als sprachliche Quellen die einzigartige Möglichkeit, ihre Formen und ihren Inhalt als Zeugen für die Kulturtätigkeit unterschiedlicher Ethnien in vor- und frühgeschichtlicher Zeit im jeweiligen geographischen Raum vorzuführen.“ (HENGST 1999:36). In derselben Weise können zum anderen Fluss- und Gewässernamen ,als Mikrotexte zur Kulturlandschaft“ und seiner Entwicklung gesehen werden und ,spiegeln ältere Gegebenheiten einer Landschaft und Veränderungen durch menschliches Wirken wider.“ (KLEEFELD 1999:4)

Während der 6. Tagung der Arbeitsgruppe für Angewandte Historische Geographie in Plauen 1996 hielt Karlheinz HENGST einen später veröffentlichten Vortrag (1999) zum Thema „Geographische Namen“. Hierbei ging es u. a. um Namenbezeichnungen von Flüssen, die bis in die prähistorischen Phasen zurückreichen und auch heute noch unseren Flüssen ihre Namen geben. „Dies“, so KLEEFELD (1999:9) in seinem Kommentar zusammenfassend, ,belegt die historische Namensforschung mit den Flußbezeichnungen als historische Mikrodokumente eindeutig, somit ist allein diese Namens-Persistenz ein Beleg der besonderen, weit zurückreichenden Bedeutung für den Menschen.“

HENGST (1999:27) unterscheidet etymologisch Hydronyme (=Gewässernamen [GN]) und Toponyme (=Örtlichkeits- bzw. Ortsnamen, z. T mit Berufsbezeichnungen [ON]) voneinander. Sie sind beide dadurch gekennzeichnet, dass sie 
- von den in der jeweiligen Landschaft tätigen Menschen gebildet wo rden sind,

- aus der Sicht der Menschen ihrer Zeit geformt und

- zu Bestandteilen einer Kulturlandschaft geworden sind.

Dies berechtigt, von einer „Sprache als Traditionsmedium“ zu sprechen oder, wie HENGST (1999:32) es auch ausdrückt, von einer ,sprachlichen Konserve“.

Historisch betrachtet hat die Namenforschung nämlich Zugang zu der deutschen, slawischen und sogar noch bis in die vorslawische Zeit. Sie hat aber auch Zugang zu noch älteren Schichten, nämlich zu germanischen Namen und auch zu vorgermanischen, den sog. alteuropäischen Namen (HENGST 1999:28). „Bei dieser ältesten Schicht handelt es sich um GN aus voreinzelsprachlicher Zeit - und damit eindeutig noch in vorkeltischer und vorgermanischer Zeit geprägt. Sie enthalten alte indoeuropäische Wurzeln für ,Wasser', ,fließen' bzw. die ,Art des Fließens' oder auch die ,Wasserfärbung،“" (:28f.) Darüber hinaus deuten sie auf Quelle, Bach, Strömung bzw. Bewegtheit oder auch von Wasser aufsteigendem Dunst, Nebel hin. Die Ausbildung dieser GN muß vor etwa 4000 Jahren erfolgt sein. Mit diesen alteuropäischen GN ,haben wir die bisher ältesten Zeugen menschlicher Benennung für lebenswichtige Naturadern [...] vor uns.“ (:29) Es handelt sich um Gewässernamen, die seitdem bewahrt und weitergegeben worden sind (:32).

In einem aktuellen Beitrag hat SCHORR (2002:125) noch einmal die Bedeutung von Gewässernamen für gewässer- wie auch siedlungshistorische Forschung bekräftigt: „Über den heute amtlichen Bestand an Gewässernamen hinaus sind in der Mikrotoponymie noch zahlreiche Namen auf -bach konserviert, die kleinste Gewässer und Gewässerabschnitte bezeichnen." Aber auch für die siedlungshistorische Forschung dokumentieren „die Vielzahl der Siedlungsnamen auf -bach [...] die Wichtigkeit, welche die Lage am Wasser für die fränkischen Siedler besaß.“ (:126) Die -bach-Orte inklusive ihrer niederund oberdeutschen Varianten -beck, -beke, -pach und -bächle gehören „,nach den Namen auf -hof, -berg und -dorf zu den wichtigsten Siedlungsnamentypen Deutschlands.“ (:124)

Disziplingeschichtlich betracht hat die historisch-linguistische Namenkunde die Entwicklung der Flussnamen erforscht, und hier sind v. a. die Forschungen des Tübinger Indogermanisten Hans KRAHE (1898 - 1965) und die von dem renommierten Namenforscher Hans BAHLOW (1900 1982) zu nennen, mit dem Ergebnis, dass sich bei Flussnamen appellativische Grundbedeutungen erschließen lassen, die immer wiederkehrend sind (KRAHE 1964:34ff.; BAHLOW 1985:Vff.). Appellativa für Wasser, Quelle, Bach, See sind jedoch „mit dem Wandel des Landschaftsbildes [...] früh verklungen“" (BAHLOW 1985:VII) und erschweren eine ehemalige Landschaftsdeutung anhand von Gewässernamen, aber Wortgüter aus der LaTene- und Hallstatt-Zeit (BAHLOW 1985:VII) stellen gleichzeitig die einzige Möglichkeit einer umweltgeschichtlichen Rekonstruktion des gewässerbezogenen Landschafts- und Siedlungsbildes im alteuropäischen Zeitalter dar.

Die alteuropäische Zeit setzt man etwa in die Mitte des zweiten Jahrtausends vor Christus (BERGER 1993:21) und dieser Zeitraum ist nahezu „nur in den Gewässernamen [...] fassbar“ (:21). Die etymologisch ,allerälteste Schicht“ tritt uns als „Bachnamen [...] entgegen“ (BAHLOW 1985:X) und diese sind „,neben den Bodenfunden die einzige Quelle, die uns noch Aufschlüsse über die Sprach- und Völkergeographie Alteuropas zu liefern vermag“ (:VII, Hervorhebung im Original). Diese vorgeschichtliche Verwurzelung zahlreicher Bach- und Flussnamen lässt den Wert der ältesten Gewässernamen Europas bewusst werden.

Einen Überblick über die Verbreitung der alteuropäischen, Wasserwörter' verschafft uns auch BERGER (1993). In ähnlicher Weise wie HENGST kommt BERGER zu dem Ergebnis, dass es ,eine ganze Reihe indogermanischer Wortbildungen“ gibt, die sich „Zwanglos auf fließendes Wasser anwenden lassen“ (:20). Um Ordnung in die Vielzahl von Wasserwörtern zu bringen, hat „die Namenforschung [...] ein ganzes System aufstellen können, das den ältesten Flußnamen in Europa zugrunde liegt.“(:20). Das Gewässernamensystem hat dabei folgende Struktur: 
„Die alteuropäische Hydronomie“, dies bedeutet der Bestand an alteuropäischen, d. h. keltischen, vorkeltischen, vorgermanischen Gewässernamen „umfaßt grundsätzlich einstämmige Namen (keine Zusammensetzungen), die aus einer indogermanischen Wurzel, einem angefügten Wortbildungselement (Suffix) und einem Element der Flexion bestehen." (BERGER 1993:20). Die alteuropäischen Gewässernamen besitzen als Kennzeichen, kurz gesagt, eine ,altertümliche Struktur aus Wurzel und Suffix“ (:21), die in verschiedenen Gruppen eingeteilt werden. Dabei muss, wenn im Folgenden Übersetzungen von Gewässernamen wiedergegeben werden, bedacht werden, dass es eine Vielzahl von Deutungsversuchen der Flussnamen und verschiedene Ansichten über den Ursprung der Gewässernamen gibt.

Eine besondere Gruppe unter den Gewässernamen bilden die Namen auf -apa. Es fällt z. B. auf, dass die Namen auf -apa „ausschließlich Bäche und kleine Flüsse benennen“ (BERGER 1993:23). Ähnliche indogermanisch-prähistorische Wörter für Wasser lauten auf $-a b,-a m b r,-a d,-a f,-a t,-a m$. Zum Beispiel: Abbe/Harz, Ammersee/Oberbayern) (BAHLOW 1985:1f.). So beruht auch der Gewässername der aus der Eifel kommenden Erft (Arnapa, Arnafa, Arlafa, Arlefa, Arffe) auf dem indogermanischen Arna (= Bach) bzw. auf dem keltisch-germanischen Ava/apa (= fließendes Wasser).

Des Weiteren lassen die in den geographischen Landschaftsräumen vorkommenden Wasserbezeichnungen gruppieren. Aus den Moorlandschaften östlich und südlich Bremens hebt BAHLOW (1985:XIV) die prähistorischen Flussnamen auf -ana, -ina besonders hervor. Zum Beispiel: Wümme (Wimene), Böhme (Bomene), Bille (Bilene) $)^{4}$.

„Eine beachtenswerte Fundgrube“ (BAHLOW 1985:XIV) sind auch die Namen der Bergwälder und Waldberge: auch sie nehmen auf Gewässer und Bodennatur Bezug, enthalten also nicht den Begriff der Höhe! So beispielsweise die niedersächsischen Höhenzüge Süntel, Deister, Ith und Hils (:XIV). „Urtümliche“ (:XIV), vorgermanische Flussnamen liefert schließlich auch der Harz. Zum Beispiel mit der Innerste (Indrista), der Oker (Ovacra) und der Söse (Suse) (:XIV).

Doch es gilt, vor allem bei den scheinbar eindeutig eine kulturhistorische Nutzung widerspiegelnden Wasserwörtern, Falsch- bzw. Fehldeutungen zu vermeiden.

Die Rottmünde, ein kleiner Zufluss zur Weser bei Boffzen im Solling, wird urkundlich als Rotmenni bezeichnet und gehört zu den prähistorischen Bachnamen auf -manio (= Wasserlauf). Rot meint „Moder“, „Fäulnis“, d.h. das „Verrotten“ und so werden auch die vielen anderen Rottenbäche verständlich (BAHLOW 1985:402). Auch BERGER (1993:227) kennt die vielen anderen Rottenbäche. Der Flussname Rott- ist nach seiner Ansicht „wohl die Substantivierung von ahd. rota ,die Rote', er bezieht sich auf die rotbraune Farbe des moorigen Wassers.“ Die Ableitung vom „Rösten“, d. h. vom „Rotten“ des Flaches wird hier nicht gesehen, obgleich sich diese Herkunft aus kulturhistorischer Sicht angeboten hätte.

Der ,Bleichenbach' bei Bad Selters ,hat nichts mit einer ,Tuchbleiche' zu tun, sondern bezeichnet ,ein Faulwasser' (vgl. blekinge = Faulung)“ (BAHLOW 1985:46). Der auf den ersten Blick ein Gewerbe, das Bleichen von Wäsche, kennzeichnende Gewässername führt in die Irre. Obschon diese Namensauslegung sinnfällig gewesen wäre, kennzeichnet sie doch eine in früheren Zeiten an das Gewässer gebundene Arbeitsweise.

\footnotetext{
${ }^{4}$ Eine Zusammenstellung der Hydronyme liegt auch für Polen vor. UDOPLH (1990) hat die polnischen Gewässernamen innerhalb der heutigen polnischen Grenzen in einem umfassenden Band systematisch dargestellt. GREULE (1971) hat die vor- und frühgermanischen Flussnamen des Elsaß, der Nordschweiz und Südbadens untersucht und beispielsweise solche Flüsse wie die Elz, Durach, Kander oder Murr hinsichtlich ihrer etymologischen Herkunft analysiert. BOSSE untersucht in Kapitel VI seiner bereits 1941 verfassten, aber wegen des Krieges erst 1962 veröffentlichten Arbeit „die Gewässer und die darauf bezüglichen Bezeichnungen“ für den Kreis Ueckermünde (hier:81-90). Er nimmt dabei eine Unterteilung in stehende Gewässer und fließende Gewässer vor. Aus dem Angelsächsischen liegt eine Arbeit zur Ortsnamenforschung (,place-name study“) vor (GELLING/COLE 2000), die nicht nur „,settlement-names“ untersucht, sondern „,evidenced also in Old English terms of watercourses, wet areas“ erbringt. Kapitel 1 beschäftigt sich mit den „Rivers and Springs, Ponds and Lakes (:1-35), während Kapitel 2 bei „Marsh, Moor and Floodplain“ (:36-64) die ,anglo-saxon topographical naming“ aufzeigt.
} 
Auch bei den Tiernamen von Fließgewässern gilt es, keine falschen Schlüsse zu ziehen.

Der Flussname Stör, ein rechter Nebenfluss der Unterelbe in Schleswig-Holstein südöstlich von Neumünster, wird aus dem mittelhochdeutschen „storen“ (= in Verwirrung bringen) abgeleitet. Die Grundbedeutung des Flussnamens ist „bewegtes Wasser“" (BERGER 1993:251) und hat mit dem Kaviar produzierenden Großfisch nichts zu tun.

Die Eselsbäche, die in Württemberg und dort im Schwarzwald anzutreffen sind, sind keine dummen oder von den ehemaligen Lasttieren zum Tränken aufgesuchte Wässerlein, sondern „Schmutzwässer“ (von niederdeutsch ädel, „Jauche“, ags, adela „Schmutz“). Zugrunde liegt auch hier das indogermanische -ad „Wasser“ (BAHLOW 1985:2).

Die Biberbäche leitet BAHLOW (1985:39) von dem keltischen Bachnamen „Bib-ara“ $a b$. Während -ara als Wasserterminus bereits bekannt ist, werden bib, biv (sinnverwandt mit $i b$, iv) von BAHLOW als „Sumpfwasser“ (:38) gedeutet. BERGER, mit einem anderen Deutungsversuch, bleibt hingegen seinem zu Beginn dargelegten anthropologischen Grundsatz bei der Herkunftsbestimmung treu: „Er [der Mensch, B.B.] baut Dämme am Flußufer wie der Biber und nennt den Fluß nach seinem Lehrmeister" (1993:9)

An anderer Stelle schränkt er diese - an sich schon recht einfache deduktive - Sichtweise ein und fügt eine noch simplere, faunistische Erklärung hinzu: „Wenn Gewässernamen Bezeichnungen von Wildtieren enthalten, muß dies nicht auf längeres oder wiederholtes Vorkommen der Tiere hinweisen (Biberach $=$ Bach, wo es Biber gibt), sondern der Name kann sich auch auf ein besonderes Jagdabenteuer an dieser Stelle beziehen (Urach = der Bach, wo ich dem Auerochsen begegnete).“ BERGER spricht in diesem Fall von „Ereignisnamen“ (BERGER 1993:9), die man aus allgemeiner Kenntnis heraus durchaus für gültig erachtet hätte

Im Gegensatz dazu deutet der Altmeister der Namenforschung BAHLOW (1985:498), Urach als Urafa bzw. Uraffa und zählt diese zu den prähistorischen Bachnamen auf -apa, -afa (= „Wasser“, „Bach“) und bezieht $U r$ auf „Moder“, „Sumpf“, „,so daß auch hier von Auerochsen (ahd. ûr) keine Rede sein kann!“ (:499)

Der Begriff Krebsfalle gewinnt als Gewann- oder Gewässername neben der naheliegenden biologischen, auf die Fischerei und den Krebsfang bezogene Bedeutung (siehe unten), aber auch einen anderen Sinn, der in Zusammenhang mit Sperrwällen und Wallschutzanlagen zu sehen ist: Die Panzerung der Landsknechte im 15. und 16. Jahrhundert umfasste auch das „Knechtsbruststück“, das man auch „Krebs“ nannte: „Vom 14. Jahrhundert ab gelang es, größere Metallplatten zu erzeugen und auch zu treiben. So bildete sich nach und nach die Plattenrüstung heraus. Zuerst bedeckte man den herkömmlichen Kettenpanzer an besonders gefährdeten Stellen mit Einzelplatten. Da eine einzelne, größere Platte aber sehr steif ist, musste an den Stellen des Körpers, an denen man sich bewegte, ein ,Geschiebe' (Geschübe) verwendet werden, also Blechstreifen, die überlappt gelegt mit Nieten an Lederstreifen befestigt waren. Solche Harnischteile bezeichnete man auch als ,Krebs' und nach der Richtung des Übergreifens als auf- oder abwärts geschoben." (KURZMANN 1985). Und eine andere Quelle berichtet: „Die Kriege veranlassten Maximilian I., verstärkt Massenware, ,Krebse' und ,Rücken' für das Zeughaus herstellen zu lassen." (ORTENBURG 1984).

Dennoch gibt es auch eindeutige Bestimmungen von Gewässernamen durch Tiere.

Als Beispiel dienen hier der Krebsbach, ein Nebenfluss der Nitz in der Eifel, Kreis Ahrweiler, und ein weiterer Krebsbach, ein rechter Nebenfluss des Mains nordwestlich von Schleifthor in der Grafschaft Wertheim (UECKER 1999:49). Bäche mit diesem eindeutigen Tierterminus dürften unabhängig der wehrhaften Deutung in der Regel besondere Habitate für Flusskrebse dargestellt haben, die, als es sie - vor allem in den so bezeichneten Gewässern - noch massenhaft gab, als Fänge zum Verzehr herausgefischt wurden. Keine anders lautende Erklärung wurde hier für diese Bäche gefunden. 
Das Vorhandensein wilder Pferde in der Senne lässt sich auch durch verschiedene Gewässernamen im Teutoburger Wald und in der Senne belegen. In der dort vorkommenden Bezeichnung ,Hasselbach' wird das Wort „Hassel" als frühe Bezeichnung für Fohlen gedeutet. Die ,Eckelau' ist ein gewässerdurchzogenes Feuchtgebiet zwischen der Kammersenne und dem heutigen Haustenbeck. Der Begriff „Ecke“ bzw. „Ekke“ wird mit dem Wort „Stute“ übersetzt (aus: www.senner.de).

Des Weiteren lassen sich mit Flussnamen mitunter auch besondere standörtliche Vorkommnisse, beispielsweise anstehende Ressourcen, verbinden. Obschon auch dies wiederum ein Beispiel für divergierende Auslegungen von Wasserbezeichnungen ist.

Die Flussnamen Saale, Salza, Sulza, Salze aus unterschiedlichen Regionen Deutschlands (FränkischThüringisch, Lippisch) werden möglicherweise von Salz bzw. Salzfluss hergeleitet, was als Hinweis für ehemalige Salzstätten gedeutet werden kann; zum anderen könnte sal-, sulz- auch einfach „Fluss“ bedeuten. Es gibt aber auch eine Ableitung, die damit den Fluss als „eilendes Wasser“ bezeichnet.

Weitere Hinweise auf den ehemaligen Gewässerzustand, der landschaftshistorisch betrachtet von großem Wert ist, lassen sich aus anderen Gewässernamen entnehmen.

Ein weiteres Beispiel ist die Düssel, in Urkunden des 11. Jh. als Dusila, Tussala, Dussale auftretend. In der ersten Silbe $d u s$ - steckt das hochdeutsche „diesen“ und „tosen“. Das folgende -ila ist ein allgemeines Suffix für Gewässer wie bei Diemel, Mindel, Mosel u. a. „Düssel“ heißt somit soviel wie „rauschendes“, „diesendes“, vielleicht auch „trübes Gewässer“. Der Name „Düssel“ ist wahrscheinlich altgermanisch und kommt in anderer Form noch mehrmals vor als Düsbach in Lippe, Dusenbach im Odenwald, als Düsse bei Soest sowie Düste bei Diepholz (KNÜBEL 1988:9).

Gleichzeitig lassen sich mit den Bachnamen weitere mit der Siedlungslage bzw. Siedlungsgenese korrespondierende Nutzungen herauslesen:

In unmittelbarer Nähe zur Gewässernamenforschung steht die von ARNOLD begründete und methodisch von SCHLÜTER weitergeführte „Ortsnamenforschung“. Die Arbeitsweisen SCHLÜTERs, schrieb der Siedlungsgeograph BORN im Jahr 1977 (:24), benutzt die siedlungsgeographische Forschung Ende der 1970er Jahre sogar ,in insgesamt nur geringfügig modifizierter Weise, abgesehen von einer stärkeren Beachtung der Siedlungsformen“; während nunmehr 25 Jahre später dieses Arbeitsfeld kaum noch von den Geographen, fast zeitgleich mit der Vernachlässigung siedlungsgenetischer Forschung, bearbeitet wird. Dies ist umso bedauerlicher, als für die gewässerhistorische Forschung die Ortsnamenforschung als Hilfsquelle gewinnbringend herangezogen werden kann.

Die siedlungsgeographische Forschung bedient sich der Ortsnamen als Hilfsmittel zur Altersbestimmung von Siedlungen, zur Bestimmung früherer Funktionen, z. B. von Flurteilen oder Siedlungen, zur Ermittlung ethnischer Siedlerschichten und deren Verbreitung, zum Ausbreitungsprozess von Siedlern bzw. Siedlungen allgemein, zum Nachweis früherer Waldverbreitung u. v. a. (HAGGETT 1983:298ff.; LIENAU 1995:161). Die Verwendung bestimmter Ortsnamen zur Altersbestimmung basiert darauf, dass bestimmte Ortsnamen bestimmten Entstehungszeiten zuzuordnen sind, wobei jene um so aussagekräftiger sind, je zeitlich begrenzter sie verwendet wurden. Verwendung für die Altersbestimmung finden dabei v. a. die Endungen von Siedlungsnamen.

Die Anwendung der Ergebnisse etymologischer Ortsnamenforschung erlaubt es also, ehemalige Landschaftszustände zu rekonstruieren und die Bedeutung von Wasser für die Besiedlung zu erkennen und zu belegen.

Je nach der Zeit, in der die Ortsgründungen stattfanden, unterscheidet man dabei folgende Abschnitte:

1. Urzeit

2. Zeit der Völkerwanderung bis etwa $200 \mathrm{n}$. Chr.

3. Die Frankenzeit

von $200-531$

4. Zeit der Kolonisation und Rodungen

$531-800$

von 800 an. 
Die Ortsnamen des ersten Zeitabschnitts enthalten entweder einfache Grundwörter oder mit diesen gebildete Zusammensetzungen. Die Grundwörter entnahm man der sinnlichen Wahrnehmung der örtlichen Umgebung und bildete sie nach dem Walde, dem Felde, der Bodenerhebung, aber auch dem Wasser oder einem sonstigen Teile der Erdoberfläche (vgl. HEINE o. J:34; siehe dazu auch die oben wiedergegebenen Ausführungen von BERGER [1993] und HENGST [1999]).

Die enge Beziehung der frühen Besiedlungen zum Wasser kommt dabei in den Ortsnamen eindeutig zum Ausdruck: Die am häufigsten vorkommenden Grundformen waren „affa“, ,aha“, ,mar", die, wie wir bereits erfahren haben, in unserer jetzigen Sprache längst erloschen sind. Affa, aha und mar waren die Bezeichnungen für Wasser. Diese alten Wasserwörter schleiften sich mit der Zeit ab; aus aha wurde $a$, af, ehe, e, au usw. und das mar zu mer (HEINE o.J:34, BAHLOW 1985:2). Prähistorisch sind auch Orts- und Städtenamen auf wand, wend, wind, aus dem indogermanischen wand- (= „Wasser") und die sich somit ebenfalls aus Bachnamen, hier Wande, Wende ableiten lassen (BAHLOW 1985:XIII). Ebenso handelt es bei war um eine „alte Wasserbezeichnung“ (:2).

Eine auf diesen älteren, vorchristlichen Wassertermini basierende gewässertopographische Ortsbezeichnung ist beispielsweise „Werther“ oder „Werder“. Der Name ist abgeleitet vom althochdeutschen ,warid“" = Insel, d. h. also eine Ansiedlung auf einem vom Wasser ganz oder teilweise umgebenden Lande. Der Ort Werther in Nordthüringen beispielsweise ist in einer Zeit entstanden, wo eine zwischen den Ortschaften Werther und Sundhausen liegende Anhöhe noch inseloder halbinselartig aus dem durch die Flussläufe Helme und Zorge gebildeten See oder einem Sumpf, der noch häufig überflutet wurde, emporragte. „Diese Lage deutet auch der früher für Kleinwerther gebrauchte Zusatz ,hor': Horwerther an, denn ,hor' heißt Sumpf.“ (HEINE o.J:35). Zahlreiche weitere Orte führen noch heute diesen Namen, z. B. Bodenwerder a. d. Weser, Altenwerder bei Hamburg und sogar das auf so einem Areal liegende Stadion des danach benannten Fußballvereins Werder Bremen.

Zusammenfassend lässt sich sagen, dass „in allen Regionen Deutschlands“ die heutigen Orts- und Städtenamen „durchweg Wasserbegriffe“ enthalten, „so daß jeder andere Deutungsversuch von vornherein hinfällig ist" (BAHLOW 1985:X). Auch wenn die Sinnverwandtschaft nicht sofort deutlich wird, wie das Beispiel „Remagen“, aus dem keltischen „Rigomagus" (= „Wasserfeld“), und Ortschaften auf den Bachnamen -andra, wie z. B. Hellenthal aus dem keltischen „Celandra“, demonstrieren. Auch die Namen auf -heim wären oft gar nicht zu verstehen, würden nicht die volleren urkundlichen Formen „das Bildungsprinzip, nämlich die Ableitung von vorgermanischen Gewässernamen", verraten (:XI). Als Beispiele seien die Ortschaften Bensheim und Büdesheim von Budenes-, Budena- (= ,am Bache“) und Eisesheim von Isanes-, Isana- (= ,am Bache gelegen“), genannt. Auf prähistorische Gewässernamen deutet auch die morphologische und geographische Geschlossenheit der oberrheinischen Ortsnamen auf -ingheim wie Budinc-, Obrinc- und Tubinc hin, heute Bietig-, Obrig- und Türkheim (Dürkheim) (:XI). Im Westerwald bei Nassau ist Selters (Saltrissa) am Suffix als prähistorischer Bachname erkennbar. Das anschließende Siegerland und Südwestfalen „liefern uns die große Gruppe der mit - apa eindeutschten Bachnamen, die vom Lenne-, Ruhr- und Sieg-Raum bis zur Lahn und Eder ausstrahlen“. (:XIII). Auch die Namen auf -lar und -mar gehören zur ältesten Schicht von Gewässernamen, so Fritzlar, Geismar, Weimar u.v.a. (:XIII)

Leichter einzuordnen ist dagegen der bereits in ähnlicher Form als Bachname bekannte und hier als Ortsname auftauchende Ort Biberach. Es handelt sich ursprünglich um einen Gewässernamen, zusammengesetzt aus althochdeutsch bibar, mittelhochdeutsch biber (= „Biber") und dem zu $-a$ verkürzten Gewässernamen - aha althochdeutsch für „Wasser“ (BERGER 1993:55).

Einige Beispiele aus dem Raum Nordhausen/Thüringen und anderen Gegenden belegen die Ableitung von Orts- aus Flussnamen: Der Flusslauf ,Salza', nördlich von Nordhausen gelegen, heißt mittelhochdeutsch „Salzaha“, d. h. Salzfluss. Der gleichlautende Name des Ortes „Salza“ bezeichnet also die Niederlassung am Salzfluss. „Furari“, wie der alte Name der Ortschaft „Furra “ lautet, hängt mit „Furt“ zusammen. Der Name bedeutet also ein Ort an der Furt, in diesem Fall durch die Wipper. Ortsnamen mit -furt und -brück sind im Übrigen charakteristisch für Siedlungsgründungen am Wasser (NIEMEIER 1977:60), wie zum Beispiel Herford in Westfalen und Bersenbrück oder Osnabrück in 
Niedersachsen. Der Name der Gemeinde „Sollstedt“ weist auf eine Lage am Sumpf hin, denn ,sol“ heißt Sumpf. Jedenfalls muss die Gegend zur Zeit der Gründung des Ortes noch sehr nass und sumpfig gewesen sein (HEINE o.J:36). Solche sumpfigen Nassbereiche, die auch als Brüche bezeichnet wurden, bedeckten einst in weiten Teilen das Gelände. Forstorte wie z. B. „Lange Brüche“, „Bärenbruch“, „Pixhaier Moor“ (-hai = Bruch) drücken dies für den Oberharz aus (HAASE 1961:6).

$\mathrm{Zu}$ den Ortsnamen, die zwar kein direktes Wasserwort in ihrem Grundwörtern enthalten, aber eine Gewässernähe bzw. eine vom Wasser abhängige Siedlungslage kennzeichnen, gehören beispielsweise solche wie „Quernheim“ oder "Quarnstedt“. Die Namensgebung der Orte ,deutet auf das bereits Vorhandensein einer Wassermühle“ hin (LANGE 1989:100) und dies aus folgendem Grund: „Die altgermanische Bezeichnung, Querne' für die Handmühle wurde durch die von den Römern eingeführte Wassermühle ,molina' verdrängt und in der Folgezeit durch das Lehnwort ,Mühle' ersetzt.“ (HÖLSCHER 1987:11). Die ,Querne' aber „fristete ihr Dasein noch weiter als Gewürz- und Senfmühle.“ (:11) und als Normmaß im Mühlsteinbau (MERTES 1995:17).

Das Dorf „Quappen“ im Oderbruch bei Falkenhagen, deutet auf den Fischfang als Erwerbsquelle hin und damit auf eine Gewässerlage hin, bedeutet doch "Quappe“ = Fisch. Interessant wird die Interpretation der Toponyme dann, wenn - aus nahe liegenden Gründen - die hier ansässige Teichwirtschaft als Namengeber gesehen wird, das Dorf aber, dies lässt sich aus historischen Karten ablesen, am ehemals hier vorbeilaufenden Oderstrom lag.

Ein weites Anwendungsfeld bietet sich für die Gewässernamenforschung als Erkennungsmerkmal bzw. als Hinweis für Wüstungen. Schon längst verschwundene, wüste Ortschaften künden mit Gewässernamen von einstiger Besiedlung und gewässerbezogener Nutzung oder zeugen von feuchtwässriger Lage, die mitunter zu der Siedlungsaufgabe geführt hat. Diese Beziehung lässt sich insofern aufstellen, als dass ,die meisten Flur- und Ortsnamen [...] aus dem fortgesetzten Gebrauch einer Stellenbezeichnung, die mit der Zeit fest wird“, entstehen (BERGER 1993:9), d. h. ,auch wenn ein Gewässername zum Siedlungsnamen wird“, wie es bei vielen Namen mit -bach und -ach geschehen ist, ,wird damit die Stelle der ersten Ansiedlung bezeugt.“(:9).

Auch aufgegebene Einzelstandorte ehemaliger wasserbezogener Einrichtungen und Gebäude lassen sich anhand von Flurnamen nachweisen. Zum Beispiel bei der Ahlftener Wassermühle. „Nur noch in der Flurbezeichnung ,Mühlen Camp' ist die Existenz einer Wassermühle in Ahlften in Erinnerung geblieben.“ (ERLER/MATTHIESEN 1989:27) Hinweise auf eine abgegangene Mühle mittels Flurnamen lassen sich auch bei der ehemals zum Gut Denkiehausen (Landkreis Holzminden) gehörenden, etwas entfernt gelegenen Wassermühle finden, die 1692 erstmalig erwähnt und 1928 abgerissen wurde. Nicht nur Bodenfunde wie ein weitgehend noch offener Trockengraben, sondern auch Flurbezeichnungen weisen auf die wasserbaulichen Anlagen der ehemaligen Wassermühle hin: „Teichklippe“, „Teichbach“ und „Bei dem Teiche“ in älteren Karten sind Zeugnisse dieses Mühlenstandortes (ANDERS/CREYDT 2004:102).

Flurnamen liefern also charakteristische Hinweise für alte Mühlenplätze. „Nicht selten“ geben Flurnamen auch „die ersten Hinweise auf ehemalige Hüttenstandorte“. (JÄGER 1965:424). Als Beispiele können Flurbezeichnungen wie ,Hüttenbleck', ,Hammershütten', ,Hüttengrund' genannt werden (:424). Der Ortsname Schmidmühlen bei Amberg in der Oberpfalz beispielsweise, der für 1028 oder schon 1010 gesichert ist, bietet ein erstes Indiz für den Einsatz wasserradgetriebener Schmiede- oder Eisenhämmer ${ }^{5}$.

Des Weiteren können Flurbezeichnungen wichtige Hinweise auf ehemalige Teichflächen liefern, die schon längst aufgelassen worden sind. Die Flurnamen ehemaliger Teiche enden meist auf die Silben $-d y k$, vereinzelt auf -stauung. Bisweilen deuten auch mit -damm zusammengesetzte Ortsnamen auf Teiche und Seen hin, zumeist jedoch auf an See- oder Kanaldeichen gelegene Ortschaften. Die Silben „Teich-“" usw. als Vorsilben in Flurnamen (z. B. Teichkoppel, Diekwiese usw.) bezeichnen allgemein die an einen Teich angrenzenden Fluren.

\footnotetext{
${ }^{5}$ Verschiedene Namen waren für diese Produktionsstätte gebräuchlich: Hammer, Hammerhütte, Hammwerk, Eisenhämmer, Eisenhütte, Eisenwerk, Eisenhüttenwerk oder einfach Hütte bzw. Hüttenwerk (ALTMANN 1999:14).
} 
RUST hat in einer Karte am Beispiel des Gutes Bothkamp durch Flurnamen rekonstruierte Teiche kartographiert:

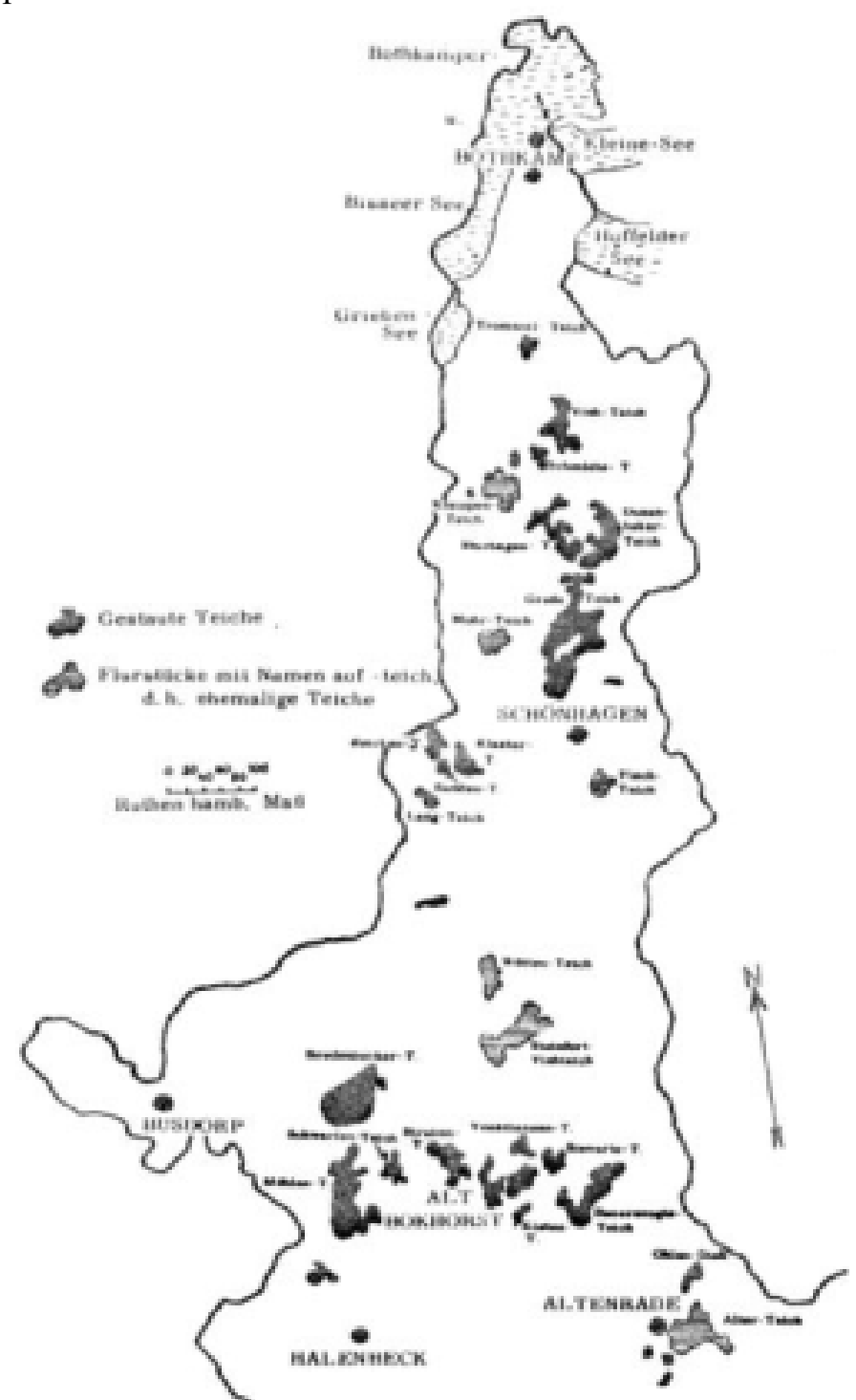

Abb. III-10: Etymologisch rekonstruierte Teichflächen des Gutes Bothkamp/Schleswig-Holstein (aus: RUST 1952:35, Karte 2)

Kennzeichnend für die Komplexität der Landnutzung ist die internationale Tradition die einzelnen Fischteiche eines Teichgebiets mit individuellen Namen zu versehen. Die Namensgebung (z.B. Großer Sandteich, Mühlenteich, Wildschweinteich, Großer Möwenteich, Fettweide) erlaubt sehr häufig Rückschlüsse auf standörtliche oder betriebliche Besonderheiten. Die Teiche werden von den Fischern wie Persönlichkeiten betrachtet und auch entsprechend unterschiedlich bewirtschaftet (SCHULTE 2000).

Eine zusätzliche Möglichkeit, ehemalige innerstädtische Gewässerlagen, d.h. Abhängigkeiten von Gewässern und von in Beziehung zu Gewässern stehenden Nutzungen für die gewässerhistorische Stadtforschung zu eruieren, besteht in der etymologischen Auslegung von „Wegenamen“, die quellenmäßig anhand historischer Adressbücher gewonnen werden können.

Bereits 1313 wird beispielsweise in Güstrow die Bezeichnung ,Hinter den Badstaven' (,Hinter den Badestuben') erwähnt. „Diese Bezeichnung kann nur so gedeutet werden, daß sich hinter der Straße ein Wasserlauf befand, der für das notwendige Badewasser sorgte.“ (LORENZ 2000:64) 
An die Lage am Wasser erinnern diverse Straßennamen in Berlin-Spandau, „wie die Otternbuchtstraße, in Erinnerung an den 1930 zugeschütteten Altarm der Spree mit dort vorhandenen Fischottern“ (STRAUSS 2002:27).

Am Beispiel des Adressbuches der Stadt Nordhausen von 1824 können anhand von Straßen- und Gassenbezeichnungen eine Vielzahl historischer Wassernutzungen belegt werden und dessen stadttopographischen Verlauf erkennen lassen. Es erscheint darin fast die gesamte, aus dem Spätmittelalter überkommene, intakte und in sich geschlossene, funktionale Stadtstruktur und seiner Wassernutzungen. Eruiert man aus diesem Adressbuch des 19. Jh. die Straßen- und Wegenamen mit Gewässerbezug, so ließe sich daraus das typologische Abbild des Spätmittelalters übertragen und kartographieren. Eine nahezu vollständige, aus dem Spätmittelalter überkommene Wassernutzung lässt sich hier - topographisch getrennt - wieder finden: In der Oberstadt lassen sich keine Gewässernamen feststellen. Die Oberstadt war der oberhalb der Zorge höhergelegene Stadtteil, in dem sich das Domkapitel und der Fürstenhof befand. Handwerkliche, in Verbindung mit der Wassernutzung stehende Arbeiten wurden „hier oben“ nicht verrichtet. Zur Wasserversorgung des Herrschaftsbereiches bestand ein Brunnen. Der zur gewerblichen und anderweitigen Nutzung benötigte Wasserlauf der Zorge und des Mühlgrabens lag in der Unterstadt. Deshalb finden sich innerhalb der Stadt nur in der Unterstadt entsprechende Straßenbezeichnungen als Wasserwörter:

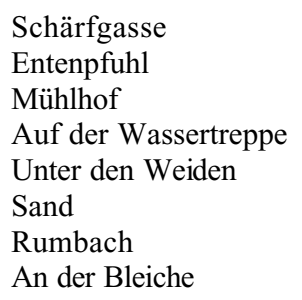

Außerhalb der Stadt befinden sich zu dieser Zeit meistens nur „Wege“, die im Adressbuch nicht aufgenommen wurden. Dennoch lassen sich einige Bezeichnungen feststellen:

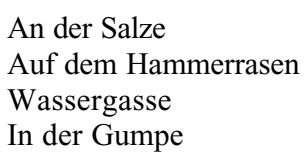

Die alten Nordhäuser Straßen- und Wegenamen und ihre wassergeschichtliche Bedeutung lassen sich dabei hermeneutisch aufschlüsseln. Einige Beispiele mögen dies verdeutlichen (aus: JUCH 1992: 18).

\footnotetext{
Schärfgasse: hier befand sich seit 1303 eine Schleifmühle, die sich der Wasserkraft bediente

Wassertreppe: an der Südgrenze der in der Oberstadt liegenden Burg Heinrich des I. liegender Treppenstieg in der Stadtmauer. Als Wasserpforte zur Wasserholung und -nutzung aus der unterhalb liegenden Zorge und dem Mühlgraben genutzt.
}

An der Bleiche: die in der Stadt wohnenden Färber legten hier ihre Stoffe zum Bleichen aus

Weidenstraße: wurde nach in der Flussaue angepflanzten Weiden benannt, die seit 1421 nachweisbar sind.

Zusammenfassend lässt sich feststellen, dass Flur- und Straßennamen Rückschlüsse auf frühere anthropogene, gewässerbezogene Nutzungsformen und Standorte zulassen, da zumindest die Wortstämme Hinweise auf mögliche Nutzungen geben, auch wenn eine Analyse des Namens nicht direkt zur Aufklärung der Nutzungsgeschichte von Flüssen und Bächen führt.

Im Rahmen der Betrachtung von Gewässerrelikten erweist sich die Sprache in Gestalt von Gewässernamen als ein Interpretationsmittel, das sogar Aussagen zum Gewässerbild vor 1000, 1500 bzw. 3000 bis 4000 Jahren ermöglicht. Geographische Namen in dieser Hinsicht sind für die gewässerhistorische Forschung vor allem als Informationsträger eines früheren Landschaftszustandes bedeutsam (HENGST 1999:36). Die tradierten, konservierten Namen spiegeln dabei sowohl ältere 
Gegebenheiten einer Landschaft als auch durch menschliches Wirken eingetretene Veränderungen wider. Insofern kann man seitens der historischen Namenkunde von einem Beitrag zur Gewässerlandschaftsgeschichte sprechen.

Aus den Gewässernamen hingegen eine landeskundliche Kulturgeschichte des Wassers und einer differenzierte Dokumentation der historischen Gewässerlandschaft auf der Grundlage des alten gewässergeographischen Namenschatzes aufzubauen, ist aufgrund der monokausalen Inhalte von prähistorischen Wasserwörtern nicht möglich. „So ist es mit dem Wesen ältester Namenschöpfung vor allem unvereinbar, in Gewässernamen Erzeugnisse menschlicher Technik und Kultur zu suchen! Es ist immer nur das Wasser selber gemeint.“ (BAHLOW 1985:XV) „Von ,kulturgeschichtlich bedeutungsvollen Namen' kann somit keine Rede sein.“ (:XVI)

Die Aussagemöglichkeiten von Ortsnamen hinsichtlich des zeitlichen Ablaufs der Besiedlung und der Übereinstimmung von Namensgebung und Siedlungsentstehung werden heute im Vergleich zur Hochzeit der Ortsnamenforschung hingegen etwas geringer eingeschätzt (BORN 1977:24), da eine Altersbestimmung durch Ortsnamen nie ganz sicher ist und andere Kriterien hinzuziehen sind (LIENAU 1995:161): „Sicher datierbar sind [...] in Deutschland nur Siedlungen, deren Entstehung in historischer Zeit quellenmäßig belegt ist. [...] Dazu kommt das Problem der Ortsnamenwandlungen und ihres Ausgleichs, aber auch die Frage der Siedlungskontinuität.“ (NIEMEIER 1977:171), wie das Beispiel des viel zitierten Ortes Biberach mit seinem mit seinem Fluss Biberach beweist, der heute als Rotbach bezeichnet wird.

Exakte Gewässerforschung kann Flur-, Fluss- und Gewässernamen im Rahmen der Beweisführung einer engen Bindung von Orten an Gewässer und zur Auffindung von Wüstungen deshalb nur mit Vorsicht verwenden und sich wohl nur selten auf sie allein verlassen. Die Auswertung historischer Namens-Lexika sind in jedem Fall ebenso notwendig wie die sprachwissenschaftliche Festlegung und Deutung von Grundwort und Bestimmungswort; für viele Regionen Deutschlands gibt es darüber eine reiche Literatur (z. B. BACH 1953/54:171). Gewiss kann aber nicht bezweifelt werden, dass bestimmte Siedlungsvorgänge oft durch resistente Ortsnamen mit gewässercharakteristischen Grundwörtern bzw. Endungen belegt sind und dementsprechend datiert werden können. Aus der hier ansatzweise dargestellten „menschenverbindenden Eigenschaft heraus wird man verstehen, warum Flußnamen so dauerhaft sind“, schreibt BERGER (1993:19; siehe dazu auch die Darlegungen im Kap. V2 „Gewässer und Siedlung").

Auch der Konstanz von Gewässernamen sind jedoch in zunehmendem Maße zeitliche Grenzen gesetzt: Gewässer verschwinden, Bachbetten trocknen aus, Quellen versiegen, alpine Wasserreservoire, gebunden in Schnee, schmelzen im Zuge der Klimaerwärmung zunächst verstärkt sturzbachartig dahin und erlöschen dann später völlig. Eventuell sind es die Gewässernamen, die ursprünglich feuchte Geländesituation lebend halten. Doch auch sie werden irgendwann in der Neuauflage einer Topographischen Karte nicht mehr erscheinen. Deshalb kann leider der Aussage von BERGER (1993:19), dass Siedlungen verfallen, „wüst“ werden können, aber „Bäche und Flüsse haben Bestand; sie können ihr Bett wechseln und die Richtung ihres Laufes ändern, aber das Wasser, das aus den Bergen kommt, wird in der Ebene nicht abreißen oder versiegen", nicht gefolgt werden. Diese Auffassung war früher, ist heute und vor allem zukünftig nicht mehr gültig.

\section{i Geländebefunde}

\section{i.1 Prähistorische Funde}

Selbstverständlich müssen als ergänzende Quellengruppe eine Reihe weitere Forschungsergebnisse herangezogen werden. Als Beispiel seien dafür zunächst die Resultate archäologischer Forschungen genannt.

Dieser Ansatz erscheint für das hier behandelte Thema besonders sinnvoll: Gerade zum Beispiel die Bereiche des wassergebundenen Alltagslebens, des Fischhandels, des Wassertransportes und der 
Wasserwirtschaft können allein anhand schriftlicher Hinterlassenschaften häufig nur ungenügend beschrieben werden. Besonders für die eher schriftlosen bzw. quellenarmen Bereiche der Alltags- und Sozialgeschichte ermöglicht die Einbeziehung der Archäologie neue grundlegende Erkenntnisse.

\section{i.2 Wüstungsbelege, Relikte und Geländeaufnahmen}

Der überwiegende Teil der bisherigen Forschungen zur Umweltgeschichte hat sich auf die schriftliche Überlieferung aus Archivquellen konzentriert. Im Bereich der anwendungsorientierten historischgeographischen Gewässerforschung sind darüber hinaus vor allem die im Raum noch vorhandenen, aber, im Vergleich zur ehemaligen Verbreitung, nur noch rudimentär vorliegenden persistenten sowie auch die fossilären gewässerbezogenen Kulturlandschaftsrelikte und -strukturen wichtige historischgeographische Quellen, mit deren Hilfe zum Beispiel die hydrologische Raumwirksamkeit von Klöstern vor dem Hintergrund der Anlage von Klosterteichen mit Hilfe seiner regionalen Verbreitung untersucht werden kann. Auszuwerten sind deshalb auf jeden Fall Wüstungsbefunde ehemaliger Siedlungen hinsichtlich ihrer Gewässer und wasserbautechnischen Einrichtungen, im Rahmen anderer historisch-geographischer Forschungen aufgenommene Kulturlandschaftsrelikte, die auf einen Wasserbezug schließen lassen, und morphogenetische Landschaftsaufnahmen mit Hinweisen auf eine ehemalige Wassernutzung.

Beispielsweise wurde mit dem Niedergang der Klöster die Bewirtschaftung vieler Teiche aufgegeben und halbverfallene Dämme künden noch heute davon, dass früher dort Fischteiche vorhanden waren (WUNDER 1956:5). Diese Reliktsituation gilt es geländetechnisch zu eruieren. Das Gelände, wie zum Beispiel um die ehemaligen Klöster, ist jedoch oftmals im Laufe der Jahrhunderte baulich derart umgestaltet worden, dass sich mittelalterliche Anlagen kaum bis heute erhalten haben können. Die Teiche der heutigen Landschaft, dies gilt es zu beachten, sind deshalb maximal die des 19. Jahrhunderts.

Des Weiteren können nicht alle aufgefundenen ,Teichreste' zwangsläufig als historische Landschaftselemente dechiffriert werden. So wurden vielfach aus ökologischen Gründen, wie beispielsweise beim Hasselbach im Solling (CREYDT 1990/91:60), in jüngerer Zeit Kleinstwasserstellen rechts und links des Baches aufgeschoben.

Ein weiteres Beispiel sind die Wassermühlenrelikte. Bei der ,Drawehner Mühle’ in Lüchow zeugen „nur noch die Sandsteinquader der Grundmauer [...] von der einstigen Mühle.“ (LANGE 1989:125) Dergleichen weiß Konrad BEDAL (1992:191f.) von vielen abgebrochenen Wassermühlen aus der Fränkischen Schweiz zu berichten (,,...nichts erinnert heute mehr an sie, höchstens einige Büsche und Steinreste"). Eine solcher Befund lässt sich ebenso für die Mühlenteiche feststellen, von denen oftmals nur noch eingesackte Teichdämme und verlandete Teichböden künden (siehe IX 2a).

Nicht die morphogenetischen Landschaftsrelikte, sondern „Gebäude und mobiles Inventar“ hat DIX (1997:34) unter dem Blickwinkel einer Wassernutzungsgeschichte untersucht. Er hat diese Sachquelle, d. h. die in situ vorhanden gebliebenen Ausstattung der Tuchfabrik Müller dahingehend befragt, ob sie „Auskunft gibt über bestimmte Produktionsweisen und -abläufe“. Und mit positivem Ergebnis: „In Verbindung mit dem Archivmaterial ergibt eine Beschäftigung mit dem Inventar der Produktionsschritte von Färberei und Naßappretur Aufschluß darüber, in welcher Weise in diesen Produktionsgängen Wasser eingesetzt wurde.“ (:34) Die Fabrik stellt somit „,wichtige Sachzeugnisse der Industrialisierung“ dar (:36) Neben der Auswertung archivalischer Quellen stand hier also „das Inventar der Tuchfabrik als Sachquelle [...] im Mittelpunkt der Untersuchung.“(:32), um umweltgeschichtliche Aussagen zum Umgang mit dem Wasser und den Gewässern zu erhalten ${ }^{6}$.

\footnotetext{
${ }^{6} \mathrm{Zu}$ Zielsetzung und Inhalt der Arbeit von DIX siehe die ausführliche Besprechung in Pkt. II.
} 


\section{Methoden}

"Yet, while methods to study the geographical attributes of landscapes are increasingly understood, methods to know their temporal contexts are not." [MARCUCCI 2000:68]

Die methodischen Instrumentarien einer historisch-geographischen Gewässerforschung habe ich aufgeteilt in zwei Methoden-Bereiche: In den Bereich ,Individual-Methoden' und in den Bereich ,Komplex-Methoden'. Die unterschiedliche Begriffsverwendung soll die verschiedenen Betrachtungsansätze verdeutlichen.

In dem ,Individual-Methoden' genannten Bereich werden Verfahrensbereiche angesprochen, die zum einen bei entsprechender Aufgabenstellung in singulärer Anwendung zu befriedigenden Ergebnissen führen können; aber natürlich erst in ihrer gekoppelten Anwendung mit anderen Methoden einen Aspekt tiefgründig zu erforschen vermögen. Zum anderem aber werden innerhalb der ,IndividualMethoden' zum Teil Verfahrensbereiche beschrieben, die wie selbstverständlich der historischgeographischen Umweltforschung zugesprochen werden, obgleich sie in ihrer ursprünglichen Herkunft in der Mehrzahl aus unterschiedlichen Forschungsdisziplinen stammen.

Die historisch-geographische Umweltforschung, so die Überlegung, die zu dieser Vereinnahmung unter dem Dach der Historischen Geographie Anlass gab, muss sich genauso hemmungslos beispielsweise auch ethnobotanischer oder dendrochronologischer Untersuchungsmethoden bedienen, wie es die geobotanische bzw. landschaftsökologische Geographie schon lange Jahre erfolgreich praktiziert, um raumhistorische Aussagen aus den Ergebnissen gewinnen. „Wir sollten uns [...] nicht fragen, was denn nun die Methoden sind, sondern vielmehr, welche Disziplinen mit ihrem methodischen Arsenal Beiträge zum Gegenstand Umweltgeschichte zu leisten imstande sind.“ (MEINECKE 1996:285, Hervorhebung im Original)

Im Gegensatz zu den ,Individual-Methoden' werden in dem Bereich ,Komplex-Methoden' praxisbezogene Arbeitsmethoden, wie zum Beispiel Kulturlandschaftskartierungen und -katastrierungen oder Kulturlandschaftswandelkarten beschrieben, die sich in der historisch-genetischen Forschung der Humangeographie herausgebildet haben (vgl. DENECKE 1997:42). „Sie sind zugleich“, und das hebt sie als Komplexmethode besonders hervor, ,,als Darstellungsweisen von Befunden in der Historischen Geographie zu verstehen." (LEXIKON DER GEOGRAPHIE, Bd. 2 2002). Sie zeichnen sich des Weiteren durch eine bewährte Methodenkopplung aus, d. h. es wird „stets eine Quellen- bzw. Methodenkombination angestrebt, um möglichst viele und sich gegenseitig stützende Belege zusammenführen zu können.“ (DENECKE 1997:42) Sie bedienen sich deshalb mindestens zweier traditioneller historisch-geographischer Methoden bzw. Quellen. Bei notwendigen thematischen und zeitlichen Beschränkungen des Arbeitseinsatzes, wie es bei einer anwendungsbezogenen Arbeitsweise der Fall ist, ,sollten diese im Ergebnis deutlich gemacht werden, bei der Zielsetzung, ausgewählte Arbeitsmethoden wenigstens in sich möglichst erschöpfend anzuwenden." (:42)

\section{a Individual-Methoden}

\section{a.1 Geländebegehung und Reliktkartierung}

„Eine lange Erfahrung hat mich gelehrt, dass die eigene Anschauung vor Ort durch nichts zu ersetzen ist.“ [Leitsatz Peter SCHOLL-LATOURs seit über 5 Jahrzehnten]

Der englische Geschichtswissenschaftler WORSTER formulierte gegen Ende der 1980er Jahre ein nach meiner Auffassung bis heute bestehendes - methodisches und instrumentelles Defizit der geschichtswissenschaftlichen Disziplin und fordert zur Behebung geographische Arbeitstechniken ein, die von einem Zweig der Historiker proklamiert werden: „Jetzt kommt eine neue Gruppe von Reformern, die Umwelthistoriker, die darauf bestehen, daß wir noch tiefer graben, bis hinunter zur 
Erde selbst als Faktor und Element der Geschichte. Hier werden wir noch grundsätzlichere Kräfte entdecken, die in der Geschichte wirksam waren. Um diese Kräfte zu verstehen, müssen wir ab und zu die Parlaments-Kammern, Kreis-Säle und Fabriken verlassen, nach draußen gehen und in den Feldern, Wäldern und der freien Luft herumlaufen. Es ist an der Zeit, ein Paar gute Wanderschuhe zu kaufen, und wir können nicht verhindern, sie zu verschmutzen.“(1988:289)

Die "Feldarbeit" als probates Lehrmittel des "learning by doing" haben auch GERBER/CHUAN wiederentdeckt: „Instead of sitting in an classroom with four walls, we were out in the environment the real world - experiencing it and making sense of the environment phenomena over which we traversed." (2000:3) "Field work", stellen sie Bedeutung und Vielfalt für die landschaftskundliche Forschung heraus, "can definitely promote all learners being able to: appreciate different landscapes; aim for sustainable practices in the use of our environments; value the beauty of environments; practise environmental conservation; and encourage the use of environmentally-friendly strategies when interacting with our environment." (:5)

Etwas später proklamiert auch der deutsche Umweltgeschichtler RADKAU, dass es „,nicht schlecht“ ist, „sich einen emotionalen Fundus an umwelthistorischen Einsichten zu erwandern." (RADKAU 2002:8) und dass „,wirkliche Durchbrüche [...] die Umwelthistorie nur durch regionale Feldforschung $\mathrm{zu}$ erzielen“ vermag (:7f.) Darin besteht nach seiner Auffassung „ein Hauptanreiz der Umweltgeschichte [...], daß sie dazu anspornt, Geschichte nicht nur an ,historischen Stätten', sondern in der Weite der Landschaft zu entdecken. [...] Die Umweltgeschichte braucht zwischendurch den ,vagabundierenden Blick'“ (:8) Deshalb hat er bei den Recherchen zu seinem Buch zur ,Weltgeschichte der Umwelt' „im Zweifelsfall denn auch vor allem solchen Arbeiten geglaubt, die diesen Lokalgeruch besaßen." (:8)

RADKAU erkennt des Weiteren, dass ,in der menschlichen Geschichte nicht die einzelnen Ideen und Aktionen, sondern das Dauerhafte und Flächendeckende: das massenhaft alltägliche, habitualisierte und institutionalisierte Verhalten über lange Zeit“ umweltprägend wirken. Dies könne dann „dem Blick des Historikers auch bei lückenhafter Quellenlage nicht so leicht entgehen“ (2002:50)

Schon lange hingegen sind Beobachtung und Kartierung im Gelände „wichtige Hilfsmittel der historisch-geographischen Analyse“ (LIENAU 1995:200). Sie gehören „,zur gründlichen Untersuchung“ kulturlandschaftsgeschichtlicher Merkmale (JÄGER 1965:421). Doch die methodische Anwendung dieser Arbeitsweisen verliert sich mittlerweile als Kopie innerhalb zweier maßgeblich an der interdisziplinären Umweltgeschichte beteiligten Nachbarfächer, der Geschichte und der Denkmalpflege: „Sind die Belege der historischen Quellen [...] hilfreiche Ergänzungen oder auch Korrektive und die Arbeiten der Historiker wesentliche Elemente zur Gewinnung eines geschlossenen historischen Bildes, so dass beide Disziplinen [= die Geschichte und die Geographie, B.B.] auf den genannten zentralen Arbeitsfeldern einander den Austausch suchen, so ist vor allem der historischgeographischen Geländearbeit, die nach dem Krieg bis in die 70er Jahre als Arbeitsfeld der Kulturlandschaftsforschung methodisch und praktisch ausgebaut worden ist, durch die breit vertretene wie auch amtlich verankerte Archäologie (Denkmalpflege) zu wesentlichen Teilen der Boden entzogen worden.“(DENECKE 2001:280)

Während, was DENECKE noch nicht so hervorhebt, also auch die Historiker - neben der Arbeit mit historischen Quellen - die mit Begriffen wie ,Regionale Feldforschung' oder ,Weite der Landschaft' verknüpften geographischen Praktiken und Betrachtungsansätze zunehmend für sich entdecken und vor allem die Archäologen obertägige kulturlandschaftsgeschichtliche Geländeuntersuchungen im hoheitlichen Auftrag durchführen, so ging infolge dieser Entwicklungen der Kulturgeographie dieses klassische Vor-Ort-Arbeitsfeld weitestgehend verloren.

Diese Entwicklung ist umso kritischer zu bewerten, als dass die Lokalisierung und Inventarisierung von früheren, heute aus verschiedenen, vor allem wirtschaftlichen Gründen nicht mehr benutzten Gewässerelementen und -strukturen durch Feldarbeit einen sehr wesentlichen Teil der historischengeographischen Gewässerforschung ausmacht (SCHMID/NAEF 1994:9) und die Grundlage für eine möglichst umfassende Rekonstruktion der mittelalterlichen und frühneuzeitlichen Gewässerlandschaft 
schafft. Die Kulturlandschaftsinventarisierung ist die zentrale Methode der , anwendungsorientierten historisch-geographischen Umweltforschung' nach DENECKE (1994). Eine solche „systematische Gesamterfassung aller Spuren menschlicher Tätigkeit im Gelände wird auch mit dem englischen Terminus des ,survey’ bezeichnet.“(LIENAU 1995:160)

Von der Historischen Geographie sind bereits Verfahren zur Inventarisierung historischer Kulturlandschaftselemente entwickelt und auch Kriterien für eine planungsbezogene Bewertung erarbeitet worden (siehe DENECKE 1985; NAGEL 1986; GUNZELMANN 1987; VON DEN DRIESCH 1988; BURGGRAAFF/KLEEFELD 1999).

Aufgrund der individuellen Aufgabenstellung und Zielsetzung, die je nach Auftrag variieren können, und da eine Standardisierung der Inventarisierung von historischen Gewässerelementen nach meinem Kenntnisstand noch nicht vorliegt, soll hier in Anlehnung an DENECKE (1972) und FEHN (1989:10) die allgemeine historisch-geographische Reliktaufnahme vorgestellt werden, die aus vier Erfassungsmerkmalen besteht:

1. Die Aufnahme historischer Bauwerke, Gebäude, Anlagen und Formen an und in Still- und Fließgewässern, die jeweils noch intakt sind und eine Funktion haben.

2. Die Aufnahme nicht mehr intakter und funktionslos gewordener Gewässeranlagen und -formen.

3. Die Aufnahme mikromorphologisch erkennbarer anthropogener Kleinformen jeder Art.

4. Die Aufnahme fossiler Bodendenkmale des Wasserbaus und alter aquatischer Kulturbodenhorizonte.

Zur Kartierung von Gewässerrelikten gehört die Ermittlung der Lage bzw. des Verlaufs ehemaliger Gewässer und deren kulturhistorischer Elemente (Lokalisierung). Als methodisches ,Arbeitswerkzeug' vor Ort ist dies die Geländebegehung und -beobachtung, die aber nicht singulär, sondern als integrativer Bestandteil der Inventarisierung ausgeübt wird. Sie ist nicht nur eine ureigene geographische Arbeitsweise, sondern als Mittel zur oberirdischen Entdeckung, Untersuchung und Formenansprache kulturhistorischer Einrichtungen und Anlagen vor Ort unverzichtbar. Die Aufnahme im Rahmen von Geländebegehungen wird ,unter Einbeziehung der Kulturlandschaftswandelkarte, der Landnutzungskarten der verschiedenen Perioden, des Urkatasters, der landschaftsgeschichtlichen Erkenntnissen und der Bodenkarte durchgeführt.“(BURGGRAAFF/KLEEFELD 1999:127).

Erste Hinweise geben oft, so haben wir in den Abschnitten zuvor erfahren, Flur- und Gewässernamen, historische Berichte und andere Arten der Überlieferung. „Ergänzende Beobachtungen im Gelände helfen, frühere Quellen und Bachläufe zu lokalisieren. Voraussetzung zum Gelingen ist die Wahl einer geeigneten Jahreszeit. Am ehesten kommen März und April in Frage, sofern die Monate eine reichliche Durchnässung des Bodens bringen, so daß dann die Quellen (meist Überlauf-, Tal- und Schichtquellen) und Bäche, die durch Wasserentnahme oder Grundwasserabsenkung in der Regel versiegt sind, vorübergehend fließen." (JÄGER 1965:411) Dieses gibt auch Martin SCHMIDT (1997:11) in seiner Anweisung zur richtigen Geländebegehung im Harz zu bedenken, wenn er auch ästhetische Gründe mit einbezieht: „Hauptwanderzeiten sind Sommer und Herbst, dann ist die Landschaft am schönsten, die Fotografen finden das beste Bild. Aber vor allem sind in diesen Jahreszeiten die ansonsten von der Vegetation überdeckten Anlagen der alten bergbaulichen Wasserwirtschaft sichtbar. „Dieses gilt selbst für die trockenen Jahre [...]. Am informativsten sind daher Wanderungen in den wenigen Wochen im Frühjahr, in denen der Schnee verschwunden ist, das neue Pflanzenkleid erst entsteht.“(:11)

$\mathrm{Da}$ aber aufgrund einer manchmal völlig veränderten hydrologischen Situation Begehungen auch in niederschlagsreichen Zeiten keinen Erfolg bringen, kann es sich diesen Fällen und je nach Aufgabenstellung als sinnvoll erweisen, nach Relikten früherer Produktionsabfälle von Glashütten zu suchen. Der Zusammenhang zwischen einem Gewässer und den Standorten von Glashütten ergibt sich dabei aus produktionstechnischer Sicht. Reste unter kleinen Schlackenhügeln, Hügel von 1-2 m Höhe und mehreren Metern Durchmesser, die aus Steinen, darunter Stücke mit Glasur und Lehm bestehen, 
finden sich als Beweisstücke, oftmals unter Wald, und sind auch dann noch Anzeiger, wenn die Bachläufe längst vertrocknet und die Bachbette nicht mehr erkennbar sind. Diese Fundstücke geben damit auch indirekt Auskunft über das frühere, verzweigte Gewässernetz in einem solchen Raum.

Quellnischen wurden zu alter Zeit zu einer Schachtpinge erweitert und vertieft: „Erfolgten doch die ersten Versuche, Erz zu finden, an solchen Stellen, wo Wasseraustritte auf Schichtverwerfungen und damit oft auch auf Erzgänge schließen ließen." (HAASE 1961:6). Dies ist auch dem Werk Georg AGRICOLAs zu entnehmen: „Die verborgenen und tiefliegenden Erzgänge aber suchen wir mit Hilfe von Kunstregeln auf, und zwar richten wir unser Augenmerk in erster Linie auf die sprudelnden Wasser der Quelle, die von den Gängen nicht weit entfernt sein können, da das Wasser ihren Spalten entspringt.“(AGRICOLA; zitiert aus HAASE 1961:6).

Die Aussagen, die aus der Geländearbeit getroffen werden können, sind dabei von verschiedener Art:

Die räumlichen Abstände oder die Form, Größe und Tiefe von Teichen beispielsweise zeigen mitunter ein bei der Anlage gebrauchtes Grundmaß an, das Folgerungen bezüglich Alter, Verwendungszeck und Besitzstruktur der Teiche erlaubt. Eventuelle Anordnungsmuster der Relikte lassen erkennen, ob regelhafte, d. h. planmäßige, Strukturen vorhanden waren.

Sichtbare Relikte (Brunnen, Gräben, Teichdämme) oder markante Oberflächenformen im Feld oder unter Wald vermögen weiterhin die Lage der ,Gewässerwüstung' anzuzeigen. Die Lokalisation einer Gewässerwüstung kann zum Beispiel durch ,morphologische Ruinen' der Teichwirtschaft (flache, wannenförmige Hohlformen) und durch unruhiges Relief erkennbar werden und mitunter auch als Siedlungsanzeiger einer wahren bzw. komplexen Wüstung gewertet werden. Insbesondere aber ist der Teichdamm dazu geeignet: Entschloss man sich nämlich früher einen Teich in Acker-, Wiesen- oder Weideland umzuwandeln, war dies mitunter ein Schritt für immer; denn es ist bei weitem leichter, einen Teich einzuebnen als einen solchen herzustellen. Dies betrifft vor allem den zeit- und kostenaufwendigen Teichdammbau. Deshalb wurde bei der Verwandlung alter Fischteiche in Ackerland, Wiesen und Weiden geraten ,wenigstens den Damm des Teichs, den man eingehen lassen will, zu schonen, zumal das leicht eine Zeit geben könnte, wo man ihn gern wieder hätte." (SPRENGEL 1838:87)

Die Deutung bzw. Bestimmung gewässerhistorischer Teichflächen, d. h. ob es sich um einen Fischteich oder einen Mühlstau als Hauptverwendungsart handelt, lässt sich oftmals erst durch ergänzende Reliktlokalisierungen feststellen, wie „die aus ERLER/MATTHIESENs (1989) „Mühlenbuch übernommenen“ Beschreibungen von Wassermühlen zeigen: Von der Wassermühle, ,ist das Gebäude und der Stau geblieben, im Boden sind Grundmauern zu erkennen und die Reste von wasserlenkenden Böschungsbefestigungen (:33). Diese Reliktsituation trifft beispielsweise für die Wassermühle zu Neumühlen an der Böhme zwischen Altenboitzen und Bierde, Landkreis Soltau-Fallingbostel, zu. Aber auch von der Wassermühle Reiningen, die der Erweiterung eines Truppenübungsplatzes zum Opfer gefallen ist, sind das Stauwehr, Reste des oberschlächtigen Wasserrades und der große langgestreckte Mühlenteich geblieben (:67). Eine ähnliche Reliktaufnahme lässt sich des Weiteren von der Wassersägemühle Wense, ebenfalls in Soltau-Fallingbostel, zeichnen: „Unmittelbar hinter der Mühle wurde 1938 die Trasse der Autobahn Hamburg-Hannover gezogen. Auch die Mühle mußte diesen Planungen weichen und wurde bis 1940 völlig abgerissen. Nur die Teiche sind in Wense heute noch vorhanden. Sie werden vom Bundesforstamt unterhalten und dienen der Fischzucht.“ (:66) Von der eigentlichen Mühle aber „blieben nur Mauerreste direkt neben der stark befahrenen Autobahn.“ $(: 66)$

Dabei ist es vor allem problematisch, künstliche von natürlichen Gewässern zu unterscheiden: So ist beispielsweise ein heute vorgefundenes Sumpf- und Teichgelände nordöstlich der Ortschaft Hammer in Schleswig-Holstein am westlichen Ufer des Elbe-Lübeck-Kanals nichts anderes als ein Relikt einer ehemaligen Stauschleuse, der Schleusenkolk der ,Kleinen Ober-' oder auch ,Erichschleuse' des ehemaligen mittelalterlichen Stecknitzkanals (GOLDAMMER 1999:66). Trotz ihrer anthropogenen Herkunft können also „auch vollständig künstliche Gewässer mit der Zeit Merkmale und Strukturen natürlicher Gewässer mit ähnlichen oder identischen Vegetationstypen aufweisen, die bei geringer 
oder fehlender Nutzung vergleichbaren Entwicklungsprozessen unterliegen. In solchen Fällen ist eine eindeutige Zuordnung spontan oft nicht möglich.“ (POTT/REMY 2000:29) Zeugnisse mittelalterlicher und frühneuzeitlicher Wasserbauten sind deshalb manchmal sehr schwer als Relikte im Feld zu erkennen, „zumal sie häufig schon mit der Landschaft regelrecht, verwachsen' sind“ (HERBST 1992:6), auch wenn keine zahlreichen Mäanderschlingen auf ein natürliches Gewässer hindeuten (vgl. KREINER 1996b:102).

Das Gelände gibt auch oftmals nur noch selten Auskunft von der einstigen energie- und landwirtschaftlichen Bedeutung kleiner Fließgewässer. „Nach Verlegung der Dumme und Verfüllung des alten Flußbettes“, beschreibt LANGE (1989:127) eine solche Situation, ,ist die einstige Mühle als solche kaum noch zu erkennen." Das bedeutet, nur noch Relikte künden dem ,Kulturlandschaftsbegeher' von der früheren Gewässersituation. Zu Zeiten des Mühlenbaus herrschten oftmals ganz andere Gewässerbedingungen, die nicht zwangsläufig mit denen der heutigen Wasserführung übereinstimmen. Heute schmale Rinnsäle oder träge dahin fließende Flussstrecken konnten früher mit ihrer Kraft mehrere Wasserräder antreiben (vgl. BINTZER 1991:247).

Ebenso ist das Grabensystem der Wässerwiesen weitgehend aus dem Landschaftsbild der Hänge und Talauen verschwunden. Bereits 1965 schrieb FIEDLER die traurigen Zeilen: „Heute sind diese Rücken weitgehend eingeebnet und nur bei genauer Betrachtung im Gelände noch zu erkennen. Auch die vielen kleinen Rinnen für die $\mathrm{Zu}$ - und Abführung des Bewässerungswassers sind verschwunden. Nur noch die intakten Wehre und Hauptbewässerungsgräben lassen auf das Funktionieren der Wässerung schließen.“ (:77) Viele Bachtäler sind durch brachgefallene Wiesen geprägt. Ganze Talabschnitte werden, oft auch im Rahmen einer Unterschutzstellung, vom (angepflanzten) Erlenwald zurückerobert oder mit Nadelholzmonokulturen aufgeforstet bzw. dem Acker- oder Feldfruchtanbau zugeführt. Hangwiesen werden, da sie nicht mit schwerem Gerät abgemäht werden können, in Abhängigkeit vom Neigungsgrad breit terrassiert oder hangparallel, im schlimmsten Fall gar hangvertikal, umgepflügt oder aber vom Weidevieh zertreten. Kurzum: Die Erkennung fällt zunehmend schwerer.

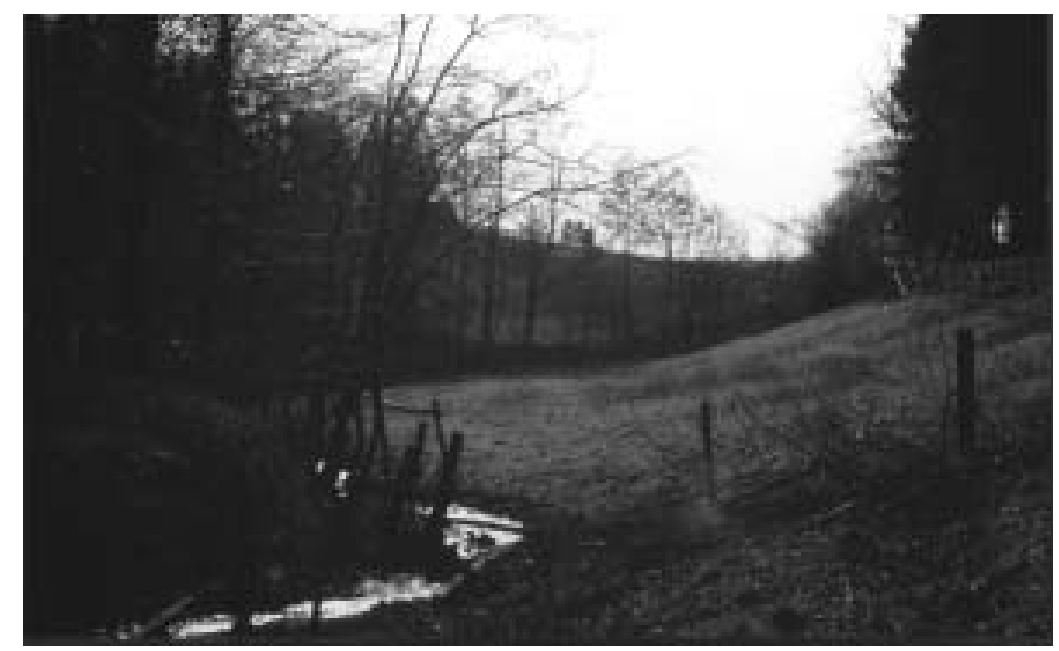

Abb. III-11: Relikte von Hangbewässerungswiesen im Bachtal von Hagendorf/Extertal durch Maschinenmahd und Viehvertritt nur noch schwach erkennbar (eig. Aufnahme 1994)

Nicht anders verhält es sich mit den zahlreichen Zeugnissen gewässergebundener frühmittelalterlicher Siedlungsentwicklung. So verfügten die Ortsgründungen des 7./8. Jahrhunderts im Zentrum der trockenen Lößbörden ,über winzige Wasserläufe. Einige von diesen Wasserläufen lassen sich heutzutage nur noch durch Trockenrinnen im Gelände rekonstruieren.“ (KREINER 1996b:77)

Darüber hinaus ist die besondere Kenntnis des Teichbaus und der Teichwirtschaft notwendig, will man die Teichtypen der vollständigen Fischzucht im Gelände voneinander unterscheiden. Gleichzeitig ergibt sich dadurch die Möglichkeit der groben zeitlichen Einordnung der Teiche, denn differenzierte Teiche einer rationellen, planmäßigen Edelzucht treten in ihrer typischen Form erst ab dem 15. Jh. auf. 
So deutete CLASEN (1952:71) rechteckig und tief ausgegrabene Teiche des Klosters Reinfeld irrtümlich als mittelalterliche Laichteiche. Es handelt sich bei den Teichen aber zum einen aufgrund ihrer Form um Hälter- bzw. Vorratsteiche, nicht um - eigentlich flache - Laichteiche, und zum anderen gehören diese Vorratsteiche nach der Art ihres Aussehens erst dem 19. Jh. an. Sie sind erst im Zuge der modernen Teichwirtschaft angelegt worden (RUST 1952:30).

„Es ist nicht leicht“, beschreibt HAASE (1961:6) - vor dem Hintergrund einer in diesem Fall kulturlandschaftlichen Überprägung - seine Schwierigkeiten bei dem Versuch einer Rekonstruktion der ursprünglichen hydrologischen Situation aufgrund der montangeschichtlichen Entwicklung im Oberharz, „die Innerste im Raum von Buntenbock herauszufinden, denn alle ihre einstigen Quelltäler sind jetzt von Teichen verhüllt.“ „Unterhalb des Teichdammes“ wurde er fündig, hier „läßt sich in einer Bodenkerbe der einstige Bachlauf der Innerste feststellen." (:6). Es ist nach seiner Auffassung mit großem Können verbunden, „die ursprünglichen Bachläufe auf dem Zellerfelde im Gelände wie auf der Karte herauszufinden. Teichflächen und Kunstgräben haben das Landschaftsbild verändert. Da die eigentlichen Gewässerrinnen nicht mehr bestehen, sind auch deren Namen entschwunden. Es empfiehlt sich, Lauf und Name dieser Gewässer erst einmal voranzustellen, um die Teich in der natürlichen Oberflächenform zu sehen“, beschreibt HAASE (:38) die den größten Erfolg versprechende Vorgehensweise. Und schnell sind wir wieder bei der Namenforschung, die in Pkt. 1 h Gegenstand der methodischen Diskussion war.

Vorsicht ist im Gelände eines vom Bergbau geprägten Areals wie im Oberharz jedoch immer geboten: Ein bergmännischer Wasserlauf, der Mönchstaler Wasserlauf, überkreuzt auf seiner Strecke an einer Stelle hangaufwärts eine Geländefurche. Dies ist jedoch „kein verlassener Graben, sondern es sind die Reste des ,Hunscherweges', der in alten Zeiten eine wichtige Harzquerverbindung darstellte.“ (HAASE 1961:32)

Nachdem die Lokalisierung von gewässerhistorischen Elementen und Strukturen im Rahmen der Geländebegehung abgeschlossen ist, folgt als ,einer der ersten Arbeitsschritte [...] die Kartierung der persistenten historischen Raumstruktur.“ (NITZ 1998:140) Bei der Reliktkartierung werden dabei besonders die persistenten bzw. rezenten Strukturen und Phänomene, d. h. die heute im Gelände noch vorhandenen und erkennbaren Relikte, erfasst und bewertet (BURGGRAAFF/KLEEFELD 1997:25; MÜCKE 1988:160). Gerade die obertägigen Relikte und Oberflächenfunde, die „,zu großflächigen und regionalen Geländebefunden“ vordringen (DENECKE 2001:283) sind „wesentliche Objekte der historisch-geographischen Geländeaufnahme [...], besonders unter dem Gesichtspunkt der anthropogenen Kleinformen.“(:283)

In die bei der Geländebegehung mitgeführten Karten (siehe 1d) werden anschließend die auffindbaren historischen Gewässerlandschaftselemente und -strukturen eingetragen. Die Kartierung, d. h. Erfassung und Bewertung des Untersuchungsgebietes, erfolgt i. d. R. auf der Grundlage der DGK 1:5.000 (BURGGRAAFF/KLEEFELD 1997:25) oder nach entsprechender Aufgabenstellung werden auch Vergrößerungen des Kartenbildes angefertigt. Zu beachten ist bei Vergrößerungskopien die Einhaltung der Maßstäblichkeit. Bei nicht möglicher maßstabsgetreuer Kartierung ist eine Erläuterung durch Maßzahlangaben, z. B. Höhe, Größenangabe vorzunehmen. Der kartographische Eintrag ist durch einen ,Begleittext', in dem besondere Merkmale aufgezeichnet werden, z. B. geologische Beschaffenheit, Verteilung der Bodenfeuchte etc., zu ergänzen (JÄGER 1965:421).

Die gewässerhistorische Kartierung beinhaltet die Aufnahme von historischen Gewässerbauten und anderen materiellen und geländemorphologischen Zeugnissen der gewässerwirtschaftlichen Vergangenheit und deren listenmäßige Erfassung (vgl. Tab. III-1), um damit eine Grundlage für die Erhaltung kulturellen Erbes zu schaffen. 
Tab. III-1: Kartierschlüssel zur Untersuchung aufgelassener Wasserwege (Kanäle): li.: Kartierschlüssel für die Kanaltrasse, re.: Kartierschlüssel für die Kanalbetriebsgebäude (aus: NAGEL 1986: 161f.).

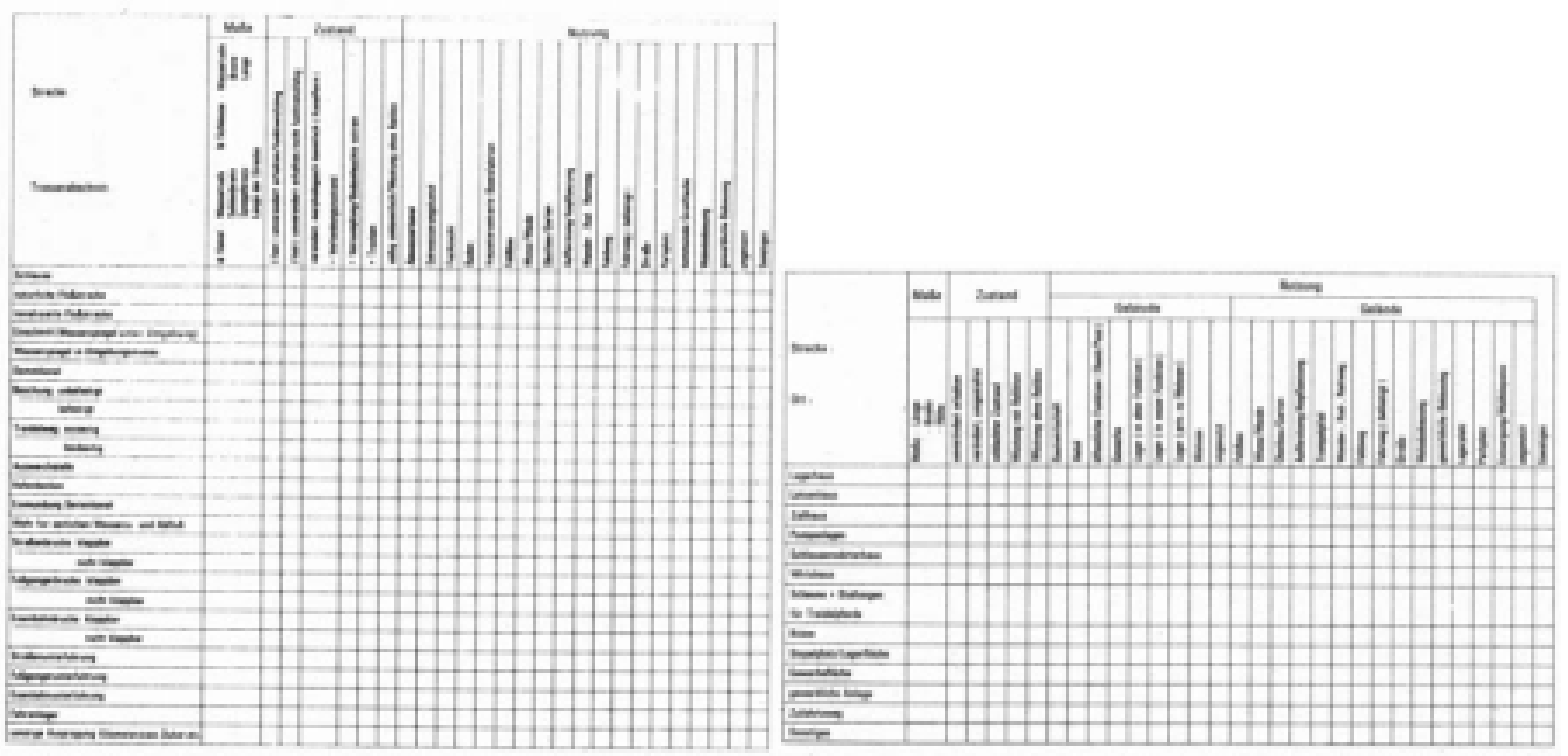

Dabei werden die ,funktionierenden' historischen Kulturlandschaftselemente und die ,funktionslosen' Relikte nach punkt-, (z. B. Teichmönch), linien- (z. B. Teichdamm) und flächenhaften (z. B. Teichfläche) landschaftlichen Elementen und Strukturen unterschieden (in Anlehnung an BURGGRAAFF/KLEEFELD 1998 und 1999:127). Die erfassten Phänomene werden für gewöhnlich in standardisierter Form, z. B. nach Aussehen, Erhaltungszustand, Alter, regionaler Bedeutung, gestalterischem Eigenwert, Landschaftswirkung, ökologischem Eigen- und Demonstrationswert, wissenschaftlichem oder touristischem Wert, näher beschrieben. Daraus ergibt sich eine Auflistung, gegliedert nach den oben genannten Objektgruppen der erlebbaren Einzelelemente. Damit sind zugleich „die wichtigsten Kriterien genannt, welche in Planungsverfahren von Bedeutung sind, die kulturräumliche Phänomene berücksichtigen." (NAGEL/SCHENK 2001:5) Soll hingegen das historische Gewässergefüge in seiner Gesamtheit repräsentiert werden, um ein kulturlandschaftliches Verständnis zu erreichen, müssen alle anthropogenen Gewässerelemente und -strukturen kartiert werden (BURGGRAAFF/KLEEFELD 1999:127).

Die Relevanz von Reliktkartierungen wird umso greifbarer, wenn bewusst wird, dass in schriftlichen Quellen nur selten Bemerkungen über die „Eingriffe des Menschen in die naturräumliche Landschaftsentwicklung in historischer Zeit“" zu finden sind (DENECKE 1989b:199). Auf der anderen Seite ,ist in der heutigen Landschaft selbst doch noch sehr viel von den Eingriffen selbst und den Folgeerscheinungen $\mathrm{zu}$ beobachten, allerdings meist in der Form von Relikten und Kleinformen, die in der aktuellen Nutzlandschaft kaum mehr eine Bedeutung haben.“(:199) Das heißt, dass trotz der seit Mitte des 19. Jh. verstärkt vorgenommener Gewässerregulierungen, Flurbereinigungen und Meliorationen alte Gewässerrelikte in rezenten Gewässerstrukturen und Fluren erhalten geblieben sind. Vor allem in Fluren mir extensiver Bodennutzung bilden Teiche auch heute noch mit Bodenabgrenzungen und Mulden bzw. Vertiefungen morphologische Kennzeichen im Gelände. Reste mittelalterlicher künstlicher Gewässerstauungen beispielsweise blieben als fossile Teichdämme, Teichböden unter Wald oder auf Grünland in der Flur erhalten. Hier und da zeugen verfallene Dammanlagen von dem einst so umfangreichen Wirtschaftszweig (RUST 1952:34). „Sie sind jedoch zu kartieren, zu typisieren und zu untersuchen als historische Kulturlandschaftselemente, in denen die Tätigkeit des Menschen in der Kulturlandschaft unmittelbar faßbar und nachweisbar wird. [...] Damit sind es auch Landschaftsdenkmale, die im Rahmen eines Altlandschaftsschutzes zu erhalten sind", beschreibt DENECKE (1989b:1999) die Bedeutung und die Aufgabenstellung einer Gelände- und Objektkartierung für die historisch-geographische Kulturlandschaftsforschung. Die gewässerwirtschaftliche Kartierung ist insofern - wie auch alle anderen historisch-geographischen Kulturlandschaftsaufnahmen - von besonderer Bedeutung und Dringlichkeit, „da eine solche schon in wenigen Jahren ein historisches Zeugnis sein kann“(JÄGER 1965:421). Darüber hinaus geben die zahlreichen, in Mittelgebirgen, aber 
auch in Wäldern nordwest- und mitteldeutscher Tiefländer kartierten Flurrelikte zwar wertvolle Hinweise auf die frühere Verbreitung von Ackerland und Waldnutzung, dagegen liefern sie nicht in dem zunächst erhofften Maße Ergebnisse zur Gewässerentwicklung und zum ehemaligen Gewässerbestand. So stellt die Kartierung gewässergebundener Kulturlandschaftsrelikte und Bodendenkmale ein sehr wichtiges Arbeitsmittel dar, denn „für die Gewässergeschichtsforschung soll es eine wichtige, weil dringende Aufgabe sein, auf der Grundlage des Vorhandenen das historische Still- und Fließgewässernetz kartographisch exakt zu fixieren, nicht zuletzt, um der Nachwelt die Möglichkeit des historischen Vergleichs zu erhalten.“ (SCHRÖDER/SCHRÖDER 1997:9)

Eine breite Palette von Verfahren entwickelte man dazu in der Wüstungsforschung (vgl. z. B. JÄGER 1953; JANSSEN 1968). Zur Bestimmung von Flurwüstungen werden systematisch Ackerterrassen, Wölbäcker, Blockwälle und Lesesteinhaufen unter Wald erfasst, zur Bestimmung ehemaliger Wohnplätze und deren Größe, Gestalt und Alter Siedlungsrelikte in Form von baulichen Resten, Scherben etc. prospektiert. Die methodische Untersuchung aufgelassener Formen der Wasserwirtschaft und der Wasserwege, wie auch die Beschreibung, Erklärung und Erfassung von punkthaften Gewässerrelikten gehört jedoch zu denjenigen Teilbereichen der Kulturlandschaftsforschung, die bisher noch wenig in Angriff genommen worden sind und für die bislang kaum spezifische Methoden entwickelt worden sind. Die schon im Jahr 1882 von G. v. BUCHWALD (1882:93) erhobene Forderung nach einer vollständigen Wüstungskarte mittelalterlicher Teiche blieb bislang ungehört.

Als Ausnahme hervorzuheben sind GRÜTZBACHER (1985), NAGEL (1986:160) und zeitlich nachfolgend GOLDAMMER (1997:177), die am Beispiel historischer Wasserwege eine Reliktkartierung anhand von Kartierschlüsseln vorgenommen haben: GRÜTZBACHER beispielsweise erarbeitete zwei Kartierschlüssel zur methodischen Untersuchung aufgelassener Binnenwasserstraßen: Kartierschlüssel 1 zur ,Kanalstraße“ und Kartierschlüssel 2 zu den „Kanalbetriebsgebäuden'. Beide Schlüssel erfassen die verschiedenen Elemente des stillgelegten Wasserweges unter den Aspekten ,Maße, Zustand' und , gegenwärtige Nutzung'. Der Kartierschlüssel für die Kanalbetriebsgebäude enthält Elemente wie Lagerhaus, Lotsenhaus usw.

Zusammenfassend lässt sich festhalten: Grundlegender Bestandteil einer Inventarisierung ist die Geländebegehung einschließlich Bestandsaufnahme (Kartierung). Eine systematische, regional bzw. lokal begrenzte Inventarisation kann beispielsweise mit der Kartierung ehemaliger Teichanlagen erfolgen. Eine solche Kartierungsmethode kann man auch als ,Reliktgewässeranalyse' bezeichnen. Eine sorgfältige Bestandsaufnahme der Gewässer und der die Gewässernutzung prägenden historischen Kulturlandschaftselemente ist dafür ebenso wichtig wie die Kenntnis der Gewässer-, Teich-, Fischerei- und Wasserbewirtschaftungsgeschichte. In der Bestandsanalyse und -bewertung (Inventarisation) werden die aufgelisteten Elemente nicht nur gewichtet, sondern auch die vorhandenen Mängel aufgezeigt.

$\mathrm{Zu}$ einem in diesem Zusammenhang praktizierten Kulturlandschaftsschutz gehört auch die stärkere Beachtung des unmittelbaren landschaftlichen Zusammenhangs (vgl. DIX 1997:36). Mit einer intensiveren Erhebung von kulturgeographischen Gewässerinformationen bereits im Rahmen der Denkmalinventarisation ließen sich noch viele Aussagemöglichkeiten sichern und letztlich die Aussagekraft gewässerbezogener Denkmäler steigern (:36). Die erfassten Gegenstände können beispielsweise als historisches Gewässerkataster ${ }^{7}$ Teil des im Aufbau befindlichen digitalen Kulturlandschaftskatasters (KuLaDig) des Landschaftsverbandes Rheinland und des Landschaftsverbandes Westfalen-Lippe werden. Am Ende dieser Bestrebungen steht als übergeordnetes Ziel ein Kulturlandschaftskataster der Bundesrepublik Deutschland (FEHN/SCHENK 1993): Die ganzheitliche Inventarisierung von kulturlandschaftsgeschichtlich und im Rahmen von Kulturlandschaftsschutz und -pflege bedeutenden Einzelelementen und Bereichen. Mit fortschreitendem Bearbeitungsstand können solche Datenbestände in einem Geographischen Informationssystem (siehe Pkt. 2a10) fortlaufend aufgefüllt, angeglichen und Kulturlandschaftsentwicklungen und -beschreibungen fortgeschrieben werden.

\footnotetext{
${ }^{7}$ Zur Vorgehensweise, zum Aufbau und zu den Zielen des Kulturlandschaftskatasters siehe auch KRACHT/MORISSEY/ SCHENK (2003: insbes. 527-529) sowie zum Digitalen Kulturlandschaftskataster, speziell das vom Landschaftsverband Rheinland aufzubauende KuLaDig, siehe BURGGRAAFF/KLEEFELD (2003:hier:19-22).
} 
Das HISTORISCHE MÜHLENKATASTER des Kreises Herford kann der digitalen Variante als analoges Vorbild dienen. Dort sind alle Anlagen aufgenommen, die ,Mühle' genannt werden, also neben Wasser- und Windmühlen auch Ross- und Motormühlen. Das HISTORISCHE MÜHLENKATASTER verfolgt das Ziel, ,die bis vor einigen Jahrzehnten noch vielfältige und lebendige Mühlenlandschaft im Kreis Herford zu dokumentieren“ (MÖRSTEDT 1995:8). Dabei werden im Einzelnen folgende Inventarisierungen vorgenommen (:8):

1. Erfassung aller bekannt gewordenen Mühlenanlagen im Kreisgebiet, gleich welcher Antriebsund Arbeitsweise, ob erhalten oder nicht.

2. Erfassung technischer und wirtschaftlicher Daten der Mühlenbetriebe, „damit der Zusammenhang von wirtschaftlichen Aufgaben und technischen Lösungen deutlich gemacht werden kann.

Ein großes Manko hingegen hat dieses ansonsten lobenswerte Mühlenkataster. Nur am Rande, in der Rubrik ,Katasterblock', wird auf die Teich- und Gewässeranlage der Mühlen eingegangen: „Der Katasterblock umfaßt Daten zur geographischen Identifizierung der Standorte. Bei Wassermühlen werden zunächst Angaben zur Gewässersituation gemacht. Neben dem Gewässernamen nach der Gewässerkarte 1:50.000 des Kreises Herford wird vermerkt, wenn die Wasserkraftanlage auch einen Betriebsgraben umfaßt, und in welche Richtung diese Ableitung vom Gewässer abzweigt. Gebietskennzahl und Stationierung sind der Gewässerstationierungskarte 1:25.000 der Landesanstalt für Wasser und Abfall Nordrhein-Westfalen entnommen. Eine Stationierungsangabe entfällt, wenn das betreffende Gewässer nicht stationiert ist oder als offenes Gewässer nicht mehr existiert. Die Angabe zur Lage bezieht sich auf die Lage der Mühle zum Betriebsgewässer, soweit vorhanden also zum Betriebsgraben" (MÖRSTEDT 1995:9)

Ein weiteres Kataster dieser Art liegt mit den Erhebungen des Westfälischen Amtes für Denkmalpflege (Referat TKD) „Wasserkraft in Westfalen” vor, dessen 1. Band „Kreis Gütersloh” bereits 1986 erschienen ist.

\section{a.3 Archäologische Methodengruppe}

Die historisch-geographische Gewässerforschung mit ihren spezifischen Methoden der Geländeuntersuchung vermag die Lage, Gestaltung und Verbreitung von Gewässern darzustellen. Bezüglich der früheren Gestaltung von oberflächig nicht mehr auffindbaren Gewässern und der zeitlichen Dauer der Anlage ist sie jedoch auf die Grabungsergebnisse der archäologischen und bodenkundlichen Forschung angewiesen (JANSSEN 1968; 1975:7). Als ergänzende Quellengruppe zur gewässerhistorisch-geographischen Forschung müssen archäologische Methoden mit herangezogen werden. Sie spielen naturgemäß v. a. in der Wüstungsforschung eine besondere Rolle (LIENAU 1995:160), während sie für die Gewässerforschung erst noch der intensiveren Erschließung bedürfen. Erste Gedanken dazu und einige erste Projekte einer archäologischen Entdeckung einer Gewässerkulturlandschaft sollen im Folgenden vorgestellt werden. Doch zuvor einige Bemerkungen allgemeiner Art:

Archäologische Funde von Gewässerbauten und Gewässernutzungsobjekten sind selten und zufällig. Eine Ausnahme bildet der gut dokumentierte Fund der Fundamentpfosten einer Wassermühle aus dem 12./13. Jh. bei Elfgen in der Elsbachniederung (ARORA/FRANZEN 1988:121; zitiert nach KREINER 1996b:53). Eine Ausnahme bilden auch die bei Grabungen auf dem ehemaligen Burgplatz in Hodenhagen entdeckten „Reste einer Stauanlage und Bohlen im Grabenbereich [...], die auf eine Mühle schließen lassen." (ERLER/MATTHIESEN 1989:51) Die Wassermühle wurde als die Hudemühle der ehemaligen Burg identifiziert. Und ein Zufallsfund stellt der bereits in den 1920er Jahren in Ahlden gefundene ,Einbaum' dar, der zunächst kurzerhand in die graue Vorzeit datiert wurde. „Vermutlich aber handelte es sich bei diesem ,Boot' um einen der Schwimmer, der eine Schiffsmühle über Wasser hielt.“(:26) 
Gewässergeschichte zu rekonstruieren ist, wie man sieht, nicht immer einfach und beruht auf vielen auch archäologischen - Fundanalysen. Wie zum Beispiel auch die eindeutige Genese eines sog. Mühlenbaches zeigt. So galt z. B. der 11 km lange Kuchenheimer Erftmühlenbach im Erftgebiet bis in das 20. Jh. hinein als ein künstlich angelegtes Gewässer. Der archäologische Befund (Auswertung von Landschaftsquerschnitten und Verteilung der Auelehm-Ablagerungen) zeigte aber, dass der Erftmühlenbach ursprünglich ein natürlicher Arm der Erft gewesen ist. Dieser wurde dann mit der Anlage von Mühlen reguliert. Erst seit dem 19. Jh. wurden die zahlreichen Mäanderschlingen des Erftmühlenbaches, die gleichfalls auf ein natürliches Gewässer hindeuten, begradigt, und der Erftmühlenbach erhielt sein heutiges Aussehen als Kunstgewässer (KREINER 1996b:102).

\section{a.3.1 Paläobotanische Methode}

Paläo-Ethnobotanik, ist „eine interdisziplinär orientierte Teildisziplin der Botanik“ (WILLERDING 1996:41) ${ }^{8}$. Diese biologische Teildisziplin, auch nur Paläobotanik bzw. in neuerer Zeit Archäobotanik genannt, hat zum Ziel „vom Menschen genutzte Pflanzen [...] als Indikatoren für die Lebens- und Umweltverhältnisse des Menschen zu werten“ (:41). Die archäobotanische Untersuchung der Pflanzenreste ermöglicht die Rekonstruktion der Lebensumwelt und der landwirtschaftlichen Anbauflächen (KÜSTER 1996:31). Bislang wurden Fragen des Wandels z. B. der Klimageschichte, zur Waldentwicklung, zum Siedelgeschehen (Ackerbau) etc. beantwortet. Es können aber auch - in diesem Kontext besonders wichtig und neuartig - Fragen zur Gewässergeschichte durch paläoethnobotanische Arbeitsmethoden beantwortet werden.

Bislang wird die Rekonstruktion der vegetationsgeschichtlichen Verhältnisse der Pflanzengesellschaften vor allem in Form der Sediment- und Pollenanalyse durchgeführt ${ }^{9}$. Da sich jedoch die Methodenauswahl auch an der Forschungsaufgabe der Anwendungsorientierung als Beitrag der historisch-geographischen Disziplin bemisst und das Ausmaß der zeitlichen Inanspruchnahme im Rahmen einer landschaftsgeschichtlichen Untersuchung oder eines Planungsbeitrages ein entscheidendes Kriterium der Praxisnähe ist, kann die laborgestützte mikroskopische Pollenanalyse bei einem anwendungsorientierten Ansatz nicht berücksichtigt werden. Sie ist das Feld des reinen Forschungsbeitrages. Sie sollte aber dennoch ihre Erwähnung finden, da auch die angewandte historisch-geographische Forschung zumindest nicht nur die Ergebnisse solcher Methoden interpretieren können muss, sondern auch im Rahmen einer Projektarbeit solche Methodiken zukünftig durchaus zur Anwendung gelangen können.

Ein in diesem Sinne geeigneteres Instrumentarium zur Auffindung von möglichen Altgewässerrelikten ist die systematische paläo-ethnobotanische Untersuchung von „pflanzlichen Großresten“ (WILLERDING 1996:42). Es handelt sich hierbei um überkommene Reste von Pflanzen, die bei archäologischen Ausgrabungen geborgen werden können (:41,65). Es überwiegen somit Fundkomplexe aus dem Hoch- und Spätmittelalter (:41).Vorzugsweise handelt es sich um Reste von Nahrungspflanzen, die Aussagen über die Ernährung in früherer Zeit liefern. „Meist erlauben sie auch Erkenntnisse über Ackerbau und Agrartechnik bzw. Gartenbau. Holzfunde aus Fachwerk- oder Steinhäusern können zu Einsichten über Holzhandwerk und Hausbau führen. Zugleich informieren sie über die damalige Beschaffenheit der Gehölzflächen, aus denen das Holz stammt. Schließlich geben Funde exotischer Gewürze oder importierter Hölzer Auskunft über Bereiche wie Handel oder Lebensstandard. Andere Fundmaterialien informieren entsprechend über weitere Elemente menschlicher Lebensverhältnisse.“(:43f.)

\footnotetext{
${ }^{8}$ Dass sich auch Geographen mit diesem Spezialgebiet beschäftigen, zeigen Personen wie der bereits stellvertretend genannte nunmehrige Hannoveraner Universitätsprofessor Richard POTT (s. Literaturverzeichnis in: JOCKENHÖVEL 1994:29).

${ }^{9}$ Von See- oder Moorsedimenten entnimmt man durch eine Bohrung ein Bodenprofil. Der Gehalt an in den einzelnen Straten des Profils eingelagerten Pollen- oder Blütenstaubkörnern (bzw. deren außerordentlich stabilen und haltbaren Pollenkornwänden) kann unter dem Mikroskop botanisch gut bestimmt werden, da die Pollenkörner der einzelnen Pflanzen unterschiedlich aussehen. Des Weiteren bewahrt die wachsartige Außenschicht Pollen unter Luftabschluss vor der Zerstörung. Anschließend werden die prozentualen Anteile der einzelnen Pollentypen in den Straten berechnet. Die von Schicht zu Schicht sich wandelnden Anteile der Pollentypen werden in einem Diagramm, dem Pollendiagramm, aufgetragen.
} 
Erweitert werden könnten diese Beispiele in Bezug auf gewässerhistorische Aussagen um entsprechende Gewässergroßpflanzen. Eine solche botanische Quelle historisch-gewässergeographischer Forschung sind pflanzliche Lebensgemeinschaften der Gewässer. Sie setzen sich allgemein aus mikroskopisch kleinen Algen und Pilzen oder aus Wasserflechten (Mikrophyten) bzw. speziell angepassten Gefäßpflanzen sowie Wassermoosen und großen, sessilen Algen (Makrophyten) zusammen. Unter dem Begriff Makrophyten werden solche makroskopisch erkennbaren Pflanzen der Gewässer verstanden, deren Lebenszyklus vollständig oder weitgehend an das aquatische Milieu gebunden ist und deren basale Pflanzenteile sich überwiegend untergetaucht im Wasser befinden (POTT/REMY 2000:11). Häufig wird der Begriff, Makrophyten' sehr weit gefasst, er schließt dann neben den aquatischen und amphibischen Wasserpflanzen, den Hydrophyten und Amphiphyten, auch die Röhrichtpflanzen (= Helophyten) im engeren Sinne mit ein (:11f.). Solche sind hier von Belang.

Diese bei archäologischen Ausgrabungen erschließbaren Pflanzenreste ermöglichen anhand der Artenbestimmung auch Aussagen über die Zusammensetzung der beispielsweise im Teich bzw. auf dem Teichboden kultivierten Nutzpflanzen in früheren Zeiten. Untersuchungen dieser Art müssen sich, um zu einer gewässerbezogenen Aussage zu kommen, weitgehend an charakteristischen Pflanzengesellschaften der Flussauen und Stillgewässer orientieren. So könnten am Beispiel des stehenden Gewässers mit Hilfe von Seggenarten (Carex), die als Anzeiger für Reste einer Süßwasserund Moorvegetation charakteristisch sind, gewässerbezogene Flurrelikte identifiziert werden. Am Beispiel von Feuchtwiesen könnten mit Hilfe von Borstgrasgesellschaften, die als Anzeiger auf einen hohen Anteil von Feuchtwiesen hinweisen, Hinweise auf eine linienartige Drainage gefunden werden. Der Beweis einer historischen Teichbewirtschaftungsweise könnte anhand der alten Flachssorte ,Arminius' gegeben werden, bei deren Weiterverarbeitung auf dem Weg von der Pflanze zur Faser man sich sog. Flachsrösten bediente. Dazu zählen auch die Funde von ,gezähntem Leindotter', einer typischen Ruderalpflanze des Flachsfeldes, die mit dem Ende des Flachsanbaues auch verschwunden ist.

Ein solches methodisches Vorgehen hat Hansjörg KÜSTER (1993:128f.) gewählt und anhand botanischer Untersuchungen die Existenz eines Mühlweihers bei der frühmittelalterlichen Wassermühle von Dassing belegt.

\section{a.3.2 Archäozoologische Methode}

Ebenso wie Pflanzenreste geben Tierknochen Auskünfte: beispielsweise über die Viehwirtschaft und das Nahrungsverhalten der Bewohner. Eine besondere Gruppe innerhalb der Knochen stellen die Fischknochen dar, „die aufgrund ihrer geringen Größe und Fragilität, aber auch wegen ungenauer Grabungsmethoden in archäologischen Ausgrabungen lange überhaupt nicht wahrgenommen wurden.“(LAMPEN 2000:13)

Der Nachweis von ehemaligen Wasserbewohnern, wie beispielsweise Wassertierknochen, -zähnen und Fischgräten usw., ist durch Ausgrabung zu erbringen, bei denen organischen Resten bestimmter Fischarten Aufmerksamkeit geschenkt wird. Diese Art von Vorgeschichtsfunden besitzt auch im Rahmen der gewässerhistorischen Forschung in mehrfacher Hinsicht besondere Bedeutung. Ihre Verbreitung vermag die Bindung von Siedlungen an Gewässer(rand)lagen zu verifizieren, die Reichweite des mittelalterlichen Fischhandels aufzuzeigen, Befunde der fischartigen Ernährungszusammensetzung zu bestätigen oder auch ehemalige Teichzuchtanlagen aufzudecken.

Kritisch bleibt anzumerken, dass besonders bei den sehr kleinen Fischknochen die sekundäre Zerstörung durch Vertritt oder durch räuberische Tiere, wie Katzen, Vögel und Hunde sehr groß ist, d. h. dass die enthaltenen Knochen normalerweise nur einen sehr kleinen Ausschnitt des ursprünglichen Bestandes widerspiegeln. Bedingt durch ihre geringe Größe und Fragilität sind Fischfunde deshalb oftmals unterrepräsentiert: „Ohne speziellen Grabungsaufwand, wie beispielsweise Feinsiebung $(<2$ mm) und Flotation, werden die Überreste besonders kleinerer Fische übersehen." (STEIN 2000:14) Aus diesem Grund fand sich wahrscheinlich bei der Fundgutanalyse einer Grabung im Niederrhein, auf die noch näher in Pkt. VI 7c beingegangen wird, auch ,nur ein einziges Fragment einer Flussmuschel [...] im Material.“ (:14) Muschelschalen zerbrechen leicht und zersetzen sich auch 
leichter. Nur mittels aufwendiger feinerer Methoden, wie etwa die oben erwähnte Feinsiebung und Flotation, können die letztgenannten systematisch erfasst werden (:130). Zudem können selektive chemische Prozesse, wie z. B. die Autolyse der Knochen besonders fettreicher Fische, das Fundbild zusätzlich verstärken.

Ein Beispiel einer solchen archäozoologischen Knochenfunduntersuchung ist die Auswertung des Knochenmaterials von ,Haus Bürgel', einem spätrömischen Kastell in der ,Urdenbacher Kämpe', einer Altrheinschleife $8 \mathrm{~km}$ südlich von Düsseldorf: Die Analyse der nach Ausgrabung geborgenen Tierknochenfragmente, $\mathrm{d}$. h. die anatomische und tierartliche Bestimmung der Skelettteile sowie ihre Vermessung ergab, dass es sich bei dem Fundgut um Schlacht- bzw. Speiseabfälle, d. h. genauer um Siedlungsabfälle tierischer Herkunft aus vor- und frühgeschichtlichen Siedlungen des Zeitraumes 364 bis $408 \mathrm{n}$. Chr. handelt (:157) (STEIN 2000:7, 128,157).

Ziel der Arbeit war es, mittels der Analyse der Tierreste Einblicke in die Ernährungs- und Lebensgewohnheiten, die tierzüchterischen Verhältnisse sowie die naturräumlichen Gegebenheiten des Kastells ,Haus Bürgel' zu gewinnen (STEIN 2000:1). Um den ersten Aspekt, der Ernährungs- und Lebensgewohnheiten, zu bestimmen, wurden die Tierfunde zunächst gewogen: „Die Bedeutung des Wiegens liegt darin, dass das Knochengewicht Rückschlüsse auf die Wertigkeit der jeweiligen Tierart für die Fleischversorgung der damaligen Bewohner ermöglicht.“ (:9) Danach wurden die Knochen nach einer üblichen Standardmethode mit Hilfe einer Schublehre bzw. eines Bandmaßes auf 0,1 mm genau vermessen.. Die Knochengröße ermöglicht es, „Aussagen über die Körpergröße sowie die Wuchsform ur- und frühgeschichtlicher Tiere zu treffen und entsprechende Vergleiche zur Gegenwart zu ziehen." (:9) Leider wurde dieser Frage in der Untersuchung in Bezug auf die Fischknochen nicht nachgegangen bzw. sie konnte aufgrund der wenigen Fragmente nicht beantwortet werden. Solche Ergebnisse im Bereich der Teichwirtschaft wären interessant zur Beantwortung von Fragen wie die Größe von Zuchtkarpfen und Teichforellen, der Besatz an Zahl und Arten in Teichen etc.

Denn mit einer archäozoologischen Fundanalyse ist eine historische Momentaufnahme der Tierwelt des Frühmittelalters möglich (vgl. STEIN 2000:1). Des Weiteren ermöglicht „die tierartliche Zusammensetzung sowohl der Haus- wie auch der Wildtiere [...], Schlüsse auf die Landschaft der unmittelbaren und der näheren Umgebung des Fundortes zu ziehen." So ergibt sich in diesem Fall „ein Bild von Auen- und Mischwäldern sowie Sumpfgebieten entlang dieses Rheinufers, daran angrenzend weites, fruchtbares Ackerland und ausgedehnte flache Wiesen. Der Rhein wird als Fluss mit großer Wassertiefem variierenden Strömungsverhältnissen, zahlreichen Alt- und Nebenarmen sowie hervorragender Wasserqualität charakterisiert.“ (:158)

Als weitere archäologische Quellengruppe liefern Fischereigeräte Aufschlüsse über die mittelalterliche Fischerei. Da es sich hierbei aber überwiegend um Werkzeuge aus vergänglichen Materialien (Holz, Textil, Flechtwerk) handelt, sind sie nur bei außergewöhnlich guten Erhaltungsbedingungen überliefert und können in dieser methodischen Aufzählung als Randerscheinung unberücksichtigt bleiben.

\section{a.3.3 Archäologische Flussfundforschung}

Eine relativ neue archäologische Methode ist die sog. Flussfundforschung, die durchaus auch für die historisch-geographische Gewässerforschung ein interessantes Arbeitsgebiet bzw. eine Hilfswissenschaft darstellen kann. Die Ergebnisse, die Flussfunde, sind schon heute als Quelle unverzichtbar, wie wir im Weiteren sehen werden.

Bereits Ernst FRIEDEL hatte 1884 (:8) den Hinweis auf Fundstücke in Kiesablagerungen der Flusstäler als Beweis einer speziellen Art von Gewässernutzung gebracht: Dort „kommen schwere Eisäxte, wie sie, zum Lumenhauen, von den Fischern gebraucht sein mögen, vor.“ Er nannte „die große Kiesanhäufung bei St. Acheul" als Beispiel, an einer Stelle, wo die Nebenflüsse ,Rone' und ,Arve' sich mit der ,Somme' verbinden und mutmaßt: ,und wahrscheinlich bot dieser Umstand einem Stamm von Fischern Veranlassung, sich an dieser Stelle niederzulassen - wie auch ähnliche natürliche Vortheile die ersten Einwohner von Amiens und Abbeville an diese Plätze gezogen haben. Besuchten 
nun jene wilden Fischerstämme dieselben Plätze hunderte und tausende von Jahren nacheinander, so kann uns die Menge der in dem Flußbett verloren gegangenen Eismeißel nicht mehr überraschen.“

Flussfunde, ,aus Flüssen gebaggerte Waffen, Werkzeuge und Schmuckgegenstände der Bronzezeit“ werden heute als Opfergaben interpretiert (HANSEN 2000:32). Dies beruht auf dem auffälligsten Merkmal der Flussfunde: die weitgehende und wiederkehrende Gleichförmigkeit der Gegenstandsauswahl. Bei den Gegenständen handelt es sich um vor allem um Waffen, wie Schwerter, Lanzenspitzen, verschiedene Teile der Panzerung, Helme sowie Äxte, „die ebenfalls zur Bewaffnung gerechnet werden können.“ (:46) Die große Zahl an Waffen in Flüssen erklärt man sich kaum mit Zufall, es wird vielmehr eine „Deutung der Fluß- und Hortfunde als Weihegaben“ vorgenommen (:48).

Der zerstörerische Aspekt, das unheimliche, „das gewalttätige Wesen Fluß“ (HANSEN 2000:48) dessen Überschwemmungen gefürchtet waren, galt es zu besänftigen. Dies wurde durch ein Opfer vollzogen. Bei den Waffenweihungen wurden dabei die vom Feind erbeuteten Trophäen in den Fluss geworfen, um so den eigenen kriegerischen Erfolg dem Heiligtum in aller Welt vor Augen zu führen $(: 53)$.

Im Prinzip sind Flussfunde aus ganz Europa, vom Tiber bis zur Elbe, von der Themse bis zur Donau bekannt (HANSEN 2000:49), die vor allem aufgrund der umfangreichen Kiesgewinnung ausgebaggert werden konnten (:37). Aber ,leider werden Flußfunde in ihrer Bedeutung vielfach noch unterschätzt.“ (:58) Doch während in der Archäologie eine solche Forschungsrichtung zumindest in Ansätzen seit gut dreißig Jahren besteht (:59), obwohl sie auch dort als ein etwas vernachlässigter Zweig gilt (:32), gibt es eine historisch-geographische Flussforschung noch nicht. Dabei hängt die Kenntnis von den Flussfunden „direkt mit dem Umfang des modernen Eingriffs in die Flußlandschaft durch den Menschen zusammen.“ (:49) Und hier könnte der Beitrag der historisch-geographischen Gewässerforschung ansetzen, denn ,zugleich müßte das methodische Instrumentarium zur Analyse der Flußfunde verfeinert werden." (:59) Für die heutigen Flussläufe ergibt sich beispielsweise aufgrund der zahlreichen Flussbettverlagerungen „die Schwierigkeit, einzeln aufgefundene Gegenstände einem Altlauf [...] zuzuweisen. So daß nur durch eine genaue topographische Analyse Klarheit über den ,Flußfundcharakter' mancher ,Einzelfunde' zu gewinnen wäre (:34,36). Durch ,Flussfundinventare' und ein ,Flussinventarkataster', das durchaus auf der Basis der in der Literatur erreichbaren Funde erstellt werden könnte, könnte eine ,Flussfundlandschaft' rekonstruiert werden, die durchaus neue Einsichten in die ehemalige symbolische, mythische oder gegenständliche Gewässernutzung erbringen wie auch die bisherigen Ergebnisse morphogenetischer Gewässerlaufänderungen verfeinern bzw. ergänzen kann.

\section{a.4 Bachbettprospektion}

Zur weiteren Forschungsmethode zur Aufdeckung gewässerhistorischer Landschaftsmerkmale gehört „die Aufnahme fossiler Bodendenkmale und alter Kulturbodenhorizonte” (FEHN 1989:10), heute als „Archäometallurgie“ (JOCKENHÖVEL 1996b) bezeichnet.

Sofern nicht durch sichtbare Relikte (Brunnen, Gräben, Teichdämme) die Lage der Gewässerwüstung angezeigt wird, kann eventuell die ,Mikroschürfung' zur Lokalisierung führen. Entsprechende Bodenuntersuchungen zur Ermittlung von zum Beispiel Flusslehm auf heute trockenen Wiesen sind mit Bohrstöcken möglich und werden als Arbeitsweise hauptsächlich von Archäologen, aber auch von Physischen Geographen (Bodenkundlern) und Landschaftsökologen generell für verschiedene Fragestellungen angewandt.

Mit der sog. Bachbettstrategraphie werden die Schichten nach Funden (Holz, Keramik) durchsucht, die z. B. einen Hinweis auf das ehemalige Vorkommen einer Wassermühle schließen lassen, wie das bei archäologischen Grabungen in Haithabu vorgenommen worden ist (SCHÖN 1995:82).

Das Profil der Probebohrungen anlässlich der ersten Flussausbauplanungen der Schwerzach beispielsweise um 1933 ließ ,auf regelmäßig bewässertes Wiesenland in früherer Zeit schließen.“ (HERBST 1987a:21) 
Mit dem Kernbohrgerät erfolgten im Jahre 1992 Untersuchungen im Bereich der wahrscheinlichen Kanaltrasse der ,fossa carolina'. Insgesamt 15 Bohrungen wurden niedergebracht. Die durchgeführten Kernbohrungen in der vorhandenen Achse der fossa dienten der Erkundung der frühmittelalterlichen Sohle. Sie ergänzten damit die kartographischen und luftbildarchäologischen Auswertungen (TRÖGL 1995:53). Um das Bild abzurunden, wurden pollenanalytische Untersuchungen der Bohrkerne durchgeführt, deren Ergebnisse ,auf ehemals größere offene Wasserflächen schließen lassen.“(:55)

Anhand der Analyse von Bachsedimenten konnten chemische Spuren des frühen Berg- und Hüttenwesens im Bachbett aufgespürt und damit frühmittelalterliche Ableitungen in Fließgewässer nachgewiesen werden, wie dies der Geograph NIEHOFF (1996) am Beispiel der Oker im Harz getan hat.

Auch JOCKENHÖVEL (1996b:18) bedient sich der „Bachprospektion“. Für ihn ist diese Prospektionsmethodik ,nach wie vor [...] die erfolgreichste“ zur Auffindung von Relikten des frühen, vorchristlichen Bergbaus bzw. der Verhüttung (Schlackenplätze). Wird ergänzend eine „flächendeckende Begehung zwischen den Bachbetten“ durchgeführt, die notwendig ist, um zu vermeiden, dass immer nur die gleiche Technologie bzw. der gleiche Zeitrahmen aufgefunden wird, werden durch sie „ca. Dreiviertel der Plätze entdeckt“ (:18).

Dieser Erfolg beruht auf der produktionsabhängigen Verbindung zwischen Gewässern und den Standorten wasserkraftgetriebener Floßöfen, sog. „Massenhütten“ (JOCKENHÖVEL 1996b:21; siehe auch V 2). „Die Verhüttungsplätze reihen sich perlschnurartig entlang der Bäche an oder liegen an Quellmulden. Nur etwa ein Zehntel zeigt keinen direkten Bezug zum Wasser.“(:18)

Aber diese Methodik hat - trotz ihrer Erfolgsaussichten - ihre Grenzen durch Störungen infolge anthropogener Eingriffe in den Gewässerlauf, wie z. B. infolge von Bachbettverlagerungen, Drainagegräben und Dammbau oder, im umgekehrten Fall, durch Verfall unter Wald (JOCKENHÖVEL 1996b:18) oder durch den Prozess der Auesedimentation: Die Eisenverhüttungsplätze sind oft ,archäologisch kaum fassbar, schon lange verschwunden oder sie liegen tief in Auen oder unter Hanglehmen begraben“"(:20).

\section{a.5 Geo- und hydromorphologische Aufnahmen}

Der Ablauf morphologischer Prozesse in historischer Zeit und die Einflüsse und Auswirkungen der Menschen auf das Gewässersystem des Neumagen kann durch geomorphologische Kartierungen und Arbeitsmethoden aufgedeckt werden. Modellhaft wendet dies Korinna THIEM (2004) in ihrer Untersuchung zu „Veränderungen an Gewässern durch historische Nutzungen im Südschwarzwald“ an. Die methodische Grundlage bildet dabei die "Geomorphologische Kartieranleitung“ nach LESER/ STÄBLEIN (1975) und die Elemente der Geoökologischen Kartieranleitung nach LESER/KLINK (1988). Ein Vorteil dieser nach dem Baukastenprinzip aufgebauten Anleitung liegt darin, dass je nach Größe Reliefformen einzeln oder als Einheit dargestellt werden können. Als Maßstab der Kartierung ist 1:25.000 geplant. Detailkartierung sollen im Maßstab von 1:5.000 erhoben werden.

Neben der Kartierung der Geomorphodynamik werden auch Geländedaten, wie Längs- und Querprofile an aktuellen und ,fossilen“ Gewässern, zur Dokumentation von Erosions- und Sedimentationsvorgängen erhoben. An repräsentativen Positionen der Gewässer, differenziert nach intensiver und schwacher Beeinflussung, wird das Längsprofil untersucht. In zeichnerischer und verbaler Form werden verschiedene Parameter der Hydromorphodynamik (Laufkrümmung, Ufererosion etc.), Eigenschaften der Sohle und des Gewässerbettes (Substrat, Tiefenvarianz, Strömungsbild etc.) sowie die Ufer- und Taleigenschaften und die umgebende Flächennutzung aufgenommen. Quantitativ werden die Auswirkungen historischer Gewässernutzungen durch Ermittlung der Anzahl der Gräben und Ausleitungen zu verschiedenen Zeitschnitten, Kartierung von Abstürzen und Stauwehren (h> 30 $\mathrm{cm}$ ) und die Ableitung eines Verbauungsindex bestimmt.

Die Ergebnisse aus der historischen Landschaftsanalyse, den Gewässeraufnahmen und der geomorphologischen Betrachtung der Talententstehung und Genese werden in einem objektbezogenen GIS 
zusammengeführt und nach naturschutzfachlichen und kulturhistorischen Aspekten ausgewertet und verwaltet. Die erhobenen Einzelelemente werden in der Datenbank nach Funktionsbereichen in sechs Kategorien: Siedlung, Landwirtschaft, Forstwirtschaft, Industrie/Bergbau, Gewerbe und Verkehr geordnet. Alter, ursprüngliche Nutzung, Nutzungswandel, Erhaltungszustand, Funktion und aktuelle Bedeutung sowie die Bewertung im Rahmen der Inventarisation werden ebenfalls festgehalten. Um weitere Elemente der Kulturlandschaft zu einem späteren Zeitpunkt hinzuzufügen, erscheint es sinnvoll, eine Einteilung nach Funktionsbereichen vorzunehmen.

\section{a.6 Vegetationskundliche Untersuchung}

Aus den Kenntnisbereichen der Landschaftsökologie lassen sich Reste ehemaliger Teiche im Landschaftsbild durch Geländebegehung rekonstruieren. Im Vegetationsbild weisen vereinzelt Flurstücke mit Bruchwald oder feuchte Wiesen mit sauren Gräsern auf mögliche einstige Teiche, Kanäle oder Wassermühlen hin.

„Frühere Mühlenstandorte verschwinden nicht plötzlich spurlos aus der Landschaft. Selbst verfüllte Wasserführungen ehemaliger Mühlen heben sich durch andersartige Boden- und Feuchtigkeitsverhältnisse und dadurch bedingten anderen Pflanzenwuchs oft bis heute deutlich aus ihrer Umgebung heraus." (GRIES 1999:117) Das Beispiel einer Sägemühle in der Eckernworth, Landkreis SoltauFallingbostel, belegt dies: „Der Mühlenteich ist im Gelände noch zu erkennen, denn die heute verlandeten Flächen sind sehr sumpfig.“ (ERLER/MATTHIESEN 1989:81)

Auch die Auswirkungen von Kanalbauten sind heute im Landschaftsbild vegetationskundlich dokumentiert. In der Landschaft begleitet zumeist eine einreihige Baumbepflanzung (die andere Seite musste als Treidelpfad freigehalten werden) die Kanaltrassen und lässt sie leicht in ihrem geraden Erscheinungsbild von einem nicht kanalisierten Gewässerverlauf unterscheiden (LORENZ 2000:12).

Des Weiteren leiten Merkmale wie Bewuchs, Quellhorizonten und Morphologie ,auch heute noch den archäologischen Prospektor, wenn er die Relikte [...] in Form von Pingen, Schächten und Stollen [...] sucht.“ (KLAPPAUF 2000:17)

\section{a.7 Luftbildinterpretation}

Die photogrammetrische Auswertung von Luftbildbildern ermöglicht die Erkennung von historischen Gewässersystemen und strukturen in der Fläche. Einige Beispiele seien dazu genannt:

In heutigen topographischen Karten werden die Altläufe der Flüsse nicht dargestellt bzw. nicht als solche gekennzeichnet. Erst im Luftbild lassen sich die ehemaligen Fließrouten im Verhältnis zur kanalisierten Wasserrinne gut erkennen (HANSEN 2000:41). Dadurch können beispielsweise siedlungsgenetische Aussagen zur ehemaligen Siedlungslage am Wasser getroffen werden, archäologische Bodenfunde als Gewässerfunde (siehe a.2) identifiziert und heute ,trockene', im Außenbereich stehende Gebäude als ehemalige wassergetriebene Mühlenstandorte lokalisiert werden.

Die Technik der photogrammetrischen Luftbildauswertung macht es des Weiteren möglich, frühere Bewässerungssysteme in der Landschaft zu rekonstruieren. Wichtigstes Rekonstruktionselement ist das Kleinrelief der Tallandschaft, das die Verteilungsmuster der Bewässerungssysteme bis heute nachzeichnet, wenn es denn auf den Luftbildern noch zu erkennen ist. Farbdifferenzierungen (hell/dunkel) auf den Luftbildern führen zu weiteren Informationen über den Verlauf der Gräben; dies auch in längst umgebrochenen Fluren. Deutlich erkennbar sind solche Geländereliefs ,,allerdings nur nach der Heuernte oder im Winter“ (TRÖGL 1995:53). Umso wichtiger deshalb ist der Zeitpunkt der Befliegung.

Das Ergebnis dieser ,Spurensuche' wird in Kartenblätter übertragen. Über Luftbildaufnahmen und deren photogrammetrische Auswertung kann so ein Kartenwerk entstehen, das das gesamte Bewässerungs- und Verteilernetz, wie es einmal in seiner größten Ausdehnung bestanden haben mag, nachbildet. LEIBUNDGUT $(1993: 15,43)$ hat mit diesem Verfahren die Rekonstruktion des Wiesenbewässerungssystems im schweizerischen Langetental durchgeführt. Die photogrammetrische 
Auswertung lieferte für seine Untersuchungen „das unentbehrliche Grundgerüst.“ (:66). Mit Ausnahme einiger Details (Seitengräben) konnte das Grabenmuster „vollständig rekonstruiert werden.“(:66)

Bei der ,fossatum magnatum', einem Kanalbauprojekt Karls des Großen, erlaubte erst eine Auswertung einer Luftbildbefliegung im Jahre 1972 „eine völlig neue Beurteilung des Werkes“ (SPINDLER 1988:64): „Die Luftbildaufnahme zeigt sicher ein rund 750 Meter langes, auf weitere rund 250 Meter mit einiger Sicherheit verfolgbares und durchschnittlich 11,5 m breites negatives Bewuchsmerkmal, das an der Kanalbiegung in Höhe der Straße Dettenheim-Grönhardt beginnt und schnurgerade in nördliche Richtung durch die feuchten Rezatauen zieht" (:64). Ein weiteres, bereits im Februar 1985 aufgenommenes, aber erst 1988 publiziertes, Luftbild ermöglicht durch das besondere Aufnahmedatum ergänzende Hinweise. Es zeigt als ,wünschenswert deutliches Schneemerkmal sogar die beiden parallel das Kanalbett nördlich der Straße Dettenheim-Grünhardt durch die Rezatauen begleitenden Wälle“"(SPINDLER 1988:65).

Durch Geländeaufnahmen wird die Luftbildauswertung verfeinert und ergänzt. Dadurch können Lücken in der photogrammetrischen Auswertung, wie z. B. durch Vegetation im Luftbild abgedeckte Gewässerabschnitte, vervollständigt und kontrolliert werden.

Des Weiteren können durch die Übereinanderschichtung von Luftbildern unterschiedlicher Aufnahmedaten verschiedene Zeitstände synchronisiert werden. Für eine solche sog. multitemporale Luftbildanalyse, „die von der Geographie [...] als Disziplin [...] methodisch herausgebildet wurde“ (SCHLOTTAU 1998:26), müssen bei den entsprechenden Firmen (z. B. Hansa-Luftbild/Münster) oder dem Bundesamt für Kartographie alle Luftbildchronologien des Untersuchungsgebietes beschafft werden.

\section{a.8 Vermessung}

Die vermessungstechnische Aufnahme eines Gewässerlaufes und deren technische Bestandteile schaffen die Grundlage in den Fällen, in denen eine punkt- und höhengenaue Geländeaufnahme detailliert gewünscht wird oder eine topographische Kartengrundlage nicht mehr vorhanden ist bzw. mit dieser abgeglichen werden soll.

Die Vermessung von morphologischen Kleinformen einer, wüsten' Gewässerlandschaft ermöglicht beispielsweise die flächengenaue Rekonstruktion von Gewässerrelikten. Über das Einlesen der Vermessungspunkte in ein CAD/GIS-System (siehe Pkt. a10) können digitale Geländemodelle (DGM) oder 3-D-Visualisierungen ehemaliger Gewässerlandschaften erzeugt werden.

Ein Beispiel dafür ist die vermessungstechnische Aufnahme des extramonasterischen Klosterteichareals des ehemaligen Zisterzienserklosters Heisterbachtal im Siebengebirge, die im Rahmen einer Projektarbeit durchgeführt worden ist (siehe Pkt. IX 1a). Eine vermessungstechnische Aufnahme hat ebenfalls die historische Geographin DENZER mit Studierenden der Universität Mainz im Frühjahr und Herbst 1990/91 durchgeführt und dabei Gewässerrelikte wie Dämme, Floßkanal, Be- und Entwässerungsgräben, Quellfassungen und Bachübergänge aufgenommen. 


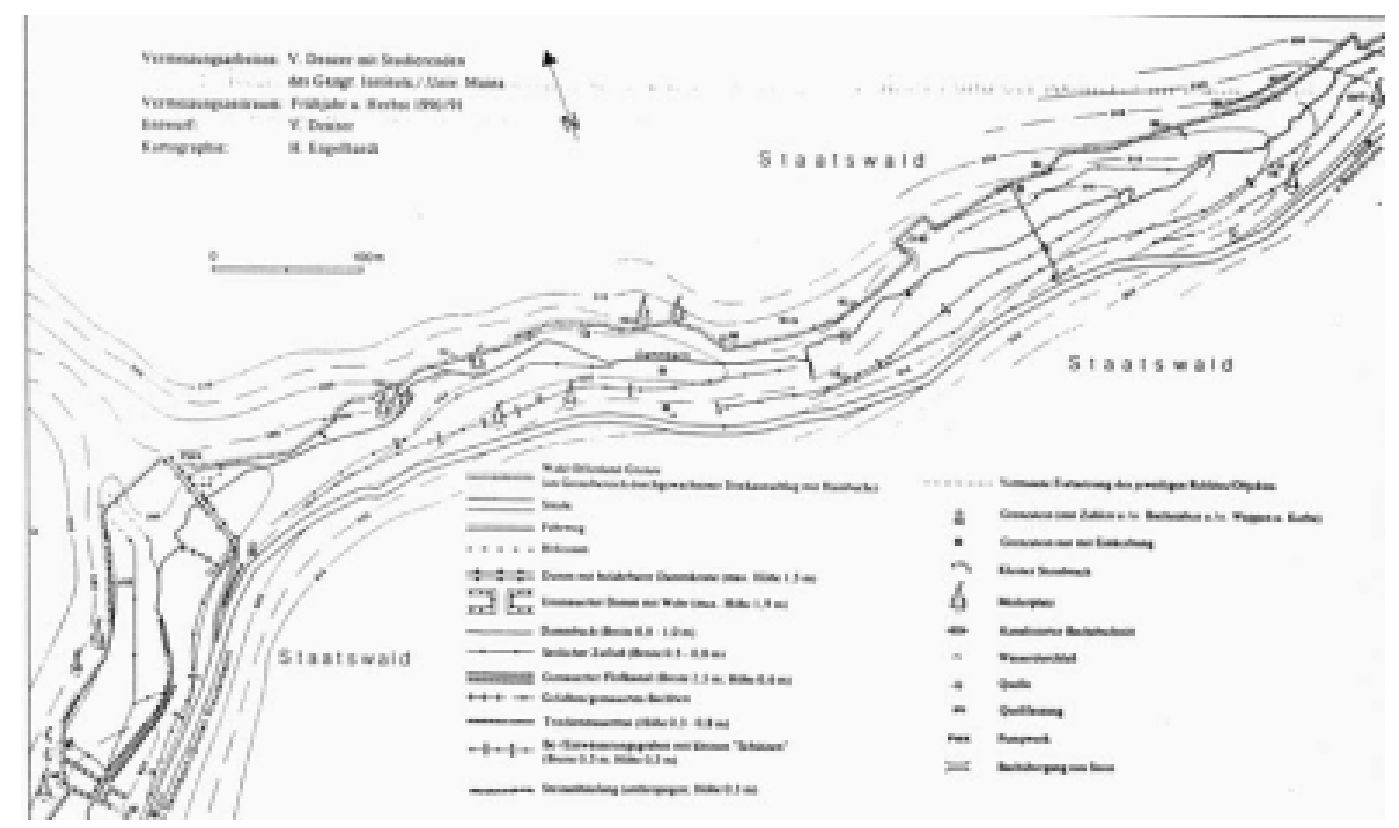

Abb. III-12: Vermessungstechnische Aufnahme eines Teilstücks des Dammbachs zwischen Rohrbrunn und Krausenbach im Spessart unter der Aufgabenstellung: „Relikte der Wiesenbewässerung und -entwässerung, der Holztrift und der Köhlerei im Dammbachtal (Gemarkung Krausenbach, TK 6122 Bischbrunn)“ (DENZER 1996, Abb. 74)

Des Weiteren sind ,Architekturmessungen' an technischen Anlagen (Stauwehr) und Gebäuden (Mühlen) möglich. Mit einer entsprechend ausgestatteten Gitternetzkamera und einer besonderen Bildaufmaßsoftware lassen sich die Gegenstände maßstabsgerecht entzerren und dreidimensional visualisieren. Es wird ein Bildplan projiziert, der den Abgriff von Flächen- und Flächenmaßen ermöglicht. Typisches Einsatzfeld ist zwar das Fassadenaufmaß, aber auch die Dokumentation von historisch-technischen Gewässerartefakten (Wehre, Schleusen) ließe sich damit bewerkstelligen.

Als Grundlage dienen ein digitales oder eingescanntes Foto sowie Referenzinformationen von dem zu erfassenden Objekt. Anhand dieser Referenzmesswerte ist ein solches Programm in der Lage, die perspektivische Verzerrung im Bild zu bestimmen und zu korrigieren. Zur Bestimmung der Referenzinformationen gibt es zwei Wege: Entweder werden tachymetrisch Passpunkte am Objekt eingemessen oder aber Passstrecken festgelegt. Die Entzerrung nach Passpunkten eignet sich vor allem für professionelle Vermessungsanwendungen mit höheren Genauigkeitsanforderungen. Die Entzerrung nach Passstrecken und Objektgeometrie ist für Anwender ohne Tachymeter gedacht, da lediglich ein Messband oder ein Handlaser für das Aufmaß benötigt wird.

Die computergestütze Vermessung der ,Kehrradstube', der ehemaligen Grube Samson in St. Andreasberg im Harz, stellt ein solches Rekonstruktionsbeispiel einer originalgetreuen Bergwerksanlage dar: „Die Geometrie der Kehrradstube und des Rades wurde eingemessen und [...] in drei Ansichten dargestellt. Es handelt sich um Daten einer computergestützten Vermessung, bei der mit Theodolit und Laserentfernungsmesser [...] die Objekte online vom Rechner aufgezeichnet und visualisiert werden." (BALCK 1999:53)

Aufgrund des Aufwandes stellen sie aber sicher die Ausnahme einer gewässerhistorischen Inventarisierung und Rekonstruktion dar.

\section{a.9 Historische Kartographie}

Die hier verwendete Überschrift ist in einer geographischen Arbeit irreführend. „Historiker verstehen unter ,historischer Kartographie' nicht die Geschichte der Kartographie, wie das die Geographen des öfteren tun, sondern das Erstellen neuer Karten mit historischen Themen." (KUNZ 1999:48) Diese Definition soll auch hier übernommen und erweitert werden um den Einsatz digitaler Medien. 
Um die Inhalte und Arbeitsweisen der historischen Kartographie und gleichzeitig die sich hieraus ergebenden Möglichkeiten für die gewässerhistorisch-geographische Forschung zu verdeutlichen, sei eine diesbezügliche Arbeit mit einer anders lautenden thematischen Schwerpunktsetzung vorgestellt. Einen Atlas zur Verkehrsgeschichte Deutschlands und angrenzender Länder hat Andreas KUNZ vorgelegt: „Ziel des Projektes ist die Erstellung eines computergestützten Atlas zur Entwicklung der mitteleuropäischen Verkehrsnetze sowie einer CD-ROM Edition des Atlas auf der Basis von (elektronisch erstellten) Karten, Texten und Grafiken bzw. Illustrationen und ggf. Animationen.“ (1999:51)

Der Atlas gliedert sich in zwei Teile: Teil 1 behandelt das 19. Jh. (1815-1918) und Teil 2 das 20. Jh. (1919 - 2000). Inhaltlicher Schwerpunkt von Teil 1 ist u. a. „der Ausbau vorindustrieller binnenländischer Verkehrswege“, zu denen neben dem Chausseebau auch der Fluss- und Kanalbau zählt (KUNZ 1999:52). So wird der Ausbau des Wasserstraßennetzes des sog. nordwestdeutschen Kanalgebietes abgebildet. Zugleich wurden die Veränderungen kartographisch erfasst, wie zum Beispiel die Ausbaustufen der Schifffahrtsstraßen, die mit dem Bau von Kanälen im Gebiet zwischen Ems und Weser im Zeitraum 1874 - 1914 einhergingen (:56).

Die bedeutendste Quellengattung aber, auch die - logischerweise - einer , historischen Kartographie', stellt die Auswertung alter Kartenquellen dar, die für eine digitale Kartographie erst entsprechend aufbereitet bzw. neu erstellt werden müssen, weil digitale historische Karten im Allgemeinen, bis auf einige bekannte Kartenwerke, (noch) nicht bei privaten Dienstleistern bzw. den Landesvermessungsämtern erhältlich sind. Die Verfügbarkeit von digitalen Karten in Form von Vektorgeometrien als Arbeitsgrundlage für die historisch-thematische Kartographie ,stellt zweifellos das größte Problem dar.“ (EBELING 1999:7) Zwar sind in einzelnen, meist räumlich begrenzten, Projekten bereits eine Reihe solcher digitaler Karten erarbeitet worden, „es fehlt allerdings bislang eine koordinierte Dokumentation, Vereinheitlichung und Bereithaltung" (:7).

Um die thematische Kartographie als Arbeitsinstrument für den gewässerhistorischen Themen- und Zeitbereich einsetzen zu können, bedarf es nicht nur der Sammlung, sondern darüber hinaus der gezielten Erarbeitung von Vektorgeometrien, insbesondere in Hinblick auf ein zeitliches und räumliches Angebot solcher Grundlagen für gewässerhistorische Raumeinheiten (Gewässernetz). Da ein solches Angebot aber bislang noch nicht vorliegt, müssen die Ungenauigkeiten alter Kartenwerke, die durch ungenaue Vermessungs- und Übertragungsverfahren bei der analogen Altkartenherstellung, aber auch aus aktuellen Gründen wie Papierverzug und Verkanten beim Scannen entstehen, dadurch behoben werden, dass sie erst neu erstellt werden. Um sie also für die Erfassung von Vektordaten, d. h. für Digitalisierungsaufgaben, vorzubereiten, müssen sie lagegetreu positioniert werden. Kartenverzerrungen können bei digitalen Rasterkarten mit softwaretechnischen Mitteln rektifiziert werden. Diese Georeferenzierung erfolgt über bekannte Passpunkte (Kontrollpunkte) bekannter Positionsdaten. Altkarten können jedoch nur begrenzt auf einen Restfehler hin minimiert werden.

Es ist, wie EBELING (1999:8) es formuliert, ein „digitales Zeitalter zur Erforschung historischer Raumstrukturen“ angebrochen. Notwendig sind hierfür „vor allem zeitdynamische Karten, um historische Prozesse im Raum abbilden zu können, und die Entwicklung eines entsprechenden georelationalen Datenbanksystems.“ Und diese Verknüpfung von Kartographie und raumbezogenen Daten führt zu einem „Historischen GIS““

\section{a.10 Historisches GIS}

„Die Geographie als integrative und interdisziplinäre Wissenschaft findet in der Geographischen Informationsverarbeitung ihr adäquates Software-Werkzeug.“ (KAPPAS 2001:10). Geographische Informationssysteme stellen dabei „immer wichtigere Hilfsmittel für wissenschaftliche Fragestellungen nicht nur in der physischen wie auch in der Humangeographie" dar (BRASSEL et al. 1998:45), sondern gewinnen auch in der historisch-geographischen Umweltforschung immer stärker an Bedeutung. 
Durch sein Handeln gestaltet und prägt der Mensch seit Jahrhunderten das Aussehen der ihn umgebenden Landschaft. Die Spuren dieser menschlichen Aktivitäten sind Zeugnisse unseres kulturellen Erbes. Zunehmend gewinnen solche Zeugnisse der Vergangenheit in der Dokumentation und Analyse von Planungsvorgängen vermehrt Einfluss, um zu identitätssichernden und zugleich zukunftsgerichteten Lösungen zu kommen. Der Einsatz eines Geoinformationssystems (GIS) ${ }^{10}$ kann dazu beitragen die Archivierung von Datenbeständen, die Dokumentation von Prozessen sowie die Bearbeitung von kulturhistorischen Fragestellungen hinsichtlich ihrer raum-zeitlichen Zusammenhänge zu vereinfachen. Eine kulturhistorische Fragestellung erfordert eine speziell angepasste Systemumgebung eines temporalen GIS, in dem der Raumbezug um die zeitliche Komponente erweitert und im Idealfall ein 4D-Raum aufgespannt wird.

Eine solche Arbeit liegt für die historisch-geographische Gewässerforschung meines Wissens noch nicht vor, aber die sich aus der zeitlichen Dimension ergebenden Veränderungen des Erscheinungsbildes einer Kulturlandschaft kann am Beispiel einer forsthistorischen Arbeit verdeutlicht werden.

KNAUFT (2000) hat in seiner Dissertation die fortschreitende Sukzession einer Waldlandschaft dargestellt und illustriert, um eine realistische Darstellung zu erreichen.

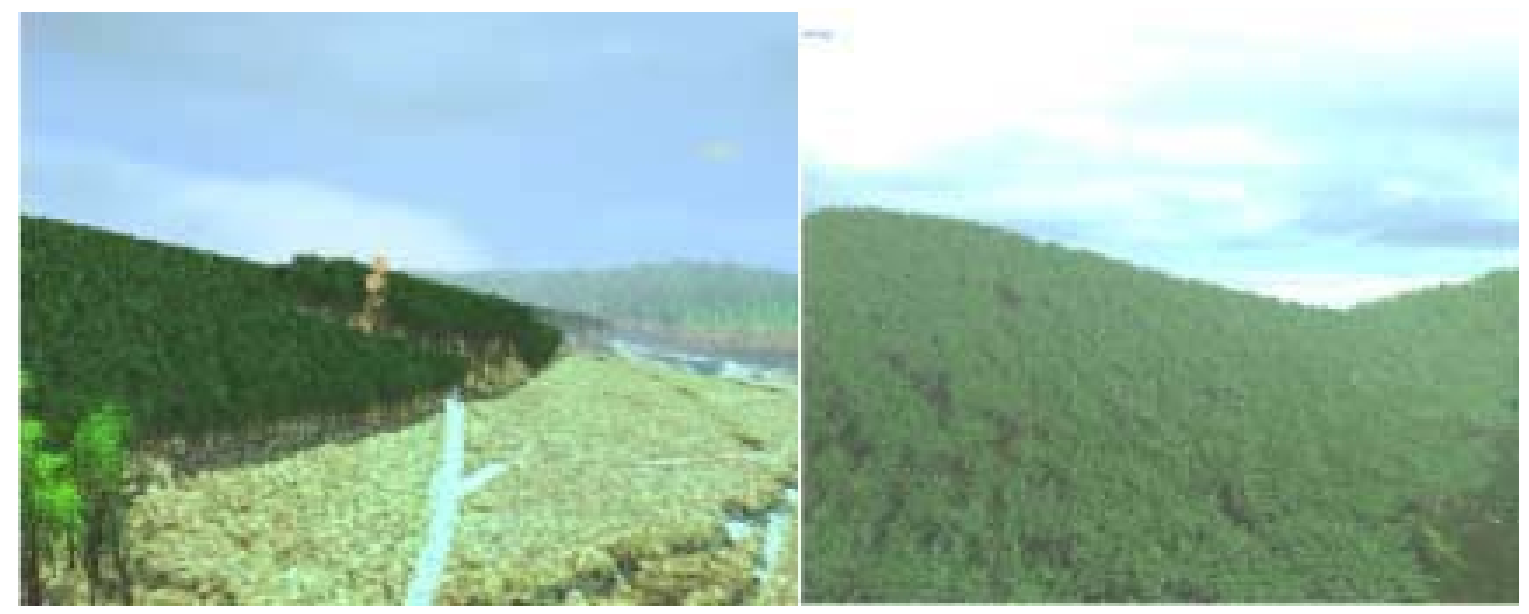

Abb. III-13: Modellierte Darstellung einer Waldlandschaft

am Beispiel des Erlebniswaldgeländes Schönhagen/Uslar unter der aktuellen Bewirtschaftung (links) und der potenziell natürlichen Waldgesellschaft (rechts) (KNAUFT 2000:82)

Die Darstellung dieses Szenarios erfolgte über das Geländemodell, welches bereits zur Visualisierung der Waldlandschaft herangezogen wurde. Die unterschiedliche Bewirtschaftungsintensität der beiden Wiesenabschnitte illustriert unterschiedlicher Grasbewuchs. Als Szenenhintergrund wurde eine Fotografie des realen Bestandsrandes eingefügt. Während sich die Baumgrößen und -verteilungen der ersten Szene am aktuellen Zustand der Fläche orientieren, ist der Entwicklungszustand der zweiten Szene eher hypothetischer Natur, soll sie doch in diesem Fall primär der Veranschaulichung einer solchen Entwicklung dienen und die Applikationsfähigkeit für die Darstellung solcher Sukzessionsszenarien deutlich machen (KNAUFT 2000:82). Schließlich erfolgt eine Illustration der Sukzession

\footnotetext{
${ }^{10}$ Geographische Informationssysteme nach der Definition von KAPPAS (2001:44), „dienen in ihren Grundfunktionen der Erfassung, Verarbeitung und der Analyse von raumbezogenen Daten. Sie fungieren somit im weitesten Sinne als Werkzeug für Raumuntersuchungen.“ Für DE LANGE (2002:310, ebenso:3) handelt es sich bei einem Geoinformationssystem um „ein rechnergestütztes System, das aus Hardware, Software, Daten und den Anwendungen besteht“ und mit dem „raumbezogene Daten digital erfasst, gespeichert, verwaltet, aktualisiert, analysiert und modelliert sowie alphanumerisch und graphisch präsentiert werden können“".

DE LANGE (2002:1) ordnet den Begriff „GIS“ der „Geoinformatik“, als jüngsten Bezeichnung, unter und sieht „GIS“ als einen, wenn auch als den zentralen Teilbereich der Geoinformatik an (:4). Geoinformatik ist nach seiner Auffassung „mehr als ein GIS“ (:3) und hebt in seiner Definition insbesondere die Nähe zur Informatik hervor: „Die Geoinformatik widmet sich der Entwicklung und Anwendung von Methoden und Konzepten der Informatik zur Lösung raumbezogener Fragestellungen unter besonderer Berücksichtigung des räumlichen Bezugs von Informationen. Die Geoinformatik beschäftigt sich mit der Aufbereitung und vor allem mit der Analyse sowie mit der Präsentation und der Verbreitung von Geodaten." (:4). Bei näherer Beschäftigung mit dieser Thematik ist insbesondere auf Kap. 9 „Geoinformationssysteme“(:309-354)zu verweisen.
} 
einer ungemähten Wiese. Neben dem aktuellen Zustand wird eine Prognose über die erfolgte Wiederbewaldung nach 10 Jahren dargestellt (:93).

An diesem Beispiel wird die Notwendigkeit für die Modellierung und hochdetaillierte Visualisierung von Waldlandschaften ersichtlich, die für eine historische Gewässerlandschaft insofern übertragen werden kann, als dass mit einer visuellen Rekonstruktion ein kulturhistorisches Gewässerbild über dem der heutigen ,trockenen' Kulturlandschaft erkennbar wird und die weitere Entwicklung aufgrund der Überformung im Verlauf einer Sukzession, die sich ohne pflegenden Eingriff des Menschen in einem absehbaren Zeitraum einstellen würde, darstellbar ist.

Im Historischen GIS werden also speziell historisch relevante Daten zusammen mit aktuellen Daten erfasst. Diese werden soweit wie möglich verortet und zeitlich eingeordnet. Die breiten Analyse- und Auskunftsmöglichkeiten, wie z. B. die Visualisierung von Entwicklungen in der Region, werden im kulturhistorischen GIS zusätzlich durch materiell nicht erfassbare Ereignisse, Begebenheiten bzw. Objekte erweitert. Ein kulturhistorisches GIS ermöglicht verschiedene Nutzungsmöglichkeiten im Denkmalschutz, bei der Heimatpflege, in verschiedenen Planungsverfahren, in der Bildungsarbeit und im Tourismus.

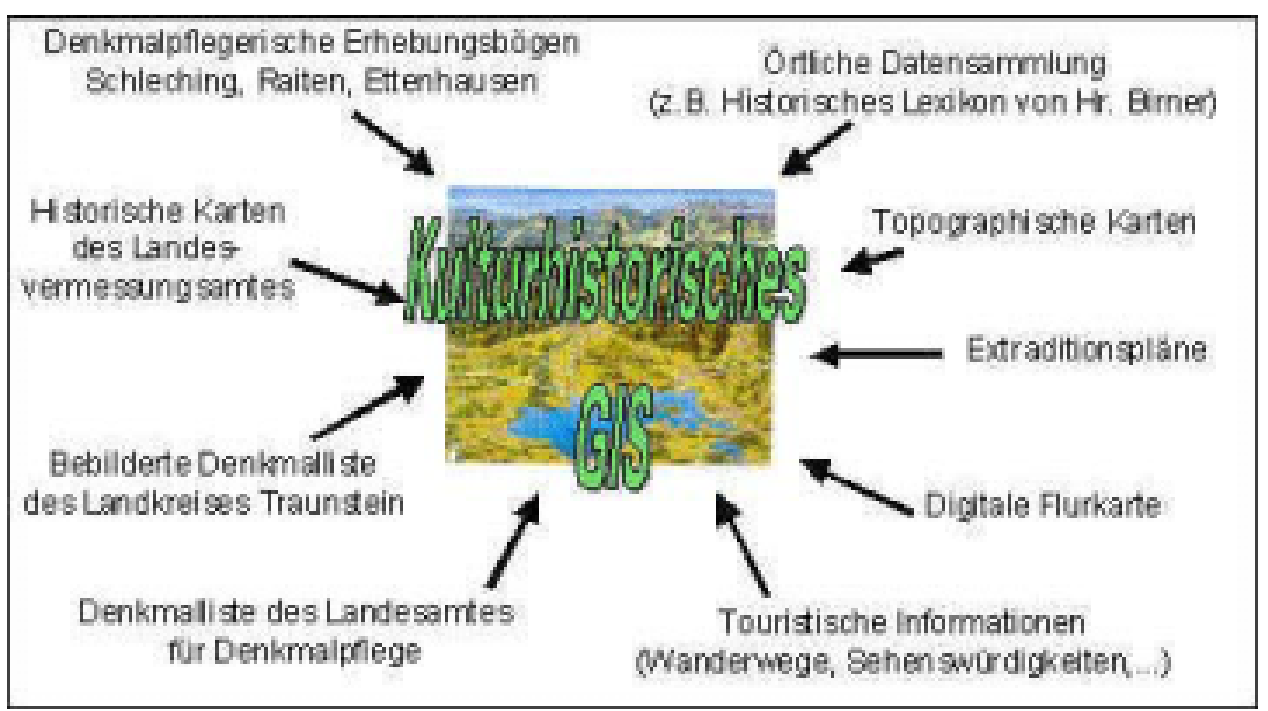

Abb. III-14: Mögliche Datenquellen für ein kulturhistorisches GIS

(Quelle: TU München, Institut für Geodäsie, GIS und Landmanagement Fachgebiet Geoinformationssysteme)

Unter einem kulturhistorischen Gewässer-GIS ist daraus folgend zum einen die Gewässerplanerstellung mit einer konstruktiven GIS-Software zu verstehen. Die einzelnen gewässerhistorischen Kulturlandschaftselemente sind hierbei als einzelne GIS-Objekte zu erfassen, d. h. einzulesen bzw. zu digitalisieren, und nach einem vorher festgelegten Ebenenkonzept auf jeweils einzelnen GIS-Ebenen (Layer) abzulegen. Eventuell wird der Zeichnung ein Pixelbild (Luftbild, Fotografie) hinterlegt.

Zum anderen beinhaltet ein solches Verfahren die Datenanbindung an ein Datenbanksystem. Die als Vektor- oder Rasterdaten vorliegenden historisch-kartographischen Gewässerinformationen werden mit einer internen, besser noch mit einer externen Datenbank verknüpft bzw. dort ablegt, die die gewässerspezifischen historischen Sach- und auch Geometriedaten (z. B. wie im DB-System ORACLE 9i) in einem vorgegebenen Datenschema verwaltet. Dies ist insofern von Vorteil, dass die komplexe Gewässerlandschaft aus optisch wahrnehmbaren Punktelementen, verbindenden Linienelementen und zusammenfassenden sowie zusammengehörigen Flächenelementen besteht (vgl. PLÖGER 1999:9).

In historisch-geographischer Betrachtungsweise ergibt sich eine solche formale Einordnung von Kulturlandschaftselementen ,aus einem funktionalen Zusammenhang und abhängig von einer thematischen sowie maßstäblichen Bearbeitungsebene. [...] Diese Sichtweise der Historischen Geographie, Objekte der realen Welt als ,diskrete' punktförmige, linien- und flächenhafte Kulturland- 
schaftselemente aufzufassen, ist Ansatz für eine modellhafte Beschreibung der Kulturlandschaft in einem Geographischen Informationssystem (GIS) für historisch-geographische Aufgabenstellungen.“ (:9, Hervorhebung im Original) Dies ist auch bei gewässerhistorisch-geographischen Aufgabenstellungen zu beachten: „Einen kleinen Fischteich wird man als Kulturlandschaftselement funktional zwar als Punktelement ansprechen, bei größeren Maßstäben und in Beziehung zu benachbarten Nutzungsflächen aber als Gewässerfläche berücksichtigen und daher im GIS als Flächenelement ansprechen." (:10)

Um diesen Schwierigkeiten zu begegnen, empfiehlt PLÖGER für eine Kulturlandschaftsgliederung in einem GIS ein hierarchisches Modell mit zwei Gliederungsebenen: In einer untersten Gliederungsebene werden Kulturlandschaftsbestandteile, d. h. die Kulturlandschaftselemente als die sozusagen ,kleinsten Bausteine', aus denen sich aufgrund räumlicher Beziehungen und zugeschriebener Merkmale (Sachdaten) Muster, Strukturen und Gefüge als weitere Kulturlandschaftsbestandteile zusammensetzen, als Punkt-, Linien- und Flächenelemente beschrieben. Auf einer nächst höheren Gliederungsebene werden Kulturlandschaftsbereiche ,als Komplexe von funktional zusammenhängenden und miteinander räumlich verbundenen Kulturlandschaftsbestandteilen definiert“ (1999:11). Dabei versteht PLÖGER Kulturlandschaftsbereiche als „Flächenelemente, die im GIS als analytisches Ergebnis in idealer Weise durch Verbindung aller innerhalb ihrer jeweiligen Grenzen liegenden Flächen der unterhalb liegenden Ebene gebildet werden.“ (:11)

Die gewässerhistorischen Kulturlandschaftselemente (z. B. Stauschütze) und -flächen (z. B. Mühlenteich) und deren zugeordnete Merkmale müssen als Sachdaten deshalb eindeutig an ein ,individuelles' GIS-Objekt (Datensatz) gebunden sein. „In historisch-geographischer Sicht sind für Kulturlandschaftselemente und -bereiche die Merkmale Zeitstellung, Funktion und Erscheinungsbild von zentraler Bedeutung" (PLÖGER 1999:12). So ist die Zuordnung von Kulturlandschaftselementen zu bestimmten Funktionsbereichen nicht immer eindeutig: zum Beispiel, ob ein Schifffahrtskanal als Gewässer oder Verkehrsweg angesprochen werden soll (:13).

Zugrunde gelegt werden Dateien relationaler Datenbanken, deren Datensätze über ein Schlüsselfeld den entsprechenden Objektgeometrien eindeutig zugeordnet werden. Spezifisch gewässerthematisch orientierte Fragestellungen wie z. B. zur Gewässerreliktkartierung, zu persistenten oder verschwundenen Gewässerobjekten können damit beantwortet werden (vgl. PLÖGER 1999:16).

Zur Verdeutlichung: Die Wasserflächen im Bereich der Klosterteiche X haben sich seit Beginn der kartographischen Aufnahme im 19. Jh. durch Ausbau von Y und Eingriffe von Z ständig verringert. Die gewässerhistorische Karte bilanziert den Wandel von Wasserflächen zu definierten Zeitschichten durch Abfragen nach Zeitstellung und Funktionswandel.

Daraus erwächst eine GIS-gestützte multitemporale Flächennutzungskartierung zur Darstellung des flächenhaften Wandels von Gewässerlandschaften von in verschiedenen zeitlichen Querschnitten, „wobei über das GIS abgefragt werden kann, entweder welche einzelne Fläche oder welcher Flächenanteil sich zwischen beliebigen Zeitschnitten der Altkarten wie oft geändert hat, oder die rein dynamische Darstellung von Flächenänderungen im Sinne einer Kulturlandschaftswandelkarte" (SCHERER-HALL 1998:367).

Moderne Geoinformationssysteme, dies lässt sich zusammenfassend betrachten, bieten variable Möglichkeiten zur zeitgeschichtlichen Wiedergabe und zur Erstellung von datenbankgebundenen Übersichts- und Detailkarten. Die verschiedenen traditionellen kartographischen Betrachtungsansätze der Historischen Geographie (retrospektiv ${ }^{11}$, topographisch-genetisch ${ }^{12}$ ) lassen sich somit vorteilhaft

\footnotetext{
${ }^{11}$ Mit Hilfe der retrospektiven oder reduktiven Methode (JÄGER 1973:12) werden Struktur, Form und Funktion schrittweise in die Vergangenheit zurückverfolgt, um sie so zugleich aus ihr abzuleiten. „Die Rückschreibungsmethode, eine reduktive Methode, macht sich die Tatsache zunutze, daß Veränderungen des Besitzgefüges [...] oft nicht von entsprechenden Veränderungen der steuerrechtlichen Einheiten begleitet sind. Aus den in alten Besitzverzeichnissen (Flurbuch, Lagerbuch, Urbar, Salbuch) aufgelisteten Zugehörigkeiten der Parzellen zu Betrieben und steuerrechtlichen Einheiten, also deren rechtlicher Charakterisierung, lassen sich ältere Besitzeinheiten durch schrittweises Zurückverfolgen rekonstruieren." (LIENAU 1995:159)
} 
visualisieren und schließlich auch - möglichst unter Hinzuziehung einer entsprechenden Softwaremoduls - als dreidimensionale historische Geländeaufnahmen realisieren.

„Geographische Informationssysteme“, das ist für BRASSEL et al. (1998:48) klar, „lösen vermehrt die Karte ab". Die Gründe dafür liegen nicht nur in der leichteren Änderbarkeit von Zeichnungen und in den variantenreicheren Möglichkeiten der Darstellung, sondern das Denken in globaler Dimension verlangt nach weltweiten und immer detailreicheren Daten, und auch die Koordination die Aktivitäten einzelner von Gewässern in ihren Aufgabenbereichen berührten Ämtern (Wasser-, Denkmal-, Umwelt- und Naturschutz, Forst, Raumplanung usw.) und Institutionen (Landschaftsverbände, Landesämter für Ökologie und Naturschutz etc.) spricht für eine Vernetzung der Systeme (:48).

„Mit der Perfektionierung der technischen Komponenten“, resümieren BRASSEL et al. (1998:49) die Entwicklung, ,hat unter den Geographinnen und Geographen im GIS-Bereich eine eigentliche Rückbesinnung auf ihre Kernaufgaben stattgefunden. So wird [...] die räumliche Analyse mit neuen Mitteln als zentrale Aufgabe betrachtet." Einige Geographen haben sich dieser neuen Aufgabe aus dem Untersuchungs- und Darstellungsbereich ,Gewässergeschichte' bereits angenommen.

Für den Bereich eines anwendungsorientierten historisch-geographischen Gewässer-IS kann die industriearchäologische Relikt-Untersuchung der Stecknitzfahrt von Götz GOLDAMMER als Beispiel angeführt werden. GOLDAMMER (2001:153, Hervorhebung im Original) versucht nach eigener Darstellung „erstmals, die wenigen erhaltenen Relikte des Stecknitzkanals übersichtlich in tabellarischer und kartographischer Form darzustellen. Dieses Kataster einer historischen Kanallandschaft verdeutlicht den starken Rückgang der Kanalbauwerke der Stecknitzfahrt. Das Kataster soll den entsprechenden zukünftigen Planwerken (z. B. Landschaftsplänen oder Umweltverträglichkeitsprüfungen) dazu dienen, den vollständigen Verlust dieser ehemals so bedeutsamen Wasserstraße zu verhindern. "Für die katastermäßige Erfassung unterteilte GOLDAMMER die Relikte des Stecknitzkanals in drei Hauptgruppen: Als erste Gruppe die Kanalbauwerke und -einrichtungen (Schleusen- und Brückenbauwerke sowie die Schleusenmeisterhäuser des Kanals), als zweite Gruppe die Kanaltrassenrelikte (Reste des Stecknitzkanalbettes) und als dritte Gruppe ausgewählte Relikte des Amtes der Stecknitzfahrer.

Anknüpfend an das 1990 - 1993 erstellte und neu überarbeitete Fließgewässerschutzkonzept von Niedersachsen (siehe RASPER et al. 1991) wurde für drei ausgewählte Teilbereiches eines Fließgewässereinzugsgebietes - das Einzugsgebiet der Hache, einem typischen Geestfluss in der sog. ,EmsHunte-Geest und Dümmer-Geestniederung' ein ,Digitales Gewässerkataster' erstellt, dessen Katasterdaten digital erfasst, ausgewertet und mit Computerkarten dargestellt werden. Das Kataster enthält alle gewässerrelevanten Parameter, die für Gewässermonitoring, Gewässerbeurteilung, Gewässerschutz und für naturnahe Planungen an Gewässern relevant sind. Daten zu folgenden Hauptparametergruppen wurden im Gewässerkataster erfasst: Einzugsparameter, Gerinneparameter, Wasserparameter (SCHIERBLING 1993:136). Bereits erfasste Daten verschiedener Landesämter (hydrologische und hydrochemische Daten, Daten des Landesamtes für Bodenforschung, Biotopkartierungen u. a.) wurden durch erweiterte Messreihen (Abflussmessungen, Wasserinhaltsanalysen, Kartierungen usw.) sowie Fernerkundungsdaten (LANDSAT-Aufnahmen und CIR-Luftbilder) ergänzt. Die Bildanalyse wurde durch Geländeaufnahmen nach den Methoden der Biotop-, Nutzungsund Gewässerkartierung mit Elementen der geomorphologischen Detailkartierung und der geoökologischen Kartierung verknüpft. Die so entstandene relationale Datenbank (dBase) floss in ein Geoinformationssystem ein (ArvInfo), „,dessen Auswertemöglichkeiten in bezug auf die ökologische Beurteilung von Fließgewässern und als Entscheidungshilfe bei künftigen Planungsvorhaben aufgezeigt werden sollten.“ (SCHIERBLING 1993:136)

\footnotetext{
${ }^{12}$ Die topographisch-genetische Methode (z. B. MÜLLER-WILLE 1944, HAMBLOCH 1960) bezeichnet eine Methode, bei der man, vom Zustand einer Siedlung ausgehend, wie er z. B. in der Urkatasterkarte dargestellt ist, deren Genese Schicht für Schicht unter Einbeziehung der Lage der Höfe und Parzellen, der Besitzverteilung, Flurnamen, Bodenuntersuchungen und Urkunden zu erklären sucht (LIENAU 1995:160).
} 
Schließlich gilt es noch, eine, wenn auch thematisch andersartige, GIS-Anwendung vorzustellen, die aufgrund ihres auf Gewässer übertragbaren historischen Modellcharakters und ihrer Aktualität ihre Berechtigung erfährt.

Seit Sommer 1999 wird an der TU München (TUM), Fachgebiet Geoinformationssysteme, gemeinsam mit dem Lehrstuhl für Bodenordnung und Landentwicklung, jährlich ein Projektseminar mit dem Titel „GIS-Einsatz in der Ländlichen Entwicklung" durchgeführt. Im Projektseminar und in Diplomarbeiten ${ }^{13}$ wurden die Möglichkeiten des Einsatzes von Geoinformationssystemen für historische bzw. touristische Anwendungen untersucht und ein Datenmodell für die Anwendung „Kulturhistorisches GIS“ entwickelt und in das Datenbanksystem von Oracle implementiert. Darauf aufbauend erhielt die TUM den Auftrag einer Projektstudie zum Aufbau eines Geoinformationssystems als Beitrag der Entwicklung ländlicher Gemeinden, um die prototypische Realisierung eines gemeindlichen GIS, insbesondere für die Anwendungen ,Ökokonten' und ,Kulturhistorie' unter Einbezug des Dienstleistungsangebots der Verwaltung, zu erarbeiten. Das Forschungsprojekt startete im Februar 2002 und gliedert sich in die beiden Teilbereiche ,Studie' und ,GIS-Realisierung'. Als Beispielkommune wurde die Achentalgemeinden der Gemeinde Schleching ausgewählt.

Ein Schwerpunkt des Projektes ist es, eine prototypische GIS-Umgebung für Gemeinden des Achentals für den Einsatz von Planungsaufgaben sowie unter besonderer Berücksichtigung von ,Tradition', ,Historie' und ,Kultur' aufzubauen. Am Beispiel der von Landwirtschaft und Tourismus geprägten, ländlich strukturierten Achentalgemeinden mit geringen Einwohnerzahlen $(<6.500)$ sollen zwei neue GIS-Anwendungsgebiete einerseits im Bereich der Eingriffs- und Ausgleichsplanungen und andererseits für die Dokumentation und Auswertung kulturhistorischer Fragestellungen erprobt werden. Als ein möglicher Beitrag der ländlichen Entwicklung zum Aufbau von Gemeinde-GIS wird das Datenangebot und die Datenqualität der digitalen Planungsdaten aus den Verfahren der Dorferneuerung untersucht. Durch die prototypische Umsetzung soll die technische Machbarkeit, der Aufwand sowie der Nutzen und der Mehrwert durch Kombination der in einer Vielzahl verfügbaren digitalen Planungsdaten in einem Gemeinde-GIS auf der Grundlage von Basis- und Fachdaten aus den Verfahren der ländlichen Entwicklung evaluiert werden.

Ein EDV-gestütztes Kataster historischer Kulturlandschaftselemente (KLEKs = Kulturlandschaftselementekataster) in der Planungsregion „Mecklenburgische Seenplatte“ hat auch die Fachhochschule Neubrandenburg entwickelt (siehe Abb III-15). Es geht dabei um die „Erarbeitung der inhaltlichen, methodischen und technischen Grundlagen für ein EDV-gestütztes Kataster historischer Kulturlandschaften und die Entwicklung einer entsprechenden lauffähigen Softwareumgebung, die Dateneinspeisung durch eigene Erhebungen historischer Kulturlandschaftselemente in der Planungsregion Mecklenburgische Seenplatte sowie die Integration von Daten verschiedener Inventare“ (BEHRENS/VETTER 2001:VI; ebenso BENDER et al. 2001:63ff.). Des Weiteren katastriert der Niedersächsische Heimatbund historische Kulturlandschaftselemente mit Hilfe ehrenamtlicher Mitarbeiter und möchte sie in ein GIS überführen (WIEGAND 2001:21).

\footnotetext{
${ }^{13}$ Diplomarbeiten: „Bestandsaufnahme und Anforderungsanalyse für ein grenzüberschreitendes historisches GIS“ (2000); „Ökokonto - Modellierung und prototypische Umsetzung einer Datenbanklösung“ (2000); „Entwicklung eines objektrelationalen Datenmodells für ein kulturhistorisches Geoinformationssystem“ (2001).

In Bearbeitung ist des Weiteren eine Dissertation von Katrin HOSSE: „GIS-Einsatz in ländlichen Gemeinden des Achentals Anwendungsmöglichkeiten und Realisierbarkeit. Aufbau eines GIS in der Ländlichen Entwicklung für die Historische Kulturlandschaft des Achentals“ (Arbeitstitel)
} 


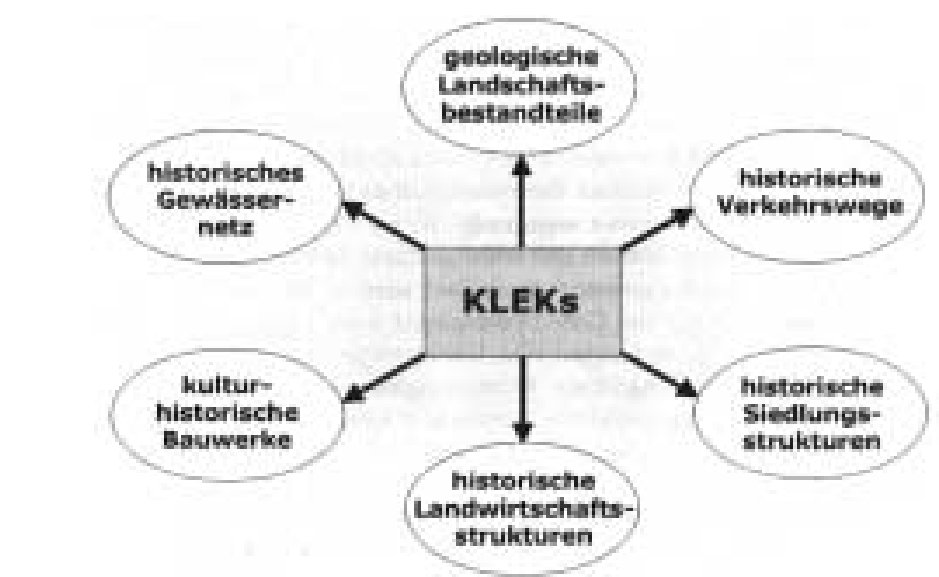

Abb. III-15: Mögliche Themenbereiche als Ergebnis des KLEKs.

Man beachte den „Qutput-Bereich“ „historisches Gewässernetz“ (aus: BENDER/VETTER 2001:65).

Mit inhaltlichen und methodischen Aspekten für ein Kataster historischer Kulturlandschaftselemente mit Hilfe von Erfassungsbögen auf der Kartengrundlage TK 25 setzten sich vor allem WÖBSE (1991, 1994), SCHERER-HALL (1996), QUASTEN (1997) sowie BURGGRAAFF/KLEEFELD 1998 auseinander.

Dennoch gibt es aufgrund der festzustellenden Fokussierung auf das GIS-gestützte Desktop-Mapping und -Publishing bereits auch kritische Stimmen, auch von Seiten der Befürworter. BRASSEL et al. (1998:43f.) bezeichnen den zunehmenden Einsatz von computerunterstützten Geographischen Informationssystemen als „Informatisierung der Geographie“ und sehen eine kritische Komponente der Entwicklung: „Die Hauptschwierigkeit und deshalb auch große Herausforderung für die Geoinformatik“ besteht nach ihren Aussagen darin, „daß bei geographischen Informationen die zugrundeliegende Abstraktion der Realität noch weitgehend unsystematisch und sehr disziplinspezifisch ist.“ (:46) „Virtuelle Räume, virtuelle Marktplätze und die sinkende Bedeutung des physischen Raumes in der Informatik stellen das traditionelle Raumverständnis der Geographie in Frage.“ (:43) „Die Erfahrungswelt, worin Wissen entstehen kann," so fahren sie in ihrem kritischen Ausblick fort, ,verlagert sich: Der Bezugspunkt und somit neue Welt der Gegenstände ist das im Netz repräsentierte, gesammelte globale Faktenwissen. Die virtuelle Welt wird in dem Maß zur wirkungsvollen, eigengesetzlichen Realität, als die ,darunterliegende' Wirklichkeit in Standardisierungen verschwindet.” (:48)

Mit zunehmendem Einsatz und Konzentration auf das schwierige und sich in immer kürzeren Zeitabständen aktualisierende Gebiet der Informatik geht das Wissen um ,Das Werden der Landschaft', um es einmal mit den früher typischen Buchtiteln genetischer Kulturlandschaftsforschung auszudrücken, verloren. Es muss die Frage nach der Auflösung des im Feld und auf der Exkursion erworbenen Landschaftswissens durch das digitale Zeitalter erlaubt sein. Kann dieses fundamentale geographische Wissen nicht mehr vermittelt werden, so hat eine Renaissance der klassischen Landeskunde stattzufinden.

\section{a.11 „Oral history“}

Geht es beispielsweise um Aussagen zur Gewässernutzung in alter, aber nur ein Menschenleben zurückliegender Zeit um ehemalige Standorte von Gewässern, die in keiner Karte auftauchen und in keiner Archivalie nachgewiesen werden können, zumindest nicht mit zu vertretbarem Aufwand, oder um Klärung zu früheren Arbeitsweisen der Teichwirtschaft und Fischereitechnik, die nicht oder nicht vollständig den alten Anleitungen zum Teichbau entnommen werden können, sind Befragungen, vor allem von Zeitzeugen, wichtig. Die Befragung ist in der angewandten Siedlungsgeographie (vgl. LIENAU 1995:200) wie auch in der empirischen Stadt- und Regionalforschung ein wichtiges Forschungsmittel, das in der angewandten historischen Geographie nur selten angewendet wird. Man kann sich dabei quantitativer und qualitativer Verfahren bedienen. 
Gespräche im Sinne der ,oral history' sollten, wenn zur Klärung von Sachverhalten notwendig und unabdingbar, mit Zeitzeugen geführt werden. Denn oftmals „handelte es sich weithin um ,tacit knowledge', um tradierte Selbstverständlichkeiten, die nur unter besonderen Umständen zu Papier gebracht wurden und sonst lediglich zwischen den Zeilen der historischen Quellen zu erkennen sind.“ (RADKAU 2002:52)

So können „zuweilen [...] aufgrund von Aussagen von älteren Dorfbewohnern Vermutungen über Lage und Ausdehnung von ehemals bewässerten Gebieten ausgesprochen werden" (SCHMID/NAEF 1994:9). Gerade auch Volkskundliches, wie die Bleicharbeit und das Rotten, basieren vor allem auf mündlich überliefertem Wissen (SIMON 1995:25f.). Des Weiteren liegen Aussagen zu zwei methodischen Anwendungen aus dem Bereich des Mühlenwesens vor: „Ich habe viele solcher Mühlen betrachten dürfen“, beschreibt BOSSE (1991:140) sein imaginäres Vorgehen, „und war dabei immer bemüht, ihren ehemaligen Bewohnern, deren geschichtliche Aufarbeitung mir oblag, Form und Gestalt zu verleihen, in sie hineinzuhorchen, um ihre Lebensgefühle zu entdecken und nachzuempfinden." MÖRSTEDT (1995:9) hat bei der Aufstellung eines historischen Mühlenkatasters neben den Beständen der relevanten Archive vor allem auch die mündliche Auskunft gesetzt: „Vielfach von entscheidender Bedeutung sind darüber hinaus die Befragungen von Müllern, Eigentümern oder Nachbarn. [...] Zahlreiche wertvolle Hinweise stammen von den ,Ortsexperten', ortsgeschichtlich besonders versierten Personen, mit deren Hilfe viele offene Fragen geklärt werden konnten.”

Als drittes Beispiel kann auf die Befragung des Verfassers verwiesen werden, der dadurch versucht, Licht in das Dunkel von Pferdeschwemmen zu bringen, da im Schrifttum dazu nichts Brauchbares gefunden werden konnte (siehe VI 17.1.2 und VII 5d).

Letztlich aber bleibt die Zeitzeugenbefragung in der Regel methodisches Hilfswerkzeug der Historischen Geographie. Um zu einer umfassenden Aussage zu gelangen, sind komplexe Methoden anzuwenden.

\section{b Komplex-Methoden}

„Wesentlich ist als verbindendes integrierendes Ergebnis ein komplexer Betrachtungsansatz, der in den Phasen und Prozessen der Kulturlandschaftsentwicklung gefunden wird, im Beziehungsgefüge raumwirksamer Tätigkeiten von Menschen und Gesellschaften in verschiedenen historischen Epochen [...] und im zusammenhängenden Werdegang der Kulturlandschaft unter dem Eingriff in die Ressourcen der Natur. Die Synthese ist damit auf historisch-geographische Erkenntnisse ausgerichtet, auf die landschaftsbezogenen Lebensumstände der Menschen in der Vergangenheit im Verhältnis zu ihrer Umwelt.“ Dieser von DENECKE (2001:283) beschriebene umfassende umweltgeschichtliche, historisch-geographische Betrachtungsansatz ist die Zielsetzung, zumindest aber Leitbild der im Folgenden unter der Überschrift ,Komplex-Methoden' subsumierten historisch-gewässergeographischen Analysen. Ein ,komplexer Betrachtungsansatz' kann nur mit ,komplexen Methoden' verwirklicht werden, will man das Phasenhafte, Prozessuale und Raumwirksame einer Entwicklung innerhalb der Kulturlandschaft - hier im Kontext Gewässer und Mensch - entdecken.

Gleichwohl wird an manchen Stellen der Eindruck entstehen, als ob sich nur um einen anderen Namen für die teils gleiche Methode handelt, die bereits zuvor als ,Individualmethode' vorgestellt wurde. Dies ist richtig und falsch zugleich: Die hier vorgestellten Methoden unterscheiden sich insofern von den Einzelmethoden, als sie umfassender und ganzheitlicher in ihrem Ansatz sind und Aspekte wie Interpretation und Bewertung von Zuständen im Rahmen der Methodenanwendung liefern. Sie gleichen aber den Individualbetrachtungen, da sie das methodische Instrumentarium, das Grundgerüst, weitgehend übernehmen. 


\section{b.1 Historisch-geographische Gewässeraufnahme}

Die angewandte historisch-geographische Gewässeraufnahme leitet sich ab von der historisch-geographischen Landesaufnahme, die als methodische Teilbereiche die Landschaftsanalyse und Landschaftsdiagnose umfasst (FEHN 1997:17) .

Die historische Landschaftsanalyse wiederum beinhaltet die Formal- und Funktionalanalyse sowie die Prozessanalyse. Ingesamt gesehen versteht man unter einer historischen Landschaftsanalyse die Rückschreibung historischer Landschaftszustände. Dabei werden Phasen und Prozesse kulturlandschaftlicher Entwicklung ermittelt und dargestellt. Sie liefert Kenntnisse über Landschaftszusammenhänge und lässt uns die individuellen Züge einer Landschaft kennen und interpretieren. Diese Form der Analyse ist ein geeignetes Mittel kulturhistorisch bedeutende Elemente aufzuspüren, zu dokumentieren und zu erhalten. Als Quellengattungen kommen Schriftquellen (Urkunden, Verwaltungsakten, Karten und Bilder) in Frage. Aber auch Sachquellen, wie Bauwerke, morphologische Kleinformen, archäologische Befunde etc. finden Verwendung. (SCHWINEKÖPER, 2000).

Die entsprechenden Methoden hierfür wurden seit Mitte der 1980er Jahre von der angewandten historischen Geographie entwickelt (WEISER 1997:77) und werden im Folgenden an die gewässerhistorische Forschung angepasst.

\section{b.1.1 Historische Gewässerlandschaftsanalyse}

Eine anwendungsorientierte historisch-geographische Gewässerlandschaftsanalyse muss, dies lässt sich einleitend zusammenfassend sagen, die raumprägenden gewässerhistorischen Strukturen und Elemente erfassen, dokumentieren und bewerten (formale und funktionale Betrachtungsweise) sowie die raumrelevanten historischen Prozesse, die zur Ausprägung des aktuellen Gewässerlandschaftsbildes führten, untersuchen und analysieren (genetische bzw. prozessuale Betrachtungsweise) (vgl. WEISER 1997:77).

Im ersten methodischen Schritt einer anwendungsorientierten historisch-geographischen Gewässeraufnahme erfolgt demnach die formale und funktionale Gewässerlandschaftsanalyse. Sie dient der Erfassung und Kartierung der in situ noch vorhandenen, aus der Vergangenheit überkommenen Gewässerelemente, -muster, -strukturen und -gefüge (in Anlehnung an FEHN 1997:17, auch DENZER 1996:15, nach FEHN 1993b:282) im Gelände, weshalb JÄGER (1965) vor dem Hintergrund der Komplexität hier auch von „historisch-geographischer Feldforschung“ spricht . Für eine solche Vorgehensweise gibt es drei Gründe:

Erstens muss zur „Erforschung der räumlichen Elemente und raumrelevanten Prozesse der Vergangenheit und ihrer Veränderung in der Zeit“ und damit zu einer ,genetischen Erklärung gegenwärtiger Strukturen und Prozesse“ zu gelangen, ,- neben der Auswertung schriftlicher und kartographischer Quellen - zunächst die Inventarisation der heute vorhandenen Kulturlandschaftselemente kommen.“(FEHN 1987:66)

Zweitens sind „mit Nachdruck umfassende Inventarisierungen zu fordern“, „um dem fortschreitenden - und zum Teil unbemerkten - Verlust von historischen Kulturlandschaftsrelikten wirksam zu begegnen“ (RIEDEL/HASLACH 1999: 174).

Und drittens ist die Bestandsaufnahme von Altlandschaftsrelikten ,unabdingbare Grundlage und erster Schritt aller anwendungsbezogenen Arbeit der Historischen Geographie mit regionalem Bezug", damit sie bei künftigen Planungen oder für anstehende Maßnahmen berücksichtigt werden können (BECKER 1998:296).

In einer historisch-geographischen Landesaufnahme wird hingegen - im Gegensatz zur Inventarisierung als Einzelmaßnahme - innerhalb eines Untersuchungs- bzw. Plangebietes immer die Kulturlandschaft in ihrer gesamten Ausdehnung mit all ihren Teilelementen berücksichtigt (FEHN 1997:17), „um damit Zeugnisse für umfassendere landeskundliche Untersuchungen zu liefern“ 
(JÄGER 1965:409). Das historisch gewachsene Gesamtsystem der Kulturlandschaft kann jedoch im Rahmen der Angewandten Forschung und aufgrund seiner Vielzahl an Komponenten nicht deduktiv erfasst werden. „Statt dessen müssen ihre historischen Einzelelemente und Bestandteile inventarisiert und dokumentiert werden.“ (WEISER 1997:78) „Verständlicherweise handelt es sich dabei durchweg um sichtbare Elemente; nicht sinnlich wahrnehmbare Strukturen und Zusammenhänge treten dagegen zurück.“ (FEHN 1997:17) Auch nach JÄGER besteht die Aufgabe der historisch-geographischen Feldforschung bzw. der Kulturlandschaftuntersuchung darin, ,gegenständliche Relikte früherer Kulturlandschaften zu erkennen, zu lokalisieren, zu beschreiben und zu interpretieren.“ (1965:409) Diese in einzelnen ausgewählten Untersuchungsarealen vorgefundenen, sichtbaren Relikte und persistenten Elemente gilt es im Rahmen einer solchen „Reliktkartierung“ vor Ort nach formal-physiognomischen Gesichtspunkten (punkt-, linien- und flächenhaft) aufzunehmen (DENZER 1996:16).

„Die anwendungsorientierte kulturgeographische Landschaftsanalyse“, beschreibt DENECKE (1997:36) die Situation, ,hat sich im Zuge der bisher im Vordergrund stehenden Landschaftsaufnahme und Inventarisation und der daraus entwickelten Kulturlandschaftskartierung (Kulturlandschaftskataster) sehr wesentlich auf Landschaftsbestandteile, auf Kulturlandschaftselemente und -relikte [...] und damit auf Einzelobjekte gerichtet, in ihrer punkthaften, linearen oder flächenhaften formalen Ausprägung.“; „,unabhängig davon“, so FEHN ergänzend, ,in welchem Zustand sie sich heute befinden und wie sie genutzt werden.“(1997:17)

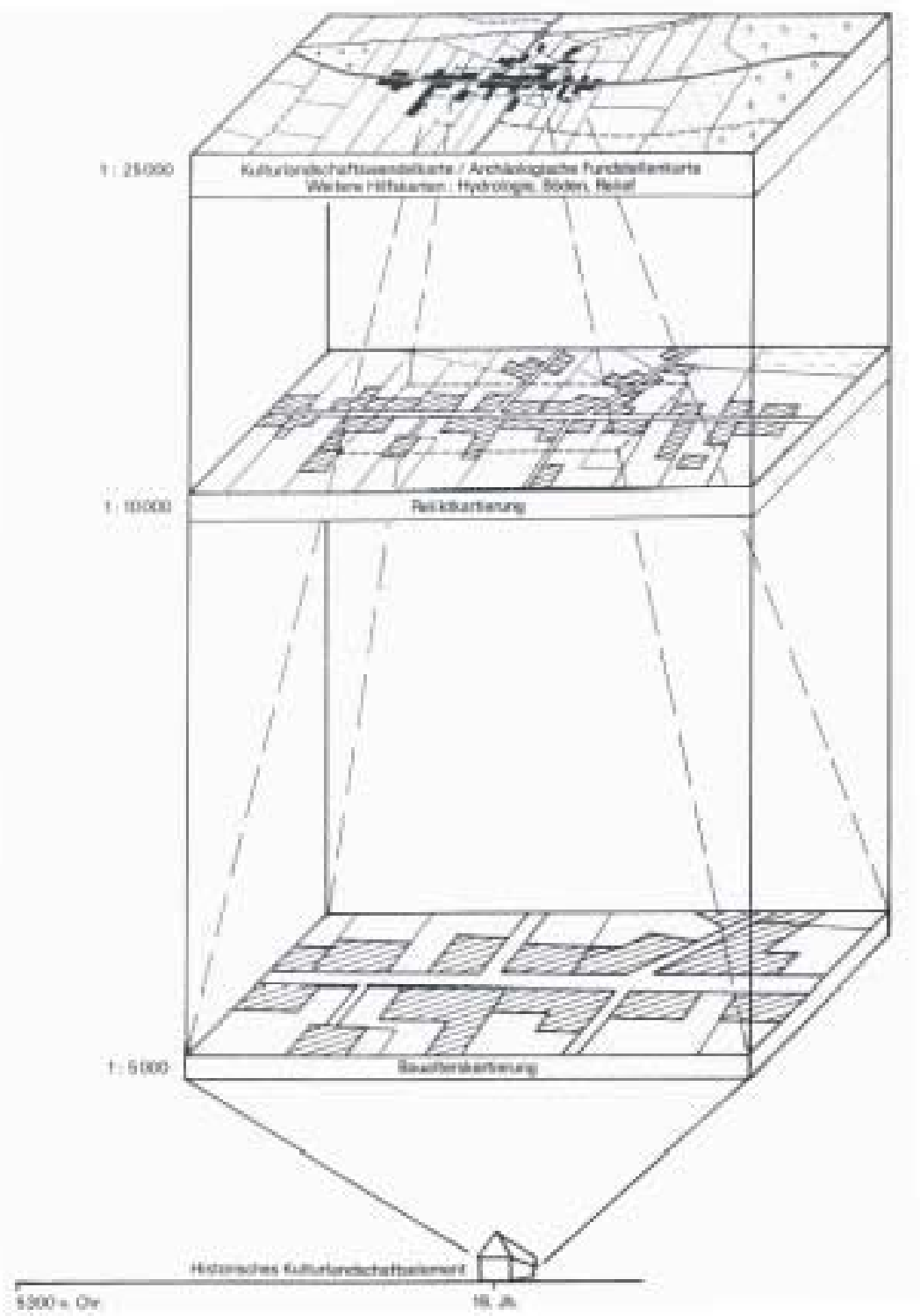

Abb. III-16: Maßstabsebenen und Elemente der historisch-geographischen Kulturlandschaftsanalyse (aus: FEHN 1997:11ff., Entwurf: Kleefeld) 
JÄGER (1965:409) versteht im Gegensatz dazu historisch-geographische Feldforschung im eigentlichen Sinne so, dass ,der Schwerpunkt auf den heute gänzlich funktionslosen Landschaftselementen liegen“ sollte, d. h. auf den „eindeutigen Relikten“ (zur ,Relikt'-Definition siehe C IV 1d). „Ferner sollen nur Relikte außerhalb geschlossener Siedlungen beachtet werden“ (:409). Auch nach Auffassung von SCHERER-HALL (1998:369) ist „das Kartieren von abgegangenen historischen Kulturlandschaftselementen im Sinne einer negativen Reliktkarte" zu verfolgen. Es bedeutet, so seine Begründung, „dem Landschaftsarchitekten gerade bei der Neuschaffung von Landschaftselementen, meist aus klimatisch-edaphisch-biotopen Gründen, eine praktische Hilfestellung, vor allem wenn bei dem zu beplanenden Gebiet besonderer Wert auf lokale Kulturgeschichte und der Erhaltung von deren besonderer charakteristischen Eigenschaften gelegt wird.“

Diese landschaftsräumliche und begriffliche Einengung auf heute nicht mehr in Gebrauch befindliche Kulturelemente des ländlichen Raumes kann jedoch in einer zunehmend urbanisierten Welt nicht mehr überzeugen. Rurale Kulturlandschaftselemente sind morgen urbane und heute noch in Funktion befindliche Landschaftselemente und können bereits heute eine ehemalige Wirtschaftsweise repräsentieren. Und setzt sich das Siedlungswachstum ungebremst fort, so sind in diesem Szenario 2070 Stadtlandschaften mit ihren Kulturelementen das verbleibende Betätigungsfeld für Historische Geographen. Vielleicht auch aus diesen Gründen ist JÄGER selbst nicht durchgängig in seiner engen Festlegung des Untersuchungsbereiches. So zählt er zu den Relikten der Landesnatur auch „heutige agrarische Nutzflächen mit Reliktcharakter" (1965:415). Demnach sind also auch rezente Formtypen mit Reliktcharakter bei einer historisch-geographischen Feldforschung zu berücksichtigen.

Die historisch-geographische Analyse ist dementsprechend zeitlich nicht beschränkt, sondern umfasst den Zeitraum je nach historischer Entwicklung bzw. Alter des Untersuchungsobjektes im Idealfall von der Vorgeschichte bis heute (WEISER 1997:78). „Inventarisiert werden ohne zeitliche Einschränkung sowohl die sichtbaren als auch die nicht mehr im Gelände erkennbaren Einzelelemente, die aufgrund des Quellen- und Literaturmaterials bzw. durch die Karteninterpretation bekannt sind und lokalisiert werden können.“(:78).

Die Einzelheiten (z. B. Teiche, Stauwehre) werden dahingehend untersucht, ,welche Bedeutung sie in ihrer Entstehungszeit hatten, welche formale Entwicklung sie durchgemacht haben, d. h. welchen Erhaltungszustand sie aufweisen, und ob sie ihre ursprüngliche Funktion erhalten haben oder ein Funktionswandel (rezentes Relikt) bzw. Funktionsverlust (fossiles Relikt) stattgefunden hat.“ (WEISER 1997:78). Diese Aspekte werden bei der historisch-geographischen Gewässerlandschaftsanalyse flächig untersucht und in ihrem Rahmen zusätzlich die Einzelelemente berücksichtigt, die beispielsweise mit Hilfe der Wandelkarte (siehe Pkt. 3c) nicht erfasst werden (vgl.:77).

Der Hauptakzent der Feldarbeit liegt dabei auf der Inventarisierung derjenigen flächen-, linien- und punktförmigen Gewässerelemente, z. B. von Kleinformen des wasserwirtschaftlich-agrarischen Mikroreliefs, die von anderen kulturlandschaftsgeschichtlichen Aktionen, wie z. B. der Inventarisation von Denkmälern durch die amtliche Denkmalpflege, nicht erfasst werden (in Anlehnung an FEHN 1997:17). Für eine solche Inventarisierung haben sich Regeln herausgebildet, die für das Gewässerinventar übernommen werden können. Anzuwenden ist demnach ein dreigliedriges Verfahren, das aus Erfassen, Typisieren und Bewerten der in der Kulturlandschaft erhaltenen Gewässerrelikte besteht (in Anlehnung an BECKER 1998:296). Die Dokumentation umfasst eine Bestandskarte und einen Katalog mit den einzelnen Erhebungsbögen: In die Bestandskarte werden die kartierten Resultate eingetragen, „bei der dann auch spezielle Aspekte wie Alter, Erhaltungszustand, flächen-, linien- oder punkthafte Verbreitung usw. festgehalten werden können. Ergänzt durch Erläuterungen [...] stellt eine solche Karte dann die Grundlage für eine praxisorientierte Verwendung dar.“ (BECKER 1998:296f.) Der Erhebungsbogen enthält alle wichtigen Informationen zum Einzelobjekt: Datierung, Lage, Erhaltungszustand, Schutzwürdigkeit, historische Entwicklung, Quellen- und Literaturangabe. Außerdem wird unter dem Stichwort ,Kulturhistorische Bedeutung' eine Beurteilung des Elementes vorgenommen, um den historischen Kulturlandschaftselementen im Abwägungsprozess des Planverfahrens das notwendige Gewicht zu verleihen (vgl. WEISER 1997:78; BECKER 1998:296; siehe auch Nr. 3 der oben genannten Gründe). 
Außer einer rein formal-physiognomischen Erfassung , gegenständlicher Gewässerrelikte' im Rahmen einer historisch-geographischen Gewässerforschung, bedarf es auch einer funktionalen Betrachtungsweise, die die Elemente und Relikte den einzelnen Funktionsbereichen zuordnet und dabei Aspekte wie Form und Vorkommen behandelt (vgl. DENZER 1996:16). Denn in einer vollständigen historisch-geographischen Gewässeraufnahme gilt es nicht nur die Daten der Kartierungsarbeiten in geeigneter Weise mehr oder minder modifiziert zu übernehmen, sondern auch „,in den neuen Gesamtzusammenhang“ einzufügen (FEHN 1997:17). Es sind genetische Zusammenhänge zu erklären und die „Stellung der Gebilde in den historischen Landschaften“ zu deuten (JÄGER 1965:409). Diese Zielsetzung verfolgt auch DENECKE (2000:205): „Bei der Erfassung, vor allem aber bei der Erläuterung geht es [...] nicht allein um die formalen Kulturlandschaftselemente und -strukturen, sondern auch um die entwicklungsgeschichtliche Dimension der Nutzung bzw. des Nutzungswandels mit der dahinterstehenden Bewirtschaftung." Ziel ist deshalb „nicht die listenmäßige Erfassung aller relevanten Einzelelemente und deren Kartierung, sondern die Erforschung von Raumgefügen und das Erkennen von Bauplänen der Kulturlandschaften. Diese sind in der Regel nicht mehr als Ganzes ablesbar, sondern müssen oft sehr mühsam rekonstruiert werden. Die Zuordnung der noch vorhandenen Elemente zu diesen historischen Zusammenhängen ist eine der Hauptaufgaben. Hierzu ist außer der historisch-geographischen Inventarisation die Erforschung der Kulturlandschaftsentwicklung nötig.“ (FEHN 1997:17)

Ein weiterer wichtiger Bestandteil der historischen Landschaftsanalyse ist darüber hinaus in der fachlichen Beurteilung noch bestehender Kulturlandschaftsrelikte $\mathrm{zu}$ sehen, denn als wichtige planerische Aufgabe gilt es, insbesondere für kulturhistorisch besonders bedeutsame Landschaftsbestandteile nach Erhaltungsmöglichkeiten zu suchen und dafür langfristig tragfähige Konzepte zu entwickeln." (RIEDEL/HASLACH 1999:179) Das Sehen und Erkennen von Elementen und Relikten in der Landschaft bildet die Grundlage einer solchen historisch-geographischen Bestandsaufnahme. Dadurch und durch die auf dieses Fachwissen aufbauende Kartierung wird die Differenzierung der historisch-geographischen Gewässerobjekte in Relikte und persistente Elemente erst möglich und erlaubt eine erste qualitative Aussage bezüglich des Gewässerlandschaftswandels (in Anlehnung an DENZER 1996:16f.). Die Schwierigkeiten bei der Anwendung der Methode der Feldforschung liegen deshalb in der persönlichen Voraussetzung, denn „die Identifikation oder Feststellung der Objekte gelingt in der Regel nur, wenn der Forscher über Erfahrungen in der Feldarbeit verfügt", die er sich durch die „Teilnahme an wissenschaftlichen Lehrausflügen“ erworben hat (JÄGER 1965:415).

Der umfassenden historisch-geographischen Formal- und Funktionalanalyse der komplexen gewordenen und gestalteten Region mit ihrer Vielzahl von vernetzten persistenten Einzelelementen folgt abschließend die Prozessanalyse als Bestandteil der Gesamtanalyse. Die genetische Entwicklung der als ein Systemzusammenhang betrachteten Kulturlandschaft wird untersucht und kurzfristige und länger andauernde Entwicklungstrends festgestellt (vgl. FEHN 1997:17). „Eine Landschaftsanalyse im Rahmen der praktischen Landschaftspflege kommt ohne das Fundament der Betrachtung des Beziehungsgefüges zwischen Mensch, Natur und Kultur nicht aus. Eine rege Verknüpfung von naturund kulturgeographischer Landschaftsforschung trägt wesentlich hierzu bei, vor allem dann, wenn sie vom entwicklungsgeschichtlich beschreibenden und genetisch erklärenden Ansatz übergeht zum Paradigma der Persistenz [...] und der [...] Präsenz landschaftsgebundener Kultur im Landschaftspotential und in der Umwelt des Menschen.“ (DENECKE 1997:37)

Um diese Zielsetzung zu erreichen, wird, neben ausgedehnten Geländestudien, der Aufarbeitung umfangreichen schriftlichen Quellenmaterials sowie historischer Risse und Pläne der Gemeinde-, Staats-, Stifts- und Privatarchive besondere Beachtung geschenkt (DENZER 1996:16). „Hierbei kann jedoch keine Grundlagenforschung betrieben werden, vielmehr wird das veröffentlichte Quellen-, Literatur-, Bild- und Kartenmaterial ausgewertet. Herangezogen werden außerdem die Informationen der anderen mit dem Untersuchungsgebiet befaßten Institutionen.“ (WEISER 1997:78)

\section{b.1.2 Historische Gewässerlandschaftsdiagnose}

Nach der Landschaftsanalyse folgt nach FEHN (1997:18) „als zweiter Schritt die Landschaftsdiagnose auf der Basis einer historisch-geographischen Bewertung der einzelnen historischen Kulturland- 
schaftselemente und der Kulturlandschaftsgefüge“; obgleich er selbst einräumt, dass „,in jedem Fall [...] die Quantifizierung des Gesamtwerts und damit die Einbettung der Einzelelements in ein Bewertungssystem eine nicht optimal lösbare Aufgabe" bleibt. Für die historisch-geographische Gewässerforschung bedeutet dies die qualitative Bewertung quantitativer Erscheinungen gewässerhistorisch bedeutsamer Elemente in der Landschaft.

Zusätzlich zu den auf den Ergebnissen der Archiv- und Feldforschung aufbauenden Geländebefunden wird der räumliche und zeitliche Wandel, $\mathrm{d}$. h. die Ist-Situation im begleitenden Text herausgearbeitet (DENZER 1996:16). Des Weiteren kann aus der erfolgten Prozessanalyse ,mit relativ großer Sicherheit der Gefährdungsgrad der einzelnen Kulturlandschaftselemente und ganzer, noch stark historisch geprägter Kulturlandschaften abgeleitet werden." (FEHN 1997:17)

DENECKE (2000:205) formuliert die Bestandteile der historisch-geographischen Landschaftsdiagnose wie folgt: „Bei der Persistenz ist die bisherige und weitere Dauerhaftigkeit zu analysieren und zu beurteilen, beim Wandel sind Wandlungsprozeß, Dynamik und Eingriffe zu verfolgen und auch zu prognostizieren, bei Landschaftsrelikten geht es letztlich dann um Dokumente der Kulturlandschaftsgeschichte, deren Bewahrung und Schutz."

Analyse und Bewertung, Darstellung und Prognose, Bewahrung und Unterschutzstellung sind demnach die Elemente, um ,Persistenz' und ,Wandel' sowie die ,Relikte' von Gewässergeschichte zu diagnostizieren. Auf Grundlage der Ergebnisse der Kulturlandschaftsuntersuchung, Analyse wie Diagnose, sind schließlich Leitlinien für das Untersuchungsgebiet im Gewässereinzugsbereich zu formulieren, deren Berücksichtigung den Erhalt der gewässerhistorischen Kulturlandschaften und ihrer Bestandteile ermöglicht (vgl. WEISER 1997:77).

\section{b.2 Ganzheitliche Inventarisation}

Die ,ganzheitliche Inventarisation' ist ein von Peter BURGGRAAFF entwickeltes Arbeitskonzept zur Erfassung der historischen Kulturlandschaft (KLEEFELD/BURGGRAAFF 1997b:57). Es verfolgt als Arbeitziel „die großflächige systematische Erfassung der historischen Kulturlandschaft in ihrer gesamten zeitlichen Vielfalt“ (:57). „In den Hauptelementen besteht dieser Ansatz aus einer detaillierten Altkartenanalyse und Zusammenfassung der Altlandschaften in eine Kulturlandschaftswandelkarte [...] und der durch Feldforschungen erstellten Reliktkarte. Die Literatur- und Archivaliendurchsicht erhält eine ergänzende Funktion zur Erläuterung der inventarisierten Elemente und der kartierten Kulturlandschaftsgenese." (:57)

Die auf einem Quellen- und Literatur- sowie Altkartenstudium und Feldforschung aufbauende ,ganzheitliche Inventarisierung' mit ihren kartographischen Erzeugnissen einer Wandel- und Reliktkarte bedeutet für den gewässerhistorischen Ansatz, sämtliche kulturgeschichtlichen Erscheinungen und Änderungen in Bezug auf das Gewässer bzw. die Gewässerlandschaft zu erfassen und textlich sowie zeichnerisch zu dokumentieren.

Aufgrund dieses umfassenden und sehr zeitintensiven Ansatzes wird dieses Verfahren in der praxisorientierten Kulturlandschaftsforschung jedoch nur selten angewandt. Aus dem Anwendungsbereich ,Gewässergeschichte' liegt ein solcher Beitrag meines Wissens bislang nicht vor.

\section{b.3 Zeitschnitte}

Nach NITZ (1998:127) gibt es drei Hauptansätze der Historischen Geographie, die für die methodische Ausgestaltung in sog. Zeitschnitten maßgeblich sind.

1. Bei dem synchronischen Ansatz werden „Raumstrukturen und funktionale Netze einer Region für einen bestimmten historischen Zeitpunkt oder eine Periode untersucht [...].“ Der synchronische Ansatz legt dabei ,häufig langandauernde Prozesse frei, die durch den zeitlichen Querschnitt in einem kurzen Stück erfaßt werden.“ 
2. Bei dem prozessorientierten Ansatz werden die Prozesse und Wandlungen erforscht, wodurch neue Strukturen geschaffen oder bestehende Muster verändert, reduziert oder beseitigt werden. „Dieser Ansatz kann auch als genetisch (im engeren Sinne des Wortes) bezeichnet werden.“

3. Der entwicklungsgeschichtliche Ansatz verfolgt „die Erforschung der historischen Entwicklung oder des Werdegangs einer Region von den ersten Anfängen an.“

Im Gegensatz zum ersten Ansatz besteht, Ludwig TREPL (1978:55) zufolge, bei dem historischgenetischen Ansatz Nr. 2 das methodische Problem, dass ,die „'Randbedingungen' sich im Verlaufe der Entwicklung, die zu dem zu erklärenden Ereignis führt, in einer Weise ändern, die nicht bereits in der Ausgangssituation beschlossen war.“ Es genüge also nicht, ,eine Ausgangsituation zu erkennen, aus der heraus sich die Erklärung (Prognose) konstruieren“ ließe. Es müsse vielmehr, klärt TREPL (:55) auf, „um jenes Verfahren von Prognose/Entwicklung anwenden zu können, die gesamte Entwicklung gleichsam durch eine Vielzahl von Schnitten zerteilt werden, und zu jedem Schnitt müßten, um den folgenden prognostizieren zu können, außer den durch die vorangegangene Prognose bereits bekannten Randbedingungen jeweils neue ermittelt werden.“. Dies anwendungsbezogen nur schwer Verwirklichbare wird bei der Methode der ,Langen Reihe' versucht aufzubauen (siehe ,Ausblick' am Ende dieses Kapitels). Der dritte Ansatz schließlich wird durch den Längsschnitt versucht darzustellen und ist beispielsweise Bestandteil des historisch-siedlungsgeographischen Betrachtungsansatzes (DENECKE 2001:281).

Die Historische Geographie ,verwendet sowohl die Querschnitts- als auch die Längsschnittmethode, um zu einem vollständigen Kulturlandschaftsbild vergangener Epochen zu kommen." (FEHN 1975a :49). Der, obgleich zeitaufwendiger zu erforschende, Längsschnitt gewinnt jedoch an Zuspruch. Während jedenfalls der bisherige zeitliche Rahmen der Hauptansätze ,auf eine Epoche ausgerichtet“ war, wie der synchronische Ansatz, werden ,in zunehmenden Maße aber auch [...] durchgehende zeitliche Längsschnitte“" verfolgt (DENECKE 2001:282).

Hinsichtlich der historisch-geographischen Gewässerforschung, beispielsweise bei der Rekonstruktion ehemaliger Gewässerverläufe im zeitlichen Vergleich, von Kanalstrecken oder der Analyse von Teichflächengrößen in unterschiedlichen Perioden, bieten Zeitschnitte sehr gute Möglichkeiten zur Feststellung von Persistenz und Wandel von fluidal-aquatischen Untersuchungsarealen und -gegenständen.

Sie stellen gleichzeitig kartographische Arbeitsmethoden der Historischen Geographie dar.

\section{b.3.1 Längsschnitt}

Man spricht dann von längsschnittlicher (diachroner) Betrachtungsweise, wenn „das zeitliche Hintereinanderschalten von mehreren Zeitschnitten auf der Basis von Quellen möglichst gleicher Qualität [...] gleichsam eine Dynamisierung der Betrachtung“" erlaubt (SCHENK 2002:112).

Längsschnitte vorzunehmen bedeutet „die Verfolgung von Entwicklungsvorgängen im historischen Ablauf“ (DENECKE 1989c:51) oder anders ausgedrückt: Ein Längsschnitt ist die „Erforschung der Entwicklung“ (FEHN 1989:8). In einem Längsschnitt-Verfahren, so beschreibt das WESTERMANNLEXIKON DER GEOGRAPHIE(1973:418) den inhaltlichen Ablauf, wird „die (Entwicklungs-) geschichte der kulturgeographischen Elemente unter besonderer Berücksichtigung der Veränderungen in ihrer Verbreitung, in ihren formalen Strukturen und Funktionen" untersucht. Ein siedlungsgeschichtlicher Längsschnitt beispielsweise führt ,von der Landnahme über Entsiedlungs- und Umstrukturierungsprozesse bis in die Transformationsprozesse der Gegenwart hinein“ (DENECKE 2001:281).

„Wird sie eigens zur Erklärung der gegenwärtigen Landschaft angewandt, so kann man sie auch als genetischen Ansatz im Sinne der genetischen Kulturlandschaftsforschung verstehen." (SCHENK 2002:112). MÜLLER-WILLE (1944) und HAMBLOCH (1960) beispielsweise verwenden in der historischen-geographischen Siedlungsforschung für den Längsschnitt den Begriff „topographischgenetische Methode“ und bezeichnen damit eine Methode, „,bei der man, vom Zustand einer Siedlung ausgehend, wie er z. B. in der Urkatasterkarte dargestellt ist, deren Genese Schicht für Schicht unter 
Einbeziehung der Lage der Höfe und Parzellen, der Besitzverteilung, Flurnamen, Bodenuntersuchungen und Urkunden zu erklären sucht“ (aus: LIENAU 1995:160).

Für die Gewässergeschichte könnte der Beitrag einer längsschnittlichen Betrachtung beispielsweise in dem Nachweis der wechselhaften Phasen von Dispersion und Kontraktion von Teichanlagen der Fischzucht, des Mühlenwesens und der Bergbauwirtschaft liegen.

\section{b.3.2 Querschnitt}

Während man mit der Längsschnitt-Methode Entwicklungsvorgänge erforscht, untersucht man mit der Querschnitt-Methode „verschiedener Zeiträume“ (DENECKE 1989c:51). Ein Querschnitt ist die „Erfassung eines bestimmten Kulturlandschaftszustandes“ (FEHN 1989:8). Die querschnittliche (synchrone) Betrachtungsweise ist dabei „stets auf die landschaftlichen Zustände einer bestimmten Vergangenheit gerichtet.“ (SCHENK 2002:112) und ermöglicht damit auch eine „Rekonstruktion älterer Landschaftszustände“ (DENECKE 2001:288).

In einem Querschnitt-Verfahren werden ,die kulturgeographischen Elemente zu bestimmten Zeitpunkten der Vergangenheit in vergleichender Betrachtung über größere Räume der Erdoberfläche hinweg" untersucht (WESTERMANN-LEXIKON DER GEOGRAPHIE 1973:418). Der deutsche Geograph Otto SCHLÜTER (1872-1959) entwickelte diese Methode einer „,vergleichenden Querschnittsbetrachtung" (MÜCKE 1988:154).

Sie ermöglicht in diesem thematischen Kontext z. B. das Aussehen von Gewässerlandschaften zu bestimmten Zeitpunkten der Vergangenheit (z. B. der Zustand der Oderbruch-Landschaft um 1400 [frühe Besiedlung] und 1700 [planmäßige Kolonistenstellen]) in zeitlichen Querschnitten zu erforschen.

Ein weiteres Beispiel für den analytischen Nutzen eines Querschnittes mag anhand der Veränderung von Teichflächen gegeben werden. So lassen sich die einsetzenden teichwirtschaftlichen Intensivierungsmaßnahmen daran erkennen, dass die Güter beginnen, große Teichflächen in einzelne kleine Teiche zu verwandeln. RUST (1952:32) hat durch den Vergleich zweier Karten (vor 1740 und 1952) diese Entwicklung am Beispiel des Gutes Lammershagen deutlich gemacht.

Anhand von vier Zeitschnitten zeigt auch die bereits genannte Arbeit von THIEM (2004) die menschlichen Eingriffe und Nutzungen auf die Gewässer auf. Die Zeitschnitte liegen zum einem im Hoch- und Spätmittelalter im 13. - 15. Jahrhundert (Gründung und Ausbau der Bergstadt Münster), im 16. - 18. Jahrhundert (Wiederaufblühen des Bergbaus; Ansiedlung von Gewerbe, Brennholztrift), im 19. Jahrhundert bis Mitte des 20. Jahrhunderts (Intensivierung Gewässerausbau, Elektrifizierung) und 1950 bis heute (Aufgabe der Wiesenwässerung). Zu den genannten Zeitschnitten werden Archivalien und kartographische Darstellungen verschiedenen Inhalts und unterschiedlicher Qualität sowie Sekundärliteratur ausgewertet. Anhand dieser Informationen werden Lage und Verbreitung der Gewässertypen (natürliche Fließgewässer, Mühlenkanäle, Schwellweiher etc.), bauliche Veränderungen sowie deren Einfluss auf die Gewässerstruktur, die Hydomorphodynamik und die Flussgenese rekonstruiert.

Hieraus ergibt sich die Möglichkeit ,mit ,genetischer Perspektive' die Kulturlandschaftsgeschichte der Kulturlandschaftsgegenwart durch ,schichtenweise Rekonstruktion' darzustellen." (MÜCKE 1988:154). „Verbindet man nun Längsschnitt- und Querschnittmethoden miteinander, können weitere Betrachtungsweisen ausgegliedert werden“" (SCHENK 2002:112), wie zum Beispiel die retrogressive und die retrospektive Methode.

\section{b.4 Rück- und Fortschreibung}

\section{b.4.1 Retrogressive Methode}

Bei der zeitschnittartigen Untersuchung vergangener Landschaften wird in der Historischen Geographie u. a. die retrogressive Methode angewandt: „In einer retrogressiven Betrachtung und 
Analyse der heutigen Kulturlandschaft sind Persistenz, Wandel und Verlust flächenhaft durch den Vergleich historischer Querschnitte (Altkarten) und eine historisch-geographische Geländeaufnahme herauszuarbeiten." (DENECKE 2000:205)

Regressive oder reduktive Methoden „gehen davon aus, dass ein enger Zusammenhang zwischen den landschaftlichen Verhältnissen zu einem bestimmten Zeitpunkt und vorangegangenen Entwicklungen besteht.“ (SCHENK 2002:112) Es ist „ein Verfahren, das darin besteht, von den bekannten Gegebenheiten der Gegenwart zu den unbekannten der Vergangenheit forschend vorzudringen." (WESTERMANN-LEXIKON DER GEOGRAPHIE 1973:418) Mit Hilfe der reduktiven oder retrogressiven Methode werden Struktur, Form und Funktion schrittweise in die Vergangenheit zurückverfolgt, um sie so zugleich aus ihr abzuleiten (JÄGER 1973:12).

Deshalb bezeichnet man sie auch als Rückschreibungsmethode. Sie macht sich z. B. in der Siedlungsgeographie „die Tatsache zunutze, daß Veränderungen des Besitzgefüges [...] oft nicht von entsprechenden Veränderungen der steuerrechtlichen Einheiten begleitet sind. Aus den in alten Besitzverzeichnissen (Flurbuch, Lagerbuch, Urbar, Salbuch) aufgelisteten Zugehörigkeiten der Parzellen zu Betrieben und steuerrechtlichen Einheiten, also deren rechtlicher Charakterisierung, lassen sich ältere Besitzeinheiten durch schrittweises Zurückverfolgen rekonstruieren“ (LIENAU 1995:159).

Für eine gewässerhistorische Fragestellung könnte der Beitrag einer retrogressiven Betrachtungsweise darin liegen, die Veränderungen einer Gewässerlandschaften rückblickend aufzuzeigen, um so zu für eine historisch-orientierte Gewässerplanung ein ,historisches Klimax-Stadium“ zu nennendes Gewässerbild zu erreichen, das einem ökologisch-manifestierten Gewässerbau als näherungsweise naturnahes Stadium als Planungs- und Ausbaugrundlage dienen kann.

\section{b.4.2 Retrospektive Methode}

Die retrospektive (progressive) Methode „besteht darin, dass die Forschung von älteren [...] zu den jüngeren Stadien [...] räumlicher Gefüge und Funktionszusammenhänge fortschreitet, um dadurch zu einer genetischen Erklärung der jeweils jüngeren Entwicklungsstufen zu gelangen." (SCHENK 2002:112). „Die retrospektive Methode erfordert also in der praktischen Anwendung einen zusätzlichen Schluss von vergangenen Landschaften über deren Fortentwicklung zu späteren, oft den heutigen Zuständen, sodass sie die Arbeit mit der retrogressiven voraussetzt.“ (:112)

In der retrospektiven Genese der Kulturlandschaftsentwicklung wird, dies geht aus dem Gesagten hervor, die landschaftsräumliche Synthese zusammenfassend verfolgt: Mit der „entwicklungsgeschichtlichen Erklärung der heutigen gewordenen und historisch gestalteten Kulturlandschaft.“ (DENECKE 2001:279)

Mit der retrospektiven Methode wird somit eine längsschnittartige Betrachtungsweise erreicht. Die retrospektive oder genetische kulturgeographische Analyse versucht „die entwicklungsgeschichtliche Erklärung gegenwärtiger geographischer Verhältnisse" (DENECKE 1989c:51), d. h. die .genetische Erklärung „der konkreten gewordenen Kulturlandschaft“ (DENECKE 2001:288). Insofern besitzt die Empfehlung von W. NORTON (1984:34) Gültigkeit, dass „for the study of relict features a retrospective approach may be appropriate".

Anhand der zeitgeschichtlichen Veränderung von Gewässerlandschaften und ihrer Elemente unterschiedlichen Entstehungs- und Erhaltungsgrades, vermag eine genetisch ausgerichtete retrospektive Betrachtungsperspektive die stetige Anthropogenese des Wandels aufzuzeigen und verbliebene Reste dieser Entwicklung in der Landschaft aufzudecken. So kann bei einer in den Anfängen beginnenden Untersuchung die Filterung besonders schutzwürdige Elemente der Gewässernutzung (Treidelwege, Teichwirtschaften, Triftkanäle) leichter erfolgen. 


\section{Kartenwerke}

Die kartographische Analyse ist im gebräuchlichen Sinne charakteristische Komponente und Wesensmerkmal des historisch-geographischen Komplex-Ansatzes, d. h. instrumenteller Bestandteil im Methodenverbund. Insofern besteht hier die Schwierigkeit, die Karte zum einen als Methode und zum anderen als Quelle anzusprechen. Denn wenn auch die Historische Geographie „die alte Karte als wichtige Quelle verwendet und thematische Karten als wichtige Darstellungsmittel ansieht" (FEHN 1975a:51), so gibt es „,nur sehr wenige Untersuchungen im Bereich der Historischen Geographie, die weitgehend oder zumindest mit erheblichen Teilen auf der Interpretation von Altkarten aufbauen.“ (FEHN 1989:10). Hier sollen im Folgenden nicht originale Altkarten, sondern die Kartenwerke angezeigt werden, sich aus der jeweiligen methodischen Analyse ergeben.

In jeder Hinsicht aber ist die Karte eigenständiges und ureigenes geographisches Instrumentarium und Quelle zugleich. Denn während „,in der Geschichtswissenschaft [...] immer noch und wohl auch in Zukunft die schriftliche Quelle die wichtigste empirische Grundlage der Forschung" darstellt, kann demgegenüber ,innerhalb der Historischen Geographie wohl die Karte und das im Zusammenhang mit ihr angefertigte Schriftgut als die originäre Quellengattung hervorgehoben werden." (MÜCKE 1988:9f.). Auch FEHN (1997:24) sieht als „zentrale Quellen für die Historische Geographie“ die Altkarten an und weist auf „die thematische Geschichtskarte“ als „eines der geeignetsten Darstellungsmittel für die Historische Geographie“ hin.

Die im Folgenden vorgestellten historisch-geographischen Kartenwerke sind also die Ergebnisse der auf Inventarisierung aufbauenden Reliktkarten wie auch der auf der Auswertung von Altkarten beruhenden Zeitschnitt- und Wandelkarten. „Ohne kartographische Rekonstruktionen“ war es HERBST (1992:39) „unmöglich, ein wirklichkeitsgetreues Bild der spätmittelalterlichen und frühneuzeitlichen Kanalverhältnisse in Biberach zu gewinnen." Denn auch wenn kein aktuelles Relikt mehr vorhanden ist, so lassen sie sich dennoch aus der Zusammenfügung verschiedener Kartenwerke und anhand von Geländereliefs erkennen (ERLER/MATTHIESEN 1989:67)

Hinsichtlich der maßstäblichen Darstellung der kartographischen Werke gibt es im Wesentlichen zwei unterschiedliche Vorgehensweisen: „Neben den fundierten, ins Einzelne gehenden Untersuchungen kleinerer Gebiete und der Darstellung der Ergebnisse in einem größeren Maßstab (1:25000, 1:10000) haben auch die weniger exakten Bestandsaufnahmen für die größeren Räume in kleineren Maßstäben $(1: 100000$ etc.) ihren Wert. Sie dienen u. a. der vergleichenden Bestimmung von Entwicklungsleitbildern für die unterschiedlichen Teilräume größerer Einheiten. Auf diesem Wege lassen sich auch am raschesten gewisse Grundvorstellungen über charakteristische Kulturlandschaftsbestandteile unter besonderer Berücksichtigung ihrer historischen Substanz herstellen.“(FEHN 1997:17f.)

\section{a Landnutzungskarte}

Die Landnutzungskarte stellt einen Ausschnitt aus einer Landschaft zu einem bestimmten Zeitpunkt dar. Die Landnutzungskarte, beispielsweise mit dem Landschaftsbild von 1800, dient als Grundlage für die Kulturlandschaftswandel- und die Reliktkarte (BURGGRAAFF/KLEEFELD 1997:25).

Eine gewässerbezogene Landnutzungskarte würde beispielsweise die Nutzung der angrenzenden Uferund Auenbereiche zu einem früheren Zeitpunkt in einem thematisch-kartographischen Überblick aufzeigen (z. B. Baumweidenanpflanzungen, Wässerwiesen, Pferdewiesen, Teichbewirtschaftungen, da sie der Landwirtschaft zugerecht werden).

$\mathrm{Da}$ es sich hier um eine ,Landnutzungskarte' handelt, aber gleichzeitig eine Gewässernutzungskarte hinsichtlich einer Flächenhaftigkeit nicht darstellbar ist, denn wie soll man beispielsweise Fischfang, Schifffahrt, Flößerei oder Wäscherei, die auf ein und derselben ,Nutzungsfläche', d. h. auf dem Gewässer stattfand, in ihrer Unterschiedlichkeit und flächenhaften Ausbreitung kartographisch 
wiedergeben, schraffiert oder farbig? -, so können sie nur symbolhaft mit ihren Elementen (Brücken, Wehre, Schleusen etc.) und eben beschriebenen Nutzungsarten ausgedrückt werden.

\section{b Reliktkarten}

Es muss unterschieden werden zwischen Erfassungen und Bearbeitungen in

- großmaßstäblichen Betrachtungsebenen kulturräumlicher Charakteristiken (1:100.000 bis 1:500.000) und einer

- kleinräumig orientierten Gliederungsebene (Bearbeitungsmaßstab 1:5.000 bzw. 1:25.000).

„In der Angewandten Historischen Geographie wird man für Aufgaben zur Inventarisation wie z. B. Reliktkartierungen größere Maßstäbe, für Landesaufnahmen zu einem Kulturlandschaftskataster kleinere Maßstäbe aus diesem Maßstabsbereich wählen.“ (PLÖGER 1999:11) (BURGGRAAFF/ KLEEFELD (1999:127) beispielsweise haben auf einer Reliktkarte im Maßstab 1:10.000 „die heute noch im Gelände erhaltenen historischen Kulturlandschaftselemente (Punkte, Linien und Flächen)“ der Dingdener Heide, Kreis Wesel (Nordrhein-Westfalen) „während einer historisch-geographischen Geländebegehung kartiert“.

Für Planungsaufgaben, in denen gewässerhistorische Beiträge eventuell eine Berücksichtigung finden können, beispielsweise in Bauleitplänen, Landschaftsplänen, landschaftspflegerischen Begleitplänen und wasserwirtschaftlichen Planungen müssen diese den Maßstabsebenen dieser Planungen angeglichen werden, oder es werden aber, entfällt diese Bindung, z. B. in informellen Planungen oder Fachgutachten, Reliktkarten in den Maßstäben 1:10000 bzw. 1:25000 verwendet, auch der besseren Vergleichbarkeit wegen.

\section{c Wandelkarten}

In den Wandelkarten werden Änderungen der Kulturlandschaft kartographisch dokumentiert. Dies gilt auch für die Wechsel der Gewässer in der Landschaft. Entsprechend der methodischen Vorgehensweise können dabei verschiedene Kartenwerke unterschieden werden.

\section{c.1 Zeitschnittkarten}

„Historische Kulturlandschaftskarten sind entweder auf einen bestimmten Zeitpunkt der Vergangenheit bezogen oder sie stellen als genetische oder dynamische Karten in einer Reihe von einzelnen Querschnitten den Werdegang der Landschaft dar." (WESTERMANN-LEXIKON DER GEOGRAPHIE 1973:420) Verschiedene Zeitebenen werden hier also auf einer räumlichen (Kartenblatt-) Ebene zusammengeführt (LEIBUNDGUT 1993:13), im ersten Fall in einer querschnittlichen, im zweiten Fall in einer längsschnittartigen Darstellung.

\section{c.1.1 Längsschnittkarte}

Die Längsschnittkarte zeigt die historische Dimension der Landschaft und veranschaulicht die Dynamik und Chronologie der kulturlandschaftlichen Entwicklung (WEISER 1997:77). Da die Längsschnittkarte eine genetische Karte ist, veranschaulicht sie den Werdegang des Untersuchungsgebietes.

Gewässer-Längsschnittkarten stellen beispielsweise die im Verlauf der Jahrhunderte hinweg sichtbare Entstehung, Ausdehnung, Rückgang und Niedergang von Gewässeranlagen, eines Talbewässerungssystems oder von Gewässerläufen in ihrem morphographischen Verlauf dar, soweit es sich noch rekonstruieren lässt.

\section{c.1.2 Querschnittkarte}


Die Querschnittskarten hingegen zeigen die Befunde zu bestimmten Zeitpunkten der Vergangenheit. Sie werden erstellt, um den Prozess des Wandels in der Kulturlandschaft zu verdeutlichen und zu untersuchen (WEISER 1997:77). Methodisch werden dabei die in den historischen Landesaufnahmen dargestellten Inhalte mit der aktuellen Topographischen Karte (1:25000) abgeglichen (WEISER 1997:77).

Beim Vergleich der Querschnittskarten erkennt man dann, wie sich die Kulturlandschaft im 19. und 20. Jahrhundert entwickelt hat und welche Strukturen der heutigen Kulturlandschaft historisch gewachsen sind (WEISER 1997:77).

Gewässer-Querschnittkarten stellen beispielsweise in einer Gegenüberstellung verschiedene Stadien der über Jahrhunderte hinweg maximal erreichte Ausdehnung von Teichanlagen, eines Bewässerungssystems oder die Änderungen von Bachläufen dar.

\section{c.2 Kulturlandschaftswandelkarte}

„Ein auf eine erhaltende Landschaftsplanung gerichtetes Instrument [...] ist die von der angewandten historischen Geographie erarbeitete flächenhafte Kartierung des Nutzungs- und Gestaltwandels der Landschaft während der letzten rund 200 Jahre“ (DENECKE 1997:41). Diese Darstellung der Entwicklung der Kulturlandschaft für die Zeit seit ca. 1800, seit der eine annähernd fortlaufende kartographische Dokumentation vorliegt, wird als sog. Kulturlandschaftswandelkarte bezeichnet. WEISER (1997:77) sowie BURGGRAAFF/KLEEFELD (1999:126) sprechen von einem Zeitraum „der letzten 150 Jahre“. Somit bietet diese Karte einen Einblick in die Datierung der Kulturlandschaftselemente und verdeutlicht die Chronologie und Dynamik der kulturlandschaftlichen Entwicklung [...], in denen die mittelalterliche Landschaft starken Veränderungen unterworfen war.“ (:126)

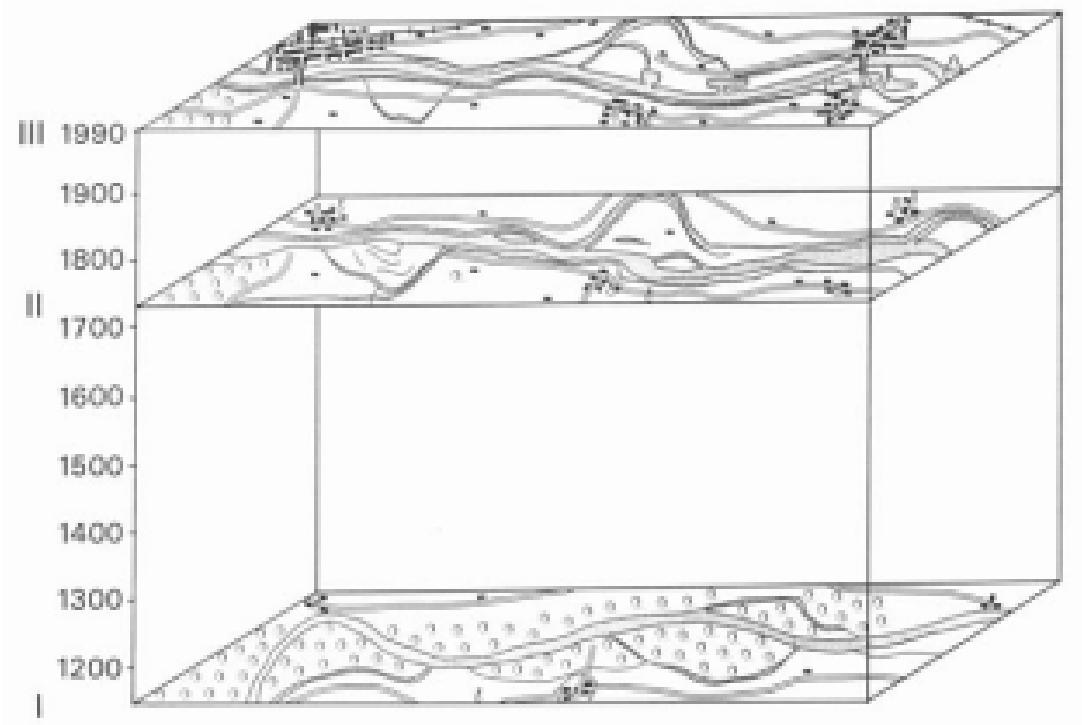

Abb. III-17: Schema einer Kulturlandschaftswandelkartierung mit Gewässerbezug (aus: FEHN 1997:14; Entwurf: Burggraaff)

In Bezug auf den Aspekt einer auf reservierende Maßnahmen ausgerichteten Landschaftsplanung sind Kulturlandschaftswandelkarten insofern von besonderer Bedeutung, da sie zum einen innerhalb von Untersuchungsgebieten deutlich zeigen, ,wo die historischen Elemente durch neuere Aktionen mehr oder minder vollständig vernichtet worden sind." Für andere Regionen hingegen ist es zum anderen „von grundlegender Bedeutung, ganz allgemein zu wissen, welche Typen von Kulturlandschaftselementen in bestimmten Phasen der Entwicklung in größerem Umfang verschwanden und welche in späterer Zeit hinzukamen.“ (FEHN 1997:17) Für die Charakterisierung der Persistenz kulturlandschaftlicher Strukturen und Elemente, ob es sich um einen Raum mit erhaltenen historischen Landschaftsstrukturen oder eine historisch ausgeräumte Kulturlandschaft handelt, ist diese „Betrachtungsweise notwendig, denn diese Elemente sind auch in der Vergangenheit fortlaufenden baulichen Veränderungen ausgesetzt gewesen.“(BURGGRAAFF/KLEEFELD 1999:127) 
Zum Ablauf des Arbeitsverfahrens zur Erstellung einer kulturlandschaftlichen Wandelkarte gibt es nach meinen Erkenntnissen keine allgemeingültige Zusammenstellung der Vorgehensweise. Es wird vielmehr folgender Arbeitsablauf vorgeschlagen:

In einem ersten Arbeitsschritt wird eine ,Kartierung' im Haus vorgenommen. Zu diesem Zweck wird eine Einteilung in physiognomische Punkt-Linien-Flächen-Gruppen vorgenommen, die bezüglich einer gewässerhistorischen Aufnahme wie folgt aussehen kann:

1. Punkte (z. B. Teichmönche, Schleusen, Wehre, Wassermühlen, Brunnen, Brücke)

2. Linien (z. B. Teichdämme, Teichkanäle, Be- und Entwässerungsgräben, Fließgewässer)

3. Flächen (z. B. Dorfteiche, Fischteiche, Bewässerungswiesen)

Oder es werden die Gewässerelemente differenziert nach ihren Funktionen kartiert: fischereiwirtschaftliche Still- und Fließgewässer, Kanäle, Gräben, Talsperren usw. (vgl. WEISER 1997:77) bzw. hinsichtlich der Flächennutzungen der zum Gewässer gehörigen landwirtschaftlichen Nutzflächen (siehe 3a).

Die ,Kartierung' erfolgt also wie gesagt zunächst in einem ersten Arbeitsschritt am Schreibtisch anhand dieser formalen Kriterien auf der Grundlage älterer Kartenwerke und wird dann auf die Maßstabsebene aktueller topographischer Karten übertragen:

„In einem zweiten Arbeitsschritt wird bei der Geländebegehung die Substanz an sich eingeschätzt“ (BURGGRAAFF/KLEEFELD 1999:127). Das bedeutet ein Abgleich zwischen der früheren kartographischen und der heute vorgefundenen Situation durch Geländearbeit. „Sie stellt die historische Dimension der Kulturlandschaft dar, indem die Kulturlandschaftselemente nach ihrer Entstehungszeit auf der Grundlage einer aktuellen Topographischen Karte 1:25.000 kartiert werden (:126).

Die eigentliche Kartendarstellung also „basiert auf einer Zusammenschau von zwei oder drei Zeitschnitten älterer Kartenwerke, woraus sich flächenhaft für die punkt-, linien- und flächenhaften Elemente der Landschaft ein allgemeines Bild der historischen Tiefe ergibt.“ (DENECKE 1997:41) In Verbindung mit der aktuellen Bestandsaufnahme vor Ort wird mit dieser Methode „die heutige Kulturlandschaft in Zeitschnitten der Entstehung ihrer Einzelelemente unterschiedlich in Punkten, Linien und Flächen dargestellt.“ (BURGGRAAFF/KLEEFELD 1997:25)

Doch neben der Geländeaufnahme und Kartenauswertung bilden auch die Luftbildanalyse und die Auswertung schriftlicher Quellen die grundlegenden Arbeitsmethoden (DENECKE 1997:42). Erst nachdem diese Quellen ausgewertet wurden, erfolgt „die Umsetzung dieser Ergebnisse in den räumlichen Zusammenhang“ durch Kulturlandschaftswandelkarten (FEHN 1997:17).

Als beispielhafte Anwendung sei die Darstellung der Entwicklung der Kulturlandschaft am Beispiel „Bockerter Heide“ (Kreis Viersen) genannt, die vom Büro für Angewandte Historische Geographie in Köln durchgeführt wurde (BURGGRAAFF/KLEEFELD 1997). Ausgangspunkt der Kulturlandschaftswandelkarte ist das Urkataster von 1812. Aufgrund des vorhandenen Quellenmaterials und der Sekundärliteratur konnte die Entwicklung der Kulturlandschaft bis ins Spätmittelalter zurückverfolgt werden. Aufgrund der erarbeiteten Grundlagen wurde eine chronologische Kulturlandschaftswandelkarte im Maßstab 1:10.000 (verkleinerte DGK 5) erstellt, in der die Entwicklung der Kulturlandschaft von 1812 bis heute mit folgenden Zeitschnitten erfasst wurde: Preußische Uraufnahme und Fortschreibung der Urkatasterkarte 1844 bis 1857, Preußische Neuaufnahme und Katasterkarte 1892 bis 1899, 1938 Fortführung der Preußischen Neuaufnahme, 1991 DGK 5.

Neben dem an diesem Beispiel und in anderen Fällen der Kulturlandschaftswandelforschung verwendeten ,großen' Maßstab der Kartenerstellung gilt es auch anderen Maßstabsebenen Beachtung $\mathrm{zu}$ schenken, um durch andersartige räumliche Perspektiven weitergehende Ergebnisse für die 
historisch-geographische Forschung zu gewinnen. „Bei kleiner werdenden Maßstäben geht es nicht um Varianten einer mehr oder weniger starken Generalisierung von Detailerfassungen, sondern um stets eigene Arbeitsansätze, bei denen zum größeren Überblick hin zunehmend eine allgemeinere kulturräumliche Dominanz und Charakteristiken ihrer großräumigen Abgrenzung herauszuarbeiten sind. Hier geht es dann vornehmlich um die jeweiligen Kernräume und weniger um die allgemein problematisch und unscharf bleibenden Grenzsäume oder Grenzgürtel.“(DENECKE 1997:39) Dieser Ansatz DENECKEs wird beispielsweise bei dem in dieser Arbeit beschriebenen Betrachtungsansatz historisch-geographischer Gewässerverbreitung vorgestellt (siehe Kap. D IX).

Historisch-geographische Karten, die Forschungsergebnisse der historisch-geographischen Gewässerforschung veranschaulichen, liegen nur vereinzelt vor und dann zumeist in Zusammenhang mit einer anderen Fragestellung. Noch seltener wurden bisher Karten veröffentlicht, die das Gewässernetz in historischer Zeit auf kleinerer Maßstabsebene enthalten. Als Beispiel hierfür kann die Untersuchung von HUBERT (1989) am Beispiel fränkischer Teichwirtschaften gelten oder die Untersuchung schleswig-holsteinischer Teichwirtschaften von RUST (1956).

\section{d Ausblick: Lange Reihe}

„Um die Lücken zwischen den rekonstruierten Zeitschnitten zu schließen“, schreibt SCHENK im LEXIKON DER GEOGRAPHIE (2002:112f.), „bemüht sich die historische Umweltforschung zunehmend um den Aufbau von ,Langen Reihen', welche sich aus seriellen Quellen (z. B. Rechnungen, Dendrochronologie) gewonnen werden. Diesen Datensätzen fehlen allerdings oft flächenhafte Informationen, dafür reichen besonders die aus naturwissenschaftlichen Methoden zu gewinnenden Informationen zeitlich weit über die schriftlichen Quellen zurück. Deshalb ist die kombinierende Auswertung einer möglichst großen Zahl von Quellen unterschiedlicher Art notwendig.“

Die historische Methode anhand von statischen und seriellen Archivquellen bringt also für die historisch-geographische Gewässerforschung oft nur ein abschnittsweises Gewässerbild. Sie muss, soll sie eine räumliche Vorstellung der ehemaligen Gewässersituation ermöglichen, serielle Quellen berücksichtigen und ergänzt werden durch die traditionell geographischen Methoden der Karteninterpretation, Flugbildauswertung und Feldkartierung. Als Anhaltspunkt im Gelände dienen dabei insbesondere die Gewässerrelikte (Teichdämme, Teichmönche, Gewässerhohlformen, Mühlkanäle, Wässergraben, relieferte Wässerwiesenauflandungsrücken, Wehre, Schleusen oder deren Fundamentsteine, markante Furten etc.).

Erst mit dieser Methodenkombination, vor allem aber durch eine detaillierte, quantitative Feldaufnahme kann eine Erfassung des Kulturlandschaftswandels und -bestandes durchgeführt werden. Der ursprüngliche Zustand nach Flächenausmaß und Ausbau des Gewässer- und Wässersystems lässt sich daraufhin meist hinreichend genau rekonstruieren.

Was den zeitlichen Bereich des Kulturlandschaftswandels betrifft, wird bei der anwendungsorientierten historisch-geographischen Gewässerkarte der zeitliche Betrachtungszeitraum derart begrenzt, dass die Jahrhunderte seit den mittelalterlichen Anfängen, worin sich eine gleichmäßig langsame Entwicklung vollzog, nur angedeutet werden können. Im Vordergrund steht der rezente Wandel des 19. und 20. Jahrhunderts. Insbesondere die Spätphase nach dem Zweiten Weltkrieg ist nach meiner Auffassung wissenschaftlich von speziellem Interesse, denn dann ,begann ein unstetiger, tief in die kulturgeographische Tradition eingreifender Landschaftsstress“ (BINGGELI 1986:124). Für diesen Zeitraum lassen sich auch für eine angewandte umwelthistorische Arbeitsweise die im Vergleich zu frühen Archivquellen zusammenhängenden und „umfangreicher“ zur Verfügung stehenden seriellen Quellen erschließen. 


\section{ALLGEMEINER TEIL}

\section{Terminologie und Typologie}

\section{Terminologie und Typologie bisheriger Gewässersystematik}

Im folgenden Kapitel beschäftige ich mich mit der Terminologie und Typologie der bislang in der Literatur der verschiedenen Fachrichtungen erwähnten Gewä sserarten.

„Jegliche Typisierung bzw. Klassifizierung dient“, den Geobotanikern POTT/REMY (2000:118) zufolge, „der überschaubaren Zusammenfassung und Darstellung vielfältiger Erscheinungsformen ähnlicher bzw. zu vergleichender Objekte in Typenklassen. Dies geschieht durch die Definition der jeweiligen Gemeinsamkeiten und spezifischer Eigenarten innerhalb und der Unterschiede bzw. Merkmalsgrenzen zwischen den Typenklassen.“ „Auch die Vegetationskunde bzw. die Geobotanik“, erkannte schon ELLENBERG (1986:6), „kommt ohne die floristisch-systematische Gliederung der Pflanzengesellschaften nicht aus.“”

Entgegen dieser Notwendigkeit nach einer strukturierten Typisierung liegen typologische und definitorische Begriffsabgrenzungen hinsichtlich der Gewässerklassifikation bislang in verwirrender Vielfalt und oft mit diffuser Begriffsverwendung vor. Die Gewässersystematik folgt der je nach Fachdisziplin gebräuchlichen Einteilung: nach Größenordnung, Gewässertiefe, Fließdynamik, Morphologie, nach Reinheitsstufe und Flussabschnitte kennzeichnenden Fischzeigerarten, nach Biotoptypen mit pflanzensoziologischer Kennzeichnung, nach Kilometrierung, Zufluss- und Abflussmöglichkeit, nach natürlicher und sekundärer Entstehung, nach Nutzungsart, energie- und abbauwirtschaftlicher Bestimmung usw., von denen die meisten bisher gebräuchlichen Bezeichnungen sowie veröffentlichten systematischen Übersichten in ihrer Einteilung und Ordnung vor allem bioökologische Kriterien berücksichtigen, d. h. der Limnologie, Botanik oder Zoologie entlehnt sind. Des Weiteren geben einige Rechtsbestimmungen in ihren Legaldefinitionen Möglichkeiten zur Begriffsfindung und abgrenzung. Und schließlich können - zwanglos wie es scheint - ,je nach Intention [...] aber auch identische Gewässer unterschiedlich typisiert werden“ (POTT/REMY 2000:118).

Da die vorliegenden Typisierungen eine Inventarisation der zu untersuchenden historischen Gewässernutzformen und der entsprechenden Landschaftselemente nach umwelthistorischen Gesichtspunkten nicht speziell ermöglichen, freilich aber eine derartige Betrachtung nicht durchführbar ist, ohne in Kenntnis einer gewässerhistorisch-systematischen Gliederung der Gewässerformen und -arten zu sein, besteht die Notwendigkeit zur Bestimmung einer exakteren Gewässerterminologie unter besonderer Beachtung der geschichtlichen Perspektive. Gerade „die im einzelnen individuelle Ausprägung von Kulturlandschaftselementen, ihre große Vielfalt und ihre regionale Gebundenheit und Differenzierung in ihrer Erscheinung wie auch ihrer Bezeichnung macht es für vergleichbare Inventare notwendig, zu einer Typologie zu kommen [...] und zu einem an dieser orientierten terminologischen Rahmen“" (DENECKE 1997:43). Gerade hier wird nämlich der Anwendungs- und Praxisbezug deutlich, denn ohne eine Systematisierung der verschiedenen historischen Gewässerformen und -typen kann eine allgemein gültige kulturlandschaftliche Bewertung nicht vorgenommen werden. Jede Aussage verliert an Wert für die historische Gewässerkunde, wenn sie sich nicht auf bestimmte Gewässertypen beziehen kann.

Vor allem ist dabei ,im Zuge einer Typologie für eine Landschaftsentwicklung das Augenmerk auf die Ausprägung im gegenwärtigen Entwicklungsstadium und Zustand zu richten, auf die Möglichkeit der Weiterentwicklung, eine drohende Beseitigung oder einen Verfall. In gleicher Weise sind Funktion und Funktionswandel weniger historisch-genetisch zu erfassen, sondern eher von der heutigen und möglichen zukünftigen Nutzung her.“ (DENECKE 1997:43) Dieser anwendungsorientierte typologische und zugleich terminologische Ansatz soll unter Beachtung der anthropogenen Zusammenhänge für eine kulturhistorisch-geographische Gewässerforschung umgesetzt werden. 
Ein Beispiel dafür, dass historisch-geographische Kriterien bei der Erstellung einer Fließgewässertypologie bislang fehlen, zeigt die FORSCHUNGSGRUPPE FLIESSGEWÄSSER (1993:18) auf. Darin ist eine schematische Übersicht über den methodischen Ansatz zur Erstellung einer Fließgewässertypologie zusammengestellt und die Zusammenarbeit innerhalb der beteiligten Fachgruppen wiedergegeben (FORSCHUNGSGRUPPE FLIESSGEWÄSSER 1993:19) - die Historische Geographie wurde dabei nicht nach ihren Ansätzen befragt. Als geographische Fachgruppe war einzig das Institut für Geographie und Geoökologie (IfGG) der Universität Karlsruhe beteiligt: Der Beitrag des Instituts umfasste jedoch in erster Linie geologische und geomorphologische und keine historisch-geographischen Fragestellungen (:22). Der Vorteil der bisherigen Negierung des kulturlandschaftlichen Ansatzes bei den typologischen Bemühungen einer Gewässereinteilung ist, dass diese noch keiner Begriffsnivellierung zum Opfer fallen konnten.

In den nachfolgenden Abschnitten soll zunächst zusammenfassend eine Auswahl der wichtigsten Typisierungskonzepte und bislang verwendeter Begriffe vorgestellt und erklärt werden, die, wie bereits erwähnt, zum größten Teil der limnologischen Literatur entstammen (FORSCHUNGSGRUPPE FLIESSGEWÄSSER 1993:28f.). Die nachfolgende Erarbeitung einer gewässerhistorischen Typologie auf der Grundlage bestehender historisch-geographischer Kriterien bildet dann den Abschluss.

\section{a Hydrobiologische Gewässereinteilung}

„Die vielfältigen Versuche der systematischen Typisierung von Fließgewässern auf biotischer Basis reichen zumindest in das vorherige Jahrhundert zurück.“ Dabei stehen, POTT/REMY (2000:126) zufolge, „Gliederungen im Vordergrund, die [...] deutlich voneinander abgrenzbare [...] Längszonen herausarbeiten. Anfangs im wesentlichen auf den jeweils kennzeichnenden Fischarten nach BORNE (1881) basierend“.

Auch nach der FORSCHUNGSGRUPPE FLIESSGEWÄSSER (1993:25) gibt es ,in der limnologischen Fachliteratur [...] eine Fülle von Ansätzen zur Klassifikation von Fließgewässern. [...] Diese Vielfalt der typologischen Ansätze läßt sich letztlich auf zwei grundlegende Prinzipien reduzieren, nach denen Fließgewässer typisiert werden können“:

1. Typisierung der physiographischen und biozönotischen Unterschiede und Veränderungen im Längsverlauf von Fließgewässern

2. Typisierung der geographischen Unterschiede zwischen verschiedenen regionalen Fließgewässern in engem Bezug zu ihren Einzugsgebieten

\section{a.1 Differenzierung nach Zeigerarten}

Bereits 1881 wurden also, wie wir erfahren haben, von BORNE Fließgewässer nach den hauptsächlich vorkommenden Fischarten in entsprechende Zonen eingeteilt. Das Konzept der Fischzonen wurde von zahlreichen Autoren in der Folgezeit weiter verfolgt, wie z. B. von THIENEMANN $(1925,1955)$.

ILLIES (1961) fasst die von THIENEMANN und anderen Limnologen gemachten Beobachtungen über eine zonale Abfolge von Lebensgemeinschaften in Abhängigkeit von der Höhenlage und die dadurch bedingten hydrologischen und ökologischen Bedingungen in einem Gliederungsschema zusammen. Er geht dabei von der klassischen Einteilung von Flussregionen anhand der Fischleiterarten aus und schlägt eine allgemein gültige Zonierung vor, die auf der stromabwärts gegliederten Verbreitung unterschiedlicher Taxa beruht (SCHÄFER 1997:97).

Basierend auf diesem Zonierungsmodell werden hydrobiologische Fließgewässertypen anhand von sog. Zeigerarten von der Quelle bis zur Mündung abwärts nach charakteristischen Fischarten klassifiziert und sie spiegeln damit die abnehmende Wasserqualität wider. Fließgewässer werden hydroökologisch differenziert in: 
1. Forellenregion,

2. Äschenregion,

3. Barbenregion,

4. Bleiregion und

5. Kaulbarschregion

Gleich der Fließgewässertypisierung werden auch Seen nach Fischzeigerarten differenziert, so dass dadurch ihre spezielle Gewässercharakteristika beschrieben werden:

1. Schleiseen [flach, eutroph, besondere Uferfische]

2. Bleiseen [bis $20 \mathrm{~m}$ tief, eutroph, vorwiegend Bodenfische]

3. Coregonenseen [tief, oligotroph, Renken]

\section{a.2 Differenzierung nach zönökologischen Fließgewässerregionen}

ILLIES (1961) hat dieses Fischzonenkonzept auf Basis der Fischzeigerarten unter Einbeziehung von Makrozoobenthon-Organismen (bodensiedelnde Kleinlebewesen der Gewässer) und wichtiger abiotischer, physikalischer Faktoren $\left(\mathrm{O}_{2}\right.$-Konzentration, Temperaturamplitude, Substrat und insbesondere die Strömung, d. h. die Fließgeschwindigkeit) zu einem als allgemein und weltweit als gültig erachteten Konzept der biozönotischen Längsgliederung in zönologische Fließgewässerregionen in Krenon (Quelle), Rhitron (Bäche) und Potamon (Flüsse) weiterentwickelt (FORSCHUNGSGRUPPE FLIESSGEWÄSSER 1993:25; POTT/REMY 2000:127).

Diese Fließgewässer-Gliederung auf zönologischer Basis beruht $u$. a. auf der Beobachtung, dass sich parallel zu den Veränderungen der abiotischen Faktoren im Längsverlauf ebenfalls deutliche Unterschiede bezüglich des Nahrungsangebotes ergeben (POTT/REMY 2000:127).

Zuvor hatte RICKER (1934) für Mitteleuropa zum ersten Mal Fließgewässer nach morphologischen und hydrologischen Merkmalen in zwei ökologisch unterschiedlich funktionierende Flussabschnitte unterteilt. Es handelt sich um die Unterscheidung von Bächen und Flüssen in Gebirgsregionen von den Fließgewässern im Tiefland, die er das Rhitral und das Potamal nannte (vgl. SCHÄFER 1997:197ff.).

Darauf aufbauend werden in gegenwärtiger Zeit die Hauptabschnitte gemäß folgender Dreiteilung bezeichnet:

\section{Krenal \\ 2. Rhitral \\ 3. Potamal}

Das Krenal bezeichnet die Quellregion. Das Rhitral bezeichnet die Gebirgsbachregion, d. h. den Oberlauf der Gewässer. Er ist der Teil des Flusses, der sich von der Quelle bis zu dem Punkt erstreckt, an dem die jährliche Amplitude der Monatsmitteltemperatur $20^{\circ} \mathrm{C}$ nicht übersteigt. Die Strömungsgeschwindigkeit ist hoch und das bewegte Wasservolumen klein. Das Substrat kann aus festen Felsen, Steinen, Kies oder feinem Sand bestehen. Schlammablagerungen kommen nur vereinzelt in Stillwasserbereichen vor (SCHÄFER 1997:197f.). Das Potamal bezeichnet die Niederungsbach- und Flussregion, d. h. den Mittel- und Unterlauf. Es ist der restliche Abschnitt des Flusses bis zur Mündung mit langsamer Strömung und größerem Nährstoffgehalt als beim Rhitral, in dem die jährliche Amplitude der Monatsmitteltemperatur $20^{\circ} \mathrm{C}$ übersteigt.

\section{a.3 Differenzierung nach Fließgeschwindigkeit}

Aufgrund der von der Quelle zur Mündung abnehmenden Durchschnittsgeschwindigkeit werden Flüsse auch in Oberlauf, Mittellauf und Unterlauf untergliedert. Es ist „die im geographischen [...] 
Sprachgebrauch übliche Gliederung von Fließgewässern“ (POTT/REMY 2000:120). Sie „dient lediglich einer räumlichen Beschreibung“ und bezieht sich auf „charakteristische Ausprägungen der Flußmorphologie und auf die durch die Erosions- und Akkumulationsleistung des Flusses ausgebildeten geomorphologischen bzw. topographischen Talformen.“ (POTT/REMY 2000:120; ebenso SCHÄFER 1997:96)

Diese Unterteilung ist eine für das heutige Verständnis teilweise überholte Definition, obschon sie den Sprachgebrauch weiterhin kennzeichnet.

\section{a.4 Gewässertypisierung ohne Differenzierung}

Im Gegensatz zur Gliederung der Fließgewässer in abgrenzbare Längszonenabschnitte (Krenon, Rhitron, Potamon) steht der Gliederungsansatz nach dem sog. River Continuum Concept (RCC) von VANNOTE et al. (1980). Diese Gliederung der Fließgewässer versucht keine Einteilung der Gewässerabschnitte, sondern die kontinuierlichen Übergänge innerhalb des Längsverlaufs zu berücksichtigen.

Es existieren in diesem Konzept lediglich kontinuierlich aufeinander folgende, aber nicht eindeutig gegeneinander in scharfe Zonen abgrenzbare, Konstellationen von Lebens- und Ernährungsformen (FORSCHUNGSGRUPPE FLIESSGEWÄSSER 1993:25; POTT/REMY 2000:129). Nach diesem Konzept sind die Fließgewässer in eine kontinuierlich flussabwärts wandelnde Folge von typischen Konstellationen aus verschiedenen Lebensformen, speziell von Ernährungsformen benthischer Lebensgemeinschaften von Makrozoen, eingeteilt. In diesem Ansatz treten Sukzessionen im Stoffhaushalt der Fließgewässer in den Vordergrund der Klassifikation.

Das RCC geht hierbei „,von weitgehend ungestörten Gewässerstrukturen aus, worin auch die natürliche Gewässer- und Ufervegetation [...] eingeschlossen ist.“ (POTT/REMY 2000:129)

Kritisch ist bei diesem ,fließenden' Konzept anzumerken, dass „die Fließgewässer der Kulturlandschaften durch anthropogene Eingriffe mit Querbauwerken und Stauhaltungen häufig mehr Diskontinuität als Kontinuität" aufweisen (POTT/REMY 2000:129) und es insofern keine Ungestörtheit voraussetzende - ineinander übergehende Fließgewässerfolge mehr gibt.

\section{a.5 Differenzierung nach Nährstoffgehalt}

Stillgewässer (Seen) werden in der Limnologie (Seenkunde), die von François Alphonse FOREL (1841 - 1912) begründet wurde, nach ihrem Trophierungszustand eingeteilt in:

1. dystrophe Seen,

2. eutrophe Seen,

3. oligotrophe Seen,

4. mesotrophe Seen und

5. polytrophe Seen.

Dieses Gliederungsschema besitzt im Allgemeinen nur bei Stillgewässern seine Gültigkeit. „In Fließgewässern treten den Stillgewässern vergleichbare Nährstoffkreisläufe und sukzessive Nährstoffanreicherungen nur innerhalb von weitgehend abgeschnürten Stillwasserbereichen des Potamals an den Flussunterläufen auf. Ansonsten erfolgt entlang der Fließstrecke eines Flusses die allmähliche Akkumulation eutrophierend wirkender Mineralstoffe.“(POTT/REMY 2000:170)

Bei den Fließgewässern wird eher die Gewässertrübung als Gliederungsmerkmal angewendet, denn „die gewässerspezifische Trübung wirkt sich in Kombination mit dem Lichtangebot, der Eigenfärbung des Wassers sowie der Gewässerbreite und -tiefe stark auf die Vegetationsdichte und die vorherrschenden Wuchsformen aus. [...] Von dieser Basis ausgehend erscheint eine allgemeine Gliederung in klare, trübe oder durch Huminstoffe gefärbte Fließgewässer sinnvoll.“(POTT/REMY 2000:129f.) 


\section{b Hydrogeographische Fließgewässereinteilung}

\section{b.1 Differenzierung nach Größe}

Der Begriff ,Fluss' meint grundsätzlich jedes fließende, von Quellwasser und gesammelten, oberflächlich ablaufenden Niederschlägen und Schmelzwässern gespeiste Gewässer des Festlandes (SCHÖN 1999:145).

Im allgemeinen Sprachgebrauch unterscheidet man aber:

1. Ströme

2. Bäche

3. Rinnsale

In wissenschaftlicher Nomenklatur werden Fließgewässer ,,nach der Abflußmenge [...] in Bach, Fluß und Strom unterteilt; geomorphologisch lassen sich dieselben aber nicht präzise voneinander abgrenzen, weshalb in der Geologie meist nur der Begriff ,Fluß' für Fließgewässer Verwendung findet.“(NIEMEYER-LÜLLWITZ/ZUCCHI 1985:9)

Das zu einem Fluss gehörige Gewässernetz bildet das sog. ,Flusssystem'. Das ,Flussgebiet' als nächst größeres Flussareal beschreibt das von dem Flusssystem entwässerte Landgebiet, also das Entwässerungsgebiet, und wird vom nächsten getrennt durch eine Wasserscheide. Die ,Flussregion' (griechisch: Rhitron) schließlich umfasst den allgemeinen Bereich der fließenden Gewässer.

Schwierig wird es, konkrete Größendefinitionen von Fließgewässern zu finden: Was sind z. B. kleine, kleinere, mittlere oder größere und große Gewässer?

Einerseits ist die Abflussmenge Bestimmungsmerkmal für die Größeneinteilung eines Gewässerlaufs. Ströme werden als ,große Flüsse', Bäche als ,kleinere Flüsse' und Rinnsäle als ,kleinste Flüsse' definiert (NIEMEYER-LÜLLWITZ/ZUCCHI 1985:9). Die Größenordnungen sind jedoch nicht vollständig, so fehlt beispielsweise in dem Dreierschema die Kategorie ,mittelgroßer Fluss' und seine entsprechende Übersetzung in ein Fließgewässerbezeichnung und zudem sind die Zuordnungen eher subjektiver Art. Abhilfe würde eine konkrete Größenangabe schaffen:

Als ,kleine und mittelgroße Fließgewässer' werden nach der Definition des LUA NRW (1999b:7) „größenmäßig all diejenigen Fließgewässer definiert, die eine Spiegelbreite bis ca. 10 m aufweisen.“

Das niedersächsische Pendant, das Niedersächsische Landesamt für Ökologie, bestimmt für kleine Gewässer eine Breite von $1-5 \mathrm{~m}$ und für mittelgroße Gewässer $5-10 \mathrm{~m}$ Breite. Große Gewässer weisen infolgedessen eine Breite von mehr als $10 \mathrm{~m}$ auf (RASPER 2001:5,13). ,Kleinste Gewässer' (sprich Rinnsäle) weisen demgemäß, dies ist zu ergänzen, eine Breite $<1 \mathrm{~m}$ auf.

\section{b.2 Differenzierung nach Wasserführung}

Fließgewässer werden entsprechend der Wasserführung unterschieden in

1. perennierende oder permanente Flüsse, d. h. solche, die das ganze Jahr über ständig Wasser führen (Dauer-Flüsse), und

2. temporäre Fließgewässer, d. h. zeitweilig versiegende Quellen, Bäche oder Flüsse.

Diese wiederum werden aufgeteilt in

2.1 periodische oder intermittierende Flüsse, d. h. regelmäßig zeitweilig wasserführende Gewässer (Fiume), hierzu zählen auch die ,ephemeren Bäche', d. h. solche Fließgewässer, die nur in kurzen Intervallen durchgehend Wasser führen und deren Quellschüttung von Jahr zu Jahr schwanken kann, und 
2.2 episodische Flüsse, d.h unregelmäßig, nur gelegentlich, also nur etwa einmal in mehreren Jahren, wasserführende Gewässer (Wadi, Rivier)

unterteilt (NIEMEYER-LÜLLWITZ/ZUCCHI 1985:9f.; LUA NRW 1999b:83).

Weiterhin werden in die Unterscheidung nach Wasserstand

3. Gletscher- oder Schmelzwasserflüsse mit aufgenommen.

Eine Kategorisierung natürlicher, aber auch künstlicher Stillgewässer, dies lässt sich zusammenfassend betrachtet feststellen, erfolgt meist anhand struktureller Merkmale wie der Uferausbildung, der Breite bzw. dem Umfang und der Tiefe eines Wasserkörpers, und sie orientiert sich darüber hinaus auch an Art und Umfang der Wasserführung (POTT/REMY 2000:158). Lässt man längerfristige Verlandungsvorgänge außer Acht und betrachtet die eher mittelfristige Konstanz der Wasserführung eines Gewässers, so ist bei den Stillgewässern, vergleichbar den Fließgewässern, eine Unterscheidung zwischen temporären (vorübergehenden) und perennierenden (ausdauernden) bzw. permanenten stehenden Gewässern möglich und sinnvoll (POTT/REMY 2000:158; SCHÄFER 1997:175).

Diese Bestimmung ist jedoch mit Schwierigkeiten verbunden, da sich natürliche Fließgewässer mehr oder weniger kontinuierlich verändern, wobei unterschiedliche Abflusszustände oder Lebensräume im und am Fließgewässer ineinander übergehen. „So haben Altwasser bei Trockenwetterabfluss den Charakter von Stillgewässern, wohingegen sie bei Hochwasserabfluss u. U. nicht unmittelbar von Fließgewässern zu unterscheiden sind.“ (POTT/REMY 2000:118) Des Weiteren nehmen die Übergangsbereiche zwischen terrestrischem und limnischem Substrat eine Sonderstellung ein, „die am Fließgewässer durch kurzfristig wechselnde Wasserstände und einen ständigen Wechsel zwischen Benetzung und Abtrocknung gekennzeichnet sind.“(NIEMEYER-LÜLLWITZ/ZUCCHI 1985:33)

Aufgrund dieser räumlichen, zeitlichen sowie strukturellen Übergänge ,beinhalten Gliederungen wie auch Typisierungen von Seen, Bächen und Flüssen die auf Wasserstände beruhen, immer gewisse Unschärfen bzw. Widersprüchlichkeiten " (POTT/REMY 2000:118) und sollten deshalb möglichst nur nach eingehender Prüfung bzw. Kenntnis der Gewässerverhältnisse angewandt werden.

\section{b.3 Unterscheidung nach Art des Wasseraustritts}

Schließlich wurde eine weitere Differenzierung der Gewässer bei der Betrachtung von Quellen vorgenommen, die am Anfang eines jeden Fließgewässerlaufes stehen, oftmals auch die Stillgewässer speisen und allein aus diesem Grund hier eine Erwähnung finden müssen. Je nach Art des Wasseraustritts unterscheidet man dabei (NIEMEYER-LÜLLWITZ/ZUCCHI 1985:55)

1. Sturz- oder Fließquellen (Rheokrenen), deren Wasser schon am Quellmund, meist aus grobsandigem oder steinigem Untergrund, mit Gefälle abströmt,

2. Tümpelquellen (Limnokrenen), die am Grund eines Beckens austreten, dessen Überlauf erst den Quellbach bildet und

3. Sicker- oder Sumpfquellen (Helokrenen), deren Wasser im Bereich einer größeren Fläche austritt und einen, Quellsumpf 'bildet.

\section{b.4 Landschaftsbezogene Typisierung}

Eine Typisierung von Fließgewässern sollte nach POTT/REMY (2000:118) ,immer landschaftsbezogen“ erfolgen. Auch RASPER (2001:8) vertritt die Auffassung, dass - aufbauend auf naturräumliche Grundlagen - Fließgewässerlandschaften unterschieden werden sollten, „da in jeder Landschaft nur ganz bestimmte Fließgewässertypen vorkommen. “ Doch was sind (Fließ-) Gewässerlandschaften?

Flusslandschaften bezeichnet DENECKE (2001:272) als „regionale Landschaftstypen“ wie zum Beispiel auch Bergbau- und Industrielandschaften oder Moor- und Marschgebiete. Das würde bedeuten, sie müssen, vergleichbar jenen anderen Landschaftstypen, durch ihr Erscheinungsbild 
dominieren, d. h. die Landschaft charakteristisch prägen sowohl sinnbildlich als auch physiognomisch und eventuell auch wirtschaftlich.

„Unter einer Gewässerlandschaft“, definiert das LUA NRW (1999a:5) anhand von physiogeographischen Kriterien, ,wird ein Landschaftsraum verstanden, der in bezug auf die gewässerprägenden geologischen und geomorphologischen Bildungen als weitgehend homogen zu bezeichnen ist, jedoch [...] im Längsverlauf eines Gewässers mehrere Gewässertypen enthalten kann.“ Das heißt, die Gewässertypen selbst können innerhalb der Gewässerlandschaften kleinräumig wechseln.

Von - vor allem aus geographischer Sicht - besonderer Bedeutung hinsichtlich der landschaftsräumlichen Abgrenzung ist ein weiteres Merkmal, das durch die Definition des LUA NRW (1999a:5) zum Ausdruck gebracht wird: „Die geographische Lage der Gewässerlandschaften ist als orientierter Überblick kartographisch darstellbar“. Solche ,naturräumlichen Haupteinheiten mit - bezogen auf die Fließgewässerbeschaffenheit - ähnlichem Charakter“, so das LUA weiter, „können zusammengefasst werden, sie werden als ,Fließgewässerlandschaften’ bezeichnet.“ (:7) Diesbezüglich gibt es bislang verschiedene Ansätze:

Ein erster systematischer Ansatz zur generellen regionalen Typisierung von Bächen wurde von OTTO und BRAUKMANN entwickelt (nach FORSCHUNGSGRUPPE FLIESSGEWÄSSER 1993:30). Dieses sog. ,regionale Bachtypenkonzept' ist hierarchisch aufgebaut und umfasst folgende - zunächst abstrakt wirkende - typologische Kategorien und Kriterien:

1. Grundtypen

1.1 Allgemeine regionale Grundtypen

1.2 Allgemeine geochemische Grundtypen

2. Subtypen

\section{$2.1 \quad$ Höhenzonale Subtypen}

Bei den ,geochemischen Grundtypen' wird eine Unterteilung der Bäche nach den im Bachgebiet vorherrschenden Gesteinsarten vorgenommen. Obgleich hier eine keine primär landschaftsbezogene Unterteilung vorliegt, sei sie dennoch mit aufgenommen, da sie Bestandteil des ,regionalen Bachtypenkonzeptes' ist. Die meisten Gesteinsarten lassen sich in dieser Klassifizierung nach den Hauptkomponenten ihrer mineralischen Zusammensetzung in zwei Gruppen einteilen:

1. Silikat-Gestein

2. Karbonat-Gesteine

Entsprechend diesen Gesteinsgruppen werden die Bäche eingeteilt in die beiden allgemeinen geochemischen Fließgewässergrundtypen:

\section{Silikat-Bäche}

2. Karbonat-Bäche

Die Zuordnung zum Silikat- bzw. Karbonattyp erfolgt, wenn mehr als $80 \%$ des Einzugsgebietes aus dem entsprechenden Gesteinstyp bestehen.

Eine weitere landschaftsspezifische Einteilung der Grundtypen erfolgt nach der Höhenlage der Bäche und den entsprechenden klimatischen Bedingungen. Sie werden als ,höhenzonale Grundtypen' bezeichnet. Die Grundtypen werden jeweils in zwei höhenzonale Subtypen weiter aufgegliedert und mit den Buchstaben $h$ (,high') und $l$ (,low') gekennzeichnet.

Eine konkret landschaftsgebundene Typisierung, die auf dem Grundprinzip der Höhe aufbaut, stellt die allgemein bekannte geographische Höhenzonierung von Fließgewässern dar. Nach geographischen Gesichtspunkten werden die Bäche aufgrund relief- und klimabedingter Eigenschaften in allgemeine regionale Grundtypen eingeteilt: 
1. Gebirgsbäche (Hochgebirge)

2. Bergbäche (Mittelgebirge)

3. Flachlandbäche (Flach- bzw. Tiefland)

Diese ,in Mitteleuropa typische Abfolge von Flußabschnitten ergibt sich aus der geomorphologischen Großgliederung in Hochgebirgs-, Mittelgebirgs- und Tieflandsregionen. Die meisten der großen Entwässerungssysteme entspringen im Hochgebirge, durchqueren Mittelgebirgsregionen unterschiedlicher Ausprägung und besitzen im Mündungsbereich einen mehr oder weniger ausgedehnten Tieflandsabschnitt.“ (SCHÄFER 1997:96)

Nach ähnlichen Kriterien werden aus der naturräumlichen Gliederung Niedersachsens drei sog. Fließgewässergroßlandschaften für das Land abgeleitet (nach RASPER 2001:8):

1. „Bergland“,

2. „Tiefland“" und

3. „Küstenmarsch“.

Eine differenziertere regionale Fließgewässertypologie hat die FORSCHUNGSGRUPPE FLIESSGEWÄSSER (1993:30) am Beispiel Baden-Württembergs aufgestellt. Dabei werden vier „HauptFließgewässerlandschaften“ unterschieden:

1. Bergland-Gewässer

2. Berg- und Hügelland-Gewässer

3. Hügel- und Flachland-Gewässer

4. Flachland-Gewässer

Weiterhin gibt es in neuerer Zeit regional bzw. naturräumlich orientierte Gliederungen von verschiedenen regionalen Gewässertypen, die regionale, geographisch-geomorphologisch bedingte Unterschiede zwischen Fließgewässern verfolgen (Hoch- und Mittelgebirge oder Flachland) und zu physiographisch verwandten ,regionalen Bachtypen“ oder gewässerlandschaftsspezifischen Typen führen (POTT/REMY 2000:125; FORSCHUNGSGRUPPE FLIESSGEWÄSSER 1993).

POTT/REMY (2000:133ff.) haben anhand verschiedener Gliederungsmerkmale aus wissenschaftlicher Sicht eine Reihe solch „,̈̈berregionaler“ oder „allgemeiner“ Fließgewässertypen Mitteleuropas abgrenzt:

1. Gletscherbach

2. Fließgewässer der Gebirge

3. Bäche und Flüsse der Mittelgebirge

4. Fließgewä sser der Hügelländer

5. Gefällearme Fließgewässer des Flachlandes bzw. Tieflandes

6. Besondere Fließgewässertypen im Flach- und Tiefland

6.1 Klare Grundwasserbäche und Quellbäche/Quellgräben

6.2 Schichtstufenbäche

6.3 Löß- und Lehmfließgewässer

6.4 Sand- bzw. Grundmoränenbäche

6.5 Klare bzw. huminstoffgefärbete Bäche mit organischem Substrat

6.6 Klare bis leicht trübe Ausfällungsbäche

6.7 Strömungsarme Tiefland- bzw. Niederungsgewässer

6.8 Fluss-Seen-Komplexe, Seeausflüsse

6.9 Haline Fließgewässer

6.9.1 Brack- und Tidegewässer

6.9.2 Salzhaltige Fließgewässer des Binnenlandes

6.10 Temporäre Fließgewässer 
Besonders aber zu erwähnen für den deutschen Landschaftsraum sind hier die typologischen Bemühungen der Länder Niedersachsen und vor allem Nordrhein-Westfalen ${ }^{1}$, die sich schwerpunktmäßig kleiner und mittelgroßer Fließgewässer angenommen haben.

$\mathrm{Zu}$ Anfang der 1990er Jahre begann man in Nordrhein-Westfalen mit der Entwicklung einer Gewässertypologie und der Aufstellung von Leitbildern auf gewässermorphologischer und biozönotischer Basis (LUA NRW 1999a und b:10). Die damit verbundene Zielsetzung lautete, eine Gliederung kleiner und mittelgroßer Fließgewässer zu erhalten. Eine Vielzahl individueller Gewässerläufe einer Region sollten $\mathrm{zu}$ Typen mit vergleichbaren Merkmalskombinationen zusammengefasst werden².

Die Aufgabe lautete daraufhin, Leitbilder für Fließgewässer zu erarbeiten, „die auf wissenschaftlichen Erkenntnissen über ökologische Zusammenhänge beruhen“ (LUA NRW 1999a:Vorwort). Zugleich wurden „weitestgehend naturnahe“, den Landestypologien ,Tiefland' und ,Mittelgebirge' zugrunde liegende Referenzgewässer (Tieflandbäche, Mittelgebirgsbäche) „nach morphologischen und biozönotischen Kriterien untersucht“ (:Vorwort), mit dem Ziel, „das in NRW vorhandene Spektrum an Gewässertypen aufzuzeigen“"(LUA NRW 1999b:7).

Daraus ergibt sich entsprechend der geologischen und pedologischen Beschaffenheit die folgende zweistufige Grundgliederung der Fließgewässerlandschaften Nordrhein-Westfalens:

1. Die Fließgewässerlandschaften des Tieflandes und

2. die der Mittelgebirgsregion.

Innerhalb dieses fließgewässerlandschaftlichen Grundsystems werden weitere Typologien („Gewässertypen“) von Tiefland- und Mittelgebirgsbächen NRW unterschieden (LUA NRW 1999a:V,VI):

\section{A. Fließgewässer des Tieflandes}

1. Fließgewässertypen der, Sandgebiete'

1.1 organisch-geprägtes Fließgewässer der Sander und sandigen Aufschüttungen

1.2 sandgeprägtes Fließgewässer der Sander und sandigen Aufschüttungen

2. Fließgewässertypus der, Verwitterungsgebiete und Flussterrassen,

$=$ kiesgeprägtes Fließgewässer der Verwitterungsgebiete und Flussterrassen

3. Fließgewässertypus der, Lößgebiete'

$=$ löß-lehmgeprägtes Fließgewässer der Bördenlandschaften

4. Fließgewässertypus der, Niederungsgebiete'

$=$ Fließgewässer der Niederungen

\section{B. Fließgewässer des Mittelgebirges}

5. Fließgewässertypen des, silikatischen Grundgebirges'

5.1 Kerbtalbach im Grundgebirge

5.2 kleiner Talauebach im Grundgebirge

\footnotetext{
1 Nordrhein-Westfalen war neben dem erwähnten Baden-Württemberg (FORSCHUNGSGRUPPE FLIESSGEWÄSSER 1993, 1998) das erste Bundesland, das die Entwicklung einer Gewässertypologie und die Aufstellung von Leitbildern in Auftrag gab. Erarbeitet wurde das System von Bachtypen von der Universität GH Essen.

${ }^{2}$ Das in dem Band „Leitbilder für kleine bis mittelgroße Fließgewässer in Nordrhein-Westfalen: Gewässerlandschaften und Fließgewässertypen" vom LANDESUMWELTAMT NORDRHEIN-WESTFALEN [LUA] herausgegebene Material beruht auf den beiden Studien „Zielvorgaben und Handlungsanweisungen für die Renaturierung von Tieflandbächen in NRW“ und „Typisierung und Leitbildfindung für kleine und mittelgroße Fließgewässer des Mittelgebirgsraumes NRW“. Der Band fasst die Ergebnisse dieser Studien zur Typologie und Leitbildbeschreibung von Fließgewässern in NRW zusammen. Beide Studien wurden erarbeitet im Auftrag des Ministeriums für Umwelt, Raumordnung und Landwirtschaft vom Institut für Ökologie der Universität-GH Essen zwischen 1991 und 1998.
} 
5.3 großer Talauebach im Grundgebirge

6. Fließgewässertypus des ,Vorlandes des Silikatischen Grundgebirges'

$=$ colliner Bach

7. Fließgewässertypen des, schwach-karbonatischen Deckgebirges'

7.1 kleiner Talauebach im Deckgebirge

7.2 großer Talauebach im Deckgebirge

8. Fließgewässertypus der, Muschelkalkgebiete'

$=$ Muschelkalkbach im Deckgebirge

9. Fließgewässertypus der, verkarsteten Kalkgebiete'

= Karstbach

10. Fließgewässertypus der, Vulkangebiete'

$=$ Bach der Vulkangebiete

Eine gleichartige, doch weniger geologisch-mineralogische als mehr pedologisch-geographische Gliederung der Gewässertypen besteht für Niedersachsen:

\section{A. Fließgewässer des Tieflandes}

- kiesgeprägtes Fließgewässer

- sandgeprägtes Fließgewässer

- organisch-geprägtes Fließgewässer

- löß-/lehmgeprägtes Fließgewässer

- Fließgewässer der großen Feinmaterialauen in Sandgebieten

- Küstenmarschgewässer

\section{B. Fließgewässer des Berglandes}

- Kerbtalgewässer

- Sohlenkerbtalgewässer

- Muldentalgewässer

- Sohlen-Auentalgewässer

Schließlich wurde jeder dieser Gewässertypen anhand eines Referenzgewässers exemplarisch beschrieben. Referenzgewässer stellen konkrete Beispiele für die ausgewiesenen Gewässertypen dar und ihnen kommt hiermit eine Vorbildfunktion für Bewertungsverfahren und weitergehende gewässertypologische Untersuchungen zu (LUA NRW 1999a:2).

Bislang dient die Ökologie als Vorbild und bestimmt die Auswahl von Referenzgewässern und damit die Gestaltung von Bächen im Rahmen beispielsweise von Renaturierungsmaßnahmen. Dies belegt eindeutig die ökologisch-motivierten Begründungen des LUA NRW zur Wahl von solchen Referenzgewässern: „Um die Funktionsfähigkeit eines Systems beurteilen zu können, müssen Leitbilder auf wissenschaftlichen Kenntnissen über ökologische Zusammenhänge beruhen. Es ist Aufgabe der Naturwissenschaft, im Rahmen der Entwicklung von regionalen Gewässertypologien die Vielzahl individueller Gewässerläufe einer Region zu Typen mit vergleichbaren Merkmalskombinationen zusammenzufassen. Abgeleitet werden diese aus der genauen Analyse möglichst naturnaher, konkreter ,Referenzgewässer'““ (LUA NRW 1999a:1) Und diesbezüglich heißt es weiter: „Da Referenzgewässer konkrete Beispiele für die ausgewiesenen Gewässertypen darstellen und ihnen hiermit eine Vorbildfunktion für Bewertungsverfahren und weitergehende gewässertypologische Untersuchungen zukommt, sollten sie aufgrund ihrer besonderen Naturnähe, aber auch für die Fragen der Wissenschaft, zukünftig unter besonderen Schutz gestellt werden.” (:2) „Referenzgewässer“, dies stellt das LUA NRW (:5) schließlich unmissverständlich klar, ,sind weitgehend naturnahe Fließgewässerabschnitte“. Das heißt, da es auch dem LUA NRW bekannt ist, dass es durchgehende, in ihrer Gesamtheit nahezu unberührte Fließgewässer nicht mehr gibt, handelt es sich bei den Referenzgewässern um „naturnahe Bäche, die zumindest auf Teilstrecken ihr naturraumtypisches Potential weitgehend behalten haben“(:1). 
Der Begriff „,naturnah“ wird trotzdem vom LUA NRW (1999a:5) als Leitbild aus der geoökologischen Literatur übernommen. Darunter wird „der potentiell natürliche Zustand eines Gewässers verstanden, der sich nach dem Ausbleiben menschlicher Einflüsse unter den bestehenden biotischen und abiotischen Bedingungen langfristig einstellen würde.” (:3) „Es erfolgt also kein Bezug zu einem irgendwie definierten historischen Zustand" schreibt das LUA NRW (1999a:5) in aller Deutlichkeit an mehreren Stellen und ergänzt diesen Betrachtungsansatz an anderen Stellen: „das Leitbild besitzt keinen Bezug zu einem konkreten historischen Zustand“" (LUA NRW 1999b:8).

Das Leitbild definiert den Zustand eines Gewässers anhand des heutigen Naturpotentials des Gewässerökosystems - auf der Grundlage des Kenntnisstandes über dessen natürliche Funktionen. „Das Leitbild schließt insofern nur irreversible anthropogene Einflüsse auf das Gewässerökosystem ein“ (LUA NRW 1999a:5). Der Bestimmung von Referenzgewässern und damit einer (regionalen) Fließgewässertypologie liegt demnach ein Leitbild zugrunde, das durch die Leitbildfindung gewonnen wurde und im Rahmen der Leitbildanalyse angewendet wird. Dabei handelt es sich um „,naturraumtypische Leitbilder“, bei denen das Leitbild „den ökologischen Maßstab” definiert (LUA NRW 1999b:8).

Die Leitbilder aber bedürfen zur Umsetzung menschliche Schaffenskraft: Deshalb bezeichnet der, dies sei hier eingefügt, - praxisnähere - Leitbild-Begriff in der Landschaftsplanung einen Soll-Zustand (= Entwicklungsziel), „der durch anthropogene Eingriffe und unter Einbeziehung von rechtlichen und finanziellen Vorgaben und der bestehenden Flächennutzung erreicht werden soll“" (LUA NRW 1999a:3]. Das - pragmatische - Entwicklungsziel hier ,definiert den möglichst naturnahen, aber unter gegebenen sozio-ökonomischen Bedingungen realisierbaren Zustand eines Gewässers nach den jeweils bestmöglichen Umweltbewertungskriterien unter Einbeziehung des gesamten Einzugsgebietes.“(:5)

Unabhängig von der jeweiligen Auslegung des Leitbild-Begriffs wird bei der ökologisch-orientierten Leitbildbestimmung eine Ausgrenzung kulturhistorischer bzw. umweltgeschichtlicher Sachverhalte vorgenommen, die sich bei der Leitbildanalyse fortsetzt. Mit einer Ausnahme: Bei der Verwendung von historischem Kartenmaterial, wie später deutlich wird.

Die Leitbildanalyse hat die Zuordnung des Untersuchungsobjektes zu einem Gewässertyp zum Ziel. Die Analyse erfolgt zunächst mit der Erhebung des Ist-Zustandes des Gewässers ${ }^{3}$. Darunter fallen die Parameter:

- Morphologie (z. B. Strukturgütekartierung),

- Geochemismus (Analyse von Leitfähigkeit, pH-Wert, Carbonat- und Gesamthärte),

- Makroinvertebratenzönose,

- Fischbesiedlung,

- Vegetation und

- Nutzung (z. B. Biotoptypenkartierung).

Diese Freilanduntersuchungen werden ergänzt durch bereits bestehende Erhebungsdaten, d. h. durch Daten des Quellenstudiums, wie naturräumliche Beschreibungen, Unterlagen der sonstigen abiotischen und biotischen Charakteristika, Pegeldaten etc.

Des Weiteren werden Kartenwerke zur Bestimmung des Ist-Zustandes ausgewertet: Neben Gewässerstationierungskarten sowie geologischen und bodenkundlichen Karten, kann „durch das Hinzuziehen von historischen Karten [...] das Gewässer in seinem aktuellen Zustand detailliert beschrieben werden.“(LUA NRW 1999a:3)

Einzig also bei den Karten der Gewässerlandschaften wird zur Zustandsbestimmung der gewässerhistorische Aspekt als Quellenbasis berücksichtigt.

\footnotetext{
${ }^{3}$ Begriffe: Leitbild, Entwicklungsziel und Ist-Zustand nach Länderarbeitsgemeinschaft Wasser 1997 (LAWA)
} 
Dabei ist die Erhebung des Ist-Zustandes von großer planungsrelevanter Bedeutung. Der Ist-Zustand ist der nach einem definierten Bewertungsverfahren beschriebene aktuelle Zustand des Ökosystems Gewässer. Aus der Differenz des Ist-Zustandes zum Entwicklungsziel (= Soll-Zustand) ergibt sich der aktuelle Sanierungsbedarf. (LUA NRW 1999a:5). „Stimmen am Ende eines Entwicklungsprozesses der Zustand des Fließgewässers und das Leitbild überein, so kann von ,Renaturierung' gesprochen werden.“ (LUA NRW 1999b:8)

Dieses ist für den Beitrag der Historischen Geographie ein entscheidender Punkt, sowohl was den derzeitigen Mangel zur Mitarbeit bei der Bestimmung von Gewässerreferenzstrecken als auch was die Beachtung bei der Leitbildfindung sowie die Beteiligung bei der Durchführung von Ist-Erhebungen und Soll-Ausführungen von - vor allem kleinen bis mittelgroßen - Fließgewässern angeht.

Angesichts des tatsächlichen, schon seit Jahrhunderten anthropogen veränderten Gewässerbildes und zur Bewahrung bzw. auch Wiederherstellung von kulturhistorischen Flusslandschaften muss die Diskussion um ein erweitertes, verändertes oder neues Leitbild geführt werden, das nicht auf rein ökologisch orientierter Zielsetzung beruht, sondern einem kulturhistorisch orientierten Wasserbau den Vorrang gibt.

Es ist somit kein ,naturraumtypisches', sondern vielmehr ein ,kulturraumtypisches Leitbild' anzustreben. Des Weiteren sind kulturhistorische Fließ- und auch Stillgewässertypen zu bestimmen (Mühlbäche, Mühlteiche, Triftbäche, Triftteiche, Fischteichzuflüsse, Fischteiche etc.). Und dementsprechend ist auch die Aufstellung kulturhistorischer ,Referenzgewässer' zu fordern. Eine Beteiligung der historisch-geographischen Fachdisziplin wäre angesichts der Thematik wünschensund erstrebenswert. Dies beinhaltet auch die kulturhistorische Ausrichtung der Leitbildanalyse, für die die Historische Geographie über entsprechend erprobte Bewertungs- und Planungswerkzeuge verfügt. Stimmen dann am Ende eines Entwicklungsprozesses der Zustand des Fließgewässers und das kulturhistorische Leitbild überein, um die Schlussfolgerung von vorhin wieder aufzunehmen, so kann von ,Rekultivierung' (bei Wiederherstellung) oder von ,historischer Gewässerlandschaftspflege' (bei Bewahrung) gesprochen werden.

Die Bedeutung und Notwendigkeit einer solchen historisch-geographischen Mitwirkung wird aufgrund der Tragweite der bisherigen Typisierung und Leitbildfindung für die Planungspraxis deutlich, die aus den Aussagen des LUA ersichtlich werden: „Die Leitbilder geben künftig die Richtung für Planungen zur naturnahen Entwicklung und Umgestaltung der Bäche und Flüsse in Nordrhein-Westfalen an”, schreibt das LUA NRW (1999b:3). Und an anderer Stelle: „Mit Hilfe der Leitbilder ist es möglich, Fließgewässer individuell und den einzelnen Gewässerlandschaften und Naturräumen gemäß zu betrachten und gegebenenfalls zu entwickeln.“ (:8) Schließlich zur Bestätigung: „Das Leitbild [...] bietet [...] eine Orientierung bei der Planung von ökologischen Verbesserungen wie der naturnahen Unterhaltung und dem naturnahen Ausbau.“ (:8)

Diese Belege widersprechen der Aussage, dass das Leitbild „kein konkretes Sanierungsziel“ ist, sondern „,in erster Linie als Grundlage für die Bewertung des Gewässerökosystems“ dient (LUA NRW 1999a:5).

Die Vorgehensweise vom Planungsobjekt Fließgewässer zu entsprechenden Maßnahmen und die Bedeutung naturraumtypischer Leitbilder wird in Abb. IV-1 verdeutlicht: 


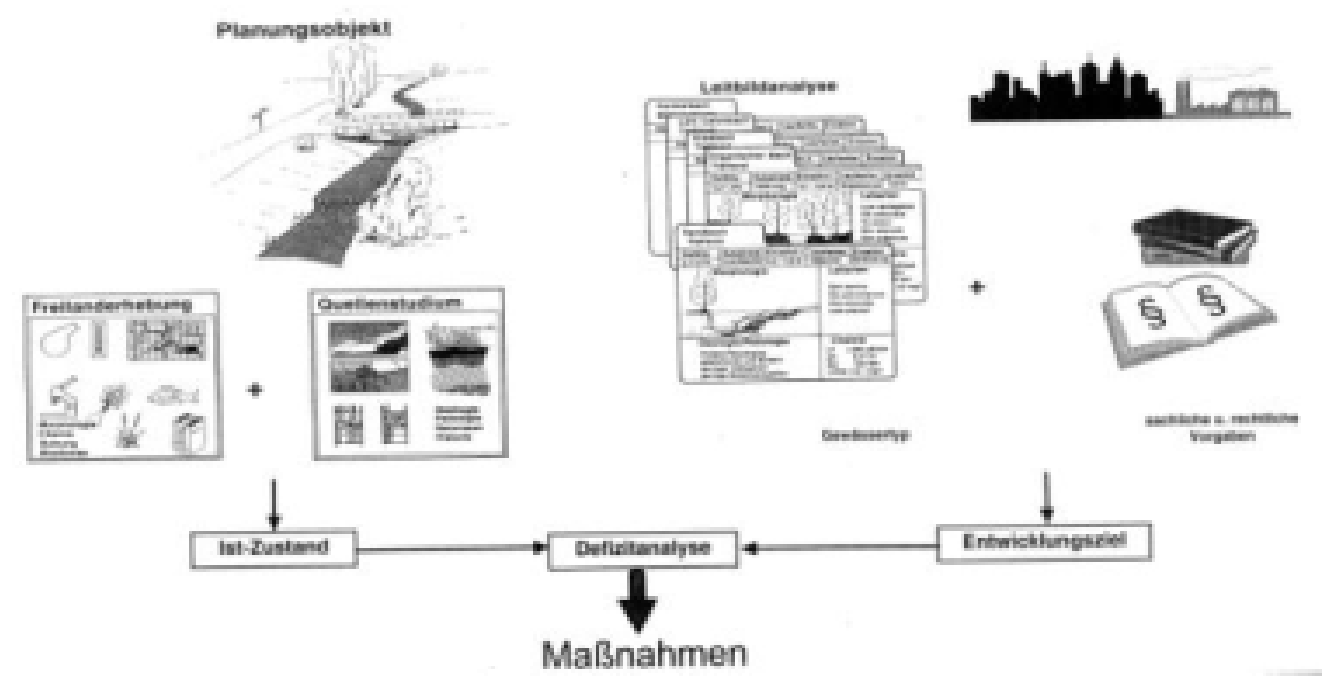

Abb. IV-1: Leitbildfindung (LUA NRW 1999b:9).

Die Bedeutung der ökologisch-ausgerichteten Handlungsanweisungen und Zielvorgaben für die Gewässerplanung wird auch an anderen Stellen der vom Landesumweltamt NRW herausgegebenen Fließgewässerstudie deutlich: So „stellen die Beschreibungen der unterschiedlichen Gewässercharakteristika Wegweiser dar für ökologische Verbesserungsmaßnahmen bis hin zu Renaturierungen.“ (LUA NRW 1999b:7) Ebenso besitzen „die ausgewählten, naturnahen Referenzstrecken [...] Leitbildcharakter für die übrigen Gewässer dieses Typs“ und „geben die Typbeschreibungen in Verbindung mit den naturnahen Referenzgewässerstrecken die Richtung an, in die sich der [...] Zustand derzeit naturferner Gewässer entwickeln sollte. [...] Sie dienen daher auch als Vorbild und wichtige Grundlage für die Planung von Renaturierungsmaßnahmen und die Aufstellung von Gewässerentwicklungsplänen.“ (RASPER 2001:5)

\section{c Naturhistorische Terminologie und Typologie}

Die vorgestellten Typisierungen erlauben eine die kulturhistorische Entstehung und Wandlung berücksichtigende Einordnung von Gewässern nicht. Gleichzeitig sehen einige Autoren die Schwierigkeiten solcher Ansätze: „In Mitteleuropa“, so stellt Alois SCHÄFER (1997:98) in seinem Studienbuch zur „Einführung in die biogeographische Areal- und Raumanalyse in limnischen Ökosystemen“ fest, ist die „biogeographische Zonierung von Flüssen und die oben aufgeführte idealisierte Abfolge von Flußabschnitten kaum noch zu beobachten; denn vor allem die Mittelgebirgsund Tieflandsabschnitte von Fließgewässern wurden durch den Menschen umgestaltet. Das gilt insbesondere für die Stauhaltung oder Regulierung der schiffbaren Flüsse." Und auch für die FORSCHUNGSGRUPPE FLIESSGEWÄSSER (1993:44) gibt es „für einige Bachtypen [...] keine naturnahen Beispiele mehr und sie müssen als ,ausgestorben' gelten. [...] Dies betrifft die Niederterrassen-Bäche und die autochthonen Flachlandauebäche insgesamt." Aus historischgeographischer Sicht interessant ist ihre daran anschließende Auffassung, dass „lediglich Aussagen zur Linienführung [...] durch Auswertung alter Karten getroffen werden“ könnten.

Wenn aber eine biohydrologische und -geographische Gewässertypeneinteilung aus anthropogenen Gründen verbleiben muss und nur ein historisch-geographisches Altkartenstudium Auflösung bringt, so unverständlicher ist die Tatsache, dass die Aufnahme historisch-bedeutsamer Gewässerformen unberücksichtigt bleibt und auch typologisch nicht erfasst wird. Damit wird beispielsweise eine gewässerkundliche Bewertung unter Beachtung historisch-anthropogener Gesichtspunkte, beispielsweise im Rahmen einer Fachplanungserstellung, erschwert bzw. unmöglich. Eine Übernahme von Gewässerrelikten, beispielsweise in einen Erfassungsbogen, und damit die Chance einer sich auf rechtlicher Basis stützenden Unterschutzstellung bzw. Reaktivierung bleibt infolgedessen aus. 
Die Vielzahl der Gewässergeschichte ist nämlich, dies bleibt vielfach bei den ökologischen Ansätzen unbeachtet, weitaus komplizierter: Die heute weltweite Verbreitung von Umweltchemikalien ist ein Beispiel dafür, dass wir nicht mehr zwischen ,natürlichen' oder , primären' und , anthropogenen' oder ,sekundären' Ökosystemen unterscheiden können. Je nach dem Grad des steuernden oder überformenden Einflusses anthropogener Aktivitäten können maximal Systeme unterschiedlicher ,Naturnähe' differenziert werden. Derartige Klassifizierungen werden im Folgenden vorgestellt:

\section{c.1 Landschaftsformen nach JÄGER}

JÄGER differenziert in Anlehnung an MORTENSEN (1894 - 1964) (JÄGER 1988:11f.; 1994: $8,91 \mathrm{ff}$.$) :$

1. natürliche und naturnahe bzw. vorwiegend naturnahe,

2. quasinatürliche sowie

3. seminatürliche Formen von Landschaftselementen

voneinander und versucht somit die anthropogene Veränderung der natürlichen Umwelten in ihrer entstehungsgeschichtlichen Vielschichtigkeit begrifflich zu verdeutlichen. Er zeigt damit zugleich einen Weg der Formenansprache auf, der eine erste Klassifizierung der Gewässer entsprechend ihrer Herkunft ermöglicht und für die Aufnahme in einem sog. Inventarisierungsschlüssel geeignet erscheint.

Als Beispiele natürlicher und naturnaher bzw. vorwiegend naturnaher Gewässer nennt JÄGER Flussauen, Moore, Sümpfe, Brüche, Quellen. Als allgemeines Landschaftselement und zur anschaulichen Erklärung von ,Naturnähe' führt er das Beispiel der Dünen an. Denn Dünen gehen ,teilweise auf rein natürliche Prozesse gegen Ende des Eiszeitalters zurück, doch sind sie andernteils unter Mitwirkung des Menschen seit urgeschichtlicher Zeit verändert worden.“ (1994:66)

Quasinatürliche Gewässer definiert er als „Formungsvorgänge und ihre Ergebnisse, die durch den Menschen zunächst herbeigeführt worden sind, aber dann mehr oder weniger eigenständig nach natürlichen Gesetzen ablaufen“. Diese sind nach seiner Auffassung „treffend als ,quasinatürliche Oberflächenformung'“ zu bezeichnen (JÄGER 1994:4). ,Quasi-natürlich“ bedeutet „,weitgehend natürlich, aber unter Einfluß des Menschen entstanden“ (:62). Als Beispiel nennt JÄGER Tilken bzw. Sieke, die „den anthropogen beeinflußten Erosionstälern verwandt“ sind (:61). Auch HAGEL sieht ,quasinatürliche Formen' ,indirekt über Veränderung von Abtragung oder Ablagerung, sei es durch Wasser oder Wind oder Einsinken über künstlich geschaffenen Hohlräumen“ bewirkt (1988:130).

Seminatürliche Gewässer, definiert JÄGER (1994:61), entstehen als „quasinatürliche Formen, die sich nur schwer von den noch stärker anthropogen gestalteten seminatürlichen Gebilden abheben, [...] durch Anstöße der Menschen und werden, sobald sie erst in Gang gebracht worden sind, allein durch natürliche Formungsprozesse fortgebildet. Solche Kleinformen besitzt vor allem der ländliche Raum.“ Sie sind ,in erheblichem Umfang anthropogener Entstehung, aber unter Mitwirkung natürlicher Formungsprozesse gebildet worden“ (:62). Als Beispiele nennt JÄGER Stufenraine, Wölbäcker, Halbtrockenrasen und auch Akkumulationskleinformen wie Erosionsrinnen und Tilken.

Eine ähnliche dreistufige Gruppierung unternimmt im anglo-amerikanischen Sprachraum WHITNEY (1994:2), indem sie je nach Tiefe des menschlichen Einflusses

1. „natural landscape“,

2. „semi-natural landscape“ und

3. „wholly humanized landscape“

voneinander unterscheidet.

Eine weitere Dreistufigkeit stellt SCHÄFER (1997:98) auf, in dem er 
1. naturnahe Ökosysteme, d. h. ohne direkten menschlichen Einfluss,

2. naturnah erhaltene Ökosysteme, d. h. durch den Menschen gesteuerte Ökosysteme, und

3. anthropogene Ökosysteme als vom Menschen geschaffene oder bewirtschaftete Ökosysteme erkennt.

Die Schwierigkeiten bei der Abgrenzung dieser drei Formenbereiche ergeben sich aufgrund von drei Problempunkten:

1. Interferielle Verflechtung: Alle drei Formenbereiche sind „eng, vielfältig, direkt und indirekt sowie mit manchem Rückkopplungseffekten miteinander verflochten und in der Zeit variabel.“ (JÄGER 1994:8) Dadurch ergeben sich „komplizierte Zusammenhänge“ multifaktoriell bedingter Erscheinungen, denn die anthropogenen Faktoren sind eng mit den natürlichen verbunden (:11).

2. Zeitliche Dynamik: „Je weiter die Umweltgeschichte als dynamisches Geschehen zur Gegenwart fortschreitet, desto stärker sind die natürlichen Prozesse mit den anthropogenen in einem komplizierten System gegenseitiger, nicht oder nur schwer trennbarer Einwirkungen verflochten.“ (JÄGER 1994:11) Dadurch ergeben Schwierigkeiten bei der Unterscheidung zwischen dem, was ein natürlicher Gewässerlauf, und dem, was historisch-anthropogener Bestandteil eines vermeintlich natürlichen Gewässers ist, im Verlauf der zeitlichen Betrachtung.

3. Geosystemare Verflechtung: Die Entwicklung ist „polygenetisch und wird durch eine Mehrzahl von interdependenten Naturbereichen und -prozessen mit und ohne Einwirkung des Menschen beeinflußt." (JÄGER 1994:66) Dadurch ergeben sich Veränderungen des Gewässers, z. B. hinsichtlich seiner chemischen Zusammensetzung (pH-Wert, Verschmutzungsgrad), die ohne direktes Einwirken des Menschen in den betreffenden Gewässerlauf entstehen oder sogar erst durch die Einflussnahme in ein zufließendes Gewässer bewirkt worden sind.

Die enge Verzahnung anthropogener Faktoren mit den natürlichen „mit vielfältigen Rückkoppelungseffekten“ macht es schwer, „natürliche von seminatürlichen und diese von anthropogenen Faktoren zu trennen.“ (JÄGER 1994:11). JÄGER trifft aus diesen Abgrenzungsproblemen heraus die folgende grobe Unterscheidung, die bewusste oder eher unbewusste Ereignisse voneinander trennt:

1. Direkte anthropogene Eingriffe in die natürliche Umwelt.

Als Beispiele beabsichtigter Eingriffe nennt JÄGER Rodung und Ackerbau. Für den Gewässerbereich könnte die Laufkorrektur oder der Gewässerstau als Beispiel genannt werden.

2. Indirekte Einwirkungen des Menschen.

Als Beispiele unbeabsichtigter Eingriffe nennt JÄGER die Vegetationsvernichtung durch Viehweide, anthropogen ausgelöste Windabtragung und -ablagerung, Entstehung von Dünen, Flugsand- und Decksandebenen. Für den Gewässerbereich bieten sich als Beispiele die Bildung von Flussauenlehm durch übermäßigen Holzeinschlag in den Hangbereichen oder die Trockenfallung von Teichwirtschaften durch übermäßigen Wasserentzug für andere Bereiche des Lebens (Trinkwassergewinnung).

\section{c.2 Landschaftsformationen nach ELLENBERG}

Der renommierte Vegetationskundler und Hausforscher ELLENBERG (1986) und - in Anlehnung an ihn - Richard POTT (1986) als Geograph und Geobotaniker unternahmen eine ähnliche Gliederung von Stadien der Umweltveränderung am Beispiel der Waldvegetationszusammensetzung, die zwar auch kulturhistorische Entstehungskomponenten berücksichtigt, aber dennoch stärker naturhistorisch orientiert ist. Beide unterscheiden am Beispiel der Vegetation: 
1. „potentiell-natürliche Wälder“,

2. „naturnahe Wälder und Gebüsche“,

3. „,vorwiegend naturnahe Formationen“ und

4. „großenteils vom Menschen mitgeschaffene und erhaltene Formationen“.

Daneben existieren von anderen Autoren zur Beschreibung des Gewässerzustandes eine Vielzahl weiterer Bewertungskriterien hinsichtlich der Gewässergüte, des Sedimentzustandes, des Abflussverhaltens oder des Ausbauzustandes eines Gewässerlaufes. So werden z. B.

1. „weitgehend natürliche“

2. „naturnahe“

3. „bedingt naturnahe“

4. „naturferne“

5. „naturfremde Uferstrukturen“

voneinander abgegrenzt (zusammenfassend in NIEHOFF 1996).

Als Ausdruck der Umformung der natürlichen Umwelt durch menschliche Eingriffe vermögen die genannten Abstufungsvorschläge den Grad der Störungsintensität ausgehend von den ursprünglichen Verhältnissen vorteilhaft zu kennzeichnen. Sie ermöglichen somit unter anderem die Bewertung von gewünschten ,naturnahen' Zuständen, beispielsweise bei der Durchführung von Planungsanlässen wie der Waldbildrekonstruktion und bei der Gewässerrenaturierung. Die Bestimmung der ,Ideal'- bzw. ,Optimal-Landschaft' ist eine Definition der Schutzwürdigkeit. Dabei wird vom Ansatz ausgegangen: je naturnäher eine Landschaft ist, desto schützenswerter ist sie (LEIBUNDGUT 1984:77). Die Schwierigkeiten dieser Abgrenzung auf Basis der Naturnähe sind jedoch andererseits offensichtlich:

1. ,Natürlichkeit' bzw. ,Ursprünglichkeit' ist angesichts der vielgestaltigen Verzahnungen anthropogener und natürlicher Faktoren mit indirekter und direkter Einflussnahme eine nicht oder nur sehr schwer einlösbare Forderung. Dies hat sich auch in der Wahrnehmung niedergeschlagen. "'Natur' ist für den modernen Menschen, der fast immer ein Stadtmensch ist, alles das, was außerhalb der Stadtgrenzen, genauer gesagt: außerhalb der Baugebiete gelegen ist, weil dort im Gegensatz zum technischen Gebilde der Stadt biologische Elemente noch die Fläche beherrschen [...] Alles, was biologisch ist, wird mit Natur gleichgesetzt. So gelangt man zur der Meinung, die Landschaft draußen vor den Toren der Stadt sei eben die Natur, und beide Begriffe verschmelzen zu einer Einheit.“ (HABER 1998:132)

2. ,Landschaft' soll ,natürlich' sein, „obwohl wir in einer alten, über Jahrhunderte hinweg durch Nutzung gewachsenen und gestalteten Kulturlandschaft leben." (HABER 1998:132) . Es wird vielfach außer Acht gelassen, dass sämtliche sog. Naturräume, die sich zum Beispiel namensgebend in so bekannten Einrichtungen wie Naturparks und Naturschutzgebieten widerspiegeln und als solche expressis verbis Eingang in das Umwelt- und Planungsrecht gefunden haben, das Ergebnis von menschlichen Formungsvorgängen sind. Europäische Naturlandschaften sind Kulturlandschaften.

Diese Kulturlandschaft, so HABER (1998:132), ist jedoch uneinheitlich. Sie besteht nach seiner Auffassung aus mindestens drei Hauptbestandteilen, von denen jeder wiederum als eigener Landschaftstyp aufgefasst werden kann: Die erste ist die Stadt selbst, die städtisch-industrielle Landschaft verkörpernd. „Eigenartigerweise empfinden sie diese - und damit sich selbst - oft gar nicht als Teil der Kulturlandschaft. [...] Für Stadtmenschen liegt die Landschaft oder Kulturlandschaft außerhalb des Weichbildes der Städte. Dort beginnt die, ländliche Kulturlandschaft' (engl. Countryside)“, als zweiter Teil der gesamten Kulturlandschaft. Der dritte Teil der Kulturlandschaft ist die ,echte' Naturlandschaft, die ,natürliche' Umwelt'“ (:132f.). Die Anführungszeichen hat HABER (:133) „,mit Bedacht gesetzt“, denn einerseits handelt es sich oft nur noch „um winzige Restbestände“ einer so wahren Naturlandschaft, andererseits „wird der 
Echtheitsanspruch in wissenschaftlicher Sicht ebensowenig erfüllt wie das Kriterium der Natürlichkeit", wie im Extremfall gas- und partikelförmiger Immissionen in das oberirdische Gewässer oder durch Bodeneintrag auch in das Grundwasser belegen. „Trotzdem glauben viele Menschen in anerzogener, romantisch beeinflußter Tradition, daß Natur und natürliche Umwelt und Landschaft sie überall umgibt.“ Die genannten drei Hauptbestandteile der Kulturlandschaft, kurz als ,Stadt', ,Land' und ,Natur' bezeichnet, lassen sich deshalb ,nicht sauber voneinander trennen. Sie durchdringen einander im Raum in einer immer wieder andersartigen Mischung." $(: 133)$.

3. Die begriffliche Verwendung von ,Natürlichkeit' und ,Naturlandschaft' erschwert oftmals eine Instandhaltung bzw. Wiederbelebung kulturhistorischer Nutzungsarten.

Das Beispiel der Wiederansiedlung von Urrindern in einem Landschaftsabschnitt eines ehemaligen Hutewaldes, des ,Reiherbachtales' im Solling, demonstriert in sehr anschaulicher Weise die Schwierigkeit bei einem Wechsel von einer Kultur- zur Naturlandschaft. Sollen mit der Einführung von Urrindern der Art Moschus- und Auerochse zum einen ursprüngliche geozoologische Zustände in der mitteleuropäischen Waldlandschaft vor 10.000 Jahren modelliert werden, um gleichzeitig aus geobotanischer Sicht die ehemalige Eichenwaldweide mit seinem Anpflanzungsmuster auf natürliche Art des simulierten Vieheintriebs zu erhalten, so beschädigen diese Rinder zeitgleich die dort vorhandenen künstlich angelegten ehemaligen Fischteiche, de aus kulturhistorischer Sicht bedauernswerterweise seit Jahren der natürlichen Sukzession überlassen wurden. Aber vor allem - und dies trägt zu einer extremen Verzerrung des Abbildes ,Hutewald' als kulturhistorische Nutzungsform bei - bleibt der Mensch in diesem Kerngebiet des Forschungsprojektes ausgeschlossen. Doch gerade dieser hatte ja vor rund 300 Jahren begonnen, den Hutewald wie auch die Fischteiche systematisch anzulegen (siehe auch Pkt. IX 1.b).

4. Die Evaluierung der Landschaft allein auf der Grundlage des naturökologischen Ansatzes bleibt einseitig und dadurch geringfügiger bei der Durchsetzung von Schutzmöglichkeiten als im Verbund; denn durch den kulturhistorischen Ansatz würde das Bewertungs- und Begründungsschema als Grundlage einer Unterschutzstellung um eine Skala erhöht.

\section{d Kulturhistorische Terminologie und Typologie}

Nach MÜCKE (1988:154) werden in der Kulturlandschaft „natürliche und kulturelle Bestandteile unterschieden“. Innerhalb dieser beiden Bestandteile existiert nach HABER (1998:134) noch eine dritte Komponente. Er fügt zwischen „natürliche Umwelt“ und „kulturelle Umwelt“ noch die „kultürliche Umwelt“. Nach seinem Modell kann die „kultürliche Umwelt“ anhand von Hauptbestandteilen und maßgebenden Prozessen (Hauptprozessen) definiert werden und dadurch in Gegensatz zur „,natürlichen Umwelt“ gesetzt werden.

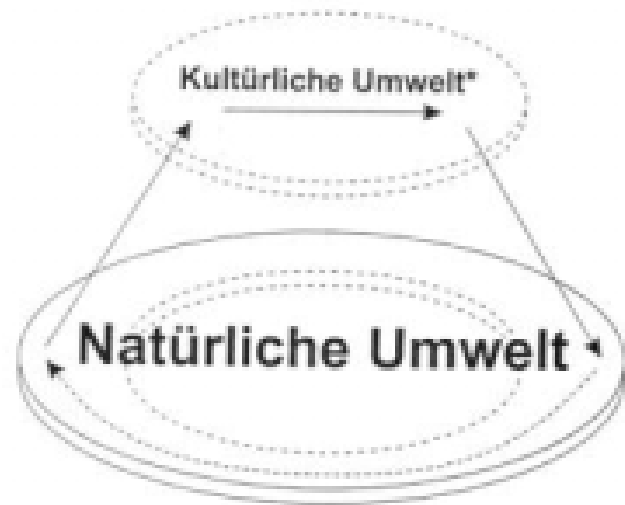

Abb. IV-2: „Zwei-Schalen-Modell“ von Umwelt.

Kulturell-zivilisatorische Umwelt mit dem technisch-industriellen Teilsystem (aus: HOFMEISTER 2000). 
Die in Abb. IV-2 dargestellten Kennzeichen der „kultürlichen Umwelt“ von HABER (1998:135) berücksichtigen auch als einen Hauptbestandteil ,künstlich geschaffene, aber überwiegend aus natürlichen Bestandteilen zusammengesetzte Ökosysteme“" und als Beispiel nennt er u. a. Fischteiche.

A. Haupthestandteile

1. Könstlich geschaffene, aber oberwiegend aus natürlichen Bestandteilen zusammengesetze Okosysteme: Agrar- und Fors-Okosysteme, Parke, Fischteiche (vgl. Obers. 2; Kantegarie 4).

2. Bautechnische Objekse: Bawwerke aller Art, oft raumlich zu Komplexen angeordnet: Techno-Okosysteme (vgl. Obers. 2; Kategorie 5)

3. Gebrauchsobjekie (werden durch Gebrauch verschlissen, aber aicht vollig verlindert)

4. Verbrauchsgegenstände (wenden durch Verwendung und Gicbeauch physikalisch und chemisch verindert).

B. Hauptprozesse

1. Biologische Prozesse zur Befriedigung von Elementarbedarfinissen ("Stoffwechser).

2. Gewinnungsprozesse für Nahrungs- und Rohstoffe aller Art.

3. Industrielle gewerbliche Herstellungsprozesse für Bauwerke, Ge- und Verbrauchsobjekte sowie Nutzenergie.

4. Verwendungsprozesse.

5. Abfallverarbeitungsprozesse.

C. Nebes- und Nachprodukte baw, "Emissionen" (i.w.S.)

1. Nicht oder nicht mehr brauchbare Gegenstande, z.B.nicht mehr nutature Bauwerke, verschlissene Gebrauchsobjekte.

2. Nicht oder nicht mehr braschbare Substanzen in festem, flassigem oder gasformigem Zustand (Abelle, Abwasser, Abgase = Abprodukie').

3. Nicht oder aicht mehr brauchbare Energien. Abwärme, radiøaktive Abfallstrahlung, Làm.

Abb. IV-3: Kennzeichen der „kultürlichen Umwelt“ im Gegensatz zur „natürlichen Umwelt“ (aus: HABER 1998:135).

In einem zweiten Schritt ordnet HABER (1998:136) Ökosystemtypen nach „zunehmender menschlicher Beeinflussung und Nutzung“ bzw. nach ,abnehmender Natürlichkeit“. (vgl. Abb. IV-4)

Des Weiteren besteht neben der landschaftsökologischen Einteilung nach HABER eine aus der Denkmalpflege stammende Unterscheidung zwischen „ungewollter Beeinflussung“, „bewusstem Eingriff“ und „,bewusster Planung“ (STEVENS 1992; zitiert nach DIX 1997b:37). 


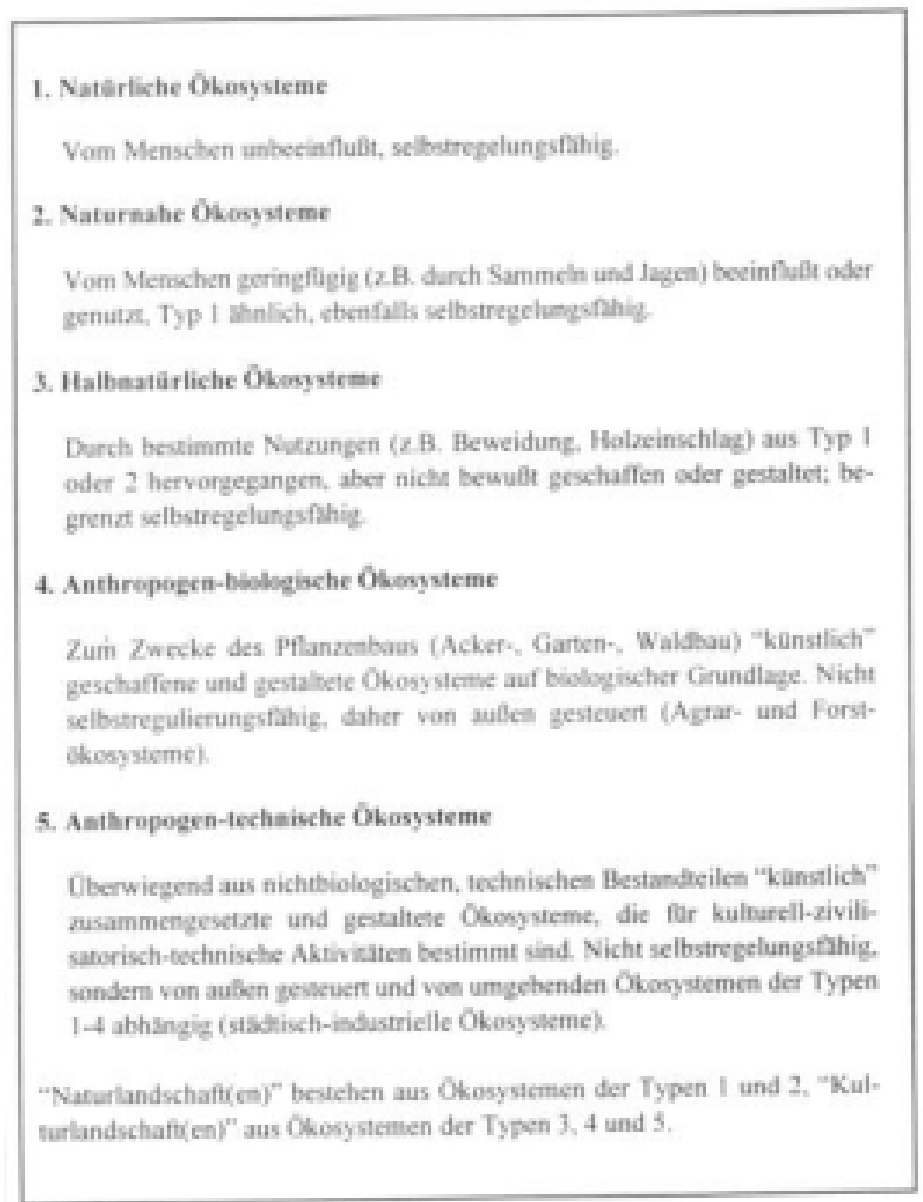

Abb. IV-4: Ökosystemare Stufung:

Ökosystemtypen geordnet nach zunehmender menschlicher Beeinflussung und Nutzung (Hemerobie) bzw. nach abnehmender Natürlichkeit (aus: HABER 1998:136, Übersicht 2).

STEVENS (1992:147-149) hat mit Beispielen aus dem Rheinland auf den Grundlagen des nordrheinwestfälischen Denkmalschutzgesetzes folgende Kategorisierung entwickelt:

Er unterscheidet zunächst

1. Landschaften oder Landschaftsteile, die durch den Menschen beeinflusst sind. Hier nennt er das Beispiel der durch intensive Beweidung entstandenen Heideflächen. In Bezug auf ein gewässerhistorisches Beispiel könnte ergänzt werden: die vielen natürlich entstandenen kleinen Stillgewässer, die durch Viehbesatz (Entenmast, Karpfenbesatz) oder -eintrieb (Schaf-, Pferdeschwemme, Tränke im Rahmen der Waldweide) verändert worden sind (Veränderung der Wasserchemie durch Dung, der Gewässerränder durch Vertritt).

Davon abzugrenzen sind

2. Landschaften oder Landschaftsteile, in die der Mensch unmittelbar eingegriffen hat. Hierunter fallen alle übrigen direkten Eingriffe. Beispielsweise der Bachlauf, der für den Mühlenbetrieb angestaut wurde, oder die Rieselwiesen, auf die das Wässerwasser geleitet wird.

Schließlich sind noch

3. Landschaften zu nennen, die vom Menschen bewusst geplant wurden. Er nennt dafür z. B. Gartenanlagen. Darunter können aber auch Fischzuchtteichanlagen, Schifffahrtskanäle, Wassergräben von Gräften und Burgen etc. fallen. 


\section{Historisch-geographische Terminologie und Typologie neuerer Gewässersystematik}

Die vorwiegend ökozentrischen Gruppierungen sowie auch die klassischen natur- und kulturhistorischen Grundklassifikationen nach JÄGER, ELLENBERG, HABER u. a. müssen aus den genannten Gründen (Verschwinden landschaftsökologischer Gewässertypen, Schwierigkeiten mit den Begriffsabstufungen zur ,Natur-Kulturnähe' etc.) um die kulturhistorisch-geographische Variabel ergänzt bzw. ersetzt werden.

\section{a Differenzierung von Gewässern nach ihrer zeitgeschichtlich-formalen Erscheinung}

„Auf die Erscheinung oder Ausprägung ausgerichtet verfolgt die Geographie in ihrer Landschaftsanalyse" nach DENECKE (1997:43) „vor allem einen morpho-genetischen Ansatz. Danach werden die Objekte und Erscheinungen in der Landschaft nicht nur in ihrem Zustand morphographisch, d. h. formal beschreibend angesprochen, sondern nach dem Entwicklungsproze $\beta$ ihrer formalen Ausprägung." Aus diesem Entwicklungsgang ergibt sich jedoch die sukzessive Auflösung ehemaliger Landschaftsformen. Die heute noch darzustellenden Nutzungsweisen sind vielfach nicht mehr lebendig, ihre Anlagen und Einrichtungen infolgedessen entweder rudimentär-persistent, reliktär oder gar nur noch fossil - und in diesem Fall dann nur mit speziellen Arbeitsmethoden zu erschließen.

Mit dieser Dreiteilung zur Charakterisierung historischer Kulturlandschaftselemente in einem RaumZeit-Bezug folge ich einer Klassifizierung von Dietrich DENECKE (1969). DENECKE unterscheidet drei wesentliche Formtypen nach ihrer zeitlichen Erscheinung im Raum:

1. rezente,

2. reliktäre und

3. fossile Formtypen.

Diese bei der Untersuchung von Hohlwegen im Rahmen seiner Dissertation entwickelte Unterscheidung soll auf die gewässerhistorische Typisierung übertragen und bei der Inventarisierung von Gewässerformen und -typen angewendet werden. Diese Klassifizierung kann beispielsweise die Grundlage bei der Aufstellung und Anwendung eines Kartierungsschlüssels in Fluss- und Gewässerlandschaften bilden, um eine zeitgeschichtliche Einteilung vornehmen zu können und damit die Bedeutung der vorgefundenen historischen Gewässerformen und -elemente hervorzuheben. Dafür jedoch ist zunächst eine eindeutige Definition und Ergänzung dieser Begrifflichkeiten notwendig.

Fossile, reliktäre wie rezente Elemente der historischen Kulturlandschaft wurden in vergangenen Zeiten, und das ist ihr besonderes und gemeinsames Kennzeichen, unter den damals herrschenden ökonomischen und sozialen Verhältnissen sowie ästhetischen Vorstellungen anthropogen geschaffen. Unter den heute existierenden Rahmenbedingungen würden sie so nicht mehr neu angelegt werden. Sie sind somit eindeutig von den aktuellen Kulturlandschaftselementen abzugrenzen (in Anlehnung an DENZER 1996:18; NITZ 1992:29; FEHN 1993a:131) Die historischen Kulturlandschaftselemente müssen aber - abgesehen von der beschrieben Gemeinsamkeit - voneinander differenziert betrachtet werden:

Rezente Formtypen (lat.: gegenwärtig noch auftretend, lebend) sind nach DÜSTERLOH (1967) in früherer Zeit entstanden, jedoch noch heute benutzt - und damit noch immer in Fortbildung begriffen. DENECKE (1969) beschreibt sie als noch bestehende und genutzte altertümliche Kulturlandschaftselemente. Als Synonym und um ebenfalls „historische Elemente von aktuellen abzugrenzen“ (WEISER 1997:78), wird der Begriff der Persistenz (lat.: anhaltend, dauernd, beharrlich) verwendet. Persistente bzw. rezente Landschaftselemente sind insofern diejenigen Elemente und Strukturen, die im Wandlungsprozess übrig geblieben sind, das heißt trotz neuer Ansprüche im gegenwärtigen Landschaftsbild noch in ihrer ursprünglichen Form und Funktion in Erscheinung treten oder als solche erkennbar sind (vgl. MÜCKE 1988:160; DRIESCH 1997:266; DENZER 1999:18). SCHWIND (1964:15) spricht von „Elementen, die heute noch lebendig sind“. 
Die Erhaltung im Rahmen eines Wandlungsprozesses kann dabei verschiedene Ursachen haben: Persistente bzw. rezente Elemente sind zum einen durch einen ,internen' Selektionsprozess gekennzeichnet, bei dem sich bestimmte Elemente und Strukturen durch die eine oder andere Art der Nutzung gegenüber anderen Elementen durchgesetzt haben (DRIESCH 1997:266, in Anlehnung an SCHWIND 1964:15). Zum anderen führte die „dauerhafte Nutzung des Raumes“ dazu, dass die aus dem Selektionsprozess Übriggebliebenen als persistente/rezente Strukturen und Elemente in der Kulturlandschaft überdauern konnten (HARD 1973:21). Diese persistenten Strukturen und Elemente stellen die „historischen Konstanten“ dar (:21). Durch diese historischen Konstanten, ,also Traditionen und Überreste“, versucht die Historische Geographie zum Beispiel die Entwicklung von Kulturlandschaften zu erklären (MÜCKE 1988:156) und den Schutz dieser Landschaften zu begründen.

Wasserbauliche persistente Landschaftselemente sind beispielsweise „ein trockengelegter Dorfteich, ein ehemaliger Graben einer Wasserburg, Flußmäander, Furten, wasserwegbegleitende Einrichtungen wie Schleusen, Zollhäuser u. ä.“ (DRIESCH 1997:266). Sie „,erzählen jeweils von historischen Nutzungen und sind in der heutigen Landschaft als solche Formen erkennbar, also persistent" (:266).

Reliktformen (lat.: vor längerer Zeit entstanden und in Resten vorkommend) sind - auf Gewässer bezogen - durch den Menschen nahezu zerstörte Gewässerformen. Die meisten Gewässertypen hingegen sind vor allem seit Mitte des 20. Jh. mit dem Ende der traditionellen Bewirtschaftungsweisen vollständig beseitigt worden. Nach DENECKE (1969) sind Relikte Restbestände aus einer untergegangenen Zeit, Hinterlassenschaft mit ehemals weiterer Verbreitung, die in Refugien, d. h. an besonders begünstigten Stellen erhalten geblieben sind, also ,überleben' konnte. Relikte sind Überbleibsel einer früheren Umwelt. „Zu diesen Überresten gehören“ nach JÄGER (1965:409) ,,im weitesten Wortverstand alle landschaftlichen Erscheinungen, die dem heutigen wirtschaftlichen, politischen und gesellschaftlichen Kräftespiel nicht mehr voll entsprechen.“.

Hinsichtlich der Nutzbarkeit von Relikten gibt es unterschiedliche Ansichten. Während für DENECKE (1969) Relikte sich dadurch auszeichnen, dass sie heute ohne Nutzung sind, spricht NEEF (1967) - im Gegensatz zu Fossilen - dann von Relikten, wenn die Elemente weiter genutzt werden (aus: MÜCKE 1988:160). JÄGER (1965:409) unterscheidet - mitunter aus dieser schwierigen Differenzierung - hinsichtlich der heutigen Nutzung zwischen

1. „eindeutigen Relikten“, die keine Funktion mehr erfüllen und

2. Relikten, die noch eine Funktion erfüllen.

Als Beispiele eindeutiger Relikte nennt er z. B. Wüstungen, Hohlwege, Bergbaupinge usw., Beispiele noch funktionaler Relikte nennt er nicht. Ergänzend könnte man aber darunter alte Teichwirtschaften, Mühlenkanäle, Wasserfurten etc. fassen. Bei genauer Auslegung der Begriffs eines ,funktionierenden' Relikts wäre es dann aber kein Relikt mehr, sondern ein rezenter bzw. persistenter Formtyp, der noch einer Nutzung unterliegt. Es soll hier deshalb der Auslegung von DENZER (1996:18) gefolgt werden, die deutlich zwischen persistenten und reliktären Elementen unterscheidet: „Während persistente Elemente [...] in der Kulturlandschaft ihre ursprüngliche Funktion von alters her weitgehend beibehalten haben, handelt es sich bei Relikten [...] um heute funktionslos gewordene Überreste historischer Kulturlandschaftselemente."

Ob weiter in Gebrauch oder funktionslos, gemeinsames Kennzeichen der Relikte ist, dass sie „als Erbe der Vergangenheit überliefert" und damit durch Gegenständlichkeit gekennzeichnet sind (JÄGER 1965:409). Sie sind „unter andersartigen Kräftegruppierungen entstanden“ (:409) und entstammen der Zeit des Mittelalters und der Neuzeit (:415). Ein Relikt - dies als Zusammenfassung - ist als ein überliefertes Kulturlandschaftselement zu verstehen, das seine Funktion zum Teil oder ganz verloren hat oder das den heutigen wirtschaftlichen Anforderungen nicht mehr genügt (BURGGRAAFF/ KLEEFELD 1997:254; DIES. 1999:127).

\footnotetext{
${ }^{4}$ Die Definition ist entlehnt von RENES (1992)
} 
$\mathrm{Zu}$ den Überresten aus früheren Stadien der Kulturlandschaftsgeschichte kann man aber auch - neben den punkt- oder linienhaften Elementen - „einige [...] Areale rechnen, die gegenwärtig noch intakt sind. Dazu gehören alle Flächen [...], deren Kultur so erheblich zurückgeht, daß mit ihrer baldigen Aufgabe zu rechnen ist“"(JÄGER 1965:421).

DENECKE (1989b:204) fasst die verschiedenen geometrischen Kategorien von Relikten zusammen und definiert sie allgemein als „ungestörte Reste solcher Dokumente ehemaliger menschlicher Nutzungstätigkeit in der Landschaft“, als Dokumente, „die der Mensch in der Landschaft in verschiedenen Epochen der Landschaftsgeschichte geschaffen hat.“ (DENECKE 2000:200) Er bezeichnet sie deshalb auch als „Altlandschaftsrelikte“.

Um neben der Geometrie die Zugehörigkeit und Herkunft von Relikten auch terminologisch nach natur- und kulturhistorischen Determinanten zu dokumentieren, gliedert JÄGER (1965:415) die Reliktformen nach systematischen Gesichtspunkten und unterscheidet

a. Relikte der früheren Landesnatur und

b. Relikte der früheren Landeskultur.

Zu den naturlandschaftlichen Relikten führt er als Gruppierungen Gewässer, Pflanzengesellschaften und Böden auf. Innerhalb der Gruppierung Gewässer sind es Gegenstände aus den Bereichen Bewässerung, Bach- und Flussregulierung, Quellen, Quellfassung, Wasserentnahme und Wassersenkung. Als Beispiel von reliktären Pflanzengesellschaften nennt er semi- bzw. halbnatürliche Formationen, wie z. B. Waldweide bzw. Hutewald oder Reliktformen der Waldwirtschaft, wie z. B. der bäuerlichen Mittel- und Niederwälder und deren Nutzungsarten. Im Bereich Böden sind es die durch die Einwirkung des Menschen, d. h. durch Pflügen, Beweiden, Düngung, Melioration und Erosion entstandenen anthropogenen Bodenformationen.

Zu den kulturlandschaftlichen Relikten zählt er agrarische Relikte, wie z. B. Wüstungen (Ortswüstung, Flurwüstung), heutige landwirtschaftliche Nutzflächen mit Reliktcharakter, forstliche Relikte, Überreste von gewerblichen und industriellen Anlagen (Hohlformen, Aufschüttungsformen, komplexe Formen), Straßen und Wege, Befestigungen.

Mit Hilfe dieser Unterscheidung - den persistenten bzw. rezenten Formen einerseits und den Relikten andererseits - kann bereits bei der Erfassung und Zusammenschau der Objekte vor Ort eine grobe Klassifizierung in Altlandschaftsgebiete bzw. Reliktlandschaften oder Traditionsräume vorgenommen werden (vgl. DENECKE 1985c:16).

Bei den Traditionsräumen handelt es sich um Gebiete, „die besonders konservative und traditionelle Züge in der Siedlungs-, Wirtschafts- und Sozialstruktur aufweisen“ (DENECKE 1985:16) und als originäre Landschaftsteile ausgegliedert werden können. „Historisch-geographisch sind diese Gebiete jedoch als Lebensräume zu betrachten, die nur geringfügig überformt oder verfremdet sind und überlieferungsgebundene Einblicke in ältere Kulturlandschaftsentwicklungen geben.“ (:16) Hier überwiegen also eindeutig die den Traditionsraum strukturierenden persistenten Elemente (DENZER 1996:19).

Deutlich davon abzugrenzen sind - wie bei den Einzelobjekten - die Reliktlandschaften, ,die nicht mehr traditionsgemäß bewirtschaftet werden, sondern in denen durch Extensivierungsprozesse vom Ackerbau zur Grünland- und Forstwirtschaft bis heute eine Vielzahl raumprägender Reliktformen früherer Landnutzungsformen erhalten sind.“ (DÖPPERT 1987:150) Diese Areale weisen sich „durch eine große Anzahl verschiedenartiger Überreste menschlicher Tätigkeiten, früherer Nutzungsformen, aufgegebener u. a. m.“ aus (DENZER 1996:19).

Als letzter der drei Formtypen sei das fossile Landschaftselement bzw. der fossile Landschaftsraum behandelt: 
Fossile Formtypen (lat.: versteinert, vorweltlich) sind nach der Auflassung durch einsetzende natürliche Überformung entstanden. Nach DENECKE (1969) sind fossile Formtypen Überreste von Kulturlandschaftselementen und bilden den Gegensatz zu rezenten Elementen. NEEF (1967a; aus: MÜCKE 1988:160) spricht - im Umkehrschluss seiner dort schon unbefriedigenden Relikt-Definition (siehe oben) - dann von Fossilen, wenn sie nicht benutzt werden.

Von einer fossilierten Landschaft kann man vielleicht dann sprechen, wenn sich die kulturlandschaftsgeschichtlichen Einzelelemente bereits unter Wald bzw. unter Wasser befinden und nur im Boden bzw. im Flussbett wiederzufinden sind. Sie besitzen oberirdisch erkennbar in der Fläche keine Zeugen mehr.

\section{b Differenzierung von Gewässern nach ihrer Entstehungs- und Nutzungsgeschichte}

In Entsprechung der Hydrodynamik der oberirdischen Gewässer des Festlandes lassen sich zunächst generell fließende Gewässer von den stehenden Gewässern unterscheiden.

Beide Gewässertypen können nach ihrer Genese einer natürlichen oder einer künstlichen Entstehung zugeordnet werden:

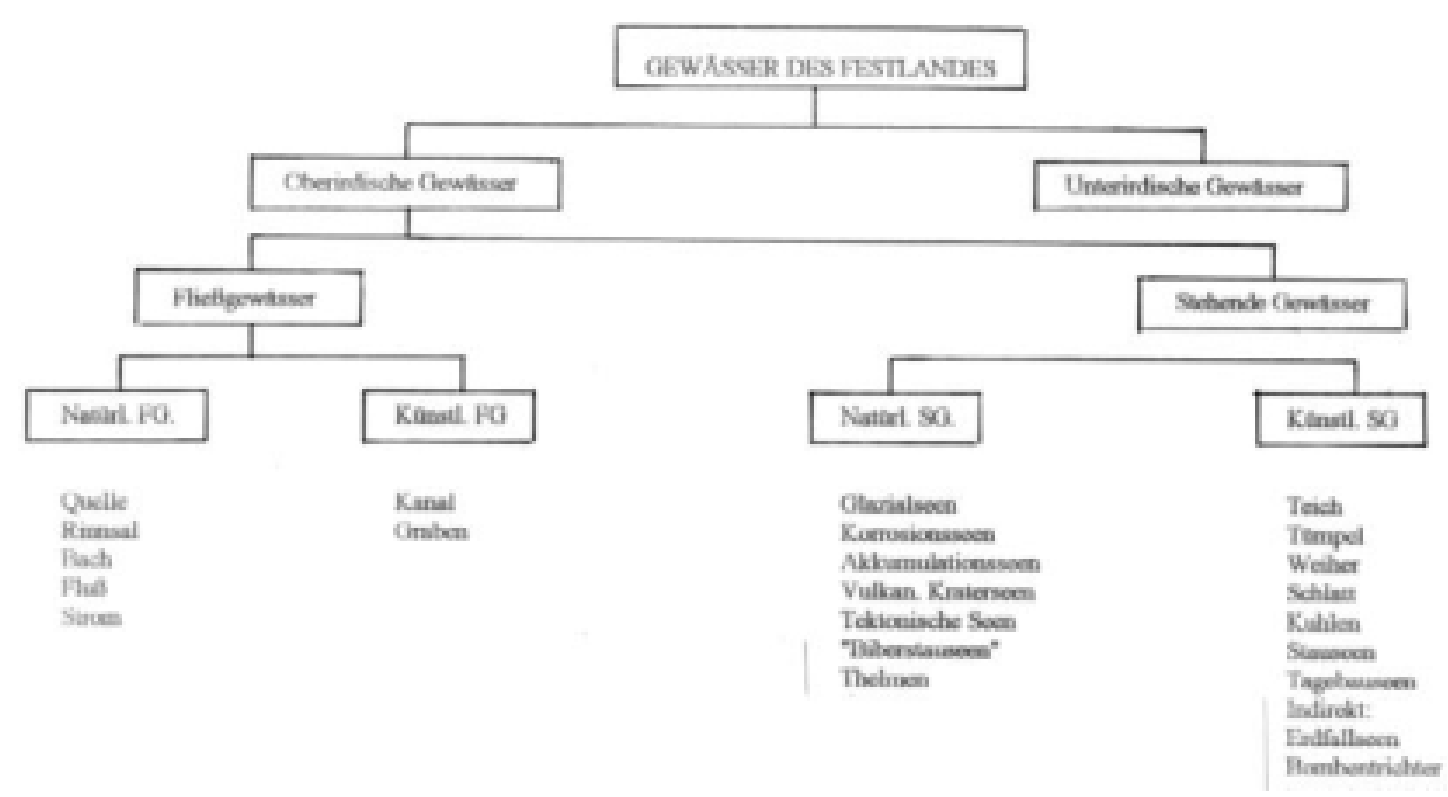

Abb. IV-5: Gewässertypen nach ihrer Entstehungsweise (eig. Entwurf)

In Anlehnung an JÄGER (1994) und HAGEL (1988) wird vom Verfasser eine kulturhistorische Gewässereinteilung entwickelt, die sowohl die Morphodynamik, d. h. die naturbedingte Entstehungsgeschichte, berücksichtigt als auch die kulturevolutorische, d. h. die vom Menschen bedingte Nutzungs- und Entstehungsgeschichte beachtet. Erst aus dieser deutlichen Kenntnis der Gewässergeschichte, so die Ansicht, können darauf aufbauend beispielhafte gewässerpflegerische Zielkonzeptionen erarbeitet und Entwicklungsmaßnahmen abgeleitet werden.

\section{Natürlich entstandene Gewässer [Natürliche Gewässer]}

Dies sind, allgemein umschrieben, durch natürliche Kräfte entstandene Gewässer. „Mit ,natürlich’ wird hier ein Zustand gekennzeichnet, der sich vor den ersten menschlichen Eingriffen ausbildete, aber damit nicht festgeschrieben, sondern selbstverständlich aufgrund der Wirkung abiotischer und biotischer Faktoren (also der natürlichen Kräfte) weiterhin verändert wird. Das fließende Wasser ist mit seiner Dynamik nach wie vor bestimmende landschaftsverändernde Kraft." (NIEMEYERLÜLLWITZ/ZUCCHI 1985:13; siehe auch die „Geomorphologischen Seetypen“ von JUNG 
[1994:189] im Anhang, Tab. A-2). Die natürlichen Gewässer lassen sich je nach Nutzungsgrad weiter differenzieren:

\subsection{Natürlich entstandene Gewässer - ohne Nutzung}

Als Beispiele dafür stehen:

- Quellen, obere Fließgewässerabschnitte,

- Glazialseen,

- wassergefüllte Hohlformen durch Erdeinbruch,

- perennierende Tümpel, die jahresperiodisch mit Wasser gefüllt sind.

Es darf jedoch bezweifelt werden, ob ,natürliche' Gewässer wirklich nie anthropogen genutzt worden sind. Deshalb scheint die nächstfolgende Kategorie wirklichkeitsnäher.

\subsection{Natürlich entstandene Gewässer - mit anthropogener Nutzung}

Hierunter sind die als ,Naturformen' zu bezeichnenden Gewässer der Gliederungsnummer $1.1 \mathrm{zu}$ zählen, da sie, wenn auch einer Nutzung unterliegend, nicht bewusst geschaffen worden sind. Sie sind offenkundig einer menschlichen Nutzung zugeführt wurden, aber in ihrem Erscheinungsbild nicht verändert worden, wie zum Beispiel:

- Glazialseen, die fischereiwirtschaftlich genutzt werden.

- Alpenseen, die als Trinkwasserreservoir genutzt werden.

- Perennierende Tümpel, die jahresperiodisch mit Wasser gefüllt sind und einer nur kurzzeitigen Nutzung unterliegen (z. B. zum Aussetzen von Fischlaichgewässer).

\subsection{Natürlich entstandene, aber anthropogen veränderte Gewässer}

Hierunter sind all diejenigen Gewässer zu subsumieren, die natürlicher Entstehung, aber durch ihre anthropogene Nutzung in erheblichem Umfang, d. h sichtbar verändert worden sind. Eine Nutzung also, die sich bautechnisch niederschlägt; denn wie die Beispiele zur obigen Gliederungsnummer 1.2 aufgezeigt haben, sind Nutzungen nicht immer raumwirksam, sondern verlaufen ohne sichtbare Eingriffe (z. B. das einfache Angeln oder das Wasserschöpfen mit einem Leineneimer). Anthropogen veränderte Gewässer natürlicher Herkunft entstanden durch „Formungsvorgänge und ihre Ergebnisse, die durch den Menschen zunächst herbeigeführt worden sind " (JÄGER 1994:8). Beispiele für Gewässer natürlicher Entstehung, die aber durch menschliche Eingriffe verändert wurden, sind:

- Flussregulierungen,

- Quellen, deren Austritt gefasst worden ist (Quelltopf),

- Fließgewässer, die reguliert oder kanalisiert wurden,

- Glazialseen, die der natürlichen Form und Größe beraubt worden sind.

\section{Anthropogen entstandene Gewässer [anthropogene Gewässer]}

Dieser Gewässertyp ergibt sich daraus, dass ,alle Prozesse der Umweltgeschichte, die nicht rein naturbedingt sind, [...] auf den Menschen zurück[gehen.]“ (JÄGER 1994:12) Die unter diesem Gliederungspunkt aufgeführten Gewässer sind nach HAGEL (1988:130) als reine ,anthropogene Formen“ zu definieren, da sie durch „direkte, bewußte Schaffung von Formen“ entstanden sind und „Zwar durch Ausräumung [...] und Aufschüttung“. Zu dieser Gruppe zählen die weitaus meisten Binnengewässer und es bedeutet keinen Unterschied, ob sie zu den Still- oder den Fließgewässern zählen. Aber auch anthropogen veränderte Gewässer können ,benutzt' werden oder ,keiner Nutzung' unterliegen und im letzten Fall eine solche Wandlung vollziehen, dass ihre anthropogene Herkunft nur schwer ermittelbar ist. Beispiele für anthropogen entstandene Gewässer sind wassergefüllte Hohlformen, wie zum Beispiel 
- Kies-, Ton-, Lehm-, Mergelgruben,

- Torfstiche,

- Karpfenteiche.

So sind Fischteiche „keine naturbelassenen unangetasteten Lebensräume, es sind nutzungsbedingte und nutzungsabhängige Neubiotope, auch wenn viele von ihnen vor mehreren hundert Jahren geschaffen wurden“"(ZOBEL 1992:28)

\subsection{Anthropogen entstandene Gewässer - ohne Nutzung}

Diese Gewässerarten sind Relikte, die durch ihre Nichtbenutzung oder bei weiter fortschreitender Nichtbenutzung dem Verfall preisgegeben sind und schließlich nur als fossiler Abdruck im Landschaftsbild erkennbar sind.

Als Beispiele für diese Kategorie anthropogener Gewässer können genannt werden:

- ehemalige Schifffahrts- oder Floßkanäle,

- ehemalige Flut- und Bewässerungsgräben,

- wassergefüllte Bombentrichter,

- Bergbaulöcher (wassergefüllte Pingen, Schürfstellen und Abraumlöcher)

Als weiteres Beispiel anthropogen entstandener Stillgewässer können die sog. ,Glockenschächte' aufgeführt werden. Es handelt sich hierbei um Reliktformen, die für den historischen Tonbergbau typisch sind: Schächte, die ca. 1,5 m Durchmesser und eine glockenförmige Schachterweiterung auf bis zu $20 \mathrm{~m}$ aufweisen. In einem Tonabbaufeld lagen viele solcher Glockenschächte dicht nebeneinander. Nach Beendigung des untertägigen Bergbaus, wurden die Schachtöffnungen durch Einsturz der Seitenwände mit Erdmaterial verfüllt. Es bildeten sich kleine Mulden, in denen sich Wasser sammelte. Heute erkennt man viele ehemalige Glockenschachtfelder daran, dass sich ,dutzende kleine, kreisrunde Wasserflächen auf engem Raum nebeneinander befinden.“ (HEUSERHILDEBRANDT 1995)

Neueren Datums und entsprechend großflächiger in ihrer Einzelwirkung sind die durch Bergsenkungen des neuzeitlichen Untertage-Kohlenbergbaus resultierenden wassergefüllten Landschaftssenkungen. Sie treten auf, weil die durch den Kohleabbau zurückbleibenden Hohlräume dem Gebirgsdruck nachgeben und zusammenbrechen. Über Tage entstehen dann spontan Sümpfe und Seen. Als „wichtigste Maßnahmen gegen die Seenbildung“" werden „Aufdeichungen der Flüsse und Bäche“" empfohlen (MAIER 1996:249).

Weitere Relikte ehemaliger Wirtschaftsweisen, die heute noch irrtümlicherweise als ehemalige Teiche identifiziert werden, sind die bereits oben genannten alten Torfstiche und ausgehobenen Töpfergruben.

\subsection{Anthropogen entstandene Gewässer - mit anthropogener Nutzung}

Diese Gewässerarten unterliegen einer aktuellen Nutzung und sind in die Neuzeit gerettete Hinterlassenschaften ehemaliger Wirtschaftsweisen. Die mit dem Gewässer verbundenen Einrichtungen und Anlagen (beispielsweise Mühlwehre an Mühlbächen oder kleine Schiebwehre an Deichgräben) sind heute noch in Gebrauch und müssen unterhalten werden.

Die klassischen, aber vielleicht auch einzigen Beispiele wassergefüllter Hohlformen anthropogener Entstehung und fortdauernder, dem Entstehungszweck gemäßer Nutzung sind die Teiche der Teichwirtschaften und - noch in Einzelfällen - des Mühlenwesens.

Gartenteiche, die schon seit römischer Zeit die Gärten der Villen zierten und nachhin die Parkanlagen der Schlösser und Herrschaftbauten zierten, gehören prinzipiell auch in die Gruppierung 
anthropogener Gewässer. Primär aber dienten sie keinem wirtschaftlichen Zweck im eigentlichen Sinne, sondern eher dem ästhetischen Anspruch und der Repräsentation, so dass sie dem hier zwingend zu erfüllenden Zusatz der ,anthropogenen Nutzung“ nicht entsprechen.

\section{c Zusammenfassung}

Die gewässerkundliche Differenzierung erfolgt bislang auf der Grundlage einer eher landschaftsökologischen Gewässertypenhebung. Kulturhistorische Belange wurden bislang weniger berücksichtigt.

Die begriffliche Orientierung fällt aber im kulturhistorischen Kontext aufgrund der terminologischen Vielfalt schwer. Zudem ist es aufgrund der verschiedenartigen Entstehungs- und Nutzungsgeschichte nicht möglich, ein Gewässer mit einem griffigen Wort zu definieren. Nur die Kombination verschiedener Beschreibungen kann den unterschiedlichen Aspekten eines Gewässers gerecht werden.

Im Bereich der Gewässer könnte eine Gewässereinteilung unter dem Kriterium der Entstehungsgeschichte lauten:

Den durch natürliche Kräfte entstandenen Gewässern (Quellaustritte, Fließgewässer, Glazialseen) wird die Gruppe der anthropogen entstandenen Gewässer (Gräben, Kanäle, Dammseen) gegenübergestellt. Während die allgemeine Nutzung künstlicher Gewässer allein aus ihrer Intention heraus vorausgesetzt werden kann (Fischzuchtteiche, Flößerschwellteiche), unterliegen bzw. unterlagen auch die im eigentlichen Sinne natürlichen Gewässer einer Veränderung und/oder Nutzung durch den Menschen. Diese Gewässer können in beiden Fällen entweder direkt (Flussteich, Mühlenstau) oder indirekt durch den Menschen beeinflusst (wassergefüllte Torfstiche, durch erosiven Sedimenteintrag aus Solifluktionsvorgängen von Rodungshängen verursachte, wasserstauende Hohlformen) entstanden sein.

Während fluidale Benutzungen im Sinne von Entnehmen, Einleiten oder Einbringen von Stoffen in Fluss- und Bachläufen der schnellen Vergänglichkeit unterliegen und insofern nur geringe Spuren auf der Erdoberfläche hinterlassen haben, sind die kulturmorphologischen Ausprägungen vergleichsweise deutlicher räumlich fassbar und folglich rekonstruierbare Elemente unserer historischen Kulturlandschaft (Teichmönch, Stauwehre, Wärterhäuschen). Die physiognomische Abbildung im Raum ist dabei nicht allein aus arbeitstechnischen Gründen Voraussetzung für die Aufnahme in den historisch-geographischen Untersuchungsrahmen. Die Beschäftigung mit historischer und im Gelände nicht mehr feststellbarer Gewässerverschmutzung wird aus diesem Grund disziplintheoretisch von mir eher dem Fach Umweltgeschichte zugeordnet und bleibt auch deshalb außerhalb der hier vorgestellten geographischen Betrachtungsperspektive. Die Raumwirksamkeit, als geographisches Kriterium schlechthin, soll also in diesem Ansatz als grundlegend betrachtet werden.

\section{Begriffliche Definitionen von Gewässern}

Im Folgenden soll versucht werden, einige wichtige Begriffe der Gewässerforschung zu erläutern. Dies geschieht auf drei Ebenen:

1. der Ebene der Wissenschaftssprache der Limnologie,

2. der Ebene der heutigen hochdeutschen Umgangs- und Hochsprache, wobei besonders regionale Aspekte zu berücksichtigen sind, und

3. der Ebene des historischen Gebrauchs der Begriffe, teilweise dokumentiert in Benennungen von Gewässern.

Dabei werden alle Kriterien, die in die Begriffsbildung eingehen, wie naturräumliche Einbindung, Wasserstandsschwankungen und Abflussverhältnisse, in ihrer Wertigkeit für exakte Definitionen geprüft. 
Dass eine solche begriffliche Konkretisierung notwendig erscheint, belegt ein solches Fehlen auch in der ansonsten hervorragenden gewässerhistorisch-geographischen Arbeit von DIX (1997). Er erwähnt nur kurz (:25) - bei den Publikationsvorstellungen zum Stand der Historischen Umweltforschung - die grobe Unterscheidung zwischen den unterschiedlichen Typen von Still- und Fließgewässern (Seen/Teiche - Flüsse/Bäche) als Differenzkriterium bei der Thematisierung in den bisher erschienenen gewässerbezogenen Arbeiten, ohne aber selbst eine zufrieden stellende Lösung anzubieten.

\section{a Wissenschaftliche Begriffsebene}

Im Sinne der heutigen Limnologie werden unter den Oberbegriff Gewässer „eine Vielzahl wasserführender Systeme oder Hohlformen unterschiedlichster Genese und Standorteigenschaften mit entsprechend völlig unterschiedlichen Lebensräumen zusammengefasst.“ (POTT/REMY 2000:11) THIENEMANN (1955:20) bezeichnet, mit dem Versuch eines kleinsten gemeinsamen Nenners, Gewässer als „eine Wasseransammlung auf der Erde“ und als ihre charakteristischen Merkmale die „Begrenzung“", die „Wasserundurchlässigkeit“ und die Bildung von „Ufer und Boden“.

Bei diesem Versuch, Binnengewässer begrifflich zu fixieren, ist zunächst die Abgrenzung ,in bezug auf die terrestrischen Bereiche nicht sehr schwierig, da der Lebensraum Wasser eine zulässige Grenzziehung zwischen beiden Ökosystemtypen erlaubt.“ (SCHÄFER 1997:18) Nach einer zoographisch orientierten Begriffsbestimmung von DE LATTIN (1967:161) wird danach „als Binnengewässer jedes Gewässer betrachtet, das als stehendes Gewässer entweder vollständig vom Meer getrennt ist oder dessen Kommunikation mit dem Meer so geartet ist, daß ein Einströmen von Meerwasser praktisch unmöglich ist [...] und zwar ungeachtet ihrer Entstehung, des Charakters ihrer Fauna und einer eventuellen früheren marinen Natur.“ „Das Grundwasser, die Quellen, Bäche und Flüsse, die Seen, Teiche und Kleingewässer“ bilden somit das Binnengewässer (THIENEMANN 1955:V).

See und Fluss sind die beiden Hauptformen der Binnengewässer (THIENEMANN 1955:19).

FOREL (1901) bezeichnet als See ,eine allseitig geschlossene, in einer Vertiefung des Bodens, einer Wanne, befindliche, mit dem Meere nicht in direkter Kommunikation stehende, stagnierende Wassermasse" (aus: THIENEMANN 1955:20). Beim See zum einen wird die geschlossene Selbständigkeit, die Ganzheit zum kennzeichnenden Hauptmerkmal (:22). Biologisch betrachtet stellen die stehenden Gewässer deshalb im Allgemeinen räumlich getrennte Biotope dar, obgleich Seen durch ihre Abläufe verbunden sein können und so Seeketten bilden (:24). Im Fall der nicht mit einem Flusssystem in Verbindung stehenden Seen handelt es sich meistens um sog. Wasserinseln, die von einem terrestrischen Umfeld umgeben sind (SCHÄFER 1997:17). Zum anderen wird die Stagnation des Wassers als Hauptmerkmal genannt, wobei dies nicht mit Stillstand gleichzusetzen ist. Seen können durchflossen sein, wobei die theoretische Aufenthaltszeit von 3 Tagen nicht unterschritten werden sollte. Als „Flussseen“ werden all die Gewässer mit einer Verweildauer von 3 - 30 Tagen charakterisiert (MATHES et al. 2002; nach NIXDORF et al. 2003).

Ein weiteres Kennzeichen des Sees ist seine ,in allen Teilen gleiche horizontale Oberfläche.“ Können auch rhythmische Schwankungen der gesamten Wassermasse, stehende Wellen von Millimeter- bis Meterhöhe, die sog. Seiches, auftreten oder Windausströmungen an der Leeseite den Wasserspiegel heben, so sind das doch „vorübergehende Erscheinungen; im allgemeinen ist die Wasseroberfläche horizontal, überall liegt sie im gleichen Niveau. Das Wasser des Sees steht.“ (THIENEMANN 1955:30)

Die zweite Gruppe von Oberflächengewässern sind die Fließgewässer, auch „lotische aquatische Ökosysteme“ genannt. (SCHÄFER 1997:193). Flüsse sind nach einer Definition von MARCINEK (1978:22) ,in langgestreckten, einseitig geöffneten Hohlformen der Landoberfläche fließende natürliche Wasserläufe, die umgrenzbare Flächen des Festlandes mit natürlichem Gefälle entwässern.“ Hydrologisch betrachtet ist ein Fluss „ein offenes System mit einem kontinuierlichen oder temporären 
Fließvorgang von der Quelle bis zur Mündung.“ (SCHÄFER 1997:194) Der Fluss ist demnach ein „offenes Gewässer““ (THIENEMANN 1955:22).

Beim Fluss kann man nicht von einer allseitig geschlossenen Begrenzung reden; nur zwei einander gegenüberliegende, annähernd parallele Ufer sind vorhanden, ,aber flußaufwärts und flußabwärts schließen sich keine Schranken.“ (THIENEMANN 1955:20). Flüsse können daher ,im Verhältnis zu den terrestrischen Lebensräumen von ihrer Gestalt und biogeographischen Funktion her eher als Vektoren oder Korridore angesehen werden.“(SCHÄFER 1997:16)

Die fließenden Gewässer eines Flusssystems, zuweilen auch benachbarter System, sind des Weiteren kontinuierlich miteinander verbunden, sie bilden - ohne menschliche Einwirkung - ununterbrochene Wasserstraßen (THIENEMANN 1955:24f.). Seine „gliedhafte Zusammengehörigkeit“, d. h. räumlich verschiedene Flussläufe miteinander $\mathrm{zu}$ verbinden, kennzeichnen ein (natürliches) Flusssystem. Zudem durchfließt ein Fluss - im Gegensatz zum See - in seinem Lauf verhältnismäßig uneinheitliche Landschaften (:24).

Ein weiteres Unterscheidungsmerkmal ist, dass die Stoffe nicht vertikal im Wasserkörper kreisen, wie bei stehenden Gewässern, sondern wie in einer Spirale flussabwärts transportiert werden (SCHÄFER 1997:194).

Schließlich kann als eigentliches Kennzeichen seine Strömung gelten. Fließgewässer unterscheiden sich um den Faktor Strömung grundlegend von den stehenden Gewässern. Als Kriterium für die Unterscheidung zwischen stehenden und fließenden Gewässern wird die gerichtete Bewegung des gesamten Wasserkörpers mit einer Geschwindigkeit von mehr als $0,01 \mathrm{~m} / \mathrm{s}$ betrachtet (SCHÄFER 1997:193). „Mag er im Hochgebirge sein Quellgebiet haben oder im Mittelgebirge, wenige hundert Meter hoch, oder gar in der Ebene, in Hügelgelände, das $100 \mathrm{~m}$ nicht übersteigt: immer ist sein Ursprung höher gelegen als seine Mündung im Meere. Und diese Höhendifferenz zwingt sein Wasser, in der seitlich begrenzten Rinne nach dem Gesetz der Schwere seinen Weg hinab zum Meere zu suchen.“(THIENEMANN 1955:30)

Nachdem die grundsätzlichen Begrifflichkeiten geklärt sind, widmen wir uns der eigentlichen Problematik: der begrifflichen Festlegung von Kleingewässern.

Nach Abtrennung der Seen und Flüsse, die man als große Gewässer bezeichnen kann, verbleiben eine Reihe von kleinen Gewässern mit den verschiedenartigsten Merkmalskombinationen und Erscheinungsbildern. Diese, zumeist nach limnologischen Kriterien vorgenommenen, Definitionen sollen im Folgenden angeführt werden.

Als Fließgewässer-Kleinform kann der ,Bach' gelten. „In erster Näherung“ definieren POTT/REMY (2000:117) Bäche ,als Fließgewässer mit relativ geringer Wassertiefe und insgesamt kleinem Gewässerquerschnitt und den daraus resultierenden starken Interaktionen bzw. Grenzeffekten zwischen Wasserkörper, Gewässersohle, Ufer und unmittelbar angrenzender Ufervegetation." Hierbei stehen nach ihrer Ansicht „Wasser- und Ufervegetation meist in unmittelbarem Kontakt; gleichzeitig erreichen an naturnahen Gewässerabschnitten die uferbegleitenden Gehölze normalerweise einen Kronenschluss über dem Wasserkörper und schränken somit den Lichtgenuss für Wasserpflanzen ein.“

Doch als eigentliches Kleingewässer sehen die beiden Autoren kleine Fließgewässer, wie den Bach, nicht. Sie betrachten „Kleingewässer“ nicht als Fließgewässer, sondern - gleichberechtigt neben See, Weiher und Tümpel - als „besonderen Stillgewässertypus“ (POTT/REMY 2000:166). Nach ihrer Definition haben Kleingewässer ,eine geringe Oberflächenausdehnung von einigen Quadratmetern bis zu wenigen Hektar. Sie erreichen zudem überwiegend geringe mittlere Tiefen, von einigen Dezimetern bis zu durchschnittlich 2 Metern und zeigen maximale Tiefen bei etwa 5 bis 7 Meter.“(:166)

\section{Charakteristische Kennzeichen von Kleingewässern nach POTT/REMY (2000:166) sind}

- $\quad$ eine im Vergleich zu ihrem relativ kleinen Wasserkörper langgestreckte Uferlinie, 
- ein dadurch besonders intensiver Kontakt mit ihrer Umgebung (Schattenwurf von Ufergehölzen),

- aufgrund geringer Tiefen eine ständige Durchmischung des Wasserkörpers,

- kaum oder nur kurzzeitige Temperaturschichtungen,

- deutliche Temperaturschwankungen im Tages- und Jahresverlauf,

- bei mangelhaftem Anschluss an das Grundwasser periodisch saisonale bzw. aperiodisch zum Teil stark schwankende Wasserstände mit Niedrigwasser,

- bei nahezu allen Kleingewässern der agrarisch genutzten Landschaften Mitteleuropas eine Einstufung als eutroph bis hypertroph,

- eine vergleichsweise geringmächtiger Wasserkörper und

- eine sehr rasche Akkumulation organischer Sedimente mit einer ebenso raschen Verlandung.

Neben den oben schon genannten Eigenschaften (fehlende Schichtung, durchgehende Möglichkeit des Bewuchses mit Wasserpflanzen) sind die Kleingewässer meist durch ein kleines Einzugsgebiet gekennzeichnet, was stärkere Wasserstandsschwankungen begünstigt. Sie bieten dem Wind wenig Angriffsfläche und weisen geringeren Wellengang als Flachseen vergleichbarer Tiefe auf. Auch die Beschattung kann oft stärkere Ausmaße annehmen. Kleingewässer sind relativ einheitliche Biotope von geringer struktureller Diversität.

Eine weitere limnologische Definition von Kleingewässern unternimmt WIEGLEB (1980:82 - 92) mit einer bekannten, nach Nährstoffen differenzierenden Gliederung. Er zielt weniger auf entwicklungsgeschichtliche Aspekte ab als auf konkrete limnologische Ähnlichkeit, die sich aufgrund der Nährstoffmenge auch in Ähnlichkeit von Flora und Fauna ausprägt.

Er unterscheidet:

1. oligotrophe Kleingewässer

2. dystrophe Kleingewässer,

3. eutrophe Kleingewässer.

Die Gruppe der oligotrophen Kleingewässer umfasst nach WIEGLEB die Moorgewässer ungeachtet ihrer entwicklungsgeschichtlichen Herkunft.

Diese dystrophe Kleingewässergruppe ist nach seiner Auffassung die heterogenste sowohl bezüglich Entstehung als auch besonders ihrer Art und Intensität der anthropogenen Beeinflussung.

In der Gruppe der eutrophen Kleingewässer sollen sowohl noch erhaltene natürliche Heidegewässer wie auch künstliche (z. B. ein Teil der Oberharzer Stauteiche; Gewässer, die durch Straßenbaumaßnahmen entstanden sind) zusammengefasst werden.

Innerhalb der Gruppen sollten nach WIEGLEB als erste Untergruppen zwischen permanenten Gewässern (Teiche) und periodischen Gewässern (Tümpel) unterschieden werden. Weitere Untergliederungsmöglichkeiten ergeben sich nach den Abflussverhältnissen, regionalen Gesichtspunkten, Art der Bewirtschaftung und Art der Entstehung. Besondere Schwierigkeiten bei der Klassifikation bereiten WIEGLEB die tiefen Kleingewässer, die er limnologisch eher den Seen zurechnet.

\section{b Allgemeinsprachliche Begriffsebene}

Häufig wird auf der allgemeinsprachlichen Ebene ein Viererschema benutzt, um die Gewässertypen voneinander abzugrenzen. Hierbei werden als Kriterien hauptsächlich Tiefe und Art der Entstehung angeführt (vgl. SCHMIDT 1974) und nicht so sehr eine auf wissenschaftstheoretischen Kriterien beruhende Umschreibung: 
Tab. IV-1: Einfaches Viererschema zur Gewässertypisierung

\begin{tabular}{|c|c|c|}
\hline & Natürlich & Künstlich \\
\hline Flach & $\begin{array}{c}\text { Weiher } \\
\text { Kleinweiher }\end{array}$ & Teich \\
\hline Tief & See & $\begin{array}{c}\text { Stausee } \\
\text { Talsperre }\end{array}$ \\
\hline
\end{tabular}

Dieses Viererschema ist durchaus nicht allgemein akzeptiert, doch liefert es eine, wenn auch unzureichende, so dennoch verständliche Typisierung, da die anthropogene Herkunft berücksichtigt bleibt. RÖSSERT (1976) als Limnologe beispielsweise nähert sich dbenfalls einer allgemeingültigen, die Herkunft beachtende Gliederung und differenziert nach der Art der Entstehung und in abnehmender Größe und führt neben dem Weiher den „Tümpel“ als besondere Kategorie mit auf:

- natürlich: See - Weiher - Tümpel

- $\quad$ künstlich: Stausee - Teich

Das klassische Stillgewässer ist auf der allgemeinsprachlichen Ebene der See: ein natürliches Gewässer mit einer gewissen Größe, Tiefe und Schichtung sowie einer Reihe weiterer Eigenschaften. Lehrbücher der Limnologie beschäftigen sich meist fast ausschließlich mit diesem Gewässertyp und erwähnen andere, wie den Teich, nur randlich (z. B. SCHWOERBEL 1993). Lehrbücher der Wasserwirtschaft beziehen beide in ihre Ausführungen mit ein. Aus gutem Grund werden denn beide auch z. B. in die bergbauliche Wasserbewirtschaftung eingebunden. Eine exakte terminologische Verwendung, die die Trennung beider Gewässerformen deutlich werden lässt, wird hingegen oftmals vermisst. HAASE $(1961: 5,25)$ beispielsweise bezeichnet die Teiche im Oberharz gleichwohl als „Bergseen“ als auch als „Höhenteiche“. Wider besseren Wissens, denn auch er weiß um die Unterschiedlichkeit von ,Seen' und ,Teichen', wie man belegen kann: „Seen“, wie im Hochgebirge die „Meeraugen“ oder die „Kar-Seen“, führt er aus, verdanken „einem natürlichen Vorgang ihr Dasein“ und können, dies benennt er als ein weiteres entscheidendes Unterscheidungskriterium, ,nicht entleert werden “ (:5). Die Teiche unterscheiden sich dementsprechend ,von den Seen [...] darin, daß sie bewirtschaftet, also nach Bedarf abgelassen oder ,gespannt' werden können“ (:5). Die ,Harz-Teiche', wie auch alle übrigen Teiche, dies sei an dieser Stelle von mir angemerkt, sind aus diesem Grund „von Menschenhand gemacht.“(:5)

Bedeutsam hinsichtlich ihrer Begriffsbestimmung ist auch das Größenkriterium bei künstlichen Anlagen. Doch einzig für Talsperren ist dies per Gesetz definiert: Erst wenn ihr Stauraum $100.000 \mathrm{~m}^{3}$ erreicht und die Dammhöhe $5 \mathrm{~m}$ überschreitet (Höhe des Absperrbauwerkes gemessen von der Sohle bzw. tiefsten Geländepunkt), gelten sie nach dem Gesetz als „Talsperren“ ( 105 Landeswassergesetz NRW). Darunter fallen nicht nur Stauanlagen klassischer Art, die die Flüsse aufstauen und der Energieerzeugung dienen, sondern auch Anlagen zum Speichern schlammiger Stoffe, de auch als ,Sedimentationsanlagen' bezeichnet werden und ,Hochwasserrückhaltebecken', die zwar das Wasser zum Hochwasserschutz nur vorübergehend speichern, aber dennoch die o. g. Kriterien für Talsperren erfüllen und den vergleichbaren Sicherheitsanforderungen genügen wie Anlagen, die das Wasser dauernd speichern ( $\$ 106$ Landeswassergesetz NRW; BEZIRKSREGIERUNG DÜSSELDORF 2004). Für die eigentlich hier anzusprechenden Gewässerkategorien gibt es eine solche (gesetzliche) Festlegung nicht.

Ein ,Tümpel' ist nach RÖSSERT dadurch gekennzeichnet, dass er ,zeitweise austrocknend“ ist. POTT/REMY (2000:158) charakterisieren Tümpel ebenfalls als „periodisch austrocknend“, im Gegensatz zu Seen und Weihern, die „als perennierende Gewässer ganzjährig Wasser“ führen und somit in der Lage sind, „dauerhaft eigenständige aquatische Lebensgemeinschaften zu beherbergen.“

HAASE (1961:49) sieht eine ganz andere, ,vegetationskundliche' Bedingung dafür, wenn man vom ,Weiher' spricht: Sind sie ,rings vom Wald umgürtet, mögen sie in ihrer Verborgenheit wohl als ,Weiher' angesprochen werden.“ Man könnte in diesem Fall dann wohl auch von ,Waldweiher' 
sprechen. Doch zum einen kann sich dieser Status der Bewaldung im Verlauf der Geschichte schnell ändern, zum anderen wäre dann der Weg frei für sich aus der Lage ergebende weitere Formen: z. B. ,Wiesenweiher', ,Bergweiher'.

Bei der Namensgebung der Teiche gab es darüber hinausgehende Benennungsmotive:

- nach der Lage (Dorfteich, Schmiedeteich, Oberteich, Vorderteich, Unterteich etc.),

- nach der Ausdehnung (Großteich, Kleinteich, Langteich, Tiefteich etc.),

- nach dem Besitz (Herrenteich, Gemeindeteich, Mönchsteich, Frauenteich, Vorwerksteich etc.),

- nach der Nutzung (Fischteich, Forellenteich, Schwemmteich, Sauteich, Mühlteich etc.)

- nach der Randbewachsung (Holzteich, Wiesenteich, Schilfteich, Rohrteich, Binsenteich etc.).

ELLENBERG (1973) hingegen bezieht sich auf die Tiefe als Definitionskriterium und verwendet statt des Ausdrucks „Weiher“ lieber „flacher See“. Dies dokumentiert das allgemeine Unbehagen des Botanikers mit einer allgemeinsprachlichen regional ausgeprägten Terminologie, wobei aber gerade hier ihre etymologischen Wurzeln liegen.

Neben den verschiedenen allgemeinsprachlichen begrifflichen Verwendungen für Stehgewässer gibt es solche selbstverständlich auch für die Fließgewässer. Was aber unterscheidet im allgemeinen Sprachgebrauch einen Bach von einem Fluss?

„Ein Fluß ist eigentlich ein schiffbares Gewässer, wenn auch die Flußschiffahrt oft nur mit Booten möglich war." (KNÜBEL 1988:9) Im Umkehrschluss ist der Bach nicht befahrbar und muss deshalb auch eine geringere Tiefe und Breite besitzen. Doch welche? Denn ist diese nicht den zeitgeschichtlichen Anforderungen und Möglichkeiten, z. B. des Schiffbaues, der Transportfähigkeit und der Warenmenge entsprechend von sehr wandelbarer Größe?

Die oftmals verwirrende Sprachvielfalt und Ungenauigkeit der Termini löst sich erst recht nicht auf, wenn die ,alten' regionalen Begriffserklärungen herangezogen werden, die auch eine historischgenetische Herleitung oftmals nicht ermöglichen.

\section{c Regional-historische Begriffsebene}

Der limnologische Terminus „See“ stimmt mit dem umgangssprachlichen Begriff „See“ weitgehend überein, wobei für die Umgangssprache mehr die Größe als die Tiefe das wichtigere Kriterium ist. Künstlich geschaffene größere Gewässer wie Stauseen, Bagger- und Tagebauseen werden allgemein als ,Seen' akzeptiert, was auch limnologisch wegen ihrer oft großen Tiefe weitgehend richtig ist. „See“ bedeutet neben „großer Binnensee“ auch „Meer“ (vgl. engl.: sea = Meer). Im nordwestdeutschen Raum heißen allerdings gerade die größeren Gewässer nicht „See“, sondern „Meer“ (Steinhuder Meer, Zwischenahner Meer, Großes Meer, etymologisch eingeschmolzen auch der „Dümmer"). „Meer“ ist von einem gemeingermanischen Wortstamm abgeleitet, verwandt mit Worten wie „Moor“, „Marsch“ und „Morast“, die alle die Bedeutung von „Sumpf, stehendes Gewässer“ umfassen.

Bei den Kleingewässern sind die Unklarheiten wesentlich größer. Das Wort „Teich“ ist norddeutsch/ostdeutsch und seit dem 13. Jahrhundert belegt (DUDEN 7). Es umfasst in seiner ursprünglichen Bedeutung sowohl die ausgehobene wassergefüllte Grube („Teich“) als auch den daraus errichteten Damm („Deich“). Gleiches gilt für das englische „dike“, „dyke“ = „Graben“ und „Deich“. Verwandt ist auch das englische „ditch“, was ebenfalls „Graben“, „Kleingewässer“ bedeutet, aber auch für den Ärmelkanal und die Nordsee verwendet wird (vgl. deutschumgangssprachlich „der große Teich“ = Atlantik). Teich in unseren Sinne heißt im englischen ,pond“ (von lat. „fundus“ = „Grube“) oder „pool“ (vgl. das niederdeutsche „pool“ und das hochdeutsche „Pfuhl“). „Teich“ hat im Hochdeutschen nicht die verengte Bedeutung des künstlichen Kleingewässers, sondern hauptsächlich die des Kleingewässers ohne Einschränkung. Dies zeigt sich in Benennungen von natürlichen Gewässern wie z. B. Denkershäuser Teich (Krs. Northeim), Zitterteiche (Krs. Osnabrück) und viele 
andere mehr (GRAHLE/STAESCHE 1964). Künstlich angelegte Teichgebiete werden deshalb oft noch zusätzlich nach ihrer Entstehung oder beabsichtigten Nutzung benannt, so etwa ,Oberharzer Stauteiche' oder, Ahlhorner Fischteiche'.

Dem norddeutschen umgangssprachlichen Wort „Teich“ entspricht das süddeutsche „Weiher“. Beide Worte werden synonym verwendet. „Weiher“ ist aber im Gegensatz zur deutschen Ableitung von „Teich“ (siehe oben) dem lateinischen entlehnt (,vivarium“ = „Fischteich“).

Die genaue Grenze der heutigen Verwendung beider Begriffe ist nur schwer zu ermitteln. Wie Landkarten ausweisen, heißen Kleingewässer in Rheinland-Pfalz bis in den Siegerländerraum „Weiher“, während weiter südlich im Hessischen der Begriff „Teich“ verwendet wird. Im Württembergischen erfuhr das Wort „Teich“ einen Bedeutungswandel dergestalt, dass es ursprünglich eine künstliche Wasserrinne, heute ein künstlich aufgestautes Gewässer bezeichnet (HERBST 1987b:28). Auch in Basel wurde das seit dem 13. Jahrhundert bestehende und gut ausgebaute System von Gewerbekanälen "Teiche“ genannt, die ihr Wasser aus der Bire, dem Birsig und der Wiese herleiteten und mehrere Gewerbesiedlungen bedienten (GLAUSER 1978:91).

In der hochdeutschen Sprache hat „Teich“ das eindeutige Primat. Zusammensetzungen wie „Teichhuhn“, „Teichrose“, „Teichmolch“, „Teichmuschel“ und „Teichbinse“ belegen dies. Mit „Weiher" gibt es keine äquivalenten gebräuchlichen Anwendungen. „Weiher“ wird in der Hochsprache nur in romantisierenden Zusammenhängen gebraucht. Mitunter ließe sich auch eine Bindung an den ehemals römischen Einflussgebieten (Limes) nachweisen.

Die Differenzierung der Begriffe „Weiher“ und „Teich“ in der Limnologie geht auf den Begründer dieser Wissenschaft, François Alphonse FOREL (1841 - 1912), zurück. FOREL war französischsprachiger Schweizer, verfasste sein Hauptwerk (Handbuch der Seenkunde, 1901) aber auf deutsch. Durch THIENEMANN (1925) wurde die Forel'sche Nomenklatur in die deutsche Wissenschaft eingeführt und von ENGELHARD (1971) popularisiert.

Nach FOREL ist der Weiher „ein See ohne Tiefe“, d.h. er ist bis zum Grunde mit höheren Wasserpflanzen (Makrophyten) bewachsen. Dies ist ein schlecht zu behandelndes Kriterium, wie man allein anhand des Zusammenhangs zwischen Wuchstiefe und Gewässerchemismus begründen kann: Die natürliche Grenze des Makrophytenbewuchses liegt bei ca. $7 \mathrm{~m}$. Sie wird vom hydrostatischen Druck bestimmt, der in größerer Tiefe die Gefäße der Pflanzen zusammenpresst. Bei verringerter Lichtdurchlässigkeit des Wassers (z. B. nach Verschmutzung) geht der Makrophytenbewuchs aber nicht bis in solche Tiefen, sondern fehlt unter Umständen ganz. Deshalb wird meist mehr oder weniger unausgesprochen der Begriff „See“ anders definiert als „Weiher“, der nur aus Epilimnion besteht, d. h. keine charakteristische Schichtung bezüglich Sauerstoffverhältnissen und Temperatur aufweist. Eine exakte Tiefe lässt sich aber so nicht angeben, so dass der zugrunde gelegte ,Tiefenbegriff' des Sees „verwässert" wird und damit auch der des Weihers.

Abgesehen von der Unschärfe der Abgrenzung bedeutet die Forel'sche Definition des Weiteren eine völlige Verkehrung der sprachlichen Bedeutung. Das weitgehend synonyme Begriffpaar „Weiher/Teich“ wird für die wissenschaftliche Begriffsbildung getrennt. „Weiher“ wird, da es mit „See“ übersetzt wird, als „natürliches Flachgewässer“ und „Teich“ als „künstliches Flachgewässer“ definiert. Diese Zuweisung ist umso verwunderlicher, als in „Weiher-vivarium“ der künstliche Aspekt noch stärker enthalten ist als in „Teich“.

Ein Gewässertyp, der sich nicht in das beschriebene Begriffsschema einfügen lässt, ist der des „Altwassers“. Altwässer entstehen natürlich oder künstlich als Restgewässer nach Veränderung eines Flusslaufes, wobei je nach Breite und Tiefe ein neues see- oder teichartiges Gewässer entsteht, auf das wegen seiner andersgearteten Form (sehr langgestreckt im Verhältnis zur Breite) die oben geschilderte Nomenklatur oft nicht angewendet wird.

Alle bisher genannten Gewässer - mit Ausnahme des Tümpels - gehören zur Gruppe der „permanenten Gewässer“ (ELLENBERG 1973), die regelmäßig Wasser führen; es sei denn, sie werden 
abgelassen, was bei Teichen und Talsperren möglich ist. Dem gegenüber stehen die periodischen Gewässer, die als „Tümpel“ zusammengefasst werden (siehe Pkt. b). „Tümpel“ ist ein mitteldeutsches Wort und erst seit dem 19. Jahrhundert belegt. Es bedeutet „mit Wasser gefülltes Loch“ und ist in etwa synonym mit „Pfütze“ und „Pfuhl“ (DUDEN 7; siehe auch oben die gleiche Übersetzung zu „Teich“). In der norddeutschen Umgangssprache hat „Tümpel“ eigentlich zwei sich überschneidende Bedeutungen, einmal als „Kleingewässer mit starken Wasserstandsschwankungen“ und auch als „kleines abflussloses Gewässer“. Vor allem die zweite Bedeutung trennt den Tümpel besser vom Teich ab, der meist einen Abfluss hat, obwohl die Überschneidung der Wortfelder auch hier sehr groß ist.

Im Bereich der Moorgewässer hat sich eine ganz eigene Nomenklatur entwickelt, deren Termini weitgehend aus dem Niederdeutschen entlehnt sind. Zu nennen sind vor allem Schlenke, Blänke, Kolk und Schlatt. Daneben gibt es auch zusammengesetzte Bezeichnungen wie „Moorsee“ und „Moortümpel“, deren Differenzierung hier vor allem nach der Größe erfolgt. Künstliche Gewässer im Moor stellen die wassergefüllten Torfstiche (niederdeutsch „Pütten“) dar. Schlenken sind relativ kleine mit Wasser gefüllte Flächen. „Schlenke“ ist kein limnologischer, sondern ein botanischer Begriff, da im Hochmoor zwischen Bult- und Schlenkenvegetation unterschieden wird. Größere Gewässer in größeren zusammenhängenden Mooren, meist Hochmooren, heißen „Blänke“ (was auch Waldblöße bedeuten kann, von „blank“ im Sinne von „bloß, frei von“) oder „Kolk“. Dieser Begriff ist eine Lautmalerei und mit „gurgeln“ und „glucksen“ verwandt. Auch die Bezeichnung „Moorauge“ wird in diesem Zusammenhang verwendet (siehe auch oben HAASEs „Meeraugen“, Pkt. b).

Schlatts sind davon deutlich abgehoben. „Schlatt“ ist die hochdeutsche Form des niederdeutschen „Slat" = moorige Vertiefung (in der Heide), was verwandt ist mit dem friesischen „,slot" $=$,Schlot, Graben“. Schlatts sind kleine Moore, die in wassergefüllten Windausblasungen entstanden sind (OVERBECK 1975). Im streng moorkundlichen Sinne sind z. B. auch der Dümmer und das Steinhuder Meer in Niedersachsen „Schlatts“. Wegen deren Größe erscheint eine solche Ausdehnung des Begriffs aber nicht sinnvoll. Der Ausdruck „Schlatt“ bezieht sich sowohl auf das Kleinmoor als auch auf das darin befindliche Restgewässer. Diese Unschärfe der Begriffe zeigt sich auch in anderen Flurnamen, wo die Gewässer ebenso ,-sumpf“, „-moor“ oder „-venn“ heißen wie die sie umgebenden Moore. Eine solche gemeinsame Betrachtungsweise, die sich auch in dem oben erwähnten Beispiel der Verwandtschaft von „Meer“, „Moor“ und „Marsch“ andeutet, hat sich erst wieder durch die neudeutsche Lehnübersetzung „Feuchtgebiete“ (vom angelsächsischen „wet lands“) eingebürgert. Das „Feuchtgebiet“, oder als verwissenschaftlicher Terminus: das „Feuchtbiotop“, umfasst ebenfalls sowohl die Gewässer als auch die (meist) sie umgebenden Moore, Sümpfe, Feuchtwiesen, usw.

Eine Vielzahl an historischen Bezeichnungen liegen auch für Wasserläufe vor:

Ein Wasserlauf ist bergmännisch gesprochen ein Stollen, der in den Berg hineingetrieben wird. Im Oberharz bezeichnet man jedoch mit "Wasserlauf" die unterirdische Strecke eines Grabens (HAASE 1961:7). Und „Quelle“ nannten Bergleute ein kleines Rinnsal.

Der künstlich angelegte oder regulierte Arm des Flusses, d. h. der Mühlgraben, wurde sowohl an der Erft wie auch an den Nebenflüssen meistens als „Mühlenbach“ bezeichnet. Den unregulierten, als Flutgraben dienenden Flussarm bezeichnete man meist als den ,alten Bach“ (KREINER 1996b:98).

Noch verwirrender, weil dem allgemeinen und wissenschaftlichen Sprachgebrauch entgegengesetzt, ist die überlieferte historische Terminologie des „Teiches“ im Zusammenhang mit Fießgewässern im Niederrheinischen: „Zwar ist die Bezeichnung Mühlenbach für die Mühlenkanäle im Erftgebiet vorherrschend, aber es existiert auch der Terminus Mühlenteich. Der Begriff bezieht sich in diesem Falle nicht auf ein stehendes, sondern ein fließendes Gewässer. Es leitet sich von ,Deich' her. Hier eröffnet sich eine Parallele zum Sprachgebrauch im Düren-Jülicher Raum, wo die aus der Rur abgeleiteten Kanäle noch heute traditionell als Mühlenteiche bezeichnet werden.“ (KREINER 1996b:98) Bei vielen frühen Quellenbelegen aus dem Erftgebiet kann man so für den Begriff ,Deich' „nicht eindeutig entscheiden, ob das Wasserbauwerk (der Deich) oder das Gewässer (der Teich) gemeint ist.“ (:98) Zum Beispiel wird der aus dem Rhenbach zur Mühle abgeleitete Mühlenkanal bei Rheinbach im 18. Jh. mit dem Begriff „Mullendeich“ bezeichnet. „Den Quellen ist eindeutig zu 
entnehmen, daß mit diesem Begriff kein Deich (Damm), sondern der Wasserlauf selbst gemeint ist.“ (:99) Vereinzelt ist in diesem Raum auch die kombinierte Bezeichnung „Teichbach“ (Deichbach) anzutreffen (:99).

Es gibt allerdings auch im Erftgebiet einige Mühlen, die über einen Mühlenteich in der Form eines Wasserrückhaltebeckens, dort „Kolk“ genannt, verfügten. Die Bäche die das Betriebswasser dieser Mühlen lieferten, hatten einen zu geringen Abfluss für kontinuierlichen Mahlbetrieb und deshalb musste das Wasser für Wassernotstandszeiten aufgefangen werden. Zum Beispiel existiert ein früher urkundlicher Beleg (1211) für einen solchen richtigen Mühlenteich für die Mühle zu Eggershoven am Gillbach bei Rommerskirchen. Auch die Bannmühle in Rheinbach verfügte nach der Urkarte von 1821 über einen solchen Teich (KREINER 1996b:99).

Auch hier zeigt sich wieder, dass von einem Namen noch lange nicht auf dessen Herkunft bzw. Funktion geschlossen werden kann. Eine differenzierte Betrachtung ist gerade bei der sprachlichen Vielfalt geboten, will man nicht Irrtümern aufsitzen. 


\section{Gewässergeschichte}

Unter Gewässergeschichte verstehe ich den zeitlichen Ablauf von Geschehnissen, die Landschaft und Flussnetz geformt haben (in Anlehnung an HANDTKE 1993:V). Darunter sind sowohl die natürlichen als auch die anthropogenen Formungsvorgänge zu fassen. Insofern handelt es sich auch um eine Geschichte der Gewässernutzung, wenn sie auch erdgeschichtlich betrachtet nur eine kurze Periode der gesamten Gewässergeschichte darstellt. Da sich diese kultur- und physiogeographische Gewässergeschichte nur auf die Gewässer des Festlandes bezieht, ist es im eigentlichen Sinne eine Binnengewässergeschichte.

In der zeitgeschichtlichen Einteilung einer Gewässergeschichte folge ich dem Ansatz von VOS/ MEEKES (1999:3-14), die generalisierend verschiedene Perioden der Landschaftsgeschichte identifizieren:

1. Natural/prehistoric landscape (from Palaeolithic till ancient Greek times),

2. Antique landscape (from ancient Greek times till early Mediaeval times),

3. Mediaeval landscape (from early Medieaval times till Renaissance),

4. Traditional agricultural landscape (from Renaissance till $19^{\text {th }}$ century, sometimes till today),

5. Industrial landscapes (mostly from mid- $18^{\text {th }}$ till mid $-20^{\text {th }}$ century, in many places till today),

6. Postmodern landscapes (today).

Von besonderer Bedeutung vom Standpunkt einer anthropogeographischen Betrachtung sind hierbei die Vorgänge im Zeitraum seit dem Mittelalter (ab Nr. 3), aus denen auch die ersten aussagekräftigen Quellen zur Gewässernutzung in Mitteleuropa vorliegen.

\section{Natürliche Gewässer- und Flussgeschichte}

Im Verhältnis zu den geologischen Zeiträumen besitzen die meisten heute existierenden Binnengewässer nur eine kurze Lebensdauer. Bis auf die Entwässerungssysteme der Kontinentalblöcke aus dem Erdaltertum sind sowohl die Flusssysteme als auch die ältesten Seen höchstens tertiären Ursprungs. Die Erdoberfläche mit ihren Abflusssystemen entstanden in der Mehrzahl maximal im Miozän, besitzen also ein Alter von höchstens 20 Millionen Jahren, gehen erdgeschichtlich betrachtet in ihrer heutigen Form aber vor allem erst auf den Zeitabschnitt des Quartärs zurück. Durch die in dieser Periode stattfindende eiszeitliche Erosions- und Ablagerungstätigkeit erhielt die Landschaft im Wesentlichen ihr heutiges Gesicht. Als einzige Ausnahme wird der Baikalsee, mit einem geschätzten Alter von mindestens 35 Millionen Jahren, genannt (SCHÄFER 1997:16; NIEMEYER-LÜLLWITZ/ ZUCCHI 1985:12).

Dabei muss beachtet werden, „daß Flüsse eine erdgeschichtlich meist längere Dauer haben als Seen“ (THIENEMANN 1955:29), mit Ausnahme der im Spätglazial und Postglazial entstandenen alten Urstromtäler Norddeutschlands. Nun gibt es zweifellos auch ,uralte' Seen, die sich lange durch geologische Epochen hindurch bis zur Gegenwart erhalten haben. Als Beispiele können der bereits genannte Baikalsee, der Tanganjika-See oder in Europa der Ohridsee in Mazedonien aufgeführt werden. Aber die meisten Seen der Erde sind nach dem Forschungsstand ,junge' Gebilde. Die Seen im Bereich der dilluvialen Vergletscherung Europas, und zwar im Gebiete der nordischen wie alpinen Eisbedeckung, sind erst nach dem Rückzug der Gletscher entstanden, und viele, ja wohl die meisten von ihnen, sind seit jener Zeit meist im Verlaufe eines natürlichen Entwicklungsprozesses, der Verlandung, durch anthropogen bedingte Eutrophierungsprozesse beschleunigt, wieder verschwunden. So sind im Vergleich mit den fließenden die stehenden Binnengewässer im Allgemeinen von viel beschränkterer Lebensdauer (:29).

Unabhängig von diesen Verlandungsprozessen sind Fließgewässer wie Stillgewässer in Mitteleuropa natürlicherweise nicht regelmäßig verteilt. In den unterschiedlichen Naturräumen haben sich jeweils 
typische Fließgewässerdichten bzw. spezifische Fließgewässersysteme herausgebildet (POTT/REMY 2000:23). Die natürliche Gewässerdichte ist dabei abhängig von verschiedenen Parametern, wie der Wasserdurchlässigkeit des Untergrundes, vom Alter der Abflusssysteme und von den Niederschlagsbedingungen (:23).

\section{a Stehende Gewässer}

„Als Seen oder stehende Gewässer werden Wasserkörper in geschlossenen terrestrischen Hohlformen bezeichnet, die einen kontinuierlichen Fluß des Wassers in seiner Gesamtheit nicht zulassen.“ (SCHÄFER 1997:175) Die Bildung solch größerer, weitgehend abgeschlossener Hohlformen mit meist permanenter Wasserzuführung entstand entweder durch tektonische, vulkanische oder glaziale Prozesse.

Nach der Genese der wassergefüllten Hohlformen werden stehende Gewässer deshalb zwei Gruppen zugeordnet:

1. Seen endogener Entstehung (hierzu gehören alle durch geotektonische Prozesse bedingte Seen) und

2. Seen exogener Entstehung (hierzu gehören alle in Zusammenhang mit der Vereisung im Pleistozän entstandenen Seen).

Sie sind also auf endogene Kräfte, wie Tektonik und Vulkanismus, zurückzuführen, als auch auf exogene Kräfte, welche Erosion bzw. Akkumulation bewirkten. Oft treten endo- und exogene Vorgänge in Kombination auf (siehe Tab. V-1) (vgl. POTT/REMY 2000:26).

Tab. V-1: Übersicht über Entstehungstypen und Alter der häufigsten europäischen Seentypen (POTT/REMY 2000:25).

\begin{tabular}{|l|l|l|}
\hline Haupttyp & Untertyp & Beispiel \\
\hline Glazialerosive Seen & Karsee & Murgsee \\
\hline & Zungenbeckensee & Zürichsee, Sempachersee \\
\hline & Erosionsmuldensee & Gr. Bärensee, Ladogasee \\
\hline & mit tekton. Anteil & Urnersee \\
\hline & Fjordsee & Hornindalsvatn (Nordfjord) \\
\hline & randglazialer See & Märjelensee \\
\hline & interglazialer See & $\begin{array}{l}\text { See Zw. } \\
\text { Morteratschgletscher }\end{array}$ \\
\hline & Supraglazialer See \\
\hline Natürliche Stauseen & subglazialer See & See auf dem Gornergletscher \\
\hline & Bergsturzriegelsee & See in Gletscherspalten \\
\hline & Lavastromriegelsee & Oeschinensee, Klontalersee \\
\hline & Surgegletschersee & Yamanakasee \\
\hline & Kalksinterdammsee & Variegatet-Glacierlake \\
\hline $\begin{array}{l}\text { Muldenseen } \text { auf Akkumulations- }- \\
\text { material }\end{array}$ & extramorän. Stausee & Band-i-Amir-, Plitvitzerseen \\
\hline & Gee auf Bergsturz & Grünsee ob. Zermatt \\
\hline & See auf Sinterbildung & Lag da Cauma \\
\hline & Vulkankratersee & Seen von Pamukkale \\
\hline Karstseen & Deflationswannensee & Lago di Albano \\
\hline & Karsthöhlensee & Tuzsee, Schott el Djerid \\
\hline & Poljesee & Drahtsee (Hölloch) \\
\hline & mit Glazialerosion & Cerkniš Jezero \\
\hline Explosivkraterseen & Kryokarstsee & Glattalpsee, Daubensee \\
\hline & Maare & Steinhudermee \\
\hline Seen in tektonischen Hohlformen & Caldera mit See & Pulvermaar, Laachersee \\
\hline & Grabenbruchsee & Lago di Bolsena \\
\hline & Synklinaltalsee & Tanganjikasee, Totes Meer \\
\hline & Nackentälchensee & Lac de Joux, Lac du Bourget \\
\hline & & Lutersee \\
\hline &
\end{tabular}




\begin{tabular}{|l|l|l|}
\hline & Einsturzdolinensee & Blauer See bei Imotski \\
\hline & $\begin{array}{l}\text { See in tekton. vorgezeichnetem } \\
\text { Flusstal }\end{array}$ & Lake Wairarapa \\
\hline Marine Akkumulationsseen & Strandsee & Lebasee (P1.), Burullessee \\
\hline & Deltasee & Etang du Vaccarès \\
\hline Seen fluvialer Entstehung & Altwasser & Giessenparksee (Bad Ragaz) \\
\hline Seen fluvio-glazialer Entstehung & Rinnenseen & Scharmützelsee, Tegelersee \\
\hline See in einem Meteorkrater & & Kratersee in Quebec \\
\hline
\end{tabular}

\section{a.1 Geologische Seen}

\section{a.1.1 Endogene Seen}

Seen endogener Entstehung wurden durch geotektonische Prozesse bedingt und werden auch entsprechend ihrer Entstehungsweise als ,tektogene' und , vulkanogene' Gewässer' bezeichnet. Sie sind die ältesten Seen und haben nur aufgrund ihrer großen Wasserkörper die langen Zeiträume überdauert.

Endogene Hohlformen entstehen zum Beispiel durch chemische und biologische Prozesse in Gebieten mit leicht wasserlöslichen Gesteinen; typisch vor allem in Karstgebieten. Aufgrund von meist tiefen, unterirdischen Erosions- und Lösungsprozessen von Kalk durch Kohlensäure aus den Niederschlägen oder aus dem Bodenwasser können sich leicht Auslaugungsvorgänge im Untergrund in Gang setzen. Diese Korrosionsprozesse ermöglichen zusammen mit Geländeeinbrüchen die Bildung von oberirdischen Hohlformen, die sich mit Wasser füllen und als Erdfallseen, Dolinenseen oder Karstseen bezeichnet werden (SCHÄFER 1997:176f.; POTT/REMY 2000:26, 29).

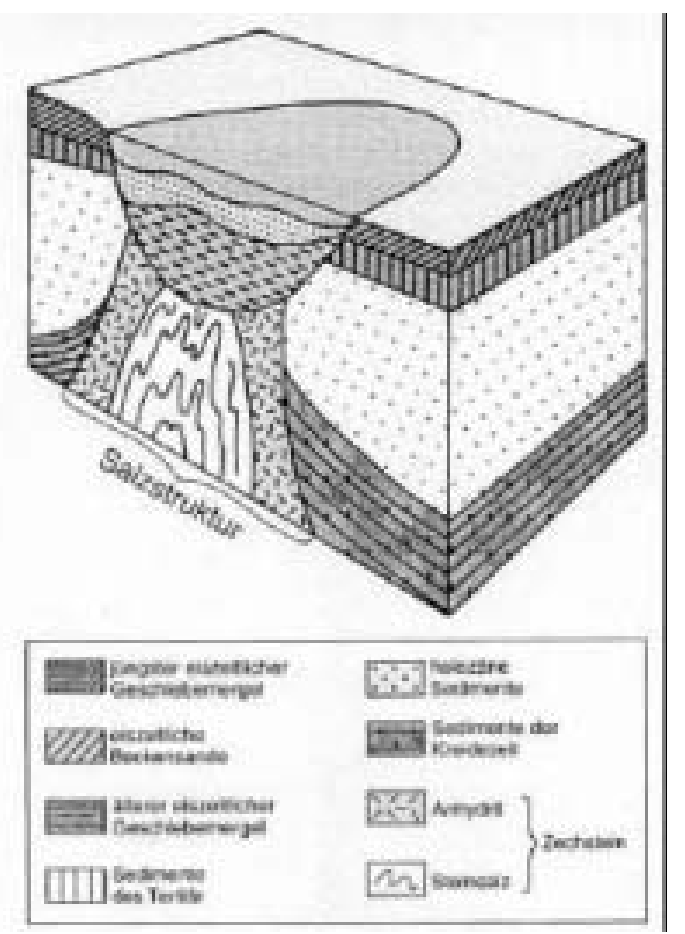

Abb. V-1: Schematische Darstellung eines durch Salzablaugung hervorgerufenen Erdfalls (aus POTT/REMY 2000:26)

Hinsichtlich der geographischen Verbreitung von solchen Karstseen gibt es in Deutschland landschaftliche Schwerpunkte: Mittelgebirge sind im Gegensatz zur norddeutschen Tiefebene arm an natürlichen Stillgewässern, da hier die letzte Eiszeit keine besonderen Landschaftsformen hinterlassen hat, die anschließend durch Wasserzufluss gefüllt werden konnten. Aufgrund des festen Bodengrundes, ob Buntsandstein im Solling oder Granite wie teilweise im Harz, entstanden auch keine äolischen Auswehungen. 
Geologische Seen der Mittelgebirge sind vor allem Erdfälle. Erdfälle, beispielsweise diejenigen im Südharzvorland oder bei Bad Pyrmont (siehe Abb. V-2), sind Karsterscheinungen. Für die Erdfallbildung in dieser Landschaft sind die Schichtenfolgen des Zechsteins von Bedeutung. Die Salze sind hier vollkommen ausgelaugt und nicht mehr vorhanden. Karst bzw. genauer Sulfatkarst entsteht auf Grund der Verkarstung von Anhydrit und Gips. Bei der Betrachtung der geologischen Karte erkennt man, dass diese Erdfälle in der Buntsandsteinlandschaft liegen. Solche ,Buntsandsteinerdfälle' entstehen aus der Auslaugung der vom Buntsandstein überlagerten Zechsteinsulfate und Salze - eben der Verkarstung -, wobei sie große und tiefe Erdfallformen bilden. BÄCKER (1982) beschreibt Erdfälle als „typische Karsterscheinungen [...], die nach Auflösung sulfatischer und karbonatischer Gesteine durch Wasserzirkulation entstehen. Infolge der Gesteinsauflösung und des Abtransportes der gelösten Komponenten bilden sich Hohlformen. Sobald diese Hohlräume eine bestimmte Größe erreicht haben, bewirkt das Gewicht der darüber lagernden Gesteinsschichten den Zusammenbruch der Hohlraumdecke oder die völlige Zermürbung des Deckgebirges. Der Bruchvorgang setzte sich nach oben allmählich im Laufe von möglicherweise Jahrhunderten fort, bis er die Oberfläche erreicht hat und als Erdfall in Erscheinung tritt.“

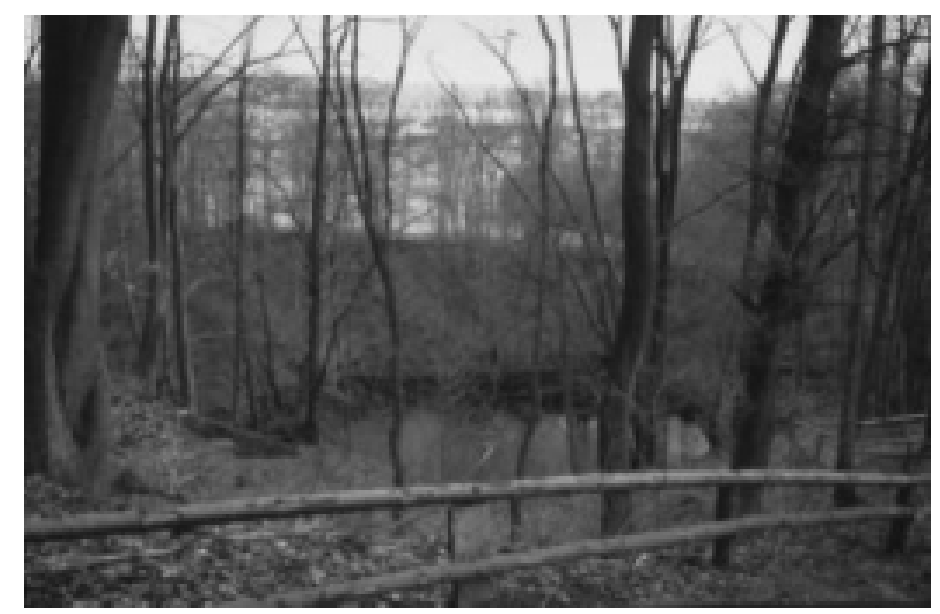

Abb. V-2: Erdfallsee bei Bad Pyrmont, nördlich des Ortsteiles Holzhausen

Neben den hier aufgenommenen ovalen „Unteren Erdfall” gibt es oberhalb den kreisrunden „Oberen Erdfall”. Ursprünglich aber waren es drei, die durch Einsturz einer Trennwand zu zwei trichterförmigen Wasserhohlformen verschmolzen. Entstanden sind sie durch Einsturz der Decke im Jahre 1645 infolge unterirdischer Auswaschungen im Muschelkalkgebirge. Der Durchmesser der Erdtrichter beträgt etwa $80 \mathrm{~m}$ und der des Wasserspiegels etwa 40 $\mathrm{m}$. Sie liegen am steil abfallenden Berghang des Bombergs auf verschiedenen Niveaus übereinander gelagert (eig. Aufnahme 1996).

Als Beispiele für Erdfälle können das ,Große' und das ,Kleine Seeloch', das ,Moosloch' sowie die ,Kelle' im Kreis Nordhausen beschrieben werden. Ähnliche Erdfälle in der Umgebung des Südharzes befinden sich im Raum Lieberode-Klettenberg und Limlingerode, und im Bereich des Zechsteinaustritts des Südharzes treten in östlicher Richtung die Erdfälle von Petersdorf hervor.

Das ,Große Seeloch“ und das ,Kleine Seeloch` liegen zwischen den Gemeinden Kleinwechsungen und Hochstedt auf dem 250 Meter hohen Seeberg (Rietberg) im Kreis Nordhausen. Die geologische Karte weist dieses Gebiet als „Erdfallgebiet“ aus und in den Messtischblättern sind die Erdfälle auch entsprechend kartographiert. Die beiden Seelöcher sind nach ihrem Aussehen trichterförmige Buntsandsteinerdfälle, deren Entstehungsgeschichte also auf dem Auslaugungsvorgang des Sulfatkarstes beruht. Das ,Große Seeloch' ist mit Wasser gefüllt und weist eine fast kreisrunde Form auf. Der Erdfall ,Kleines Seeloch' ist gegenüber dem Großen „meist trocken bzw. schwach sumpfig; selten sind hier kleinere Wassertümpel vorhanden. Der Durchmesser beträgt etwa $65 \mathrm{~m}$. Er hat eine steile Uferböschung mit einem Neigungswinkel von etwa 45 Grad und eine kesselartige Vertiefung." (TAUCHMANN 1990:62). Auf Grund seiner Sattellage auf dem Rietberg erhält dieser Erdfall auch „keinerlei Zuflüsse; die Niederschläge versickern bzw. verdunsten allmählich.“ (:62)

Das ,Moosloch' befindet sich, genau wie die beiden Seelöcher, auch auf dem Rietberg. Es hat im Gegensatz zu ihnen „einen ganz spezifischen Charakter: es ist ein vermoorter Erdfall“ (TAUCH- 
MANN 1990:63). In der Moortyp-Kategorie kann es als ein hochmooriges sog. Sauer-Zwischenmoor eingestuft werden (:66). Der nahezu kreisförmige Erdfall hat einen Durchmesser von $73 \mathrm{~m}$ und nimmt eine Gesamtfläche von 0,49 ha ein (:63). Kleine Wassertümpel unterbrechen dabei bisweilen die Moorlandschaft, die eigentlich eine Karstlandschaft ist.

Bei dem Beispiel der ,Kelle' handelt es sich ebenfalls um ein mit Wasser gefülltes Erdloch. Es ist am ,Klosterberg' gelegen, vier Kilometer östlich von Ellrich, an der Grenze zwischen den alten Grafschaften Hohnstein und Klettenberg. Der Name ,Kelle' wird mit Kehle = Höhle in Verbindung gebracht. Die wohl älteste Erwähnung der Kelle findet sich auf der Karte „Abriß des Amtes Hohnstein 1589 durch Johann Aemilius zu Blankenburg gefertigt" (HERCYNIA CURIOSA 1703, aus: KUHLBRODT 1990:2)

Neben den Mittelgebirgen lassen sich aber auch Erdfälle im Norden Deutschlands nachweisen, wie z. B. der ,Kleine See' unterhalb des Kalkberges in Bad Segeberg, der noch im ausgehenden Mittelalter eine Burg trug und dessen Ruinenreste dann dem Abbau des als ,Segeberger Gips' weichen musste, der für zahlreiche Stuckarbeiten in Hamburg und Lübeck verwendet wurde und dessen Abbaugebiet als Freilichtkulisse der Karl-May-Festspiele dient. Den kleinen Erdfallsee unterhalb des Bühnengeländes aber beachtet kaum jemand.

Eine Sonderform dieser Karstseen stellen die sog. Poljeseen der Gipskarstlandschaften. Es sind dies natürliche episodische bis periodische Wasseransammlungen, die sich nach Starkregen oder Schneeschmelzen im Karstverwitterungsgebiet der Kalkalpen bilden. Hier staut sich gelegentlich über unlöslichen Sedimenten oder über Verwitterungsschichten das Wasser (POTT/REMY 2000:29).

Kalksinterterrassen hingegen führen zum Aufstau von Wasserkörpern und entstehen durch den umgekehrten Prozess: Durch Fällung von Kalk aufgrund biologischer Prozesse und durch höhere Verdunstung bei einer Temperaturzunahme bilden sich solche aufgestauten Kalkgewässer (SCHÄFER 1997:177).

Ebenfalls endogener Entstehung sind die Vulkanseen. Sie sind Folge rezenter oder in Verbindung mit plattentektonischen Prozessen abgelaufener Vulkanaktivitäten. Hier ist zwischen den eigentlichen Kraterseen und den Maaren zu unterscheiden.

Kraterseen liegen aufgrund des Lava-Ausstoßes auf den Vulkankegeln, über dem Niveau der umgebenden Landschaft, d. h. sie liegen in Hohlformen, die durch vulkanische Eruptionen an der Oberfläche gebildet wurden. Diese auch Lavastauseen genannten Vulkanseen wurden durch ausgeflossene Lavamassen aufgestaut.

Im Gegensatz zu den Kraterseen sind Maare durch unterirdische vulkanische Explosionen entstanden, wenn Magma und Grundwasser zusammenkommen. Maarseen sind infolgedessen als ehemalige Explosionstrichter in die Landschaft eingetieft und höchstens von einem Wall aus nicht-vulkanischem Auswurfmaterial umgeben.

Das Alter der Vulkanseen ist unterschiedlich. Die jüngsten Maare in der Eifel, z. B. der Laacher See, sind in einer Phase des ausklingenden Vulkanismus unmittelbar nach der letzten Eiszeit im Pleistozän und Holozän entstanden und sind damit etwa 12000 Jahre alt (SCHÄFER 1997:16, 175).

\section{a.1.2 Exogene Seen}

Stillgewässer exogenen Ursprungs repräsentieren die Mehrzahl der heute existierenden stehenden Gewässer (POTT/REMY 2000:26). Die „weitaus überwiegende Zahl“ entstand im Anschluss an die letzte Vereisung im Pleistozän, die weite terrestrische Bereiche überdeckte und überformte (KLAPPER 1999:211). Sie sind also in ihrer Anlage höchstens 14.000 Jahre alt. Es handelt sich dabei um die ausgedehnten Seenplatten in den nördlichen Bereichen der Holarktis, der Eisrandlagen der ehemaligen Weichsel-Würm-Vergletscherung im Norden Mitteleuropas sowie die Gebirgsseen der 
Faltengebirge und ihrer Vorländer im Umkreis der Alpen (SCHÄFER 1997:16; POTT/REMY 2000:27). Sie werden auch als, glaziale Seen' bezeichnet.

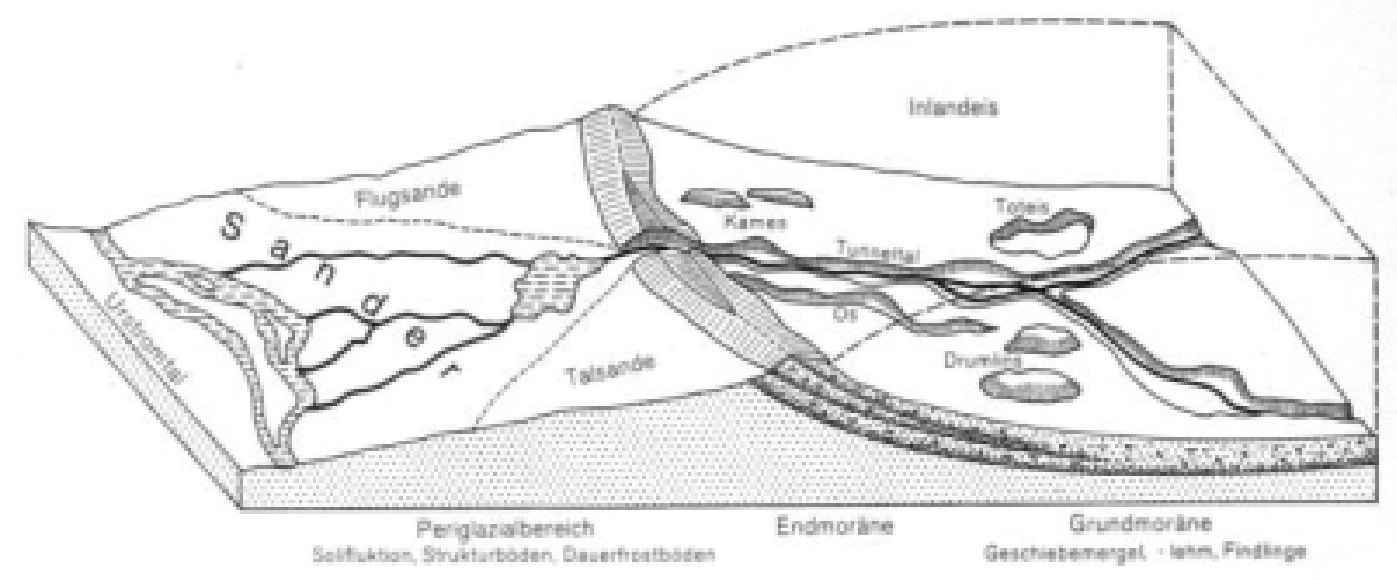

Abb. V-3: Ausbildung von Seen im Periglazialbereich (aus: NRW 1999b:Abb. 2)

Die für die Seebildung wichtigsten und in direktem Zusammenhang mit der arktischen Vergletscherung stehenden Prozesse waren hierbei die oberirdische glaziale Erosion der letzten Vereisungsphasen, die zur Ausräumung und Überformung des Reliefs führte, sowie die glaziale Akkumulation, die zum Aufstau von Flüssen führte (POTT/REMY 2000:32). Durch Aufstau von Flusssystemen oder als Schmelzwasserseen an den Gletscherrändern bildeten sich große kontinentale und periphere Eisrandseen, die nach dem Rückzug des Eises entweder durch die sich neu formierenden Flusssysteme abgelöst wurden oder nur noch in isolierten Restseen vorhanden sind (SCHÄFER 1997:176). „Solche Gebiete besitzen ein glazigenes, ungeordnetes Geländerelief, das sich aus unterschiedlichen Bildungen einer glazialen Serie zusammensetzt (z. B. Suberosionsrinnen, Drumlinfelder, Moränenwälle, Toteislöcher). Hier behindern bindige Grundmoränen vielfach die Versickerung aller Niederschläge und es gibt eine Vielzahl z. T. primär abflussloser Vertiefungen unterschiedlicher Genese. Es bilden sich Seen und Weiher, deren Überläufe, dem Gefälle folgend, tieferliegende Hohlformen fluten. Auf diese Weise ist die Mehrzahl der Seen aller mitteleuropäischen Jungmoränenlandschaften entstanden.“ (POTT/REMY 2000:24)

Die größte Dichte an natürlichen Seen bzw. Seegruppen und das vielgestaltigste Stillgewässerinventar Mitteleuropas gibt es in Dänemark, Südschweden, Schleswig-Holstein, Mecklenburg-Vorpommern, Brandenburg sowie in Nordpolen und im Süden im Voralpengebiet von Bayern, Baden-Württemberg sowie in Österreich und in der Schweiz. Mit über 2800 Seen, die größer als 1 ha sind, und insgesamt etwa 10.200 ständig wassergefüllten Hohlformen ist Brandenburg das gewässerreichste Bundesland Deutschlands (MIETZ 1999a), gefolgt von Mecklenburg-Vorpommern mit über 2000 Seen mit einer Größe von mehr 1 ha (MATHES/SCHÖNBERGER 1996; aus: POTT/REMY 2000:29). Dieser Reichtum an Gewässern und Gewässertypen ist nur hier, in den norddeutschen Jungmöranenlandschaften der letzten Vereisungsphase ausgebildet, wo der geomorphologische Formenschatz der glazialen Serie noch weitgehend vollständig vorhanden ist (vgl. POTT/REMY 2000:33). Aber auch in Süddeutschland, wie oben aufgezählt, entstanden Seen aus klimageschichtlichen Prozessen. Als vor 10.000 Jahren der eiszeitliche Rheingletscher abschmolz, hinterließ er in Oberschwaben Moränen sowie auch Senken. Ihr Schotteruntergrund war durch feine Tone der Schmelzwässer versiegelt und damit wasserundurchlässig. So entstanden in diesem Raum zahlreiche Naturseen, wie z. B. der Rösslerweiher.

MARCINEK und ROSENKRANZ (1996) unterscheiden insgesamt 9 glaziale-geomorphologische Seetypen:

\section{Rinnenseen}

2. Karseen 
3. Moränenseen

4. Rundhöckerseen

5. Toteisseen

6. Thermokarstseen

7. Limane

8. Nehrungsseen

9. Strandseen

Rinnenseen liegen in subglazialen, d. h. unter den Gletschern durch Schmelzwasserausfluss gebildeten Hohlformen (Bsp.: Schmale Luzin in Brandenburg).

Karseen sind kleine, normalerweise kreisrunde Gewässer ehemals vergletscherter Gebiete. Sie sind häufig in Skandinavien, in den Alpen und in ehemals vergletscherten höheren Mittelgebirgen (Bsp.: Feldsee/Schwarzwald; Arbersee/Bayerischer Wald).

Moränenseen sind entweder durch Endmöränen aufgestaut (Endmoränen-Stauseen) oder liegen in Hohlformen von Grundmoränen (Grundmoränenseen). $\mathrm{Zu}$ letzteren gehören auch die zwischen Drumlins gelegenen Drumlinseen. Beispiele für Möranenseen sind im Alpenvorland der Ammersee, im Schwarzwald der Titisee, in Schleswig-Holstein der Plöner See und in Mecklenburg-Vorpommern der Schweriner See. Einen besonderen Typ innerhalb der Moränenseen bilden die in glazialen Zungenbecken gelegenen sog. Zungenbeckenseen (Bsp: Genfer See, Bodensee).

Rundhöckerseen liegen in Hohlformen zwischen glazigenen Rundhöckern, worunter vom Gletschereis geschliffene Felskuppen oder andere harte Gesteinsformationen zu verstehen sind. Dieser Gewässertyp tritt häufig im Alpenraum auf.

Eine Sonderform exogener Entstehung ist die Bildung von Toteislöchern, die heute nur noch in wenigen Fällen mit Wasser gefüllt sind. Die Prozesse der glazialen Seebildung laufen rezent nur noch in den Gletscherregionen der Hochgebirge ab. Die Verbreitung dieser Seen wird demnach durch die Ausdehnung der Vereisungsgebiete der letzten Eiszeit und durch die Lage von Hochgebirgen bestimmt (SCHÄFER 1997:176). Toteisseen oder Sölle und die relativ flachen Thermokarstseen sind auf Volumenverluste im Untergrund durch verspätetes Abschmelzen isolierter, z. T. unterirdischer, Eismassen entstanden, die nach dem Gletscherrückgang in der Grundmoräne zurückgeblieben waren. Die Hohlformen der Sölle gingen aus kompakten Toteisblöcken hervor: „Tausende von Toteisblöcken sind im Postglazial aufgetaut, der Boden konnte nachstürzen, und an der Oberfläche entstanden die kreisrunden, mit Wasser gefüllten Sölle.“ (KLAPPER 1999:211) Solche Toteisseen sind in den ehemaligen Glaziallandschaften zwar noch immer sehr häufig, aber in ihrem Bestand stark rückläufig.

Die Entstehung zweier weiterer, bereits genannter großer Flachseen in Nordwestdeutschland (Steinhuder Meer und Dümmer) beruhen auf einer syngenetischen Bildung von Thermokarst. Ursächlich hierfür ist das Ausschmelzen von diffus im weichseleiszeitlichen Untergrund eingelagerten Eislinsen während des frühen Spätglazials (POTT 1999a).

Auf die Aktivität des Meeres gehen die Limane zurück. Als Folge der pleistozänen Vereisung und postglazialer Klimaschwankungen haben sich durch isostatische und eustatische Meeresspiegelschwankungen (marine Transgressionen und Regressionen) an Ausgleichsküsten eine große Zahl von Küstengewässern gebildet. Die Mehrzahl dieser durch Meerestransgressionen des Atlantikums entstandenen „Meerseen“ ist damit weniger als 6000 Jahre alt (SCHÄFER 1997:16, 176). Bei diesen meist senkrecht zur Küste orientierten Seen handelt es sich um Flusstäler, die durch die Brandungsstrandwälle vom Meere abgetrennt sind. In ähnlicher Weise sind die meeresnahen Nehrungsseen entstanden (z. B. Oehe-Schleimünde an der Schlei) und durch Strandwälle haben sich auch die küstennahen Strandseen herausgebildet (POTT/REMY 2000:33). 


\section{a.2 Aquatische und äolische Seen}

Ein weiterer Teil kleiner und relativ flacher Stillgewässer befindet sich in den Auen größerer Fließgewässer, wo sich aufgrund der natürlichen Dynamik durch Erosions- und Akkumulationsprozesse fortlaufend Altwasser abschnüren und wo sich ständig Flutmulden mit und ohne Grundwasseranschluss bilden können. Die Dynamik der Wasserführung sowie die Frachten von leicht erodier- und sedimentierbarem Material führen vor allem in den Überschwemmungsebenen von Tieflandflüssen zur Bildung einer großen Zahl von solchen kurzlebigen und regelmäßig überformten Wasserkörpern in der Flussaue. In allen Überschwemmungsgebieten sind solche ephemeren Seen vorhanden; die Regulierungsmaßnahmen in Europa haben allerdings dazu geführt, dass hier kaum noch solche Gewässer anzutreffen sind (SCHÄFER 1997:176).

Entstanden sind solche Flussseen bereits in den Gebieten der vorletzten Vereisung, soweit sie nicht von dem jüngsten Eisvorstoß überdeckt wurde. In dieser erdgeschichtlichen Periode wandelte sich die Oberoberfläche zu einer seenarmen Altmoränenlandschaft mit deutlich geringerem Relief und einem hierarchischen Tal- und Flussnetz. Hier entstehen durch fluviatile Akkumulation in den Mäanderzonen der großen Flüsse die von Flussschleifen abgeschnürten Altwasserseen, die im Deltabereich der großen Flüsse als sog. Deltaseen beispielsweise an der Donau zu finden sind.

In dieses Kapitel der Seenbildung fallen aber nicht nur die entlang von Flussläufen. Auch die weichseleiszeitlichen Landschaften Schleswig-Holsteins, Mecklenburgs und Pommerns sind reich an natürlichen Stillgewässern sowie auch das westliche Niedersachsen ursprünglich mit natürlich entstandenen Stillgewässern reichhaltig ausgestattet war. Von Natur aus oligotrophe Klarwasserseen gab es in diesen Räumen sehr zahlreich in den nährstoffarmen Heidesandgebieten. Teils handelte es sich um tiefere, vielleicht als Dolinen oder durch die Eiszeit (Toteis, Strudellöcher) entstandene Seen, teils füllten sie flache Senken aus. Es wird von manchen Forschern angenommen, dass die Ausbildung der flachen Hohlformen, der sog. Kaven, in die Zeit des Holozäns zurückgeht und die Seen durch aquatische Abtragung oder Sedimentation entstanden sind und damit Kennzeichen erdgeschichtlich älterer Sedimentationsräume sind. Aber es könnte sich bei den Eintiefungen auch um äolische Kaven handeln, die entweder durch äolische Akkumulation oder Abtragung entstanden sind. Kennzeichnend für diese vom Wind geschaffenen Hohlformen ist ihre meist nur geringe Wassertiefe von weniger als $2 \mathrm{~m}$ und die enge Nachbarschaft zu äolischen Ablagerungen. So treten diese flachwannigen Mulden in unmittelbarer Nähe zu älteren Flugsanddecken oder Talsandflächen auf (KAISER 2001).

Diesen hier beschriebenen Naturseen werden heute die ,man-made lakes' gegenübergestellt (KLAPPER 1999:212): Talsperren, Tagebaurestseen, dazu gehören aber auch die seit dem Mittelalter angelegten Wasserspeicher zum Betreiben bergbaulicher Wasserkünste und Teiche für die Fischzucht. In Abschnitt VI werden die historischen, Seen' anthropogener Entstehung ausführlich beschrieben.

\section{b Fließende Gewässer}

Fließgewässer entstanden frühzeitig als primäre Entwässerungssysteme des Festlandes.

Die Ursprünge von mitteleuropäischen Flüssen aus älteren Gebirgsmassiven, d. h. solche, die in Festgesteine eingetieft sind und nicht nennenswert im Quartär überprägt wurden, lassen sich bis ins Erdaltertum, ins Paläozoikum, zurückverfolgen (HANDTKE 1993:1; POTT/REMY 2000:26). Im Mittelund Unterlauf dieser Flüsse queren jüngere Sedimente aus dem Erdmittelalter, dem Mesozoikum, seinen Lauf und ihre Entwicklung endet in der Erdneuzeit, in der Tertiärzeit, vor allem in ihren jüngeren Abschnitten des Oligo-, Mio- und Pliozän (HANDTKE. 1993:1). Insbesondere die tektonischen Prozesse im Tertiär führten in Bereichen der entstehenden Faltengebirge zu einer kompletten Veränderung der alten Abflusssysteme oder zu einer Neuanlage von Einzugsgebieten, die dann im Verlauf der pleistozänen Vereisungen und im Postglazial wiederum überformt wurden (SCHÄFER 1997:16). 
Die meisten Flussgebiete des mitteleuropäischen Tieflandes zwischen Rhein und Weichsel haben sich als holozäne Bildungen, also erst im Spätglazial, in ihrem gegenwärtigen Verlauf herausgebildet (HANDTKE 1993:1). Im Quartär erfolgten die prägenden glazialen Einflüsse, die sich am deutlichsten in den Moränengebieten Norddeutschlands und des Alpenvorlandes manifestieren (POTT/REMY 2000:22). Die heutige Oberflächenstruktur kleiner Fließgewässer wurde somit erst im jüngsten Erdzeitalter (Quartär) durch das Abflussregime der großen Flüsse und die periodisch vorstoßenden polaren Eismassen der verschiedenen Eiszeiten (Pleistozän/Diluvium) geprägt.

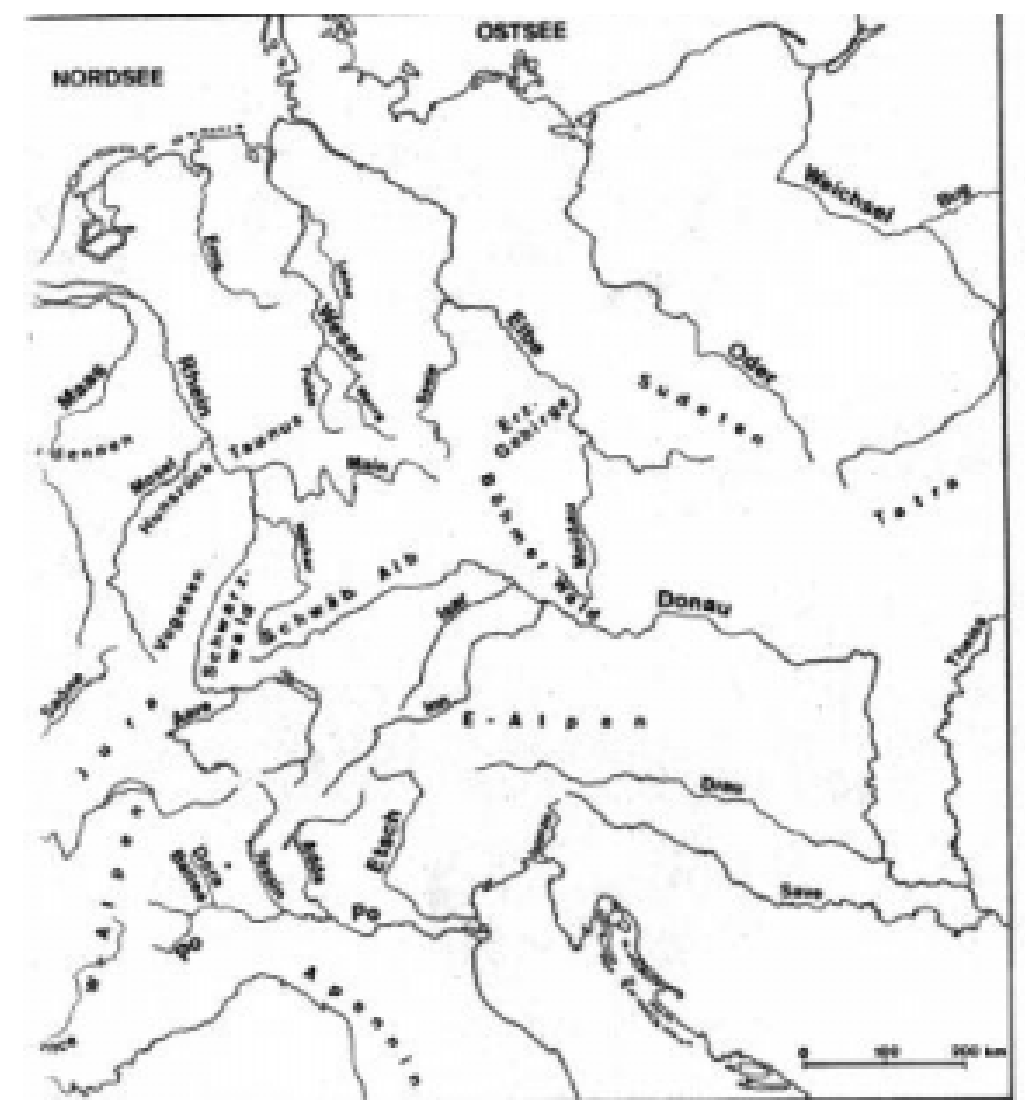

Abb. V-4: Die großen Flusssysteme Mitteleuropas

(aus: HANDTKE 1993:2)

Für die Flussgeschichte entscheidend sind flache, tektonisch vorgegebene ,Tal-Wasserscheiden'. Schon geringfügige Hebung und Senkung im Längsprofil verändert hier die Entwässerungsrichtung. Seit dem mittleren Tertiär haben solche Prozesse das Flussnetz Mitteleuropas mehrmals verändert: die vorausgehenden tektonischen Prozesse werden in der erdgeschichtlichen Forschung mit Emporstau, Talverschüttung und Niederschleifen von Transfluenzen bezeichnet (HANDTKE 1993:8). Täler sind auch aus anderen Gründen von der Tektonik vorgezeichnet: in Eruptivgebieten durch klaffende Risse, Scherungen und Aufschiebungen, in Sedimenten durch aufgerissene Falten, Mulden, Deckenränder, Querstörungen, Grenzblätter und Blattverschiebungen (:8) und deshalb für die geologisch frühe Flussgeschichte von besonderer Bedeutung: „Die Täler haben stets Wasser und Eis den Weg gewiesen.“ (:8) In diesen Taleinschnitten sind auch die Quellbereiche tektonisch vorgezeichnet.

Weitere Eintiefungen und Ausräumungen folgten im Früh- und Spätglazial tektonischen Vorzeichnungen der Erdgeschichte durch Schmelzwasserschübe (HANDTKE 1993:166 mit dem Beispiel der Mosel). Wegen des Permafrostbodens sowie wegen der großen Geschiebefracht existierten im Einflussbereich der quartären Vereisungen bis zum Ende der letzten Kaltzeit breit angelegte fluviatile Rinnensysteme miteinander verflochtener, kaum eingetiefter Flüsse (POTT/REMY 2000:22f.). Die gegenwärtige Form der mäandrierenden, in die Niederterrasse eingetieften und auf wenige Fließrinnen konzentrierten Flusssysteme bildete sich erst zu Beginn des Holozän ab 8300 v. Chr. (:22f.). Durch flächenhafte Erosion entstanden an den Ober- und Mittelläufen der Flüsse - in die Niederterrasse eingetieft - die Talauen als natürliche Standorte der heute weitgehend vernichteten Auenwälder (:23). Die heute mächtigen Auelehme vieler Flussauen wurden in Mitteleuropa erst nach den Waldrodungen 
mit der Schaffung großer waldfreier, der Erosion ausgesetzter Flächen seit dem Neolithikum ab 5000 v. Chr. abgelagert. Ihren Höhepunkt erreichte die Sedimentation von Auelehm jedoch erst in der Zeit der größten Waldzerstörung seit dem Mittelalter; sie dauerte bis in das 18. Jahrhundert (CASPERS et al. 1995; zit. nach POTT/REMY 2000:23).

Schließlich ist der nicht anthropogen-wasserbaulich fixierte Flachlandfluss von einer Kette halbmondförmiger Altwässer und Altarme begleitet, wobei alle Übergänge vom fließenden zum stehenden Gewässer angetroffen werden können.

\section{Anthropogene Gewässer- und Flussgeschichte}

„Natürliche Lagebedingungen lassen sich auch bei hochentwickelter Technik nicht einfach ausschalten.“ [SCHÖLLER. 1969:13]

\section{a Einleitung}

„Die Beziehungen zwischen Wald und Siedlung waren in historischer Zeit unauflösbar. Es gibt daher Sinn, eine Historische Geographie Mitteleuropas vom Wald und der Siedlung her zu schreiben." Diese Empfehlung von SCHENK (2001:11) an die Historische Geographie als Fachdisziplin gerichtet, ist bislang nicht erfüllt worden. Doch nicht nur ein umfassendes siedlungsgeographisches Werk, das diesen Zusammenhang aufzeigt, vermisst man. Auch die „Beziehungen zwischen Wasser und Siedlung“ - wechselt man die Umwelten aus - waren in historischer Zeit unauflösbar miteinander verbunden. Es würde daher auch Sinn machen, um mit Schenks Worten zu sprechen, „eine Historische Geographie Mitteleuropas vom Wasser und der Siedlung her zu schreiben." Natürlich kann diese Thematik nicht an dieser Stelle, schon gar nicht innerhalb eines Kapitels, auch nur annähernd vollständig behandelt werden. Einen Einblick in die Zusammenhänge zwischen Wasser und den menschlichen Siedlungsplätzen sollen aber die folgenden Ausführungen ermöglichen.

Wasser ist lebensnotwendig. Deshalb siedelte der Mensch in frühester Zeit bevorzugt an hochwassergeschützten - Plätzen, die ihm das kostbare Nass sicherten: an Quellaustritten, kleinen Bächen, Flussläufen, Seen sowie in Küstennähe. Denn gleichzeitig boten solche Standorte wichtige Ressourcen: beispielsweise Weidenstöcke, Reetgräser, Ufer- oder Seebodenschlamm und anderes Material für den Hausbau, Weidemöglichkeiten für das Vieh in den fruchtbaren Überschwemmungsbereichen (Auen) und später auch als Wasserkraft und als Transportweg für Handelsprodukte. Flüsse und Gewässer bewirkten eine siedlungsräumliche Konzentration, Niederungen und Flussmündungen wurden als bevorzugte Siedlungslagen ausgesucht. In späterer Zeit jedoch änderte sich die naturdeterministische Siedlungswahl, wie wir sehen werden. Und auch die war nicht immer - zu jeder Zeit und in jeder Region - an das unmittelbare Vorhandensein von Wasser gebunden.

In diesem Kapitel soll zunächst ein Überblick über die Geschichte der Siedlungswahl in Zusammenhang mit der naturräumlichen Gewässerausstattung gegeben werden. Beginnend mit dem Nachweis menschlicher Siedlungen und der Frage, nach welcher topographischen bzw. hydrographischen Präferenz diese ausgesucht worden sind, soll die Geschichte der Gewässer als Mittelpunkt menschlicher Ansiedlungen nachgezeichnet werden. Die Deskription der Siedlungslage und die räumliche Verteilung der frühen Siedlungen in Verbindung mit dem Wasserelement stehen zunächst im Vordergrund. Dabei wird auch die Siedlungslage heute noch existierender Ureinwohner an einigen Stellen zum Vergleich herangezogen, deren Lebensweise mit denen der Frühmenschen in Mitteleuropa verglichen werden kann.

Anschließend wird ein Rückblick in die siedlungs- und kulturlandschaftsgeschichtlich prägende Siedlungsphase geboten: Beginnend mit dem Vormittelalter über das Nachmittelalter und endend in der frühindustriellen Periode, werden die Siedlungslagen in Gewässernähe beschrieben, die durch die planmäßige Wassernutzung und Gewässeranlagen, deren Sinnbild beispielsweise die Flussregulierungen, Mühlgräben und Kanalbauten sind, erst möglich wurden. Eine besondere Rolle spielen dabei die Klöster, die oftmals auf vorchristlichen Kultstätten aufbauten, doch weniger 
aufgrund der Symbolik, sondern vielmehr aus Gründen der Wasserlage maßgeblich zur Umgestaltung der Gewässerlandschaft beitrugen.

Den Abschluss bildet die neuzeitliche Phase: die umweltbedeutende Industriegeschichte von Flüssen, die Wachstumsperiode der Urbanisierung an Gewässerläufen nach dem Zweiten Weltkrieg, bis zum modernen Städtebau, der das Medium Wasser als präferierten Wohn- und Dienstleistungsstandort unter dem Stichwort „Wohnen und Arbeiten am Wasser“ wiederentdeckt hat. Den unter siedlungsgeschichtlichen Aspekten interessanten Siedlungsbau in der nationalsozialistischen und sozialistischen Raumordnung auf seine Gewässerbezogenheit hin zu überprüfen, muss hingegen aus Zeitgründen unberücksichtigt bleiben.

\section{b Die hydrologisch-topographische Lage als Siedlungsvoraussetzung}

Am Anfang von allen Bedürfnissen und Wünschen der Menschheit stand die Suche nach Wasser zur Sicherstellung des Bedarfs an täglichem Wasser ,an erster Stelle“ (MAGER et al. 1989:9; ebenso TÖLLE-KASTENBEIN 1990:8). Dabei ging es „,nicht nur um die Ernährung des Menschen (wer immer es sich leisten konnte, vermied Wasser zu trinken, sott die Speise in Wein, statt in Wasser), sondern auch um eine geographische Determinante "(SCHUBERT 1989:31), denn die Verfügbarkeit von Wasser ,ist eine Grundvoraussetzung menschlicher Siedlung“ (:31; ebenso TÖLLEKASTENBEIN 1990:8; BERGER 1993:19). „Das wichtigste“, dass es dann innerhalb einer Siedlung zu erreichen galt, „war, daß ein Haus in günstiger Lage zur Wasserstelle gebaut wurde.“ (HÜTTEN 1988:39). Das Vorhandensein von Wasser war und ist für Mensch und Vieh unentbehrlich und so „lockte der Wasserreichtum zur Siedlung“, fasst HÜTTEN (:39) wie auch im Folgenden BERGER (1993:19) die einseitige Beziehung und Standortdeterminante zusammen: „Ein Fluß, ein See, ein Bach oder zumindest eine Quelle bietet ihm die Möglichkeit, sich niederzulassen, seine Tiere zu tränken, Acker und Garten anzulegen und zu bewässern. Aber nicht nur als Siedlungsplätze sind die Gewässer wichtig, sondern auch als Wegweiser. Der Mensch kann dem Lauf eines Flusses hinauf oder hinunter folgen, er wird immer wieder auf andere Gewässer treffen, und wo günstige Übergänge sind, werden sich bald mehrere Wege vereinigen oder kreuzen, die die Landschaft erschließen und mit anderen Landschaften verbinden.“ Es ist somit die hydrologische Lagewahl, die „den Zusammenschluß mehrerer Menschen in Siedlungen aller Art“ (TÖLLE-KASTENBEIN 1990:8) kennzeichnet.

Die Lage bezeichnet allgemein „die Position eines Ortes auf der Erdoberfläche“ (LIENAU 1995:123). Die relativen Lagebestimmungen wiederum beziehen sich auf den engeren physischen Kontext und bezeichnen eine topographische bzw. geotopologische Lage (:124).

Die topographische Ortslage wird generell unterschieden nach Relief (z. B. die Ortslage auf der Ebene, am Hang, auf dem Gipfel, der Terrasse) und nach der Lage zum Wasser (NIEMEIER 1977:54). Die daraus resultierenden geotopologischen Lagebestimmungen hinsichtlich einer Gewässerbeziehung bezeichnen die Lage in einer Quellmulde (Quellmuldenlage), in einem Talgrund (Tallage) oder auch am oder im Wasser. Diese Geotopographie wird in der Literatur als „Wasserlage“ bezeichnet (LIENAU 1995:124). Diese von mir infolge ihrer Gewässernähe als hydro-topographische Lage bezeichnete Siedlungslage soll uns im Nachfolgenden interessieren.

Wassersiedlungen, als ein von Harald UHLIG 1979 gewählter Oberbegriff für eine spezielle Siedlungsform, sind Siedlungen, für die die Lage zum Wasser der bestimmende Lagefaktor ist. Das Wasser bestimmt Bau- und Wohnweise dieser Siedlungen sowie Art und Weise des Wirtschaftens (LIENAU 1995:125). Schaut man sich aber einen beliebigen Landschaftsausschnitt aus einem Gebiet der Erde an, so konzentriert sich das Leben, nicht nur in Trockengebieten, immer in Form von Landwirtschaft und Siedlungen entlang von Wasserläufen, Seen, Quellaustritten oder ähnlichem Nass.

Jäger und Sammler beispielsweise, die sich auf Jagd und Fischfang in sumpfartiger und wasserreicher Umgebung spezialisiert hatten, bewohnten Wassersiedlungen - wie auch noch in heutiger Zeit die Beispiele der Pfahlbauten und der Mangrovensiedlungen zeigen. Wasserlagen werden aber auch, sofern es sich um landwirtschaftliche Siedlungen handelt, sowohl von Nassreis-Bauern als auch von 
Marschenbauern bevorzugt. Für SO-Asien, wo Wassersiedlungen ein sehr verbreiteter Typus sind, beschreibt UHLIG (1979) unterschiedliche Formen von Wassersiedlungen: wie zum Beispiel die Lage auf natürlichen Flussdämmen, die Lage auf künstlichen Inseln oder Hügeln innerhalb wasserreicher Umgebung. Gleiches gilt für die Wurtenbauern in den Nordsee- und Flussmarschen.

Die Bedeutung der Landschaftsausstattung hinsichtlich des Vorkommens von Wasser und der auf sie bezogenen Landnutzung ist für die topographische Lage der Siedlungen offensichtlich. Die gesamte siedlungsgeschichtliche Entwicklung kommt in dem topographischen Lagebezug zu Gewässern zum Ausdruck; entweder in der eher unkomplizierten Anpassung an die natürlichen Voraussetzungen, beispielsweise von Wasserläufen, zum einen, oder aber in der Überwindung der durch die Natur gegebenen Schwierigkeiten, beispielsweise des Wassermangels oder des Wasserüberschusses, zum anderen.

Es scheint unbestritten, dass die hydrotopographische Lage von Städten und Siedlungen - neben der rein naturdeterministischen Lebensvo raussetzung des Vorhandenseins von Wasser - „häufig der klare Ausdruck ihrer Zweckbestimmung ist" (SCHÖLLER 1980:13). Die geohydrologische Lagewahl ergibt sich aus den Funktionen und den daraus abgeleiteten Anforderungen, die Bewohner an einen Lagerplatz oder eine Siedlung haben. Ursprünglich stellte sie einen Kompromiss hinsichtlich der naturräumlichen Ausstattung insofern dar, als z. B. eine Siedlung sowohl dem Schutz vor Hochwasser und vor feindlichen Überfällen als auch der Versorgung mit Trinkwasser und der guten Erreichbarkeit der Wirtschaftsflächen genügen musste (LIENAU 1995:124). Oft aber führte erst die Bündelung von Faktoren zu einer persistenten Ansiedlung. Wasser besaß dabei jedoch immer die primäre Lagebedingung. Die Lage zum Wasser, gleichgültig ob dabei durch Grundwasser, Quellen, fließende Gewässer - schiffbar oder nicht - , Seen oder Küste gekennzeichnet, wirkte seit jeher siedlungsbestimmend (NIEMEIER 1977:54).

Die Ortslage und damit auch die Anordnung der Behausungen wurde durch die Wassernähe (Quell-, Bach-, Grundwasser) beeinflusst und zeigte oft eine enge Beziehung zur gewässerräumlichen Ausstattung, wobei als Leitlinie ein Flussufer, ein Kanal, ein Damm bzw. Deich diente oder durch die Grenzlage zwischen Meer-, See- oder Fluss- und Landfläche bestimmt wurde (NIEMEIER 1977:44f.). „Flüsse“, wie SCHUBERT (1989:32) es ausdrückt, „bestimmten menschliche Siedlungen, als sie noch nicht in vorgezeichnete Betten gezwängt, sondern in den Ebenen mäandrierend, Stromarme mit geringem Tiefgang bildend und versumpfte Ebenen haben entstehen lassen. Den Flüssen näherten sich die Siedlungen, weil diese die wichtigsten Verkehrswege bildeten, sie verharrten aber bis ins Spätmittelalter hinein in respektvoller Entfernung, das Hochwasser fürchtend.“ Denn „Flüsse, ja selbst Bäche, waren unerläßlich für die Nahrungsversorgung der Menschen. Es ging weniger um das Wasser, das meistens viel zu brackig war, um getrunken werden zu können, das meist nur als Vieh- und Pferdetränke genutzt wurde, sondern mehr um den Fischreichtum.“ (:33)

Die Rolle des Trinkwassers bei der Siedlungsentwicklung muss vielmehr anhand des Vorkommens von Quellen beantwortet werden. „The gradual shifting of the city centre of medieval Warsaw [...] provides“, begründet DUNIN-WASOWICZ (1990:97) den Platzwechsel für das mittelalterliche Warschau, ,an excellent example of a shift which took place probably because of the need of new sources of drinking water. Some of the springs discovered at that time are used to this day." In früherer Zeit wurde der Wasserbedarf der Bevölkerung also normalerweise durch das natürliche und saubere Wasserangebot aus Quellen und durch Brunnen gedeckt, deren Schächte bis zum Grundwasserspiegel senkrecht abgeteuft wurden (SCHNEIDER 1992:182).

Den Verkehr bündelnde Geofaktoren, wie z. B. ein Flussübergang, begünstigten darüber hinaus die Entwicklung lagebedingter Funktionen und die Herausbildung von Nah- und Fernverkehrsbeziehungen (LIENAU 1995:128). So stellte die Verkehrsanbindung ein entscheidendes Kriterium zur Siedlungswahl am Wasser dar. Schiff- oder treidelbare Flüsse können als eine entscheidende Voraussetzung des überregionalen Warentransportes gesehen werden und naturnahe Häfen an diesen Wasserläufen wirkten als Warenumschlagplätze lagebestimmend für die Ansiedlung von Handel und Gewerbe. 
Innerhalb des Landes waren Ströme und selbst kleinere Flüsse Leitlinien der Siedlungsentwicklung, „wobei Endpunkte der Schiffbarkeit - in Europa bis um 1800 selbst an kleinen Flüssen -, Flußgabeln und querende Landwege (Furten) ds verkehrsbrechende und die Stadtentstehung oder -entwicklung begünstigende Faktoren hervortraten." (NIEMEIER 1977:60) Mit Hilfe historisch-geographischer Methoden hatte DENECKE 1967 das mittelalterliche Verkehrsnetz des mittleren Leineberglandes rekonstruiert und „mit ihm das Bild der an ihm orientierten Anlagen, Siedlungen und Wirtschaftsplätze“ (:293) gezeichnet. Diese Wegeforschung ergab: „Die ältesten Knotenpunkte waren an Furten gebunden“(:294).

Städte haben sich also oft „,an Brechungspunkten des Verkehrs“ (NIEMEIER 1977:59) gebildet; dort, „wo der Verkehr gehemmt wird“ (SCHWARZ 1988:367), d. h. beispielsweise an der Stelle, wo der Transport durch See- oder Flussschiffe sein Ende findet. Neben dem Fernverkehr zu Lande, der sich vor allem auf Tiere stützte, ,spielte in früherer Zeit, insbesondere für Warentransporte, derjenige auf Flüssen eine weit größere Rolle als heute“ (:364), und bei geeigneten Wasserstraßen sowie den Schwierigkeiten in der Benutzung anderer Verkehrswege kam dem traditionellen Fussverkehr eine bedeutende Rolle zu.

Ähnlich wie der Fernverkehr auf den Straßen benötigte auch der auf den Gewässern ,Relaisstationen'. Denn obgleich die Schiffer auf den Booten wohnten, konnte die Fahrt aufgrund der vielen Stromschnellen, Untiefen und den jahreszeitlich unterschiedlichen Wasserständen doch nur tagsüber und an wenigen Tagen durchgeführt werden. „Für die topographische Lage der kleinen Hafenplätze an den Flußwegen [...] war im Rahmen der an einem Tage zu meisternden Strecke die günstige Lande- bzw. Ankermöglichkeit an geschützten Stellen maßgebend." (SCHWARZ 1988:364) Doch darüber hinaus kam, ähnlich wie bei den Fernverkehrsstraßen, denjenigen Punkten besondere Bedeutung zu, wo der Verkehr auf Schwierigkeiten oder Hindernisse stieß. Aus desem Grund war die Lage ober- oder unterhalb von Stromschnellen beliebt (:364).

Dort, wo bei relativ schnellem Wechsel des Wasserstandes - etwa bei der Einmündung von Nebenflüssen - eine Umstellung auf andere Bootstypen erfolgen musste, lagen günstige Bedingungen für die Ausbildung von Raststationen vor. Ebenso entwickelten sich Verkehrssiedlungen gern an den binnenwärts gelegenen Endpunkten der Schifffahrt, wo diese vom Landtransport abgelöst wurden (SCHWARZ 1988:364f.). Überall dort, wo der Umschlag von See- auf Flussschiffe erfolgte, entstanden Hafenstationen, die zumeist nicht weit von der Küste entfernt lagen. Deshalb waren Küsten mit einem Naturhafen und entsprechendem Hinterland städtegünstig, da sich besonders dort der Umschlag vom Seeschiff auf das Flussschiff oder auf Landverkehrsmittel vollziehen konnte. An Gezeitenküsten liegen die Hafenstädte an Flussmündungen in der Regel landein nahe der Grenze von Gezeitenbewegungen. Sehr viele große schiffbare Ströme weisen mündungsnahe Hafenstädte auf (NIEMEIER 1977:59). Die tief landein reichenden Buchtwinkel von Meerbusen und die Lage an Nebenmeeren bedeuteten gleichfalls einen siedlungsgeographischen Vorzug, wie das Beispiel der Stadt Wilhelmshaven zeigt.

Auch kann das Wasser zur Schutzwirkung herangezogen werden. In sehr verschiedener Lage ist die wasserständige Lage entwickelt: flache Inseln, die ihre Wahl allein der Isolierung durch das Wasser verdanken, in Seen hinausragende Halbinseln, die mit Hilfe eines Grabens gegenüber der Landseite abgeriegelt werden, oder schmale Landzungen zwischen eng benachbarten Seen: Sie haben „zu allen Zeiten den Menschen bestimmt, sich hier Schutzsiedlungen zu schaffen “ (SCHWARZ 1988:391).

Flussschlingen - besonders in Verbindung mit Steilrelief - boten zudem Schutzlagen (Bern, Luxemburg, Burg a. d. Wupper, Monschau i. d Eifel, zahlreiche Moselstädte), ebenso Inseln oder Halbinseln an Meeresküsten (Kap Arkona auf Rügen, die Kanalinseln zwischen Frankreich und England) oder Inseln im Fluß (Paris, Berlin-Cölln, Bodenwerder i. Weserbergland) bzw. in einem See (aztekisches Mexiko, Mainau i. Bodensee). Die topographische Lage aller solcher Städte ist im Einzelnen sehr verschieden, doch spielen Hochwasserfreiheit, leichte Überschreitbarkeit von Flüssen, das Vorhandensein von Naturhafenbecken usw. eine entscheidende Rolle (vgl. NIEMEIER 1977:60). 
Mit Beginn der Neuzeit und der überseeischen Expansion Europas begann auch die Anlage von befestigten Handelsfaktoreien, besonders zahlreich in Küstenbereichen Schwarzafrikas, Asiens und Latein-Amerikas. Einige waren zunächst nur Versorgungsplätze für die Segelschiffe mit Frischwasser und Lebensmitteln, so Kapstadt seit 1652. Allein an der Oberguinea-Küste zwischen Sambia- und Volta-Fluss sind 37 frühere Faktoreien gezählt worden. Als europäische Handelsfaktoreien begannen auch einige nordamerikanische Städte in Gewässer- bzw. Küstennähe: Quebec (1608) im Mündungstrichter des Lorenzstromes, Montreal auf einer Flussinsel (1542), New Orleans (1718), in einer Flussschlinge des Mississippi (NIEMEIER 1977:147).

In Gebieten mit längeren jahreszeitlichen Trockenperioden war die Ortslage zwingend zunächst durch das Wasservorkommen bestimmt. In den trockenen Höhengebieten der Erde, beispielsweise den Steppenhochflächen Inneranatoliens, war „für die topographische Lage der Siedlungen naturgemäß die Wasserversorgung entscheidend.“ (SCHWARZ 1988:71f.) Die Siedlungen knüpften an den Bergfuß und die dort austretenden Täler an, denn hier waren „die Voraussetzungen für die Nutzung der episodisch oder periodisch abkommenden Flüsse oder des Grundwassers zur Bewässerungswirtschaft gegeben“ (:70). Es wurde versucht, „die Forderung nach zentraler Lage des Wohnplatzes innerhalb des Feldareals mit der nach günstiger Wasserbeschaffung zu vereinen." (:70) Auch in den sommertrockenen Mittelmeerländern prägten sich Relief und Notwendigkeit der Wasserversorgung in den topographischen Lageverhältnissen aus (:72).

In den winterkalten oder immerwarmen Trockenregionen der Erde wird die Verteilung der Siedlungen ebenfalls durch das Vorhandensein von Wasser bestimmt. Große Flächen können nur dann als Weideland genutzt werden, sei es durch Hirtennomaden wie in der Alten Welt, sei es von Dauersiedlungen aus, wie insbesondere in den Kolonialräumen mit Trockenklima, wenn de Versorgung mit Wasser gesichert ist. „Die Hirtennomaden errichten ihre Lagerplätze in der Nähe von Quellen, Brunnen oder Wadis, wo Wasser leicht erreichbar ist; den periodischen Niederschlägen folgend, wechseln sie in festgelegtem Rhythmus ihre Weidegebiet.“(SCHWARZ 1988:30; ebenso NIEMEIER 1977:56)

In Wüsten und Wüstensteppen waren die Siedlungen streng an die Oasen oder die Flüsse, wie im Niltal gebunden. Den ausgedehnten und nur dürftig besiedelten Wüstensteppen und Steppen stehen die kleinräumigen und dicht bevölkerten Oasen gegenüber. Diesem Gegensatz begegnen wir überall in den Trockengebieten. Als kleine Inseln, in denen sich die Menschen drängen, erscheinen die Grundwasseroasen der Sahara. Am Rand der Gebirge, wo das Wasser der besser beregneten Höhen genutzt wird, reihen sich die Oasen auf, wie es in Nordwestafrika, Vorder- und Zentralasien zu beobachten ist. Die größten zusammenhängenden Oasenlandschaften treffen wir zu beiden Seiten der großen Fremdlingsströme, insbesondere aber am Nil (SCHWARZ 1988:31). Dort, wo diese aus einem niederschlagsreichen Gebiet kommenden Flüsse die Wüstensteppen und Steppen durchqueren, wo Grundwasser in reichlichem Maße zur Verfügung steht oder unterirdische Wasserschätze vorhanden sind, können diese Vorräte für Bewässerungszwecke in Anspruch genommen werden.

In den lößbedeckten Ebenen, beispielsweise in den Steppengebieten Ost- und Südosteuropas „steht die Wasserversorgung bei der Wahl des Wohnplatzes an erster Stelle. So sind die Siedlungen in der Walachei an die Täler der größeren Flüsse gebunden, und in der südrussischen Steppe halten sich die Orte an die kleinen, in die Bergufer eingerissenen Schluchten (Owrag) ${ }^{1}$, an die Terrassen bzw. Hochufer; sie versuchen, dem Wasser so nahe wie möglich zu kommen, weichen aber dem Überschwemmungsgebiet aus“" (SCHWARZ 1988:70).

In den Trockengebieten der Erde war für die Stadtentwicklung die Wasserversorgung oft so maßgeblich, dass der Verlauf der Fernstraßen sich nach solchen Zielpunkten gerichtet hat. So bei den

\footnotetext{
${ }^{1}$ Owrag [russ. Owragi]: junge, steilwandige Erosionsschluchten in den sommertrockenen Anbaugebieten der südrussischen Steppe, mit dauernden Veränderungen und Neubildungen bei Schneeschmelze und Gewittergüssen. Mit zunehmendem Alter bildet sich aus einem Owrag die „Balka“ [russ. Bezeichnung für eine ältere Erosionsschlucht].

Ein bekannter Owrag ist beispielsweise der „Schirjaewskij Owrag“ [Schirjaewskijer Schlucht] im Gebiet der „Wolgadeutschen“ in der Schlucht der Samara, die beim Dorf Schirjaewo in die Wolga mündet. Gegenüber dem Dorf Schirjaewo an der Wolga liegt die größte Stadt des Wolgalandes Samara, die 1935 so hieß und danach in ,Kujbyschew' unbenannt wurde (BROCKHAUS 1979; SCHIRJAEWO 2004).
} 
„Wüstenstädten“ oder „Caravan Cities“ wie Damaskus, dem untergegangenen Palmyra ${ }^{2}$, Laghout ${ }^{3}$ und den Städten am „Gegenufer“ der Wüste in Mesopotamien bzw. im Sudan (vgl. NIEMEIER 1977:61).

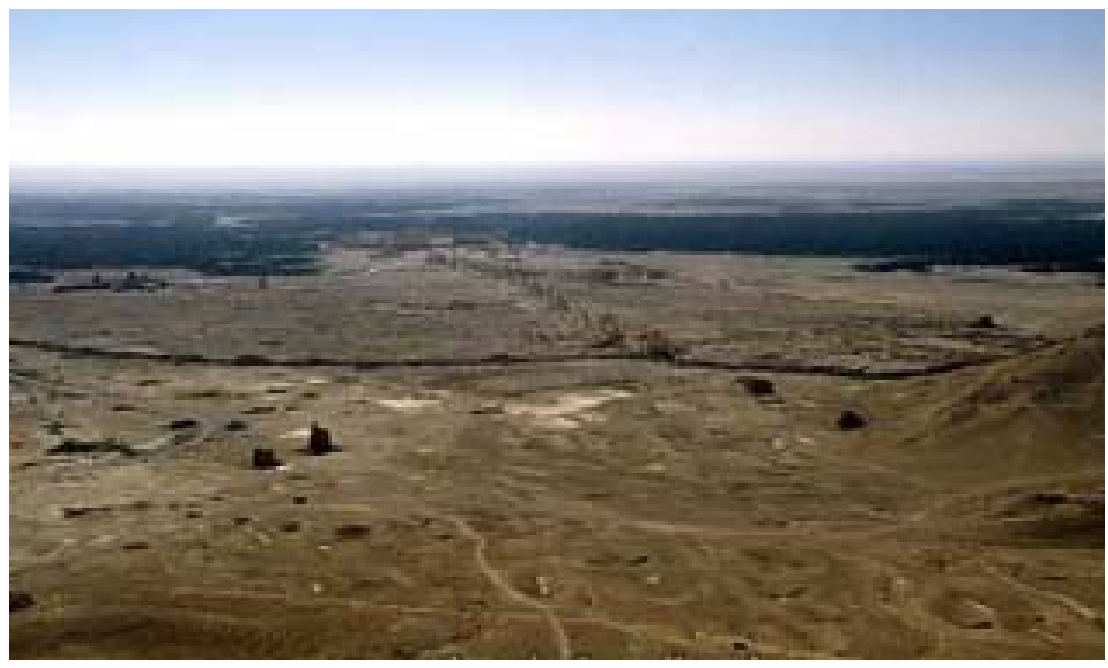

Abb. V-5: Oase Tadmor mit den Ruinen von Palmyra im Hintergrund der Bildmitte (aus: ARCHAEOLOGIE 2004, Foto. M. Meyer)

Die Verteilung der Viehfarmen, Ranches usw., die für Australien und den Westen Nordamerikas, für den Süd- und Nordosten Südamerikas und den Westen Südafrikas eine typische Erscheinung darstellen, ,ist ebenfalls abhängig von der Möglichkeit, Wasser zu beschaffen.“(SCHWARZ 1988:30)

Ähnlich steht es in Patagonien, dessen Plateau von tiefen Canons zerschnitten wird. „Nur hier ist Wasser erreichbar [...], so daß sich die Wohnplätze in weiten Abständen an die Talräume halten“ (JAMES 1942:313 ff.). So bringen auch hier ,die besonderen Bedingungen der Wasserbeschaffung jeweils ein besonderes Verteilungssystem der Siedlungen hervor.“ (SCHWARZ 1988:30f.)

Auf den mineralischen Nassböden der mittleren Breiten dienten Uferdämme der Flüsse als Leitlinien der Ortsgründungen bzw. -erweiterungen. Zunächst auf natürlichen und nachfolgend an künstlich errichteten Uferdämmen der Ströme und Flüsse führten sie zu Reihensiedlungen, in den mittleren Breiten wie auch in China und den tropischen Tiefländern (NIEMEIER 1977:56). Leitlinie dieser oft viele Kilometer langen Siedlungen ,ist meist ein Tal, ein Flußufer, ein Kanal oder Deich“ (NIEMEIER 1977:46). Auf welligem Relief boten sich die Niederterrassen bzw. die Ursprungsmulden der Bäche als gewässernahe Siedlungslage an (NIEMEIER 1977:57).

„Insbesondere die von Gebirgen umrahmten Stromaufschüttungsebenen zogen den Menschen an. Zwar war es meist notwendig, sich vor Überschwemmungen der Flüsse zu schützen, so daß die Verteilung der Siedlungen, vor allem im jungen Alluvialland, durch das Netz der Deiche, natürliche Uferdämme und Strandwälle bestimmt wird; aber in dieser Bindung kann sich die Bevölkerung hier in einzigartiger Weise konzentrieren, am stärksten in der Nähe des Ströme selbst.“ (SCHWARZ 1988:32)

\footnotetext{
${ }^{2}$ Palmyra: Die Ruinen der antiken Stadt Palmyra befinden sich in der Oase Tadmor, inmitten der syrischen Wüste zwischen Mittelmeer und Euphrat. „Seine Existenz verdankt der Ort den Efqa-Quellen, die bereits in der Antike die einzige Wasserstelle weit und breit darstellten.“ (ARCHAEOLOGIE 2004) Daher war der Siedlungsplatz Anlaufstelle für die großen Handelskarawanen, die zwischen Euphrat und Mittelmeer durch die syrische Wüste zogen. Die Ursprünge der Siedlung reichen bis in das Neolithikum zurück, die steinernen Überreste entstammen aber der römischen Zeit (1./2. Jh. n. Chr.), erst im 7. Jh. wurde die Stadt muslimisch. Das heutige Tadmor mit ca. 30.000 Einwohnern wurde zu Beginn des 20. Jh. unter französischer Herrschaft außerhalb der antiken Stadtanlage gegründet, weshalb fast das gesamte Ruinenfeld von Palmyra vor der modernen Zerstörung bewahrt werden konnte.

${ }^{3}$ Laghout [Laghouat]: Oasensiedlung in Süd-Algerien am Südabfall des Sahara-Atlas, an der Transsaharastraße, ca. 25.000 Einwohner, zugleich Bezirkshauptstadt (Wilayate) und wichtige Wüsten-Diozöse (BROCKHAUS 1979, CITYPOPULATION 2004; ERDKUNDE-ONLINE 2004)
} 
Die Verteilung von Siedlungen an Flüssen entlang und an Seen kann auch in höheren Breiten, beispielsweise in den ausgedehnten borealen Nadelwaldregionen jenseits der Polargrenze nachgewiesen werden. Auf dem Reichtum an Pelztieren, Holz und Bodenschätzen beruhte die Erschließung dieser unermesslichen Waldgebiete. Für den Verkehr aber spielten die Flüsse eine wichtige Rolle, denn wenn auch im Sommer die Eisdecke nur für kurze Zeit verschwindet, so stellten sie doch die wichtigsten Verkehrsadern dar, in einem Gebiet, in dem das Auftauen des Bodeneises für den Landverkehr die größten Schwierigkeiten mit sich bringt. Infolgedessen gaben die Flüsse die Leitlinien für die Verteilung der Siedlung ab. „Die Pelzhandelsstationen der Hudsonbay-Company [...] waren an den Flüssen und an den Ufern der Seen aufgereiht. Auch die russischen Pelztierjäger, die in die sibirischen Wälder eindrangen, hatten ihre Stützpunkte an den Flüssen." (SCHWARZ 1988:29) Der Flusstransport stellte zudem eine notwendige Voraussetzung der Holzwirtschaft dar, so dass auch die damit zusammenhängenden Siedlungen - abgesehen von den Holzfäller-Lagern - die Nähe der Stromadern aufsuchten $(: 29)$.

Auch die Jäger Nordamerikas hatten sich weitgehend auf Pelztierfang eingestellt, „obgleich Jagd und Fischfang zur Sicherung der eigenen Ernährung bestehen blieben." (SCHWARZ 1988:65) So war damit nicht unbedingt eine Änderung der episodisch-temporären Siedlungsart und der topographischen Lage ihrer Siedlungen verbunden. Die Flüsse und Seen stellten im Sommer die Verkehrsadern zwischen den Siedlungen dar; mit dem Boot gelangen die Trapper ebenso wie die Indianer in ihre Fangbereiche. So lagen die Wohnstätten der Pelzjäger fast ausnahmslos an höher gelegenen Fluss- und Seeufern, genau wie die der einheimischen Jäger (:65), denn auch Pelztierjäger ziehen trockene Lagen in Flussnähe vor, „weil der Fluß Transportweg ist.“(NIEMEIER 1977:56)

Fischer und Seesäugerjäger wählten wie auch die Pelztierjäger ufer- oder küstennahe Lagen aus, nicht aber primär um den Transportweg auf dem Wasser zu nutzen, sondern um die Nähe der besten Fanggründe zu gewährleisten (NIEMEIER 1977:56).

Die Dauersiedlungen der Intensiv-Hackbauern und der Pflugbauern zeigten ,immer eine Ortslage nahe den Feldflächen auf trockenem Baugrund mit naher Wasserversorgung“ (NIEMEIER 1977:56f.).

Bei der landwirtschaftlichen Erschließung von nordischen Landschaften zeichnete ,sich deutlich die Bevorzugung der Flußtäler ab“ (SCHWARZ 1988:29f.). In der Verteilung der Siedlungen, die sich wie schmale oder breitere Siedlungsbänder in den Flussauen entlangziehen, lässt sich dies dokumentieren. Im nördlichen Schweden und Finnland etwa lässt sich die bandförmige Aneinanderreihung der Siedlungen gut beobachten, ebenso wie in Russland, zum Beispiel an der Dwina ${ }^{4}$ oder Petschora ${ }^{5}$, oder an den sibirischen Strömen.

In den innertropischen Urwaldtiefländern wie in Amazonien und dem Kongobecken entspricht die Verteilung der Siedlungen dem vorher gezeichneten Bild: „Ebenso wie in den Nadelwäldern der höheren Breiten ist der Verkehr auch hier im wesentlichen an die Flüsse gebunden. Die Verbindung von Ort zu Ort vollzieht sich in den Regenwaldtiefländern mit ihrem dichten Unterwuchs zumeist auf den Wasserwegen. Infolgedessen liegen die Siedlungen an den Flüssen oder Altwasserarmen außerhalb des Überschwemmungsbereiches.“ (SCHWARZ 1988:30)

Zusammenfassend lässt sich feststellen, dass die mit natürlichen Gewässern ausgestatteten Flächen in sämtlichen bewohnbaren geographischen Breiten bevorzugte Siedlungsräume darstellen. Als gepunktetes oder lineares Siedlungsband erstreckten sich die Wohn- und Handelsplätze entlang der

\footnotetext{
${ }^{4}$ Dwina [Nördliche Dwina]: Größter Strom Nordrusslands, entsteht bei Welikij Ustjug aus Suchona und Jug; von hier 744 $\mathrm{km}$ lang und mündet bei Archangelsk mit einem $900 \mathrm{~km}^{2}$ großen Delta in die Dwina-Bucht des Weißen Meeres. Wichtige Nebenflüsse sind Wytschegda und Pinega (von rechts). Trotz des Frühjahrshochwassers, das weite Überschwemmungen bringt und Eisbedeckung von 160-180 Tagen, hat die Dwina große Bedeutung für den Holztransport nach Archangelsk. Über das Dwina-Kanalnetz ist sie mit der Wolga verbunden (BROCKHAUS 1979)

${ }^{5}$ Petschora: Fluss im NO des europäischen Teils Russlands. 1809 km lang, entspringt am Westfuß des Nordurals, mündet in einem $45 \mathrm{~km}$ breiten Delta in die $100 \mathrm{~km}$ lange, 40 - $120 \mathrm{~km}$ breite, im Mittel $6 \mathrm{~m}$ tiefe Petschora-Bucht der Barentssee. Für Seeschiffe bis Narjan-Mar, für Flussschiffe $1515 \mathrm{~km}$ bis Jakscha schiffbar. Wichtige Nebenflüsse sind (von rechts) Workuta, (von links) Koschwa und Ischma (BROCKHAUS 1979).
} 
fließenden oder stehenden Gewässer. Obgleich, dies soll im Folgenden deutlich werden, die bevorzugte hydrologisch-topographische Lage ab einem gewissen Zeitpunkt einem grundlegenden Wandel unterworfen war.

\section{c Der hydrologisch-topographische Lagewert und sein Wandel}

Der Lagewert unterliegt seit jeher einem geschichtlichen Wandel, denn oft war bereits „bei der Platzwahl eine bestimmte kulturgeographische Situation bestimmend "(NIEMEIER 1977:55)

Die Entwicklung der Besiedlung und Bodennutzung lässt sich nur bei Berücksichtigung der ursprünglichen Verteilung von trockenem und nassem Gelände verstehen. Rodungen, Entwässerung, Drainung oder umgekehrt: Bewässerung, und außerdem Bach- und Flussregulierungen sowie Quellfassungen bei Einführung der zentralen Wasserversorgung, haben den früheren Wasserhaushalt der Landschaften tiefgreifend verändert (JÄGER 1965:411). Ein Verständnis der Siedlungs-, Wirtschafts- und Landschaftsentwicklung ist deshalb ohne Berücksichtigung der anthropogenen Einflüsse in den Gewässerhaushalt nicht möglich.

„The capitals of early medieval states often lie“, wie wir eben gesehen haben, ,at points of convergence of natural routes of communication, i. e. roads and waterways [...]. It seems, however, that an abrupt change took place in the network of waterways in the northern European plain during the $13^{\text {th }}$ century. This was", so beschreibt DUNIN-WASOWICZ (1990:97) weiter die verkehrstechnischen und siedlungsgeographischen Gründe, ,probably due to human interference in the natural course of rivers, with the development of transport by land. The latter was facilitated by the more widespread use of modern horse-drawn vehicles. [...] A further factor was the economic development of cities, which were often without natural waterways."

Die bis zu einem Zeitpunkt gültige hydrologisch-topographische Lagezuweisung änderte sich also u. a. durch Entwicklungen in der Transporttechnik und der Versorgungsleitungen, die die Unabhängigkeit von natürlichen Wasservorkommen vor Ort ermöglichten.

Der Lagewert war bis dahin dadurch gekennzeichnet, dass die primäre Gewässerlage bei den früheren menschlichen Besiedlungen den Standort bestimmt hat. In der weiteren Zeitenfolge jedoch konnte das Wasser ,dienlich' gemacht werden. Die unmittelbare Wassergebundenheit als Trink- und Bewässerungswasser fiel sukzessive fort. Durch Wasserleitungen, Wasserkünste, künstliche Kanäle etc. wurde die unmittelbare Standortabhängigkeit aufgelöst.

Zahlreiche archäologische Funde liefern die Kenntnis beispielsweise von prähistorischen Siedelstätten in Tirol am Vinschgauer Sonnenberg, ,und zwar an Stellen, an denen ein Dasein ohne künstliche Wasserzufuhr nur schwer vorstellbar erscheint.“ (MENARA 1994:147) Ein besonders prägnantes Beispiel hierfür ist die kleine Höfegruppe Talatsch hoch oberhalb der Ortschaft Schlanders am extrem steilen Berghang, wo in den 1970er Jahren bronzene Sicheln, Vierkantmeißel und Beile aus der älteren Eisenzeit (etwa 700 v. Chr.) aufgedeckt wurden. Im 18. Jh. wird über die extreme Wasserarmut dieser Höfe geklagt, wenn in deren Waal (siehe VII 6b.2.2), der vom Schlandraunbach heraus führt, das Wasser ausbleibt. „Hier wie an anderen ähnlichen Punkten läßt sich demnach vermuten, daß bereits die vorgeschichtlichen Bergbauern des Vinschgaus künstlich angelegte Wasserzuleitungen besaßen.“ (:147) Ebenfalls in dieser Dekade wurde nahe der Ortschaft Pfatten im Südtiroler Unterland ein großer Wasserwaal bei archäologischen Ausgrabungen entdeckt. Der Kanal konnte einwandfrei in das 6 . vorchristliche Jahrhundert datiert werden und er beweist somit, „daß bereits den damaligen Siedlern der Bau gemauerter Waale vertraut war." (:147) Das prospektierte vor- und frühgeschichtliche Waalnetz stützt somit die Vermutung, „daß der seßhafte Mensch immer schon imstande und auch gezwungen sein dürfte, das Wasser mittels eines Bodenkanals dorthin zu leiten, wo es benötigt wurde. Unter dieser Voraussetzung wird denn auch erst das Vorhandensein vieler bronzezeitlicher Siedlungsreste auf wasserlosen Hügeln leichter verständlich.“ (:147f.) 
„Andererseits“, so NAEF (1994:26) „muß man sich fragen, warum Menschen sich ausgerechnet dort, wo Wiesen und Äcker bewässert werden müssen, überhaupt angesiedelt haben?“

Die Lösung von der Wasserlage jedenfalls wurde durch wasserbautechnische Maßnahmen weiter vorangetrieben. Flüsse wurden reguliert, jedoch nicht nur um Überschwemmungen zu mildern und um zusätzliche Bauflächen zu schaffen, sondern um den Transport dieser Lasten - möglichst ganzjährig zu ermöglichen. Schifffahrtskanäle wurden gegraben, um die Lageungunst aufzuheben und einen Warenverkehr mit den abseits der schiffbaren Flüsse liegenden Städten zu ermöglichen und die bestehenden schneller zu verbinden.

Mit den sich verändernden ökonomischen, sozialen, politischen und vor allem technischen Rahmenbedingungen veränderte also sich die Bewertung von Wasserlagen. Die Siedlungswahl wurde mehr oder weniger unabhängig von der Standortvoraussetzung, Wasser' bzw. anderen wurden die Gewässer ,vor die Haustür' gebracht.

Mittlerweile weisen auch viele Siedlungen in Trockengebieten der Erde dieses Lagekennzeichen nicht mehr auf, die bis in unsere Zeitrechnung auf eine unmittelbare Wasserlage angewiesen schienen. Mit den Erfindungen von künstlichen, wassersammelnden Tunneln (sog. Foggaras ${ }^{6}$ ), Grundwasserbrunnen, artesischen Tiefbrunnen oder Zisternen machte man sich in den Trockenzonen der Erde „weitgehend unabhängig von dieser Bindung“ (SCHWARZ 1988:72). Die künstliche Wasserversorgung bildet zwar noch oft genug die Lage der Siedlungen heraus - sie liegen immer noch in den Talungen, den ,Wadis', da hier zum einen der höhere Grundwasserstand den Brunnenbau vereinfachte und zum anderen hier durch Sperrwerke episodische Hochwässer gestaut werden konnten, um sie zum Versickern und Anreichern des Grundwassers zu bringen oder durch Kanäle auf seitlich gelegene Felder und Gärten zu leiten (NIEMEIER 1977:57) -, aber die Wasserversorgung findet auch auf den in erheblicher Entfernung zum natürlichen Gewässer befindlichen Wirtschaftsflächen statt und wird durch Zisternen geregelt.

Gleiches trifft für die oben erwähnten Viehfarmen zu. Da die Wasserhebung - teilweise schon seit dem 19. Jh. - in der Regel mit Hilfe von Wind- oder Motorpumpen geschieht, konnte die Bindung

\footnotetext{
${ }^{6}$ Foggaras [in Afghanistan „Kareze“, im Iran „Qanat“ genannt]: ein ausgeklügeltes unterirdisches Kanalsystem der Grundwassersammlung im afrikanisch-islamischen Raum (Libyen, Algerien, Marokko, Ägypten, Tunesien, Iran). Fossiles Wasser, welches sich in der Schwemmfächerzone an einem Gebirgsfuß einer Oase (sog. Qanat- bzw. Gebirgsfußoase) der Schwerkraft folgend abwärts bewegt, kann mittels Foggaras ohne eine Hebevorrichtung vom Gebirge talabwärts und an die Oberfläche gefördert werden: es wird ein leicht geneigter Stollen (Galerie) im Untergrund des Schwemmfächers (Däscht) angelegt. Dieser wird mit senkrechten Schächten (Mutterschächte oft über $100 \mathrm{~m}$, Ergänzungsschächte bis zu $40 \mathrm{~m}$ Tiefe) versehen, die zur Anlage, Bearbeitung, Reinigen und Belüftung der Galerie dienen. Von einer Kette von Bauschächten aus wird dabei die unterirdische Verbindung zwischen den jeweils benachbarten Schächten hergestellt. An dem Punkt, wo die Galerie den Grundwasserspiegel schneidet, wird der Mutterschacht angelegt. Von diesem Punkt aus zum Berg hin ist die Galerie ein wassersammelnder Stollen, da der Grundwasserspiegel über der Galerie liegt und sich Wasser sammeln kann. Darunter befindet sich der wasserableitende Stollen. Am Wasseraustritt befindet sich die Siedlung und weiter bergab die bewässerten Felder. Am Wasseraustritt wird es zunächst in einem Becken gesammelt und von dort über kleine Kanäle, die oft aus Lehm gebaut sind, zu den einzelnen Feldern geleitet. Solche Grundwasser-Sammelsysteme besitzen eine stabile Wasserführung, die bis 100 1/s, selten über 2500 1/s Wassermenge erreichen.
}

Diese Art Wasser nutzbar zu machen ist bereits 2500 Jahre alt und wurde von den vorderasiatischen Völkern ca. 300 v. Chr. erfunden. Im 7. Jh. wurde diese Arbeitsweise von den Arabern verbreitet. Städte wie Teheran, Marrakesch und Madrid wurden durch Foggaras mit Wasser versorgt. Im Iran wird die Gesamtzahl von Qanaten vor dem II. Weltkrieg auf ca. 35.000 geschätzt, da viele Dörfer auf diese Weise bewässert wurden. Heute liegt deren Anzahl deutlich unter 15.000, da viele im Rahmen der „Revolution der Wasserversorgung“ (Brunnenbau, Flächenplanierungen, Be- und Entwässerungskanäle) abgelöst wurden, aber besitzen dennoch eine Länge von über $125.000 \mathrm{~km}$ und einer Bewässerungsfläche von 1.000 .000 ha. Die Vorteile dieser Art der Bewässerung sind offensichtlich, handelt es sich doch um Erschließung sonst ungenutzter Wasserressourcen und eine Methode der Wasserförderung, bei der Verdunstungsverluste infolge der unterirdischen Wasserführung sehr gering sind. Darüber hinaus ist dies eine Technik, die ohne hochtechnisierte Hilfsmittel über Jahrtausende ausgekommen ist. Die Nachteile liegen hauptsächlich in den hohen Instandhaltungskosten und in der gravierenden Absenkung des Grundwasserspiegels, wodurch viele Qanaten versiegen. Allerdings werden alte, bestehende Foggaras mühevoll gepflegt, hauptsächlich im iranischen Hochland, wo sie ein bedeutendes Kulturgut sind.

Tunnel in Qanat-Bauweise sind in Europa seit der Etruskerzeit bekannt und dienten selbst bei den ersten Eisenbahntunneln noch als Vorbild. $\mathrm{Zu}$ besonderer Blüte kam diese Bauweise in römischer Zeit, in der sie besonders im Aquäduktbau angewendet wurde (vgl. SCHÜLER DUDEN - DIE GEOGRAPHIE 1997:178; AFGHANISTAN 2004; ARABIEN 2004; FRONTINUS 2004; IRAN 2004). 
vom natürlichen Wasservorkommen gelöst und eine größere Streuung der Wohnplätze erreicht werden (SCHWARZ 1988:30).

Die Bindung zum Wasser löste sich generell - parallel zum technischen Fortschritt - in dem gleichen Maße auf, sobald vorwiegend Feldanbau betrieben wurde. Hier wurde die Gemarkung, die zu beackernde, fruchtbare Flur, zum lagebestimmenden Motiv, obgleich die Wasserlage, wenn auch nicht mehr unmittelbar, dennoch gesucht wurde. Aufgrund veränderter Ansprüche spielte in anderen und in „nicht wenigen Fällen“ nicht die Gewässer(rand)lage, sondern das Schutzmotiv für die Ortslagen die erste Rolle. Es konnte sogar so stark sein, dass die Nutzung der Wirtschaftsflächen und oft sogar die Wasserversorgung beeinträchtigt wurden (NIEMEIER 1977:57), beispielsweise dort, wo agrarische Siedlungen auf oder nahe Berggipfeln liegen - oft ohne Quellen zur Wasserversorgung - , wie der größte Teil der Stadtdörfer im südlichen Spanien und Italien oder in den on Kabylen bewohnten Bergländern Nordafrikas. Diese befinden sich auf den Gipfeln der Berge, auf steilwandigen Riedeln und auf hochliegenden Hängen, während das Kulturland tief unten an den Hängen und in den Tälern liegt. Die Ursache dafür ist nach NIEMEIER (:58) in den jahrhundertelangen Fehden zu suchen, die auch heutzutage noch ausgetragen werden, und hier ist besonders das Motiv der Schutzlage bestimmend gewesen (:161).

Andererseits wurden sogar aufgrund der besonderen Wasserlage vorher unbewohnbare Plätze bewohnbar gemacht. Auf den gesackten oder tektonisch gesunkenen oder sinkenden Nordseemarschflächen wurde sogar der Wassernähe und der fruchtbaren Böden wegen Überschwemmungsgefahr in Kauf genommen und dieser - vor dem Bau von Seedeichen (um 1000 n. Chr.) - durch künstliche, mehrfach dem steigenden mittleren Hochwasser angepasste Hügel (sog. Wurten, Terpen, Wierden) begegnet, die als Standort für Einzelhöfe und Dörfer dienen (NIEMEIER 1977:56f.). Nach Eindeichung der Seemarschen bereits in der vormittelalterlichen Siedlungsperiode, sind dann die Deiche Leitlinien von langgereihten Siedlungen geworden (:57; BEHRE 1988).

Eine weitere siedlungsstrukturelle Lageveränderung entstand mit Beseitigung der natürlichen Vegetation und ihres Wurzelwerkes und der dann einsetzenden Bodenlockerung durch Pflügen und Hacken. „Die Wälder wurden zur Gewinnung von Holzkohle für Verhüttung und von Grubenholz für die Bergwerke großflächig abgeholzt. Daneben mußte eine zahlreiche Einwohnerschaft der Bergbauorte mit Bauholz, Brennholz [...] versorgt werden.“ (BARTELS 2000:33). Neben den umfangreichen Waldrodungen hatten die Waldzerstörungen durch Waldweide beträchtliche Auswirkungen (NIEMEYER-LÜLLWITZ/ZUCCHI 1985:90f.): Durch diese Tätigkeiten setzte in hängigem Gelände aufgrund erhöhter Oberflächenabflüsse und verstärkter Erosion eine flächenhafte Abschwemmung sowie ein linienhaftes Einreißen (sog. „Gully-Erosion“) ein. Das abgeschwemmte, erodierte Material wurde in die Bäche geführt und auf flacheren Bachstrecken bei nachlassender Fließgeschwindigkeit des Wassers sedimentiert. Während die Bachtäler im unberührten Zustand ein steinig-kiesiges Bett und in ihren Oberläufen eine noch kerbtalmäßige Form aufweisen, führt die Sedimentation von erodiertem Boden und darunterliegendem feineren Verwitterungsmaterial in vielen Flußauen (insbesondere der Ebene) zur Bildung einer mächtigen Auesand- und Auelehmdecke, die im Laufe der Zeit mehrere Dezimeter bis über einen Meter Dicke erreichen kann (NITZ 1989:190; NIEMEYERLÜLLWITZ/ZUCCHI 1985:90f.).

Wenn auch die natürliche Dynamik bei der Mehrzahl unserer Fließgewässer bis ins 19. Jh. hinein erhalten blieb (NIEMEYER-LÜLLWITZ/ZUCCHI 1985:90f.), so konnten nun auf diesem Auelehmsediment Ansiedlungen geschaffen werden, die - im Vergleich zur vorherigen Situation - durch die Höherlage vor Überschwemmungen einigermaßen sicher waren. Die verschiedenen Auelehmsedimentationsphasen über einem bis dahin grobkörnigen Flusskiestalboden, der eine erosive Abtragung vorausging, setzte in der späten Eisenzeit ein, verstärkte sich im Frühmittelalter (8./9. Jh.), einer Phase umfangreicher Rodungen mit Dorfneugründungen, und endete im Spätmittelalter bzw. der Frühneuzeit, als klimatische Schwankungen mit zeitweise erhöhter Starkregenhäufigkeit zu einer verstärkten Abtragung führten (NITZ 1989:191): „Der im Frühjahr feuchtigkeitsdurchtränkte Boden gerät mit dem Gefälle ins Fließen“ (:190), es „bildeten sich breite Bach- und Flußauen über den steinreichen älteren Sedimenten, und hier war die Anlage von Wiesen und Angerweiden möglich, die 
eine bessere Futterversorgung der Viehhaltung ermöglichten als die reine Waldweide." (:191) DENECKE (1989b:203) spricht sogar von einer „Versiegelung der Täler mit Auelehm“.

Bis in die vorindustrielle Zeit wurden in Europa - neben den lößreichen Böden der Börden - jedoch nicht die unmittelbare Flussaue, sondern „,bevorzugt die hochwasserfreien Terrassen der Flußtäler landwirtschaftlich genutzt.“ (NIEMEYER-LÜLLWITZ/ZUCCHI 1985:90) Die Flussauen blieben „bis zum Ende der vorindustriellen Zeit [...] in der Agrar-Kulturlandschaft neben den Gebirgswäldern (der Mittelgebirge und Alpen) und Moorgebieten [...] weitgehend als naturnahe Landschaftsteile erhalten.“ $(: 90)$

Mit Beginn der bäuerlichen Bewirtschaftung ist es jedoch immer wieder zu Besiedlungsversuchen mit partiellen Rodungen der Auen-Wälder gekommen. Einzelgehöfte wurden dabei auf künstlichen Hügeln, den ,Wurten', errichtet; vereinzelt wurden Dörfer auch durch die Anlage von Hochwasserdämmen geschützt. In Kenntnis der vom Fluss ausgehenden Naturgewalt wurde aber bei der Mehrzahl der Siedlungs- und Stadtgründungen der Vorteil der erhöhten Lage auf der Niederterrasse ausgenutzt. Siedlungen in der Aue wurden regelmäßig durch Hochwässer teilzerstört oder ganz ausgelöscht; bis ins 19. Jahrhundert kam es immer wieder zu großräumigen Flussbettverlagerungen (NIEMEYERLÜLLWITZ/ZUCCHI 1985:90). Diese Situation schildert LAUTERBORN (zit. bei SCHÄFER 1974 :303f.) am Beispiel des Rheins:

„In dieser Stromwildnis mit ihren Sümpfen, Flutrinnen und verschilften Altwassern, die bis um 1800 selbst den Biber noch bargen, in den fast undurchdringbaren feuchtgründigen Auenwäldern, wo unter den Kronen mächtiger Eichen, Ulmen, Schwarzund Silberpappeln das Gesträuch und Gestrüpp von Schlingpflanzen durchwucherte, zu schier tropischer Üppigkeit aufschoß - in einem solchen, stets von Überschwemmungen bedrohten Gelände, war kein Platz für Dauersiedlungen und geregelten Landbau. So ging der Wandel zur Kulturlandschaft, wie er sich auf den höheren Lagen der Ebene vollzog, an der eigentlichen Rheinniederung beinahe spurlos vorüber. “

Im Rahmen der industriellen Expansion jedoch änderte sich das Bild. Die Folge war das zunehmende Vordringen von Gewerbe- und Wohnsiedlungen, Verkehrs- und Hafenanlagen in die Auengebiete hinein. Die industriell-gewerbliche Entwicklung vollzog sich sogar insbesondere an den ,Lebensadern' der Wirtschaft, den Flusstälern. Der Flächenanspruch der sich ausdehnenden Gewerbe- und Wohngebiete betraf zunehmend alle Flussgebiete. Solche Nutzungen an Flüssen erforderten eine möglichst weitgehende Kontrolle über das Wasser (NIEMEYER-LÜLLWITZ/ZUCCHI 1985:97), um sie für die wirtschaftliche Nutzung effektiv und gewinnbringend einzusetzen. Die Lage an einem Flusslauf war also strategisch wichtig für den Transport zu Wasser, für den Energienantrieb durch Wasserkraft, aber auch vorteilhaft durch die bautechnisch und logistisch favorisierte ebene Baulage.

Zusammenfassend lässt sich feststellen: Durch die Gewässer und die Verfügbarkeit von Wasser wurden die Grundlagen in der Verteilung von Siedlung und Bevölkerung bestimmt. Die wesentliche Umgestaltung der Gewässerbindung aber übernahm und übernimmt der Mensch selbst. Unterschiede in der Bodengüte und des Untergrundes, unterschiedlicher Grundwasserstand und Oberflächengestaltung werden durch den Menschen nachträglich festgelegt. „Dies bedeutet, daß die anthropogeographischen Faktoren wesentlich bei der Verteilung der Siedlungen und der Bevölkerung zu berücksichtigen sind.“(SCHWARZ 1988:33)

\section{d Die hydrologisch-topographische Lage der Wohnplätze und Siedlungen}

\section{d.1 Ur- und Frühgeschichte}

„Nicht immer hatten es die Bewohner der Städte so bequem, daß sie in ihrem Hause nur den Hahn der Wasserleitung zu drehen brauchten, um aus der Wand einen rauschenden Quell herausfließen zu lassen. In den frühesten Zeiten kam nicht das Wasser zu den Menschen in ihre Wohnungen, [...], sondern die Menschen mußten zu dem Wasser kommen. Sie suchten einen 
Fluß oder eine Quelle, einen ,Born', auf und schöpften hier das zum Leben so unentbehrliche köstliche Naß. An solchen Wasserstellen entstanden daher auch die ersten menschlichen Ansiedelungen." (HEINE o. J.:18)

Da erste Lebensvoraussetzung das Wasser ist, das uns in den Gewässern entgegentritt und zugänglich wird, wie wir erfahren haben, so gilt in besonderem Maß „eine Beziehung für die Gewässer und ihre Wirkung auf die menschliche Kultur.“ (THIENEMANN 1955:145). Dieses Gefüge, d. h. sowohl die Beziehung zum als auch die kulturelle Wirkung von Wasser, war am Anfang einseitig in ihrer Abhängigkeit, danach wechselseitig und erst später, zunächst in langsamen und darauffolgend in immer schnelleren Zeitschritten, entstand die durchdringende Kraft der formenden und schließlich überformenden Unterwerfung. Der Übergang der anthropogen unbeeinflussten ,Naturgewässerlandschaft' zur anthropogen beeinflussten ,Kulturgewässerlandschaft' ist in einem Prozess erfolgt, in dem die Bestimmung eines genauen Zeitpunktes nicht möglich ist. „Die paläolithischen und mesolithischen Jäger- und Sammlerkulturen waren in Migration befindlich, vermutlich häufig in einer periodischen, an bestimmten Lagerstellen wiederkehrenden Wanderung [...]. Auch wenn es temporär bewohnte Stätten gegeben hat, fehlt dieser Lebensweise die Zielsetzung der bewußten Landschaftsveränderung.“ (KLEEFELD/BURGGRAAFF 1997b:64) Erst „mit der Seßhaftigkeit der Menschen wurden die Gewässer sowohl genutzt als auch umgestaltet“"(GIESECKE 1991:26).

Die hier zu skizzierende ur- und frühgeschichtliche Phase umfasst - neben gelegentlichen Abstechern in die Vorgeschichte - hauptsächlich die frühe und mittlere Steinzeit, also jene Jahrtausende nach dem Ende der letzten Kaltzeit vor etwa 10.000 Jahren bis zum Beginn der jungsteinzeitlichen Ackerbaukulturen. In diesem Abschnitt soll die Siedlungsgeschichte Mitteleuropas bis zur Ackerbau und Viehzucht treibenden Sesshaftigkeit in Abhängigkeit zur Gewässerlage beschrieben werden - eine Phase, von der nur wenige bauliche Zeugnisse übrig blieben und deshalb kaum irgendwo Siedlungskontinuität nachgewi esen werden konnte.

Trotzdem: Auf die Rekonstruktion der Wohnplätze und Siedlungen in dieser sog. Altlandschaft (nach SCHLÜTER 1952), also der Siedlungsräume der frühgeschichtlichen Menschen, zielt die Beschreibung dieser Phase; wenn, wie gesagt, sicher auch keine allgemeine Gesetzmäßigkeit zwischen frühzeitlicher Siedlungswahl und Wassernähe aus Gründen fehlender archäologischer Rekonstruktionsmöglichkeiten abgeleitet werden kann, so lassen sich doch bestimmte Beziehungen erkennen.

Die von BOBEK (1959:259ff.) ausgegliederten ersten beiden Gruppen der Menschheitsentwicklung, die als „Wildbeuter“ zusammengefassten primitiven Sammler, Jäger und Fischer und die Gruppe der spezialisierten Jäger und Sammler bewohnten auf dem kontinentalen Festland einfache Behausungen.

Die einfachen Wildbeuter, die unter dem Zwang der Nahrungssuche einen ständigen Wechsel des Rastplatzes vollzogen und nur wenige Tage an ein und derselben Stelle verweilten - wenn auch der gleiche Platz im Laufe des Jahres mehrfach benutzt wurde und sie auch keine Lastentiere oder andere Verkehrsmittel besaßen, um beispielsweise transportierbare Wohnstätten mit sich zu führen -, nutzten als Obdach das, was ihnen die Natur bot. Als Behausungen dienten standfeste Naturunterkünfte wie hohle Bäume, Erdhöhlen, Felsnischen, überhängende Felsen und Felshöhlen (NIEMEIER 1977:91). So boten Felsschutzdächer, sog. Abris, nacheiszeitlichen Jägern Schutz. Die Abris als von Natur aus vorgegebene, ohne größeren Zusatzaufwand herrichtbare Wohnplätze wurden gern durch wildbeuterische Gruppen des Paläo- und Mesolithikums aufgesucht (GROTE 1989:236).

Im Buntsandsteingebiet des südlichen Leineberglandes zwischen Heiligenstadt, Göttingen und NörtenHardenberg ist die größte zusammenhängende Gruppe von Abris in Mitteleuropa vorhanden. Entstanden sind sie durch geomorphologische Verwitterungsvorgänge. Diese haben im mittleren Buntsandstein über die Felsklippenbildung hinaus in extremer Auswirkung zur Modellierung von Hohlkehlen, vorkragenden Felsdächern und Pilzfelsen geführt. Vor allem aufgrund chemischer Auflösung der Bindemittel weicherer Gesteinsschichten sind in den Talschluchten des Rheinhäuser Waldes Hunderte von z.T. mehrere Meter vorkragenden Felsdächern entstanden. Diese oft geräumigen Halbhöhlen boten seit dem Mittelpaläolithikum (ca. 70.000 bis 50.000 Jahre vor heute) bis zum Mittelalter und zur Neuzeit wiederholt Behausungs- und Zufluchtsmöglichkeiten. Es hat sich 
aufgrund verschiedener Prospektionsmethoden gezeigt, dass schon bei überdachten Innenflächen von rund $5 \mathrm{~m}^{2}$ und mehr (bis $50 \mathrm{~m}^{2}$ kommen vor) mit archäologischen Überresten zu rechnen ist.

Bis heute wurden hier 1600 (!) Felsdächer erfasst, bei denen es sich aufgrund der Funde um Jägerlager gehandelt haben muss. Diese urgeschichtlichen Wohnplätze lagen in klippenreichen Schluchten des Wendebachtales im Rheinhäuser Wald des Leineberglandes südöstlich von Göttingen, d. h. oberhalb eines Bachlaufes in Gewässernähe. Prospektierte faunistische Reste, darunter Mollusken und Nahrungsabfälle, u. a. Teichmuschelschalen erlauben die Rekonstruktion durchaus längerfristiger Aufenthalte wildbeuterischer Kleingruppen an diesen bevorzugten, wassernahen und naturgeschützten Plätzen. Die Fundstellen wurden auf ca. 16 - 17.000 Jahre vor heute datiert, in die Zeitstufe der jüngsten Altsteinzeit, der ausgehenden Phase des Hochglazials, kurz vor Beginn der Erwärmung, die die Weichseleiszeit beendete (GROTE 1999:235-237).

Eine der größten altsteinzeitlichen Fundstellen Mitteleuropas (KIND 1987:13) sind die sog. „Felsställe“ in der südlichen Schwäbischen Alb und belegen ebenfalls nicht nur die Wohnform in einem Abri, sondern auch dessen Lagebezug zum Wasser, wie unter anderem die Einschlüsse von Molluskenschalen beweisen (KIND 1987:41): Hydrogeographisch stellt sich die Situation so dar, dass nordöstlich der Stadt Obermarchtal an der Donau bei Lauterbach eine präwürmzeitliche Schlinge der ,Urdonau' vom heutigen Verlauf des Donautals abzweigt. Diese ehemalige Donauschlinge ist noch heute wasserführend. Das zentrale Wasser der Schlinge wird durch kleine Bäche aus insgesamt vier kleinen Seitentälern gespeist, die von Norden von der Albhochfläche her kommend nach Süden in die bis in die Riss-Vereisung von der Donau durchflossene Schlinge einmünden. An den Talrändern findet sich eine ganze Reihe von Felsen, die teilweise Höhlen oder Felsdächer bilden. Einer dieser Massenkalkfelsen, ein großes Abri, sind die genannten „Felsställe“"7 (BERKE/KIND 1987:355; KIND 1987:15). Die Abfolge der Felsställe umfasst einen Zeitraum von rund 12.000 Jahren und reicht vom Hochglazial bis hin zum Beginn des Atlantikums (KIND 1987:41).

Sowohl die vier Seitentäler als auch die Schlinge besitzen heute alle eine mehr oder weniger starke Wasserführung. Sie werden durch Quellen auf der Hochfläche oder an den Talrändern gespeist. Die Bäche sind jedoch zum Teil kanalisiert, die Quellen gefasst (BERKE/KIND 1987:355; KIND 1987:15). Die hydrologischen Verhältnisse waren aber zu der Zeit grundsätzlich andere und damit auch die Spezifikation der Lagewahl: Die kleinen Gewässer wären nicht beständig genug gewesen, schreiben BERKE/KIND (1987:355), um Fische zu beherbergen. Im karstigen Untergrund der Rinnsale versickerte das Quellwasser schnell, „sonst müssten innerhalb der Mikrofauna des böllingzeitlichen Horizontes vom Felsställe die Reste kleiner Fische [...] vertreten sein." Eine durchgehende Wasserführung ist dagegen im Donautal und wahrscheinlich auch in der alten Donauschlinge zu erwarten. „In diesen Fluß- und Bachsystemen kamen Forellen, Äschen und Forellen vor.“ (:357) Die Siedlungslage ist also differenziert zu betrachten. In hochwassersicherer Lage von der Donau und dennoch in Reichweite der fischführenden Schlingen und Verschwenkungen suchten sie die Felsbehausungen auf, deren wenn auch nur temporär bzw. für einen Fischbesatz nicht tiefgründig genug fließenden, Seitentalbäche zumindest aber eine Wasserversorgung der oberhalb liegenden Wohnstätten boten.

In den Schichten des Tertiärs und der Kreide, wie in Frankreich beispielsweise, schufen gar die Frühzeitmenschen verzweigte Höhlenwohnungen. In jungtertiären vulkanischen Tuffen (z. B. im Hochland von Anatolien oder Afghanistan) stellen künstliche Höhlen noch immer einen bezeichnenden Wohntyp dar. In Nordchina wie auch in Mitteleuropa wurden Höhlenwohnungen gar in den Löß von Flusssteilufern gegraben. Für Deutschland zeigt das bekannte Beispiel des Neandertales (Kreis Mettmann bei Düsseldorf) in anschaulicher Weise nicht nur diese Wohnform, sondern auch die unmittelbare Bindung der frühen Menschen an ein Gewässer.

Dies trifft auch für die Karsthöhlen im oberen Erftgebiet $z u$, in denen schon die Altsteinzeit (Paläolithikum) mit sporadischen Siedlungsfunden vertreten ist (KREINER 1996b:76). Ebenso gibt es

\footnotetext{
${ }^{7}$ Der Name „Felsställe“ dürfte erst im Verlauf des 19. Jh. aufgekommen sein und rührt von seiner Nutzung als Viehstall in der Offenweide (KIND 1987:16).
} 
Belege dafür, dass bereits vor ca. 20.000 Jahren Menschen entlang der Saale lebten (BROMME 1933:22f.),: Die Besiedlung des gesamten Gebietes der Oberen Saale hat jedoch im Vergleich zu anderen Flussgebieten verhältnismäßig spät eingesetzt, was auch die geringe Zahl von frühneuzeitlichen Funden sowohl im thüringischen als auch im fränkischen Teil bedingt. „Nur im höhlenreichen Riffzechstein, der das Schiefergebirge in etwa umsäumt, boten Höhlen dem Urmenschen vielfach ,Gelegenheit zum Unterschlupf', und das besonders im Raum Pößneck, Ranis und Saalfeld. Dort gaben auch zahlreiche Funde Zeugnis von menschlichen Aufenthalten." (PASOLD 1992:11). Neben den frühen Belegen, verteilen sich über das gesamte zu beschreibende Gebiet Funde hauptsächlich aus der Bronze- und Hallstattzeit (2000 bis 500 v. Chr.).

Das Beispiel früher Besiedlungen in Nordhausen beweist ebenso die gewässerbezogene Siedlungswahl:

An den erhöhten Ufern und Terrassenkanten der Zorge und des ehemaligen großen Sees der ,Goldenen Aue', nach Regulierung und Trockenlegung im wahrsten Sinne des Wortes die „Kornkammer" der Stadt, befanden sich auch die ersten menschlichen Ansiedlungen in der Umgebung von Nordhausen und in der Stadt selbst: Spuren davon konnten noch an einzelnen Fundplätzen aufgedeckt werden. Beim Graben von Ton auf dem ,Hohenrode', einer Erhebung nördlich von Nordhausen stieß man auf zerbrochene und zerspaltene Knochen eines Riesenhirsches, dessen mächtige Geweihstangen in roher Art zu Meißeln oder Hämmern verarbeitet waren. Am Südwestende des ,Petersberges ‘ in Nordhausen lagen Urnen und Scherben von Töpfen in der Erde. Am ,Soolberge' bei Aueleben entdeckte man einen ausgedehnten Begräbnisplatz: in den bloßgelegten Gräbern lagen Urnen mit verschiedenen Bronzegegenständen, wie Nadeln, Messern, Ringen, die im städtischen Museum in Nordhausen aufbewahrt werden und aus der sog. Hallstattzeit (8. - 6. Jh. v. Chr.) stammen.

Weitere archäologische Untersuchungen sowie urgeschichtliche Fundstücke bestätigen auch den Standort eines solchen frühen Wohnplatzes für den ,Nordhäuser Berg' (FÖRSTEMANN 1827), auf dem achttausend Jahre später eine der Reichspfalzen Karls d. Großen errichtet wurde. Bei punktuellen archäologischen Untersuchungen und bei Rettungsgrabungen in dem Zeitraum 1992 - 1994, belegen weitere auf dem Gelände ausgegrabene Gegenstände die Annahme. Es handelt sich bei den dort geborgenen Gegenständen um Speisereste (Knochen), Steinpflasterung, Mauerreste und Scherben aus der Bronzezeit (Urnenfelderkultur), aus der Hallstatt-, Latene- und römischen Kaiserzeit.

Aufgrund der eben beschriebenen physiogeographischen Situation (Wasserreichtum in Verbindung mit geschützten Höhenlagen) war das Gebiet des Südharzes bzw. der ,Goldenen Aue` seit Beginn des Neolithikums immer wieder Anziehungspunkt für Menschengruppen, sich hier niederzulassen und zu siedeln. Fundmaterial aus dem ,Hopfenberg' in Nordhausen beispielsweise, stammt aus der Zeit der Bandkeramik (um 4.200 v. u. Z.), der ältesten Bauernkultur in Mitteleuropa (vgl. BEHRENS 1973:171; HEEGE 1989:8). Das Gelände, auf dem die Funde gemacht wurden, fällt nach Osten hin leicht ab und wird in dieser Richtung durch den ,Roßmannsbach', ein Zuflussgewässer der Zorge, begrenzt. Östlich dieses Baches steigt das Gelände dann steil an. Im historischen Messtischblatt von 1853/54 ist die Flurbezeichnung ,auf dem Tisch“ für das Gebiet des Hopfenberges angegeben. Hier war wahrscheinlich wiederum die besondere Bodengüte und Fruchtbarkeit der Aue des Bachlaufes, die den Siedlern günstig schien, ausschlaggebend, denn ,unter einer Humusschicht von $30-40 \mathrm{~cm}$ begann der anstehende Lößboden, der stellenweise eine Mächtigkeit bis zu $4 \mathrm{~m}$ erreichte. Bis zur Bebauung wurde diese Fläche vor allem als Wiese genutzt, wobei im Frühjahr und Herbst das Gelände oft überschwemmt und feucht war.“(GRÖNKE 1991: 31)

Eine weitere alte Niederlassung auf dem Boden der heutigen Stadt Nordhausen war wohl ein Dörfchen am Fuße des sog. Frauenberges. Das nötige Wasser gab den Bewohnern der, Rumbach', nach dem ein Stadtteil benannt ist. Er fließt auch heute noch, ,scheint aber früher bedeutend stärker gewesen und aus mehreren Quellen, die hier am Fuße des Berges zutage traten, gespeist worden zu sein; jetzt ist nur noch eine Quelle [...] vorhanden, die ihr Wasser nach der Straße zu sendet.“ (HEINE o. J.: 34)

Eine andere siedlungsarchäologische Fundstelle liegt nördlich von Werther unmittelbar östlich der Landstraße nach Wolkramshausen, auf einem leicht nach Osten abfallenden Gelände im Dorf namens 
Schate. In einer schon fast typischen Situation fließt knapp $150 \mathrm{~m}$ von der Fundstelle entfernt am Fuße des Hanges der Tiefenbach entlang. Eine weitere Fundstelle befindet sich etwa $50 \mathrm{~m}$ östlich. Sie liegt bereits in der Niederung des Tiefenbaches und wird im historischen Messtischblatt als „der Mersch“ bezeichnet.

Durch den Grabungsfund von Keramikscherben ist eine Datierung dieser Fundstelle in die Rössener Kultur ${ }^{8}$ möglich.

Dass die spätere Bandkeramik im engen Zusammenhang mit der Rössener Kultur stand und mit ihr durch eine Reihe von Kulturelementen verbunden ist, zeigen viele archäologische Funde. So übernahmen sie im Wesentlichen den Hausbau mit bis zu $50 \mathrm{~m}$ langen und bis zu $8 \mathrm{~m}$ breiten Gebäuden, die oft einen trapezförmigen Grundriss hatten, die Siedlungsweise, bzw. die Wirtschaftsstruktur, aber auch die Form der Steingeräte, wurde von den Bandkeramikern übernommen bzw. weiterentwickelt. Im Verlauf des 5 Jahrtausends v. Chr. kam es zur Einwanderung von Volksstämmen aus dem mittleren Donauraum ins Mittelelbe-Saale-Gebiet. Diese brachten die Kenntnis von Bodenbau und Viehzucht mit und werden nach der besonderen Verzierung ihrer Tongefäße eben als Bandkeramiker bezeichnet (BEHRENS 1973:29). Bevorzugt besiedelt wurden von diesen Menschen die fruchtbaren Lößböden. Auf diesen Böden wurden von ihnen neben Emmer, Einkorn und Gerste auch schon Linsen, Erbsen, Hirse und Lein angebaut. Dies bedeutet eine stärkere Inanspruchnahme von Auenböden auf den Flutungsflächen von Gewässerläufen (GRÖNKE 1986:59). Es ist vorstellbar, wenn auch noch nicht bewiesen, dass in dieser Zeitperiode auch schon in Mitteleuropa eine Form des Bewässerungsfeldbaus betrieben wurde, die eine Regulierung von Fließgewässern anstrebte, um auf den günstigen Ertragsflächen der Auenböden Wiesen- und Feldwirtschaft zu betreiben.

Die meisten der ur- und frühgeschichtlichen Felsüberhänge und Rastplätze liegen also an Flussläufen (ERGERT 1983:205f.). „Wohl hat der Mensch schon in frühesten Zeiten“, wie THIENEMANN (1955:146) ausführt, ,an Seen wie Flüssen mit Vorliebe seine Behausungen errichtet und als Fischer im Wasser geerntet, aber den Fluß hat er doch bevorzugt.“ Denn wenn auch die Flüsse, vor allem in Kriegszeiten, Grenzen und schwer zu nehmende Hindernisse waren, „,im allgemeinen bildeten die Flußtäler die natürlichen Einfallstore, von denen aus der Mensch [...] die Urlandschaft seiner Kultur erschloß. Das Wasser selbst konnte schon damals zur Straße werden, auf der er in das Innere der Kontinente eindrang“. Des Weiteren ermöglichten Flusstäler die Bewässerung ihres landwirtschaftlich genutzten Geländes auf leichte Weise. Und so sind Flusstäler schon früh zu Kulturzentren geworden. „Man spricht von ,Flußkulturen’; aber ,Seen-Kulturen’ in diesem Sinne gibt es nicht.“ (:147).

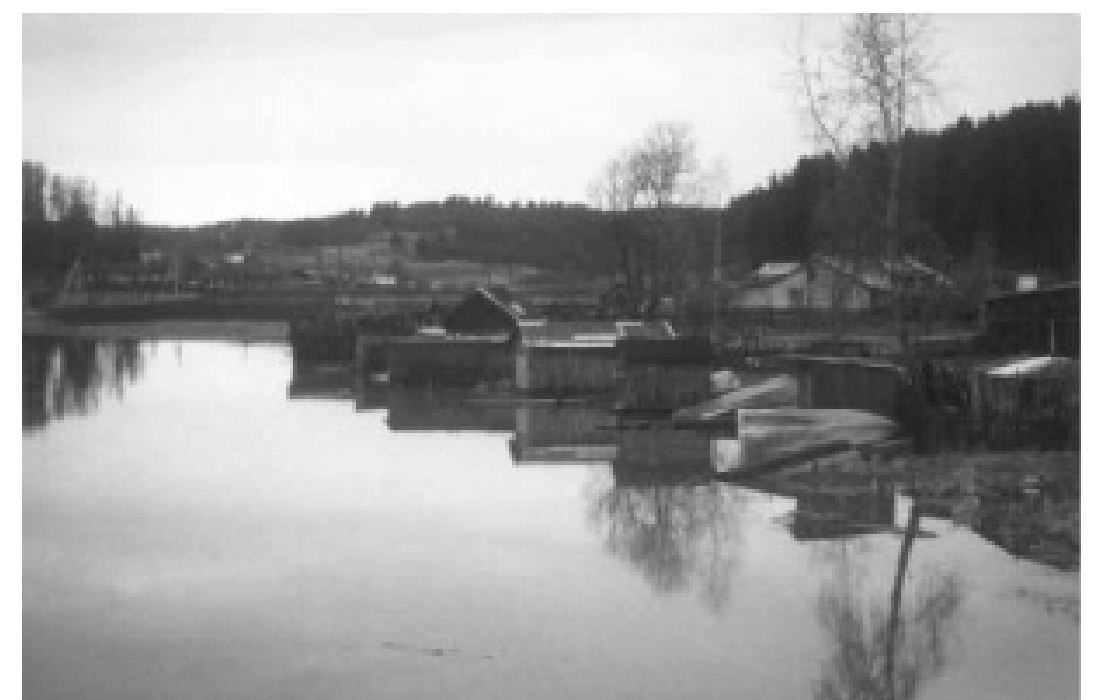

Abb. V-6: Jungsteinzeitliche Siedlungsstätte einer „Flusskultur“ in Priozersk/Ostkarelien Die Wohnhütten befanden sich, gleich dem Standpunkt der Aufnahme, oberhalb des Flusslaufes in trockener und sicherer Höhe. Die „Fischerstatt““ hingegen lag, wie noch hier sehen, unmittelbar im Uferbereich des Flusslaufes.

\footnotetext{
${ }^{8}$ Ihren Namen erhielt diese Kultur von einem Gräberfeld im Kreis Merseburg in der Nähe des Ortes Rössen, und sie gehört in die frühe Jungsteinzeit, etwa um $3350 \mathrm{v}$. Chr.
} 
Die infra- und siedlungsstrukturelle Situation entspricht dem westlichen Mitteleuropa des 18./19. Jahrhunderts (eig. Aufnahme 1992).

Die Seen, gleichsam ,Wasserinseln' in der Landschaft, waren hingegen in der Regel schwerer zu erreichen; es sei denn, sie lagen eingeschaltet in einen Flusslauf oder waren ihm angeschlossen. Dann zogen sie, wie beim Beispiel des Bodensees, die Besiedlung an sich, wie der Fluss, zu dessen System sie gehörten. Gerade an ihren Ufern konnte die Kultur sich besonders entwickeln. Wo, wie in Norddeutschland, langgestreckte Seen durch Flüsse verbunden in großer Zahl vorhanden sind, bildeten auch sie die natürlichen Wege, auf denen die Erschließung des Landes vor sich ging und an denen sich die Besiedlung entwickelte (THIENEMANN 1955:146).

In Landschaften, wo die natürlichen Übernachtungsmöglichkeiten nicht zur Verfügung standen, bauten die steinzeitlichen Volksstämme im Übrigen schnell zu errichtende und nach der Benutzung verfallende einfache Wind- oder Wetterschirme, Baumrinden-Hütten oder einfache sog. Bienenkorbhütten aus Zweigen mit Blätter- oder Grasdach (NIEMEIER 1977:91) in Gewässernähe. Mesolithische Fischer und Jäger benutzten die Vegetation der Gewässer und Feuchtgebiete in vorteilhafter Weise zum Hüttenbau. Diese steinzeitlichen kuppelförmigen Hütten bestanden zumeist aus einem Gerüst aus Birkenstangen und Erlenästen und einem Fußboden aus Stämmen dieser beiden Baumarten aus der Familie der Birkengewächse, der auf den moorigen Untergrund gelegt wurde. Zum Binden der Zelte bzw. der Hütten wurden Hautriemen und Rentiersehnen verwendet, das Gerüst wurde aus Birkenstangen gefertigt, welches mit zusammengenähten Rentierfellen gedeckt war (AHRENS 1990:71). Die Eindeckung erfolgte mit frischem Schilf und Tierhäuten vom Rentier oder Hirsch (:75).

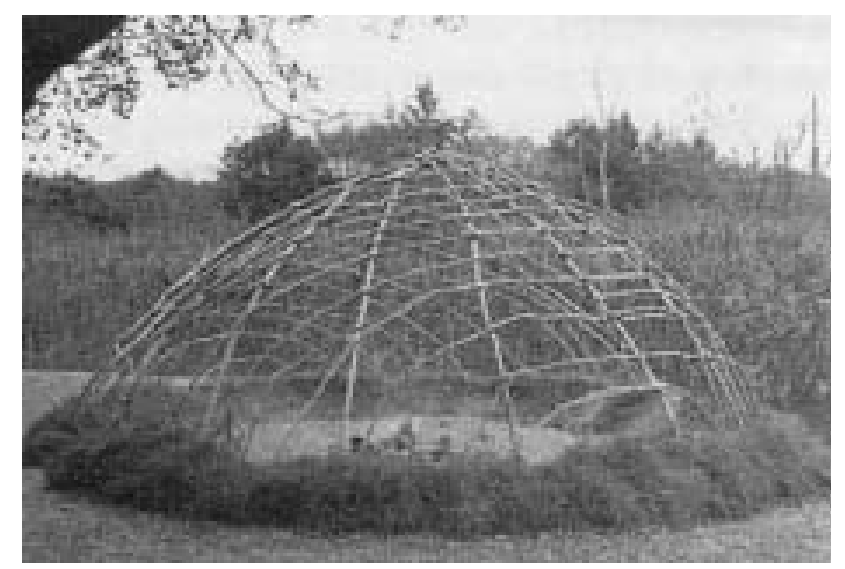

Abb. V-7: Halbfertige, kuppelförmige mesolithische Hütte. Rekonstruktion (aus: AHRENS 1990:73).

Neben der Hauptwildjagd (Wildpferd, Bison, Mammut und Ren) wurde ,auch immer wieder der Fisch auf Felswänden abgebildet“ (ERGERT 1983:206). Aufgrund dieser erhaltenen Beweisstücke kann man annehmen, dass der Fisch und sein Fang große Bedeutung für die Ernährung hatten und die Siedlungslage unmittelbar beeinflusste: „Als Nahrungsmittel sind Fische in allen Kulturen belegt. Schon in der Steinzeit wurden Fische gejagt, um unabhängig vom vorbeiziehenden Wild über eine zusätzliche Nahrungsquelle zu verfügen. Wandzeichnungen, Felsbilder, sowie Harpunen und Reste von Netzbestandteilen aus paläolithischen Siedlungen belegen diese intensiv betriebene vorgeschichtliche Fischerei“ (LAMPEN 2000:37).

Es zeigt sich aber, dass das Schuppenwild in der Kleinkunst des paläolithischen Menschen sehr viel häufiger dargestellt wurde als an Höhlenwänden. Es handelt sich dabei um verzierte und geschmückte altsteinzeitliche Knochen- und Horngeräte, dekoriert mit Fischmotiven bzw. Fisch-Themen. Eine besonders eindrucksvolle Fischdarstellung ist aus dem ,Abri du Poisson' im Tal der Vézère, einem rechten Nebenfluss der Dordogne in Südwest-Frankreich, bekannt: ein $1 \mathrm{~m}$ langes Flachrelief an der Deckenwölbung einer Steinzeithöhle, gestaltet vor 30.000 Jahren (ERGERT 1983:205). Bis in die Bronzezeit hinein ist die Fischdarstellung ein beliebtes Motiv (:209) und auch ,die ältesten bis jetzt bekannten Großplastiken - von der Wissenschaft auf 7000 bis 5000 v. Chr. datiert - haben einen engen Bezug zum Fischfang und stellen vermutlich sogar Fischgottheiten dar.“(:209) 
Der Übergang von der Altsteinzeit zur Mittelsteinzeit wird mit dem gegen 8000 v. Chr. erfolgten Wechsel von der letzten Kältephase - der Würmeiszeit - zur Nacheiszeit definiert. „Die Ausgrabungen zeigen, daß zu diesem Zeitpunkt die Steinzeitmenschen ihre natürlichen Schutzorte verlassen und die flachen Terrassen der Flüsse besiedeln oder sich mit Vorliebe direkt auf den schnell abtrocknenden Sandböden der Gewässerufer ansiedeln." (ERGERT 1983:208f.; siehe auch oben das Nordhäuser Beispiel) Dieser Ortswechsel hat seine Ursache in den klimatischen Schwankungen, die grundlegende Veränderungen in der Landschaft mit sich brachten: in wärmeren Zwischenperioden der Eiszeit, den sog. Interstadialzeiten, breitete sich der Wald aus und entzog den Renjägern die Existenzgrundlage. Die Menschen wandten sich den Seen, den Flussläufen und - in Norddeutschland - der Küste zu und betrieben neben der Jagd auf Waldtiere zunehmend auch Fischfang (OPITZ 1997:16). In der Donauterrasse ,Lepenski Vir' ${ }^{9}$ und der nach der Fundstelle benannten ,Lepenski-VirKultur' beispielsweise entdeckte man eine Fischer- und Jägersiedlung mit einer Fülle von Artefakten in genau dieser Siedlungslage, wie sie schon von anderen Fundstellen bekannt waren (ERGERT 1983:210). Die Mittlere Steinzeit, das Mesolithikum, dies lässt sich erkennen, „brachte erste Ansätze von Seßhaftigkeit, die durch die Bindung an die Gewässer gegeben war. Die Benutzung von Booten zum Fischfang mußte von festen Plätzen ausgehen.“ (OPITZ 1997:16) So wurde wahrscheinlich ein Gewässer nicht nur aufgesucht, um Fischfang zu betreiben, sondern auch beispielsweise um „bei Niedrigwasser die trocken gefallenen Strandflächen nach eßbaren Kleintieren“ abzusammeln (NIEMEIER 1977:90f.). In diesem Kontext ist auch die Siedlungslage an Flussterrassen der Täler und Sandböden der Gewässerufer zu erklären, wie oben berichtet und wie DUNIN-WASOWICZ (1990:96) bestätigt: „Historians have always agreed about the importance of river valleys and the bassins of channel-valley lakes as primary locations for settlement.“

Nach einem Beispiel von VILEISIS (1997) aus „coastal Maryland“ und „Virginia“ sind als drittes, besonders wassergebundenes ehemaliges Besiedlungsgebiet - neben den Flussuferterrassen und den Felsschutzdächern in Gewässernähe - „wetlands“ hervorzuheben: „wetlands were [...] the habitat of many Native Americans [...] before colonization“ und dies, weil „cleared river floodplains provided fertile places to grow corn even in protected clearings within heavily forested swamps. [...] Native people valued wetland for the fish, fowl, and other food supplied." (:17) Am Beispiel der Ureinwohner Amerikas zeigt VILEISIS damit auf, dass Feuchtgebiete, wie Sümpfe und Auenwälder, durchaus als Siedlungsgebiet aufgesucht wurden, um nicht nur zu jagen (v. a Wasservögel), zu fischen (u. a. auch Wasserschildkröten), sondern auch zur Ergänzung des Nahrungsmittelangebotes besondere „wetland food plants“ zu ernten, „such as wild turnips ${ }^{10}$ and water-lily tubers ${ }^{11}$." Die Erntemethoden waren dabei sehr ungewöhnliche: „Locating the roots with their feet, native women often pulled the tubers in waist-deep water. Wild rice was also a staple: [...] gathered rice by arching the tops of the rice stalks and then knocking ripe grains into the bottom of their canoes with wooden rice sticks. (...) In addition to gathering the bounty of the bogs and marshes, native peoples hunted waterfowl, fish and turtles." $(: 20)$

Bei ephemerer Siedlungsart, d. h. bei Wohnstätten, die die Natur zur Verfügung stellt, oder solchen, die bei jedem Lagerwechsel von neuem errichtet werden, bleibt jedoch ,die topographische Lage ein vergängliches Element" (SCHWARZ 1988:61). Bei Menschen, von denen keine Bauten, vor allem nicht ihre Wohnunterkünfte, erhalten geblieben sind, erschließen sich aufgrund fehlender archäologischer Fundstücke ihre prähistorischen Wohn- und Lebensmilieus leider nur unzureichend (abgesehen von ihrer Ernährung, deren Zusammensetzung durch Knochenfunde gut dokumentiert werden konnte). Ihre Bindung zum Wasser ergibt sich aber allein aus der menschlichen Notwendigkeit zur Flüssigkeitsaufnahme und daraus, dass es in mesolithischer Zeit keine technischen Möglichkeiten gab, beispielsweise des Wassertransportes auf künstlich errichteten Kanälen.

\footnotetext{
${ }^{9}$ Lepenski Vir: vorgeschichtliche Siedlungs- und Kultstätte am ,Eisernen Tor' in Jugoslawien, einem Donaudurchbruchstal zwischen den Südkarpaten und dem Ostserbischen Gebirge. Mächtige Kulturschichten enthielten bisher unbekannte Wohnund Kultbauten sowie Bestattungen der Mittel- und Jungsteinzeit. Bedeutung haben v. a. aus Flussgeröllen gefertigte Skulpturen mit fischmenschlichen Zügen, die wohl Flussgottheiten darstellen sollen.

${ }^{10}$ engl. turnip $=$ Kohl-, Steckrübe

${ }^{11}$ engl. water lily tubers $=$ Seerosen-Knollen
} 
Nimmt man die Lebensweisen der heute noch wenigen Naturvölker als ethnographisches Vorbild an, so zeigt sich jedoch, dass man sich häufig genug - insbesondere bei zeitweiligen Siedlungen - vom Wasser als Voraussetzung der Standortwahl absetzt und etwas entferntere Rastplätze aufsucht. Dafür gibt es mehrere Gründe: Zum einen können Sammler und Jäger durch das Sammeln safthaltiger Wurzeln und Früchte zumindest zeitweise auf Wasser verzichten; das Beispiel der Aborigines zeigt diese Fähigkeit in besonderer Weise. Zum anderen will man das Wild nicht verscheuchen, das sich an Wasserstellen begibt, so dass zum Beispiel Buschmänner ihre Lagerplätze immer abseits des Wassers aufsuchen.

Bei allen Lagebeziehungen, die sich heute für die Lagerplätze der Wildbeuter ergeben, wird aber zu berücksichtigen sein, dass Letztere in Gebiete abgedrängt wurden, die die Völker ursprünglich nicht als ihren Lebensraum ausgesucht haben. Die Erforschung der eigentlichen Lebensräume der Ureinwohner Australiens zeigt, dass sie nicht freiwillig die Wüstengebiete ausgesucht haben, sondern in diese verdrängt worden sind.

Hinsichtlich der Dauer ihrer Siedlungsweise zeichneten sich die einfachen Wildbeuter durch flüchtige Unterkünfte und die Siedlungen der spezialisierten Jäger, Fischer und Sammler „ebenfalls durch episodisch-temporäre Siedlungsart und vielfach [...] durch bodenvage Behausungen aus" (LIENAU 1995:184). Aber bereits in der Altsteinzeit gab es wahrscheinlich auch schon Wildbeuter, die standortgebundene Unterkünfte, das heißt, bodenstete' Behausungen errichteten. Denn es ist schwer nachvollziehbar, wie ein durch archäologische Grabungen entdecktes prähistorisches Wohnzelt mit den Möglichkeiten der späteiszeitlichen, sicher nur familiengroßen wandernden Gruppen transportiert werden konnte, auch wenn man davon ausginge, dass Transportschlitten und gezähmte Rentiere für die Beförderung aus zugefrorenem Wasserwege verfügbar waren. Immerhin wiegt ein solches Zelt von $4 \mathrm{~m}$ Durchmesser und etwa gleicher Höhe gute $170 \mathrm{~kg}$. Selbst wenn man es niedriger baut und die Felle enthaart, sind es immer noch gute $90 \mathrm{~kg}$, wie rekonstruierte Versuche ergeben haben. Und selbst wenn man die Last auf Träger verteilte, würden doch die Beweglichkeit und damit die tägliche Marschstrecke stark eingeschränkt, und „es dürfte schwierig gewesen sein, damit hunderte von Kilometern zweimal im Jahr den wandernden Rentierherden zu folgen. Möglicherweise blieben solche Zelte doch einfach stehen, um im nächsten Jahr wieder benutzt zu werden.“ (AHRENS 1990:72)

Diese Rentierjäger aus der Schlussphase des Paläolithikums waren durchaus nicht die ersten Menschen, von denen bekannt ist, dass sie Wohnbauten errichteten. Schon aus viel früherer Zeit, seit den Anfängen des Paläothikum, hat man Kenntnis von zahlreichen und recht unterschiedlichen standortgebundenen Unterkünften. Teils wurden Erdgruben ausgehoben, die z. B. mit Walrippen verstärkt wurden, teils hat es sich offenbar um Hütten oder Zelte gehandelt, bei denen mehrfach Knochen großer Säugetiere und Stoßzähne vom Mammut in irgendeiner Weise als Baumaterial dienten (AHRENS 1990:72).

Doch sowohl die rein ephemeren Lagerplätze der einfachen Wildbeuter sind geprägt durch die Lage „an einem Bach oder dessen Nähe“ auch für die Siedlungen der höheren Jäger, die eine episodischtemporäre Siedlungsart pflegen, ist kennzeichnend, dass die Lagerplätze ,in den Flußtälern oder an Seen aufgeschlagen“ wurden (SCHWARZ 1988:62). Dies belegen für die mittlere Steinzeit „die sehr zahlreichen Siedlungsplätze, die man oft [...] an ehemaligen Seeufern“ findet (AHRENS 1990:75). „Spuren und Überreste der Hütten mesolithischer Jäger und Fischer sind an einer ganzen Anzahl von meist in unmittelbarer Nähe zum Wasser gelegenen Plätzen gefunden worden.“ (:73) Beispiel dafür ist ein spätmesolithischer Fundplatz an den Rethlager Quellen bei Detmold oder am Seeburger See östlich von Göttingen.

Um wiederum die Standortverhältnisse der heute lebenden Naturvölker als Beispiel früherer Lebensweisen heranzuziehen:

Die wenigen heute noch lebenden Waldindianer des amerikanischen Nordens halten sich ebenso wie die Inlandeskimos ,in jeder Weise an die Nähe von Flüssen und Seen“ (SCHWARZ 1988:63). Mehrere Ursachen sind hierfür verantwortlich zu machen: Die Flüsse bilden im Sommer die wichtig- 
sten Verkehrsadern. Teilweise findet die Jagd vom Boot aus statt, und mit dem Boot wird die Verlagerung der Wohnplätze in dieser Jahreszeit vorgenommen. Seen und Flüsse ermöglichen zusätzlichen Fischfang, und das früher die Lebensgrundlage bildende Karibu wurde vor allem bei der Durchquerung von Flüssen und Seen gefasst. So erscheint es verständlich, dass die Lagerplätze am Rande von Fluss- und Seeufern errichtet worden sind (:63).

Auch Wildbeuter der Tropen suchen für ihre Rastplätze in den periodisch trockenen Randtropen Wasser auf - „,wenn auch zuweilen die unmittelbare Nähe der Wasserstelle gemieden wird, um die Lockung der Wildtränke nicht zu beeinträchtigen “ (NIEMEIER 1977:56).

Wo Flüsse oder Seen einen Fischreichtum begründeten, konnten sich gar steinzeitliche Fischervölker herausbilden, deren Existenz in erster Linie auf den Fischfang ausgerichtet war. Diese Fischervölker konnten unter Umständen - abweichend von der temporären Lebensweise der Jäger und Sammler bereits eine semi-permanente Siedlungsart aufbauen, da die Ernährungsgrundlage sozusagen, vor ihrer Haustür' lag (SCHWARZ 1988:35). Fischer aber benötigten die unmittelbare Nähe von großen fischreichen Gewässern und Wasserläufen zwingend, so dass sie auch feuchtes Gelände für ihre Siedlungen in Anspruch nehmen mussten. Häufig wurde aber auch eine erhebliche Entfernung zwischen Wohnplatz und Wirtschaftsfläche trotz ihrer reziproken Verknüpfung in Kauf genommen, weil der gewählte stationäre Wohnplatz Vorteile beispielsweise hinsichtlich eines trockeneren Untergrundes bot. Die mittelsteinzeitlichen Jäger und Fischer der Zeit um etwa 6000 bis 4000 v. Chr. sind, nachdem sie vielleicht einen Sommer lang direkt am Seeufer gelebt haben, anscheinend in ihre Winterbehausung umgezogen, die nur ein kurzes Stück Weges im Wald versteckt lag (AHRENS 1990:76).

Sowohl also die temporäre Sommerunterkunft der mit den Jahreszeiten wandernden kleinen Jägergruppen als auch das episodische Winterquartier wurde in Beziehung zum Gewässer ausgesucht, wenn auch die Wegentfernung des Sommer- bzw. Winterquartiers zum Fluss bzw. See differierte oder aber gar ein ganz anderes Gewässer am Winterstandort zur unmittelbaren Wasserversorgung aufgesucht wurde. Die Reste von im Schilf eines Seeufers gefundenen Einbäumen belegen neben den Siedlungsfunden diese Annahme; wie auch der Speiseplan Beweise für die Lagewahl am bzw. im Gewässer liefert: So fanden sich unter den erhaltenen Speiseabfällen eines mesolithischen Seewohnplatzes neben Knochen von Hirschen, Wildschweinen und Vögeln vor allem große Mengen von Süßfischen (AHRENS 1990:75f.).

Bei der siedlungsräumlichen Bewertung von archäologischen Grabungsplätzen und -funden muss hingegen bedacht werden, dass die klimatischen Veränderungen während und nach der letzten Eiszeit zu einer Verschiebung der Wohnplätze geführt haben. Dazu einige Beispiele von der Ostsee: Ausgrabungsbefunde von Skateholm an der Südküste Schonens, eines ehemaligen „heute am Rand einer kleiner Anhöhe, gut einen halben Kilometer von der Ostseeküste entfernt" liegenden Wohnplatzes, war vor 6000 Jahren „eine Insel in einer Bucht des Meeres und nur mit einem Boot zugänglich.“ (AHRENS 1990:76) Auch in Tingby bei Kalmar in Schweden „sah es vor 8500 Jahren erheblich anders aus als heute. Damals stand das Haus der mesolithischen Fischer- und Jägerfamilien unmittelbar an der Küste der Ostsee. [...] Im Zuge der allmählichen Hebung der ganzen skandinavischen Halbinsel verschob sich die Küstenlinie seither mehr und mehr nach Osten, so daß die Entfernung zur Ostsee heute mehr als $10 \mathrm{~km}$ beträgt.“ (:79)

Vermutlich hängt auch die Entstehung der ältesten Bauernkulturen im alten Orient außerhalb der großen Stromoasen ,damit zusammen, daß dort ein nacheiszeitlich begünstigter Naturraum bestanden hat, in dem das winterfeuchte Etesienklima, das auch die Wüstensteppen und Wüsten der Sahara eingeengt hat, weiter landein gereicht hat als heute und Regenfeldbau auch dort begünstigt hat, wo er heute nicht mehr möglich ist. Umgekehrt können Klimaänderungen mit längeren Dürreperioden Nomaden aus ihren Lebensräumen vertrieben und in Stromoasen gedrängt haben." (NIEMEIER 1977:138)

Zwischenzeitlich lässt sich festhalten: Die Siedlungsart der steinzeitlichen Wildbeuter war ephemer, episodisch-temporär oder semi-permanent und sie alle waren unmittelbar auf das angewiesen, was die 
Natur ihnen bot, waren aber vor allem an das natürliche Vorhandensein von Trinkwasser gebunden. Aber „erst wenn standfeste Wohnstätten die topographische Lage fixieren, geht letztere als ein wesentlicher Zug in die Physiognomie der Siedlungen ein“ (SCHWARZ 1988:61) und gibt darüber Aufschluss, in welcher Beziehung der Mensch zum Siedlungsfaktor ,Wassernähe' stand und in welcher Form er es genutzt und geformt hat.

Während es feste Unterkünfte, wie wir oben gesehen haben, durchaus bereits auch in der Wildbeuterstufe gegeben hat, traten feste Häuser gemeinhin erst auf, als Ackerbau und Viehhaltung und damit eine mehr oder minder dauerhafte Sesshaftigkeit die hauptsächlichen Lebensgrundlagen des Menschen waren. Dies tritt in der jüngeren Steinzeit auf, für deren Beginn nach OPITZ (1997:16) die Einführung des Ackerbaus und damit die standortgebundene Lebensweise das entscheidende Kriterium ist. Nach Ansicht des Geographen SAUER (1952) begann die Domestikation von Pflanzen in Südostasien durch fischende Völker, die erkannten, dass die Ressourcen aus Seen und Flüssen eine stabile Wirtschaft und eine sesshafte oder halbsesshafte Lebensweise begünstigten (aus: GOUDIE 1994:19). Nach herrschender Meinung hingegen begann der Wechsel vom Wildbeuter zum Bauern, die ,Neolithisierung', im vorderen Orient, und von dort aus breitete sich die ,Neolithische Revolution', wie dieser historisch höchst bedeutsame Prozess auch genannt wird, über Jahrtausende allmählich aus und erreichte über Südwesteuropa etwa im 5. Jahrtausend Mitteleuropa (AHRENS 1990:80).

Während für frühe Lager- und Rastplätze, wie zum Beispiel Felsunterstände oder Höhlen, die Wassernähe zwar gesucht wurde, aber durch die vermutliche Wechselhaftigkeit der Unterkünfte keine Siedlungskonstanz nachgewiesen werden konnte, ist man aber für die ,starre' Anlage einer Siedlung in jedem Fall „auf das Vorhandensein von Wasser angewiesen“ (SCHWARZ 1988:61), denn überall ist bei den frühen ländlichen Siedlungen der Wohnplatz mit der Wirtschaftsfläche eng verknüpft.

Um also neben Ackerbau und Viehzucht auch weiterhin oder hauptsächlich Fischfang betreiben zu können, errichteten die frühgeschichtlichen Menschen oftmals ihre Wohnplätze im Wasser bzw. im amphibischen Bereich zwischen Wasser und Land. So bauten sie einfache Pfahlbauten, die sie aus Mangel an Stangenholz aus Schilf bzw. Rohrkolben herstellten und mit Schilfblättern überdeckten, um in ihrer Nähe oder auch auf ihnen ihre Siedlungen bzw. Behausungen zu errichten.

Noch heute ist dies in Südamerika, am oberen Amazonas und in dessen Mündungsbereich, in Afrika, in den Lagunen der Oberguineaküste zu sehen, allgemein dort, „wo Schutz vor Feuchtigkeit des Untergrundes notwendig ist und [...] Fischfang eine maßgebliche Rolle im wirtschaftlichen Leben spielt" (SCHWARZ 1988:86), d. h. ,an den Seen [...] und in den der Überschwemmung ausgesetzten Zonen der größeren Flüsse" (:87).

Unter Pfahlbauten (engl. pile-dwellings, franz. palafittes) versteht man hauptsächlich aus Pfahlwerk oder mit Benutzung von solchem in Gewässern errichtete, vorübergehende oder dauernde Wohnstätten.

Es werden drei verschiedene Arten unterschieden (in Anlehnung an FRIEDEL 1884:28f.):

1. Pfahlbauten freistehend im Wasser, über das Roste errichtet wurden, die die Wohnhütten trugen.

2. Pfahlwerke, innerhalb deren Rahmen Holzlagen gehäuft waren, welche auf dem Wasser oder Morast schwimmen und je nach dem Wasserstand sich heben oder senken. Diese Bauweise wurde bei sehr schlammigem Boden, der das Eintreiben von Pfählen ver- und stark behindert, angewendet.

3. Packwerkbauten, bei welchen die Pfähle nur als äußerer oder innerer Halt für Faschinen, Stein-, Dung- und Erdschüttungen dienten, mittels welcher eine Art von künstlicher Insel, durch andauerndes Nachschütten im Lauf der Jahre gebildet wird.

Neben dem Schutz vor Bodenfeuchtigkeit und Überschwemmung boten Pfahlbauten Schutz vor Raubtieren, dienten als Fluchtsiedlung, zur einfachen Unterbringung des Kleinviehs zwischen den 
Pfählen und auch zur Linderung der Mückenplage, indem man unter dem Haus Feuer anzündete und durch Rauchentwicklung die Insekten vertrieb (PALLMANN 1866: 49ff.).

Der wahre Zweck der großen Mehrzahl der Pfahlbauten, neben der Sicherung gegen menschliche Feinde und räuberischen Tiere, war sicherlich auch der, von ihnen aus den Fischfang, sei es gewerbsmäßig, sei es wenigstens als Notbehelf, sobald der Verkehr mit dem Lande abgeschnitten war, zu betreiben (FRIEDEL 1884:29). In all diesen Seewohnungen oder Wasserburgen (engl. lakedwellings, franz. habitations lacustres) der Stein- wie der Metall-Periode wurden Fischreste gefunden, sofern das sie umgebende Gewässer ein Fischgewässer und nicht etwa lediglich ein Verteidigungsgraben oder ein fischloser Morast war (:29). Wie häufig Fische verspeist wurden beweist die Tatsache, dass in der Schweizer Pfahlbaute Robenhausen unmittelbar über dem Seekalk eine 6 bis $9 \mathrm{~cm}$ mächtige Schicht von Fischschuppen vorgefunden wurde (:30).

Doch die Nahrung setzte sich nicht nur aus Fisch zusammen. Die Gesamtmenge der in der Schweizer Pfahlbautensiedlung Robenhausen bisher aufgefundenen Wirbeltiere belief sich auf ungefähr 70 Spezies, wovon 10 auf Fische, 4 auf Reptilien, 26 auf Vögel (meist Wasservögel), die übrigen auf Säugetiere fielen. Von den Letzteren konnten etwa 6 Arten als Haustiere bezeichnet werden, nämlich Hund, Schwein, Pferd, Ziege, Schaf und wenigstens zwei Ochsenarten. Zwei Tierarten, eine wilde und eine gezähmte, waren am zahlreichsten vertreten, nämlich der Hirsch und die Kuh. Die Überreste dieser Spezies übertrafen diejenigen aller übrigen Arten zusammen (FRIEDEL 1884:31), - ein Beweis dafür, dass neben Fischfang auch Jagd und Viehzucht betrieben worden ist. Das auch Ackerbau zu den Wirtschaftsweisen der Pfahlbausiedlungen zählte, belegen die in dem Fund mehrfach vorkommenden kultivierten Gewächse: drei Weizensorten, zwei Gerste- und zwei Hirsearten, während Roggen, Hafer und Hanf fehlten. Des Weiteren ist Flachs sowohl roh als auch verarbeitet gefunden worden (:31).

$\mathrm{Da}$ nun aber aus lediglich archäologisch zu erschließenden Kulturen in der Regel nur sehr fragmentarische Erkenntnisse vorliegen, sind archäologische Rekonstruktionen, wie bereits erwähnt, immer in Zusammenhang globaler Umweltveränderungen zu sehen.

Nach heutigem Kenntnisstand glaubt man zu wissen, dass beispielsweise die bekannten jungsteinzeitlichen und bronzezeitlichen Pfahlbauten der Alpenseen weitaus überwiegend normalerweise nicht im Wasser standen, sondern im Uferbereich gestanden haben, wo es gelegentliche Überschwemmungen gegeben haben mag. Wenn ihre Reste heute unter Wasser liegen, vielerorts noch als große Felder von Pfahlstümpfen erkennbar, „so ist dafür ein Anstieg des Wasserspiegels der Seen die Ursache.“ (AHRENS 1990:12) „Da lagen“, beschreibt AHRENS (:91) die Fundsituation und -analyse, „eingebettet in Torfschichten, die scharf abgegrenzten Lehmfußböden mehrerer Häuser. Dieser Befund ist in einem Gewässer nicht denkbar, denn Torf bildet sich nicht am Seegrund, sondern weist auf ein sumpfiges Gelände hin. Vor allem aber sind erhaltene Lehmfußböden von Pfahlbauten im Wasser beim Verfall [...] gewiß nicht wie eine stabile Betonplatte abgesunken und im bewegten Wasser [...] unversehrt geblieben. Der Spiegel des Bodensees, daran führt kein Weg vorbei, muß im Neolithikum etwa 3 m niedriger gewesen sein, zumindest im Überlinger See.“

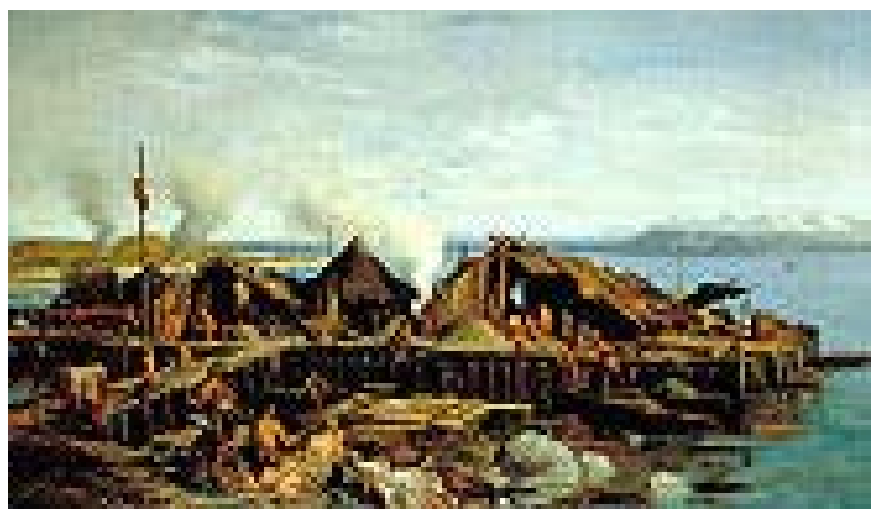

Abb. V-8: Pfahlbauer-Kolonie. „Pfahlbaudorf aus der Jungsteinzeit“ (1867) Gemälde von Auguste Bachelin (aus: SCHWEIZERISCHES LANDESMUSEUM ZÜRICH 2004) 
Die Pfahlbauten im Überlinger See sind also vielmehr ,Ufersiedlungen' im temporären Überschwemmungsbereich (AHRENS 1990:16). Diese Erkenntnis der Siedlungswahl jungsteinzeitlicher Bauern durch archäologische Grabungsfunde unterstützt auch die These, dass zwar nicht nur - doch schwerpunktmäßig - Fischfang betrieben wurde, sondern im fruchtbaren Überschwemmungsbereich hinter den Wohnplätzen Ackerbau und Viehzucht.

Neben dem bekannten Beispiel der historischen Pfahlbausiedlung des Bodensees, gibt es noch weitere, heute noch rezente Pfahlbauten im europäischen Ausland, wie die aus dem Dojransee an der Grenze zwischen Mazedonien und Griechenland. Um die Bau- und Lebensweisen heute noch existierender Pfahlbauten und deren Bewohner als historischen Vergleich heranzuziehen, sei dieses - auch aus fischereigeschichtlicher Sicht interessante - Beispiel geschildert:

Der älteste Bericht über die Pfahlbauten im Dojransee findet sich in den Historien des bekannten griechischen Geschichtsschreibers Herodot (484 - 422 v. Chr.) aus Halikarnassos. Er schreibt:

\begin{abstract}
„Mitten in dem See befinden sich [...] hölzerne Gerüste aufhohen Pfählen, die vom Land aus nur über eine einzige schmale Brücke zugänglich sind. Die Pfähle unter den Gerüsten wurden in älterer Zeit von der ganzen Gemeinde aufgestellt. [...] Auf dem Gerüst hat nun jeder seine eigene Hütte, in der er wohnt und aus der eine Falltür durch das Gerüst in den See hinunterführt. Die kleinen Kinder binden sie am Fuße mit einem Seil fest, damit sie nicht ins Wasser fallen. Ihre Pferde und ihr Vieh füttern sie mit Fischen, die es dort in solcher Menge gibt, daß, wenn man durch die Falltür einen leeren Korb an einem Strick ins Wasser läßt und ihn nach kurzer Zeit wieder heraufzieht, der Korb voller Fische ist.“ (zit. aus KOENIG 1983:67).
\end{abstract}

Die von Herodot für den Dojransee erwähnten Pfahlbauten haben wahrscheinlich sehr ähnlich ausgesehen wie die erhaltenen Pfahlbauhütten (KOENIG 1983:70). Sie bestehen aus groben unbehauenen Holzstämmen, Ästen, Matten und Bindeseilen aus Schilf. Der Hüttengrundriss misst etwa 2,5 x 2,5 m. Vor dem Eingang befindet sich, vom überragenden Dach geschützt, eine Plattform. Auf ihr kann auch gekocht werden. Über eine Leiter steigt man vom Boot in die Hütte bzw. erforderlichenfalls auf das Dach.

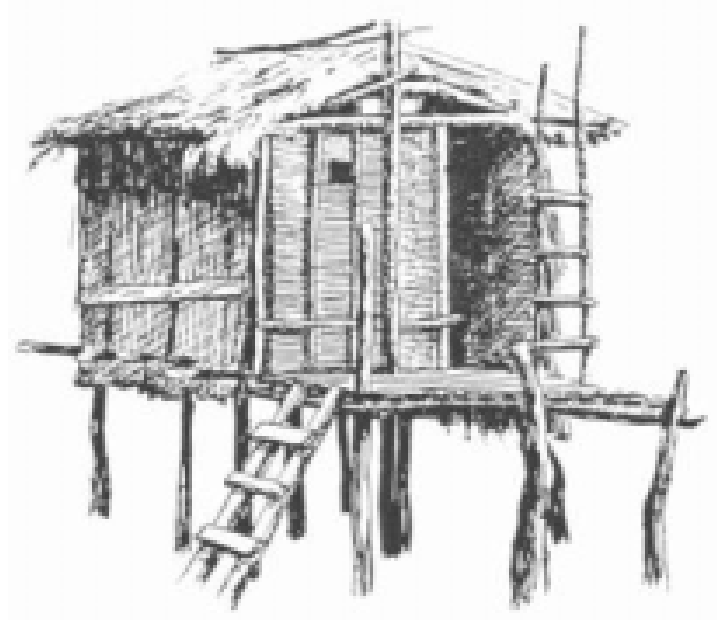

Abb. V-9: Pfahlbauhütte

(aus: KOENIG 1983:70).

Der Dojransee ,gilt als fischreichster See Europas und dient erstaunlich großen Vogelscharen als nahrungsreiches Überwinterungsquartier. [...] Der Fischreichtum des Sees ist sicherlich nicht nur Ursache, sondern gleichzeitig auch Folge der Vogelansammlungen, da der Vogelkot die Entwicklung von Kleinkrebsen sehr fördert, die wiederum ein ideales Jungfischfutter darstellen." (KOENIG 1983:67) Während der kalten Jahreszeit ziehen deshalb große Mengen von Fischen, namentlich verschiedene Weißfische und Barsche, in die Rohrwälder des Dojran. Da die fischenden Vögel nun 
aber am liebsten gegen den Wind von Süden nach Norden hinauf schwimmen, treiben sie die Fische noch zusätzlich mehr und mehr in die Schilfzonen des Sees hinein.

Diese bioökologischen Gegebenheiten, das Verhalten zwischen Fisch und sich vom Fisch ernährenden Seevogel als Folge der Nahrungskette, „haben sich die Fischer am See offensichtlich schon vor zwei Jahrtausenden zunutze gemacht“ (KOENIG 1983:68) und das ,Vogelfischen' als Methode zum Fischfang eingesetzt: Sie stellten sehr große, gegen den See hin vorerst offene viereckige Abzäunungen aus dicht geflochtenen Schilfmatten, sogenannte ,Mandri' in den Rohrwald (Abb. V10). Darinnen stauten sich nun die einziehenden Fische, da sie hier nicht weiterschwimmen können. Schiene den Fischern die Mandris reichlich voll, so schlossen sie die bislang offene Seeseite und hatten die Fische nun im Gehege. Dieses Eintreiben und Einpferchen von Wildtieren zählt zu den ältesten Fang- und Jagdtechniken der Menschheit überhaupt und ist bereits aus der älteren Steinzeit nachgewiesen.“ (:68) Am Dojransee hat man die eben diese Methode nur in das Wasser verlegt.

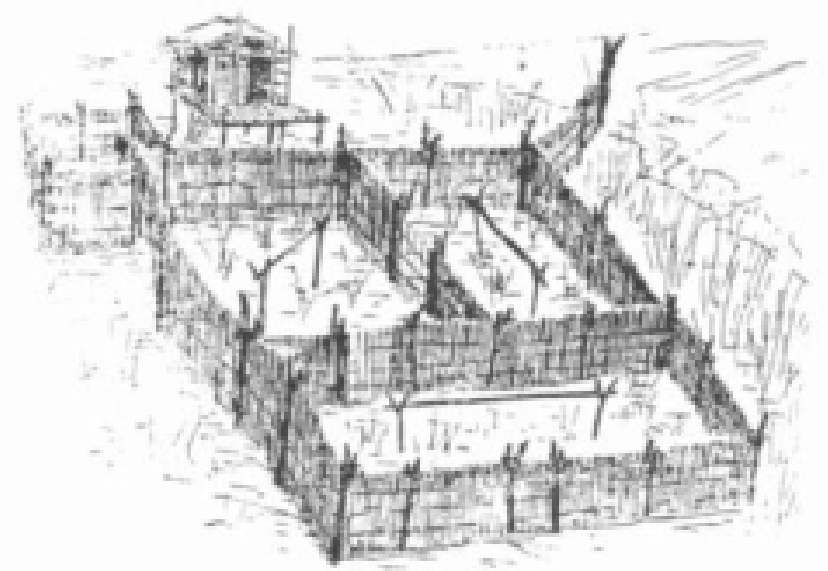

Abb. V-10: Schematische Darstellung eines Fangplatzes (KOENIG 1983:68).

Während des Wochen dauernden Zeitraumes des Vogelfischens waren die Pfahlbauhütten nur periodisch bewohnt und im Bedarfsfall mit je einem Fischer besetzt, der von hier aus die anderen fischfressenden ,Wildvögel' mit einer Steinschleuder auf Distanz hielt, d. h. nicht tötete, sondern nur zum Abfliegen bewegte. Die Hütten blieben während der Einzugsperiode auch nachts besetzt. Dieses ,Hüten' der Fangzäune begann Ende Oktober und endete erst nach Wochen, wenn genügend Fische darinnen stande. Nach dem Winterfischfang gab es dann noch einen die laichenden Fische betreffenden Frühjahrsfang, doch wurde die gesamte Arbeit spätestens im April eingestellt, weil sich dann die Uferregionen zu sehr erwärmten und die Fische in tiefere Wasserschichten ausweichten (KOENIG 1983:70f.).

Um sich die Lagegunst zwischen Wasser und Land stehender Siedlungsformen zu verschaffen, haben die bronzezeitlichen Bauern neben den am bzw. im Wasser stehenden Pfahlbauten künstliche ,Wurten' aufgetürmt:

Charakteristisch für diese Art künstlicher prähistorischer Aufschüttungssiedlungen in wasserreicher Umgebung sind die Rundhäuser auf den Britischen Inseln aus dem 7. Jh. v. Chr. Eine Form dieser Ringsiedlungen in manchen der irländischen Seen, „crannogs“ genannt, werden als „künstliche Wasserburgen“ beschrieben (FRIEDEL 1884:34). Sie ähneln den Schweizer Pfahlbauten der geschilderten dritten Art, den sog. Packwerkbauten, sind aber insofern unterschiedlich, als sie rings von eingerammten Bäumen umgeben werden (:34). Nach WILDE, der im Jahr 1836 zuerst in den ,Proceedings of the Royal Irish Academy' diese Wohnstätten beschrieb, bedeutet ,crannog' so viel wie Holzinsel, ,wobei dahingestellt bleibt, ob jene Holzpfähle oder die Holzhütten der Inseln gemeint sind.“(FRIEDEL 1884:34)

Ein ,crannog' besteht also aus einem palisadenumgebenen Hofplatz, der auf einer künstlichen Insel, meistens in einem See oder in sumpfiger, unzugänglicher Umgebung, errichtet wurde. Für eine solche 
künstliche Insel wurde zunächst eine Packung grober Steine auf den Grund des Sees versenkt, auf der dann Reisig, große Äste, alte Holzplanken und sonstige gebrauchte Holzteile, gelegentlich auch Bootsplanken, aufgeschichtet wurden. Das ganz sicherte man durch bis in den Seegrund getriebene Pfähle und bedeckte es zum Schluss mit Sand und Erde, um auf der so geschaffenen Plattform die Gebäude des Gehöftes errichten zu können (AHRENS 1990:120).

Frühere Forschungen gingen davon aus, dass ein crannog ,als Kern immer eine natürliche Insel“ besaß. Diese natürlichen Inseln sind dann durch Steinpackungen und Eichenstämme allmählich aufgehöht worden (FRIEDEL 1884:34). Nach meiner Auffassung kommen beide Entstehungsvarianten in Betracht. War eine natürliche Insel vorhanden, wurde diese allmählich erhöht, ansonsten musste der schwierige bzw. zeitaufwendigere Weg der vollständigen künstlichen Aufschüttung gegangen werden. Der Crannog-Kern jedenfalls war wenigstens bei Flachwasser immer sichtbar und enthielt neben vielen Säugetierresten auch Fischreste (:34).

Der größere Teil der Crannogs gehört wohl der Bronzezeit an und diente als Zufluchtsstätten, von denen aus gelegentlich Fischfang betrieben wurde (FRIEDEL 1884:34). Und einige, so besagen frühe Forschungsberichte zu Ende des 19.Jh., waren „,noch im 17. Jahrhundert unserer Zeitrechnung bewohnt.“(:34).

Weitere Wurten, die zu einem Vergleich mit den eigentlichen Pfahlbauten der Bronzezeit einladen und von manchen Forschern als Wohnstätten von Fischerstämmen angesehen werden, für andere wiederum eine alte Kulturstätte mit auf Pfählen errichteten Hütten andeutet (FRIEDEL 1884:35), sind die sog. „Terramare“ Mittelitaliens. Als Terramare-Gebiet wird die Region zwischen zwischen Parma, Reggio und Modena seitens des Po und seiner südlichen Zuflüsse bezeichnet (:35).

Unter einer Terramara (wörtlich: „fette Erde“) versteht man eine leichte Erhebung über dem Boden (FRIEDEL 1884:35). Es sind Wasserburgen oder Sumpfansiedlungen, die im ehemaligen Sumpfwasser auf Pfählen stehen, die aus Ulmen und Eichen bestehen. Die sumpfig-wässrige Lage kann dabei natürlicher Art sein oder aber auch bewusst geschaffen worden sein, denn ein Teil der Terramare ist ,in ehemaligen theils natürlichen, theils künstlich angelegten oder umgestalteten Wasserbecken, die zum Theil noch jetzt sumpfig sind, angelegt" (:35). Die gewaltigen Überschwemmungen, welchen das Terramare-Gebiet seit alters her bis in die Gegenwart asgesetzt sind, scheinen die Anlegung von Pfahlbauten begünstigt zu haben (:35).

Sicher ist bei der Betrachtung der räumlichen Situation in Abhängigkeit vom Gewässerbezug nur, dass bei überwiegend permanenter Siedlungsart und sobald der Landbau einen Teil der Existenzgrundlage ausmacht, die Verhältnisse komplizierter werden als bisher. Nur ,wenn dem Fischfang neben dem Anbau besondere Bedeutung zukommt", wird „dann durch ihn die topographische Lage bestimmt" (SCHWARZ 1988:66) und die Eigenart der Lageverhältnisse verständlich.

Bei der Loslösung vom Fischfang als primärer bzw. unverzichtbarer Nahrungsquelle werden andere Topographien für die Siedlungswahl bevorzugt, auch wenn hier, wenn auch nicht so unmittelbar wie beim Pfahlbau, der Gewässerbezug erhalten bleibt.

Mit der Tendenz und der naturräumlichen Möglichkeit zur Ausbildung permanenter Siedlungen stieg gleichzeitig auch das Schutzbedürfnis, da dauerhafte Wohnplätze allein bedingt durch ihre Siedlungskonstanz größeren Angriffen ausgesetzt war. Es wurden deshalb topographische Lageverhältnisse aufgesucht, die das Bedürfnis nach Sicherheit widerspiegeln. Interessanterweise sind typische ,Schutzlagen' gleichzeitig häufig solche Bereiche „stark gekrümmter Flußmäander“ (SCHWARZ 1988:67) oder liegen auf Inseln innerhalb des Flusslaufes, wo sowohl der Sicherheits- als auch der Versorgungsaspekt gewährleistet werden kann. Diese Inseldörfer pflegten mit dem Flussufer durch einen Steg verbunden zu sein, dessen Balken nachts entfernt werden konnte, so dass der Übergang gesperrt war (JAEGER 1933:109). Bei ebenerdiger Lage wurde also „der wasserständigen Lage der Vorzug gegeben“ (SCHWARZ 1988:392) und durch Umfassung mit natürlichen Wasserläufen ein gewisser Schutzstatus erreicht (:394). Dennoch wurde manchmal die Notwendigkeit des Schutzes vielfach höher bewertet als die essenziellen Belange, so dass aus diesem Grunde mitunter sogar 
Schwierigkeiten bei der Wasserversorgung dadurch entstanden, dass der freie Zugang zum Wasser durch Schutz bietende Barrieren verhindert war (:67). Seitdem Menschen sesshaft wurden, hob man deshalb zu diesem Zweck Brunnenschächte aus und kleidete deren Wände mit verschiedenen Materialien aus (TÖLLE-KASTENBEIN 1990:28).

Zusammenfassend lässt sich feststellen: Bis zum Ende der Steinzeit warden Gewässer als Fischgründe, zur Versorgung mit Trinkwasser und als natürliche Schutzlage der Wohnplätze ausgesucht. Gestaltende anthropogene Eingriffe in die Gewässerstruktur wurden, soweit bekannt, dabei nicht - und wenn, dann ohne schwerwiegende bauliche Hinterlassenschaften - durchführt. Die Gewässerlandschaft präsentierte sich demnach, so können wir annehmen, in ihrer weitgehend ursprünglichen Form, und die Siedlungswahl orientierte sich an den Vorgaben des Naturraumes. Die Nachzeichnung der ,Siedlungs-Urlandschaft' beschreibt eine vom ersten Menschen noch nahezu unberührte Gewässerlandschaft vor ihren ersten nachhaltigen anthropogenen Eingriffen.

\section{d.2 Frühe Hochkulturen}

Die frühen Hochkulturen ${ }^{12}$, die ersten permanenten Ursiedlungen und Städte, entstanden in unmittelbarer Nähe des Wassers, an den großen alluvialen Flüssen Vorderasiens, den großen Strömen Hoangho ${ }^{13}$, Indus, Euphrat/Tigris und Nil (SELBMANN 1995:7; SCHÖN 1999:147). Und nicht zufällig entstanden sie dort. Denn während sich als Folge von Erwärmung und Klimastabilisierung ab ca. 8000 v. Chr. in Mitteleuropa ein geschlossener Waldmantel entwickelte, trockneten im Raum der antiken Hochkulturen weite Gebiete aus. Der Vormarsch der Wüste schränkte die Lebensmöglichkeiten der Menschen immer mehr ein und zwang schließlich zur Abwanderung in bisher gemiedene Dschungelsumpfgebiete der Flussauen, welche durch die Wasserzufuhr aus den Quellgebieten noch ausreichend bewässert wurden. In dieser unwirklichen Gewässerurlandschaft wurden die Menschen sesshaft und entwickelten die bäuerliche Lebensweise, eine Entwicklung, die in Mitteleuropa ohne den Zwang zur Besiedlung engster, extremster Räume erst ca. 4000 Jahre später einsetzte (NIEMEYERLÜLLWITZ/ZUCCHI 1985:89).

Talauen sind besonders fruchtbar. Wegen ihres feinkörnigen, leicht pflügbaren Bodens und der Möglichkeit der Bewässerung wurden sie bevorzugt für den Bodenanbau genutzt. Für die Besiedlung wurden vor allem die Terrassenränder sowie inselartige Erhebungen genutzt, da die niedrigen Bereiche von Überschwemmungen bedroht waren (ZANGER 1999:455). Flüsse können also ,als Ursache für Entstehung von Seßhaftigkeit und Urbanismus“ gelten (SCHÖN 1999:147). Als Beispiel sei das alte Jericho unweit des Jordan genannt (siehe unten). Ähnliche Siedlungen entwickelten sich - wie oben bereits angeführt - um 4000 v. Chr. in den Tälern des Tigris und Euphrat und am Nil in Afrika. Dies gilt auch fernere Kulturen, wie die Täler des Indus (um 2500 v. Chr.), des Ganges (um 1000 v. Chr.), des Gelben Flusses und des Jangtse (um 3000 v. Chr.) sowie für die Einzugsgebiete der in den Aralsee mündenden Flüsse Syr-darja ${ }^{14}$ und Amu-darja ${ }^{15}$ (um 300 v. Chr.). „Gemeinsam sind diesen Flüssen

\footnotetext{
${ }^{12}$ Hochkultur bedeutet die Schaffung von Staatswesen und ein Wesenmerkmal staatlicher Einheiten sind die Städte. Eine Stadt-Land-Wirtschaft bildet sich heraus, um das anzubieten, was die jeweilige anautarke Wirtschaft aufgrund gestiegener Lebensansprüche nicht herstellen kann. Mit der Differenzierung im gesellschaftlichen Aufbau eines Volkes bilden sich Bevölkerungsgruppen heraus, deren Lebensbedürfnisse Handel und Gewerbe benötigen. Die dazu notwendigen Erzeugnisse oder Rohstoffe versucht man durch Einfuhr bzw. durch Handel zu erwerben, wenn die eigene Umgebung versagt. Damit ergibt sich eine Verdichtung der ländlichen Siedlungen. Die Lagegunst ist dabei von entscheidender Bedeutung (SCHWARZ 1988:44).

${ }^{13}$ Hoangho [chines. Hwangho, Huangho, in lat. Buchstaben Huang he: „Gelber Fluss“"]: zweitlängster Fluss Chinas, 4875 km lang, entspringt im Hochland von Tibet und strömt in großen Windungen am Südrand der Gobi und um das Ordos-Plateau herum in die Nordchinesische Ebene und mündet in das Gelbe Meer. Die gelbe Farbe rührt von den Sinkstoffen her, die der Hoangho auf seinem Lauf durch die Lößprovinzen Kansu, Shensi und Shansi aufnimmt (jährlich fast $1 \mathrm{Mrd}^{3} \mathrm{~m}^{3}$ ) und im Unterlauf ablagert. Dadurch liegt der eingedeichte Fluss stellenweise bis zu $10 \mathrm{~m}$ über dem benachbarten Land und hat wiederholt sein Umland verheerend überschwemmt und seinen Lauf häufig verlegt. Im Hoangho-Bogen liegt die Wiege der chinesischen Kultur, die durch die besonderen Probleme dieses ,Sorgenflusses' seit jeher vom Wasserbau geprägt war (,hydraulische Kultur").

14 Syr-Darja [im Altertum ,Iaxartes']: Strom in Mittelasien mit einer Länge von 2212 km: Der Syr-Darja entsteht im Ferganabecken aus den Quellflüssen Naryn und Kara-Darja und mündet, nur im Unterlauf an Kalsalinsk schiffbar, in einem Delta in den Aralsee.
} 
ausgedehnte Schwemmgebiete, die der jährlichen Überflutung unterlagen, was zu mächtigen Sedimentablagerungen führte.“ (SCHÖN 1999:147) „Für die am Fluß und durch den Fluß in einer sonst eher lebensfeindlichen Umgebung entstandenen Zivilisationen“ aber war der Fluss „der Lebensnerv an sich.“ (SCHÖN 1999:147). Und so begründet sich auch der Aufstieg und Fall der einseitig von Flüssen und damit von der Verfügbarkeit von Wasser abhängigen Hochkulturen. SCHÖN (:147) spricht hier von „flußabhängigen Hochkulturen“.

Die extremen Klimaschwankungen und der damit verbundene starke Wechsel in der Wasserführung der Flüsse erforderten die Entwicklung großräumiger Be- und Entwässerungssysteme, mit zahllosen Kanälen, Gräben, Deichen, Stauanlagen usw. Solche ,Bewässerungskulturen' entstanden in dieser Zeit an den genannten Flüssen Nil, Euphrat, Tigris, Jordan und Indus. In diesen „Flussländern“ Mesopotamiens, Ägyptens, Indiens und China war die Notwendigkeit zur möglichst einheitlichen Organisation und Verwaltung dieser hochkomplizierten Be- und Entwässerungssysteme der primär veranlassende und erhaltende Faktor für staatlich organisierte Hochkulturen (NIEMEYERLÜLLWITZ/ZUCCHI 1985:89). Die Einführung von Bewässerungsanlagen und die Ausdehnung von Bewässerungssystemen sowie der Wasserhaltung ist - neben der Erfindung des Hackpflugs - mit der Verbreitung einer siedlungspermanenten Wirtschaftskultur unmittelbar verbunden. Die Ausbildung der ältesten Hochkulturen jedoch ist erst ,im Zusammenhang mit der Organisation der Bewässerungswirtschaft entstanden“"(SCHWARZ 1988:43).

Als Beispiel der frühen Stadtentstehung, bedingt durch natürliches Wasservorkommen und der technischen Möglichkeit der künstlichen Wasserhaltung, kann die Orientstadt Jericho angeführt werden. Nahe Jericho, am Westrand des Jordanfluss-Tales, wurde bei einer reichen Karstquelle und unweit des Jordan die derzeit als älteste stadtartig befestigte Siedlung der Erde (um 8000 v. Chr.) geltende Ansiedlung ergraben (SCHÖN 1999:147). Innerhalb der ältesten Stadtmauer, die eine Gruppensiedlung mit einer auf 2000 bis 3000 Einwohner geschätzten Bevölkerung umschließt, wurden große Wasserspeicher gefunden, die in das präkeramische Neolithikum des 8 . bis ersten Drittels des 9. Jt. v. Chr. (nach Radiokarbondatierungen) eingeordnet werden konnten (NIEMEIER 1977:137). Durch von Bau von Kanälen konnte das Wasser aus den Wasserspeichern für die Be- und Entwässerung benutzt und Trockenperioden somit überbrückt werden.

Freilich muss aber auch ,ausdrücklich betont werden, daß nicht immer eine Wiege der Zivilisation mit Flüssen in Verbindung gebracht werden muß. So entstanden komplizierte städtische Systeme in Mexiko, Peru, aber auch im östlichen Mittelmeer (von 2000 v. Chr. an) an Stellen, die keine unmittelbare Abhängigkeit von den Ressourcen von Flüssen besaßen.“(SCHÖN 1999:147).

Die altamerikanischen nicht-potamogenen Kulturen als herrschaftlich organisierte Agrargesellschaften weisen Bauten und Einrichtungen der Wasserhaltung und Wasserführung auf, die die Wasserarmut bzw. Wasserferne egalisieren sollten: auf der Halbinsel Yucatán das Maya-Reich (ca. 4. - 12. Jh.), im Hochland von Mexiko die Reiche der Tolteken/Azteken (ca. 1000-1500), in den Anden zwischen $10^{\circ}$ n. Br. und $36^{\circ} \mathrm{s}$. Br. der Priesterstaat der Inkas (ca. 12. - 16.Jh.). Es sind auch dies frühe Wasserbaukulturen, die mit künstlichen Wasserbauten Bewässerungsfeldbau betrieben und Lageungunst durch künstlich erstellte Gewässer bzw. Gewässersammelbecken wettgemacht haben. Wegen ihrer schnellen und frühen Auswirkungen auf die Umwelt war die Einführung der (Terrassen-) Bewässerung eine höchst wichtige Entwicklung in der Landwirtschaft. Dies geschah um einiges später als die Domestikation. „Einer der ersten Belege für künstliche Bewässerung befindet sich auf dem Zepterkopf des ägyptischen Skorpionskönigs, eines der letzten prädynastischen Könige, der auf der etwa 5050 Jahre alten Darstellung [...] zeremoniell einen Bewässerungsgraben aussticht. Möglicherweise begann die künstliche Bewässerung im Irak sogar noch früher.“(GOUDIE 1994:22)

Störungen dieser ,Bewässerungskultur' mussten dementsprechend tiefgreifende Auswirkungen haben, und tatsächlich kann der Niedergang mancher Hochkulturen in Zusammenhang mit solchen Störungen

\footnotetext{
${ }^{15}$ Amu-Darja [arab. Jaihun, in der Antike ,Oxus']: der wasserreichste Fluß in Mittelasien (Russland). Ensteht durch die Flüsse ,Pjandsch' und ,Wachsch' und mündet in den Aralsee. Von den Quellflüssen des Pjandsch im südlichen Pamir (,Wachan-Darja' und ,Pamir-Darja') ist er $2540 \mathrm{~km}$ lang.
} 
gebracht werden. Hier hat sich insbesondere der mit der Ausdehnung der übervölkerten Siedlungsgebiete und zunehmende Holzbedarf für den mit Haus- und Schiffbau verbundene Raubbau an den Waldgebieten in den Einzugsgebieten der Flüsse negativ ausgewirkt (NIEMEYERLÜLLWITZ/ZUCCHI 1985:88f.). Die Kulturen hatten zwar mit komplizierten Wasserbauanlagen die Wassermassen in den Niederungen gebändigt, aber die Bedeutung großer Wälder für eine geregelte Wasserführung nicht erkannt. Rodungen und Landbebauung infolge der Besiedlung von Gewässerlandschaften brachten aber in diesen Gebieten keinen Erfolg, sondern weitere Probleme. Der Raubbau an den Wäldern entzog den Flüssen für den größten Teil des Jahres erhebliche Wassermengen, welche sich demgegenüber in der Regenzeit umso massiver über die Ebene ergießen konnten. Störungen in der Wasserführung mit längeren Trockenzeiten und größeren Überschwemmungen waren nach HORNSMANN (1956) mitverantwortlich für den Niedergang der mesopotamischen Hochkulturen, während z. B. Altägypten kaum davon betroffen wurde, da die Wassereinzugsgebiete des Nil (abessinische und ugandische Wälder) ökologisch intakt blieben (NIEMEYER-LÜLLWITZ/ZUCCHI 1985:89). Auch der Untergang des mesoamerikanischen MayaReiches wird nach neuesten Forschungen mit Wassermangel begründet. Eine mehrjährige, $6-8$ Jahre währende, Trockenzeit konnte dieses Hochgebirgsvolk mit seinen gespeicherten Wasserreserven nicht überdauern, und sie bereitete einem ganzen Staat den Untergang (WNA 2003). So wurde Teotihuacán/ Mexiko, etwa im 2. Jh. v. Chr. gegründet und - um 600 n. Chr. mit 150.000 Einwohnern zu diesem Zeitpunkt weltweit die sechstgrößte Stadt - um 700 aufgegeben. Wie bedeutsam Wasser für die Inkaund Mayakulturen waren, ist an ihrer Religion abzulesen: Zwei Götter standen im Zentrum des Kults von Teotihuacán: der Sturm- oder Regengott und die ,Große Göttin', von der man Wasser und Fruchtbarkeit des Bodens erflehte. „Beide Götter verweisen auf die elementare Bedeutung des Wassers für die Bewohner Teotihuacáns, und vermutlich trug sein Ausbleiben zum Niedergang der Stadt bei.“(BROCKHAUS 2002)

Neben dem klimatisch bedingten Umzug an die Flüsse und der Bewässerungswirtschaft bildeten sich Ansatzpunkte protourbaner Siedlungen und Ursprünge des Städtewesens, ,an den Flüssen als Verkehrsadern“ (SCHWARZ 1988:44) auf der Grundlage des Fernhandels aus. Der römische Agronom Cato („De agricultura“) stellte an einen solchen Standort folgende Anforderungen: „Es soll genug Arbeitskräfte geben, gutes Trinkwasser, und eine prosperierende Stadt soll in der Nähe sein, möglichst auch das Meer oder ein Flu $\beta$, auf dem Schiffe fahren, oder eine vielbefahrene Straße“ (SCHNEIDER 1992:130).

Schon während des 3. Jahrtausends v. Chr. verfügten die Zivilisationszentren in Ägypten und Mesopotamien über leistungsfähige Schiffe, mit denen auf großen Flüssen Güter in beträchtlichem Umfang transportiert wurden (SCHNEIDER 1992:140). In der Antike waren selbst in den großen Binnenräumen Galliens die Flüsse für den Güteraustausch und das Wachstum der Städte wichtiger als die Straßen (:171). Lediglich auf schwierigen Wegen, wie beispielsweise beim Überqueren eines Gebirges, blieben Esel und Maultiere für das antike Transportwesen unentbehrlich (:133).

Sieht man von Stromschnellen und dergleichen einmal ab, so waren im Altertum aber nur die großen Ströme über mehrere hundert Kilometer ganzjährig schiffbar. Es handelte sich um die Rhone, den Rhein, die Donau, den Nil und den Euphrat, wobei die beiden letzten am weitaus stärksten frequentiert wurden. Der Tigris eignete sich wegen seiner reißenden Strömung nicht für die Schifffahrt, und der Indus war nur auf einigen Abschnitten schiffbar (WARNECKE 1999:443).

Befördert wurden zu Schiff neben Getreide auch große Mengen von Wein und Öl, aber auch Keramik und Glasgefäße wurden transportiert und dies sowohl als Fertigprodukte als auch als Rohstoffe und Halbfertigprodukte (SCHNEIDER 1992:143). Generell bestanden Schiffsladungen normalerweise nicht aus schnell verderblichen Gütern (:141) und es handelte sich hauptsächlich um Massengüter wie z. B. Agrarprodukte, Wein und Öl (Olivenöl als Nahrungsmittel und als Brennstoff für die Beleuchtung), die auf schiffbaren Flüssen befördert wurden.

Auch der der Transport von großen und schweren Werkblöcken, wie zum Beispiel Granit- und Sandsteinquadern aus Steinbrüchen, wurde bereits in antiker Zeit auf Flüssen wie dem Nil durchgeführt. Nachdem ein bis zu $30 \mathrm{~m}$ langer Obelisk an Ort und Stelle geglättet und mit Steinen und 
Schleifpulver (Quarzsand) poliert worden war, wurde er auf einer Transportrampe bis zur Verladestelle am Nil gezogen. Eine solche ,ausgefütterte Sandbahn' wurde aus getrockneten Nilschlammziegeln und Holzbohlen aus Palmstämmen hergestellt, ein Belag aus Nilschlamm erhöhte dabei die Gleitfähigkeit der Rampe. Des Weiteren wurde vor die Kufen des Transportschlittens ständig Wasser in den Sand gegossen, um bessere Gleitfähigkeit zu erreichen und zu hohe Reibungshitze zu vermeiden. Von dort wurde er auf Spezialschiffen nilabwärts zum Bestimmungsort, in diesem Fall zu den Tempeln in Luxor und Karnak (altes Theben), gebracht (KLEMM 1982:65ff.).

Für den Warenumschlag waren Verlademöglichkeiten notwendig. So sind als Vorläufer des heutigen Hafens Karachi in Westpakistan im Deltamündungsgebiet des Indus sieben Hafenorte seit der Zeit Alexanders d. Gr. (325 v. Chr.) festgestellt worden. Sie zeigen als wesentliche Ursache ihres Unterganges als Hafenorte die ständigen Veränderungen der Flussarme und ihrer Schiffbarkeit im Deltagebiet, das im Bereich des heutigen Stromlaufs seit 325 v. Chr. um rund $75 \mathrm{~km}$ ins Meer vorgewachsen ist (WILHELMY 1968, aus: NIEMEIER 1977:165). Ein weiteres archäologisch fundiertes Beispiel bietet die 1999 gefundene Hafenstadt Histria, die in der Antike an der thrakischen Küste am Schwarzen Meer und an der Flussmündung der Donau lag. Heute befindet sich die antike Siedlung an einer seichten Bucht am Sinoë-See. Seit der Spätantike war der Wasserspiegel so sehr angestiegen, dass Histria heute direkt am Wasser liegt. Auch wurde die antike Geländeoberfläche durch stetige Sandablagerungen so sehr verändert, dass kein Hafengelände mehr erkennbar ist (ZEELAND 2001).

Neben verkehrsgeographischen Gründen spielte bei der Anlage von frühen Städten auch die „fortifikatorische Bedeutung von Flüssen“ eine Rolle (SCHÖN 1999:149). Um beiden Kriterien zu genügen, siedelten schon die Griechen an Flussgabelungen (Delphi, Theben [Euphrat/Tigris], Sparta, Larissa, Sardes). Einen noch besseren Schutz genossen Städte an Flussschlingen (Orchomenos, Magnesia am Meander).

Während zuvor die Gründe für die Ansiedlung und Ausbildung von Hochkulturen an Gewässern dargestellt wurden, so lässt sich die zunehmende Konzentration von Siedlung und Bevölkerung auf engem Raum entlang von Flüssen, Küsten und anderen Gewässern aber nicht allein durch den Bau von Bewässerungsanlagen, als Ergebnis der Benutzbarkeit als Transportweg oder aus Sicherheitsbestrebungen zu erklären, sondern durch die Möglichkeit der Wasseraufspannung zum Zwecke der Bevorratung von Wasserreserven vor Ort. „Mit dem Seßhaftwerden des Menschen und dem dadurch lokal erhöhten Bedarf an Trinkwasser und Bewässerungswasser wurde insbesondere in den ariden und halbariden Gebieten eine Speicherung von Wasser erforderlich." (DVWK 1991:Umschlagseite). Die Speicherung von Wasser zunächst in Gefäßen und Zisternen und nachfolgend durch Dämme und Staubecken erfolgte bereits in vorgeschichtlicher Zeit. Die Anfänge des Talsperrenbaus mit Staudämmen und Staumauern zur Wasserversorgung sind aus dichter besiedelten Regionen der alten Welt mit jahreszeitlich stark schwankenden Wasserangebot, in denen Zisternen für die Versorgung der Bevölkerung nicht mehr ausreichten, seit mehr als 5000 Jahren bekannt (ALBRECHT 1999c:595; GOUDIE 1994:199). Zur Schaffung einer solchen „verläßlichen Wasserversorgung" (GOUDIE 1994:199) waren dabei erhebliche Eingriffe in das Gewässer durch Flussumleitungen und Flussausbauten notwendig (ALBRECHT 1999c:597).

Der wohl älteste Staudamm der Welt befindet sich rund $12 \mathrm{~km}$ südöstlich von Helwan im Wadi Gerauwi, $20 \mathrm{~km}$ südlich von Kairo. Nach Größe und Form der Dammblöcke sowie nach bautechnischen Details datieren ihn die Forscher auf etwa 2600 v. Chr. Der Staudamm wurde erstmals von dem deutschen Naturforscher Georg SCHWEINFURTH beschrieben, der ihn auf seinen naturkundlichen Wanderungen durch Ägypten 1894 entdeckte (KLEMM 1982:71). Der Damm schließt ein tief eingeschnittenes Wadi, das als Mündungsrinne zahlloser Nebenwadis anzusehen ist, ab. Er misst in seiner Kammlänge rund $115 \mathrm{~m}$, die durchschnittliche Höhe beträgt $12 \mathrm{~m}$, die Tiefe des Dammes beträgt an der Basis rund $45 \mathrm{~m}$. Der Damm wurde beidseits in gleicher Höhe wie die Talwände geführt und lehnt sich bündig an die sich nach oben erweiternden Wände an. Neben diesem Hauptdamm gab es an den Seitenwadis noch einige Nebendämme. Der Damm ist nicht als integraler Bestandteil eines Bewässerungssystems oder gar als Trinkwasserversorgungsanlage anzusehen, sondern wurde vermutlich als Schutzmauer gegen Sturzfluten errichtet, die sich durch gelegentliche Regengüsse in 
der östlichen Wüste ausbilden können und ein sonst trockenes Wüstenwadi in einen reißenden Fluss $\mathrm{zu}$ verwandeln vermögen und mit zerstörerischer Kraft ins besiedelte Niltal drangen. Da der Damm ohne Bindemittel in Pyramidenbauweise und auf sandigem Wadigrund errichtet wurde, brach er in späterer Zeit auf einer Länge von $42 \mathrm{~m}$ an der Dammmauer ein.

Des Weiteren spielte in den Hochkulturen der natürliche wie der künstliche Fischfang eine große Rolle. Während der griechischen und römischen Zivilisation wurde der Fischfang zum ersten Mal ausführlich beschrieben (ERGERT 1983:212). Als Göttin von Flüssen verehrt wurde „Potamia“; Tochter des Zeus, zugleich auch Göttin der Jagd und Geburtsgöttin sowie der Flussgott „Alpheioas“.

Ein Beweis für die Wandlung der Fischerei vom Flussfischfang zur künstlichen Fischzucht in Teichen hin zur landschaftsgebundenen Lustwandlung an solchen bereits in den Hochkulturen ist die Überlieferung aus Altägypten: Ursprünglich waren die Fischteiche nur auf den Nahrungserwerb ausgerichtet und bis zu frühesten Darstellungen in Privatgräbern der 5. und 6. Dynastie (2465 - 2160 v. Chr.) sind deshalb nur Untergebene bei dieser Tätigkeit zu erkennen. In der 18. und 19. Dynastie (1551 - 1186 v. Chr.) nun wird „der Grabherr und seine Frau bei der Erholung am künstlichen Fischteich gezeigt“"(ERGERT 1983:211).

\section{d.3 Römerzeit}

Während der Römerzeit in Germanien, dies beweist der archäologische Befund, waren die fruchtbaren Lößbörden mit einem dichten und gleichmäßigen Netz von Gutshöfen (villae rusticae) überzogen, Dörfer und Weiler aber fehlten nahezu, diese wurden erst in nachrömischer Zeit angelegt bzw. ausgebildet.

Zur Veränderung der Gewässerstruktur trugen die Römer erheblich bei. Zwar waren die Menschen, seit sie an den Flussläufen siedelten, darauf bedacht, den Fluss für sich nutzbar zu machen, doch sichere Erkenntnisse über die Schifffahrt, zum Beispiel vom Neckar, liegen erst zur Zeit der Römer im 2. Jahrhundert vor (HAGEL 1988:31).

Dass die Römer bevorzugt an Flussläufen siedelten, belegt das spätrömische Kastell „Haus Bürgel“ südlich von Düsseldorf. Dies lag bis zum Durchbruch des Rheins im Jahre $1374 \mathrm{n}$. Chr. linksrheinisch, heute befindet es sich aufgrund der Flussbettverlagerung auf der rechten Rheinseite. Der am „Haus Bürgel“" vorbeifließende Rhein bot den zwischen 150 und 200 zählenden Einwohnern gute Möglichkeiten des Fischfangs (STEIN 2000:2,14).

Doch nicht nur im gewässergebundenen Transport- und Versorgungswesen, sondern auch durch den Bergbau förderten die Römer den Ausbau von Siedlungen in Gewässerlage. Die „nach dem kleinen Flüßchen Gose benannte Siedlung Goslar entwickelte sich dank reicher Erzausbeuten zu einer der blühendsten Städte im Heiligen Römischen Reich deutscher Nationen.“ (LIESSMANN 1997:13)

\section{d.4 Mitteleuropäische Siedlungsphase}

Die Siedlungen der frühzeitlichen Menschen und deren topographische Siedlungswahl in Bezug zur hydrologischen Situation haben wir betrachtet. Auch die Hochkulturen und ihre Bevorzugung von Gewässerlagen oder, falls sie nicht oder nur unreichend vorhanden waren, die Schaffung von künstlichen Wasserreservoirs standen im Blickpunkt der bisherigen Betrachtung. Nachfolgend sollen die ersten bäuerlichen Siedlungen in Mitteleuropa und ihre zeitlichen Entwicklungsstufen in ihrer Standortbeziehung zum Wasser betrachtet werden.

Mit der Wirtschaftsform des Pflugbaus bzw. eines intensiv betriebenen Hackbaus, die diese Phase kennzeichnen, lag zum einen die Wirtschaftsfläche durch die vorgegebene Bodengüte fest. Um unnötige Wege zu vermeiden, versuchte man deshalb zum anderen den Wohnplatz in eine annähernd zentrale Lage innerhalb der Wirtschaftsfläche zu bringen (SCHWARZ 1988:68). Sowohl für die Anbau- und Weidefläche, als auch für die Wohnbauten war des Weiteren ein trockener Boden 
notwendig. Daraus ergibt sich, dass sich Pflugbauern mit einer spezifischen Siedlungsform den natürlichen Gegebenheiten anpassten (:68).

So wurden in dieser Siedlungsphase kleine Höhen aufgesucht, Moränenhügel und langgestreckte Oser, die das Feuchtgelände überragten (SCHWARZ 1988:69). Die topographische Lage lässt sich so beschreiben, dass sich die ländlichen Siedlungen im Bereiche der Flusstäler an die Hochufer und hochwasserfreien Terrassen hielten (KÜSTER 1995; SCHWARZ 1988:68). In den diluvialen Ausräumungs-Flachländern geschah das Anknüpfen an das terrassierte Fluss- und Seeufer, um einerseits die Bodengüte und andererseits den Fischreichtum der Gewässer zu nutzen. Als ein dritter Aspekt kommt auch hier hinzu, dass Verkehrsverbindungen auf den Gewässerläufen begünstigend für eine Ansiedlung wirkten (SCHWARZ 1988:68f.).

In der altdiluvialen Aufschüttungslandschaft Nordwestdeutschlands und der angrenzenden Niederlande waren die Grundwasserstände für die Siedlungslage entscheidend. Nur die trockenen Geestinseln mit ihren leichter zu bearbeitenden Sandböden kamen in der Frühzeit der Besiedlung als Feldland in Frage. Die entsprechenden Siedlungen waren dem Feldland deshalb „randlich zugeordnet“ (SCHWARZ 1988:69). Trotz des Ausweichens vor den feuchten Gründen wurden der Niederungsrand und damit die Nähe zum Gewässer in die Ortslage mit einbezogen. Dadurch wurde „eine Mittellage des Wohnplatzes zwischen den Ackerflächen der Höhe und dem Weideland der Niederungen erreicht" $(: 69)$.

\section{d.4.1 Frühgeschichtliche Landnahmezeit}

Die als frühgeschichtliche Landnahmezeit charakterisierte Periode kennzeichnet die Zeit der $-\mathrm{u}$. a. durch Klimaverschlechterung ausgelösten - Völkerwanderung mit dem Eindringen germanischer Stämme (u. a. Franken und Alemannen) aus dem Norden und Osten und deren Sesshaftwerdung. Eine Zeit, die verbunden ist mit dem Untergang des Römischen Reiches. Die Aufgabe des im 1. Jh. n. Chr. unter Domitian begonnenen Obergermanisch-rätischen Limes Ende des 3. Jh. und der endgültige Abzug der Römer aus Germanien im 4. Jh. mögen als Beginn dieser Phase genommen werden, die Konsolidierung der Besiedlung, die im nordwestlichen und mittleren Deutschland wohl erst im 7. und 8. Jh. erfolgte, als deren Ende (BORN 1977:29).

Mit der Neubesiedlung im Zuge der Völkerwanderung entstand im westlichen Mitteleuropa ein Grundgerüst von Siedlungen, die das Siedlungsmuster bis heute mitbestimmt. Es ist die hydrologischtopographische Lage der frühgeschichtlichen Landnahmezeit des 3./4. - 6./7. und 8. Jh. (LIENAU 1995:169f.).

Bei der Landnahme wurden - verständlicherweise - die aus landwirtschaftlicher Sicht günstigsten Gebiete bevorzugt. Die wichtigsten Merkmale ungelenkter Besiedlung, als Kennzeichen der Landnahmezeit, bildeten die freie Wahl der Siedlungsstandorte und der Parzellierungsprinzipien von Wohnplatz und Flur durch die Siedler (BORN 1977:40). Diese freie Lagewahl war nur möglich aufgrund der relativ geringen Siedlerzahlen, die bei der Landnahme germanischer Stämme in vorher römischen Gebieten Mitteleuropas gegeben waren (:41).

Bevorzugte Siedlungsformen waren Einzelhof und Kleingruppensiedlung (LIENAU 1995:170). BOELCKE (1974:28) erklärt die alemannische Einzelsiedlung der Landnahmezeit mit dem Bestreben der einzelnen Gehöfte, einen Bach oder eine Quelle zu besitzen, die von keinem anderen Gehöft genutzt werden konnte.

Auch die Besiedlungsgeschichte der fränkischen Landnahmezeit im 6./7. Jh. gehorchte charakteristischen Gesetzmäßigkeiten: „Bevorzugt wurden Lagen mit leicht zu bebauenden fruchtbaren Böden in der Nähe fließenden Wassers." (KREINER 1996b:77). Die ersten Siedlungen reihten sich wie eine Perlenschnur an den größeren Flussläufen und Nebenarmen auf. In erster Linie wurde dabei die „Hanglage am Terrassenrand zur Flussaue“ aufgesucht. So ließ sich optimale Nähe zum Wasser und größere Sicherheit vor Hochwasser miteinander vereinbaren. Fließendes Wasser galt 
den fränkischen Siedlern offenbar als unverzichtbare Voraussetzung für eine dauerhafte Niederlassung.

Auch die Ortsgründungen des 6./7. und 8. Jahrhunderts im Zentrum der trockenen Lößbörden „verfügten über winzige Wasserläufe.“ (KREINER 1996b:77) KREINER (:77) beschreibt diese Situation für das Erftgebiet während der fränkischen Landnahmezeit: „Die Region mit dem dichten (nahezu parallelen) Gewässernetz von oberer Erft, Eschweilerbach, oberem Vey-, Blei-, Rot- und Nefelbach (Kalkeifel und Zülpicher Voreifel) entwickelte sich seit dem 6./7. Jh. neben dem Kölner Raum zur am dichtesten besiedelten ländlichen Zone der nördlichen Rheinlande. Die gewässernahe Lage verband sich hier - im Grenzsaum zwischen Zülpicher Börde und Waldeifel - mit Muschelkalk-Ackerboden, der für die fränkischen Siedler leichter zu bearbeiten war als die schweren Lößböden der Ebene.“

Die heidnischen Slawen und besonders die Wenden, die im 6. Jh. in die Mark Brandenburg und viele andere benachbarte Landen einwanderten, bevorzugten die Niederungslage in den Tälern. Und im Bereich der Grundmoränenlandschaften wählten sie Standorte aus, an denen genügend Wasser vorhanden war, das heißt am Bach- und Seeufer (SCHWARZ 1988:69). Als charakteristisch für viele Rundplatzdörfer, die die Slawen errichteten, bezeichnete ENGEL (1953:218; ebenso NITZ 1989:196) ihre Lage auf spornartigen natürlichen Vorsprüngen an Niederungsrändern. Zeitlich wurden sogar „künstliche Sporne durch Aufschüttung geschaffen“ (NITZ 1989:196). Auch für die Rundlinge im elbischen Wendland weist LANGE (1989:34) darauf hin: ,alle in Hufeisenform erbauten Dörfer sind in einer Hanglage, zwischen Geestrücken und Bach- oder Grabenniederung so gelegen, daß sie von Gräben oder einem Bach mehr oder weniger umschlossen werden." Durch die Zahl der Höfe und den damit verbundenen Platzbedarf ergab sich in einigen Dörfern sogar, „daß einige mit ihrer Hoffläche über den Bach zu liegen kamen, der Bach also über den Hof floß.” (:34) Darüber hinaus stellten die von Osten in den Südharz einwandernden Wenden und Slaven, die ihre Orte in Form der Rundlinge anlegten, „um einen freien, meist mit einem Teich versehenen Platz [...] die Häuser kreisförmig auf“ (BAD SACHSA 2003).

Die wendische Bevölkerung, Sorben in der Ober- und Niederlausitz, Wilzen in der Mark Brandenburg und in Pommern sowie Obotriten in Mecklenburg, lebten noch zu Ende des 19. Jh., wie FRIEDEL (1884:41) aus persönlicher Anschauung zu berichten weiß, in geschlossenen Dörfern, sog. Rundlingen, „in der Nähe der Fischgewässer.“ Dieser Gewässerbezug kommt auch in der Beschreibung von Rundlingen zum Ausdruck, die FRIEDEL (1884:41f.) als ,rundliche Schanzen und Burgwälle im nördöstlichen und südöstlichen Deutschland“ beschrieb, die zur Sicherung der Dörfer dienten. Sie wurden zum Teil unter Benutzung natürlicher Bodenerhebungen angelegt, zum Teil auf Pfahlrosten oder Packwerken oder durch eine einfache Anschüttung erbaut inmitten wasserreicher Umgebung (FRIEDEL 1884:41f.).

FRIEDEL (1884:42) zitiert an anderer Stelle in seinem Aufsatz aus einem Schriftstück eingehender über die Siedlungslage und den Bau von Rundlingen:

„Ueber die slavische Herkunft der Wasserburgen und ihre Entstehungsweise haben wir durch M. J. de Goeje ${ }^{[16]}$ in Leiden kürzlich eine neu aufgefundene interessante Notiz erhalten, welche Abu Obeid al-Bekri ${ }^{[17]}$, einem um 1160 lebenden Spanisch-Arabischen Schriftsteller aus einem Bericht mitgetheilt wird, den ein jüdischer Agent Ibrahim ibn

\footnotetext{
${ }^{16}$ de Goeje, M.[ichael] J.[an], Prof. Dr. der Universität Leyde [Leiden]/Niederlande, ( $\left.1836-\dagger 1909\right)$ : Oriental-Spezialist in arabischer Philologie, islamischer Autor, Geograph und Reisender des 20. Jh., Hrsg. des Standardwerks zu islamischen Länderkunde der „Bibliotheca Geographorum Arabicorum“ [Leiden ab 1870]. Hierin sind Werke der mittelalterlichen arabischen und persischen Geographen al-Istakhri (schrieb um 951), ibn Hauqal (schrieb 977), al-Muqasdasi (schrieb um 985) enthalten. Aus diesen Quellen wird eine regelrechte Systematik der Landeskunde erarbeitet, die noch immer im Literaturverzeichnissen zu Seminaren genannt wird (z. B. Orientalisches Seminar der Universität Tübingen, Islamische Geographie der Universität Frankfurt).

${ }^{17}$ Abu-Obeid-al Bekri, Mohammed El.: spanischer Geograph, um 1094 entstand sein bekanntes Werk: Déscription de 1'Afrique [Beschreibung Nord-Afrikas]. - Neuaufl. Algier, 1913 [frz. Übers. v. Baron de Slane]
} 


\begin{abstract}
Jakub $^{[18]}$, welcher sich um 965 am Hof Kaiser Otto's I. in Merseburg aufhielt, abgefaßt hat. ,Abraham Jakobsohn' spricht vom Lande der Obotriten und sagt: , Willi-Grad (d. i. das jetzige Städtchen Mecklenburg an der Bahn zwischen Kleinen und Wismar) ist an einem Süßwassersee, wie die meisten Burgen der Slaven, erbaut. Wenn sie nämlich eine Burg errichten wollen, so suchen sie ein Bruchland aus, das reich an Wasser und Schilfmorast ist, und stecken da einen runden oder viereckigen Platz ab, nach der Gestalt und dem Umfang, welchen sie der Burg geben wollen. Dann heben sie darum einen Graben aus und häuften die ausgegrabene Erde auf. Mit Planken und Balken wird diese Erde so fest gestampft, bis sie die Festigkeit einer Lehmmauer erhält. Wenn der Wall bis zur gewünschten Höhe aufgeführt ist, wird in den Rand, wo man es begehrt, ein Thor angebracht und von diesem eine hölzerne Brücke über das Wasser gebaut“.. .
\end{abstract}

Die wendischen Rundlingsbewohner standen nach FRIEDEL (1884:43f.), ,in innigster Wechselbeziehung“ zum Fischfang bzw. waren „in vieler Beziehung gradzu auf denselben angewiesen“, daher die vielen bei solchen Wasserbauten gefundenen, auf das Fischwesen bezüglichen Gegenstände wie als Fischgerät aller Art (Netze, Schnüre, Netzsenker, Netzheber, Netzheber von Holz, Fischotterfallen, mehrzinkige Fischstecher, Fischspeere, Angelhaken, Eisäxte, Schlittenknochen, Eisschlitten, Fischernachen mit Ausrüstungsgegenständen) sowie Nahrungsrückstände (Fischgräten, Fischschuppen, Wassergeflügelknochen, Muscheln, Schnecken u. dgl.).

Zur Verteidigung wie wohl auch aus religiösen Gründen dienten den nichtslawischen, frühen sesshaften Bewohnern in anderen Gebieten Deutschland auch sog. Wall- und Fluchtburgen. Um sich sowohl gegen feindliche Angriffe zu schützen als auch um zu opfern, legten sie auf hervorragend gelegenen Bergspitzen Befestigungen an, welche meist aus Wall und Graben bestanden und zum Teil noch jetzt deutlich unter Wald erkennbar sind. Hier bargen die Menschen sich und ihr Vieh in Zeiten der Gefahr. „Eine notwendige Bedingung für die Anlage solcher Befestigung war die Nähe des Wassers und der gesicherte Zugang dazu von der Burg aus.“ (HEINE o. J.: 33)

Wallburgen mit Gewässeranschluss befanden sich beispielsweise im Südharzgebiet auf dem Konstein und dem Mühlberg bei Niedersachswerfen, auf dem Burgberge bei Ellrich, auf der Löwenburg bei Bleicherode, auf der Wöbelsburg bei Hainrode und auf der Hasenburg bei Buhla. Als weitere Beispiel außerhalb der Harzes seien hier die Wall- und Fluchtburgen Heisterburg im Deister bei Rodenberg (Bad Nenndorf, Ldkrs. Schaumburg), die Hünenburg im Wesergebirge oberhalb Todenmann (Stadt Rinteln) und die Uffoburg oberhalb Hagendorf im Extertal genannt. Überall in den Mittelgebirgen stehen sie in unmittelbaren Zusammenhang mit einem Gewässer- oder Quelllauf, auch wenn die Quellschüttung heute versiegt ist oder der ehemalige Flusslauf nur noch als Bächlein oder als Rinnsal rudimentär bzw. temporär erkennbar sein sollte.

Solche Landwehre mit ihren linienförmigen Gebietsbefestigungen hat man vom 16. Jahrhundert ab eingeebnet, doch sind bis heute, namentlich im Wald und Dreischland, noch manche Abschnitte mit deutlichen Profilen erhalten. „In den Landwehrzug eingefügt wurden als natürliche Befestigungen Fluß- und Bachläufe, Steilhänge und Sumpfgebiete“ (JÄGER 1965:426), wie dies auch bei der Heisterburg bei einer Geländebegehung erkennbar ist.

Zugleich diente das Gewässer, an dem man siedelte, als Grenzfluss zwischen verschiedenen Volksstämmen. Der Rhein zum Beispiel grenzte im Westen den germanischen Volksstamm von den Römern

\footnotetext{
${ }^{18}$ Ibrahim Ibn Jakub [al Isreali]: als jüdischer Handelsreisender, Kaufmann oder auch als sarazenischer Gesandtschaftsarzt bezeichnet, der als Gesandter des Kalifen [,Agent“] aus dem damals maurischen (moslemischen) Spanien (Cordoba) eine islamische Gesandtschaft zu Kaiser Otto I. (Magdeburg) begleitete. Er reiste um 965/66 bis 973 n. Chr. von Nordspanien über Frankreich nach Mitteldeutschland, ins Land der Prußen und Wenden. Sein Weg führte ihn u. a. vom Märkischen Land über das besagte Magdeburg, nach Prignitz und Wurzen bis nach Prag und Krakau (Böhmen). Er verfasste darüber einen Reisebericht [Ibrahim Ibn Jakub [Reisebericht]. - In: Jacob, G. (Hrsg.): Arabische Berichte von Gesandten an germanische Fürstenhöfe aus dem 9. und 10. Jahrhundert. - Berlin 1927], der z. T. einzigartige Fakten und Landesbeschreibungen überliefert; z. B. über die [untergegangene] Weltstadt Vineta und über die die arabischen Worte, die in der deutschen Übersetzung als „Morast“ erscheinen, tatsächlich aber „Fruchtland“ beschreiben, trocken gelegte Sümpfe, die dann als Marschen- und Auenland unvergleichliches Fruchtland sind (GOLDMANN 1982; GRANSOW 2004)
} 
ab, während im Osten die Saale die Grenze zwischen Germanen und Slawen bildete, wie Karl der Große um 805 verkündete.

\section{d.4.2 Mittelalterliche Si edlungsphase}

Die mittelalterliche Siedlungsbewegung beschreibt eine Besiedlung, die „früh von den besiedelten breiten Flußtälern allmählich in die gebirgigeren Gegenden vorrückte, in denen eher gefällereiche, kleine Bäche zu finden sind.“ (BEDAL 1992:32) Solche Besiedlungsvorgänge, die mit starken Rodungsaktivitäten verbunden sind, geschahen meist gelenkt; so z. B. während des Landesausbaus und der deutschen Ostsiedlung im hohen Mittelalter. In etwas geringerem Maß waren Siedlungslenkungen während des frühneuzeitlichen Landesausbaus im 15./16. Jh. spürbar, dagegen traten sie während des absolutistischen Landesausbaus im 17./18. Jh. bei der Peuplierung ${ }^{19}$ durch die Aufnahme von Glaubensflüchtlingen und bei der Erschließung von Mooren, Überschwemmungsgebieten und Heiden durch Staatssiedlungen wieder stärker hervor, z. T. handelte es sich hierbei schon um geplante Besiedlung (BORN 1977:45).

Eine geplante Besiedlung strebt „eine geometrisch-schematische Flur- und Wohnplatzgestaltung“ an (BORN 1977:53). Die Parzellierung folgt dabei „meist einem gewissermaßen am Schreibtisch entworfenen Ordnungsplan, der die Geländeverhältnisse nur selten berücksichtigt“ und ,beruht [...] auf einem die Gründlichkeit des Siedlungsplaners oder -förderers veranschaulichenden Streben nach Ordnung, Übersichtlichkeit, Ästhetik oder dient zur Erleichterung der Vermessungspraxis.“ (:53). Gleichwohl kann eine ,geometrisch-schematische Gestaltung [...] an bestimmten natürlichen Gegebenheiten angepaßt oder förderlich sein“(:53) .

Durch Lenkung sollte deshalb nicht nur der Rodungs- und Erschließungsvorgang gefördert werden, darüber hinaus beinhaltete sie auch Vorstellungen über die Anordnung der Siedlungen. Und diese orientierten sich oftmals an Gewässern. Als Träger des gelenkten Ausbaus fungierten dabei geistliche und weltliche Grundherren (LIENAU 1995:171), die entweder der wachsenden Bevölkerung Platz verschaffen oder den Zuzug bzw. die Ansiedlung benötigter Arbeitskräfte ermöglichen wollte und für die Ernährungsgrundlage dieser Neubürger wiederum landwirtschaftliche Hofstellen schaffen mussten.

\section{d.4.2.1 Frühmittelalterlicher Landesausbau}

Der frühmittelalterliche, systematische Landesausbau beschreibt die Zeit vom 8./9. - 12. Jh. Die königlichen Domänen (,fisci“) lagen zu der Zeit in den Flussgebieten, zum Beispiel von Rur und Erft (KREINER 1996b:90) und dienten der Versorgung der Pfalzen Karls des Großen, in diesem Beispiel der Pfalz Aachen. Aber auch an den Schifffahrtsstraßen zwischen Regensburg und Würzburg bzw. Frankfurt ,reihten sich wie Perlen an einer Schnur in regelmäßigen Abständen [...] die Königshöfe entlang Donau, Altmühl, Schwäbischer Rezat, Rednitz und Main, als da sind Eichstätt, Treuchtlingen, Weißenburg, Roth, Fürth, Forchheim und Hallstadt, um im Streckenabschnitt zwischen mittlerer Altmühl und dem Mainknie unterhalb Bambergs zu bleiben“ (SPINDLER 1988:92), so dass „fast die gesamte Strecke mit dem Schiff befahren werden konnte" (TRÖGL 1995:50). Der Abstand der fränkischen Königshöfe entsprach einer Entfernung von 25 bis $30 \mathrm{~km}$, die ungefähr der täglichen Treidelstrecke für eine Bergfahrt entsprach (SPINDLER 1988:92; TRÖGL 1995:50).

Hinsichtlich der Lagewahl für die in dieser Zeit gegründeten Bauerndörfer und Einzelhöfe besteht ebenso eine gewässerbezogene Lagewahl. Die Bauernhöfe liegen ,in aller Regel zum Gewässer hin orientiert: oberhalb der Bachaue am Rand des Talhangs oder einer Bach-bzw. Flußterrasse. Auf diese Weise war die in der vormodernen Zeit notwendige eigene Wasserversorgung für Mensch und Vieh zu sichern: durch Zugang zum Bach und durch leichte Erreichbarkeit des Grundwassers für den Bau von Brunnen.“ (NITZ 1989:195) Im Folgenden einige Beispiele dazu:

\footnotetext{
${ }^{19}$ Historisch-geographischer Ausdruck für die zielbewusste Besiedlung eines Territoriums zum Zwecke des Ausbaus des Siedlungsnetzes und der Stärkung des Staates und seiner Wirtschaftskraft. Der Begriff wird vor allem auf die von den Landesfürsten betriebene Wiederaufsiedlung nach den Bevölkerungsverlusten des Dreißigjährigen Krieges und die Binnenkolonisation durch Glaubensflüchtlinge im 17./18. Jh. angewendet (DIERCKE 1987:69f.).
} 
Gelenkte Rodungen, beispielsweise nach dem Waldhufenprinzip, geschahen in den Mittelgebirgen mit Beginn des Landesausbaues seit dem frühen Mittelalter (BORN 1977:46) und weisen den Hof- und Wirtschaftsplätzen eine Gewässerlage zu. Waldhufensiedlungen bestehen aus Reihendörfern mit hofanschließenden Breitstreifenparzellen in Einödlage. Die Streifenparzellen verlaufen mehr oder weniger senkrecht zur Gehöftleitlinie. Die Gehöfte ordnen sich dabei an einer vorgegebenen oder geschaffenen Leitlinie, ,häufig an einem Bach“ an (:46).

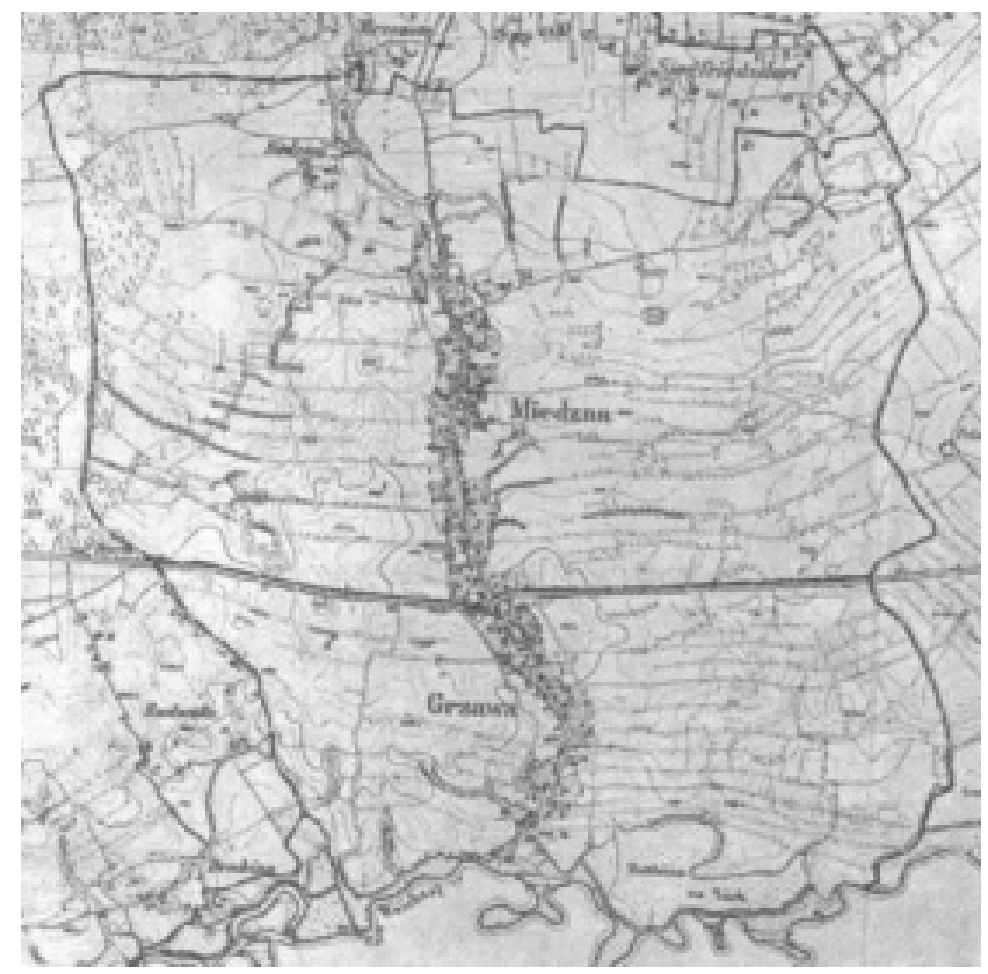

Abb. V-11:Die Waldhufendörfer Kunzendorf (Miedzna) und Heinwald (Grzawa) im Lößstreifen südöstlich Pleß an der Weichsel, die im unteren Bildrand den verkleinerten Messtischblattauszug durchfließt. Es handelt sich um deutsche Gründungen aus der zweiten Hälfte des 13. Jahrhunderts. Die fortlaufende Dorfzeile wird von einem zur Weichsel entwässernden Bachlauf durchschnitten. Die Waldhufen streichen von Westen nach Osten und sind durch die Feldwege gut kenntlich. In der Mitte des unteren Bildrandes ist der unmittelbar der Weichsel angegliederte „Statthaus-Teich“ zu erkennen (aus: KUHN 1954:302).

Eine Sondererscheinung des Waldhufenprinzips bildeten die seit etwa 1200 aus einfachen Vorformen gegründeten Hagenhufensiedlungen. Der Begriff ,Hagen“ bezieht sich auf das vor allem in den nördlichen Mittelgebirgen verbreitete ,Hagenrecht', das als hochmittelalterliches Rodungsrecht Vorteile bei der Siedlungstätigkeit gewährte. Die Form der Hagenhufensiedlung fand Anwendung bei langfristigen Rodungen in Waldgebieten und ihre Verbreitungsgebiete sind das Weserbergland, vor allem Schaumburg-Lippe und das Extertal sowie küstennahe Gebiete Mecklenburgs und Pommerns (BORN 1977:47). 


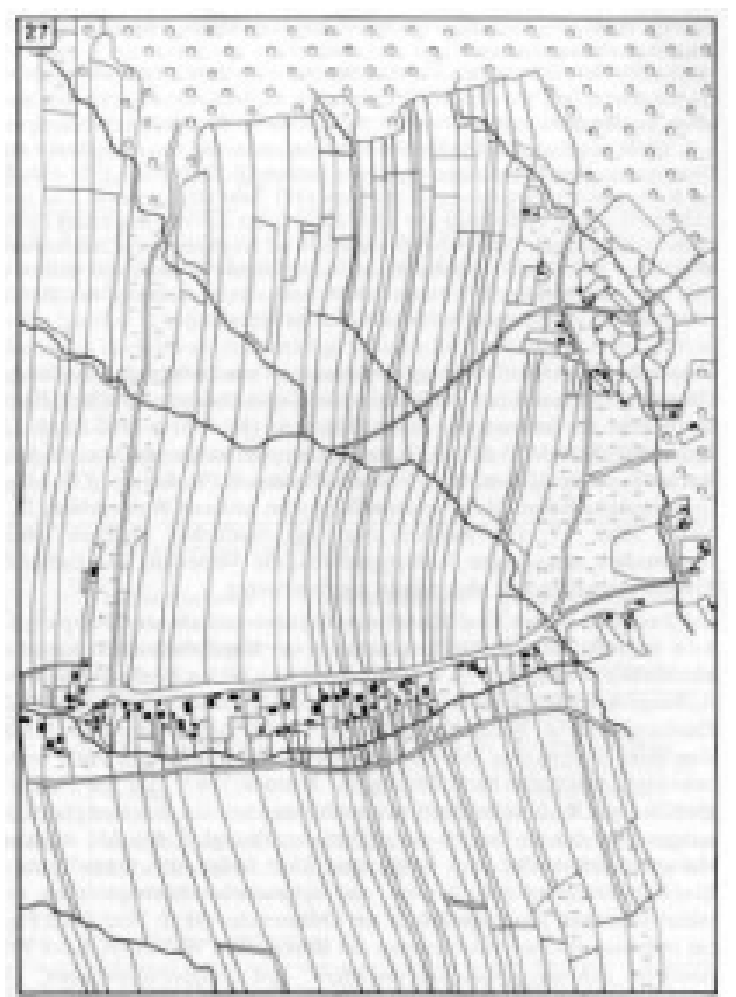

Abb. V-12: Pollhagen (Schaumburg/Lippe) als aufgesiedelte hochmittelalterliche Hagenhufensiedlung (um 1750) mit streifenförmiger Einödflur (nach R. BLOHM 1943 S.101).

„Ein häufig auftretender Formentyp von Hagenhufensiedlungen“, schreibt BORN (1977:47), „wird durch einzeilige Gehöftreihen längs einer Straße, die etwa parallel zu einem Bach verläuft, gekennzeichnet“. Die Anpassung der Gehöfte dieser frühmittelalterlichen Rodungssiedlung folgt also „einem Bach als Leitlinie“ (:162) und ist ,als einzeiliges Reihendorf zwischen Weg und Bachlauf" (:162) angeordnet. Charakteristische Erscheinungen der Grundform von Hagenhufensiedlungen bilden neben Einzelhofreihungen auch Hofpaare in Tälern. NITZ (1989:195) spricht „,bei doppelzeiliger Anlage beiderseits eines schmalen Baches“ von einem „Bachangerdorf“, das entlang eines Bachlaufes entsteht. Die Talreihung muß als Anpassung an die Naturausstattung verstanden werden: sie beachtet ökologische Schutzlagen, Zugänglichkeit, die Bodenverhältnisse und Erfordernisse der Wasserversorgung. Dementsprechend entstanden Hofreihungen vor allem in den Mittelgebirgen, in denen ausgeprägte Gegensätze in der Siedlungseignung von Tälern und angrenzenden Plateaus vorhanden sind (:112).

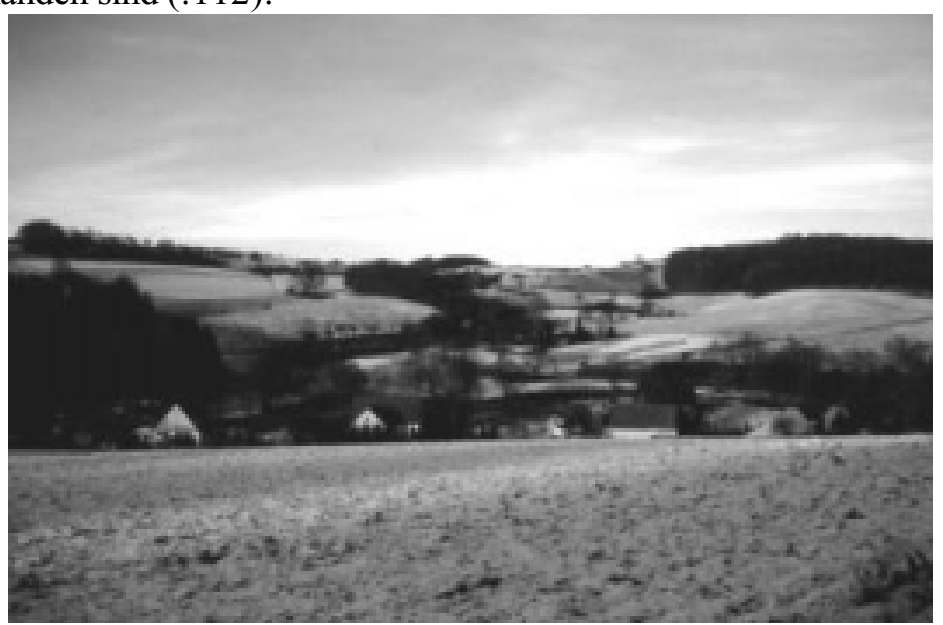

Abb. V-13: Hagendorf im Extertal

Die Charakteristik der einzeiligen Gehöftreihung entlang eines Bachlaufes ist bei dieser Hagenhufensiedlung noch gut erkennen. Aufforstungen hingegen, die von einem oberhalb dieses Standpunktes gelegenen Forstgut vorangetrieben worden sind, verwässern das Erscheinungsbild eines ehemaligen „Rodungsdorfes“. Bis Ende der 1950er Jahre dienten die Holzungen zur Belieferung der im Westfälischen liegenden Tabakfabriken zur Herstellung von Zigarrenkästen (eig. Aufnahme) 
Allgemein, und nicht nur in den Hagensiedlungen, war in den Hochlagen der Mittelgebirge die topographische Lage der bäuerlichen Siedlungen durch das Talnetz vorgezeichnet. Hier wich man dem feuchten Talboden aus und suchte Terrassen und Hangleisten in der Nähe von Nebenbächen aus, wenn die Bewässerung des Nutzlandes eine Rolle spielte (SCHWARZ 1988:73). Die Gehöftstandorte der frühmittelalterlichen Besiedlung folgten oft einer natürlichen gewässerbezogenen Leitlinie, wie einem Bachlauf, einer Uferterrassenkante oder einem Quellhorizont (vgl. BORN 1977:112), die somit die Siedlungsform prägten. Während ein dominanter Bachlauf die Leitlinie für die Ausbildung von Gehöftreihen bildete, konnte eine besondere Dichte von kleinen Wasserläufen und Quellen Streu- oder lockere Dorfsiedlung fördern (BRANDT 1971:32).

Trat oberhalb der Talaue ein Quellenhorizont aus, wurden hier ,vielfach auch Teiche angelegt, vor allem dann, wenn sich der Talhang zu Mulden, Dellen oder engeren Nischen ausbuchtete und sich in einer solchen Quellmulde der optimale Platz für einen Gemeinschaftsteich ergab, um den herum sich die Höfe mehr oder weniger regelmäßig kranzförmig oder auch ,haufenmäßig' gruppieren.“ (NITZ 1989:195)

Handelt es sich jedoch um Kalkhochflächen wie auf der Schwäbischen Alb oder wie in den breiteren Tälern der Alpen, mit wenigen, aber breiten Tälern und gestaltete sich die Wasserversorgung unter Einschaltung einer sommerlichen Trockenzeit besonders schwierig, „dann fanden sich die Siedlungen ausschließlich in den Tälern in der Nähe des Wassers" (SCHWARZ 1988:71). Hier finden sich fast regelmäßig die älteren Gruppensiedlungen: an der Spitze von Schwemmfächern von in diesen eingeschnittenen Nebenflüssen bei deren Einmündung ins Haupttal. „Dies gewährt Sicherheit vor Hochwasser und leichten Zugang zu den besten Ackerflächen auf den Schwemmflächen." (NITZ 1989:196).

Den Rodungen der Mittelgebirge entspricht die Neulandgewinnung in den See- und Flussmarschen durch Eindeichungen und Errichtung künstlicher Dämme seit dem 11. Jh. und in den großen Hochmoor- und Übergangsmoorgebieten Nordwestdeutschlands, die durch Moorkultivierung gewonnen wurde (LIENAU 1995:172).

Im Gegensatz zur Rodung wurde Neulandgewinnung insbesondere in den Flussniederungen durchgeführt, da hier die Wasserlage besondere Standortvorteile bot. In den Flussmarschen wurden als „geotopologischer Standort die natürlichen Uferwälle [...] aufgesucht“ (NITZ 1989:196). In diesen geotopologischen Lagen ,auf der Übergangsstufe zwischen feuchter Niederung und trockenem Hang“ war zugleich „eine funktionale Zwischenlage zwischen Grünland und Ackerland erreicht.“ (:195) Die bevorzugte Lage war die am höheren Rand der Niederung „zwischen Wiesenland und Esch“ (HETZEL 1957:20). Häufig wird der Siedlungsplatz sogar durch die Einmündung von Nebenbächen oder alten Rieden in das entsprechende Flussauental noch näher bestimmt, wie HETZEL (:20) am Beispiel des Huntetales nachweist: „Es scheint so, als ob hier die Rücksicht auf dorfnahes, sicheres Weideland, das nicht sicher durch den ungebändigten Huntefluß gefährdet war, eine Rolle spielte. Außerdem war auch die Wasserversorgung überhaupt von Bedeutung, da man an die Hunte ja nicht unmittelbar heranrücken konnte, sondern meist noch einige hundert Meter entfernt am Rande der Talaue bleiben mußte.“

Diese überschwemmungsgefährdeten Bereiche verlangten jedoch insofern eine besonders intensive Planung, als vor der eigentlichen Siedlungstätigkeit die zu erschließenden Areale vor natürlichen Hochwassergefahren geschützt werden mussten. Diese Notwendigkeit zeigte sich in Mitteleuropa wahrscheinlich schon im Hochmittelalter bei der Erschließung von Flusstälern in Mitteldeutschland durch flämische Siedler, besonders deutlich aber dann bei der Anlage von Marschhufensiedlungen in der Weserflussmarsch, die der Bremer Erzbischof 1106 oder 1113 holländischen Siedlern aus der Diozöse Utrecht zur Kultivierung überließ (FLIEDNER 1970).

Holländersiedlungen wurden auch in rückwärtigen Niederungen der Elbmarschen seit dem 12. Jh. angelegt (HÖVERMANN 1951, FLIEDNER 1970:64). Und auch in weiteren binnenländischen Gebieten nutzten die Niederländer ihre Erfahrungen in Hochwasserschutz und Entwässerung zur 
Erschließung überschwemmungsgefährdeter Flussniederungen; so am klevischen Niederrhein, östlich des Teutoburger Waldes, an der Mittelweser, an der Lenne, in der Warburger Börde an der Diemel, nördlich des Harzes im Großen Bruch und südlich des Harzes in der Goldenen Aue (PETRI 1972: 735).

Im Gegensatz zu den Flussniederungen bildeten in den Flussaufschüttungsebenen die älteren und jüngeren Flussdämme und in den Flussdeltas die Strandwälle Ansatzpunkte zur Gehöftansiedlung. In den alluvialen Ablagerungsebenen der Marschgebiete der Nordseeküste beispielsweise „wurden zunächst die Geestvorsprünge bzw. Strandwälle oder die höhere Marsch besetzt. Als diese durch Sturmfluten bedroht wurde oder man sich beim Siedlungsbau zu sehr in das Feuchtgelände hinein wagte, ging man dazu über Wurten zu schaffen und die Wohnplätze auf diesen zu errichten (SCHWARZ 1988:70). Diese Hofwurten entstanden in den Marschen beim frühmittelalterlichen Ausbau (HAARNAGEL 1979:217). Erst später legte man in den Marschländern der Nordsee die Wohnplätze im Schutz der Deiche oder - in einer späteren Siedlungsphase - innerhalb der entwässerten Bereiche in Flächenlage an.

Die Siedlungsstruktur in Zusammenhang mit der Gewässerlage sah in Deutschland zu Beginn der mittelalterlichen Siedlungsperiode also wie folgt aus: Edaphische und hydrographische Gegebenheiten förderten das Aufkommen von Einzelsiedlungen. Diese Siedlungsstruktur dürfte vielfach durch die räumliche Beschränktheit trockener Ländereien bedingt sein. Andererseits erzwang die Hochwassergefährdung in größeren Talauen eine Reihung von Einzelhöfen (GIESE 1968:68). Eine auf dichtem Gewässernetz beruhende gute Wasserversorgung ermöglichte auf Hängen am Rande feuchter Niederungen Einzel- und Schwarmsiedlung (BRANDT 1971:33).

Neben der gelenkten Ansiedlung von Neusiedlern im Binnenland vor dem Hintergrund ausreichender Wasserversorgung wurde aber auch der Fluss- und Seeschifffahrt große Bedeutung beigemessen, um den Austausch der auf langer Fahrt erworbenen Waren zu bewerkstelligen.

So waren im frühen Mittelalter vor allem wikingische und friesische Wanderkaufleute die Vermittler eines weitgreifenden Fernhandels zwischen Nordsee-, Ostseeraum und Byzanz. Ihre Handelsniederlassungen, die Wikingerorte, führten Namen wie Birka, Haithabu, Dorestad, Bardowick, Lundenwik oder Riebe. Diese frühen Fernhändlerniederlassungen, sog. „Wik-Orte“, die noch nicht unbedingt den Charakter einer Stadt zu haben brauchten, begannen z. T. als periodisch besuchte Treffpunkte von Fernhändlern und lagen jeweils an geschützten Meeresbuchten nahe der Küste, in Mündungsgebieten großer Ströme und schiffbarer Flüsse oder verkehrsgünstigen Umschlagstellen binnenländischer Fernwege, wie an den alten Salzstraßen, an Furten usw.. Küsten-Wike beispielsweise waren Birka bei Stockholm, Haithabu bei Schleswig an der Schlei, Vitte auf Rügen sowie Stade und Emden. Binnenländische Wike an Flußübergängen hingegen waren Bardowik bei Lüneburg, wahrscheinlich auch Hannover und Braunschweig, an der Rheinmündung lag Dorestad, an der Themse Lundenwik (London) oder lagen wie Ribe am Zusammenfluss von Ribe und Tved. Weitere Wike bestanden in den Ländern um Ost- und Nordsee, „bis weit in die Hinterländer hinein“ (NIEMEIER 1977:146; SCHWARZ 1988:420; OPITZ 1997:47).

Diese Markt- und Handelsfaktoreien sind als Institution wahrscheinlich aber älter. So ist Lundenwik bereits seit 604 bekannt und Haithabu, Marktort an verlandeter Ostsee-Nebenbucht der Schlei, heute $30 \mathrm{~km}$ landeinwärts bei Schleswig gelegen, ist Wik bereits seit etwa 800 . Seine Blütezeit fällt in das 10. Jh. und war zur damaligen Zeit ein bekannter und großer Hafenort an der Ostsee. In SchleswigHolstein verbindet sich kaum ein Name oder ein Begriff so eng mit der Wikingerzeit wie die Geschichte des Handelsplatzes Haithabu. Aber warum kamen die friesischen Kaufleute nach Haithabu? Die Stadt verfügte über einen bedeutenden Hafen, von dem aus der Verkehr zu allen wichtigen Handelsplätzen im Ostseeraum aufgenommen wurde. Haithabu lag für die Kaufleute der Zeit ideal, nämlich an der schmalsten Stelle der kimbrischen Halbinsel. Die Händler brauchten nicht mehr um Jütland herumzusegeln, sondern für die Schiffe der Wikingerzeit waren die Eider und auch deren Nebenfluss Treene schiffbar bis Hollingstedt (OPITZ 1997:44). In Hollingstedt überquerten sie den $20 \mathrm{~km}$ breiten Landstreifen nach Haithabu, wo sie schleiabwärts (den Fluss herunter) den Seeweg nach Osten fortsetzten. Es ist nicht bekannt, ob sie ihre Waren in Hollingstedt auf Karren luden oder 
ob sie ihre Schiffe über Land schleppten. So wurde Haithabu in kurzer Zeit der größte Marktplatz des Nordens. Nach der Zerstörung im 11. Jh. und der für einige Zeit von der am Nordufer der Schlei aufgebauten Siedlung Schleswig übernommenen Funktion Haithabus wurde die Stadt an der Schlei von Lübeck als zentralem Handelsplatz an der Ostsee abgelöst.

Im 9. Jh. haben des Weiteren ,Genossenschaften' von schwedischen Krieger-Kaufleuten, die Waräger, auf der Suche nach Überlandverbindungen von der Ostsee zu den Märkten des Orients, vor allem Byzanz, befestigte Stützpunkte angelegt. Diese lagen an russischen Strömen und Seen, der ,uralten Wasserstraße" (KÜRY 2004), die von der Ostsee zum Schwarzen Meer führt und sich aus den Teilstücken Newa - Ladogasee - Wolchow - Ilmensee - Wolga - Dnjepr sowie über Düna und Beresina und andere Zuflüsse des Dnjepr zusammensetzt, mit unbedeutenden Landschleppstrecken für Boote zwischen den verschiedenen Flusssystemen, die leicht zu überwinden waren (NIEMEIER 1977:146).

In welchem Umfang das frühe Mittelalter bereits in der Lage war, Wasserverbauungen zu errichten, zeigen die bis zu zehn Meter breiten Landungsstege am Flussufer von Dorestad im Rheinmündungsgebiet. Dafür wurden an diesem frühmittelalterlichen Handelsplatz in den Niederlanden „Tausende von Holzpfählen in den Untergrund gerammt, mit Erde aufgefüllt und an den Seiten mit Faschinen aus Flechtwerk gesichert.“(SPINDLER 1988:83)

Ein Beispiel eines im frühen und hohen Mittelalter (8. - 12. Jh.) bedeutsamen Fluss-/Seehandelsplatzes im Odermündungsgebiet ist Menzlin. Am nördlichen Ufer der Peene, in der Flur „Altes Lager“ beim Dorf Menzlin, befand sich dieser wichtige frühmittelalterliche Seehandelsplatz, der nach heutigen Kenntnissen vor allem in das 8. und 9./10. Jahrhundert datiert und im frühen 10. Jh. aufgelassen wurde: „Man kann [...] annehmen, dass der Seehandelsplatz im 8. Jahrhundert von Skandinaviern unter Beteiligung von Slawen als Handelsort gegründet und von diesen Völkerschaften auch während des 9. Jahrhunderts besiedelt wurde.“ (BIERMANN 2003:3)

Menzlin war „Wirtschaftszentren des Ostseehandels“ und hatte die Funktion „als Mittler im Handel zwischen dem Ostseeraum, der Odermündung und dem vorpommerschen Gebiet“ (BIERMANN 2003:2). Die archäologisch untersuchte Siedlung nahm „einen sandigen, allseits von Feuchtgebieten umgebenen, natürlich geschützten Horst an der Niederung ein und dürfte gut 9,7 ha Größe besessen haben.“ (:2) Das gesamte Wirtschaftszentrum erstreckte sich jedoch beidseits der Peene, d. h. auch zum gegenüberliegenden Ort Görke.

„Zum zweifellos vorhandenen Hafen am Peeneufer gibt es bislang keine archäologischen Befunde“ (BIERMANN 2003:3), aber eine ungefähre Lokalisierung wurde dennoch - auf Menzliner Seite vorgenommen (siehe Abb. V-14). 


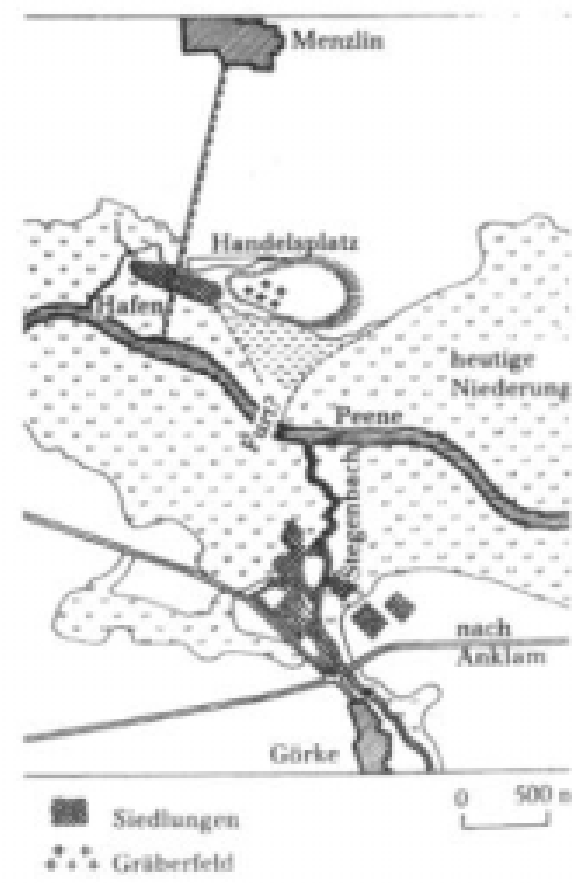

Abb. V-14: Plan des Seehandelsplatzes Menzlin-Görke (nach U. Schoknecht, aus: BIERMANN 2003:1)

„Die Verdichtung solcher Ort an der Odermündung ist nicht zufällig: In nahezu allen vor- und frühgeschichtlichen Epochen spielte diese Areal eine besondere Rolle im wirtschaftlichen und kulturellen Austausch zwischen dem Ostseegebiet und Zentraleuropa bzw. zwischen Skandinavien und dem nordwestslawischen Binnenland.“ (BIERMANN 2003:1)

\section{d.4.2.2 Hoch- und Spätmittelalter}

Der hochmittelalterliche Landesausbau vollzog sich in Rodungsperioden vom 8. - 13. Jh., die nachmittelalterliche Ausbausphase fand gegen Ende des 15. Jh. ihren Abschluss. In mehreren Phasen zogen in hoch- und nachmittelalterlicher Zeit Landesherren bzw. weltliche und geistliche Grundherren, eine besondere Rolle spielten dabei die Zisterzienser (siehe d5), Siedler aus dem Westen als bäuerliche Kolonisten, aber auch als Kauf- und Bergleute in das Land (LIENAU 1995:173). Dies führte zu umfangreichen Neu- und Wiederbesiedlungen seit der Hälfte des 15. Jh. Der dadurch entstehende große Landbedarf machte darüber hinaus die Erschließung auch für die Landwirtschaft ungünstiger Gebiete notwendig. Dazu gehören die höheren Bereiche der Mittelgebirge und die weiten Buntsandsteinlandschaften im mittleren und südlichen Deutschland sowie feuchte Waldgebiete im Flachland (:172). „Auch die bisher siedlungsfreien versumpften Talniederungen erfuhren jetzt eine Besiedlung, vor allem durch die in den Flußniederungen [...] sehr zahlreichen festen Höfe und Wasserburgen." (KREINER 1996b:78) Viele Orte sind in merowingischer Zeit in ausgesprochener Sumpfrandlage an der Terrassensteilkante gegründet worden (:102). Diese Ungunstlage mag auch ein Grund für die Wüstungsperiode der 1. Hälfte des 14. Jh. bis 2. Hälfte 15. Jh. gewesen sein, denn ,auch naturgeographische Ungunst und Wandlungen können $\mathrm{zu}$ Wüstungen führen." (NIEMEIER 1977:165).

So vertritt HEINE (o.J.:38) die Ansicht, „es wäre nun aber ein Irrtum, wenn man glauben wollte, daß ein großer Teil der Dörfer nur durch Seuchen, Fehden oder Kriege, etwa der dreißigjährige entvölkert und zerstört worden sei. Gewiß sind auch manche in solchen wilden Zeiten von der Erde verschwunden; aber die meisten verdanken ganz natürlichen Ursachen ihren Untergang, wie zum Beispiel insbesondere dem Mangel an Wasser.“ Aber ob die Mehrzahl der Wüstungen ,auf ein freiwilliges Aufgeben der bisherigen Niederlassungen seitens ihrer Bewohner zurückzuführen" ist, wie HEINE (:42) mutmaßt, ist zweifelhaft. DUNIN-WASOWICZ (1990:97) sieht dafür „climatic changes in the 
early Middle Ages $\left(11^{\text {th }} / 13^{\text {th. }}\right)$ “ als Ursache. "These changes coincided with topographical shifts in settlements patterns."

War im frühen Mittelalter die traditionelle Siedlungsbindung im Binnenland durch das Vorkommen an natürlichen Gewässern zum Zwecke der Bewässerung und der Schifffahrt gekennzeichnet, so wurde diese Bindung auch im Hochmittelalter zwar gesucht, aber nur selten erreicht (siehe den Zusammenhang zwischen Wüstung und Aufsiedlung). Die hochmittelalterlichen Siedlungsgründungen auf den Rodungshochflächen der Mittelgebirge lagen zwar trockener, mussten dafür aber Schwierigkeiten bei der Wasserversorgung in Kauf nehmen (GRADMANN 1913:68).

Die weiter unten befindlichen Täler waren hingegen zumeist für eine landwirtschaftliche Betätigung zu eng und boten für eine Besiedlung zu wenig Raum. In diesen Lagen ,gesellte sich im Nachmittelalter ein neuer Typ von Siedlungen hinzu, der einen durchaus industriell anmutenden Einschlag zeigte" (SCHWARZ 1988:44) und die Gewässer als Wasserkraft benutzte. Hier hatten Wassermühlen ihren Standort, die zwar zu den Siedlungen der Hochfläche gehörten, innerhalb dieses Bereiches aber nicht die genügende Wasserkraft zur Verfügung hatten (:71). Mühlen, Schmieden, Sägen und Stampfen hießen ,genau jene Betriebe, die von der Wasserkraft abhängig waren und deswegen neben Bächen und Flüssen gelegen sind“" (GIUS 1994:165).

Des Weiteren führte der hochmittelalterliche Erzbergbau durch die Verbindung von Erzvorkommen, Holz und Wasserkraft zum Entstehen von Bergbausiedlungen und Hüttenorten in bislang überhaupt noch nicht nennenswert besiedelten Gebirgshöhen (z. B. Harz, Erzgebirge) oder zu einer Verdichtung der Bevölkerung in bis dahin nur landwirtschaftlich genutzten Gebieten (z. B. Siegerland). Von dieser Aufsiedlung betroffen waren insbesondere die bis dahin noch weitgehend unbeeinflussten natürlichen Gewässersysteme. Auch in Norddeutschland (Schleswig-Holstein) konzentrierten sich die Raseneisenerzlagerstätten ,in den Niederungsgebieten einiger kleiner Auen und Bäche.“ (HAUKE 1966:60) und wurden somit in den Veränderungsprozess einbezogen.

Seit dem Mittelalter - und bis zur Mitte des 19. Jh. - gab es zur Erzzerkleinerung nur die sog. Pochwerke, „die in großer Zahl an Bachläufen nahe der Gruben standen.“ (LIESSMANN 1997:95f.) Für die nachfolgende Verhüttung der Erze, d. h. für das Verschmelzen der Erze mittels einfacher Schmelzöfen wurde zunächst Brennstoff benötigt, der in vorindustrieller Zeit durch Holzkohle gegeben war. Für die Wahl der ersten Hüttenplätze von Waldschmieden, den Bauernrennfeuern, war deshalb das Vorhandensein größerer Waldbestände mit bestimmten Holzarten für qualitative Holzkohlen, z. B. Buchen und Birken, am Ort des Bergbaus selbst entscheidend, da sich in den Anfängen ein Transport von Holzkohle über größere Entfernungen verbot. Darüber hinaus begünstigte die Hüttenansiedlung eine möglichst günstige Lage zu Verkehrswegen, um das Eisenerz bequemer heranzuschaffen und um das erzeugte Schmiedeeisen gut abtransportieren zu können (ALTMANN 1999:31).

Doch nicht nur ausreichender Waldbestand für eine gesicherte Holzkohlenversorgung, die Anbindung an Verkehrswege und natürlich verwertbares Erzvorkommen in der näheren Umgebung war für den Schmelzbetrieb notwendig. Ebenso unabdingbar war ,das Vorhandensein von Wasser in der Nähe des Hüttenplatzes“ (ALTMANN 1999:31) in Form von kleinen Bächen oder für Sammelteichen für

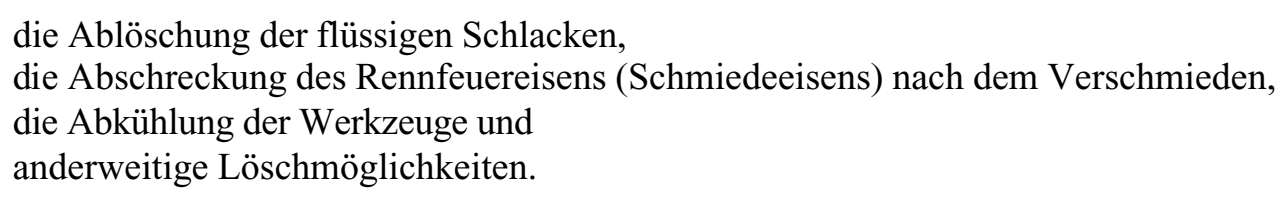

Es lassen sich in Bezug auf die naturräumliche Ausstattung zwei Standorttypen der Eisenverhüttung, die sich an den Fundplätzen der Schlackenhaufen, als Reliktform und Standort früherer Eisenverhüttung, orientieren, am Beispiel des Harz-Vorlandes erkennen, „wo die meisten Hüttenstellen dieser Art auftreten“ (JÄGER 1965:423):

1. kleine Schlackestellen an spärlich bis periodisch fließenden Nebenbächen ohne Teichanlagen

2. ausgedehnte Schlackenplätze mit ehemaligen Teichanlagen. 
Ein steigender Schmiedeeisenbedarf ${ }^{20}$ im 14. Jahrhundert zwang die Bergschmieden zu Produktionserweiterungen. Jetzt entstand aus der Nebentätigkeit der Bauernrennfeuer für die Landwirte die Haupttätigkeit des Betriebes der Schmiedehütten - und die Landwirtschaft wurde mehr in Nebentätigkeit betrieben.

Um dem erweiterten Produktionsumfang gerecht werden zu können, wurden nun nicht mehr die kleinen Quellschüttungen und Bäche mit den von ihnen gespeisten ,Löschteichen' als Hüttenstandort aufgesucht, sondern die Täler mit genügender Wasserkraft; die sog. „Großtäler“ (LIESSMANN 1997: 224) bildeten die bevorzugten Ansatzpunkte von Erzhütten. Wann dies genau geschah, ist strittig. ALTMANN (1999:32) spricht davon, dass spätestens im 14. Jahrhundert die einfachen Schmiedehütten (Bauernrennfeuer) an die Gebirgsbäche und -flüsse verlegt worden sein dürften, „um jetzt die mechanische Energie des Wassers, zur Erleichterung der menschlichen Arbeit, als Antriebselement für Blasebälge und mechanische Hämmer zu nutzen.“ KLEßEN (2000:4) hingegen meint, dass „das erzverhüttende Gewerbe etwa seit dem 16. Jh. durch den Gebrauch von Wasserrädern als Energielieferant an die größeren Flußläufe gebunden war." Dies war jedenfalls dann der Fall, sobald sich der Blasebalg als künstliche Kraftquelle durchsetzte, aber vor allem, seitdem dieser durch Wasserkraft angetrieben wurde - eine Erfindung, die erst im Hochmittelalter in die west- und mitteleuropäischen Bergbaugebiete gelangte (SCHWARZ 1988: 311). JOCKENHÖVEL (1996b:23) geht ebenfalls davon aus, dass sich offenbar ,im ausgehenden Hoch- und Spätmittelalter der gewaltige Umschwung in der Verlagerung von alten Rennofenverhüttungsplätzen von den mittleren und oberen Hangflächen, Quellmulden und Seifen $\left[{ }^{21}\right]$ in die größeren Bachtäler landschaftsbezogen und zeitlich versetzt" vollzog, ist jedoch der Meinung, dass „im ausgehenden Mittelalter Eisenwerke mit und ohne Wasserkraft in direkter Nähe nebeneinander existiert haben“ und differenziert noch einmal „,zwischen wassergetriebenen Bälgen und wassergetriebenen Hämmern.“

Tatsache aber ist, dass sich die Verhüttungsplätze, ob im Sieger- und Sauerland oder im Schwarzwald, „perlschnurartig entlang der Bäche“ reihen oder ,an Quellmulden“ liegen. Nur etwa ein Zehntel von Schlackefundstellen zeigt keinen direkten Bezug zum Wasser (JOCKENHÖVEL 1996b:18).

Besonders die Schmelzhütten waren große Holzverbraucher, die schnell die umgebenden Waldflächen gerodet hatten. Sie lagen deshalb immer an den Flüssen oder Bächen, auch um das Triftholz möglichst schnell empfangen zu können (SCHMIDT 1997:202). So lagen beispielsweise die bisher in großer Zahl nachgewiesenen Hütten des Unterharzgebirges zur Verhüttung der Rammelsberger Erze „meist an Flüssen und Bächen, die dieses nach Norden verlassen, wie Innerste, Grane, Oker, Radau.“ (KAUFHOLD 2000:41) Die ausgebauten Schmelzhüttenplätze des Bergbaus sind insofern strukturiert durch ein System von Wassergräben, die, mit Holz ausgekleidet, der Aufbereitung des Erzes oder aber auch der Schlacken gedient haben dürften, und durch einen ebenfalls ausgekleideten Gewässerabschnitt, über den das Triftholz geflößt wurde (vgl. KLAPPAUF 2000:20).

Eine ähnliche Entwicklung lässt sich für Glashütten feststellen, die vom 15. bis ins 18. Jh. auf Waldstandorten in der Nähe einer Quelle oder eines Baches episodisch betrieben wurden (JÄGER 1965:424). „Fast immer befanden sich die Glashütten an Bachläufen, sehr oft sogar am Zusammenfluß zweier Bäche." (GRÖNKE 1990: 131)

Das Beispiel einer fossilär vorliegenden Glashütte des 17. Jh. am Nordufer des ,Lakenteiches' im Solling verdeutlicht diesen gewässerhistorischen Zusammenhang. Der davor befindliche Lakenteich

\footnotetext{
20 Um eine Vorstellung von den produzierten Geräten zu bekommen: Bergeisen (mit Spitze, mit senkrechter oder waagerechter Schneide, gebogene Eisen), Gruppe der Ritzeisen, Vorder- und Hinterachsen, Spurnägel und Beilagscheiben, eisernes Geleucht, Zimmermannsaxt, Schaufel, Kratze, Keil sowie die für den Bergbaubetrieb nicht unmittelbar notwendigen Gegenstände wie einfache Steigeisen, sog. Grödeln, Messer, Schlüssel, Hufeisen und Feuerschläger gehörten zu den geschmiedeten Geräten (nach KLAPPAUF 1996:150).

${ }^{21}$ Seife: Ablagerung von sandigem Feinmaterial und/oder Geröll mit abbauwürdiger Konzentration an Schwermineralien oder Edelsteinen. Seifen sind sekundäre Lagerstätten. In typischer und häufigster Form treten sie als Geröll- oder Sandbänke in Flussläufen auf, in denen sich durch einen natürlichen Schlämmvorgang das schwere und wertvolle Material (z. B. Gold durch Goldwäscherei) angereichert hat (DIERCKE 1987:199).
} 
am Fuße einer Quelle wurde dabei aber erst in späterer Zeit zu Zwecken der Holztrift aufgestaut (siehe VII 5t).

Die Waldglashütten mussten, hatten sie ihren Holzvorrat in ihrer Nähe aufgebraucht, im Laufe der Jahrhunderte wandern. Immer jedoch versuchte man, den neuen Hüttenstandort nicht allzuweit von dem Verkehrsweg Wasser entfernt anzulegen, da sowohl für den Transport von Hafenton (Schmelzofen bzw. Schmelztiegelton), Sodaasche und Kalk als auch für den Abtransport der fertigen Waren „der Wasserweg von hervorragender Bedeutung war“ (HENCKEL 1988:74).

Mit zunehmendem Siedlungsbau stieg der Produktionsbedarf im Nachmittelalter erheblich an und damit auch der Bedarf an Glashütten. Ende des 16. Jahrhundert beispielsweise siedelte der Coburger Herzog Johann Casimir aus dem Schwarzwald und aus Böhmen kommende Glasmacher am Südhang des Thüringer Waldes an. 1597 nahmen am Fehren- und am Lauschabach die ersten größeren Glashütten die Produktion auf (IGNASIAK 1994).

Auch im Südharz hat es seit dem 16. Jh. zahlreiche größere Glashütten gegeben. So ist 1596 eine Glashütte in der Nähe von Wieda und eine in der Nähe des Harzer Waldortes ,Rothesütte' belegt. Andere Glashütten lagen bei Steina (1593/94) bzw. am Glasebach bei Breitungen im Kreis Sangerhausen (TENNER 1925:13 ff.).

Die große Konzentration von Glashütten in einigen Tälern bzw. Forsten mit Gewässerdurchfluss führte bald $\mathrm{zu}$ einem akuten Holzmangel. Auf Grund eines herzoglich-braunschweigischen Holzverbotes von 1618 beispielsweise musste in diesem Herrschaftsbereich der Hüttenbetrieb zugunsten der Eisenhüttenwerke eingestellt werden bzw. die Gläsner wurden gezwungen sich nach neuen Energiequellen umzusehen. Mit der Steinkohle war die neue Energiequelle gefunden. Sie führte aber gleichzeitig auch zu einer Abwanderung der Glashütten aus dem Walde. Damit war der Übergang zu einer industriellen Glasproduktion an verkehrsgünstigen, wasserungebundeneren Standorten eingeleitet (vgl. GRÖNKE 1990: 132).

Im Flachland setzten sich im Zuge der Peuplierungsbestrebungen die bereits zu Beginn des 12. Jh. begonnenen umfangreichen Kultivierungsarbeiten der norddeutschen Niedermoor- wie auch insbesondere Hochmoorgebiete, weiterhin fort (SCHWARZ 1988:71). Die Hochmoorsiedlungen, die zumeist auf abgetorften Grund errichtet wurden, halten sich dabei an die bereits während der frühmittelalterlichen Siedlungsperiode errichteten Kanäle und Flussläufe, weil diese zumindest in früherer Zeit die wichtigsten Verkehrsadern abgaben (:71).

Auch die im 14. Jh. geplanten Flussmarschhufen wurden im Rahmen der Durchführung der Moorkolonisation an Gewässer gebunden. $\mathrm{Zu}$ schiffbaren Flüssen ausgebaute Fließgewässer oder künstlich errichtete Torfkanäle beförderten den abgetorften Brennstoff und andere Waren in die Städte (BORN 1977:57). Ähnlich wie bei den Holländerhufen des Frühmittelalters wurden die Fluren der Moorhufensiedlungen in den Niederungsmooren der Weserflussmarsch binnenwärts durch Achterdeiche begrenzt, ,flußwärts lagen die Gehöfte locker aufgereiht an Wegen, die an Nebenflüssen entlangführten“(FLIEDNER 1970:67).

Die größte Siedlungsausweitung aber verband sich mit der Ostkolonisation. Mit dieser bereits seit dem 12. Jh. erfolgten, aber erst in der hoch- und nachmittelalterlichen Besiedlung durchgeführten Landbelegung, begann die wirtschaftliche und kulturelle Erschließung der Gebiete östlich von Elbe, Saale und Böhmerwald (LIENAU 1995:172). Auch hier wurden Siedlungslagen in Gewässernähe bevorzugt. Der reine Fischfang, der zumeist der höfischen bzw. geistlichen Versorgung diente, entwickelte sich zur Fischerei, d. h. zum eigentlichen Gewerbe.

Viele deutsche Städte verdanken der Gewässerlage ihren Ursprung, sie war ,zur Zeit der Stadtwerdung oder Stadtgründung von entscheidender Wichtigkeit" (GLAUSER 1978:63), zunächst um sich so ihre Nahrungsquelle, die Fischerei, zu erschließen. So zitierte bereits FRIEDEL (1884:46f.) einen - mir nicht bekannten - Berliner Historiographen König, der mit Sicht auf Brandenburg ausführte: „Wirft man einen Blick auf die Lage der alten Städte der Mark Brandenburg, so findet man, 
daß sie mehrentheils, mit kluger Absicht, an Gewässer und schiffbare Flüsse angelegt worden sind, welche wohl anfänglich nicht sowohl zur Handlung dienen sollten, als weil sie den ersten Bewohnern Unterhalt gaben. Die Fischereien in der Mark sind von jeher sehr ergiebig gewesen, und gaben den ersten Nahrungszweig ab. Leider haben sie in neueren Zeiten sehr abgenommen, und sein nicht mehr, was sie waren, wovon nicht allein die zugenommene Menge der Menschen, welche die Wasserbewohner in großer Anzahl aufzehren, sondern die Einschränkungen der Flüsse, durch das häufige Urbarmachen, Ursachen geworden sind. Verschiedene Städte, z. B. Wrietzen an der Oder, trieben einen so ansehnlichen Fischhandel im Auslande, daß man den alten Nachrichten davon kaum Glauben zustellet, und die Kietze und Kietzer sind Namen, die man sehr im Brauch findet, wo fischreiche Städte sind. Natürlich ließen sich also die Kolonien des Markgrafen Albrecht gern an solche Flüsse nieder, wo ihnen die Natur sogleich einen so bestimmten als reichhaltigen Unterhalt anwies."

Im Mittelalter mied man aber die feuchten Talsohlen der Hauptflüsse und suchte auch am Fluss ausgesprochen trockenes Gelände auf (GLAUSER 1978:64). Wo immer möglich, zog man es vor, die Stadt auf einer Terrasse auf dem Steilufer zu errichten. Beispiele dafür sind Basel, Kaiserstuhl, Klingnau und Baden. Alle diese Städte ,lagen gleichermaßen an alten Übergängen über Aare, Saane und Reuss"(:64).

Bei der Wahl des Standortes einer Stadt am Fluss trat infolgedessen ein nicht unwesentlicher Gesichtspunkt regelmäßig zurück: die Wasserversorgung. „So paradox es klingen mag, die Flussstädte litten meist an Wassermangel, genauer gesagt Mangel an gutem Wasser.“ (GLAUSER 1978:64), wenn auch doch da und dort zumindest in der Frühzeit der Fluss als Wasserlieferant gedient haben muss (:64).

Höhere Ansprüche an die Lebens- und Hygieneverhältnisse und ein gestiegene Bevölkerungszahlen in den Städten führte im Hochmittelalter zu Siedlungslagen außerhalb der unmittelbaren Wasserversorgung und infolgedessen zum Bau von Wasserkünsten, von Laufbrunnen und ihren hölzernen Zuleitungen. Dennoch blieb die grundsätzliche Bedeutung der Gewässerlage bestehen. Städte konnten ,nur dort existieren, wo bestimmte topographische Voraussetzungen erfüllt waren. Sie lagen stets am Wasser, am Fluß oder am See oder an der Meeresküste, entweder auf einem hohen Sporn direkt oberhalb des Gewässers oder auf einem steilen Hang. [...] An flachen Ufern baute man keine Städte“, beschreibt KÜSTER (1998:133) die hydrologische Lage in Angst vor der Hochwassergefahr und fährt fort: „Erst spät dehnten sich die Städte auch in niedrig gelegene Gebiete aus, wo man nicht sicher vor Überflutungen sein konnte." Die Wahl der Schutzlage nämlich, die gerne hervorgehoben wird, „kam erst an zweiter Stelle“. Die Stadt als Befestigungsanlage war ja eine Geländeverstärkung, um Fluss und Flussübergang in den Griff zu bekommen. „Sie hatte nicht Schutz zu suchen, sondern Schutz zu bieten“ (GLAUSER 1978:63). Der Fluss selbst bot, wenn die Stadt direkt am Ufer stand, als natürlicher Stadtgraben den ersten Schutz. So war denn die Stadt gegen die Flussseite hin in der Regel genau gleich befestigt, wie entlang den übrigen Stadtgräben. „In jedem Fall lehnte sie ihre Breitseite an den Fluß an und dehnte sich mit Vorliebe dem Ufer entlang aus." (:63)

Wasser war darüber hinaus vielmehr ein wichtiges „Versorgungsgut“. „Über das Wasser kamen wichtige Waren in die Stadt, die für das Überleben der Stadt und ihrer Bewohner essentiell waren, das Wasser trieb die Mühlen an, das gewerbliche Herz der Städte.“ Überhaupt, „schon wenn die Initialen einer Stadt errichtet wurden, brauchte man Wasser" stellt KÜSTER (1998:133) das unbedingt Notwendige einer Städtegründung dar: „Man schuf einen Mühlenstau, baute also ein Wehr, mit dem man das Wasser anstaute, um seinen Lauf zu lenken.“

„Großstädte“ der damaligen Zeit hingegen wuchsen an ,großen' und ,mittleren' Flussläufen heran. Hier war die Schiffbarkeit, aber auch die Überquerbarkeit ein entscheidendes Kriterium. So boten seichte Flussabschnitte, wie beispielsweise in der Weser oder in deren aufspaltenden Mündungsarmen Werra und Fulda, ideale Furten und führten im Mittelalter zur Gründung von Städten wie Huxori (Höxter) und Münden (vgl. HANDTKE 1993:93).

Die schiffbare und fischreiche Oberweser war überhaupt seit dem Mittelalter mit 12 unmittelbar am Fluss gelegenen Klöstern und bedeutenden mittelalterlichen Handelsstädten die Achse eines damalig 
bedeutenden Kulturraumes. Die in der Talaue am südlichen Ufer der mittleren Weser liegende Ort Rinteln beispielsweise war von Sumpfgebieten, seeartigen Flussarmen und der Exter als Zufluss zur Weser umgeben. Bereits 1150 wird eine ältere Siedlung nördlich des Flusses unter dem Namen „Rintbehi“ erwähnt. In diesem Alt-Rinteln bestand auch ein Benediktinerinnenkonvent, das 1238 in die am linken Weserufer gelegene, als Civitas bezeichnete Stadt, verlegt wurde. Die Stadt, die 1239 durch Graf Adolf IV. zu Schaumburg das Lippstädter Stadtrecht verliehen bekam, wurde bis zur Industrialisierung in der zweiten Hälfte des 19. Jh. von keinen überregionalen Fernhandelsweg berührt. „Vornehmlich die Weser als schiffbarer Handelsweg erlaubte der Stadt eine bescheidene Teilnahme am Fernhandel“" (SPRENGER 1995:23).

Auch die meisten der im Hochmittelalter aufblühenden Handelsstädte waren mit Schiffen erreichbar. Zur Zeit Heinrichs des Löwen war Braunschweig an der Oker noch Hafenstadt für den Schiffsverkehr nach Bremen, und das Lüneburger Salz nahm seinen Weg nach Lüneburg auf Frachtkähnen über die Ilmenau und den 1390 - 98 erbauten Stecknitzkanal. Eine besondere Bedeutung haben Gewässer für die Entwicklung des Berliner Raumes gehabt: Berlin-Cölln ist auf einer Insel in der Spree gegründet worden. Auch hier bildete die Querung des Flusses den Ausgangspunkt der Stadtentwicklung (STRAUSS 2002:17). Ebenso verdankt der Ort Spandau seine frühere Bedeutung der ,günstigen topographischen Lage im Mündungsbereich der Spree in die Havel.“ (:24) Dies geht auch aus der Namensgebung hervor, bedeutet der slawische Name „Spandowe“ doch „Zusammenfluss“ (:24). Die erste größere Siedlung Spandaus befand sich als slawische Burganlage auf der Höhe des Burgwalls südlich der heutigen Altstadt, gegenüber dem ursprünglichen Mündungsbereich der Spree in die Havel. Nicht die Spree und Havel allein sind als Gewässer prägend für die Entwicklung der Stadt Berlin gewesen. Neben der Dahme, der Wuhle und der Panke gliedert eine Vielzahl kleiner Bäche und Gräben die Stadtstruktur. Bereichert wird die Gewässerlandschaft um die zahlreichen großen und kleinen Seen und die seenartigen Aufweitungen der Flüsse mit dem Wannsee und dem Müggelsee als den größten Seen (:7). In der historischen Entwicklung im Berliner Raum wurde so „dem Wasser immer eine Funktion zugewiesen“, während hingegen „eine gestalterisch-ästhetische Integration der Flüsse [...] versagt blieb.“ (:8)

Doch nun zu Hamburg, dem Inbegriff einer ,amphibischen Stadt ${ }^{\star 22}$. Hier sah die Situation der Einbeziehung des Wassers in die Stadtstruktur ganz anders aus. Die beruht auf dem Ineinandergreifen von Wasser und Land - mit Alster, Bille und Elbe sowie deren Marschen.

Auf dem Geestsporn, der sich in Form einer Zunge von Osten her zwischen dem Elbezufluss Alster und der südlich verlaufenden Bille als Alsterarm zur Elbe vorschiebt, lag als Keim der Stadt der HolzErde-Wall der karolingischen ,Hammaburg' mit einem Durchmesser von rund $120 \mathrm{~m}$, die noch heute durch Petrikirche und Rathaus als das Zentrum der Stadt repräsentiert wird. Das schmale Gewässer diente der Hammaburg als Schiffsgelände; Uferbefestigungen und regelrechte hölzerne Kaianlagen, besetzt anscheinend mit Speicherhäusern, entstanden hier seit der Mitte des 9. Jh. als die ersten HafenKunstbauten der Stadt. Bereits im 9. und 10. Jh. war Hamburg eine blühende Hafen- und Fernsiedlung (HIPP 1990:28).

Nach der wiederholte Zerstörung Hamburgs durch slawische Obotriten im 11. Jh. gab ein umfassender Neuaufbau der künftigen Stadt dauerhafte Strukturen. Um diese Zeit wurde Hamburg von der sich schnell entfaltenden Binnenkolonisation erfasst, die auch zur ersten Besiedlung der Elbmarschen führte (HIPP 1990:29) und das stetig wachsende „suburbium“ breitete sich in der ausgedehnten Flussmarsch weiter aus. Bis ca. 1230 aber besaß die Stadt keine andere Befestigung als die Gewässer und den alten Heidegraben (:30).

\footnotetext{
${ }^{22}$ Hier kann die prosaische Definition von HIPP (1990:32) überzeugen: „Sie [die amphibische Stadt, B.B.] ist dem Wasser abgewonnen, vom Wasser durchdrungen und sie lebt davon. Sie hat auch oft darunter gelitten". Generell handelt es sich bei einem ,amphibischen Raum' „um Räume, in denen der Mensch wegen der Vernässung weder Wohnstätten errichten noch wirtschaften kann.“(LESER et al. 1987, Bd. 1:28)
} 


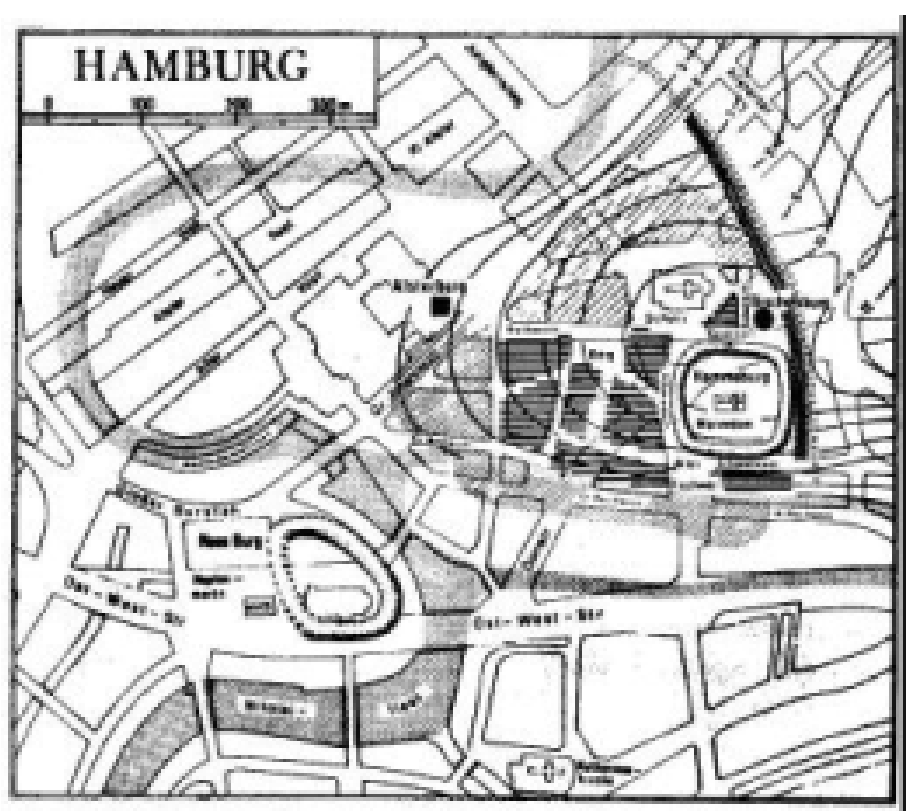

Abb. V-15: Die Alster im alten Hamburg

Aus der Darstellung ist die Spornlage an der Alsterschleife gut sichtbar (aus: HIPP 1990:29).

Fernhandels- und Hafenstadt sollte die Neustadt sein, und die Lage an der Alster schuf die Voraussetzungen für ein Schiffgelände, das im Uferbereich vermutet werden muss. In Zusammenhang mit der Gründung der „Neustadt“ im Jahr 1186/1187 war die Alster am Großen Burstah (Mühlenbrücke), auf dem Gelände der Neuen Burg, für eine Wassermühle aufgestaut worden. Spätestens um 1235 zog man einen neuen Mühlendamm quer durch das Tal, den heutigen Jungfernstieg. Er staute die Alster bis hinauf nach Eppendorf. Der See von Binnen- und Außenalster ist also nichts anderes als der Hamburger Mühlenteich (HIPP 1990:29f.).

Seit dem 13. Jh. haben die Hamburger auch die Wasserlandschaft im Stromspaltungsgebiet der Elbe durch Ableitungen, Abdeichungen und Durchstiche der Wasserläufe systematisch verändert, kulminierend in der Heranführung der Norderelbe an die Stadt im 16. und frühen 17. Jh. Selbst die heute idyllische Alster ist im 15./16. Jh. zur Wasserstraße umgebaut worden, wenngleich der zwischen 1525 und 1529 hergestellte - und 1448 - 52 schon einmal vergeblich begonnene - Alster-Trave-Kanal nicht zu einer dauerhaften Wasserverbindung mit Lübeck geführt hat (HIPP 1990:32).

Auch Dessau, die ehemalige Residenzstadt des Staates Anhalt verdankt der Spornlage, die Stadt liegt auf eine Höhe von $62 \mathrm{~m}$, an Elbe und dem Zusammenfluss der kleineren Mulde seine Bedeutung. Durch die Übergänge von Mulde und Elbe „war es eine günstige Lage für die Entwicklung der Stadt.“ (HUHN 1992:1)

Doch nicht die Elbe, sondern „Rhenus fluvium princeps“ - der Rhein ist der Fürst aller Flüsse - sagte das Mittelalter. „Wie der Nil den alten Ägyptern und der Ganges den Indern mehr war und ist als bloßer Wasserlauf, so ist uns der Rhein heilig, er ist der Schicksalsstrom“, er ist „Sinnbild deutschen Lebens“, wie KOLB (1989:10f.) pathetisch ausführt.

Doch nicht allein der „Geist dieses Stromes“ (KOLB 1989:11) war von Bedeutung, sondern auch seine siedlungsgeographische Bindungskraft, denn an den rheinischen Ufergebieten und Nebenflüssen entwickelten sich Städte, Dörfer und Burgen in buntem Wechsel. „Besonders wichtig wurde für den später von der Wissenschaft so bezeichneten ,inneren Landesausbau' in Deutschland“, schreibt SEIBT (1999:151) in seinem Werk zur wechselvollen Geschichte des Mittelalters, „das Rheingebiet mit seinen Nebenflüssen. Hier lagen am Hauptstrom von Köln bis Basel Altsiedelräume, auch mainaufwärts und an der Mosel. [...] An der Sieg und im Westerwald, an der Lahn und um Limburg gab es ebenfalls alte Siedelräume. Von hier aus wurde seit dem 10. Jahrhundert allmählich Neuland erschlossen, zunächst in den Niederungen, dann bachaufwärts im naßkalten Sauerland bis in höhere Waldregionen und schließlich im Westerwald. [...] Der Rhein war vom 10. bis zum 13. Jahrhundert 
die Schlagader des deutschen Lebens [...] und“, so fährt er in seiner Beschreibung fort, „weil sich die alten Straßen sowie der Lastenverkehr nach Flüssen und Bächen richtete, schuf das ganze Flußsystem auch besondere Zusammenhänge von Freiburg bis nach Wesel. Dieses Netz zog sich bis in den Schwarzwald, die Eifel und die nördliche Schweiz“.

Wie auch schon an der Elbe, so werden auch am Rhein dieselben Siedlungsmuster erkennbar, wie das Beispiel Düsseldorfs zeigt. Das Dorf an der Düssel lag auf einem Sandhügel, 6 bis $8 \mathrm{~m}$ über dem Normalwasser des westlich vorbeifließenden Rheins. Im Süden fiel das Gelände ziemlich steil ab bis an die unterhalb liegende Düssel und grenzte im Norden bis zum Eder, dem Rest eines alten Rheinarms. Das Niveau des Düssel-Bachlaufs ,war damals wesentlich tiefer als heute, weil das Wasser noch nicht gestaut war.“(SPOHR 1988:45)

Die Düssel wurde in die Befestigung miteinbezogen und die Gräben von ihr bewässert. Die erst 1377 urkundlich belegbare Burg lag außerhalb der befestigten Stadt an der Düsselmündung. Das dort leicht ansteigende, aber nicht hochwasserfreie Gelände war durch die sich im Mündungsgebiet teilenden Düsselarme von Wasser umgeben und daher als Bauplatz für die Wasserburg besonders geeignet. Unmittelbar vor der Stadt hatten sich entlang der Düssel die verschiedensten Gewerbe angesiedelt. Im 14. Jahrhundert ist beispielsweise unterhalb der Kornmühle eine Ölmühle nachgewiesen und daneben befand sich eine Walkmühle (SPOHR 1988:45).

„Das zweite große deutsche Flusssystem an der Donau“ hat hingegen für die mittelalterliche Landesentwicklung und auch später ,nie dieselbe Bedeutung gewonnen wie der Rhein mit seinen Nebenflüssen." (SEIBT 1999:151) Obschon auch hier frühe bedeutende Handels- und Kulturzentren entstanden sind. Am rechten und linken Ufer des Donaustromes beispielsweise, mit den jeweiligen Stadtteilen Buda und Pest, dem heutigen Budapest, errichteten die Römer mit Aquincum bereits im 2. Jh. n. Chr. eine römische Siedlung am pannonischen Limes zum Schutz vor den Angriffen der Barbaren.

Doch nicht immer müssen große Ströme siedlungsfördernd gewirkt haben. Auch die Vielzahl an kleinen Gewässerläufen können maßgeblich für eine Entwicklung gewesen sein, denn ,im allgemeinen war der Fluß nicht geeignet, Wasser für den täglichen Bedarf innerhalb der Stadt zu liefern“ (GLAUSER 1978:64). Dies schon deshalb nicht, weil er immer die unterste Ebene der Stadt bildete: Zum einen war dadurch das nötige Gefälle für die Wasserzufuhr nicht vorhanden und es mussten, wie vorher dargestellt, aufwendige Wasserkünste errichtet werden und zum anderen, weil das Gefälle aber die Abfuhr von Abfällen und der Kanalisation förderte. Für die Wasserversorgung war deshalb das Wasser aus rasch fließenden Bächen dem Flusswasser vorzuziehen. „Aber durch das Gelände, das für den Stadtbann ausersehen war, floß meistens kaum ein Rinnsal, geschweige denn ein Bach. Praktisch überall vernehmen wir, wie Bäche künstlich in die Stadt gelenkt werden mussten“" (:64), wie das Beispiel des mittelalterlichen München belegt. „Der vorhandene Wasserreichtum“, deutet KOHL (1970:8) in seiner im Schwerpunkt eigentlich rechtsgeschichtlichen Dissertation an, „dürfte auch eine nicht unwesentliche Rolle bei der Auswahl des Gründungsplatzes Münchens gespielt haben.” Die flößbare Isar, ihre zahlreichen natürlichen Nebenarme und die von diesen wiederum abgeleiteten Stadtbäche lieferten ideale Voraussetzungen zum weiteren Ausbau einer Siedlung und der in hoch- und nachmittelalterlicher Zeit zahlreichen wasserbetriebenen Mühlen und wassernutzenden Gewerbebetriebe. Denn Betriebe, „Bleichereien wie Brauerei bedurften klaren Quellwassers“ (UNVERFEHRT 1989:51). Bereits gegen Ende des 16. Jahrhunderts gab es in fast allen Städten zahlreiche Bleichwiesen und Brauereien, die sich des ,sauberen' Wassers bedienten.

Vergleichbar, wenn auch nicht in ihrem späteren Wachstum, mit München ist die Mittelstadt Güstrow mit ihrer Gewässerlage. Güstrow liegt an den beiden Wasserläufen Nebel und Teuchelbach, und neben den ,weiten Auen der Nebel“ umschließen zwei an die Stadt grenzende Seen die Stadt (LORENZ 2000:15).

Und wenn es auch noch kleiner wird in der Bemessung der Siedlungsgröße, das gewässerbezogene Siedlungsschema bleibt bestehen als Voraussetzung für die im Hoch- und Nachmittelalter immer bedeutender werdenden Möglichkeiten zum Mühlenantrieb. Die Ortschaft Rethem im Landkreis 
Soltau-Fallingbostel zum Beispiel beweist dies, denn „die geographische Lage auf einer leichten Anhöhe an der Aller im Mündungsgebiet mehrerer Bäche macht den Ort zum idealen Standort für [...] Wassermühlen.“(ERLER/MATTHIESEN 1989:67)

Und schließlich genügt eine „reichliche Wasserschüttung am Quellhorizont“, die „schon früh eine Siedlungsgründung oberhalb der Talaue begünstigt haben“ dürfte, wie HERBST (1992:26) am Beispiel der kleinen Ortschaft Streitberg in Oberschwaben vermutet.

Die Bevorzugung von Gewässerlagen bezeugen auch die zahlreichen hoch- und spätmittelalterlichen Burgen und Herrensitze, so z. B. Wasserburgen wie das heutige Schloss Steinfurt, gelegen ,auf einem großen ovalen, künstlichen Hügel inmitten der Flußläufe der Aa“" (MUMMENHOFF 1977:9) und auch die gesamte Oberburg des heutigen Schlosses Rheda „liegt auf einem ovalen ,Berg' über der Ems“ $(: 9)$.

Lagen natürliche Spornlagen zur Anlage einer Burg nicht vor, so stellte man sie durch Aufschüttung selbst her. Burgen auf künstlichem Hügel, sog. Motten, breiteten sich im 11. Jh. in den Tal- und Flussauenbereichen aus, wie zum Beispiel die 1280 erstmals erwähnte Motte Zoppesmur auf einem mächtigen, aus einem zur Wupper hin abfallenden Hang herausgeschnittenen Burghügel von etwa $50 \mathrm{~m}$ Basisdurchmesser und ca. 8 m Höhe, mit Resten einer Ringmauer am Rande eines Hochplateaus und kräftigem Wall zur Talseite hin. „Eine Burg in der Form einer Motte war [...] nahezu uneinnehmbar [...], wenn breite wassergefüllte Grabenringe die hölzernen Verteidigungsanlagen verstärkten.“ (MUMMENHOFF 1977:10) Der „Wassergraben“ der Motte Zoppesmur besteht heute nur noch aus einem kleinen Bächlein, das zur Wupper entwässert (siehe Abb. V-16).

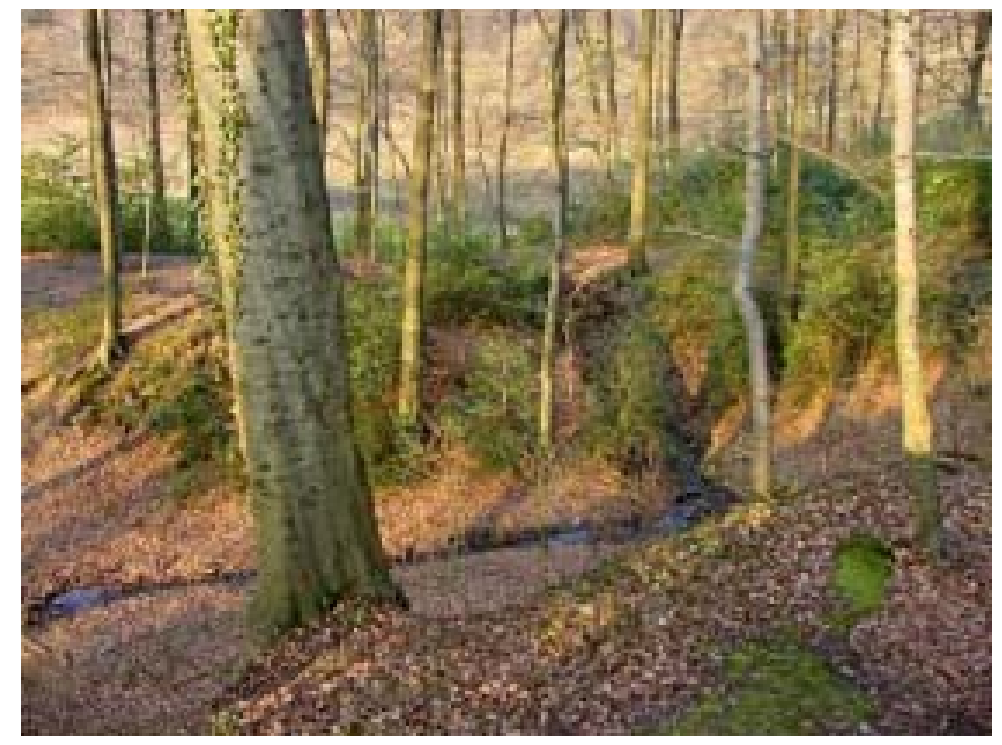

Abb. V-16: Motte Zoppesmur: Bächlein, das die Motte um- bzw. durchfließt (eig. Aufnahmen 2002)

Aus Niedersachsen sind wasserbezogene Mottenhügel aus Bernshausen am Seeburger See (Ldkrs. Göttingen) und beim Weiler Rhode (Ldkrs. Goslar) bekannt.

Der enge Zusammenhang von Burgen des Typs Motte und Turmburgen ist von der Forschung herausgearbeitet worden. Auch von den im späten 11. und 12. sowie im 13. und 14. Jh. errichteten Turmburgen lagen ,eine ganze Reihe im Wasser“ (MUMMENHOFF 1977:16), allein aus dem Grund, dass sie oftmals auf den Fundamenten eines Mottenhügels entstanden sind. Die Turmburg mit ihrem in der Regel - zentralen, festen Gebäude und eng umschließender Ringmauer oder Palisade bietet wie die Motte - nur wenig Platz für Nebengebäude. Motte und Turmburg bilden demnach zwei Varianten des gleichen Bautyps. Der Unterschied liegt in der Überhöhung des Baukörpers. Ein Wohnturm oder Turmhaus erhebt sich optisch-symbolhaft über die ländlich-bäuerliche Bevölkerung, repräsentativ 
und wehrhaft gegenüber den adeligen Standesgenossen. Durch den Mottenhügel erhält dies noch eine weitere Steigerung.

Das umgebende Wasser hatte aufgrund des wehrhaften Charakters nicht mehr allein direkt abwehrende und versorgende Funktion, da - standen andere Getränke zur Verfügung - Wasser nicht als Trinkflüssigkeit genutzt wurden, sondern diente auch der Gefahrenabwehr, indem man heißes Wasser angreifenden Feinden überschüttete.

Das späte Mittelalter dann ist die Zeit der gotischen Wasser- und Niederungsburg und des Ausbaus der Höhenanlagen, wobei die Gewässereingriffe geländetopologisch bedingt bei den Niederungsburgen von größerer Tragweite sind. Aber auch die Höhenburgen lagen zumeist oberhalb eines schiffbaren Gewässers, galt es doch gerade bei den großen Burganlagen, standesgemäße Versorgungs- und Luxusgüter heranbringen zu können.

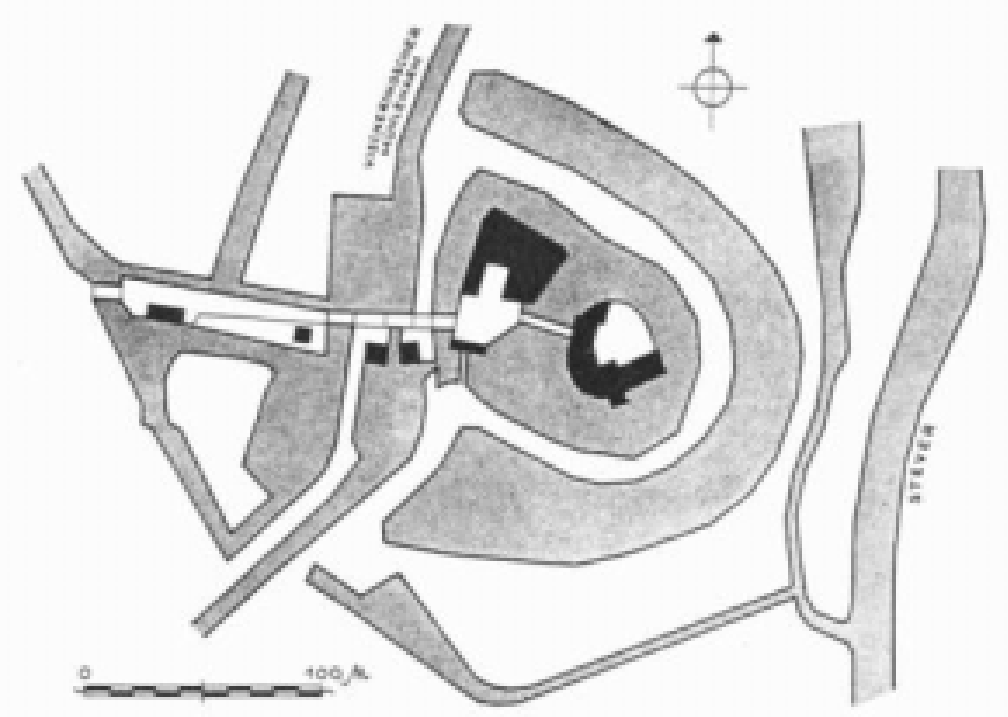

Abb. V-17: Schematischer Lageplan Burg Vischering. Rekonstruktion nach dem Urkataster

Die anthropogen hergestellte Umgrenzung mit Wasser und die „Wasserlage“ an der Stever wird deutlich (aus: MUMMENHOFF 1977:15).

Die zunehmende Bedeutung der Flüsse als Verkehrswege für die an den Flussläufen entstehenden Städte lässt die Menschen infolgedessen eindringlicher in die (Gewässer-) Landschaft eingreifen (SCHUBERT 1989:32). Nutzungseingriffe bei schiffbaren Flüssen in dieser Zeit umfassen das Ausbaggern der Fahrrinne, z. B. die Ilmenau bei Lüneburg (1322 Jh.), oder die Umleitung von Flusswasser zum Kanalbau, wie der der um 1400 abgeschlossene erste Kanalbau des Elbe-StecknitzKanals (:32).

\section{d.4.3 Frühneuzeitliche Aus- und Umbauperiode}

Die frühneuzeitliche Aus- und Umbauperiode fällt in die Zeit der 2. Hälfte des 15. Jh. bis zur 2. Hälfte des 17. Jh. Ein erneutes Bevölkerungswachstum ab der 2. Hälfte des 15. Jh. führte zunächst zur Wiederbesiedlung von Ortswüstungen bzw. zur An- und Eingliederung von Wüstungsfluren in bestehende Fluren (LIENAU 1995:174). Erweiterte technische Möglichkeiten der Wassergewinnung mögen vormalige Ungunstlagen zur steten Besiedlung geführt haben. Das Dorf Riehe beispielsweise, ehemals zum Amt Rodenberg und der Grafschaft Schaumburg gehörig, hat ursprünglich an einer anderen Stelle gelegen als heute: auf dem sog. ,Lindenbrink', einer kleinen Erhebung süd-westlich des heutigen Dorfes. Diese Ansiedlung, bestehend aus 5 Bauernstellen, haben ihre Besitzer aber verlassen und sich nordöstlich des Lindenbrinks wieder neu angesiedelt. Die Flur hier heißt „Fauler See“. „Man nimmt an, daß die Bewohner zu diesem Schritt veranlasst wurden, weil sie, besonders in trockenen Zeiten auf dem Lindenbrink nicht genügend Wasser für sich und ihre Tiere hatten, während die Gegend des heutigen Riehe über Wassermangel nicht zu klagen hatte.“ Anlass zu dieser Vermutung geben auf dem Lindenbrink ausgepflügte Grundsteine. Wie aus dem Lagerbuch von $1783 \mathrm{zu}$ erfahren 
ist, war hier die Wasserversorgung durch drei Dorfbrunnen und zwei Bäche gesichert: den Radbach und den Ammerbach. Der Radbach entsprang im nördlichsten Teil des Deisters und trieb zwei Wassermühlen an (SCHRÖDER 1979).

Zudem führte wiederholte Neulandgewinnung in den Marschen und Neurodungen in den Gebirgen ebenfalls zur Erweiterung des Kulturlandes in dieser Phase. Dazu trat als drittes die Neubelebung der Ostkolonisation (sog. zweite Ostsiedlung) mit Anlagen von Plansiedlungen, beispielsweise im bereits während der ersten Kolonisationsstufe meliorierten Danziger Werder oder der Netzeniederung ${ }^{23}$ in Ostpreußen (LIENAU 1995:175). In der frühen Neuzeit wurde sogar wieder das Marschhufenprinzip bei der Entwässerung des Danziger Werders und auch bei der Weichselniederung bei Thorn angewendet (BORN 1977:55).

Die Wiederaufsiedlungen wie auch die Neurodungen erfolgten an den Rändern bestehender Fluren und in den Allmenden, in denen man Nachsiedler ansiedelte (LIENAU 1995:174). Hinsichtlich des Gewässerbezuges können aufgrund ähnlicher Siedlungsformen gleichartige Gewässerlagen angenommen werden. In den Mittelgebirgen scheint die aus dem Mittelalter überkommene Einzelsiedlung im Zuge des frühneuzeitlichen Ausbaus nicht wesentlich verstärkt worden zu sein, so dass auch hier die Grundrisse der Gewässerrandlagen Bestand hatten. Auch das relativ große Hofsiedlungsgebiet des mittleren Schwarzwaldes dürfte weniger durch zielstrebigen Landesausbau als eher durch betriebsstrukturelle Veränderungen, die eine ausreichende Ackernahrung sichern sollten, die Grundmerkmale seines noch heute gültigen Erscheinungsbildes erhalten haben. Die allmähliche Durchsetzung des Anerbenrechts um 1500 konsolidierte den bäuerlichen Besitz, intensivierte die Bodennutzung und ließ die charakteristischen Gehöftreihungen entlang von Gewässern aufkommen.

So wird nicht ausgeschlossen, dass ein Teil der frühneuzeitlichen Gehöftreihen des Schwarzwaldes in hochmittelalterlichen Reihensiedlungen im Zuge Landesausbaus seine Vorläufer hat. Leitlinien dieser hochmittelalterlichen gelenkten Hofgruppierungen waren aber auch hier im Allgemeinen Bachläufe oder Wege (HAABE 1960), die dann von den frühneuzeitlichen Gehöftreihen übernommen worden sind. Bezüglich des Abstandes der Gehöfte von den Wasserläufen und der als Standort gewählten Hangseite aber blieb die Regelhaftigkeit gering, ausschlaggebend waren lokale Standortgegebenheiten (BORN 1977:102). (vgl. auch Abb. V-18)

In die Zeit ab dem 16. Jh. fällt auch der Schlossbau, der das Wasser als Repräsentanzsymbol in die zumeist ehemalige Burganlage integriert. „Der umgebende Wassergraben stützte jeweils noch mit seiner sehr bewußten Erschließung, wie durch den , abgehobenen' Eindruck, die repräsentative Ambition bzw. den symbolischen Herrschaftsanspruch." (KRÄMER 1987:5). Die Bedeutung, die man einem Wasserumlauf beim Schloss(um)bau zumaß, wird daraus ersichtlich, wenn ,zu jener Zeit vor dem Anlegen eines Wassergrabens durch Angehörige des niederen und mittleren Adels eine ,Ahnenprobe' notwendig gewesen sein“ soll, man forderte „nämlich den Nachweis von 16 adeligen Vorfahren“(:5), wie dies beispielsweise beim Beverner Schlossbauherrn Statius von Münchhausen der Fall gewesen ist (Umbau von 1603 - 1612). Das zufließende Wasser der Bever wurde also, wie auch an anderen Stellen, in die Errichtung des Schlosses zu anderen als Wehrzwecken integriert, zur gestalterischen, räumlichen Erhöhung der Fassaden, die ,durch die formale Ausbildung des Wassergrabens noch unterstützt wird.“ (:7). Die Gewässerlage hatte aber, wenn auch aus einer grundsätzlich anderen Motivation, weiterhin Bestand.

\footnotetext{
${ }^{23}$ Netze [poln. Noteæ]: rechter und größter Nebenfluss der Warthe, $389 \mathrm{~km}$ lang. Als Quellfluss gilt der östliche Arm, der südöstlich des Goplosees in der Nähe der Stadt Hohenslaza (Woiwodschaft Bromberg) entspringt und diesen durchfließt. Südlich von Bromberg erreicht die Netze das ,Thorn-Eberswalder Urstromtal' und fließt in westliche Richtung. Durch den Bromberger Kanal besteht eine Verbindung mit dem schiffbaren Unterlauf der Brahe und - nach der Einmündung - mit der Weichsel; schiffbar von der Mündung (östlich Landsberg/Warthe) zum Goplosee [,obere Netze], von hier durch einen Kanal zur Warthe bei Konin (Küstrin), dem größten Nebenfluss der Oder (BROCKHAUS 1979).
} 


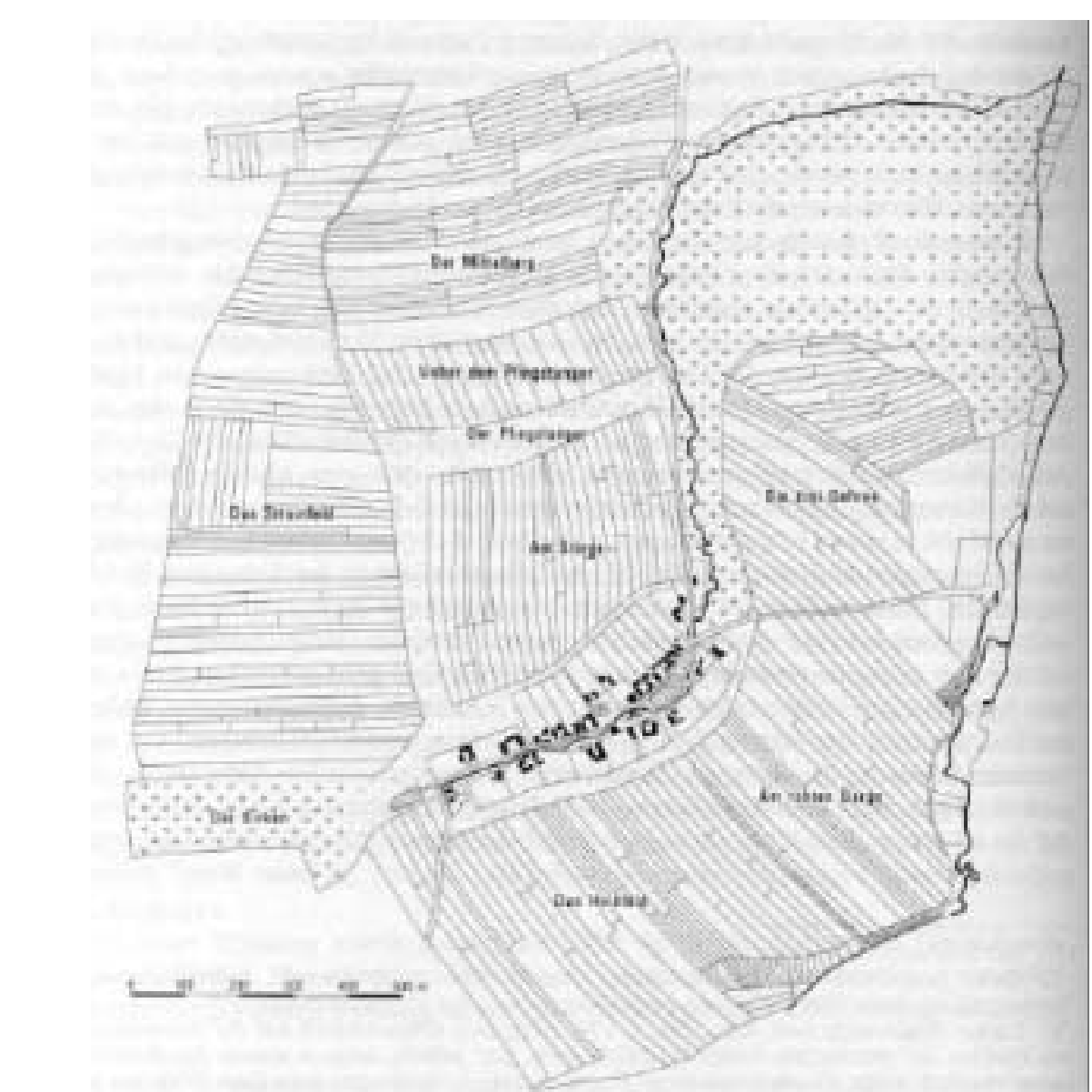

Abb. V-18: Die ehemalige Wüstung Falkenhagen/Südniedersachsen nach einer Karte von 1880/81 mit der rekonstruierten planmäßigen Neuaufsiedlung Mitte des 16. Jh. als langgestrecktes Bachangerdorf (aus: NITZ 1984/1994:314).

\section{d.4.4 Absolutistischer Landesausbau}

In der 2. Hälfte des 17. Jh. beginnend, ist diese Phase gekennzeichnet durch umfassende staatliche Lenkung der Entwicklung der ländlichen Kulturlandschaft. Sie bewirkte Landesausbau, Strukturverbesserungen und auch Einkommenssteigerungen von Landbesitzern und erwuchs aus Peuplierungsbestrebungen, d.h. eine Bevölkerungshebung durch Kolonistenzuzug in strukturschwachen Gebieten auf der einen Seite als auch aus Bevölkerungsdruck aus bevölkerungsstarken Regionen auf der anderen Seite (BORN 1977:105f.). Durch vom Staat getragene ländliche Neusiedlung, als innere Kolonisation bezeichnet, wurde das Siedlungsland nicht unerheblich ausgeweitet bzw. verdichtet (LIENAU 1995:178).

Der innere Ausbau wurde dabei durch den Ausbau der Besitzverhältnisse gesteuert. Die Aufteilung der agrarischen Allmenden wie auch der bereits vorhandenen gemeinschaftlichen Bewässerungseinrichtungen gehörten ebenso zu den Maßnahmen wie die Neulandgewinnung im Rahmen der erweiterten Binnenkolonisation. Wiederum vor allem in den großen Mooren und Stromniederungen sowie in einigen Mittelgebirgen wurden die Kolonisationsbestrebungen durchgeführt. In dieser frühen Neuzeit wurde das Ortswachstum vor allem durch die Ansiedlung von Nachsiedlergruppen getragen (BORN 1977:48).

Auch die Anlage von Plansiedlungen, vor allem in Form von sog. Fehnkolonien ${ }^{24}$ in den ausgedehnten Hochmoorgebieten Nordwestdeutschlands, gehört dazu (LIENAU 1995:176). Dies vor dem demosko-

\footnotetext{
${ }^{24}$ Als Fehnkolonien („Fehn“ bezieht sich appellativisch auf Moore mit Torfabbau) werden die relativ dichten schnurgeraden Reihensiedlungen im Hochmoor mit hofanschließender Streifenflur und einem Kanal als Hauptachse bezeichnet, deren Existenz auf dem Abbau des Torfes und Ackerbau auf dem abgetorften Land basierte (Fehnkultur, vgl. BÜNSTORF 1966;
} 
pischen Hintergrund, dass das vor allem nach dem Dreißigjährigen Krieg vorhandene Streben der Landesherrschaft nach Peuplierung zur Folge hatte, dass sich in größeren Territorien erste Anzeichen für Überbevölkerung bemerkbar machten. Angesichts des zunehmenden Bevölkerungsdruckes galt es, besitzarme Gruppen wirtschaftlich zu aktivieren. Die Landesherren versuchten dies durch die Bereitstellung von Land, das der Bevölkerung aus rechtlichen Gründen nicht zugänglich oder aufgrund natürlicher Gegebenheiten nicht nutzbar war. Es kam zu weiterer Moorkolonisation und Ödlanderschließung - eben der o. g. Fehnkolonien (BORN 1977:56).

Der Übergang vom bloßen Torfstich zur Fehnsiedlung geschah seit Beginn des 17. Jh. Bei den in dieser Zeit in Ostfriesland entstandenen Fehnsiedlungen (BÜNSTORF 1966) ist die Landgewinnung als Motivwahl aber nicht ohne dahinter stehende Ressource zu sehen. Das zugrunde liegende Motiv für die Entstehung von Fehnkolonien bildete der Torfabbau, als aufgrund steigender Nachfrage nach Torf Moore zu wirtschaftlichen Spekulationsobjekten wurden (BORN 1977:57). Die Moore gehörten den jeweiligen Landesherrn, die eine Gewinnbeteiligung an dem Torfabbau erwarteten. Hierzu waren in den Hochmooren zum Abtransport des Torfes Schifffahrtskanäle erforderlich. In völlig oder - je nach Erbauungszeit - nur in einzelnen Teilstücken geradlinigem Verlauf sollten sie zur beherrschenden Erscheinung der Fehnsiedlungen werden und ihre Größe und Reichweite bestimmen.

In den ältesten Fehnsiedlungen verlaufen die Kanäle etwa parallel zu den Moorrändern und besitzen so für jeweils nur kurze Strecken Geradlinigkeit. Arbeitsteilig errichteten die ersten Fehnpächter ,seit der Mitte des 17. Jh. als Oberpächter [...] die Hauptkanäle mit den Schleusen und Brücken, die Abtorfung und Kultivierung wurde von Unterpächtern übernommen.“(BORN 1977:57)

Im darauffolgenden 18. Jh. kam es zur planmäßig betriebenen Großerschließung der Moore. Die dabei entstandenen Fehnsiedlungen bildeten große Anlagen mit einem streng geradlinigen Kanalsystem (BORN 1977:57). Insgesamt lässt sich feststellen, dass durch die Kanäle in den Abtorfungsgebieten „eine regelhaft-reihenförmige Gehöftverteilung über die gesamte Gemarkung erzwungen“ wurde (:57), d. h. der Schifffahrtskanal bildete die zentrale Siedlungsachse.

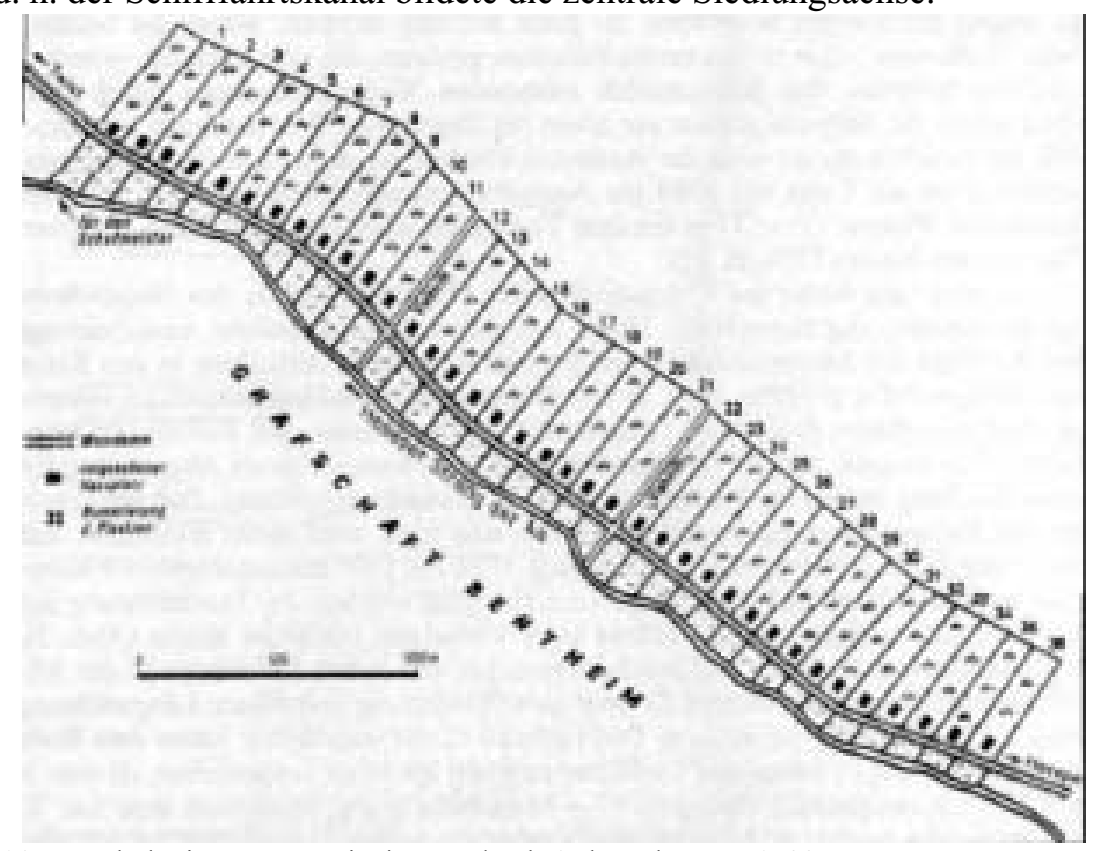

Abb. V-19: Moorkolonie Hesepertwist im Emsland, Anlageplan von 1788.

Die Gestaltung der neuen fürstbischöflich-münsterschen Kolonie macht die Verwirklichung der Kolonatenstellen entlang der durchziehenden Bachniederungen mit relativ futterreichem Niederungsmoor - hier am Beispiel der Aa - deutlich. Sie folgen dem Lauf der leicht mäandrierenden Aa, nicht um der Schiffbarkeit wegen, sondern weil so ein jedes Kolonat zur Grünlandnutzung über geeignetes Niederungsmoor verfügen konnte. Wegen des hohen Wertes von Grünland war die Lage der Hofplätze ausschließlich auf der Hochmoorseite vorgeschrieben (aus: NITZ 1976/1994:351).

LIENAU 1995:138). Als Moorsiedlungen werden im Gegensatz dazu die Hochmoorsiedlungen bezeichnet, deren Existenz von Anfang an auf Landwirtschaft basierte und denen darum ein schiffbarer Kanal für den Transport des Torfes fehlt (NITZ 1976b:163, aus: LIENAU 1995:138). 
Neben der Moorkolonisation wurden auch weitere Flussauen nach dem Marschhufenprinzip melioriert. Dieser Prozess fand sich schließlich wiederum auch bei Großprojekten der Friderizianischen Kolonisation (KUHN 1971). So ließ Friedrich Wilhelm der I. „,bisher nicht nutzbare Flußniederungen und Feuchtgebiete wie beispielsweise zwischen 1719 und 1724 das havelländische Luch zwischen Nauen, Friesack und Rathenow urbar machen.“ (KAUP 1996:118) Eine Entwässerung des havelländischen Luchlandes begann mit der in diesen Zeitraum fallenden Anlegung des Havelländischen Hauptkanals durch Friedrich Wilhelm I. (BROCKHAUS, Bd. 5:221). Grundlegend ist hier die Unterscheidung zwischen hohem und niederem Bruch. Während ,im niederen Bruch mit einer Wasserstandshöhe nur zwischen einem und 14 Metern über NN vor der Urbarmachung kein Ackerbau möglich war (KAUP 1996:119), liegt der höhere Bruch zwischen 14 und 20 Metern über NN. Damit konnte das Hohe Bruch in weiten Teilen ackerbaulich genutzt werden. Die Häuser der Fischerdörfer finden sich nur am westlichen und östlichen Rand in der Nähe der Flussläufe (:119). Weitere Trockenlegungen betrafen das mittlere und niedere Oderbruch (1747 - 53), das Netzebruch (1763 - 67) und das Warthebruch (1765 - 86) (BORN 1977:55).

Die Siedlungsentwicklung durch preußischen Landesausbau im 17. und 18. Jh. traf so auch die Oder. Durch Eindeichung bzw. Eindämmung und Entwässerungsmethoden (Durchstiche, Vorflutgräben) zum Zwecke der Neulandgewinnung entstanden Altwasserarme („Stille Oder"), die keine Verbindung mehr zur Oder besaßen. Die weitere Landschaftsveränderung wurde getragen durch Maßnahmen der Rodung und der Veränderung bzw. Verlegung des Flusslaufs (Kanalbau). Durch die Ansiedlung von Kolonisten auf dem dadurch neu gewonnenen Bruch wurden insgesamt 29 Dörfer neu geschaffen (HERRMANN 1997).

Im Zuge der Ostkolonisation wurde das Siedlungsnetz weiter ausgedehnt. Die Neuanlage von Dörfern erfolgte auch in bisher für Siedlungen ungünstigen Gegenden, so durch erste lokale Entwässerungen im Talsandgebiet, und ebenso auf den höhergelegenen trockenheitsgefährdeten Sanderflächen. Die Entstehung von Gutssiedlungen in dieser Zeit ist unter anderem mit der Tatsachse verbunden, dass sich in West- und Südeuropa ein großer Getreideabsatzmarkt entwickelte (vgl. KRENZLIN 1952). „Erst mit der Durchführung der Separation Mitte des 19. Jh. konnten die Niederungen und Sumpfflächen weitflächig melioriert, Bäche und Flüsse begradigt werden [...]. Die Landwirtschaft konzentrierte sich nun auf die fruchtbaren Böden der Niederungen (Grünland). Dagegen wurde die Bewirtschaftung der nun zunehmend trockenheitsgefährdeten höheren Sandflächen wieder aufgegeben. Waren die Dörfer vorher von Sümpfen und Erlenbruchwäldern umgeben und hatten ihr Ackerland auf den Hügeln der Tal- und Flugsandinseln gehabt, so trockneten Letztere jetzt völlig aus und mussten zum Teil aufgeforstet werden. Die ehemaligen Wiesen und Weiden wurden trocken genug, um als Ackerland genutzt zu werden (KUCHARSKI 1949). 


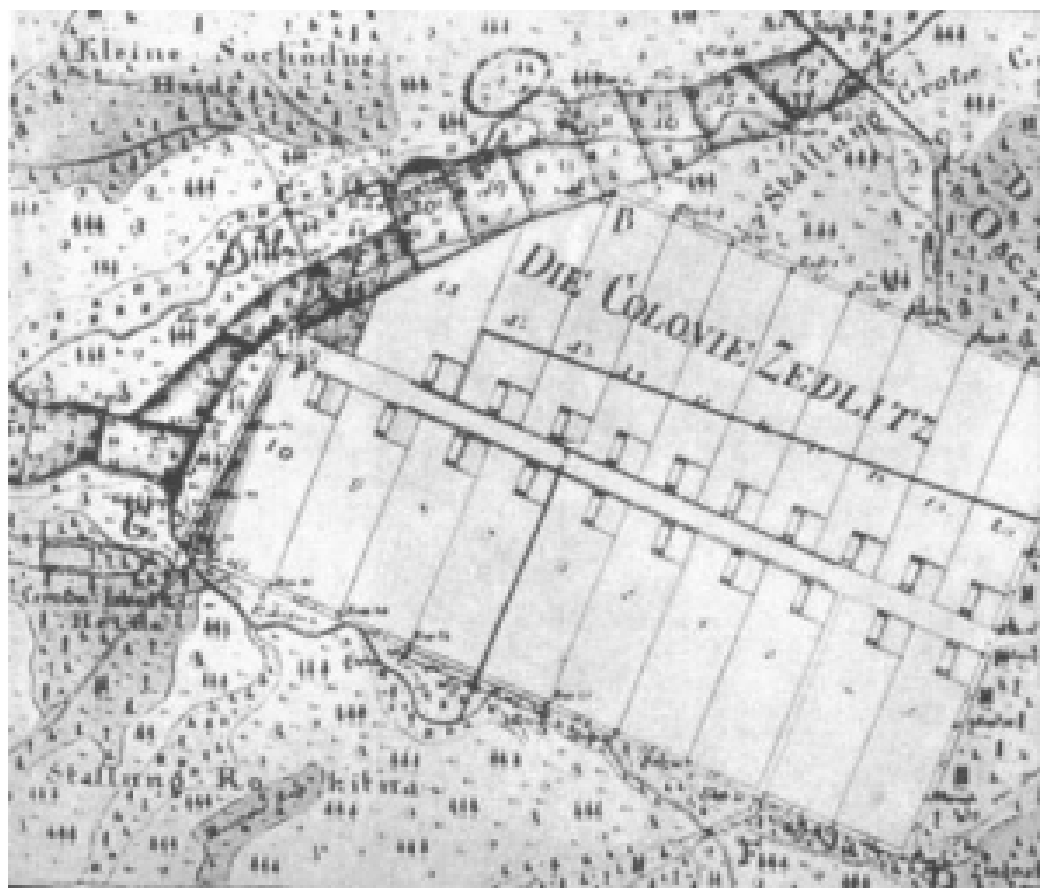

Abb. V-20: Die „Colonie Zedlitz“ nördlich von Oppeln

Alte Planskizze einer friderizianischen Holzfällersiedlung, die 1773 mit 20 Hofstellen angelegt worden ist. Die rund 4,5 Hektar großen Stellen liegen jeweils in einem Streifen mit Hofanschluss auf einer Rodungsfläche vor dem Zusammenfluss zweier Gewässerläufe (aus: KUHN 1954:337).

Ein charakteristisches Merkmal der geplanten Siedlungsentwicklung mit schematischen Siedlungsformen bildete weiterhin die Wiederbesiedlung von Ortswüstungen in den Mittelgebirgen, die überwiegend von Nachsiedlern getragen wurde (BORN 1977:53,100).

Kennzeichnend für den absolutistischen Landesausbau des 18. Jh. war in diesem Zusammenhang die von Grund- und Landesherren gelenkte oder tolerierte Einzelsiedlung von Bauern und Nachsiedlern.

Extensiv genutzte Ländereien beispielsweise wurden vor allem nach 1770 in der Rhön, ihrem Vorland, auf dem Landrücken und am östlichen und südlichen Vogelsbergrand durch staatlich geförderte Einzelhofsiedlung erschlossen (RÖLL 1967). Diese Höfe waren „locker an Quellhorizonten des Muschelkalk oder in oberen Tallagen“" angeordnet (BORN 1977:106).

Die größer gewordenen Bauten der Hammer- und Eisenhütten als herrschaftlich betriebene Mühlhütten des 17. bis 19. Jh. in den Mittelgebirgen, wie zum Beispiel dem Westerzgebirge, hatten ihren „Standort in Talwannen und Niederungen an Fluß- oder Bachläufen“ (ALTMANN 1999:128), man könnte sagen, beibehalten. Zugleich musste bei den arbeitsnah gelegenen Wohnstätten die Wasserversorgung gewährleistet sein. Dies lag bei den Arbeiterhäusern der Hammer- und Eisenhüttenwerke seit Beginn des 18. Jh. „meist außerhalb und erfolgte durch Röhrenfahrten sowie Brunnen. Das Wasser wurde in Tröge geleitet und dort geschöpft. Die Gefahr des Einfrierens trat bei der erheblichen Strömungsgeschwindigkeit des Wassers erst bei hohen Frosttemperaturen ein.“ (:158)

Doch nicht nur im Mittelgebirge, auch in den Flachländern, wurden seit der 2. Hälfte des 18. Jh. weitere Wassermühlenwerke als singuläre Siedlungskörper im ländlich-peripheren oder suburbanen Bereich errichtet. Sie füllten die gewässerdurchzogenen Tallagen bis zur Grenze der Wirtschaftlichkeit weiter auf. Sogar Quellflüsse wurden nun vermehrt in die Energienutzung einbezogen. Wie die letzte im vormaligen Amt Reinbek angelegte Wassermühle, die sog. Mühle zu Ohre. Sie wurde 1740 an einer auf dem ,Oher Feld' entspringenden kleinen Au unweit ihrer Einmündung in die Bille errichtet. (FINK 1969:238)

Nicht zu vergessen sind die in diesen Zeitraum fallenden Anlagen von Herrensitze des 17./18. Jh. Die Ensembles der Stadt- und Landschlösser entwickelten dabei einen originären Bezug zum Wasser. In 
dem genannten Zeitraum entstanden allein zum Beispiel in Berlin zahlreiche Residenzen am Wasser: Köpenick, Charlottenburg, Monbijou, Bellevue und schließlich die Potsdamer Kulturlandschaft (STRAUSS 2002:17).

Es lässt sich zusammenfassend erkennen, dass vor dem Einsetzen der Industrialisierung und dem Erfinden der künstlichen Energiegewinnung durch Turbinenkraft auch beim erhöhten Siedlerdruck in der 2. Hälfte des 17. Jh. bis zum zweiten Drittel des 18. Jh. noch eine mittelbare Verknüpfung zum Wasser festzustellen ist, sie wurde geradezu bei der Siedlungslenkung gesucht und teilweise auch grenzwertig ausgeschöpft. Wenn auch der Bau künstlicher Gewässer die Siedlungsbindung zu den natürlichen Gewässern als Verkehrsweg teilweise aufgehoben hat, so spielte dennoch die Wassernähe für die Handwerks- und Gewerbebetriebe eine bedeutende Rolle, denn "all diese Betriebe konnten nur auf der Basis eines ausreichenden und konstanten Zustroms von Wasser existieren." (ALTHÖFERWESTENHOFF/WAGNER 1997:37) Für die Herrschaftssitze waren die Inszenierung von Wasserspielen und die Einbindung von Gewässern Ausdruck von Landschaftsempfinden und Landschaftsästhetik.

\section{d.5 Kultstätten und Klöster}

Hinsichtlich der hydrologisch-topographischen Lage der Kultstätten und Kultsiedlungen sind vielfach besondere Verknüpfungen hinsichtlich der Bindung der Religionen und ihrer Kultformen an bestimmte Plätze zu bemerken (SCHWARZ 1988:395). So legte man die dem griechischen Heilgott Asklepios geweihten Heiligtümer, die man noch heute in Epidauros, in Kos oder Pergamon bewundern kann, nicht nur in bevorzugter klimatischer Lage an, sondern auch in unmittelbarer Nähe von Quellen und Flussläufen an (MURKEN 1991:11). Die Wallfahrts- bzw. Kultorte wurden im 5. Jh. v. Chr. zum Aufenthalt von Kranken eingeführt und dienten der Inkubation ${ }^{25}$.

Gewässer waren in vorchristlicher Zeit auch im deutschstämmigen Raum häufig Orte heidnischer Kultstätten. Als Beispiel eines typischen vorchristlichen Naturheiligtums früh- oder vormittelalterlicher Zeit kann das Felsenheiligtum Hurkutstein genannt werden. Seine Lage in der Abgeschiedenheit des zentralen Rheinhäuser Waldes im Leinebergland bei Göttingen ist gekennzeichnet durch ein schluchtartig enges Nebental (Klustal) des Wendebachtales zwischen den Ortschaften Reinhausen und Bremke und einem isoliert stehenden mächtigen Sandsteinfelskopf vor einer platzartig aufgeweiteten Nebentaleinmündung. Hier tritt am Fuße des Felsens eine Quelle aus. An diesem Ort wurde eine höher gelegene, ,aus einem Vertikalspalt des Felsens herausgearbeitete Höhle [...] mit künstlicher Bodenwanne" gefunden, in der vielleicht Wasser gesammelt worden ist (GROTE 1989:238). An diesem Platz entstand später - wie so häufig - ein mittelalterlicher Sakralort: eine seitens des Klosters Reinhausen initiierte und vom Mönch namens Heinrich Hufnagel bezogene Einsiedelei (:238). Auch zwei angestaute Teiche, die im Vorgelände noch vorhanden sind, gehen in ihrer Anlage urkundlich auf das späte 15. Jahrhundert zurück und lassen sich mit dem Kloster in Verbindung bringen (:239).

Im entstehenden Mönchtum um die Mitte des 4. Jahrhunderts, bildeten sich schon in frühchristlicher Zeit alle wesentlichen Elemente der christlichen Kultstätten aus: Gotteshäuser und Wallfahrtsstätten, Eremitenklausen und Klöster. Fehlen dem Protestantismus Kultstätten und Kultsiedlungen besonderer Art, weil keine eigentliche Priesterhierarchie besteht und Mönchtum sowie Heiligenkult abgelehnt werden, so hat das östliche und das katholische Christentum solche in reicher Zahl entwickelt.

So wurde unter anderem auch ein „Wasserkult“ betrieben. Vorchristliche Kultbauten und -plätze wurden bevorzugt auf Wasseradern oder in der Nähe des Wassers errichtet. Nachfolgend knüpften christliche Kultstätten an die antiken und germanischen heiligen Plätze an und die christliche Kirche benutzte oftmals die Anlagen älterer heidnischer Kultstätten als ihre eigenen. Als Beispiel einer

\footnotetext{
${ }^{25}$ Inkubation [grch. Enko mesis]: in der Religionsgeschichte der Tempelschlaf in der Antike, der im Traum göttliche Offenbarungen und besondere Heilung von Kranken bringen sollte; besonders in den Heiligtümern des Asklepios. Mit Fasten und anderen Reinigungsriten wurde die Inkubation vorbereitet. Nach dem heilenden Schlaf legten Priester das dem Kranken offenbarte Orakel aus.
} 
solchen Wasser-Lage sei das Kloster Bursfelde an der Weser genannt, dessen Altar an der Stelle errichtet wurde, an der zuvor ein heidnischer Opferplatz stand.

Überhaupt war die schiffbare und fischreiche Ober- und Mittelweser seit dem Mittelalter mit zahlreichen unmittelbar am Fluss gelegenen Klöstern und Stiften ausgestattet, wie zum Beispiel mit den Frauenklöstern Lippoldsberg und Hessisch Oldendorf sowie der bedeutenden Reichsabtei Corvey. Die Verkehrsbedeutung von Flüssen im frühen Mittelalter lässt sich u. a. daran erkennen, dass sehr viele bei der Einführung des Christentums neu gegründeten Missionsklöster und Bistümer an schiffbaren Gewässern angelegt wurden: wie die Klöster Fulda, Hersfeld, das bereits genannte Corvey, Hameln und die Bischofssitze Minden, Hildesheim, Verden und Bremen, die Abtei Seligenstadt am Main, St. Emmeran bei Regensburg am Inn und die Abtei Füssen am Lech.

Aber ob schiffbar oder nur Quellschüttung oder Bachlauf, ob fließend oder stehend, die Lagebeziehung zu Gewässern war symptomatisch für die Lage aller ,Tal-Klöster'. Sie waren sämtlich zumindest durch eine - wie auch immer geartete - Wasserlage gekennzeichnet. „Nach den Regeln des hl. Benedikt von Nursia sollte ein Kloster womöglich so eingerichtet sein, daß alles Nötige, d. i. Wasser, Mühle, Garten, Bäckerei und was sonst noch zu des Leibes Notdurft zählt, innerhalb der Klosterfriedung liege, damit die Mönche nicht gezwungen seien, mit der Außenwelt zu verkehren. Und so sehen wir sie bei allen frühen Klostergründungen bei Auswahl der Örtlichkeit sorgsam darauf Bedacht nehmen, daß das Kloster an einem vorüberfließenden Gewässer, dem ,Zellbach' nächst anliegendem See, dem ,Zellsee' liege, die die entsprechende ,Fischweide' liefern sollten, während das fließende Gewässer außerdem der ,Zellmühle’ dienstbar gemacht wurde.“(CNOPF 1927:10) Wie zum Beispiel die Zisterzienserabtei im Düsseltal am Fuße des Grafenberger Waldes, heute gehobener Stadtteil von Düsseldorf: „Die Düssel, die durch das Areal der Abtei floß, spielte eine große Rolle. Ihre Wasserkraft stand dem Orden zu freier Verfügung.“ (SCHMITZ-PORTEN 1988:25)

Auch die geo-ökonomische Lage des Zisterzienserklosters Hayau war günstig, „denn der Ort lag hochwassersicher oberhalb der Fulda und war eingebunden in das System der "Langen Hessen“ (MÜLLER 2001:13). Fernstraßen, die damals entlang der Höhenrücken zum Beispiel Kassel und Nürnberg sowie Frankfurt mit Thüringen verbanden, sollen sich im Ort Morschen, zwischen Rotenburg und Melsungen an dem Wasserweg der Fulda, gekreuzt haben, wo das Kloster Haydau angesiedelt war.

Eine solche gewässerbezogene Lagewahl dharakterisiert ebenso die Klöster Zinna (an der Nuthe), Magdeburg (an der Elbe und den in die Elbe mündenden Bördebäche), Riddagshausen (an Wabe und Mittelriede), Walkenried (an der Wieda), das Zisterzienserinnenkloster Anrode unweit des Dorfes Büttstedt bei Dingelstädt (im Tal der Luhne und der Gieße), das Zisterzienserkloster Schulpforta (an der Saale), das Kloster Ebrach (an der Ebrach), Maulbronn (an der Salzach), Salem (an der Salemer Ach), das Kloster Tegernsee (am Tegernsee), und sie gilt auch für das oberschwäbische Kloster Ochsenhausen, das durch seine Lage an Hungerbach, Krummbach und Rottum gekennzeichnet war, die durch den Klosterbezirk flossen (HERBST 1992:73). Die Aufzählung ließe sich beliebig fortführen.

Durch diese Siedlungslage haben sie mäurlich auch in die Gewässerstruktur nachhaltig eingegriffen und sie zum Teil massiv verändert, obschon bereits vor der Ansiedlung von benediktinischen, prämonstratensischen, vor allem zisterziensischen Ordensgemeinschaften, die kleinen und leicht regulierbaren Gewässerläufe spätestens im 11. Jh. für den Betrieb von Mühlen ausgebaut und Auenland zur Heugewinnung trockengelegt wurde. Das heißt, sie mussten über kleine Einrichtungen zum Wasserstau und zur Wasserableitung verfügen, wie HERBST (1992:80) für die Klöster Ochsenhausen, Mönchsrot und Gutenzell nachweist.

Für Zisterzienserklöster war vorgeschrieben, geschützte Täler abseits bestehender Siedlungen in größerer Entfernung von Städten aufzusuchen (SCHWARZ 1988:407). Sie drangen im 14. und 15. Jahrhundert in die Waldlandschaften vor und hatten sich zum Ziel gesetzt, durch Rodung und Melioration Ödland in Kulturland zu verwandeln und die bewusste Erschließung von Wald- und Sumpfland voranzutreiben. (:408) Dies gilt auch, wie SCHENK diesbezügliche Forschungen zusammenfasst, für 
das Kloster Ebrach als Beispiel: „Zweifelsohne war aufgrund der am Talende der Mittleren Ebrach zusammenlaufenden Bäche die Aue stark vernäßt, wenn nicht gar versumpft, damit wenig zugänglich und im Vergleich zum Steigerwaldvorland agrarisch wenig attraktiv.“ (1998:15) Nach SCHENK (:15) ist das Kloster Ebrach also aus topographischen und hydrographischen Überlegungen heraus an dieser Stelle errichtet worden.

Die Gewinnung von ,Neuland' durch Rodung und Trockenlegung solcher Siedlungsbereiche geschah dabei zunächst durch die Klosterinsassen selbst. Als dann vor allem der Adel um der guten Werke willen im 16. und 17. Jh. dazu überging, die Klöster mit Land auszustatten, trat nun das Streben der Klöster ein, Landbesitz und Reichtum zı mehren - vornehmlich dadurch, dass sie Bauern heranzogen und in ein grundherrliches Abhängigkeitsverhältnis vom Kloster brachten Dieses führte vor allem im nordöstlichen Deutschland ,zum Herabsinken der ehemaligen Bauern zu leibeigenen Landarbeitern“ (SCHWARZ 1988:408). Teils bildeten sie aber auch Eigenbetriebe aus (:408).

Unter den verschiedenen Lagetypen kommt - neben dem Wasserkult und dies sei hier erwähnt und mit Beispielen aufgefüllt, damit keine einseitige Schräglage entsteht - der Bergverehrung eine besondere Bedeutung zu. Bergheiligtümer, wie die Meteora-Klöster auf den nahezu senkrecht abfallenden Sandsteinfelsen in Griechenland, bildeten wichtige Kultstätten des Volkes. Doch auch diese extremen Berggipfelklöster haben einen Gewässerbezug und eine diesbezügliche Gründungsvergangenheit. Im Tal des Penios, einem Fluss in Thessalien im östlichen Mittelgriechenland, erheben sich in enger Nachbarschaft diese bis $400 \mathrm{~m}$ hohen Felsen, Meteora genannt, die vor 60 Millionen Jahren entstanden. Die Abgeschiedenheit der Landschaft zog im 9. Jh. Eremiten an, die aber nicht auf dem hohen Plateau, sondern in Höhlen am Fuße der Meteorafelsen und damit in Flussnähe ihre Klausen einrichteten. Erst zu Beginn des 14. Jh. bildeten sich aus den Einsiedeleien klösterliche Gemeinschaften heraus, die sich nun aber auf den - nur unter größten Mühen erreichbaren - Gipfeln der Felsen niederließen. Von den 24 Klöstern, die es auf und in dieser thessalischen Felsengruppe bei Kalabaka, nordwestlich von Trikala, schließlich im 16. Jahrhundert gab, sind heute noch sechs bewohnt (BROCKHAUS-Jahreskalender 16./17. Februar 2002).

Als weiteres Beispiel einer Höhenlage kann das berühmte Kloster Monte Cassino angeführt werden, das an die Stelle eines Apolloklosters trat. Im katholischen Abendland wurde das Klosterleben - wie oben dargestellt - durch Benedikt von Nursia auf eine gesetzgeberische Grundlage gestellt und die Lage der Klostersiedlungen häufig genug durch das Vorbild des Mutterklosters, durch die Ordensregel selbst oder die besondere Zielsetzung eines Ordens bestimmt. Nach dem Beispiel des Mutterklosters Monte Cassino z. B. fand ein Teil wichtiger Benediktinerklöster auf Berghöhen ihren Platz wie etwa das von Montserrat oder Mont-Saint-Michel. Für Klosteranlagen wurde vielfach auf die Höhenlage vornehmlich dann zurückgegriffen, wenn besonderer Wert auf den Abschluss von der Welt und auf ein rein kontemplatives Leben gelegt wurde (SCHWARZ 1988:397). Die Lagewahl drückt sich in der hohen Bewertung von Askese und Meditation aus. Das Asketentum wollte die Erschwernisse des eremitischen Lebens, zu dem dort oben auch die schwierige Versorgung mit Frischwasser gehört, erleben, bevor das weitere, in Klöstern straff organisierte Mönchstum vor allem die Gewässernähe als Nahrungs- und Energiequelle gesucht und unter anderem dafür die hydrologischen sowie hydraulischen Verhältnisse nachhaltig verändert hat.

Das Asketentum war der Vorläufer und weitere Begleiter des Mönchstums. An vielen Orten im christlichen Raum findet man sie, die Mönchszellen der Einsamkeit ${ }^{26}$, oft nur aus einem windigen Mäuerchen bestehend, das eine winzige Felsnische nach außen hin abschließt. In Frankreich ${ }^{27}$, Italien ${ }^{28}$ und Ungarn ${ }^{29}$, aber auch in den Alpen und den deutschen Mittelgebirgen gab es Höhen-Einsiedeleien,

\footnotetext{
${ }^{26}$ Für eine weitergehende Beschäftigung mit dem Thema, siehe WATTECK 1972 und LEENEN 2001.

${ }^{27}$ Frankreich: Grotte de l'Ermite bei Plambois-Vennes/Doubs; L'ermitage Saint Antoine bei Georges de Galamus [St. Paul de Fenouillet]/Pyrénées-Orientale; Grotte de l'Ermite Remonot/Doubs.

${ }^{28}$ Ligurien: „Spelunke der Valmasca“ im oberen Rosa-Tal, Grotta dell’ Eremita im Bormidatal, Tana di S. Giorgio zwischen Finale und Vado, Grotta del Frate bei Feglino, S. Lucia bei Tirano, Höhle des Hl. Ampelio, Höhle des Einsiedlers zwischen Mentone und Sospel.

${ }^{29}$ Budapest: Bathorihöhle, Einsiedlerhöhle im Remetetal/Stadtgebiet.
} 
wobei auch eine Verbindung zwischen dem Eremitenleben (grch. Éremos = Wüste, Einsamkeit) und denen von Höhlen bewiesen zu sein scheint. Angestoßen durch das Vorbild des heiligen Antonius, eines Eremiten in Mittelägypten, dem ja auch ein Leben in Höhlen zugeschrieben wurde ${ }^{30}$, versuchten auch andere, weit weg von der Zivilisation und nahe der Natur, einen Weg zu Gott zu beschreiten. Die späteren Einsiedler des Mittelalters lebten dabei nach den Regeln des Dritten Ordens des Heiligen Franziskus $^{31}$. Zum Gelübde des Gehorsams und der Keuschheit legten Eremiten auch jenes der Armut ab. Sie lebten von den Zuwendungen der Gäste, die hierher kamen und führten ein karges, abgeschiedenes Leben. Felshöhlen waren auch hier die zunächst bevorzugten Einsiedlerwohnstätten. Schließlich gehört zum „Heiligen“ auch der ganz enge Kontakt mit den Steinen, wie es dem Heiligen Franzikus nachgesagt wird ${ }^{32}$. Noch heute im Übrigen schleifen die Menschen an den Wallfahrtsstätten an den Felsen entlang, mit den Fingern, mit dem Körper, und manche küssen sogar den Stein.

Aber auch neu reflektierte theologische Forschungen in Verbindung mit archäologischen Ausgrabungen auf der Suche nach dem Ort der Menschwerdung Gottes belegen solche Spuren. Justin der Märtyrer erwähnt erstmals um 150 n. Chr. in einem Dialog mit den Juden die Geburt Jesu in einer Höhle. Auch das in dieser Zeit entstandene apokryphe Jakobus-Evangelium kennt eine „Höhle“ als Geburtsort Jesu. Der bedeutende Theologe und Schriftgelehrte Origenes (185 - 258) kennt die Verehrungsstätte sogar aus eigener Anschauung. In seiner Streitschrift gegen Celsus schreibt er im Jahre 245, dass es eine Höhle in Bethlehem war, in der er geboren wurde und in einer Krippe in Windeln gewickelt lag. Auch den Ausgrabungen zufolge wird in einer Grotte, in einer Höhle also, der Standort der Krippe lokalisiert. Die spätere Kirche überbaut nur den verehrten älteren Schauplatz (THEN 2003).

Daneben lassen sich auch in Deutschland weitere Orte nennen, wo man noch heute „Einsiedlerhöhlen“ besuchen kann: In der Südeifel beispielsweise die „Klausenhöhle“ bei Kordel in der Südeifel, nördlich von Trier, oder die „Hieronymushöhle“333 hoch über dem Ort Echternacherbrück. Auch im ${ }^{30}$ Antonius der Einsiedler: Er stammte aus Komé in Mittelägypten. Im Alter von 20 Jahren gab er um das Jahr $270 \mathrm{n}$. Chr.
sein reiches Erbe auf, verteilte die Güter unter den Armen und zog sich in die Höhlen der Thebaischen Wüste im oberen
Niltal zurück. Von ihm heißt es, dass er sich 15 Jahre, in einem Felsspalt lebend, in Askese und Gebet übte. Ein Minimum an
Nahrung, Kleidung und Schlaf genügten dem Eifrigen. Um sich diesen geringen Lebensunterhalt erwerben zu können,
knüpfte er Palmblätter zu Körben und Matten. Um allen Anfechtungen zu entgehen (Versuchungen, Vorstellungen der
Wollust) zog sich Antonius noch tiefer in die Einsamkeit zurück und bezog eine neue Wohnstätte am Fuß des Berges Kolzim.
Dort bildete sich ein richtiges Einsiedlerzentrum um ihn herum. Im Alter von 105 Jahren sei er gestorben nach einem Leben
in bester Gesundheit. Zurück ließ er nur einen alten, zerschlissenen Mantel und 2 Tuniken in Sackform.

${ }^{31}$ Heiliger Franziskus [Franz von Assisi]: die Mitglieder (Franziskaner) der von Franz von Assisi gestifteten Gemeinschaft bestehen aus drei Orden: Der Erste Orden („Minoriten“) wiederum besteht seit dem 16. Jh. aus den „Observanten“ (vorzugsweise „Franziskaner“ genannt), den „Konventualen“ und den „Kapuzinern“. Sie gehören sämtlich zu den Bettelorden und suchen das Evangelium durch Askese, besonders durch Armut, und durch apostolische Arbeit in Seelsorge und Mission. Der Zweite Orden (,Klarissinnen“) gegründet von seiner Jugendfreundin Klara von Assisi ist ein beschaulicher Frauenorden. Neben dem männlichen ersten Zweig und dem weiblichen zweiten Zweig der katholischen Kirche gibt es noch den Dritten Orden („Terziaren“) der katholischen Kirche. Ihr gehören Mitglieder beiderlei Geschlechts an, aber auch solche Personen, die durch ihre Lebensumstände (z. B. Ehe) am Klostereintritt gehindert waren, in ihren Möglichkeiten das Ordensideal zu verwirklichen. Es gibt männliche, weibliche und gemischte Terziaren.

${ }^{32}$ Es heißt, das sich der heilige Franz von Assisi auf eine einsame, von Birken gekrönte Felsenspitze des Monte Penna, nahe bei La Verna (Toskana), begab und dort eine Nische zwischen zwei Felsbrocken zu einer Einsiedelei machte. An dieser Stelle soll er im Jahre 1224 im Gebet die Stigmata erhalten haben.

33 Hieronymus, Aemiliani [Girolamo Miani]: Heiliger, Ordensstifter ( 1486 Venedig $-\uparrow 1537$ Somaska). Hieronymus stammte aus einer altadeligen Familie. Sein Vater war Senator. Nach dem frühen Tod des Vaters wurde er von seiner Mutter sehr fromm erzogen. Schon in früher Jugend wurde er Soldat und führte während dieser Zeit einen recht ausschweifenden Lebenswandel. Seine Kriegsgefangenschaft im Jahre 1511 wurde für ihn zum Wendepunkt seines Lebens. Nach seiner Freilassung kehrte er nach Venedig zurück und führte dort ein frommes Leben in tätiger Nächstenliebe. 1518 wurde er zum Priester geweiht. In den folgenden Jahren errichtete Hieronymus in mehreren Städten (Venedig, Brescia, Bergamo, Verena, Como und Mailand) Waisenhäuser, in denen er verwahrloste Jugendliche von der Straße aufnahm. 1528 gründete er die Genossenschaft der „regulierten Kleriker“, die sich später - nach ihrem Gründungsort - Somasker nannten. Die letzten Jahre vor seinem Tod verbrachte Hieronymus einsam und zurückgezogen in einer Höhle. Seine Heiligsprechung nahm 1767 Papst Clemens XIII. vor. Papst Pius XI. erklärte ihn 1928 zum Patron der Waisen und der verlassenen Jugend. Sein Fest wird am 20. Juli gefeiert (BAUTZ, Bd. II 1990:Spalte 822).

In der Kirchengeschichte gibt es jedoch noch einen anderen Eremiten „Hieronymus“, der wohl aufgrund seiner Lebensgeschichte eher als Namenspate für die Höhle angesehen werden kann. Dieser wird in der Zeit des 4. Jh. gesehen, 
„Klusfelsen“, einer fast $20 \mathrm{~m}$ hohen und $50 \mathrm{~m}$ langen Felsrippe in Goslar, befindet sich eine ehemalige Eremitenklause, die zum benachbarten Petersstift (1527 zerstört) gehörte (siehe Abb. V21). Den Vorläufer des Zisterzienserklosters Michaelstein bei Blankenburg/Harz bildet der Einsiedler St. Volkmar, der sich in einer Höhle auf einer Klippe im Michaelsteiner Forst aufhielt. Er und seine spätere Brüderschaft, die sog. „Volkmar-Anstalten“, bezogen „das nöthige Wasser [...] theils aus dem Kröppel - einem angrenzenden Forstorte - theils aus dem Volkmarbrunnen, am Fuße des Berges gegen Süden. Im Kröppel wurde das Wasser in einem Hälter aufgefangen und in einer Röhrenleitung [...] den oberen Gebäuden zugeführt.“ (BORNE 1883:45)

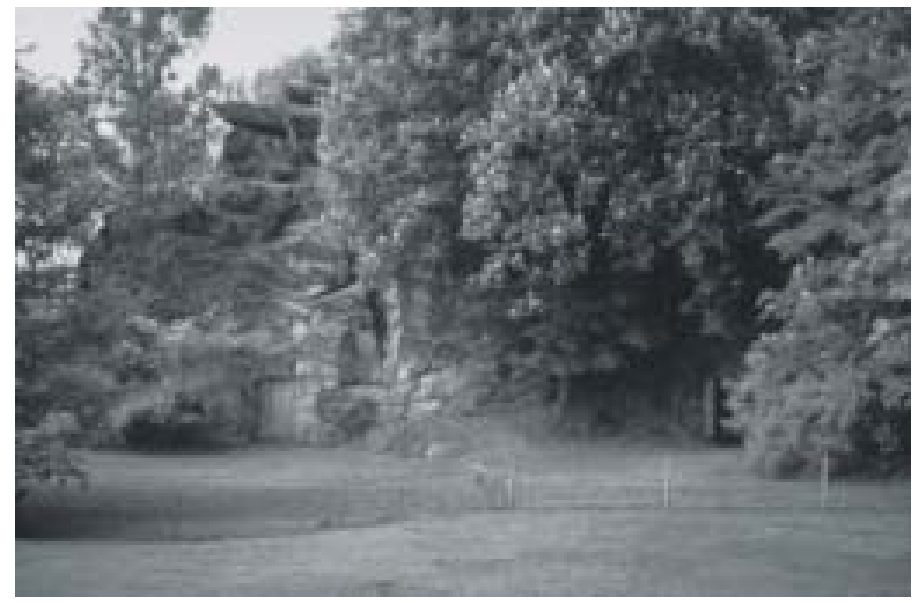

Abb. V-21:Der Klusfelsen in Goslar

Der Felsen besteht aus Hils-Sandstein, abgelagert vor etwa 120 Mio. Jahren im Unterkreide-Meer. Noch heute befindet sich hier eine in den Fels gehauene „Kluskapelle“, in deren Raum an einigen Tagen im Jahr Gottesdienste abgehalten werden (eig. Aufnahme 2004).

Auf dem Annaberg bei Sulzbach-Rosenberg waren über Jahrzehnte hinweg Eremiten zu Hause. Zu ihren Aufgaben gehörte es, die 1656 von Pfalzgraf Christian August (1648 - 1708) errichtete Kapelle zu bewachen und Messner- und Ministrantendienste zu versehen. Die Klause an der Ostseite der Kirche errichtete 1736 der erste Eremit Johann Baumgartner auf eigene Kosten. Von da an wurde sie mit Unterbrechungen bis 1923 von Einsiedlern bewohnt. Im Jahr 1968 wurde sie zu einer Wohnung ausgebaut und dient jetzt, nachdem sie 1986-1988 nochmals von einem Eremiten bewohnt war, als zusätzliche Sakristei für die Kirche.

Auch zu der mehr als 300 Jahre alten „Wallfahrtsstätte Eremitage“ auf dem Rödgen der Gemeinde Wilnsdorf im Siegerland, in der bis heute die Tradition der Wallfahrten gepflegt wird, gehören neben einer Kapelle, einem Heiligenhäuschen und einem Waldaltar (,Andachtsraum“ in freier Natur) eine Eremitenklause samt Eremitengrab, die zu den ältesten Fachwerkbauten des Siegerlandes zählt. In ca. 350 m Entfernung, südöstlich des „Einmann-Klosters“, entspringt der Limbach. Dieser Bach fließt nach Norden in den Ortsteil Niederdielfen ab.

Zu Füßen der Burg Gleichenstein bei Dingelstädt, in einem stillen Waldtal des eichsfeldischen Westerwaldes, zwischen den Orten Wachstedt und Martinfeld, liegt der Wallfahrtsort „Klüschen Hagis“. Neben der Kapelle erhob sich hier in den Jahren 1573 - 1620 eine Eremitenklause, in der ein

zwischen 376 und 379 n. Chr., als er sich als Eremit in der Wüste von Chalkis aufhielt. In der modernen Forschung wird sein Geburtsjahr um 347 angesetzt, so dass er zu Ende also etwa 30 Jahre alt war.

Wie auch immer die genauen Umstände des Wüstendomizils beschaffen sein mögen, als gesichert wird angenommen, dass Hieronymus einerseits nicht alleine, sondern in mehr oder weniger enger Gemeinschaft mit anderen Eremiten, gelebt hat und dass er andererseits auch seinen Kontakt mit der Außenwelt nicht abbrach, sondern in regem geistigem Austausch mit ihr stand; davon legen verschiedene literarische Werke Zeugnis ab, die aus dieser Zeit hervorgingen.

Das mönchische Leben - allerdings in den eher westlichen, gemäßigten Formen - denen er selber sein weiteres Leben hindurch folgen sollte, auch wenn er literarisch eher die östliche Form des radikalen Asketentums darstellte und pries - hatte er aber bereits als junger Mann nach seinem Studium in Trier kennengelernt und in seinem asketisch lebenden Freundeskreis in Aquileia vertieft (KERKLOH 2003). 
Einsiedler oder „Klausner“ Wohnung nahm ${ }^{34}$. Im Klüschen Hagis entspringt der Eselsborn und der Muttergottesborn und deshalb war die Versorgung mit Wasser gesichert. Auch für die Burg, denn von hier, vom Eselsborn, der nach Auskunft von RICHWIEN (2004: mündl.) seinen Namen daher bezieht, weil früher Esel das Wasser auf die Burg transportierten, bezieht noch heute die Burg ihr Wasser. Vom Klüschen Hagis fließt das Wasser Richtung Martinfeld in die Rosoppe und dann weiter in die Frieda.

Ein Ende fand das Eremitenwesen erst mit der Säkularisation zu Beginn des 19. Jh., oschon auch heute noch einige das Leben des Eremiten - von der Gemeindekasse als Touristenattraktion bezahlt nachleben. Nördlich der Stadt Solothurn/Schweiz beispielsweise, in der Stille der Verenaschlucht, liegt die Einsiedelei. Hier geht noch heute ein Einsiedler seiner „frommen“ Arbeit nach. Die Eremitenklause und die benachbarte Kapelle ist ein beliebtes Ausflugsziel und wird jährlich von Tausenden von Touristen besucht:

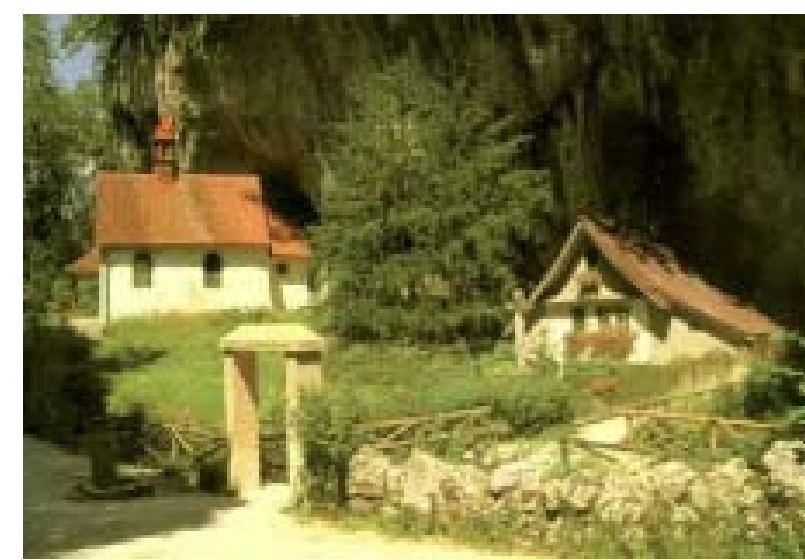

Abb. V-22:Einsiedelei St. Verena Solothurn/Schweiz

In Österreich befindet sich am St.-Georg-Palfen bei Saalfelden die einzige noch bewohnte Felsenklause Europas“. Bereits 1664 hatte sich dort ein Eremit niedergelassen, der nach den Regeln des III. Ordens des heiligen Franziskus lebte. In den Felsen hinein wurde die Eremitage 1664 auf Ansuchen eines Bauernburschen Namens Thomas Pichler gebaut (STADTGEMEINDE SAALFELDEN 2004).

\footnotetext{
${ }^{34}$ Es handelt sich hier eigentlich um eine Wüstung des zwischen 1100 und 1300 entstandenen Dorfes Neuenhagen. Der Ort wurde im späten Mittelalter wüst, als die wenigen Einwohner (1358: 22) in die umliegenden Ortschaften zogen. Es ist zu vermuten, dass er sich hier um Burgknechte, Dienstboten und Angestellte der Burg handelte. An das einstige Dorf erinnert heute nur noch der Name Hagen. Im Dreißigjährigen Krieg wurde das Klüschen Hagis geplündert und verwüstet, und die Eremitenklause ging in den Wirren des Krieges unter. Über 100 Jahre später, in den Jahren 1751 - 1771, aber wurde die Kirche grundlegend erneuert und erhielt die heutige Form. Aber bereits 1820 starb der letzte Pfarrer vom Klüschen Hagis und die Wallfahrtskirche wurde von nun an von der Pfarrei Wachstedt-Büttstedt aus betreut.
} 


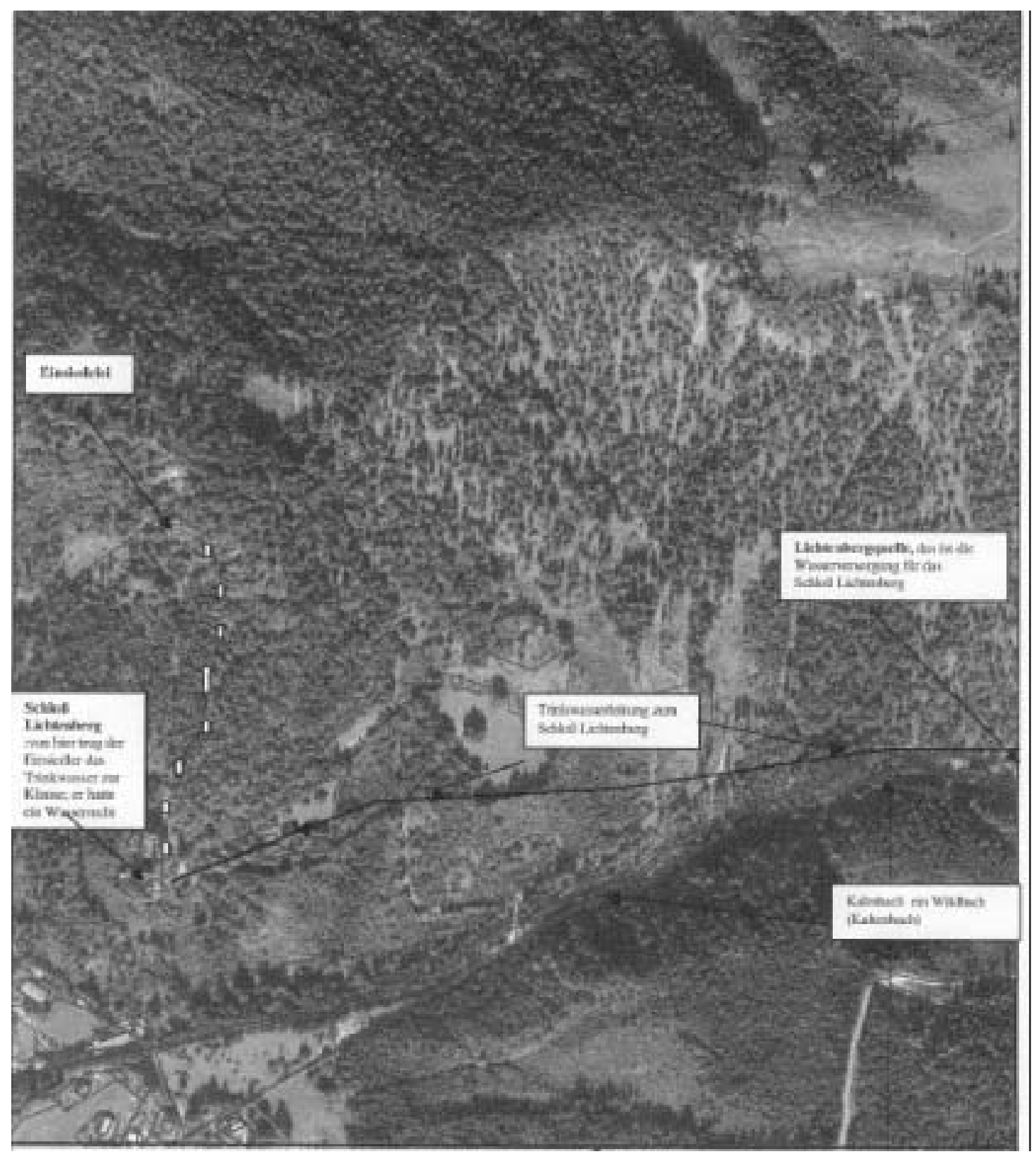

Abb. V-23:Luftbild Eremitenklause und Schloss „Lichtenberg“/Saalfelden (STADTGEMEINDE SAALFELDEN, Bauabt.)

Aber auch dieser Einsiedler der ist eher Fremdenführer für die rund 15.000 Besucher, die zur Sommersaison hier heraufkommen und Angestellter der Pinzgauer Stadtgemeinde Saalfelden. Aber nicht nur in neuerer Zeit, in den Habit, in das Gewand des Einsiedlers, sind aber im Laufe der über 300 Jahre, die die Einsiedelei besteht die unterschiedlichsten Typen geschlüpft. Ob Bauernburschen, wie der Klausengründer, Kunstköche oder Soldaten, die in Stille ihren Lebensabend verbringen wollten, das Spektrum reicht vom Schwermütigen bis zum Lebemann. Bruder Karl beispielsweise, der 1967 die Einsiedelei übernommen hatte und bis 2001 geführt hatte, war eigentlich gelernter Verkäufer. Die Überlieferung zeigt, dass unter all den Männern, die in der Eremitage Dienst gemacht haben, kein einziger Heiliger, Mönch bzw. in den Diensten Christus Berufener war.

Gemeinsam ist ihnen allen aber, und vielleicht den Bürgerlichen umso mehr, die Notwendigkeit der Wasserversorgung. Deshalb liegen alle diese Klausen entweder oberhalb eines Gewässerlaufes, die im Übrigen erst durch ihre erodierende Kraft die Höhlenbildungen verursacht haben und auch schon den Jägern der Altsteinzeit als Wohnstätten bzw. Unterschlupf dienten (die Klausenhöhle oberhalb der Kyll, die Hieronymushöhle an der Sauer, die Eremitenhöhle am Palfen oberhalb der Saalach), sogar in Verbindung mit einem Teich (Klusfelsen oberhalb der Gose und des ,Klusteiches'), an einem 
Quellaustritt (St. Wolfgang-Höhle, Eremitenhöhle in der Veranaschlucht/Solothurn), einem Wasserfall (der Elbesbach an der Käsegrotte bei Bad Bertrich) oder es war (zusätzlich) die Möglichkeit gegeben, durch Spalten sickerndes Kluftwasser aufzufangen (Klausenhöhle).

\section{d.6 Vor- und industrielle Zeit}

„Wichtigster Energieträger der vorindustriellen Zeit war das Wasser“ (PAULINYI 1982:255), das als Energieumwandler fungierte. Trotz der häufig aufgestellten Behauptung, erst die Dampfmaschine habe die Fabrik geschaffen, hatte „das Wasserrad bei der Entstehung der Textilfabriken die eigentlich entscheidende Rolle gespielt.“ (:255) In der vorindustriellen Textilproduktion Englands, beispielsweise der Kammgarn- und Baumwollspinnerei, die weitaus früher als Deutschland auf Dampfbetrieb umgestellt hatten, wurden die Spinnmaschinen sogar um 1800 noch mit Wasserradantrieb betrieben (:234, siehe Abb. V-24).

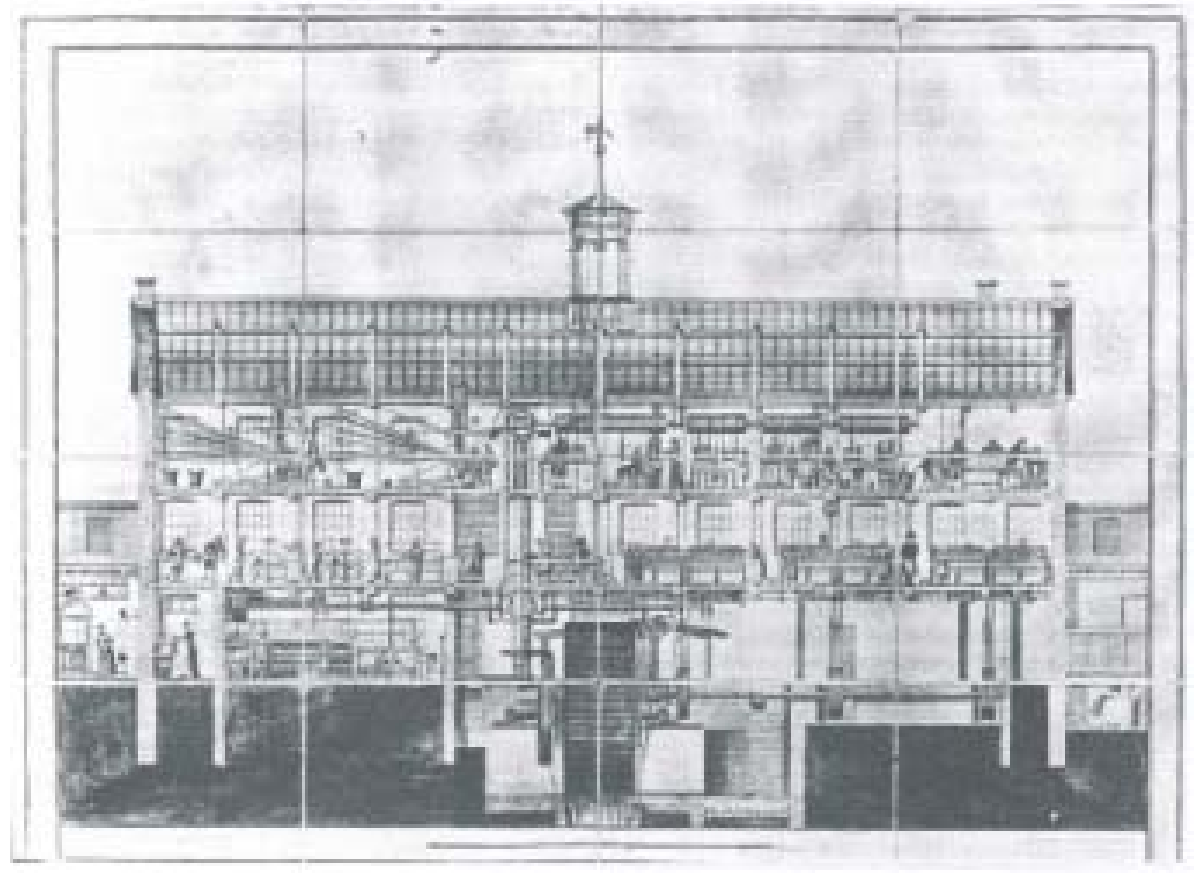

Abb. V-24:Mächtiges Wasserrad der Kammgarnspinnerei Bedworth bei Coventry um 1800

Wasserradantrieb der Vorspinn- und Feinspinnmaschinen im 1. und 2. Stock (aus: PAULINYI 1982:235)

Ein oberschlächtiges Wasserrad erbrachte im 18. Jh. eine Leistung von etwa 10 PS (PAULINYI 1982: 255). Unter günstigen Standortbedingungen, d. h. überwiegend außerhalb städtischer Ballungszentren, wurde die Wasserkraft deshalb auch gelegentlich noch zu Anfang des 20. Jh. von Großbetrieben eingesetzt. PAULINYI (:256) liefert dafür den Beweis am Beispiel einer großen Baumwollspinnerei in Styal/England, die bis 1904 mit einem 120 PS-Wasserrad von 9,75 m Durchmesser und 6,4 m Breite betrieben wurde. In der Regel, so weiß er weiterhin zu berichten, setzten kleinere Unternehmen mit geringem Energiebedarf Wasserräder unter etwa 5 PS ein. Diese Wasserräder des 19. Jh. bestanden dann auch aus eisernen Wasserrädern.

Die Nachteile dieser meistverbreiteten Kraftmaschine lagen nicht so sehr in ihrem Wirkungsgrad bzw. ihrer Leistung, „sondern darin, daß als Grundvoraussetzung ein fließendes Gewässer in entsprechender Menge vorhanden sein mußte.“ (PAULINYI 1982:255) Die Textilveredlung war abhängig „,von einem ausreichenden Wasserdargebot." (HERBST 1992:69) Die Nutzung der Antriebsenergie des Wassers aus dem Erftmühlenbach hat DIX (1997:84) für die gesamte Betriebszeit der Tuchfabrik Müller an dem Standort ab 1801 nachgewiesen. Vor allen der mechanische Webstuhl, aber auch andere Arbeitsgänge wie die Walkerei und Wäscherei wurden bis in die gründerzeitliche Expansionsphase (1871) hinein durch Wasserkraft geleistet (:53). Das Wasserrad dafür befand sich zumeist in einem eigenen Radhaus am Bach, das an das Hauptgebäude angebaut war (:84f.). 
Der Einsatz des Wasserrades war also standortgebunden und von geographischen sowie klimatischmeteorologischen Gegebenheiten abhängig (PAULINYI 1982:255). Flussläufe und vor allem Schwemmfächer boten deshalb dem wassergebundenen Textil- und Lederhandwerk nahezu ideale, wenngleich auch hochwassergefährdete Siedlungs- und Produktionsbedingungen (HERBST 1992:69).

Im Bereich der ländlichen Siedlung führte die ab Mitte des 19. Jh. verstärkt einsetzende Industrialisierung mit den Erfindungen der Agrartechnik und -chemie, z. B. dem Kunstdünger durch Justus von LIEBIG um 1840, zu Umwälzungen der Landwirtschaft und der ländlichen Gesellschaft, wie es sie „,innerhalb so kurzer Zeit vorher nie gegeben hat“ (LIENAU 1995:176f.). Bewässerungs- und Rieseleinrichtungen, die zur Verteilung von Gewässerschwebstoffen und damit zur Düngung von Hangwiesen beigetragen haben und auf benachbarte Gewässer angewiesen waren, wurden damit obsolet. Der künstliche Düngerersatz wurde nunmehr als Kalk aufgetragen. Hinsichtlich der Lagewahl von Hofstellen und der für die früher so wertvollen Hang- und Auenwiesen notwendigen Bachläufe ergab sich kein Zusammenhang mehr.

Im Gegensatz zu dieser Entfernung von einer Gewässerlage, wurden durch andere Prozesse Fließgewässer in besonderer Weise weiterhin gesucht. Die zur Schmelze der Erze gegründeten, an ihrem Gründungsstandort weiter gewachsenen Hüttenbetriebe blieben der Nutzung der Wasserkraft und der Brennstoffverarbeitung wegen, aber auch aufgrund bestehender Beschäftigungs- und Absatzstrukturen, weiterhin an die wald- und wasserreichen Mittelgebirgstäler gebunden (SCHWARZ 1988: 312). Die vermehrte Herstellung von Roheisen zog vielfach die von Schmiedeeisen in den Hammerwerken mach sich. Ihre Lagen aber entsprachen auch weiterhin dem üblichem Schema: an Gewässerläufen, an denen die Hämmer durch Wasserkraft angetrieben wurden (: 312). Erst in der industriellen Phase, in der der Antrieb der Hämmer und Schmelzöfen mit Wasser durch Kohle und Dampfkraft substituiert wurde, lösten sich die gewässerhistorischen Bindungen. Wenn aus verschiedenen Gründen der Standort gehalten wurde, dann auch, um den ehemaligen Energielieferanten als Vorfluter für die Abwasserlast zu benutzen.

Umfangreiche Flussregulierungen und Kanalbauten wurden für das gesteigerte Transportaufkommen für Massengüter, Halb- und Fertigwaren an weiter entfernt gelegene Absatzmärkte und für die Zulieferung von Rohstoffen notwendig. Gleichzeitig führten die künstlichen Gewässerlagen in diesem Zeitraum zu neuer Industrieansiedlung, die die künstlichen Wasserläufe als Transportweg nutzten.

War zunächst die Erzeugung von Eisen und Glas der treibende Motor der gesamten mittelalterlichen waldgewerblichen Kolonisation gewesen, so wurde später in einigen Gegenden - aufgrund der vorherrschenden Waldarmut in den Umgegenden der expandierenden Städte - die Gewinnung von Stammholz so wichtig, dass eigens zu diesem Zwecke Flößersiedlungen ins Leben gerufen wurden. Flößer bildeten nunmehr einen wichtigen Berufsstand, der zwischen waldgewerblichem und schiffereigewerblichem Stand angesiedelt war.

Sägewerkmühlen entstanden infolgedessen an Fließgewässern in zahlreicher Form. Sie waren in der vorindustriellen Zeit auf die Nutzung der Wasserkräfte angewiesen, so dass die dazugehörigen Siedlungen an den Flüssen im Innern des Landes lagen. Bis dahin wurden die Stämme geflößt und von hier aus das Schnittholz wieder den Flüssen anvertraut (SCHWARZ 1988: 328). Nachdem der Wert des Holzes für die Zellulose- und Papierherstellung erkannt worden war, bildete dies die Grundlage einer nochmaligen Intensivierung der Holzindustrie, und es trat eine Verlagerung der Sägewerke ein. Die Flussmündungen waren es nunmehr, in denen die Industriesiedlungen mit den riesigen Bretterlagern und den rauchenden Schornsteinen der Zellulosewerke das Bild bestimmten (:328f.).

Mit der Erschließung globaler Ergänzungsräume, vor allem in den überseeischen Kolonialländern, die nun vielfach als Monokultur-Betriebe Nahrungsmittel oder industrielle Rohstoffe importierten, war eine Verdichtung der Siedlungen verbunden und zugleich ein besonderes Wachstum der Hafen- und Handelsstädte vorgegeben (SCHWARZ 1988:46). Getreidespeicher errichtete man in vielen Fällen dicht am Wasser, wie die noch zumindest baulich existierenden Beispiele von der Weser in Hameln und Holzminden zeigen. Nicht nur aus verkehrstechnischen Gründen wurde die Lage gesucht, sondern auch deswegen, weil dort bei dem schnell entzündlichen Getreide im Falle eines Falles Löschwasser 
zur Verfügung stand (HIPP 1990:30). Die Nähe zu großen schiffbaren Strömen und vorteilhaft zu nutzender Flussmündungshäfen bestimmten das Wachstum dieser an Gewässer orientierten Städte. Eine Vielzahl von Großstädten und Industrielandschaften entwickelte sich dort, wo besondere Voraussetzungen vorlagen. Hierzu zählte insbesondere die Lage an Küsten- und Binnenhäfen und an schiffbaren Flüssen.

Diese am überseeischen Handel partizipierenden Handelsleute erreichten erheblichen Wohlstand. Ausdruck dieses Reichtums wie auch der Verbundenheit mit dem Strom, der erst den Warentransport und damit den beruflichen Aufstieg ermöglichte, waren die Villen in Gewässernähe. Die Elbchaussee in Hamburg mag als bedeutendes Beispiel in Deutschland gelten. Doch nicht nur die mit dem Gewässer wirtschaftlich in einem Abhängigkeitsverhältnis Stehenden suchten die Gewässerlage als bevorzugte Wohnlage auf. Auch an den Binnengewässern Norddeutschlands, wie z. B. am Berliner Wannsee, oder an den Voralpenseen, wie Starnberger See und Tegernsee, erbauten wohlhabende Industrielle und Literaten ihre großzügigen (Zweit-) Wohnsitze. Kurt Tucholskys 1927 veröffentlichtes Gedicht vom - unerfüllbaren - „Ideal“ des Wohnens (und Lebens) mag stellvertretend die präferierte Wohnlage dieses Zeitalters wiedergeben: „Ja, da möchste: Eine Villa im Grünen mit großer Terrasse, vorn die Ostsee, hinten die Friedrichstraße; mit schöner Aussicht, ländlich-mondän, vom Badezimmer ist die Zugspitze zu sehn [...].“

Die entscheidende Wandlung zum Industriezeitalter und im Verlauf dessen die Veränderung der gewässergeographischen Gegebenheiten aber „brachte erst die Inwertsetzung der Kohle und die Vielzahl der technischen Erfindungen seit dem Ende des 18. Jh.s.“ (SCHWARZ 1988:45) 1785 wurde in Deutschland bei Hettstedt im Mansfelder Land die erste Dampfmaschine in Betrieb genommen und 1788 wurde die erste aus England importierte Dampfmaschine unter Friedrich dem Großen in den Blei- und Silbergruben von Tarnowitz im heutigen Polen aufgestellt. Diese Erfindung hatte in den Folgejahren für die Gewässernutzung weitreichende Folgen: Nicht die Kraft der Gewässer trieb seitdem die Hämmer und Mahlwerke an, sondern der durch Kohle erhitzte Dampf, der schließlich über die Drehbewegungen der Kolben Wärmeenergie produzierte und die Maschinen antrieb.

Eine Vielzahl von Siedlungen, Großstädten und Industrielandschaften entwickelte sich zum einen Teil fortan nicht mehr dort, wo allein Wasserkraft zur Verfügung stand, sondern dort, wo andere industriewirtschaftliche, infrastrukturelle Voraussetzungen additiv vorlagen, wie beispielsweise eine Eisenbahnanbindung. Die Zerstörung der gewässergebundenen Industriekultur findet hier ihren Anfang (BÄRTSCHI 2002).

Und noch ein anderer Aspekt, der mit der möglich werdenden Nichtverfügbarkeit bzw. nicht ausreichenden Verfügbarkeit von Wasser an den neuen Standorten zusammenhängt, prägte diese industrielle Phase. „Before 1850, the water supply [...] was small-scale, with local communities being supplied from the local river or we 1l. [...] The small, dispersed population had, for the most part, relied on the natural purification capacities of the natural environment." (MC DONALD 1999:138) Ab 1850 dann ist die zentrale Wasserversorgung im Entstehen begriffen: „City corporations developed their own water undertakings, each city being supplied by its own reservoir system independently from the resource developments of adjacent cities." (:138) Mit Folgen für das Gewässersystem: "the scale of the reservoirs increased and the size of catchwaters and aqueducts increased dramatically."(:138)

\section{d.7 Zeit von 1933 bis 1945}

BAKER sieht Landschaft "as a system of signification, expressive of authority" (1992:5) und führt aus, dass historische Landschaftsstrukturen ,are created and creatively destroyed within an ideological context: such studies must therefore also acknowledge that landscapes are shaped by mental attitudes and that a proper understanding of landscapes must rest upon the historical recovery of ideologies." $(: 3)$

Will man sich also dem Siedlungswesen und seinem Gewässerbezug in der nationalsozialistischen Zeit nähern, so führt gerade hier der Weg über den Betrachtungsansatz der Landschaft als Ausdruck ideologischer Prägung. Und mir ist mit WALTER (1996:16) klar, „wer eine wirkliche Umweltgeschichte 
schreiben will, muss [...] die Ideologien und Mentalitäten untersuchen.“ (WALTER 1996:16) Aber leider lässt der Umfang dieser Arbeit keine intensive Beschäftigung mit den vergangenen totalitären Systemen zu, auch weil generell ein Forschungsdefizit besteht hinsichtlich des Lagebezuges und auch der Gewässerumgestaltung in der nationalsozialistischen Raumordnung. Die Schwierigkeit wird dadurch verstärkt, dass es für diesen Zeitraum zwar „viel Pläne, aber wenig realisiertes, wenig bebautes“ (FEHN 2004: mündl.) gibt. Dennoch seien einige Bemerkungen zum Thema Wasser und seine anthropogene Inanspruchnahme in der Zeit von 1933 bis 1945 versucht:

DENECKE bietet in einem kurzen kritischen Beitrag zu ideologisch basierten Aktivitäten als einem Element zur Gestaltung der Landschaft (,,ideologies are created and developed to affect or guide people's thoughts, behaviour and activities.“ [1992:303]) einen Überblick über ,the ideology of the German Nazi regime (fascism) and its schemes of spatial reorganization" (:319-324). Vor allem die innerstädtische städtebauliche sowie architektonische Neugestaltung sowie die geplante, aber aufgrund des Krieges verhinderte Neubebauung stand hier im Vordergrund. Aber das politische System in seinem baulichen Ausdruck bezog sich auch auf die Landschaft und das bäuerliche Siedlungswesen.

1936 begann eine rege und langanhaltende Bautätigkeit vor allem in den ländlichen Gebieten und auf den deutschen Inseln: (FAUST 2001:228). Die Nationalsozialisten hatten sich gerade in Pommern die Verbesserung der ländlichen Siedlungsverhältnisse und den Landarbeiterwohnungsbau sehr stark auf ihre Fahnen geschrieben (FAUST 2001:228). Nach dem Reichsheimstättengesetz musste genügend Land für den ländlichen Siedlungsbau zur Verfügung gestellt werden, und infolgedessen wurden vor allem Kleinsiedlungen mit bescheidenen Doppelhäusern errichtet (FAUST 2001:228). Begonnen wurde 1936 z. B. mit der sog. Siedlung Kloster auf Hiddensee (FAUST 2001:228).

Durch den Siedlungsneubau bedingt fielen in diese Zeit auch viele Dammbauten zum Schutz vor Sturmfluten und zur Sicherung von Hochufern. Durch den Dammbau sollte nicht nur das Steilufer geschützt, sondern auch der enorme Sandabtrieb reduziert werden (FAUST 2001:229). Bestehend aus Faschinensenkstücken aus Kiefernästen, Findlingen und gebrochenen Granitsteinen, wurde auf Hiddensee ein Damm aufgeschütte, der ursprünglich $4 \mathrm{~km}$ lang geplant war, davon aber nur $400 \mathrm{~m}$ zur Ausführung kamen. Er besaß eine Höhe von 2,80 m über Mittelwasser und eine Kronenbreite von $1 \mathrm{~m}$ und überstand zwar bisher alle Sturmfluten praktisch unbeschadet, hatte allerdings eine unangenehme Nebenwirkung: „Durch die geänderten Strömungsverhältnisse verlor der Strand von Kloster, der schon immer sehr steinig gewesen ist, endgültig so gut wie allen Sand.“ (FAUST 2001:230)

In diesem Kontext sei zur weiteren siedlungshistorischen Beschäftigung mit diesem Thema auf die Veröffentlichungen von Andreas DIX (2002) hingewiesen, der in seiner Habilitationsschrift die aufbauend auf die nationalsozialistischen Vorplanungen und seiner Doktrin festhaltenden „Siedlungsplanung im ländlichen Raum der SBZ und frühen DDR“ darstellt und auf die im gleichen Kontext stehende Dissertation stehende Dissertation von Wolfgang AMAN (1999) über den „Städteund Siedlungsbau in Wien 1945-1958“, des Weiteren auf die Arbeit von Michael HARTENSTEIN (1998), der in seiner Dissertation die „Neuen Dorflandschaften“ der nationalsozialistischen Siedlungsplanung, wie beispielsweise die Reichsgauplanungen in den eingegliederten Ostgebieten von Heinrich Dörr 1943-1944, beschreibt, und auf die Dissertation von Jan SMIT (1983) über die „Neubildung deutschen Bauerntums“ im Dritten Reich am Beispiel von Schleswig-Holstein. Des Weiteren sei hier verwiesen auf den Beitrag von FEHN (2002) zur ,germanisch-deutschen Kulturlandschaft" als Handlungsfeld der Historischen Geographie.

Für eine umwelthistorische Beschäftigung empfohlen sei der Beitrag von Helmut MAIER (1996:247266) u. a. über den „Wasserkrafttaumel“ nationalsozialistischer Naturschutz- und Energiepolitik und der von Joachim RADKAU und Frank UEKÖTTER (2003) herausgegebene Band über den Naturschutz im Nationalsozialismus.

\section{d.8 Zeit nach dem Zweiten Weltkrieg}

Das Ende des Zweiten Weltkrieges brachte ,die völlige Veränderung der Agrarstruktur und mit ihr der Struktur der ländlichen Räume, ihrer Siedlungen und Fluren“ (LIENAU 1995:178) mit sich. 
Im westlichen Teil Deutschlands stellt ein Hauptproblem nach Kriegsende die Ansiedlung von heimatvertriebenen Landwirten aus den Ostgebieten dar. Mit einer weitreichenden Bodenreform, fortgesetzter Moorkultivierung und Neulandgewinnung durch Eindeichung (z. B. Friedrich-Wilhelm-LübkeKoog bei Dagebüll/Kreis Nordfriesland) wurde eine agrarstrukturelle Neuordnung geschaffen (LIENAU 1995:178). Eine enge Gewässerbindung ist jedoch nicht mehr zu erkennen und spielte auch bei der Auswahl von Plätzen für Heimatvertriebenenansiedlungen keine Rolle mehr. Das Flurbereinigungsgesetz von 1953 und 1976 und die auf diesem Gesetz basierenden räumlichen Gesamtplanungen beeinflussten maßgeblich auch das kleinteilige Gewässernetz des ländlichen Raumes durch flächenhafte Kanalisierung und Trockenlegung der Gewässer. Die Anlage eines geradlinigen Gewässer- bzw. Entwässerungsnetzes, in dem Bäche und Flüsse zu Vorflutern degradiert wurden, sind Kennzeichen der ersten Phase der ,Dorferneuerung' (:180). In der jüngeren Entwicklung, der Phase der ,erhaltenden Dorferneuerung“ hingegen, stehen Maßnahmen der Natur stärker im Vordergrund und sind gekennzeichnet durch die Wiederanlage von Dorfbrunnen und die Renaturierung von Bächen (:180). Diese Überlegungen werden aber nicht gesteuert vom Gewässervorkommen bzw. der Lage zu Gewässern.

\section{d.9 Moderne}

Die aktuelle räumliche Verteilung von Siedlungen und Bevölkerung in der modernen Industrie-, Dienstleistungs- und Verkehrswirtschaft mit ihren Auflösungserscheinungen des „urban sprawl“, angeregt durch perfekte Telekommunikation des Mobile Computing und der zeitsparenden Verkehrstechnologie, stellt die Stadt als räumliches, abgrenzbares und definierbares System in Frage, sie mutiert zu einem „,nonplace“ (LICHTENBERGER 1986:17).

Einzig einige Hafenstädte, so scheint es, benötigen in Deutschland weiterhin die Lage an Flüssen bzw. Flussmündungen mit Meerzugang (Bremerhaven an der Weser, Hamburg an der Elbe, Emden an der Ems), obgleich auch hier schon „Offshore-Häfen“ in der Diskussion sind. Kleinere Fließgewässer bzw. Fließgewässerabschnitte des Binnenlandes haben schon lange ihren Wert als Werftstandort aufgeben müssen, wie die Beispiele Bodenwerder und Vlotho an der Weser zeigen. Und die ewige Diskussion um die Meyer-Werft an der Ems zeigt deutlich die zunehmende wirtschaftliche Bedeutungslosigkeit von mittelgroßen Fließgewässern. Einzig die an den großen mitteleuropäischen Strömen (Elbe, Rhein, Donau) liegenden Binnenhäfen können an den modernen Kapazitäten des Warenumschlags partizieren (Duisburg und Leverkusen am Rhein, Hamburg und Magdeburg an der Elbe) und mit den heutigen Tonnagen und Schubverbänden der Schiffe befahren werden.

Aufgrund des Standards des Frischwassertransportes über teilweise Hunderte von kilometerlangen Kanalleitungen ist Wasser in den Haushalten und an den Firmenstandorten ubiquitär in Deutschland vorhanden. Mitunter erst durch die flächenhafte Verfügbarkeit dieser ,Dienste' konnten siedlungsstrukturelle Prozesse wie Sub- und Deurbanisierung ablaufen, die eine weitere Unabhängigkeit vom Gewässernetz produzierten. Binnengewässerlage wird von den Unternehmen nur noch in Einzelfällen gesucht, beispielsweise bei der Ansiedlung von Kernkraft- und Braunkohlenkraftwerken, um Kühl und Reinigungswasser zuzuleiten und dieses als erwärmtes - und bei den Kernkraftwerken zusätzlich als radioaktives Abwasser innerhalb der genehmigten Grenzwerte wieder abzuführen (KKW-Lingen in die Ems, Grohnde in die Weser, Cattenom in die Mosel u. a.) (KÜPPERS 2003:1ff.) oder von der chemischen Industrie, die eine gesetzlich nach WHG und AbwAG zugelassene verdünnte Einleitung zur günstigen Vermischung ihrer industriellen Abwässer über Rohrleitungsanlagen in die Fließgewässer immer noch vornimmt (z. B. die chemischen Fabriken WACKER, BASF, KNOLL AG in Minden in die Weser oder DOW CHEMICALS in Stade in die Elbe).

Aufgrund der Gewässerverschmutzung haben Fließgewässerstandorte für viele höherwertige Nutzungen, wie z. B. die oberirdische Trinkwassergewinnung und für die gewerbliche Flussfischerei ihre Bedeutung weitgehend verloren, vielmehr ist die Berufsfischerei nahezu erloschen. An der Weser beispielsweise gehen die beiden letzten Berufsfischer auf der nordrhein-westfälischen Mittelweser unterhalb der Staustufe Schlüsselburg bei Petershagen und auf dem niedersächsischen Mittellauf 
zwischen Polle und Bodenwerder ihrer Tätigkeit nach. Der Fischertrag ging von $200 \mathrm{~kg} / \mathrm{ha}$ in den 1920 er Jahren über $80 \mathrm{~kg} / \mathrm{ha}$ in den 1960er Jahren auf heute $4-5 \mathrm{~kg} /$ ha zurück (KIRCHOFF 2002).

Des Weiteren hat der Umbau der kleinteiligen Landwirtschaft eine massive Lösung vom Gewässer zur Folge. Der Anteil von Weidetieren im Verhältnis zur Weideflächengröße und auch die Lage der Weiden bemißt sich nicht mehr an der Verfügbarkeit von Gewässerläufen zur Tränkwasserbereitstellung. Tiefgründige Pumpen erfüllen diese Funktion aufgrund versiegter Quellläufe durch übermäBige Abschöpfung - nicht nur zum Zwecke der Landwirtschaft. Permanente Stallhaltungen erleichtern gleichzeitig die Auflösung der ehemaligen Standortbindungen von Hofstellen zur Gewässerlage.

Die urbane Wassernutzung der Moderne ist die einer Inszenierung. In unserer Freizeitgesellschaft wird Wasser zu einem Freizeitmedium degradiert und dadurch in seiner Funktion bestimmt: zum RiverRafting auf den Gebirgsflüssen, zum Canyoning in den Wasserfallspalten, zum Flößen als gesellschaftliches Ereignis durstiger Keglergruppen. Für ehemalige Flößerdörfer wie Wolfratshausen ist dadurch aber ihre Gewässerlage weiterhin von Bedeutung, wenn auch mit anderer touristischer Zweckbestimmung. Andere, neue gewässerbezogene Sportarten, wie das Wassermotorradfahren, siedeln sich ferner mit ihren Verleih- und Ausrüstungsstationen an bzw. in Gewässernähe an.

Auf der anderen Seite gewinnt die Ansiedlung von Bauten an oder in Gewässern im ausgehenden 20. bzw. beginnenden 21. Jahrhundert wieder an Bedeutung. Das Leben am und mit dem Wasser wird in die Architektur- und Städtebauplanung einbezogen. Ein wesentlicher, zunehmend stärker diskutierter städtebauliche Aspekte ist das der „Wasserstädte“ (JACOB 1997:37).

Das Paradigma des urbanen Lebens ist das Leben am und mit dem Wasser, so lautete die Feststellung von Architekten und Urbanisten anlässlich eines 1997 stattgefundenen Kongresses in Berlin zum Thema „Europäische Wasserstädte' (JACOB 1997:37). Leitgedanken solcher ,Wasserstädte' sind Bestrebungen wie die „Reintegration der Gewässer in das Leben der Stadt und das Bewußtsein der Bevölkerung“ (STRAUSS 2002:216), d. h. ,in Zukunft soll das Wasser im Leben und im Gefüge der Stadt wieder erlebbar gemacht werden" (:215). Dies bedingt eine Integration des Wassers in die Stadtstruktur, die durch eine entsprechende Stadtentwicklung gewährleistet werden soll. Dann wird auch von einer „amphibischen“ oder gar „hydrophilen“ Stadtentwicklung gesprochen (:216). Eine ,hydrophile Stadt' bedeutet aber ,nicht die Ausnutzung aller Funktionen des Wassers im Sinne einer Ausbeutung, auch nicht der Erholungsfunktion [...] der hydrophile Ansatz ist im eigentlichen Sinne der Nachhaltigkeit zu verstehen.“ (:216) Eine ,hydrophile Stadt’, präsentiert sich modern als „die nachhaltige Stadt.“ (:216) Diese visionär-ökologische Auffassung vertritt auch der bekannte englische Landschaftsarchitekt WILKIE (1998:7): „Das Konzept einer Stadt, die aus mehreren Orten entlang einem Fluß besteht, aufgeteilt durch Parks und Wiesen“, könnte nach seiner Vorstellung „das Modell urbaner Nachhaltigkeit darstellen“.

Zehn Metropolen brachten im Verlauf des o.g. wegweisenden Kongresses ihre wasserstädtischen Erfahrungen ein. Aus Berlin, Amsterdam, Barcelona und Lissabon, aus London, Budapest und Wien stellten Stadtbaumeister Projekte vor, diskutierten Urbanisten und Architekten über die Wege zur Wasserstadt. Für Augusto BURELLI ${ }^{35}$ beispielsweise waren Handel und Kommunikation seit jeher Notwendigkeit und Herausforderung, Chance und Bedrohung. Nicht allein pro domo plädierte der Venezianer für spezifisch wasserstädtische Bautypologien. Die Durchgangshalle des venezianischen Hauses, in dem Menschen und Waren ohne ,Umschlag' direkt vom Wasser ins Gebäude gelangen, könne nach seiner Auffassung auch Prototyp für andere Standorte sein (JACOB 1997:37). In Amsterdam bahnte man eine Gracht durch vormaliges Festland, in Cardiff errichtete man einen mit Wohnhäusern bebauten Damm, durch den ein Binnensee mit dreizehn Kilometer neugewonnener Uferstrecken entstand.

\footnotetext{
35 Burelli, Augusto Romano: italienischer Star-Architekt; Professor für Entwurf und Gestaltung an der Fakultät für Architektur an der Universität Venedig und seit 1991 dort Leiter der Abteilung Architekturplanung. Außerdem betreibt er mit seiner Frau ein Architekturbüro in Udine und ist Partner eines Architekturbüros in Berlin-Charlottenburg. Die visionären Gestaltungsideen hat er in städtebaulichen Planungen bzw. Planungswettbewerben in Friaul, Berlin, Potsdam und in Heidelberg umgesetzt bzw. vorgelegt.
} 
Auch die deutschen Städte an Flüssen und Seen haben mittlerweile zahlreiche Projekte konzipiert, die sich unter dem Motto ,Neue Hinwendung zum Wasser' bzw. ,Öffnung der Stadt zum Wasser' betrachten lassen. Diese wasserbauliche Orientierung basiert auf einer realistischen Einschätzung von demographischen, sozialen, ökologischen und wirtschaftlichen Rahmenbedingungen, die zeigen, dass die Städte an besonders attraktiven Stellen nachhaltig weiterwachsen werden - und dazu gehören insbesondere die Lagen an der Wasserfront. Doch „nicht die Planung komplett neuer Wasserstädte, sondern stufenweise kleinräumige Umsetzungskonzepte sind die Antwort auf gewandelte Bedürfnisse und auf knappe öffentliche Mittel“" (BITTENFELD et al. 2003:48; STADTENTWICKLUNG BERLIN 2004).

So bestehen in Hamburg Pläne zur Entwicklung einer „Perlenkette“ am nördlichen Elbufer, Konzepte für den Harburger Binnenhafen und vor allem das Projekt der Hafen-City, bei dem das Hafenareal südlich der Speicherstadt als Innenstadterweiterung definiert wird (SCHUBERT 1999:70ff.). So soll dem Niedergang der Hafenanlagen an den innenstadtnahen Uferkanten der Stadt durch städtebauliche Planungen entgegengewirkt werden. Brachgefallene Hafenflächen wurde auch in der Weser auf dem ,Bremer Werder' durch neue gemischte Siedlungsgebiete mit Wohnungsbauten, Arbeitsstätten sowie Einkaufsstätten und Gastronomie ersetzt. „Die Revitalisierung der Brachflächen wird als planerische Herausforderung angesehen, die Städte zum Wasser zu öffnen, das Wasser im Bewußtsein der Bevölkerung zu stärken und so eine neue ,Adresse' zu entwickeln.“ (STRAUSS 2002:16), wie dies Anfang der 1990er Jahre in den Londoner Docklands versucht wurde.

Allgemein haben „Wasserstädte als Leitidee für Brachflächen-Recycling und Konversionsvorhaben [...] - auch dort, wo die Realisierung stockt - Konjunktur" (ZWAFELINK 2002:382). In Frankfurt am Main begann die Revitalisierung von Uferflächen mit der Einrichtung eines Museumsufers in den 1980er Jahren. Mit diesen und anderen Projekten soll die Stadt ihrem Städtenamen gerecht werden und sich neu dem Fluss zuwenden (LAMPUGNANI et al. 1992:16ff.).

Im ,Düsseldorfer Medienhafen' wird zurzeit die Hafenentwicklung der nächsten 15 bis 20 Jahre in Bebauungsplänen vorbereitet. „Neue Wohngebiete am Wasser sind begehrt“, so ein Sprecher einer großen Immobiliengesellschaft (GLODECK 2003:9), und auch der Düsseldorfer Oberbürgermeister stellt in diesem Zusammenhang eine „Re-Urbanisierung“ fest. Es entstehen hier durch Umnutzung ehemaliger alter Hafenareale in unterschiedlichen Plangebieten Luxuswohnungen, zum Teil mit dem begehrten unverbauten Rheinblick. Gleiches entsteht in Mülheim an der Ruhr mit dem Städtebaukonzept „Ruhrbania“ oder in Duisburg im ehemaligen Innenhafen.

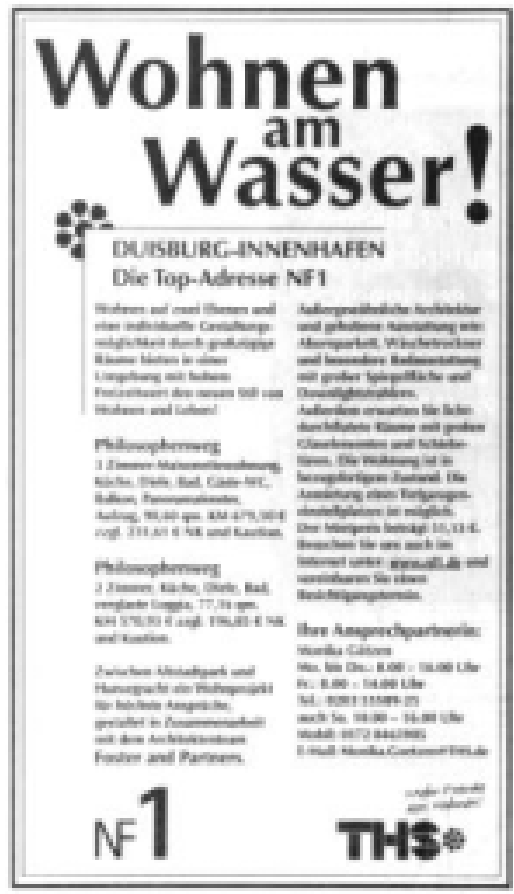

Abb. V-25:Zeitungsausschnitt, der die Aktualität des Themas „Wohnen am Wasser“ widerspiegelt 
Eine besondere Stellung in der Entwicklung von Wasserstandorten nimmt Berlin ein, wo auch der Städtebaukongress abgehalten wurde. Seit den 1990er Jahren wurden hier zahlreiche Projekte zur Hinwendung zum Wasser in der Stadt entwickelt. In Berlin entstand das Regierungsviertel, am Ufer der Spree entstehen die Entwicklungsmaßnahmen ,Rummelsburger Bucht' und die ,Spreestadt Charlottenburg', an der Havel die ,Wasserstadt Spandauer See', auch ,Wasserstadt Berlin-Oberhavel' genannt. Es handelt sich dabei um eine 206 ha große städtebauliche Entwicklungsmaßnahme, die sich derzeit am Ende der Realisierung befindet. Hervorgegangen ist sie aus einem bereits Ende der 1980er Jahre geplanten Vorhaben, in Spandau entlang der Havel und Spree eine „Wasserstadt Unterhavel“ mit einer Neuansiedlung von Wohn- und Arbeitsstätten zu realisieren. Der Entwicklungsbereich wurde dann aus nicht näher bekannten Gründen einfach nach Norden verlagert. Die „Wasserstadt am Spandauer See“ verfolgt dabei eine Stadtentwicklung, die zunächst von der Landseite aus betrieben wird. Die Integration der Wasserseite erfolgt erst nach der Realisierung aller Bauprojekte innerhalb dieses Bereiches (STRAUSS 2002:175).

Aus Berlin gibt es darüber hinaus in diesem Gebiet ein weiteres städtebauliches Konzept, das eine Öffnung zum Wasser verfolgt. Das sog. „Planwerk Westraum“ des Landes Berlin sieht eine „Umwandlung von Uferrandflächen in neue Siedlungsgebiete für eine ,städtische' Nutzung von Wohnen und ,sauberem' Arbeiten“ vor (STRAUSS 2002:8). Es handelt sich um eine Nutzung der Uferrandflächen von Spree und Havel durch Hafenanlagen und Produktionsstätten, indiziert durch das Verkehrsprojekt Deutsche Einheit Nr. 17, hier Ausbau von Spree und Havel. Das Förderziel ist die „Ansiedlung städtischer Quartiere unter Ausnutzung des Ambientes zweier Flüsse und ihres Zusammenflusses“ (SCHMIDT-EICHSTAEDT 2002: Vorwort). Die planungsphilosophische Intention des „Planwerk Westraum“ in Spandau ist es, „Stadt und Wasser einander näher zu bringen. Dabei wird dem Leben am Wasser, dem Städtebau, der Vorrang eingeräumt.“ (STRAUSS 2002:62)

Die zukünftigen städtebaulichen Wasserplanungen sind so umfangreich, dass in der Stadt Berlin erstmals mit dem gesamtstädtischen Wasserlagenentwicklungsplan (WEP) „ein gesamtstädtisches, umfassendes Regelwerk für die Stadtentwicklung am Wasser" entstand (BITTENFELD et al. 2003:48). Die Volumina der wasserbezogenen Stadtentwicklung sind extrem: Entlang einer insgesamt $18 \mathrm{~km}$ langen „Waterfront“ sollen ,in den nächsten Dekaden bis zu 35.000 Wohnungen und bis zu 145.000 Büroarbeitsplätze entstehen“ (:48). Insbesondere die Wasserlandschaften von Dahme, Havel und vor allem die Spree mit ihren Seitenkanälen sollen den Schwerpunktraum der Entwicklung bilden. Generell aber sind in Berlin zunächst ,alle Flächen entlang der schiffbaren Flüsse und Kanäle“ Gegenstand der Untersuchung potentieller Entwicklungsflächen (:49).

Berlin soll sich, so lautet die Zielvorgabe, in den nächsten 15 - 20 Jahren als „Wassermetropole“ weiter profilieren: „Ziel ist es über naturnah gestaltete Uferpromenaden und Grünzüge die Quartiere und Gewässer in eine bisher nicht vorhandene Beziehung zu setzen und gleichzeitig die Ausflugs- und Wassersportgebiete mit regionaler Ausstrahlung aufzuwerten.“ (BITTENFELD et al. 2003:49) „Besondere Chancen liegen in der Vernetzung bestehender Stadtquartiere mit neuen Quartieren am Wasser. Attraktive, mit dem bestehenden Stadtgefüge vernetzte Uferlagen versprechen in den nächsten Jahren die beste Marktfähigkeit.“ (:48) Die Perspektiven der Wasserlagenentwicklung sind hierfür nach Ansicht der beratenden Architekten und der Stadtplaner des Senates ,günstig, weil der Strukturwandel der Wirtschaft, die Fokussierung auf qualitative hochwertiges Wohnen und neue Freizeitanforderungen günstige Voraussetzungen für Transformationsprozesse darstellen“ (:48f.). Interessant ist vom Ansatzpunkt historisch-geographischer Betrachtung, dass über die Aufwertung altindustrieller Standorte am Wasser hinaus, „bauliche Relikte des 19. Jahrhunderts, lokale Identitäten und historische Spuren mit städtischen Wohn- und Arbeitsformen des 21. Jahrhunderts verknüpft werden" sollen $(: 48)$.

Ein weiteres Beispiel modernen wasserbezogenen Städtebaus sei genannt: ein noch auf die Realisierung wartendes Konzept zur Nutzung des Warnow-Ufers der Hansestadt Rostock im Jahr 2010. Es sieht u. a. das Wohnen am Wasser vor. Entlang der „Entwicklungsräume am Wasser“ sollen Uferbereiche der Unter-Warnow geöffnet und als zukünftige Nutzungsbereiche der Neugestaltung 
übergeben werden, während sensible natürliche Uferbereiche entlang der Oberwarnow, eingebettet in das NSG „Oberes Warnowtal“" mit FFH-Einstufung unzugänglich bleiben (KÖPPEN 2003:14ff.).

Die städtebaulichen Entwicklungsmaßnahmen an Wasserstandorten wurden zum Teil initiiert und gefördert durch das EU-Programm „INTERREG II C - Baltic Sea Region - Waterfront Urban Development ${ }^{\star 36}$. Weitere Städte, in denen wasserbauliche Projekte entwickelt und realisiert werden, sind für Deutschland - neben Berlin mit gleich drei Projekten („Wasserlagen“, „Oberschönwalde“, „Rummelsburger Bucht") - Potsdam und Werder sowie Lübeck und Rostock, für Polen Gdansk (Danzig), Gdynia (Gdingen), Elblag (Elbing), Tczew (Dirschau), Szczecin (Stettin), für Russland St. Petersburg, Kaliningrad (Königsberg) und Baltijsk (Pillau), Tallinn (Reval) in Estland, Riga in Lettland, Klaipeda (Memel) in Litauen, Vaasa in Finnland, Göteborg in Schweden und Køge in Dänemark. Neben der Zielsetzung, ehemalige Hafenareale und am Wasser gelegene Industriegelände in Wohnanlagen, Technologie- oder Forschungszentren in Wasser- bzw. Ostseenähe zu konvertieren, bei gleichzeitiger Integration der reduzierten industriellen Funktion oder einer (Re-) Etablierung der freizeitlichen und touristischen Potentiale dieser Anrainerlagen, sollte eine Neubewertung auch innerstädtischer Wasserstandorte als zukünftige Entwicklungsareale vorgenommen werden (,innercity-waterfront areas"). Beispiel für diese Typen sind Berlin, Elblag und Tczew.

Im Gegensatz zu den EU-initiierten Planungskonzepten steht die „Wasserstadt Povel“ in Nordhorn. Die „Wasserstadt Povel“ ist ein national und international beachtetes Städtebauprojekt, das eine Altlastensanierung auf dem Gelände einer ehemaligen Textilfirma verknüpft hat mit einer zukunftsorientierten Folgenutzung. Gefördert wurde das Vorhaben durch das Umweltbundesamt und des Bundesbauministeriums aus dem Programm „Experimenteller Wohnungs- und Städtebau mit einer Sanierungsförderung als Pilotprojekt". „Streng lineare Wasserzüge bilden quasi das freiräumliche Rückgrat der Konzeption.“ (ZWAFELINK 2002:384) Durchzogen von einem „Grachtennetz“ beinhaltet der erste Bauabschnitt kleinteilige zwei- bis dreigeschossige Stadthäuser mit eingestreuten kleinen Praxen und Büros für Freiberufler: „Er bildet eine geschlossene Inselbebauung, die durch Grachten und Wassergärten zu den weiteren Bauabschnitten abgegrenzt ist.“ (:384)

Zusammenfassend kann für den Städtebau konstatiert werden: „The cities of Europe are rediscovering their embankments and waterfront areas. After decades of negligence the metropolitan waterfront areas, pollution of rivers and canals and their degrading to second-class transport options, waterfront areas have once again become a subject of urban development." (WATERFRONT URBAN DEVELOPMENT 2004)

Dies lässt sich auch an den folgenden Einzelobjekten beispielhaft nachweisen:

Eine kulturelle Nutzung wurde mit dem - teilweise amphibischen - Stelzenbau des Lothar-Günter Buchheim-Museums am Starnberger See geschaffen, der - umglast auf Wasserstegen geführt - bis weit in den See hinein reicht.

Direkt am und teilweise im Neuenburger See in Monruz/CH wurde als Projekt für die EXPO 2002 ein Fünf-Sterne-Hotel für den Teilkomplex im Wasser in archaischer Pfahlbauweise errichtet. Die aufgeständerte Bauweise des nach dieser Bauart benannten Hotels „Palafitte“ (ital.: „Pala fitta“ =

\footnotetext{
${ }^{36}$ Das Programm INTERREG II C wurde von der EU-Kommission ins Leben gerufen, um - insbesondere - ökonomische und soziale Prozesse zu unterstützen und eine nachhaltige Regionalentwicklung (,sustainable regional development") anzuregen. Die Koordination umfasst u. a. auch Planungsprojekte (,spatial planning projects“), die im Rahmen von INTERREG II C (EU-Mitgliedsstaaten) finanziert werden, unter Beteiligung solcher Programme wie PHARE (zukünftige EU-Mitgliedsstaaten) und TACIS (Osteuropäische Staaten).

Teil des INTERREG II C-Programms ist das Projekt „Waterfront Urban Development“ [WUD]. Es handelt sich dabei um ein europaweites Projekt, das auf die Bedeutung von innerstädtischen Wasserfrontarealen für städtebauliche Entwicklung abzielt. Von besonderer Priorität ist dabei die Vorbereitung und Implementierung von Pilotprojekten speziell für die ,investment areas“" in den betreffenden Städten. Weiterhin dient es dazu ein Netzwerk von Ostsee-Anrainer-Städten („Baltic Sea Region“) aufzubauen, die ihre spezifischen Erfahrungen zur Stadtentwicklung zum Vorteil aller austauschen und Kooperationen bilden. Die koordinierende Partnerorganisation bildet die Gemeinsame Landesplanung Berlin-Brandenburg. Der offizielle Eröffnungskongress fand am 20./21. Mai 1999 in Potsdam statt. Für weitere Informationen siehe die Projekt-Homepage http://www.waterfront-urban-development.org
} 
„eingerammter Pfahl“) umfasst 24 aneinandergereihte Pavillons, die im Wasser stehen. Die anderen 16 sind direkt am Seeufer errichtet.
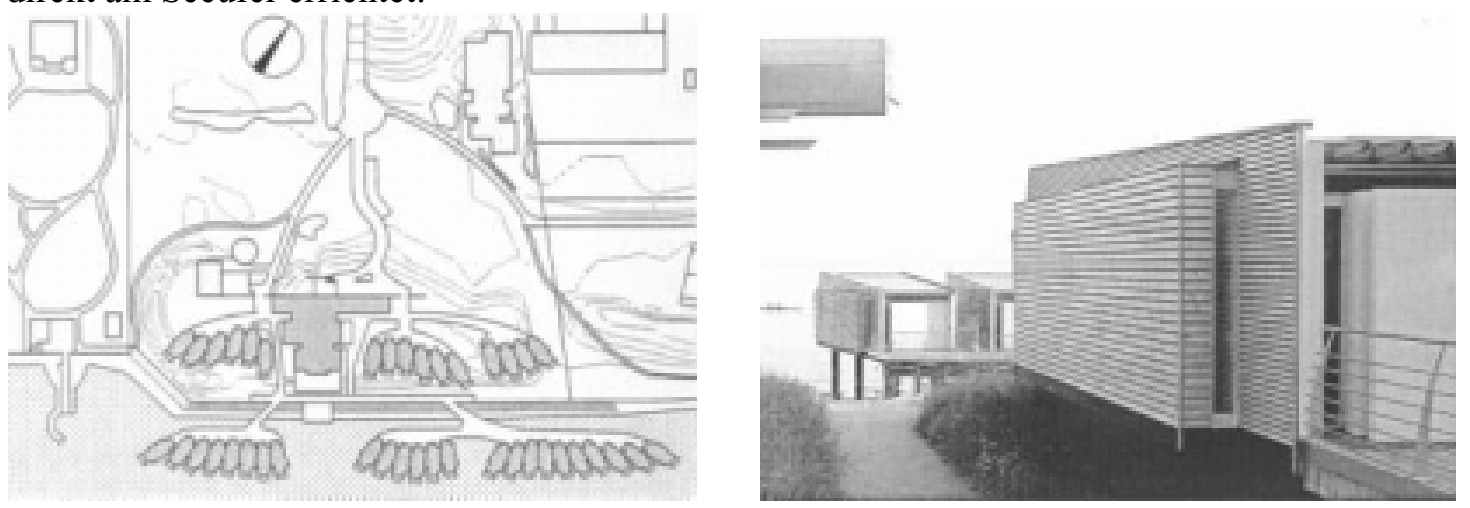

Abb. V-26: Lageplan und Ansicht Hotel Pallafitte, Monruz/Schweiz (aus: DBZ 2003: 203f.)

Die Anlage steht auf öffentlichem Grund und war für die Dauer der EXPO mit einer temporären Betriebsbewilligung bis zum Herbst 2003 ausgestattet. Vorgesehen war der Abbau und Aufbau an einem anderen Ort, die Holzbauweise mit vorgefertigten Elementen ermöglicht ein solch einfaches Umsetzen ohne Infrastruktur am Boden. Die grosse Beliebtheit bei Bevölkerung und Behörden, die innovative Ausstrahlung, die Fondation internationaler Unternehmen (Sandoz-Familienstiftung, Siemens) und die Tatsache, einziger verbleibender Zeuge der EXPO 02 in Neuchâtel zu sein, hat den aktuellen Prozesse bezüglich einer definitiven Erlaubnis dieses ursprünglich zeitlich begrenzten Experiments ins Rollen gebracht.

Nicht an einem natürlichen, sondern inmitten einer neu-künstlichen Teichlandschaft wurde das neue Produktions-, Lager- und Bürogebäude der Fa. B!otop in Weidling/Österreich errichtet. Die umgebenden $1000 \mathrm{~m}^{2}$ Teiche und Teichkanäle sind zugleich „Schaubiotop“ und Referenzobjekt der Firma, die 1985 das kombinierte System aus Biotop, d. h. einer Pflanzenkläranlage mit Regenerationszone am Ufer, in der das Wasser natürlich gereinigt wird, und Schwimmbad erfand.

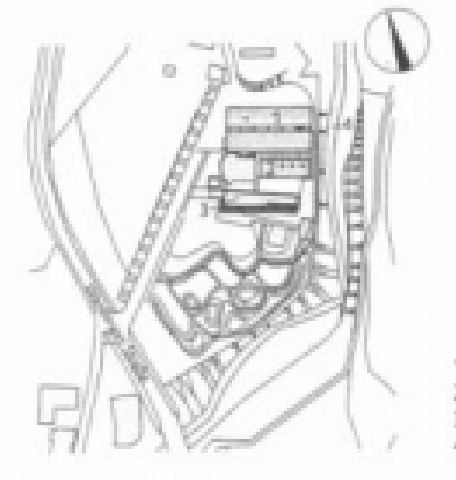

Lageplan, M 1:5000

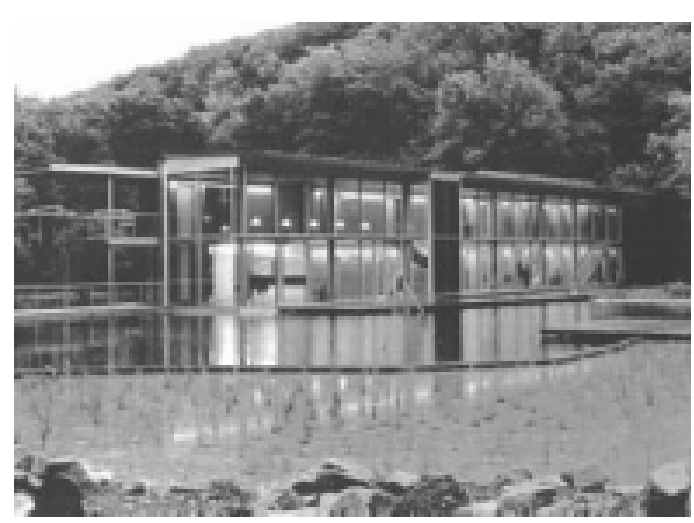

Abb. V-27:Fa. B!otop: Plan und Unternehmenszentrale mit Empfangs- und Kommunikationsbereich in Weidling/Österreich inmitten einer künstlichen Teichlandschaft (aus: DBZ 2003: 228f.)

Im Gegensatz zum Leben am Wasser wurde bei einem anderen Planungsobjekt, das Leben auf dem Wasser realisiert. Eine private Marina in Lauterbach auf Rügen vermietet erstmalig neugebaute Hausboote. Die ein- oder zweigeschossigen "schwimmenden Ferienhäuser“ mit Anleger für Sportboote können je nach Belieben weitertransportiert werden. Weitere Standorte dieser „Floating houses“ gibt es in der „Marina Kröslin“ (siehe Abb. V-28) an der Peenemündung nördlich von Wolgast, auf der Insel Usedom im „Naturhafen Krummin“ am Peenestrom sowie in Brandshagen/Neuhof und in Barth. 


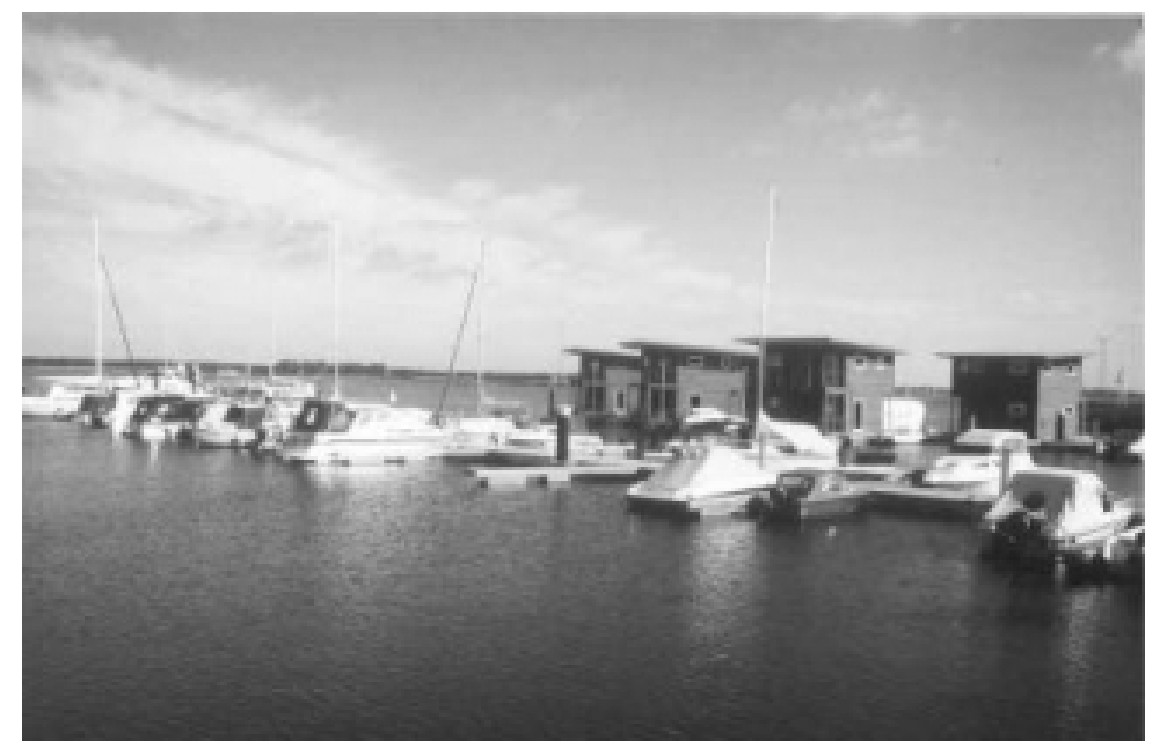

Abb. V-28: Hausboote in Kröslin/Wolgast (eig. Aufnahme 2003)

„Floating homes“ - die neue Wasser-Wohnwelt - hat auch die RAG Immobilien AG, Tochter der Essener RAG, ein Kohle-Unternehmen mit 70.000 konventionellen Wohnungen im Besitz und mit 17.000 ha zweitgrößter Flächen-Eigentümer in Nordrhein-Westfalen hinter dem Land NRW (RP Nr. 63, v. 15. März 2003), für sich entdeckt. Mit „Floating homes“ will RAG Immobilien einen Meilenstein für die Zukunft setzen: Wohn- und Freizeitimmobilien, die in aufgeschäumten Betonschalen liegen - im Winter am Ufer, im Sommer draußen auf dem Wasser. Es handelt sich dabei ein Projekt, das ursprünglich für die Lausitzer Braunkohlen-Vereinigung entwickelt wurde, das nach Angaben von Projekt-Entwickler Hans-Peter Noll aber auch schon anderswo Nachahmer gefunden hat.

Es handelt sich bei den Wohnformen auf dem Wasser um semistationäre Einheiten, d. h. um vertäute Schiffe ohne eigenen Antrieb, die aber dennoch variabel den Liegeplatz bei Bedarf wechseln können. $\mathrm{Da}$ sie rechtlich damit wie ein normales Boot behandelt werden, unterliegen sie damit nicht dem Baurecht.

Die Revitalisierung von Flächen an der Wasserfront betreiben zur Zeit viele weitere Städte mit unterschiedlichen Zielsetzungen. Durch Verkehrstrassen abgetrennte Flussufer werden öffentlich zugänglich gemacht, wie dies Düsseldorf mit einer Untertunnelung der Rheinuferpromenaden bereits geschafft hat, und kontaminierte und anthropogen überformte Uferzonen werden einer Wohnnutzung zugeführt, wie das Beispiel des Duisburger Innenhafens zeigt. Die landschaftsplanerischen Visionen gehen dabei teilweise in Richtung Landschaftsparks am Wasser, ,mit mindestens sechzig Meter breiten öffentlichen Boulevards entlang der Strände“ (JACOB 1997: 37).

Bei diesen Maßnahmen zur Revitalisierung geht es aber weitestgehend lediglich um einen Städtebau am Wasser, bevorzugt an küstennahen Standorten, der seine Bezüge zum Fluss bzw. zum See nur durch eine Erholungsfunktion sowie eine Freizeitnutzung oder ein hyper-modernes Arbeiten auf den bzw. an Gewässern herzustellen versucht. Zudem fordern die Planungen zwar die Wiederentdeckung der Uferflächen, meinen dabei aber die gestalterische Anlage am Wasser und nicht die Nutzung der Gewässer im Sinne einer sozioökonomischen Inwertsetzung. Dies würde mit den beschriebenen Vorhaben auch disharmonieren.

Den städtebaulichen Planungen der Moderne fehlen nach STRAUSS (2002) zwei Ansatzpunkte:

1. All den Wasserbauprojekten fehlt ein ganzheitlicher, integrativer Ansatz, „,der die sektoral geprägten Intentionen, einmal das die Nutzung des Wassers als Gütertransportweg und zum 
anderen die Stärkung der Erholungsfunktion des Wassers, miteinander verknüpft und in eine nachhaltige Stadtentwicklung integriert" (:9). Eine Umnutzung von Uferrandflächen zu Wohnund Erholungszwecken und eine Integration der Belange des Wassers in die Stadtentwicklung bedeutet für ihn, dass „Wasser als Ressource“ und die „Stärkung der Flussbänder als übergeordnete Grün- und Biotopstrukturen" in die Leitvorstellungen aufgenommen werden (:62).

2. Die „amphibische Betrachtungsweise“ ist bislang bei den gestalterischen Projekten noch nicht zur Ausführung gekommen. Die Integrationsfähigkeit des Wassers in die Stadtentwicklung kann am ehesten in einer sog. amphibischen Übergangszone erreicht werden. Nur hier, am eigentlichen Übergangsbereich „zwischen Fluss und Land“ (:135), zwischen den Nutzungen „auf und im Wasser“" (:66) erlebt die Stadt oder die Ansiedlung ,einen Aggregatsübergang von ,flüssig’ nach ,fest'““(:65) „Wenn es gelingt,“ stellt STRAUSS (:135) in Aussicht, „diese besondere Zone der Stadt am Fluss gestalterisch und funktional aufzuwerten und hier eine besondere Nutzung zu verorten, wird eine neue Adresse ,am Wasser' mit den historischen und wiederauflebenden Geist des Ortes verknüpft.“

Wenn auch schon bei STRAUSS die mangelnde Berücksichtigung der Flusshistorie anklang, so soll als dritter Betrachtungsansatz der historisch-geographische explizit genannt werden. Die Hoffnung auf eine wasserspezifische, historisch-geographische Strukturen berücksichtigende Planung und Durchführung bleibt im zeitgenössischen Städtebau zur Zeit in den meisten Städten Desiderat, da sie von vornherein nicht intendiert werden. Historische Dimensionen und Verflechtungen werden in den meisten Fällen nicht beachtet bzw. gehen über das denkmalgeschützte Einzelobjekt nicht hinaus. Deshalb sind weitergehende Konzepte zu einer Stadtentwicklung mit dem Wasser, die auch die historisch-geographische Perspektive miteinbeziehen, zu fordern.

Dies umfasst vor allem auch Lösungen zur Neugestaltung bzw. Restrukturierung von kleineren „Flussstädten", die an Wasserwegen im peripheren Hinterland liegen und einer wasserbezogene Geschichte vorweisen können. Dieser Anspruch ist nur zu einem geringen Teil in dem modernen Städtebau des „Urban Water Developments“ verwirklicht worden.

\section{e Zusammenfassung}

Es dürfte also aus dem Vorhergesagten „bewiesen sein, daß technische Eingriffe in den Wasserhaushalt seit Seßhaftwerdung des Menschen vorgenommen und entsprechend der jeweiligen wirtschaftlichen Zielsetzung weiterentwickelt worden sind. Dabei sind weder niederschlagsreiche noch morphologisch-hydrologisch schwierige Räume von wasserbautechnischen Entwicklungen ausgespart geblieben.“ (HERBST 1992:5)

Das Medium Wasser war bei vielen Siedlungsgründungen ein wichtiger Faktor in der Standortwahl: Es diente als Transportweg im ökonomischen Geflecht, war Kommunikationsweg, es bot Schutz im fortifikatorischen Sinne, war gestalterisches Element und schließlich bildete es die Lebensgrundlage für die Ernährung, die Hygiene und das Wohlbefinden der Einwohner.

Im Laufe der Zeit entwickelten die Städte ein eigenes unverkennbares Gesicht zum Ufer: „der Übergang zwischen Wasser und Land, die amphibische Schnittstelle wurde inszeniert, als harte Stadtkante oder weicher Übergang.“ (STRAUSS 2002:13). Der moderne Städtebau nimmt in jüngster Zeit Wasserlagen als Standorte wieder auf, der historisch-geographische Aspekt hingegen bleibt bei diesen Planungen entrückt. 


\section{Geschichte der Gewässernutzung}

In diesem Abschnitt wird der Blick auf das Gewässer selbst gerichtet und versucht werden, die sich durch die an ihm vorgenommenen Nutzungen ergebenden Veränderungen aus vergangener Zeit zu rekonstruieren. Es stellt sich nachfolgend die Frage, welchen anthropogenen Nutzungsarten die kleineren Flüsse und Bäche vor Beginn der heutigen Zeitrechnung, d.h. bis zum Niedergang der überkommenen Wirtschaftsweisen ausgesetzt gewesen sind, wie sich die anthropogenen Einflüsse und Eingriffe in den Wasserhaushalt und im Landschaftsbild niedergeschlagen haben und wie die Gewässer aus den naturgegebenem Ort ihres Flussgebietes hinaus- und zu den verschiedenen Gebrauchsstätten hingeführt wurden.

Um einen Eindruck über die Arten von Eingriffen, die mögliche Vielfalt, Unterschiede in der Intensität der Eingriffe sowie eine mögliche Unterscheidung von punkthaften, flächenhaften und linearen Auswirkungen zu erhalten, ist „eine systematische und typisierende Übersicht“ (DENECKE 1989b:200) notwendig. Diesem Betrachtungsansatz DENECKEs folgend, sollen in diesem Abschnitt am Beispiel der nach Nutzungsarten strukturierten Verwendung von Gewässern die vielgestaltigen Arten der historischen Gewässernutzung v. a. kleinerer Fließgewässer zusammengestellt werden. Denn Wasser hatte eine Vielzahl von Aufgaben zu erfüllen: „Wasser war Lebensmittel und diente der Beschaffung von Lebensmitteln, es war Energieträger, gewerblicher Rohstoff, Transportweg, Mittel der Verteidigung, der Gestaltung und Repräsentation, es diente der Abfallbeseitigung, Straßenreinigung und, nach damaligem Verständnis, auch der Reinigung der Luft. Neben der nützlichen hatte es aber auch eine bedrohliche oder schädliche Komponente, wenn es als Hochwasser Überschwemmungen herbeiführte, die Mühlen lahmlegte und bei Eisgang diese und die Brücken zerstörte." (GROHMANN 2000:56) Diese zentrale Funktion des Wassers mit der Zielsetzung „Trinkwassergewinnung, Baden, Bewässern und Tränken, Kühlen, Landschaftsästhetik- oder vielleicht ein Naturrecht des Gewässers “ (SANZIN 1995:15) macht es deshalb zu einem „umweltgeschichtlich relevanten Thema" (GROHMANN 2000:56).

Hinsichtlich der Betrachtung aus dem Blickwinkel einer anwendungsorientierten historisch-geographischen Umweltforschung, die sich primär mit der Erfassung wahrnehmbarer Kulturlandschaftselemente beschäftigt, ist das Problem von Nutzungen, dass sie oftmals keine dinglich sichtbaren Spuren in der Landschaft hinterlassen. Dies betrifft besonders die indirekten Einwirkungen des Menschen auf die Gewässer.

Werden diese Nutzungen jedoch wiederholt ausgeführt, zur Ausführung von Wirtschaftsleistungen oder zur Gewinnung von Energien oder Ressourcen beispielsweise, und bedürfen diese Nutzungen bestimmter Einrichtungen und Anlagen, so wirken diese alternierenden Handlungsweisen formenbildend fort und können als historische Elemente in der Kulturlandschaft wiedergefunden werden. Diese aus der Gewässernutzung resultierenden Gewässerformen werden schwerpunktmäßig jedoch erst in dem nächsten Kapitel anhand ausgesuchter Beispiele beschrieben.

Hier jedenfalls soll durch die Auswahl der verschiedenen Nutzungsmöglichkeiten von Gewässern ein Eindruck von der Vielfalt vermittelt werden, die das Wasser als Quelle, als Bach- oder Flusslauf zu bieten hatte. Durch diesen Querschnitt an Beispielen verschiedener Einsatz- und Nutzungsbereiche wird ein näherungsweiser Anspruch auf Vollständigkeit erhoben, mögen auch noch viele fehlen oder vergessen worden sein.

Wie zahlreich die verschiedenen Gewässernutzungen gewesen sein mögen, zeigt Tab. VI-1, in der die statistische Aufnahme des Jahres 1858 des Kreises Nordhausen wiedergegeben ist. An Flüssen sind bei der Erfassung neben der Zorge die Südharzflüsse Wipper, Bode und Helme in der Aufstellung berücksichtigt worden. Die Aufzählung der an diese Gewässer gebundenen Einrichtungen kennzeichnen längst verblichene Berufe und vermögen eine Vorstellung davon zu vermitteln, wie kumulativ sogar kleine Gewässerabschnitte in einem Betrachtungsgebiet von der Größe eines Landkreises genutzt worden sind. 
Tab. VI-1: Übersicht über die 1859 an die Gewässer des Kreises Nordhausen gebundenen Gewerbe ${ }^{1}$

\author{
Gerber u. Lederarbeiter \\ Färber aller Art \\ Bleicher (außer Fabrikarbeiter) \\ Korbwarenmacher \\ Mühlenbauer, Mühlenflicker \\ FISCHER (GEWERBSMÄßIGE) \\ Bademeister \\ zur Verf. [...] von Tuchen \\ zum Bleichen von Stückgeweben \\ zum Bleichen von Garn \\ zum Färben \\ zum Mahlen von Getreide
}

\author{
59 (inkl. Meister, Gesellen, Lehrlinge) \\ 51 \\ 33 \\ 14 \\ 21 \\ 11 \\ 1 \\ 2 Fabriken mit 54 Arbeitern u. 36 Handstühlen \\ 18 Bleichereien mit 53 Arbeitern \\ 3 Bleichereien mit 10 Arbeitern \\ 12 Färbereien mit 65 Arbeitern \\ 89 Wassermühlen mit 153 Mahlgängen, 88 Meistern u. \\ 106 Gehilfen $u$. Lehrlingen \\ 3 Windmühlen mit 3 Meistern u. 1 Lehrling \\ 4 Dampfmühlen mit 7 Mahlgängen u. 9 Arbeitern \\ 39 Ölmühlen mit 59 Arbeitern \\ 2 Walkmühlen mit 3 Arbeitern \\ 5 Lohmühlen mit 5 Arbeitern \\ 8 Sägemühlen mit 16 Arbeitern \\ 4 Stück mit 25 Arbeitern \\ u. a. 1 Kupferhammer mit 3 Arbeitern \\ 1 Papiermühle mit 3 Arbeitern u. 1 Schöpf-Bütte
}

Betrachtet man die Nutzungen am bzw. im Gewässerlauf selbst, so werden die gravierenden Veränderungen deutlich, die diese Handlungen nach sich gezogen haben. Der Zeitraum dafür ist generell schwer abzugrenzen. Man kann jedoch davon ausgehen, dass die Gewässer, seit man im Verlaufe des 19. Jahrhunderts im Zuge der Industrialisierung das Flussbett durch Auf- und Ausräumung des Bettes selbst, durch Befestigung der Ufer und durch den Aushub von Fahrrinnen für die Aufnahme großer Wassermassen und die Schifffahrt geeignet machte, seit man Sande und Kiese aus den Flusstälern als Rohstoffe für die Bauwirtschaft ausbeutete, seit man weitergehende Pläne und Maßnahmen durchführte, ehemalige Mäanderflächen für landwirtschaftliche Zwecke nutzbar zu machen und durch den Durchstich kürzere Kanalverbindungen schaffte sowie mit der Fischereiwirtschaft begann, seit man also in historisch neuem Maßstab in die Flusslandschaften eingriff, eine nachhaltige Überformung erfahren haben (vgl. SCHÄFER 1997:152).

Mit diesen anthropogenen Nutzungen hat sich seit dem Ende des letzten Jahrhunderts das Erscheinungsbild vieler mitteleuropäischer Fluss- und Bachlandschaften tiefgreifend verändert. Es gibt heute in Mitteleuropa keine natürlichen Gewässerläufe mehr. Wir können uns von dem tatsächlichen Ausmaß keine rechte Vorstellung mehr machen, denn die tief eingeschnittenen, kanalisierten Flussbetten von heute haben nichts mehr gemein mit den mäandrierenden oder in ein Kerbtal eingeschnittenen Flüssen der Vorgeschichte aber auch des Mittelalters. „Wo ein größerer Fluß durch breite Talung mit flachem Boden schloß, bestand er gewöhnlich aus einem System von mehr oder weniger parallelen bis bogenförmigen, noch durchflossenen oder toten Wasserläufen, wobei zeitweise dieser, dann ein benachbarter Arm Haupstrom war. Dazwischen lagen Inseln mit Wald oder Grünland, Sand- und Kiesbänke, sowie Sümpfe, die aus ehemaligen Flußarmen hervorgegangen waren, in verschiedenster Ausdehnung. Niederungen großer Flüsse, wie des Rheins im oberrheinischen und im niederrheinischen Tiefland, der Elbe, Oder, Weichsel oder des Po waren so gestaltet.“ (HANSEN 2000:38)

\footnotetext{
${ }^{1}$ Die hier in den Sachzusammenhang gestellten Fakten entstammen dem „Zeitungs- und Jahresbericht des Magistrats der Stadt Nordhausen aus dem Jahr 1859“ (STADTARCHIV NORDHAUSEN, Akten DA I/62-I/70, Ziff. IV). 1863 erschien zudem eine statistische Publikation über den Kreis Nordhausen (STATISTISCHE DARSTELLUNG DES KREISES NORDHAUSEN 1863: 219), die teilweise auf diesen „Bericht“ aufbaut.
} 
Dieser Veränderungsprozess, die Umformung der natürlichen Gewässerlandschaft, wurde maßgeblich ausgelöst durch „kulturgeschichtliche“ Wassernutzungen. Doch wie lassen sich „Wassernutzungen“ systematisieren?

Ein im Auftrag des Umweltbundesamtes schon 1983 herausgegebener und vom Institut für Siedlungswasserwirtschaft der Universität Karlsruhe verfasster Bericht stellt einige „Ansätze zur Klassifizierung der Gewässernutzungen“ vor (BOGARDI et al. 1982), und zwar vor dem Hintergrund der Zielsetzung des Pilotprojektes „die Entwicklung eines Instrumentariums, das zur Entscheidungsfindung bei der Abwägung zwischen alternativen wasserwirtschaftlichen Planungen und Bewirtschaftungsmaßnahmen in einem Flussgebiet eingesetzt werden kann." (:Vorwort) Dies führt zum Beispiel zur Auflistung der „Nutzungsmöglichkeiten der Gewässer in Abhängigkeit von der Gewässergüte“ (wie Fischerei, Trinkwassergewinnung, Bewässerung etc.) (:8).

Eine „mögliche Klassifizierung der Gewässernutzungen“ führt aber auch zur Aufstellung eines Schemas von Gewässernutzungen als a) punktuelle Nutzungen (Wasserkraft, Entnahmen) oder b) Nutzungen entlang der Gewässer (Erholung, Schiffahrt). Weiterhin nach a) Nutzung im Gewässer (Fischerei), b) Nutzung am Gewässer (Uferrandnutzung, Grundwasseranreicherung) und c) Nutzung vom Gewässer (Verwendung des entnommenen Wassers) (BOGARDI et al. 1982:12).

Neben diesen „Gewässernutzungsklassen“ wird auch noch eine „Klassifizierung der Einzelnutzungen“ nach verschiedenen Kriterien vorgenommen. 1. Nach dem Nutzungszweck des Wassers. Darin wird unterschieden zwischen a) Leben von Mensch, Tier und Pflanze, b) Verkehr, c) Energiegewinnung und d) Transport von Stoffen und Wärme.. 2. Danach, ob die Wassernutzung unmittelbar im Gewässer erfolgt (direkte Entnahme) oder das Wasser dem Gewässer entnommen wird (indirekte Entnahme). Daraus ergibt sich weiterhin die Frage nach den Nutzergruppen: a) Nutzung für Mensch und Tier, b) Industrie und Gewerbe, c) für die Landwirtschaft (Bewässerung), d) als Kühlwasser und den Funktionen Fischerei, Erholung, Ansiedlung (BOGARDI et al. 1982:19f.).

All dieses führt zu einem umfangreichen hierarchischen Modell der Gewässernutzungen, wobei - hier wesentlich - zwischen natürlicher und anthropogener Nutzung unterschieden wird. 


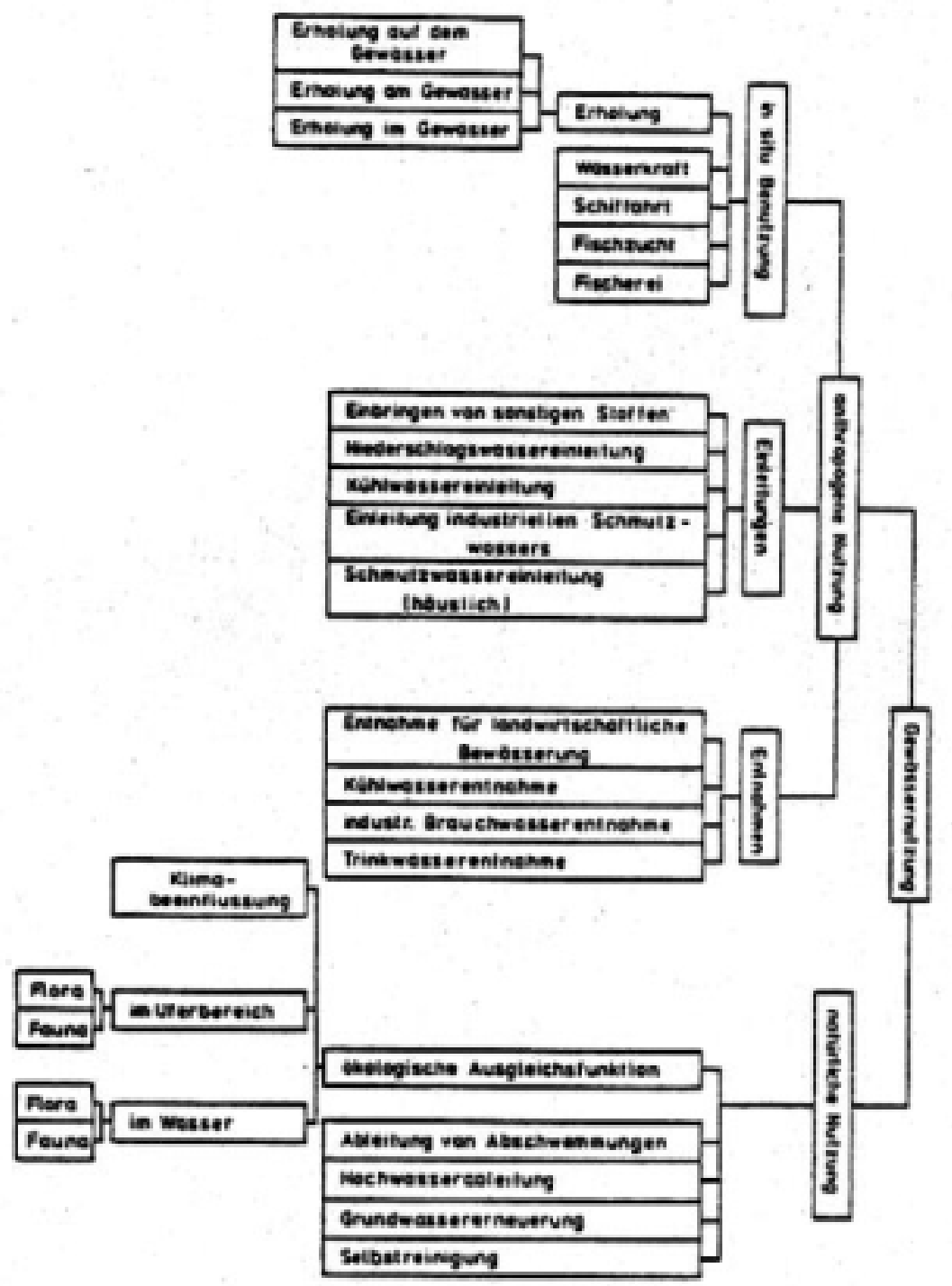

Abb. VI-1: Hierarchisches System der Gewässernutzungen (aus: BOGARDI et al. 1982:21).

In dieser Gliederung fehlt hingegen die kulturhistorische Komponente völlig. Nun soll diese modellhafte Nutzungseinteilung für die Aufstellung von wasserwirtschaftlichen Rahmenplänen hilfreich sein und vor allem die ökonomischen Nutzungsmöglichkeiten von Gewässern darstellen. Zudem weist das Jahr der Veröffentlichung auf ein zu diesem Zeitpunkt noch nicht allgemein verbreitetes kulturgeschichtliches Bewusstsein von Gewässernutzungen hin.

Von Bedeutung aber ist diese Aufstellung insofern, als hier erstmals ein strukturierter Ansatz vorgenommen worden ist, die Vielfalt an Gewässernutzungen zu klassifizieren, um daraus eine sinnvolle Berücksichtung der Nutzungsinteressen und Nutzungsvielfalt bei der Aufstellung von Rahmenplänen abzuleiten und zu integrieren.

Bezüglich der kulturellen Funktion ist zu unterscheiden zwischen Nutzungen, die Wasser verbrauchen, und solchen, die das Wasser nur gebrauchen (in Anlehnung an LEIBUNDGUT 1986:153).

Heute wird das Wasser fast ausschließlich zu zwei Hauptnutzungen verwendet, als Trägermedium, d. $h$. Energierlieferant, und als Aufnahmemedium. Eine Ausnahme bildet die Erholungsnutzung am und im 
Wasser, aber auch sie betrachtet das Wasser bzw. die Landschaft häufig nur als Konsumgut (LEIBUNDGUT 1986:154). Dieses Verhältnis war in früherer Zeit ein anderes: Die Bäche verloren zwar einen Teil ihrer Wassermenge für unterschiedliche Aufgaben und das Wasser wurde auch bereits zur Römerzeit mittels einer Fernwasserleitung aus den Quellgebieten in die Städte geholt, aber der Wassergebrauch war ein anderer. Ob gemessen an der Bevölkerungszahl weniger Wasser pro Kopf verbraucht wurde, lässt sich mutmaßen, entscheidend bei dieser Betrachtung hier ist der zu erbringende Nachweis, dass Wasser intensiver, im Sinne der kleinteiligen, differenzierten Wassernutzung gebraucht wurde. Auch kleinste Quellnischen und Bachläufe unterlagen einer Inwertsetzung. Im Laufe der Zeit trat eine gar solche Intensivierung ein, dass es spätestens ab den 1840er Jahren, ,für alle Nutzungen auf der schmalen Wasserbasis des Baches sehr eng“ wurde (DIX 1997).

Dabei ist bei der folgenden systematischen und typisierenden Darstellung zu berücksichtigen, dass die Nutzungen untereinander korrespondierten: „Während auf der einen Seite an die Bereitstellung natürlicher Ressourcen (Wassermenge und Wassergüte) hohe Anforderungen gestellt wurden, verschlechterte die Industrie auf der anderen Seite diese natürlichen Grundlagen.“ (DIX. 1997:27) Zur Herstellung wird also einerseits Frischwasser zugeleitet (Wasserversorgung), andererseits nach dem Produktions- bzw. Verarbeitungsprozess das mit festen oder flüssigen Abfällen verseuchte Wasser wieder dem Bachlauf eingeleitet (Wasserentsorgung). Oder, wie TÖLLE-KASTENBEIN (1990:9) es ausdrückt: „Die Wasserableitungen sind als ebenso fester Bestandteil eines Wassersystems $\mathrm{zu}$ betrachten wie die Wasserzuleitungen.“

Die Gegensätzlichkeit der Papierindustrie beispielsweise ist dadurch gekennzeichnet, dass sie zum einen die Flüsse zum Ableiten ihrer Laugen benötigt und zum anderen ihren großen Brauchwasserbedarf aus denselben abdeckt, wodurch sich wiederum Nachteile für die Beschaffenheit, Festigkeit und Leimung des Papiers ergeben (vgl. BÜSCHENFELD 2000:90; SCHUBERT 2001:119).

Diese „,industrielle“ bzw. „gewerbliche Wasserkonkurrenz“ (BÜSCHENFELD 2000:90) trifft auch für die Textilindustrie zu. Für die Färberei, die gleichzeitig in die Gewässer ableitet (siehe Pkt. 2 ,Wasserentsorgung'), bringt die Entnahme von Wasser aus Bächen und Flüssen, ,welche durch gewerbliche Abwässer verunreinigt sind“ (DIX 1997:183), Gefahren mit sich. Beispielsweise vor allem für solche Dampfkesselbetreiber, die salzbelastetes Flusswasser als Kesselspeisewasser verwendeten (BÜSCHENFELD 2000:80), denn das mit „Endlaugen“ belastete harte Wasser war besonders für den Dampfkesselbetrieb schädlich. Die Dampfkessel nahmen durch die erhöhte Chloridkonzentration Schaden (:90) und schließlich führte die Verhärtung und Verchlorung der Gewässer zu hohen Kosten für die Wasserenthärtung.

Doch nicht nur der sekundäre, sondern auch der primäre Sektor steht in einem Verursacher- und Betroffenheitsverhältnis - dahingehend, „daß die Landwirtschaft in den Entwässerungsgebieten der Industrie ihre durch Kali gesteigerten Erträge von den Abfällen der Kunstdüngerproduktion zunehmend gefährdet sah.“ (BÜSCHENFELD 2000:86) Diese zusätzliche Zumischung der Kalisalze zum Rieselwasser rief beispielsweise „Schäden in der Unstrutniederung“ (:87) hervor und führte zu einer weitflächigen Wiesenversalzung und damit zu einer Beeinträchtigung der landwirtschaftlichen Nutzung als Viehfutter und Heumahd.

Dieses schizophrene, schwer zu trennende Abhängigkeitsverhältnis des Ge- und Verbrauchs, d. h., wenn sich verschiedene Produktionzweige gegenseitig schädigen, wird vor allem bei der Wasserver- und -entsorgung offensichtlich.

\section{Wasserversorgung}

Entsprechend des überlebenswichtigen Bedürfnisses des Menschen nach Flüssigkeitsaufnahme gehörte die Entnahme von Trinkwasser zu den ersten Nutzungsarten beim Gebrauch eines Gewässers. Deshalb ist es nur logisch, diese archaische Gewässernutzung an den Anfang dieses Kapitels zu stellen. 
Das oberirdische Schöpfen von Wasser mit größeren Behältnissen (Eimer, Kübel) entstand in der Folgezeit zuerst, da zum einen die Wohnstätten außerhalb der unmittelbaren Gewässernähe lagen und für die Wasserbevorratung von Mensch und Vieh Sorge getragen werden musste, zum anderen aber eine in die Stadt führende Wasserleitung noch nicht oder nicht in ausreichendem Maße zur Verfügung stand.

Doch gerade zu dem Zeitpunkt, als die Versorgung der Bevölkerung mit Flusswasser gewährleistet schien, konnte die oberirdische Entnahme von Trinkwasser nicht mehr oder nicht mehr bedenkenlos durchgeführt werden. Zum einen, weil unterschiedliche Pegelstände - bedingt durch Mühlenstau sowie natürliche niederschlagsarme Zeiten - Perioden des Wassermangels bedeutete und zum anderen, da die Verschmutzung durch Abwässer der Haushalte sowie des Gewerbes, eine oberflächige Wasserentnahme vor Ort unmöglich machte bzw. gänzlich verbat. Am Erftmühlenbach zum Beispiel, „war eine unmittelbare Nutzung des ungereinigten Bachwassers mit Risiken verbunden, die sich aus der schon seit Beginn des 19. Jahrhunderts bestehenden gewerblichen Verunreinigung des Baches ergaben“(DIX 1997:184).

Diese Situation bestand angesichts einer bereits im 2. Jahrhundert nach Christus gebauten $95 \mathrm{~km}$ langen Fernwasserleitung vom Vey- und Urfttal nach Köln (KREINER 1996b:88) schon sehr früh. Was auch erklärt, warum Klöster, aber auch die Städte, bei der mittelalterlichen Standortwahl die „Zweiflüsse-Lage“ bevorzugten: an einem größeren, zumeist schiffbaren Gewässer des Transportes und des Handels wegen und an einem kleineren Fließgewässer oder Quelllauf, um sauberes Oberflächenwasser zu erhalten. Beim Kloster Walkenried beispielsweise wurden bei archäologischen Grabungen verschiedene Kanäle vor allem aus der gotischen Zeit freigelegt: „Zu erkennen war, daß damals das Frischwasser [...] von einem durch den Klosterbezirk führenden Nebenarm der Wieda in den Klausurbereich gelangte“" (MAIER/KEIBEL-MAIER 1997:44).

Der Mensch musste sich deshalb also zur Sicherung seiner Wasserversorgung und zum Schutz vor den zerstörerischen Kräften des Wassers wasserbaulicher Maßnahmen bedienen, d. h. künstlicher, von Menschenhand geschaffener Einrichtungen zur Wassergewinnung und Wasserfassung, zur vertikalen und horizontalen Wasserförderung und zur Wasserspeicherung (ALBRECHT 1999c:595). „Klares, sauberes Wasser - das war dringendes Erfordernis für die Bevölkerung einer Stadt.“ (SCHUBERT 1989:34) und mit den Mitteln der Einrichtung zunächst dezentraler und dann zentraler Wasserversorgungssysteme sollte dies erreicht werden.

Als Mittel der Grundversorgung mit sauberem Wasser dienten vor allem eine größere Anzahl Grundwasserbrunnen (GROHMANN 2000:57).

Brunnen, so auch die Definition, „sind technische Anlagen zur Gewinnung unterirdischen Wassers (Grundwassser) und zur Übergabe von Wasser an die Benutzer.“ (SONNABEND 1999b:73) Der Brunnenbau gilt als Zeichen für die „Bedeutung des Wassers für Ernährung und Hygiene des Menschen“ (SCHUBERT 1989:33), in Zeiten unzureichenden natürlichen Wasserdargebots vor Ort und der Notwendigkeit zur Gewinnung sauberen Wassers.

Nach der Art der Herstellung werden Bohr- und Schachtbrunnen, nach der Form der Darbietung des Wassers Schöpf- oder Ziehbrunnen und Röhren- oder Laufbrunnen unterschieden (SONNABEND 1999b:73). In Städten mit großem Wasserbedarf reichten Schachtbrunnen zur Versorgung der Bevölkerung nicht aus. Quellen wurden unterirdisch gefasst und das Wasser in Behälterkammern gespeichert. Bei Lauf- und Röhrenbrunnen konnte der Benutzer das Wasser unmittelbar am Speier in Gefäße füllen.

Unabhängig von der Art des Brunnenbaus bestand in den mitteleuropäischen Städten des Mittelalters und der frühen Neuzeit die Wasserversorgung auf drei Ebenen:

1. privater Hausbrunnen

2. genossenschaftlicher Brunnen

3. städtische Brunnen (GROHMANN 2000:54). 
Neben den Grundwasserbrunnen sicherten vereinzelte Leitungssysteme die Versorgung. Dieser Standard des Spätmittelalters blieb bis weit in die Neuzeit hinein bestimmend (GROHMANN 2000:54f.).

Die Wasserversorgung der mittelalterlichen Stadt Göttingen beispielsweise erfolgte in ähnlicher Weise: über hölzerne oder steinerne Hausbrunnen, die erst in der Neuzeit durch öffentliche Brunnen, die von einer Holzwasserleitung gespeist wurden, abgelöst wurden. Lediglich der Marktbrunnen und der „Fischstein“ wurden schon im Mittelalter durch Wasserleitungen versorgt (SCHÜTTE 1989:242).

Die ältesten Tiefbrunnen des 12. und 13. Jahrhunderts waren aus Holz gezimmert. Sie wurden abgelöst durch steinerne Anlagen aus Feldsteinen und Backsteinen mit einem geringen Durchmesser von 1 bis $1 \frac{1}{2}$ Meter (SCHUBERT 1989:33), um - so scheint es - durch das Mauerwerk einen wirksameren Schutz gegen Infiltration zu gewährleisten. „Aber irgendwann schützte auch der Steinbau nicht vor Qualitätsminderung des Wassers durch undichte Fugen. Der Grundwasserspiegel war durch die Abfallschächte und die Kloaken in den Häusern, die bis zu zwölf Meter in die Tiefe gegraben wurden, erreicht. Verjauchung des Grundwassers mit der unvermeidlichen Folge typhoser Erkrankungen und Vergiftungen der Darmwege gehörten zur dicht bebauten Innenstadt, wo auch die meisten Brunnen lagen." (:33)

Wie wichtig die Anlage eines Hausbrunnens auch für damalige Bauvorhaben gewesen ist, zeigt das Beispiel des Neubaus einer Windmühle in der Lüneburger Heide, westlich der Ortschaft Herber bei Hemsen, Landkreis Soltau-Fallingbostel. Sie sollte anstatt einer abgerissenen Wassermühle - die Gründe hierfür werden nicht genannt - an anderer Stelle errichtet werden sollte. Es fehlte das für den Bau notwendige Wasser, ,weil noch kein Brunnen vorhanden war. Also holte man es in Fässern aus dem Mühlenteich und fuhr es zum Bauplatz.“(ERLER/MATTHIESEN 1989:50)

Zugleich war es durch das Anwachsen der Bevölkerung in den städtischen Zentren des Mittelalters notwendig geworden, entfernt und tiefer gelegene Wasservorkommen zu erschließen und das Wasser mit Hilfe langer Leitungen in die Stadt zu führen (SCHNEIDER 1992:182). Infolgedessen wurde durch hölzerne Wasserleitungen, „, bei denen die durchbohrten Baumstämme mit Metallmänteln vernietet wurden“ (:34), aus weiter entfernt gelegenen Gebieten das Wasser in die Stadt geführt: In Hannover wurde der Diekborn bei Linden durch eine Wasserleitung in die Stadt geführt, in Hameln wurde der Brunnen auf dem Marktplatz seit 1568 durch eine Leitung vom Boxberg gespeist (:34). In Aschersleben konnte die Stadt „die ständig wachsende Chloridbelastung durch die Kaliwerke nur deshalb aushalten, weil sie seit den 1930er Jahren über eine $200 \mathrm{~km}$ lange Wasserleitung aus der Sösetalsperre im Harz versorgt wurde“ (BÜSCHENFELD 2000:100). Bis in die 1950er Jahre schließlich war die Quelle der Innerste in ein Rohr gefasst und eine Brunnenleitung hat lange Zeit hindurch von hier Trinkwasser für Clausthal geliefert (HAASE 1961:6). Und auch die Überläufe des ,Röhrensumpf ‘ aus der Harzer Hochfläche, ein Quellgebiet, in dem zahlreiche Quellen zu Tage treten, flossen nicht nur in einen Graben, sondern speisten über eine Rohrleitung die eisernen Wasserbottiche für die Bevölkerung in Zellerfeld (:46).

Die Gewinnung und Zuleitung sauberen Wassers spielte auch aufgrund der seit dem frühen Mittelalter im Stadtgebiet ansässigen Brauereien und Brennereien eine bedeutende Rolle. Zum Brauen eines guten Bieres gehört neben der Gerste und dem Hopfen ,vor allem ein schmackhaftes und mineralreiches Brunnen- oder Quellwasser“ (ALTMANN 1999:116), ohne das der Brauer nicht das Grundgetränk der Stadtbevölkerung herstellen konnten (SCHUBERT 1989:34). Dies besaß gar eine so große Bedeutung für die Ernährung, dass das in Trockenzeiten noch verfügbare Wasser zuerst für die Brauereien und nicht für die Mühlen etc. genutzt wurde (LORENZ 2000:32). In Städten mit gewässerhydrologischer Trockenhöhenlage konnte aufgrund der topographischen Höhenunterschiede das notwendige Trink- und Brauwasser nur gehoben werden.

Hydrotechnische Anlagen, d.h. vom Wasser angetriebene Holzpumpen, förderten seit dem 13. Jh. das Wasser in einen hölzernen Hochbehälter. Von diesen Wassertürmen, den Wasserkünsten, führte das Wasser in die Stadt. Die Behälter lagen recht hoch und so konnte das Wasser an Druckpfosten entnommen werden und den öffentlichen Brunnen zugeleitet werden. Ein Schieber gab das Wasser frei. Diese Art der Wasserversorgung bestand in Güstrow bis 1882 (LORENZ 2000:33) und in Bautzen ist die Wasserkunst noch heute funktionsfähig zu besichtigen und Wahrzeichen der Stadt. 


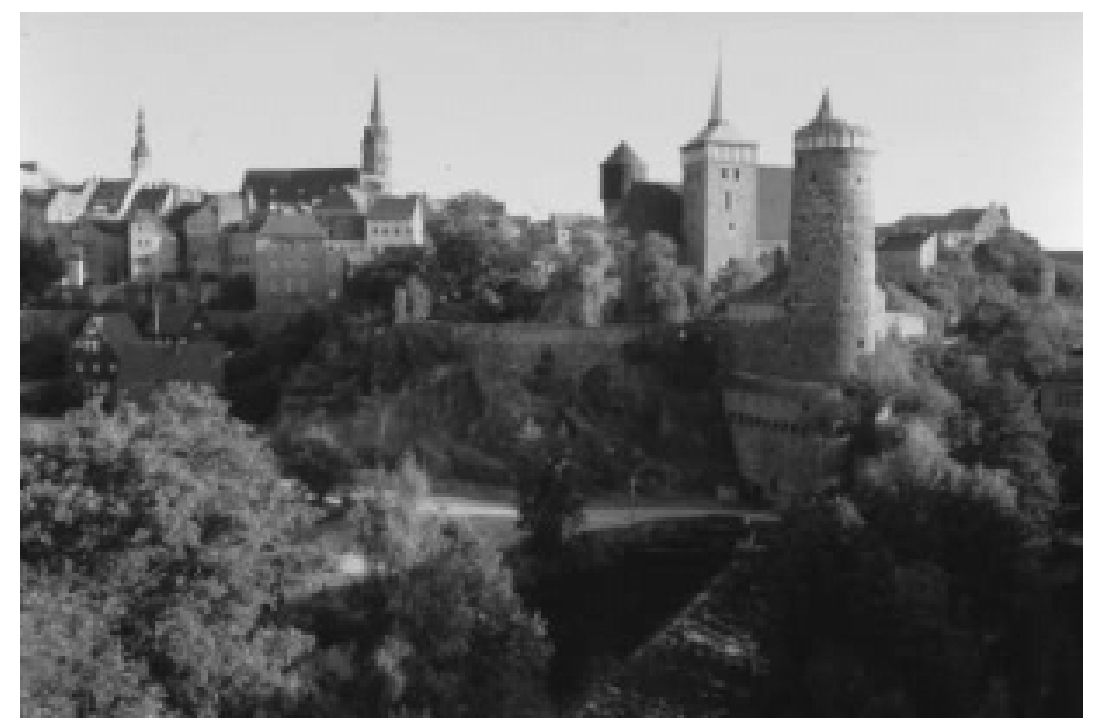

Abb. VI-2: Wasserkunst der Stadt Bautzen

(eig. Aufnahme 1994)

Quellwasserleitungen und Flusswasserpumpwerke dienten meist zur Deckung des über den häuslichen Bereich hinausgehenden Bedarfs. Die Existenz solcher Versorgungseinrichtungen hing dabei stark von den örtlichen Gegebenheiten ab; ,im norddeutschen Flachland waren Quellwasserleitungen mangels Gefälle eher selten, Flußwasserpumpwerke jedoch häufiger zu finden.“ (GROHMANN 2000:55) Die Altstadt von Hannover beispielsweise verfügte dazu seit 1535 über ein Flusswasserpumpwerk, das in erster Linie die Brauhäuser versorgte (vgl. GROHMANN 2000:57). Nicht aber das Flusswasser, sondern das ,in der Wiese [...] befindliche Quellwasser“'2 wurde dabei zumeist für eine Verwendung als Brauwasser und auch als Trinkwasser benutzt, das über eine Wasserleitung den Brauhäusern und den städtischen Brunnen zugeführt wurde, wie das Beispiel der Zorge in Nordhausen zeigt.

Hervorgehend aus verschiedenen Klosterbrauereien gab es zum Beispiel in der Stadt Nordhausen im Jahr 1880 noch 17 Brauereien (ALLGEMEINER ANZEIGER v. 13. Mai 1998), die mit diesem „Wiesenwasser“ versorgt wurden. Dieses uferfiltrierte Wasser kam jedoch in den 20er Jahren des $20 \mathrm{Jh}$., ,nicht mehr in Frage [...], nachdem die Untersuchung das Vorhandensein von Kolibazillen ergeben hat ${ }^{\star 3}$. Die Gründe dafür wurden in der zunehmenden Nitrifikation der Wiesenflächen gesehen, nachdem mit Fluss- und Mühlgrabenwasser wahrscheinlich die Wiesen gewässert worden sind: „Es ist fast selbstverständlich, dass, nachdem das Wasser erst mit der Oberfläche einer gedüngten Wiese in Verbindung gekommen ist und dieselbe auf einer - wenn auch nur kleinen - Strecke geflossen ist, derartige Bazillen aufgenommen werden. ${ }^{* 4}$

Da also auch die jahrzehntelange Uferfiltration keine ausreichende Klärung des Wassers mehr versprach, sollte eine sachgemäße Quellfassung das Problem der unsauberen Wasserversorgung lösen.

Es erging deshalb 1929 vom Magistrat der Stadt Nordhausen ein Antrag, durch einen ,auf dem städtischen Grundstück Gemarkung Nordhausen Kartenblatt 7 Parzelle 137/3 befindlichen Rohrbrunnen unterirdisches Wasser dauernd zum Gebrauch und Verbrauch über die Bedürfnisse der eigenen Wirtschaft hinaus zu Tage fördern zu können“. Eine motorisch betriebene Pumpanlage saugte das juvenile Wasser aus einem $8 \mathrm{~m}$ tiefen Filterbrunnen an und drückte es sodann in die städtische Wasserleitung ${ }^{5}$.

Nachdem die Wirtschaft versorgt war, folgte 1932 ein „Antrag der Stadtgemeinde Nordhausen auf Verleihung des Rechtes zur Zutageförderung unterirdischen Wassers“ für andere Zwecke. Es wurde darin die

\footnotetext{
${ }^{2}$ Kreistiefbauamt Tgb. No 541 T. A. Northeim, den 7. Juli 1928. An den Landrat in Ilfeld

${ }^{3}$ Wasserbuchbehörde Nordhausen, 15.3.1929, Magistrat

${ }^{4} \mathrm{ib.}$

5 ib.
} 
„Verleihung des dauernden Rechts“ beantragt, ,unterirdisches Wasser bis zur Höchstmenge von 3059 cbm in 24 Stunden durch zwei Brunnen zutage zu fördern und zur Wasserversorgung der Stadt abzuleiten “6. Beide Pumpanlagen wurden bereits im Jahr 1913 in der Nähe des Kurhauses auf zwei bestehenden Brunnen errichtet und waren ursprünglich zum Zweck der Kurhausversorgung bestimmt.

Doch nicht nur für das Brauwesen, sondern auch für textile Verarbeitung, wie dem Färbeprozess, war die Wasserqualität von entscheidender Bedeutung. So hing der „Griff“ der Tuche und Loden unter anderem von der Wasserqualität entscheidend ab (DIX 1997:116). Zu Beginn der technischen Entwicklung des Kesselbaus im 18. und zu Beginn des 19. Jahrhunderts suchte man deshalb als Kesselspeisewasser „vorrangig das Oberflächenwasser der Flüsse und Bäche einzusetzen, das erfahrungsgemäß weniger Kesselstein verursachte als Brunnenwasser.“ (:191) Zunächst bezogen die Tuchfabriken ihr Wasser auch aus dem Bach, wie DIX (:193) am Beispiel der Tuchfabrik Müller in Kuchenheim (Vordereifel) schildert. Mit wachsender Gewässerverschmutzung war man aber gezwungen, auf das härtere Brunnenwasser zurückzugreifen, und versuchte die stärkere Kesselsteinbildung durch besondere Konstruktionen zu verhindern (:191). Spätestens seit 1860 bezog die Tuchfabrik ihr Wasser ,zusätzlich aus einem Brunnen und wurde zuletzt 1936 an die zentrale Wasserversogung aus der Steinbachtalsperre angeschlossen.“ (:193)

Nicht nur zur Entnahme von reinem Trink- und Brauwasser, sondern auch zur Brauchwasserentnahme wurden die Gewässerläufe angezapft. Es entstand bereits im Mittelalter ein hoher Wasserbedarf für Bäder, Fischbehälter, Wassergräben, Gewerbe und Gärten. So stieg im Zuge des Ausbaus der adeligen Gartenanlagen der Wasserbedarf auch für die entstehenden Wasserspiele ständig (GROHMANN 2000:58). Beispielsweise wurde zur Versorgung der herzoglichen hannoverschen Sommerresidenz, deren Grundstein 1639 gelegt wurde, über mehrere Röhrenleitungen Wasser nach Herrenhausen geführt und 1720 mit dem Bau einer eigenen Wasserkunst für die Gartenanlagen begonnen. Zudem wurden Quellleitungen zur Wässerung des herzoglichen Küchengartens angelegt (:58).

Durch die zumeist hölzerne Bauweise städtischer Häuser und deren Brandgefährdung wurde außerdem Löschwasser gebraucht, das im Falle eines Brandes über hölzerne Wasserrohre bereitgestellt wurde. Und für die Brennereien, wie in Nordhausen, lieferte der Flusslauf bzw. der Mühlgraben das Kühlwasser. In späteren Jahren, als die offene Abwasserentsorgung durch ein zunächst einfaches Freispiegelkanalsystem abgelöst wurde, musste Wasser zur Kanalisationsreinigung, d.h. zur Kanalspülung abgeleitet werden. Die Stadtgemeinde Nordhausen besaß das Recht, „Wasser aus dem Mühlgraben zeitweilig nach Bedarf zur Spülung der Stadtentwässerungsleitungen zu entnehmen“" ${ }^{\text {"7 }}$ Die zur Spülung der Stadtentwässerungsleitungen notwendigen Ableitungen bestanden aus Steinzeugrohren mit Durchmessern von 150 bzw. $200 \mathrm{~mm}$. Sämtliche Ableitungen waren mit ,gußeisernen Schiebern mit Spindelbewegung verschlossen“. Die dafür benötigten Anlagen wurden in den Jahren 1912 und 1913 erbaut $^{8}$.

Der Mühlenbesitzer der Martinimühle beschwerte sich nach Bekanntwerden der Planungen über die Absicht des Magistrats Nordhausen, „den Triebwerken am Mühlgraben Wasser unrechtmäßig zu entziehen“. Darauf antwortete die Regierung in ihrem Schreiben", das „die mit dem Kanalnetz in Verbindung gebrachten Schleusen im Mühlgraben [...] nur in wasserreicher Zeit zur Kanalspülung vorübergehend geöffnet werden [sollen] und zwar so, daß die zu entnehmende Wassermenge vorher bei der Abzweigung des Mühlgrabens aus der Zorge über den normalen Bedarf in den Graben geschickt wird. Da bei der Abzweigung ständig der Schleusenwärter anwesend ist und der Merkpfahl die Kontrolle des Wasserzuflusses jederzeit gestattet, so kann es zu einer Entziehung von Wasser für die Triebwerke nicht kommen.“

Fast 20 Jahre später stellte die Stadt Nordhausen 1930 einen Antrag auf „Rücknahme der Eintragung des Rechtes ,Inanspruchnahme des Wassers des Mühlgrabens zur Spülung der städtischen Kanalleitungen' in das Wasserbuch“, da es sich „um einen Gebrauch des Mühlgrabenwassers handelt, der nicht über das der Stadtgemeinde als Eigentümerin des Mühlgrabens, gemäss $\S 40$ des Wassergesetzes zustehende

\footnotetext{
${ }^{6}$ Wasserbuchbehörde Nordhausen, 24.08.1931, Magistrat

${ }^{7}$ Eintrag in das Wasserbuch am 23.4.1929; aus: Städt. Wasserbuchanträge betr. Mühlgraben (u. Kunstgraben) 1913-1931 [X 370$]$. ${ }^{8} \mathrm{ib}$.

${ }^{9}$ Schreiben des Regierungspräsidenten zu Erfurt; Journal-Nr. 8169 Ia. - Erfurt, 08.08.1913 an den Mühlenbesitzer Herrn Marmuth, Martinimühle in Nordhausen. aus: Städt. Wasserbuchanträge betr. Mühlgraben (u. Kunstgraben) 1913-1931 [X 370 ].
} 
Verbrauchsrecht hinausgeht, und dass Schädigungen dritter Personen, insbesondere der Mühlenbesitzer, durch die nur zeitweilig und in geringem Umfang stattfindende Wasserentnahme nicht in Frage kommen.“ Deshalb sei eine Eintragung nicht erforderlich ${ }^{10}$.

\section{Wasserentsorgung}

„Das Entsorgungsproblem ist so alt wie die Entstehung ortsfester Siedlungen“ (HERRMANN 1989:151). Während frisches und klares Wasser entnommen wurde, gelangte verschmutztes Wasser und andere Bestandteile in die Fließe zurück. Bis zur Einführung von Sickergruben, Rieselfeldern und hygienerechtlichen Vorschriften, aber auch weit darüber hinaus bis in das heutige Zeitalter, flossen zunächst Fäkalien und gewerbliche Abwässer ungeklärt in die Fließgewässer, „Flüsse und Stadtbäche wurden als Kloaken benutzt.“ (SCHUBERT 1989:34), das Gewässer zur Abwasserrinne deklariert. Doch „,das zumindest seit der Antike praktizierte Prinzip der Entsorgung durch das fließende Wasser eines Baches/Flusses ist in seiner allgemeinen Form bis heute in Gebrauch: Das Prinzip der Verlagerung. Die mittelalterlichen Städte knüpften an diese Tradition an. Was immer möglich, wurde ins Wasser geschüttet oder geworfen.“ (HERRMANN 1989:151)

Voll erfüllte der Fluss seine Aufgabe als große und bequeme Kloake. Die Städte waren so angelegt, dass die Abwässer leicht und ungehindert abflossen (siehe Punkt V 2). Unterhalb der Stadt, in den Flussquartieren der Unterstädte, war man noch unbekümmerter. In Luzern zum Beispiel erhielten Mitte des 15. Jahrhunderts die Anlieger eine Entschädigung dafür, dass sie befehlsgemäß ein totes Pferd in die Reuss verfrachtet hatten (GLAUSER 1978:65).

Tierische Exkremente sammelte man in Misthaufen, menschliche Fäkalien und Urin in Abortgruben. Der Misthaufen gelangte als Dünger auf die Felder oder in die Gärten, die Latrinen wurden in unregelmäßigen Abständen entleert und ihr Inhalt in den nächsten Wasserlauf entsorgt (ALTHÖFERWESTENHOFF/WAGNER 1997:85; GROHMANN 2000:55). In Zürich ergossen sich sich die Aborte seit dem Mittelalter bis Mitte des 19. Jahrhunderts in eigentliche Kloaken, in Gräben, die an den Rückseiten der Häuser, zwischen den Häuserzeilen, den Parzellengrenzen entlang verliefen (WALTER 1996:60). Eine Ausnahme bildeten die Häuser, die über eine Sickergrube verfügten. Erst eine schwere Typhusepidemie 1865/66 führte zum Aufbau eines umfassenden Abwassernetzes.

Doch nicht nur in fließende, sondern auch stehende Gewässer wurde eingebracht. Der ,Rosenhöfer Teich' im Hochharz war 1622 beispielsweise ständig von Verschlammung durch Kehricht und Mist bedroht und musste, da er als Bergbauteich eine besondere Funktion erfüllte, ausgeräumt werden. Ebenso wurde der ,Sorge-Teich', der einmal den kleinen Sorgebach im Innern von Clausthal staute, allzu gerne ,als Füllort für allen Unrat" benutzt (HAASE 1961:542). Das Bild der schmutzstarrenden Städte des Mittelalters, der frühen Neuzeit und auch noch so lange, wie es den Typus der Ackerbürgerstädte gab, d. h. auf jeden Fall noch bis zum ausgehenden 19. und beginnenden 20. Jahrhundert ist berechtigt: Viele von ihnen waren noch agrarisch geprägt, so dass auf den Straßen Misthaufen genauso alltäglich waren wie freilaufendes Kleinvieh.

Aber auch die ansonsten als vorbildlich und fortschrittlich geltenden Klöster bedienten sich dieser einfachsten Form der Entsorgung. Beispielsweise weiß man vom Kloster Walkenried, dass unter den Nezessarien, d. h. den Latrinen der Klöster, ein Wassergraben hindurchgeführt worden war. Dieser ist aber leider 1863 zugeschüttet wordent (MAIER/KEIBEL-MAIER 1997:32). Ebenso wies HERBST am Beispiel des Klosters Ochsenhausen bei Biberach nach, dass ein sog. Nordkanal die Klosterkonvents in einen Ableitungskanal der Unteren Rottum abschwemmte. Dieser und weitere Kanäle, die zum Beispiel die Abwässer aus dem Refektorium und der Klosterküche entwässerten, bewässerten mit ihrer mineralstoffreichen Kloake gleichzeitig die Klosterwiesen und lieferten einer Stampfmühle das nötige Triebwasser (!) (HERBST 1992:94). Beim Kloster Corvey indessen ist das System der mittelalterlichen und frühneuzeitlichen Wasserversorgung und -entsorgung teilweise noch präsent. Ein Kanal führte frisches Wasser zur großen Kochküche. Neben der Entnahmestelle in der Küche gab es Schächte, in die sämtliche

\footnotetext{
${ }^{10}$ aus: Städt. Wasserbuchanträge betr. Mühlgraben (u. Kunstgraben) 1913-1931 [X 370].
} 
Küchenabwässer geschüttet wurden und die von dort als Küchenabwasserkanal mit den Speiseresten in die Weser liefen.

Die Ableitung von Spül- und Waschküchenabwässern und anderen Haushaltsabwässern sowie von gewerblichen Abwässern erfolgte in den allermeisten Fällen oberirdisch durch in der Regel offene Gossenabzüge, die manchmal auch durch hölzerne Rinnen abgedichtet waren und die ebenfalls in den nächsten Wasserlauf führten. Abwässer wie Fäkalien wurden zumeist über Abzugsrinnen in nahegelegene Gewässer geleitet (SCHUBERT 1989:34; GROHMANN 2000:55f.). So trägt ein Vorfluter in Hannover heute noch die Bezeichnung „Kotgraben“ (GROHMANN 2000:58). In anderen Ortschaften, zum Beispiel in Leimbach bei Sandhausen nahe Schwetzingen, wurden auch sog. Land- und Schweinsgräben gegraben, die „das Ab- und Sumpfwasser“ der Orte (OPEL 1991:12) nach einer längeren Strecke dem Bachlauf zuführten. Sie lagen aber oftmals zu tief und konnten das Wasser nicht richtig abführen. Es kam daraufhin zu einer dauernden Überschwemmung der Wiesen.

Neben den Haushaltsabwässern verunreinigten ebenfalls die in einem jeden Ort vorhandenen Bade- und Waschhäuser mit ihren Laugen die Bachwässer. Zentrale Plätze, wie der Marktplatz und andere Repräsentationsbereiche, wurden zu Anfang des 15. Jahrhunderts mit Kieselsteinen gepflastert, um die Fäkalien nicht unmittelbar in den Boden einsickern zu lassen, sondern dem Stadtbach zuzuführen, der wiederum in den eigentlichen Bachlauf mündete (HERBST 1992:43f.).

Die spätmittelalterlichen und frühneuzeitlichen Hygienevorstellungen brechen aber nicht bei der Entsorgung von Haushaltsabwässern und dem Inhalt der Aborte ab, denn auch Blut und Flüssigkeiten aus Jauche- und Abtrittsgruben sowie Abfälle von geschlachtetem Vieh und geronnenes Blut (ALTHÖFERWESTENHOFF/WAGNER 1997:89) wurden in offenen Rinnsteinen und über Abwasserkanäle dem Fluss zugeleitet. Im Wasser schwammen gar „von Zeit zu Zeit Tierkadaver“, wie die beiden Autoren (:37) am Beispiel der Werre in Herford und der Else in Bünde (Westfalen) zu berichten wissen. Eine ähnliche Situation weist HERBST (1992:44,52) für den Oberen Stadtbach von Biberach nach, wo das Schlachthaus den Stadtbach zur Kühlung des Fleisches und zur Abfuhr von Schlachtabfällen benötigte.

Auch, um wieder ein klösterliches Beispiel zu zitieren, die Ableitungen aus den ehemaligen Rinder-, Schweine- und Pferdestallungen des Klosters Ochsenhausen bei Biberach im 15. und 16. Jh. zeigen die gewässerzuführende Entsorgung tierischer Exkremente auf, wie sie aber wahrscheinlich in jedem Mahrstall, Vorwerk oder jeder Domäne praktiziert worden ist. Besonders ist aber ihre landwirtschaftliche Zweckverwendung:

Zunächst wurde zur Ableitung der Exkremente Schwemmwasser mit Hilfe eines Pumpwerkes, da ein Höhenunterschied überwunden werden musste, aus einer getrennt geführten Frischwasserleitung zu den Bauten geführt. Die Abwässer der Stallungen gelangten dann über weitgehend unterirdische Kanalisationsstollen zu einem unterirdischen Reservoir außerhalb des Stalles. Dort floss die Jauche jedoch nicht auf dem schnellsten Weg in das Bachbett, sondern wurde über Hangbewässerungswiesen außerhalb der Klostermauern geleitet. Offensichtlich düngte das Abwasser, nunmehr mit sämtlichen Fäkalien aus dem Bereich der Stallungen und der Küche angereichert (s.o), die Klosterwiesen und gelangte von dort schließlich in einen Vorfluter, der in den Unterlauf des ,Krummbaches' einmündete. Dieser wiederum trieb nach der Klostermühle auch noch das Räderwerk der klösterlichen Sägemühle an (HERBST 1992:82,94).

In Göttingen wie auch in anderen Städten entledigte man sich darüber hinaus eines Teils des Abfalls, der nicht weggespült werden konnte, durch Liegenlassen, der andere weitaus größte Teil jedoch wurde einfach in den Leinekanal - einem früheren natürlichen Nebenarm der Leine - geworfen, der alles wegschwemmte. „Besonders losgerissene Ballen von Flachs aus den Flachsrotten verstopften die Durchlässe des Flusses durch die Stadtbefestigung.“ (SCHÜTTE 1989:243) Die Belastung des Gewässers stieg weiterhin noch einmal durch die zahlreichen Gerberbetriebe entlang des östlichen Ufers (:243), die im Allgemeinen die Gewässer nahezu jeder Stadt verunreinigten (UECKER 1999:17). Aus diesen Gründen „kippte“ vermutlich 
bereits 1328 erstmalig mit der Themse in England ein Flusslauf um $^{11}$ (HERRMANN 1989:151). Im Sinne des Verlagerungsprinzips wurden daraufhin wasserbelastende Betriebe flussabwärts von den Schöpfstellen errichtet (:151).

Mit der spätmittelalterlichen Bebauungsverdichtung begann man, nicht nur natürliche, sondern auch künstliche Wasserläufe abzuzweigen. In Göttingen beispielsweise wurde vom Mühlenkanal ein kleinerer zur Abwasser- und Fäkalienbeseitigung bestimmter Kanal, die sog. Kuhleine, abgeleitet (SCHUBERT 1989:34). Auch die Münchner Stadtbäche, natürliche Nebenarme der Isar, lieferten nicht nur den Mühlgräben das Mühlwasser, sondern auch das Wasser für die Stadtgräben und dienten so als natürliche Kanalisation (KOHL 1970:8).

Ebenso konnte das in der ländlichen Kleinstadt vorherrschende Prinzip der Fäkalien- und Abwasserentsorgung von der zunehmenden Bevölkerungszahl und einer damit einhergehenden Bebauungsdichte und Versiegelung von Flächen nicht unberührt bleiben. Bis weit ins 19. Jahrhundert änderte sich jedoch kaum etwas an diesen Zuständen (ALTHÖFER-WESTENHOFF/WAGNER 1997:37,85).

Im Zuge der zunehmenden Industrialisierung im 19. Jahrhundert entstanden zudem immer größere Mengen industrieller Abwässer und eine „kaum zu bewältigende Fäkalienflut“ (GROHMANN 2000:53). Nach Rekonstruktion von GROHMANN (:53) waren „bis in die 70er Jahre des 19. Jahrhunderts [...] die Zustände deutscher Flüsse kaum mit denen englischer vergleichbar, doch die wirtschaftliche Entwicklung der Gründerzeit in Verbindung mit dem Städtewachstum machte [...] die Ableitung der Abwässer zum Problem.“ (:53) Die eigentliche Flussverschmutzung ist nach GROHMANN (:53) sogar erst „im Zusammenhang mit Industrialisierung und Verstädterung“ zu sehen. Industriebranchen wie die Zucker-, die Papier- und die Textilindustrie sowie ,im Prinzip alle Dampfkesselbetreiber, die das [...] Flußwasser als Kesselspeisewasser verwendeten“ (BÜSCHFELD 2000:79), verschmutzten die Gewässer in erheblichem Maße.

Die Abwässer aus Zuckerfabriken, beispielsweise der Anklamer Zuckerfabrik in den Peenefluss, enthielten neben sehr viel Kalk und anderen Salzen nicht unbeträchtliche Mengen anderer gärungsfähiger Zuckerarten, organische Basen, Ammoniak und Amide, Pflanzeneiweiß, aus dem Zucker gebildete Butter- und Milchsäure u.s.w. (BAYERL/TROITZSCH 1998:366). Des Weiteren wurden Rübenreste, wie Rübenschwänze, Wurzelenden und Schnitzelstücke, einfach in die Flussläufe geworfen. Neben dieser Entsorgungsart wurden die organischen fäulnisfähigen Substanzen aus den Zuckerfabrikabwässern und des zur Anwendung gelangenden Kalkes durch eine Berieselung von Ackerboden mit dem Abwasser beseitigt (BAYERL/TROITZSCH 1998:366 ${ }^{12}$; WALLBAUM 1998:315-324; NEUBER 1996:195f.).

Hoffmann's Stärkefabriken in Bad Salzuflen-Schötmar, im ehemaligen Fürstentum Lippe-Detmold gelegen, haben ebenso verunreinigende Abwässer aus hrer Fabrik in die Werre geleitet. Diese flossen an an der Werre gelegenen Grundstücken nicht nur vorbei, sondern füllten auch die Becken des $2 \mathrm{~km}$ flussabwärts gelegenen Badeanstaltsbesitzers Overbeck. Nach erfolgreicher Klage gegen dieses Verfahren wurden die Stärkeabwässer seit 1886 durch Wiesenberieselungen geklärt und anschließend als Abwässer in die Werre sowie in die umliegenden Bäche Salze und Bega geleitet (BAYERL/ TROITZSCH 1998:359 ${ }^{13}$ ).

Die frühindustriellen Abwässer von Papier- und Sodafabriken, die sich hauptsächlich aus den Kalkrückständen aus der Sodaherstellung zusammensetzten, wirkten vor allem schädigend auf die Fließdynamik und den Sauerstoffhaushalt. Ein richtiger Kalkbrei ergoß sich zum Beispiel aus den Papierfabriken bei Weißenfels und Merseburg täglich in die Saale auf einer Länge von ca. $500 \mathrm{~m}$,und riegelte den Fluß förmlich ab" (SCHUBERT 2001:129).

\footnotetext{
${ }^{11}$ Mit der Aussage liegt HERRMANN über 500 Jahre früher, als es die Berechnung von GROHMANN (2000:53) darstellt, nach der „Flussverschmutzung zwar zunächst auch in England und hier bei der Themse“ auftrat, aber erst „,im Zusammenhang mit Industrialisierung und Verstädterung [...] 1857 [...] zu einer Verschmutzung der Themse" führte.

12 BAYERL/TROITZSCH (1998:365-367) zitieren hier aus ,Deutscher Fischerei-Verein (Hrsg.), Zs. f. Fischerei und deren Hilfswissenschaften, Bd. IX. - Berlin 1901/02:33-34'

${ }^{13}$ BAYERL/TROITZSCH zitieren hier aus ,Lippischer Heimatbund (Hrsg.): Materialien zur lippischen Landesgeschichte, Band I: Lippe im Industriezeitalter, Detmold 1987:180-182'; urspr. in: ,Kraut, Karl: Der Prozeß der Stadt Herford und des Wirths und Badebseitzers Overbeck gegen die Actiengesellschaft Hoffmann's Stärkefabriken zu Salzuflen wegen Verunreinigung der Werre. Mit Benutzung der Acten dargest. Als Ms. gedr. Darmstadt 1890:26ff.'
} 
Die Situation in der Tuchindustrie, besonders ihre wasserintensiven Veredelungsarbeitsgänge der Färberei und Nassappretur, dem Scheren und Rauhen „war denen in der Chemischen Industrie ähnlich.“ (DIX 1997:35) Nach der Wäsche wurden die Tuche entweder erst in der Wollfärberei gefärbt oder kamen gleich in den ersten Arbeitsgang der Spinnereivorbereitung, der Wolferei (:77). In der Wollfärberei gelangten die Färberabwässer beim Beispiel der Tuchfabrik Müller direkt in das nächste Fließgewässer, den Erftmühlenbach. Nicht nur eine auffällige Färbung war die sichtbare Folge, auch bestand die Gefahr der Einleitung von Giftstoffen, da bei einigen Farbstoffen Arsensäure eingesetzt wurde (:236). Aber auch in der Wolferei entstanden gesundheitsschädigende Substanzen. Das beim Waschen der Wolle entfernte Fett musste in geringer Menge wieder zugeführt werden, um die Fasern geschmeidiger zu machen. Dazu wurde ein „Schmälzmittel“ mit Hilfe einer Gießkanne aufgetragen. Als Schmälzmittel dienten verschiedene Fette wie z. B. Olivenöl oder Olein, das eine Mischung verschiedener Ölsäuren darstellt (:80). Diese Schmälze musste bei der anschließenden Walke und Wäsche aus den Tuchen wieder auswaschen werden (:80). Ingesamt, fasst DIX (:239) die bei diesem Produktionsprozess bestehende Situation zusammen, wurden „die Abwässer der Tuchfabrik Müller [...] auf die denkbar einfachste Art abgeleitet. Sie flossen von den Waschmaschinen direkt in einen Abwassersammelschacht im Fußboden und dann in einen Kanal, der das Wasser unterhalb der Turbine in den Bach leitete. Reinigungsmaßnahmen waren nicht vorgesehen.“

In der vorindustriell und industriell geprägten Jahrhundertwende des 20. Jahrhunderts waren bereits auch in Mittelstädten zahlreiche Produktionsbetriebe als Anlieger auch an kleineren Flussläufen ansässig, die das Flussgerinne, das Ufer und damit im weiteren Sinne auch die Auenwiesen für ihre Belange nutzten.

Im Jahr 1911 beispielsweise waren im Einflussbereich der Zorge in Nordhausen unter anderem Kornbranntwein-Brennereien, Mechanische Webereien und Bleiche, Bonbon- und Schokoladen-Werke sowie eine Firma für Eisen-Metalle-Felle-Woll-Lumpen-Sortierung ansässig. Die Firmen besaßen alle ein „Streifen Terrain, zu der Zorgestrasse und am Zorgefluß liegend", welches auch entsprechend genutzt wurde ${ }^{14}$. Die Mechanische Weberei Fa. Riemann zum Beispiel beantragte die Eintragung ,eines Rechtes zur Einleitung von Abwässern in den Mühlgraben“. Es handelte sich dabei „um Einleitung von Bleichereiabwässern“"15.

Entsprechend der hygienischen Fortschritte und Rechtsgrundlagen wurden zu Anfang des 20 Jahrhunderts künstliche Filteranlagen gebaut. Einem „Antrag auf Eintragung in das Wasserbuch“ der Stadt Nordhausen ist beispielsweise zu entnehmen, dass bereits 1910 (an der Halleschen Str. 377) eine Kläranlage bestand. Es wurde ein Wassereinleitungsrecht beansprucht, ,die jeweils der Einwohnerzahl entsprechend anfallenden Abwässer geklärt in Mühlgraben und Zorge einzuleiten“. Zur Ausübung des Rechts war ein Ableitungsgraben mit Abzweig vorhanden, der aus einem offenen Betongraben mit Tonrohrschalen von 700 mm Durchmesser bestand. Dennoch wurde die Zorge weiterhin auch als gewerbliche Abwasserrinne benutzt. Aktenkundig wird dies im März des Jahres 1930 durch eine von der Maschinenfabrik Fa. H. Anger's Söhne Akt.-Ges. an den Magistrat Nordhausen herangetragene Beschwerde, mit dem Inhalt, dass ,das Zorgebett bzw. die in derselben Rinne auf der Strecke von der Sundhäuserbrücke bis zum Schlachthofsteg dringend der Reinigung bedarf", denn die Abwässer der Spritfabrik könnten nicht in die Rinne ablaufen und erzeugten mit den anderen Abwässern „einen unerträglichen Gestank ${ }^{\star 16}$.

Auch noch im Jahre 1928 ist des Weiteren von „Schlammansammlungen an der Siechenbrücke“ die Rede, die eine „unerträgliche Belästigung der Anwohner“ darstellten. „Durch Eingrabung einer Rinne“, so lautet der Vorschlag zur Behebung der Geruchsemissionen, ,soll das Abwasser nach der Mitte gezogen werden““ ${ }^{17}$

Die Einleitung von Kalisalzen in Flussabschnitte des ländlichen Raumes begann mit der Entdeckung im Jahr 1857, als in den Abraumsalzen der bergmännischen Steinsalzgewinnung - eher zufällig - ein hoher Gehalt an Kali und Magnesium festgestellt wurde (BÜSCHENFELD 2000:83).

\footnotetext{
${ }^{14}$ Auszug aus dem Sitzungsprotokoll der Stadtverordneten-Versammlung v. 13. März 1911. - In: Regulierung der Zorge (18791932).

${ }^{15}$ Aktenz. V. W. 210-214.31.

${ }^{16}$ Maschinenfabrik Fa. H. Anger's Söhne Akt.-Ges., Beschwerde an den Magistrat Nordhausen v. 11.03.1930. In: Regulierung der Zorge. 1879-1932)

${ }^{17}$ Magistrat an Stadtverordneten-Versammlung v. 27.09.1928; In: Regulierung der Zorge (1879-1932).
} 
Bis 1880 dominierte die gewerbliche Verwendung der aus dem Chlorkalium gewonnenen Produkte in der chemischen, der Textil-, Farben- und Glasindustrie. Seit etwa 1880, nach der Verbilligung des Stickstoffund Phosphatdüngers, konnte der Absatz von Kaliprodukten an die Landwirtschaft erheblich gesteigert werden. 1887 verbrauchte die Landwirtschaft erstmals den größeren Teil der Kalisalze. 1913 konzentrierten sich nun etwa $90 \%$ der Gesamtproduktion auf die Landwirtschaft. Mit dem seit etwa 1880 drastisch gestiegenen Absatz von Kaliprodukten an die Landwirtschaft ist seit den 1890er Jahren bereits von einer erheblichen Dauerbelastung der Gewässer auszugehen. Das Reichskaligesetz von 1910 beinhaltete schließlich mit der sog. gewerblichen Endlaugenkonzession, „die Erlaubnis zur Ableitung großer Abwassermengen in die Flüsse“ und „leistete somit der Gewässerversalzung Vorschub " (BÜSCHENFELD 2000:83f.).

Betroffen von den salzhaltigen Abflüssen aus der bergmännischen Steinsalzförderung waren zum einen die Gewässer in der Mitteldeutschen Kaliabbauregion: die Unstrut, die Wipper, die Saale und andere linksseitig in die Saale einmündende kleine Nebenflüsse (BÜSCHENFELD 2000:87; SCHUBERT 2001:119). Vor allem in den Oberwassern der Wehre und Schleusen kam es bei Niedrigwasserzeiten zu einer Konzentration der Kaliabwässer (SCHUBERT 2001:119). Zum anderen gab es bergmännische Steinsalzgewinnung und damit das Ablassen der Endlaugen in die Flüsse in der Gegend um Staßfurt und Nienburg a. d. Saale im Saale-Elbe-Gebiet. 1876 war ,in der Staßfurter Region [...] das Wasser der Bode zum Tränken des Viehs und zum Begießen der Gewächse nicht mehr gefahrlos zu verwenden.“ (BÜSCHENFELD 2000:86)

Am bekanntesten hingegen auf westdeutschem Gebiet war die zunehmende Verschmutzung des Werra- und Weserflusses durch die Salzfrachten aus den Kalibergwerken entlang der Werra. Aber auch im Weserflusssystem an Leine, Aller und Innerste waren vor dem Ersten Weltkrieg allein insgesamt 44 Unternehmen ansässig (vgl. BÜSCHENFELD 2000:101).

Seit den 1960er Jahren erfolgte eine Umwandlung von Süßwasserbiotopen zu „salinaren Binnengewässern“ (BÜSCHENFELD 2000:102). In den versalzten Flussstrecken an der Werra entsprach der Salzgehalt 1976 dem der Nordsee bzw. übertraf diesen Wert zeitweise um das Doppelte. Die Schädlichkeit von Kaliabwässern, aber vor allem der Kaliendlaugen betraf vor allem die Wasserflora und -fauna und hier insbesondere die niederen Wassertiere, besonders die Fischnährtiere. Durch Kaliabwässer wurde sogar eine dauerhafte Veränderung des Artenspektrums ausgelöst. Zum Beispiel wurde in den 1980er Jahre an der Oberweser der natürliche Besatz des Flohkrebs ,Gammarus pulex“ von der salztoleranten Brackwasserart ,Gammarus tigrinus' ersetzt (:89f.).

Die Zerstörung der Mikrofauna schädigt aber nicht nur die Fischerei und beeinträchtigt das Selbstreinigungsvermögen, die biologische Kraft eines Flusses, auch für den in diesen Flussgebieten siedelnden Menschen wurde es eng. Nicht nur das Uferfiltratwasser, sondern sogar das Grundwasser wurde so verchlort, dass es unbrauchbar wurde (BÜSCHENFELD 2000:91). Denn nicht nur in die Flüsse wurde eingeleitet. Schon um 1900 wurde die Versenktechnik in den Boden praktiziert. Bei der Endlaugenversenkung sind bis zum Anfang der 1990er Jahre in Mitteldeutschland etwa $900 \mathrm{Mio.}^{3}$ Abwasser ins Erdreich gepumpt worden.

Die reinigende Kraft des Wassers hatte aber schon viel eher seine Grenzen, spätestens dem 19. Jahrhundert, als erkennbar wurde, dass ,die Innerste den jahrhundertealten, schwermetallbelasteten Abraum des Harzer Bergbaus auf die Flußauen schwemmte und das Weidevieh starb.“ (HERRMANN 1989:151). Große Probleme bereitete auch das aus den Stollen austretende Sauerwasser, eine schwermetallreiche Dünnsäure, die das Flusswasser vergiftete (vgl. LIESSMANN 1997:124).

Zusammenfassend bestand die Verunreinigung der Gewässer auch noch im 19. Jahrhundert aus einer Vielzahl von Verursachern - wie einer Beschwerde von 1878, die sich gegen die Verunreinigung der Flüsse, im Detail gegen das „methodische Abschwemmen von menschlichen und thierischen Auswurfstoffen aus Waterclosets, Aborten, Schlachthäusern und Dungstätten in die Wasserläufe, Flüsse und öffentlichen Seen“ und ebenso gegen das „Einleiten, Einschütten und Zuführen von groben, Verschlammung, Fäulniss oder Gährung erzeugenden Abfallstoffen jeglicher Art, sowie von Thierkadavern, Thierresten und voluminösen Schmutzmassen, ingleichen von arsenhaltigen wie anderen giftigen Substanzen und ferner von solchen 
Stoffen, welche direkt der Fischzucht schaden oder durch ihre Zersetzung stinkende Gase und andere schädliche Produkte erzeugen können." wandte, zu entnehmen ist ${ }^{18}$.

Dennoch war man sich seitens der Industrie keiner Schuld bewusst: „Die Ableitung der Fabrik-Abwässer in die Flüsse ist nothwendig und berechtigt. Die Flüsse sind als die natürlichen Ableiter der Abwässer anzusehen und zu benutzen.“19

Durch die „Verunreinigung der Flussläufe durch Kanaljauche und Industrieabfälle“ und das praktizierte Einleiten von Exkrementen und die dadurch bedingte ,systematische Flussverunreinigung durch Fäkalstoffe“ (BAYERL/TROITZSCH 1998:359-362) entstand nicht nur die Befürchtung vor einer Verschleppung von Krankheiten durch Kanalwasser und Flüsse - sie wurde Wirklichkeit. Mitte des 19. Jahrhunderts hatte deshalb zur infektiösen Eindämmung die Einrichtung zentraler Wasserversorgungssysteme begonnen (GROHMANN 2000:53). Seit 1867 waren weiterhin Bemühungen erkennbar, das englische Schwemmsystem, d.h. das Abschwemmen aller Fäkalien und allen durch Wasser transportfähig zu machenden städtischen Unrats in Flüsse oder auf Rieselfelder, in größeren Städten einzuführen. Mit negativen Folgen: Einerseits wurde durch die Schwemmkanalisation der Wasserbedarf weiter erheblich gesteigert, andererseits rief sie eine zusätzliche Flussverschmutzung hervor, die erhebliche Rückwirkungen auf die Wasserversorgung hatte (:53). Schließlich aber wurde das Kanalwasser oftmals weiterhin direkt in den Fluss geleitet, „weil das billiger sei und der Unrath einer Stadt in einer großen Wassermasse eines vorbeiziehenden Flusses sehr bald verschwinde.“ (BAYERL/ TROITZSCH 1998:359-362). Letztlich aber „muß davon ausgegangen werden, daß in den frühneuzeitlichen Städten Sachzwänge existierten, die zur Duldung von Verschmutzungen führten, ähnlich wie heute ein gewisses Maß an Luftverschmutzung durch industrielle Produktion und Autoverkehr akzeptiert wird.“(GROHMANN 2000:53).

\section{Bewässerung}

Siedlungshistorisch ist die Bewässerung, d. h. die Ableitung von Wasser zur Bewässerung und Düngung von landwirtschaftlichen Flächen - sowohl in kühl-gemäßigten als auch in trockenen Breiten - gebunden an die Sesshaftigkeit und an die Ausweitung der landwirtschaftlichen Flächen. Doch nicht nur landwirtschaftliche Anbauflächen, d. h. Äcker, Felder und Wiesen, auch Gartenland wurde schon früh bewässert, indem man Quell- und Flusswasser durch Gräben zu den Beeten leitete (SCHNEIDER 1992:182). Neben den bewässerbaren Äckern und Grünlandern gab es vom spätmittelalterlichen bis in das nachindustrielle Deutschland hinein auch bewässerbare Flachsäcker (HERBST 1992:69) und bewässerbare Bleichwiesen (:15), auf denen Wasser zum Wässern zugeführt wurde. Die unfreiwillige Bewässerung durch Mühlenstau, „wenn durch das Stauen die anliegenden Wiesen überschwemmt wurden“ (SCHEFFLER1982:45) oder die Bewässerung durch Überschwemmung infolge zum Beispiel eines Hochwasserereignisses, das durchaus auch anthropogen verstärkte Ursachen haben kann, gehören aber nicht zum Bereich der eigentlichen Bewässerung, da es nicht gesteuert oder aus Gründen der Bewässerung ablief.

Der Zweck der Bewässerung war und ist allerorts derselbe. Man wollte oder möchte mit der Wasserzufuhr und zeitlichen Verteilung des Wasserbedarfs über die landwirtschaftliche oder gewerbliche Nutzfläche höhere Erträge erzielen, sei es durch einen dichteren Bewuchs, sei es mit dem Erreichen einer zusätzlichen Ernte. Oder es galt mit Hilfe der Bewässerung überhaupt einen Bodenertrag zu erzielen. Das heißt, die erste Aufgabe einer Bewässerung ist die einer Anfeuchtung in Zeiten oder Regionen des Wassermangels.

So standen Ackerbau und Viehzucht von Anbeginn der altägyptischen Kultur unter dem Zwang der künstlichen Bewässerung. Die Gründe dafür liegen in den trockenen, sehr warmen und nahezu niederschlagfreien klimatischen Verhältnissen, die einer natürlichen Vegetation im Tal des Nils entgegenstehen. Die Ägypter nutzten jedoch sein sommerliches, durch den Monsunregen des Abessinischen

\footnotetext{
${ }_{18}$ Aus ,Internationaler Verein: Petition des „Internationalen Vereins“ gegen Verunreinigung der Flüsse. Gesundheit 3 (1878):209212; hier zitiert nach: Engelbert SCHRAMM (Hrsg.): Ökologie-Lesebuch. - Frankfurt/Main 1984:172-176, aus: BAYERL/TROITZSCH 1998:360-365).

19 Aus ,Die Verunreinigung der Gewässer. Eine Denkschrift im Auftrage der Flusscommission des Vereins zur Wahrung der Interessen der chemischen Industrie Deutschlands, bearbeitet von Dr. Konrad Wilhelm JURISCH. Berlin 1890; aus BAYERL/TROITZSCH 1998:359-360).
} 
Hochlandes gefülltes, Hochwasser, indem sie die Felder in eingedeichte Bassins, in denen das Flutwasser viele Wochen gespeichert wurde, einteilten. Als Quellen der Wasserversorgung dienten neben dem Flusswasser ferner Grundwasser und Überschwemmungen.

Die Technik der Wiesenbewässerung wurde seit historischer Zeit in vielen Gebieten der Erde mit oftmals recht unterschiedlichen Mitteln und mit unterschiedlicher Ausdehnung und Überformung der natürlichen Abflusssysteme betrieben (SCHÄFER 1997:21). In der Antike wurden an Stellen, die das Hochwasser nicht erreichte, kleine Stichkanäle gegraben, von denen aus das Wasser in die Felderbassins eingeleitet wurde. Das Wasser blieb so während der dreimonatigen Überschwemmungszeit auf den Feldern stehen. Dadurch wurde eine gute Durchfeuchtung des Bodens erreicht. Der stark tonhaltige Nilschlamm beispielsweise, aus dem das Fruchtland aufgebaut ist, ließ das Wasser lange Zeit auf dem Felde stehen. Nach Abfließen des Überschwemmungswassers wurde die Saat eingebracht.

Von Anbeginn dieser Bewässerungswirtschaft waren Schöpf- und Hebegeräte in Betrieb, um das Wasser, von Menschen oder Tier gehoben, auch außerhalb der Überschwemmungszeit von niedrigerem zu höherem Niveau zu befördern. Anschließend wurde das Wasser über eine Holzrinne entleert, die in einen Stichkanal mündete, von dem aus dann wieder einzelne, mit niedrigen Erdwällen abgedämmte Felderbassins bewässert wurden.

Unabhängig von der Art des Wasserhebegerätes - Voraussetzung für alle Bewässerungssysteme war ein ausgereiftes Kanalsystem, welches in $\mathrm{Zu}$ - und Abläufen die zu bewässernden Areale durchzog. Es war die herausragende intellektuelle Leistung der Ägypter, die Notwendigkeit eines solchen Systems erkannt und entwickelt zu haben, was im Grunde den Übergang vom Nomadendasein zur Sesshaftwerdung in der Niloase erst ermöglichte (KLEMM 1982:70ff.).

\section{a Wiesenbewässerung}

Der Grund, der im mittelalterlichen Zentraleuropa Anlass zur Bewässerung gab, war ein ähnlicher wie in der Alten Welt. Im Mittelalter bestand, „offensichtlich durch Klimaschwankungen mit höheren Jahresmitteltemperaturen, über lange Zeit die Notwendigkeit zur Bewässerung landwirtschaftlicher Nutzflächen“" (HEIL 1994:VII). Ein anderer oft angeführter Vorteil der Bewässerung, der über den reinen Lebenserhalt hinausgeht, und in späteren Jahren den Zweck der Bewässerung im Meinungsbild bestimmte, war der, dass sie in unseren klimatischen Räumen eine Steigerung der Heuernte durch mehrmalige Mahd und einen zeitlich verzögerten Grummetschnitt im Jahr erlaubte (siehe VII 6 und VIII 4.; auch DIX 1997:169, ALTMANN 1999:111). Und ein weiterer Grund für die Anlage eines Bewässerungssystems lag nicht nur in dem Wunsch zur Steigerung der Viehzucht, sondern auch darin, ,zusätzlichen Naturdünger für den ehemals intensiven Hopfenbau“ zu gewinnen, wie GIGGLBERGER (1989:102ff.) und GUNZELMANN (1999:2) es am Beispiel einer oberfränkischen Bewässerungsanlage darstellen.

Die anthropogen gesteuerten Eingriffe in den Gewässerlauf waren hier zunächst geringer Natur. Während die Talrandlagen mit den Hofstellen besetzt waren und die Uferterrassen als Ackerland genutzt wurden, eignete sich der untere Teil des Tales zur Anlage guter Wiesen - bedingt durch die hydrographisch günstige Zone der breiten, aufgeschwemmten Tafeln von schlickigem und tonigem Sand beiderseits des Flusslaufes. Hier waren die Böden bei normalen Sommerwasserständen relativ trocken.

Die regelmäßige Winter- und Frühjahrüberflutung der Talwiesen brachte zwar außerordentlichen Schaden an den Gewässern sowie den Flussdeichen, die natürlichen Überschwemmungen führten allerdings alljährlich dem Boden Nährstoffe zu, durchfeuchteten ihn gründlich und erhöhten so die Fruchtbarkeit der Wiesen. Sie wurden daher von den Eigentümern auf jede mögliche Weise gefördert. So wurden an vielen Stellen ,im Winter Durchstiche an den kleinen Deichen vorgenommen“, mit denen man sich eigentlich vor den Winterfluten zu schützen suchte. Auf diese Weise war man bestrebt, die Wasserabgänge des Winters besser über die Wiesen strömen zu lassen (vgl. HETZEL 1957:34). So nahmen die „besseren Wiesen“ um die Mitte des 19. Jahrhunderts deutlich ausgeprägte breite Streifen längs des Flusses ein. „Geringe“ und „schlechte Wiesen“" sowie unkultiviertes Land waren ganz und ausschließlich an den Rand der Niederung gedrängt. Aber die Niederungslagen waren auch von Versumpfung bedroht. Hier trug das aus dem Höhenrand der 
Niederung austretende Grundwasser wesentlich zur Vernässung bei. So gab es zum Ausgang des 19. Jahrhunderts in den Niederungen noch ausgedehnte Ödlandflächen und Brüche.

Erst bei der Entstehung der großen Bewässerungsanlagen, die bereits recht früh angelegt wurden, griff man massiv in den Gewässerlauf ein und es entstanden die ersten eigentlichen Bewässerungsanlagen auf kleinen Flächen und in mannigfacher Art. So wurde zum Beispiel für die Bewässerung subalpiner Talwiesen im schweizerischen Langetental im 13. Jahrhundert ein „Kanal gegraben, der noch heute den Langetenlauf bis zum Zusammenfluss mit der Roth darstellt.“(LEIBUNDGUT 1993:33)

Doch erst zu Beginn des 19. Jahrhunderts begann man mit der bautechnischen Nutzbarmachung der Gewässer zu Bewässerungszwecken. Um eine optimale Wasserverteilung zu erreichen und da die Wiesenfläche bei der Rieselbewässerung Stunden bis Tage mit einer dünnen Wasserschicht kontinuierlich überströmt werden musste, waren zudem ausgeklügelte Bewässerungssysteme notwendig, die eine umfangreiche Umgestaltung der Fliessgewässer und seiner Randbereiche bedingte.

Für den Gewässerbereich waren vor allem die Schleusenwerke von Bedeutung, die zunächst die Ableitung von Wasser aus dem Talfluss in das Verteilernetz regeln. Stauschleusen und die großen Seitenschleusen waren die augenfälligsten Knotenpunkte und Bauwerke im Flussabschnitt einer solchen Bewässerungsanlage. Dort, wo die Flusssohle unter dem Niveau der umgebenden Landoberfläche lag, sind Stauschleusen quer zum Bachbett errichtet worden. Über die Seitenauslässe der Kanalschleusen wurde das gestaute Bachwasser anschließend weitergeleitet (LEIBUNDGUT 1993:36). Dort, wo die Bachsohle dagegen über dem Niveau der zu bewässernden Fläche lag, floss das Wasser durch seitliche Kanalschleusen (Seitenschleusen) im Flussufer direkt ab.

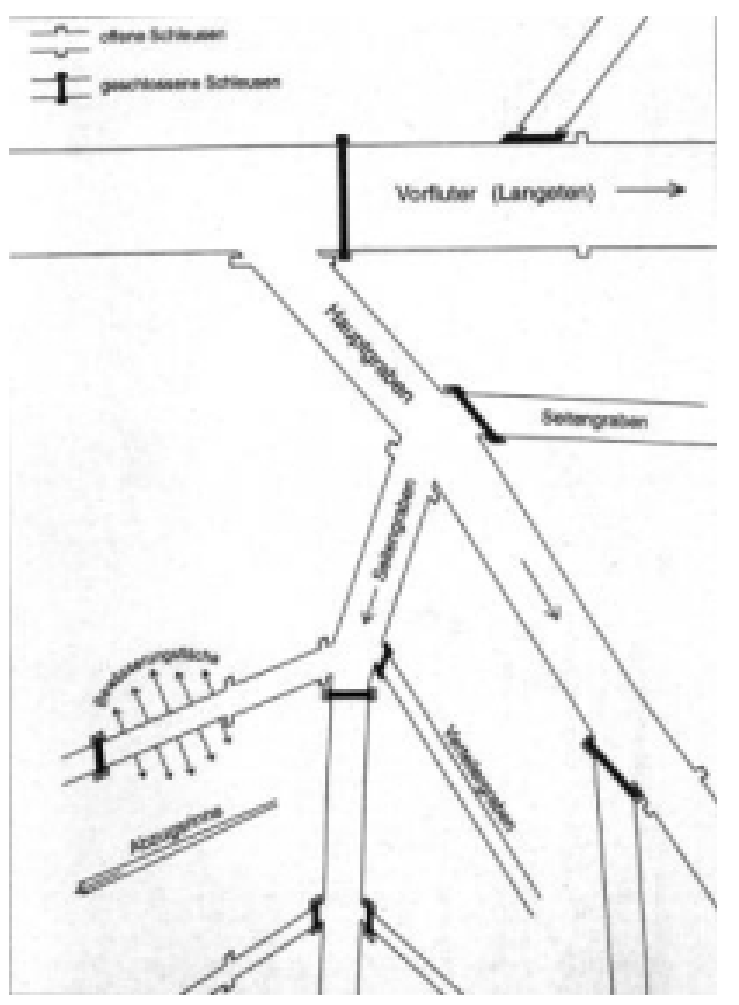

Abb. VI-3: Schleusenanlagen zur Wiesenbewässerung (aus: LEIBUNDGUT 1993:36)

In beiden Fällen wurde das Wasser des Talflusses zunächst einem Hauptgraben zugeleitet. Hier steuerten nun kleinere Schleusen zum Aufziehen oder Aufdrehen die Wasserzuleitung zu den kleineren Seitengräben. In ihnen sorgten einfache Anlagen mit Stellfallen oder Stauschützen für die Zuleitung in die Verteilergräben oder mit dem Wässerbeil bzw. der -axt in den Grabenrand gehauene Kerben direkt für ein flächenhaftes Überfließen des Wassers über die Wiesen. Die Wasserrückläufe wurden in natürlichen Senken oder 
angelegten Abzugsrinnen gesammelt und dem Talfluss oder Vorfluter nach der Bewässerung wieder zugeleitet (LEIBUNDGUT 1993:36).

Für eine bedeutende Begradigung, die im Zusammenhang mit dem Ausbau der Bewässerungsanlagen erfolgte, kann das Beispiel des Flusslaufs der emsländischen Hunte geschildert werden (HETZEL 1957). Die künstliche Regulierung des Flusses durch eine Reihe von Durchstichen an Flussbögen (von 1874 bis 187812 Durchstiche) verkürzte den ehemaligen Gewässerlauf erheblich, um zum einen für die Zuleiter und Entwässerungsgräben da Platz zu gewinnen, wo die Hunte dem Talrand sehr nahe kam und somit die Gräben zu dicht an den hohen, abbrüchigen Ufern hätten entlanggeführt werden müssen, und zum anderen, um zusätzliche Wiesenflächen zu gewinnen (:41).

Die Flusslänge auf den ehemaligen Vogteikarten betrug in dem $36 \mathrm{~km}$ langen Tal von Wildeshausen bis Oldenburg vor der Korrektion rund $57 \mathrm{~km}$ und wurde durch die Regulierung auf rund 45,6 km verkürzt (HETZEL 1957:71). In gleichem Maße wuchsen die Bewässerungswiesenflächen. Entstanden vor dem Erlass der Wasserordnung (1868) insgesamt nur 80 ha wilde Rieselwiesen im Amte Oldenburg und 48 ha im Amte Wildeshausen (:34), so wuchs die Fläche nach der Korrektion auf 600 ha an. Dieses Regulativ begann 1874 und schon 4 Jahre später, im Jahr 1878, war der Ausbau der Hunte im Wesentlichen beendet (:71).

Eine komplizierte und vollständige Bewässerungsanlage wurde in jahrelanger Arbeit fertig gestellt und es wurde „praktisch das gesamte Tal umgestaltet“ (HETZEL 1957:49). Physiognomisch erfuhren die Talabschnitte, wenn auch in unterschiedlicher Intensität, starke Veränderungen. Vor allem dadurch, dass, wie oben erwähnt, der Lauf der Hunte durch viele Durchstiche verkürzt wurde (:62). Die bei der Wiesenbearbeitung, dem Ausheben der Gräben und der notwendigen Begradigung des Flusses anfallenden großen Bodenmengen schaffte man zum Teil durch Schlämmen in die alten Huntebetten (:49) und erhöhte dadurch zunächst natürlich das Flussbett. Die sonst üblichen Folgen der Überschwemmung trat jedoch hier nicht ein, wie die folgenden Ausführungen zeigen.

Seit der Korrektion aber, die, dies sei hier noch einmal betont, nicht etwa der besseren Schiffbarkeit, sondern den Erfordernissen der Wiesenbewässerung galt, bestand für die Ufer die Gefahr des Einbrechens. Dies wurde durch das tiefe Einschneiden des Flusses in seinen sandigen Untergrund hervorgerufen. Deshalb wurden während der 1930er Jahre flache Sohlschwellen von 0,30 - 0,50 m Höhe aus Buschpackungen und Steinen in Abständen von 150 - 200 m eingebaut. Um des Weiteren ein Sandtreiben aus der Hunte zu verhindern, wurde ein sog. Sandfang angelegt. Dieser bestand aus einer tiefen Ausbaggerung und teichähnlichen Verbreiterung des Huntebettes, womit die Strömung so verlangsamt wurde, dass der Sand Gelegenheit hatte, sich abzusetzen. Er wurde dann von Zeit zu Zeit ausgebaggert (HETZEL 1957 :72).

Die starke Sandführung der Hunte wurde aber nicht allein durch das tiefe Einschneiden und die dadurch verursachten Uferabbrüche als Folge der Bewässerungsmaßnahmen hervorgerufen, sondern lag auch an Ausschwemmungen von feinem Sand bei niedrigem Sommerwasserstand aus den Wässerwiesen in das Flussbett. Das ist vor allem dann der Fall, wenn durch die Bewässerung ein Überdruck in den Sanden auftritt. Ohne die Beseitigung der starken Krümmungen aber wäre die Anlage der großen Wiesenflächen und ohne Vergrößerung des relativen Gefälles und die dadurch bewirkte Senkung des Flusswasserspiegels die vollständige Entwässerung nicht möglich gewesen (HETZEL 1957: 70). Der Plan zur Umlegung der Hunte oberhalb von Oldenburg geschah also aufgrund der Nutzung des Wassers zu Bewässerungszwecken.

Mit der Korrektion des Huntelaufes von Wildeshausen bis Oldenburg erfolgte aber sehr schnell eine beträchtliche Eintiefung des Stromes (bis etwa $2-3 \mathrm{~m}$ ). Sie hatte eine starke Absenkung des Grundwasserspiegels zur Folge, so dass dieser bei Außerachtlassung der Bewässerung weit unter der für eine Wasserversorgung des Grünlandes wirksamen Höhe lag, vor allem bei Berücksichtigung der Bodenarten, die einen hohen Grundwasserstand unbedingt erfordern (HETZEL 1957:45). Viele Wiesen trockneten förmlich aus. Paradoxerweise wurde also erst durch die Hunte-Korrektion zu Zwecken der Wiesenanlage der weitere Ausbau zum Bewässerungssystem in den 1880er Jahren notwendig. Hatte also zunächst die Frage der Entwässerung im Vordergrund gestanden, so stand nunmehr vor allem die Berieselung der Wiesen im Mittelpunkt (:32). 
Durch die Anlage komplexer Kunstwiesen aber entstand für die Landwirte der weitere Nachteil, dass die Wiesen nicht beweidet werden konnten. Weidenutzung war auf kunstvollen Bewässerungswiesen nur in einzelnen Fällen mit besonderer Erlaubnis möglich, wenn dadurch das eng verzahnte Bewässerungssystem nicht gestört wurde (HETZEL 1957:53). Ja, man wandte sich gar gegen eine Entwässerung durch Verbreiterung und Begradigung der Hunte, weil damit die zuvor durchgeführte wilde Bewässerung durch die Huntehochfluten im Winter aufhört hätten (:41). Es müssten dann notgedrungen teure und nur zum Wiesenschnitt geeignete Bewässerungswiesen angelegt werden. Außerdem gab man zu bedenken, dass die Bewässerung eine Änderung der ganzen bisherigen Wirtschaftsweise nach sich zöge, da man dann zwar über große Mengen Heu, aber über zu wenig Weiden verfügte (:41).

Durch die daraufhin veranlasste Hebung der Hunte flussabwärts von Wardenburg in den 1920er Jahren hat sich die Lage unabhängig von der Bewässerung wesentlich gebessert, da der Stau der gehobenen Hunte sich positiv auf den Wiesenfeuchte auswirkt und die Grundwasserverhältnisse beeinflusst. Dadurch konnte die Unterbilanz in der Wasserversorgung vielfach ausgeglichen werden (HETZEL 1957:45). Dennoch blieben mit der Huntekorrektion die Überschwemmungen, die einst die Anlage von Wiesen häufig erst ermöglichten, praktisch aus (:45).

Der frühere Landschaftszustand von Flussstrecken, wie beispielsweise der Hunte, in dem natürliche Talränder, feuchte, moorige Niederungen ohne oder ohne sicheren landwirtschaftlichen Ertrag, viele Flusssandaufschwemmungen, mäandrierende Laufstrecken und hohe Flussufer mit Weiden und Erlenbestand dominierten, es jedoch nur relativ wenige gute Wiesen gab, „dieses Bild der Tallandschaft erfuhr infolge der Einrichtung der Genossenschaft eine völlige Umwandlung“ (HETZEL 1957:51). Eine „völlig ebene, von einem dichten Grabennetz durchzogene Wiesenlandschaft" bot sich dem Auge dar (:51).

Das Beispiel der Erft verdeutlicht ebenfalls die - zeitlich unterschiedlichen - Eingriffe in den Fluss und die Nutzung des Flusswassers zur Ertragssteigerung von Wiesen für ein niederrheinisches Gebiet.

Wiesenbewässerung an der Erft und den Erftmühlenbächen waren in den 1840er Jahren noch recht einfach. Man unterschied die nur temporär für eine Bewässerungsperiode angelegten und die dauerhaft eingerichteten Bewässerungsanlagen. Temporäre Einrichtungen waren einfache Ufereinschnitte und den Bach sperrende Erddämme, die leicht entfernt werden konnten. Nachdem die Bewässerung durchgeführt war, wurden die Ufereinschnitte wieder zugeworfen und die eingesetzten Erddämme in dem Bach beseitigt und den Mühlen das während der Dauer der Bewässerungszeit entzogene Wasser wieder zugeführt. Die Eingriffe in den Gewässerlauf waren von recht geringer Bedeutung.

$\mathrm{Zu}$ den dauerhafteren Einrichtungen gehörten stabile Stauwehre, den Bach sperrende Schleusen und Uferschleusen, die der Aufstauung des Bachwassers und Abführung des Wassers auf die Wiese dienten (DIX 1997:170). Eine solche intensiv betriebene Wiesenbewässerung prägte den Uferbereich entlang des Erftmühlenbaches. 1841 wurden bei der Begehung des Bachlaufes 94 Einrichtungen für die Bewässerung gezählt. Es handelte sich dabei „zum größten Teil um einfache Ufereinschnitte und sog. Erken (Schleusen), die entweder in das Bachufer eingelassen waren oder den Bach ganz absperrten“(:171).

Die beschriebenen bautechnischen Eingriffe veränderten das physiognomische Gewässer- und Landschaftsbild nachhaltig. Doch nicht $\mathrm{zu}$ vergessen sind die bioökologischen und biochemischen Veränderungen, die durch die den Ertragsprozess steigernden Einleitungen und Abflüsse hervorgerufen wurden.

Der Hauptzweck der Bewässerungsanlagen lag in der Düngung, die noch wichtiger war als die Anfeuchtung (FIEDLER 1965:27). Eine Grundvoraussetzung für jede Bewässerung war deshalb die Beschaffenheit des Wassers. Es musste reich an Pflanzennährstoffen sein (:21). Aus diesen Gründen wurden Siedlungsabwässer, wie die städtische Kloake, ursprünglich mit dem Bach auf nahegelegene Bewässerungswiesen geführt, wie HERBST (1992:70,119) am Beispiel des Breitenbachs in Altendorf nachweist. Seine Untersuchungen zeigen ferner, dass die ortsnahe Bewässerungswirtschaft auch ,auf jene Düngestoffe angewiesen war, die innerhalb [...] der klösterlichen Wirtschaftshöfe als Fäkalien in die Bäche geleitet wurden.“ (:140) Des Weiteren wurde während der so wichtigen Herbstbewässerung durch die kräftigen Herbstregen aus den Dörfern, von den Feldern und Straßen besonders viele Düngestoffe in die Gräben und Bäche geleitet und damit auf die Wiesen 
geschwemmt. Besonders das Zulaufwasser aus den agrarisch geprägten Dörfern und die Zuflüsse aus den Ackerländereien enthielten viele Nährstoffe in gelöster Form, unter anderem aus Jauchegruben und Dunghaufen (FIEDLER 1965: 21,27).

War diese Düngezufuhr anfänglich ein willkommener Wachstumsbeschleuniger, so waren dagegen Wasserläufe, die Abwässer aus Berg- und Hüttenwerken und anderen industriellen Anlagen aufnahmen, aufgrund ihres Schwermetallgehaltes nicht geeignet für eine Wiesenbewässerung (FIEDLER 1965:21f.).

Nichtsdestotrotz setzte aufgund der positiven Wirkungen ein wahrer „Wiesenboom“ ein, der in den damaligen landwirtschaftlichen Mitteilungen und Schriften sein Echo fand: „Namentlich würden im ausgedehnten Thale [...] die beträchlichsten Wiesenanlagen zu machen sein, wenn nur erst diese Wiesen entfettet und verkoppelt, sowie die Flüsse begradigt und mit den nöthigen Stauwerken versehen wären“, schrieb KIRCHNER 1845 (:107ff.).

Seit der Mitte des 19. Jahrhunderts wurden „in fast allen Wiesentälern“ (FIEDLER 1965:58) Bewässerungsanlagen geschaffen (siehe VIII 4b). Sie bedeuteten nicht nur eine besondere Kulturmaßnahme für die Wiesen selbst, sondern veränderten auch das Aussehen der Gewässerläufe in starkem Maße. Landschaftsgeschichte und Gewässernutzungsgeschichte sind beim Thema Wiesenbewässerung eng miteinander verzahnt. Das Aussehen der Bachtäler vor der Anlage der Wässerwiesen variierte je nach Bodenbeschaffenheit, Talform und -lage von mäandrierend in weiten Wiesentälern bis hin zu einem eher vorgegebenen Lauf in engeren Kerbtälern. Doch allgemein waren bis weit ins 19. Jahrhundert hinein viele Bachtäler auf weiten Strecken noch durch Flussauen, Bruchwälder und niedermoorartige Flächenbestände geprägt oder zumindest nur extensiv bewirtschaftet. Bei den Flussstrecken handelte es sich bis dahin oft noch um relativ naturnahe Flüsschen. Noch immer waren bis Mitte des 19. Jahrhunderts einige Abschnitte sowie die Quellbereiche unkultiviert.

Seit Mitte des 19. Jahrhunderts trat dann durch die Kultivierung der Wiesentäler eine Veränderung der Gewässerlandschaft ein (FIEDLER 1965:60). Mit dem Einzug des Rückenbaus, der Hangbewässerungen sowie der Schwemmwiesen änderte sich das „ursprüngliche“ Bild innerhalb weniger Jahrzehnte grundlegend: Die letzten noch nicht kultivierten Talabschnitte wurden erschlossen: Bruchwälder und Auen wurden entwässert und beseitigt, Altarme und Senken verschwanden, bestehendes Wiesenland, ob bewässert oder unbewässert, völlig überformt. Stattdessen wurden Entwässerungsgräben gezogen, neue Wiesenplaggen aufgerollt.

Die Bachläufe, die bereits seit vielen Jahrhunderten durch Mühlenwehre aufgestaut, in Mühlkanäle abgeleitet sowie in Mühlenteiche aufgestaut waren, wurden einer weiteren Nutzung zugeführt, und es wurde in ihren Lauf und in ihre Retentionsräume eingegriffen. Die Gewässerläufe wurden einerseits erheblich begradigt, um einen rationellen Zuschnitt dieser kostenintensiven Flächen zu erhalten. Das daraus resultierende erhöhte Gefälle der Fließgewässer musste häufig durch Sohlschwellen ausgeglichen werden, die dann meist mit den ohnehin notwendigen Stauschleusen verbunden waren.

Andererseits wurden die Gewässerläufe in mehrere Arme aufgeteilt, damit der gesamte Talgrund mit Wasser versorgt werden konnte und die Verteilung des Bewässerungswassers über Einlassschleusen und Zuleitungsgräben geschehen konnte. „Ein geordnetes und wohldurchdachtes System“ (FIEDLER 1965:61) von Zufluss-, Verteilungsgräben und Bewässerungsrinnen wurde angelegt und mit dem Wasser des jeweiligen Baches gefüllt, $d$ er natürliche Bach diente zugleich als Abflussgraben (:60). Selbst die Mühlbäche mussten ihre Funktion erweitern und wurden in ein weitgefächertes System an Wiesenbe- und entwässerungskanälen übergeleitet (HERBST 1992:24,28). Es sind im Zuge der Herstellung von Bewässerungsanlagen sogar ,ganze Bäche verlegt [...] worden.“ (FIEDLER 1965:33)

So erhielt die Lopau im Fürstentum Lüneburg bei der Anlage von Bewässerungswiesen im Bereich des früheren Amtes Ebstorf „durchgängig ein neues Bette“ (WEYER 1800:51). Führte der Fluss zu viel Wasser, da sonst die Wassermasse in den Schwemmgräben zu groß wurde und das zur Düngung wertvolle Sediment wieder zu schnell abführte, so wurde Erdmasse hineingeworfen, um überschüssiges Wasser zu stoppen. Auch das Wasser der Seeve (Seve) zwischen Harburg und Winsen, der Schwalau, der Luhe zwischen Bahlburg und Einemhof im Amt Winsen, der Oerze zwischen Wolthausen und Banneize, der Böhme im Amt 
Rethen und einer „großen Menge Bäche im Lüneburgischen“ mehr, wurden zur Wiesenanlage ab- und zugeführt (:13,119).

Für die Wiesenschwemmung wurden nicht nur Flüsse und Bäche abgeleitet, sondern auch Teiche „abgezapft“, deren Teichwasser zum Betrieb einer Mühle oder einer anderen Wasserkraftmaschine sowie zur Fischerei diente. In diesen Fällen jedoch hatte die mühlen- und fischereiwirtschaftliche Nutzung Vorrang vor der Schwemmarbeit, wor allem dann „wenn er nicht von sehr großem Umfange ist“" (WEYER 1800:92). Die Bemessungsgrenze wird bei Teichen, bei denen ,nur noch wenig zu machen“ sei, mit 10 bis 20 Morgen angegeben (:93). Die Einverständnis bzw. das Geständnis des Wasserwerkbesitzers und des Teichwirtes, „daß die vorhandene Wassermenge noch eine Nebennutzung zulasse“ (:93) war jedoch unabhängig der Eignung eines Teiches zur Wasserentnahme nur beschwerlich herauszuholen. Zudem wurde argumentiert, dass durch die zu erbauende Schleuse der Obermühle Schaden zu führen würde, ,wenn der Rückstau das Mühlrad erreichte“ (:95). Es dürfte also nur ,thunlich seyn [...], aus Teichen, die zum Betriebe einer Maschine dienen, Flößungen zu veranstalten.“ (:96) Umgangen wurde das Argument der Wasserentnahme aus den Teichen damit, dass ,das Wasser auf seinem Wege zum Teich aufgefangen und gebraucht - und nach dem Gebrauch [...] dem Teich zugeführt wird.“(:96)

Damit die den Mühlenbetrieb störenden Erdpartikel nicht in den Fluss oder Bach gerieten, „war es nöthig, denselben zu beufern" (SPRENGEL 1838:95), denn dadurch sammelte sich das Wasser, ehe es in den Bach floss. Trat ein Ablagerung nicht ein und wurden die Sedimente weitergetragen, so wurde, um die unterliegenden Mühlen in ihrer Funktion nicht beeinträchtigen, „quer durch den Fluß, ehe derselbe die Mühle erreicht", ein Damm gezogen. Diese Sperrung sollte das Wasser noch einige Zeit davor halten und es zum Absatz der Tonteile nötigen. (:95). Mit Faschinen aus Wacholder-Sträuchern, die durch ihre Nadeln so eine große Dichtigkeit erlangen, wurde am Flusslauf eine Bewallung errichtet, damit das Wasser nicht gleich in denselben fließt, sondern sich erst über den Boden verteilt.

Zusätzlich wurde zu dem - nur temporär dem Wasserstau dienenden, aber faktisch als Flussbetterhöhung wirkenden - Erdeinwurf durch die angebrachten Stauschleusen ,das Wasser eines kleinen Flusses [...] zu einem höheren Wasserspiegel gehoben und in Zuleitungs-Canäle getrieben [...], aus welchen es sich über die Wiesen ergießt.“ (THAER 1800:I)

Auf der anderen Seite war die Folge der künstlichen Bewässerungen der Wiesen teilweise die, dass die Schleusen derart geöffnet oder zugestellt wurden, dass die Bachbetten vollständig trockengelegt waren, so dass dadurch die Fischbrut sowie Jährlinge restlos eingingen (FIEDLER 1965:34). Die eingegangenen kleinen Fische, weiß FIEDLER (:34) zu berichten, wurden anschließend „,im trockenen Bachbett von Raben und Elstern aufgenommen.“

Auch wenn beim Zustellen der Bewässerungsschleusen wenigstens etwas Wasser das Bachbett durchlief, fielen durch den Wasserabzug während der Sommerzeit trotzdem viele Wasserläufe trocken. Denn es wurde auch eine Sommerbewässerung durchgeführt, die die Aufgabe hatte, die Wiese bei Trockenheit anzufeuchten. Dies bedeutete einen schweren Eingriff in den natürlichen Wasserhaushalt der Wiesentäler (FIEDLER 1965:35), obschon der ,Meisse'-Bach beispielsweise auf einer Länge von ungefähr 2 Meilen 10mal gebraucht und wieder gebraucht wurde (WEYER 1800:14) und somit ein Beispiel ressourcenschonender Bewirtschaftungsweise darstellt.

Die Anlage von Bewässerungswiesen beseitigte also nicht nur die alten - in breiten Tälern - mäandrierenden Bach- und Flussbetten, sondern vielfach auch noch die ökologische Durchlässigkeit der jeweiligen Gewässer.

Hinzu kam noch, dass durch die Anlage der Rücken mit ihren Gräben und Grippen die gesamte Oberfläche des Talgrundes überformt wurde. Durch den Vorgang des Wiesenschwemmens (siehe VII 6b.1.1.1) schuf man eine erste Schwemmbank „bis an das Bette des alten Flusses“ (THAER 1800:III). Anschließend beuferte man sie und schwemmte in weiteren Arbeitsschritten weitere neue Wiesenflächen auf, „so weit es die Ortsverhältnisse erlaubten“" (:III). Um 1900 war oft der ganze Talgrund bedeckt von Rieselwiesen und oft wurden ganze Täler einschließlich ihrer Nebentäler durch Wiesenflächen eingenommen. Unkultivierte Abschnitte waren verschwunden, lediglich einige Talgrundparzellen wuden noch nicht bewässert. Auch in 
den norddeutschen Heidegebieten hatten der Betrieb und die Einrichtung von Bewässerungsanlagen „erhebliche Auswirkungen auf das Landschaftsbild, die Flora und Fauna dieser Tallandschaften“ (GROTTIAN 2001:2).

Die schmalen Bachtäler am Ober- und Mittellauf der Bäche waren von den Menschen durch Hangbewässerung, aber vor allem die breiten Talsohlen am Unterlauf der Bäche durch Rückenbau zu einer intensiv genutzten agrarischen Kulturlandschaft geworden (FIEDLER 1965:60f.). Bei der Hangbewässerung wurde das zur Bewässerung ausgesuchte Bachwasser in einem Zuflussgraben über die höchste Stelle der Wiese geführt. Das Wasser rieselte über Verteilungsgräben und Wasserrinnen den Hang hinab und floss so dem Abflussgraben, dem natürlichen Bachbett, zu, der es an der tiefsten Stelle der Wiese aufnahm (siehe Pkt. VII 6).

In breiten Wiesentälern mit geringem Gefälle trat an die Stelle der Hangbewässerung die Rückenbewässerung. Bei der Anlage einer Wiese im Rückenbau mussten tiefgreifende Arbeiten im Gewässerverlauf ausgeführt werden. So waren zahlreiche Zufluss- und Abflussschleusen zu errichten, um die vollständige Berieselung der Wiese zu gewährleisten (FIEDLER 1965:25).

Wiesenbewässerung beeinflusste und veränderte schließlich auch den Landschaftswasserhaushalt nachhaltig. Sie führte, zumal wenn auf großen Flächen gewässert wurde, zu einer Kolmatierung (Sedimentation von Schwebstoffen) und damit zu einer Veränderung des Mikroreliefs, zu einer höheren Trophiestufe der Böden und zu einer veränderten Vegetation; Einflüsse, die mutmaßlich bis auf den heutigen Tag wirken und somit aus ihrer Geschichtlichkeit herauswachsen zu einer Gegenwartsbezogenheit.

\section{b Gartenlandbewässerung}

Die historische Nutzung von Fluss- und Quellwasser zur Bewässerung von städtischem, wahrscheinlich in privater Nutzung befindlichem und gewerblichem Gartenland, ist bislang noch nicht in seinen Auswirkungen und seiner Form untersucht worden. Auf der Grundlage von leider wenigen erhaltenen Archivquellen lässt sich am Beispiel der Mühlgrabenableitung der Zorge für die Stadt Nordhausen folgendes Bild zeichnen. Die Quellen geben dabei die Situation für die Jahre von 1913 - 1931 wieder.

Aus dem Mühlgraben der Stadt Nordhausen wurde, so lange wie der Mühlgraben bis in die Nachkriegszeit existierte, „das seit jeher ausgeübte Recht“ praktiziert, „Wasser aus dem Mühlgraben zur Bewässerung städtischer Grundstücke an der Hindenburgallee“ abzuleiten. Diese Wasserableitungen aus dem Mühlgraben zum Zwecke der Wässerung fanden durch kleine Abzweiggräben auf die entsprechenden Grundstücke statt.

Das Recht zur Ableitung von Wasser aus dem Mühlgraben zur Bewässerung städtischer Grundstücke, die an der Hindenburgallee lagen, wurde im Wasserbuch von 1930 vermerkt ${ }^{20}$. Die folgende Wasserbucheintragung $^{21}$ belegt das Wasserableitungsrecht für die Gärtnereien:

\section{„Dem Eigentümer der Parzellen 61/12 und 15 des Kartenblattes 17 der Gemarkung Nordhausen, eingetragen im Grundbuche von Nordhausen Band 8 Blatt 8, steht seit rechtsverjährter Zeit das Recht zu, durch eine Rohrleitung von $30 \mathrm{~mm}$ Weite aus dem Mühlgraben Wasser zur Wässerung der auf dem Grundstücken befindlichen Gartenanlagen abzuleiten und das bei der Wässerung nicht verbrauchte Wasser durch den südlichen Stadtparkteich in die Zorge einzuleiten. "}

Gleiches Recht stand auch der sog. „Mühlgraben-Gärtnerei“ auf mehreren Teilflächenvon zusammen 1,2 ha zu. Dieses Wasserableitungsrecht, d. h. das Recht „das für die Gärtnerei erforderliche Wasser aus dem Mühlgraben zu entnehmen“" wurde hier mit einem Ableitungsrohr von $80 \mathrm{~mm}$ lichte Weite genehmigt ${ }^{22}$.

\footnotetext{
${ }^{20}$ Aus: Städt. Wasserbucheinträge betr. Mühlgraben (u. Kunstgraben) 1913-1931 [X 370].

${ }^{21}$ Auszug aus dem Wasserbuch für die Zorge, Bd. III, Abt. A; Unterabt. 1, Spalte 2, Gemarkung Nordhausen, Nr. 1100 B.A.W., 30; eingetragen am 25.10.[19]31.

22 Fragebogen betr. Antrag auf Eintragung in das Wasserbuch. - In: Auszug aus dem Wasserbuch für die Zorge, Bd. III, Abt. A; Unterabt. 1, Spalte 2, Gemarkung Nordhausen, Nr. 1100 B.A.W., 30; eingetragen am 25.10.[19]31.
} 
Ein ebensolches Wasserableitungsrecht, „Wasser aus dem Mühlgraben [...] abzuleiten“ wurde für weitere Grundstücke mit einer Parzellengröße von ca. 1,6 ha bewilligt, so dass nach solchen Unterlagen insgesamt ca. 1,8 ha Gartenland auf diesem Wege bewässert wurde. Der nicht verbrauchte Rest wurde - durch den Stadtparkteich - der Zorge wieder zugeführt.

\section{c Bleichwiesenbewässerung}

Im Vergleich zur klassischen Wiesenbewässerung ebenfalls wenig beachtet blieb bisher die Wässerung von Bleichwiesen.

In Biberach, gegen Ende des 15. Jahrhundert eines der mitteleuropäischen Zentren für die Herstellung hochwertiger Flachs-Baumwoll-Mischgewebe (Barchent), führte man auf den Bleichwiesen eine Bewässerung durch.

Ein sog. Bleicherbach innerhalb der Stadt Biberach beispielsweise bewässerte bis zum Ende des 18 . Jahrhunderts die Bewässerungswiesen vor der Nordstadt, die am Rande der ehemaligen Wässerwiesen lagen (HERBST 1992:45). Die Bleichwiesen erhielten aber zur Veredlung der dort ausgebreiteten Leinwand kein verunreinigtes Stadtbachwasser, sondern Frischwasser aus einem vom Bach abgeleiteten Kanal (:70). Eigens für diesen Vorgang wurde die Ableitung eines großzügigen Bewässerungskanals von der Riß um die Stadt herum durchgeführt. „So wurden die unmittelbar an die Stadtmauer grenzenden Bleichwiesen mit vergleichsweise sauberem Rißwasser beliefert“" (:140).

Die Beileitung von Wasser auf die Bleichwiesen ist auch von den anderen oberschwäbischen Textilzentren Ravensburg und Kloster Weingarten für die 1. Hälfte des 14. Jahrhunderts bezeugt (HERBST 1992:138).

Auch die Flussufer der Zorge mit ihren Auenwiesen wurde als Bleiche genutzt. In Nordhausen war um 1900 die Fa. J. Mautner als Mechanische Buntweberei und Stückbleiche ansässig. Diese Weberei Mautner benutzte $2.850 \mathrm{~m}^{2}$ des „Unlandes“, wie die Bezeichnung für die Zorgeuferwiesen damals lautete, als Stückbleiche ${ }^{23}$.

Ähnlich wie die Wiesenbewässerung verlangt auch die Rasenbleiche eine entsprechende Lage und Präparierung des Untergrundes. Die Beschaffenheit und Lage der Bleichewiesen hat der „Leggeinspektor“ Reichardt aus Göttingen am Beispiel der ehemaligen „Musterbleiche Sohlingen“ bei Uslar für das Jahr 1827 beschrieben: „Solche bilden einen sanften Abhang von Norden nach Süden, haben von Auf- und Untergang die Sonne, sind frei von Bäumen und Gesträuchen und sind von einem aus einer darüberliegenden Quelle entspringenden Bach durchschnitten, welcher [...] zu allen Jahreszeiten hinreichend mit Wasser versehen ist, [...] auch bei anhaltendem heftigem Regenwetter stets klares Wasser enthält, das für das Bleichgeschäft von besonderer Wichtigkeit ist.“ (aus: SCHRECKENBACH 1995:27)

${ }^{23}$ Schreiben an den Magistrat Nordhausen v. 21.04.1911. - In: Regulierung der Zorge (1879-1932). 


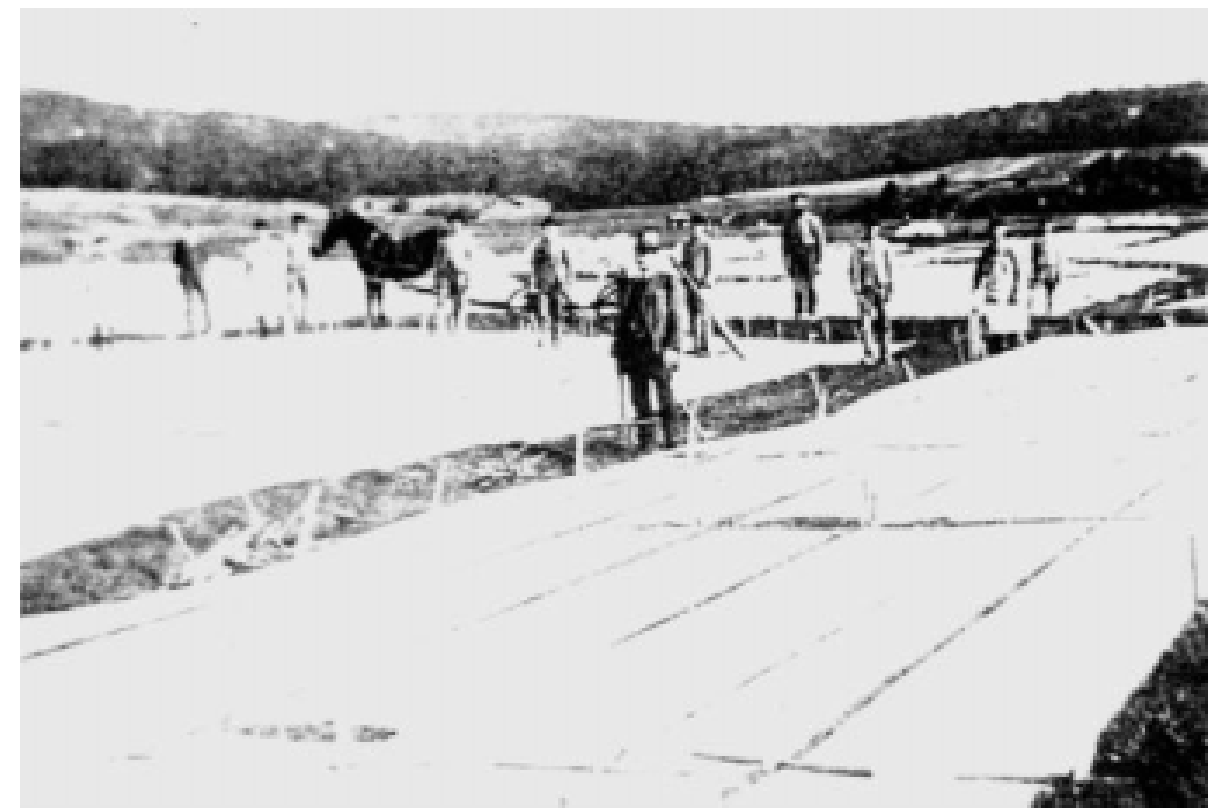

Abb. VI-4: Linnenbleiche auf dem Bleichplan Sohlingen bei Uslar.

Zwischen den größeren „Kreuzungspunkten“ der Linnenstrecken lagen gefasste kleinere Teiche, aus denen das Wasser zum Benetzen unmittelbar herausgeschöpft wurde. Oberhalb der Bleichplanen befinden sich noch heute einige terrassierte Teiche, die wahrscheinlich der Wasserbevorratung zur Leinenbleiche dienten (mündl. SCHÄFER 2004; Foto aus: BIRKIGT et al. 1995:29).

Im Laufe der Jahre umfassten die auch „Bleichpläne“ genannten Bleichwiesen einen Raum von ca. 40 Morgen. Das besonders weiche, klare Bleichwasser entsprang, wie der zitierten historischen Aussage zu entnehmen ist, einer ergiebigen Quelle und wurde ,über mehrere Sammelteiche den Bleichanlagen zum Benetzen der ausgelegten Leinenbahnen zugeführt.“ (SCHRECKENBACH 1995:28; siehe zu ,Bleichteichen' Pkt. VII 5.m)

Eine andere, ganz in der Nähe befindliche Bleichanstalt war die in dem niederhessischen Dorf Vernawahlshausen. Drei Voraussetzungen ermöglichten die Blüte des heute unscheinbaren Ortes: „ausreichend große Rasenflächen, ein genügender Vorrat an Pottasche und vor allem das klare und weiche Wasser, das aus vielen Quellen innerhalb der Vernawahlshausener Feldmark sprudelte. ${ }^{24}$ Die ausreichend großen Rasenflächen waren mit den Talwiesen der Schwülme, die nördlich am Ort vorbeifloss, gegeben, der Vorrat an Pottasche, bevor es generell durch Soda ersetzt wurde, durch die umliegenden Waldungen des Brahmwaldes und des Sollings ebenfalls. Doch nicht das Flusswasser der Schwülme wurde als Bleichwasser angezapft, die war wahrscheinlich zu diesem Zeitpunkt schon zu dreckig, sondern ,entlang der Schwülme durchzogen zahlreiche kleine, von den Quellbächen abgeleitete Gräben die Bleichwiesen, so daß die darauf ausgespannten Leinentücher bequem begossen werden konnten.“ (QUEST/SCHÄFER-RICHTER 1995:25) Diese Form der Wiesen wie auch die belegte Tatsache der Wässerwiesenanlagen im Schwülmetal (siehe VIII 4b) lässt vielmehr auf eine kombinierte Bewirtschaftung der Wiesen zu Zwecken der Wiesenbewässerung und der Leinenbleiche schließen.

Auf der Bleichestelle wurde das Leinen aufgezogen. Die Bahnen wurden straff gezogen und durch befestigte Schlaufen Pflöcke in den Boden geschlagen, um das Überschlagen der Bahnen bei Wind zu verhindern. Nun musste das Leinen ungefähr acht Tage lang auf der Erde liegen. Dreimal am Tage, an heißen Tagen mehrere Male, wurde es „geleggt“. Mit der „Leggeschaufel“" „schöpfte der Bleicher das Wasser aus dem Seitengraben, schüttete es in großen Bögen über die Leinenbahnen eines Quartiers, die eine Hälfte aus dem linken, die andere Hälfte aus dem rechten Graben.“ (SIMON 1995:26)

Am Ende der ersten Maiwoche waren „die Quartiere mit Leinen belegt“. Nach einer Woche wurde das Leinen wieder abgezogen und in Kesseln mit Buchenasche gebükt. Erst nach vier bis fünf Wochen war das Leinen weiß. „Am 24. Juni waren die Wiesen frei, der erste Aufzug war beendet [...]. Nun begann die

${ }^{24}$ St.Arch. Marburg, Best. 180, Hofgeismar Nr. 232; zit. aus: QUEST/SCHÄFER-RICHTER 1989:146-149 . 
Heuernte. Der zweite Aufzug begann Anfang August und duerte bis Ende September, danach wurde die Grumet gemacht", beschreibt SIMON (1995:26) den Rasenbleichvorgang.

Auch wenn viele Arbeitsprozesse, z. B. das Spülen des Gewebes oder die Walke, im Laufe der Zeit in neu errichtete Bleichgebäude verlagert wurden, so blieb es auch nach 1890 bei Leinen und Halbleinen ,aber grundsätzlich bei der allgemein bewährten Rasenbleichmethode“" (SCHRECKENBACH 1995: 28). Im 19. Jahrhundert jedoch setzte sich Baumwolle als Konkurrenzfaser wegen der leichteren Verarbeitung und des geringeren Preises mehr und mehr durch.

Neben den Bleichanstalten, die Leinen im arbeitsteiligen Prozess im großen Stil nur blichen, gab es auch die Walkenmühlen, die nahezu sämtliche Fertigungsgänge der Leinenverarbeitung übernahmen. Nach dem Walken hatte das gewebte Leinen noch immer kleinste Faserteilchen an sich. Es wurde angefeuchtet und gefaltet und dann ebenso wie vorher der Flachs unter dem Stempel der auch als „Bückemühle“ bezeichneten Walkmühle mit einem vom Wasserrad getriebenen Stempel gestoßen. Das Leinen musste mehrmals nassgemacht und anders gefaltet werden. Anschließend breitete der Walkenmüller das Leinen auf der umliegenden Wiese zum Bleichen aus und konnte sich des Wassers aus dem Mühlgraben bedienen (SCHRECKENBACH 1995:27).

\section{Trockenlegung}

Bei dem Prozess der Trockenlegung ist zwischen einem direkten und einem indirekten Eingriff zu unterscheiden. Während es sich bei der Entwässerung um einen bewusst herbeigeführten Prozess handelt, gründet sich die Sedimentation auf einen Vorgang, dessen Ursache in einer anderen Eingriffsart - sowohl was den Gegenstand als auch das Medium und den Standort betrifft.

\section{a Entwässerung}

Bedeutende Eingriffe in das Gewässernetz stellten die Drainierungen und Meliorationen dar. Feuchte Naturlandschaften wie in den Flussniederungen entlang der Tieflandflüsse wurden ehemals von Sümpfen und Mooren gebildet. Deren Kultivierung machte ein Absenken des Wasserstandes notwendig. Vor allem zum Beispiel in den Niederungsgebieten der Niederlande wurden schon seit dem frühen Mittelalter entsprechende Techniken angewendet und als Innovationen im frühen 12. Jahrhundert in die Weser- und Elbniederungen übertragen (NITZ 1989:192).

Um die durch Absenken des Grundwassers drainierten Flächen endgültig zu kultivieren, ackerfähig zu machen und diesen Zustand auch zu halten, ,was im Mittelalter und auch noch bis ins frühe 19. Jh. erwünscht war, um die lokale Getreideversorgung zu sichern“ (NITZ 1989:192), wurden die zwischen den parallelen Entwässerunggräben liegenden Landstreifen zu gewölbten Ackerbeeten aufgepflügt, zwischen denen wiederum Furchen eingetieft waren. „Dieses Wölbäckerrelief bot eine gewisse Gewähr, daß auch in regenreichen Jahren wenigstens auf den Beetrücken die Getreideernte reifen konnte.“(:192) Diese Wölbacker-Reliefierung ${ }^{25}$, die auf den ehemaligen Flussauen aufgesetzt wurde, ist bisweilen ,noch heute in den Fluß- und Seemarschen unter der inzwischen angelegten Grasdecke der reinen Grünlandnutzung zu erkennen.“(:192f.)

Neben der Anlage von Ackerstreifen galt die Melioration der Bereitstellung von Weidegründen, wie HERRMANN (1997:4) am Beispiel der Oderregulierung 1747 aufzeigt. Der Milch- und Weidviehbestand konnte erhöht werden, es kam nicht mehr so viel Vieh durch Ertrinken um und anstelle des ausgedorrten, schilfigen und bitteren Sumpfgrases wurde dem Rindvieh Heu als Winterfütterung dargeboten. Vor diesen Eingriffen in den Gewässerlauf werden sich die landwirtschaftlichen Bewohner mit der Gewinnung dessen begnügt haben, was ihnen die Talaue von sich aus bot, unter anderem auch des hier und dort spärlich wachsenden Grases. Zunächst reichte das, was man aus der Flussniederung unter den natürlichen Bedingungen gewinnen konnte, zur Sicherung des Existenzminimums aus. Extensive Schafhaltung und

${ }^{25} \mathrm{Zu}$ der Wölbacker-Technik und zu den übrigen angewendeten Flurtechniken siehe NITZ 1989:192. 
gelegentliche Ochsenmast wurde von den bruchrandständigen Gütern aus bis ins tiefe Bruch- und Aueland betrieben, in einem kleinen Teil auch von den Bruchdörfern aus, und bestimmte einen erheblichen Teil wirtschaftlicher Nutzung der Landschaft vor den Meliorationen.

Bald genügte indessen die Ausnutzung des natürlichen Grasbewuchses nicht mehr. Aus dem Bedürfnis, das Heuland zu verbessern und zu vergrößern, schritt man zur künstlichen Anlage von Wiesen. Dieses Bedürfnis erwuchs dadurch, dass der zur Feldbestellung, zum Transport sowie zur Mast erforderliche Mindestbestand an Pferden und Rindern den Winter über im Stall durchgehalten werden musste, und dazu brauchte man zur Fütterung neben dem Stroh auch Heu. Es lag nahe, die dazu günstigsten Teile der natürlichen Landschaft in stärkerem Maße heranzuziehen (HETZEL 1957:29).

Der betriebswirtschaftliche Ablauf war dabei folgender: Im Spätsommer, wenn sich das Wasser des Frühjahrhochwassers endlich verlaufen hatte, wurde auf den dann zutage tretenden Wiesen Futter (Heu) für die Wintermonate gemacht und anschließend den Pferden zur Grasung gegeben, während die Rinder zur Hute in die Waldweide begleitet wurden.

Vor allem in der Nähe von Flussläufen stationierte Dragoner-Regimenter ließen ihre Pferde auf den Auewiesen grasen. Lagen diese in einer Insel- bzw. Werderlage, so wurden dieselben sogar ,,auf Flößen und zusammengebundenen Kähnen überführt“, wie HERRMANN (1997:46) am Beispiel des Oderbruchs aufzeigt. Auch die emsländischen Huntewiesen dienten einer solchen Nutzung. Vor allem die Oldenburger Dragoner waren gute Abnehmer für Rieselwiesenheu und nach HETZEL (1957:52) gingen „bis 1914 beträchtliche Mengen an das Proviantamt nach Oldenburg“. Der Mehrertrag an Futter wurde aber zuvorderst im eigenen Betrieb verwendet. Durch die Sicherheit des Ertrags konnte dem Betrieb eine feste Grundlage für eine stärkere Viehzucht gegeben werden, die unter den damaligen Bedingungen für die Bewirtschaftung des Ackers von ausschlaggebender Bedeutung war (:52).

Ein stärkerer Anstoß zur Steigerung der agrarischen Produktion und damit zur „Verbesserung“ des Kulturzustandes der Flussniederungen setzte in der zweiten Hälfte des 18. Jahrhunderts ein, nicht zuletzt durch das Wachsen der Bevölkerung hervorgerufen, deren Versorgung größere Anbauflächen und Kulturländereien erforderte. Einen kräftigen Impuls erhielt diese Entwicklung dann zusätzlich durch die Gemeinheitsteilungen, da das Niederungsland die verkürzten Weidemöglichkeiten in der Gemeinen Mark (Allmende) am ehesten ersetzen konnte (HETZEL 1957:29).

Doch auch nach dem Übergang der Talauen in das Einzeleigentum der Altbauern schritt man zwar zur Anlage von Wiesen, unternahm ernstlich jedoch noch nichts, die Hydrographie grundsätzlich zu beeinflussen und damit das Höchstmögliche an wirtschaftlichem Nutzen aus der Niederung zu ziehen. Das Erworbene und Geschaffene reichte zur Erhaltung des erforderlichen Betriebsgleichgewichts einstweilen aus.

Erst in der zweiten Hälfte des 18. Jahrhunderts „,setzten die Versuche ein, einen gründlichen Wandel zu schaffen, vor allem, indem man dem Fluß selbst zu Leibe ging“ (HETZEL 1957:31). So war es bis in die zweite Hälfte des 18. Jahrhunderts hinein jedem Landanlieger überlassen, mit dem Wasser auf seine Weise fertig zu werden. Erst Anfang des 19. Jahrhunderts wurde es mit diesen Bemühungen wirklich ernst. Die Gemeinheitsteilungen mit ihren Folgen zwangen nach und nach die in der Talaue liegenden, noch ungenutzten Reserven der Wirtschaft dienstbar zu machen. Man versuchte das kostbare Heuland soweit wie möglich auszudehnen. Man war zum Beispiel „bestrebt, Anlandungen herbeizuführen, indem man Schlengenwerk in den Strom legte oder Weiden dicht am Ufer pflanzte.“ (:31) Des Weiteren wurden Uferbefestigungen angelegt zur Sicherung der hohen, abbrüchigen Ufer, damit nicht Wiesenland verloren ging, sowie Reinigungen und Aufräumungen durchgeführt. Das Flussbett sollte von allen Hindernissen befreit werden, die dem Strom eine veränderte Richtung geben konnten (siehe Pkt. 5 ,Fließgewässerpflege'). Mit der Urbarmachung wurde die nutzbare landwirtschaftliche Fläche ausgeweitet. Dies war zugleich „der Auftakt zu einer Reihe von Flußbegradigungen in Deutschland, die ihren Höhepunkt in der Tulla'schen Korrektur des Oberrheinlaufs finden." (KAUP 1996:112f.)

Gleichzeitig wurden erste Klagen der Landbesitzer laut gegen die zu starke Ausräumung des Flusslaufes, weil dadurch ein zu schneller Zufluss der Wasser, besonders bei Hochfluten, eintrat, „,durch den ihre Wiesen auch zur Unzeit, d. h. im Sommer, überschwemmt wurden.“(HETZEL 1957:32) 
Trockenlegungen von Gewässern erfolgten auch im höheren Mittelgebirge, wenn auch nicht primär aus Gründen der Feldlandgewinnung. So wurden die Niedermoore des Harzes entwässert, um diese Wässer anschließend zur Füllung der Bergbauteiche bzw. zur Beaufschlagung der Kehrräder und Pumpenkünste der Gruben zuzuleiten. Die Ableitung der Wässer aus den Moorgebieten des Brockenvorfeldes über verschiedene Gräben zur Bespannung der Clausthaler Teiche seien hier als Beispiel genannt.

\section{b Sedimentation}

Die mittelalterliche Montanwirtschaft führte noch aus einem anderen Grund zur weitflächigen Trockenlegung von Fließgewässern und deren Einzugsgebieten. Die Entwaldung der Mittelgebirge als Folge der mittelalterlichen und frühneuzeitlichen Montanaktivität führte zu einer dauerhaften Denudation der Gebirge und infolgedessen zu einer auflandenden Sedimentation in den Gewässern und Auenbereichen. Durch die zur Aufrechterhaltung und zum weiteren Ausbau des Grubenbaus notwendigen Rodungen wurden feine Mineralkomponenten in die Gewässer befördert und über eine lange Wegstrecke transportiert. Der Stollenbau der Bergwerke begann so, in die Grundwasserverhältnisse auch ortsferner Gewässersysteme einzugreifen (BARTELS 2000:41).

Die Veränderungen durch bergbauliche Eingriffe sind erst in ihrer historischen Dimension wirksam: Sie sind dauerhaft und ihre Folgen kumulieren über die Jahrhunderte und Jahrtausende hinweg und reichen selbst in geographische Räume fernab von den montanwirtschaftlichen Zentren, mag die Bergbauaktivität selbst auch erloschen sein.

So wurden Auelehmschichten in Bremen „,von ca. 1350 an sedimentiert und bilden die Folge einer intensiven Rodungstätigkeit im Wassereinzugsbereich des Flußsystems Weser-Aller-Fulda, das die Mittelgebirgsregionen u. a. des westlichen Harzes, des Sollings, Teile des hessischen Berglandes sowie das östliche Sauerland entwässert.“(BARTELS 2000:32)

Diese so entstandenen Auelehme waren vielleicht fruchtbar, aber nicht frei von Giftstoffen. Nach Überschwemmungen der Innerste beispielsweise kam es zur Ablagerung giftiger Minerale auf den angrenzenden Wiesen und Äckern, die, mit der Nahrung aufgenommen, Großvieh und Geflügel oder Kaninchen verenden ließen (BARTELS 2000:34). Dieser Vorgang belegt zugleich die nachhaltige und raumübergreifende Umweltbeeinflussung und Gewässerlandschaftsveränderung durch das Montanwesen weit über den Rahmen der engeren Produktionsgebiete hinaus schon im Mittelalter.

\section{$5 \quad$ Fließgewässerpflege}

Auch die Pflege und Reinigung von Gewässern ist eine Gewässernutzung und kann eine erhebliche Gewässerveränderung bedeuten. Vor allem dann, wenn neben den gewöhnlichen Reinigungs- und Räumungsmaßnahmen kleine Korrekturarbeiten an den Gewässern mit durchgeführt werden.

Eine Gewässerpflege und -reinigung wurde einerseits dann notwendig, wenn „,normale“, sukzessive Prozesse abliefen. Vor allem langsam fließende Bäche und Kanäle verkrauten schnell und aufgrund des geringen Gefälles setzen sich dort Schwemmsand und Blätter leicht ab, so dass eine grundlegende Säuberung notwendig wird. Solche Reinigungsarbeiten kamen bei Turbinen häufiger vor, da Laub oder Wasserpflanzen sie verstopfen konnten. So drohte die Turbinenanlage einer fränkischen Wassermühle durch die starke Verlandung der Rezat unbrauchbar zu werden und der Müller musste den Flussbewuchs vor der Mühle häufig entfernen, um überhaupt mahlen zu können (BEDAL 1992:88).

Doch Vorsicht ist geboten, wenn die Verkrautung in den Zusammenhang einer natürlich ablaufenden Sukzession gestellt wird. In dem Zeitraum der Verbreitung dieser horizontalen Antriebsart bei Wassermühlen (1880 - 1920) zum Beispiel kam es durch die verstärkte „Industrialisierung“ der Bachläufe zu Abwassereinleitungen aus Industrie, Chemie und Landwirtschaft (siehe Pkt. b2 ,Wasserentsorgung'): Sie führten schon früh zu dem Problem der Nitrifizierung und damit zu erhöhtem Pflanzenwachstum. Regulierungen der Flussläufe verlangsamten zudem den Lauf und die an den Mühlenbächen gelegenen 
Mühlen hatten den Flusslauf ohnehin zumeist durch den Wasserstau in stillgewässerähnliche Verhältnisse versetzt.

Andererseits wurden Reinigungsmaßnahmen notwendig, wenn rein anthropogen verursachte Prozesse zu Veränderungen am Gewässerlauf führten. Dies betrifft zum Beispiel das Einwerfen von Schalen, Kohlenstaub, Sägemehl, Reisig und Gerbeloher in die Saale im 18. Jahrhundert (SCHUBERT 2001: 117) oder von „viel Holz und Gestrüpp unterhalb der Mühle in den Ölbach [...], so daß sich der Bach aufstaute, die Mühle ,absoff” und einige Zeit stillstand“ (TERHALLE 1992:115). „Oberhalb der Mühle wurde alles Mögliche ins Wasser geworfen,“ weiß TERHALLE (:115f.) weiter zu berichten, „so daß dieses, wenn es in die Bottiche der Papiermühle floß, in denen die Lumpen zerstoßen wurden, diese schwarz werden ließ.”

Damit das nicht mehr passierte, wurde das Einlegen von Flachs, Garn, Leinen, Tierhäuten, Fischkörben, Latten, Bauholz und anderen Gegenständen untersagt (DIX 1997:178, der eine Polizeiverordnung für das Erftgebiet von 1838 zitiert). Einen weiteren Einblick in die Verbote gibt die „Schauordnung“ des Stadtkreises Nordhausen von 1914, hier in ihren wesentlichen Aussagen wiedergegeben:

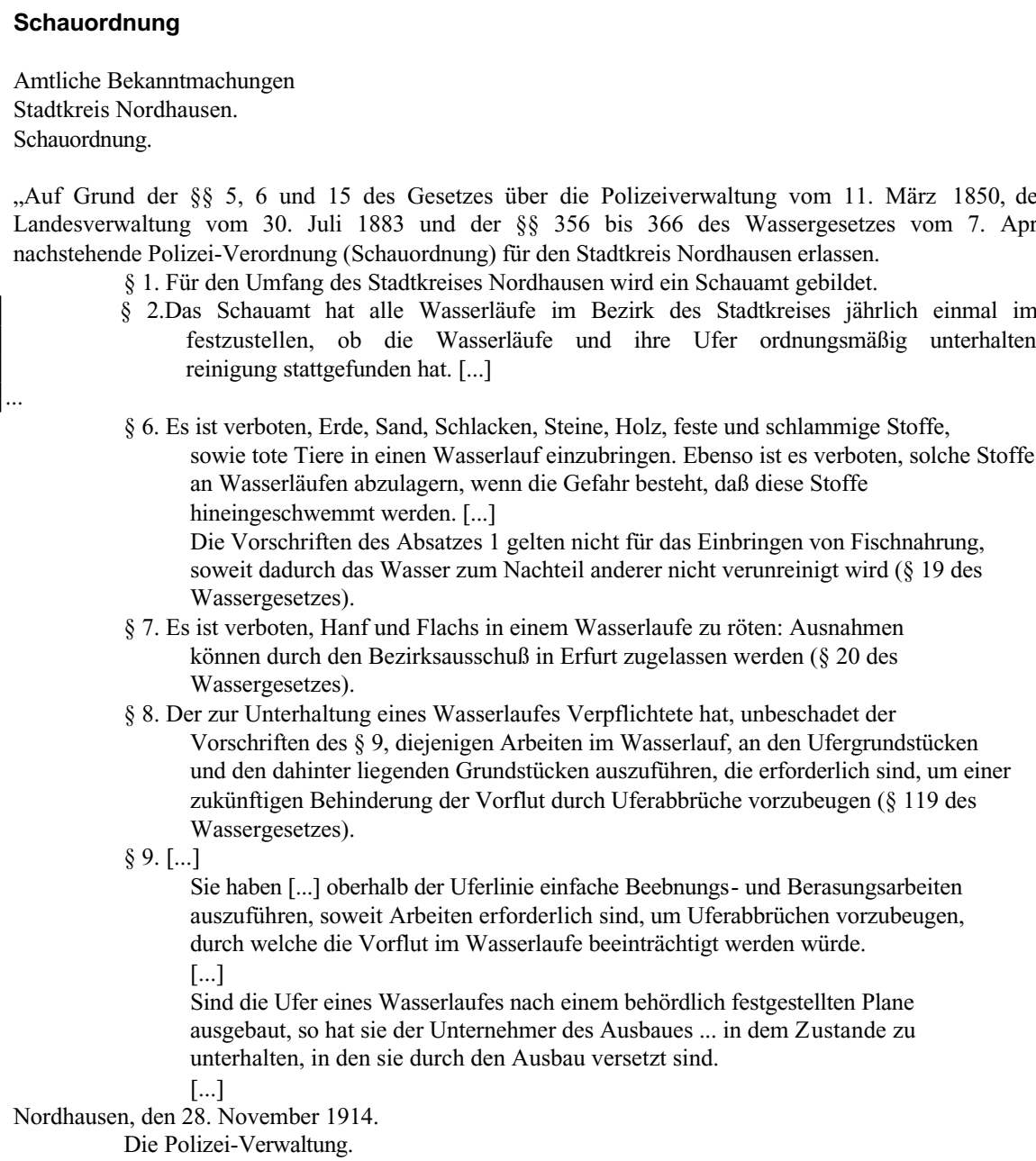

§ 7. Es ist verboten, Hanf und Flachs in einem Wasserlaufe zu röten: Ausnahmen können durch den Bezirksausschuß in Erfurt zugelassen werden ( 20 des Wassergesetzes).

§ 8. Der zur Unterhaltung eines Wasserlaufes Verpflichtete hat, unbeschadet der Vorschriften des $§ 9$, diejenigen Arbeiten im Wasserlauf, an den Ufergrundstücken und den dahinter liegenden Grundstücken auszuführen, die erforderlich sind, um einer zukünftigen Behinderung der Vorflut durch Uferabbrüche vorzubeugen (§ 119 des

Abb. VI-5: Schauordnung der Stadt Nordhausen 1914

Für die Durchsetzung dieser Verbote gab es beispielsweise in der zweiten und dritten Hälfte des 19. Jahrhunderts an Issel, an Emscher und Erft eine Flussufer- und Mühlenpolizei ${ }^{26}$.

\footnotetext{
${ }^{26}$ Aus: Nr. 35190-107/1, Bd. 71839 - 1843, Hauptstaatsarchiv Düsseldorf; 212.12.2, Bd. II; Klage wegen Haarwäschereien in der Ruhr: Nr. 36254 - 389/1; Bd. 11885 - 1889; 212.12.21; Bd. II]
} 
In Franken gab es dafür den Wassergraf, ein wichtiges Ehren- und Vertrauensamt, den zum Beispiel der Markgraf in Franken selbst berief und der darauf vereidigt wurde, sich um alle Angelegenheiten zu kümmern, die die Wasserläufe der Mühlen betrafen. Zumeist ging es um das Setzen neuer oder die Begutachtung alter Eichpfähle, um die Begutachtung der Stauwerke und die Einhaltung der Stauhöhe. Daneben hatten die Wassergrafen auch das Sauberhalten der Bachläufe, das „Fegen“, zu organisieren (BEDAL 1992:146f.). Erst mit dem Übergang der Markgrafenschaft Ansbach-Bayreuth an Preußen im Jahre 1791 und 15 Jahre später an Bayern verschwindet das Wassergrafenamt (:146).

Die Nichteinhaltung der oben genannten Verbote hatte für die Gewässer- und Siedlungslandschaft sowie für die Bevölkerung erhebliche Folgen:

Baumstämme und Unrat, die die Flüsse mit sich führten, verstopften die Öffnungen des Gerinnes von Wassermühlen. Infolgedessen staute sich das Wasser an dem Wehr wie an einem Staudamm, bildete einen mit Trümmern und Wasser angefüllten Stausee, breitete sich in der Niederung aus und führte zur Versumpfung der am Bach gelegenen Wiesen und Holzungen und übergoss sich in Massen hinter dem Wehr und beschädigte bzw. zerstörte mitunter das Mühlrad bzw. das ganze Mühlgebäude (LANGE 1989:54; BOSSE 1991:100).

Die Inhaber der Wassermühlen hatten deshalb allen Grund, auf die Reinhaltung und regelmäßige Räumung der Wasserläufe bedacht zu sein, da zudem ein ungehinderter Wasserzufluss des Betriebswassers für die ständige Mahlbereitschaft ihrer Mühlen lebenswichtig war (DOBELMANN 1980:38).

Das Recht auf Wasser, das „Wasserrecht“, das die Müller besaßen, schloss allerdings gleichzeitig auch die Verpflichtung für den Müller ein, seinen Mühlbach zu reinigen, ihn zu „fegen“ (BEDAL 1992:128). Die rechtliche Pflicht zur Räumung des Baches blieb dem Müller bis in neuere Zeit (LANGE 1989:54); körperlich aber oblag sie zu feudaler Zeit im Allgemeinen dienstpflichtigen Einwohnern (DOBELMANN 1980:38). Handelte es sich um Mühlkanäle oder zum Betrieb von Mühlen gehörende Flussläufe, so sind aus früherer Zeit Frondienste an Bachbetten bekannt (SCHENK 1998:246). „Diese Verpflichtung der Bauern zur Räumung des gesamten Baches mag ursprünglich vielerorts, wenn nicht gar überall, bestanden haben.“ (LANGE 1989:55) Im Wendland zum Beispiel bestätigte ein höchstrichterliches Urteil Ende des 19. Jahrhundert die Räumpflicht der Bauern an der Dumme (:55). Die Arbeit wurde mit „Rüffeln“ (Spaten), „Quicken“, das sind breite schwere Hacken, und Äxten ausgeführt. „Die Räumungsarbeiten gestalteten sich im moorigen Gelände sehr schwierig. Das Flußbett war stark verkrautet und der Bodenaushub mußte mühsam auf Tragen heraus und an Stellen gebracht werden, an denen er zur ,Dammung' gebraucht wurde“, beschreibt LANGE (:55) die körperlich anstrengende Arbeit. Hinsichtlich der Entlohnung war ,für mancherlei Arbeiten und Leistungen [...] eine bestimmte Menge Bier als fester Teil des Entgeltes mit einbezogen.“(:53)

Doch nicht nur zum Schutz der Mühlen, sondern auch aus Hochwasserschutzgründen wurde seitens der Administration in der zweiten Hälfte des 16. Jahrhunderts die Bevölkerung dazu aufgerufen, sämtliche Fließgewässer zu entkrauten und zu entschlammen sowie die Ufergehölze zu pflegen, um eine mögliche Hochwasserkatastrophe abzuwenden.

Diese jährlichen Wartungsarbeiten, die aus der Reinigung der Bachbetten und die Beseitigung des Abraums bestanden, dienten dazu, die Verschlammung und Verstopfung der Zuleitungskanäle zu den Mühlen zu verhindern, Hochwassergefahren vorzubeugen und die Möglichkeit der Wiesenbewässerung zu erhalten (SCHENK 1998:246).

Regelmäßige jährliche Unterhaltungsarbeiten bestanden bei den Flüssen des Erftgebietes aus der einmal stattfindenden Trockenlegung und Entschlammung des Baches. Diese fand meist im Sommer in den Monaten Juli oder August statt (DIX 1997:178). Im München des 17. Jahrhunderts wurden die Räumung der Bäche und die anfallenden Reparaturen an den Bachufern während der „Bachauskehr” vorgenommen. Diese fanden alljährlich im September oder Oktober statt und dauerten etwa drei Wochen (KOHL 1970:126). Zu Zwecken der Bachräumung wurde im Amte Lüchow, Kreis Wendland, im Jahre 1855 angeordnet, dass der Bach unterhalb der Mühle von den Anliegern in der Zeit zwischen dem 1. und 8. Juni zu räumen sei. Der Müller war verpflichtet, an den Räumungstagen die Schleusen von $3 \mathrm{Uhr}$ morgens an zuzusetzen. Außer 
dieser Räumung mussten jährlich in den letzten Maitagen von den Bachanliegern Krautschneidungen vorgenommen werden (LANGE 1989:52). Der Zwang zum ständigen Entkrauten und Räumen der langen und schmalen Wasserläufe gestaltete sich als zeitraubender Arbeitsaufwand. Infolgedessen blieben Aufforderungen, Mahnungen mit Fristensetzungen und Strafandrohungen zum Entkrauten und Entschlammen der Mühlengewässer nicht aus.

Bis zum Ende des Feudalismus wurde die periodische Reinigung der Flutgräben in der Niederung mit den Diensten, d.h. den jeweiligen Amtsinhabern, zum Beispiel den Wassergrafen, organisiert. Mit der Aufhebung der feudalen Lasten nach 1794 oblagen diese Arbeiten nur noch den Anliegern, in der Regel den Müllern und Wiesenbesitzern. Oberhalb der Mühle waren Räumung und Unterhaltung des Teiches wie des Baches fortan alleinige Aufgabe des Müllers (LANGE 1989:52). Müller sowie überhaupt alle Grundeigentümer waren fortan verpflichtet, den Bach zu reinigen.

Die notwendigen Maßnahmen der Flussunterhaltung bestanden in der Aufrechterhaltung der Normalbreite und Tiefe des Bachbettes und der Beseitigung all dessen, was Aufstau und Überschwemmungen verursachen konnte „sowie überhaupt von allem demjenigen zu reinigen was dem Wasserlauf und Eisgang hinderlich sein könnte“"(DIX 1997:164, zitiert eine Polizeiverordnung zum Erftmühlenbach).

Dazu gehörten insbesondere die Reinigung des Flussbettes bis auf dessen Sohle, das Ausräumen von Kiesbänken und angesetzten Sandinseln und allen den freien Wasserlauf behindernden Ablagerungen und Anwächsen (DIX 1997:142,178), wie zum Beispiel das Ausschlagen der in den Bachbetten festgesetzten Wasserpflanzen und das Schneiden des Krautes im Fluss, und die Wegschaffung allen Wurzel- und Holzwerks, der Büsche, Sträucher und Kräuter sowie der Zweige und Riede, die in das Flußbett hineinragten oder überhingen (BOSSE 1991:173). Dies beinhaltete zum Beispiel das Abhauen des Gesträuchs am Ufer und das Ausroden unterspülter Bäume (DIX 1997:142). Auch der in den Teichgräben und Mühlteichen befindliche Schlamm und Morast war an die Ufer zu ziehen und fortlaufend in Stand zu halten, damit die Fische nicht ,gedempfett“ würden (BOSSE 1991:173). In Gegenden hingegen, an denen das Wasser in den karstartigen Untergrund versickerte, versuchte man als weitere Pflegemaßnahme die Stellen im Flussbett mit Lehm abzudichten (KROLL/KONOLD 1994:407).

Diese gewöhnliche Räumung und „Beschlächtung“ (KOHL 1970:125) diente dem Offenhalten der Fließgewässer. Dabei wurden in der Regel kleine Korrekturarbeiten an den Gewässern mit durchgeführt. Dazu gehörte zum Beispiel die Ausgleichung der scharfen Ecken in den Uferkrümmungen, die Auffüllung oder Abböschung, die Befestigung durch Bedecken der neuen Ufer mit Rasen wie auch die Sicherung des Fußes der Böschung mittels Flechtwerk, Steinpackung und Steinstickung, um die Ufer vor weiteren Einbrüchen zu schützen (DIX 1997:142, 178), bis hin zur Tieferlegung des Flussbettes (KROLL/KONOLD 1994:407). Solch größere Planungen ,nahm man dann in Angriff, wenn eine Laufveränderung verhindert werden sollte" (DIX 1997:142) und lassen sich teilweise nur schwer von Meliorationen und Regulierungen unterscheiden.

Eine in früheren Jahren jahreszeitlich wiederkehrende Besonderheit stellte die Eisräumung dar. Sie hatte mit Flusseisgewinnung als eigentlichem Nutzungsanlass (siehe. Pkt. 13.1) jedoch nichts gemeinsam.

Durch winterliche Eisbildung wurde der Wasserlauf gehemmt, zum einen durch die Bildung von Oberflächeneis und zum anderen, in besonders eisigen Wintern, durch Grundeisbildung. Beide Vereisungsgrade jedoch wurden in den langsam fließenden und wenig tiefgründigen Mühlkanälen und Stadtbächen relativ schnell erreicht. Im Winter konnte das Grundeis bewirken, dass die Turbinen so weit einfroren, dass der Mahlbetrieb eingestellt werden musste. Von dieser Grundeisbildung waren Turbinen stärker betroffen als Wasserräder, da sie tiefer im Wasser lagen (BEDAL 1992:88). Obgleich auch Beschädigungen des Mühlenrades bzw. der Wasserbauten eintraten, so dass bereits baulich eingerichtete Sprossen vor den Mühlenschaufeln zu große Eisstücke fernhalten sollten.

Die Erkenntnis, dass „die Ausbildung der winterlichen Eisdecke [...] durch Stauwerke, Flußkrümmungen, Wechsel in der Weite des Hochwasserbettes, aber auch durch Beschattung durch Wälder beeinflusst und die Entwicklung von Eisversetzungen während des Eisganges gefördert" wird (KAUP 1996: 119), hatte weitreichende Konsequenzen: Um Eisstauungen und damit Schäden durch Überschwemmungen und 
Betriebsstillegungszeiten zu vermeiden bzw. zu reduzieren, wurde durch geeignet erscheinende Maßnahmen versucht, diese in ihrer Wirkung abzufangen. Die Krümmungen eines Flusses, so die frühere Ansicht, war verantwortlich für größere Eisstauungen (DIX 1997:164) und so griff man mancherorts zur Abwendung der Gefahren zum Mittel der Rektifikation von Gewässerläufen.

Dies war nicht immer in fließenden Gewässern ausreichend möglich, denn Eisgang ist „unberechenbar“ (KAUP 1996:119). Ein jeder Mühlenbesitzer oder Pächter war deshalb per Verordnung verpflichtet „das unterhalb seiner Mühle bis zur nächsten Mühle befindliche Eis jeden Morgen aus dem Bach zu heben und zur Seite des Baches niederzulegen." (DIX 1997:163, zitiert eine Polizeiverordnung von 1838, die die Abwehr der Gefahren durch Eisstau sehr detailliert regelte). In einzelnen Arbeitsschritten sollte das Eis - bei Bachläufen - von den Ufern abgehauen, bei Mühlkanälen die Seitenwände von Eis befreit und in jedem Fall auch aus dem Flussbett ausgehauen werden.

Auch zur Aufrechthaltung der Funktionen der Münchner Stadtbäche war im Winter nicht selten eine „Abeisung” vonnöten (KOHL 1970:124). Dies war nicht nur für den Fortgang des Mühlenbetriebes unabdingbar, sondern, da die Bäche auch zusätzlich eine Kanalisationsfunktion erfüllen mussten, für das Wegspülen der Fäkalien notwendig. In besonderen Fällen waren ,mehrere hundert Leute zur Abeisung und Eiswacht nötig" (:127).

Die Pflicht der einzelnen Mühlenbesitzer und Anlieger, das Eis im Winter auf der Bachstrecke zwischen den einzelnen Mühlen zu beseitigen, wurde früher oft gern vernachlässigt. Heute müssen sie dieser Verpflichtung nicht mehr nachkommen, denn ,aufgrund der zunehmenden Gewässererwärmung, bedingt durch Abwässer, bildete sich in den letzten Jahrzehnten so gut wie kein Grundeis mehr in mittelfränkischen Flüssen." (BEDAL 1992:88)

Notwendig war die Reinhaltung des Flussbettes, d. h. die Räumung von allen möglichen Hindernissen, auch um die Vorflut für die Wiesenbewässerung zu erhalten. Essentieller Bestandteil einer funktionsfähigen Wiesenbewässerung war die Ableitung des den Wiesen künstlich zugeführten Wassers, die Entwässerung. Ein Übermaß an Wasser, hervorgerufen durch starke Gewitter in Verbindung mit einem mäanderreichen Fließgewässerverlauf und darin befindlichen Hindernissen, hatte zur Folge, „daß bei zugewachsenen Gräben und Flußläufen die angrenzenden Wiesen unter der Nässe litten“ (BOSSE 1991:101).

Ebenso galt es Werterhaltungsarbeiten an Kunstgräben und Teichen des Bergbaus vorzunehmen. (ALTMANN 1999:108). Bei der Aufbereitung von Sandstein für die Bleierzgewinnung fielen große Mengen an Sand an, die auf Halden aufgeschüttet wurden. „Dieser Sand wurde durch Wind und Wasser weiträumig verlagert und führte u. a. zu Bachversandungen, wodurch Bachsande teilweise bis zu $30 \mathrm{~km}$ bachabwärts geschwemmt wurden. Die Versandungen traten das ganze 19. Jahrhundert hindurch auf.“ (DIX 1997:143) Durch die geringere Strömungsgeschwindigkeit aufgrund von zahlreichen montanwirtschaftlichen und molinologischen Wehrbauten und Gewässerstauungen verstärkt, bildeten sich zudem diese Sandbänke vermehrt. Als Gegenmaßnahmen galten neben der Befestigung und Bepflanzung der Halden, die aber erst um die 20. Jahrhundertwende durchgeführt wurden, das Offenhalten des Baches.

Die Oberharzer Aufschlaggräben und Wasserstrecken beispielsweise waren sorgfältig in einzelne Grabenstrecken eingeteilt. Für das jeweilige Revier hatten die sog. Grabenwärter ihrer Pflicht nachzugehen, die darin bestand mit einem „Häckel“ oder „Hackel“, ein Handstock, mit einem kleinen Beil versehen war, im Wasser treibende Gegenstände herauszuholen oder die Schützenbretter zu lösen (HAASE 1961:23). In ihren Bereichen hatten sie den glatten Durchgang der Wasser und die damit verbundene Sicherheit der Dämme zu überwachen (:24).

Schließlich musste auch rechtzeitig vor Beginn einer Brennholzflöße das Gewässer instand gesetzt werden. Dies betraf die Uferräumung von hinderlichen Baumstämmen, festgewachsenem Buschwerk sowie die Behebung von Schäden am Mühlendamm, damit eine reibungslose Beförderung des Holzes gewährleistet war. Das „Wasserräumen“ war vor jeder Trift erforderlich, da diese Form des Holztransportes ohne solche Maßnahmen noch verlustreicher gewesen wäre als dies ohnehin schon der Fall war. Immer wieder verfingen sich trotz vorgenommener Säuberung Scheite und Stammstücke an den Ufern der Gewässer (BORGERKEWELOH/KEWELOH 1991:22). 


\section{Wasserstau}

Im Gegensatz zur Trockenlegung steht die Wasseraufstauung symbolisch für eine Wasseranreicherung, wenngleich auch diese zur Austrocknung natürlicher Gewässerläufe, vor allem aber amphibischer Bereiche beigetragen hat. Bevor nämlich zum Beispiel ein Teich angelegt wurde, den man mit einem Damm absicherte, floss der wasserzuführende Bachlauf durch ein Wiesenthal, wie ERLER/MATTHIESEN (1989:81) am Beispiel der Fintau in Eggersmühle bei Wesseloh, im Nordwesten des Landkreises SoltauFallingbostel, aufzeigen. Vor allem aber hat der Wasserstau die Vernässung weiter Bereiche erheblich gefördert, wie in der Einleitung zu dieser Arbeit ausgeführt:

In Mitteleuropa ist der Aufstau vor allem durch eine Vielzahl von kleineren Wasserschützen und Wehren charakterisiert, die in den Gewässerlauf gestellt wurden. Nach SCHUBERT (2001:59) stellen diese gar die ersten baulich-lokalen Eingriffe in das Flussökosystem der Saale dar.

Getragen wurde der Wasseraufstau insbesondere kleinerer und mittlerer Gewässer vor allem durch Wassermühlen. So existierten im 13. Jahrhundert an der unteren Saale bereits 12 Mühlenwehre, die das Wasser zum Mühlradantrieb regelten. Zwei Kilometer beispielsweise staute sich vor der Mündung der Böhme in die Aller der Fluss durch ein Mühlenwehr auf und rund vier Kilometer flussaufwärts davor betrieb das Kloster Walsrode einen Gewässerstau (ERLER/MATTHIESEN 1989:33).

Durch den Mühlenstau, der die Vorflutverhältnisse in der Flussniederung störte, lag das Flussbett von Flachlandflüssen im Bereich der Bruchniederung oft höher als der umgebende Talgrund. Die Wehre der großen Mühlenanlagen in manchen Gewässerabschnitten stellten eine Art „Sedimentfalle“ dar. Durch Ablagerungen erhöhte sich das Flussbett kontinuierlich und musste in Dämme gefasst werden. Sonst wäre infolge des Grundwassergefälles das Gelände versumpft und ein Bruch entstanden. Da der Mühlenstau jedoch weiter erhöht wurde, um zum einen Wasservorrat zu besitzen und zum andereren mit der größeren Wasserkraft größere oder mehrere Mühlenräder anzutreiben, vernässten weite Gebiete der Flussniederungen.

Doch nicht erst seit dem Bau von Stau- und Ableitungswehren - eine erste starke Erhöhung des Flussbettes muss schon in der Zeit um 1200 durch starke Sedimentation erfolgt sein. Infolge von Rodungen der Hänge und Berge und der frei daliegenden Ackerflächen waren diese Flächen der Erosion ausgesetzt (siehe Pkt. 4b ,Sedimentation').

Im städtischen Umfeld hatte der Wasserstau nicht nur hydrologische und landschaftliche, sondern auch nasale und hygienische Auswirkungen. Das hinter einer Schleuse stehende Wasser, weiß LANGE (1989:58) zu berichten, ,verbreitete vornehmlich im Sommer bald einen starken Gestank, da aus ihm noch Färber und andere Handwerker das Wasser für ihre Arbeit nutzten. Es wurde daraufhin angeordnet, die Schleuse stets um 3 Zoll geöffnet zu lassen. In ganz trockenen Sommern sogar noch mindestens 1 1/2 Zoll, um den ungesunden Zustand abzustellen.“

Wasserabflusshemmende Wirkung hatte auch die Flößerei von Hölzern. Seit Beginn der Flößerei wurden Wehre und Stauschleusen in Bächen errichtet, um das Triftholz aus den Wäldern zu sammeln und hinab zu flößen. Bei der Stammholz- und Langholzflößerei hingegen stellten einerseits die bereits vorhandenen Mühlenwehre teilweise ein Hindernis dar und andererseits, da sie die Wehre regelmäßig zerstörten, gab es Zwistigkeiten zwischen den Flößern und den Mühlenbesitzern bzw. -betreibern.

Bis ins 19. Jahrhundert dienten die Wehre primär der Bereitstellung von Wasser für den Mühlenbetrieb, der Gewährleistung der Flößerei in Niedrigwasserzeiten sowie dem lokalen Hochwasserschutz (SCHUBERT 2001:60f.). Nach DÜSING (1906:503, zitiert nach SCHUBERT 2001:60) sind die Schleusen zunächst bis ins 15. Jahrhundert reine Flutrinnen bzw. einfache Schiffdurchlässe gewesen.

Erst dann setzte der Umbau der Mühlenwehre mit einer Schleusenfunktion ein, die in engem Zusammenhang mit der sukzessiven Schiffbarmachung der Gewässer, vor allem der Unterläufe bis zur Einmündung, steht, wie SCHUBERT (2001:60) am Beispiel der Saale verdeutlicht. Doch die Schiffbarmachung von Fließgewässern durch den Bau von Schleusen ist auch von kleineren Gewässerläufen bekannt. An der Stelle einer ehemaligen Mühle ist in der ersten Hälfte des 19. Jahrhunderts eine sog. Stauschleuse zur Verbesserung 
der Berkelschiffahrt angelegt worden, die das Wasser 90 bis $125 \mathrm{~cm}$ aufstauen konnte und damit den Schiffen den Weg vom ,Berkelhafen' an der ehemaligen Abteimühle bis zur ,Hühnerbrücke' erleichterte (TERHALLE 1992:28,54).

Die nächstfolgenden Einrichtungen des Wasserstaus, die in neuer Dimension in den Gewässerhaushalt eingriffen und auch zur Aufgabe historischer Wirtschaftsweisen führten, waren die neu gebauten Talsperren: Die Saale ist auch hier ein exzellentes Beispiel für den einsetzenden industriellen Talsperrenbau. Mit der 1920 bis 1940 entstandenen sog. „Saalekaskade“ wurden zahlreiche Saaleschleifen überflutet und der Fluss durch die Staumauern auf $28 \mathrm{~km}$ Tallänge gestaut bei einem Stauraum von 9,2 $\mathrm{km}^{2}$ Wasser. Um den Ablauf auszugleichen entstand $5 \mathrm{~km}$ unterstrom bei Schloß Burg a. d. Saale ein Ausgleichsbecken mit einem Fassungsvermögen von 5,6 Mio. $\mathrm{m}^{3}$, von dem aus das Wasser zur nochmaligen Verwendung in das Oberbecken zurückgepumpt werden kann. Es handelt sich also um ein Pumpspeicherwerk (PASOLD 1992:15).

Neben der Erzeugung von Elektroenergie dienten die Saale-Stauwerke zum einen der Regulierung des Wasserstandes in der mittleren Elbe im Interesse der Schifffahrt, zum anderen zur Abgabe von Brauchwasser für die Chemiewerke im Raum Halle. Der ausschlaggebende Grund aber, weshalb die Talsperrenkette entstand, war der Hochwasserschutz (PASOLD 1992:18).

Kulturhistorische Folge des Talsperrenbaus war, dass es auch keine Floßfahrt mehr gab; was einen schweren Einschnitt in das Wirtschaftsleben bedeutete, denn „die Saale von Saaldorf bis Camburg diente seit dem Mittelalter als Haupttransportweg der Ware Holz zu den Holzmessen im mittleren Saalegebiet.“ (PASOLD 1992:18)

Die Veränderungen der hydrologischen Umwelt durch seit dem Mittelalter errichtete Wasserstaue sind bislang historisch noch nicht erforscht ${ }^{27}$. Doch ergibt sich daraus eine Verminderung der Ablagerung von Nährstoffen auf den Feldern bei geringeren Überschwemmungen durch eine Verminderung des Strömungsmaximums flussabwärts und dadurch, dass der Stau einen erheblichen Teil des fruchtbaren Schlammes abfängt (GOUDIE 1994:206). Eine besonders wichtige Konsequenz einer Wassersperre ist die flussaufwärts erhöhte und die flussabwärts verminderte Sedimentfracht (:202). Dies hat für den jeweiligen Unterlauf, proportional zu den Wehren und Schleusen, eine zunehmende Erosion des Flussbettes und erosionsbedingte Einschnitte in das Tal zur Folge, da weniger Sediment für eine Anhebung des Bettes vorhanden ist. Der letztgenannte Vorgang wird oft als „Klarwassererosion“ bezeichnet (:204f.).

Die baulichen Eingriffe durch die Errichtung von Wehren waren derart, dass für das Fundament der Boden tief geräumt sowie geebnet und dafür das Wasser abgehalten werden musste. Bei kleinen Bächen und im ungünstigten Fall geschah dies durch Hand-Schöpfen, in anderen Fällen durch „Niederländisches Schöpfen“. Bei größeren Bächen musste während der Bauzeit durch eine Abdämmung das Wasser abgehalten werden. Nach der Härte des Bodens wurden Fundament-Pfähle „,von gutem Erlen- oder Eichen-Holz eingeschlagen“ (LEUPOLD 1735:17). Und je nachdem, ob ein Boden locker oder dicht ist, wurden kurze oder lange Pfähle genommen. Bei einem harten und festen Boden „müssen die Pfähle ohngefähr 6 bis 7 Schuh lang seyn, und unten mit eisernen Spitzen, so man Schuh nennet, beschlagen werden.“ (:17) In einen lockeren und sumpfigen Boden hingegen ,müssen Pfähle auf 10, 12, und mehr Schuh lang, und [...] 10 oder 12 Zoll dicke

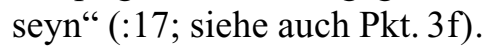

Schließlich soll an dieser Stelle die Vielzahl an künstlichen Teichanlagen erwähnt werden, die aber nicht nur aufgrund ihrer Bedeutsamkeit eine separate Behandlung erfahren. Teiche wurden nicht durch mittigen Aufstau des Hauptgewässers errichtet und ihre Anlage der $\mathrm{Zu}$ - und Ablaufabrichtungen auch nicht quer zum Bachbett, d. h. inmitten eines Gewässerlaufes aufgestellt. Aus diesen Gründen subsumiere ich Teiche nicht

\footnotetext{
${ }^{27}$ Aus aktueller Sicht liegt eine Problemdarstellung der „Stauraumverlandungen“ durch Sedimenttransport in Fließgewässern vor, die der DVWK 1993 vorgelegt hat. Eine Vielzahl der Voralpen- und Mittelgebirgsflüsse ist, so lautet die Problembeschreibung, „teilweise oder ganz durch Stauanlagen ausgebaut, wodurch der Sedimenttransport, besonders der Geschiebebetrieb, zum Erliegen kommt.“ (DVWK 1993:V). Die eintragenen Feststoffe lagern sich in den Stauhaltungen weitgehend ab und beeinträchtigen dadurch den Betrieb und die Unterhaltung. Besondere Bedeutung kommt hierbei dem ökologischen Aspekt zu, „da Sedimente grundsätzlich ein Anlagerungspotential für im Gewässer enthaltene Schadstoffe besitzen, wodurch bei Sedimentation Senken und bei Remobilisierung Quellen von Schadstoffen entstehen können.“(DVWK 1993:V).
} 
unter die Nutzungsart „Wasserstau“. Es ist vielmehr eine Wasseraufspannung und -sammlung auf ehemalig zumeist trockenerem Grund, etwas abseits des eigentlichen Fließgewässers angelegt.

Vielfach unbeachtet blieb dabei in historisch-geographischem Zusammenhang die durch die Stauaktivitäten des Menschen seit historischer Zeit bewirkte Veränderung der ökologischen Biogeographie, wie zum Beispiel der Verbreitung der Süßwasserfauna (SCHÄFER 1997:152).

Auf der einen Seite wurden durch zahlreiche Kanalsysteme neue Wanderwege für Fische eröffnet (siehe Pkt. 7). Auf der anderen Seite aber wurden durch den Aufstau von Mittelgebirgs- und Flachlandflüssen Wanderungen erschwerende oder gar verhindernde mechanische Barrieren errichtet. Diese Nutzungsformen der Ressource „Wasser“ führten zur Einschränkung der „Dispersionsmöglichkeiten für limnische Taxa“ (SCHÄFER 1997:21).

Des Weiteren haben all diese wasserbaulichen Maßnahmen die Fauna der Fließgewässer in anderer Weise beeinflusst. Im Oberlauf der Mittleren Ebrach und anderer Steigerwaldflüsse beispielsweise wurde durch die eingebauten Wasserstaumaßnahmen der Lauf so verlangsamt, dass dort ähnliche Milieus zu finden waren wie in den dazwischengeschalteten oder nahe gelegenen Teichen (SCHENK 1998:248; ähnlich ZULEEG 1933:2 für die Aisch).

In direktem Zusammenhang damit steht die ebenfalls jahrtausendealte Fischwirtschaft, die in regionalen Dimensionen durch den künstlichen Gewässeraufstau zu einer Verfremdung der natürlichen Fauna zugunsten einer für die menschliche Ernährung nutzbaren Artenzusammensetzung führte (SCHÄFER 1997:21).

\section{$7 \quad$ Fischerei und Fischzucht}

Fischerei ist Fischfang, Jagd und Sammeln zugleich, abhängig davon, welche Art von Wassertieren befischt werden sollen, wo und wie dies geschieht. Zu den ,gefischten“ Wassertieren zählen Fische und Mollusken, zu den „bejagten“ Krebse und Biber und zu den ,gesammelten“ Wasserschnecken.

Die Bewirtschaftung künstlich hergestellter Gewässer, den Teichen oder Weihern, wurde, nachdem man aller Teichfische durch Ablassen des Wassers habhaft werden konnte, als „Zahme“ Fischerei bezeichnet und gehörte zur landwirtschaftlichen Fischzucht. Das Nachstellen der freilebenden Fische in Flüssen und Seen, auf „freier Wildbahn“ dagegen galt als „wilde Fischerei“ bzw. „Wildfischerei“ und war Waidhandwerk (SKOWRONNEK 1904:8). Das veraltete Wort „Fischwaid“, so SKOWRONNEK (:1), ,besagt mehr als der farblose Ausdruck Fischerei, denn es begreift auch die Angelei in sich“ Allein dessen zweite Silbe zeige ja deutlich genug, ,wie nahe verwandt Fischfang und Jagd sind.“(:1)

Aufgrund ihrer eindeutigen historischen Anthropogenität, die aber dennoch keine fassbare Geländesituation hinterlassen hat, soll sie vor dem Hintergrund der hier zu behandelnden Thematik eine Erwähnung finden. Sie beschreibt eine Zeit, als die noch nicht von den Anglern zunehmend ausgeübte Praxis des „catch \& release" im Vordergrund stand, denn die Fischerei war Handwerk und diente gleichermaßen dem Nahrungserwerb und dem Handel.

\section{a Fischfang}

Fließgewässer und deren Altarme boten seit Jahrtausenden einer Vielzahl von Fischarten Schutz und Nahrung. Dieser Fischreichtum wurde seit „urdenklichen Zeiten“ im Rahmen einer traditionellen Fischerei genutzt (FISCHEREI EINST UND JETZT 1983).

Als Nahrungsmittel sind Fische in allen Kulturen belegt (LAMPEN 2000:37). Die Nahrungsgewinnung durch Fangen von Fischen zählt zu den ältesten Formen der Gewässernutzungen (SOLYMOS 1983:50). Schon in der Steinzeit wurden die Schuppenträger mit Speer und Angelhaken erbeutet, um unabhängig vom vorbeiziehenden Wild über eine zusätzliche Nahrungsquelle zu verfügen. Wandzeichnungen, Felsbilder, sowie Harpunen und Reste von Netzbestandteilen aus paläolithischen Siedlungen belegen diese intensiv betriebene vorgeschichtliche Fischerei (LAMPEN 2000:37). Zahlreiche Funde aus der Mittelsteinzeit - vor 
ca. 8000 Jahren - wie Schlundzähne und Fischwirbel, „die meist an den Siedlungsplätzen nahe am Wasser gefunden wurden, lassen darauf schließen, daß der Fisch beliebte Nahrung war.“ (ERGERT 1995:11)

Die Ausgrabungen der Jungsteinzeit, ganz besonders der Pfahlbauten - die vor ca. 5000 Jahren bewohnt waren - bezeugen eine Fülle von Fischereigeräten, wie im feuchten Moorboden erhalten gebliebene Netzfragmente, Bootspaddel und Fischspieße, und lassen auf gekonnten Fischfang schließen (ERGERT 1995:11). In dieser Epoche erscheint auch zum ersten Male ein lanzettförmiges Gerät, das man vielleicht als einen Vorläufer des heutigen Angelhakens bezeichnen kann. Dieser „Knebel“, der sich nicht nur bei Naturvölkern bis in unser Jahrhundert erhalten hat, wurde aus Knochen, Stein, Holz oder auch aus einer Muschelschale gefertigt. Der Köder, ein Fisch oder eine Muschel, wurde auf den Knebel aufgesteckt. Hatte ein Fisch angebissen, stellte sich diese Fangvorrichtung durch den Anhieb des Anglers im Fischmaul quer und die Beute konnte gelandet werden (:11).

Es scheint, dass auch der Ackerbauer und Viehzüchter der bronzezeitlichen Kulturen vor ca. 3500 Jahren dem Fischfang weiterhin große Bedeutung gab. Bronzene Angelhaken, die man als Grabbeigaben in Hügelgräbern aus dieser Zeit fand, sollten den Verstorbenen auch im Jenseits das Angeln möglich machen (ERGERT 1995:11).

Und noch im 18. Jahrhundert stellte die Fischerei in einigen Regionen gar den wichtigsten Wirtschaftszweig dar. So verlegte sich beispielsweise die Einwohnerschaft der Stadt Dietesheim am Main, die keinen Bach aufwies, der eine Mühle hätte treiben können, auf die Mainfischerei. Damit betrieb Dietesheim ebenfalls, neben der allgemeinen dörflichen Feldwirtschaft, ein Spezialgewerbe, das seit dem Mittelalter zünftig organisiert war. Auch im Oderbruch und für die Dörfer im niederen Bruch war die Fischerei sogar die einzige Erwerbsquelle, die immer ausgeübt werden konnte, während die Möglichkeiten zur Viehmast - als zweite Einkommensmöglichkeit - abhängig war vom Wasserstand (HERRMANN 1997:25). „Allerdings“, schränkt HERRMANN (:27) ein, „lebten die Menschen nicht ausschließlich von der Fischerei.“ So waren die Fischer oftmals zugleich auch Handwerker, wie beispielsweise Bäcker, Schneider, Leineweber usw.

Es gilt aber noch einen weiteren Aspekt zu beachten bei der Bedeutungbemessung der frühneuzeitlichen Fischerei in fließenden Gewässern: Da die einfachen Bauernfischteiche auf ungleich niedrigerem Niveau standen als die Teiche der klösterlichen Teichwirtschaft, war verständlicherweise ein Drang der Untertanen zur Fischereinutzung der Bach- und Flussläufe festzustellen. Aus der herrschaftlichen Sicht waren dies jedoch geschützte Fischereigerechtigkeiten. So besaßen die Klöster, wie beispielsweise die Abtei Ebrach im Steigerwald, die Fischfanggerechtigkeiten in den Ebracher Gewässern, die sie als ursprünglichen Teil des dorfherrlichen Bachrechtes schrittweise an sich gezogen hatten (SCHENK 1998:246).

Technisch gesehen betrieb man bis zum frühen Mittelalter die Fischerei fast ausschließlich als „wilde Fischerei“, d. h. der Fischerei mit Angel, Hamen, Reusen, Streichgarnen oder mit der Hand. Sie gehörte zu dieser Zeit zum Jagd- und Waidhandwerk. Einige Methoden des historischen Fischfangs in natürlichen Fließgewässern sollen an dieser Stelle erwähnt werden:

Gewiss die älteste Fangmethode ist es, den Fisch mit der Hand zu ergreifen (FRIEDEL 1884:11; SOLYMOS 1983:50). Vor allem in Überschwemmmungsgebieten, wie später deutlich wird, aber auch in Uferhöhlen oder in den Gruben des Flussbettes und nicht primär inmitten des Flusslaufes, wie oft vermutet, wurde versucht, die dort befindlichen Fische zu fangen. Die damaligen Fischer waren in den entsprechenden Fangmethoden Spezialisten und außerdem ,fähig, nach dem Fisch unterzutauchen, auch in kaltem Wasser“ (SOLYMOS 1983:50). Solche archäischen Fangmethoden wurden einem Bericht zufolge auch noch im zweiten Drittel des 19. Jahrhunderts ausgeübt: „Mit der Hand werden sehr viele Forellen gefangen; der Fischer watet im Wasser, durchsucht in den Strömungen hohle Steinplatten, die Ränder großer Blöcke, hohle Ufer und Wurzelstöcke, und nimmt die Forellen mit der Hand heraus.“ (BORNE 1886b:674)

HERRMANN (1997:44) zitiert aus alten Quellen, dass die Fischbestände in der Oder in der Mitte des 18. Jahrhunderts so unvorstellbar zahlreich waren, dass man sie mit Händen greifen konnte, und stützt damit die Erzählung. „Die Gewässer wimmelten im strengsten Sinne des Wortes von Fischen“, beschreibt er (:44) die Situation. An Hechten gab es in den Jahren 1693, 1701 und 1715 bei Wriezen ,so viele, dass man sie mit Keschern fing und selbst mit Händen greifen konnte.“ Dabei galten Hechte als die „Herrenfische“ (:27), 
wobei die Wortwahl eine gewisse Besonderheit, wenn nicht Seltenheit zum Ausdruck bringt und man durchaus vermuten kann, daß andere Fischarten noch viel häufiger vorkamen. Vor der Entwässerung von Bruchlandschaften, berichtet HERRMANN (:177) aus einer Quelle vom Oderbruch, war der Fischreichtum an Plötzen, ,so häufig, daß, weil sie nicht alle versilbert werden konnten, man die Schweine damit mästete.“

Das Handgreifen der Fische geschah dabei entweder - natürlicherweise -, wenn sie im fließenden Wasser schwammen oder - vorteilhafter -, wenn sie nach Rückzug des Wassers nach einer Hochwasserperiode aus den natürlichen Retentionsräumen abgesperrt waren (FRIEDEL 1884:11).

Gleichwohl stellt diese einfachste Methode des Fischfangs zugleich die schwierigste dar. „Leichter ist es, den Fisch zu fangen, wenn man ihn irgendwie betäubt“, erkannte man recht früh. Deshalb rührte man „,im Randwasser den Schlamm auf und sammelt dann die nach Sauerstoff schnappenden Fische zusammen“ (SOLYMOS 1983:50).

Es war auch üblich, die Fische im Winter mit auf das Eis gehauenen Steinschlägen zu betäuben (FRIEDEL 1884:11; SOLYMOS 1983:50), nachdem man sie ,unter dem durchsichtigen Eis durch Feuerschein gelockt hatte" (FRIEDEL 1884:11). Anschließend zog man die unter dem Eis liegenden Fische durch ein Loch heraus.

Eine sehr anstrengende, gefährliche und zeitraubende Arbeit war die Eisfischerei mit dem Zugnetz. Das Eis konnte splittern und brechen, und auch sehr dickes Eis senkte sich unter der Last, zumal die durchgehende Eisdecke eine Unterbrechung erfuhr und mit Lastenschlitten und mehreren Fischhelfern begangen wurde. Wo das Netz ins Wasser gelassen werden sollte, wurde mit dem Eispickel, einem langen spitzen Brecheisen gleich, eine fast einen $1 / 2 \mathrm{~m}$ dicke Eistafel von $4,5 \mathrm{~m}^{2}$ ausgehackt. Nachdem die erste große „Wuhne“, wie man diese Löcher im Eis in Ostpreußen nannte, geschlagen war, wurde sie unter das Eis gedrückt, da eine solche Scholle zum Herausheben zu schwer gewesen wäre, sowohl für die Fischer als auch für die umgebende Eisdecke.

Noch an weiteren Stellen wurde ein Loch in das Eis geschlagen um zum einen den Weg des Netzes dirigieren zu können und es schließlich auch herausholen zu können. Während es sich bei den Eisöffnungen um kleinere Löcher gehandelt hat, die als „Landmarken“ funktionierten und unter denen mit Treibsttangen und Zugleine die Flügel des Netzes unter das Eis geschoben wurde, musste die „Wuhne“ zum Einholen des Netzes ein ähnlich großes Loch wie die „Einlaßöffnung“ sein (SKOWRONNEK 1904:146ff.).

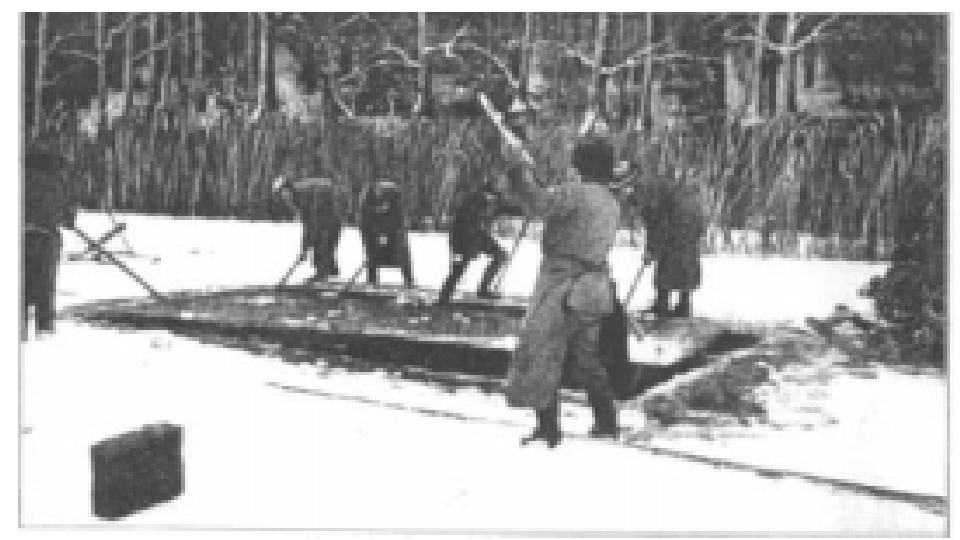

Abb. VI-6: Eine Eisscholle wird gehoben und nachfolgend abgesenkt.

Sie stellt die erste von zwei großen und vielen kleineren „Wuhnen“ dar, die zur Netzfischerei in das Eis geschlagen wurden. Die Fotografie stammt von SKOWRONNEK (1904:146) und wurde am Spirdingsee bei Rudczanny/ Glodowenin (Masuren) Ende des 19. Jahrhunderts aufgenommen.

Ebenso alt vielleicht wie das Betäuben durch Schläge war das Fangen der Fische in den Gelegen während der Laichzeit mit Stock und Schlinge, das sog. „Schleifen“ (FRIEDEL 1884:11).

Das Speeren, Spießen oder Harpunieren der großen Fische scheint, nächst dem Greifen der Fische mit den bloßen Händen, „die älteste Art des künstlichen Fischfangs gewesen zu sein.“ (FRIEDEL 1884: 11) Neben 
den Höhlenmalereien als bildliche Dokumente stammen ältere Spuren des Fischfangs in Europa aus „Kent's Hole“, einer Höhle in Devonshire im südwestlichen England. Dieselben bestehen aus Resten von zwei knochigen Fischspeeren oder Harpunen (:5f.). Mit diesem einzackigen Fischspeer oder der mehrzackigen „Fischgabel“ stachen die Fischer „,blindlings, aber es wurde auch auf gesehene Fische geworfen“ - ähnlich der Harpune (SOLYMOS 1983:51). Diese mehrzackigen, harpunenähnlichen Fischgabeln wurden aus Hirschhorn geschnitzt und mit bis zu 10 Widerhaken versehen, um so größere Fische einzeln zu erbeuten (FRIEDEL 1884:30).

Des Weiteren bestand die Methode des händischen Fischfangs darin, entweder mit Angeln, Netzen oder Fischfallen, sog. Reusen, Fische zu fangen (TAURKE 1927:188):

Die Fischerei mit der Angel wurde schon in der Bronzezeit praktiziert, denn aus dieser Periode sind aus Holz, Stein, Knochen und eben aus Bronze gefertigte Angeln bekannt (SOLYMOS 1983:51). „Schon a priori“, mutmaßte FRIEDEL 1884 (:13f.), musste „eine so technisch bewanderte Völkerschaft [...] außer dem Fischfang mit dem Speer, auch den Fischfang mit der Angel, obwohl derselbe mehr Ueberlegung, List und Gewandtheit vorauszusetzen scheint, gekannt haben." Dem war auch so, wie man aus späteren Funden rekonstruiert hat: Man hat Angeln, zwar nicht die spätere Krumm-Angel oder den Angel-Haken, wohl aber die Spitz-Angel, die einfachste spindelförmige und gerade verlaufende Angel, die auf beiden Enden zugespitzt und in den Leib des Köders hineingesteckt wird, in den Höhlen gefunden, ebenso durchbohrte Steinchen, welche als Angel-Senker gedient haben können.

Die als höchste Ausbildungsstufe des Fischfangs bezeichnete Netzfischerei wird bereits zu Ende des Quartärs, im Jungpaläolithikum bekannt gewesen sein, denn man hatte bereits im zweiten Drittel des 19. Jahrhunderts Knochen-Nadeln zusammen mit Fischresten entdeckt (FRIEDEL 1884:14f.), die den späteren Netzstricknadeln ähnelten und die sich in diese Zeit zurückdatieren lassen.

Von den Netzen selbst ist aus dieser geologischen Epoche hingegen nichts bekannt geworden. Dies liegt wohl an der Vergänglichkeit des früher verwendeten Materials, bei welchem man an Baumbast (Linde, Weide), Binsen, Rohr und dergleichen zu denken hat. Vermutlich aus dem gleichen Grund haben sich Reusen oder ähnliche Fanggeräte bis jetzt nicht nachweisen lassen.

Aus der Zeit der Steinzeit-Pfahlbauten wurden jedoch bereits auch im zweiten Drittel des 19. Jahrhunderts in Niederweil und Robenhausen (Kanton Zürich) Netze aufgefunden, die sich von den zu diesem Zeitpunkt gebräuchlichen Netzen kaum unterscheiden ließen. Diese Netze wurden unten durch Netzsenker, das sind mit Erdpech umwickelte Steine, in die Tiefe gezogen und oben durch Schwimmer aus Rinde vor dem gänzlichen Sinken bewahrt (FRIEDEL 1884:30).

Die Fischerei mit Netzen in eisfreien Gewässern wurde dabei auf vielfältige Weise betrieben:

$\mathrm{Zu}$ den frühen Formen zählte die Fischerei mit dem Hamen. Eine Form des Hamenfischens wurde mit dem sog. Stielhamen durchgeführt. Dieser wurde viel ,zum Fangen von Forellen und Aeschen in kleinen Bächen benutzt.“ (BORNE 1886b:600) Der Stielhamen (Abb. VI-7) ist ein sackförmiges Netz, dessen Öffnung an einem Bügel von Holz oder einem eisernen Ring befestigt ist und durch eine Stange getragen wird, mit der der Fischer das Netz handhabt. Die Öffnung des Hamens ist in der Regel $2-2,5 \mathrm{~m}$ weit, die Tiefe des Sackes beträgt ungefähr 1,25-1,5 m. Die Maschen stehen sehr eng, oft nur 8-10 mm weit (:599).

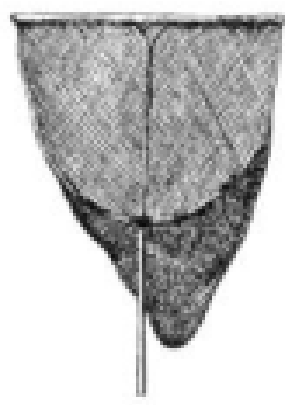

Abb. VI-7: Stielhamen

(aus: BORNE 1886b:600) 
Eine Technik, den Hamen zum Fischfang zu gebrauchen, bestand darin, das Netz an hohle Ufer, Weidengebüsche, Wurzelstöcke und dergleichen vorzustellen und so die Fische aus ihren Verstecken in den Hamen zu jagen (BORNE 1886b:600). Dies sah dann so aus: „In den Forellenbächen [...] gehen zwei Fischer in dem Bache watend langsam stromauf, und jagen die Forellen in ihre Verstecke. Dort stellen sie Hamen vor und [...] ein Mann [...] sucht [...] die Forelle [...] in ein Netz zu jagen. Zum Durchstöbern der Schlupfwinkel benutzt er eine geschmeidige Ruthe.“ (:600f.) Bei einer weiteren Variante stellen zwei Mann „den Bach ober- und unterhalb der zu befischenden Stelle mit Hamen zu; ein Dritter treibt die Forellen hin und her, bis sie in eines der Netze gerathen." (:601) Oft vereinigten sich eine größere Zahl von Fischern zu gemeinsamem Fange und trieben einander die Fische zu (:599).

Neben der Hamenfischerei mit mehreren Personen gab es auch eine Fischereiweise mit dem Stielhamen, bei dem ein einzelner Fischer auf Fang geht. Sie wird von BORNE (1886b:599) so beschrieben: „Der Fischer geht bis an den Gürtel ins Wasser, legt das Querholz des Hamen auf den Grund und schiebt das Netz vor sich her. Sobald er einen größeren Fisch fühlt, hebt er das Netz sofort aus dem Wasser [...]. Man fischt in dieser Weise sowohl bei Tage wie bei Nachte." Die andere Form des individuellen Hamenfischens ist neben dem Schieben das „Stülpen“: „Das Stülpen hat Aehnlichkeit mit der Wurfnetzfischerei. Der Stielhamen wird vom Ufer mit der Mündung voran auf das Wasser geworfen, schnell auf den Grund gesenkt, und dann so ans Ufer gezogen, daß er stets den Grund berührt. Dann wird der Inhalt ans Ufer geworfen.“(:599)

Als ein weiteres „ebenso beliebtes wie empfehlenswerthes Fanggeräth für die Fischerei in langsam fließenden Bächen und Gräben“ (BORNE 1886b:601) galt der sog. „Stechhamen mit dem Töcker“: „In einer Entfernung von ca. $15 \mathrm{~m}$ werden zwei Töcker mittelst einer an der Oese befestigten Stange quer über den Bach geschoben. Das dazwischen befindliche Wasser wird mit dem Stechhamen ausgefischt." (:601) In den Maschen der Töcker, die gewöhnlich $6 \mathrm{~m}$ Staulänge, $2 \mathrm{~m}$ Stauhöhe und $28 \mathrm{~mm}$ Maschenweite besaßen, verfingen sich anscheinend auf diese Weise viele Fische (:602).

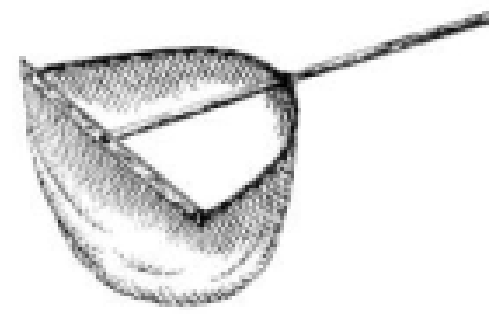

Abb. VI-8: Stechhamen

(aus: BORNE 1886b:601)

Die Bachfischerei wurde des Weiteren betrieben mit verwandten Hamengeräten wie dem Scheerenhamen, dem Zweistangenhamen oder dem Wickelhamen. Gemeinsam ist ihnen - in Anpassung an die jeweilige Fließgewässersituation - die allgemeine Fischereiweise, die Ausdruck einer Gewässernutzung ist und die vor allem die Bachbetten betrifft: „In ruhigem Wasser schiebt der Fischer den Hamen vor sich her, in schnell fließendem Wasser steht er still und kehrt den Hamen gegen die Strömung.“ (BORNE 1886b:602) Er watet also durch das Wasser, die Hame in der Hand oder, bei einer langstieligeren und schwergewichtigeren Hame unter dem Arm und fängt auf diese Weise die Fische des fließenden Wassers - zumeist Forellen.“ (:604)

Eine andere Variante der Fischerei wurde mit dem Senknetz bzw. Senkhamen betrieben.

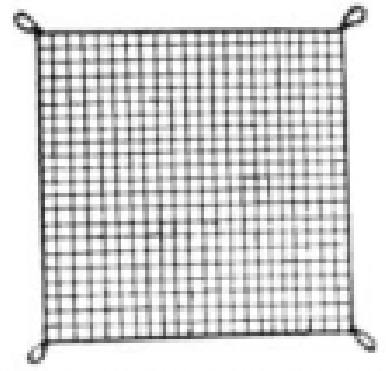

Abb. VI-9: Itzehoer Senknetz (aus: BORNE 1886b:604) 
Bei dieser Fischereimethode wurde bereits mit Ködern gearbeitet: „In stillem Wasser werden die Fische angeködert durch öfteres Auswerfen von Fleisch, Brotkrume, geronnenem Blut [...]; oder durch Schnüre, auf welche Regenwürmer gezogen sind, und die man auf dem Senknetze befestigt.“ (605ff.)

Kleinere und leichte Senknetze wurden mit der Hand eingelegt, auf den Grund versenkt und nach einiger Zeit schnell wieder gehoben (:607). Die kleineren Senknetze für die Fischerei in kleinen Gewässern hatten ein Netztuch von 1,50-3 $\mathrm{m}^{2}$ Größe oder einen eisernen Ring von $1 \mathrm{~m}$ Durchmesser, der mit einem Netz bespannt war. Sie waren an jeder Ecke an Schnüren aufgehängt, die sich zu einer noch stärkeren Schnur vereinigten. Die Stange war zwischen 3 und $4 \mathrm{~m}$ lang und aus leichtem, haltbarem Holz. Man fischte damit im Wasser von mindestens $2 \mathrm{~m}$ Tiefe, in mäßiger Strömung, „und in leichten Strudeln, ferner in Seen und Teichen.“ (:606) Mit dieser Art von Senknetzen wurde „besonders an den Mündungen größerer Bäche, an Buhnenspitzen und auf überschwemmten Wiesen" gefischt (:607).

Neben Hamen und Senknetz wurde in der Fischerei auch mit dem Wurfnetz gearbeitet, auch „Stülpfischerei“ genannt (SOLYMOS 1983:51ff.). Das Wurfnetz wird als „ein höchst wirksamer Fangapparat“ beschrieben, mit dem man ,sowohl im flachen, wie im Wasser bis $5 \mathrm{~m}$ Tiefe fischen [und] damit Barben, Karpfen, Hechte, allerlei Arten Weißfische, Forellen, Maifische u. a. m." fangen konnte (BORNE 1886b:612). Die Stelle, wo geworfen wurde, sollte ,gewöhnlich eine Bachmündung, der Endpunkt einer Furth, ein ruhiger Dümpel oder ein tiefes Kolk“ sein (:613).

Das Wurfnetz selbst ist ,ein kegelförmiges Netz, dessen Peripherie mit einer 8 bis 40 Pfd. tragenden Bleileine“ eingefasst ist, und ,an dessen Spitze sich eine $3^{1 / 2}-8 \mathrm{~m}$ lange Wurfleine befindet.“ (BORNE 1886b:608). Wenn es geworfen wird, so breitete sich die Bleileine aus, und Leine wie Netz nahmen die Form eines Kreises an. Wurde das Netz anschließend an der Wurfleine emporgehoben, so fielen die Bleikugeln zusammen und das Netz zog sich zusammen. Kleine Wurfnetze wurden zum Fang von Köderfischen benutzt (:609), größere Wurfnetze zum Fang von Speisefischen (:610).

Der Erfolg der Fischerei hing in diesem Fall bezeichnenderweise vom Wurf ab. Davon, dass man es verstand, „das Netz vollständig ausgebreitet in kreisrunder Form auf das Wasser zu werfen. Dort sich selbst überlassen, sinkt es wegen der großen Beschwerung schnell zu Boden und bedeckt die Fische, welche sich darunter befinden." (BORNE 1886b:611) Durch das Ende der Wurfleine, das vorher am Handgelenk befestigt worden war, zog man das am Boden liegende Netz schließlich wieder heraus.

Als die dritte, ebenfalls sehr alte Form der Fischerei in Fließgewässern kann der Fischfang mit Reusen genannt werden. Wie bei den Hamen, gilt auch hier der Grundsatz: so unterschiedlich die Gewässerbedingungen, so verschieden die Reusenarten.

Eine einfache Form einer Reuse der Fließgewässer stellte der sog. Garnschlauch dar. Der Garnschlauch war „ein langes, schlauchartiges Netz, mit welchem in stark strömendem Wasser“ gefischt wurde (BORNE 1886b:643). Die Mündung einer Schlauchreuse war weit, damit sie eine große Menge Wasser aufnahm und so die Strömung das Netz gespannt hielt. Die von der Gewalt der Strömung in den Schlauch getriebenen Fische konnten aus einer Schlauchreuse nicht zurückschwimmen, auch deshalb nicht, weil der lange Schlauchdie Fische am Zurückschwimmen zu hindern vermochte. Bisweilen war auch am Ende des Garnschlauches eine Kehle angebracht, die die Fische zurückhielt. Die Garnschläuche waren 13 - 18 m lang und das Ende des Schlauches war entweder mit einer Leine zugebunden oder es befand sich dort „ein aus Weiden geflochtener Korb, der mit einer Thür zum Ausschütten der Fische“ versehen war (:643, verweist damit auf Pkt. 13f).

Die Garnschläuche wurden offensichtlich auch an Mühlwehren eingesetzt, und zwar in der Form, dass der Schlauch - an einem viereckigen Holzrahmen befestigt und dadurch offengehalten - stromab in das stark strömende Wasser des Mühlgerinnes, in die untere Falz der Fluttore, eingesetzt wurde, so dass sich das Netz im Unterwasser befand (BORNE 1886b:644). Am Ende des Netzes wartete „ein hölzerner Korb mit Kehle“ auf die Beute (:644). 
Wenn kein Mühlenwehrtor zur Verfügung stand, das den Fischen die Umkehr unmöglich machte, beispielsweise auf einer freien Bachstrecke, wurde auf der Gegenseite eine sog. Elften- bzw. Maifischwand aufgestellt. Es handelte sich dabei um eine Netzwand, die ,an eingeschlagenen Pfählen tief unter Wasser, quer gegen die Stromrichtung“, aufgestellt wurde (BORNE 1886b:645). Wenn ein stromauf schwimmender Fisch die Netzwand traf, „,so kehrte er erschrocken um, und geriet in den Garnschlauch.” (:645) Diese Art der Fischerei mit Stellnetzen bzw. Fangzäunen wurde Sperrfischerei genannt und spielte auch bei der anfänglichen Teichwirtschaft eine große Rolle (siehe Pkt. VII 2.b.1).

Eine andere Form der Reuse, die „in Süddeutschland viel in schnellfließenden Bächen“ benutzt wurde (BORNE 1886b:645), ist der sog. Treibhamen. Er hatte ebenfalls - „der Größe des zu befischenden Wassers entsprechend“(:645) - verschiedene Dimensionen.

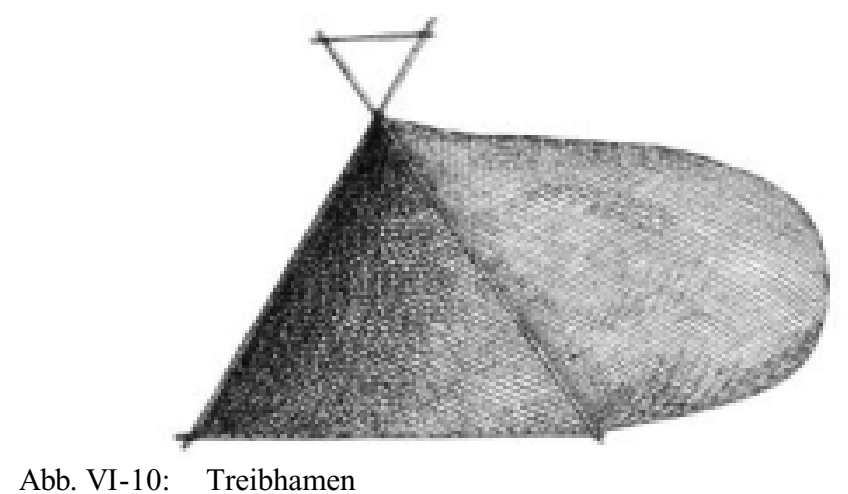

(aus: BORNE 1886b:644, Fig. 499)

Ebenfalls in schnellfließenden Bächen wurde häufig die sog. Forellenreuse eingesetzt. Sie ist $0,70 \mathrm{~m}$ lang, $0,20 \mathrm{~m}$ hoch und wurde - der Bezeichnung entsprechend - zum Forellen-, aber auch zum Aeschen- und Krebsfang benutzt (BORNE 1886b:649).

Hinsichtlich der verwendeten Holzart bei der Reusenherstellung wurde auch indirekt wieder das Gewässer in Anspruch genommen. Vor allem die Weide, die in Ufernähe stand und als Gehölzanpflanzung gezüchtet wurde, benutzte man dafür. So wurden beispielsweise die „Flügel“, d. h. die Seitennetze und die „Bügel“, die die Eingangsöffnung und die Durchgänge $\mathrm{zu}$ den Flügeln eines Netzes offen halten, bevorzugt aus geflochtenen Weidenruten hergestellt und die Netzwand (Elftenwand) aus Weidentauen (BORNE 1886b:644f.), aber auch die wärmeliebende Hasel wurde bisweilen als Spannholz von Reusen gebraucht und „die Forellenreuse [...] zwischen Haselruthen aufgespannt“ (:649).

Doch warum das alles, wird sich der geneigte Leser fragen, diese detaillierte Schilderung der früheren fischereiwirtschaftlichen Fangmethoden und -geräte?

Bei der Beschreibung der Fischereigeräte und Fangtechniken wird erstens „,deutlich, wie vielfältig diese im Mittelalter waren. Jede Nische wurde ausgenutzt: Für praktisch jeden Gewässertyp und jede Fischsorte entwickelten die Menschen das angepasste Gerät und die entsprechende Handhabung." (AMACHER 1996:86) Die Fischereigeräte und Fischfangmethoden fügten sich „zu der Natur der Fische und des Fischwassers und zum Charakter des Flußbettes." (SOLYMOS 1983:50) So gab es selbst so ungewöhnliche Methoden wie den berittenen Fischfang, wie Abb. VI-11 zeigt: 


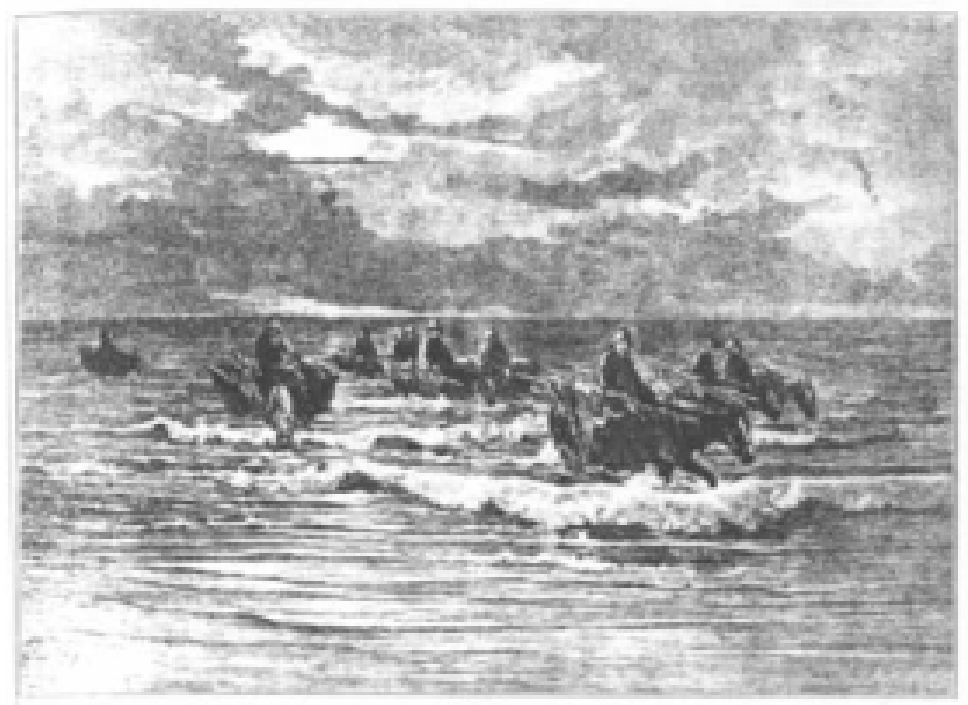

Abb. VI-11: Berittene Fischer in Cornde/Flandern

Nach einem Gemälde von Felix Coyen (aus: SKOWRONNEK 1904:9)

Zweitens wird deutlich, in welcher Form eine „historische Bachwirtschaft“ - auch wenn es sich um eine der Gewässernatur angepasste gehandelt hat - den Gewässerlauf genutzt und verändert hat: Der Fischer ist darin gewatet, hat die stockbewehrten Netze über den Grund geschoben, Reusen in den Boden gesteckt und darin auch Netze bespannt. Die Wiederholung auch dieser leichten Eingriffe muss zu Veränderungen geführt haben: hinsichtlich zum Beispiel der Störung der Bachsedimente, ihrer darin vor allem lebenden Invertebraten sowie der Bachgrundvegetation.

Zum Dritten soll verdeutlicht werden, dass der wilden Fischerei in kleinen Fließgewäsern - neben den in Teichen gezüchteten Karpfen - die größte Bedeutung bei der Versorgung adeliger und kirchlicher Grundherren mit Fisch zukam und Ausdruck ehemaligen Fischreichtums ist. Im Bereich der Vogtei Elbingerode im Harz etwa fing der bedienstete Fischer ca. 2000 - 3000 Forellen jährlich. Sie wurden fast ausschließlich an den Grafen von Wernigerode geliefert (WÜSTEMANN 1982:23). Zur Landgrafenzeit in Kassel dienten im Reinhards- und Habichtswald nicht weniger als siebzehn Forellengewässer der Verstärkung der Forellenerzeugung aus Forellenteichen

Eine besondere Bedeutung für die Ernährung von Klöstern besaßen Fische, da sie als Fastenspeise genutzt wurden. Doch neben der Teichwirtschaft, die allgemein den Klöstern als Erfindung zugerechnet wird (siehe zur kontroversen Diskussion dazu VIII 1a), besaßen sie auch das Recht zur Flussfischerei. So stand dem Stift Marienwerder in Garbsen bei Hannover das Recht zu, neben den stillen Gewässern auch in dem Bach, der sich aus dem Stöckener Moor in die Leine ergoss, zu fischen.

Die Zeiten der Fischerei sind jedoch vorbei: Auf den kleineren Fließgewässern sind die Berufsfischer schon lange ganz verschwunden. Aber auch die Flussfischerei, stellte PLANANSKY schon vor 20 Jahren fest (1983:77), „welche infolge der Gewässerverunreinigung merklich zurückgegangen ist“, wird nur noch selten hauptberuflich ausgeübt. Dabei war noch zu Beginn des 20. Jahrhunderts „,die Flußfischerei die tragende Säule der Binnenfischerei.“ (ZOBEL 1992:23) Heute ist die jahrhundertealte Berufsfischertradition oft bedeutungslos und viele Fischer, sogar die auf den großen Strömen, wie beispielsweise die Elbe- und Rheinfischer, haben ihre Existenz verloren (:23). Auf der Mittelweser, zwischen Stahle und Bodenwerder beispielsweise, gibt es nur noch einen Berufsfischer. Ihnen wurde im Laufe der Zeit schlicht die Einkommensgrundlage entzogen: Der Stör beispielsweise, der als Wanderfisch nur zu bestimmten Zeiten flussaufwärts zu seinen Laichgründen zog, ist bereits seit dem Mittelalter in Europa ausgestorben (LAMPEN 2000:33) und der ehemalige Wildkarpfen wird nur noch als Zuchtkarpfen in der Teichwirtschaft gehalten.

Damit ist der vierte Aspekt deutlich geworden: der kulturhistorische Bedeutungsverlust. 


\section{b Krebsjagd}

Die Gewässer wurden nicht nur zum Fangen von Fischen genutzt, die in erster Linie der Ernährung des Menschen mit Wassertieren dienten, sondern - allgemein weniger bekannt - auch Flusskrebse wurden aus ihnen geholt, die sogar in zweiter Linie die Ernährungsgrundlage der Fischerei bildeten (THIENEMANN 1955:91) und zu deren Hauptabnehmern Adelshäuser und Klöster zählten (BOHL et al. 2001:2). Dabei sprach man - aus den Gründen der Bewaffnung von Krebsen mit Scheren - nicht vom Krebsfang, sondern von der „Krebsjagd“ (HERRMANN 1997b).

Flusskrebse zählen zu den ältesten Lebewesen der Erde. Es gab sie schon vor 250 Mio. Jahren und „seit Menschengedenken gilt das schmackhafte Krebsfleisch als Delikatesse.“(BOHL et al. 2001:2)

Abb. VI-12: Der Flusskrebs

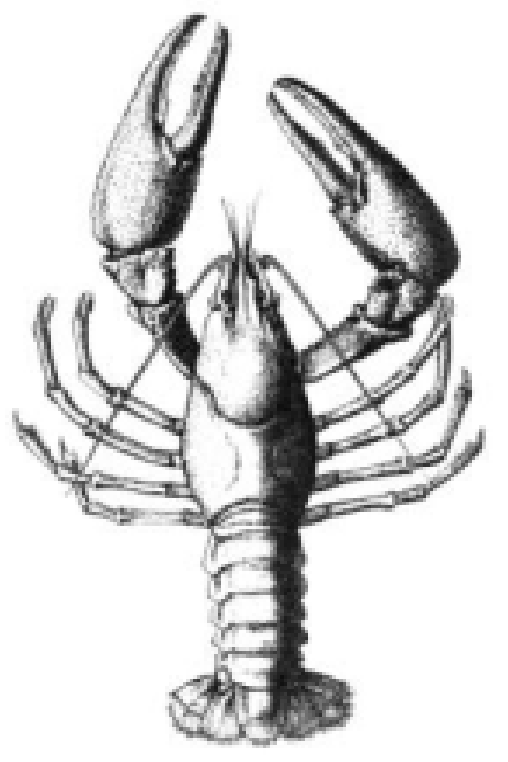

(aus: BENECKE 1885:104, Fig. 64)

Dass die früher klaren Flüsse nicht nur reich an Fischen, sondern auch an Krebsen waren, davon künden einige historische Berichte und alte Überlieferungen. Alten Aufzeichnungen zufolge waren Krebsgerichte schon im Mittelalter ein fester Bestandteil der Küche in Adelshäusern und Klöstern (BOHL et al. 2001:32). Noch heute schwärmt Peter Wißmuth ${ }^{28}$, Fischereifachberater des Bezirks Oberbayern: „Edelkrebssuppe - in gut zweistündiger Prozedur sorgfältig zubereitet - gilt unter Kennern als unvergessliches Gaumenerlebnis“. Des Weiteren wurde in den Klösterspitälern Krebspulver gegen Depressionen eingenommen (HERBST 1992:158). „Panzerritter“, wie die Krebse auch genannt wurden, waren früher also ein begehrtes Psychopharmakon wie auch Bestandteil heimischer Esskultur. Besonders anschaulich zeigt das bekannte Jagd- und Fischereibuch Kaiser Maximilians I. von 1504 den nächtlichen Krebsfang in der Drau.

${ }^{28}$ Wißmuth, Peter. - In: SZ Nr. 217 v. 20./21. Sept. 2003. 


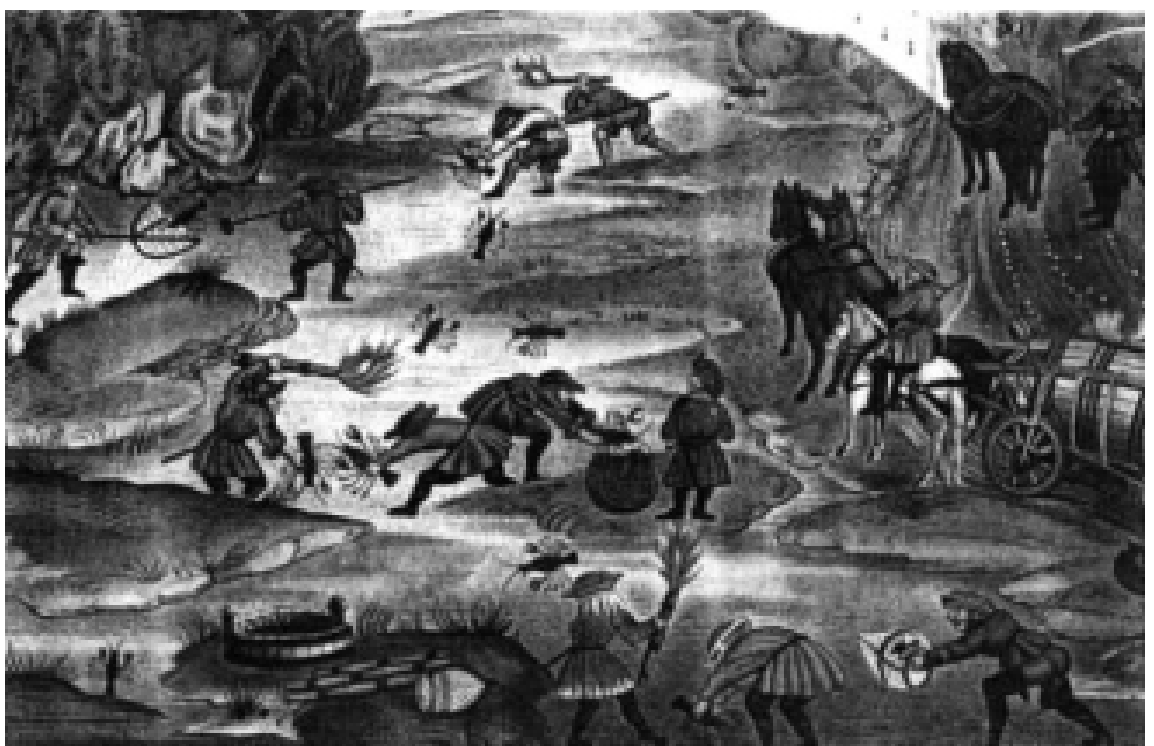

Abb. VI-13: Nächtlicher Fang in Krebsgewässern, hier der Drau

(Fischereibuch Kaiser Maximilian I, aus: BOHL et al. 2001:29)

BÄRWINKEL (1927; zitiert aus SCHUBERT 2001:73) schreibt, dass der Saalfelder Senat 1552 neben diversen Flussfischen dem Kurfürsten Friedrich dem Großmutigen 10 Schock Krebse schenkte.

Flusskrebse galten als so häufig vorkommendes Nahrungsmittel, dass sie Mitte des 18. Jahrhunderts aus Fließgewässern wie beispielsweise der Oder gleich kilogrammweise herausgefischt wurden. Für die Flüsse der Mark-Brandenburg zum Beispiel ist ABEL mit den Worten zu zitieren, dass „,von dem herrlichen Uberfluß ihrer Fische und Krebse" auch viele andere Provinzen haben versorgt werden können (ABEL 1711, Kap. IV, § 4, aus: KAUP 1996:114). Die Oderbruchgegend lieferte Krebse zum Ausgang des 16. Jahrhunderts in großer Fülle und in solchem Überfluss, dass man zu dieser Zeit sechs Schock ${ }^{29}$ schöne, große Krebse für sechs Pfennige meißnerischer Währung kaufte und dass in Küstrin von hundert Schock durchgehender Krebse ein Schock als Zoll abgegeben werden musste und auch konnte (HERRMANN 1997:44). So erwähnte COLERUS in seiner ,Oeconomica ruralis', dass dieser Zoll in einem Jahre 325.000 Schock Krebse eingetragen habe. Danach, so rechnete HERRMANN (:44) vor, ,wären denn bloß in dieser einen Stadt in einem Jahre 331/2 Millionen Schock Krebse versteuert worden." Diese Zahl, so auch HERRMANN (:44) ,sprengt [...] unseren Vorstellungswillen.“ Es gab 1717 - 1719 so viele Krebse im Oderbruch, dass man sie „am Oderufer mit den Händen auflesen konnte“ und sie als Schweinefutter verwandt wurden (:44). Auch in den Bächen und Flüssen des Harzes waren die Edelkrebse (Astacus astacus) mehr als ein beliebter Beifang, wie WÜSTEMANN (1982:23) zu berichten weiß. Sogar noch im Jahr 1826 wurden in den „Krebsbächsken“ entlang der Düssel und in mehreren Teichen entlang der Düssel oberhalb des Neandertals Krebse gefangen und als „Eidamshauser Krebse“ im alten Rast- und Gasthaus Eidamshaus an der kölnischen Straße bei Mettmann verköstigt (HÜTTEN 1988:39). Krebse wie auch das Gasthaus Eidamshaus gibt es im Übrigen nicht mehr, die beliebte Einkehr musste einem Kalksteinbruch weichen.

Zum Krebsfang wurden kleinere Senknetze, auch Krebshauben, Krebsteller, Krebsringe genannt, benutzt (siehe Abb. VI-14). Hierbei ist ein eiserner Ring von 0,25 bis 0,30 m Durchmesser mit einem Netz bespannt und in ähnlicher Weise an Schnüren aufgehängt wie die anderen beschriebenen Senknetze: Die Mittelschnur war „mit einem Floße versehen oder am Ende einer 2 m langen Stange befestigt, um vom Lande aus den Teller ins Wasser legen zu können. Als Köder werden abgehäutete Frösche oder Weißfische angebracht.“ (BORNE 1886b:607f.) In den warmen Sommermonaten wurden abends am Ufer des Flusses oder Sees in Entfernungen von „20 Schritten und mehr“ eine große Zahl solcher Teller (oft bis 30 Stück) ins Fließwässer gelegt (:608).

\footnotetext{
${ }^{29} 1$ Schock $=60$ Stück
} 


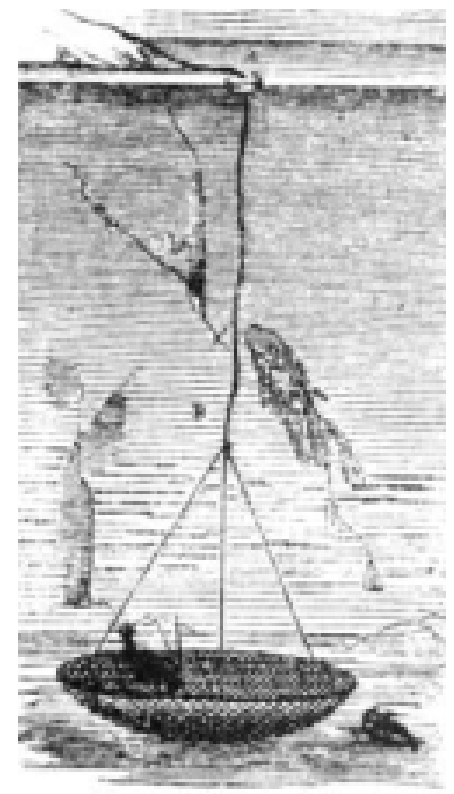

Abb. VI-14: Krebsteller und Krebshaube (aus: BORNE 1886b:608)

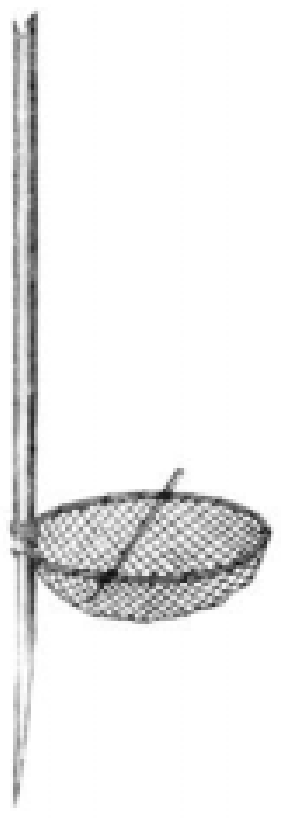

Neben diesen Senknetzen wurde „hauptsächlich und in der wirksamsten Weise“ die Reuse zum Krebsfang eingesetzt. Ein Fischer pflegte dabei mit ca. 60 Krebsreusen zu fischen (BORNE 1886b: 649). Bei der Krebsreuse wurde „quer durch die Reuse [...] ein Stock gesteckt“. An diesem wurde auch hier „,als Köder ein Fisch oder ein abgehäuteter Frosch befestigt“ (:649). Die Reuse wurde mit Steinen beschwert versenkt ,und die Stelle durch ein Floß kenntlich gemacht.“ (:649) Gewöhnlich waren die Krebsreusen 0,45 m lang und $0,30 \mathrm{~m}$ hoch (:649).

Der Edelkrebs (Astacus astacus), oft auch nur „Flusskrebs“ genannt, war in Mitteleuropa die dominierende Krebsart (BOHL et al. 2001:7). Er ist nachtaktiv und versteckt sich tagsüber in selbstgegrabenen Höhlen, hohlen Ufern sowie auch nur unter Wurzeln, Steinen sowie am Grund zwischen Wasserpflanzen, unter Stämmen, versunkenen Holzstücken und allem, was sich noch als Deckung anbietet (BENECKE 1885:103). „Möglicherweise aus diesen Habitatansprüchen“, so die Krebsexpertin BOHL (BOHL et al. 2001:27) zu der diesbezüglichen historischen Gewässerveränderung, ,hat man in den Fließgewässern den Krebsen durch Anlegen von solchen Wohnquartieren" etwas nachgeholfen.

Für den Aufenthalt und die Zucht von Krebsen in Bächen und Flüssen der verschiedensten Größe, war „eine langsam oder mäßig schnell fließende Strömung“ notwendig und Wasser, das „nicht übermäßig hart und nicht nicht übermäßig kalt ist.“ (DRÖSCHER 1906:105) Zum einen beeinträchtige „starke Strömung und steiniger, felsiger, besonders granitener Grund“ ihn in seinem Wachstum und „morastiger Boden in seinem Wohlgeschmack.“ (:105) Zum anderen böten „Wasserläufe, die jährlich regelmäßig Hochwasser haben und viel trübe Stoffe führen, [...] keine allzu günstigen Aussichten zur dauernden Neubesiedlung mit Krebsen“, denn das Hochwasser führe „die Krebse nur allzu leicht abwärts.“ (:105)

Deshalb wurde es als besonders günstig angesehen, ,wenn der Lauf durch Wiese und Waldungen geht, und wenn die Ufer mit schilfartigen Uferpflanzen bewachsen sind." (DRÖSCHER 1906:105) Hinsichtlich der Ufer- und Bodenbeschaffenheit sagt dem Krebs ferner ein „mergeliger, lehmiger, toniger oder kalkhaltiger, auch torfiger Boden in der Uferregion“ zu (:105). In derartigen Ufern sei „das Anlegen seiner Höhlen am leichtesten“ (:105). Diese Bedingungen wurden, waren sie natürlicherweise nicht gegeben, künstlich geschaffen.

Von DRÖSCHER wird immer betont, dass ,der Krebs zu seinem Gedeihen reichlicher Schlupfwinkel bedarf, in denen er vor seinen eigenen Artgenossen sowie vor seinen sonstigen Feinden und ebenso auch vor dem Sonnenlichte Schutz finden kann." Fehle es an geeigeneten, natürlicherweise vorkommenden Schlupfwinkeln, so sollen ihnen ,solche künstlich geboten“ werden. Ihre massenhafte Vermehrung, dies 
wird in Aussicht gestellt, wird „sicher eintreten.“(:105) Als dafür geeignete Plätze (besonders auch für junge Krebse) galten „Ufer, welche von Natur hohl oder leicht zu unterhöhlen sind und durch ausgespültes Wurzelwerk, namentlich von Weiden und Erlen, durch Schilf und andere Wasserpflanzen" (:105f.) ideale Rückzugs- und Vermehrungsräume boten.

Über viele Jahrtausende bevölkerten also Edelkrebs und Steinkrebs ${ }^{30}$ als heimische Krebsarten unsere Bäche, Flüsse und Seen in heute unvorstellbaren Mengen. Solche mit besonders zahlreichen Vorkommen oder weil sie entsprechend präpariert worden sind, wurden auch „Krebsbäche“ (BENECKE 1885:112) genannt. Die Gründe für die plötzlich auftretende Bestandsdezimierung nach Beginn der zweiten Hälfte des 19. Jahrhunderts lagen aber nicht in der Verschmutzung der Bäche und Flüsse, wie sie im Abschnitt ,Wasserentsorgung' (Pkt. 2) geschildert worden sind. Erst als um 1860 - vermutlich über den Import amerikanischer Flusskrebsarten in die Gewässersysteme - eine tödliche Infektionskrankheit, die sog. Krebspest, eingeschleppt wurde, „starben in einem dramatischen Seuchenzug die einst blühenden Krebsbestände Europas bis auf wenige Restvorkommen“(STEIN/GÖTTLE 2001:1).

Mit der Einschleppung der Krebspest aus Amerika im 19. Jahrhundert verfiel schlagartig, wie BOHL et al. (2001:16) es ausdrücken, ,,der schier unerschöpfliche Reichtum der bayerischen Gewässer an Krebsen.“ Die europäischen Krebse wurden durch immer wiederkehrende Seuchenzüge fast flächendeckend ausgerottet. Denn die Krebspest ist eine seuchenartig verlaufende Infektionskrankheit mit besonderer Virulenz. Auslöser ist der Schlauchpilz Aphanomyces astaci, wie man heute weiß, der bei Kontakt mit einem europäischen Krebs gleich welcher Art unweigerlich dessen Tod herbeiführt (:17). Die Krankheit erfasst in aller Regel den gesamten Krebsbestand eines Gewässers, der dann meist innerhalb von 3 Monaten vernichtet wird (:17).

Selbstverständlich verhinderte auch die Beeinträchtigung der Gewässer durch die bereits einsetzende Industrialisierung und die Intensivierung der Landwirtschaft eine natürliche Erholung der Restbestände zu damaliger Zeit, denn „,vor allem aber verlangt der Krebs möglichst reines Wasser.“ (DRÖSCHER 1906:105)

Wiederholte Versuche zur Wiederansiedlung von Edelkrebsen schlugen in den vergangenen Jahren stets fehl. Erst in jüngster Zeit wurde eine Aktion des Bezirks Oberbayern und der Fischereigenossenschaft Walchensee zur Wiederansiedlung des Edelkrebses in bayerische Gebirgsseen gestartet. Aus dem Eibsee unterhalb der Zugspitze wurden 1900 Edelkrebse gefangen und in den Walchensee (Kreis Bad TölzWolfratshausen) wieder eingesetzt, denn einzig im Eibsee, der in einem Gebirgskessel endemisch eingeschlossen ist, überlebten die Krustentiere unbeschadet.

\section{c Sammeln von Muscheln}

Neben dem Fang von Flusskrebsen wurden auch Flussmuscheln gesammelt (HERRMANN 1997:179). Die Muschelschalen dienten der Schmuckherstellung (STEIN 2000:128), ihr Fleisch bzw. die Innereien wurden sowohl von Mensch als auch Tier verzehrt (STEIN 2000:129; FRIEDEL 1884:37).

Dabei gilt es grundsätzlich zwischen zwei Arten von Flussmuscheln (Unionidae) zu unterscheiden: Die „Malermuschel“ (Unio pictorum) bewohnt Flüsse, Bäche und Seen, während die „Dicke Fluss-“ bzw. „Bachmuschel“ (Unio crassus) nur in fließenden Gewässern anzutreffen ist (STEIN 2000:127). Als dritte Süßwassermuschel werden für die deutschen Standgewässer die „Teich-“ oder „Schwanenmuschel“ (Anodonta cygnea) mit - aus den bekannten umweltökologischen Gründen - jeweils geringen Stückzahlen genannt (SCHLAUCH 1999:15f.). Sie gehören den langsamwüchsigen Tierarten an und erreichen ein Alter zwischen 60 bis 110 Jahren (SCHUBERT 2001:110).

\footnotetext{
30 Der Steinkrebs (Austropotamobius torrentium) ist eine stammesgeschichtlich sehr alte Krebsart, die sich schon früh die Binnengewässer des südlichen Mitteleuropas erschlossen hat (BOHL et al. 2001:7). Seine typischen Habitate sind „,sommerkalte Oberlaufbäche und -gräben und kalte Alpenseen.“(:10) Heute finden wir Steinkrebsbestände hauptsächlich in naturnahen Wald- und Wiesenbächen extensiv bewirtschafteter Regionen. In Südbayern und im Bayerischen Wald kommt er gebietsweise noch häufig vor, gelegentlich auch vergesellschaftet mit dem Edelkrebs. Sein Lebensraum beschränkt sich überwiegend auf wenige stabile Kleingewässer. Seine Verbreitung ist deshalb weitgehend natürlich geblieben (:10).
} 
Bereits die Bewohner früher Pfahlbausiedlungen, so zum Beispiel die Terramarebewohner Italiens, widmeten sich dieser besonderen Art von Fischerei: dem Fang von Süßwassermuscheln. Bei frühen archäologischen Untersuchungen sollen „ungeheure Massen der Teich- und Malermuscheln (Anodonta anatina und piscinalis, Unio pictorum, tumidus, crassus und batavus)" gefunden worden sein (FRIEDEL 1884:36).

STEIN (2000) konnte in ihren Untersuchungen am römischen Kastell ,Haus Bürgel' in Urdenbach/ Benrath, an einem früheren Rheinverlauf gelegen, eine solche Anzahl nicht bestätigen. Das von ihr gefundene „Muschelfragment kann entweder von einem verzehrten Exemplar stammen [...] oder ihre Schale wurde von einem Bewohner aus irgendeinem Grund aufgesammelt. Aber auch infolge einer Überschwemmung kann die Muschel, und zwar auf natürliche Weise, in das Sediment gelangt sein.“ (:129) Ein eindeutiger Verwendungszweck fehlt also. In jedem Fall ist nach ihrer Meinung davon auszugehen, „dass diese Tierarten, wenn überhaupt, nur eine geringe wirtschaftliche Bedeutung für die Bewohner des ,Haus Bürgel' hatten.“(:129).

Dass es aber eine Bedeutung in früherer Zeit gegeben haben muss, belegt J. S. SCHRÖTER (1779) mit seinem in Halle erschienen Werk „Die Geschichte der Flußconchylien mit vorzüglicher Rücksicht auf diejenigen welche in thüringischen Wassern leben“ (zit. aus: SCHUBERT 2001:108), in dem er das Molluskenvorkommen in der Saale erstmals in umfassender und wissenschaftlicher Weise beschreibt. Darin werden 15 Arten von Süßwassermuscheln für die Saale bzw. deren Nebenflüsse genannt. Auch Bestände der Perlmuschel, die zur Perlenerzeugung genutzt wurden, waren in diesen Gewässern zu finden. In der Weißen Elster wurde Anodonta mutabilis gefischt, die als Nahrung diente.

Die interessante Frage aber, die sich Ernst FRIEDEL 1884 (:37) stellte, war Folgende: „hat das weichliche, aber saftige Fleisch dieser ,Süßwasseraustern' als menschliche Nahrung gedient oder haben die germanischen Fischer der Vorzeit ihre Schweine eigenthümlicher Rasse mit dem Fleisch gefüttert?“ „Wahrscheinlich“, so seine Annahme, „sind diese Muscheln gefischt worden, um, [...] als Futter für Schweine zu dienen (:35f.; siehe auch die Verwendung von Krebsen als Schweinefutter in Pkt. b). Als Beweis der Verwendung von Muscheln als tierische Speise verweist FRIEDEL (1884:37) auf seine aus den 80er Jahren des 19. Jahrhunderts stammenden persönlichen Beobachtungen:

„Fast möchte man, da alterthümliche Gebräuche der Gegenwart, zumal bei einer so am Althergebrachten klebenden Beschäftigung wie die Fischerei ist, zu Rückschlüssen auf die Vergangenheit berechtigen, jene Frage bejahen. Noch jetzt kann man an warmen Sommertagen sehen, wie die erwachsenen Mädchen der Fischerdörfer längs der Oder jener Gegend dieselben Muschelarten in großen Mengen einsammeln. [...Sie] fahren [...] auf seichte Stellen und wühlen dort, aus dem Kahne weit nach vorn übergebeugt, mit den Händen im Flußsand nach den in diesem steckenden Muscheln. [...] Für den der Landessitte ungewohnten Wanderer ein seltsames, primitives und an die vorgeschichtliche Kultur der Fischerbevölkerung anstreifendes Schauspiel. Die von den Fischertöchtern gesammelten lebenden Muscheln werden hernach ausgeschrapt und das so gewonnene Fleisch an die Schweine, die davon fett werden sollen, verfüttert."

Ebenfalls zur Schweinemästung Verwendung fanden nach seinen Beschreibungen Flussmuscheln aus einem nahe der Stadt Buckow in der Märkischen Schweiz gelegenen Stobberbach (:38). Dasselbe ist in den Dörfern, die dem Main bei Frankfurt nahe liegen, der Fall: „Watende und badende Kinder holen die Thiere aus dem Flusse.“(:38)

Der Grund für die Verwendung von Teich- und Malermuscheln bloß als Viehfutter und außerdem ,als Angelköder“ liegt wohl in ihrer „Zähigkeit“ und ihrem „faden Geschmack“ (FRIEDEL 1884:38). Obgleich, dies widerspricht der alleinigen Verwendung als minderwertiges Viehfutter, diese Muscheln auch noch zu Ende des 19. Jahrhunderts als menschliche Speise dienten.

Als zweite - und aufgrund ihrer Bedeutung separat zu behandelnde Süsswassermuschelart - ist in Deutschland insbesondere noch die Flussperlmuschel (Margaritifera margaritifera) von Interesse, die, wie ihr Name bereits verrät, zu den nicht-marinen Mollusken, den sog. „Binnenmollusken“, gezählt wird und auf die 
ein reger Molluskenfang ${ }^{31}$ betrieben wurde. Die Nutzung von Flussperlmuscheln war stets mehr auf die Bildung und den Verkauf von Perlen denn auf Ernährung ausgerichtet und die entsprechende Sammlung von nur sehr untergeordneter Bedeutung (SCHLAUCH 1999:3)

Erste schriftliche Überlieferungen einer Fischerei auf diese Art in deutschen Gewässern stammen aus dem 4. Jahrhundert. So weist das bekannte Gedicht von Ausonius, in dem er auf das Vorkommen der Flussperlmuscheln in der Ruwer, einem Nebenfluss der Mosel, zu sprechen kommt, auf die schon zu diesem Zeitpunkt betriebene Form der Flussfischerei hin.

Tatsächliche Relikte der Flussperlmuscheln bzw. deren Schalen wurden in einem slawischen Wall ca. $800 \mathrm{n}$. Chr. in der Nähe von Leipzig gefunden. Zudem belegen urkundliche Zeugnisse die Fähigkeit von Fischern, sog. Perlzeichen ${ }^{32}$ zu erkennen, bereits für das 1 . Jahrtausend.

Eine systematisch angelegte Fischerei auf Flussperlmuscheln in Deutschland lässt sich erst für das 15. Jahrhundert mit Sicherheit nachweisen. Klosterakten dieser Zeit belegen, dass beispielsweise 1442 die Äbtissin Katharina von Hoya „dem Kloster Wienhausen das beste Altar-Laken mit Perlen besetzt“ stiftete (BISCHOFF et al. 1986:35) und eine Urkunde der Herzöge Ernst und Albrecht III. (Herzog von BayernMünchen) aus dem Jahre 1437 besagt, dass ,in allen Flüssen und Wassern im Bayerischen Wald, sonderlich im Regenfluß und in der Teisnach, feine Perlen wachsen“(OEFERLE 1763; zit. aus: STEIDLE 1986:14).

Etwa 200 Jahre später wurde die Perlmuschelfischerei Kronregal, dessen Verordnungen mehr oder weniger ausführlich dokumentiert sind: So durfte ab 1621 nur noch die vom jeweiligen Kurfürsten ernannte „Kurfürstliche Perlenfischerei“ die Perlengewässer nutzen bzw. war für deren Pflege wie das Umsetzen von bedrohten Populationen oder die Neubesiedlung von Bächen und die Organisation der Fischerei verantwortlich. Gewisse Bestimmungen, zum Beispiel dass ein Bach oder ein Fluss nur einmal alle zehn Jahre befischt werden durfte, regelten die Fischerei. Die Gewässer wurden hierfür in Schläge eingeteilt. Lediglich mit einem Sammelbeutel und - je nach Region - mit unterschiedlichem Öffnungswerkzeug wie Flacheisen und Muschelzange ausgestattet, spreizten die Perlfischer vorsichtig mit einem Perlzeichen versehene Muscheln (BAER 1995:98).

Besonders durch die Verwendung des von Malachias Geiger in den 30er Jahren des 17. Jahrhunderts erfundenen sog. Perlschlüssels konnten vor allem in Bayern durch den Einsatz dieser Muschelzange, einer Art Schraubzange, die Muscheln geöffnet werden, ohne sie zu töten. Nach der Perlenentnahme wurde die Muschel wieder, mit einer Jahreszahl versehen, an ihrem alten Platz ausgesetzt.

Die gesamten Erträge hatten die Muschelfischer an den Hof abzuliefern. Da die Perlmuschelfischerei in vielen Gegenden eine sehr profitable Teilzeitbeschäftigung war, gab es allerdings vielerorts Perlräuberei, der man durch strikte Kontrollen und harte Strafen, wie Augenausstechen, Abhacken der Hand bis hin zum Galgentod zu begegnen suchte (STEIDLE 1986:29). Gerade diesen illegalen Perlfischern war meist nicht bekannt, dass durch oben genannte Beachtung der Perlzeichen und Benutzung spezieller Werkzeuge nicht unbedingt alle Muscheln aufgebrochen und zerstört werden mussten. So verendete ein Großteil des gesamten Flussperlmuschelbestandes an Land.

Dennoch geriet die Perlenfischerei laut BOETTGER (1954:28) mit der Zeit in Vergessenheit. Erst als mit der ab dem beginnenden 18. Jahrhundert eintretenden sukzessiven Erlöschung des Perlregals die Kontrollen immer nachlässiger und Verstöße kaum noch geahndet wurden und das Perlregal faktisch nicht mehr ausgeübt wurde, öffnete dies den Einheimischen den Weg zur Perlplünderei (BISCHOFF et al. 1986:39; BAYERISCHES LANDESAMT FÜR UMWELTSCHUTZ 1995:9). Später, als um 1866 die Fischerei auf

\footnotetext{
${ }^{31}$ Umfassende Zusammenstellungen der Fischerei auf Flussperlmuscheln in Deutschland finden sich in BISCHOFF et al. (1986); STEIDLE (1986), WÄCHTLER (1986), BAER (1995), BAYERISCHES STAATSMINISTERIUM FÜR LANDESENTWICKLUNG UND UMWELTFRAGEN (1999) UND SCHLAUCH (1999).

${ }^{32}$ Um Perlen muschelschonend zu entnehmen und nicht zu viele nutzlose „leere“ Muscheln ohne Perlen zu zerstören und somit für immer der Perlenproduktion zu entziehen, richteten sich die Perlenfischer bei ihrer Suche nämlich nach Perlzeichen (BOETTGER 1954:24). Dies sind rinnenförmige Vertiefungen oder sonstige Verletzungen der Muschel. Da die Bildung einer echten Perle immer mit Verlagerung von Mantelmaterial ins Innere der Muschel verbunden sein muss, lassen derartige Missbildungen der Schalen darauf schließen, dass die Muschel eine Perle besitzt.
} 
Flussperlmuscheln im Zuge der nationalen Einigung für alle zugänglich wurde, brach geradezu ein Perlenfieber herein. Die Folge war eine unkontrollierte und wenig bestandsschonende regelrechte Plünderung der Bestände, von der ein damaliger Zeitzeuge berichtete (zit. aus: BISCHOFF et al. 1986:44): „Alt und jung eilte ans Wasser, auch aus entfernten Gegenden. Hamburger Juweliere kauften an Ort und Stelle auf. Die aufgebrochenen Muscheln lagen zu Tausenden an den Ufern herum, denn es war nicht schwierig für einen einzigen Sammler, mehrere Tausende an einem Tag aus dem Bachgrund zu holen.“

Erschwerend kam hinzu, dass im Zusammenhang mit in diese Zeit fallenden wissenschaftlichen Veröffentlichungen $\mathrm{zu}$ Mollusken ein regelrechtes Perlfieber entbrannte, welches praktisch alle Bevölkerungsschichten ergriff (BISCHOFF et al. 1986:44). Damit war das Schicksal der Flussperlmuschel in Deutschland besiegelt. Die Fischerei auf Süßwassermuscheln ist in deutschen Binnengewässern seit dem Ende des 19. Jahrhundert ein ausgestorbener Wirtschaftszweig (SCHLAUCH 1999:15).

Vorschläge zur Wiederbevölkerung der Bäche mit Muscheln, einer zweckmäßigen Nutzung der Perlbäche, der Einführung von Schonzeiten für die Tiere und eines Verbotes des Aufschneidens der Muscheln zur Perlenentnahme, zum Beispiel des Landrats von Tzschoppe 1886 vor dem preußischen Staatsministerium für Landwirtschaft in Berlin, scheiterten zum einen an der preußischen Bürokratie (WELLMANN 1938:493f.), zum anderen nahmen infolge der wachsenden Verschmutzung der Flüsse, Bäche und Seen - insbesondere wegen industriellen Vergiftungen durch Chemikalien, vor allem aber durch die Effekte der intensivierten Landwirtschaft und des Bergbaus, aus denen eine beginnende Eutrophierung vieler Gewässer resultierte, die auf alle Gewässernetze übergriff - sowie des ab den 80er Jahren des 19. Jahrhunderts vermehrt einsetzenden und heute ausschließlichen Imports japanischer Zuchtperlen - die Bestände der ursprünglich in deutschen Gewässern heimischen Süßwassermuscheln kontinuierlich ab (SCHLAUCH 1999:15). Des Weiteren waren am Niedergang der Flussperlmuschel und damit deren Fischerei durch konkurrierende kulturelle Gewässernutzungen indizierte Umweltschäden zumindest beteiligt. Nahezu jeder in irgendeiner Weise für Flößerei nutzbare Bach- und Flusslauf wurde im Lauf der Zeit ohne Rücksicht auf die dort siedlende Fauna begradigt (BOETTGER 1954:33). Diesen Veränderungen waren die an Optimalbedingungen gewöhnten Flussperlmuscheln nicht gewachsen und ganze Muschelsiedlungen wurden im Zuge dessen zugeschüttet bzw. von der einsetzenden Verschlammung ergriffen und regelrecht erstickt.

Denn sie bewohnen ausschließlich kühle, sauerstoffreiche, kalkarme und schnell fließende oligotrophe Gewässer von hoher Wasserqualität, die gleichzeitig Forellen beheimaten (SCHLAUCH 1999:22). Die Vorliebe für hohe Fließgeschwindigkeiten begründet sich darin, dass sich Kies- und Schotterbänke als ihre Heimstätte bilden müssen, die nicht versanden (BISCHOFF et al. 1986:16). Allerdings darf die Fließgeschwindigkeit auch nicht ein Verdriften der Muscheln begünstigen. Aufgrund dieser speziellen Vorlieben ist das Verbreitungsgebiet der Flussperlmuschel in Deutschland heute stark eingeschränkt. „Ihr Biotop ist heute ausschließlich auf Bäche des Bayerischen Waldes und des Fichtelgebirges beschränkt [...]. Daneben lassen sich vereinzelte Standorte in einigen Mittelgebirgsflüssen wie der Rhön oder Eifel finden. Tieflandstandorte liegen in der Lüneburger Heide, frühere Vorkommen im oberen Elbe- und Odergebiet sind heute nicht mehr existent.“(SCHLAUCH 1999:25)

Zugleich, und dies hat den Niedergang beschleunigt, macht die schmarotzerhafte Lebensweise der Süßwassermuscheln diese zu ungleichen Konkurrenten der Süßfisch-Fischer. Sie heften sich im Larvenstadium in den Körper des Fisches, die dabei entstehende oberflächige Wunde des Fisches verwächst zu einer Zyste, und ernährt sich über Wochen von den Körperstoffen des Wirtes, zum Beispiel einer Forelle (SCHLAUCH 1999:15), „Erst wenn die Süßwassermuschel den Übergang zum Jungmuschelstadium erreicht hat, fällt sie von ihrem Wirt wieder ab und siedelt sich am Boden an. So sind beispielsweise die Larven der Flussperlmuschel verantwortliche Parasiten für die Pilzlamellen der in deutschen Flüssen heimischen Forellenart Salmo trutta.“(BISCHOFF et al. 1986:14)

Nachteilig für den Fortbestand wirkte sich also auch die Biologie der Flussperlmuschel aus, die gleichermaßen an die eben genannten hydrologischen Bedingungen wie auch an die Verbreitung der Bachforelle gebunden ist (SCHLAUCH 1999:25).

Trotz all dieser Negativfaktoren und kaum existierenden Schutzmaßnahmen hat es nicht an ökonomisch motivierten Pflegemaßnahmen und Kultivierungsprogrammen für die ca. 60 - 100 Jahre alt werdende 
Muschel gefehlt: Nachdem man zum Beispiel erkannt hat, dass Perlen künstlich gezüchtet werden können, sind in Deutschland in den späten 20er Jahren des 20. Jahrhunderts Muschelzuchtanlagen eingerichtet worden. Doch weit weniger als 1\% aller Perlenmuscheln tun dies allerdings im Laufe ihres Lebens und durchschnittlich nur jede 2.700ste Muschel bildet eine qualitativ gute Perle (SCHLAUCH 1999:15).

Jedoch konnten - nicht zuletzt wegen des komplizierten Lebenszyklus dieser Art und ihren zwingenden ökologischen Anforderungen wie Wasserqualität und Begleitfauna - auch diese nicht verhindern, dass die Gesamtpopulation der Flussperlmuschel in Deutschland seit dem Beginn des 20. Jahrhunderts von ca. bis zu 1/4 Milliarde Individuen (BISCHOFF et al. 1986:20; BAER 1995:7) auf etwa 5 Mio. Mitte der 1980er Jahre geschrumpft war und die andauernde Umweltzerstörung sie seitdem durch Bestandsrückgänge von über 90 \% nahezu zum Aussterben gebracht hat (WÄCHTLER 1986:232).

Die Aussagen, die aus der beschriebenen historischen Flussmuschelfischerei zusammenfassend gezogen werden können, sind neben der kulturhistorischen Bedeutung vor allem ökologischer Natur. Fluss- wie Perlmuscheln haben hohe ökologische Ansprüche und sind an saubere und strukturreiche Bäche und Flüsse gebunden, vielmehr ist zu beachten, dass die Unionaceae, so die Biologin STEIN (2000:127), ,ausschließlich in sauberen Gewässern“ leben. Unter anderem aus diesen Gründen gelten sie - auch mit der noch existierenden Bestandsgröße - als ausgestorben (SCHUBERT 2001:110). Heute noch vorkommende Restpopulationen von Margaritifera margaritifera in oberfränkischen Gewässern sind ausnahmslos überaltert (SCHUBERT 2001:110).

Dennoch lässt sich, ähnlich wie bei den Fischen, anhand der Molluskenfunde aus umwelthistorischer Sicht, die frühere Wasserqualität der Gewässer „nur eingeschränkt rekonstruieren“ (SCHUBERT 2001:109). Zu unterschiedlich seien die früheren Lebensräume gewesen, mit unterschiedlichen Saprobiewerten und zu unterschiedlich die spezifischen Ansprüche der Art. Dass die Gewässerumwelt aber eine andere, sauberere gewesen sein muss, kann als feststehend betrachtet werden.

\section{d Sammeln von Kuriositäten und Spezialitäten}

Des Weiteren wurden Wasserschnecken aus den Gewässern gesammelt. Abgesehen von gewissen Zierschnecken, ist ganz besonders die „Purpurschnecke ${ }^{633} \mathrm{zu}$ erwähnen. Sie wurden in der Absicht gefangen, „die Thiere zum Schönfärben zu verwenden“(FRIEDEL 1884:41).

In Bleicherode, einer im Wipper- und Helmetal am Südharz gelegenen Kleinstadt, war insbesondere die Leinwandindustrie ansässig. Die Handweber in den umliegenen Dörfern webten das Garn zu Leinwand und bleichten das Leinen auf den Talwiesen. Eines von diesen bachdurchflossenen Bleichtalgebieten trägt die Bezeichnung „Schneckenhengst“. Woher kommt dieses Tal zu diesem Namen? Wenn auch hier die zweite Silbe ,-hengst“ nicht geklärt werden kann (aber ein Zusammenhang mit der Beweidung der Bleichwiesen von Pferden durchaus Sinn verspricht), so weist SCHUBERT (2001:62, 109) in einem anderen Zusammenhang darauf hin, dass es bei einigen Landschneckenarten, zum Beispiel den Egelschnecken (Deroceras laeve), einen fließenden Übergang zwischen terrestrischer und limnischer Lebensweise gibt, da sie sich nur temporär im Wasser aufhalten. So auch hier: Die in den umgebenden Südharzer Muschelkalkgebieten vorkommende bekannte graue Weinbergschnecke galt früher und auch jetzt noch als Leckerbissen und wurde gern gekauft. Es gab einige Züchter in Bleicherode, die sich durch das Aufsuchen einen lohnenden Erwerb verschaffen konnten. „Die Besitzer von Berggärten sammelten die Tiere und brachten sie an Wassergräben, die sie mit Wellholz einschlossen, damit sie nicht entkommen konnten und fütterten sie mit Kohlblättern so lange, bis sie zum Verkauf herangewachsen waren." (JUNKER 1997) Bachläufe und künstlich zur Bewässerung von Berggärten angelegte Gräben dienten also der Zucht und „Mästung“" von zum Verkauf und Verzehr bestimmten Weinbergschnecken.

Ein für die Spitäler der Mönche häufig benötigtes „Heilmittel“ waren Blutegel. Sie wurden von armen Leuten im Stillen Bach und in den Weihern gefangen und an das Kloster verkauft (HERBST 1992:158).

\footnotetext{
${ }^{33}$ FRIEDEL (1884:40) bezeichnet die Purpurschnecke mit dem lat. Namen „Purpura haemastoma“; im „BROHMER“ (1984:75) dagegen findet man sie unter dem Namen „Nucella lapilus L.“
} 
Blutegel dienen zum Aderlass, um krankes Blut herauszuziehen und die Produktion von neuem Blut anzuregen.

Die Blutegelzucht intensivierte sich nach Mitte des 19. Jahrhunderts, wobei zwischen einer intensiven und extensiven Zuchtmethode unterschieden wurde: Bei ersterer wurden in der Regel auf einem extra hergerichteten begrenzten Räume bzw. Teiche geschaffen, eine großen Menge Blutegel erzielt. Bei der extensiven Methode wurden die Blutegel ,auf weitem Terrain im Bereiche von durch Huthungen oder Brüche fließendem Gewässer“" gefunden. (ACKERHOF 1869:139)

Aber bereits nach der zweiten Hälfte des 19. Jahrhunderts stellte ACKERHOF (1869:139) einen Populationsrückgang dieser Ringelwürmer fest: Plätze, auf denen 1839 ,in sehr bedeutender Menge Blutegel gefangen wurden“, ließen schon 30 Jahre später „nicht 1 Exemplar entdecken.“ Die Gründe für das Verschwinden sieht ACKERHOF (:139) im „ungeregelten Einfangen“, im „Aufhören der Behutung nach erfolgter Separation“ sowie in der „Entsumpfung“.

Auch Schildkröten wurden in den Flussläufen zum Verzehr gefangen (THIENEMANN 1955:91f.; HERRMANN 1997:177). Am Beispiel der Oder vor der Eindeichung und Melioration zeigt dies HERRMANN (1997:177) anhand einer alten Buchquelle des 18. Jahrhundert auf: So soll man vormals in der Ucker- und Neumark ,einen ziemlichen Handel mit den daselbst häufigen Flußschildkröten getrieben, und sie zu vielen Fudern nach Schlesien und Böhmen zu den Catholiken in der Fastenzeit geführt haben“. Und auch nach ACKERHOF (1869:138) machte , in früheren Jahren“, d. h. vor Hälfte des 19. Jahrhunderts, „,die gewöhnliche Fluß-Schildkröte einen bedeutenden Handelsartikel der Mark Brandenburg und Polens nach Böhmen aus.“ Die Europäische Sumpfschildkröte, um die es sich hier handelt, galt als begehrte Fastenspeise in katholischen Gegenden und sie war früher in den Brüchen so häufig, dass von Wrietzen und Frankfurt a. d. Oder ganze Pferdefuhrwerke sogar bis nach Prag versandt wurden (HERRMANN 1997:45)

Infolge des Jahrhunderte währenden intensiven Schildkrötenfanges zählte diese Art schon Ende des 19. Jahrhunderts zu den Seltenheiten in Deutschland und gehört heute zu den am stärksten bedrohten Reptilienarten in unserem Land. Einzig im Bundesland Brandenburg hat die Art noch eine Reihe gesicherter Vorkommen. Eines davon liegt im Naturpark Märkische Schweiz, in wenig vom Menschen gestörten Feuchtgebieten, an kleinen Seen und Weihern.

Die, wenn sie erfolgreich den zahlreichen Gefahren hat widerstehen können, mehr als 50 Jahre alt werdende Europäische Sumpfschildkröte bevorzugt pflanzenreiche, flache Seen und gut erwärmbare Stillwasserzonen großer Flüsse, aber auch Tümpel, Teiche und Bäche. Sie ist ein äußerst scheues Tier und reagiert empfindlich auf Störungen durch den Menschen und Verunreinigungen der Gewässer. An sonnigen Uferabschnitten verweilt sie gern auf alten Ästen und Baumstümpfen und tankt die Wärme der Sonne. Zur Nahrungssuche in der Dämmerung sucht sie bevorzugt am Gewässerboden, aber auch an Land, nach Insektenlarven, Krebsen, Würmern und Kaulquappen. All die genannten Habitatansprüche machen deutlich, dass es sich um eine „Zeigerart“ für industrialisierte, entkernte und mit Schadstoffen belastete Gewässer sowie für ehemals gewässerreiche, mittlerweile vertrocknete Landschaften allgemein handelt.

Rücksichtslos verfolgt und bejagt, was beinahe bis zur Ausrottung führte, wurde ebenso als Nicht-Fisch der Biber (Castor fiber), dessen Zahl im 18. Jahrhundert „allerdings außergewöhnlich hoch gewesen sein muß“ (HERRMANN 1997:27). So waren Biber bis ins 19. Jahrhundert in Europa an allen Flüssen und Seen weit verbreitet (BOESSNECK 1958:56).

Zum einen waren sie eine beliebte Jagdbeute wegen ihres schmackhaften Fleisches (SCHÄFFER/DRIESCH 1983:21). Dies beweist eine archäozoologische Analyse eines Fundes bei einem unmittelbar am Rhein gelegenen spätrömischen Kastell. Wenngleich auch erwartungsgemäß die Masse der Funde die bäuerlichen Nutztiere mit annähernd $95 \%$ darstellen (Rind, Schaf und Ziege), lag ein vergleichsweise hoher Anteil an Knochen von Jagdwild vor (3,7 \%): Neben dem die Knochenfunde dominierenden Rothirsch $(1,82 \%)$, dem in der Anzahl folgenden Wildschwein (0,88 \%), Reh $(0,68 \%)$ und Hase $(0,12 \%)$ besitzt - mit einem Anteil von 9 Stück (das entspricht einem Prozentsatz von $0,06 \%$ aller bejagten Tiere) - der Biber vor den Wildtieren wie Rotfuchs $(0,02 \%)$ und dem Elch, Bär, Marder und Dachs mit jeweils 0,01\% den höchsten Jagd- bzw. Verzehranteil. Über gleichartige Funde von Biberknochen in römerzeitlichen Siedlungen entlang 
des Rheins berichten auch andere Veröffentlichungen. Einen besonders hohen Prozentsatz an Biberknochen $(5,8 \%)$ beispielsweise weist das Fundgut des frühkaiserzeitlichen Kleinkastells Osterhofen-Haardorf bei Deggendorf auf (STEIN 2000:92).

Zum anderen wurden sie ihrer Akzeptanz als klösterliche Fastenspeise wegen und wegen ihres Pelzes sowie des Weiteren aufgrund des sog. Bibergeils (casteorum), eines in den Duftdrüsen zwischen After und Geschlechtsöffnung produzierten Sekrets, bejagt. Bibergeil wurde als Allheilmittel geschätzt und war deshalb sehr gefragt (STEIN 2000:91). Schließlich jagte man ihn auch wegen seiner Lebensweise, die der weiteren Siedlungsexpansion hinderlich war. So fiel der Biber im Oderbruch nachweislich der Urbarmachung zum Opfer. Seine Neigung, seinen Bau in Hochufern anzulegen, führte zu einer Untertunnelung der neu angelegten Oderdämme und damit bestand die Gefahr des Deichbruchs. Ein identisches Problem gab es auch an der Elbe unterhalb Magdeburgs, so dass Friedrich II., der Große (17401786), am 8. August 1765 die Ausrottung der Biber befahl (HERRMANN 1997:180).

Während Fisch nur auf den Speisezettel der reichen Kaufleute und Handwerker und Biber nur auf den Refektorientischen der Klöster erschien bzw. aufgrund rechtlicher Vorgaben nur dort erscheinen durfte, bereicherten sich die Bauern selbst ihren kargen Nahrungstisch mit Fröschen. Frösche waren ursprünglich eine Speise der Armen. Das ist einleuchtend, denn Frösche gab es reichlich, waren jedermann zugänglich und hatten deshalb keinen Preis (KONOLD 1987:16).

\section{e Wilde Fischzucht}

Die Arten der Fischwirtschaft, die in künstlich errichteten Teichen betrieben wurden, bezeichnete man in der historischen Fischwirtschaft als „zahme Fischerey“ (DYHRN 1782:6).

Ihr wurde die sog. „wilde Fischerei“ gegenübergestellt, die nach TAURKE (1927:XXI) die „Fischzucht in natürlichen Gewässern, Bächern und besonders Seen“ beschreibt. Da sie aber, wie unter Pkt. a dargelegt, auch gleichzeitig das normale „Nachstellen der freilebenden Fische in Flüssen und Seen auf ,freier Wildbahn'“ bezeichnet, soll, um eine inhaltliche Verwirrung bzw. Überschneidung zu vermeiden, die Begriffsauslegung von TAURKE verworfen und anstelle dessen der Begriff der „wilden Fischzucht“ verwendet werden. Dies drückt nach meiner Auffassung die Intention der bewussten Förderung der Fischvermehrung in einem bestimmten, aber dennoch frei fließenden Bachrevier besser aus. Man könnte insofern auch, um die Ähnlichkeit mit der (historischen) Teichwirtschaft zu beschreiben, von einer (historischen) „Bachwirtschaft“ sprechen.

Beide Formen der Fischwirtschaft, sowohl die „zahme“ wie auch die „wilde“ Fischzucht, wirtschafteten dabei nach den Regeln der sog. „Allgemeinen Fischzuchtlehre“. Diese wird beschrieben als „eine für viele Fische gültige (daher , allgemein' genannte) spezielle Ausführung der bei der Züchtung der einzelnen Fische [...] angeführten Anweisungen.“ (TAURKE 1927: XXI) Beide Formen der Fischwirtschaft benötigen jedoch zweifellos eine wasserhaltige Aufzuchtumgebung, d. h. einen oder mehrere künstlich angelegte Teiche oder, wie in diesem Fall, natürlich entstandene Gewässer, die aufgestaut oder aber zumindest abgeriegelt werden mussten. Zum einen, um sog. „Fischfeinden“ den Eintritt zu erschweren, und zum anderen, um den Fischen den Austritt zu verwehren.

Die sog. Fischzucht stellte dabei eine einschneidende Intensivierung der Fischerei dar (vgl. AMACHER 1996:18). Während bei der „wilden Fischerei“ allein der natürliche Besatz aus natürlichen Gewässern gefischt wurde, konnte nach künstlicher Aufzucht in Gewässern der Fischbestand stark erhöht werden. Dabei wird Fischzucht nach allgemeiner Vorstellung synonym mit Aufzucht in künstlichen und extra dafür errichteten Teichen gleichgesetzt (:18), obgleich dies - gemessen an der Bedeutung der Aufzucht in künstlich errichteten Teichen - zwar richtig ist, aber hinsichtlich der Einschränkung der Verortung faktisch für falsch gehalten werden kann.

Frühe (mittelalterliche) Fischereiwirtschaft in natürlichen Gewässern mag so ausgesehen haben, wie sie SOLYMOS (1983:47) am Beispiel der Donau beschreibt: „Neben den nicht regulierten Flüssen zogen mehrere Kilometer breite Überschwemmungsgebiete ein. Bei der Überschwemmung ströme das Wasser 
durch natürliche oder künstliche Kanäle [...] auf das Überschwemmungsgebiet und füllte mit frischem Wasser und Fischen die Vertiefungen auf. Als das Wasser zurücktrat, verhinderten die Fischer, daß die Fische in das Flußbett zurückkehrten. [...] Auf den Überschwemmungsgebieten bildeten sich ganze Teichsysteme aus, welche sie regelmäßig in gutem Zustand hielten und welche auch für den Fischnachwuchs günstige Umstände sicherten." Bis Anfang des 19. Jahrhunderts fand die Fischerei meistens in solchen „Überflutungsbereichen“ oder „Altarmen“ statt, ,auf dem Fluß haben sie eher nur Hausen (Huso huso L.) gefangen." (:48)

Diese Art der Fischerei wird als „Sperrfischerei“ bezeichnet. Ein Teil der Sperrgeräte - Ruten oder Schilfwände - versperrt beim Zurücktreten des Wassers den Ausfluss der Überschwemmungen aus den Nebenarmen und Kanälen und verhindert, dass die Fische ins Flussbett zurückkehren (SOLYMOS 1983:52). Diese Absperrzäune ähneln den Heringsfängen an der Ostsee, wie sie noch beispielsweise in der Schlei bei Kappeln in Gebrauch sind.

In dieser Art und Weise wird auch die anfängliche „wilde Fischzucht“ betrieben worden sein. Für die gezielte Fischvermehrung wie auch den Fischfang wurden Gewässer und deren abgetrennte Flutungszonen benutzt - die künstlichen Eingriffe in dieselbigen hielten sich aber in Grenzen. Sie lassen sich nicht so umfangreich darstellen wie die Fischzucht in Teichen, da diese Art der Fischwirtschaft nur sehr selten morphogenetische Formen im Gelände hinterlassen hat; und wenn, dann in viel temporärer und subtilerer Weise. Dass aber auch diese durch die Fischerei unberührt erscheinenden Gewässer nicht unbeeinflusst blieben, dafür legen die überlieferten Handlungsanleitungen zur Fischkunde Zeugnis ab. Durch ihre naturnah anmutenden Eingriffe können diese zwar keinesfalls mit wirklich umweltschädigenden Faktoren (Wasserverunreinigung, Flussregulierung, Flusssäuberung, Rodung, Stauwehre, Meliorationen u. a.) verglichen werden, aber gerade deshalb, weil uns die Elemente der wasserbezogenen Kulturlandschaft in Gänze interessieren und weil eine historisch-geographische Geschichte der kleineren Fließgewässer auch die Fischzucht in den Gewässerläufen und ihre Hinterlassenschaften nicht vergessen darf, erfolgt diese kurze Darstellung von „Kulturlandschaftselementen“ der Fischerei in Bächen. Sie liefert jedoch einen Beweis dafür, dass auch für die Optimierung der Fischzucht in Bächen, Veränderungen am Gewässer vorgenommen wurden, wie im Folgenden deutlich wird.

Die Fischzucht in kleinen Fließgewässern muss eine derart große Bedeutung besessen haben, dass man entsprechend den verschiedenen Zuchtstadien der Fische - ähnlich wie in der Teichwirtschaft - die Bäche unterschied in:

1. Brutbäche und

2. Abwachsbäche

Brutbäche, so die Definition von TAURKE (1927:46f.), eignen sich für die Aufzucht der Brut. Es handelt sich dabei um flache Bäche, die ,alljährlich im Herbst [...] rein abgefischt werden“. In die sog. „Abwachsbäche“ werden „stets Setzlinge eingesetzt“. Als Abwachsbäche dienen „tiefere Bäche“, aus denen vor Besatz von Bächen dieser fischereiwirtschaftlichen Kategorie mit Setzlingen zuerst die anderen Raubfische, besonders die Hechte, beseitigt wurden (:46).

Diese beiden Bacharten mussten, damit die Fische Brut- und Abwachsgeschäft verrichteten, nicht nur von Fischfeinden befreit, sondern zum Teil auch speziell präpariert werden. Dies betraf insbesondere die sog. Flachlandbäche. Diese eigneten sich nicht zur vollständigen Forellenzucht, „wohl aber [...] zum alljährlichen Aussetzen von Brut oder von Setzlingen.“ (TAURKE 1927:46) 


\section{e.1 Künstliche Laichstätten}

Durch die Schaffung von Laichgelegenheiten in fließenden Gewässern konnte und musste züchterisch auf die Vermehrung von Wildfischen eingewirkt werden (TAURKE 1927:55). Diese Laichplätze besaßen je nach Fischart und Fließgewässertyp unterschiedliche Gestaltungsformen:

Die Forellen benötigen „einen lebhaft fließenden Bach“ und „,zum Laichen [...] Kies“ (BORNE 1886: 217). Denn ,in den Teichen selber laicht die Forelle [...] niemals, sondern sucht dazu eine Bachstrecke mit schnell fließendem Wasser auf.“ (BENECKE 1885:101) Aus diesem Grund erfolgten besondere Eingriffe in das Flussbett. Zum einen wurden Laichplätze aus Kies zusammengehäuft. Handelte es sich um ein steiniges Bachbett, wie bei den meisten Gebirgsbächen, bediente man sich des vor Ort vorhandenen Kieses bzw. war eine Nachhilfe seitens des Menschen gar nicht notwendig. Bei erdigem Flussbett legte man aus anderen Quellen gewonnenen Kies hinein. Auch soll „das Einlegen von Reisig an geeigneten Stellen“ schon gute Resultate geliefert haben (TAURKE 1927:46). In den Bächen wurden mit den Kieselsteinen und dem Strauchwerk ,kleine Stauwerke“ angelegt, ,um Dümpel zu bilden und den Fischen Schutz zu gewähren. [...]. Besonders nützlich haben sich diese Schlupfwinkel im Frühjahr während des Holzflößens erwiesen.“ (BORNE 1886:277f.) Diese Methode der Forellenzucht wurde beispielsweise im zweiten Drittel des 19. Jahrhunderts beim Kloster Michaelstein angewandt. Die Brut hier „befand sich in den $11 \mathrm{~km}$ langen Bachläufen und in den Wildgerinnen, wo sie unter Steinen und Geröll willkommenen Schlupfwinkel fand.“ (:277f.)

Auch für wenige Karpfen und karpfenartigen Fischen legten die Fischer ,seit unvordenklicher Zeit [...] Strauchwerk [...] an die Laichplätze.“ (BORNE 1886:218) Diese künstlichen Laichstätten für die Karpfenartigen wie Karpfen, Blei, Schlei und dergleichen in fließenden Gewässern, werden auch als „bewegliche Laichstätten“ bezeichnet. Das sind „schwimmende, mit Wacholderstrauch ausgeflochtene Horden oder Faschinen, die an flach geneigten Ufern, in ruhigen Dümpeln, an einer Seite mit Steinen beschwert, in das Wasser versenkt werden." (:218)

Auch für Barbe, Döbel, Gründling und Zander wurden Laichareale geschaffen. „In ruhig strömendem, flachem Wasser” - die ideale wässrige Umwelt dieser Fische - schichtete man ,an stark geneigtem Ufer [...] Haufen von Steinen und Kies.“ (BORNE 1886:218) Für den Zander brachte man „Haufen von Sand, Kies, Steinen, Wurzelgeflecht, versunkenes Holz [...] mit Erfolg an“ (:218). In der Nähe errichtete man zudem „durch Pfähle, große Steine, Holz, Aeste u. dgl., welche die Strömung brechen, Zufluchtsstätten für die Fische" (:218).

Der für die Fische zum Ablaichen gesammelte Kies, die sog. Laichsteine, wurde, war er im Flussbett bereits vorhanden, durch Zusammenharken zu kleinen Hügeln und Dämmen aufgetürmt. Das nach einiger Zeit notwendig gewordende Reinigen dieser Kieshaufen geschah durch Umschaufeln und Umharken. Wenn der Kies im Flussbett natürlicherweise fehlte, so wurde er „in den Fluß gebracht.“ (BORNE 1886:217) „Einige Karrenladungen“ (:217) von dem Flussgeschiebe wurden dazu in „kleine quellreiche Bäche mit vielem Gefälle“ (:218) verladen. Als „Laichsteine“ wurden ,,am zweckmäßigsten“ Steine ,in Nuß- und Faustgröße“ (:279) bzw. „Kies von Haselnuß- bis Hühnereigröße“ (:276) aufgeschichtet. In nächster Nähe zu den Laichplätzen wurden ,sichere Zufluchtstellen eingerichtet durch Herstellung hohler Ufer, Versenkung von Holz, Strauchwerk, hohl gelegte Bretter, große Steine u. dgl. [...], um sie vor den „Enten, Gänsen, Schwänen und anderen Wasservögel unzugänglich" zu machen (:217f.).

\section{e.2 Bachhälter}

Nach den Kieshaufen wurden als „die nächsthöhere Stufe“ von Laichplätzen Laichbehältnisse in natürliche fließende Gewässer eingesetzt und „Körbe, Reusen und Garnsäcke, die an Pfählen ausgespannt“ wurden, eingebracht (WALTER 1933:80). Zur Gewässernutzung zum Zwecke der Fischzucht zählen diejenigen kleinen „Brutanstalten“ der Fischzüchter, die nicht in Teichen (siehe Pkt. VIII 1), sondern in speziellen Brutgefäßen in Fließgewässern betrieben wurden. Dies vor allem deshalb, weil die Eier, wurden sie an geeigneten Stellen in Bächen ,ausgesäet“, vielen Gefahren ausgesetzt waren. Deshalb war es seit Mitte des 
19. Jahrhunderts üblich, kleine Brutanstalten zu errichten, die von den überall im Lande erwachsenden Centralen Fischzuchtanstalten mit Forelleneiern versorgt wurden (FRIČ 1874:6).

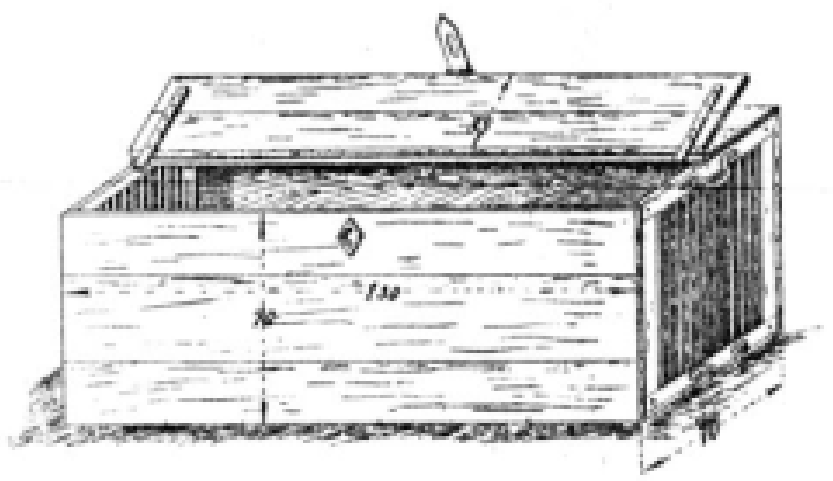

Abb. VI-15: Fischkasten zum „Einsetzen“

(aus: WALTER 1933:80, Abb. 26)

Der Kasten der Abb. VI-15 wurde temporär in das Wasser eingesetzt. Die Befestigung erfolgte durch zwei Stäbe, die durch die an den beiden Schmalwänden angebrachten bogenförmigen Eisen in den Boden gestoßen wurden (WALTER 1933:80). Die sog. Bachhälter, auch Fischkästen genannt, setzte man hauptsächlich in geschützte Bereiche des Wassers. Vorgezogen wurde schwach fließendes Wasser, in stark fließendem wählte man stillere Buchten oder bedeckte „,wenigstens die Stirnseiten der Lattenkästen mit Brettern“"(:81).

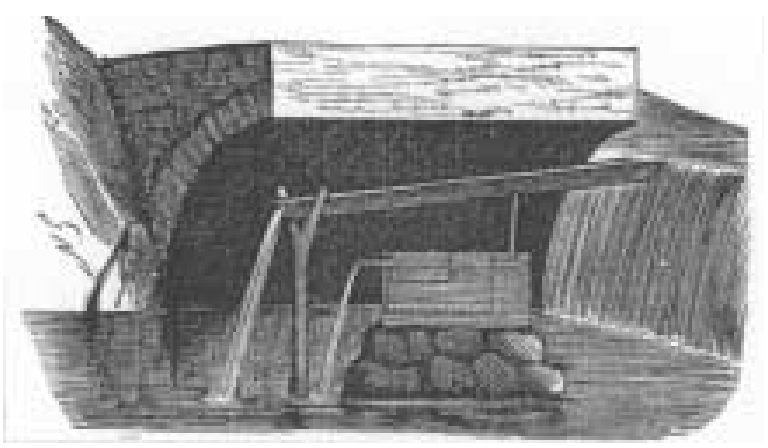

Abb. VI-16: Aufstellung von Bruttrögen in Fließgewässer

Unterhalb eines Schutz bietenden Brückenbauwerkes wird ein Sockel aus womöglich Flusssteinen aufgeschichtet. Oberhalb des Wasserüberfalls leitet eine hölzerne Rinne, gestützt auf eine stabile Astgabel, Wasser ab, welches durch ein kleine Öffnung den Bruttrog mit Frischwasser füllt (aus: BENECKE 1881:488, Fig. 232, Beispiel aus Matzicken).

Neben diesen transportablen Fischkästen wurden die Hälter auch als seitliche Erweiterung mit hölzernen oder steinernen bzw. zementierten Wänden und mit Deckel in einen Quell- oder besser Bachlauf fest eingebaut (WALTER 1933:81).

So ein fester und deshalb aufwendigerer „schwimmender Bruttrog“ wurde als „Californischer Bruttrog“ (BORNE 1886:261) bezeichnet. So ein „Bach-Apparat“ wurde, wie der Holzschnitt der Abb. VI-17 zeigt ,in fließendes Wasser so gestellt, daß die Strömung von unten den Siebboden und die darauf befindlichen Eier oder Fischchen durchfließt.“ (:236) In der Vorderwand des äußeren Kastens [A] besteht der untere Teil [b] aus einem weitmaschigen Drahtsieb, das durch einen Schieber mehr oder weniger frei gelegt werden kann. Der Bruttrog wurde so tief in das strömende Wasser gestellt, dass die Abflusshülle [e] zum Teil unter Wasser stand und so ausgerichtet, dass das Sieb bei $[\mathrm{b}]$ von der Strömung getroffen wird. Das Wasser floss dann hier ein und durch das Sieb [c] und die Tülle $[\mathrm{e}] \mathrm{ab}$. 


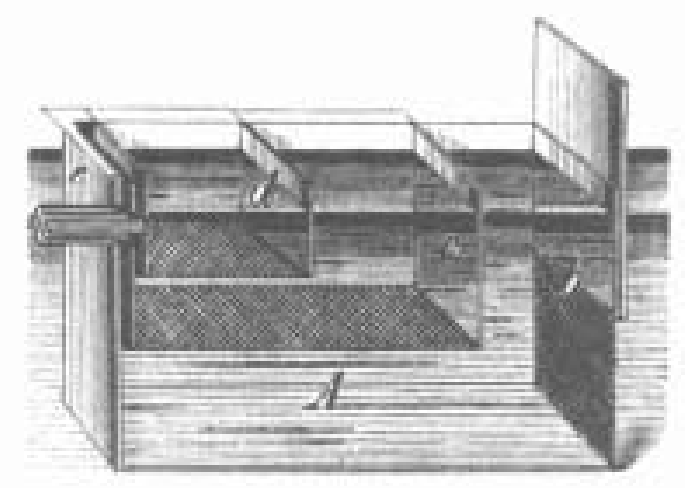

Abb. VI-17: Grundriss eines festen „Bach-Apparats“

(aus: BORNE 1886:236)

Eine andere Vorrichtung wurde nach Darstellung von BENECKE (1881:488) erstmals im Winter 1880/81 an verschiedenen Orten probeweise errichtet: kleine schwimmende Brutanstalten. Diese konnte man ,überall einrichten [...], wo in Bächen und kleinen Flüssen die Strömung so schnell ist, dass das Wasser selbst bei niedriger Temperatur nicht zufriert"(:488f.).
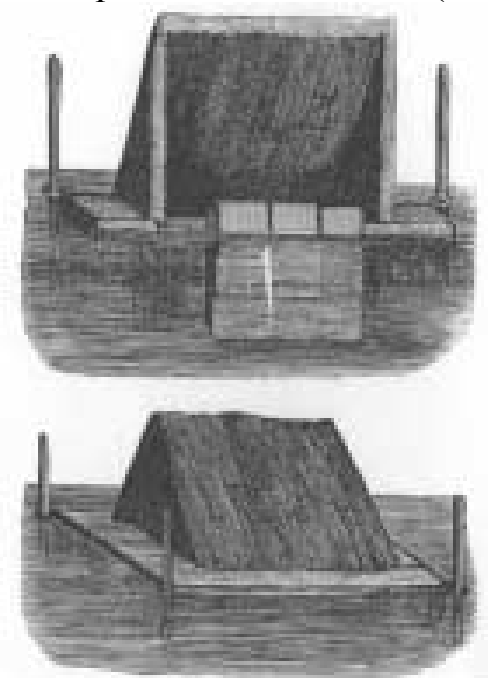

Abb. VI-18: Schwimmende Brutanstalt (Durchsicht und Ansicht)

Bestehend aus einem Californischen Bruttrog, der in einem schwimmenden Holzrahmen so befestigt ist, dass sein Ausflussrohr etwa bis zur Mitte im Wasser liegt. Die gegenüberliegende Siebwand wird gegen den Strom gerichtet, der Wasserzufluss durch einen Schieber reguliert und das Floß so befestigt, das es den veränderungen des Wasserstandes leicht folgen kann (BENECKE 1881:489).

Der „Californische Bruttrog“ von BORNE (1883:27) beispielsweise bot Gelegenheit, „an jedem Wehr oder laufenden Brunnen, oder Teich für wenige Mark eine solche kleine Brutanstalt herzustellen." Die Lage von solchen einfachen Brutapparaten geht eine „Symbiose“ mit den Wassermühlen ein und deshalb werden auch oft Wassermüller als frühe Fischzüchter beschrieben. Dies nicht allein aufgrund ihrer teilweise zum Antrieb notwendigen Mühlteiche, sondern das dafür benutzte kalte Quellwasser muss vor allem im Winter aufgrund seiner niedrigen Temperaturen zunächst in Reservoiren abgekühlt werden, bevor es auf die Brutapparate geleitet wird, und da bot sich eine Vorwärmung in den Mühlteichen an.

Die Fischzüchter, wie beispielsweise der „älteste Fischzüchter Böhmens“, der eine Mühle an einem Nebenbett der Loučná, oberhalb des Dorfes Nedoschin in der Gegend zwischen Leitomischel und Hohenelbe in Böhmisch-Trübau betrieb, legte im Gründungsjahr 1865 bloß „schwimmende Rahmen mit Glasstäben“ auf die zu den Mühlgängen führenden Rinnen. Später führte er das Wasser ,auf die im Räderraume aufgestellten Brutapparate“ (FRIČ 1874:5). 


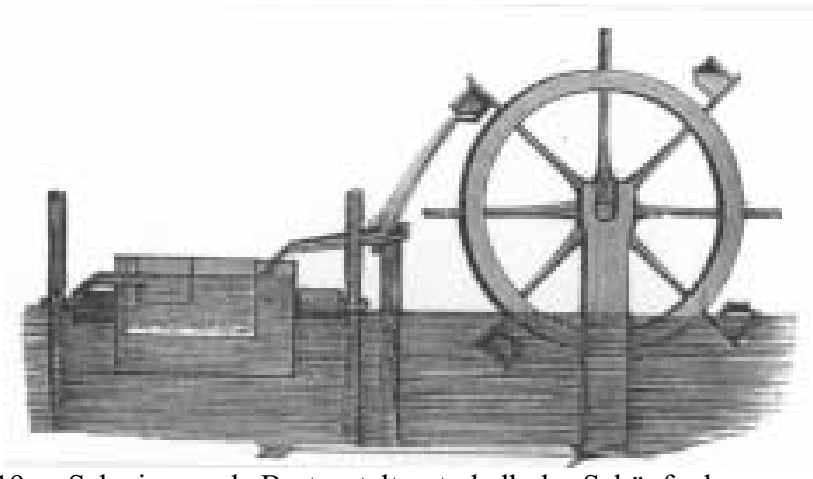

Abb. VI-19: Schwimmende Brutanstalt unterhalb des Schöpfrades

So kann eine solche Vorrichtung ausgesehen haben (BENECKE 1881:486; Beispiel aus Lanskerofen).

Und im weiteren Verlauf besaßen die Fischzüchter sog. Kuffrische Bruttiegel mit größeren Apparaten. Teilweise wurden auch von einigen Züchtern extra „Bruthütten“ (siehe Abb. VI-20) errichtet. Die in diesen Gestellen bzw. Hütten erbrüteten Forelleneier wurden in die Bäche der Umgebung eingesetzt, besaßen aber keine unmittelbare Gewässerbindung mehr, sondern Wasserleitungen führten das nötige Quellwasser aus einiger Entfernung heran. Bei einem von dem genannten Wassermüller und Fischzüchter ausgesetzten Bestand von 155.000 jungen Forellen innerhalb von 8 Jahren lässt sich der Fischreichtum ermessen, wenn FRIČ (1874:5) davon spricht, dass es allein auf der Strecke von der Mühle bis zu den Quellen, „die etwa ein $1 / 4$ Stunde lang ist, [...] Tausende von Forellen" gibt.

Gleichzeitig wurden „beim großen Forellenfange mit Netzen [...] einige Tausend 4löthige Barsche, welche hier den jungen Forellen sehr schaden“" vernichtet (FRIČ 1874:6). Im Gefolge der prioritären Forellenzucht wurden also andere Fische als ,Schädlinge“ gesehen und die Gewässer von größeren Barschen befreit.

Diese kleinen Brutanstalten besaßen machmal, wie in dem geschilderten Fall, ,einen kleinen Teich für junge Forellen“ (FRIČ 1874:7), doch reichten oftmals die Mittel nicht aus, um in größerem Maßstab die Anstalten zu erweitern.

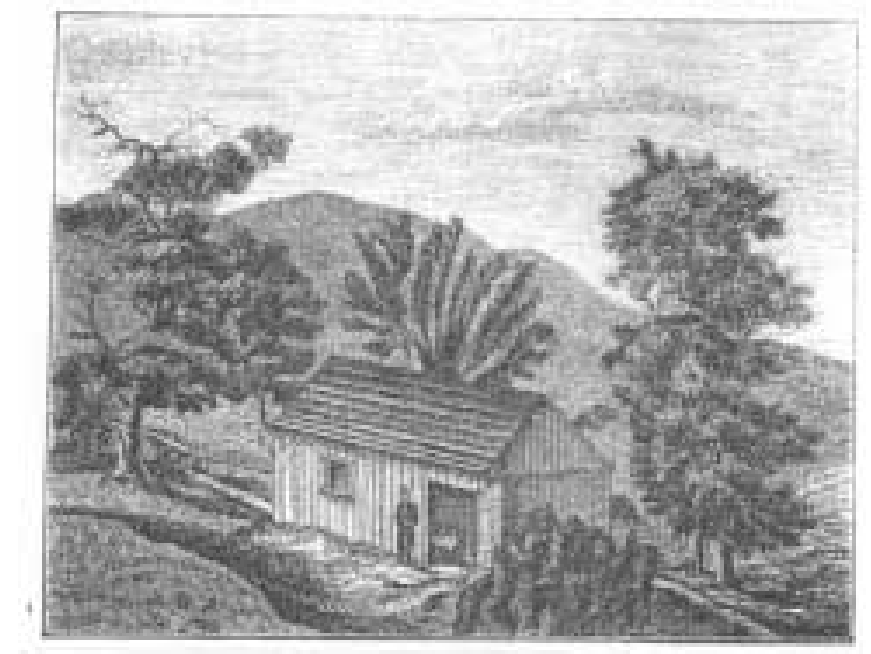

Abb. VI-20: Bruthütte bei Schüttenhofen/Böhmen

(aus: FRIČ 1874:9)

Brutanstalten gab es aber auch in anderen Gegenden. Die zahlreichen, zumeist „Domanial“ - wie auch vereinzelt - „Privatbrutanstalten“ sind von DOSCH (1899:42-43) für das Großherzogtum Hessen aufgezählt: In der Provinz Starkenburg mit den Kreise Bensheim, Heppenheim und Erbach gab es zu Ende des 19. Jahrhunderts 8 Brutanstalten, in der Provinz Rheinhessen mit den Kreisen Main und Alzen zwei und in der Provinz Oberhessen mit Gießen, Alsfeld, Lauterbach und Schotten fünf zum Ausbrüten von Bachforellen oder Bachsaiblingeier.

Bruttröge wurden in Fließgewässern auch in Ost- und Westpreußen aufgestellt: 1879/80 in Matzicken bei Heydekrug, 1880 in Heilsberg, hier wurde das Wasser der Simser abgeleitet und 1880/81 in Plietnitz bei 
Jastrow, 1879 in Sophiental bei Reichenau, im gleichen Jahr in Sommersin bei Tuchel, in Althof-Memel sowie in Wangotten und noch zahlreiche weitere mehr (BENECKE 1881:486ff.).

Die darauffolgenden, um 1900 gegründeten, zahlreichen teichwirtschaftlichen Versuchsstationen, die in künstlich errichteten Teichanlagen Fischaufzucht betrieben, hatten dann eine ganz andere Wirkung auf die Fließgewässerlandschaften. Die Teiche der 1912 gegründeten teichwirtschaftlichen Versuchsanlage in Wielenbach in Oberbayern beispielsweise waren „ursprünglich saure einmahdige Wiesen.“ (LIEBMANN/KEIZ 1965:11) und liegen im eingedeichten Gebiet der Ammer bzw. des Brunnenbaches (HETTCHE 1981:110). Mit der Einrichtung der „Königlich Bayerischen Teichwirtschaftlichen Versuchsstation“" wurden der wasserzuführende Brunnenbach auf kurzem Wege zur Ammer geführt, d. h. begradigt, das dargebotene Quellwasser für die Zwecke der Teichwirtschaft gefasst und der frühere Unterlauf des Brunnenbaches als Vorfluter der Versuchsstation verwendet (:110).

Auf der anderen Seite gehört das flache Teichgelände zum Verlandungsgebiet des präglazial wesentlich größeren Ammersees (HETTCHE 1981:110) und stellt dadurch, indem es nur ehemaliges Seengebiet in die Anlage mit einbezieht, man könnte sagen den näherungsweisen Ursprungszustand wieder her.

\section{e.3 Fischleiter}

Wasserfälle, aber vor allem die im Zuge der Regulierungen, Gewässeraufstauungen und Bewässerungseinrichtungen installierten Wehre und Schleusen verhinderten das Auf- und Weiterschwimmen der Fische in die Flüsse und Bäche, um die Laichstätten aufzusuchen.

Niedrige Wehre bis ca. $1 \mathrm{~m}$ Höhe konnten gewöhnlich „bei reichlichem Wasser von den Fischen ohne besondere Vorrichtung“ überwunden werden (BORNE 1886:310). Bei höheren Wehren jedoch waren „künstlichere Vorrichtungen erforderlich“, um den Fischen das Aufsteigen möglich zu machen (:311).

Fischleitern sind nach einer Definition von BORNE (1886:310) Bauwerke, „welche den Fischen Wasserfälle, Wehre, Schleusen passirbar machen und dadurch ihre Laich- und Waidplätze vergrößern.“. Eine solche Fischleiter bestand zunächst einmal generell darin, einen „Einschnitt von $0,6-1 \mathrm{~m}$ Weite“ vorzunehmen, der „durch eine Schütze verschließbar“ ist. Dieselbe konnte zu den Zeiten „wo die Wanderfische zu steigen pflegen“, geöffnet werden ${ }^{34}(: 311)$.

Hinsichtlich der Führung durch das Wehr unterschied man zwei Hauptklassen von Fischleitern: erstens „solche mit konstantem Gefälle des Wasserspiegels“ und zweitens sog. „Treppenpässe“. Gemeinsames Kennzeichen bei allen war „die Lage der Mündung des Passes im Unterwasser“. Sie musste „,so angebracht sein, daß der Fisch sie leicht finden kann“ und lag „hart an dem Kolk, in welchen das über das Wehre fließende Wasser stürzt, und zwar möglichst nahe an dem Absturz.“ Ferner sollte ,so viel Wasser durch den $\mathrm{Pa}$ fließen, daß dadurch die Aufmerksamkeit der Fische erregt" wurde (BORNE 1886:311).

Max von dem BORNE (1886:311) führt in seinem Lehrbuch einige Beispiele englischer bzw. irischer Fischleiter-Konstruktionen auf. Daraus ist zu schließen, dass England - früher als Deutschland - auf dem Gebiet der Fischleitung besondere Errungenschaften erworben hatte: Die „Ballisodare-Leiter“ in Irland beispielsweise war nach seiner Ansicht „ein berühmtes Beispiel von einem gelungenen Treppenpasse“ (siehe Abb. VI-21).

\footnotetext{
${ }^{34}$ An dieser Stelle wird das Problem des Wasserentzugs für den Mühlenantrieb deutlich. Insbesondere dann, wenn man bedenkt, dass eine Fischleiter, wie sie im Folgenden vorgestellt wird, pro Sekunde ungefähr 0,5 $\mathrm{m}^{3}$ Wasser brauchte (BORNE 1886:310), um den Fischen das Steigen entgegen der Strömung zu ermöglichen. Man kann daraus berechnen, wie viel Wasser einem Mühlrad durch eine solche Leiter entzogen wird. Geht man nur von einer Öffnung für einen Zeitraum von 1 Stunde aus, dann flossen bereits $1800 \mathrm{~m}^{3}$ Wasser durch diese Öffnung. Mit dieser Wassermenge konnte ein kleines Wasserrad, unter der Annahme einer Fallhöhe von 3 m, ungefähr 2,2 Stunden lang betrieben werden.
} 

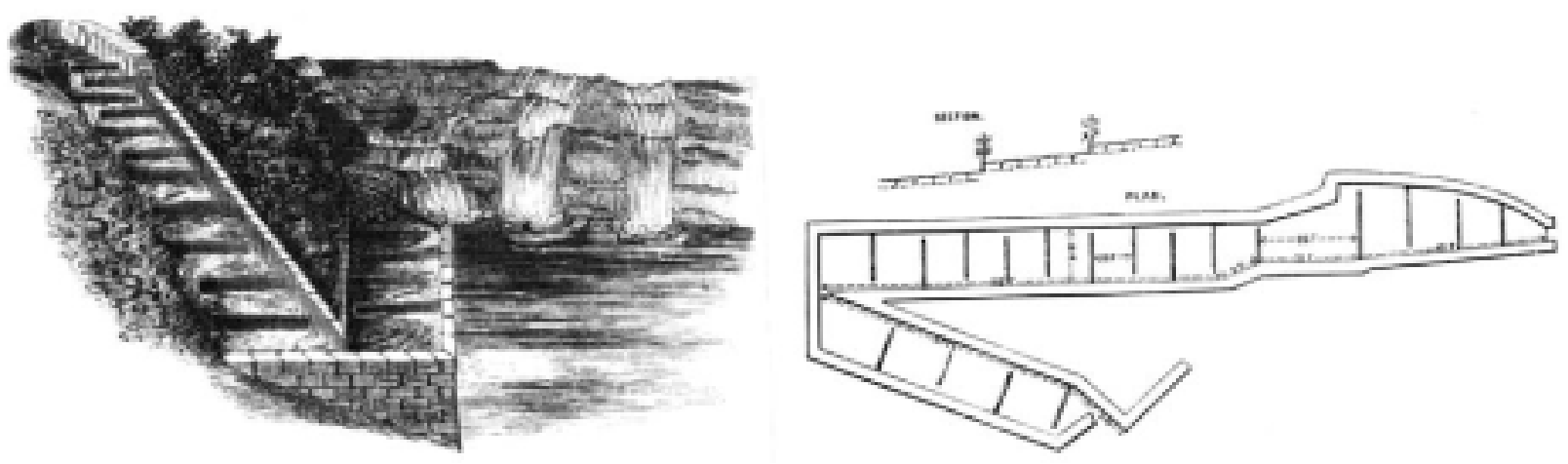

Abb. VI-21: „Ballisodare-Leiter“/Irland. Vordersicht und Aufsicht (aus: BORNE 1886:312)

Die Abmessungen zeigen jedoch, dass die Anlage von Fischleitern ein umfangreiches und kostspieliges Unterfangen war. Der Wasserfall über das Wehr war bei diesem zitierten Beispiel 5,5 m hoch, die Leiter 72 $\mathrm{m}$ lang und ihr Gefälle betrug 1:13. Die oberen Bassins, d. h. die einzelnen Stufen der Fischleiter waren 3,5 $\mathrm{m}$, die unteren $4 \mathrm{~m}$ lang und die Schlupflöcher 0,3 m weit (BORNE 1886:312f.). An dieser Leiter hat sich BORNE wahrscheinlich bei seinen Konstruktionsvorgaben orientiert. Danach betrug die Neigung der Treppenpässe im Allgemeinen nicht mehr als 1:10 und die Stufen sollten ,wenigstens $3 \mathrm{~m}$ breit, $3-4 \mathrm{~m}$ lang und 0,6 - 0,7 m tief sein." (:312f.). Eine solche Fischtreppe kam beispielsweise auch beim Neubau des Ellermühlen-Wehres in Nordhausen-Crimderode im Jahr 1906 zur Ausführung.

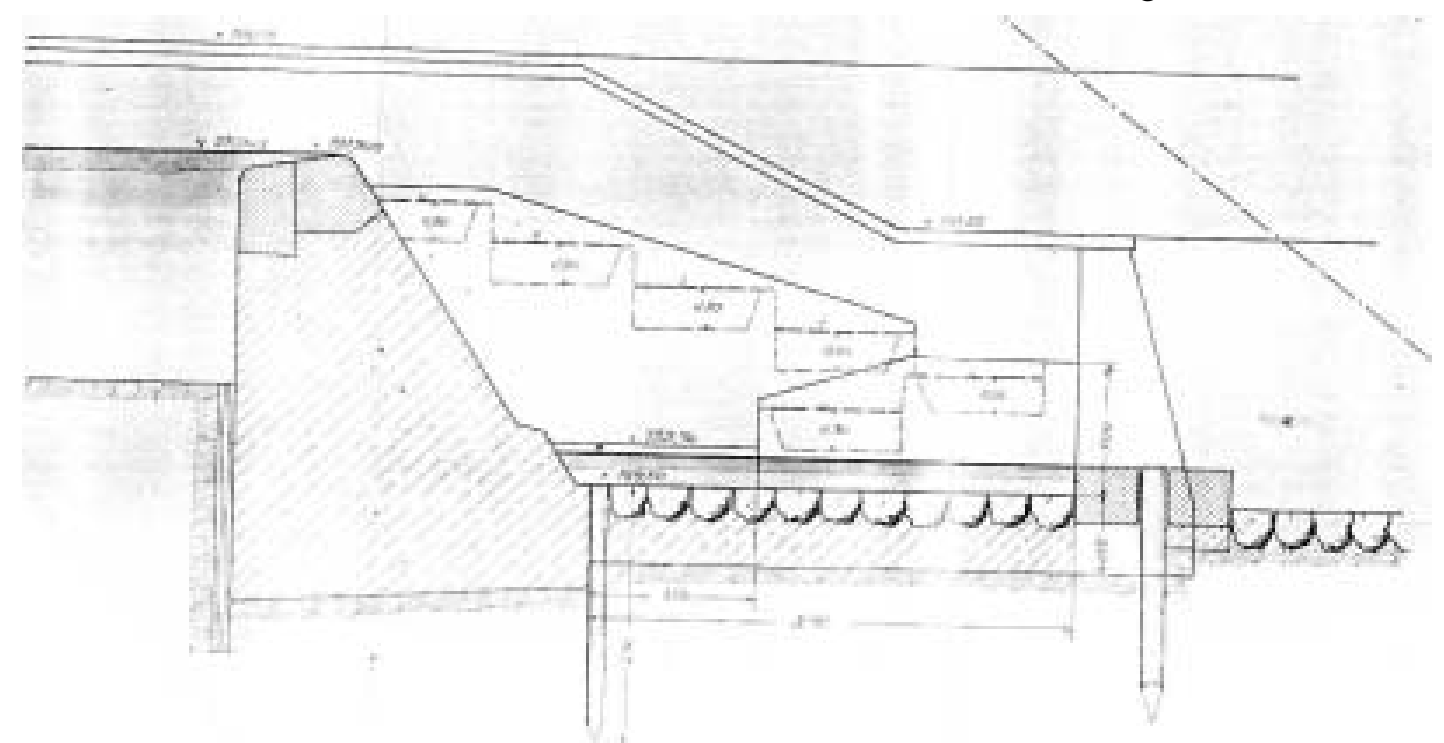

Abb. VI-22: Längsschnitt der Fischtreppe im „Ellermühlenwehr“ mit den einzelnen Aufstiegszellen (Stadtarchiv Nordhausen)

Neben dieser seitwärts, entlang des Ufers, geführten getreppten Fischleiter, gab es auch den sog. Diagonalpass (siehe Abb. VI-23). Dieser, so BORNE (1886:312), „erfüllt bei nicht zu großer Höhe oft den Zweck". Als Beispiel nennt er das Bransfordwehr am Temefluss in England. 


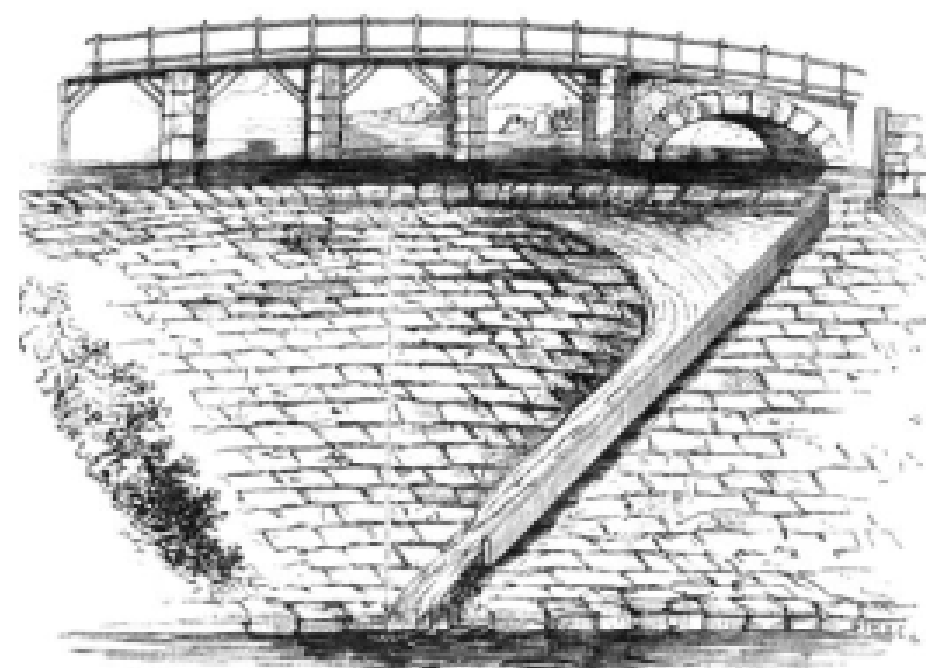

Abb. VI-23: „Diagonalpass“, auf einem geneigten Wehr angebracht. Beispiel: Bransford/Teme (aus: BORNE 1886:311)

Als weiteres Beispiel einer Fischtreppe, die nach ihrem Erfinder R. Cail, Manor of New-Castle-Upon-Tyne, benannte Cail'sche Fischleiter (siehe Abb. VI-24), verdient aufgrund seiner charakteristischen Konstruktion - manche Cail'schen Fischleitern besitzen die Form einer Wendeltreppe - besondere Erwähnung. Die genannten Fischpässe waren unter anderem im Einsatz am Dinsdalewehr am Tees, zu Telton am Coquet und zu Warkworth am Coquet.

BORNE (1886:312) beschreibt sie wie folgt:

„Die Bassins sind $2 \mathrm{~m}$ lang und breit und $1 \mathrm{~m}$ tief, die Schlupflöcher sind 0,3-0,4 $m$ breit und 0,4 - 0,45 m hoch, und ihre Oberkante befindet sich unter dem Wasserspiegel der nächst unteren Treppenstufe. Die Stufen liegen 0,4 - 0,5 m übereinander. Wenn die Treppe mit Wasser gefüllt ist, so daß ein wenig Wasser über die Stufen fließt, so passirt eine lebhafte Strömung die Schlupflöcher und die Fische können ohne Beschwerde vom Unter- zum Oberwasser gerade aufschwimmen."

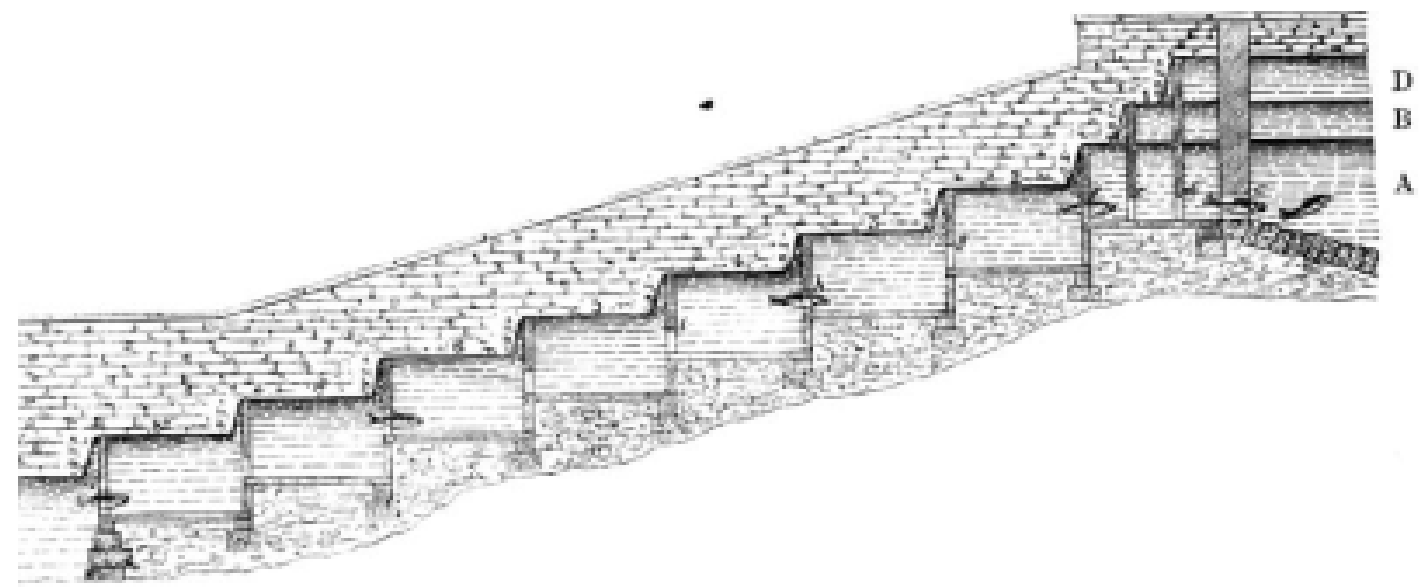

Abb. VI-24: „Cail'sche Fischleiter“

Mit A ist der Wasserstand bezeichnet, wo das Wehr anfängt überzulaufen, B ist Mittel- und D Hochwasserspiegel. Das Wasser kann nur durch die Öffnung C zur Fischleiter fließen. Die Leitzellen $(1-8)$ haben zwei Öffnungen, durch die die Fische ein- und hochsteigen. Die oberen Öffnungen der Leitzellen sind mit einem Gitter bedeckt, die das Fischen, das Eindringen von Holzstücken und anderen schwimmenden Gegenständen den Eintritt in die Leitzellen unmöglich macht (aus: BORNE 1886:314).

Diese in mittelgroßen Flüssen erbauten Fischleitern konnten aufgrund ihrer kostengemäßen Dimensionalität in kleineren Forellenbächen nicht zur Anwendung gelangen. Hier genügte „oft ein ganz kleiner, für geringe Kosten, aus leichten Brettern zusammengenagelter Fischweg, der sich leicht aufstellen, fortnehmen und transportiren läßt. Oft ist ein $0,15 \mathrm{~m}$ im Quadrat weiter Querschnitt des Hauptgerinnes ausreichend." 
(BORNE 1886:315) Man schuf also einen „Cail'schen transportablen Fischweg en miniature“, deshalb die Schilderung des englischen Vorbildes. Diese mobile und kleinere Fischleiter besaß Schlupflöcher von 0,10 bis $0,15 \mathrm{~m}$ Durchmesser, konnte zu ,geringen Kosten aus leichten Brettern hergestellt werden und dürfte für Forellenbäche, selbst an den höchsten Wehren, seinen Zweck vollständig“" erfüllt haben, wenn die Höhe der Stufen 0,4 bis $0,5 \mathrm{~m}$ nicht überstiegen (:313). Mit solchen Konstruktionen konnten die durch die Verwehrungen verursachten Hindernisse beim Fischewandern umgangen werden.

Der besondere Vorteil dieser Fischleiterlösung war, dass diese den „verschiedenartigsten Verhältnissen“ angepasst werden konnte. Für große Flüsse, die Lachse und andere Wanderfische bevölkerten, konnte man den Fischweg ,so geräumig machen, daß er im Stande ist, den ganzen Fluß aufzunehmen; er wird dann solide aus Mauerwerk, Holz und Eisen construirt.“(BORNE 1886:315)

Besondere Aufmerksamkeit schenkte man den Aalwanderungen. Die kleinen und mittleren Flüsse wurden bekanntlich im Interesse von Mühlen und anderen industriellen Anlagen vielfach durch Stauwerke gesperrt, die oft zu hoch waren, um von der Aalbrut in größerer Anzahl überklettert zu werden (BORNE 1886:318). Es galt, den jungen einwandernden Fischen, der Aalbrut, durch Anlage von sog. Aalbrutleitern das Aufsteigen in das Oberwasser zu erleichtern und sie dadurch in Gewässer einzuführen, „die ihnen sonst verschlossen geblieben wären.“(BENECKE 1885:48)

Namentlich den Wassermüllern wurde die Anlage solcher Einrichtungen im Eigeninteresse umso mehr empfohlen, als die Mühlen oft an ihren Freischleusen einen Aalkasten hatten, in dem die zum Meer wandernden Aale gefangen wurden. Je mehr junge Aalbrut nun in die oberhalb der Mühlen gelegenen Gewässer einwanderte, umso mehr erwachsene Aale konnten später im Aalfang erbeutet werden (BORNE 1886:318).

Die Wandererleichterungen mit Hilfe einer Fischleiter mussten anscheinend trotz der besonderen Fähigkeiten der Aale, die BORNE (1886:317f.) mit ihren früheren Populationsgrößen eindrucksvoll beschreibt, ergriffen werden:

\begin{abstract}
„Die jungen Aale unternehmen ihre Wanderungen in großen Schwärmen, die oft mehrere Meter breit und tief und Hunderte, ja Tausende von Metern lang sind, so daß man sie an manchen Orten ununterbrochen viele Tage lang hat vorbeiziehen sehen. [...] An jedem einmündenden Nebenflusse oder Bache zweigt sich eine Abtheilung des Schwarmes ab und dringt stetig bis in die kleinsten Gewässer vor, alle möglichen Hindernisse mit großer Hartnäckigkeit überwindend. So gelangen sie durch nur zeitweise vom Regen gefüllte Gerinne in Teiche und Dümpel, die sonst gar keinen Zusammenhang mit fließendem Wasser haben, kriechen über nasse Dämme und Wege fort, klettern über Steine und niedrige Wehre und steigen vermöge ihrer Klebrigkeit und Leichtigkeit selbst mehrere Meter hoch an senkrechten Wänden empor, um über Schleusen und andere Stauwerke fort weiter stromaufwärts zu gelangen."
\end{abstract}

Es mussten für die Aalwanderung aber keine großartigen Maßnahmen getroffen werden. Es reichten ,äußerst billige Aalpässe“ aus, die daher ,an keiner Wassermühle fehlen“ sollten (BORNE 1886:318). „Schon ein schräge liegendes rauhes Brett, welches aus dem Unterwasser nach dem Oberwasser führt und durch sickerndes Wasser nur feucht gehalten wird“, böte „den jungen Aalen eine willkommene Gelegenheit zum Aufstieg.“ (:318)

Komfortabler für den Aalaufstieg aber war es, ihnen eigene Leitern anzulegen. Am besten eignete sich nach BORNE (1886:318f.) dazu

„,eine vierkantige krippenartige Rinne aus rauhen ungehobelten Brettern, die mit einer Steigung von etwa 1:6 aus dem Unterwasser bis zum Spiegel des Oberwassers gelegt wird. Dieselbe kann eine Breite von 20 und eine Tiefe von $10 \mathrm{~cm}$ haben und braucht nicht in gerader Richtung zu verlaufen, sondern kann, den örtlichen Verhältnisse angemessen, nach Erforderni $\beta$ winklig gebrochen sein, um Hindernisse zu umgehen. Das obere Ende der Rinne wird im Oberwasser so befestigt, daß der Boden etwa $2 \mathrm{~cm}$ unter dem Wasserspiegel liegt, das untere Ende wird zweckmäßig schaufelartig verbreitert, um den jungen Aalen das Auffinden des Weges zu 
erleichtern. Auf dem Boden der Rinne werden in Abständen von je $20 \mathrm{~cm}$ querüber Leisten von etwa $1 \mathrm{~cm}$ Höhe aufgenagelt, die den Zweck haben, groben Kies von Haselnußgröße, mit dem man die Rinne ihrer ganzen Länge nach etwa $2 \mathrm{~cm}$ hoch füllt, am Abrutschen zu hindern.

Das durch die Rinne abfließende Wasser wird also zum größten Theil durch den ihren Boden bedeckenden Kies herabrinnen und diesen feucht halten, wodurch den Aalen das Aufsteigen viel leichter gemacht wird, als wenn ein auch nur schwacher Wasserstrom frei durch die Rinne herabflösse."

Aufgrund des früher zahlreichen Aufstiegs von Aalen erschien es gerechtfertigt, ,jeden Besitzer von Wassermühlen und anderweitigen Stauwerken zur Anlage einer billigen Aalbrutleiter aufzufordern.“ (BORNE 1886:320). Da der Aufstieg der Aalbrut nur im Frühjahr und Vorsommer stattfindet, konnten die Leitern „später abgenommen und bei Seite gelegt werden, um nicht Beschädigungen durch den Eisgang ausgesetzt zu sein.“(:320)

\section{Grenzgewässer}

Kleine Gewässer waren oft „Grenzflüsse“ zwischen verschiedenen Territorien, Verwaltungsbezirken oder sie trennten Fortbezirke voneinander.

Die sumpfige Auenlandschaft der Dumme bildete zum Beispiel nicht nur Jahrhunderte eine natürliche Abgrenzung des Wendlandes zur Altmark, sondern war auch bis 1866 durch die Annektion Hannovers durch Preußen in jenem Jahr Grenzfluss zwischen den beiden Ländern (LANGE 1989:55). Das Amt Neuhaus, seit Mitte des 13. Jahrhunderts Teil des Herzogtums Sachsen-Lauenburg, hatte seine Grenzen mit dem Herzogtum Lüneburg und dem Herzogtum Mecklenburg „zu großen Teilen an der Elbe, der Rögnitz und anderen Wasserläufen" (GREVE 1999:5). Diese kleinen Grenzflüsse waren zum Beispiel Neue Sude zwischen Brahlstorf und Sückau, die Krainke zwischen Preten und Besitz, der Leppel Bach usw. Die Bille bildet bis heute den Grenzfluss zwischen den Kreisen Stormarn und dem Herzogtum Lauenburg. Die Warmenau bildete die Grenze zwischen den Territorien Osnabrück/Hannover und Preußen beziehungsweise den heutigen Kreisen Osnabrück und Herford (MÖRSTEDT 1995:200). Der Bierschbach (Bersbach) ist seit Jahrhunderten und bis heute politische Grenze zwischen den Orten Bierschbach und Drees, Krs. Ahrweiler in der Eifel (MERTES 1995:68). Und auch heute noch ist die Uess von Furth bis Bad Bertrich Grenzbach zwischen den Regierungsbezirken Koblenz und Trier (:118). Die Prüm bildete seit dem 8. Jahrhundert die Grenze zwischen dem Wald des Pfalzgrafen und dem des gleichnamigen Klosters (KREINER 1996b:91). Und in der bis ins 10. Jahrhundert zu datierenden Grenzbeschreibung der Diozöse Hildesheim werden die Harzer Quellflüsse der Rotenbeeke und die Wolfswarte aufeinanderfolgend aufgezählt und sind 1548 als Harzburger Amtsgrenze überliefert: Die Grenze ging ,...bis ahn die Wulffeswart bis dar der Rodenbeegk springet.“ (HAASE 1961:18, zitiert aus alter Quelle) Dieser Bach zieht noch heute eine Forstgrenze (:18). Der Spiegelbach als einer der wichtigsten Zuflüsse der Innerste ist ebenfalls klösterliches Grenzgewässer und bildet die Umgrenzung des Waldbesitzes des Klosters Cella (HAASE 1961:40). Das Schneidwasser, um im Oberharz zu bleiben, war seit der Communion-Verfassung von 1635 der neue Name für den bisher die Altenau genannten Bach, der im Unterlauf zum Schultal geworden ist. Das Schneidwasser war Grenze „Schneede“ - gegen den jenseits (rechts) liegenden „Communion-Oberharz“. Die Communion-Verfassung regelte die Verhältnisse in den welfischen Harzlanden nach dem Aussterben der Wolfenbütteler Herzöge. Ihr Gebiet ging in die gemeinschaftliche Verwaltung (Communion) der erbenden Linien über (HAASE 1961:21). Diesseits des Grenzwassers befand man sich im ehemals Grubenhagen'schen Oberharz (:22). Des Weiteren besaß der Zellbach neben seiner wasserwirtschaftlichen Bedeutung auch Grenzfunktion (HAASE 1961:47) und bildete einst die Grenze zwischen den beiden Orten Zellerfeld und Clausthal (:25). Die Holzminde im Solling ist Grenzbach gewesen zwischen den braunschweigischen Ämtern Fürstenberg und Allersheim und zugleich wolfenbüttlisch-hannoverscher Grenzbach (RUHLENDER 1998:296).

Die Eingriffe in kleine Wasserläufe zur Hervorhebung ihrer Funktion als Grenzgewässer waren von bescheidener Art und hatten eher Verwaltungscharakter: einige Grenzpunkte bzw. Grenzpfähle, die manchmal in das Ufer oder die Bachmitte gesetzt wurden und die Grenzlinie markierten. In den meisten Fällen jedoch blieben sie ohne Folgen, denn in damalig ,so unwegsamen sumpfigen und dazu häufig noch bewaldeten Gebieten“ waren die Grenzen, „dort wo sie Wasserläufe verließen, nicht immer sicher vereinbart und schon gar nicht mit festen Grenzmarken versehen." (GREVE 1999:5). 
An größeren Flüssen hingegen, die aufgrund ihrer Breite oder auch Tiefe ein Querungshindernis für feindliche Truppen bildeten, wurden flussbegleitend im Mittelalter Bollwerke und Trutzburgen zur zusätzlichen Sicherung der Landesgrenzen errichtet.

\section{Befestigung}

Das Schutzbedürfnis des Menschen ist urtypisch. Dies konnte nur durch Höhe oder wasserflankierte Tiefe erreicht werden. Der Schutz von Siedlungen durch Umgebung mit Wasser ist bei vielen frühen Siedlungsformen, zum Beispiel den angelsächsischen „crannogs“, und auch bei den auf kleinen Hügeln gelegenen Motten des 8. - 11. Jahrhunderts zu erkennen (siehe auch V 2d). Auch die großen alten deutschen Volks- und Hünenburgen lagen „stets auf Bodenwellen oder Uferterrassen“ (MUMMENHOFF 1977:8). Sie besaßen aber „,keine nassen Gräben, sie füllten sich höchstens gelegentlich mit Grund- oder Regenwasser.“:8)

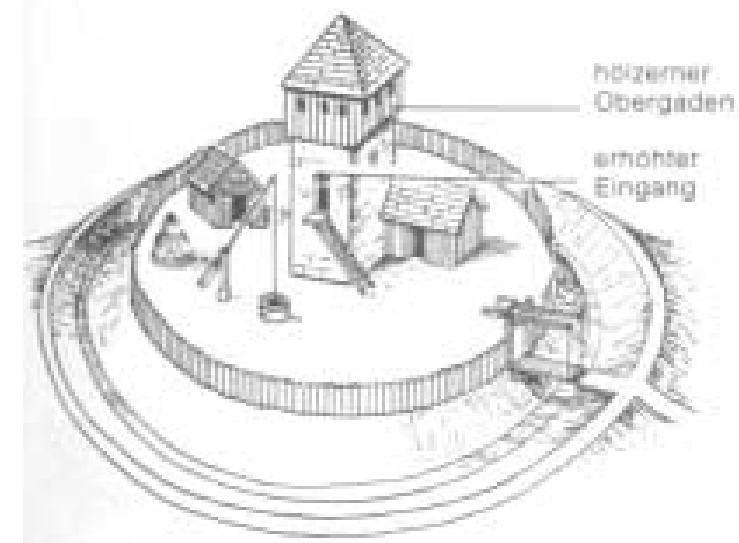

Abb. VI-25: „Motte“:

Ältester Ringburgtyp, seit dem 8. Jahrhundert, nachweisbar. Künstlicher Hügel aus Grabenaushub (aus: KOCH 1994:299)

Die Lage im oder am Wasser übte dabei eine zweifache Funktion aus: Schutz vor Hochwasser und Schutz vor Feinden. „Das Wasser“, schreibt MUMMENHOFF (1977:6), „,im Sumpfland reichlich vorhanden und aus dem Bach- oder Flußlauf durch künstliche Seitenarme oder Stauanlagen für die Gräben zu gewinnen, mußte die steilen Berg- und Felsflanken der Höhenburgen ersetzen.“

Die Frühformen der Wasserbefestigungen kann man aber noch nicht als Wasserburgen bezeichnen (MUMMENHOFF 1977:8). Wasserburgen sind gekennzeichnet durch die ,durchgedachte technische Anlage, Gräben oder tiefliegendes Gelände planmäßig mit Wasser zu füllen, das feuchte Element also bewußt zur Verteidigung $\mathrm{zu}$ benutzen. $\mathrm{Zu}$ den technischen Anlagen, die eine Wasserbefestigung ermöglichen, gehören Stauwehre, künstliche Flußarme oder die sorgfältig gewählte Lage der Burg in einer Flußschleife, wo sie durch einen Durchstich vom Umland zu trennen war.“ (:8)

Aus fortifikatorischen Gründen wurde also „erheblich in die naturräumliche Situation der Flussbänder eingegriffen.“ (HERBST 1992:57): „Der Fluß wurde durch eine künstlich nachgeformte Schleife für das Ringgrabensystem mitbenutzt, oder durch den Stau eines Baches bzw. Flusses wurden die Gräben mit Wasser versorgt.“ (MUMMENHOFF 1977:9). Dafür wurden Mäander unterbrochen, Flsssläufe kanalisiert, Altarme verkürzt oder die Feuchtgebiete trockengelegt und Bäche und Gräben wurden zum Teil verrohrt und so das Wasser den Herrschafts- und Wehrsitzen zugeführt. Beim Fluten der umfangreichen Stadtbefestigungsgräben im Verteidungsfall wurde „die oftmals bescheidene Wassermenge eines Bachlaufes [...] auch zur Durchspülung des Befestigungsgrabens gebraucht. (HERBST 1992:57).

Die Regulierung der Bachläufe hat durch den Bau von Burganlagen und die Ableitung des Wassers zu den Festungsgräben erheblich zur Landschaftsgestaltung und zur Umgestaltung des Gewässersystems beigetragen. Zahlreiche Schleusen und Wehre wurden 1796 beispielsweise an der Düssel von den Franzosen 
errichtet, um zur Verteidigung die Flutung des gesamten Geländes vor der Außenbefestigung zu ermöglichen (SPOHR 1988:50f.).

Die Anlagenform der spätestens im 14. Jahrhundert errichteten und zum Teil aus dem Umbau der „Erdhügelburgen“ folgenden Tieflandsburg ,ist im Grundprinzip in allen Ländern gleich“ (MUMMENHOFF 1977:6). Die wichtigste Neuerung war dabei der seit Anfang des 12. Jahrhunderts aufkommende Bau der wasserumgebenden Ringmauer (MUMMENHOFF 1977:14). Regionale Besonderheiten zeigen sich lediglich in der Bauart der einzelnen Burggebäude (:6).

Die Anlageform gibt Hinweise zum einen auf die Art des Gewässereingriffs. Bezüglich der geographischräumlichen Verbreitung und damit auch der Intensität von solchen Eingriffen ist zum anderen festzustellen: „Wasserburgen [...] der Ebene gibt es überall.“ (MUMMENHOFF 1977:6) Die bedeutendsten „WasserburgLandschaften" auf deutschem Gebiet im Verhältnis zur Landesgröße besitzt das deutsche niederrheinische Gebiet. Es folgen Westfalen, Niedersachsen, Friesland, Schleswig-Holstein und die Ostseeländer (:6). „Fast in jeder westfälischen Gemeinde lag ein Adelssitz, meist eine Wasserburg.“ (:29) Bei den vor allem gegen Ende des 13. und im ganzen 14. Jahrhundert entstandenen typischen Burganlagen des Lehns- bzw. Dienstadels im Münsterland handelte es sich ausschließlich um Wasserburgen. Bei manchen Wasserburgen wurde ein ganzes Labyrinth von nassen Gräben als Wasserbefestigungen errichtet, wie zum Beispiel bei der Paulsburg des Fürstbischofs Christoph Bernhard von Galen in Münster. Überflüssiges Wasser wurde dabei durch eine Umflut um den Burgbezirk herumgeleitet (:20).

Typisch ist auch die Anlage auf von Wasser umgebenden Inseln, wie beispielsweise bei Burg Vischering. „Die ganze Anlage ist zwischen zwei Flußläufe gesetzt: zwischen die Stever und den zum Betrieb der Mühlen künstlich gegrabenen sogenannten ,Vischeringschen Mühlenarm'“ (MUMMENHOFF 1977:14).

Hervorgegangen sind die Wasserburgen des Münsterlandes aus den sog. „Gräftenhöfen“: „Beim Gräftenhof umschlossen Wassergräben ein rundes oder ovales Gelände, auf dem das Bauernhaus und seine Nebenbauten wie Scheune, Ställe, Schuppen, Backhaus, Speicher und Torhaus verteilt lagen. Der Speicher war oft gesondert durch einen Grabenring befestigt, oder er lag in einer teichartigen Erweiterung des Grabens." (MUMMENHOFF 1977:17). Das Hauptmerkmal dieser Gräftenhöfe und ihrer Zwischenstadien zur Wasserburg aber ist - abgesehen von dem für sich im Wasser liegenden Speicher als Not- und Nutzbau „die Lage aller Gebäude auf nur einer Insel.“ (:18) Beim Ritterhause Lage, einer ehemaligen Kommende im Nordkreis Osnabrück hingegen dienten die die Gesamtanlagen umgebenden Gräften gleichzeitig auch als Umfluten (DOBELMANN 1980:27).

Die wassergefüllten Wehr- und Schutzgräben existierten bis zur Schleifung der Burg- und Gräftengräben in der absolutistischen Zeit oder überlebten als historische Reminiszenz, wie beispielsweise im Westmünsterland bei dem Stammsitz von Annette von Droste-Hülshoff in Münster-Roxel oder auch beim Wasserschloss Lembeck, dessen Gräfte vom Lembecker Wiesenbach und Schlumpenbach gespeist wurde (LUA NRW 1999a:70), aber auch in Niedersachsen wie beim Wasserschloss derer von Münchhausen in bei Aerzen bei Hameln oder dem Bückeburger Schloss.

Aus Befestigungsgründen wurde jedoch auch noch in anderer Weise der Gewässerlauf beeinflusst: durch Deichbau.

Im antiken Europa sind Deiche als wasserbauliche Anlagen in größerem Stil erstmals im mykenischen Griechenland nachweisbar. Sie hatten den Schutz menschlichen Lebensraums, d. h. von Siedlungen und landwirtschaftlich genutzten Flächen vor Überschwemmungen bei Hochwässern zum Ziel (KNAUSS 1999a:91). Auch in den offenen mitteleuropäischen Flusslandschaften des 18. Jahrhunderts wurden Erddämme und Deich-Mauern aus dem gleichen Grund errichtet.

„Die akute Zunahme der Hochwassergefahr in der ersten Hälfte des 18. Jahrhunderts“ (HERRMANN 1997:153) fiel zusammen mit den herrschaftlichen Bestrebungen um weiteren Landesausbau. Eine Gewinnung von Ackerland durch Eindeichung und Drainung impliziert somit ,zugleich den Schutz der Anlieger vor Hochwasser.“ (:153), denn „,mit der Eindeichung ist auch die Dynamik der Flußbettverlagerung stark eingeschränkt bzw. fast völlig aufgehoben worden.“ (:154) Uferabbrüche an Flusskrümmungen hatten 
für das Siedlungswesen verheerende Folgen. So fielen in der Magdeburger Elbaue seit 1350 über einem Abschnitt von rd. 75 km nahezu 30 Siedlungen durch Flusslaufveränderungen wüst (:154).

Aus ebensolcher Absicht wurde die Flussregulierung des Else-Flusses im Kreis Herford noch in den 1920er Jahren durchgeführt. Ein etwa 95 ha großes Areal - von der Brücke an der Sachsenstraße bis zur Eschenbrücke - bestehend aus Wiesen, Acker- und Gartenland sowie aus wertvollem bebautem Gelände sollte vor Hochwasser geschützt werden. Das Projekt wurde nicht zuletzt wegen der hohen Arbeitslosigkeit unter den Tabakarbeitern als Notstandsarbeit anerkannt (ALTHÖFER-WESTENHOFF/WAGNER 1997:122).

Mit Dämmen und Deichen wurde also versucht die Ausuferung von Flüssen zu begrenzen. Man wollte Neuland gewinnen, indem man Siedelland den natürlichen Retentionsräumen abzwang und musste in einem zweiten Schritt dies wiederum vor Überflutungen schützen.

\section{Landschaftsparks und Herrengärten}

Die im 16. Jahrhundert neu erbauten Herrenhäuser und die zu offenen Schlossbauten umgestalteten Wasserburgen des 16. und frühen 17. Jahrhunderts (MUMMENHOFF 1977:34) nutzten die umgebenden Wassergräben als Zier und zur Dekoration. Auf den Gräften schwammen mit einmal „zahlreiche Zuchtenten und Schwäne, deren hölzerne Ställe auf Pfählen im Wasser standen“ (:32). Die neuen Anlagen blieben aber dem bewährten alten Prinzip treu: Sie blieben weiterhin vom Wasser umgeben.

Überall in Europa wurden dann im Barockzeitalter an der Schwelle des 18. Jahrhunderts ,riesengroße, fast ins Maßlose gehende Schloßanlagen geplant und gebaut.“ (MUMMENHOFF 1977:40), wie zum Beispiel das Schloss Nordkirchen oder das Schloss Sassenberg. Die Funktion des Wassers änderte sich auch noch einmal, es wurde als architektonisches Element eingesetzt. Bei dem von Johann Conrad Schlaun, Westfalens großem Architekten, verwirklichten Stadtschloss Münster zum Beispiel dienten die Wassergräben nur zur Unterstreichung der großen Baulinien (:42). Das Wasser scheint bei all den in dieser Epoche entstandenen Bauten nur verwendet worden zu sein, ,um die Schönheit des Gebäudes durch Spiegelung noch mehr zu betonen.“ (:44) Der „glänzenden äußeren Erscheinung der Wasserschlösser“ entsprachen „kostbar ausgestattete, repräsentative Innenräume.“ (:46)

Künstlich angelegte Brunnen, eingefasste Teiche, Gräben und Wasserkünste dienten der Repräsentanz dieser oft nur selten im Jahr von der Herrschaft bewohnten Anlagen.

Die Anlage eines Parks bedeutete zu „bauen mit den Elementen der Natur, [...] mit [...] fließendem, springendem und stehendem Wasser.“ (ZACHER 1998:11) Die Eingriffe in die Gewässerführung waren dabei zum Teil heftig, wie das Beispiel des rheinischen Schlosses Benrath/Düsseldorf eindrucksvoll zeigt:

Das im 15. Jahrhundert zu einer Wasserburg ausgebaute und Mitte des 17. Jahrhunderts zu einem Schloss umgebaute und als Sommer- und Jagdresidenz der Pfalzgrafen von Pfalz-Neuburg dienende Schloss Benrath wurde im 18. Jahrhundert zu einem Lustschloss im französischen Stil („maison de plaisance“) umgestaltet. Der Bauherr, Carl Theodor von Pfalz-Sulzbach berief gar einen eigenen Baumeister als „Intendanten der Gärten und Wasserkünste“, der während der Bauzeit von 1755 bis 1773, auf der vorhandenen „wasserbaulichen Situation“ die Neugestaltung vornahm.

Das Schloss war zu Beginn der Umbauperiode von einem einfachen Wassergraben umgeben und lag inmitten von Feldern, die von dem zum Schloss gehörenden Hof landwirtschaftlich genutzt wurden. Nach den auch zeitlich danach vorgenommenen Umgestaltungen im Wandel des streng geometrischen „Französischen Garten“ zum „Englischen Garten“ - zum Beispiel wurde in der Mitte des 19. Jahrhunderts die steinerne Einfassung der Weiher aufgegeben und die Ufer bepflanzt (ZACHER 1998:11) - präsentierte sich der Schlosspark als „ein ca. $612.000 \mathrm{~m}^{2}$ großes, von einem Wassergraben umschlossenes Areal.“(:11) Auf diesem Areal aber,gehörten zu den maßgeblichen Gestaltungselementen Teiche unterschiedlicher Form und Größe: „Wie im Corps de Logis großen Gesellschaftsräume von den privaten Wohnräumen 
unterschieden werden, so werden auch im Park ,offene' Gartenräume - wie die großen Weiher - von kleineren intimeren abgelöst.“"(:12)

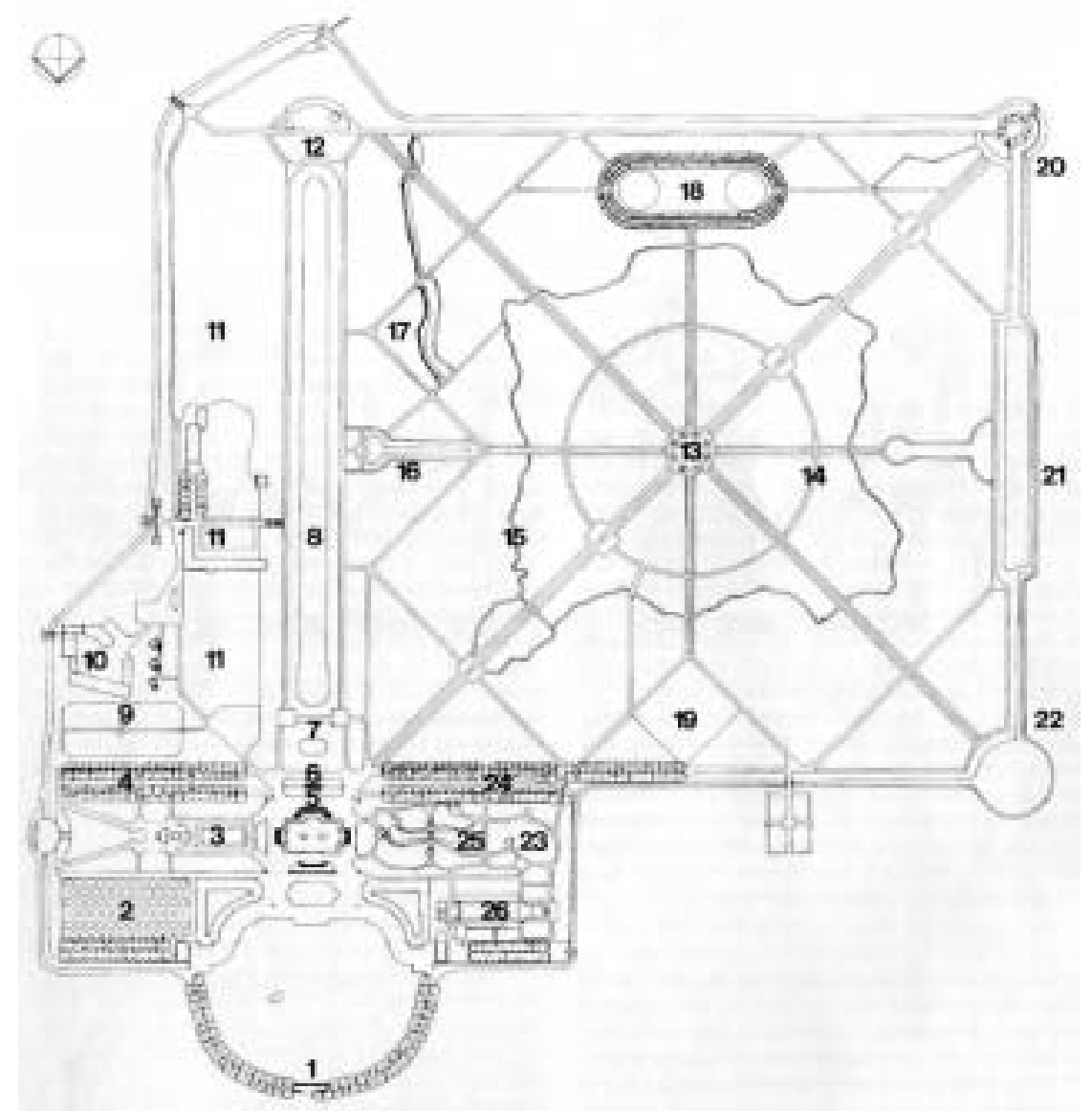

Abb. VI-26: Plan der heutigen Parkanlage Schloss Benrath.

Die zur Kenntlichmachung der Wasserflächen bedeutsamen Ziffern lauten: 1 Schlossweiher, 8 Spiegelweiher, 16 die „Trompet“, 20 der Rheinkopf, 21 Viereckweiher, 22 Kopfweiher (aus: ZACHER 1998:12).

In der vorderen und hinteren Parkanlage befinden sich zahlreiche Weiher und Wasserbecken aus der französischen und englischen Gartenkunst. Aus der französischen Gartenkunstperiode beispielsweise stammt noch ein ovales Wasserbecken, aus dem ein Wasserfall (Kaskade) zunächst in ein ovales, dann ein ein großes trapezförmiges, danach in kleinere, tiefer gelegene Becken fällt.

Ein südlich an das Hauptgebäude anschließender „Spiegelweiher“ erstreckt sich als „,kanalähnliche Anlage in einer Länge von $470 \mathrm{~m}$ nach Süden“ (ZACHER 1998:15). Wie der nördlich vor dem Hauptgebäude angelegte „Schlossweiher“, wurde auch der „Spiegelweiher“ mit Trachytsteinen eingefasst und „,in ein sanft ansteigendes Rasenfeld gebettet" (:15). Die Teiche wurden dabei in ihrer Anordnung als effektsteigerndes Mittel eingesetzt: So verdankt der „Spiegelweiher“ seinen Namen „der Spiegelung des Lichtes auf der Wasserfläche, das in die Räume des Hauptgebäudes zurückgeworfen wird, wie sich auch das Hauptgebäude selbst in seinem Wasser spiegelt." (:15)

Als weitere gefasste Wasserfläche ist die sog. „Trompet“ zu nennen. Dieser westlich des „Spiegelweihers“ gelegene Teich, dessen eigenwillige Form ähnlich einer Trompete namensgebend für die Bezeichnung war, wurde als Überlaufbecken geplant (ZACHER 1998:17). Weiterhin sind als Teichflächen der „Viereckweiher“, der „Kopfweiher“ sowie diverse andere Teiche mit gekrümmten Formen und natürlicher Uferbefestigung vorhanden (:18ff.).

Um diese Stillgewässer mit Wasser zu fluten und zu versorgen, wurde nicht etwa Wasser des nahe liegenden Rhein abgeleitet, dies verbat sich allein aufgrund der erhöhten Terrassenlage des Schlossgeländes, sondern die aus Osten her zufließende Itter. In einem ersten Schritt wurde der natürliche Verlauf weiträumig verlegt, um dann durch einen extra angelegten sog. Kapuzinerkanal das Wasser der Itter in den Park zu leiten 
(ZACHER 1998:6). Zur Ab- und Zuführung des Teichwassers durchfließen des Weiteren ein „Umfassungsgraben“, der ebenfalls einen Ableitungsgraben von der Itter darstellt, und der Schlangenbach, ein Arm des Itterbaches, der hier einem natürlichen Bachlauf folgt, das Parkgelände (:18).

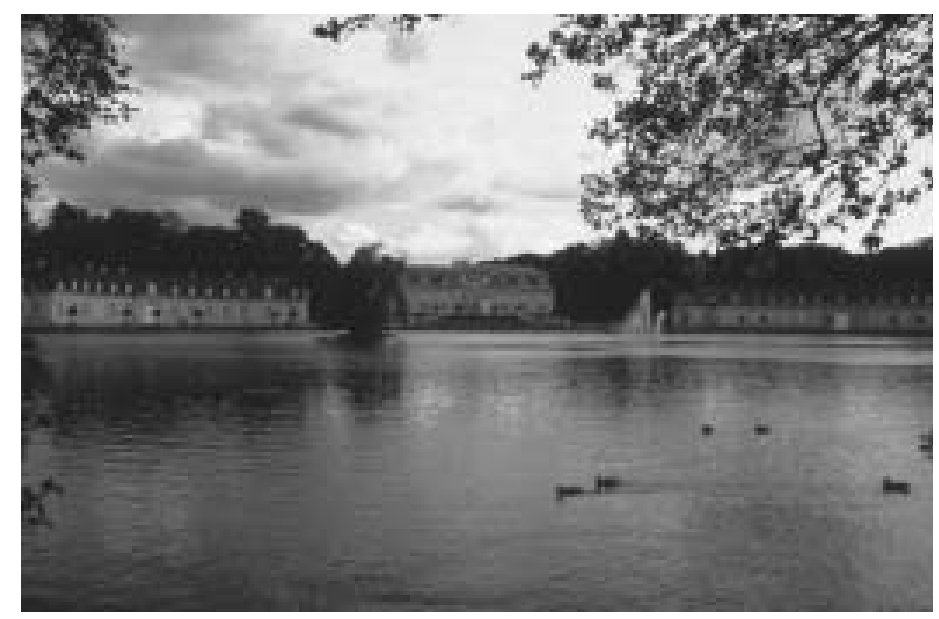

Abb. VI-27: Wasserschloss Benrath

Die von dem kurpfälzischen Oberbaudirektor und „Intendant der Gärten und Wasserkünste“ Nicolas de Pigage von 1755 errichteten Schlossgebäude liegen im nordöstlichen Teil der Anlage und gruppieren sich um den „Schlossweiher“. Das nördliche Ufer des Weihers hat eine natürliche Uferbepflanzung, das südliche besitzt eine aus Trachytsteinen gemauerte Einfassung in geschweifter Form. Diese Einfassung wurde 1979/80 nach historischen Plänen und Grabungen wiederhergestellt. Die kleine Insel wurde 1841 angelegt. Die Fontäne in der Mitte des Weihers stammt aus den Gründerjahren, als mit den Besuchen Kaiser Wilhelms I. ein erhöhtes Repräsentationsbedürfnis entstand (ZACHER 1998:12). Heute befindet sich in den Nebengebäuden das Deutsche Museum für Gartenarchitektur (eig. Aufnahme 2004).

Neben also der Durchgestaltung der Landschaft rings um die Wasserschlösser nach dem französischen Anlageprinzip, das im Wesentlichen mit der Wasseranlage des Schlosses Benrath ausgeführt worden ist, traten zeitgleich und insbesondere nachfolgend stärker gärtnerische Anlagen in der Umgebung des Schlosses hervor, die dem englischen Landschaftsgartenmodell folgten. Die mit Wasser durchzogenen Anlagen des Klassizismus und der Romantik an der Schwelle zum 19. Jahrhundert waren aber nur möglich bzw. wurden wesentlich erleichtert, weil zum einen der tiefe und breite Wassergraben zu den wesentlichen Kennzeichen des Vorgängerbaus zählte und damit schon vorhanden war (MUMMENHOFF 1977:34) und zum anderen in der Nähe vorbeifließende Gewässer zur Ableitung und Bespannung der Wasserflächen genutzt werden konnten.

Zur Vollendung wurde die Gartenbaukunst in den Landschaftsparks des Dessau-Wörlitzer Gartenreiches und des Fürsten Pückler-Muskau gebracht. Es verdient hinsichtlich der Einbeziehung und der Gestaltung von Wasser in den Landschaftsgarten angemerkt zu werden, dass die in unmittelbarer Nachbarschaft des Hauses gelegenen Gräben zugeschüttet wurden und man nur in größerem Abstand einen Teich duldete. Das ist, wie MUMMENHOFF (1977:50) es signifikant ausdrückt, „zum ersten Mal eine deutliche Abkehr vom Prinzip des Wasserschlosses.“

Fürst Pückler, Schriftsteller und Weltreisender, war neben Peter Joseph Lenné und Friedrich Ludwig von Sckell einer der bekanntesten deutschen Gartengestalter. Hermann Fürst von Pückler-Muskau (1785 - 1871) legte sowohl auf dem Familienbesitz der Grafen von Pückler, Schloss Branitz, als auch auf dem durch Heirat zugefallenen Muskau einen nach englischem Vorbild gestalteten Landschaftsgarten an. Der von ihm geschaffene, und unter seinem Nachfolger Heinrich Graf von Pückler (1835 - 1897) vollendete Landschaftspark, ist ein Gartenkunstwerk von internationaler Bedeutung und demonstriert anschaulich die Gestaltung von Gewässern als wesentlichen Bestandteil der Gartenkunst.

Gewässer spielten eine große Rolle bei der Gestaltung der Fläche und dementsprechend tiefgehend waren die Eingriffe in die Wasserverhältnisse. Fürst Pückler nutzte den anstehenden hohen Grundwasserstand und die in der Nähe gelegene Spree, um in seinem Park ein künstliches Gewässersystem zu schaffen. Mit dem gewaltigen Aushub aus den Seen und Kanälen ließ er das Geländerelief des Parks anlegen. 


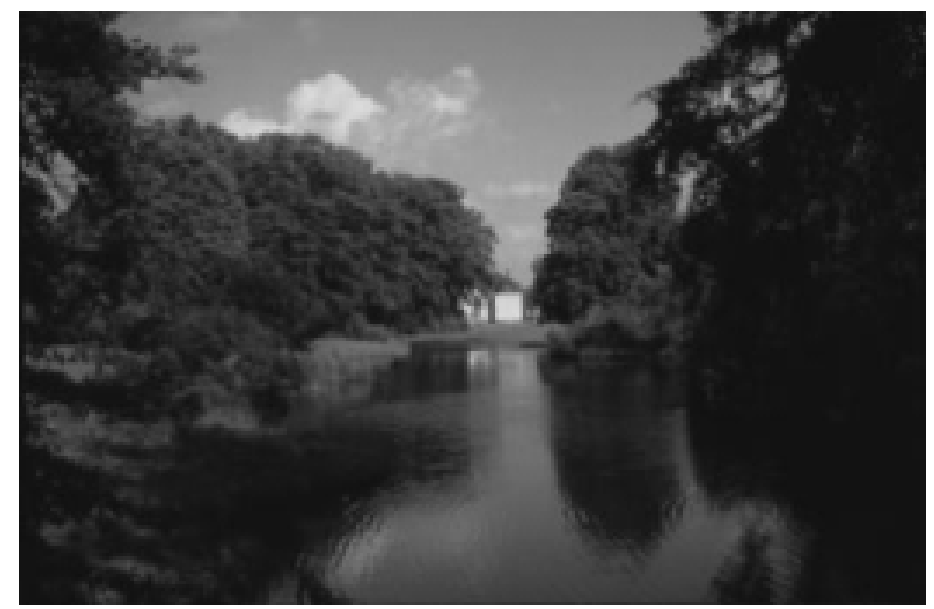

Abb. VI-28: Wasserlandschaft im Landschaftsgarten Schloss Branitz/Cottbus Im Hintergrund das Schloss (eig. Aufnahme 1993).

Verdeutlicht man sich die Vielzahl an Landschaftsparks und Herrengärten insgesamt, die vor allem in der Zeit des 19. bis 20. Jahrhundert errichtet wurden, so lassen sich die Dimensionen der Gewässerumformung und des Wasserver- und -gebrauchs erahnen.

\section{Transport und Verkehr}

\section{a Einführung}

Die systematische Nutzung der Gewässerläufe als Wasserwege, befindet WARNECKE (1999:438) „hat das Antlitz der Welt grundlegend verändert“ und nach seiner Ansicht „kann die Schiffahrt vielleicht als die wichtigste technische Innovation der Menschheit gelten (wichtiger als die Erfindung des Rades; die frühen Ägypter, deren Hochkultur ohne Fluss- und See-Schiffahrt nicht entstanden wäre, benutzten das ihnen bekannte Rad nicht).“

Das mehrheitliche Transportmittel des Handels bis zum Aufkommen der motorisierten Fortbewegung war auf dem mitteleuropäischen Festland das Pferde- und Ochsenaufgespann und der eigentliche Landverkehr erfolgte auf unbefestigten Wegen, die noch heute als Wegeformationen in der Landschaft erkennbar sind. Auf diesen Wegen voller Pfützen, Mahlsand, Löcher, Querrinnen, Karrenspuren und ausgefahrener Gleise war jede Fahrt mit dem bespannten Wagen „,der halbe Tod“ (TARR 1978; GRIEP/JÄGER 1983, 1987:8f.; BAUSINGER et al. 1990). Die schlechten Straßenbedingungen stellten hohe Anforderungen an Menschen, Zugtiere und Transportwagen (ALTMANN 1999:124). Die großen Handelsstraßen des Mittelalters waren, mit Ausnahme der von den Römern besetzten Gebiete, die Steinstraßen bauten, Naturwege. Sie waren wenig attraktiv: Sie verliefen in der Regel auf den Höhen, um vor den sumpfigen Talniederungen auszuweichen, und es bedurfte großer Anstrengungen von Mensch und Tier, auf den unbefestigten Wegen Waren zu transportieren.

Das Zusammenspiel von mittelalterlichen Wegezuständen lässt sich auch gut am Transport von Getreide und Mehl erkennen. Mit Pferden und vollgeladenen Planwagen mussten sich die Müller regelrecht abrackern: „Trassenbefestigte Landstraßen gab es damals kaum, zumeist nur Feldwege, immer weiter sich verbreiternd im Gewirr fußtief ausgefahrener Wagenspuren. In der wanderdünigen, sandigen Lüneburger Heide war das mitunter ganz besonders schlimm. Die Bauernkarren, besonders aber Müllers klobige Mühlenfuhrwerke bewältigten die oft kilometerlangen Strecken - beladen dreißig bis vierzig Zentner schwer mit Mehlsäcken deshalb zumeist nur mühsam, immer aber zeitraubend.” (ERLER/MATTHIESEN 1989:18)

Das Abholen und Zurückbringen des Mahlgutes mit dem Mühlenfuhrwerk, d.h. Korn anzufahren und den Leuten das Mehl wieder ins Haus zu bringen, war eine besondere Dienstleistung der Müller, die über die Jahrhunderte, wie zum Beispiel in Franken, erhalten blieb (BEDAL 1992:157). Zwangmühlen, die einem „Mühlenzwang“ innerhalb eines Herrschaftsbereiches eines Grundherrn unterlagen, zwangen die Hörigen 
darüber hinaus „zu vielen Kilometern langen“ Mühlenfuhren (MAGER et al. 1989:128). So wurde Korn für Brauereien und Brennereien angeliefert und Mehl für die Bäcker in die Stadt gefahren. Denn in einigen Gegenden, wie beispielsweise in der Kur und Mark Brandenburg, war es um 1680 den Müllern verboten, zu brauen und Branntwein zu brennen und einzuschenken. (LANGE 1989:69) Die Bestimmung gemäß Mühlenweistümer ${ }^{35}$, dass der Müller das Getreide der Kunden innerhalb der Bannmeile auf seine Kosten mit Pferdekarren oder Eseln abzuholen habe, ist weniger als Privileg für den Müller denn als Pflicht im Interesse der Mahlgäste anzusehen (KREINER 1996b:169).

In bestimmten Gegenden jedoch gab es diese ,jahrhundertealte Kundenmüllerei“ (ERLER/ MATTHIESEN 1989:20) seit alters her überhaupt nicht (BEDAL 1992:159). So holten die Bauern in der Mark Brandenburg, „solange die bäuerliche Kultur intakt war, noch zwischen den Weltkriegen das ,Büdelmehl ${ }^{36}$ [...] selbst aus der Mühle.” (LANGE 1989:73)

Als Zugtiere wurden Pferde und in einigen Regionen auch Esel eingesetzt, wobei letztere das typische „Transportmittel“ des Müllers darstellten (BEDAL 1992:159). So erfolgte beispielsweise der Transport von Mehl im Nachkriegsjahr 1814 von den Müllern meist durch Packesel, wie MERTES (1995:88) berichtet.

Die Verwendung von Eseln als Lasttiere hängt eindeutig mit einer bestimmten topographischen Lage zusammen. Von tief eingeschnittenen Tälern, in denen die Wassermühlen in bergigen und gebirgigen Gebieten oftmals lagen, führten lange Zeit nur steile Fußsteige, „Saumpfade“, zur Stadt hinauf, die mit Fuhrwerken nicht zu befahren waren. Als im 18. Jahrhundert eine Straßenverbindung hergestellt wurde, verloren die Esel schnell an Bedeutung und wurden durch Pferdegespanne ersetzt (BEDAL 1992:159). Aber auch in ebeneren Landschaften ergeben sich Belege für den Esel als Lastentier des Müllers. Die Stadtmühle von Euskirchen erhielt ihren Zufluss über den sog. „Eselsgraben“ aus dem Stadtweiher. Im Jahr 1656, so die alten Aufzeichnungen, wurde der Graben gereinigt und wieder erweitert, „,aß wie von alters her ein Esel mit einem Maltersack durchgehen könne“(KREINER 1996b:214; aus alten Aufzeichnungen).

Dass die schwer wiegenden Korn- und Mehlsäcke, sobald sich die Möglichkeit ergab, auf dem Wasserwege transportiert wurden, verwundert nicht. Vor allem, weil die Wege immer länger wurden: So wurde im 19. Jahrhundert im Wendland verstärkt Weizen angebaut, da das als „Dannenberger Mehl” bekannte Mahlgut von so guter Qualität war, dass es auch in der für damalige Verhältnisse relativ weit entfernten Stadt Lüneburg bedeutenden Absatz fand (LANGE 1989:37). In einem Fall führte der beschwerliche Landweg zur Umgehung der Sumpfniederungen des Jeetzeltales in Nord-Süd-Richtung über die Höhen des Drawehn (:37).

Demgegenüber steht der bislang in der wissenschaftlichen Darstellung vernachlässigte Gebrauch von Wasserläufen als Transportweg. Dies erscheint umso unverständlicher, als dass Wasserwege bis zum 19. Jahrhundert die leistungsfähigsten Güterverkehrsstraßen waren - und dies schließt kleinere Fließgewässer mit ein. Neben den Landwegen und größeren Fahrwassern dienten nämlich, aus heutiger Kenntniss, auch kleine Fließgewässer dem Transport von Waren, Gütern und Personen, wenn auch aufgrund der zu geringen Breite in kleinerem Maßstab.

Die Anfänge der Schifffahrt, d. h. des Transportes mit Booten, kleinen Schiffen und Flößen, gehen weit in die vorgeschichtliche Zeit zurück. Schon vor der Entwicklung des Rades in der Jungsteinzeit sind die deutschen Seen, Ströme und auch kleinen Flussläufe von steinzeitlichen Fischern und Jägern mit Flößen, Fellbooten und Einbäumen befahren worden (GOUDIE 1994:23; GREWE 1995:37). Als Antriebskraft

\footnotetext{
${ }^{35}$ Weistümer: Ländliche Rechtsquellen des Spätmittelalters und der Frühen Neuzeit, die das dörfliche Leben sowie das Verhältnis der Bauern untereinander und zur Grundherrschaft regeln (gewohnheitsrechtliche Rechtssätze). Sie beruhen auf einem förmlichen Verfahren des Fragens und Weisens durch ein Gremium von Rechtskundigen (z. B. Schöffen des Dorfgerichts). Entstanden sind sie dadurch, dass in einer überwiegend schriftlosen ländlichen Rechtskultur des Mittelalters Recht auf der Grundlage des mündlich tradierten Gewohnheitsrechts gesprochen wurde. Zu diesem Zweck wurden den Schöffen hypothetische Fragen gestellt, wie sie in dem jeweiligen Rechtsfall entscheiden würden. Diese Fragen und Antworten wurden seit dem 11. Jahrhundert zunehmend aufgeschrieben. Diese Aufzeichnungen stellen die Weistümer dar. Im weiteren Sinn also alle Rechtsquellen, die auf Weisung Rechtskundiger zurückgehen (WERKMÜLLER 1985:103ff.). In dieser Bedeutung auch bei KÖBLER (1999:635): „Weistum ist das durch mündliche Erklärung alter Männer als bestehend erwiesene Gewohnheitsrecht [...] Ihre Aufzeichnung findet vor allem im Spätmittelalter statt.“

${ }^{36}$ Büdelmehl: Beutelmehl zum Backen von Kuchen und Stuten
} 
dienten zunächst nur die natürliche Strömung und vor allem dort, wo keine vorhanden war, die Muskelkraft zum Rudern und Staken (GREWE 1995:37). Schlittenkufen, die in skandinavischen Sümpfen gefunden wurden, datierte man sogar in das Mesolithikum zurück (GOUDIE 1994:23) und fanden sogar noch im Mittelalter als Unterbau von Transportschlitten auf den zugefrorenen Fließgewässern Verwendung (siehe unten).

Man kann davon ausgehen, dass schon damals der Transport auf dem Wasser dem Transport auf dem Lande vorgezogen wurde, wenn das Ziel über den Wasserweg erreichbar war (GREWE 1995:37). Denn „in Europa waren schon in vorgeschichtlicher Zeit die Flüsse bis weit in den Oberlauf hinein schiffbar." (TRÖGL 1995:50) So ist nachweislich im Jahr 500 v. Chr. die Oberweser mit einem Einbaum befahren worden, wie der 1938 geborgene Fund bei der Einmündung des Beverbaches nach paläobotanischer Datierung beweist (MÜLLER 1990/91:3f.).

Zur Römerzeit wird im Zusammenhang mit den Heerzügen von Drusus und Germanicus von einer Weserschiffahrt berichtet (SEEDORF/MEYER 1996:625). Aber auch Saar (SCHÄFER 1997:157), Erft (KREINER 1996b:109), Weser, Elbe und auch die Ems (SEEDORF/MEYER 1996:620) galten in der Römerzeit als schiffbar und wurden als Wasserstraße von den Fernhändlern befahren.

Die intensive Nutzung deutscher Flüsse als Wasserstraße geht somit bis in die Römerzeit zurück. Dadurch ergibt sich seit mindestens 2000 Jahren die Möglichkeit des Güter- und Personentransports durch den Schiffs- oder Floßverkehr im zentralen mitteleuropäischen Raum (SCHÄFER 1997:156f.).

Schwere Lasten, wie Baumaterial für den Städtebau, waren in früheren Zeiten nur auf dem Wasserweg zu transportieren, und dazu dienten in erster Linie die schiffbaren Flüsse (GREWE 1995:37). Und auch in dem Zeitraum der großen Völkerwanderung im 4. Jahrhundert wurden die Flüsse mit kleinen Booten und Flößen befahren (SCHUBERT 2001:32).

In der Karolingerzeit benutzten die Händler diese Wasserwege weiter. So bereisten friesische Händler und im Hochmittelalter hansische Kaufleute Ems, Weser und die Elbe einschließlich ihrer Nebenflüsse als wichtigste Transportwege bis weit in das Binnenland (SEEDORF/MEYER 1996:625).

Durch Funde ist belegt, dass auf der Werra schon um 600 Handelsschifffahrt mit der Nordseeküste betrieben worden ist. Die Klöster Fulda (gegr. 744) und Hersfeld (gegr. 775) besaßen bei Eisenach Güter, mit denen sie auf dem Wasserweg über die Hörsel, einen Nebenfluß der Werra, der Werra selbst und der Fulda verbunden waren. Dies ist aus einer Urkunde Kaiser Otto II. von 979 belegt, in der er die Breite der Durchfahrt durch ein Fischwehr in der Hörsel festlegte, um einen Streit zwischen beiden Klöstern zu schlichten: zwei „Schiffe“ von je 3 Fuß (rd. $1 \mathrm{~m}$ ) Bodenbreite sollten dort aneinander vorbeifahren können (ECKOLDT 1995:11).

Im 8. Jahrhundert schiffbar ist auch Altmühl, die Rezat bei Weißenburg (ECKOLDT 1995:11). Der erste urkundliche Nachweis für die Schiffbarkeit der Saale stammt aus dem Jahr 981 (SCHUBERT 2001:32). In der damaligen Zeit boten des Weiteren heute kleine Flussläufe wie Lahn, Eder und Diemel günstige Voraussetzungen für die Nutzung zum Gütertransport.

Im Mittelalter waren Aller, Leine und Oker wichtige Schiffahrtswege von Braunschweig bzw. Hannover nach Bremen. Die wirtschaftliche Bedeutung beider Städte beruhte damals zu einem großen Teil auf ihrer Lage an einem schiffbaren Fluss. Schon um 800 befuhren Schiffe die Leine bis nach Elze. Die früheste Nachricht über das Treiben auf dem Fluss lieferte um das Jahr 1000 ein Geschichtsschreiber aus Hildesheim. Er schrieb, zur Zeit Karls des Großen hätten friesische Schiffe die Leine bis nach Elze ${ }^{37}$ befahren. Es liegt die Vermutung nahe, dass sich um Hering und Stockfisch als Fracht gehandelt hat (:46). Und bereits seit dem späten 12. Jahrhundert ist eine Transport-Schifffahrt auf der Stecknitz vom Möllner See bis Lübeck überliefert (OPITZ 1997:160). Die Schiffbarkeit besaß so eine große Bedeutung, dass die an der Ilmenau

\footnotetext{
${ }^{37}$ Die Erwähnung von Elze liegt darin begründet, dass zunächst die Absicht bestanden hatte, den Bischofssitz hier einzurichten. Erst etwa später entschied man sich dann für Hildesheim. (:46)
} 
gelegenen und die Schifffahrt behindernden Mühlen 1366 von Lüneburg gekauft und abgebrochen wurden (LANGE 1989:56).

Eine besondere Erwähnung verdient an dieser Stelle Haren, der wohl traditionsreichste Hafen- und Schifferort an der Ems. Es waren vor allem die Harener Schiffer, die vom späten Mittelalter bis in dieses Jahrhundert hinein mit ihren hölzernen Pünten die Schifffahrt auf der Ems und den emsländischen Kanälen, später auch die Küstenschifffahrt geprägt haben (SEEDORF/MEYER 1996:620).

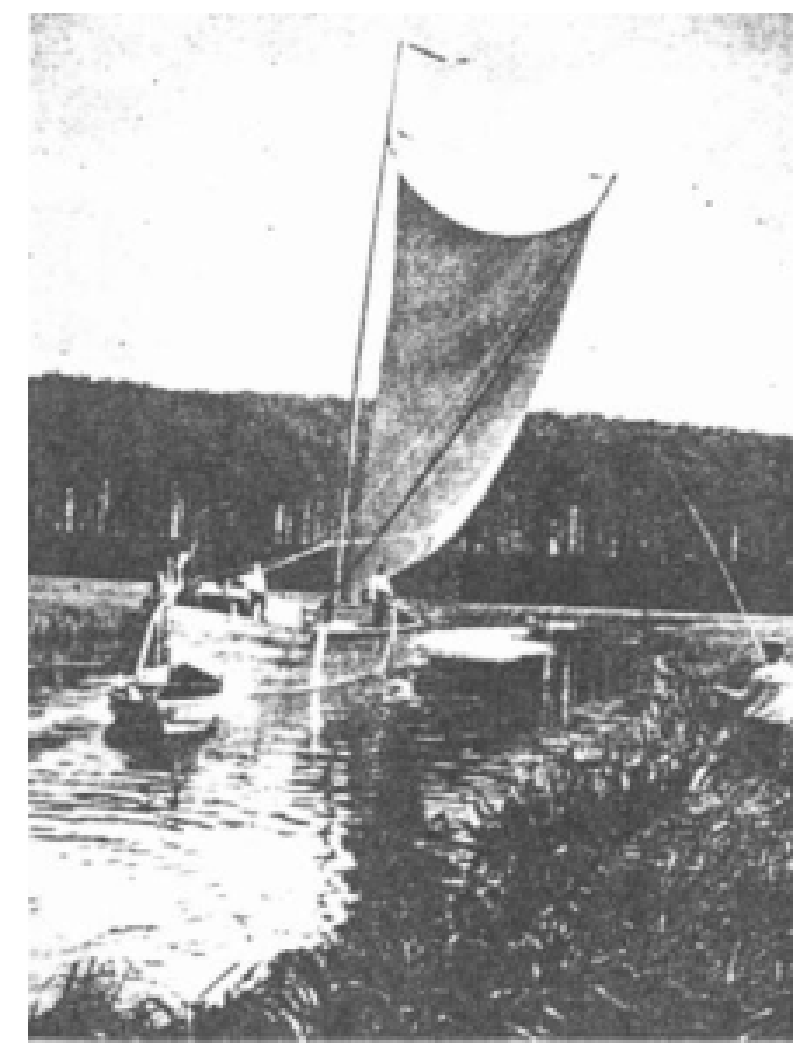

Abb. VI-29: Stecknitzkahn, vergleichbar mit der Emspünte, mit Spritsegel vor dem Vossberg bei Mölln etwa 1890 (aus: DER ELBE-LÜBECK-KANAL o. J.:13)

Angetrieben wurden die kleinen Schiffe in der Regel durch Treideln mit Mensch und Pferd, Segeln, Fahren mit kaltem Druck (Talfahrt) und Staken (TÖNSMANN 1995:17).

Doch nicht nur von Frühjahr bis Herbst, auch im Winter wurden kleine Fließgewässer im Mittelalter zum Transport genutzt. Die Ausgrabung eines Mittelfußknochens vom Pferd in Nordhausen in der Nähe der Zorge gibt zu dieser Vermutung Anlass. Der Knochen wurde gemäß Datierung im frühen Mittelalter so bearbeitet, dass er auf der Oberseite zwei Bohrungen besitzt, die senkrecht zur Gleitbahn verlaufen und $2 \mathrm{~cm}$ tief sind. Die Unterseite weist starke Gebrauchsspuren auf und ist zum Teil bis auf die Spongiose abgeschliffen. „Der Knochen wurde als Kufe unter einem Schlitten befestigt. Möglicherweise sind damit unsere Vorfahren auf der zugefrorenen Zorge Schlitten gefahren bzw. haben den Schlitten im Winter als Transportmittel benutzt.“ (BARTHEL 1969: 205ff.)
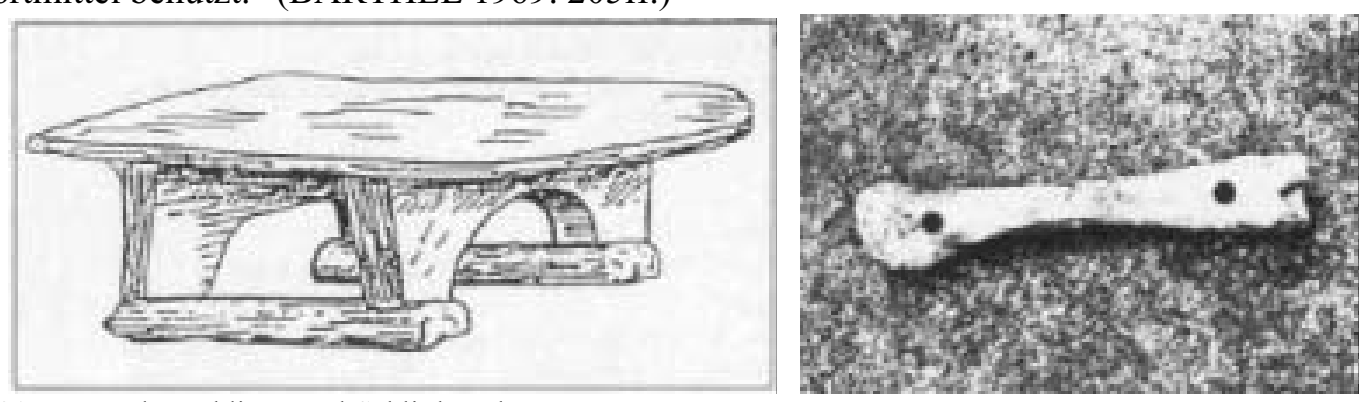

Abb. VI-30: Knochenschlitten und Schlittknochen (aus: GRÖNKE 1994: 7) 
Zunächst gab es im Mittelalter solche Verbindungen, die geographischen Gegebenheiten folgten und auf künstlich geschaffene Verkehrswege verzichteten. Als Beispiel kann die Verbindung zwischen Nord- und Ostsee gelten, die die gefährliche und zeitraubende Skagerrak-Fahrt umging. Die Treene, ein zur Nordsee fließender Fluss zwischen Hollingstedt und Haithabu an der Schlei, dem Zugang zur Ostsee, war im Mittelalter eine solche Verbindung (OPITZ 1997:160). Die Fahrt führte entlang der Nordseeküste von Dorestadt an der Rheinmündung bis zur Eidermündung. Auf der Eider und deren Nebenfluss Treene fuhren die Schiffe bis Hollingstedt. Von Hollingstedt bis zum Haddebyer Noor am Ende der Schlei waren es anschließend nur etwa 15 Kilometer Landweg (:44).

Mittelalterliche Schifffahrt auf kleineren Flüssen ist auch aus dem Alpenraum bezeugt. Hauptflüsse des schweizerischen Mittellandes waren neben dem Rhein die Aare, Reuss und Limmat, des Weiteren die schiffbaren Nebenflüsse Saane und Zils. Diese mehr lokale Flussschifffahrt jedoch ist schwer zu erfassen. Schiffe treten in den Quellen fast nur in der Fischerei sowie im Fährbetrieb in Erscheinung. Bei Kleinstädten blieb ihr Anteil am Transport zum Beispiel von Baumaterial beschränkt, vielmehr fand auf ihnen „die Fahrt zum Markt" statt (GLAUSER 1978:78f.).

Die Überlegenheit des Transportes zu Wasser dem Landtransport gegenüber, bestand vor allem in ökomomischen und technischen Vorteilen (SCHNEIDER 1992:141): Der Landtransport war so teuer, dass die Beförderung von Massengütern wie Getreide mit Wagen über längere Entfernungen unrentabel war (:142). Gleichzeitig besaßen im Vergleich zu den Wagen Schiffe eine außerordentlich hohe Ladekapazität und auch Ladetragfähigkeit (:141). Bis zum Aufkommen der Eisenbahn um die Mitte des 19. Jahrhunderts spielte die Frachtschifffahrt auf den Flüssen eine so große Rolle, weil sie nicht nur billiger als der beschwerliche Landverkehr war, sondern sie bot angesichts der schlechten Straßen und gebrechlichen Fuhrwerke auch die einzige Möglichkeit, schwere Lasten über größere Entfernungen zu transportieren.

Zudem war die Schifffahrt anders als der Landverkehr anfangs nicht auf eine aufwendige Infrastruktur angewiesen. Unter diesen Voraussetzungen war das Schiff das wichtigste Transportmittel für den überregionalen Handel (SCHNEIDER 1992:142). Nicht ohne Bedeutung für den Handel und Verkehr auf den Gewässern war der „Klosterverkehr“. So hatten beispielsweise auf der oberen Weser die Weserklöster Corvey, Helmershausen, Lippoldsberg, Bursfelde und das Stift Hilwartshausen zwischen den Grangien (auswärtigen Vorwerken), den Vogteien und den Stadthöfen einen lebhaften Güteraustausch.

Und schließlich erfolgte der binnenländische Warenumschlag nicht nur preiswerter, sondern auch rascher als auf den europäischen Landwegen (UNVERFEHRT 1989:52). Somit ermöglichte die Schifffahrt den relativ schnellen und preiswerten Transport von Rohstoffen und Massengütern über große Distanzen.

Damit jedoch kein falscher Eindruck entsteht: „Obwohl Lasten zu Schiff leichter zu transportieren sind als mit dem Fuhrwerk, zumal wenn es noch kein ausgebautes Straßennetz zu Lande gibt, ist doch stets weit mehr auf Landstraßen als auf Wasserwegen transportiert worden." (HOFFMANN 1995:83) So hat der Güterverkehr auf den Flüssen im Mittelalter ,zeitweilig zwar eine große Bedeutung besessen, der Achstransport hat aber eine wesentlich stärkere Rolle im Umland gespielt.“, im Vergleich der beiden Transportweisen im vorindustriellen Mitteleuropa etwa das 6 fache (:83).

\section{b Gütertransport}

Der „Warenkorb“ der transportierten Güter auf dem Wasser war in vorindustrieller Zeit dabei äußerst vielseitig und nicht auf große und unverderbliche Frachten beschränkt, anders als in der Gegenwart, wo die Binnenschifffahrt unter dem Konkurrenzdruck von Eisenbahn und Straßenverkehr im Wesentlichen den Transport von schwerer Ladung und Massengütern übernommen hat.

Rohprodukte, wie zum Beispiel Holzkohle und Pottasche bzw. Sodaaschen wurde bis in das späte 19. Jh. von allen waldreichen Dörfern zu den Hüttenstandorten der Glas- und Eisenhütten verschifft, dergleichen Kalk, Ton und Quarzsand für die Schmelzöfen der Glaser und der Tontöpfer. 
Die Fertigprodukte wurden wieder dem Wasserweg anvertraut. So dienten zum Beispiel die Kalkwerke im Umland von Berlin als Lieferanten von Ziegelsteinen für den Bau der Gründerzeitviertel. „Berlin“, so sagt man, „wurde aus dem Kahn erbaut.“ (STRAUSS 2002:21) Aber auch Tonwaren sowie Porzellan wurden in zahlreichen Formen auf dem Wasserweg transportiert. Vor allem die sperrigen Glasscheiben, wie Kirchenfenster und Fenster der Profanbauten, wurden mit Vorliebe mit dem Schiff befördert, so zum Beispiel auf der Weser und Leine zu den herrschaftlichen Höfen in Kassel, Hannover, Braunschweig und Münden. Trinkgläser, Flaschen, Humpen, Becher, Römer und Schalen waren oft Schifffracht (HENCKEL 1988:82). Für Wissenschaft und Medizin wurden aus Glas gefertigte Rohre, Trichter, Apothekerflaschen und Uringläser auf die Wasserkähne verladen.

Das gleiche Schema trifft für Textilware zu. Die Sendungen Rohleinen aus Kassel beispielsweise „kamen meistens mit dem Schiff bis Lippoldsberg" (SIMON 1995:26). Dort wurde zur gleichen Zeit das gebleichte Leinen wieder zurückgegeben. Ursprünglich wurde auch Waschgut mit Kähnen auf dem Flussweg transportiert, so zum Beispiel von Bonn-Beuel nach Köln mit dem „Wäscheboot““(BÜCHER 1988:81).

Blaufarben wie Indigo wurden von den Einbecker Tuchfärbern bei den Leineschiffern bestellt, Ungegerbte Häute, Böttcherwaren in Zahlung gegeben. Tafelwasser, in Flaschen abgefüllt, wurde in Bodenfelde aufgegeben und auf Weserkähne verladen.

Zur Verladung von Braun- und Steinkohle entstanden ganze Verladeplätze. Um 1800 wurde zum Beispiel die Schaumburger Steinkohle von Rinteln weseraufwärts geschifft, um hier als Schmiedekohle für Nordhessen umgeschlagen zu werden. Braunkohle diente, über den Brennwert hinaus, als Farbpigment für die Herstellung von Anstrichfarben sowie von feinen Farbstoffen, und wurde beispielsweise Mitte des 19. Jahrhunderts in Calbe und Umgebung abgebaut und das Haupttransportgut der Saale-Schifffahrt.

Im frühen Mittelalter wurden Wasserwege darüber hinaus genutzt „for the transport of heavy goods, such as timber and rock salt“ (DUNIN-WASOWICZ 1990:97). Zu diesen beiden Transportgütern sei Folgendes gesagt:

Bauholz in Form von unbehandelten Baumstämmen wurde in gebundener Form zu den Städten geflößt (THIENEMANN 1955:90f.; siehe auch Pkt. f6.1). Das geschnittene Holz hingegen wurde verschifft, wie das Beispiel der Wassersägemühle Eckernworth an der Fulde in Soltau-Fallingbostel vorgibt. Dort wurde das Schnittholz „mittels Pferdegespannen nach Inschede bei Verden gebracht und von dort über Aller und Weser nach Bremen verschifft.“ (ERLER/MATTHIESEN 1989:81)

Schnittholz wurde also verladen wie auch das Kohlholz, das zum Beispiel bis in die erste Hälfte des 20. Jahrhunderts von den Reinhards- und Bramwalddörfern auf der Weser nach Bodenfelde verschifft wurde.

Eine eher dem Flößen von Stamm- und Brennholz vergleichbare Bedeutung kam auch dem Salztransport zu Wasser zu.

Für die Konservierung des Fleisches geschlachteter Tiere und von Fischen blieb das Salz bis zum Gebrauch von Gefrierschränken und Kühlanlagen das wichtigste Handelsgut (KETTENHOFEN 1999:435). So war der Hering aus der Ostsee, „eine wichtige Fastenspeise des Binnenlandes“ (SEIBT 1999:176). Der Transport erfolgte im Binnenland per Schiff auf Flüssen, daneben sind eigene Salz-Straßen bezeugt.

Im Ostalpenraum wurde bereits 785 in Reichenhall und Ende des 12. Jahrhunderts in den Salinen von Schellenberg und Hallein Salz abgebaut. Die Produktion ging auf dem Wasserweg über Saalach, Salzach, Inn und Donau hauptsächlich nach Böhmen “ (MÜLLER/LUDWIG 1982:157). Für die andauernde Salinennutzung jedoch waren weitere Verkehrsmöglichkeiten zu Wasser zu erschließen, die - entgegen dem bisherigen Kenntnisstand - auch in den höher gelegenen Gebieten erschlossen wurden: „It may seem that in the higher regions, particularly in the mountains, lakes and streams played a lesser role. West European specialists, however, have supplied evidence that mountain streams and high-lying lakes were used for purposes of transport [...]. For some years now Swiss geographers [...] have been providing evidence that an extensive communication network existed between the alpine lakes, with relatively short stretches of roads." (DUNIN-WASOWICZ 1990:97) 
Im mittelalterlichen Mitteldeutschland wurde auf der Saale das Hallesche Salz umgeschlagen (SCHUBERT 2001:32) und im norddeutschen Tiefland wurden ebenfalls auf dem Wasserweg Güter transportiert. Auf der Stecknitz beispielsweise wurde in erster Linie das Lüneburger Salz in Richtung Ostsee transportiert. Der tatsächlich durchgeführte Schiffsverkehr auf der Stecknitz ist urkundlich erstmals 1237 erwähnt. Aber bereits im sog. „Barbarossa Privileg von 1188“ wird der Stadt Lübeck die Hoheit über den Verkehr auf der Stecknitz bis zum Möllner See zugesprochen (GOLDAMMER 1999:63).

Auch der Salztransport von der westfälischen Saline Unna-Königsborn zur Versorgung der preußichen Territorien am Niederrhein (Kleve, Geldern und Moers), mit einheimischem Salz erfolgte seit den 1740er Jahren aus Kostenersparnis ,überwiegend auf dem Wasserweg“ (FESSNER 2000:113). Er führte von der Saline Unna-Könisgborn über dem Landweg nach Forck und von dort „mit flachen Oderkähnen über die Lippe zum Rhein hin und weiter rheinabwärts nach Wesel“(:113).

Doch nicht nur „konservierte“ Nahrungsmittel, d. h. Fische, die man salzte und später in der Sonne trocknete, wurden auf dem Wasserwege transportiert. Auch bei fangfrischem Fisch benutzte man den Wasserlauf als Transportweg. Und der Transport von Nahrungsmitteln wie von Fischen nahm generell zu dem Zeitpunkt an Bedeutung zu, als die Versorgung der zunehmenden städtischen Bevölkerung durch das Umland gesichert werden musste.

Der Transport auf Gewässern bot sich insbesondere bei „grünen Fischen“ deshalb an, weil man die gefangenen Fische bis zur Verwertung am Leben halten musste. Die andere Möglichkeit bestand darin, wie oben erwähnt, den Fisch zu konservieren, d. h. zu trocknen oder zu salzen. Kleinere Ladungen wurden in mit Wasser gefüllten Versandfässern, sog. „Schüttelfässern“, wie man die ovalen, liegenden, sich beim Bewegen des Wagens schüttelnden Transportfässer nennt (LIETMANN 1941:66), auf Wagen oder zwischen Eis mit Fuhrwerken zu den in der Nähe liegenden Märkten getragen (SOLYMOS 1983:59). Auf kleine Entfernungen gar wurden die Karpfen einfach in feuchtes Stroh verpackt und hielten so einen Transport von mehreren Stunden aus (BENECKE 1885:36).

Insbesondere bei warmem Wetter und auf weiten Strecken bei mehrtägigen Reisen musste das sich erwärmende Wasser mehrmals täglich teilweise erneuert bzw. zur Erfrischung des Wassers in den Bottichen aufgefüllt werden. Zum Wassereinschöpfen benutzte man Schöpfkellen aus Holz. Das Wasser durfte dabei nicht über $10^{\circ} \mathrm{C}$ warm werden (BENECKE 1885:36,267; BORNE 1886:266). Wurde auch in der warmen Jahreszeit die Abkühlung der Fische durch „etwas zerschlagene Eisstückchen nebst Sägespänen oder Torfmull zum Auffangen des Schmelzwassers“ "bzw. „durch äußerliche Eispackung in Säcken oder durch das Einhängen von eisgefüllten Gazebeuteln“ (WALTER 1933:82) erreicht, so gelangte hinsichtlich der Frischegarantie in entfernteren Absatzmärkten der Transport auf dem Landweg an seine Grenzen.

Auf große Entfernungen wurde der Lebendfisch - vor dem Einsetzen des Eisenbahntransports - mit „Barken“38 geliefert. Bis zur Fastenzeit wurden die Fische in der Barke behalten, dann wurde ein Teil mit einem Wagen auf den Markt gebracht, die anderen wurden direkt an der Landestelle vor Ort verkauft (SOLYMOS 1983:59). Große Vorteile hatten diese Fischerbarken, da man in ihren Fächern mehrere Zentner sortierten Fisch längere Zeit am Leben halten, ja sogar über weite Wege transportieren konnte:59).

Auf dem Wasserweg erschloss man beispielsweise so die Absatzmärkte für Teichfische (Karpfen) aus dem Aischgrund in Bamberg, Würzburg und Frankfurt (vgl. HOFMANN 1958: 154). „In erster Linie wurden sie in Gegenden mit Bevölkerung orthodoxer Konfession exportiert, wo diese Fische in der Fastenzeit verzehrt wurden." (SOLYMOS 1983:59) In zweiter Linie war der Fischbedarf der wohlhabenden Stadtbevölkerung zu decken. Die nördlichen und östlichen Provinzen Preußens setzten ihre Fische vor allem in Berlin ab (TAURKE 1927:83) und transportierten sie beispielsweise auf der Havel in die Hauptstadt. HERRMANN (1997:44) und KUHN (1954:154) berichten davon, dass sich an den Markttagen aus den Oderbruchdörfern Hunderte von Kähnen in Wrietzen einfanden und ihren Vorrat an Fischen und Krebsen an die dort versammelten Händler verkauften. Die Karpfen waren eine wichtige Ausfuhrware Oberschlesiens. „In

\footnotetext{
${ }^{38}$ In der Binnenschifffahrt bezeichnet Barke einen mastlosen Kahn.
} 
durchlöcherten Fischkästen wurden sie lebend auf der Oder und Weichsel weithin nach Deutschland und Polen verschickt.“ (KUHN 1954:154)

Aber der Wasserweg wurde nicht nur für die Verbringung an den Verzehrort genutzt. Der Transport der Fische zu den Fischhältern, wenn diese sich nicht in der Nähe befanden, geschah ebenfalls auf den Binnengewässern (TAURKE 1927:185).

Im 18. Jahrhundert gelangten neben Fisch noch andere Nahrungsmittel auf zum Teil weiten Wasserwegen zum Absatzort: Besonders Wein und Öl aus Südeuropa sowie Tabak, Reis, Zucker, Kaffee, Tee und Gewürze aus Übersee und die sog. Bremer Waren, unter denen man die Bremer Importware und Seefisch verstand, wurden auf der Weser zum Hessischen Landgraf nach Kassel befördert, des Weiteren Honig aus Skandinavien und dem Baltikum sowie Feld- und Baumfrüchte. Mit Marktschiffen, beispielsweise den sog. Äppelkähnen, ,wurden aus Werder die landwirtschaftlichen Erzeugnisse des Brandenburger Umlandes direkt bis in die Mitte von Spandau transportiert (STRAUSS 2002:138). Doch nicht nur Lebensmittel wurden den Schiffen aufgegeben, selbst die Post beispielsweise von welfischen Dörfern nach Münden und von den hessischen Dörfern nach Karlshafen, wurde nicht einem Boten, sondern dem nächsten Schiff anvertraut (HENCKEL 1988:60f.).

In welchen Mengen und Gewichtslasten in Beziehung zur Gewässergröße beispielsweise der zuerst genannte Wein transport worden ist, lässt sich an einem Beispiel aus der Stadt Quakenbrück verdeutlichen (siehe Abb. VI-31): Weinfässer für die Weinhandlung Gebr. Köster wurden auf der Hase bis nach Quakenbrück transportiert. In der Stadt gab es nach mündlicher Überlieferung einen „Schiphorst“ genannten Hafen, der Umschlagplatz für kleine, flache Kähne war, die früher die Hase von der Mündung bis Quakenbrück befuhren. Heute ist die Straßenseite, an der im 18. Jahrhundert noch der Flussarm verlief, bebaut (BÖNING 2003: mündl.)

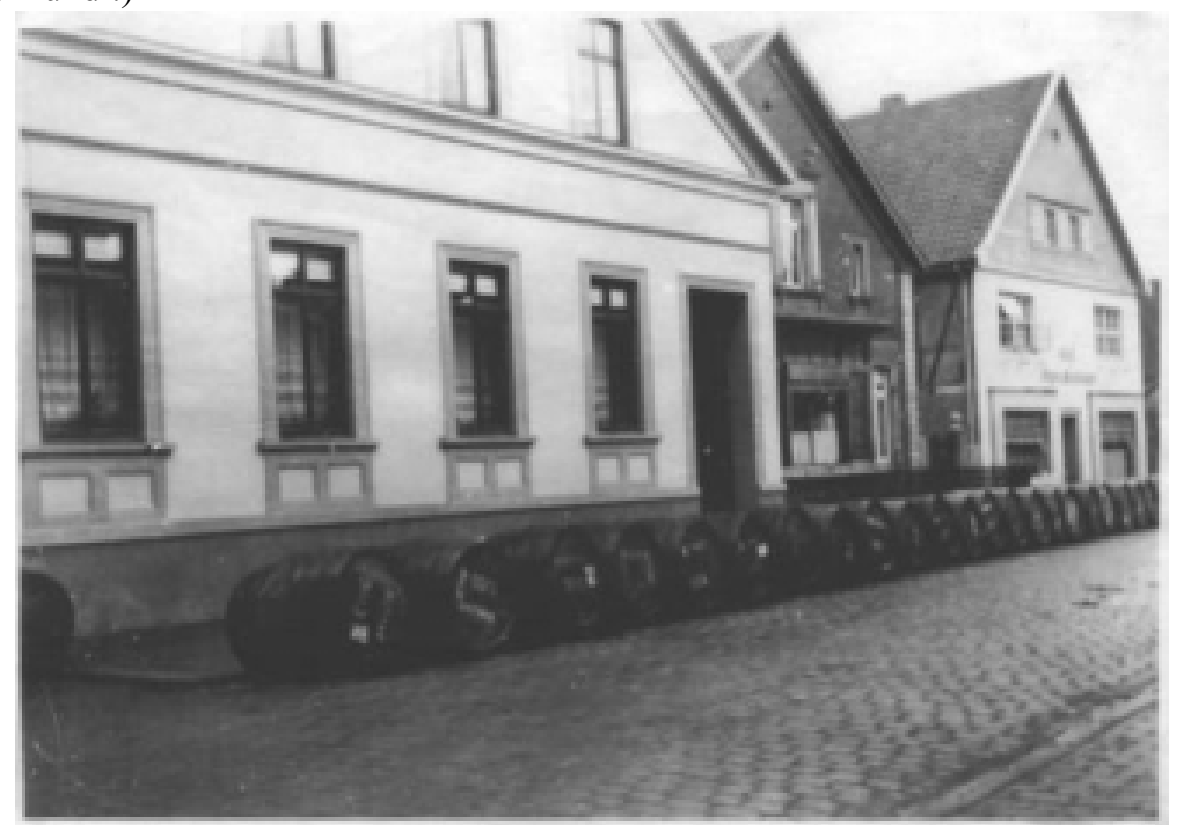

Abb. VI-31: Anlandung von Weinfässern vor der Weinhandlung Gebr. Köster in Quakenbrück, Aufname ca. um 1900 (freundl. Leihgabe von Herrn Böning, Stadtmuseum Quakenbrück, 2003)

Vor allem aber „der Transport von Massengütern konnte im vorindustriellen Zeitalter wegen der schlechten Straßenverhältnisse kaum über eine größere Distanz wirtschaftlich geführt werden. Er fand deshalb, soweit es ging, auf dem billigeren Wasserwege statt.“ (FESSNER 2000:106) Hier ist die Steinkohle zu nennen, bei der die Schwierigkeit des Landtransportes über längere räumliche Distanzen bestand. Die Reichweite nahm sogar mit dem Anstieg des Brennholzpreises zu, der vor allem infolge eines Holzmangels anstieg (:112). Die Berliner Schmieden zum Beispiel bezogen in den 1740er Jahren auf dem Wasserweg preisgünstiger Steinkohle aus England über Stettin als über den Landweg aus Schlesien, nicht zuletzt infolge der katastrophalen Straßenverhältnisse (:112). Die Verbreitung der Steinkohlennnutzung muss dementsprechend auch „unter dem Aspekt der Existenz und des Ausbaus entsprechender Verkehrsinfrastrukturen gesehen werden.“ (:113) Die Lippe zum Beispiel war aufgrund ihres geringen Wasserstandes und ihrer weiten 
Entfernung von den Steinkohlengruben nur bedingt für den Kohlentransport geeignet. Die mitten durch die Zechengebiete fließende Ruhr hingegen bot weitaus günstigere geographische Bedingungen zur Schiffbarmachung. Diese erfolgte zum Zwecke des Kohlentrans- und -exports im Bochumer Raum in den 1770er Jahren. Ruhrschifffahrt erfolgte danach vor allem nach Holland, das wegen seiner prosperierenden Wirtschaft sehr nachfragestark war (:113).

Auch „die Eisenwerke stützten sich auf fest etablierte Verkehrsnetze (wobei nicht nur Straßen und Pfade, sondern gelegentlich auch Wasserwege einbezogen wurden)“ (DOSWALD 1996:170). Dabei wurde das Transportgut neben Schiffen auch auf Flößen verladen. Die Benutzung von Wasserwegen wundert angesichts der alternativen schwierigen Transportkette dabei nicht. Der Eisenerztransport vom Bergwe rk zu den Hütten erfolgte in der Regel bis weit ins 19. Jahrhundert hinein durch bäuerliche, von Ochsen oder Pferden gezogene zweirädrige Karren, deren Ladekapität etwa $660 \mathrm{~kg}$ betrug. Die steilen Erzwege, die „Karrenwege“, zeigten trotz der intensiven Benutzung, „keinerlei besondere Befestigung der Fahrbahn“, wie DOSWALD (:155) für den Schwarzwald berichtet. Ausnahmen waren die Hauptverkehrswege in der Talsohle. In anderen Fällen wurde das Erz bei den Mundlöchern in große Transportsäcke abgefüllt und die steilen Felsschutthalden herunter transportiert. Dies geschah in Form der äußerst anstrengenden und gefährlichen Fahrt auf dem Erzschlitten, den der sog. Schlitter bis zur flacheren Zwischenstation lenkte, und $a b$ hier erfolgte dann erst der Umschlag der Lasten auf Karren oder aber sie wurden direkt - ohne Umladung - zu den Eisenwerken in den wasserreichen Tälern ,geschlittet“ (:158).

Ein solcher Erztransport wurde wahrscheinlich überwiegend im Winter durchgeführt, wenn genügend Arbeitskräfte zur Verfügung standen und die Schneedecke die Verwendung von Erzsäcken erlaubte, die mit Schweinshäuten überzogen waren und von Menschen gezogen wurden bzw. talabwärts gebremst werden mussten. Die Bauern benutzten dabei ihre eigenen, langsamen, von Ochsen gezogenen Heuschlitten und profitierten von der jahreszeitlichen Schneedecke. Für die Periode 1730 - 46 gibt es außerdem einen Hinweis darauf, daß auch im Sommer Erz talwärts geführt wurde; dabei scheint man große Schlitten gebraucht zu haben (DOSWALD 1996:159). Aber auch kleine, immerhin ca. 300 - $450 \mathrm{~kg}$ fassende Erzschlitten, sog. Handschlitten, fanden zwischen 1806 und 1827 Verwendung und führten zur Ausbildung von gestreckten, nur ca. $1 \mathrm{~m}$ breiten Schlittwegen, die in den oberen Partien stellenweise gepflastert und mit Stützmauern gesichert waren $(: 161)$.

Steine jedoch „waren wohl das größte Massentransportgut des Mittelalters“ (SEIBT 1999:176). „Vielfach [...] brach man die Steine möglichst an Ort und Stelle, oder man suchte den billigen Wassertransport“ (SEIBT 1999: 176).

Neben dem Bauholz, das gebunden zu den Städten und Bauplätzen geflößt wurde, wurde so auch Baumaterial aus den Steinbrüchen auf den beschiffbaren Gewässern zu den zumeist städtischen Verwertungsorten transportiert.

Steinbrüche lieferten Werk- und Dachsteine auch in die nähere Umgebung und weit darüber hinaus nur auf dem Wasserweg. Sollinger Wesersandstein wurde als Dachsteinplatten geschliffen, zu Mauerwerk und zu Futtertrögen hergestellt oder der Grus einfach als Schiffsballast bis nach Nordamerika verschifft. Die Anlegestellen der Lastschiffe und Steinbrüche, zum Beispiel am Karthagenberg unterhalb von Fürstenberg, sind historisch belegt. Zur Gewinnung von Steinmaterial legte man in der preußischen Zeit, d. h. nach 1866, an vielen weiteren geeigneten Uferstellen kleine Steinbrüche an der Oberweser an, von denen die Schuten direkt beschickt werden konnten (HENCKEL 1988:50). Sogar Sammelplätze für Sandstein, der nicht unmittelbar aus den flusslaufnahen Steinbrüchen verladen werden konnte, wurden eingerichtet. Wie zum Beispiel die Schlagd in Holzminden, von der Sandsteine aus dem Solling für Bauten der Weserrenaissance bis nach Bremen befördert wurden (SEELIGER 1987/88).

Anstelle des heimatlichen Werkstoffes wurde auch Kalktuff von Quellen und Bächen aus dem italienischen Travertin als Baumaterial und zur Herstellung von Skulpturen auf Schiffen den weiten Weg nach Deutschland gebracht (THIENEMANN 1955:90f.).

Des Weiteren hatte die Verladung von Mühlsteinen einen großen Anteil am Steintransport auf dem Wasserweg. Mahlsteine waren sehr schwer. Wegen der Transportprobleme wurden deshalb früher nur 
kleinere Steine verwendet. Die Mühlsteine besaßen zu römischer Zeit im Durchmesser $60-90 \mathrm{~cm}$, wurden aber im Laufe des Mittelalters und der Neuzeit, bedingt durch die stetig steigende Menge an Aufschlagwasser, bis auf etwa 1,50-1,60 m und in Ausnahmen noch mehr vergrößert und blieben so bis in unsere Zeit. Die Steine wogen je nach Größe zwischen 0,25 bis 2,5 Tonnen, wenn es sich um einen großen Mühlstein, einen sog. 17er gehandelt hat (MERTES 1995:10,17; LORENZ 2000:39f.). Die französischen, besonders harten, Steine waren gar so schwer, dass sie in Stücken gefertigt und exportiert, und von den Mühlsteinfabriken im Land zusammengesetzt und verkittet und mit Esenreifen außen verbunden wurden (MERTES 1995:16). Andere wiederum, wie die Mühlsteine aus den Basaltlavasteinbrüchen der Eifel wurden in einem Stück aus dem Fels geschlagen (:12).

Durchaus verständlich ist also, dass man dafür den Transport zu Wasser vorzog. Die Verbreitungsmuster der Funde aus dem Mittelalter und den vorhergehenden Zeiten bestätigen dies und verstärken den Eindruck, dass die Verteilplätze der Mahlsteine „von den See- und Flußhandelsrouten her aufgeschlossen wurden.” (SCHÖN 1995:104)

Der Bedarf an Steinen in der Müllerei war groß: Alle Wassermühlen waren für die Kornverarbeitung im Allgemeinen mit mehreren Mahlgängen ausgestattet. Ein Mahlgang benötigte dabei konstruktionsbedingt jeweils einen Lagerstein und einen Läuferstein (DOBELMANN 1980:33). Ebenfalls bestanden die steinernen Mühlgerinne aus den Mahlsteinarten, in der Regel aus gebrauchten Sandsteinen (BINTZER 1991:41). Generell gab es daneben einen lebhaften Handel mit gebrauchten Steinen (BEDAL 1992:48). Da aber der Fuhrlohn, einschließlich Zoll, einen wesentlichen Bestandteil der Kosten eines Steines für den Müller bedeutete, wurden wahrscheinlich keine gebrauchten Steine verschifft, sondern nur vor Ort gehandelt.

In der früheren Zeit wurden Mühlsteine, der wichtigste Teil aller Kornmühlen, zumeist aus Sandstein geschlagen (LORENZ 2000:39) und es kristallisierten sich wahre Schwerpunkträume des Mühlsteinbaues heraus:

Mühlsteine wurden einige Jahrhunderte in Mündener Buntsandsteinbrüchen gehauen und gefertigt und mit dem Schiff auch über größere Strecken transportiert (HENCKEL 1988:71). Die Steine aus dem Sollingsandstein waren jedoch begehrter, mussten diese doch erst nach einer Woche geschärft werden, im Gegensatz zu den Mündener Mahlsteinen, bei denen dies nach nur ca. 20 Betriebsstunden notwendig war. Die aus Sandstein gefertigten Mühlsteine wurden aus dem Solling oder dem Reinhardswald per Schiff auf der Weser bis Vlotho und dann im Landtransport weiter zum Abnehmer, wie zum Beispiel zur Mühle in Bramsche, gebracht (DOBELMANN 1980:33).

Andere Sandsteinmühlsteine kamen vorwiegend aus dem Elbsandsteingebirge und dem Zittauer Gebirge, hier vor allem aus den Sandsteinbrüchen in Jonsdorf (LANGE 1989:74), und wurden auf der Elbe zum Beispiel nach Güstrow geschifft.

Aber auch einfache Granitsteine wurden genutzt. Im Küstenbereich von Schleswig-Holstein etwa wurde für die Mahlsteine auf die einheimische Rohstoffbasis, den einheimischen Granit, zurückgegriffen, wenngleich Importe von Mühlsteinen aus Basalt bereits für das 5. - 6. Jahrhundert vorliegen (SCHÖN 1995:84). Bei diesen dürfte es sich aber um Handmahlsteine gehandelt haben. Solche Basaltmühlsteine sind für das frühmittelalterliche Schleswig-Holstein erst selten nachweisbar. Nur wenige Siedlungen wurden dort zunächst an der Westküste mit diesem Material versorgt (:84).

Erst als die Ansprüche an die Qualität des Mehles stiegen, wurden Porphyr-Steine aus dem Thüringer Wald oder rheinische Steine aus verschlacktem Basalt eingesetzt. Die Mühlsteine einer Mahlmühle mit zwei Gängen bestanden dann teils aus Basalt, verwendet für die Herstellung von Mehl, teils aus Sandstein, die der „groben Müllerei” und der Graupenherstellung dienten.

Rohstoff für die Basaltmühlsteine in Norddeutschland war seit dem Frühmittelalter vornehmlich der aus der Vulkaneifel, aus dem Gebiet des Laacher Sees, stammende Basalt. Er gelangte als Halbfertigfabrikat auf dem Wasserweg, vermutlich über den Rhein, entlang der Nordseeküste nach Schleswig-Holstein und erreichte über die Eidermündung Haithabu als letztendlichen Verbrauchs- und Handelsort oder aber die Elbe hinauf bis auf die Höhe von Artlenburg. Von dort setzte sich diese Handelsroute offenbar auf dem Landweg nach 
Norden über Müssen und Hammer auf der Strecke der späteren Salzstraße bis Lübeck fort, von wo sie auf den nach Norden anschließenden Landstraßen an ihr Verteilzentrum geliefert wurden (SCHÖN 1995:97,113). Es wäre hierbei in Forschungsarbeiten zu prüfen, ob nicht auch die Stecknitz und die Trave als Transportweg genutzt worden ist.

Auf dem Elbweg wird auch das Wendland die aus verschlacktem Basalt bestehenden Andernacher Eifelmühlsteine bezogen haben (LANGE 1989:74). Aber erst im Laufe des 18. Jahrhunderts setzte im Wendland vermehrt der Anbau von Weizen ein und damit der Bedarf an härteren und feineren Mahlsteinen. Um diesen zu hochwertigem Mehl verarbeiten zu können, wurde der „Rheinische Stein“, noch heute von alten Müllern als „Franzosen“ (siehe nächste Seite) bezeichnet, benötigt.

Zuvor, zu Beginn des 18. Jahrhunderts, wurden im Wendland wch die weicheren Mühlsteine aus dem Elbsandsteingebirge bezogen. Auf der Elbe sind die Steine bis Magdeburg, bis zum Amt Dannersberg oder auch zu den Mühlsteinstapelplätzen Hitzacker, Wittenberge oder zur „Steinfaktorei Tangermünde“ befördert worden (LANGE 1989:74). Von dort wurden sie mit einem „mit 4 Pferden bespannten Expresswagen” (BOSSE 1991:132; aus Archivalien) abgeholt.

Einen etwas kürzeren Weg hatten die Mühlsteine, die in den Getreidemühlen des Erftgebietes benutzt wurden. Sie stammten ebenfalls, wie die des Wendlandes und des Schleswig-Holsteinischen Gebietes, aus den Basaltlavasteinbrüchen der Vulkaneifel, vor allem aus der Gegend um Mayen und Niedermendig, die als „das älteste und größte kontinuierlich betriebene Mühlstein-Produktionsgebiet in Westeuropa“ bezeichnet wird (MERTES 1995:12). Für die runden Mühlsteine eigneten sich die Mayener und Mendiger Basaltlava vorzüglich, weil sie die von den Mühlen geforderte Porösität und Härte besessen haben.

Um sich eine Vorstellung von der Größe und der Bedeutung des Eifeler Mühlsteingewerbes und des Transports dieser runden Steine auf dem Wasserwege machen zu können, muss man wissen, dass in wenigstens 56 ober- und unterirdischen Mühlsteinbrüchen der Eifel die Steine gebrochen wurden. Dabei wurde das zwischen Mayen-Ettringen-Kottenheim liegende große Basaltlavafeld schon in vorrömischer Zeit im Tagebau betrieben, die etwas weiter nördlich bei Mendig liegenden kleineren Abbaugebiete stammen aus 14. Jahrhundert (MERTES 1995:14). Noch 1900 gab es in Mayen und Niedermendig 291 Mühlsteinbrüche mit insgesamt 2607 Arbeitern (:18). Des Weiteren gab es mehr als 90 andere lokale Mühlsteinbrüche in der Eifel (:14).

Die Mühlsteine wurden zunächst auf mehrzügige Fuhrwerke von den Mayener und Mendiger Brüchen nach Andernach angeliefert und dann mit Kranen auf die Schiffe verladen. Bis 1559 geschah die Verladung mit auf dem Strom schwimmenden Kranen (siehe Abb. VI-32). Erst ab diesem Jahr wurde ein Hauskran gebaut und in Betrieb genommen und so blieb es bis zur Stillegung in den Jahren 1921/1922 (MERTES 1995:15).

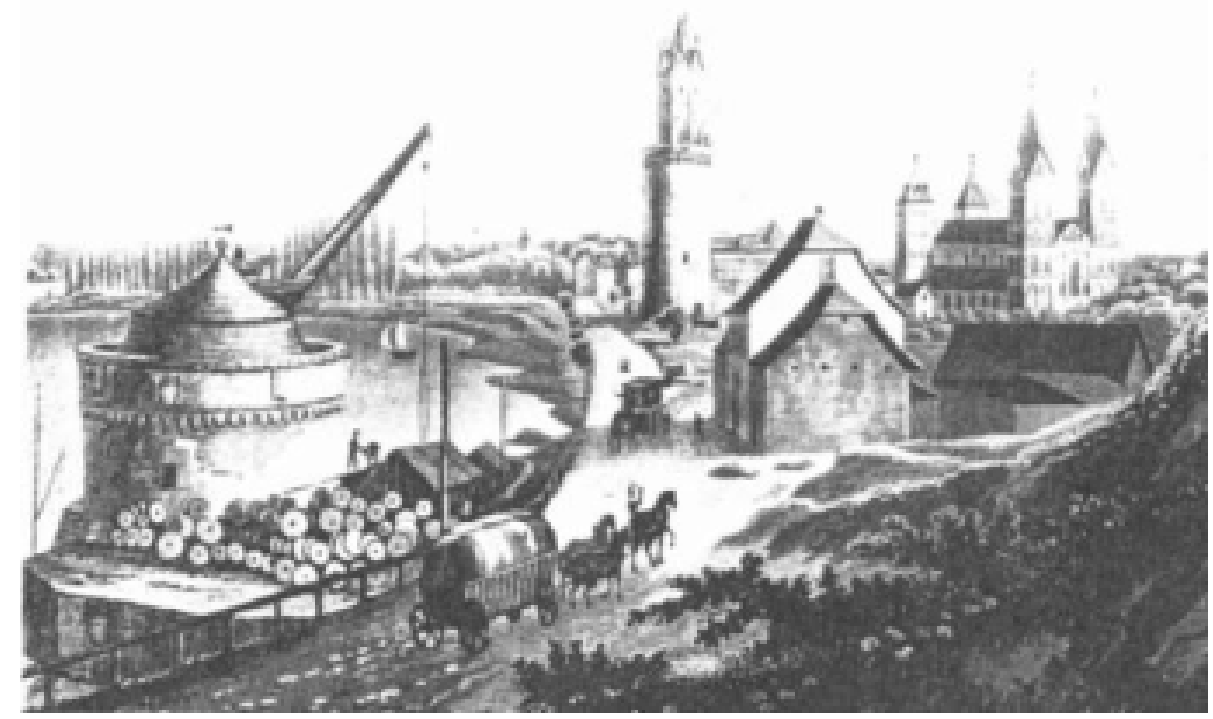

Abb. VI-32: Andernach mit Kranen-Verladung von Mühlsteinen auf Schiffe (aus: MERTES 1995:15) 
Andernach war einer der größten Umschlagplätze für die Mayen-Mendiger Mühlsteine (MERTES 1995:15). Nachdem sie auf Schiffe verladen waren, wurden sie für die näher liegenden Mühlen nach Köln oder Neuss transportiert, von wo sie auf dem Landweg die Mühlen, zum Beispiel an der Erft erreichten (KREINER 1996b:130). Im heutigen Westfalen sind sie „möglicherweise von Westen her über die Lippe ins Land gekommen." (SCHÖN 1995:104) Auch für das nordwestliche Münsterland sind Blaubasaltsteine aus Niedermendig in der Eifel nachgewiesen (TERHALLE 1992:76). Die Basaltsteine für das Osnabrücker Nordland kamen ebenfalls ,meistens aus der Eifel, wurden per Schiff auf dem Rhein nach Wesel und dann auf dem Landwege an ihre Bestimmungsorte oder in Mühlsteindepots (u. a. in Osnabrück und Rheine) gebracht" (DOBELMANN 1980:33). Die Mayener und Mendiger Steine wurden rheinauf und rheinab in viele Länder verschickt: nach Russland, Holland, England, Brandenburg und verschiedene nordische Länder (MERTES 1995:17).

Zur Deckung ihres Bedarfs an Mühlsteinen hatten bereits die Römer zahlreiche andere, über das gesamte Imperium verstreute Basaltlagerstätten in Europa und Nordafrika erschlossen (SCHÖN 1995:84). In der Völkerwanderungszeit kam der Basalthandel offenbar weitgehend zum Erliegen, blühte aber im Mittelalter wieder auf und machte den Basalt „für mehrere Jahrhunderte in Nordwesteuropa zum wichtigsten Rohstoff für Mühlsteine.“(:97)

Archäologisch ist der wassergebundene Handel mit Fertigprodukten ,schwer zu beweisen, es sei denn als unmittelbarer Nachweis zum Beispiel anhand von Schiffsfunden" (SCHÖN 1995:100). Die Ladung auf einem gesunkenen Rheinschiff im Kreis Moers zum Beispiel enthielt Basaltmühlsteine und auch aus einem spätrömischen Schiff aus einem Altrheinarm bei Wanzenau wurden 30 noch unfertige Mühlsteine aus Basalt geborgen. Dieser Fund bringt somit zudem einen Beleg für den Schiffshandel mit Halbfertigfabrikaten $(: 100)$.

Besser als die deutschen Sandstein- und Basaltmühlsteine waren jedoch die französischen Steine. Mit „Französischer Stein” werden Süßwasserquarzite bezeichnet, die aus der Gegend um La Ferté, Départment Seine et Marne, Frankreich, stammten und deshalb auch „Champagnersteine“ genannt wurden (MERTES 1995:16). Sie waren wegen ihrer besonderen Härte und des kleinteiligen Ausbrechens einzelner Steinteilchen beim Abmahlen hervorragend als Mühlsteine geeignet. Durch die feinen Aussplitterungen beim Mahlvorgang erneuerte sich ihre Schärfe selbst, was wie ein ,automatisches“ Nachschärfen wirkt. Ihr Mahlgang erbrachte feineres, d. h. weißeres Mehl als die Steine aus Basaltlava. Solche Steine waren teuer, hielten aber auch etwa 80 Jahre. Die begehrten französischen Mühlsteine hielten schon im 18. Jahrhundert in nahezu allen Mühlenregionen Einzug (HENCKEL 1988: 71). Im 19. Jahrhundert verdrängten die „Franzosensteine“ vielerorts sogar die Steine aus Basaltlava.

Daraus wird ersichtlich, welch beträchtliche Entfernungen im Mühlsteinhandel zurückgelegt worden sind. Es kann sogar letztlich ,nicht ausgeschlossen werden, daß die Mühlsteinhauer in Begleitung ihrer Produkte als Wanderhandwerker tätig waren und die Halbfabrikate am Verkaufsort gebrauchsfertig machten" (SCHÖN 1995:93).

Auch für Franken kamen die Mühlsteine im Allgemeinen von weit her. Nur in ganz wenigen Brüchen gab es geeignetes Steinmaterial, das sowohl die nötige Härte als auch Gleichmäßigkeit besaß (BEDAL 1992:47). Für die fränkischen Wassermühlen gab es offenbar im Mittelfränkischen nur einen heimischen Herkunftsort: die Sandsteinbrüche Wendelstein bei Schwabach. Der sog. „Wendelsteiner“ war vermutlich der am meisten verbreitete Mühlstein in Mittelfranken (:47). Trotzdem waren in Franken Steine aus weit entlegenen Steinbrüchen üblich: aus Krawinkel bei Naumburg in Thüringen und aus dem Sormitzgrund im thüringischen Frankenwald sowie aus Mels in der Schweiz/Kanton St. Gallen wurden die Mühlsteine herangebracht (:47).

Während aber nun die „Wendelsteiner“ auf dem Landweg mit Fuhrwerken transportiert wurden, „gab es für die anderen Steine offensichtlich auch den Wasserweg, wenigstens was den Hauptteil der Wegstrecke anbelangt.“ (BEDAL 1992:48). In Ober- und Unterfranken hatten vermutlich die Thüringer Steine eine größere Verbreitung (:47), da sie auf der Saale transportiert werden konnten (SCHUBERT 2001:32). 
Aber auch auf dem Main wurden sie befördert und die Häfen in Würzburg oder Marktbreit dürften „ein lebhafter Umschlagplatz für Mühlsteine vom Wasser zu Land gewesen sein.“ (BEDAL 1992:48). Von dort „mußten dann natürlich wieder Fuhrwerke den Transport bis zur Mühle übernehmen.“ (:48)

Doch nicht nur die schweren Mahlsteine, sondern auch die bereits erwähnten beschwerlichen Mühlenfuhren wurden, sofern es ging, auf das Wasser verlagert: „Korn, das auf dem Wasserwege herangeschafft worden war, wurde auf Feldbahnschienen durch Wasserkraft den steilen Weg vom Elbufer zur Mühle befördert", wie LANGE (1989:94) am Beispiel der Wassermühle Thalmühle bei Vietze im Wendland erläutert. Und dies dürfte kein Einzelfall gewesen sein, denn das Korn musste beispielsweise auch zu 13 Branntweinbrennereien in Schnackenburg a. d. Elbe gebracht werden, die es 1792 noch gab (:101). Auch auf der Saale (SCHUBERT 2001:32) und auf der Werra (BINTZER 1991:66) wurde das Mahlgut zu den Mahlmühlen befördert.

Schiffe waren für Mühlen und Zunft in den Zeiten der damaligen Hochkonjunktur noch in anderer Weise unentbehrlich. Die größeren Gerbereien Eschweges zum Beispiel nutzten zum Transport der Eichrinde den Mühlgraben. Um 1840 wird erwähnt, dass direkt vom Schiff aus die Eichenrinde über eine Seilrolle auf die Trocken- bzw. Mahlböden gezogen, dort gelagert oder sofort verarbeitet wurde (BINTZER 1991:66). Die Erde, die zur Abdichtung der Mühlengräben und der Teichböden oder zur Erhöhung von Dämmen und Ufern der Bäche und Teiche erforderlich war, wurde zwar in der Regel per Fuhrwerk angefahren. An Bachabschnitten aber, wo dies nicht möglich war, wurden sie in einem Kahn zu den Wassermüllern und Teichwirten gebracht (LANGE 1989:52).

Schließlich diente das Wasser auch der Wärme- und Personentransport. Die Anlieferung der Torfsoden aus den Torfstichen der ehemaligen Moorgebiete, zum Beispiel des Bourtanger, des Emsländischen oder Worpsweder Moores, erfolgte zumeist über den Wasserweg (ERLER/MATTHIESEN 1989:76).

In den ostfriesisch-oldenburgischen Marschen und Mooren, im „Rheiderland“ und in der „Krummhörn“, hatte sich im Mittelalter die sog. „Loogschiffahrt ${ }^{\star 39}$ herausgebildet. Da es in dem anmoorigen und sumpfigen Gelände kaum befahrbare Straßen gab, betrieben Loogschiffer nicht nur den Warentransport, sondern auch den Personenverkehr zwischen den einzelnen Dörfern und der Hafenstadt Emden auf den zahlreichen Fließgewässern.

Unter anderem zu diesem Zweck wurde auch die Dumme in „geringem Maße mit Kähnen befahren“. (LANGE 1989:55). Die Dummekähne dienten hauptsächlich dem Transport von Holz und Brenntorf aus den Waldungen und Mooren auf altmärkischer Seite. Dabei bildeten hier und auch anderswo die Wassermühlen erhebliche Hindernisse. Beim Beispiel der altmärkischen Wustrower Wassermühle führte in alter Zeit von der Dumme und vor der Mühle abzweigend, ein Graben direkt in die Jeetzel, der es den Kähnen erlaubte, die Mühle zu umgehen. Der spätere Einbau einer Schleuse hatte die Verschlammung dieses Grabens zur Folge und bedeutete, dass in zeit- und kraftaufwendiger Weise zu transportierende Güter von den Dummekähnen über Land auf Jeetzelkähne umgeladen werden mussten (LANGE 1989:55). Da dieses Problem auch an anderen Orten auftrat, setzte eine Umkehrbewegung ein.

Während des 13. Jahrhunderts schien es, ,that an abrupt change took place in the network of waterways in the Northern European plain.“ (DUNIN-WASOWICZ 1990:97) DUNIN-WASOWICZ (:97) begründet dies mit der "human interference in the natural course of rivers“" und, „with the development of transport by land.” "The latter“, so seine Ursachenforschung „was facilitated by the more widespread use of modern horse-drawn vehicles. [...] A further factor was the economic development of cities, which were often without natural waterways." Zudem wird von anderen Autoren (KAACK 1991; aus: GOLDAMMER 1999:63) das bereits oben genannte Problem angeführt, dass zur damaligen Zeit an manchen Flussabschnitten eine aufwendige Umlandung auf den Landweg erforderlich war, das für den direkten Transport mit Pferden sprach. Schließlich waren schon im Mittelalter des 14. Jahrhundert die Boote auch zum Fischen so groß, dass die zum Verkehr gedachten Fische nicht mehr auf den schmalen Gewässerwege, sondern über Land verfrachtet zum Abnahme- bzw. Marktort verfrachtet werden mussten (KREINER 1996b:109).

\footnotetext{
${ }^{39}$ Loog: Dorf, Ortschaft
} 
Auch stellten für die damalige Bootsfahrt die „ungezähmten“ Flusswege aufgrund ihrer natürlichen Flussmorphologie unangenehme Hindernisse dar: Mäander, Altarme, Uferbewuchs, Untiefen und Stromschnellen waren nicht für eine Schifffahrt, erst recht nicht des aufblühenden mittelalterlichen Handels, geschaffen (SCHUBERT 2001:32).

Zudem traten seit dem Hochmittelalter an den meisten Flüssen anthropogen bedingte Veränderungen auf, die sich auf die Schifffahrt im Laufe der Jahrhunderte sehr negativ auswirkten: Durch die Umwandlung der Auwälder in Grünland und Ackerflächen und durch die umfangreichen Waldrodungen in den Einzugsgebieten der Flüsse veränderte sich das Abflussverhalten der Fließgewässer, die nun bei Hochwasser große Mengen Trübstoffe und Sande mitschleppten, die sich als Auelehmdecken bzw. als Sandbänke ablagerten. Vor allem im Zuge einsetzender Bergbauaktivitäten findet eine Aufschließung der natürlichen Vegetations- bzw. Bodendecke statt, was zu einer Bildung von Angriffsflächen für die Erosion führt. Großflächige Rodungen insbesondere im wald- und wasserreichen Mittelgebirgsraum erfolgen einerseits zur Freilegung von Erzlagerstätten, zur Gewinnung von Bauholz sowie vor allem von Holz bzw. Holzkohle als Energieträger. Andererseits fiel der Wald auch dem Ausbau der Infrastruktur sowie der Erweiterung von Siedlungsraum und landwirtschaftlichen Nutzflächen zum Opfer. Hat die Zerstörung der Bodendecke begonnen, erhöhen sich in der Folge die fluviatilen Abtragungsraten, weil die Oberflächenwässer wegen der nicht mehr vorhandenen Speicherwirkung der Vegetationsdecke bzw. des Bodens rascher abgeführt werden. Hiervon besonders betroffen waren vor allem die topographisch exponierten Lagen der Mittelgebirge. Gleichzeitig stiegen in den tiefergelegenen Ablagerungsräumen die Sedimentationsraten (GOLDENBERG 1996:233). In Talauen des Schwarzwaldrandes beispielsweise wurde festgestellt, dass Fundhorizonte aus der Zeit des Hoch- und Spätmittelalters mit ihrer Basis deutlich unter der heutigen Geländeoberfläche liegen und mit Auesedimenten dezimeter- bis meterhoch überdeckt sind, so dass die heutigen Geländestrukturen nicht mehr den früheren entsprechen. Auch hierfür wird eine erhöhte Erosion im Hinterland verantwortlich gemacht, wie sie als Folge des sehr umfangreichen mittelalterlichen Bergbaus angenommen werden kann (:235). Auch flussnahe Wehsande und Wanderdünen, hervorgerufen durch die Verwüstung der Geestwälder sowie durch Überweidung und Plaggenhieb, trugen Sand in die Gewässer (siehe auch Pkt. 4b). Die Folge war, dass sich beispielsweise auf Ems, Weser und Aller die Bedingungen für die Schifffahrt immer mehr verschlechterten und Bremen aufgrund der Versandung der Unterweser zeitweilig nicht mehr angelaufen werden konnte (KAUP 1996:116; SEEDORF/MEYER 1996:625).

Zusätzlich zu den wandernden Sand- und Kiesbänken waren Abbrüche von den Ufern, Auskolkungen sowie ganze Talwegverlagerungen infolge des Abschneidens von Flussschlingen bei Hochwässern häufige Erscheinungen. Hinzu kamen Hindernisse in Form von treibenden oder festsitzenden Baumstämmen, mitten im Flussbett liegenden Felsblöcken oder Stromschnellen wie am Durchbruch der Weser durch die Porta, den Hannoverschen Klippen bei Karlshafen oder den Liebenauer Steinen. Nicht selten nahmen die Fahrzeuge bei starkem Stromgang an solchen Hindernissen Schaden. An anderen Stellen behinderten sie das Fortkommen derartig, dass die Fracht mit großem Zeitverlust auf kleinere Leichterschiffe ${ }^{40}$ umgeladen werden musste. Obwohl ortskundige Treidler und Lotsen auf den Schiffen mitfuhren, waren Haverien eine häufige Begleiterscheinung und das Risiko der Schifffahrt auf den nicht ausgebauten Flüssen mit ihren Untiefen, Furten, Fischwehren, Inseln, Stromschnellen und schmalen Fahrrinnen, den sog. Gassen, hoch. Besondere Schifffahrtshindernisse waren zudem lang anhaltende Niedrigwasserperioden, Hochwässer und Eisgang (SEEDORF/MEYER 1996:625; siehe auch Pkt. 5). Das heißt, dass ,auch die Gestalt des Flußlaufs selbst ein Hindernis für die Schiffahrt und für die Flößerei“ war (KAUP 1996:116).

Der Zustand der natürlichen Binnenwasserwege war aber nicht nur auf die schwierigen „natürlichen“ Abflussbedingungen zurückzuführen, sondern hatte auch in fehlender oder unzureichender Instandhaltung seine Ursachen, denn ähnlich den Landstraßen führten auch die Wasserstraßen ein vernachlässigtes Dasein, trotz verordneter Fließgewä sserpflege. Weitere Gründe, die die Schifffahrt be- oder verhinderten, waren die vielschichtigen Flussnutzungen, an kleineren Flussläufen die Fischwehre und Aalfache, schleusenlose Wehre von Wassermühlen (KAUP 1996:116) und bei größeren Fließgewässern die im Strom treibenden

\footnotetext{
${ }^{40}$ Leichterschiffe hatten geringen Tiefgang für die Beförderung von Frachten und wurden deshalb auf flachgründigen Flusstrecken oder auf Brackwasser, beispielsweise im pommerschen Haff bevorzugt eingesetzt. Gleichzeitig verfügten sie über eine Tragfähigkeit von 600 Zentner
} 
Schiffsmühlen. Zu den baulichen und „natürlichen“ Hindernissen gesellten sich die politischen in Form von Stapelplätzen und Zollplätzen.

Nur weil die Zustände der Landstraßen noch wesentlich schlechter waren, konnte die Flussschifffahrt auf den Flüssen überhaupt noch bestehen (vgl. SEEDORF/MEYER 1996:629).

Als jedoch mit der Eisenbahn ein völlig neues Verkehrsmittel in den Wettbewerb um die Fracht trat, hatten die Wasserstraßen von ihrer früheren Bedeutung als Transportmittel für den Güterverkehr ungemein verloren. Zunächst verlor nur die Passagierschifffahrt viele Reisende an die schnelleren und bequemeren Eisenbahnen, aber nach den 1850er Jahren auch der Güterverkehr, zum Beispiel beim Steinkohlentransport. Der Rhein zum Beispiel hatte aufgehört, die alleinige große Handelsstraße zwischen Holland und der Schweiz zu sein.

Um dies zu verbessern und wieder zu einer Konkurrenz der Eisenbahn zu werden, war man dazu aufgerufen, den Schiffahrtsbetrieb vor allem zu Berg zu fördern und zu erleichtern. Denn auch als die Fluss- und Seeschiffe neben den Segeln und schließlich statt derselben Dampfmaschinen erhielten, erhöhte sich zwar die Beweglichkeit und Transportfähigkeit, aber die Verlässlichkeit und vor allem die Schnelligkeit der Schifffahrt blieb weiterhin ein Negativkriterium. So verlor das Dampfschiff durch das Zurückweichen des Wassers hinter den Radschaufeln oder der Schraube besonders in Strömen den größten Teil der verwendeten Kraft (SCHOLL 1985:13).

Zudem waren die Heck-, Seiten- und Mittelraddampfer aufgrund ihres beachtlichen Tiefgangs sehr wasserstandsabhängig, so dass es in den Sommermonaten immer wieder zu längeren Betriebspausen und damit zu schmerzlichen finanziellen Verlusten der Schiffseigner kam (ZESEWITZ/DÜNTZSCH 2003).

Aus diesem Grund wurden Versuche unternommen, die in schnell und gering abfließendem Wasser wenig wirksamen Schaufelräder und Wasserschrauben der Dampfschiffe ganz überflüssig zu machen, indem man die Maschinenkraft unmittelbar auf das Voranziehen des betreffenden Schiffes an einem festgeankerten Seil wirken ließ (SCHOLL 1985:17f.).

Die im ersten Drittel des 19. Jahrhunderts unter Fortentwicklung der „Warpschifffahrt“ aufgekommene Idee, „eine Art Eisenbahn mit unbeweglicher Schiene im Wasser“ (SCHOLL 1985:14) zu konstruieren, wollte auf Flüssen den Vorzug der Beweglichkeit des üblichen Dampfschiffes zugunsten eines vergrößerten Gütervolumens und gesteigerter Geschwindigkeit aufgeben, mindestens stark einschränken, indem man eine Kette oder ein Seil als Schiene teils und zeitweise auf dem Boden des Flusses bzw. im Wasser, teils und zeitweise auf dem Schiff selber verwandte und dabei die auf dem Deck des Schiffes stehende Trommel gewissermaßen in ein Zahnrad umwandelte (TREUE 1985:8).

Bei der Methode des Stromaufwärtswindens, der sog. Kettendampfschleppschifffahrt, „,wurde auf der ganzen zu durchfahrenden Stromstrecke eine angemessen starke Kette gelegt, die - an ihrem oberen Ende festgeankert - als Zugseil für das stromaufwärts zu ziehende Fahrzeug diente. Anstatt diese Kette vom Schiff aus durch Menschen oder Tiere ziehen oder winden zu lassen, setzte man eine auf dem Schiff befindliche Dampfmaschine ein, die ein oder zwei Kettenräder oder trommeln drehte, um die die Zugkette ein- oder mehrmals geschlungen wurde. Vorne wurde die Kette aus dem Wasser gehoben, und um nicht die ganze Kettenlänge auf der Trommel zu behalten, verblieben nur die ersten Umschlingungen auf ihr, während sich die Kette auf der unteren Trommelseite wieder abwickelte und in das Flussbett zurückfiel.“ (SCHOLL 1985:18)

Die Kettenschifffahrt wurde zunächst in Frankreich perfektioniert. 1825 wurde auf der ganzen zu befahrenen der oberen und unteren Seine eine Strecke von insgesamt $180 \mathrm{~km}$ als Kettentauerei betrieben (SCHOLL 1985:14f.,20), zwei Jahre später auch auf der Saône zwischen Givors und Lyon (:15). Und Anfang der 1860er Jahre war dieses Schleppsystem auf der Oise, der Yonne, der Loire, dem Canal du Nord und anderen künstlichen Wasserstraßen eingeführt (:20). 
Das aus Frankreich stammende System, an einer im Fluss verlegten eisernen Kette spezielle Schlepper fahren zu lassen, war zur damaligen Zeit wohl allein in der Lage, größere Ladungsmengen über weite Strecken zu transportieren (ZESEWITZ/DÜNTZSCH 2003).

Auch auf der Elbe wurde in den 1860er Jahren das neue Schleppsystem der Kettenschifffahrt eingeführt. Ewald BELLINGRATH (1838-1903) war der Initiator der Aktiengesellschaft „Kettenschleppschiffahrt der Oberelbe“. Die von ihm geleitete Gesellschaft entwickelte sich im Laufe eines Jahrzehnts zum führenden Unternehmen der deutschen Elbschiffahrt (ZESEWITZ/DÜNTZSCH 2003). Er hat die durchgehende Kettenschiffahrt auf $745 \mathrm{~km}$ Länge von Melnik in Böhmen bis Hamburg organisiert und wird daher auch als „Vater der Kettenschiffahrt“ bezeichnet.

Zwar hatte man sich seit der Mitte der 1860er Jahre mit der Kettenschleppschifffahrt auch auf dem Rhein als „eine der Eisenbahn nachempfundenen Weise“ beschäftigt (SCHOLL 1985:13), doch wurde 1865 das Prinzip der Kettenhauerei auf dem Rhein zunächst ad acta gelegt. Die Schwierigkeiten der Flusskrümmungen, die Flößerei und die Probleme mit der übrigen Schifffahrt ließen im Wesentlichen ein solches Projekt nicht zu. Wenn denn auch ab den Jahren 1872/73 eine Seilschleppschifffahrt auf dem Rhein aufgenommen worden ist (:10), so wurde sie nach 30 Jahren, im Jahr 1905 wieder liquidiert und das Seil aus dem Rhein entfernt (:142).

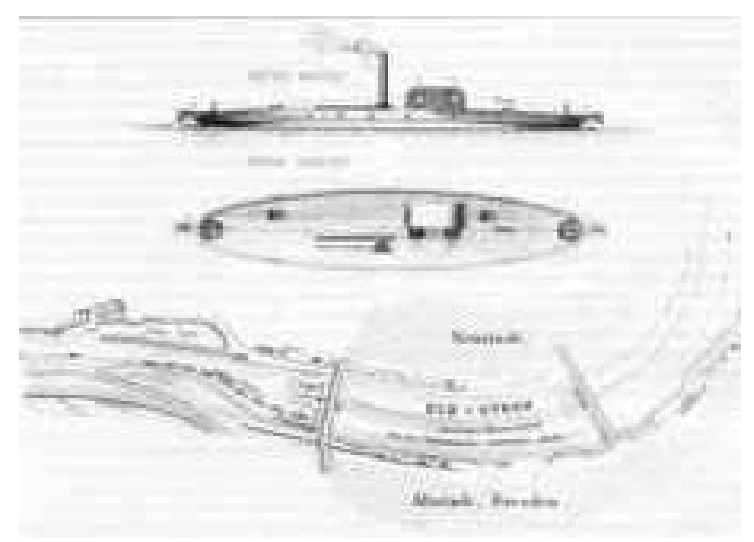

Abb. VI-33: Prinzipskizze eines Kettendampfers und Lage der Kette in der Elbe bei Dresden vermutlich von Bellingrath entworfen (aus: ZESEWITZ et al. 2003)

Auch in anderen deutschen Flüssen wurde im zweiten Drittel des 19. Jahrhunderts das Drahtseil im Strombett versenkt, wie in der Oder und Havel, in Donau und Saale (SCHOLL 1985:150), dem Main oder dem Neckar. Seit 1878 wurde eine „Ketten- und Seilschleppschifffahrt“ auf dem Neckar betrieben (:10), die zunächst mit Pferdegöpeln angetrieben wurden (:12), und auch noch auf einer Abbildung von 1935 ist ein Kettendampfer auf dem Neckar zu sehen (:42).

Fallende Kohlenpreise, die die Ersparnisse bei den Tauern im Vergleich zu den Schleppern drastisch verminderten, Erhöhung der Tragfähigkeit der einzelnen Schiffe, die einen Schlepplastverband nicht mehr notwendig erschienen ließen, aber vor allem die Veränderungen der stromtechnischen Bedingungen, die die Voraussetzungen zur Tonnage- und Schiffsgröße erst schufen, leisteten dem Niedergang Vorschub.

So wurde auf dem Rhein wie auch anderswo unter der Führung Preußens ein umfassendes Stromregulierungswerk durchgeführt, das dem Rhein eine Fahrtiefe brachte, die den Einsatz von zunehmend größeren Fahrzeugen ermöglichte. Während dieser Arbeiten musste häufig zeit- und kostenaufwendig die Seillage verändert werden, und durch den Durchstich der Krümmungen verlor die Seilschleppschifffahrt ihre besondere Einsatzfähigkeit, die vor allem in flachen und mäandrierenden Flussläufen bestand.

Des Weiteren setzten die häufigen Kettenbrüche und der hohe Zeitaufwand, der auf mittelgroßen Flüssen bei Gegenverkehr für das Ein- und Ausspannen der Kette nötig war, aber auch diesem System enge Grenzen (SEEDORF/MEYER 1996:630). 
An der Oder stellte man 1873 - 1875 und an der Havel 1876/77 die Seilschleppschiffahrt ein (SCHOLL 1985:150). Auf der Donau und der Saale sind 1901 bzw. 1922 die letzten Versuche mit Kettenschleppern endgültig eingestellt worden (:150).

Dagegen wurde die Kettenschleppschifffahrt auf den Flüssen mit engem Strombett und starken Krümmungen wie dem Neckar und Main noch bis 1935 bzw. 1938 betrieben. Auf der Elbe fand sie als letztes 1948 ihr Ende (SCHOLL 1985:150).

\section{c Personenverkehr}

Neben dem Gütertransport darf der Personenverkehr zu Wasser nicht vergessen werden, der sowohl auf den Fließgewässern als auch auf den Kanälen stattfand.

Hier ist zu trennen zwischen der eigentlichen Personenschifffahrt und dem Personentransport auf dem Wasser. Während mit der Personenschifffahrt die gehobene Form des Reisens bzw. der Beförderung von Personen bezeichnet werden kann, zum Beispiel als touristisches Vergnügen, bezieht sich nach meiner Auslegung der Transport von Personen auf eine rein zweckmäßige, in der Regel unbequemere Verbringung von einem Ort zum anderen und ist nicht primär auf diesen Zweck ausgelegt, sondern eher als „Beifuhr“ zum Gütertransport. Unterhalb der Personenschifffahrt, die der Beförderung mehrerer Leute gilt, kann des Weiteren noch der Bootsverkehr abgegrenzt werden, der eine geringere Anzahl von Menschen befördert. Eine Abstufung bzw. Einschränkung nach beschiffbarer Gewässergröße kann aber damit nicht verbunden werden: Beide Transportarten, die Bootsfahrt bzw. der Personentransport zu Wasser wie die in der Regel komfortablere Personenschiffahrt, können sowohl auch auf einem größeren wie auch auf einem kleineren Fließgewässer stattfinden. Sie alle lassen sich schließlich unter dem Oberbegriff „Personenverkehr“ subsumieren.

\section{c.1 Personentransport}

Eine besondere Form des Personentransports im Grenzgebiet zwischen dem Emsland und den Niederlanden waren die sog. Hollandgänger.

„Hollandgängerei“ bezeichnet „eine periodische Arbeiterwanderung aus den Geestgebieten Nordwestdeutschlands in die küstennahen landwirtschaftlichen Intensivgebiete, die Hoch- und Niedermoore sowie (untergeordnet) in die Hafenstädte der Niederlande.“ (BECKER 1998:255) Ihre Gesamtzahl belief sich um 1811 auf rd. 35.000, in der zweiten Hälfte des 18. Jahrhunderts sollen gar mehr als 40.000 Personen periodisch aus dem Binnenland zur Küste gewandert sein (BÖLSKER-SCHLICHT 1987:36). Im 18. und 19. Jahrhundert haben 20.000 - 25.000 Hollandgänger allein Lingen passiert. Nach 1870, als es in den Landstrichen Nordwestdeutschlands besseren Verdienst gab und große öffentliche Bauten durchgeführt wurden, hörte die Hollandgängerei auf (LENGERICHER GESCHICHTE(N) 1996:2f.; LINGENER TAGESPOST 1999)

Unter den landwirtschaftlichen Tätigkeiten, denen Hollandgänger in den Niederlanden nachgingen, stand das Heumachen in den Marschgebieten an erster Stelle. Die Zeit der Heugewinnung stellte eine kurzfristige saisonale Arbeitsspitze dar, zu deren Bewältigung Wanderarbeiter herangezogen wurden. Daneben brauchte man in Holland Zeitarbeiter für den Torfstich (LINGENER TAGESPOST 1999). „Es war die schwerste Arbeit, die auch am höchsten bezahlt wurde.“(LENGERICHER GESCHICHTE(N) 1996:2f.)

Fürs Torfstechen zog man bereits April/Mai fort. Am Sonntag nach der Kirche wurde von den Hollandgängern der gemeinsame Aufbruch vereinbart. Für die Reise, die auf traditionellen, festen Routen, den sog. Hollandgängerwegen erfolgte, die immer wieder benutzt wurden, existierte ein bewährtes logistisches System: „Das schwere Gepäck - je Person ca. $30 \mathrm{~kg}$ - wurde von Fuhrleuten befördert oder auf dem Wasserwege von Flußschiffern transportiert.“ (BECKER 1998:255f.) Das hohe Gewicht des Wanderarbeitergepäcks kam unter anderem dadurch zustande, dass die Hollandgänger Arbeitskleidung, Gerät und möglichst viel Proviant für viele Woche von daheim mitbrachten, um Ausgaben in Holland zu vermeiden (:256). 
Auf der Ems, der Hase und den verschiedenen Kanälen wurden die Leute zum Teil in Booten und auf Flößen in die niederländischen Gebiete gebracht. Umgekehrt dürfte ein solcher teilweise kombinierter Wassertransport auch von den vielen holländischen Wasserbauingenieuren genutzt worden sein, die vor allem im 13. bis 17. Jahrhundert die Aufträge für zahlreichen Meliorationen entlang der Flussgebiete bekamen.

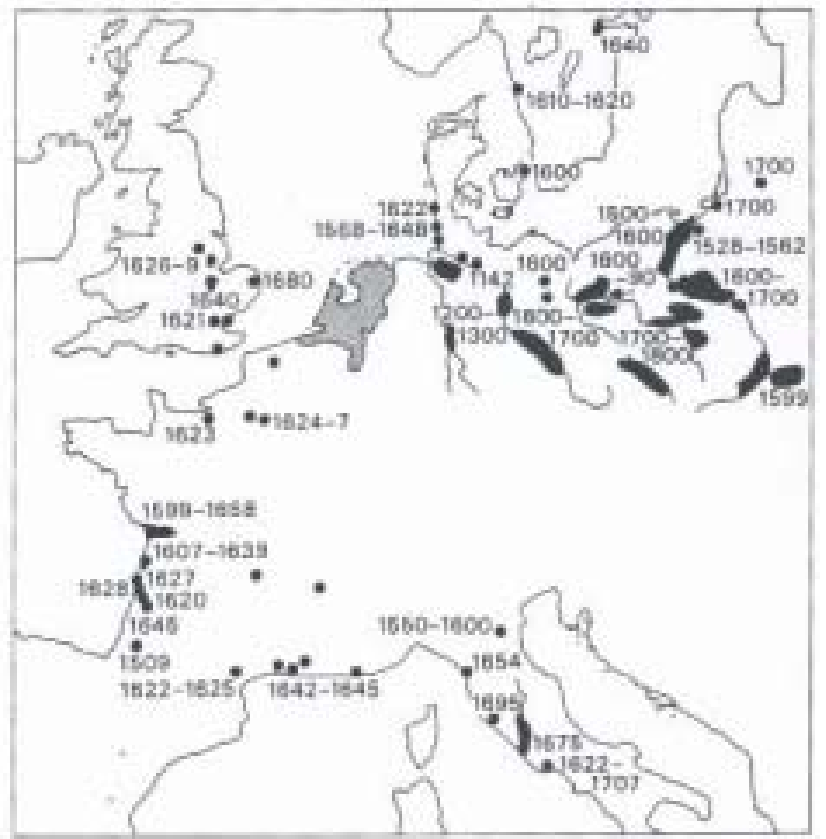

Abb. VI-34: Gebiete, in denen holländische Ingenieure in Urbarmachung von Feuchtgebieten involviert waren (aus: GOUDIE 1981:148)

\section{c.2 Personenschifffahrt}

Personenverkehr innerhalb des Berliner Raums wurde für das Jahr 1702 nachgewiesen. Schiffe fuhren zweimal täglich die Strecke Charlottenburg - Spandau - Potsdam im Treckschutenbetrieb, von Pferden entlang der heute noch vorhandenen Treidelwege gezogen. Diese Verbindung diente vorrangig dem Ausflugs- und Vergnügungsverkehr. Zur gleichen Zeit wurde eine Schiffsverbindung für Personen zwischen Spandau und Berlin betrieben (STRAUSS 2002:22).

Auf der Havel verkehrten muskelbetriebene Boote und Kähne. Bis in die 1880er Jahre hinein wurden zum Beispiel die sog. „Moabiter Gondeln“ für den Personenverkehr auf dem Wasser eingesetzt. Die Schiffe hatten eine Kapazität von rd. 70 Personen, wurden durch Staken angetrieben und dienten eher dem Amüsement. Ende des 19. Jahrhunderts wurde der Betrieb eingestellt (STRAUSS 2002:23).

Den gleichen Zweck erfüllten die ,abendlichen Wasserfahrten auf der Fulda mit Illumination“, zu denen in den 1860er Jahren in Kasseler Tageszeitungen des Öfteren eingeladen wurde (KLAUBE 1995:115). Mit Familie und Gästen unternahm man an einen an der Fulda gelegenen Ort diese Vergnügungsfahrt. Hierfür benutzte man Sandkähne, die flussaufwärts gezogen wurden. Bei eintretender Dunkelheit wurden sie dann beleuchtet (:115).

Bereits zuvor, im Jahr 1835, wurde die Personenschifffahrt auf der Oberweser aufgenommen (ECKOLDT 1995:13).

Heute jedoch beleben nur noch die weißen Personenschiffe, die auf Teilstrecken zwischen Hameln und Hann. Münden pendeln und in den bekannten Ferienorten Anlegestellen haben, auf ihren sommerlichen Linienfahrten das Bild dieser ehemaligen „Wasserstraße“. Und wenn in trockenen Sommermonaten die Fahrtiefe auf der Oberweser stellenweise unter $1 \mathrm{~m}$ sinkt, so ist trotz modernem Schiffsbau nur noch mit Hilfe von Zuschusswasser aus der Edertalsperre, das zu vereinzelten Zeiten als Welle abgegeben wird, eine Schifffahrt durchführbar, wobei die Schiffe dann auf den Zuschusswellen talwärts fahren. Aber auch die 
Weiterführung der historisch begründeten Personenschiffahrt auf der Ober- und Mittelweser ist seit dem Konkurs der „Weser-Dampfschifffahrt“ im Jahr 2003 fraglich. Eine sog. Auffanggesellschaft, ein Konsortium von Land, Anliegerkommunen und einem Privatinvestor, versucht einige Linien aufrechtzuerhalten.

\section{c.3 Bootsverkehr}

Auf welch kleinen Gewässerläufen ein (touristischer) Bootsverkehr stattfand, lässt sich heute nur schwer vorstellen, sieht man aus heutiger Sicht ihre Breite.

Im ehemaligen fürstlichen Sol-Thermal-Bad Salzuflen wurde seit 1898 in dem damals tieferen Wasser des „Kunstgrabens“ gerudert, der in den sog. „Gondelteich“ mündete, von wo aus der Bootsverleih betrieben wurde. Der „Kunstgraben“ diente ursprünglich, wie in anderen Solebädern auch (zum Beispiel in Bad SoodenAllendorf, dem Wasseraufstau für das Wasser-Antriebswerk des Gradierwerkes, wo ein 1770 mechanisch eingerichtetes Rollengestänge die Pumpen bewegte und damit die Sole auf die Gradierwerke hob (RAU 1989:73).

Dass die Kahnpartien sehr beliebt waren, vermag das unten stehende Archivfoto zu dokumentieren.

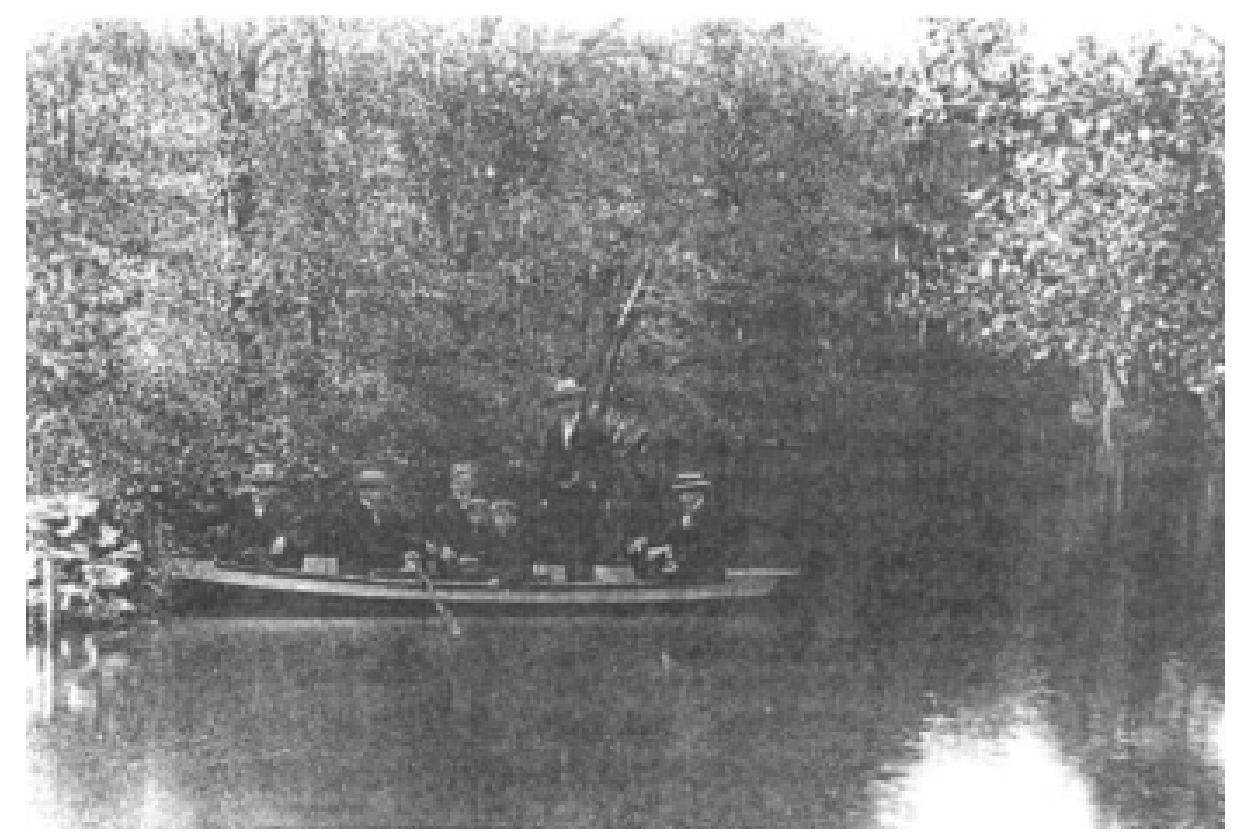

Abb. VI-35: Bootsverkehr auf dem sog. Kunstgraben im Kurpark des Kurbades Salzuflen, um 1900

Seit 1898 konnte man in dem Wasser des Kunstgrabens und des sog. Gondelteiches entlang rudern. Hier befand sich auch der sog. Aalfang, ein Reusenfang, mit dem der damals reiche Fischbestand an Aalen und Forellen kontrolliert und abgefangen wurde (aus: RAU 1989:73).

Schiffsfahrten auf den aufgrund der darauf stattfindenen Gondel- und Ruderfahrten „Gondelteich“ genannten Teichen gab es an vielen Orten. Vor allem Mühlenteiche wurden für diese Vergnügung benutzt. Sei es, dass die Müller sich damit ein Zubrot verdienten, sei es, dass nach Stilllegung des Mühlenbetriebs ein Gaststättenbetrieb eingerichtet wurde, wie zum Beispiel auf dem Mühlenteich der Eggersmühle bei Wesseloh: „In der heute nicht bestehenden Wirtschaft konnte sich jeder Sommerfrischler einen Kahn mieten, um auf dem großen und herrlich gelegenen Teich umherzuschippern." (ERLER/MATTHIESEN 1989:81) Oder auf dem Teich der ehemaligen Wassermühle Heidberger Mühle im Ittertal, dessen ehemalige Verwendung für Bootspartien noch heute zu erkennen ist. 


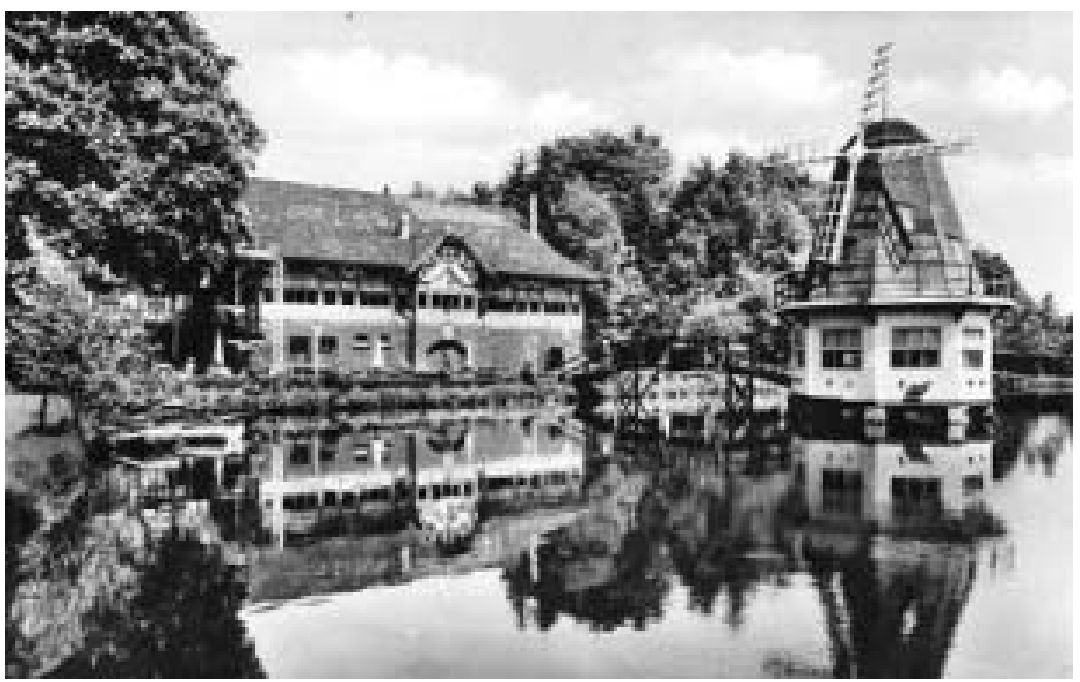

Abb. VI-36: „Gondelteich“ der Heidberger Mühle im Ittertal zwischen Solingen und Haan

Die eigentliche Fachwerkmühle steht nicht mehr. Die 1683 erstmals genannte Mahl- und Ölmühle bestand schon vor dem Dreißigjährigen Krieg. Auf einer Skizze von 1880 ist sie noch verzeichnet und lag schräg gegenüber, etwas unterhalb dem 1784 erbauten und noch heute bestehenden Haupthaus (heute: Gasthaus). Die heutige Gewässersituation leitet jedoch in die Irre. Das Wasser zum Antrieb der Mühle wurde von der Itter abgezweigt und in dem „Obergraben“ dem Wasserrad zugeleitet. Einen Mühlenteich hatte diese Mühle nur augenscheinlich. Das Teichgelände ist auf der Skizze von 1880 als Wiese mit hochstämmigen Bäumen (Weiden oder Obstbäumen?) und sich dazwischen erhebenden Beetrücken (Wässerwiese?) dargestellt. Erst auf einer Aufnahme von 1905 ist dann der „Mühlenteich“ zusehen, aber nicht mehr die Mühle. Die stilisierte Windmühle in der Mitte des Teiches war zu diesem Zeitpunkt auch noch nicht erbaut, auch nicht auf einem Foto von 1920. Erst 1944, nach der Wiedereröffnung nach einem Bombenschaden, erscheint die Windmühle auf einem Foto. Die Heidberger Mühle präsentierte sich nunmehr als Ausflugslokal, als „Familienpark“. Hier konnte man Kahn fahren, Kaffee trinken und tanzen [URL = http://www.heidberger-muehle.de; 25.05.2004; http://www.solingeninternet.de/si-hgw/idylle; 25.05.2004].

Des Weiteren entstanden seit Anfang des 20. Jahrhunderts zahlreiche Ruder- und Kanuclubs, die aber aus eher sportlichen Erwägungen Fließgewässer, wie zum Beispiel die Mulde (HUHN 1992: Abb. 140), und vor allem Kanalstrecken für den Wassersport nutzten. Mit dieser Bewegung entstanden Bootshäuser und Einsatzstellen, die durchaus einer gewässerhistorischen Einzelbetrachtung wert wären.

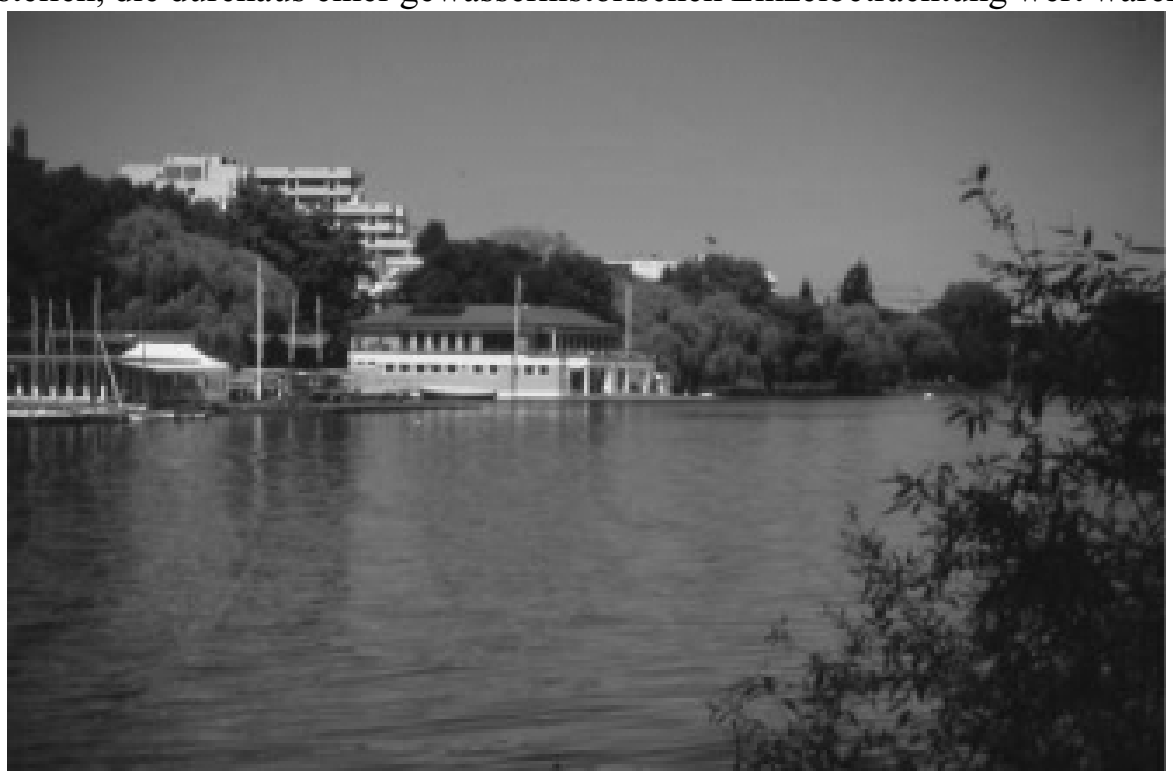

Abb. VI-37: Ruderclub auf der Alster/Hamburg

Die Abbildung zeigt das 1924 erbaute, einen Vorgängerbau ablösende Boots- und Vereinshaus des „Hamburger und Germania Ruder Club“ am Alsterufer, Deutschlands ältester und weltweit - nach dem Leander Boat Club in Henley (UK) zweitältester Ruderclub. Der 1836 von 11 jungen Hamburger Kaufleuten gegründete Club markierte damit auch den Anfang des deutschen Rudersports, der in der Folge an nahezu jedem ruderbaren Fließgewässer einsetzte [URL = http://www.der-club.de/20_CLUB/x_CLUB_A.htm; 25.05.2004] (eig. Aufnahme 2004). 


\section{d Flussausbau}

Unter „Flussausbau“ verstehe ich Eingriffe in die natürlichen Fließgewässer zum Zwecke der besseren Befahrbarkeit. $\mathrm{Zu}$ unterscheiden ist hierbei im engeren Sinne die „Regulierung“ von der „Kanalisierung“. Bei einem regulativen Eingriff wird nur in bestimmten Flussabschnitten in den ansonsten frei fließenden Stromlauf korrigierend eingegriffen. Das Gewässerbild bleibt ein weitgehend naturähnliches. Bei einer Kanalisierung hingegen wird der gesamte Flusslauf oder eine Flussstrecke in ein starres Bett gezwängt, das in seiner Form dem eines Kanals ähnlich ist. Doch oftmals ist je nach Ausführung und Zeitdauer einer eventuellen Naturüberlassung von alten Kanalstrecken eine Unterscheidung nur schwer möglich, überhaupt vor dem Hintergrund des Bildes von Gewässerläufen, das durch Regulierung geprägt worden ist. Und solange nicht in den Gewässerlauf korrigierend eingegriffen wird, kann man nicht von einem „Flussausbau“, sondern nur von Gewässerpflege bzw. -reinigung sprechen.

Der Gegensatz dazu ist der Kanalbau, der einen weitgehenden künstlichen Gewässerneubau bedeutet, wenn auch manchmal natürliche Flussabschnitte in den Verlauf mit einbezogen werden.

\section{d.1 Regulierung}

Um Schwierigkeiten, wie den stetig schwankenden Pegelständen zu entgehen, wurden die schiffbaren Fließgewässer zunächst einfach reguliert ${ }^{41}$, denn die Schiffbarkeit von Gewässern stellt die grundlegende Bedingung für die Binnenschiffahrt und damit zum Transport von Gütern dar. Zur weiteren Förderung von Handel und Flößerei durch Verbesserung der Schiffbarkeit kam es daraufhin zu größeren Eingriffen in die Flussökosysteme und $\mathrm{zu}$ einer weitreichenden Schiffbarmachung auch kleinerer Gewässer (KAUP 1996:112). Doch im Einzelnen:

Da die Schifffahrt an verschiedene Voraussetzungen gebunden ist, als deren notwendigste eine hinreichende Fahrwassertiefe zu gelten hat, mussten zunächst die Flussschiffe desen Erfordernisse durch niedrigen Tiefgang angepasst werden und später, mit Erhöhung der Tonnage, die Flüsse entsprechend vertieft werden.

Schifffahrtswege und Kanäle bedurften jedoch nach der Vertiefung ganzjährig einer sehr aufwendigen Wartung und Pflege. Insbesondere war das Kanalbett regelmäßig von dem aus dem Untergrund mit dem Grundwasser eingedrückten Sand zu befreien.

Ein Privileg Kaiser Ludwigs von Bayern aus dem Jahre 1333 beschäftigte sich bereits mit dem Ausbau des Neckar (HAGEL 1988:31). Und 1545 ordnete deshalb Landgraf Philipp von Hessen (1504 - 1567) Maßnahmen zu Erleichterung der Schifffahrt an: Die Fahrrinne der unteren Fulda war zu räumen. Räumen heißt dabei „,in erster Linie, Untiefen und Hindernisse auf der Floßsohle mit Hilfe rechenförmiger Kiespflüge zu beseitigen" (HOFFMANN 1995:85).

Die für die Schifffahrt erforderlichen Wassertiefen lagen im 16. Jahrhundert bei 0,7-0,8 m (RÖTTCHER 1995:171). Diese mussten teilweise auch durch Auspflügen des Gewässers sichergestellt werden. Des Weiteren galt es, Verlandungen in für die Schifffahrt genutzten Flüssen oder in anderen künstlichen Wasserläufen entgegenzuwirken. Dafür benutzte man sog. Kiespflüge und Kratzen. Es handelte sich dabei um kammähnliche, rechen- oder eggenartige Geräte (siehe Abb. 6-38), die, an Seilen befestigt, vom Ufer aus von Pferden oder Menschen zum Ufer hin gezogen wurden und das Geröll mit sich zogen. Die aufgewühlten Sedimente bzw. das gelockerte Sohlenmaterial wurde entweder durch die Transportkraft des Gewässers fortgespült oder das Baggergut wurde aus der Fahrrinne entfernt und am Ufer, zum Beispiel zur Ufersicherung abgelagert und so die Fahrrinne vertieft. Angewendet wurde dieses Verfahren zur Zeit des kleinen Wassers, mithin bei niedrigem Wasserstand (SPINDLER 1988:84; ECKOLDT 1995:13; RÖTTCHER 1995:171).

Auch in der Weser und Werra wurden seit Mitte des 18. Jahrhunderts Kiespflüge eingesetzt, um Sand- und Kiesbänke zu beseitigen (ECKOLDT 1995:13; RÖTTCHER 1995:171).

\footnotetext{
41 Einfache Regulierung: Hierbei handelt es sich „nur“ um regulierte und ansonsten frei fließende Stromläufe bzw. -abschnitte.
} 


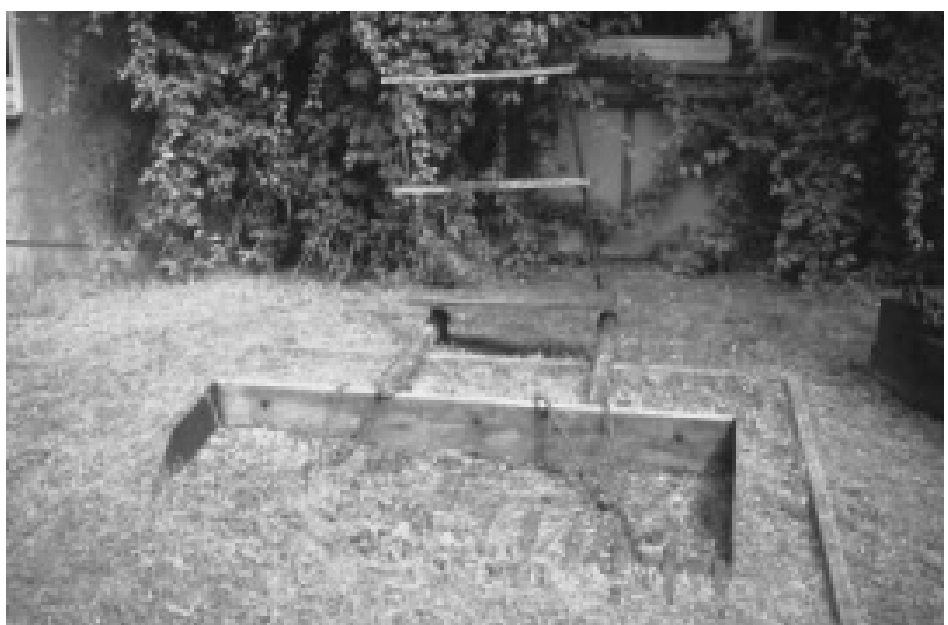

Abb. VI-38: Kiespflug für kleinere Fließgewässer

Zur Gewässervertiefung wurde der Pflug quer zur Fließrichtung, von Ufer zu Ufer, gezogen. Ein oder zwei Personen standen zur Beschwerung und Lenkung auf der „Lenkleiter“. Von einer Drehwinde oder von Pferden gezogen wurde der Kies im Flussbett verteilt, der auf der Schaufel verbliebene Kies an Land gezogen und als Baumaterial verwandt. Hauptsächlich aber diente das Kiespflügen der Flussvertiefung. (eig. Aufnahme 2004: Informationszentrum Schachtschleuse des Wasserstraßenkreuzes Minden).

Um die Beeinträchtigungen für die Schifffahrt weiter zu bereinigen, wurden Untiefen, Sandbänke und felsige Stromschnellen beseitigt und durch Aushauen von Fahrrinnen der Gewässerlauf schiffbar gemacht.

Als weitere Beeinträchtigung der Schifffahrt erwies sich häufig die Verlagerung von Mündungsarmen, wie zum Beispiel im großen Maßstab im Rhein- und Elbedelta. Anscheinend wurden schon im frühen Altertum die Mündungsarme mancher Flüsse durch Vertiefung und Begradigung schiffbar gemacht (WARNECKE 1999:448).

Schließlich musste die Uferbeschaffenheit der Gewässer verändert werden, unter anderem um Landungsmöglichkeiten zu bieten. „In frühhistorischer Zeit landeten alle Schiffe an Stränden und flachen Ufern, doch erforderten die hinsichtlich Tonnage und Anzahl schnell zunehmenden Handelsschiffe anthropogene Häfen." (WARNECKE 1999:441) Besonders in römischer Zeit wurden auch die Flusshäfen ausgebaut, vor allem am Rhein und an der Donau (WARNECKE 1999:441). Solche Anlandungsstellen oder Hafenbecken mussten immer wieder gereinigt bzw. neu ausgehoben werden, um die Schifffahrt sicherzustellen (WARNECKE 1999:448).

Diese Maßnahmen gingen jedoch nicht weit genug. Zur weiteren Erleichterung der Schifffahrt, um die Lenkbarkeit des Schiffes zu vereinfachen sowie den Fahrweg zu verkürzen, wurden Fahrrinnen abgesteckt, und der Fluss wurde begradigt, indem Mäander durch Durchstechen von Krümmungen beseitigt wurden (KAUP 1996; 116f.; SCHUBERT 2001:32).

Uferbefestigungen an natürlichen und künstlichen Gewässern sind aus frühmittelalterlichen Städten wohlbekannt. In Haithabu wurde der die Ansiedlung durchfließende Bach zunächst geradlinig ausgebaut, gleichsam kanalisiert, und mit einem die Böschungen stabilisierenden Uferschutz versehen (SPINDLER 1988:83). Die frühesten, vielleicht noch ins 8. Jahrhundert zu datierenden Ufersicherungen bestanden aus Flechtwerkfaschinen. Später wurden diese durch Reihen eingerammter Rundhölzer und unterschiedlich gespaltener Pfähle ersetzt, die teilweise waagegerecht hintergebrettert wurden. Schließlich gab es auch aufwendige Bauarten mit in regelmäßigen Abständen eingeschlagenen Rundstämmen, in deren uferparallel eingekerbte Köpfe horizontal Bretter eingelegt wurden: 


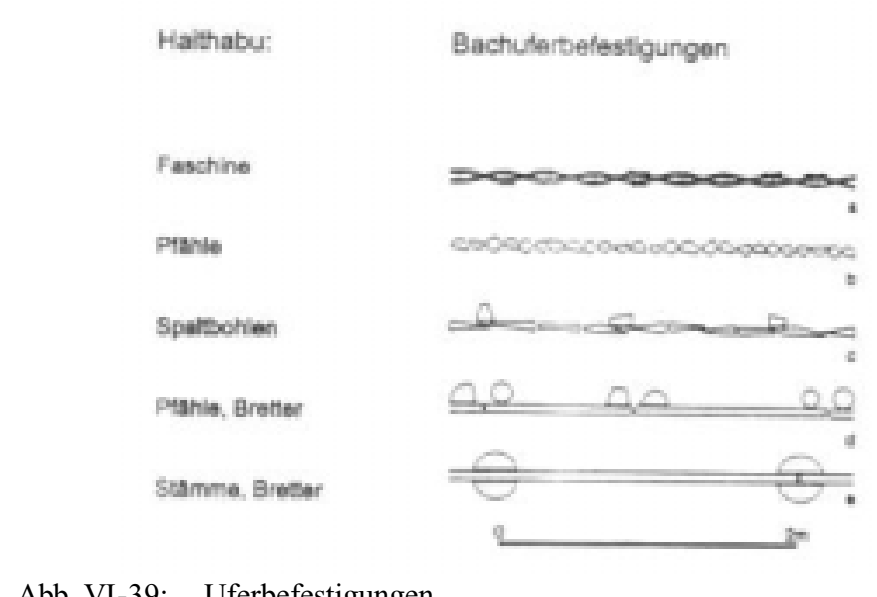

Abb. VI-39: Uferbefestigungen

(aus: SPINDLER 1988:82)

Bei den Kanalbauten reichten einfache Ufersicherungen aus Flechtwerkfaschinen aus, um die Uferwände zu stabilisieren und das Kanalbett vor dem von den Böschungen herabrieselnden Sand zu schützen. „Auf diese Weise wäre zugleich der neben dem Kanal für den Schiffstransport angelegte Treidelpfad hinreichend angestützt worden.“(SPINDLER 1988:83)

$\mathrm{Zu}$ den weiteren Maßnahmen gehörte der Bau von Dämmen. Bevor die Hochwässerschäden durch Deichbau begrenzt wurden, errichtete man sie zum Zwecke der besseren Schifffahrt. Deichbau ist im hohen Oderbruch beispielsweise seit dem Mittelalter urkundlich nachweisbar. Ein geordnetes Deichwesen, der Ausbau und die Erhöhung der Deiche, wurde aber erst seit 1746 unter Friedrich Wilhelm I. wieder eingeführt (KAUP 1996:117,120).

Im Laufe der Jahrhunderte wurden verschiedene Maßnahmen zur Regulierung durchgeführt, von denen im Folgenden einige chronologisch aufgeführt werden sollen.

Der Hessische Landgraf Wilhelm IV. plante eine durchgehende Schiffsverbindung von der Residenzstadt Kassel zu der etwa $60 \mathrm{~km}$ südwestlich liegenden Landesfestung Ziegenhain. Die Arbeiten beschränkten sich im Wesentlichen auf die Schwalm, die auf eine für die Schifffahrt ausreichende Wassertiefe gebracht werden sollte. Dazu wurden ein Rampenbau an den Mühlwehren (Kettenwinden zum Hinwegziehen über die Wehranlage) durchgeführt, Durchlassvorrichtungen in den Wehren (Schiffsdurchlässe), hölzerne Schleusenbauwerke (Schleusenkammern) gebaut und Leinpfade angelegt. 1575 waren die Arbeiten schon weit vorangeschritten, wurden aber aus nicht bekannten Gründen richt zu Ende geführt. 1594 erfolgte der Ausbau der hessischen Lahn nach dem gleichen Prinzip und im gleichen Zeitraum erfolgte die Vertiefung und Räumung der norddeutschen Delvenau, „daß man darauff beladene Schiffe fahren lassen kann und daß zwei Schiffe an einander vorbei fließen können“ (OPITZ 1997:160, nach einer alten Quelle). Trotz des Baus von Schleusen, die bei all den Regulierungsmaßnahmen erforderlich wurden, blieben aber die Flussstrecken gewunden und die Wassertiefe gering.

18. Jh.

Nach den an zahlreichen Flüssen vorgenommenen einfachen Regulierungen erhöhte sich gegen Ende des 18. Jahrhunderts die Schiffsfrequentierung auf den Gewässern beträchtlich. In der Folge kam es zu zahlreichen weiteren wasserbaulichen Eingriffen, auch im Oberlauf der Flüsse. Vor allem diesen noch weitgehend unberührten und nicht durchgehend schiffbaren Flussabschnitten galt die Aufmerksamkeit.

Verbesserungen des Fahrwassers ließ beispielsweise die Schiffergilde in Hann. Münden schon im 18. Jahrhundert gegen Entgelt durch die Weseranlieger durchführen. In diesem Fall sollte durch eine Einengung des Profils eine bessere Schiffbarkeit erreicht werden. Einfache Buhnen wurden in das Fahrwasser eingebaut. Sie bestanden aus eingerammten Erlenholzstämmen, die mit Faschinen verflochten und mit Steinen überfüllt wurden (HENCKEL 1988:49). Des Weiteren wurden vor allem im zweiten Drittel des 18. Jahrhunderts Flusskorrekturen durchgeführt, die bedingt durch Hochwasserereignisse von den Landesherrschern angeordnet wurden (SCHUBERT 2001:32). Auch hier machten sich wahrscheinlich schon die zahlreichen 
anthropogenen Eingriffe, wie zum Beispiel die gesteigerte Urbarmachung von Auenländern und die kanalisierte Fassung auch kleinerer Fließgewässer bemerkbar, wie die im 18. Jahrhundert erfolgte „Schiffbarmachung“ der Unstrut (1791 - 1795) und Saale (1792 und folgend). Durch diesen Ausbau hatten die Salinen Artern und Frankenhausen direkten Zugang zu den wichtigen Handelsmärkten in Naumburg, Weißenfels und Leipzig, zugleich konnten bestimmte Waren, wie etwa Kohle und Holz, schnell und kostengünstig per Schiff zu den Salinen befördert werden (TOMASZEWSKI 1990:133ff.; DEUTSCH 1988:190ff.; SCHUBERT 2001:32; PÖRTGE 2003: FN 23).

Nachdem im Jahr 1815 der Wiener Kongress die Freiheit der Schifffahrt auf allen Flüssen beschlossen hatte, kam es zu einem weiteren „Ausbauboom“.

Besonders hinderlich für die Schifffahrt, wie bereits oben erwähnt, waren die zahlreichen Stau- und Überfallwehre. Allein im schlesischen Bereich der Oder gab es im 16. Jahrhundert 11 Wehre (KAUP 1996:116). Man versuchte, diese durch die Anlage von Schleusen zu umgehen (:116).

1819 beispielsweise genehmigte König Wilhelm I. „zur Emporhebung der Schiffahrt auf dem oberen Neckar" den Bau eines Verbindungskanals mit Schleuse in Heilbronn. Dies hatte unter anderem zur Folge, dass zwischen 1821 und 1865 der Neckarfluss zwischen Heilbronn und Cannstatt mit Stau- und Kammerschleusen für eine durchgehende Schifffahrt von Mannheim bis Cannstatt versehen wurde (HAGEL 1988:31).

An der oberen Saale erbaute man zwischen 1822 und 1826 insgesamt 7 Steinschleusen (SCHUBERT 2001:32). Und 1836, nach ergänzenden Regulierungsmaßnahmen (neue Buhnen, Leitdämme und Sohlschwellen), verkehrte schon das erste Dampfschiff auf der Saale. Ab der Unstrut-Einmündung stromabwärts war die Saale damit schiffbar. Schifffahrt wurde im großen Maßstab nur auf der sachsenanhaltinischen Saale betrieben. Auf Thüringer Gebiet spielte sie nur eine untergeordnete Rolle (:32).

Der eigentliche Ausbau der Oberweser erfolgte erst, nachdem die Anliegerstaaten nach den Vereinbarungen im Jahr 1823 die Weserschifffahrtsakte unterzeichnet hatten. Die Normalbreite der Weser sollte im Mündener Raum 13 Ruthen (ca. $62 \mathrm{~m}$ ) und die Fahrwassertiefe drei Fuß (ca. 0,90 m) betragen (HENCKEL 1988:49). Von 1833 bis 1848 wurden die Inseln und flachgründigen Sandbänke, die bis dahin für die Fischerei von Vorteil gewesen und an die häufig Fischhamen und Aalwehre gekoppelt waren, durch Abgraben und Abpflügen entfernt (:49).

Aus etwas späterer Zeit, aus dem Jahr 1879, stammt der erste Entwurf einer planmäßigen Regulierung der Weser. 1893 war das Ausbauziel - $80 \mathrm{~cm}$ Wassertiefe bei Normalwasser zwischen Münden und Karlshafen im Wesentlichen erreicht (ECKOLDT 1995:13). Es wurde vor allem durch die ersten planmäßigen Uferbefestigungen erreicht. So wurde der aus dem 18. Jahrhundert stammende bestehende Buhnenbau verbessert. Auf grobe Steinschüttungen aus senkrecht oder schräg zur Stromrichtung angelegten Dämmen setzte man nun ein schweres Pflaster, wobei die Neigung der Buhne am Ufer stärker und zur Flussmitte hin schwächer war. 


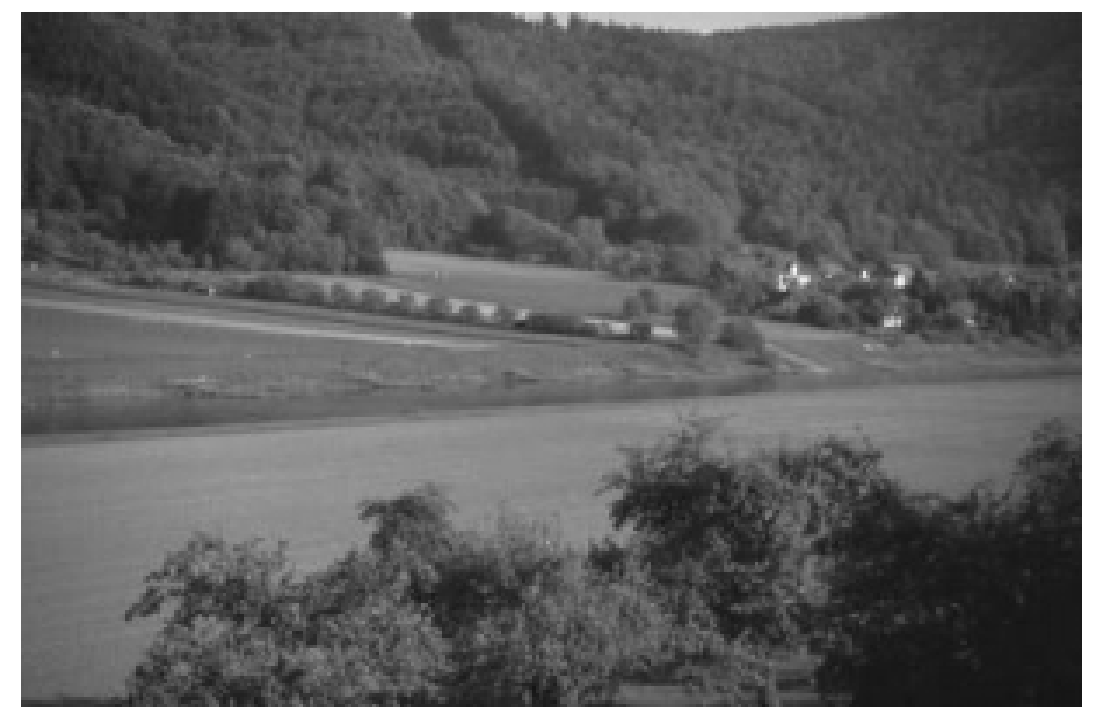

Abb. VI-40: Buhnen an der Weser mit Blick auf Glashütte bei Hannoversch Münden

Es handelt sich hierbei um bereits stark mit Getreide vergraste Buhnenbauten, die aus Steinblöcken geschichtet wurden. Die schwache Wasserführung schon im Mai ermöglicht einen solchen Bewuchs (eig. Aufnahme 2004).

Die Buhnen drängten das Wasser nicht nur in den breiten und flachen Flussabschnitten zusammen, sondern sorgten auch dafür, dass die Fließgeschwindigkeit in der Fahrrinne erhöht und Ablagerungen verhindert wurden. Bei hohem Wasserstand, der über die Buhnen hinwegging, wurde dahinter die Strömung verlangsamt und die vom Hochwasser mitgeführten Geschiebe, Sande und Lehme setzten sich in dieser Beruhigungszone $a b$.

Auch Parallelwerke in Form von Steindämmen wurden angelegt und mit Traversen (Querdämmen) mit dem Ufer verbunden, damit bei Hochwasser keine auskolkende Strömung entstand (HENCKEL 1988:49).

In den Jahren von 1878 bis 1886 wurden zusätzlich Grundschwellen zur Abflachung des Gefälles auf der Strecke Münden-Karlshafen eingebaut. Sie wurden gegenüber den Buhnenköpfen aus Senkfaschinen gesetzt und sollten die zerstörende Wirkung der Strömung auf die Wasserbauwerke möglichst verhindern oder wenigstens mindern.

1876 wurde der erste Dampfbagger im Amtsbezirk Münden eingesetzt. Große Steine im Fahrwasser wurden mit einer gewaltigen Zange, die auf einem Schiff montiert war, beseitigt. Klappschuten, deren Name von der besonderen Konstruktion dieses Schiffes stammt, da der Boden aufgeklappt werden kann, ohne dass Wasser eindringt, transportierten das gelöste Gestein und entleerten ihre Fracht in Flussbereichen mit überdurchschnittlicher Tauchtiefe (HENCKEL 1988:50f.).

Von 1899 bis 1907 wurde auch die weitere Regulierung der Siegstrecke von Siegburg abwärts abgeschlossen, nachdem schon ab 1854 die Grundzüge einer großdimensionierten Siegkorrektion von Blankenburg bis zum Rhein vorgenommen worden waren: Durchstiche wurden angelegt, Böschungen abgeflacht und zum Teil gepflastert (DIX 1997:139). Und auch die Rur unterlag ab den 1890er Jahren einer umfangreichen Regulierung, bei der man sich der gleichen Maßnahmen bediente.

\section{d.2 Kanalisierung}

Den Begradigungen als Flusslaufkorrekturen folgten die Kanalisierungen, die den Flussläufen nicht nur ein strenges, sondern vor allem ein andersartiges Verlaufsprofil gaben. Kanalisierungen sind fast von allen für den Transport und die Versorgung wichtigen Flussläufen bekannt: Um 1690 erfolgte beispielsweise die Kanalisierung der Ebrach (Steigerwald) (SCHENK 1998:244). Die Kanalisierung der Oder wurde zwischen 1747 und 1753 durchgeführt, 1832 erfolgte die Abtrennung der „Alten Oder“ vom Oderstrom bei Güstebiese und im Jahr 1848 die Regulierung der Oder von Hohensaaten bis Stolpe. In den 1880er Jahren erfolgte mit der Kanalisierung und Begradigung ,der größte sichtbare Eingriff“ in die Unterweser. „Dieses gigantische 
Wasserbauprojekt sollte langfristig die Versandung des Flusses verhindern“" und so die Schiffbarkeit des Flusses gewährleisten (WÖBSE 2000:154).

Der Fluss, ehemalig ein dynamisches Gebilde, wurde durch diese Eingriffe zunehmend in ein Korsett gezwungen. Veränderte er bis dahin beständig seinen Lauf, wie beispielsweise der Vergleich zwischen dem mesolithischen und dem spätneolithisch sowie bronzezeitlichen Verlauf des Rheins bei Xanten zeigt (Abb. VI-41) (HANSEN 2000:44), so führte die Umgestaltung zu Schifffahrtsstraßen zu tiefgreifenden anthropogenen Eingriffen in die Flusslandschaften.

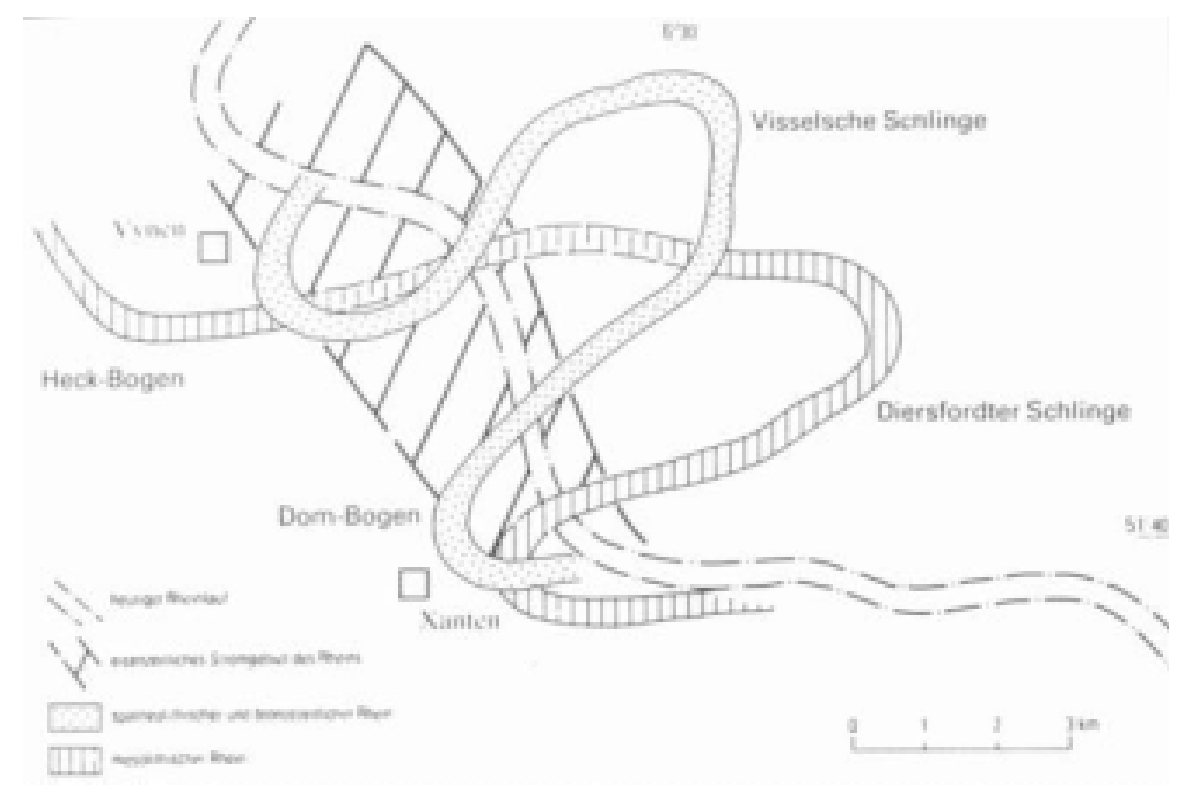

Abb. VI-41: Rheinverlauf bei Xanten (aus: HANSEN 2000:44)

\section{e Kanalbau}

In einem weiteren Stadium, das aber in Abhängigkeit vom jeweiligen Flusslauf zeitlich parallel zu den anderen Eingriffen der Schiffbarmachung verlief, wurden diese natürlichen Schifffahrtswege nach den Begradigungen und den Kanalisierungen nunmehr durch künstliche Wasserstraßen ergänzt, vernetzt oder auch gänzlich neu gestaltet. Kanäle ${ }^{42}$ sollten fortan die natürlichen Ströme untereinander verbinden und so ein weitgespanntes Netz von Durchgangswasserstraßen für die Großschifffahrt schaffen.

Dies kann als das Hauptmotiv der Kanalerstellung und der Kanalisierungen gelten: die Verkürzung von Schifffahrtswegen, vor allem zur Förderung des Handelsverkehrs, d. h. der Wunsch nach infrastruktureller und verkehrstechnischer Erschließung. Insofern lag hier ein ähnlicher Grundgedanke vor wie bei den Straßen- und Brückenbauten. Gelegentlich lagen auch militärisch-strategische Erwägungen oder beschäftigungspolitische Motive zugrunde, wie zum Beispiel die Beschäftigung untätiger Soldaten oder Arbeitsloser, die in den 1930er Jahren durch den Reichsarbeitsdienst rekrutiert worden sind. Als ein weiteres Motiv kann selbstverständlich die Regulierung von Überschwemmungen genannt werden (SONNABEND 1999c:244). In manchen Fällen schließlich ging es den Erbauern einfach nur um das Prestige einer großartigen technischen Leistung.

Nach SONNABEND (1999c:243) gehört „die Anlage von künstlichen Wasserstraßen [...] zu den gravierendsten Eingriffen des Menschen in die von der Natur vorgegebenen landschaftlichen Verhältnisse." Bereits aus der Antike sind zahlreiche durchgeführte bzw. geplante Kanalbauten bekannt. In der Mehrzahl waren die antiken Kanäle Binnenkanäle, d. h. sie dienten zur Verbindung von Binnengewässern. Seekanäle, durch die zwei Meere miteinander verbunden wurden, stellten demgegenüber die Ausnahme dar.

\footnotetext{
${ }^{42}$ Wir bezeichnen heute über Land führende, künstlich ausgehobene Schifffahrtswege durchweg als Kanal, ein Wort das letztlich auf den lat. Begriff „canalis“ zurückgeht, was „Rinne“ oder „Röhre“ bedeutet (SPINDLER 1988:60).
} 
„Die aktivsten Kanalbauer der Antike waren die Römer.“ (SONNABEND 1999c:244), die in Europa die ersten Schifffahrtskanäle errichteten. Auf dem Gebiet der germanischen Provinzen des Imperium Romanum, also dem Kerngebiet des späteren Karolingerreiches, sind drei Kanalbauprojekte in den Schriftquellen überliefert: Bei dem heute nicht mehr genau lokalisierbaren Kanal „Fossa Drusinae“ handelte es sich vermutlich um ein System von Kanälen im Rheinmündungsgebiet, das den Niederrhein mit der Nordsee (Rhein-Ijssel-Verbindung) verband, um über die Nordsee in die Ems und Weser zu gelangen, dessen Trassenführung indes von der Forschung kontrovers diskutiert wird (SPINDLER 1988:48). Des Weiteren wird von einer „Fossa Corbulonis“ berichtet, einem Kanalbau, der auf einer Länge von 23 römischen Meilen bzw. $37 \mathrm{~km}$ um $46 \mathrm{n}$. Chr. die Maas und den Rhein miteinander verband und der heute zwischen Leidschendam östlich von Den Haag zwischen Maasmündung und dem Oude Rijn vermutet wird (SPINDLER 1988:48; SONNABEND 1999c:244). Bis zu diesem Zeitpunkt war die Binnenschifffahrt durch die eigentlichen Flussläufe im Wesentlichen vorgegeben. Am bekanntesten ist allerdings das Projekt eines „Mosel-Saône-Kanals“, der das Mittelmeer mit der Nordsee verknüpfen sollte, aber offenbar nicht über das Planungsstadium hinausging (SPINDLER 1988:48).

Das kühnste Kanalbauprojekt des frühen Mittelalters, das das Kanalsystem der Römerzeit ergänzen sollte, war der im Jahre 793 von König Karl (später Karl der Große) begonnene und nach Forschungen von SPINDLER (1988:55) „nach mindestens einjähriger Bauzeit“ erfolgreich abgeschlossene Rhein-DonauKanal, der „Fossatum magnum“43. Seit römischer Zeit waren in Mitteleuropa keine künstlichen Wasserstraßen mehr gebaut worden. Insofern stellte der Fossatum magnum ,einen Innovationsschub dar, der $[\ldots]$ auch in den folgenden Jahrhunderten das einzige Projekt dieser Art blieb“ (:47).

„Sinn des Unternehmens war es, an geeigneter Stelle die Wasserscheide zwischen den Stromnetzen der Donau und des Rheins mit einem Kanal zu überwinden“ (SPINDLER 1988:48). Die Ingenieure Karls des Großen wählten dafür jene Landbrücke wenig nördlich von Treuchtlingen im südlichen Mittelfranken, an der jedenfalls damals schiffbare Gewässer die geringste Distanz bei minimaler Höhendifferenz aufwiesen (:49). Zwischen den beiden Flüssen Rednitz und Altmühl wurde ein schiffbarer Graben ausgehoben, den der König im Herbst 793 zur Schiffspassage von Regensburg nach Frankfurt benutzte (:51).

\footnotetext{
${ }^{43}$ Für das Kanalbauprojekt Karls des Großen wird am häufigsten die Bezeichnungen „,fossatum“ und „,fossatum magnum“, seltener der Begriff „,fossa“ gebraucht. Es ist eine einigermaßen korrekte Übersetzung für die seinerzeit wahrscheinliche umgangssprachliche Wortform „Graben“, die im heutigen Ortsnamen erhalten geblieben ist (867 „Groba“).

In der Antike meinte man mit „fossa“ oder „fossatum“ meist einen um ein Lager oder um eine Stadt künstlich ausgehobenen und häufig wohl mit Wasser gefüllten Graben. Ebenfalls wurden Schiffskanäle durchweg mit fossa bezeichnet (SPINDLER 1988:59).
} 


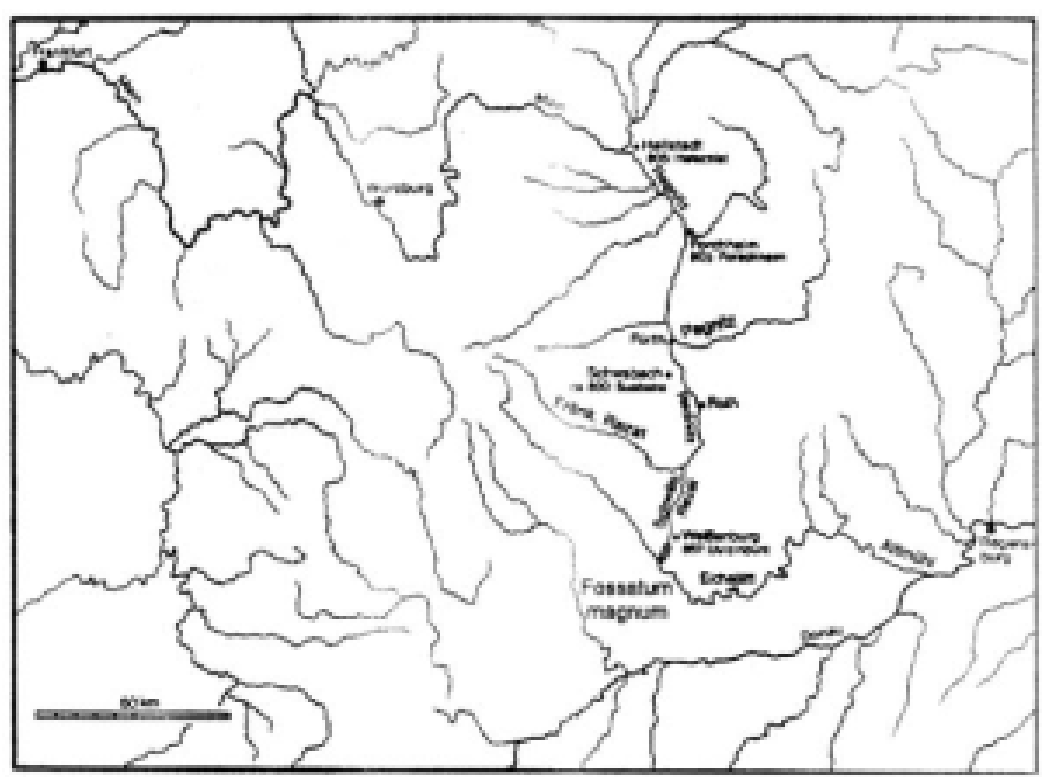

Abb. VI-42: Kennzeichnung der geographischen Lage des „Fossa“ zwischen Donau und Main auf der Grundlage der Hydronomie der Gewässersysteme (aus: SPINDLER 1988:50)

Die natürliche Schifffahrtsroute sah dabei von Regensburg kommend zunächst die Donau, dann die Altmühl flussaufwärts bis zum heutigen Ort Graben vor. Dort begann das künstliche Kanalbett des „Fossatum magnum“, das, mehrfach gewinkelt und bestehende Dorfteiche in den Verlauf integrierend (siehe Abb. VI43), schließlich in das sog. Ried, das Quellbecken der Schwäbischen Rezat, mündete. Aus ihrem Quellgebiet strebt die Schwäbische Rezat in nördliche Richtung, um sich nach 25 Kilometern Lauf mit der von Westen her einmündenden Fränkischen Rezat zur Rednitz zu vereinen (SPINDLER 1988:49). Nach knapp 40 Kilometern fließt diese Rednitz mit der Pegnitz zusammen, um sich nun als Regnitz weiter im Norden in den Main zu ergießen. Über den Main wird an Würzburg und Frankfurt vorbei schließlich der Rhein erreicht (:49).

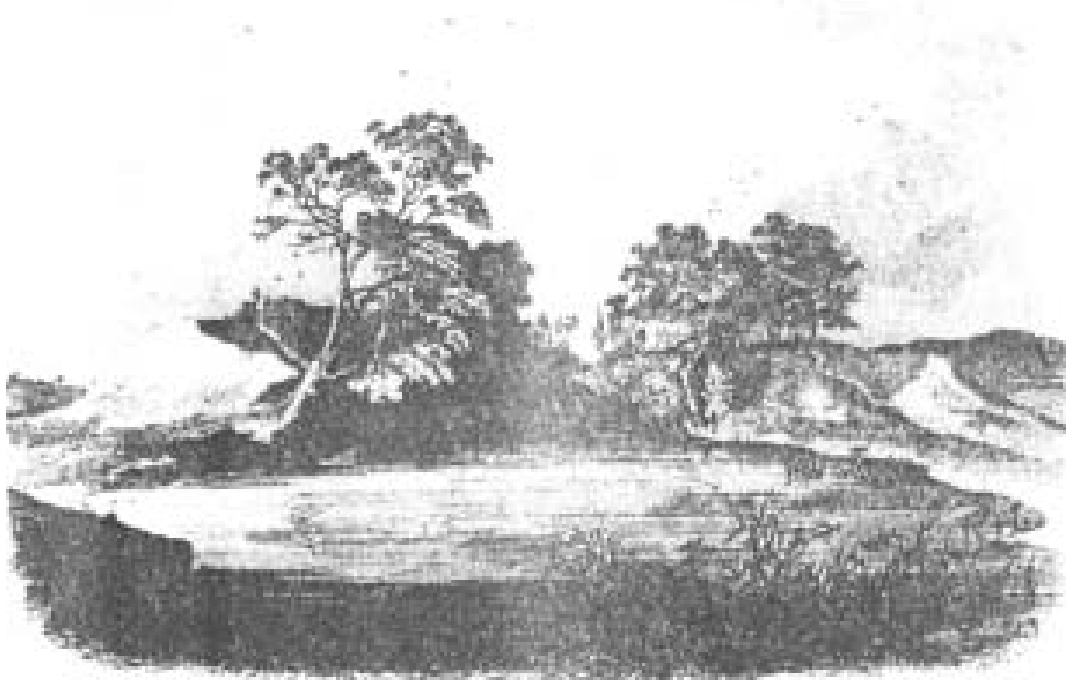

Abb. VI-43: Der Dorfweiher von Graben als Teil des „Fossatum magnum“

Vom Staudamm am Nordostende des Ortes in östliche Richtung gesehen. Stahlstich von Redenbacher 1844 (aus SPINDLER 1988:49).

Die Nutzung der Fließgewässer als Transportwege führte vor allem seit dem hohen Mittelalter zu ausgedehnten Kanalbauten, die vor allem als Stichkanäle die schiffbaren Gewässer miteinander verbinden sollten.

Der Ursprung des mittelalterlichen Kanalbaus wird in England gesehen, da, so die Begründung, Englands Wasserstraßen vor allem der Beförderung von Kohle, dem wichtigsten Rohstoff der Industrie dienten und ein 
Anschluss vom Fördergebiet an die Energieabnehmer gegeben sein musste (BRIX 1988:26f.). Aber auch aus Frankreich, den Niederlanden und Holland stammten die Vorbilder. „Keinem anderen Verhältnisse als der Schiffahrt auf den Flüssen, in den Kanälen und auf dem Meere“, schreibt REUTER (1837:7), „haben sie ihren und den privaten Wohlstand zu verdanken.“

Da waren zuerst die frühen englischen „Contour Canals“, die sich mit möglichst wenig Schleusen den Geländeverhältnissen anpassten, was ihnen ein flussähnliches Aussehen gab. Hügel wurden mit Schleifen umgangen, Talgründe durch Haltungen in Hanglage gemieden, auch um den Preis beträchtlicher Umwege. Die gegenüber der frühen Contour Canals angewendetete spätere ,cut-and-fill“-Technik ermöglichte eine mehr lineare Trassierung. Dieses Verfahren umfangreicher Erdverschiebungen, den Wechsel von tiefen Geländeeinschnitten und hohen Dämmen, letztere mit der Aushubmasse der „cuts“ aufgeschüttet (,fill“), bedeutete jedoch einen größeren Landschaftseingriff. Die direkte Trassierung der Kanäle brachte zudem einen erhöhten Bedarf an Schleusen mit sich. Starke Geländeunterschiede wurden mit Schleusen-Treppen gemeistert, einer kaskadenartigen Gruppierung zahlreicher Schleusen (BRIX 1988:26f.).

Der Bau des ersten Kanals in deutscher Hand war die „Stecknitzfahrt“ (OPITZ 1997:160), eine Kanalverbindung zwischen Trave und Elbe.

Zunächst aber wurde mit verhältnismäßig geringen künstlichen Eingriffen der natürliche Lauf der Stecknitz für den Transport genutzt und in der Mitte des 14. Jahrhunderts nur durch Schleusenbauwerke kanalisiert (GOLDAMMER 1999:63). Erst aufgrund eines Vertrages vom 24. Juni 1390 zwischen der Hansestadt Lübeck und Herzog Erich II. von Sachsen-Lauenburg wurde zwischen 1391 und 1398 ein elf Kilometer langer „Graben“ gebaut, der den Anschluss des Möllner Sees an die Delvenau herstellte: die künstliche Wasserstraße des Stecknitzkanals. Dieser verband die Stecknitz, einen rechten Nebenfluss der Trave, mit der Delvenau, einem rechten Nebenfluss der Elbe, und somit unmittelbar Lübeck über Mölln und Lauenburg mit Lüneburg und Hamburg, schließlich die beiden Meere Nord- und Ostsee (OPITZ 1997:160). Die Anlage des Stecknitzkanals ist primär auf den lukrativen Salzhandel zwischen der Salinenstadt Lüneburg und dem Ostseeumschlagplatz Lübeck zurückzuführen. Der Kanal bot in der Vergangenheit ,einen sicheren und, im Vergleich zum Landtransport, preiswerten Weg für die wertvolle Salz-Fracht.“ (GOLDAMMER 1999:64). Im späten 15. Jahrhundert wurden so 40.000 t Salz jährlich auf dem Schiffsweg nach Lübeck befördert, wobei neben der Salzfracht auf dem Stecknitzkanal auch gebräuchliche Handelsgüter transportiert wurden (:64).

Die Kanalfahrt wurde ermöglicht durch das Ablassen des vor den Stauschleusen, die am Ende des 14. Jahrhunderts 15 Schleusenbauwerke (3 Kasten- und 12 Stauschleusen) zählten und deren Zahl sich am Ende des 17. Jahrhunderts auf 17 erhöhten (GOLDAMMER 1999:63), angesammelten Wasservorrats, durch die wechselweise zeitlich begrenzte Verstärkung des Wasserabflusses durch Niederschlagshöhen und die dadurch bewirkte Auffüllung des Kanalbettes. Da oft Wassermangel herrschte, wurde bei den Stauschleusen meist nur an jedem zweiten Tag geschleust. Die zu Tal fahrenden Schiffe glitten dabei auf der abgelassenen Stauwelle bis zur nächsten Schleuse hinab, die aufwärts fahrenden Schiffe wurden während dieses Vorgangs gegen den Strom des abfließenden Stauwassers getreidelt, d. h. geschleppt, gezogen. Ein Hinweis auf sog. Schwellungen, d. h. der Schifffahrt auf Stauwellen, ist auch dem grundlegenden ingenieurtechnischem Werk von FRANZIUS/SONNE (1879:306) für den Travekanal zu entnehmen.

Mit der Erfindung der Kammerschleuse (vermutlich 1438 in Mailand), die sich zunächst über Frankreich nach England und dann nach Deutschland ausbreitete und im 16., 17. und 18. Jahrhundert die hohe Zeit der Binnenschifffahrt einleitete, „kann man von einem regelrechten ,Kanalbaufieber' sprechen“ (TÖNSMANN 1995:17), wenn sich auch die umgreifende Erhitzung nicht immer einstellte. 


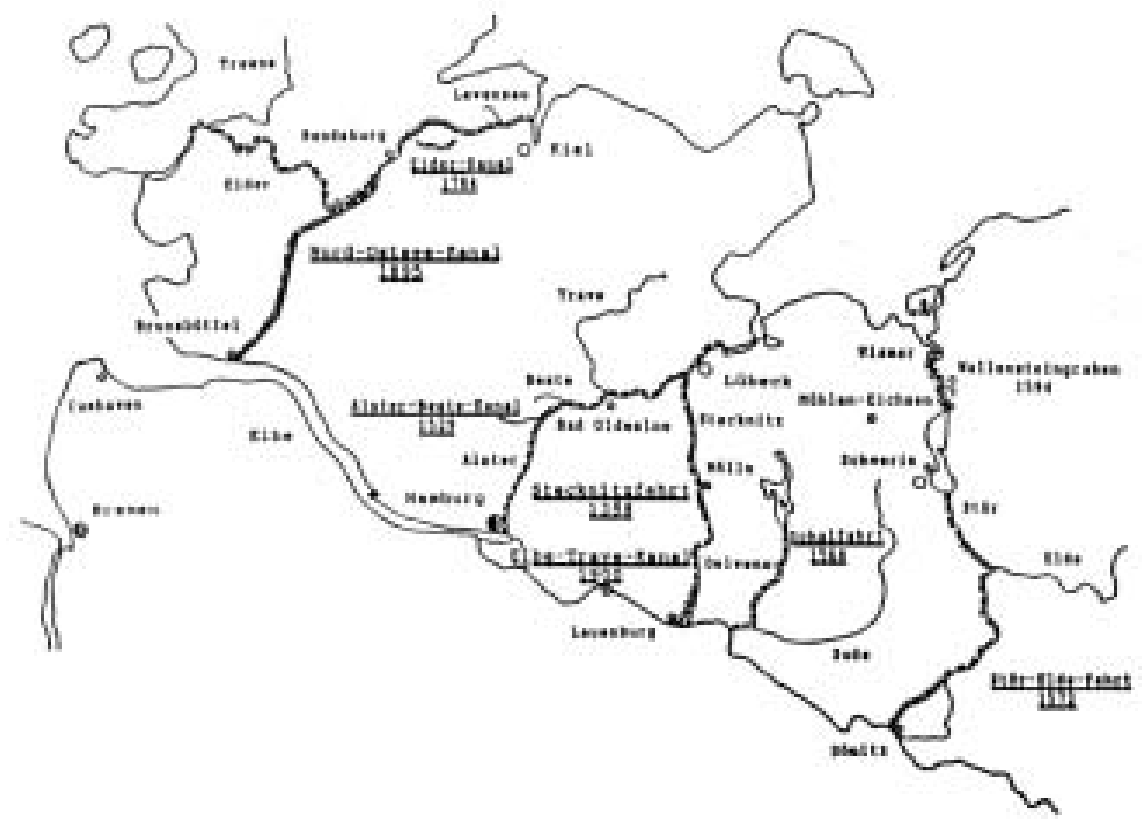

Abb. VI-44: Norddeutsche Wasserstraßen und das Jahr ihrer Inbetriebnahme (aus: GOLDAMMER 1999:72)

Um eine weitere Verbindung zwischen den Hansestädten zu schaffen, wurde zwischen 1452 und 1453 der Versuch gestartet die Alster mit der Beste zu verbinden. Die Schwierigkeiten müssen jedoch zu groß gewesen sein, der „Alster-Beste-Kanal“ konnte nicht fertig gestellt werden. Erst 1525 wurde der alte Plan wieder aufgegriffen, einen solchen Kanal zu graben. Der Kanal wurde auch 1529 eröffnet, war aber nur etwa 20 Jahre in Betrieb, dann blieb er ungenutzt und verfiel.

Der Herzog Julius von Braunschweig-Wolfenbüttel (1568 - 1589) ließ Pläne für einen Kanal ausarbeiten, der die Oker über das „Große Bruch“ östlich von Hornburg mit der Bode verbinden sollte, um so seinem Land einen Schifffahrtsweg zur Elbe zu öffnen, der heute noch „Schiffgraben“ heißt. Doch auch diese Bestrebungen blieben Planwerk.

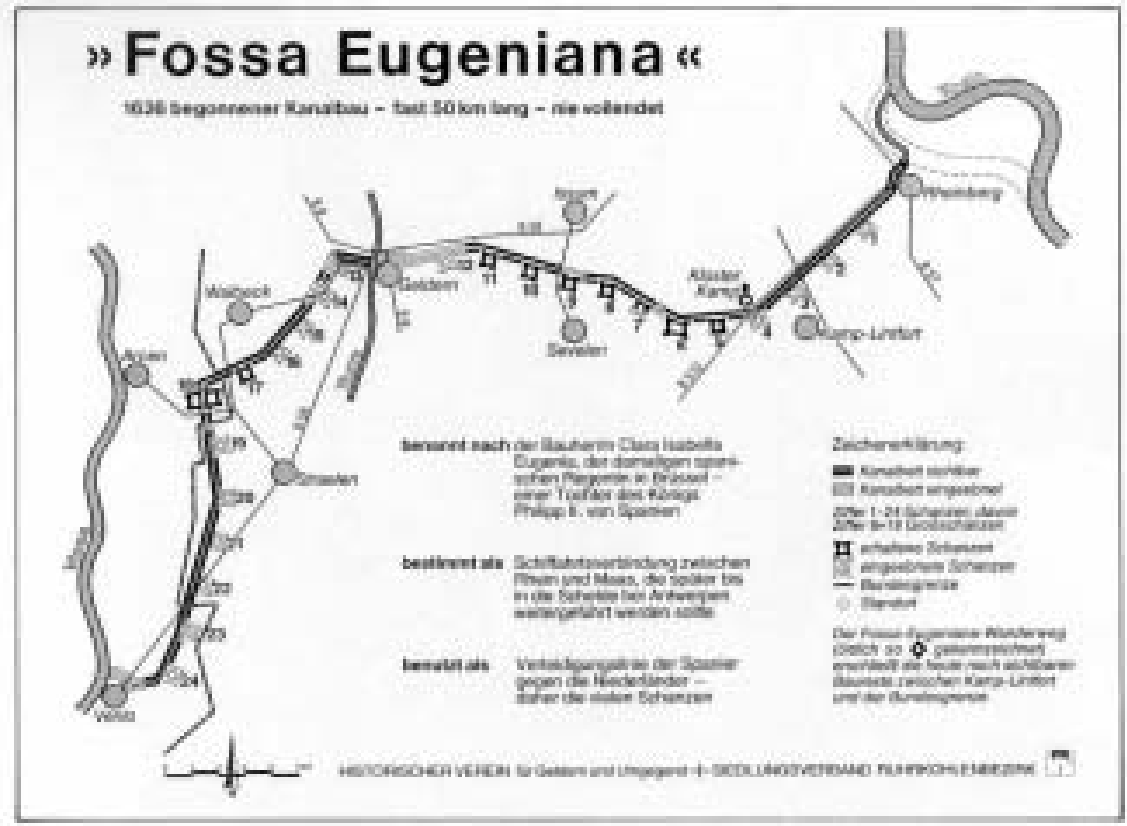

Abb. VI-45: Übersichtsskizze vom Verlauf der Fossa Eugeniana

Der fast $50 \mathrm{~km}$ lange Kanalbau wurde nach der Bauherrin, der damaligen spanischen Regentin Clara Isabella Eugenia in Brüssel benannt, einer Tochter des Königs Philipp II. von Spanien. Seine Bestimmung hatte der Kanal nicht nur als Schifffahrtsverbindung zwischen Rhein und Maas, sondern wurde auch als Verteidigungslinie der Spanier gegen die Niederländer benutzt, daher auch die vielen auf der Planzeichnung zu sehenden Schanzen (aus: PISTOR/SMEETS 1979:10). 
Als weitere europäische Kanalbauprojekte entstanden im 17. Jahrhundert in der Region Westdeutschland unter anderem der „Fossa Mariana“ (zwischen Arles und dem Mittelmeer), der 1626 von den Spaniern begonnene „Fossa Eugenia“ (zwischen Rhein und Maas), dessen Bauarbeiten 1628 eingestellt wurden, sowie der 1638 angefangene „Canal d“ Entreroches“ als Verbindung der Nordsee mit dem Mittelmeer (GREWE 1995:37).Als Landesprojekt plante gegen Ende des 17. Jahrhundert der hessische Landgraf Carl einen Kanal, der die Residenzstadt Kassel mit der für den überregionalen Transport wichtigen Weser verbinden sollte.

Landgraf Carl von Hessen ließ dazu als erstes 1699 an der Mündung der Diemel in die Weser, einen hessischen Weserhafen anlegen. Er wurde später nach ihm Carlshaven benannt, das jetzige Bad Karlshafen. Sodann ließ er 1710 den Bau eines Kanals von dort unter Umgehung Mündens nach Kassel planen, um den Umlade- und Stapelzwang in Münden zu umgehen, der erst 1866 endete. Die Bauarbeiten begannen 1713. Von der etwa $54 \mathrm{~km}$ langen Kanaltrasse wurden $21 \mathrm{~km}$ im Tal der Diemel und Esse fertig gestellt und auch befahren (ECKOLDT 1995:11f.).

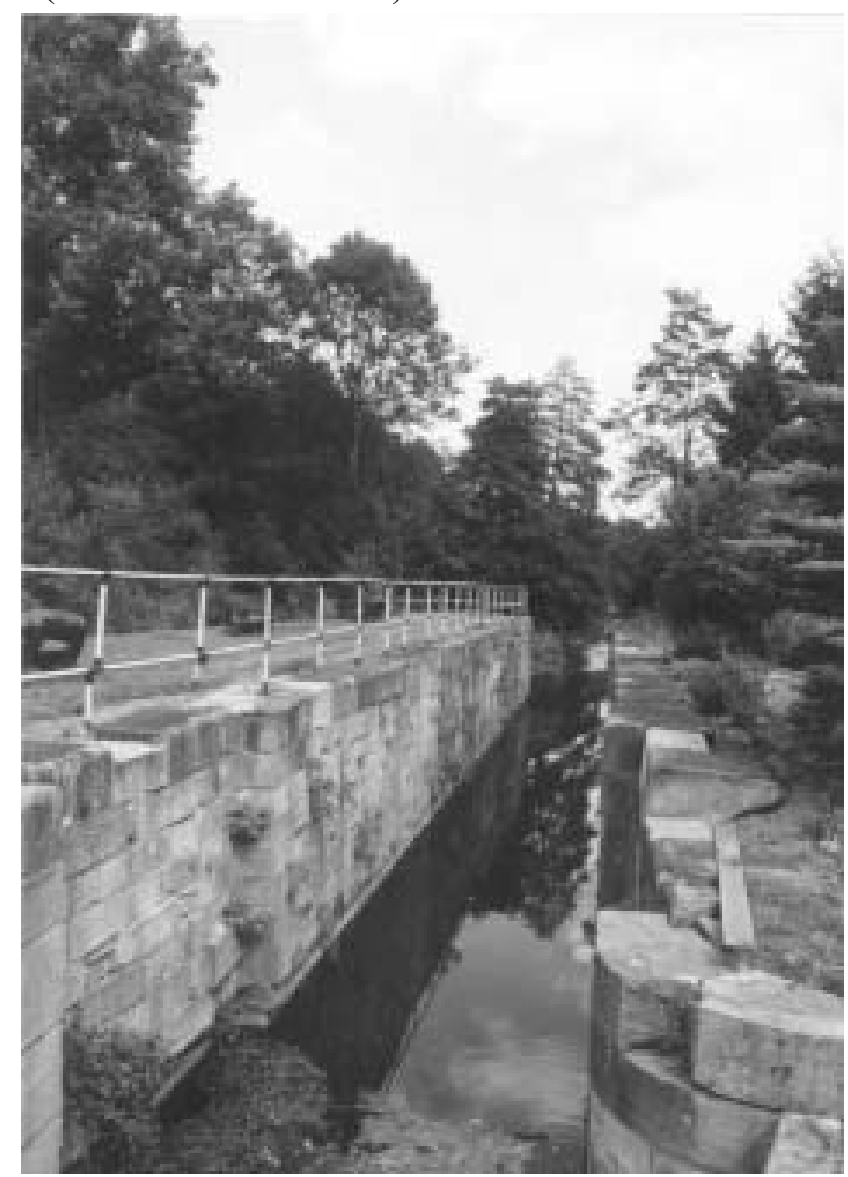

Abb. VI-46: Schleusenrelikt des Diemelkanals in Trendelburg (eig. Aufnahme)

1710 ließ er auch Pläne für einen Kanal der Fulda über Eder, Schwalm und Ohm zur Lahn ausarbeiten. Dies war der Versuch, das Wesergebiet mit dem des Rheins zu verbinden. Unter Carl von Hessen entstand 1716 des Weiteren noch der Plan eines Kanals von der Fulda bei Bebra zur Werra (ECKOLDT 1995:12). Schließlich sollte die Diemel bis Warburg schiffbar gemacht werden und auch auf der Fliede und der Kinzig sollten Kanäle entstehen (:12).

Während auf den meisten Kanälen die gleichen Waren transportiert worden sind wie auf den natürlichen Wasserwegen (Weizen, Roggen, Gerste, Hafer und Leinsamen, Heringe, Käse und Salz, Leinwand, Bretter, Kupfer, Eisen, Stahl und Blei) (OPITZ 1997:160), wurden kleine schiffbare Kanäle auch speziell für den Erztransport erbaut. 
Berühmtheit erlangte der dem Erztransport dienende künstliche Wasserweg zwischen der sächsischen Erzabbaugrube, dem ,Churprinz-Friedrich-August-Erbstollen' bei Großschirma nähe Freiberg, und dem Verhüttungsplatz. Dieser Kanal, dessen Anfangsstück noch erhalten ist, war ein schmaler 5,3 Kilometer langer Wasserweg, der, von einem Stauteich kommend, stromaufwärts neben der ,Mulde' anlegt wurde und in den Untertagebereich der Churprinz-Grube hinein führte, um dort als Aufschlagwasser zum Betreiben des Wasserrades eine zweite Funktion zu erfüllen. Wegen des Höhenunterschiedes musste der Kanal in einen oberen und einen unteren Abschnitt unterteilt werden. Am Berührungspunkt der beiden Teilstücke entstand 1788 - 1790 das wahrscheinlich erste Schiffshebewerk der Welt. Die ca. 7,5 - 8,50 m langen, 1,60 m breiten und bis zu 50 Zentner fassenden Kähne wurden mit einem fünffachen Flaschenzug um annähernd sieben Meter in den oberen Kanalabschnitt gehoben. Das Erz wurde also auf Lastkähne geladen, diese wurden eine künstliche Wasserstraße entlang gezogen, auf andere Höhen gehoben und schließlich zur Verhüttung transportiert. Diese Anlage war bis 1868 in Betrieb (CZAYA 1990:37).

Doch nicht nur obertägig verlaufende Kanäle wurden in der Montanwirtschaft geschaffen. Im Harz gab es einen lebhaften Kahnverkehr auch unter Tage.

Für verschiedene Bergbaureviere des Oberharzes wurde ein gemeinsamer unterirdischer schiffbarer Kanal aufgefahren. Die „Tiefe Wasserstrecke“, wie die 1835 fertig gestellte Kanalstrecke genannt wurde, verband die Gruben Clausthal und Zellerfeld miteinander. Sie entstand zunächst aus der Notwendigkeit heraus, die Wasser in möglichst tiefem Niveau abfließen zu lassen. Sie führte zur Anlage von Stollen, die bis $30 \mathrm{~km}$ lang wurden und die Bergwerke eines immer größeren geographischen Bereichs miteinander verbanden.

Diese wasserführenden Stollen versorgten nicht nur die Antriebsmaschinen mit Wasser und führten das Grubenwasser ab, sondern „konnten bei geschickter Anlage für den Transport von Erz und Gestein mit Kähnen genutzt werden, wenn man das Gefälle entsprechend gestaltete und das Wasser zu einer gewissen Höhe aufstaute." (BARTELS 2000:44f.) Um sie der Schifffahrt dienbar zu machen, hatte man sie deshalb horizontal angelegt. In einer Tiefe von $400 \mathrm{~m}$ unter Tage und auf einer Länge von $6.570 \mathrm{~m}$ bewegte sich auf schwerbeladenen Holzkähnen, die an unter der First laufenden Treibseilen bzw. Drahtseilen fortbewegt wurden, der Erztransport von Schacht zu Schacht. Eine kostengünstige und dennoch sehr effektive Methode, die sich bis zur Einführung der elektrischen Streckenführung nach 1905 außerordentlich bewährt hat (CZAYA 1990:37f.; LIESSMANN 1997:138).

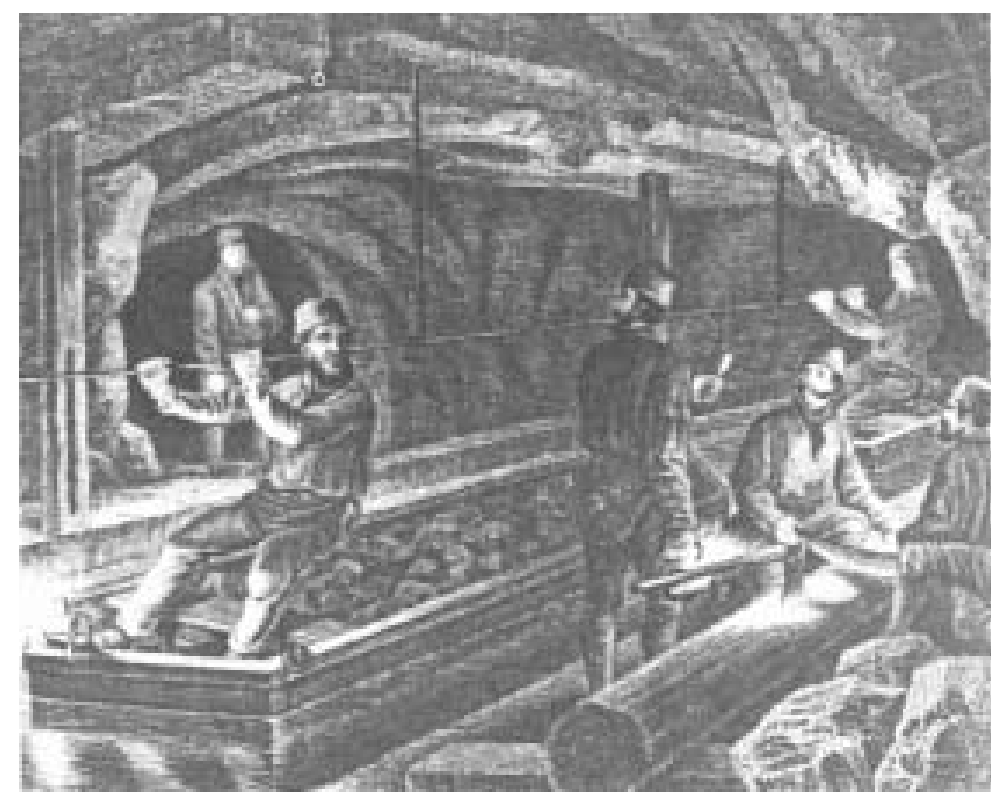

Abb. VI-47: Erztransport auf der ,schiffbaren Wasserstrecke“ (aus: LIESSMANN 1997:139)

Sehr anschaulich schildert BREDERLOW (1851; zit. aus: LIESSMANN 1997:138) diese Erzverschiffung:

„Gewiß die merkwürdigste Transportart des Oberharzes ist die unterirdische Schiffahrt; auf schlankem Kahne schifft der Bergknappe mit Bergesbeute hinab, wobei das trübe Grubenlicht 
sein Polarstern und sein Compass ist; das kühnste Meisterstück der Bergbaukunst. Allerdings sollte anfänglich diese tiefe Wasserstrecke nur ein Wasserreservoir sein; um sie nun aber auch zur Schiffahrt zu benutzen, mußte die Strecke in Weite und Höhe größere Dimensionen erhalten und bis zu 1 11/4 Liter Lachter Höhe und 1 Lachter Weite ausgebauet werden. Hin und wieder wurde das lose Gebirge nicht wie gewöhnlich ausgezimmert, sondern ausgemauert und auf einer Strecke von 520 Fuß wurden auf der zu rissigen Stollensohle, welche die Grundwasser fallen ließ, eiserne Gefluder gelegt. - Dem Querdurchschnitte des ganzen Orts wurde eine elliptische Form gegeben, der Wasserstand auf eine Höhe von 50-60 Zoll getrieben. Die unterirdischen Boote sind paralleleliptische Wannen von ungefähr 30 Fuß Länge, 4 Fuß Breite und 34 Zoll Tiefe, an beiden Enden zugeschärft; zusammengesetzt und repariert werden sie auf einer unterirdischen Schiffswerfte; jedes Boot ladet 100 Ctr.; der Bootsmann zieht sich an einer Kette, die längs der ganzen Wasserstrecke unter der Förste ausgespannt ist, mit seinem Boote fort. Die Geschwindigkeit bei voller Füllung ist ungefähr 6 Lachter minütlich; bei leerem Kahne geht's lustig und schnell weiter; die Bahn ist 2000 Lachter lang und von den Dorotheer Rollschächten bis zum Altenseegener Schachte dauert die Hin- und Rückfahrt 8 Stunden; die jährlich zu verschiffende Erzmasse beläuft sich auf circa 400,000 Ctr. “

Im 19. Jahrhundert dann begann die Gründerzeit: die große Zeit des Kanalbaus, aber nicht alle kamen zur Ausführung:

Sogar die kleine Düssel sollte im frühen 19. Jahrhundert nach den Plänen des Düsseldorfer Regierungsrates von BÜLOW (1781 - 1816) schiffbar gemacht werden, um so den Rhein mit der Wupper zu verbinden. „Eisenstein“ aus dem Bergischen Land, Kalk aus dem Neandertal und Holzkohle und Kohle aus der Region sollten auf ihr transportiert werden. Die Düssel sollte als Kanal „schnurgerade“ von Düsseldorf bis Erkrath geführt werden. Zwanzig Kastenschleusen sollten zusätzlich zur industriellen Wasserkraftnutzung gebaut werden. Von Erkrath über Gruiten bis zur Wupper bei Elberfeld wären noch einmal vierzig Schleusen notwendig, um die steilen An- und Abstiege zu überwinden. Die Planungen blieben aber Utopie (TROTTMANN 1988:97f.).

Ebenso scheiterte das Projekt des „Hanekenkanals“, einem frühindustriellen Kanalbau zur Schiffbarmachung der Ems. Das Projekt scheiterte wegen der unterschiedlichen Interessen von Preußen (Ruhrgebiet) und Hannover (Ostfriesland bis 1866). Teile sind in den Ende des 19. Jahrhunderts gebauten Dortmund-EmsKanal eingegangen, andere sind als Relikte erhalten geblieben, wie zum Beispiel eine alte Stauschleuse in Lingen (OVERMANN 1989:46ff.)

König Ludwig I. wagte das Projekt eines Ludwig-Donau-Main-Kanals nicht allein aus wirtschaftlichen, sondern auch aus deutsch-patriotischen Motiven. Als ein einigendes Band der bis dahin zersplitterten deutschen Nation sollte der "Ludwigs-Kanal“ die Verbindung zwischen Rhein und Donau herstellen, innerdeutsche Grenzen überwindend. Als billiger Transportweg sollte die Wasserstraße aber auch dem Export bayrischer Rohprodukte, vor allem aus dem Südosten des Königreiches, verhelfen: Salz, Getreide, Steine und Holz. Vor allem die Menge von Brennholz, die bislang stromaufwärts mit viel Mühe und großen Kosten nach Würzburg und seine Umgebung gebracht wurde, konnte alsdann stromabwärts nach Aschaffenburg, Hanau, Frankfurt und Mainz geflößt werden (REUTER 1837:16). 1836 erfolgte der erste Spatenstich und 10 Jahre später die Aufnahme des Vollbetriebes. Mit dem Bauwerk entstand eine Wasserstraße mit 101 Schleusen, die bei Bamberg ${ }^{44}$ beginnt und über Nürnberg nach Kelheim führt. Für das letzte Stück der Trasse nutzte man den Unterlauf der Altmühl (BRIX 1988:25).

Der Preußische Staat, dem 1866 mit der Annexion Hannovers auch die weitaus größten Flussstrecken zugefallen waren, begann daraufhin das Fahrwasser der norddeutschen Ströme vom Rhein über Weser und Elbe bis zur Oder und Weichsel auszubauen, wie wir erfahren haben, um auf ihnen von der Transportdauer unabhängige Massengüter billig zu transportieren: Kohle, Kalisalze und andere Bergbauprodukte, Steine, Kies und Sand, Getreide und Futtermittel u. a. m. Dazu gehörte auch der Neubau von Kanälen. Es enstanden

\footnotetext{
${ }^{44}$ In Bamberg ist ein Teilstück des Main-Donau-Kanals in gutem Zustand noch vorhanden: Insgesamt sind hier vier alte Kranen an den Umladestellen erhalten geblieben einschließlich der Schleuse $100 \quad$ [URL $=$ http.//www.bayern.de/wwa-ba/wassererleben/lkrba/ldm-kanal.htm].
} 
in der Folgezeit zum Beispiel der Dortmund-Ems-Kanal (1892 - 1898), der Mittelland-Kanal (1906 - 1938), der Küstenkanal $\left(1920\right.$ - 1935) und viele weitere ${ }^{45}$.

Überhaupt spielte der Wassertransport auf Kanälen im norddeutschen Flachland eine große Rolle. Dort, wo wenig Brennholz zur Verfügung stand, wurde vor allem in den Haushalten die Befeuerung mit gepressten Torfziegeln durchgeführt. Eine besondere Gattung von Kanälen stellen die „Torfkanäle“ dar, die zu unterschiedlichen Zeiten gebaut wurden, aber nicht nur in Zusammenhang mit der Beförderung von Torf gesehen werden dürfen.

Der Hunte-Ems-Kanal zum Beispiel diente zunächst in erster Linie der Erschließung der großen Moorgebiete im Westen des Landes und in Ostfriesland. Dicht oberhalb von Oldenburg beispielsweise diente die Hunte schon lange dem Verkehr. Schon 1813 bestand ein Kanal, der Oldenburg über die Hunte mit dem Hundsmühler Moor (Witte-Moor) verband, das die Stadt mit Brenntorf versorgte (HETZEL 1957:32). Der erweiterte Hunte-Ems-Kanal, in den 1840er Jahren projektiert und dessen Bau 1856 begonnen wurde, konnte erstmals 1894 auf der ganzen Strecke befahren werden. Oberhalb von Oldenburg benutzte er, ähnlich wie beim Ludwig-Kanal und eigentlich allen Kanälen, noch ein Stück der „Alt-Hunte“. Mit diesem Errichtungszeitraum war er aber einer der letzten Torfkanäle.

Im Flussbereich zwischen Leda und Jümme und ihren südlichen Zuflüssen, besonders der Sagter Ems, sorgte die Torfschifffahrt aus den Saterländer Mooren in die ostfriesischen Marschengebiete und die Emshäfen für regen Schiffsverkehr. Die Torfschifffahrt erfuhr einen starken Aufschwung, als seit dem 17. Jahrhundert die Fehnkolonien, zum Beispiel in Papenburg und Rauderfehn, mit ihren Moorkanälen gegründet wurden (siehe V 2d.4).

Zur Versorgung dieser Kolonien wurden Gebrauchsgüter benötigt, die als Rückfrachten aus den Torfabnehmergebieten herbeigeschifft wurden, und bald entwickelte sich die Torfschifffahrt zu einer Frachtschifffahrt: Für den Hausbau wurden Baumaterialien (Steine, Muschelkalk, Holz etc.) benötigt, für die Düngung der nach dem Torfabbau und trotz des Torfbrandes verarmten Mooräcker Schlick, der bei Ebbe in den Deichvorländern abgegraben wurde, sowie der Mist der Marschbauern.

Der zwischen 1880 und 1887 erbaute 72 km lange Ems-Jade-Kanal zwischen Emden und Wilhelmshaven diente früher zur Entwässerung der ostfriesischen Zentralmoore und zum Torftransport aus den Moorkolonien. Gleichzeitig war er dafür bestimmt, nach dem Bau des Dortmund-Ems-Kanals die Verbindung zum Marinehafen Wilhelmshaven herzustellen, um die Kohleversorgung der deutschen Flotte zu sichern.

Für die Entwässerung und Kultivierung der ausgedehnten Moorgebiete des Emslandes wurde in den Jahren 1871 bis 1903 das $112 \mathrm{~km}$ lange linksemsische Kanalnetz geschaffen. Von gewisser Bedeutung für die Torfschifffahrt war bis in die 1950er Jahre auch der von Nordhorn nach Rütenbrock führende Nord-SüdKanal, der auch der Regulierung des Wasserstandes in den Moorgebieten diente.

Von 1850 - 1860 wurde auch der Hadelner Kanal angelegt, um das teilweise unter Meeresniveau liegende Hadelner Sietland von den winterlichen Überflutungen zu befreien. Der Hadelner Kanal, auch „Binnenschiffahrtsweg Elbe-Weser“ genannt, verbindet auf einer Strecke von $32 \mathrm{~km}$ Länge, einer durchschnittlichen Breite von $25 \mathrm{~m}$ und einer Tiefe von nur 1,5 m die Weser (Bremerhaven) mit der Elbe (Otterndorf) (SEEDORF/MEYER 1996:624f.).

Wie in allen Regionen entstand ab 1850 mit dem Bau von Eisenbahnen eine Konkurrenz, die den Schifffahrtskanälen ein jähes Ende setzte, wie GOLDAMMER (1999:64) den Zusammenhang zwischen der Aufgabe des Stecknitzkanals und der 1851 vollendeten Lübeck-Büchener Eisenbahn beispielhaft herstellt. Am 13. August 1886, so das Niedergangsdatum des Wassertransports in Schleswig-Holstein, wurde die Stecknitzfahrt endgültig eingestellt.

\footnotetext{
${ }^{45}$ Duisburger K., Mülheim-Ruhr-K., Fulda-Lehn-K., Lippe-Ijssel-K., Lippe-Seiten-K., Rhein-Herne-K., Rhein-Ems-K., RheinDonau-K., Rhein-Maas-K., Weser-Elbe-K., Rhein-Dortmund-K., Ruhr-K., Rhein-Weser-K., Stichkanal in Walsum, Kanal WeselDatteln usw.
} 


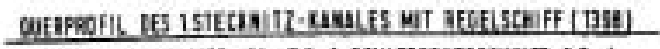

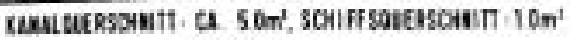
IRAEAALEEIT. 751

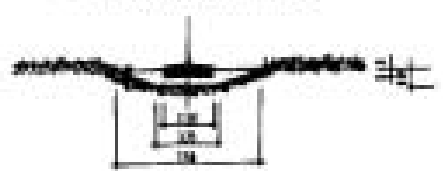

EUE⿱㇒⿴囗十

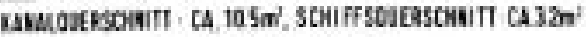
IBAIFAHGHEIt: TA SOL

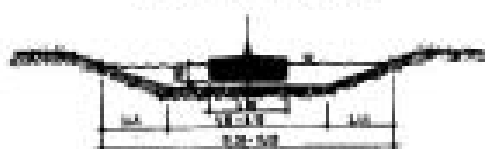

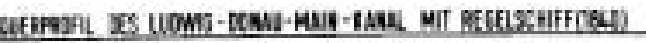
Rам.

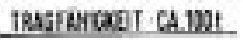

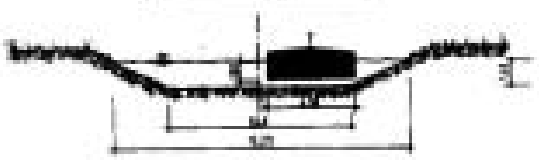

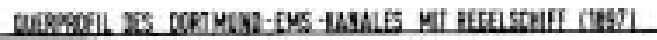

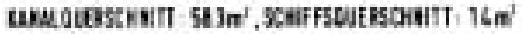

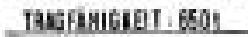
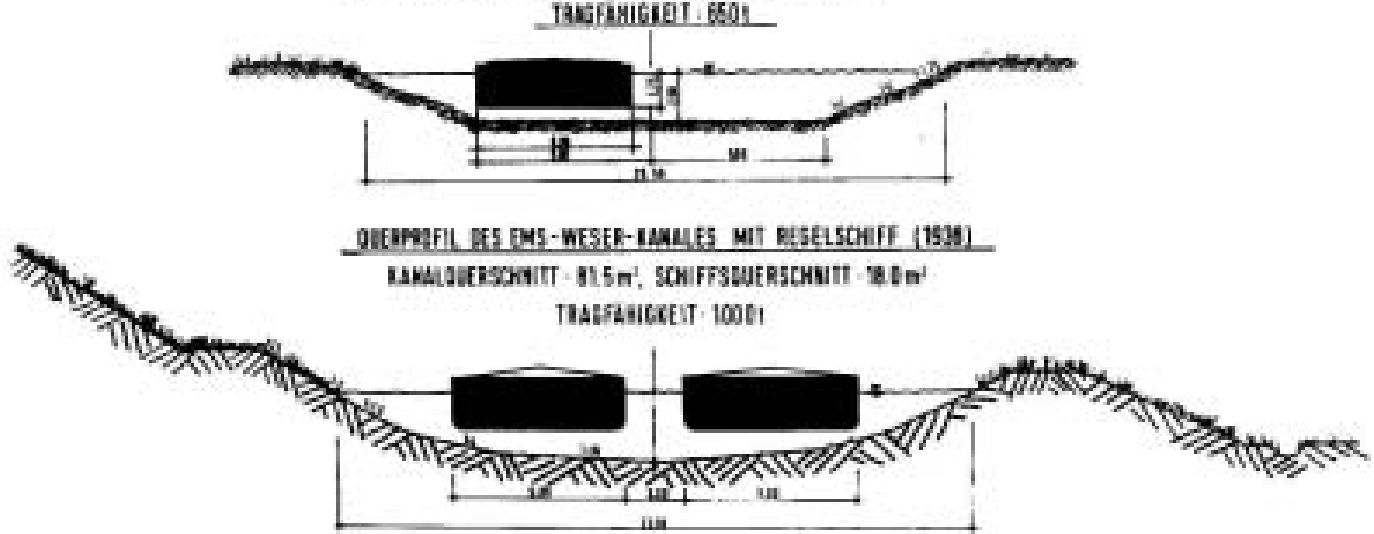

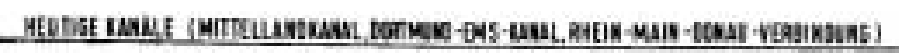

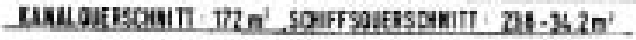

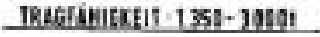

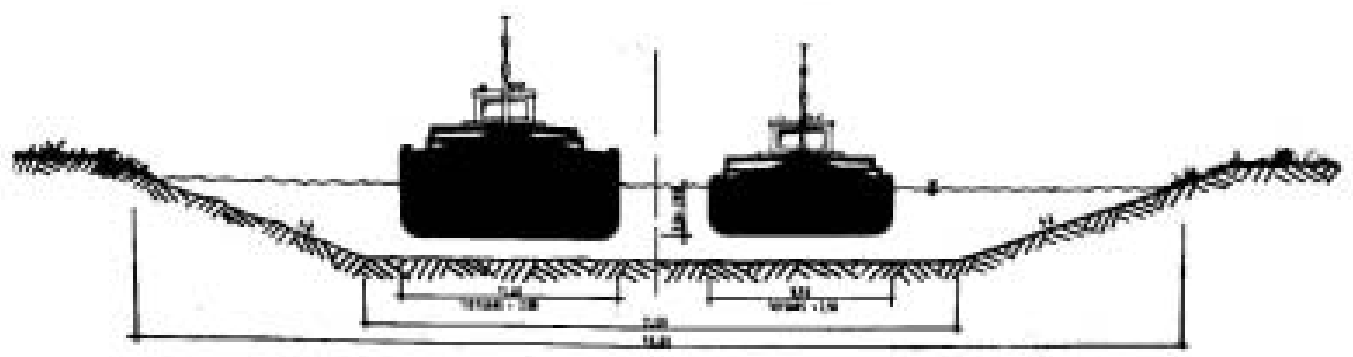

Abb. VI-48: Entwicklung des Kanalquerschnitts über die Jahrhunderte (aus: WASSER- UND SCHIFFAHRTSDIREKTION MITTE 1993:24)

Die Transportprobleme der industriellen Revolution mussten vorerst jedoch durch die Erhöhung der Leistungsfähigkeit der alten Techniken des Land- und Wassertransportes bewältigt werden (PAULINYI 1982:272). Packesel oder Maulesel konnten auf schlechten Pfaden kaum mehr als $200 \mathrm{~kg}$ befördern. Bei einem Pferdegespann mit $4-6$ Pferden lag die Gewichtsgrenze auf nichtbefestigten Straßen bei 1,5 t; ein Schlepppferd vor einem Kanallastkahn dagegen zog in den 1820er Jahren im Durchschnitt bis zu 30 t (:273). 
Vor der flächendeckenden Einführung der Dampfeisenbahn führte also der effektivste Weg zur Bewältigung des steigenden Transportaufkommens hauptsächlich bei sperrigen Gütern über eine größtmögliche Verlagerung des Transports auf Wasserstraßen (PAULINYI 1982:273), die durch Wettbewerbsanreize forciert wurde (TÖNSMANN 1995:17). Wenn sich auch Land- und Wassertransport weiterhin gegenseitig ergänzten, kam dem Ausbau der Wasserstraßen für den Gütertransport eine tragende Rolle für die beginnende Industrialisierung zu: Es ging zum einen um die weitere massive Regulierung der Flüsse, zum anderen um den Bau von neuen und den Ausbau der bestehenden Kanäle (PAULINYI 1982:273; TÖNSMANN 1995:17).

Gegen Ende des 19. Jahrhunderts wurde der Ludwig-Donau-Main-Kanal zum Beispiel weiter ausgebaut, damit größere Schiffe mit einem höheren Tiefgang, der fast $80 \mathrm{~cm}$ betragen konnte, eine höhere Tragfähigkeit erreichten (OPITZ 1997:160). Doch durch zu knappe Ausmaße der Kanäle auch für die damaligen Anforderungen begann nach 1860 eine stetige Abwärtsentwicklung, die vor allem aber in der Überlegenheit der Eisenbahn begründet liegt. Trotz seiner Unwirtschaftlichkeit blieb der Kanal bis zum Ende des Zweiten Weltkrieges in Betrieb. Erst 1945 wurde er aufgelassen, nicht zuletzt wegen stellenweiser Kriegsbeschädigungen, deren Behebung nun endgültig unrentabel erschien (BRIX 1988:25).

Auch die Kanalverbindung zwischen zwei Schweizer Seen, dem Neuenburger See und Genfer See, wurde aus mangelnder Wirtschaftlichkeit eingestellt, nachdem 1852 auf derselben Strecke eine Eisenbahn verkehrte (GREWE 1995:37).

Ein weiteres Problem stellte die Behinderung der Schiffbarkeit durch Hochwasser dar, wenn zahlreiche Schleusentore (zur Erinnerung: die Stecknitz besaß davon 17) überflutet wurden und aufgrund der höheren Strömungsgeschwindigkeit die Lenkbarkeit des Schiffes beeinträchtigt wurde (SCHUBERT 2001:33).

Der Niedergang traf im Übrigen auch nicht nur die Kanäle, obgleich sie besonders heftig, da sie einzig zu diesem Zweck erbaut worden waren. Auch die schiffbaren Flüsse litten darunter, wie die Saale unter der im Mai 1871 eröffneten Saale-Eisenbahn (SCHUBERT 2001:33). Ein weiteres, eher flussspezifisches Problem stellte das Niedrigwasser dar, das in den Sommermonaten oft zur völligen Einstellung des Schiffsverkehrs führte (:33). Diese Reglementierung versuchte man vor allem in den 20er Jahren des 20. Jahrhunderts durch den Bau von Talsperren $\mathrm{zu}$ beheben. Auf der Saale wurden gar ganze Talsperrengruppen (Bleichlochtalsperre, Hohenwartetalsperre) errichtet.

Das Ende der Binnenschifffahrt in den deutschen Ländern wurde des Weiteren beschleunigt durch den ab 1800 beginnenden Bau von Chausseen. Diese neuen Chausseen, versehen mit Schotterdecken zur besseren Verlegbarkeit des Militärs, waren eine wachsende Konkurrenz zu den Wasserstraßen (TÖNSMANN 1995:17).

Überlebt haben den Eisenbahnboom für einige Zeit die vielen innerstädtischen Kanalbauten, die im Zuge des Handels und des Städtebaus erbaut bzw. weitergenutzt wurden und bei dieser Betrachtung nicht vergesssen werden sollen. Dieser urbanen Kahnschifffahrt wurde große Aufmerksamkeit geschenkt, da Kähne wesentlich mehr Transportgut fassten als Fuhrwerke und die Häuser auch von der Wasserseite aus beliefert werden konnten, die hier auch ihre Be- und Entladungseinrichtungen hatten.

Aufgrund des niedrigen Heizwerts und des schnellen Aufschlusses von Torf löste zum Ende des 19. Jahrhunderts der Abbau von Kohle das Torfstechen zur Brennstoffgewinnung ab. Zu dem Transport von Brennmaterial auf Kanälen gehört deshalb auch der Transport von Kohle zu den Lagerstätten und anschließend zu dem Verbraucher, so zum Beipiel aus dem Hamburger Hafen mit Schuten zu den lokalen Lägern am Kanal, wie RULLE (2001:174) von der Jahrhundertwende berichtet.

Neben Brennstoffen wurden auf den Kanälen Baustoffe transportiert und in Einzelfällen extra dafür errichtet. Die für den Bau von neuen Häusern im Hamburger Stadtteil Isebek benötigten Ziegel wurden größtenteils in den Ziegeleien in Niedersachsen in Schuten verladen und von dort aus direkt über die Elbe und die Alster bis an die Landungsplätze an den Ufern des Kanals transportiert. „Dieser Transportweg wurde besonders in den ersten zwei Jahrzehnten des 20. Jahrhunderts genutzt, als die genossenschaftliche Bebauung des südlichen Isebekufers in großem Rahmen aufgrund der stetig wachsenden Bevölkerung vorangetrieben wurde“ (RULLE 2001:174). 
Aber dies soll nicht zu der Ansicht führen, dass nun sämtliches Handelsgut vor dem Beginn der Eisenbahn auf dem Wasserweg transportiert worden wäre. Salpeterpulver zum Beispiel wurde von Wagenknechten in Körben von den Pulvermühlen zu den Garnisonsstädten gebracht. Denn ungekörntes Pulver konnte sich beim Transport entmischen, Funken reißen, entzünden und so das ganze Boot sowie auch auf dem Weg befindliche Schleusen und Mühlen in Brand setzen.

Zusammenfassend lässt sich festhalten: Der Kanalbau stellt eine historische Gewässernutzung in zweierlei Hinsicht dar, da durch ihn das Oberflächenwasser in zweifacher Weise genutzt wurde: einmal, wie auch bei den natürlichen Fließgewässern, als transportable Oberfläche. Zum anderen aber als Wasserlieferant zum Füllen der Kanalläufe. Damit waren die Eingriffe in den Gewässerhaushalt ungleich höher als bei der Regulierung und Kanalisierung der Flussläufe. Nicht nur, dass der vollständig künstliche Kanalbau landschaftsfremd wirkte, da er in keinster Weise die Physiognomie und Reliefierung eines natürlichen Fließgewässers nachbildete und zur zusätzlichen Verwässerung der Landschaft beitrug, sondern auch, dass der Kanalbau zu einer Ableitung von Flusswasser in großem Stil führte. Das Wasser für die Anlegung der Kanäle, das aus den Flüssen genommen wurde, floss wiederum aus den Bächen und Quellen zu, wie REUTER bereits 1837 (:21) erkannte. Diese Dimension des anthropogenen Wasserwegebaus könnte zum Beispiel Gegenstand einer eigenständigen umwelthistorisch-geographischen Untersuchung zur abgeführten Wassermenge und des dadurch veränderten Gewässer- und Klimahaushaltes sein, die eintretenden Versandungen durch Gebirgsabgänge, die schon damals die Schifffahrt und die Flößerei auf den Kanälen behinderte (:51), einmal außer Acht gelassen.

\section{f Flößerei}

Neben den Schiffen und Kähnen ist noch eine Sonderform des historischen Gütertransportes zu erwähnen, die auf nahezu allen Hauptflüssen und ihren Nebenflüssen seit alter Zeit üblich war (vgl. SEEDORF/MEYER 1996:627): die Flößerei. Die Besonderheit ist, dass es sich bei dem „Floß“ um das Transportgut selbst handelte.

Flößerei dient als Oberbegriff für zwei Formen des Holztransportes: der Bau- und der Brennholzflößerei (SEEDORF/MEYER 1996:627).

Die erste Form der Flößerei war die von Langholz, das als Bauholz Verwendung fand. Da die Langholzflößerei die wohl älteste Art darstellt (SCHUBERT 2001:28), wird hier auch einfach vom „Flößen“ gesprochen. Beim Flößen wurden mehrere nebeneinander liegende Baumstämme miteinander zu einem festen Floß verbunden und auf dem Fluss stromabwärts transportiert (Definition in Anlehnung an SEEDORF/MEYER 1996:627 und SCHUBERT 2001:28). Deshalb wird bei dieser Holztransportform auch von der „gebundenen Flößerei“ gesprochen (STELTMANN 1995:211). Diese Form war vor allem auf den größeren Flüssen üblich (SEEDORF/MEYER 1996:627).

Die zweite Form der Flößerei war die von Kurzholz, das als Brennholz benötigt wurde. Deshalb spricht man auch von „Scheitholzflößerei“. Fast ausschließlich auf kleineren, nicht schiffbaren Bächen, Flüssen und Flussabschnitten wurde diese Flößereiform betrieben (STELTMANN 1995:211; SEEDORF/MEYER 1996:627). Kurze, unverbundene Stämme wurden bei hohem Wasser in den Bach bzw. in den Fluss geworfen, über kürzere Entfernungen einzeln treiben gelassen und im Bedarfsfall vom Ufer aus mit langen Stangen dirigiert und vorangetrieben (STELTMANN 1995:211; SEEDORF/ MEYER 1996:627; SCHUBERT 2001:28). Bei dieser Holztransportform spricht man deshalb vom „Holztreiben“ bzw. von der „Trift“ bzw. - doppeldeutig - von der „Brennholztrift“ (STELTMANN 1995:20,211). Als „Trift“, so die Definition in Anlehnung an BORGER-KEWELOH/KEWELOH $(1991: 9,20)$ wird „die Schwemmung bzw. Beförderung von einzelnen Stammstücken (Scheitholz bzw. Knüppelholz) von 1, 2, 3 und in seltenen Fällen auch von $5 \mathrm{~m}$ Länge in unverbundenem Zustand auf Bächen und Flüssen über kürzere Entfernungen“" bezeichnet.

Hierbei ist nach meiner Ansicht die Unterscheidung zwischen „Schwemmung“ und „Beförderung“ wichtig, die BORGER-KEWELOH/KEWELOH in ihren zwei Definitionen $(1991: 9,20)$ fälschlicherweise synonym 
verwenden, die aber vom Ablauf her nicht zusammen gehören. Die Triftbeschreibung „Schwemmung“ deutet auf den Einsatz von Teichen oder eines anderen Wasserschwalls hin, der die Hölzer von allein auf dem Wasser fortschwimmen lässt. Im Gegensatz dazu kann aus der Verwendung des Begriffes „Beförderung“ der menschliche Einsatz geschlossen werden, dessen es bei der Holztrift korrigierend und lenkend bedarf.

\section{f.1 Flößen}

„Die älteste Form des Wassertransportes war die Flößerei.“(CZAYA 1990:37). Und im zeitlichen Vergleich beider Flößereiformen ist die Langholz- oder auch gebundene Flößerei ,,in ganz Deutschland wohl die älteste Form der Flößerei, älter als die Trift.“ (STELTMANN 1995:213; ebenso BORGERKEWELOH/KEWELOH 1991:42 und SCHUBERT 2001:28). Aussagen zur Frühzeit der Flößerei, mit Ausnahme der schriftlichen Beurkundungen des Mittelalters, liefert der einer Genossenschaft der Schiffer oder Flößer gewidmete Ettlinger Neptunstein, der älteste Hinweis über das Floßwesen in BadenWürttemberg, der beweist, dass bereits um 150 bis 200 n. Chr. die Flößerei hier eine bedeutende Rolle gespielt (SCHEIFELE 1993:101). Vor allem aber ist die Flößerei eine Transportform des Mittelalters.

Im Mittelalter mangelte es schon früh an Bauholz, später auch an Brennholz. Den Brennholzbedarf konnte man durch Nutzung der stadtnahen Niederwälder und Heideflächen noch länger decken; auch gab es ausgedehnte Moore, deren Torf man zur Wärmegewinnung verbrennen konnte. Bauholz aber war nicht verfügbar (KÜSTER 1998:144).

Schon 1549 wird das Floßholz im Bramwald erwähnt. Es handelte sich dabei um Eichenholz, das erst durch die Entrindung und Lagerung schwimmfähig gemacht wurde (HENCKEL 1988:62). Seit 1680 bestand auf der Leine eine Flöße, die den wachsenden Brennholzbedarf des fürstlichen Hofes, der Behörde, Kasernen und landesherrlichen Bediensteten mit dem Brennholz aus dem Solling deckte (GEBHARDT 1995:126ff.). Auf der Saale soll es die Flößerei sogar bereits 1258 gegeben haben (SCHUBERT 2002:28).

Und sogar im Harz stammt die Holzflößerei im Vergleich zur bergbaulichen Wassernutzung ,aus einer viel älteren Wasserwirtschaft.“ (HAASE 1961:17) Erst „zu Agricolas Zeiten wurden Flößergräben ausgehoben, über die das für die Verhüttung benötigte Holz herbeigeschafft wurde.“ (CZAYA 1990:37)

Die zumeist beschriebene Langholzflößerei bezieht sich im Wesentlichen deshalb auf die Stammholzflößerei (vgl. STELTMANN 1995:211), da vor allem die Städte für ihren Aufbau und für das Wachstum langes Stammholz brauchten. Weil die Städte dicht am Fluß lagen, kam das Holz ,auf dem Wasser in die Stadt.“ (KÜSTER 1998:143)

Dieser lange Transport auf dem Wasserweg war notwendig geworden, weil die umliegenden Stadtwälder und andere Gehölze in Stadtnähe abgeholzt waren und auch nicht die Möglichkeit hatten wieder in die Höhe zu wachsen - Bau- und Brennholz war im „suburbanen“ Raum nicht mehr verfügbar. Neue Quellen für Holz zu erschließen war nur durch Fernhandel möglich (KÜSTER 1998:153). Aber auch die immer weiter entfernt gelegenen Wälder des vorstädtischen Raumes waren durch Plünderei, Waldweidewirtschaft und den hohen Bedarf an Holz der Hüttenwerke in ihrem Bestand minimiert worden. Besonders viel Holz im deutschen Gebiet gab es im hohen Mittelalter und auch später noch in den mitteleuropäischen Gebirgen, dort wo bisher nur wenige Siedlungen, vor allem kaum Städte, existierten (:143). Von den waldreichen Gebirgen zu den waldarmen Flachland- und Küstenregionen verlaufen die großen Ströme. Auf ihnen konnte das Holz geflößt oder getriftet werden. Die Flößerei gewährleistete so über Jahrhunderte hinweg die Holzbringung von den waldreichen in die waldärmeren Gebiete (BORGER-KEWELOH/KEWELOH 1991:17). Ein dicht geknüpftes Wassernetz, das den Zugang selbst zu entfernter gelegenen Waldgebieten ermöglichte, machte die großen Holzreserven für die volks- und gewerbereichen „Holzmangelgebiete“ (SCHEIFELE 1993:9), d. h. den Städten, und vor allem für das baumarme Tiefland und den Küstenraum verfügbar. „Nur der Wasserweg ermöglichte einen Transport dieses schwimmfähigen Massengutes, denn weder die Fernhandelsstraßen noch die Fuhrwerke waren solchen Schwertransporten gewachsen" (SEEDORF/MEYER 1996:627). Für das Massengut Holz - Hauptenergieträger und wichtiger Baustoff der Zeit - war die Verfrachtung auf Bächen und Flüssen die billigste Transportmöglichkeit und bei dem Mangel an guten Straßen und brauchbaren Holzabfuhrwegen und den durchweg sehr schlechten Wegeverhältnissen die 
einzige, um die benötigte Menge aus den dichten Waldungen zu bewältigen und das Holz über weite Strecken zu befördern und zu den Verbrauchern zu bringen (SCHEIFELE 1993:9).

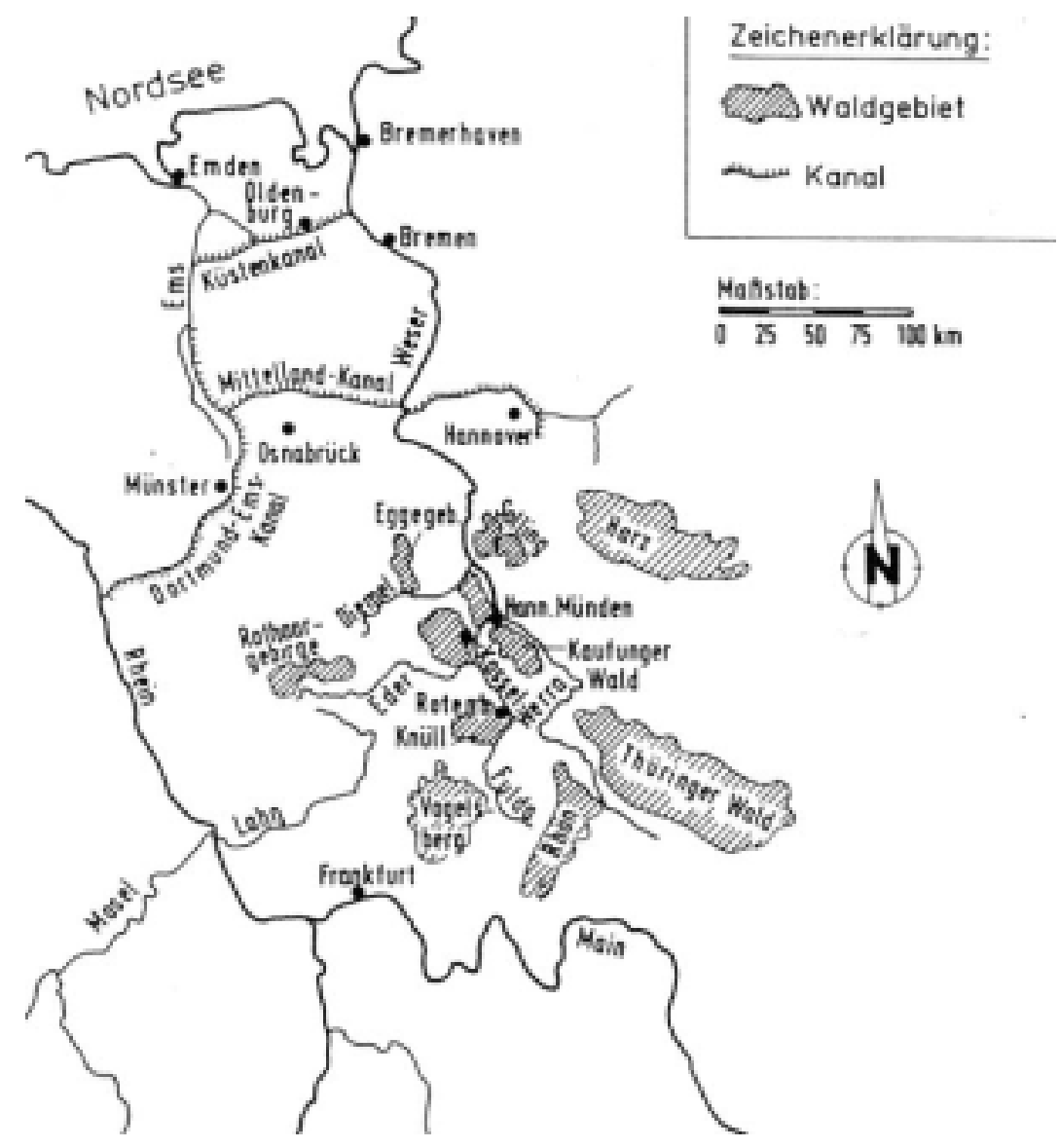

Abb. VI-49: Übersicht über die Flößerstraßen

Sie nutzten die Flöße aus den waldreichen Gebieten der Weser, Fulda und Werra, um das Holz in die waldarmen Küstengebiete Norddeutschlands zu bringen (aus: STELTMANN 1995:209).

Regulierung, Kanalisierung, Eindeichung und Kanalbau hießen die Maßnahmen auch für den Transport von Holz, mit denen Gewässer verändert, reglementiert und künstlich hergestellt worden sind. Für den so bedeutsamen Holztransport wurde selbst in die kleinsten Gewässerläufe eingegriffen, wie die späteren Beispiele zeigen.

Der Bedarf an Bauholz ${ }^{46}$ war hoch, da eine extreme Abhängigkeit unserer Vorfahren vom Holz bestand. So wurde beispielsweise für das nördliche Flachland über den im 16. Jahrhundert neu errichteten, „Schaalfahrt“ genannten, Kanal Holz bis aus Mecklenburg herangeführt (MÜLLER/LUDWIG 1982:160). Denn für die Küsten- und Hafenstädte bestand großer Holzbedarf: Für den Bau von Hafenmolen und Werften, für den Schiffsbau und die schifffahrtstechnischen Bauten die auch durch den Kanalbau notwendig wurden, wie Schleusen, Brücken usw., für die Anlage von Uferbefestigungen, wie den Deich- und Dammbau, für die Einrichtung von Entwässerungsgräben und Sieltoren etc.

Aber auch für den Städte- und Hausbau, der weitgehend aus Fachwerk bestand, wurde Bauholz benötigt: Für die in Ständer- und Etagebauweise ausgeführten Holzbauten der Wohn- und Patrizierhäuser, für die Wasserburgen und Gräftenhöfe, die zumeist auf Pfahlroste errichtet wurden (KÜSTER 1998:153), für Häuser, die in Niederungsgebieten auf Pfähle gründeten, für Hütten mit Bretterverkleidung sowie Schindeloder Bretterabdeckung (ALTMANN 1999:141), als Straßen- und Wegbauholz sowie für den Bau zahlreicher Wind- und Wassermühlen war die Beschaffung des hölzernen Rohstoffs erforderlich.

\footnotetext{
${ }^{46}$ Den Gebrauch und die Notwendigkeit von Bauholz ist vielschichtig. Einen gut zusammengefassten Überblick über die verschiedenen Holznutzungen gibt KÜSTER in seiner „Geschichte des Waldes“ (1998) in dem Kapitel „Die Wälder der Städte“ auf den Seiten 133-142.
} 
Fast alle Gebäude von Wassermühlen waren in Fachwerkbauweise errichtet und auch deren Grundwerke, Wehre, Zu- und Ablaufgerinne samt Absturz bestanden in älterer Zeit aus Holz, nur der Mahlstein stellte eine Ausnahme dar: er bestand aus Stein. Die Verwendung von Ziegelsteinen im Mühlenbau lässt sich erst für das 16. Jahrhundert nachweisen. Vollständig aus Stein errichtete Mühlenbauten hat es wohl erst im 18. Jahrhundert gegeben (KREINER 1996b:123). Und auch das Wasserrad mit dem Wellbaum war vor dem 19. Jahrhundert, als die eisernen Wasserräder aufkamen, vollständig aus Holz gebaut, wie auch das ganze gehende Werk der Mühle fast ausschließlich aus Holz bestand. Nur für einige Teile, wie zum Beispiel für Nägel oder Lagerzapfen, fand Eisen Verwendung (:132).

Auch für die alte Wasserbaukunst des Bergbaus lieferte die Flößerei das Holz für den Bau von Pferdegöpeln, Radstuben, Wasserrädern sowie den Grubenausbau. Auch die Pumpen, um das Wasser aus dem Grubenstollen in den Abflußstollen zu heben bestanden aus Holz (siehe Abb. VI-50), ebenso die Gestänge, die diese Pumpen antrieben. Hölzer wurden auch gebraucht, um in hölzernen Gerinnen, die, um ein Tal zu queren, auf Holzböcken standen, Wasser zu den Radstuben als Aufschlagwasser zu transportieren (CZAYA 1990:31f.,37).

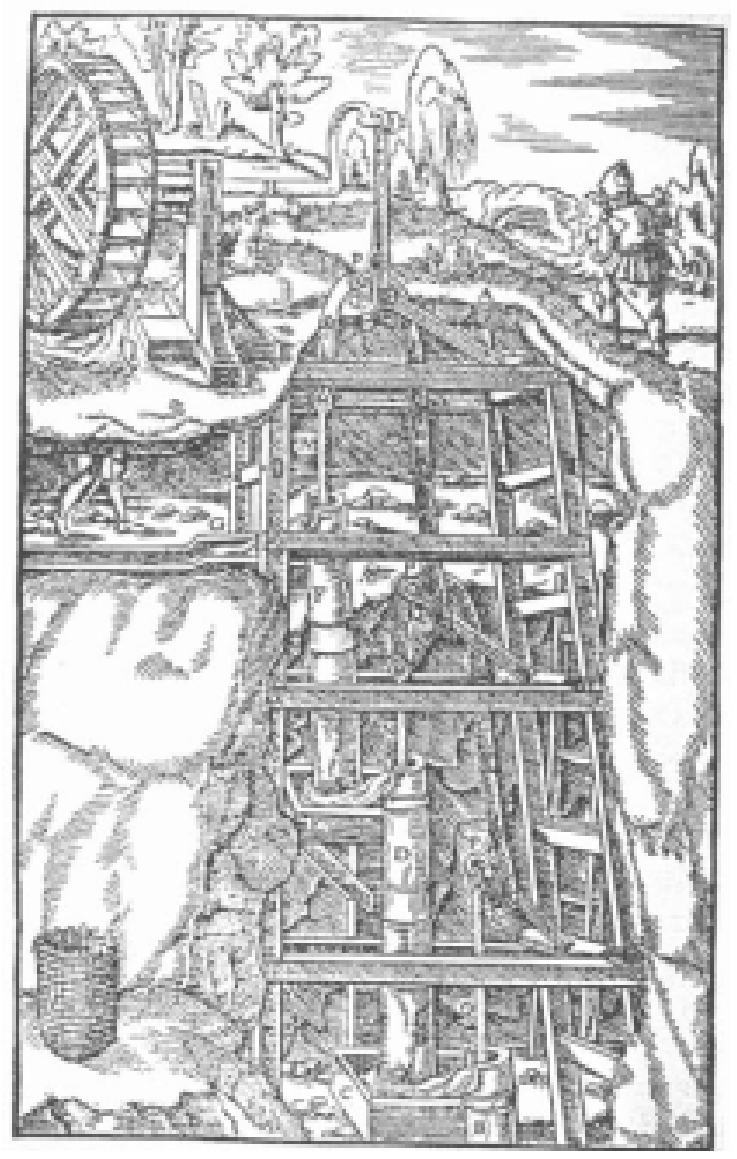

Abb. VI-50: „Hölzerner Bergbau“

Wasserrad und Welle, Pumpengestänge, Untertagegerüst aus gezimmertem Holz (AGRICOLA 1556, aus CZAYA 1990:31)

Des Weiteren sind im Zusammenhang mit der Verarbeitung des geförderten Erzes die Hütten- und Hämmerwerke zu erwähnen, deren Hammerstämme aus starkem Langholz hergestellt wurden. Die Aufzählung ließe sich noch um einige Beispiele weiterführen, doch die Dimensionen des Flößens allein von Bauholz dürfte deutlich geworden sein.

Der Holzmangel verschärfte sich, zugleich wurde der Langholzbedarf in den gewerblichen Zentren immer größer: für repräsentative Bauten, profane und religiöse Bauten, für Schiffsflotten, für verstärkte Ufer- und zusätzliche Hafenbefestigungen, für den Bau von Gradierwerken zur Filterung der Sole usw. (vgl. KÜSTER 
1998:143). Doch nicht die zu befördernde Holzmenge, sondern auch der Anspruch bzw. die Notwendigkeit, verschiedene Holzarten zu verwenden, mehrte sich und machte diese zu begehrten Handelsobjekten.

Beim Wassermühlenbau zum Beispiel wurden für das Mühlgerinne meistens Eichenpfähle und -bohlen verwendet (BEDAL 1992:40). Die Mühlwelle und das Mahlwerk der Wassermühlen waren fast ausschließlich aus dem widerstandsfähigen Eichenholz hergestellt (KREINER 1996b:132). Es wurde aber nicht nur Eichenholz für den Mühlenbau benutzt; einige Teile des Getriebes, wie die Radzähne (Kammen, Kämme) der Wassermühlen waren aus Hainbuche, Erlenholz oder besser noch aus Mispelholz (Mespilus germanica) hergestellt (TERHALLE 1992:19; KREINER 1996b:132).

Auch wurden die Hammerstämme aus Buchen- und Eichenholz für die Walkhämmer und Stampfen gebraucht. Vor allem aber die Eiche als Schiffsbauholz hatte es im 17. und 18. Jahrhundert erforderlich gemacht, dass dieses Holz in großem Umfang geflößt wurde (STELTMANN 1995:211).

Da Eichenholz jedoch „senk“, also nicht schwimmfähig war wie es in der Fachsprache hieß, musste es zwischen einer ausreichenden Zahl von spezifisch leichteren Weichholzstämmen eingebunden bzw. als Oblast befördert werden (JAUERNIG-HOFMANN 1990:9). In anderen Fällen wurden Fässer als Tragkörper eingebunden (STELTMANN 1995:211).

Während bis in die Mitte des 19. Jahrhunderts nur Laubholz verflößt wurde, gewann in der zweiten Hälfte des 19. Jahrhunderts die Flößerei von Nadelholz an Bedeutung (HENCKEL 1988:62), das als schnellwüchsige Arten auf den gefällten Laubholzflächen angepflanzt wurde. Mit der Kommerzialisierung des Holzes wuchs die Bedeutung der Fichte: schnell wachsend, leicht und damit gut „flößbar“, qualitativ hochwertig - die Nachfrage war groß, und die Fichte verdrängte andere Baumsorten. Die ersten Pflanzversuche im Oberweserbergland wurden im Solling 1737, im Reinhardswald 1764, im Bramwald 1771/72, im Kaufunger Wald 1784 und im Mündener Stadtwald 1785 gemacht (:62). Flöße aus Fichten des eigenen Anbaugebietes sind aber erst ab 1870 überliefert, da erst ab der ersten Hälfte des 19. Jahrhunderts größere Flächen in den Wäldern mit schlagfähigen Fichten und größere Bestände bepflanzt waren (:62). So wurden bis zur ersten Hälfte des 19. Jahrhunderts Fichten aus dem Thüringer Raum auf dem Landwege an Münden vorbei bis nach Gimte gebracht und erst dort zu Flößen eingebunden (:62)

Aus diesem und aus dem Grund, dass Harthölzer allein nicht schwimmfähig sind bzw. gegenüber Weichholz tiefer liegen (ALTMANN 1999:20), bezieht sich die zumeist beschriebene Langholzflößerei im Wesentlichen auf die Stammholzflößerei, die in erster Linie aus Nadelholz, vor allem aus Fichte und Tanne, aber auch aus Kiefer und Lärche, bestand, in die Laubholzstämme eingebunden werden mussten (siehe oben). Das geflößte Holz war als Baumaterial sehr geschätzt, da durch das Wassern aus dem Holz die Gerbsäure abdiffundierte, wodurch das Holz fester und verwindungssteifer wurde (SCHUBERT 2001:28).

Verbreitet war diese Form des Holztransportes scheinbar auf nahezu allen Gebirgs- und Mittelgebirgsflüssen. Bekannt ist sie aus dem Süden Deutschlands, aus Bayern, dem Schwarzwald, Frankenwald, aber auch aus mitteldeutschen waldreichen Gebieten. Nicht nur auf den größeren Flüssen wie der Weser selbst oder mittelgroßen wie auf Fulda, Werra, Aller, Oker und Leine, sondern auch auf einer großen Zahl von kleineren Nebenflüssen wurde geflößt. Erwähnt seien zum Beispiel der Werranebenfluss Schleuse, die Oertze aus der Heide oder wie die Oker mit ihren Nebenflüssen Radau und Ecker aus dem Harz sowie Rhume, Söse und Innerste als Leinenebenflüsse (vgl. BORGER-KEWELOH/KEWELOH 1991:42). Sogar auf der kleinen Ise, die in die Aller mündet, kam es, nachdem zuvor bereits getriftet wurde, 1662 zur Verflößung von Langholz auf der etwa $65 \mathrm{~km}$ langen Strecke von Warendorf bis Celle (:58). Und auch auf der Zwickauer Mulde wurde sowohl Brenn-, als auch Bauholz nach Zwickau geflößt (ALTMANN 1999: 23). Überhaupt stellt die Kombination von gebundener und ungebundenerer Flößerei ein Wesensmerkmal mittelgroßer Fließgewässer dar, während auf den zuführenden Bächen ausschließlich nur Scheitholz verbracht worden ist, das als Feuerholz für die Stadt genutzt wurde (:23). 


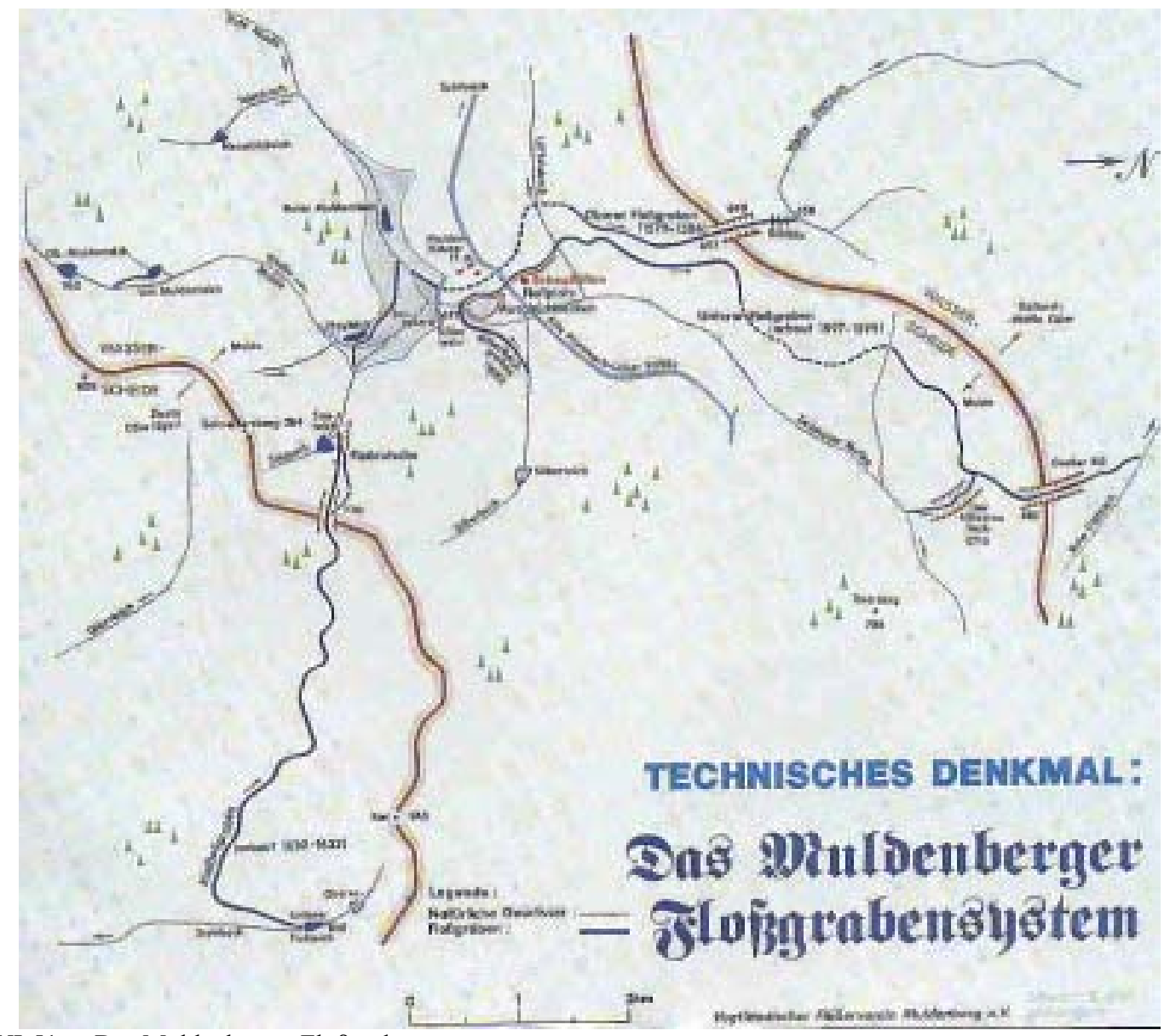

Abb. VI-51: Das Muldenberger Floßgrabensystem

Ein Technisches Denkmal (Quelle: Vogtländischer Flößerverein Muldenberg e.V.).

Zwei (nach BORGER-KEWELOH/KEWELOH 1991:42) bzw. einige (nach SEEDORF/MEYER 1996:627) „Nebenflussflöße“ wurden dann zu einem „Hauptflussfloß“ zusammengebunden. So hatten beispielsweise die Werraflöße eine Länge von gut $20 \mathrm{~m}$ und eine Breite von 3,50 m vorn und $4 \mathrm{~m}$ in der Mitte. 4 bis 5 dieser Werraflöße wurden in Hann. Münden zu einem Weserfloß zusammengebunden. Solche Weserflöße hatten eine Länge von bis zu 100 Metern (SEEDORF/MEYER 1996:627). 4 Weserflöße ergaben ein einziges Rheinfloß (STELTMANN 1995:216). So entstanden Flöße mit einer Länge von 360 m mit Besatzungen von 500 bis 800 Personen, wie sie für das 18. Jahrhundert überliefert sind (:217). In Raumgrößen ausgedrückt, führte im Mittelalter ein Floß etwa 30 bis 40 Festmeter, 50 bis 60 Festmeter waren es im 19. Jahrhundert und im letzten Krieg hat es Flöße bis zu 200 Festmeter auf der Weser gegeben (HENCKEL 1988:65). 


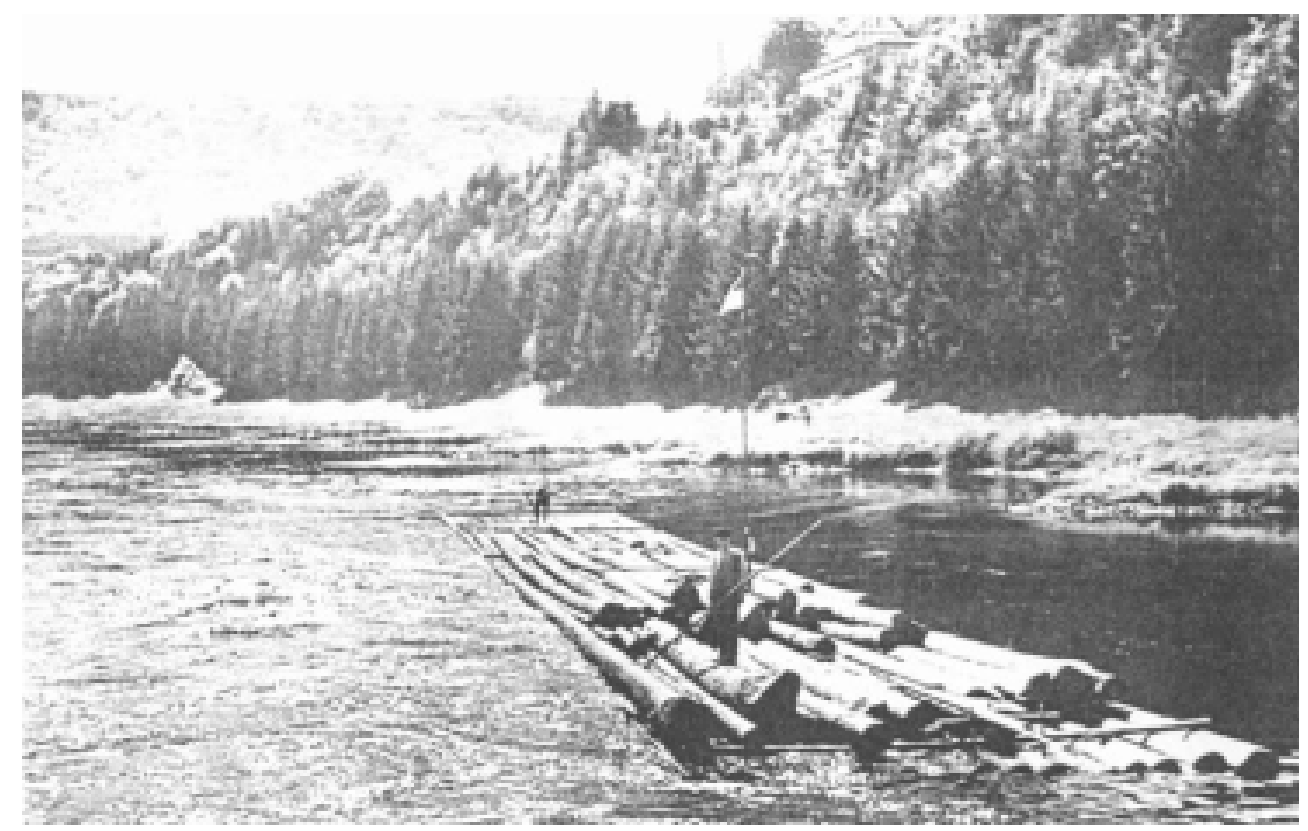

Abb. VI-52: Weserfloß. Aufnahme aus den 1950er Jahren

(aus: BORGER-KEWELOH/KEWELOH 1991:11)

Häufig wurde das Floßholz über große Strecken auf dem Wasserweg zum Bestimmungsort befördert. So kam es vor, dass Bauholz aus dem Kaufungerwald und dem niedersächsischen Weserbergland in Bremen, Emden und sogar in Holland (sog. Holländerholz) verkauft wurde (STELTMANN 1995:211). So steht Amsterdam beispielsweise zum Teil auf Pfählen aus Holz aus dem Frankenwald, in dem Flößerei schon im Jahr 1386 erstmals urkundlich erwähnt ist.

Aber auch aus Thüringen, auf der Saale, mussten Stämme Hunderte von Kilometern weit herbeigeschafft werden, um den riesigen Bedarf an Bauholz der Städte und Schiffswerften im norddeutschen Tiefland und dem Küstengebiet zu decken (SEEDORF/MEYER 1996:627). Saaleflößerei, und zwar auf der Thüringischen Saale, d. h. dem noch kleinen Oberlauf mit anfänglich noch Bergbachcharakter bis hin zur Einmündung der Ilme bei Großheringen, wurde urkundlich bereits im Jahr 1275 erwähnt (SCHUBERT 2001:9). Eine Langholzflößerei im Harzvorland wurde betrieben, vor allem, um die Residenzstädte Braunschweig, Wolfenbüttel und Hannover mit Bauholz zu versorgen (SCHMIDT 1997:202).

Die mittelrheinischen Städte wurden seit dem 15. Jahrhundert durch die Murgschiffer mit Holz aus dem Schwarzwald versorgt (SCHWARZ 1988: 313). Ebenso bezogen sie ihr Holz von den Floßstrecken der württembergischen Flüsse Enz, Nagold und Kinzig. Durch die Jahrhunderte hindurch war die Flößerei wichtigster Wirtschaftszweig des Kinzigtales und seiner Seitentäler. Die früheste nachweisbare Erwähnung der Flößerei auf der Kinzig geht dabei auf das Jahr 1339 zurück. In der Blütezeit der Kinzigflößerei, im 16. und 17. Jahrhundert fuhren etwa 100 bis 300 Flöße, wobei das größte eine heute angesichts der Flussweite kaum vorstellbar Länge von bis zu 600m (!) besaß, das Tal hinunter bis Willstadt. Hier wurde das Holz verkauft und später auf dem Rhein zu großen Flößen umgebaut. Oft war das Ziel, wie oben beschrieben, Holland, wo man es zum Schiffbau und als Fundamente für den Städtebau benötigte. Vor allem nach dem Dreißigjährigen Krieg wurden aus Süddeutschland in zunehmendem Maße große Mengen von Eichenholz nach Holland exportiert. Es waren insbesondere Schiffbauhölzer der verschiedensten Art gefragt, daneben spielte das sog. Wainscot (dt.: Wagenschuss) für hochwertige Täfelungen eine besondere Rolle.Die spezifisch schwere Eiche wurde in Nadelholzflöße eingebunden, „,verspannt“ oder als Oblast nach Holland gebracht (SCHEIFELE 1993:46). 1896 fuhr das letzte Kinzigfloß hinab ins Land, mit der Ausnahme einer weiteren Flößerfahrt 1925 anläßlich einer Gewerbeausstellung in Schiltach.

Schließlich ist bezüglich der Gebirgsflößerei die Alpen-Flößerei zu nennen. So wurden beispielsweise das Bauholz aus den Alpen mit Hilfe von Flößen auf dem Po nach Ravenna gebracht (SCHNEIDER 1992:162). Wie so eine waghalsige Floßfahrt die Wildbäche des Schwarzwaldes, aber vor allem der Alpen ausgesehen haben mag, vermittelt ein alter Stich, der mir zufällig in die Hände gefallen ist. 


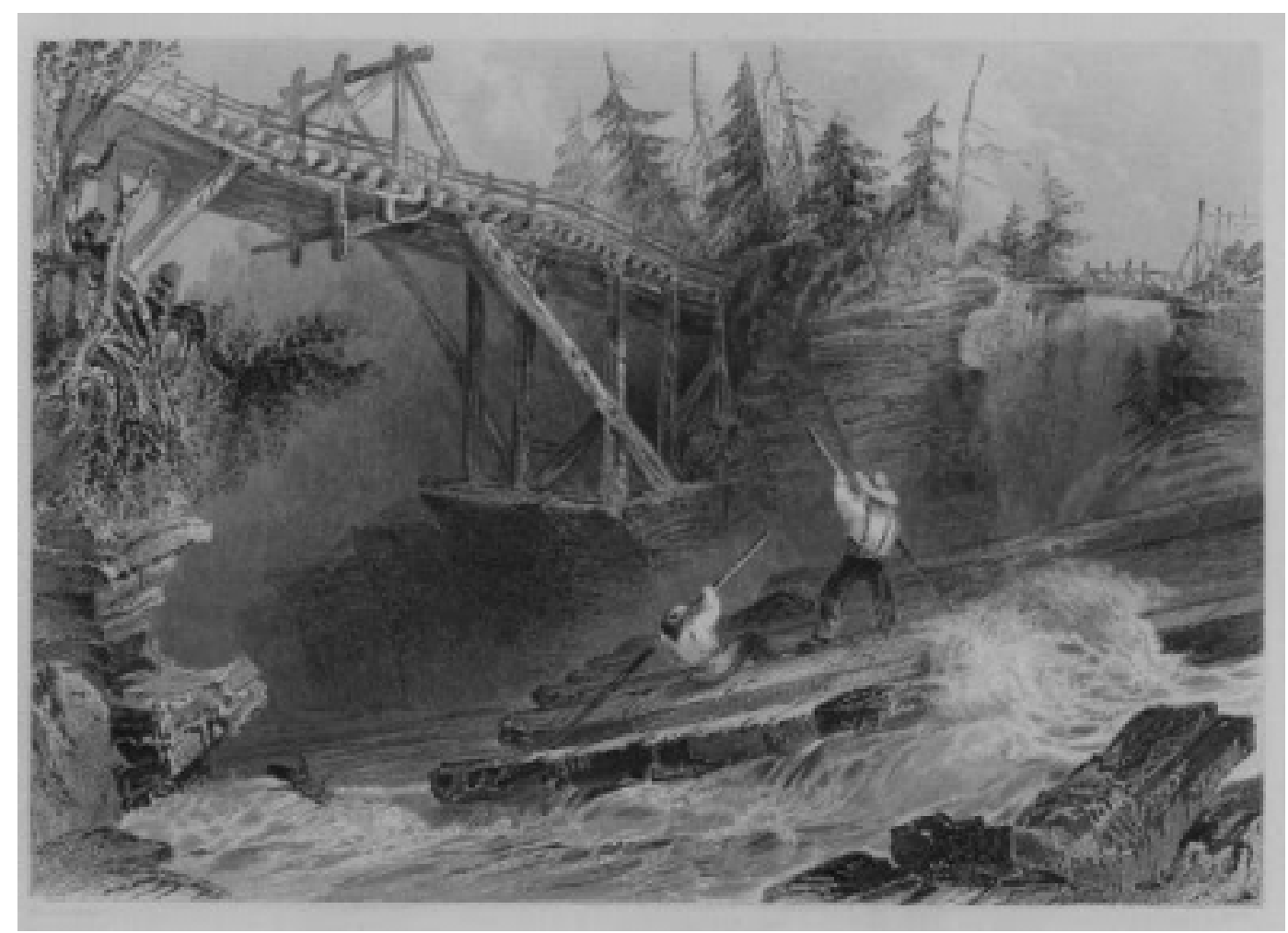

Abb. VI-53: Flößerei („timber raft“) von gebundenem Holz auf einem Wildbach vermutlich Mitte des 19. Jahrhunderts in England (eig. Bestand)

Auch im Flachland wurde trotz geringerer Strömung gewerbliche Flößerei betrieben, und zwar hatten die Flöße ihren Ausgangspunkt verständlicherweise vorzugsweise dort, wo Waldreichtum bestand, und ihre Abnehmer dort, wo dieser Rohstoff aus Holzmangel verstärkt nachgefragt worden ist. Der Holzbedarf Lübecks beispielsweise konnte bereits im 14. Jahrhundert nicht mehr durch die im Barbarossa-Privileg von 1188 zur Nutzung für den eigenen Bedarf überlassenen großen Waldungen bei Dassow und Klütz rechts der Trave und bei Brodten links der Trave gedeckt werden (SANDER-BERKE 1996:191).

Das Beispiel Hamburgs belegt, dass für die Brennholzversorgung und die Eichel- und Buchenmast die stadtnahen Wälder genutzt wurden, für die Bauholzversorgung man jedoch auf Zukäufe aus waldreichen, weiter entfernten Gebieten zurückgriff, um die eigenen Wälder zu schonen. Die Abhängigkeiten und einseitige Ausbeutung von eigenen Waldanteilen wurden auch in anderen Städten möglichst vermieden, wie zum Beispiel in Soest, das das Brennholz für die Sassendorfer Saline Mitte des 15. Jahrhunderts aus dem Münsterland bezog (SANDER-BERKE 1996:193).

Wegen der verkehrsgünstigen gewässerreichen Lage Lübecks wie auch Hamburgs konnten die Städte aber bei der Versorgung mit wertvollem Bauholz auch auf die reichen Vorkommen im baltischen und östlichen Ostseeraum zurückgreifen (SANDER-BERKE 1996:192).

Bedingt durch den Holzreichtum beispielsweise in Lychen und Umgebung und den reichlich vorhandenen Gewässerverbindungen im Müritzgebiet bot sich dort das Flößen als billigste Transportart an. In Verbindung mit der Grafschaft Boitzenburg, die gleiches Interesse hatte, wurden zu Beginn des 18. Jahrhunderts im Küstrinbach fünf Schleusen zum Abtransport des Holzes angelegt. „De Küstrinsch Beek“ galt dabei als schwierig zu beflößen, denn es war ein Gewässer mit vergleichsweise starkem Gefälle - immerhin vom Küstrinsee bis zum Oberpuhlsee über $8 \mathrm{~m}$. So konnte von Boitzenburg und Lychen über Spandau und Havelberg bis nach Hamburg Holz geflößt werden.

Auf der Havel (siehe Abb. VI-59) wie auch auf der Spree wurde aber bereits spätestens seit dem hohen Mittelalter geflößt, wodurch vor allem Berlin und Dresden Holz erhielten. Holz für den norddeutschen Raum wurde auch auf Eider und Treene, auf Pinnau, Krückau und Stör geflößt, um es von dort nach Hamburg und 
Lüneburg zu transportieren. Von der Elbe aus wurde das Holz auf der Ilmenau sogar flussaufwärts nach Lüneburg getreidelt (siehe Pkt. g). Auf der Oder kam Holz nach Breslau (KÜSTER 1998:152).

Des Weiteren baute man Flöße auf Weichsel und Memel, der Lippe, der Mosel, dem Neckar, Main und dem Rhein. Gewerbliche Flößerei bestand auch auf den bayerischen Flüssen wie Inn und Isar, Lech oder Regen nur um noch einige weitere Langholzgewässer zu nennen (KÜSTER 1998:144).

Das Langholz wurde, nachdem es in den Wäldern gefällt worden war, mit Pferden und Pferdefuhrwerken zu den Einbindestellen an die Flüsse gebracht (STELTMANN 1995:211). Denn im Gegensatz zur Kurzholztrift, bei der kleine Bachläufe als Transportweg für das ungebundene Holz genutzt wurden, konnte die Langholzflößerei nur auf größeren bzw. mittelgroßen Flüssen durchgeführt werden. Das Holz musste dazu aus den Wäldern zunächst auf dem Landweg an die Flüsse herangebracht werden. Im Weserraum erfolgte die Rückung des Holzes ausschließlich mit Pferden (BORGER-KEWELOH/KEWELOH 1991:28). Gerade in schwierigem Gelände machte sich ihr Einsatz bezahlt. Aus den Forsten herausgerückt, wurde das Holz auf Pferdefuhrwerke verladen und zu den Einbindestellen am Wasser verbracht.

Es bildeten sich in waldreichen Siedlungen ganze Flößersiedlungen entlang der flößbaren Wasserläufe heraus. Und wenn nicht Siedlungen, dann wurden zumindest spezielle Flößerplätze geschaffen. Noch 1952 gab es beispielsweise an der Weser zwischen Hann. Münden und Karlshafen 30 Einbindestellen auf beiden Uferseiten (STELTMANN 1995:213). Aus einigen dieser Floßeinbindeplätze, dort zumeist, wo sich mehrere Nebenflüsse trafen oder ein besonderer Holzreichtum mit ihren Fachkräften vorhanden war, entstanden Zentren der Flößerei. So waren die Weserdörfer Gimte, Wernshausen und Gieselwerder oder Wolfratshausen an der Isar früher bekannte Flößerdörfer. Wichtige Floßumschlagplätze an der Saale gab es in Ziegenrück, Kahla und Kösen, wobei Kösen 1870 Hauptumschlagplatz für Langholzflöße war (SCHUBERT 2001:29). Im Erzgebirge gab es Holzanger im Amt Schwarzenberg in Grünstädtel (heutiges Gelände der Bahnanlagen des Bahnhofes und Baumarktes) und in Schwarzenberg selbst, am Zusammenfluss von Mittweida und Schwarzwasser (Nähe des Eisenbahnviaduktes) sowie auch in der Nähe des ehemaligen Schwarzenberger Kugelhammers am Schwarzwasser (ALTMANN 1999:22). Und das oben erwähnte Lychen wurde neben Bredereiche, Zootzen, Beutel und Templin eine der Flößerhochburgen der Uckermark.

Die Flöße brachten aber nicht nur das Stamm- oder Dielenholz, für das sie eigentlich konstruiert wurden, flussabwärts. Es wurden auch Brenn- und Schnittholz (Latten) sowie zugerichtete Werkhölzer als Oblast mitgeführt, das sich nicht im Floß einbinden ließ. Des Weiteren wurde nicht nur Frischholz, sondern auch Gebrauchtholz, d. h. das Holz abgerissener Bauwerke über größere Entfernungen geflößt. Und selbst Handelsartikel wurden mitgenommen und im Rahmen eines regelrechten Kleinhandels in den Ortschaften an der Weser verkauft (HENCKEL 1988:62; SEEDORF/MEYER 1996:627).

DELFS (1952:27) erkannte im Warentransport auf Flößen gar eine Frühform des Fernhandels: „Auf den flachen Flußläufen der Werra, Fulda, Leine und Oker sind die Flöße vor allem im Oberlauf, der nie schiffbar gemacht wurde, lange das einzige Beförderungsmittel gewesen.“

Der Transport von holzfremden Waren beinhaltete auch die Beförderung von Torf. Auf hölzernen Paletten, die auf kleine Dielenflöße gebunden wurden, wurde der in Harzer Mooren gestochene Brenntorf auf der Radau zu den Bestimmungsorten Braunschweig-Wolfenbüttel und der Saline Juliushall im heutigen Bad Harzburg geflößt (MÜLLER 1968:57; SCHMIDT 1997:210).

Des Weiteren wurde der Transport von Kieselsteinen und Schlacken zur Pflasterung von Straßen und Plätzen auf Flößen bewerkstelligt, wie von der Oker und der Radau nachgewiesen: „Die Kieselsteine wurden im Radaubett aufgelesen und auf das schwimmende Floß aufgeladen, wobei jedes Floß etwa 100 Steine tragen konnte. Jedoch war der Steintransport nur bei gutem Wasserstande möglich, da sonst die schweren Flöße auf den Kiesbänken in den Steinfeldern der Radau und Oker aufliefen.“ (MÜLLER 1968:137).

Die Neuenbürger Knappen verbrachten ihr Erz auf der Enz als Oblast auf Flöße verladen nach Pforzheim, wo das Hüttenwerk Benckiser ein bedeutender Abnehmer war. Zumindest so lange, bis der damalige Herzog Karl 1790 per Dekret bestimmte, dass das Neuenbürger Eisenerz mit seinem hohen Mangan-Anteil nicht mehr ins „badische Ausland“ exportiert werden dürfe, sondern fortan mittels Ochsengespannen zu den 
Hüttenwerken nach Christophstal bzw. Friedrichstal bei Freudenstadt gebracht und verarbeitet werden müsse (STADTVERWALTUNG NEUENBÜRG 2003).

Nicht nur grobes Bau- und Abbaumaterial ließen die Regierenden auf Flößen transportieren. Auch die Spiegel zur Ausstattung seines Schlosses in Corvey ließ im 19. Jahrhundert der Landgraf von HessenRothenburg auf Flößen über die Weser heranbringen (BORGER-KEWELOH/KEWELOH 1991:154).

Mündener Fayence, aus der ehemaligen von 1755 - 1855 bestehenden Mündener Fayence-Fabrik, Fürstenberger Porzellan sowie Töpferwaren (Steinzeug, Irdenware) wurde auf Flößen transportiert. Die Töpfer schätzten den Wasserweg, weil er nicht nur billig, sondern auch ohne große Erschütterungen vor sich ging (HAMPE 1986:13). Hier muss man sich den bereits geschilderten Zustand der Straßen zu der Zeit ins Gedächtnis rufen (siehe Pkt.11.b.2,Gütertransport'), über die schlecht gefederte Pferdefuhrwerke rumpelten. Ein Floß war da ein vergleichsweise sicheres, erschütterungsarmes Gefährt.

Mineralwasser, ursprünglich als Luxusartikel und als vornehmes Gesundheitswasser, dem medizinische Wirkung zugeschrieben wurde, in Steingutflaschen abgefüllt, wurde auf Flöße verbracht, wie auch viele Artikel, die sonst auf dem Schiff transportiert worden sind, wie zum Beispiel Weinfässer (siehe Pkt. 11.b.2). So geht der früheste urkundliche Nachweis von Weintransport über die Kärntener Drauflößerei in das 13. Jahrhundert zurück. Viktringer Mönche hatten über den Wasserweg leere Weinfässer in die Untersteiermark transportiert, die in den stiftseigenen Weingütern abgefüllt und über die Drauwaldstraße zurückgebracht wurden (BERCHTOLD-OGRIS 2001:164). Die Drau wurde aber nicht nur in Friedenszeiten, sondern auch und gerade in Kriegszeiten, wie zur Zeit der Türkenkriege, als Transportweg auch für Waffen und Munition. Zum Schutz der Waren griffen die Schiffer eher auf gedeckte „Plätten“ und „Scheiken“ (abgedeckte Flöße) zurück, die das empfindliche Schießpulver und Mehl besser trocken hielten als offene Flöße (:165).

Bis weit ins 19. Jahrhundert hinein blieb die Flößerei die nahezu einzige Möglichkeit, abseits liegende und nur kaum genutzte Waldungen zu erschließen (SCHEIFELE 1993:9). Ohne die Flößerei wäre auch die Herausbildung und Expansion unserer mittelalterlichen Wirtschaftszentren angesichts ihres hohen Holzverbrauchs nicht möglich gewesen (:10). Dann aber, und bereits beginnend im zweiten Drittel des 19. Jahrhunderts, kam der Floßbetrieb allmählich zum Erliegen.

Der mit dem technischen Fortschritt verbundene Aus- und Neubau von Transportwegen außerhalb des Flusses und der dadurch bedingten geringeren Qualitätsminderungen unter gleichzeitiger Verringerung der Zeitinanspruchnahme beim Landtransport, da der planmäßige Ausbau der Landstraßen eine wesentliche Verbesserung der Verkehrsverhältnisse brachte, machte den Holztransport von den Floß-Wasserstraßen immer unabhängiger, wodurch die Flößerei als Transportmittel des Holzes zunehmend an Bedeutung verlor. Des Weiteren können die Einführung der Kohle und nachfolgend des Diesel als neuen Brennstoff, die Abnahme der Holzbedarfs und die Erschöpfung der Holzvorräte aus den heimischen Wäldern als die Hauptursachen für das Aussterben der Flößerei angesehen werden (SCHEIFELE 1993:99ff.; SCHUBERT 2001:29).

Zum Niedergang trug weiterhin $\mathrm{zu}$ bei, dass die Wasserkraft immer mehr gewerblich genutzt wird (SCHEIFELE 1993:99). Die Sägewerke im Rodungsgebiet zur Primärverarbeitung des geschlagenen Holzes vor Ort können als Ursache für die Einstellung der Flößerei genannt werden, so dass es zum sukzessiven Rückgang und schließlich zur Aufgabe der Flößerei kam.

Außerdem waren, wie oben beschrieben, nur Weichhölzer gut flößbar, andere Hölzer mussten umständlich beigepackt werden. Schließlich gab es auch zum Teil heftige Materialverluste bzw. -beschädigungen durch das Zurichten und Einbinden der Stämme (SCHUBERT 2001:30).

Zudem stellten von Beginn an die Wehre der Wassermühlen ein großes Hinderniss dar. Die Flöße passierten mehrere Mühlenwehre, die für sie extra geöffnet werden mussten. Dies wirkte sich störend auf den Mühlenbetrieb aus, da dieser zum Stillstand kam. Zugleich stellten die Wehre eine besondere Gefahr für die Flöße dar und zwangen oft zum Anlegen vor dem Öffnen des Wehres. Umgekehrt war eine Beschädigung der Mühlenanlagen durch die Flöße nicht selten (BORGER-KEWELOH/ KEWELOH 1991:57). Zunehmend kam es demzufolge zu Prozessen wegen Entschädigungsforderungen der Müller und anderen 
Wasserwerksbesitzern, die das Wasser für ihre Zwecke nutzen, „während die Floße durchfahren wollen“ (SCHEIFELE 1993:99).

Schließlich sind noch die natürlichen Nachteile der Flößerei zu nennen. Ihr langsamer, zeitaufwendiger Transport war bestimmt durch die Abhängigkeit von den klimatischen (Wind-, Sichtverhältnisse) und hydrologischen (Wasserverhältnisse) Bedingungen. Aber auch anthropogen verursachte Gründe erschwerten den Flößen den Wettbewerb. Nach der Kanalisierung von Flüssen waren sie wegen der geringen Strömung und der Schleusungen zusätzlich auf Schlepper angewiesen und die dieselbetriebene Binnenschifffahrt bedingte zusätzlich eine Verkürzung der Floßlängen (SEEDORF/MEYER 1996:627).

Doch besaß die Maxime des Wassertransportes auch dann noch Gültigkeit, als Straßen- und Wegeverhältnisse schon wesentlich besser geworden waren. Die weitaus billigste Methode war weiterhin der Wassertransport (BORGER-KEWELOH/KEWELOH 1991:24), der sich aber auf die größeren Fließgewässer konzentrierte. Auf den kleineren Flüssen war er schon um die Wende vom 19. zum 20. Jahrhundert zu Ende gegangen (:9). Die letzte offizielle Talfahrt eines Floßes auf der Saale fand 1938 statt (VÖLKEL 1991; zitiert nach SCHUBERT 2001:28).

Durch die Notzeiten des Zweiten Weltkriegs und der Nachkriegszeit erfuhr die Flößerei auf größeren Flüssen dann noch einmal einen Aufschwung. Bis 1950 wurden die meisten der geschlagenen Fichten regelmäßig verflößt (HENCKEL 1988:65). Mitte der 1960er Jahre waren nur die großen Flüsse Weser, Main und Rhein ,als einzige von den zahlreichen Flüssen und Bächen übriggeblieben, auf denen ursprünglich in Deutschland Floßholz transportiert wurde." (BORGER-KEWELOH/ KEWELOH 1991:9). Auf diesen ist noch das sog. Holländerholz aus den deutschen Mittelgebirgen auf Flößen über Main und Rhein in die Niederlande transportiert worden (DENZER 1996:204).

Doch schon bald erholten sich Eisenbahn und - bevor es sie selbst traf - die Schifffahrt von den Folgen und machten zusammen mit dem Lastverkehr der Flößerei das Frachtgut Holz streitig. Die Flößerei von Nutzholz wurde zu teuer (HENCKEL 1988:65).

Im Juli 1964 schwamm nach BORGER-KEWELOH/KEWELOH (1991:9) das letzte kommerzielle Floß weserabwärts, nach HENCKEL (1988:65) ging erst 1971 das letzte Floß auf der Oberweser von Gimte aus zu Tal. Danach wurde die gewerbsmäßige Flößerei eingestellt.

Heute wird die Flößerei als rein touristische Attraktion zur Belebung des Fremdenverkehrs betrieben, zum Beispiel werden seit 1987 alle 2 Jahre zu Pfingsten Flößerfeste vom Uhlstädter Saaleflößerverein der oberen Saale durchgeführt. Touristenflößerei wird außerdem im „Floßdorf Wolfratshausen“ auf Isar und Loisach, in Wallenfels auf der Rodach und auf anderen Flussläufen angeboten.

Das Floß wird als ein naturhaftes Fahrzeug begriffen, das kein Fremdkörper in der Natur, sondern eher eine Ergänzung ist. In diesem Sinne finden sich Flöße übrigens auch als romantische Staffage auf Landschaftsbildern (siehe Abb. VI-88).

Die systematische Flößbarmachung von Gewässern bedeutet jedoch zum Teil erhebliche Eingriffe in den Gewässerlauf, die vor allem kleinere Gewässer betrafen, und die eine Romantisierung vermissen lassen.

Der große Holzbedarf der Städte, wie am Anfang erwähnt, führte früh zu einer Auszehrung und Verwüstung der stadtnahen Wälder. Immer weiter musste man ausgreifen, wollte man die stetig steigende Nachfrage befriedigen. Aus immer entlegeneren Waldungen wurde das lebenswichtige Holz über immer größere Entfernungen transportiert. Einer uneingeschränkten Nutzbarmachung sämtlicher, auch der entferntest gelegenen, Holzvorräte stand aber die verkehrliche Unzulänglichkeit der meisten Waldgebiete hinderlich entgegen. Waren solche einmal vorhanden, befanden sie sich in aller Regel in solch erbärmlichen Zustand, dass der Transport von Baumstämmen - zumindest auf der Achse über größere Entfernungen - gänzlich undenkbar und unmöglich war. Den einzigen Ausweg boten die Wasserstraßen: die Bäche und Flüsse (BORGER-KEWELOH/KEWELOH 1991:17). Doch auch diese mussten für die Holzflöße erst einmal präpariert werden: 
Während große Flüsse wie die Weser, Werra und Fulda sowie Aller und Leine ohne besondere Maßnahmen grundsätzlich flößbar waren - sieht man einmal von trockenen Sommern ab -, mussten kleine Bäche erst zur Langholzflößerei hergerichtet werden, wie die Oker, Radau oder Innerste im Harzgebiet. Im 16. Jahrhundert machten die Herzöge von Braunschweig-Wolfenbüttel die Obere Oker und ihre Nebenflüsse sowie die Radau und Innerste flößbar, so dass nicht nur die in den Tälern gelegenen Hüttenwerke, sondern auch die Städte Braunschweig und Wolfenbüttel mit Bau- und Brennholz aus dem Harz und von den Höhenzügen des Harzvorlandes versorgt werden konnten. Auch um die kleinen Gewässer des Schwarzwaldes, wie z. B. Holzbach, Maisenbach und Alb für Langholzflöße befahrbar zu machen, waren umfangreiche Arbeiten erforderlich (SCHEIFELE 1993:80).

Die Bäche wurden nicht in dem verwucherten Zustand zum Flößen benutzt, in dem man sie heute sieht. Das Flussbett wurde dreimal jährlich von Schilf und Kraut gereinigt und von Sandbänken geräumt (BORGERKEWELOH/KEWELOH 1991:58). Vor allem aber mussten Bäche verbreitert, begradigt oder Windungen durchstochen, mehrere Wasserstuben neu angelegt und an den Wehren von Mühlen und Wasserwerken die alten Floßgassen verbreitert werden. Zusätzlich waren kostbare Wiesenflächen dafür abzustechen, was bei deren Besitzern auf Unmut stieß. Für die Langholzflößerei, d. h. um bis zu $30 \mathrm{~m}$ lange Tannen geflößt zu bekommen, mussten nämlich bisherige „Scheiterholz-Floßkanäle“ begradigt und verbreitert werden. Manchmal sogar war ein neuer Kanal erforderlich. Gleichfalls mussten die zu niedrigen Brücken erhöht werden (SCHEIFELE 1993:80). Zu einem „Gestör“" wurden höchstens vier Tannenstämme eingebunden und etwa 5 - 6 Gestöre umfasst ein Langholzfloß auf kleinen Bächen bzw. Flussläufen, wie beispielsweise der Alb. Ein Holländer Albfloß war somit 90-130 m lang und etwa 3-4 m breit (:80f.).

Darüber hinaus bezogen sich die Maßnahmen zur Flößbarmachung auf die Flussbettvertiefung und den Bau von Stichkanälen, um die Mühlen zu umgehen. So wurden bei der Schunte, einem Fluss bei Braunscheig im Bereich Campen, sogar zwei Stichkanäle unter Aufnahme eines Altarmes des Flusses hergestellt, um die Hindernisse im Flussbett zu umgehen. Insgesamt konnte so das Passieren von 11 Mühlenwehren vermieden werden (BORGER-KEWELOH/KEWELOH 1991:58). Mit all diesen Maßnahmen sollte ein geregeltes Flussbett gewonnen werden.

Das Beispiel der Flößbarmachung der Ise im 17. Jahrhundert soll dies verdeutlichen: Zuerst wurde die Reinigung des Flussbettes vorgenommen. Nur so konnte die genügende Wassertiefe erreicht werden. Wie auf der Schunte wurden dann Stichkanäle angelegt. Diese sollten in diesem Fall nicht Wehre, sondern zu starke Flusswindungen umgehen, da die Ise vor der neuzeitlichen Begradigung nicht nur durch ein waldreiches, sondern auch durch ein feuchtes und unwegsames Gelände mäandrierte. Der erste war der später ,Fischergraben' genannte 2 km lange Kanal im Gebiet des Forstortes Espenleu, der zweite ein Kanal nördlich von Gifhorn mit 3 km Länge.

Auch bei der Radau stand zuächst die Reinigung des Flussbettes am Anfang der Flößbarmachung. Der Ausbau erfolgte dann seit 1571 unter Herzog Karl von Braunschweig. Hier waren nicht nur Sand, Algen und Baumteile zu entfernen. Vor allem die Steine im Flussbett erwiesen sich als störend und verhinderten eine ausreichende Tiefe, so dass sie gehoben werden mussten. Ein Teil der entfernten Steine wurde jedoch nach jedem Hochwasser ins Flussbett zurückgeschwemmt, so dass eine regelmäßige Räumung wie auch, bedingt durch das Algenwachstum, eine Reinigung erforderlich war (BORGER-KEWELOH/KEWELOH 1991:59).

Die Beseitigung von Felsriffen, Kiesbänken, die Verhinderung der Ausuferungen etc., ganz allgemein gesprochen die Beseitigung der Abflusshindernisse, gehörten zu den Maßnahmen einer dauernden Flößbarhaltung. Es galt nicht nur die einmalige Flößbarmachung, sondern eine ständige Flussbettpflege zu betreiben. 


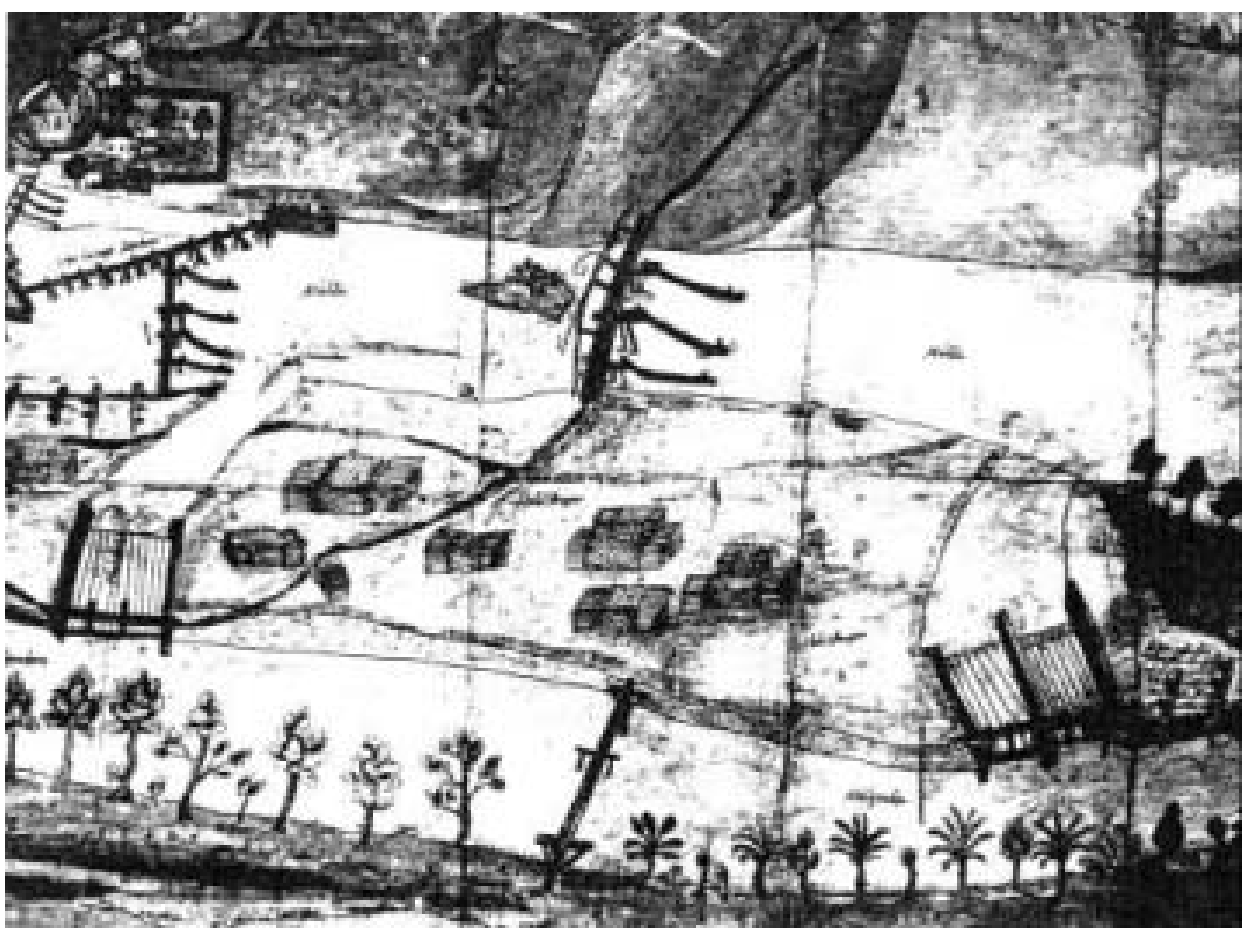

Abb. VI-54: Flößholzrechen, -wehre und Flößbahnen in der Zwickauer Mulde und Malgraben mit Holzanger Ausschnitt zwischen Schedewitz und Zwickau aus einer Bildrolle über die Zwickauer Flöße um 1570 (Stadtarchiv Zwickau, aus: ALTMANN 1999:21)

Des Weiteren sind auch die zur Flößerei früher eingerichteten Wasserbauten im Wesentlichen zugrunde gegangen. Dazu gehörten die Befestigung der Ufer mit Faschinen und Buhnen sowie der Wehrbau. So wurden bei Oker und Radau zusätzlich Wehre eingebaut, um das nötige Zuschusswasser für die Flöße zur Verfügung zu haben (SEEDORF/MEYER 1996:627).

Wehre waren für die Flößerei vor allem auf sehr kleinen und mittleren Flüssen unabdingbar. Immer dann, wenn das Flussbett nicht auf eine andere Weise auf genügende Tiefe zu bringen war oder die Fließgeschwindigkeit nicht ausreichte, mussten solche Anlagen errichtet werden.

Ein Blatt mit Schleusenentwürfen von Hans VREDEMANN DE VRIES ${ }^{47}$ zeigt 7 Schleusenanlagen für gebundene Flöße und einen stattlichen Floßteich. Es handelt sich um Vorschläge für Flüsse im Herrschaftsgebiet des Herzogs Julius, die nicht nur Aufschluss über die Konstruktion von Stauschleusen der Zeit geben, sondern auch über die Eingriffe in ein kleineres Gewässersystem zu Zwecken des Holztransportes informieren (die Auswertung des Skizzenblattes hinsichtlich des Floßteiches erfolgt in Pkt. VII 5.t ,Flößerteich').

\footnotetext{
${ }^{47}$ VREDEMANN DE VRIES: Nachfolger DE RAETS am Hof in Wolfenbüttel, arbeitete für Herzog Julius von 1587 bis zu dessen Tod 1589. Es gibt insgesamt 13 Entwürfe von ihm aus dem Jahre 1587; das hier betreffende Blatt trägt die Nr. 11. Die Flussskizzen sind wenig detailliert und bieten nur eine übergreifende Vorstellung von der Gestaltung eines Flussabschnittes. Es hat auch nicht die Funktion einer Bauvorlage, sondern die Zeichnung gibt eine Vorstellung davon, wie eine solche Schleuse funktioniert und aussieht.
} 


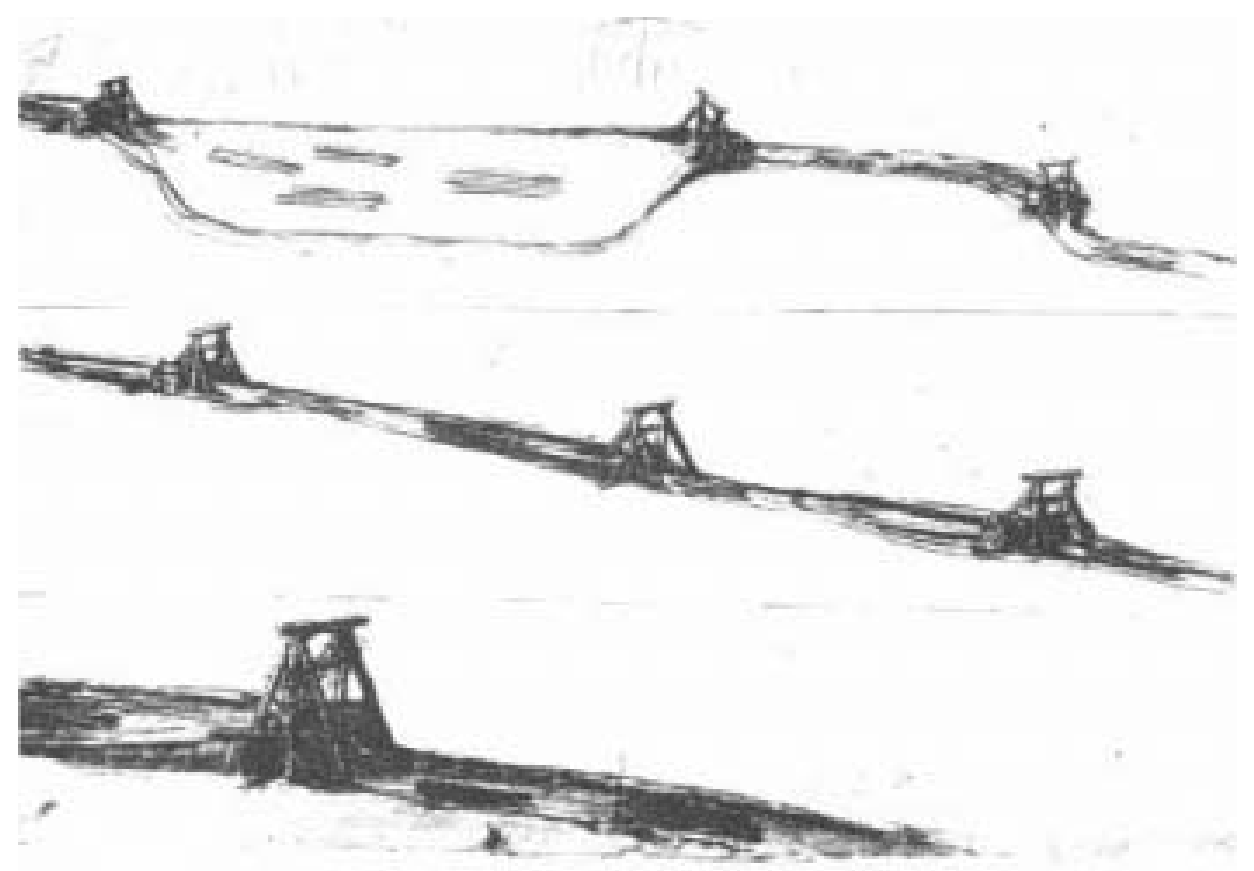

Abb. VI-55: Skizze von Stauschleusen bzw. Wehren in einem Flusslauf mit Floßteich (BORGER-KEWELOH/KEWELOH 1991:64 vermuten die Ecker). Johann Vredemann de VRIES. Aqu. Federzeichnung, 1587 (Nieders. Staatsarchiv Wolfenbüttel) (Druck in eig. Bestand)

Aus der Zeichnung ist ersichtlich, dass in einem Flusslauf, der hier in drei Teilstücken übereinander gezeichnet ist und als Verlängerung des jeweils anderen gedacht ist, zum Zwecke der Holzflößerei zahlreiche Wehre und Stauschleusen eingebaut worden sind. Auf der anderen Blattseite ist eine der Anlagen [zbd] vergrößert detailliert dargestellt: Ein Schott zwischen zwei hohen Balken schließt das Wehr, das über eine radförmige Kurbel betätigt wird. Die Anlage erlaubt, das Wehr direkt, nachdem das Floß passiert hat, wieder zu schließen, ohne unbedingt das ganze Wasser ablaufen zu lassen. Bei einer solchen Anlage sprach man auch von einer „Floßstraße“(JÄGERSCHMID 1828).

\section{f.2 Triften}

„Flößbar ist der kleinste Fluß“ (BORGER-KEWELOH/KEWELOH 1991:52). Wer heute in der Landschaft Flüsse und Bäche sieht, für die Flößerei überliefert ist, wird diese Aussage bestätigen, aber gleichzeitig die schmalen Bäche und Flüsse unglaubwürdig ansehen und fragen: Sollen diese wirklich zum Holztransport gedient haben?

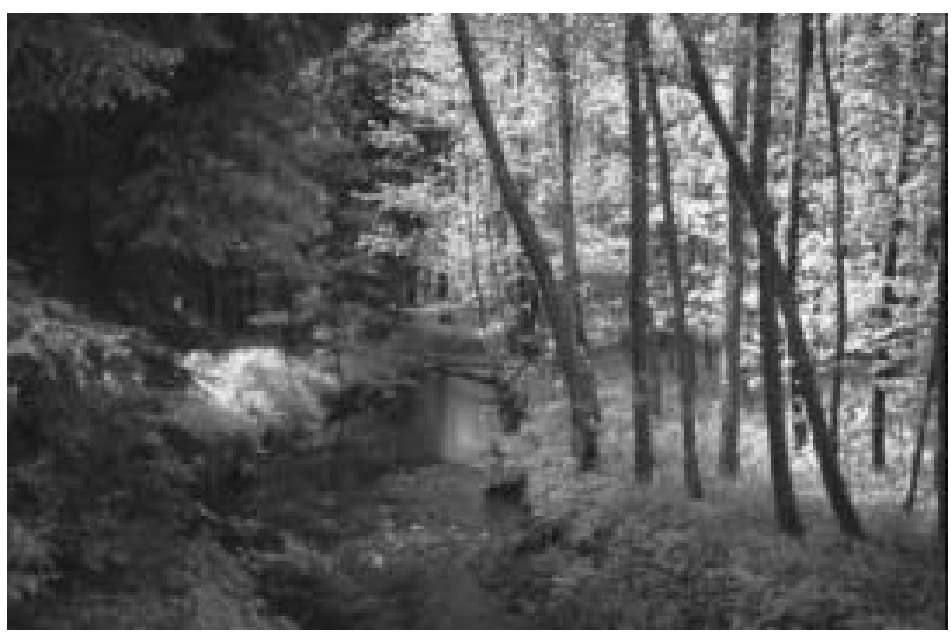

Abb. VI-56: Triftbach im Solling, von zwei aufgestauten Flößteichen in seiner Wasserkraft unterstützt

Bei der Betrachtung des heutigen kleinen und verwilderten Flussbettes der Ilme lässt sich nicht mehr erahnen, das hier bis Mitte des 19. Jahrhunderts gespaltenes Holz („Scheitholz) bis zur Leine getrift worden ist (eig. Aufnahme 1999). 
Doch gerade diese kleinen Gewässerläufe stehen in einem unmittelbaren Zusammenhang mit der Vorsorgung von höfischen und klerikalen Haushalten sowie vor allem der gewerblichen und vorindustriellen Tätigkeit und des wirtschaftlichen Wachstums.

Grundvoraussetzung für die notwendigen technischen Prozesse zur Gewinnung des Metalls war der Brennstoff. Dieser mußte in Form von Holz und der daraus gewonnenen Holzkohle zur Verfügung gestellt werden. Unzählige Platzmeiler, auf denen seit dem 12./13. Jahrhundert die Kohlemeiler errichtet wurden, waren in allen Mittelgebirgen wie beispielsweise im Harz vorhanden (KLAPPAUF 2000:17). Die große Zunft der Köhler lebte davon, die Schmelzhütten mit dem wichtigen Energieträger zu versorgen. Holz diente für die Erzhütten als Energieträger für den Spaltungsprozess, d. h. zur Zerkleinerung und Erhitzung (Röstung) des Erzes, um die dadurch bewirkte Trennung reines Silber oder und Blei zu gewinnen (Entsilberung). Die Holzkohle blieb Energielieferant für den Verhüttungsprozess bis zur Einführung des Steinkohlenkokses Mitte des 19. Jahrhunderts (LIESSMANN 1997:101).

Das Erz musste, falls es nicht auf der Lagerstätte verhüttet werden sollte, zu den entsprechenden Schmelzhütten gebracht werden. Bepackte Menschen, möglichst aber Trag- und Zugtiere bewegten sich auf den Erzabfuhrwegen, den Hohlwegen, auf und ab (KLAPPAUF 2000:17). Die zum Betrieb der Hütten notwendige Holzkohle wurde aber nur zum Teil in den umliegenden Wäldern von freien Köhlern hergestellt und in Fuderkörben auf dem Landwege angeliefert. Daneben wurden Scheithölzer auf den Hochwasserwellen zu den Hütten geflößt (BÖTTCHER 2000). Obgleich es davon auch Ausnahmen gab: Weil im Mansfelder Land im ausgehenden Mittelalter nicht mehr genug Holz zur Verarbeitung des Erzes zur Kupfergewinnung zur Verfügung stand, „transportierte man das Erz [...] auf der Saale flußaufwärts bis in den Thüringer Wald." (KÜSTER 1998:158) Man transportierte also kosten- und zeitaufwendig das Erz zum Brennstoff. Die Regel lautete jedoch wie gesagt anders: Der Brennstoff, das Holz, wurde zu den Verhüttungs- und anderen Verarbeitungsstätten geflößt.

Riesige Waldflächen wurden zur Gewinnung von Holzkohle für die Verhüttung und von Grubenholz für die Bergwerke abgeholzt, denn ,die mittelalterlichen Hütten des Harzraumes sowie der Bergbau entfalteten einen gewaltigen Holzbedarf. Man fand bei der frühneuzeitlichen Wiederaufnahme von Gruben, daß im Mittelalter selbst Haselstämmchen, Weiden und Birken für den Grubenausbau benutzt wurden“ (BARTELS 2000:40). Dies führte bald auch im Vorland der Gebirge zu umfangreichen Rodungen. „Die Wälder in den Bergbaurevieren waren bis zur Einführung einer geordneten Forstwirtschaft seit Anfang des 18. Jh. gebietsund zeitweise baumleer.“(LIESSMANN 1997:101)

Für den Transport von Rüstholz der Bergzimmerleute und für das Brennholz der Hütten- und Siedefeuer allein bedurfte es also riesiger Rohstoffmengen (MÜLLER/LUDWIG 1982:160), die herbeigeschafft werden mussten.

Allein das Holz für die Grubenfeuer, das Abbrennen von Brennholz in der Tiefe des Berges, verschlang enorme Mengen. Nach einer Regel durfte der Bergbau nie erkalten, damit auch zukünftige Generationen noch Erze gewinnen konnten. Die Hitze der Feuer verstärkte die Bildung von „Vitriolen“, die, auf Klüften und Spalten ausgeschieden, die Wasserzuflüsse verminderten und gebräches Gebirge wieder verfestigten. „Erst als 1876 nach Einführung des maschinellen Bohrens und der Verwendung brisanterer Sprengmittel eine effektivere Erzgewinnung möglich wurde, konnte auf das mittelalterliche Feuersetzen ganz verzichtet werden." (LIESSMANN 1997:115) Der Vorteil war, dies nebenbei bemerkt, dass der ganze Berg durch das fortwährende Abbrennen der Holzfeuer angenehm warm und hinreichend gut bewettert war, so dass das Schlafen in der Grube bei Bergleuten, diese Regelung bestand bis nach etwa 1830, nicht unangenehm war (:118). 


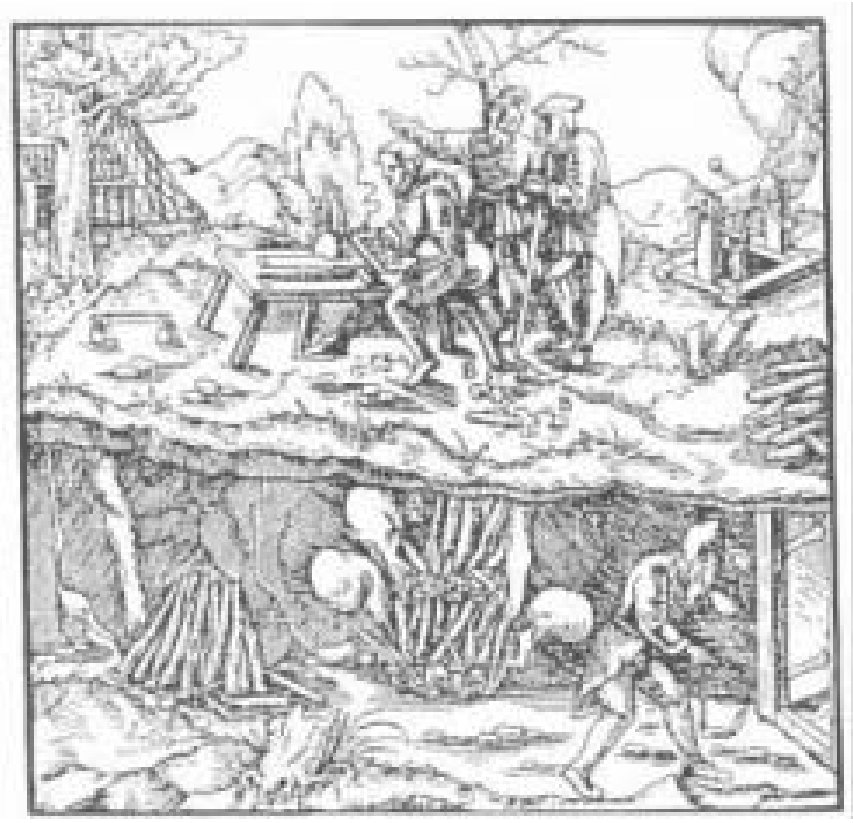

Abb. VI-57: Darstellung des Feuersetzens in einem Holzschnitt aus AGRICOLA (1556) (aus: LIESSMANN 1997:57)

Um 1700 wird von einem akuten Holzmangel in der Montanwirtschaft ausgegangen. Der Verbrauch an Brennholz war aber auch in anderen Sektoren außerordentlich hoch: Wahre „Holzfresser“ waren die Glashütten, die für die Glasherstellung Pottasche als Katalysator brauchten, Hammerwerke, die für die Anheizphase des Hochhofens Floß- bzw. Triftholz (Scheitholz) als Feuerungsholz benötigten (ALTMANN 1999:51), und auch die Salinenkoten, in denen mit Holzbefeuerung zur Gewinnung von Salz das Salzsieden in großen Sudpfannen durchgeführt worden ist. Und davon gab es bis um die 20. Jahrhundertwende zahlreiche in allen Salzstädten wie Salzdahlum bei Wolfenbüttel, Salzhemmendorf, Lüneburg, Salzungen, Sooden usw. Allein in Sooden an der Werra gab es 55 kleine Koten, die Holz zur Salzsiedung benötigten.

Darüber hinaus war der Bedarf für das wichtige holzverarbeitende Gewerbe stark: Wagenmacher, Schreiner und Fassmacher, sog. Böttcher, benötigten geeignetes Stabholz. „Ohne die aus gutem Eichenholz, dem sogenannten Stabholz, gefertigten Fässer war im Mittelalter kein Handel zu betreiben. Die Fässer waren, vergleichbar den heutigen Containern, das allseits benutzte Verpackungsmittel, welches den Fernhandel überhaupt erst möglich machte." (STELTMANN 1995:210) Nicht nur Holz zur Herstellung von Bottichen aller Art, wie beispielsweise Färbebottiche, Fisch- und Salzfässer, ,,ausgepichte Holzfässer als Lager- und Transportbehältnisse für Bier“ (ALTMANN 1999:116) und Wein, sondern auch die Fördergefäße des mittelalterlichen und frühneuzeitlichen Vertikalbergbaus waren hölzerne Tonnen, die gefüllt etwa 230 - 280 $\mathrm{kg}$ wogen und über Ketten- oder dicke Hanfseile hinaufgezogen wurden (LIESSMANN 1997:73). Holzfässer wurden erst nach und nach zu Beginn des ausgehenden 18. Jahrhunderts und vor allem im 19. Jahrhundert von Weißblechfässern abgelöst (ALTMANN 1999:77f.) und finden in einigen Bereichen, wie der Weinkelterei und der Bierabfüllung, teilweise noch heute Verwendung.

Des Weiteren galt es die Brennholzversorgung der Städte sicherzustellen. Im 16. Jahrhundert begann mit der anwachsenden Bevölkerung ein hoher, ständig steigender Bedarf an Feuerholz und Holzkohlen (ALTMANN 1999:18).

Die Wälder der Umgebung müssen schon im 16. Jahrhundert stark abgeholzt gewesen sein und Stürme und Borkenkäferbefall (LIESSMANN 1997:118) die dezimierten Bestände weiterhin in einem Ausmaß geschädigt haben, dass zu diesem Zeitpunkt mit der Trift ein großer Teil des Brenn- und Stabholzes von weiter entfernten Wäldern transportiert werden mußte.

Die Holzflößerei von kleinen Stämmen, auch „Holztreiben“, „Wildholzflößerei“ oder „ungebundene Flößerei“ genannt, aber zumeist als „Holztrift“ bezeichnet, war auf allen größeren und sogar auf vielen kleinen Gebirgsbächen und -flüssen zur Flößzeit eingerichtet (DENZER 1996:203; SCHMIDT 1997:202; 
ALTMANN 1999:20). Holz wurde auf den kleinen Bachstrecken beispielsweise getriftet, um die Salinen im Salzburger Land mit Holz $\mathrm{zu}$ versorgen. Ganze Netze von Triftstrecken entstanden in den Salzgewinnungsgebieten im bayerischen und salzburgischen Alpenvorland. Auf der salzburgischen Traun beispielsweise wurde Holz zu den unterhalb liegenden Salinen gebracht. Die Reichenhaller Saline wurde von der Saalach beliefert (vgl. KÜSTER 1998:158).

Vor allem auf den Nebenflüssen und kleinen Hauptflüssen des Berglandes und des Mittelgebirges war das Treiben von Kurzstämmen verbreitet (STELTMANN 1995:211), während das nördliche Deutschland kaum in Betracht gezogen wurde, weil die geforderte Fließdynamik unzureichend war.

Auf der oberen und mittleren Werra und ihrer Nebenflüsse Schleuse, Rosa, Schmalkalde und Druse wurde nachweislich seit der 2. Hälfte des 16. Jahrhunderts Brennholz vor allem aus dem Thüringer Wald getriftet. Diese Trift wurde zur Sicherung des Brennholzbedarfes der Salinen in Salzungen und Sooden-Allendorf eingerichtet (STELTMANN 1995:211; KÜSTER 1998:158).

Der Brennholzversorgung der Kasseler Residenz diente seit dem 16. Jahrhundert die Scheitholzflößerei auf der Fulda, die das Holz aus den an der Fulda gelegenen Waldungen heranschaffte (STELTMANN 1995:211). Seit dem 17. Jahrhundert wurde Holz auf verschiedenen Gewässerläufen des waldreichen Sollings zur Versorgung des Hofes nach Hannover geflößt: auf Ilme (siehe auch Abb. VI-56), Leine und seit Anfang des 18. Jahrhunderts auf der Diesse (BORGER-KEWELOH/KEWELOH 1991:20). Der Brennholztransport führte unter anderem zum Lustschlossbau Herrenhausen und dem kurfürstlicher Tiergarten in Linsburg. Auf der Leine wurde auch Brennholz von Friedland nach Göttingen gebracht (:24). Darüber hinaus wurde auf den Bächen Hasselbach, Rottmünde und Reiherbach zu wasserreichen Frühjahrszeiten, überreifes Birkenholz und unfruchtbare alte Hölzer zur Weser oder zur Leine geflößt. Einem gutachterlichen Bericht von REINHARD, dem Geschichtsschreiber der Dasseler Grafen, aus dem Jahre 1588 zufolge sollte auch das an der Toppenbeck (1603: „Teppkenborn“), einem Nebenfluss der Ahle, und dem Höxterbrunn (1603: „Hoxerscher Born“) befindliche Holz zur Weser geflößt und dort gestapelt werden. „Die Wasserläufe hält Reinhold [sic] für ausreichend zu diesem Zweck“, schreibt WEISE (1989:81), dem ich die historische Notiz und Bewertung entnommen habe. „Für die Ahle empfiehlt er jedoch, sie vor der Mündung in die Schwülme, weil diese Grenzfluß gegen Hessen ist, durch einen Kanal auf braunschweigischem Gebiet unmittelbar in die Weser zu leiten, wo sie mit einer Ableitung des Reiherbaches zusammentreffen könnte.“ (:81) Zur Ausführung ist dieser Vorschlag hingegen wohl nicht gekommen (:81).

In der Umgebung von Merseburg entstanden im 16. Jahrhundert ebenfalls zahlreiche Salinen, zum Beispiel in Bad Dürrenberg sowie an anderen Orten Saiger-, Eisen- und Alaunhütten, die Holz als Energiequelle benötigten. Dieses Brennholz wurde mit Hilfe der Scheitholzflößerei aus den Saalenebenflüssen des Fichtelgebirges und des Thüringer Waldes auf der Saale selbst zu den Orten des Verbrauchers transportiert. Diese Form wird für die Saale erstmalig 1572 erwähnt (SCHUBERT 2001:28).

Brennholztrift gab es auch auf der Ecker, Innerste, Oker, Radau und zahlreichen weiteren kleinen Bächen, die die Versorgung der Hütten und Bergwerke im Harz, vor allem des Rammelsberges übernahmen.

Bei der Eisenhütte Altenbrak im Harz zum Beispiel befand sich auf dem gegenüber dem Hüttenplatz liegenden Ufer der Bode der Flößplatz, der teilweise überschüttet ist und heute als Freizeitgelände genutzt wird. Daneben wurden Reidel- und Scheithölzer, also mittlere Rundhölzer bzw. gespaltene Stämme, auf den Hochwasserwellen nach Altenbrak geflößt, wo das Holz mit einem quer in der Bode stehenden Harken aufgefangen und auf dem Flößanger (vgl. auch Abb. VI-54 und VI-58) und der Umgrabenwiese neben der Bode von hütteneigenen Köhlern in aufgesetzten Meilern verkohlt wurde. Eine Besonderheit war der angelegte Flößgraben, der mit einer Schleuse versehen neben dem Harken in der Bode abzweigte. Vom Bode-Harken konnte so das Holz über die Schleuse in den Flößgraben geleitet werden, wo es sich wiederum vor einem Harken kurz vor der Einmündung in die Bode sammelte (BÖTTCHER 2000; JORDAN 2000). 


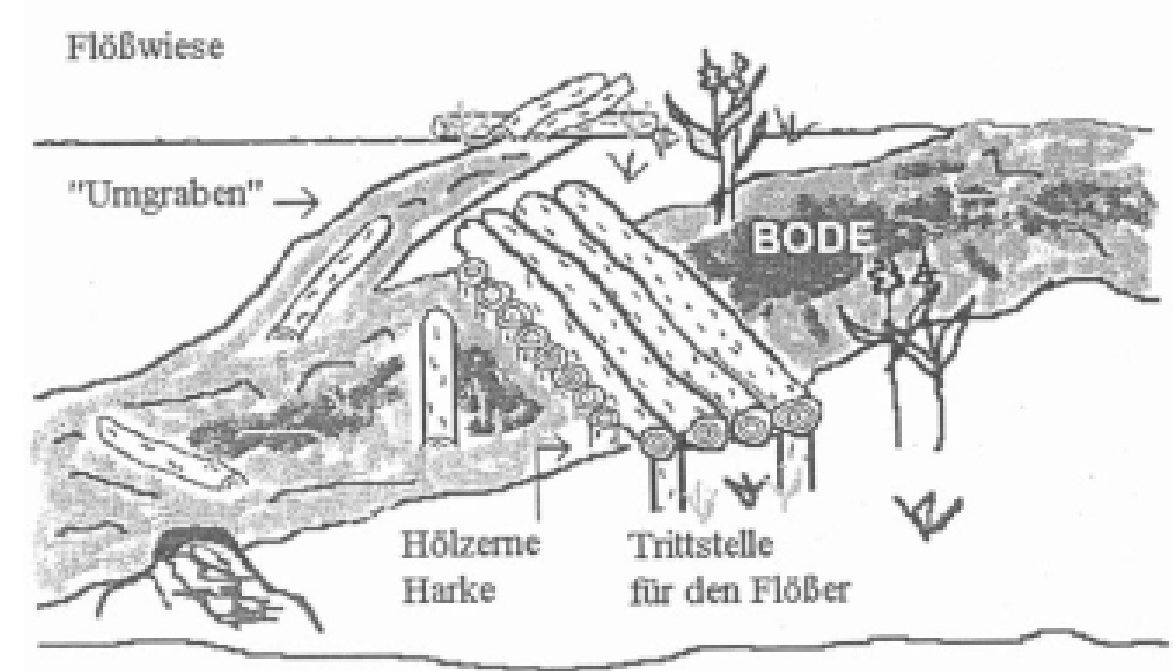

Abb. VI-58: Schematische Darstellung eines Flößplatzes an der Bode mit Flößgraben („Umgraben“) und Palisadensperre („Harke“) (aus: JORDAN 2000:124)

Von Triftflößerei wird auch aus Bayern, vom Frankenwald und aus dem Schwarzwald berichtet. Seit dem Mittelalter wurde in der Region um die Wutach zwischen dem Feldberg und der Stadt Stühlingen das Flößen von Scheitholz betrieben. Einer der größten Abnehmer war das Eisenschmelzwerk in Eberfingen. Alle der Wutach zufließenden Bäche waren aufgrund des enormen Energiebedarfes früher flößbar gemacht worden: Stauweiher, Wehre, Stellfallen mussten angelegt und Begradigungen geschaffen werden. Durch den Ausbau des Krähenbaches bis zum Klosterwald (Friedenweiler) wurden immense Holzmengen erschlossen. Mittels Holzriesen und sogar Schlitten wurde es zur Wutach transportiert. Tiroler Holzfäller, die über große Erfahrungen verfügten, siedelten sich deshalb in der Region an. Um 1750 waren fast alle erreichbaren Waldungen bis einschließlich des Feldberges kahlgeschlagen. Eine allgemeine Holznot war die Folge. Holz wurde insbesondere vom Fürstlich Fürstenberger Hof in Donaueschingen benötigt: für die Fürstenberger Residenz, die Brauerei, die Ziegelhütte und die Gebäude der Bediensteten.

Auch für den Neumagen und die Möhlin lässt sich Scheitholzflößerei nachweisen. Auf der Neumagen wurde zwischen 1708 und 1748 geflößt, Belege für die Scheitholzflößerei auf der Möhlin fallen in das Jahr 1716. Anfangs wurde auf dem Neumagen Brennholz zum Staufener Eisenwerk transportiert. Im Jahr 1734 wurden die Möhlin und der Neumagen für die Versorgung der Festung Breisach mit Brenn- und Bauholz zum landesfürstlichen Holzfloßkanal ausgebaut. Zwischen 1734 und 1744 betrieben die Gebrüder Litschgi aus Krozingen im Auftrag der vorderösterreichischen Regierung den hoheitlichen Holztransport auf Möhlin und Neumagen. Mittelst Kähner ${ }^{48}$ und Holzrießen ${ }^{49}$ wurde das Brennholz aus dem Grindenwald über die Wiesen des Klosters Neumagen und des Klostermüllers verbracht. Im Bachbett der Möhlin wurde das Holz bis Ehrenstetten getriftet. Ab hier transportierte man es im Floßkanal bis Breisach (THIEM 2004).

Die Kunst des Flößens, im Sinne der Scheiterholztrift wurde auch auf der Ettlinger Alb betrieben. Die Alb, wie sie auch in Kurzform bezeichnet wird, entspringt etwa $4 \mathrm{~km}$ südlich von Herrenalb, ist rund $52 \mathrm{~km}$ lang und mündet bei Neurat in den Rhein. Die älteste bekannte Urkunde von 1440 über die Alb-Flößerei bezieht sich auf das zollfreie Flößen des Klosters Frauenalb (SCHEIFELE 1993:37). Es ist aber zu vermuten, dass schon vor 1440 zumindest Versuche mit dem Flößen auf der Alb gemacht wurden, um die Brennholzversorgung der Stadt Ettlingen sicherzustellen (:38f.). Nach dem Dreißigjährigen Krieg gab es gar Überlegungen, neben der Murg auch die Alb für die Langholzflößerei herzurichten, um Bauholz für den Wiederaufbau der Stadt Ettlingen beizuflößen, aber auch um Langholz und Sägwaren auf der Alb zum Rhein und dann nach Holland zu verflößen (:44).

\footnotetext{
${ }^{48}$ Die Kähner waren in der Regel holzgefertigte und von Wasser durchflossene Kanäle; Dieser Begriff wird auch für Holzkanäle gebraucht, die das aus dem Obergraben kommende Wasser auf das oberschlächtige Rad einer Wassermühle geleitetet haben.

${ }^{49}$ Holzrießen bzw. Holzriesen waren Rinnen zum Holzrücken, eigens für die (winterlichen) Holzverbringung von Berg zu Tal gebaute „Rutschen“, in denen die geernteten Baumstämme zu Tal glitten, in der Regel zum Sägewerk.
} 
Auf der Isar wurde die kurzen Stämme nach München geflößt, von wo aus von den aus vier Bachsystemen bestehenden Münchner Stadtbächen einer der Triftkanal war: „Beim Triftkanal handelt es sich um ein von den inneren und äußeren Bächen weitgehend unabhängiges Bachsystem, das zur Holztrift benutzt wurde. Erst im 19. Jahrhundert arbeitete an einem Ausläufer des Triftkanals eine Getreidemühle“ (KOHL 1970:9).

In der Oberpfalz, auf der Naab und ihren Nebenflüssen betrieb man die Triftflößerei, wenn auch nicht so intensiv wie anderswo, ,so daß die Wälder der Oberpfalz offenbar noch nicht so stark geplündert waren wie die anderer Gebiete.“ (KÜSTER 1998:158)

1840 wurde auch die Lieser zum Holzflößen benutzt. Sie entspringt oberhalb Beinhausen und mündet nach ca. $70 \mathrm{~km}$ Lauf bei dem gleichnamigen Ort in die Mosel (MERTES 1995:132).

Zur Zeit der Wende vom 16. zum 17. Jahrhundert stieg auch der Brennholzbedarf des Mainzer Hofes. Es ging deshalb darum, Buchen- und Eichenbrennholz sowie Birkenscheitholz zu den herrschaftlichen Holzhöfen an den Main zu flößen (DENZER 1996:213). Mangels Erschließung des Spessarts durch ein ausreichendes Netz von Verkehrswegen wurden vornehmlich die Spessartbäche zum Triften des Holzes bis an den Main ausgebaut. Die Holztrift, deren Stämme eine Länge von $90-120 \mathrm{~cm}$ hatten, wurde, wie DENZER (:204) nachweist, ,auf fast allen Spessartbächen betrieben“. Nur von wenigen Bachläufen (Zinserbach, Rechtenbach und Faulbach) fehlen entsprechende Hinweise. Von dort ging dann der Transport auf Flößen und Kähnen weiter zu Untermain und Rhein (:203).

Auch von den kleinen Flüssen des Westerzgebirges ist seit Mitte des 16. Jahrhundert der Floßbetrieb von Scheitholz bekannt (ALTMANN 1999:20): Zwei große Holzflöße wurden durch das kurfürstliche Amt Schwarzenberg eingerichtet: die „Schwarzwasserflöße“ und die „Zwickauer Muldenflöße“. Im Jahre 1533 erwarb der Kurfürst Johann Friedrich der Großzügige die Schönecker Wälder und die Kottenheide. Kurfürst August I. von Sachsen brachte 1563 - 1582 die Wälder derer von Planitz und die Ellefelder Wälder in seinen Besitz. Zur besseren Vermarktung des Holzes und um den Abtransport des Holzes weniger umständlich und schneller zu gestalten, begann man 1579 mit dem Bau von Floßgräben (,obere“ und ,untere Floßgräben“, „Kielfloßgraben“, der im ersten Drittel des 17. Jahrhunderts weitgehend beendet worden ist. Der ,untere Floßgraben", heute zum technischen Denkmal erklärt, hatte eine Gesamtlänge von 850 Schnur, das entspricht ca. 7,15 km. Sein Damm mit einem auf ihm verlaufenden Weg ist in voller Länge erhalten. Wasser führt der Graben aber nur noch vom Ausgleichsbecken der Muldenberger Talsperre bis zum ehemaligen Sägewerk Leonhardt in Hammerbrücke. Vermessung und Bau des Grabens wird auch heute noch als Meisterleistung angesehen, da das Gefälle auf der gesamten Strecke nur sechs Meter beträgt. Nach alten Dokumenten wurden von 1633 bis 1635 jährlich 2000 Klafter Kurz- bzw. Scheitholz mit einem Gewinn von 6000 Gulden in das Elster- und Saaletal geflößt. Hauptabnehmer des Brennholzes waren hier Salinen und zahlreiche Städte, wie Zeitz, Pegau, Leipzig und vor allem Halle, zu denen ständige Lieferkontakte bestanden. Die straff organisierte Flößerei auf diesen Gräben wurde über 280 Jahre lang äußerst gewinnbringend für die sächsischen Kurfürsten betrieben, während die harte Arbeit der Muldenberger Flößer, die zum Teil als Frondienst ausgeübt werden musste, nur spärlich belohnt blieb.

Weitere kleine Holzflöße gab es im 16. Jahrhundert auf der Großen und Kleinen Mipe und im 17. Jahrhundert auf dem Pöhlbach, um die zahlreichen Hammer- und Eisenhütten im unteren Tal in Mittweida und Raschau, sowie den Floßanger in Grünstädtel zu versorgen (ALTMANN 1999:22). Auf der Zwickauer Mulde und ihren zuführenden Bachläufen wurde Feuerungsholz nach Zwickau geflößt (:23). In den sächsischen Bergbaugebieten wurde zudem 1556 - 1659 der 15 km lange Floßgraben von Albernau über Aue nach Schlema zur Versorgung der Schneeberger Hütten gebaut (CZAYA 1990:37).

Der Transport von zu Flößen verbundenen Holzstämmen war auch in Österreich bis in das 19. Jahrhundert üblich. Auf der Donau und ihren Nebenflüssen wurden damit Salz und Eisen transportiert, die Flöße wurden nach der Ankunft zerteilt und als Nutzholz verkauft. Holzflößerei war auch hier auf kleineren Flüssen und Bächen, die zu diesem Zweck durch Klausen gestaut wurden, üblich. Im 18. und 19. Jahrhundert wurde damit die Versorgung von Wien mit Nutz- und Brennholz gesichert. Nach dem Bau der Eisenbahnen wurde die Flößerei aufgegeben. 
So bestand am Ausgang des 17. Jahrhundert ein relativ dichtes, kleines Wasserstraßen- und -wegenetz in den mittelhohen und hohen Gebirgsräumen. Hansjörg KÜSTER (1998:152) spricht deshalb auch von regelrechten „Triftnetzen“.

Doch von Natur aus war kaum ein Bach triftfähig. Für Langholz- oder Rundholzflößerei waren die natürlichen Flussbedingungen ungünstig und bedurften einer teils massiven Anpasssung (siehe Pkt. f.1), aber auch für den Transport kleiner Stämme mussten die Bedingungen erst einmal geschaffen werden. Durch das Scheitholzflößen erfuhren die kleinen Bachläufe massive Eingriffe und Umgestaltungen.

Anfangs wurde das Flussbett von störenden Sanden und Steinen befreit, die beispielsweise von Bergstürzen entlang der in das Tal eingeschnittenen Steilhänge stammten (SCHUBERT 2001:28). Das geschah zum Teil bereits im 16. Jahrhundert (WILSDORF 1979:32). Weil Knappheit an Heizmaterial aber erst später auftrat als Knappheit an Bauholz, „begann die massenhafte Trift erst später als die Flößerei, nämlich erst zur Zeit des größten Holzmangels, im 18. Jahrhundert“ (KÜSTER 1998:153). Man machte die ,alten“ Bäche und Flüsse triftbar, auf denen man nicht mit Flößen fuhr (:153). Sie alle mussten durch Beräumen von Gesteinsbrocken, durch Beseitigung von Wildgehölzen im Uferbereich, durch Ausgrabung und Vertiefung von seichten Stellen, durch Begradigung und Verbreiterung (SCHEIFELE 1993:75) sowie durch Befestigung der Flussufer mit Sandsteinblöcken zum Erosionsschutz floßfähig gemacht werden. Insbesondere der Bau von Wasserstauungen, sog. „Schwellen“ oder „Wasserstuben“, gehörten zur Anlage eines Triftbaches hinzu (siehe Pkt. VII 5.t ,Flößerteich'). Sie dienten dem sicheren Transport des Scheitholzes (DENZER 1996:204) bzw. machten die Holztrift trotz des gefährlichen menschlichen Rückeeinsatzes (siehe unten) überhaupt erst möglich. Des Weiteren wurde längs der Bäche „Flößerpfade“ angelegt, die aber nur einen Schug $(30 \mathrm{~cm})$ breit sein durften, zudem waren die Flößer verpflichtet, hintereinander zu gehen. (SCHEIFELE 1993:81)

Der Bedarf an Bau- und Brennholz stieg bis in die zweite Hälfte des 19. Jahrhunderts stetig an, so dass größere Flussumgestaltungen wie die Beseitigung scharfer Krümmen, der Durchstich von Flusskrümmungen oder die Sprengung störender im Flussbett liegender Felsen notwendig erschien. Häufig wurde sogar die Bachsohle gepflastert, um einen sicheren Weg der Trifthölzer zu ermöglichen. Sohlstellen aus Stein und Holz bremsten die Strömungsgeschwindigkeit. Des Weiteren mussten die Ufer durch Mauern und mächtige Holzbohlen verschalt werden, damit die Flöße daran entlang gleiten konnten, sowie durch den Einbau von Gleitbühnen über Wasserstürze und Blockgerölle und den Bau von Abweisschwimmern vor Mühlgräben für die Passage von Flößen hergerichtet werden. Zum Teil wurden auch noch zu Beginn des 20. Jahrhunderts ganze Flussläufe zur besseren Funktion der Flößerei verlegt, wie der Lauf der Rodach in Wallenfeld im Frankenwald (HOHL 1921, aus: SCHUBERT 2001:27; KÜSTER 1998:144f.; GUNZELMANN 1999:5; FLÖßERMUSEUM UNTERRODACH/ BAYERISCHES LANDESAMT FÜR DENKMALPFLEGE 1999).

Die Flößerei beeinflusste somit die Gewässerlandschaft nachhaltig. Die Bäche und kleinen Flüsse wurden entsprechend den Bedürfnissen der Flößerei umgestaltet. Für die Floßfahrt aus dem Gebirge mussten die Wasserwege im Bergland erschlossen werden. Große Waldgebiete waren durch ein relativ dichtes Wasserstraßennetz aufgeschlossen (BORGER-KEWELOH/KEWELOH 1991:17). Die noch nahezu ungestalteten Bäche und Flüsse konnten dabei nur unter großen Mühen flößbar gemacht werden. Das Wasser im Schwarzwald beispielsweise fließt mit sehr hoher Geschwindigkeit in engen, tief eingeschnittenen Tälern zum niedrig liegenden Rhein (KÜSTER 1998:144). Doch „erst in der frühen Neuzeit gelang es, aus diesen Wildbächen flößbare Gewässer zu machen“ (:145), die der Landschaft ein eigenes Gesicht verliehen: „Eine Kulturlandschaft der Flößerei ist eine Landschaft der menschlichen Eingriffe in das Flusssystem, die bis hin zum kanalartig ausgebauten Flussbett reichen." (GUNZELMANN 1999a)

Die Flößbarmachung der Flüsse erforderte zudem den wiederkehrenden Einsatz: In jedem Jahr musste der einmal kanalisierte Weg wieder ausgebessert werden, denn die Trift führte zu zahlreichen Beschädigungen des nunmehr kanalisierten Wasserweges, und auch Hochwasser und Eisgang hinterließen ihre Spuren (KÜSTER 1998:145).

Für die Ausbesserungs- und Reparaturarbeiten standen die Zeiträume zur Verfügung, in denen nicht geflößt wurde, denn die Bergflößerei war an jahreszeitlich bedingte Floßzeiten gebunden: Bei Eisgang im Winter verbot sich die Flößerei einerseits wegen der Gefahr des Festfrierens. Im Dezember, Januar und Februar wurde deshalb im Allgemeinen nicht geflößt (SCHEIFELE 1993:81). Andererseits war für die Trift ein 
Wasserstand von $60-100 \mathrm{~cm}$ nötig. Bei kleinen Gewässern konnte das Hochwasser der ersten Schneeschmelze im Frühling die normalerweise mangelnde Wassertiefe oft ausgleichen. Aus den gleichen Gründen nutzte man auch die sog. Herbstzeitflut in den Herbstmonaten (ALTMANN 1999:20).

Aber auch die Wiesenbewässerung regulierte die Triftzeiten. Geflößt werden durfte im Frühjahr nicht länger als bis zum 1. April und dann wieder im Herbst, aber erst nach der Öhmdzeit bis Mitte Oktober (SCHEIFELE 1993:81).

Doch zuvor musste im Winter das Holz zu den Einwurf- oder Bindestellen gebracht werden, um rechtzeitig bereit zu liegen. Das Triftholz wurde in der Regel bereits ein Jahr, bevor es auf die Reise geschickt wurde, gefällt. Zum Flößen bestimmtes Holz musste möglichst vor dem Frühling, auf jeden Fall vor dem Sommer und am besten in den Wintermonaten, geschlagen werden, damit es austrocknet und gut flößt, denn trockenes Holz ist schwimmfähiger als das noch im Saft stehende (ALTMANN 1999:20).

Bereits am Fällort oder am Stapelplatz wurden die Baumstämme floßgerecht zu kürzeren Enden in Längen von $1-3$ m geschnitten. Und weil auf den schmalen Bachläufen aus den inneren Mittelgebirgen nur das entastete Scheitholz getriftet werden konnte, wurde dieser Arbeitsvorgang bereits auch im Wald erledigt (MÜLLER/LUDWIG 1982:160).

Dennoch gestaltete sich der Transport der bereits vor Ort zugehauenen und entasteten Scheithölzer zu den Einwurfplätzen an den Triftwässern besonders bei feuchter Witterung recht schwierig. Er erfolgte zunächst mit Hilfe von Rückepferden bei Einzelstämmen und dann mit den von Pferden oder Ochsen an Schleppgeschirren gezogenen Fuhrwerken (BORGER-KEWELOH/KEWELOH 1991:22; STELTMANN 1995:211; DENZER 1996:214; ALTMANN 1999:20). In Einzelfällen kamen auch Schlitten zum Einsatz, die bei ungünstigem Untergrund auf extra errichteten sog. Schmierbahnen die Holzware zum Schwellplatz bzw. zu den Einwurfstellen rodelten. Sie bestanden aus in den Boden eingelassenen glatten Buchenscheiten, die zum besseren Gleiten mit Talg oder Speck eingerieben wurden (DENZER 1996:214).

Am Lagerplatz wurde das Holz gestapelt (BORGER-KEWELOH/KEWELOH 1991:22). In der folgenden Floßzeit erfolgt dann der Transport auf dem Floßwasser. Es kam darauf an, die günstigsten Wasserverhältnisse gut auszunutzen und das entlang des Flusses massenweise aufgestapelte Holz so rasch wie möglich ins Wasser einzuwerfen ${ }^{50}$ (SCHMIDT 1997:202; ALTMANN 1999:20). Aber auch im Walde bereits grob bearbeitete Holzteile wurden in die Bäche gelegt, damit sie ,in nassen Zeiten talwärts schwimmen konnten“" (SCHMIDT 1997:202). Auf der Ilme im Solling beispielsweise wurde das Holz im März eingeworfen und bis Relliehausen getriftet. „Die zweite Flöße führte dann im April bis Holtensen bei Einbeck, die dritte Flöße auf der Leine konnte noch später erfolgen“ (BORGER-KEWELOH/KEWELOH 1991:53).

Zu späterer Zeit jedoch herrschte Wassermangel. Um das „Holztreiben“ - vor allem auch in wasserärmeren Zeiten - zu ermöglichen, zu erleichtern, zu beschleunigen und zeitlich besser disponierbar zu machen, wurden Einrichtungen gebaut, die kurzfristig ein kleines „Hochwasser“ erzeugen konnten. Diese geschah durch kleine Stauteiche, die mit „Schleusen“ versehen wurden, an denen durch das Herausziehen oder Umlegen von Staubrettern das Wasser schwallartig freigegeben wurde. Hiervon sind nur noch wenige Überreste erhalten, da diese Anlagen zu einem erheblichen Teil aus Holz bestanden haben (siehe auch Pkt. VII 5.t,Flößerteich').

Für große Holztriften wurden „oft weit über hundert Personen, auch Frauen, tageweise rekrutiert“ (SCHMIDT 1997:202), vor allem um das Holz vor dem Festsetzen zu bewahren. Darum waren so viele Helfer geboten (:202; ebenso ALTMANN 1999:20,108). Auf der Ise beispielsweise waren im Jahr 1661 für die Trift von $2035 \mathrm{~m}^{3}$ Holz 112 Flößereihilfskräfte, die sich in der Regel aus Bauern zusammensetzten, beschäftigt (BORGER-KEWELOH/KEWELOH 1991:53).

\footnotetext{
${ }^{50}$ Neben den Bachtriften ließ man in machen Gegenden (Schwarzwald, Bayern) auf Holzrutschen, den sog. Riesen, das Holz aus höheren Berglagen zu den tiefer liegenden Eindebindeplätzen herabgleiten (BORGER-KEWELOH/KEWELOH 1991:28).
} 
Nachdem das Flussbett entsprechend vorbereitet war, damit sich möglichst kein Holz verfangen konnte, „wurden stärkere Wasserführungen (,flößbare Wasser’) abgewartet.“ (SCHMIDT 1997:202)

Überall dort, wo das Triftholz zum Verbrauch oder zum Weitertransport aus dem Wasser herausgeholt werden musste, wurden sog. Fang- oder Holzrechen im Bachbett errichtet. Hier wurde das Holz durch Rechen angehalten und von den Triftarbeitern mit Haken aus dem Wasser gezogen. „Hierzu mußten die Arbeiter oft im eiskalten Wasser stehen." (SCHMIDT 1997:202) Da diese Baulichkeiten immer auch ein Hindernis im Wasser darstellten, zum Beispiel für die Fischerei, wurde ein solcher Rechen oftmals nur bei Bedarf, d. h. zur Triftzeit errichtet und ist als temporäre Einrichtung und nicht als störendes Hindernis im Flussbett verblieben.

Für den Niedergang der Trift jedoch waren diese Hindernisse nicht verantwortlich. Die Gründe dafür sind verschiedene:

Zum einen stellten die voher genannten Flößzeiten ein Problem dar. Im Winter herrschte Eisgang, im Spätfrühjahr und in den Hochsommermonaten führten die kleinen Bäche zu wenig Wasser. Wegen des zu niedrigen Wasserstandes kam die Triftflößerei oftmals zum Erliegen und die geforderten Liefermengen entsprachen deshalb oft nicht der Bestellung (BORGER-KEWELOH/KEWELOH 1991:53). Dieser Wassermangel „lag nicht nur an der Hitze allein. Vielmehr wurde gerade während der Trockenperiode das Flußwasser auch zum Wässern der Wiesen benutzt.“(:55)

Ein weiterer Verlustgrund war ein zu hohes spezifisches Gewicht mancher Holzsorten, das die Schwimmfähigkeit der Stücke beeinträchtigte und sie auf den Grund der Gewässer absinken ließ. Die Senkeigenschaft galt in besonderem Maße für Knüppel- und Stangenholz, das im Gegensatz zum aufgespaltenen Stammholz, dem Scheitholz, langsamer trocknete (BORGER-KEWELOH/KEWELOH 1991:22).

Um die Holzverluste möglichst gering zu halten, mussten neben Floßkommissar und Floßaufsehern auch eine große Zahl von Hilfskräften eingestellt werden, die entlang der Triftstrecke das Holz mit Stangen vom Ufer abzuhalten hatten. Sie mussten auch in einer Nachsuche das auf den Grund abgesunkene Holz auffischen. Auf größeren und breiteren Triftflüssen, wie der Leine, lenkten die Leute von Kähnen aus die Scheite. Dies erforderte eine große Anzahl an Personen, die koordiniert und organisiert werden mussten, was insbesondere bei dem mithelfenden Landvolk ein großes Problem darstellte, und sie mussten dafür auch entlohnt werden, so dass die Trift auch ein kostenträchtiges Unternehmen wurde. Insgesamt betrachtet bedeutete Floßholz jedoch in der Fracht billiges Holz (ALTMANN 1999:20). Im Vergleich zur Langholzflößerei wurde die Holztrift allerdings schon viel eher durch Maschinen ersetzt (BORGERKEWELOH/KEWELOH 1991:9).

Ebenso wie zu wenig war auch zu viel Wasser für die Flößerei problematisch. Hier bestand die Gefahr, dass die Hölzer in der reißenden Strömung abtrieben und die Ufer beschädigten (BORGERKEWELOH/KEWELOH 1991:53). Zudem nahmen die Scheithölzer auf den mittelgroßen Floßstrecken die ganze Flussbreite in Anspruch und behinderten somit die Langholzflößerei, welche zeitweise sogar in den Hintergrund gedrängt wurde (SCHUBERT 2001:28).

Infolge eines Dammbruches 1744 mit verheerenden Zerstörungen wurde das Scheitholzflößen auf der Möhlin eingestellt. Nur auf dem Neumagen wurde noch bis 1748 weiterhin Holztrift betrieben. Ein erneutes Hochwasser im dem Jahr, das viele Grundstücke und Wiesen zerstörte, gab schließlich auch hier Anlass zur Aufgabe (THIEM 2004).

Spätestens 1925 war für die Flößerei auf kleinen Flüssen in den Waldgebieten das Ende gekommen, da sie der industriellen Nutzung der Wasserkraft in diesen Gebieten doch allzu hinderlich war (BORGERKEWELOH/KEWELOH 1991:9). Auf der Elsava im Spessart wurde die Holztrift bereits zu Beginn des 19. Jahrhunderts eingestellt, auf den anderen Spessartbächen erst ca. 30 bis 50 Jahre später (DENZER 1996:204). 
Für die technisch-mechanischen Anlagen des 19. und 20. Jahrhunderts begannen Metalle das Holz als wichtigsten Baustoff abzulösen (ALTMANN 1999:141) und auch der motorisierte Transport ersetzte den Transport auf den Gewässern. Sie beschlossen somit das Ende dieser wald- und gewässerhistorischen Transportform auf kleinen Gewässern.

Der Rückblick soll aber nicht schließen, ohne die Aufmerksamkeit auf einen Aspekt zu lenken, der bislang noch nicht in der Literatur diskutiert worden ist: Die historisch-klimatologische Frage, ob nicht auch eine anthropogen bedingte nachlässige Wasserführigkeit die Trift in kleinen Bächen unmöglich gemacht oder erschwert haben könnten bzw. ob nicht - in verstärkender Weise - die abschwächenden Winter durch das Ausbleiben einen kräftigen Schneeschmelze zu Frühjahrsbeginn, insbesondere in den Bergland- und Mittelgebirgshöhen, einen weiteren Weg für den Niedergang der ungebundenen Flößerei bereitet haben. Dies wäre anhand der Auswertung alter klimatologischer Daten zu verifizieren.

\section{g Treideln}

Ein großer Wasserschwall zur Fortbringung des Holzes und der Schiffswaren konnte in früheren Zeiten auf den größeren Flüssen nicht erzeugt werden, hätte auch flächenhafte Überschwemmungen mit Schäden an Haus und Flur zur Folge gehabt, die . Um die Ware auf den Flüssen und Kanälen an ihren Zielort zu bringen, benötigten gebundene Flöße wie auch Binnenschiffe zur Vorwärtsbewegung tierische und menschliche Muskelkraft.

In mittelalterlicher Zeit setzte man zwar auf den Flüssen und Kanälen Schiffstypen mit Takelage ein, doch konnte die Kraft des Windes nur in sehr begrenztem Umfang zur Fortbewegung der Boote genutzt werden. $\mathrm{Zu}$ Tal trieben diese Schiffe mit der Strömung und setzten bei günstigem Wind zusätzlich noch ein Segel. Zu Berg wurde nach Möglichkeit ebenfalls gesegelt und gestakt. Doch zum einen waren die Flüsse noch stark gewunden und man konnte deshalb den Wind für die Wasserfahrzeuge nicht für ein Vorankommen ausnutzen. Vor allem in den Mittelgebirgen waren die Winde zudem noch unbeständiger und vor allem schwächer als auf den küstennahen Flachlandflüssen. Die beispielsweise in den Flusstälern des hessischen Berglandes auftretenden Winde waren ,nicht so beständig, um eine geregelte Segelschiffahrt zu ermöglichen." (HOFFMANN 1995:85) Von Anfang an waren da die Bedingungen im wasserreichen norddeutschen Tiefland für die Schiffahrt besonders günstig, denn es bot sich hier nicht nur ein stärkerer Wind und ein verhältnismäßig engmaschiges Netz natürlicher Binnengewässer, außerdem standen die küstennahen Flüsse unter dem Gezeiteneinfluss und waren deshalb auch von seegängigen Schiffen mit der Tidewelle weit aufwärts zu befahren. Zum anderen aber besaßen auch die künstlichen Kanäle keine ausreichende Fließgeschwindigkeit, um eine „Talfahrt“ - auch unter Segeleinsatz - zu ermöglichen.

Typische Flussschiffe wurden daher normalerweise (zusätzlich) mit Rudern oder Stechpaddeln angetrieben. Flussaufwärts war vielerorts aber auch der Antrieb durch Rudern oder Paddeln wegen der andauernden und zum Teil reißenden Gegenströmung nicht möglich. Auf seichten Gewässerstrecken hingegen reichten, ähnlich wie der Segeleinsatz, die Ruderhilfen auch flussabwärts nicht aus (WARNECKE 1999:448).

„Aus diesem Grunde hat sich letztlich nur die Treidelschiffahrt durchsetzen können.“ (HOFFMANN 1995:85) Bezüglich der Frage zum Einsatz von Mensch oder Tier ist von der Leineschiffahrt bekannt, dass bis zum Ende des 17. Jahrhunderts die Lastkähne auf den Treidelwegen von Pferden gezogen wurden. Zur fraglichen Zeit transportierte man zum Beispiel schwere Steine auf dem Fluss mit Lastschiffen, die im Pferdezug getreidelt wurden (HOFFMANN 1995:46). In der Folgezeit wurde der Schiffzug mit Pferden nur höchst selten geübt, weil zahlreiche Beschwerden der Anlieger, aber auch der Treidler erfolgte. Erst um 1800 war es wieder erlaubt, Pferde vor die Kähne zu spannen. Von 1700 bis um 1800 wurden die Schiffe durchweg nur von Menschen getreidelt (HOFFMANN 1995:46,59). Gewöhnlich begleitete eine Mannschaft von etwa vier bis acht Mann für einen Taler täglich die Lastenschiffe. Von Bremen bis Hannover benötigten sie neun, in umgekehrter Richtung etwa drei bis vier Tage.

1813 führte die Hannoversche Verwaltung den Schiffszug mit Pferden allgemein wieder ein und gab den Schiffen Männer mit, die die Flurschäden sofort wieder regeln sollten (HOFFMANN 1995:59). Auf der Weser zwischen Bremen und Hoya war der Schiffzug durch Menschen noch bis 1815 üblich und für die 
Anwohner eine kräftezehrende, aber lebensnotwendige Einnahmequelle (SEEDORF/MEYER 1996:626f.). Wie der unten abgebildete Stich zeigt, haben mehrere, am Ufer mühsam voranschreitende Menschen die stromauf zu bringenden Kähne am Ufer getreidelt Die körperliche Anstrengung der Treidelknechte wird durch ihre weit vorgebeugte Haltung zum Ausdruck gebracht.

So wurden die Kähne und auch die Flöße mit Seilen von Menschen gezogen, an den Nacken der Rinder oder Ochsen (SCHNEIDER 1992:150) gebunden, vor allem aber als Geschirr den Pferden als Zugtiere umgelegt Und „häufig waren es verkrüppelte Tiere“ (BRIX 1988:29), die dafür eingesetzt wurden. „Auf allen Kanälen mußte getreidelt werden“ (:29) und stromaufwärts wurden auf vielen Flüssen Schiffe getreidelt. Nach der speziellen Funktion wurden sie auch ,Treidelkähne' genannt.

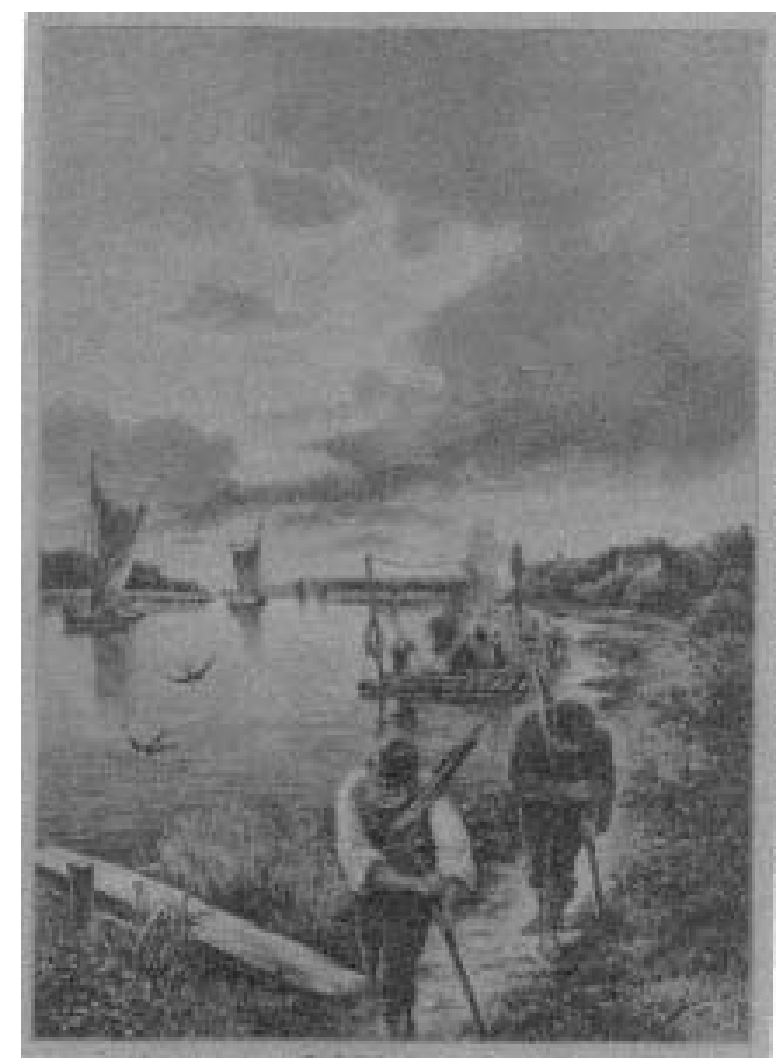

Abb. VI-59: „Das Treideln auf der Havel“.

Zeichnung von W. Stöwer (eig. Bestand).

Die Zugleinen waren am Treidelmast befestigt und führten zum Heck des Schiffes. Der Mast stand im vorderen Drittelpunkt des Schiffes, im sog. Vorderschiff, kurz hinter dem Bug und hatte nicht nur die Aufgabe, die Zugleine möglichst hoch zu halten, sondern trug auch das Segel, das bei günstigem Wind die Fahrt stromauf und stromab unterstützte. Ein Mann konnte mit der ihm vom Schiff zugeworfenen und über die Schulter gelegten Leine eine Last von einer Tonne im Wasser ziehen. Für ein Pferd dagegen rechnete man je nach der Strömung zwischen 10 bis 30 t Last. Der Schiffer hatte während des Treidelns gegenzusteuern und auch mit der Stakstange nachzuhelfen, damit das Schiff nicht durch den schrägen Zug des Treidelns ans Ufer gezogen wurde.

Da aus den beschriebenen Gründen die Treidelfahrt die bevorzugte Transportart auf Binnengewässern war, sich aber auf gewundenen Flusstrecken als schwierig erwiese, wurden in Holland beispielsweise Kanäle schnurgerade angelegt und waren bis 1665 auf mehr als $400 \mathrm{~km}$ Länge angewachsen. Vom Wetter unabhängige „Trekvaarten“ mit von Pferden gezogenen Schuten verkehrten auf diesen Kanälen nach regelmäßigem Fahrplan, teils im Stundentakt, um das Handels- und Transportgut aus dieser Region zu befördern, das seit der Mitte des 13. Jahrhunderts vornehmlich aus Käse, Butter und Torf bestand (UNVERFEHRT 1989:53). Sir William TEMPLE, von 1668 bis 1671 englischer Gesandter in Haag, hatte errechnet, dass ein einziges Treidelpferd mehr Last beförderte als von 50 Pferden gezogene Wagen (:52). 
Welches Ausmaß das Treideln auf größeren Flüssen gehabt hat, sieht man am Beispiel der Donau: Auf der Talfahrt transportierte ein Spediteur etwa 2000 Zentner, auf der Bergfahrt war er nur mit 300 - 400 Zentner oberländischer Weine ${ }^{51}$ beladen. Für das Stromaufwärtsziehen eines Schiffzuges, bestehend aus zwei gebräuchlichen Schiffen und verschiedenen Beibooten, wurden ungefähr 40 Zugpferde benötigt und die Fahrt von Wien nach Regensburg dauerte nach Jahreszeit zwischen 29 und 48 Tagen (SCHÖNFELD 1978:123).

Auf der Weser verkehrte der sog. Weserbock, auch Lichtebock oder Bulle genannt, als der übliche Schiffstyp. Gewöhnlich bestand so ein Schiffszug aus einem Hauptschiff, an dessen Mast die Zugleine befestigt wurde, und einem oder zwei sog. Achterhängen. Ersteres, der Bock, war ungefähr $35 \mathrm{~m}$ lang und 5 Meter breit - die Anhänger besaßen etwa 30 Meter. Das beladene Schiff besaß einen Tiefgang von 1,00 bis $1,20 \mathrm{~m}$. Eine Ladung wog gewöhnlich 60 Tonnen (:47).

Die Schiffergilden achteten darauf, dass nicht mehr als zwei Lastfahrzeuge in einem Verbund gefahren werden durften. Als Beiboot, um das Seil zum Treideln an Land zu bringen, den Anker einzuholen oder Lotsen überzusetzen, dienten kleine Lattenboote. Ein unbeladener Bulle konnte mitgeführt werden, um die Ladung zu erleichtern oder die Treidelmannschaft von einem zum anderen Ufer überzusetzen. Während auf der Talfahrt der Verbund durch die Strömung trieb, musste bei der Bergfahrt getreidelt werden. Mittels eines langen Seiles am Mast des ersten Fahrzeugs zogen bis zu 90 Menschen, später auch Pferde vom Ufer aus den Verbund (Neue Westfälische Nr. 203 v. 16.12.2000).

Doch seit dem ersten Drittel des 18. Jahrhunderts fand noch eine andere Form des Treidelns statt, die sog. „Warpschifffahrt“. Nach dieser Methode „brachte man an besonders schwierigen Flussabschnitten das Treidelseil in einem Boot stromaufwärts, befestigt es an einem Anker oder an einem festen Punkt an Land und ließ die Schiffe durch Zugknechte und die Mannschaft von Deck aus vorwärtsziehen." (SCHOLL 1985:14). Dieses Verfahren der Warpschifffahrt war auf französischen und deutschen Flüssen, vor allem der Elbe, gebräuchlich (:14). Später ersetzte man die Menschenkraft zunächst durch Pferde, bis man um 1820 zunächst auf der Rhône und Seine eine Wattsche Dampfmaschine einsetzte, die eine Geschwindigkeit von einem Kilometer pro Stunde brachte (:14).

Die ersten Wasserbaumaßnahmen zur Verbesserung der Befahrbarkeit auf den schiffbaren Flüssen galt sicherlich den Treidelwegen, d. h. den Uferpfaden, von denen aus die Schiffe stromauf gezogen wurden (HENCKEL 1988:48). Für diese Dienste erhielten die Treidler im Übrigen das vereinbarte Recht, die Fischerei auf einem bestimmten Streckenabschnitt auszuüben. Man nannte sie deshalb „Erbleihfischer“ (:48). Sie hatten nicht nur als Treidler, sondern auch als Fischer Interesse daran, dass das Ufer von Bewuchs und Geröll freigehalten wurde, denn auch die Schlepp- und Treibnetze verlangten bei höherem, zum Fischen geeignetem Wasserstand ein geräumtes Ufer (HENCKEL 1988:48; KAUP 1996:116).

Die Ziehwege oder Treidelpfade waren in der Regel zweieinhalb Meter breit und lagen einen knappen Meter über dem Wasserspiegel. Wo Grasbewuchs nicht ausreichte, belegte man die Wege mit einem leichten Pflaster.

An den Dammseiten stand, wie 1789 beim Neckarufer, Weidengebüsch. Ein solcher „lebendiger Wasserbau“ ist schon im 18. Jahrhundert allgemein vorgeschrieben worden. Wo es hingegen ,notwendig war, das Ufer zu pflastern, mußte er natürlich unterbleiben“ (HAGEL 1988:19). So hatte man zum Beispiel an der Gröninger Mühle, wo der Neckar auf das schräg in den Fluss gebaute Mühlenwehr traf, dessen Aufgabe es war, der Wassermühle stets genug Wasser zuzuleiten, für Schifffahrt und Flößerei im Wehr eine Gasse offen gelassen. Weil an diesem Punkt die Strömung relativ groß war, hatte man deshalb einige Jahre zuvor das Ufer befestigt: „Gepflästerter Leinpfad“ ist dort auf den alten Flusskarten eingetragen (:19f.). Nicht immer also waren es „natürliche“ Uferwege, die als „Trampelpfad“ nur einen geringen Eingriff in den Uferzonen des Flusses bedeutet. Die Leinpfade wurden - zumindest an bestimmten Stellen, wie zum Beispiel auch an Fährübergängen - mit Steinplaster belegt (:21).

\footnotetext{
${ }^{51} \mathrm{Im}$ 18. Jh. wurde das kg definiert über die Masse eines Kubikdezimeter Wassers. Desdhalb die gebräuchliche Verwendung des alten metrischen Gewichtsmaßes Zentner für Weine, das heute wiederum in Tonnenmaß angegeben wird (1 Tonne $=20$ Zentner).
} 
Doch die Treidelwege wurden, dort wo der Zugverband durch Aufwuchs nicht gestört wurde, für den Kulturanbau genutzt. An den Außenseiten der Ziehwege wurden Obstbäume in ordentlichen Reihen und genormten Abständen gepflanzt: Apfel und Birne auf tonigen, Kirsche auf sandigen Böden. Selbst die Rückseiten der Dämme ließen sich gewinnbringend mit zusätzlichen Zwetschgenbäumen kultivieren (BRIX 1988:29).

Die ersten Anzeichen des Niedergang traten bereits recht früh auf: Schon während der Hochphase bzw. gerade in dieser, häuften sich Beschwerden der Grundstücksbesitzer gegen die Schiffer. Am Ufer musste der Treidelpfad in Ordnung gehalten und Buschwerk oder Bäume entfernt werden. In Hecken oder Zäunen im Uferbereich sollten Pforten oder Tore vorhanden sein. Nicht selten erfolgten Klagen über Flurschäden, welche die Pferde der Schiffer verursacht hatten. Seit 1800 mussten regelmäßig sog. Achtermänner mit den Schiffen reisen und solche Schäden sofort an Ort und Stelle regeln (HOFFMANN 1995:47). Hecken, Zäune, Weiden und Papeln, aber auch die Pfähle der früheren Wehre, Mühlen und Brücken sowie Strucken und dicke Bäume im Flussbett behinderten die Anlage eines wagenbreiten Pfades, auf dem im Vergleich zum Fußsteig eine höhere Last hätte gezogen werden können.

Um 1800 passierten jährlich noch etwa 20 bis 30 Schiffszüge die Leine nach Hannover, doch nahm ihre Anzahl stetig ab, nachdem die Eisenbahnlinie eröffnet worden war. 1870 kam die Schifffahrt dann gänzlich zum Erliegen. Die Zeit der Treidler und Schiffszieher ist längst vergangen(HOFFMANN 1995:47).

In der Folgezeit dürfte die Flussschifffahrt dadurch nachhaltig gestört worden sein, dass in der Leine zahlreiche Wassermühlen und Wehre errichtet wurden. Des Weiteren ruhte bei schlechtem Wasserstand im Sommer sowie während der Wintermonate der Verkehr auf dem Fluss (HOFFMANN 1995:47).

Das Treideln fand ein Ende, als die Dampfschleppschifffahrt im 19. Jahrhundert die Flüsse erreichte (HOFFMANN 1995:85). Erst seit 1884 hatten die Kettenschleppdampfer die Treidelei oder Treidelschiffahrt auf der Saale verdrängt (SCHUBERT 2001:32). Auch darf nicht unerwähnt bleiben, dass der Bau der Eisenbahn im 19. Jahrhundert ,eine bedrohliche Konkurrenz für die Treidelschiffahrt auf dem Neckar wurde" (HAGEL 1988:31). Der Transport mit Pferdekraft war langsamer als die Konkurrenz. Zudem waren die Tiere auch störrisch und „verlangten ein gutes, ab dem 3. Lebensjahr beginnendes Training“ (STEIN 2000:135).

Mit dem Niedergang des Treidelwesens ging nicht nur eine, im Vergleich zu den anderen kommenden Transportformen, ökologisch bilanzierte Fortbewegung von Gütern zu Ende, sondern auch eine kulturhistorisch-geographische Erscheinungsform, die nicht nur im Bereich des Flusses landschaftsprägend gewirkt hat (Treidelunterstellplätze, Leinpfade). Interessant wäre es in einer landschaftsgeographischen Betrachtungsweise zum Beispiel der Frage nachzugehen, wie viele Pferde man damals für das Treideln gebraucht hat. Bei der Vielzahl an treidelbaren Flüssen und Kanälen bedeutet dies einen erhöhten Futterbedarf, der nur über ausreichende Weideflächen bzw. über eine erhöhte Heuproduktion geregelt werden konnte. Dies wiederum hätte die Anlage von Wässerwiesen bedingt.

\section{h Querungen}

Die Fernhändler in der Hansezeit suchten, wie dargestellt worden ist, aus verschiedenen Gründen auch für kurze Transporte nach einem Wasserweg. Die Landstraßen waren in den Bergen, im Winter oder bei starkem Regen kaum passierbar, für das Fortkommen eines Fuhrwerkes bedurfte es der Anspannung von vier bis sechs teuren Zugpferden und außerdem ergaben sich - auch dadurch bedingt - für den Landweg höhere Transportkosten. Doch auch der Wasserweg hatte seine Gefahren- und Problembereiche (siehe VI 11d.1) und manchmal besaß auch der Landweg Transportvorteile: zum Beispiel auf kürzeren oder direkten Wegen, bei denen sich eine Verladung nicht lohnte, bei Massentransporten wie von militärischen Truppenverlegungen oder wenn es gar keine direkte Wasserverbindung gab. Nicht von allein haben all diese Landtransporte ihre spezifischen Wegeformationen in der Landschaft hinterlassen (DENECKE 1969) und erfuhren Begrifflichkeiten wie den „Seidenweg“ oder den „Sälzerweg“, auf dem das Salz von den Soodener Salinen über steile Bergpfade transportiert wurde. Aber auch diese Transporte erreichten irgendwann Gewässer, die es zu passieren galt; wie zum Beispiel die sog. Altstraße, „die von Salzlagern an der Kocher kommend die 
Altmühl bei Treuchtlingen überquerte und über Dollnstein zur keltischen Großstadt Manching führte“ (TRÖGL 1995:50).

Neben dem längsgerichteten Gewässerverkehr, flussauf- oder -abwärts, gab es so auch den querenden. An seichter Stelle wurde das Gewässer als Querung für den Landverkehr genutzt. Bevor Stege und Brücken gebaut wurden und für einen trockenen Übergang über das Wasser sorgten und auch noch vor der Zeit, als Fließgewässer aufgrund ihrer Regulierung keine faschinierten bzw. gemauerten Steilufer besaßen, wurden Wasserläufe an flachen Stellen in der Furt durchwatet bzw. durchfahren (WEGNER 1994:13; STRENZ 1996:98). Dies trifft nicht nur für den Personen- und Güterverkehr zu, sondern auch für die Viehtrift.

Anlässlich des Vorhabens zur Zorgeregulierung besagt die Einwendung eines gewissen Rittergutspächters Max Samberg bezüglich „Wegfall des Triftweges“"52, dass ,als Ersatz des Triftweges [...] ein angemessener breiter Landstreifen neben dem Wehre zur Uebertrift von Vieh hergestellt und zur Sicherung der Landwege deren Ufer gegen Abbruch genügend gesichert werden“ müsse. Als Ausgleichmaßnahme fordert er die „Herstellung einer $3 \frac{1}{2} 2 \mathrm{~m}$ breiten Uebertrift neben dem Wehre“, die Sicherung der Landzunge „durch Trockenpflasterung [...] auf eine Länge von $10 \mathrm{~m}$ aufwärts“ und eine „unterhalb des neuen Wehrbaues liegende Angerfläche von etwa 2 Morgen Grösse [...].“

Unter „Furt“ (griech.: poros, lat.: vadum) versteht man die Untiefe eines Wasserlaufs, durch die ein Mensch zu Fuß oder auf Tieren und Wagen das andere Ufer erreichen kann, ohne schwimmen zu müssen (SAUER 1999:159). Bis ins Mittelalter überquerte man Flussläufe nur durch Furten, also natürliche Flachstellen, durch die man bei entsprechend niedrigem Wasserstand waten bzw. reiten konnte und die den Flussübergang erleichterten. Solche Flachstellen begründeten sich vor allem an Einmündungen von Bächen, die mit der Schneeschmelze Geröll und Sand bergab tragen, oder an Ausweitungen des Flussbettes, in denen das Wasser bei verminderter Fließgeschwindigkeit durch Ablagerungen Untiefen und Inseln, sog. Werder, schafft (WEGNER 1994:10).

Wegen der häufigen Flussbettverlagerungen war hier die Tiefe der Flüsse vielfach kein Hindernis zu ihrer Durchquerung. Im 19. Jahrhundert betrug zuweilen selbst in schon regulierten Abschnitten der Elbe im Königreich Sachsen die Wassertiefe nur 50-60 cm. Vielmehr behinderten die Bruch- und Auenwälder den freien Zugang zum Fluss. Ob ein Fluss mithilfe einer Furt überwunden werden konnte, hing neben Faktoren wie Wassertiefe, -temperatur, Strömung, Jahreszeit, auch von der Beschaffenheit des Flussbettes und der Ufergestalt $a b$. Furten mussten gefunden und möglichst verlustfrei benutzt werden. So wurden durch Flussteilung künstliche Furten geschaffen. Wo ein Fluss regelmäßig überschritten werden musste, wurden natürliche Furten präpariert.

Die Befestigung bestand zumeist in der einfachen Einebnung des Flussbettes im Bereich der Furt. Reichte eine derartige Konstruktion nicht aus, weil das Flussbett zu weich oder zu uneben, die Strömung zu stark oder das Wasser zu tief war, wurde eine gepflasterte Furt über einen Damm geführt; es handelte sich hier gewissermaßen ,um eine Brücke unter Wasser“ (SAUER 1999:159f). Die zusätzliche Pflasterung bestand aus einem Belag aus Holzbalken oder Steinen. Im Einzelnen fanden unterschiedliche Techniken Anwendung:

1. Steinplatten, verlegt auf eingeebnetem felsigem Flussbett

2. Pflasterung aus Kieselsteinen

3. Steine auf einem Bett aus Steinsplitt

4. Steinpflasterung auf Unterbau aus Eichenpfählen

5. Steinpflasterung, eingefasst von Pfählen zwecks Sicherung gegen Unterspülung

6. Pflasterung mit Geleisen, die das Abrutschen der Wagen verhindern sollten.

Eine weitere Variante der Furtsicherung bestand darin, die Wasserfurt durch einen flussaufwärts angelegten, die Strömung bremsenden Damm zu schützen (SAUER 1999:160).

52 aus:Stadtarchiv Nordhausen „Regulierung des Abzugsgrabens an der neuen Mühle 1885-1916“ [X 997] 
Aus Sicherheits- und Bequemlichkeitsgründen wurden Furten durch Brücken ersetzt, die aus einer auf Pfeilerfundamenten sich stützenden Tragkonstruktion bestehen. Manche Furten aber wurden parallel zu den Brücken weitergenutzt, blieben also als Relikte mit ihrer Pflasterung bestehen. In der Nordhauser Gemeinde Bielen ist bis heute unterhalb der bestehenden Brücke die Furt zu erkennen. Sie steht damit kennzeichend für den hier beschriebenen Werdegang.

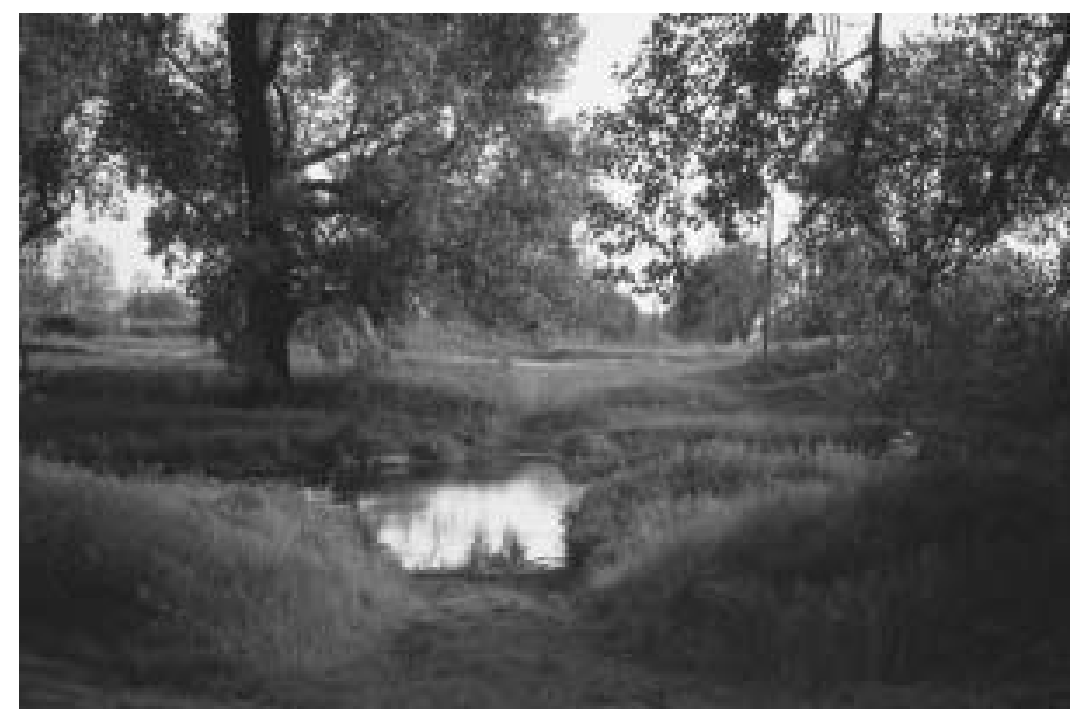

Abb. VI-60: Furt in der Zorge in Bielen/Thüringen

Diese Furt besteht aus einer befestigten, mit Steinen bzw. Steinplatten belegten Flussdurchfahrt und war scheinbar noch bis zum Bau der parallel errichteten Brücke in Benutzung. Die seit 1994 zur Stadt Nordhausen gehörende Gemeinde geht aus einer Wendensiedlung des 10. Jahrhunderts hervor. Bielen (wendisch: bjel = weiß oder gut) wird gedeutet entweder als „Ort am weiß glänzenden Wasser“ oder als „Ort mit gutem, fruchtbarem Boden“. Am Rande des Flusssumpfes der Helme und Zorge gelegen, konnten die direkten Verbindungswege zu den Nachbarsiedlungen, insbesondere zu Zeiten der Überschwemmungen im Frühjahr, nur über Fußstege oder Knüppeldämme erfolgen. In weniger nassen Zeiten und vor dem Brückenbau wurde die seichte Passage der Furt zur Querung genutzt. In dem kleinen, unscheinbaren Ort Bielen existierten ehemals drei Güter: jeweils ein dem Domstift und dem Frauenbergskloster in Nordhausen gehörendes Gut und das Rittergut deren von Rüxleben ${ }^{53}$. Die Furt wird vor allem vom landwirtschaftlichen Verkehr zu den jenseits der Zorge gelegenen Ländereien in der fruchtbaren Au genutzt worden sein. Diese Funktion hat auch heute noch nicht ausgedient: Die schmale Brücke verhindert ein Überqueren der schweren und breiten landwirtschaftlichen Fahrzeuge und Agrargeräte, so dass diese die Furt durchfahren müssen (eig. Aufnahme 1998).

Im Zuge der Regulierungen und Kanalisierungen zu Ende des 19. Jahrhunderts verlief der Fluss zunehmend in einem Bachbett, und dadurch war sein Lauf nunmehr weitgehend vorgegeben. Des Weiteren vertiefte sich die Fahrinne aufgrund dieser Maßnahmen zur besseren Schiffbarkeit der Gewässer. Für die Beseitigung der Unregelmäßigkeiten in den Fahrrinnen unter anderem durch Ausbaggerung der Verschlämmungen, die bis in die Mitte des Flussbettes reichten und so erst eine durchschreitbare Furt begründeten, entfiel die seichte Querungsmöglichkeit. Um auch bei höheren Wasserständen trockenen Fußes über einen Fluss zu kommen, halfen Fähren den tiefer und enger fließenden Fluss an einer Stelle zu queren und die Orte und die zum Teil gegenüberliegende Acker- und Feldflur miteinander zu verbinden.

Die ältesten Fähren bestanden aus ausgehöhlten und nebeneinandergebundenen Baumstämmen, also aus einem kleinen Floß. Anfangs wurden die Fähren auch von einem zum anderen Ufer mit Stangen ,gestakt“, bei Hochwasser gerudert. Später, seit dem 17. Jahrhundert, wurden sie an einem Seil, einer Leine, von der anderen Seite gezogen. Für den Personenverkehr nahm man ein Boot, ein „Dielen-“ oder „Lattenschiff“, das wesentlich einfacher und leichter zu handhaben war als ein Floß (WEGNER 1994:12). Ein kleiner Prahm diente der Nutzung durch Einzelpersonen, die größeren Schifffähren der Überfahrt von Fahrzeugen und Viehherden. Fahrende Händler, Salzfahrer, Koppelknechte und Soldaten wurden damit befördert, und selbstredend kam den Fährschiffen in Kriegszeiten eine erhöhte Bedeutung zu. Zum Beispiel hat die Fähre bei Schloss Ricklingen, die eigentlich für die Besucher des Marktes von Ricklingen nach Wunstorf den Leineübergang ermöglichen sollte, für die hier im Jahr 1807 einquartierten französischen Truppen in sieben

\footnotetext{
${ }^{53}$ Jahrbuch des Landkreises Nordhausen 1994:62; Heimatblatt „Vom Südharzrand zur Goldenen Au“, Okt. 1994:7.
} 
Wochen 534 Pferde und 70 Wagen übergesetzt. Nach heutigen Maßen war sie etwa 14,70 m lang und 3,20 m breit (HOFFMANN 1995:48).

Bei einigen solcher Fährstellen hatte es sich als notwendig erwiesen, etwas oberhalb der Fähre ,eine Steinzeile im Fluß anzulegen, um an dieser relativ flachen Stelle genügend Fahrwasser zu haben. [...]. Sie bewirkte die erstrebte Bündelung des fließenden Wassers, konnte aber bei Hochwasser überströmt werden. “ (HAGEL 1988:21) „Am Gegenufer führte eine durch Steinpflaster gesicherte Rampe zum Leinpfad“ und schloss an die weiteren Landwege an, wie HAGEL (:21) die Zeit um 1834 aus einem Lageplan für den Neckar bei Hochberg rekonstruiert.

Eine sehr alte Fährverbindung ist auch zwischen dem beiderseits an der engsten Stelle der Schlei gelegenen Ort Missunde bekundet. Er wurde bereits im frühen Mittelalter, um 1115 als „Versund“ (Ver-sund = Ver = Fähr-Möglichkeit und Sund $=$ Meerenge $=$ Missunde) erwähnt. Eine Fähre verband hier seit dem 14 . Jahrhundert die beiden $130 \mathrm{~m}$ auseinanderliegenden Teile Missundes miteinander (MISSUNDE 2004).

Auf historischen Fährverbindungen, wie zum Beispiel an der Feste Zons über den Rhein oder in Wahmbeck, Lippoldsberg und Polle an der Weser, können noch heute an zahlreichen brückenlosen Übergängen Querungswartende übersetzen.

Gegen Ende des 18. Jahrhunderts - mit dem Bau von Chausseen - verloren auch die Fähren ihre Bedeutung und dienten nur noch der Landwirtschaft und dem lokalen Verkehr (WEGNER 1994:17).

Jahreszeitliche Ereignisse erschwerten bzw. verhinderten zudem die Nutzung der Fähren. In strengen Wintern, wenn der Fluss zugefroren war, sind nicht nur Fußgänger, sondern auch Wagen über diese natürliche „Brücke“ gegangen und umgingen somit den Kosten der Fährüberfahrt. Ebenso hatte der Fährmann Einnahmeausfälle zu verzeichnen, wenn durch die Überschwemmungen der Frühjahrs- und Herbsthochwässer eine Benutzung der An- und Ablegestellen nicht möglich und durch die Strömung auch zu gefährlich war.

Um trockenen Fußes das andere Ufer erreichen zu können, wurde wohl auch über mehrere Nachen ein Holzsteg gelegt. „Es ist anzunehmen, daß der Besitzer die Verankerung dieser Schiffsbrücke bei auflaufendem Hochwasser oder wenn die Treidelschiffe und Flöße vorbeikamen, am gegenüberliegenden Ufer löste, so daß die Schiffe mit den Laufbohlen ans diesseitige Ufer trieben.“ (HAGEL 1988: 24). Bis zum Brückenbau behalf man sich mit also einer Fähre oder einer „Schiffs- bzw. Bootbrücke“, deren Betrieb durch Hochwasser und Eisgang im Winter häufig gestört war (WEGNER 1994:13).

Brücken wurden bereits in römischer Zeit errichtet. Im Jahre 58 v. Chr. schlug Caesar über den Rhein bei Neuwied eine Kriegsbrücke. DÖBLER (1973:170) beschreibt den Rhein damals als ,einen wilden, durch die Einöden unendlicher Wälder fließenden Strom“. Die Brücke hatte $400 \mathrm{~m}$ der reißenden Strömung zu überwinden.

Nach den römischen Brücken, den Brückenbauten Karls des Großen und der Klöster - so bauten Fuldaer Äbte schon im 9. Jahrhundert eine Brücke über die Fulda (MASCHKE 1978:14) - setzte die Überquerung von Flüssen in Deutschland erst vom späten 11. Jahrhundert und beginnenden 12. Jahrhundert an langsam wieder ein. Mit der Zunahme der Bevölkerung seit dieser Zeit sowie der Gründung und dem Wachstum von Städten nahm der Güterverkehr zu, den es zu bewältigen galt.

Massengüter, wie vor allem das Getreide, mussten über oft beträchtliche Strecken zu Lande transportiert werden. In der ersten Hälfte des 12. Jahrhunderts übernahm der vierrädrige Wagen mit beweglicher Vorderachse den Transport und um die Mitte des 13. Jahrhunderts war dieser Wagentypus allgemein verbreitet (MASCHKE 1978:10f.). Sie ersetzten das Tragtier und den zweirädrigen Karren - unter der Voraussetzung eines hinreichend breit und stabil ausgebauten Brückensystems (:11). Um diese Traglast zu bewerkstelligen, sind seit dem 13. Jahrhundert Brücken nicht wie vorher nur aus Holz und aus Stein, sondern auch aus Eisen errichtet worden (MASCHKE 1978:10; MECHLER 1978:43). 
Seit dem 12. Jahrhundert sind Brücken vor allem in den Stadtgebieten an verschiedenen Orten entstanden (SEIBT 1999:176). Denn neben den ländlichen Brücken und „Außenbrücken“, „die eine am Fluss gelegene Siedlung mit den Räumen auf der anderen Seite des Flusses verbanden“ (MASCHKE 1978:12), wuchsen den „Binnenbrücken“, die einen die Stadt durchziehenden Fluss überquerten, mit zunehmendem Städtewachstum und Zusammenwachsen der Stadtteile, eine besondere Bedeutung zu, zum Beispiel in Nürnberg die Überquerung der Pregnitz, in Königsberg in Preußen über die Pregel oder in Kreuznach über die Nahe.

Die Brücke des Mittelalters ,war eine Konstruktion zur Überwindung natürlicher Hindernisse, insbesondere von Flüssen, für den Verkehr.“ (MASCHKE 1978:9) Die alten Brücken suchten „die kürzeste Verbindung von Ufer zu Ufer herzustellen.“ (GLAUSER 1978:77) Wenn auch der größere Teil des Nord-Süd-Handels den Wasserweg flussabwärts und teilweise auch flussaufwärts dem Landweg vorzog, so vermittelte die Brücke den Nahverkehr und Ost-West-Handel (MECHLER 1978:47). „Für die Stadt am Fluß war die Brücke von vielseitiger wirtschaftlicher Bedeutung. Dem Güterverkehr des Fernhandels und dem reisenden Kaufmann brachte sie größere Sicherheit und Schnelligkeit. Sie schuf oder steigerte die Zentralität der Stadt, deren wirtschaftliche Beziehungen beide Uferlandschaften des Flusses umfassten. Sie erleichterte die Versorgung der Stadt auf dem Nahmarkt und hatte selbst Marktfunktionen, da auf den größeren von ihnen Buden und Marktstände errichtet wurden.“ (MASCHKE 1978:38).

Wie dem Kaufmann, so diente die Brücke auch dem Pilger. Sie sollte beispielsweise im 14. und 15. Jahrhundert den Pilgern und Kaufleuten den Zugang über die Mosel nach Aachen oder nach Leipzig über die Elbe den Zugang zu diesen Stätten erleichtern. „Sie hat hiernach übergeordnet einen religiösen und einen kommerziellen Aspekt.“ (MASCHKE 1978:9)

Die Brücke erweckte aber auch abergläubische Vorstellungen, denen zufolge unter ihnen Geister und Hexen hausten, und wer über sie ging, wurde von Krankheiten befallen oder unter Einhaltung bestimmter Bräuche von ihnen geheilt. In Wirklichkeit aber hausten unter ihnen die Außenseiter der Gesellschaft (MASCHKE 1978:39) - ein Zustand, der bis heute nichts von seiner Realität verloren hat.

Schließlich diente sie auch dem Recht als Richtstätte. Es war wohl ihre herausgehobene, isolierte Lage, die sie zur Gerichtsstätte wie auch zum Strafvollzug geeignet machte. Von diesen „Brückengerichten“ wurden die zum Tode des Ertrinkens Verurteilten im Wasser ertränkt oder von ihrer Höhe in den Fluss geworfen (MASCHKE 1978:38).

Da sich das Leben gegen Ende des 19. Jahrhunderts mit dem Anwachsen der Städte, dem Entstehen von größeren Gewerbebetrieben und Fabriken, dem Bau der Eisenbahnen und der beginnenden Individualmotorisierung grundlegend änderte und das vermehrte Reisen der Menschen über Land und der Güterlandverkehr begann, ,wurde der Wunsch nach einer Brücke immer lauter und drängender.“ (HAGEL 1988:54) Dies zum einen aus dem Grund, weil die Kahnfähren und Holzstege kein Übersetzen mit Fahrzeugen zuließ, sondern nur von Pferdegespannen bzw. Personen. Zum anderen, weil für den zunehmenden Schiffsverkehr und die Flößerei die Fähren hinderlich waren. Des Weiteren fiel bei Eisgang oder auch extremer Trockenheit der Transport aus und man musste entweder auf das tragende Eis hoffen oder die Furt wieder aufsuchen. Die Brücke galt, verglichen mit Furt oder Fähre, als sicherer (MASCHKE 1978:20).

Boten Holz- und Steinbrücken gewiss auch größere Sicherheit, so waren sie aber auch von Hochwasser, Eisgang und auf schiffbaren Flüssen von Schiff- und Floßbruch bedroht (MASCHKE 1978:20,30; MECHLER 1978:41). Hölzerne Brücken waren überdies nicht nur von Wasser, sondern auch von Feuer bedroht (MASCHKE 1978:22). Daher forderte nicht nur der Bau einer Brücke sehr beträchtliche Mittel, sondern auch die Folgekosten der Reparaturen und der Personalkosten für den „Brückenmeister“ mussten abgedeckt werden (:22). Zölle auf Waren, die über die Brücke transportiert wurden, sowie die Gebühren für die Benutzung der Brücke durch Fußgänger, Tiere und Fuhrwerke standen an der Spitze der Einnahmen (:25). Andererseits gab es auch die Gebührenfreiheit und der Brücke wurden regelmäßige Einkünfte aus anderen öffentlichen Mitteln überlassen (:26).

Die Eingriffe in ein Gewässer durch künstliche Querungen sind unterschiedlich zu bewerten. Bis der vorindustrielle Eisenbrückenbau anstelle der anderen aus Holz konstruierten Passiereinrichtungen Einzug 
hielt, haben Teile der Brücke nicht immer auf Pfählen oder Pfeilern, sondern oft behelfsmäßig auf Schiffen oder Booten gestanden, die durch Anker und Seile festgehalten und untereinander verbunden waren (MECHLER 1978:43,51). Hierdurch wurden kaum Veränderungen am Gewässerlauf notwendig, von den Verankerungen und Zugängen einmal abgesehen.

Erst durch den festen Brückenbau wurde in den Gewässerlauf nicht unerheblich eingegriffen: Bei Holzkonstruktionen wurden von Kähnen aus Pfähle in den Grund gerammt. Bei Steinbrücken standen die Pfeiler auf einem quadratischen Fundament von Holzpfählen, deren Zwischenraum mit Steinen aufgefüllt war. Bei der ältesten erhaltenen, ab 1343 in Stein erbauten Moselbrücke der Stadt Koblenz, nach dem Kurfürst Balduin („Erbischof Baldewin“) auch Balduinbrücke genannt, zum Beispiel, die eine Länge von $325 \mathrm{~m}$ hat, führten ursprünglich 14 Bögen über 13 im Flussbett stehende Pfeiler (MASCHKE 1978:20). Hiervon wurden in neuster Zeit einige zur Besserung der Moselschifffahrt zusammengefasst.

Beim Brückenbau wurde des Weiteren erheblich in die Hydrologie des Flusslaufs eingegriffen, da die damals üblichen Pfeilerbrücken die Strömung hemmten. Die durch den Druck der Pfeiler gestaute und durch das unterschiedliche Niveau oberhalb und unterhalb der Brücke beschleunigte Strömung spülte mehr Kies und Sand aus als vorher, der sich unterhalb wieder anlagerte und durch Räumung entfernt werden musste. Weiterhin bestand die Gefahr, dass die Pfeiler unterhöhlt wurden und es zum Einsturz kam. „Schon zu Caesars Zeiten wurden deshalb Pfähle in das Flußbett gerammt, und zwar von Hand mit einfachen Holzrammen. Sobald eine Art Kasten aus Pfählen entstanden war, pumpte man ihn trocken und hob den Schlamm aus, bis man auf gewachsenen Fels stieß, eine mühsame und gefährliche Arbeit mitten im unregulierten Flußbett. Schließlich wurde der Brückenpfeiler aus Steinen hochgezogen; sein Fundament verstärkte man mit aufgeschichteten Felsbrocken.“(DÖBLER 1973:173).

Aber bereits während der eigentlichen Bauphase einer Brücke wurde in den Gewässerlauf eingegriffen: Bei der Errichtung der Pfeiler musste das Wasser verdrängt werden, was durch den Bau einer sogenannten Wasserstube gelang (MASCHKE 1978:20). Von solchen temporären Spundwänden bzw. Fangdämmen zur Ausgrenzung des Wassers aus dem Baubereich über die Verlagerung des Gewässerlaufes durch den Aushub eines Stichgrabens bis hin zu Aushubarbeiten im Flussbett und im Uferbereich und von Plasterung der Fundamente usw. gingen die Eingriffe zur Errichtung des Brückenfundamentes (vgl. HAGEL 1988:27). In den meisten Fällen suchten Konstrukteure auch natürliche „Inseln“ in das Bauwerk mit einzubeziehen (MECHLER 1978:49), die dadurch verloren gingen.

Schließlich ist auch an die Verbindung von Mühle und Brücke zu erinnern, die sich aus der Lage am bzw. im Fluss ergab. In Konstanz standen in der Mitte der Rheinbrücke mehrere Mühlen auf großen Pfahlkonstruktionen, in Regensburg standen Mühlen in der Donau. Des Weiteren gab es regelrechte „Brückenmühlen“: in Rottweil stand eine Mühle an einer steinernen Brücke, in Leisnung lagen Muldebrücke und Niedermühle beiander, in Jena gehörte die Brückenmühle zur Saalebrücke. In Zürich stand je ein Wasserrad auf der Rathausbrücke und auf der Münsterbrücke, in Bremen stand im 14. Jahrhundert das Wasserrad an der Weserbrücke und diente der Wasserversorgung der Städte (MASCHKE 1978:37).

Die rationale Zusammenfassung aller auf das Wasser bezogenen technischen Konstruktionen am gleichen Ort war also verbreitet und führte zu einer Konzentration der Wasser- und Wasserkraftnutzung: „Die Brücke, die den Wasserlauf überwandt, war Ansatzstelle für Bauten zur Nutzung der Wasserkraft, wie die Mühle oder das Wasser selbst, wie Rad und Badstube. Am Flußufer ließen sich offenbar Stellen finden, an denen die Standortbedingungen für alle diese Einrichtungen günstig waren.“ (MASCHKE 1978:37).

\section{Urbarmachung}

Nicht nur der besseren Schifffahrtbarkeit wegen wurde in Gewässerläufe regulierend und kanalisierend eingegriffen. Andere Gründe der Korrektion waren die der Urbarmachung und damit auch die Verhinderung von Überschwemmungen und von Eisgang: das heißt die Landgewinnung und Landsicherung.

Kleine, nicht schiffbare Gewässer sind zunächst zumeist reguliert worden, um Flächen für neue Wiesen und Äcker zu gewinnen. Bedingt zum einen durch steigendes Siedlungswachstum und das Interesse einer 
möglichst intensiven landwirtschaftlichen Nutzung und Erweiterung der Ländereien und mitunter zum anderen begründet durch die schon erfolgten Gewässereingriffe kam es bereits im Mittelalter zu größeren Hochwasserereignissen und zu Bergsenkungen. Um dieses auszugleichen fand seit dem Mittelalter ein allmählicher Ausbau der alten Flussbetten und Nebenarme statt.

Schon im 18. Jahrhundert wurden aufgrund landwirtschaftlicher Umwälzungen und wachsender Bevölkerungszahlen weitere intensivere Versuche unternommen, die noch naturnahen Auengebiete umzugestalten. Hier tat sich insbesondere das Land Preußen hervor, zum Beispiel mit der Urbarmachung des Oderbruchs nach dem Siebenjährigen Krieg (1756 - 1763), den ersten größeren Strombaumaßnahmen am Niederrhein oder den Dammbaumaßnahmen gegen die Allerhochwasser im Drömling (vgl. NIEMEYERLÜLLWITZ/ZUCCHI 1985:91f.).

Doch erst im 19. Jahrhundert wurde überall mit Hilfe der fortschreitenden Technik mit Regulierungsarbeiten begonnen, in deren Verlauf die natürlichen bzw. noch naturnahen Verhältnisse gründlich verändert werden sollten (NIEMEYER-LÜLLWITZ/ZUCCHI 1985:91f.).

Für alle nachfolgenden Wasserbaumaßnahmen wurde die nach den Plänen des Ingenieurs Johann Gottlieb TULLA von 1816 - 1874 durchgeführte Rhein-Rektifikationen zum Vorbild. Zur Lösung von Überschwemmungsproblemen und zur Schaffung von Grund zur Anlage von Gehöften und Dörfern (SCHÄFER 1974:333) entwarf TULLA die Pläne zur Rektifikation des Flusslaufs, welche er durch eine Wasserspiegelabsenkung erreichen wollte: „Die möglichst gerade Leitung der Flüsse, die Abschneidung ihrer Nebenarme, [...] oder mit einem Wort, die Rektifikation der Flüsse ist diejenige Operation, durch welche ihren Zerstörungen Einhalt getan und ihr Wasserspiegel so gesenkt wird, daß die Nachteile der Überschwemmungen und die Eisgänge vermindert oder vollkommen beseitigt werden“ (TULLA 1825, zit. bei SCHÄFER 1974:337)

Nach diesem Plan wurde bis 1874 der Oberrhein Abschnitt für Abschnitt in ein festes Bett von 200 bis $250 \mathrm{~m}$ Breite gezwungen. In der Furkationszone wurden dabei die zahlreichen Seitenarme durch abriegelnde Dämme abgeschnitten, wodurch sich das Wasser des ganzen Stromes gebündelt, summiert und mit größerer Geschwindigkeit in der verbleibenden Rinne bewegte. Auf diese Weise trat hier die von TULLA gewollte Tiefenerosion und damit die Wasserspiegelabsenkung ein. In der Mäanderzone wurde das Gleiche mit abkürzenden Durchstichen der Mäanderbögen erreicht, die danach zwar oft als Altrheine erhalten blieben, aber zunehmend verlandeten (vgl. NIEMEYER-LÜLLWITZ/ZUCCHI 1985:92f.).

Das Modell der Rheinrektifikation führte mit seinem Vorbildcharakter zu weitreichenden Gewässerveränderungen. Sie war fortan „Grundlage der meisten Flußregulierungen und gab dem Wasserbau in den nächsten 150 Jahren seine überwiegend technische Orientierung.“ (NIEMEYER-LÜLLWITZ/ ZUCCHI 1985:93) Nach dem Vorbild der TULLA'schen Rektifikation begannen im Laufe des 19. Jahrhunderts ,an zahllosen Flüssen" Regulierungsarbeiten, so zum Beispiel um 1820 an der Ems, etwa ab 1850 am Main und ab 1860 an der Aller. An der Isar wurden mit Beginn des 19. Jahrhunderts erste Regulierungsmaßnahmen durchgeführt; die systematische Korrektion nach der am Oberrhein entwickelten Methodik wurde hier ab 1870 im Abschnitt unterhalb Münchens begonnen (:93).

Nachdem die großen und mittleren Gewässer einer Korrektion ihres Laufes unterzogen worden waren, begann man - oft schon zeitgleich - das TULLA'sche Modell auf kleinere Gewässer auszudehnen und anzuwenden. Auch all die hier angewendeten wasserbaulichen Maßnahmen ,sollten vorrangig der Verhinderung von Hochwasserschäden und oder Verbesserung der Ertragskraft landwirtschaftlicher Flächen dienen.“(DIX 1997:141)

Während die Korrektionen der großen Flüsse meist von staatlichen Bauverwaltungen organisiert wurden, bildeten sich an kleineren Gewässern genossenschaftliche Verbände der Anlieger (Wiesengenossenschaften, Meliorationsverbände, Entwässerungsgenossenschaften u. a.), die später zusammenfassend als Wasser- und Bodenverbände bezeichnet wurden.

An der Hase führten solche Verbände schon seit 1869 zahlreiche Begradigungen und Regulierungen durch (KELLER 1901). Außerdem wurden hier zunehmend Flussräumungen vorgenommen, bei denen die 
Flusssohle von Sand- und Schlammablagerungen befreit und im Uferbereich Schilf, Sträucher und Bäume entfernt wurden, um den Wasserabfluss zu beschleunigen (HERZOG 1938).

Von 1860 bis 1866 wurde auch die Melioration der Erft durchgeführt, nachdem bereits im Jahre 1774 an der mittleren Erft die erste Rektifikation stattgefunden hatte (KREINER 1996b:74). Im Zuge der Erftmelioration Mitte des 19. Jahrhunderts wurde in der Niederung zwischen Brüggen und Glesch der schnurgerade Erftkanal angelegt. Reglementierungen der Niers sind aus den Jahren 1553, 1596, 1726 überliefert, aber erst 1841 began der planvolle und umfassende Eingriff, um zusätzliches Siedlungs-, Wiesen- und Weideland zu erhalten (:75). Starke Flusskrümmungen wurden durchgestochen und auch die Breite und Tiefe des Flusses wurde geändert.

Dennoch ist zu bedenken, dass noch zu Beginn des zweiten Drittels des 20. Jahrhundert „mit Ausnahme der im Flachland verlaufenden Emscher, Niers und unteren Erft [...] bis zu diesem Zeitpunkt in der Rheinprovinz keine umfassenden Regulierungs- und Meliorationsprojekte für den gesamten Flußlauf oder größeren Gewässerabschnitt aufgestellt worden“ waren (DIX 1997:138). Aus dem Fehlen eines größeren zusammenhängenden Regulierungsprojektes ist aber gleichzeitig „nicht zu schließen, daß der Erftverlauf vom Mensch gänzlich unbeeinflußt gewesen wäre. Es sind eine Vielzahl an periodischen Eingriffen nachzuweisen, die vor allem lokale Laufveränderungen und Uferabbrüche verhindern sollten.“(:142)

Flusslaufbegradigungen, Vorflutvergrößerungen, Seefällungen und Riedentwässerungen, die ab der Mitte des 18. Jahrhunderts auf der Grundlage von Agrarreformen entstanden um zusätzliches Wiesenland zu gewinnen, führten zu erheblichen Hochwasserübertritten. Der Abbruch der Stadtbefestigungen mit der zeitgleichen Auffüllung der obsolet gewordenen Ring- und Grabensysteme führte zu einem weiteren Verlust von Wasserrückhalteflächen. Der Ausbau eines Grabennetzes zu Wiesenbewässerungs- und Drainagezwecken für den Siedlungsbau und einer besseren Entwässerung der Ortslagen durch Pflasterrinnen und Rohrleitungen beschleunigte zudem die Wasserrückführung bei starken Regenperioden und zu einer Veränderung der Flussdynamik.

\section{Ressourcenabbau}

\section{a Eisgewinnung}

Fließgewässer wurden auch für die Gewinnung von Eis, und hier ist Kühleis zum Tieftemperieren von Getränken und Lebensmitteln gemeint, genutzt; in einer Zeit, als es noch keine strombetriebenen Kühlschränke, aber dafür strenge und lange Winter gab.

Fließgewässer wurden sogar zur gewinnbringenden „Eispacht“ vergeben und dies bis in die 30er Jahre des 20. Jahrhunderts. Dies geht am Beispiel der Zorge indirekt aus einem Schreiben des Nordhäuser Stadtbaurates vom 11.12.1933 hervor ${ }^{54}$ : „Der Magistrat hat die Fischerei in der Zorge an den Fischhändler Streitberger verpachtet. Streitberger legt großen Wert darauf, daß gerade jetzt, z. Z. wo die Forelle laicht, kein Eis auf der Zorge gemacht wird“. Ein gewisser Gröbel, so erfährt man weiter, „läßt Eis machen“, und hat ,für das widerrechtlich entwendete Eis mindestens 10 RM zu zahlen."

1896 wurde von der Lübecker Eisgenossenschaft das Eis von der Wakenitz gestochen bzw. gesägt und in hölzernen Eisschuppen aufbewahrt (LÜTGERT 2000:85). Zunächst wurde eine quadratförmige Fläche mittelst Eispfluges losgelöst und dann mit Eissägen in lange schmale Streifen zerteilt. Diese wurden durch einen im Eis angelegten Kanal mit Stangen zu dem Eisgebäude befördert und dann nach voheriger Zerkleinerung gelagert. Ähnlich verlief die Eisgewinnung auf der Bille in Hamburg (:86).

Doch da Fließgewässer in der Regel später zufroren als flachgründige und unbewegte Teiche und größere Flüsse und Kanäle im Sinne der Schifffahrt und der Langholzflößerei und kleinere Bachläufe im Sinne des Mühlenantriebes und der Trift von Eis frei gehalten wurden (siehe Pkt. 5 ,Fließgewässerpflege'), wurde das „Eis machen“ eher auf Teichen und wasserstehenden Wiesen betrieben. Insofern darf nach meiner Ansicht

\footnotetext{
${ }^{54}$ Stadtarchiv Nordhausen: Schreiben des Nordhäuser Stadtbaurates [Signatur „R“] vom 11.12.1933 [X310].
} 
diese Quelle als Besonderheit gesehen werden, zumal die Zorge als Gebirgsfluss, auch wenn sie reguliert durch das Stadtgebiet floss, in der Regel durch ihren Strömungsgang und ihre Mitteltemperatur im Normalwinter eisfrei war.

\section{b Kiesgewinnung}

Vor der Zeit der flächenhaften, industriell betriebenen Nassauskiesung in ursprünglichen Flussbecken, die erst den Auelehm abtragen, zur Freilegung von Grundwasser beitragen und anschließend die ehemaligen Niederungslandschaften und späteren landwirtschaftlichen Anbau-, Wiesen- und Weidenflächen in Luftbildern betrachtet wie Mosaikbausteine in einem Puzzle aussehen lassen, wurden geschiebeführende Fließgewässer zur Kiesgewinnung genutzt. Nachweislich wurde noch zu Beginn des 20. Jahrhunderts aus dem Zorgeflussbett Geschiebe herausgeholt.

Aus einem Lehnbrief eines Rittergutsbesitzers in der Ortschaft Crimderode nördlich von Nordhausen vom 30.04.1822 geht hervor, dass die „Kiesgewinnung im Zorgebett auf der ganzen Crimderöder Feldflur nur dem Rittergut Crimderode zusteht" und „,ieses seit Jahrhunderten bestehende Recht" sich nicht nur auf die Gewinnung für den Eigengebrauch, sondern das alleinige Recht sich auch auf die „Verpachtung der Kiesnutzung im Zorgeflußbett" bezieht. Dieser Rechtsanspruch erwächst nach damaligem Recht daraus, dass das Flussbett als „Bestandteil des Flusses und nicht der Ufergrundstücke“ definiert wird. ${ }^{55}$

Im Rahmen der späteren Planungen zur Zorgeregulierung sieht das Rittergut Crimderode eine „Beeinträchtigung der Kiesnutzung im Zorgeflussbett“. Dieser Einwand wurde protokolliert auf einer Versammlung am 16.09.1906. ${ }^{56}$

\section{c Flusssandgewinnung}

$\mathrm{Zu}$ den wichtigsten Rohstoffen für die Glasproduktion gehörte neben Pottasche, Soda und Kalk vor allem Sand. Sand, und hier besonders Quarzsand, ist bei der Glasherstellung der wichtigste technische Glasbildner.

Um den Sand zu schmelzen, sind Temperaturen von etwa $1.700^{\circ} \mathrm{C}$ erforderlich. Schmelzgefäße, die so hohe Temperaturen aushalten, sind nur sehr schwer herzustellen. Daher versuchte man durch ein Flussmittel den Schmelzpunkt des Sandes zu senken. Zur Erniedrigung dieser Einschmelztemperatur wird der Glasschmelzsand unter anderem mit Pottasche versetzt. Pottasche $\left(\mathrm{K}_{2} \mathrm{CO}_{3}\right)$ ist ein körniges weißes Pulver, welches im Mittelalter durch Auslaugung von Holzasche (Buche oder Eiche) gewonnen und in großen Tongefäßen, den „Pötten“, gelagert und transportiert wurde (STREITPARTH 1971). Glasarten waren unter anderem das im Altertum geschätzte Hämatinon, im Mittelalter und in der frühen Neuzeit das Waldglas. Im Mittelalter wurde an verschiedenen Orten Waldglas erzeugt, ein grünliches oder schwärzliches, blasiges Produkt, das sich bis ins 17. Jahrhundert behauptete.

Um den für die Glasherstellung so wichtigen Quarzsand zu fördern, wurden insbesondere die Betten von Bachläufen von Sand geräumt. In Neuhaus im Solling gibt es noch eine Flur, die die Bezeichnung „Sandwäsche“ trägt. Hier wurde für die etwa $12 \mathrm{~km}$ entfernt gelegene „Fürstenberger Porzellanmanufactur“ Sand aus dem Bachbett „gewaschen“( (siehe Pkt. 15.e ,Sandwäsche').

Eine weitere Nutzung der Flusssande ergab sich im Bausektor. Ein häufig verwendetes Bindemittel war Baukalk, der, vermengt mit Sand und Wasser, nach dem Trocknen ein festes und im Unterschied zum Gips witterungsbeständiges Konglomeratgestein ausbildet. Für die Bereitung des Mörtels empfahl bereits der römische Fachschriftsteller Vitruv im 1. Jahrhundert v. Chr. Flusssand zu verwenden. So erhielt man ein hydraulisches Bindemittel, dass nicht so leicht ausgewaschen werden konnte (SCHUETZ 1999:54).

\footnotetext{
${ }^{55}$ Stadtarchiv Nordhausen: Rittergut Crimderode: Einwendung an den Magistrat Nordhausen v. 29.09.1910 [.........].

${ }^{56}$ Stadtarchiv Nordhausen: „Regulierung des Abzugsgrabens an der neuen Mühle 1885-1916“ [X 997].
} 


\section{d Lehm- und Tongewinnung}

Ebenso wie Flusssand wurde lehmiger Boden aus dem Fließgewässergrund und den Auenböden gehoben. Beim Hausbau fand Lehm als Binde- und Verputzmittel beim Fachwerkgefache Verwendung und neben den behauenen Natursteinen war Ziegel ein wichtiger Baustoff, der schon in der Antike bekannt war. Neben dem weitaus älteren luftgetrockneten Ziegel gibt es den beständigeren Brandziegel, der noch heute verwendet wird. Zur Herstellung der Ziegel musste der Rohstoff gewonnen und als Rohmasse aufbereitet werden. „Dazu bediente man sich der häufig an Flußauen und Bachtälern anstehenden Lößlehme und alluvialen Tone. Der Rohstoff der Ziegel war somit in den bevorzugten Siedlungsräumen, den Flußtälern, vorhanden.“ (SCHUETZ 1999:52).

Ton, ein Verwitterungsprodukt von Feldspat, wurde durch Wasserläufe oder Starkregen aus den ursprünglichen Lagern entfernt. Zur Verarbeitung musste man sich zur Filtrierung fließenden Wassers bedienen. Ton findet sich zumeist stark verunreinigt und vermengt mit Pflanzenresten, Sand und anderen Bestandteilen in sekundären Lagerstätten, die sich nur wenige Meter unter der Erdoberfläche befinden (SCHNEIDER 1992:99). Deshalb wurde der Ton in Schlämmgruben durch Herbeileitung von Fließgewässern in Rinnen mit Wasser versetzt; die Fremdstoffe sanken zu Boden oder setzten sich an der Oberfläche der Tonlösung ab und konnten relativ leicht beseitigt werden. Nach Verdunstung des Wassers wurde der zurückgebliebene Ton der Schlämmgrube entnommen und dann längere Zeit bis zur Verarbeitung gelagert (:100). Ton wurde vor allem in der Keramikproduktion eingesetzt und zu Gefäßen und Tonlampen verarbeitet $(: 99,104)$.

\section{e Goldwäsche}

Goldgewinnung wurde neben dem bergmännischen Abbau von Erzen durch Waschen von Flusssänden praktiziert, denn auch hier, in den Sanden der Flüsse, wurde das Gold gefunden (STEUER 1999:50). Metalle treten selten in reiner Form auf; nur Gold wird in größeren Mengen in Flüssen (sog. Waschgold) und in Ablagerungen an Flussläufen (sog. Alluvialgold) gefunden (SCHNEIDER 1992:75; ALBRECHT 1999a:55). Die Gewinnung von reinem Gold war technisch somit nicht aufwendig, weil ein spezielles Verhüttungsverfahren nicht notwendig war (SCHNEIDER 1992:75).

Auf der historischen Nutzung von Fließgewässern zur Goldgewinnung gründet bereits die frühmittelalterliche Sage vom „Rheingold“. „Mit Sicherheit“, sind MÜLLER/LUDWIG (1982:149) der Ansicht, „ließ sich in einigen mitteleuropäischen Flüssen Flitter- oder Seifengold aus den Kies- und Sandbänken abgetragener eiszeitlicher Schotterfluren waschen, die insbesondere nach abziehenden Hochwässern auftauchten."

In den Sedimenten der Niederterrassenschotter des Rheins ist das Edelmetall Gold enthalten. Die Herkunft des Goldes ist im alpinen Bereich (primäre Lagerstätten im Bereich der alpinen Rheinzuflüsse) sowie im schweizerischen Voralpenland (sekundäre Lagerstätten) zu suchen. Die Goldpartikel oder Flitter sind sehr klein, etwa 100.000 bis 200.000 Flitter ergeben ein Gramm Gold und die Größe der Goldflitter nimmt von Süden nach Norden mit zunehmender Entfernung von den Liefergebieten ab. Sehr wahrscheinlich betrieben bereits die Kelten Goldwäscherei im Rhein (GOLDENBERG 1999:14).

Strabo (64 v. Chr. - 23. n. Chr.) berichtet im 4. Buch seiner Geographica über die Nutzung, die Eingriffe und die Folgen des Wasser- und Flussgebrauchs zu Zwecken der Goldgewinnung. Es ist zwar eine Schilderung aus Iberien, doch dürfte die Anwendung auch auf den mitteleuropäischen Raum anwendbar sein (aus: GOLDENBERG 1996:231):

„Am nützlichsten aber zur Gewinnung des Goldes war ihnen (den Salassiern) der Durias (heute: Duero) wegen der Goldwäschen, weswegen sie das Wasser in viele Gräben ableiteten, wodurch der Hauptstrom geschwächst wurde. Dies war zwar ihnen selbst für die Gewinnung des Goldes sehr nützlich, setzte aber diejenigen, welche tiefer unten wohnten und Feldbau trieben, da sie der Wässerung beraubt waren, in Noth, indem der Fluß nicht mehr im Stande war, die Gegend zu tränken. “ 
Die Römer haben sich zur Erschließung dieser Vorkommen nicht nur der Flüsse selbst, sondern auch der Wasserkraft bedient, um an das Alluvialgold, d. h. an das von Flüssen im Boden abgelagerte Gold, zu gelangen. Dieses Gold stammt aus dicht unter der Erdoberfläche gelegenen Goldadern, die durch Erosion ausgewaschen wurden. Die am Rand von Flussläufen entstandenen Goldlager sind dann durch teilweise mehrere Meter hohe Erd- oder Gesteinsschichten zugedeckt worden (SCHNEIDER 1992: 78). „Dazu war es notwendig, das Wasser aus den kleinen Flüssen und Bächen der Umgebung durch Anlage von Wasserleitungen zum Goldlager zu führen; diese oft weit mehr als zehn Kilometer langen Leitungen wurden in schwierigstem Gelände - teilweise an nahezu senkrechten Felswänden entlang - gebaut. Oberhalb der Goldlager wurden große Wassertanks angelegt, in denen das Wasser aufgefangen und gespeichert wurde. [...]; durch Öffnen der Tanks stürzten beträchtliche Wassermengen auf die oberen Erdschichten und schwemmten sie fort. Anschließend wurde das Goldlager durch einen kontinuierlichen Wasserstrom ausgewaschen und das Metall in Gräben, durch die das Wasser mit den Erd- und Goldpartikeln hindurchgeleitet wurde, aufgefangen“"(:78).

Kleine Bäche wurden regelrecht filtriert, um nach Gold zu suchen. So gab es in Blankenrode, einer um 1200 gegründeten und später wüstgefallenen mittelalterlichen Bergbaustadt im Harz, in den kleinen Flussläufen im Umfeld der Stadt Waschgold-Gewinnung (BARTELS 2000:32f.). Goldwäscher-Siedlungen entstanden auch in Deutschland entlang der vermeintlich goldführenden kleinen Wasserläufe. Ortsnamen verraten noch heute von dieser Zeit, wie zum Beispiel die Ortschaft „Goldmühl” bei Bad Berneck im Fichtelgebirge, wo heute noch alljährlich ein „Goldsuch-Spektakel” Tausende von Menschen anzieht, um in dem Bächlein Goldmühl nach dem begehrten Edelmetall zu suchen.

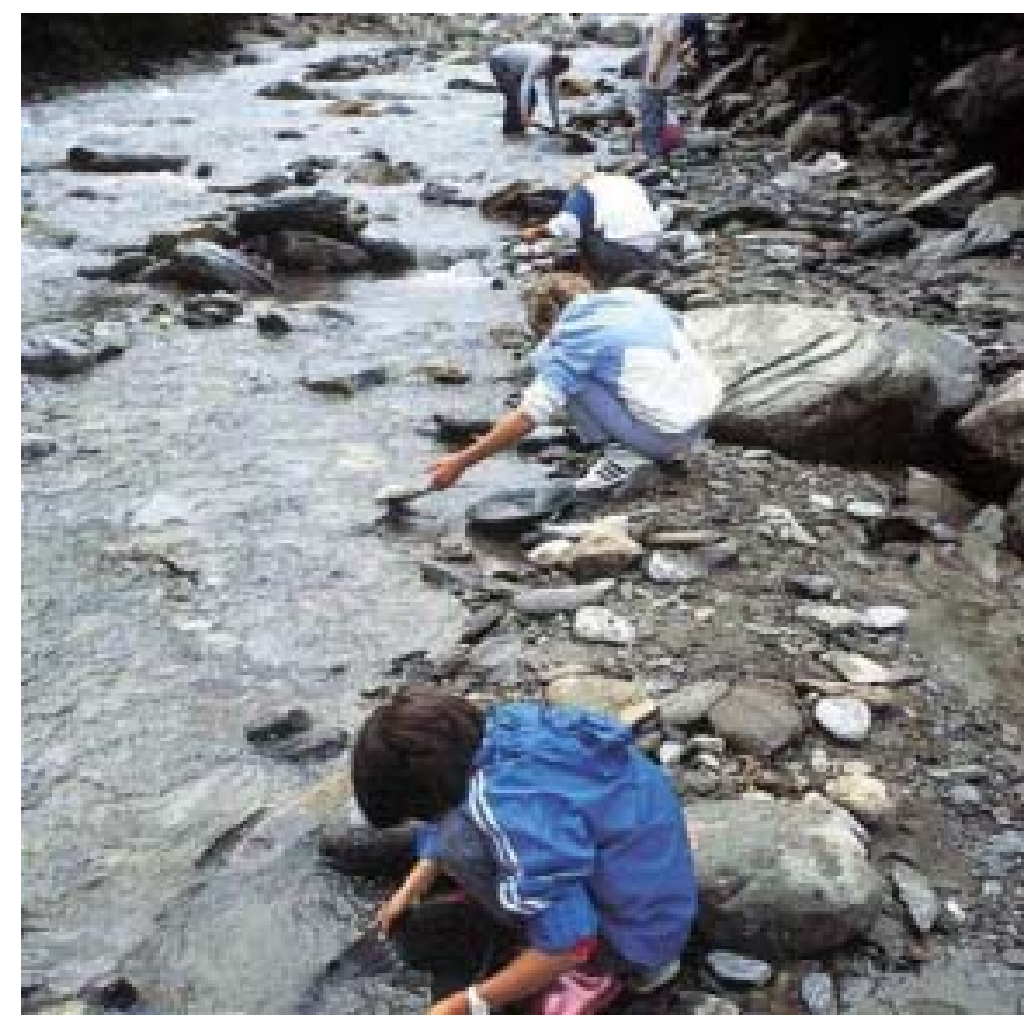

Abb. VI-61: Goldwaschen im Raurisertal/Maria Alm (Österreich)

[aus: URL = http://www.mariaalm.at/maria/index.htm; 21.01.2004]

Als abbauwürdige Goldlagerstätten kamen im europäischen Raum aber nur wenige eng begrenzte Gebiete in Betracht. Die seit dem 13. Jahrhundert erschlossenen Vorkommen lagen im Altvater- und Eulengebirge, im Gebiet der Hohen Tauern, im oberen Lavanttal in Kärnten, im Zillertal, in Ungarn und Siebenbürgen, im Fichtelgebirge, im Thüringer Wald, im Oberhessischen sowie im bereits erwähnten Rheingebiet. Seit dem Mittelalter und bis ins 19. Jahrhundert hinein wurde an zahlreichen Orten zwischen Waldshut am Hochrhein und Mainz Gold gewaschen (GOLDENBERG 1999:14). 


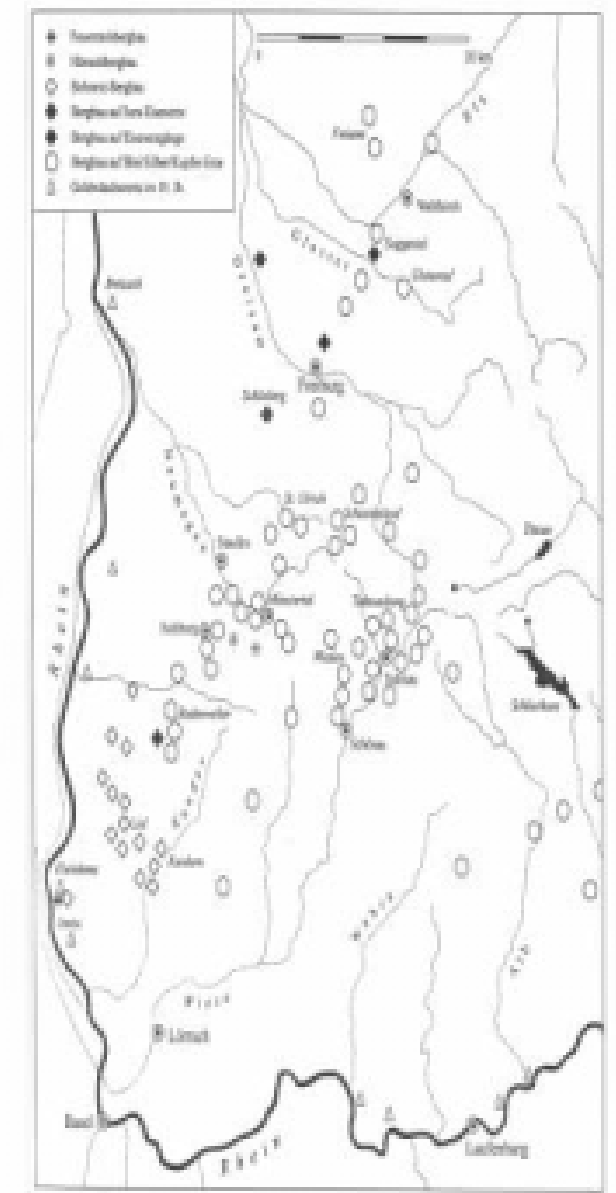

Abb. VI-62: Goldwaschplätze im Hochrheingebiet

Die wichtigsten Erz- und Mineralvorkommen im Südschwarzwald und in der Vorbergzone (aus: GOLDENBERG 1999:11)

Anfang des 19. Jahrhunderts betrug die durchschnittliche Jahresausbeute am badischen Rhein zwischen 1 und $3 \mathrm{~kg}$ Gold, die sich auf mehrere 100 Goldwäscher verteilten. Das Jahr 1831 erbrachte den größten Jahresertrag im 19. Jahrhundert mit einer Gesamtmenge von 12,89 kg Gold. Im Jahr 1832 waren in Baden zwischen Basel und Phillipsburg 405 Goldwäscher registriert (GOLDENBERG 1999: 14). Ein weiteres, allerdings nur sehr kleines Vorkommen liegt im Bereich des Sulzbachtales, kann aber mit der Goldwaschpfanne nachgewiesen werden. Aufgrund der geringen Mengen ist eine Goldgewinnung in historischer Zeit kaum anzunehmen und bislang auch nicht nachweisbar gewesen (:14).

Aus Süd- und Südwestböhmen haben sich Kulturlandschaftsrelikte der vorgeschichtlichen, mittelalterlichen und neuzeitlichen Goldgewinnung und -förderung, beispielsweise der Goldwäsche in den Alluvionen des Flusses Otava, erhalten können und liefern Zeugnis ab über diesen Montanbereich. Über 700 Fundplätze wurden auf einer Fläche von einigen hundert Quadratkilometern nachgewiesen und „beweisen, daß Böhmen auf den Umfang der Goldgewinnung einst zu den führenden Ländern Europas gehörte“ (MICHALÉK 1999:66; siehe Abb. VI-63). 


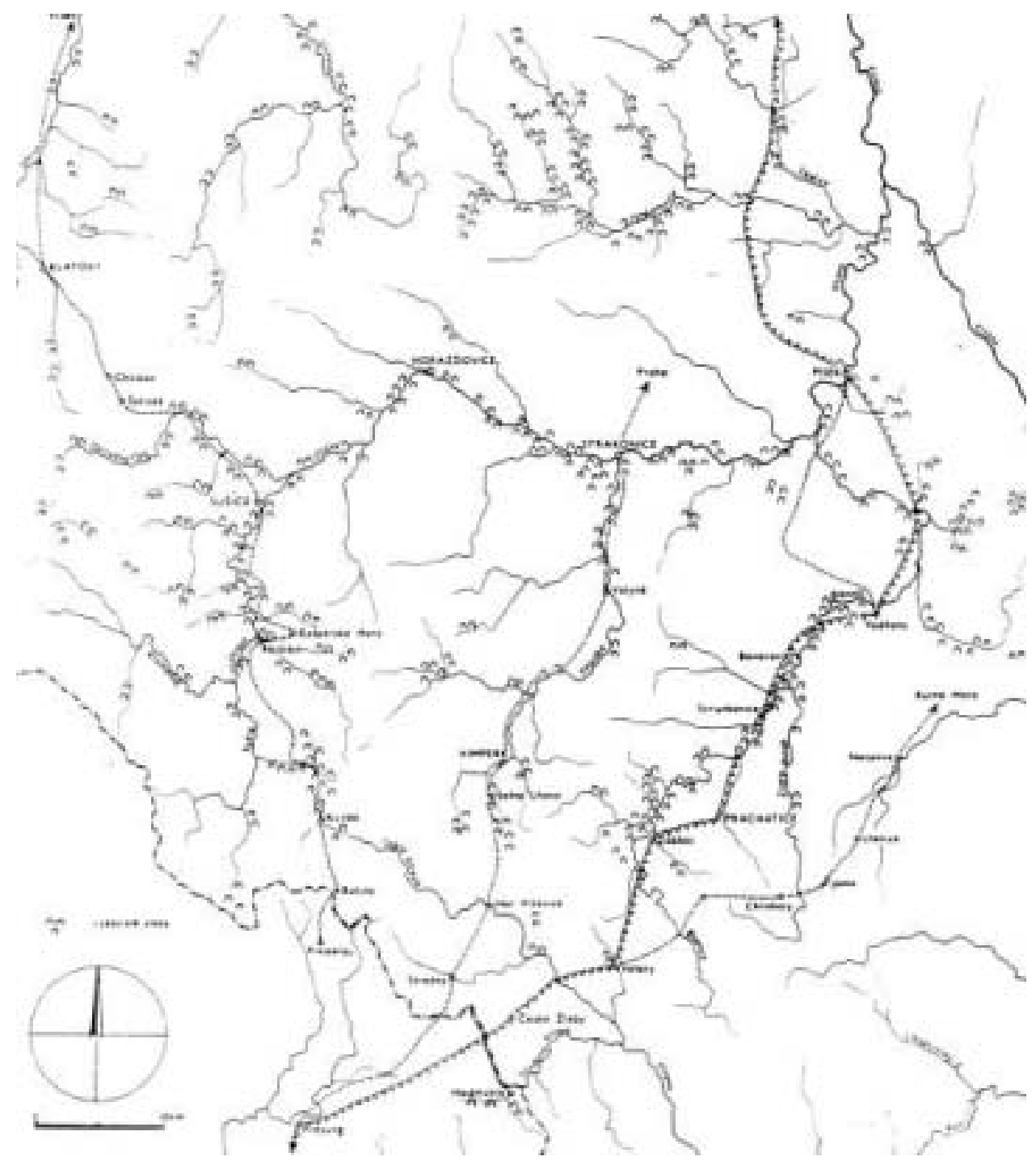

Abb. VI-63: Plätze der Goldgewinnung in Südwestböhmen auf einer Karte der Verbreitung der Goldseifenplätze (aus: MICHALÉK 1999:66, Abb. 1)

$\mathrm{Zu}$ den böhmischen Zeugnissen der vorgeschichtlichen bis neuzeitlichen Goldförderung gehören neben ehemaligen Grubenbergwerken und oberirdischen Goldseifen, die die Überreste der Goldwäscherarbeiten in den goldhaltigen Flussanschwemmungen darstellen, auch frühere Goldwaschplätze und Anlagen, mit denen Wasser zu den Goldwaschanlagen herbeigeführt wurde. Es wurden Belege gefunden, die nachweisen, dass die Goldgewinnung von Fluss-(Wasch-)gold in Modlesovièe bei Strakoniôe im Mittelalter, und zwar vom Ausgang des 12. bis zum 15. Jahrhundert, ihren größten Umfang erreichte. Der Abschluss fällt ins 16. Jahrhundert (MICHALÉK 1999:66).

Übrig geblieben von den Flussbettauswaschungen auf der Suche nach Gold und als morphologische Relikte im Gelände erkennbar, sind ehemalige Goldwaschplätze und Goldseifenfelder in der Umgebung und in der Nähe von Flüssen und Bächen.

\section{f Weidennutzung}

Korbweiden wurden seit dem Mittelalter bis zur frühen Neuzeit in mannigfacher Weise verwendet: Für die Herstellung der früher sehr verbreiteten Flechtzäune zur Einfriedung und Einfassung von Feldern und Wiesen (Schafpferche) wie auch für das Flechtwerk in den Gefachen von Fachwerkhäusern wurden große Mengen von Kopfholz benötigt (WILLERDING 1989:209; BRAUN/KONOLD 1998:32,35). Des Weiteren wurden sie verwendet für die Korbflechterei zur Herstellung von Weidenkörben, beispielsweise zum Transport von Fischen (BORNE 1886:289) und Krebsen, denn „die Versendung der Krebse erfolgt am 
besten in Weidenkörben, in denen sie auf trockenes, glattes Stroh gelegt und mit demselben bedeckt werden“ (BENECKE 1885:113), - wobei zu beachten war, dass die Enden der Weidenruten in den Fischkörben niemals nach innen gerichtet sein durften, um nicht die Fische bei Transport zu verletzen (ACKERHOF 1869:136) -, für Wäschekörbe zum Transportieren der Schmutz- und Bleichwäsche und auch für große Korbwagen für Holzkohlentransporte.

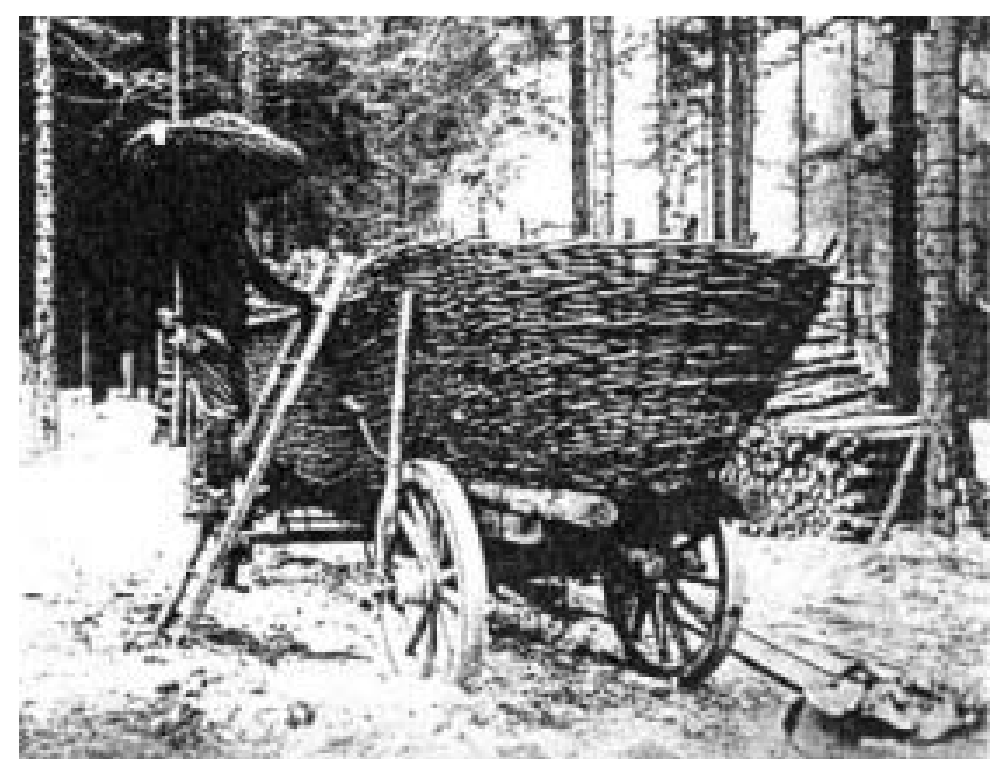

Abb. VI-64: Korbwagen mit Pferdeanspannung für Holzkohlentransporte

Im Hintergrund Meilerplatz bei Arnsfeld um 1925. Diese Transportmittel hatten auch im 18. und 19. Jahrhundert gleiches Aussehen (aus: ALTMANN 1999:189).

Solche „Transportkörbe“ (BENECKE 1885:113) wurden vor allem seit Mitte des 18. Jahrhunderts in den sog. „Korbmacherdörfern“ Dalhausen bei Beverungen und Sand a. Main in Franken hergestellt (DORFCHRONIK 1988), Letzteres beschreibt ein Gebiet zwischen dem nördlichen Auslauf des Steigerwaldes und dem mittleren Maintal. Deren Erwerbsleben war ganz auf die Weidenzucht in den Flusstälern und die Weiterverarbeitung ausgerichtet. Genauso wichtige Zentren der Weidenkulturen waren die Täler der Rur und andere Flüsse am Niederrhein.

Aber auch in Ermangelung von Bauholz wurden zahlreiche Weidenpflanzungen gebraucht. Die Baumnutzung schien gar so groß, dass Weidenanpflanzungen im 16. Jahrhundert an den meisten Bachläufen zur Herstellung von Hopfenstangen als Rankhilfe für die Hopfenkulturen der Brauereien und als Zaunholz gefördert wurden (HÄNNI 1994:21). Bis vor einigen Jahren, schreiben BRAUN/KONOLD (1998:3) in ihrem Weidenbuch, wurden die dünnen Ruten der Korbweiden, „aber auch Weidenruten, die aus Stockausschlägen gewonnen“ wurden, sogar primär zum Anbinden von Weinreben in den Rebanbaugebieten, ,seltener zum Flechten“ gebraucht (:3, auch: 27,51). Binderuten wurden aber auch für das Anbinden von Mais und Tabakpflanzen verwendet.

Darüber hinaus sind eine Vielzahl an weiteren historischen Verwendungen von Weiden bekannt: Für Korbmöbelgestelle, zur Bindung von Fassreifen, als Gerätestielholz (Gabel- und Schaufelstiele, Sensenbäume), für den Wasserbau (Faschinen-, Damm- und Deichbau, Buhnenbau, Uferbefestigung), als Stangen (Hopfen-, Bohnenstangen), als Laubfutter, Einstreu und Schnitzwaren (Holzschuhe, Schüsseln, Teller, Mollen, Kähne, Wellholz, Flöten), als Arznei (Blätter, Rinde), Gerberlohe, Kohle (Zeichenkohle, Schießpulver) sowie als Bienenstöcke, Färbemittel und Mulm ${ }^{57}$ (BRAUN/KONOLD 1998:38,59,63,66f.). Zwei Verwendungsbereiche sollen dabei zur einer näheren Erklärung herausgegriffen werden: die Verwendung als Arznei und als Gerberlohe

Die sekundären Pflanzeninhaltsstoffe der Weidenorgane, vor allem das Salicin in der Rinde, aber auch die Blättern und Blüten, besitzen fiebersenkende, entzündungshemmende und schmerzlindernde Wirkung und wurden gegen Rheuma eingesetzt und als Salbe gegen Hornhaut und Hühneraugen, zur Behandlung gegen

\footnotetext{
57 Als Mulm wird das im Kopfbereich der Weide liegende Erd- und mehr oder weniger zersetzte Holzmaterial bezeichnet. Das vermoderte Holz der Weide eignet sich vorzüglich als Dünger (BRAUN/KONOLD 1998:76).
} 
Schuppen und weitere Kopfhauterkrankungen (BRAUN/ KONOLD 1998:13). In historischen Quellen wird über die heilende Wirkung der Rinde, der Blätter und Samen von Weiden berichtet. Als Heilmittel gegen „Darmgicht“ und „Blutspeien“, zum Blutstillen, Weidenblätter als Badezusatz für die Schlafförderung, gegen Gichtschmerz von Füßen und gegen Schwindsucht.

Eine weitere wichtige Stoffgruppe, die in den Weiden vorkommt, sind bestimmte Gerbstoffe, die schmerzmildernd wirken und Entzündungen hemmen bzw. betäuben (:15). Sie können aber auch äußerlich angewendet werden: In der Ledergerberei wurde zwar in Deutschland vor allem die Eichenlohe verwandt, aber auch die Rötel-Weide ${ }^{58}$ („Gerber-Weide“) soll hohe Gerbstoffgehalte besitzen (BRAUN/KONOLD 1998:15).

Weidenruten gewann man in Niederungsgebieten, wo man in der Neuzeit gar Korbweidenkulturen anlegte. Dafür eigneten sich weite Flusstäler besonders gut, wo es immer wieder zu Hochwasser kam oder in denen ein Fluss den anderen zeitweise aufstaute und das Wasser schlecht abfloss. Flach geneigte Täler wie die der Elbe waren ideale Orte für Korbweidenkulturen und dort, in der unterhalb von Hamburg gelegenen Haseldorfer Marsch war der Berufsstand der „Bandreißer“ ansässig, wo Fassreifen für die zahlreichen Fässer hergestellt wurden, die man in Hamburg benötigte.

Anbau und Verarbeitung lagen zusammen auch in Lichtenfeld (Oberfranken) und in der Rur-WurmNiederung am Niederrhein (BRAUN/KONOLD 1998:38). Kopfweiden als Zeugnis einer alten Wirtschaftsform gehören auch $\mathrm{zu}$ den landschaftsprägenden Elementen in der rheinischen Altarmverschwenkung „Urdenbacher Kämpe“:

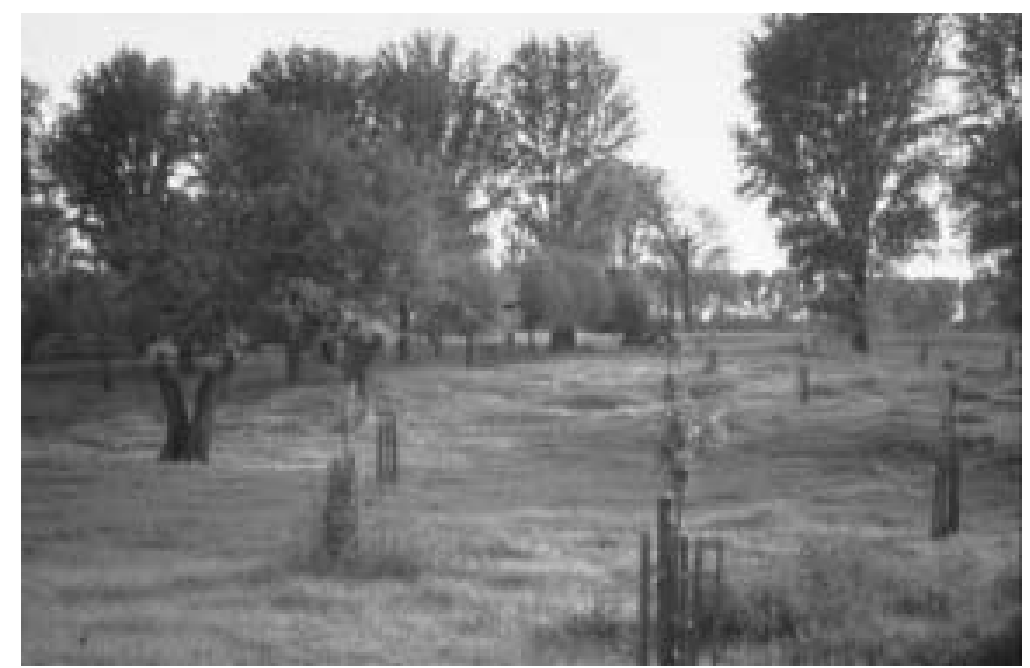

Abb. VI-65: Weidenbäume in den „Urdenbacher Kämpen“

Das Naturschutzgebiet „Urdenbacher Kämpe“ ist eine der letzten, nicht eingedeichten und somit noch regelmäßig überfluteten Auenlandschaften am Niederrhein. Diese alte Kulturlandschaft ist gegliedert durch Wiesen und Weiden, die insbesondere von Pappelreihen und Kopfweiden geprägt ist. Dazwischen stehen hier auch teilweise $80-90$ jährige hochstämmige Obstbäume. Sie wurden jedoch durch eine projektgebundene Wiederanpflanzung nachgezüchteter alter Sorten in den Kämpen derartig flächenhaft an- und nachgepflanzt (20 ha), und dies auch im Rahmen von Ausgleichsmaßnahmen, dass das eigentlich besondere Charakteristikum der Landschaft - das der Korbweiden mittlerweile unterrepräsentiert erscheint und der Eindruck einer Streuobstwiese erweckt wird. So ist eine Überalterung der Weiden eingetreten, nur wenige Neuanpflanzungen verjüngen das Gesamtbild. Die betreuende Biologische Station teilt jedoch mittlerweile diese Sichtweise und will zukünftig auch wieder den Weiden größere Aufmerksamkeit schenken und die Schieflage des historischen Landschaftsbildes korrigieren (eig. Aufnahme 2004).

In der zweiten Hälfte des 19. Jahrhunderts verbreitete sich die großflächige Anbau von Flechtweiden, da die Nachfrage insbesonders der städtischen Bevölkerung nach Korbwaren angestiegen war, so dass das „wildwachsende“ Weidenmaterial nicht mehr ausreichte (BRAUN/KONOLD 1998:51). Tausende von „Bandreißen“ waren zu diesem Zeitpunkt mit der Herstellung und Verarbeitung von Flechtwerk

\footnotetext{
${ }^{58}$ Es ist nicht klar, welche Weide BRAUN/KONOLD (1998:15) hier meinen, wenn sie von einer „Rötel-Weide“ sprechen, gibt es denn einen solchen botanischen Namen nicht, wahrscheinlich „Salix rubens“ (ein Bastard aus Salix fragilis [Bruch-Weide] und Salix alba [Silber Weide]) oder aber „Salix purpurea [Purpur-Weide].
} 
eingebunden. Neben den oben genannten lagen die Haupterzeugergebiete bis zum Zweiten Weltkrieg in Brieg in Schlesien, Tirschtiegel an der Obra sowie in Guben und Fürstenberg an der Oder (BRAUN/KONOLD 1998:38).

Sogar in dem anschließenden Garten des Fährhauses Schloss Ricklingen waren in der zweiten Hälfte des 19. Jahrhunderts 60 Weidenbäume gepflanzt (siehe Abb. VI-66), denn auch für Herstellung des Fährseils wurden Weidenruten benutzt, die im Windenhaus des Fährhauses am Windenpfahl gebunden wurden (HOFFMANN 1995:50).

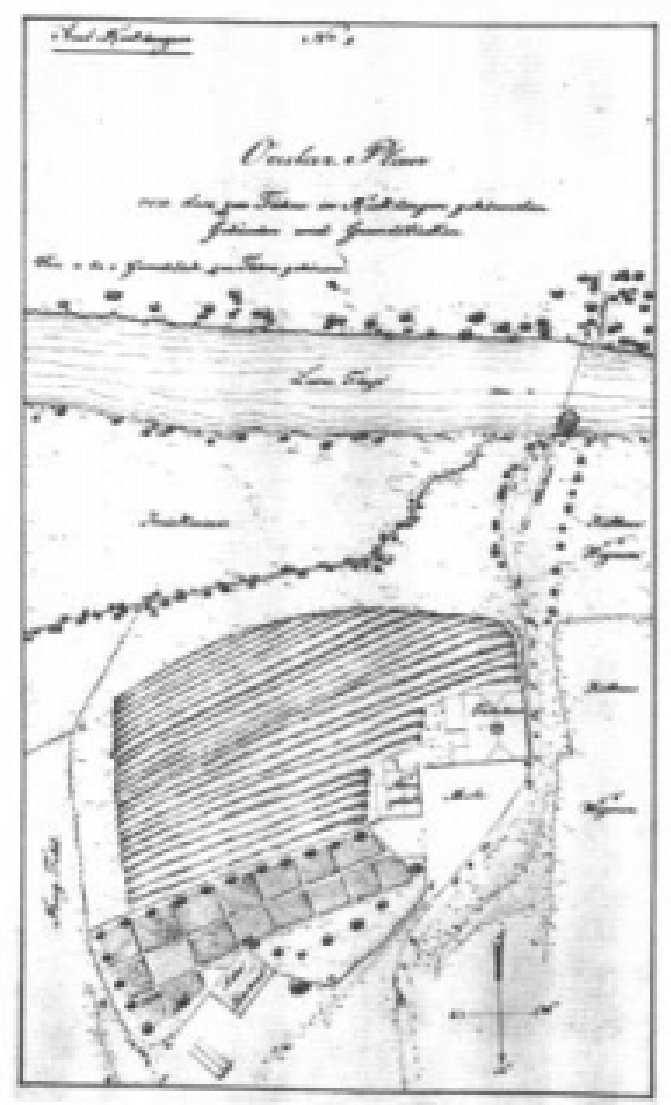

Abb. VI-66: Weidenanpflanzungen am Fährhaus an der Leine

(Plan zum Vertrag des Fährenpächters von 1834) Zu der Weidenplantage galten eine ein Morgen große Wiese und 11/2 Morgen Acker als Zubehör zum Fährdienst, denn der Pächter sollte in der Lage sein, sich ein Kuh und ein Schwein zu halten (Norden ist am unteren Kartenrand).

Natürlich könnte man davon ausgehen, dass die natürlicherweise im Uferbereich stehenden Weiden dafür hätten genutzt werden können, aber die zahlreichen Weiden und Pappeln im Uferbereich hinderten die Schifffahrt in unzulänglicher Weise, zudem war das Offenhalten des Treidelweges zu gewährleisten und die Ufer wurden durchweg landwirtschaftlich genutzt, so das die etwas abseits stehenden Weidengärten angelegt werden mussten.

„Kopfbäume“ in Form geköpfter Weiden standen vereinzelt auch an Teichen, begleiteten zumeist aber linear Flüsse und Bäche (BRAUN/KONOLD 1998:45,55). Für den Flusslauf der Zorge konnte aus Archivquellen ein später Nachweis von Weidenkulturen ausgewertet werden:

Am 16.06.1928 richtete die Fa. Schmalz, Holzwarenfabrik und Sägewerk in Nordhausen, Kasselerstr. 54, deren Spezialität die Stieleherstellung gewesen ist, eine Anfrage an den Magistrat, die eigentlich die Erlaubnis zur Wasserentnahme zwecks Bewässerung aus dem Gumpegraben, einem Seitenbach der Zorge betraf. Aus diesen Schriftstücken erfahren wir in diesem Zusammenhang, dass der Firmeninhaber Schmalz von der Altendörfer Kirchengemeinde ein Stück Land am Nonnenteich, einem Gelände in der stadtnahen Zorgeaue, gepachtet hat: „Dieses Land soll zur Kultur von Weiden dienen, aus denen ich Schaufelstiele herstellen möchte”. Es hatte sich dabei nach seinen Angaben herausgestellt, „dass ohne Bewässerung ein günstiges Ergebnis dieser Anlage nicht erreicht werden kann.“ Die Möglichkeit zur Bewässerung würde 
dadurch gegeben sein, dass ihm gestattet würde ,aus dem Gumpebach Wasser durch eine $10 \mathrm{~cm} \mathrm{L.W.}$ Rohrleitung zu entnehmen. Dieses Wasser würde nach meinem Dafürhalten genügen, um die Kultur im Wachstum soweit voraus $\mathrm{zu}$ bringen, dass eine genügende Bewurzelung stattfindet und damit die Entwicklung der Stecklinge gewährleistet wird.“

Der Magistrat erteilte die Genehmigung unter Auflagen und gestatte in seiner Antwort am 29. Juni 1928 ${ }^{59}$, dass ,auf jederzeitigem Widerruf und gegen Zahlung einer jährlichen Anerkennungsgebühr von 20,Reichsmark" für die Bewässerung der Weidenplantage am Nonnenteich, Wasser aus dem Gumpegraben „durch eine Rohrleitung von etwa $10 \mathrm{~cm}$ L.[ichter] W.[eite]“ entnommen werden darf. Falls jedoch die Bewässerung der Stadtparkteiche „das Wasser erfordert, muß für die Zeit bis zur Anfüllung die Wasserabgabe unterbleiben“ “60. Die Bestimmung über das Aufhören der Entnahme stand der städtischen Gartenverwaltung zu.

Das Anpflanzen von Weidenbäumen und anderen Baumarten muss aber bereits schon in früheren Jahren praktiziert worden sein, wie aus einer Mühleninventaraufzählung aus dem zweiten Drittel des 18. Jahrhunderts, dem „Inventarium über die so genandte Stein-Mühle“661 $\mathrm{zu}$ lesen ist, die auch die umliegenden und zur Mühle gehörigen Gärten mit aufgenommen hat: Insgesamt besaß die Wassermühle 50 „WeydenBäume“, die zum Teil über den „Waßergraben“ mit einem „Steg mit Handlehnen“ erreichbar waren.

Doch nicht nur zur Herstellung von Schaufelstielen wurden Weiden in der Zorgeniederung gepflanzt. Aus einer „Acta specialia betreffend die Verpachtung der Weidenanpflanzungen am Zorgeflußbett zwischen Crimderoder Straße und dem sogenannten Hartmannsdamm"62 des Jahres 1807 geht hervor, dass an der Zorge stehende Weiden von Korbmachern gepachtet und zur Herstellung von „weißen Arbeiten“ und - bei bedeutendem Käferbefall - zu „grünen“ Körben, Wannen etc., also zu Korbwaren für den Alltagsgebrauch verwendet worden sind:

Verpachtet wurden die Weidenflächen von der Stadtverwaltung Nordhausen meistbietend im öffentlichen Bieterverfahren, wie aus einer im Jahre 1868 veröffentlichen Zeitungsannonce hervorgeht:

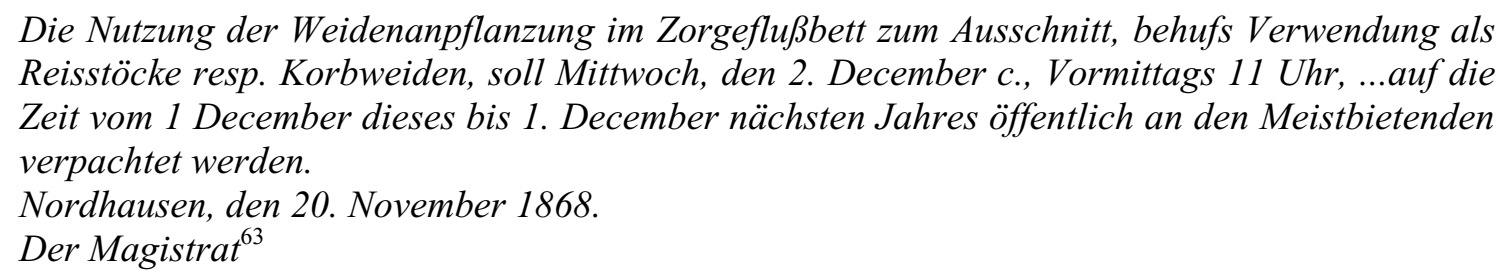

Dabei wurde auch die Nutzung festgeschrieben und paraphiert. In den Pachtverträgen wurde nicht nicht nur die Art der Weidennutzung festgelegt, sondern sie vermitteln auch einen Eindruck von der allgemeinen Bedeutung der damaligen Weidennutzungen und die für einen entsprechenden Erhalt und Ertrag notwendige Pflege der Weiden: Die Verpachtung „,von Weidennutzung im Zorgeflußbett“ erfolgte ausschließlich „behufs Verwendung als Reisstücke oder Korbweiden“ und „zu einer kunstgerechten und pfleglichen Benutzung“.

Der nächste Schritt nach einer wahrscheinlich zu geringen Ertragsbilanz der Weidenbaumnutzung war der parzellierte Verkauf dieser damals wertvollen Baumtriebe. Im Oktober des Jahres 1872 lautet ein Inserat in

\footnotetext{
${ }^{59}$ Stadtarchiv Nordhausen: Vertrag des Magistrats zur Genehmigung der Weiden-Bewässerung v. 19. Juli 1928, Antwort am 29.Juni 1928 [B II].

${ }^{60}$ Stadtarchiv Nordhausen: Vertrag des Magistrats zur Genehmigung der Weiden-Bewässerung v. 19. Juli 1928 [B II].

${ }^{61}$ Stadtarchiv Nordhausen:, Inventarium über die so genandte Stein-Mühle, verfertiget den 1sten May 1776 von unterschriebenen vereydeten Amts-Deputatis" Actum Nordhausen den 1sten May 1776.

${ }^{62}$ Stadtarchiv Nordhausen: „ACTA specialia betreffend die Verpachtung der Weidenanpflanzungen am Zorgeflußbett zwischen Crimderoder Strasse und dem sogenannten Hartmannsdamm”Registratur des Magistrats zu Nordhausen, A. 30.141, 9. September 1807, DB III/122 Nordhausen den 25 Septbr 1807 ad No 8317 I.

${ }^{63}$ Stadtarchiv Nordhausen: „Nordhäuser Courier v. 28. December 1868 “.
} 
der Nordhäuser Zeitung betreffend Weidenverkauf, das „die Weiden in der Anpflanzung vor dem Altenthore [...] in 9 Parcellen zum Abschnitt verkauft werden“" sollen ${ }^{64}$.

Es wurden aber nicht die Weidenflächen und die darauf bestandenden Weiden zum Verkauf ausgelobt, sondern es wurden nur die Rechte am Schnitt der Weiden verkauft. Doch auch dieser „Verkauf“ unterlag bestimmten rechtlichen Vorgaben, die sich auch auf die Art und Weise der Nutzung bezogen

So geschah der Verkauf nur unter der Bedingung, dass die Weiden innerhalb des Zeitraumes „,vom 1. October 1872 bis zum 1. März 1873 [...] geschnitten resp. abgeholzt sein“" mussten. Der Schnitt der Weiden musste dabei ,kunstgerecht und regelmäßig kurz am Stamme etwa 1 bis 2 Zoll über der Erde geschehen und zwar so, daß mindestens zwei Triebaeste erhalten bleiben. “65

Versäumter Abschnitt der Weiden wurde ,auf Kosten und Gefahr des Käufers auf Veranlaßung des Magistrats anderweit ausgeführt". Den durch dieses Säumnis etwa herbeigeführten Schaden hatte der Käufer zu ersetzen, er war auch zudem ,verpflichtet, die durch einen etwaigen regelwidrigen Abschnitt entstehenden Kosten und Schäden zu erstatten.“

Die vormals an zwei Korbmacher verpachteten Weiden wurden also nachfolgend zum Asttriebabschnitt an 4 Gärtner, 1 Korbmacher und eine beruflich nicht näher zu bestimmende Person verkauft. Der Verkauf bezog sich dabei allein auf die Asttriebe. Die neuen Besitzer dieses Nutzungsrechtes jedoch fanden eine sehr stark desertifizierte Fläche vor und beschreiben mit ihrer nachstehend wiedergegebenen Beschwerde an den Magistrat der Stadt das Spiegelbild einer frühneuzeitlichen Intensivnutzung einer am Flusslauf stehenden Nutzholzart. Demnach befand sich ,die Weidenholznutzung, am Zorgeufer [...] in einem jammervollen Zustande“" und es ,,ist ungeheuerlich darin gehaußt" worden. Und würden die Pflanzung nicht verbessert, so würden ,die Stämme bald vertrocknen und absterben, oder blos Reißig statt Nutzholz erzeugen“. Verursacht wurde dies dadurch, das „Einige nur das Beste zu ihrem Bedarf heraus geschnitten [...] und den Rest, zu ihren Nutzen als Brennholz an Andere verkauft" haben. ${ }^{66}$

Infolge des im Jahr 1875 angelegten Stadtparks „tritt eine andere Bewirtschaftung der Weiden ein“. Sie werden Bestandteil der neuen „Stadt-Anlage“. Einige Weidenflächen können infolgedessen gänzlich nicht mehr zur privaten Nutzung angeboten werden; andere können durch eine Flächenneuordnung weiterhin zum „Abtrieb“ zur Verfügung gestellt werden; an anderer Stelle wiederum ergaben sich Ersatzflächen: So hatte sich zwischen dem linken und rechten Zorgeufer „ein Weidenhorst gebildet, der [...] zur Ausnutzung verpachtet werden" konnte ${ }^{67}$.

Wie viele Weiden zur Nutzung am Zorgeflussbett standen, lässt sich nicht aus den Archivquellen entnehmen, aber allein am kleinen Rossmannsbach, einem kleinen Zorgezufluss, dies geht aus einem Schriftstück hervor, gab es 1875584 Weidenbäume, die ,in Abtheilungen von 100, beziehungsweise von 84 öffentlich an den Meistbietenden zur Nutzung bis zum 1tn März künftigen Jahres verpachtet" wurden ${ }^{68}$.

Die flächenmäßige Lokalisation der Weidenanpflanzugen an der Zorge hingegen erschließt sich aber aus den Verpachtungs- und Verkaufsverträgen. Die Weidenanpflanzung verlief demnach von Nord nach Süd entlang „am [...] Ufer der wilden Zorge von der Crimderöder Grenze zum Altendorfer Stege“. Weitere Weidenparzellen bestanden im Nordhäuser Stadtgebiet auch noch am Flusslauf der Helme „von der Rodenbrücke abwärts“. Durch diese Vielzahl an Weiden und Weidenflächen kann also für die Stadt Nordhausen eine regelrechte "Weidenplantage“ entlang der Fliessgewässer mit angeschlossener Verarbeitung dieses Holzes zu verschiedenen Zwecken nachgewiesen werden.

\footnotetext{
${ }^{64}$ Stadtarchiv Nordhausen: „Nordhäuser Courier v. 11. October $1872 “$.

${ }^{65}$ Stadtarchiv Nordhausen: „Nordhäuser Courier v. 16. October 1872“.

${ }^{66}$ Stadtarchiv Nordhausen: Acta spec. A. 30. No. 141, No. 8203 I; v.2. October 1875.

${ }^{67}$ Stadtarchiv Nordhausen: Acta spec. A. 30. No. 141, No. 2281 I. - 15. October 1875.

${ }^{68}$ Stadtarchiv Nordhausen: „Nordhäuser Courier v. 5. November $1875^{\circ}$.
} 
Dieser Wirtschaftszweig ist in den letzten Jahrzehnten nahezu erloschen, was dazu führte, dass die Kopfweiden nicht mehr von den Eigentümern bzw. Pächtern gepflegt und sogar in großer Anzahl beseitigt wurden (LÖLF 1982:13ff.).

Eine besondere Verwendung fand die Weide in der Flößerei. Sie war das ,an allen Floßgewässern in Deutschland“ übliche Bindematerial, bevor die Holzflöße in den 1930er Jahren mit Eisennägeln genagelt und mit Bindedraht zusammengebunden wurden (BORGER-KEWELOH/KEWELOH 1991:37) und die alte, elastische Bindemethode ihr Ende fand.

Der Flößer benutzte zur Holzverbindung von Boden und Rungen vor 60 Jahren sog. Wieden, die 1,50 bis 2,00 m lang sein mussten (HENCKEL 1988:65), nachdem man sie im Wasser eingeweicht und im Winter wohl auch am Küchenherd erhitzt hatte.

Diese Wieden waren Taue, die ursprünglich aus Weidengerten hergestellt wurden, woher auch der Name kommt (BORGER-KEWELOH/KEWELOH 1991:37). Die Wiede war ,das unentbehrlichste, dauerhafteste und wohlfeilste Befestigungsmittel für den Floßbau, weil es sehr elastisch und dennoch sehr haltbar war." (STELTMANN 1995:214) Zudem kosteten Hanfseile Geld und mussten wieder zurücktransportiert werden, die Wieden konnte man noch als Anmachholz verkaufen.

Nachher verwendete man dafür 6, 8, 12 oder auch mehr Fuß, also etwa 2 - 3 m lange, grüne Tannenstämmchen. Sofern diese nicht in ausreichender Menge zur Verfügung standen, konnte man auch ,junge, gerade gewachsene Eichen- oder Fichtenbäumchen“ (HENCKEL 1988:65) verwenden oder auch Buchenund Birkenstämmchen oder auf Haselsträucher zurückgreifen (BORGER-KEWELOH/ KEWELOH 1991:37).

Zum Bau eines Werrafloßes waren 45 bis 50 Wieden, für ein Weserfloß sogar $5-6$ Bündel zu je 22 Stück notwendig (STELTMANN 1995:214). Über den Boden der $42 \mathrm{~m}$ langen, vorn $7 \mathrm{~m}$ und hinten $6 \mathrm{~m}$ breiten Holzlage wurden 6 Querhölzer - die Rungen - gelegt. Hierauf wurden gewöhnlich vier Lagen Stämme eingebunden.

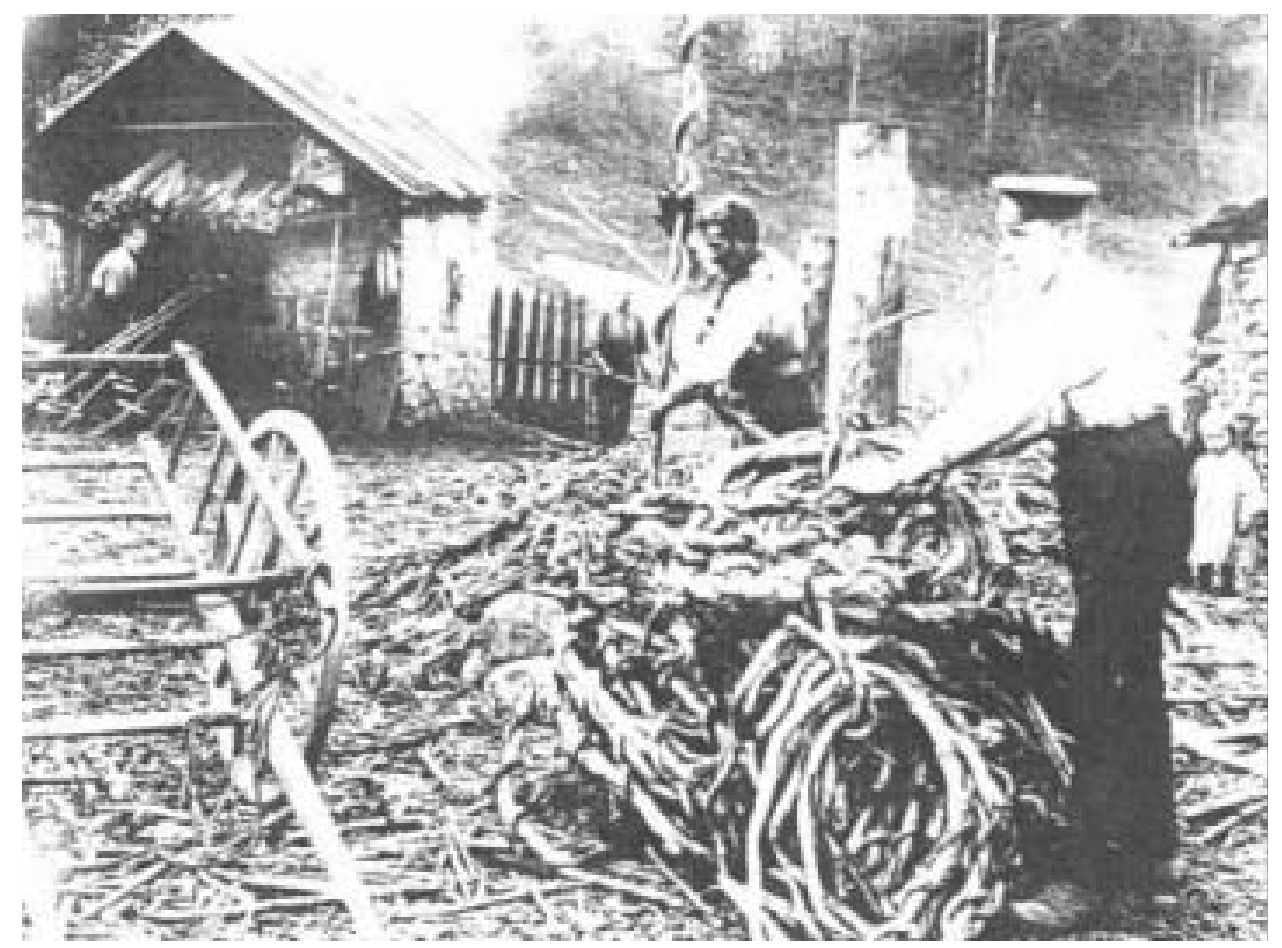

Abb. VI-67: Wiedendrehplatz zum gewerblichen Wiedendrehen im nördlichen Schwarzwald, um 1900 (aus: BORGER-KEWELOH/KEWELOH 1991:117)

Die in Bach- und Flussauen wachsenden Kopfweiden eigneten sich für diese Arbeiten in besonderer, man würde heute sagen „nachhaltiger“, Weise: Sie besitzen „eine Austriebskraft, die bewirkt, dass aus den 
verbleibenden Baumstümpfen Stockausschläge hervorbrechen und zu relativ geraden Ruten, Knüppeln bzw. Stangen heranwachsen“ (WILLERDING 1989:209). Ein in 1 - 2 Meter Höhe gekappter Stamm reagiert mit dem „auf den Kopf setzen“ mit dem Austrieb zahlreicher Zweige, die als nachwachsende Ressource vielfältige Verwendung fanden.

In der mittelalterlichen Kulturlandschaft, so das Ergebnis paläo-ethnobotanischer Untersuchungen, waren die Überschwemmungsflächen in den Fluss- und Bachauen weitgehend mit weniger produktivem Feuchtgrünland bedeckt, das meist einschürig genutzt wurde. „Eine agrarische Nutzung bis an die Ufer der Gewässer - wie heute vielfach üblich - fand nicht statt. Das Ackerland befand sich auf Flächen, die oberhalb der Auen lagen und daher nicht durch Überschwemmungen gefährdet waren." (WILLERDING 1996:63). „Bis zu den Kanalisierungen des 20. Jh.“, datiert SCHENK (1998:253) die Situation für den Weidenbaum am Beispiel des Mains, „ließ der Main aufgrund seines flachen Laufes über Sand und Kies in fluviatiler Morphodynamik immer wieder aufs neue Seitenarme, Altwässer und Sandbänke entstehen. Die Anschwemmungen erweiterten die knappen Weideflächen im Maintal als ,Graßweidt' und dienten als ,Bandwehrt', also als Gebiete zum Austreibenlassen von Weidenzweigen durch ,Niederziehen und Hefften' für die Korbwarenherstellung.“

Bis zu dieser Zeit also konnten die entlang der Uferstreifen der Bächlein und Flüsse stehenden potentiell natürlichen Weiden genutzt werden. Später, beispielsweise im 19. Jahrhundert, als durch Kanalisierungen, Treidelpfade und Entwässerungen viele dieser Habitate vernichtet worden waren, aber der Bedarf nach Kopfweiden noch weiterhin bestand, wurde sogar daraufhin gewiesen, dass „die Gewinnung von Korbweiden auf den Dämmen" der Teichwirtschaften [...] nicht außer Acht gelassen werden“ darf (BENECKE 1885:43).

Mit dem Aufkommen fossiler Energiequellen aber verlor die Weide ihren Wert als Brennstofflieferant. Und auch im Weinbau sowie in den übrigen Landwirtschaftsbereichen wurde sie durch geeignetere Materialien ersetzt (BRAUN/KONOLD 1998:3). Die „Kopfholzwirtschaft“(:51) geriet zur Bedeutungslosigkeit.

Auf der anderen Seite wurden bereits in dem Verwaltungsbericht der Königlichen Baden-Württembergischen Ministerialabteilung für den Straßen- und Wasserbau von 1897 bis 1899 die Kopfweiden bei Hochwasser als ungeeigneter Uferschutz angesehen, da sich hinter und neben den Stämmen Wirbel bilden und so die Ufer beschädigt werden (BRAUN/KONOLD 1998:55).

In neuerer Zeit sorgten der Ausbau der Gewässer und das Verschwinden von kleinen Gewässerstrukturen wie Gräben, Teichen und Mühlkanälen für eine weitgehende Beseitigung dieser nicht mehr benötigten Kulturlandschaftselemente (BRAUN/KONOLD 1998:52).

\section{g Sumpf- und Wasserpflanzengewinnung}

Die Rekonstruktion früher Grünlandflächen auf der Grundlage fossiler Pflanzenreste ergeben in vielen Landschaften Mitteleuropas „bis ins Mittelalter [...] nur Hinweise auf das Vorhandensein von Feuchtgrünland. Wie u. a. auch schriftliche Quellen zeigen, befanden sich derartige Flächen im Bereich von Fluß- und Bachauen.” (WILLERDING 1989:215) In diesen Gebieten wurde „damals der Auelehm sedimentiert. Als Weideflächen kamen diese Landschaftsbereiche daher kaum in Betracht. Dieses Feuchtgrünland war vergleichsweise unproduktiv und wurde vermutlich nur einschürig genutzt.“ (:215f.)

Doch auch dieses „unproduktive“ Feuchtgrünland samt seinen Randbereichen, d. h. all das, was die Gewässer und die Einzugsbereiche von Gewässern an Erzeugnissen lieferte, wurde vom Menschen praktisch verwertet (THIENEMANN 1955:60). An Altarmen der Fließgewässer und in anderen Feuchtmulden der Auen konnten sich Röhricht- und Schilfgesellschaften entwickeln. Denn angesichts der früher in den Flussauen verbreiteten Fließrinnensysteme ist damit zu rechnen, dass ,sich ähnliche Vegetationsverhältnisse einstellten, sobald die Auenwälder gerodet waren” (WILLERDING 1989:215f.).

„Derartige Röhrichte und Schilfgesellschaften dürften jedenfalls in den an Seen armen Landschaften das zum Dachdecken erforderliche Baumaterial geliefert haben. Das Stroh der frühen Getreidearten Einkorn, Emmer 
und Gerste war für diesen Zweck wegen seiner geringen Länge ohnehin kaum geeignet.” (WILLERDING 1989:216) Das Reet bzw. Reth (Schilf), das die Fischer im Winter schnitten, wurde jedoch nicht nur als Deckmaterial für die Rethdächer und als Baumaterial für Fachwerkhäuser, sondern auch als Brennmaterial und zur Anfertigung von Rethdecken verwendet. Und aus den Binsen wurden kräftige Matten und Teppiche, schöne Handtaschen und dergleichen geflochten (THIENEMANN 1955:60).

Die getrockneten Rhizome der Rohrkolben wurden zu Mehl verarbeitet, junge Triebe als Gemüse gegessen, geröstete Rhizome verwendete man als Kaffee-Ersatz. Die trockenen Blätter nahm man als „Büttnerschilf“ um die Fassfugen abzudichten. Außerdem steckte man die Fruchtwolle als Federersatz in die Bettdecken (KONOLD 1987:16). Der reife Rohrkolben (Typha) wurde gelegentlich ,als Polstermaterial verwendet“ (THIENEMANN 1955:91).

Des Weiteren wurde Gewinnung von Schilfstreu zur Einstreu in die Stallungen und die Rohrernte in der Teichwirtschaft propagiert (BENECKE 1885:43). Die Ernte war aber kostspielig und zeitraubend: Sollte es als Streu, d. h. als späteres Düngermaterial verwendet werden, so wurde die Gewinnung im Winter ,auf dem Eise" als leichteste Form empfohlen (ACKERHOF 1869:105). Stand das Rohr in tieferem Wasser, konnte die Ernte nur durch Kähne geschehen, von denen aus das Schneiden mit der Sichel erfolgte (:105).

Verschiedene Wasserpflanzen und Wurzelstöcke aus dem Schilfgürtel der Teiche und Binnengewässer galten auch den Menschen als Nahrung. So wurde zum Beispiel der "Gemeine Froschlöffel“" (Alisma plantago-aquatica) als Gemüse verwendet (HERBST 1992:175). Während des Ersten Weltkrieges wurden die Blätter des oben erwähnten Schilfs ,,zur Herstellung von Zucker, Alkohol und eines sog. ,Morgentranks' verwendet.“ (THIENEMANN 1955:91)

Erwähnt sei ferner, dass der mehlige Kern der Wassernuss (Trapa natans), einer schwimmenden Pflanze, den frühen Pfahlbaufischern als Nahrung gedient zu haben scheint, denn sie kommt in den steinzeitlichen Fischerstätten von Moosseedorf und Robenhausen vor. Eine größere verwandte Spezies wurde von der Fischerbevölkerung in gewissen Gegenden Chinas zumindest noch im 19. Jahrhundert ,als Nebenprodukt eingesammelt und ähnlich wirtschaftlich verwerthet.“(FRIEDEL 1884:60)

Die jungen Sprosse der Teichschachtelhalme aß man außerdem als „Spargel“. Wegen seines hohen Kieselsäuregehaltes eignete sich der Schachtelhalm des Weiteren gut zum Polieren von Zinn, Möbeln und Holzböden (KONOLD 1987:16).

Die Samen des in Gewässern weit verbreiteten „Flutenden Schwadens“ (Glyceria fluitans), auch Mannagras bzw. Manna-Schwaden genannt, waren ein sehr geschätztes und hochwertiges Nahrungsmittel. Man erntete sie, indem man entweder frühmorgens mit einem feinen Sieb durch die taufeuchten Ähren ging, oder man schöpfte die bereits abgefallenen Samen mit Hilfe von Sieben und Mullkeschern aus dem Weiher. Anschließend wurden sie in der Sonne getrocknet. Die Körner trennte man mit einem Mörser von den Spelzen und verarbeitete sie weiter zu Grieß („Mannagrütze“) oder Mehl (KONOLD 1987:16).

Die jungen, stärkereichen Rhizome der „Weißen Seerose“ (Nymphea alba) wurden zu Mehl verarbeitet; die reifen, gerösteten Samen dienten als Kaffee-Ersatz. Die älteren Wurzelstöcke eigneten sich wegen ihres Tanningehaltes zum Gerben und Färben. Medizinische Verwendung fanden alle Pflanzenteile. Man sagte ihnen nach, sie hätten eine stärkende Wirkung für das Herz und sie würden den Haarwuchs fördern (KONOLD 1987:16f.).

Die dicken, fleischigen Rhizome des Fieberklees (Menyanthes trifoliata) konnte man getrocknet zu Mehl verarbeiten. Teile der Pflanze verwendete man als Hopfen- und Teesurrogat. Die Blätter, in Wismut gekocht, ergaben eine kräftige gelbe Farbe. Als Drogen setzte man Fieberklee fast universell ein: zur Appetitanregung und Verdauungsförderung, als fiebersenkende Droge, außerdem gegen Magenleiden, Brust- und Lungenkrankheiten, Wassersucht, Leberbeschwerden, Skorbut und Hauskrankheiten (KONOLD 1987:17).

Kalmus (Acorus calamus), ein hohes Kolbengras, wurde von Destillateuren, Apothekern und Konditoren verwendet. Der geschnittene Kalmus wurde ,glatt geputzt und getrocknet für die Destillationen, aber geschält und frisch verkauft für die Conditoreien." (ACKERHOF 1869:106) Der aromatisch riechende 
Kalmus wurde um die Mitte des 16. Jahrhunderts aus Indien eingeführt. Seitdem ist er bei uns heimisch (SCHMEIL/FITSCHEN 1982:576). Zunächst hatte man ihn als Gewürzpflanze („Falscher Ingwer“) kultiviert, die inneren, zarten Blätter und der Wurzelstock wurden gegessen. Nachfolgend wurde er in der Heilkunde und in der Volksmedizin, also auch in der Selbstmedikation, verabreicht bei Magen-, Darm- und Gallenbeschwerden, bei Appetitlosigkeit und zur Anregung der Verdauungsorgane (KONOLD 1987:16). Bis Mitte des 19. Jahrhunderts wurde der Kalmus ,in den Bächen Norddeutschlands gesammelt, verschwindet aber mehr und mehr durch die Regulirung der Flüsse und Trockenlegung der Brüche“" (ACKERHOF 1869:107). Seit dieser Zeit wurde er infolgedessen in Teichwirtschaften gezogen, heute kommt er nur noch verwildert vor.

\section{Handwerk und Gewerbe}

\section{a Wasserrotte}

Flachs gilt als die älteste wirtschaftlich genutzte Faserpflanze und kommt schon bei den Hochkulturen des vorderasiatischen Raumes vor. Der früheste Nachweis steht in Zusammenhang mit der sumerischen Kultur (ca. 4.000 - 3.500 v. Chr.). Vermutet wird, dass die Pflanze in der Steinzeit von Spanien aus durch die Kelten nach Westeuropa gebracht wurde (FAHMÜLLER 1982:52; BUSSE 1995:4).

Flachs (ahd.: Flahs, zu flechten) wird im deutschen Schrift- und Brauchtum auch „Lein“ oder „Linum“ genannt und gehört zur Gattung der Leingewächse. Der botanische Name der Pflanze aber ist „Linum usitatissimum“ (lat.: „,er aufs Äußerste gebrauchsfähige Lein“) und weist darauf hin, dass alle Teile der Flachspflanze verwendet werden konnten:

Ihrer stark ölhaltigen Samen wird als Beimischung ins Backwerk gegeben, findet medizinische Verwendung und ergibt schließlich auch das sog. Leinöl oder Öllein, das bis zur Einführung des Petroleums zur Füllung der Öllampen diente und als Lichtquelle in Haus und Stall gebraucht wurde. Der ausgepresste Leinsamen, der sog. Ölkuchen, fand als hochwertiges Viehfutter Verwendung, die holzigen Abfälle gebrochener Stängel und Wurzel, das sog. „Schewe“, lieferte Stallstreu und wurde auch als Bindemittel dem Lehm beim Hausbau zugegeben. Die auf dem Feld abgefallenen Blätter dienten als Dünger und das Abfallprodukt des bearbeiteten Flachses als „Werg“ zur Füllung von Polstermöbeln (BUSSE 1995:4).

Schließlich wurden die Fasern unter der Epidermis des Stängels als Bastfasern oder Flachsfasern zur Gewebeherstellung benutzt. Dieses Produkt wird als der eigentliche Flachs oder als Faserlein bezeichnet und die fertigen Gewerbe heißen „Leinen“, „Linnen“ oder „Leinwand“ und dieser Herstellungprozess in früherer Zeit ist hier in gewässerhistorischer Sicht von besonderem Interesse:

Die Flachsfaser wurde bei der Herstellung von Säcken, Tauwerk, Netzen, Knoten und anderen Seilerwaren verwendet. So wurden aus dem wild wachsenden Flachs (Linum angustifolium) die ersten Fischernetze sowie feinere Gewebe hergestellt (FRIEDEL 1884:32). Auch das nach dem Pochvorgang in sog. Sümpfen aufgefangene Korn der Erze verarbeitete man auf sog. Planherden. Sie bestanden aus viereckigen, etwas geneigt stehenden Tischen, „die mit Leinentüchern belegt waren.“ (LIESSMANN 1997:97) Im rauhen Gewebe blieben die Erzpartikel haften, während die Gangkörnchen mit der übrigen Trübe davonflossen (:97). Des Weiteren wurde feines Tuch auch für die Ummantelung der Beutelkästen der Mahlmüllerei benötigt (LANGE 1989:72).

Aber vor allem kam sie bei der Herstellung von Textilien zum Einsatz, wenn auch ein Großteil der benötigten Textilien am Spinnrad und Webstuhl aus Wolle gefertigt wurde (SCHACHTNER 1988:31). „Die Haushaltswäsche, also Bettwäsche, Tisch- und Handtücher, bestand nahezu ausschließlich aus Leinen.“ (:32). Und auch die Leibwäsche und die Hemden waren reinleinene Kleidungsstücke. Für einen Schlosshaushalt hat v. LÖWENSTEIN (1988:118) ihre Erinnerungen zusammengefasst, die allein schon eine vage Vorstellung über die Anzahl der aus Leinen bestehenden Textilien zu damaliger Zeit ermöglichen. Danach wurden für die Herrschaft, die zahlreichen Kinder, unverheiratete Diener und Hausmädchen, Köchinnen und Küchenmädchen, alle sonstigen Bediensteten in Haus und Hof, außerdem Privatlehrer der Kinder, sowie für Gäste und Feste die dafür benötigten Textilien aus Leinen hergestellt. „Schloßherren und 
Gäste schliefen in weißem Damast, für Kinder und Hauslehrer gab es Halbleinen, kariertes Grobleinen für die Diener", schildert sie die Verhältnisse. Über die Leibwünsche hinausgehend bestanden die meterlange Tischdecken, Buffetts- und Tafeldecken, Mundtücher, Servierlivreen der Diener, Bettwäsche (Bettlaken, Bezüge, Kopfkissen), die Windeln der Kleinkinder, Wäsche des Personals, Handtücher und Lappen aus Küche und Bad aus Leinen oder Damast (:118f.)

Leinen - und dies trug zu seiner Beliebtheit entscheidend bei - war nicht nur aufgrund seiner Strapazierfähigkeit, Reißfestigkeit und Dichte so gut für viele Zwecke geeignet, wenn dem auch eine geringe Elastizität gegenüberstand, sondern auch, weil man es waschen und kochen konnte (SCHACHTNER 1988:33). Dementsprechend weit verbreitet waren auch die Anbauflächen.

Da die Flachspflanze sehr genügsam ist, kann sie überall in Deutschland angebaut werden. Dennoch bildeten sich in früherer Zeit für die verschiedenen Leinsorten bevorzugte Anbaugebiete heraus, weil zum Beispiel guter Faserlein dort wächst, wo die Sommer mäßig warm, durch hohe Luftfeuchtigkeit und einem Jahresniederschlag von $700-1000 \mathrm{~mm}$ geprägt sind. In Deutschland waren es die Bergländer sowie die niederen und mittleren Mittelgebirge und deren luvseitigen Vorländer. Und seit dem 13. Jahrhundert wird Leinen in Flachs-Monokulturen ,auch in höheren Mittelgebirgslagen gewonnen.“ (SEIBT 1999: 175)

Traditionelle Anbaugebiete befanden sich in Schlesien (Striegau, Sagan) und der Ober- und Niederlausitz aus denen die ältesten Nachrichten über die deutsche Leinenindustrie stammen. Ein zweites Zentrum lag mit der „Bielefelder Bleiche“ in Westfalen, wo noch heute der zum Rummel verkommene „Leinewebermarkt“ alljährlich abgehalten wird, aber auch in Thüringen, Württemberg und Bayern wurde Flachs angebaut. In Süd-Deutschland waren es vor allem die Städte Konstanz, Ravensburg, Biberach, Ulm, Kempten und besonders Augsburg, wo die Fugger den Flachshandel betrieben. Im Hunsbrück, Westerwald, in Teilen der Eifel, im Taunus wurde noch um 1930 Flachs angebaut und verarbeitet, am Niederrhein und in der Pfalz wurde der Flachsanbau hingegen bereits vor der Jahrhundertwende aufgegeben (SCHACHTNER 1988:31f.).

In Niedersachsen eigneten sich auch die sandigen Lehmböden der Buntsandsteinlandschaften in Luvlage zum Solling und zum Bramwald für den Flachsanbau (BUSSE 1995:5). Der Adelebser, Uslarer und Lippoldsberger Raum mit dem Dorf Lödingsen, war ,sehr stark durch die Leinenweberei geprägt“ (BUSSE 1995:6). „Die Bleichen im Amte Uslar, besonders in Sohlingen waren von jeher die bedeutendsten im Königreich Hannover“" (SCHRECKENBACH 1995:27; siehe Pkt. 3.c ,Bleichwiesenbewässerung').

Neben dem Flachs war in der antiken bis vorindustriellen Textilproduktion die Wolle der wichtigste Rohstoff (SCHNEIDER 1992:123). Während Wolle vor dem Import von Baumwollpflanzen hauptsächlich durch das Scheren von Schafen gewonnen wurde, musste das Rohmaterial für die Leinenherstellung agrarisch angebaut werden und konnte erst durch die Aufbereitung von Flachs gewonnen werden. Der Flachsstängel enthält zusammenhängende Bastfasern, die in einem „langwierigen Aufbereitungsvorgang des Wässerns, Dörrens, Brechens und Hechelns (FAHMÜLLER 1982:52) von der Rinde und dem hölzernen Kern getrennt werden müssen, um daraus textiles Gewebe zu gewinnen (SCHNEIDER 1992:123)

Dieser Prozess - vom Flachs zum Leinen - beinhaltete historische, sehr arbeitsaufwendige Verarbeitungstechniken und einen für die historische Gewässernutzung entscheidenden Vorgang:

Der im Frühjahr ausgesäte Flachs wurde im Sommer, kurz nach dem Eintreten der Reife bzw. kurz vor der Samenreife, da ist man sich in der Literatur nicht einig, durch „Raufen“, d. h. durch Herausziehen der ca. 100 bis $120 \mathrm{~cm}$ langen Pflanze samt der Wurzeln mit der Hand, geerntet. Zum einen, damit möglichst lange Fasern gewonnen werden konnten, denn diese gehen bis in die Wurzeln, zum anderen damit sich die Stängel während der „Rotte“ an etwaigen Schnittstellen nicht bakteriologisch zersetzten. Die Flachsernte, das Flachsraufen, wurde überwiegend von Frauen durchgeführt, die den Flachs in kleinen Bündeln zusammenfassten und trocknen ließen.

Für die Leinölherstellung wurden danach die Samenkapseln vom Stroh „geriffelt“, d. h. mit einem sog. Riffelkamm abgestreift und getrennt. Anschließend erfolgte das Ausdreschen der Samenkapseln mit dem Dreschflegel und der Verkauf an die Ölmühle. 
Die Aufbereitung für die Fasergewinnung geschah dann anschließend traditionellerweise in der aufwendigen Tau- oder Wasserrotte; und zwar dadurch, dass die im Flachsstängel eingelagerten Faserbündel durch die Röste freigelegt wurden. „Rösten“ oder auch „Rotten“ bezeichnet allgemein ,den Rotteprozeß, dem der Flachs nach der Ernte unterzogen wird“" (KONOLD 1994:318) und beschreibt die Aufbereitungsstufe in der frühen Textiltechnik zur Gewinnung von Spinnfasern aus Bastfaserstängeln. Störende Rinden-, Holz- und Markteile von den Bastfasern mussten aufgelockert werden, um das Fasermaterial isolieren zu können. Dies geschah durch Einlegen des Flachses in Gewässer. Hier wurde der Flachs eingeweicht und gespült. Man legte die getrockneten Stängel in von der Sonne erwärmtes Wasser, wobei man sie beschwerte, damit sie vom Wasser ganz bedeckt waren. Die Pflanzen wurden von Bakterien zersetzt, so dass die Fasern sich von den anderen Bestandteilen des Stängels lösten (siehe auch Pkt. VII 5.1 ,Rottekuhle').

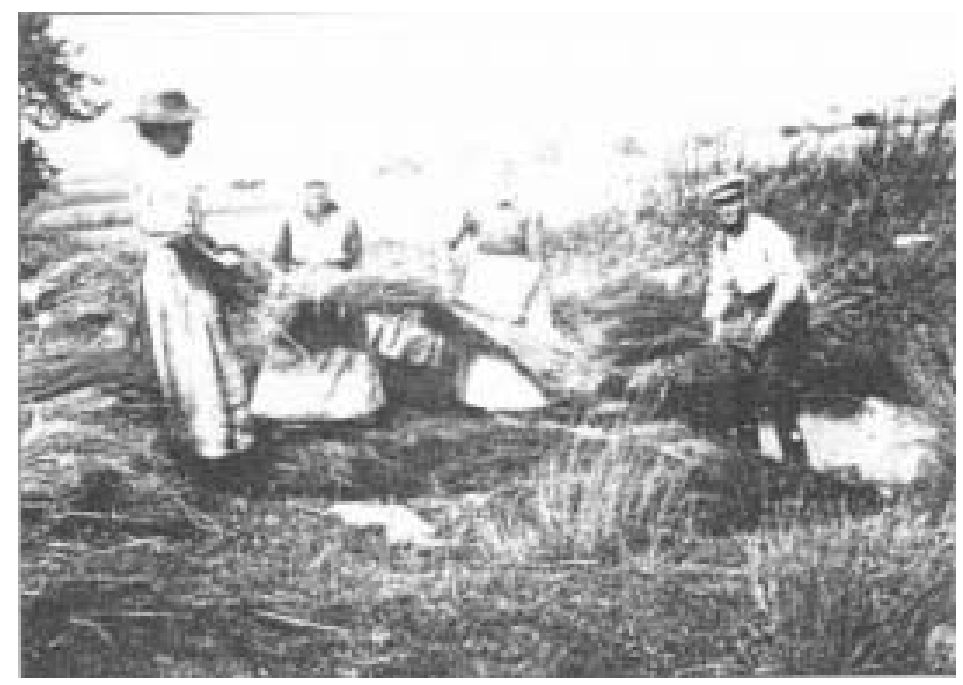

Abb. VI-68: Einbringen der Wasserbunde in die Rottekuhle, Wibbecke um 1910 (aus: BIRKIGT-QUENTIN et al. 1995: 9)

Nach dem Rotten wurden die Bündel ausgewaschen und zum Trocken erneut auf ein trockenes Feld gelegt oder am Herd bzw. in speziellen Backöfen ,gedörrt“, anschließend mit einem an der Unterseite geriffelten Holzhammer („Bokehammer“), einem Klopfer oder bei größeren Mengen in sog. Bokemühlen mit einem Stampfwerk weich geklopft, um das mürbe gewordene Holz von dem Bast zu lösen und die Fasern voneinander zu trennen.

Nach dem Boken geschah dann die vollständige Entfernung der Holzteile durch das Schwingen des Flachses. In späterer Zeit erfolgte das Brechen des Flachses mit der „Breche“, einem 50 - $70 \mathrm{~cm}$ hohen Holzgestell mit Holzschienen zum Schneiden oder einer handangetriebenen Maschinenbreche. Hier wurden die holzigen Bestandteile des Stängels zersplittert, sie lösten sich von den Bastfasern und fielen zu Boden.

Die aus Stängeln gewonnenen Faserbündel (Länge: $60-70 \mathrm{~cm}$ ) bestehen aus $20-40$ feinen Einzelfasern, die auch nach diesem Prozess durch Pflanzenleim weiterhin miteinander verbunden waren.

Die noch vorhandenen Holzteilchen und kurze und verworrene Fasern wurden mit einem Schwingbrett ausgeschlagen (,schwingen“), letzte Holzpartikel und kurze Fasern ausgekämmt („hecheln“) und zu Zöpfen zusammengedreht. Beim Hecheln wurde der Flachs über ein Brett, auf dem mehrere Reihen Nägel angebracht waren, gezogen; auf diese Weise wurden die letzten Rinden- und Kernteile entfernt und die noch zusammenhängenden Fasern voneinander getrennt. Nach diesem Arbeitsgang lag endlich eine verspinnbare Faser vor. In den Wintermonaten wurde der in Zöpfen gedrehte, gehechelte Flachs am Spinnrad versponnen und auf eine Spule gewickelt. Um das gesponnene Garn nach einem einheitlichen Maß abzumessen, wurde der fortlaufende Faden von der Spule auf eine geeichte Haspel gewickelt. Das Garn wurde vor dem Verweben gesäubert und mit Buchenholzasche gekocht (,büken“), gebleicht und zum Teil gefärbt.

Anschließend wurde das Garn, nachdem zuvor weitere Arbeitsschritte wie das „Spulen“ und „Schweren“ folgten, am Webstuhl verwebt. 
Nach dieser Vielzahl von Bearbeitungsgängen folgte das - nach dem Rotten - unter gewässerhistorischem Aspekt interessante Bleichen; man sagt auch: das Leinen wurde „veredelt“. Damit es möglichst weiß aussah, wurde es vorab in einem Bottich mit Buchenasche gebükt (,buiken“ = Buche) und anschließend auf dafür spezielle Bleichflächen einige Tage und Nächte ausgelegt und mehrmals befeuchtet gewendet. Die Leinwand wurde zuweilen auch auf lange Holzgestelle gespannt (FAHMÜLLER 1982:52; SCHNEIDER 1992:123f.; BUSSE 1995:18f.).

In der Zeit vom 16. bis 18. Jahrhundert hatten sich Flachsanbau und -vearbeitung so stark entwickelt, dass auch die Ausfuhr von Leinen eine große handelspolitische Bedeutung erlangte.

Die Durchsetzung der Industrialisierung in den Textilgewerben veränderte die Verhältnisse grundlegend: „Infolge der massenhaften Produktion in großen Fabriken verbilligten sich die Stoffe und die Verbraucher webten immer seltener selbst. Außerdem mußten Kleidungsstücke und Wäsche nicht mehr so lange halten, sondern konnten öfter ersetzt werden. Gleichzeitig verdrängte die Baumwolle das herkömmliche Leinen, da dieses schlechter maschinell zu verarbeiten war." (SCHACHTNER 1988:31). An die Stelle von Leinen, Halbleinen und Baumwolle traten später vielfach Stoffe aus synthetischen Fasern (BÜCHER 1988:82).

Waren die textilen Eigenschaften des Leinens (Strapazierfähigkeit und Dichte) zu früherer Zeit noch ein Vorteil, wandelten sie sich zu einem Wettbewerbsnachteil. Denn auf dem Weg vom Flachs bzw. Hanf zum Leinen waren sehr viele einzelne Arbeitsschritte zurückzulegen, wie man der Schilderung entnehmen kann. Während der Flachs nach der Ernte erst umfangreich und intensiv bearbeitet werden muss, ist die Baumwolle bereits als Rohmaterial spinnfähig.

Die Industrialisierung im 19. Jahrhundert mit der Einführung der Spinnmaschine und des mechanischen Webstuhls und des Flachsimportes aus Russland führte $\mathrm{zu}$ großen Einbrüchen im Flachsanbau. Die maschinelle hergestellte Baumwollfaser verdrängte mehr und mehr die Flachsfaser und damit gingen auch die Anbauflächen zurück, die manuelle Leinenweberei wurde unbedeutend.

Der Flachsanbau blieb seit Ende des 19. Jahrhundert in Deutschland unbedeutend. Nur während der beiden Kriege nahm er wieder zu, um anschließend erneut zur Bedeutungslosigkeit abzusinken.

Hauptziel des heutigen weltweiten Flachsanbaues ist die Leinölgewinnung sowie - als weitere nichttextile Anwendung - der Ersatz von Asbest und die Futtermittelherstellung. In jüngster Zeit ist im kleinen Umfang eine Revitalisierung des Flachsanbaus und der Leinenherstellung festzustellen.

Das Garn aus welchem beispielsweise die Fischernetze, das Tauwerk und die Knoten gefertigt wurden, bestand aber nicht nur aus Flachs, sondern ,auch aus gutem Hanf“ (BORNE 1886b:564).

Hanf wurde eigentlich als Rohmaterial ,am meisten gebraucht“, da er „wegen der Länge und Festigkeit seiner Fasern besonders geschätzt" wurde (BORNE 1886b:563). Die Stängelfaser des Hanf diente außer der Fischereiwirtschaft zur Herstellung von Nähgarnen, Bindfäden, Schnüren und Seilen sowie von Segeltuch, Gurten, Teppichen. Wie beim Flachs enthält auch der Hanfsamen Öl (Hanf-Öl), das zur Seifenherstellung und mit Leinöl vemischt als Firnis verwendet wird. Hanf (ahd.: Hanaf) wurde also ebenfalls zur Gewinnung der - gleichfalls Hanf genannten - Fasern und des Samens angebaut.

Spätestens im 5 Jahrhundert v. Chr. war Hanf auch bei den Germanen bekannt, im 3. Jahrhundert v. Chr. auch den Galliern im Rhonetal. Hauptanbaugebiete im 19. Jahrhundert waren der Breisgau und das Elsass, aber Hanf wurde auch schon zu dieser Zeit aus Italien (Bologna), Russland, Neuseeland, von den Molluken und den Philippinen importiert (BORNE 1886b:563), da er sich je nach Herkunftsland hinsichtlich Härte, Festigkeit und Dauerhaftigkeit unterschied.

Die zu Bündeln vereinigten Einzelfasern, der Bast, wurde, wiederum vergleichbar wie beim Flachs, durch Rösten, Schwingen und Hecheln gewonnen. Auch der beim Hecheln des Hanfes gewonnene Abfall, das sog. Hanfwerg, wurde bei der Fabrikation von Tauen zur Anfertigung von Seilen benutzt und zu anderen Seilerwaren verarbeitet (BORNE 1886b:563). 
Einem zumindest beim Wassergang gleichartigen Verarbeitungsprozess unterlag auch die Gewinnung des zum Blaufärben benötigten Färberwaid. Die Blätter der Waidpflanze wurden 2 - 3 mal im Jahr geerntet. „In den Waidmühlen wurden die Blätter gestampft oder von Steinen zerquetscht und anschließend in heißem Wasser ausgelaugt“ (KREINER 1996:147), um den begehrten Farbstoff für das Textilgewerbe zu gewinnen.

Das Hauptanbaugebiet lag in Thüringen, bei den sog. Waidstätten Erfurt, Gotha, Tennstedt, Arnstedt, Laugensalza. Die „besten Waidanbaugebiete“ hingegen lagen „im Herzogtum Jülich an der unteren Rur und der Wurm“ (KREINER 1996:147). Bis zum Jahr 1910 lässt sich sogar ein Anbau bis 1950 m Höhe in Mittelwallis/Schweiz nachweisen.

Die Wasserrotte von Flachs und Hanf hatte jedoch ein gravierendes Problem: die starke Verunreinigung der Gewässer. Es ,wirkt in jedem, auch fließendem, Gewässer sehr schädlich auf die Fische ein und darf daher, wo Fische gehalten werden, nicht zur Ausführung kommen." (TAURKE 1927:162) Im Mittelalter legten Bauern Hanf zum Einweichen in die Bäche, deren Wasser oftmals den Fischteich speiste. Durch das sog. „Rotzwasser“ gingen die Fische „im Weiher elend zugrunde“, so weiß AMACHER (1996:96) aus der Schweiz im Jahr 1466 zu berichten. Denn ,wurde Hanf oder Flachs zum Mürbemachen (Hanfrotten) in Wasser gelegt, geben sie Substanzen ab, welche die Fische nicht ertrugen.“ (:105) Die schädigende Wirkung des „stinkenden, trüb-gelb aussehenden Flachsröstabwassers“ ist vor allem auf die sehr starke Sauerstoffzehrung des Abwassers zurückzuführen (TAURKE 1927:162). Deshalb wurde den Bäuerinnen das Hanfrotten in fischreichen Seen und Teichen verboten (AMACHER 1996:105).

Bereits Friedrich II. delegierte zum Schutz der „Reinheit der Luft, [...] daß es fortan niemandem erlaubt sein soll, in die irgendeiner Stadt bzw. Burg benachbarten Gewässer mindestens eine Meile im Umkreis Flachs oder Hanf zum Reifen zu legen [...]. Wer solches tut, soll den besagten Flachs und Hanf zugunsten des Hofes einbüßen.“69

Der Ausschluss der Verwendung eines Fischgewässers zum Hanfeinlegen hatte zur Folge, da die meisten kleineren Wasserläufe auch durch einen Wasserabzweig die Teiche nährten, dass gleichzeitig mit dem Aufkommen der Teichwirtschaft die natürlichen Fischgewässer der Nutzung zum Hanfrotten entzogen wurden (AMACHER 1996:105).

Wie die Fischer auf der einen Seite diese Anordnungen begrüßten, so wehrten sich auf der Gegenseite die Flachsbearbeiter gegen die Verbote. So hatten beispielsweise die Vertreter der Realgemeinden des Kreises Nordhausen in ihren Sitzungen „Einwendungen wegen des erschwerten Flachsröstens“ zu behandeln ${ }^{70}$.

Auch in den Bächen im Vredener Land wurde geröstet, wie das Beispiel des dortigen Ölbaches beweist. Für die Anlage einer Papiermühle an dem - für einen Mühlenbetrieb - mit geringer Wasserführung ausgestatteten Bachlauf gab es eine Zusage der Stadt an den Pächter anlässlich des Pachtvertrages im Jahre 1729, dass künftig im Ölbach kein Flachs mehr ,geteichet” werden solle (TERHALLE 1992:112); was offensichtlich „,in dem langsam fließenden Bach üblich war, die Wasserqualität aber erheblich minderte und somit die Papiererzeugung unmöglich machen mußte, bei der man auf besonders reines Wasser angewiesen war.“ (:112f.). Aus Bruchstücken der Korrespondenz zwischen der Stadt Vreden und der landesherrlichen Behörde in Münster, die TERHALLE (:115) ausgewertet hat, ,geht hervor, daß auch später noch an mehreren Stellen Flachs in den Ölbach zum Einweichen gelegt wurde.”

Auch bezüglich der Dumme im Wendland „,ist darüber geklagt worden, daß alljährlich von den Dörfern unterhalb des Gains der Flachs zum Röten in den Fluß gelegt würde. Zur Beschwerung des Flachses würden darauf Grassoden gelegt. Diese würden jedoch nur zu einem Teil wieder aus der Dumme geholt, was eine ständige Erhöhung des Flußbettes und dadurch Schaden zur Folge habe.“ (LANGE 1989:55) Des Weiteren ist das Flachsrösten ,auch an der Saale im Uferbereich“ praktiziert worden (SCHUBERT 2001:117) und

\footnotetext{
${ }^{69}$ (Friedrich II., Konstitutionen für Sizilien (13. Jh.) - Tit. XLVIII „Vonn der Reinhaltung der Luft“. Hier nach: Hermann Conrad/Thea von der Lieck-Buyken und Wolfgang Wagner: Die Konstitutionen Friedrich II. von Hohenstaufen für sein Königreich Sizilien. - Wien 1973:308, aus: BAYERL/TROITZSCH 1998:113)

${ }^{70}$ Stadtarchiv Nordhausen: „Regulierung des Abzugsgrabens an der neuen Mühle 1885-1916“ [X 997].
} 
auch in dem Rotbachwasser in Ochsenhausen wurde der Flachs, vor seiner Weiterverarbeitung in den Dörröfen „,im Rotbachwasser einem mehrwöchigen Fäulnisprozess ausgesetzt.“ (HERBST 1992:47)

Mit dem Preußischen Fischereigesetz vom 30. Mai 1874 wurde „das Rösten von Flachs in nicht geschlossenen Gewässern“ verboten (EBERTS 1904:8) und es mussten separate etwa $1 \mathrm{~m}$ tiefe Wasserkuhlen angelegt werden (BUSSE 1995:10; siehe Pkt. VII 5.1 ,Rottekuhlen').

Auch das notwendige Einweichen des Färberwaids wurde als „raotse“ oder „rösten“ (= verrotten) bezeichnet (HERBST 1992:43). Zunächst in einer hand-, später wasserbetriebenen Waidmühle sind durch „Quetschen“ gemahlene Blätter aus der Pflanze gewonnen worden. Anschließend wurden diese Blätter in offenes Gewässer oder in einem Färbebottich als „schwimmendes Garn“ zur Gärung ausgelegt, durch Kneten anschließend Ballenformen erzeugt und auf dem Bodenraum zur Trocknung verbracht.

HERBST (1992:43,69) weist den Vorgang des Einweichens in Fließgewässer und Einrichtungen zur Wasserröste von Färberwaid im Oberen Stadtbach von Ochsenhausen nach, wo der Streckenabschnitt die Bezeichnung „Rozzegraben“ bzw. „Ratzengraben“ trägt.

Da das Reinigen und Färben Wasserverschmutzungen auslöste und geruchsbelästigend wirkte, wurden die Färbereien „meist in gesonderten Vierteln - oft den Gerbern benachbart - angesiedelt.“ (FAHMÜLLER 1982:57).

\section{b Gerben, Walken, Färben}

„Wichtigste Voraussetzung“ für die Ausübung des Gerberhandwerks „war die Lage am fließenden Wasser“ (KONOLD 1994:317). Gerber und Schuhmacher, welche bisweilen die Gerberei mitbetrieben, benötigten große Mengen Wasser unter anderem zur Reinigung der Häute und zum Spülen des gegerbten Leders.

Deshalb wollten die (wenigen) in der Stadt ansässigen Gerbereien das Wasser komplett durch die Stadt fließen lassen, damit es „ein jeder hinter seiner Wohnung zu seinem Gewerbe gebrauchen“ konnte, wie ALTHÖFER-WESTENHOFF/WAGNER (1997:36) am Beispiel der Werre belegen konnten. Deshalb reizten sie die Stauhöhe an den Wehren bis aufs Äußerste aus und riskierten so zudem immer neue Überschwemmungen.

Wie schon beim Wasserverbrauch, so zählten die Gerbereien auch in puncto Gewässerverschmutzung zu den Hauptverantwortlichen. Von ihnen ging durch den Verarbeitungsprozess eine erhebliche Gewässerbelastung aus:

Zunächst wurden die Häute vor dem Schaben geweicht. Dafür wurden „Wässerungsplätze“ im Flusslauf zugewiesen, die durch Stege erreichbar waren. An jenen Plätzen wurden an den Stegen die Felle auf Pfähle gebunden und einige Tage im Fluss gewässert, bevor sie anschließend enthaart wurden. 


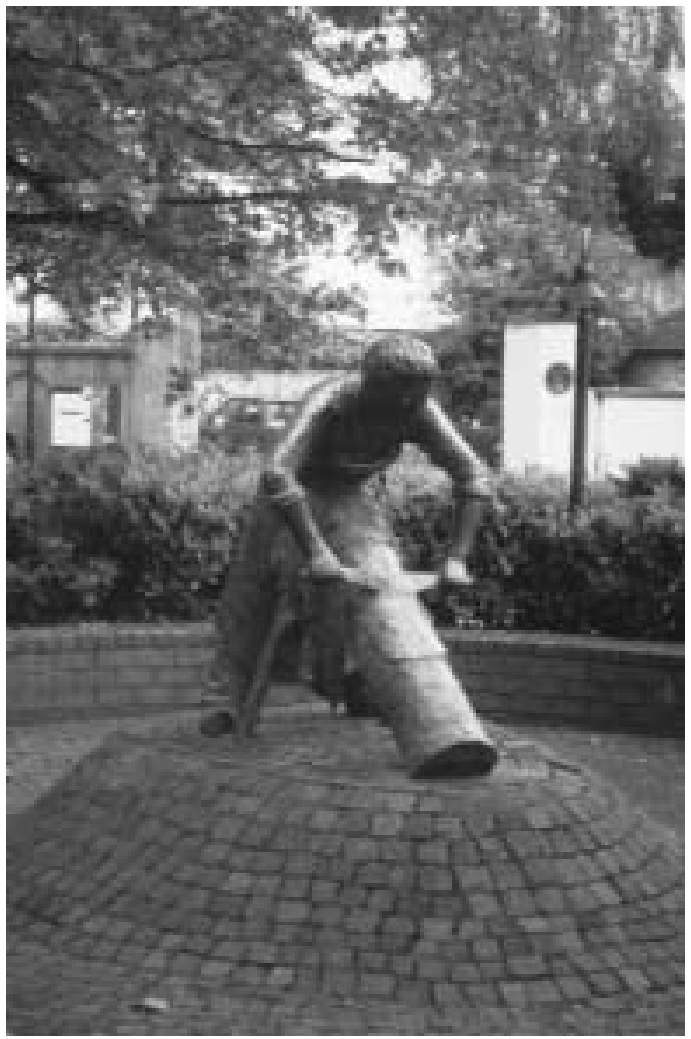

Abb. VI-69: Gerber mit Schabemesser beim Enthaaren von Häuten

Skulptur von Olaf HÖHNEN (1986) unweit des Itterflusses in Hilden. Sie erinnert symbolisch an die Lederfabrik Jüntgen, die hier von 1860 - 1983 anstelle des „City-Centers“ gestanden hat (eig. Aufnahme 2004).

Die Wässerungszeiten waren von den Gerberei-Meistern geregelt:

1. In den Strom sollten nur Häute zum Ausspülen eingehangen werden und nicht länger als zwei Stunden.

2. Der „Handwerksstrom” von der Stege aus darf nur zum Ausspülen des Leders und nur eine Stunde benutzt werden (BINTZER 1991:171).

Mit Hilfe des Schabeisens wurden, so beschreibt KONOLD (1994:317) den Ablauf, „Fleischreste, Blut, Fett und das die Häute konservierende Salz entfernt." Der Schabeplatz, d. h. der zweite den Lohgerbern von den Städten gemäß Gewerbeordnung zugewiesene Platz, auf dem vor allem die Haare von den Fellen geschabt wurden, befand sich in der Regel hinter den Stegen am Rande des Wasserlaufs (BINTZER 1991:171).

Beide Plätze waren wetterfest überdacht. Es wird ein Bild hektischen Treibens auf der Schabe vermittelt, unter den Schuppendächern und auf den Stegen: „Jeder versuchte, einen Platz zum Weichen oder zum Schaben zu ergattern [...]. Besonders begehrt waren jene Plätze, die im Strom der Mühlengerinne lagen, denn die Strömung bewirkte eine intensive Wässerung und damit einen Zeitgewinn.“ (BINTZER 1991:173f.).

„Um die Haare zu lockern, wurden die Häute in Urin, Kalkmilch oder Pottasche eingelegt; anschließend wurden sie abgeschabt. Ebenso wie die Reste von der Fleischseite kamen die Haare und die Abwässer in den Bach vor der Werkstatt. Bei der Loh- oder Rotgerberei fielen aus den Gerbbottichen Abwässer mit Gerberlohebrühe und Kalialaun an“ (KONOLD 1994:317). Das bei der Lederproduktion benutzte Wasser wurde anschließend ungeklärt wieder in den Fluss geleitet (ALTHÖFER-WESTENHOFF/WAGNER 1997:37).

Die zusammengefassten Erinnerungen eines Gerbers von 1890 an der Werra in Eschwege vermitteln einen lebendigen Eindruck von der historischen Gewässernutzung vorindustrieller Lederproduktion (BINTZER 1991:282): Die sog. Schabe war hinter den Mühlen neben dem kleinen Wehr. Dabei handelte es sich um 2-3 Reihen Stege mit drei starken Eichenbohlengängen, woran die Häute an starken Tauen [...] befestigt im Wasser weichten. Die Häute wurden ,, alle paar Tage auf die Ströme der Mühlen gebracht, um ganz salzrein 
zu werden. Nach 8 bis 14 Tagen waren die Häute rein und weich und wurden dann in die Gerberein gebracht und in einem Kellerraum luftdicht aufgehängt, die sog. Schwitze. Nach zwei bis drei Tagen war die Haarseite leicht angefault, sodass die Haare abgeschabt wurden, was von den kleineren Gerbern auf der Schabe gemacht wurde. Es war dort eine gemeinschaftliche Halle, wo dann die Häute auch geschoren wurden. Es gab 5 Ströme und musste man sehr aufpassen, dass man zum Weichen einen Strom freibekam."

Die letzte Aussage deutet auf eine Gewässerumgestaltung der Werra hin, deren Verlauf im Stadtbereich während des Mittelalters noch durch Werder gekennzeichnet war. Um 1400 erschlossen die Gerber in Eschwege ,den sandigen und kiesigen Überschwemmungsabschnitt zwischen den zwei Brücken aus Platzmangel“" (BINTZER 1991:215).

Gerben war jedoch neben der gewässerschädigenden und gewässerlaufverändernden vor allem auch eine stinkende Angelegenheit, so dass aus Gründen der Luftreinhaltung und Hygiene am Ende des 18. Jahrhunderts diesem Gewerbe gewisse Auflagen verfügt wurden, in der Form, ,daß Gerbereien [...] nur am fließenden Wasser, beim Abfluß desselben vor der Stadt, und nur an Orten, wo der freie Zug der Luft nicht durch Bebauung gehindert ist, angelegt werden sollen." ${ }^{\text {"71 }}$

Die Werkstätten lagen also aus ordnungsrechtlichen Gründen außerhalb städtischer Bebauung am fließenden Wasser, in dem die Waschbänke angebracht waren. Diese Ansiedlung außerhalb der Stadtmauern brachte natürlich auch eine soziale Isolation des ,anrüchigen“ Gewerbes mit sich.

Mit Beginn des Industriezeitalters werden die Prozesse in der Fabrik zentralisiert. Neben der Lohherstellung wird auch die Wässerung der Felle dorthin verlagert. In großen Bassins wurden bei ständiger Wasserzufuhr die Häute entsalzt und geweicht. Da die fabrikeigenen Brunnen für den erhöhten Wasserbedarf nicht ausreichten, musste das Wasser der Werra in die Fabriken geleitet werden (BINTZER 1991:183).

Neben dem Gerben von Leder gehörte auch das Walken, mit dem man Stoffe zu Tuchen verfilzte, zu den Gewerbeeinrichtungen, die zunächst an Gewässerläufen lokalisiert waren und Wasser für die Verarbeitung benötigten.

Das Walken entwickelte sich erst in römischer Zeit zum Gewerbe und zur regelrechten Industrie. In einer Tuchwalkerei wurde von den Walkern unter Zusatz von Soda, fauligem Urin oder sog. Walkerde in mehreren Arbeitsschritten „das Gewebe im Wasser anhaltend getreten, anschließend gewaschen, geschlagen, mit Disteln oder Bürsten gerauht, im Schwefeldampf gebleicht und schließlich in einer Schraubenpresse ,gebügelt'.“(FAHMÜLLER 1982:57)

Die Gewebe wurden also zunächst in Holz- oder Metallgefäße oder in kleine Teiche gelegt, die mit Wasser und dem Reinigungsmittel (Pottasche, Seifenkrautwurzel) gefüllt waren. Die Haupttätigkeit des Walkens und daher die Berufsbezeichnung - bestand darin, die in der Flüssigkeit liegende Gewebe 24 Stunden, teilweise auch länger, mit den Füßen zu treten. Das Walken diente dazu, das Gewebe von Schmutz und Wollfett gründlich zu reinigen und die Verfilzung der Fäden zu fördern (SCHNEIDER 1992:126).

Später übernahmen dann die wassergetriebenen Walkmühlen diesen Verarbeitungsprozess um Tuche zu fertigen (siehe 14b); die Nutzung von Wasser aber, wenn nunmehr auch als Energielieferant, blieb bei diesem Fertigungsprozess bestehen.

Im Gegensatz zur oben beschriebenen Herstellung des Färberwaids, also der Gewinnung des Farbextraktes aus der Pflanze, beschreibt das Färbverfahren einen Gewässerbenutzungsprozess, der durch Zu- und Ableitung von Fließwasser gekennzeichnet und „bis zur Mitte des 19. Jh. nur einem geringen technologischen Wandel unterworfen“ war (DIX 1997:92): „Stets wurde die Wolle entweder als loses Fasermaterial, Garn oder fertiges Tuch in Farbkesseln mit in Wasser gelösten Farbstoffen gefärbt.“

\footnotetext{
${ }^{71}$ (G. F. Lamprecht: Von der Kameralverfassung und Verwaltung der Handwerke, Fabriken und Manufakturen in den Preußischen Staaten und insonderheit in der Kurmark Brandenburg. Berlin 1798, Sieben und zwanzigstes Kapittel, Von den Lohgerbergewerken, $\S$ 468:353, aus: BAYERL/TROITZSCH 1998:164)
} 
Zunächst musste das Farbbad hergestellt werden, indem die Farbstoffe in Wasser gelöst wurden. Dieses Farbbad wurde seit dem 17. Jahrhundert (KREINER 1996:147), spätestens im Verlauf des 18. Jahrhunderts bis zum Beginn des 19. Jahrhunderts (DIX 1997:103) nicht mehr aus heimischen Färberwaid gewonnen, sondern aus verschiedenen tropischen Farbhölzern, so dass es vom Markt verdrängt wurde. Zu den den Küpenfarbstoffen (Küpen = blauen) gehörte vor allem der Indigo, aus dem der Farbstoff durch Mahlen und Extraktion des Holzes pulverisiert gewonnen wurde.

Die pulverförmigen Farbstoffe mit der Farbstoffmischung konnten in der vorliegenden Form noch nicht gefärbt werden (DIX 1997:103). Sie mussten „erst mit Wasser angeteigt und dann durch heißes Wasser aufgekocht werden, damit sich die Farbstoffe vollständig lösten. Anschließend ließ man das Wasser zulaufen, berechnet nach dem [...] Verhältnis Wasser - Farbstoff“"(:103).

Dazu wurde Beize gegeben (Alaun, Weinstein oder Eisenvitriol). Es wurden in Färbereien für die Wollverarbeitung Beizen- und Küpenfarbstoffe, mitunter auch kombiniert, angewendet (DIX 1997:93). Bei dem alleinigen Färben mit Küpenfarbstoffen sprach man von einer Küpenfärbung. In den anderen Fällen fand der Färbevorgang in Kesseln statt, weshalb man diesen Vorgang als Kesselfärbung bzw., da Beize zur Verwendung kam, als Beizfärbung bezeichnet. Diese beiden Färbeverfahren beschreibt DIX (:93) für das zweite Drittel des 19. Jahrhunderts.

Es folgte das Ausfärben, d.h. das Entwässern der Wolle nach dem Färben, bei dem man sich einer „Quetsche“ bediente, eines oben offenen Holzbottichs mit einer Haspel (DIX 1997:95). Danach schloss sich „das Ausspülen der gefärbten Zeuge im Flußwasser an“ (:92f.). Die Färbekessel, die für die Färberei mit Beizenfarbstoffen benutzt wurden, wurden einfach in den Gewässerlauf entleert. Neben den Farbstoffen wurden zum Färben große Mengen an Säuren und Salzen benötigt (Natriumsulfat, Essigsäure, Chromkali u. a.), ,die in großen Mengen in der Färberei zum Einstellen des pH-Wertes der Färberflotte oder als Hilfsmittel zum gleichmäßigen Aufziehen der Farbstoffe [...] gebraucht wurden.“(:100)

In der Tuchfabrik des 19. Jahrhunderts wurden diese Essenzen und Abwässer der Küpe nicht direkt ins Bachwasser, sondern ,durch offene Abflußgräben im Fußboden unterhalb der Turbine in den Freilauftunnel [...] direkt über ein Rohr in den Erftmühlenbach abgeleitet. Eine Klärung der Abwässer fand nicht statt, lediglich ein Gitterrost diente dazu, die festen Stoffe wie Faserreste zurückzuhalten. [...] Nach dem Ablassen der Farb/Wassermischung [...] wurde das Material mit frischem Wasser gründlich gespült, um alle anhaftenden Verunreinigungen zu beseitigen.“(:105)

\section{Reinigung}

\section{a Leibwäsche}

„Die Ufer ihrer Flüsse suchten die Städte nach Möglichkeit zu befestigen. Das war schon deshalb unerläßlich, um Waschstege anlegen zu können“, so die Vermutung von SCHUBERT (1989:32) zur Bedeutung von Wascheinrichtungen im Zusammenhang mit Eingriffen in die Ufergestaltung. So fanden sich Waschstege bis weit in die industrielle Zeit hinein überall an den Gewässern des ländlichen, dörflichen und kleinstädtischen Raumes, wie zum Beispiel auch 1890 am linken Elseufer in Bünde/Westfalen, auf denen das Flusswasser zum Wäsche Spülen und Begießen genutzt wurde (ALTHÖFER-WESTENHOFF/WAGNER 1997:93).

Die einzelnen Arbeitsgänge des Wäschewaschens waren jedoch komplizierter, als es der einfache Waschsteg am Flussufer verheißen mag: Zunächst begann das Fleckenentfernen bzw. das Einreiben sehr schmutziger Stellen vor Ort im Haus. Auch noch in Notjahren des Zweiten Weltkrieges wurde dazu die Seife selbstgemacht: aus Schwarten, Knochen und Darmfett vom Schwein (DÖRING/GANSOHR 1988:22), aber auch von Rinder-, Hammelfett und von Fett von Geflügel (KRAMARCZYK 1988:128). Diese mechanische Säuberung der Wäsche, d. h. Waschbrettrubbeln, hartnäckige Flecken mit Seife eingerieben und wieder gerubbelt, geschah in einer Lauge aus tierischen Abfällen (DÖRING/GANSOHR 1988:14). 
Ein uraltes Mittel zur Laugenherstellung, das bis zu Anfang dieses Jahrhunderts des Weiteren bei uns noch Anwendung fand, war Holzasche (KRAMARCZYK 1988:127; DÖRING/GANSOHR 1988:14,22). Diese Holzaschenlauge entsteht, wenn Holzasche mit heißem Wasser übergossen wird. Sie entfaltet alkalische Eigenschaften, die bewirken, dass sich der Schmutz in der Wäsche löst (KRAMARCZYK 1988:127). Zur Herstellung von Holzasche wurde Buchenholz, sowie die Asche von Eichen, Birken, Maulbeerbäumen, Rebenholz, Tabakpflanzen, Stroh und Farnen, Efeublätter, Rosskastanien oder Kartoffeln aus der heimischen Gegend benutzt, ,je nachdem, welches Material in ausreichendem Maße zur Verfügung steht [...] Früher streuten die Frauen die Asche direkt auf die Wäsche, die sie schichtweise in einen hölzernen Waschbottich legten und mit heißem Wasser übergossen." (:127f.) Das Kochen der Wäsche wurde anschließend in einem Waschkessel auf dem Herdfeuer vorgenommen, der mit Brennholz erhitzt wurde.

Dann erst kam die Weißwäsche, gut ausgewrungen, nach draußen, wo sie im Fluss- oder Bachlauf ,in kaltem, fließendem Wasser“ (WIERLING 1988:45) gespült und kalt ausgewaschen wurde, bis die Wäsche ohne Lauge war. Dieser mehrteilige Vorgang wurde ebenso für die anschließende Buntwäsche, die nachfolgenden Blauwäschen und letztlich auch für die Wollstrümpfe durchgeführt.

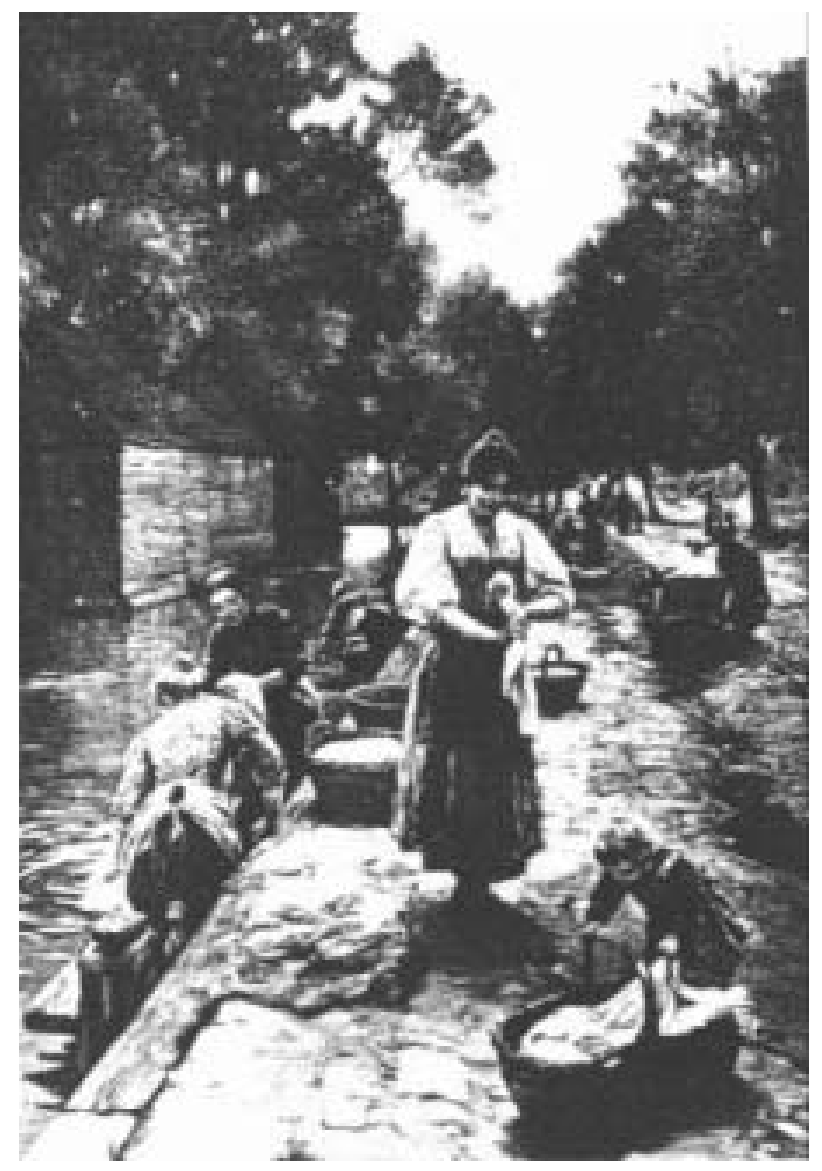

Abb. VI-70: Wäscherinnen am Fluss

Holzstich nach einem Gemälde (Berthold Genzmer), um 1890 (aus: BÜCHER 1988:91)

Diese über Jahrhunderte bestehende Situation bestand sogar noch fast unverändert in den 1920er Jahren, wie sie Isabelle von LÖWENSTEIN (1988:120) aus ihren persönlichen Erinnerungen beschreibt: „Über fließendes Wasser verfügten die meisten Schloßhaushalte in der Zwischenkriegszeit. Nur selten mußte das Wasser von Hand herangeschafft werden. In diesen Fällen wurde dann jedoch die herrschaftliche Wäsche zum Spülen dorthin getragen, wo auch die Dorfbewohner wuschen: an den nächsten erreichbaren Bach.“

Zum Spülen der Wäsche begab man sich also entweder zum Bachlauf selbst oder das Wasser wurde in Krügen geholt. „Diese ganze, aufwendige Prozedur fand im durchschnittlichen, bügerlich-städtischen Haushalt alle 4 - 6 Wochen statt.“ (WIERLING 1988:45) 
Nachdem auch die leinenen Wäschestücke gewaschen und ausgewrungen waren, wurden sie an trockenen Sommertagen zum Bleichen auf der Wiese bzw. dem eigenen Rasen ausgebreitet. Nach ungefähr drei Stunden wurden dann ab und an die Leintücher und Bezüge mit der Gießkanne besprengt ${ }^{72}$; wieder ein paar Stunden danach wurde die Wäsche gewendet und wieder begossen. Von der Bleiche genommen, wurde die Wäsche noch zweimal aufgewaschen (DÖRING/GANSOHR 1988:15; LÖWENSTEIN 1988:121). Die Wäsche wurde häufig nach dem Waschen gebleicht, um den grau-gelblichen Farbton des Leinen aufzuhellen (SCHACHTNER 1988:33). Bleichen bewirkte das strahlende Weiß (KRAMARCZYK 1988:128).

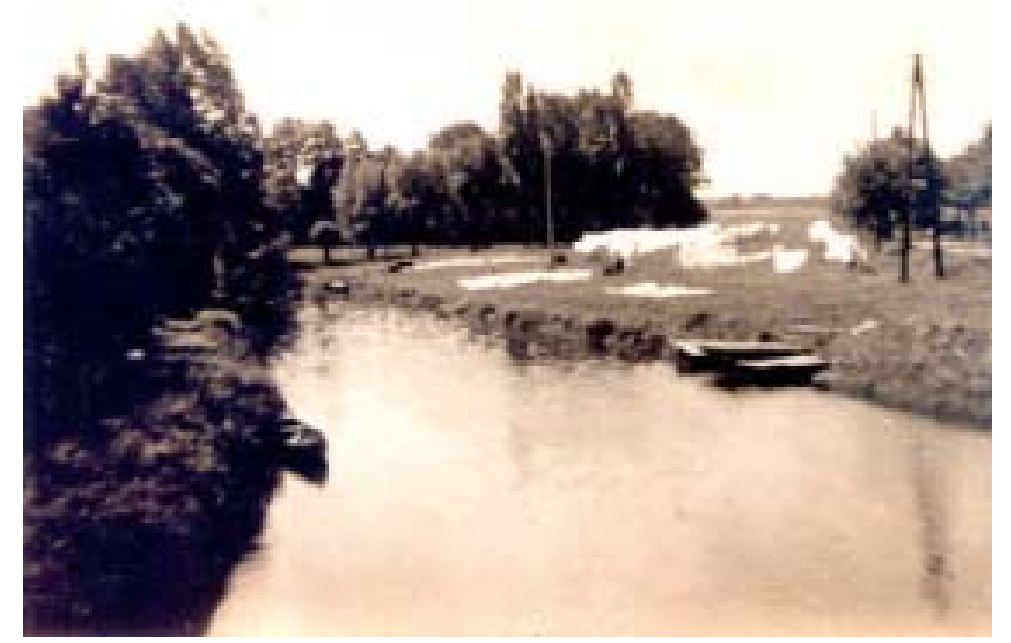

Abb. VI-71: Städtische Bleiche an der Else

(Quelle: Stadtarchiv Bünde)

Als die Kernseife vom Waschpulver abgelöst wurde, erübrigten die neuen optischen Aufheller die Wäschebleiche am Fluss. Die Wäsche konnte sofort aufgehängt werden (WIERLING 1988:45).

Doch nicht nur neue chemische Zusätze ließen die Weißtrocknung durch Sonneneinwirkung entbehrlich werden. Durch die starke Luftverschmutzung schon in den 1930er Jahren, vor allem in den Städten „verschwand [...] nach und nach die Rasenbleiche in den Siedlungen, denn häufig machten die Frauen die Erfahrung, daß sie die Wäsche nach der Bleiche noch einmal auswaschen mußten, weil sie mit Ruß aufs neue verschmiert war." (SCHEFFRAN 1988:65f.)

Neben dieser Anpassung bzw. Technisierung der Waschtechnik lag der entscheidende Grund in der Textilentwicklung selbst. Ab den 1950er Jahren setzte eine zunehmende Verbreitung von synthetischen Fasern ein (Nylon, Perlon, Orlon usw.), die die natürlichen Fasern wie Baumwolle, Leinen oder Wolle ersetzten (ORLAND 1988:49).

„Das markanteste Novum der Nachkriegshaushaltstechnisierung sollte die Erledigung der gesamten Wascharbeit in der privaten Wohnung werden, der Verzicht auf öffentliche, gemeinschaftlich genutzte Plätze der Wäschepflege“ (ORLAND 1988:48). Zwar gab es in den städtischen Haushalten um die Jahrhundertwende bereits einige Wäschgeräte als Hilfsmittel: Waschkessel, Waschbrett und Bürste, eventuell sogar eine Waschmaschine, die aus hölzernen Flügelschrauben, die mit Hilfe eines Hebels hin- und herbewegt wurde sowie eine Wringmaschine, die die nasse Wäsche durch zwei hölzerne Walzen hindurchgepresste (WIERLING 1988:45), doch all diese „Waschmaschinen, ob aus Holz oder Metall, beheizbar oder mit einem elektrischen Antrieb blieben vor dem Zweiten Weltkrieg letztlich folgenlos für die häusliche Wascharbeit.“ (ORLAND 1988:55) Sie waren letzlich nur „Hilfsmaschinen, die den traditionellen Ablauf der Waschtage noch nicht veränderten, und wegen ihres Gewichts, ihrer Größe, ihrer Reparaturanfälligkeit und wegen ihres Preises keineswegs aufstellbar in jedem Haushalt.“(:55)

\footnotetext{
${ }^{72}$ Diese Beschreibung gilt für den häuslichen Gebrauch; beim gewerblichen Bleichen wurden bewässerte Bleichwiesen verwendet (siehe Pkt. 3.c ,Bleichwiesenbewässerung').
} 
Erst die in Hannover 1951 auf der Bauausstellung vorgeführte erste vollautomatische Haushaltswaschmachine löste das Waschen am bzw. im Fluss endgültig ab.

\section{b Wollwäsche}

Die rohe Wolle, die nach der Schafschur verarbeitet werden sollte und auch als „Schweißwolle“ bezeichnet wird, enthält bis zu $60 \%$ Fett vom Vliesgewicht, daneben durch den Herdentrieb über die Heide- und Cämpeflächen erdige Verschmutzungen, pflanzliche und andere tierische Bestandteile wie Ungeziefer oder Kot (MATTHES 1985:247). In dieser Form kann sie nicht verarbeitet und muss zunächst gewaschen werden (DIX 1997:77), obgleich die Schäfer die Wolle der Schafe auch schon auf der Weide von Kot befreit hatten, wie der letzte gelernte Schäfer in Hilden und Umgebung berichtet. ${ }^{73}$

Das „Spülen in sehr großen Mengen reinen Wassers“ ließ sich zunächst nur im fließenden Gewässer bewerkstelligen (DIX 1997:230). 1872 wurde auf dem Gelände der Wassermühle „Käsmühle” an der ,Bieber' in Offenbach beispielsweise eine Wollfärberei betrieben und der Besitzer ,hatte zu diesem Zweck einen Teil des Mühlbaches mit hölzernen Häuschen überbauen lassen, in denen die verarbeitete Wolle mit fließendem Wasser gewaschen oder ausgespült werden konnte.“ (GRIES 1999:55)

Solche Waschhäuser ${ }^{74}$ befanden sich nahezu an allen Bächen (DIX 1997:230). Wie auch am Veybach im Niederrhein, wie DIX (:230) nach Berichten aus dem Jahr 1845 eine solche Anlage schildert: „Von diesem Waschhaus führte nur einfacher Steg über den Bach, von wo aus die Wolle in Körben in den Bach gehängt werden konnte.“

Nach anderen Berichten aus der Niederlausitz in der ersten Hälfte des 20. Jahrhunderts waren dort die Verhältnisse einfacher: „Von einer in den Fluß oder über den Bach gebauten Spülbank wurde die Wolle in Körben in den Bach gelassen und dort ausgespült.“ (DIX 1997:230)

Um die Mitte des 19. Jahrhunderts wurde das Waschen der Wolle aus einheimischer Wollerzeugung, also ihre Reinigung nach der Schur von Schweiß und Unrat, von spezialisierten Wollwäschereien vorgenommen. Dieser Arbeitsschritt in der Wollindustrie benötigte neben Färbereien und Nassappretur ${ }^{75}$ das meiste Wasser (DIX 1997:229).

In den ersten Wollwäschereien wurde die Wollspüle aber noch durch Menschenhände durchgeführt, in einem Kessel mit einer Flüssigkeit aus Urin und Wassergemisch (DIX 1997:229). Nach Vollendung wurden die Wollpartien in einen Kasten, der am besten mit viel fließendem Wasser durchströmt wurde, getaucht (:229). Die Beseitigung der Rückstände, der verbrauchten Waschflotten und Spülwässer geschah durch Ablassen der Bottiche über den offenen Abwassersammelschacht direkt in den Bach, vor allem abends und nachts (:119). Dieser Arbeitsgang trug erheblich zur Wasserverunreinigung am Verarbeitungstandort bei, der später nicht immer identisch mit dem Produktionsstandort war. Wolle wurden von den Tuchfabriken des 19. Jahrhunderts „oftmals schon im gewaschenen Zustand von entfernt liegenden Wollwäschereien bezogen“. (:119) So bekam die Tuchfabrik Müller, obschon am Erftmühlenbach in Euskirchen gelegen, ihre gewaschene Wolle aus Bremen, Hannover und Leipzig.

\footnotetext{
${ }^{73}$ Rheinische Post, 19.04.2003, Nr. 92: „...Und der Schäfer muß still stehen“

74 Bei den Waschhäusern handelt es sich bedeutende bauliche Kulturlandschaftselemente der Gewässergeschichte der vorindustriellen Phase. Nach meiner Recherche sind an keinem Bachlauf solche Häuschen erhalten geblieben und auch museal bislang nicht berücksichtigt worden.

${ }^{75}$ Unter Nassappretur fasst man das Walken, Waschen, Rauhen und Karbonisieren zusammen, die sich an den Verarbeitungsgang der Weberei anschlossen. Die Arbeitsgänge der Appretur dienten dazu, das Gewebe zu verdichten. Das Gewebe, das vom Webstuhl kommt, ist für die Konfektion noch nicht gebrauchsfertig. ,Es ist verschmutzt, in der Bindung zu locker und hat eine unregelmäßige Oberfläche. Das eventuell von der Begrifflich unbekannte „Karbonisieren“ umfasst die Reinigung des fertigen Tuches von pflanzlichen Bestandteilen und stellte den letzten Arbeitsgang der Nassappretur dar (DIX 1997:82).
} 


\section{c Getreidewäsche}

Die Hauptaufgabe der Müllerei besteht seit alters her in der Vermahlung von Getreide, vor allem von Weizen und Roggen zu Mehl, das als Grundstoff des Brotbackens eine elementare Rolle für die menschliche Ernährung spielt (BEDAL 1992:25).

Die Verarbeitung des Getreides zum Mehl ist im Wesentlichen in drei Schritte gegliedert: Reinigen - Mahlen - Sichten. Das heißt, das Getreide muss vor dem eigentlichen Zerkleinerungsprozess gründlich gereinigt werden.

Diese Arbeit verrichtete der Bauer bis zum 18. Jahrhundert selbst, seit diesem Zeitpunkt wurde von amtlicher Seite ein nochmaliges Reinigen in der Mühle empfohlen: Spreu, Strohreste, Erdklumpen, Steine, Staub und fremde, gifthaltige Samenkörner müssen aus dem eigentlichen Mahlgut entfernt werden, damit sie nicht in das Mehl gelangen und es verunreinigen, seine Qualität beeinträchtigen oder schlimmstenfalls sogar ungenießbar machen.

Die Reinigung des Mahlgutes geschah ursprünglich zunächst mit Hilfe von verschiedenen grobmaschigen Handsieben. Um Spreu, Grannenrest und Staub auszusondern, wurde das Getreide in dem Sieb hochgeschleudert, damit der Wind sie wegblies. Große Erdklumpen wurden mit der Hand ausgelesen. Feine Steinchen, Staub und fremde Samenkörner wurden durch engmaschige Siebe, die keine Getreidekörner durchließen, abgesondert.

Aber ,in der Längsfurche des Getreidekorns läßt sich der Staub schlecht entfernen“ (BEDAL 1992: 22). Deshalb wurde das Getreide gewaschen und anschließend in der Sonne getrocknet. Dies geschah vor allem, wenn das Getreide von Pilzkrankheiten, wie zum Beispiel von „Rost“, befallen war (:22).

Der venezianische Mathematiker Fausto VERANZIO (1551 - 1617) beschrieb um etwa 1615/16 die Reinigung des Getreides folgendermaßen: „Mit großem Nutzen kann das Getreide gesäubert werden, indem man es mit Wasser wäscht, der Staub läßt sich durch das Wasser besser entfernen, als wenn man das Getreide im Sieb bewegt. Dies soll aber an einem großen Fluß oder an einem rinnenden Brunnen geschehen, oder das Getreide soll in großen Zubern gewaschen werden. Siebe oder Körbe können dazu verwendet werden. ${ }^{676}$

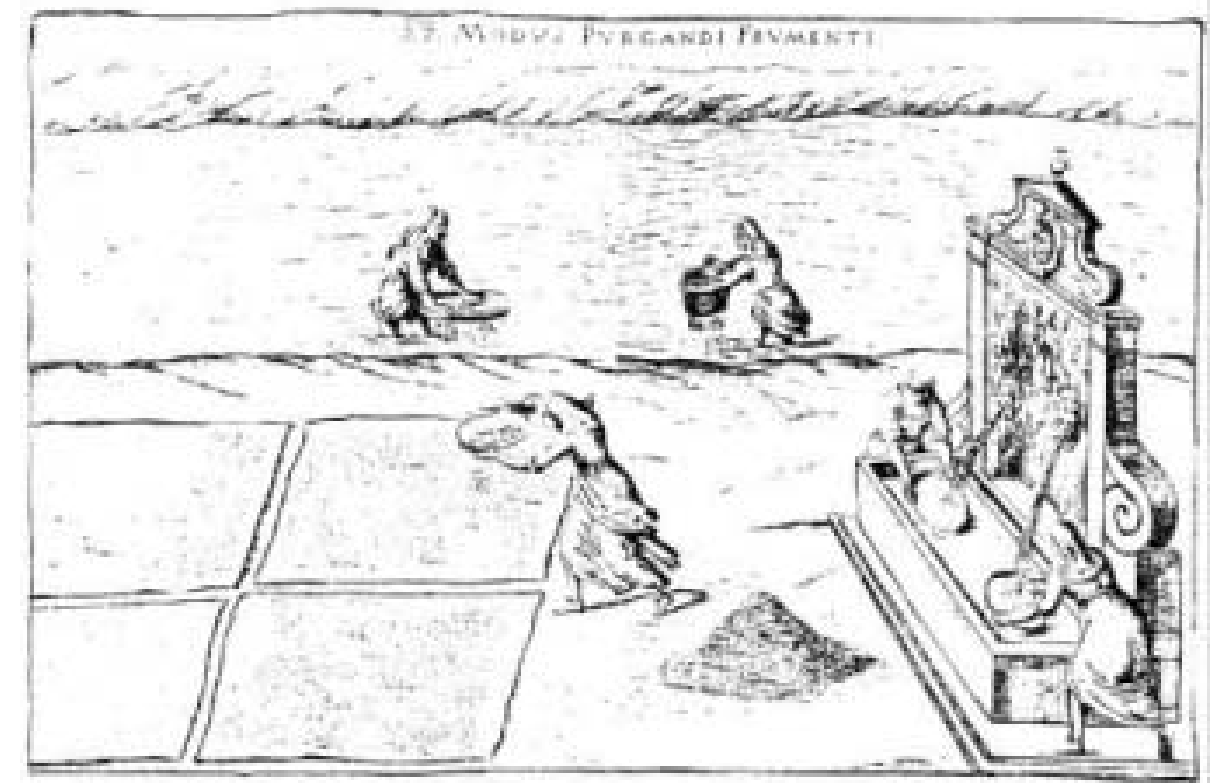

Abb. VI-72: $\quad$ Reinigung der Getreidekörner nach Fausto VERANZIO (ca. 1616)

Das Getreide wird in fließendem Wasser, an einem Brunnen oder in einem Fluss, gewaschen und anschließend zum Trocknen auf Tüchern ausgebreitet (aus: JOIST 1992:22).

\footnotetext{
${ }^{76}$ (VERANZIO, Fausto: Machinae Novae. - Venedig, um 1615; Nachruck als: Erfindungen von Einst. - Dortmund 1982; hier: 27. Tabelle ,MODVS PVRGANDI FRVMENTI':65f., zitiert aus BEDAL 1992:22f.)
} 
Beim Mahlvorgang der alten deutschen Mühle wurde nur ein unvollkommen gereinigtes Getreide ausgemahlen. Die Haltbarkeit des erzeugten Mehles war trotz der händischen Wassereinigung nur von kurzer Dauer, da Unkrautsämereien wie der Getreidekeimling dadurch vor der Vermahlung nicht ferngehalten werden konnten und mitvermahlen wurden. Diese enthielten Fett, das schon durch die Reibungswärme des Mahlvorgangs ranzig werden konnte, zumindest aber eine lange Lagerfähigkeit des Mehles ausschloss. Ebenso gelang es nicht, die Kleie vollständig vom Mehlkörper zu trennen, so dass ,zu keiner Zeit ein vollständig weißes Mehl erzeugt wurde“ (BEDAL 1992:94). Später gab es dafür in der Mühle den Säuberer bzw. den eigenen sog. Windfang (:62f.).

\section{d Kuttelwäsche}

„Als die Oberstadt entstand“, so wird aus der Stadt Nordhausen berichtet, „mußte man hier seinen Trinkwasserbedarf aus künstlich gegrabenen Brunnen entnehmen, während man das Wasser für das Vieh und zu Reinigungszwecken aus dem Mühlgraben herauf holte [...]. Auf drei Treppen gelangte man zu ihm hinab: auf der Wassertreppe, der Kutteltreppe [...] und der Johannistreppe.“ (HEINE o.J.)

Während - der Namensgebung entsprechend - auf den steilen Steinstufen der Wassertreppe die Bewohner der Stadt, Hausangestellte oder auch Wasserträger das kostbare Nass aus dem Mühlgraben durch die Stadtmauer hinauf in die Stadt schleppten und auf der Johannistreppe die Kirchgänger aus der Unterstadt zur Oberstadt hinaufstiegen, wurde die sog. Kutteltreppe von den Fleischern und Metzgern benutzt. Die Kutteltreppe wurde ,so genannt nach den Kuttelhäusern der Fleischer, die hier standen und in denen die Kutteln oder Gedärme der geschlachteten Tiere gereinigt wurden.“ (HEINE o.J.)

Die Eingeweide von Tierleibern wurden im altdeutschen „Kutteln“ genannt. Die Metzger aus der Stadt Nordhausen kamen also über die sog. Kutteltreppe aus der Oberstadt an das Wasser des Mühlgrabens, der mitten durch die Unterstadt unterhalb des Steilabhanges der Oberstadt floss, und wuschen die Eingeweide darin.

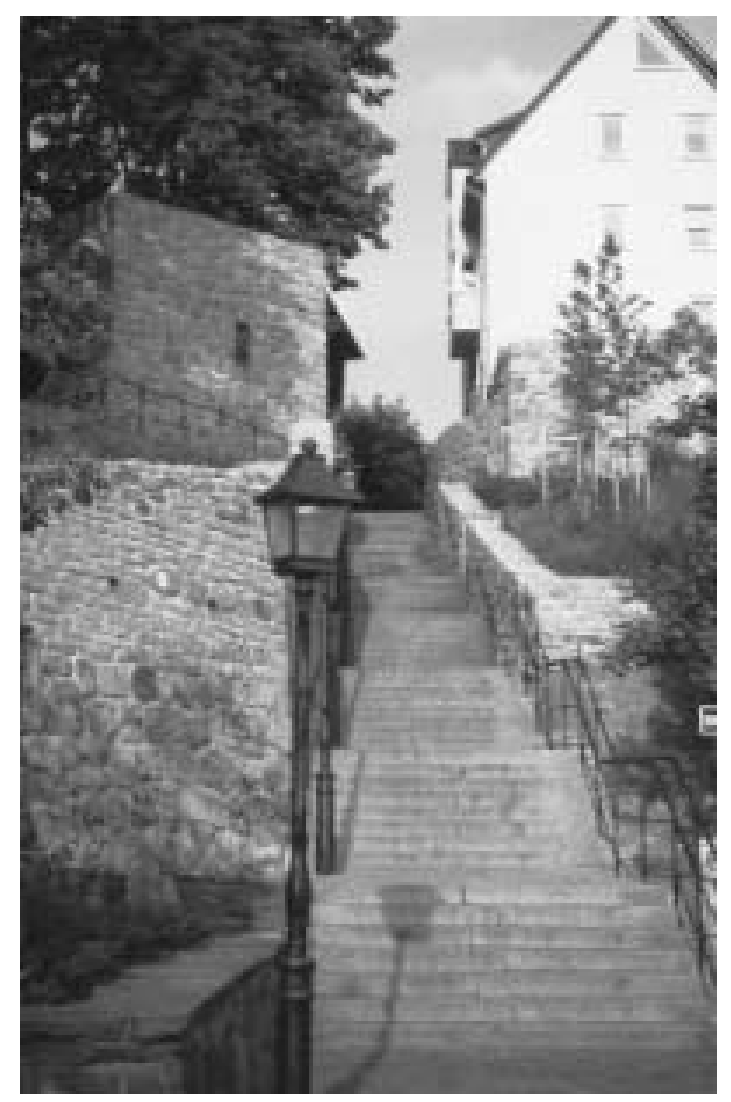

Abb. VI-73: Die „Kutteltreppe“ in Nordhausen (eig. Aufnahme 2004) 


\section{e Sandwäsche}

Dem Oberjägermeister Johann Georg von Langen wurde 1745 die Aufsicht über die Forsten im Solling übertragen. Auf seine Empfehlung hin wurden einige manufakturistische Betriebe gegründet: unter anderem die „Fürstenberger Porzellanmanufactur“ (1747), die Spiegelglashütte in Grünenplan, die Glasurmühle in Fohlenplacken und - hier von besonderem Interesse - die „Sandwäsche“ in Neuhaus, die aber wiederum Folge dieser Ansiedlungen war: denn feinster Sand besaß herausragende Bedeutung bei der Glas- und Porzellanherstellung. Doch die Anforderungen gingen darüber hinaus: für die Glas- und Porzellanherstelllung benötigte man gewaschenen Sand.

Aber am Ende des 19. Jahrhunderts wurde „gewaschener weißer Sand auch in den Wohnungen zum Einstreuen auf die teilweise noch vorhandenen Lehmfußböden genutzt.“ (RUHLENDER 1998:103) Nach einigen Tagen der Einstreu wurde dann der Sand mit dem anhaftenden Schmutz ausgekehrt (:106).

Wanderglashütten haben den benötigten Sand aus der Neuhäuser Sandwäsche zunächst ausschließlich im Tagebau abgebaut. Das reiche Vorkommen von tonhaltigen weißen Quarzsanden entlang des Verlaufes der Holzminde führte zur Ansiedlung der Wäsche in diesem Bereich (RUHLENDER 1998: 102). Eine Gewinnung von Flusssand aus dem Fließgewässer, wie in Pkt. 13.c beschrieben, kam hier nicht in Betracht, obwohl die Holzminde durch diesen Abschnitt führt. Sie trägt hier aber die Bezeichnung „Rotes Wasser“ und kennzeichnet damit die Farbe des Moorwassers des oberhalb liegenden Bruches, wo sie entspringt (:296). Der Quarzsand wurde demnach nicht aus, sondern entlang des Bachlaufes entnommen.

Nach dem Wechsel der Wanderglashütten zu ortsfesten Glashütten in Ortslagen vor allem nach der ersten Hälfte des 18. Jahrhunderts, d. h. von der handwerklichen zur fabrikmäßigen Produktion, wurde der Sand auch im Untertagebau gewonnen und 1850 erhielt die Sandwäsche durch die Gründung einer Glashütte auch einen erneuten Aufschwung und der aus der Grube gewonnene Sand musste mit einer Feldlore zur „Sandwäsche“ gekarrt werden. Zuvor schon, um 1800, hatte die Förderung von Sand für die Porzellanfabrik in Fürstenberg Hochkonjunktur und zum Abbau von Sand geführt.

Der Bezug zur historischen Gewässernutzung wird insofern bedeutsam, als „Sandwäsche“ ein historischbauliches Objekt als auch eine Vorgangsbezeichnung bezeichnet. Da aber hierfür „keine Akten zur Verfügung stehen“ (RUHLENDER 1998:103), kann die Geschichte der Sandwäsche von der Glashüttengründung bis in die 50er Jahre des 20. Jahrhunderts nur aus der Erinnerung des Sohnes des letzten und Enkel des vorletzten Pächters geschrieben werden (:103). Dies ist demnach auch ein Beispiel der angewandten „Oral History“, hier neben den historischen Landschafts- und Baurelikten (Sandgruben, Sandwäschehaus) einziges methodisches Instrumentarium zur Aufdeckung dieser speziellen Gewässernutzungsgeschichte.

In Neuhaus, nordöstlich, auf halbem Fußweg vom Schloss nach Silberborn befindet sich das sog. Sandwäschehaus. Die Bergleute Karl und Ludwig Danne (Vater und Sohn) bewohnten das zur Sandwäsche gehörige, aber nicht dazu dienende, herrschaftliche Haus. Angeblich soll es auch als Zollhaus gedient haben (RUHLENDER 1998:112). Die eigentliche Sandwäsche wurde in einer separaten Sandwäschehütte durchgeführt, die nicht mehr besteht, und bereits auf einem Foto von 1952 waren nur noch die baulichen Überreste zu sehen. 


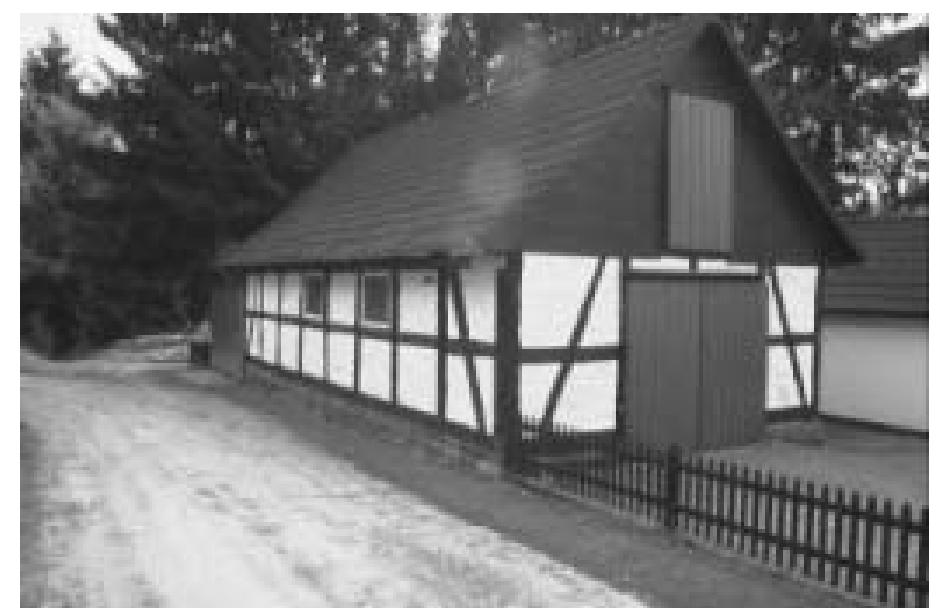

Abb. VI-74: Das Sandwäschehaus in Neuhaus i. Solling

Dieses Gebäude wird heute als das „Sandwäschehaus“ bezeichnet. In diesem oberhalb des Bachlaufes am „Sandwäscheweg“" stehenden Fachwerkhäuschen fand aber nicht das Waschen des Sandes statt, sondern hier wurde der abtransportierte Sand kontrolliert und gewogen (bzw. geschätzt), bevor er zur Fürstenberger Porzellanmanufaktur gefahren wurde (eig. Aufnahme 2004).

Die Sandwäschehütte mit der Sandwäscheanlage befand sich in unmittelbarer Nähe des Sandwäschebaches, der Holzminde bzw. dem „Roten Wasser“, aus dem das Wasser abgeleitet wurde.

Ein Leitungsrohr führte das Wasser aus dem nahegelegenen Bachlauf in einen offenen Holzkasten, der den Sand in die nachfolgenden Siebe abschwemmte. Es ist anzunehmen, dass in früheren Jahren eine hölzerne Rinne das Wasser zuführte. Nach mehreren Ausschwemmungen wurden die so gefilterten Quarzkörner getrocknet und zu der Verladestelle gebracht.

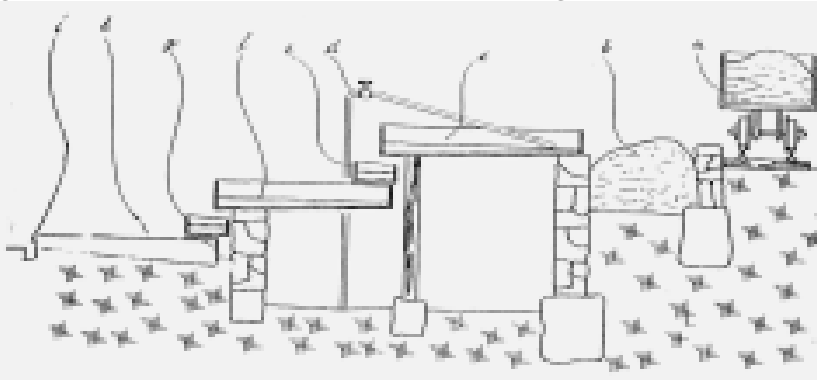

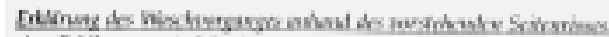

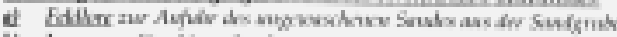

B Legram nir idipon Sind

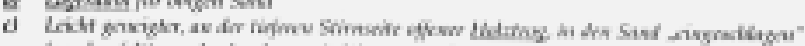

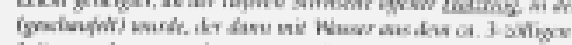

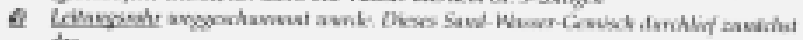
da:

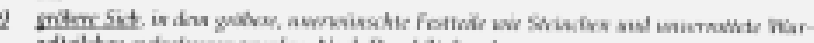

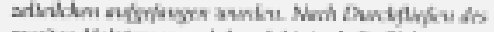

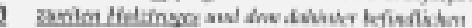

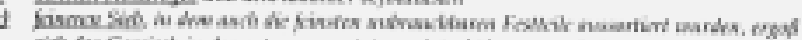

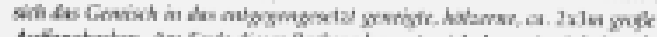

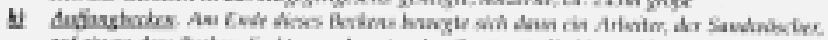

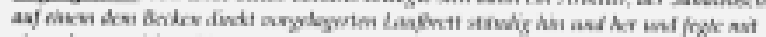

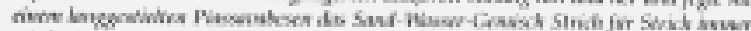

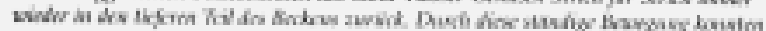

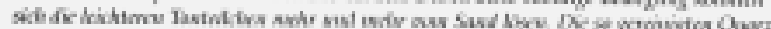

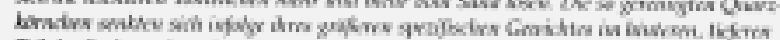

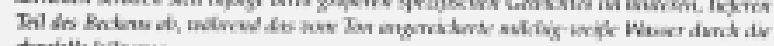
Angalls botarne

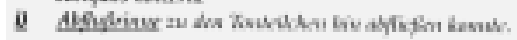

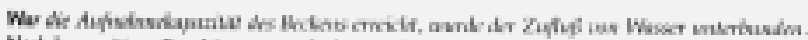

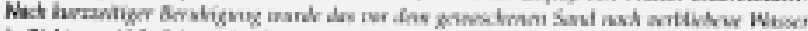

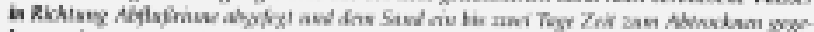

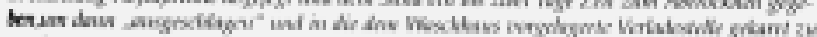
amint

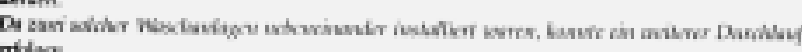
milow.

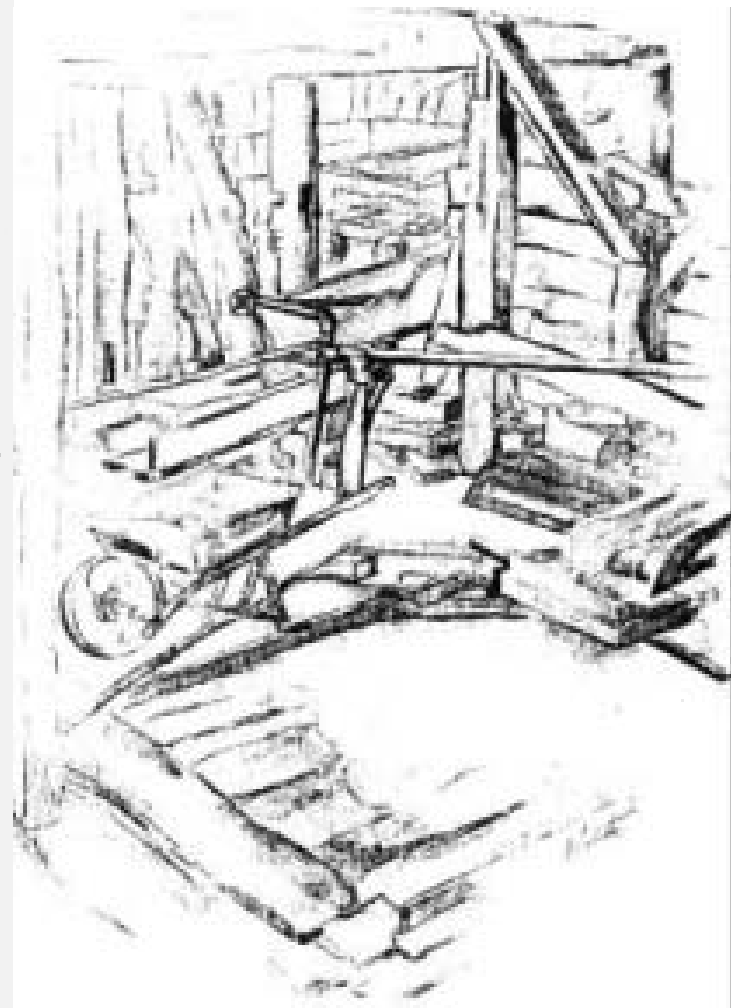

Abb. VI-75: Sandwaschvorgang und Rekonstruktion des Innenraums der abgegangenen Sandwäschehütte (aus: RUHLENDER 1998:105) 
In der Sandwäsche selbst, die in der „Sandwäschehütte“ erfolgte, waren 5 - 7 Arbeiter beschäftigt und drei Pferde wurden vor dem Ersten Weltkrieg zur Sandauslieferung gehalten. Abnehmer waren die 1927 stillgelegte Neuhäuser Glashütte und die Fürstenberger Porzellanfabrik (RUHLENDER 1998:103).

Des Weiteren wurde auch Bausand aus dem Abbaugebiet gewonnen, doch dafür war die Sandwäsche nicht mehr notwendig.

Der letzte Pächter (1883 - 1964) konnte den Sandwäschebetrieb nur noch mit seiner eigenen Arbeitskraft im Nebenerwerb aufrechterhalten. Gewaschener Sand wurde nur noch gelegentlich zu den Boffzener Glashütten und zur Fürstenberger Porzellanmanufactur mit angemietetem Gespann geliefert (RUHLENDER 1998:106). Die Konkurrenz des maschinell gewaschenen Sandes aus anderen Gebieten Deutschlands und Osteuropas, aus denen man den feinen Sand bezog, war gegenüber der hiesigen kleinräumigen und aufwendigen Sandwäsche übermächtig ${ }^{77}$.

Nur noch der Wegename und Flurname „Sandwäsche“ und das alte Dannesche „Bergmannshaus“ erinnert an die alte Form der Bachwässernutzung. Die übrigen Flächen sind zugewachsen und mit Fichten aufgeforstet worden. Aber auch die Sandwäsche hat in das Gewässersystem eingegriffen. Wasser wurde aus dem Bachlauf zugeleitet und es wurde viel Wasser zum Waschen von Sand gebraucht. Dennoch kann diese historische Gewässernutzung als gering in ihren Auswirkungen bezeichnet werden: Das benutzte Wasser wurde dem Gewässerlauf durch den reinen Waschvorgang ohne Schadstoffe wieder zugeführt. Aus landschaftshistorischer Sicht hingegen ist zu erwähnen, dass diese Fläche ehemals zu den ausgedehnten Gestütsweiden des Schloss Neuhaus gehörte und es sich um eine Bruchweide gehandelt hatte.

\section{f Salzwäsche}

Neben dem gelben und dem sandigen wurden Gewässer auch für die Gewinnung und Veredelung des „weißen Goldes“ benutzt. Der Übergang zum Ackerbau und damit zur Pflanzenkost in der Jungsteinzeit erforderte eine Ergänzung der Nahrung durch Kochsalz. Die Gewinnung erfolgte bereits zu dieser Zeit durch Verdampfen von Meer- und salzhaltigem Quellwasser und durch Abbau von salzhaltigem Gestein. Im Mittelalter kam die Extraktion von Salz durch Eindampfen von Sole in Pfannen hinzu, um Lebensmittel haltbar zu machen ${ }^{78}$.

Dazu wurden tieferliegende, solehaltige Quellen angezapft, die in einem Brunnen zusammenflossen. In Bad Sooden beispielsweise steht die $12 \%$-haltige Sole bis $6 \mathrm{~m}$ unter der Erdoberfläche. Zunächst Mitte des 12. Jahrhunderts mittels Eimern an die Oberfläche befördert, wurde die Sole später durch Pferde betriebene Turmgöpel, sog. Rosskünste, oder durch mit abgeleitetem Flusswasser betriebene Wasserräder aus der Tiefe geholt und auf eine bestimmte Höhe gehoben, um die Sole auf das Gradierwerk zu bringen. Über hölzerne Wasserleitungen, die auf $3 \mathrm{~m}$ hohen Sandsteinsäulen lagen, wurde dieses salzhaltige Wasser den Gradierwerken von oben zugeleitet, wo die Ausscheidung von Sole an den früher aus Strohgebünden, später dann aus Schwarz- oder Weißdornreiser bestehenden Gradierwänden erfolgte - das Salz wurde gewaschen, wie man sagte. Durch das Herunterrieseln wird die Sole durch Verdunstung von Wasser auf $25 \%$,gradiert“ (konzentriert), so dass mit diesem Verfahren viel Holz und später Braunkohle gespart werden konnte.

$\mathrm{Zu}$ diesem Zweck wurden künstliche Ableitungen aus den vorbeifließenden Gewässern angelegt, die zum einen das Aufschlagwasser für das Solehebungswerk zuführten und zum anderen das als Antriebswasser benutzte Wasser mit dem „Solegraben“ wieder in das Gewässer einleiteten. Beim Beispiel Sooden wurde die Sole ursprünglich auf 22 Gradierwerke geleitet und anschließend im Solebrunnen gesammelt, aus dem die gradierte Sole den rund 80 Siedehäusern der mittelalterlichen Stadt zugeleitet wurde.

\footnotetext{
77 Auskunft des Porzellanmuseums Fürstenberg, das der Porzellanmanufaktur angeschlossen ist; über die genaue Herkunft des Sandes wollte man aber keine Auskunft erteilen.

${ }^{78}$ Die natürliche Salzbildung entstand dadurch, dass sich Salzgesteine durch Eindampfung von Wasser in abgeschlossenen marinen Becken absetzten. Nach dem Grad der Löslichkeit erfolgte die Ausscheidung der verschiedenen Salze in gesetzmäßiger Reihenfolge: in der Regel beginnend mit Carbonaten und Sulfaten (Gips) folgten Stein-, Kali- und Magnesiumsalze. Die Bildung von Salz ist an trockenwarme Klimazonen gebunden. Optimale Bedingung ist anhaltender Wechsel von einströmenden Meerwasser und Verdunstung über längere Zeit.
} 


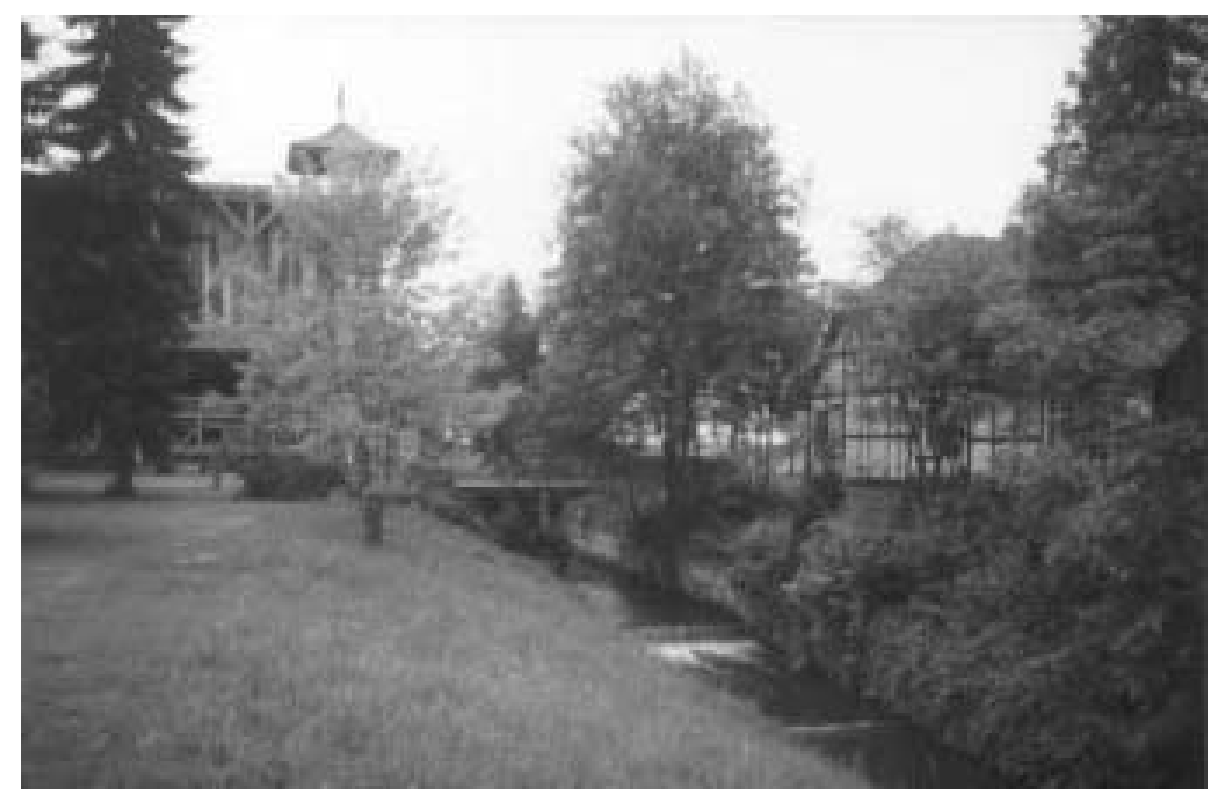

Abb. VI-76: Solegraben - Ableitung in Bad Sooden (eig. Aufnahme)

Der Besitz von Solequellen und die Kontrolle des sich auch stark völkerverbindend auswirkenden Salzhandels waren frühzeitig ein Machtfaktor und eine Quelle des Reichtums. Als erste Salinenstädte erscheinen Reichenhall (1163), Hallein (1177) und Lüneburg (1200). Mit der Gewinnung von Salz durch das Siedeverfahren entstanden zusätzliche Salzstädte wie Salzuflen, Lüneburg, das erwähnte Sooden u.a..

Über die Gewinnung von Salz an den natürlichen Lagerstätten hinaus entstanden ganze „Salzgärten“: künstliche flache Becken, besonders am Meer in Gebieten mit hoher Verdunstungsintensität, in denen Salzwasser zur Speisesalzgewinnung eingedunstet wird, wie zum Beispiel die Salzgärten an der Südküste der Bretagne (Brockhaus 1979: Bd. 10).

\section{g Eisensteinwäsche}

Die Aufbereitung von gold- und silberhaltigen Erzen bestand aus zwei Arbeitsschritten: der mechanischen Zerkleinerung und der Trennung von erzhaltigem und taubem Gestein. Für das Ausbringen des Metallgehaltes der Erze traten neben die Ofenschmelze zunehmend die brennstoffsparenden „,nassen“ Verfahren, die letztlich auf dem Prinzip des Ausschlämmens in „Waschanlagen“ beruhten. Beim nassen Verfahren wurden wasserdurchflossene Gerinne angelegt, in denen ein Wasserstrom über das gemahlene Erz geleitet wurde. „Dafür nahm man den nächstgelegenen Bach oder Fluß in Anspruch“ (DIX 1997:194).

In einem gleichmäßigen Wasserfluss ließen sich durch die unterschiedliche Schwerkraft und Größe der metallischen Teilchen die notwendigen Separierungen erreichen: die schweren metallhaltigen Teile sanken schnell ab und wurden in Auffangbecken gesammelt, das taube Material wurde vom rinnenden Wasser nicht ohne Umweltbelastung - mitgenommen und dem Gewässerlauf zugeführt (MÜLLER/LUDWIG 1982:173f.; SCHNEIDER 1992:78ff; DIX 1997:194).

Das Bedürfnis, so vermuten MÜLLER/LUDWIG (1982:174), die beträchtliche Staubentwicklung durch Befeuchtung der Erze zu vermeiden, könnte den Anstoß zu einem solchen Nasspochwerk gegeben haben, das sich seit 1512 nachweisen lässt. Es verlegte den Arbeitsgang der Erzzerkleinerung in einen neu gestalteten Pochtrog, durch den Wasser hindurchfließen konnte.

Zwei grundlegende Typen von Waschanlagen wurden dabei verwendet (SCHNEIDER 1992:79): 
1. Form: Ein rechteckiger Waschtisch, an dessen Seiten die Wasserrinne angebracht ist, die um den Waschtisch herumgeführt wurde, um das Wasser mehrfach zu nutzen und einen Wasserkreislauf zu bilden. „Die Wasserknappheit [...] zwang dazu, mit Wasser äußerst sparsam umzugehen.“

2. Form: Eine leicht geneigte Wasserrinne, die viele Querrillen besaß: Am höchsten Punkt der Anlage wurde das Wasser in die Rinne geleitet; das zerkleinerte Erz wurde in den Wasserstrom geschüttet, wobei die Teile mit hohem Metallgehalt früher als die leichten, tauben Partikel an den Querrillen hängenblieben. Am niedrigen Ende der Anlage befand sich ein Becken, aus dem das Wasser ausgeschöpft und wieder der Rinnen zugeführt werden konnte.

Da die oftmals perennierenden Flussläufe eine immerwährende Bewässerung nicht gewährleisteten, sind die Waschanlagen anstelle des direkten Wasserzuflusses oftmals auch mit großen Zisternen verbunden worden, in denen Regenwasser gesammelt wurde.

In allen Bergbaugebieten, in denen Erze gewonnen wurden, sind Erzwäschen anzunehmen. So wurden, neben dem übermächtigen Harz, zum Beispiel in der Eifel an zahlreichen Orten auf kleinen Lagerstätten oberflächennah nach Braun- und Roteisenstein gegraben.

Spülwässer der sog. Eisensteinwäschereien oberhalb von Münstereifel an der Erft und den Erftnebenflüssen im Raum Euskirchen gehörten neben der Tuchindustrie, dem Bleibergbau „,zu den wichtigsten Verursachern von Gewässerverschmutzung“ (DIX 1997:184). Umfangreiche Eisensteinwäschereien wurden bei Urfey und Sötenich an der Urft betrieben, auch an der Erft, zum Beispiel bei Arloff oder am Eschweiler Bach (:194).

Tuchmachereien, Leder- und Papierfabrikation litten unter dem feinen gelösten Eisenschlamm im Wasser des Wasserlaufes, obgleich sie selbst Verursacher von Gewässerverschmutzung und Gewässereingriffen waren. Beim Walken beispielsweise nahmen die Tücher die Farbe nicht an und beim Papierschöpfen entzündete sich die Haut auf den Händen und überhaupt war es nicht möglich gutes Papier mit verschmutztem Wasser herzustellen (DIX 1997:194).

\section{Wasserkraftnutzung}

Wichtigster Energieträger und Energieumwandler der vorindustriellen Zeit war das Wasser (PAULINYI 1982:255).

Seit mehr als vier Jahrtausenden ist die Wasserkraftnutzung zur Arbeitserleichterung bekannt. Wasserräder zur Umwandlung der Energie des strömenden Wassers in mechanische Energie lassen sich bis ins dritte Jahrtausend v. Chr. zurückverfolgen (GIESECKE 1991:39).

Bis dahin und darüber hinaus wurden Schöpfräder, die beispielsweise in den römischen Bergwerken der Wasserförderung dienten, von Menschen angetrieben, indem sie von oben mit den Füßen gedreht wurden. Im archaischen und klassischen Griechenland wurden die Getreidemühlen, die einen unteren unbeweglichen Mühlstein besaßen, sogar meist von Frauen betätigt: „die Sklavinnen mahlten das Getreide, indem sie am höheren Ende des unteren Steines kniend den oberen Mühlstein hin- und herbewegten." (SCHNEIDER 1992:41,87)

Mit der Weiterentwicklung der Getreidemühle wurde die Voraussetzung dafür geschaffen, dass die Arbeitskraft der Tiere für das Mahlen von Korn genutzt werden konnte. Dies gelang mit einem neuen Mühlentyp, der allgemein als „Pompeianische Mühle“ bezeichnet wird: „Am oberen Mühlstein wurde normalerweise ein Esel oder ein Pferd angeschirrt. Auf kleinstem Kreis mit extremer Körperbiegung und verbundenen Augen voranschreitend bewegten diese Tiere die Mühlen." (SCHNEIDER 1992:44). Dieser Typ der Pompeianischen Mühle war im 2. Jahrhundert n. Chr. noch häufig in Griechenland und Rom anzutreffen und die Getreideversorgung somit von der tierischen Arbeitskraft abhängig (:46).

Neben dem Einsatz tierischer und menschlicher Kraft als Mühlantrieb wurde seit spätestens dem 1. - 2 . Jahrhundert n. Chr. auch die Wasserkraft genutzt (WARNER 1982:115; ALBRECHT 1999b:353). Frühe 
schriftliche Hinweise auf die Verwendung von Wasserrädern bzw. Wassermühlen belegen den Bekanntheitsgrad bereits zu diesem Zeitpunkt (SCHNEIDER 1992:46).

Die Nutzung der Wasserkraft zur Hebung von Wasser durch wassergetriebene Schöpfwerke bzw. Wasserräder ist um 230 v. Chr. belegt (ALBRECHT 1999c:596). Die Beschreibung einer solchen Konstruktion liefert Vitruv in der zur Zeit des Augustus verfassten Schrift „De architectura“ (ALBRECHT 1999b:353). In dieser Schrift erwähnt Vitruv unter den Geräten („,organa“), die der Wasserförderung dienten, auch solche Schöpfräder, die von der Strömung eines Flusses angetrieben wurden. Für diese wassergetriebenen Schöpfräder war aber das Fehlen eines Übertragungselementes charakteristisch; Antriebsrad und Schöpfrad waren hier identisch (SCHNEIDER 1992:45).

Die erste Darstellung einer Wassermühle und ihrer Kraftübertragung vom Wasserrad über Zahnräder auf den Mühlstein gibt ebenfalls Vitruv in der genannten Schrift „De architectura“ (ALBRECHT 1999b:353).

Bei der Wassermühle handelt es sich - im Gegensatz zum Wasserschöpfrad - um einen sehr viel komplizierteren Mechanismus: Die Drehbewegung des Wasserrades wurde auf einen Mühlstein übertragen, wozu ein sog. Transmissionsmechanismus erforderlich war (SCHNEIDER 1992:45). Diese, seit der Antike bekannte, Nockenwelle erlaubte es auch, die Wasserkraft für andere Zwecke als zum Drehen von Mahlsteinen zu nutzen, wie wir sehen werden.

Nach einer Notiz des Plinius wurde die Wasserkraft bereits während der zweiten Hälfte des 1. Jahrhunderts n. Chr. in Italien zum Enthülsen von Getreide genutzt (SCHNEIDER 1992:47). Neben dem Mahlen von Getreide ist als einziger weiterer Arbeitsvorgang, für den in der Antike die Wasserkraft als Antrieb genutzt wurde, das Sägen von Marmorblöcken bezeugt (:48) und in der Spätantike, d. h. im 4. Jahrhundert n. Chr., auch an der Mosel für die Umgebung von Trier nachgewiesen (WARNER 1982:115; SCHNEIDER 1992:161). Um Marmor mechanisch sägen zu können, war es notwendig, die Rotationsbewegung des Wasserrades in eine hin- und hergehende Bewegung umzuwandeln (SCHNEIDER 1992:49); eine Konstruktion, die erst im Verlauf des Mittelalters eine weite Verbreitung fand.

Wasser zum Antrieb der Wassermühlen, insbesondere der städtischen, entstammte nicht nur aus dem unmittelbaren Gewässerlauf bzw. aus einer nahgelegenen Ableitung, sondern wurde in römischer Zeit von weit her transportiert. In der Stadt Rom beispielsweise entstand ,am Abhang des Ianiculum ein Mühlenviertel, das Wasser von einem Aquädukt erhielt“", das zugleich die Ernährung der stadtrömischen Bevölkerung sicherte und bis in die Zeit der Ostgoten fortbestand (SCHNEIDER 1992:47). Eine ähnliche Anlage, weiß SCHNEIDER (:47) zu berichten, existierte in der Spätantike in der Nähe von Arles: ein Aquädukt endete an einem steilen, tiefen Abhang, an dem acht Mühlhäuser mit jeweils zwei Mühlrädern standen (siehe Abb. VI-77). Auch in anderen Regionen des Mittelmeeraumes lagen die Mühlen an Wasserleitungen. Dieses System hatte ,den Vorteil, daß ein ständig gleichbleibender Wasserfluß gewährleistet war und die Mühlen unabhängig von Flüssen waren, deren Wasserstand jahreszeitlich bedingt stark schwankte."

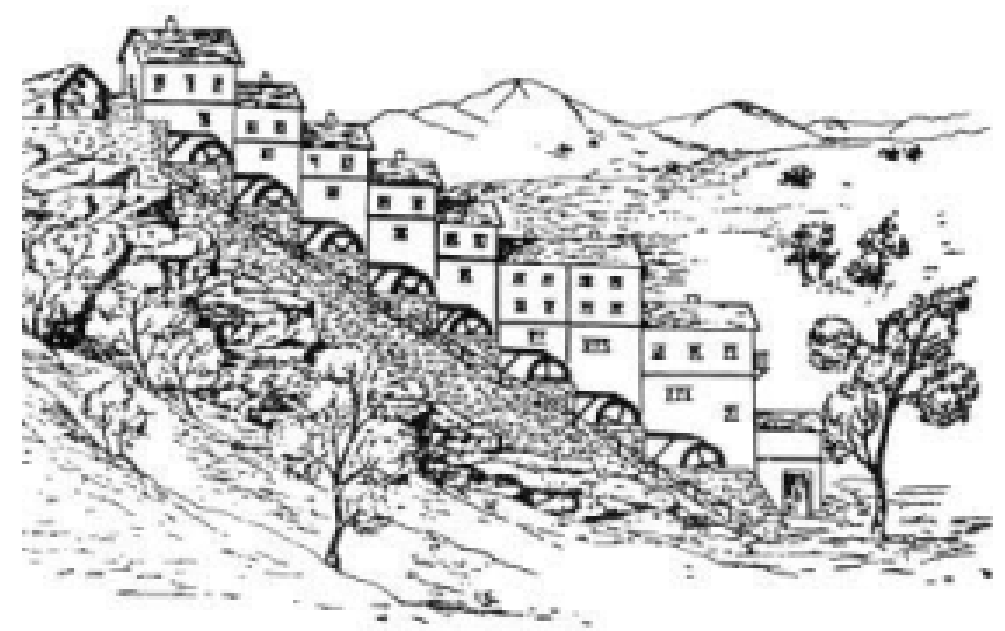

Abb. VI-77: Das berühmte „Mühlenhäuser-Aquädukt“ von Arles (aus: SCHNEIDER 1992:47) 
In der Spätantike scheint es auf vielen Gütern Wassermühlen gegeben zu haben. Auch in der Merowingerzeit war die Wassermühle relativ weit verbreitet (SCHNEIDER1992:47). Bereits um $200 \mathrm{n}$. Chr. existierten Mühlen, die ein horizontales Wasserrad besessen haben und bei denen die Achse des Rades direkt mit dem Mühlstein verbunden war. Somit entfiel der komplizierte Transmissionsmechanismus (:48).

Bei den Mühlenstandorten bestand jedoch das Problem, dass die während der Sommermonate geringe Strömung der Flüsse als Antrieb für eine normale Wassermühle nicht ausreichte. Deshalb wurde der Zulauf stark verjüngt und so die Strömung des Wassers beschleunigt. Der Zulauf endete seitlich an einem kreisförmigen Schacht, in dem das Wasserrad gelagert war (SCHNEIDER 1992:48).

Da der Süden Europas, so wird vermutet, mit über das Jahr hin gleichmäßig fließenden Gewässern weniger gesegnet war, verbreiteten sich die Wasserräder wohl mehr in den nördlichen Provinzen des römischen Reiches, sofern sie nicht an Aquädukte angeschlossen waren (WARNER 1982:115).

\section{a Mühlen und Hammerwerke}

Im Mittelalter wurden die Errungenschaften der antiken Technik zunächst rezipiert und dann weiterentwickelt. Die Wasserkraft wurde seit dem 11. Jahrhundert in großem Umfang im Gewerbe genutzt: mit Wasserkraft betriebene Walkmühlen und Eisenhämmer sind im Hochmittelalter, Drahtziehmühlen im Spätmittelalter in großer Zahl nachweisbar. Als landschaftsprägende sowie zugleich von der Landschaft geprägte Technologie tritt die Wassermühle in nahezu allen mit Wasser durchflossenen Tallagen in Erscheinung (siehe Pkt. VIII. 2.b).

Die Voraussetzung für die Anwendung der Wasserkraft in der gewerblichen Produktion war die Fähigkeit, wie zuvor gesagt, die Drehung des Wasserrades in eine hin- und hergehende oder in eine stoßende Bewegung umzuwandeln (SCHNEIDER 1992:15). Diese, wie dargestellt, bereits in der Antike bekannte Technik diente spätestens seit dem 10. Jahrhundert als Triebwerk und Transmission für Werkzeugbewegungen, zunächst wohl von Stampfen (MÜLLER/LUDWIG 1982:152).

Aber erst im 13. Jahrhundert erfolgte in Europa der erste größere Ausbau der Wasserkraft. Eisenwerke, die die genannte Energiequelle nutzten und deren Vorkommen vorher nur vereinzelt gesichert war (siehe oben), lassen sich nun von Italien bis Skandinavien und von England bis Polen nachweisen (MÜLLER/LUDWIG 1982:152).

Eine solche wasserbetriebene Mühlanlage aber, dessen Produkt bei einer Mehlmühle auch als ,weiße Kohle“ (THIENEMANN 1955: 141) bezeichnet wurde, musste mehrere Teil umfassen: die Ausbaustrecke eines Gewässers, dessen Fassung (bestehend aus Wehr und Einlaufbauwerk), den Mühlkanal und das Mühlhaus mit der eigentlichen Kraftmaschine: dem Wasserrad. Und sodann die jeweiligen vom Wasser angetriebenen Arbeitsmaschinen: Im Eisenwesen gehörten dazu die Hämmer, grob unterschieden in Schwanz-, Stiel- oder Stab- und Aufwerfhämmer, sowie die zum Teil wasserbetriebenen Blasebälge ${ }^{79}$.

Das spezifisch ausgebildete Rad als eigentlicher Antrieb ließ sich oberschlächtig, mit dem Aufschlagwasser drehend, anordnen oder unter- und mittelschlächtig, gegen den Wasserstrom drehend (MÜLLER/LUDWIG 1982:152). In Deutschland sind ,alle die alten Mühlräder [...] unterschlächtig; das oberschlächtige Rad erscheint erst im 14. Jahrhundert.“ (DÖBLER 1973:182), obschon in den Hochkulturen bereits um 520 oberschlächtige Wasserräder in Betrieb waren. (SCHNEIDER 1992:47). Das oberschlächtige Wasserrad erfordert zwar in der Regel die Anlage von Mühlteichen und Mühlgräben, aber es besitzt eine wesentlich höhere Effizienz als das unterschlächtige Rad, weil das von oben auf das Rad stürzende Wasser auch durch sein Gewicht auf die Schaufeln einwirkt. Verschiedene Produktionsbetriebe und -werkstätten nutzten die

\footnotetext{
79 Doch nicht nur Wasserkraft wurde hierfür verwandt: Zwischen der „Dicken Eiche“ und „Niemannsvilla“ oberhalb von Holzminden befand sich einst eine Nagelschmiede. Deshalb wohl auch der Name „Nagelbach“. Die Schmiede wurde von einem Blasebalg mit Frischluft versorgt. Ein Hund lief in einem breiten Rad und bewegte so eine Kurbel, die den Blasebalg arbeiten ließ. Dieses System war nur für Nagelschmieden anwendbar und nach Zeitzeugenberichten im 20. Jahrhundert noch praktiziert.
} 
ober-, mittel- oder unterschlächtig beaufschlagte Wasserkraft (siehe auch Pkt. VII 3.c ,Arten der Wasserzuführung'):

Die Harnischmacher, die eine Plättnerei, d. h. eine Rüstungsherstellung betrieben, bei der den ganzen Körper bedeckende dünne Eisenplatten durch Scharniere kunstvoll miteinander zur Rüstung verbunden wurden, betrieben im 13. Jahrhundert ihre Polierscheiben mit Wasserkraft (MÜLLER/LUDWIG 1982:154). Nach nicht genau belegbaren Angaben nutzten die Kettenharnischmacher von Iserlohn und Altena im Sauerland für die Drehbewegung der Drahtrollen Ende des 14. Jahrhunderts bereits die Wasserkraft. In Nürnberg entstanden in der ersten Hälfte des 15. Jahrhunderts die ersten Drahtziehmühlen (:155).

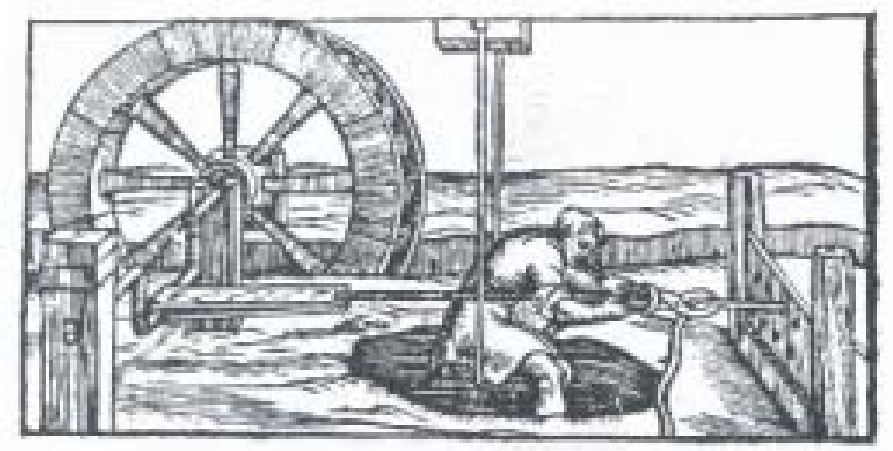

Abb. VI-78: Drahtziehmühle: Drahtzug mit Hilfe der Wasserkraft

(in: Biringuccio: Pirotechnia. - Venedig 1540, aus MÜLLER/LUDWIG 1982:176)

Der innovatorische Durchbruch zur modernen Drahtziehmühle, bei der die Kraftübertragung vom Wasserrad durch eine gekröpfte Welle erfolgte, gelang in Nürnberg zwischen 1408 und 1415. Bis zur Jahrhundertmitte entstanden dort mindestens 20 Produktionsstätten, so dass die Nürnberger Drahtmühlunternehmer in früherer Zeit ein Oligopol besaßen (MÜLLER/LUDWIG 1982:155f.).

Spätetens im 14. Jahrhundert kam in der Oberpfalz sowie im Ostalpenraum auch die Blechmacherei auf. Zunächst handelte es sich ausschließlich um Schwarzblech, aber seit Mitte des 15. Jahrhundert konnte auch Weißblech zum Schutz gegen Rost mit einem Zinnüberzug versehen werden (MÜLLER/LUDWIG 1982:156).

Ein Arbeitsschritt zur Herstellung von Blechen sieht vor, die geschlagenen Bleche in Kleiewasser zu beizen und danach das Schwarzblech zu waschen. Es folgten „Unschlittbäder“ der Bleche, zumeist im Trog, aber auch in fließendem Wasser, um Voraussetzungen für eine gute Annahme des Überzugs zu schaffen sowie weitere Arbeitsgänge, bei denen aber das Wasser keine Rolle spielte (MÜLLER/ LUDWIG 1982:156f.).

Diese Bleche wurden vor allem zu Salzsiederpfannen zusammengenietet, worin die geschöpfte Sole in den Sudhäusern erhitzt wurde, um das kristalline Salz zu erhalten.

Auch im Bereich der mittelalterlichen Papierherstellung wurde die Wasserkraft genutzt und zur Einleitung benutzt, insbesondere seit der Erfindung der Buchdruckkunst durch Johannes Gutenberg Mitte des 15. Jahrhundert.

Bis zur Mitte des 19. Jahrhunderts verwandte man als Rohstoff zur Papierherstellung fast nur Hadern (Lumpen), gewonnen aus alten Kleidungsstücken. Diese „Altkleider“ aus Baumwolle oder Leinen wurden von einer wasserradbetriebenen Stampfe unter ständigem Wasserzu- und abfluss zugleich gereinigt, zerrissen und zu einem Brei zerschlagen. Danach ließ man den Lumpenbrei einige Tage in Wasser eingeweicht liegen und brachte ihn anschließend auf die Stampfmühle. Der Faserbrei kam in die Schöpfbütte, wo er sich unter Zusatz von Klebstoff zu einer milchigtrüben Flüssigkeit verwandeln ließ. Aus der Bütte schöpfte der Papiermacher den stark verdünnten Papierbrei mit einer Schöpfform (Drahtsieb) heraus und drückte das sich bildende Papierblatt auf einen Filz. Die Filze mit den Papierbogen legte man übereinander und presste (gautschte) sie stapelweise, damit das Wasser entwich. Anschließend wurde das Rohpapier zum Trocknen aufgehangen (MÜLLER/LUDWIG 1982:178; MERTES 1995:37). 


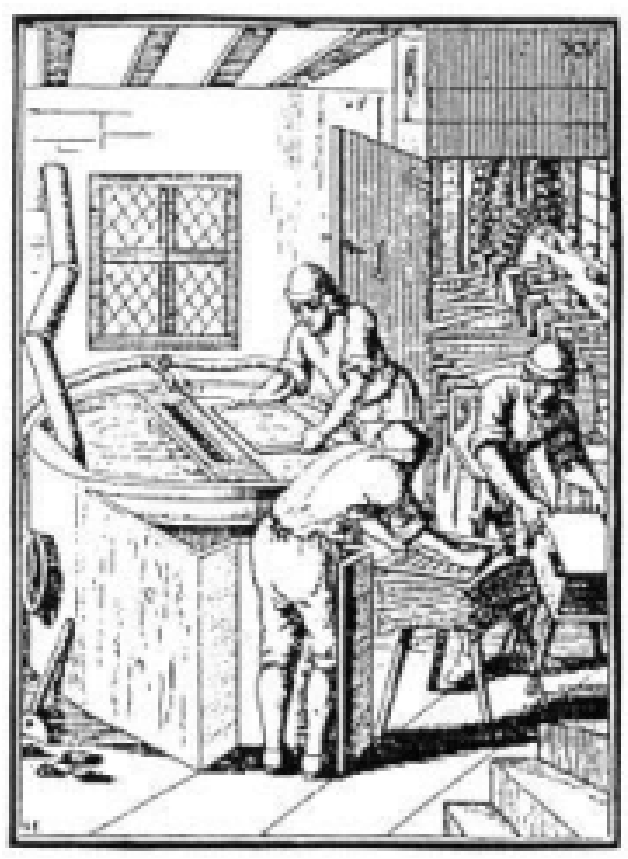

Abb. VI-79: Die Papiermühle: Papierbottich mit Wasserzufluss (aus: UECKER 1999: 85).

Die vermutlich erste Papiermühle wurde um $144 \mathrm{n}$. Chr. bei Valencia errichtet (MÜLLER/LUDWIG 1982:178). Sie erlaubte die Nutzung alter Gewebe und Gespinste anstelle der zuvor verwandten pflanzlichen Rohstoffe, unter anderem Hanf und Papyrus bzw. das im Abendland zuvor genutzte, aus den Häuten junger Schafe und Ziegen hergestellte Pergament. In Deutschland entstanden die ersten Papiermühlen 1390 in Nürnberg am Pegnitzfluss (Hadermühle) und in Ravensburg (Ravensburger Papiermühle).

Neben der Produktion von Druck- und Schreibvorlagen war die intensive Nutzung von Wasserkraft Motor für die beginnende vorindustrielle Massenanfertigung von Textilien. Trotz der häufig aufgestellten Behauptung, erst die Dampfmaschine habe die Fabrik geschaffen, spielte „das Wasserrad bei der Entstehung der Textilfabriken die eigentlich entscheidende Rolle“ (PAULINYI 1982:255).

In der vorindustriellen Textilproduktion, beispielsweise der Kammgarnspinnerei, wurden die Spinnmaschinen noch um 1800 mit Wasserradantrieb betrieben (siehe Abb. V-24) (PAULINYI 1982: 234,254). Die kurzen Flachsfasern wurden durch den Vorgang des Spinnens zu einem längeren Faden, zu Garn, weiterverarbeitet (SCHNEIDER 1992:124).

Als Weben hingegen bezeichnet man ,jenen Arbeitsprozeß, durch den rechtwinklig sich kreuzende Fäden so miteinander verschlungen werden, daß ein Gewebe oder Stoff entsteht; als Instrument wird hierzu der Webstuhl benutzt.“ (SCHNEIDER 1992:125) Auch für diesen zunächst händischen Verarbeitungsprozess wurde ein wasserradgetriebener mechanischer Webstuhl eingesetzt (siehe PAULINYI 1982:234).

Diese Wasserräder des 19. Jahrhunderts bestanden aus eisernen Wasserrädern und wurden erst gegen Ende des 19. Jahrhunderts durch dampfbetriebene Maschinen ersetzt.

Fast vergessen im öffentlichen Bewusstsein ist auch die Tatsache, dass Wassermühlen den ersten elektrischen Strom zur Versorgung des Dorfes mit elektrischem Licht lieferten. Technisch wurde über das Wasserrad oder die Turbine ein Dynamo angetrieben.

Die Versorgung der Glühbirnen in einer begrenzten Anzahl von Haushalten mit Lichtstrom konnte eine Wassermühle sicherstellen; erst der vermehrte Bedarf von Strom in der Landwirtschaft, den privaten Haushalten und in der Industrie seit den 1920er Jahren und oft erst nach dem Zweiten Weltkrieg überstieg die Leistungskraft des vom Wasser erzeugten Mühlenstroms (BEDAL 1992:112). 
Die Landwirtschaft schließlich setzte, falls sie über eine wasserbetriebene Einrichtung zum Mahlen von Getreide verfügte, auch für das vor dem Backen stehende Dreschen des Getreides wasserbetriebene Dreschmaschinen ein.

Die rotierende Bewegung des Wasserrades ist des Weiteren - mit Ende des 12. Jahrhunderts - zum Betätigen von Fallhämmern beim Tuchwalken, zum Zerquetschen von Färberwaid und zum Pressen von Eichenrinde für die Herstellung der Gerberlohe verwendet worden. Schließlich hat man auch Schmiedehämmer, Pochwerke zum Zerkleinern von Erz, Sägewerke und Schmiedebälge mit Wasserrädern angetrieben (DÖBLER 1973:181f.). Auch um in Bergwerken und in Salzgruben Wasser zu pumpen oder Kohle und Salz zu fördern, wurde seit dem 15. Jahrhundert das Wasserrad eingesetzt (:182). Die großen, bis zu drei Meter durchmessenden vertikalen Schleifsteine der Schleifkotten und Poliermühlen wurden ebenfalls durch Wasserkraft betrieben, und nach Erfindung der Turbine benutzte man Wasser dann auch zur Gewinnung von Strom.

Früher, das sollte aus dieser Zusammenstellung deutlich werden, wurde die Wasserkraft von Gewässerläufen als Energieträger in einem heute kaum noch vorstellbaren Umfang genutzt. Der Gebrauch der Wasserkraft führte - für damalige Verhältnisse - zur teilweise hochverdichteten Ansiedlung von Gewerbe an Flussläufen und zur Entstehung ,großer“ Betriebe, die die Wasserkraft und damit letztlich die Gewässerläufe intensivst nutzten und auch - zumindest in ihrem Lauf -veränderten: „Bis auf die Schiffsmühle (siehe Pkt. 16.d) ist allen Wassermühlen gemeinsam, daß sie mit mehr oder minder umfangreichen Wasserregulierungsanlagen verknüpft sind, um die gewünschte Wassermenge möglichst effektiv und stetig den Wasserrädern zuzuführen: die Wassersammlungen in Teichen, den Stau und die Regulierung durch Dämme, Wehranlagen und Staubretter (Schütze) sowie die Zuleitungen." (MAGER et al. 1989:56f.).

Mit der Einrichtung und Unterhaltung von solchen Wasserbauten, wie beispielsweise Mühlgräben, Stauwehranlagen und Dämmen, wurde massiv in die Gewässerläufe eingegriffen. Die Ruhr zum Beispiel hat man für den Betrieb stationärer Wassermühlen , in den Griff bekommen“, indem man diagonal im Strom sog. Mühlenschlagden aufschüttete, durch die ein Teil des Wassers auf das Mühlrad gelenkt wurde.

Die Wasserkraft hatte allen anderen Antriebskräften gegenüber die größeren Vorteile, weil Wasser am kräftigsten, beständigsten und gleichförmigsten wirkt. Diese Attribute konnten aber nur mit den schon genannten Eingriffen, wie dem Stau von Wasser, den Flussableitungen usw. verwirklicht werden.

Die Gesamtheit der kontrollierten Ableitungen von Flusswässern in die künstlichen Anlagen der Mühlenbäche für den steten Mühlenantrieb ist hinsichtlich der Bedeutung für das Gewässersystem noch keineswegs großmaßstäblich erfasst. Bachableitungen wurden gegraben, die das Wasser für die neuerbaute Mühle in den Mühlbach ableiteten und dadurch „den freien Bach in seinem gewohnten Lauf" behinderten (DOBELMANN 1980:38). Die Ableitung des Erftmühlenbaches zum Beispiel beeinflusste die Wassermenge in der Erft erheblich. Am Flussabzweig war die Gefällestufe so ausgebaut, „daß bei geöffnetem Wehr bis zu einer bestimmten Wasserspiegelhöhe das gesamte Wehr in den Erftmühlenbach abfließt." (DIX 1997:136) In extrem trockenen Monaten konnte deshalb das Flussbett auf dieser Strecke ganz trockenfallen.

Durch den Sohlenbau und die dadurch bedingte Erhöhung des Flussbettes mit der Absicht, ein möglichst hohes Gefälle zu haben, kam es in der Folge zu großflächigen Überschwemmungen. Gleichzeitig bestand durch den Mühlenbau ein massiver Wasserentzug in den natürlichen Gewässerläufen. Die Räume ehemaliger Papierfabriken beispielsweise lagen unterhalb des Bachniveaus: nur so konnte „man das Wasser bequem aus dem Bach direkt den verschiedenen Maschinen der wasserintensiven Papierindustrie zuleiten.“ (DIX 1997:107)

Neben den wasserbaulichen Veränderungen war der Betrieb von wasserbetriebenen Werkmühlen mit einer Reihe von unangenehmen Folgen für das sie erst in Betrieb setzende Wasser verbunden. Erhebliche Geruchsund Lärmemissionen korrespondierten mit Verunreinigungen des Flusswassers mit ätzenden Abwässern. 


\section{b Bergbau und Hüttenwesen}

Der Montanbergbau war auf die Inwertsetzung der Wasserkraft in zweifacher Hinsicht angewiesen: bei der Gewinnung und bei der Verarbeitung.

Eines der drängendsten Probleme des Untertagebergbaus war die Entwässerung der Gruben (WIESEMANN 1996:82). Der Bergbau litt unter gravierenden Wasserhaltungsproblemen, die stetigen Wasserzuflüsse mussten beherrscht und Hohlräume von oft vielen 1000 Kubikmetern Rauminhalt wieder vom Wasser befreit werden (BARTELS 2000:40). In den Bergwerken, die unter dem Grundwasserspiegel lagen, mussten deshalb leistungsfähige Entwässerungsanlagen installiert werden, um deren Überfluten zu verhindern (SCHNEIDER 1992:77).

Bereits Mitte des 14. Jahrhunderts wurden Kanäle (,,aquaeducti“) angelegt, die Grund- und Regenwasser über natürliches Gefälle zum nächsten Flusslauf ableiteten, wie WIESEMANN (1996:82f.) am Beispiel des Steinkohlenbergbaus aus dem Aachener Umfeld berichtet. Es handelte sich dabei um einen Entwässerungskanal (mittelhochdt.: aducht), einen Stollen, der in den Berg getrieben wurde, um so eine unterirdische Entwässerung durch Ableitung von Grubenwasser zu leisten.

Die Entwässerung von Bergwerken mittels Stollen ist jedoch nur so lange möglich, wie die Geländeverhältnisse es zulassen. Bei Aachen waren sie günstig, weil tief eingeschnittene Erosionstäler genügend Gefälle zur Verfügung stellten. Aber auch hier war naturgemäß das Abbauniveau zu einem bestimmten Zeitpunkt auf die Höhe der Vorfluter abgesunken. „Jetzt waren Techniken vonnöten, mit deren Hilfe das Wasser aus größeren Teufen auf Stollenhöhe hochgepumpt werden konnte.“ (WIESEMANN 1996:84)

Bis zum 15. und 16. Jahrhundert waren es oft 500 bis 600 Wasserknechte mit Schöpfgefäßen, die täglich in einer vierstündigen Wechselschicht das Wasser mittels Ledereimern, Kübeln oder Tonnen im Schacht von Mann zu Mann in einer Kette nach oben weitergereicht und bis zu völligen Erschöpfung gearbeitet hatten (MÜLLER/LUDWIG 1982:170; WIESEMANN 1996:82; BARTELS 2000:44). Seit ältester Zeit wurde das Ausschöpfen des Wassers mit einer Haspel durchgeführt, an deren Seil Eimer oder Ledersäcke das Grubenwasser zutage förderten. „Noch bis ins 19. Jahrhundert war bei Tiefen von 40 bis 60 Metern [...] die zweimännische Haspel das im Erzbergbau gebräuchlichste Fördermittel.“ (CZAYA 1990:31) In gleicher Weise war auch ,über Jahrhunderte hinweg“ der Transport des Festmaterials unter Tage und die Förderung zutage schwere Muskelarbeit.“ (:30) Zutage gebracht wurde das Fördergut in Körben, in Ledersäcken aus Ochsenhaut (Bulgen) oder Trögen und „lange Zeit wurden die gefüllten Behälter auf dem Rücken oder den Schultern geschleppt.“ (:30).

Im Erzgebirge und im Harz waren in der ersten Hälfte des 16. Jahrhunderts auch Pferdegöpel verbreitet, Bulgenkünste, die über ein Stockgetriebe und eine senkrechte Welle von oberirdisch arbeitenden Pferden angetrieben wurden (WIESEMANN 1996:84). Die Bulgenkünste stammten aus Ungarn und wurden im Erzgebirge erstmals in der 2. Hälfte des 15. Jahrhundert aufgestellt. In solchen Säcken hob man das Wasser auf das Niveau des Erbstollens, über denen es zutage floss (CZAYA 1990:32). Aber auch später, als die „Künste“ (siehe unten) das Vordringen in zunehmende Tiefen ermöglichten und immer stärkere Antriebsenergie vonnöten war, wurde Pferdekraft eingesetzt, aber im Allgemeinen nur dort, „wo nicht genügend Aufschlagwasser vorhanden war.“ (:34). „Wo immer möglich, wurde der Wasserkraft gegenüber der Pferdekraft Vorrang gegeben.“ (:35)

Seit dem 15. und 16. Jahrhundert wurden als Wasserhebegerät unter anderem Wasserräder verwendet. „Am Radkranz des Wasserrades waren Behälter angebracht, die sich beim Eintauchen in das Wasser füllten und, am höchsten Punkt des Rades angelangt, sich wiederum leerten.“ (SCHNEIDER 1992:77) Das lästige Grundwasser wurde dabei mittels Wasserrad getriebener Wasserkünste gehoben (MÜLLER/LUDWIG 1982:170). 


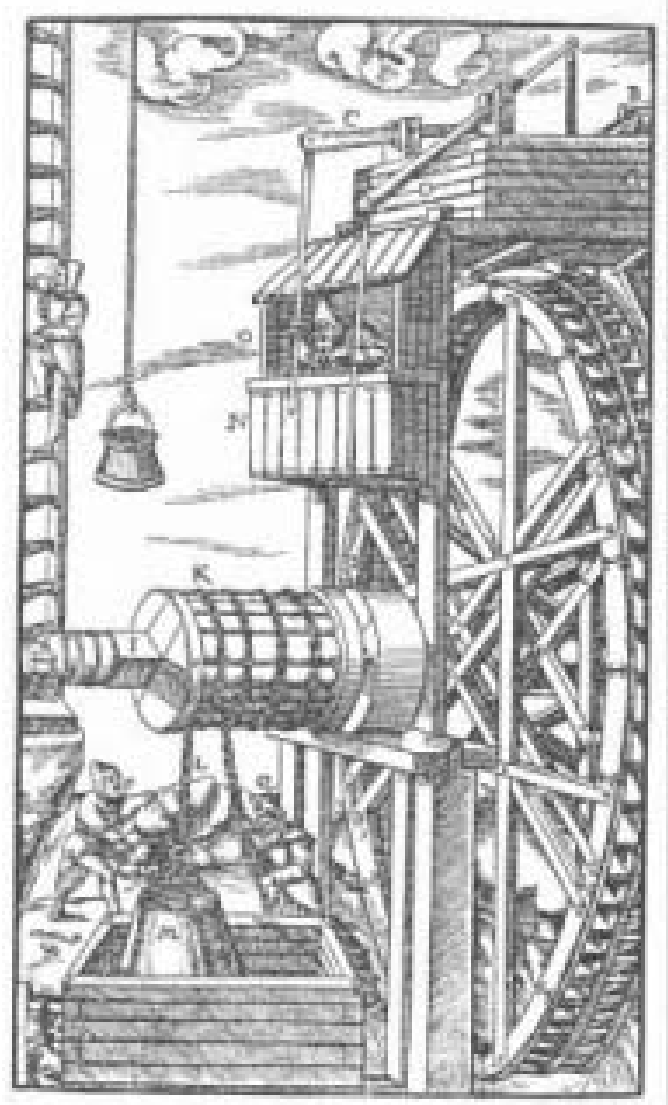

Abb. VI-80: Grubenentwässerung (,Wasserhebung“) mit Kehrrad und Bulgen

Die Person des Regulators kann durch Stangenhebel steuern, welche Radhälfte bewässert wird und in welche Richtung das Rad sich demzufolge dreht (Holzschnitt aus AGRICOLA „De re metallica“ 1556).

Das „Wasserziehen“ galt als wichtige bergbauliche Tätigkeit (BARTELS 2000:38). Das älteste bekannte Privileg stammt aus dem Jahr 1315, aus dem Bergbaugebiet Böhmen. Mittels gezielter Wasserführung sollten sechs Mühlräder sommers und winters zur Trockenlegung genutzt werden (MÜLLER/LUDWIG 1982:164). Diese im Bergbau verwendeten Entwässerungsanlagen ermöglichten es erst, Metallvorkommen zu erschließen, die der Antike unzugänglich waren (SCHNEIDER 1992:15). Zudem bedeutete dies Erleichterung, aber auch Wegfall eines Berufsstandes, der der Schöpfknechte.

Diese neuen Entwässerungstechniken der Erzgewinnung hatten jedoch „unter anderem zur Konsequenz, daß die Tiefenausdehnung der Bergwerke sowie die Raumschaffung unter Tage insgesamt [...] exponentiell anwuchsen, was wiederum die Massen zu hebenden Wassers mindestens ebenso rasch anschwellen ließ“ (BARTELS 2000:43f.).

Schon im Mittelalter bemühte man sich deshalb darum, mit Hilfe von Wasserhebemaschinen der Probleme mit dem Grubenwasser Herr zu werden. Als fortschrittlichste Entwicklung auf dem Gebiet der Wasserkünste erschienen im 16. Jahrhundert wasserradgetriebene Saugpumpen (MÜLLER/LUDWIG 1982:170): Hydraulische Wasserhebemaschinen, die mit einer aufwendigen Pumptechnik das Wasser aus tieferen Bauen mit den Maschinen hochpumpten (WIESEMANN 1996:84; BARTELS 2000:44). Sie legten den Grundstein für eine tiefgehende Veränderung im Bereich der Wasserhaltung, die bis in erhebliche Tiefen - bis etwa 250 m unterhalb der Ebene des Abflusses mit natürlichem Gefälle - maschinell bewältigt werden konnte (:44).

Die Wasserräder der Maschinen wurden vom (Kraft-) Wasser eines Fließgewässers angetrieben, d. h. das Antriebswasser wurde von der Tagesoberfläche in die Grubenbaue eingeleitet (BARTELS 2000: 44). Sie setzten Pumpgestänge in Bewegung, welche über ein geeignetes Gestänge Kolben hoben und das Lastwasser aus den Sümpfen in die Wasserseige des Stollens holten, in der es sogar als Aufschlagwasser für weitere Antriebsräder dienen konnte (MÜLLER/LUDWIG 1982:170). Durch in mehreren Sohlen übereinander gestaffelte Stollen- und Streckensysteme mit zahlreichen Verbindungsschächten wurde es möglich, das in den oberen Sohlen zudringende Grundwasser mit auf die Wasserräder zu leiten und so technisch nutzbar zu 
machen (BARTELS 2000:44). Da der Antrieb mittels Wasserrädern auf der Schwerkraft beruht und die Räder vom höchsten Punkt, zu dem man Antriebswasser zu leiten vermochte, bis zum tiefsten Niveau des Wasserabflusses über einen Stollen kaskadenförmig gestaffelt werden konnte, vermehrte eine Zunahme der verfügbaren gesamten Fallhöhe durch Anlage neuer tiefer Stollen die Zahl der einsetzbaren Wasserräder $(: 44)$.

Wasserkünste waren damals in Mitteleuropa schon seit etwa 200 Jahren bekannt. 1385 arbeitete die erste derartige Anlage nach Angabe von WIESEMANN (1996:84) in den Karpaten. Nach BARTELS (2000:42) hingegen ist die Konstruktion von Gestängepumpen mit Wasserradantrieb erstmals bezeugt um 1540 in Ehrenfriedersdorf im Erzgebirge.

Die Entwässerung der Gruben mittels Wasserkünsten sollte bis zur Einführung der Dampfkraft Ende des 18. Jahrhunderts und noch bis Mitte des 19. Jahrhunderts hinein das Kernstück der bergbaulichen Wasserhaltung bleiben (WIESEMANN 1996:85; BARTELS 2000:44).

Die Bergbauaktivitäten des „hydraulischen“ Mittelalters und der frühen Neuzeit, wie beispielsweise zunächst am Rammelsberg im Harz, später dann vor allem im Oberharz ,schrieben sich insbesondere durch die Nutzung der Wasserkraft in die Landschaft ein“ (BARTELS 2000:42). Man kann sie als Großtechnologie auf der Basis von Wasser umschreiben:

Schon im 16. Jahrhundert waren die natürlichen Fließgewässer in den Tälern nicht in der Lage, den beständigen Wasserzufluss zu gewährleisten, der nötig war, um all die Wasserräder im Bergbau zu bewegen. Die Pumpenanlagen in den Gruben waren hier ein besonders kritischer Bereich: Sie mussten dauerhaft arbeiten, damit die Bergbaubetriebe wasserfrei blieben. Zu Beginn des 17. Jahrhunderts, als der Bergbau eine neue Blüte erlebte und der Bedarf an Wasserrädern für die Pumpen und Fördermaschinen exponentiell anwuchs, waren die Bergbaulandschaften regelrecht durch die Wasserkraftmaschinen geprägt (BARTELS 2000:45), die alle mit Antriebswasser beschickt werden wollten. Die Gestängepumpe mit Wasserradantrieb „legte den Grundstein für eine tiefgehende Veränderung im Bereich der Wasserhaltung, die fortan bis erhebliche Tiefen - bis etwa $250 \mathrm{~m}$ unterhalb der Ebene des Abflusses mit natürlichem Gefälle - maschinell bewältigt werden konnte" (:42), aber damit auch die vollständige Ausrichtung des Gewässernetzes auf bergbauliche Belange. Gleichzeitig ging damit eine „enorme Erhöhung des Wasserverbrauchs“ (:47) einher.

Um eine Wassersäulenmaschine anzutreiben, welche das Grubenwasser aus den Tiefbaufeldern pumpte, wurde beispielsweise in den 1840er Jahren der „Kalte Bach“ bei Nienstädt „oft wochenlang [...] abgeleitet.“ (NEUBER 2000:62) Zwar stand auch eine Dampfmaschine zur Verfügung, doch hielt es das Bergamt wegen der höheren Betriebs- und Reparaturkosten für günstiger, diese nur in Zeiten völligen Mangels an Aufschlagwasser einzusetzen ,und ansonsten lieber die Bachanlieger dafür zu entschädigen, daß sie mehrmals täglich ihre 151 Pferde und 395 Rinder von den Wiesen holen und an den Hofbrunnen tränken mußten.“(:62)

Um die nötigen Antriebs-Wassermengen zu mobilisieren und eine möglichst gleichbleibende Beschickung der Räder unter den stark durch jahreszeitliche Niederschlags-Schwankungen beeinflussten Bedingungen gewährleisten zu können, wurden großflächige Wasserbaumaßnahmen erforderlich, die Anlage von Wassersammelgräben, Stauteichen, Zufuhr- und Ableitungsgräben für die Wasserräder. „All das mußte sich dem Diktat des Gefälles und damit den Gegebenheiten des geographischen Reliefs unterordnen." (BARTELS 2000:45)

Auf dem Gebiet der Wassersammlung war um 1760 ein Stand erreicht, bei dem alle mobilisierbaren Wasserreserven angezapft und so weit wie möglich zum Bergbaugebiet umgeleitet waren. Im Oberharzer Raum beispielsweise wurden zwischen 1640 bis 1740 auf rd. $100 \mathrm{~km}^{2}$ Teiche und kleine Stauseen angelegt und kilometerlange Verbindungsgräben durch die Landschaft gezogen (BARTELS 2000:45). Allein zwischen 1640 und 1660, rechnete BARTELS (:47) aus, entstanden drei neue große Stauteiche mit 0,8 Mio. $\mathrm{m}^{3}$ Volumen und zwischen 1660 bis 1680 nicht weniger als 25 Teiche mit $3,15 \mathrm{Mio}^{3} \mathrm{~m}^{3}$ Speicherkapazität, die die Wasserräder mit „Kraftwasser“ versorgten. Die wasserangetriebenen Hütten, Hammerwerke, Bohrmühlen und Sägegatter sind dabei noch unberücksichtigt. 
Der Stollenbau der Bergwerke in Bergbaubauregionen hatte im Laufe der bergbaulichen Aktivitäten nicht nur in die Grundwasserverhältnisse eingegriffen, sondern auch in das oberflächige Abflussregime. Die gesamte Landschaft wurde „hinsichtlich ihrer Gewässergestalt systematisch umgebaut und auf die Funktion für den Bergbau hin organisiert" (BARTELS 2000:47): So wurde der Abfluss des Veybachs im Erftgebiet durch Grubenwässer aus dem ,Burgfeyer Stollen' erhöht und führte häufig mehr Wasser als die Erft selber. Außerdem war durch diesen künstlichen Wasserzufluss sein Abflussverhalten im Jahresverlauf gleichmäßiger (DIX 1997:135).

Der Steinkohlenbergbau in der Schaumburger Ebene, angelegt im ausgehenden 18. und in der ersten Hälfte des 19. Jahrhunderts und um 1960 stillgelegt, „beeinträchtigte die traditionellen Wassernutzungsgewohnheiten.“ (NEUBER 2000:61) „Bäche versickerten durch die so entstandenen Klüfte im Untergrund, Quellen versiegten, Mühlen mußten aufgegeben werden, und in ganzen Ortschaften fielen die Brunnen trocken.“ (:62) Des Weiteren erschwerte bzw. verhinderte der Bergbau zum Beispiel „die landwirtschaftliche Nutzung von Wiesen“ (:62). Das fortan aus den tieferliegenden Stollen abfließende Wasser war „derart stark mit Ockerschlamm verunreinigt, daß es für land- und hauswirtschaftliche Zwecke unbrauchbar wurde und bei Überschwemmungen die anliegenden Wiesen schädigte.“ (:62)

In Zellbach bei Clausthal wurden, wie an vielen anderen Orten im Oberharz, bereits frühzeitig im 16. Jahrhundert „natürliche Bachläufe [...] umgeleitet, aus dem Talgrund an den Berghang verlegt“, um Wasserräder des Bergbaus anzutreiben (BALCK 1999:17).

Speicherteiche überformten die alten Quellen und Wasserläufe. Gleiches geschah mit den Seitentälern. Die Talmulde des Horbachs im Oberharz ist heute durch zwei Teiche verhüllt (HAASE 1961:40). Im Tal des Kleinen Furbach „bedecken zwei Teiche die nebeneinanderliegenden Quellmulden“ (:40f.). Weitere Sammelbecken liegen eingesenkt „,in den Tälern der Innerste und ihrer kleineren Seitenbäche“ (:49). Die wiederum erhalten aus anderen Bergbauteichen regelmäßige Abgaben, die es der Innerste überhaupt erst ermöglichen, „dass sie wieder als Gewässer in der Landschaft kenntlich wird.“ (:49) Selbst das Wasser der Laute ist oberhalb Lautentahl im Teich gesammelt worden (:49). Der kräftigste Nebenarm des Spiegelbaches, der Grumbach, ist ,durch die Wasserwirtschafts- und Bergwerksanlagen stärker als andere Täler verändert worden“"(:41). Die notwendigen Aufschlagwasser gedachte man ferner von der Schalke zu holen. Der Bergquellfluss lag aufgrund seiner hohen Niederschläge besonders günstig für die wasserwirtschaftliche Nutzung (:41). Die Quellen der Sieber werden an einem Wehr abgefangen, und „ständig vermehrt sich nun unterwegs die Menge der vom Moor austropfenden Wasser“ (:18). Diese Beispiele verdeutlichen das Prinzip des Gewässereingriffs: „Die Wasser wurden aus ihren Vorratsräumen zu den eigentlichen Gebrauchsstätten hin geleitet.“ (:41)

Nachdem akuter Wassermangel in der Mitte des 17. Jahrhunderts und und wiederholte katastrophale Trockenzeiten in den Jahren 1732 - 1734 eintraten, wurden mit einem langen Damm die weiter entfernt liegenden Gewässer und Quellläufe angezapft. Anfangs in einer gemauerten und seit 1870/72 in einem betonierten Gerinne flossen über eine Länge von $940 \mathrm{~m}$ und einer Höhe von 16 m, eine breite Talmulde querend, in einem „Dammgraben“ Wasservorräte des Hohen Harzes den Bergbaustollen zu. Nachdem die Wasservorräte des Brockenmoores erschlossen waren, begann man zwischen 1820 und 1840 die fernen Ausläufer der Gewässerräume, die äußersten Quellbereiche des westlichen Hochharzes, zu erschließen (HAASE 1961:15).

Die Wasserkraftnutzung beschränkte sich aber nicht nur auf die Gruben. Nach der unterstützenden Gewinnung von Bergbauerzen und der Möglichkeit, eingedrungenes Wasser durch Wasserkraft zu heben, galt es das Material - unter Zuhilfenahme von Wasserkraft - in den Hütten zu verarbeiten. „Nicht so sehr durch den Bergbau als vielmehr im Bereich des Hüttenwesens begannen Eingriffe in das Gewässernetz, indem man die Wasserräder der Erzmühlen und der Blasebälge der Schmelzöfen über Gräben mit Aufschlagwasser versorgte.“ (BARTELS 2000:34)

Im Bereich der Verhüttung wurden die Blasebälge mit Wasserkraft betrieben. Das anfachende Gebläse des Herdes eines Hammerwerkes wurde von einem unterschlächtigen Wasserrad angetrieben. (MÜLLER/LUDWIG 1982:152). Erste Belege dafür, dass die Wasserkraft Blasebälge antrieb, finden sich 1214 im Silberbergbau von Trient. Spätestens im 15. Jahrhundert ersetzte der Blasebalg flächendeckend die 
menschliche oder tierische Arbeit und erlaubte die Erzeugung höherer Schmelztemperaturen und auch die Steigerung der Arbeitsproduktivität (:152). Das wasserradgetriebene Gebläse konnte zwei Bälge und damit zwei Öfen, einen Schmelz- und einen Treibherd, bei der Silbererzeugung antreiben (:163).

Im Übergang zur Verarbeitung der Massenerze wurde auch die Erzaufbereitung auf den Einsatz wasserkraftbetriebener Pochwerke umgestellt (BARTELS 2000:45). Seit dem Ende des 16. Jahrhunderts war im Erzbergbau des Harzraumes das „Nasspochen“ der Roherze gängige Aufbereitungstechnik. Das grob von anhaftendem taubem Material befreite Erz wurde nach dem Ausklauben reiner Erzstücke ,in wasserradgetriebenen Pochwerken aufbereitet, wobei schon der Pochvorgang im strömenden Wasser erfolgte.“ (:34)

Da abhängig von reichlich Betriebswasser, waren diese Abschnitte der Aufbereitung nur manchmal auf dem Grubengelände anzutreffen. „Häufig wurden sie in den Talgrund oder zumindest an Standorte unterhalb von Sammelteichen verlegt, wo das Brauchwasser und die Wasserkraft voll genutzt werden konnten." (CZAYA 1990:38) Dort aber war das Wasser von vielen begehrt. Die auf kleinem Raum gewinnbaren Wassermengen mussten intensiv genutzt werden. Umständliche Leitungen waren nötig, um das gleiche Wasser zu wiederholtem Gebrauch von einer Stelle zur anderen zu bringen (HAASE 1961:38). Der ,am Hang liegende Werkplatz" war strukturiert durch ein System von Wassergräben, die, mit Holz ausgekleidet, der Aufbereitung des Erzes oder aber auch der Schlacken gedient haben (KLAPPAUF 2000:20f.).

\section{c Glasmacher}

Am Anfang stand die Entdeckung, dass durch Schmelzen von Sand und Soda Glas entsteht. Glas unterscheidet sich von den anderen verwendeten Werkstoffen insofern, als keine natürlichen Vorkommen dieses Materials existieren und es aus verschiedenen Rohstoffen hergestellt werden muss. Die wichtigsten Bestandteile von Glas sind Quarzsand und Pottasche, das durch Soda ersetzt worden ist (SCHNEIDER 1992:108). Die Beimengung von Flussmitteln wie Soda oder Pottasche hat die Funktion, den Schmelzpunkt des Quarzsandes zu senken. Als Stabilisator, der verhindert, dass Glas sich in Wasser auflöst, dient zusätzlich Kalk. Mit Hilfe von Muscheln konnte dem Glasgemenge in Produktionsstätten leicht Kalk hinzugesetzt werden $(: 113)$.

Der Ursprung des Glases liegt nach den heutigen Erkenntnissen in Nordsyrien bzw. Mesopotamien. Im 4. Jahrtausend v. Chr. kannten die Ägypter bereits die Glasur und Fayencenherstellung. Die Glashütten der assyrischen Festung Nimruds waren im 8. Jh. v. Chr. die bekanntesten des Alten Orients. Über die römischen Glashütten, beispielsweise Köln, in dessen Umgebung ein fast reiner Quarzsand gefunden wurde und wo die Produktion gegen Mitte des 1. Jahrhunderts n. Chr. einsetzte (SCHNEIDER 1992:110), kam dann das Glas im Mittelalter auch in die deutschen Mittelgebirge.

Hinzu kam, dass Glas seit dem 12./13. Jahrhundert zunehmend gefragt war. Auf die Stilrichtung der Romanik mit ihren kleinfenstrigen Bauten folgte die Gotik mit ihren offenen Baustrukturen. Fensterglas wurde ein besonders wichtiger Handelsartikel. Allmählich zunehmender städtischer Wohlstand öffnete einen Markt für Trinkgläser und Flaschen (BACHMANN 1996:184).

Jahrhundertelang gehörte die Glasherstellung zu den strukturbestimmenden Gewerben der Mittelgebirgsregionen wie zum Beispiel im Thüringer Wald, im Harz, Solling und Spessart sowie in der Rhön und im Vogelsberg, um die beim Bergbau anfallenden Sande und die lokalen Hartholzvorräte zu nutzen. Die Wahl dieser Standorte war wesentlich von den Rohstoffvorkommen abhängig, von Quarzsand, Kalkstein und vor allem von Holz wie SCHNEIDER (1992:111) betont. Und für CERNA (1996:176) waren diese Rohstoffe „die wichtigsten Voraussetzungen zur Gründung einer jeden Glashütte.“ Aber was oftmals vergessen wird: ebenfalls von Wasser.

Natürlich ist die Bezeichnung „Waldglas“ ein Hinweis darauf, dass die Glashütten zunächst vor allem an solchen Standorten lagen, an denen Holz als Brenn- und Rohstoff im genügenden Maße zur Verfügung stand. Die Bedeutung von Holz für die Glasproduktion kommt sehr anschaulich darin zum Ausdruck, dass etwa $2400 \mathrm{~kg}$ Holz benötigt wurden, um $1 \mathrm{~kg}$ Glas herzustellen. Dabei wurden $97 \%$ des Holzes für die 
Herstellung von Pottasche verwendet, und $3 \%$ brauchte der Gläsner für den Schmelzvorgang des Sandes (ROTH 1988:123ff.). Nach etwa 20 - 30 Jahren war der Holzbedarf um eine Glashütte aufgebraucht, das Holz an einem Hüttenplatz erschöpft, so dass ein neuer Standort für die Hütte gesucht werden mußte (GRÖNKE 1990:133). Daher der Begriff der Wanderglashütte. Nach ungefähr 100 Jahren war die Rückkehr an einen ehedem aufgelassenen Hüttenstandort erlaubt.

„Dies war jedoch nur sinnvoll, wenn am wieder zu nutzenden Platz das für den Betrieb unerlässliche Wasser (Quellen, Bäche usw.) noch gesichert und nicht zwischenzeitlich versiegt war. Wasser war nicht nur als Trinkwasser für die Arbeiter am heißen Ofen unerlässlich, es diente auch zum Kühlen der Werkzeuge (Glasmacherpfeifen).“ (BACHMANN 1996:184) Die Wasserverhältnisse waren - beeinflusst zum Beispiel durch wasserstauende Lettenschichten und Quellaustritte an Klüften im Buntsandstein - maßgebend für die Standortwahl von Glashütten. Dementsprechend „finden sich schon die ältesten Glashüttenplätze an Bergrücken und Oberhängen neben Quellen“ (:185). Wegen der allmählichen Änderung des Wasserhaushaltes seit dem hohen Mittelalter haben sich aber die Glashütten „,im Lauf der Zeit zunehmend in die Täler verlagert", wie BACHMANN (:185) die Veränderung der hydrologischen Situation für den Spessart beschreibt. Auch GRÖNKE (1990:131) stellt fest, dass die mittelalterlichen und frühneuzeitlichen Glashütten, wie auch im Pkt. V 2 dargelegt worden ist, „fast immer an Gewässerläufen“ standen. Hier konzentrierten sich die Glasmacher aufgrund der Wasserkraft, die die Blasebälge der Schmelzöfen und der Schleif- und Poliermaschinenen antrieb.

Allein im Spessart sind vom 12. bis zum 18. Jahrhundert die Wasser und Wälder von Glasmachern und Kalkbrennern industriell genutzt worden. Es wurde in diesem Zeitraum in etwa 150 bis 160 Wanderhütten Glas erzeugt (BACHMANN 1996:181,184).

Böhmen gehörte mit Sicherheit zu den wichtigsten Produktionszentren im Hoch- und Spätmittelalter „wie aus der Anzahl der Glashütten hervorgeht“" (CERNÁ 1996:177). Vor allem im östlichen Teil des Erzgebirges existierten mittelalterliche Glashütten: in den Bezirken Chomutov und Teplice, darüber hinaus auch auf den Kämmen des Erzgebirges, so zum Beispiel bei Kalek (Bezirk Chomutov), bei Brandov, Mnisek und Kliny (alle Bezirk Most). Das Netz dieser alten Hütten ist offensichtlich viel dichter gewesen, als man früher angenommem hat (:173ff.).

Zusammen mit der schon auf der ältesten Sollingkarte von 1603 verzeichneten Glashütte südlich der Waldmühle von Schießhaus zum Beispiel ergeben sich auf der Grundlage von Begehungen vier Glashütten, „die sich im Laufe der Jahrhunderte das Wasser des Hasselbaches zu Nutze gemacht haben“ (CREYDT 1990/91:60).

Während es hier um Alltagsglas ging, wird schon für das 15. Jahrhundert von Versuchen am Spiegelbach in Oberode im Kaufunger Wald berichtet, Spiegelglas herzustellen. In der absolutistischen Zeit waren die Landesherren bestrebt, nicht nur nach Möglichkeit eine eigene Fayence-Manufaktur zu besitzen, sondern auch die Spiegel der Schlösser in einer eigenen „Spiegelglashütte“ herstellen zu lassen. Zu Beginn des 18. Jahrhunderts dann begannen die staatlichen Manufakturen mit den Waldglashütten zu konkurrieren, die ab 1720 ihre Produktion allmählich einstellten (BACHMANN 1996:187).

Für den hessischen Landesherrn arbeitete im Tilketal im Reinhardswald eine hessische Spiegelglashütte, aber nur mit wenig Erfolg in den Jahren von 1713 bis 1724. Sie lebt heute in dem Ortsnamen „Weiße Hütte“ am linken Weserufer fort (HENCKEL 1988:83). Bei Knickhagen an der Fulda bestand 1716 eine „Spiegelmühle“ und von 1774 bis 1929 existierte die Herzoglich-Braunschweigische Tafel- und Spiegelglashütte Amelith im Reiherbachtal.

Zusammen mit ihr bildeten die Glashütten in Bremke südlich von Polier im 17. und 18. Jahrhundert ein richtiges Glashüttental, das von 1770 bis 1779 sowohl eine grüne als auch eine weiße Hütte beherbergte. Der ungewöhnliche Ortsname Polier wird dabei verständlich, wenn man weiß, dass hier die flach ausgewalzten Glasscheiben zu makellos ebenen Glastafeln geschliffen und „poliert“ wurden, bevor man auf ihrer Rückseite die spiegelnde Quecksilberverbindung auftrug. 

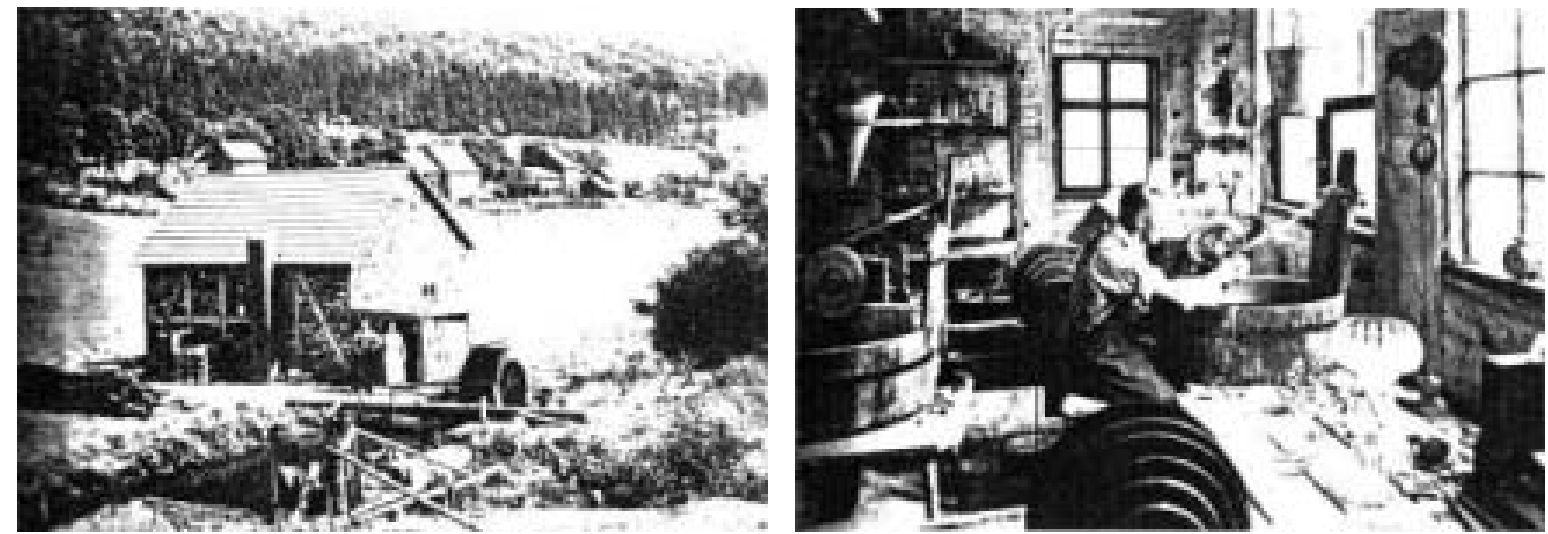

Abb. VI-81: Glasschlieferkotten im Ort Polier am Reiherbach unterhalb des Jagdschlosses

Nienover bei Uslar. Diese Aufnahme stammt aus den 1920er Jahren und zeigt eine wiedererrichtete, einzelne Polierglashütte, in der nicht Glastafeln, sondern Gläser und Krüge u. a. Glasgefäße mittels wasserkraftbetriebener Ziselierbohrer verziert worden sind. Die Vielzahl an Polierglashütten steht zu diesem Zeitpunkt nicht mehr und sie standen auch an einem abgeleiteten Kanal höher zur Siedlung hin (Foto aus: HENCKEL 1988:276; mündl. Hr. SCHÄFER, Stadtmuseum Uslar).

Nach Auflösung dieser Hütte verblieb hier, ähnlich wie am Schedebach, ein Glasschleiferkotten bis in die 1. Hälfte des 20. Jahrhunderts, in dem Glasschleifer Trinkgläser und Gebrauchsgläser geschliffen und verziert haben (HENCKEL 1988:83).

\section{d Schiffsmühlen}

Neben den Mühlen, ,welche mit ihren Grund-Wercken und Gebäuden unbeweglich sind“ (LEUPOLD 1735:71), gab es auch und gibt es wieder Mühlen der „beweglichen Art“, die man „auf grosse Ströhme zu erbauen pfleget“ - die „Schiff-Mühlen“80, die man auch als „Haus-Schiff“ bezeichnet (:71).

Diese Form der Wassermühle, die nicht am, sondern auf dem Gewässer lag, erscheint in der Literatur des 6. Jahrhunderts zum ersten Mal (SCHNEIDER 1992:47f.).

In der neueren Literatur erscheint die Lage von Schiffsmühlen bezüglich der Gewässergröße hingegen undeutlich: HÖLSCHER (1987:11) sieht Schiffmühlen „auf vielen Flüssen Europas verbreitet.“ SCHNEIDER (1992:48) behauptet, dass sie ,auf große Flüsse angewiesen“ sei. Nach ERLER/ MATTHIESEN (1989:43) konnten Schiffsmühlen „nur in Flüssen betrieben werden, die eine sehr starke Strömung haben“. Ebenso waren nach Quellenlage von MERTES (1995:31) Schiffsmühlen „einst auf allen größeren deutschen Flüssen weit verbreitet, wie wir auf alten Holzschnitten und Stichen aus dem 15. - 17. Jahrhundert ersehen können (Schedelsche Weltchronik, Merianstiche u. a.).“ Nach VOGT (1998:39) hingegen fanden sie sich ,,auf nahezu allen großen und mittleren Flüssen“ und ergänzt: „Schiffmühlen auf den nicht schiffbaren Nebenflüssen hielten sich sogar noch länger" Belege für diese Lageverortung von Schiffsmühlen auf mittleren oder sogar kleineren, im Sinne von nicht schiffbaren, Gewässerläufen, liefert VOGT zwar leider nicht, aber dafür geben ERLER/MATTHIESEN (1989) eine kurze Beschreibung am Beispiel der Schiffmühle „Rethem“ an der Aller, wie man sich kleine Schiffmühlen auf Fließgewässern mittlerer Größe vorzustellen hat:

Die „Schiffmühle Rethem“ lag auf der Aller im Bezirk Osterheide des Landkreises Soltau-Fallingbostel, die, obwohl ein Flachlandfluss, hier eine „enorm hohe“ Fließgeschwindigkeit besitzt (ERLER/MATTHIESEN 1989:43). Die Schiffmühle „,war Teil einer kompletten Wehr- und Schleusenanlage, die die Aller absperrte. [...] Die Schloßherrschaft in der Allerstadt als Eigentümerin nutzte dieses Wehr nicht nur für die Mühle, sondern auch zum Fischfang. 100 Eichenpfähle hielten die Sperranlage auf dem Grund der Aller fest." Sie war des Weiteren „mit Steinen eingefaßt, die man mit Ton verschmiert hatte, um dem Wasser keine Angriffsmöglichkeit zu bieten.“ (:67) Im Landkreis Fallingbostel lassen sich urkundlich an der Aller auch in

\footnotetext{
${ }^{80}$ Der Begriff Schiffs- oder Schiffmühle ist noch nicht eindeutig festgelegt und wird in der Literatur immer wieder konsequent zweifach verwendet. Beide Bezeichnungen stehen gleichwertig nebeneinander, wobei im süddeutschen und alpinen Raum vorwiegend das Fugen-s im Wort Schiffsmühle verwendet wird.
} 
Ahlden und Essel Schiffsmühlenplätze nachweisen (:17,26). Doch an diesem Flusslauf hatten die Schiffsmühlen augenscheinlich kein Glück gehabt: in Rethem, dessen ältester schriftlicher Nachweis aus dem Jahr 1499 datiert (:67) und Essel, die als erste Schiffsmühle 1360 beim Allerdorf Essel urkundlich nachweisbar ist (:86), blieb der Getreidetransport zum Schiff zu beschwerlich. Im Winter riss sich weiterhin bei Eisgang „,das Schiff aus der Verankerung, wurde weggetrieben und dabei vermutlich zerstört.“ (:44) Der zu unterschiedliche Flusswasserstand verhinderte zudem einen geregelten Mühlenbetrieb. „Schließlich übten sich die Flußschiffer in zerstörerischem Haß gegen diese ,Mühlenklippen' mitten in der Fahrrinne der ohnehin aufgrund ihrer Größe schwer zu beschippernden Aller" (:17), so dass diese beiden Schiffmühlenstandorte Mitte des 17. Jahrhunderts aufgegeben wurden (:26,43).

Die Ahldener Schiffsmühle war bis etwa 1609 gleichzeitig Hauptmühle, die ,direkt hinter den Gärten des Ortes auf dem Fluß verankert war.“ (ERLER/MATTHIESEN 1989:26). Diese Mühle musste aufgegeben werden, als die Aller ,ihr Bett nach Norden verlagerte und der Mühlenstandort plötzlich ein toter Seitenarm des Flusses wurde. Die Amtsverwaltung in Ahlden versuchte mit großem Aufwand die Leine umzulenken und sie durch den Altarm der Aller fließen zu lassen. Die Versuche scheiterten.“ (:26)

Neben den erwähnten Aller-Mühlen sind seit dem 14. Jahrhundert Schiffsmühlen von der Ilmenau bei Lüneburg bekannt ${ }^{81}$ :

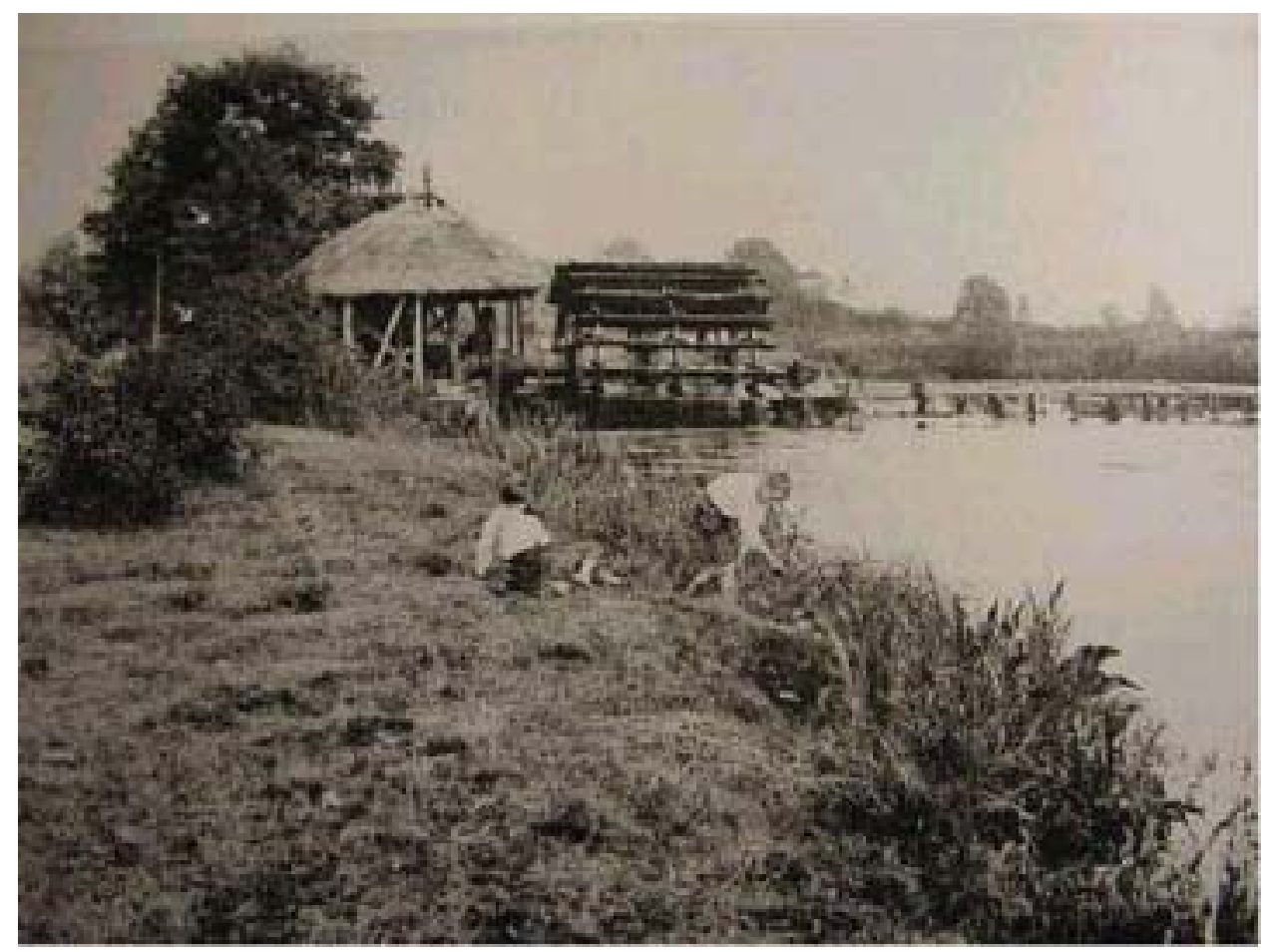

Abb. VI-82: Schiffmühle in bzw. an der Ilmenau bei Bienenbüttel.

Foto des Flensburger Fotografen Wilhelm Dreesen im Jahre 1903. Am linken Bildrand, vom reetgedeckten Getriebehaus ausgehend, verliefen vor dem Baum zwei Seile (mit weißen Pfeilen markiert), die wohl endlos über Seilscheiben liefen und an 4 Stahlmasten im Abstand von ca. $60 \mathrm{~m}$ geführt wurden. - Diese Transmission von Antriebskräften blieb - zumindest im Bereich der Lüneburger Heide, wenn nicht im gesamten norddeutschen Raum - einmalig (aus BEHNKE 1997:56f.)

Auf der Preußischen Landesaufnahme von 1898 ist die Schiffmühle südöstlich von Bienenbüttel mit der Signatur eines Wasserrades in der Ilmenau verzeichnet. Eine weitere, linienhafte Signatur mit Rauten in der kartografischen Darstellung zeigt eine „Seilbahn“von der Schiffsmühle zur nahe gelegenen „Hönkenmühle“.

\footnotetext{
${ }^{81}$ Entgegen der Darstellung von LANGE (1989:56), die an der Ilmenau gelegenen Schiffmühlen seien, da sie die Schiffahrt behinderten, schon sehr früh, 1366, von Lüneburg gekauft und abgebrochen worden, belegt das historische Foto die Existenz einer solchen Schiffmühle noch für Anfang des 20. Jahrhunderts.
} 


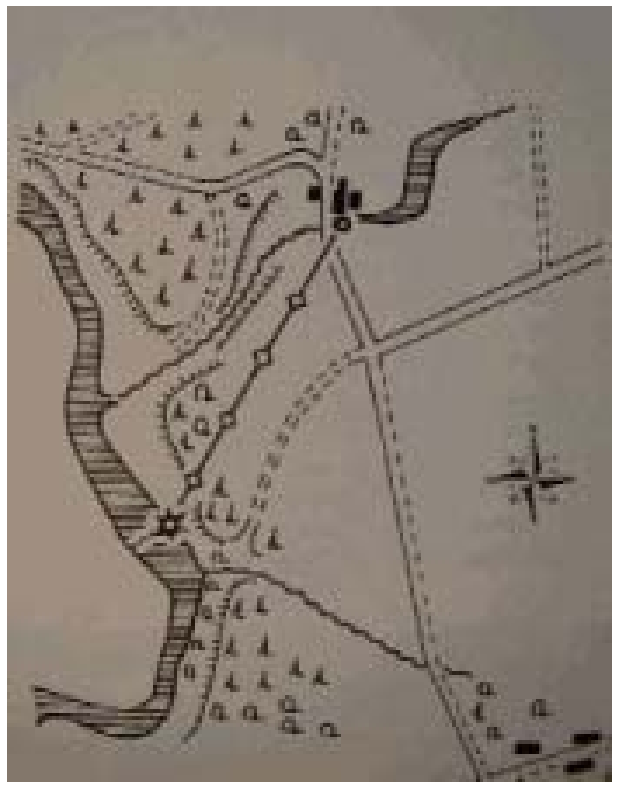

Abb. VI-83: Ausschnitt aus der Preußischen Landesaufnahme von 1898

$\mathrm{Zu}$ sehen ist die Signatur für die Schiffmühle an der Ilmenau und die „Seilbahn“ zur Hönkenmühle (Foto aus BEHNKE 1997:56f.).

In einem zeitgenössischen Bericht der Lüneburgschen Anzeigen vom 22. Dezember 1887 werden die Gründe für diese technische Konstruktion geschildert, die Heinrich Friedrich Ferdinand MÜLLER, seit 1876 Besitzer der Hönkenmühle, trotz schwerer Bedenken von „Experten" aufbaute, um die betrieblichen Einbußen infolge zeitweiliger Wasserknappheit seiner Mühle mit dem kontinuierlichen Energieangebot des Flusses Ilmenau zu mildern:

„Die geringe Menge von atmosphärischen Niederschlägen, welche in den letzten 1 1/2 Jahren gefallen sind, haben eine so erhebliche Erniedrigung des Wasserstandes zur Folge gehabt, daß vielfach sonst gute Brunnen versagt haben und die Quellen mehr oder weniger versiegt sind. Die kleinen Bäche, welche früher den größten Theil des Jahres Mühlen treiben konnten, haben jetzt nur für wenige Stunden des Tages Wasser dazu, und in der Mitte zwischen den großen Handelsmühlen in Medingen und Lüneburg haben die Landleute Noth gehabt, ihr Korn gemahlen zu erhalten. Das hat nun den einsichtigen und tathkräftigen Besitzer der nahe Wichmannsburg gelegenen Hönkenmühle, der trotz seiner Wasser- und Windmühle seine Mahlkunden nicht befriedigen konnte, auf den Gedanken gebracht, das auf dieser Strecke nutzlos dahin strömende Ilmenauwasser zum Treiben seines Mühlwerks zu nutzen. Mit Genehmigung des Kreistages in Uelzen ist dem Müller, nachdem kein als berechtigt anzuerkennender Widerspruch von Seiten der Anlieger, Fischer und der anderen Mühlenbesitzer eingegangen war, durch lebhafte Befürwortung des Unternehmens durch den Herrn Gutsbesitzer Hagelberg-Solchtorf, gestattet, in der Ilmenau ein Wehr anzulegen. Neben demselben, das eine Stauhöhe von etwa $40 \mathrm{~cm}$ hat, befindet sich eine Freifluth zur Durchfahrt für die Fischer, und innerhalb des Wehres ist ein etwa $5 \mathrm{~m}$ breites und ebenso hohes Wasserrad mit $1 / 2 m$ tiefen gewaltigen Schaufeln angebracht, das sich ähnlich wie die Wasserräder auf den Schiffsmühlen bei Magdeburg und bei Mainz dreht. Die Kraft des Stromes wird von hier durch ein starkes Drahtseil nach der über 500 Schritt $(c a .350 \mathrm{~m})$ entfernten Hönckenmühle, deren Wasserkraft häufig versagt, geleitet und so das Gangwerk derselben getrieben. Den Bau hat der Müller selbst geleitet, und verschiedene Techniker, welche das Unternehmen während des Baues angesehen, bezweifelten die Ausführbarkeit. Seit 3 Tagen nun ist der Betrieb eröffnet und arbeitet so trefflich, daß alle Zweifler verstummt sind und ein Techniker aus Lüneburg, der sich die Einrichtung angesehen hat, die nun nutzbar gemachte Wasserkraft auf $60.000 \mathrm{M}$ Werth schätzt. " 82

\footnotetext{
${ }^{82}$ Lüneburgsche Anzeigen vom 22. Dezember 1887 „Neue Mühlenanlage“; aus: BEHNKE 1997:56f.
} 
Leider hatte Ferdinand Müllers interessante „Seilbahn" nur ein kurzes Leben. Er verstarb im Jahre 1901, sein Nachfolger konnte die Mühle nicht halten und geriet 1907 in Konkurs. Seither ist die Hönkenmühle nicht mehr in Betrieb gewesen und wird heute nach einigen Umbauten und Umnutzungen - unter anderem als Geflügelzuchtanstalt - zu Wohnzwecken genutzt (BEHNKE 1997:56f.).

Den Erfolg, den Schiffmühlen auf allen Fließgewässergrößen gehabt haben, lässt sich mit der Tatsache erklären, dass die großen Flüsse generell ungeeignet waren, traditionelle Wassermühlen anzutreiben. Sie waren zum einen in ihrem Lauf von Menschen nur schwer zu beherrschen. Zum anderen kamen feste Bauwerke im Fluss schon wegen der ständig wechselnden Wasserstände und wegen des Eisganges im Winter nicht in Betracht. Außerdem wären standortgebundene Wassermühlen mitten im besten Fahrwasser eine stetige Behinderung der Schifffahrt und Flößerei gewesen (VOGT 1998:39).

So erwies sich die Schiffsmühle als überaus nützlich: Zum einen konnten die Mühlen ,auf weniger breiten Flüssen [...] beiseite gezogen werden, wenn ein Lastschiff oder ein Floß Durchfahrt verlangte" (VOGT 1998:37), zum anderen konnten sie sich ohne Schwierigkeiten an den wechselnden Wasserstand der Flüsse anpassen (SCHNEIDER 1992:48). Des Weiteren konnten die Standorte der Flussmühlen in der Regel marktnah gewählt werden; also dicht bei den Städten und somit die Bevölkerung ohne großen Transportweg mit gemahlenem Getreide versorgen. Dort suchte man jeweils die Stellen mit der größten Fließgeschwindigkeit aus: Bevorzugt wurden sie dort festgemacht, ,wo der Strohm den stärksten Risch hat, damit ihr Wasser-Rad von dem daran schlagenden Strohm behörig umgetrieben werde." (LEUPOLD 1735:72) Zum Beispiel zwischen Brückenpfeilern, da hier eine besonders starke Strömung vorherrschte.

Die Stromgeschwindigkeit war insofern von großer Bedeutung, als dass die Mühlsteine von Schiffmühlen in der Regel kleiner waren als die bei ortsfesten Mühlen, „denn die Häuser der meisten Schiff-Mühlen sind nicht sonderlich hoch, sondern so niedrig, als es sich immer thun lassen will, angeleget." (LEUPOLD 1735:72). Die Mühlsteine mussten sich also, um eine annähernd gleiche Mahlleistung zu erbringen, schneller drehen. Zudem geht konstruktionstechnisch bedingt „,das Wasser-Rad an einer Schiff-Mühle [...] viel langsamer, als die Wasser-Räder bey andern Mühlen“"(:72). Insofern richtete der Mühlenbaumeister sein Augenmerk bei Anlegung seiner Schiffmühle „hauptsächlich auf die Schnelligkeit des Wassers“(:72).

Die Schiffmühlen stellten also ihre Betriebseinheiten ,auf Brücken und Stegen im Fluß draußen auf und ließ sie durch die freie Strömung antreiben.“ (GLAUSER 1978:92). Die deshalb auch „Flussmühle“ genannte Schiffmühle bestand meistens aus einem Unterbau mit zwei Schwimmkörpern, die durch einen Steg und einen Abstandshalter (Baum) miteinander verbunden waren. Die Konstruktion glich der eines Katamarans. Zwischen den Schwimmkörpern (Schiffen) befand sich das sehr breite Schaufelrad (Wellrad), das durch den Wasserdurchfluss angetrieben wurde. Die 8-12 Schaufeln hatten eine Länge von 5-6 m. Später setzte sich die Aufteilung in ein breiteres „Hausschiff“ mit der Mahleinrichtung und ein schmaleres „Wellschiff“ als Träger des Radwellenkopfes durch. Das Kammrad im Hausschiff übernahm diese Energie und leitete sie weiter zu den Mühlsteinen, die das Getreide mahlen. Da man die Schiffmühlen lediglich am Ufer festmachte, waren sie von den erheblichen Schwankungen des Wasserspiegels unabhängig (GLAUSER 1978:92).

Die Schiffmühlen hoben sich und senkten sich mit dem steigenden oder fallenden Wasser, mussten aber mit starken Seilen oder schweren Ketten fest am Ufer bzw. an Brückenpfeilern vertäut bzw. befestigt werden, teilweise wurde die Schiffsanlage auch noch verankert.

Des Weiteren war, zu besonderen Zeiten wie bei Hoch- oder Niedrigwasser oder bei Eisgang, ein „ordentlicher Winter-Stand“ notwendig, wohin man die Schiffmühlen ziehen konnte. Dies war problemlos möglich, da die gesamte Konstruktion, Haus wie auch Well-Schiff ,auf platten Schiffen erbauet“ sind, und „von einem Orte zum anderen“ gebracht werden konnten (LEUPOLD 1735:71). 


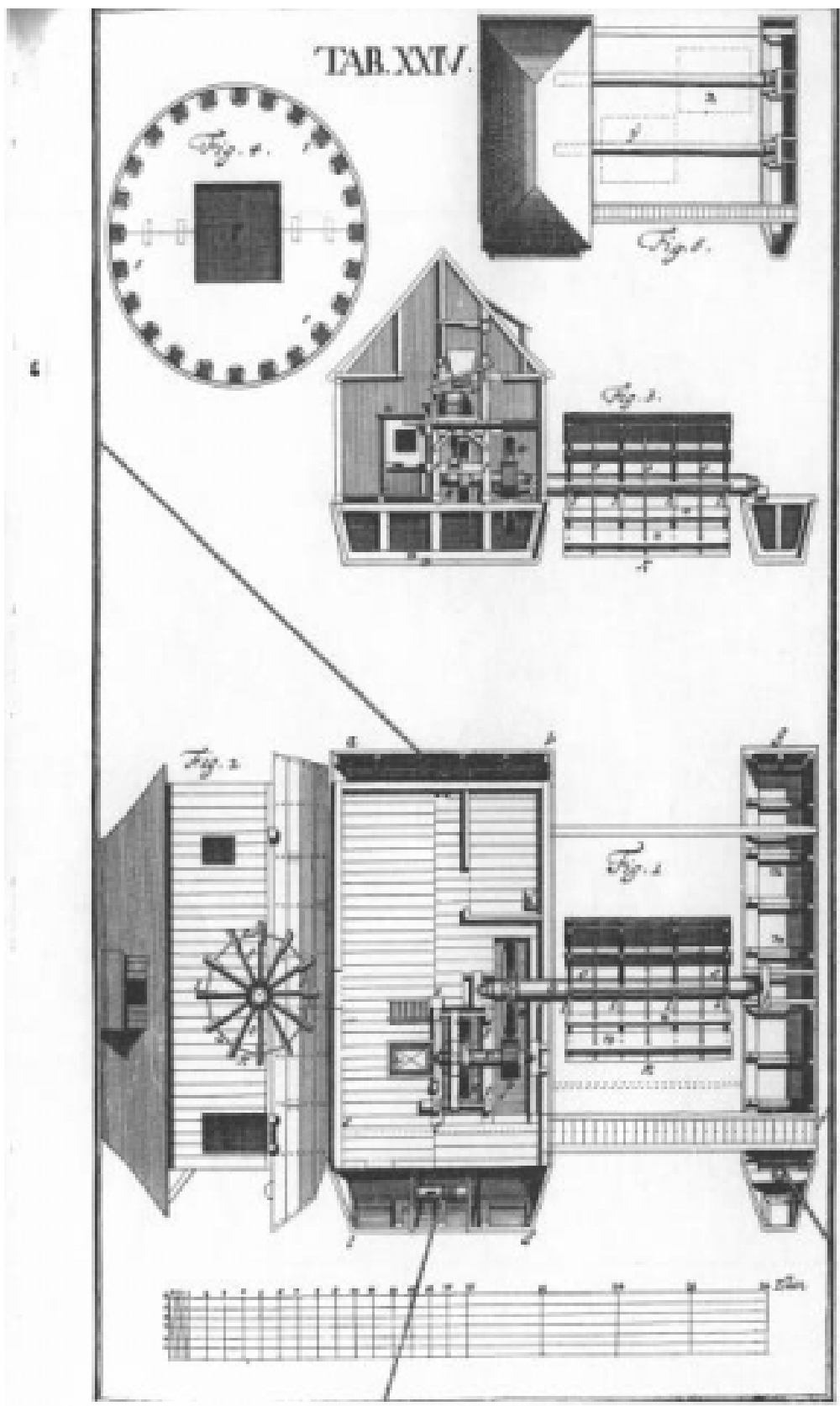

Abb. VI-84: „Weiset die Beschaffenheit einer Schiff-Mühle, nach ihren Grund- und Aufrissen.“

(LEUPOLD 1735: 71, Tab. 24). In der Abbildung der „Tab. XXIV“ sieht man in Fig. 1 eine solche Mühle im Grundriss und Fig. 2 gibt das Profil des Hauses wieder. In Fig. 3 wird der Querschnitt der gesamten Mühle gezeigt. Der seitliche Ausleger [f, g, Fig. 1] wird das „Well-Schiff“ genannt, „weil auf solchen die Welle [...] auflieget.“ Welle und Haus wurden vorzugsweise aus eichenen Pfosten erbaut, zwischen die Fugen „Moos getrieben“ und das „ganze Schiff über und über mit Ther bestrichen, welche Art zu bauen denen Schiff-Bauen zur Genüge bekannt ist.“ Vorne beim Wasserrad [k, Fig. 1] wurde eine „Schütze“ oder ein „Schutzbrett“ angebracht und damit konnte, wenn die Mühle stehen soll, das Wasser zwar nicht gänzlich, aber zumindest etwas aufgehalten werden und die Kraft aus dem Zustrom genommen werden (aus: LEUPOLD 1735:71).

Während des Mittelalters und in der jüngeren Neuzeit hatte man in vielen Städten solche Schiffsmühlen zum Getreidemahlen verwendet (SCHNEIDER 1992:48); manchmal ist auch zu lesen, dass ,auf allen größeren mitteleuropäischen Flüssen Hunderte Schiffmühlen eingesetzt" worden waren. ${ }^{83}$

Die älteste bekannte Schiffsmühle in Deutschland hat man Anfang der 1990er Jahre bei Gimbsheim am Rhein, Kreis Alzey-Worms, ausgegraben. Sie wird in die spätmerowingische Zeit um 760 n. Chr. datiert.

\footnotetext{
${ }^{83} \mathrm{URL}=$ www.schiffsmuehle.at $/$ muehle.htm, 5.11.03
} 
Spätere gab es um 840 auf dem Rhein bei Straßburg und 1112 bei Mainz, Mitte des 10. Jahrhunderts in Köln, seit 1355 bei Speyer und 1498 in Andernach auf dem Rhein (MERTES 1995:30; LINDGREN 1997:174).

Auf der Elbe zum Beispiel hatte es zur Zeit der Reformation nicht weniger als 534 Elbmühlen gegeben. 1852 wurden noch 115 gezählt. Erst 1910 stellt die letzte ihren Betrieb ein. Allein vor Magdeburg lagen um das Jahr 170023 Schiffmühlen. Neben Getreide wurden hier auch Wein, Ö1 und Fett aufbereitet. Der Müller arbeitete und lebte dabei auf dem Boot.

Die Schiffsmühle „Schnackenburg“ unterhalb des gleichnamigen Ortes auf der Elbe zum Beispiel lagerte „am kleinen Flügeldeich, wo am Ufer eine besonders starke Strömung herrschte“ und war ,an einem eigens dazu angelegten Grundbette verankert.“ (LANGE 1989:100). Über die Erbauungszeit ist zwar nichts bekannt, aber „die Mühle bestand aus zwei, durch Balken verbundenen Schiffen, zwischen denen sich das in den Schaufeln 18 Fuß breite und sechs Fuß tief ins Wasser heruntergehende Mühlrad befand.“ (:100)

Auf dem Rhein ist zwar auch von einer großen Anzahl von Schiffsmühlen auszugehen, in Köln aber beispielsweise gab es im Jahre 1527 lediglich acht Schiffsmühlen, was angesichts der damaligen Stadtgröße im Vergleich zu Magdeburg als nicht besonders viel erscheint, im Jahr 1800 waren es auch nur noch zwei (MERTES 1995:31) und schon um 1850 gab es auf ganzen Rheinstrecke nördlich von Mainz keine einzige Schiffmühle mehr. Nur in Mainz-Ginsheim, gegenüber von Mainz, hatte sich eine letzte Flussmühle noch bis 1926 halten können (VOGT 1998:38f.). Auf einem Foto von 1932 ist sie noch als Kulturdenkmal zu sehen, bevor sie im Zweiten Weltkrieg 1944 durch einen Fliegerangriff vollständig zerstört wurde (MERTES 1995:31).

An der Mosel gab es im 14./15. Jahrhundert eine Schiffsmühle zu Trier und eine flussaufwärts in Winneburg-Beilstein. Vor allem das Kloster Himmerod errichtete mehrere Mühlen auf der Mosel: 1402 gegenüber von Kesten, 1468 bei Ürzig, 1492 bei Pünderich und schon 1346 bei Zeltingen (MERTES 1995:31).

Vorübergehend waren im auch oberen Wesertal bei Hemeln und Heinsen und auch bei Bodenwerder Schiffsmühlen im Gebrauch (HENCKEL 1988:71; HÖLSCHER 1987:11). Ein Foto aus dem Jahre 1906 zeigt noch die Boderwerdersche Schiffsmühle, die zum Schleifen von Sandsteinplatten diente. Sie wurde 1907 aufgegeben und ist „wohl die letzte ihrer Art auf der Weser“ gewesen (HÖLSCHER 1987:11). Eine früher in Minden an der Weser vorhanden gewesene Flussmühle ist als Rekonstruktion wieder aufgebaut worden.

Die erste urkundliche Erwähnung von Mindener Schiffmühlen geht auf das Jahr 1326 zurück, als die Stadt gleich sechs Liegeplätze für Schiffmühlen auf der Weser verpachtete. Auf Kupferstichen aus dem 17. Jahrhundert sind sogar zwölf Schiffmühlen zu sehen, die gestaffelt nebeneinander lagen.

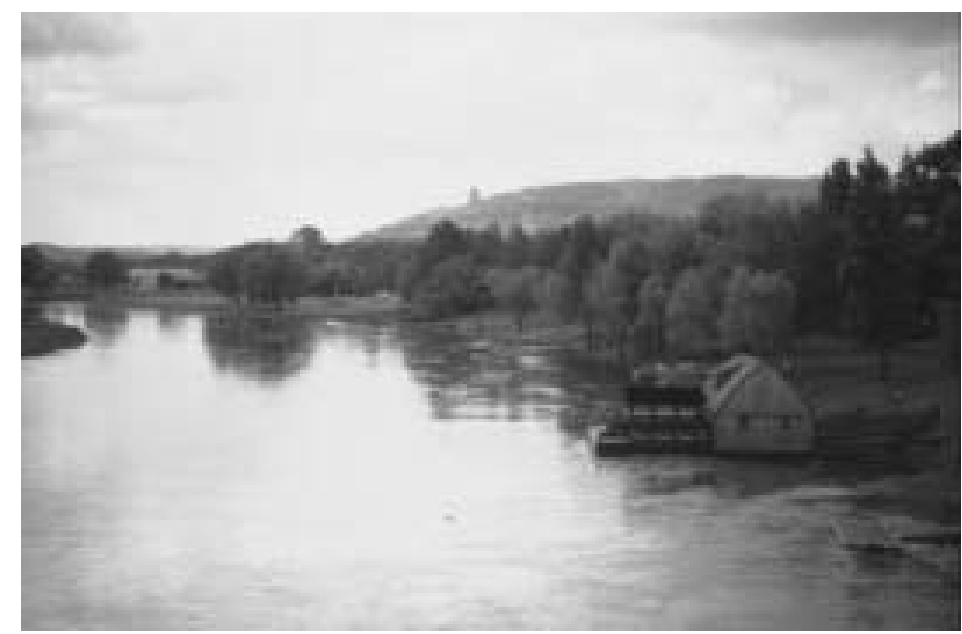

Abb. VI-85: Schiffmühle auf der Weser bei Minden

Zum 1200jährigen Stadtjubiläum Mindens im Jahr 1998 entstand die Idee der Rekonstruktion einer Schiffmühle. Zu sehen ist das Hausschiff mit dem kleineren Wellschiff. Während die Konstruktion aus Haltbarkeitsgründen aus Stahl nachgebaut wurde, entspricht die innere Mahltechnik (Kamm- und Korbräder) der früheren Bauart aus Holz (eig. Aufnahme 2004). 
Auf mittleren Gewässerläufen wurde für die Leine bei Mandelsloh im nördlichen Landkreis Hannover eine Schiffmühle archäologisch nachgewiesen in Form der Bergung eines sog. Wellkahnes, einem 9,25 m langen Eichenstamm, der parallel zum Hauskahn mit der Mühle lag und zwischen denen sich das mit beiden Schwimmkörpern verankerte Wasserrad in der Flussströmung drehte (ERLER/MATTHIESEN 1989:17).

Auch die Lippe besaß - an ihrem Unterlauf sogar ausschließlich - Schiffsmühlen, ebenso die aus der Westeifel entwässernden Rur und Wurm.

Schiffsmühlen in Franken sind wohl nur am Mittelmain bekannt. Das Foto in Abb. VI-86 zeigt eine Schiffsmühle im Main bei Steglitz, um 1900.

Abb. VI-86: Schiffsmühle im Main bei Steglitz, um 1900

(aus: BEDAL 1992:34)

Ab dem Jahre 1844 schwamm für fast 30 Jahre eine Schiffsmühle als Getreidemühle auf der Mulde. Nach einem Brand wurde die sog. „Schiffsmühle Höfgen“ an Land wieder errichtet ${ }^{84}$.

Jahrhundertelang drehten sich auch auf der unteren Mur in Österrreich die großen Räder der Schiffsmühle als Schrot- und Getreidemühle. Bis gegen Ende des 19. Jahrhundert gab es des Weiteren auf Donau, Inn und Salzach Schiffsmühlen ${ }^{85}$. Und auch in Zurzach, Stilli, Gippingen und Brugg an der Aare/Schweiz ist die verstärkte Strömung unterhalb der Flussenge seit dem 15. Jahrhundert mit Schiffmühlen ausgenutzt worden (GLAUSER 1978:91).

Buchweizen wurde ebenfalls von einer Schiffsmühle auf dem Fluss Mura vermahlen. Sie stellt wohl eine der letzten original in Europa bestehenden Schiffmühlen dar:

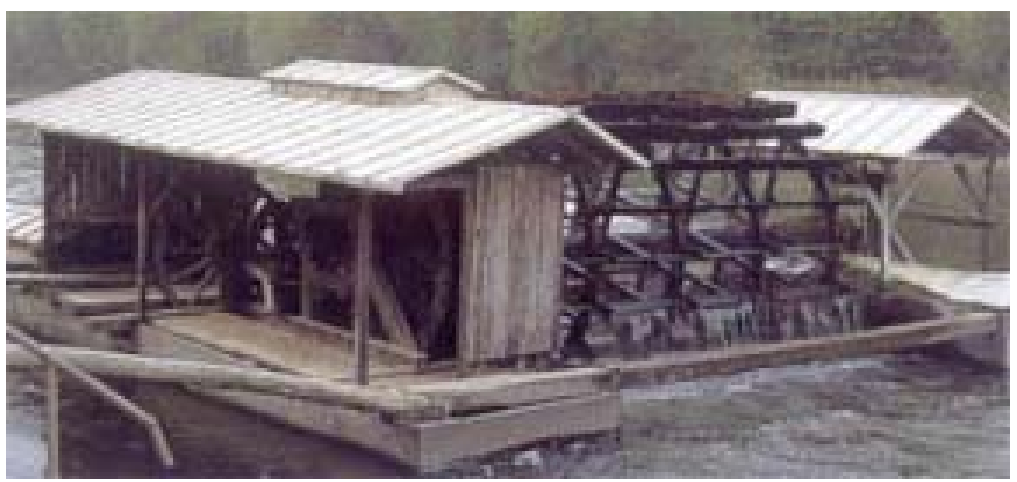

Abb. VI-87: Schiffsmühle auf der Mura

(Foto: KREFT 2001)

\footnotetext{
${ }^{84}$ [URL $=$ www.hoefgen.de/schmuehle.html, 10.11.2003].

${ }^{85}[\mathrm{URL}=$ bayerwald.net/redaktion/artikel_detail_redaktion_197.html, 5.11.03].
} 
Dass sie an den mittelgroßen und mittleren Flüssen so zahlreich waren, lag einerseits an dem Charakter größerer Gewässer: Große Ströme waren schwer zu beherrschen, so bei Hochwasserereignissen und starkem Eisgang, und das Wasser konnte auch nicht auf höhenfeste Mühlgerinne geleitet werden. Andererseits besaßen mittelgroße Flüsse die notwendige Strömungkraft und konstante Wasserführung.

Zudem erleicherte der niedrige Tiefgang der Schiffmühlen eine Verortung auch auf flacheren Flussbetten, wie ein modellhaftes Beispiel zeigt. Hatten beide Schwimmkörper eine Gesamthöhe von 1,35 m und eine idealisierte Schwimmgrundflächen von $20 \mathrm{~m}^{2}$ beim Wellschiff und ca. $50 \mathrm{~m}^{2}$ beim Hausschiff, so würden beide Schiffe zwar bis zu einem Meter eintauchen, aber würde man eine Person mit $100 \mathrm{~kg}$ Gewicht oder zwei Getreidesäcke mit je $50 \mathrm{~kg}$ an Bord bringen, würde das die Einsinktiefe, nur auf das Hausschiff bezogen, nur um $2 \mathrm{~mm}$ (!) vergrößern, was bei 20 Personen (je $100 \mathrm{~kg}$ ) eine Vergrößerung des Tiefganges von $4 \mathrm{~cm}$ ausmachen würde ${ }^{86}$.

Durch ihre Lage auf dem Wasser, gleich einem Hausboot mit Mahlwerk und Wohnung, und dem Wellschiff, das im Wesentlichen nur als Auflage für das Wasserrad diente, waren bei der Anlage von Schiffmühle nur unwesentliche Eingriffe in den Gewässerlauf vorzunehmen. Es handelt sich jeweils um vertikale Schaufelräder, die man zwischen zwei Kähne einfach in den Strom gehängt hat und die unterschlächtig von der Strömungsgeschwindigkeit der Flüsse angetrieben wurden (LINDGREN 1997:174). Lediglich ordentliche Vertäuungen oder Anpflockungen am Ufer und eventuell eine schnell einholbare starke Ankerung auf Gewässergrund sowie Uferstege zum Be- und Entladen von Mahlgut zeugen von der Anlage der Schiffs- bzw. Schwimmmühlen. Flussbettveränderungen und Eingriffe in die Wasserführung sind bei Flussmühlen auf kleineren Flüssen dann festzustellen, wenn sie, wie beim Beispiel der Aller, Teil einer Wehr- und Schleusenanlage war, und den Flusslauf zur Wasserspeicherung und zur Erhöhung der Aufschlagskraft abriegelte. Dennoch sind sie eher als Teil des Wehres anzusprechen als umgekehrt (HÖLSCHER 1987:11; ERLER/MATTHIESEN 1989:44; MERTES 1995:31; LINDGREN 1997:174).

\section{Viehnutzung}

Die tierische Nutzung der Gewässer ist vielschichtig. Die hier herausgearbeitete Gewässernutzung beschränkt sich auf das landwirtschaftliche Nutztier - das Vieh, um den Nutzungsaspekt besonders hervorzuheben. Da die Tiernutzung nicht nur in Fließgewässern, sondern auch an Stillgewässern vorgenommen wurde und zum Teil daran gebunden war, insbesondere solche von Teichwirtschaften, werden diese hier auch behandelt.

\section{a Viehwäsche}

Hier soll diejenige Form der Viehwäsche beschrieben werden, die Hof fern, in der freien Gemarkung, während der Waldweide oder Schaftrift vorgenommen wurde. Die wassergefüllten Hohlformen denen man sich bediente, waren bereits vorhanden oder wurden zu diesem Zweck mitunter auch etwas umgestaltet.

\section{a.1 Schafwäsche}

Von den zahlreichen Karsterdfällen im Südharzvorland sei der wassergefüllter Erdfall mit der Bezeichnung „Großes Seeloch“, zwischen den Gemeinden Kleinwechsungen und Hochstedt im Kreis Nordhausen gelegen, als Beispiel für eine besondere Art der Gewässernutzung genannt: die Schafwäsche.

Der Heimathistoriker TAUCHMANN (1990:60) berichtet aus historischen Quellen von einem tragischen Ereignis, das als Hinweis für die Nutzung von Gewässern zum Zwecke des Waschens von Schafen gelten kann, als ,am 08. Juni 1877 der Schafmeister Keil aus Kleinwechsungen und der Arbeiter Dannenberg aus Haferungen durch einen Unfall nach dem Waschen der Schafe ums Leben“kamen.

\footnotetext{
${ }^{86}[\mathrm{URL}=$ www.schiffsmuehle.at $/$ muehle.htm, 5.11.03].
} 
Von einer flussnahen Schafweide wird ebenfalls aus Nordhausen berichtet. Die zwischen dem „Mühlgraben“ und dem „Feldwasser der Zorge“ liegende Fläche war in alter Zeit „eine wüste Kiesfläche, in welcher sich das wilde Wasser ungehindert und nach Gefallen bald hier, bald da ein Flussbett bildete. Und dieses Auengelände war noch in der ersten Hälfte des vorigen Jahrhunderts ein mit Weidengebüsch bewachsenes, versumpftes Flussgebiet, das bei Hochwasser unter Wasser stand und sonst als Schafweide genutzt wurde. “877 Es ist davon auszugehen, obschon keine Nachrichten von diesem Vorgang vorliegen, dass die Schafe in diesen Überflutungsbereichen - nicht aber im stark strömenden Zorgefluss - gesäubert wurden.

Das Waschen von Schafen wurde auch in kleinen Dorfteichen durchgeführt, wie TAURKE in seinem Fachbuch zur Fischzucht berichtet. Dies war für die Fischteiche von großem Vorteil, denn „die vom Vieh stammenden Exkremente düngen das Wasser, und die harte Flora wird durch den Tritt der großen Tiere vernichtet oder wenigstens im Wachstum beschränkt. Gerade durch das Schwemmen des Viehes [...] werden die Dorfteiche zu großer Fruchtbarkeit gebracht.“ (1927:162) Für die Fische stellte der Vieheintrieb angeblich kein besonderes Problem dar: Sie würden sich, berunruhigt, einfach in tiefere Stellen zurückziehen, so TAURKE (:162). Die Schafwäsche wirkt jedoch in solchen Gewässern ,welche mit Fischen besetzt sind oder bald besetzt werden müssen, schädlich und kann die Fische zum Absterben bringen. Forellen können in Teichen, die zur Schafwäsche dienen müssen, überhaupt nicht gehalten werden, wohl aber in größeren Teichen und Seen anderer Fische. Sollen auch in kleineren derartigen Teichen Karpfen gezogen werden, so muß man nach der Wäsche im Frühjahr bis zum Einsetzen der Fische einige Wochen verstreichen lassen, während welcher Zeit sich die schädliche Wirkung der aus den Schaffließen ausgewaschenen Stoffe, der ätzenden Waschstoffe und stark teerhaltigen Seifen verliert.“(:162)

RUMP (2001:42f.) erwähnt einen bei der Haburger Wasserlohmühle gelegenen ,Lohmühlenteich', der im 17. Jahrhundert „Schafwäscherteich” genannt wird und von einem Bach gespeist wird. Nach seiner Auffassung ergibt sich daraus ,ganz offensichtlich die Nutzungsart“".

Diese kurzen Hinweise zur Existenz einer Schafwäsche und zum Vorgang der Schafwäsche in Fischzuchtteichen vermögen vor dem Hintergrund der Anzahl an Schafen in früherer Zeit nur einen kleinen Teil von dem Ausmaß darstellen, den das Waschen von Schafen in Gewässern gehabt haben muss. Wie bereits dargestellt, wurde nicht nur die geschorene rohe Wolle, die auch als „Schweißwolle“ bezeichnet wird, gewaschen, bevor sie in die Tuchfabriken und Walkmühlen geliefert wurde, auch wurden die Schafe vom Hirten bzw. Schäfer vor dem Scheren von erdigen Verschmutzungen, Unrat, kleinen Stöcken sowie Kot und Ungeziefer durch die Tierkörperwäsche befreit, die das Fell durch den Herdentrieb über die Heide- und Cämpeflächen aufnahm, wie der letzte gelernte Schäfer in Hilden und Umgebung berichtet ${ }^{88}$ (RHEINISCHE POST 19.04.2003; dazu auch MATTHES 1985:247). Dieser Teil der Wollverunreinigungen wurde vor dem Waschen ausgeklopft und als Dünger verkauft (DIX 1997:231).

Vergewissert man sich angesichts der Anzahl an Schäfereien und der Menge an Weidetieren, die in früherer Zeit in einer Herde in den Wäldern und auf den Feldern gehütet und zur nächsten Weide getrieben wurde, um von den Bauern für den Schafsdung kleine Mahlzeiten zu erhalten, so kann man sich ein Bild von der „massenhaften“ Schaf- und Wollwäsche in den Gewässern machen.

So belegen die Quellen des 16. Jahrhunderts allein für die Standesherrschaft Muskau, welche Tierherden von den Bauern in die Heiden zur Hutung getrieben worden sind. „Nach dem Muskauer Urbar von 1552 hielten die Bauern von dreizehn Herrschaftsdörfern ungefähr 6.000 Schafe, in den meisten Dörfern kamen im Durchschnitt dreißig bis vierzig Schafe auf eine Bauernwirtschaft, in vier Heidedörfern besaß jeder sogar durchschnittlich bis zu achtzig Stück“(ARNIM/BOELCKE 1992:258).

Auffällig ist, dass keine Fließgewässer als Waschplätze von lebenden Schafen genannt werden. Hier ist zu vermuten, dass die Gewässertiefe nicht ausreichend gewesen ist oder die Strömung zu stark war. Weiterhin wäre denkbar, dass die Uferzugänge zu steilabfallend gewesen sind, obschon auch ein Karstloch, wie anfangs beispielhaft genannt, keinen seichten Land-Wasserübergang besitzt; im Gegenteil: vielmehr steil

\footnotetext{
${ }^{87}$ Allgemeiner Anzeiger Nordhausen/Sondershausen v. 29. Dezember 1997

${ }^{88} 1985$ schließlich, als die Preise für Wolle von 7 auf 1 Mark in den Keller gingen, gab der letzte Schäfer von Hilden und Umgebung seine Tiere $\mathrm{ab}$ und führte nur noch den Landwirtschaftsbetrieb.
} 
zum Trichter abfällt. Da es sich aber um die Nutzung bestehender natürlich entstandener Wasserformen handelt, die nicht für diesen Zweck errichtet worden sind, seien sie hier mitaufgeführt.

\section{a.2 Pferdeschwemme}

Das Eintreiben von Vieh in ein Gewässer zum Waschen, das sog. „Schwemmen“, wurde vor allem bei Pferden, und hier wahrscheinlich insbesondere bei Zuchtpferden und besonderen Pferden praktiziert, die nicht allein des Reitens und Fahrens wegen eine besondere Stellung genossen: Der griechische Philosoph Plutarch (ca. 46 - $120 \mathrm{n}$ Chr.) beispielsweise empfiehlt für Angelschnüre geflochtenes Pferdehaar. Bis ins 20. Jahrhundert hinein konnten sich diese Vorfächer beim Fischen behaupten, und immer wieder stößt man auf die Empfehlung, dass das Haar vom Hengst genommen werden sollte. Wallachhaare seien schlechter und die der Stute unbrauchbar, da der Urin sie zersetze (ERGERT 1995:12). Erst gegen Ende des 17. Jahrhunderts wurden „,neben dem Vorfach aus Roßhaar [...] für die Hauptschnur Hanf und Seide empfohlen.“ (:13) Solche Pferde galten als wertvoller Besitz und diesen Tieren ließ man eine gute Pflege angedeihen.

Dieses Motiv wurde auch von einigen Landschaftsmalern aufgegriffen. Die festgehaltenen Szenen veranschaulichen in idealisierter Darstellung eine typische Form der Pferdewirtschaft.

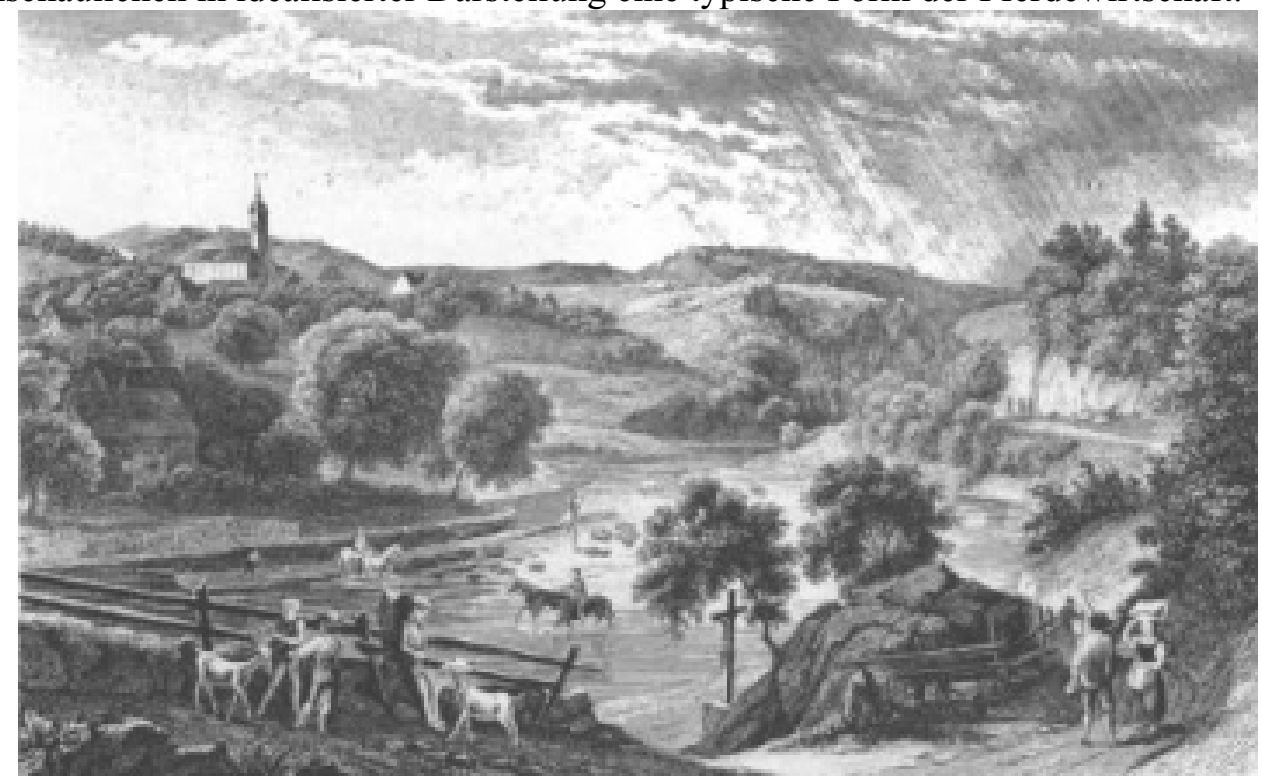

Abb. VI-88: Forbach im Murgthale

Alter Stahlstich, um 1840. Hier sieht man zwei Pferdewirte, die jeweils zwei Pferde in das seichten Flussbett führen bzw. in diesem herumführen (aus: DAS MALERISCHE UND ROMANTISCHE DEUTSCHLAND 1988:64).

Da das „Schwemmen“ von Pferden, erst recht wenn es sich um „Schwimmen“ handelt, eine gewisse Gewässertiefe voraussetzt, muss die Bachstrecke aufgestaut worden sein, falls nicht natürliche „Untiefen“ (Kolke) vorhanden waren. Dass dafür im Gelände vorhandene Fischteiche benutzt worden sind, scheint zunächst aufgrund der Störungen und des Damm- und Teichbodenvertritts unwahrscheinlich. Auf der anderen Seite befand sich zum Beispiel auf dem Gelände der Klosterteichwirtschaft Michaelstein ein sog. „Pferdeheller Teich“ (BORNE 1886:277) und auch vor der Stadt Nordhausen gab es einen „Pferdeteich“ (siehe Abb. 0-8).

Hier soll nicht eine simple etymologische Nutzungsexegese angestellt werden, doch zumindest ist denkbar, dass diese Teiche ehemals - auch - zur Pferdewäsche der zahlreichen klostereigenen Reit- und Ackerpferde genutzt wurde.

\section{b Viehtränke}

Wo Schweiß und Verunreinigungen gewaschen wurde, konnte nicht gleichzeitig getränkt werden; zumindest nicht in überschaubaren, zumindest zu bestimmten Zeiten abflusslosen wassergefüllten Hohlformen, wie zum Beispiel in einem Erdfallsee oder in einem Fischteich. 
Bis zur Erfindung von Pumpen, die das Saufwasser für die Weidetiere dem Grundwasserspiegel entnehmen konnten und bis an Weidehänge hinauf die Wasserversorgung ermöglichten, waren für „bäuerliche Anlieger [...] die Wasserläufe als Viehtränken [...] wesentlich“ (DOBELMANN 1980:35). Wasserlage war in früherer Zeit unabdingbares Kriterium für die Freilandhaltung.

Als „Kuhlager“ während der Waldweide dienten so „meist schattige, am Wasser gelegene Plätze, auf denen sich das Vieh lagerte“ (DENECKE 1969:271). Diese Gewässerstellen dienten vor allem als Tränke. Auch von HAASE (1961:88) erfahren wir, dass der, Oderberger Teich' im St. Andreasberger Bergbaurevier lange verlassen lag, doch ,jetzt hält er wieder Wasser für die Viehtränke.“ Die Waldungen wie auch die Wiesen hatten keine Umzäunung (JOOSTEN/JUNG 1995:25) und so konnten die Tränkstellen ungehindert aufgesucht werden.

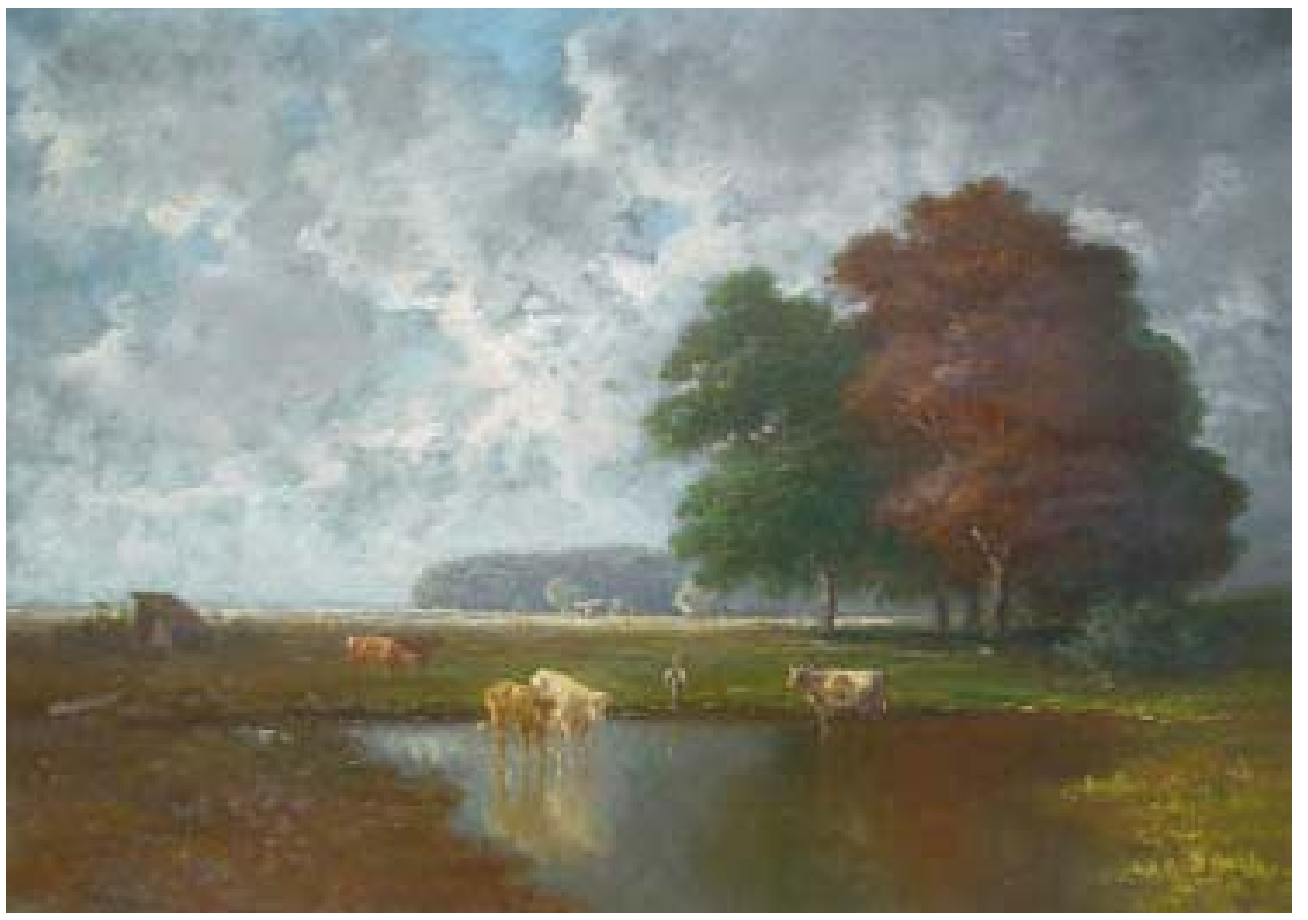

Abb. VI-89: Heinrich Neppel (1874 - 1936): „Landschaft mit Kühen an einem kleinen Weiher“

[aus: URL = http://www.galerie-jaud.de/neppelh.htm; 12.03.2004]

Auch Streckteiche der Teichwirtschaft wurden früher als Viehtränke benutzt, da der durch den Weidevieheintrieb „in das Wasser gelangende Mist die Entwicklung niederer Tiere begünstigt“ (BENECKE 1885:28). Zugleich wurde die harte Flora durch den Tritt der großen Tiere vernichtet oder wenigstens im Wachstum beschränkt (TAURKE 1927:162). Diese Nutzung wurde jedoch nur in solchen Teicharten zugelassen, wo „eine Beschädigung der Fische durch das Vieh nicht mehr zu befürchten ist.“ (BENECKE 1885:28). In Laichteichen war diese Gefahr zu groß und deshalb durfte das Vieh ,in demselben nicht getränkt werden, da es mit den schwimmenden Blättern des Mannagrases den Laich fressen oder ihn zertreten würde." (:22)

Später, nach Verkoppelung und Aufgabe der Waldweide wurde das Wasser, sofern nicht direkt vor Ort vorhanden, mittels Rohrleitungen von einer Quelle herangeführt (JOOSTEN/JUNG 1995:64).

\section{c Viehfutter}

Die Gewässer bzw. die mit ihnen verbundenen pflanzlichen Lebensgemeinschaften wurden nicht allein als Nahrungs- und Heilmittel sowie Baumaterial des Menschen gewonnen, sondern dienten auch der Ernährung des Viehs. Bei dieser hier vorgestellten Nutzungsart geht es um die Verwendung von Fluss- und Teichpflanzen als Viehfutter. 
THIENEMANN (1955:90f.) weiß zu berichten, dass die Wassernuss (Trapa natans) ,als Schweinefutter verwendet" wurde und „einen besonders guten Speck“ abgab. Auch die Flechtbinse wurde ,von den Kühen besonders gern gefressen“, ebenso galten die jungen Triebe der Teichschachtelhalme als gutes Viehfutter (KONOLD 1987:16).

Im 19. Jahrhundert bildete zudem das Teichrohr (Phragmites communis), von VOGEL (1898:23) noch als „Zeichen des Verfalls“ für einen Teich bewertet, neben seiner Benutzung als Streu, Dachdeckungsmaterial oder „zum Berohren der Decken und Wände“ (ACKERHOF 1869:103), „ein von dem Vieh sehr gerne gefressenes Futter.“ (BENECKE 1885:29) Für ACKERHOF (1869:103) war deshalb das Rohr „die wichtigste aller Wasserpflanzen“. Wo sich Rohrkolbengewächse in der Teichwirtschaft zu unerwünscht mächtigen Horsten entwickelten, wurde ihr weiteres Wachstum unterdrückt, indem man es im Frühjahr ,,mit langgestielten Sensen dicht über dem Grunde abhaut" und es sehr jung dem Vieh zu fressen gab (BENECKE 1885:29). Man rühmte „seine Nahrhaftigkeit für Pferde und Fohlen“ (ACKERHOF 1869:103). Die gekochten Rhizome der Rohrkolben hingegen wurden den Schweinen verfüttert (KONOLD 1987:16).

Es wurde bereits im 18. Jahrhundert festgestellt, dass junges, aber schon recht hohes Rohr, getrocknet einen hohen Proteingehalt und einen hohen Gehalt an süßen Nährstoffen besitzt. Es wurde daher in regelrechten „Plantagen“ (ACKERHOF 1869:105) durch Samen, Wurzelballen und Stecklinge künstlich angepflanzt bzw. vermehrt. In einer anderen Methode befestigte man abgeschnittene Halme des Rohres an Pfählen im Wasser. Die Wurzeln schlagen alsdann nach unten aus, bis der Boden erreicht ist. In gewissen Abständen wurden ganze Reihen solcher Würste eingelegt (:104). Man sprach deshalb auch von einer „Cultur der Wassergewächse“"(:103).

\section{d Halten von Wassergefügel und Schweinen}

Eine weitere Form der tierischen Gewässernutzung ist in der Haltung von Geflügel, wie zum Beispiel von Enten und Gänsen, zu sehen. Vor allem in der traditionellen Teichwirtschaft wurde diese Art des Gewässerbesatzes durchgeführt. „Das Wassergeflügel“, so der beschriebene Nachteil, „nimmt den Fischen zwar einen Teil der Fischnahrung weg, da es aber außer der von ihm im Wasser zusammengesuchten Nahrung noch anderes Futter bekommt und seinen Dünger teilweise im Wasser entleert und gleichmäßig über den Teich zerstreut, so ist es als sehr nützlich [...] zu betrachten." (TAURKE 1927: 161). Gerade durch das Aufsetzen von Wassergeflügel würden auch „,die Dorfteiche zu großer Fruchtbarkeit gebracht“ (:162). Nur auf Brutteichen durften Enten und Gänse auf keinen Fall geduldet werden, da sie dort durch Wegfressen der Brut Schaden anrichten könnten (CRONHEIM 1907: 25; TAURKE 1927:161).

Aus diesem Grund wurde in den 1920er Jahren die „Vereinigung von Geflügelzucht und Fischzucht (Fischhaltung)“ propagiert, denn dadurch „könnte noch eine große Anzahl kleiner Teiche in Deutschland sehr gewinnbringend gemacht werden“ und eine „besondere Düngung der Teiche [...] meistens wegfallen.“ (TAURKE 1927:161f.)

Damit die kombinierten Teichgewässer nicht umzukippen drohten, sollte „der Besatz mit Wassergefügel reglementiert werden, wie auch die Großvieheinheit auf den Äckern pro Hektar gezählt wird. Denn das Beispiel von ungepflegten Dorfteichen, zu denen Enten ungehinderten Zutritt haben, zeigt, dass sie meistens vollständig frei von Fischen sind (TAURKE 1927:161). Je Hektar, so die Empfehlung, könnten jährlich etwa 200 Enten, in Ausnahmefällen auch bis 500 und mehr, gehalten werden. Diese Besetzungsdichte galt aber nur für ablassbare Teiche (SCHÄPERCLAUS 1961:295).

Aus demselben Grunde, um der Düngerproduktion willen, wurde auch das Halten von Schweinen in den Lehrbüchern der Teichwirtschaft begünstigt (WALTER 1933:65). Deren Ställe sollten „vom Ufer aus über dem Wasser errichtet werden.“ (:65) Durch diese Schweinehaltung, so die damalige Überzeugung, „kann nach vielen Erfahrungen die Fischerzeugung erheblich gesteigert werden.“ (:65) 


\title{
18 Wasserweihungen und Opfergaben
}

In vielen Religionen des Altertums wurden Gewässer, vor allem Quellen, als Heiligtum verehrt. So bestand diese Form der Wasserverehrung in vorchristlicher Zeit auch bei uns. Horte, an denen Gegenständliches bestimmten Zwecken geweiht wurde, sind ,nicht selten in der Nähe des Flußufers, im Bereich von Flußmündungen [...], in unmittelbarer Nähe der Einmündung eines Baches oder auf Inseln im Fluß niedergelegt worden.“ (HANSEN 2000:54)

„Hortfunde entlang des Flußlaufes - in näherer oder weiterer Entfernung vom Fluß“ (HANSEN 2000:54) können nach Ansicht von HANSEN (:58) deshalb so oft prospektiert werden, „,weil das Opfer am Fluß während der Bronzezeit eine wichtige Rolle im Gesamtgeschehen der Deponierung spielte." Ihre Preisgabe an den Fluss, so die Erklärung, erfolgte „öffentlich als Dank für ein erfülltes Gelübde, welches sich auf das Gelingen irgendeiner Unternehmung bezog.“ (:54) Die Weihegabe besaß öffentlichen Charakter und verfolgte das Ziel, ,einerseits die Wirkmächtigkeit der Gottheit herauszustreichen und andererseits an den Erfolg sowie die Opferbereitschaft des Spenders zu erinnern." (:54f.) Verschiedene Studien zu den Flussfunden weisen auf eine solch praktizierte antike Flussverehrung hin (:57).

Wasser spielte darüber hinaus ,,in allen antiken Heiligtümern eine wichtige Rolle, sei es, daß sie an einer Quelle oder direkt an Flüssen gelegen waren.“ (HANSEN 2000:58) Für die Wahl eines Opferplatzes in der Bronzezeit war die Nähe zum aquatischen Milieu ausschlaggebend: Quellen und Wasserläufe wurden bereits genannt. „Sicherlich eine zentrale Rolle kam den Furten als Flußübergängen und den zu ihnen führenden Wegen durch die Auenwälder zu. Damit verbunden ist das Problem der Übergangsriten, die den räumlichen Wechsel von einem zum anderen Ufer begleiteten, und der zuweilen den Wechsel von der einen in eine andere, fremde Welt markieren konnte. Manche Stellen am Flußlauf, wie Strudel oder Stromschnellen [...], Felsformationen am Ufer [...] oder Flußmündungen [...] mögen mit der Faszination der Naturerscheinung zusammenhängen“ (:58; siehe zur Furt auch Pkt. 11.h ,Querungen').

Die mythologische Bedeutung der Gewässer zeigt sich auch im Odenwald: Schließlich zeugen Quellheiligtümer, Rituale wie der Osterwasserbrauch und sagenhafte Wasserwesen, etwa der „Neckargeist Nöck“, von den mystischen und religiös-spirituellen Vorstellungen, die der Mensch mit den Gewässern verbindet.

Das Wasser immer eng mit Glaubensvorstellungen verknüpft war, davon erzählt nicht zuletzt der Mystiker Rainer Maria Rilke (1875 - 1926) in einem seiner Sonette an Orpheus (Erster Zyklus, IX. Teil):

\author{
oft uns verschwimmen: \\ Wisse das Bild. \\ Erst in dem Doppelbereich \\ werden die Stimmen \\ ewig und mild."
}

„Mag auch die Spieglung im Teich

\section{Badenutzung}

\section{a Heilbäder und Mineralquellen}

Wasser gehört zu dem ältesten Heilmittel der Menschheit und nimmt „seit jeher eine überragende Stelle in der Volksmedizin ein.“ (GRABNER 2000:154)

Schon in der älteren und jüngeren Steinzeit hat sich der Mensch dabei die Heilwirkung der natürlichen Mineral- und Thermalquellen zunutze gemacht und die Wasserkur betrieben. Aufgrund von archäologischen Funden lassen sich „,mit Recht therapeutische Maßnahmen mit Hilfe von besonderem Quellwasser vermuten“ (MURKEN 1991:10). Am Übergang zu den Hochkulturen lag die Nutzbarmachung von mineralhaltigen oder mit höheren Wärmegraden der Erde entströmendem Wasser durch den Menschen zur Heilung und Linderung von Schmerzen, Schwellungen und Versteifungen von Gelenken, Muskeln und 
Extremitäten noch näher (:10). In den Schriften des griechischen Arztes Hippokrates (um 370 v. Chr.) spielt das Wasser als Heilmittel eine große Rolle. So empfahl er beispielsweise bei Gehirnhautentzündungen das Waschen bzw. Baden in mineralhaltigen Gewässern. Viele dieser hippokratischen Heilanweisungen sind in ähnlicher Weise auch in den heutigen volksmedizinischen Therapien noch geläufig (GRABNER 2000:154f.).

„In der Regel waren solche Anwendungen von Thermalwasser noch lange Zeit von religiös-mythischen Anschauungen überlagert.“ (MURKEN 1991:11) Es gab „vielschichtige Maßnahmen des Heilzaubers und Gesundbetens in den frühen Stufen der Zivilisation“ (:11). Solche magischen Heilrituale, die aufgrund ,ihrer suggestiven Kraft" tatsächlich Wunder bewirken können, haben „häufig auch das Wasserbad mit in die Maßnahmen eingeschlossen“ (:11). Das Bad im Wasser diente „dem Kampf gegen Verunreinigungen, die von außen Körper oder Seele des Menschen belasten oder beschmutzen.“(:11) Kranke, so glaubten die Menschen aller vor- und frühgeschichtlichen Völker, seien von Geistern und Dämonen besessen, die vor allem das Wasser fürchteten (siehe Pkt. 18 ,Wasserweihungen und Opfergaben' und V 2.d.5 ,Kultstätten und Klöster'). „Was lag also näher, als Kranke in einen Fluß, einen Teich [...] zu tauchen, um die krankmachenden Dämonen damit zu vertreiben?” (GRABNER 2000:154)

Neben dem gewöhnlichen Brunnenwasser kommt besonders dem fließenden Wasser, das nicht bloß reinigt, sondern auch „fortträgt“, erhöhte Bedeutung zu. Namentlich bei der Kulthandlung des „Wegschwemmens“ waren Fluss- und Quellwasser deshalb „vorzügliche magische Mittel“ (GRABNER 2000:154). Die uns heute als einfache und natürliche Reinigungsmaßnahme erscheinende Körperreinigung war in einstiger Zeit nämlich eine ganz andere, ,eine magische Zeremonie zur Entfernung böser Einflüsse, vor allem der Krankheiten.“ (:154)

Schon im alten Assyrien versuchte man den Kranken dadurch von bösartigen Wesen und Bezauberung zu befreien, indem man ihn wusch und mit Wasser besprengte. Bekannt sind die Waschungen in Euphrat und Tigris, deren Wasser man zu Heilzwecken auch zum Trinken verwendete. Auch in Indien wurde versucht, Krankheiten dadurch zu heilen, dass man Flusswasser über den Patienten goss, wovon er gewöhnlich auch trinken musste. Kinderlose Frauen mussten sogar gegen Unfruchtbarkeit im Wasser baden (GRABNER 2000:154). Das Beispiel der Hindu-Religion mit dem Bad in Ganges und Indus ist sogar noch heute gegenwärtig. Selbst in den christlichen Religionen hat sich in der Taufe mit geheiligtem Wasser aus dem Taufbecken etwas von diesen uralten Überlieferungen und Riten gehalten. „Bis zum Beginn des Abendlandes haben sich auf diese Weise altes Vorstellungsgut, mythische Überlieferungen und therapeutische Erfahrung beim Gebrauch des Wassers für den menschlichen Körper miteinander verwoben." (MURKEN 1991:11)

Auch dem Mittelalter war der Glaube an die Heil- und Zauberkraft des Wassers nicht unbekannt. „Nach altem Volksglauben konnte man eine Krankheit wegschwemmen, wenn man einen Teil des kranken Menschen oder etwas, das mit demselben in Berührung gekommen ist, in fließendes Wasser warf. So goß man z. B. auch den Harn des Kranken hinein oder übergab Nägelschnitzel oder Kleidungsstücke des Patienten dem fließenden Wasser. Auch pflegte man Flußwasser zu schöpfen und den Körper des Kranken [...] damit abzuwaschen." (GRABNER 2000:155).

Der Glaube, dass Wasser große Heilkräfte besitzt, galt bis in die unmittelbare Gegenwart für das Wasser der Osterzeit, wie Elfriede GRABNER (2000:155) aus der Steiermark berichtet. Man ging am Karfreitag und am Ostermorgen die Brunnen vor Sonnenaufgang schweigend besuchen, um aus ihnen Wasser zu schöpfen.

Noch im 18. Jahrhundert galt auch der Wasserschaum, vor allem wenn er von Mühlrädern stammte, als heilkräftig. So lautet eine aus dem Erzgebirge stammende Heilanweisung dieser Zeit gegen Kopfleiden: „Einer / der die Haupt-Krankheit hat / soll sein Haupt mit dem Wasser / so von den Mühlrädern zurück springt / waschen.“(GRABNER 2000:156)

Besonders in den Heilpraktiken der mittelalterlichen Volksmedizin spielte das Wasser eine wichtige Rolle. Fließendes Wasser kam bei der Fieberheilung zur Anwendung. So wurden verschiedene Gegenstände in den Bach geworfen (beschriebene Handzettel, Zehennägel, Weidenruten, Pflanzenstäbe etc.) und dabei Glaubens- und Heilformeln gesprochen (GRABNER 2000:156). 
Aber nicht nur die forttragende Kraft des fließenden Wassers hat im Volksmund heilkräftige Wirkung. Hier waren es vor allem die vielen wallfahrtsmäßig verehrten Quellen und heiligen Brunnen. Diese wurden von Fieberkranken aufgesucht. Diesen Wässern schrieb man fieberheilende Wirkung zu (z. B. der St.UlrichQuelle bei Graz) (GRABNER 2000:157).

Das Wasser von im Klosterhofbrunnen versenkten Heiligenreliquien wurde mit einem besonderen Segen geweiht und galt als heilkräftig bei vielen Krankheiten, besonders bei schweren Geburten, indem man die Mutterbrust damit bestrich sowie bei Viehkankheiten und in Cholerazeiten. Aber auch in Wasser getauchte Kreuzlein wurden in die Äcker gesteckt, um Schädlinge von den Feldern fernzuhalten (GRABNER 2000:157). Eine Waschung mit frischem Brunnenwasser wurde als Heilmittel gegen Augenleiden verwendet und geweihtes Wasser galt auch als pestheilend und deshalb wurden auch Stall und Vieh mit Wasser besprengt (:157).

In rein magischer Weise verwendete man das Wasser, um Geschwülste und Hauterkrankungen zu heilen. Man ging beispielsweise in der Obersteiermark bei zunehmendem Mond in der Nacht zu einem Bach oder einer Quelle und benetzte die leidende Stelle dreimal mit Wasser. „Der Mondschein, der in das Wasser fällt, bildet mit diesem gleichsam eine Lösung, die Gschwüre und Geschwülste“ zerstören soll (GRABNER 2000:158).

Quellwasser, das man in der Nacht vor dem Tag der Heiligen Drei Könige geschöpft hatte, galt als sehr heilkräftig. Auch als Mittel gegen Ungeziefer und Gespenster sollte es taugen.

Wasser spielte also in den volksmedizinischen Heilverfahren und in der Naturheilkunde keine unbedeutende Rolle: Die forttragende und daher reinigende Kraft des Wassers, die das Übel fortschwemmen sollte. Daneben wurde dem natürlichen Wasser, besonders den mineralhaltigen Quellen besondere Heilkraft zugeschrieben.

Neben dieser ritualen und magischen Bedeutung von Wasser gab es aber bereits seit dem Mittelalter eine hygienisch-medizinische Bedeutung bei der Benutzung von Wasser. Vor allem kalte Bäder wurden seit der Mitte des 16. Jahrhundert vereinzelt auch von Ärzten als Kur verordnet (GRABNER 2000:159).

Der berühmte, an der Schwelle zur Neuzeit stehende, Arzt Paracelsus (1493 - 1541), der eigentlich Theophrastus Bombastus von Hohenheim hieß und 1493 als Sohn eines schwäbischen Arztes in Einsiedeln geboren wurde, hat sich vielfach mit den „Heilwässern“ beschäftigt. So bemühte sich Paracelsus, den „Genius der Bäder“ an den einzelnen Quellen selbst zu erkunden, indem er die Wirkungen auf gesunde und kranke Menschen beobachtete und beschrieb (GRABNER 2000:159).

Die Wirkung heilkräftiger Trinkwässer und die abhärtende Anwendung vom Bade in kaltem Flusswasser wurden in der Folgezeit von vielen Ärzten immer wieder empfohlen. Von jeher hat man die Wunderkräfte und gesundheitsfördernde Wirkung des kalten frischen Wassers (Aqua fontana frigida) zum Trinken und Baden gekannt.

Bereits 1639 wurde nach der Entdeckung einer „Heilquelle“ im Lempetal östlich der Stadt Hofgeismar unter Landgraf Karl die Erschließung der Quellen vorgenommen. Das heilkräftige Wasser half, einer zeitgenössischen Quelle zufolge, Verwundungen auszuheilen. Des Weiteren sollte die Wunderquelle „Blind-, Taub- und Stummheit" geheilt haben. Der Brunnen mit seinem rötlichen, sehr eisen- und salzhaltigen, etwas nach Schwefel schmeckenden Wasser wurde jedenfalls Ausgangspunkt für den Badeort Bad Gesundbrunnen (BÖTTGER 1989; BRUNNEN - BÜRGER - BÄDER 1989).

Vor allem aber hat der berühmte Berliner Arzt Christoph Wilhelm Hufeland (1762 - 1836), die gesundheitsfördernde Wirkung dieses Elements zur physischen Wiederherstellung besonders herausgestellt (GRABNER 2000:160).

Es entwickelte sich daraus die Hydrotherapie (Wasserheilverfahren), die Bäder in kaltem Wasser als Heilmittel anwendete. Genannt seien hier nur stellvertretend Prof. Joachim Dietrich BRANDES (Driburger 
Badearzt), Pfarrer Sebastian KNEIPP (Wörrishofen) sowie Sigmund HAHN und Söhne (Schweidnitz/Schlesien) und Vinzenz PRIESSNITZ (Gräfenberg/Sudetenland).

Wasserheilkuren fanden später ihre wissenschaftliche Begründung. Wasserärzte wurden klinische Bäderärzte und es entstand sogar in Deutschland ein medizinischer Zweig „medizinische Limnologie“, bei der Heilschlämme aus Binnenseen gewonnen werden (THIENEMANN 1955:92f.). Die Anwendungen wurden in der Folgezeit aber nicht in frei fließenden Gewässern durchgeführt, sondern fanden in Zubern statt. Auch hier zeigte die einsetzende Wasserverschmutzung die Grenzen der Wassernutzung auf: „Einfaches“, „schlichtes“, „bloßes“ kaltes Wasser, wie damals das natürliche klare Wasser hieß, konnte nicht mehr vor Ort getrunken werden und auch das Waschen und Begießen bzw. darin zu Baden war nicht länger heilsam, sondern krankheitsfördernd. Dies bekam später auch der Badebetrieb zu Zwecken der reinen Erholung und des Freizeitvertriebs zu spüren.

\section{b Badebetrieb}

Primär war das Schwimmen und Baden bei der Nahrungsversorgung und bei kriegerischen Auseinandersetzungen vom Vorteil Doch bald stellte sich auch heraus, dass das Schwimmen eine hygienische und gesundheitliche Wirkung hatte (HEINY/POLAT 2002:3).

Die Nutzung des Elements Wasser zu hygienischen und auch freizeitlichen Zwecken ist wahrscheinlich in der gesamten Vorzeit, vor allem aber bei den Römern der Kaiserzeit, sehr verbreitet gewesen (SONNABEND 1999a:50). Dabei waren zunächst natürliche Warmwasserquellen von Nutzen, wie die Thermen in Pompeji. Den Römern aber kommt das große Verdienst zu, mit den Bauten von Thermalbädern das ausgiebige und regelmäßige Baden zu einem öffentlichen Anliegen gemacht zu haben (MURKEN 1991:11).

Im Zuge der Romanisierung wurde das römische Bad in alle Teile der römisch dominierten Welt exportiert. Jedes römische Kastell hatte sein eigenes $\mathrm{Bad}$, was insbesondere für die in den kälteren Regionen stationierten Legionäre ein Stück Annehmlichkeit und Zivilisation bedeutete (SONNABEND 1999a:51).

Die hohe Zahl der Bäder, in Rom gab es im 4. Jahrhundert n. Chr. nach einem antiken Verzeichnis 11 Thermen und 856 weitere öffentliche Bäder, verursachte einen hohen Wasserverbrauch und machte entsprechende Versorgungsmaßnahmen erforderlich (SONNABEND 1999a:51). Die Thermen-Reservoire wurden von speziellen Aquädukten beliefert. Gespeist wurden auch diese Bäder also letztlich wieder von mitunter kilometerweit entfernt liegenden - Quellen oder Flussläufen. Neben den öffentlichen Bädern gab es eine große Zahl von privaten Bädern. Diese gehörten zum Standardinventar der „villas“ der Reichen.

Vergessen wird oftmals, dass nicht nur das Sitz- und Tauchbad praktiziert wurde, sondern bei den Griechen, Römern und den Hochkulturen der Antike das Schwimmen besonders beliebt war. Für das Erlernen des Schwimmens wurden Stätten wie Heißluftbäder, Duschbäder und Badebecken gebaut. Wettkämpfe waren eher selten, doch geht aus vielen Überlieferungen hervor, dass die griechischen Helden und Götter sehr starke Schwimmleistungen hervorgebracht haben.

Aus den Sagen der Germanen geht hervor, dass das Schwimmen nützlich zur Lebenserhaltung war und vor allem im Kampf gegen die Römer vom Vorteil war. Bei den Germanen wurden auch Schwimmwettkämpfe abgehalten. Bei den alten Germanen war das Baden auch ein wirksames Mittel gegen Krankheiten, Schuld und ähnlichen Verdruss. Da es keine Kleiderordnung gab, schwammen und badeten alle nackt (HEINY/POLAT 2002:3).

Im römischen Reich hatte das Schwimmen hohes Ansehen und gehörte zur körperlichen Ausbildung der Jugend. Es wurden Thermal- und Dampfbäder gebaut sowie zum Teil beheizte Schwimmbecken und Stadtbäder, in denen über 1000 Menschen Platz fanden. 
Diese Bäder waren Geschenke der Kaiser an das ganze römische Volk, das hieß, dass auch Personen aus den „Unterschichten“ die Bäder besuchen konnten. Die Bäder wurden aber vor allem zu Stätten wichtiger gesellschaftlicher und politischer Transaktionen.

Die Badekultur erreichte, vor allem durch die Eroberungen der Römer, weite Teile Europas. Als das römische Reich unterging, wurden die Thermen zu Orten der Sittenlosigkeit, und da sie nicht mehr gepflegt wurden, verfielen sie und mit ihnen auch die Badekultur (HEINY/POLAT 2002:4f.).

Mit dem Aufkommen des Christentums im beginnenden Mittelalter versiegte allmählich die antike Badekultur (MURKEN 1991:15). Die letzten Ausläufer der spätrömischen Badesitten verkörperte im 9. Jahrhundert Karl der Große. Er ließ auf den Ruinen der Aachener Thermalanlagen ein Badebecken bauen. Dieses lag seiner Pfalz, in der er seit 795 residierte, unmittelbar benachbart.

\section{b.1 Flussbadeanstalten}

Neben den seit dem späteren Mittelalter bis in die Neuzeit bestehenden städtischen Badehäusern bzw. Badestuben, weil das eigene Bad in vielen Häusern noch fehlte, gab es in den Sommermonaten, bei entsprechenden Wassertemperaturen, die Möglichkeit zum Bad in dem die Stadt durchfließenden Gewässer.

Dabei geht es hier nicht um das freie Flussbad an gerade geeigneter Stelle; dies ist für fast alle Fließgewässer und Mühlbäche noch bis die 1940er Jahren bezeugt. So war zum Beispiel der von der Bieber abgeleitet Mühlbach, „,bevor man die Abwässer ganzer Gemeinden [...] einleitete, [...] oberhalb des Wasserfalls für die Kinder [...] ein beliebter Badeort“" (GRIES 1999:25).

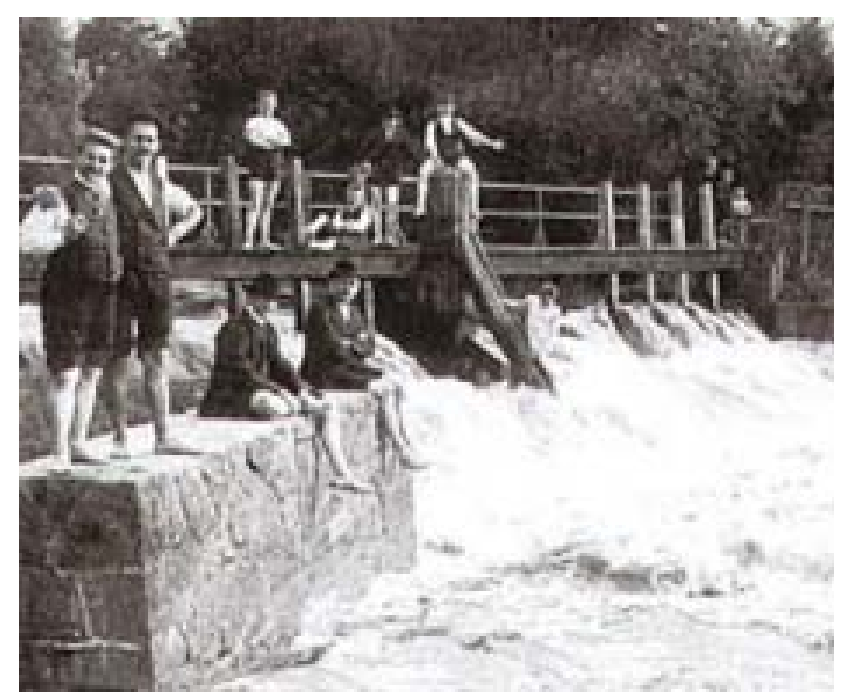

Abb. VI-90: Badende in der Pleisse am Dölitzer Wehr, um 1900 (aus: HUHN 1992)

Der zunächst freien Wassernutzung zum Zwecke des Freizeitvergnügens bot man vor allem seit dem 20. Jahrhundert einen passenden baulichen und abgegrenzten Rahmen. Die verschiedenen Gruppen der Reformbewegung wie Freikörperkultur und die Sportbewegung verlangten nach entsprechenden Möglichkeiten zum Schwimmen. Zahlreiche sog. Flussbadeanstalten wurden in den Flussläufen im Binnenland eingerichtet (HEINY/POLAT 2002:10; WOLSCHKE-BULMAHN 2002). „Das waren schwimmende Pontons mit integrierten Umkleidekabinen etc., die es ermöglichten gefahrlos im Flusswasser zu baden, da sie gewissermaßen in den Fluss verlegte Schwimmbecken mit eigenem Holzboden darstellten. ${ }^{\text {(89 }}$

Das Bauprinzip war einfach: Auf leeren Petroleumfässern oder Pontons schwamm eine große hölzerne Plattform. In diese war als Schwimmbassin eine Art eiserner Käfig mit Holzboden ins Flusswasser eingehängt, wo sich die Badenden einigermaßen gefahrlos bewegen konnten. Um die Schicklichkeit zu

${ }^{89}$ Aus: URL = www.raddampfer-kaiser-wilhelm.de/museum/archiv_sonder/Sonder/Badespass/Badespass.htm; 07.10.2003 
bewahren, schirmten zur Landseite Bretterbuden mit Umkleidekabinen gegen Einblick ab. Am Steg, der zur Badeanstalt führte, wurden Getränke und Badeutensilien verkauft sowie Badekostüme und Handtücher verliehen (HEINY/POLAT 2002:10).

Als Aufsichtspersonal waren Fischer oder Schiffer mit Schifffahrtspatenten eingesetzt, die teilweise den Sommer gemeinsam mit ihren Familien in einer Wohnung auf der schwimmenden Badeanstalt verbrachten, denn oft konnten Fischer und Schiffer sehr gut schwimmen. Die Aufsicht musste ständig darauf achten, dass genügend „Wasser unterm Kiel“ war. Ärger bereiteten bei Flussbadeanstalten, die auf großen schiffbaren Flussläufen aufgebaut waren, die gelegentlich zu schnell vorbeifahrenden Motorkähne, deren Wellen in die Schwimmkörper der Badeanstalten schlugen. Vornehme Besucher mieteten sich eine der wenigen Einzelkabinen. Dabei war die Benutzung von Bade- und Handtüchern häufig im Preis einbegriffen. Am Ende jeder Badesaison schleppte man die Badeanstalten in einen nahen Hafen, wo sie repariert und für das kommende Jahr aufbereitet wurden (HEINY/POLAT 2002:10).

Der Grund für die Ausweisung von Badeanstalten mag zum einen darin gelegen haben, dass durch Verengung des Raumes vor allem durch ufernahe Wohnbauten, die den Wasserzugang suchten, Freiflächen zur Erholung und zum Zeitvertreib gesichert werden mussten. Zum anderen stieg das Bedürfnis nach entsprechenden Sicherheitsvorkehrungen in teilweise von Schiffen befahrenden Strömen (Absperrungen, Aufsichtspersonal), nach Hygieneeinrichtungen durch entsprechende Vorschriften (Nasszellen, Umkleidekabinen) und Kunst- und Spaßbauten (Sprungtürme, Rutschen etc.). Diese Anstalten waren „Freizeitzentren“ damaliger Art, wo neben dem Baden auch die Gastronomie nicht zu kurz kam.

Diese „schwimmenden Flussbadeanstalten“ sind in fast allen deutschen Flüssen vor allem anhand historischer Fotografien nachzuweisen: zum Beispiel in der Elbe bei Blankenese, in Hohnstorf und Lauenburg. Alle drei Standorte haben eine lange Tradition. Für Lauenburg wird bereits um 1900 eine „schwimmende Badeanstalt" im Hafenbereich erwähnt: auf pontonähnlichen Schwimmkörpern standen Umkleidekabinen und Wirtschaftsgebäude. An der Alster in Eppendorf entstanden schon früh in der Mitte des 19. Jahrhunderts gleich drei Flussbadeanstalten: ein Männer-Schwimmbad um 1840 aus einem freien Badeplatz hinter dem Garten des Senators Hayn durch den Bau eines Badeschuppens („Jacobs-Bad“), die Frauen erhielten ein Stück weiter nördlich bei der Eppendorfer Mühle eine kleine, durch Planken hermetisch von der Umgebung abgeschlossene eigene Badeanstalt, und zwischen den beiden Bädern legte man 1869 die Militär- und Schwimmanstalt des zweiten Hanseatischen Infanterie-Regiments Nr. 76 an (HANKE 2001). Weitere Beispiele sind bekannt von den Isarauen in München, im Roten Main in Bamberg, in der Weser, zum Beispiel in Rinteln und Höxter, und vor 1910 lag ein schwimmendes Badehaus im Wasser der Mulde, das hauptsächlich für das weibliche Geschlecht bestimmt war.

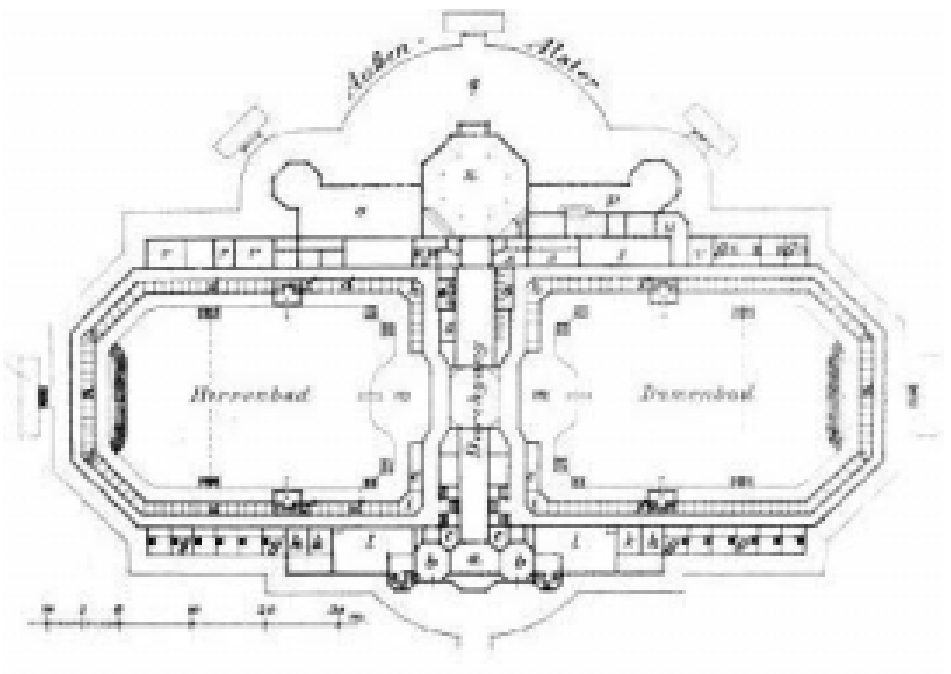

Abb. VI-91: Flussbadeanstalt „Alsterlust“, Hamburg 1888

[aus: URL = www.raddampfer-kaiser-wilhelm.de/museum/archiv_sonder/Sonder/Badespass/Badespass.htm, 06.10.2003]

An dem Standort der Badeanstalten konnte aber oftmals zum einen wegen der Veränderung des Flusslaufs nicht festgehalten werden. Zum anderen sprachen auch hygienische Gründe dagegen, weil einige primitiv 
geklärte Hausabwässer vor der alten Badeanstalt in den Flusslauf einmündeten, wie beispielsweise ALTHÖFER-WESTENHOFF/WAGNER (1997:131) am Beispiel der Else schildern. In diesem Fall wurde 1928 zunächst eine neue Badeanstalt auf einem anderen Grundstück flussaufwärts errichtet: in unmittelbarer Nähe zur Einmündung der Alten Else in den Flusslauf.

Vor allem die Gewässerverschmutzungen haben zur Schließung fast aller Flussbadeanstalten geführt. Letztlich wurde auch die alte Bünder Badeanstalt auf das Festland verlegt und noch heute zeugen die Standorte der Freibäder nur wenige Meter vom Fließgewässer entfernt in erhöhter überschwemmungssicherer Lage von der ehemaligen Einrichtung im Flusslauf. Auch die seit dem 18. Jahrhundert in Berlin entstandenen zahlreichen Wasch-, Schwimm- und Badeanstalten an den Flussufern wurden „wegen der zunehmenden Wasserverschmutzung [...] zu Beginn des 20. Jahrhunderts [...] demontiert.“ (STRAUSS 2002:23).

Bis Mitte des 20. Jahrhunderts waren die Flussbadeanstalten dennoch vielerorts noch im Einsatz (HEINY/POLAT 2002:10).

\section{b.2 Teichbadeanstalten}

In der Zeit des Rokoko begannen die höfischen Gesellschaften wieder zusammen zu baden. „In kleinen Seen, Flüssen oder in privaten Teichen" stiegen Frauen und Männer in voller Bekleidung ins Wasser, wie HEINY/POLAT (2002:9) schreiben. Das Nacktbaden war undenkbar und wiedersprach der moralischen Einstellung vieler. Über diese Teichbadegänge ist weiter nichts bekannt, auch nicht, ob es sich um eigens dafür angelegte Teiche gehandelt hat oder um bereits genutzte Teiche. Der Verdacht liegt nahe, dass es sich in den meisten Fällen um Fischteiche gehandelt hat, denn solche Doppelnutzung war bis in die gegenwärtige Zeit üblich, wie ich es selbst noch Anfang der 1970er Jahre gar bei - schlammigen und eher flachgründigen Karpfenteichen erlebt habe und wie das untere Beispiele des Forellenteiches zeigt. Die Berührungen mit im dicht mit Karpfen besetzten Wasser sind jedoch nicht jedermanns Sache und lassen auch aus Gründen der Flachgründigkeit im Allgemeinen eher das historische Bad in Forellenteichen wahrscheinlich erscheinen. Ein weiterer Gesichtspunkt ist das der früher praktizierten Einleitung von Dung und anderen Fäkalien vornehmlich in Karpfenteiche (siehe Pkt. VII 2.b), so dass diese auch aus eben diesen Gründen höchstwahrscheinlich nicht für ein Bad in Frage kamen.

Wahrscheinlich auch aus Gründen der Fließgewässerverschmutzung zunächst an den größeren Flussläufen, aber vielleicht auch um zusätzliche Einnahmequellen zu schaffen bzw. wegfallende zu kompensieren, haben einige Teichwirtschaften in den 1920er und 1930er Jahren Möglichkeiten zur Freischwimmbenutzung geschaffen.

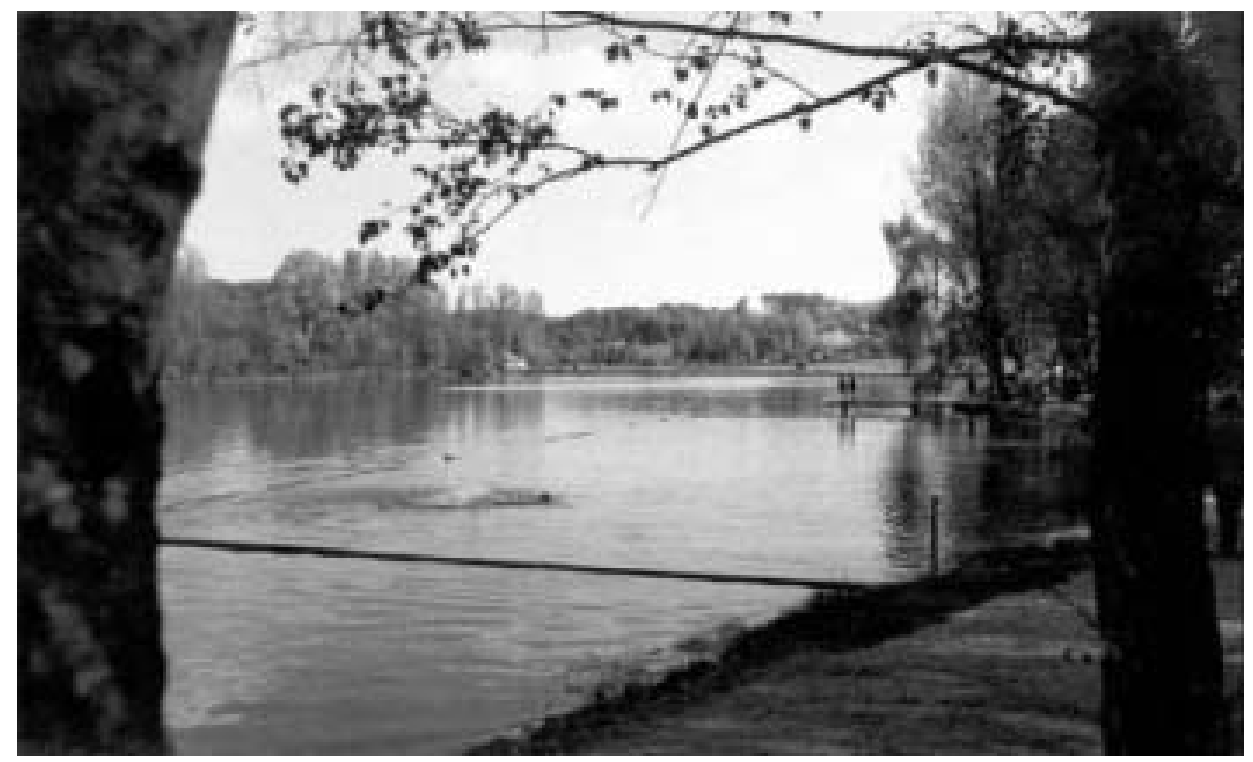

Abb. VI-92: Badeteich der Forellenzucht „Bögerhof“ bei Rinteln 
Ein außerhalb des Bildes stehender 3 m-Sprungturm bestand nach eigener Erinnerung mindestens noch bis 1996. Das Badehäuschen ist bis heute erhalten geblieben und dient im verfallenden Stadium als Wohnung. Im Hintergrund ist der Fischhof zu sehen. Die über 500 Jahre alte Teichwirtschaft „Bögerhof“ wurde ursprünglich vom nahen Kloster Rohbraken, einem heutigen Ziegelstein- und Dachplattenwerk, errichtet. Als der Landesstraßenausbau 1989/90 hier auch das letzte verbliebene Teilstück erreichte, wurden einige Teiche verfüllt, andere verkleinert und die Teichanlage regelrecht zerschnitten. Dahin ging auch die angeschlossene Gaststättenidylle und mit ihnen die Kundschaft. Der historische Bögerhof wurde versteigert, die historische Teichwirtschaft verfällt (Museum „Eulenburg“, Rinteln).

Später, als auch die Teich- und Mühlenwirtschaft sich nicht mehr lohnte, wurden an den Stellen der Wassermühlen- und Fischzuchtteichen auch Freibäder errichtet. So hatte im März 1931 die Gemeinde Bieber das Anwesen der Lindenmühle erworben. Die Gebäude wurden abgerissen und auf dem Gelände errichtete man ein kleines Freibad. Für ein sportliches Schwimmen zwar nicht geeignet, diente es dem „Wannen- und Brausebad". Hinsichtlich der Wasserspannung und dem Ablass änderte sich gegenüber der ehemaligen Mühlenteichnutzung nichts: Bedingt durch seine Lage am Mühlbach entnahm man das Wasser zur Beckenfüllung offenbar ungeklärt und leitete auch das Austauschwasser sowie die Abwässer der Wannenund Brausebäder wieder ein (GRIES 1999:78). Das eingepumpte Bachwasser litt aber oft unter Algenbefall, so dass ein häufiger Austausch notwendig war (:78).

Auch in Güstrow „soll sich früher am Mühlenteich eine Badestelle befunden haben.“ (LORENZ 2000: 64). Um die Jahrhundertwende musste der Mühlteich an der Nebel dem Bau der Städtischen Badeanstalt weichen.

Ein Beispiel der Umwandlung eines ehemaligen Weingartener Klosterteiches („Froschweiher“) zunächst in ein Militär-Schwimmbad und dann in ein allgemeines Freischwimmbad führt HERBST (1992:23f.) auf.

Nicht nur brachfallende Fisch- und Mühlenteiche, auch Bergbauteiche wurden als Teich-Badeanstalten genutzt. Der im Jahr 1715 als Wasserspender für den Harzer Bergbau gebaute und 1804 erneuerte ,Kleine Okerteich' diente bereits in den 1950er Jahren den Kurgästen von Altenau als Badeteich (HAASE 1961:22). Und auch der im Gebiet der Oker liegende ,Schalker Teich' lud in den 1960er Jahren die Erholungssuchenden zu Bad und Rast ein (:31).

\section{b.3 Bade-Stuben}

Die Christen wollten im frühen Mittelalter nichts von den römischen Bädern wissen. Baden und Schwimmen konnte man nicht mit dem christlichen Glauben vereinen.

In der Ritterzeit wurde das Baden und Schwimmen besonders bekämpft, weil damit eine Entblößung verbunden war und diese nicht ins heroische Bild passte. Unter dem Einfluss der Kreuzzüge zu Anfang des 11. Jahrhunderts fand die Zeit des ,asketischen Wohlgestanks" statt und der Gang ins Bad war somit überflüssig. Jedoch erkannten die Kreuzritter im Verlauf ihrer kriegerischen Pilgerfahrten während des 12. und 13. Jahrhunderts zum Beispiel in den türkischen Bädern die wohltuende und heilsame Wirkung des Bades. Sie genossen es jeden Tag ein heißes Bad zu nehmen und sich dabei zu entspannen. Daheim wurden wieder öffentliche Badestube eröffnet - aber diesmal nicht nur zum Baden, sondern um auch dort zu essen, zu tanzen und zu spielen.

Die „Bademeister“ betätigten sich auch medizinisch und zogen zum Beispiel Zähne, versuchten Verletzungen zu heilen oder schnitten einfach nur die Haare der Besucher. Die Bademode bestand allein aus der Kopfbedeckung. Die Frauen trugen immer wieder den neuesten ausgefallensten Kopfschmuck. Es wurde nackt gebadet und dies entsprach auch der sinnesfreudigen Auffassung des ausgehenden Mittelalters. Das Badehaus war wieder Treffpunkt für alle. Es wurde geredet, gegessen, getrunken, gespielt oder gesungen. Badehäuser waren auch Orte, an denen man sich kennen lernte und später auch vielleicht heiratete.

An den durch die Stadt fließenden Gewässern lagen im Binnenland die Badeanstalten oder, wie sie im Mittelalter hießen, die „Badestuben“ der Stadt. Es waren Badehäuser mit Wannen und Schwitzbädern sowie mit ganz kleinen Schwimmbecken.

In der Stadt Nordhausen lagen die Badehäuser an dem Mühlgraben. Es werden hier im Mittelalter vier Badestuben erwähnt, in die das Wasser hineingeleitet wurde: Die Badestube unter dem sog. Barfüßertor, dem 
westlichen Eingangstor zur Stadt, hinter dem Kloster St. Elisabeth gelegen, wird 1366 erwähnt. Eine zweite befand sich unter dem „Neuen Weg“ und zwar neben dem „Hurenhause“. Sie wird bereits 1359 „Badestube under dem Nuwenwege an der Zorgeenge“" genannt.

Neben der „Kuttelmühle“ lag eine dritte: im 15. Jahrhundert hatte die „Badestube under dem Kottelberge 1 Schock gut Geld als Jahreszins an das St. Georgenhospital zu zahlen“. Die vierte schließlich befand sich in der Sundhäuser Straße neben dem Stubengäßchen, das seinen Namen nach ihr erhielt. Sie gehörte dem Frauenbergkloster. $\mathrm{Ob}$ die anderen Badestuben auch den Klöstern gehörten oder im privaten bzw. öffentlichen Besitz waren, kann nicht beantwortet werden.

Das Badevergnügen ging wieder sehr stark zurück, als das Brenn- und Heizmaterial zur Befeuerung der Bäder aufgrund der allgemeinen Brennholzknappheit teurer wurde (siehe Pkt. 11.f ,Flößerei') und Krankheiten sich verbreiteten. Vor allem die Pest und die Syphilis schlichen sich ein. Es gab wieder ein Badeverbot und wer trotzdem badete, wurde hart bestraft. Die Menschen fingen wieder an zu riechen und der körpereigene Geruch wurde mit Puder oder Parfum überdeckt (HEINY/POLAT 2002:5f.). Obgleich es bis zum Zeitpunkt des Einbaus wohnungseigener Bäder solche „Badestuben“ in den Städten, wo die offenen Gewässer und Stadtgräben nicht zum Baden einluden bzw. solche in nächster Nähe auch gar nicht vorhanden waren, bis in die neuere Zeit immer gegeben hat.

Im Jahr 1858 beispielsweise befand sich eine „Badeanstalt“ in der Straße Grimmel Nr. 853 (heute: Nr. 6), deren Wasser, wie für das Mittelalter beschrieben, dem Mühlgraben entnommen wurde. Der Eigentümer war Kautabakfabrikant G. A. Hanewacker. Für die Bedienung der männlichen Kunden war ein Bademeister verantwortlich, für die weiblichen eine Bademeisterin. $\mathrm{Zu}$ den Leistungen gehörten unter anderem Schwefel, Salz-, Eisen-, Malz-, warme und kalte Wannenbäder.

\section{b.4 Bade-Anstalten}

Seit der zweiten Hälfte des 18. Jahrhunderts wurden schon die ersten „Badeanstalten“ erbaut, wie zum Beispiel in Paris 1760 oder in Frankfurt am Main 1793. Ebenfalls in diese Zeit fällt der Beginn des deutschen Seebades, 1793 wurde das erste deutsche Moorbad in Heiligendamm bei Doberan eröffnet und 1797 folgte Norderney; diese Thematik soll aber hier im Kontext der Binnenbäder nicht weiter vertieft werden. Die aufgeklärten Mediziner forderten die Eröffnung der Bäder. Aber trotzdem galt das Baden, auch noch in der Aufklärung, als ungesund, gefährlich und unmoralisch (HEINY/POLAT 2002:6f.).

Im 19. Jahrhundert folgte dann die Wende: 1828 wurde in Liverpool die erste Schwimmhalle der Welt gebaut und 1837 besaß London schon sechs Hallenbäder. Die Badeanstalten waren ein Abbild der Gesellschaft, die für Sauberkeit, Ordnung und Disziplin stand. In dieser Zeit entwickelte sich das freie Baden und 1837 badeten in Deutschland in 998 Bädern 4136 Besucher (HEINY/POLAT 2002:7).

Nachdem die kleinen Badestuben, die zuvorderst der Körperreinigung dienten, im Zuge der allgemeinen Hygienisierung und durch den Einbau eigener Haus- und Wohnungsbäder seit Ende des 19. Jahrhunderts zunehmend an Bedeutung verloren, standen die frühen Sport- und Erholungsbäder, die sog. Volksbäder, im Blickfeld des nunmehr öffentlichen Bäderwesens. Und dies aus folgendem Grund, wie das Beispiel des am 01. Juni 1891 veröffentlichten Aufrufs zur Errichtung der ,ersten städtischen Bade-Anstalt“ in der Zorgeaue zeigt $^{90}$ :

„,Um der Bürgerschaft Nordhausens die großen Segnungen eines das ganze Jahr hindurch zu benutzenden Schwimmbades für beide Geschlechter zu sichern und öffentlich unserer männlichen und weiblichen Jugend die für eine gesunde Körperentwicklung so hochwichtige Gymnastik des Schwimmens zu ermöglichen, haben die städtischen Collegien beschlossen, ein städtisches Schwimmbad in Verbindung mit Volksbrausebädern auf unentgeltlich herzugebendem städtischen Grund und Boden zu errichten und zu verwalten [...]. “

\footnotetext{
${ }^{90}$ Stadtarchiv Nordhausen: Acta Badeanstalt 1. Juni 1891.
} 
Das Ziel bestand genau darin, eine vollständige Badeanstalt zu errichten, „deren Wasser künstlich mittels einer Dampfmaschine erwärmt wird“. Es sollte damit der Versuch gemacht werden, „eine öffentliche Schwimm- und Badeanstalt [...] ins Leben zu rufen [...], die auch im Winter benutzt wird“, d. h. es sollten im „Winter und Sommer benutzbare Schwimmbassins“" entstehen ${ }^{91}$.

Die im Laufe des Jahres 1891 erbaute „Dampf-Badeanstalt“ wird wie folgt beschrieben ${ }^{92}$ :

Das Gebäude ist massiv erbaut und theils mit Schiefer (Schwimmhalle) theils mit Holz (die um die Schwimmhalle liegenden Bäume) gedeckt. Nur das Kesselhaus hat Dachpappen. Die innere Einrichtung besteht im Erdgeschoß aus der Schwimmhalle mit Schwimmbassin von 13,50 m Länge und 7,0 $\mathrm{m}$ Breite. Dasselbe ist für Schwimmer und Nichtschwimmer hergestellt und hat eine Tiefe von 0,70 $\mathrm{m}$ und 2,10 m. Außerdem befinden sich in der Schwimmhalle noch an der einen Langseite in 2 Etagen, die durch Treppe verbunden sind, 24 Auskleidezellen.

Um die Schwimmhalle gruppieren sich durch Gänge getrennt:

3 Wannenbadzellen I. Klasse mit gemauerten Fliesenwannen,

7 Wannenbadzellen II. Klasse mit Holzwannen

1 allgemeiner Auskleide- und

1 allgemeiner Waschraum (Reinigungsraum mit Brausen),

4 Räume mit Dampf- und Heißluftbad (bestehend aus Ruheraum, Doucheraum, Dampfraum und Heißluftraum,

2 Räume für 7 Volksdouchen,

1 Waschraum zum Reinigen der Wäsche,

1 Wäsche- und Kasseraum nebst Entree und Hofraum und

1 Kesselhaus mit Dampfkessel und Dampfschornstein.

Im 1. Stock befand sich zudem die Wohnung des Bademeisters mit Wartezimmer (5 Räume) sowie 2 „Reservoirräume“ für Warm- und Kaltwasserbottiche.

Bei der Standortentscheidung zum städtischen Schwimmbad in der Zorgeaue spielten zwei Beweggründe eine Rolle:

1. Die Grundstücksfrage

2. Die Wasserfrage

Bei der Platzfrage kam „vor allem die leichte und ausgiebige Wasserversorgung der Anstalt in Betracht ${ }^{\star 99}$, damit bei stetem $\mathrm{Zu}$ - und Abfluss ein vollständiges Füllen und Ablassen des im Schwimmbassins enthaltenen Wassers erfolgen kann.

Bei der Benutzung einer Wasserleitung verbleiben drei Möglichkeiten:

1. Entnahme des Wassers aus dem Grundwasser des Zorgeflussbettes,

2. Benutzung des Mühlgrabenwassers.

„Da [...] die Möglichkeit vorliegt, das Wasser des Mühlgrabens oder Kunstgrabens, natürlich künstlich erwärmt, für die Badezwecke zu verwenden, so fällt die meist kostspielige Wasserfrage hier nicht erschwerend ins Gewicht" und die Frage der Wasserversorgung wurde ,im vollsten Maße" zugunsten der Möglichkeit 2 entschieden ${ }^{94}$.

\footnotetext{
${ }^{91}$ Stadtarchiv Nordhausen: Acta Badeanstalt 2. Mai 1891.

92 Stadtarchiv Nordhausen: Acta Badeanstalt 10. April 1891.

${ }^{93}$ Stadtarchiv Nordhausen: Acta Badeanstalt 2. Mai 1891.

${ }^{94}$ Stadtarchiv Nordhausen: Acta Badeanstalt 2. Mai 1891.
} 
Bei einem Schwimmbassin von ca. 13.200 Ltr. Fassungsvermögen, ingesamt 10 „Wannenbadzellen“ mit unter der Annahme einer Fassung von je 150 Ltr. - einem Wasserinhalt von 1500 Ltr. und den zwei „Reservoirbottichen“ mit 300 Ltr. mussten täglich, geht man davon aus dass die Wannenbäder täglich ausgewechselt und das Schwimmbecken nur zu einem Drittel mit Frischwasser neu aufgefüllt worden sind, ca. 6200 Ltr. Wasser dem Mühlgraben entnommen werden. Ob jedoch eine Wiederfüllung des Bassins und Wannen ohne Unterbrechung der Benutzung, also in der Nacht von etwa 21.00 bis 5 Uhr, gänzlich aus dem Mühlgraben möglich sein würde, wurde nach den vorhandenen Unterlagen vorab nicht berechnet.

\section{b.19.2.5 Freibade-Anstalten}

Viel bedeutsamer aber in ihrer umwelthistorischen Wirkung auf die Gewässernutzung waren die späteren „Freibäder“. Solche gingen zumeist aus zunächst freien „Badeplätzen“ bzw. „-stränden“ hervor, die nahezu an sämtlichen Flussläufen lagen.

Ein Beispiel findet sich am Lauenburger Ufer an der Elbe, westlich der Stadt, wie auch auf der gegenüberliegenden Hohnstorfer Seite. Hier hatten sich bedingt durch die Elbströmung große Sandablagerungen mit sauberem Elbsand gebildet, die auch im Wasser sehr flach verliefen. Das um die 20. Jahrhundertwende eingerichtete Hohnstorfer Strandbad war ein Anziehungspunkt für Touristen nicht nur aus der nahen Umgebung. Die Ausstattung bestand aus umfangreichen Freizeitanlagen wie Schaukel- und Spielgeräten, Kiosken und einem Terrassenrestaurant.

Der Lauenburger „Badestrand“ hingegen lag teilweise in Buhnenfeldern und am geraden Ufer, die sehr schnell in tieferes Wasser wechselten. Daher gab es hier auch einen Sprungturm. Die Verbindung zwischen den beiden Badeplätzen erfolgte über die Elbe mit der Lauenburger Fähre.

Diese beiden wichtigen Badeplätze damaliger Zeit konnten spätestens mit Inbetriebnahme der Staustufe Geesthacht 1959 nicht mehr genutzt werden. Als Ersatz entstand in Lauenburg im „Kuhgrund“ das heutige moderne beheizte Freibad - unabhängig vom Wasser der Elbe ${ }^{95}$.

Um etwa 1900 begann auch im Sandbeckerbruch, oberhalb von Gut Sandbeck, die Geschichte des Badewesens in Osterholz-Scharmbeck. Diese erste künstliche Badestelle, nachdem den Badefreuden zuvor in Tümpeln, Teichen, der Hamme und der Beeke gefrönt wurden, verfügte sogar über Umkleidezellen und ein Sprungbrett ${ }^{96}$.

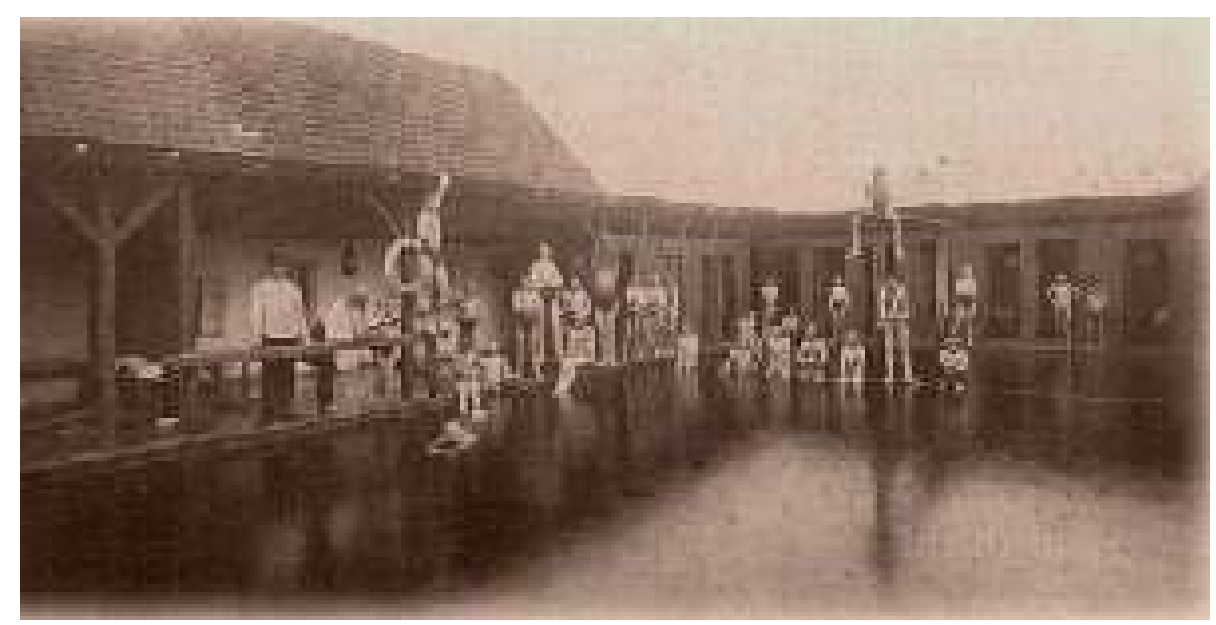

Abb. VI-93: Badeanstalt Sandbeck

Mit dieser Entwicklung in Zusammenhang steht auch die Entstehung der ersten Sportvereine in Deutschland Ende des 19. Jahrhunderts. Hiermit begann sich auch das Leistungsschwimmen zu entwickeln. So gründete sich 1908 in London aus zehn nationalen Schwimmverbänden der Schwimmweltverband FINA (Féderation

\footnotetext{
${ }^{95} \mathrm{URL}=$ http://www.raddampfer-kaiser-wilhelm.de/museum/archiv_sonder/Sonder/Badespass/Badespass.htm; 7.10.2003

${ }^{96} \mathrm{URL}=\mathrm{http}: / / \mathrm{www}$. allwetterbad.de/historie/historie.htm; 07.10.2003
} 
Internationale de Natation Amateur) und im Verlauf der schwimmsportlichen Entwicklung erfolgte eine Polarisierung und Spezialisierung im Schwimmsport nach Schwimmarten und Wassersportarten (Wasserball, Wasserspringen und Synchron- bzw. Kunstschwimmen). Das Sportschwimmen ist seit den ersten Olympischen Spielen 1896 eine olympische Sportart. Vier Jahre später kam dann das Wasserballspiel dazu und seit 1904 ist Wasserspringen olympisch. In Stockholm wurde 1912 das Frauenschwimmen olympisch ${ }^{97}$.

Seit den 1920er Jahren, vor dem Hintergrund der allgemeinen Aufforderung zur Körperertüchtigung und zu Leibesübungen und vor dem Hintergrund des Niedergangs von Flussbadeanstalten, wurden neben den Schwimmhallen künstliche Freiluft-Badeanstalten errichtet, wie ebenfalls ein Beispiel aus Nordhausen zeigt:

Die Aufgabe der Wasserzuführung zu Badezwecken übernahm in diesem Fall aufgrund der näheren Lage zur Badeanstalt nicht die Zorge, sondern die Helme, die die auf einige Monate konzentrierte Wasserzufuhr zur schnellen Aufspannung der Badebecken bewältigen konnte. Dem Nordhäuser Mühlgraben konnte man nicht so viel Wasser entziehen und es ist zu vermuten, dass die Zorge den Wasserqualitätsstandard nicht oder nicht so gut erfüllen konnte wie die an der Stadt vorbeifließende Helme, und auch die Wasserversorgung, zumal sie auch den Mühlgraben mit Wasser versorgen musste, oft nicht gewährleistet schien, denn ,zu Zeiten ist in der Zorge überhaupt kein Wasser vorhanden" 98 Um aber auch bei der Helme über eine ausreichende Wasserversorgung zu verfügen, wurde darin extra ein Stauwehr errichtet:

Auf Grund des rechtskräftigen Beschlusses des Bezirksausschusses in Erfurt vom 1. Mai 1930 Nr. 237 BAW steht der Stadt Nordhausen das Recht zu, $952 \mathrm{~m}$ unterhalb der Kramer'schen Mühle, -Brockenmühle in Nordhausen in den Bademonaten Mai bis September jeden Jahres das Wasser der Helme bis zur Höhe $+177,00 \mathrm{~m}$ N.N. anzustauen, in den genannten Monaten 50-60 sl Helmewasser durch eine Rohrleitung nach dem Volksbade abzuleiten und die gleiche Menge Wasser durch eine Abflußleitung der Helme wieder zuzuleiten. ${ }^{99}$

Dieses Wasserrecht wurde „,von Amtswegen eingetragen“ am 3. Oktober $1930^{100}$.

Das Helme-Wehr wurde als „Dammbalkenwehr“ errichtet, verknüpft mit der Bedingung des ,Preußischen Kultur-Bauamtes, „daß der Dammbalkenverschluß durch einen jederzeit - auch bei Hochwasser bedienbaren - Schleusenverschluß ersetzt werden muß “101.

\section{Zusammenfassung und Ausblick}

Flüsse und Bäche sind seit Anbeginn menschlichen Lebens genutzt, seit Anfang anthropogener Siedlungsaktivitäten auch nachhaltig beeinflusst worden, aber erst mit Beginn von mittelalterlicher und frühneuzeitlicher Industrialisierung, durch eine Vielzahl tiefgreifender Eingriffe wie beispielsweise dem Bau von Wehren, Wasserkraftanlagen, Stauschleusen, Flußbegradigungen sowie toxischen Einleitungen erfuhren sie eine negative, alle Regionen erfassende tiefgreifende Veränderung. Dabei sind es vor allem diejenigen Betriebe gewesen, die das Wasser gleichzeitig zu ihrer Produktion verwendet haben. So unterlagen die Bäche und Flüsse bereits in früherer Zeit einem langandauernden Nutzungsdruck.

Ihr Wasserhaushalt war aus diesen Gründen - neben natürlichen - einer Vielzahl von „künstlichen“ Wasserspiegelschwankungen ausgesetzt. Neben den natürlichen Faktoren Trockenheit, Hochwasser und Eisgang war der Wasserentzug durch Mühlenstau, Bergbau, Wiesenbewässerung und Teichwirtschaft eine der Ursache dieser Schwankungen. Doch gleichzeitig konkurrierten diese Nutzungen um die Wassermengen.

\footnotetext{
${ }^{97} \mathrm{URL}=\mathrm{http}: / /$ www.olympia-lexikon.de

${ }^{98}$ Stadtarchiv Nordhausen: Akte Stadtbauamt, Dezember 1929.

99 Stadtarchiv Nordhausen: „Antrag auf Verleihung eines Wasserrechtes zur Errichtung einer Volksbadeanstalt für die Stadt Nordhausen“ 1927-1930 [X 371].

100 Stadtarchiv Nordhausen: „Antrag auf Verleihung eines Wasserrechtes zur Errichtung einer Volksbadeanstalt für die Stadt Nordhausen“ 1927-1930 [X 371].

101 Stadtarchiv Nordhausen: „Antrag auf Verleihung eines Wasserrechtes zur Errichtung einer Volksbadeanstalt für die Stadt Nordhausen" 1927-1930, Schreiben des ,Preußischen Kultur-Bauamtes' in Erfurt v. 8. Mai 1929 [X 371 ].
} 
Um die Ausnutzung des Bachwassers noch weiter zu optimieren und die natürlichen Schwankungen zu beseitigen bzw. auszugleichen und eine reibungslose Wassernutzung zu ermöglichen, wurden Maßnahmen ergriffen, die den Verlauf des Baches, seinen Querschnitt und seine Uferbereiche weiter veränderten. Die wirtschaftliche Entwicklung und die mit ihr verbundenen baulichen Veränderungen forderten im zeitlichen Fortgang immer wieder Eingriffe in die Wasserläufe.

Dennoch sei dem Eindruck entgegengetreten, in früherer Zeit seien die Gewässer - zumindest in ihrer Physiognomie - in einem schlechteren Zustand gewesen als gegenwärtig. Dies ist, auch wenn die Gewässer einer vielleicht differenzierteren und damit intensiveren Nutzung unterlagen, falsch. Am Ende des 19. Jahrhunderts zeigten ,die meisten der kleineren und auch der größeren Wasserläufe noch ein ,natürlicheres' Bild als heute“(DIX 1997:140).

Die intensive Nutzung der Fließgewässer und die Eingriffe in die Gewässerlandschaft lückenlos zu rekonstruieren, ist aufgrund der Fülle und Komplexität nicht möglich. Bei der Vielzahl der direkten und indirekten historischen Gewässernutzungen, wie zum Beispiel der Waldweidentränke, ist es verständlich, dass nicht alle mit ihrer ausführlichen Geschichte behandelt werden konnten. Und mit Sicherheit fehlen auch noch einige ursprüngliche Gewässernutzungsarten. Des Weiteren ist bei manchen zwar eine intensivere Ausführung geschehen, bei anderen hingegen fiel die Schilderung etwas schmaler aus. Bei wiederum anderen konnte die Situation der kleineren Flüsse und Bäche nur unzureichend präzisiert werden, da auf lediglich von größeren Fließgewässern vorliegende Untersuchungen zurückgegriffen werden musste. In allen Fällen konnten aber - dies jedenfalls Anspruch und Glaube - tiefergehende Eindrücke historischer Wassernutzungen gewonnen werden. In der präsentierten Zusammenschau entstand das Gefüge von ineinander greifenden wie einander bedingenden Nutzungen vor allem von solchen Gewässern, die heute als klein erscheinen. 


\section{Ausgewählte Anlagen und Elemente anthropogener Gewässernutzung}

Im vorigen Kapitel wurden die zahlreichen historischen anthropogenen Gewässernutzungen beschrieben.

In diesem Abschnitt sollen einige daraus resultierende bauliche und morphologische Gewässerformen ehemaliger Gewässerinanspruchnahmen, die direkt im oder am Flußlauf lokalisiert sind bzw. waren, d. h. mit diesem in unmittelbarer räumlicher Nähe und nutzungsbezogener Verbindung stehen bzw. standen, herausgearbeitet werden. Solche vergangenenen Anlagen und Elemente früherer Gewässernutzungen sind oftmals noch im Weichbild der Landschaft vorhanden, wenn vielfach auch nur in Resten wahrnehmbar und zumeist auch nicht mehr in Gebrauch; deshalb der sich oftmals überschneidende grammatikalische Gebrauch von Vergangenheit und Gegenwart. Historische Gewässeranlagen sind aber nicht nur einfach abgeleitete Kunstformen ehemaliger Eingriffe in Gewässer. Die verschiedenen Arten des Wassergebrauchs setzen zum Teil diese künstlichen Eingriffe erst voraus, die wiederum als künstliche Anlagen raumgestaltend und kulturlandschaftsprägend wirken. ,Teiche' z. B. sind solche einzelnen, oft auch miteinander verbundenen Elemente einer komplexen Landschaft, die einen historischen Landschafts- und Wirtschaftszusammenhang kennzeichnen. So war die Anlage von Fisch- und Mühlenteichen zunächst gebunden an wasserhaltenden Auelehm und wurde ,sehr wesentlich ermöglicht durch die ackerbaulich bedingte Abtragung bzw. der Einschwemmung von Feinboden in die Talzonen hinein.“ (DENECKE 1992:17). Es besteht also ein siedlungs- und wirtschaftsgeschichtlicher Zusammenhang zwischen Rodung und Ackerbau einerseits und der Anlage von naturgemäßen Teichwirtschaften infolge von Auelehmbildung andererseits. Es sind diese Formen der umwelthistorischen landwirtschaftlichen Wassernutzung, die zum einen aufgrund ihrer kulturlandschaftlichen Bedeutung und zum anderen aufgrund ihrer schon historischen Bewirtschaftungsweise im Folgenden einen besonderen Stellenwert einnehmen.

Hinsichtlich der Objektauswahl sollen aber nur solche künstlichen Anlagen betrachtet werden, die unmittelbar zur Gewässernutzung entstanden sind. Wassergefüllte Kleinformen (wie z. B. Torfstichgewässer, Mergelgruben, Töpferteiche), die zwar anthropogener Entstehung, aber eher zufällig durch zu hohen Grundwasserstand im Rahmen des Torfabbaues, der Mergelung für den Flachsanbau, des Tonabbaus und nicht durch Gewässerbenutzung entstanden sind, fallen nicht in diesen Betrachtungsrahmen.

Im Mittelpunkt der Ausführungen steht der Gewässertypus der Fischteiche. Fischerei-, mühlen- und landwirtschaftliche Bewirtschaftungsformen haben diese physiognomische Situation an zahlreichen Stellen in der Landschaft hinterlassen. Gleichwohl nur selten zu erkennen ist, „daß Fischteiche erst das Ergebnis menschlicher Naturgestaltung sind. Das liegt an der Landschaftsgebundenheit der Teichwirtschaft" (RUST 1956:43). Diese spezifischen anthropogenen Gestaltelemente eines Fischteiches - aber auch die anderer Teichformen -, die die nach Zahl und Fläche bedeutsamsten Anlagen ehemaliger gewässerbezogener Wirtschaftsweisen beschreiben, sollen schwerpunktmäßig im Folgenden benannt werden.

Die Quellen zur mittelalterlichen Wirtschaft liefern aber nur sehr wenige Hinweise auf die Fischzucht. Selbst die sonst sehr aussagekräftigen klösterlichen Quellen, die Statuten des Klosters Corbie und der St. Gallener Klosterplan ${ }^{1}$, einer idealen Vorstellung einer Klosteranlage des Frühmittelalters, enthalten keine Hinweise, wie der Bau der Fischteiche organisiert war und wie sie bewirtschaftet wurden. Aus dem ersten Abschnitt der Statuten von Corbie geht lediglich hervor, daß die Pfründner (provendarii) des Klosters in zwei Gruppen unterteilt werden: diejenigen, die ,infra monasterium', und die, die ,extra monasterium' arbeiteten. Zu den Handwerken, die außerhalb der Klostermauern lagen, gehörten die Mühlen, die Ställe, die Gärten und die Fischereien, zu deren Bewirtschaftung Pfründner bestimmt wurden (LAMPEN 2000:138). Auch der Plan zeigt zwar eine detaillierte Gestaltung des Wirtschaftsbereichs, in dem alle aus den Kapitularien bekannten Handwerke verzeichnet sind, „um so erstaunlicher ist es, daß die Fischereien fehlen: Es sind weder Fischteiche eingezeichnet, noch sind

\footnotetext{
${ }^{1} \mathrm{Zu}$ dem St. Gallener Klosterplan gibt es eine Vielzahl von Publikationen; z. B. von ZETTLER 1990
} 
spezielle Vorrichtungen für die Verarbeitung der Fische vorgesehen. “2 Durch die Hinweise aus den Statuten „kann jedoch davon ausgegangen werden, daß die Fischereien extra monasterium, wahrscheinlich bei den Mühlen, angesiedelt waren.“(:138)

Zur Erfüllung des historisch-geographischen Anwendungs- und Pflegebezuges ist es aber wichtig die Fragen des „wo und wie wurden die Fischteiche gebaut?“ zu beantworten. Um eine historische Rekonstruktion zu ermöglichen sind des Weiteren die Fragen zu klären: „Wie wurde die Fischzucht gehandhabt?" und „Welche Fische wurden gezüchtet?" Gleichlautende Fragen hatte sich bereits AMACHER (1996:18) am Beispiel des Untersuchungsraumes der Schweiz gestellt und sie versucht anhand schriftlicher Originalquellen zu beantworten. Während die letzten beiden Fragen detailliert erörtert wurden, blieb die erste Frage unbefriedigend beantwortet. Der geographische, insbesonders großräumige Aspekt des „wo“ wurde ebenso wenig ausreichend berücksichtigt wie der handwerklichtechnische Aspekt des ,wie“.

Es geht mir im Folgenden deshalb auch darum, die praktizierte Teichwirtschaft in ihrer besonderen Art und Weise der Ausübung zu beschreiben. Denn nur mit dem historischen Wissen der ,Practischen Teichwirthschaft', „welche lehret, neue Teiche anzulegen, alte auszubessern, in denselben, zu gehöriger Zeit, Fische anzuziehen und zu erhalten, als auch dieselben Teiche wiederum, auf gehörige Art, als Gartenland, Ackerland und Wiesen zu gebrauchen“ (DYHRN 1782:5), können Fischteiche als prägendes Element der historischen Kulturlandschaft bewahrt resp. wiederhergestellt werden, wie es unter dem Leitbild ökologisch-orientierter Renaturierung mit zahlreichen Fließgewässern schon seit vielen Jahren praktiziert wird (siehe Kap. E IX).

Dass dabei gerade auch die Ausführung früherer Teichbewirtschaftung eine gegenwartsbezogene Bedeutung besitzt, darauf verweist LIEPELT (1992:54f.) wenn er ausführt, dass ein effektiver Schutz des Lebensraumes ,Fischteich' auf Dauer nur sinnvoll und möglich ist, „wenn die Nutzungsweisen, die zu seiner Entstehung geführt haben, bekannt sind und (wenn auch mit geringer Anpassung an die heutigen Lebensumstände) fortgeführt bzw. wiederaufgenommen werden (z. B. Art und Stärke des Fischbesatzes, Technik der Wasserstandsregulierung und des Entlandens, Methoden der Fütterung und Düngung etc.). Hinzu kommt das Wissen über eventuelle Nebennutzungen wie Ernte von Rohrkolben als ,Büttnerschilf', Zucht medizinischer Blutegel oder gar Anbau von Getreide auf dem Teichboden in Jahren der Dürre. [...] Die daraus gewonnenen Erkenntnisse sind für die zukünftige Kulturlandschaft nutzbar zu machen.“

Auch nach JÄGER (1965b:421) sind für die historische Landesforschung besonders Sonderkulturen von Belang, ,deren Anbau sich mit bestimmten gesellschaftlichen oder agrarischen Verhältnissen verbindet". JÄGER nennt beispielhaft die Tabakkultur, aber auch die Teichwirtschaft oder die FeldTeich-Wechselwirtschaft, die ebenso zu den landwirtschaftlichen Sonderanbauten zählt und von ihm als Ausdruck volkswirtschaftlicher Verhältnisse bezeichnet wird.

Die Schwierigkeit einer Aufarbeitung und Darstellung früherer Teichbewirtschaftungsformen ist vor allem vor dem Hintergrund der zumeist benutzten schriftlichen Altquellen zu sehen, die eine solche Auskunft aber gar nicht zulassen, wie das oben genannte Beispiel AMACHERs zeigt. Die Rekonstruktion der ehemaligen Fischzucht, will sie umsetzbare Ergebnisse erzielen, muss auf neuzeitlichen Schriften beruhen. Ausgehend von dem Hintergrund, dass sich in der Teichbewirtschaftung bis zum Beginn des 20. Jh. und in einzelnen ländlichen Rückzugsräumen gar bis Mitte der 1960er Jahre, d. h. vor den Einsetzen der umfassenden Modernisierungs- und Technisierungswelle, die wesentlichen Arbeitsweisen nicht verändert hatten, müssen ältere Fachbücher und andere Sekundärliteraturen ausgewertet werden, will man einen anwendungsorientierten Beitrag historisch-geographischer Art leisten. Bei dieser Aufgabe kommt dem Verfasser das geschriebene Vorurteil zum Charakterikum des ,Fischers' entgegen, der für die Unveränderlichkeit, dabei aber nicht Gleichartigkeit, der Fischereimethoden steht und so eine Kolportierung der historischen Teichbewirtschaftung in die Neuzeit erst ermöglicht: "Der Fischer [...]

\footnotetext{
${ }^{2}$ In einem Plan des Wassersystems der Abtei von Canterbury aus der Mitte des 12. Jh. ist ein Raum eingezeichnet, der ausschließlich zum Waschen der Fische diente (BOND 1988: 71, Fig. 1.)
} 
mit verschwindenden Ausnahmen reist nicht und er liest nicht [...] nicht einmal was ihn und sein Gewerbe unmittelbar berührt [...] und er unterrichtet sich also nicht. Er [...] fischt mit denselben Geräthen, welche dort immer in Gebrauch waren. [...] Die Fischer müßten reisen wie andere Handwerker, ja sie haben es noch mehr nöthig als diese, denn die Verschiedenheit der Fischereimethoden ist eine ganz außerordentliche.“(DALLMER 1886:334f.)

In dieser Indolenz der deutschen Fischer mag auch ein Grund zu sehen sein, warum es - angesichts der früheren wirtschaftlichen und flächenmäßigen Bedeutung - nur eine relativ geringe Anzahl von (deutschsprachigen) Lehrbüchern und Fachzeitschriften zur Teichwirtschaft gibt, auf die ich hier zurückzugreifen gezwungen bin. Gleichzeitig aber kann davon eine nur geringfügige Veränderbarkeit der Methoden abgeleitet werden, wie sich einer Veröffentlichung des BAYERISCHEN LANDESAMTES FÜR WASSERWIRTSCHAFT (2001) zum ,Bau und Betrieb von Fischteichen' entnehmen lässt.

Da also die Teichwirtschaftstraditionen nahezu bruchlos vom Mittelalter zur Neuzeit bisweilen sogar in die Moderne übergehen, darf man mit den nötigen Einschränkungen (z. B. Baustoffe, Futtermittel, Personaleinsatz) Darstellungen des 16. bis 19. Jahrhunderts auf ältere Zeitläufe retrospezieren (vgl. die Meinung von SPINDLER [1988:48] zur Kanalbauwartung und -pflege).

\section{Teiche}

\section{a Begriff des Teiches}

Das Wort ,Teich' [mhd.: tich] wird, genauso wie in Süddeutschland das Wort Weiher, in den einzelnen deutschen Landschaften in sehr verschiedenem Sinne gebraucht. Doch weder die Definition, dass ein Teich „kleiner als ein See“ sei, noch die Definition, dass ein Weiher „ein See ohne Tiefenregion“ ist (PICHLER 1947), ist haltbar. Derartige Begriffsfestlegungen sind nach Erachten von SCHÄPERCLAUS (1961:147), ,völlig abwegig“.

Im umgangssprachlichen Bereich wird gar der Begriff ,Karpfenteich' für alle Teiche verwendet (siehe Pkt. 2a), zumindest aber für alle Fischteiche; wahrscheinlich aus dem Grund, weil Karpfen in fast jedem Gewässer zu ziehen sind. In genauer Auslegung der Zweckbestimmung sind aber nur solche Teiche als Karpfenteiche zu bezeichnen, „worinnen Karpfenfische, oder gar im genauesten Verstande, worinnen eigentlich sogenannte Karpfen gezogen werden.“ (DYHRN 1782:8)

Obgleich DYHRN hier bereits den Versuch einer funktionalen Differenzierung unternimmt, versteht er in enger fischereiwirtschaftlicher Auslegung unter einem Teiche „nie etwas anderes, als ein Stück Land, welches, wenigstens um in rechter Ordnung Fische darauf zu ziehen und zu erhalten, nach Erforderung der Umstände, sowohl unter Wasser gesetzet, als auch wiederum von demselben entblößet werden kann.“ (1782:8) Auch TAURKEs (1927:131) über 50 Jahre später vorgenommene Auslegung des Begriffes, Teich' weist eine einseitig fischereiwirtschaftliche Bedeutung auf, bezieht aber andere Teichformen mit ein: „Man kann aber auch die kleinen Dorf-, Hof- und Feldtümpel, wenn sie auch nicht ablaßbar sind, manchmal zu den Teichen rechnen, nämlich dann, wenn sie 1. von Wildfischen frei gehalten, 2. vollständig abgefischt werden können, 3. düngende Zuflüsse erhalten, welche die Trockenlegung und sonstige Pflege ersetzen." Und führt an späterer Stelle (:120) in gleicher Weise aus: „Weil aber viele Tümpel und Wasserlöcher, falls sie gut abfischbar sind, so wie Teiche bewirtschaftet werden können [...], werden sie trotzdem in der Praxis oft als Teiche bezeichnet.“"

Bei der begrifflichen Festlegung des Wortes Teich sind aber neben den Dorf-, Hof- und Feldtümpel mit ,integrierter' fischereiwirtschaftlicher Nutzung noch $\mathrm{zu}$ anderen Zwecken angelegte ,Wasserlöcher' zu ergänzen. Als funktionale Teichtypen sind dies entsprechend ihrer Nutzungs- oder Entstehungsweise beispielsweise Mühlteiche, Hammerteiche, Trinkwasserteiche, Feuerlöschteiche, Dorfteiche, Parkteiche, Eisteiche usw. „Teiche“, so auch KEIZ (1995:18) „wurden in alter Zeit aus den verschiedensten Gründen angelegt, sei es zu Befestigungszwecken oder etwa zum Betrieb 
mechanischer Werke mit Wasserkraft, als Wasserreservoir zum Löschen von Feuersbrünsten oder für die Haltung von Wassergeflügel.“ Doch KEIZ stellt - wie die alten Autoren zuvor - die fischwirtschaftliche Bedeutung als logische Folge heraus, indem er sagt: „Die Nebennutzung dieser Teiche mit Fischen lag auf der Hand" (:18). Ebenso sollten nach SCHÄPERCLAUS (1961:10) die unterschiedlichen Teichformen „möglichst weitgehend zur Fischzucht herangezogen werden.“

Die fischereiwirtschaftliche Inwertsetzung von Teichen gleich welcher ursprünglichen Hauptnutzung und begründet damit die fischlastige Definition von Teichen wird hieraus deutlich, wird aber den eigentlichen baulichen Charakteristika nicht gerecht, die sowohl DYHRN als auch TAURKE in ihren begrifflichen Umschreibungen bereits angerissen haben.

Eine erste, die konstruktive Seite beinhaltende Umschreibung lieferte BENECKE (1885:1). Er definierte Teiche als „stehende Gewässer beliebiger Größe, die willkürlich trocken gelegt (abgeschlagen) und wieder mit Wasser gefüllt (angespannt) werden können.“. Ein Jahr darauf bezeichnet BORNE (1886:218) mit Teich ,ein Wasserbecken, welches angestaut und trocken gelegt werden kann, im Gegensatz zum See, der nicht abgelassen werden kann.“ Nach VOGEL (1898:21) sind Teiche, „im Sinne eines rationellen Teichwirthschaftsbetriebes, Anstauungen von Wasser, bewirkt durch ein Stauhinderniß auf Aeckern, Wiesen, Waldthälern und auch Oedländereien mit der Grundbedingung, daß jederzeit die gesammte Wassermenge aus dem Teiche abgelassen werden kann, durch eigenen freien Lauf, ohne mechanische Kraft.“

Auch TAURKE ergänzt das teichspezifische Kennzeichen der Ablassbarkeit an zwei Stellen in seiner Veröffentlichung. Teiche, so seine erste Definition sind „ablaßbare Gewässer, welche von Menschen durch Aufstauen von Wasser vermittelst eines Dammes hergestellt werden.“ (TAURKE 1927:130). Dabei sollte der Ausdruck Teich „für ein natürliches Gewässer [...] nicht gebraucht werden, da man unter einem Teich“, und wiederholt das besondere Kennzeichen in seiner zweiten Begründung „ein künstlich aufgestautes Gewässer versteht, welches man ablassen kann.“(:120)

In Zusammenfassung dieses Begriffssinns ist ein Teich „kein gegrabenes Loch“ (LIETMANN 1941:8), sondern ein künstlich über dem Gelände durch einen Damm gestautes, stehendes Gewässer beliebiger Größe und Tiefe, das jederzeit angefüllt (gespannt) oder abgelassen werden kann. Alle nicht ablassbaren Gewässer gehören nicht zu den Teichen (VOGEL 1898:21). Die begriffliche Festlegung durch die Nutzungsart, beispielsweise die Bezeichnung Fischteich für einen zur Fischnutzung angelegten Teich, lässt zwar den primären Zweck der Anlage eindeutig erkennen; seine eigentliche Nutzung ist jedoch oftmals wesentlich vielseitiger, und so vermischen sich Haupt- und Nebennutzungen zu einer komplexen Nutzungsgeschichte. Doch auch diese verschiedenen Nutzungen werden unter den folgenden Begriff des Teiches mit eingeschlossen. Teiche können somit verstanden werden als „eine Sonderform des Wasserstaues“ (KEIZ 1995:18), die hinsichtlich der Charakteristika einer weitergehenden typologischen Differenzierung unterliegen.

\section{b Teicharten}

Abhängig von verschiedenen Kriterien hat man versucht, die Teiche in verschiedene Arten einzuteilen (WUNDER 1956:58). Die Klassifizierung der Teiche ergibt sich daraus wie folgt. Der zum Teil starke fischereiwirtschaftliche Hintergrund lässt sich dabei nicht vermeiden, ebenso wenig wie die wiederholte Aufführung der funktionalen Gliederung, die sich der Vollständigkeit halber in Listenpunkt 10 wieder findet:

1. Nach ihrer Größe

2. Nach der Art ihres Grundes

3. Nach der Tiefe

4. Nach der Temperatur des Wassers

5. Nach der Herkunft des Wassers 
6. Nach der Dauer ihrer Bespannung

7. Nach der Zeit, während welcher die Teiche Fische beherbergen

8. Nach der in Teichen gezüchteten Fischart

9. Einteilung der Teiche nach ihrer Ertragsfähigkeit und Güte

10. Nach ihrer Lage und Funktion

11. Unterscheidung der Teiche nach ihrer Entstehung

\section{zu 1: Unterscheidung der Teiche nach ihrer Größe}

Teiche werden nach ihrer Größe in große und kleine Teiche unterschieden. Eine konkrete Größenangabe ist dabei in der allgemeinen Literatur nicht zu finden. Einzig in der fischereifachlichen Literatur sind entsprechende, wenn auch zum Teil nur vage, Versuche einer größenmäßigen Zweiteilung unternommen worden:

ZOBEL (1992:10) definiert Kleinteiche als „Gewässer, die nur einige Quadratmeter groß sind.“ DYHRN (1782:16) hingegen definiert Kleinteiche nach ihrer Besatzdichte mit Karpfen, ,worein aufs höchste einhundert Schocke ${ }^{3}$ zu Karpfen eingesetzt werden können.“ Eine genaue Verhältniszahl, aus der man der Größe berechnen könnte, bleibt er jedoch dem Leser schuldig. Kleine Teiche, so heißt bei ihm weiter, geben, weil sie wärmer und nahrungsreicher als große sind, verhältnismäßig höhere Erträge und seien aufgrund ihrer besseren Temperatureigenschaften die Teiche des Karpfens. In dieser, die Charakteristika der Kleinteiche beschreibenden, Art ohne die Benennung einer konkreten Größenangabe versuchen sich auch die anderen Autoren der Teichwirtschaft.

Bei TAURKE (1927:16) ist lediglich zu lesen, dass kleine Teiche einer intensiveren Befütterung als große Teiche bedürfen, denn ,nur bei Anwendung der Wasserdüngung und der Fütterung können die [...] zahlreichen Fische in demselben Teiche groß gezogen werden.“

In Kleinteichen wird des Weiteren vor allem die Erzeugung von Speisefischen oder Satzfischen empfohlen (ZOBEL 1992:12). Das bedeutet, in kleinen Teichen wird die Arbeitstechnik des einjährigen Umtriebs durchgeführt: die Teiche werden in jedem Frühjahr mit Fischen besetzt und im Herbst desselben Jahres wieder abgefischt; der Teich liegt dann den Winter über trocken (WALTER 1933:29). Die Besetzung erfolgt dergestalt, „daß im 1-jährigen Umtrieb 2-sömmrige Karpfen zu marktfähigen Speisefischen heranwachsen." (RUST 1956:43). Kleinteiche haben demzufolge, indem sie der Erzeugung von Speisefischen dienen, den Zweck der reinen sog. Abwachsteiche im Gegensatz zu Großteichen, die zu verschiedenen Funktionen angelegt wurden.

RUST (1956:43) unternimmt eine Unterscheidung der Teiche in Anlehnung an die Betriebsgröße. Er definiert Betriebe mit Teichflächen unter 3 ha Größe als „Kleinteichwirtschaften“ und Teiche innerhalb dieser Kleinteichbetriebe werden von ihm einfach als „Kleinteiche“ bezeichnet.

Definitionen zu großen Teiche - gleich welcher Art - wurden in der zur Verfügung stehenden Literatur gar nicht gefunden, lediglich der Begriff „Großteiche“ für sich genommen und die Aussage, sie seien gewöhnlich tiefer und daher auch kälter als kleine Teiche.

Die Definitionsversuche zur Bestimmung und zur Unterscheidung von Klein- und Großteichen orientiert sich demzufolge an der Besatzdichte, dem Temperatur- und Tiefenverhältnis und an der Zugehörigkeit zu einer Betriebsgröße. Sie bleiben jedoch unklar und subjektiv.

\footnotetext{
${ }^{3}$ Die edlen Speisefische (Hechte, Karpfen, Weißfische usw.) wurden nach „Schock“ gezählt (1 Schock = 60 Stück Fische); die weniger wertvollen maß man mit Gefäßen (1 Schock $=1$ Zuber (Zober), ein Gefäß mit zwei Griffen (nach FORELLENZUCHT_LAUTERTAL 2004; RADEBURG 2004)
} 


\section{Zu 2: Unterscheidung der Teiche nach Art ihres Grundes}

Nach der Art ihres Untergrundes können schlammige und kiesige Teiche oder Teiche auf Sand-, lehmigen Sand-, Lehm- und Tonboden unterschieden werden. WUNDER (1956) wie auch LIETMANN (1941:8) klassifizieren nach unterschiedlichen Böden 4 Teichtypen:

\section{Der arme sterile Sandteich}

Derartige Teiche wie auch die ganze Umgebung sind vielfach dadurch gekennzeichnet, dass sie dürftigen Pflanzenwuchs aufweisen. Teiche mit Sanduntergrund weisen meistens einen stark wasserdurchlässigen Boden auf, infolgedessen der Wasserstand zur heißen Jahreszeit nachlässt. Im Umgebungsbereich findet man bei dem Sandboden mangelhaft wachsenden Kiefernwald. Der „arme sterile Sandsteich“ ist der Teich der Heide (WUNDER 1956:58).

Bei diesem Teichtyp vergehen „Jahre, bis nach Verbesserung des Kulturzustandes, nach Anreicherung des Gewässers mit Nährstoffen, nach stärkerer Besiedlung mit weichen höheren Wasserpflanzen [...], nach Anreicherung mit Nahrungstieren der Fische und nach Bildung einer gewissen Schlammschicht" ein ausreichender Fischertrag erreicht werden kann (WUNDER 1956:59). WUNDER vergleicht einen sterilen Sandteich mit einem neu ausgebaggerten Teich: „Es vergehen oft 2-3 Jahre, bis die Voraussetzungen erfüllt sind.“(:59)

2. Sandteich mit hart verwachsenen Rändern

Dieser Teichtyp bezeichnet einen Teich mit Sanduntergrund, der mehrere Jahre zur Fischzucht benutzt wurde. Bei flachen Rändern stellt sich sehr bald vom Ufer her eine Verwachsung mit harter Flora (Schilf, Rohr, Seggen usw.) ein, die diesen Teichtypus kennzeichnen (WUNDER 1956:59). Diese Teiche können „meistens leicht trockengelegt werden“ und bieten „für die Bodenbearbeitung und landwirtschaftliche Nutzung keine Schwierigkeiten“ (:60). Auch „hart verwachsene Gegenden des Bodens solcher Teiche können dadurch für die Produktion im Teich wieder zurückgewonnen werden, daß sie geackert [...] werden.“ (:50).

3. Teiche mit tonigem oder lehmhaltigem Untergrund

Diese Teiche besitzen einen undurchlässigen, tonigen oder lehmigen Untergrund. Es handelt sich meistens um „die fruchtbarsten Teiche“ (WUNDER 1956:61), die „unter Umständen schwer trockengelegt und bebaut werden“ können (:60).

4. Teiche mit moorigem Untergrund

Dies sind Teiche in Heide- und Moorgegenden mit vielfach ph-saurem Wasser. Deshalb ist der Untergrund in der Tiefe meistens stark versauert. Es haben sich oft riesige Mengen bräunlicher, modernder Pflanzenmassen abgelagert, welche Torf bilden. „Wenn dieses Wasser aber eine Zeitlang steht und von Pflanzen besiedelt wird, ändert es seinen Zustand vollständig” Es kann dann „für die Speisung von Fischteichen sehr wohl nutzen.“(WUNDER 1956:61) Die Nutzung beschränkt sich aber aufgrund des Wasserchemismus auf die Karpfenzucht.

\section{zu 3: Unterscheidung der Teiche nach der Tiefe}

Nach der Tiefe werden Teiche in ,flache' und ,tiefe Teiche' eingeordnet. Flache Teiche sind solche bis $\mathrm{zu} 1$ oder $1 \frac{1}{2} \mathrm{~m}$ Wassertiefe; solche mit höherem Wasserstand werden tief genannt (WALTER 1933:25)

\section{zu 4: Unterscheidung der Teiche nach der Temperatur}

Nach der Temperatur des Wassers werden Teiche in ,kalte' und ,warme Teiche' eingeteilt. Kalt sind die Quellteiche, warm die Bach-, Fluss- und Himmelsteiche, besonders wenn sie flach sind (zur Unterscheidung nach Art des Wasserzuflusses siehe Nr. 5).

Warme Teiche sind „,im wesentlichen für Enpriniden (karpfenartige Fische) [...] geeignet“ (WALTER 1933: 11). Sie werden deshalb auch „Karpfenteiche“ genannt (:30), während kalte Teiche „im wesentlichen [...] für Salmoniden (forellenartige Fische) geeignet" sind (:11) und deshalb synonym 
auch als „Forellenteiche“ (:44) bezeichnet werden. Die kalten Teiche ,erhalten ihren Charakter entweder durch die Höhenlage oder durch ihren Zufluß von sommerkühlen Quellen oder Quellbächen. Im Flachland überwiegen deshalb ganz die warmen, im Gebirge die kalten Teiche." (:44) Obgleich es auch in den tieferen Gebirgslagen Teiche und Staubecken gibt, ,in denen der Karpfen noch gedeiht" (:44), so genießt hier ,die Forelle den Vorzug“ (:44), weil sie dem kühlen Wasser der Quellregionen wie beispielsweise in Quellbächen und Quellteichen besser angepasst ist (:44).

\section{zu 5: Unterscheidung der Teiche nach der Herkunft des Wassers}

Die Teiche werden nach Art und Herkunft des Wasserzuflusses eingeteilt in:

1. Himmelsteiche

2. Quellteiche

3. Bach- und Flussteiche

(BENECKE 1885:1; BORNE 1886:218f.; LIETMANN 1941:8; SCHÄPERCLAUS 1961:147; WALTER 1933:10; HUBERT 1991:14).

Die Art der Wasserversorgung ist insofern von großer Bedeutung, als dass nur dann Fischzucht betrieben werden kann, wenn, wie BORNE (1886:295) es ausdrückt, "wir den rechten Fisch in's rechte Wasser bringen". Deshalb ist es so ,wichtig zu wissen, welche Eigenschaften des Wassers die verschiedenen Fischarten zu ihrem Gedeihen brauchen und wie unsere Gewässer in dieser Beziehung beschaffen sind.“(:295).

\section{zu 1. Himmelsteiche}

Himmelsteiche werden diejenigen Teiche genannt, die über keinen regelmäßigen bzw. ständigen Wasserzulauf verfügen, d. h. ohne Zufluss aus Flüssen oder Quellen allein vom atmosphärischen Niederschlagswasser und Schmelzwasser gespeist werden, das teils direkt in sie hineinfällt, teils von umliegenden, höher gelegenen Ländereien abfließt (BENECKE 1885:1; WUNDER 1956:9; PLANANSKY 1983:79; ZOBEL 1992:57). Himmelsteiche werden also vorwiegend aus den Regenund Schneefällen (sog. Tagewasser) des umgebenden Niederschlagsgebietes und durch Gräben gefüllt (SCHÄPERCLAUS 1961:147). „Manchmal enthalten sogenannte Himmelsteiche jedoch auch kleine Quellen auf dem Grunde“ (TAURKE 1927:132).

Ihr Kennzeichen ist, dass sie in der Regel „bei trockenem Wetter versiegen“ (BORNE 1886:218f.), insbesondere dann, wenn die Teiche geringer Tiefe sind und es zu jahreszeitlich starker Erwärmung kommt. „Versiegt ihr Wasser [...] auch in trockenen Sommern nicht gänzlich, so können sie auch als Streck- oder Abwachsteiche dienen.“ (TAURKE 1927:132) Besonders für Himmelsteiche ist es deshalb ,sehr vorteilhaft, wenn eine Anzahl von beständig laufenden Drains in sie ausmündet, deren Wasser im Sommer verhältnismäßig kühl ist.“ (BENECKE 1885:2) Himmelsteiche, die nur auf die Niederschläge der Umgebung angewiesen sind, passen sich auch in ihrer Temperatur der Umgebung an: „Wir haben es [...] meist mit warmen, für Karpfen geeigneten Teichen zu tun.“ (WALTER 1933:10)

Himmelsteiche in freier Feld- und Wiesenlage lassen des Weiteren gute Erträge erwarten, weil sie aufgrund ihrer primären Wasserzufuhr als raubfischsicher gelten (RUST 1956:45). Aber nur sofern in Trockenzeiten ihr Wasserspiegel nicht zu sehr absinkt und die Niederschläge ausreichend sind. In anderem Falle, d. h. in extremen Trockenzeiten müsste oft notabgefischt werden (WALTER 1933:10; PLANANSKY 1983:79).

zu 2. Quellteiche

Quellteiche sind solche Teiche, welche direkt von Quellen gefüllt werden. Sie erhalten ihr Wasser aus Quellen, die im Teich aufgehen oder sich oberhalb am Rande des Teiches befinden (SCHÄPERCLAUS 1961:147; PLANANSKY 1983:79; ZOBEL 1992:57). 
Es finden sich in dieser Gruppe aber auch Übergänge einerseits zu den Himmelsteichen, andererseits zu den Bachteichen, in letzterem Falle dann, „,wenn der Zufluß aus kleinen, kühlen und klaren Quellbächen besteht.““(WALTER 1933:10)

Die Quellteiche im eigentlichen Sinne enthalten also „im Grunde oder an ihrem Rande Quellen, die bei mäßiger Ergiebigkeit nur den durch die Verdunstung verursachten Abgang ersetzen und den Wasserstand ziemlich konstant erhalten, bei reichlichem Zufluß aber den Abgang eines Baches oder Flusses aus dem Teiche zur Folge haben." (BENECKE 1885:1) Solche Teiche sind kühl, enthalten keinen Schlamm und sind ,infolge dauernder, stauender Nässe weniger fruchtbar“, aus diesen Gründen „mehr für Forellen geeignet“ (TAURKE 1927:31) und haben in der Regel „einen konstanten Wasserstand.“(PLANANSKY 1983:79)

Teiche aber, so eine alte teichwirtschaftliche Ansicht, die durch Quellwasser gespeist werden, ,sind zur Ueberwinterung von Fischen nicht brauchbar, denn diese sticken in der Regel, sobald sich die Wasserfläche - wenn auch nur zum Theil - mit Eis belegt.“ (BORNE 1886:225) Diese Nutzungsbegrenzung gibt gleichzeitig einen Hinweis auf die ehemalige Funktionalität eines solchen reinen Quellteiches, wurde er als Fischteich genutzt. Er konnte demnach verschiedenen Zwecken innerhalb einer Forellenbewirtschaftung dienen, nur nicht zur Winterung. Ob jedoch ein ,Quellteich' überhaupt aufgrund seiner konstanten Wassertemperatur zufrieren könnte und ob hier ein Sauerstoffmangel eintreten kann, muss an dieser Stelle unbeantwortet bleiben, sollte jedoch zu Nachforschungen anregen.

\section{zu 3. Bach- und Flussteiche}

Bach- und Flussteiche, auch als Durchflussteiche, sog. „Wehren“ (PLANANSKY 1983:79) oder zusammenfassend als „Fließteiche“ (LIETMANN 1941:8) bezeichnet, erhalten ihr Wasser von Bächen oder Flüssen (ZOBEL 1992:57), die „entweder durch sie hindurchgehen, oder mit denen sie durch längere oder kürzere, größere oder kleinere Gräben, Gerinne oder Kanäle verbunden" sind (BENECKE 1885:1). Bach- und Flussteiche können deshalb je nach der Art der Anlage sein (nach SCHÄPERCLAUS 1961:148):

- Talsperren- oder Bachverbauungsteiche, bei denen der Bach oder Fluss in einem Tal durch einen Damm angestaut wird, oder

- Zuleiterteiche, bei denen von einem Bach oder Fluss ein Zuleitungsgraben abgezweigt wird, der die Fischteiche speist. Hierzu sind auch die Teiche zu rechnen, deren Zuflusswasser durch Pumpen aus benachbarten Seen oder Fließen gehoben und durch Gräben in die Teiche geleitet wird.

Gemeinsam ist den Bach- und Flussteichen, dass sie aus fließenden Gewässern gespeist werden (BORNE 1886:218f.). Bach- und Flussteiche, die von größeren Bächen gespeist werden und deshalb ständige Zuflüsse haben, sind jedoch „nicht raubfischsicher“ (RUST 1956:45).

Diese Bäche haben des Weiteren nach längerem Lauf bereits den Quellwassercharakter verloren, die Niederschläge des Durchflussgebietes aufgenommen und im Sommer hohe Temperaturen angenommen. Die Bachteiche können sich je nach dem Charakter des eigenen und des vom Bach durchflossenen Gebietes aus diesen Gründen (Nährstoffzufuhr) als mehr oder weniger fruchtbar erweisen. Ihr Ertrag ist jedoch im Vergleich mit den anderen Zuflusstypen am schlechtesten und sie eignen sich ihrer höheren Temperaturen wegen mehr für Karpfen als für Forellen. Nur die Regenbogenforelle kommt für ausgesprochenes Niederungswasser noch in Betracht (WALTER 1933:10f.).

Eine künstliche Düngung dieser Teiche ist wegen der Ausschwemmungsgefahr meist unmöglich und eine Beifütterung mangels natürlicher Nahrung fast unrentabel. Sichere Wasserverhältnisse und rasche Auffüllung nach ihrer Abfischung sind ihre Vorteile (PLANANSKY 1983:79) 
Dieser Teichtypus verdeutlicht hinsichtlich seiner Konstruktion von allen drei Teichtypen am besten den Eingriff in einen Gewässerlauf und stellt somit gleichzeitig eine Gewässernutzungsart dar, die erhebliche Auswirkungen auf die Gewässerstruktur bewirkt hat (siehe Pkt. 2c).

\section{zu 6: Unterscheidung nach der Dauer ihrer Bespannung}

Nach der Dauer ihrer Bespannung werden Teiche in ,einhitzige' und ,mehrhitzige Teiche' unterschieden (siehe dazu b.2.1.3).

\section{zu 7: Unterscheidung nach der Zeit, während welcher die Teiche Fische beherbergen}

Nach der Zeit, während der die Teiche Fische beherbergen, unterscheidet man Sommer- und Winterteiche. Letztere sollen bei geringem Wasserdurchfluss mindestens $3 \mathrm{~m}$ tief sein; bei lebhafter Wassererneuerung genügen 1 $1 \frac{1}{2}-2 \mathrm{~m}$. Die Sommerteiche werden nach dem Zweck ihrer Benutzung eingeteilt in sog. Laich- bzw. Streichteiche, Brut-, Streck- und Abwachsteiche. Die Brutteiche können (bei der Karpfenzucht) aus Vorstreck- und Brutstreckteichen bestehen.

\section{zu 8: Unterscheidung nach der in Teichen gezüchteten Fischart}

Die deutsche Teichwirtschaft besteht im Wesentlichen aus der Karpfenzucht (oft auch mit Nebenfischen, wie Schleie, Hecht, Zander sowie Futterfische) und der Forellenzucht.

Nach der in Teichen gezüchteten Fischart unterscheidet man deshalb

1. Karpfenteiche und

2. Forellenteiche (SCHÄPERCLAUS 1961:166).

Bereits an dieser Stelle muss zur Aufklärung der immer wieder anzutreffenden Behauptung der strikten Trennung dieser beiden Hauptfischarten in Teichen beigetragen werden: Die allgemeingültige Kenntnis, dass Forellen speziell als Fische des kalten, schnell strömenden, ungestümen Bergwassers und Karpfen als Fische des träge fließenden Flusses und des verschlammten Teiches anzusprechen sind (CRONHEIM 1907:3), entspricht zwar zum einen der richtigen Einordnung ihres Habitatumfeldes, entspringt zum anderen jedoch einer fortwährenden Verklärung. Denn „daß sogar Bachforellen unter günstigen Umständen Hitzegrade ganz leidlich überstehen können, daß die Regenbogenforelle sogar direkt in Teichen mit dem Karpfen zusammen gezüchtet werden kann, während anderseits der Karpfen mit Vorteil auch in höheren Lagen [...] noch gedeiht.“ (:3), bleibt meistens vielfach unbekannt und verrückt die klassische Einteilung der Teichwirtschaft nach gezüchteter Fischart.

\section{zu 9: Einteilung der Teiche nach ihrer Ertragsfähigkeit und Güte}

Eine weitere Einteilung der Teiche wird nach der Ertragsfähigkeit nach Gewicht pro Flächeneinheit vorgenommen:

$\begin{array}{lll}\text { I. } & \text { sehr gute Teiche } & \text { über } 200 \mathrm{~kg} \mathrm{je} \mathrm{ha} \\ \text { II. } & \text { gute Teiche } & \text { bis } 200 \mathrm{~kg} \mathrm{je} \mathrm{ha} \\ \text { III. } & \text { mittlere Teiche } & \text { bis } 100 \mathrm{~kg} \mathrm{je} \mathrm{ha} \\ \text { IV. } & \text { geringe Teiche } & \text { bis } 50 \mathrm{~kg} \mathrm{je} \mathrm{ha} \\ \text { V. } & \text { schlechte Teiche } & \text { unter } 25 \mathrm{~kg} \mathrm{je} \mathrm{ha}\end{array}$

Nach der natürlichen Güte werden Teiche eingeteilt in:

1. Hof- und Dorfteiche

2. Viehweidenteiche

3. Feldteiche

4. Wald- und Moorteiche (LIETMANN 1941:8) 
Während mit der Bewertung nach Ertrag je Flächeneinheit die klassischen Maßstäbe der Intensivfischhaltung angesetzt werden, die eine auf verschiedene Fischarten abgestellte Ertragskraft vermissen lässt, entzieht sich die Güteklassifikation einer nachvollziehbaren Logik und berücksichtigt nicht die unterschiedlichen Habitatansprüche von Speisefischen.

\section{zu 10: Unterscheidung der Teiche nach Lage und Funktion}

Nach ihrer geographischen Lage werden Teiche in Dorf-, Haus- und Hofteiche, Garten- und Parkteiche, Wiesen-, Feld-, Wald-, Heideteiche usw. unterschieden.

Nach ihrer Funktion unterscheidet man sie in Fischteiche, Mühlteiche, Feuerlöschteiche, Hammerteiche, Schwemmteiche, Rieselteiche, Fabrikteiche, Klär- und Drainwasserteiche usw. (vgl. u. a. TAURKE 1927: 131ff.).

Da diese Kategorisierung die wirtschaftliche Nutzungsweise bzw. Zweckbestimmung widerspiegelt, wird sie für eine historisch-geographische Fragestellung als besonders geeignet angesehen und in dieser Arbeit als Unterscheidungsform angewandt.

\section{zu 11: Unterscheidung der Teiche nach ihrer Entstehung}

Entsprechend der naturhistorischen Terminologie (nach JÄGER 1965) können die Teiche nach ihrer Entstehungsgeschichte differenziert werden als:

1. Künstliche Anlage und

2. seminatürliche Anlage.

Nur in seltenen Ausnahmefällen ist es möglich kleine Fischteiche, wie etwa einzelne Forellenteiche, durch Ausschachtung herzustellen (SCHÄPERCLAUS 1961:149). In diesem Fall würde es sich um eine rein ,künstliche Anlage' handeln. Für gewöhnlich müssen Fischteiche auf dem gewachsenen Boden dort errichtet werden, wo es möglich ist den Boden mit Wasser zu überstauen und durch künstlich angelegte Dämme diese Überstauung zu erhalten. Ein solcher Teich wäre als ,seminatürliche Anlage' zu bezeichnen.

Am besten sind deswegen für den Bau von Fischteichen genügend breite Täler, die durch Dämme in terrassenförmig untereinander liegende Teiche verwandelt werden können, oder ausgedehnte Ebenen geeignet. In der Regel wird auf dem gewachsenen Boden in der zum Bau vorgesehenen Ebene zwischen zwei Dämmen ein künstlicher Zuleitungsgraben angelegt, von dem aus dann die einzelnen, durch Dämme voneinander getrennten, Teiche bewässert werden. Abflussgräben an tiefsten Stellen sorgen für die Entwässerung.

In Tälern kann der ursprüngliche Bach als Abflussgraben dienen; wenn dieser zuviel Wasser führt, muss am Hang um den Teich herum ein Umflutgraben geschaffen werden (SCHÄPERCLAUS 1961:149; siehe dazu auch Pkt. 2c).

\section{c Teichwirtschaft}

\section{c.1 Definition}

Teichwirtschaft wird allgemein definiert als die Fischzucht in Teichen. Sie wird im weiteren Sinne definiert als die Haltung von Fischarten in Teichen (LIETMANN 1941:5). Im engeren Sinne beschreibt sie die Haltung und die geplante Aufzucht von Fischen in den von Menschen angelegten Gewässern mit regulierbarem Zu- und Abfluss, so dass das Wasser abgelassen und das Fischbecken vollständig ausgefischt werden kann (in Anlehnung an SCHÄPERCLAUS 1961:166). Hinsichtlich des Fischbesatzes wird unter Teichwirtschaft „im allgemeinen sowohl die Forellen- als auch die Karpfenund Schleienteichwirtschaft“ verstanden, „,weil diese Fischarten meistens in künstlich angelegten, also 
ablassbaren Teichen gehalten werden. Im engeren Sinne versteht man unter Teichwirtschaft aber vorwiegend die Karpfen- und Schleihaltung“ (LIETMANN 1941:5).

Schließlich wird auch im umgangssprachlichen Bereich die traditionelle Karpfenteichwirtschaft allgemein kurz als die „Teichwirtschaft“ bezeichnet (SCHÄPERCLAUS 1961:166), was natürlich der Realität nicht entspricht. Dies mag damit zusammenhängen, dass sich mit Ausnahme der Karpfenartigen die meisten Fische in Gefangenschaft nicht fortpflanzen, und eine Brutaufzucht - als wesentliches Kennzeichen der Teichwirtschaft - somit entfällt (AMACHER 1996:97).

Zur Teichwirtschaft im engeren und eigentlichen Sinne, die Fischzucht vom Laichfisch bis zum Speisefisch betreibt, gehören vor allem eine größere Anzahl von Teichen. „Eine vollständige Fischzucht läßt sich nicht aufbauen, wenn nur ein oder zwei Kleinteiche zur Verfügung stehen.“ (ZOBEL 1992:11) Eine gewisse Zahl von Teichen ist somit ein eindeutiges Merkmal einer Teichwirtschaft. Sie stellt damit nicht nur eine einschneidende Intensivierung der Fischerei in der Landschaft dar, sondern ist auch Anhaltspunkt für eine Ansprache und Fixierung von Teichrelikten im Gelände.

Die Fischzucht in Teichen unterscheidet sich des Weiteren in wesentlichen Punkten vom Fischfang in der freien Natur. In der Teichwirtschaft besteht die Zucht darin, dass in die leeren Teiche nur Nachkommen ausgesuchter Eltern gesetzt werden und dass durch angemessenen Besatz (Fischsorten, Zahl) und rationelle Pflege (Trockenlegen der Teiche, Düngung, Fütterung, Wasserzufuhr) optimale Bedingungen geschaffen werden. Zum einen wird damit dafür gesorgt, dass die einzelnen Fische bei der Abfischung eine gewisse Größe und ein gewünschtes Gewicht haben, sowie zum anderen gewährleistet, dass der Fischbestand nicht durch natürliche Feinde, sog. ,Fischfeinde', und Krankheiten dezimiert wird. Auf solche Weise soll „eine gute, schnellwüchsige Rasse“ gezüchtet werden (TAURKE 1927:55).

Zum Ablassen und zur Einstellung des Wasserspiegels werden in einer Teichwirtschaft Zu- und Ablaufvorrichtungen, in der Regel sog. Mönche, verwendet. Der Teichboden besitzt Gräben und ist zum Auslaufen geneigt, damit sich beim Ablassen die Fische in der Fisch- bzw. Schlegelgrube oder mit abfließendem Wasser - hinter dem Mönch sammeln, wo sie abgefischt werden.

\section{c.2 Einordnung und Gliederung}

Die Teichwirtschaft gehört zur Fischerei (AMACHER 1996:18), doch beschäftigt sie sich nicht nur damit, wie aus der von Graf Ernst von DYHRN, im 18. Jh. ,Freyherr zu Schönau, Direktor der OelsMielitschen Fürstenthumslandschaft, Erbherr auf Reesewitz, Ober- und Nieder-Mühlwitz, Rudelsdorf, Rabine und Dyhrnfeld' in den $\S \S 1$ und 3 seiner 1782 erschienenen „Kurze[n] Anleitung zu der Teichwirtschaft" zu entnehmen ist (:3f.). Es ist die älteste von mir aufgefundene Schrift zur Beschreibung einer geordneten bzw. - wie DYHRN (:5) es nennt - „ordentlichen” Teichwirtschaft.

\section{$\S 1$}

„So zeitig man auch in der Welt angefangen hat, sich auf die Viehzucht zu legen, und also nicht bloß mit der Jagd zufrieden zu seyn: so späte mag man wohl auf den Gedanken gekommen senn, Hälter, Canäle und Teiche mit Wasser anzufüllen, und sie wiederum abzulassen, um sie ordentlicher Weise mit Fischen zu besetzen, und diese wiederum zu willkührlich bestimmter Zeit herauszufischen, also die zahme Fischerey, und dadurch die Teichwirthschaft, einzuführen.

\section{$\S 3$}

Auf der anderen Seite lernte man auch durch die Erfahrung, obwohl viel später, einsehen, daß auf einem neuerlich unter Wasser gesetzten Stücke Landes, besonders wenn es vorher als Ackerland bearbeitet worden, die Fische viel besser wüchsen, und also viel mehrere derselben gezogen werden könnten, als in einem beständig bewässerten Teiche. Hieraus ist nun nach und nach diejenige Art der Wirthschaft entstanden, vermöge welcher man ein Stück Landes, wechselweise, eine Zeit lang unter Wasser setzet, und zur zahmen 
Fischerey benutzet, und wiederum eine Zeit lang mit Getreide, Gartengewächsen und Futterkräutern anhauet. Und dieses kann eigentlich eine ordentliche Teichwirthschaft genennet werden. “

DYHRN spricht zwei Formen der gewässerbezogenen Landwirtschaft an, die nur im Zusammenhang betrachtet das vollständige Bild einer Teichbewirtschaftung ergeben:

1. die eigentliche Teichwirtschaft,

2. die Feld-Teich-Wechselwirtschaft.

DYHRN (1782:5f.) reduzierte die Teichwirtschaft nicht auf die reine Fischzucht, sondern sieht die von ihm auch als „praktische Teichwirthschaft“ bezeichnete vielmehr als eine „Art der Landwirthschaft, welche lehret, neue Teiche anzulegen, alte auszubauen, in denselben, zu gehöriger Zeit, Fische anzuziehen und zu erhalten, als auch dieselben Teiche wiederum, auf gehörige Art, als Gartenland, Ackerland und Wiesen zu gebrauchen.“. Die Teichwirtschaft wird also als integraler Bestandteil der Landwirtschaft verstanden.

Auch nach der Mitte der 1950er Jahre geäußerten Auffassung von RUST ist die Teichwirtschaft „ein Glied der Landwirtschaft“. Innerhalb dieser wiederum bezeichnet er sie als „eine Sonderkultur mit geringer Flächenausdehnung“ (RUST 1956:1). Denn ,auch in der Fischerei gelten nach jeder Richtung hin die Prinzipien der Landwirtschaft“, so CRONHEIM 1907 (:5) vor dem Hintergrund, „daß das Wasser, der Boden, dem der Teichwirt seine Ernte entnimmt, der also gewissermaßen seinen Acker darstellt, auch ganz so wie ein solcher behandelt werden will.“ Doch nicht nur der Teichboden, ,auch die Fische wollen so behandelt sein, wie man es bei den warmblütigen Haustieren gewöhnt ist. Auch sie wollen gewartet sein, auch sie verlangen ein tadelloses Futter.“(:5)

Als weiterer Vergleichspunkt zur Landwirtschaft wird die günstige Verwertung der Futtermengen von Teichfischen herangezogen: „Wir finden bei den sonstigen Haustieren mit Ausnahme des Schweines nichts annähernd dem Karpfen Gleiches, der im ersten Sommer [...] sein Gewicht vervierzig- bis verfünfzigfacht, im zweiten versechs- bis versiebenfacht, im dritten verdrei- bis vervierfacht [...]. Auch Forellen und Schleien zeigen ähnliche, wenn auch nicht so hervorragende Resultate" (CRONHEIM 1907:27). Die Erträge, die gut bewirtschaftete Karpfenteiche bringen, sind also in vielen Fällen denjenigen der Landwirtschaft deutlich überlegen. „Es kommt sogar noch hinzu, daß in der Teichwirtschaft im Verhältnis für eine große Fläche weniger Arbeitskräfte benötigt werden“ (WUNDER 1956:6).

Und schließlich wird - wie in der Landwirtschaft - innerhalb der Teichwirtschaft hinsichtlich der Betriebsgröße zwischen Haupterwerbs- (,vollkommenen“) und Nebenerwerbsbetrieben („Teilbetrieben“) unterschieden (PLANANSKY 1983:78f.).

1. Vollkommene Betriebe

Es handelt sich hierbei um größere Betriebe, d. h. sie produzieren im eigenen Betrieb vom Ei bis zum Speisefisch alles selbst. Die Bewirtschaftung einer vollkommenen Teichwirtschaft erfolgt nach einer auf zwei bis drei Jahre festgesetzten Wirtschaftsplanung, dem Besatzungs-, Düngungs- und Fütterungsprojekt. In diesem sind Brut-, Streck- und Abwachsteiche so eingeteilt und ihre Besatzaltersklasse und Besatzdichte so abgestimmt, dass das für das nächste und übernächste Wirtschaftsjahr erforderliche Besatzmaterial als auch der für den Verkauf notwendige Speisefisch produziert wird.

2. Teilbetriebe

Betriebe, die ein- oder zweisömmrige Besatzfische von großen Nachbarbetrieben kaufen und im ein- oder zweisömmrigen Umtrieb zum Speisefisch ziehen, d. h. heranwachsen lassen. Da keine Hälterungsmöglichkeiten bestehen, verkaufen solche Teichwirte ihre Fische gleich bei der Abfischung an Interessenten ab Teich. 


\section{Fischteiche}

\section{a Begriff des Fischteiches}

Teiche „sind am besten geeignet, um von Karpfen, Bleien, Schleien, Goldfischen, Orfen, Plötzen, Hechten, Zandern, Barschen und anderen Sommerlaichfischen Brut zu gewinnen, ferner um Karpfen, Hechte, Zander, Forellen, Saiblinge u. a. m. aufzuziehen", lautet die zweifache Grundvoraussetzung von BORNE (1886:218). Die Teiche, die diesen fischereiwirtschaftlichen Zweck erfüllen und „vollständig trocken gelegt und sicher wieder gefüllt werden“ können (:218) werden allgemein als ,Fischteiche' bezeichnet.

Nach SCHÄPERCLAUS (1961:147) hat der „Fischteich im eigentlichen Sinne“ folgende Eigenschaften:

1. Er ist so flach, dass ein echtes Hypolimnion fehlt.

2. Er ist vollständig ablassbar und fast immer künstlich angelegt.

3. Er ist meistens periodisch unter Wasser, liegt also in der Regel zeitweise trocken.

Innerhalb der Fischereiwirtschaft wird grundsätzlich zwischen Fischzucht ${ }^{4}$ und Fischhaltung ${ }^{5}$ differenziert. Innerhalb der Fischzucht wird der Fischteich, je nachdem, ob er der Fischbrutgewinnung oder der Fischaufzucht dient, als Fischbrut- oder als Fischzuchtteich bezeichnet. Die reine Haltung von Fischen wird dem Begriff entsprechend in sog. Hälterteichen vollzogen.

Nach dieser Einteilung der Fischteiche gibt es also drei zweckgebundene Hauptteichformen, die den Begriff ,Fischteich' diversifizieren: Fischbrut-, Fischaufzucht- und Fischhaltungsteiche. Diese lassen sich funktional und morphologisch voneinander unterscheiden und auch noch weiter differenzieren, wie wir im Folgenden sehen werden. Diese Mehrteichwirtschaft repräsentiert die betriebswirtschaftlich organisierte Idealform, wie sie im Verlauf des 19. Jh. Gestalt gewann und in den Lehrbüchern favorisiert wurde. Nehmen wir an, dass sich viele Teichwirte bei der Anwendung der

\footnotetext{
${ }^{4}$ Innerhalb der Fischzucht gibt es wiederum die Aufteilung in ,natürliche' und ,künstliche’ Fischzucht:

Die natürliche Fischzucht beschäftigt sich planmäßig mit der Fortpflanzung von Fischen, aber auf biologischem Wege, d. h. mit der natürlichen Befruchtung der Eier durch Milch des Rogner und der nachfolgenden Aufzucht der Brut für den eigenen Zuchtbetrieb oder den allgemeinen Verkauf. Sie verläuft bis zu dem Stadium, indem sie entweder zum Besetzen von Gewässern, als fertige Elternfische oder als Speisefische Verwendung finden können. Die Fischzucht wird prägnant allgemein beschrieben als ,eine Fischwirtschaft vom Ei bis wieder zum Ei““(TAURKE 1927: XXIII).

Unter künstlicher Fischzucht versteht man ,die künstliche Befruchtung der Fischeier durch Abstreichen laichreifer Fische, und Mischung der Eier mit Samen und Wasser sowie die Ausbrütung der Eier in Bruttrögen“ (BORNE 1886:227) oder Brutteichen. Die künstliche Fischzucht in kleineren Fischzuchtanstalten mit ihren Brutapparaten, Bruttrögen und sog. kleinen Fischzuchtanstalten (Californischer Trog) kann in einer historisch-geographischen Betrachtung unberücksichtigt bleiben. Sie hinterlässt keine landschaftsbestimmenden Elemente. Größere Fischzuchtanstalten hingegen mit ihren speziellen Brutteichen beispielsweise können den gewässer- und landschaftsgebundenen historischen Anlagen und Einrichtungen zugerechnet werden und finden somit ihre Behandlung im entsprechenden Abschnitt dieses Kapitels. Die Tätigkeit der künstlichen Fischzucht zerfällt dabei ,in die Gewinnung des Laiches, die künstliche Befruchtung der Eier, ihre Ausbrütung, die Aufzucht der jungen Brut bis zum Verlust der Dotterblase und ihre Aussetzung in die geeigneten Gewässer.“ (BENECKE 1885:50).

Allgemein ist es das Ziel des Fischzüchters, wie bei jeder anderen Tierzucht auch, seine Rasse oder Lokalsorte so zu verbessern bzw. zu veredeln, dass ,seine Fische in kurzer Zeit möglichst viel wertvolles Fleisch hervorbringen.“ (TAURKE 1927:XXIV) Die Fischzucht hat also den Zweck, „die Vermehrung und das Gedeihen der Fische zu befördern und die werthvollen Arten den geringwerthigen gegenüber zu bevorzugen.“ (BORNE 1886:217) Es war und ist demgemäß, dessen sollte man sich ohne romantisierende Betrachtung der Teichanlagen von Fischzuchtbetrieben bewusst sein, die Gewinnung „eines möglichst hohen Reinertrages“ (TAURKE 1927:XXIV) Grundlage einer - auch historischen - Fischzuchtwirtschaft. Diese Gewinnabschöpfung, in Zusammenhang natürlich mit dem hohen Genuss beim Verzehr die sog. Edelfische, war seit den Anfängen der planmäßigen Fischzucht, erklärtes Zuchtziel der Fischzüchter und Landbesitzer.

${ }^{5}$ Die Fischhaltung ist im Gegensatz zur Fischzucht diejenige Form der Fischwirtschaft, ,,welche sich nur damit planmäßig beschäftigt, gute Satzfische zu kaufen, sie zu Speisefischen (oder auch nur zu älteren Satzfischen) heranwachsen zu lassen und sie gewinnbringend wieder zu verkaufen.“ (TAURKE 1927:XXI) Es werden hier - im Gegensatz zur Zucht - „,die Fische nicht gefüttert“ (:XXI). Dies ist „,der einzige, wenn auch tiefgreifende Unterschied.“(: XXIV)
} 
Fischwirtschaft an diese Fischzuchtregeln gehalten haben, so lassen sich diese Regularien aus den alten Lehrbüchern auf die Praxis und damit auf die Teichgewässerlandschaft übertragen.

\section{b Fischteichanlage}

Die verschiedenen Typen von Fischteichanlagen lassen sich grob in drei Betriebsarten einteilen: die Gehalter, den Femelbetrieb und die dreistufige Fischzucht. Bei einer solchen Beschreibung ist allerdings zu beachten, dass sie die Teichwirtschaft nur modellhaft wiedergibt:

a) Die Gehalter gehören nicht zur eigentlichen Fischzucht. Es sind Vivarien, kleine Fischbecken, in denen gefangene Fische bis zum Zeitpunkt des Verzehrs oder Verkaufs im Wasser gehalten werden.

b) Die einfachste und zeitlich weit zurückliegende Form der Fischzucht war der sog. Femelbetrieb $^{6}$ (ZOBEL 1992:11; AMACHER 1996:97). Man ließ die Fische zunächst in einem ablassbaren Teich laichen und alle Jahrgänge der Fische blieben vom Laichstadium bis zur marktfähigen Größe darin. Beim jährlichen Ablassen des Teiches wurden dann die ausgewachsenen Fische herausgenommen, die klein gebliebenen jedoch in den sogleich wieder aufgestauten Teich zurückgesetzt und dort belassen, bis auch sie die erforderliche Größe erreicht hatten. In einem Femelbetrieb unterschied man bei den Abfischungen die Fische nicht richtig nach Jahrgängen, sondern nur nach der Größe. Das Sortieren der einzelnen Größenklassen nannte man ,Bracken'. Man sprach dann von drei Größenklassen: Unter ,Großbrack' verstand man Speisefische, unter ,Mittelbrack' Satzfische und unter ,Kleinbrack' Brut (WUNDER 1956:7). Auf diese Weise wurden aber oft gerade die besonders gut zur Zucht geeigneten Fische weggefangen, denn dabei wurden oft schlecht wachsende, klein bleibende Fische immer wieder zurückgeworfen, und vielfach bestanden die Laichfische aus derartigen schlecht wachsenden Tieren, deren Alter unbekannt war (:7). Der Femelbetrieb wird heute nicht mehr praktiziert, weil es bei dieser Betriebsart nicht möglich ist, die Jahrgänge auseinander zu halten und züchterisch tätig zu werden (ZOBEL 1992:11f.).

c) Im Gegensatz zu dem Femelbetrieb hält man seit dem 19. Jh. die einzelnen Altersklassen des Karpfens in getrennten Teichen (WUNDER 1956:7), denn erst als man anfing, die verschiedenen Jahrgänge in getrennten Weihern zu halten, wurde eine gezieltere Züchtung im Sinne einer Auslese möglich (HITZBLECK 1971:96; AMACHER 1996:97). Und auch die Karpfenbezeichnungen änderten sich: Da der Karpfen während der warmen Sommermonate abwächst, zählte man sodann sein Alter in Sommern. In den deutschen Produktionsgebieten arbeitet man überwiegend im dreisömmrigen Umtrieb. Im ersten Sommer werden bei hohen Besatzdichten kleine Karpfen (sog. $\mathrm{K}_{1}[30 \mathrm{~g}]$ ) erzeugt, im zweiten Sommer kräftige Karpfen $\left(\mathrm{K}_{2}[250 \mathrm{~g}]\right)$ und erst im dritten Sommer erntet man speisefähige Karpfen $\left(\mathrm{K}_{3}\right.$ [ca. 1250g]) (HUBERT 1991:14).

Bei dieser dreistufigen Teichwirtschaft wurden die Fische je nach Stadium dementsprechend auch in drei verschiedenen Teichen gehalten: die Elterntiere und der Laich im ,Streichteich', die einjährigen Kärpflein im ,Streckteich' und die erwachsenen im ,Setzteich'. In den Streichteich, auch ,Laichteich' oder ,Mutterweiher' genannt, wurden ausgesuchte Zuchtfische eingesetzt, die dort den Laich abstreiften. Die sich entwickelnde Karpfenbrut wurde das erste Jahr im Streichteich belassen. Im Mutterweiher durften keine Hechte oder anderen Fische vorhanden sein. Im Streckteich, auch ,Wachsweiher' genannt, erfolgte das Aufziehen der Brut ${ }^{7}$, und im Setzteich, auch als ,Abwachsteich' bezeichnet ließ man die Karpfen bis zur marktfähigen Größe auswachsen (HITZBLECK 1971:96;

\footnotetext{
${ }^{6}$ Im Gegensatz zum fischereiwirtschaftlichen Femel gibt es zwei weitere altgebräuchliche ,Femel': Der Femel, Femmel (Fimmel) ist die männliche, schwächer entwickelte Pflanze beim Hanf, die herausgebrochen wird. Im Femelwald (Plenterwald), einem ungleichaltrigen Mischbestand, werden jeweils nur die ältesten Bäume geschlagen und so der Wald verjüngt.

${ }^{7}$ In Streckweiher werden „ohne Laichkarpfen die Büeble oder kleine Kärpfle - die wachsen und sich strecken sollen gesetzt.“ (nach Fisch- und Karpfen-Ordnung St. Gallen 1724:352ff., aus: AMACHER 1996:97).
} 
AMACHER 1996:97). In den Abwachsteich - und nur in diesen - setzte man häufig Hechte als Beifische ein. Diese sorgten dafür, dass im Setzteich keine junge Brut aufkam, die den zu mästenden, nun geschlechtsreifen Karpfen die Nahrung streitig machen konnte. Die Hechte sollten aber nicht zu groß sein (AMACHER 1996:97).

Neben dieser dreiteiligen Teichwirtschaft gab es auch die einfachere Form der zweiteiligen. Hier wurde der Aufenthalt im Streckteich ausgelassen, d. h., die Karpfen kamen erst als Zweisömmrige aus dem Laich- in den Hauptteich (HITZBLECK 1971:96; AMACHER 1996:98).

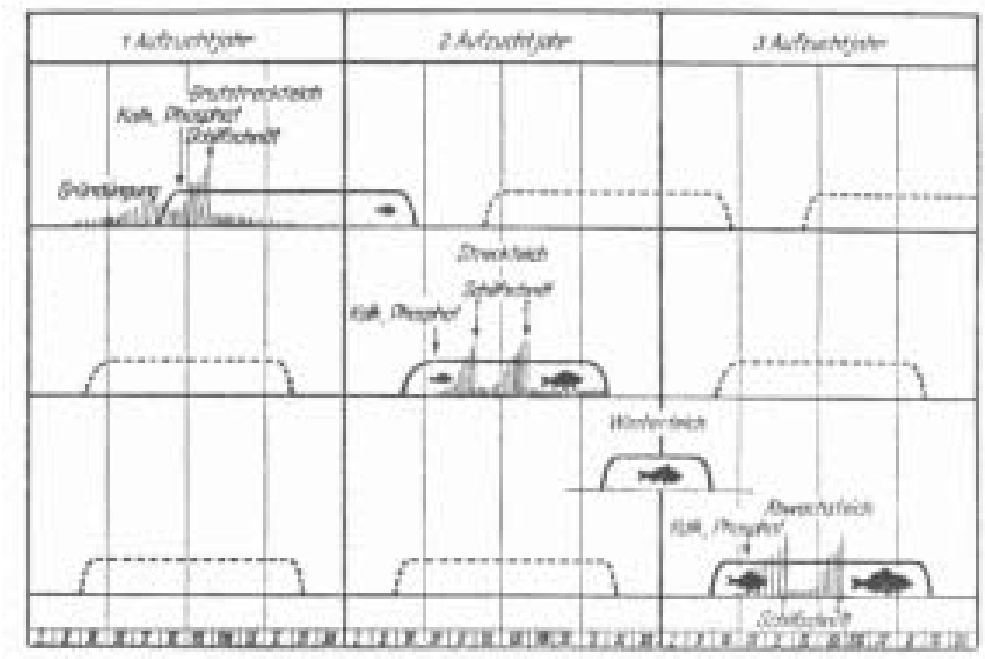

Abb. VII-1:Schematische Darstellung der Teichtypen einer Karpfenaufzucht im 3jährigen Umtrieb (aus: SCHÄPERCLAUS 1961:234)

Die Erkennung dieser verschiedenen Teiche im Gelände kann nach den für das Leben der Fische wesentlichen Eigenschaften vorgenommen werden. Deshalb sind die Lebensansprüche der Fische Hinweis auf die Gestalt und Lage der Teiche, die schon früh erkannt wurden: „Aus dem Vorkommen oder Fehlen der leitenden Fischarten kann die Beschaffenheit des Gewässers und der darin lebenden anderen Fischarten beurtheilt werden. Wenn sich der Charakter des Gewässers ändert, so ändert sich auch die Fischfauna, welche darin lebt.“"(BORNE 1886:295)

Um einen ehemaligen Karpfen- oder Forellenteich, d. h. ohne den prägnanten Fischbesatz, auch als solchen im Gelände bestimmen zu können, ist die Kenntnis der Lebensweise und Aufzucht des Fisches notwendig. Daraus ergibt sich die ehemalige Beschaffenheit, Morphologie und Nutzungsform der Teiche, die eine Bestimmung ermöglichen kann. Doch bevor in Pkt. b.2 die ,Spezialteiche' nach Alter und Besatz beschrieben werden, die anscheinend notwendig waren, um planmäßig Fischzucht betreiben zu können, stellt sich die Frage der zeitlichen Einordnung und Form der vielen einzelnen Teiche, die in der Landschaft festzustellen sind. Oder sind dies nur Einzelrelikte einer ehemaligen Mehrteichanlage, dessen übrige nur nicht mehr im Feld erkennbar sind und es der zusätzlichen Altkartenanalyse bedarf, um die Regelhaftigkeit einer geschlossenen Form auch räumlich getrennt liegender, aber einander bedingender Teiche zu belegen?

Am Anfang der Teichwirtschaft, vor der lehrbuchhaften Darlegung, dürfte jedoch die einfache Einteichanlage gestanden haben. Doch ist deshalb daraus abzuleiten, dass sie auch noch im Mittelalter die vorherrschende Betriebsform gewesen ist?

\section{b.1 Die mittelalterliche Einteichanlage}

Wie die mittelalterliche Teichanlage ausgesehen hat, darüber gibt es verschiedene Auffassungen:

Nach Auffassung von HERBST (1992:25) handelte es ehemalig um eine „künstliche Überflutung der Talwiesen“, d. h. die „Wiesen wurden im 15. Jh. einfach überstaut“. 
Nach Meinung von LAMPEN (2000:124f.), deren Belege auf Auswertung einer Vielzahl von Urkunden und anderen alten Schriftquellen beruhen (z. B. der Capitulare de Villis, in: Capitularia regum Francorum, cap. 21 und 65), zeigen die ,ältesten Hinweise auf künstliche Fischteiche [...] deutlich, daß es sich in diesen Fällen wohl eher um Reservoire für gefangene Fische, um sogenannte Hälterungsbecken, handelte.“ „Komplizierte Teichanlagen mit separaten Weihern für die verschiedenen Aufwuchsphasen”, sind nach ihren Recherchen „erst ein Kennzeichen des späten Mittelalters und der frühen Neuzeit." So weiß sie von einem urkundlichen Vertrag zwischen der Stadt Lübeck und einem Pächter aus der Mitte des 14. Jahrhunderts (1357) zu berichten, in dem der Bau von vier neuen Teichen geregelt wurde. Die notwendigen Maßnahmen - genannt ist etwa die Aufstauung eines Flusses mit Namen Falkenbeke durch mehrere Dämme - und die Anzahl der übertragenen Teiche „macht deutlich, daß zu dieser Zeit, im 14. Jahrhundert, nicht mehr einzelne Teiche zur Hälterung und Aufbewahrung, sondern große Teichanlagen gebaut wurden, die separate Becken für die einzelnen Aufzuchtphasen umfassten. Dafür spricht nach ihrer Auffassung ,auch die Gegenüberstellung des fossatum, der lediglich zur Aufbewahrung der Fische diente, und der piscina in der Urkunde“" (:139f., Hervorhebung im Original).

Was die Art des Wirtschaftsbetriebes betrifft, so weist CNOPF (1927:30f.) am Beispiel des fränkischen Klosters Heilsbronn für Mitte des 16. Jh. nach, dass durchaus nicht, wie vielfach angenommen wird, der Femelbetrieb, d. h. das Halten der verschiedenen Jahrgänge in einem Teiche vorherrschte, sondern ,daß man schon nach Jahresklassen züchtete, d. h. die Aufzucht nur eines Jahrganges in einem Teiche betrieb." Allerdings wurden reine Laichteiche, die nur für die Brut bestimmt waren, fast nie angetroffen. „Immer gab man noch Fische anderer Jahrgänge hinzu. Man betrieb die Zucht der Fische in dreijährigem Umlauf und unterschied, wie heute noch, Brut (einjährige), Setzlinge (zweijährige) und Speisekarpfen, auch Marktfische oder Zentnergut genannt (dreijährige)“ (:30f.).

Dieser Fischzucht in weitläufigen Teichanlagen stehen die Erkenntnisse AMACHERs (1996:98ff.) gegenüber, der die Teichwirtschaft des Spätmittelalters in der Schweiz untersuchte und in einem Untersuchungsraum lediglich Belege für eine Hälterung in Teichen fand. In der Fischmarktordnung der Stadt Zürich, nach seinem Wissen die früheste Erwähnung von Weihern, ist 1359 von ,hechten usser wijern" die Rede. Desgleichen werden 1400 wieder nur Hechte als Teichfische genannt, zusammen mit „spisfisch“ (Futterfischen) für die Hechte. Und als 1481 in den Urkunden ein Fischergeselle seinem Herrn Fische aus einem Weiher entwendet, handelt es sich wiederum um Hechte (:98). Aus diesen zwei Beispielen wird für AMACHER (:99) „ersichtlich, dass um 1400 die Weiher keine eigentlichen Fischzuchtgewässer, sondern Fischhalter waren: Man fing aus freien Gewässern Hechte, setzte diese in die Weiher aus und hielt sie dort bis zum Verzehr/Verkauf.“

In einem anderen Untersuchungsgebiet, im Raum Andelfingen, jedoch, so fand AMACHER (1996:100f.) heraus, wurde „eine mehrteilige Teichwirtschaft [...] angewandt.“ Auch am Beispiel der Stadt Alt-Regensberg weiß er weiterhin von einer „,vielfältigen Fischzucht“ in den 1460er Jahren zu berichten, die aus fünf Weihern bestand: Es gab den ,Katzensee', einen ,neuen See', einen ,Burgweiher' und zwei ,kleine Weiher'. Der ,Burgweiher' wurde hierbei als „Mutterweiher“ betrieben. Hierin wurden Karpfen und andere Fische gehältert, „die Laich und Jungfische erzeugten“. Der Burgweiher wurde demnach sowohl ,als Fischgehalter benutzt“ als auch als Brut- und Streckteich.

Dem 1927 erschienenen Lehrbuch von TAURKE zufolge wurden hingegen früher „die verschieden alten Karpfen in denselben Teichen gehalten“ (:2). Diese Form der gemeinsamen Unterbringung verschiedener Altersklassen, der Femelbetrieb, wurde insbesondere für die damalig dominante Karpfenzucht angewendet: Das heißt, es fand bei diesem „alten Züchtungsverfahren“ (:12) kein Umsetzen der Fische statt, sondern ein und derselbe Teich wurde als Laich-, Vorstreck-, Streck- und Abwachsteich sowie als Winterteich benutzt (LIETMANN 1941:8).

Im Mittelalter und in der Neuzeit dienten demzufolge also mittlere oder große Karpfenteiche gleichzeitig sowohl als Brutteiche als auch als Aufzuchtteiche, wobei der Teil des Teiches mit Fischbrut einfach durch Weiden- oder Netzgeflecht von den Mutterfischen abgehalten wurden 
(TAURKE 1927:12). Bei den dann folgenden Abfischungen „unterschied man die Fische nicht richtig nach Jahrgängen, sondern nur nach der Größe. Das Sortieren der einzelnen Größenklassen nannte man „Bracken'. Man sprach dann von drei Größenklassen: Unter ,Großbrack' verstand man Speisefische, unter ,Mittelbrack' Satzfische und unter ,Kleinbrack' Brut. Dabei wurden oft schlecht wachsende, klein bleibende Fische immer wieder zurückgeworfen, und vielfach bestanden die Laichfische aus derartigen schlecht wachsenden Tieren, deren Alter unbekannt war.

Dies bedeutet jedoch nicht, dass die mittelalterliche Teichwirtschaft eine Einteichwirtschaft war und nur aus einem Teich bestand. Die Vielzahl von vielen aufeinander folgenden Fischteichen des Mittelalters beruhte darauf, dass „die Karpfen ihre Nahrung hauptsächlich an den flachen Rändern finden“, so wie es im Allgemeinen besser war, „statt eines größeren tiefen, mehrere kleinere flache Karpfenteiche anzulegen.“(BORNE 1886:20)

In den mittelalterlichen Quellen und in den neueren Lehrbüchern die aus alter Zeit berichten, sind also modellhafte Prinzipien einer mittelalterlichen Teichwirtschaft, d. h. ob ein-, zwei oder mehrteilig, nicht feststellbar, und die Nachrichten über die Teiche können nicht eindeutig einem Teichtyp zugeordnet werden. Feststellbar ist nur, dass der Karpfen anscheinend im Mittelpunkt der mittelalterlichen Teichwirtschaft stand, er spielte die „dominierende Rolle“. Er war „Hausherr und Träger der Teichwirtschaft“, ihm galt „,die ganze Fürsorge und Pflege“(CNOPF 1927:31), kurzum, er wird als „der Teichfisch par excellence“ (DYHRN 1782:6) beschrieben: Karpfen „,sind hauptsächlich diejenige Art Fische, die man zu einer zahmen Fischerey in Teichen am besten gebrauchen kann" (:6f.) und ,so wird bey der zahmen Fischerey, in ordentlich angelegten Teichen, das Hauptaugenmerk eigentlich auf die Karpfen gerichtet." Forellen hingegen wurden in den Bachläufen selbst gefangen.

Der Karpfen liebt wenig bewegtes, d. h. ruhiges, seichtes, weiches und vor allem warmes Wasser. Deshalb wird der Karpfen auch als „Fisch der warmen Teiche“ (TAURKE 1927:7) bezeichnet. Er bevorzugt deshalb stehende Gewässer - Weiher und Seen, die sich im Frühjahr schnell erwärmen und ist schnellwüchsig. Er beweidet den verschlammten Grund, auf welchem er mit seinem ausstülpbaren Maul die Kleinlebewesen und Pflanzen , ansaugen' kann. Zu ihm setzte man neben den Hechten auch Schleien, Barben u. a. als Beifische in den Teich. Die Schleien im Streckweiher sollten den Teichgrund aufwühlen und die Kleinlebewesen, die den Karpfen als Nahrung dienten, hervorgraben (AMACHER 1996:98).

Der Karpfen ruht im Winter und hält seinen Winterschlaf auf dem Gewässergrund. Seiner Eigenschaft zufolge, ,selbst in Eis eingefroren“ (TAURKE 1927:5) lebensfähig bleiben zu können, entspricht denn auch die in der früheren Praxis angewandte Methode, einen möglichst flachen, sich schnell erwärmenden Teich ganzjährig für die Karpfenzucht zu nutzen, auch wenn dieser in den harten und langen Wintermonaten zufror.

Karpfenteiche sind große, periodisch überstaute Teiche, deren Wasser im Sommer über $20^{\circ} \mathrm{C}$ warm wird, mit großen ,Weide-Flächen', die den Karpfen weitgehende natürliche Ernährung sichern (SCHÄPERCLAUS 1961:148, 166), denn, so die logische Entwicklung, ,je mehr sich das Wasser erwärmt, um so größer ist sein Appetit, und um so schneller wächst er." (BORNE 1886:262) Da das Wasser sich also möglichst rasch und anhaltend erwärmen sollte, wurde er bevorzugt in flachen Teichen gezüchtet. Dies sind solche mit einer durchschnittlichen Tiefe von $50-75 \mathrm{~cm}$, die an der Ablassstelle, dem Mönch, bis zu $1 \mathrm{~m}$ ansteigen (CRONHEIM 1907:41; TAURKE 1927:4). Nach SCHÄPERCLAUS $(1961: 148,166)$ beträgt die Tiefe auf den Hauptflächen im Mittel sogar bis etwa $130 \mathrm{~cm}$. BORNE (1886:20) definiert die zweckmäßige Tiefe bei „1 $\mathrm{m}$ und weniger“. Wenn auch in Karpfenteichen tiefere Stellen ausgegraben wurden, ,um den Fischen bei großer Hitze und hoher Erwärmung des Wassers Gelegenheit zu geben, kühlere Stellen aufzusuchen." (CRONHEIM 1907:41), gilt im Allgemeinen die Faustregel, dass die Karpfenteiche „nicht so tief wie die Forellenteiche" sind (:41).

Karpfen wurden hinsichtlich der Art der Wasserspeisung sowohl in Bach- und Fluss-, als auch in Himmelsteichen gezüchtet (TAURKE 1927:7). In Quellteiche wurden Karpfen als „Nebenfische 
neben Forellen“ beigesetzt (CRONHEIM 1907:3). Lediglich „Gebirgsteiche mit kaltem Wasser eignen sich nicht zur Karpfenzucht“ (BORNE 1886:263).

Bei der Anlage eines Karpfenteiches als Bach- oder Flussteich galt es zu beachten, dass ein ständiger Durchstrom von Wasser, der die Wassertemperatur herabsetzen und das Nahrungswachstum einschränken würde, unerwünscht war, denn Karpfen benötigen als Grundlage ihrer Ernährung „stets ausreichend Naturnahrung" und lassen sich „unter mitteleuropäischen Bedingungen nicht ausschließlich künstlich füttern.“ (SCHÄPERCLAUS 1961:148,166) Die Möglichkeit des Wasserabschlusses ist also bei der Anlage eines durch Fließgewässer bespannten Karpfenteiches ein entscheidender Gesichtspunkt und wurde durch Ab- und Umleitung des Zuflusses und durch den Bau von Zufluss- und Umlaufgräben gewährleistet (siehe unten, Pkt. c.2.5).

Da beständiger Wasserzufluss aufgrund der Habitatansprüche aber keineswegs notwendig beim Karpfenteich ist (TAURKE 1927:7) bzw. durchaus gänzlich fehlen kann, wurden insbesondere Himmelsteiche für den Karpfenbesatz ausgesucht. Wobei in letzteren aufgrund der Gefahr des Erstickens bei zu geringer Luftzufuhr nur dann ein Besatz vorgenommen werden kann, „falls sie [...] auch in trockenen Sommern nicht austrocknen“ (:7) und „wenn mit dem Zugnetz rein abgefischt werden kann" (:4).

Als später, zu Ende des hohen Mittelalters, durch die vermehrte Errichtung von Mehrteichanlagen die Fische des zweiten und dritten Jahres in separaten Streck- und Abwachsteichen zu Verkaufsfischen herangezogen wurden (TAURKE 1927:12), bestand, so ist anzunehmen, parallel die traditionelle Karpfenhaltung in Einteichwirtschaften fort, die nicht nur dem Fischbesatz diente und die zumindest bis in die 1920/30er Jahre erhalten geblieben ist, wie das folgende Beispiel beweist. TAURKE (:16f.) beschreibt in sehr anschaulicher Weise die ehemals vielschichtige Nutzung eines solchen einzigen Fischteiches, so wie man sich wohl auch den mittelalterlichen Einteich vorzustellen hat:

„Als Abwachsteich kann ein einzelner Teich, z. B. ein Dorfteich, sehr großen Nutzen
bringen. Selbst wenn ein Teich als Viehschwemme benützt wird und wenn, wie
gewöhnlich, Jauche hineinfließt, so ist das für die Fische nicht schädlich, da durch den
Dünger des Viehs die Nahrung der Fische indirekt vermehrt wird. Auch Gänse, Enten
und andere Wasservögel schaden nicht in solchen nahrungsreichen Teichen [...], sind sie
nur dann schädlich, wenn durch eine zu große Anzahl von ihnen der Teich zur Mistpfütze
wird. [...] Auch als Streckteiche werden Dorfteiche und allerlei Wassertümpel [...] oft
verwendet [...].“

Diese Art der Teichhaltung konnte nur bei Karpfen und nur aufgrund ihrer Nahrungsbreite durchgeführt werden, denn „Karpfen leben im Teich auf einer Art Naturweide. Sie ernähren sich von den im Teich selbst natürlicherweise erzeugten Kleinlebewesen. Deren Bestand ist mit maßgebend für die Produktivität des Teiches. [...] Mit der Karpfenhaltung in Teichen wird somit eine Eiweißquelle für die Erzeugung von Fischfleisch erschlossen, die sonst ungenutzt bliebe.“ (KEIZ 1995:18). Seine Nahrung besteht neben der natürlichen Ufernahrung aus Flohkrebsen, Froschlarven, Mückenlarven, Würmern und Schnecken sowie aus der Bodenfauna im Teichschlamm. Dabei „verschmäht er selbst Exkremente von Tieren und Menschen nicht“ (BORNE 1886:262; ebenso TAURKE 1927:5). Folglich war er der prädestinierte Dorfteichbewohner, da hierin vielfach sämtliche Einleitungen von Abfällen zusammenliefen (siehe Pkt. VI 5e) und somit konnten ,viele Dorfteiche [...] ohne großen Mühen zu hohen Erträgen gebracht werden.“ (TAURKE 1927:7) Eine Gefahr für die Gesundheit der Fische sei „dabei kaum zu befürchten“(ACKERHOF 1869:129).

Nach GAUCKLER fütterte man die Karpfen in Teichen mit Abfällen aus Landwirtschaft, Garten und Küche, mit Kohlblättern, verschiedenen Pflanzen, Luzernhäcksel, Schalen von Kartoffeln, Rüben, Gerste, Malztrebern, Guano. Ferner war „sehr gut frischer Mist von Mastschweinen oder Pferden, getrockneter, auf Weiden gesammelter Kuhdünger, Pudrette ${ }^{8 ،}$.

\footnotetext{
${ }^{8}$ Pudrette (frz.: Poudrette) bezeichnet einen Handels- oder Kunstdünger. Es handelt sich dabei um geruchlos gemachte, getrocknete und gepulverte Menschenexkremente, vermischt mit trockenen Substanzen (Erde, Torf, Kohlenpulver, Asche,
} 
LIETMANN empfahl „möglichst reinen Schweinekot“, der am besten wirke, wenn er entweder vom Ufer oder von einem Kahn aus mit Wasser verrührt „und gut auf die Wasserfläche verteilt wird.“; ebenso auch andere organische Dungstoffe, z. B. Fäkalien aus Schlachthöfen u.a. (1941:41). Des Weiteren wurden die Karpfen „mit größtem Erfolge mit Froschlarven gefüttert.“ Der Froschlaich wurde gesammelt und in die Karpfenteiche gebracht (BORNE 1886:271).

Fisch der Wahl in der Teichwirtschaft war somit der Karpfen. Schnellwüchsig, vollfleischig, als Allesfresser anspruchslos und rauhe Behandlung vertragend, eignete er sich hervorragend für die Teichhaltung.

Die Weiher unterlagen aber nicht einer pisciwirtschaftlichen Nutzung allein, sondern waren zugleich Dorfteich wie auch „unentbehrliche Wasserreservoire bei Feuersgefahr“ (CNOPF 1927:122) und dürften sowohl der Fischhaltung als auch einer ausgeklügelten Wassermengenbewirtschaftung gedient haben, wie HERBST (1992:36) am Beispiel des Rotbaches in Biberach mutmaßt. In historischer Betrachtung haben „Landwirtschaft und Fischzucht [...] eine gemeinsame geschichtliche Entwicklung durchlaufen“ (RUST 1956:1; siehe auch Pkt. b.4), und dieses System wurde bis in die Neuzeit beibehalten.

Darüber hinaus wurden sie als Viehtränke benutzt. So war zum Beispiel beim Kloster Auhausen im Markgrafentum Ansbach im Jahre 1723 von den vorhandenen 10 Weihern Tränkrecht in 4 Weihern vorhanden (CNOPF 1927:83). Im Klosteramt Bemberg/Ansbach wurde in einem Fischweiher neben Tränkrecht sogar Hutungsrecht geltend gemacht (:83). Daneben waren Weiderecht, Heuzehnt und Wasserjagdrecht andere Lasten, die den geistigen und herrschaftlichen Herren zustanden $(: 112,117)$.

\section{b.2 Die neuzeitliche Mehrteichanlage}

Die neuzeitliche Fischzucht ist um die Wende des 19. zum 20. Jh. entwickelt worden und unterscheidet sich deutlich von der mittelalterlichen Pisciwirtschaft. Sowohl die Einrichtungen wie auch der Betrieb der Weiher waren in wesentlichen Bereichen anders als im Mittelalter (siehe Pkt. b.1) und im Vergleich zur modernen Fischwirtschaft (siehe Pkt. b.3).

Bei diesem System werden weibliche und männliche Elterntiere aus dem Teich (bei Karpfenartigen) beziehungsweise aus einem Fluss oder See (bei Forellenartigen) gefangen und gestreift, d. h. man nimmt dem Rogner die Eier und dem Milchner den Samen. Nur bei karpfenartigen Fischen kann eine Embryonengewinnung in Gefangenschaft erfolgen, aber auch hier ist die Karpfenbrutgewinnung ein sehr schwieriges Kapitel, weshalb mit der Erfindung des sog. ,Dubischverfahrens' seit dem 19. Jh. dieses verbesserte Aufzuchtverfahren fast überall zur Anwendung kam:

In kleinen, 10 bis $22 \mathrm{~m}^{2}$ großen, mit Gras bewachsenen Laichteichen, die nur für diesen Zweck Verwendung fanden, wurden bei entsprechender Wassertemperatur $\left(20-22^{\circ} \mathrm{C}\right)$ die in Hältern

Fleisch- und Kotabfall, Kehricht, Ziegelpulver etc.). Dieser Fäkaliendünger wurde zuerst in Paris als Handelsartikel hergestellt und auch deutscher oder künstlicher Guano bzw. ,das braune Gold' genannt. Auch zu Ende des 19. Jh. wurde die Poudrette am meisten, abgesehen von China, wo die Mischung von Exkrementen mit Ziegelpulver als ,Taffö' verkauft wurde, in Frankreich hergestellt und verbraucht, ebenso das in ähnlicher Weise aus Harn gewonnene Urat. Aber auch in Deutschland wuchsen Ende des 19. Jh. die Städte rasant und mit ihnen das Aufkommen von Fäkalien. Nicht alles konnte sofort abgeholt und genutzt werden, Lagerung war notwendig und somit wurde die Geruchsbelästigung immer schlimmer. In Bremen beispielsweise kam „Schieten-Alfes“ auf die Idee, Fäkalien zu einem besser transport- und lagerfähigen Dünger umzuwandeln - zu Poudrette. Die erste Poudrette-Fabrik entstand in Bremen am Arsterdamm. Hier wurden die Exkremente mit Schwefelsäure zersetzt, im Rührwerk verarbeitet, angewärmt und in einem Verdampfungsgerät sowie weiteren Apparaten durch Wasserentzug eingedickt. Der so entstandene Brei wurde schließlich gewalzt und im letzten Arbeitsgang in heißer Luft getrocknet. Entstehende Fäkaldämpfe wurden kondensiert, um sie nicht nach außen dringen zu lassen. Das gelang allerdings nur mangelhaft (http://www.hansewasser.de [06.01.2004])

Die Poudrette bildet eine dunkelschwarze pulverförmige Masse von großer Hygroskopizität und „ist deshalb vorzüglich geeignet für Sandböden“; sie wurde nicht nur in der Teichwirtschaft, sondern auf Ackerland und Wiesen sowohl zur Saat wie während des Wachstums beigegeben, da sie, so die damals vertretene Ansicht „den Wurzeln nicht schadet“ (MEYERS KONVERSATIONSLEXIKON 1888, Bd. 21:442) 
bereitgehaltenen Laicher ausgesetzt, nach dem Laichgeschäft wieder herausgenommen und in Hälterteiche zurückgeführt. Die befruchteten Eier entwickelten sich hindessen in den Laichteichen unter idealen Bedingungen zu Fischembryonen und anschließend zu Jungtieren. Die nach vier bis fünf Tagen frisch geschlüpfte Jungbrut $\left(\mathrm{K}_{\mathrm{o}}\right)$ wurde schließlich in spezielle Vorstreckteiche, später in Streck- und letztlich in ihre Überwinterungsteiche übersetzt oder in einem freien Gewässer ausgesetzt, bis sie auf dem Markt verkauft werden konnten (PLANANSKY 1983:79). Der Vorteil durch das mehrmalige Übersetzen in immer neue Lebensbedingungen lag darin, daß die Jungbrut „,weit besser heranwachsen und infolge ihrer Größe und guten Kondition den Winter weit leichter überstehen“ konnte als in den davor vorhandenen einzelnen alten Brutteichen (:79).

Wie aus der Trennung zwischen Fischzucht und Fischhaltung abzuleiten ist, waren für eine vollständige Zucht mehrere Teiche notwendig, während für die reine Aufzucht von Verkaufsfischen oder für die reine Fischbrutgewinnung nur jeweils ein einzelner Teich ausreichte (TAURKE 1927:8). Die Fischteichwirtschaft musste also durch die Anlage von unterschiedlichen Fischteichen betrieben werden, die zumeist im räumlichen Verbund errichtet wurden (in Anlehnung an BORNE 1886:217):

1. durch Anlage künstlicher Laichstätten (Laichteiche),

2. durch Fischaufzucht in Teichen (Aufzuchtteiche),

3. durch künstliche Fischhaltung (Hälterteiche).

Betrachtet man das mosaikartige Areal eines größeren Fischzuchtbetriebes des $19 \mathrm{Jh}$., so lassen sich eine Vielzahl von größeren und kleineren Einzelteichen ausmachen. Diese dienten zum einen der nach Art und Alter verschiedenen - Aufnahme von Fischen und zum anderen der, nach Jahreszeiten erforderlichen, Umsetzung in dafür speziell angelegte Teiche.

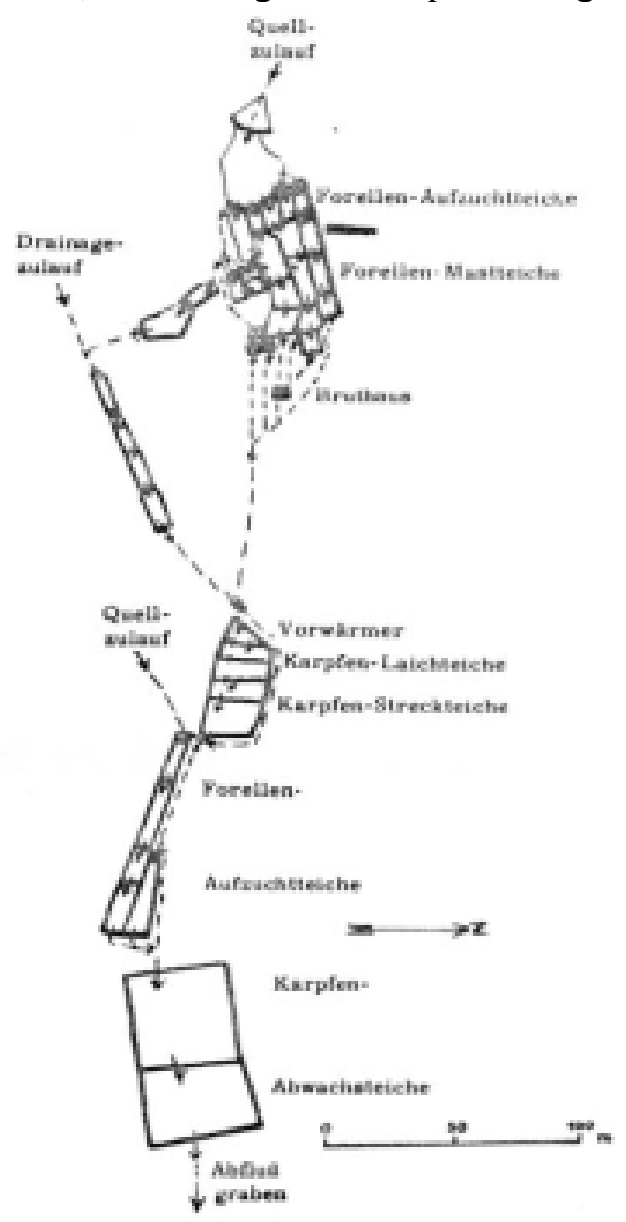

Abb. VII-2:Kombinierte Forellen- und Karpfenzucht Sarlhusen-Papiermühle/Schleswig-Holstein

Teicharten und Wasserführung einer aus einer frühneuzeitlichen Mühlenanlage hevorgegangenen Teichwirtschaft mit einer Teichfläche von 3,5 ha. Eine solche kombinierte Teichwirtschaft wurde beispielsweise auch Nindorf bei Hohenwestedt betrieben. Auffällig sind die großflächigeren Karpfen-Abwachsteiche (aus RUST 1952:138 11). 
Seit den 20er Jahren des $19 \mathrm{Jh}$. ließ man „die Laichkarpfen in besonderen Teichen ablaichen“ und versetzte die Fischchen „bis zum Frühjahr des Verbrauchsjahres mehrere Male in immer größere Teiche" (TAURKE 1927:2). Der Karpfenstrich, d. h. die Fischbrut, wurde in den aufkommenden großen Karpfenzuchtanstalten ,zweimal oder wenigstens einmal in immer größere Teiche versetzt, damit sie stets genügend Nahrung findet" (:6) . Das bedeutet, dass für eine vollständige Züchtung samt der Aufzucht der Brut nicht ein oder zwei Teiche, sondern eine ganze Anzahl verschiedener Teiche erforderlich wurden (:7f.). Solche Betriebe wiesen im Durchschnitt aber schon in der Zeit des Absolutismus Teichflächen von 20 - 30 ha, in wenigen Fällen sogar über 100 ha auf ${ }^{9}$.

Seit der neuesten Zeit wendete man neben der Karpfenzucht auch der Züchtung von Schleien, Forellen und anderen Fischarten, selbst solchen ausländischen Ursprungs, erhöhte Aufmerksamkeit zu. Sogar der zarte, d. h. gegen Schädlichkeiten wenig widerstandsfähige, aber äußerst wohlschmeckende Zander wurde „hier und da bereits in Teichen gezüchtet“, so TAURKE (1927:2) ohne nähere Ortsangabe.

Die Begrifflichkeiten sowie der Teichbau der Teichwirtschaft werden bis heute von der frühen Fischzuchtlehre des 19. Jahrhunderts geprägt, in Ausnahmefällen zurückreichend bis ins Mittelalter. Sie können vorteilhaft bei der funktionalen Bestimmung von Teichrelikten im Gelände herangezogen werden.

\section{b.2.1 Teicharten der Karpfenzucht}

Zum Betrieb einer vollkommenen Karpfenzucht gab es nach der ,alten Wirtschaftsform“ (PLANANSKY 1983:79), wie vorher beschrieben und hier noch einmal zusammenfassend dargestellt, verschiedene Arten von Teichen, die je nach Verwendung für bestimmte Altersstufen ${ }^{10}$ und Jahreszeiten unterschieden werden: Streichteiche zur Vermehrung der Fische, Streckteiche zur Aufzucht der ein- und zweisömmrigen, Abwachsteiche für ältere Fische, Winterteiche zur Überwinterung verschiedener Altersklassen und Vorratsteiche (Heller oder Hälter) ,zur Beherbergung eines Vorrats an verkäuflicher Ware.“(BENECKE 1885:20; PLANANSKY 1983:79).

Dieses sog. ,alte' Verfahren der mehrteiligen Karpfenteichwirtschaft geht auf den Fischzüchter Thomas DUBISCH (1813-1888) zurück, der diese Methode nacheinander geschalteter, spezieller Aufzucht- und Wachstumsteiche zuerst in den Teichen auf den schlesischen Gütern des östereichischen Erzherzogs Albrecht bei den Orten Teschen und Saybusch angewendet hat. Es hatte zum Ziel, die Erzeugung von Karpfenbrut sicherzustellen und die Erträge der Teiche bedeutend zu steigern (BORNE 1886:264, 268; TAURKE 1927:11). Bei diesem Verfahren vollzieht sich das Laichen der Karpfen in besonderen Laichteichen, die als Streichteiche oder Dubischteiche bezeichnet werden (SCHÄPERCLAUS 1961:236f.).

In dem alten Verfahren der Karpfenteichbewirtschaftung kannte man also

1. Streichteiche,

2. Streckteiche,

3. Winterteiche,

4. Abwachsteiche und

5. Vorratsteiche.

\footnotetext{
${ }^{9}$ Besonders das 16. Jahrhundert gilt als das Jahrhundert des Teichbaus. Aus dieser Zeit stammt auch der größte Fischteich (Karpfenteich) Europas, Rozmberk bei Trebon in Südböhmen, der 500 ha groß ist und in der Zeit 1584-1591 angelegt wurde (BENECKE 1885:410; AMACHER 1996: 87f.).

${ }^{10}$ Der Karpfen wurde nach seinem Alter und nach seiner Bestimmung begrifflich eingeteilt: Der eigentliche Karpfen hieß erst im 4. oder 5. Lebensjahr ,Karpfen'. Im 1. Lebensjahr wurde er als ,Karpfenstrich', im 2. Lebensjahr als ,zweijähriger Karpfen' und im 3. Lebensjahr als dreijähriger ,Karpfensaamen' bezeichnet. Alsdenn hieß er im vierten Jahre ,Teichsaamen' (DYHRN 1782:8).
} 
Die prozentuale Flächenaufteilung der verschiedenen Teicharten innerhalb eines solchen vollständigen Karpfenteichbetriebes wird nicht einheitlich gesehen, aber aus der Zusammenstellung (Tab. VII-1) ergibt das tendenzielle Bild, das schon oben deutlich wurde, die Größen- und Flächendominanz der Abwachsteiche:

Tab. VII-1: Einteilung der Teichflächen

\begin{tabular}{|l|c|l|}
\hline Teicharten & \multicolumn{2}{|c|}{ Anteil an der Gesamtfläche } \\
\hline & nach PLANANSKY (1983:79) & nach SCHÄPERCLAUS (1961:235; Tab. 45). \\
\hline Laichteiche (Streichteiche) & $10 \%$ & $2-6 \%$ \\
\hline Streckteiche & $29 \%$ & $20-25 \%$ \\
\cline { 3 - 4 } Winterteiche & $60 \%$ & $2 \%$ \\
\hline Abwachsteiche & $1 \%$ & - \\
\hline $\begin{array}{l}\text { Hälteranlagen } \\
\text { (Vorratsteiche) }\end{array}$ & & \\
\hline
\end{tabular}

Diese Teicharten weichen nicht nur in ihrer Funktion, sondern auch hinsichtlich Form und Tiefe voneinander ab und werden auch als ,Jahreszeitenteiche' bezeichnet (SCHÄPERCLAUS 1961:148). Die sog. Sommerteiche umfassen die Teiche 1,2 4 und 5. Sie gibt es aufgrund der in diese Jahreszeit fallenden Wachstums- und Aufzuchtperiode in einer großen Variabilität. Die sog. Winterteiche, die im Sommer nicht fischereiwirtschaftlich genutzt werden, verdienen insofern besondere Aufmerksamkeit, als sie für eine Teichbodenbewirtschaftung in der Sommerzeit zur Verfügung standen. Doch je nach Teichbewirtschaftungsform konnten auch Brutstreckteiche als Winterteiche fungieren.

\section{b.2.1.1 Brutteiche}

Unter dem Oberbegriff ,Brutteiche' werden der Laich- bzw. Streichteich, der Brutstreckteich und der Vorstreckteich zusammengefasst und unterschieden (BENECKE 1885:25; TAURKE 1927:10).

Diese drei Teicharten blieben in der frühen Form der vollständigen Teichbewirtschaftung den Winter über trocken liegen und wurden „zur Unterdrückung von Fischfeinden“ (WUNDER 1956:18) erst im Frühjahr, „kurz vor Besatz und Ablaichen“ neu bespannt (WUNDER 1956:18; TAURKE 1927:11).

Der Züchter nahm dabei zur Aufzucht „die kleineren und flacheren, fruchtbaren, gut trockengelegten und gedüngten, möglichst am oberen Ende des Zuflusses gelegenen Teiche“ (WALTER 1933:47).

Den besonderen Verwendungszweck erreichte man durch Herstellung von kleinen rechteckigen Brutteichen, die $15-25 \mathrm{~m}$ lang und $4-6 \mathrm{~m}$ breit waren und einen Wasserstand von $40-60 \mathrm{~cm}$ Tiefe hatten. An einer Längs- und einer Breitseite des Teiches wurde ein $30 \mathrm{~cm}$ tiefer Graben ausgehoben, in welchen das Speisewasser eingeleitet wurde. Es konnten natürlich mehrere solcher kleinen Teiche miteinander in Verbindung gebracht werden, auch unmittelbar nebeneinander liegend. Die Gräben dieser Brutteiche wurden „mit beschwerten Brettschwarten, welche Lücken zum Durchschlüpfen bieten müssen“, überdeckt (TAURKE 1927:39).

\section{b.2.1.1.1 Streichteiche}

„Wenn eigentliche Karpfen zum Streichen, das heißt, um sich zu vermehren, hineingesetzt werden, so heißen sie in solcher Absicht Strich- oder Streichteiche“, so DYHRN (1782:8) zur Herkunft und Definition des Wortes. Streichteiche bzw. auch Laichteiche sind also Teiche ,in denen die Karpfen streichen oder laichen, und wo Karpfenbrut gezüchtet wird“ (BORNE 1886:263). Laichteiche dienen somit der reinen Brutgewinnung (TAURKE 1927:9) „wie sie früher üblich war“ (ZOBEL 1992:98).

Mit der Aussage „Streck- oder Saamenteiche bringen mehr ein als Karpfenteiche, und Strichteiche das allermehreste" hebt DYHRN (1782:101) die Bedeutung von Strichteichen innerhalb der Karpfenzucht hervor. Aus diesem Grund wird ihnen in der Teichwirtschaftslehre auch ein so großer Wert 
beigemessen, der sich in der eingehenden Beschreibung in der älteren teichwirtschaftsfachlichen Literatur widerspiegelt.

Die Streichteiche, die den Zweck haben, Fischbrut, sog. Karpfenstrich, zu erzeugen „müssen so beschaffen sein, daß sie den Fischen für das Laichen die günstigsten Verhältnisse bieten und auch die Entwicklung der Eier und der jungen Fischchen möglichst fördern“ (BENECKE 1885:20). Es handelte sich hierbei nach ZOBEL (1992:98) und SCHÄPERCLAUS (1961:237) um kleine Teiche von 50 bis $100 \mathrm{~m}^{2}$ (z. B. 6 x 9 m), höchstens aber bis $200 \mathrm{~m}^{2}$ Größe. Die kleinsten Streichteiche erreichten ein Ausmaß von 3 x 3 m (:237). Die ideale Größe eines Karpfenlaichteiches wird von TAURKE (1927:9) mit ca. 5 - $10 \mathrm{Ar}^{11}$ benannt.

Nachdem die Teiche - mit Ausnahme der Streichzeit - das ganze Jahr über, „so lange wie möglich“ (BORNE 1886:226,268) trocken lagen, ,damit sich der Teichboden möglichst erwärmt und nicht sauer wird“ (TAURKE 1927:9), wurden sie ,erst kurz vor der Laichzeit - gewöhnlich Mitte Mai“, d. h. „zu Beginn von Schönwetterperioden“, bei „Wassertemperaturen um $20^{\circ} \mathrm{C}^{\prime \prime}$ mit Wasser gefüllt (BORNE 1886:226,268). Das Prozedere des Anstauens begann - nach der unter den früheren klimatischen Bedingungen noch gültigen Regel - nicht „,vor den kalten Tagen im Mai“ (BORNE 1886:228). Erst bei Erwärmen des Wassers auf etwa $19^{\circ} \mathrm{C}$ gegen Ende des Monats Mai wurden die Karpfen in den kurz vorher bespannten Streichteich gebracht (TAURKE 1927:9). Laichteiche wurden dabei nur ganz kurze Zeit zum Ablaichlassen unter Wasser gesetzt. Sie waren gewissermaßen nichts anderes als kleine überschwemmbare Wiesen, auf denen die Karpfen genauso wie in den Überschwemmungsgebieten der großen Ströme, in denen sie natürlicherweise vorkommen, laichen können. Dies geschah entweder „durch $30-50 \mathrm{~cm}$ hohes Anstauen von Bach- oder Himmelswasser auf Wiesen oder Weidegrund“" (TAURKE 1927:9) oder durch einen sog. Vorwärmer. Der Wasserstand im Laichteich sollte sich dabei durch den - durch Wasserzufluss bedingten - ansteigenden Boden von im Durchschnitt $40 \mathrm{~cm}$ auf $10 \mathrm{~cm}$ verringern und durch regulierten Zufluss gehalten werden. Die geringe Wassertiefe sicherte eine rasche Erwärmung und günstige Sauerstoffbedingungen (ZOBEL 1992:99).

Max von dem BORNE (1886:268) beschreibt den Laichteich zu Mitte des 19. Jh. wie folgt:

\begin{abstract}
„Der Streichteich braucht nicht größer wie 0,1 ha zu sein, 0,3 - $1 \mathrm{~m}$ ist eine zweckmäßige Tiefe; der Grund ist weich: Der Wasserspiegel muß wenigstens 0,3 m unter die Teichsohle gesenkt werden können, damit diese vollkommen austrocknet, wenn der Teich trocken liegt; sie ist deshalb mit hinreichend tiefen Gräben durchzogen. (...) Der Teich liegt im Winter und Frühjahr trocken und wird erst kurz vor dem Einsetzen der Streichkarpfen bespannt. Dadurch werden alle schädlichen Thiere, wie Käfer, Larven $u$. dgl. zerstört, und der Boden entsäuert.“
\end{abstract}

Die Streich- oder Laichteiche verfügten also, dies bestätigen auch andere Quellen (z. B. ZOBEL 1992:98f.), über einen umlaufenden oder auch durchgehenden Graben und wiesen, da sie auf weichem Weide- oder Wiesengrund errichtet wurden, einen Grasbestand auf. Um ideale Brutbedingungen zu schaffen, sollten deshalb die Teiche möglichst mit Laichstätten für die Fischarten versehen sein. Die künstlichen Laichstätten, auch Brutbeete genannt, belegte man mit Strauchwerk von Wacholder oder Birken, sog. Birkenreiser, damit die Fische ihre Eier daran absetzten. Diese flachen Bereiche des Teiches wurden mit Gras oder Schilf bewachsen und von circa $1 / 2 \mathrm{~m}$ tiefen Gräben durchschnitten, damit beim Trockenlegen der Spiegel des Grundwassers so weit sinkt, dass die Brutbeete ganz austrocknen können, um sich wieder schnell erwärmen zu können (BORNE 1886:226).

Auch SCHÄPERCLAUS (1961:238) berichtet von einem Graben, der „ringsherum am Damm entlang“ ausgehoben wurde und von dem aus ,zur Mitte hin dachförmig der auch als Laichbeet oder Laichbett benannte Laichrasen bis auf eine Wassertiefe von $20 \mathrm{~cm}$ anstieg." Der Graben durfte aber nicht schroff mit einer steilen Kante in den Laichrasen übergehen, sondern der Anstieg sollte ganz

\footnotetext{
${ }^{11}$ Ar [lat. area: Fläche], frühere Maßeinheit zur Angabe der Fläche von Grund- und Flurstücke. $1 \mathrm{a}=100 \mathrm{~m}^{2}$. Die Teichgröße entsprach somit $500-1000 \mathrm{~m}^{2}$.
} 
allmählich erfolgen, damit die im Graben stehenden Laichkarpfen eine Übersicht über die gesamte ansteigende Teichfläche haben, „weil beobachtet wurde, daß sie nur dann gut laichen“ (:238). Der Laichteich konnte aber auch gänzlich ohne Gräben derart angelegt werden, dass der Laichrasen aus einer tiefen Region von $80-100 \mathrm{~cm}$ nach einer Seite hin gleichmäßig bis zur Wasseroberfläche ansteigt (:239). Als Gras für den Laichrasen wurde ,Deutsches Weidelgras' (Lolium perenne) empfohlen: „Derartige Gräser faulen nicht so leicht und erzeugen daher weniger leicht Sauerstoffmangel“", so die Begründung (:238). Eine archäobotanische Untersuchung, die für diesen Bereich nach meinem Kenntnisstand noch nicht vorliegt, könnte für die weiter zurückliegende Vergangenheit diese Aussage auf ihre Übertragbarkeit hin überprüfen.

Im Herbst wurden die flachen Streichteiche abgefischt, um über Winter trocken zu liegen, „während die Fischchen in tiefe, frostsichere Winterteiche gebracht werden, aus denen sie [...] im Frühjahr in die Streckteiche gelangen." (BENECKE 1885:26)

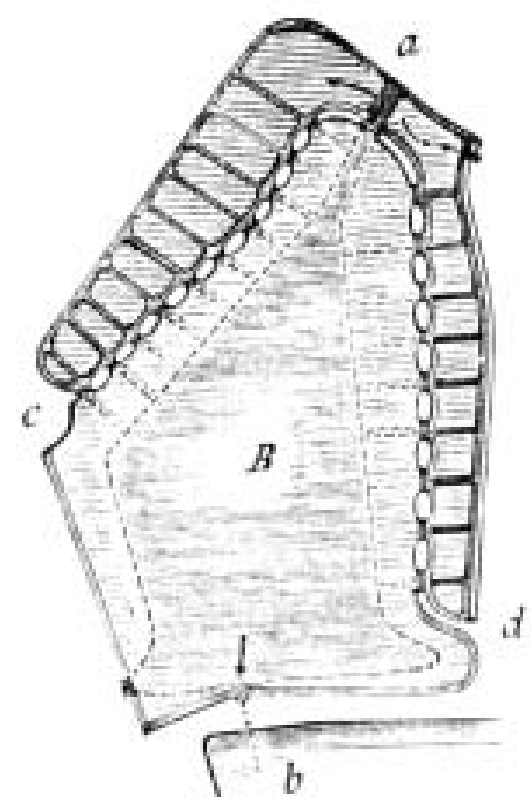

Abb. VII-3:Streichteich

Die Abbildung stellt einen Streich- bzw. Laichteich im Teichgebiet Lübbinchen, heute Landkreis SpreeNeiße/Südbrandenburg dar: bei $a$ fließt das Wasser ein, bei $b$ ist die Ablassschleuse, und $c d$ ist ein Fußsteig, der über die Brutbeete führt. Der Teil $B$ des Teiches ist wenigstens $1 \mathrm{~m}$ tief, damit die Laichfische dort Schutz finden können (aus: BORNE 1886:226).

Normalerweise strichen die Fische, sowie sie in den Teich gesetzt worden sind; war dies indes nach einigen Tagen noch nicht geschehen und fing das Wasser an trübe zu werden, so unterblieb das Laichen bisweilen ganz. Die Lösung für dieses unerklärliche Verhalten, das eine teichwirtschaftliche Katastrophe bedeutet hätte, fand man nach BORNE (1886:269) wie folgt: „Bringt man aber dieselben Fische in einen soeben bespannten anderen Streichteich, so laichen sie in der Regel sofort“ und „nach wenigen Tagen wimmelt der Teich von kleinen Karpfen". Damit bei einem Versagen des Ablaichens sofort ein neuer Laichteich für einen zweiten Versuch bereitsteht, war es in der schon intensiven, betriebswirtschaftlich geführten Fischzucht Mitte des 19. Jh. „nothwendig, mehrere Streichteiche [...] in Reserve zu haben, obgleich sie nur selten gebraucht werden.“ (BORNE 1886:268f.) Selbst kleine Betriebe müssten ,mindestens 2 Laichteiche besitzen. Besser ist es aber, wenn 5 oder mehr Laichteiche als Reserve vorhanden sind.“ (SCHÄPERCLAUS 1961:240)

Da der Streichteich frei von Hechten, Barschen, Stichlingen und anderen Fischarten sein muss, um den Laich zu erhalten, wählte man zweckmäßigerweise durch atmosphärischen Niederschlag sich bespannende ,Himmelsteiche', kleine Teiche von nur 0,1 bis 0,5 ha Fläche auf leichtem, aber undurchlässigem Humus-, Lehm-, oder lehmigem Sandboden (BENECKE 1885:20; BORNE 1886:264). Erhielt der Teich Zuflüsse aus Gewässern, welche nicht fischleer waren, so musste das Wasser durch einen Kiesrechen geleitet werden, damit kein fremder Fisch in den Streichteich gelangte 
(BORNE 1886:264). Gegen Druckwasser aus benachbarten Teichen waren sie durch die Art der Anlage oder durch den Bau von Schweißgräben zu schützen (SCHÄPERCLAUS 1961:238) .

Wo Himmelsteiche nicht angelegt werden konnten, „sind auch aus Flüssen oder Seen zu speisende Teiche zu gebrauchen, doch muß dann das Wasser vor seinem Eintritt in den Streichteich durch große, mit gewaschenem, grobkörnigem Kies gefüllte Gruben oder Kasten filtriert werden, um das Eindringen von Fischen und schädlichen Tieren aller Art [...] zu verhindern.“ (BENECKE 1885:20f.)

Gemeinsam ist den Laichteichen, ob von der Art der Anlage Himmelsteich oder Flussteich, dass sie nach der Benutzung vollständig trockengelegt werden können (SCHÄPERCLAUS 1961:238).

Laichteiche müssen des Weiteren warm sein. Eine Wassertemperatur von mehr als $+14^{\circ} \mathrm{C}$ ist dabei eine „wesentliche Bedingung“ (BORNE 1886:268). Sie sollen deshalb gut von der Sonne beschienen und gegen Wind geschützt sein, um die Teiche nicht zu starker Wellenbewegung auszusetzen. Aufgrund dessen wurden die Laichteiche früher mit dichten Hecken oder Wänden aus Rohrmatten eingezäunt oder an der der Sonne abgewandten Seite von einem dichten Gehölz begrenzt (SCHÄPERCLAUS 1961:240).

Dem regional unterschiedlichen Klima, den örtlichen Teich- und Wasserverhältnissen entsprechend sowie, je nach örtlichen Gepflogenheiten, der Erfahrung der Bewirtschafter, lassen sich 4 verschiedene Verfahren der Brutgewinnung unterscheiden (SCHÄPERCLAUS 1961:236).

Tab. VII-2: Verfahren zur Karpfenbrutgewinnung (aus: SCHÄPERCLAUS 1961:237)

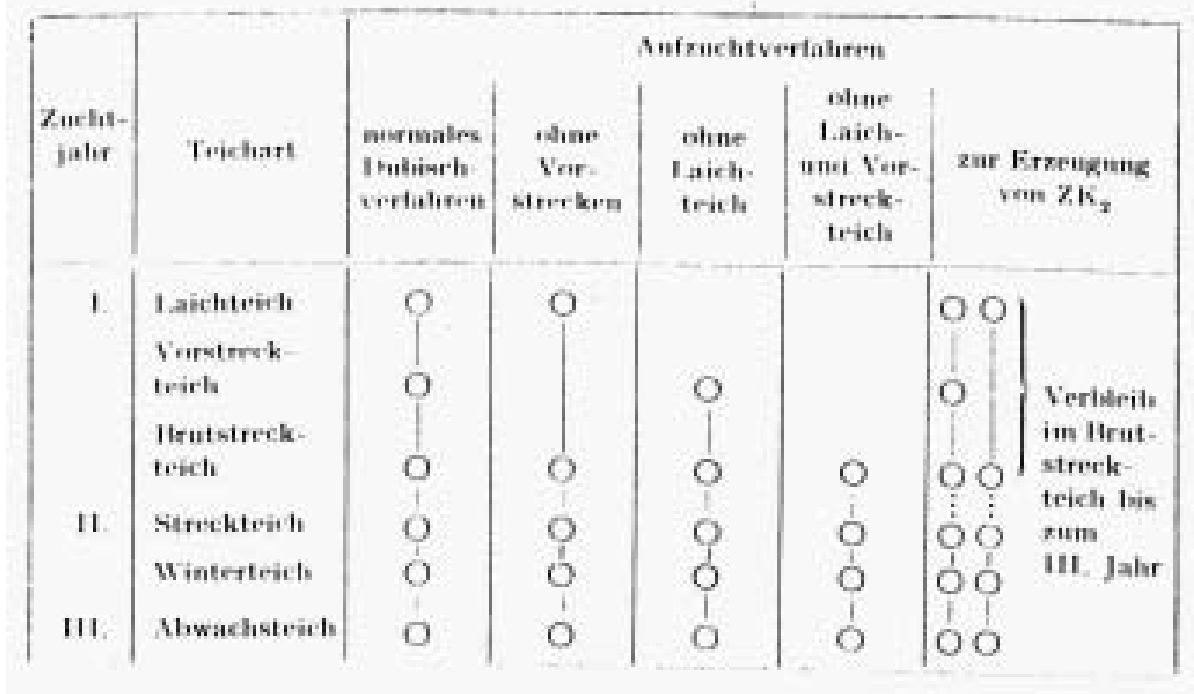

Die aus der Brut erwachsenden sog. ,Streicher' werden dann im Winter mit jungen Karpfen zusammen in einem Kammerteiche aufbewahrt ,und im Frühjahr in einen hölzernen, oder gemauerten Hälter gesetzt, wo sie nicht fressen und keine Luft zum Laichen haben.“ (BORNE 1886:268)

\section{b.2.1.1.2 Streckteiche}

Nach ca. 4 - 5 Wochen Aufenthalt in den Laichteichen wurde die dann $5 \mathrm{~cm}$ lange vorgestreckte Brut, der sog. Monatskarpfen, in spezielle Teiche verbracht (TAURKE 1927:10; SCHÄPERCLAUS 1961:260). Dies geschah Ende Juni bis Anfang Juli. Diese zur Aufzucht von einsömmrigen Besatzkarpfen aus vorgestreckten Karpfen oder der schwimm- und fressfähigen Karpfenbrut dienenden Teiche, werden als Brutstreckteiche bezeichnet (ZOBEL 1992:59). In diesen Streckteichen verbringen die Karpfen das zweite Zuchtjahr. Hier wachsen sie von ein- zu zweisömmrigen Karpfen heran (:59). In einfacherer Weise bezeichnet BENECKE (1885:26) Streckteiche allgemein als „diejenigen Teiche, in welche die jungen Karpfen eingesetzt werden, um heranzuwachsen oder sich zu strecken." 
Unabhängig von der Altersklasse, ob „,zwei- und dreijährige, auch wohl vierjähriger [...] Saamen“ darinnen gezogen wird (DYHRN 1782:8), und des Abfischungszeitpunktes werden Streckteiche in der frühen fischereiwirtschaftlichen Literatur allgemein als solche Teiche definiert, „,in welchen die Brut wächst, d. h. sich streckt.“ (BORNE 1886:263) In die Streckteiche werden meistens auch, nach Geschlechtern getrennt, die Laicher ausgesetzt, weil sie hier nicht laichen können (SCHÄPERCLAUS 1961:270). Dies bedeutet, dass entweder ein Streckteich durch Faschinen oder Reiser, durch die die Fische nicht hindurch schwimmen konnten, geteilt wurde, oder aber zumindest zwei Brutstreckteiche notwendig waren: einen für den Rogner und einen für den Milchner.

Spätestens 8 Tage vor der Besetzung - aber auch nicht früher - wurden die Brutstreckteiche, die bis unmittelbar vor ihrer Besetzung trocken lagen (BENECKE 1885:25), bespannt, damit in den Teichen Nahrung entstehen konnte (TAURKE 1927:10). Ein Aufspannen der Teiche schon viele Wochen vorher wurde jedoch nicht empfohlen, da sich sonst die gefürchteten ,Fischfeinde' und ,Raubinsekten' und deren Larven einfinden.

Nach BORNE (1886:264) und BENECKE (1885:26,28) wurden die Brutstreckteiche (wie die Streichteiche) anschließend im Herbst abgefischt, um über den Winter trocken zu liegen, während die Fischchen in tiefe, frostsichere Winterteiche gebracht wurden, aus denen sie im Frühjahr in die Streckteiche gelangten. Brutstreckteiche wurden, selbst wenn sie winterungsfähig sein sollten, nach mehrheitlicher Meinung nicht zur Überwinterung genutzt. Lediglich nach CRONHEIM (1907:42) fischt man sie ,am besten im Herbst [...] nicht ab, sondern beläßt sie im Streckteich, den man dann im Frühjahr abfischt und trocken legt.“

Die Vorteile der winterlichen Trockenlegung lag einerseits darin, dass in den abgelassenen Teichen das Ungeziefer und die Wildfische gründlich vernichtet und durch Entwässern, Entsäuern und Durchfrieren neue Nährstoffe im Teichboden aktiv gemacht werden konnten. Des Weiteren war es „bei einem planmäßigen Wirtschaftsbetriebe nötig [...], schon im Herbst zu erfahren, wie die Besatzung eines jeden Teiches gediehen ist.“ Andererseits würde es schwer sein, einer größeren Zahl von Teichen während des Winters die erforderliche Sorgfalt zu widmen (BENECKE 1885:30; ebenso WALTER 1933:29).

Die zur Aufnahme der Fischchen bestimmten Brutstreckteiche sind von gleicher Beschaffenheit wie die oben beschriebenen Streichteiche (BENECKE 1885:25): „Als Streckteich dient am besten eine fruchtbare Wiese“ (CRONHEIM 1907:42). Hierbei handelt es sich um „flache, vollkommen

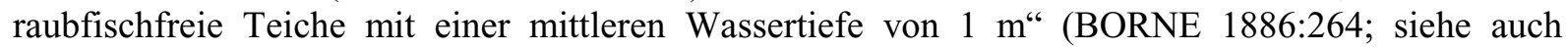
ZOBEL 1992:59).

Sollen sie aber zugleich, wie CRONHEIM (1907:42) es vorschlägt, ,als Winterteich dienen, so soll der Boden weich sein, damit die Fische darin ihr Lager suchen, aber nicht sehr schlammig und genügende Stellen mit einer Tiefe von 1,5-2 m aufweisen, die im Winter nicht ausfrieren, und ein reichlicher Wasserzufluß zur Verfügung stehen." Wo Hochwassergefährdung bestand, wurden Umleiter angelegt, damit Nährstoffe und Jungbrut nicht ausgeschwemmt werden (PLANANSKY 1983:80).

Hinsichtlich der Größe finden wir einzig bei SCHÄPERCLAUS (1961:260) eine konkrete Angabe, die besagt, dass Brutstreckteiche höchstens 15 ha (!) groß sein dürfen, weil sonst die Abfischung der kleinen einsömmrigen Karpfen sehr erschwert ist. Während sich die Größenordnung auf sehr große Teichwirtschaften bezieht und hier zudem eine Maximalzahl vorgegeben wird, hilft meiner Meinung nach eher die Verhältniszahl, die auf die jeweilige Größe der Teichwirtschaft bestimmt ist: Demnach müssen die Teiche ,aber so groß sein, daß aus einem Brutstreckteich immer ein oder mehrere Streckteiche vollständig besetzt werden können, so daß eine Vermischung des Besatzes der Streckteiche aus mehreren Brutstreckteichen nicht notwendig ist." (:260) Hieraus wird ersichtlich, dass es bei den Streckteichen wiederum Unterformen gibt, die die Anzahl an solchen dem eigentlichen Wachstum dienenden Teichen erhöhen. 
Bei dem bereits oben erwähnten Dubischverfahren neuzeitlicher Karpfenteichbewirtschaftung wurde die mehrmalige Versetzung der Brut praktiziert. Die in einem kleinen Teich erzielte und kurze Zeit gehaltene Brut wurde allmählich - entsprechend dem Fischwachstum - in immer zahlreichere und größere Teiche zum Strecken überführt (BENECKE 1885:25,27). Die erste Übertragung fand dabei schon ,5 - 8 Tage nach dem Ausschlüpfen der Fischchen statt“ (:25). Der Grund liegt darin, dass „kleinere Fische neben größeren derselben Art schlecht gedeihen, weil sie von ihren stärkeren Genossen in der Nahrung beeinträchtigt werden." (:27)

Folglich legte man in einer größeren Teichwirtschaft, die nach dem Dubisch-Verfahren Karpfenzucht betrieb, nicht nur mehrere, sondern auch verschiedene Streckteiche an, in denen die zu streckenden Fische getrennt gehalten wurden. Dafür gebrauchte BENECKE $(1885: 25,27)$ die Bezeichnungen:

- Brutstreckteiche 1. Ordnung (Vorstreckteich bzw. Streckteich 1)

- Brutstreckteiche 2. Ordnung (Streckteich bzw. Streckteich 2) und gelegentlich auch

- Brutstreckteiche 3. Ordnung (Streckteich 3).

Deren Einteilung ergibt sich aufgrund des Fischalters: Einsömmrige Karpfen werden in Streckteiche erster Ordnung, zweisömmrige in solche zweiter Ordnung gesetzt usw.

Brutstreckteiche 1.Ordnung, auch ,Vorstreckteiche' genannt, dienen der Erzeugung von vorgestreckten Karpfen $\left(K_{v}\right)$ (ZOBEL 1992:100). Zum Zeitpunkt des Schlüpfens der Karpfenbrut in den Streichteichen werden die Vorstreckteiche allmählich unter Wasser gesetzt (:101). In diesen Teichen ,sollen die Fischchen [...] in etwa 4 Wochen einige Centimeter lang werden [...] und, um kräftig weiter zu wachsen, abermals versetzt werden.“ (BENECKE 1885:25; ebenso ZOBEL 1992:100 mit Längenangabe [4-6 cm])

Der Vorteil eines separaten Vorstreckteiches liegt darin, dass die Besatzdichte der Teiche genauer eingehalten werden kann als mit Karpfenbrut. Außerdem sind vorgestreckte Karpfen widerstandsfähiger und haben im Regelfall geringere Verluste als Karpfenbrut (ZOBEL 1992:100).

Die zur Aufnahme der einsömmrigen Karpfen bestimmten Streckteiche erster Ordnung besitzen eine ähnliche Lage und Beschaffenheit wie die Streichteiche. Vorstreckteiche besitzen ,entsprechend der Größe der Fische, eine durchschnittliche Tiefe von $1 / 2-1 \mathrm{~m}^{\prime \prime}$ (BENECKE 1885:27) und sind 0,25 bis 2 ha groß (ZOBEL 1992:100). Sie können aber auch erheblich größer sein und eine Fläche von mehreren Hektar bedecken (BENECKE 1885:27). Ihre Ränder waren flach und zweckmäßig mit Mannagras angesät; eine mäßige Vegetation von Schilfrohr, Kalmu ${ }^{12}$, Rohrkolben (Typha) und Schwertlilien (Iris) an den Teichrändern bildete gleichzeitig „eine Zierde für den Teich und Gelegenheit zur Entwickelung niederer Tiere, die den Fischchen zur Nahrung dienen.“(:27)

Je größer die Fische werden, umso größer ist ihr Futterbedarf und infolgedessen benötigen große Fische eine größere Wasserfläche als kleine, um vollauf Nahrung zu finden: „Wenn die in dem Streckteiche ausgeschlüpfte Brut die Dotterblase verzehrt hat, so fängt sie an zu fressen, und der Teich wird für sie zu klein. [...] Sie wird deshalb ca. 5 Tage nach dem Ausschlüpfen herausgefischt und in den Streckteich Nr. 1 gesetzt“ (BORNE 1886:269). Dieser erste Streckteich, auch Streckteich 1. Ordnung genannt und der erste von insgesamt drei, hat vor dem Besatz so lange wie möglich trocken gelegen, damit er frei von ,Fischfeinden' und reich an Nahrung ist, denn durch das lange Trockenliegen und Ausfrieren des Teiches wurde „die Entwicklung der kleinen Crustaceen, die der Karpfenbrut zur Nahrung dienen, sehr befördert“ (:269). Aber außer der ,Naturnahrung' wurden in den Streckteichen 1. Ordnung neben den einsömmrigen Karpfen „keinerlei andere Fische geduldet“ (BENECKE 1885:2).

\footnotetext{
${ }^{12}$ Kalmu, eigentlicher dt. Name „Kalmus“ (bot. Ácorus cálamus L.), gehört zur Familie der Aronstabgewächse (Aráceae) und erscheint an Gräben, Teichen, Ufern. Im 16. Jh. aus ihrer Heimat O-Asien eingeführt und seither vollständig eingebürgert (SCHMEIL/ FITSCHEN 1982:576).
} 
Nach wiederum ca. 4 Wochen wurde der Streckteich 1 gefischt und die Fischchen nochmals versetzt, weil die Brut mehr Futter brauchte, als ihr der Streckteich 1. Ordnung gewähren konnte (BORNE 1886:269). Die Brutstreckteiche 2.Ordnung, „für die zweisömmerigen Fische bestimmt“ (BENECKE 1885:28), nahmen nun die „Monatskarpfen“ auf (:25).

Auch der neue Streckteich war bis möglichst kurze Zeit vor der Besetzung trocken gewesen (BENECKE 1885:25): „er war mit Grünfutter (Wickfutter) ${ }^{[13]}$ bestellt, welches kurz vorher abgeerntet worden ist.“ (BORNE 1886:270) Die Streckteiche 2. Ordnung konnten noch größer, tiefer und pflanzenreicher sein als die vorigen (BENECKE 1885:28). BORNE (1886:270) spricht von 3 ha großen Streckteichen 2. Ordnung.

Im Gegensatz zu den Streckteichen 1. Ordnung konnten sich in den Teichen 2. Ordnung „,neben den Karpfen [...] ohne Schaden auch einige Schleihen und Aale halten, die mehr im Grunde wühlen als jene und sich von dort Futter suchen" (BENECKE 1885:28).

Im zweiten Sommer dann setzte man die jungen Karpfen entweder nochmals um in einen Streckteich 3. Ordnung oder, was anscheinend häufiger praktiziert worden ist, sie wurden direkt aus dem Streckteich II in einen Überwinterungsteich überführt. Die Streckteiche selbst wurden wie andere nach der Herbstfischerei den Winter über trocken gelegt (BORNE 1886:270).

\section{b.2.1.2 Winterteiche}

Da die flachen Sommerteiche in den früheren sehr kalten und langen Wintern bis auf den Grund zufroren und den Fischen hier eine eisfreie Zone fehlte, mussten besondere Teiche angelegt werden. Solche Teiche, „worein die Fische, um sie zu wintern, das heißt, um sie im Winter zu erhalten, gesetzet werden, heißen Winterteiche." (DYHRN 1782:8f.) . Sie wurden früher auch einfach „Winterung“ genannt (BENECKE 1885:30) oder als „Kammerteiche“ bezeichnet (TAURKE 1927:194).

Die Begrifflichkeit ,Kammerteich' stammt daher, dass in kleinen Teichwirtschaften die wenigen wintertauglichen Teiche bei Aufnahme verschiedener Fischsorten durch Zwischenräume in einzelne Abteilungen oder Kasten eingeteilt werden mussten. Diese unterteilten Winterteiche werden als „Kammer-,, oder auch als „Kastenteiche“ bezeichnet (TAURKE 1927:10,18,132). Sie wurden des Weiteren oftmals durch Zäune gegen Fischdiebstahl durch ,Fischfeinde' gesichert (SCHÄPERCLAUS 1961:532).

Winterteiche dienen der Überwinterung und Aufbewahrung verschiedener Fischklassen und -sorten „für längere Zeit und für größere Fischmengen“ (TAURKE 1927:194) - in fischereifachlichem Ausdruck: zur Überwinterung von $\mathrm{K}_{1}$ - und $\mathrm{K}_{2}$-Karpfen (ZOBEL 1992:59). Fische wurden also in der früheren Teichwirtschaft den Winter über nicht in dem Teich gehalten, in dem sie sich den Sommer über streckten. Sie überwinterten in besonders hierzu geeigneten Teichen, währen die sommerlichen Wachstumsteiche den Winter über still lagen (TAURKE 1927:18,28). In diesen Winterteichen verblieben sie bis zum Wiederaussetzen in die neuerlich bespannten Sommerteiche im nächsten Frühjahr.

Die Notwendigkeit zur Aufbewahrung der Fische ergibt sich daraus, dass die aus den Teichen abgefischten oder in den natürlichen Gewässern gefangenen Fische oft eine gewisse Zeit aufbewahrt und überwintert werden müssen, weil sie - die Setzlinge in der Teichwirtschaft - im nächsten Jahre noch größer werden sollen oder - die Speisefische - nicht sofort verkauft werden sollen oder können (TAURKE 1927:194).

\footnotetext{
${ }^{13}$ Wickfutter nennt man die Mischsaat von Hafer, Wicken und etwas Mais, auch Gerste und Erbsen; es verträgt, wie der Mais und die Runkeln, stärkste Düngung und wird meist zu verschiedenen Zeiten gesäet, um dauerndes Grünfütter zu haben (MEYERS KONVERSATIONSLEXIKON 1888, Bd. 21:622)
} 
Winterteiche, Winterungen bzw. Kammerteiche sind also in der Karpfenteichwirtschaft zum einen besonders bei ein- und zweisömmrigen Satzkarpfen notwendig und zum anderen dort, wo keine wintersicheren Brutstreckteiche zur gefahrlosen Überwinterung der Fischbrut vorhanden sind. Außerdem sind noch alljährlich Laichfische und Nachwuchslaicher zu überwintern, während die tieferen, mit älteren Fischen besetzten Abwachsteiche ,ihren Bewohnern auch im Winter einen sicheren Aufenthaltsort bieten“ (BENECKE 1885:30; siehe auch SCHÄPERCLAUS 1961:540).

Der Hauptgrund für die Unterbringung der Brut, der Laicher und der Ein- und Zweisömmrigen in Winterteichen ist der, dass deren sommerliche Aufwachsteiche in der Regel nicht wintersicher sind; „ihre Tiefe ist nicht so groß, daß auch bei sehr starker Eisdecke genügend Wasser übrigbleibt.“ (SCHÄPERCLAUS 1961: 540f.)

Zuverlässige Winterteiche sind deshalb „ein notwendiges Erfordernis einer regelrechten Karpfenzucht, wo sie nicht vorhanden sind, muß man sich auf bloße Karpfenhaltung beschränken." (BENECKE 1885:30). Sie sind in jedem Betrieb notwendig, ,in dem nicht die Satzfische so angekauft werden, daß sie in einem Sommer Speisefische werden." (CRONHEIM 1907:42). Winterteiche sind also für größere Teichwirtschaften absolut notwendig (TAURKE 1927:194) und daher ein besonderes Kennzeichen dieser.

Der Grund für die Anlage - entweder von mehreren Winterteichen oder von Kammerteichen - besteht darin, dass in die Winterteiche nicht die verschiedenartigsten Fischarten und -altersklassen aus mehreren Teichen zusammengesetzt werden können. „Die Anlage der Teiche soll so erfolgen, daß ein Winterteich [...] nur aus einem Streckteich besetzt wird.“ (SCHÄPERCLAUS 1961:545)

Im Gegensatz zu kleineren Teichbetrieben mit ihrer praktizierten Winterung in Kammern eines Teiches müssen in größeren Teichwirtschaften „mehrere Winterteiche zur Aufnahme der verschiedenen Altersklassen der Karpfen und für die Raubfische vorhanden sein." (BENECKE 1885:30).

Während sich die Frage der Anzahl von Winterungsteichen zum einen aus der Betriebsform und größe und zum anderen aus den zu überwinternden Fischarten ableiten lässt, so ist die allgemeine Notwendigkeit zur Winterhalterung schließlich eindeutig.

Die Winterteiche und Hälter zeichnen für die Aufgabe der Winterung durch folgende Eigenschaften und Formen aus, deren Kenntnis für eine Geländebestimmung notwendig erscheint:

Die Winterteiche für Karpfen sind derselben Art wie die der ganzjährigen Forellenteiche: kleine, tiefe Teiche, mit festem Boden und mit lebhaftem, gut regulierbaren $\mathrm{Zu}$ - und Abfluss, „in denen es den Fischen auch im Winter unter der Eisdecke nicht an Sauerstoff mangelt“ (TAURKE 1927:10, ebenso:18,28). In den einzelnen Erkennungsmerkmalen bedeutet dies:

1. Lage:

Der Winterteich weist eine „möglichst geschützte Lage“ auf (BENECKE 1885:30). In großen Teichwirtschaften ist die Lage der Winterteiche durch die Nähe der Aufsicht führenden Person gekennzeichnet, damit die Pflege der zu überwinternden Fische erleichtert und Diebstähle bequem verhindert werden können.

2. Ablassbarkeit:

Winterteiche sollen auch, wie alle Teiche, ablassbar sein, damit sie trocken gelegt werden können.

3. Größe

Winterteiche können im Verhältnis zu den Sommerteichen bedeutend kleiner bemessen sein, weil sie die Fische nur während der Winterzeit beherbergen, in der sie keine oder nur ganz 
wenig Nahrung zu sich nehmen. Infolgedessen „können sie sehr stark besetzt werden“ (BENECKE 1885:32). Ein Winterteich von $100 \mathrm{~m}^{2}$ Größe beispielsweise kann bis zu 30 Zentner Speisekarpfen aufnehmen. Nach dem Kriterium der Menge der Wasserzufuhr im Verhältnis zur Teichgröße wurden die Winterteiche in ,Große Winterteiche' und ,Kleine Winterteiche' unterschieden. Konkrete Zahlenangaben bzw. Erklärungen dieser Verhältniszahl hingegen konnten in der ausgewerteten Literatur nicht gefunden werden. Es ist aber anzunehmen, da die Teiche extrem dicht besetzt wurden, dass hier nicht die Fischmengen von primärer Bedeutung und damit Definitionskriterium waren, sondern tatsächlich die Wasserzufuhr, die über die Besatzmenge entschied, ursächlich für die Zuordnung zu einem großen oder kleinen Winterteich herangezogen wurde.

4. Wasserzu- und -durchfluss

Ein Winterteich muss bei konstantem Wasserstand einen „womöglich regelmäßigen“ (BENECKE 1885:30), „nicht zu starken“ Wasserzufluss haben (BORNE 1886:265). Er muss auf der einen Seite so stark sein, um ein Zufrieren der Winterteiche zu verhindern (Luftmangel), auf der anderen Seite jedoch ist ein übermäßiger Wasserdurchfluss zu vermeiden, weil durch einen solchen „die Fische beunruhigt werden“ (TAURKE 1927:197). Es musste aber „vor allem darauf geachtet werden, daß die [...] zuverlässige Wasserversorgung wirklich vorhanden ist.“ (SCHÄPERCLAUS 1961:541). Deshalb sei „allein ordentliches, von außen in einen Teich einfallendes, fließendes Wasser [...] zur Fischwinterung am sichersten zu gebrauchen." (DYHRN 1782:15) Von außen zufließendes Wasser war sogar Bedingung bei der Anlage kleiner Winterteiche, denn es wurde als schädlich angesehen, „wenn die Quelle innerhalb denselben befindlich ist“ (:15). Für die Teichwirtschaft waren innerhalb von Teichen entspringende Quellen entweder zu warm oder zu kalt und mineralhaltig und wiesen somit angeblich schädliche Eigenschaften für Fische auf.

\section{Art und Temperatur des Wassers}

Die günstigste Temperatur für die überwinternden Fische ist die von wenigen Graden über Null, bei welcher die Fische in die Winterruhe verfallen. Bei zu hoher Temperatur bleiben die Fische unruhig, wodurch sie abmagern; bei zu kalter findet starke Eisbildung statt, die sehr unbequem und schädlich werden kann. Quellwasser ist im Winter eigentlich etwas zu warm, Bach- und Flusswasser hat dagegen meistens die richtige Temperatur oder ist etwas zu kalt (TAURKE 1927:195). Von anderer Seite wiederum wird ausgesagt, dass „Drain- und Quellwasser [...] seiner höheren Temperatur wegen dem kühleren Fluß- oder Bachwasser vorzuziehen“" sei (BENECKE 1885:30f.), oder zumindest „Quellwasserbeifluß aus der Nähe“ (LIETMANN 1941:59).

6. Form

Winterteiche sollten, wenn möglich, am besten in länglicher Gestalt hergestellt werden. Der $\mathrm{Zu}$ - und Abfluss des Wassers muss an den schmalen Seiten stattfinden, damit sich kein Teil des Wassers im Hälter der beständigen Erneuerung entziehen kann.

\section{Tiefe}

Aufgrund der Jahreszeit, in denen die Winterteiche genutzt werden, musste vor allem darauf geachtet werden, dass eine hinreichende Tiefe vorhanden ist (BORNE 1886:265; SCHÄPERCLAUS 1961:541). Werden die Überwinterungs- oder Kammerteiche durch Quellen gespeist und kann das Zufrieren verhindert werden, „so genügt oft schon eine Tiefe von $1 \mathrm{~m}$; frieren aber die Teiche zu - bei Speisewasser aus Bächen und Flüssen - so ist es gut, wenn sie mindestens $1 \frac{1}{2}-2 \mathrm{~m}$, bei schwachem Durchfluß sogar 3 und mehr Meter tief sind, damit der Vorrat an Atemluft für die Fische nicht zu gering ist.“ (TAURKE 1927:197) Im Allgemeinen sollte der Winterteich eine Tiefe von $2-4 \mathrm{~m}$ haben (BENECKE 1885:30), zumindest sollte eine Wassertiefe von 1,80 m auf wenigstens $75 \%$ der Fläche gegeben sein (ZOBEL 1992:100). 


\section{Tiefe Neigung der Uferränder}

Die Ufer des Winterteiches müssen steil abfallen, da die Karpfen in Winterteichen ,mit nicht ganz steil abfallenden Rändern leicht an die flachen Ufer geraten und dort [...] an der Unterseite des Eises anfrieren und zugrunde gehen." (BENECKE 1885:31) Des Weiteren sollen die Ränder des Ufers der Winterteiche sehr schräg sein, „um den Dämmen Halt gegen Abbröckeln zu geben.“ (TAURKE 1927:197) „Die Uferböschung der Winterteiche soll rasch auf eine Tiefe von $1 \mathrm{~m}$ und mehr absinken." (SCHÄPERCLAUS 1961:541) Neben einer genügenden Tiefe sollten Winterungen also „möglichst allseitige Steilböschungen“ mit „wenig Flachstellen" aufweisen (LIETMANN 1941:59).

9. Wände

Um die Schräge zu erhalten, wurden die Wände der Winterteiche oft mit Brettern oder Bohlen bekleidet, damit die Ufer nicht einfallen. Diese Bretterwände können steil hinunter in die Tiefe gehen. Die Wände der Hälter werden oft gleichfalls aus Holz hergestellt oder gemauert. Sog. Erdhälter wurden aber von den Teichwirten für besser erachtet, denn ,in solchen mit Holzoder gar Steinwänden beschädigen sich die Fische leichter“" (TAURKE 1927:197).

\section{Teichgrund mit Winterlager}

Der Teichgrund sollte möglichst schlammfrei sein, damit sich „unter dem Eise nicht giftige Gase bilden könne“ (BENECKE 1885:31). Falls sich dennoch Schlamm auf dem Teichboden ablagerte, so sollte die Schlammhöhe an den tiefsten Stellen höchstens $25 \mathrm{~cm}$ betragen (TAURKE 1927:197). Er solle weiterhin fest, aber nicht hart sein (BENECKE 1885:31) und am besten für Karpfen, Schleien und Aale aus Lehm oder Ton, für Zander aus Sand und für andere Raubfische (Forellen, Hechte, Barsche) aus Kies bestehen.

In den Winterteichen musste sich jedoch im Teichboden ,zumindest eine größere vertiefte und schlammfreie Stelle befinden, in welchem die Friedfische bei Frost ihren Winterschlaf halten“ (TAURKE 1927:197; ebenso BENECKE 1885:31; BORNE 1886:265). An dieser Stelle, die man das Winterlager oder die Fischstätte nannte, sammelten sich die Karpfen bei eintretendem Frost und blieben dort, „bis sich das Wasser wieder erwärmt, ruhig liegen, indem sie in einen [...] Winterschlaf verfallen“ (BENECKE 1885:31).

\section{Einteilung}

Kleinere Mengen von Friedfischen, selbst wenn die Fische nicht dasselbe Alter hatten, konnten in einem einzigen Winterhälter überwintert werden. Bei größeren Fischmengen aber und wenn auch Raubfische zu überwintern waren, mussten die Winterteiche entweder in verschiedene Abteilungen eingeteilt oder es mussten mehrere Winterteiche hergestellt werden (TAURKE 1927:197).

\section{b.2.1.3 Abwachsteiche}

Erst im Abwachsteich werden die eigentlichen Speisekarpfen produziert. Sie dienen der Aufzucht und Aufnahme von Speisekarpfen des dritten Zuchtjahres, der sog. dreisömmrigen Karpfen (BENECKE 1885:29). Hier beginnt das sog. Abwachsenlassen (BORNE 1886:263; TAURKE 1927:11).

Aus den Winterteichen gelangen jeweils im Frühjahr die jetzt zweijährigen Karpfen $\left(\mathrm{K}_{2}\right)$ in die Abwachsteiche (TAURKE 1927:11; SCHÄPERCLAUS 1961:271), in denen sie zu Speisefischen gezogen werden. In ihnen verbringen die Karpfen das dritte und damit das letzte Zuchtjahr (ZOBEL 1992:59).

Bei Vorliebe schwererer Karpfen, wie sie „in manchen Gegenden Deutschlands“ (TAURKE 1927:11, ohne nähere Ortsangabe) anzutreffen ist, wird auch ein „viersömmriger Umtrieb“ praktiziert, d. h. erst nach vier Sommer werden die Karpfen dem Abwachsenlassen überlassen (:11). Das Zuchtziel hier ist, 
dass die Abwachsteiche marktfähige Karpfen von mehr als 2 Pfd. Gewicht liefern sollen (BORNE 1886:265).

Neben den Karpfen wurden in Abwachsteichen - und nicht in besonderen Streichteichen - Hechte und Zander gezüchtet: „Die Hecht- und Zanderbrut wird bei der Fischerei in ein- und zweisömmerige sortirt und sofort in die Abwachsteiche gebracht" (BORNE 1886:265). Diese Vorgehensweise ergab sich daraus, dass die Karpfenfische in den dafür ungeeigneten Abwachsteichen nicht streichen durften. Deshalb setzte man im Verhältnis von 10 Karpfen zu 1 Hecht oder auch statt der Hechte Zander ein (:265).

Als Abwachsteiche wurden größere und tiefere und damit kühlere Gewässer benutzt (BENECKE 1885:29), die je nach Größe 1 - 3 Jahre bespannt blieben (BORNE 1886:265).

Je nachdem, wie viele Sommer über der Abwachsteich bespannt bleibt, wird zwischen „einhitzigen“ und „mehrhitzigen Teichen“ unterschieden.

Als einhitzige Teiche werden solche Teiche bezeichnet, die nur einen Sommer bespannt sind, d. h. unter Wasser stehen (TAURKE 1927:132).

Mehrhitzige Teiche sind mindestens zweihitzige Teiche. Es handelt sich hierbei infolgedessen um diejenigen Teiche, welche zwei Sommer und den dazwischen liegenden Winter bespannt sind (TAURKE 1927:132). Hierbei handelt es sich um „sehr große Abwachsteiche“, die „oft nicht in demselben Sommer gefüllt und wieder abgelassen werden" können (:12). Für eine Füllung ist zum einen nicht genügend Wasser vorhanden, zum anderen müssen zum Ablaufen bei diesen Teichgrößen 1 - 2 Monate kalkuliert werden. Man lässt sie also zwei oder auch sogar drei Sommer und die dazwischen liegenden Winter bespannt. Der Teichwirt sagt dazu, „man gibt ihnen zwei bis drei Hitzen“ (:12). Der Nachteil bei den mehrhitzigen Teichen besteht darin, dass sie im Winter unter Wasser stehen, dadurch die Möglichkeit verlieren, bearbeitet und wieder verjüngt zu werden. Sie „versauern, verwachsen und verlieren hierdurch bedeutend an Nährkraft.“ (:12)

\section{b.2.1.4 Hälterteiche}

Nach der Abfischung, die im Herbst, meistens in der Zeit von Oktober bis November vorgenommen wird, kommen die Karpfen zunächst in die sog. Hälter (SCHÄPERCLAUS 1961:271). In diesen Hältern findet die Hälterung statt, d. h. die Unterbringung von Speise- und auch von für den Weiterverkauf bestimmten Besatzfischen. Dieser Fischteichtyp wird auch als Heller, Verkaufs- oder Vorratsteich bezeichnet (BENECKE 1885:33; SCHÄPERCLAUS 1961:531) und stellt „in jedem größeren Betrieb eine unumgängliche Notwendigkeit“ dar (PLANANSKY 1983:80).

Es sind kleine, häufig gemauerte oder mit Holzwänden versehene Behälter, die im eigentlichen Sinne zur Aufnahme der in kurzer Frist zu verkaufenden Fische dienen (BENECKE 1885:33). In Verkaufshältern werden die zum Verkauf bestimmten Fische 3 - 4 Tage zur Geschmacksverbesserung gehältert.

Es ist in der Teichwirtschaft manchmal die vorübergehende Aufbewahrung von sofort verkäuflichen Fischen notwendig, nämlich dann, wenn diese Fische aus mehr oder wenigen schlammigen Teichen abgefischt worden sind, „weil solche Fische einen unangenehmen, muffigen Geschmack haben, wenn sie sofort verzehrt werden. [...] Man muß daher die Fische sich in reinem Wasser einige Tage oder Wochen wieder auswässern oder ,ausspeien’ lassen.“ (TAURKE 1927:194) Besonders Karpfen, ,die aus moorigen Gewässern stammen, müssen in reinem, womöglich fließendem Wasser etwa 8 Tage ausgewässert werden.“ (:194)

Die Hälterung dient der vorübergehenden Aufbewahrung von Fischen aber nicht nur nach der Abfischung, sondern auch vor dem Einsetzen (SCHÄPERCLAUS 1961:531). Vom Hälter aus 
gelangen die Speisekarpfen also entweder direkt in den Handel oder werden von hier aus erst in andere Funktionsteiche übergesetzt (:271).

Zum Zwecke der Aufbewahrung von Fischen für kürzere Zeit sind also Hältereinrichtungen notwendig: für größere Teichwirtschaften mit größeren Fischmengen und längerer Hälterung waren eigene Hälterteiche zu bauen, für kleinere Mengen von Fischen reichten gemauerte oder hölzerne offene Behältnisse, auch Hälterkasten oder Fischhälter genannt, aus (DYHRN 1782:9; TAURKE 1927:194).

Die eigentlichen, größeren und weitaus besten Hältervorrichtungen stellen dabei kleine Erdhälter“ (WALTER 1933:81; SCHÄPERCLAUS 1961:532) dar, in denen die Fische im Winter, aber auch zu anderen Jahreszeiten für den Verbrauch - und nicht wie bei den Winterteichen für das weitere Größerwerden - aufbewahrt werden (TAURKE 1927:132). Hälterteiche werden also ,im Frühjahr zur vorübergehenden Aufbewahrung von Satzkarpfen oder Laichfischen und im Herbst für die Aufbewahrung von Speisefischen in der Zeit von der Herbstabfischung bis Weihnachten, Neujahr oder sogar Ostern verwendet.““ (SCHÄPERCLAUS 1961:532)

Die Eigenschaften der Hälter sind deshalb die gleichen wie bei den Winterteichen (TAURKE 1927:197; siehe auch b.2.1.2, Winterteiche'). Damit sie frostsicher sind, müssen sie 1,50-2 m tief gemacht werden (SCHÄPERCLAUS 1961:531). Natürlich kann man deshalb zur Überwinterung: „ebensogut dazu auch Hälter verwenden, die im gewachsenen Boden angelegt und etwa $1 \frac{1}{2}-2 \mathrm{~m}$ tief sind“ (CRONHEIM 1907: 43). Die Sohle hatte dabei pro $1 \mathrm{~m}$ ca. $2 \mathrm{~cm}$ Gefälle, um das Wasser ,aus einiger Höhe in die Behälter fallen zu lassen." (BORNE 1886:250)

Ihre Größe und Form war je nach dem Zweck der Hälterung verschieden. Bei steilen Böschungen wurden die Wände manchmal mit Holz verkleidet oder die Böschungen erhielten eine Befestigung aus Bruchsteinen (SCHÄPERCLAUS 1961:532). Hälterungen wurden zudem oftmals durch hohe Zäune gegen Diebstahl geschützt (:532). Weitere Kennzeichen sind ein weicher, aber nicht verschlammter Lehmboden und vor allem ein gesicherter, regulierbarer, reichlicher Zufluss guten Wassers (BENECKE 1885:33; PLANANSKY 1983:80). Derartige Teichbehälter in sicherer, gut kontrollierbarer Lage, ,sind unentbehrlich, wenn es sich darum handelt, die Produktion von den Zufälligkeiten der jeweiligen Marktlage unabhängig zu machen und den Absatz zur günstigen Zeit und zu gutem Preis zu sichern" (WALTER 1933:81). Nicht nur an ihrer Größen- und Tiefengestaltung können die Winterteiche erkannt werden, sondern auch aufgrund ihrer Lage innerhalb einer Teichwirtschaft. Sie befanden sich immer in Nähe zum ,Betriebszentrum' und zum Weg bzw. Straße, damit sie von dort jederzeit auch mit Gespannen erreicht werden konnten (PLANANSKY 1983:80).

In guten Erdhältern lässt sich ,auf kleinem Raume die gesamte Speisefischernte großer Teichflächen vorübergehend hältern“ (SCHÄPERCLAUS 1961:532). „Bei genügendem Zufluß und für nicht zu langen Aufenthalt“, gibt BENECKE (1885:33) den Besatz mit 50 kg Karpfen pro Quadratmeter an.

Neben den morphologisch identifizierbaren offenen Hellerteichen gibt es noch weitere Formen der Hälterung nach der Abfischung. Dazu zählen einfache Bottiche, Tröge, provisorische Netzhälter, kleine transportable Hälterkästen oder provisorische Unterteilungen von Fischgräben als Hälter (SCHÄPERCLAUS 1961:531).

Des Weiteren wurden auch Fischkästen mit durchlöcherten Wänden aus Drahtgitter oder mit Wänden aus senkrecht stehenden Holzlatten und festem verschließbaren Deckel verwendet, die auch noch „mit besonderen Hebe- und Windevorrichtungen zum Heben und Versenken versehen werden können“ (WALTER 1933:80) ,Zum Aufbewahren von Fischen für kürzere Zeit“ (LIETMANN 1941:61). Diese „meist nicht absolut ortsfest abgebrachten Holzlattenkästen“ (:61) wurden nicht nur im ziehenden Wasser in Bach- oder Flussbuchten verwendet, sondern sie wurden einfach in Teiche gehängt oder gestellt (:61f.). Die Lattenkästen (vgl. Abb. VI-15) sind in in ihrer Form länglich oder quadratisch und die Größe der Kästen beträgt gewöhnlich 1,5 x 1,5 m oder 1,5 x 2 m mit einer Höhe von etwa 1,25 m. Der Boden ist dicht und wird außen mit einer etwa $20 \mathrm{~cm}$ hohen Brettleiste versehen. In diesen Raum 
wurde reiner Lehm (Ton) eingefüllt. In solch einem Kasten können Speisekarpfen bis Neujahr hältern und „Satzfische [...] zum Versand bereit gehalten werden.“ (:61)

Bereits im zweiten Drittel des 19. Jh. wurde der Fischhälterung in solchen kleinen erbauten Fischbehältern der Vorzug gegeben, da es nach damaliger Meinung viel sicherer ist, „wenn man die Fische nicht in Teichen, sondern in kleinen Hältern hat, weil in den Teichen ein Herr von Feinden sich einschleicht“ (BORNE 1886:250). Einzig „bei beschränktem Wasserzufluß oder größerer Erwärmung sind allerdings die Teiche sicherer, weil darin die Gefahr der Epidemien geringer ist." (:250) Und so wurden weiterhin in der Teichwirtschaft Hellerteiche angelegt oder zumindest die alten in besonderen Zeiten weiter benutzt. Da die kleinen Fischkästen allesamt temporäre und transportable Einrichtungen oder aber Einrichtungen der fließenden Gewässer waren, sind sie für Feststellung historischer Teichformen weniger interessant, mehr jedoch als reliktärer Bestandteil ehemaliger Teichbewirtschaftungen.

\section{b.2.2 Karpfen-Nebenfischteiche}

Andere Fischarten wurden in Karpfenteichen, speziell in den Abwachsteichen, zwar „nicht gern [...] gesehen, weil sie den Karpfen Nahrung entziehen “(BORNE 1886:263). Trotzdem spielten Nebenfische in der traditionellen Teichwirtschaft eine bedeutende Rolle, konnte doch so zum einen die Ausnutzung der Nahrung durch einen ertragssteigernden Mischbesatz ergänzt werden (WALTER 1933:42). Zum anderen sollten daneben mit einem Nebenfischbesatz unerwünschte Wildfische abgehalten und vernichtet werden. Dann aber blieb „nichts anderes übrig als dem Raubfisch die Rolle des Polizeifisches zu überlassen“ (:57).

In dieser Funktion wurden den Karpfenteichen Hechte oder Zander zugesetzt. Zu denen wiederum setzte man zusätzlich besonders Uckelei, Plötze und Gründling als Hecht- oder Zanderspeise (BORNE 1886:264). Neben den zuvor genannten gebräuchlichsten Speisefischen führt DYHRN (1782:7) weitere Speisefische an, die ,wohl auch mit zur zahmen Fischerey gebraucht" wurden, als da er nennt: „Welse, Giesen, Pärschken, Karsche, Schleyen, Weißfische“. Daneben wurden als „Polizeifische“ noch der Aal und stellenweise auch die Regenbogenforelle beigesetzt, die aber zumeist, wenn „beide Fische [...] sich ihrer Aufgabe als Polizeifisch nicht gewachsen“ zeigten, durch „den großen Räuber Hecht" substituiert wurden (WALTER 1933:57).

Es waren also im Karpfenabwachsteich verschiedene Besatzformen möglich:

\section{Hecht-Karpfenteich}

Waren die großen Karpfen-Abwachsteiche mehrhitzig, so wurde ein Zusatz von Hechten in diesen Teichen nicht nur notwendig, sondern vielmehr für den Karpfenzüchter unentbehrlich, wie vorher beschrieben (vgl. BORNE 1886:273).

Neben den länger bespannten mehrhitzigen Abwachsteichen war auch in den regulären einhitzigen Abwachsteichen sowie in den Streckteichen der Hecht anzutreffen. Nämlich dann, wenn es nicht möglich war, von den Teichen Wildfische fernzuhalten (TAURKE 1927:13). Die 1927 von TAURKE (:13) wie auch noch 1956 von RUST (:45) mit „Fischunkraut“, d. h. als Nahrungskonkurrenz der Zuchtfische, bezeichneten wildlebenden Fische, gelangten entweder durch das Fließwasser als Laich in den Teich oder setzten sich, an Gefieder und Läufen von Wasservögeln haftend, in das stille Teichwasser ab und vermehrten sich. Der Hecht, in der früheren fischereiwirtschaftlichen Literatur wie erwähnt als der „,beste ,Wasserpolizist'“ gepriesen, vertilgte „die minderwertigen Weißfische, die Nahrungskonkurrenten des Karpfens, gründlich“" und gedieh gleichzeitig ,in allen unseren Gewässern“ (:13). Schließlich, so wurde pragmatisch argumentiert, sind die Weißfische „,in den bloß zur wilden Fischerey tauglichen Wässern am häufigsten zu bekommen“"(DYHRN 1782:7). RUST (1956:45) führt jedoch - eine solche Fischartenkombination befürwortend - an, obgleich er obige Auffassung vertritt, dass das „Fischunkraut [...] die Nahrungskonkurrenz der Zuchtfische“ bildet, dass die „wildwachsenden Fische“, d. h. in seinem Sinne die nicht speziell gemästeten Teichfische, wie z. B. Karauschen, Brassen, Hechte, Barsche usw., ,in großen Teichen [...] als zusätzliche Ernte eine wichtige wirtschaftliche Rolle" spielen. 


\section{Karpfen-Forellenbarschteich}

Als ebensolcher „Wasserpolizist“ wurde der amerikanische Forellenbarsch angesehen und als alternativer Zweitbesatz für den Karpfenteich benannt. Aber nicht nur, weil er insbesondere die von Teichwirten so verschmähten Nahrungskonkurrenten, Kaulquappen und Frösche, vertilgt - ,er ist der beste Froschvertilger" (TAURKE 1927:14) -, sondern weil er darüber hinaus den entscheidenden Vorteil bietet, dass sein „Fleisch [...] noch besser als das des Hechtes“ schmeckt (:14).

Die ideale Besatzproportion entspricht dem Karpfen/Hecht-Verhältnis. Bei einhitzigen Abwachsteichen sollten 2jährige Forellenbarsche eingesetzt werden.

\section{Karpfen-Regenbogenforellenteich}

Unter der Voraussetzung, dass „die Abwachsteiche vor Wildfischen genügend geschützt“ sind, konnten „zur Vertilgung von Karpfenbrut und kleinen Wildfischen“ auch noch andere Raubfische benutzt werden (TAURKE 1927:14). Hierbei wurde insbesondere als weiterer Nebenfisch die Kalifornische Regenbogenforelle genannt, die wertvolleres Fleisch als der Hecht lieferte und ,in den Zuchtanstalten ganz überwiegend zur Mästung“" verwendet wurde (WALTER 1933:44).

Das gefühlte Kennzeichen dieser Teiche ist das nicht so kalte Wasser wie bei der Bachforelle und bei der Bodenbeschaffenheit wird auch ein schlammiger oder auch verunreinigter Teichboden vom Fisch akzeptiert und auch angetroffen. Sie ist ,weit weniger empfindlich gegen wärmeres und getrübtes Niederungswasser und deshalb besonders für die ,Übergangsteiche', ja als Nebenfisch sogar für eigentliche Karpfenteiche geeignet, wenn sie nicht allzu sehr verschlammt sind“ (WALTER 1933:44).

Der ideale Karpfenteich für die einsömmrige Regenbogenforellen ist der mehrhitzige Karpfenteich, der etwas Wasserdurchfluss oder „wenigstens einige tiefere Stellen mit kälterem Wasser“ und geringere Bewachsung aufweist (WALTER 1933:43).

\section{Karpfen-Zanderteich}

Als Nebenbesatz der Karpfenabwachsteiche werden weiterhin die Zander genannt (WALTER 1933:54) Dabei wurde anscheinend oft der Zander statt des Hechtes in Abwachsteiche gesetzt (BORNE 1886:263).

Die Zucht und Aufzucht des Zanders ist erst seit der 19. Jahrhundertwende in Angriff genommen worden (TAURKE 1927:50). Mit der Zanderzucht zu dieser Zeit beschäftigten sich, so TAURKE (:51) rückblickend, ,vorwiegend: die Fischzüchter U. Hübner in Frankfurt a.[n] d.[er] O.[der], M. v. d. Borne in Berneuchen ${ }^{[14]}$, ferner die Fischzuchtanstalten in Hüningen ${ }^{[15]}$, Wittingau ${ }^{[16]}$, Crangen ${ }^{[17]}$, verschiedene Landes- und Provinzial-Fischereivereine“.

Der Zander, früher auch Schill oder Amaul genannt, lebte ursprünglich „sowohl in fließendem wie stehendem Wasser, auf sandigem und steinigem Grunde, in der Blei- und Barbenregion, besonders in trübem Wasser“ (BORNE 1886:274). Damit also Zander auch in Karpfenteichen neben den Karpfen gestreckt und zum Abwachsen gebracht werden konnten, musste ein kleiner Wasserdurchfluss vorhanden sein und das Wasser durfte nicht zu warm, der Teich nicht zu klein und flach sein (TAURKE 1927:50). Dieses Nebeneinander von Karpfen und Zander wurde in den Karpfenstreckund abwachsteichen der Fischzuchtanstalt in Wittingau auch praktiziert (BORNE 1886:275).

Karpfen-Zanderteiche werden also beschrieben als „größere Teiche mit möglichst schlammfreien, kälterem Wasser und einem sandigen, kiesigen oder lehmigen Grund, ohne Gras und Schilfwuchs. Am besten eignen sich vor allem Teiche, „welche mit Bächen in Verbindung stehen, welche kleinen

\footnotetext{
${ }^{14}$ Berneuchen in der Neumark/Pommern zwischen Neudamm (poln. Debno) und Wartenberg (poln. Chelm Dolny)

${ }^{15}$ Hüningen(frz. Huningue), Stadt im fränzösischen Depártment Haut-Rhin, am linken Rheinufer nahe der Schweizer Grenze, nördlich der Stadt Basel

${ }^{16}$ Wittingau (tsch. Trebon), südböhmische Kleinstadt

${ }^{17}$ Crangen (Krangen) (poln. Krag), Kirchspiel im Kreis Schlawe (poln. Slawno)/Pommern (siehe auch Pkt. D VII 1)
} 
Fischen Zutritt gewähren“ (BORNE 1886:275; ebenso TAURKE 1927:15). Für Karpfenteiche mit ruhigem, stehendem und warmem Wasser eignet sich der Zander nicht (TAURKE 1927:50).

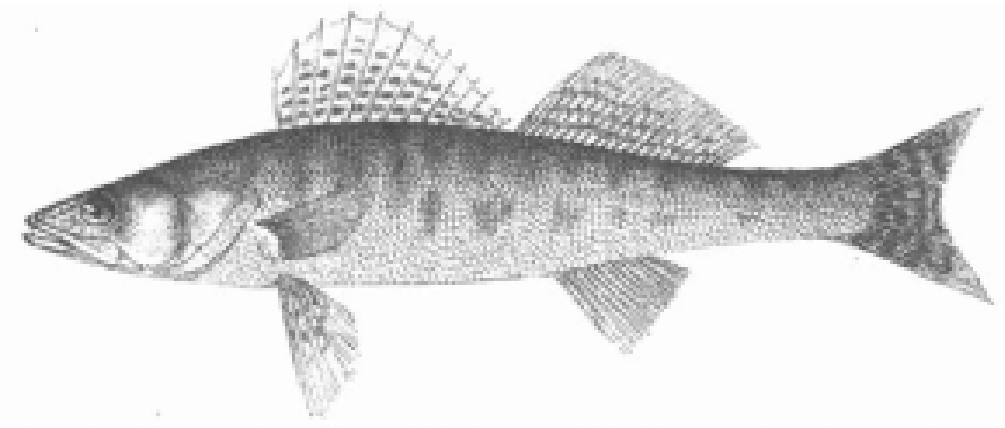

Abb. VII-4:Der Zander (Lucioperca sandra Cuv.) (aus: BORNE 1886, Fig. 77).

Für die vollständige Zanderzucht sind ebenso wie bei der Karpfenzucht verschiedene Teichnutzungsarten notwendig. Gleichwohl werden hier in den meisten Fällen die vorhandenen Karpfenteiche mitgenutzt und somit können sie denn auch nicht - insbesondere weil in diesen die Karpfen dominieren - nach meiner Ansicht als reine Zanderteiche klassifiziert werden. Die Bezeichnung ,Karpfenteich' mit den verschiedenen Nutzungsformen halte ich demgegenüber weiterhin für gerechtfertigt. Insbesondere auch deshalb, weil die hier angesprochenen Teiche für die Karpfenzucht angelegt worden sind und die Zander nur als „Nebenerzeugnis“ (WALTER 1933:54) dienen. Nur in wenigen Fällen wurden extra Zanderteiche angelegt:

Die Streichteiche mussten besondere Qualitäten zur Züchtung von Zandern aufweisen, denn „,der Kreis der Teiche“, in denen die Zandersetzlinge gedeihen, ,ist noch viel kleiner als beim Hecht" (BORNE 1886:226f.). Sie mussten zum einen „hinreichend tief“" sein (:275), denn die Zanderbrut ,gedeiht [...] am besten in größeren, tieferen, hartgründigen und nicht zu stark verkrauteten Teichen mit überwiegender freier Wasserfläche“ (WALTER 1933:54). Die Teiche sollten deshalb „steinigen, kiesigen, oder sandigen Grund, und Wasser von $1 \mathrm{~m}$ und mehr Tiefe haben“" (BORNE 1886:226f.). Bisweilen sprach man sogar von 2 - 3 m Wassertiefe (TAURKE 1927:51f.).

Karpfenstreckteiche, die zum Laichen für Zander zwar ausreichend tiefgründig waren, aber keinen kiesigen oder sandigen Grund hatten, mussten deshalb durch bestimmte Vorkehrungen präpariert werden, um als Laichplätze geeignet zu sein: Entweder „vom Ufer aus ward Sand in's Wasser geworfen“ oder ,in Wasser von 1 m und mehr Tiefe“ wurden „größere Plätze mit Kies und Geröllen bedeckt und außerdem einige Kegel von Geröllen aufgeschüttet.“ In der Nähe wurden ästige Baumwipfel, Strauchwerk aus grünem Nadelholz oder Wacholderzweige oder Baumstubben mit weit verzweigtem Wurzelgeflecht gelegt und das Geäst über dem Wasserspiegel abgeschnitten (BORNE 1886:275; ähnlich TAURKE 1927:51f.)

Dann wurde der Teich bespannt und mit 6 - 10 Laichzandern besetzt. Die abgelegten Eier klebten anschließend an den eingelegten Zweigen oder Baumwurzeln fest (TAURKE 1927:52).

Von manchen Teichwirten, weiß TAURKE (1927:52) zu berichten, sind die „Eier [...] in kleinen, eigens zu diesem Zweck in der Nähe der Aussetzungsstelle angelegten seichten Teichen [...] ausgebrütet worden." In der Regel jedoch wurde nach dem Ablaichen und Schlüpfen der Brut diese in den Brutstreckteich überbracht und anschließend lag der Laichteich „so lange wie möglich trocken“ (BORNE 1886:226f.).

Am Tage des Ausschlüpfens der Zandereier im Brutteich wurde die Brut in die Brutstreckteiche gesetzt. Dafür benutzte man am besten die (einhitzigen) Karpfenstreckteiche. „Besonders wenn sie nicht zu flach sind“, sind sie als Streckteiche „für Zander sehr geeignet" (TAURKE 1927:52f.). Umgekehrt konnte ,,man kann die Eier auch im Streichteiche selbst ausschlüpfen lassen und erst im Herbste abfischen, also den Streichteich auch als Brutstreckteich benützen.“ (:53) 
Den Winter über kamen die Zander in Winterteiche (TAURKE 1927:53), da die Brutteiche den Sommer über trockengelegt wurden und die sommerliche Teichbodenbearbeitung begann.

Dem Einsetzen in Streckteiche und der Winterung folgte im nächsten Jahr die Überbringung in die Haupt- oder Abwachsteiche (TAURKE 1927:53). Als Abwachsteiche eigneten sich besonders die mehrhitzigen Karpfenteiche, „weil mehrhitzige Karpfenteiche [...] die für den größeren Zander wünschenswerte Wassertiefe und Wassertemperatur haben, was bei einhitzigen gewöhnlich nicht der Fall ist “ (:53). Während der Entwicklungs- und Wachstumsphase erreichten die Zander als Speisefische eine Länge von $35-50 \mathrm{~cm}$ (:50). Diese Aufzuchtreihenfolge stimmt mit der Zucht des Karpfens überein.

\section{Karpfen-Schleienteich}

Auch die Schleie wurde bis um die 19. Jahrhundertwende als Nebenfisch in Karpfenteichen gezüchtet (BORNE 1886:272; TAURKE 1927:20,22). Da Forellenteiche, d. h. Quellteiche, für die Schleie gänzlich ungeeignet waren (TAURKE 1927:20), setzte man sie zu den Karpfen. Als Nebenfisch im Karpfenteich erfreute sich die Schleie gar ,großer Beliebtheit“ (KEIZ 1995:18).

Das alte Verfahren, Schleien zu züchten, war sehr einfacher Art: Die Schleie war nur Nebenfisch in Karpfenteichen, da sie zum Karpfen keine wesentliche Konkurrenz bildete. Es wurden daher sowohl in Karpfenstreckteichen (2. Ordnung) als auch in Abwachsteichen eine Anzahl Laichschleien zugesetzt (BENECKE 1885:44): „Laichten sie nicht in dem einen Teiche, dann vielleicht in einem anderen.“ (TAURKE 1927:23) Man konnte aber auch in eigenen kleinen Streichteichen laichen lassen und „die Brut sehr zweckmäßig zur Besetzung flacher, krautreicher und schlammiger Teiche" benutzen (BENECKE 1885:43). Die Heranzucht von Elternfischen lief so ab, dass ,gute zwei- oder dreijährige Fische mehrere Sommer in Karpfenabwachsteichen oder [...] in besonderen, nur für sie bestimmten Teichen gehalten“" wurden (TAURKE 1927:26).

Eine Aufzucht von Schleien in eigenen Streckteichen wurde gemeinhin nicht empfohlen (BENECKE 1885:44) und die Fälle, in denen man den Teich ausschließlich mit (zweisömmrigen) Schleien besetzte, waren sehr selten. Es kamen dafür nur entsprechende Teiche mit den schon genannten Eigenschaften und fruchtbaren Zuflüssen in Betracht (WALTER 1933:43). Die sog. ,Schleienteiche' (:43) sind also als Ausnahme anzusehen und die Fische dienten eher als Nebenfischbesatz in Karpfenteichen.

Eigene Teiche war auch nicht notwendig, können sie darüber hinaus in aus anderen Zwecken errichteten wassergefüllten Hohlformen eingesetzt werden. Die Schleie „liebt schlammige, ruhige Gewässer" (BENECKE 1885:43) und so konnte sie nicht nur in Karpfenteichen als Nebenfischbesatz, sondern selbst in Teichen ,mit ziemlich unreinem Wasser, in Hof- und Dorfteichen, früheren Lehmund Mergelgruben, Torf- und Moorlöchern“ gehalten werden (TAURKE 1927:20). Für sehr stark verschlämmte Gewässer (Torf- und Moorlöcher usw.) eignete sich die Schleie sogar bedeutend besser als der Karpfen und konnte sich in solcher Umgebung auch als alleinige Nutzung bewähren (:22). Diese Anspruchslosigkeit liegt in dem geringen Luftbedürfnis begründet: „Die Schleie erstickt unter dem Eise äußerst selten [...]. Dies ist für nicht ablaßbare Gewässer, welche nicht alljährlich abgefischt werden, von der größten Bedeutung." (:21) Dies betrifft beispielsweise solche Gewässer, in denen sich Stubben und Wurzelstöcke usw. befinden und die infolgedessen mit Zugnetzen nicht rein abgefischt werden können (:22). Der Fang der Schleie erfolgte deshalb ,auch mit in Reisig versteckten Reusen und Stellnetzen“"(:22). 


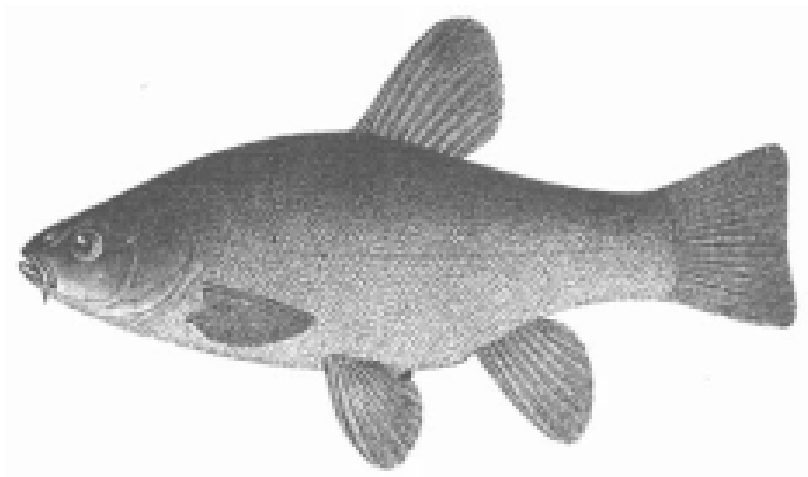

Abb. VII-5:Der Schlei (Tinca vulgaris Cuv.)

(aus: BORNE 1886, Fig.131).

Für das Schleien-Züchtungsverfahren in teichwirtschaftlichen Betrieben waren jedoch mindestens zwei nährkräftige Sommerteiche nötig, denn der eine Teich wurde als Laich- und Brutstreckteich (Brutteich), der andere oder die anderen als Streckteiche benutzt (TAURKE 1927:24). Gleichzeitig waren bei diesem Züchtungsverfahren auch Winterteiche notwendig.

Zu Laichteichen für Schleien wurden nur ,gute', im Sinne der Teichwirtschaft fruchtbare Teiche gewählt, welche, wenn möglich, düngende Zuflüsse aus der Teichumgebung erhalten sollten. Wärmere Teiche wurden vor der Bespannung mit Stallmist oder Jauche gedüngt. Der Brutteich musste mit $1-2$ $\mathrm{m}$ breiten Gräben gut durchzogen sein, „damit die einsömmrigen Schleien beim Abfischen nicht im Schlamme stecken bleiben“" (TAURKE 1927:24). Die Schleienteiche wurden derart zum Laichen präpariert, dass Pflanzen, wenn sie im Laichteich natürlicherweise nicht vorhanden waren, in wilden Gewässern gesammelt und im Schleienlaichteich, mit Steinen beschwert, versenkt wurden (:24).

Neben den o. g. Abfischungstechniken in abflusslosen Gewässern wurde in ablassbaren Teichen zum Abfischen der einsömmrigen Schleien eine sog. Abfischkiste notwendig, die außerhalb des Teiches am Abflussrohr befestigt wurde. Die Wände dieser Kiste bestanden aus feinem Drahtgeflecht, so dass das gesamte Teichwasser durch sie filtriert wurde und die Schleien aus ihr herausgenommen und in Winterteiche gebracht werden konnten (TAURKE 1927:25). Im nächsten Frühjahr dann wurden die einjährigen Schleiensetzlinge in Streckteiche gesetzt. Diese mussten möglichst nährkräftige, d. h. gedüngte Teiche sein (:25). Als Nebenbesatz in hauptsächlichen Schleienteichwirtschaften eigneten sich wiederum Karpfen „zur besseren Wasserausnutzung für Streckteiche sehr gut.“ (:26)

Zusammenfassend lässt sich feststellen, dass man außer dem Karpfen „gewöhnlich nur noch einen anderen Fisch in demselben Wasser" (TAURKE 1927:15) hielt. Nur sehr selten wurde ein Teich mit bis zu drei Fischarten besetzt. Dieser Fall trat besonders dann ein, wenn sich die Karpfenabwachsteiche auch für Schleien eigneten und wenn außerdem Hechte unentbehrlich waren (:15f.). Der Teichboden eines mit solchen Nebenfischen besetzten Teiches war aufgrund der Habitatvorlieben schlammig bis modrig und gegen Wildfische abgesperrt.

Des Weiteren wird die Karausche häufig in Karpfenteichen als Nebenfisch genannt und bildete mit diesem Bastarde, Karausch- oder Diebel-Karpfen genannt (BORNE 1886:272). Und bisweilen wurden auch Aale zur Abweidung der ganz flachen Uferränder zugesetzt (TAURKE 1927:15). Am besten waren hierfür Teiche mit weichem, schlammigem Grund, weichem Kraut und einem Bestand an Weichtieren und Schnecken geeignet (WALTER 1933:43). Schließlich werden auch Beispiele großer Teichwirtschaften genannt, in denen der Wels (Silurus glanis L.) in einem „Karpfen-Abwachsteiche, der zum Theil torfigen und schlammigen, zum Theil sandigen Grund hat" (BORNE 1886:273), gelaicht hat.

\section{b.2.3 Teicharten der Forellenzucht}

Eine für die praktische geländemorphologische Erkennung sehr bedeutungsvolle Unterscheidung zwischen Karpfen und Forelle betrifft die Besatzdichte, da „die Forellen gewissermaßen ganz typische 
Stallfische sind, die sich auf engem Raum heranfüttern lassen, wenn nur die Wasserdurchströmung eine reichliche ist.“(CRONHEIM 1907:3).

$\mathrm{Da}$ in einer Teichwirtschaft als ein Zweig der Landwirtschaft die Erträge pro bewirtschafteter Landfläche die entscheidende betriebswirtschaftliche Kenngröße darstellt, wurde - ließen es die Umstände zu - eine Intensivierung der Tierstückzahl pro Raumeinheit betrieben.

Die Forellenteichwirtschaft benutzt daher bei intensivem Betrieb kleine, stark durchströmte, oft bis 2 $\mathrm{m}$ tiefe Teiche, deren Wasser im Sommer immer unter $20^{\circ} \mathrm{C}$ bleiben. Brut und Laichfische hingegen können auch in kühlen, größeren Teichen, Laichfische sogar auch in Bächen herangezogen werden (SCHÄPERCLAUS 1961:166).

Aus diesen Gründen sind Karpfenzuchtwirtschaften ,stets große Betriebe von mindestens 30 - 40 ha mit bis zu etwa 2000 ha Teichfläche und solche der Forellenzucht stets kleine Betriebe, die im Höchstfall [...] kaum über eine Wasserfläche von 5 ha hinauskommen." (SCHÄPERCLAUS 1961:166) „Man kann auch in einem einzigen kleinen Teiche die Forellenhaltung betreiben.“ (TAURKE 1927:34) Selbst ganz kleine Teichflächen, „,welche ihnen nur Wohnung und Atmungsluft geben“, werden vorteilhaft zur Forellenzucht ausgenutzt (:34f.); ,,die Fische müßen dann aber gefüttert werden.“ Sogar „kleine Gräben und Bäche mit fließendem Wasser und festem Grunde können zur Forellenhaltung verwendet werden.“ Zur vollständigen Zucht der Forelle sind aber dennoch, ähnlich der Karpfenzucht, mehrere Teiche notwendig (:35), obschon große Teichflächen bei der Forelle keineswegs notwendig sind, wie wir gelesen haben. „Im Futterbetrieb der Forellenwirtschaft, für die sich [...] hauptsächlich Regenbogen-, viel weniger Bachforellen und Saiblinge eignen, nimmt man [...] kleine Teiche von 200 - 500 qm“ (CRONHEIM 1907:40) und sie werden ,so stark besetzt, daß für jede Forelle ein Raum gerechnet ist, der so lang und breit ist, wie der Fisch lang ist, z. B. für eine 30 cm lange Forelle werden $900 \mathrm{~cm}$ gerechnet" (BORNE 1886:251).

Hinsichtlich der Teichtiefe und -größe wurde von BORNE (1886:251) der Grundsatz aufgestellt, ,die Teiche sollen so tief sein, daß die Forellen am Grunde Schutz vor den Sonnenstrahlen finden, und so breit, daß man überall den Grund übersehen kann." TAURKE (1927:34) nennt eine durchschnittliche Tiefe der kalten Teiche von $50-80 \mathrm{~cm}$ am vorteilhaftesten. Andere Autoren finden erst eine Teichtiefe von 1- 2 m genügend (CRONHEIM 1907:40). Die Regenbogenforellen, aber auch die Bachforellen, können außerdem in flache Teiche gesetzt werden, dann aber dürfen die Teiche „nicht sehr groß sein und müssen beständig einen kräftigen Zufluß stets kühlen Wassers haben. Besteht der Zufluß aus Bachwasser, welches sich im Sommer stärker erwärmt, so muß der Teich wenigstens am Abfluß 2 bis 3 m tief sein.“(TAURKE 1927:35f.)

Bedingung für eine Forellenwirtschaft ist, ob sie in Fließgewässer oder Teichen durchgeführt wird, neben der Teichtiefe und -breite eine ,reichliche Wasserversorgung im Betrage von $5-10$ Sekundenliter“ sowie ein „starkes Gefälle“ (CRONHEIM 1907:40). Generell gilt: Dort wo man Quellteiche mit kaltem, beständig strömendem Wasser zur Verfügung hat oder herstellen kann, ist die Forellenzucht und -haltung am besten zu realisieren (TAURKE 1927:34). Nach BORNE (1886:251) darf sich das Wasser nie über $12^{\circ} \mathrm{C}$ erwärmen, SCHÄPERCLAUS (1961:148) hingegen spricht davon, dass die Wassertemperatur im Sommer unter $20^{\circ} \mathrm{C}$ bleiben muss. Diese Temperaturanpassung ist Folge der Züchtung von Forellen in Teichwirtschaften, die sich mitunter durch die verschlechternde Gewässerqualität, aber auch durch die zeitaufwendigere Bachwirtschaft ergeben hat. Das Wasser darf darüber hinaus für Forellen - im Gegensatz zu Karpfen - kalkhaltig sein, ,selbst ein ganz geringer Gehalt von Eisenocker schadet nicht“ (TAURKE 1927: 34), so dass sie auch in anmoorigen Gewässern gedeihen.

Die Teiche in der intensiven Forellenzucht, fasst SCHÄPERCLAUS (1961:148) zusammen, sind also „klein und stark durchströmt, bis zu 2 m tief und dienen den Forellen im normalen Fütterungs- und Veredlungsbetrieb lediglich als Aufenthaltsort, vergleichbar einem Stall.“

Innerhalb der Teichwirtschaft gibt es drei verschiedene Arten der in unseren Teichen gehegten Salmoniden: 
1. Bachforelle,

2. Bachsaibling und

3. Regenbogenforelle.

Die Bachforelle ist die verbreiteste und hochwertigste Forellenart und bei uns einheimisch. Sie ist der Bewohner rasch fließender Bäche und Flüsse mit tiefem Grund, kann auch in kalten Quell- und Bachteichen ohne Schlamm vorteilhaft gehalten werden, verlangt aber auch hier kühles, bewegtes, $\mathrm{d}$. h. sauerstoffreiches Wasser (TAURKE 1927:29,31,35; WALTER 1933:44). Sie gedeiht am besten bei einer Temperatur des Wassers von nicht mehr als $+15^{\circ} \mathrm{C}$ (BORNE 1886, aus: TAURKE 1927:31). Thre natürliche Vermehrung ist „sehr viel geringer als die der sommerlaichenden karpfenartigen und barschartigen Fische" und die künstliche Fischzucht blieb deshalb lange Zeit im Wesentlichen auf die Karpfenzucht beschränkt (BENECKE 1885:49). Doch schon im zweiten Drittel. des 19. Jh. wurde die Bachforelle „sehr viel künstlich gezüchtet, weil sich ihre Eier leicht künstlich befruchten und erbrüten [...] lassen; ferner weil sie ein sehr geschätzter Leckerbissen ist und theuer bezahlt wird. Sie frißt nur animalische Kost und zwar hauptsächlich Insekten, Larven, Crustaceen, Schnecken und anderen kleine Tiere, weniger häufig Fische.“ (BORNE 1886:276; siehe auch zu künstlichen Befruchtung Pkt. VIII 1a)

Der Bachsaibling hingehen ist „aus dem Mississippigebiet Nordamerikas“ in die mitteleuropäischen Gewässer eingeführt worden (TAURKE 1927:29; WALTER 1933:44). Er „gedeiht am besten in den kühlsten Quellwässern“ (WALTER 1933:44) und „kältesten Quellteichen“ (TAURKE 1927:31,35). Der Bachsaibling wird nach Herkunft unterschieden zwischen (:30):
a. amerikanischer Saibling,
b. einheimischer Saibling und
c. ,Elsässer Saibling ${ }^{18}$..

Die Regenbogenforelle ist ebenfalls aus Amerika, aus Kalifornien, bei uns eingeführt worden (TAURKE 1927:29; WALTER 1933:44). Sie zählte noch in den 1930er Jahren als in den kalten Bächen ,wenig eingebürgerte und auch wenig dazu geeignete“ Forellenart (WALTER 1933:44). Für wärmere Bach- und Flussteiche aber „eignet sich die Regenbogenforelle am besten“, sie kann sogar „,in tiefen Karpfenteichen“ gehalten werden (TAURKE 1927:31,35).

In der Allgemeinheit und auch in der Fachliteratur herrscht die Bestimmung vor, „die Forellen sind die Fische mehr oder minder kalten Wassers, d. h. der Quellteiche und der kalten Bäche“ (TAURKE 1927:34). Wenn dieses auch für ihren ursprünglichen Lebensraum zutraf, so ist in den 1920er Jahren die Feststellung publiziert worden: „Die Forellenarten scheinen sich, seit sie in Teichen gezogen werden, auch an höhere Temperaturen, [...] mehr und mehr zu gewöhnen.“ (:31; siehe auch zur Temperaturfrage obige Ausführung). Vielleicht, diese Vermutung soll hier hinzugefügt werden, lassen sich die Temperaturanpassungen auch mit einer sich abzeichnenden Erhöhung der Wassertemperaturen im Jahresmittel begründen. Genauere Temperaturabgleiche würden hier Klarheit verschaffen.

Die Nahrung der Forellen ist tierischer Art, denn die Forellen sind Raubfische. Die natürliche Hauptnahrung bilden für sie, wie bereits erwähnt, ,größere Insekten, Weichtiere, Krustentiere und Würmer“ (TAURKE 1927:32). Man fütterte die Forellen aber auch mit „Schlachthausabfällen, Geflügeldärmen, geronnenem Blut und anderen Dingen“, wie der Darstellung TAURKEs (:39f.) zu entnehmen ist. Als Futter für die Forellenbrut diente, ,in erster Linie ganz frische, geschabte Milz und [...] aushilfsweise Hirn, Leber, Lunge von Schlachttieren“, aber auch „frischer Weißkäse“ und „Seefischeier“ gehörten zum Speiseplan und werfen einen Blick auf die ehemalige Bedeutung von

\footnotetext{
${ }^{18}$ Die Kreuzung zwischen Bachsaibling und Seesaibling wurde im deutschen Sprachgebrauch als „Elsässer Saibling“ bekannt (SPINDLER 1997:13). Durch die Kreuzung erhofft(e) man sich Heterosiseffekte, d. h. Nachkommen mit besserer Leistung im Vergleich zur durchschnittlichen Leistung der Elternteile (REITER 2003:1). Der „Amerikanische Seesaibling“ wurde erst in den 1970 Jahren in den deutschsprachigen Raum gebracht (SPINDLER 1997:13).
} 
Forellenteichwirtschaften. Ebenso gelangte „Blut, welches mit 10 Prozent Getreidemehl vermischt und gekocht werden muß,“ zur Fütterung. War die Brut schon etwas größer, konnte man „besonders mageres Fleisch, zermahlen in Breiform“, füttern. Am besten bewährte sich „mageres Fischfleisch [...] von der Nordseeküste“ oder „Fischmehl“" (:40). Die berufsmäßigen Fischzuchtanstalten verwendeten z. B. „gekochtes Fischmehl mit Roggenmehl und dazu frisch gemahlene Fische [...] das ganze vermengt und durch die Fleischmühle getrieben." (:42) Doch nicht nur Seefisch wurde den Binnenfischen zur Mästung bereitgestellt. Die Fütterung konnte ,auch mit jungen Plötzen usw. geschehen, welche eigens zu diesem Zwecke in besonderen Teichen" gezüchtet wurden (:42). Zu den „anderen Dingen“ mögen auch die „Mäuse, Schnecken usw.“ gehören, die ebenfalls zur Fütterung verwendet wurden (:40). Dieses zum Teil erlesene Nahrungsangebot hatte seinen Grund, denn die Forellen brachten, so zeigte die Erfahrung, ,aus der oben genannten Nahrung Fleisch hervor, welches seines hervorragend guten Geschmackes wegen als Delikatesse überall geschätzt" wurde (:32).

Hinsichtlich der geographischen und landschaftlichen Erkennung ist wichtig zu wissen: „Einzelne Forellenteiche kommen seltener als einzelne Karpfenteiche vor.“ (TAURKE 1927:44). Dies liegt zum einen aufgrund der Lebensweise der Forelle im Teichbau begründet, der die Herstellung größerer Teichtiefen und den Zufluss kälteren Wassers notwendig macht. Zum anderen ist es unmöglich, in demselben Teich verschieden große Fische zu halten, weil große Forellen die kleinen auffressen. So besetzt man bei Forellen nur gleiche Altersklassen und Fische gleicher Größe. $\mathrm{Zu}$ groß ist sonst die Gefahr des Kannibalismus (CRONHEIM 1907:40), denn „besonders die Bachforelle ist ein arger Kannibale; auch der Saibling ist nicht viel besser“ (TAURKE 1927:44).

In einfachen und kleinen Forellenwirtschaften, in denen nicht genügend Teiche vorhanden sind, wird deshalb keine Zucht, sondern ausschließlich Forellenhaltung betrieben. In diesem Fall „bezieht man am einfachsten einjährige Forellen im Frühjahr aus [...] Zuchtbetrieben, setzt sie [...] in die Teiche ein und fischt sie im Herbst oder Frühjahr wieder ab.“ (TAURKE 1927:44)

Im Gegensatz zur Bewirtschaftung einzelner Forellenhaltungsteiche, in denen eine alljährliche Abfischung der Teiche erfolgt, werden in größeren Zuchtbetrieben Forellenteiche nach ihrer Verwendung für bestimmte Altersstufen errichtet und unterschieden in Brutteiche, Mastteiche, Laichfischteiche und Winterteiche.

Andererseits, so ist zu lesen, wird manchmal der Besatz mit verschiedenen Forellenarten praktiziert. So sei es „manchmal vorteilhaft, alle drei Forellenarten zusammen, oder wenigstens in kältere den Saibling und die Bachforelle, in nicht so kalte die letztere und die Regenbogenforelle einzusetzen.“ (TAURKE 1927:42)

\section{b.2.3.1 Brutteiche}

Die Brutteiche werden nach dem Kriterium der Nahrungszufuhr, d. h. ob künstlich zugefüttert wird oder der Teich allein als Nahrungsquelle dient, voneinander unterschieden. Die Teiche mit künstlicher Zufütterung werden - in Entsprechung der landwirtschaftlichen Begrifflichkeit - „Mastteiche“ genannt (TAURKE 1927:44).

Inneres Merkmal zur Unterscheidung von ,Naturnahrungsteichen' gegenüber ,Mastteichen' bietet die Besatzstärke, die sich wiederum bestimmend auf die Teichgröße auswirkt und Rückschlüsse auf die Größe der ehemaligen Teichwirtschaft zulässt: „Jeder Setzling braucht“, so eine Faustregel, „,wenn er sich sein Futter selbst suchen muß“, d. h. in einem Naturnahrungsteich untergebracht ist, „,im groben Durchschnitt 16 - 20 qm Teichfläche. Hiernach würden pro 1/4 ha etwa 125 - 156 Fische eingesetzt werden müssen“ (TAURKE 1927:41). Oft wird aber auch die Besetzung der Teiche nach dem Gewicht angegeben. Die Forellenzucht in Seewiese ${ }^{19}$ besetzte 0,25 ha Teich mit 7 Pfd. Forellen, was, den Setzling zu 20 g gerechnet, 187 Stück, zu 15 g pro Setzling 250 Stück ausmachen würde (:42).

\footnotetext{
${ }^{19}$ Die „Forellenzucht Seewiese“ liegt in der Gemeinde Gräfendorf, zwischen dem Naturpark Südlicher Spessart und der Rhön und wird als „Deutschlands älteste Forellenzucht“ beschrieben (http://www.gräfendorf.de; 06.01.2004).
} 
Erfolgt die Aufzucht der Forellenbrut in sog. Brutaufzuchtteichen, in denen die Brut künstlich aufgefüttert werden, so kann natürlich wieder der Besatz viel größer sein als oben angegeben (TAURKE 1927:38,42).

\section{b.2.3.2 Streckteiche}

Im Spätherbst oder im nächsten Frühjahr werden die Forellensetzlinge dann, „so lange die Witterung noch kühl ist, nach Ablassen des Wassers in die tieferen und größeren Streckteiche übertragen“ (BENECKE 1885:97) und wachsen hier heran (TAURKE 1927:41).

Wie solche - in weiterer Entfernung hintereinander geschachtelte - Streckteiche unter Einschluss natürlicher Bachstrecken angelegt wurden und welche Form sie haben, beschreibt BENECKE (1885:98) in anschaulicher Weise:

„Zur Anlage von Streckteichen für die ein- und mehrjährigen Forellen sind kleine, lebhaft fließende Bäche, wie sie so häufig in Wald-oder Feldschluchten sich finden und meistens ohne jeden Ertrag bleiben, vortrefflich geeignet. Durch sehr unerhebliche Dammschüttungen von 2-3 m Höhe und die Anlage von Mönchen ist es gewöhnlich leicht, im Laufe solcher Bäche eine Anzahl vortrefflicher Teiche anzulegen, die am Einfluß ganz flach, am Ausfluß 2-2 1/2 m tief sind, eine Größe von 1/4 bis 1 Morgen haben mögen, und vorteilhaft in einer solchen, durch die Größe des Gefälles bedingten Entfernung von einander liegen, daß oberhalb eines jeden eine Bachstrecke von hundert oder einigen hundert Metern ungestaut bleibt, so daß die Fische nach Belieben sich im Bache oder Teiche aufhalten können und, trotz ihrer Gefangenschaft, unter ganz natürlichen Verhältnissen leben. [...] Am besten [...] ist eine Beschattung der Bäche und Teiche durch Erlen, die dort gewöhnlich selber wachsen, [...] hin und wieder sollten kleine Bachstrecken der Sonne ausgesetzt sein und namentlich ist es gut, wenn die flacheren Partien des Teiches stark von der Sonne beschienen werden, weil sich in dem wärmeren Wasser eine größere Menge von Insekten, Krebstieren ec. entwickelt. In den Bachstrecken, wie in den Teichen selber, sind große Steine, unter denen die Forellen sich gerne verbergen, auch dadurch nützlich, daß sie das Ziehen von Netzen unmöglich machen und den Fischdiebstahl außerordentlich erschweren. Liegen die Teiche zwischen höheren Bergen in engen Schluchten, so muß, mit Rücksicht auf die bei heftigen Regengüssen zu erwartenden Hochwasser, der Querschnitt der Mönche eine Breite von 1 $m$ oder mehr erhalten, auch muß durch Anlage eines hinreichend breiten Wildgerinnes [...] der Zerstörung der Dämme und dem Verluste von Fischen vorgebeugt werden."

Auf den Teichbau selber wird im nächsten Pkt. c näher eingegangen. Hier sollte schon einmal ein komprimierter Eindruck die zu einer Forellenzucht gehörigen Streckteich- und Bachanlagen geboten werden, die nicht voneinander getrennt zu sehen sind, sondern in ihrer Anlage - Teiche und Bäche fließend ineinander übergehen und sich einander bedingen.

\section{b.2.3.3 Winterteich}

In der Forellenteichwirtschaft bedarf es für die Überwinterung der Forellen in der Regel keiner besonderen Einrichtung (SCHÄPERCLAUS 1961:540). Die meisten Forellenteiche eignen sich auch zur Überwinterung der Fische, weil sie oft die Eigenschaften des Winterteiches, wie zum Beispiel die Tiefe bzw. tiefere Stellen im Teichboden, von Natur aus besitzen (TAURKE 1927:41). Zudem schützt ein stärkerer Zufluss von Quellen oder Quellbächen die Teiche vor dem Ausfrieren (WALTER 1933:46).

Sind die Brut- oder die Streckteiche also selbst zur Überwinterung geeignet, so sind besondere Winterteiche nicht notwendig. Die Fischchen werden dann, beispielsweise im Herbst, direkt in die 
Streckteiche eingesetzt (TAURKE 1927:41). Somit können und müssen die Forellenteiche auch über einen längeren Zeitraum bespannt bleiben. Bei einem zwei Jahre bespannten Forellenteich werden dann die Forellen im ersten Herbst mit Netz und Angel heraus gefangen (WALTER 1933:56).

Nur in gewissen Fällen sind auch Winterteiche notwendign nämlich dann, wenn die Wintertemperaturen in Forellenzuchten generell sehr niedrig sind, ist es hin und wieder üblich, auch Forellen in speziellen Winterteichen zusammenzuziehen oder, wenn die Forellengewässer direkt über Quellen angelegt wurden oder so seicht sind, dass ein Gefrieren bis auf den Grund möglich ist (TAURKE 1927:41; SCHÄPERCLAUS 1961: 540). Solche Gewässer müssen daher schon im Herbst abgefischt und die Fische in Winterteiche übertragen werden, wo sie bis zum Aussetzen in die entsprechenden Teiche im nächsten Frühjahr verbleiben (TAURKE 1927:41). Dies betrifft insbesondere die alljährliche Überwinterung von Laichfischen und Nachwuchslaicher (SCHÄPERCLAUS 1961:540).

\section{b.2.4 Forellen-Nebenfischteiche}

Diese Thematik wird in der teich- und fischereiwirtschaftlichen Literatur nicht eindeutig geklärt und kontrovers behandelt. Auf der einen Seite wird ausgesagt, dass „von Nebenfischen [...] in den kleinen Forellenteichen möglichst ganz Abstand genommen werden" soll (WALTER 1933:46). Denn im Gegensatz zum Karpfen, der Raubfische als Nebenbesatz in seinen Abwachsteichen benötigt (siehe Pkt. b.2.2), sind die Forellen „bis zu einem gewissen Grade [...] als gemäßigte Raubfische auch selbst imstande, [...] Konkurrenz zu bekämpfen.“ (:46)

Während also das Miteinsetzen von Karpfen in kleinen Forellenteichen zu unterlassen sei, so lohne sich auf der anderen Seite ein Zusatz von sonstigen Friedfischen in großen Forellenteichen, weil diese Teiche auch den Karpfen Nahrung geben, welche von den Forellen ziemlich verschieden sei (TAURKE 1927:42, nach BORNE 1886).

Wurde dementsprechend von der artendifferenten Besetzung mit Friedfischen in Forellenteichen mit Ausnahme der Großteiche eher abgesehen, so können die Forelle und der Saibling ,gut in demselben Bache und demselben Teiche gehalten werden und nutzen das Gewässer besser aus als jeder Fisch für sich allein.“(TAURKE 1927:36)

\section{b.2.5 Teiche anderer Fischarten}

Für die Aufzucht anderer karpfenartiger Fische wurden, da sie „niedriger im Preise“ standen als die Karpfen, meistens nur ,Teiche' von geringerer Güte und indirekter Entstehung, wie zum Beispiel Torflöcher, Mergelgruben und dergleichen verwendet (BENECKE 1885:43). Dieser Umgebungsqualität entsprach auch der eigene geringe Habitatanspruch dieser Fischsorte, die auch mit „kleinen und flachen Teichen“ vorlieb nehmen (:45).

Die Karausche beispielsweise war ein Fisch solch minderer Gewässer. Nach BENECKE (1885:44) nimmt sie ,mit dem schmutzigsten Wasser vorlieb und vermehrt sich in den kleinsten Tümpeln aller Art“. Zur Ausnutzung schlammiger Wasserlöcher, kleiner Hofteiche, der eben zitierten Torf- oder Mergelgruben sowie „zur Einsetzung in schlammige Seen, alte koupierte Flußarme und ähnlicher Gewässer von geringer Ausdehnung und unbedeutendem Wert ist sie sehr brauchbar.“ 


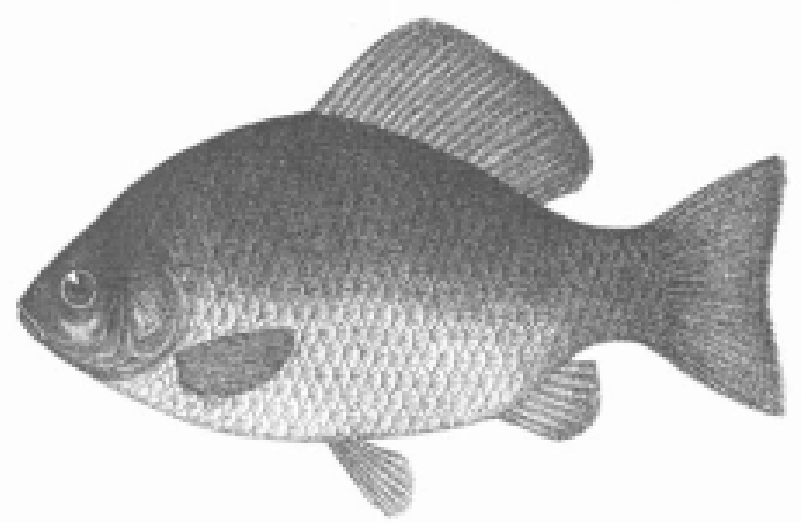

Abb. VII-6:Die Karausche (Carassius vulgaris Nils) (aus: BORNE 1886, Fig. 130).

„Die Karausche“, so auch BORNE (1886:272), „,ist außerordentlich zählebig und hält sich in den kleinsten Wasserlachen“. Deshalb konnte man ,kleine Wasserbecken, auch mit schlammigem Grund, in denen andere Fischarten leicht auswintern“, d. h. aussticken, „mit Vortheil mit Karauschen besetzen." Im Herbst aber mussten sie abgefischt werden, da sie sonst ,im Winter unter dem Eise in den kleinen schlammigen Tümpeln [...] ersticken würden.“ (BENECKE 1885:44)

Ein anderer, ebenso in Teichen geringerer Qualität gezüchteter, aber im eigentlichen Sinne nur gehaltener Fisch war der Aal, denn die Vermehrung des Aales findet bekanntlich nur im Meer statt, wo die männlichen Fische sich dauernd aufhalten, während die junge Brut, die im Frühjahr oder Vorsommer „in ungeheuren Schwärmen in alle süßen Gewässer“ aufstieg und „Wehre und Felsen überklettert, um in den oberen Lauf der Flüsse und die an ihnen gelegenen Seen zu gelangen“, um sich dort ausnahmslos zu Weibchen zu entwickeln. Diese müssen, wenn sie - herangewachsen - sich vermehren wollen, wieder ins Meer wandern, „und auf dieser in den Sommer- und Herbstmonaten ausgeführten Wanderung beruhen die großen in manchen großen Flüssen in Aalsäcken, Reusen und in den Aalkasten der Wassermühlen erzielten Fänge.“ (BENECKE 1885:47). Da daher ,auf eine Vermehrung des Aales im süßen Wasser [...] unter keinen Umständen zu rechnen“ ist (:47), wurde nach Aalbrut in den Flüssen gesucht, um große Massen derselben zu sammeln und - ,in feuchtem Kraut“" gewickelt - „weithin zur Besetzung von Teichen, Mergelgruben und Torfstichen zu versenden.“ (:48) . Das spätere Abfischen der Aale gestaltete sich etwas schwierig. Nicht nur, weil wassergefüllte Torf- und Mergelgruben keine teichmäßig präparierten Wasserhohlformen waren, sondern auch, ,weil sich diese Fische meistens tief in den Grund eingraben; sie werden deshalb auch beim Ablassen der Teiche erst gefunden, wenn man den Schlamm mit Harken durchzieht.“ (:48)

Ein anderer, allgemein weniger bekannter Fisch, der in Teichwirtschaften zur Ablaichung übertragen wurde, ist der ,Bressen, ${ }^{20}$. Er bevölkert große und etwas tieferer Seen und ,wird namentlich im Winter unter Eis [...] gefangen“ (BENECKE 1885:45). Für die Aufzucht in Teichen schien er „,weniger geeignet, [...] wohl aber ist es höchst zweckmäßig, ihn in [...] mit Brutbeeten versehenen Streichteichen laichen zu lassen“ (:45). „Am einfachsten geschieht das, wenn die Brutteiche neben den Seen angelegt und mit diesen durch kleine Gräben verbunden sind, durch Öffnung der in letzteren zum Schutze gegen das Eindringen von Stichlingen und größeren Raubfischen angebrachten Sperrgitter.“ (:45f.) Anschließend wurde die „Brut im Alter von einigen Wochen oder Monaten in die Seen [...] übertragen“"(:45f.).

Die Schmerle galt in der Teichwirtschaft bzw. im eigentlichen Sinne in der in durch Aufstau von kleinen Fließgewässern betriebenen Fischwirtschaft, als „,einer unserer feinsten Fische“ (BENECKE 1885:46), denn „,in manchen Gegenden“, weiß BORNE (1886:273) zu berichten, „wird das Fleisch der Schmerle sehr gern gegessen." Sie gedeiht ,in kleinen Teichen mit sandigem und kiesigem Grunde und regelmäßigem, reichlichem Wasserdurchfluß“ (BENECKE 1885:46) und ist ,in Teichen, die keine Raubfische enthalten, leicht zu züchten." Nach Angaben von BORNE (1886:273) hatte sie sich

\footnotetext{
${ }^{20}$ Bressen (Abramis brama), auch Brassen, Brachsen oder Blei genannt. Art der Karpfenfische, Länge bis $75 \mathrm{~cm}$
} 
z. B. in der Teichwirtschaft Michaelstein im Harz bei Blankenburg in den dortigen Forellenteichen „erstaunlich vermehrt, nachdem Hechte und Barsche entfernt" worden waren.

Am besten war es, so die Erfahrung, ,Schmerlenteiche in Bächen durch eine kleine Stauung und Abschluß einer Bachstrecke durch Flechtzäune herzustellen.“ (BENECKE 1885:46). Als "sehr gewöhnlich“ wurde es bezeichnet, „mit Schafmist gefüllte Körbe in die Teiche zu stellen.“ (:46) Gefangen wurden „die Schmerlen am leichtesten in kleinen, enggeflochtenen Reusen, in die man Träber, gekochte Kartoffeln, gekochtes Blut, Käse oder ähnliche Köder“ legte (:46).

Der Gründling wurde ebenfalls „in ganz ähnlicher Weise wie die Schmerle“ in der Teichwirtschaft gehalten. Er war ein begehrter Speisefisch, der „gebacken eine vortreffliche Speise liefert“ (BENECKE 1885:46).

Bei der „starken Vermehrung beider Fische“, der Schmerle wie dem Gründling, war es zweckmäßig, so die Empfehlung, „mehrere kleine Teiche anzulegen.“(BENECKE 1885:46).

Daraus ist zu entnehmen, dass es zum einen nicht nur Forellen- oder Karpfenwirtschaften gegeben hat, dessen Teiche mitunter zusätzlich mit Nebenfischen besetzt worden sind, sondern zum anderen auch mit anderweitigen Fischsorten besetzte Teiche und abgesteckte Bachstrecken eingerichtet wurden.

Doch darüber hinaus wurden nicht nur Speisefische beigesetzt bzw. in Einzelteichen gezüchtet, es gab auch spezielle sog. Futterfischteiche, in denen einzig zur Fütterung verwendete Fische gezüchtet wurden.

\section{b.2.6 Futterfischteiche}

So wurden die Plötze (Leuciscus rutilus L.), das Rotauge (Scardínius erythrophthálmus L.) und die Uckelei (Alburnus lucidus Heck.) $)^{21}$ als „Raubfischfutter“ gezüchtet (BORNE 1886:272).

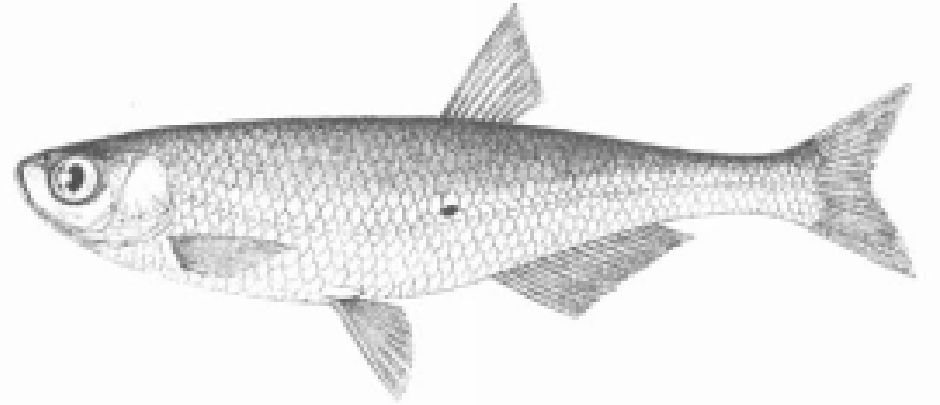

Abb. VII-7:Die Uckelei (Alburnus lucidus Heck.) (aus: BORNE 1886, Fig. 138).

Die Züchtung, beispielsweise der Uckelei, erfolgte, „um den Zandern Futterfische zu verschaffen.“ (BORNE 1886:272) So wurde eine „,massenhafte Produktion von Brut“ angestrebt, die „,schon in ganz jungem Zustande ausgefischt und verfüttert“ wurde (BENECKE 1885:45). BORNE (1886:273) berichtet von einem „Fischermeister Kock in Stobbendorf, Kreis Marienburg ${ }^{\text {“22 }}$, der seit 1881 neben Plötze und Rotauge auch die Brasse (Blei) ,in drei kleinen [...] Teichen in großer Menge gezüchtet“ hat.

\footnotetext{
${ }^{21}$ Im ,BROHMER’ (1984:425f.) erscheint die Plötze gemeinsam mit dem Rotauge als „Rutilus rutilus“, die Rotfeder wird vielmehr mit ihrem faunistischen Namen „Scardínius erythrophthálmus L. erwähnt. Als „Leuciscus rutilus“ erscheint hier keine Familie der Karpfenartigen. Als „Leuciscus souffia“ wird der ,Strömer' genannt, „Leuciscus idea“ als ,Aland', „Leuciscus cephalus” als ,Döbel' und als „Leuciscus leuciscus“ die ,Hasel'. Die Uckelei (Uklei) wird mit dem zoologischen Namen „Alburnus alburnus“ angegeben. Aber hier sollte der Originalquelle anstelle des modernen Bestimmungsbuches der Vorzug gegeben werden.

${ }^{22}$ Marienburg (poln. Malbork), ehemalige Kreisstadt im Regierungsbezirk Westpreußen, an der Nogat gelegen.
} 
Bezüglich des Aussehens und der Erkennung einer Futterfischteichanlage ist wichtig zu wissen, dass bei einer frühzeitigen Verfütterung natürlich die Anlage von Streck- und Abwachsteichen nicht erforderlich war, dagegen mussten die für diese Fische bestimmten Teiche möglichst günstige Verhältnisse für die Ablage des Laiches und die Entwicklung der Brut bieten. Sie sollten daher flach sein, um sich schnell zu erwärmen, und sehr zweckmäßig war es weiterhin, in ihnen sog. Brutbeete einzurichten, wie man sie in Karpfenteichen anwendete (BENECKE 1885:45).

\section{b.2.7 Raubfischteiche}

Die Zucht von sommerlaichenden Raubfischen wie Hecht, Barsch und Zander war ,sehr viel weniger verbreitet als die Zucht und Haltung des Karpfens und anderer karpfenartiger Friedfische" (BENECKE 1885: 46). Besonders waren „froschreiche Gewässer für die Hechthaltung sehr geeignet, da Frösche eine Lieblingsnahrung dieses Fisches" bilden (:47). Meistens beschränkte man sich jedoch darauf, ,junge Hechte in Streck- und Abwachsteiche der Karpfen oder in Karauschenteiche zu setzen“ (:46; siehe Pkt. b.2.2).

Unter den Raubfischen konnte besonders der Barsch (Perca fluviátilis L.) „leicht in Teichen gezüchtet werden“ (BORNE 1886:274); obschon auch er meistens ,als Zugabe in Streck- und Abwachsteiche der Karpfen- und Karauschenteiche gesetzt" wurde (BENECKE 1885:47).

Ebenso wurde der Zander, obschon er eigentlich „etwas tieferes, kühles, reines Wasser mit hartem Sand- oder Kiesgrund“ liebt, „vielfach als Beigabe in größeren und tieferen Abwachsteichen von Karpfen gehalten.“ (BENECKE 1885:47) Als Laichplätze sind „Baumstubben mit stark verzweigten Wurzeln in der Nähe der Ufer“ versenkt oder „kegelförmige Stein- und Kieshaufen von $1 \mathrm{~m}$ Höhe an verschiedenen Stellen" angelegt worden (:47).

Als Beispiel einer ,Züchtung des Zander in Teichen' kann der Bericht von BORNE (1886:275) herangezogen werden. Er selbst, so schreibt er, ,und der Gutsbesitzer Al. von Gostkowski in Galizien“'23 haben ,,in Teichen Zander gezüchtet“: „,Der galizische Teich ist 13 ha, der meinige 11,5 ha groß. In Wasser von $1 \mathrm{~m}$ und mehr Tiefe werden größere Plätze mit Kies und Geröllen bedeckt und außerdem einige Kegel von Geröllen aufgeschüttet; in der Nähe werden ästige Baumwipfel gelegt und das Geäst über dem Wasserspiegel abgeschnitten. Der Kies wird jedes Jahr von Schlamm gereinigt und der Teich liegt so lange wie möglich trocken."

Ähnliche Bedingungen wie der Zander stellt auch die „recht empfindliche große Maräne“, infolgedessen man sie in für den Zander geeignete Teiche und damit zumeist den Karpfen zugesetzt hat (WALTER 1933:54).

\section{b.3 Die moderne Mehrteichanlage}

Die Unterschiede einer modernen Mehrteichanlage Ende des 20. Jh. zur vorher beschriebenen mittelalterlichen und vor allem vorindustriellen Teichanlage sollen im Folgenden dargestellt werden, um zum einen die Geschichtlichkeit dieser Teichformen hervorzuheben und eine Erkennung sowie Unterscheidung solcher überkommenen Teichanlagen in der heutigen Gewässerlandschaft zu ermöglichen, falls sie einem - zumeist in reliktärer Erscheinungsweise - gegenübertreten sollten.

In der modernen Teichwirtschaft werden die Muttertiere der Salmonidenarten (Rogner und Milchner) zu ihrer Laichzeit künstlich abgelaicht, die Eier künstlich befruchtet, in Bruthäusern in verschiedenen Apparaten bei ständigem reinem Wasserzulauf erbrütet und die Jungbrut in Futtertrögen oder Aufzuchtbecken bei täglicher, oft mehrmaliger Fütterung mit meist Fertigfutter (Mischfuttermittel) zum Besatzfisch und anschließend in kleinen Forellenteichen zum Speisefisch gezogen oder schon als Besatzfisch an die verschiedensten Interessenten verkauft (PLANANSKY 1983:78). Die hierbei

\footnotetext{
${ }^{23}$ Die Provinz Galizien bestand unter diesem Namen seit dem späten 17. Jh. Nach den polnischen Teilungen 1772 und 1795 führte Österreich-Ungarn diese Bezeichnung für die annektierten Gebiete, Klein-Polen und Ruthenien, als die westlichen und östlichen Teile der ursprünglichen Provinz [http://www.polishroots.org/genpoland/galizien.htm; 06.01.2004]
} 
betriebene ,Pelletintensivwirtschaft' sieht eine Verfütterung vollwertiger Mischfuttermittel mit hohem Eiweißanteil vor. Bei dieser Verfahrensweise kann der Fischbesatz bis zu $300 \%$ gesteigert werden (ZOBEL 1992:94).

Die Bewirtschaftung einer modernen, vollkommenen Teichwirtschaft erfolgt nach einer auf zwei bis drei Jahre festgesetzten Wirtschaftsplanung: dem Besatzungs-, Düngungs- und Fütterungsprojekt. In diesem sind Brut-, Streck- und Abwachsteiche so eingeteilt und ihre Besatzaltersklasse und Besatzdichte so abgestimmt, dass das für das nächste und übernächste Wirtschaftsjahr erforderliche Besatzmaterial wie auch der für den Verkauf notwendige Speisefisch produziert wird (PLANANSKY 1983:79). Elektroanschlüsse übernehmen vor allem in den Forellenteichen die aufgrund der hohen Besatzdichte notwendige technische Belüftung.

Des Weiteren werden bei der modernen Karpfenzucht Karpfenteiche nach ihrer Verwendung für bestimmte Altersstufen im Vergleich zur Teichwirtschaft des 19. Jh. noch detaillierter unterschieden (SCHÄPERCLAUS 1961:148): Ergänzend gibt es Klassenteiche und Vorwärmteiche. Unter den Oberbegriff ,Brutteiche' werden Streichteiche, Brutstreckteiche, Vorstreckteiche und Streckteiche zusammengefasst. Während es Streich-, Brutstreck- und Streckteiche bereits schon früher gab, ist innerhalb dieser Kategorie der Vorstreckteich als zusätzlicher Brutteich hinzugekommen. Winterteiche, Abwachsteiche und Vorratsteiche haben ihre Funktion beibehalten.

Die Aufteilung der Gesamtteichfläche auf die einzelnen Teicharten ergibt sich dabei entsprechend dem oben beschriebenen Verfahren für die verschiedenen Arten von Teichen aus folgender Gliederung:

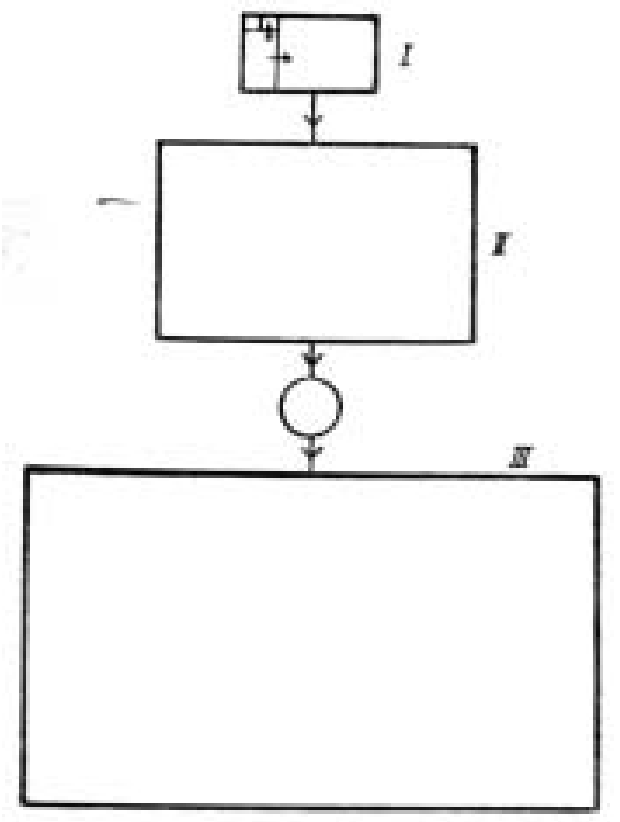

Abb. VII-8:Größenverhältnis der Teichflächen In diesem Verhältnis werden sie im I.-III. Aufzuchtjahr in der Karpfenteichwirtschaft benötigt. Es beträgt relativ ca. 1:6:18 (aus: SCHÄPERCLAUS 1961:236).

Das Größenverhältnis änderte sich jedoch selbstredend, wenn beispielsweise Besatzstärken, Verluste und Wachstum der Fische variierten und kann deshalb nur als Richtwert bei der Flächenbestimmung von Teichwirtschaften gelten.

Die Erzeugung von Speisekarpfen wird in modernen teichwirtschaftlichen Vollbetrieben normalerweise im 3jährigen Umtrieb, im sog. Klassenbetrieb, in speziellen Klassenteichen durchgeführt. Bei dem allgemein verfolgten Zuchtziel, Speisekarpfen von $1250 \mathrm{~g}$ zu erzeugen, wird ein 2jähriger Umtrieb in Deutschland für unrationell erachtet, vielmehr ein 3- oder 4jähriger Umtrieb favorisiert. Die eigentlich vorteilhafte Einsparung an Aufzuchtfläche von einem Karpfenteich im 2jährigen Umtrieb wird durch höheren Hektarzuwachs und geringere Stückverluste bereits im 
3jährigen Umtrieb mehr als ausgeglichen. Der 4jährige Umtrieb gar - beruhend auf erhöhter Naturnahrungsausnutzung infolge von größerer Fischbesiedlungsdichte in den ersten 3 Jahren und einer Art von Wachstumssimulation der zurückgehaltenen Karpfen im 4. Jahr - soll den Karpfen eine noch bessere Ausbildung der Resistenz aufgrund des langsameren Wachstums in der Karpfenjugend verschaffen (SCHÄPERCLAUS 1961:235). Zu diesem Zweck wird in den großen Teichwirtschaften jeder Teich in der Regel nur mit einem Fischjahrgang besetzt (:234). Das heißt, dass in dem Fall des Klassenbetriebes der Karpfenzuchtbetrieb mindestens drei oder gar vier separate Karpfenteiche allein für die jeweiligen Altersklassen bereithalten müsste.

In einigen besonderen Teichwirtschaften stand am Anfang der Teichabfolge zunächst der sog. Vorwärmer (Vorwärmteich), der sich in den Beschreibungen zu den Teichwirtschaften des 19. Jh. nicht wiederfinden lässt. Aus diesem fließt das ,vorgewärmte' Wasser in einen Laichteich. Als Vorwärmer werden kleine, möglichst oberhalb gelegene flache und stets fischfreie Teiche bezeichnet, die wenige Tage vor dem Bespannen der Laichteiche diese mit Wasser füllen (ZOBEL 1992:99). Diese Vorfluter müssen soviel Wasser enthalten, dass die benötigten Laichteiche gefüllt und auf ihrem Wasserstand erhalten werden können (SCHÄPERCLAUS 1961:239). In die Vorwärmteiche wird stets - gleich allen Karpfenteichen - „eine bestimmte Menge Jauche aus dem Wirtschaftshofe eingeleitet [...]. Dann erst wird das Wasser zum Speisen der Fische benützt.“ (TAURKE 1927:18)

Standen spezielle Vorwärmteiche nicht zur Verfügung, wurde, da Laichteiche warm sein müssen, eine Warmwasserheizung derart eingerichtet, „daß neben den Laichteichen, etwas tiefer gelegen, ein Warmwasserkessel angebracht wird, von dem aus eine isolierte Rohrleitung von oben her an den Boden der Teiche und von dort zurück führt.“ (SCHÄPERCLAUS 1961:240) Dieser Warmwasserkessel befand sich in größeren Teichwirtschaften in einem separaten Heizungshaus.

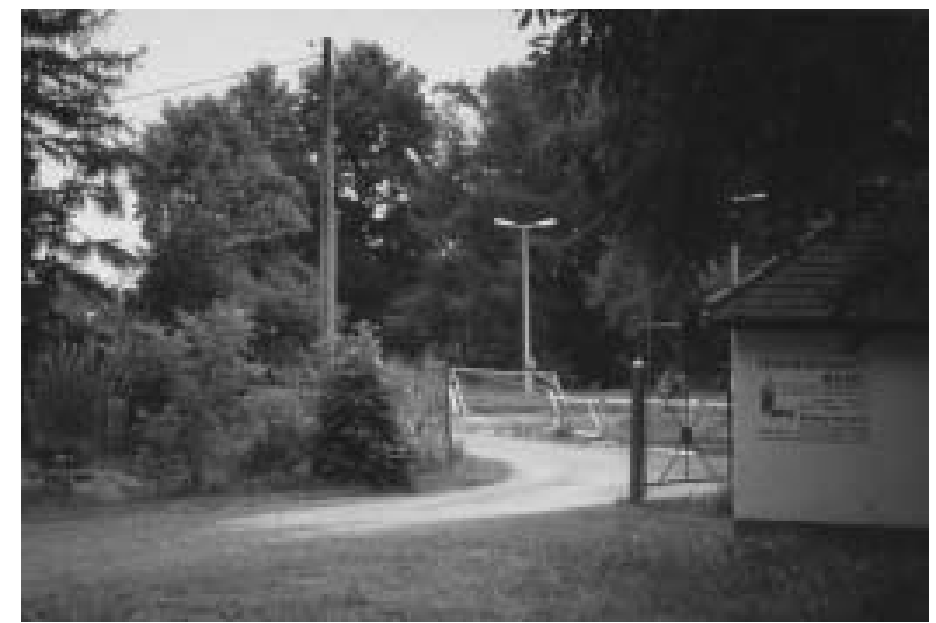

Abb. VII-9:Teichwirtschaft Milkel/Sachsen

Industriell geführte Karpfenzuchtanlage mit großem gepflasterten und beleuchteten Wirtschaftsbereich (An- und Ablieferung), um auch in der Dämmerung bzw. Dunkelheit Abfischung und Hältererei betreiben zu können. Das Schloss Milkel mit seinen weitläufigen, künstlich geführten Wasserläufen befindet sich in unmittelbarer Nähe (eig. Aufnahme 1994).

Entgegen der Bewirtschaftungsweise des 19. Jh. blieben bei der modernen Variante nach SCHÄPERCLAUS die einsömmrigen Karpfen - ohne Herbstabfischung - über Winter in den Brutstreckteichen stehen. Die Brutstreckteiche besitzen deswegen die Eigenschaften guter Winterteiche, d. h. sie müssen hinreichend tief sein, und außerdem muss die Möglichkeit bestehen, sie auch im Winter mit Wasserdurchstrom zu versorgen (:540). Die Brutstreckteiche werden dann in der Zeit von März bis April als erste von allen Teichen abgefischt (:260). Diese Vorgehensweise beinhaltet, dass bei dieser Teichbewirtschaftungsform die Brutstreckteiche über Winter nicht trocken lagen.

Wenn die Brutstreckteiche aber gleichzeitig die Funktion von Winterteichen übernehmen sollen, „müssen aber Stellen von $1,50-2,00 \mathrm{~m}$ in genügender Ausdehnung vorhanden sein.“ (SCHÄPERCLAUS 1961:260). Doch „gelegentlich“, räumt SCHÄPERCLAUS (:269) ein, werden die 
Karpfen nach dem alten Vorbild, ,auch schon im Herbst des ersten Zuchtjahres aus den Brutstreckteichen [...] abgefischt und dann in besondere Winterteiche eingesetzt.“

Im zweiten Zuchtjahr werden die Karpfen, die im Frühjahr des zweiten Zuchtjahres aus den zur Überwinterung dienenden Brutstreckteichen abgefischt werden, schließlich in den Streckteichen herangezogen (SCHÄPERCLAUS 1961:269). Die späteren Betonhälter wurden innen „,mit glattem Speckbeton versehen“ oder sie wurden „mit Praeolit, Inertol oder Chlorkautschukfarben ${ }^{24}$ gestrichen.“ (:532) Diese naturfremden und neuzeitlichen Hälterungen werden hier jedoch nicht weiter beachtet.

\section{b.4 Teich-Wechselwirtschaft}

Mit dem Aufruf „Laßt das Vieh an die Teiche!“ versuchte ,Fischzuchtmeister und Fischerei-Inspektor im Reichsnährstand der Landesbauernschaft Ostpreußen' LIETMANN anzuknüpfen an eine alte Form der Teich-Wechselwirtschaft, die nach seiner Auffassung „die beste Unterstützung im Kampf gegen die Verwachsung und billigste Düngerhilfe“ (LIETMANN 1941:18) bot: die „Feld-Teich-“ bzw. „Teich-Weiden-Wechselwirtschaft“.

„Der Gebrauch,“ schreibt ACKERHOF im Jahre 1869 (:93) hingegen, „Teiche, welche sich trocken legen ließen, von Zeit zu Zeit, oftmals in regelmäßigem Wechsel, dem Ackerbau zu übergeben, ist ein weit verbreiteter, der jetzt noch in der Lausitz, und wenigstens früher, in Holstein ausgeübt worden ist." War diese Betriebsweise also auch schon etwa Mitte des 19. Jahrhunderts nicht mehr überall üblich, so gehörte sie anscheinend dennoch in großen Teichwirtschaftsgebieten zu den beobachtbaren Bewirtschaftungsformen von Fischteichen. Die Anlegung von Fischteichen zum Getreide- und Futterbau beschreibt auch SPRENGEL (1838:65ff.).

In früheren Jahrhunderten benutzte man also vielfach die gleiche Fläche als Teich und dann als Acker oder Weide und diese im dreijährigem Wechsel (WUNDER 1956:7). Diese Form der Benutzung der Teiche kann man als „Teich-Acker-Weiden-Wechselwirtschaft“ bezeichnen.

Die Vorteile der alten Methode der Wechselwirtschaft wurde nicht nur darin gesehen, „in schlammigen Teichen reiche Ernten, ohne Anwendung von Dünger, und der damit verknüpften Ausgaben, zu erlangen", sondern es erfolgte auch durch Wiederbesatz, unmittelbar nach der Getreideernte, „ein bedeutend größerer Zuwachs an Fischen.“ (ACKERHOF 1869:93) Vor allem, preist sogar noch WUNDER 1956 (:7) diese Form der Teichwirtschaft an, ließe sich „,durch Wechsel zwischen landwirtschaftlicher und teichwirtschaftlicher Nutzung die Erträge bei armen Bodenklassen deutlich steigern“. Das durch das Abweidenlassen des Teichbodens „,befürchtete Wundwerden und Aufbersten der Euter und Striche trat nur dann ein, wenn das Vieh im flachen, verschmutzten Wasser watete und die Schädigungen durch Dreckspritzer verursacht wurden." (LIETMANN 1941:18) Einen weiteren Nachteil, „,das an kleineren Teichen oft störende Abtreten der Dämme durch Vieh“, wurde durch eine entsprechende Abzäunung verhindert. Ebenso verhinderte man das Durchschwimmen des Viehes durch den Teich ,durch Ziehen eines Zaundrahtes etwa 0,30 m über dem Wasserspiegel der Länge nach durch den Teich." (:18) Bei der Weidenutzung wurden jedoch Schafe ausgeklammert, vielmehr sogar vor Schafbeweidung von abgelassenen Teichböden gewarnt, „da ein Boden, der lange unter Wasser gestanden hat, anfänglich immer noch Pflanzen hervorbringt, die dieser Thierart sehr nachtheilig sind.“ SPRENGEL (1838:89) berichtet ferner, dass seinem eigenen Erleben, „ganze Schafherden dadurch zu Grunde gingen, daß man sie auf Weiden trieb, die man aus alten Fischteichen geschaffen hatte.“

Auch ist man bei Winterteichen und bei Brutteichen immer wieder darauf zurückgekommen, dass die zeitenweise betriebene landwirtschaftliche Nutzung bei einem Teichboden große Vorteile für die Teichwirtschaft mit sich bringt (WUNDER 1956:7). Sei es, das die Nachlese von Körnern, feinen Samen und Blättern als die Nahrung, die die faulenden Wurzeln und Stängel des Getreides böten, als

\footnotetext{
${ }^{24}$ Es handelt sich bei diesen Produkten um Korrosionsschutzanstriche bzw. pulverisiertes Fertigungsmaterial zur Glättung, Beschichtung und Abdichtung (Versiegelung) gegen Wasser. Es sind auch für Binnengewässer und Schwimmbäder zugelassene Systeme. Hersteller ist z. B. die Intertol AG/Schweiz (Inertol) oder die Fa. Rembrandtin Lack GmbH/Wien.
} 
Gründe angeführt wurden, oder es die Würmer, Mollusken und Insekten waren, die sich in der bestellten Land-Teichfläche eingefunden hatten.

Auf der anderen Seite bot die wechselseitige Nutzung auch für den Ackerbau besondere Vorteile. Der „Mannaspörgel“25 pflegte ,in den ersten Jahren nach einer Bestellung kräftiger zu gedeihen, als später“ (ACKERHOF 1869:93).

Ein Teich nämlich, der ständig und über viele Jahre unter Wasser steht, bildet allmählich am Boden eine mächtige Faulschlammschicht. Durch starke Fäulnis entsteht Sauerstoffzehrung, Humussäuren und Schwefelwasserstoff können auftreten. Schließlich findet eine zunehmende Versauerung und Verarmung des Teichbodens statt (WUNDER 1956:7). Nach Ablassung der Teiche wurden die Teichböden deshalb zunächst trockengelegt: Der Teichschlamm trocknet dadurch aus und sinkt durch Wasserabgabe oft auf 1/10 seiner Höhe zusammen. Die eindringende Luft und der Frost machen den Boden mürbe, es treten Sprünge auf. Dadurch findet eine Bodenbelebung statt, wodurch Nährstoffe wieder mobilisiert werden. Liegt der Boden längere Zeit trocken, so wird er rasch von Unkräutern und verschiedenen Landpflanzen besiedelt (:7).

Die Früchte, die neben der Kartoffel im Teichlande vorzugsweise ackerbaulich für $1-2$ Jahre angebaut bzw. angesät wurden, waren je nach Bodengüte Weizen, Hafer, Gerste, „Runkelrüben“, „Rothklee“ mit „Heublumen“, „schwedischer Klee“ und „Culturgräser“ (ACKERHOF 1869:94; CNOPF 1927:136). Nachdem der Teichboden durch „mehrmahliges Pflügen, Eggen und Ruhren“ durchgearbeitet wurde, besäte man ihn mit dem genannten Getreide, aber auch mit „Sommerraps oder Hanf" (SPRENGEL 1838:85).

Diese Betriebsmethode des Fruchtwechsels konnte aber nur in größeren Teichwirtschaften angewandt werden. Sie konnte, wenn weiterhin eine Fischzucht betrieben werden sollte, nur zur Anwendung gelangen, wenn zumindest ein größerer Teich vorhanden war. Gestattete der Teich eine Teilung in mehrere Teile, so wurden dafür Dämme errichtet und so bewirtschaft, „daß stets ein Theil unter Spiegel, der andere unter dem Pfluge sich befindet" (ACKERHOF 1869:94). Diese notwendige „Schlag-Eintheilung“ begründet sich allein mit den verschiedenen Teichtypen, die für eine vollständige Teichbewirbewschaftung erforderlich sind (siehe oben Pkt. b.2).

Neben der wechselseitigen Nutzung als Teich-, Acker- und Weideland, kam die Teichwirtschaft auch dem „Wiesenwachs“ zugute. Befanden sich unterhalb des Teiches Wiesen, so wurden das düngerhaltige Teichwasser auf die Wiesen zur Wässerung abgleitet. Nicht nur die schwebstoffartig vorliegenden Exkremente der Fische, sondern auch diejenigen, die sich während der Bespannung auf dem Boden des Teiches abgesetzt hatten und sich beim Abfließen des Teichwassers lösten, trugen zur Ertragssteigerung der Wiesen bei. Durch das Bewässern der Wiesen wurden denselben nicht nur die

\footnotetext{
${ }^{25}$ Manna (hebräisch, auch im lat. und im althochdt. des 8. Jh. tritt ,manna' auf; etymologisch auch verwandt mit dem arabischen Verb manna „Gnade erweisen“). Das biblische Manna ist traditionell das „Brot vom Himmel“, das „Himmelsbrot“, da das Volk Israel das Brot als Manna bezeichnete (2. Mose 16). Allgemein gesprochen ist Manna eine „himmlische Speise“.

Gedeutet wird das biblische Manna auf verschiedenen Weise: als „Maulbeer-Manna“, als die vom Himmel regnenden Maulbeeren [URL = http://www. Dryfruit.de/spezialitaeten/maulbeermanna.html; 22.03.2004], als biologisches Ausscheidungssekret der Schildlaus, nahrhafte, süßlich schmeckende weißliche Tröpfchen, die die Insekten nach dem Genuss von Tamarisken-Saft (Rispelstrauchsaft) absondern [URL $=$ http://www.sonntagsblatt-bayern.de/03/03-03-19.01.20031042646200-39045.htm; 22.03.2004] und als pflanzlicher Heilsaft. Das pflanzliche Manna wird aus der sog. Mannaesche bzw. Blumenesche (Fraxinus ornus aus der Familie der Oleáceae, Ölbaumgewächse) gewonnen. Es entsteht natürlicherweise, wenn Eschenzikaden und andere Insekten in die Rinde stechen und daraufhin der Pflanzensaft als süße Masse austritt. Das offizielle Manna, das heute ein Arzneimittel aus der Kräutermedizin bezeichnet, besteht aus dem durch Einschnitte in die Stamm- und Astrinde von Fraxinus ornus LINNÉ gewonnenen und getrockneten Saft. Er wird als abführendes Mittel und in wirksamer Dosierung gegen krankhafte Verstopfung eingesetzt und von Juni-August geerntet [URL = http.//www.heilpflanzen-welt.de/monographien/texte/040905.htm; 22.02.2004].

Hier aber ist mit „Mannaspörgel“ bzw. „Mannaspargel“ die Kartoffel als „Manna des kleinen Mannes“ gemeint (LOREY 2000:32). Die Namensgebung macht darüber hinaus deutlich, wenn bekannt ist, dass die Kartoffeln des 19. Jahrhunderts auch als „Zapfenkartoffel“ bezeichnet wurde (:32).
} 
Feuchtigkeit, sondern auch die im Wasser enthaltenen pflanzlichen und tierischen Nährstoffe zugeführt.

Die außerordentlichen Erträge, die Wiesen lieferten, die zugleich mit Wasser und Düngstoffen aus der Teichwirtschaft bewässert wurden, ließen ,sehr bald die Ueberzeugung entstehen, daß Fischerei und Futtererzeugung, hauptsächlich durch Wiesenwachs, eine weit höhere Rente gewähren muß, als im Wechsel mit Ackerbau.“ (ACKERHOF 1869:94) Insofern wurde „Wiesenwachs mit Bewässerung in einem Theile des Teiches" betrieben (:121).

Es wurde gar im früheren Schrifttum ein fiktives „Project“ umschrieben und anschließend ausführlich beschrieben nach dem Motto: „Es soll aus einem Grundstück, welches früher Teich gewesen, jetzt als geringe Wiese liegt, eine Teichwirtschaft angelegt werden, derartig, daß dieselbe einen möglichst hohen Ertrag aus der Fischerei, dem Wiesenwachs durch Viehhaltung und sonstigen etwa anwendbaren Nutzungsweisen verspreche." (ACKERHOF 1869:122). So rechnete ACKERHOF (:128) vor, es liefere „1 Kuh, welche täglich 30 Pfd. Heuwerth erhielt, im Mist Futter für durchschnittlich 3 Schock 2pfündige Karpfen [...]. 21 Stück Rindsvieh würden demnach 63 Schock Karpfen bezeichneter Qualität nähren“.

Das ganze ineinandergreifende System zwischen Fischerei, Wiesenwachs und Viehzucht gestaltete sich folgendermaßen: Der Teich wurde an der höchsten Stelle in drei gleiche Teile, ,welche bestimmt sind zu Teichen auf die Dauer liegen zu bleiben“, durch Dämme abgegrenzt (ACKERHOF 1869:94f.).

Nur der übrige Teil wurde mit den weiterhin bespannten Teichen bewässert. Das heißt, hier wurde die Teichbaufläche zwar flächenmäßig reduziert, aber weiterhin eine Fischbewirtschaftung auf einer Teilfläche betrieben, zumal zu bedenken war, dass die Größe der Teiche zu der bewässerbaren, in Wiesen umzuwandelnden Fläche in einem gewissen Verhältnis stehen musste (ACKERHOF 1869:95). Das im Sommer gewonnene und zu fütternde Gras konnte als Mist den Karpfen wieder als Nahrung dienen. Das gewonnene Futter musste in den Sommermonaten gefüttert werden, „weil sonst, wenn solches auch im Winter geschähe, keine Verwerthung des Mistes als Fischfutter stattfinden könnte“ mit der Folgerung, dass ,also auch nur im Sommer Vieh gehalten werden“ kann (:132).

Diese Form der „Dreifelderwirtschaft“ hatte darüber hinaus folgenden Vorteil: „Die Abtheilung des Teiches in drei Hälften ist deshalb zweckmäßig, weil dann alljährlich gefischt werden kann, wenn die Fische zwei Jahre sitzen sollen, und der dritte Theil kann zum Ackerbau bestimmt bleiben, um den im Teiche niedergeschlagenen Mist in dem je dritten Jahre ausnutzen zu können, wenn nöthig auch zur Gewinnung von Herbstfutter zu benutzen, falls in dieser Zeit der Graswuchs nachläßt." (ACKERHOF 1869:95)

Diese Betriebsmethode, bei der sowohl Teichwirtschaft, Ackerbau und Wiesenbewässerung auf einer ehemals alleinig der Fischwirtschaft dienenden Teichfläche betrieben worden ist, schaffte dreierlei: den Fischen Futter, den Wiesen einen reicheren Ertrag und dem Acker Dungstoffe.

Dazu kam für die Karpfenteichwirtschaft die Ansicht, dass „eine im Frühjahr gut gedüngte Wiese, mit Wasser überstaut, [...] für die Zeit eines Sommers der ertragreichste Karpfenteich“ ist. „Eine solche Wiese“, schreibt VOGEL (1898:22) fort, „wird im ersten Sommer bei warmer Witterung und niederem Wasserstand in allen ihren Theilen geradezu ein Brutherd von Karpfennahrung sein“. 


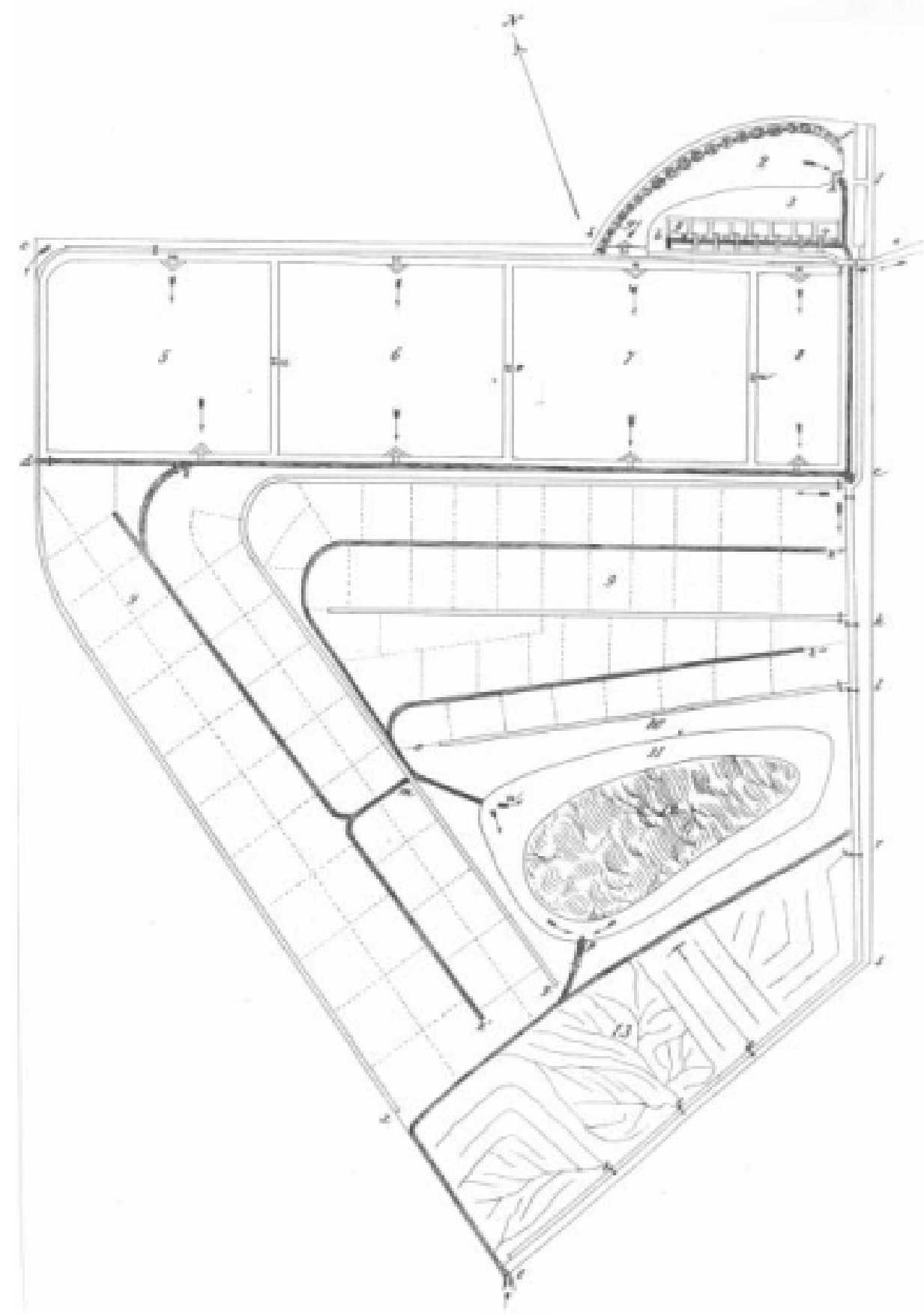

Abb. VII-10: „Situations-Plan einer Teichwirthschaft verbunden mit Wiesenwachs.“

(aus: ACKERHOF 1869:Anhang). Hieraus wird ersichtlich, dass Fischteiche, wie SPRENGEL (1838:67) es ausdrückt, als „Reservoire des Wassers“ benutzt wurden, „welches man zur Bewässerung nahe gelegener Wiesen und selbst Felder nöthig hat." Alles von den Feldern fließende Wasser sollte in den Teichen aufgefangen werden. In dem von ACKERHOF leider und unverständlicherweise nicht näher beschriebenen Plan einer kombinierten Teich-Wässerwiesen-Anlage lässt sich die Dreiteilung in Flächen für die Teichwirtschaft (Teiche 5-8), für den Ackerbau (9) und den Wiesenwachs (13) sehr gut erkennen. Nr. 12 ist aller Wahrscheinlichkeit nach ein Sammelteich, der die von den Äckern abfließenden Dungstoffe sammelt und den Wiesen zuführt. Des Weiteren sind zahlreiche $\mathrm{Zu}$ - und Ableitungsgräben eingezeichnet, die Wasser und mit Wasser versetzte tierische Kloake befördern. Nicht dargestellt ist die von ihm beschriebene Weiterführung des Hauptzuleitungsgrabens zur Stallung des Hofes. Hierdurch konnte „,der Mist unmittelbar aus dem Stalle in den Graben geworfen werden.“ (ACKERHOF 1869:133) Das „Inventarium“, das für den Wiesenwachs und für die Fischerei notwendig war (Netze, Kescher, Fischkörbe, Transportfässer etc.), wurde in einem Wagen aufbewahrt, der als mobiler und „unbedeutender“" Bestandteil ebenfalls nicht dargestellt ist. Auffällig sind die kleinen schmalen, rechteckig erscheinenden Ackerbeete, wobei die Ackerfurchen nicht eingezeichnet sind. Zieht man die Darstellung von SPRENGEL (1838:85) hinzu, so muss es sich um schmale, 6-8furchige Ackerbeete gehandelt haben; aus folgendem Grund: „Beim Eggen der schmalen Ackerbeete geht das Zugvieh in den Furchen, und knetet deshalb den Boden nicht fest, kurz die schmalen Ackerbeete sind, wenn der Boden nicht nicht recht trocken sein sollte, von äußerster Wichtigkeit““. 
Darüber hinaus wurden nicht nur Zwischen-, sondern auch einige Nebennutzungen mit der Fischteichwirtschaft verbunden. Der Teich des 19. Jahrhunderts sah nicht so streng uniform und trostlos aus, wie es die Fokussierung auf die Fischzucht erwarten ließe: zum Verkauf bestimmter Rohrkolben und Kalmus (siehe VI 17c), Wasserlinsen, an denen sich Würmer und Mollusken aufhielten und die der Pferdenahrung dienenden Blätter der Wassernuß wurden sehr wohl begrüßt und sogar durch Anpflanzung und Düngung oder „Geilung“ gefördert (ACKERHOF 1869:105ff.; CNOPF 1927:128). So wurden manche Teiche ,jährlich mit einer bestimmten Anzahl Fuhren Schafmist gedüngt.“ (CNOPF 1927:128)

In bestimmten Bereichen von Teichen dürfte es mitunter zeitweise so ausgesehen haben, wie es der Sukzession überlassene Wasserflächen darstellen mit der Ausnahme, dass auch eine Aberntung erfolgte.

Insofern konnte der Ertrag durch „Verbindung der Teichwirthschaft mit einer vollständigen Landwirthschaft" sehr profitabel sein. Dazu kamen noch weitere Nebennutzungen, die nicht nur den eigentlichen Teichboden betrafen: Der Teichdamm großer Teichanlagen gewährte Schafen, „wegen seiner hohen trockenen Lage eine vortreffliche Weide" (SPRENGEL 1838:87). Er wurde in Zeiten der Benutzung des Teiches als Ackerland gar umgepflügt und mit Getreide besät, ,denn dadurch wird der Dichtigkeit der Basis, worauf es bei Teichdämmen so sehr ankommt, nicht geschadet.“ (:87)

\section{c Teichbau}

In diesem Abschnitt soll der Teichbau einer sog. ordentlichen Teichwirtschaft beschrieben werden. Die vorhergehenden Ausführungen haben zwar belegt, dass nahezu sämtliche Teiche, die früher als Dorfteiche bezeichnet wurden oder als Feuerlöschteiche dienten, vor allem mit Karpfen besetzt worden sind und Forellen in Fremdteichen als Nebenbesatz gehalten wurden. Diese ,Einteiche' wurden i. d. R. aber mit einer anderen primären Zweckbestimmung errichtet als die der Fischzucht und oft nicht nach den Regeln des meisterlichen Teichbaus. Doch genau dieses Handwerkszeug eines Teichbauers soll nachfolgend vorgestellt werden, das sich in bestimmten Teichformen niedergeschlagen hat und heute noch in unterschiedlichen Erhaltungsstufen im Gelände wieder zu finden ist. Will man diese oftmals reliktären Strukturen zum Beispiel für eine historischlandschaftskundliche Kartierung erkennen oder wird ein (historisch-orientierter) Wiederaufbau einer solchen Teichanlage z. B. im Rahmen einer musealen Präsentation, eines geförderten Naturschutzgroßprojektes oder aufgrund einer Privatinitiative angestrebt, so ist die Kenntnis des historischen Teichbaus unerlässlich.

Die Quellenlage dazu jedoch ist dürftig: „Über die Technik des Weiherbaus gibt es bis in die frühe Neuzeit keine Quellen aus dem deutschen Raum.“ (KONOLD 1991:356) Die römischen Quellen beschrieben im Wesentlichen die Methoden der Fischerei, wie z. B. bei Petrus de Crescentiis ${ }^{26}$ (1230 1310) (KOCH 1925: 28). Lediglich bei Albertus Magnus ${ }^{27}(1193$ - 1280) findet man den Hinweis auf

\footnotetext{
${ }^{26}$ Petrus (Peter) de Crescentiis (Pier de 'Crescenzi), geb. in Bologna ( um 1230/33 - † um 1310 bzw. 1321 je nach Quellenlage), Begründer der Agronomie in Europa, war Advokat und später Senator in seiner Vaterstadt. Er studierte in seinem Heimatort Medizin, Logik, Naturwissenschaften und Recht. Nach mehreren Dienstjahren widmete er sich seit 1298/99 auf seinem Landgut in Norditalien der Landwirtschaft. Seine vielfachen Erfahrungen über den Landbau legte er in seinem zwischen 1304 und 1309 entstandenen Handbuch der Landwirtschaft „Opus rurallum commodorum libri XII“ (kurz: „Ruralia commoda“) nieder, das eines der ersten gedruckten Werke und das einzige während des abendländischen Mittelalters ist. Ende des 15. Jh. (Erstausgabe Augsburg 1471) wird die sehr einflussreiche agronomische Schrift ins Deutsche übersetzt und unter dem Titel „Von dem Nutz der Dinge, die in Äckern gebaut werden“ herausgegeben. Seitdem wurde das populäre Werk in über 100 Handschriften überliefert und wurde mehrfach in lateinischer und deutscher Sprache sowie in weiteren Volkssprachen gedruckt. Es blieb bin in das 16. Jh. das führende Standardwerk über die Landwirtschaft. Dieses Traktat enthält in seinen 12 Büchern Anleitungen zum Landhausbau, zur Feldbestellung, zum Getreideanbau, Weinbau, Obstbau, Gartenbau, zur Waldpflege, Viehzucht, Jagd und eben auch zur Fischzucht. (zusammengestellt aus: MEYERS KONVERSATIONSLEXIKON 1888:336; http://www.eab-paderborn.de/aus_ink.htm; 6.1.2004; http://mdz2.bibbvb.de/mdz/baende.html?baende=inkunabeln; 06.01.2004).

${ }^{27}$ Albertus Magnus (Albert der Große, zu seiner Zeit Albert der Deutsche, eigentlich Graf Albert von Bollstädt), der größte deutsche Philosoph und Theologe des Mittelalters ( wahrscheinlich 1193 in Lauingen an der Donau im bayerischen Schwaben als Sohn des Grafen von Bollstädt, einer staufischen Ministerialienfamilie $-\uparrow 1280$ in Köln), studierte in Padua
} 
die Teichbautechnik, dass man den frisch ausgehobenen Weihergrund mit einem Lehmschlag versehen sollte (STADLER 1921).

Als ältestes rein teichwirtschaftliches Buch gilt das des Janus Dubravius ${ }^{28}(1486$ - 1553), der dort mit Sicherheit die ganzen Erfahrungen der vorhergegangenen Jahrhunderte hat einfließen lassen (KONOLD 1991:356) Die frisch ausgehobene Grube, ist auch darin zu lesen, wurde, bestand der Weihergrund aus durchlässigen Schottern, um sie dicht zu machen mit ,Letten', einem Lehmschlag ausgekleidet. Während der Damm dann geschüttet wurde, (man sollte keinesfalls wegen der Stabilität des Dammfußes das Schüttmaterial ${ }^{29}$ aus dem künftigen Weiher nehmen), hat man das Bodenmaterial mit Pferden feststampfen lassen.

$\mathrm{Da}$ es also in den ältesten zur Verfügung stehenden Quellen, in denen die Fischerei angesprochen wird, keine Aussagen zum Verfahren und zur Technik der Teichwirtschaft gibt (vgl. LAMPEN 2000), ist man auf vor allem die neuzeitliche und spätneuzeitliche Fachliteratur angewiesen, die im Folgenden rezipiert wird.

$\mathrm{Zu}$ betonen ist abschließend die generelle und bereits herausgearbeitete Unterschiedlichkeit der Karpfen- und Forellenteichwirtschaft aufgrund ihrer differenten Lebensansprüche, die sich insbesondere in ihren morphogenetischen Erscheinungen im Raum niederschlagen. Prinzipiell jedoch mögen die Darstellungen allgemeingültigen Charakter besitzen, so dass nur an den betreffenden Stellen auf die Unterschiedlichkeit hingewiesen wird.

\section{c.1 Teichgräber}

Gleichsam dem Wiesenmeister, dem Schleusenbauer und dem Weidengärtner gab es für den Bau der Fischweiher sog. ,Teichgräber', als welche oft auswärtige Spezialisten engagiert wurden. Diese Männer waren keine Fischer, ihre Aufgabe bestand in der handwerklichen Anlage eines Fischteiches und sie schufen die technischen Einrichtungen für die Fischzucht (AMACHER 1996:92).

Aus den vorliegenden Aktenfundstücken des Jahres 1657 zur „Anlage eines neuen Forellenteiches an der Salza bei der Öl- und Schleifmühle ${ }^{\text {(30 }}$ in der Nähe der Stadt Nordhausen, werden das grobe Aufmaß, der Aufbau eines Forellenteiches und die dafür verwendeten Materialien ersichtlich. Zugleich wird bekannt, dass eine Naturalienlohnbeigabe in Form von Bier vereinbart wurde - wahrscheinlich für die schweißtreibende Arbeit beim Aushub einer Teichgrube. Weiterhin wird auch hier die enge Verbindung von Teich- und Mühlenwirtschaft ersichtlich.

und wurde dort 1223 Dominikaner und lehrte und arbeitete an verschiedenen Universitäten und Konventen in Deutschland und Frankreich (Köln, Hildesheim, Freiburg/Breisgau, Würzburg, Regensburg, Straßburg und Paris). Er war Philosoph, Naturwissenschaftler, Theologe und Bischof von Regensburg. Durch seine umfangreichen naturwissenschaftlichen (Botanik, Chemie, Physik und Mechanik), medizinischen und philosophischen Kenntnisse überragte er alle seine Zeitgenossen. Dies verschaffte ihm den Namen Magnus (der Große) und den Ehrentitel „Doctor universalis“. Durch ihn fand auch - nach Jahrhunderten des Vergessens - das Gedankengut der Antike wieder Einzug in die europäische Kultur. So war er gründlicher Kenner des Aristoteles und seiner Philosophie und damit erster großer Aristoteliker des Mittelalters. A. M. wurde 1622 seligund 1931 heilig gesprochen; im selben Jahr wird auch das Albertus-Magnus-Institut in Bonn gegründet. Die Naturwissenschaftler ernennen ihn 1941 zu ihrem Schutzpatron (zusammengestellt aus: BAUTZ, Friedrich Wilhelm: Biographisch-Bibliographisches Kirchenlexikon - Verl. Traugott Bautz, Bd. 1 (1990):Spalten 86-88; http://www.weltchronik.de/bio/cethegus/a/albertus.html; 6.1.2004; http://www.net-lexikon.de/Albertus-Magnus.html; 6.1.2004).

28 Johannes (tschech. Janus [Jan] Skála z Doubravky) Dubravius, Bischof von Olmütz (tschech. Olomouc [Stadt in Nordmähren, bis 1641 Hauptstadt Mährens, seit 1063 Bischofssitz]): „De piscinis et pisciu ... - Breslau 1547, Zürich[?]: 1559 (weitere Ausgaben: Leipzig 1774, Frankfurt/M. u. Leipzig 1779, Neapel 1794) („Buch von den Teichen und den Fischen, welche in denselben gezüchtet werden.“ - übersetzt und bearbeitet von A. Wüstner und J. Kollmann. - Wien 1906). Schon in der 1. Hälfte des 16. Jh. konstruierte und benutzte Dubravius einen Gravitationsnivellier mit Diopter für den Teichbau (HÁNEK 2004)

${ }^{29}$ Das Schüttmaterial bestand in Oberschwaben aus Geschiebemergel, Moränenschutt und Kiesen.

${ }^{30}$ Actum in Cuna 21. May. A. 1657: Akte „Anlage eines neuen Forellenteiches an der Salza bei der Ö1- und Schleifmühle 1657“ (Stadtarchiv Nordhausen R Ef 42) 


\begin{abstract}
„Dem Teichgräber [...] Meister Andreas Kreger ist zur Einrichtung eines Neuen Forellen Teiches bey der Oel- undt Schleiffmühle anlieget worden eine Vierkante Ruthe inderzeit einer Ellen tieff vor.

10. gl. undt daneben Ihme dem Meister täglich wenn er darane arbeitet ein Stübich ${ }^{[31]}$ Bier: Hierzur sindt ihme $24 \mathrm{gl}$. zum Birkauf gegeben und verzeheret worden. Die Dämme aber hatt er von diesem Gedinge auf Rutenzahl außgenommen, undt solche absonderlich bezahlett habenn wolle: Endlich aber war Setzung solcher 2. Dämme eine vor allen 2. [...] Breter undt Schaube [...] will [...] ihm dazur schaffen. Was er aber an Holzwert außroden wird, soll sein aber bleiben. [...] soll zur Concent ihme ein Malz auch gerichtet werden. “
\end{abstract}

Teichgräber waren also nicht nur Dammbauer, die nur den Damm aufschütteten, sondern auch diejenigen, die die Schließ- und Ablassvorrichtung aus Holz installierten und die Abflussrinne aushoben (vgl. auch AMACHER 1996:92). Ein „fries“332, wie er auch genannt wurde, musste also sowohl große Erdbewegungen als auch Zimmermannsarbeit bewältigen können (:92). Offenbar waren die spezialisierten „tichtgräber“ so verbreitet, dass diese Dammbauer geradezu als sprichwörtliches Musterbeispiel für fremde Berufsleute gelten konnten. Allerdings dürften die professionellen Teichgräber vorwiegend für die Bauleitung verantwortlich gewesen sein. Die Erdbewegungen in großen Teichwirtschaften waren ja so groß, dass sie kaum ohne eine beträchtliche Zahl von schaufelnden Handlangern ausgeführt werden konnten (:92). Am Bau eines 50 Jucharten $^{33}$ großen Hecht- und Rötel-Weihers ${ }^{34}$ bei Oberwil im Kanton Baselland beispielsweise arbeiteten 1506/07 insgesamt 4 einheimische Zimmerleute und 68 fremde Friesen, von denen die Mehrheit für 8 bis 14 Wochen engagiert waren (:92).

\title{
c.2 Anlage eines ablassbaren Teiches
}

Anstelle einer selbstverfassten Einleitung zu dieser Thematik sei die beispielhafte Arbeitsanleitung von SCHÄPERCLAUS (1961:154) zum Bau bzw. zur Anlage von Teichen durch einen Teichwirt in „einem von einem kleinen Bach durchflossenen Tal“ wiedergegeben, die in dieser Form schon in früheren Zeiträumen beachtet worden ist, wie wir den späteren Ausführungen entnehmen können:

„Die erste Voraussetzung hierfür ist, daß die nötige Vorflut (genügend Abfluß) vorhanden ist, so daß der Teich vollständig abgefischt und hinterher trockengelegt werden kann. Wenn die Gefällsverhältnisse günstig sind, $d$. $h$. wenn der Boden so allmählich ansteigt, daß sich größere Teile des Geländes $50-150 \mathrm{~cm}$ hoch überstauen lassen, ist die Anlage eines Teiches möglich. Der Damm, der das Tal absperrt und das Wasser anstaut, ist möglichst in einer Einschnürung des Tales zu errichten, damit er recht kurz und billig wird. Dort, wo der Bach den geplanten Damm kreuzt, ist wohl immer die tiefste Stelle des zukünftigen Teiches. Hier muß deswegen die Ablaßvorrichtung, der Mönch, eingebaut werden. Außerdem ist von hier aus das Nivellement vorzunehmen. [...]

Stellt es sich heraus, daß der Teich nicht das ganze zur Verfügung stehende Tal einnimmt oder daß der obere Teil zu flach wird, so ist entweder die Tiefe am Mönch größer zu wählen oder es sind mehrere Teiche terrassenförmig übereinander anzulegen. Günstig ist es, wenn überall ziemlich steile Böschungen entstehen, so daß der Teich auch in den

\footnotetext{
31 Stübchen = auch heute noch in Nordhausen/Thüringen bekannter Ausdruck für eine gewisse Menge Bier (Dr. Kuhlbrodt/Stadtarchiv Nordhausen, mündl. 1997)

${ }^{32}$ Fries (auch ,gruber') = altdt., switzerdt. Bezeichnung für Damm- und Erdarbeiter, Grabenmacher

${ }^{33}$ Juchart $=$ altes, nichtmetrisches schweizerisches und auch bayerisches Flächenmaß (Einführung des metrischen Systems in der Schweiz erst im 19. Jh.). Die von einem Ochsengespann am Tag zu bearbeitende Ackerfläche wurde als ,Juchert', ,Jauchart' oder ,Joch' bezeichnet. 1 Juchart entspricht 40.000 bzw. 45.000 Quadratfuß (Quadratfuß als gebräuchliche vormetrische Maßeinheit, schwankend: z. B. Luzerner Maß $\left[0,08 \mathrm{~m}^{2}\right]$, Nürnberger Maß $\left[0,09 \mathrm{~m}^{2}\right]$, Pariser Maß $\left[0,11 \mathrm{~m}^{2}\right]$ ) oder 36 a (schwankend je nach Region: z. B. 32 a $17 \mathrm{~m}^{2}$ [Schaffhausen] bis 36 a $8 \mathrm{~m}^{2}$ [Luzern], oder Flächenart: 1 Juchart Wald $\left[=40\right.$ Aren], Acker [= 36 Aren], Reben [= 32 Aren]. 100 Aren entsprechen $10.000 \mathrm{~m}^{2}$ oder 1 ha [http://www.staluzern/forschung/laengemass.html; 07.01.2004; http://home.t-online.de/home/va_abe/masse.htm; 07.01.2002] ${ }^{34}$ Der Seesaibling (Salvelinus alpinus salvelinus L.) wird in der Schweiz als Rötel bezeichnet (BROHMER 1984:420; http://www.lebensmittellexikon.de; 07.01.2004)
} 
flachsten Teilen $50 \mathrm{~cm}$ tief wird. Nur dann können die Fische am flachen Ufer gut weiden, und die Gefahr einer Verschilfung ist nicht übermäßig groß. Bei allzu flach auslaufenden Ufern kann das Erdreich [...] ausgehoben [...] und dann zum Dammbau verwendet werden.

Anzustreben ist stets, daß jeder Teich seinen eigenen $\mathrm{Zu}$ - und Abfluß erhält. Das gilt auch für Forellenteiche, die zur Schaffung eines stärkeren Durchstromes hintereinander geschaltet werden. Nur dann ist es möglich, jeden Teich für sich zu bewirtschaften und abzufischen".

Aus dieser komprimierten Zusammenfassung zum Bau eines Teiches sind zunächst Bedingungen genereller und naturräumlicher Art abzuleiten und herauszufiltern.

\section{c.2.1 Allgemeine Voraussetzungen}

Der für eine spezifische Teichnutzung entsprechende Wasserzufluss ist die Grundbedingung für die Anlage eines Ablassteiches: „Will man [...] einen Teich anlegen, so muß mindestens so viel Wasser zufließen können, wie versinkt", lautet der logische Leitsatz von BORNE (1886:219).

Die nachfolgende zweite Bedingung nach Gewährleistung der Wasserversorgung von Teichen ist die, „daß man das natürliche Gefälle ausnutzen kann“ (CRONHEIM 1907:8f.). Des Weiteren soll drittens „unter Benutzung des natürlichen Gefälles [...] die Versorgung derart vorgenommen werden, daß möglichst jeder Teich unabhängig von dem anderen ist und für sich gespeist wird.“ (:9)

Die vierte - logische - Bedingung an eine geregelte und regulierbare Wasserspannung heißt: wo eine Wasserzufuhr existiert, dort muss es auch ein Wasserabtransport geben und diese erfüllt sich durch die Herstellung von Wasserabzugsvorrichtungen.

Die o.g. zweite Voraussetzung für eine sinnvolle Teichanlage, das Vorhandensein eines ausreichenden Gefälles dergestalt, dass der einfallende Wasserzufluss und abgängige Wasserabfluss innerhalb der Teichabfolge gewährleistet ist, bedingt die fünfte Prämisse zum Teichbau: eine reliefierte morphologische Geländeform. Denn die Teichabfolgen, aufgrund ihrer hintereinander geschalteten Terrassierung auch Terrassenteichanlagen genannt, sind gebunden an - und können mit geringen Arbeitsmitteln erst entstehen durch - welliges Gelände in Form von Talmulden: „Nicht selten ziehen sie sich mit mäßigem Gefälle weit hin [...], so daß es leicht gelingt, eine größere oder geringere Zahl über einander gelegener Teiche einzurichten, was von besonderem Vorteil ist, da man in diesem Falle von unten anfangend, einen Teich nach dem anderen abzulassen und nach der Abfischung aus den oberen sofort wieder zu füllen vermag.“ (BENECKE 1885:3f.; vgl. Abb. VII-11)

Von Anlagen, „bei denen man [...] das Wasser mit Maschinenkraft heben muß“, wurde „auf das entschiedenste“ abgeraten, denn nur „,in den seltensten Fällen“ würden sie die Kosten decken (CRONHEIM 1907:9). Aber, ,auch wenn man sich einer umsonst zur Verfügung stehenden Naturkraft, etwa des Windes, bedient, sind sie nicht zu empfehlen, denn man läuft so immer Gefahr, daß [...] der Zufluß versagt." (:9) Das Gefälle bedingt also die Form der Anlage eines Teiches und die Möglichkeiten zur strukturierten Teichfolge, die eindeutiges Indiz zur Erkennung einer Teichwirtschaft im Gelände darstellt.

CRONHEIM (1907:9) beschreibt die Idealform einer terrassierten Anlage durch eine abgekoppelte und individuelle Wasserzufuhr, die nur durch externe und interne Gräben mit einem steten Gefälle gewährleistet werden kann (s. u.) und gibt damit das sechste Erfordernis zum Teichbau bekannt: Die Herstellung eines Grabensystems zur Regulierung des Wasserzu- und -abflusses.

\footnotetext{
${ }^{35}$ Bei der Mehrzahl dieser topologischen und aufeinander folgenden Reihung von Fischteichen jedoch, die im Gelände häufig bei Mehrteichwirtschaften $\mathrm{zu}$ beobachten ist, wird im Gegensatz zur unabhängigen separaten Wasserzufuhr die nacheinander folgende, Wasser sparende Wasserspeisung praktiziert: Das Wasser des einen Teiches füllt das Becken des anderen.
} 
Bei der Herstellung von Teichen ist also zu beachten, dass die Teiche vorteilhaft nur durch „Benutzung von Bodensenkungen [...] hergestellt werden“ können (BENECKE 1885:2). Eine weitere Möglichkeit wäre die der Grabung. Nur in seltenen Fällen jedoch (siehe Pkt. c.2) „wird ein Teich durch Ausschachten des Bodens hergestellt, gewöhnlich geschieht dies dadurch, daß man ein unebenes Terrain an der am tiefsten gelegenen Stelle durch einen Erddamm einschließt" (BORNE 1886:220), denn ,im allgemeinen werden Teiche nur da mit Aussicht auf eine lohnende Verzinsung angelegt werden können, wo sie wenig Erdarbeiten erfordern.“ (BENECKE 1885:3)

Am günstigsten schien deshalb die Benutzung „,breiter, flacher Thalmulden mit mäßigem Gefälle, deren Ränder hoch genug sind, um einen schädlichen Rückstau des Wassers auf die benachbarten Felder zu verhindern, und sich stellenweise einander so weit nähern, daß zu ihrer Verbindung nur kurze Dämme hergestellt zu werden brauchen.“ (BENECKE 1885:3) „In solchen Mulden ist die geeignete Stelle für die Anlage der Staudämme leicht zu finden“ (:4) und „,bei geschickter Nutzung des Terrains werden oft kleine Dämme von wenigen Metern Länge zur Herstellung großer Teiche genügen“ (:2).

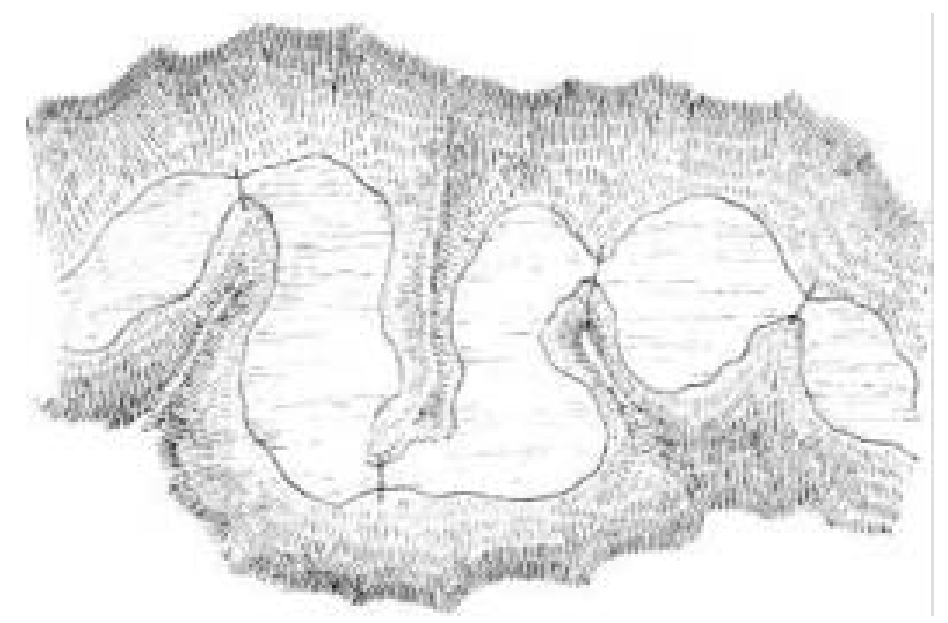

Abb. VII-11: Talmulde mit Bezeichnung der zur Anlage von Dämmen geeigneten Stellen (aus: BENECKE 1885:3, Fig. 1)

Durch die Anlage von Dämmen wurde nicht nur der „gewünschte maximale Aufstau der Teiche“ (WALTER 1933:15) und die Terrassierung gewährleistet, man verhinderte so auch den möglichen Beckenabfluss des sich innerhalb der ausgehobenen Grube oder der Bodensenke befindlichen Wassers, der beispielsweise durch Wellenbildung hätte verursacht werden können - nicht des durch Abzugsvorrichtungen geregelten Wasserabganges. Und schließlich bot der Damm auch einen Windschutz, der eben diese unruhigen Wasserbewegungen verhindern bzw. lindern sollte.

\section{c.2.2 Naturräumliche Voraussetzungen}

Teiche, so die einfache Regel des Teichbaus, können bevorzugt überall dort angelegt werden, „wo man durch Aufschütten eines Dammes Quellen oder kleine kalte Bäche abfangen kann" (TAURKE 1927:35) . Aber vor allem waren es Himmelsteiche in Talmulden, die ihr Wasser ,nur durch Zuflüsse bei Niederschlägen aus der höher gelegenen Umgebung“ bekommen (VOGEL 1898:83). Solche Himmelsteiche in solchen Lagen sind fast immer sehr fruchtbar, „,besonders in gewitterreichen Jahren, da ihnen, vorausgesetzt, daß die Umgebung fruchtbares Culturland ist, werthvolle Zuschwemmungen sicher sind.“ (:83)

Hinsichtlich der Bevorzugung von Quellen als Standorten zur Errichtung von Teichen, den sog. Quellteichen (siehe Pkt. 1b), lag der Grund darin, dass dies „oft mit geringen Kosten ausführbar“ war, „weil Quellen gewöhnlich nur in ebenem Terrain zu Tage treten, so daß der Damm meist nicht lang gemacht werden braucht“ (TAURKE 1927:35). Der Teich solle aber ,nicht direkt über der Quelle angelegt werden, sondern das Wasser soll, wenigstens einige Meter, über Steingerölle rieseln, damit es Sauerstoff aufnehmen und Kohlensäure und Eisenocker abgeben kann" (:35). Bei starkem Gehalt an Eisenocker wären zusätzliche ,kleine Klärteiche notwendig“(:35) . 
Sollten dennoch „im Teich selbst Quellen entspringen“, so wäre „für deren ständigen Abfluß zu sorgen“ (CRONHEIM 1907:21). Es musste also „durch ein geeignetes Gräbensystem dafür Sorge getragen werden, daß nirgends Wasser oder nur sumpfige Stellen“ zurückblieben (:21). Ließen sich sumpfige Stellen absolut nicht entwässern, versuchte man „durch Aufschütten von Boden“ Abhilfe zu schaffen $(: 22)$.

Es waren jedoch nicht nur - wie bei der Teichanlage favorisiert - natürliche Senken, die sich für eine Teichanlage eigneten, „selbst nicht $\mathrm{zu}$ umfangreiche Ausschachtungsarbeiten“, so TAURKE (1927:35), „werden sich für Forellen gewöhnlich gut bezahlt machen“. Wurden gar solche Ausschachtungen „,in zweckmäßiger Weise am Fuße quelliger, versauerter Wiesen vorgenommen“, so lag der Vorteil darin, dass ,gleichzeitig oft die Wiesen entsäuert und verbessert (und vielleicht Wiesenkalk ${ }^{[36]}$ gewonnen) werden“" konnten (:35).

Neben der künstlichen, erweiterten Aushebung von Erdteichen auf der Grundlage von natürlich vorgegebenen Senken und Kuhlen sollten auch, wie bereits oben erwähnt, ,kleine Bäche zu Teichen benutzt werden" (TAURKE 1927:35). In diesem Falle aber gestaltete sich das Anstauen des Baches, also die Bildung von Stauteichen innerhalb des Fließgewässers, als gefährlich, da die so errichteten Bachteiche „bei starkem Wasserandrang leicht zerstört und die Fische entführt werden“ konnten (:35). Vor der Anstauung eines Bachlaufes war vom Teichbauer also „vorher zu prüfen, ob sie gelegentlich [...] Hochwasser führen" (:35).

Aber auch wenn die fachliterarischen Anweisungen zum Teichbau eine kosten- und zeitsparende Bauweise empfahlen, die in erster Instanz die Form des ,einfachen' Quell- oder Fließgewässeraufstaues besaßen, so galt als eigentliche Richtlinie „die Teiche lieber neben dem Bache“ anzulegen und eine „Umleitung des den Teich bespannenden Wassers“ zu erwägen (TAURKE 1927:35).

\section{c.2.3 Bauplan und Nivellement}

Diejenige Geländeform, die ,am leichtesten für Teichanlagen zu verwenden“ war, ist die Talmulde (VOGEL 1898:82). Für den Bau des Fischteiches wurde hier einfach, wie Figur 1 deutlich macht, in günstigem Gelände durch Absperren eines flachen, wasserführenden Tales eine Talsperre errichtet. Den Bach oder die Quelle, die den Teich speisen sollten, staute man mit ,ganz kurzen Dämmen“ (:82), „wenn die Talränder hoch genug waren, um den schädlichen Rückstau auf die angrenzenden Felder oder Wiesen zu verhindern“ (ZOBEL 1992:60). Wenn es das Gelände zuließ, wurde auch nur eine natürliche Erhebung höher gemacht (AMACHER 1996:90).

Zur Absperrung des Bachtals wurden die Stellen ausgewählt, ,,an denen sich die Talränder am meisten nähern, so daß mit kurzen Dämmen eine große Wasserfläche gewonnen werden kann“ (ZOBEL 1992:60; siehe Punkt a, b, c in Abb. VII-12). Teilweise wurde auch ein ganzes Landstück mit dem Damm eingefasst, so dass der Staudamm aus einer Erdaufschüttung von oft erstaunlichen Ausmaßen bestand (AMACHER 1996:92). Zuvor leiteten die Dammbauer, falls nötig, noch zusätzliche Bäche auf das zu überschwemmende Gebiet um (:91). Abschließend, um Nährstoffverluste in Karpfenteichen zu verhindern und damit sie hochwassersicher sind, wurde ein Umleitungsgraben angelegt, der das überschüssige Wasser aufnahm (ZOBEL 1992:60).

\footnotetext{
${ }^{36}$ „Wiesenkalk“ beschreibt die Kalkausfällung an den Wurzelbahnen von Gräsern. Dies kann dann entstehen, wenn Gleye von kalkreichen Grundwässern durchströmt wird. Die Entstehung ist also auf hydromorphe Böden beschränkt und beschreibt eine Nutzungsform der Moore: Seit der römischen Kaiserzeit (etwa ab 2. Jh. v. u. Z) sind Kalkbrenngruben bekannt, die den aus Moorniederungen abgebauten Wiesenkalk verarbeiteten. Besonders seit dem 13. und 14. Jh. und bis ins 19. Jh. hatten der Abbau und die Verarbeitung von Wiesenkalk aus Verlandungsmooren zur Herstellung von Branntkalk für Feld- und Backsteinmauerwerk eine große Bedeutung. Örtlich wird noch heute Wiesenkalk als Bodenverbesserungsmittel abgebaut (SUCCOW/JOOSTEN 2001:404f.).
} 


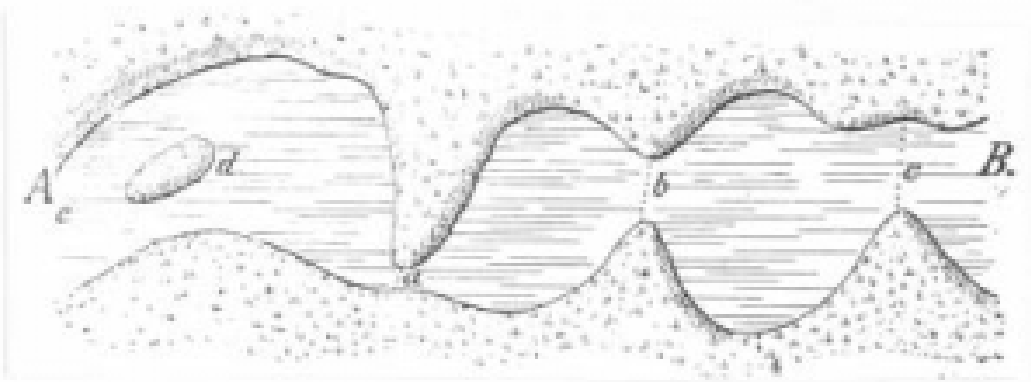

Abb. VII-12: Anlage eines Bachverbauungsteiches

Nach VOGEL „die am häufigsten vorkommende Terrainformation“ (aus: VOGEL 1898:82).

Dazu kam die wichtige Vorrichtung, um den erzeugten Wasserstau zum Ausfischen möglichst vollständig auslaufen zu lassen, die von verschiedener Gestalt sein konnte. AMACHER (1996:92) berichtet von mittelalterlichen Teichen, die „in etwa halber Höhe des Dammes“ einen Einschnitt ausgespart hatten, um den Überlauf bei hohem Wasserstand zu regulieren, oder die Ablaufvorrichtung bestand aus einer Röhre: „Diese Abflussöffnung war aus Baumstümpfen angefertigt, die an der Sohle des Dammes [...] durch die Aufschüttung hindurch eingefügt wurden." Die Dammröhre beispielsweise, im Schweizerischen ,Kännel' genannt, war gegen den Teich hin abgeschlossen durch eine Art Schieber, den sog. ,Strümpfel'. Dieser bestand aus einem Stöpsel oder einem Fallbrett an der Ausflussöffnung des Teichs. Der ,Strümpfel' wurde vom Damm aus mit einer Stange oder einer Art Galgen bedient. Im Teichgrund wurden Ablaufgräben ausgehoben, die das Wasser zum Grundkännel leiteten (:93).

Die zur Farmhaltung verwendeten natürlichen Seen und wohl auch die künstlichen Teichgewässer mussten zudem an der Auslauföffnung mit einem Rechen versehen sein, damit die Fische nicht wegschwammen. Eine einfache Version war das Einrammen von Pfählen in der Abflussrinne, und zwar mit solchen Zwischenräumen, dass das Wasser abfließen, die Fische aber nicht aus dem See bzw. Teich entkommen konnten. Es gab aber auch schon ausgeklügeltere Vorrichtungen mit einer hölzernen Grundschwelle und zwei seitlichen Pfosten: in diese Halterung wurde ein Holzrahmen (Gatter) eingeschoben, der mit einem Holz- oder Metallgitter versehen war. Mit zwei Ketten wurde das Gatter an der Grundschwelle festgemacht, damit der Rechen von Unbefugten nicht hoch gehievt werden konnte (AMACHER 1996:93).

Doch nicht nur in den Hauptteichen der mittelalterlichen Karpfenzucht, auch „neben den Teichen (oder unterhalb) wurden Fischgruben ausgehoben, die ebenfalls mit einer Abflussvorrichtung versehen waren. In diesen Gruben wurden die aus dem Weiher gefangenen Fische bis zum Wegtransport aufbewahrt“ (AMACHER 1996:94f., siehe auch 2b.2.1.4). „Beim Leerfischen des Teiches wurden in diesen Gruben auch jene Fische gehalten, die nach dem Auffüllen des Weihers wieder dorthin zurückgesetzt wurden“(:95).

Seitlich angebrachte „Dammfluther“ hatten in einem fortgeschrittenen Teichbaustadium den Zweck, „alle Hochwässer an den Seiten des Dammes abzuführen, sobald der Wasserspiegel des Teiches den gewollten Höchststand überschreitet (VOGEL 1898:84).

Neben der Bautechnik mussten die für die einzelnen Jahrgänge benötigten Teiche in der erforderlichen Größe und Tiefe angelegt werden. Weiterhin musste die Größe der Flächen für die verschiedenen Jahrgänge und, entsprechend der Besatzstärke, für die Winterteiche und für die Hälter im richtigen Verhältnis zueinander stehen (SCHÄPERCLAUS 1961:153). „Durch ein einfaches Nivellement“ wurde „das Gefälle ermittelt und danach die Größe bestimmt, welche der Teich erhalten soll“ (BENECKE 1885:4). Darauf, dass aber der Olmützer Bischof und Teichspezialist DUBRAVIUS bereits in der 1. Hälfte des 16. Jh. einen Gravitationsnivellier mit Diopter ${ }^{37}$ für den Teichbau konstruierte und benutzte (HÁNEK 2004), wurde bereits hingewiesen.

\footnotetext{
${ }^{37}$ Gravitations-Nivellier: ein transportables geodätisches Instrument, bezogen auf den physikalischen Effekt der Gravitation, das dazu dient die Waagerechte festzulegen (Höhenbestimmung). Die Messung der Schwere (Gravitation) beruht auf dem
} 


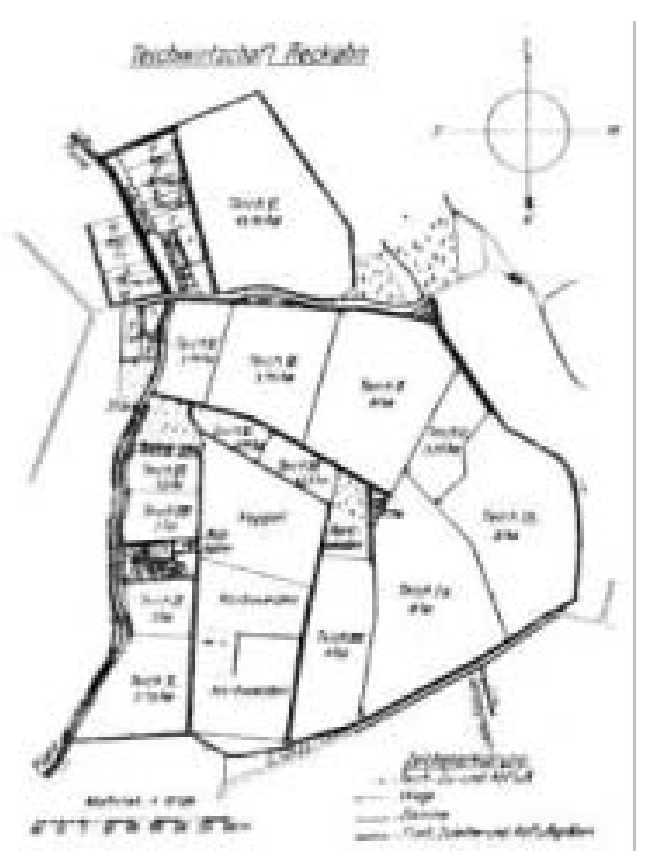

Abb. VII-13: Lageplan der Teichwirtschaft Reckahn (aus: SCHÄPERCLAUS 1961:153)

Zum Teich gehörte im Weiteren auch eine Garnwiese: ein Stück Wiese, wo die Netze zum Trocknen aufgehängt werden konnten (AMACHER 1996:95), die als „Sonderfläche“ bei der Veranlagung berücksichtigt werden musste. Als besondere Fläche innerhalb einer Teichwirtschaft wurde auch die Anlage von Korbweidenkulturen ausgewiesen, wie aus der Übersichtsdarstellung der „Teichwirtschaft Reckahn“ zu entnehmen ist.

\section{c.2.4 Tiefe und Form}

Teiche unterschieden sich hinsichtlich Tiefe und Form, wie wir oben gesehen haben, hinsichtlich des Besatzes, d. h. ob es sich um Karpfen- oder Forellenteiche handelt und hinsichtlich des Zwecks, dem sie dienen sollen. An dieser Stelle sollen die für den Teichbau generellen Konstruktionsparameter genannt werden. Aufgrund der größeren Bedeutung, die die Karpfenzucht bei der Teichwirtschaft gegenüber der Forellenhaltung in früherer Zeit gehabt hat, da Forellen zumeist aus Fließgewässer gefischt wurden, bezieht sich die in der Literatur vorgefundene Beschreibung zumeist auch auf die von Karpfenteichen.

Die Teichtiefe ist zunächst einmal ,abhängig vom Geländegefälle und der Staumöglichkeit“ (LIETMANN 1941:9). Der Teich wird nach Aussage von BENECKE (1885:4), ,natürlich am tiefsten am Damm und läuft nach dem anderen Ende hin flach aus.“ Eine Tiefe „von mehr als $2 \mathrm{~m}$ im Durchschnitt“ wäre „für die meisten Zwecke nicht vorteilhaft.“ Vielmehr wären „Teiche mit einer mittleren Tiefe von 0,50 bis $1 \mathrm{~m}$ im allgemeinen vorzuziehen." (:2)

Flachere Teiche wurden dabei mehrheitlich den tieferen vorgezogen, nicht nur weil tiefe Teiche nicht leicht die für den Karpfen wünschenswerte Wärme annehmen, sondern außerdem auch weil, und dies trifft für alle Fischarten zu, sie „hohe, um genügend widerstandsfähig zu sein, sehr breite und kostspielige Dämme erfordern“ (BENECKE 1885:2f.). Aber schließlich durften sie auch nicht zu seicht gebaut werden, denn in allzu flachen Teichen ließe sich „,der Schilfbestand schwer beherrschen“ (LIETMANN 1941:9).

Prinzip der Federwaage; beobachtet werden die durch eine Änderung der Schwere bewirkte Änderung der Federlänge 1 oder des Winkels á. Die Bestimmung der absoluten Schwere erfordert eine Zeit- und Längenmessung. Sie erfolgt durch Fall- oder Pendelversuche, deren technische Ausführung außerordentlich schwierig ist, da zahlreiche Störfaktoren auftreten können. Die Höhenmessung erfolgt dabei bezogen auf ein einfaches Bezugssystem.

Diopter [grch. Späher]: Visierung, ergänzendes Gerät zur Bestimmung einer Ziellinie 
Der Ufergestaltung wurde beim Teichbau besondere Aufmerksamkeit geschenkt. Das Ufer wurde „als die eigentliche Stätte der Entstehung der Naturnahrung“ angesehen, da sich „am sanft abfallenden Ufer [...] das Wasser am schnellsten erwärmt. Im Karpfenteich schaute man auf „ein flach ansteigendes Ufer“ und bemühte sich „durch künstliche Vergrößerung desselben“ die Nahrungsbildung und Erwärmung möglichst zu begünstigen (CRONHEIM 1907:41f.).

Hinsichtlich der Form von Teichen als Gesamtbild im reliefierten Gelände wurde die Anlage von Terrassenteichen favorisiert: „Wo Teichanlagen auf stark geneigtem Terrain gemacht werden sollen, empfiehlt es sich daher, statt eines großen und an der einen Seite sehr tiefen, lieber eine Reihe stufenförmig über einander gelegener, kleinerer und flacherer Teiche zu bauen" (BENECKE 1885:2f.).

\section{c.2.5 Teichgräben}

Nachdem die natur- und standörtlichen Verhältnisse zum Bau eines Teiches bzw. einer Teichanlage erklärt worden sind, die zukünftige Anlage abgesteckt und die Konzeption zum Teichbau die Form und Tiefe betreffend festgelegt worden ist, folgte die Herstellung der wasserzu- und wasserabführenden Teichgräben, so dass danach ,alle Gräben, [...] die [...] zum Abfluß des Wassers erforderlich sind, aufgeworfen und in guten Stand gesetzet werden, damit man die Erde aus denselben [...] zu dem Damme mit anwenden kann“ (DYHRN 1782:20).

Bevor wir uns aber dem Kapitel des Dammbaus zuwenden, gilt es im Teichbau nicht nur die umlaufenden und innen liegenden Gräben des Wasserablaufes auszuheben, die besonders für die gründliche Trockenlegung der Teiche bzw. der Teichböden notwendig sind, sondern auch die schwierige Frage des Wasserzulaufes mittels Gräben zu klären:

Aus diesen verschiedenen Funktionalitäten heraus können vier Teichgrabentypen innerhalb einer Teichanlage unterschieden werden (DYRHN 1782:13,18):

1. „im Teiche drinnen”

2. „oberwärts”

3. „hinter demselben“ bzw. „unterwärts“

4. „auf der Seite“ („Fluthgraben“).

Die erste Gruppe von Grabentypen, die zur Trockenlegung des Teichbodens dienenden Teichbodengräben, werden in Pkt. c.2.6.2 näher beleuchtet, so dass in diesem Abschnitt die für die Geländeerkennung morphologisch bedeutsamen, ,außerhalb' des Teiches befindlichen Zu-, Um- und Ablaufgräben Gegenstand der Betrachtung sind.

\section{c.2.5.1 Zulaufgraben}

Zulauf- bzw. Zuleitungsgräben, wie sie auch genannt wurden, mussten dann ausgehoben werden, wenn die Teiche ihr Füllwasser nicht aus Quellen oder Himmelswasser bezogen und nicht als reine Durchflussteiche konzipiert waren, sondern neben dem eigentlichen Gerinne errichtet wurden, wie das in der Regel aus Hochwasserschutzgründen der Fall war. Durch diesen Graben wurde das Wasser zur Bespannung des Teiches zugeleitet und reguliert (zu Zulaufvorrichtungen siehe c.2.8).

Des Weiteren musste bei einer strukturierten Teichanlage, bei der man in der Lage ist, den Zufluss dieser Teiche zu regulieren oder herumzuleiten, der Charakter des Teiches und der des Zuflusses gegeneinander abgewogen werden. Wies der Teich an sich in Boden und Umgebung genügende Fruchtbarkeit auf, während der Zufluss arm an Nährstoffen war, so konnte der Durchfluss eher schädlich als nützlich wirken, indem er den Teich abkühlte und die teicheigenen Nährstoffe wegführte. In einem solchem Fall war es also besser, den Zufluss teilweise oder ganz um den Teich 
herumzuleiten. Umgekehrt jedoch konnte natürlich auch „ein reicher Zufluß einem armen Teich wertvolle Nährstoffe zuführen“ (WALTER 1933:11).

Zur richtigen Beurteilung der „Zuflussfrage“ spielte also erstens der Nährstoffgehalt von Teich und Bach, zweitens die Temperatur, drittens das Verhältnis der Wassermenge des Zuflusses zur Teichwassermenge eine Rolle (WALTER 1933:11) und viertens schließlich waren alle die genannten drei Punkte vor dem Hintergrund des Fischartenbesatzes und ihrer Wasseransprüche zu bewerten, wie zu diesem letzten Aspekt bereits zu lesen war.

\section{c.2.5.2 Umlaufgraben}

Umlauf-, Umleitungs- bzw. Abweisungsgräben oder ,Flutgräben', wie sie auch genannt wurden, dienen dem Hochwasserschutz und führen überschüssiges Wasser ,auf der Seite, neben dem Teiche vorbei“ (DYRHN 1782:13) ab.

Bei zu starkem Wasserzufluss wurde also ein seitwärts gelegener ,Umlauf' bzw. ,Wildgerinne' um den Teich herum angelegt, der bzw. das zum einen dem Eindringen von Schneeschmelzwässern bei Winterteichen, die den pH-Wert bei kalkarmen Wässern rasch erniedrigen konnten, vorbeugen sollte (SCHÄPERCLAUS 1961:541f.) und durch den das Wasser am Teich vorbeigeleitet werden konnte (TAURKE 1927:131f.).

Zum anderen sollte man „nur an einem [...] bei der Anlage unter allen Umständen festhalten, und das ist der Schutz vor Hochwasser. Sollte auch nur die leiseste Gefahr bestehen, daß man Hochwasser zu befürchten hat, so soll neben der Zuleitung für die Teiche auch noch eine Umleitung bestehen, die nötigenfalls alles oder wenigstens einen Teil des Wassers um die Teiche herumführt" (CRONHEIM 1907:9).

Vor allem, so wurde geraten, wenn „mehrere Teiche in einem abhängigen Thale hinter einander“ liegen, so wird es erforderlich, ,den Zuleitungsgraben an denselben vorbeizuführen und seitwärts Einlässe zu machen.“ (SPRENGEL 1838:77) Zweckmäßig sei es ferner, ,jeden Teich für sich aus einem Flusse oder Bache zu speisen“(:77). Und dies nicht nur zum Schutz vor Hochwasser. Man sei außerdem so imstande, wie CRONHEIM (1907:9) ausführt, „,bei Trockenlegung von Teichen den Wasserzufluß gänzlich abzusperren“. Denn, wie auch in Abschnitt b.2.1.2 zum Thema ,Winterteiche’ ausgeführt, „die erste Bedingung für eine rationelle Pflege des Bodens ist die Möglichkeit, ihn im Winter trocken zu legen." (:21)

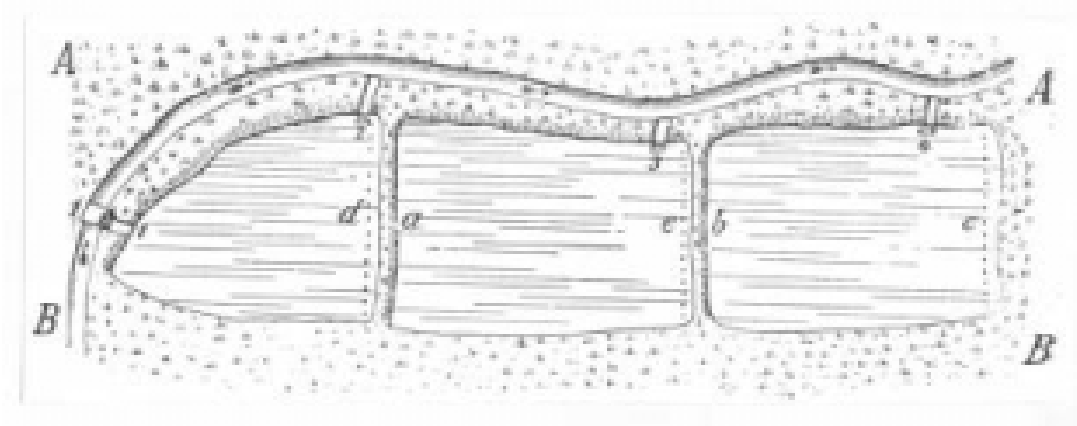

Abb. VII-14: Teiche in einem flachen Wiesenterrain mit Umlaufgraben oder Bachlauf und $\mathrm{Zu}$ - und Ablaufeinrichtungen (aus: VOGEL 1898:85)

Max von dem BORNE (1886:220) fasst die Funktion eines Umlaufgrabens aus damaliger Sicht wie folgt zusammen:

„Das Wildgerinne oder der Abweisegraben hat den Zweck, das Wasser von Flüssen und Bächen an dem Teiche vorbei zu leiten. Bei Bächen und Flüssen, welche bei Regenwetter und Schneeschmelze stark anschwellen, ist dies wichtig, weil die Hochwasser viel 
Schlamm, Sand und Gerölle mitführen, welche den Teich bald ausfüllen, wenn sie darin zur Ablagerung kommen. Wenn bei Hochwasser die Teiche plötzlich anschwellen, so tritt die Gefahr ein, daß die Dämme überfluthet und durchbrochen werden. Gegen diese Gefahr schützt ein geräumiges Wildgerinne und ein breiter Ueberfall im Teichdamme. Bei der Trockenlegung ist das Wildgerinne nützlich, weil es dazu benutzt werden kann, das Bachwasser um den Teich laufen zu lassen und diesen vollständig trocken zu legen."

BENECKE (1885:18) hebt in seiner Darstellung in ähnlicher Weise die Funktion und Bedeutung von Umleitungsgräben hervor:

\begin{abstract}
„Abweisungsgräben oder Wildgerinne sind namentlich bei den in Schluchten oder Thälern gelegenen Teichen erforderlich, um das von den Abhängen herabstürzende Schnee- und Regenwasser, welches Sand, Geröll ec. mit sich führt und die Teiche verschlammen oder versanden würde, abzufangen und fortzuleiten. Dieselben werden also im allgemeinen den Rändern der Thalmulde und des Teiches parallel zu führen sein und müssen breit und tief genug sein und die erforderliche Vorflut haben, um die erfahrungsgemäß zu erwartenden Wassermassen zu fassen und schnell abzuführen."
\end{abstract}

Neben der Verhinderung von Hochwassergefahren konnten Abweisegräben „auch zum Abfangen schädlicher Zuflüsse aus Flachsrösten oder Gerbereien, Färbereien und anderen industriellen Anlagen erforderlich sein (BENECKE 1885:18). Und dass solche Schadstofffrachten in hohen Mengen transportiert worden sind, wurde bereits in Abschnitt VI 1, zum Beispiel in Pkt. VI 1b dargelegt.

Zum Bau eines Umleitungsgrabens war längs der abgesteckten Dammlinie zunächst ein Graben aufzuwerfen, der je „nach Proportion der Höhe des Dammes, und der Größe des Teiches, eine und eine halbe bis drey Ellen ${ }^{[38]}$ breit, und, nach Beschaffenheit des Erdbodens, eine bis drey Ellen tief seyn muß“ (DYHRN 1782:20).

Um die nötige Wasserundurchlässigkeit zu gewährleisten, musste man „,so lange graben [...], bis man festen Grund bekommt“ (DYHRN 1782:21) oder die Gräben „mit leimige oder lettige Erde oder derselben“(:21) auffüllen.

Dass diese Form des Teichbaus praktiziert worden ist, lässt sich noch heute dem Gelände entnehmen und ist auch von den früheren Fischzuchtkundigen beschrieben worden, wie das Beispiel des Kloster Michaelstein belegt. Auch hier wurde für die Teiche ein ,Wildgerinne' errichtet und oberhalb des sog. Trockenteiches abgeleitet. Es hatte zum einen die Funktion, das ,Flutwasser' bei Regengüssen und Schneeschmelzen neben dem Teich vorbei zu führen und die in den Harzbächen sehr bedeutenden Massen von Geröllen, Sand und Schlamm von den Teichen fern zu halten, so dass Letztere weniger schnell durch Niederschläge ausgefüllt werden. Gleichzeitig fließt das Wasser durch das Wildgerinne $\mathrm{ab}$ und es wird dadurch möglich, die Teiche vollständig trocken zu legen. Des Weiteren war das Wildgerinne dazu geeignet, dass die Forellen aus dem Unterwasser, d. h. aus den Laichstrecken im Bach in den Teich hineingelangen konnten (BORNE 1886:277f.).

\title{
c.2.5.3 Ablaufgraben
}

Hinsichtlich der baulichen Gestaltung eines Ablaufgrabens ist der Literatur wenig zu entnehmen. Terrassierte Teichanlagen besitzen durch ihre unmittelbar hintereinander gelegene Teichfolge zumeist nur eine verlängerte Abflussröhre des vorigen Teiches, aus der das Teichwasser in den nachfolgenden geleitet wird.

Doch für flächige Teichwirtschaften oder auch für Einteichwirtschaften gab es zuweilen Ablauf- bzw. Auslaufgräben, um überschüssiges Fischwasser abzuleiten oder in das Fließgewässer zurückzuleiten.

\footnotetext{
${ }^{38}$ Elle: früher gebräuchliches Längenmaß von sehr unterschiedlicher Länge, abgeleitet von der Länge des Unterarmes; misst zwischen 0,5 und $0,8 \mathrm{~m}$, aber auch beträchtlich länger. In Deutschland gab es über 100 verschiedene Ellenmaße.
} 
Diese wurde direkt von der Ablaufvorrichtung am Dammaustritt abgebracht und von hier künstlich, zum Teil sehr verzweigt und in einiger Länge in den Boden gegraben.

\section{c.2.6 Teichboden}

Nachdem das morphologische Grundgerüst, bestehend aus den nivellierten Abmessungen und den Gräben, abgesteckt war, galt es nun in schwerer Arbeit den Boden des Teiches entsprechend zu präparieren:

Zunächst mussten ,Stubben' (Wurzelwerk, Baumstümpfe) und Steine entfernt und der Teich von größeren Unebenheiten befreit werden, weil nur bei glatten Teichbodenflächen Schilfschneidegeräte, Fischnetze und ähnliche Gerätschaften richtig eingesetzt werden können (SCHÄPERCLAUS 1961:157).

Des Weiteren musste der Boden des Teiches nach „der tiefsten, am Damme gelegenen Stelle, an welcher der Abfluß erfolgt, eine allseitige Neigung haben“ (BENECKE 1885:8) und dieses Gefälle musste, falls es nicht im Gelände von Natur aus gegeben war, hergestellt werden.

Weiterhin wurden Teichplätze und Bodengräben geschaffen, die der vollständigen Abfischung und Trockenlegung oder aber als Rückzugsräume für die Fische dienten.

Und schließlich mussten in den Teichwirtschaften, in denen keine separaten Brutteiche zur Verfügung standen, gleichzeitig mit den anderen bodentechnischen Maßnahmen sog. Brutbeete angelegt werden.

\section{c.2.6.1 Teichbodenplätze}

\section{c.2.6.1.1 Brutbeete}

Brutbeete, so beschreibt BENECKE (1885:45) die Form und Funktion der künstlichen Aufwerfungen des Teichbodens, ,sind beetartige Erhöhungen des Teichbodens, welche reihenweise in angemessenen Zwischenräumen angelegt werden, und deren Oberfläche mit Schwadengras, Brunnenkresse und anderen auf nassen Wiesen gedeihenden Pflanzen angesäet, oder mit dem von solchen Wiesen gestochenen Rasen bedeckt, 10 bis $20 \mathrm{~cm}$ unter dem Wasserspiegel liegt. Die Fische benutzen diese Stellen mit großer Vorliebe zum Laichen, die Eier [...] an Gras und Kräutern klebend, [...] und die junge Brut findet zwischen den Pflanzen willkommene Verstecke und reichliche Nahrung. Vor großer Hitze können sich die Fische leicht schützen, indem sie sich in die zwischen den Brutbeeten gelegenen tieferen Gräben zurückziehen.“

Der Bodenboden, dies wird schon hier deutlich, ist also kein ebenes Unterwassergelände, sondern durch künstlich erzeugte Höhen und Tiefen reliefiert, wobei die Aufwerfungen an die Wölbäcker des Ackerbaus erinnern. Die „Zwischen den Brutbeeten gelegenen tieferen Gräben“, wie die Rückzugsräume genannt wurden, werden in Pkt. c.2.6.2 näher beschrieben.

\section{c.2.6.1.2 Der Zug}

Neben den Brutbeeten wurden weitere Bodenbearbeitungen vorgenommen. Vor der Abflussvorrichtung, dem Mönch (siehe c.2.8.3.5), wurde im Teichboden ein Abfischplatz angelegt.

„Auf der tiefsten Stelle im Teiche, so nahe an dem Abzuge, als es etwar möglich ist, legt man eine, gemeiniglich viereckige Grube [...], an, deren Größe sich nach der Größe des Teiches, und nach der Menge der daraus zu fangenden Fische regulirte; worein sich zuletzt alle Fische versammlen müssen, so daß man sie mit ganz leichter Mühe darinnen fangen kann" (DYHRN 1782:44).

Diese Grube, die ,Zug' genannt wird und auch die Bezeichnung Fischgrube, Schlägel- oder Schlegelgrube trägt, ist eine regelmäßig begrenzte Vertiefung von gleichmäßiger Tiefe, ,in welcher 
sich die Fische sammeln, wenn der Teich abgelassen wird. Sie muß vollkommen trocken gelegt werden können“ (BENECKE 1885:9). Sie wurde deshalb, so die weitere bautechnische Anleitung, zweckmäßigerweise „unmittelbar am Damme“ (:9), „da, wo das Wasser die Teichröhre verlässt“ (BORNE 1886:222), angebracht, und die „Sohle der Vertiefung muß mit dem Boden des Abflußrohres in gleicher Höhe liegen“" (BENECKE 1885:9).

Die Grube durfte keinesfalls tiefer liegen als das Abflussrohr der Abzugvorrichtung, um vollständig ablassbar zu sein und sie durfte „,besonders bei Saamen- und Strichteichen, nicht tiefer sein, als daß man zuletzt auch aus der Grube alles Wasser ablassen, und die letzten Fische mit den Händen auflesen kann“ (BORNE 1886:222). Andererseits musste sie „stets mit Wasser gefüllt sein, damit die Teichröhren immer im Wasser liegen und vor Fäulnis geschützt werden“ (:222).

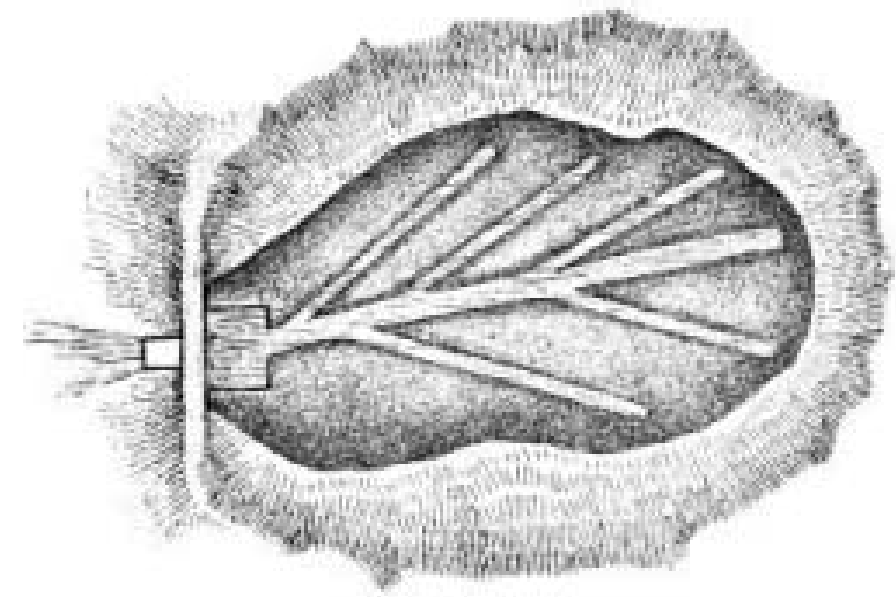

Abb. VII-15: Boden des Teiches mit Fischgrube (,Zug“) und Gräben (BENECKE 1885:8)

Ein solcher Zug wurde „manchmal, in lockerem, weichem Boden“ (BORNE 1886:222) und „auch wohl der größeren Haltbarkeit wegen“ (BENECKE 1885:9), ,,an den Seiten oder Rändern mit Bohlen ausgekastet, und mit einer festen Sohle von Sand, Steinen oder Brettern versehen" (BORNE 1886:222). Da er „bei beschädigtem Rechen“ die Fische aufnehmen sollte, war er „deshalb am Abfluß durch einen Rechen geschlossen“ (:222).

\section{c.2.6.2 Teichbodengräben}

Aus dieser Fischgrube, von der tiefsten Teichstelle, an der die Abflussvorrichtung steht, wurden fischgrätenförmig - Gräben gezogen, die in einen sog. Hauptfischgraben mündeten (SCHÄPERCLAUS 1961:157, 239; ZOBEL 1992:30). Das heißt, durch „die ganze Länge des Teiches“" wurde ein sich allmählich verflachender Hauptgraben gezogen, ,in welchen [...] von den Seiten her kleinere Gräben geführt werden [...], die unter spitzen Winkeln in den Hauptgraben einmünden“"(BENECKE 1885:9).

Zur Tiefe und Anzahl der Gräben erfährt man in der älteren Fachliteratur wenig, in der neueren gar nichts. Bei ZOBEL (1992:60f.) wird lediglich gesagt, der Hauptgraben muss ,genügend tief und breit sein, damit der Teich restlos trockengelegt werden kann.“ Von BENECKE (1885:22) ist zu erfahren, dass, um Karpfenteiche vollständig trocken legen zu können, diese „,von einem oder (bei größerer Fläche) mehreren $1 \mathrm{~m}$ tiefen Gräben durchzogen“ sein sollten, im Übrigen aber „nur eine Tiefe von 20 $-30 \mathrm{~cm}$ und ganz flach auslaufende Ränder" besitzen sollten.

Das Grabensystem erfüllte dabei einen zweifachen Zweck:

Es diente zum einen dazu, wie bereits angeklungen, ,die Fische mit den letzten Resten von Wasser noch zum Hauptfischgraben und in diesem vor den Mönch zu führen“ (SCHÄPERCLAUS 1961:157); denn „bei Ablassen des Wassers ziehen sich die Fische nach und nach in die Gräben und schließlich in die Fischgrube zurück, aus der sie dann mühelos herausgenommen werden können“ (BENECKE 
1885:9; genauso ZOBEL 1992:30). Zum anderen musste „für eine schnelle und gute Entwässerung der Teichbodenfläche nach der Abfischung gesorgt werden“" (SCHÄPERCLAUS 1961:157). Die Teichbodengräben dienen also sowohl der Abfischung des Fischbesatzes als auch der Entwässerung und Trockenlegung des Teichbodens.

\title{
c.2.6.3 Schutzpfähle
}

In den Teichboden wurden nun noch Schutzpfähle gegen Fischdiebe eingeschlagen, die BENECKE (1885:9) wie folgt beschreibt:

\begin{abstract}
„Zum Schutze gegen Fischdiebe ist es gut, kleine Pfähle in Abständen von je einigen Metern in den Teichboden zu schlagen, die $20-30 \mathrm{~cm}$ aus dem Grunde vorragen und den Gebrauch von Zugnetzen hindern. Zweckmäßig wählt man dazu Nadelholzwipfel, die von ihren Zweigen befreit, mit dem dünnen Ende eingeschlagen werden, und an deren frei in das Wasser ragendem Ende man die Äste eines Quirles einige Centimeter lang stehen läßt. [...] An solchen Pfählen zerreißen die Diebe ihre Netze [...]. Sind Nadelholzwipfel nicht zur Stelle, so kann man sie ersetzen, indem man in gewöhnliche Pfähle seitlich einige Nägel einschlägt, deren Köpfe jedoch nicht zu scharfrandig sein müssen, um Verletzungen der Fische zu vermeiden."
\end{abstract}

Dass die Fischräuberei verhindernden Pfahlspitzen im Teichboden scheinbar zu allen Zeiten notwendig gewesen war, zeigt anschaulich die von Johann von SCHWARZENBERG ${ }^{39}$ verfasste ,Bambergische Peinliche Halsgerichtsordnung' von 1507, in der auf Blatt 56b das Strafmaß bei Fischdiebstahl festlegt ist:

\section{„Straff der jhenen / die visch stelen}

Item welcher auß weyern oder beheltnussen visch stelt / ist auch einem diebstal gleych zustraffen / So aber einer auß einem fließendem ungefangen wasser visch fienge / das einen andern zustünde / der mag im kercker oder an seinem gut gestrafft werden / nach gelegenheydt und gestalt der person und sachen / und rate der verstendigen."

,Diebstahl' wird im Kommentar von MEYERS KONVERSATIONSLEXIKON (1888:949) in Anlehnung an das Deutsche Strafgesetzbuch definiert als „[Entwendung, Furtum], die Wegnahme einer fremden beweglichen Sache in der Absicht, dieselbe sich rechtswidrig zuzueignen." Der Begriff des Diebstahls bezog sich dabei nur einen unpersönlichen (fremden), körperlichen, d. h. beweglichen Gegenstand. Die widerrechtliche Aneignung von Geistesprodukten, der sog. literarische Diebstahl, war kein Diebstahl im strafrechtlichen Sinne, ebenso wenig eine herrenlose, in niemandes Eigentum stehende Sache. So war z. B. „der Fisch, welcher sich nicht in einem abgeschlossenen Behälter, sondern im offenen Wasser befindet, in niemandes Eigentum, und ebendarum“ fiel „das unbefugte [...] Fischen oder Krebsen, der [...] Fischdiebstahl, nicht unter den Begriff des eigentlichen Diebstahls, sondern unter besondere Strafbestimmungen.“

\footnotetext{
${ }^{39}$ Die ,Bambergische Peinliche Halsgerichtsordnung' (Constitutio Criminalis Bambergensis) von 1507 gilt als „Markstein und Wendepunkt in der deutschen Strafrechtsentwicklung." Sie drängte die Privatklage zugunsten der amtlichen Strafverfolgung zurück, regelte das Ermittlungs- und Beweisverfahren, definierte klar die Straftatbestände und setzte die ihnen entsprechenden Strafen fest.

Das aus der italienischen Jurisprudenz übernommene Inquisitionsprinzip erhob allerdings das Geständnis zum zentralen Beweismittel und sah zu seiner Förderung den Gebrauch der Folter vor. Auch die in der Bambergensis festgesetzten harten Strafen an Leib und Leben trugen nicht zur Humanisierung des Strafrechts bei.

Verfasser des Reformwerks war nicht ein gelehrter Jurist, sondern ein fränkischer Ritter, der als Hofmeister des Bischofs von Bamberg seit 1501 oberster Verwaltungsbeamter des Fürstbistums und Vorsitzender seines Hofgerichts war: Johann der Starke, Freiherr von Schwarzenberg und Hohenlandsberg (1463/65 - 1528) Der Ritter, der kein Latein gelernt hatte, schrieb neben der juristischen Fachprosa auch moralisch-satirische Gedichte und bearbeitete Übersetzungen anderer aus dem Latein.
} 
Bei Betrachtung heutiger Teichwirtschaften wird - im Gegensatz zur wehrhaften Methode - mit über den Teich gezogenen Garnen bzw. Netzen versucht, vor allem tierischen ,Fischdieben', wie dem Reiher oder dem Kormoran, den Zugang zu verwehren. Gleichwohl wird auch heute noch Fischdiebstahl verübt, wie Polizeiberichten aus den fränkischen Teichgebieten zu entnehmen ist:

So befanden sich in einem Kleinteich zwischen bei Gleußen und Herreth, nähe Coburg, am Tag der herbstlichen Abfischung im September 2001 nur 50 anstelle der 200 Forellen. Ein weiterer Fischdiebstahl wurde aus Region Erlangen-Höchstadt gemeldet (Polizei Coburg, Polizeibericht v. 07.09.2001). Fischdiebstahl wurde auch aus einem Fischteich im Bereich der ,Fehnen-Schneidmühle' bei Wilhelmstal, nordöstlich von Kronach, gemeldet. Im Mai 2002 entwendeten Unbekannte dort ca. 120 Forellensetzlinge (Polizeiinspektionen Kronach und Ludwigsstadt, Polizeibericht v. 22.05.2002). Im gleichen Monat wurden in unmittelbarer Nähe aus einer Teichwirtschaft zwischen Posseck und Grössau ebenfalls Regenbogenforellensetzlinge (Polizeiinspektion Ludwigsstadt, Polizeibericht v. 05.06.2002) und im Oktober 2003 entwendeten Unbekannte aus einem Weiher nördlich von Zeckern insgesamt 60 Karpfen (Polizeidirektion Erlangen, Polizeibericht v. Samstag/Sonntag, 25./26. Oktober 2003).

Aber auch im Oberbergischen Kreis betraten im Oktober 2003 unbekannte Täter eine Teichanlage in Gummersbach-Liefenroth, obschon diese mit besonderen Schutzvorkehrungen abgesichert war. „Sie zerschnitten den zur Sicherung gespannten Stacheldraht und ausgelegte S-Rollen. Aus dem Teich wurden auf unbekannte Art und Weise 300 bis 350 Regenbogenforellen im Wert von ca. 1500,- $€$ entwendet.“ (Kreispolizeibehörde Oberbergischer Kreis, Polizeibericht v. Mittwoch, 22.10.2003)

Im Jahre 2002 wurden in Mecklenburg-Vorpommern die Verluste der Binnenfischerei durch Diebstahl von Fanggeräten und Fischdiebstahl mit 83000,- $€$ veranschlagt. In diesem Zusammenhang erfolgten 12 Anzeigen bei der Polizei (AGRARBERICHT 2003).

\section{c.2.7 Damm}

Ein Damm ist ein künstlich errichteter Wall, vergleichbar dem Deich, doch liegt bei dem Damm eher das Verbindende, beim Deich eher das Trennende im Vordergrund. Verschiedene Arten des Dammes werden unterschieden: man spricht vom ,Bahndamm' nach der Funktion, vom ,Knüppeldamm' nach der Bauweise und in Norddeutschland verstand man unter einem Damm auch ein (befestigte) Straße, die Fahrdamm hieß (vgl. Kurfürstendamm) (NET-LEXIKON 2004). Darüber hinaus gibt es aber eben auch den Teichdamm in der Teichwirtschaft.

Hier ist der Teichdamm „das wichtigste“ (LIETMANN 1941:9) und bei wüsten Teichen ein wesentliches morphologisches Erkennungsmerkmal eines Fischteiches. Der Damm einer Teichanlage stellt daher das bedeutendste historische gewässerbezogene Kulturlandschaftselement dar.

Bereits im zweiten Drittel des 19. Jh. wurde die Forderung erhoben, dass ,wenn Teichwirthschaften aufgegeben werden, so sollte man die Dämme bestehen lassen und keine Gebäude in den Teichgründen ausführen, damit bei veränderter Conjunktur die Teiche leicht wieder hergestellt werden können“ (BORNE 1886:224). Nun gründet dieser erhaltende Kulturlandschaftsgedanke auf betriebsund volkswirtschaftlichen Erwägungen, dennoch ist es mitunter gerade dieser auf agrarische Notzeiten bauende, weitsichtige Wirtschaftsaspekt gewesen, der einige Teiche und damit die Teichdämme hat so manche Rationalisierungsüberlegungen überstehen lassen.

Um eine an historische Teichbauweisen sich orientierende Teichwirtschaft wieder zu beleben bzw. auf ehemaligem Teichgelände wieder aufzubauen, ist die Schilderung der Technik des Dammbaues unverzichtbar. Aber auch, um den Teichdamm als Beispiel eines oftmals nur noch subtil im Gelände wahrnehmbaren anthropogenen Kulturlandschaftswandels für das Auge sichtbarer zu machen. 


\section{c.2.7.1 Material}

Hinsichtlich der Materialverwendung waren ,am gebräuchlichsten, billigsten und allen Anforderungen entsprechend [...] einfache Erddämme“" (BENECKE 1885:4).

Der Teichdamm konnte dabei „aus verschiedenartigem Material ausgeführt werden“ (BENECKE 1885:4): Als das „das beste Material für die Herstellung des Teichdammes“ wurde „ein fetter, nicht zu sandhaltiger Lehm, der für Wasser im höchsten Grade undurchlässig ist“", beschrieben (BENECKE 1885:4; desgl. BORNE 1886:220).

Ein solcher Lehmdamm wurde zwar präferiert, gewöhnlich aber machte man den Damm „aus dem nächstliegenden Material“, aus dem ,zugleich die Fischgrube gebildet wird“ (BORNE 1886:220). Die Erde dazu wurde v. a. von den ,im Teiche befindlichen Anhöhen und Hügeln, oder von den Rändern desselben“ genommen (DYHRN 1782:22). Es war dabei von Bedeutung, „,den Teich in seiner Tiefe nicht gar zu sehr auszuhöhlen“, damit der Teich „ohne alle Hindernisse völlig abgelassen werden kann, so daß gar kein Wasser in demselben stehen bleibt [...] und [...] der Teich desto besser und weiter ausgieße" (:22).

Wo also Lehm „nicht, oder nur in weiter Entfernung“ zu haben war, wurde „der Damm auch aus Kies oder anderem Material geschüttet und durch eine nur 20-30 cm dicke Lehmschicht, die entweder an der dem Teiche zugewandten Böschung aufgetragen oder im Innern des Dammes bei der Schüttung hergestellt wird, wasserdicht gemacht“ (BENECKE 1885:4). „Selbst reiner Sand und Moorerde“, so SCHÄPERCLAUS (1961:156), ,sind zum Dammbau verwendbar“.

Konnte jedoch die Hauptmasse des Dammes „,nur aus Kies oder anderem durchlässigen Material geschüttet werden“, so galt es zu berücksichtigen, „den dem künftigen Teiche zunächst gelegenen Graben mit Lehm zu füllen und auf ihm während des Fortschreitens der Schüttung die oben erwähnte Lehmschicht aufzuführen und fest zu stampfen“"(BENECKE 1885:5f.).

Nachdem der Hauptkörper des Dammes aus Erde aufgeschüttet worden war, wurde dieser Erddamm manchmal, insbesondere bei großen Teichen, gegen die Teichseite „durch eine senkrechte Spundwand“ begrenzt. Diese konnten aus Holzscheiten, aus Bruchsteinen, aber auch - bereits im zweiten Drittel des 19. Jh. - aus Zement oder in Betonmasse ausgeführt werden.

Der wesentliche Nutzen solcher Spundwände oder Mauern bestand darin, „daß sie in sehr großen Teichen den Damm gegen Beschädigungen durch Wellenschlag“ schützten (BENECKE 1885:4). In kleineren Teichen, in denen sich bedeutende Wellen nicht bilden können, fiel dieser Schutz gänzlich weg oder ließ sich „viel einfacher und billiger erzielen“ (:4), wie in c.2.7.2.2 beschrieben wird.

Gleich aus welchem Material der Teichdamm bestand, ob es sich um einen Lehmdamm, KiesSanddamm oder einen Sand-Moorerdedamm handelte, waren aber die Arbeitsschritte zur Dammerstellung im Wesentlichen gleich.

\section{c.2.7.2 Dammbau}

Für den Teichdamm verwendet man ,aufeinander gesetzte Stücke Rasen, so daß er auf beyden Seiten seine gehörige Abdachung bekommt [...] ohngefähr auf die in der Kriegsbaukunst bey Anlegung der Wälle gebräuchlichen Art" (DYHRN 1782:22).

Die dem Teich zugewandte Seite des Dammes wird als vordere oder ,Brustseite' bezeichnet. Im Gegensatz zu der anderen, die hintere oder, Rückseite' genannt wird (BENECKE 1885:7).

Der Extrakt aus einer Arbeitsanleitung von BENECKE (1885:5) zum Dammbau zeigt die Vorgehensweise und Konstruktion eines solchen Erdwalles im Teichbau der klassischen Teichwirtschaftslehre auf: 
„Beim Beginn der Arbeit wird zunächst die Sohle des Dammes abgesteckt und von Rasen, Buschwerk etc. vollständig befreit. Dasselbe gilt natürlich auch von den Rändern der Mulde, an welche sich der Damm anschließen soll. Ist dabei ein undurchlässiger Grund freigelegt, so kann der Damm [...] begonnen werden. [...] Ist man überall auf geeignetem Boden angelangt, so empfiehlt es sich, namentlich auch bei Dämmen von geringerer Breite, eine verzahnte Verbindung des Dammes mit dem Mutterboden vorzunehmen. Zu diesem Zwecke werden in der ganzen Ausdehnung der Dammsohle, parallel den Rändern des künftigen Dammes, zwei oder mehr Gräben von etwa $50 \mathrm{~cm}$ Breite und Tiefe gezogen, deren Sohle man wohl auch breiter macht als die obere Öffnung. Erst nachdem diese Gräben mit demselben Material, welches den Damm bilden soll, gefüllt und gehörig vollgestampft sind, wird die Schüttung des Dammes begonnen. “

Weiterhin „,тиß auch darauf geachtet werden, daß nicht Holz, Wurzeln oder andere Gegenstände mit in den Damm geschüttet werden, durch deren Fäulnis später Lücken entstehen..., welche die Festigkeit des Dammes beeinträchtigen und das Eindringen von Wasser ermöglichen würden." (BENECKE 1885:6)

Grundsätzlich sollte dort, wo der Damm errichtet werden soll, auf dem sog. Dammfeld, „d. h. die Fläche, auf welcher der Damm zu schütten ist" (LIETMANN 1941:9), die Gras- bzw. Wiesennarbe entfernt, von Wurzeln, Steinen usw. befreit und die oberste Bodenschicht darunter angerauht werden. Durch das Ausheben eines kleinen Grabens in der Mitte des Dammfußes ließ sich der Damm noch besser mit dem Untergrund verbinden, so dass er nicht abrutschen konnte.

In ebenem Gelände konnte Material zum Dammbau dadurch gewonnen werden, dass ,im Teich selbst parallel zum Damm ein flacher Graben ausgehoben wird." Er durfte aber nicht niedriger liegen als das Abflussrohr der Abzugvorrichtung (SCHÄPERCLAUS 1961:156).

Als Anhaltspunkt zum richtigen Dammverlauf mussten für die Teichbauer oder für den vom Teichwirt selbst gebauten Teichdamm ,die Konturen des Dammes in Abständen von je zwei Metern mit Stangen und Latten abgesteckt werden“ (BENECKE 1885:6).

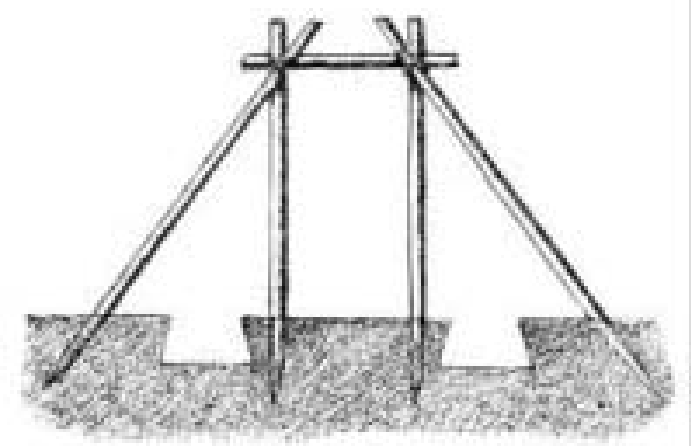

Abb. VII-16: Absteckung des Dammes

(aus: BENECKE 1885:6)

Während also die Festlegung der Teichkonturen - aus heutigem Blickwinkel nachvollziehbar - durch einfache Absteckung im Gelände erfolgen konnte, gab es zur Dimensionierung des Teichdammes gewisse Formeln und Handlungsanweisungen, die hinsichtlich ihrer Konkretisierung unterschiedlicher Natur waren. $\mathrm{Zu}$ beachten war ferner die geländemorphologische Ausprägung, der sich die Dammziehung anzupassen hatte.

\section{c.2.7.2.1 Dammsohle und -krone}

Hinsichtlich der wichtigen Fragen der Bemessung der Dammsohle, d. h. des Dammfußes und der Dammkrone sowie deren Größen- und Neigungsverhältnis zueinander, gibt es unterschiedliche Auffassungen. Die Stärke und Breite des Teichdammes, so lautet beispielsweise eine einfache Bauformel aus dem 18. Jh., „läßet sich öfters [...] schon durch das Augenmaß bestimmen“, Längen- 
und Höhenbestimmung eines Dammes seien jedoch „nur durch Meßkunst bestimmbar“ gewesen (DYHRN 1782:18). Andere Arbeitsanleitungen hingegen geben auch für die Dammbreite bestimmte Verhältnis- und Größenangaben, die im Nachfolgenden genannt werden. Weiterhin finden innerhalb der von einigen Lehrbüchern vertretenen Auffassung Kriterien Berücksichtigung, die sich mit den örtlichen Bodenverhältnissen, der Teichgröße und der geographischen Lage beschäftigen. Rückschlüsse auf eine allgemeingültige Dammform lassen sich somit aber nicht ziehen. Die zu unterschiedlichen Lehrbuchinhalte zu diesem Thema erlauben dies nicht. Dennoch sollen die in der älteren Fachliteratur aufgefundenen, Richtlinien' zum Bau des Dammlängs- und querprofils wiedergegeben werden, um eine fundierte Reliktanalyse und bei Bedarf eine originalgetreue Rekonstruktion zu ermöglichen.

BENECKE (1885:5) führt in seinem alten Lehrbuch zur Teichwirtschaft zum Dammprofil aus:

„Die Sohle des Dammes muß zweimal so breit sein als der Damm hoch werden soll, die Dammkrone, $d$. h. die obere Fläche desselben, macht man gewöhnlich halb so breit als die Höhe; es ergiebt sich daraus, daß die Böschungen mit der Sohle einen Winkel von etwa 50 Grad bilden. Steilere Böschungen sind wegen des leichten Abrutschens [...] unzweckmäßig, unter Umständen wird man den Böschungswinkel vorteilhaft bis auf 45 Gr. reduzieren. “

SCHÄPERCLAUS (1961:156) vertritt in seinem Standardwerk zur Teichwirtschaft ein anderes Breiten- und Höhenverhältnis und differenziert nach den örtlichen Gegebenheiten:

„Das Profil eines Teichdammes soll für gewöhnlich so beschaffen sein, daß die Dammkrone so breit gemacht wird, wie der Damm hoch ist, und daß die Böschung auf der Wasserseite eine Neigung von 1:2, auf der Außenseite von 1:1 besitzt.

Bei einer Kronenbreite und Höhe von 1,50 m muß der Fuß normalerweise $6 \mathrm{~m}$ breit sein. Nur in Ausnahmefällen kann bei sehr kleinen Teichen und schwerem Boden die Böschungsneigung auf der Wasserseite auf 1:1 herabgesetzt werden. Bei lockerem Boden, großen Teichen, starkem Wellenschlag kann aber unter Umständen auch ein Böschungsgefälle bis zu 1:4 oder mehr notwendig werden. Zur Ersparung von teuren Erdbewegungen wird gelegentlich auf der Teichinnenseite auch eine Böschung von 1:1,5 angelegt und dann in mittlerer Höhe dieser Böschung im stumpfen Winkel nochmals eine flachere Böschung mit einer Neigung von 1:4 angeschüttet. “

Bezüglich der Dammhöhe gibt SCHÄPERCLAUS (1961:156) eine konkrete Zahl in Relation zur Bespannungshöhe vor: „Der Damm soll den Wasserspiegel um mindestens $30 \mathrm{~cm}$ überragen, außerdem muß er um 5-10 \% höher geschüttet werden, da das Dammmaterial später mehr oder weniger zusammensackt.“

BENECKE (1885:5) orientierte sich an den jeweiligen Verhältnissen und Zielsetzungen, gab aber eine konkrete Empfehlung zur Dammhöhe: „Die Höhe des Dammes richtet sich natürlich nach der beabsichtigten Wassertiefe; um Beschädigungen der Krone zu vermeiden, empfiehlt es sich, sie etwa um einen Meter größer zu nehmen als die des normalen Wasserstandes.“

Die Mindest-Dammkronenbreite jedoch ergab sich aus der zwingenden Notwendigkeit zur Begehbzw. Befahrbarkeit. Musste der Damm begangen werden können, beispielsweise um Reparaturen oder Teichpflegearbeiten durchzuführen zu können, so war die Gehbreite das vorgegebene Mindestmaß. Sollte der Damm von einem Wagen, beispielsweise einem vom Menschen oder Vieh gezogenen Karren, befahren werden - das dürfte stets dort der Fall gewesen sein, wo sich die Abzugsvorrichtung befindet - so musste er entsprechend breit angelegt werden. 


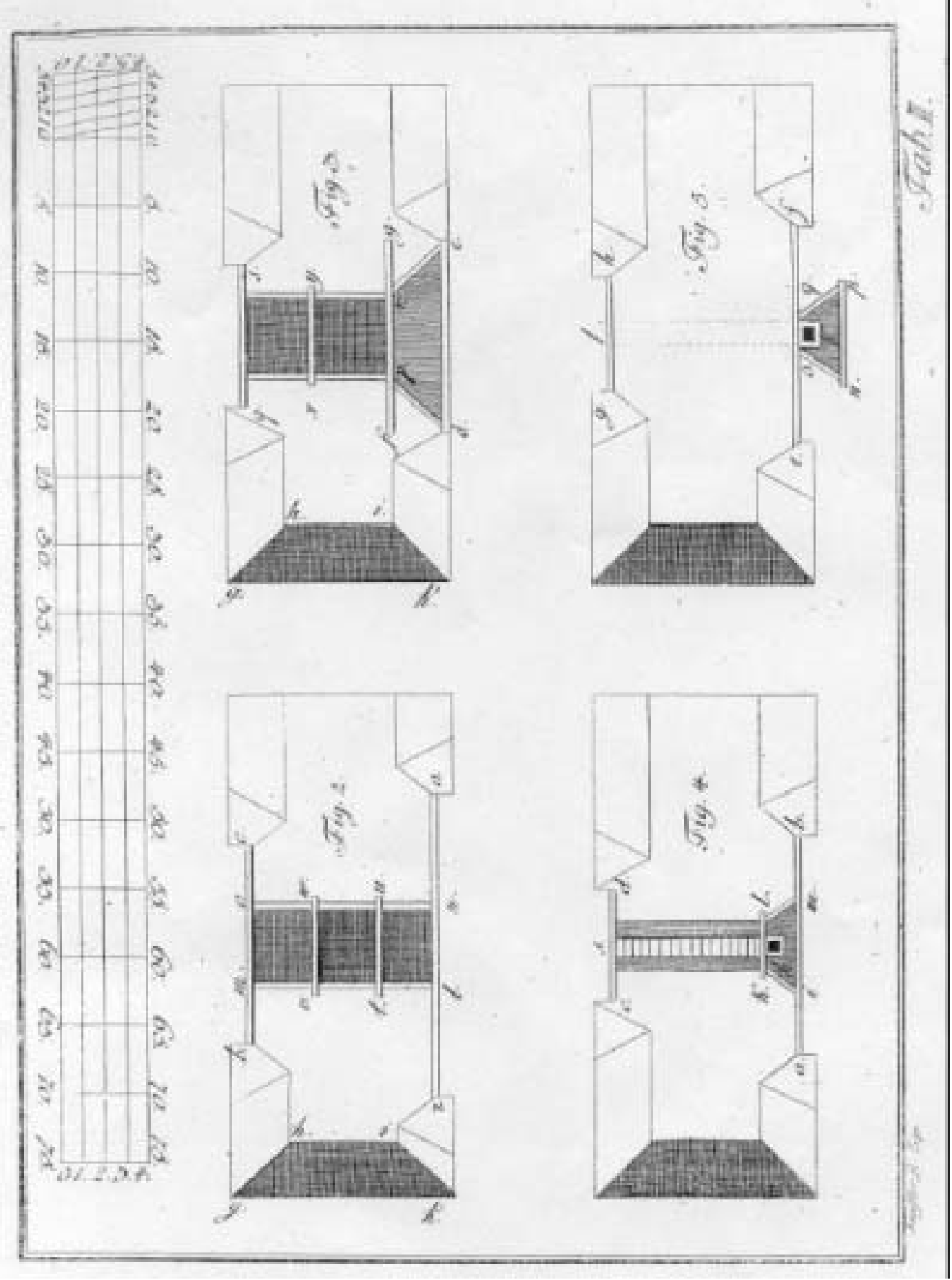

Abb. VII-17: Höhe des Dammes, Größe des Teiches, Dammbreite (g.h., i.k., l.m. + g.h., i.k ), (aus: DYHRN 1782:22)

\section{c.2.7.2.2 Dammbekleidung}

Zum Schutz des Dammes war „eine Bekleidung seiner Böschungen dringend notwendig“ (BENECKE 1885:6f.). Bei der Dammauflage wurden unterschiedliche, je nach zur Verfügung stehende Materialien benutzt, wobei verschiedene Arbeitstechniken zur Anwendung gelangten.

Die Dammbekleidung erfolgte ,am einfachsten mit regelrecht ausgeschnittenen Rasenziegeln“ (BENECKE 1885:6f.). Die Rasenziegel wurden zur Bedeckung der inneren Dammes, d. h. der Dammbrust und der äußeren Böschung, der Rückseite verwandt (SCHÄPERCLAUS 1961:156). 
Zunächst wurden im Wiesengelände quadratische Rasenziegel mit 30 - $40 \mathrm{~cm}$ Kantenlänge und 10 $15 \mathrm{~cm}$ Dicke ausgehoben und beidseits gesetzt (BENECKE 1885:6f.; ebenso SCHÄPERCLAUS 1961:155). Diese Rasenziegel wurden ,von der Sohle zur Krone des Dammes fortschreitend, so gelegt [...], daß die einzelnen Rasenziegel genau aneinander stoßen und die senkrechten Ränder der Ziegel einer Reihe, wie bei Mauerwerk, immer auf der der Mitte der Ziegel der nächsten Reihe stehen“" (siehe Abb.)“(BENECKE 1885:6f.).

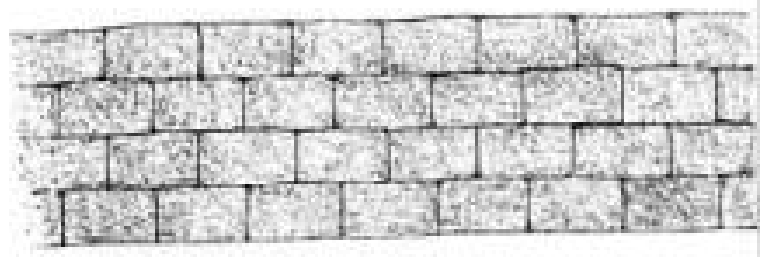

Abb. VII-18: Lage der Rasenziegel

(aus: BENECKE 1885:7)

Die Rasenziegel wurden also gewöhnlich „flach im Verband angeordnet“. Bei starkem Wellenschlag, so die Empfehlung, ,können sie auch dachziegelartig übereinandergelegt werden“ (SCHÄPERCLAUS 1961:156).

An der Brustseite des Dammes konnte aber auch „bis zur Höhe des Wasserspiegels an Stelle von Rasenziegeln, da das Gras unter Wasser doch abstirbt und beim Verfaulen der Wurzeln die von ihnen zusammengehaltene Erde ihren Halt verliert, sehr vorteilhaft ein stark faseriger Torf benutzt werden, wo solcher leicht $\mathrm{zu}$ erhalten ist. Derselbe kann [...] in größeren Flächen etwa $10 \mathrm{~cm}$ dick ausgeschnitten werden und bildet eine zähe, der Fäulnis nicht ausgesetzte Decke“ (BENECKE 1885:7).

Die als Dammschutzmaterial verwendete Rasen- und Torfbekleidung wurde schließlich „,der größeren Haltbarkeit wegen“ mit Holzpflöcken an den Damm ,angenagelt' (BENECKE 1885:7f.; desgl. SCHÄPERCLAUS 1961:156).

Zur Befestigung der Bekleidung wurden dazu zweckmäßigerweise „20 bis $30 \mathrm{~cm}$ lange Stücke von einjährigen Weidenästen“ verwendet, „die bald Wurzeln schlagen und die Böschungen mit dichtem Gebüsch bedecken, dessen Zweige regelmäßig geschnitten und zu Flechtarbeiten verkauft werden können“"(BENECKE 1885:7f.):

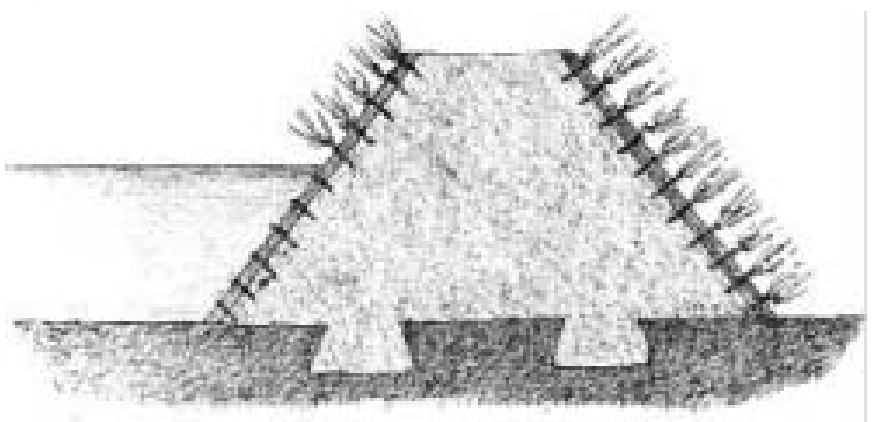

Abb. VII-19: Durchschnitt des Dammes: Dammbekleidung mit Weidenpflanzung (aus: BENECKE 1885:7)

Aus dieser dem Teichdammbau gewidmeten Beschreibung wird eine Nebennutzungsart - die des Weidenanbaus - deutlich, die hinsichtlich ihres Gewässerbezugs eine umfangreichere Darstellung in Pkt. VI $13 \mathrm{f}$ findet.

Abschließend wurde Sand auf die Dämme getragen. Sand galt auch früher als der beste Schutz wider das Anspülen des Wassers, wie man heutzutage bei den umfangreichen Deich- und Küstenschutzmaßnahmen vor der Nordseeinsel Sylt beobachten kann. Deshalb wurde schon in der frühen Teichwirtschaft empfohlen, „Brust oder Abdachung des Dammes gegen das Wasser zu mit 
Sand“ zu überziehen. Solche Dämme, so heißt es weiter, sind „vor dem Abspülen der Erde vom Damme, ja sogar vor dem Ausreißen, ziemlich sicher“ (DYHRN 1782:107).

\section{c.2.7.2.3 Dammbepflanzung}

Als letzte Baumaßnahme zur Anlage eines Teichdammes folgte die „Besetzung und Verwahrung des Dammes“ mit Bäumen, Sträuchern und Gräsern (DYHRN 1782:44). Diese Maßnahme sollte „den Schaden verhindern mögen, der an dem Damme durch das Anspielen des Wassers verursacht" wird (:44f.). Die Anpflanzung ,höher wachsender Bäume auf dem Damm und an den Teichrändern“ sei jedoch ,nur bei sehr großen Teichen, wo sie blos einen ganz unerheblichen Teil der Wasserfläche beschatten können“, zulässig (BENECKE 1885:8).

SCHÄPERCLAUS (1961:156) dagegen vertritt die modernere Ansicht, Pflanzungen „,sollen möglichst weggelassen werden." Sie erschwerten die Zugänglichkeit und die Übersicht und böten Fischfeinden und Fischdieben willkommenen Schutz. Nach ZOBEL (1992:30) dürften Bäume „nur auf sehr breiten Teichdämmen angepflanzt werden, wo sie die Rolle von Windschutzhecken übernehmen. Hohe Bäume auf den Teichdämmen gefährdeten bei starkem Wind unnötig die Dammfestigkeit, beschatteten die Ufer und können, falls sie umstürzen, Dammbrüche verursachen und so beträchtlichen Schaden anrichten.“ Ebenso führte der starke Laubfall in die Teiche „zu einer schädlichen Verschlammung" und isoliert den fruchtbaren Teichboden (:31).

TAURKE (1927:163) verstärkt das kontroverse Thema pro und contra Bepflanzen der Ränder und Dämme der Teiche mit Gehölzen, und führt Flgendes aus:

„,-- Bäume und Sträucher in der Nähe der Gewässer gewähren gewisse Vorteile, indem sie vor allem einer Menge von Insekten Aufenthalt bieten, welche ins Wasser fallen und den Fischen zur Nahrung dienen, oder deren Brut sich im Wasser entwickelt. Auch der Schutz vor starken Winden und bei Forellenteichen vor starker Erwärmung ist von Nutzen. Die Nachteile bestehen dagegen darin, daß die Dämme durch die Wurzeln undicht werden können, das herabfallende Laub den Teich beschattet, die Aufsicht über den Teich erschwert wird und die Fischfeinde guten Unterschlupf finden. Weil die Fischfeinde unter den Vögeln hier ihren Ansitz haben, ist Gehölz bei Brutteichen schädlich. [...] Sonst aber haben sich die Nachteile meistens als nicht belangreich herausgestellt. Man darf jedoch beim Anpflanzen des niedrigen Gehölzes nicht bis unmittelbar an den Rand des Teiches herangehen, weil alsdann durch das Gesträuch das Arbeiten vom Ufer aus (Düngen, Füttern) erschwert, weil ferner der Teich beschattet werden würde und auch zu leicht Laub in ihn hinein gelangen könnte. Vielfach hat sich in der Nähe der Ufer großer Teiche und Seen die Kultur der Korbweide sehr gut bewährt. Die Dämme sollten jedoch niemals bepflanzt werden, damit ihr Undichtwerden ausgeschlossen erscheint."

Aus den Ausführungen von TAURKE und den anderen wird deutlich, dass bei der Bepflanzungsfrage beim Dammbau keine Eindeutigkeit zu erkennen ist. Höher wüchsige Bäume und manchmal sogar auch eine Strauchbepflanzung waren zu vermeiden, aber in der Nähe und bei großen Teichen durchaus erwünscht und dann wiederum gänzlich unerwünscht. Und die heutige Situation einer Baum bestandenen Bepflanzung offener Teiche mag Folge einer natürlichen Sukzession sein und nicht die historische Situation widerspiegeln. Dennoch wird deutlich, dass zur weitergehenden Klärung des Sachverhalts, ob eine Dammbepflanzung durchgeführt worden ist oder nicht, die verschiedenen Dammbestandteile unterschieden und differenziert werden müssen.

So wurde auf die Dammkrone Gras (z. B. Trespen) oder an feuchten Stellen Klee (Erdbeerklee) angesät. Sie verhüteten die Verunkrautung, mussten aber regelmäßig durch Ziegen, die hier eine besondere Erwähnung finden, abgeweidet oder abgemäht werden (SCHÄPERCLAUS 1961:156). Der Einsatz von Ziegen oder der etwas trittstärkeren Schafe bei der Dammweide kann in Teichwirtschaften heutzutage immer noch beobachtet werden, wie bei der Teichanlage ,Timmerhorner' in Ammersbek. 


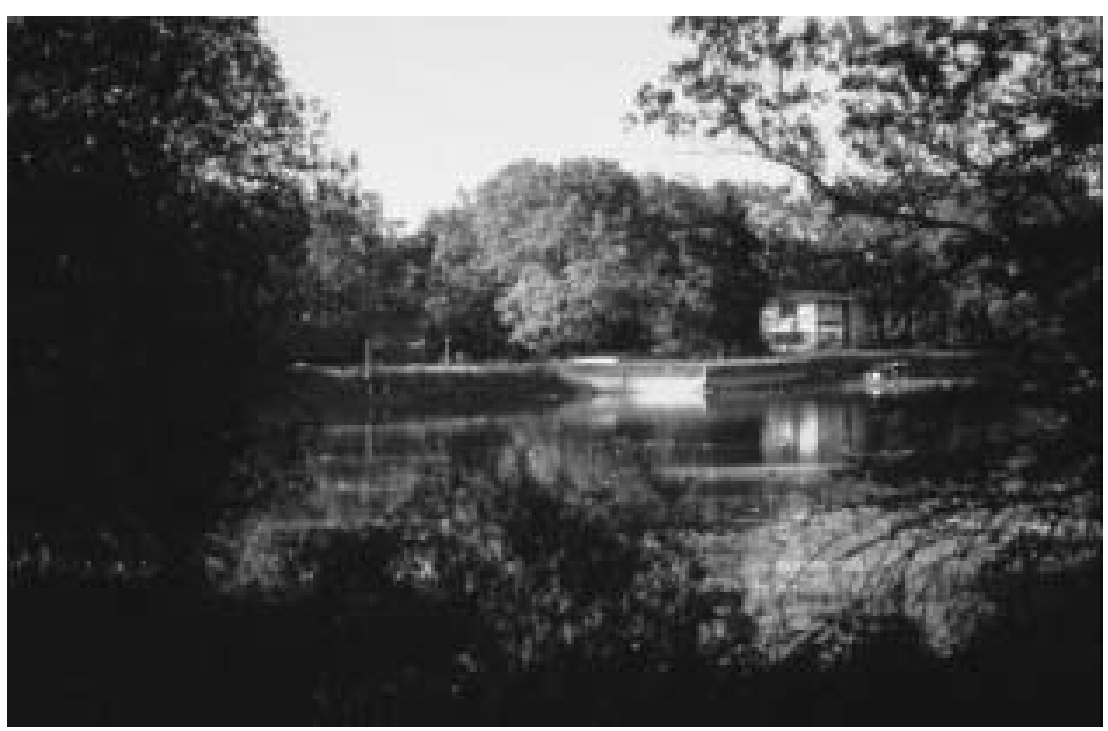

Abb. VII-20: Weideschafe auf dem Areal der Teichwirtschaft ,Timmerhorner Teiche'

in Ammersbek, OT Rehhagen/Schäferdresch. Sie sollten hier aktualfotografisch dokumentiert werden. Im Oktober 2003 jedoch ist die Teichwirtschaft „Timmerhorner Teiche“ im Ahrensburger Amtsgericht zwangsversteigert worden (BÜDDIG 2003). Der bereits seit 1999/2000 ruhende Betrieb habe sich gegen die Konkurrenz aus dem Osten nicht behaupten können, so heißt es. Das rund acht Hektar große Gelände an der Alten Landstraße (L 222) zwischen Hamburg und Bargteheide besaß eine Wasserfläche von rund 7,1 Hektar, die sich auf drei große Gewässer und mehrere Kleinteiche verteilten. Gezüchtet und verkauft wurden vor allem Edelfische wie Karpfen, Schleie, Hechte und Forellen.

Auf dem Betriebshof stehen neben diversen Wirtschafts- und Wohngebäuden aus dem Jahr 1966 ein Bruthaus, ein Fischkeller sowie kleinere Fischhälterbecken. Obgleich nach § 35 BauGB (Außenbereich) nur „privilegierte“ Betriebe dort zulässig sind und das Gelände nach den örtlichen Bebauungsplänen der Gemeinde Ammersbek zum größten Teil als landwirtschaftliche Fläche und als Gewerbefläche für eine Fischzucht eingestuft ist, wird dieses Areal als mögliches Bauerwartungsland bewertet. So gibt es tatsächlich Überlegungen, nördlich der Teiche Bauplätze zu schaffen. Die Teiche würden dann, so ist zu vermuten, mit Ausnahme eines kleinen Restteiches in der Nutzung als Regenrückhaltebecken, verfüllt und damit auch die Historie. Diese beginnt mit einem frühzeitlichen Rittersitz (,curia“), einem befestigten Hof mit Burggraben. Der Ritter Strus gilt als Begründer der Timmerhorner Fischteiche, die in den Flurkarten von 1746 und 1765/66 noch unter ihrem mittelalterlichem Namen „Großer und kleiner Strus-Teich“ wiederzufinden sind (GEMEINDE AMMERSBEK 1988) (eig. Aufnahme 2004).

Von der Pflanzung von sehr großen Bäumen, wie beispielsweise von Eichen und Rüstern auf der Dammkrone wird abgeraten, da aufgrund ihrer weit verzweigten Wurzeln die Gefahr des Dammbruchs durch Absterben oder bei Ausriss besteht. Auch die Begeh- bzw. Befahrbarkeit des Dammes würde dadurch zu stark eingeschränkt.

Andererseits jedoch wird aus ästhetischer Sicht auf breiter Dammkrone eine Baumreihe in Betracht gezogen, denn man dürfe sich aber nicht ,des Vergnügens [...] berauben, welches man durch solche auf Dämmen angelegte schöne Alleen erlangen kann“(DYHRN 1782:45).

Entgegen der o. g. Meinung wider einer generell Bepflanzung, vertrat DYHRN (1782:44) die Ansicht, die beiden wassernahen Dammseiten sollten möglichst „mit haarweidenen Sträuchern“ bepflanzt werden. Das Bepflanzen der Dammseiten, besonders mit Weiden, geschah nach dieser Auffassung einerseits, damit durch das Wurzelwerk „,der Damm immer fester werde“ (:44) und eine Empfehlung zur Bepflanzung wurde von BENECKE (1885:8) auch ausgesprochen: „Am besten eignen sich für diesen Zweck die eigentliche Korbweide, Salix viminalis, und für sandige oder kiesige Dämme die caspische Weide, S. caspica ${ }^{[40] ،}$.

Weiden übernahmen zum Weiteren auch die Funktion von Windschutzhecken. „Als Umrahmung von Winterteichen“ beispielsweise können sie „sehr nützlich sein, weil sie starke Windeinwirkungen und damit erhebliche Wasserströmungen und Beunruhigungen der überwinternden Fische verhüten“

\footnotetext{
${ }^{40}$ Eine caspische Weide (Salix caspica) konnte in den einschlägigen Bestimmungsbüchern (SCHMEIL/FITSCHEN 1982, MITCHELL/WILKENSON 1987) nicht gefunden werden. Vermutlich handelt es sich aufgrund des Verbreitungsgebietes um die Salweide (Salix caprea).
} 
(SCHÄPERCLAUS 1961:156f.). So wird es schon seit alters her als vorteilhaft angesehen, wenn die im Winter bespannten tiefen Teiche ,an der Nordost-, Nord- und Nordwestseite vor den kalten Winden und Stürmen durch Wälder, Berge, Büsche, Gebäude, Bäume, auch nur einigermaßen durch Dämme gesichert seyn kann“ (DYHRN 1782:11). Doch auf der anderen Seite sei es „sehr gut, wenn ein Teich gegen Süden, Südosten und Südwesten frey liegt“ (: 10).

Auch nach BORNE (1886:278) sollten die Dämme nicht nur mit Rasenziegeln, sondern auch mit Bäumen (Weiden, Erlen, Eschen etc.) besetzt sein, um nicht nur den nötigen kühlenden Schattenwurf zu erzeugen, sondern auch für „Naturnahrung“ zu sorgen.

Schließlich wurde „dort, wo das Wasser anspielt“, d. h. am unteren Dammrand, ein besonderer Dammabschluss ebenfalls aus Weiden hergestellt: „Am besten macht man an derselben Stelle einen niedrigen Zaun von geflochtenen weidenen Ruthen, welche, besonders die zu Pfählen gebrauchten Stücke, hernach Wurzeln fassen und ausschlagen“ (DYHRN 1782:45).

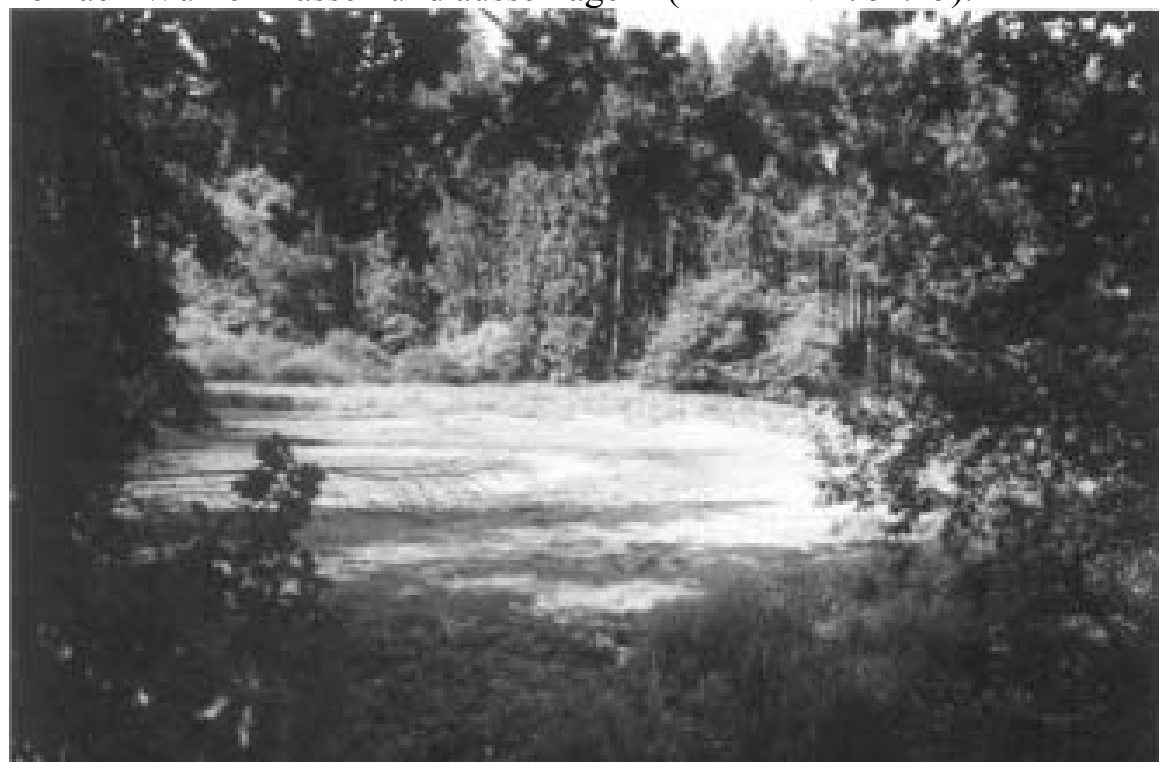

Abb. VII-21: Aufgelassener Teich (,Seelzer Teich“) im Reinhardswald

zwischen Beberbeck und Sababurg. Deutlich ist auch bei diesem relativ kleinen Teich die Dammbepflanzung mit hochwüchsigen Bäumen zu erkennen. Aufgrund des Sukzessionsstadiums des Teiches (Verlandungsprozesse, aber noch kein Aufwuchs auf dem Teichboden), kann eine natürliche Baumentstehung ausgeschlossen werden (eig. Aufnahme 1998).

Aus den kontroversen Ansichten zum Thema „Teichdammbewuchs“ resp. „Baumlosigkeit“ lässt sich Folgendes zusammenfassen:

Die Bestockung des Teichdammes mit Bäumen wie Eichen oder Buchen in aufgelassenen Teichwirtschaften scheint zunächst das Ergebnis natürlicher Sukzession. Die Überlieferung, dass auf Teichdämmen keine Bäume standen, kann mit der historischen Teichbauliteratur widerlegt werden. Es wurde sogar angeraten, die Dämme mit Obstbäumen oder Kopfholz zu bepflanzen, ,deren Früchte und Laub einigen Nutzen liefern" (SPRENGEL 1838:87). Die Baumlosigkeit trifft lediglich für den Fall der Umwandlung alter Teiche zu ackerbaulichen Zwecken, „denn wer hat wohl gern einen Zufluchtsort der Vögel u.s.w. mitten in seinen Feldern liegen“", fragt SPRENGEL (:87). In einer "ordnungsgemäßen Teichwirtschaft" des 19. Jahrhunderts hingegen scheint eine Bestockung willkommen gewesen zu sein. Die Bepflanzung der Dämme solcher Teiche, die nur zur Fischzucht dienen, als Verbuschung wurde befürwortet, sofern es das Wasser nicht zu sehr beschattet. „Das dicht gepflanzte Buschholz schützt das Wasser gegen heftige Winde, es hält sich deshalb wärmer, und trägt somit auch zur Entstehung von Würmern und Insekten bei.“(:87) Vor allem Weidensträucher wurden an den Dammseiten bewusst als Schutzpflanzung gegenüber Wind und Dammabbruch gesetzt und waren Erkennungsmerkmal vor allem von Winterteichen.

Die Darstellungen zum Damm-, Graben- und Grubenbau sind hiermit beendet. Es folgen die technischen Einrichtungen, die einen Teich erst regulierbar machen. 


\section{c.2.8 Zu- und Ablaufvorrichtungen}

Die Voraussetzung einer geregelten Teichwirtschaft ist nur gegeben, wenn der Teich abgelassen und trockengelegt werden kann. Die Ablassbarkeit ist ,diejenige Eigenschaft, die zunächst in ausschlaggebender Weise die Bewirtschaftung der Teiche bestimmt“ (WALTER 1933:29) .

Der ablassbare Teich hat gegenüber anderen Gewässern wesentliche Vorteile. Der Fischbestand kann jederzeit ohne viel Mühe nach Bedarf reguliert werden, d. h. die Abfischung lässt sich verhältnismäßig leicht durchführen. Außerdem ist es möglich, den Teich trockenzulegen, zu ,desinfizieren' und den Boden zu bearbeiten.

$\mathrm{Zu}$ einem ablassbaren Teich gehören aber zwingend - neben den verschiedenen Vorrichtungen zur Ablassbarkeit - auch die Einrichtungen zum Wasserzulauf.

Die Entwässerung der Teiche erfolgte dabei in manchen Fällen seit den 1920er Jahren durchaus auch ohne eigentliche Abflusseinrichtung. Die Entwässerung der Teiche geschah zu diesem Zeitpunkt bereits durch motorenbetriebene Pumpwerke, so beispielsweise mit Zentrifugalpumpen (TAURKE 1927:19).

Vor dieser Zeit jedoch, viele Jahrhunderte früher und in traditionellen Teichwirtschaften auch noch bis in die heutige Zeit, wurde der ,maschinenlose' traditionelle Teichbau betrieben. (Hölzerne) originale und manuell $\mathrm{zu}$ bedienende Ablauf- und Zulaufvorrichtungen sind deshalb als historische Teichbauelemente anzusprechen und stellen wichtige Relikte in einer (ehemals) von künstlich angelegten Kleingewässern geprägten Kulturlandschaft dar. Sie sollen deshalb in ihrer (ehemaligen) Funktion beschrieben werden. Zeichnungen und Abbildungen der entsprechenden teichbaulichen Einrichtungen unterstützen die Beschreibungen visuell.

\section{c.2.8.1 Zweck und Funktion}

Die Zu- und Abflussvorrichtungen an den Teichen dienen vier verschiedenen Zwecken:

1. Der Spannung der Teiche,

2. der teilweisen oder völligen Entleerung des Teiches,

3. dem Abfluss des überflüssigen, durch Zuleitungsgräben oder durch plötzliche Regengüsse dem Teiche zugeführten Wassers und

4. um fremde Fische und Fischbrut von den Teichen fern zu halten und das Austreten der Teichfische zu verhindern (BORNE 1886:219)

Die Füllung des Teiches erfolgt durch Öffnen der Einlaufgräben und durch Verschluss der Ausflussöffnungen, die Entleerung im umgekehrten Sinn durch Schließen des Wasserzulaufs und durch Öffnen der Abflussvorrichtungen. Also, je nach dem ersten oder zweiten Fall und in Abhängigkeit der Vorrichtungen entweder durch Schluss oder Öffnen der Schütze vor den Ein- oder Abflussöffnungen oder durch ,Stecken' eines Zapfens oder durch Einsetzen der Staubretter in den Mönch (BENECKE 1885:20). Der dritte Zweck wurde erreicht durch die Regulierung durch Wehre oder Überfälle und durch Anlage von Flutgräben (:10). Der vierte Zweck wurde zusätzlich „durch ein Gitter von Holz oder von Drahtgeflecht" vor den Zu- und Ablaufanlagen erfüllt; oder man brachte ein Strauchwehr oder andere Filtervorrichtungen an (BORNE 1886:219).

\section{c.2.8.2 Filtervorrichtung}

Besondere Schutzvorkehrungen wurden getroffen, wenn der Teich Zuflüsse aus Gewässern erhielt, welche nicht fischleer waren. Um den anderen fremden Fischarten den Eintritt in den Teich zu verwehren und die eigene „Fischbrut von den Teichen fern zu halten“ (BORNE 1886:219), hat man „das Speisewasser durch einen Kiesrechen [...] fließen“ lassen (:264). Insbesondere der Zufluss in den Streichteich sollte durch einen Rechen geleitet werden (:264). Diese Filterung betraf, so die zunächst 
widersprüchlich anmutende Aussage von BORNE, „die aus Flüssen gespeisten Teiche ebenso [...] wie Himmelsteiche“ (:219). Während eine solche Vorrichtung für diejenigen Teiche mit einer Wasserfüllung durch Fließgewässerwasser sich selbst erklärt, kann nach meiner Auffassung im letztgenannten Fall nur die Bespannung resp. Versorgung eines Teiches mit einem aus Niederschlagswasser bespannten Teich (Vorwärmer, Reservoir) gemeint sein. Wasservögel können hier Fischeier aus anderen Teichgebieten oder Flüssen, am Federkleid behaftet, mit einbringen und so ist hier ein Durchflussschutz zwischen den Teichen angebracht. In einem rein aus Regenwasser gefüllten singulären Himmelsteich ohne einen weiteren teichwirtschaftlichen Zusammenhang erscheint eine solche Lösung unlogisch.

Aus Latten wurde deshalb ein der Teichgröße entsprechender langer Kasten gebaut und „mit gesiebtem Kies gefüllt, der die Größe von Haselnüssen bis der von Hühnereiern hat" (BORNE 1886:219).

Neben einer Kieskonstruktion bestand eine andere Filterung aus einem Strauchwehr. Zur Herstellung desselben band man ,aus feinem Strauchwerk Faschinen von 1 1 $1 / 2 \mathrm{~m}$ Länge“ und errichtete daraus einen quer durch den Teich verlaufenden Damm, den das Wasser nicht umgehen konnte, sondern durchströmen musste (BORNE 1886:219). Wenn das Strauchwehr mit der Zeit zusammensank, so wurden es einfach ,durch neu aufgelegte Faschinen erhöht“" (:219).

\section{c.2.8.3 Abzugvorrichtungen}

Der Abzug „ist eine der wichtigsten Einrichtungen des Teiches“. Er ermöglicht „eine leichte, verlustlose und vollständige Abfischung sowie eine gründliche Trockenlegung und eine Neubespannung bis zu beliebiger Höhe“ (SCHÄPERCLAUS 1961:158). Es ist deshalb auch „die einfachste und zweckmäßigste Abfischungsart, weil hierbei nicht [...] Schlamm aufgerührt" wird und die Fische hierbei ,am wenigsten leiden“ (TAURKE 1927:186).

Voraussetzung für diese Abfangmethode ist, dass die die Ablaufvorrichtung tief genug liegt, so dass das Wasser „gänzlich aus dem Teiche entfernt werden kann“ (TAURKE 1927:186).

Um den Teich ablassen zu können, wurden dabei verschiedene Einrichtungen geschaffen:

\section{c.2.8.3.1 Abzug mit Zapfen}

Der sog. Zapfenabzug oder auch Zapfenverschluss besteht aus einem - an der tiefsten Stelle des Teiches quer durch die Basis des Teichdammes geführten - Rohr, das an dem außerhalb des Teiches gelegenen Ende offen, an der in den Teich hineinragenden Wasserseite aber durch einen Zapfen beliebig geöffnet und geschlossen werden kann.

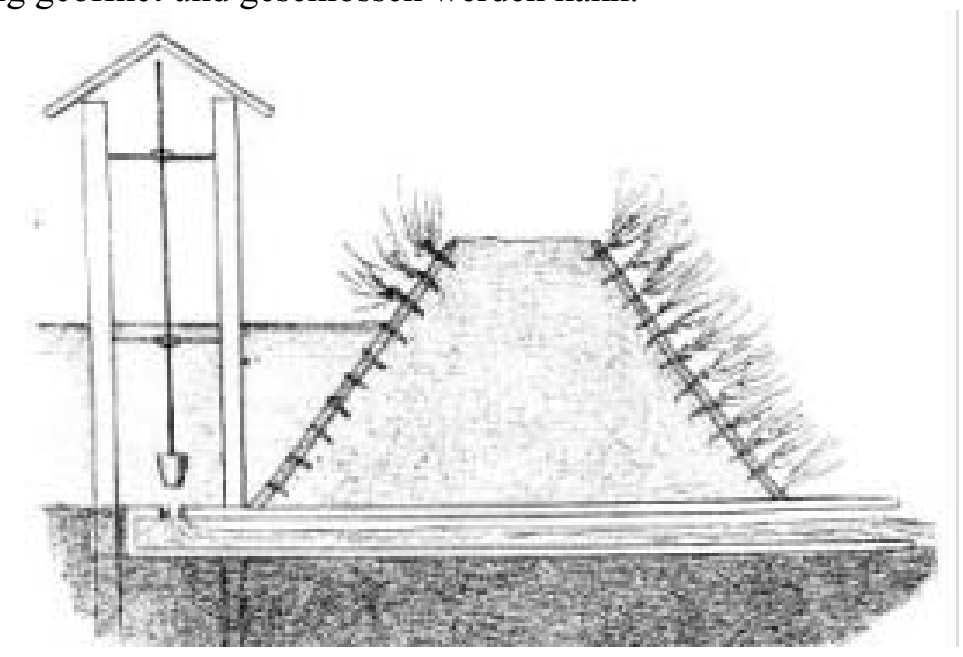

Abb. VII-22: Zapfenabfluss (aus: BENECKE 1885:11) 
Im Mittelalter (SCHÄPERCLAUS 1961:158) und noch bis Ende des 19. Jh. (BENECKE 1885:10f.) bestand das Rohr ,aus starken ausgehöhlten Baumstämmen, deren Rinde unverletzt war, weil sie sich besser hielten und die eine ca. 0,3 m starke Umhüllung von Moos und fettem Lehm, die gut durchgeknetet waren, erhielten.“ Die Teichabzugrohre wurden ,gewöhnlich aus einem Tannen- oder Eichenstamm gebohrt" (BENECKE 1885:10f.). Seit der Hälfte des 19 Jh. wurden die Teichröhren auch gemauert, oder sie bestanden aus gebrannten Ton; an der Wasserseite legte man sie oft auch in eine Spundwand oder Zementmauerung ein (BORNE 1886:220f.).

Die lichte Weite eines Rohres beträgt meistens 25 bis $30 \mathrm{~cm}$. Bei großen Teichen legte man mitunter mehrere solche Röhren nebeneinander durch den Damm (BENECKE 1885:10f.).

Im Teich, d. h. auf der Wasserseite, hat das am Ende verschlossene Rohr oben ein trichterförmiges Loch, das durch einen keilförmigen Zapfen verschlossen werden kann. Die Abflussstelle befindet sich unter Wasser, ist aber aufgrund der geringen Teichtiefe nicht zu übersehen (SCHÄPERCLAUS 1961:158f.). Der Zapfen musste bis zur Abzugöffnung „fest eingetrieben und nötigenfalls noch mit Werg verdichtet und mit Lehm oder Thon verstrichen werden.“ (BENECKE 1885:20).

In das Bauelement des Abzuges mit Zapfenverschluss integriert - bestand das Abzugrohr aus Holz war eine Abflussgrabenschütze und das aus folgendem Grund: „Da die Holzröhren sich am besten erhalten, wenn sie dauernd im Wasser liegen, ist es rätlich, im Abflußgraben eine kleine Schütze anzubringen, die hoch genug ist, um das Abflußrohr ganz unter Wasser zu halten. Beim Ablassen des Teiches muß diese Schütze natürlich entfernt werden, um den Teichboden vollständig trocken legen zu können.“(BENECKE 1885:16).

Zapfenverschlüsse „,werden heute kaum noch gebaut“ (ZOBEL 1992:69). Der Zapfenverschluss war zwar dauerhafter und fester als ein sog. Ständerbau, wie zum Beispiel der Mönch (SCHÄPERCLAUS 1961:158f.; vgl. c2.8.3.5), besaß aber einige gewichtige praktische Nachteile: Ein Nachteil ist, dass sich der Wasserstrom nur schwer regulieren lässt (ZOBEL 1992:69). Der Teich war gegen das Entweichen von Fischen kaum absperrbar und die Abfischung gestaltete sich daher schwierig (SCHÄPERCLAUS 1961:158f.). So konnte man den Teich nicht nach Belieben und nur unter größeren Umständen (Ziehen des im Wasser gelegenen Zapfens) hoch und niedrig aufspannen und die Schäden durch willkürliches Ziehen des Zapfens durch Teichgegner waren groß. Der Zapfen, der die Abflussleitung verschließt, wird vor dem Abfischen oft mit Hilfe eines Flaschenzuges gezogen, und das Ablaufen des Wassers kann dann kaum noch beeinflusst werden. Bewährt haben sich Zapfenverschlüsse bis in heutiger Zeit in Diebstahl gefährdeten abgelegenen Teichen, da sie ,am Grunde des Teiches kaum auszumachen sind.“ (ZOBEL 1992:69)

\section{c.2.8.3.2 Abzug mit Klappe}

Um die Nachteile des Zapfenabzuges zu beheben, wurde das Rohr „besser durch eine Klappe geschlossen, welche durch eine mit Schraube versehene eiserne Stange gehoben oder gesenkt werden kann" (BORNE 1886:220f.).

In Kombination mit einem Abschlagfluder bzw. einer Flutrinne konnten insbesondere zuflussstarke Teiche dadurch beliebig hoch und niedrig angespannt werden. 

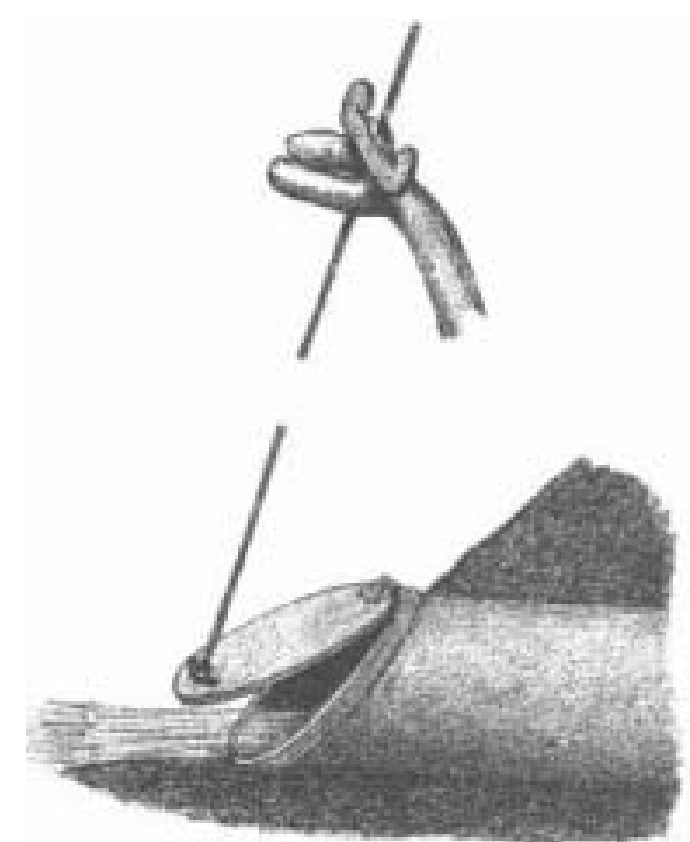

Abb. VII-23: Abflussrohr mit Klappventil und der zum Öffnen desselben erforderlichen Schraubenvorrichtung (aus: BENECKE 1885:13)

\section{c.2.8.3.3 Zapfenhaus}

Eine Weiterentwicklung des einfachen Zapfenabzugs stellt das sog. Zapfenhaus dar: Es besteht aus einer Kombination aus herkömmlichem Zapfenverschluss und Hebelzugstange des Klappenverschlusses. BENECKE (1885:11f.) beschreibt es so:

„In das einen oder mehrere Meter in den Teich hineinragende Ende des Rohres ist von oben her ein konisches Loch von etwa $20 \mathrm{~cm}$ Durchmesser gebohrt, welches durch einen Zapfen von gleicher Form geschlossen wird. Mit diesem Zapfen ist eine starke Stange verbunden, die senkrecht über das Wasser hervorragt. In gleichem Abstande von dieser Zapfenstange (etwa um $30 \mathrm{~cm}$ entfernt) sind 4 gleichlange viereckige Pfosten fest in den Teichboden getrieben, die Führungen tragen, in denen die Zapfenstange senkrecht gehoben und gesenkt, und in der beabsichtigten Stellung durch Schrauben oder Bolzen festgehalten werden kann. Bis zum Wasserspiegel sind die Pfosten durch horizontale vierkantige Leisten verbunden, die ein Gitter mit 2-3 cm weiten Zwischenräumen bilden, welches als Rechen bezeichnet und Fische, Laub etc. abhalten soll. Oberhalb des Wasserspiegels sind die 4 Pfosten durch Aufnageln von Brettern zu einem viereckigen Kasten geschlossen, der oben gewöhnlich durch ein Dach geschützt wird. Die ganze Vorrichtung [...] wird das Zapfenhaus genannt". 


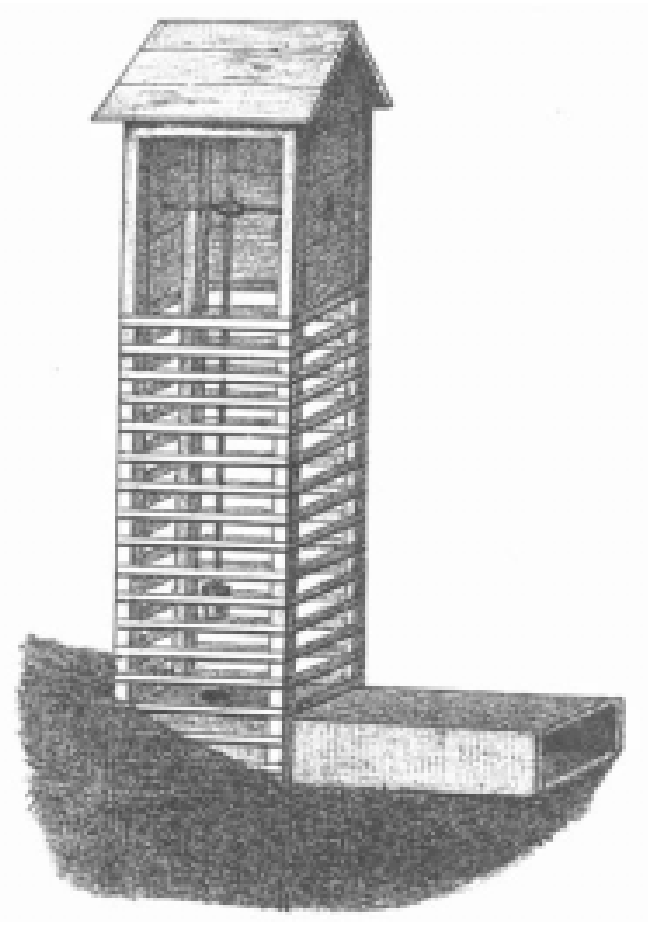

Abb. VII-24:Zapfenhaus aus Holz

Das Ablassventil kann durch eine Stange auf- und zugeschoben werden. Das Standrohr ist durch eine Vergitterung so weit geschlossen, dass die Fische nicht durch das hochgezogene Zapfenloch entweichen können (BENECKE 1885:12).

Wird also der Zapfen gehoben oder gezogen, so fließt das Wasser durch das Zapfenloch in das Rohr und durch dieses nach außen ab und die Fische werden durch die Rechen des Zapfenhauses zurückgehalten (BENECKE 1885:12). Das äußere Ende des horizontal angebrachten Abflussrohres wurde dabei ,bei dem Zapfenabfluß nach seinem Austritt unter dem Damme zweckmäßig noch 1-2 m weiter geführt, um Beschädigungen des Dammes durch Unterspülen zu verhüten, auch belegt man die ersten 5-10 m der Grabensohle vorteilhaft mit Steinen, um Auswaschungen zu vermeiden, die ein Nachstürzen der Grabenwände zur Folge haben könnten“ (:16).

Der Zapfenabfluss war ,wesentlich billiger als eine Schützenanlage“, teilte aber mit dieser den Nachteil, „daß das Wasser am Boden des Teiches mit hohem Druck abläuft und den Abflußgraben leicht beschädigt.“ (BENECKE 1885:12).

Seit dem zweiten Drittel des 19. Jh. werden ,„̈hnliche Abflüsse häufig an großen Teichen aus Cementröhren oder Mauerwerk hergestellt und statt der Zapfen kommen dann Klappventile zur Verwendung, die durch Schrauben gehoben werden“"(vgl. Abb. VII-23) (BENECKE 1885:13).

\section{c.2.8.3.4 Schützung}

Die Schütze oder auch als Schützung bzw. Schüttung bezeichnet, gehört zu den bekannteren historischen Zuund Abflussvorrichtungen in einem Teich. Schützen, wie sie an Wassermühlen gebräuchlich sind (Abb. VII25), fand man im zweiten Drittel des 19. Jh. „vielfach noch an großen älteren Teichen“ (BENECKE 1885:10). 


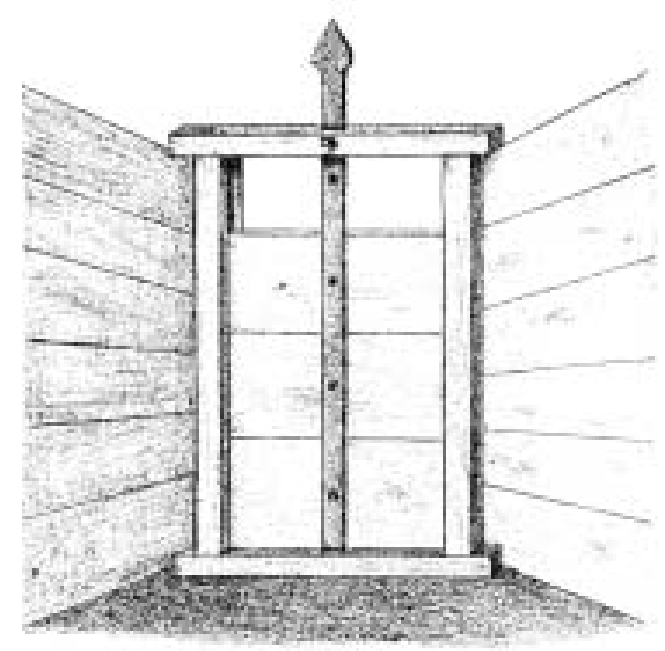

Abb. VII-25: Schütze

(aus: BENECKE 1885:10)

Ihre Zahl reduzierte sich - neben dem zeitlich bedingten Abgang durch Offenlegung einer Teichanlage - vor allem dadurch, dass diese Ablaufkonstruktion als Teichabfluss ungeeignet erschien:

\begin{abstract}
„Ihre Anlage bei neuen Teichbauten ist nicht zu empfehlen, da sie einerseits eine bedeutende Zimmerarbeit erfordern und leicht schadhaft werden, andererseits den Nachteil haben, daß, wenn sie auch nur teilweise geöffnet werden, das Wasser unten, also mit dem vollen Druck, der der Tiefe des Teiches entspricht, durch die Öffnung hervorstürzt, Fische und andere Gegenstände leicht mitreißt und bei weiterer Öffnung Boden und Seitenwände des Abflußgrabens stark abspült.“ (BENECKE 1885:10).
\end{abstract}

Wenn eine Schütze gezogen wird, tritt also das Wasser mit starkem Druck am Grund aus und kann die Fische leicht mitreißen. Außerdem wird der Abflussgraben durch den heftigen Wasserstrom so stark ausgespült, dass die Seitenwände einstürzen können (ZOBEL 1992:69).

Für das Ablassen des Teiches wurden die Bretter Stück für Stück, ,so wie das Wasser abfällt“ (DYHRN 1782:27) weggenommen. Vor dem erneuten Anspannen des Teiches wurden die Bretter in die Schütze wieder eingesetzt und die Bohlenritzen zwischen den Brettern „durch dazwischen, aber nicht zu dicke, gelegten Mooß wohl verwahret“ (:28), damit das Wasser nicht zu leicht durchdringen konnte.

In der Mitte der Schütze befand sich eine (Holz-) Stange, die von oben durch ein Loch mit den Querbrettern beweglich verbunden war (DYHRN 1782:27). Die Schütze besitzt zum Vorstecken verschiedene Löcher. Dadurch konnte die ,ganze Schützung nach Belieben, entweder in die Höhe gehoben, oder niedergelassen werden“ (:27).

Diese Art der variablen Stangen-Schützung wurde indessen nur bei Teichen mit übermäßig starkem Zufluss angewendet. Bei großen oder tiefen Grundfludern wurde beispielsweise anstatt des Rechens aus Sicherheitserwägungen noch eine zusätzliche Schützung, ,also zusammen zwey Schützungen“ angelegt (DYHRN 1782:106). Diese wird auch als ,Doppelte Schützung' bezeichnet (:106).

\title{
c.2.8.3.5 Mönch
}

Um die Teiche ablassen zu können, befindet sich an der tiefsten Stelle vor dem Damm der Mönch (ZOBEL 1992:32).

Der Ablaufmönch bzw. Teichmönch oder kurz ,Mönch' bzw. synonym auch ,Ständer', ,Ständerabfluss' oder ,Rinnständer' genannt (Abb. VII-26 und 27), galt als die „,die vorzüglichste Abflußvorrichtung“ (BENECKE 
1885:14) und „die dritte Art, einen Abzug zu einem Teich zu bauen“(BORNE 1886:221). Sie ist gleichzeitig die bekannteste.

„Schon beim Spannen des Teiches ist der Mönch den anderen Abflußvorrichtungen dadurch überlegen“ (BENECKE 1885:20), „daß das Wasser immer an der Oberfläche, und nur mit geringem Drucke abfließt, also weder Fische durch die Strömung mit fortgerissen, noch Grund und Seitenwände des Abflußgrabens beschädigt werden“ (:15). Dies ist einer der Hauptvorteile des Teichmönches. Der andere besteht darin, dass man mit Hilfe von einzelnen Staubrettern „den Wasserspiegel leicht bis zu der gewünschten Höhe heben kann, auf welcher er dann ohne weiteres Zuthun sich konstant erhält“ (:15), also „er eine ganz allmähliche Erhöhung des Wasserspiegels gestattet" (:20).

Will man die Abflussvorrichtung im Detail beschreiben, so handelt es sich bei dem Begriff ,Mönch' um einen Sammelbegriff für eine spezielle Abflussvorrichtung, die aus mehreren Einzelelementen besteht. Ein Mönch besteht aus einem, wie BORNE (1886:221) es ausdrückt, ,,auf eine horizontal liegende Grundrinne perpendiculair“ aufgesetzten Standrohr, „wodurch man in einem Teiche das Wasser nach Belieben so hoch aufspannen und so tief ablassen kann, als man für gut befindet.“

Um dieses zu erreichen, besteht der Mönch, dies sei in verständlicher Form noch einmal zusammengefasst und detaillierter ausgeführt, erstens aus einem horizontalen Abflussrohr bzw. Abflussrinne, die durch den Damm führt und am Ende einen nach oben offenen ,Kopf' besitzt. Die Faustregel lautet dabei, dass das Rohr „gut so lang sein muß wie der Dammfuß breit ist“ (SCHÄPERCLAUS 1961: 159f.). Der Begriff ,Rohr' induziert dabei eine runde, geschlossene Form, während man mit Rinne eher eine oben offene, rechteckige Abflussform verbindet.

Zweitens besteht der Mönch aus dem damit verbundenen senkrechten Teil, der ,Staukasten' oder ,Standrohr' genannt wird und am obersten Ende einen sog. ,Mönchkopf' besitzt. Für die Unterscheidung ,-kasten' und ,rohr' gilt die Annahme wie zu dem zum Abfluss gesagten. Die Sprache der Teichwirtschaft unterscheidet hier aber nicht. Das horizontale ,Abflussrohr' wie das vertikale ,Standrohr' hat, wenn es aus Holz hergestellt wird, einen quadratischen oder rechteckigen Querschnitt.

Das senkrechte, frei im Teich stehende Mönchrohr, das kaum höher als der Damm ist, um seine Funktion zu erfüllen, hat einen hufeisenförmigen Grundriss und ist zum Teich hin offen. In Nuten an beiden Seitenwänden werden 1 oder 2 Reihen von Staubrettern eingeschoben, und zwar so viele, dass die gewünschte Wasserspiegelhöhe erreicht wird, wobei der ,zweifalzige Mönch', in den zwei Staubrettreihen gesetzt werden können, besonders beliebt war.

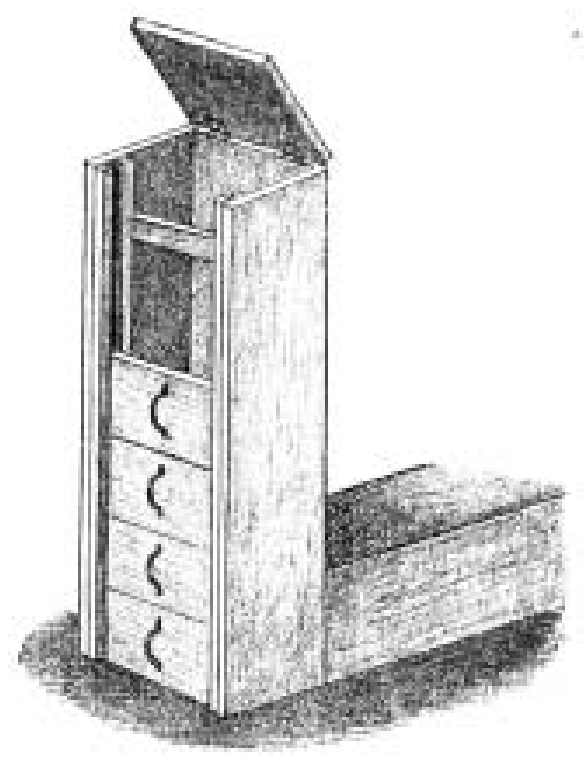

Abb. VII-26: Perspektivische Ansicht eines hölzernen Mönches mit Staubrettern (aus: BENECKE 1885:14) 
Mit Hilfe des Mönches ist es möglich, durch Staubretter einen beliebig hohen Wasserstand im Teich zu halten und den Teich auch vom Grund restlos abzulassen. Durch ein eingesetztes Schutzgitter bzw. -sieb kann verhindert werden, dass die Fische entweichen.

Das horizontale Abflussrohr wird so hingelegt, dass es unbedingt an der tiefsten Stelle des Hauptfischgrabens liegt und nach außen hin sanft geneigt ist. Der senkrechte Teil des Mönchs soll sich dort auf dem waagerechten Rohr erheben, wo der Dammfuß im Teich endet. Der hölzerne Mönchkopf darf nicht im Damm stehen und nicht an die Böschung angelehnt werden, weil er dann leicht fault, ohne an Festigkeit zu gewinnen. Der im Wasser frei aufragende Mönchkopf wird vom Damm aus mit Hilfe einer Laufplanke erreicht (SCHÄPERCLAUS 1961: 159f.)

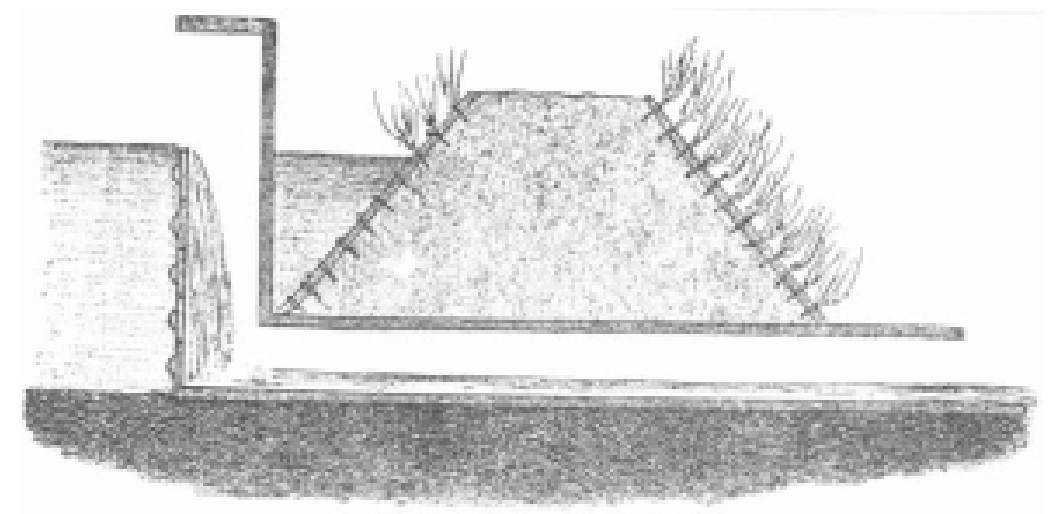

Abb. VII-27: Querschnitt durch einen Teichdamm mit eingebauten Mönchabfluss (aus: BENECKE 1885:13)

Der historische Mönch wird in seinem Aufbau von BENECKE (1885:14f.) gleich einem Bauplan folgendermaßen beschrieben:

„Wie beim Zapfenabfluß wird ein horizontales Rohr quer durch die Sohle des Dammes hindurch geführt. Dasselbe kann gemauert sein, wird aber gewöhnlich aus starken eichenen Planken vierkantig angefertigt [...]. Die Höhe der inneren Öffnung beträgt gewöhnlich 20-30 cm, die Breite bei kleineren Teichen ebensoviel, bei großen Teichen kann sie erheblich vergrößert werden, doch müssen dann zwischen Boden- und Deckplanken hin und wieder kräftige Stützen angebracht werden, um genügende Sicherheit gegen den Erddruck zu gewähren. An dem um einen Meter oder weiter in die Fischgrube des Teiches hineinragenden Ende des horizontalen Rohres ist ein vertikales von gleichem Durchschnitt befestigt, welches etwa um einen Meter über den höchsten Wasserstand hinausragt, nötigenfalls seitlich durch kräftige Strebepfeiler gestützt wird, und dessen dem Teich zugewandte Seite von oben bis unten offen steht. An der Innenseite der Seitenplanken ist zunächst ihrem freien Rande durch Aufnageln je zweier starker Längsleisten jederseits ein tiefer und breiter Falz hergestellt, in welchen von oben her eine Anzahl gut zugepaßter, starker Staubretter von je 15-20 cm Höhe eingeschoben werden können."

Ein weitere und ähnliche Beschreibung des Mönchs erhält man von Max von dem BORNE (1886:221), der seine Konstruktion beschreibt als

„Standrohr, [...] welches senkrecht auf der horizontalen Teichröhre steht und auf der Vorderseite von der Sohle bis zum Wasserspiegel durch aufeinander gesetzte Staubrettchen geschlossen ist. Diese Brettchen können nach Belieben aufgesetzt und fortgenommen werden, je nachdem man den Teich spannen oder ablassen will. Wo kleine Bäche den Teich passiren, haben die Standröhren den Vortheil, daß sie die Spannung gleichmäßig erhalten, indem das Wasser über das oberste Staubrettchen und durch die Standröhre abfließt - sowie daß man den Wasserstand durch Aufsetzen oder Fortnahme von Brettchen beleibig verändern kann. Es empfiehlt sich, außer dem Ablaßventil auch ein Standrohr zu haben, wenn der Teich längere Zeit trocken liegen soll, weil das Ablaßventil angegriffen wird, wenn das Wasser lange durchläuft. Deshalb läßt man das Sammelwasser während des Trockenliegens durch das 
Standrohr ablaufen, und man wirft Moder auf das Ablaßventil, wenn der Teich wieder gefüllt wird, damit das Ventil vollkommen dicht schließt."

Zusammengefasst lässt sich der Mönch in seinem Aufbau wie folgt beschreiben und durch die Abbildungen veranschaulichen: Die Abfluß- bzw. Grundrinne bildet die Konstruktionsbasis. Auf diese Teichröhre, die horizontal in den Teichboden eingelassen ist, wird der ,Ständer' bzw. das ,Standrohr' des Mönchs vertikal aufgesetzt.

Die Grundrinne ist vorn, „wo sie in den Teich trifft“ (DYHRN 1782:37) nicht geschlossen. Sie besitzt, wie man in der Fischwirtschaft sagt, einen ,Kopf', auf den das als ,Ständer' bezeichnete Standrohr des Mönchs aufgesetzt wird. Auf den offenen Grundrinnenkopf wird also eine senkrechte Rinne, der sog. ,Ständer' gesetzt, der zur Wasserseite offen ist, um die Staubretter aufzunehmen. Der Ständer muss in seinen Ausmaßen dem Querschnitt des Abflussrohres entsprechen und hat etwa eine Breite von $20-100 \mathrm{~cm}$. In der Höhe überragt er den Teichdamm etwa um $20 \mathrm{~cm}$ (ZOBEL 1992:71).

An den beiden Seitenwänden des Ständers, an den beiden äußersten Kanten innen liegend, wird auf jeder Seite eine Pfalz ausgearbeitet, ,welche auch in den Seitenwänden der Grundrinne [...], bis an den Boden derselben continuiert werden“" (DYHRN 1782:38). In diese Falze werden, sowohl in dem Grundrinnenkopf als auch darüber in dem Ständer, Bretter oder Bohlen eingepasst.

Die in die Falzen des Ständers einzupassenden Bretter werden ,Staubretter' oder ,Vorsetzbretter' genannt. Die Staubretter sind ,deshalb sehr vorteilhaft, weil sie es ermöglichen, die Wassertiefe mit zunehmendem Wachstum der Fischchen nach und nach zu erhöhen und, durch die allmähliche Überstauung der vorher trocken liegenden Teich- oder Grabenränder, die Vermehrung von Insekten, Flohkrebsen, Wasserasseln und ähnlichen Futtertieren zu begünstigen“ (BENECKE 1885:97). Zu beachten sind der Anlage dabei folgende Konstruktionsmerkmale (:15, vgl. Abb. VII-28):

\begin{abstract}
„Diese Staubretter werden durch den Druck des Wassers gegen die innere Leiste des Falzes angedrückt, welche deshalb sehr breit, stark befestigt und, ebenso wie die Anlageflächen der Staubretter, sehr glatt gehobelt sein müssen. [...] Bei Anwendung breiter Mönche müssen die Seitenplanken natürlich an der nach dem Teiche gekehrten Seite durch starke Querhölzer fest mit einander verbunden sein. Auch muß dann, um ein Durchbiegen der Staubretter infolge des Wasserdruckes zu vermeiden, das senkrechte Rohr durch eine starke Planke in zwei Hälften geteilt werden, so daß die Mitte der Staubretter an dieser Scheidewand einen festen Widerhalt findet.“
\end{abstract}

Die Staubretter sind nur etwa $20 \mathrm{~cm}$ hoch, damit ganz allmählich abgelassen und jede beliebige Stauhöhe gewählt werden kann. Den Staubrettern eine größere Höhe als $20 \mathrm{~cm}$ zu geben, ,ist nicht zu empfehlen, da sie dann schwerer zu handhaben sind und bei Aufnahme eines Brettes das Wasser mit zu großer Gewalt in den Mönch stürzt.“ (BENECKE 1885:15; genauso noch SCHÄPERCLAUS 1961:162)

In der Mitte eines jeden Staubrettes wurde „ein kräftiger Bügel von verzinktem Eisen aufgeschraubt, um die Bretter mittelst eines Hakens leicht heben zu können“" (BENECKE 1885:15; ebenso SCHÄPERCLAUS 1961:162).

Die Staubretter werden dann, wenn der Teich angespannt werden soll, in die vorderste Seite des Ständers „und zwar in die Pfalze aufgesetzt“ (DYHRN 1782:38). Bei Ablassen des Teiches wurde im Umkehrschluss von oben ein Stück nach dem anderen, so wie das Wasser immer stärker abfällt, weggenommen (:38).

Der Verschluss der Vorsatzbretter bei den Mönchen ist gegen Wassereintritt zu sichern, indem die Ritzen durch dazwischen gelegtes Moos abgedichtet werden, ,so daß kein Wasser durch kommen kann“ (DYHRN 1782:38) oder sie werden „mit Werg verdichtet und mit Lehm oder Thon verstrichen“ (BENECKE 1885:20).

Über das oberste Staubrett des Abflusseinlaufs werden verschiedene Sieb- oder Gitterkonstruktionen angebracht. Diese Bestandteile der Ablaufvorrichtung ,Mönch' stellen den sog. ,Mönchkopf' dar und können aus unterschiedlichen Materialien hergestellt sein. 
In der Höhe des gewünschten Wasserspiegels wurde bei dieser Konstruktion an Stelle des obersten Staubrettes ein Sieb in den Mönchkopf eingeschoben, durch das überschüssiges Wasser unter Zurückhaltung der Fische abfließen konnte. Je größer die Fische waren, umso gröber konnten die Siebe sein (SCHÄPERCLAUS 1961:162).

Unter Beachtung der örtlichen Verhältnissen und der vorhandenen Fische wurden die Mönchsiebe recht verschieden gestaltet und aus Zinkblech, einer Holzplatte oder Drahtgeflecht hergestellt.

Je nach Bauart des Mönchs bestand eine andere Variante darin, über das Sieb Staubretter bis an die obere Kante des Mönches zu setzen, so dass dann der darauf aufsetzende verschließbare Deckel auf dem Mönchkopf verhindern konnte, dass Unbefugte die Staubretter herausreißen konnten (ZOBEL 1992:72f.).

Durch das Anbringen eines zweiten Siebes am Grund der 1. Reihe konnte zudem - neben den Oberflächenwasser des ersten Siebes unmittelbar auf dem Mönchkopf - Bodenwasser auf einfache Weise abgelassen werden (ZOBEL 1992:73).

Eine andere Art des Mönchfilters bestand darin, dass der Abfluss anstelle des Siebes „durch einen Rechen von Holz gegen den Zutritt der Fische abgeschlossen“ wurde (BORNE 1886:221). Der hölzerne Mönchrechen musste dabei ganz unter Wasser stehen, damit er gegen Fäulnis geschützt war. Eiserne Rechen hielt hingegen BORNE (:221) für unzweckmäßig, ,weil sie schnell durch Rost zerstört werden.“

Ein Mönchrechen bestand aus einem Rahmen in der Breite der Staubretter, in den parallele Stäbe, ,am besten Rundstäbe" (SCHÄPERCLAUS 1961:162), eingesetzt wurden. Hinsichtlich der Anbringung lassen sich zwei Formen von Rechen unterscheiden:

1. horizontaler Mönchrechen und

2. vertikaler Mönchrechen.

Ein Rahmengitter mit horizontal angeordneten Stäben galt als sehr haltbar. Es hielt die Fische auf der einen Seite sehr gut zurück, ließ auf der anderen Seite aber die ,an der Oberfläche schwimmenden Blätter und Holzstückchen besser durchgehen“" (SCHÄPERCLAUS 1961:162). Werden die Stäbe senkrecht angeordnet, so hatten sie jedoch den Vorteil, dass sie „von oben her mit Stielbürsten besonders gut zu reinigen“ sind $(: 162)$.

„Um jede Möglichkeit des Entweichens von Fischen auszuschließen“, wurde anstatt des hölzernen Rechens über dem obersten Staubrett ,ein in einen Holzrahmen gefaßtes Gitter von verzinktem Eisen in den Falz eingeschoben“" (BENECKE 1885:15). Aufgrund der Verzinkung ${ }^{41}$ griff auch der Einwand von BORNE nicht mehr, aus Eisen gefertigte Filtereinsätze würden in kurzer Zeit verrosten.

Die Bau eines Mönchgitters stellte - dies sagt der Begriff schon aus - ein im rechten Winkel angebrachte Konstruktion von sich kreuzenden vertikal und horizontal angebrachten Eisenstäben dar, die aufgrund ihrer größeren Engmaschigkeit einen noch besseren Schutz gegen das Entfliehen von Fischen während des Wasserablaufes boten.

\footnotetext{
${ }^{41}$ Verzinkung: Verfahren, bei dem durch Elektrolyse (Galvanotechnik) oder Schmelztauchen, d. h. in geschmolzenem Zink (Feuertechnik) ein Grundmetall wie Eisen oder Stahl mit einer dünnen Schicht Zink beschichtet wird, um es gegen Korrosion zu schützen. Man kann das verzinkte Eisen noch nachträglich verzinnen, um eine größere Haltbarkeit seines Überzuges unter den Einflüssen der Witterung zu erzielen. Die Verzinkung mit geschmolzenem Zinn war schon im Altertum bekannt, archäologische Funde in der Nähe von Bagdad/Irak belegen, dass vor rund 2000 Jahren die galvanische Metallabscheidung bekannt gewesen sein müsste. Die Verzinnung des Eisens erwähnt zuerst AGRICOLA, und sie scheint im 16. Jh. noch nicht häufig geübt worden zu sein. Eisenblech wurde angeblich zuerst in Böhmen verzinnt. Vor dort kam das Verfahren 1620 nach Sachsen und 1670 nach England. Es wurde also zuerst in den ,Teichgroßlandschaften' Böhmen und Sachsen angewandt.

1742 teilte der Franzose Malouin mit, dass man durch Behandeln von Eisen mit Zink statt mit Zinn eine Art Weißblech erhalten könne (Zinkblech), und der Engländer Watson beschrieb 1786 das Verfahren so, wie es im Wesentlichen noch gegenwärtig ausgeführt wird: Drahtgewebe aus Schwarzblech bspw. wird mit Säure gebeizt, gespült, mit gestoßenem weißen Pech bestreut, in sehr heißes geschmolzenes Zinn getaucht, durch einen Stoß von überschüssigem Zinn befreit und zwischen Walzen geglättet (MEYERS KONVERSATIONSLEXIKON 1888, Bd. 16:171; BROCKHAUS 1979, Bd. 12; LEUZE 2004)
} 


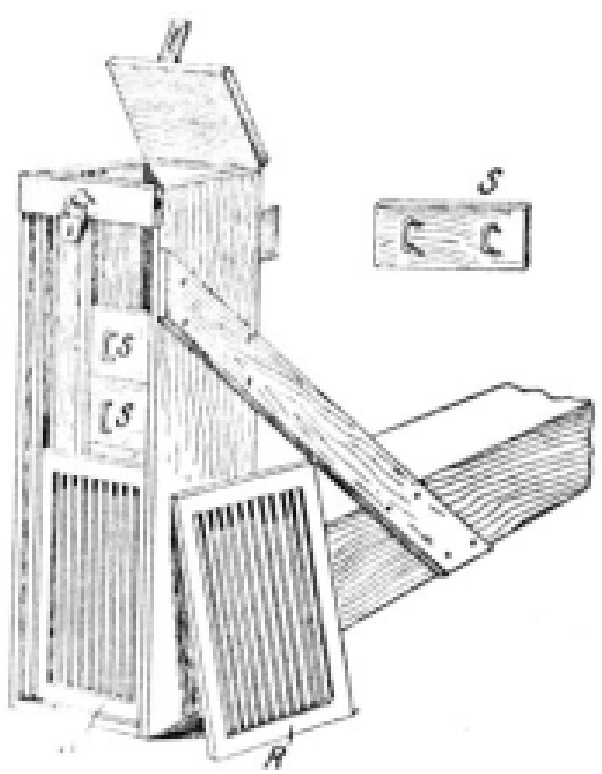

Abb. VII-28: Ablassvorrichtung (Teichmönch) mit Rechen (R) und Staubrettchen (S) (aus: WALTER 1933)

Der Kopf des Ständers, d. h. jenes Ende, „,welches über das Wasser zu stehen kommt“, wird abschließend „mit einem ringsum etwas überragenden Stück Bohle bedeckt, auf welches man wieder noch ein kleineres, ringsum zurückstehendes Stück Bohle [...] nageln kann, und also wider das zu zeitige Verfaulen verwahret“ (DYHRN 1782:37f.).

Anstelle des starren Mönchkopfbrettes, setzte man aus Sicherheitsgründen lieber einen abschließbaren sog. Mönchkopfdeckel auf den Mönchständer, wie man BENECKE (1885:15f.) entnehmen kann: „Gegen unbefugte Hantierung an den Staubrettern schützt man sich am besten dadurch, daß der Mönch oben durch einen im Chanier beweglichen und mittelst eines starken Schraubenbolzens verschlossenen Deckel gesperrt wird."

Je nach verwendetem Baumaterial der statischen Hauptbestandteile lassen sich vier verschiedene Mönche unterscheiden, wobei sich mit steigender Reihenfolge das Alter der Mönche verjüngt.

Am Anfang des Teichbaus mit Mönchen mag der Holzmönch gestanden haben. Die ältesten Mönche waren zum Schutz vor Verwitterung vor dem Einbauen gut mit Karbolineum, flüssigem Holzpech oder anderen Mitteln getränkte oder lasierte Holzmönche und besaßen eine Haltbarkeit von 20-30 Jahren (SCHÄPERCLAUS 1961:160; ZOBEL 1992:70). So ist es eine Tatsache, dass „die Deckbretter des Horizontalrohres der Holzwände unrettbar eines Tages durchfaulen“" (SCHÄPERCLAUS 1961:160f.). Von den ältesten Teichmönchen ist also keiner im Original erhalten geblieben. Der Anstrich vor allem mit Karbolineum war jedoch oft giftig, weshalb erst nach längerem Wässern ein Fischbesatz möglich war (ZOBEL 1992:70).

Als Baumaterial wurde bei Holzmönchen in der Regel astfreies Kiefernholz aus Winterfällungen verwendet, da das teure Eichenholz kaum zur Verfügung stand. Die Dicke des Holzes betrug je nach Größe des Mönches $4-8 \mathrm{~cm}$. Die horizontale Abflussrinne hat, ist sie aus Holz hergestellt, einen quadratischen oder rechteckigen Querschnitt. Bei weichem oder nachgiebigem Torfboden ist der Holzmönch aus Stabilitätsgründen nochmals mit Holz unterlegt worden (ZOBEL 1992:73). Der senkrechte hölzerne Mönchkopf hat einen hufeisenförmigen Grundriss.

Doch Holz war im Mittelalter und in der Neuzeit knapp und so wurden bereits zu dieser Zeit die Mönche „immer seltener ausschließlich aus Holz hergestellt“ (SCHÄPERCLAUS 1961:160). So gab es denn haltbarere Abflussrohre aus glasierten Tonröhren und seit Anfang des 19. Jh. auch aus Betonröhren, die sich für diesen Zweck gut bewährt hatten und sich im Laufe der Jahre durchsetzten (ZOBEL 1992:70; ohne eine nähere Jahresangabe). 
Bei dem aus den Materialien Holz und Ton kombinierten Mönch (Holz-/Tonmönch) wurde der senkrechte Mönchkopf aus Holz hergestellt und etwa $50 \mathrm{~cm}$ tief in den Boden eingelassen. Das horizontale Abflussrohr bestand aus Ton und wurde in den Teichboden eingesetzt.

Aber die Haltbarkeit auch von Tonrohren ist begrenzt. Sie werden in saurem Substrat nach 10 bis 20 Jahren zerstört (SCHÄPERCLAUS 1961:161) und stehen insofern von der Haltbarkeit her den Holzmönchen nicht vor. Nimmt man an, dass mit der Herstellung von keramischen Tonröhren seit den Anfängen des Teichbaus dieser Baustoff in der Teichwirtschaft zum Einsatz kam, sind auch die Nachfolger des reinen Holzmönchs nicht mehr in ihrer ursprünglichen Form vorhanden.

Immer häufiger wurden aber die senkrechten Mönchteile aus Bruchsteinen gemauert (Steinmönch) (SCHÄPERCLAUS 1961:161). Damit die Staubretter, die in der Regel auch aus Steinplatten hergestellt werden, „gut liefen“, wurden bei Steinmönchen eiserne U-Schienen verwendet, „die mit 3-4 eingelassenen Steinbolzen fest mit dem Mauerwerk verbunden waren" (:162), um die schweren Steinplatten fixiert heben zu können.

Einen weiteren Materialmix stellt der aus Holz in Verbindung mit Beton hergestellte Teichmönch dar (Holz(Betonmönch). Während zwar, wie beim Holzmönch, der Mönchkopf aus Holzteilen zusammengesetzt ist, wird er aber nicht tief in den Boden eingelassen, sondern auf einen in den Boden eingesenkten Betonsockel gesetzt. Gleichzeitig wird in den Grund eine Betonröhre als Verbindungsstück zum Damm eingesetzt. Aber auch Betonrohre werden in sauren Böden oft in 10-20 Jahren zerstört (SCHÄPERCLAUS 1961:161).

Schließlich wurde der gesamte Teichmönch vollständig ,aus Beton an Ort und Stelle hergestellt“ (Betonmönch) (SCHÄPERCLAUS 1961:162).

Auch die Staubretter bestehen bei den Betonmönchen aus Zementbausteinen und es wird als Falz zum Aufund Ablassen der Staubretter die gleichen Konstruktion wie bei den Steinmönchen verwendet (eiserne USchienen mit Bolzenverankerung) (SCHÄPERCLAUS 1961:162), da - vergleichbar den Steinplatten aufgrund des höheren Gewichts diese stärkere Verankerung notwendig erschien.

Im selben Maße wie die Baumaterialien der Mönche eine begriffliche Differenzierung ermöglichen, lassen sich - nach ihrer Position innerhalb des Teiches - drei verschieden Arten des Abzuges mit dem Mönchständer unterscheiden:

1. den Dammständer,

2. den Freiständer und

3. den Wandständer

Der Dammständer- DYHRN bezeichnet den von mir ,Dammständer' genannten Mönch umständlich als „Ständer, der in den Damm zurückgelegt wird“ - wird hinter die vorderste Wand in den Damm hinein zurückgesetzt. Dieser wird durch zwei schief auseinander laufende Seitenwände mit der vordersten Hauptwand verbunden und die dadurch entstandene Lücke ,durch eine Reihe perpendiculair, aber nicht fest aneinander stehender Stäbe bzw. Rechen ausgefüllt““ (DYHRN 1782:39).

Der Freiständer hingegen wird vor die inwendige Hauptdammwand ,ganz nah an derselben“, frei im Teich aufgesetzt und nur unten mit der Grundrinne „genau und fest verbunden“ (DYHRN 1782:32).

Der hölzerne Mönchkopf ist immer ein Freiständer - nach DYHRN (1782:32) „Ständer, der frei vor der Wand steht" -, denn er darf nicht im Damm stehen und nicht an die Böschung angelehnt werden, weil er dann leicht fault, ohne an Festigkeit zu gewinnen. Der im Wasser frei aufragende Mönchkopf wird vom Damm aus mit Hilfe einer Laufplanke erreicht (SCHÄPERCLAUS 1961:160).

Der Wandständer schließlich wird in die vorderste Hauptwand, die als gerade Linie verläuft, „,in der Mitte derselben mit eingesetzt, und mit derselben verbunden" (DYHRN 1782:33). Von den beiden Seiten des 
Ständers an, weiter in den Teich hinein, werden ein Paar schief auseinander laufende niedrige Seitenwände oder Flügel - vergleichbar mit der Art des Zapfenabzuges (siehe c.2.8.3.1) - angelegt.

Die Funktion dieser zwei Seitenflügel vor dem Ständer ist dergestalt, dass „,vornen im Teiche, in der Tiefe“ der Ständer des Mönchs durch die Seitenflügel, „die von dem Wasser übergossen werden, geschützt wird“ (DYHRN 1782:40).

Der Vorzug dieser Bauart mit dem „Ständer mit der geraden Vorderwand verbunden“ (DYHRN 1782:33) und den beiden Seitenflügeln ,,ist wohl, wegen der großen damit verbundenen Bequemlichkeit, und wegen des festen, dauerhaften und wohlfeilen Baues, allen anderen Arten weit vorzuziehen“ (:40).

Weiter bauliche Zusatzbestandteile eines Mönches sind neben dem eigentlichen Ständer der „Abfischkasten“ sowie der „Auffangkasten“.

Der sog. Abfischkasten ist eine Abfischvorrichtung, mit der die „schonendste Abfischung“ (WALTER 1933: 79) erfolgte. Der Abfischkasten wurde entweder - mit Sperrgittern - hinter dem Mönch oder vor dem Mönch angebracht und galt für den Abfischvorgang hauptsächlich von kleinen und empfindlichen Jungfischen als unerlässlich (:54).

Da er somit als integrativer und notwendiger Bestandteil des Mönches zu bewerten ist, wird er dem Teichmönch als Bauelement zugewiesen und hier behandelt.

Der Abfischkasten besteht aus ,einer großen länglichen Kiste mit Wänden aus Drahtgeflecht oder durchlochtem Blech, die unter den Ausfluß des Mönchs gesetzt wird, und in der sich die aus dem Mönch auslaufenden Setzlinge sammeln. [...] Von hier werden sie mit Gazekeschern herausgenommen“" (WALTER 1933:79). Die eventuell in dem Teich vorhandenen älteren Karpfen wurden vom Zugang zum Mönch durch Netze oder Absperrgitter abgehalten (:54).

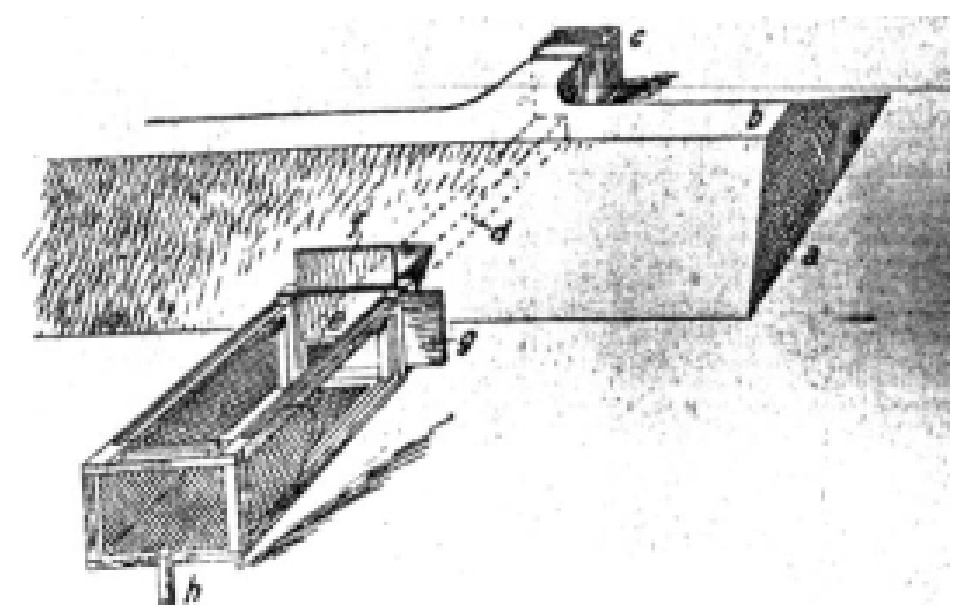

Abb. VII-29: Fangkasten hinter dem Mönch

a) Damm, b) Dammkrone, c) Mönch, d) Abflussröhre, e) Ausfluss, f) g) Schieber, h) Pflock zur Befestigung des Fangkastens (aus: WALTER 1933:79)

Diese Abfischkästen konnten aber auch anwendet werden, wenn Forellen und andere große Fische, beispielsweise Karpfen abzufischen waren. Sollten beide zusammen durch den Mönch geschleust werden, wurde ein Einsatzboden in den Kasten gesetzt, durch dessen Stabgitter die Setzlinge oder Forellen in den unteren Raum des Kastens schlüpfen konnten (WALTER 1933:79).

Nicht um Fische in einfacher Form zum Versatz zu sammeln oder abzufischen, sondern ,um Verstopfungen des Gitters durch Wasserpflanzen, abgefallenes Laub und dergleichen von der Strömung mitgeführte Gegenstände zu vermeiden, die meistens an der Oberfläche oder dicht unter derselben treiben", kam ein weiterer Kasten zum Einsatz, der von mir als „Auffangkasten“ bezeichnet wird, da sich kein spezieller Terminus in der Literatur finden ließ. Vor der Teichseite des senkrechten Abflussrohres wurde empfohlen, einen ,aus zwei unter spitzem Winkel mit einander verbundenen Brettern bestehenden Kasten“ aufzustellen, der „um 
etwa $20 \mathrm{~cm}$ über den höchsten Wasserstand hinausragt und etwa um ebensoviel vom Grunde des Teiches absteht.“ Das Wasser konnte dann ungehindert dem Mönch zuströmen, „während die an der Oberfläche schwimmenden Körper sich an dem Kasten ansammeln und von Zeit zu Zeit leicht entfernt werden können." (BENECKE 1885:16)

Zusammenfassend ist der Mönch, wie ich ihn verstehe, der Oberbegriff für eine Ablaufvorrichtung, die aus einem horizontal durch den Damm in die Wasserseite des Teiches verlaufenden Rohr bzw. einer Grundrinne besteht, auf dem bzw. auf die ein senkrechtes Standrohr befestigt wird. Dieses Standrohr bezeichne ich als Ständer im eigentlichen Sinne. Das Standohr besteht aus vier viereckig oder quadratisch angeordneten Pfählen mit Seitenwänden. In die Vorderseite sind an Falzen entlang einzelne Staubretter eingeschoben, die bei Bedarf herausgenommen werden können. Auf der Oberseite des Standrohres ist ein Gittergeflecht, ein sog. Mönchgitter angebracht, die der Filtration des Wassers dienen und ein Fortschwimmen von kleinen Fischen sowie Geäst und Laub etc. verhindern.

Für den Betrieb einer Teichwirtschaft hat der Ablaufmönch durch seine Konstruktion entscheidende Vorteile gebracht (in Anlehnung an SCHÄPERCLAUS 1961:159):

1. Er gestattet einen ständigen Durchstrom durch den Teich.

2. Siebe, die das Entweichen von Fischen verhindern sollen, können in beliebiger Art und Größe angebracht, ständig überblickt und leicht gereinigt werden.

3. Es ist möglich, das abfließende Wasser nach Belieben an der Oberfläche, am Grunde oder in jeder beliebigen anderen Höhe aus dem Teich zu entnehmen.

4. Bei Anbringung von 2 Staubrettreihen kann eine vollständige Abdichtung des Mönches vorgenommen werden, und beim Abfischen lässt sich der Teich ständig durch Siebe absperren, so dass kein Fisch entweichen kann.

5. Beim Ablassen wird das Wasser von oben her abgelassen, so dass es nie unter Druck steht.

6. Durch Stehenlassen von ein oder zwei Staubrettern kann bei der Abfischung der letzte Rest des Wassers vor dem Mönch und im untersten Teil des Fischgrabens zurückgehalten werden, so dass die gesammelten Fische in Ruhe aus dem Wasser herausgenommen werden können.

\section{c.2.8.4 Zulaufvorrichtungen}

Die Zulaufvorrichtungen sind für die Wässerung der Teiche und für die Einhaltung des Wasserstandes zuständig und spielen insbesondere in der Forellenteichwirtschaft eine große Rolle.

Das bedeutet jedoch nicht, dass diese Einrichtungen variabel eingesetzt worden sind. Vielmehr war es vor allem in der Karpfenhaltung das Bestreben, ,den Wasserstand so viel wie möglich unverändert erhalten [...], weil die Fische [...] dem frisch einströmenden Wasser entgegen gehen, von ihren Weideplätzen fortgelockt werden und dem Diebstahl ausgesetzt sind.“(BORNE 1886:220)

Erst „wenn das Wasser bei trockenem Wetter fällt, die Ränder trocken werden“, wurden diese Vorrichtungen zwischenzeitlich gebraucht, denn wie oben beschrieben, verließen die Karpfen ihre Weideplätze und gingen in tiefes Wasser. Des Weiteren würde ansonsten in den Streichteichen der an Gräsern und dergleichen abgelegte Laich trocken und absterben (BORNE 1886:220). Weiterhin wird die Funktion dieser Zulaufvorrichtungen deutlich, wenn von dem BORNE (:220) ausführt, es sei ,vortheilhaft, wenn Teiche, die den Sommer vorher bestellt worden sind, allmählich angestaut werden, so daß das Vieh die höher gelegenen Theile beweidet und den Insekten Brutstätten gewährt werden.“

Die das Wasser zuführenden künstlich ausgehobenen Zulaufgräben sind in Pkt. c.2.5.1 beschrieben worden. An diese Teichgräben schließen sich die Zulaufvorrichtungen teichwärts an, zu denen die folgenden Bauteile gehören: 
1. Zulaufrohr

2. Zulaufsieb

3. Überfluter

Das Zulaufrohr, von den Zulaufgräben durch den Teichdamm zu der eigentlichen Zulaufvorrichtung verlaufend, wurde in den Teichen, wie beim Mönch, aus Holz, Ton- und später aus Betonrohren hergestellt. Durch dieses fällt das Zuflusswasser frei in den Teich hinein (SCHÄPERCLAUS 1961:163). Unterhalb des Zulaufrohres, d. h. horizontal unter dem einlaufenden Wasser wurde ein sog. Zulaufsieb angebracht: Zum einen wurde dadurch „das Hineinspringen von Forellen“ verhindert, zum anderen reicherte das Sieb gleichzeitig das Zuflusswasser mit Sauerstoff an (:163).

Reichte bei Durchströmung von mehreren hintereinander geschalteten Forellenteichen das Gefälle nicht mehr aus um das Wasser von oben her, beispielsweise durch ein Zulaufrohr einfallen zu lassen, so konnten mit Brettern verschalte Überfluter in der Dammkrone angelegt werden, die durch Schräggitter und senkrechte Gitter gegen den Fischwechsel gesichert waren (SCHÄPERCLAUS 1961:163f.).

Überfluter wurden in dem flachsten Teil der Dämme angelegt, waren jedoch sonst „,möglichst zu vermeiden, weil sie die Dammkrone und damit den ganzen Damm leicht einrissen“ (SCHÄPERCLAUS 1961:164).

\section{c.2.8.5 Absperrungsvorrichtungen}

„Bei Teichen mit kleineren Zuflüssen brauchen oft keine besonderen Absperrungen der Zuläufe vorgenommen zu werden, wenn die Teiche mit größeren Karpfen besetzt sind“ (SCHÄPERCLAUS 1961: 163). Bei stärker wasserführenden, insbesondere periodisch schwankenden Wasserständen, waren jedoch Absperrungsvorrichtungen der Zuflüsse notwendig. Sie konnten aus verschiedenen Konstruktionen bestehen und sind denen des Abflusses vergleichbar:

1. Zulaufmönch

2. Schräg- oder Horizontalgitter

3. Schleusen

4. Wehre

Eine „sehr einfache Art der Absperrung des Zulaufes gegen das Entweichen von Fischen“ bildete ein sog. Zulaufmönch, „der in der gleichen Weise wie die Ablaufmönche gebaut wird“ (SCHÄPERCLAUS 1961: 163). „Am Einlauf wird der Mönch dazu verwendet, den Zufluß zu regeln und abzusperren.“ (ZOBEL 1992:70)

Eine andere Art der Absperrung konnte durch Schräg- oder Horizontalgitter erreicht werden: Diese bestanden aus parallel zur Stromrichtung stehenden Stäben oder gelochten Blechplatten (in Anlehnung an SCHÄPERCLAUS 1961:163).

Eine weitere Möglichkeit zur Absperrung des Zuflusses bestand in der Errichtung von Schleusen und Wehren.

Jede ungewohnte Bewegung des Wassers durch starke Strömung, wie sie leicht infolge der Schneeschmelze oder heftiger Regenfälle im Frühjahr des vorigen Jahrhunderts auftrat, bringt Karpfen in Aufruhr. Bei den in der Ebene gelegenen Teichen genügten Mönche von entsprechender Weite zur schnellen Ableitung des überschüssigen Wassers und zur Erhaltung des normalen Wasserstandes. Dagegen mussten die zwischen Bergen und Hügeln gelegenen oder von öfter anschwellenden Bächen oder Flüsschen gespeisten Teiche, die häufigem Hochwasser ausgesetzt sind, gegen Überflutung und Beschädigung der Dämme, die leicht zu Durchbrüchen Anlass geben, „durch Wehre besonders geschützt werden.“ (BENECKE 1885:16) Vor allem bei dem von Berglandflüssen aus gespeisten Winterteichen waren daher „Überfallwehre höchst notwendig.“ (:31), während die Sommerteiche ohnehin nicht bewirtschaftet wurden. 
Eine andere Form des Hochwasserschutzes bestand aus den sog. Abweisungsgräben, die in Kap. c.2.5.2 besprochen wurden.

Wehre sind also besondere Einrichtungen der Berg- und Hügellandteiche und solche von temporär hochwasserführenden Flussläufen gespeisten Flachlandteichen, deren Bau als Notwendigkeit empfohlen wurde:

„Wo Teiche von Flüssen oder größeren Bächen durchströmt werden, thut man wohl, an letzteren schon vor ihrer Einmündung in den Teich derartige Wehre anzulegen, um das Hochwasser und den etwa mitgeführten Schlamm etc. gar nicht erst in den Teich eintreten zu lassen. “(BENECKE 1885:17f.)

Die Wehre (siehe Abb. VII-30 und 31), auch ,Überfälle' oder ,Flutbetten' genannt, ,werden gewöhnlich an dem einen Ende des Teichdammes angelegt, wo derselbe der geringeren Wassertiefe halber keinem hohen Drucke ausgesetzt ist" (BENECKE 1885:17). Der Bauplan eines solchen Teichwehres in der Ausführung eines Überfallwehres liest sich wie folgt:

„Je nach der Größe der Teiche und der Menge des voraussichtlich abzuleitenden Hochwassers erhalten sie eine Breite von 3-10 m oder noch mehr. Die Wehrkante mu $\beta$ [...] 1/2-1m tiefer liegen als die Krone des Dammes; die Böschungen, welche man vorteilhaft viel flacher macht, als die des übrigen Dammes, stoßen in der Wehrkante dachartig zusammen und werden mit einem dicht gefugten Bohlenbelage versehen. Auch die Seitenwände des Wehres müssen natürlich, um Abspülungen zu vermeiden, durch feste Spundwände geschützt werden. Wird der Damm als Weg benutzt, so muß das Wehr überbrückt werden.“ (BENECKE 1885:17).

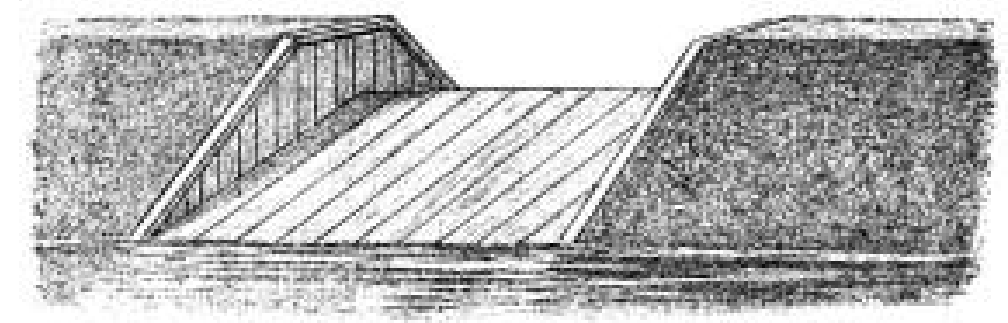

Abb. VII-30: Ansicht eines Überfallwehres (aus: BENECKE 1885:17)

Die historisch betrachtet frühzeitigste Lösung zur Absperrung von hochwasserführenden Fließen, stellen aus Strauchwerk hergestellte hölzerne Wehre, sog. Strauchwehre dar. Solche Strauchwehre wurden ,von dünnem 1 1 $1 / 2-2 \mathrm{~m}$ langem Faschinenstrauch ausgeführt, welches in der Richtung der Strömung gelegt wird und den höchsten Wasserstand etwa um $1 / 2 \mathrm{~m}$ überragen muß.“ (BENECKE 1885:18).

Später wurde mit dem Einsatz eines Wehrrechens eine vorteilhaftere Lösung praktiziert: „Um zu verhindern, daß mit dem Hochwasser Fische über das Wehr mit fortgehen, wird auf oder vor demselben ein Rechen angebracht, d. h. ein Gitter aus Holz- oder verzinkten Eisenstäben, welches bei breiten Wehren der Wehrkante parallel läuft, bei schmäleren gerne spitzwinkelig gegen die Strömung gestellt wird, um dem Wasser mehr Durchflußöffnungen zu bieten und sich weniger leicht durch antreibendes Kraut, Land u. dergl. zu verstopfen“ (BENECKE 1885:17).

Um also das Entweichen von Fischen aus dem Teich in den einmündenden Fluss oder Bach zu verhindern, muss dessen Mündung durch einen an den Wehren eingerichteten Rechen oder durch ein Strauchwehr versperrt werden. Zu diesen Absperrvorrichtungen gehörte auch ein Wehrbalken. Ob vor Metallwehren oder vor Strauchwehren, es wurde „zweckmäßig, um Verstopfungen zu vermeiden, ein schwimmender Balken in schräger Stellung befestigt.“ (siehe Abb. VII-31) (BENECKE 1885:18) „Sehr wirksam“ wurde solchen Verstopfungen auch durch ,ein hochkant gestelltes Brett begegnet, welche, in sehr schräger Stellung zur Strömung vor dem Rechen befestigt, die an der Oberfläche herantreibenden Gegenstände aufhalten und nach dem Ufer hinlenken, wo sie sich anhäufen und leicht entfernt werden können.“(:17) 
Dieser Balken wird außerdem auch als ,Wehrbrett' oder, falls es sich um schwimmende Konstruktion handelte, als ,Schwimmbalken' bezeichnet.

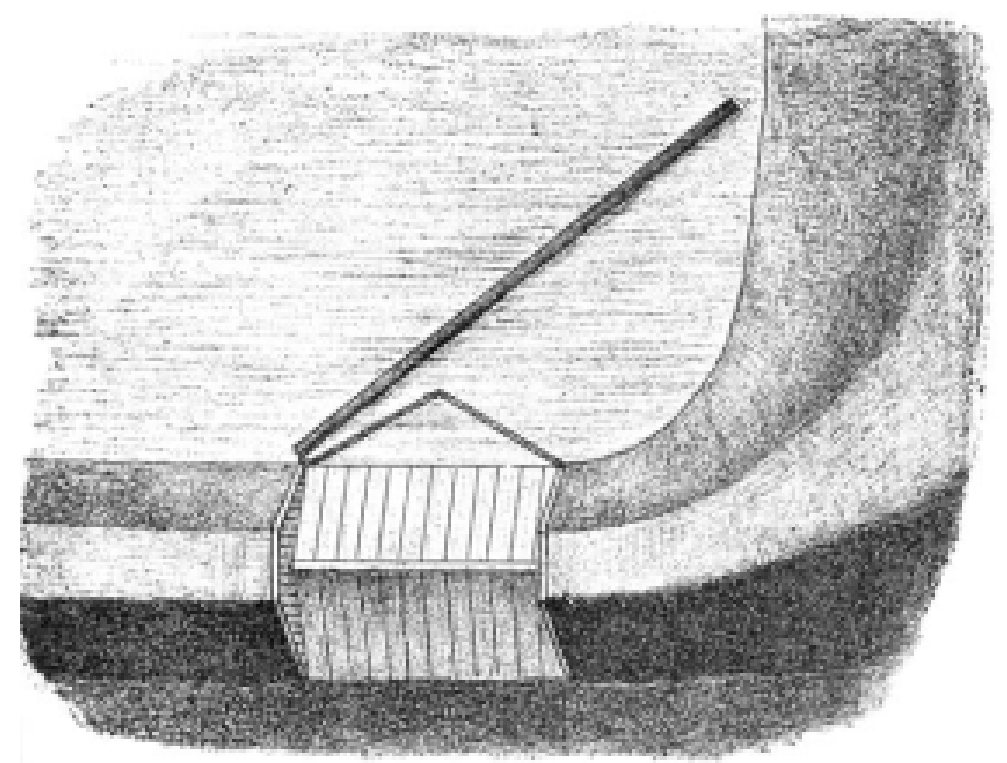

Abb. VII-31: Ansicht des Dammes mit Wehr, Rechen und Schwimmbalken (aus: BENECKE 1885:19)

Der Teichbau ist, betrachtet man rückblickend die verschiedenen Bausteine, eigentlich eine simple Konstruktion: ein möglichst kurzer Dammbau, darauf nur kleine Weidenhölzchen anpflanzen, Zu- und Ablaufvorrichtungen einrichten und den Teichboden präparieren. Doch besieht man die unterschiedlichen Bauweisen, die Anfertigung der Filtereinrichtungen, die Abwägung des idealen Bauplatzes, ihre anschließende Absteckung bzw. Vermessung und den auch in einer günstigen Talenglage massiven Erdaushub für eine Vielzahl an unterschiedlichen Teichformen, insbesondere bei Forellen- und Winterteichen, so ergibt sich ein anderes, diffizileres Bild des Teichbaus. Vor allem bestanden die wasserwirtschaftlichen Maßnahmen im Gegensatz $\mathrm{zu}$ frühen Bewirtschaftungsformen darin, Umlaufgräben einzurichten, Vorrichtungen zu bauen, um bei Hochwasser die Dämme öffnen zu können und in Trockenzeiten dieselben zu verschließen, um Schäden an Weiher- und Fischbestand zu vermeiden. Die vorgenommene detaillierte Darstellung des Teichbaus vermag einer Simplifizierung entgegenzuwirken und eine differenzierte Bewertung von Teichen in der Landschaft zu ermöglichen.

\section{Mühlteiche}

\section{a Begriff der Wassermühle}

Der Begriff der ,Mühle' war und ist nicht auf das Mahlen von Getreide beschränkt. Man unterscheidet Mühlen nach den Kriterien Antriebskraft (Wind-, Wasser-, Ross-, Ochs-, Esel-, Hund-, Tret- oder Handmühle etc.), Mahl- bzw. Fördergut (Weizen-, Graupen-, Hirse-, Knochen-, Muschel-, Moddermühle ${ }^{42}$ etc.), Verarbeitung (Dresch-, Heckerling- ${ }^{43}$, Flachs-, Walk-, Waid-, Gerber-, Öl-, Lohe-, Pulver-, Papier-, Säge-, Bohr-, Schleif-, Trass-, Tabakmühle etc.), Technik (Stampf-, Hammer-, Stockmühle), Standort (Fluss-, Teichdamm-, Werdermühle) und nach den Eigentumsverhältnissen bzw. dem geographischen Lagebezug

\footnotetext{
42 „Modder-Mühlen“ (oder auch Baggerte) sind „diejenigen Maschinen, womit aus den Häfen, Unfurthen und Kanälen der Sand, Schlamm und Moder, der diese verschlemmt hat heraus zu schaffen und rein zu halten und ihnen die gehörige Tieffe wiederum zu geben“ (LEUPOLD 1735:121).

43 „Heckerlings-Mühlen“ (oder Hächsel- bzw. Hechselmühlen): mittels wasserbetriebenem Schaufelrad wurde hier das Stroh mit Messern und anderen Schneidwerkzeugen zusammengedrückt (LEOPOLD 1735:81f.). Nach LEUPOLD (:118) wird eine Heckerlings-Mühle ,einzig und alleine auf grossen Meyer-Höfen, wo viele Pferde gehalten werden, einigen Nutzen bringen“, d. h. dort, wo viel Stroh erbaut wird.
} 
(Bauern-, Dorf-, Kloster-, Burg- oder Stadtmühle) ${ }^{44}$. KREINER (1996:47) versteht die Mühle deshalb - in einem umfassenden Sinne - ,als ein Instrument zur Bewältigung unterschiedlicher Arbeiten unter Nutzung verschiedener Energieformen“.

Wie aus der begrifflichen Darlegung ersichtlich, bezeichnete man alle technischen Anlagen, die durch Naturkräfte angetrieben wurden, in früheren Jahren als Mühlen, auch dann, wenn sie nicht zur Getreidevermahlung bestimmt waren und keine Mühlsteine besaßen. Deshalb empfiehlt WIEMER (1988:79) für die Wassermühle auch den Begriff, Wasserkraftanlage' anstelle von Mühle zu verwenden, ist doch im Volksmund ,nahezu jede Fabrikation, die mit einem Wasserrad angetrieben wurde [...] eine ,Mühle"“ (UECKER 1999:7).

Die Wassermühle bezeichnet allgemein eine „Methode, aus Wasser Energie zu gewinnen“ (UECKER 1999:14) und das Werk der Wassermühle wird als die „erste Maschine der Menschheit“ beschrieben, „,die ohne Muskelkraft Arbeit verrichtet“ (BEDAL 1992:31) und die „die wichtigste Kraftmaschine des Mittelalters“ war (MÜLLER/LUDWIG 1982:131). Doch das Wasser für den Antrieb, dies wird vielfach übersehen, wird erst mit Hilfe des Wasserbaus für die Mühle nutzbar gemacht (:31). So wird bei der Wassermühle, technisch betrachtet, ,die Kraft des Wassers auf ein horizontal oder vertikal gestelltes und mit Schaufeln oder Paddeln versehenes Mühlrad gelenkt und dessen Drehbewegung direkt oder über einen Übersetzungsmechanismus auf den Mühlsteinoberlieger übertragen“ (SCHÖN 1995:81, Hervorhebung im Original) . Für diese Art der Kraftübertragung und der dafür notwendigen Lenkung des Wassers bedurfte es also einer Gewässerinanspruchnahme, die verschiedene gewässerbezogene Anlagen und Elemente hinterlassen hat, die noch heute in der Landschaft sichtbar und teilweise auch in ihrer ursprünglichen Funktionalität erlebbar sind. Doch im Gegensatz zu anderen Antriebsarten ist nur für den Antrieb mit Wasserkraft ein Wasserstauteich - aber auch nicht in allen Fällen (siehe VII 2b) - Bestandteil einer Wassermühlenanlage.

Entscheidend für den Bau eines Mühlenteiches und seiner Wasserzu- und -abführungseinrichtungen war eine zu geringe Stärke und Menge an Wasser sowie ein unzureichendes Gefälle zur Nutzung der potentiellen Energie des Wassers. Sie bildeten die natürlichen Voraussetzungen für die Anlage von Wassermühlteichen. $\mathrm{Da}$ also die physiogeographischen und topologischen Verhältnisse für die zahlreichen von einem Gewässerlauf partizipierenden Wassermühlen für den Betrieb oftmals nicht ausreichend waren, mussten in vielen Fällen diese Voraussetzungen durch wasserbautechnische Anlagen überhaupt erst geschaffen oder verbessert werden, um die Technologie anwenden zu können. Diese „umfänglichen wasserwirtschaftlichen Bauten tragen in besonderem Maße zur Landschaftsveränderung bei - nicht selten das Landschaftsbild bereichernd“ (VOIGTMANN 1999:74). Sie selbst und ihre technischen Einrichtungen sind somit „Relikte mit einem hohen Informationswert über frühere Wassernutzungen“ (DIX 1997:25).

Kulturlandschaftsgeographische Kennzeichen der erhaltenen Mühlenstandorte sind, wie bei den landwirtschaftlichen Hofstellen und Weilern zum einen ihre historische Bausubstanz. Aber darüber hinaus, auch wenn die baulichen Hinterlassenschaften nicht mehr vorhanden sind, „die Teiche und Gräben, über die das Wasser der Bachläufe in die Teiche ab- bzw. zurückgeleitet wurde“ (WEISER 1997:85). Eine wasserradgetriebene Mühle prägte ihre Umgebung förmlich durch künstliche Anlagen wie Stauteiche und Mühlgräben und umfasste andere Einrichtungen, die zur Heranführung des Wassers notwendig waren: die Ausbaustrecke des Gewässers, deren Fassung zur Regulierung des anstehenden Wasserdruckes, bestehend aus mitunter mächtigen Wehranlagen und Einlaufbauwerk, den Werkskanal und das Krafthaus mit der eigentlichen Kraftmaschine, das Triebwerk und sodann die jeweiligen Arbeitsmaschinen (MÜLLER/LUDWIG 1982:152; ALBRECHT 1999b:353). „Gebäude, Teich und Gräben bilden funktional eine Einheit, was bei den bisherigen Unterschutzstellungen als Bau- bzw. Bodendenkmal nicht berücksichtigt wurde.“(WEISER 1997:85)

Von historisch-kulturlandschaftsgeographischem Interesse und innerhalb dieser funktionalen Einheit weitgehend unberücksichtigt blieben bislang häufig vor allem die bodenbezogenen Elemente und Anlagen

\footnotetext{
${ }^{44}$ Hier ist nicht der Raum zur Darstellung aller verschiedenen Mühlenarten: Die von Johann Georg KRÜNITZ (1728 - 1796) herausgegebene „Ökonomisch-technologische Encyklopädie“ zählt nicht weniger als 138 verschiedene Mühlenarten auf (KRÜNITZ 1804 , Bd. 95 und 96; aus: TROITZSCH 1991:33).
} 
außerhalb des Mühlenhauses: die Mühlteiche - auch wenn sie mit ihrer morphogenetischen Ausformung für die Beaufschlagung und damit für den Mühlenantrieb wichtig und oftmals sogar entscheidend waren. Der allgemein gehaltende Terminus ,Wassermühle' darf demnach nicht auf das eigentliche Mühlhaus eingeengt werden, sondern umfasst im engeren Sinne die Gesamtheit der wasserbezogenen Mühlanlagen und -einrichtungen einschließlich der Mühlteiche.

\section{b Mühlentopologie}

Unter dem Kriterium der hydrologisch-geographischen Topologie gibt es zwei Formen von Wassermühlen, die sich bezüglich der Art ihrer Anlage am Fluss wesentlich voneinander unterscheiden. Es handelt sich um die Wassertriebwerke, die

a. am Mühlengraben oder

b. direkt am Hauptfluss

gelegen sind.

Die meisten Mühlen sind so angelegt, dass sie von einem Mühlenkanal (Mühlenbach) angetrieben werden, der mittels eines festen Wehres vom Fluss abgeleitet wird. So waren z. B. alle Mühlen an den Erftnebenflüssen und an der Erft oberhalb Bergheims in dieser Art angelegt (KREINER 1996:100) und auch die Mühlen an der Zorge oberhalb und im Stadtgebiet von Nordhausen. Im Gegensatz zur Erft und zur Zorge konnten am Erft- bzw. Zorgemühlenbach wegen der geringeren Bachbreite die Wasserräder direkt in den Bachlauf hineingebaut werden (vgl. für die Erft DIX 1997:156).

Anders als diese Mühlenanlage an Flussableitungen stand der zweite Standardtypus am Fluss- bzw. Bachlauf selbst. Sie unterscheiden sich nicht nur in der Größe und Anzahl der Wasserräder, die eine Hauptflussmühle kennzeichnet, sondern auch insbesondere und logischerweise, doch nicht weniger kennzeichnend, dadurch, dass sie nicht an einem Mühlenkanal lagen, sondern direkt am Hauptfluss. An einer solchen Mühle wurde der Fluss in voller Breite durch ein Schützenwehr aufgestaut. Durch Öffnen und Schließen der hölzernen Schützen konnte der Wasserstand reguliert werden. Das Hochwasser wurde durch einen Flutkanal um die Mühle abgeführt. Die Anlage solcher Großmühlen war aber nur an nicht schiffbaren Flussläufen möglich, wo eine Behinderung der Schifffahrt ausblieb (KREINER 1996:109).

\section{c Arten der Wasserzuführung}

Man unterscheidet beim vertikalen Wasserrad nach Beaufschlagung drei Arten der Wasserzuleitung: 1. Die unterschlächtige, 2. die mittel-, und 3. die oberschlächtige Wasserzuführung (SCHEFFLER 1982:43). Statt von unterschlächtigen Rädern sprechen einige Autoren auch von unterpfortigen, statt von mittelschlächtigen Rädern von hinterschlächtigen, hinterschlägigen oder mittelpfortigen Rädern usw. (DOBELMANN 1980:28). Sie erhielten ihre Bezeichnungen wegen der im unteren, mittleren oder oberen Teil des Rades auf die quer zur Strömung angebrachten Schaufeln oder Zellen wirkenden Beaufschlagung (MAGER et al. 1989:56; siehe auch VI 16a).

Eine weitere Unterscheidung in Zellen- oder Schaufelrad ergibt sich durch die um das Rad herum angebrachten wasseraufnehmenden Zellen, oder die dem Wasserdruck nur Widerstand bietenden Schaufeln.

Ausschlaggebend für die Art der Wasserzuführung, d. h. wo die Wasserkraft auf das Mühlenrad einwirkt, ob ober-, mittel- oder unterschlächtig, ist die Wassermenge und das Wassergefälle (HÖLSCHER 1987:11). 


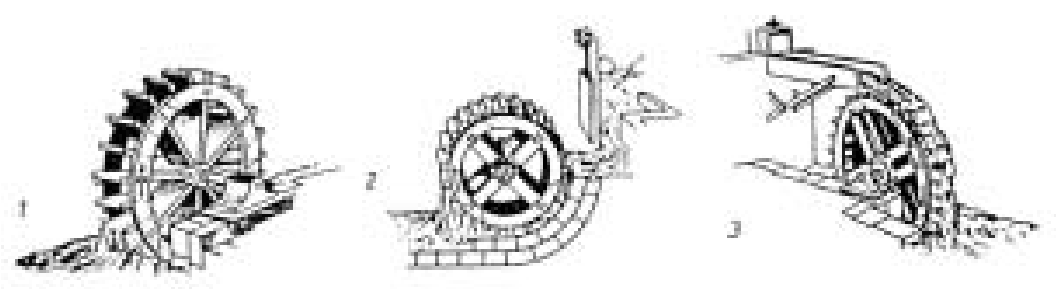

Abb. VII-32: Typen von Wasserrad-Antrieben: 1. unter-, 2. mittel-, 3. oberschlächtig (aus: VOGT 1998:21)

Die älteren, sicher zuerst dominierenden Formen gehören sämtlich zu den durch ,unterschlächtiges Wasser' angetriebenen Mühlen, bei denen der Druck des abfließenden Wassers die Drehung des Mühlrads bewirkte (DOBELMANN 1980:28; SCHEFFLER 1982:43; MAGER et al. 1989:56; BEDAL 1992:32). In das unterschlächtige Wasserrad läuft das Wasser unten hinein und lediglich die Strömung des Wassers wird ausgenutzt (LORENZ 2000:38). Die Beaufschlagung erfolgte dabei knapp über dem Unterwasserspiegel (MAGER et al. 1989:56), in den das untere Radteil eintaucht und dadurch rückwärts bewegt wird.

Die meisten dörflichen Mühlen, so (GRIES 1999:20), wurden mit einem unterschlächtigen Rad angetrieben, „da dieses System ohne zusätzlichen wasserbaulichen Aufwand auskam“. Voraussetzung dafür war, dass „der Bach genügend Wasser führt und eine Tiefe von 50 bis $70 \mathrm{~cm}$ “ besaß (:20).

Diese Zuleitungsform war nur für Gewässer mit starker Wasserführung und geringem Gefälle geeignet. Im Unterschied zu den anderen Rädern war hier nicht das Gewicht des Wassers, sondern seine Bewegungsenergie für die Drehung des Rades verantwortlich. Deshalb benötigten unterschlächtige Wasserräder eine bestimmte Wassermenge von mindestens ca. 50 Liter in der Sekunde, dafür nur einen geringen ,Absturz', der weit unter einem Meter betragen kann (BEDAL 1992:32). So erlaubten die unterschlächtigen Schaufeläder die Nutzung sehr kleiner Fallhöhen bis zu einer Untergrenze von $30-40 \mathrm{~cm}$, weshalb sie sehr häufig an den durch geringe Fließgeschwindigkeiten charakterisierenden Unterläufen der Bäche und Flüsse zum Einsatz kamen (LUNKENHEIMER 1990:11; BEDAL 1992:32) ${ }^{45}$. Die aber, um möglicht viel Wasser auf die Schaufel zu bringen und einen hohen Durchflusss zu erzielen, möglichst breit sein mussten.

In der Leistung waren sie aber nicht nur abhängig vom Wasserdruck, sondern von vielen anderen Faktoren wie Radumfang, Stellung, Größe und Form der Schaufeln und weiteren Konstruktionselementen (MAGER et al. 1989:56). Besondere Bedeutung für die Energieumwandlung erlangte deshalb bei diesen Konstruktionen die Schaufelform. Die Bewegungsenergie des Wassers wurde umso intensiver genutzt, je weniger das einströmende Wasser in seiner Bewegungsrichtung beeinflusst wurde und je besser es drallfrei wieder aus den Schaufeln heraustreten konnte (WIEMER 1988:81).

Es existieren hinsichtlich des Konstruktionsprinzips der Schaufeln verschiedene Formen des unterschlächtigen Wasserrades. Die einfachste Form, das sog. Strauberrad (siehe Abb. VII-33), besaß nur einen Radkranz, auf dem quer zur Strömung die Schaufeln aus geraden Brettern befestigt waren. Das sog. Staberrad hingegen bestand aus zwei Radkränzen und hatte einen größeren Durchmesser. Zwischen den Felgen waren kastenähnliche Schaufelfächer (Zellen) angebracht. Das Staberrad wurde dann verwandt, wenn größerer Wassermengen verfügbar waren (VOGT 1998:23) Vergleiche haben gezeigt, „daß bei breiteren Flüssen, wo nur mit unterschlächtigen Grindeln (Wasserrädern) gearbeitet werden konnte, zwei oder drei Grindeln hintereinander gestaffelt angeordnet waren." (LANGE 1989:90)

\footnotetext{
45 Im Gegensatz dazu schreibt MÜLLER/LUDWIG (1982:131), dass „schnell fließende Gewässer“ die Wassermühle „unterschlächtig“" antreiben.
} 


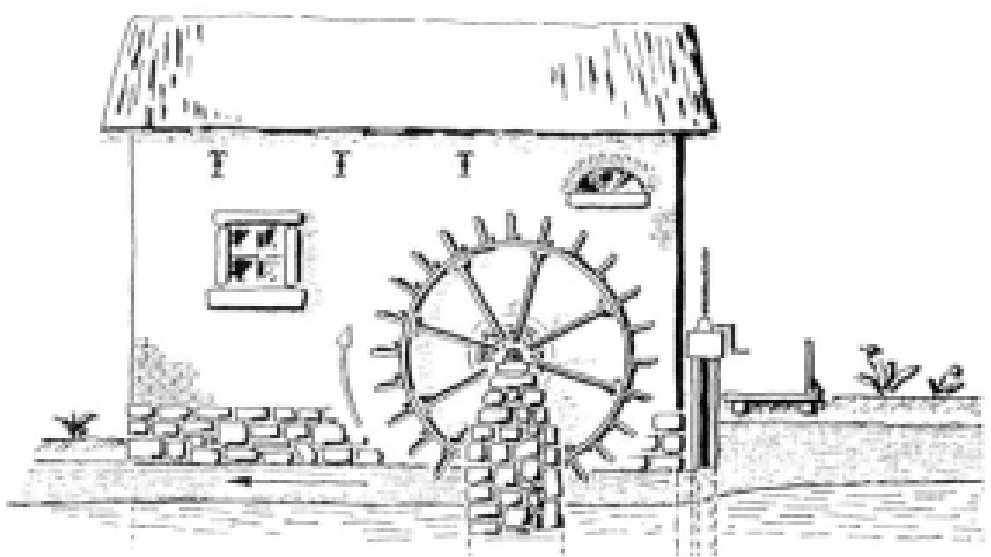

Abb. VII-33: Modellskizze einer unterschlächtigen Mühle mit Strauberrad (aus: VOIGT 1998:22)

Bei den mittelschlächtigen Rädern traf das Wasser in Höhe der Radnabe auf Zellen oder Schaufeln auf (VOGT 1998:23). Das mittelschlächtig zugeführte Wasser trifft das Rad in Brusthöhe und heißt daher auch ,Brustwasser' (SCHEFFLER 1982:43). Die Drehung dieses Rades war wie bei dem unterschlächtigen dem Wasserzufluss entgegengesetzt.

Der große Vorteil der mittelschlächtigen Räder wird bei stark differierender Wasserführung und Fallhöhe deutlich: Schwankende Wasserstände konnten durch wechselnden Eintritt des Triebwassers in den Radbereich mittels entsprechender Steuerung der Schützenöffnung kompensiert werden, so dass der Wirkungsgrad auch bei ungünstiger Wasserführung nahezu stabil gehalten werden konnte (WIEMER 1988:80f.). Mittelschlächtig beaufschlagte Wasserräder wurden, obgleich nicht hiervon der Name, sondern von der Achshöhe des Rades abgeleitet wird, am besten bei mittlerem Gefälle eingesetzt.

Entgegen der weit verbreiteten Ansicht, wie sie zum Beispiel DOBELMANN (1980:28), LUNKENHEIMER (1990) und GRIES (1990:20) vertreten, mittelschlächtige Wasserzuführungen seien „wegen des geringen Gefälles und der schlechten Ausnutzung des Wassers [...] selten benutzt" worden (LUNKENHEIMER 1990: 11), eher selten und beispielsweise im Osnabrücker Nordland überhaupt nicht anzutreffen, wurden ,bis auf zwei Ausnahmen“ in allen Mühlen des Erftbaches mittelschlächtige Wasseräder betrieben, ,die den Verhältnissen am Erftmühlenbach am besten angepasst waren.“(DIX 1997:156)

Wie der Name schon sagt, stürzte das Wasser bei oberschlächtigem Betrieb von oben in die Schaufeln des Mühlrads (DOBELMANN 1980:28; VOGT 1998:23) und „wirkt nicht nur durch Druck, sondern auch durch Schwere" (DOBELMANN 1980:28). Durch das zunehmende Gewicht des Wassers sanken die Zellen nach unten und setzten das Rad in eine fortwährende Drehbewegung um (DOBELMANN 1980:28; WIEMER 1988:80; VOGT 1998:23; LORENZ 2000:38).

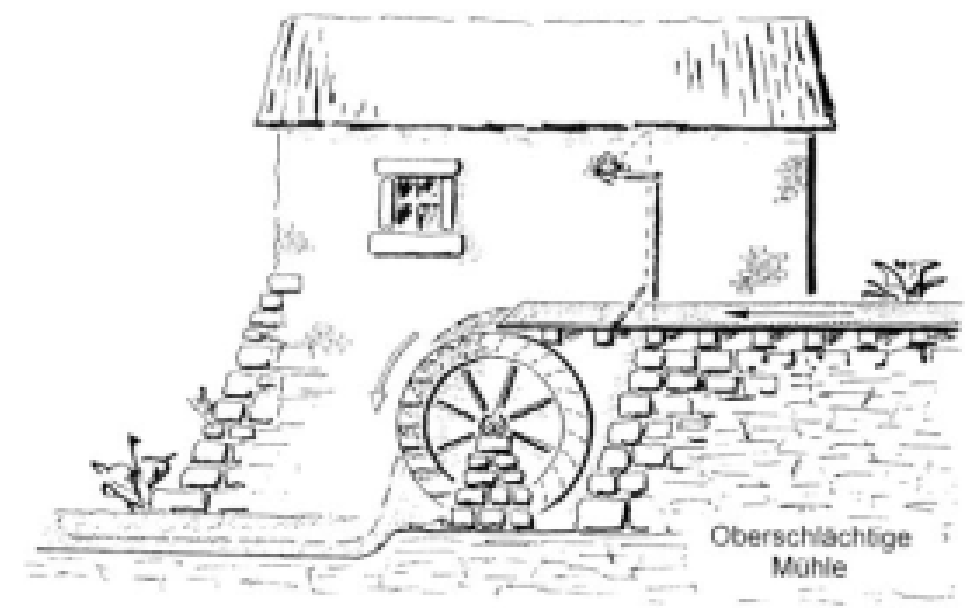

Abb. VII-34: Modellskizze einer oberschlächtigen Mühle mit Strauberrad (aus: VOGT 1998:23) 
Das aber setzte ein größeres natürliches Gefälle (VOGT 1998:23), zumindest aber eine größere Fallhöhe des Wassers an der Mühle, den sog. Absturz, voraus. Denn je höher der Absturz, desto geringer kann die zufließende Wassermenge bei gleicher Leistung sein. Gleichzeitig berechnete man nach der zur Verfügung stehenden Wasserkraft, die über das Mühlrad den Mahlgang trieb, den Durchmesser der Mühlsteine (BINTZER 1991:249). Ein oberschlächtiges Rad setzte ein Gefälle von mindestens 21/2 m voraus, konnte aber auch $3 \mathrm{~m}$ und bis über $10 \mathrm{~m}$ betragen (DOBELMANN 1980:28). Deshalb waren lange Mühlgräben, die das notwendige Gefälle erst herstellen mussten, häufig (GRIES 1999:20).

Die sog. oberschlächtigen Mühlen haben sich nach Angaben von DOBELMANN (1980:28) erst im 13./14. Jahrhundert, nach BEDAL (1992:32) sogar erst im Spätmittelalter (14./15. Jh.) entwickelt und ihre Wasserräder waren deutlich breiter als die anderen Räder aufgebaut und der im Einzelfall verfügbaren Wassermenge angepasst, damit die Zellen ausreichend viel Wasser aufnehmen konnten. Denn darauf kam es an: nicht der Druck des fließendes Wassers, wie gesagt, war entscheidend, sondern das Gewicht des in den entsprechend profilierten Zellen festgehaltenen und ständig nachlaufenden Wassers, das das Rad unaufhörlich nach unten drückte (VOGT 1998:23).

Wo immer der Höhenunterschied es zuließ, wurden oberschlächtige Wasserführungen bevorzugt. Aber auch dort, wo die Gefälleverhältnisse nur einen unterschlächtigen Antrieb zuließen, wie zum Beispiel den Gebirgsvorlanden, wurden die Mühlen in der Mehrzahl oberschlächtig angetrieben. Aber erst um 1820 begann die Umrüstung von unter- auf oberschlächtig, denn erst durch die Verwendung von Stahl und Gusseisen konnten oberschlächtige Wasserräder mit einem Durchmesser von weniger als $2 \mathrm{~m}$ konstruiert werden (KREINER 1996:113). Bis zu diesem Zeitpunkt also waren die Mühlen an gefällearmen Bach- bzw. Flussläufen unterschlächtigen Antriebs. Oberschlächtige Wassermühlen waren wesentlich leistungsfähiger als unterschlächtige. Während deren Wirkungsgrad bei etwa $35 \%$ lag, wurden bei oberschlächtigem Antrieb $70 \%$ und mehr erreicht (VOGT 1998:23). Bei gleichen Bedingungen erzeugen diese Räder fast doppelt so viel Energie wie unterschlächtige Wasserräder (DOBELMANN 1980:28). Diesen Vorteil konnten normalerweise nur Gebirgsbäche bieten und so waren oberschlächtige Wasserräder „vor allem in Gebirgsgegenden [...] der bevorzugte Antrieb für Mühlen“ (GRIES 1999:20), gebunden an gefällereiche Gewässer des Berglandes, während im Flachland unterschlächtig angetrieben wurde (KREINER 1996:100). Gleichwohl gab es ,auch am Niederrhein oberschlächtige Mühlen, aber nur dort, wo das Geländeprofil deutlich genug vom Flachland abwich.“ (VOGT 1998:23)

Bisweilen existierten auch Mischformen der Wasserzuführung: Aufgrund besonderer Gewässerkraft wurden zum Beispiel zwei Mühlräder angetrieben. Das dem Schütz nächste Rad wurde mittelschlächtig betrieben, während beim zweiten Rad die Beaufschlagung von unten durch ein Holzgerinne erfolgte (WIEMER 1988:80).

Im Wendland wurde in einer Mühle ein schmales Wasserrad, ein sog. ,Tiroler Rad' eingebaut, mit dem es möglich war, bei hohem Gefälle geringe Wassermengen intensiv wirtschaftlich zu nutzen (LANGE 1989:95). Daneben gab es noch im 16. und 17. Jh. die sog. ,Panstermühlen', deren Wasserräder an Ketten hingen und entsprechend dem Wasserstand gehoben oder gesenkt werden konnten (HÖLSCHER 1987:11).

Floss das zur Verfügung stehende Wasser reichlich, wurden zusätzliche Gerinne gebaut, in denen noch weitere Räder nebeneinander angetrieben werden konnten. Bei einer relativ langen Gefällstrecke des Wassers konnte man mühelos drei Mühlräder hintereinander laufen lassen (BINTZER 1991:247ff.).

\section{d Elemente der Wasserzuführung}

Ausschlaggebend waren für alle Antriebsarten die zur Verfügung stehende Wassermenge und das Gefälle; von ihnen hing die Art und die Anzahl der Mühlräder, ihr Radius und die Schaufelbreite ab (BINTZER 1991:247).

Die Schwierigkeit bestand immer darin, festzustellen, wie die durch Strömungsgeschwindigkeit und nutzbare Fläche des Wassers zu bestimmende Wasserenergie in die Drehbewegung des Rades umgesetzt werden konnte. Das fließende Wasser sollte möglichst lange auf die Fläche des Rades wirken. Gerade in der 
Erfüllung dieser Forderung lag der große Vorteil der oberschlächtigen Räder, da das Wasser hier zusätzlich zu seiner Bewegungsenergie auch durch sein Gewicht wirkte.

In der praktischen Umsetzung allerdings wurden erhebliche Eingriffe in die Wasserführung erforderlich: Um Wasserräder und vor allem oberschlächtige Räder antreiben zu können, die ein größeres Gefälle voraussetzen (VOGT 1998:23), mussten Dämme, Zuleitungs- oder Mühlgräben, das Staubauwerk mit Gleitschütz für die Regulierung des Wasserzulaufs und Mühlteiche angelegt werden (WIEMER 1988:82).

\section{d.1 Grundwerk}

Das Wasserbauwerk unmittelbar an der Mühle nannte man das Grundwerk (STURM 1815:2-4). Hier wurde das Wasser nochmals gestaut, bevor es mit Gefälle auf das Mühlrad bzw. die Mühlräder geleitet wurde (KREINER 1996:119).

Es besteht aus dem Gerinne (,unteres Grundwerk'), dem Fachbaum, dem eigentlichen Stauwerk und dem Geschränk (,oberes Grundwerk')

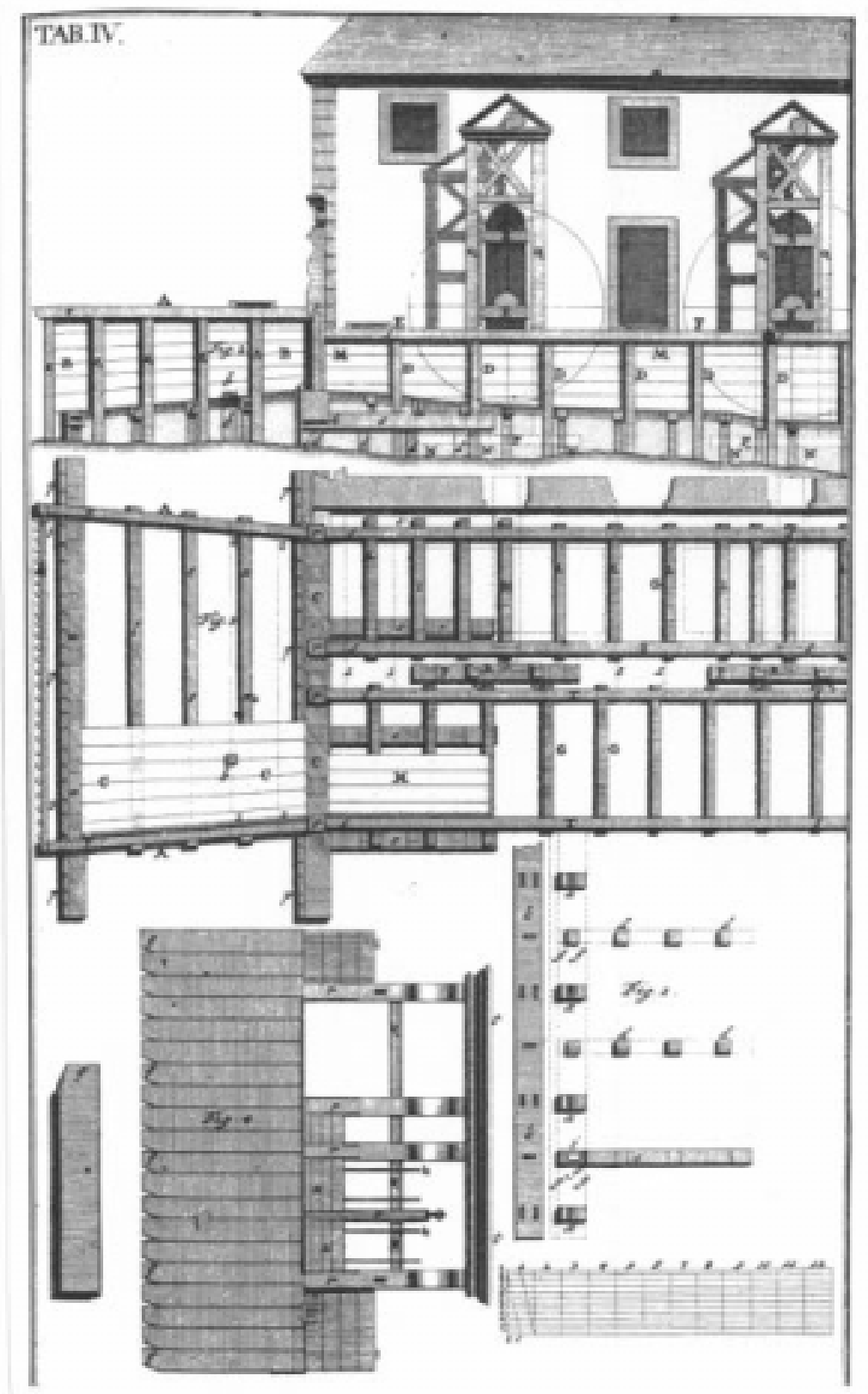


Tab. IV. der Abbildung zeigt ein an einer unterschlächtigen Mühle zu errichtendes hölzernes „Grundwerk“. Man erkennt die eingeschlagenen Pfahlreihen zur Legung des „Fachbaumes“ $(c)$ sowie die vier Reihen Pfähle („Heerd-Schwellen“ bzw. „Heerd-Pfähle“) vor dem Fachbaum (Fig. 3). Die Tiefe der Pfähle war neben dem starken Verbund (Verzapfung, Verspundung) und der Veruferung insofern von großer Bedeutung, das ,der Heerd desto besser mit Sande verschüttet oder verschlämet werden können, damit man sich des Unterwaschens und Durchbrechens destoweniger zu befahren habe." (LEUPOLD 1735:13). Auf dem Fachbaum kommt das „Grieß-Werck“ ( $r$ t, Fig. 4) mit seinen „Grieß-Säulen“ (r) zu stehen. Hinter diesen Grießsäulen werden die Pfähle ( $D$, Fig. 2) des „Mahl“- oder „Wüsten Gerinnes“ eingestossen und auf diesen die Bretter der Bodenschwellen ( $E F)$, die sog. „Wende-Bänke“ aufgelegt. Auf besagte Schwellen setzte man die „ZiehErcker" oder „Gatter-Scheiden“ ( $Q$, Fig. 2), damit die Wellen des Mahlbaumes samt ihren Wasserrädern durch Hilfe der „Ausziehe-Gatter“ ( $R$, Fig. 2), und dem dazu gehörigen „Zieh-Zeugen“, aufgezogen werden können (LEUPOLD 1735).

\section{d.1.1 Unteres Grundwerk}

Den unteren Teil des Grundwerks der Mühle, den letzten Teil der Wasserzuführung auf die Räder, bildete das Gerinne (vgl. BEDAL 1992:39), die auch als ,unteres Grundwerk' bezeichnet werden. Über das Mahlgerinne wurde das Wasser auf bzw. gegen die Schaufeln des Mühlrades geleitet. Der Bachverlauf unmittelbar vor dem Wasserrad wurde dem Gerinne in seinem Querschnitt den hydraulischen Gegebenheiten angepasst (DIX 1997:156).

Das Gerinne der unterschlächtigen Mühle bezeichnete man als ,Mühlenbett'. Es handelte sich dabei in der Regel um hölzerne, offene Wasserleitungen, deren Boden mit Brettern verschalt war (KREINER 1996:119). Dieser Grund des Mahlgerinnes war entweder der Form des Mühlrades angepasst (,gekröpftes Gerinne') oder als schiefe Ebene angelegt (KREINER 1996:119). Bei beiden Anlageformen musste oben der seitliche Abstand zwischen Mühlrad und den Wänden wenigstens $25 \mathrm{~cm}$ betragen, damit das Rad im Winter nicht so schnell festfrieren konnte. Unten musste das Gerinne dagegen möglichst schmal gehalten sein, damit nicht zuviel Wasser ungenutzt neben dem Rad verströmte (:119).

Durch Höherlegen der Zuleitung versuchte man bei oberschlägigen Mühlen zunächst die Einwirkungszeit des Wasserdrucks auf die Schaufeln zu verlängern. Das vor dem Rad gestaute Triebwasser wurde über das Gerinne, das dem Radprofil angepasst war, von oben auf das Rad geleitet und konnte so die eimer- oder becherförmigen Zellen füllen (DOBELMANN 1980:28; ERLER/MATTHIESEN 1989:80).

Die Gerinnewände bestanden aus Eichenschwellen, der Boden aus einer 2⿺辶⿸厃㔾丷-zölligen Bebohlung (BINTZER 1991:251). Die Abdämmung des zufließenden Wassers bei größeren Gerinnearbeiten ,geschah durch Pferdemist, der zwischen dicht eingerammten Pfahlreihen gestopft wurde.“ (:123) Alle Mahl- und wüsten Gerinne waren voneinander durch Pfahlwände getrennt, die beidseitig mit Brettern verschalt und oben durch einen waagerechten Balken begrenzt wurden (KREINER 1996:119).

STURM (1815:2f.) beschreibt in seinem frühen Standardwerk zur Mühlenbaukunst das „Gerinne der gemeinen deutschen Mühlen“ wie folgt (siehe Abb. VII-36): Demnach wurden in den Mühlenkanal (EFGH) „, drei, viertehalb, bis vier Fuß weit von einander, nachdem das Wasser mächtig, und das Werk groß ist, Pfähle K mit der Handramme, oder mit einer Fallramme [...] eingeschlagen, wonach sich auch die Länge der Pfähle richten muß. Nachdem diese Pfähle [...] werden Grundschwellen F und [...] über diese queer herübergehenden Balken G gelegt, auf welche hernach an beiden äußersten Enden wiederum Schwellen gelegt [...]. Endlich werden über die Balken, und beiderseits an den Wänden hinauf starke wohlgefügte und mit Werk und Theer eingestrichene Bretter geschlagen, ihre Fugen aber noch dazu mit Leisten übernagelt, so ist der Kanal fertig." 


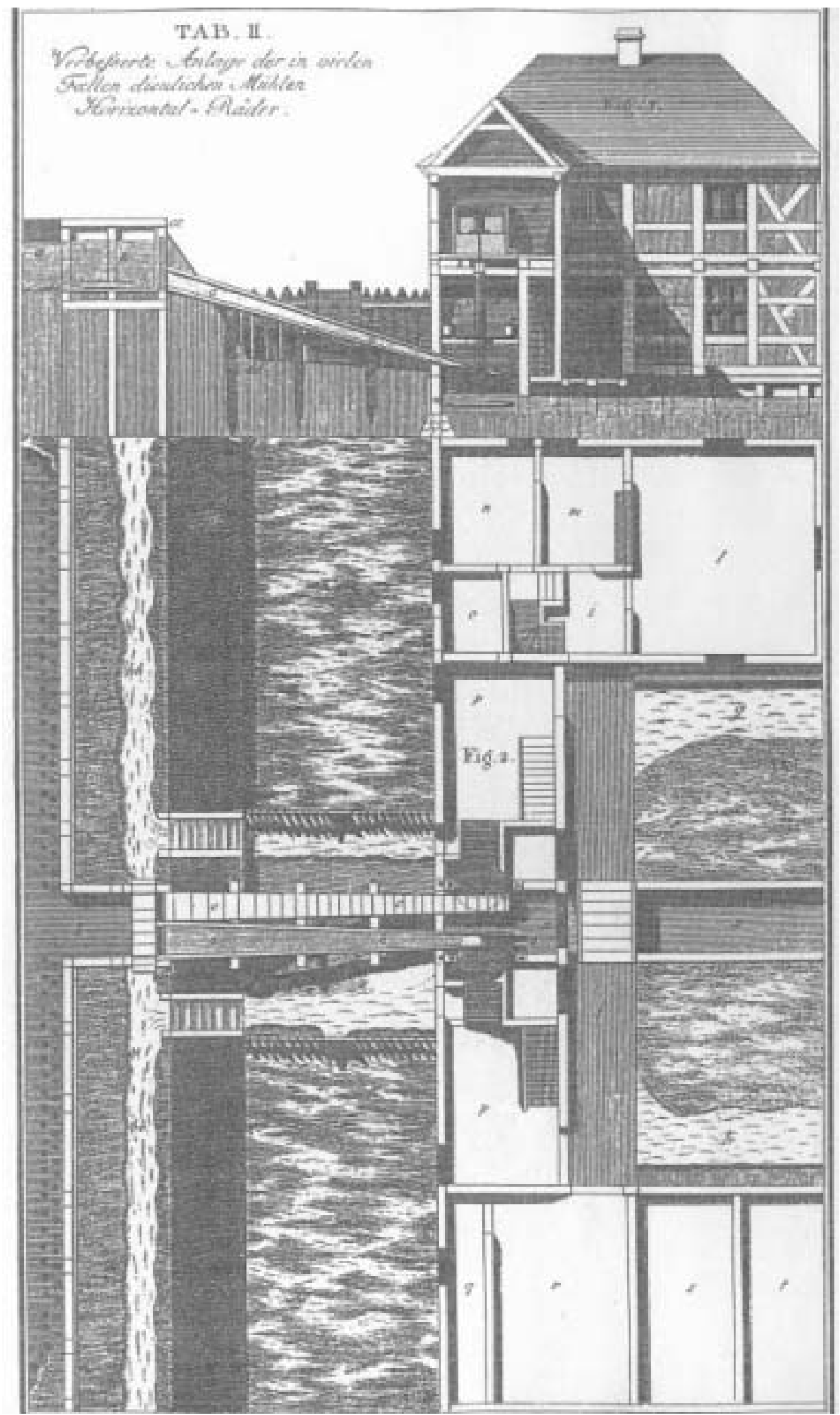

Abb. VII-36: Grundwerk „Mühlenkanal“

(aus: STURM 181)

Es handelt sich also um eine solide Zimmermannsarbeit im Wasserbau der Mühlenbaukunst, deren Schwierigkeit in der Bemessung des Gefälles lag. Schließlich sollte dem Wasser mit dem Gerinne, d. 
h. dem Grundwerk, im Sinne der Energiegewinnung zu einem höchstmöglichen Aufschlag verholfen werden. Die stabile Ausführung des unteren Grundwerks ist Beleg für die Last, die das konzentriert einlaufende Mühlwasser bewirkte und die darüber hinaus bei Hochwasser erwartet wurde.

\section{d.1.2 Fachbaum}

Vor dem Gerinne lag der Fachbaum, auch Grund- oder Spundbaum (BINTZER 1991:251), oder Weidebaum bzw. Pfahlwerksmauer (KREINER 1996:119) genannt. Der Fachbaum, ein horizontal angebrachtes Kantholz, über das sich das Wasser in das Gerinne ergoss, markierte die Mindeststauhöhe (:119).

Da im Bereich des Oberwassers der Wasserspiegel durch Wehre reguliert wurde, war für die Stauhaltung entscheidend die Höhe des im Wehr liegenden Fachbaumes, der nicht nur den höchsten möglichen Wasserstand für die Mühle markierte, sondern auch die Wasserentnahme regelte, indem er die Breite des zufließenden Wassers normierte. Von der Höhe des Wasserspiegels und der am Standort der Mühle vorhandenen Gefälledifferenz schließlich war die Leistungsfähigkeit des Rades abhängig (DIX 1997:156).

Der Fachbaum war das Wichtigste am Gerinne, und er rangiert vor dem Eichpfahl, der die Höhe des Wasserstandes anzeigte (BINTZER 1991:251). Da am gleichen Wasserlauf immer mehrere Mühlen lagen und an einem Stauwerk beteiligt waren, waren bei der Anlage von Mühlgräben und Wehre bestimmte Regeln einzuhalten. So hatte der Wasserspiegel der jeweils talwärts gelegenen Mühle mindestens eine Handbreit niedriger zu sein als der Spiegel des Unterwassers der hangwärts gebauten. Wurde nämlich die Stauhöhe zu hoch bemessen, so bestand die Gefahr, dass das Wasser dem Oberlieger unter die Räder rückgestaut wurde und dies so zu einem Stillstand des Rades führte. (KOHL 1970:132; DOBELMANN 1980:35; ROGGE 1993:20)

Darum musste für den waagerechten Einbau des Fachbaumes ein Nivellement erstellt (ROGGE 1993:20) und der Grundbaum sorgfältig mit den in den Grund getriebenen Pfählen und den daran befestigten Grundschwellen verzapft werden, da er dem Wasserdruck standhalten musste (KREINER 1996:119).

Die Anlage des Flussbettes mit Pfahlfundamentierung und Brettverschalung war erforderlich, damit das Wasser nicht direkt vom Fachbaum herabstürzte, denn dies hätte zur Auskolkung des Untergrundes und zur Unterspülung des Fachbaums geführt (KREINER 1996:119).

Die erlaubte Stauhöhe, d. h. die Festlegung, bis zu welcher Höhe die Betriebe an den Bächen das Wasser aufstauen dürfen, wurde durch das Setzen von ,Stauzielen', sog. ,Mühlenpässen' festgelegt, die zum Beispiel durch „eine an der linken Vorsetzmauer der Mühlenbrücke eingeschlagene Kerbe“ bezeichnet wurden (LANGE 1989:58).

Die Setzung einer Staumarke erfolgte im 18. und 19. Jh. mittels eines Nivelliergerätes (LANGE 1989:56). Sie erfolgte, um eine Überschwemmung der Wiesen und Unstimmigkeiten mit den oberhalb liegenden Wiesenbesitzern zu verhindern (:58). „Um eine Stauhöhe festzusetzen“, schildert ein Altmüller den Vorgang (aus: BOSSE 1991:109), „erschien 1795 ein Landbaumeister und legte das Stauziel, z. B. auf 4 Fuß $(120 \mathrm{~cm})$ vom Grundbaum aus gerechnet bis zum Wasserspiegel, fest. Zugleich wurde verabredet, daß beide Freischütten bis zur festgelegten Höhe abgestimmt und markiert werden sollten. Dazu wurden an der südlichen Seite des Flußbettes 2 Striche in den Quaderstein gehauen und angeordnet, daß der obere, mit einem weißen Strich gekennzeichnet, immer sichtbar bleiben müsse, während die untere schwarze Strichmarkierung unter der Wasseroberfläche liegen solle.“

Die bekannteste Form, die Stauhöhe vor den Wasserrädern amtlich festzulegen, war der Eichpfahl. Diese sog. Wassereiche diente dazu, die zulässige Stauhöhe eindeutig und für alle nachprüfbar anzuzeigen. Deshalb wurden Markierungspfähle beiderseits der Stauwerke geschlagen (DOBELMANN 1980:35). 


\section{d.1.3 Stauwehr}

Vor den Rinnen liegt das eigentliche Stauwerk, auch ,Grießwerk', ,Flut- oder Mühlenwehr' genannt und zuweilen auch als ,Schleuse ${ }^{, 46}$ bezeichnet. Es lagerte auf dem Fachbaum oder besaß ein eigenes Pfahlfundament. Es regelte den Abfluss des Baches und diente dazu den Wasserzulauf möglichst konstant zu halten: „Ein Wehr ist gleichsam ein im Wasser befestigter Damm von Steinen oder Holz, vermittelst dessen ein fließender Strohm aufgedämmet, daß er höher und tieffer wird, und seinen Lauff durch einen dabey gemachten Graben, nach einer Neben-Gegend nehmen muß.“ (LEUPOLD 1735:16).

Die Abzweigung des Zulaufs mit einem Wehr, gerade bei oberschlächtigen Mühlen, geschah oft kilometerweit aufwärts von der Mühle:

Zur Regulierung des Wasserabflusses wurden bei den Stauwehren zwei Konstruktionen verwendet:

\section{1. Überfall- bzw. Überlaufwehr}

2. Schützen- bzw. Aufziehwehr

Da die Wasserräder für den Antrieb von Mühlen in der Regel sog. ,Kropfräder' waren, deren Wellen fest gelagert sind und somit nicht dem jeweiligen Wasserstand angepasst werden konnten, musste das zufließende Wasser durch ein Wehr geregelt werden (KOHL 1970:7).

Wurde der Mühlenkanal durch ein festes, unbewegliches Überfallwehr vom Fluss oder Bach abgeleitet, so lief das überschüssige Wasser nach Überschreiten einer bestimmten Höhe ständig ab (DOBELMANN 1980:27). Die Wehre wurden so anlegt, „daß alles übrige Wasser über dieselben hinweg schiessen kann.“ (LEUPOLD 1735:16) Das Überfallwehr taucht in der Literatur auch einfach als ,Wehr' oder ,Damm' auf.

Das feste Wehr bei Neuss-Selikum zum Beispiel, durch das die künstliche Obererft von der Erft abzweigt, wurde seit ältester Zeit auch „Ark“ genannt (KREINER 1996:116). Allgemein findet hinsichtlich der geographischen Verbreitung in der alten Mühlenbauliteratur die Aussage, ÜberfallWehre „lassen sich bey bergigen Landen, oder wo das Wasser in hohen Ufern gehet, am füglichsten anbringen“ (LEUPOLD 1735:17). Man findet sie ,auch bey manchen Mühlen im flachen Lande“, vornehmlich dann, ,wenn der untere Nachbar dem oberen das Wasser zu hoch hält, oder in die Wasser-Räder treiben will, so wird es durch diese Wehre verhindert, weil es seinen Abfall über dieselbigen nehmen kann.“(:17)

Für die Konstruktion eines Überfallwehres wurden quer durch den Fluss eine Doppelreihe oder mehrere Reihen Holzpfähle in den Grund gerammt. Sie bildeten das Grundgerüst des Wehres, dessen Zwischenraum mit Erde, Buschwerk (Faschinen) und Bruchsteinen ausgefüllt wurde. Die Krone des Wehrs wurde meist mit Steinplatten abgedeckt. Neuere Wehre, beginnend im 18. Jahrhundert wurden zuweilen vollständig aus Stein neu aufgebaut (DOBELMANN 1980:27; TÖNSMANN 1985; DIX 1997:154).

Für steinerne Wehre, wie in Abb. VII-37 skizziert, wurde auf die eingeschlagenen Fundamentpfähle ein gezimmertes „Rost“ gelegt und „mit Nägeln und Klammern befestigt“ (LEUPOLD 1735:18). Dieses wurde mit „Wack oder Kießling“ (Grauwacken und Kieselsteinen) ausgeschlagen oder mit Branntziegeln ausgefüllt, um die Last des Mauerwerks zu tragen. Hinter die Mauern wurde „beste lettige Erde geschüttet, und wohl ausgestossen [...], damit die Mauer trocken bleibet, und die Wasser nicht mehr dahinter kommen“ (:18). Die Lettenerde wurde mit Brettern umschlossen, damit „das Wasser in den Letten nicht auslecken möge“ (:18). Zwischen die Fugen wurden allseits „Gemösse gestopffet“ und die Steinfugen zusätzlich mit ,guten Stein-Kitt ausgestrichen“, damit „,das Wasser

\footnotetext{
${ }^{46}$ Diese Bezeichnung hatte aber keinen Bezug zur Schifffahrt, weil die meisten kleinen Flüsse nicht schiffbar waren. Der Begriff ,Schleuse“ leitet sich vom mittellateinischen Wort ,sclusa' (,exclusa') her, einer Bildung zum lateinischen Verb excludere (=ausschließen, absondern, abhalten) (KREINER 1996:119).
} 
nicht darzwischen heraus rinne.“ (:18) Schließlich wurde der oberste Teil des Wehres (A), der „Sattel“ genannt, aufgesetzt.

Alle Wehre, ob aus Holz oder Stein, wurde ,gar spitzig und scharff gemacht [...], damit man nicht leichtlich hinüber kommen kann.“ (LEUPOLD 1735:18)

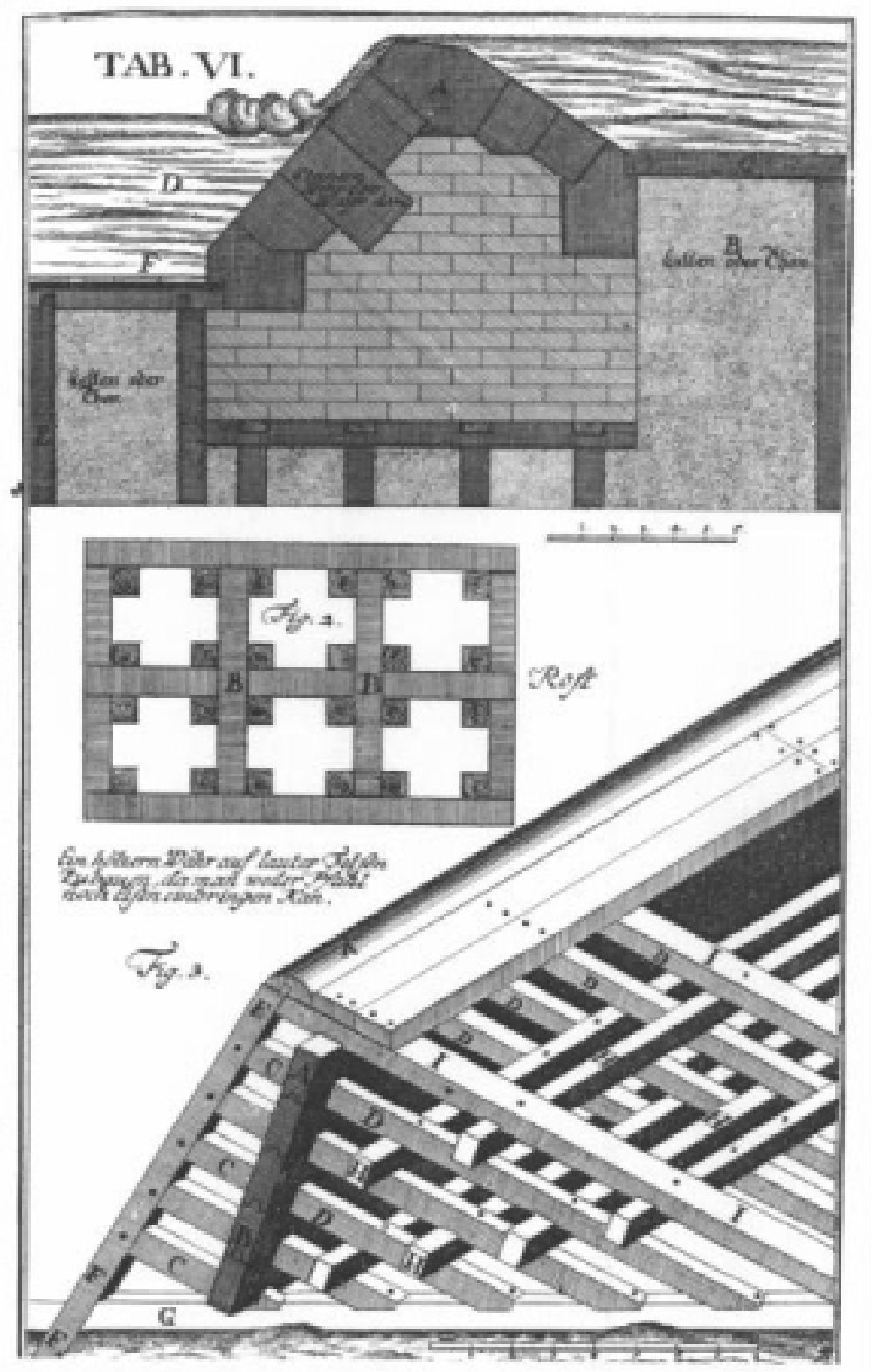

Abb. VII-37: „Steinernes Wehr“

(aus: LEUPOLD 1735:18)

Das Aufziehwehr (vgl. Abb. III-4) besteht aus einem „Heerd“ und einem „Fluth-Bette“. Der Heerd wurde auf die gleiche Art hergestellt wie beim Grundwerk. Hinter den Heerd kommt das „FluthBette“. Dieses wird länger gemacht, damit das herabschießende Wasser nicht gleich am Fachbaum niederfällt und sowohl den Fachbaum selbst als auch die Heerd-Pfähle unterwäscht, sondern seinen Abschuss bei $i$ über das Fluth-Bette nehmen muss. Auf den Fachbaum kommt das das „Grieß-Werck“ zu stehen (LEUPOLD 1735:16).

Aufzieh-Wehre ,findet man gemeiniglich an Oertern, wo das Land niedrig, und die Flüsse wenig Gefälle haben “ (LEUPOLD 1735:16). Die Begründung dafür ist, dass

„,man auf solchem Erdreich flüssende Wässer gemeiniglich so spannet oder dämmet, daß sie bey nahe dem Ufern des Landes gleich zu stehen kommen; damit nun bey 
anwachsenden Wassern das daran liegende Land, als Felder, Wiesen, Hölzer, und dergleichen, nicht so leicht überschwemmet und ersäuffet werden können, so bauet man ein dergleichen Wehr, welches auch gar gute Dienste thut, maßen man den Fach-Baum desselbigen so tieff zu legen pfleget, als des Flusses Grund oder untere Fläche ist, so hoch nun der Fluß aufgedämmet werden kann, [...], so hoch müssen die Schutz-Breter gemachet, und auf den Fach-Baum gesetzet seyn; diese können denn nach Proportion des anwachsenden Wassers, wenig und viel, nachdem sich der Fluß geschwinde oder langsam ergiesset, aufgezogen werden, wodurch der Fluß so lange in seinen Ufern erhalten wird, bis endlich das Wasser sich so ergiesset, daß es auch das Land überschwemmen würde, wenn gleich kein Wehr oder Mühle allda wäre. “

Waren die Stauwehre als Aufziehwehre mit beweglichen Schützen konstruiert, besaßen die Schützenwehre gegenüber den Überfallwehren den Vorteil, dass man das Wasser bis zur Uferkante aufstauen konnte. Die äußeren Schützen regulierten den Wasserzufluss zu den Mahlgerinnen, die anderen waren Freischützen, die den Wasserstand des Flusses regulierten. Bei Hochwasser aber konnte durch das Öffnen der Freischützen eine vorzeitige Überschwemmung vermieden werden (KREINER 1996:119). Die Funktion eines solchen Wehres bestand also darin, „daß man bey Eißfahrten und grossen Wassern die davor stehenden Schutz-Breter ziehen, und dem Eiß und Wasser Lufft machen kann, daß es dadurch seinen behörigen Laufff nehmen könne.“ (LEUPOLD 1735:15) Reichte hingegen bei einem Überfallwehr das Wasser in kritischen Zeiten zum Betreiben aller Mühlen nicht aus, so musste dieses zusätzlich erhöht werden (BINTZER 1991:249).

Die senkrechten Wehrsäulen wurden oben durch einen Balken (den Spannrahmen) abgeschlossen. Diese Schwelle der Schütze, über die das Wasser in die Rinnen gelangt, ist der Haarbaum bzw. Schüttbalken, der ähnlich wie der Grundbaum bzw. Fachbaum, beim Wehr die Absturzhöhe der Mühle regelt. Unten bestanden die Schützsäulen aus einer mit Falzen versehenen Führung, zwischen denen die verschiebbaren Schützbretter bzw. Holztafeln vertikal über Hebel oder Ketten auf und nieder gezogen werden konnten (BEDAL 1992:39). Oberhalb des Stauwerks verlief ein schmaler Steg (Brücke), von dem aus der Müller oder Schleusenwärter die Schützen bedienen konnte (KREINER 1996:119).

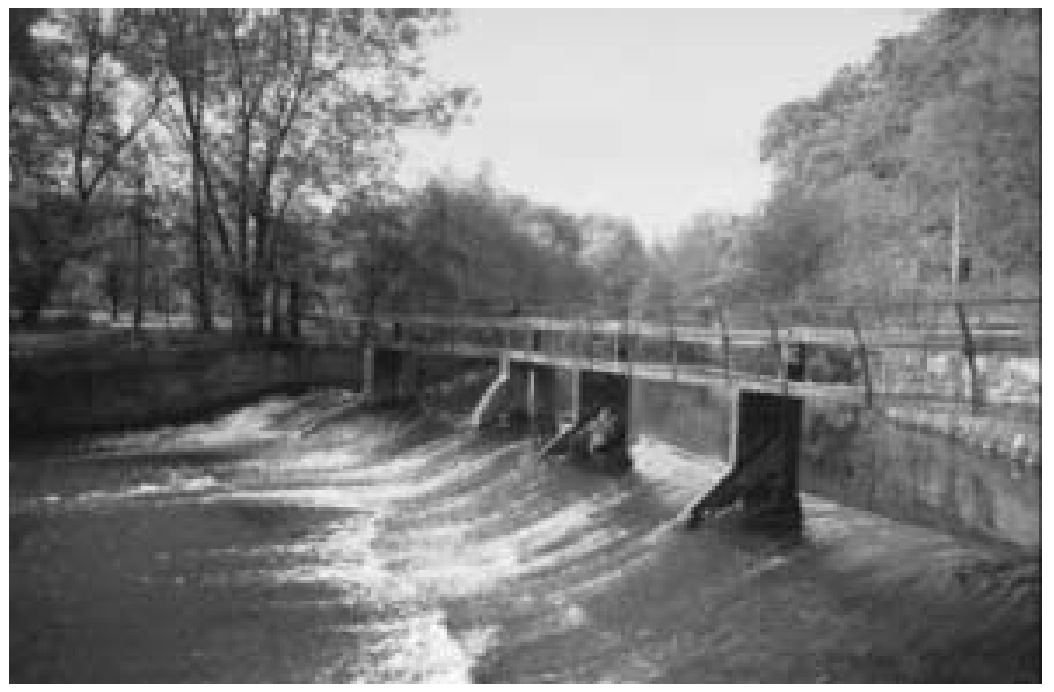

Abb. VII-38: Aufziehwehr der Ellemühle in Nordhausen mit Steg (eig. Aufnahme 2004)

Durch die Schützen, auch Schütte, Schutt, Schott oder Erken genannt, ließ sich zum einen die Menge des Wassers, die auf das Wasserrad auftrat, regulieren, zum anderen konnte mit ihrer Hilfe das Wasser für die Räder aber auch gänzlich abgesperrt werden (SCHEFFLER 1982:44; BINTZER 1991:251; BEDAL 1992:39; DIX 1997:162f.). Es waren also eine oder mehrere Schützen erforderlich, die geöffnet werden mussten, wenn das Mühlrad stillstehen oder überschüssiges Wasser abgeführt werden sollte (KREINER 1996:119). Vor dem Einlauf war zudem ein Rechen angebracht, der grobe Verunreinigungen wie Holz auffing (DIX 1997:86). 
Nach STURM (1815:2f.) ergibt sich folgende Bauweise zur Errichtung eines Schützenwehres:

„So wird nun erstlich bei dem Schutz, oder bei der Schütte, wo das Wasser auf die Mühle abgelassen wird, eine lange Reihe Spundpfähle [...] bis eine Strecke in beide Ufer hinein geschlagen, welches geschiehet um die erste vest zu halten, daß sie nicht weichen, und das Wasser nicht durchbrechen könne, daher es andere lieber bei [...] haben wollen, weil daselbst der Druck des Wassers am stärksten ist. Hinter den Spundpfählen [...] welche 7 bis 8 Zoll dicke; 15 bis 16 Zoll ungefehr breit seyn müssen, je breiter, je besser, werden starke Pfähle [...] eingeschlagen, die so weit oben heraus stehen, daß die Schutzbretter in Falzen dazwischen können auf- und niedergezogen werden, die Spundpfähle aber werden abgeschnitten, daß oben längs darüber ein starkes Holz gelegt werden kann, welches zugleich zwischen die Pfähle [...] mit verbunden wird, und mit seiner Oberfläche accurat dem Grunde des Kanals gleichkommt."

Bis hierhin lässt der Ablauf einer Wasserbeaufschlagung wie folgt zusammenfassen: Das Antriebswasser der Mühlen strömte also an den Stauanlagen (Wehre) vorbei, über sie hinweg oder durch sie hindurch, floss durch ein Grundwerk bzw. Gerinne und über den ,Schüttbalken' in das Wasserrad (DOBELMANN 1980:27).

\section{d.1.4 Oberes Grundwerk}

Oberhalb des Fachbaums, im sog. Heerd oder Kanal mussten mehrere Reihen Pfähle senkrecht in den Grund gerammt werden. Sie bildeten das Fundament für die Heerd- bzw. Kanalschwellen (KREINER 1996:119). So wurde der Grund oberhalb des Stauwerks gesichert und dessen Unterspülung verhindert.

Die Ufer (Lehrwände) wurden durch eine Reihe weiterer senkrechter Pfähle gesichert, und mit Brettern verschalt. Zusätzlich wurden noch Heerd- oder Spundwände waagerecht in das Ufer vorgetrieben, um dessen Stabilität zu erhöhen.

Das so entstandene „Geschränk“, das in seiner baulichen Gesamtheit hinsichtlich seiner Anordnung als ,oberes Grundwerk' bezeichnet wird, wurde plan mit Ton, Lehm, Moos oder Steinen aufgefüllt und abschließend mit Brettern gedeckt. Die Art der Fundamentierung des oberen Grundwerks im Heerd entsprach im Prinzip derjenigen des Gerinnes (KREINER 1996:119).

Das eigentliche Geschränk des Grundwerks musste, vor allem bei schlechtem Baugrund, sehr sorgfältig ausgeführt werden. War der Bau mangelhaft, d. h. undicht oder instabil, konnten das Grundwerk und das Mühlengebäude, selbst bei ziemlich kleinen Gewässern, schnell unterspült werden (KREINER 1996:119).

\section{d.2 Mühlenkanal}

Im Allgemeinen ist die Mühle nicht direkt am natürlichen Wasserlauf gelegen; nur in seltenen Fällen und dann auch nur am gefällearmen Unterlauf der Bäche - wurde das Rad direkt in den Bach gehängt (siehe Pkt. b).

Die meisten Wassermühlen bezogen ihr Betriebswasser über einen eigens zu diesem Zweck angelegten abgezweigten Kanal, der als Mühlen- oder Werkkanal oder auch als Oberwasser bzw. am bekanntesten als ,Mühlenbach' bezeichnet wurde (bei dem es sich aber trotz dieser am häufigsten kolportierten Bezeichnung (,,-bach“) um ein künstliches Gebilde handelt) und es über einen weiteren künstlichen Wasserarm - als Unterwasser (siehe unten) - auch wieder abgibt (BEDAL 1992:38). Die Ausführung eines solchen - im eigentlichen Entstehungssinne - „Mühlgrabens" ist der modellhaften Konstruktionszeichnung von LEUPOLD (1735:9) zu entnehmen: 


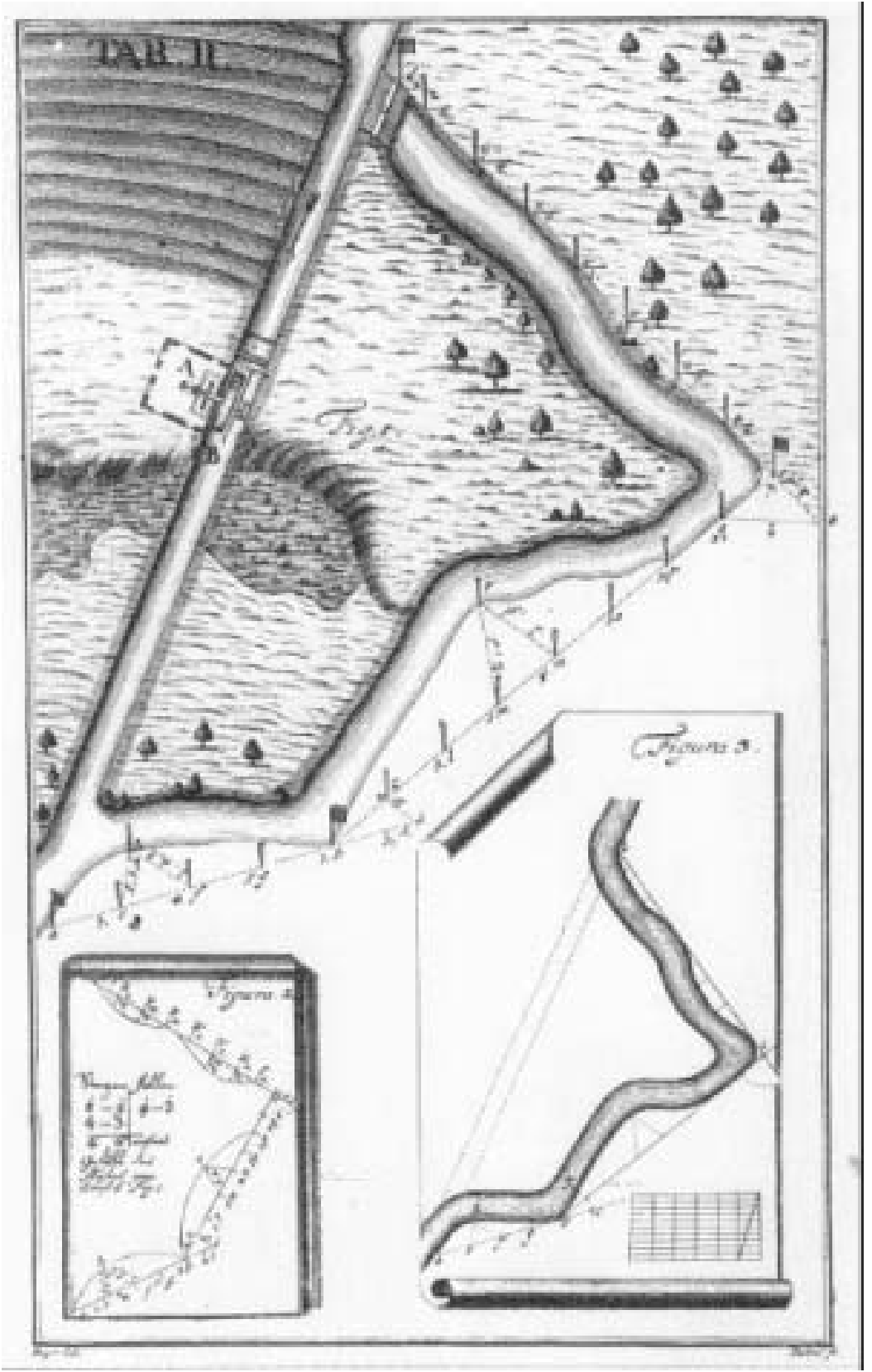

Abb. VII-39: Mühlenkanal

Tab.II aus LEUPOLDS Werk ,stellet die Ableitung eines Mühl-Grabens von seinem Haupt-Flusse vor, und wie dessen Krümmen und Biegungen auszumessen seyn.“ (LEUPOLD 1735:9)

Zur Länge solcher Mühlgräben führt LEUPOLD (1735:8) zur Begründung an, dass sich solche Gräben, wie sie in Tab. II, Fig. 1 und 3 von a -d dargestellt sind, ,zuweilen ganze, je wohl 2, 3 Meilen lang führen, da denn manches mahl viel Mühlen an eine solchen Graben befindlich, so alle von einem Wehre mahlen."

Es soll nicht Aufgabe sein, die verschiedenen Messvorgänge wiederzugeben, die LEUPOLD in seiner Anleitung zum Wassermühlenbau zur Anlage eines Mühlgrabens eingehend beschreibt. Hervorzuheben aber ist, dass auf der vermessungstechnischen Grundlage eines Feldrisses das Areal mit Richtschnur und „Meß-Fahnen“ abgesteckt und mittels Zirkel die Winkel in eine Reinzeichnung übertragen werden sollten: Die „Krümme“ wurde ausgemessen und „zu Papiere gebracht“, wie LEUPOLD (1735:8) den Vorgang ausdrückt.

Die vergleichende Auswertung der modernen topographischen Karten und der historischen Katasterkarten zeigt, dass die Mühlkanäle über weite Strecken isohypsenparallel so am Hang entlang laufen, dass ein optimal nutzbares Gefälle für den Mühlenbetrieb erzielt wurde (KREINER 1996:205). 
Diese Verlaufs- und Anlageform eines Mühlgrabens garantierte nicht nur gleich bleibende Fallhöhe, sondern bot auch Schutz vor Hochwasser, Eisgang und Geschiebe (ERLER/MATTHIESEN 1989:86) und gewährleistete einen ausreichenden und auch schnellen Wasserzufluss (LAMPEN 2000:132). So wurde dem Gefälle bzw. der Fließgeschwindigkeit große Bedeutung beigemessen, „denn ein schneller Graben kan sich nicht so leicht von Eiß schützen, als einer der sehr langsam fließet.“ (LEUPOLD 1735:8). Deshalb bedurfte es der Anlage spezieller Wasserkanäle für die Zuleitung des Wassers über die Gerinne auf die hölzernen Antriebsräder. Das Kloster Corbie beispielsweise besaß bereits um 800 einen Wasserkanal, ,an dem die Mahlwerke des Klosters hintereinandergereiht lagen.“ (LAMPEN 2000:132)

Diese vom natürlichen Flusslauf abgezweigten und oft über lange Strecken parallel zum eigentlichen Bach geführten Mühl- und Hammergräben sind im Gelände noch recht gut erhalten und zum Teil auch noch, entweder bei gezogener Schütze, Hochwasser oder in regenreichen Zeiten zumindest periodisch mit Wasser gefüllt, wie das Beispiel des Nordhäuser Mühlbaches zeigt.

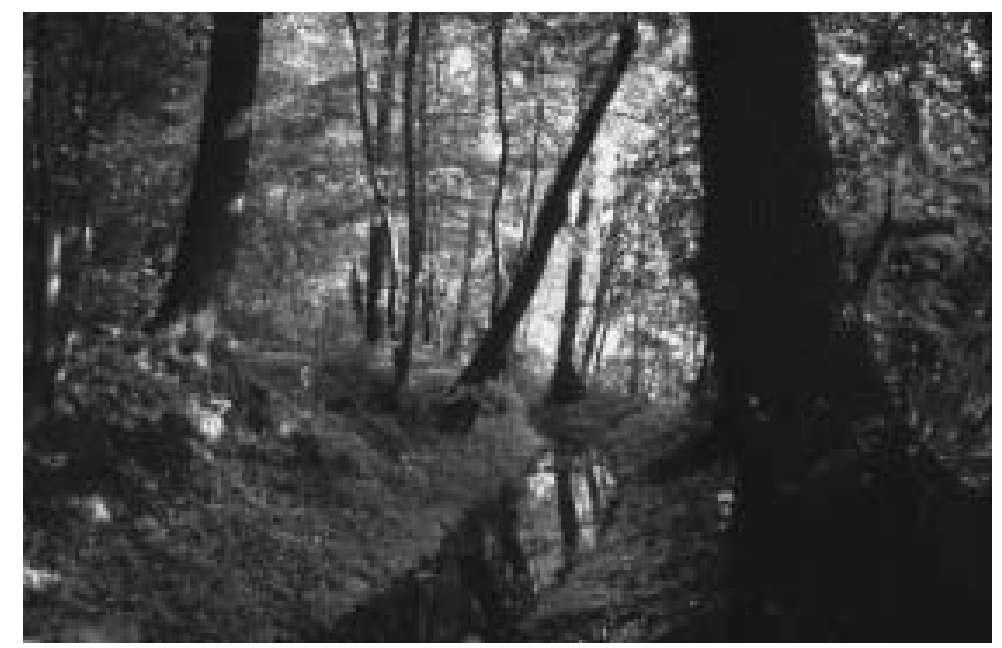

Abb. VII-40: Nordhäuser Mühlenkanal

Reliktärer, nur noch in Teilen vorhandener mittelalterlicher Mühlenkanal als Ableitung von der Zorge und zur Zuführung des Antriebswassers zu den Nordhäuser Stadtmühlen (eig. Aufnahme 1997)

Eine andere Art, das benötigte Wasser zuzuführen, um ein größeres Gefälle zum Betrieb eines oberschlächtigen Mühlrades zu erzielen, bestand darin, das Wasser über gemauerte Arkaden von einem oberhalb der Mühle liegenden Gelände auf die Mühlräder zu führen. So wurden die letzten 100 $\mathrm{m}$ des neuen Mühlgrabens der Uhlstädter Mühle am Uhlsbach im 18. Jahrhundert als steinernes Gerinne, in Form eines römischen Aquäduktes, ausgebaut. Später wurden die steinernen Bögen aus Stabilitätsgründen, bis auf einen, zugemauert. Dieses Mühlenaquaedukt ist „eines der wenigen noch funktionsfähigen Zeugnisse deutscher Wasserbaukunst in Thüringen“" (ROGGE 1993:28). Ein anderes Beispiel nennt OPEL (1991:13) vom Rohrbach aus Schwetzingen, bei dem eine auf Arkaden verlaufende Tonröhrenleitung von Mühle zu Mühle führte und insgesamt so sechs Mühlen mit hohem Aufschlagwasser versorgte. Anstelle eines gemauerten Mühlenaquäduktes wurde das Wasser auch auf gestelzten Holzrinnen der (oberschlächtigen) Mühle zugeleitet. Zumeist hingegen war jedoch auch „höchstens die letzte Strecke des Mühlbaches auf Stelzen schwebend mit Holzrinnen versehen“ (BEDAL 1992:39).

Doch bleibt diese Konstruktion, die entgegen BEDALS Ansicht (1992:39) nicht „nur in gefälle- und wasserreichen Gebirgslandschaften [...] anstelle eines eigenen Mühlkanals und Mühlweihers“ errichtet wurde, sondern auch im norddeutschen Tiefland Verwendung fand, eine Ausnahmeerscheinung. 


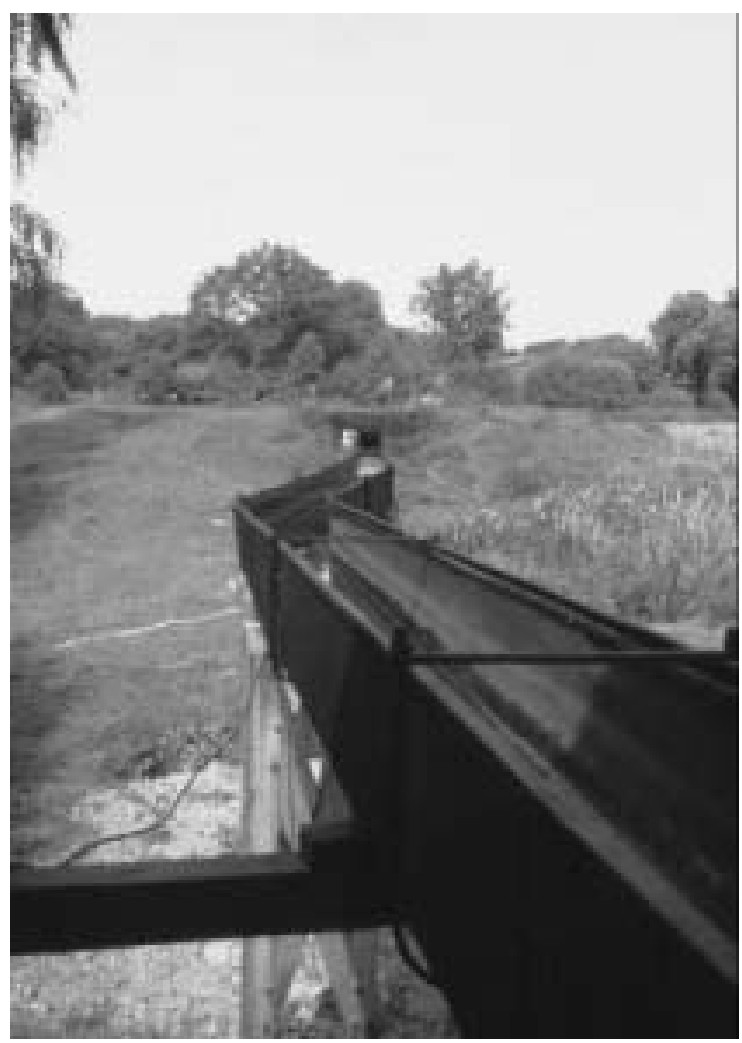

Abb. VII-41: Stelzenkanal der Wassermühle Ruschkamp (am Ruschkamp) in Scharmbeckstotel nördlich von Bremen. Im Hintergrund der hoch aufgedämmte „Mühlenteich“, der von vier Quellen gespeist wird (eig. Aufnahme 1995).

\section{e Elemente der Wasserabführung}

\section{e.1 Freikanal}

Um die Mühlengebäude gegen Hochwasser besser abzuschirmen, legte man vielfach Wasserableitungen, sog. Umfluten, an, die das Zuviel an Wasser um die Mühlenanlagen führten (DOBELMANN 1980:27).

Diese am Anfang des Mühlengerinnes abzweigende ,Schuss- bzw. Freirinne', auch ,Ablass' genannt, ist von den Rinnen, die dem Wasserzulauf dienen, zu unterscheiden. Hierbei handelt es um einen parallel zu dem Bachufer bzw. Mühlkanal angelegten Nebenkanal, der zur Abführung der nicht benötigten Wassermenge diente und das Wasser an den Rädern vorbeileitet (KOHL 1970:7; BEDAL 1992:40).

Zur Konstruktion dieses Wasserableitungsgrabens gehört neben dem eigentlichen linearen ,Freigerinne' die sog. ,Freischütze' bzw. ,Freischleuse' - eine handbetriebene Schütze, die hoch und nieder gewunden werden kann (SCHEFFLER 1982:44). Das in dem Mühlkanal zufließende überschüssige ,Freiwasser' konnte durch dieses Schott reguliert werden: Es wurde in das „wüste Gerinne“, den sog. Frei- bzw. Freilaufkanal, abgeleitet (KREINER 1996:119; DIX 1997:156).

Dieser ,Leerschuss', Wasser bei Stillstand der Mühle vorbeizuführen, war insbesondere bei Hochwasser und anfallenden Reparatur- und Wartungsarbeiten notwendig (SCHEFFLER 1982:44; BEDAL 1992:40). War das Wehrschütz geschlossen oder kam zuviel Wasser an, konnte die Umflutschleuse geöffnet und das Wasser über das Freigerinne abfließen.

An seiner Stelle kann aber auch ein eigener Überlauf weiter aufwärts am Oberwasser - vor dem Aufstau - eingerichtet sein (BEDAL 1992:40). 


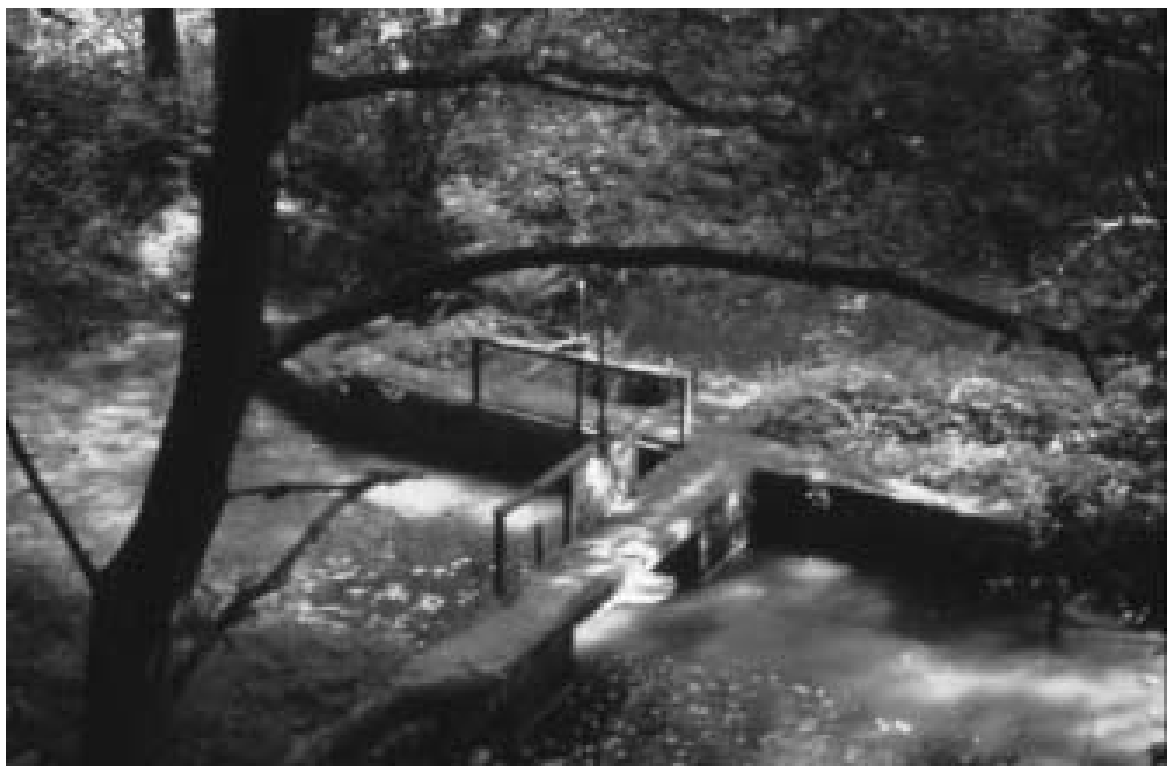

Abb. VII-42: Umflutschleuse am Itterbach (eig. Aufnahme 2001)

\section{e.2 Unterwasser}

Man muss sich vergegenwärtigen, dass technisch bedingt das Rad einer Mühle jener Punkt ist, an dem die regulierte Wasserführung ihr Optimum durch Beschleunigung des Bachs oder durch die erzielte Fallhöhe erreichen muss. Weiter bachabwärts spielen diese Dinge praktisch keine Rolle mehr. Aus diesem Grund werden Mühlbach und Abschlaggraben, die bis zum Rad getrennt geführt wurden, normalerweise wenige Meter unterhalb der Mühle wieder vereint. Das nach der Drehung des Rades frei gegebene Antriebswasser wurde an das „Unterwasser“ abgegeben und vereinigte sich dort mit dem Überschusswasser aus dem Freigerinne (WIEMER 1988:80). Eine weitere Getrenntführung des Wassers hätte keinen erkennbaren Nutzen mehr, sondern lediglich einen erhöhten Erhaltungsaufwand für die Wasserbauten zur Folge (GRIES 1999:117).

Wird ein Mühlbach aber auch noch unterhalb der Mühle über eine Distanz von z. B. $200 \mathrm{~m}$ getrennt vom Abschlaggraben geführt, so kann dieser technische Mehraufwand nur dann sinnvoll sein, wenn außer der betrachteten Mühle noch eine weitere Mühle von der Wasserführung des Mühlkanals abhängig war.

Unterhalb von Stauwerk und Mühlrad lag als schiefe Ebene ein aus Balken oder Steinen errichtetes Flussbett, das eine Unterspülung der Stauanlage verhindern sollte und in eine Flutmulde auslief, die das Wasser aufnahm (DOBELMANN 1980:28).

\section{f Stauanlagen}

Um das Wasser an die Mühle und auf die Räder zu leiten, vor allem aber um eine ausreichende und kontinuierliche Wassermenge für den Betrieb zu erreichen, waren umfangreiche Wasserbauarbeiten vor der Mühle erforderlich.

Da in der Ebene im Allgemeinen die Strömung der natürlichen Wasserläufe zu gering war, um das Wasserrad in Schwung zu setzen, legte man Stauanlagen an, die sich oft kilometerlang erstrecken konnten oder als Reservebecken (Mühlteiche) ausgeprägt waren.

Aber auch in anderen, für einen Mühlenbetrieb vorteilhafteren geographischen Lagen benötigte vor allem der Mahlmüller für eine geregelte Kapazitätsausnutzung große und ausgeglichene Wasserreserven, besonders ab August, wenn nach der Getreideernte ein erhöhter Mahlbedarf einsetzte. 
Die für eine gesicherte Antriebsenergie bei Wassermühlen so wichtigen Gewässerstauungen geschahen je nach Landesnatur, d. h. der vorhandenen Wassermenge, der natürlichen Fließgeschwindigkeit und der anthropogenen Eingriffe, zur Erhöhung dieser und nach Anzahl der Mühlen an einem Bachlauf (Mühlendichte) auf unterschiedliche Art und Weise:

1. durch Stau der Mühlbäche oder/und

2. durch Anlage eines Sammelbeckens.

Die verschwommene Begrifflichkeit des Mühlenstaues und der Mühlenteiche hingegen verlangt nach einer Klärung.

\section{f. 1 Mühlenstau}

Diejenigen Flüsse mit guter Wasserreserve ersparten den Müllern die Sorge um den Energievor- und -nachschub. Hier wirkte die jeweilige Flussstrecke zum einen ,als Auffang, damit der Schuß des Wassers seinem Mühlengebäude nicht schade”, wie BOSSE (1991:50) aus einem alten Amtsprotokoll zitiert. Zum anderen diente die Hemmung des Flusslaufes dem Ausgleich jahreszeitlicher Wasserstandsschwankungen. Trockene Sommer hingegen erwiesen sich dann als besonders kritisch, wenn der Wasserfluss zum Antrieb des Mühlrades nicht mehr ausreichte. Um dem Mangel vorzubeugen, baute der Müller Schleusen, Wehre und Dämme, weil sie für eine gesicherte Wasserbevorratung unentbehrlich waren (:52).

Des Weiteren diente das Aufstauen des Wassers dazu, den Wasserdruck und damit die verfügbare Energie zu steigern. Außerdem kann durch Veränderung der das Rad antreibenden Wassermenge die Geschwindigkeit der umlaufenden Mühlsteine geregelt werden (KOHL 1970:7). Insbesondere, um das Wasser auch für oberschlächtige Räder nutzen zu können, wurde der Mühlbach hoch angestaut (SCHRÖDER 1978:8; LORENZ 2000:32).

In diesen Fällen wirkte die jeweilige Flussstrecke als Staubecken. Der Wasserzulauf wurde lang gehalten, damit das Wasser möglichst weit zurück gestaut werden konnte: „Unmittelbar oberhalb einer Mühle konnte sich der Mühlenkanal zu einem Mühlenteich (Kolk) weiten, der die Funktion eines Wasserrückhaltebeckens erfüllte", schreibt KREINER (1996:116). In gleicher Hinsicht formuliert BEDAL (1992:38): „Der meist nahezu gefällose, als Stauhaltung wirkende Mühlbach, kann sich vor der Mühle selbst zum Mühlweiher ausweiten. Das ist vor allem dann nötig, wenn die zufließende Wassermenge für den Mühlbetrieb nicht ausreicht, so daß sich im Mühlweiher erst genügend Wasser ansammeln muß.“

Es gilt also grundlegend zu unterscheiden zwischen einem Kanalstau, der durchaus zwar MühlweiherCharakter, d. h. vor allem Stillwassercharakter, besitzen mag, und einem echten Mühlenteich: zum einen durch die Physiognomie: Ein Staukanal hat einen gleichmäßigen, linearen, länglichen Verlauf, der durch das Zuleitungs- und Stauwehr abgeschlossen ist und durch den das Antriebswasser direkt zufließt; zum anderen in der Funktionalität: Mit Hilfe eines Mühlenstaus wird das Gefälle gewissermaßen von Wassermühle zu Wassermühle aufgeteilt, um das zum Antrieb erforderliche Wasser zu sammeln (SCHEFFLER 1982:44f.; LANGE 1989:54).

Um genügend Wasser ansammeln und dieses auch mit einer dementsprechenden Aufschlagskraft dem Wasserrad zuführen zu können fand eine Aufdämmung des Flusses bzw. des Mühlkanals statt. Denn bei einer normalen Ableitung fände man ,nicht einmahl so viel Gefälle [...], als zu einer Mühle erfordert wird“" (LEUPOLD 1735:8). Um dieses zu erhöhen, begründet er den Flussstau, „,muß man in diesem Falle, wann es wegen der am Fluß Liegenden unbeschadet geschehen kann, das Wasser aufdämmen."(:8).

Ein ,echter' Mühlenteich hingegen hat eine andersartige Aufdammung, die in der Regel der Morphologie eines Geländes angepasst erscheint: ungleichmäßiger, mit der Tendenz zu einer eher rundlich-ovalen Form. Die Wasserzuführung aus dem Mühlenteich besitzt des Weiteren in der Regel nur Ergänzungsfunktion für den Mühlradantrieb. Das Stauwasser wird dem Hauptgerinne, dem 
Mühlenkanal, bei Bedarf, d. h. bei Wassermangel, durch eine separate Zuleitung zugeführt. Teichschützen ergänzen die Wehranlage und regulieren mit ihrem seitlichen Zufluss die dem Wasserrad zugeführte Wassermenge, wenn der Wasserfluss zum Antrieb des Mühlrades nicht mehr ausreichte. Der bespannte Mühlenteich ist also eine eingedeichte Ergänzungsanlage, während der gestaute Mühlenbach einen künstlichen Abzweig aus dem Fließgewässer darstellt. Der Mühlenteich im Verständnis nach BEDAL und nach KREINER ist dementsprechend nichts weiter als ein aufgestauter Mühlbach.

Die historische Darstellung, die DIX (1997:143) aus alten Quellen des Stadtarchivs Euskirchen wiedergegeben hat, mag die Erklärung dafür liefern, warum hier eine Fehlinterpretation von Mühlenfachleuten vorliegt: „Die Mühlenbäche waren um die Mitte des 19. Jh. in einem so verwilderten Zustand, ein solcher Graben war manchmal weit, bald verengt er sich, die Ufer waren oft einhängend mit Gesträuch und Baumwurzeln so verwachsen, „vor mehreren Mühlen sind sie sogar beträchtlich erweitert, so daß sie als Sammelteiche betrachtet werden können, aus denen die betreffenden Mühlen gespeist werden können."

Zusammenfassend ist ein Mühlenteich in einer übergeordneten Systematik als Wassersammelanlage zu bezeichnen, während es sich bei einem Mühlgraben um einen Wasserstau handelt. Nur der Wassersammelteich für Wassertriebwerke kann als wahrer ,Mühlteich' angesprochen werden.

Die Unterscheidung ist auch hinsichtlich der Auswirkungen von Bedeutung: Ein zu hoher Stau konnte sich bis zum Unterwasser der nächst höher gelegenen Mühle auswirken und ihre Absturzhöhe und damit ihre Leistung mindern, konnte aber auch Wiesen überschwemmen und damit deren Nutzung einschränken. Ein Mühlenteich hingegen vermochte diese Gefahr durch sein zusätzliches Wasserreservoir zu verhindern bzw. zu mildern.

Nur in einer Weise glichen Mühlenstau und Mühlenteich einander - in der Zielsetzung. Bei geringer Wasserführung konnte entweder der Wasserzufluss ganz aufgestaut oder die Arbeitszeit ausgedehnt werden, um die geringe Leistungsfähigkeit des Wasserantriebs auszugleichen. War in trockenen Zeiten der Bach so klein geworden, dass mit dem bestehenden Wasser die Mühle nicht mehr in Betrieb zu setzen war, so wurde mittelst Schließung der Schützen das Wasser vor dem Rad so lange aufgehalten, bis die zum Betrieb nötige Menge gesammelt worden war, und gaben diese, nachdem die Schützen geöffnet wurden, in den Mühlenbach frei. Nur auf diese Weise war es möglich, die Mühle auch bei niedrigem Wasserstand in Betrieb zu halten (DIX 1997:162f.; zitiert einen Stauberechtigten aus dem Jahre 1840).

In einem zweiten Fall liegt von der Rur und der Wurm eine falsche Begriffsverwendung vor: So legte man, um die beträchtliche Kraft der Rur zu nutzen, im 12./13. Jh. parallel zum Fluss „Seitenkanäle“ an, die als "Mühlenteiche“ angesprochen wurden. Sie sind aber nicht mit den Stauweihern zu verwechseln, die nur eine Sammelfunktion hatten und der Reservehaltung dienten. Vielmehr waren es künstliche Kanäle in „mühlengerechter“ Breite, mit denen der Raum zwischen Düren und Jülich erschlossen wurde. Sie lagen zu beiden Seiten des Flusses. Ab dem jeweiligen Einleitungswehr hatten sie einen so gleichmäßigen Durchfluss, dass sich Stauweiher erübrigten. Auch die im 14./15. Jh. von den Heinsbergern geschaffene ,Junge Wurm' trug die Bezeichnung „Seitenkanal“ und diente einem Zweck. Die Mühlenteiche genannten „Seitenkanäle“ an Rur, Wurm und Junge Wurm hatten für eine gleichmäßige Wasserführung zu sorgen. Der Wasserzufluss wurde jeweils an der Abzweigung über ein Einleitungswehr gesteuert (VOGT 1998:18).

\section{f.2 Mühlenteich}

Wasser war ein unzuverlässiger Partner. So trockneten viele Flüsse im Sommer so weit aus, dass Mühlen nicht mehr bewegt werden konnten (MÜLLER/LUDWIG 1982:136). Da es sich beim Ausnutzen der Wasserkraft nicht immer um Gebirgsbäche mit starkem natürlichem Gefälle und großer Wassermenge oder um große Ströme handelte, wurde an den nicht so begünstigten Fließgewässern „ein Stauen des Mühlenbaches zum Mühlenteich notwendig“, um Mühlen kontinuierlich in Gang halten zu können (SCHEFFLER 1982:44; ebenso VOGT 1998:18). In der Regel wurde nur dort ein 
Mühlteich angelegt, wo die zufließende Wassermenge für den Mühlbetrieb zu gering war und ein zusätzlicher Wasserschub erforderlich war (BEDAL 1992:38ff.). Eine ununterbrochene Arbeit war an kleinen Bächen also oft schon durch die zu geringe Wasserzufuhr unterbunden. Lagen zudem an einer, wenn auch wasserreichen, Gefällestrecke mehrere Mühlen, so war auch hier „ein Wassersammelteich eine absolute Notwendigkeit“ (LUNKENHEIMER 1990:46), ,,aus dem es dann bei Bedarf entnommen wurde" (MERTES 1995:22). Er befand sich vor dem Stauwerk und funktionierte wie eine Batterie, die tagsüber den elektrischen Strom liefert und nachts wieder aufgeladen wird (VOGT 1998:18).

An der Itter nahe Solingen beispielsweise wurde, um die Wasserversorgung auch des Unterliegers sicherzustellen, das Wasser in einem Teich unterhalb der ersten Mühle gesammelt. Von da aus gelangte es in einen kurz oberhalb der zweiten Mühle gelegenen Graben. Wurde in dieser Mühle gearbeitet, so war der unterhalb befindliche Hammer stillgesetzt. Während dieser Zeit sammelte sich das Betriebswasser, das den oberen Hammer passiert hatte, in dem zum letzteren Hammer gehörigen Teich. So konnte die Arbeitszeit in der natürlichsten Weise der Menge des im Bach und in den Teichen verfügbaren Wassers angepasst werden. Beide Hämmer zugleich betreiben zu lassen, war wegen des ungenügenden Wasserzuflusses nicht möglich. Somit ergab sich, dass vormittags in dem oberhalb und nachmittags in dem unterhalb gelegenen Hammerwerk gearbeitet wurde (LUNKENHEIMER 1990:46).

Stauteiche entschieden aber nicht nur über Weiterbetrieb oder Stilllegung, sondern besaßen auch einen erheblichen Einfluss auf die Art der Beaufschlagung und damit auf die zur Verfügung stehende Wasserkraft. Nicht nur in Abhängigkeit von der Wasserausstattung der Bach- und Flussläufe, sondern auch je nach Stauteichverhältnissen arbeiteten die Schaufelräder der Wassermühlen ober- oder unterschlächtig (ERLER/ MATTHIESEN 1989:86).

Um eine höhere Energieausnutzung zu erreichen, wurde deshalb der zeit- und kostenaufwendige Gewässerstau in Mühlenteichen betrieben, der sich nicht allein in der Anlage des Stauteiches erschöpfte:

„Bei der Anlage eines neuen Stauteiches mußte ein neuer Seitenarm des Baches hergestellt werden, der aus einem Ober- und einem Untergraben bestand. Eine verschließbare Einlaufschleuse - Gewaltschütz - genannt, regelte die Wasserzufuhr vom Bache her. Das vom Bach abgeleitete Wasser sammelte sich in einem Stauteich. Der Teich hatte meistens zwei Ausläufe, durch die das Wasser in den Untergraben gelangte, um sich an dessen Ende wieder mit dem Mühlbach zu vereinigen. An einer geeigneten Stelle ließ man bei dem Bau des Teichdammes eine Öffnung und setzte dort ein Flutschütz ein, wobei überschüssiges Wasser durch das Flutschütz in den Untergraben abfloß. Der zweite und wichtigste Auslauf des angestauten Wassers führte durch die Freiarche über das Wasserrad zum Untergraben. Die Freiarche - auch Flutkasten genannt - war ein rechteckiger Wasserbehälter vor dem Wasserrad; er bestand aus Gußeisen, Stein oder auch aus Holz. " (LUNKENHEIMER 1990:10f.)

Dass die Wasserzufuhr auf unterschiedlichste Weise gelöst wurde, macht diese nächste Variante deutlich, die ROGGE (1993:53f.) aus eigenen Erinnerungen für die Hahle schildert:

„Von der Mühle kommend, fließt das Wasser zunächst in einen Vorratsteich. Durch ein Wehrsystem kann der Wasserverbrauch entsprechend des Aufkommens und Bedarfs geregelt werden. Bei gefülltem Teich floß das Wasser durch die obere Öffnung in den Mühlgraben. War nicht genügend Zufluß vorhanden, wurde das untere Rohr geöffnet und die Reserve eingesetzt. Das Wasser floß durch den Mühlgraben über ein Gerinne auf ein übergroßes, aber schmales Mühlrad. Nicht benötigtes Wasser wurde durch einen mit einem Wehr ausgestatteten Beigraben abgeleitet. Unterwasser und Beigraben vereinigten sich hinter der Mühle wieder zur Hahle. “

Während also bei der ersten Variante der Mühlbach zur Wasserbevorratung abgeleitet wurde, floss das Mühlbachwasser bei der zweiten Variante erst in einen Sammelteich und dann dem Mühlrad zu. 
Die Umleitung über Wassergraben und Mühlenteich hatte den Vorteil, dass das Wasser zum Mühlrad leichter von Treibholz und im Winter von Eis freigehalten werden konnte als in den Bachläufen selbst, denn die Umleitung war bei Hochwasser und Eisgang leichter zu kontrollieren. Mittels Schützenwehr und Schieber konnte die Wasserzufuhr genau dosiert und sogar abgestellt werden (MERTES 1995:22).

Dabei wurde nicht nur ein Teich als Aufschlagreserve mit Wasser gefüllt. Bei der Wassermühle Thalmühle bei Vietze beispielsweise wurden Dämme ,quer durch das Tal gezogen, um in drei Teichen das Wasser des kleinen Bächleins zu sammeln“ (LANGE 1989:94). Die Sammelteiche wurden durch Staubretter erhöht oder abgelassen, um die kostbare Betriebskraft auf die Mühlräder zu bringen (LUNKENHEIMER 1990:10). Für diese und andere Tätigkeiten (Teichpflege, Teichräumung) war manchmal auch ein Teichmeister für den Teich angestellt (BOSSE 1991:126). Ebenso wie an den Mühlkanälen gab es auch an Teichen Staumarken. So wurden noch im Jahre 1970 Staupegel an den Teichen verschiedener Mühlen im Hannoverschen Wendland gesetzt. Diese sind noch sichtbar an den Mühlenteichen Wöhningen, Brüchau, Oldendorf, Karmitz, Kähmen und Sarchem, wie LANGE (1989:59) zu berichten weiß.

Wie der Mühlenteichbau, insbesondere der Dammbau und der Auslassbereich zu Beginn des 19. Jh. ausgeführt werden sollte, erklärt STURM (1815:1) in einem „Figuren in der Mühlenbaukunst“ genannten Kapitel:

„darinnen ist ein Stück des Sees oder Wasserhalters, in dem das Ufer des Dammes [...] mit einer doppelten Reihe vorgeschlagener Pfähle versehen ist, welche dergleichen Dämme trefflich verwahret, wenn im Winter, oder sonst bei lange anhaltendem Regen das Wasser sehr und schnell anwächset, und noch dazu von starkem Winde gegen den Damm getrieben wird, in welchem Fall sonst die Dämme gar mit großem Schaden durchbrechen. Denn die Gewalt des Ströhmens, und der andringenden Last des Wassers wird durch solche Pfähle, sonderlich wenn sie verschränkt geschlagen werden, wie die Figur zeigt, fast gänzlich gebrochen. Wenn man solche Dämme machen will, muß der Grund unten wohl dazu ausgestochen, abgeebnet, und mit Ramen wohl eingegleichet werden. Alsdenn тиß die Erde darauf geführet, und schichtweise stark auf einander gestampfet werden, damit nicht der geringste Ri $\beta$ darinnen bleibe, da Wasser durchkommen könne, weil die Erfahrung lehrt, daß, wenn auch nur Mäuselöcher in solchen Dämmen sind, das sich darein schleichende Wasser heimlich den Damm minire, daß man hernach oft nicht weiß, warum es durchbricht. Darum muß man ja keine Feldsteine in solche Dämme bringen. Faschinen aber und Sand dazwischen geschüttet, geben einen guten Damm. Die Schmiege oder Dossirung des Dammes [...] muß stärker gemacht werden, als in dem Riß, wegen Mangel des Raumes, angedeutet worden, nämlich zum wenigsten $F u \beta$ auf Fuß.

In diesem Damm ist nun hier das Grundwerk [...] auf gemeine Art gelegt [...]. Von diesem Grundwerk gehen die Rinnen [...] auf die Mühlräder hinab, von denen dieses sonderlich zu merken ist, daß das Wasser überaus dabei kann gespahret werden, wenn sie um und um als Röhren verschlossen gemacht, und langsam immer enger gemacht werden, doch so, daß die Gewalt des Wassers nicht gar zu streng werde, und die Röhren zerreisse, daher es genug ist, wenn sie auf jede zehn Fuß um zwey Zoll enger werden. Dadurch wird das Wasser zu einer sehr großen Geschwindigkeit gebracht, daß man mit 36 gevierten Zollen Wasser, das ist, das durch eine Röhre laufet, deren Mündung sechs Zoll ins Gevierte hält, mehr treiben kann, als das auf gemeine Art mit einem Fuß oder mit hundert vier und vierzig Zoll laufende Wasser nicht zu thun vermag. Es kann durch diesen Handgriff ein verständiger Mechanismus sehr viel ausrichten, und bei allen Arten der Mühlen sehr viel verbessern. Es ist aber dabei zu beobachten, daß man sie oben muß öffnen können, damit man sie reinige, aufeise, und andere Reparation desto bequemer daran verrichte. So laufet nun das Wasser auf die Mühle [...].“ 
Die früheren Mühlenteiche aber waren in ihrem Aussehen nicht mit einem See vergleichbar, ,sondern ein mit begrasten Inseln durchsetztes und mit unterschiedlichen Tiefen ausgestattetes Feuchtgebiet [...], das je nach Jahreszeit, mehr oder weniger große Wassermassen speicherte.” (BOSSE 1991:125) Dies ist ein wesentliches Unterscheidungskriterium, da ein Fischteich im besetzten Zustand einen kontinuierlichen Wasserstand aufweisen musste und ein mit Forellen besetzter zudem einer permanenten Frischwasserzufuhr bedurfte, während ein einzig bzw. im Wesentlichen zum Antrieb der Wassermühle dienender Mühlenteich in Perioden großer Wasserarmut nicht zwingend mit Wasser gefüllt werden musste und mangels Wasser auch nicht konnte.

Darüber hinaus gab es noch eine weitere Unterschiedlichkeit: Während der Mühlenteichbau zwar in seinen Grundzügen dem der Fischteiche gleicht und hier nicht weiter vertieft zu werden braucht (siehe auch Pkt. 2c), besaßen Ober- und Untergraben des Mühlenkanals „noch weitere Ausläufe, die alle durch ein Schutz verschließbar waren und zum Bewässern der umliegenden Wiesen dienten.“ (LUNKENHEIMER 1990:10f.). Da Forellenteichwirte ihre Forellen zum Ablaichen in den Bachstrecken hielten, kam für sie eine solche Wasserabgabe aus den $\mathrm{Zu}$-, Um- und Ablaufgräben schon aus diesem Grund nicht in Frage (Fischverlust), und auch die großen Karpfenteichwirte benötigten das gerade zu dem Zeitpunkt spärlich zufließende Wasser, wenn es auch zur Wiesenanfeuchtung gebraucht wurde (Wasserverlust) (siehe Pkt. 6.a.). Zudem ist aus der vorliegenden Literatur nicht zu entnehmen, dass Teichwirte mit einer vollständigen Teichwirtschaft Wiesenbau betrieben haben; im Gegensatz zur fast ,Symbiose' zu nennenden Bewirtschaftung von Mühlen und Wiesen seitens der Müller.

Der Teichbau war aber manchmal auch der Fischzucht gleich, weil in einigen Fällen der Wasserablauf aus den Weihern für den Mühlenantrieb verwendet wurde, die primär und ehemalig für die Fischzucht angelegt worden waren. Insbesondere dann, wenn es zu einer Umnutzung oder zu einem Mühlenneubau an einem Gewässerlauf kam, der die vorhandenen Mühlen gerade ausreichend mit Wasser versorgen konnte, wie OPEL (1991:17) am Beispiel des Neubaus einer Mahl- und Walkmühle aufzeigt. Doch aus dieser Konstellation heraus entstanden bekanntermaßen auch Streitigkeiten, wenn große oder auch mittelmäßige Fischteiche deswegen nicht besetzt werden konnten, weil Mühlen an denselben angelegt waren und diese still stehen bleiben müssten, würde man den Wasserabfluss zum Wasserantrieb verhindern: „so thut man sehr wohl, wenn man neben dem Teiche vorbey einen besondern Mühlgraben, und, wie es meistentheils angeht, neben oder hinter dem Teiche, einen besondern Mühlteich, und an diesem Graben oder Teich die Mühle anlegt“" (DYHRN 1782). Es bestehen also mehrere Gründe für die anzutreffende Separierung des Teichbaus für die Fischbewirtschaftung von denjenigen für die Mühlenwirtschaft.

Ist auch oben die Beziehung zwischen den Teichbau und der Wasserführung dargestellt worden, so wäre als nächstes die Frage zu beantworten, woraus die Art der Beaufschlagung abgeleitet werden kann. Die oben vorgenommene Differenzierung der Mühlen hinsichtlich der Form der Beaufschlagung des Wassers in ober-, mittel- und unterschlächtig war abhängig von der Wassermenge und dem Gefälle. „Allgemein kann man [...] sagen, daß mit abnehmender Fallhöhe des Wassers, die oberschlächtigen Räder in mittel- und unterschlächtige Bauarten übergingen." (MERTES 1995:23) Es besteht aber kein Zusammenhang zwischen der Anlage von Mühlteichen und der Art der Wasserzufuhr auf die Räder. Das heißt, es lassen sich keine Rückschlüsse ziehen dergestalt, dass, wenn ein Wassersammelteich vorhanden war, es sich zwangsläufig bei dem Mühlenrad um ein oberschlächtiges gehandelt hat. „Die Frage, ob oberschlächtig, mittel- oder unterschlächtig, war letztlich anhand der Wasserverhältnisse zu entscheiden.“ (:23) Und auch die Bespannung von Mühlenteichen war gerade bei kleinen Bächen eine langwierige Angelegenheit und die Wasserfüllmenge war gerade oft nur so groß, um geringe Stillstandszeiten von wenigen Stunden zu überbrücken.

Des Weiteren gab es nicht nur ,Bachmühlen' mit angeschlossenem Gewässerstau. Auch ,Teichmühlen', die einzig und allein nur vom Wasservorrat des Teiches lebten, der aus Quellen und in dem Teich liegenden Quellaustritten gespeist wurde, lassen sich nachweisen (siehe auch VII 1b). Wie groß ein solcher Mühlenteich in seinen Abmessungen, aber auch in seinen Schwierigkeiten sein konnte, geht aus einer Darstellung von BOSSE (1991:126) hervor: „Wegen des mangelnden Wassers 
an der ,Stöckener Teichmühle' wurde 1697 eine ,Rönne' (Rinne, Kanal) von ungefähr 360 Ruten Länge (1.680 Meter) und einer Breite von einer Rute (4.67 Meter) und drei Fuß tief $(90 \mathrm{~cm}) \mathrm{im}$ Teich gegraben.“ Die Rönne diente dazu, „das Wasser zu leiten und damit dem permanent drohenden Wassermangel dieser Mühle abzuhelfen“ (:126). Während es sich nach meiner Interpretation hier um die Wandlung eines Mühlenteiches in einen Mühlenkanal handelt, lässt sich aus der Länge der Rinne die Längsstreckung des Mühlenteiches ableiten, die ca. 1,7 km betragen hatte.

Weiterhin gab es auch ,Seemühlen', die die aus einem See abfließenden Wasser zunächst in einem Mühlenteich sammelten, und schließlich sogar kombinierte ,Wasser-Windmühlen', die den Teich als Reservoir für windstille Zeiten anlegten bzw. umgekehrt den Windaufsatz als Ergänzung bzw. Substitut bei wasserarmen Zeiten nutzten:

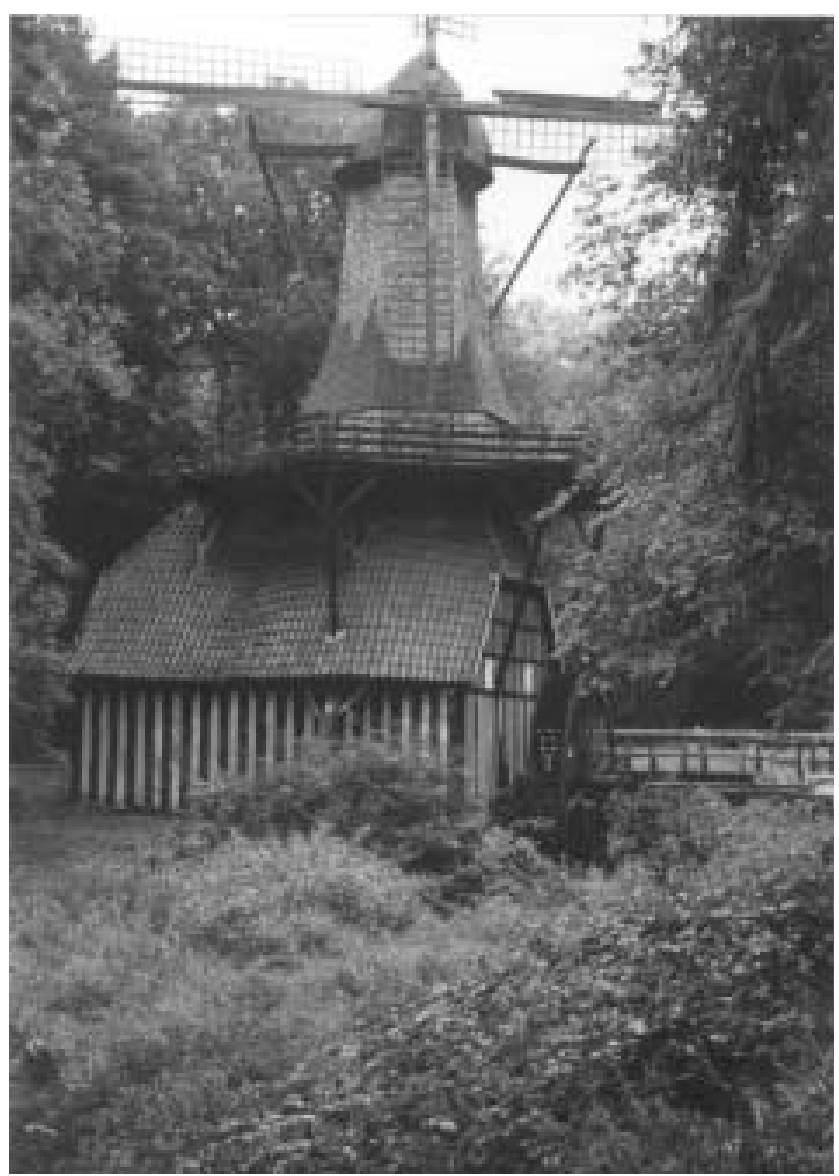

Abb. VII-43: Kombinierte Wasser-Windmühle: „Hüvener Mühle“ (eig. Aufnahme 2003)

Zusammenfassend lässt sich feststellen, dass die Wasserstauhaltungssysteme von Mühlen recht unterschiedlich sein konnten und der Begriff des ,Mühlenteiches' missverständlich verwendet wird. Eine klärende Zusammenschau erscheint daher abschließend notwendig:

1. Der Mühlenstau im Mühlkanal: Er hinterlässt mit seinem Staucharakter eines nicht bzw. kaum wahrnehmbar fließenden Gewässers zwar das Bild eines stillgewässerartigen Mühlenteiches, ist aber keiner. Besondere Zu- und Ableitungssysteme, die den Mühlenteich kennzeichnen, sind hier nicht notwendig.

2. Der Mühlteich als zwischengeschalteter Wasserstauer: Der schmale Mühlgraben bzw. der Bach wird in seinem Verlauf vor dem Gerinne durch ein Wehr in ausladender Breite aufgestaut. In diesem Fall kann am ehesten von einem Kanalteich gesprochen werden.

3. Seitenkanäle die als „Mühlenteiche“ bezeichnet werden: Sie ließ man seitwärts des Mühlbaches anlegen, um zusätzliche Aufschlagwasser zu gewinnen. Darüber hinaus ermöglichen seitliche Schützen die Ableitung von Wässerwasser für die Wiesen. 
4. Der eigentliche Mühlteich: Er wird durch einen Mühlgrabenabzweig mit Wasser versorgt und oberhalb der Mühle und seitlich vom eigentlichen Fließgewässer angelegt. Durch zwei Öffnungen kann überschüssiges Wasser zur Teichbespannung zugeleitet oder aber Bedarfswasser dem Mühlkanal zusätzlich zugeführt werden. Umfangreiche Damm- und Einbauten, der Fischteichanlage vergleichbar, waren hier zusätzlich notwendig.

\section{Bergbauteiche}

Es würde ein ganzes Buch füllen, auch nur annähernd auf den Aufbau und die Entwicklung der Anlagen des montanen Wasserwirtschaftssystems eingehen zu wollen. Verwiesen sei auf die ausgezeichneten Monographien zu diesem Thema von HAASE/LAMPE (1985) sowie SCHMIDT (1987 und 1989) für die Oberharzer Wasserwirtschaft.

Deshalb soll hier die kontextbezogene Beschreibung der bergbaulichen Teichwirtschaft den Schwerpunkt bilden. Doch - wie bei der Darstellung der Mühlenteiche - lässt sich der Teichbau nur im Zusammenhang mit dem zur Teichbewirtschaftung gehörenden Wasserübertragungs-, Wasserzuführungs- und Wassersammelanlagen verstehen, die Bestandteil des gesamten bergbaulichen Wasserbewirtschaftungssystems waren.

$\mathrm{Da}$ der geographische Fokus auf dem Oberharz liegt, begründet sich mit der herausragenden Stellung, die dieses Gebiet im Bergbau sei frühester Zeit innehatte und durch die teilweise Erhaltung wasserwirtschaftlicher Anlagen und Elemente bis in heutige Zeit eine tief greifende Rekonstruktion zur Funktionalität und zum Umfang des Wasserbevorratung im Bergbau ermöglicht. Das gleiche Prinzip der Teichbewirtschaftung ist aber auch in anderen Bergbauregionen wie Freiberg und Aachen erkennbar. „Heute sichtbarstes Zeichen dieses großartigen, in drei Jahrhunderten schrittweise entstandenen Systems“, schreibt LIESSMANN (1997:162) in seiner Darstellung des Oberharzer Wasserregals, ,sind die zahlreichen kleinen - und großen Teiche auf der Clausthaler Hochfläche, die sich so harmonisch in die Oberharzer Landschaft einfügen, als hätte es sie schon immer gegeben.“ „Teiche mit ihren Staudämmen, Dammgräben und andere kunstvoll trassierte und gebaute Wassergräben gehören, insbesondere im Harz“, hebt auch JÄGER (1965b:425) hervor, „zu den weiteren gegenständlichen Relikten des früheren Bergbaus.“

Da es im Oberharz aber in der Regel keine starken Fließgewässer in der Nähe der Erzgänge gab, erforderte der Einsatz der Wasserkraft zuvor umfangreiche Baumaßnahmen. Trotz der vergleichsweise hohen natürlichen Niederschläge reichten die kleinen Bäche in der Nähe der Gruben kaum aus, um permanent Antriebsenergie zu liefern. Speicherteiche und Sammelgräben, die das Wasser von anderen Berghängen und Tälern heranführten, waren zu bauen. Darüber hinaus benötigte man ,Leitungen', Gräben und Wasserläufe, um das Wasser von den natürlichen Bächen oder Quellgebieten zur Füllung zu den Speicherbecken zu leiten und anschließend oder es aber auf direktem Wege ohne Bespannung der Teiche als Antriebswasser den Antriebsmaschinen, d. h. den Radstuben zur Verfügung zu stellen, die die Kraft der Maschinen mittels Feldgestänge zu den Gruben weiterleiteten (BALCK 1999:17).

Für die Wasserversorgung der reichen Bergbaureviere nutzte man schon früh als Wasserspender die niederschlagsreichen Höhen. Im Einzugsgebiet der hier entspringenden Gewässer entstanden „zahlreiche Stauteiche, deren Wasser durch einen Kunstgraben zu den Gruben gelangte oder deren Wasser durch ein System von Hanggräben und untertägigen Wasserläufen zu den Gruben geführt wurde“ (LIESSMANN 1997:162f.). Zweck dieser Anlagen der Wasserwirtschaft war es, „das zum Antrieb der vielen Radkünste notwendige Wasser zu sammeln, zu speichern und den Gruben zuzuleiten.“ (:162) Diese Grundzüge der alten bergbaulichen Wasserwirtschaft sollen zunächst kurz vorgestellt werden, um daraus die Stellung der Bergbauteiche ersichtlich erscheinen zu lassen. 


\section{a Grundzüge der alten bergbaulichen Wasserwirtschaft}

Im Mittelalter kannte man das Erz an sich, aus dem das edle Metall zu schmelzen war, wusste aber nicht es systematisch aufzuspüren ${ }^{47}$. Anfangs nahm der Bergmann den Abbau dort auf, wo die Erzgänge unmittelbar an der Erdoberfläche ,ausstrichen' und sich durch auffällige ,Huterze' sowie durch eigentümliche Vegetation verrieten, das heißt, wo sie an den ,Ausbissstellen' gewissermaßen zutage traten (LIESSMANN 1997:57). Hatten die Knappen das ihnen dicht unter der Ackerkrume leicht erreichbare Erz ausgehauen, verließen sie die Stelle und schlugen an einer anderen von neuem ein (CZAYA 1990:20). Beim glücklichen Fund spielten auch der Zufall und die vermeintlichen Fähigkeiten von Wünschelrutengängern eine Rolle (:19).

Im Weiteren folgten sie den Gängen in die Tiefe (CZAYA 1990:20). Lagen die Ausbisse an flachen Hängen oder auf Hochebenen, so erfolgte der Abbau zunächst durch einfache Gräberei in Schürfgruben. Dieser extensive Bergbau, der in der Landschaft zahlreiche dieser ,Pingen' hinterließ, konnte nicht lange währen.

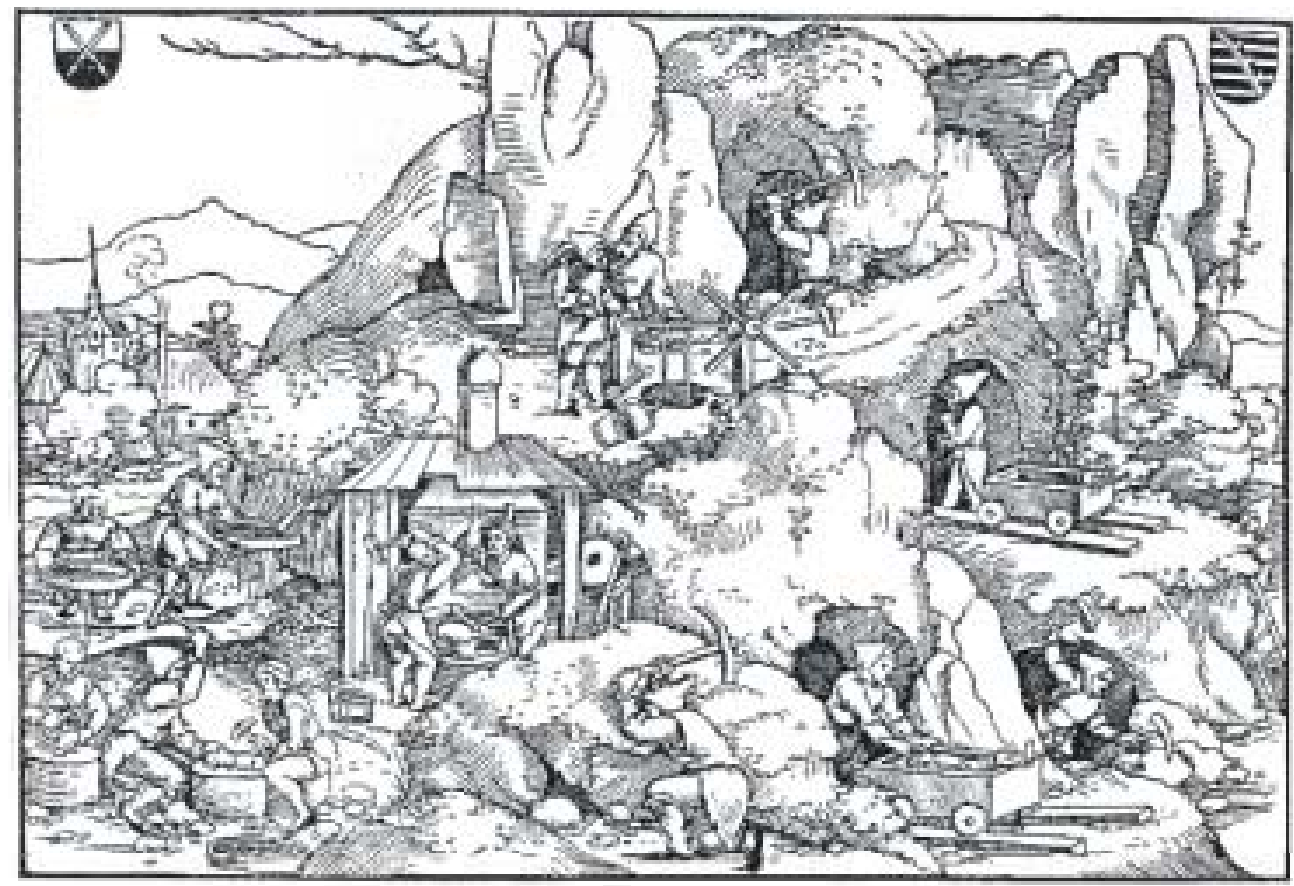

Abb. VII-44: Tätigkeiten im Bergwerk

Die Wappen verweisen auf das sächsische Erzgbirge (Holzschnitt von Hans Sebald Beham 1530; aus: CZAYA 1990:15).

$\mathrm{Ab}$ dem 12. Jh. ging man von kleinen Schächten und Tagesstollen aus nun verstärkt zur Gewinnung der dichten, zähen Primärerze über. In Freiberg beispielsweise waren die Bergleute, um Erze zu gewinnen, schon vor 1300 gezwungen in die Tiefe vorzudringen (CZAYA 1990:20; LIESSMANN 1997:115). Allerdings setzte mit dem Fortschreiten der Abbaue zur Teufe hin das zufließende Grundwasser und das Niederschlagswasser, das in Schächte und Stollen einsickerte, dem frühen Kleinbergbau rasch Grenzen, obwohl aufgrund des undurchlässigen Nebengesteins (Tonschiefer) die Wasserzuflüsse verhältnismäßig gering blieben (LIESSMANN 1997:115). Schachttiefen von mehr als 10 - 14 oder im Höchstfalle 20 oder gar 30 m dürften kaum erzielt worden sein (CZAYA 1990:20; LIESSMANN 1997:57,72). Also ließen auch diese Bergmänner ihren Bau liegen, sobald ihnen eindringendes Wasser beim Abbau des Erzes Halt gebot. Noch fehlten der Wasserlösung dienende

\footnotetext{
${ }^{47}$ Silber ist zumeist Bestandteil von Erzen, die wiederum auch andere Metalle, wie z. B. eine Beimengung von Gold, enthalten können. Reines metallisches Silber kommt in der Natur höchst selten vor. Silber findet sich zumeist in Gemeinschaft mit dem ebenfalls sehr begehrten Kupfer, wie zum im Mansfelder Land des östlichen Harzvorlandes, und mit Metallen wie Blei, Zink, Nickel, Kobalt und Wismut. Die silberhaltigen Erze treten auch nicht immer offen zutage, sondern sind zumeist in alten tektonischen Brüchen und Spalten der Erdkruste anzutreffen, in die in geologischer Vorzeit mineralische Lösungen oder Gesteinsschmelzen eindrangen.
} 
Stollenbauten ebenso wie wirksame ,Kunstgezeuge' zur Hebung der Grubenwässer. Ein Ausweichen auf neue Wirkungsstätten war aber nur so lange möglich, wie genügend freies Feld zur Verfügung stand.

$\mathrm{Zu}$ Beginn des Bergbaus stand zur Grubenentwässerung wie zur Schachtförderung nur die menschliche Muskelkraft zur Verfügung. Dutzende von Wasserknechten, übereinander auf Fahrten stehend und eine Menschenkette bildend, reichten sich Wasser gefüllte Ledereimer zu (HAASE 1961:55; LIESSMANN 1997: 81,115). Das Wasserziehen mit „Bulgen' löste nachfolgend die Wasserknechte ab. Bei dieser Methode wurden ledernde Wassersäcke, die sog. Bulgen, die auf eine endlose Hanfkette montiert waren, wie Fördertonnen mit Handhaspeln im Schacht emporgezogen (LIESSMANN 1997:81,115). Diese von Haspelknechten bediente Handhaspel diente als Grundlage aller Vertikalförderung seit den Anfängen bis ins 19. Jh. hinein (:72).

Anfang des 16. Jh. stellte die sog. Heinzenkunst eine wichtige, die Wasserkraft nutzende, Neuerung dar (LIESSMANN 1997:81f.). Sie bestand aus einer Folge aufeinander gesetzter Holzrohre. Durch diese Rohrleitung wurde an ein umlaufendes Seil geführt wurde, an der im Abstand von $1-2 \mathrm{~m}$ lederne Bälle befestigt waren. Jeder der dem Rohrdurchmesser genau angepassten Bälle nahm nun beim Umlauf des Seiles die darüber stehende Wassersäule mit sich nach oben (CZAYA 1990:32; BALCK 1999:115). Solche Anlagen waren unter Tage in Betrieb, um eine gewissen Menge Grubenwasser von der am tiefsten in der Grube gelegenen Sammelstelle, dem ,Schachtsumpf', nach oben bis zum vorgesehenen Wasserabflussniveau zu heben (CZAYA 1990:32; LIESSMANN 1997:82). Nach AGRICOLA konnte man dabei schon eine Förderhöhe von 60 - 70 m erreichen. Im Harz wurde diese, aus dem sächsisch-böhmischen Erzgebirge übernommene, Technik um 1535 eingeführt (LIESSMANN 1997:82).

Im 15. und vor allem im 16. Jh., als die Erzgewinnung in großem Umfang systematisch wieder aufgenommen wurde, hatte sich die geologische Technik so weit entwickelt, dass die Bergleute tiefer in den Berg vorstoßen konnten (CZAYA 1990:20f.). Man begann auf den Gängen Schächte abzuteufen, als vertikale Zugänge zu den Erzmitteln. Jedoch: Je tiefer man bei diesem Gangerzbau kam, umso größere Mengen tauben Gesteins mussten gebrochen und bewegt werden. Der Bergmann sah sich auch erhöhten Gefahren ausgesetzt. Unter Tage fehlte es an Frischluft, giftige Gase traten aus und es kam zur vermehrten Ansammlung von Wasser.

Das eine Problem erforderte, Wetterkünste', die der, Wetterhaltung', also der Be- und Entlüftung der Gruben, dienten, und das andere Anlagen zur ,Wasserhaltung', die für die Entwässerung sorgten (CZAYA 1990:21.f.). Während es einerseits notwendig war, die zufließenden Grundwasser aus den Tiefbauen herauszupumpen, war es andererseits wichtig, sauerstoffreiche ,Wetter ${ }^{6}$ hineinzuleiten (LIESSMANN 1997:91).

Zur Grubenbelüftung wurden anfänglich ganze Batterien von Blasebälgen durch Muskelkraft und später durch Wasserkraft betätigt. Der Einsatz von Blasebälgen nach Art der Hüttenwerke erwies sich aber als zu uneffektiv. Zur Beschaffung einer natürlichen Bewetterung, eines Luftstromes, der ausreichte, um vor Ort arbeiten zu können, gab es seit Anfang des 18. Jh. im Harzer Bergbau Versuche, sog. Wettermaschinen zu entwickeln. Eine wichtige Neuerung war die nach den Plänen des Clausthaler Gelehrten Henning CALVÖR ${ }^{48}$ (1685 - 1766) gebaute ,Wassertrommel’: „Sie erzeugte strömende Druckluft aus fallendem Wasser. Ein durch ein hölzernes Rohr in einen Holzkasten eingeleiteter Wasserstrom zerstäubte beim Austritt aus den am Ende des Rohres befindlichen Bohrlöchern. Die beim Zerstäuben des Wassers freiwerdende Luft sammelte sich in einer Glocke und

\footnotetext{
${ }^{48}$ Henning CALVÖR (je nach Literatur $1685 / 86$ oder 1689): Rektor der Bergakademie in Clausthal, verfasste auch theologische und historische Schriften. Berühmt wurde er jedoch durch sein Hauptwerk zum Bergbau (1763). Es zeigt in eindrucksvoller Weise den Stand der Bergbautechnik des 18. Jh. in Maschinenwesen, Markscheiden, Schacht- und Grubentechnik sowie im Bereich Förderung und Aufbereitung der Erze im Oberharz.

Calvör besuchte das Adreanum in Hildesheim und die Rektoratschule in Zellerfeld. Er studierte Theologie, wandte sich aber daneben dem Bergbau und der Mechanik zu, wurde 1713 Konrektor und 1725 Rektor der Bergschule. Ferner führte er selbst neue Maschinen im Bergbau ein, z. B. die ,Harzer Wasser- bzw. Wettertrommel'.
} 
trat als frischer Wetterstrom aus. Eine angeschlossene Holzrohrleitung führt die leicht komprimierte Luft dem wetternötigen Ort zu“(LIESSMANN 1997:93).

Der erste Schritt zur Beseitigung des eingesickerten Wassers war rein bergmännischer Art und bestand in der Ausnutzung von Stollen. Man wählte eine nach dem Tal zu etwas abfallende Sohle, damit das der Grube zufallende Wasser in der Wasserseige ${ }^{49}$ von selbst ablaufen konnte. Die Gewinnung von Erzen in größeren Tiefen war in früheren Jahrhunderten jedoch nur möglich, wenn gleichzeitig getriebene Stollen den Schächten ,Wasserlösung' brachten (LIESSMANN 1997:89). Es wurden deshalb spezielle Wasserstollen, sog. Haupt- oder Erbstollen angelegt, deren Aufgabe darin bestand, für die Entwässerung und Bewetterung nicht nur einer Grube, sondern später der Gruben eines ganzen Reviers zu sorgen. Schon Mitte des 12. Jh. war im Harz der Bau eines tiefen Wasserlösungsstollens unbedingt erforderlich geworden, um alle auf dem Lager bauende Gruben gleichzeitig zu entwässern. Der um 1140/50 angelegte ,Ratstiefste Stollen' am Rammelsberg gilt als der älteste befahrbare Großstollen im Harz (HAASE 1961:54). Seit 1384 ist die älteste Freiberger Entwässerungsanlage urkundlich belegt.

Solche Wasserlösungsstollen wurden von den nächsten Eintalungen aus angesetzt und entlang der Erzgänge in Richtung Bergwerk getrieben, um die Wasserlösung für die Grube bringen und die einzelnen Schächte miteinander zu verbinden. Dadurch konnte, neben der Einleitung von Atemluft (,frische Wetter'), das eingesickerte Wasser herausgeführt werden. „Die Wässer“, wie es im Sprachgebrauch der Oberharzer Bergleute stets hieß, wurden ,gelöst“. Für jeden der Oberharzer Gangzüge ist deshalb mindestens ein sog. Wasserlösungsstollen von Tälern innerhalb des Harzes aus vorgetrieben worden. Alle über diesem Niveau befindlichen Grubenbaue konnten so auf natürliche Weise, der Schwerkraft folgend, entwässern (HAASE 1961:55; LIESSMANN 1997:57, 89).

Die geringe Tiefe der frühen Schächte verlangte nur kurze, den benachbarten Flusstälern zugewandte Lösungsstollen, die wenig, Teufe' einbrachten (HAASE 1961:55). Doch mit dem Vorstoß in die Tiefe versagten die alten Abzugsstollen; es mussten immer wieder neue in immer größerer Tiefe angelegt werden.

Mit fortschreitender Tiefe der Schächte, beginnend im 13. oder 14. Jh. und mit Schwerpunkt im 16. bis 18. Jh., wurde der Bau tiefer reichender Stollen notwendig, so dass das „Mundloch weiter abwärts im Flußtal angesetzt werden mußte" (HAASE 1961:55), damit das unterirdische Wasser daraus frei ablaufen und die jeweiligen Entwässerungskanäle erreichen konnte (:57). Hatte man sich früher „,mit den nahegelegenen Flußtälern und geringen Teufen begnügt, so strebte man jetzt bis an die tiefen Harzrandflüsse oder den Harzrand selbst.“ (:57) Beim Wiederaufblühen des Montanwesens im 16. Jh. wurden in allen Revieren solche Stollenbauwerke in Angriff genommen (LIESSMANN 1997:89). Im 16./17. Jh. hatten solche von Hand getriebenen, mit Schlägel und Eisen aufgefahrenen Stollen einen Querschnitt von 1,5 bis $2 \mathrm{~m}^{2}$ und, wie beispielsweise der Rammelsberger Stollen, eine Länge von $1000 \mathrm{~m}$.

Im Freiberger Revier betrug die Gesamtlänge der größeren Stollen - zum Abfluss des Grubenwassers und des für untertätige Wasserkraftmaschinen benutzten Kunstgrabenwassers - im 18. Jh. ohne Verzweigungen 105 Kilometer und mit den bekannten Verzweigungen 239 Kilometer (CZAYA 1990:22). Allein im Oberharzer Revier wurden bis 1606 rund $20 \mathrm{~km}$ Wasserlösungsstollen nur in Schlägel- und Eisenarbeit aufgefahren. Bis 1865 erhöhte sich ihre Gesamtlänge auf mehr als $95 \mathrm{~km}$ ! (LIESSMANN 1997:89) Im Harz maß allein der, Georg-Stollen' von der Bergstadt Grund über Clausthal nach Bockswiese am Ende im Jahr 1799 eine Gesamtlänge von 20 Kilometern (CZAYA 1990:22). Der tiefste Wasserlösungsstollen, der 1864 eröffnete ,Ernst-August-Stollen', reichte bis nach Gittelde im südlichen Vorharz. Jeder Wasserlösungsstollen brachte für die betroffenen Gruben zunächst einen Aufschwung, weil man nun mit geringerem Aufwand die Gruben trocken halten und auch weiter abteufen konnte (BALCK 1999:14).

\footnotetext{
${ }^{49}$ Wasserseige: Gerinne zum Ableiten der Grubenwässer in Strecken.
} 
Aus den darunter liegenden Bauen hingegen sammelten sich die Wasser in den Schachtgesenken und mussten auf die Stollensohle emporgehoben werden (LIESSMANN 1997:89). „Wasserwirtschaft“, fasst HAASE (1961:54) die Bedeutung zusammen, ,das war im Anfang des Bergbaus vor allem der Zwang, das Wasser in den Gruben ,los zu werden' - zu ,lösen', denn sonst war kein Abbau [...] möglich.“

Die Gruben bereits der mittelalterlichen Bergbauperiode hatten vielleicht schon eine beträchtliche Ausdehnung, aber, wie berichtet, nur geringe Tiefen bis $20 \mathrm{~m}$ und ließen sich mit einfachen Mitteln trocken halten. Für den im 16. Jh. wieder einsetzenden, nun aber wesentlich tiefer gehenden Bergbau war es nicht mehr möglich, das Wasser durch Schöpfen der, Wasserknechte' so tief zu halten, um Erz $\mathrm{zu}$ gewinnen. Eines der großen Probleme des Oberharzer Bergbaues war das in die Gruben einsickernde Wasser. Es behinderte oder verhinderte den Abbau der Erze.

Wenn auch zunächst Pferde, die in einem ,Huthaus' im Kreis herumliefen, als Antrieb eingesetzt wurden und aus bis zu 200 m tiefen Schächte fördern konnten, so waren auch hier die Möglichkeiten nur sehr begrenzt, das Wasser herauszuschöpfen. Um das Wasser über pferdegetriebene Göpelanlagen zutage zu fördern, fehlte zudem die Futterbasis.

Die Entwässerung der Gruben war stets ein derart vorrangiges Problem, dass neue Techniken auf diesem Gebiet Voraussetzung für den Vorstoß in größere Tiefen waren und nur mit Hilfe der Wasserkraft konnten stärkere Antriebe gebaut werden, sofern genügend Antriebswasser und geeignete Technik zur Verfügung standen (CZAYA 1990:32).

Nachweislich zuerst 1564 am Rammelsberg waren auch bereits einfache Kolbenpumpen im Einsatz, die im Bergbau als die ,Kunst mit dem krummen Zapfen’ bekannt waren (siehe Pkt. b.1; auch Pkt. 3a).

Im 16. Jh. konnte man das Wasser mit 10 bis 20 Pumpen um $200 \mathrm{~m}$ auf den Abflussstollen heben. Im 18. und 19. Jh. wurden schließlich bis zu 40 Kolbenpumpen untereinander montiert (CZAYA 1990:32).

Der Bergbau litt aber mit zunehmender Tiefe „unter gravierenden Wasserhaltungsproblemen, die mit der Ausdehnung der Grubenbaue bald mehr und mehr den Betrieb behinderten." (BARTELS 2000:40) Dies war umso bedeutender als dass "im Vergleich zur anfallenden Menge an Erz und Gestein [...] das in die Gruben einsickernde Wasser das wichtigste Fördergut“ war. „Ohne ständiges Pumpen wäre der Bergbau zu manchen Jahreszeiten rasch zum erliegen gekommen. Dagegen konnte die Förderung des losgebrochenen Gesteins intermittierend erfolgen “ (BALCK 1999:115).

Das ,Wasserziehen' auf der einen und das ,Wasserzuführen' auf der anderen Seite war von außerordentlicher Wichtigkeit für den gesamten Komplex von Bergbau und Verhüttung, der nahezu alle Bereiche des Arbeitsprozesses unter und über Tage durchdrang (CZAYA 1990:17; BALCK 1999:21). „Wasser mit Wasser heben“ hieß die Devise. Dazu wurden die Künste eingesetzt. So wurde zum einen das Wasser auf den Wasserlösungsstollen gefördert, daneben hoben andere Einrichtungen die Erzkübel an die Oberfläche. Das Wasser wurde von der Bedrohung, die weiterhin bestehen blieb, zu einer Hilfe des Bergmannes. Es galt die Faustregel: Ohne Wasser kein Bergbau! (SCHMIDT 1997:14)

Diese Zuführung von Wasser zur Hebung von Wasser und Gestein hatte erhebliche Folgen für das Gewässersystem und den Wasserhaushalt: „Schon im 16. Jahrhundert waren die natürlichen Fließgewässer in den Tälern nicht in der Lage gewesen, den beständigen Wasserzufluß zu gewährleisten, der nötig war, um all diese Wasserräder zu bewegen.“ (BARTELS. 2000:45) Die Pumpenanlagen in den Gruben mussten aber dauerhaft arbeiten, damit die Bergbaubetriebe wasserfrei blieben. Die Menge der Niederschläge, die jahreszeitlichen Schwankungen, die Bindung von erheblichen Wassermengen im Winter durch Frost waren jedoch „unveränderliche Faktoren“ (:47), die durch eine künstlich erzeugte Stabilität, veränderlich’ gemacht werden mussten. 
„Um die nötigen Antriebs-Wassermengen zu mobilisieren und eine möglichst gleichbleibende Beschickung der Räder unter den stark durch jahreszeitliche Niederschlags-Schwankungen beeinflussten Bedingungen gewährleisten zu können, wurden großflächige Wasserbaumaßnahmen erforderlich: die Anlage von Wassersammelgräben, Stauteichen, Zufuhr- und Ableitungsgräben für die Wasserräder. All das musste sich dem Diktat des Gefälles und damit den Gegebenheiten des geographischen Reliefs unterordnen.“ (BARTELS 2000:45). „Mit ausgedehnten Systemen von künstlichen Gräben wurden Bäche und Flüsse angezapft, um aus ihnen das Wasser teils den Sammelbecken, teils direkt den Radwerken zuzuleiten. Teilweise wurde das Wasser auch in dafür angelegten Stollen (Röschen) unterirdisch heran- oder durch hinderliche Geländeerhebungen hindurch geleitet."(CZAYA 1990:36)

Vor allem nach Wiederaufnahme des Bergbaus im 16. Jh. entstanden in der Folgezeit für jeden der ausreichend Erz führenden ,Züge', auf denen sich ein Abbau lohnte, nicht nur unter Ausnutzung der örtlichen, sondern auch der entfernter gelegenen Gegebenheiten, ein eigenes Wasserver- und entsorgungssystem. $\mathrm{Zu}$ diesen wasserbaulichen Anlagen der Bergbauwirtschaft, die im Harzer Bergbaurevier unter dem Begriff ,Oberharzer Wasserwirtschaft' zusammengefasst wird, zählen fünf immer wiederkehrende Elemente: Gräben, hölzerne Rinnen (,Gefluder'), Stollen (,Wasserläufe'), Teiche und Radstuben (Kraftwerke).

Die Maßnahmen waren im weiteren Fortgang so umfangreich, dass schon zu Beginn des 17. Jh. die (Bergbau-) Landschaften durch diese Elemente des (montanen) Wasserbaus geprägt waren (BARTELS 2000:45).
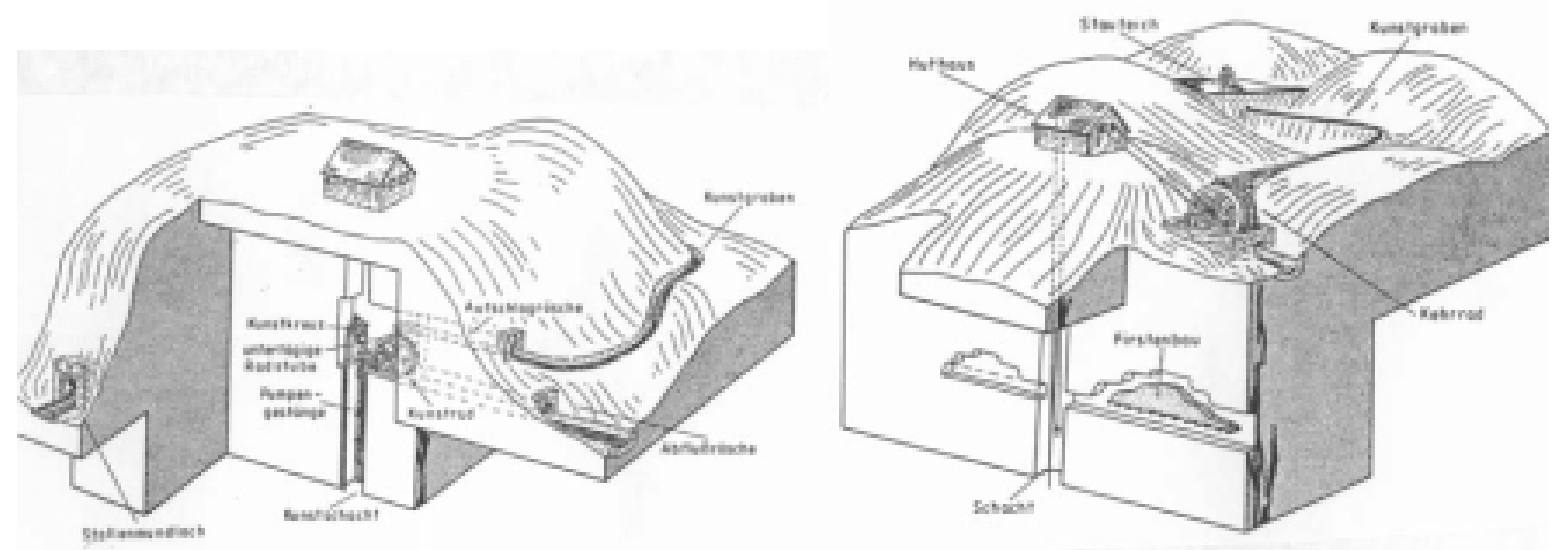

Abb. VII-45: Gewässerhistorische Elemente des montanen Wasserbaus Stauteich, Kunstgraben, Aufschlag- und Abflussrösche (aus: LIESSMANN 1997:49)

\section{b Wasserübertragungsanlagen}

Wasser ist aber auch nicht überall hinzuleiten. Vor allem konnte Aufschlagwasser nicht zur Schachtöffnung geführt werden, wenn sich diese hoch oben am Berghang befand. Aber nicht nur bedingt durch den Verlauf der Erzgänge, sondern auch durch das Relief des Geländes und der Gegebenheiten für das Antriebswasser wurden separate ,Radstuben' errichtet, und zwar dort, wo sich das Wasser am rationellsten nutzen ließ. Dorthin wurde das Wasser mittels ausgeklügelter Zuleitungssysteme transportiert und auf Wasserräder übertragen.

\section{b.1 Radstuben}

Ein Schacht hatte daher in der Regel abseits gelegene Maschinenhäuser, die Radstuben, die je nach Geländeform sowohl oberhalb als auch unterhalb des Schachtes liegen konnten (BALCK 1999:21). Bei den Radstuben handelt es sich um über- und untertägige Kraftwerke, in denen sich im Durchmesser 7 bis $12 \mathrm{~m}$ hohe und mit Zellweiten von $60-80 \mathrm{~cm}$ ausgestattete Wasser betriebene 
Kunst- und Kehrräder drehten. Zwischen 220 und 250 sind im Verlauf der Bergbauzeit allein im Westharz gebaut worden, etwa 50 davon unter Tage (:17).

Transmissionen aus Holz, sog. ,Stangenkünste' bzw. ,Kunst- oder Feldgestänge', bei denen es sich aber auch um längere Seiltriften handeln konnte, übertrugen die durch Wasserbeaufschlagung gewonnenen Kräfte zu den Bergbauschächten. Dort wurden wiederum hölzerne Pumpen angetrieben, die das Grubenwasser aus Hunderten von Metern Tiefe herausbrachten (SCHMIDT 1997:17f.). Mit dieser Konstruktion war es möglich, auch die Kunst eines hoch am Berg gelegenen Schachtes durch ein im Tal bzw. Hang abwärts aufgestelltes Wasserrad anzutreiben (LIESSMANN 1997:72). Die Wasserkraft wurde also immer dann über ein Feldgestänge zum Schacht übertragen, wenn es nicht möglich war, Aufschlagwasser direkt in den Schacht zu leiten, weil dieser auf einer Anhöhe lag. Deshalb verlegte verlegt man das Kunstrad weiter nach unten und übertrug dessen Kraft mittels eines ,Feldgestänges“ (:72).

Mit dieser nach 1550 im Harz eingeführten Übertragungsmethode, der sog. ,Kunst mit krummen Zapfen', war es möglich, mechanische Bewegungsenergie über Distanzen bis zu $1000 \mathrm{~m}$ zu transportieren (LIESSMANN 1997:82). Die Pumpenkunst wird hierbei mit einem Wasserrad über eine Kurbelwelle angetrieben. Diese Kurbelwelle setzt die Drehbewegung des Wasserrades in eine Hubbewegung des im Schacht hängenden Pumpengestänges um. Dieses Modell der Wasserhebung ist praktisch der Vorläufer der ausgedehnten Übertragungssysteme, die Mitte des 16. Jh. aufkamen und seit dem 17. bis ins 19. Jh. hinein im Erzbergbau Verwendung fanden (CZAYA 1990:35; LIESSMANN 1997:72).

Für den Antrieb des ,Kunstgezeuges' genügte ein einfaches Wasserrad mit unverändert bleibender Drehrichtung. Den Wechsel zwischen Heben und Senken des Kolbens bewirkte eine Pleuelstange (CZAYA 1990:34). Seit dem 16. Jh. wurde die Kraft des Wassers bei der leistungsfähigeren ,Kehrradförderung' eingesetzt, mit der Tiefen von mehr als $500 \mathrm{~m}$ überwunden werden konnten (LIESSMANN 1997:72). Die von oben mit Wasser beaufschlagten (oberschlächtigen) hölzernen Räder hatten zwei Schaufelkränze, deren Zellen entgegengesetzt gerichtet waren. Die Laufrichtung bestimmte der ,Schützer' durch das wechselweise Ziehen der beiden ,Schütze', womit er einmal auf den einen, dann wieder auf den anderen Zellkranz Wasser aufschlagen ließ (:72; siehe Pkt. VI 16b, Abb. VI-80).

Doch nicht nur die Förderung des Gesteins und der Hebung des Wassers, sondern auch die Personenbeförderung, das ,Steigen' auf hölzernen ,Fahrten' (Leitern) funktionierte nach dem Prinzip des Wasserantriebs (LIESSMANN 1997:77). Die ursprünglich gebauten Fahrkünste, um die Bergleute zu ihrem Arbeitsplatz tief im Berg zu bringen, bestanden aus zwei parallel in den Schacht eingehängten Balkenkonstruktionen. Diese beiden aus Vierkanthölzern gefertigten Gestänge wurden von einem Wasserrad (Kunstrad) über eine Kurbel- und Schubstangenkonstruktion in eine gegeneinander gerichtete Auf- und Abwärtsbewegung versetzt (:77). 


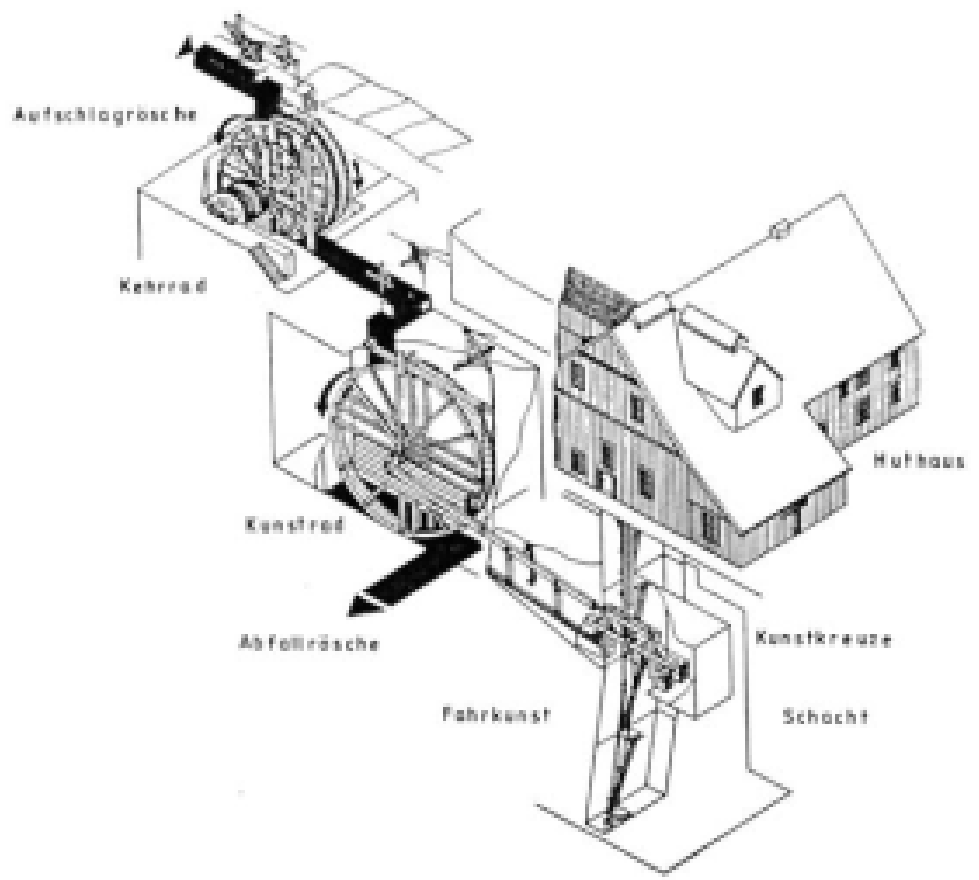

Abb. VII-46: Funktionsprinzip einer Harzer Fahrkunst mit ihren Wasserrädern Blockbild der Grube Samson (aus: LIESSMANN 1997:195)

Doch nicht nur die in der Landschaft stehenden Anlagen wurden mit Wasser betrieben. Auch unter Tage wurden, wie bereits bei der Beschreibung der Radstube angedeutet, Wasserräder in den Gruben eingebaut. Das hatte den Vorteil, dass größere Gefälle und damit stärkere Antriebskräfte erzielt werden konnten. „Obwohl das Wasser - blieb es unkontrolliert - zu den schlimmsten Feinden des Bergmanns zählte, wurde es zur Energieversorgung bewußt in das Bergwerk hineingeführt" (CZAYA 1990:34f.).

Mittels ausgeklügelter Zuleitungssysteme war es möglich, das Gefälle in mehreren Sohlen auszunutzen, d.h. dasselbe Wasser nacheinander über mehrere Räder in unterschiedliche Tiefenniveaus zu leiten (CZAYA 1990:35). Auf den Gangzügen wurden besondere ,Kunstschächte“ angelegt, in denen manchmal bis zu 20 übereinander angeordnete Pumpensätze das Grubenwasser bis auf das Niveau des tiefsten Wasserlösungsstollens hoben. Durch gemeinsame Wasserstrecken konnte so die Last der Wasserhebung gleichmäßig auf verschiedene Gruben verteilt werden (LIESSMANN 1997:82). Um das kostbare Aufschlagwasser mehrmals zu verwenden, setzte man die Wasserräder gewöhnlich übereinander. Dazu war es notwendig, unter Tage in Schachtnähe Kammern zur Aufnahme der Wasserräder auszuhauen (Radstuben). Oft nutzten mehrere Gruben nacheinander das gleiche Wasser, bis es über den tiefsten Wasserlösungsstollen, gemeinsam mit dem aus den Tiefbauen empor gepumpten Wasser, abfloss.

Wegen der durch das Gelände vorgegebenen großen Gefällehöhe, wenn aber auch vergleichsweise geringen Wassermenge, wurden aufgrund ihrer besseren Energieumwandlung nur oberschlächtige Wasserräder in den obertägigen Radstuben gesetzt (BALCK 1999:17).

Dennoch war der Wirkungsgrad dieser Technik, d. h. das Verhältnis von eingesetztem Aufschlagwasser zum letztendlich emporgehobenen Grubenwasser, gering. Vor allem die langen Stangenkünste bewirkten beträchtliche Reibungsverluste (LIESSMANN 1997:72,85). Die Folge war, dass immer mehr Wasser den Kunsträdern und Schächten zugeführt werden musste, wollte man die stetig steigende Fördermenge bergen, das aufgrund der verstärkten Teufe einsickernde Schachtwasser heben und eine größere Zahl Bergleute mit der Fahrkunst ein- und ausfahren lassen.

Erst die im Jahr 1748 für den bergbaulichen Einsatz weiterentwickelte, bereits seit dem 17. Jh. bekannte, ,Wassersäulenmaschine' setzte neue Zeichen: Bei dieser modernen Art der 
Wasserkraftnutzung wird ein in einem liegenden Treibzylinder geführter Kolben durch Auffüllen mit Druckwasser in Bewegung gesetzt. In ihr waren Wasserkraftmaschinen und Pumpe vereinigt. Allerdings war hierzu eine komplizierte Ventilsteuerung notwendig, die den hohen Wasserdrücken standhalten musste. Im Gegensatz zum Wasserrad benötigte eine solche Maschine im Verhältnis zur Leistung relativ wenig Wasser, dafür aber musste sie mit entsprechend höherem Gefälle beaufschlagt werden, damit sich der Kolben der Antriebsmaschinen durch den Druck des Wassers in Bewegung setzt. Des Weiteren traten in der Praxis erhebliche Wasserverluste, insbesondere an den Ventilen, auf (LIESSMANN 1997:86).

Nachdem die Anzahl an Wassersäulenmaschinen im Harz bis 1761 auf 15 gestiegen war, wurden während des Siebenjährigen Krieges die Maschinen stillgelegt, verfielen und kamen später aufgrund ihrer vielen Fehler auch nicht wieder zum Einsatz, bis in den ersten Jahrzehnten des 19. Jh. eine neue ,Zwillingssäulenmaschine' erfunden wurde. Diese arbeitet erstmals 1830/35 in Clausthal (LIESSMANN 1997:86).

Mit Dampfkraft angetriebene Pumpen kamen im Harzer Bergbau erstmalig 1829 in Herzgerode im anhaltinischen Teil des Unterharzes zur Anwendung. Die zum Heizen der Kessel verwendeten Kohlen kamen aus dem Ilfelder Revier am Südharzrand (LIESSMANN 1997:86). Ein wesentliches Argument gegen die Verbreitung solcher Dampfmaschinen war der enorm hohe Verbrauch an Steinkohle, die es im weiten Umkreis nicht gab (:86). Der damit verbundene Untergang der bergbaulichen Wasseranlagen ist unter VIII 3a näher beschrieben.

\section{c Wasserzuführanlagen}

Zu den Wasserrädern der Radstube wurden hölzerne Zuleitungen, sog. Gefluder, geführt. Das Wasser, das in die Gefluder geleitet zum Antrieb der Bergwerksmaschinen diente, kam von einem hoch über oder unter dem Tal gelegenen Wasserlauf bzw. aus einem Quellgebiet und wurde in einem Graben gesammelt (HAASE 1961:41). Vom Graben wurde das Aufschlagwasser über jene hölzerne Rinne, das Gefluder, auf das Kunstrad in der Radstube geleitet. Vom Ende des Grabens bzw. vom Grabenabzweig bis zum Wasserrad betrug die Entfernung war bis zu $50 \mathrm{~m}$. In schwierigem Gelände hatte man anfangs auch über viele Kilometer Holzrinnen verlegt. Aber nachdem der Bergbau das Waldgebirge Harz durch seinen Bau- und Brennholzbedarf ständig kahl zu fressen drohte, führte man die Gräben näher an die Radstube heran.

Nachdem das Wasser das Kunstrad angetrieben hatte, floss das Abfallwasser durch die Ablaufrösche und gelangte von oben in die Kehrradstube (BALCK 1999:56). Das Ablaufprinzip war dabei Folgendes: „Das Wasser kommt vom Kehrrad, fließt über das Kehrrad zum Kunstrad und dann über die Ablaufrösche weiter zum unteren Kunstrad"(:102). Die für die Ableitung des Wassers gemauerte Rösche besaß ein kunstvoll gemauertes Portal, ein Steingewölbe, durch das das Wasser nach Süden abfloss. Wie oben beschrieben, trieben die Wasserräder über ein langes Feldgestänge sodann die im entfernt liegenden Schacht unter dem Hubhaus installierten Pumpen an $(: 56,63,69,72)$.

Aber nur wenn genügend Gefälle für das Antriebswasser zur Verfügung stand, ließen sich beide Räder, Kunst- und Kehrrad, hintereinander schalten. Weil man auf diese Weise das Wasser zwei Mal nutzen kann, reduzierte sich der Verbrauch auf die Hälfte. Gelang dies nicht, kam das Wasser für die beiden Räder von zwei Gräben. Darüber hinaus stand das Abfallwasser vom oberen Rand auch dem unteren zur Verfügung. In Trockenzeiten konnte zusätzlich noch Wasser aus dem Dammgraben gezogen werden (BALCK 1999:71).

$\mathrm{Zu}$ jedem Wasserzulauf gehörte auch, wie bei der Teich- und Mühlenwirtschaft, ein ,Fehlschlag', durch den das Wasser am Rad vorbeifließen kann, wenn es z. B. wegen einer Reparatur stillstehen muss (BALCK 1999:72). Dieser ist Bestandteil der nächsten Ausführungen. 


\section{d Wassersammelanlagen}

Unter Wassersammelanlagen sind Kunstgräben zu verstehen, die das zum Betrieb der Bergwerke erforderliche Wasser sammelten. Lange Hanggräben sollten alles in der Höhe erreichbare Wasser abfangen und in Verbindung mit den Wasserläufen zu den eigentlichen Gebrauchsstätten, den Wasserrädern, und zu den Vorratsstätten, den Teichen, leiten.

\section{d.1 Sammelgräben}

Sollten nennenswerte Wassermengen zum Beispiel zu den Radstuben transportiert werden, so mussten bis weit in das 19. Jh. hinein nicht nur hölzerne Wasserzuführanlagen verlegt, sondern auch künstliche Gräben ausgeschachtet werden, die das zuzuführende Wasser zunächst sammelten. Denn auch wenn die natürlichen Bachläufe des bergbaulichen Mittelgebirges als wasserreich bezeichnet werden konnten, so boten sie für den ausgedehnten Grubenbetrieb nur sehr geringe Wassermengen. Nahm man jedoch die übrigen Niederschlagsflächen eines Gebietes mit hinzu, so vergrößerte sich die Menge erheblich. Zur künstlichen Vergrößerung des natürlichen Zuflusses eines Gebietes dienten sog. Sammelgräben, die etwa parallel der Isohypsen mit leichtem Gefälle angelegt wurden und die auszunutzenden Wasser auf langen, manchmal $8 \mathrm{~km}$ weit entfernten künstlichen Wegen aus vielen Flussläufen heranholten oder den Anschluss an ein natürliches Gewässer bildeten (HAASE 1961:17,41).

Das Prinzip war einfach: Um Wasser hinter einer Wasserscheide herholen zu können, musste der zugehörige Bergrücken mit einem möglichst horizontalen Graben umfahren oder mit einem unterirdischen Wasserlauf durchquert werden. Sogar Talsenken überquerte man, wie das Beispiel des Sperberhai-Damms demonstriert (BALCK 1999:17). Das Dammgrabensystem brachte ,alle die Gewässer des Hohen Harzes weiter" (HAASE 1961:19) über all die kleinen Täler bis zu den Schächten (:41). So stand beispielsweise nach dem Bau des Sperberhai-Damms ab 1734 Wasser sogar aus dem Gebiet des Brockens zur Verfügung, um den inzwischen weiter gestiegenen Bedarf im Clausthal-Zellerfelder Abbaugebiet zu befriedigen (BALCK 1999:17). Im weiteren Fortgang eines Dammgrabens ,wechseln breite Grabenstücke, in denen das Wasser sacht dahinfließt, und schmale Rinnen voll rasch eilender Wasser miteinander ab.“ Solchen Eilstrecken folgte „dann meist ein Beruhigungsbecken." Kunstvolle Fehlschläge, Überläufe, Schottwehre oder Schlammfangkästen in den Zubringern ergänzen die Anlage (HAASE 1961:22) .

Nach Anlegung von ,Sammelgräben' an den Berghängen stand für das nächstliegende Revier ausreichend Wasser zur Verfügung, das durch die zusätzlichen Speicherteiche bei Buntenbock oder in Clausthal in Trockenzeiten oder bei strengem Frost nutzbar war (BALCK 1999:17). Man war interessiert, möglichst alles im Zuge eines Grabens anzapfbare oder zufließende Wasser zu sammeln, damit eine Wasserentnahme aus dem Teich erst in trockenen Zeiten notwendig wurde.

Um eine Wasserreserve zu besitzen gaben die Gräben unterwegs Wasser aus den Quellgebieten an einige Teiche ab (HAASE 1961:41). In gewissen Abständen befand sich dazu im Graben eine ,Ableitungsstelle'. Hier wandten sich die Wasser der Gräben nicht mehr ihrem künstlichen oder natürlichen Vorfluter zu, sondern wurden auf die Sammelteiche verteilt. Der große Dammgraben beispielsweise, dem viele Gräben ihr Wasser zubrachten, verteilte sein Wasser fingerartig, um die großen Teiche $\mathrm{zu}$ versorgen (:27f.). In die Gräben wurde an manchen Stellen ein solide steinerne Entlastungsanlage eingebaut, ein ,Fehlschlag', der bei stärkeren Zugängen die vom Graben nicht bewältigten Wasser zum Teich ableiten, „fehl schlagen“, sollte (:18).

Eine Ausnahme dieses Sicherheitssystems stellt die ,Huttaler Widerwaage' dar. Hier besteht die Möglichkeit, das Wasser nach beiden Richtungen hin fließen zu lassen. Läuft das Wasser im Wasserlauf in Richtung des Gefälles, so erreicht es den jenseits der Wasserscheide im Innerste-Gebiet gelegenen ,Hirschler Teich'. Entfernt man die an der Widerwaage eingebauten Dammbalken, kann der Hirschler Teich gegen das Huttal hin abgesenkt werden, das Wasser fließt dann in entgegen gesetzter Richtung. Diese Maßnahme wurde getroffen, um die unterhalb vom Hirschler Teich befindlichen drei 
Pfauenteiche nicht durch ungewollte Überläufe zu gefährden. Über die Pfauenteiche geht das Wasser des Hirschler Teichs der Kraftnutzung zu (HAASE 1961:28).

Die wichtigsten Gräben kleidete man mit einem Trockenmauerwerk aus. So waren die Grabenwände gegen Solifluktion der Uferbereiche geschützt und auch der Winterbetrieb wurde erleichtert, da auf diese Art Reisig-, Fichten- oder Bohlenabdeckungen, die einen Schnee- und Wärmeschutz bieten sollten, leichter verlegt werden konnten. Früher sicherte man den Graben mittels Holzbohlen oder Eisenschienen und darüber gelegtem Fichtenreisig. In langen Wintern konnten gering und träge fließende Wasser keine großen Schneemengen auflösen. Die Grabenwasser froren hoch, Eis füllte das Grabenprofil aus und bei Tauwetter und Hochwasser drohte eine Katastrophe (HAASE 1961:26).
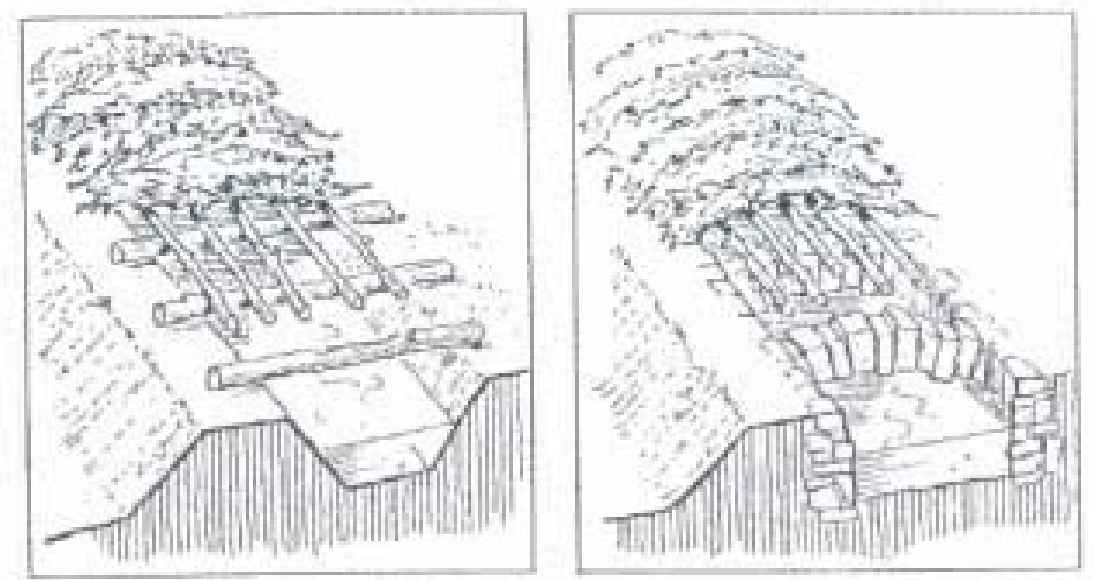

Abb. VII-47: Grabenabdeckung: Formen der Winterabdeckung (,Beheckung“) der Gräben Um die Querstangen zu sparen, wurden kleine Steinbögen über Trockenmauerwerk gespannt (aus: SCHMIDT 1997:197).

\section{d.2 Wasserläufe}

Die seit dem 17. Jh. praktizierte Abdeckung der offenen Gräben mit darüber gelegtem Fichtenreisig, um ein Zufrieren in eisigen Zeiten oder Zuwehen bei starkem Schneefall zu verhindern und das zu einem Stillstand der Wasserräder und damit zu einem Aufgeben der Energieversorgung geführt hätte, war angesichts der immer knapper werdenden Holzversorgung nicht mehr durchzuhalten. Besser erreichte man dies, wenn die zur Verkürzung langer Grabenumwege hergestellten ,Wasserläufe' das Wasser für einige Zeit vor Frost bewahrten.Es wurden daher an wichtigen Gräben verstärkt Abkürzungen durch den Bau von Stollen geschaffen, so dass die langen Grabenverläufe ,um die Berge herum', die den Höhenlinien folgten, aufgegeben werden konnten.

Stollen als unterirdische Gräben werden im Harz, Wasserläufe' genannt und wurden wie im gesamten Bergbau üblich, anfangs nur mit Schlägel und Eisen aus dem Berg herausgemeißelt und erst später, nach der Bereitstellung von Sprengmittel aus den Pulvermühlen und bei der im Zuge der Erweiterung des Bergbaus notwendigen Heranführung zusätzlicher Wässer aus weiter entfernt liegenden Wasserund Quellgebieten, wurden Sprengstoffe verwendet. Der Holzverbrauch für die Grabenabdeckungen konnte reduziert werden, unterirdisch geführt froren die Wasser nicht zu und Wasserscheiden konnten unterfahren werden.

Beide Ziele, Erwärmung und Laufverkürzung, sind im 19. Jh. ständig verfolgt worden, wenn sie auch zuletzt als Betonrinne errichtet wurden und zur Abdeckung eine Betonplattendecke diente. 1834 ist die erste größere Rohrleitung zur Querung des Grunder Tales verlegt worden (SCHMIDT 1997:14).

Heute noch zu sehende Mundlöcher weisen auf den Aus- bzw. Eingangsbereich der Wasserläufe hin. 


\section{e Wasserstauanlagen}

Existentiell für das Wirtschaftsleben war eine gesicherte Wasserver- und -entsorgung. Wie schon in der Einführung erläutert, stellt das Wasser nicht nur eine energetische Hilfe, sondern auch eine Notwendigkeit und Last im Bergbau dar. Eingesickerte Wasser mussten auf der einen Seite gehoben werden, sollte der Bergbau nicht gestört bzw. gänzlich unterbunden werden. War auf der anderen Seite das Betriebswasser, das Aufschlagwasser knapp, so war es auch mit der Wasserlösung zu Ende. "Daraus ergab sich die auf den ersten Blick paradoxe Situation, daß der Wassermangel in trockenen Sommern zum "Absaufen" der Grubensenke führte." (LIESSMANN 1997:81)

\section{e.1 Zechenteiche}

Der Einsatz von Wasser, wie es im Bergbau benutzt und benötigt wurde (siehe VI 16b), setzte vor allem voraus, dass entsprechende Wassermengen zur Verfügung standen. Doch daran mangelte es oft. Niederschläge fallen auch in den regenreichen hohen Mittelgebirgslagen nur sehr unregelmäßig und in den Wasserläufen wechseln Zeiten des Überflusses und des Mangels - vor allem vor den massiven Eingriffen des Menschen in den hydrologisch-klimatologischen Kreislauf - natürlicherweise einander ab. Auch selbst im regenreichen Oberharz war angesichts des bergbaulichen Großbedarfs nicht immer genug Wasser verfügbar. Es gab regenarme Wochen und Monate, es gab vor allem Frost und kalte Winter, in denen trotz reichlich Schnee wenig abfloss. Die Bäche schrumpften zu Rinnsalen. Besonders in Perioden der Trockenheit ließen sich nur wenige Tonnen Erz fördern (CZAYA 1990:35). Noch schlimmer war, da ständig weiter Wasser zusickerte, wenn die Pumpen ungenügend arbeiteten, weil oberirdisch nicht genügend Wasser zum Antrieb der Wasserräder verfügbar war, um das Wasser aus den Gruben herauspumpen zu können und die eindringenden Grubenwässer nicht mehr zu bewältigen waren. Dann blieben die Künste und die Züge wegen des wenigen Wassers alle stehen $(: 35)$.

Für diese Wassermangelzeiten und um über das begehrte Wasser möglichst reichlich und kontinuierlich verfügen zu können, wurden Sammel- oder Vorratsbecken geschaffen. Sie ermöglichten es, auch in Trockenzeiten das notwendige Antriebswasser bereitzustellen, und bildeten das Rückgrat der Wasserversorgung zum Betrieb der Wasserräder.

Schon im 15. Jahrhundert wurden künstliche Reservoire gegraben. Vor allem wurden oberhalb der Grubenreviere an geeigneten Stellen große Zechenteiche angestaut, in denen man die Wässer der Umgebung sammelte (CZAYA 1990:36). Je höher im Gelände das Wasser gewonnen werden konnte, umso öfter konnte es über ein Wasserrad fallen. Das Wasser aus hochgelegenen Staubecken ließ sich etwa sechs Mal, aus tiefer gelegenen entsprechend weniger oft, über die Räder leiten. „Daraus erklärt sich, warum man gerade im höchstgelegenen Bereich der Bachursprünge schon Sammelteiche anlegte." (HAASE 1961:7) Andererseits hatte dies den Nachteil, dass es in der Höhe nur kleine Einzugsbereiche und entsprechend geringe Wasserzugänge gab. Man war bestrebt, aus ähnlich hoch gelegenen, benachbarten, aber auch weiter entfernt gelegenen Räumen weiteres Wasser heranzuführen $(: 7,9)$.

Bei den Teichen um Buntenbock beispielsweise trifft man drei verschiedene Teich-Höhensysteme an, die sich jeweils aus einer Vielzahl von Teichen zusammensetzten, deren Aufzählung hier erspart bleiben soll (HAASE 1961:9ff). Wichtig ist in diesem Zusammenhang, dass verborgene Wasserläufe und offen zutage tretende Gräben (siehe oben) aus unterschiedlichen Höhenniveaus den Sammelteichen das Wasser zugeführt haben. Der Teichbau ist „wasserbauliches Kernstück der Oberharzer Teichwirtschaft" (:94). 


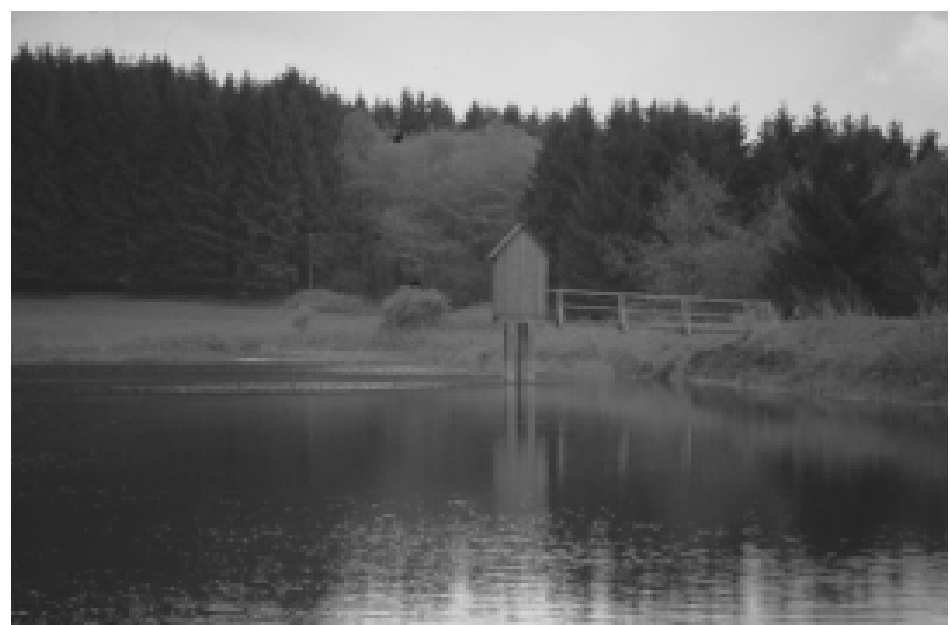

Abb. VII-48: Oberharzer Bergwerksteich mit früher typischem geständertem Striegelhäuschen

vor dem Damm im Wasser stehend. Diese Aufnahme zeigt den „Wasserläufer Teich“, im Volksmund auch „Schweineteich“ genannt. Es ist nach Auskunft des Bergwerkmuseums Zellerfeld der einzige Teich mit einem frei im Wasser stehenden Striegelhaus, wobei es sich auch bei diesem um einen Neuaufbau von 1999 handelt (eig. Aufnahme 2004).

Aber nicht nur im Oberharz, wenn auch hier bevorzugt - für alle Reviere legten die Bergleute entsprechende Teiche an, die ihnen langfristig, über das Jahr verteilt, genügend Antriebswasser sichern sollten (BALCK 1999:18). Windkraft war natürlich auch schon bekannt, aber Windkraft ist als solche nicht direkt speicherbar. Erst auf dem Umweg über das Hochpumpen von Wasser mit Hilfe einer Windmühle in ein Speicherbecken kann man sie speichern (TRUNZ 2000:VI).

Trotz eines ausgeklügelten Verbundsystems jedoch, das mit der Aushebung von Kunstteichen, um Wasser aus den nassen Zeiten auch für trockene Wochen verfügbar zu haben, und mit der Anlage von Umlaufgräben für eventuelle Teichreparaturen seine Vollständigkeit erfuhr, „gab es Zeiten, in den manche Gruben wegen Mangel an Antriebswasser für die Pumpen absoffen und ihre Bergleute mangels Arbeit hungern mußten. [...] Man mußte mit dem Wasser haushalten und seine Vorräte kalkulieren“ (BALCK 1999:17f.). Manche Trockenzeit im Harzer Bergbau beispielsweise dokumentierte man mit beschrifteten ,Hungersteinen' auf dem Grund eines trockenen Teiches (:18).

Verkürzt dargestellt beginnt die Reihe der Ersatzwasserzuführung mit einem Bergbauteich: Das Wasser fließt durch einen Obergraben zum Wasserlauf und am Ende des Wasserlaufs in einen anderen Graben. Hier trifft es sich mit dem Wasser wiederum aus einem anderen Grundgraben und aus anderen Teichanlagen. All diese Wasser fließen weiter zu einem anderen Sammelteich und werden schließlich über sog. Aufschlaggräben auf das Wasserrad zu einer Grube geführt.

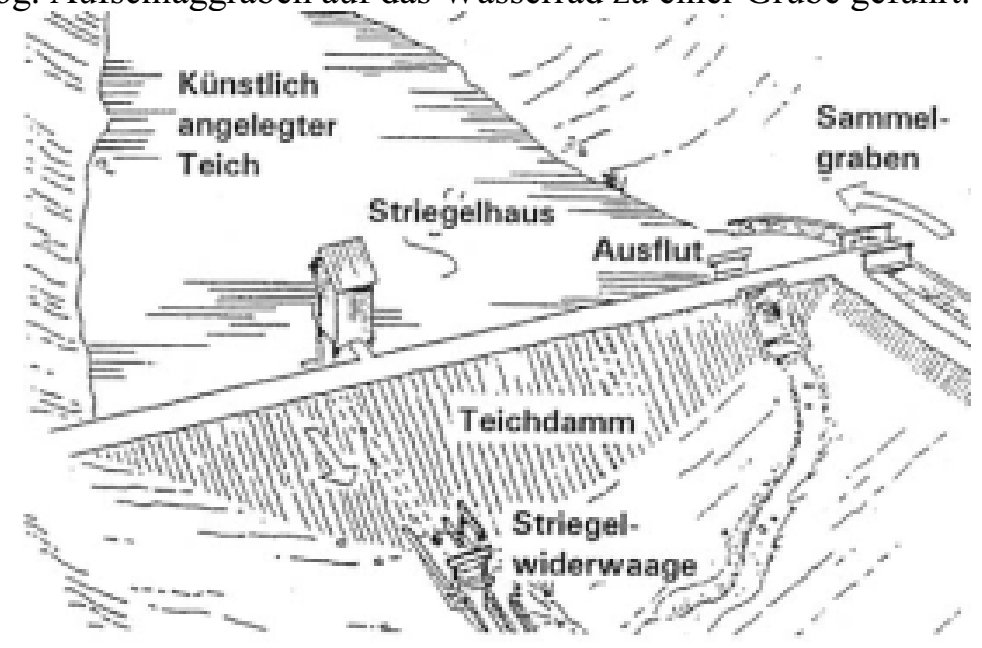

Abb. VII-49: Bergwerksteich und sein wasserbauliches System (aus: TRUNZ 2000, Abb. 10) 


\section{e.1.1 Dammbau}

„Ausschließlich durch Dämme“ (SCHMIDT 1997:17) sind die Teiche auf dem Oberharz gebaut worden.

Da Lehm oder Ton zur Dichtung dieser Staudämme kaum vorhanden waren, wurden aus Rasensoden sorgfältig ,Rasenhäupter' als Außendichtung aufgeschichtet (SCHMIDT 1997:17; KLEßEN 2000:30). Dem Teichbau von Clausthal stand mit dem weiten Wiesengelände reiches Rasenmaterial zur Verfügung, mit dem man die Dichtung vornahm (HAASE 1961:94). Die sichernde Schicht, das ,Rasenhaupt', untermischte man mit feiner grusiger, mit Köhlererde vermengter Erde, der sog. ,Dammerde'. Diese dem Wasser ausgesetzte empfindlichste Zone des Dammes wurde zwar durch grobe Steine vor starkem Wellenschlag geschützt - bei dieser Dammbauweise der älteren Art legte man den wasserdichten Teil nicht in die Mitte, sondern auf die Wasserseite des aus Erde und Steinen aufgeschütteten Dammes -, aber Eisbewegung, Mäusegänge, Wurzeln der Bäume lockerten mit der Zeit hier das Gefüge. „Mancher Teich dieser Bauart“, weiß HAASE (:94), „,ist bei Hochwasser durchbrochen".

Darum hat man die Erfahrungen sächsischer Teichbauer, „die eine vorteilhaftere Methode“ (HAASE 1961: 94) des Dammbaus anwandten, in den Harz geholt. Die neuere Bauweise verlegte den Dichtungskörper, also das ,Rasenhaupt', in die Mitte des Dammes. Diese senkrechte Kerndichtung aus Dammerde wurde beiderseits mit Erdreich und Steinen aufgeschüttet (KLEßEN 2000:30). Die neueren Teiche besaßen infolgedessen einen viel breiteren Dammfuß (HAASE 1961:95). Als erster der neuen Art ist 1724 der, Wiesenbeeker Teich' bei Lauterberg gebaut und nach dem Ausbruch des ,Schalker Teiches' zu Weihnachten 1733 auch dieser Teich nach dem neueren Bauprinzip erneuert worden (:94f.). „Unter Wasser gehalten, sind sie noch heute, nach 400 Jahren, wasserdicht", urteilt SCHMIDT (1997:17) über die Qualität dieses Teichbaus, lässt daraus aber auch schon die Notwendigkeit eines fortwährenden Bespannung resp. Inwertsetzung von Teichen erkennen, die für den historischgeographischen Betrachtungsansatz so elementar ist (siehe I 3d, 4a, 5b und d).

Während dieses Dammbausystem für den Bau „relativ kleiner Teiche“ (SCHMIDT 1997:195), d. h. mit Dämmen von 6 bis 15 m Höhe, „bis in unsere Tage erhalten geblieben“ ist und nur der Dichtungskern, das ,Rasenhaupt' auf der Wasserseite, nicht mehr aus Rasenerde, sondern aus Beton hergestellt wird (HAASE 1961:95), wurde für den Damm des großen Oderteiches, der in der Sohle 44 $\mathrm{m}$ und in der Krone $16 \mathrm{~m}$ Breite maß, eine andere Bauart angewandt. Hier wurden große Granitblöcke hergerichtet und in Trockenmauerung neben- und aufeinander gefügt. Granitverwitterungsgrus, mit fließendem Wasser vermengt, gab ein ausgezeichnetes Dichtungsmaterial her. Diese Granitblöcke stammten wahrscheinlich aus dem Brockengebiet, der aus diesem Gesteinsmaterial besteht. Das ist umso erklärlicher, als im steilen Odergebiet keine Rasenplaggen als sonst üblicher Baustoff vorhanden war (:92). Die Befestigung der Steine im Verbund besorgten Eisenklammern, die Fugen zwischen Stein und Eisen sind mit Blei ausgefüllt. Zwischen die Steinschichten wurde Moos gebettet. Während man so die Wasser wie auch die Luftseite des Dammes von Grund hoch führte, wurde als eigentliche wasserdichte Schicht dazwischen ein $6 \mathrm{~m}$ mächtiger, auf den abgeräumten Fels errichteter Granitgruskörper lagenweise aufgebracht und festgestampft (:94).

Mit Ausnahme des großen, einzeln stehenden Oderteiches wurden die kleineren Teiche meist in Gruppen, kaskadenförmig untereinander angeordnet. „Die Technik des Bauens von Kaskaden kann hier sehr intensiv studiert werden.“ (TRUNZ 2000:VII), wie nachfolgende Abbildung zeigt.

Um den Rohstoff Wasser möglichst effizient zu nutzen, wurde möglichst jedes Zoll an Gefälle ausgenutzt. Ein geringes Gefälle der Gräben, die das Wasser heranführten oder weiterleiteten, war der erste Schritt um möglichst viele Teiche hintereinander zu schalten. Der zweite Schritt war die stete Erhöhung der Teichdämme, soweit wie das technisch möglich war und man es sich unter Berücksichtigung der notwendigen Sicherheit zutraute. Wenige zusätzliche Meter Dammhöhe ergaben ein neues Gefälle und das Wasser konnte auf höherem Niveau zu einem der vorhandenen Räder gebracht werden. 


\section{e.1.2 Striegelanlagen}

Zur kontrollierten Wasserentnahme wurden im Dichtungskörper Striegelanlagen aus Holz gebaut (siehe folgende Abbildungen), bei denen sich wie beim Dammbaueine ,alte' und ,neue' Bauart voneinander unterscheiden lassen:

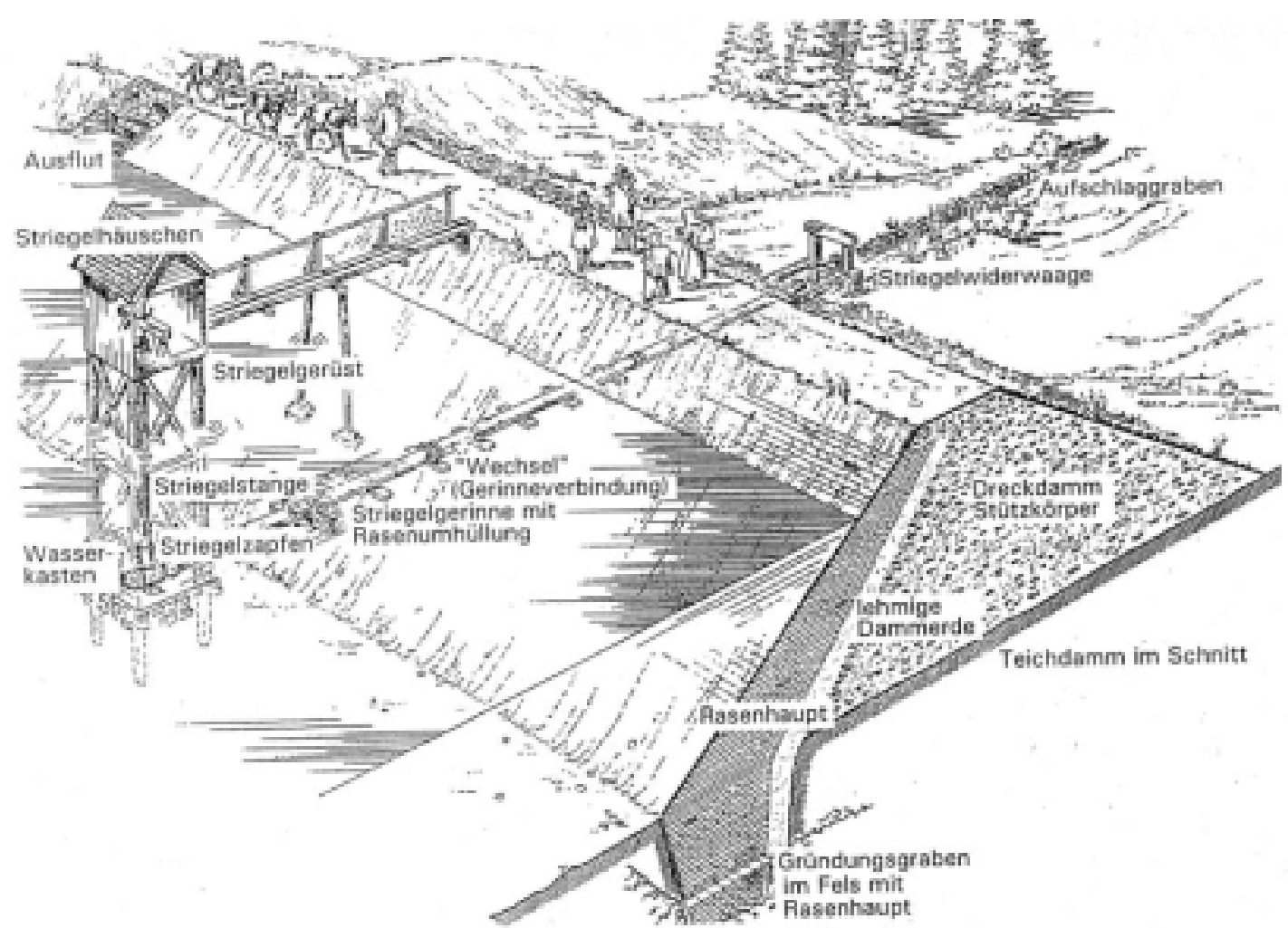

Abb. VII-50: Teichdamm in der alten Bauart im Oberharz bis 1733

(TRUNZ 2000, Abb. 7)

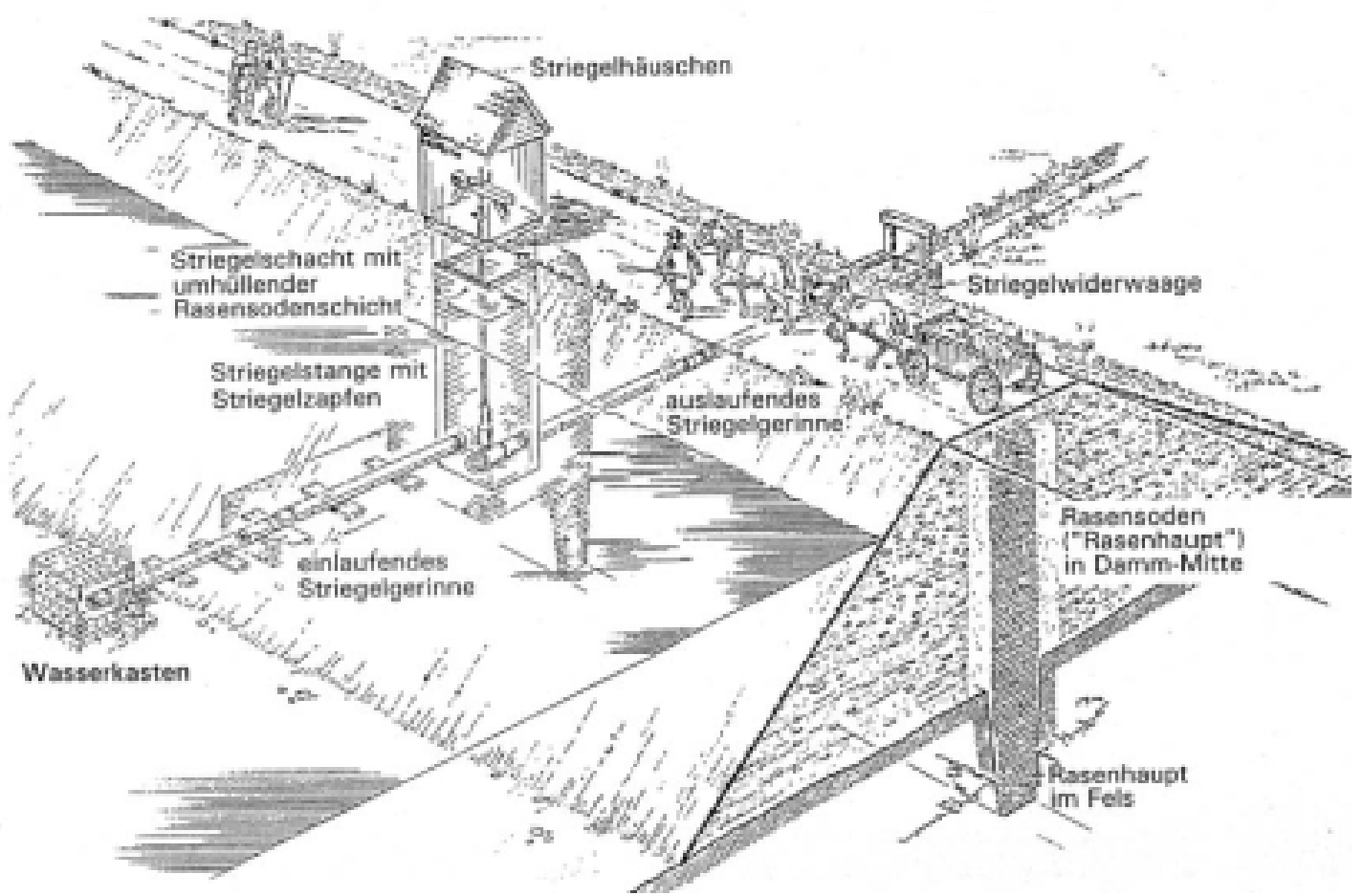

Abb. VII-51: Teichdamm in der neuen Bauart

Diese wurde im Oberharz 1733 zum ersten Mal angewendet (TRUNZ 2000, Abb. 8). 
Bei der ,alten' Bauweise ist das sog. Striegelhäuschen auf einem Gerüst im Wasser erbaut (KLEßEN 2000: 30). Es befindet sich vor dem Damm, in dem der meist vom Wasser verhüllte Dammfuß die Verschlüsse trägt. Das Striegelhaus erscheint dann frei im Wasser stehend, von ihm reichen die Striegelstangen hinunter zum Striegel (HAASE 1961:94). Bei dem ,Striegel' handelt es sich dabei um einen röhrenförmigen Schacht, der von der Sohle bis zur teilweise $18 \mathrm{~m}$ hohen Dammkrone reicht. Der Striegelschacht ,steht mit dem Wasser des Teiches durch einen Zuführungskanal aus Granitsteinen in Verbindung, so daß der Teichspiegel sich im Striegelschacht einstellt. Nach der Luftseite hin leiten zwei ,Striegelgerenne' aus Eichenholz das Wasser nach außen. Je ein Zapfen aus Eichenholz, der „Striegelkopf', verschließt oder öffnet den dafür vorgesehenen Auslaß in den Striegelkästen. Lange eichene Stangen führen hinauf bis zur Dammkrone, wo in einem ,Striegelhaus' das Ziehen und Schließen der Striegel erfolgt“ (:94). Nach dieser Umschreibung von HAASE sind etwa ,alle jene jahrhundertealten Teichverschlüsse im Harz gestaltet" (:94). Wind, Wellen- und Eisgang führten jedoch oft zur Beschädigung der Striegelanlage (KLEßEN 2000:30), so dass eine Änderung der Bauart herbeigeführt wurde.

Ein Unterschied besteht darin, dass nicht - wie am Oderteich - der Striegel im Damm selbst angebracht ist. Das Striegelhäuschen der, neueren' Bauart befand sich nun direkt auf bzw. in dem Damm über einem mit Rasenpackung umhüllten Striegelschacht. Von hier wurden die Abflussventile (,Striegelkopf') betätigt. Das Wasser floss durch ein Gerenne aus Eichenholz in das luftseitig gelegene ,Tosbecken', im Harz ,Widerwaage' genannt. So stand das hölzerne Gerenne unter Luftabschluss, um den Fäulnisprozess zu unterbinden. Diese Bauweise wurde im Westharz erstmals 1724 beim Bau des ,Wiesenbeeker Teichs' bei Lauterberg angewendet (KLEßEN 2000:30). 


\section{e.2 Mühlhüttenteiche}

Von den Wasserbauten des Bergbaus werden die die bergbaulichen Produkte verarbeitenden Mühlenbetriebe unterschieden, obgleich sie verarbeitungstechnisch dem Bergbau angegliedert sind und oftmals die gleichen Wasser stauenden Einrichtungen benutzten.

Sie müssen eng genommen den Wasserwerken - sprich den Mühlen - zugeordnet werden, doch da sie oft unmittelbar mit dem Bergbau räumlich und wirtschaftlich verbunden waren, sollen sie an dieser Stelle eingefügt werden. In Ableitung von der Mahlmühle mit Wasserradantrieb fand denn auch ,für mit Wasserkraft betriebene Anlagen im Eisenwesen die Bezeichnung Mühlhütte Anwendung.“ (ALTMANN 1999:14, Hervorhebung im Original)

Man unterscheidet bei der Gewinnung der Metalle zwei wichtige Verfahrensgänge: die für die Verhüttung erforderliche Aufbereitung der Erze, bei der auf mechanische Weise Erzminerale und taube Gangarten separiert werden, und die Verhüttung, bei der sich die Erzminerale in der Hitze eines Kohlenfeuers zersetzen und die in Schmelze überführten Wertmetalle anschließend durch geeignete metallurgische Prozesse voneinander getrennt werden (LIESSMANN 1997:95; ALTMANN 1999:29).

Für beide Prozesse, den Trennprozess der Aufbereitung, Pochen (Zerkleinern) - Klassieren (Schlämmen bzw. Waschen) - Sortieren (Setzen), wie auch für die Verhüttung wurde Wasser benötigt.

Während die Erzscheidung, bei der erzhaltiges Gestein vom tauben Gestein getrennt (,geschieden') wurde, durch Handarbeit geschah, gab es seit dem Mittelalter bis Mitte des 19. Jh. zur Erzzerkleinerung nur die sog. Nasspochwerke, ,die in großer Zahl an Bachläufen nahe der Gruben standen." (LIESSMANN 1997:95f.) . Zur Beaufschlagung der Wasserräder, die, wie Abb. VII-52 zeigt, die Pochsätze ${ }^{50}$ antrieben, nutzte man häufig auch die von den Wasserkünsten der Gruben abfallenden Wasser aus.

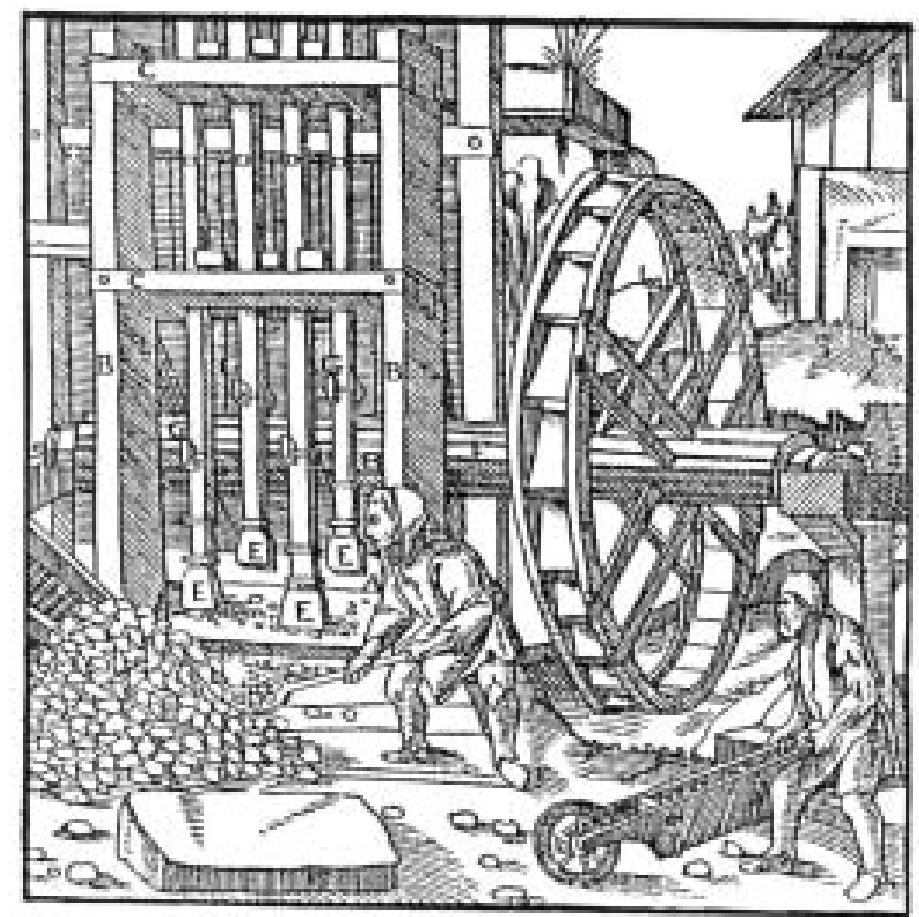

Abb. VII-52: Einfaches wasserkraftgetriebenes Stempelpochwerk

Dies wurde so bis ins 19. Jahrhundert hinein im Bergbau verwendet: A) Pochtrog, B) Pochsäulen, C) Querhölzer,

D) Stempel, E) Pochschuhe, F) Welle, G) Hebling, H) Däumling (AGRICOLA 1556)

\footnotetext{
${ }^{50}$ Pochsatz: Anzahl der Pochstempel mit einem bestimmten Profil auf der Schlagseite.
} 
Die eisernen Pochschuhe wurden durch die Wasserkraft über eine Welle in eine gewisse Höhe gehoben und fielen sogleich wieder nieder.

Auch im weiteren Arbeitsschritt - zur besseren Aufbereitung der Erze - mussten besonders die mit Ton verunreinigten Erzpartikel nach dem Pochen in Sieben im Waschtrog oder in einem Gerinne tatsächlich gewaschen werden; aber in der Bergmannsprache bedeutet, waschen' die Aufbereitung durch die Kraft des Wassers, das die leichten, tauben Teilchen wegspült und die erzhaltigen Brocken nach Gewicht sortiert (ALTMANN 1999:29). Die nach dem Pochvorgang und dem Auffangen der Erzpartikel folgende Sortiermethode der Erzgemische funktionierte also nur unter Wasserzusatz (LIESSMANN 1997:97).

Die Einführung wasserkraftgetriebener Setzmaschinen (erstmals 1820 bei Clausthal) machte die Setzarbeit zwar wesentlich rationeller und seit 1832 brachten zudem die zur Zerkleinerung eingesetzten Walzwerke (Walzenmühlen) eine beträchtliche Verbesserung, indem sie ein gleichkörnigeres Gut als die Stempelpochwerke ergaben (LIESSMANN 1997:97), doch parallel zum technischen Fortschritt war auch ein größerer Wasserbedarf vonnöten.

Das Gleiche gilt auch für den nächsten Entwicklungsschritt, der durch die um 1850 konstruierte ,hydraulische Setzmaschine' charakterisiert ist: Mit einem beweglichen Kolben wurde Wasser stoßweise durch die Siebe hindurch gedrückt (LIESSMANN 1997:99).

Das letzte Glied in der langen Kette der Metallerzeugung ist die Verhüttung, die aus den Prozessen Rösten - Schmelzen - Treiben besteht. Das feine Erzpulver enthielt neben Blei und Silber Bestandteile von anderen Metallen (Kupfer, Zink, Eisen etc.) und außerdem Reste von Gangartmineralien wie Quarz und Kalkspat. Zur Gewinnung von reinem Silber und reinem Blei mussten beide Metalle getrennt und von störenden Verunreinigungen befreit werden.

Völlig andersartig als die geschilderten Metallhüttenprozesse lief die Erzeugung von Gusseisen und Stahl im sog. Eisenhüttenprozess ab (LIESSMANN 1997:107), der die Herstellung von Fertigerzeugnissen (Pflugschare, Hacken, Schaufeln, Ketten, Nägel, Hämmer, Meißel, Sicheln, Sensen, Bergeisen usw.) zum Ziel hatte. Zur Gewinnung von metallischen Eisen musste diesen Erzen durch reduzierendes Schmelzen der Sauerstoff geraubt werden. „Schon im Mittelalter benutzte man hierfür Hochöfen mit wasserkraftgetriebenen Gebläsen, die an die Stelle der vorher benutzen einfachen Rennfeueröfen traten.“ (:107), wie die folgende Abbildung von AGRICOLA zeigt. 


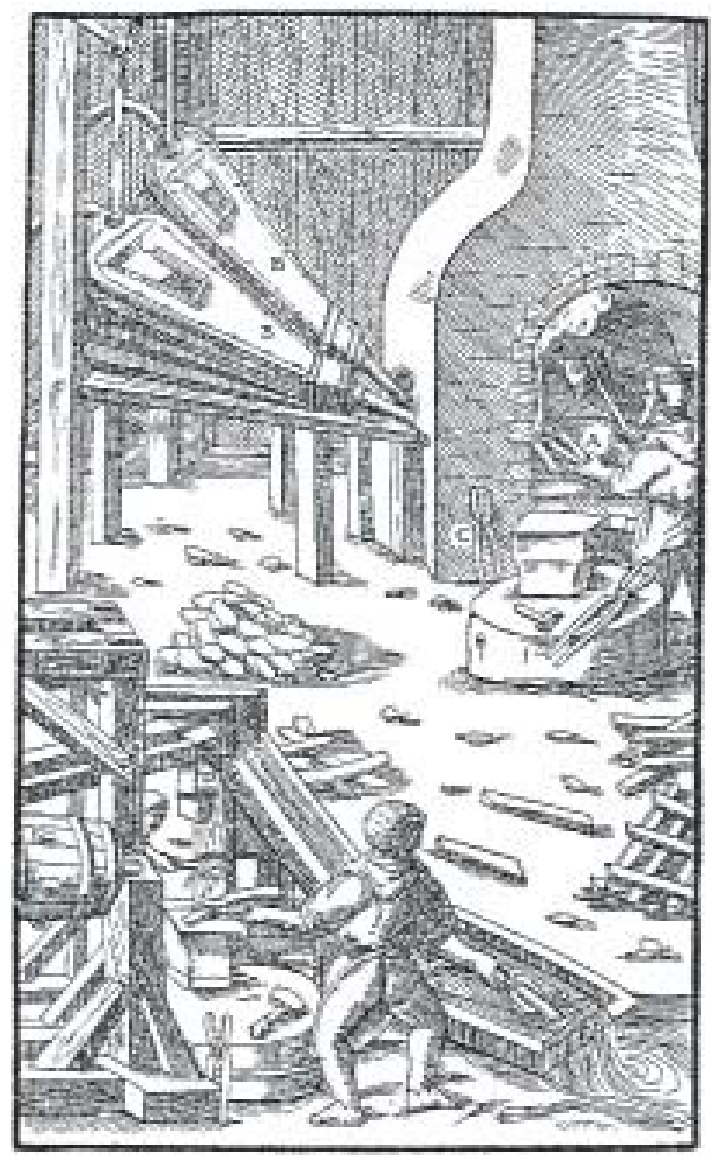

Abb. VII-53:Hochofen mit wasserkraftbetriebenem Gebläse (AGRICOLA 1556)

Während des Verhüttungsprozesses reagierte der Sauerstoff aus der eingeblasenen Luft (Wind) mit der glühenden Holzkohle unter Bildung von Kohlenmonoxid (CO). Zur Gewinnung der restlichen, nicht unbeträchtlichen, Eisenmengen, die in der frühen Zeit, als die Blasebälge noch nicht hinreichend effektiv waren und größere Mengen an Eisen in den Schlacken, d. h. in den eigentlich verschlackten tauben Bestandteilen der Erze, verblieben, betrieb man Schlackenpochwerke und Schlackenwäschen (LIESSMANN 1997:107).

Da das flüssige Eisen während des Schmelzvorgangs im Hochofen auch Kohlenstoff aufnahm, war das so erzeugte Roheisen sehr spröde und konnte höchstens als Gusseisen verwendet werden. Zur Herstellung von geschmeidigem Schmiedeeisen (Stahl) musste der Kohlenstoffanteil gesenkt werden. Bei diesem Vorgang, hüttenmännisch „Frischen“ genannt, musste das Eisen in einem Herdfeuer, das einer Schmiedeesse ähnlich war, wieder eingeschmolzen und oxidierend behandelt werden, so dass der überschüssige Kohlenstoff entwich (LIESSMANN 1997:107).

Die dafür notwendigen wasserbetriebenen mechanischen Hämmer als die Produktionsstätten der Schmiedeeisenerzeugung und -verarbeitung, Roheisenerzeugung und -umschmelzung des 14. bis 19. Jh., „waren die größten und technisch kompliziertesten Anlagen für die direkte Schmiedeeisenerzeugung - bis zur Einführung des Holzkohlenhochofens" (ALTMANN 1999:14). Die Standorte dafür ergaben sich aus dem Bedarf an Wasser für den Produktionsprozess: "Die vielfältigen Betriebsanlagen einer Hammer- und Eisenhütte, die eine annähernd gleiche Wasserkraft als mechanische Antriebsenergie benötigten, baute man in mitunter größeren Abständen entlang eines Baches oder Flusses, um einen möglichst kontinuierlichen immer wiederkehrenden Gebrauch an Wasserkraft zu gewährleisten." (:128) So waren die Anlagenkomplexe erzgebirgischer Hammer- und Eisenhütten beispielsweise ,aufgrund der natürlichen Bedingungen, wie Flußläufe, Talniederungen, als dezentralisierte oder zentralisierte Betriebsstätten errichtet und betrieben worden.“(:128). 
Hämmer und Eisenhütten als Mühlhütten in der Mitte des 16. Jh. besaßen deshalb, genau wie andere wasserbetriebene Energiewerke, stets das Wasserrad, Kunstgräben, Fluter mit Flutergraben und Fluterschütz. Ferner waren Spannteiche zugehörig (ALTMANN 1999:38,128,141).

Auf der folgenden Abbildung von AGRICOLA sind zunächst die linearen und technischen Wasseranlagen zu sehen. Vor dem Herd ist der Rennmeister zu sehen. Er regelt den Gebläsewind, indem er durch Verstellen die Schütze) einstellt, die den Wasserzufluss und damit die Drehzahl des Wasserrades für den Antrieb der Blasebälge verändert. Das Wasserrad ist auf dieser Abbildung nicht $\mathrm{zu}$ sehen, der wasseradbetriebene Blasebalg nur zur Hälfte. Ein Schmied arbeitet an einem mechanischen Brusthammer. Die Regulierung des Wasserzulaufs auf das Wasserrad erfolgt durch ein Gestänge, das den zweiten Fluterschütz öffnet oder schließt. Dadurch kann der Schmied je nach der gerade zu tätigenden Arbeit die Schlagzahl des Hammers direkt von Hand regeln (ALTMANN 1999:39).

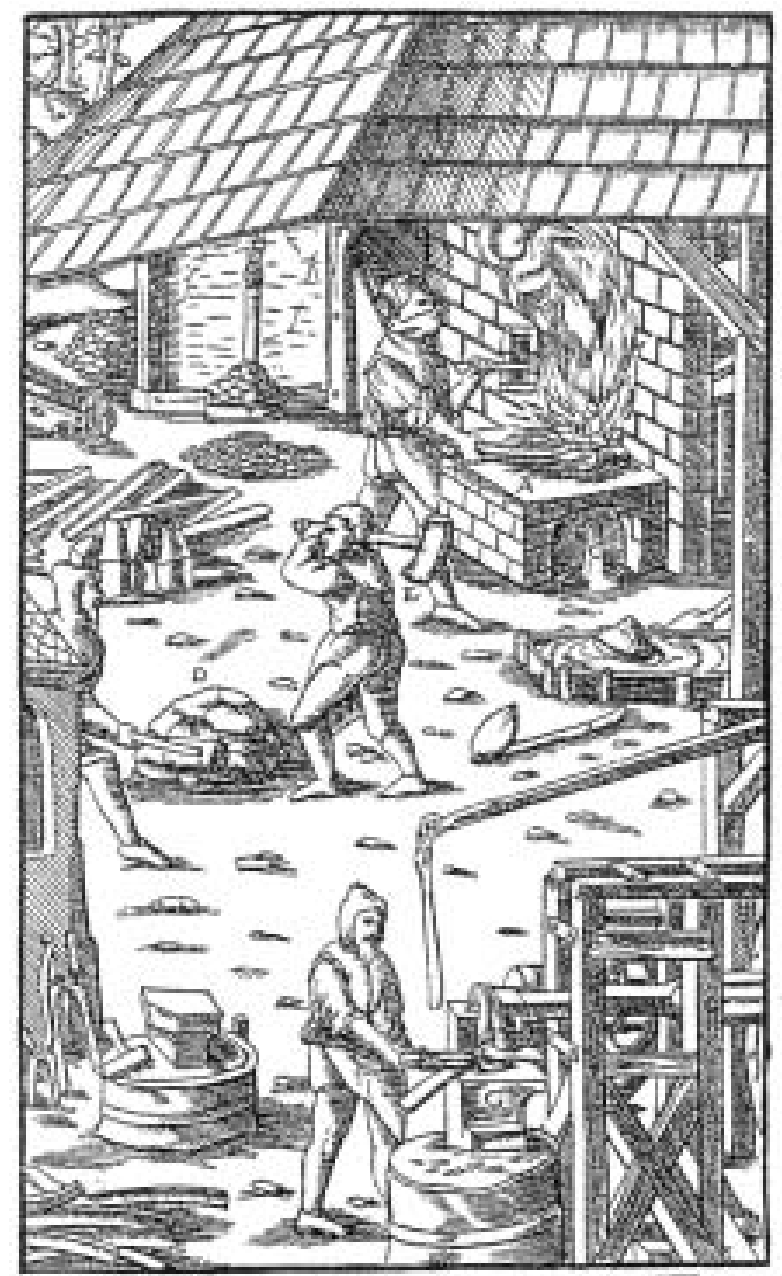

Abb. VII-54: Hammerhüttenbetrieb mit Rennwerk und Rauchabzug. 1. Hälfte des 16. Jahrhunderts (AGRICOLA 1556)

Da zu den technischen Anlagen auch die Blasebälge zum Betrieb der Herde und Öfen notwendig und auch die Wellen und Antriebsgestänge von der Bewegungsübertragung des Wasserrades abhängig waren, war die Anlage von Wasserstauteichen Bestandteil einer Eisenhütte, die ALTMANN (1999:142) wie folgt beschreibt:

„Den Zulauf für den Antrieb der Wasserräder leitete man über eine Wehranlage im Bach oder Fluß, die eine Wasserteilmenge abzweigte und über einen Kunstgraben mit geringstmöglichem Gefälle die Fallhöhe erreichte. Neben einem Überlauf für eventuelles Hochwasser regulierte der Schütz im Kunstgraben die auf das Wasserrad zugeleitete 
Wassermenge so, wie man sie für die erforderliche Zahl der Hammerschläge und Hubzahl der Blasebälge brauchte. Für den konstanten Wasserfluß in den Kunstgräben wurde oftmals zwischen dem natürlichen Wasserlauf und dem Schützen ein Hammerteich, auch Spannteich genannt, dazwischengeschaltet. Die Flüsse und Bäche des Erzgebirges lieferten eine verhältnismäßig kontinuierliche Wasserversorgung für die Hammer- und Eisenhütten. Ausgenommen waren Jahreszeiten mit starker Schneeschmelze und Regen oder besondere Trockenperioden im Sommer."

Die Größe der Hammer- und Eisenhütten war unterschiedlich und neben den Standortfaktoren wie Holzvorkommen, Eisenerz, Verkehrsbedingungen und Absatzmöglichkeiten vor allem auch von der zur Verfügung stehenden Wasserkraft abhängig. Deshalb waren sie ,gekennzeichnet durch einigermaßen konstant die erforderliche Wassermenge führende Bach- und Flußläufe, die notfalls in Stauteichen (Spannteichen) auf Vorrat gehalten werden mussten“ (ALTMANN 1999:36).

Wie wichtig ein solcher den Wasserzulauf verstärkender bzw. unterstützender Hammermühlenteich für den Hüttenbetrieb war und welche Kraft dieser entwickeln musste, wird bei der Dimension eines typischen Hammers deutlich, der 2 bis 3 Zentner wog: Allein vom fließendem Bach wurde durch das Wasserrad und dessen Wellbaum die am hinteren Teil des Hammers befindlichen Hebarme aufgehoben und das auf dem großen Amboss untergelegte glühende Eisen durch das schwere Niederfallen des Hammers geschmiedet (ALTMANN 1999:55).

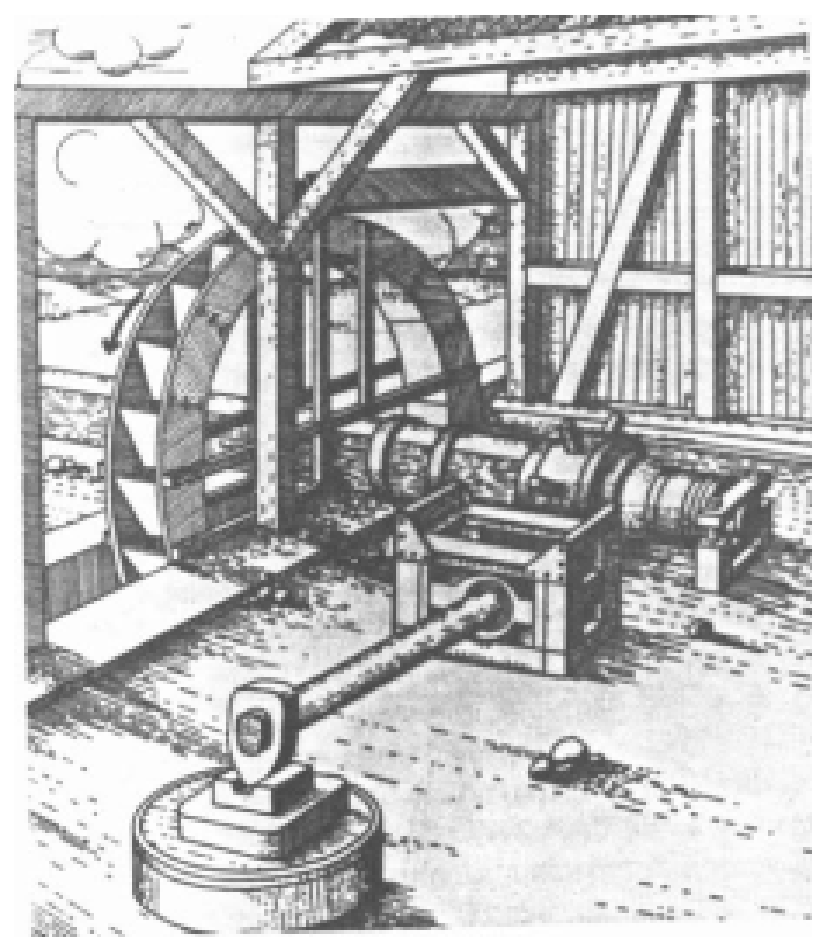

Abb. VII-55: Darstellung einer frühen Form einer Hammerhütte des 16. Jahrhunderts

Auf diesem Bild ist die Funktion des mechanischen Schwanz- oder Stielhammers mit Antrieb durch ein oberschlächtiges Wasserrad beschrieben (Zeichnung aus dem Zisterzienserkloster Oliva bei Danzig, aus: MÜLLER/LUDWIG 1982:153).

\section{Sonstige Teichtypen}

In den vorigen Abschnitten wurden die Fisch-, Mühl- und Bergbauteiche als spezifische Form der Teiche behandelt. Die Beweggründe für diese Schwerpunktsetzung liegen neben der kulturlandschaftlichen Bedeutung und aktuellen Präsenz in ihrer vielschichtigen Haupt- und Nebennutzung.

Um jedoch nicht eine Reduzierung des Teichbegriffs auf den der Teichwirtschaft, der Mühlenwerkes und des Bergbaus zuzulassen, sollen im Folgenden weitere historische Teichformen individuell 
skizziert werden. Dies beinhaltet auch solche „Teiche“, die im engeren Sinne keine sind. Gruben, Kuhlen und wassergefüllte Senken besitzen in der Regel keine Zu- und Ablaufvorrichtung. Sie nähren sich zumeist vom Grundwasserstand oder vom Regenwasser. Dennoch sollen auch sie hier mit aufgenommen werden, da es sich um wasserbespannte historische Hohlformen handelt, die zumeist primär zu speziellen Nutzungszwecken errichtet worden sind. $\mathrm{Zu}$ beachten ist aber bei dieser funktionalen Typisierung, dass auch ein spezieller Nutzungs- oder Entstehungstyp in der Regel mehrere Nutzungen umfasste.

Nicht in dieser Betrachtung mit aufgenommen werden Teiche und wassergefüllte Hohlformen, die indirekter Entstehung sind und durch eine andersartige Wirtschaftsweise nur ,zufällig“ entstanden sind, wie zum Beispiel Ton- und Mergelgruben, Ziegelteiche oder Torfstichgewässer.

\section{a Trinkteich}

Trinkwasserteiche sind im zentral mitteleuropäischen Raum erst Erscheinungen vor allem des 20. Jh. Vorher gab es Zisternen zur Wasserhaltung. Diese waren aber geschlossene Behältnisse und für die Trinkwasserversorgung des Menschen i.d. R. der städtischen Bevölkerung errichtet. In der Wasserversorgung ging aufgrund der anhaltenden Gewässerverschmutzung die Tendenz allgemein dahin, von den Schwankungen der natürlichen Wasserqualität unabhängig zu sein.

Die Wasserbevorratung in Sammelbecken zu Trinkwasserzwecken läßt sich beispielsweise für das 19. Jh. im Harz nachweisen. Nicht alle Teiche des Oberharzgebietes dienten der Speicherung von Aufschlagwasser für den Bergbau allein. Als Lieferant für Trinkwasser wurden kleiner Weiher, wie beispielsweise der ,Röhrenbrunnenteich', errichtet, „dessen Name auf die ehemalige Trinkwasserversorgung hinweist". Er wurde von der Altenau mit sauberen Trinkwasser versorgte (HAASE 1961:23).

Andere ehemalige Bergbauteiche im Oberharz, wie der ,Hirschler Teich', wurden erst nach Aufgabe des Bergbaus umfunktioniert und dienten fortan der Trinkwasserversorgung von Clausthal (HAASE 1961:29). Auch am ,Oberen Kellerhalsteich' steht ein Wasserwerk, das die Gemeinden Bockswiese und Zellerfeld mit Trinkwasser aus dem Teich versorgt (:45).

\section{b Tränkteich}

Als weiteres Beispiel einer künstlichen Teichanlage in dieser Aufzählung können die Tränkteiche genannt werden. Hierunter sind diejenigen Teiche zu verstehen, die eigens zum Zweck der Trinkwasserversorgung des Nutzviehs, in der Regel handelt es sich hierbei um Weidetiere, errichtet worden sind. In vielen Fällen aber konnte nicht zwischen der Versorgung von Mensch und Tier unterschieden werden und so dienten sie sowohl der Wasserversorgung des Nutztiere als auch der Bauernschaft des Hofes selbst.

Solche Teiche mussten vor allem immer dort angelegt werden, wo keine ausreichende Versorgung mit geeignetem Trinkwasser vorhanden war. Deshalb besteht bspw. auf einer Wurt (gleichbedeutend Warft, als Bezeichnung für einen - meist künstlichen - Hügel im Überflutungsbereich von Salzwasser) ein solcher „Tränkteich“. Dieser hatte die Funktion eines Süßwasserreservoirs für die tierischen und menschlichen Bewohner der landwirtschaftlichen Hofanlage (Altgarmsiel/Ziallern; Carolinensiel). 


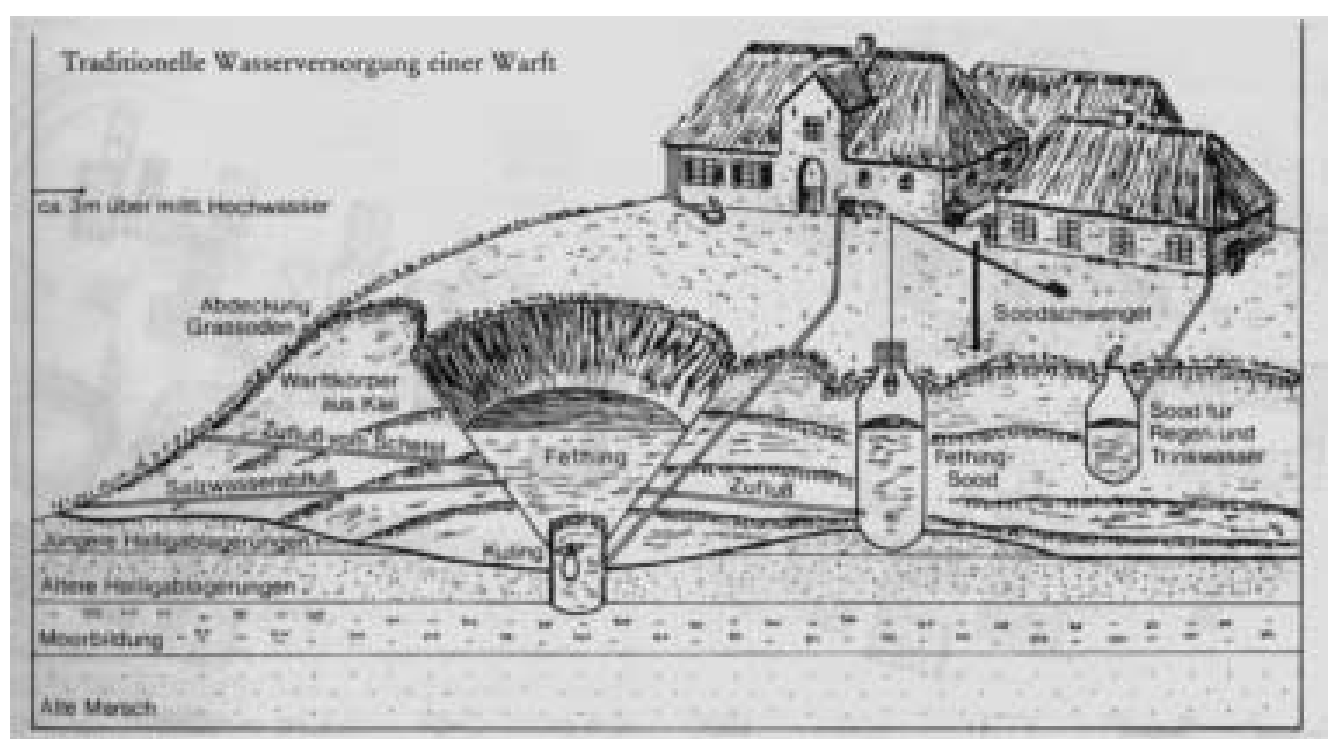

Abb. VII-56: „Traditionelle Wasserversorgung einer Warft“

Hier zu sehen der „Fething“ auf einem Viehbauernhof einer Warft auf Hallig Hooge (aus: ELLENBERG 1990:227; nach RIECKEN 1982, etwas verändert).

Niederschläge waren jahrhundertelang die einzige Tränk- und Trinkwasserquelle auf den Halligen. Sie wurden in Soode (auch Soot) abgeleitet. Dabei kamen pro Warft zwei Soode zum Einsatz: zum einen der separate Trinkwasser-Sood, in den ausschließlich das über die Dächer der Gebäude und Stallungen ablaufende Wasser eingespeist wurde und der damit die Versorgung mit sauberem Trinkwasser sicherstellte und zum anderen der „Fething-Sood“ der aus dem Fething gespeist wurde, und dessen Wasser zum Tränken des Viehs verwendet wurde (Tränkwasser). Die Trennung war nötig, da sich im Fething-Sood neben dem Regenwasser auch Oberflächenwasser der Warft sammelte und das konnte sschon mal durch Viehdung verunreinigt sein (KÖNIG 2004).

Bei den Sooden handelte es sich aber um mehr oder weniger tiefer Brunnen am Hallighaus, um gemauerte Zisternen, die meistens bis zur Sohle der Warft hinab reichte. Der eigentliche Tränkteich hingegen war der „Fething“, eine trichterförmige, unbedeckte Zisterne im Zentrum einer Warft,, die in kleinen Dellen des tonigen Bodens angelegt waren (s. Abb. VII-56) und bis ins salzarme Grundwasserkissen der Warft hinabreichten. Vom Fething aus lief es in Ziehbrunnen oder wurde später durch Motorpumpen direkt in den Stall gebracht. War bei Sturmflut Meerwasser in den Fething geraten, öffnete man den Abfluss. Erst seit Wasserleitungen die Halligen vom Festland her mit Wasser versorgen, sind diese Sammelteiche für das von den Dächern abfließende Regenwasser überflüssig geworden (ELLENBERG 1990:227).

Die Warft musste deshalb, um „die Trinkwasser-Vorräte im Fething [...] der Warft, vor Versalzung zu schützen“ (ELLENBERG 1990:227), und natürlich, um einen Schutz vor Springtidenhub und Sturmfluten zu bieten, auf jeden Fall hoch genug sein, um Mensch und Vieh vor Schaden zu bewahren.

Doch nicht nur auf den von Salzwasser umgebenen Hofanlagen sind sie zu finden, sondern auch in den Alpen. Dort, wo auf den Almen Quellaustritte nicht in ausreichender Zahl vorhanden, dienten wassergefüllte Hohlformen als Wasserspender. Besonderes Kennzeichen der alpinen Tränkteiche ist ihre hofferne Lage: nicht auf dem Hofareal, aber noch auf der eigenen Almweide befanden sie sich. 


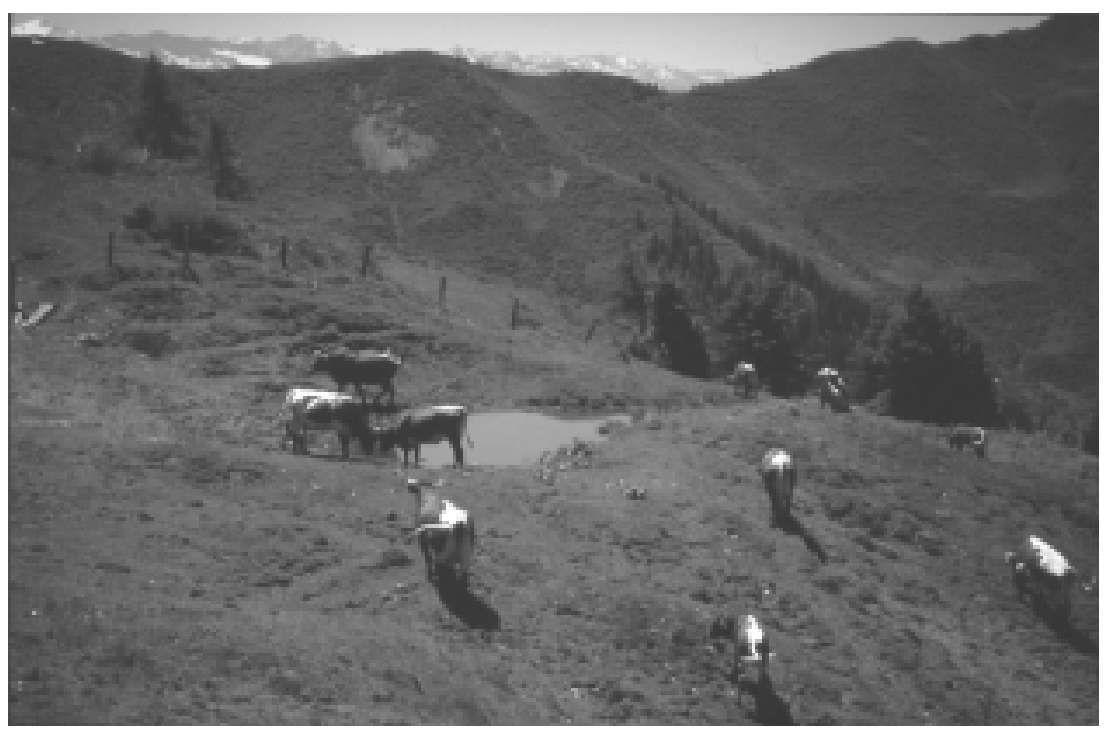

Abb. VII-57: Tränkteich unterhalb der "Schwalbenwand" zwischen Maria Alm und Zell a. See/Österreich (eig. Aufnahme 1999)

\section{c Bauernhofteich}

Anders hingegen ist die Lage bei den Hofteichen der Bauern, die zunächst einer begrifflichen Klarstellung bedürfen. „Bauernhofteiche“ sind von den „Bauernteichen“, vor der kirchlichen Einverleibung und nach der Säkularisierung als Besitzstandsanzeige vergleichbar den sog. Klosterteichen der offenen Feldflur, zu unterscheiden. Die Bauernteiche, die Teiche bäuerlicher Teichwirtschaft (sowie auch die im Gemeindebesitz befindlichen Teichflächen) sind im Verlauf von Klostergründungen vom Kloster weitgehend arretiert worden. Der Besitz von Teichen, vor allem nach dem Dreißigjährigen Krieg, war weitgehend ein klösterliches Monopol geworden. Den Bauern verblieben zur Fischzucht überwiegend tümpelartige „Wässerungen“, die kaum einmal in den fiskalischen Urkunden höher als „geringe Seelein“ taxiert wurden. Die Erträge waren folglich sehr gering (SCHENK 1998:246).

Bauernhofteiche hingegen verstehe ich hingegen als solche Teiche, die sich nicht nur in bäuerlichem Eigentum, sondern auch auf bäuerlichen Hofgrund befinden. Doch diese sind nur schwer aufzufinden und nicht bei allen Hofformen anzutreffen. So sind sie beispielsweise beim fränkischen Bauernhaus nicht anzutreffen. Hier gruppieren sich die Gebäude im Allgemeinen um einen viereckigen Hof, der in der Mitte die Düngerstätte enthält.

Bei anderen Hofformen wiederum sieht man manchmal maximal noch einen Brunnen beim Hofe, aus dem das Trink-, Tränk- und Speisewasser gehoben wurde. Doch die heutige Wasserversorgung der Höfe erfolgt in den allermeisten Fällen vielfach über zentrale Wasserleitungen. Aber auch vor dem Bau von Kettenbrunnen, mit drehbarer Rolle und in die Tiefe hinabgehender Kette mit Eimer, oder Wippbrunnen, bei dem die Stange mit Eimer in den Brunnenschacht hinabtauchte, sowie von Laufbrunnen, die das Wasser von einer Quelle heranführten, konnte das kostbare Nass von den Bachläufen herangeholt werden, an denen sich viele Höfe gruppierten bzw. entlangreihten (siehe V 2d). Die Anlage eines offenen, hofnahen Standgewässers aus diesen Gründen ist deshalb unwahrscheinlich. Weiterhin ist es unwahrscheinlich, dass ein Hofteich zur Trinkwasserbevorratung angelegt wurde, da freilaufendes Federvieh auch bei entsprechender Umzäunung die Wasserfläche angeflogen hätte.

Ich habe deshalb auch nur zwei solcher Bauernhofteiche ausfindig machen können, an denen der Nutzungszweck eines Hofteiches erklärt werden kann. Auch in den entsprechenden Publikationen zur „Bauernhausforschung“ sind - mit Ausnahme des o. g. Beispiels des ,Tränkteichs' aus der Veröffentlichung von ELLENBERG (1990) - die Hofteiche aus der Betrachtung ausgeklammert. Dies ist umso unverständlicher, als dass „nahezu neben jedem größeren Bauernhof [...] ein Teich“ war wie 
Alois HUHN (2003) aus seinen Kindheitserinnerungen aus dem Dorf Lotterbach im Kreis Braunsberg/Ostpreußen (poln. Braniewo) berichtet: „Diese Teiche dienten einmal zum Tränken des Viehs, zum Züchten von Fischen und als Auslauf für das Wassergeflügel. Bei strengem Frost im Winter waren die Teiche zugefroren. Wenn die Eisdecke es zuließ, rutschten die Kinder darauf und manche liefen auch Schlittschuh. Wir hatten uns kleine Kufen beim Schmied unseres Dorfes anfertigen lassen. Diese wurden unter die Holzpantoffeln geschlagen und ab ging es aufs Eis!“

Der Beispielbauernhofteich liegt an der Regionalbahnstrecke Hardegsen - Northeim, in der Nähe des Dorfes Schnedinghausen. In geradezu klassischer Lage inmitten des Hofareals befindet sich der eingezäunte Bauernhofteich.

Ein weiteres Beispiel eines „Bauernhofteiches“ ist im nördlichen Stadtgebiet der Stadt Hilden zu entdecken. Der zum seit dem 14. Jahrhundert bestehenden Bauernhof „Hof Flee“ gehörige Teich liegt nicht inmitten des geschlossenen Vierkanthofes, sondern außerhalb des Innenhofes an den westlichen, ältesten Flügel der Stallungen angrenzend.

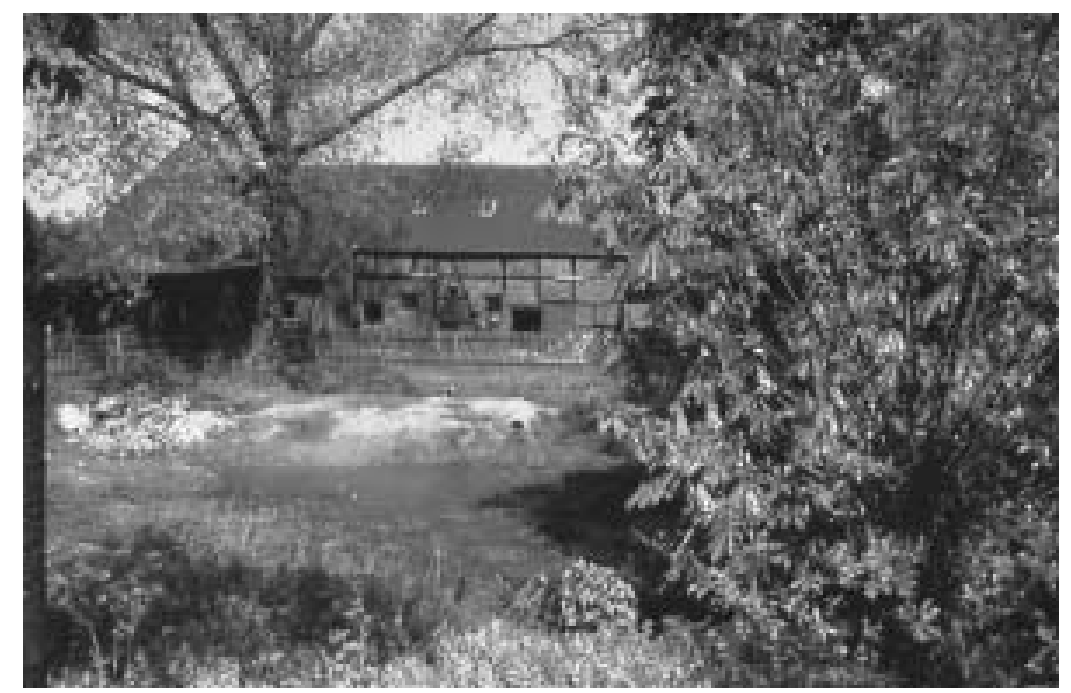

Abb. VII-58: Außerhalb des Innenhofes gelegener Bauernhofteich beim Hof Flee, Hilden

Dieser bereits seit dem 14. Jahrhundert bekundete Hofplatz mit einem Giebel aus dem Jahr 1680 hatte den Teich zur Regenwassersammlung angelegt. Wasser von den Dächern und dem Hofareal wurde mit einer Rohrleitung in das Becken geleitet. Teich wie auch Rohrleitung waren früher doppelt so groß, doch seit dem Anschluss an die städtische Kanalisation im Jahr 2000 zieht er kein Wasser mehr an. Ausgetrocknet und funktionslos geworden, wird er zusehends mit Bauschutt und Erdmaterial zugefüllt. Einer fischwirtschaftlichen Nutzung unterlag dieser nach Erinnerung des Landwirts mindestens seit 60 Jahren bestehende Teich zu keiner Zeit (eig. Aufnahme 2004).

\section{d Pferdeschwemme}

Pferde wurden gewaschen, um sie zum einen von Ungeziefer und Erdstaub zu befreien, der nach dem Abspann, dem Austritt, der Feldarbeit oder einfach nach einem wohltuenden Erdbad auf dem Fell lag. Zum anderen wurden sie in ein Wasser getrieben, weil ein Wasserbad schonend für die Gelenke und Knochen wirkte, und schließlich einfach, weil es eine Wohltat war, sich z. B. in heißen Tagen eine Abkühlung zu verschaffen (KÖHLING 2003).

Da zum einen das Ganzkörperwaschen von Pferden eine gewisse Wassertiefe und -breite voraussetzte, eine zu starke Strömung zum anderen aber hinderlich war und wenn zudem ein entsprechendes Gewässer in erreichbarer Nähe nicht immer vorhanden gewesen ist, so erbaute man auch künstliche Pferdeschwemmen. Vor allem Guts- und Klosteranlagen und erst recht Gestüte errichteten solche „Pferdeteiche“. Auf einer Karte der Fischzuchtanstalt Michaelstein/Harz von 1886 ist ein sog. „Pferdeheller“ eingezeichnet, der unmittelbar an den Stallungen des zum Kloster gehörigen Vorwerks grenzt (siehe VIII 1d.2.2.2, Abb. VIII-12). 
Die ehemalige Bedeutung und Vielzahl solcher Pferdewasch- und -abkühlteiche wird dann vorstellbar, wenn man sich vergegenwärtigt, dass allein das Kloster Marienwerder in Alt-Garbsen bei Hannover 80 Pferde besaß. Dabei ist zu bedenken, dass Gespanne nicht nur für die Reisen der Stiftsdamen oder des Klosteramtmanns, sondern, wie in anderen forst- und landwirtschaftlichen Wirtschaftsbetrieben auch, zur Feldarbeit und für die Holzabfuhr wie für die Geschäftsfahrten nach und in Hannover gebraucht wurden (HAMANN/EDERBERG 1977:14).

Weiterhin waren sog. Parforcepferde zur privilegierten Hirsch- oder Sauhatz vom Marstall zu stellen. Sie durften nicht wasserscheu sein, mussten jedoch geschickt im Springen und im Durchlaufen eines Grabens sein (HASEDER/STINGLWAGNER 1996:584).

Im Innenhof des ehemaligen norddeutschen Gutes Hoisbüttel beispielsweise, dessen gleichnamige Gemeinde 1978 in die neu gegründete Großgemeinde Ammersbek eingegliedert wurde, die im Übrigen den Namen des durchlaufenden Baches - der Ammersbek - trägt, ist eine gefasste Pferdeschwemme erhalten geblieben. Vorbildlich wurde der Pferdeschwemmteich im Rahmen des 1988 begonnenen Umbaus des Gutsgeländes als original erhaltene Anlage übernommen. Die in den ehemaligen Wohn- und Wirtschaftsgebäuden untergebrachten Einrichtungen Gemeindeverwaltung, Bauhof, Dorfgemeinschaftshaus und Gastronomiebetrieb, gruppieren sich um den ehemaligen Pferdeteich des Gutes.

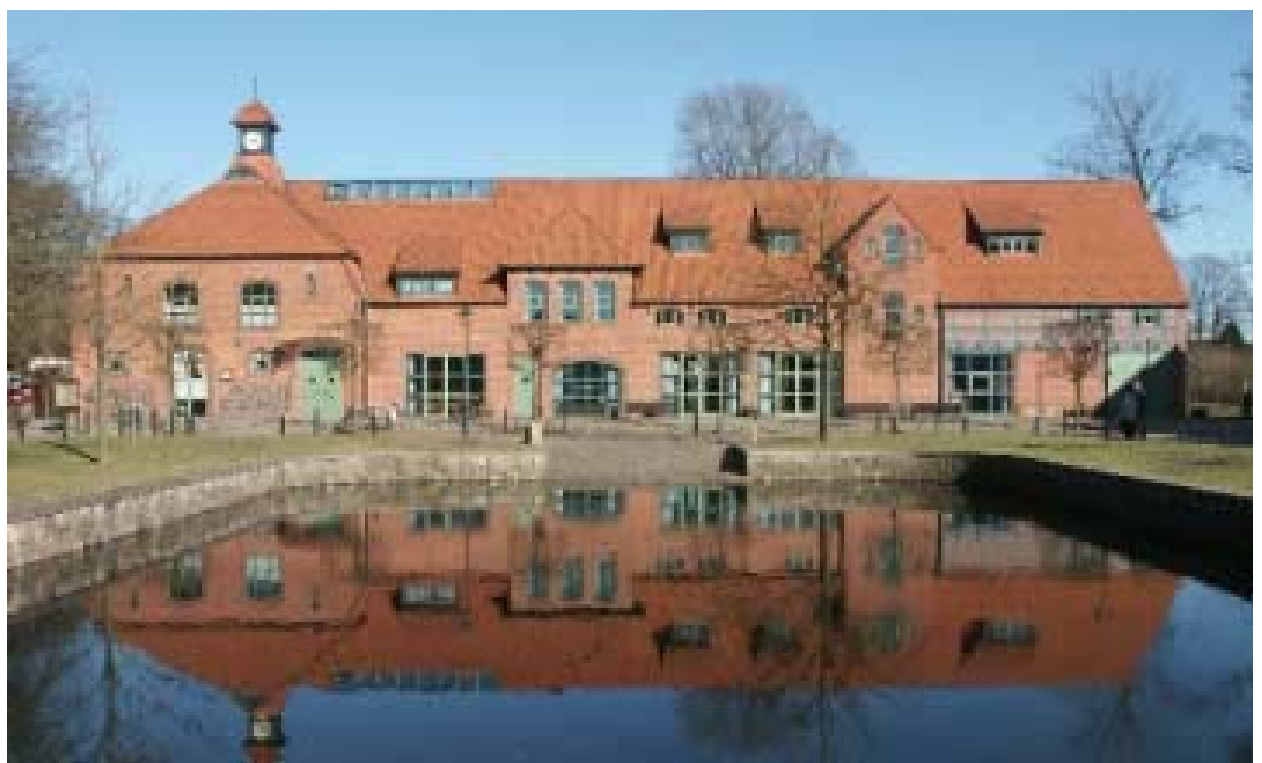

Abb. VII-59: Pferdeschwemmteich des ehemaligen Gutes Hoisbüttel, Großgemeinde Ammersbek Aufnahme von Süd nach Nord (eig. Aufnahme 1999)

Hoisbüttel (im 14. Jh. „Hoyersbuttle“, im 18. Jh. Junker-Hoisbüttel), wurde 1262 als Besitztum adeliger Grundherren erstmals erwähnt. Das adelige Gut mit seinem im 19. Jh. ca. 200 ha umfassenden Grundbesitz und ca. 20 ha Holzungen einschließlich Wassermühle, erlebte seit dem 16. Jh. eine überlieferte wechselvolle Geschichte. Blaublütige und bürgerliche Besitzer wechselten einander in enger Folge $a b^{51}$. Da sich vor allem der fruchtbare Boden im hügeligen Osten des Gutes als Ackerland anbot und gleichzeitig auch ein Forst bewirtschaftet werden musste, werden 48 Pferde für den Gutsanteil im Amtsbezirk genannt. Wenn davon auch einige 2 Halbhufen und einige kleinere Hofstellen mit eigenem Pferdebesitz für Spanndienste abgezogen werden müssen, die im 18. Jh. noch Eigentum des Gutsherren waren, so dürften dennoch ca. 20-30 Pferde für den gutsherrlichen Wirtschaftsbetrieb übrig geblieben sein. Daraus wird die Größe des Pferdeteiches mit ca. 25 x 20 m

\footnotetext{
${ }^{51}$ Gut Hoisbüttel, im Amtsbezirk Bergstedt/Hamburg, seit 1803 holsteinisch. Der Besitzer v. Heest verkaufte es 1598 an Heinrich v. Buchwaldt, dessen Nachkommen 1711 an die Familie v. Spenner und darauf die Familie v. Cossel; 1781 J. H. Behn aus Altona; 1788 Major v. Gustedt; 1793 Hofrat F. W. v. Schütz; 1798 Sultow; 1802 Amtsverwalter Neumann; 1803 Asmus Heinrich Priehn, unter ihm kam es zum Konkurs und das Gut wurde an Cornelius Gosvinus de Jager verkauft; 1808 übernahm es Legationsrat J. E. Leiching; 1810 Hedwig Gräfin Schmettau; 1857 Schröder; 1869 Eduard Dreyer; 1906 Eberhard Willmann aus Schöneberg bei Berlin (OLDEKOP 1908).
} 
und dessen Bedeutung ersichtlich, die auch aus der räumlichen Anordnung inmitten der Vierseitanlage hervorgeht.

Ein anderes Beispiel für eine gutsherrliche Pferdeschwemme ist das Rittergut Meinbrexen ${ }^{52}$ derer von Mansberg. Wie in anderen Gütern auch, war auch hier das Pferd bis zum Aufkommen der Motorisierung Zug-, Transport- und alleiniges Reittier. Das Rittergut Meinbrexen hatte in den Marställen ${ }^{53} 15$ Zug- und Reitpferde aufgestallt. „Die Pferde wurden, und nur wenn sie vom Feld dreckig waren, durch das Becken durchgeführt. Vorn herein und hinten wieder hinaus, fertig. Diese Teiche waren ja nicht tief $75 \mathrm{~cm}$ oder $1 \mathrm{~m}$. Die Hufe sollten gereinigt werden“, weiß der Nachfahre Lothar von MANSBERG (2003) aus eigener Anschauung zu berichten.

\footnotetext{
${ }^{52}$ Rittergut Meinbrexen [„Haus des Meinbrecht“] - in der Nähe von Fürstenberg a. d. Weser wird 1222 urkundlich zum ersten Mal erwähnt: Ein Johan von Meinbrechtshusen, der in der Mitte des 10. Jh. ins Stift Corvey kam, siedelt sich zu Meinbrechtshusen, an der Weser gelegen, an. Ein Cuno von Meinbrechtshusen, so ist des Weiteren überliefert, sei durch einen begangenen Mord im Jahr 1169 um Titel, Name, Schild und Heim gekommen. Schließlich werden um 1196 noch Johan von Meinbrechtshusen und 1238 dessen Sohn Henrich genannt. Mit Untergang dieses Geschlechts, sollen dann die „vom Hagen“, wahrscheinlich Verwandte der von Meinbrechtshusen, nach Meinbrexen gekommen sein. Darauf folgend wechselten die Besitzer des Rittergutes noch mehrere Male, bis im 18. Jh. die von Mansfeld das Rittergut übernahmen.

53 Der Begriff „Marstall“ geht auf mhd. ,marah’ für ,Mähre' zurück. Der Begriff bezeichnet Gebäude zur Unterbringung von Pferde, Wagen und Geschirr (FAHRBACH 1989).
} 


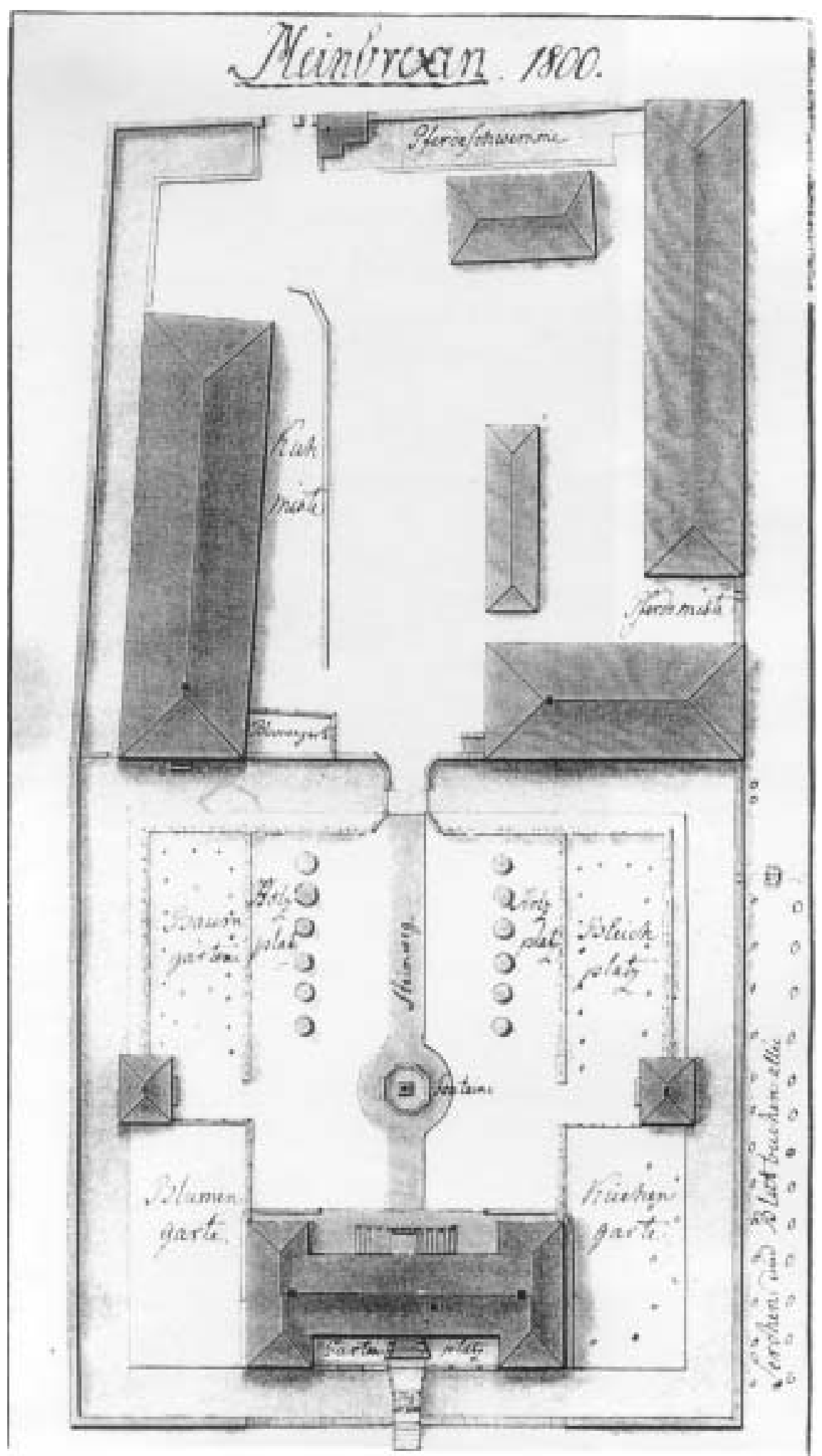

Abb. VII-60: Pferdeschwemmteich auf dem Vorhof des adeligen Rittergutes Meinbrexen“ um 1800

Das Gebäude vor der Pferdeschwemme ist der Mitte des 18. Jahrhunderts neu aufgebaute Pferdestall. Links der Pferdeschwemme am Eingang befindet sich das „Pfort-Haus“. Das längsseitige Gebäude rechts neben der Schwemme ist die große Kornscheune, unterhalb befindet sich das Brauhaus mit dem „Schwein-Haus“, dem ehemaligen Pferdestall. Das einzeln vertikal stehende schmale Haus ist der Schafstall, das gegenüberliegende große Längsgebäude das Vorwerk mit den Kuhstallungen. Unterhalb des Vorhofes mit den Wirtschaftsgebäuden und flächen schließt das Schlossgelände an. Der umlaufende Wassergraben umfasste wahrscheinlich ehemals nicht nur einen Teil des Vorhofes, sondern das gesamte Areal, so dass die dargestellte Pferdeschwemme, so ist zumindest zu vermuten, zuvor ein Teilstück des Wassergrabens gewesen ist. Durch den Ausbau der Kreisstraße wurde der obere Einfriedungsbereich geschliffen, dem auch die Pferdeschwemme zum Opfer fiel (Orig. im Besitz der Fam. v. Mansberg). 
Als Drittes sei die Sababurg als Beispiel für eine reliktäre Pferdeschwemme herangezogen, die aufgrund einer früheren Bildquelle bezeugt ist. Theodor ROCHOLL ${ }^{54}$ hat als Maler durch seine Motivwahl Zeugnis abgelegt von der Pferdewäsche im Bereich der Burg.

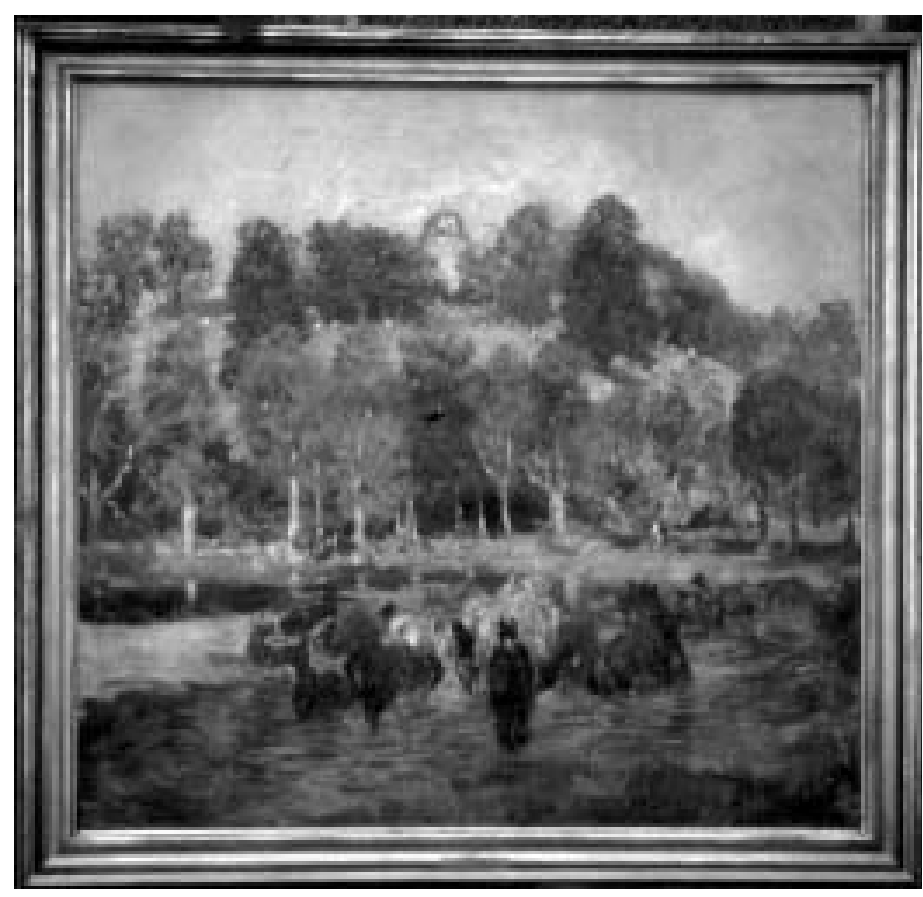

Abb. VII-61:Das Beispiel der Pferdeschwemme unterhalb der Sababurg

Gemälde von Theodor ROCHOLL (Orig. im Stadtmuseum Hofgeismar; eig. Aufnahme 2004)

Die Geschichte der Pferdezucht im hessischen Reinhardswald lässt sich bis ins 16. Jh. zurückverfolgen. Aus den „Wilden von der stut Zapfenburg“ entwickelten sich unter Landgraf Wilhelm I. zwischen 1589 und 1591 die als besonders hart geltenden, auf solidem Fundament stehenden „Sababurger“. Die von spanischen und neapolitanischen Hengsten abstammenden Pferde waren als gesuchte Paradereitpferde, aber auch wegen ihrer räumenden Gänge als Wagenpferde für die Staatskarossen begehrt.

Durch die 1724 auf königliche Anordnung erfolgte Vereinigung des Hofguts Beberbeck mit dem Gestüt Sababurg entstand das kurfürstliche und königliche Landgestüt Beberbeck auf dem ehemaligen Jagdschloss Beberbeck, 10 Kilometer nordöstlich von Hofgeismar. Zuchtziel war ein edles Kavalleriepferd. Hierzu wurden hauptsächlich Englische, Normannische, Mecklenburger und Hannoveraner Pferde genutzt. Auch 16 reine Sennerstuten fanden hier 1876 in dem nun Preußischen Hauptgestüt eine neue Heimat. Über 200 Jahre hatte das Beberbecker Gestüt die Aufgabe, Hauptbeschäler für die Remontenzucht zu stellen. Die Beberbecker Edelblutpferde waren auch als hervorragende Wagenpferde beliebt. Das Gestüt wurde jedoch 1929, noch bevor in den 1960er Jahren auch in anderen Zuchtgebieten eine große Krise eintrat, ausgelöst durch die Verdrängung des Arbeitspferdes in der Landwirtschaft, aufgelöst und die meisten Pferde nach Polen, auch nach Trakehnen, verkauft. Die Hengste Optimus, Obelisk und Lehnsherr wurden bedeutende Hengste in der Trakehner Zucht. Der Sohn des letzten preußischen Landstallmeisters von Beberbeck, Clemens Freiherr von Nagel, sammelte jedoch Beberbecker an seinem ererbten Schloss Vornholz bei Ostenfelde und züchtete dort noch viele Jahre den Beberbecker weiter. Der Vornholzer Schimmel

\footnotetext{
${ }^{54}$ Der Maler Theodor Rocholl stammt aus Sachsenberg/Waldeck, wo er am 11. 6. 1854 geboren wurde. Um 1883 beginnt er in Düsseldorf seine Karriere als »Schlachtenmaler«. Die Beschäftigung mit dem deutsch-französischem Krieg 1870/71 macht ihn bekannt und bringt erste Erfolge. Ab 1897 bis 1914 nimmt er an mehreren Feldzügen während der Balkankriege teil, 1900 im Auftrag des Kaisers auch an der Niederschlagung des Boxeraufstandes in China. Mit dem Ende des Ersten Weltkriegs endet auch seine Beschäftigung mit militärischen Motiven. Rocholl wendet sich jetzt der Landschaftsmalerei zu, findet einen neuen Schwerpunkt in der Darstellung von Pferden. Aus dem »Schlachtenmaler« wird der »Pferdemaler«. Die Anregungen zu seinen Bildern bekommt er an der Sababurg im Reinhardswald bei Hofgeismar. Am 14. 9.1933 stirbt Theodor Rocholl nach einem Verkehrsunfall in Düsseldorf.
} 
Ramzes wurde bis zu seinem Ableben 1966, als fast Dreißigjähriger, zum wichtigsten Vererber in der deutschen Nachkriegsgeschichte. Heute ist das ehemalige Landgestüt Staatsdomäne und Übergangswohnheim für Über- und Aussiedler.

KÖHLING, derzeitiger Administrator der Staatsdomäne, weiß persönlich von keinem künstlich angelegten Pferdewaschplatz im Hofbereich des Gestüts. Er vermutet vielmehr, dass durch einen einfachen Damm oder Schütze einer der vielen Bachläufe in der Nähe des Gestütes aufgestaut wurde, um so eine Pferdeschwemme mit der notwendigen Tiefe und Breite zu erzielen, und dass man dort die Tiere hineingetrieben hat. Vorstellbar ist nach meiner Ansicht auch ein Absperren einer bereits vorhandenen Stauschleuse, die zu Bewässerungszwecken oder zum Teichstau errichtet wurde. In diesem Fall hilft die Auswertung der kunsthistorischen Landschaftsmalerei von ROCHOLL diese Vermutung zu bestätigen.

Nicht nur auf ländlichem Großgrundbesitz, auch im vor- und innerstädtischen sowie dörflichen Bereich gab es solche Pferdeteiche, die zum Teil auch eine große Fläche in Anspruch nahmen. KONOLD (1994:315) berichtet aus der Stadt Isny/Allgäu: „Südlich des Roßmarktes verbreiterte sich der Stadtbach zur, wettin', also zu einem kleinen Weiher, in dem die Pferde gewaschen werden konnten. Das ganze Quartier hieß ,In der Wösch'.“

Im schaumburgischen Dorf Riehe speisten die beiden Bäche Radbach und Ammerbach ebenfalls einen Pferdeteich, der heute von einem Sportplatzgelände überdeckt ist (SCHRÖDER 1979)

In alten Dokumenten des 15. bis 18. Jahrhunderts wird der Ort Sachsa als Marktflecken „In der Sachse“ als Versorgungsstützpunkt und Verkehrsknoten für die Bergbauplätze des Andreasbergs und der Wieda beschrieben, mit einer besonderen Bedeutung für die Versorgung von Pferden: „Am Pferdeteiche kamen die Rösser ein letztes Mal zu Tränke, bevor sie durch Hohlwege den steilen Anstieg in die rauhe Bergregion begannen.", so wird die Situation dargestellt (BAD SACHSA 2003, Hervorhebung im Original). Der Pferdeteich hier also nicht (nur) als Schwemme, sondern (zugleich) Tränkteich.

In der relativ nahegelegenen Stadt Nordhausen gab es eine Vielzahl von Teichen, von denen einer „Pferdeteich“ hieß (siehe Abb. 0-8). Auf einer kartographischen Rekonstruktion der Stadtphysiognomie lässt sich dieser Teich aus den ehemals vorhandenen zahlreichen Teichen, Tümpeln u. Ä. im Auegebiet der Zorge gut wiedererkennen. Es ist aufgrund der Bezeichnung zu vermuten, daß es sich - wenn auch nicht um einen für das Pferdeschwemmen angelegten -, zumindest aber dafür speziell benutzten Teich handelt.

Nach der Kartendarstellung handelt es sich um eine verhältnismäßig große Gewässerfläche. Mit etwa 50 x $250 \mathrm{~m}$ Seitenlänge war dieser Teich über 1 ha groß. Jedoch waren seine Tage auch gezählt. Auf einem der folgenden Stadtpläne (Grundriss der Stadt Nordhausen, 1859) ist der Pferdeteich nicht mehr verzeichnet, und auch der Zorgelauf besitzt, wie noch für 1834 kartiert, in seinem Bett keine Inseln mehr.

Das „Wässern“ der Pferde in einem Teich oder einem aufgestauten Bachabschnitt wurde noch vor dem allgemeinen Niedergang der Pferdezucht und der landwirtschaftlich und gewerblich motivierten Pferdehaltung aufgegeben. Eine Rolle mag die Angst vor dem Verlust von Hufen gewesen, die bei der damaligen Art der Behufung anscheinend häufig der Fall gewesen war (KÖHLING 2003, mündl.).

Dass die Teiche nicht allein gute Viehtränken lieferten und zum Reinigen von Pferden, sondern auch „zum Waschen der Schafe“ benutzt wurden, erfährt man aus SPRENGEL (1838:67). Ferner deuten Teiche mit dem Namen „Schafweiher“ auf eine solche Nutzung hin (DOSCH 1899:34, Nr. 1). 


\section{e Dorfteich}

Dorfteiche hatten vielfältigste Funktionen zu erfüllen. Die Meinungen und Forschungen über die Funktionen hingegen gehen ebenso weit auseinander:

SCHENK (1998:246) hat auf archivalischer Quellenbasis für Franken nachgewiesen, dass die Teiche im Dorf, die sog. „Wethe“, nur für „die Viehtränk ohngefüllt und nit besetzt“ waren und als Löschweiher „für Feuersbrunst“ genutzt“ wurden. Der Dorfteich hier präsentiert sich also ein Tränkteich und Feuerlöschspeicher.

HEINE (o.J.:53) berichtet von dem häufig ,in der Mitte des Dorfes“ gelegenen Dorfteich, ,auf dem Gänse und Enten sich tummeln."

Aus den alten Lehrbüchern der Teichwirtschaftslehre ist zu entnehmen, dass die Dorfteiche auch der Karpfenaufzucht dienten. Aus diesem Zweck, so empfahl man, ,sind Zuflüsse, welche aus Dörfern und von Aeckern kommen, vortheilhaft, weil sie viel Nahrung haben“" (BORNE 1886:219). Doch zur Zuführung von „Düngern“ aus Zuleitungen, Gräben und Kanälen von Dörfern und Äckern kam hinzu, dass die Dorfteiche - wie oben erwähnt - mit „,großen Scharen von Geflügel“ besetzt waren und dass sie durch deren Exkremente sowie den „Zufluß von Jauch“ zur Jauchengrube oder Kloake verkamen. „In solchem Schmutzwasser“, prangert TAURKE (1927:74) an, „können Fische selbstverständlich nicht gedeihen." So kam es auch, dass im Sommer ein allgemeines Sterben der Fische eintrat (BORNE 1886:225).

Trotzdem wurde in der früheren fischereifachlichen Literatur nicht nur auf die Benutzung, sondern auch immer wieder auf die einfache Einrichtung kleiner Gewässer als Dorfteiche hingewiesen: „Man braucht nur dem Gefälle zu folgen und ab und zu einen Querdamm zu errichten, der die Mulde des Bächleins abschließt.“ (SKOWRONNEK 1904:143) Zu Beginn des 20. Jahrhunderts wurde gar von wissenschaftlicher Seite ,ganz systematisch die wirtschaftliche Ausnutzung der Dorfteiche in die Hand genommen.“ (:144). Dies vor dem Hintergrund, dass bekannt war, „daß namentlich die Dorfteiche, in die von den umliegenden Gehöften die Jauche hineinfließt, ein geradezu überreiches Futter für Karpfen besitzen.“ (:144)

Es bestand zudem die Gefahr des Erstickens unter der Eisdecke, wie es beispielsweise vielen Karpfen „bei dem strengen Frost, der im Dezember 1902 einsetzte“, erging (SKOWRONNEK 1904:144). Im Allgemeinen also konnte man ,die Karpfen in den Dorfteichen nicht überwintern [...], da die meisten zu flach sind und bei starkem Frost von der Eisdecke so hermetisch abgeschlossen werden, daß die aus dem Schlamm emporsteigenden Gase keinen Abzug finden. Selbst wenn man fleißig große Löcher in die Eisdecke schlägt und durch hineingelegte Strohbündel offen hält, besteht stets die Gefahr, daß die Karpfen bis auf den letzten absterben.“ (:145) Aber, so die Begründung, es wäre ,ja auch gar nicht nötig, daß man die Karpfen den Winter über darin hält.“ Es genüge ja, „wenn man den Zuwachs erbeutet, den sie innerhalb des Sommers erreicht haben." (:145)

Bei der Bewirtschaftung dieser „kleinen und kleinsten Wasserflächen“ kommt es auf geringe Kosten an, deshalb wurde angeraten, dass sich die Dorfteichbewirtschafter gemeinschaftlich die jungen Karpfen bestellen und auch das Netz zum Herbstabfischen nutzen sollten (SKOWRONNEK 1904:145).

\section{f Feuerlöschteich}

Eine scharfe Trennung zwischen Dorf- und Feuerlöschteich ist für die Anfänge der Brandbekämpfung nicht möglich. So ist eine kombinierte Funktion als Dorf- und Feuerlöschteich zum Beispiel aus dem Dorf Werlte im Emsland bekannt.

Deutlich aber wird die Nutzung von Teichen als Löchwasserreservoir bzw. die Anlage zu diesem Zweck vor dem Hintergrund, dass die Häuser bis zum Hochmittelalter und weit darüber hinaus 
zumeist Ständerbauten mit Holzgefache waren, größtenteils aus Holz und Lehm bestanden und je nach natürlichem Vorkommen mit Heide und Stroh eingedeckt waren, obgleich bereits seit dem 13. Jh. zuerst in Norddeutschland - die Ziegelkunst wieder aufkam, die während der Völkerwanderung und der nachfolgenden politischen und kulturellen Neuordnung der westeuropäischen Reiche verloren gegangen war (PITZKA 1996). Die Feuerstelle war zudem offen und diente häufig als einzige Lichtquelle. Gelegentlich wurden auch Lumpen in Petroleum getaucht, an Holzstäben befestigt und als Fackel in einen Eisentopf gestellt. So konnten schnell Brände entstehen.

Haus- und hofeigene Brunnen reichten bei Bränden aber bei weitem nicht aus, um der Flammen Herr $\mathrm{zu}$ werden. Wasser musste deshalb aus den Dorfteichen beschafft werden, die aber gerade in Trockenperioden meist nicht genügend Vorrat vorhielten. Als dann die ersten Feuerwehren entstanden, sorgten diese dafür, dass Naturteiche vertieft oder spezielle Feuerlöschteiche angelegt wurden, um das ganze Jahr über ausreichend Löschwasser für die zudem steigende Anzahl an Bauten zur Verfügung zu haben. Das ganze Dorf war früher bei Ausbruch einer Feuersbrunst bzw. eines Hausbrandes zur Stelle, um aus Teichen Wasser zu schöpfen und in Eimern von Hand zu Hand weiterzureichen. Später pumpten Männer Löschwasser in Knochenarbeit aus den „Dorfteichen“ (LINGENER TAGESPOST v. 3. Mai 2003).

Einen heute noch bestehenden Löschteich gibt es beispielsweise in der Ortschaft Wielings/Niederösterreich oder auch in der Ortschaft Hellental im nördlichen Solling, von dem nachfolgende Abbildung stammt.

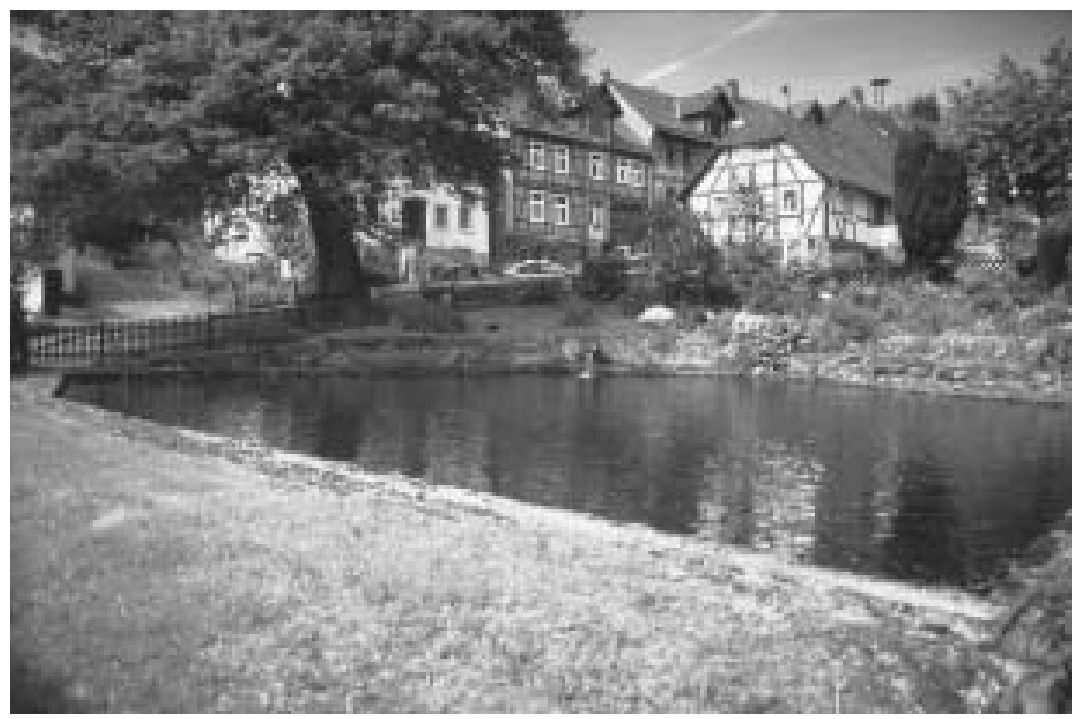

Abb. VII-62: Löschteich in Hellental, Landkreis Holzminden

(eig. Aufnahme 2004)

Gemeinsam ist dem Solling mit der Fränkischen Schweiz der Untergrund. In dem stark durchlässigen Sandstein der Fränkischen Schweiz versickert das Niederschlagswasser fast vollständig, so dass es in diesem Bereich - wie im Solling - kaum oberirdische Gewässer gibt.

Um Wasser zur Viehtränke und für den Brandfall zur Verfügung zu haben, wurden im Ort oder am Ortsrand annähernd kreisrunde Weiher mit wasserundurchlässigen Lehmschichten abgedichtet. Ein Beispiel für viele sind die fünf „Hüllweiher“ (Löschteiche) rund um den Ort Ottenhof im Landkreis Bayreuth. 


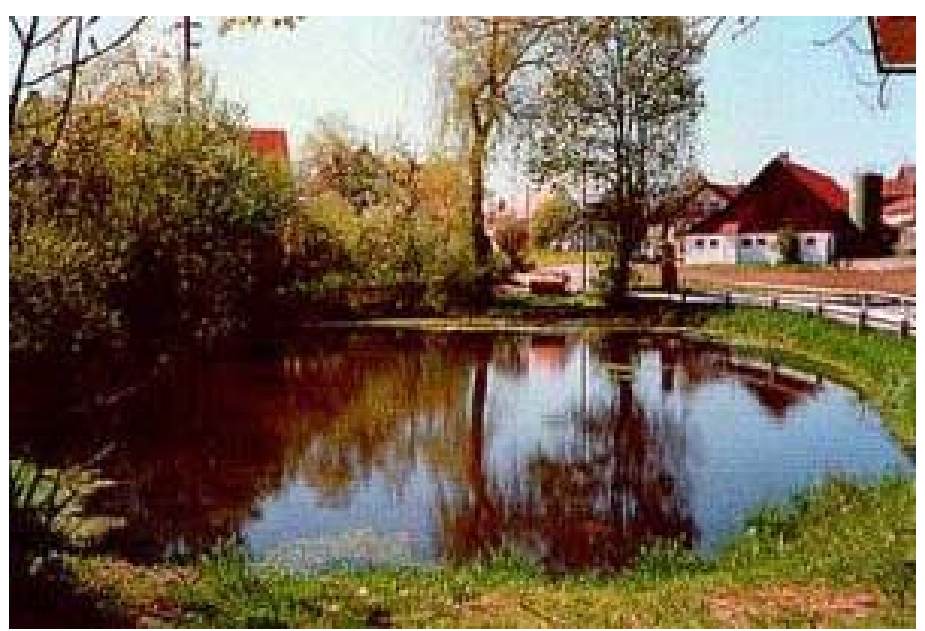

Abb. VII-63:Hüllweiher in Plech, OT Ottenhof, Landkreis Bayreuth (eig. Aufnahme 1991)

\section{g Stadtparkteich}

Wasser ist seit Jahrtausenden eines der faszinierendsten Elemente der Gartengestaltung. Seit den Gärten Ägyptens, den römischen Gärten und vor allem seit der Gartenkunst der Renaissance findet sich Wasser in den unterschiedlichsten Formen, als Becken, Fischteich, Fontäne, Kaskade und anderes mehr (siehe auch Pkt. VI 10). In diesem Abschnitt wird die Entwicklung und Verwendung von „Teichanlagen“ in der Park- und Gartengestaltung in Deutschland dargestellt. Dabei wird deutlich, dass Vorstellungen zur Gestaltung von Gärten nicht nur auf den ästhetischen Vorstellungen der Entwerfenden beruhen, sondern auch von gesellschaftlichen, politischen und umwelthistorischen Rahmenbedingungen abhängen.

Mit der endgültigen Schleifung von alten Wallanlagen, der Öffnung ehemals privater Gärten, der Schaffung von Naherholungsgrün für die wachsende Stadtbevölkerung, die zugleich die Grünflächen dezimierte, und aus weiteren Anlässen entstanden auf ehemaligen Aueflächen Parks und - in diesen integriert - Stadtparkteiche.

In der zweiten Hälfte des 19. Jahrhunderts dominierte in Deutschland der landschaftliche Gartenstil. In den Großstädten fanden sich Parks, die im Anklang an die feudalen Vorbilder überwiegend landschaftlich gestaltet waren. Sie enthielten oft aufwendig gestaltete, natürlich anmutende Teichanlagen. Aber auch die kleineren Städte wollten nicht auf Wasser als Schmuckelement verzichten. So besaß wohl fast jede Stadt ihren „Schwanenteich“ und „Gondelteich“ (WOLSCHKEBULMAHN 2002).

So auch im Fall der Stadt Nordhausen, wobei deren Entstehungsgeschichte aber noch auf anderen Überlegungen aufbaute: Als der Zorgefluss trotz der bereits existierenden Stauwehre noch relativ unreguliert und ,wild“ durch Nordhausen floss, drangen seine Fluten in wasserreichen Zeiten über die Ufer in Richtung untere Altstadt. Im Laufe der Zeit, so wird berichtet, hatte sich hier sogar ein neuer Flusslauf gebildet, wodurch ein Teil des Geländes in eine Insel verwandelt wurde.

Bereits zu Beginn des 18. Jahrhunderts war ein Teil dieser Fläche in Gärten verwandelt worden. So lag hier 1733 beispielsweise der nach der Nordhäuser Bürgerfamilie Kuchen benannte „Kuchen-“ oder „Küchengarten“. Ein älterer Teil, das zwischen der Zorge und der alten Heerstraße vom „Altentor“ bis in die Nähe des „Schurzfells“, das eine alte, an der Heerstraße liegende Feldschmiede bezeichnet, befindliche Ackerfeld der Nordhäuser, trug seit dem 16. Jahrhundert den sinngebenden, den Untergrund bezeichnenden Flurnamen „Das Steinfeld vor dem Altentore“ (MEYER o. J.: 35). 


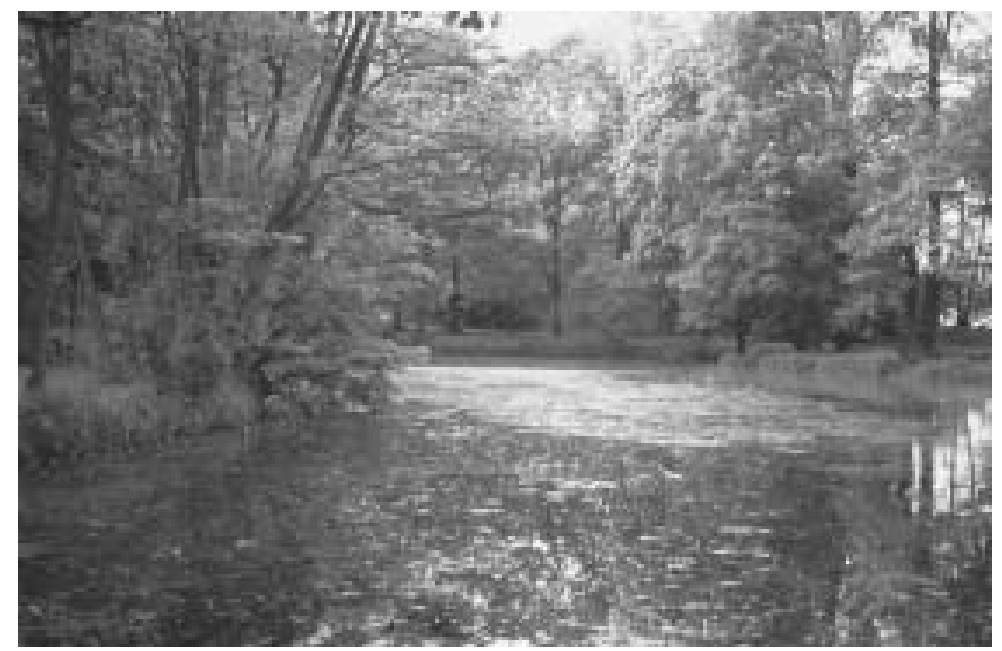

Abb. VII-64: Stadtparkteiche Nordhausen mit Umgebung (eig. Aufnahme 1998)

Nach anhaltendem Regen im Dezember 1854 trat der Fluss aus seinem Bett, überschwemmte das Gebiet des heutigen Stadtparks und unterspülte die östlich vom Zorgelauf verlaufende Chausseeverbindung. Dieses Ereignis, vor allem die Unterbindung des aufwendig errichteten Landwegs war Veranlassung genug, dass der damalige Stadtrat Karl Hartmann der Stadtverwaltung den Plan vorlegte, die Insel zu durchstechen und längs der Zorge vom Wehr bis nahe an die „Altendorfer Brücke“ einen Damm als Schutz gegen Hochwasser aufzuwerfen. Dem Vorschlag wurde zugestimmt und die finanziellen Mittel in Höhe von 300 Talern bewilligt (ALLGEMEINER ANZEIGER 12/1997).

Nach Anlage des sog. ,Hartmanndammes' konnte der umgangssprachlich, wahrscheinlich aufgrund seiner häufig die Äcker und Felder überschwemmenden Eigenschaft, als „Feldwasser“ bezeichneten Zorge im vorigen Jahrhundert zunächst ein stetiges Bett zugewiesen werden und es konnte auf der ehemals wüsten Kiesfläche, dem „Steinfeld“ nach und nach der heutige „Stadtpark“ entstehen (MEYER o. J.: 34). Die Regulierung der Zorge in diesem Bereich durch den Hartmanndamm ermöglichte folglich das Anlegen eines Stadtparks.

$\mathrm{Ab} 1880$ arbeitete man viele Jahre planmäßig an der Parkanlage mit der Zielsetzung „die Wildnis [...] zu verwandeln“. Als besonderen Bestandteil dieses schließlich 14 Hektar großen Stadtparks wurden Teiche angelegt. Einst belebten gar Goldfische und Schwäne die Parkteiche. Den oberen Teich, ehemals als "Gondelteich" genutzt und auch so bezeichnet, zierte ein Springbrunnen (ALLGEMEINER ANZEIGER 12/1997).

Im Rahmen von Arbeitsbeschaffungsmaßnahmen wurden 1995/96 die zum Teil schon verlandeten und flachgründigen Teiche entschlammt (ALLGEMEINER ANZEIGER 12/1997).

Nach der Endphase des Kaiserreiches brachte die Weimarer Republik, obgleich auf Ansätzen aus der Zeit des Kaiserreiches aufbauend, neue Qualitäten in die Park- und Gartengestaltung ein. Wasseranlagen waren nun nicht mehr primär für den ästhetischen Genuss gedacht; Plantschbecken für die Kinder wurden zum festen Bestandteil der neuen Volksparks, die nun in zahlreichen Großstädten angelegt wurden (WOLSCHKE-BULMAHN 2002).

Für die Volksparkbewegung war Wasser ein unerlässliches Element der neuen Parks. Gartendirektor Ludwig LESSER, einer der Initiatoren dieser Bewegung, forderte 1927 in seinem Buch „Volksparke heute und morgen“ zur Ausstattung von Volksparks: „Ein Volkspark muß enthalten: [...] c) Wasserflächen, teilweise als Badeteiche nutzbar." Auch in Hannover wurden unter dem Gartendirektor Kube Plantschbecken angelegt, so zum Beispiel in der Eilenriede (zit. aus: WOLSCHKE-BULMAHN 2002). 
Die Machtergreifung der Nationalsozialisten bedeutete nach Ansicht von WOLSCHKE-BULMAHN (2002), Professor für Grünplanung und Gartenarchitektur der Universität Hannover, „,das Ende für die Volksparkbewegung in Deutschland und die Unterbrechung der Weiterentwicklung einer demokratischen Parkkultur. Damit verschwand zwar nicht das Wasser als Gestaltungselement aus den städtischen Parkanlagen, aber der NS-Staat hatte keinerlei Interessen an einer freizügigen und demokratischen Parknutzung.“

Mit der Machtergreifung der Nationalsozialisten verschwanden Artikel über Volksparkanlagen aus den Fachzeitschriften. Vielmehr kam dem Hausgarten und damit auch einer mehr oder weniger subtilen Vermittlung des nationalsozialistischen Familienideals zunehmende Bedeutung zu. So finden sich in Fachbüchern aus der Zeit des Nationalsozialismus über Hausgartengestaltung immer wieder Fotos von Wasserbecken, „häufig mit plantschenden Kindern darin“ (WOLSCHKE-BULMAHN 2002). „Nationalsozialistischen Propagandainteressen“, so WOLSCHKE-BULMAHN nach Auswertung von Beiträgen in der Fachzeitschrift „Gartenkunst“" waren auch jene unterworfen, die über „Schönheit am Arbeitsplatz“, so der Titel eines Beitrags aus dem Jahr 1935, berichteten. Diese Beiträge über Grünanlagen an Fabrikbauten und Bürogebäuden waren mit Fotos illustriert, die aufwendig gestaltete Gartenanlagen, oft mit Wasserbecken, zeigten. „Dadurch sollte eine besondere Fürsorge des NS-Staates für die arbeitende Bevölkerung suggeriert werden." (WOLSCHKEBULMAHN 2002).

Nach der Befreiung vom Nationalsozialismus scheint zunächst von einigen Gartenamtsleitern an fortschrittliche Ideen der Weimarer Zeit angeknüpft worden zu sein, die unter anderem Plantschbecken in Volksparks vorgesehen hatten. „Doch in einer Phase, in der Vorstellungen zur Hygiene von der Werbung für das ,makellose Weiß' von Persil und anderen Waschmitteln geprägt wurden, scheinen Plantschbecken aus medizinisch-hygienischer Sicht in städtischen Parks nicht länger tolerabel gewesen zu sein - es sei denn, nur unter aufwendigen und nicht finanzierbaren technischen Maßnahmen.“(WOLSCHKE-BULMAHN 2002)

Paul Kynast, Gartendirektor in Berlin-Tempelhof, stellte in „Garten und Landschaft“ 1956 bedauernd fest: „Nach einer Verfügung des Hauptgesundheitsamts Berlin dürfen Plantschbecken ohne betonierte Wasserflächen und ohne Umwälz- und Chlorierungsanlagen aus hygienischen Gründen nicht mehr freigegeben werden." (zit. aus: WOLSCHKE-BULMAHN 2002) Gartendirektor Ulrich Wolf entwickelte 1956 spezielle Wasserspielplätze für die Stadt Düsseldorf, die diesen hygienischen Anforderungen gerecht werden sollten. Doch letztlich brachten die neuen hygienischen Anforderungen ein weitgehendes Ende für die Anlage von Plantschbecken in städtischen Parkanlagen (WOLSCHKEBULMAHN 2002).

\section{h Burg- und Schlossteiche}

Sehr alte Weiher dürften auch die Burg- bzw. Burgmühlteiche sein, denn die ersten Ringburgen, die „Motten“, wurden seit dem 8. Jh. bis ins 10./11. Jh. gebaut; der Höhepunkt des Burgenbaus lag im 12./13. Jh. 


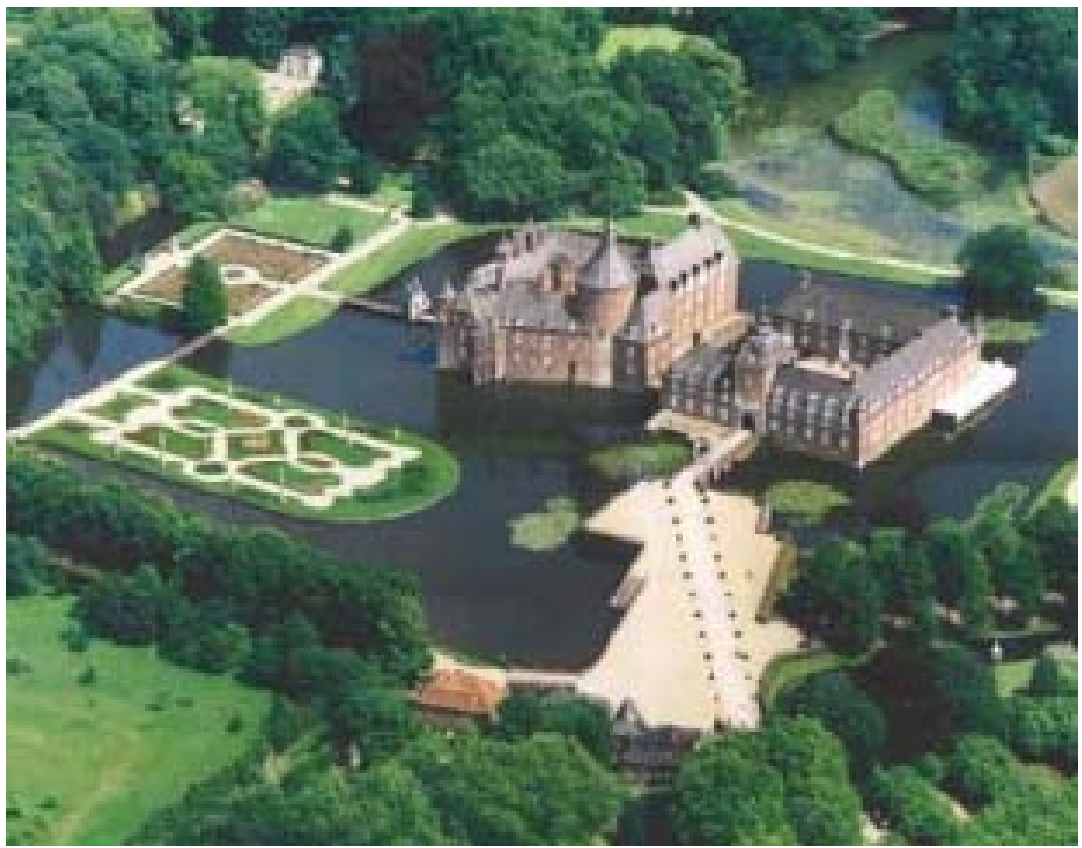

Abb. VII-65: Burggräben als Reminiszenz um das Schloss Anhold bei Isselburg

Die im 14. Jahrhundert als barocke Residenz ausgebaute und auf Eichenpfählen und einem Steinfundament ruhende Wasserburg ist noch heute als eine von wenigen Burgen in Privatbesitz. Sie gehört den Fürsten zu SalmSalm. Durch Heirat gelangten sie bereits 1645 in den Besitz der Herrschaft Anholt in Westfalen. Nachdem 1793 durch die Französische Revolution und die darauf folgenden Eroberungskriege Kaiser Napoleons I (1769 - 1821) ihr souveränes Fürstentum Salm (Hauptstadt Senones in Lothringen/Frankreich), infolge des Friedens von Lunéville (1801) ihre reichsunmittelbaren wild- und rheingräflichen Territorien (Kyrburg und Rheingrafenstein) und beim Wiener Kongress (1815) die Souveränität des Fürstentums Salm und der Herrschaft Anholt definitiv aufgehoben wurde, verblieb die Wasserburg Anholt seitdem den Fürsten zu Salm und zu Salm-Salm als Hauptresidenz. Seit 1966, nach dem Wiederaufbau der zum Ende des Zweiten Weltkrieges schwer zerstörten Wasserburg, Museum mit Bibliothek und Archiv, nachfolgend daneben Hotel- und Gastronomiebetrieb. Neben den wassergefüllten Burggräben ist die Wasserburg von weitreichenden Wasseranlagen umgeben.

Diese Burgteiche, die zwar aufgrund ihrer umlaufenden Form eigentlich als Burggräben bezeichnet werden, aber, wenn sie zu- und ablauffähig sind, einen weiteren Wasserbereich umfassen und da gleichzeitig oftmals dem Mühlantrieb dienten, dürfen nach meiner Auffassung durchaus als Burgweiher bezeichnet werden. Sie haben außer als Mühlstaubecken als Auffangbehälter der Aborterker und der dieser Nährstoffzufuhr nicht widersprechenden Karpfenzucht vor allem eine militärstrategische Bedeutung gehabt.

Sind die Gräben der Höhenburg seltener mit Wasser gefüllt, so ist dies bei Niederungsburgen die Regel. Das Ringgraben bzw. -teichsystem umgab die gesamte Anlage einer Wasserburg. Diese Wasserelemente wurden bei der baulichen Wandlung in ein Schloss beibehalten bzw. integriert.

Wassergefüllte Schlossgräben sind beispielhaft in Gifhorn (Schloss Gifhorn), in Wolfsburg (Schloss Wolfsburg), ursprünglich nördlich des Schlosses entlangfließende Aller, und im Burgpark Neuhaus, nur wenige Kilometer von Wolfsburger Stadtzentrum, zu nennen.

\section{i Jagdteich}

Als man die zur friedlichen Wohnungsnutzung ohnehin zu unbequemen Bergschlösser zu vernachlässigen begann, zumal sie für den Krieg immer mehr ihre Bedeutung verloren, wurden zur Jagd besonders eingerichtete Schlösser ein Bedürfnis.

Die Grundherren bauten immer mehr Jagdschlösser oder bestehende Schlossanlagen bzw. Burgen seit dem späten Mittelalter in solche um. Als Beispiel seien Clemenswerth im Emsland und Moritzburg bei 
Dresden genannt. Der Graf von Dassel baute die Burg Nienover ${ }^{55}$ im Solling zum Jagdschloss um, der hessische Landgraf Wilhelm II. begann 1490 die Zapfenburg (jetzt Sababurg genannt) im Reinhardswald wieder aufzubauen. Unter Landgraf Philipp wurden auch mehrere eingegangene Klöster in Jagdhäuser umgestaltet, z. B. das Kloster Heida bei Melsungen. Aber es wurden von ihm auch komplett neue Jagdhäuser errichtet (1591 Elbrighausen, 1572 Kranichstein, 1609 die Jägersburg bei Hauserwald).

Entsprechend dieser neuen Funktion wurden auch die umgebenden Wälder angepasst Viele Forsten wurden so gestaltet, dass man optimal darin jagen konnte. In Tiergärten wurden vor allem die begehrten weißen Hirsche eingesetzt (LANDAU 1849:260). Tiergärten im Mittelalter wurden allein in Hessen 1346 bei Gudensberg, 1414 zwischen Melsungen und Schwarzenberg und 1487 bei Marburg errichtet. Den größten Tiergarten in Hessen hingegen aber legte Wilhelm IV. 1571 bei Jagdschloss Sababurg an. Später, im 18. Jahrhundert, entstanden noch kleinere Tiergärten, wie zum Beispiel in Wilhelmshöhe und in der Karlsaue bei Kassel (:204), diese aber mehr zum Amüsement als zu einer ernsthaften „Hohen Jagd““.

In diesen Forsten und auf der Jagd trieb man an Lebendhecken entlang das Wild ,in einen Weiher, der von den Jägern mit ihren Hunden umstellt war.“ (KÜSTER 1988:126,128)

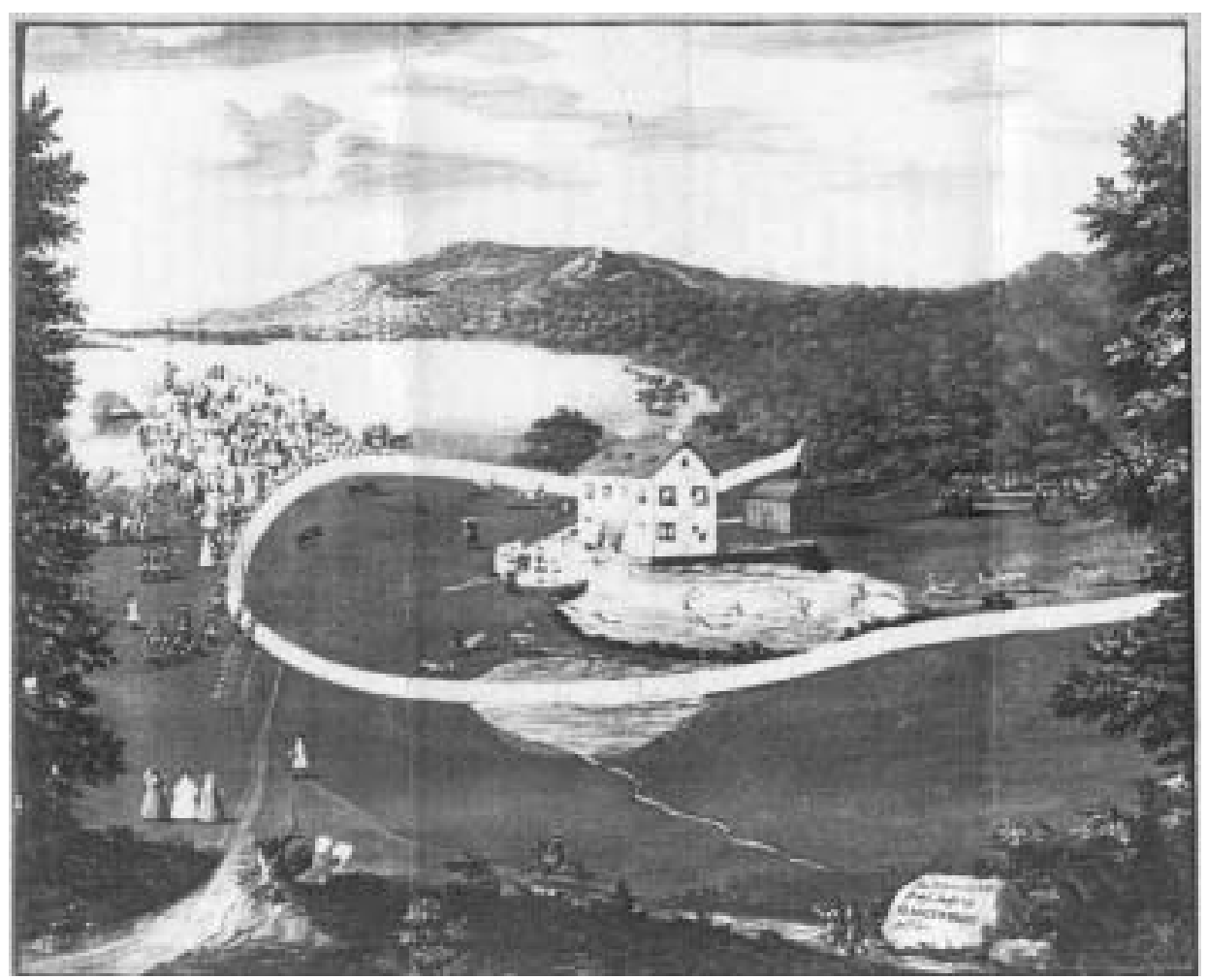

Abb. VII-66: Wasserjagd in einem Teich bei Kloster Michaelstein

Sie wurde 1734 abgehalten vom Blankenburger Hof.

Die Darstellung zeigt einen von Leinwand eingefassten Teich, in den von rechts aus dem Wald bergab Rotwild herabgetrieben und schwimmend erlegt wird. In einer anderen gemalten Abbildung von 1723 wiederholt sich die Szenerie, wobei sogar von einem Floß aus Rot- wie auch Schwarzwild im Teich erschossen wird. Im Fasanenschlösschen des Moritzburger Schlosses/Sachsen soll sich auch noch ein altes, aber wohlerhaltenes Riesengemälde von hohem künstlerischen und kulturgeschichtlichen Wert befinden. Es zeigt eine Wasserjagd auf dem Großteich. Man sieht auf dem Bild u. a., wie ein Bär, der auf einer der Inseln des Teiches gehalten wurde (Stern- oder Bäreninsel im heutigen Ostbecken des Teiches) bei Jagden das Wild, das sich auf die Insel zu flüchten versuchte, besonders Wildsauen und Hirsche, wieder in das Wasser zurück trieb (Museum Kleines Schloss,

\footnotetext{
${ }^{55}$ Nienover [Niegen Overe]: „Over“ ist im Niederdeutschen „Öwer“ und im Plattdeutschen des Sollingraumes heißt das Wort „Aeuwer“. In allen Fällen bezeichnet es ein Flussufer (WEISE 1989:1). „Nien“ [„Niegen“] steht als Zusatz für Neu. Von einer primären Auslegung als Ufer kann auch beim Namen „Hannover“ ausgegangen werden WEISE (:2) hingegen hat ein Problem mit der Bezeichnung „Flussufer“ bei Nienover, wogegen er dies im Fall der Residenz Hannover nicht hat, „,weil die Leine ein ansehnlicher Fluß ist und weit auseinanderstehende Ufer hat."
} 
Blankenburg, Kopie aus STEINACKER 1922, zur Verfügung gestellt von Museumsleiter Herrn Wegner; Orig.Gemälde in der Marienburg, Nordstemmen).

Vor allem die Parforcejagd, bei der par force, d. h. mit Gewalt, ein einzelner Hirsen mit der Hundemeute gejagt wurde und die früher meist im Sommer und Herbst stattfand, bildete die Kulisse für einen künstlichen Teich, der aber wahrscheinlich durchaus nicht allein zu diesem Zweck errichtet worden ist.

Wenn der stundenlang von der jagenden Meute, einer zwischen 50 und 100 Tieren bestehenden Jagdhundestaffel, gehetzte Hirsch vom übrigen Wild getrennt und ermüdet war, stellte er sich entweder zu Land oder zu Wasser. Bei den Jagden im zweiten Drittel des 16. Jahrhundert hatte Landgraf Wilhelm gar „seinen Affen mit, welcher mit den Hunden um die Wette die Hirsche verfolgte“ (LANDAU 1849:255).

Dem gestellten und ermüdeten Hirsch wurden dann mit dem „Hirschfänger“, einem speziellen Hauptschwert mit Beimesser, die Hächsen der Hinterläufe, d. h. die Beugesehne beim Haarwild oberhalb des Sprunggelenkes an der Hinterseite des Hinterlaufes durchgeschlagen, damit er die Hunde nicht „forkeln“, d. h. mit seinem Geweih oder Gehörn nicht verletzen konnte und der Jagdherr oder Ehrengast ihn beim Wasserhalali durch einen Kugelschuss aus der Pistole auf den Kopf erlegen konnte (HASEDER/STINGLWAGNER 1996:251,308,582).

LANDAU (1849) beschreibt die Hirschjagd des 16. Jahrhunderts für das Landgrafentum Kassel unter Auswertung historischer Quellen in anschaulicher Weise, die in einer Zusammenstellung der wichtigsten Passagen hier wiedergegeben werden soll und die Stellung der verfolgten Jagdtiere im Wasser bestätigen: Als 1535 die Herzoge von Sachsen nach Kassel kamen, veranstaltete Philipp unter anderen Festlichkeiten auch mehrere Hirschjagden. Für die erste Jagd waren am Fahrenberge am Habichtswald 10 feiste Hirsche zu den Schützen vorgetrieben, einer wurde durch Herzog Georg III. geschossen, die anderen aber wurden durch die Hunde gefangen (:246). Am darauf folgenden Tag wurden im Reinhardswald von 15 Hirschen 7 geschossen und die übrigen von den Hunden gefangen (:246). Und so ging es die nächsten Tage an anderen Plätzen weiter (Webelsberg, Bastholz, Solling). „Für die Frauen war ein Schirm zum Zuschauen bereitet, in welchem gespielt, gegessen, getrunken und allerlei Kurzweil getrieben wurde. Mehrmals wurden die Hirsche bis vor den Schirm getrieben und das Kalb durch die Verfolgung geängstigt und ermüdet, flüchtete in den Schirm, wo es die Frauen in Schutz nahmen und erquickten und labten.“ (:247) In der Sommer- und Brunftjagd des Jahres 1560 pirschte allein Landgraf Philipp 154 Hirsche und 1588102 meist feiste Hirsche. Im Juli 1585 jagte Landgraf Wilhelm in der Herrschaft Schmalkalden und in 7 Jagden starben durch die Landgrafen 100 Hirsche. Die Jagdbeute des Landgrafen Ludwig betrug in diesem Jahr 300 Hirsche und 1586230 Hirsche (:253).

Die Hirschjagd beschreibt Landgraf Philipp selbst auf der Rückreise von dem Kurfürsten von Sachsen und bestätigt zunächst die oben beschriebene Vorgehensweise der Niederstreckung: ,, [...] ritten eine gute Weile mit den Hirschen, ging dicke in einander, hatten Sorge wir würden zween schießen, wenn wir einen treffen; zuletzt malten wir einen aus und schossen demselben vorne mitten ein Bein morsch entzwei und ritten dann vor den andern Hirschen und schossen ihn noch zwei mal " (aus: LANDAU 1849:248).

Über die Brunftjagd im Seulingswald, auf der Landgraf Wilhelm in der Waltersberger Aue einen Zweiundzwanziger schoss, berichtete derselbe seinem Bruder Landgraf Philipp im September 1567 und von ihm erfährt man die Bedeutung des Wassers bei der Jagd: , [...] mit demselbigen haben wir und unsere Gemahlin gar trefflich guten Lusten gehabt, denn wie er geschossen worden, ist er wieder nach dem Thüringer Wald nach Dankmarshausen zu ins Wasser gelaufen. [...] ....und haben folgends den Hirsch daselbst im Wasser gefangen. " (aus: LANDAU 1849:249) 


\section{j Wippeteich}

Historisch-geographische Elemente der Gerichtsbarkeit sind auch aus dem Wasserbereich zu benennen.

Aus dem nordhessischen Hofgeismar wird von einem sog. „Wippeteich“ berichtet. „Dieser Teich wurde über einen Graben mit Wasser aus dem Kelzer Berg versorgt und war in früherer Zeit von ganz besonderer Bedeutung. Feld- und Gartenfrevler, Bäcker, die zu kleines Brot backten, und Metzger, die es mit dem Gewicht nicht allzu genau nahmen und sich zu ihrem Vorteil verrechneten, wurden in diesem Teich gewippt. Frauen, die ihre Männer schlecht behandelten oder gar das sechste Gebot übertraten, erging es ebenso. Die Übeltäter wurden in einen Korb gesetzt, festgebunden und mittels einer als Hebel dienenden Stange, die an einem Ständer befestigt war und zur Hälfte über den Teich ragte, ins Wasser getaucht und wieder herausgehoben, und zwar so oft, wie die Sünder es verdient hatten oder bis sie Besserung gelobten.“ (IBA 1988:16).

Die noch bis zum ersten Drittel des 18. Jahrhunderts betriebene Hexenverfolgung basierte in ihrer Gerichtsbarkeit auf der „Peinlichen Halsgerichtsordnung Karl V. von 1532, die Folter und "Gottesurteile“ zuließ. Zu der in Hexenprozessen üblichen „Beweiserhebung“ gehörte auch die „Wasserprobe“. Dabei wurden die Frauen an Händen und Füßen gefesselt und in ein Gewässer, in einen Fluss oder tiefen „Wippeteich“, geworfen. Blieben sie oben, waren die mit dem Teufel im Bunde und wurden verbrannt. Ertranken sie, waren sie „unschuldig“ gestorben (BUSSANG 2004).

\section{k Lohgruben}

Seit Jahrhunderten hatte die Gewinnung von Eichenrinde und gelegentlich anderer Baumarten für die Lohgerberei eine große Bedeutung. Die „Rotgerber“ (Lohgerber) verwendeten zur Lederherstellung Lohe (gemahlene Baumrinde; in der Regel Eichenrinde als bester Gerbstoff mit einem hohen Anteil Gerbsäure) als Gerbmittel, die das bei der Gerbung benötigte Wasser rötete. Die Rotgerberei brachte festes, derbes, nicht ausdehnungsfähiges Leder (Sohlleder) hervor, denn im Gerbprozess gewannen die Häute auf Kosten der Fläche an Dicke und wurden zu Leder ${ }^{56}$ (KREINER 1996:141).

Die mit einem löffelartigen Schäleisen von dem vornehmlich vom Niederwald oder vom Unterholz des Mittelwaldes geschälte Rinde wurde in kleinen Bündeln aus den Wäldern zu den Lohmühlen gebracht. So wurde zum Beispiel die gebündelte Rindensammlung des Reinhardswaldes zu den Lohmühlen nach Grebenstein, Kassel oder in die Mündener Lohmühle gebracht. In diesen wurde die Lohrinde fein zerstoßen und zu Pulver zermahlen. Die pulverfeine Rinde wurde abwechselnd mit den vorbereiteten Häuten in der Lohgrube eingestapelt und auch mit diesem Gerbmittel bedeckt. Die Häute blieben - unter Wasser bedeckt - je nach Lederstärke und weiterer Verwendung 4 bis 5 Monate oder länger in diesen Gruben, bei Sohlleder etwa 2 Jahre lang (HENCKEL 1988:33; KREINER 1996:141). Zum Gerben der Häute benutzte man wasserdicht ausgemauerte Gruben oder in die Erde eingelassene Holzkästen, die man, nachdem man abwechselnd Lohe und die Häute darin ausgebreitet hatte, am Schluss voll Wasser laufen ließ (KREINER 1996:141). Solche Gruben sind für Münden unmittelbar neben der Lohmühle und im Innenhof des „Ochsenkopf“, dem letzten mittelalterlichen Ständerbau in Südniedersachsen von 1528, überliefert (HENCKEL 1988:33).

Die Lederherstellung war damit nicht beendet, denn es handelte sich ein langwieriges, äußerst unappetitliches und wasserbelastendes Geschäft. Nachdem die Häute eingeweicht waren, folgte als ein weiterer (nicht als nächster) Arbeitsschritt bei den Fellen das Kalken in einer wasserdicht ausgemauerten Grube, zur Auflockerung der Haut und Lösung der Haarwurzeln.

\footnotetext{
${ }^{56}$ Zum Verfahren der Lederherstellung siehe HERZBERG 1987:34f.; SCHMIDTCHEN 1992:542-548
} 


\section{Rottekuhle}

Andere, meist kleinere Weiher wurden gebaut, um Flachs zu rösten, d. h. die Faser durch einen Gärungsprozess vom übrigen Gewebe zu trennen, denn um den Flachs zu verarbeiten, war es notwendig, diesen einige Zeit im Wasser aufzuweichen (TERHALLE 1992:112f.). Auch diese Nutzung geht vermutlich weit ins Mittelalter zurück (BUSSE 1995:4).

Die „leeren“ Flachsstengel bündelte man zunächst, d. h. sie wurden zu großen „Wasserbunden“ zusammengebunden (BUSSE 1995:9). Diese Wasserbunde wurden in Teiche und sog. „Rottekuhlen“ geschichtet und mit Brettern und Steinen beschwert, um den Flachs ständig unter der Wasseroberfläche zu halten. Mit dem Rotten begann die Gewinnung der Gespinstfasern. Hierbei bewirkte ein Fäulnisprozess unter Wasser eine Art Gärung, bei der durch Einweichen im Wasser die die einzelnen Fasern verbindenden Bestandteile zersetzt wurden und infolge die Lösung der Bastfaser aus ihrem natürlichen Verbund eintrat. Die Faser löste sich dabei vom Holzkörper so weit, dass eine mechanische Trennung möglich wurde (:9).

In den Flachsteichen, bei denen es sich nach ihrer Form eher um „Kuhlen“ gehandelt hat und die nach dem in ihnen stattfindenden Verarbeitungsprozess „Flachsröste“, auch „Röste“-, „Rötte“ bzw. „Rötekuhle“ genannt wurden, wurde der Flachs nach der Ernte gewässert. Je nach Wassertemperatur dauerte die Wasserrotte etwa ein bis zwei Wochen und länger. Notwendig waren eine permanente Wasserdecke oder Böden mit Staunässe.

Wegen der starken Geruchsentwicklung bei der Rotte wurden sie an die Waldränder „,möglichst weit entfernt von menschlichen Wohnplätzen in Bereichen mit Staunässe“" (BURGGRAAFF/KLEEFELD 1997 :30) gelegt, vorzugsweise im Quellbereich von Bächen. Dort, in der Nähe der Quellen, wurden viereckige, etwa bis $2 \mathrm{~m}$ tiefe Gruben mit einer durchschnittlichen Größe von 3 x 5 m angelegt, deren Wände und Böden durch Lehmauftrag wasserundurchlässig gemacht wurden. Erfahrene Personen überwachten diesen Vorgang, entnahmen Proben und legten den Zeitpunkt fest, an dem der Flachs aus dem Wasser genommen werden musste. Eine zu kurze oder zu lange Rotte beeinflusste die Faserqualität. Bei einer Überrottung griff der Fäulnisprozess schon die Faser an; bei zu kurzer Rottezeit ließen sich die Fasern nur schwer von den Holzteilen lösen. (BUSSE 1995:9)

Darüber hinaus durfte das Wasser für den Rottungsvorgang nur einen geringen Kalkgehalt aufweisen, weil dieser die Faserqualität verschlechterte.

Danach wurde der Flachs sechs Wochen getrocknet und dann durch das sog. „Schwingen“ gereinigt und weiterverarbeitet.

Im Zuge eines historisch-geographischen Gutachtens im Rahmen der Aufstellung eines Landschaftsplanes zur Begründung der Ausweisung des Naturschutzgebietes „Bockerter Heide“ im Kreis Viersen durch BURGGRAAFF/KLEEFELD (1997:24), wurden in einem 200 ha großen NSGGebiet 14 Flachsröste gefunden. Bei den schwierigen Datierungsversuchen dieser Rottekuhlen konnte festgestellt werden, dass im Untersuchungsgebiet Viersen im Jahr 1580 etwa 800 Webstühle in Betrieb standen. Nach 1945 wurden die Kuhlen nach der Aufgabe des Flachsanbaues nicht mehr genutzt (:30). 


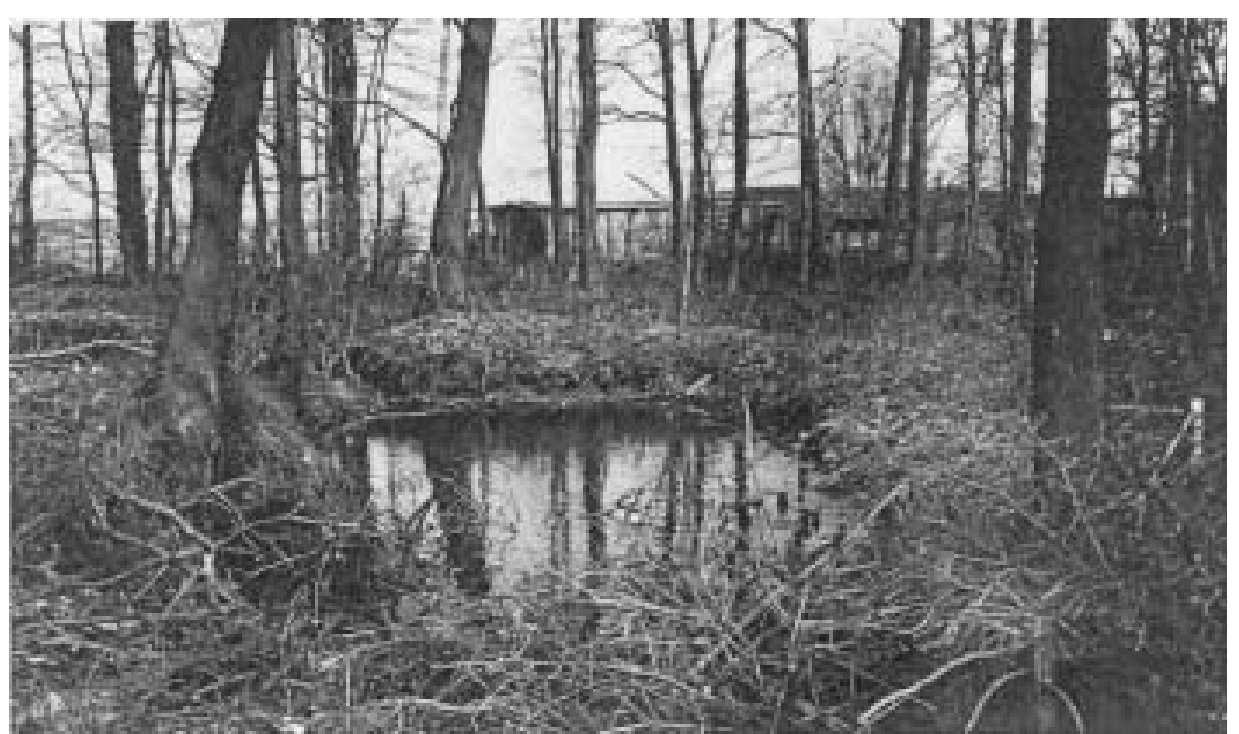

Abb. VII-67: Flachskuhle am Niederrhein

(aus: BURGGRAAFF/KLEEFELD 1997:31)

Aus einem anderen Untersuchungsgebiet, im Raum Garzweiler/Erkelenz, in der Gemarkung von Holzweiler, sind der Flachsanbau und die anschließende Weiterverarbeitung zu Leinen und vor allem zu Seilen überliefert. Der Flachsanbau zur Leinengewinnung ist im Untersuchungsgebiet, das wiederum zum Flachland bei Erkelenz gehörte, bereits in das 9. Jh. datierbar und hat somit kontinuierlich 1000 Jahre bestanden.

Auch hier sind Reste der Weiterverarbeitung noch im Gelände in Form von leichten Bodenvertiefungen, die ehemaligen Flachsröste, erkennbar, wie in Holzweiler am Weg zu Ortschaft nach Keyenberg.

Belegt ist, dass die Flachsrösten in großer Zahl über Jahrhunderte hinweg ein regionaltypisches Element im Untersuchungsgebiet waren. Weitere Flachsanbaugebiete und Flachsröste bestanden in der Otzenrather Gemarkung. Die Flurbezeichnung „Babbelskuhl“ beispielsweise weist auf eine Flachskuhle in Holz hin (KLEEFELD/BURGGRAAFF 1997b:60).

Flachrösten sind auch aus einem anderen Schwerpunktraum der Weberei bekannt. Aus der Seidenweberstadt Bielefeld und ihrer weiteren Umgebung sind solche Röstekuhlen bekannt. In Kirchlengern, Kreis Herford, wurden noch in den 1930/40er Jahren Kuhlen zum Wässern in den Uferwiesen der Else ausgehoben und Flachs dort zum Rotten hineingelegt (HAGEMEYER 2002:mündl.). Ebenso hat es in den Wiesen an der Linnenbeeke in Valdorf, einem Ortsteil von Vlotho, eine Röstekuhle gegeben, zwischen dem Hof Prött und der Mühle Triebold (MÖRSTEDT 1995:231).

Doch nicht nur in den klassischen Flachsanbau- und -verarbeitungsgebieten, auch in anderen ländlichen Bereichen sind Rotteteiche überliefert. In dem im Zusammenhang mit dem Nachweis einer Pferdeschwemme bekannten Dorf Riehe im Schaumburg-Lippischen (siehe Pkt. d) speisten die beiden Bäche Radbach und Ammerbach auch die Röstekuhlen für die Flachsvorbereitung (SCHRÖDER 1979).

Neben der Flachsrotte gab es noch die Taurotte: Der Flachs musste dazu auf einem abgeernteten Getreidefeld oder einer Wiese ausgelegt werden; er war den Witterungseinflüssen so lange ausgesetzt und wurde von Zeit zu Zeit gewendet, bis die Stengel den erforderlichen Rottegrad hatten. Dieser Vorgang dauerte länger, etwa 3 bis 4 Wochen. Tau, aber auch Regen waren dazu erforderlich. Durch das mehrmalige Wenden war die Taurotte sehr arbeitsaufwendig (BUSSE 1995:9f.). 


\section{m Bleichteich}

Es gab Bleicheweiher, aus denen in früherer Zeit Wasser geschöpft wurde, um die ausgelegte Leinwand mit Wasser zu benetzen.

KONOLD (1994:307ff.) berichtet aus dem Allgäu, im südlichen Stadtgebiet von Isny, von einem sog. Bleichweiher. Dieser von ihm als Rückhaltebecken bezeichnete Teich war in diesem Untersuchungsraum neben der „alten oberen Bleiche“ gelegen. „Der Weiher diente“, so seine Interpretation, ,höchstwahrscheinlich auch als Speicher für die Schöpfgruben, deren Wasser man für das Benetzen der Leinwandbahnen verwendete.“

Aus dieser Deutung lässt sich das zweifache Vorkommen von Bleichteichen ableiten. Einmal der eigentliche und vermutlich größere Bleichteich und die von ihm gespeisten kleinen "Schöpfteiche“ bzw. „Schöpfgruben“ oder „-gräben“, aus denen man mit einer Bleichkelle oder -kanne das saubere Wasser für das Benetzen oder Begießen der Leinwände holte.

Grundwasser von der Bleiche selbst konnte man hier nicht gebrauchen, da es wegen der Vermoorung der anmmoorigen Auewiesenfläche in diesem Gebiet braun gefärbt war (KONOLD 1994:308). Daraus kann man wiederum schließen, dass insbesondere in moorigen Gebieten bevorzugt solche Bleicheweiher angelegt wurden, die von einer „sauberen“ Quelle gespeist wurden.

Der Bau des Bleicheweihers in Isny geht - parallel zur Einrichtung der „alten Bleiche“ als Wiesengelände - auf die Zeit des wirtschaftlichen Aufschwungs der Stadt zurück. Definitiv genannt wird er 1539 im Grundbuch des Klosters als „Weiher ob der Bleiche“ und 1621 im klösterlichen „Verzeichnis aller Weiher und Gruben“ (KONOLD 1994:308).

Der Bleichweiher konnte alternativ zum nahegelegenen Rotbach oder zum Krummbach - je nach Bedarf - abgelassen werden und besaß damit die einen Teich kennzeichnende teichbautechnische Konstruktion einer Ablassvorrichtung. Auch der westliche Teil der „alten Oberen Bleiche“ konnte eingestaut werden, entweder zum Zweck der Wasserbevorratung oder der Milderung von Abflussspitzen (KONOLD 1994:308).

Auch aus späterer Zeit, im zweiten Drittel des 19. Jh., als in manufakturistischer Arbeitsweise Leinen hergestellt wurde, sind Bleichteiche überliefert. Die „Bleichpläne“ der königlichen Musterbleiche in Sohlingen bei Uslar umfassten im Laufe der Jahre einen Raum von ca. 40 Morgen (nach hannoverschem Maß ca. 10,48 ha). „Das besonders weiche, klare Bleichwasser entsprang einer ergiebigen Quelle und wurde über mehrere Sammelteiche den Bleichanlagen zum Benetzen der ausgelegten Leinenbahnen zugeführt." (SCHRECKENBACH 1995:28) Aber schon einige Jahre nach der Gründung der Musterbleiche wurde anstelle der Bleichteiche ein einfaches Bleichgebäude geschaffen, mit Wasserbehältern zum Spülen des Gewebes (:28).

Noch in den 1940er Jahren wurden in den Auenwiesen der Else kleine Gruben ausgestochen, die sich mit dem saubereren Uferwasser füllten und aus denen die daneben ausgelegte Leinenware benetzt wurde (HAGEMEYER 2002:mündl.).

\section{n Salzteich}

Der Übergang zum Ackerbau und damit zur Pflanzenkost in der Jungsteinzeit erforderte eine Ergänzung der Nahrung durch Kochsalz. Vorgeschichtliche Salzgewinnung für das Gebiet bei Schwäbisch Hall ist von der Mitte des 5. Jahrtausend v. Chr. bis zur Mitte des 3. Jahrhundert n. Chr. belegt (SMETTAN 1996:89). Der Grund, weshalb man etwa doppelt so viel Salz benötigte wie heute in Deutschland, liegt darin, „daß man es weniger zum Würzen als fast ausschließlich zum Einpökeln, also zum Haltbarmachen von Fleisch verwendete.“ (:89) 
Die Gewinnung erfolgte seit dem Mittelalter bis zum frühen 20. Jahrhundert zunächst durch Verdampfen von salzhaltigem Quellwasser, danach hauptsächlich durch Eindampfen von Sole in Pfannen und wurde abgelöst durch Abbau von salzhaltigem Gestein.

Es entstanden in trockenwarmen Klimazonen infolgedessen ganze „Salzgärten“, das sind künstliche flache Becken in Gebieten mit hoher Verdunstungsintensität, in denen Salzwasser zur Speisesalzgewinnung eingedunstet wird, zum Beispiel an der Südküste der Bretagne.

Aber auch in Deutschland wurden bei der Solegewinnung Salzteiche angelegt, wie zum Beispiel im Kurpark Sooden (siehe Abb. VII-68) oder im Kurpark von Bad Nauheim. Hier liegt ein ,Großer Teich' an der Usa, der auf einen vorgeschichtliche Salinenbetrieb verweist. Dieser war auf das westliche Ufer der Usa beschränkt, „,während sich die Solequellen fast ausschließlich auf der gegenüberliegenden Flussseite nachweisen lassen.“(VOGT 1996:70)

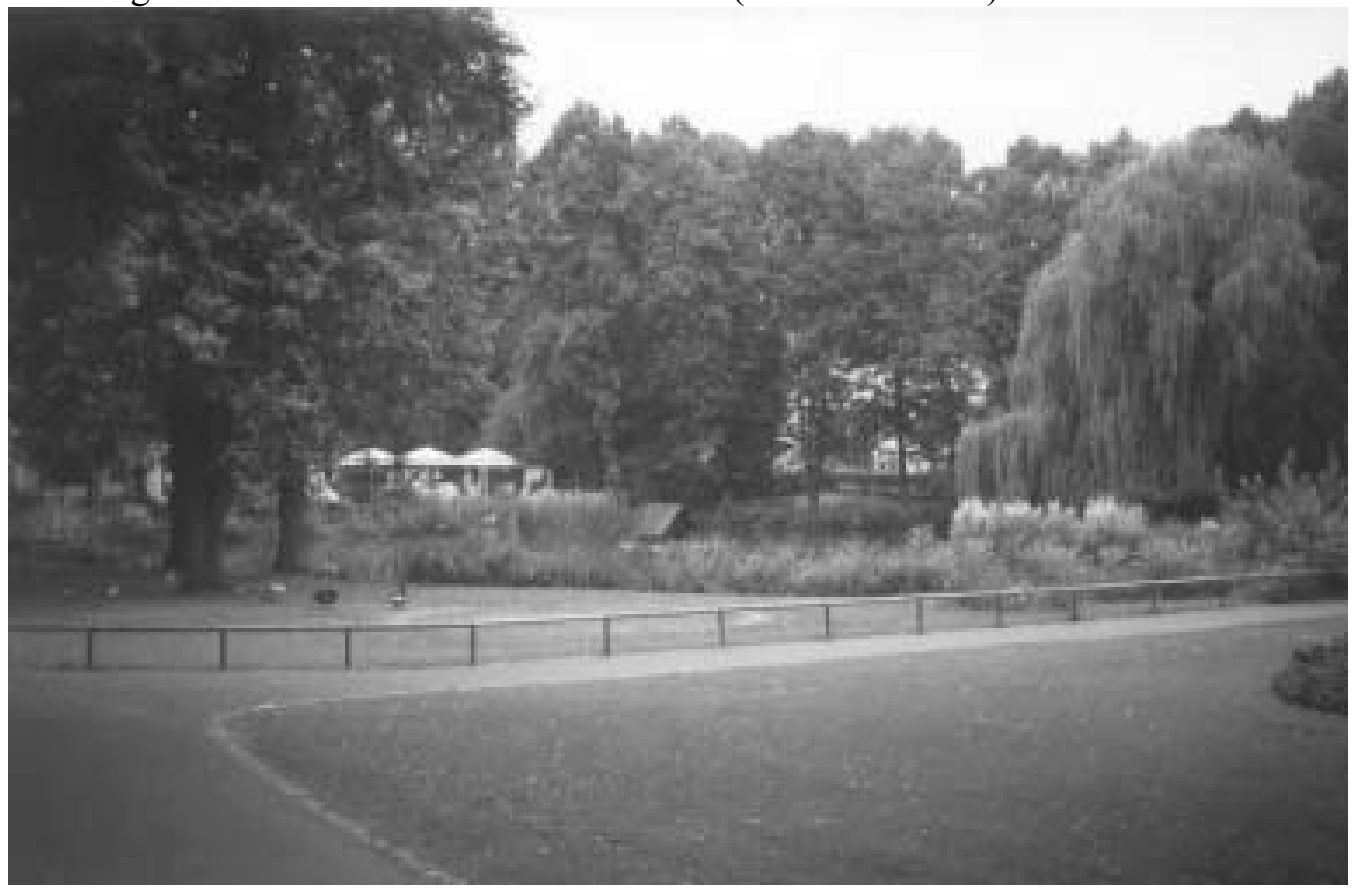

Abb. VII-68: Ehemaliger Salzteich in Bad Sooden

In veränderter Form (wie mit Entenhäuschen, Bewuchs und sanftem Uferzugang) heute Bestandteil des Kurparks (eig. Aufnahme 2003).

Die Gründe für die Einrichtung von Salzteichen liegt in der Methode der Soleaufbereitung, dem Gradierverfahren, begründet. Da man erst im 19. Jahrhundert begann, das in den Tälern als Salzquelle austretende „weiße Gold“ bergmännisch abzubauen, musste bis dahin die Sole eingedampft werden (SMETTAN 1996 :87). Während der Latènezeit wird der Siedebetrieb witterungsbedingt nur saisonal betrieben worden sein. Insbesondere die flachen Gradierbecken mit ihrer großen Oberfläche konnten die gewünschte Verdunstung nur während der Sommermonate gewährleisten. In den Wintermonaten ruhte der Salinenbetrieb (VOGT 1996:76).

Während man früher den Vorgang der Soleaufbereitung in Bottichen annahm, ist nach den Ausgrabungsbefunden in Bad Nauheim vom Sommer 1993 die Vorgradierung in Gradierbecken in Betracht zu ziehen. Diese Gradierbecken konnten mit $28 \mathrm{~m}^{2}$ nicht einmal zur Hälfte freigelegt werden. Die Seitenlänge der aus Flechtwerk gesetzten Wände waren bis zu $7 \mathrm{~m}$ weit zu verfolgen, ohne sie auf ihrer ganzen Länge erfassen zu können (VOGT 1996:76). Ein hoher Kalkanteil machte diese Vorgradierung der Rohsole erforderlich, um die Bildung von Pfannenstein zu vermeiden. Für Bad Nauheim ,sind sogenannte Quelltümpel beschrieben, in denen diese erste Vorgradierung vorgenommen sein könnte.“ (:77) Statt gefasster Quellen sollen „umzäunte Sümpfe“ üblich gewesen $\operatorname{sein}(: 77)$. 
Darüber hinaus gab es in der Latènezeit auch „künstlich angelegte Gradierbecken“ (VOGT 1996:77). In Bad Nauheim konnten zwei solcher Solereservoirs (Becken) teilweise freigelegt werden. Somit dürfte die Aufbereitung der Rohsole durch Kaltgradierung in der Latènezeit praktiziert worden sein (:77). War sie schließlich ausreichend konzentriert, konnte sie in flachen Schalen auf gemauerten Herden eingedampft werden (SMETTAN 1996:87).

\section{o Eisteich}

Vor der Erzeugung künstlicher Kälte war die „Bevorratung von Eis und Schnee [...] primär zum Zwecke der Kühlung von verderblichen Lebensmitteln in speziellen baulichen Vorrichtungen" eine früher weit verbreitete kulturelle Erscheinung (LÜTGERT 2000:5). Die herkömmliche Methode der Eisbeschaffung auf dem Lande war dabei „,noch bis vor wenigen Jahren die winterliche ,Eisernte', die aufgrund der hierzulande reichlich vorhandenen Teiche und Bäche im Januar und Februar fast überall möglich war.“ (:80) „Diese im Volksmund auch als ,Eishauen’ bezeichnete Tätigkeit geschah mittels spezieller ,Eisäxte', vereinzelt auch besonderer ,Eissägen'. Es war eine gemeinschaftliche Arbeit, die mehrere Personen, bei größeren Entfernungen außerdem einen Pferdewagen und aufgrund fehlender technischer Hilfsmittel viel Körperkraft und Zeit erforderte.“ (:80; zum Eisstechen siehe auch VI 13a)

Kühleis wurde zwar auch aus Flusseis gewonnen (siehe ebenfalls V 13a), in der Regel aber wurde das Eis in schneller zufrierenden Teichen gebrochen. Anschließend wurde es in spezielle Lager- und Kellerräume, in sog. Eishäuser, verbracht und gestapelt. Ein solches Eishaus aus dem ersten Drittel des 18. Jahrhunderts ist beispielsweise noch im Ort Jersbek/Kreis Stormarn erhalten geblieben, in das das vom Gutsteich des Barockschlosses Jersbek im Winter gebrochene Eis zur Kälterung transportiert worden ist.

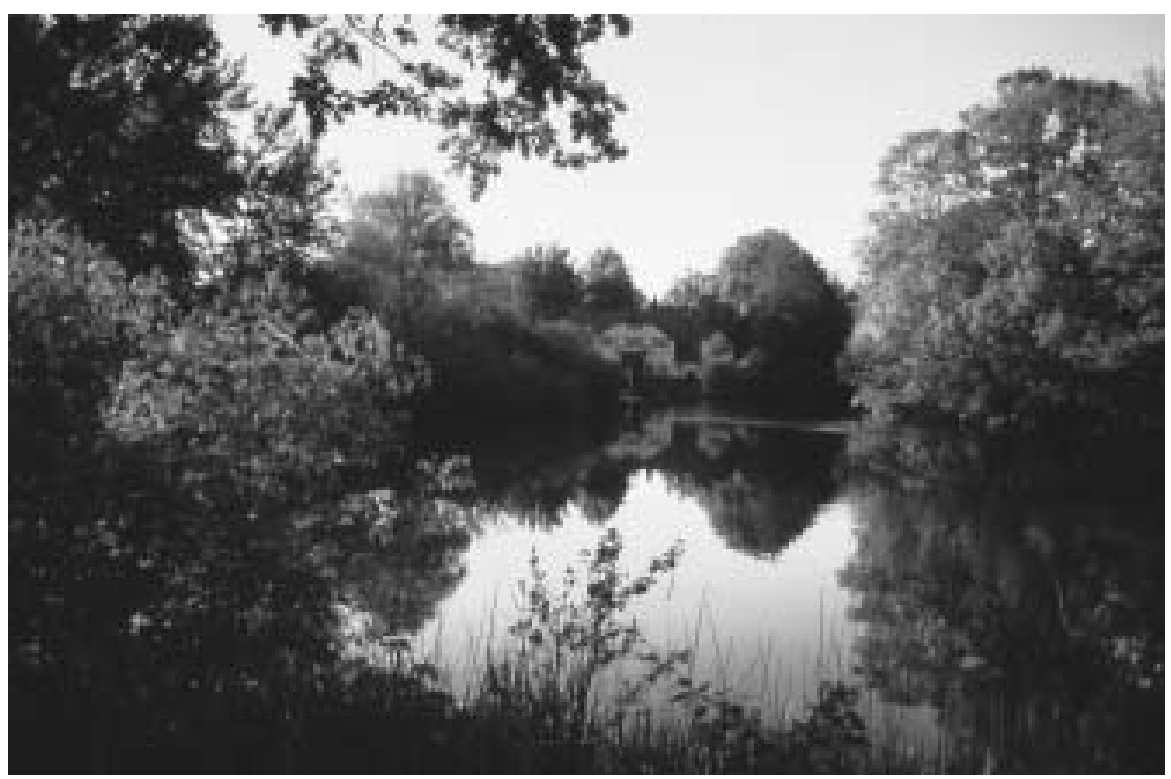

Abb. VII-69: Eisteich mit Eiskeller Gut Jersbek, Kreis Stormarn

(eig. Aufnahme 1999). Gegenüber, westlich des Gutshauses auf einer Geländeerhebung, liegt der wahrscheinlich in den Jahren 1736/37 errichtete Eiskeller mit einem rechteckigen Grundriss von ca. 12 x 7 m mit steilem reetgedeckten Walmdach. Es besteht aus einem 4,5 x 4,5 m großen Kühlraum aus Feld- und Ziegelsteinen und einem überwölbtem Eisraum mit einem ca. $7 \mathrm{~m}$ tiefen und bis $6 \mathrm{~m}$ breiten Eistrichter aus trocken aufgemauerten Feldsteinen. Das Gebäude wurde zusätzlich von ursprünglich wohl 18 Bäumen (Kastanien und Linden) beschattet, heute werden hier auch standesamtliche Trauungen vorgenommen (LÜTGERT 2000:165).

Während nach Ansicht von LÜTGERT (2000:91) zunächst anscheinend die Verfeinerung des Geschmacks im Vordergrund der Eisgewinnung stand, war es später die konservierende Wirkung des Eises vor allem im Sommer. Diese Verschiebung ist zum einen mit der früher vorherrschenden Form der Haltbarmachung durch Pökelung zu erklären, zum anderen in Zusammenhang mit der steigenden Vielfalt der „Außer-Haus“-Produktion, einer erhöhten Transportdauer und Lagerung von frischen 
Lebensmitteln durch Bevölkerungsanstieg, zunehmendem Warenverkehr verderblicher Waren und Güter, veränderte Konsumansprüche usw. zu sehen.

Vor allem in Teichwirtschaften, die mit Frischfischen handelten, brauchte man Eis zur Lagerung vor Ort, zum Beispiel von unmittelbar zum Verkauf bestimmtem Fisch. Insbesondere aber in großen Teichbetrieben mit überregionalen Absatzbeziehungen, brauchte man Eis zum Kühlhalten von Speisefisch während des Transportes (ROGGE 1993:32). „Verschickt man im Sommer Fische [...] bei heißem Wetter“, so lautete die Empfehlung von LIETMANN (1941:66), „,ann kühle man die Fässer $\mathrm{ab}$, indem man nach dem Einsatz der Fische geschlagenes Eis hineingibt bis das Wasser etwa 12 $14^{\circ} \mathrm{C}$ hat." Bei höheren Temperaturen hingegen riet er von jeglichem Lebendtransport ab, ebenfalls bei Gewitterschwüle (:66). Lebendfisch wurde auf dem Landweg zumeist in wassergefüllten Fässern transportiert; wurden sie auf dem Wasserwege zum Marktort befördert, hatte man durch flusswassergefüllte Bassins dieses Problem der Lebendhaltung nicht.

Die Fischzuchtanstalten bauten dafür ihre Eiskeller, wie beim Beispiel die Buschlebsmühle an der Wipper bei Worbis in Thüringen. Sie betrieb um 1910 eine Fischzucht und errichtete dafür in Nähe der Fischzuchtanstalt Eiskeller zur Kühllagerung der Speisefische während des Transportes (ROGGE 1993:32). Dort wird auch wahrscheinlich die Eisgewinnung vorgenommen worden sein, ,entweder im Flußlauf der Wipper selbst, oder aber, was häufiger vorkommt, in einem stillen Teich, der eher zufror als die bewegte Wipper“(:32).

$\mathrm{Da}$ es an anderen Kühlgelegenheiten mangelte, betrachtete man die Eisgewinnung in Teichwirtschaften aber auch mit Sorge. Auf Fischteichen, die der Winterung von Fischen dienten, war sie anscheinend gar ein ernsthaftes Problem, sieht man als Beweis die Benennung von Verboten in der fischwirtschaftlichen Fachliteratur des 19. Jh.: „Es darf [...] über Winterteiche weder gegangen noch gefahren werden, das Schlittschuhlaufen ist auf denselben ebensowenig zu dulden, wie die Gewinnung von Eis zur Füllung von Eiskellern." (BENECKE 1885:31) Denn die „Eisgewinnung vom Teiche“ wurde durch die „plötzliche Erschütterung“ als Ursache des Fischabsterbens gesehen; zumindest in solchen Teichen, bei denen sich „unter dem Eise Verwesungsgase“ gebildet haben (VOGEL 1898:97).

Dennoch wurde die Eisgewinnung auf Fischteichen als Nebenerwerb praktiziert. Ein besonderer Fall von Eisnutzung, die über den Gebrauch hinausgeht, ist aus der Altmark bekannt. Die von der Isenbeck gespeisten ;Isenbeck' und ,Stackmanns Teiche' wurden ,als Fischteiche bewirtschaftet und im Winter abgeeist. Das Eis wurde in der Brauerei und in den Wittinger Schlachtereien gebraucht." (BURGHARD 1988c:31)

Eis aus Eisteichen ist vielfach für die Kühlung von Frischfleisch verwendet worden. In den 1930er Jahren beispielsweise ist ein kleiner Teich am Südhang des Gesehrberges oberhalb der Fahrstraße nach Oderberg im Harz, der „Sickerwasser aus den Wiesen sammelte [...], von den St. Andreasberger Fleischereibetrieben als Eisteich genutzt worden" (HAASE 1961:88).

Auch auf den Spannteichen der Hammer- und Eisenhütten wurde Eis geschnitten. Diese Arbeiten wurden durch die Arbeitskräfte ausgeführt, die infolge von Stillstandszeiten der Mühlenwerke frei wurden und sodann im oftmals parallel betriebenen Landwirtschaftsbereich der Mühle zum Einsatz kamen (ALTMANN 1999:108).

Natureis wurde zum Beispiel auch für Wild- und Geflügelgeschäfte aus den nahegelegenen Mühlenteichen herausgesägt, sobald das Wasser gefroren war und somit „hielt“. Das „Eisen“ konnte beginnen und anschließend in den Eiskeller gebracht bzw. das Eishaus gefüllt (LÜTGERT 2000:81) werden. Die konservierende Wirkung des Eises nutzten zudem Gaststätten, Cafés, Konditoreien, Butterhandlungen und Privatkunden, auch für die Medikation in der Krankenpflege wurde es eingesetzt (:91).

Eiskeller gab es des Weiteren bei jeder Brauerei und da es früher sehr viel mehr Hausbrauereien gab, brauchte es des Eiswassers aus der nahen Umgebung. Das gewonnene Kühleis wurde auch den Gastronomen mit den Getränken gegen Entgelt geliefert. Viele Eisweiher wurden vor allem dann 
angelegt, als man begonnen hatte, neben den Weißbieren auch untergärige Braunbiere zu brauen, die für die Gärung und die Lagerung gleichbleibend niedrige Temperaturen verlangten. Das Kühlmittel in den Kellern war das Eis vom Eisweiher, das zerhackt bis in den nächsten Winter hinein seine Funktion erfüllte. Standen keine künstlichen Hohlformen zur Verfügung, so wurden eingedämmte bzw. eingedeichte Wiesen unter Wasser gesetzt. Zwischen Weener und Möhlenwarf in Ostfriesland beispielsweise, „lagen etwa bis zum Jahre 1920 in Höhe des Tannenhofes rechts an der heutigen Bundesstraße 75 Wiesen, von einem Deich umzogen. Sie wurden im Winter unter Wasser gesetzt und die Bierbrauerei Ludwig R. Hesse in Weener ließ hier Eis zum Kühlen der Getränke schlagen“, wie Rudolf C. HOEK (1986:76) in seiner Heimatchronik zur Mühlengeschichte des Rheiderlandes berichtet. Der Eiskeller lag in unmittelbarer Nähe auf einem Flurstücke mit der Bezeichnung „Postpaddje“ und zur Bewässerung der Wiesen diente eine sog. „Flutter“, bei dem es sich nach meiner Ansicht nicht um einen Bachlauf, sondern eventuell um einen Entwässerungsgraben gehandelt haben.

Im Winter wurden auch an der Scherzach in Oberschwaben „,Zwei Eisweiher aufgestaut [...]. Wenn das Eis dick genug gefroren war, wurde es mit Äxten zu transportfähigen Stücken verladen und in die Brauereien gefahren, damit man im Sommer das Bier kühlen konnte“"(HERBST 1987a:27).

Ebenfalls diente in Groß-Bieberau der im Eigentum der Bierbrauerei Schönberger stehende und 0,20 ha große Teich hauptsächlich zur Eisgewinnung (DOSCH 1899:32, Nr. 24).

Mehrere brauwirtschaftlich genutzte Eisteiche wurden auch im Tal der Nethe angelegt. Im Jahr 1686 wurde Christian Falcko Freiherr von MENGERSEN dem Besitzer des Rittergutes Rheder, vom damaligen Fürstbischof von Paderborn das Recht verliehen und verbrieft, in Rheder „Bier zu browen und auszuschenken“. Die Familie siedelte bereits um 1400 nach Rheder und verwaltete die Güter des Stifts Paderborn und des Klosters Neuenheerse. Die Ortschaft Rheder, selbst erstmals um 1120 urkundlich erwähnt, zählt heute zur Großgemeinde Brakel im Kreis Höxter/NRW.

Im Jahr 1710 werden die Felsenkeller angelegt, die noch heute der im Familienbesitz befindlichen Brauerei als Gär- und Lagerkeller dienen. Im Jahr 1800 legt der Nachfolger Friedrich Wilhelm Bruno Frhr. v. MENGERSEN drei Eisteiche an, um im Winter Eis zu erzeugen, welches für die Kühlung des Bieres benötigt wird. Auf den ehemaligen Eisteichen stehen heute Weiden (SPIEGEL 2004).

Zeitgeschichtlich betrachtet übernahmen in der zweiten Hälfte des 19. Jahrhunderts dann in den größeren Städten gewerbliche Natureiswerke die Versorgung der Wirtschaft mit Eis (LÜTGERT 2000:81). Bierbrauereien, die große Menge von Eis benötigten, deckten ihren Bedarf hingegen weiterhin selbst $(: 81)$.

Hinsichtlich der hydrologischen Lage unterscheiden sie sich aber nicht: Gemeinsam ist den Eiswerken bzw.

-anlagen, dass sie „fast ausnahmslos an Flussläufen situiert“ waren (LÜTGERT 2000:88). Wohl aber zeigen sich Unterschiedlichkeiten bezüglich der Art und Weise, wie das Eis gewonnen wurde: In Ermangelung von geeigneten Stehgewässern wurde zum einen in der überschwemmten Flussniederung ,geeist“ (:82). Von der Germania-Brauerei in Wandsbek beispielsweise ist durch LÜTGERT (:82) bekannt, dass sie noch 1913 über eine „Eisweise“ verführte

Neben einer gefluteten „Eiswiese“, die über niedrige „Deiche“ verfügt haben muss, damit das Wasser nicht ungeregelt übertrat, wurden auch künstliche Flussstauungen herbeigeführt. Die Lübecker Brauerei zum Beispiel „erhielt das Eis durch Aufstauung der hinter der Eishalle von 1902 vorbeifließenden Rothebek.“ (LÜTGERT 2000:82)

Darüber hinaus sind Formen bekannt, die als „Teich“ angesprochen werden: Die 1863 gegründete Actien-Brauerei in Bergedorf/Hamburg ,ließ zum Zwecke der rationellen Eisgewinnung drei [...] flache Eisteiche künstlich anlegen, die mit Billewasser (,Bacheis') gespeist wurden." (LÜTGERT 2000:82) 1891 wurde zur Eisgewinnung gar ein 24 ha großes Wiesengrundstück an der Bille in Kirchsteinbek eingedeicht (:84). Gewerbliche Natureisproduktion und -vertrieb gab es beispielsweise seit 1862 in Hamburg am ,Diebsteiche', wobei das gebrochene Eis in großen Eisschuppen lagerte 
(:82). 1888 war der ,Diebsteich' bereits trockengefallen, doch wurde in diesem Jahr durch eine Neuverpachtung ,im Winter zur Ermöglichung der Eisernte mit Leitungswasser künstlich wiederhergestellt"“(:83).

Im fortgeschrittenen 19. Jahrhundert konnte die norddeutsche gewerbliche Natureisproduktion den Bedarf nicht mehr decken. Bedingt durch die ,natürlichen“ Schmelzverluste von jährlich 44\% ,in Verbindung mit der in den 1890er Jahren wiederholt auftretenden milden Witterung“ (LÜTGERT 2000:86), führte dies zum einen zu höheren Schmelzgraden bei Eis, zum anderen zu einem Bedarf auch in sonst weniger Kühleis benötigenden Jahreszeiten und machte zunächst den Ankauf des teuren norwegischen Importeises nötig (:86). Aber auch aus Bayern wurde zu Anfang des 20. Jahrhunderts Eis von den oberbayerischen Seen beschafft (:91). Obschon sich der Import von Natureis aus Skandinavien für Hamburg, Berlin und Leipzig bis weit in das 19. Jahrhundert zurückverfolgen lässt, blieb es aber bis 1865 ein sporadisches Geschäft (:89).

Seit dem Beginn der 1880er Jahre und vor allem seit dem einsarmen Winter 1884 fand die Kältemaschine zunehmend Eingang in die Lebensmittelkonservierung, doch wurde das Natureis keineswegs sofort vom Markt verdrängt. Noch in den 1940er Jahren besaß es eine gewisse volkswirtschaftliche Bedeutung (LÜTGERT 2000:96). Vor allem dort, wo reines Eis liefernde Seenund Teichflächen zur Verfügung standen, hatte das Kunsteis die Versorgung mit natürlichem Eis noch nicht nennenswert beeinflusst (:96).

\section{p Eiswiese}

Eiswiesen gab es über die Gewinnung von Kühleis hinaus zu einem weiteren Nutzungszweck: Aus dem Mühlgraben in Nordhausen wurde in den Wintermonaten Wasser abgeleitet, um „die Schlittschuhwiese bei der Rotleinmühle" entstehen zu lassen.

Das Wasserableitungsrecht der Stadtgemeinde Nordhausen bestand gemäß Eintrag im Wasserbuch darin, „Wasser des Mühlgrabens durch den Kunstgraben auf die Rotleinmühlenwiese zur Gewinnung einer Eisbahn zu leiten und es nach Gebrauch wieder in den Mühlgraben oder durch die städtischen Entwässerungsleitungen der Zorge zuzuführen“. Das Recht zur Wasserableitung zum Zwecke der Schlittschuhwiesenbewässerung beruhe dabei ,auf unvordenklicher Verjährung“ (AUSZUG AUS DEM WASSERBUCH FÜR DIE ZORGE 1929).

Im Antrag zur Gewässernutzung heißt es in ähnlicher Weise: „Der Stadtgemeinde Nordhausen steht seit rechtsverjährter Zeit das Recht zu, durch den Kunstgraben aus dem Mühlgraben auf die Rotleinwiese [...] Wasser zur Gewinnung einer Eisbahn zu leiten und das benutzte Wasser in den Mühlgraben wieder einzuleiten oder es zur gänzlichen Entleerung der Wiese in die städtische Entwässerungsanlage einzuleiten.“ (AUSZUG AUS DEM WASSERBUCH FÜR DIE ZORGE 1929).

Die winterliche Wiesenbewässerung betrifft Parzellen, die einen Flächeninhalt von 1,3147 ha aufweisen (FRAGEBOGEN ZUR EINTRAGUNG IN DAS WASSERBUCH 1929) 


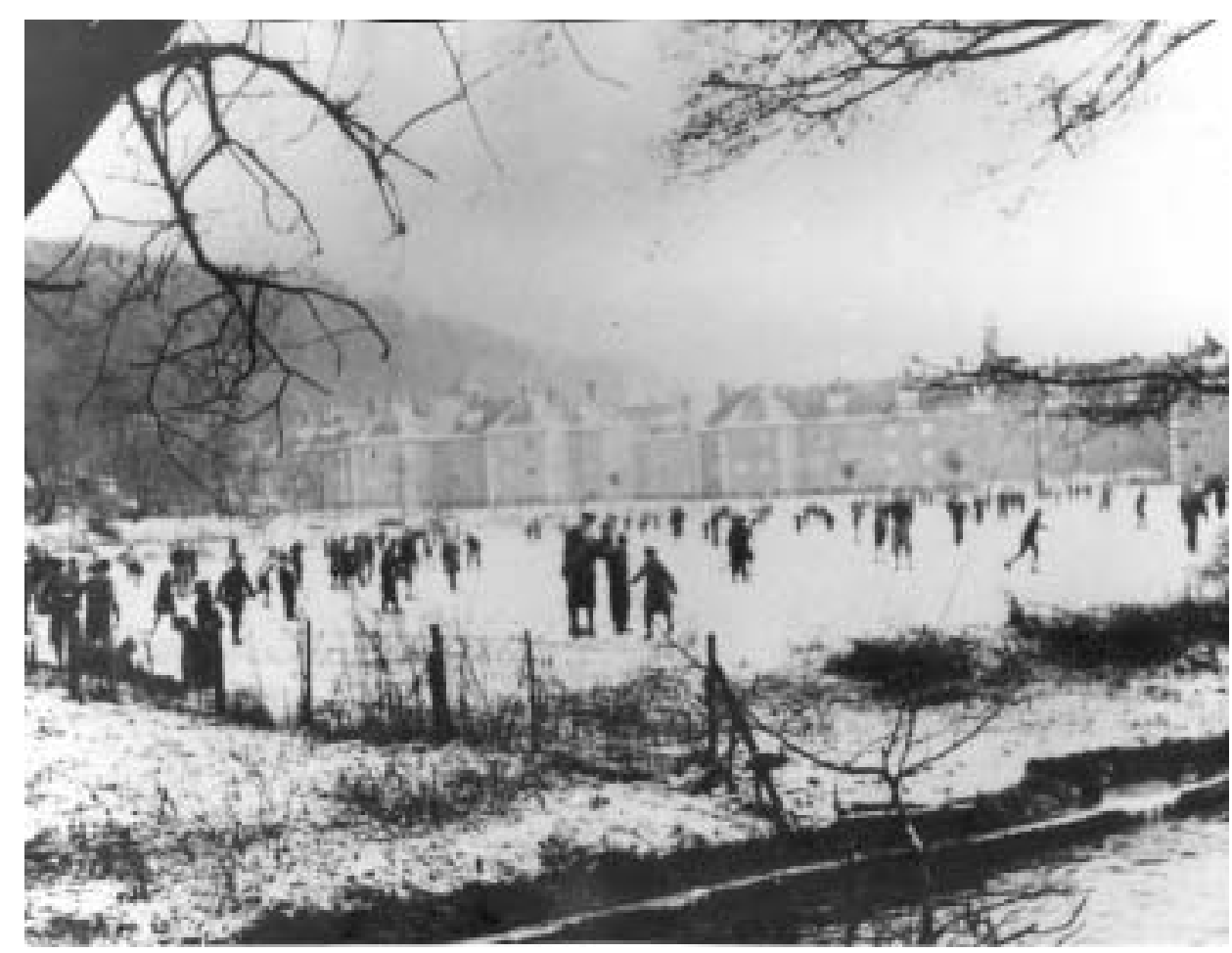

Abb. VII-70: Schlittschuhwiese an der Rotleinmühle

Das Foto zeigt die Eiswiese vor der Rotleinmühle, etwa um 1930. Vorn ist noch der Mühlgraben zu sehen. Die Eiswiese ist bereits 1914 als solche genutzt worden; wie lange, ist leider nicht bekannt. Sie reichte früher bis fast an die Häuser des Bingerhofes (im Hintergrund). Heute befindet sich auf dem größten Teil dieser Fläche der Sportplatz der Jugendherberge „Rotleimmühle“ (Stadtarchiv Nordhausen).

An Anlagen zur Wasserableitung und -zuführung zur Bildung der Eiswiese waren vorhanden:

1. Zwei Ableitungen aus dem Kunstgraben (Mühlgraben), bestehend aus zwei Steinzeugrohren von je $200 \mathrm{~mm}$ Durchmesser lichter Weite.

2. Ein in den Mühlgraben führendes Tonrohr von $300 \mathrm{~mm}$ Durchmesser. Während des Eisbahnbetriebes, d. h. während der Eiszeit, wurde das dauernd zufließende Wasser durch dieses Tonrohr abgeleitet und dem Mühlgraben wieder zugeführt.

3. Zur gänzlichen Entleerung ein Tonrohr von $200 \mathrm{~mm}$ lichter Weite. Nur bei vollständiger Entleerung der Wiese floss das restliche Wasser durch ein Tonrohr von $200 \mathrm{~mm}$ lichter Weite unter dem Mühlgraben hindurch in die städtische Entwässerungsanlage und durch diese in die Zorge (aus: AUSZUG AUS DEM WASSERBUCH FÜR DIE ZORGE.1929).

In dem Stadtpark wird seit 1998 ein Projekt verfolgt, dass diese Nutzung der Flussauenwiese wieder aufgreift, wie sie vom 18. Jahrhundert bis in die 30er Jahre des 20. Jahrhunderts üblich gewesen ist: „Die Eiswiese soll ganzjährig etwa eine Hand breit unter Wasser gesetzt werden. Am Ende des Sommers wird sie dann trockengelegt, gemäht und zum Winterbeginn wieder angestaut, so daß die Wiese zum Eislaufen geeignet ist." (WOCHEN-CHRONIK der Stadt Nordhausen v. 17./18. Januar 1998).

Im Übrigen stellt dies ein sehr gutes Beispiel einer Umsetzung historisch-geographischer Forschung in die Verwaltungspraxis dar. Hier war es die Stadtverwaltung Nordhausen, Sachgebiet Grünflächen und Friedhöfe in Zusammenarbeit mit der Unteren Naturschutzbehörde sowie mit der Thüringer Landesanstalt für Umwelt und Naturschutz Jena.

\section{q Absatzteich}

HERBST (1992:88) berichtet vom Kloster Ochsenhausen in Oberschwaben von einer frühen Form des Klärteiches, wobei aber nicht die chemische Verschmutzung Anlass gab Wasser aus einer Frischwasserleitung, die aus dem nahegelegenen Bach Wasser in das Kloster herbeiführen sollte, 
zunächst in einem Absatzteich zu filtern. Der noch heute bestehende Weiher im Michelsgarten des Klosters hatte die Funktion eines Absatzbeckens für Sand und mitgeschwemmtes Laub, das innerhalb des Klosterhofes die Triebwerkseinrichtungen der Mühle verstopft und zu Betriebsausfällen geführt hätte. Vermutlich wurde der Weiher mit gebrannten Ziegeln ausgekleidet, um die Sohle leichter von Schwemmsanden säubern zu können.

Daneben bestand aber auch eine Frischwasserzufuhr, die Wasser direkt aus dem Quellbereich zugeführt hat. Hierfür war ein solcher Absatzteich nicht notwendig.

\section{r Überschwemmungsteiche}

Schon zu Mitte des 18. Jahrhunderts wurden Überschwemmungsteiche eingerichtet. Das sind solche Teiche an niedrigen Ufern von Flüssen, die den Überschwemmungen widerstehen und das über die Ufer gespülte Wasser aufnehmen sollten, wie KAUP am Beispiel der Oder und Elbe aus einer Literaturquelle rezitiert: „daher werden längst denselben an niedrigen Ufern kostbare Teiche [...] gehalten, den Überschwemmungen zu widerstehen " (Samuel Buchholz: Versuch einer Geschichte der Churmark Brandenburg. - Berlin 1765, Bd. 1:6; aus KAUP 1996:115).

Eine ebensolche Funktion von Teichen hält HERBST (1992:71) schon für eine frühere Zeit und auch für kleinere Fließgewässer für denkbar: Die Mönche des o. g. Benediktinerklosters und späteren Reichsabtei Ochsenhausen (1093/1495 - 1825) „kontrollierten mit Hilfe von Weihern im ausgedehnten Einzugsgebiet des Baches das Fließgewässer, so daß im Spätmittelalter frühe Formen einer gezielten Ausgleichsbewirtschaftung von Hoch- und Niedrigwasser [...] durchaus angenommen werden können.“

Diese wasserwirtschaftliche Bedeutung von Kleinteichen hebt auch der „Landesfischereirat Dr. Wohlgemuth“ am Beispiel von Sachsen für das 20. Jh. hervor (zitiert aus: WALTER 1933:60): „Mit Ausnahme der Elbe verfügt Sachsen nur über kleine Wasserläufe, die überwiegend auf dem Kamm des südlichen Grenzgebirges ihren Ursprung haben. Die außerordentlich schwankende Wasserführung dieser Quellbäche wird etwas ausgeglichen durch die Vielzahl der ihnen anliegenden Kleinteiche. [...] Die großen Teiche der sächsischen Niederung andererseits [...] bilden eine Wasserreserve, gespeichert zur Zeit des Überflusses [, ...] die Nutzung weiter landwirtschaftlicher und forstwirtschaftlicher Flächen erst ermöglicht. Gerade jetzt, wo in größtem Umfang eine Begradigung der Wasserläufe erfolgt, in deren Auswirkung der Wasserabfluß erheblich beschleunigt wird, scheint das Vorhandensein zureichenden Speicherraums zur Rückhaltung von Wasser für die niederschlagsarme Jahreszeit von ausschlaggebender Bedeutung" .

Diese wenigen Beispiele der Schaffung von künstlichen Retentionsbecken sowohl zu Zeiten des Wassermangels als auch des Wasserüberflusses verdeutlichen, dass es zu dieser Zeit bereits Wetterereignisse gegeben haben muss, die eventuell infolge von Gewässerbegradigung, Melioration, Mühlenbau und anderer Eingriffe in das natürliche Abflussverhalten verstärkt worden sind, so dass die Anlage von die Hochwassermengen speichernden Sammelteichen notwendig wurde.

\section{s Schifffahrtsweiher}

„Schifffahrtsweiher“ sind im Zusammenhang mit dem frühen Kanalbau entstanden, als es darum ging Wasserverbindungen zwischen den künstlichen Wasserstraßen und den natürlichen schiffbaren Fließgewässern herzustellen, wie SPINDLER (1988) und TRÖGL (1995) von der Rezat zu berichten wissen. Nach den Ergebnissen der neuesten Forschungen gehen sie davon aus, dass die Entfernung zwischen der im 8. Jh. n. Chr. bereits schiffbaren Altmühl bei Graben und der schiffbaren Rezat bei Weißenburg mit mehreren Rampen und einer „getreppten Weiherkette“ (SPINDLER 1988:93) überwunden wurde. Als Beweis dient zum einen die Geländesituation, die ,noch heute [...] das Vorhandensein von größeren Feuchtflächen (Riedwiesen) im Tal der Schwäbischen Rezat" zeigt. „Dies dürften mehrere Weiher gewesen sein, deren Wasserversorgung über die zahlreichen seitlichen 
Quellen erfolgte.“ (TRÖGL 1995:55,58). SPINDLER (1988:64) sieht die Weihertreppe als „Fortsetzung des heutigen Dorfweihers“" (siehe Abb. VI-43).

Für die Weiherlösung spricht zum anderen ebenfalls „,das Auffinden von bis zu 1,5 m mächtigen tief anstehenden Torfschichten im heutigen Querschnitt der fossa. Mehrere um 1700 entstandene Karten zeigen ebenfalls drei bis vier Weiher bei der Ortschaft Graben“ (TRÖGL 1995:58). Vor allem eine Karte von 1704 ,zeigt mit hoher Präzision die bogenförmigen Reste des Kanals zwischen Altmühl und Rezat als geschlossene viergliedrige Weiherkette.“ (SPINDLER 1988:63) Aber schon die „die jüngeren Karten des 18. Jahrhunderts weisen auf eine zunehmende Verlandung dieser Weiherkette hin“(:63).

Neben der Teichabfolge wird der Transport der Lastkähne in Bereichen, wo keine Wasserführung möglich war, über Rampen erfolgt sein. „Erleichtert worden dürfte das Ziehen der Lastkähne durch quer auf den Erdrampen liegende Holzstämme sein, die durch von oberhalb abfließendes Wasser eine glitschige und damit glattere Oberfläche erhielten." (TRÖGL 1995:58). Bei einer Länge der Kähne von rd. $6 \mathrm{~m}$, einer Breite von 1,2 m Breite und einer Wassertiefe von max. 0,5 bis 1,0 m bei einer Tragfähigkeit ca. 1 Tonne wird sowohl die kurzzeitige Form des Landtransportes denkbar als auch die Dimension der Teiche ersichtlich, die nur eine geringe Schleusenbreite aufweisen mussten.

\section{t Flößteich}

Die Flößbarmachung von kleineren Flüssen, Bächen und Gräben zum Transport von in handliche Längen geschnittenem Holz erschöpfte sich häufig nicht in der Reinigung und Vertiefung des Flussbettes, in Stichkanälen und der Befestigung und Sicherung der Ufer, denn im Allgemeinen reichten die Quellschüttungen der kleinen Zubringerbachläufe für einen gesicherten Holztransport von Stammholz aus den Wäldern zu den Floßangerplätzen nicht aus. Um die Holztrift in den sehr engen und mäandrierenden Bachbetten mit jahreszeitlich stark schwankender Wasserführung überhaupt durchführen zu können, mussten zusätzliche wasserbaulicher Einrichtungen geschaffen werden, die in der Lage waren, die Holzflößung vor Ort sicher zu gewährleisten bzw. überhaupt erst zu ermöglichen. Erst recht traf dies für Langholzflöße zu, die nämlich „nämlich mehr Wasser als die Scheiterholztrift“ brauchten (SCHEIFELE 1993:80). So entstanden in vielen Bachläufen in den Bergschluchten eine Reihe von dammartigen Talquerverbauungen und Wasserspeicher, mit denen das Wasser gestaut und für den eigentlichen Floßvorgang in ausreichender Wassermenge bereitgestellt werden konnte, „um schon möglichst früh im Gebirge das Holz einwerfen zu können." (:55)

Bei den erwähnten dammartigen Talverbauungen mit integrierter Wehranlage handelte es sich um Floß- oder Schwellteiche, sog. „Schwallungen“, „Triftklausen“, „Klausen“ oder „Klaus“- bzw. „Wasserstuben“, in denen Wasser angesammelt wurde, um dann auf einer Flutwelle Stammabschnitte bach- und flussabwärts zu ihrem Bestimmungsort triften zu können. Sie ermöglichten die Beförderung des Scheitholzes selbst bei geringer Wasserführung der Triftgewässer.

Mit Hilfe dieser Anlagen war es möglich, das Wasser zu kleinen Seen aufzustauen sowie die abzugebende Wassermenge über eingebaute Wehre zu portionieren. Diese Anlagen befanden sich aus bautechnischen Gründen hauptsächlich in den engsten Talabschnitten. Neben den Talabschnitten wurden aber auch häufig in Quellbereichen der Bäche und Flüsse Wasserstaubecken eingerichtet (BORGER-KEWELOH/KEWELOH 1991:21; STELTMANN 1995:211).

Bei großen Triftstrecken musste Wasser in zahlreichen Wasserstuben gesammelt werden, die das Floß auf seiner Talfahrt „,unterstützten“. Ohne diese Maßnahme wäre das Floß auf Grund gelaufen, oder es hätte sich an den Flussufern verhakt, weil zu wenig Wasser im Flussbett war. Im Oberlauf der Flüsse betrugen die Abstände zwischen den Wasserstuben nur wenige Kilometer.

Nicht überall aber waren solche Schwemmteiche für die Trift erforderlich. Sie waren dort entbehrlich, wo man angesichts ausreichender Wasserführung des Flusses auf deren Anlage verzichten konnte, wie zum Beispiel an der Werra (BORGER-KEWELOH/KEWELOH 1991:21). 
Hinsichtlich Funktion und Größe wurden die „Schwöllungen“ unterschieden in

1. Hauptschwöllung und

2. Nebenschwöllung

Die Schwöllungen wurden zumeist aus dem umliegenden Bodenmaterial hergestellt. Doch gab es auch sog. „steinerne Schwöllungen“, die zur Stabilisierung und Talabsicherung aus behauenen Steinen aufgeschichtet wurden.

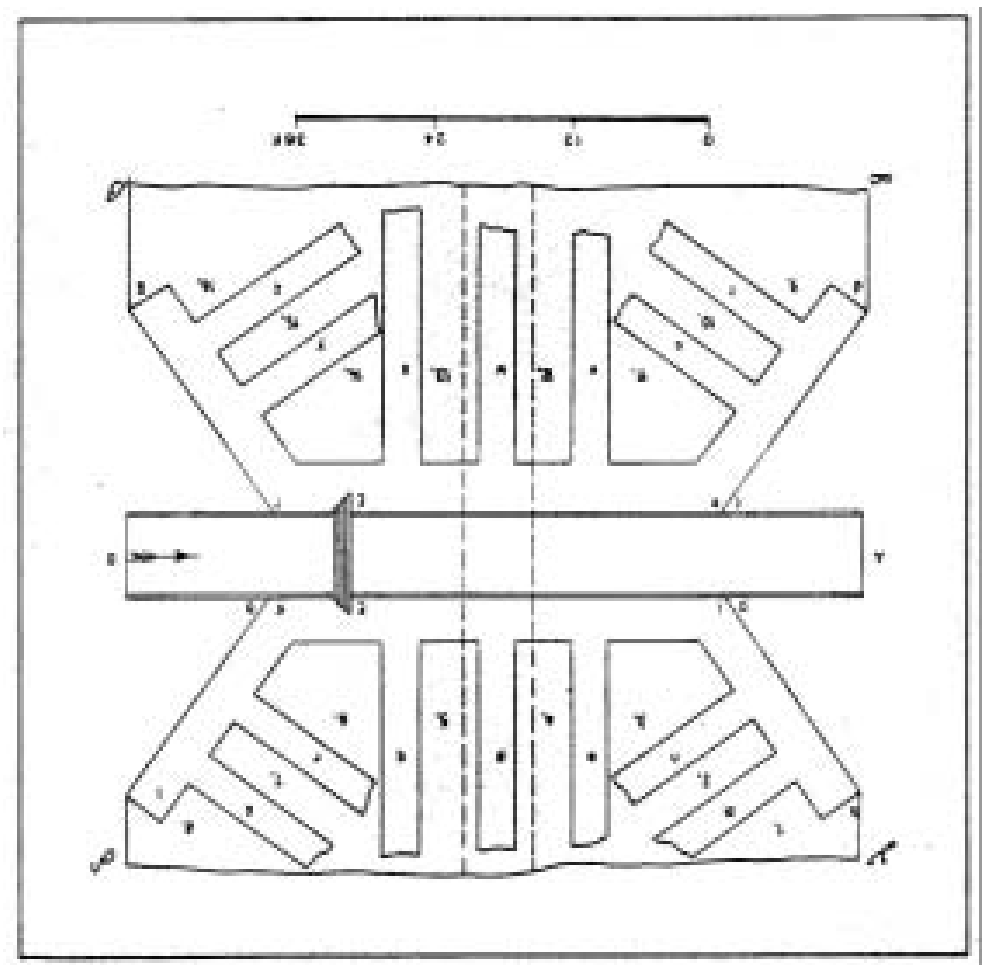

Abb. VII-71: „Steinerne Schwöllung“

(nach JÄGERSCHMID 1827/28, 3, Bd., Tab. XXI, Fig. 1 aus: DENZER 1996:209). A.-B = Wasserpforte mit 40 Fuß Länge und 8 Fuß Breite; i.k. und e.f. sind Widerlagermauern mit einer Dicke von ca. 4 Fuß, h.i., k.l., d.e, f.g. sind ihre Flügel in der gleichen Stärke; m-z sind 3 Fuß hohe Strebmauern - alle aus Quadersteinen aufgeschichtet; 1-16 sind Zwischenräume, die bis zur Höhe des Mauerwerks mit Leinen ausgestampft werden, damit kein Wasser zwischen die Fugen der Quadersteine durchdringen kann. Hinter diesem Bauwerk schließt auf beiden quer durch das Tal ein Damm an $[\alpha-\beta, \gamma-\delta]$.

Gleichzeitig war es für den Triftvorgang zunächst erforderlich, das durch den Wasserstau des Schwellteiches ausgetrocknete Flussbett, in welchem das Floßholz aufgesetzt war, mit dem sog. „Vorwasser“ auf einen mittleren Wasserstand zu bringen. Dies erfolgt nach JÄGERSCHMID (1827/28; aus DENZER 1996:215) meist mit Seitenschleusen. Erst danach konnte die Hauptschleuse des Schwellteiches geöffnet und das Floßholz mit dem sog. „Hochwasser“ zu Tal getriftet werde. In einem Fall wurde das Triftholz entlang der Wasserstrecke in den anschwellenden Bach geworfen. JÄGERSCHMID nennt diese Triftvariante die der ,zügigen Wässerung“. Sie war dann vorteilhaft, wenn das Triftholz bereits im Flussbett umherlag.

In einem anderen Fall wurde der Floßteich nicht nur als reiner „Schwemm“- bzw. „Schwellteich“ benutzt, sondern die behauenen Baumstämme, die sog. Rundlinge, wurden in dem Floßteich zunächst gesammelt und nach dem Öffnen der mit dem Wasserschwall zu Tal gelassen. Hier diente der Floßteich als „Wasserstube“ im eigentlichen Wortsinn. In einem weiteren Fall, wenn es sich um breitere Fließgewässer handelte, wurden die Flöße auf den Teichen zum Teil auch schon gebunden der Trift übergeben (KÜSTER 1998:146). 
Diese aufwendigen Flößanlagen waren Bestandteil der Frühindustrialisierung. Sie dienten zum einen für die Versorgung mit Bau- und Brennholz der Städte, zum anderen für die Versorgung der Hüttenbetriebe.

Ein solcher Schwemmteich wurde beispielsweise 1680 bei der Einrichtung der Brennholzflöße an Leine und Ilme gebaut. 1737 folgte ein weiterer an der Diesse (BORGER-KEWELOH/KEWELOH 1991:21). Zwei weitere Schwellteiche sind aus dem Solling bekannt, die als Teichrelikte erhalten geblieben sind und mit einer Schildertafel über die ehemalige Bedeutung als Flößteich aufklären.

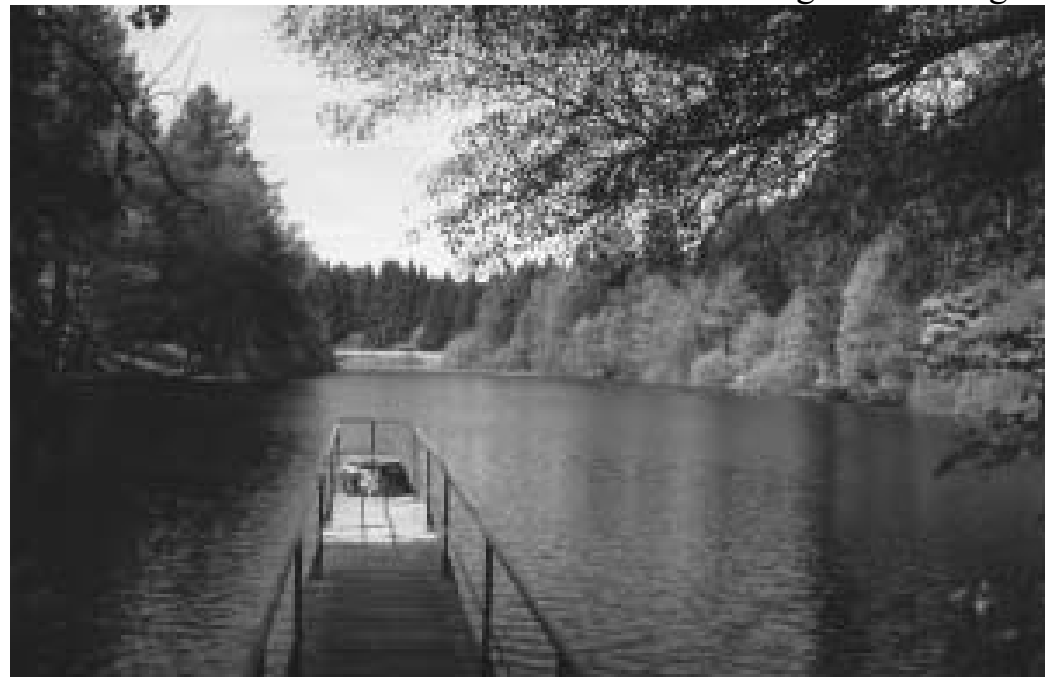

Abb. VII-72: Schwellteich im Solling

Bereits im Jahre 1680 wurde zum Zwecke der Holzflößerei der sog. „Lakenteich“ angelegt. 1737 dann entstand ca. 1,5 km östlich davon ein weiterer Teich, der hier abgebildete „Neue Teich“. Von hier aus mussten jährlich 20004000 Klafter Kurzholz mit Hilfe der Wasserwege des geöffneten Teiches über die Ilme und die Leine nach Hannover geflößt werden. Diese Holzlieferungen wurden etwa 100 Jahre später während der Amtszeit des Sollinger Forstmannes Christian von Seebach abgeschafft, um Raubbau am Wald zu verhindern. Für die Fischerei ist das Wasser nicht geeignet. Wegen des hohen Säuregrades leben außer Amphibien nur noch Schleien darin (eig. Aufnahme 2004).

Als Ort der Anlage einer Schwallung wird von DENZER (1996:215) ebenso das Dammbachtal, unmittelbar unterhalb des Libischbrunnens, genannt und auch „,im Oberlauf des ,Mittweidabaches’ bei Crottendorf, ist heute noch der Damm des Floßteiches für die ,Mipe-Flöße' (Mittweidaflöße) ersichtlich“"(ALTMANN 1999:22). Belegt ist diese Nutzung auch für den ,Bannbühlweiher' auf der Gemarkung Schlier, östlich von Weingarten (HERBST 1995).

In Bergbaugebieten zählte die Flößerei zur bergbaulichen Wasserwirtschaft im weiteren Sinne, da sie vor allem der Holzversorgung der Gruben, Hüttenwerke und Ortschaften diente. Auch die innerharzerischen Bergbauteiche wurden in begrenztem Umfang zur Verstärkung der Wasserführungen herangezogen und die Flößteiche im Harz übten insofern eine Doppelfunktion aus: „,in erster Linie waren es Bergbauteiche, die der Wasserver- und -entsorgung im Bergbau dienten, und nur im begrenzten Umfang wurden sie zur Verstärkung der Wasserführung herangezogen, um die Flößerei zu ermöglichen.“ (SCHMIDT 1997:202)

Herzog Julius von Braunschweig (1528 - 89) unternahm Mitte des 16. Jh., an ältere Maßnahmen seines Vaters Heinrich (1514 - 1568) anschließend, enorme Anstrengungen, um Flüsse und Bäche seines Herrschaftsgebietes flößbar zu machen. Auf diese Weise wollte er die Holzversorgung seiner Residenz, aber ebenso der Steigerhütten im Harz sicherstellen (BORGER-KEWELOH/KEWELOH 1991:14). Der ,Untere' und ,Obere Spiegelthaler Teich' in der Nähe des Spiegelthaler Zechenhauses zwischen den Orten Bockswiese und Zellerfeld beispielsweise, ist vom Spiegelbach für diesen Zweck der Triftflößerei gefüllt worden. Aus dessen Ausflut wurde der Spiegelthaler Flößgraben gewässert, so dass die Schleppkraft zum Transport der 1 bis $3 \mathrm{~m}$ langen Holzstämme entwickelt werden konnte. Der ,Obere Spiegelthaler Teichdamm' ist, nachdem er zu Ende des 16. Jh. erbaut worden war, darauf 
folgend - wahrscheinlich beginnend schon vor 1673 - mindestens einmal erhöht worden. Er war etwa $85 \mathrm{~m}$ lang und knapp $8 \mathrm{~m}$ hoch.

Hier wie an anderen Flößteichen wurde ein Flößwasserauslass angelegt, um den Weitertransport des Holzes in Richtung Hauptfluss zu ermöglichen. Dazu war einmal ein Gerüst für das Einsetzen von Staubrettern aufgestellt worden. Durch deren Herausnahme konnte ein Schwall erzeugt werden, der die kurzen Holzstämme talwärts schwemmte. In sehr nassen Zeiten konnte der Auslass auch als Ausflut dienen, aber er reichte offenbar allein nicht zur Hochwasserabfuhr aus, wie eine weitere Ausflut am anderen Ende des Dammes belegt.

Da der Floßteich durch den Dammverbau einen Höhensprung im Gelände geschaffen hatte, wurden die Stämme über ein längeres „Flößgefluder“, eine lange, aufgeständerte Holzrinne geführt und die Holzscheite rutschten dann unter Wasserspülung talwärts in den eigentlichen Spiegelbach. Dort wurden sie dann durch verstärkte Abgaben aus den Flößwasserabläßen der Teiche weitergeschwemmt bis in die Innerste (SCHMIDT 1997:201).

Des Weiteren entstanden in dem Zusammenhang mit der Errichtung von Schwellteichen Flößgräben, wie der Spiegelthaler Flößgraben, aus der Notwendigkeit heraus, die anderen für den Bergbau unverzichtbaren Bergbauteiche zu umfahren. Entlang der Teiche hatten die Gräben eine relativ großen Querschnitt, da hier das gesamte Wasser in den jeweiligen Flößgraben eingeleitet wurde, und ein starkes Gefälle, um die Holzmassen transportieren zu können. Diese Gräben wurden mehr als 150 Jahre nicht mehr für die Flößerei benutzt und sind zum Teil stark verlandet.

Zwei Flößteiche sind im Oberharz auch von dem Unteren Grumbach bezeugt. Unterhalb der oberen Teichserie der ,Mittleren Grumbacher Teiche' liegen noch zwei andere Teiche, die als ,Oberer' und ,Unterer Flößteich' erscheinen (HAASE 1961:71). Der ,Obere Flößteich' hieß früher der ,Kleine Auguster Teich', der ,Untere Flößteich’ nur einfach ,Flößteich' (:71). Diese alten Teiche dienten demnach vor der bergmännischen Nutzung der Flößerei (:72). Im Grumbachtal steht noch heute der einzige Flößwasserauslass samt Flößgefluder des Oberharzes, der noch erhalten ist.

Auch der ,Schalker Teich', von der Schalke bespannt und im Gebiet der Oker gelegen und 1679 in der Forstabrisskarte auch ,Holtzer Teich“ genannt, „dürfte wohl erst der Flößerei gedient haben“. Im Dezember 1733 wurde sein Damm durch eine Flut gebrochen (HAASE 1961:31). Er ist als früherer ,Unterer Schalker Teich' allein von insgesamt drei Teichen im Flusslauf der Schalke übrig geblieben. Die beiden anderen (,Oberer Schalker' und ,Mittlerer Schalker Teich') sind nach 1783 zerstört worden $(: 31)$.

Ebenfalls wird von HAASE (1961:69) im „Pißtal“, einem Abzweig vom Spiegeltal, ein kleiner Weiher als „Rest des Floßteiches“ gedeutet.

Flößerstauungen wurden zum Zwecke der besseren Flößerei des Weiteren in der Bode errichtet. 1531 einigten sich die Grafenbrüder Ernst und Martin von Reinstein (Regenstein) -Blankenburg in einem Vertrag mit Graf Botho III. von Stolberg-Wernigerode ${ }^{57}$, dass die Bode zur beiderseitigem Vorteil zwischen Braunlage und Thale zur Flößung genutzt werden durfte. Somit konnten nun beide Parteien das Brennholz, Kohlholz, Balken, Träger, Fass- und Böttcherholz auf dem Wasserweg befördern, um so auch die Gefahren des Holztransportes von den Revieren am Brocken zu den verarbeitenden Gewerben aus der Welt zu schaffen (JORDAN 2000:124).

Am Gestade der Bode kam es in der Folge zu zahlreichen Räumungsarbeiten, Strauchwerk und Felsen mussten weichen. An einigen Stellen wurde die Bode erweitert und teilweise sogar aufgestaut. (JORDAN 2000:124). Jede der beiden Parteien hatten nacheinander jeweils 3 Wochen Zeit, die Gunst des aufgestauten und fließenden Wassers zu nutzen. Trotz der vorherigen Wassersammlung war die

\footnotetext{
${ }^{57}$ Botho III., genannt der Glückselige (1467 - 1538), war der Enkelsohn des Grafen Botho d. Älteren. Er dürfte einer wichtigsten Grafen des Hauses Stolberg gewesen sein, weil zu seiner Zeit die Grafschaft ihre größte Ausdehnung erreichte (BOLTE 2004).
} 
Besorgnis der Flößmeister groß, falls das Hochwasser ausblieb oder es während des Flößtermines zu Niedrigwasser kam.

Weit hinter den Teichauslässen errichtete man hölzerne „Haken“ an den Stellen, wo das Holz aus dem Wasser gezogen werden sollte. Vor ihnen stauten sich das Holz und auch noch einmal das Wasser; zumindest aber wurde es in seiner Strömung gemindert (siehe Abb. VI-58). Die Fluten aber besaßen eine solche Kraft, dass nicht selten trotzdem einige Haken mitsamt der Holzfracht in die Fluten gerissen wurden.

Ein Flößer, der auf der hölzernen Hake stand, leitete die Stämme in einen seitlichen „Umgraben“. Von dort konnte man das Holz bequemer aus dem Wasser holen, um auf der „Flößwiese“ mit dem Verkauf zu beginnen, oder ein Zwischenlager, einen Stapelplatz, einzurichten.

Weiterhin wurden bei der Radau im oberen Radautal bei Torfhaus umfangreiche Wasserbauten eingerichtet, um den für Trift und Flößerei nötigen Wasserstand zu erreichen. Im Radaubett wurden bei Radauborn insgesamt sieben Teiche ausgehoben. Der Aushub, verstärkt durch Material aus direkt anliegenden Steinbrüchen, wurde zum Aufschütten von Dämmen jeweils unterhalb dieser Teiche benutzt. Der Fluss wurde sozusagen mit Teichen gestuft.

Die ersten fünf oberen Teiche sind die älteren und gehen zum Teil auf Mitte des 16. Jh. zurück. Herzog Heinrich der Jüngere von Braunschweig-Wolfenbüttel hat hier zwischen 1565 und - in Weiterführung über seinen Tod hinaus - bis 1575 auf einer Länge von knapp $300 \mathrm{~m}$ die erste Kette von Flößteichen bauen lassen. Den sechsten Teich hatte Willem de Raet ${ }^{58}(1537-1583)$, der Hochbaumeister vom Sohn Heinrichs, Herzog Julius, 1576 erbaut. Der untere siebte Damm ist noch jünger. Die Höhen dieser Stauanlagen betrugen 3,2 bis 5,7 m, die Längen 28 bis $49 \mathrm{~m}$. Die Dämme hatten jeweils ein Floßloch, das für das Triftholz bzw. die Flöße geöffnet wurde. Aufgabe dieser „Schleusentreppe“ war es, einen Wasserschwall, ein kleines künstliches Hochwasser zu erzeugen. Wenn nacheinander alle Löcher aufgezogen wurden, ergab sich ein relativ lang anhaltendes Hochwasser, das zum Durchflößen ausreichte.

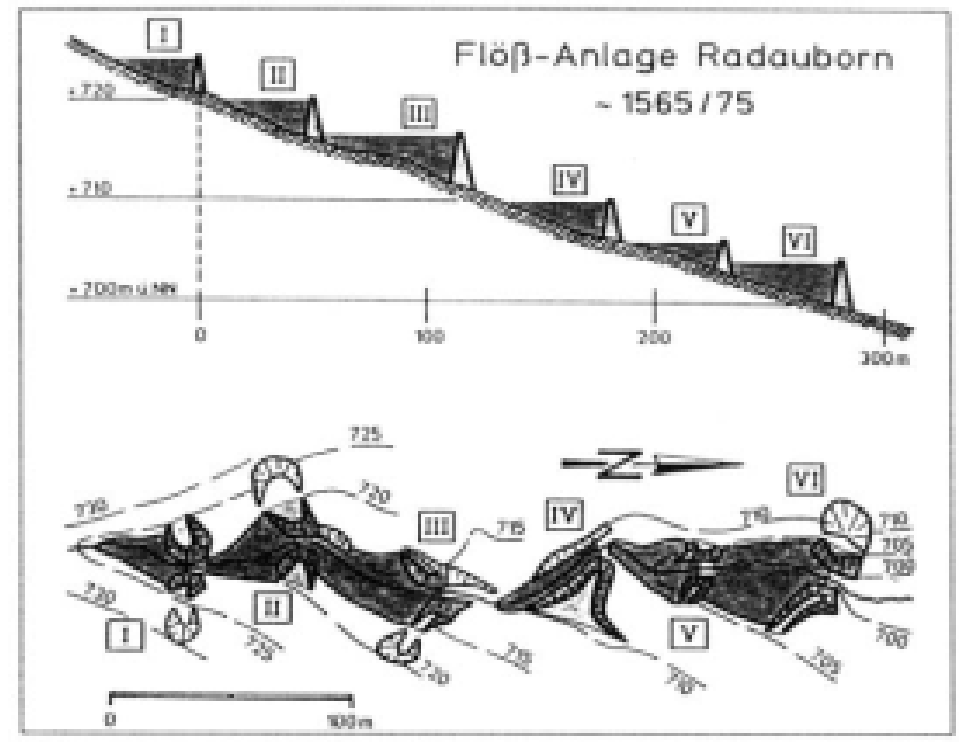

Abb. VII-73:Lageplan und Längsschnitt der Flößschleusen im Radauborn (aus: SCHMIDT 1997:210)

\footnotetext{
${ }^{58}$ De Raet, Willem [Wilhelm] (安 um 1537 s’Hertogenbusch [Niederlande] - † vermutlich in der Toskana): Baumeister und Flussregulierer des Herzogs Julius zu Braunschweig-Wolfenbüttel. Verantwortlich für die Regulierung von Oker und Innerste südlich von Wolfenbüttel und den Bau des Juliusstaudammes. Er zeigte sein Können auch im Festungsbau und sorgte für die Ausdehnung der Verteidungsanlagen von Wolfenbüttel. Begann auch mit der Durchführung eines von Herzog Julius erstrebten Plans, eine Verbindung der unteren Oker mit der Elbe - unter Umgehung der dem Landesherrn feindlich gesinnten Stadt Braunschweig - herzustellen. Der Plan konnte nicht verwirklicht werden. Seit 1577 in der Toskana mit der Trockenlegung eines Areals von etwa 1.600 ha in der Gegend von Massaciuccoli befasst, musste sich aber drei Monate im Jahr in Wolfenbüttel aufhalten (SMEST 1965:147ff.).
} 
Eine zusätzliche größere Schleuse errichtete Baumeister de Raet weiter unterhalb. Sie wird auf einer Harzkarte von 1680 als „Große alte Schleuse“ bezeichnet. Das Harzburger Erbregister von 1666 bemerkt: „Bey dem Seldenborn, alda die erste große Stauerung gebawet“ (zitiert nach MÜLLER 1968:59).

Die 6 Flößschleusen waren hölzerne Steinkistenwehre beiderseits des Baches, die aus örtlich geschlagenen Bäumen aufgesetzt, mit Sand, Schotter und Fels gefüllt und mit Moos gedichtet waren. Dazwischen wurden aufziehbare hölzerne Tafeln installiert. Wurden die Tafeln zwischen den beiderseitigen Steinkisten hintereinander hochgezogen, so floss über eine längere Zeit ein stärkerer Wasserstrom ab und schwemmte Baumstämme von 1 bis $3 \mathrm{~m}$ Länge talwärts, die vorher in den Bach gelegt worden waren. Waren die kleinen Speicherbecken entleert, so wurden die Holztafeln abgesenkt und nach Füllung der Becken erneut gezogen ${ }^{59}$.

Verstärkt wurde die Flößerei auf der Radau zur Zeit des Herzog Julius um 1575 durch den Zufluss der Abbe. Die Abbe im Harzgebiet diente nicht nur dem Transport von Aufschlagwasser zu den Bergbauschächten, sondern auch zur Füllung der Sammelteiche. Wenig unterhalb der Ableitung des Abbegrabens ging früher ein „Abbearm“ von der ,Abbe“ zur ,Radau“ hin. Die Teilung hieß „AbbeSchut" (Schütz). Heute ist die Anlage nicht mehr in Gebrauch, der Graben durch große Granitsteine versetzt (HAASE 1961:17).

Daneben wurde aber auch auf den Oberläufen von Innerste und Oker eine ungebundene Flößerei für das Harzvorland betrieben. Auf der oberen Oker waren Schleusen und Stauteiche notwendig, um einen ausreichenden Wasserstand zu erzielen, um Brennholz und Bauholz okerabwärts in seine Residenzstadt Wolfenbüttel und nach Braunschweig zu flößen. Zwei dieser Schleusen, der ,Große' und ,Kleine Juliusstau', wie sie später genannt wurden, liegen heute unter Wasser im Bereich des Staubeckens der Okertalsperre (SCHMIDT 1989:27). Die Schleusen hatten zum Teil gewaltige Ausmaße. Der Große Juliusstau gilt als die höchste deutsche Talsperre des 16. Jh. mit ursprünglich einer Stautiefe von $48 \mathrm{Fuß}$, das sind etwa 15 Meter Höhe, einer Breite von 49 m und einer Länge von 1320 m (MÜLLER 1968:60f.; SCHMIDT 1997:211). Herzog Julius von Braunschweig-Wolfenbüttel hat um 1570 die kleine Flößstauung mit einer doppelstöckigen hölzernen Flößschleuse bauen lassen, die im Grundriss ein dreieckiges Steinkistenwehr darstellt. Auf jeder Seite und in dem öher aufragenden Teil lag dazwischen ein Durchlass, der mit einer Holztafel geschlossen und geöffnet werden konnte. Durch Freigabe dieser drei Öffnungen konnte ein kleines künstliches Hochwasser erzeugt werden. An derselben Stelle steht heute die Oker-Hauptsperrmauer.

\footnotetext{
${ }^{59}$ Die davon verbliebenen „Reste von 6 Teichdämmen“ jedoch, die HAASE noch 1961 (:17) im oberen Radautal nachwies, konnte ich während einer Begehung im Jahr 2004 nicht mehr auffinden.
} 


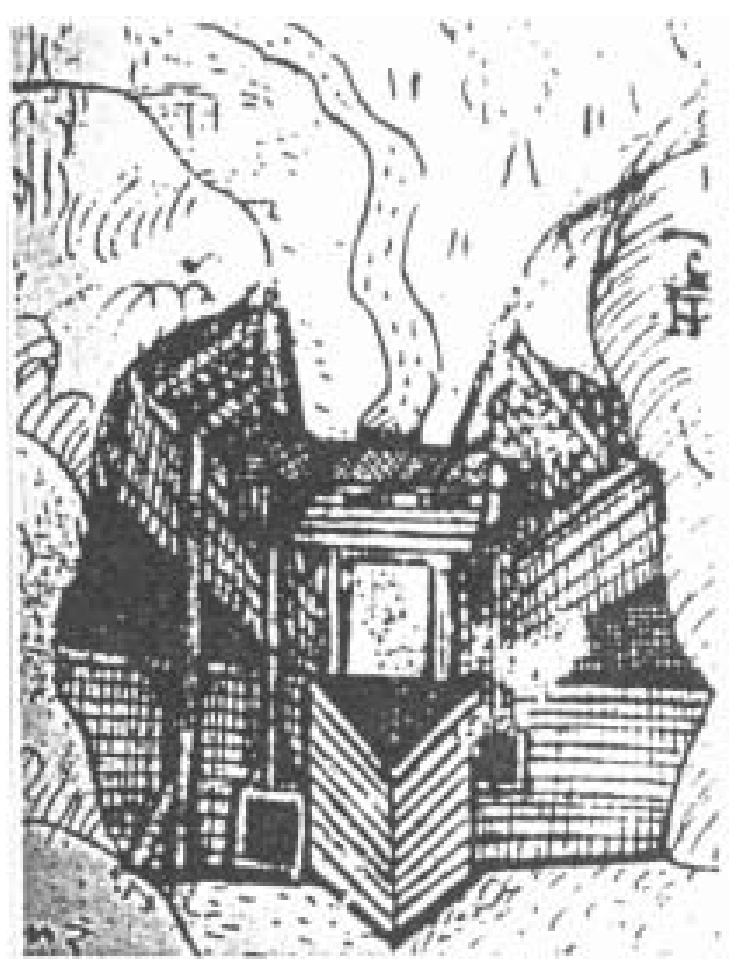

Abb. VII-74: Der Große Juliusstau im Okertal nach einem Riss von 1573 (aus: SCHMIDT 1997:211)

Anschließend wurde 1573/74 im Gemkental eine weitere Flößschleuse errichtet: der ,Kleine Juliusstau”, einst „Harz-Riti“ oder „Harzris“60 genannt (HAASE 1961:19), der sich ebenfalls im heutigen Becken der Okertalsperre befindet (SCHMIDT 1997:211) und auch hier Wasser für die Flößerei ansammelte. Er war von gleicher Bauweise, seine Höhe aber betrug im Vergleich zum „großen Bruder" lediglich 13,7 m, seine Breite $57 \mathrm{~m}$. Noch heute kündet ein Bedarfsanleger der Schifffahrt auf dem Okersee von der ehemaligen Zuflusssituation.

Wie so eine Flößerstauanlage ausgesehen haben mag, zeigt ein Blatt mit Schleusenentwürfen von Hans Vredemann de VRIES ${ }^{61}$. Dort sind 7 Schleusenanlagen für gebundene Flöße und ein stattlicher Floßteich eingezeichnet (siehe Abb. VI-55). Es handelt sich um Vorschläge für Flüsse im Herrschaftsgebiet des Herzogs Julius und sie geben nicht nur Aufschluss über die Konstruktion von Stauschleusen der Zeit, sondern informieren auch über die Eingriffe in ein kleineres Gewässersystem zu Zwecken des Holztransportes.

Die Zeichnung zeigt einen Flusslauf in drei Teilstücken übereinander, die jeweils als Fortsetzung des anderen gedacht sind. Den Fluss unterbricht sofort am linken oberen Rand ein Teich, dessen Größe durch vier eingezeichnete Flöße anschaulich wird. Die zahlreichen eingezeichneten Flöße zeigen, dass es sich um eine Planung zugunsten der Flößerei handelt. Der Teich ist deutlich künstlich eingefasst. Dies markieren die Doppellinien, während der normale Flusslauf jeweils nur eine einfache Kontur aufweist. Der Floßteich ist zwischen zwei Wehren angelegt. Weitere Aussagen über die Art der Einfassung sind nicht möglich.

\footnotetext{
${ }^{60}$ Unter „Riti“ oder „Ris“ wird die aus riese, rûse = Runse zu deutende „steile und schmale Schlucht“ gesehen, die im Oberlauf die Natur des Gemkentales kennzeichnet (HAASE 1961:19).

${ }^{61}$ DE VRIES, Vredemann (夈 1527 Leeuwarden [Friesland] - +1604 Antwerpen): Ausbildung als Maler in den südlichen Niederlanden. Wanderleben infolge der Religionskriege mit Stationen in den Niederlanden, Frankfurt/M., Wolfenbüttel, Hamburg, Danzig, Prag usw. Nachfolger de Raets am Hof in Wolfenbüttel. Arbeitete für Herzog Julius von 1587 bis zu dessen Tod 1589 als Bauaufseher, Baumeister, Bautheoretiker und Maler. Er gibt insgesamt von ihm 13 Entwürfe aus dem 1587; das hier betreffende Blatt trägt die Nr. 11. Die Flussskizzen sind wenig detailliert und bieten nur eine übergreifende Vorstellung von der Gestaltung eines Flussabschnittes. Es hat auch nicht die Funktion einer Bauvorlage, sondern die Zeichnung gibt eine Vorstellung davon, wie eine solche Schleuse funktioniert und aussieht (THÖNE 1960:47ff.).
} 
Im weiteren Verlauf folgen noch weitere Wehre. Auf der anderen Blattseite ist eine der Anlagen vergrößert detailliert dargestellt [zbd]. Anders als bei den durch Dämme und ein einfaches Floßloch abgesperrten Teichen wie im Radauborn handelt es sich hier um eine Stauschleuse. Ein Schott zwischen zwei hohen Balken schließt das Wehr, das über eine radförmige Kurbel betätigt wird.

Die Anlage erlaubt, das Wehr direkt, nachdem das Floß passiert hat, wieder zu schließen, ohne unbedingt das ganze Wasser ablaufen zu lassen, wie es bei den gedämmten Teichen im Radauborn der Fall war. Diese Vorrichtung zum raschen Abschotten des Wassers hat ihren Grund im Nebengebäude des Wehrs, einer Wassermühle. Diese benötigt das Flusswasser dringend für ihren Betrieb. Je schneller es wieder zur Verfügung steht, desto weniger wird die Mühle beeinträchtigt. Der Mühlbach zweigt vor der Stauschleuse ab, läuft über das Mühlrad und mündet unterhalb des Wehrs wieder in den Fluss.

De VRIES dachte also über die Flößerei hinaus. Da die Wasserkraft für die Flößerei durch Wasserbauten gebündelt werden musste, sollte man gleich das gestaute Wasser doppelt nutzen und Mühlen in die Planung einbeziehen. „Unter Herzog Julius von Braunschweig waren im 16. Jahrhundert Mühlen als Nebenprodukte von Flößwehren gebaut oder zumindest geplant worden.“ (BORGER-KEWELOH/KEWELOH 1991:67). Wie das Wehr, das de VRIES zeichnete, funktionieren bis heute Überfallwehre.

Doch die Niederländer de RAET und nachfolgend de VRIES wurden nicht nur verpflichtet die Radau, Innerste und Oker im Harz und Vorderharz zu Zwecken der Flößerei auszubauen und aufzustauen. Auch die Altenau und die Wabe wurde nach ihren Plänen reguliert, um sie mit Flößen befahren zu können. Eine Nachricht von 1577 besagt, dass die Durchführung sehr schwierig sei. Es fehle nicht nur am Gelde, sondern auch ein Mangel an Facharbeitern wurde beklagt, die aus den Niederlanden herangezogen werden müssten. Nur einiges sei bisher geschafft, so sei „die Altenau auf einer Länge von $12 \mathrm{~km}$ begradigt, deren Flussbett auf $30 \mathrm{~m}$ verbreitert [?], in welchem Flöße mit Holz und Kalk aus dem Elme zur Oker gelangen könnten." Auch hier sorgte ein eingebautes Stauwehr bei Dettum für die erforderliche Wassertiefe. Eine Fortsetzung dieser Arbeiten sollte 1590 unter Herzog Heinrich Julius, einem Sohn von Herzog Julius, erfolgen. 1601 wurde jedoch nur eine „Verbesserung des Schiffahrtskanales" vorgenommen (ELM-ASSE 2003].

Auch im Frankenwald prägt die Triftflößerei mit ihren Teichen die Kulturlandschaft. Die Fluss- und Bachtäler des Frankenwaldes zeugen noch heute auf einer Länge von fast 200 Kilometer von der jahrhundertelangen Beeinflussung durch den Menschen. In der Mitte des 19. Jahrhunderts bestanden insgesamt 26 Flößerteiche im fränkischen und thüringischen Teil des Frankenwaldes, wie zum Beispiel der Floßteich ,Schwarzer Teich' im Quellgebiet der Fränkischen Muschwitz. Oft ist sogar noch das Teichschutzhäuschen erhalten (GUNZELMANN 1999:5,7; FLÖßERMUSEUM UNTERRODACH/BAYERISCHES LANDESAMT FÜR DENKMALPFLEGE 1999; GUNZELMANN 2003:7).

Klausen sind ebenfalls an der Alb nachgewiesen, so zum Beispiel die nach 1756 in der Nähe der heutigen Plotzsägemühle erbaute. Noch heute heißt diese Stelle „Klause“, zu ihr führt der „Klausenweg“ (SCHEIFELE 1993:55). Ober auch jene Wasserstuben im Albtal oberhalb der Kochmühle (beim Bahnhof Etzenrot) und im Holzbachtal, die um 1800 neu gebaut wurden. Ebenfalls wurde im Maisenbachtal unweit der Brücklesägemühle eine neue Schwallung angelegt und eine weitere bachabwärts am ,Frauenalber Brückle' errichtet (:80).

Bei der Schwarzwaldflößerei waren alle der Wutach zufließenden Bachwässser bis zur erforderlichen Höhe aufgestaut worden. Die Stauweiher besaßen zur Regulierung des Wasserstandes auf der gesamten Strecke Wehre und Stellfallen. In Schiltach war der Kirchweiher der Hauptspannplatz für das Einbinden der meisten Flöße auf der Kinzig; von hier kam aber auch das für die Floßfahrt unbedingt benötigte Schwellwasser. Im Tal der Möhlin errichtete man mit einem Aufwand von 1500 Gulden zwischen 1734 und 1736 in Höhe der Gütlemühle einen Schwellweiher, dessen Staumauer noch heute als Relikt erhalten ist (HUGARD 1895). 
Ehemalige Schwemmteiche sind auch aus dem Wald- und Mühlviertel Österreichs bekannt, die am Oberlauf einiger Flüsse wie zum Beispiel der Naarn und der Aist zur Brennholztrift angelegt wurden (KRANZ 2000: 23).

Neben den einzelnen Klausen gab es gar richtige „Holzgärten“ wie zum Beispiel beim Schloss Gottesaue bei Karlsruhe, die durchzogen von Gräben sind, auf denen das Holz zu den Lagerplätzen geflößt worden ist.

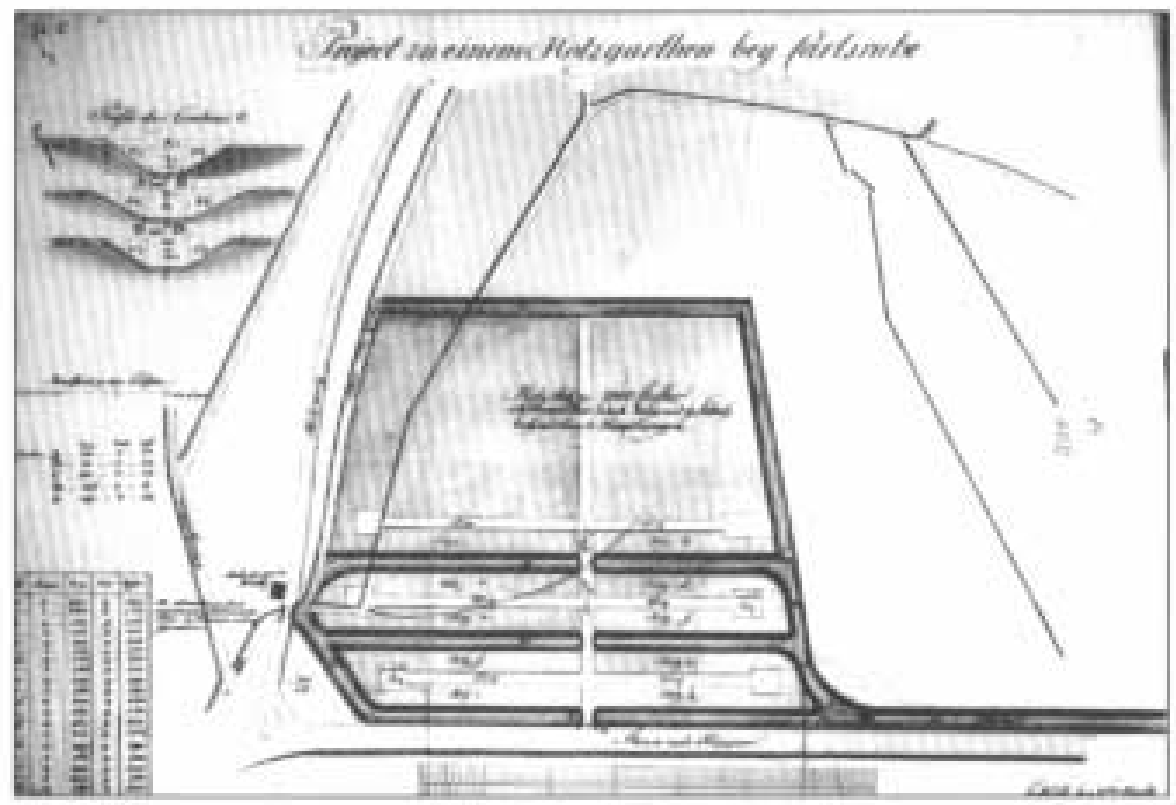

Abb. VII-75: Plan von 1792 für einen neuen Holzgarten beim Schloss Gottesaue/Karlsruhe (aus: SCHEIFELE 1993:74)

\section{u Deichelweiher}

Es gab Deichelweiher, etwa in Isny, Wurzach und Ravensburg, in denen die für die Wasserleitung durchbohrten Holzröhren, die hier „Deichel“ oder „Teichel“ genannt werden, gelagert wurden, damit sie nicht rissen.

\section{v Wässerteich}

Es gab Weiher, die als Staubecken für die Wiesenbewässerung dienten und eine dreifache Funktion ausübten: die der Wasserbevorratung, der Erwärmung und der Säuberung.

Reichte die von den Flüssen mitgeführte Wassermenge nicht zu jeder Zeit und an jedem Ort zur Wiesenbewässerung aus, wie beispielsweise KROLL/KONOLD (1994:404) vom Fluss Fehla bei Neufra (Schwäbische Alb) und auch HELLEBART (1994:189f.) am Beispiel des Oberinntals berichten, so wurden kleine Weiher angelegt, die man in Nordtirol „Pitzen“ (HELLEBART 1994:190), in Südtirol „Tschött“ (MENARA 1994:165) und in Oberschwaben „Schwellweiher“ oder „Kohlweiher“ (HERBST 1992:88) nennt. Der „Schwellweiher“ für die Wiesenbewässerung, den HERBST aus seinem oberschwäbischen Untersuchungsgebiet aus dem Jahr 1860 aufführt, war ein von Quellbächen gespeister Weiher und musste vorher erwärmt werden, bevor die Bewässerungseinrichtungen geöffnet wurden. Quellwasser wurde zwar für geschwemmte Wiesen als das „beste“ angesehen (WEYER 1800:12), wenn aber das Quellwasser „zu kalt aus der Erde kommt, so dient es nicht gleich zur Bewässerung." (:13) Das zu kalte Berg- oder Gebirgswasser sollte vorher erwärmt werden, damit es dem Pflanzenwuchs nicht schadete. Die Erwärmung des Wassers ist besonders im Frühjahr von Bedeutung, wie in Pkt. VI 3a dargestellt worden ist. 
In diesem Fall, so erfahren wir bei WEYER (1800:13), wurde es ,in einer Art von Behälter angehalten“, ohne aber dass er explizit von einem Teich spricht. Wärmeres Wasser löst „den Nahrungsstoff der Pflanzen besser auf [...] und befördert die Fermentation, folglich das stärkere Wachsthum der Pflanzen.“

Bei Bruch- und Moorwasser wurde so verfahren, dass es zur Qualitätsverbesserung „vor dem Gebrauche über Sand oder Kies" geleitet wurde. Zudem wurde es mit frischem Quellwasser versetzt. Dies war der Fall bei der Meisse, die dem Wietzendorfer Moor entspringt. Sie bewässerte erst die geschwemmten Wiesen, ,nachdem sie eine Beimischung von gutem Quellwasser erhalten und etliche 100 Ruthen in einen sandigen Schlauch geflossen ist"(WEYER 1800:14).

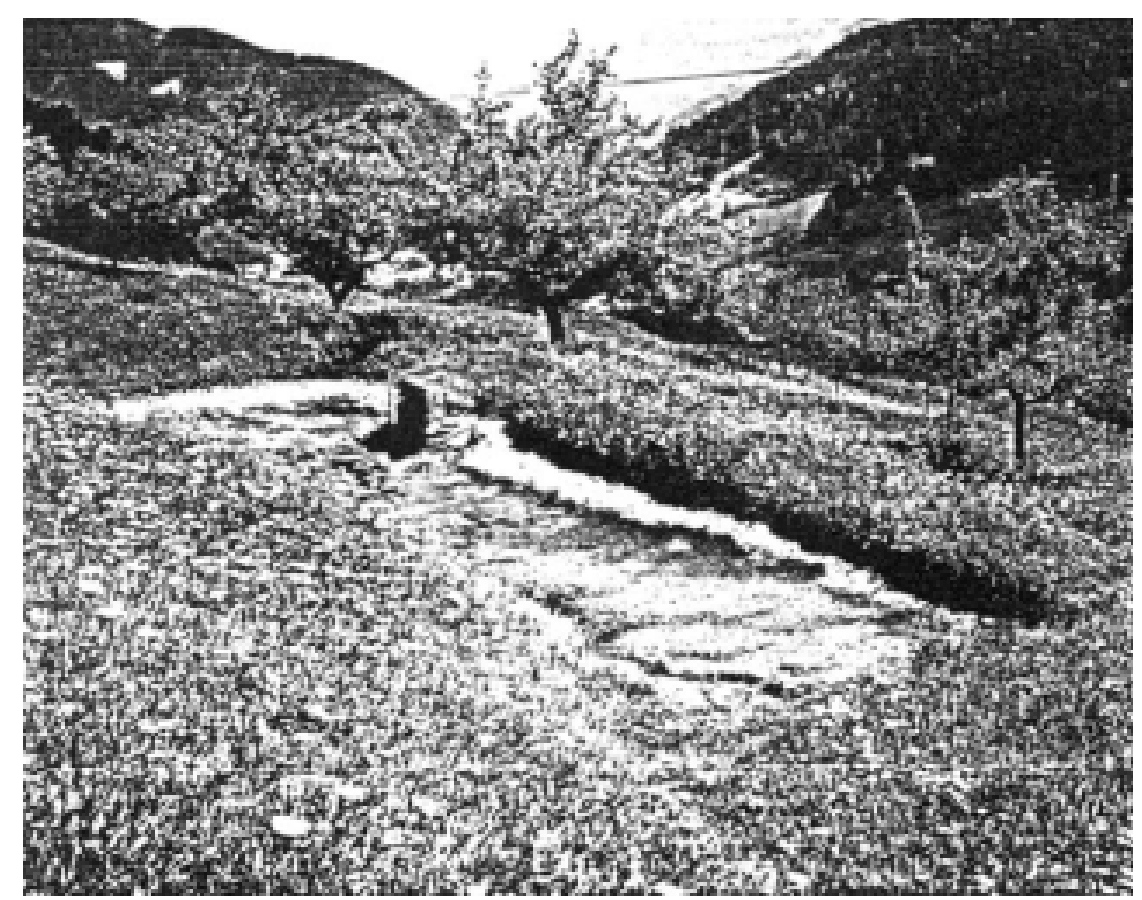

Abb. VII-76: Eine „Pitze“ in Stanz bei Landeck (aus: KONOLD 1994:334)

Des Weiteren wurde „das vom Regen entstehende Sammelwasser, welches über Saatländereyen, Höfe und Straßen, auch wohl durch Mistpfützen fließt, zum Bestauen der natürlichen Wiesen sehr dienlich“ angesehen (WEYER 1800:15). Demnach muss es vereinzelt auch kleine Sammelteiche gegeben haben, die dieses mit Düngebestandteilen angereicherte „Schmutzwasser“ aufgenommen und weitergeleitet haben.

Eine andere, wenn auch temporäre, Teichstauung ergab sich auf dem Wiesengelände selbst. Gewöhnlich bediente man sich zur Hervorbringung des Staus der Schleusen, von denen mindestens zwei notwendig waren: die erste am Anfang der Wiese zur Wasserzuführung, und die zweite am Ende derselben zur Abführung des Rieselwassers. Aber es muss sich nicht immer um hölzerne oder steinerne und damit ortsfeste Anlagen gehandelt haben: „An etlichen Orten behelfen sich die Wiesenbesitzer auch mit Staudämmen, die beim Anfange jeder Bewässerungszeit eingelegt und am Ende derselben wieder weggenommen werden.“ (WEYER 1800:82) Nur kleine Flüsse bzw. „mittelmäßige Bäche“ (:83) ließen eine solche Stauung zu. Bei dieser Stauart des Teichdammbaus bestand jedoch die Gefahr, dass ein Teil der relativ einfach aufgeschütteten Erde oder des Sandes vom Wasser fortgerissen wurde. „Bey plötzlich eintretenden Wasserstürzungen bricht entweder der Damm, oder die Wiesen [...] werden auf eine nachtheilige Weise überschwemmt“ (:83).

Aus diesem Grund wurde bei kräftiger fließenden Bächen zusätzlich zu solchen Stauwerken ein „Umlauf" errichtet, „worunter eine solche natürliche oder künstliche Sinke oder Grabenleitung verstanden wird, wodurch das überflüssige Oberwasser, wenn es die bestimmte Stauhöhe übersteigt, mit Vorbeigehung und ohne Berührung des Staudammes, in das Unterwasser anfließen kann“ 
(WEYER 1800:83). Grundsätzlich aber lassen „große Bäche und kleine Flüsse [...] dergleichen Staudämme ohne Gefahr nicht zu.“ (:84)

Auch das aus den Bewässerungskanälen des Vinschgaus/Südtirol transportierte Wasser zur Berieselung der Wiesen wurde in kleinen Sammelweihern, eben „Tschött“ genannt, auf dem Weg zu den Wiesen zwischengesammelt, in denen sich das Wässerwasser erwärmen konnte (MENARA 1994:165).

Die Notwendigkeit der Speicherung bestand - über den Grund der Erwärmung hinaus - in mehrfacher Hinsicht: zum einen, um auch dann Wasser zu besitzen, wenn aus irgendeinem Grund im Bach oder Waal das Wasser ausblieb. Dies war dann der Fall, wenn beispielsweise das Flussbett wegen Versickerung in geologisch sprödem Untergrund verlief (Weißjuraschutt) und wegen der Ableitung des Wassers zur Bewässerung weiter flussaufwärts gelegener Wiesen häufig trocken fiel. Auch musste die Wiesenwässerung wegen Wassermangels zugunsten der an den betreffenden Flussläufen gelegenen Wassermühlen und -werke zeitweise sogar eingestellt werden (KROLL/KONOLD 1994:404). Zum anderen wurden Wässerteiche angelegt, um vom Waal oder Gewässerlauf herangebrachtes Schwemmmaterial aufzunehmen. Dadurch sollte das Wasser gesäubert werden, bevor es zur Bewässerung gelangte. Die Pitzen selbst nämlich trockneten zeitweise aus und mussten ausgeräumt werden, um nicht vom angeschwemmten Material zu verlanden (HELLEBART 1994:194).

Erdwälle bilden bei den Wässerteichen die Einfassung und schließen entweder im offenen Viereck oder halbkreisförmig an das Gelände an (ZADERER 1950, aus: HELLEBART 1994:189f.).

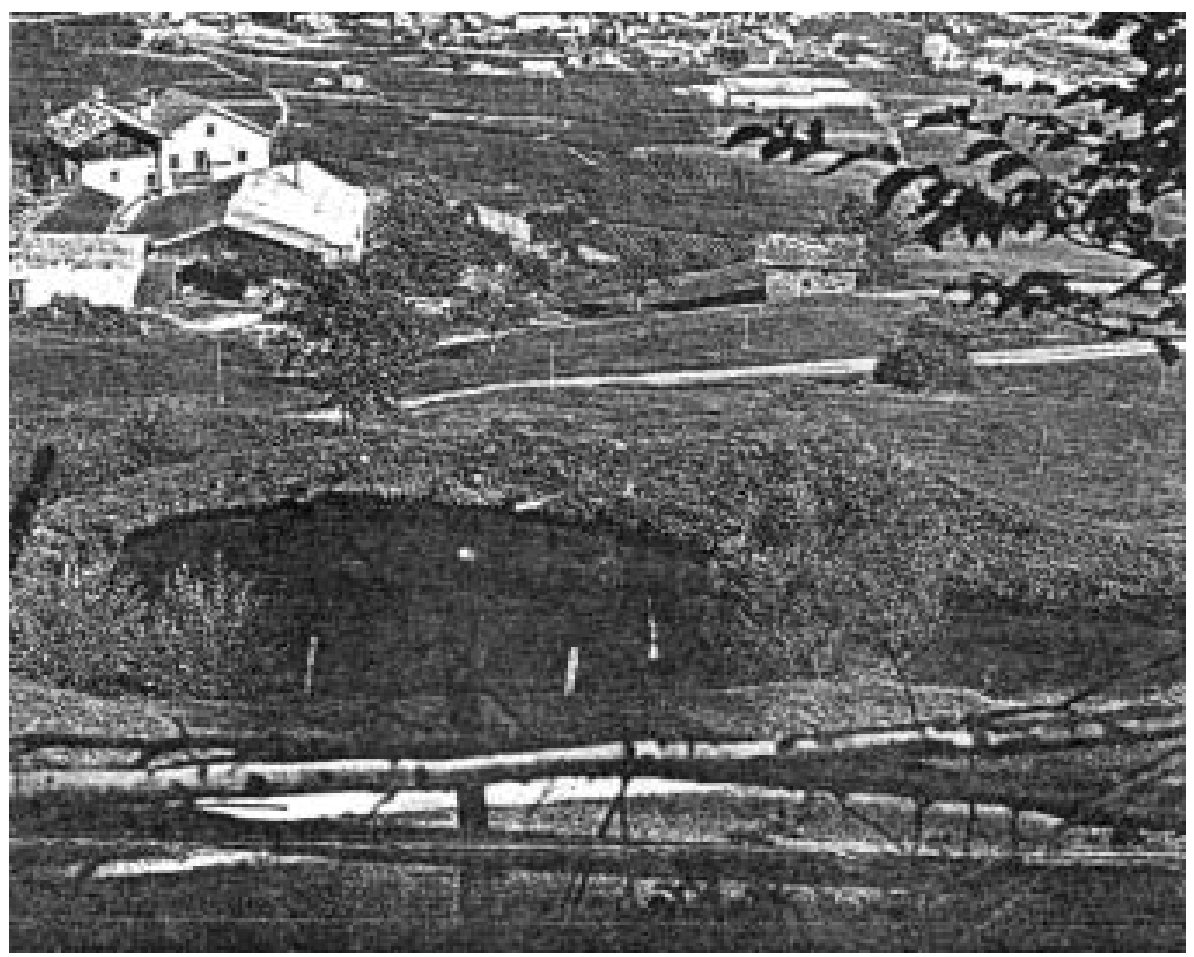

Abb. VII-77: Kleiner Wässerwasser-Sammelteich („,Tschött“)

(aus: MENARA 1994:165)

In den hochgelegenen Wässergebieten, wie zum Beispiel in Fließ (Nordtirol) war die Pitzenbewässerung stark verbreitet. Hier gab es nach Zählung von HELLEBART (1994:193) über 100 dieser Wassersammelbecken. In Stanz bei Landeck wurden für die Speicherung und Anwärmung des Wassers 11 Pitzen mit $50-100 \mathrm{~m}^{2}$ Fläche angelegt (:194). 


\section{w Bachteiche}

Um in der Forellenteichwirtschaft zum einen nicht die umfangreichen Teichgräben und -senken ausheben zu müssen und zum anderen eine bessere Kontrolle über die Brutstrecken in den Bachläufen ausüben zu können, legte man aus diesem Grund in Forellenwirtschaften sog. Bachteiche an, "welche oberhalb mit einer längeren oder kürzeren Bachstrecke zusammenhängen. In diese wandern die laichluftigen Forellen [...] ein, man braucht also nur den Ausfluß des Baches mit einem Sacke zu verstellen“ (BENECKE 1885:100). Der Hauptbeweggrund jedoch muss ein anderer gewesen sein. Da die Forellen zu damaliger Zeit nur in ,natürlichen“ Bächen und nicht in künstlichen Teichanlagen laichten, blieb, wollte man eine vollständige Forellenzucht innerhalb einer arealmäßig abgegrenzten Teichwirtschaft betreiben, keine andere Möglichkeit als die der Integration eines Bachlaufes. Obgleich man sich der Gefahr dieser „Durchlaufteiche“ bewusst gewesen sein mochte, ansonsten hätte man sich ja nicht umfangreicher Absperr- und Zulaufeinrichtungen bedient, so wurden diese Bachteiche dennoch in einer Vielzahl von Fällen errichtet.

Während die Ablaichung in kleinen Rinnsalen, wie oben erwähnt, noch durch das Versperren mit einem einfachen Sack gelang, so musste die Abfischung von Bachläufen dadurch vorgenommen werden, ,indem das Wasser durch einen kleinen, leicht herzustellenden Erddamm auf kurze Zeit zurückgestaut wird, so daß die Fischchen in dem trocken werdenden Bachbette leicht gesammelt werden können.“ (TAURKE 1927:48)

Solche kleinen, temporär errichteten Bachdämme waren für die Brutfische anscheinend hoch genug, um sie nicht überwinden zu können. Die Aufstauung zur Ablaichung wie die Trockenlegung durch Absperrung zum Zwecke der Abfischung stellte jedoch aus ökologischer Sicht einen Eingriff in den Fließgewässerlauf dar, dessen Schwere und Umfang nach Kenntnis des Verfassers bislang gänzlich unbeachtet blieben. Es ist auch nicht bekannt inwiefern eine solche Gewässersperre mit den Interessen der unterhalb liegenden Mühlenbesitzern korreliert, denn wie dargestellt lagen Mühlen früher auch an kleinsten Gewässerläufen.

Dass eine solche Methode der Forellenzucht bestand, ist von BORNE (1886) von dem Kloster Michaelstein beschrieben worden. Es wurde demnach ein Bachlauf hergerichtet und in die Teichanlage integriert (bzw. eigentlich anders herum), um eine natürliche Brutstrecke für Forellen zu simulieren. Hier wurden Anlagen und Elemente der Historischen Teichwirtschaft mit denen der Historischen Bachwirtschaft kombiniert: Den Teichen, in denen sich die Mutterforellen befanden, floss „das Wasser in einem Bächlein zu, welches mit starkem Gefälle über Geröll und Kiesel herabkommt und die reifen Forellen zum Laichen einladet. Es entströmt einem oberen Teiche und kann dort durch Staubretter abgestellt werden. Von Mitte Oktober bis Mitte December sind die Forellen laichreif und steigen von 9 Uhr vormittags an in den Bach, um zu laichen". (:277) Es wurde für das Ablaichen der Forellen dann täglich der Bach an seinem Einfluss in den Teich „,mit einem Netz zugestellt, dann das Wasser oben abgestellt, so daß der Bach fast trocken wird, die Forellen werden herausgenommen, abgestrichen und in den Teich gesetzt. Dies wird tagtäglich wiederholt und es werden dabei ausschließlich laichreife Forellen gefangen." (:277) So wurden 1882/83 in der Teichwirtschaft Michaelstein ungefähr 1600 Rogner und 100 Milcher abgestrichen.

\section{x Krebsteiche}

Die Krebsteiche stellen eine Besonderheit in der Teichbewirtschaftung dar. Wenn sie auch oft als Nebenprodukt oder als Fischfutter in einer Teichwirtschaft gezüchtet wurden, so sind Krebsteiche insofern von den Fischteichen unterschiedlich, als dass sie zum Beispiel keine Fischgrube vor dem Teichmönch benötigen, da sie nicht mit dem ablassenden Wasser mitschwimmen. Eine zentrale Sammlung und Abfischung war somit schon nicht aus natürlichen Gründen möglich. Des Weiteren war die Ablassbarkeit aus einem anderen Grund nicht erwünscht: Speisekrebse sollten ausschließlich mit Reusen erbeutet werden, weil sich beim Teichablasse die Kiemen der Krebse mit Schlamm vollsaugen und es Wochen dauern kann, bis sich diese in der Hälterung reinigen. Derartig 
verschmutzte Krebse eignen sich nicht für den Verzehr, denn der Krebssud würde „erbärmlich nach Schlamm schmecken“ (BOHL et al. 2001:32).

\section{x.1 Flohkrebsteich}

Um das Futter für die in Teichwirtschaften gezüchteten Salmoniden zu beschaffen, wurden sog. „Futterteiche“ angelegt, denn die Nahrung dieser Fische bestand in vorchemischen Zeiten „fast nur in animalischen Stoffen" (BORNE 1886:253). Bei den kleinen Wassertieren, von denen sich die Forellenartigen im Freien ernähren, handelt es sich um Wasserasseln (Asellus aquaticus), Wasserschnecken und um Flohkrebse (Gammarus pulex) (:253). So benutzte beispielsweise ein großer Fischzüchter namens Thomas Andrews aus Guildford in England Mitte des 19. Jh. „von 45 Forellenteiche 3 zu Züchtungen von Flohkrebsen und Wasserschnecken“"(:253).

In kleinen Teichwirtschaften hingegen sammelte man aufgrund nicht separierter Teiche „Krustenthierchen in Massen mit Keschern und Netzen von Gaze in klaren und trüben Dümpeln und Lachen, in Mistpützen und Torfgruben“ (BORNE 1886:253). In kleinen Einteichwirtschaften wurde die Züchtung kleiner Crustaceen hingegen nicht betrieben.

Neben den speziellen Flohkrebsteichen, benutzten einige Mehrteichwirtschaften auch die Fischteiche zur Krebschenzucht, indem sie wechselseitig bewirtschaftet wurden (BORNE 1886:253), und zwar mit relativ geringem Aufwand, denn es war „,nur nöthig, den Teich vollständig trocken liegen, und im Winter gehörig durchfrieren zu lassen,“ dann war „im Frühjahr das Wasser dicht erfüllt mit Krebsthierchen“ (:253). Das Gefrieren im Winter schien gar die Entwicklung zu begünstigen, denn im Frühjahr entwickelte sich so in frisch bespannten Teichen, welche den Winter über trocken gelegen haben, „eine erstaunliche Menge Flohkrebse“ (:224). Auf diese Weise entstand „eine große Menge Fischfutter, welches das Wachsthum der Fischbrut sehr befördert“ (:224).

Als Nahrung von Krebsen wurden tierische und pflanzliche Stoffe aller Art gefüttert, die gerade am billigsten zu haben waren: gehacktes Fleisch, Fische, Frösche, Eingeweide von Schlachttieren, gekochtes Blut, Mohrrüben, Futterrüben, Molkereiabfälle mit Staubmehl zusammengeknetet etc. (BENECKE 1885:113).

\section{x.2 Flusskrebsteich}

Die heimischen (Fluss-) Krebsarten sind aber für die folgende Darstellung noch einmal zu differenzieren, zwei Arten: in Steinkrebs und Edelkrebs: Der Steinkrebs (Astacus [alt: Austropotamobius] torrentium) lebt in kleineren und kühleren Gebirgsbächen und zeichnet sich eine durch geringe Größe, sehr dunkle Färbung und sehr feinen Geschmack aus (BENECKE 1885:103; BROHMER 1984: 148). Wegen seiner geringen Größe von max. $11 \mathrm{~cm}$ besaß der Steinkrebs jedoch keine wirtschaftliche Bedeutung und wurde im Gegensatz zum Edelkrebs kaum gehandelt und besetzt. Aber nicht nur seine Reproduktion ist im Vergleich zum Edelkrebs geringer, auch ,lassen sie sich in Teichen und Becken nicht sehr erfolgreich vermehren" (BOHL et al. 2001:10).

Der Edelkrebs (Astacus astacus), oft auch nur „Flusskrebs“ genannt, war in Mitteleuropa die dominierende Krebsart (BOHL et al. 2001:7). Zum einen, weil er sich wegen seiner hohen Anpassungsfähigkeit sehr erfolgreich in Teichen halten und auf natürliche Weise reproduzieren lässt (:27). Zum anderen, weil der Edelkrebs ,eine größere und hellere Form“ besaß (BENECKE 1885:103) und eine Größe von $20-25 \mathrm{~cm}$ erreichen (:109). Von ihm ist im Weiteren als Krebs des Teiches die Rede.

Er wurde insbesondere seit dem ausgehenden 19. Jh. als Delikatesse in Teichen herangezüchtet, zumal die Nachfrage nach denselben und sein Preis sich immer mehr steigerte (BENECKE 1885:IV). So wurden die weiblichen Krebse ,in ungeheurer Menge fortgefangen und [...] zum Garnieren von [...] Gerichten nach Frankreich verkauft" (:109). Dies ist umso erstaunlicher, als erste Versuche, diese Art in speziell angelegten Krebskanälen heranzuziehen, bereits um 1860 aus Frankreich bekannt sind (BOHL et al. 2001:30). Doch nicht allein die steigende Nachfrage, die sich mit dem Aufkommen des 
wohlhabenden Bürgertums erklären lässt, übertraf den mengenmäßig möglichen Krebsfang aus den natürlichen Habitaten der fließenden Gewässer. Zugleich wurden Flusskrebse bereits zu Ende des 19. Jh. aus einem anderen Grund immer seltener:

Die im beginnenden Industrialisierungszeitalter einsetzende Umweltverschmutzung und die Eingriffe in den natürlichen Gewässerlauf gaben einen weiteren Grund für die Schere zwischen Konsumentenverlangen und Liefermöglichkeit.

\begin{abstract}
„Infolge mancher Schädlichkeiten, welche sich in den öffentlichen Gewässern geltend machen, der Verunreinigung unserer Flüsse durch die Industrien, der Korrektionsarbeiten, noch mehr aber an vielen Orten durch die übermäßige Ausbeutung und schonungsloses Fortfangen der eiertragenden Mutterkrebse und der noch nicht fortpflanzungsfähigen Jungen ist der Krebsbestand unserer Gewässer erheblich vermindert, die Durchschnittsgröße der Krebse an den meisten Orten bedeutende herabgedrückt. An manchen Orten hat die in ihren Ursachen noch nicht hinreichend erforschte Krebspest ehemals reiche Krebsgewässer total verödet.“ (BENECKE 1885:109).
\end{abstract}

Nach dem Zusammenbruch der Edelkrebsbestände durch die Krebspest griff der Speisekrebshandel bereits um 1900 auf den osteuropäischen Markt zurück, wobei Russland den Hauptlieferanten darstellte (BOHL et al. 2001:11). Aber auch der Galizier- oder Sumpfkrebs (Astacus leptodactylus) war nicht, wie sich bald herausstellte, gegenüber der Krebspest immun. Der Galizierkrebs aber erträgt geringere Sauerstoffkonzentrationen sowie höhere Wassertemperaturen als der Edelkrebs und fühlt sich auch in schlammigen, wenig strukturreichen Gewässern wohl. Mitunter auch in Zusammenhang mit dem Rückgang des heimischen Krebses wurde dieser importiert.

Als erste europäische Art kam Ende des 19. Jh. der aus dem Osten Nordamerikas stammende Kamberkrebs (Orconectes limosus) als „Suppenkrebs“ nach Deutschland und besiedelte sehr schnell die großen Flüsse, Kanäle und Seen. Er breitete sich beispielsweise in Bayern in Donau, Main und Regnitz aus und bildete dort große und zusammenhängende Bestände (BOHL et al. 2001:12). Wie man heute weiß, ist er ein pestübertragender Krebs. Wo er auftritt, erlöschen die heimischen Krebspopulationen innerhalb weniger Jahre.

Die Hebung des Krebsbestandes wurde damals insbesondere dadurch erreicht, ,indem man, ähnlich wie bei der künstlichen Fischzucht, die Eier und die jungen Krebschen vielfachen Gefahren dadurch entzieht, daß man sie in abgesperrten Bachstrecken oder in größeren Bassins hält und aufzieht.“ (BENECKE 1885:109f.)

Es wurden also neben der Präparation von Bachabschnitten (siehe Pkt. VI 7b) zu diesem Zwecke Krebsteiche errichtet. Dazu ,sind große, in die Erde eingegrabene Bottiche oder kleine, steilwandige, in festem Boden ausgegrabene Teiche geeignet, denen durch ein $2-3 \mathrm{~cm}$ weites Rohr ein beständig laufendes reines Wasser zugeführt wird; die durch enge Drahtgitter abgeschlossen und mittelst eines kleinen Mönches oder in anderer Weise leicht trocken gelegt werden können.“ (BENECKE 1885:110)

Während sich kleinere Teiche und Becken vor allem für die Satzkrebsaufzucht eigneten, wurden für eine wirtschaftliche Speisekrebserzeugung größere, weitgehend naturbelassene Teiche errichtet, die auf diese speziellen Bedürfnisse des Edelkrebses eingingen. In Gefangenschaft siedelte er nämlich nicht in jedem Teich, sondern nur in solchen ,mit regelmäßigem und nicht zu geringem Wasserzufluß“ (BENECKE 1885:IV), der darüber hinaus von hoher Reinheit sein muss (:113). Schließlich wird in der Literatur noch darauf aufmerksam gemacht, dass „Quellwasser mit einer Temperatur von weniger als $12^{\circ} \mathrm{C}$ sich nicht zur Ausbrütung von Krebsen eignet" (:112).

In Deutschland sind derartige Anlagen zuerst im Jahre 1876 von einem Ökonomierat Brüssow in Schwerin „mit bestem Erfolge gemacht worden“ (BENECKE 1885:110). Den ersten Versuch dieser Art beschreibt Brüssow in den Zirkularen des deutschen Fischereivereins wie folgt (zit. aus BENECKE 1885:110 ff.): 


\begin{abstract}
„Zu diesem Zwecke ließ ich ein Bassin von 46 Fuß Länge, 20 Fuß Breite und 4 Fuß Tiefe wasserdicht von 2zölligen Planken erbauen, versenkte dasselbe in den Boden und stellte den mit einem Hahne versehenen Auslauf einer Wasserleitung in dasselbe.

Darauf ließ ich zur Wohnung für die Krebse 2 Zoll weite Drains rundum an den Wänden des Bassins in mehreren Etagen über einander derart aufschichten, daß die hintere Öffnung der Drainröhren durch die Seitenwand des Bassins geschlossen war, während die vordere dem Einschlüpfen der Krebse offen stand. [...]

In zwei Ecken des Bassins ist ein fetter mergelhaltiger Lehm 3 Fuß hoch und zum Boden schräg abfallend eingeschüttet und auf diesem ist Schilfrohr, Brunnenkresse und Wasserpest angepflanzt. Darauf ließ ich das Bassin voll Wasser laufen [...] setzte diese (die Mutterkrebse, B.B.) in das Bassin [...]; das Wasser lief in einem runden, 1 Zoll dicken Strahl ununterbrochen in das Bassin und wurde ein vergitterter Ablauf eingerichtet, um das Entweichen der Krebse zu verhindern."
\end{abstract}

Diese „hölzernen“ Krebsteiche besaßen also umgerechnet eine Größe von 14,4 m Länge, 6,3 m Breite und 1,3 m Tiefe. An den Rändern wurden herkömmliche Drainageröhren mit 0,05 m Durchmesser in mehreren Lagen übereinander belegt, so dass die Krebse darin ihre „Wohnung“ nehmen konnten. Außerdem wurden einige größere Steine in das Wasser gelegt, die Böden mit lehmigen Mergel angefüllt und mit Wasser- und Sumpfpflanzen bepflanzt.

Die Teichbeschaffenheit war also im Gegensatz zu den Fischteichen eine andere: Der Krebsteich war mit reicher Vegetation, einem guten Bestand an Über- und Unterwasserpflanzen ausgestattet und besaß einen hohen „Uferquotienten“, $d$. h. das Verhältnis von Uferlänge zu Wasserfläche war größer. Des Weiteren wurde Tonröhren als Wohnhöhlen im Krebsteich eingelegt, während der Fischteich in der Regel frei von Einlagen sein sollte, um die Abfischung nicht unnötig zu erschweren, und schließlich war in einem Krebsteich möglichst nur geringer oder besser gar kein Fischbestand vorhanden.

Solche Bassins wurden im Frühjahr mit 1400 eiertragenden Krebsweibchen besetzt; sie wurden mit Fleisch, Fischen, Fröschen und Mohrrüben gefüttert und es wurde Wasser in einem schwachen Strahl zugeführt, der dennoch das Bassin in $70-80$ Stunden zu füllen im Stande war. Von den 1400 Muttertieren erhielt man sich Mitte Oktober desselben Jahres 20.760 junge Krebse (BORNE 1886:294). Dieselben wurden ,zum Preise von 20 Mark pro Mille an gewerbsmäßige Fischer verkauft“" (BENECKE 1885:111). Das heißt, ein einziger Krebsteich erwirtschaftete in einem Jahr ca. 415 Mark $^{62}$ und ermöglichte damit schon ein grundständiges Leben, wenn auch die Kosten für Betriebshaltung davon noch zu bestreiten waren.

Neben fließenden Gewässern und den speziellen Krebsteichen waren aber für die Krebszucht „stehende Gewässer der verschiedensten Größe“ geeignet: „von den nicht allzu kleinen Söllen, Wasserlöchern, Mergelgruben und einzelnen günstigen Torfstichen an bis zu größeren Landseen, soweit die ein genügend klares Wasser enthalten, und soweit der Untergrund in der Uferregion für das Wachstum von Wasserpflanzen geeignet, jedoch nicht weich und mottig, sondern fest ist." (DRÖSCHER 1906:104) Diese Fähigkeit zur Habitatbildung trug wahrscheinlich zu seiner früheren Verbreitung erheblich bei.

Die Nahrung des Flusskrebses besteht normalerweise aus Schnecken, Muscheln, Würmern, Insektenlarven und toten Tieren aller Art, aber auch aus weichen, mehlreichen Pflanzenstoffen, wie den Wurzeln und jungen Trieben der Seerosen, des Schilfes usw. Mit Vorliebe soll er Armleuchteralgen (Charazeen) verzehren, deren Kalkgehalt er, ebenso wie den der Muschel- und Schneckenschalen, zum Aufbau seines Panzers braucht (BENECKE 1885:103).

\footnotetext{
${ }^{62}$ Zum Vergleich: Karl MAY, der Erfolgsschriftsteller fand 1875 eine Anstellung als Redakteur in einem Dresdener Verlagshaus (Kolportageverl, Besitzer: Heinrich Gotthold Münchmeyer [1836 - 1892]) mit einem Jahreseinkommen von 600 Mark; im gleichen Jahr beträgt das Jahreseinkommen des Bürgermeisters von Alsdorf bei Köln 1.350 Mark und ein Lehrer in der Dorfschule Kreuth am Tegernsee verdient durch den Schuldienst 367 Mark.
} 
Da der Krebs jedoch auch seine eigenen Jungen frisst, wurde für die Krebszucht - ein extra Teich war für die Satzzucht nicht gegeben - ein Kasten in den Teich gestellt, in dem sich ein kleiner Behälter befindet, der zur Aufnahme eiertragender Weibchen bestimmt war. Dieser Behälter hatte einen durchlöcherten Boden, damit die jungen Krebse hindurchfallen, sobald sie die Mutter verlassen haben (BORNE 1886:294).

\section{y Blutegelteich}

Fischegel wurden aus verschiedenen Gründen in eigenen Teichen gezüchtet. Zum einen diente die Zucht von Fischegeln als Fischfutter, denn Schleien, so die Meinung, sollen auch Fischegel gerne fressen (nach FLOERICKE, aus: TAURKE 1927:20). Zum anderen wurden Fischegel in der Naturheilkunde zum Entgiften geschätzt.

Das Aderlassen mit Hilfe von medizinischen Blutegeln war eine häufig geübte Praxis der Ärzte und Bader zur Behandlung der verschiedensten Krankheiten; eine Badestube gab es fast in jedem Ort. Im Gut Nessenreben, dem Erholungsort für die Mönche des Klosters Weingarten, gab es beispielsweise eigens ein „Aderlaßhaus“, wie KONOLD (1987:15) berichtet: „Man brauchte also Blutegel in großen Mengen“, die zumeist von den einfachen Leuten gesammelt wurden, die sich damit ein Zubrot verdienten.

Der „Egelfang“ dürfte deshalb „sehr weit verbreitet gewesen sein.“ (KONOLD 1987:14). KONOLD belegt die Bedeutung dieses Erwerbszweiges vor allem namenkundlich mit den Begriffen „Egelsee“ oder „Egelseelein“, die sehr häufig in Oberschwaben als Namen für noch bestehende Gewässer oder als Flurnamen in Senken auftauchen, in denen sich in historischer Zeit ein flaches Gewässer befunden hat (:14). Hinweise auf einen „Egelsee“ gibt es beispielsweise aus dem Jahr 1416, als das Kloster Weisenau einen sog. Egelsee bauen wollte (:15). Dabei scheint „Egelsee“ ein „stehender Begriff“ gewesen zu sein. Damit wurden Weiher bezeichnet, „die überwiegend für den Egelfang genutzt wurden." (:15)

\section{z Klärteiche}

Meistens wurden die Abwässer in früherer Zeit ungeklärt in die Gewässer eingeleitet. Spätestens seit dem letzten Drittel des 19. Jahrhundert hingegen traten mit der Industrialisierung und dem Wachstum der Produktion derartige Verschmutzungsprobleme an den Gewässern auf, vor allem an Gewässern mit hoher Industriedichte, dass sie eine Klärung - in Teichen - notwendig machten.

\section{z.1 Fabrikteich}

Zur Reinigung der ockerhaltigen Bachwässer aus den Bergbaurevieren wurden Klärteiche angelegt, 1884 in Bramsche, in welchem der Ockerschlamm der Hase aufgefangen wurde. Auch in den übrigen Revieren des niedersächsischen Steinkohlenbergbaus wurden Ansatzbecken ,zur Reduzierung der Entschädigungskosten" angelegt (NEUBER 2002:219).

In diesem Zeitraum wurden die Fabrikanten „gezwungen, Klärbecken anzulegen“ (DIX 1997:279). Die Einleitung von Abwässern aus Spülerei und Walkerei einer Tuchfabrik in Aachen zum Beispiel wurde schon zur Mitte des 19. Jh. nur unter Auflagen genehmigt (:239f.). Da die polizeiliche Kontrolle über die Einrichtung und den Betrieb von Kläranlagen bei einzelnen Fabriken intensiviert worden war, sind bis zum Jahr 1905 bei jeder Fabrik mehr oder weniger umfangreiche Klärvorrichtungen eingerichtet worden (:248).

Die Klärverfahren bestanden anfangs nur aus fabriknahen Becken, in denen sich feste Stoffe absetzen sollten. Wahrscheinlich sind neben den Absatzbecken und Filtern für die Ausfällung gelöster Stoffe 
noch zusätzliche Fällungsmittel eingesetzt worden, wie zum Beispiel in Form der Zugabe von Kalkmilch (DIX 1997:279f.).

Das zur Abklärung des in der Walkerei und Spülerei verwendeten Wassers wurde über einen Klärgraben in zwei nebeneinander gelegene Klärteiche geleitet, jeder zwei Ruten breit und drei Ruten lang und $6 \mathrm{Fuß} \mathrm{tief}{ }^{63}$. Durch diese Klärteiche sollte das Abwässer nacheinander durchfließen und dadurch abgeklärt werden. Oft waren zwischen den Absetzbecken wie auch in dem Graben Filter installiert, die entweder aus Reisiggeflecht oder aus Koks bestanden und in denen sich Feststoffe fangen sollten.

Die Klärteiche waren so anzulegen, dass bei der Füllung des Klärteiches X das Wasser in den folgenden Klärteich Y überläuft. Des Weiteren sollte das Wasser die Teiche nur verlassen, wenn dieselben gefüllt waren. Da auch diese Teiche in gewissen zeitlichen Abständen gesäubert werden mussten - die Reinigung der Klärteiche musste erfolgen, nachdem sich $1 \mathrm{Fuß} \mathrm{Schlamm} \mathrm{(ca.} \mathrm{0,30} \mathrm{m)}$ darin gesetzt hat -, musste schließlich für die Reinigung eines dieser Teiche die $\mathrm{Zu}$ - und Abführung des Wassers so angelegt sein, dass das zu- resp. abfließende Wasser den zu reinigenden Teich nicht berührt (DIX 1997:243).

\footnotetext{
${ }^{63}$ Gemessen an der Preußischen Rute (3,76 m) besaß ein solcher Klärteich ein Ausmaß von 7,52 m x 11,28 m x 1,80 m.
} 


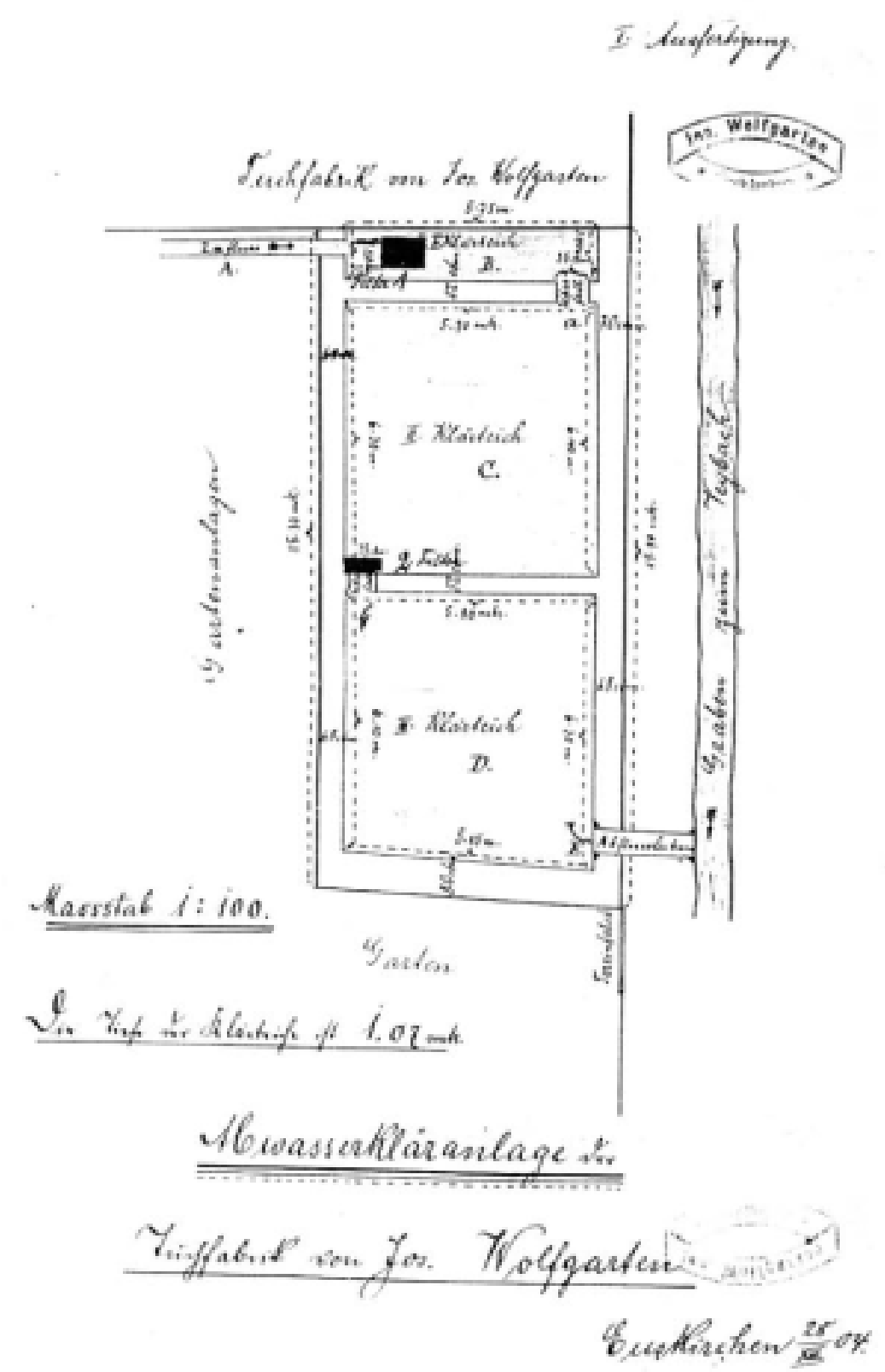

Abb. VII-78: Klärteiche der Tuchfabrik Wolfgarten (aus: DIX 1997:251).

Die beiden hier abgebildeten Klärteiche der Tuchfabrik Wolfgarten von 1904 zeigen ein gebräuchliches, sehr einfach aufgebautes System: Die Abwässer der Tuchfabrik flossen in einem offenen Graben durch zwei Klärgruben von einem Meter Tiefe, vor denen jeweils ein Reisiggeflecht als Filter für grobe Verunreinigungen angebracht war. Die 1,07 m tiefen Becken waren durch einen Überlauf miteinander verbunden, so dass die abgesunkenen Stoffe nicht mit dem geklärten Wasser in das nächste Becken gelangten (DIX 1997:249f.).

$\mathrm{Zu}$ der Anlage von Klärbecken gehörte demnach wie in der Fischwirtschaft der Bau eines Zu-, Umund Ableitungskanals sowie von Schleusen bzw. Teichmönchen, die sowohl die Befüllung als auch den Ablass des Teiches regelten.

Da das Abwasser aus der Wollwäscherei und Walkerei sowie der Spülmittel aus der Wäscherei und Färberei in den beiden Klärteichen nicht hinreichend abgeklärt werden konnte, mussten weitere Klärteiche angelegt werden (DIX 1997:243). Je nach topographischer Situation bestanden diese Klärvorrichtungen aus hinter- oder nebeneinandergeschalteten Becken, durch die die Abwässer langsam hindurchfließen und sich die Schwebstoffe absetzen konnten (:248). Durch Verwertung des 
Schlammes als Düngestoffe sollten die Kosten der Anlage zumindest teilweise wieder kompensiert werden.

Konnten die Reststoffteiche auch noch mit Fischen besetzt werden, so wurde diese auch noch zu fischwirtschaftlichen Zwecken genutzt. Die Teiche landwirtschaftlicher Industrien, wie beispielsweise die Schlammbassins von Zuckerfabriken, konnten ,zum Abwachsen von Karpfen dienen. Die Schlammassen müssen zunächst bis auf eine Schicht von 10-15 cm herausgeschafft werden. Dann ist [...] ein Kalken nötig, zu welchem der Scheideschlamm der Fabrik benützt werden kann. Der [...] Scheideschlamm muß mit dem Schlamm des Bassins durch Umschaufeln vermischt werden. Gut ist es, wenn hiernach das Bassin noch einige Wochen trocken liegen kann, um auszulüften. Alsdann wird das Wasser eingelassen und einige (2-4) Wochen gewartet, bis es abgegoren ist und Kleinfauna sich gebildet hat. [...] Jetzt erst ist es Zeit, die Karpfen einzusetzen.“(TAURKE 1927:162f.)

Eine andere Form teichwirtschaftlicher Nutzung von Industrieteichen ist von Brauereien überliefert. Da die Teiche „das ganze Jahr über Zuflüsse“ von Brauereien bekamen, konnten sie ebenfalls fischwirtschaftlich inwertgesetzt werden. Hier musste jedoch erst „durch einen Versuch mit wenigen Fischen entschieden werden, ob sie zur Fischhaltung geeignet sind oder nicht“" (TAURKE 1927:163).

\section{z.2 Rieselteich}

Neben den Produktionsfirmen entstanden auch bei der öffentlichen Hand zumeist Mitte des 19. Jh. die ersten Kanalisationspläne für die Ableitung von Fäkalien und Abwasser aus den Stadtflächen zu drainierten Flächen in die Peripherie.

Die Städte, wie beispielsweise Berlin, Dortmund und Münster, klärten ihre Abwässer dadurch, dass sie sie auf Stauwiesen, auch „Rieselwiesen“ bzw. „Rieselfelder“ genannt, in den sandigen Boden einsickern ließen. Alsdann wurde auf ihnen, die hierdurch sehr humos und nährstoffreich geworden sind, vor allem Gras angebaut, das aufgrund der großen Fruchtbarkeit im Jahr fünfmal und noch öfter geschnitten werden konnte.

In Berlin ging das erste Teilsystem 1878 in Betrieb. Der Bau der zwölf Radialentwässerungssysteme dauerte bis 1907. Die Rieselfelder wuchsen bis zur Bildung von Groß-Berlin im Jahre 1920 auf eine Fläche von insgesamt rund 11.000 ha an.

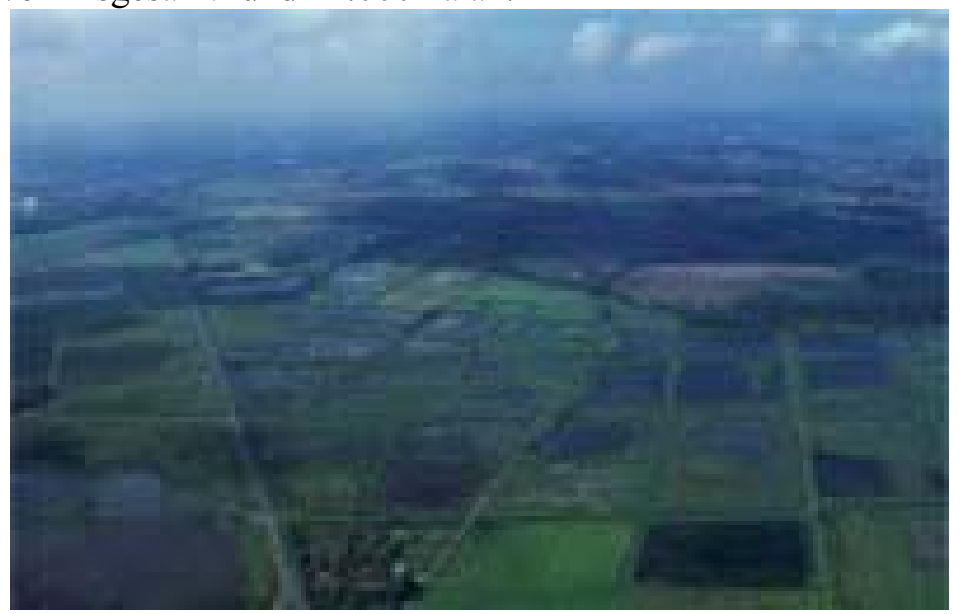

Abb. VII-79: Rieselfelder Münster.

Diese anthropogen geschaffene ehemalige Verrieselungsfläche der $6 \mathrm{~km}$ entfernten Stadt Münster (Stadtzentrum) bietet, aus der Luft betrachtet, das Bild einer großen Seenplatte. Über 130 Einzelteiche kennzeichnen noch heute mit ihrer schachbrettartigen Parzellierung das obere „Reservat“, wenn auch viele der ursprünglich meist 100 x 100 $\mathrm{m}$ großen Einzelteichen zu größeren Einheiten zusammengelegt wurden. Zudem sind fast alle Teiche mit einem mehr oder weniger dichten Schildgürtel umgeben und aufgrund der geringen Wassertiefe von Verlandung bedroht. In einem unteren „Naturerlebnisgebiet“ wurde im Zeitraum 1997 - 2000 die Rückverwandlung trocken gelegter und danach intensiv landwirtschaftlich genutzter ehemaliger Rieselfelder auf 233 ha durchgeführt. Die historische Kleinkammerung des Rieselgebietes wurde jedoch nicht wieder erreicht. Beide Gebiete zusammen besitzen den Rang eines Europäischen Vogelschutzgebietes (Europareservat für Wat- und Wiesenvögel) (URL = http://www.rieselfelder-muenster.de; 24.05.2004). 
In ihrer Anlage ähneln Rieselteiche äußerlich den großen Karpfenfischzuchtteichen, nur, dass die umgebenden Dämme eine geringere Höhe aufwiesen, es sich somit vielmehr um kleine Wälle und entsprechend wenig tiefgründige Teiche gehandelt hat und die einzelnen Absetzbecken eine weitgehend annähernd gleiche Größe und Form aufwiesen.

Trotz des durchlässigen Sandbodens mussten solche Stauwiesen jedoch drainiert werden. Das abfließende Drainwasser enthielt zwar noch viel Pflanzennährstoffe, war andererseits aber hinreichend vorgeklärt und wurde daher dazu benutzt, in zumeist tiefer liegendem Terrain Fischteiche zu speisen, „,in denen Karpfen und sogar Forellen vortrefflich gedeihen“ (TAURKE 1927:79). Zur Ausnützung des Drainwassers von Rieselwiesen wurden demnach Fischteiche in der Nähe angelegt.

CNOPF (1927:149) bezeichnet es als das ,zukunftsreiche Verfahren der Reinigung der Abwässer in Fischteichen“. Es sieht in der „Selbstreinigung der Abwässer in Weihern [...] nichts anders, als die Ueberführung wertloser organischer Substanz in wertvolles Fischfleisch.“ (:149). In einigen Städten, wie Straßburg, Amberg, Königsbrunn, Brünn, Grafenwöhr, Kitzungen und Nürnberg, weiß CNOPF zu berichten, „wurde dieses Verfahren mit Erfolg durchgeführt.“ An der mittleren Isar bei Unterföhring/München entstand kurz nach 1900 ein „Riesenprojekt": eine neue AbwasserFischteichanlage mit einem Flächenraum von 230 ha (:149f.). Es handelte sich dabei um die Kombination von städtischer Abwasserreinigung und Teichwirtschaft, das „AbwasserFischteichverfahren", wie der Birkenhof bei Ismaning im Norden Münchens mit seinen Abwasserfischteichen der Bayerischen Wasserkraftwerke AG noch heute dokumentiert (BOHL/RUF 1987:195).

Die Rieselfelder waren aber bereits in den 1920 und 1930er Jahren stofflich überlastet, weshalb die Reinigungsfähigkeit der Böden sank. Dagegen wurde die Gesamtmenge des zu behandelnden Abwassers aufgrund der rasant steigenden Bevölkerungszahl immer größer. Ab den 1920 Jahren folgte dann schrittweise der Bau und Einsatz einer biologischen Kläranlage.

Gleichermaßen machten die Fortschritte der Wasserversorgung die traditionellen Hof-, Dorf- und Feuerlöschweiher überflüssig (KONOLD 1987:424ff.). Die Wässerungsweiher wurden überflüssig, weil an die Stelle der düngenden Bewässerung zunehmend der Einsatz von Gülle und mineralischem Dünger trat, die Röstgruben, weil der Flachsanbau zurückging, die Eisweiher wurden überflüssig, weil statt des Eises Kältemaschinen in den Brauereikellern eingesetzt wurden, die Deichelweiher, weil man die Holzrohre durch Eisenrohre ersetzte. Die Floßweiher schließlich wurden überflüssig, weil man das Holz billiger und schneller mit der Eisenbahn transportieren konnte (:424ff.).

Zusammenfassend lässt sich sagen, dass es - trotz der hier gebotenen Systematik - in historischer Zeit in aller Regel keine singulär genutzten Teiche gegeben hat: Der Dorfteich beispielsweise diente als Fischaufzuchtbecken, als Viehtränke, der Pferde- und Schafwäsche, dem Futterbau, der Beweidung, war der Gänsezucht nützlich, als Feuerlöschteich und Reservoir der Wiesenbewässerung usw.

Dennoch erlauben die zu primären Zwecken angelegten Teiche eine solche Klassifizierung. Vielmehr kann nach meiner Auffassung erst aus dieser strukturierten Behandlung eine näherungsweise vollständige Zusammenschau historischer Teichnutzungsformen ermöglicht werden.

\section{Wiesenbewässerung}

\section{a Grundzüge der Wiesenbewässerung}

Zum einen aufgrund ihrer (ehemaligen) kulturlandschaftlichen Bedeutung und zum anderen aufgrund ihrer schon historischen Bewirtschaftungsweise in Abhängigkeit von Wasserläufen, nehmen Formen und Anlagen von Wiesenbewässerungsformen einen besonderen historisch-geographischen Stellenwert ein. Denn die historische Bewässerung beschreibt verschiedene Methoden zur Ertragssicherung und Ertragssteigerung auf Wiesen und anderen Erdflächen für eine Zeit vor der 
modernen Bewässerung durch Beregnung, die die natürlichen Niederschläge nachahmt, und bei der das Wasser von einer zentralen Wasserentnahmestelle (Tiefbrunnen, Gewässerlauf, seltener örtliches Wasserleitungsnetz) durch eine Pumpanlage auf die zu beregnenden Flächen geleitet wird.

In $\S 2$ seiner Lehrbucheinleitung zur „ordentlichen“ Teichwirtschaft beschreibt Graf Ernst von DYHRN (1782:5) - neben seiner zunächst „,verhaltensbiologischen“ Theorie der Bewässerung - die einfache Bewässerungsform der Überschwemmung sowie die unterschiedlichen Anwendungsgebiete der historischen landwirtschaftlichen Wassernutzung, die sich nicht nur auf die Bewässerung von Wiesen beschränkte, sondern die Bewässerungsanlagen einschloss:

„Die Erfahrung lehrte die Menschen ferner, daß die manchmalige, zu rechter Zeit geschehene, Ueberschwemmung eines Stücks Erdbodens mit Wasser, dasselbe zum Ackerbau, Gartenbau, wenigstens zum Grasbau, viel geschickter und fruchtbarer machte. Daher kamen die Bewässerungen der Wiesen und Aecker durch dazu gemachte Canäle, Wasserleitungen und Dämme“.

Entgegen den allgemeinen Darstellungen wurde nicht nur die Bewässerung von Wiesen durchgeführt, sondern es gab auch Äckerbewässerung, Weidenbewässerung, Gärtenbewässerung, Rebbergbewässerung usw. Es existierten demnach eine Reihe von Bewässerungskulturen in wechselfeuchten Breiten, die sich wiederum mit- und untereinander wechselseitig vermischten. So wurden die Wässerwiesen zwar vor allem als Heuwiesen, teil- und zeitweise aber auch als Weiden genutzt (LEIBUNDGUT 1993:22). Das Niederungs- bzw. Auenland, das in der vorindustriellen Zeit im Gegensatz zu heute einzig als natürliches, wasserführendes Dauergrünland zur Verfügung stand, musste bei dem Mangel an Dreeschweide ${ }^{64}$, an ausreichenden Grünteflächen ${ }^{65}$ und an Weideservituten in den Forsten meist noch als Weide für Pferde und Rindvieh dienen. Daher wurden die Wiesen nach dem (ersten) Schnitt nachgeweidet, zum Teil auch wegen Winterfuttermangels vorgeweidet. Die schlechteren Stücke dienten überhaupt nur als extensive Weide. Die Grenzen zwischen Weide, Hutung, Heide und Ödland waren in der Tat recht fließend (HETZEL 1957:24f.). Nach einer anderen Darstellung hingegen, die HERBST (1992:80) aus dem Stifterbrief des Klosters Ochsenhausen um 1100 ableitet, unterschied man streng zwischen solchen Wiesen, die ausschließlich der Heugewinnung dienten und bewässert wurden (,prata“) und solchen, die dem Vieh als Weideland zur Verfügung standen (,„pascua“). Beide Bewirtschaftungsformen scheinen richtig.

Ursprünglich war der Ertrag dieser Feuchtwiesen im Wesentlichen abhängig vom Niederschlag. Dabei fällt ungünstigerweise häufig der maximale Wasserbedarf der Gräser während ihres frühsommerlichen Wachstums mit einer Periode geringen Niederschlags zusammen. Da die Wiesen wegen ihrer Bindung an die Täler flächenmäßig nicht ausgeweitet werden konnten, war eine Ertragssicherung bzw. steigerung, die notwendig wurde, um das Vieh durch den Winter zu bringen, nur durch künstliche Bewässerung zu erreichen (SCHRÖDER 1997:9). Den zu bewässernden Gebieten wurde das Wasser dabei auf verschiedene Arten zugeführt (NAEF 1994:25). Diese Verschiedenartigkeit der Bewässerung mit ihren unterschiedlich gegen Vertritt und Verbiss empfindlichen Anlageformen mag es gewesen sein, die einmal eine Beweidung in Interimszeiten erlaubte und ein anderes Mal die Viehnutzung gänzlich verbot.

Allen Wässerwiesen gemeinsam war, dass das Wasser der Bäche gestaut und auf die Wiesen geleitet wurde, um die mit Hilfe der künstlichen Wässerung verbundenen Vorteile zu gewinnen: um Feuchtigkeit, Wärme und Nährstoffe zuzuführen, Bodenpflege zu betreiben und Schädlinge abzuwehren. Gleichzeitig war auf den komplexen Wässerwiesen die Bewässerung mit einer effektiven Entwässerung kombiniert, weshalb man auch von Be- und Entwässerungsanlagen spricht (GROTTIAN 2001:14). In einer gegliederten Übersicht lassen sich die Vorteile darstellen (Zusammenstellung aus: PRAGER/VENT 1954:206; HETZEL 1957:45ff.; WEBER 1971:29;

\footnotetext{
${ }^{64}$ Dreeschweide: Brache als Weide, sog. ,beschränkte Brache', d. h. man ließ nur einige Wiesenstücke zur Weide im Grünen liegen, ohne jedoch eigentliche Futterkräuter darauf zu bauen.

${ }^{65}$ Grünte: niederdeutsche Bezeichnung für eine extensive Weidefläche in der Nutzungsform einer Hutung.
} 
LEIBUNDGUT 1993:22f.; DENZER 1996:135f.; SCHRÖDER/SCHRÖDER 1997:9; DENECKE 1989b 1989:200):

1. Wasserzufuhr: Die Wiese soll in der trockenen Jahreszeit bewässert werden, um den gegen Wassermangel sehr empfindlichen Gräsern günstige Wachstumsbedingungen zu verschaffen.

Die Wiesenbewässerung bestand je nach Bewässerungsmethode (siehe unten) darin, die Wiesen vollständig zu wässern, oder aber auch - zur Deckung zeitweiliger Wasserdefizite in langen Trockenperioden während der Sommermonate - den Boden möglichst gleichmäßig anzufeuchten. Durch die Zuführung von Wasser zur Befeuchtung von Wiesenflächen, bei denen der Wasserbedarf in Mangelzeiten aus dem Grundwasser nicht gedeckt werden konnte, spielte die anfeuchtende Bewässerung „eine ausschlaggebende Rolle“ (HETZEL 1957:45). Des Weiteren wurde dem Boden durch die Bewässerung das durch Vegetation und Verdunstung entzogene Wasser wieder zugeführt.

2. Düngung: Der zweite mit der Bewässerung verbundene Zweck und die Hauptaufgabe der Bewässerung bestand in der Düngung der Wiesen, d. h. der Heranführung und dem Absatz von suspendierenden Nährstoffen, um vollen Ersatz für die dem Boden durch das Heu entzogenen Pflanzennährstoffe zu liefern (HETZEL 1957:43).

Durch Überleiten des nährstoffreichen Bachwassers sparten die Wiesenbesitzer wertvollen Dünger ein. Die Bachläufe reicherten sich früher mit Dungstoffen aus Haus und Stall an. Diese organischen Schwebstoffe wurden mit der Bewässerung auf die Wiesen verteilt. Der Eintrag von Nährstoffen auf die Wiesen mittels Bachwasser war insofern bedeutsam, dass in den vergangenen Jahrhunderten der Mist vor allem dazu verwendet wurde, die kargen Äcker zu düngen (Plaggenentnahme). Die Verwendung des trüben, schlammreichen Wassers im Winter und zur Zeit des Hochwassers verbesserte die Qualität des Grünfutters im Frühjahr insofern, als eine sichtbare Steigerung des Milchertrages festgestellt werden konnte. Die im Rieselwasser enthaltenen Schwebstoffe, die darin gelösten Nährstoffe wie auch der Sauerstoffgehalt des Wassers machten dies möglich. Des Weiteren war man bis in die 1960er Jahre der Ansicht, dass man mit Kunstdüngerabgaben statt der Rieselung die erzielten Erträge wesentlich höher bezahlen müsste (HETZEL 1957:57). Gleichzeitig warnt HETZEL (:43) vor einer Überbewertung des Wassers in Bezug auf seinen Gehalt an gelösten Düngestoffen und das Ziel der „Fettwässerung“, d. h. der vollsten Ausnutzung des Wassers zu suchen.

3. Wärmung: Der dritte Vorteil der Bewässerung liegt in ihrer anwärmenden Wirkung der Wiesenflächen.

Im Frühjahr sollte das Wasser, das zu dieser Jahreszeit häufig wärmer als der Boden ist, diesen erwärmen. Die Folge ist: Der Heuschnitt kann sehr früh beginnen. Dadurch konnte der erste Wiesenschnitt bis zu vier Wochen vorverlegt werden. Ein anderer Vorteil der anwärmenden Bewässerung ist der Schutz vor zu starker nächtlicher Ausstrahlung und Nachtfrösten. Dem Bodenfrost sollte entgegengewirkt werden, um so die Entwicklung des Pflanzenwuchses zeitlich positiv zu beeinflussen. Dies konnte durch rechtzeitige Wässerung im Frühjahr, wenn der Boden noch ungenügend erwärmt ist, erzielt werden. Dies war beispielsweise der Hauptgrund für die im Spessart durchgeführte Wiesenbewässerung (DENZER 1996:135).

4. Bodenpflege: Als viertes wesentliches Kriterium der Bewässerung ist die Entsäuerung und Durchlüftung des Bodens, d. h. die Auswaschung schädlicher Bodenbestandteile zu nennen.

Sie besteht darin, dass das durchfließende Rieselwasser einerseits schädliche Stoffe, beispielsweise Säurereste aus Wurzelausscheidungen, aus dem Boden auswäscht, sie in die Entwässerungsgräben führt und dort beim Weiterlauf durch Oxidation unschädlich macht, andererseits aber auch im Boden selbst oxidierend wirkt. Wichtig sind dabei eine ständige Erneuerung des Wassers sowie der stete Wechsel von Wässerung und Trockenlegung in kürzeren Perioden. Stagnierendes Wasser ist tödlich, da der mit Wasser gesättigte Boden kein neues Wasser aufnehmen kann und sich mit schädlichen Säuren anreichert. Versauerung des Bodens und Fäulnis der Pflanzen sind die Folge. Mit dem Wasser wird schließlich auch Luftsauerstoff in den Boden gezogen und so insgesamt eine gute Durchlüftung herbeigeführt. 
5. Schädlingsbekämpfung: Schließlich erleichterte diese Kulturtechnik die Vertreibung von tierischen Schädlingen wie Mäusen, Maulwürfen und Engerlingen.

Damit die beschriebenen Vorteile auch wirksam wurden, musste die Wiesenbewässerung, wie andere landwirtschaftliche Bereiche (Ackerbau, Teichwirtschaft), in ein festes Zeitschema eingepasst werden. Allgemein, ohne auf die komplizierten Einzelheiten der Bewässerungszeiten einzugehen, wird grundsätzlich unterschieden zwischen:

a. einer Frühjahrswässerung mit einer düngenden und erwärmenden Wirkung,

b. einer Wässerung im Sommer zur Anfeuchtung sowie

c. einer wiederum düngenden Herbstwässerung

(1t. Dienstinstruktion für die Wiesenwärter, abgedruckt bei JOX 1862:182ff.; aus: DENZER 1996:135).

Die erste Wässerung im Jahresverlauf fand im zeitigen Frühjahr mit Beginn der Wachstumszeit statt. Die Frühjahrsbewässerung sollte den Boden vor zu starker Abkühlung schützen, d. h. hier diente das Wasser vor allem der Erwärmung des Bodens. Man bewässert nachts, um zu verhindern, dass der Boden in den zu dieser Jahrszeit noch vorkommenden Nachfrösten stark abkühlt. Die düngende Wirkung spielt nur eine untergeordnete Rolle. Dann im April rückt die anfeuchtende Bewässerung in den Vordergrund. Im Sommer wurde jeweils nach dem Einbringen von Heu gewässert. Auch hier wurde während der Nacht eine sehr vorsichtige Bewässerung durchgeführt, die alle $8-10$ Tage stattfand. Die Bewässerungsdauer hängt stark von der Lufttemperatur ab. Man kann umso ausgiebiger bewässern, je kühler die Witterung ist. Der Herbst (Oktober - November) ist vorwiegend die Zeit der düngenden Bewässerung, weil das Wasser aus Bächen und Flüssen zu dieser Zeit infolge der erhöhten Auswaschung durch die Herbstniederschläge mit den transportierten Sinkstoffen am nährstoffreichsten ist. Im Herbst wurde deshalb mehrere Tage und Nächte hintereinander die Bewässerung durchgeführt. Nach 8-tägiger Bewässerung hingegen folgte eine 14-tägige Entwässerung, damit der Boden wieder genügend durchlüftet wird. Nach dem Abmähen oder Abweiden des letzten Grases wurde im Spätherbst die letzte, aber auch wichtigste Wässerung des Jahres durchgeführt. Diese Winterwässerung diente hauptsächlich der Schwebstoffausbringung mit dem Ziel der Bodenbildung und Strukturverbesserung sowie der Mäusebekämpfung (LEIBUNDGUT 1993:22). Durch die Bewässerung während einiger Tage jeweils im Frühjahr, im Sommer und Spätherbst/Frühwinter konnten die Erträge der Naturwiesen gesteigert werden.

Dieser Bewässerungsablauf stellt ein Grundschema dar, von dem es aber zahlreiche regionale Abweichungen gibt: Die Rieselung fand im Wendland beispielsweise in der Zeit vom 15. Oktober bis zum 15. Mai des Jahres 1861 statt (LANGE 1989:56). Das bedeutet, im Sommer und Frühherbst fehlte die Wässerung völlig. Genau entgegengesetzt waren die Rieselzeiten der Landwirte aus dem Ort Güntersen an dem Flusslauf Auschnippe. Sie durften ihren Wiesenkomplex von 24 Morgen jährlich abwechselnd vom 15. Mai und vom 20. Juni bis 1. August wässern. Innerhalb dieser Periode wässerte dann jeder einen oder zwei Tage (SCHRÖDER/SCHRÖDER 1997:11 ${ }^{66}$ ). Hier wurde demnach die Winterung außer Acht gelassen.

Unter den Besitzern von Wiesen mit Wasserrecht treffen wir neben Landwirten auch Müller, Lehrer und Wirte, aber auch Institutionen sowie Stadtbewohner (WEBER 1971:23). Schaut man sich die Ausdehnungen von Wässerwiesen an und betrachtet man die Wässerungsregeln ${ }^{67}$ und den Umfang und die Aufgaben einer Wiesenbewässerung und Wiesenpflege, so wird verständlich, warum oftmals ein Wiesenmeister angestellt war und wie viel so ein Wiesenmeister leisten musste. Bei Klosterwiesen und bei den späteren Genossenschaftswiesen beispielsweise wurden die anfallenden Arbeiten von einem Wiesenmeister oder Wiesenwärter (:27) bzw. Feldhüter (FIEDLER 1965:85) ausgeführt. Die Arbeiten umfassten die Überwachung der Bewässerung, Behebung von Mängeln an Fallen und deren Bedienung, die Schließung von Wehren zu den Wässertagen (:85), die Versteigerung des Heu- und

\footnotetext{
${ }^{66}$ Aus dem Familienarchiv Adelebsen Fund-Nr. F.F.A IV, 5,4; 7. August 1874

${ }^{67}$ Siehe zu den Regeln beispielhaft WEBER (1971:28).
} 
Emdgrases $^{68}$, Instandhaltung der Wege (WEBER 1971:27) und der Abzugs- und Zuzugsgräben. So musste der Schlamm und der abgelagerte Schlick geräumt und die Gräben gesäubert werden. Hierbei wurden vor allem die Grabenwände von den Pflanzen befreit, um ein regelmäßiges Rieseln zu gewährleisten (FIEDLER 1965:46). Bei weniger Wasser gehörte auch die Aufstellung des Verteilerplanes und Bestimmung der Wassermassen zu den Aufgaben eines Wiesenwärters (WEBER 1971:28).

Bei kleineren bäuerlichen Wiesengrößen, wie es sie beispielsweise im Erzgebirge gab, zog im Frühjahr, wenn die Flüsse vollufrig vom Schmelzwasser waren, ,der Bauer die kleinen, in die Grasdecke eingeschnittenen Gräben mit der Rutha, d. h. Rodehacke nach, die dann die Wiese bewässern“. Außerdem räumte er die Wiesen und stieß Maulwürfshügel zu (ALTMANN 1999:112, aus alter Quelle).

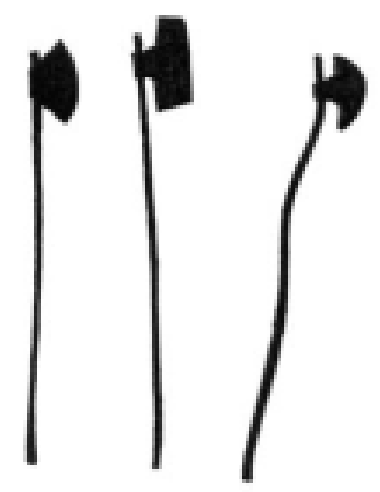

Abb. VII-80: Verschiedene Formen der zum Gräbenstechen und -nachziehen benutzten Wiesenäxte (aus: WEBER 1971:16, Abb. 7, nach mündlichen Berichten gezeichnet)

Der Zweck dieser Tätigkeiten wie der Wiesenbewässerung generell bestand darin, die landwirtschaftliche Produktion zu steigern. Das frühzeitigere Wachstum der Vegetation ermöglichte einen vorzeitigen und mehrmaligen Heuschnitt, „mancherorts sogar einen dritten Schnitt“ (WEBER 1971:23). Doch genauso wenig, wie es ein für alle Regionen einheitliches Bewässerablaufschema gab, existierte nur ein Wiesentyp. Den Wässerwiesen lag eine ehemals hoch entwickelte, den Landschaftsformen entsprechende komplexe Wiesenkultur zugrunde.

\section{b Typen der Wiesenbewässerung}

In geographischer Betrachtung lassen sich in vier Grundtypen von Wiesenbewässerungssystemen unterscheiden (nach LEIBUNDGUT 1993:21):
A. der Flachlandtyp,
B. der Mittelgebirgstyp,
C. der Alpenvorlandtyp und
D. der Alpine Typ.

Die Wiesenbewässerungssysteme und Bewässerungsmethoden wurden dabei in ihren unterschiedlichen Formen dem Gelände angepasst. Folgende zwei Wiesenformen, die durch die Bewässerungsarten (physiognomisch) geprägt werden, gilt es in topographischer Abhängigkeit zu unterscheiden:

\footnotetext{
${ }^{68}$ Emdgras: heute noch in der Schweiz gebräuchliche Bezeichnung für den zweiten Futterwiesenschnitt. Da dieser im Hochsommer (Juli) vorgenommen wurde, brannte das für die Winterfutterversorgung so wichtige Emdgras häufig ab (WENSLINGEN 2004), wenn keine Aufsicht stattfand. Eine Bewässerung nämlich, die dies natürlicherweise hätte verhindern können, wurde in den Sommermonaten nicht durchgeführt (siehe oben).

Aber auch in der Bibel, im Buch Amos, 7. Kapitel, Vers 1, taucht der Begriff ,Emdgras' als Grasschnitt nach der Heuernte auf. Dort heißt es: „Solches ließ Gott, der HERR, mich schauen: Siehe, er machte Heuschrecken, als das Emdgras zu wachsen begann; und siehe, es war das Emdgras nach der Heuernte des Königs.“
} 
1. Talbewässerungswiesen und

2. Hangbewässerungswiesen.

Diese Grundtypen weisen in ihrer Form und Entwicklung gewissen Modifikationen und, dies muss an dieser Stelle betont werden, es gibt selbstverständlich - gemessen am Parameter ,Höhe über $\mathrm{NN}^{\star}$ Bewässerungsformen des Flachlandes auch im Hochgebirge, z. B. wenn flache Talböden in einem breiten hochgelegenen Talkessel vorhanden sind. So existieren auch im subalpinen Alpenbereich sowohl Hangbewässerungswiesen, in diesem Sprachraum als ,Hängwässermatten' bezeichnet, als auch ,Talwässermatten'. Letztere werden hier sogar als ,echte Wässermatten' und deshalb auch einfach ,Wässermatten' genannt, die Hangwässermatten hingegen als „untergeordnete Kategorie“ eingestuft. Zum einen, weil sie in Seitentälern vorkommen, zum anderen, weil im subalpinen Bereich ein genügender Zufluss vorausgesetzt werden kann (BINGGELI 1986: 127). Generell aber korrespondieren Topographie und Geographie, denn die Bewässerung hochgelegener alpiner Trockenrasen in Ausprägung der Hangbewässerung kann nun mal nicht als ,Bewässerung in der Ebene' festgestellt werden.

Um aber dennoch die Schwierigkeiten einer zonalen Gliederung zu umgehen, sei hier der funktionalen Gruppierung der Vorzug gegeben. Hinsichtlich der Bewässerungsart, d. h. wie die Wiesen bewässert werden, lassen sich folgende Systeme unterscheiden:

Die wichtigste unter ihnen ist die Bewässerung durch Gräben. Bei dieser Methode wird hauptsächlich zwischen
a. Staubewässerung und
b. Rieselbewässerung

unterschieden.

Welche von beiden Arten zur Anwendung kam, hing vor allem von den örtlichen Verhältnissen ab. Die Bewässerungssysteme der Anstauung und der Überstauung können aufgrund der besonderen Geländeerfordernisse nur auf Talwiesen angewandt werden. Die Überrieselung fand sowohl auf Talund Niederungsland, hier wurde sie als Rückenbau ausgeführt, als auch auf Hanggelände statt. In jedem Falle aber wurden zur Verteilung des Wässerwassers mehrere $\mathrm{Zu}$ - und Abführeinrichtungen in Form von Gräben notwendig.

„Bewässerungsgräben bilden meist ein geschlossenes System von verzweigten Neben- und Hauptgräben (DENECKE 1989b:200). Die Gestaltung der in sich hierarchisch gegliederten Grabensysteme in Zuleitungs-, Verteilungs-, Stau- und Rieselgräben sowie deren Konstruktion (Breite, Tiefe, Winkel zur Hangneigung) war und musste stets dem Relief, der Größe des zu bewässernden Areals und dem jeweiligen Bodentyp angepasst sein. „Maßnahmen dieser Art mit einem offenen Grabensystem haben vor allem im 18. und 19. Jh. eine Anwendung gefunden“ (:200).

Im Gelände sind Wässerwiesen zumeist nur als feines „Binnenrelief“ (BINGGELI 1986:136) wahrnehmbar. Es handelt sich um ein überaus reiches Kleinstrelief nicht nur von Gräben, sondern entsprechend der Bewässerungsart auch von Mulden und Rücken, die, sind sie noch vorhanden, aus gewisser Entfernung fast unbemerkbar, beim Begehen der Wiesen jedoch in aller Deutlichkeit erlebbar sind. Vor allem die älteren Wässerwiesen weisen allgemein eine ,naturnahe Anlage' mit dichtem, gewundenem und stark verzeigtem Grabennetz auf. Jüngere Systeme hingegen wurden rationeller angelegt, die Gliederungsdichte ist dementsprechend geringer (:139).

\section{b.1 Talbewässerung}

\section{b.1.1 Staubewässerung}

Bei der Staubewässerung unterscheidet man nochmals zwischen 
a.1 Überstaubewässerung und

a.2 An- bzw. Einstaubewässerung.

Die im Folgenden dargestellte , oberirdische Staubewässerung' beschreibt die erste Form der Talbewässerung und konnte nur im Talboden ausgeführt werden. Die weiter unten dargestellte ,Rieselung', die als Tal- und Hangbewässerung ausgeführt wurde, steht auf einer höheren baulichen Komplexitätsstufe.

\section{b.1.1.1 Überstauung}

Die einfachsten Bewässerungssysteme waren Überstauungswiesen, die VINCENT (1858:3f.) als „wilde Rieselung“ bezeichnet. Bei den ,wilden' Rieselungen bestanden die Bewässerungsanlagen lediglich aus einem Stau, der das Wasser des betreffenden Baches oder Flusses über die Ufer treten lässt (Überstauung), von wo aus es in mehr oder weniger breiter Ausdehnung über den Talgrund strömt. Im Talverlauf konnten diese Anstauungen wiederholt werden, so dass auf diese Weise ganze Bachtäler überströmt werden konnten. Zumeist aber wurden die Wiesen in einzelne Talabschnitte, in Polder, unterteilt, die mit niedrigen Wällen umgeben waren (:3f.).

Der Unterschied zur Anstaubewässerung besteht darin, dass hier das Wasser so hoch gestaut wird, dass es die ganze Wiese überflutet und nicht nur seitlich und von unten durchfeuchtet (PRAGER/VENT 1954:204).

Um die Flutung eines Bachtales zu ermöglichen wurde mit Hilfe von Schleusen das Flüsschen ganz aufgestaut und das Wasser auf die Wiesenoberfläche geleitet. Um es dort zu halten, lag das Gelände entweder tiefer oder das Bachtal wurde durch den Bau von Erddämmen gestaut. Die Dämme umgrenzten die Wiese und ihre einzelnen Abteilungen (siehe Abb. VIII-52). (FUNK 1882:245ff.; HÄFENER 1847:238ff.; PERELS 1877:622).

Überstauungen wurden ebenfalls ganz bewusst herbeigeführt, da das Wasser auf der überstauten Wiese einen Teil seiner Nährstoffe absetzte. Bei einer Überstaubewässerung wurde die zu bewässernde Fläche aber nur kurzzeitig ganz unter Wasser gesetzt, damit die Gräser nicht abstarben (SCHRÖDER/SCHRÖDER 1997:12).

Durch die Methode der Überstaubewässerung wurden die vielen Bewässerungsrinnen überflüssig. Aber dennoch kam auch die ,einfache' Überstauung nicht ohne Bewässerungsanlagen aus. Bei der Überstaubewässerung wurden ein Zuflussgraben, mehrere Verteilungsgräben und ein Abflussgraben benötigt; darüber hinaus Entwässerungsgräben, die das Wasser nach einer Überstauung der Wiese in den Abflussgraben leiten, da sonst die Wiese versumpfte.

Die Wassereinspeisung konnte durch eine ,Schutzschleuse' reguliert werden. Jeder der Polder besaß einen Einlass, wodurch auf den Flächen ständig frisches Wasser nachfließen konnte. Dies hatte jedoch einen sehr hohen Wasserverbrauch zur Folge. Wurde die Schleuse geöffnet, so strömte das Wasser in die entlang der Dämme gezogenen Gräben. Zum Ablassen des Wassers dienten ,Kastenschützen' oder ,Auslassschleusen', die in die Dämme eingelassen waren. Sie stellten gleichzeitig eine Verbindung zwischen den einzelnen Wiesenabteilungen her (KONOLD/POPP 1994:382; DÜNKELBERG 1907:144ff.; SCHEWIOR 1941:30ff.).

War das Fließgefälle des Gewässerlaufs zu gering, um eine Überflutung zu gewährleisten, so wurde das Wasser mit Wasserschöpfanlagen in die Bewässerungsgräben gehoben (DENZER 1996:145).

Handelte es sich bei den Überstauungsflächen um Talwiesen, so wurde zeitweilig auch die Technik des Wiesenschwemmens angewandt. Dies geschah vor dem Hintergrund, dass „die natürlichen Wiesen [...] oftmals uneben“ waren. Sollten sie zur Bewässerung eingerichtet werden, so waren ,die größesten Höhen abzutragen und in die tiefsten Sinken zu versetzen." (WEYER 1800:22) 
Das Wiesenschwemmen war im Wesentlichen eine Rationalisierung des im 18. Jh. verbreiteten ,Kunstwiesenbaus' und keine neue Bewässerungstechnik (GROTTIAN 2001:11). Sie schuf erst die Voraussetzungen für die spätere eigentliche Bewässerung. Das „Schwemmen oder Wegflößen der Hügel mittelst Wassers in tiefer gelegene Gründe“ (SPRENGEL 1838:91) bestand darin, ,daß man die, ein nach allen Seiten stark abhängiges Flußthal einschließenden lehmigen oder sandigen Anhöhen, mittelst hinangeleiteten Wassers, in die niedrigen, meist sumpfigen Theile des Thales dergestalt flößt, daß aus den abgeschwemmten Hügeln, und der mit Erde ausgefüllten Niederung eine ebene, etwas abhängige Fläche entsteht, die in der Folge als Wiese dient, da sie durch den beuferten, früher zum Schwemmen benutzten Graben berieselt wird. Das Schwemmen ist eine Operation, mittelst welcher aus dürren, unfruchtbaren Sandhügeln und nutzlosen Sümpfen die fruchtbarsten Wiesen geschaffen werden, und ist eine Grundverbesserung, die eben [...] auch sehr nützlich und einträglich ist."

Dabei wurde „der Bach oder Fluß, dessen Wasser man sich zum Schwemmen bedienen will, [...] mittelst eines Wehres, so hoch als möglich im Thale hinaus angelegt, aufgestauet" (SPRENGEL 1838:92) und von dort mit einem Graben abgezweigt. Dem einströmenden Wasser wurde durch zahlreiche Arbeiter die zuvor losgestochene Erde in kleinen Mengen vorgeworfen und mittelst breiter Hacken beständig ,umgerührt“ (siehe Abb. VII-80). Das „Zerrühren der etwaigen Erdklumpen“ durfte hingegen ,am wenigsten unterbleiben.“ (:93)

Der Wasserzufluss musste ein so bedeutendes Gefälle und eine solche Wassermenge besitzen, dass die Kraft des Wassers ausreichte, die vorgeworfene Erde weit genug mitzureißen und fortzuführen, $d . h$. fortzuschwemmen, um sich unterhalb, in der Niederung, wo es zur Ruhe kommt, abzusetzen und diese damit zu erhöhen (SPRENGEL 1838:92f.). Die Erde legte sich im Talgrund zuerst dort ab, „wo sie Vertiefungen und Löcher findet, und sind diese ausgefüllt, so verbreitet sie sich gleichmäßig über die ganze Fläche.“ (:94) Man schwemmte deshalb auch „,immer in der Jahreszeit, wo die Flüsse und Bäche in der Regel das meiste Wasser führen, also im Spätherbst oder Frühjahr.“ (:92f.) Des Weiteren wurde versucht, um möglichst viel Fläche in Wiesenland umzuwandeln, ,wenn es nicht an Wasser zur künftigen Bewässerung des Schwemmgrundes fehlt, so weit wie möglich in den Berg hineinzugehn“ (SPRENGEL 1838:94; THAER 1800:II).

Es war dazu ,ein Fluß oder Bach erfordert, der ein nicht gar zu geringes Gefälle von Natur besitzt oder einen zweckmäßigen Stau zulässt; der ferner einen Bruch, eine Sinke, ein Moor zur Seite hat, und weiter landeinwärts durch sandige Ufer, Anhöhen oder Berge eingeschlossen wird. Durch Hülfe solcher Flüsse oder Bäche, die man durch ein Wehr aus dem tiefen natürlichen Bette heraushebt und zu dem Fuß der sandigen Anhöhen oder Berge hinandrängt, wird der daselbst losgerührte oder ausgegrabene Sand in jenen Bruch oder in jenes moor-artige Thal in der Maaße hinabgeflößt, daß die neue Fläche die mindest-mögliche Schräge bekömmt. Denn je geringer diese Schräge ist, desto mehr Sand oder Erde kann in die auszufüllende Sinke hineingeworfen werden, und desto weiter kann man in die Anhöhe oder den Berg eindringen, und desto größer wird dann die künftig zu inundirende, folglich zur Wiese gemachte, Fläche. "(WEYER 1800:7f.)

Beim ,Wiesenschwemmen' oder ,Flößen' wurde also Wasser aus einem aufgestauten Wasserlauf in einem Graben zum Fuß der Talböschung geleitet. Dort löste man mit Schaufeln und Hacken Sand und Erde aus dem Talhang, warf nun das losgearbeitete Material zum Wegschwemmen vor und ließ es vom Wasser in den Talgrund schwemmen, wo es sich ablagerte. Im Zuge der Arbeiten wurde der Graben nach und nach entlang der Böschung weitergetrieben, so dass der aufgestaute Bach schließlich als Verlängerung des Grabens auf der Höhe an der Wiese herumlief. Um die Wiesenfläche zu vergrößern, wurde, wenn die Höhe des Wasserspiegels es erlaubte, in den Fuß der die Wiesenfläche umgebenden Hügel hineingegraben. Des Weiteren galt es, so viel Wasser als möglich wieder aufgefangen, um konzentriert eine kräftigere Wirkung hervorzubringen." (GROTTIAN 2001:11) Dieser Vorgang wird durch Abb. VII-81 veranschaulicht.

In der angeblich früheren Form des Wiesenebnens bzw. der Wiesenglättung wurde nicht durch „Schwemmen“, sondern durch manuelles Abkarren der höheren Ränder „,in die tiefen und sumpfigen Sinken“ die Anlage von Bewässerungsflächen hergestellt (THAER 1800:II). Erst die spätere 
Erkenntnis, dass aufgestautes Wasser „zur Abschwemmung der Hügel und Ebnung der Wiesenfläche“ führte, ohne dass die Wiesenfläche völlig geebnet war, und dass dieser „mit Sand überschwemmte Wiesenfleck bei fortgesetzter Bewässerung sich bald vernarbte, und nun eine vorzüglich ebene Wiesenfläche bildete“(:II), führte zur Ausbildung der Technik des „Wiesenschwemmens“. Es ist nach THAER (:II) ohne Zweifel, ,daß diese Ebnung und Vergrößerung der Wiese besser vermöge der Kraft des Wassers, als durch Abkarren geschehen könne.“

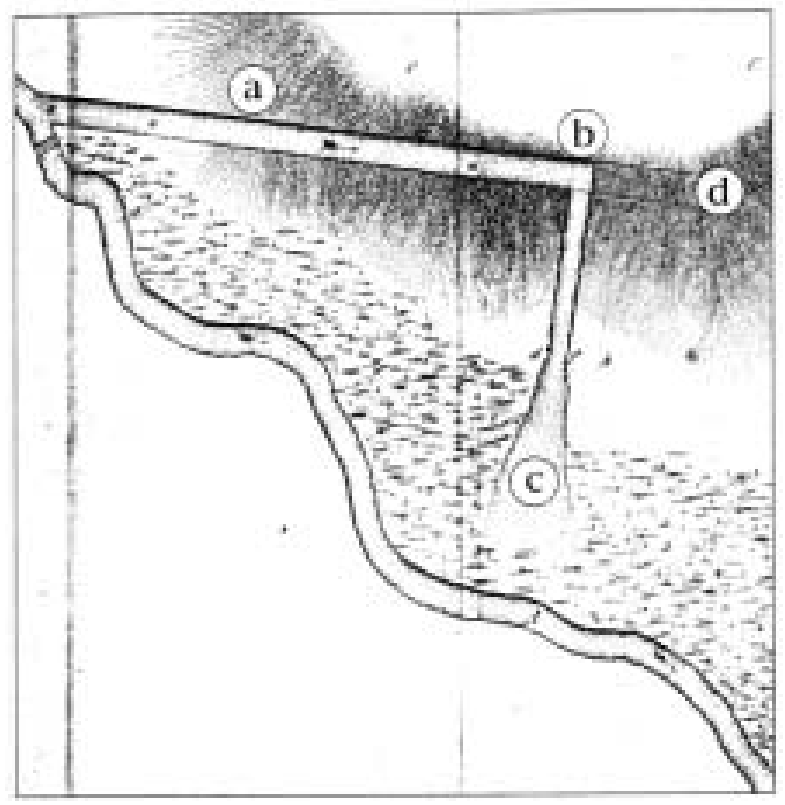

Abb. VII-81: Anlage einer Schwemmwiese:

a. Ableitungsgraben (,hangparallel“), b. Fuß der Talböschung, c. Schwemmfächer, d. geplanter Vortrieb des Grabens (aus: GROTTIAN 2001:8).

Mit dieser Schwemmtechnik wurde im Wesentlichen in verkürzter Zeit eine trockene, breite und möglichst plane Wiesensohle hergestellt, auf der alle Senken und Mulden beseitigt waren (GROTTIAN 2001:13). Der Gewässerstau ermöglichte mit seiner entblößten Kraft die wirkungsvolle Verteilung, wobei sich zunächst ein Schwemmfächer bildete, der weiter wuchs.

Das „Schwemmen“ bzw. „Flößen“ stellte also den ersten Arbeitsschritt und die massivste Geländeveränderung dar, um eine möglichst ebene und weitflächige Bewässerungswiese zu schaffen. Anschließend wurde diese „Kunstwiese“ „mittelst regulärer Bewässerung“ (WEYER 1800:2) als eine fruchtbare Heu- und Mähwiese bewirtschaftet. Gleichzeitig wurde durch die dazugewonnene Breite der Wiesen der Wiesenboden in Richtung Gewässer verschoben. Die Lopau beispielsweise erhielt durch „den Niederschlag des Sandes [...] durchgängig ein neues Bette.“ (:51)

Diverse Gräben und Ableiten waren zudem für einen Kunstwiesenbau notwendig, der in seiner Gesamtheit und weiten räumlichen Verbreitung betrachtet einen erheblichen Eingriff in die Gewässerund Auenlandschaft darstellte: „Zuleitungsgräben“, die von den Flüssen und Bächen idealerweise oberhalb des Stauwerks seitwärts abgezweigt und an den Ort hingeleitet wurden, „wo geschwemmt oder gewässert werden soll.“ (WEYER 1800:8). „Bewässerungsgräben“ wurden ebenfalls oberhalb des Stauwerks ,aus dem Fluß oder Bach heraus“ eingerichtet und an dem höchsten Rand der Wiesen herumgeführt. Kleine „Bewässerungsgrippen“ mit einer Breite von „1 bis höchstens 2 Fuß“ wurden parallel zum Bewässerungsgraben „gleich hinter dessen Beuferung und ferner im Innern der Wiese, geschnitten“. Wurde eine Beuferung der Bewässerungsgräben nicht durchgeführt, erhielten „die vorderen Wiesen bei Aufstauung des Wassers zu viel, die hinteren gar nicht" (THAER 1800:VI). "Zubringer", die den Bewässerungsgrippen das Wasser aus dem Bewässerungsgraben zuführen, „Entwässerungsgräben“, sog. Recipienten, wurden in der größten Senke der Wiesenfläche angelegt. „Gewöhnlich dienen die Flüsse und Bäche dazu, aus welchen oberhalb das Wasser herausgestauet worden.“ „Fanggräben“ galt es herzustellen, die von einzelnen Wiesenstücken oder sog. großlächigeren Revieren das Wasser auffangen und in den Entwässerungsgraben abliefern. Und 
schließlich verschiedenartig gestaltete „Schwemm- oder Flößgräben“, die aus dem Zuleitungsgraben abgehen ,und sich vor der Schwemmbank hinunterziehen.“ (WEYER 1800:9f.)

Des Weiteren erleichterten die ausgeglichenen Flächen der Schwemmwiesen zwar eine gleichmäßige Verteilung des Bewässerungswassers, das Gefälle reichte jedoch in der Regel nicht aus, um eine Stagnation des Wassers und damit die Bildung von Staunässe mit nachfolgender Versauerung des Bodens zu verhindern (GROTTIAN 2001:11). Um eine Vernässung effektiv zu verhindern, ging man dazu über, geneigte Schwemmwiesen ohne Rückenbau anzulegen.

\section{b.1.1.2 Anstauung}

Ein relativ einfaches Bewässerungssystem war ebenfalls die „Anstauungsbewässerung“. Dabei wurde das Wasser nicht auf die Oberfläche der Wiese gebracht, sondern in Gräben aufgestaut. Die Methode der Ein- bzw. Anstaubewässerung beruht auf der Anlage mehr oder weniger horizontaler Gräben, die mit Wasser gefüllt werden. Für die Anstaubewässerung wurde ein Zuflussgraben geschaffen, von dem das Wasser in die Verteilungsgräben, welche die Wiese gleichmäßig durchziehen, geleitet wird (Abb. VII-82). Das Wasser tritt aber nicht aus den Gräben aus, sondern versickert seitlich im Boden und bewirkt so eine Grundanfeuchtung der Grasnarbe in der trockenen Jahreszeit von unten her (PRAGER/VENT 1954:203).

Dieses System führte man dort durch, wo das Wasser nicht so hoch gestaut werden kann, dass die ganze Wiese vom Wasser überflutet wird (PRAGER/VENT 1954:203), zum Beispiel bei eben gelegenen Wiesenflächen. Entscheidend war dabei die anschließende vollständige Entwässerung. War der Boden genügend angefeuchtet, dann wurde das Wasser aus den Verteilungsgräben in einen Abflussgraben abgelassen. Diese wurde durch mehrere Ableitungsgräben oder Drainröhren, welche in größere Hauptgräben mit ausreichendem Gefälle mündeten, geschaffen. Durch Einbau einer Schleuse konnte das Wasser zu jedem beliebigen Zeitpunkt angestaut werden (DÜNKELBERG 1907:141ff; SCHEWIOR 1941:28ff).

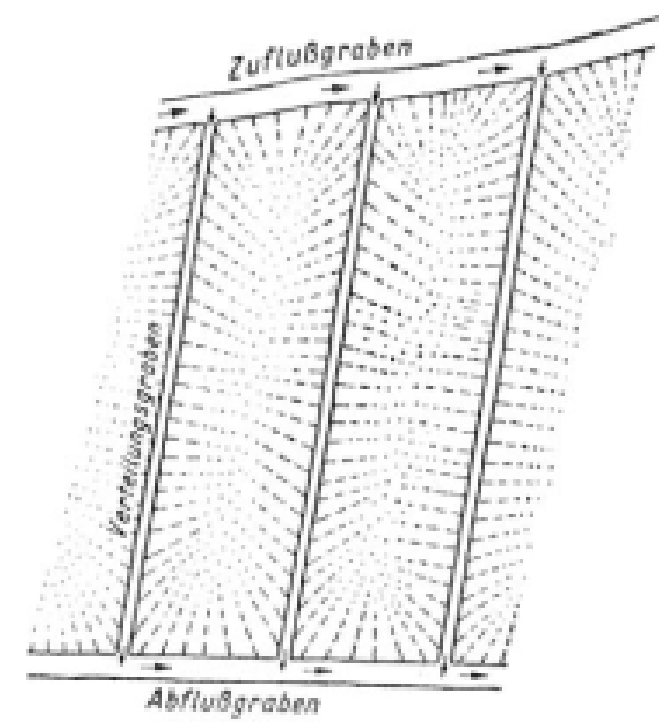

Abb. VII-82: System der Anstauung mit Zu- und Abflussgraben sowie Verteilungsgräben Die Schleuse fehlt hier leider in der Zeichnung (aus: PRAGER/VENT 1954:204). 


\section{b.1.2 Rückenbewässerung}

Bei der Rieselbewässerung wird nochmalig zwischen Überrieselung im

b.1 Hangbau oder

b.2 Rückenbau

unterschieden.

Bei natürlichem Gefälle wurde die Rieselbewässerung im Hangbau angewendet, in ebenem Gelände hingegen war eine solche nur durch die Herstellung eines künstlichen Gefälles, den Rückenbauanlagen, als sog. Beetberieselungen möglich. Die Rückenbewässerung bietet im ebenen Gelände die einzige Möglichkeit, eine Rieselbewässerung durchzuführen. Deshalb wurde die „Bewässerung in der Ebene“ (NAEF 1994:25), d. h. in breiten und zugleich ebenen Talböden, wie sie vor allem im norddeutschen Flachland (z. B. Huntetal) vorkommt, aber auch im Mittelgebirge (z. B. Spessart) nachgewiesen worden ist, zumeist in Form der Rückenbewässerung durchgeführt. Wiesenrücken, künstlich aufgeworfene Beete, legte man bevorzugt in solchen Tälern an, die wegen ihres sehr ebenen Talbodens nicht das erforderliche Gefälle hatten (HÄFENER 1847:229; PERELS 1877:624; FUNK 1882:234). Man spricht deshalb auch von Talbewässerung.

Charakteristisch für das bei dieser mikromorphologisch interessanten Bewässerungsform angewandte System der Überrieselung waren die ,Rieselrinnen' oder ,Wässerungsrinnen'. Diese wurden so angelegt, dass das Wasser über eine oder beide Oberkanten der Rinnen auf die Wiese rieseln konnte. Hierbei wurden geringste Reliefunterschiede genutzt, um das Bewässerungswasser über ein Verteilnetz an Wassergräben und Verteilereinrichtungen gleichmäßig über die feinreliefierten Wiesen zu verteilen (LEIBUNDGUT 1993:34). Dazu war eine gewisse Neigung der Wiesenfläche erforderlich (PERELS 1877:623; DÜNKELBERG 1907: 147ff.; SCHEWIOR 1941:34ff.). War diese nicht vorhanden, wurde sie künstlich geschaffen (KONOLD/ POPP 1994:382f.).

Man erzeugte sie durch den Bau der Beete, deren Herstellung und Wartung sehr arbeitsintensiv waren (SCHRÖDER/SCHRÖDER 1997:10). Der Rückenbau, sagt DENZER (1996:142), war „die technisch aufwendigste Art des Kunstwiesenbaus“. Zur Herstellung dieser Kunstwiesen bedurfte es umfangreicher Erd- und Planierarbeiten, bei denen die gesamte Wiesenoberfläche umgeformt wurde. Dabei wurden auf dem ebenen Talboden zahlreiche, parallel zueinander ziehende, flache, dachförmige Auflandungsrücken geworfen und so ein zusätzliches künstliches Oberflächenrelief geschaffen (siehe Abb. VII-88). Die Breite des Rückens hängt von der Qualität des Rieselwassers sowie von der verfügbaren Wassermenge ab. Je geringer die letztere ist, desto schmaler müssen die Rücken sein (HETZEL 1957:48). Die Breite der angelegten Rücken betrug beispielsweise im Spessart zwischen 5,40 bis 8,50 m (DENZER 1996:142f.) und im Huntetal $6 \mathrm{~m}$ (HETZEL 1957: 48). Wie die Breite der Rücken nach der Wasserqualität und -quantität, so richtet sich ihre Länge nach der günstigten Länge der horizontal liegenden Bewässerungsrippen, d. h. nach der Länge, bei welcher ein möglichst gleichmäßiger Überschlag des Wassers über die Seitenkanten stattfindet (:48). Die Längsstreckung im Spessart betrug ca. $70 \mathrm{~m}$, im Oldenburgischen Huntetal $20 \mathrm{~m}$. Die Gesamtgröße einer sog. Rückentafel betrug dann z. B. 7 x $70 \mathrm{~m}$ im Spessart und im Huntetal 6 × $20 \mathrm{~m}$. 


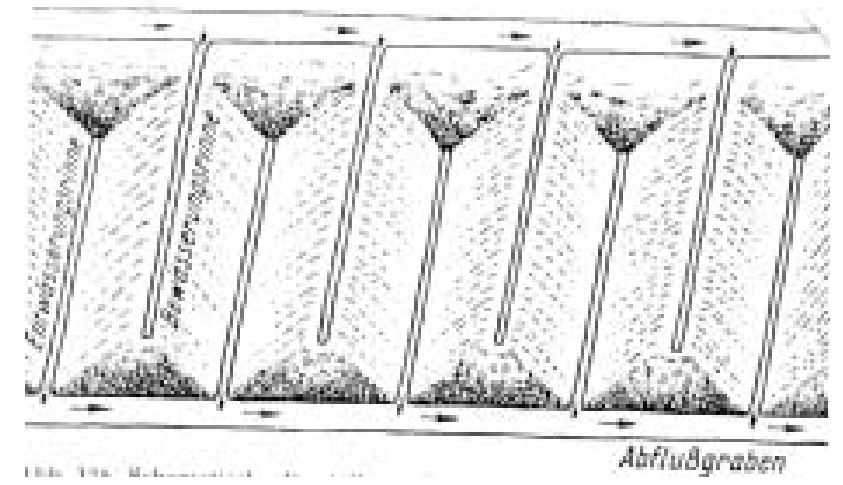

Abb. VII-82: Schematische Darstellung einer Rückenbewässerung (aus: PRAGER/VENT 1954:205)

Das Prinzip der Wässerung entsprach dem des Hangbaus. Die Erdrücken wurden an einer Stirnseite durch einen Damm miteinander verbunden. Über diesen wurde das Wasser aus einem Zuflussgraben in die Bewässerungsrinnen geleitet, die auf der höchsten Stelle der Erdrücken verlaufen. Jedes dieser Beete hatte ursprünglich auf seiner Scheitellinie eine schmale Rinne, von der das sehr langsam fließende Wasser über die Ränder trat und nach beiden Seiten über die Rücken rieselte, sich zwischen den Beeten in einer Entwässerungsrinne bzw. -graben sammelte und das Wasser dem Abflussgraben resp. dem Fließgewässer wieder zuführte (SCHRÖDER/SCHRÖDER 1997:10f.). Die kleinen Bewässerungsgräben auf den Beetrücken, die ob ihrer kleinen Größe heute oftmals nicht mehr erkennbar sind, hatten ein etwas geringeres Gefälle als die parallel zu den Rücken ziehenden Entwässerungsrinnen, durch die das überschüssige Wasser in den Vorfluter zurückgeleitet wurde (DENZER 1996:142f.).

Das den Rieselrinnen von dem künstlichen Hauptzuleitungsgraben am Talrand zugeführte Wasser wurde seinerseits durch ein talaufwärts im Gewässerlauf gelegenes Stauwehr gespeist (SCHRÖDER/SCHRÖDER 1997:10). Das gestaute Wasser wurde hier von dem Wehr in einem Graben bis an den Talrand geführt, der sich dann, wie oben geschildert, in einen talrandparallelen Damm fortsetzte. Von ihm zweigten die schmalen Rinnen ab, aus denen das Wasser über die Wiesen rieselte (:10f.).

Die Überrieselung mit Hilfe von Stauschleusen, mit denen das Bach- oder Mühlgrabenwasser abgeleitet wurde, war die am meisten praktizierte Bewässerungsart (SCHRÖDER/SCHRÖDER 1997:9). Da aber eine solche Anlage erhebliche Bau- und Erdarbeiten erfordert, die mit großen Kosten verbunden sind, wurde die Rückenbewässerung im ebenen Gelände schnell durch die Beregnungsanlage abgelöst.

In Tälern mit keinem weiten Talboden, sondern mit einem muldenförmigen Querprofil, wie er vor allem im Mittelgebirge anzutreffen ist, staute man manchmal den Bach nicht durch ein Wehr, sondern durch einen Damm und leitete von dort das Wasser in einen hangparallel verlaufenden Graben. Er besaß ein so geringes Gefälle, dass es möglich war, von ihm aus das Wasser über die Wiesen rieseln zu lassen. Der Rückenbau war dann von gleicher Ausführung wie beschrieben.

Im Unterschied zur Hangbewässerung (siehe unten) tritt bei der Rückenberieselung das Wasser über beide Grabenkanten aus. Trotz des dadurch bedingten sparsamen Verbrauchs reichte der Zufluss natürlich nicht zur gleichzeitigen Bewässerung der ganzen Wiesenflächen, die früher mehrere hundert Hektar groß sein konnten (siehe VIII 4), aus. Es wurden daher mehrere - oftmals genossenschaftlich organisierte und hintereinander gelagerte - Bewässerungsabteilungen und Unterabteilungen gebildet (HETZEL 1957:60).

In der Regel wurde bei jeder Kunstanlage das abgerieselte Wasser von den Anlagen des einen Stauberechtigten zum nächsten geführt. Die letzten erhielten nur abgerieseltes Wasser (HETZEL 1957:60), d. h. weniger schwebstoffhaltiges Wasser, und brachten das mitunter überschüssige Wasser 
wieder in die Hunte (:55). Maximal wurde das Rieselwasser - zum Teil mit Zuschuss frischen Wassers -12 mal gebraucht (:54).

Die Brauchbarkeit des Flusswassers zur Berieselung hörte bei einer gewissen, zu langsamen Wasserführung wegen der dann starken Sandführung des Flusses auf. Dies war vor allem in Sandbodengebieten des norddeutschen Geestlandes der Fall (HETZEL 1957:60).

Obschon das Prinzip des Rückenbaus in allen Talbewässerungsgebieten gleich war, können hinsichtlich der Bauart der Rückenwiesen folgende Varianten unterschieden werden:

1. angedeuteter Rückenbau,

2. natürlicher Rückenbau,

3. Etagen-Rückenbau und

4. Kunstrückenbau.

Bei der Form der Bewässerung im angedeuteten Rückenbau wurden die Rücken durch das vom Wasser mitgebrachte und abgesetzte Material geschaffen. Dies war die einfachste Form des Rückenbaus.

Der natürliche Rückenbau, die sog. ,Grippen'- bzw. ,Grüppen'-Bewässerung ,ist eine Vorstufe des künstlichen Rückenbaus“" (HETZEL 1957:54). Diese auch ,wilde' Bewässerung genannte Bewässerungsform passt sich ohne erhebliche künstliche Veränderungen dem vorhandenen Gelände an; man schafft höchstens auf den höheren Stellen Grüppen zur Bewässerung, in den tieferen Teilen Rinnen zur Entwässerung. Oft sind überhaupt keine Entwässerungsgräben vorhanden, so dass sich das abfließende Wasser seinen Weg selbst suchen muss (:54).

Die Rückenform entstand hier durch Aufdämmen der Wässerungsrinnen mit Rasensoden und Erde. Mit dem Material der jährlichen Grabenräumungen wurde allmählich ein Gefälle von den Dämmen zu den Ableitungsgräben geschaffen (siehe Abb. VII-89) (DÜNKELBERG 1907:151f.; SCHEWIOR 1941:42). Der natürliche Rückenbau erhielt seine endgültige Gestalt erst mit der Zeit bei langsamer Aufhöhung des Rückens (HETZEL 1957:54).

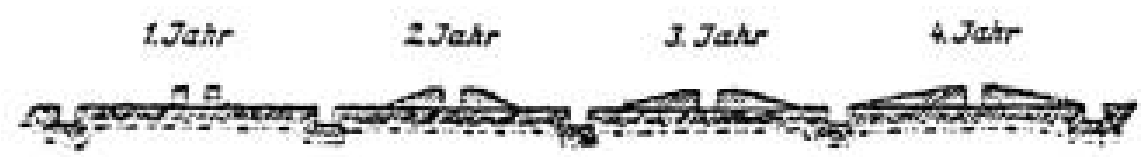

Abb. VII-83: Schematische Darstellung des natürlichen Rückenbaus bzw. der Grippenbewässerung (nach SCHEWIOR 1941, aus: KONOLD/POPP 1994:384, Abb. 5)

Bei Materialknappheit konnte der Rücken abgesetzt werden, wodurch, wie Abb. VII-90 verdeutlicht, die waagerechte Wässerungsrinne langsam auf ein niedrigeres Niveau abfiel und treppenähnliche Absätze entstanden (DÜNKELBERG 1907:151f.).

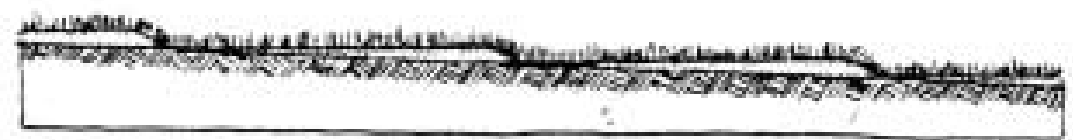

Abb. VII-84: Abgesetzter Rücken des natürlichen Rückenbaus im Profil (nach Dünkelberg 1907, aus: KONOLD/POPP 1994:384)

Die Formen sind insgesamt sehr mannigfaltig, und es bestehen auch vielfache Übergänge zum Kunstbau, wenn da und dort zur besseren $\mathrm{Zu}$ - oder Ableitung des Wassers Veränderungen des Terrains vorgenommen werden. Eine solche Übergangsform zeigt VII-91. 


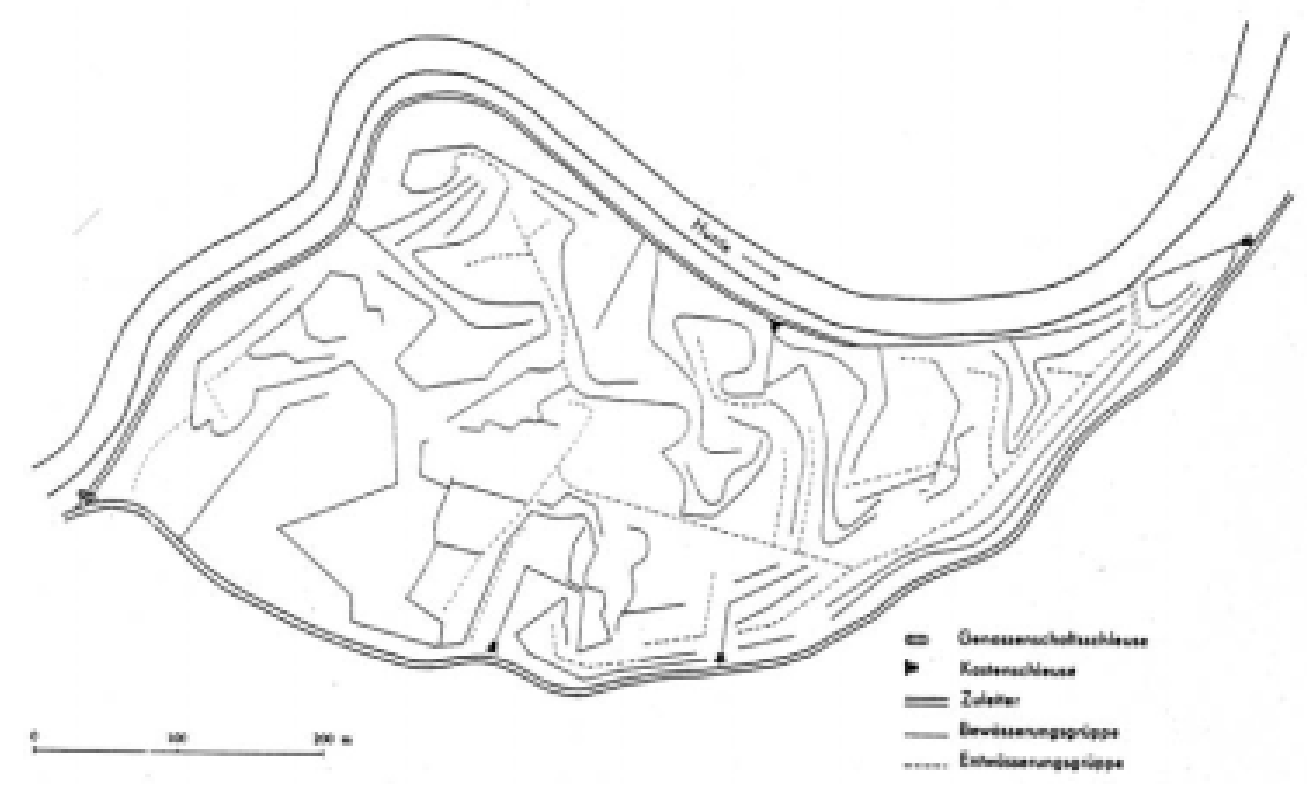

Abb. VII-85: Unreguläre, wenig schematische Anlage; d. h. „,natürlicher Bewässerungsbau“

in Kombination mit der Steuerung des Zuflusses durch Gräben und Schleusen am Beispiel des Huntelaufs (aus: HETZEL 1957:54)

Trotz mancher Verbesserungen in der Wasserführung ist ein planmäßiger Bau bei der wilden Bewässerung - nomen est omen - nicht zu erkennen.

Die Handhabung der Bewässerung war dafür eine denkbar einfache: Die Zuführung des Wassers erfolgte entweder direkt aus dem aufgestauten Gewässerlauf oder mit Hilfe der wenigen Bewässerungsgräben, die das Wasser bis zu den einzelnen Wiesenstücken brachten, wo es dann jeder Besitzer nach Belieben gebrauchen konnte. In gleicher Art erfolgte die Ableitung durch die Gräben (HETZEL 1957:55). Mitunter genügten auch in die Zuleitungsgräben eingelegte Grasplaggen zum Aufstau oder zur Änderung der Fließrichtung des Wassers (DENZER 1996:138).

Das Grabennetz war also wenig ausgedehnt und die Besitzer ziemlich selbständig. Jeder konnte mit dem Wasser, das an sein Grundstück herangeführt wird, „bis zu einem gewissen Grade tun und lassen, was er will“ (HETZEL 1957:56f.). HETZEL (:55) bezeichnet diese Form des Rückenbaus als „,wilde Überrieselung mit billigsten Mitteln“.

Bei dieser einfachen Handhabung liegt die Vermutung nahe, dass es sich bei dieser Bewässerungsform um eine einfache Anlage handelt, die nach einer Wiesennutzung leicht wieder für eine Beweidung präpariert werden konnte und auch ein bedeutend größerer Anteil der Flächen als beispielsweise bei anderen vollendeten Kunstbauten beweidet wurde (HETZEL 1957:54f.; DENZER 1996:138). Es handelte sich um ein ,ausgewogenes Verhältnis von Wiese und Weide“ (HETZEL 1957:57).

Häufig wurde das Wasser auch sich selbst überlassen, worauf sich kleinere oder größere Tümpel bildeten, die dann während kürzerer oder längerer Zeit in den Wiesen liegen blieben; besonders dann, wenn der Boden bereits stark durchfeuchtet war und keine Abflussmöglichkeiten bestanden.

Der Entwässerung in mehr oder weniger ebenen Gebieten musste eine nahezu ebenso große Bedeutung beigemessen werden wie der Bewässerung. Sumpfige Stellen waren zu vermeiden bzw. zu beseitigen, da sie der Heuzubereitung zusätzliche Schwierigkeiten bereiteten. Die entsprechenden Tümpel und Feuchtstellen wurden durch improvisierte Gräben entwässert (WEBER 1971:15).

Beim Etagen-Rückenbau oder Staffelrückenbau liegen mehrere Rückenflächen in der Längsrichtung etagenartig untereinander (HETZEL 1957:59). Dieser Bau ist dem Grippenbau sehr ähnlich. Allerdings konnte die Rückenbreite bei diesem System bis $\mathrm{zu} 30 \mathrm{~m}$ breit abgelegt werden 
(KONOLD/POPP 1994:384). Für das lang gestreckte Huntetal liegt die Breite bei je $10 \mathrm{~m}$ und die Länge der Beete misst hier zwischen 60 und 80 m (HETZEL 1957:59).

Zur gleichmäßigen Verteilung des Wassers wurden waagerechte Rieselrinnen eingeschnitten, in die der ,Transportiergraben' auf dem Rückenfirst sein Wasser ergoss. Der Transportiergraben war ein Ast des Hauptleiters mit der Funktion, den einzelnen Wiesenteilen das Wasser zuzuführen.

Das Längenprofil in VII-92 zeigt die einzelnen Etagen. Die Rücken wurden waagerecht gebaut und kamen so gegen die ursprüngliche Wiesenfläche immer höher zu liegen. Da das Erdmaterial nur in begrenztem Umfang vorhanden war, wurden wie beim Grippenbau Absätze eingebaut (DÜNKELBERG 1907:152ff.).

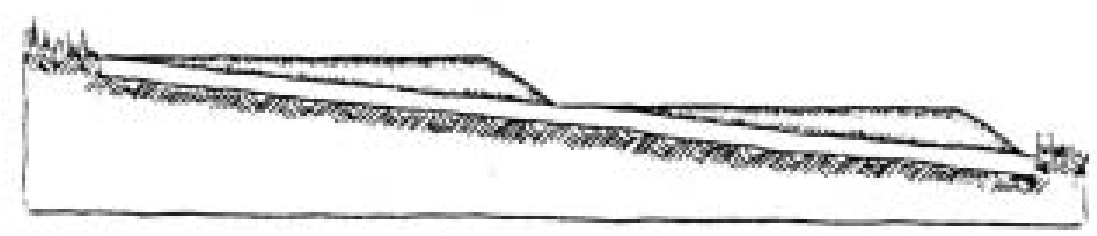

Abb. VII-86: Rücken des Etagen-Rückenbaus im Profil

(nach DÜNKELBERG 1907; aus: KONOLD/POPP 1994:384)

Der Kunstrückenbau besitzt im Unterschied zu den bisherigen Bewässerungsformen die planvollste Anordnung. Er wird deshalb auch als, regelmäßiger Rückenbau' bezeichnet.

Es gab drei verschiedene Formen des Kunstrückenbaus:

a). schmaler Rückenbau,

b). breiter Rückenbau und

c). Beethangbau.

Die beiden erstgenannten Bauarten unterschieden sich nur in der Breite der Rücken und den dadurch bedingten $\mathrm{Zu}$ - und Ableitungssystemen. Während beim breiten Rückenbau ein Transportiergraben angelegt wurde, der das Wasser in die zu beiden Seiten liegenden Rieselrinnen führte, besaß der schmale Rückenbau nur eine einzige horizontale Rieselrinne (Abb. VII-93) (SCHENK 1826:180; HÄFENER 1847:230ff).

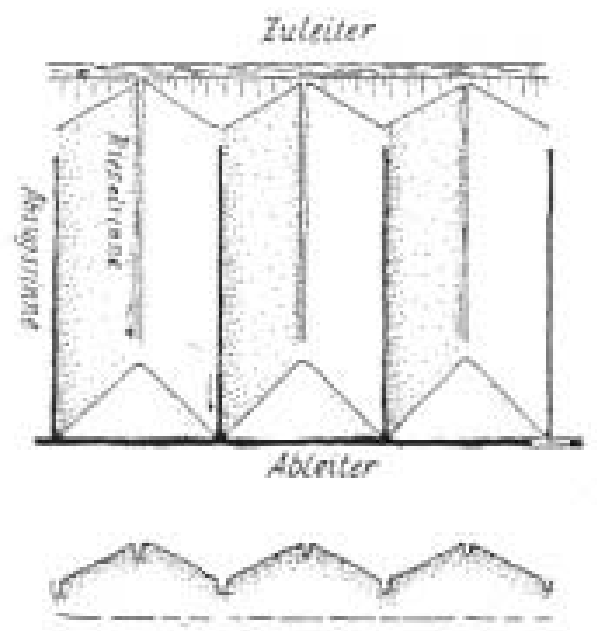

Abb. VII-87: Aufsicht und Längsschnitt des schmalen Rückenbaus (nach SCHEWIOR 1941, aus: KONOLD/POPP 1994:385)

Der Beethangbau wurde angewendet, wenn die Fläche ein für den Rückenbau zu starkes Gefälle aufwies und ein günstiges Nebengefälle vorhanden war: 


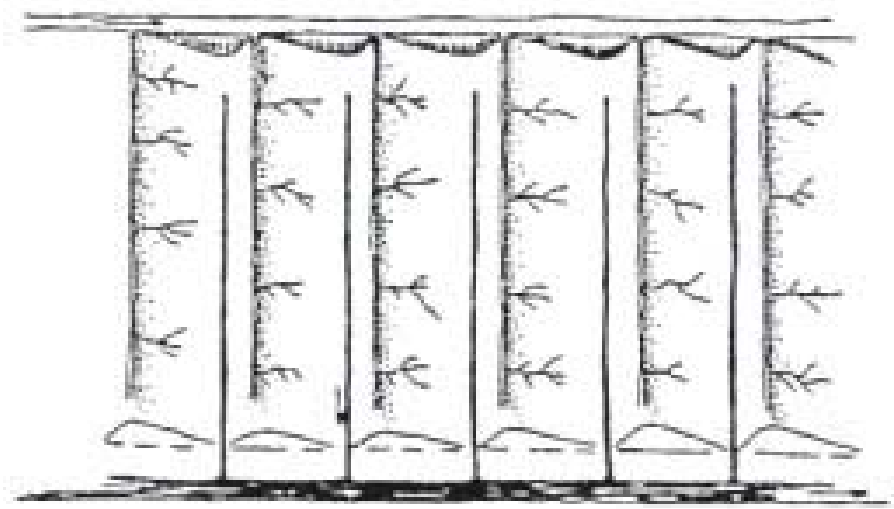

Abb. VII-88: Schematische Darstellung des Beethangbaus (nach HÄFENER 1847, aus: KONOLD/POPP 1994:385)

Unter diesen Bedingungen war dieses System gegenüber dem Rückenbau billiger und erforderte weniger Grundarbeiten: Das Wasser strömte über den Zuleiter in die Rieselrinnen hinein. Von da rieselte es über die geneigte Fläche hinweg in den Ableitungsgraben. Damit das Wasser die Rieselrinne an jeder Stelle verlassen konnte, wurde diese gegen den Ableitungsgraben hin immer schmaler (HÄFENER 1847:235ff.).

\section{b.2 Hangbewässerung}

\section{b.2.1 Hangberieselung}

Bei der Hangberieselung (Abb. VII-95) wird das Bachwasser von einem Zuflussgraben, der sich möglichst an der höchsten Stelle der Wiese befindet, entlang von Talböschungen in die Verteilgräben geleitet. Von diesen läuft es in die eigentlichen Wasserrinnen. Diese sollen parallel zum Zuflussgraben liegen, damit das Wasser über den Rand der Wasserrinne möglichst gleichmäßig dem natürlichen Gefälle folgend über die Wiesenfläche der tiefsten Stelle zurieselt, an der sich der Abflussgraben befindet.

Der Hangbau kann sowohl künstlicher als auch natürlicher Art sein: Beim natürlichen Hangbau werden Zufluss- und Wasserrinnen möglichst den Bodenunebenheiten angepasst. Die Wasserrinnen verlaufen demnach meist nicht geradlinig. Beim künstlichen Hangbau werden die Bodenunebenheiten beseitigt und die Wasserrinnen geradlinig und parallel angelegt.

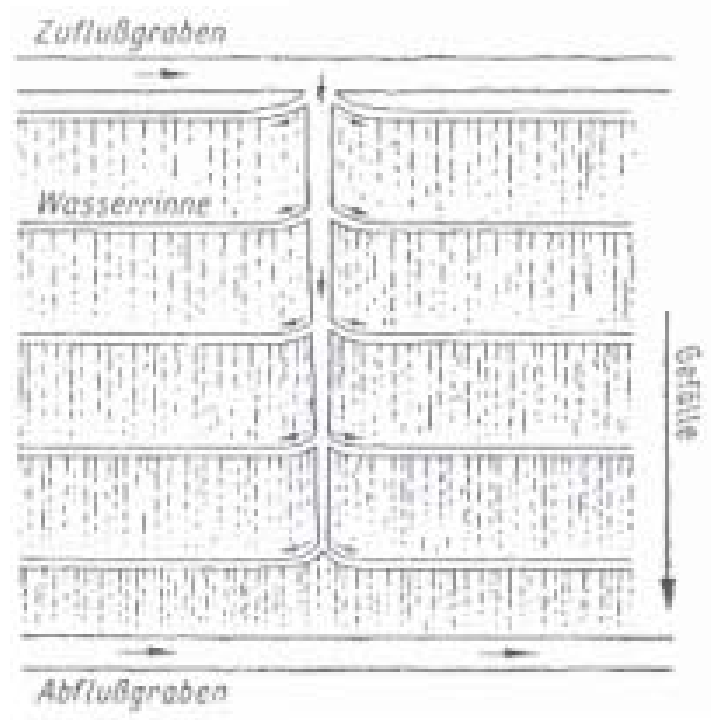

Abb. VII-89: Schematische Darstellung einer Hangbewässerung (aus: PRAGER/VENT 1954:204, Abb. 138) 
Die einfachste und sehr wahrscheinlich auch ursprünglichste und am weitesten verbreitete Form der Hangbewässerung (Abb. VII-91), ist der natürliche Hangbau, der stufenlos in den künstlichen Hangbau übergeht (BÖHM 1990:4).

Der natürliche Hangbau kommt im Allgemeinen erst in Betracht, wenn die Wiese ein Gefälle von ungefähr $2-2 \frac{1}{2} \%$ besitzt (HETZEL 1957:48). War das Gefälle geringer bzw. diese Wiesenoberfläche uneben, so wurde ein gleichmäßiges Gefälle künstlich geschaffen.

Bei diesem System wurde das zur Bodenmelioration benötigte Wasser entweder oberhalb des zu bewässernden Geländes unmittelbar vom Bach abgeleitet oder von seitlich zufließenden Quellwässern direkt in die Bewässerungsgräben geführt (DENZER 1996:138ff.). Von diesen Verteilerrinnen wiederum zweigten in Bögen kleinere Rieselrinnen ab. Direkt aus diesen oder aus den parallel zum Bach bzw. seitwärts versetzt verlaufenden Hauptgräben wurden diese Hänge berieselt (HETZEL 1957:48). Streckenweise wechseln die Gräben ihre Funktionen, d. h. sie dienen einmal als Be-, dann als Entwässerungsgräben (:50). Das überschüssige Wasser, das vom Boden nicht aufgenommen werden konnte, wurde dem im Talgrund verlaufenden Bach wieder zugeführt (KONOLD/POPP 1994:383; PERELS 1877:624ff; DÜNKELBERG 1907:149).

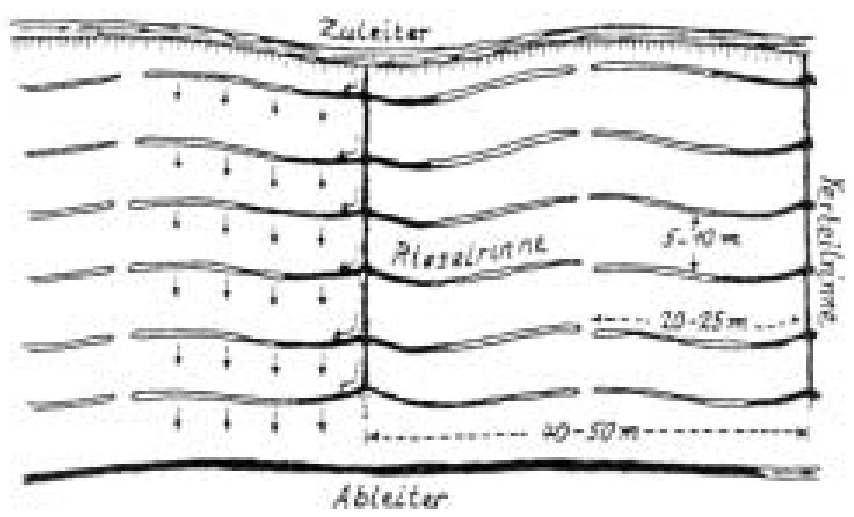

Abb. VII-90: Schematische Darstellung eines natürlichen Hangbaus (nach SCHEWIOR 1941, aus: KONOLD/POPP 1994:383)

Relikte der ehemaligen Bewässerung sind die im Gelände fast waagerecht verlaufenden Bewässerungs- oder Zuleitungsgräben mit einer Sohlenbreite von $40 \mathrm{~cm}$ und einer Tiefe von 50 bis 60 cm (DENZER 1996:137).

Geländemorphologisches Erkennungsmerkmal und zugleich gewässerhistorisches Flächenrelikt stellt die manchmal zu beobachtende auffällige Stufung des Talhanges dar, die auf der Hangfläche in Form von zwei schmalen Verebnungen entlang der Gräben deutlich zu erkennen ist. Sie entstand im Laufe der Zeit durch regelmäßiges Reinigen der Rinnen. Das anfallende Aushubmaterial wurde stets unterhalb derselben aufgeworfen (DENZER 1996:137).

\section{b.2.2 Exkurs: Waale}

Eine technologische Besonderheit und Bewässerungsrelikt der alpinen und subalpinen Hangbewässerung stellen die sog. Waale dar; in der Schweiz wird das alpine Wasserleitungssystem als „Bisse“ bezeichnet (NAEF 1994:25). „Diese großen, kilometerlangen Aquädukte sind die Kronzeugen der ehemaligen Bewässerungswirtschaft, und vor allem sind sie höchst eindruckvolle kulturgeschichtliche Denkmäler.“ (MENARA 1994:146). Die Funktionsweise dieses HochgebirgsWasserleitungssystems soll im Folgenden vorgestellt werden:

Das Wort „Waal“ bezeichnet im engeren Sinne einen künstlich geschaffenen Kanal für die Wasserzuleitung und im weiteren Sinn auch einen Bodenkanal, in dem kein Wasser fließt (MENARA 1994:146). Waale sind insofern auch keine reinen Bewässerungsanlagen, als dass manche von ihnen 
nicht nur zur Bewässerung dienten. Eine andere wichtige Aufgabe war die Trinkwasserversorgung. Besonders dort, wo kein Quellwasser zur Verfügung stand, musste das Trinkwasser aus dem Bach abgeleitet bzw. an einem Gletscherende gefasst werden (MENARA 1994:146; NAEF 1994:25). Insbesondere auf den Almen war dies der Fall. Doch nicht nur Trinkwasser für den Menschen wurde aus dem Waal entnommen, sondern auch das Tränkwasser für das Vieh. Weiterhin konnte ein Waal zur Feuerlöschwasserversorgung verwendet werden. Die Bewässerungskanäle boten daher vielen Siedlungen die Möglichkeit, genügend Wasser nahe an die Brandstelle heranzubringen.

Mit einem Waal konnte auch das Abwasser entsorgt werden. Man glaubte, mit der Aufnahme der Abwässer würde der Nährstoffgehalt größer, und damit seien die berieselten Wiesen ertragreicher. Eine weitere Verwendungsmöglichkeit des Waales lag bei der Ausbringung des Stalldüngers. Diese Möglichkeit wurde besonders auf Almen oder Bergwiesen gepflegt. In Körben (siehe Pkt. VI 13f) wurde der Mist auf dem Rücken auf die steilen Hänge verbracht. Durch das Ausschwemmen auf die Wiesen konnte man sich das Mistausbreiten ersparen, das auf den Steilhängen eine mühsame Arbeit war. Diese alte Methode des ,Mistauswaschens' in längst in Vergessenheit geraten.

Manchmal wurde das Wasser von Hauptwaalen auch als Antriebswasser für Mühlen oder Sägewerke verwendet, wenn Gefälle und Wasserführung hierfür ausreichten. Weiter bestand die Möglichkeit, mit Hilfe des Wassers eines Waales Lawinenreste wegzuschmelzen. Mit Hilfe des bereits wärmenden Wassers konnten Schneereste so aufgeschmolzen werden.

Ein Waal diente auch der Entwässerung. Bei Schneeschmelze oder bei Unwetter nimmt er das überschüssige Wasser auf und leitet es schadlos ab (HELLEBART 1994:192f.).

Hinsichtlich der Aufgabe, die das zugeleitete Wasser zu erfüllen hat, wurde deshalb unterschieden etwa zwischen einem ,Mühlwaal', dessen Wasser das Mühlrad antrieb, einem ,Sagwaal' zum Betrieb eines Sägewerkes, dem ,Schmiedwaal', dem ,Haarwaal' zur Benässung des ausgebreiteten Flachses $($ Haar $=$ Flachs) und dem ,Dorfwaal', ihm oblag unter anderem auch die Trinkwasserversorgung (MENARA 1994:146).

Schließlich aber erfüllte der Waal neben den verschiedenen Nebennutzungen auch seinen Hauptzweck: den der Bewässerung. Ein solcher Waal zum ,Wassern', also zum Bewässern, wird als ,Wasserwaal' bezeichnet.

Beim Bewässerungswaal wird zwischen dem Hauptwaal, auch ,Tragwaal' genannt, weil er das Wasser vom Bach zu den landwirtschaftlichen Fluren ,trägt', und den zahlreichen kleinen, der eigentlichen Bewässerung dienenden Zweigwaalen unterschieden (MENARA 1994:146).

Allgemein werden unter einem „Waal“ die erwähnten Haupt- oder Tragwaale verstanden, von denen einige im Gelände bis heute noch erhalten sind und als waagerecht verlaufende Vegetationsstreifen in den Hängen besonders auffallen.

Da das Ende des zu errichtenden Waals von der Lage der zu bewässernden Fläche bereits vorgegeben war, ging es zunächst darum, von diesem Endpunkt bis zu einer einigermaßen günstigen Fassungsstelle am - allerdings oft weit entfernten - Bach eine Trasse festzulegen. War dies geschehen, konnte man nun vom Bach ausgehend einen ersten kleinen Kanal ziehen (MENARA 1994:155). „In seiner einfachsten und ursprünglichsten Form ist ein Waal ein aus dem Boden gehackter Kanal.“ $(: 154)$

Bei großen Waalen wurde ein größerer Aufwand getrieben: Wenige Meter nach der Erfassungsstelle ergoss sich das Wasser zunächst in den ,Sander' (Sandfang, Sandstube). Hier lagerten sich Kies und grober Sand ab. Das nur noch mit mineralreichem Feinschlamm gesättigte Wasser floss erst nach dieser Filterung in den eigentlichen Graben des Waals. Je nach Bodenbeschaffenheit und Verlauf ist dieser aus Felsgestein herausgemeißelt oder im Boden ausgehoben. 


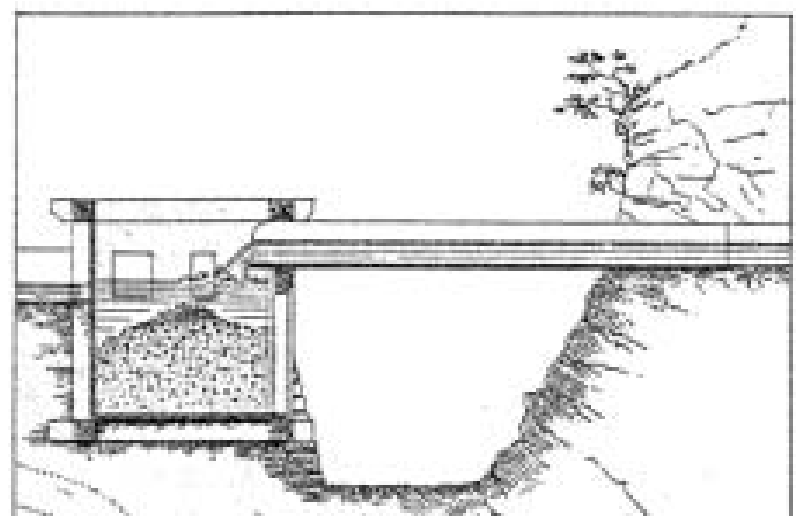

Abb. VII-91: Auffangkasten („Sander“)

Hierin setzt sich das durch einen „Holzkandel“ transportierte Geschwemmsel ab (aus: BLOTNITZKI 1994:41).

Musste ein Waal beispielsweise eine Felswand queren, wurde er entweder als Tunnel oder, sofern sich zufällig ein Absatz dazu anbot, als Rinne in den Fels gemeißelt.

In einem weiteren Fall leiteten sog. Kandeln bzw. Kännel (lat. canalis = Kanal), das sind aus Baumstämmen gefertigte massive große Holzrinnen, die an der Felswand befestigt oder zum Überqueren von Geländeeinschnitten errichtet worden sind, das Wasser weiter (MENARA 1994:154).

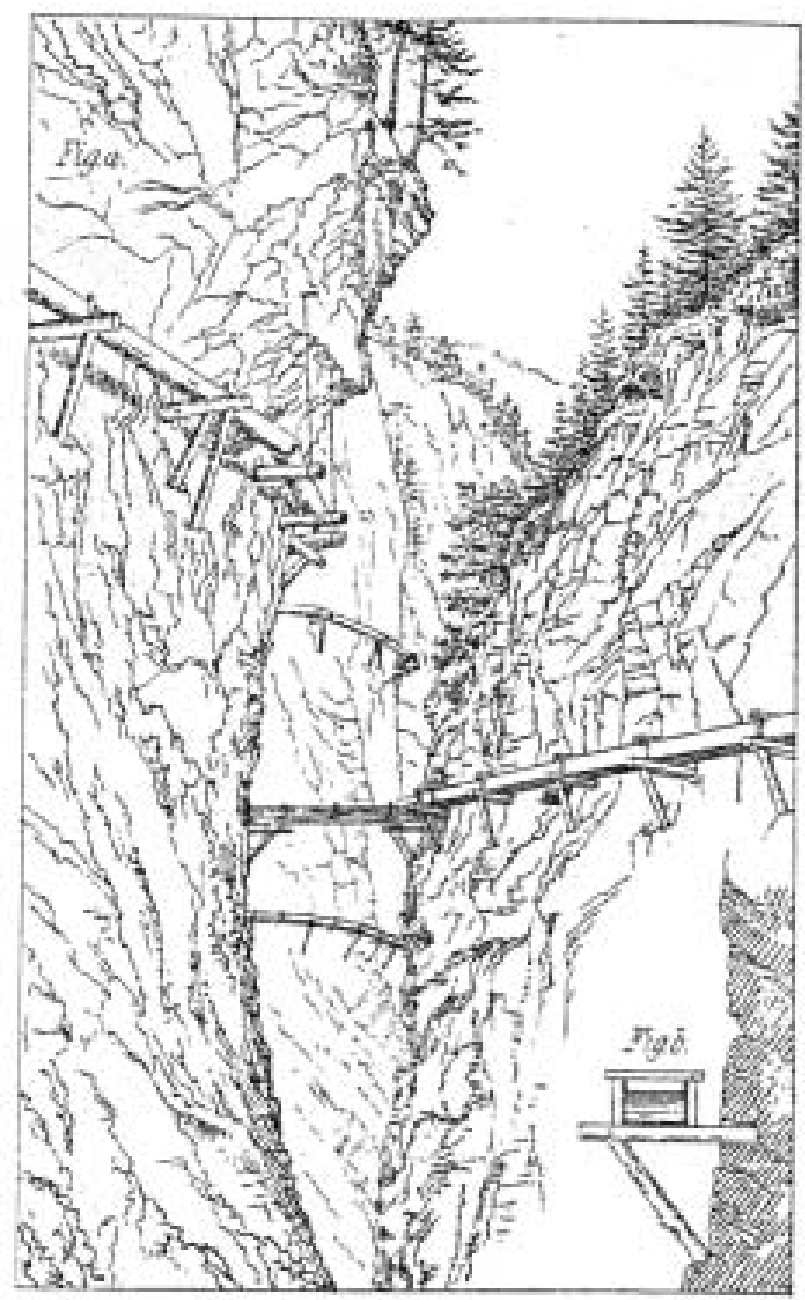

Abb. VII-92: Alpine Bewässerungskanäle

Bei überhängenden Felsen wurden die Kanäle entweder aus Holz hergestellt [1a] und auf hölzerne Traggerüste gelegt [1b], die mittels hölzerner oder - in neuerer Zeit - eiserner Stangen befestigt wurden, deren eines Ende in den Felsen eingelassen ist, während das andere an Drahtseilen aufgehängt wird. Oder aber die „Bisse“ wurden in den Stein gehauen bzw. in Mauerwerk ausgeführt. Eine Arbeit, die manchmal mit Lebensgefahr verbunden war, da die Arbeiter mit Seilen an den Felsen hinuntergelassen werden mussten. Wo Steinschläge vorkamen, mussten die 
Kanäle etwas tiefer in den Berg hineingelegt und abgedeckt werden. Falls nicht zur Überführung von Schluchten und Felsspalten hölzerne Brücken geschlagen wurden, kamen Tunnel aus Ausführung. Die Tunnel wurden mit solchen Ausmaßen ausgeführt, dass ein Mann darin - gebückt - arbeiten konnte. Wie auf der Zeichnung angedeutet, wurde ein hölzerner Steg auf Querbalken gelegt, damit die Arbeiter darauf stehen konnte und bei Steinabbrüchen die Wasserführungen nicht blockiert wurden (aus: BLOTNITZKI 1994: 38f.).

In lockerem Boden mussten beidseits des Wassergrabens Stützborde errichtet werden. Diese wurden bei kleineren Waalen aus starken, biegsamen Weidengerten geflochten. Zwischen das Holzgeflecht wurden Rasenstücke und faustgroße Steine eingedrückt. Bei großen Waalen mit entsprechend stark erodierender Tätigkeit des Wassers und bei Waalen an steilen Hängen sind deshalb die „Seitenwände mit Steinen gemauert, auch die Sohle ist oft gepflastert oder mit Platten ausgelegt. Die im Querprofil größten Südtiroler Waale dieser Art sind bis zu 1,5 m breit und 2 m tief" (MENARA 1994:154).

In der Wasserleitung (,Leite') sind vielerorts Wasseruhren oder Wasserschlegel angebracht. Das fließende Wasser bewegt ein Schaufelrad, an dem ein Hammer befestigt ist. Dieser schlägt auf ein Blech- oder Holzstück und zeigt dadurch weit hörbar, dass genügend Wasser fließt. Steht die Wasseruhr still, kann sofort nachgesehen werden, wo die Wasserleitung unterbrochen ist (NAEF 1994:25; MENARA 1994:154).

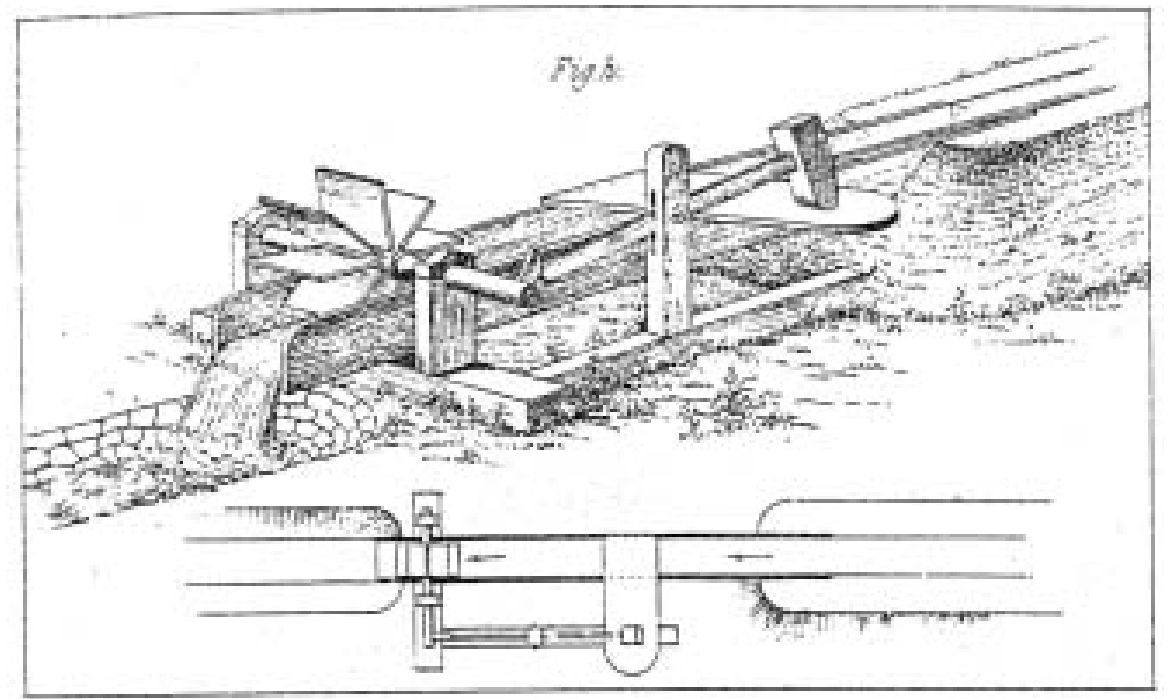

Abb. VII-93: „Schadensmelder“ in einem alpinen Bewässerungssystem

Kleines Wasserrad im Kanal, das in einer Hammerschmiede einen Hammer in Bewegung setzt (aus: BLOTZNITZKI 1994:40).

\section{c Bewässerungseinrichtungen}

Wehre, Schleusen bzw. Fallen, Gräben und Kanäle als Wasserverteilungs- bzw. Wassertransporteinrichtungen sowie Dämme als Überstauungsbegrenzung bilden das Kernstück von Bewässerungsanlagen (WEBER 1971:10).

Von der Verschließbarkeit der Einrichtungen hing im Wesentlichen das zuverlässige Funktionieren der Wiesenbewässerung ab (WEBER 1971:13). Denkt man an die unterschiedlichen Wässerungszeiten und die Folgen einer ungeregelten Wasserzufuhr, wird einem die Bedeutung dieser bautechnischen Einrichtungen bewusst.

Das zur Bewässerung geeignete, nährstoffreiche Wasser muss schnell über die Wiese geleitet und wieder fortgeführt werden. Stände es längere Zeit als stauendes Wasser auf der Wiese, würde sie versauern, Feuchtwiesengräser (Sauergräser) würden überhand nehmen und das Wachstum der wertvollen Süßgräser und Kleearten gehemmt (FIEDLER 1965:22). Aus diesem Grund musste jede Bewässerungsanlage mit einer gründlichen Wasserzufuhr- und -ableitung durch Gräben und Kanäle versehen werden. 


\section{c.1 Dämme}

Um das Wasser auf einer ebenen und breiten Wiesenfläche für einen gewissen Zeitraum zu überstauen, mussten für einige Bewässerungsformen Erdwälle errichtet werden. Eingeteilt in einzelne Talabschnitte lagen die Seitenwände der Dämme im Innenbereich aneinander und grenzten randlich die Wässerwiese zu dem Bachlauf und zum Zuführgraben ab (siehe Abb. VIII-52).

Aber auch in Tälern, die keinen ebenen Talboden, sondern ein muldenförmiges Querprofil haben, schichtete man einen Damm auf, beschritt aber konstruktiv einen anderen Weg: Man staute den Bach durch einen Damm und leitete das Wasser in einen hangparallel verlaufenden Graben. Dieser hatte ein so geringes Gefälle, dass es möglich war, von ihm aus das Wasser über die Wiesen rieseln zu lassen (SCHRÖDER/SCHRÖDER 1997:12).

$\mathrm{Zu}$ der Bautechnik von Dämmen ist in VII c.2.7 ausreichend viel gesagt worden. Doch aufgefundene Dammreste wie auch der eigentliche Zweck einer Bewässerung lassen davon ausgehen, dass die Dämme flacher waren als die zum Beispiel der Forellen- und Winterteiche in der Teichwirtschaft. Doch die flachen Streich- und Ablaichteiche der Karpfenzucht, die den Charakter eines Wiesenteiches aufweisen, können mit den Überstauteichen zum Zwecke der Bewässerung verglichen werden. Mitunter sogar zu einer Verwechslung im Gelände führen, lassen Flurnamen wie „Teichwiese“ (SCHRÖDER/SCHRÖDER 1997:10) eine eindeutige Kennzeichnung der ehemaligen Wirtschaftsweise nicht zu.

Erschwerend kommt hinzu, dass auch in die Erddämme der, Wiesenteiche' kleine Fallen eingerichtet waren, die den $\mathrm{Zu}$ - und Abfluss des Bewässerungswassers regelten.

\section{c.2 Schleusen}

Für diese Technik bedurfte es des Baues einer Stauschleuse und einer Schütze, zum einen, um das Wasser aufzustauen, und zum anderen, um das Bachwasser geregelt in den Ableitungsgraben leiten zu können. Wollte man eine Überstauung des oberhalb des Wehres gelegenen Wiesen verhindern, so musste der Gewässerlauf gedämmt und das Wehr mit Schließen ausgestattet sein (GROTTIAN 2001:11).

Zwei Arten, die sich nicht nur in der Bauweise, sondern auch in ihrer Funktion unterschieden, fanden bei der Wiesenbewässerung Verwendung:

1. die eigentlichen Bachschleusen, auch als Hauptschleusen bezeichnet, und

2. die Kehr- bzw. Steckschleusen oder auch Seitenschleuse (WEBER 1971:10).

Diese Stauvorrichtungen befinden sich in der Regel auf den Besitzgrenzen der Wässerwiesen und werden in der Literatur und den Archivalien häufig als ,Schleusen', ,Schleuschen', ,Fallen' oder ,Wasserschützen' bezeichnet (in Ergänzung zu DENZER 1996:138). Auch die kleinen Seitenschleusen, die den Wasserfluss in den zahlreichen Wiesenbewässerungsgräben regulierten, bezeichnet man stellenweise als Schützen.

Die Bachschleusen bestanden zunächst aus einem Grundgerüst, das früher eine Holzfundamentkonstruktion war und später zumeist aus Pflastersteinen bestand und die ganze Einrichtung stabilisieren und vor dem Wegschwemmen schützen sollte.

In dieses Bodengerüst wurden bei der Holzkonstruktion eichene Pfosten verwendet, beim Steinbau rechteckig zugehauende Steinpaare aus Sandstein, in die lotrechte Nuten eingefügt waren, in die bisweilen zur Verstärkung Eisenstäbe eingesetzt waren. In diese Pfosten, Einkerbungen bzw. Schienen wurden zu Stauzwecken Holzbretter oder Bohlen eingelassen. 


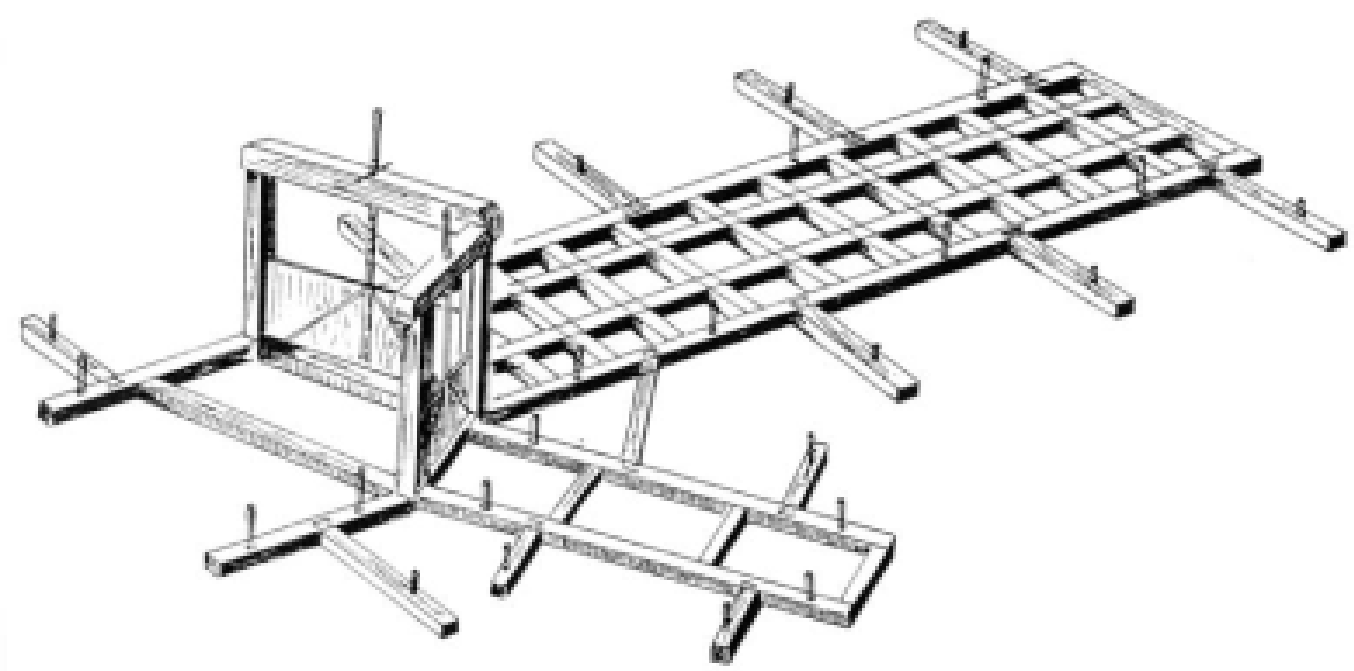

Abb. VII-94: Bodengerüst mit Ansicht der Schleusen-Konstruktion (1)

Die Haupt- und Seitenschleuse sind eingesetzt (aus: WEBER 1971:11, siehe auch nächste Abbildung).

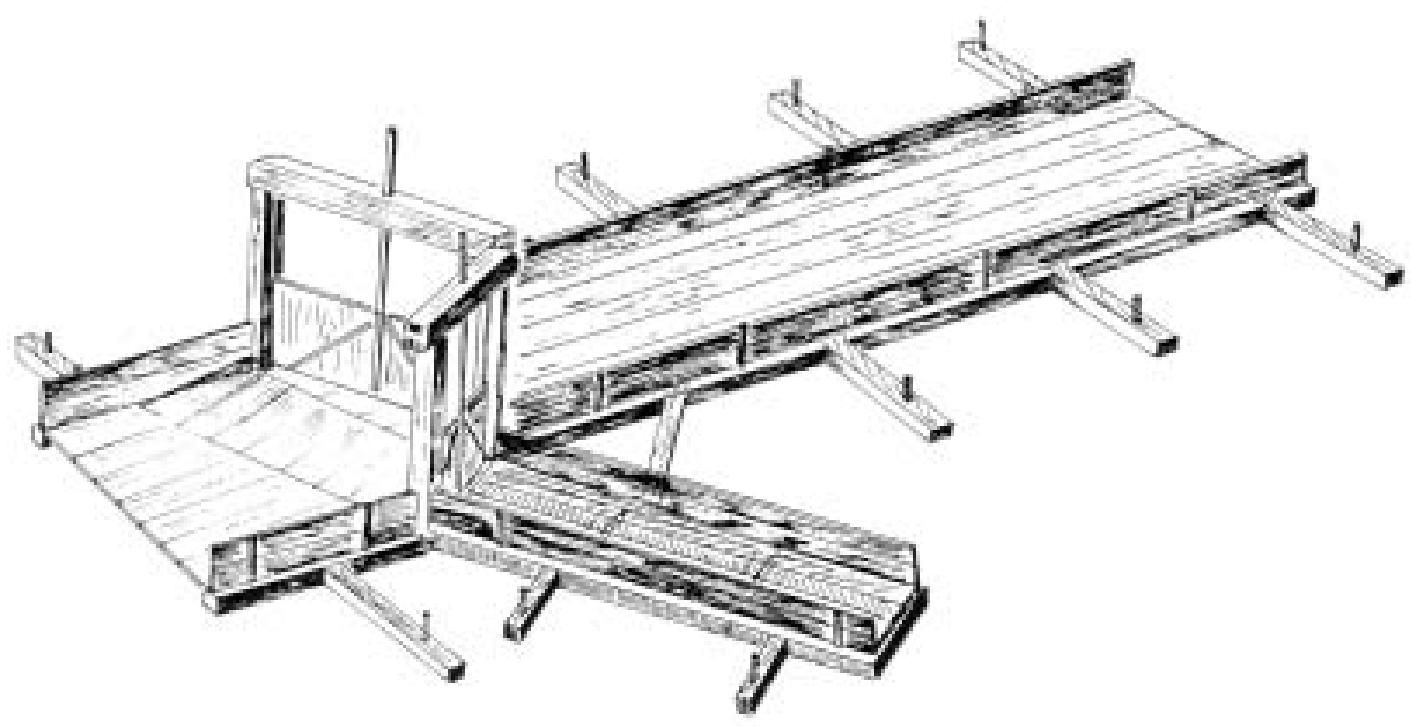

Abb. VII-95: Bodengerüst mit Ansicht der Schleusen-Konstruktion (2)

Zusätzlich zu Haupt- und Seitenschleuse sind Boden- und Seitenbretter eingesetzt (aus: WEBER 1971:11).

Bestand die Anlage nicht aus einem, sondern aus mehreren Brettern, so waren diese aneinandergekettet. Das Brett bzw. die miteinander verbundenen Einzelbretter wurden schließlich mit einer oder zwei eisernen Ketten an einer Welle befestigt, die mittels einer Haspel in der Vertikalen bewegt werden konnten. Handelte es sich um eine größere Staueinrichtung, so vermochten es zwei Männer auf dem Schleusensteg - einem Brett, das vor der Schleuse über den Bach gelegt wurde - die Schleuse durch gleichzeitiges Winden hochzuziehen. 


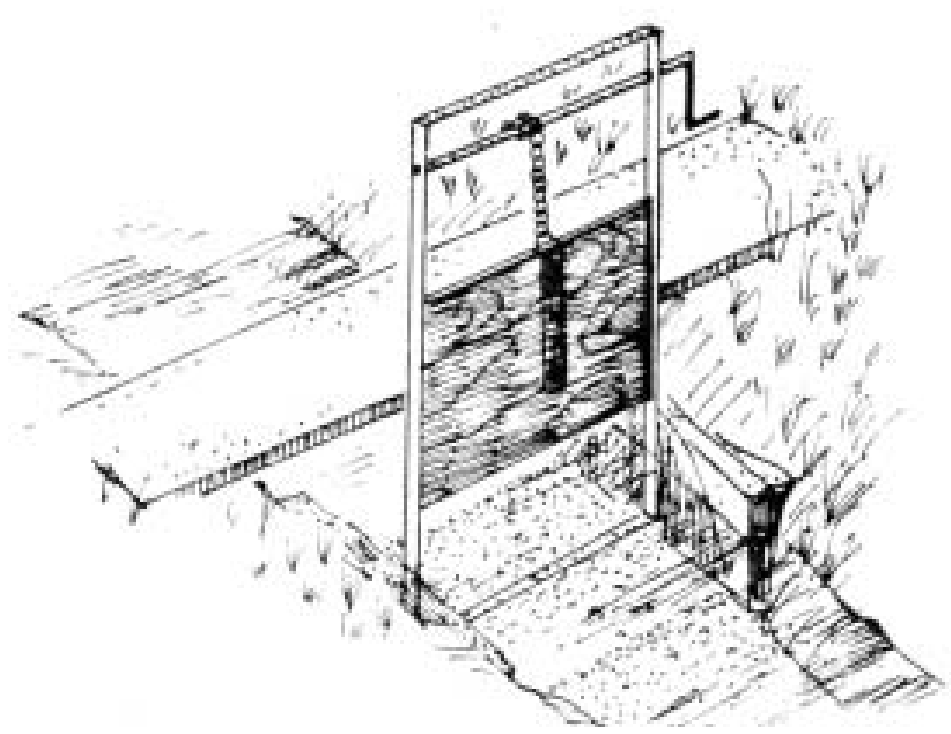

Abb. VII-96: Bachschleuse mit Haspel und einer Kette

Mit der Haspel wurde das Staubrett nach oben gewunden (aus: WEBER 1971:66).

Diese Form der „Fallenkonstruktion“ kam bei Hauptschleusen in Hauptgräben zur Anwendung. Daneben gab es auch Vorrichtungen mit Drehschrauben.
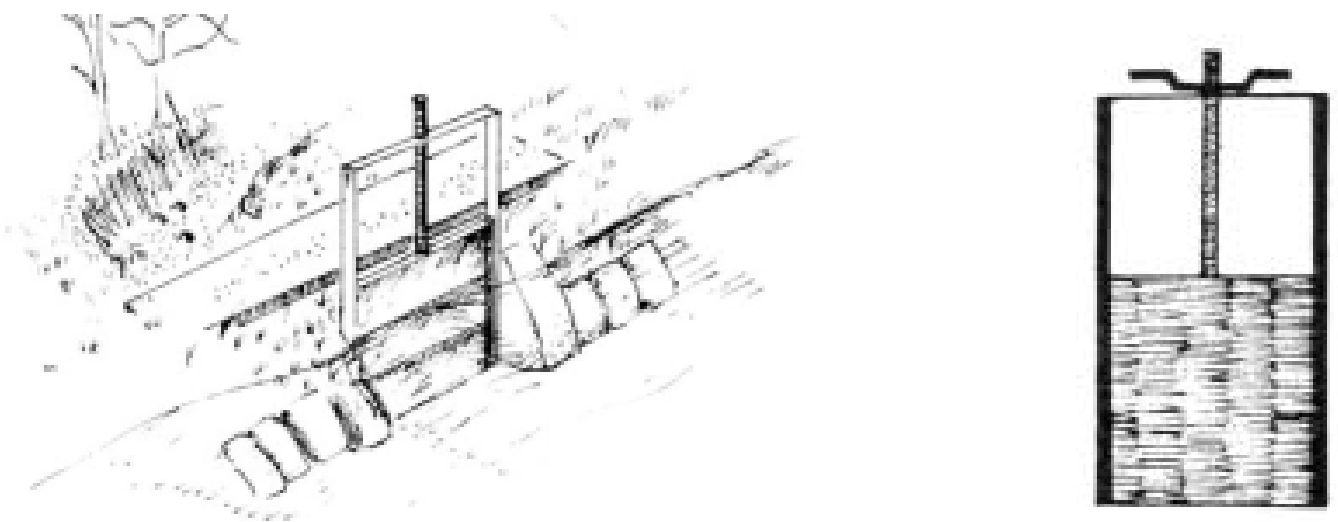

Abb. VII-97: Bachschleuse wie in Abb. VII-102, aber mit Gewinde und Drehschraube (aus: WEBER 1971:66)

Bei Nebengräben waren kleinere Fallen ausreichend, um den Wasserzu- und -abfluss zu regulieren:
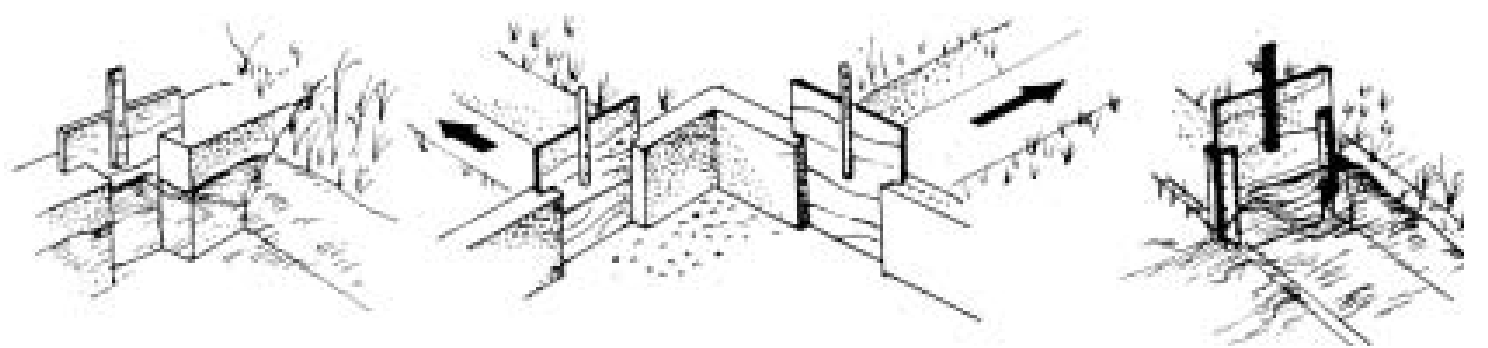

Abb. VII-98: Ansichten verschiedener, kleinerer Schleusen bzw. Fallen (1)

links: Schleusenbretter in Stein- oder Betonfundamenten (aus: WEBER 1971:67) 

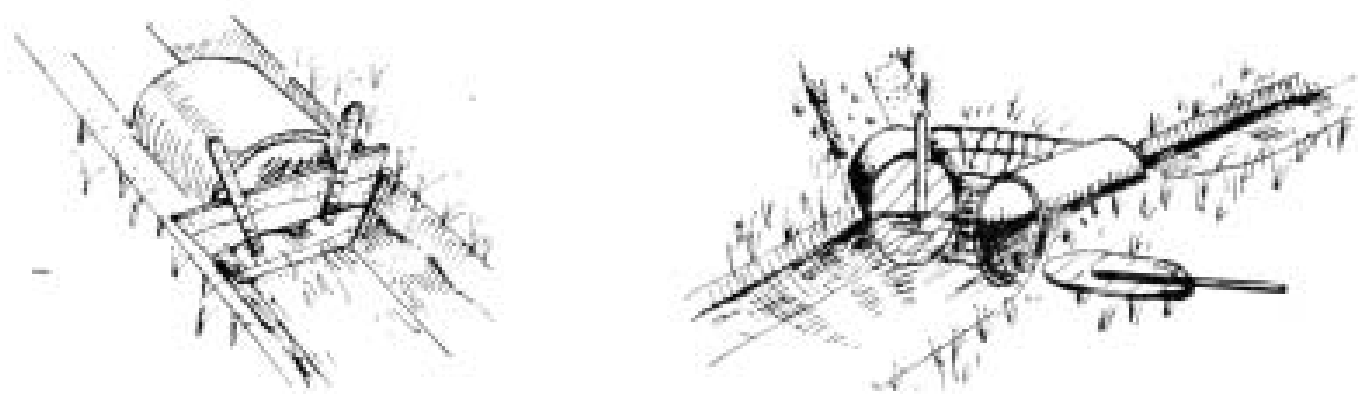

Abb. VII-99: Ansichten verschiedener, kleinerer Schleusen bzw. Fallen (2)

Provisorische Verankerung von Staubrettern vor Röhrenelementen (aus: WEBER 1971:67)

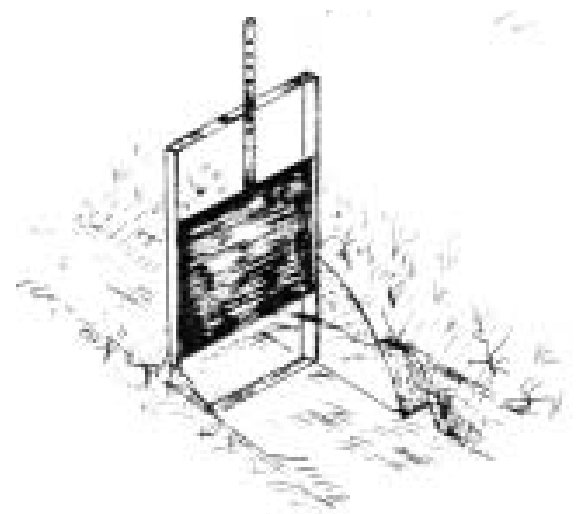

Abb. VII-100: Ansichten verschiedener, kleinerer Schleusen bzw. Fallen (3)

Rahmenverankerung eines Staubrettes zur besseren Stabilisierung (aus: WEBER 1971:67)

Die Beschreibungen der Schleusenkörper ähneln sich. SCHRÖDER/SCHRÖDER (1997:10) beschreibt die Vorrichtungen in ähnlicher Weise wie WEBER (1971:13) und DENZER (1996:138): „Der ,Schleusenkörper' bestand aus einer steinernen Grundplatte auf der Sohle des Flusses und den seitlichen Wänden aus behauenen Buntsandsteinblöcken. Sie hatten senkrechte Falze, die als Führungen für die hölzernen Schütter dienten. Diese konnten durch einen Drehmechanismus auf und ab bewegt werden."

Die Seitenschleusen waren in der Handhabung einfacher. Das wesentlich kleinere und leichtere Schleusenbrett konnte durch eine Person mittels eines in regelmäßigen Abständen durchlöcherten Stabes, der am Brett befestigt war, hochgezogen und durch Einstecken eines Nagel oder kleinen Holzes in jeder Richtung fixiert werden.

Mit Hilfe dieser Vorrichtungen wurde das Wasser nun in den Zuleitungsgräben aufgestaut und auch wieder freigegeben. Das durch die Hauptschleusen aufgestaute Wasser konnte durch die Seitenschleusen mengenmäßig und zeitlich dosiert in die Kanäle und später in die einzelnen Wiesen geleitet werden. Schloss man die Seitenschleusen, so strömte das Wasser an dieser Einrichtung vorbei und drang nicht in die Gräben ein (WEBER 1971:13). 

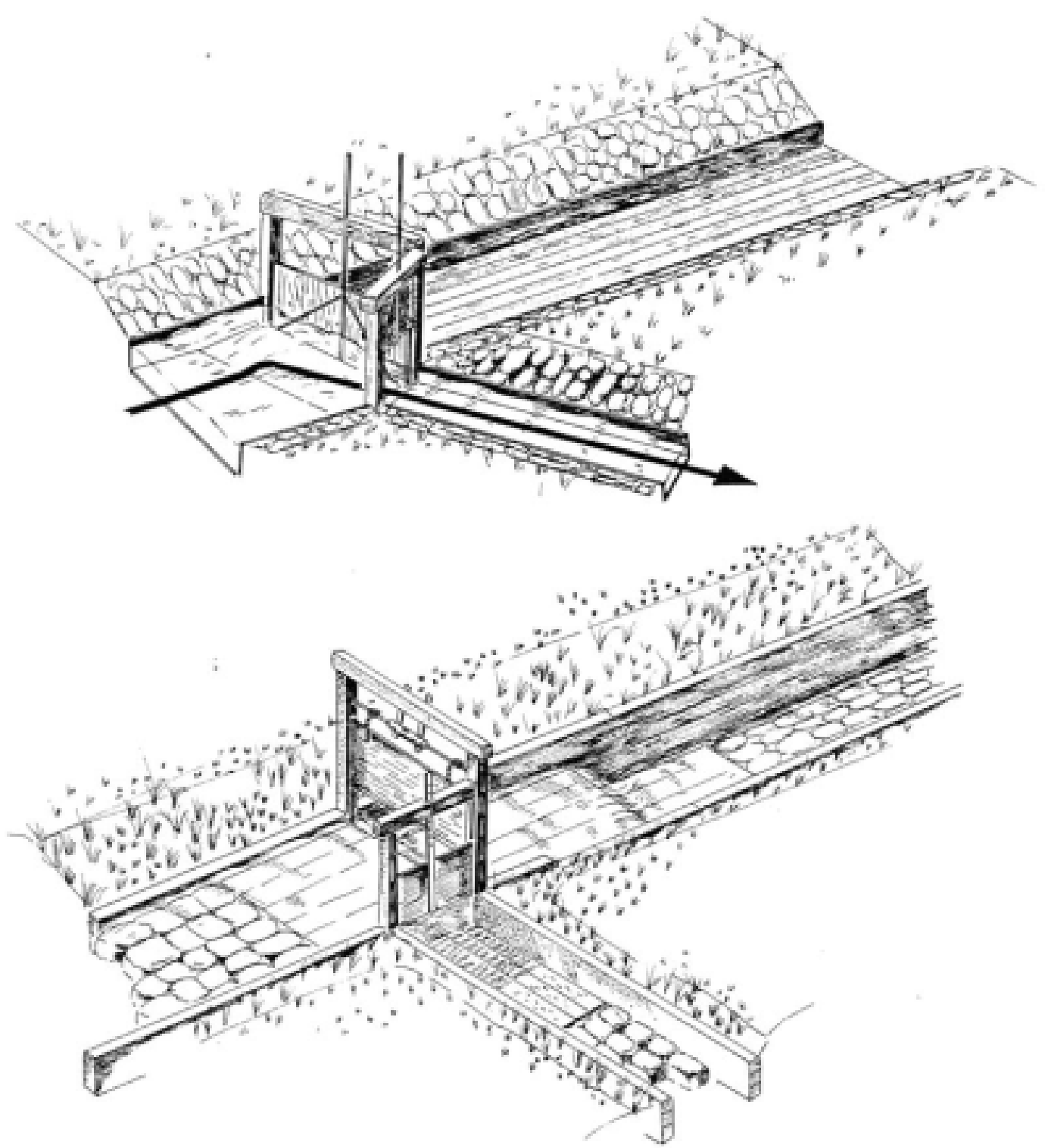

Abb. VII-101: Ansicht einer stabil eingebauten Schleusenkonstruktion

oben: mit Hauptschleuse (geschlossen) und schräg gestellter Seitenschleuse (geöffnet), unten: mit Hauptschleuse (geöffnet) und Seitenschleuse (geschlossen) im rechten Winkel und Grabenbettfundamentierung und Beuferung (aus: WEBER 1971:12, Abb. 3d; :14, Abb. 4b).

Für die Bewässerung von Wiesen wurden viele vom Bach abgehende Stauschleusen und Bewässerungsschützen errichtet und dies aus einem einfachen Grund: „Man machte nämlich die Erfahrung, dass die positive Wirkung des Rieselwassers mit zunehmender Entfernung von der Bewässerungsrinne nachließ. Das lag zum einen daran, dass sich die düngenden Schwebstoffe bis dahin bereits abgesetzt hatten. Zum anderen konnte mit zunehmender Entfernung von der Bewässerungsrinne nicht mehr genügend sauerstoffreiches Wasser in den Boden eindringen.“ (GROTTIAN 2001:13)

\section{c.3 Bach- und Kanalverbauungen}

Um die Standfestigkeit und damit die Haltbarkeit der Staueinrichtungen zu gewährleisten, wurden verschiedenen Bach- und Kanalverbauungen geschaffen. Diese sollten der Erosion an Sohle und Böschung Einhalt gebieten, vor allem an den Stellen, wo die Wasserkräfte durch Umlenkung der Fließrichtung besonders stark waren. 

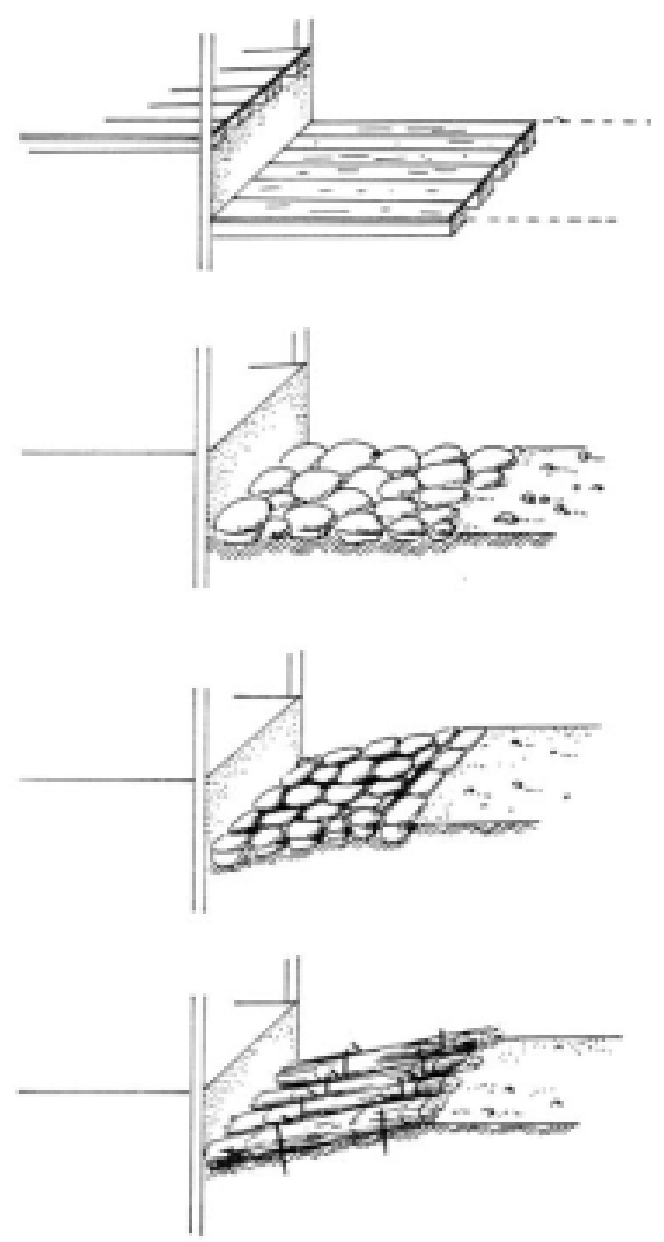

Abb. VII-102: Ausführungen zur Stabilisierung der Grabenbette vor Schleuseneinrichtungen (links, aus: WEBER 1971:19, Abb. 8)

Abb. VII-103: Ausführungen zur Beuferung von Bewässerungsgräben (rechts, aus: WEBER 1971: 20, Abb. 9)

\section{c.4 Kanäle und Gräben}

Von dem zur Bewässerung geeigneten Bach musste ein Zuflussgraben abgeleitet werden. „Dieser mußte so angelegt werden, daß er das Rieselwasser in horizontaler Richtung zu den einzelnen Verteilungsgräben führte. Um eine gleichmäßige Wasserführung zu ermöglichen, war es erforderlich, daß er in seinem Verlaufe etwa die Höhe beibehielt, die er an der Stelle seiner Ableitung vom natürlichen Bach besaß.“ (FIEDLER 1965:26)

Entsprechend ihrer Größe und Funktion werden die Kanäle in solche 1., 2. und 3. Ordnung eingeteilt. Kanäle 1. Ordnung, die den Zufluss auf die Wiesenfläche regelten, nannte man ,Hauptgraben' (in der Schweiz ,Wuhr' oder ,Wasserlaiti'), diejenigen 2. und 3. Ordnung, die die Verteilung auf den Wiesnflächen besorgten, ,Graben' (Schweiz: ,Schlenz'). 


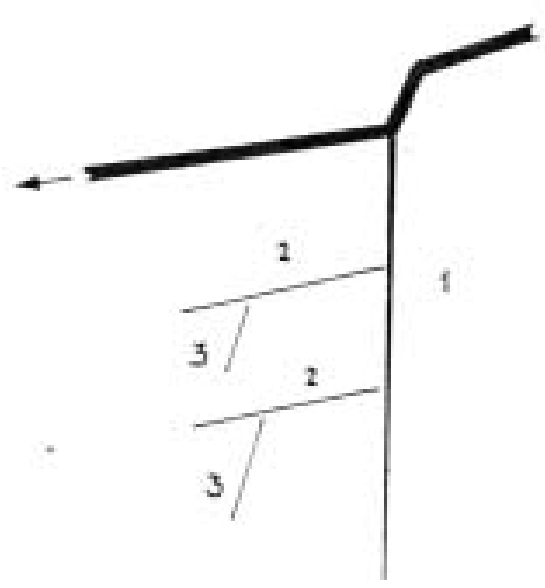

Abb. VII-104: Kanal- bzw. Grabentypen

1. = Kanal 1. Ordnung, 2. = Kanal 2. Ordnung, 3. = Kanal 3. Ordnung (aus: WEBER 1971:16)

Die Zufuhrgräben waren so angelegt, dass möglichst viele Wiesenparzellen bewässert werden konnten. Vor allem hatten sie den Wassertransport bis zum untersten Grundstück zu garantieren.

Die kleineren Gräben leiteten das Wasser in die entsprechenden Parzellen hinein und setzten je nach der gelieferten Wassermenge und der Topographie des Grundstückes die ganze Wiese oder nur eine Teilfläche unter Wasser.

Je nach Anlageform führten sie quer durch die Wiesenflächen hindurch, meistens aber nur am Rande der Grundstücke, an den sog. Kopfbreiten, hindurch (WEBER 1971:15):

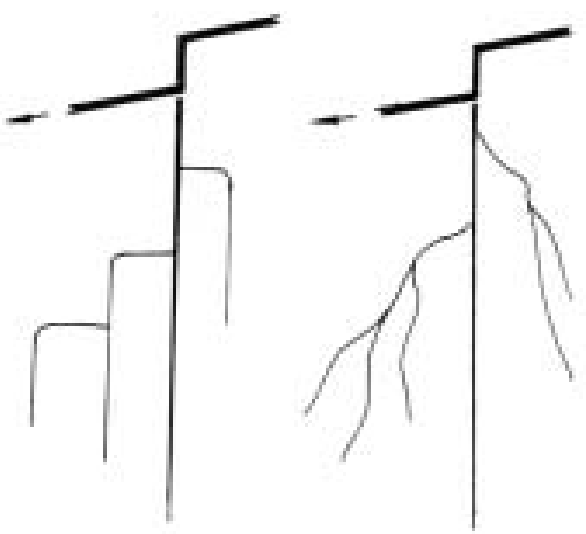

Abb. VII-105: Verlauf der Kanäle und Gräben

links: entlang der Grundstücksbegrenzung, rechts: quer durch die Wiesenparzelle (aus: WEBER 1971:16)

Das sich alsdann in einer Senke ansammelnde Wasser wurde mittels kleiner Rinnen, die mit der Wiesenaxt (vgl. Abb. VII-80) oder der Hacke geschlagen wurden, von den Besitzern oder vom Wiesenmeister nach Möglichkeit zu verteilen versucht. Oft pflegte man das anfallende Endbächlein durch kleine Erdhäufchen oder Rasenbrocken in die gewünschte Richtung zu lenken. Solche Maßnahmen waren vor allem deshalb nötig, da die Wiesenflächen in den wenigsten Fällen gleichmäßig geneigt waren (WEBER 1971:15).

Um eine gleichmäßigere Verteilung des Wassers zu erreichen, erstellte man an den entsprechenden Teilstücken der Kanäle Kerben verschiedener Länge und Tiefe, wodurch das angestaute Wasser höher gelegene Teilflächen besser erreichen konnte (WEBER 1971:77): 


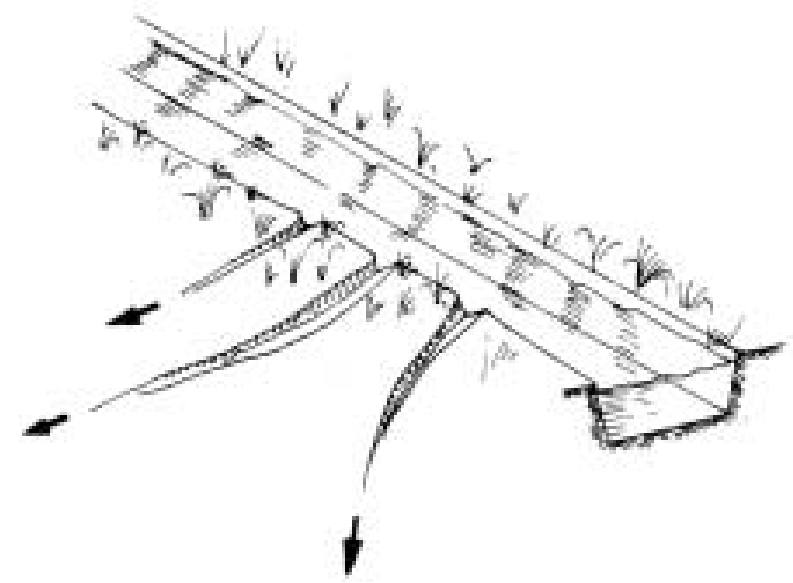

Abb. VII-106: Seitlich an den Gräben angebrachte Kerben

Sie erleichterten den Wasseraustritt und ermöglichten eine gleichmäßigere Befeuchtung der Wiesenfläche (WEBER 1971:78) 


\section{REGIONALER TEIL}

\section{Historische Wassernutzungen in ihrem Landschaftsbezug: geographisch- großräumige Verbreitungen und regionale Schwerpunkte gewässerhistorischer Nutzungen}

In diesem Kapitel soll der Frage nachgegangen werden: Wo und in welcher Größe wurden Fischteiche gebaut, Mühl- und Bergbauteiche errichtet oder wo Wiesenbewässerungen angelegt? Das heißt, welche Verbreitung hatten die ausgewählten landwirtschaftlichen und frühindustriellen Formen der Wasserhaltung und Wasserbewirtschaftung und welchen regionalen Schwerpunkt kann man noch heute erkennen? $\mathrm{Zu}$ welchem Zeitpunkt entstanden sie und wann und warum gingen sie unter und entstanden wieder neu? Darauf soll an dieser Stelle eine Antwort gegeben werden.

Dabei geht bei es dieser Auflistung von Teichen nach ausgewählten Regionen nicht um eine akribische Inventarisation aller Fisch-, Mühl-, und Bergbauteiche innerhalb Deutschlands und des zentralen mitteleuropäischen Raums, wie sie einmal bestanden und noch heute im Gelände zu sehen sind. Dies wäre an dieser Stelle personell und zeitlich nicht zu leisten. In diesem Abschnitt geht es vielmehr um die Übersicht der wichtigsten Teichbewirtschaftungs- und gewässergebundenen Bergbaugebiete und eine Auswahl der Mühlengewässer, an denen eine Vielzahl an Wassermühlen einschließlich ihrer Mühlenteiche standen. Des Weiteren soll durch die Nennung auch eine Vorstellung davon vermittelt werden, wo überall und warum diese gewässerorientierten Nutzungsbauten einmal so verdichtet in der Landschaft vorkamen und - in reduzierter Form - noch heute zu entdecken sind.

Hinsichtlich einer landschaftlichen Einteilung für diese Übersicht habe ich die klassische geographische Kategorisierung nach Höhenstufen vorgenommen. Differenziert nach Tiefland, wobei hier im Wesentlichen das Norddeutsche Tiefland gemeint ist, Mittelgebirge, wobei hier auch das niedrigere Berg- und Hügelland wie auch, undifferenziert, das mittlere, höhere und hohe Mittelgebirge mit eingeschlossen ist, sowie die diesen vorgelagerten Tieflandsbereiche. Schließlich erfolgt die Darstellung des Hochgebirges, das im Wesentlichen die Alpen einschließlich ihres Vorlandes umfasst.

Der Schwerpunkt liegt deutlich auf der Darstellung der räumlichen Verbreitung der für die Fischzucht und

-haltung errichteten Teiche. Aufgrund der besonderen Bedeutung, die die Teichwirtschaft in den „ehemaligen Reichsgebieten und Protektoraten" eingenommen hat, werden diese in einem eigenen, gleich lautenden Kapitel vorgestellt. Zudem handelt es sich dabei um osteuropäische Beitrittsländer zur Europäischen Union, die seit dem Jahr 2004 das geeinte Europa um die zentralen osteuropäischen Gebiete erweitern. Insofern besitzt die Kenntlichmachung der besonderen gewässergebundenen Kulturgeschichte auch einen aktuellen Wert für eine zukünftige Beachtung dieser Vergangenheit im Zuge der Integration.

\section{Teichwirtschaften}

Die Verbreitung der Kleinteichwirtschaft ist heute in erster Linie von kulturgeographischer und touristischer bzw. freizeitlicher Bedeutung. Erst in zweiter Hinsicht stellt sie die notwendige lokale und private Fischversorgung sicher (BRANDENBURG 2003:11). Dies war früher anders.

\section{a Historisch-umweltgeschichtliche Entwicklung}

Die Entwicklung der Teichwirtschaft ist eng verbunden mit der Ausbreitung des Karpfens. Dieser Fisch, der in Nordeuropa ursprünglich fremd war, verbreitete sich ausgehend von seinem natürlichen Lebensraum überall in Europa, da er sich besonders gut als Teichfisch eignete. 
Die Wildform dieses Fisches stammt aller Wahrscheinlichkeit nach aus den warmgemäßigten Gewässern Eurasiens (zwischen Japan, China, Mittelasien sowie dem Schwarzen Meer) und soll zuerst auf der Insel Zypern gezüchtet worden sein. Dieser Herkunft entstammt auch seine zoologische Bezeichnung Cyprinus, die zugleich namensgebend für die Familie der Cyprinidae (Karpfenartige) steht (vgl. SCHÄFER 1997:111; BROHMER 1984:423). Von Zypern aus gelangte er auf dem Handelsweg nach Griechenland und von dort verbreitete er sich mit dem Vordringen dieser Kultur in ganz Europa (TAURKE 1927:1). Hier beschränkte sich der „wilde“ Karpfen auf die Zuflüsse und Deltaregionen des Schwarzen und des Kaspischen Meeres, also auf die Unterläufe von Dnjestr, Dnjepr, Don, Wolga, Ural und der Donau (LAMPEN 2000:134). Durch seine Brackwasserverträglichkeit vermochte er insbesondere in der Nähe seichter Mündungsarme und deltas zu habitieren.

In Mitteleuropa kommt der Karpfen im Gebiet der unteren Donau nachweislich schon etwa seit eineinhalb Jahrtausend vor und war bereits zur Zeit der Römer als Speisefisch sehr geschätzt (WUNDER 1956:5). Neben den schriftlichen Quellen belegen auch die Funde archäologisch nachweisbarer frühmittelalterlicher Karpfenreste die Herkunft des Karpfens aus dem engeren und weiteren Donaubereich. Die aufgefundenen wenigen Reste können mit dem natürlichen Verbreitungsgebiet des Karpfens in Verbindung gebracht werden, der langsam weiter in die Nebenflüsse der Donau vordrang. Dafür spricht auch die Tatsache, dass die Größe der Tiere der natürlichen Größe des Wildkarpfens entsprach, es sich hier also nicht um die domestizierte Form des Karpfens handelt (LAMPEN 2000:135f.). „Diese wenigen Karpfenreste, schriftliche wie archäologische, können die These von einer frühen Karpfenzucht außerhalb des eigentlichen Naturraumes nicht begründen“ und ,weisen von daher nicht unbedingt auf Teichzucht hin“. (:136)

In Deutschland lebte die bis $160 \mathrm{~cm}$ lange Wildform der verschiedenen Zuchtformen, der sog. Flusskarpfen, auch noch bis zu Anfang des 20. Jahrhundert ,nicht allzu selten in flachen Flußläufen und Seen" (TAURKE 1927:4). Der wildlebende Flusskarpfen gilt heute in Deutschland als ausgestorben und europaweit als vom Aussterben bedroht. ${ }^{1}$

Im Zuge der zunehmenden Expandierung und Spezialisierung der Teichwirtschaft entwickelte sich der Karpfen vom begehrten Flussfisch zum wichtigsten Teichfisch Europas. Im Altertum und im Mittelalter wurde fast ausschließlich der Karpfen gezüchtet und seine Zucht in großem Umfang betrieben (BENECKE 1885:IV), obschon es sich bei der Fischzucht anfänglich eigentlich eher um das Halten von durch die wilde Fischerei gefangenen Speisefischen im Weiher (vivarium) handelte (AMACHER 1996:87).

Obgleich der Karpfen der unumstrittene Teichfisch ist, bedeutet Teichwirtschaft nicht gleich Karpfenzucht. In der Literatur und Forschung werden auf Grund mangelnder Differenzierung beide Phänomene häufig gleichgesetzt: In Teichen wurden im Mittelalter nämlich nicht nur Karpfen gezüchtet. Vor allem am Beginn der Entwicklung kultivierten die Teichbauern die verschiedensten Süßwasserfische, vor allem karpfenartige Fische und wertvolle Sorten wie den Hecht; und die alten Römer, so weiß TAURKE (1927:1) zu berichten, züchteten daneben sogar Muränen. Trotz des engen Zusammenhangs müssen daher beide Bereiche, Teichwirtschaft und Karpfenzucht, unabhängig voneinander und nicht als Synonym betrachtet werden (LAMPEN 2000:125).

Über viele Jahrhunderte und noch bis in die 30er Jahre des 20. Jahrhunderts galt der Karpfen als der beliebteste Weihnachtsfisch und wurde deshalb in bisweilen riesigen Teicharealen gezüchtet. Anders als die Wildform des Karpfens, die schlanker als die domestizierte Form ist und nur 30 bis $50 \mathrm{~cm}$ groß

\footnotetext{
${ }^{1}$ Wenn heute Angler einen Flusskarpfen landen, wie zum Beispiel in einem Hafenbecken des Rhein-Main-Donau-Kanals bei Nürnberg geschehen (WEBER 2003), so handelt es sich um die domestizierte Form Dennoch gibt es Versuche der Wiedereingliederung wie das österreichische „Flusskarpfenprojekt“. Seit dem Jahre 2000 ist der Fischereiverein Enns bemüht, in den Donaugewässern die früher weit verbreiteten Fluss- oder Wildkarpfen einzusetzen. Durch fortwährenden Besatz von Flusskarpfen versucht der Verein, diese wieder im Stauraum der Donau, zwischen den Kraftwerken Abwinden und Wallsee, heimisch zu machen (FISCHEREIVEREIN ENNS 2004). Wildlebende Flusskarpfen findet man heute zum Beispiel an der türkischen Küste des Mittelländischen Meeres zwischen den Städten Antalya und Alanya vor der Halbinsel Side (Selimiye) (SIDE 2004).
} 
und 0,5 bis $1 \mathrm{~kg}$ schwer wird (Ausnahmen von über $100 \mathrm{~cm}$ bestätigen die Regel), kann die Teichform bei warmen Temperaturen und Zufütterung eine Größe von mehr als $120 \mathrm{~cm}$ und ein Gewicht von über $30 \mathrm{~kg}$ erreichen. Als Lebensraum bevorzugen sie warme, langsamfließende bis stehende Gewässer mit Sand- und Schlammgrund und reichen Pflanzenbeständen und stellten somit den idealen, anspruchslosen Teichfisch dar (MEYERS KLEINES LEXIKON TIERE 1988:169; LAMPEN 2000:134; siehe auch Pkt. VII 2b.2.1).

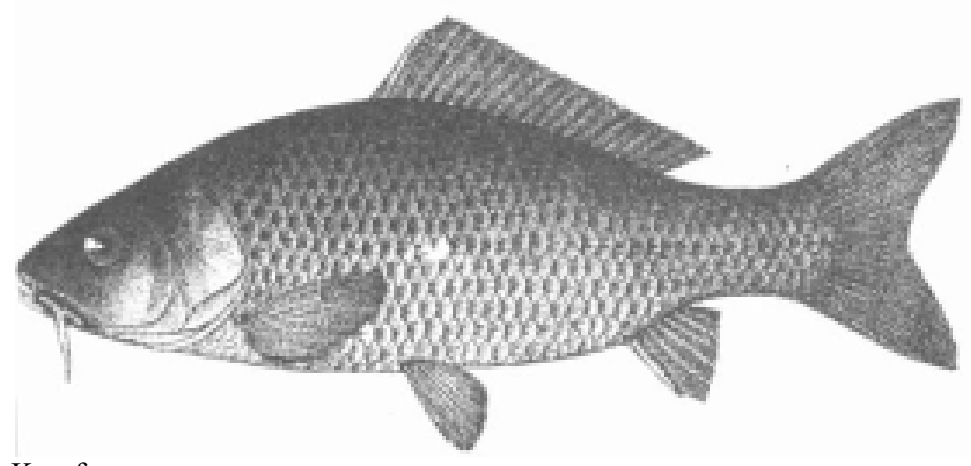

Abb. VIII-1: Der Karpfen

(aus: BENECKE 1885, Abb. 21)

Da die vollständige Karpfenzucht eine entwickelte Teichkultur mit mehreren Teichen voraussetzt, kann sie nicht gleichzeitig zur bloßen Haltung von Fischen entstanden sein. Flächendeckende Hinweise auf die Domestizierung dieses Fisches in Literatur und archäologischen Befunden gibt es vermehrt erst seit dem 13. Jahrhundert (LAMPEN 2000:134). $\mathrm{Zu}$ diesem Zeitpunkt war der Flusskarpfen bereits bis an die Nordsee, hier vor allem im Rheinmündungsgebiet, und bis zur Ostsee (Lübeck) vorgedrungen (:137). „Deutlich muß jedoch herausgestellt werden, daß die Karpfenzucht erst in einigem zeitlichen Abstand zur allgemeinen Teichkultur ihren Einzug in das Gebiet nördlich der Donau gefunden hat.“ (:137) Zunächst musste nämlich erst einmal bemerkt werden, dass die Fische sich in den Teichen nicht nur hältern ließen, sondern auch eine Gewichtszunahme zeigten, und dass eine gezielte Vermehrung möglich war.

Im 13. Jahrhundert belegen erste Archivalien den beginnenden Teichbau und verdichten sich im 14 . Jahrhundert (KONOLD 1991:355). Im späten Mittelalter des 14. Jahrhunderts, in der Zeit nach den bevölkerungsdezimierenden Pestjahren, wurde die Karpfenzucht intensiviert und entwickelte sich zu einem selbständigen Gewerbe (AMACHER 1996:87f.). In diesen Zeitraum treten in den Quellen auch Hinweise auf eine stärkere Bautätigkeit und eine vermehrte Nutzung von bestehenden kleinen Gewässern als Fischweiher augenfällig entgegen (:88). Darüber hinaus nahm man erste kleinflächige Entwässerungen und Moortrockenlegungen zum Zwecke der Fischwirtschaft vor (VIETINGHOFFRIESCH 1961). Die Teiche und damit die Fischzucht entstanden im Verlaufe des Mittelalters in zunehmender Anzahl und Größe.

Die ersten Teichwirtschaften entstanden jedoch in den Talsohlen des Hügel- und Gebirgsvorlandes als Anstau der Bäche zu Teichketten. In den Talsandheiden mit ihrem unausgeprägten Gefälle und Fließgewässersystem sowie den durchlässigen Böden erfolgte die Teichanlage vermutlich erst später. Hier war es nötig, vorher ein komplexes, gut regulierbares Grabensystem anzulegen und meist um den gesamten anzulegenden Teich Dämme aufzuschütten (SCHMIDT 1985).

Gefördert hat den künstlichen Teichbau bzw. die Umwandlung natürlicher Gewässer in Fischteiche die „Agrarkrise“ des Spätmittelalters im letzten Viertel des 14. Jahrhundert. Die Getreidepreise begannen anhaltend zu fallen, wohingegen die Löhne relativ hoch blieben (ABEL 1978:57ff.; AMACHER 1996:89). „Die Verschiebung der Preisrelationen wirkte auf die Wirtschaftsstruktur zurück: Viele Bauern reduzierten den Ackerbau, dafür dehnten sie Sonderkulturen aus, zu denen auch die Fischzucht $\mathrm{zu}$ rechnen ist und deren Produkte sich im Preis besser hielten als das Getreide (HITZBLECK 1971:28; ABEL 1978:78; AMACHER 1996:89). Die Teichwirtschaft bedeutete geradezu „ein Ausweichen der Wirtschaft aus dem durch das Sinken der Getreidepreise unrentabel gewordenen Ackerbau“ (KUHN 1954:152). Hierzu boten sich zum einen Grenzertragsböden an, die bei tiefen Kornpreisen nicht rentabel bebaut werden konnten, aber gerade auch bisher extensiv genutzte 
Sumpfwiesen und Riedflächen, die sich sehr gut eignen, um dort Fischteiche anzulegen. Diese sind in der Regel flach, zum Beispiel verlandete ehemalige Seen, und Wasser ist meist auch genügend vorhanden (AMACHER 1996:89). Die Fischzucht hatte den bisher wenig genutzten Flussniederungen plötzlich einen erhöhten Wert gegeben (KUHN 1954:154). Gleichzeitig verbesserte die Teichwirtschaft ihrerseits die Böden in den Niederungen, indem sie über Sand- und Schotterlagen eine Schlamm- und Humusschicht absetzte (:154).

Die zunehmende Anlage von Teichen steht auch in Verbindung zu den verbesserten Absatzmöglichkeiten aufgrund von besseren Transportwegen: Während zunächst der Fischzucht- bzw. -fangort gleichzeitig auch den Verkaufsort bildete, wurde alsbald nach der Gewinnung von Salinen zum Haltbarmachen von Fischen und der Aufbewahrung von Lebendfisch in Wasserbottichen der Transport in die zuweilen entlegenen städtischen Adelssitze gebräuchlich. Als Transportmittel zu den Absatz- und Verkaufsmärkten, beispielsweise der schleswig-holsteinischen Teichwirtschaften nach Hamburg, Lübeck und Kiel, diente auf kürzeren Strecken zunächst das rinder- bzw. pferdebespannte Wagenrad auf unbefestigten Landwegen, die sich in die Landschaft „hineingefressen“ haben und sich als Hohlwege und Streuwege zum Teil bis heute morphologisch noch erkennen lassen. Später wurden auf künstlich errichteten Heeresstraßen, den Chausseen, die Handels- und Reichsstädte und Adelssitze auf Pferdefuhrwerken beliefert. Aber auch der Wasserweg spielte für den Transport von Fisch aus entfernter gelegenen Teichanbaugebieten eine gewichtige Rolle. Zunächst auf zunehmend regulierten Flüssen und später auch auf künstlich errichteten Wasserwegen, den Kanälen, konzentrierte sich der Speisefischabsatz in Gebiete, in denen die Wildfischerei wie auch die Teichfischzucht nicht so günstig erschien (Klimaungunst) oder in verstädterten Räumen auch gar nicht möglich war. Insbesondere bediente man sich auf längeren Strecken und zum Lebendfischtransport kleiner Barken, die auf den Wasserstraßen zu den Abnehmern getreidelt wurden (siehe auch Pkt. VI 7, 11b).

Die weiteren Gründe für den erhöhten Fischkonsum und damit den Ausbau der Teichanlagen im Verlauf des Mittelalters liegen zusammengefasst darin, dass die Bevölkerungszahl - trotz einiger Rückschläge durch Pestepidemien - über einen langen Zeitraum hinweg anstieg. Es bildeten sich städtische und dörfliche Siedlungsstrukturen heraus und mit den Handel und Wirtschaft treibenden Bürgerschaften entstand eine neue kapitalkräftige Schicht, wodurch eine verstärkte Nachfrage nach Luxusgütern entstand und der Fisch gehörte auch zu diesen Luxusgütern. Fisch galt als teuer (1 kg Karpfen kostete zeitweilig viermal so viel wie ein Kilogramm Rindfleisch), war ein ausgesprochenes Herrenessen und genoss ein hohes gesellschaftliches Ansehen (KONOLD 1991:356). Die heute so begehrten „Meeresfrüchte“ waren zu diesem Zeitpunkt zudem auch noch den Mittelmeerländern vorbehalten und darüber hinaus steigerte im 15. Jahrhundert das Ausbleiben der regelmäßigen Heringszüge in die Ostsee den Bedarf an Süßwasserfischen (KUHN 1954:152).

Des Weiteren betrieben die Klöster, nachdem sie jahrhundertelang überwiegend Schenkungen verwaltet hatten, eine aktive Wirtschaftspolitik: Fisch besaß eine außergewöhnlich gute Marktlage nicht nur weil er als Fastenspeise im Mittelalter immer eine große Rolle spielte (KUHN 1954:152); die Renditen waren hervorragend, denn Fisch brachte, wie bereits oben genannt, ein Mehrfaches als Rindoder Schweinefleisch ein, und die Baukosten amortisierten sich insofern schnell. Infolgedessen nahm die Kaufkraft der herrschenden klerikalen Schichten zu, und, was den Teichanbau zusätzlich beflügelte, er kam beileibe nicht nur an den Fastentagen auf den Tisch (KONOLD 1991:356).

In der Betrachtung der Geschichte des klösterlichen Teichbaus darf ein Aspekt nicht außer Acht gelassen werden: Bereits im frühesten Mittelalter ließ „das rücksichtslose Wegfangen der laichreifen Fische in ganz kurzer Zeit die Nahrungsquellen versiegen.“ (SKOWRONNEK 1904:8). Nicht nur das „Räuberwesen auf den Gewässern“, sondern auch die Gerechtsamen, Adel wie Klöster selbst fischten ,jeder in rücksichtsloser Weise [...], um dem Gegner Abbruch zu tun.“ (:8) und lagen untereinander in erbittertem Kampf wegen der Fischereigerechtigkeit: „Da sperrte einer den Abfluß [...], um den zum Laichen heranziehenden Fischen den Austritt zu wehren, der andere fing natürlicher zur Vergeltung die notgeringen am Seeufer laichenden Fische in großen Massen weg, und zur Abwechselung lieferten sich die beiderseitigen Knechte regelrechte Wasserschlachten, bei denen es sehr heiß zuging." (:9) 
Wenn auch die Klöster schon recht früh weitgehende Privilegien zur Beschaffung ihrer Fastenspeise erteilt bekamen, so bekamen aber auch sie den Fischnotstand zu spüren. „Infolge dieser Entwicklung“, so die Argumentation von SKOWRONNEK (:9), „griffen die geistlichen Herren zu einem sicheren und besseren Mittel: sie legten Fischteiche an.“

$\mathrm{Ab}$ dem 14. Jahrhundert setzte ein regelrechter Boom in Sachen Teichbau ein - KONOLD (1991:356) spricht von einem wahren „Weiherboom“ -, in dessen Verlauf das Landschaftsbild durch Dämme und Wasserflächen nachhaltig geändert wurde (:355). Es war eine regelrechte Teichbauindustrie, wobei hauptberufliche Tichtgräbermeister mit zahlreichen Gesellen quer durch das Land zogen und zum Teil ausgedehnte Teichanlagen schufen. In allen Teilen des Reiches ,wurden zahllose Weiher und Teiche gebaut.“ (:356) Ab Anfang des 16. Jahrhunderts erfolgte der Aufbau von für die damaligen Verhältnisse sehr leistungsfähigen Teichwirtschaften, die hauptsächlich im Besitz der Gutsherren, Städte und Klöster waren. Die Teiche wurden entweder auf grundwassernahen Standorten (vernässten Wiesen) angelegt, wobei der Oberboden nach außen zu Dämmen aufgeworfen wurde, oder aufgelassene Torfstiche, Raseneisenerz-, Lehm- oder andere Gruben wurden in Teiche umgewandelt (FÜLLNER 1995). Dies ging schließlich so weit, dass Kaiser Rudolph II. (1576 - 1612), König von Ungarn, Böhmen und Mähren, auf dem Reichstag den Bau von Weihern ohne besondere Erlaubnis verbot, da „des Anbauens der Teiche kein Ende gewesen“ (aus: KOCH 1925:28).

Gegen Ende des Mittelalters war die Karpfenzucht in Deutschland und Europa weit verbreitet. Ihren Höhepunkt erreichte die Fischzucht jedoch erst in der frühen Neuzeit. Hier erfolgten die Maßnahmen des Teichbaus im größeren Umfang (VIETINGHOFF-RIESCH 1961; LAMPEN 2000:134). Komplizierte Teichanlagen mit separaten Teichtypen für die verschiedenen Aufwuchsphasen sind das Kennzeichen dieser späteren Geschichtsperiode (LAMPEN 2000:124f.; siehe Pkt. VII 2.b.2).

Die Blütezeit der schleswig-holsteinischen Teichwirtschaft beispielsweise reicht vom 15. bis weit in das 17. Jahrhundert hinein. Die holsteinischen Klöster besaßen den größten Teil des Kulturlandes und auch die darin liegenden ausgedehnten Teichflächen. Dies lässt sich allein damit begründen, dass durch die weiteren Kongregationen hierbei auch die Anlage von Teichen eine ständige Mehrung erfuhr. Seit Beginn des 16. Jahrhunderts kam dann die gutsherrliche Teichwirtschaft hinzu. Ein halbes Jahrhundert prägten sodann Klöster und Güter gemeinsam die Wirtschaftsform und damit die Kulturlandschaft Ostholsteins (RUST 1952:21). KOCH (1924) nimmt an, dass im ausgehenden Mittelalter in Franken eine 3 - 4fache Anzahl von Karpfenteichen in Nordbayern bestanden habe als in den 1920er Jahren.

Infolge der mit der Zeit immer strenger lautenden Fastenvorschriften der katholischen Kirche wurde der Teichwirtschaft der Boden geebnet dadurch, dass eine immer größere Nachfrage nach der Fastenspeise, den Fischen, entstand (CNOPF 1927:17). Aber nach CNOPF (:17) darf dabei ein sehr wichtiger Faktor nicht übersehen werden, die „Erziehung des Geschmackes“. Er hält „dieses Moment für das primäre“ und argumentiert: „Strenge Fastenvorschriften waren gegeben, aber das war nicht gleichbedeutend mit ausschließlichem Verzehr von Fisch an Fastentagen, sondern bedeutete nur Enthaltung von Fleischgenuß an diesen Tagen. Diese Geschmackserziehung konnte sich erst im Laufe langer Zeiträume so gründlich durchsetzen und einbürgern, wie es dann später tatsächlich der Fall war."

Wir sehen also, dass mit ausgehendem Mittelalter der Fischkonsum eine erstaunliche Dimension in geistlichen wie weltlichen Kreisen gewonnen hatte. Zudem wurde eine nicht unbeutende Menge an Seefischen konsumiert, die wegen der hohen Frachtspesen zu hohen Preisen feilgeboten wurden. Der naheliegende Schluss, dass die Fische infolge der ausgedehnten Teichwirtschaften sich durch besonders billigen Preis ausgezeichnet hätten, trifft aber nicht zu (CNOPF 1927:17f.). Nicht jedenfalls der Mangel an Angebot, der infolge der unzähligen Teichanlagen nicht gegeben war, trieb die Preise in die Höhe und führte zu einem Neu- und Ausbau von Fischweihern.

Zuerst durch den Bauernkrieg (1524/26), nachfolgend durch den Dreißigjährigen Krieg (1618 - 1648) - nur unterbrochen durch eine kurze Erholungsphase danach - endete die Zeit ertragreicher Teichkultur. Die Kriegswirren führten zu ihrem Niedergang mit Preisverfall unter Auflassung vieler 
Teiche (KEIZ 1995:18). Viele Weiher wurden von durchziehenden Soldaten zerstört. Manche Dämme und Ablassvorrichtungen setzte man nur notdürftig oder auch gar nicht mehr instand (KONOLD 1991:364). Doch der Dreißigjährige Krieg war nur ein markanter Punkt (:364): Es folgte der langsame Verfall der Teichwirtschaften, verstärkte sich nachfolgend durch die Reformation und das damit verbundene Ende der strengen Fastengebote (CNOPF 1927:23) sowie durch die Klosterauflösungen (Säkularisation) seit Beginn der zweiten Hälfte des 16. Jahrhunderts, um sich im zeitlich versetzten Gefolge im 18. Jahrhundert weiter nennenswert zu verringern und zu Anfang des noch jungen 19. Jahrhundert fast völlig von ihrer Höhe abgezogen zu werden. Diesen Abfall hatte bereits BORNE (1886:262) erkannt und die reliktäre Landschaftssituation mahnend beschrieben:
„Die Karpfenteichwirthschaft ist uralt, sie wurde früher in viel größerem Umfange betrieben wie heute, und noch jetzt deuten an vielen Orten alte Teichdämme oder Namen von Feldern und Wiesen darauf hin, daß dort früher Teiche vorhanden waren. Im 16. Jahrhundert wurde in Deutschland der Teichbau mit ganz besonders großem Eifer betrieben, in späteren Jahrhunderten wurden die Teiche zum großen Theil kassirt [...]."

Die Teichdämme zerfielen, die Fische degenerierten. Statt die Dämme wieder herzustellen, wurden die Teiche zumeist vollständig trocken gelegt und zu Acker oder Wiese umgebrochen. Teiche, welche infolge periodischer Vernässung nicht gut trockengelegt werden konnten, wurden „meistens zu verwahrlosten Wasserlöchern " (TAURKE 1927:1). Bei den verbleibenden Weiherflächen waren bei der Bewirtschaftung mangelnde Professionalität und Sorgfalt zu verspüren (KONOLD 1991:364). Das Resultat dieses Umbruchs und des Aufbruchs war unter anderem die Trockenlegung zahlreicher, überwiegend großer Weiher. Die Wertschätzung des Fisches war auf dem Tiefpunkt angekommen: Waren im schleswig-holsteinischen Kloster Reinfeld, bevor es im Jahr 1582 königliches Amt wurde, jährlich 61 Teiche gestaut, so betrug die Anzahl in der Folgezeit: im Jahr 169251 Teiche, 1773-85 15, 1798 11, 18528 und 1952 - dies sei der Vollständigkeit halber hier angeführt - nur noch 6 Teiche (RUST 1952:36).

Ein weiterer Grund ist in der Entwicklung der feldbaulichen Landwirtschaft zu suchen. Im 18. Jahrhundert zogen die Getreidepreise an, so dass die Ackerbauflächen auf Kosten anderer Nutzungen ausgedehnt wurden (KONOLD 1991:365). Durch die Zunahme der Bevölkerungszahl stieg zudem der Bedarf an Getreide und damit sein Preis, während tierische Erzeugnisse an Wert verloren. So nahm beispielsweise seit 1748 die preußische Bevölkerung bis zum Ausgang des 18. Jahrhundert jährlich um rund $10 \%$ zu. Dieser demographische Übergang, gebunden an ein Faktorengefüge (verbesserte medizinische Versorgung, Anhebung der Allgemeinbildung, Interesse am Kinde, verbesserte Administration, neue Nahrungs- und Futtermittel, Anstieg der Hygiene usw.) stellt die eigentliche Ursache des Bevölkerungsanstiegs dar. Unter dem wachsenden Bevölkerungsdruck war es dringend erforderlich, die Nahrungsgüterproduktion zu steigern (HERRMANN 1997:155). „Das wichtigste und unelastisch nachgefragte Grundnahrungsmittel war das Brotgetreide Roggen, von dem in Preußen je Person und Jahr das Zwölffache des heutigen Verbrauchs verzehrt wurde.“ (:155)

Durch die Mergelung, das Anziehen der Kornpreise sowie durch die größere Nachfrage nach lebensnotwendigen Agrarprodukte in den schnell wachsenden Städten wurde der Ackerbau immer rentabler. Hatte man im Mittelalter den Wald gerodet, um die ackerbaulichen Kulturflächen zu vergrößern, so legte man in der Neuzeit die Teiche trocken, weil Äcker und Weiden dringender benötigt wurden und höhere Erträge lieferten (BUCHWALD 1882:93). Und „wie immer bei Momenten erwacht der unstillbare Trieb nach Land unter der Landbevölkerung.“ (CNOPF 1927:114)

Durch die gesteigerte Viehhaltung bzw. Aufstallung war der Bauer zudem „gezwungen sich nach Futterland umzusehen" (CNOPF 1927:137). Zum Beispiel begründete die Gemeinde Waldeck ihr Gesuch an die Obervogtei Dinkelsbühl zum Erwerb eines Weihers damit, dass die Gemeinde großen Mangel an Wiesen habe und dass dadurch ihre Viehhaltung eine sehr beschränkte sei. Dies wirke sich durch den Mangel an Spannvieh auch auf den Ackerbau aus, und die Düngung der Felder sei infolgedessen ebenfalls eine ungenügende (aus: CNOPF 1927:114). 
Bei den bestehenden Verhältnissen, die jegliche Intensivierungsbestrebungen zur Unmöglichkeit machten, lag der Ausweg in dem Erwerb von Wiesen, die nicht der Restringierung der Weiderechte, des Flurzwanges oder der Bewässerung unterworfen waren. Deshalb zielte das Bestreben der Landbevölkerung darauf hin, die in Überzahl vorhandenen Weiher in ihren Besitz zu bringen. Als nun die Teichwirtschaft durch die Folgen des Krieges und die mangelnde Pflege in ihren Erträgen immer weiter zurückging, setzte, auf dem Tiefstand der Teichwirtschaft, eine stürmische Nachfrage nach diesen begehrten Weiherflächen ein, die in der Regel wegen ihres feuchtgründigen Bodens bestes Wiesenland abgaben. So wurde nach über 500 Jahren der mittlerweile wieder ausgebaggerte und ursprünglich vom Kloster Isernhagen angelegte ,Isernhagener See' in der zweiten Hälfte des 19. Jahrhunderts zugeschüttet, da man dringend Wiesen benötigte (BURGHARD 1988b:27). Aber auch für geringwertigere Teiche, die bei Trockenlegung nur saure Gräser und Schilf tragen konnten, also nur als sog. „Streuwiesen“ genutzt werden konnten, bestand lebhaftes Interesse, da der Bedarf für Streu wegen der gesteigerten Sommerstallviehhaltung ebenfalls ein großer war (CNOPF 1927:145). WEYER (1800:90) berichtet von einem „entwässerten und zur Wiese gemachten großen Teich bey Ebstorf“ im Lüneburgischen, dem Zentrum des Kunstwiesenbaus. Dass sich ein regelrechter „Run“ auf diese Teiche einstellte, wundert angesichts der vergleichsweise niedrigen Pacht und der Erträge nicht: „Dieser Teich von 150 Morgen that in der letzten Zeit nur 10 1/2 Rthlr. Pacht, und erträgt jetzt jährlich 150 Fuder Heu zu 1200 Pfund.“ (:90). Zudem waren die wasserbaulichen Anlagen zur Wasserzuführung (Schleusen) und des Wasserstaus (Staudämme) einer Kunstwiese bereits vorhanden.

Der wichtigste Fortschritt der Landwirtschaft im 18. Jahrhundert - aber gleichzeitig der Hauptgrund für die Einbeziehung von Teichböden in die ackerbauliche Nutzung -, war der teilweise Übergang von der Dreifelderwirtschaft zu der ,verbesserten Dreifelderwirtschaft“, d. h. die Einreihung von Klee und anderen Futtergewächsen sowie von Hackfrüchten in das System der Fruchtfolge. Diese Bestrebungen entsprangen der Erkenntnis, bei der stark angewachsenen Bevölkerung einen erhöhten Ertrag von der Ackerfläche erzielen zu müssen. Dies hatte aber gesteigerte Düngung des Bodens und somit auch erhöhte Viehhaltung zur Voraussetzung. Das Ackerland hatte sich über Gebühr ausgedehnt, so dass die Wiesen- und Weidenutzung auf engen Raum beschränkt war. Den Mangel an Viehfutter durch den Anbau von Futterpflanzen auf dem Ackergelände auszugleichen, standen Hutungsrechte, Flurzwang, Gemengelage im Weg.

Zudem war im 18. Jahrhundert die landwirtschaftliche Nutzfläche auch noch erheblich kleiner als heute. Die vernässten Niederungen konnten noch nicht in dem Maße bewirtschaftet werden, wie sie benötigt wurden, so dass man auf die bisherigen Teichböden zurückgriff. Und als im Zuge der Binnenkolonisation dann diese Bereiche in Acker-, Weide- und Hofland umgewidmet wurden, entstand gleichzeitig jedoch ein so hoher Siedlungsdruck, den die zur Verfügung gestellten Flächen nicht auszugleichen vermochten. So zog Friedrich Wilhelm I. zahlreiche Kolonisten beispielsweise in die weiten Landstrecken nach Litauen und sein Sohn Friedrich der Große bewirkte durch den Zuzug von Kolonisten in das Oder- und Warthebruch eine Kultivierungsarbeit, die die Auen als Ackerland den Hofreiten zuwies.

Mit der zunehmenden Nachfrage nach Ackerland wurden nicht nur die jährlichen Brachen, sondern auch die Teichböden zum zeitweisen Ackerbau genutzt. Diese sog. Sömmerung, der Anbau auf zeitweise trockengelegten Teichböden, wurde hin und wieder auch schon im Mittelalter betrieben. Aber erst ab dem 18. Jahrhundert erfolgte sie vielerorts systematisch. Fischzucht und Ackerbau wechselten in einem örtlich festgelegten Rhythmus ( 3 bis 8 Jahre Fischzucht, 1 bis 3 Jahre Ackerbau). Wenn gesömmert wurde, baute man Roggen, Schwaden, Hafer oder Weizen an. Hin und wieder wurden die Teichböden auch zur Hutung genutzt. Hatten Schweine an den Michaelsteiner Klosterteichen ,viel Schäden angerichtet und Krebse gefressen [...], so wurde dem Hirten befohlen, sie fern zu halten." (BORNE 1883:49) Andere Nebennutzungen bestanden im Schilf- und Binsenschnitt (Einstreugewinnung), in der Rohrgewinnung (Bau- und Dämmstoff) und in der Teichschlammgewinnung (Dünger) (BfN 2000:D-6). Und um diese Nebennutzungen durchführen zu können, bestand das Interesse nicht in der Offenhaltung der Teiche, sondern in der allmählichen Verlandung, die erst eine Ausbreitung von Schilf und Rohr produzierte. 
Vor allem die immer stärker auftretende Verlandung der Weiher bedeutete „eine große Gefahr“ (CNOPF 1927:131). Da die Beseitigung des Aufwuchses auch schon in früherer Zeit sehr kostenintensiv gewesen ist, wurden diese Maßnahmen - wie in noch heute gültiger Methode - nicht ausgeführt bzw. auf einen späteren Zeitpunkt verschoben: „Die Räte der Hofkammer, die über die Ausgabekosten für die Fischerei zu entscheiden hatten, waren kühle Rechner.“ (:140) Zudem maß man anfänglich „der Verschilfung und Versumpfung der Weiher keine allzu große Bedeutung bei, bis man die Gefahr richtig erkannte, war es reichlich spät geworden." (:139) Nicht allein die hohen Kosten der Teichpflege aber waren es, sondern ,sicher wird auch die aufstrebende Landwirtschaft mit ihren wachsenden Erfolgen dazu beigetragen haben, daß man mit Gleichgültigkeit und Passivität die Sache ihren Lauf nehmen ließ.“ (:131)

Die im Laufe der Jahrhunderte eingetretene starke Verlandung und Verschilfung war von den angrenzenden Bauern zudem als willkommener Anlass benutzt worden, ihre Hutungs- und Weiderechte auszudehnen. Möglich wurde dies aufgrund der zunehmend mangelhaften Vermarkung und Versteinerung der Weiher, die CNOPF (1927:117) zu Ende des 17. Jahrhunderts wie folgt beschreibt: ,[...] teilweise waren die Marksteine in dem Morast und Schlamm versunken und nicht mehr auffindbar, teils hatten die Angrenzer die Steine einfach entfernt oder zum eigenen Vorteil in den herrschaftlichen Grund vorgeschoben."

Eine Begründung bei schlechtem Fischausfang war auch, dass sich durch zu starkes Graswachstum die Egel in dem Grase so stark vermehrt hätten, „daß die Fische buchstäblich mit diesem Ungeziefer überzogen gewesen seien, so daß man sie mit Strohwischen abreiben mußte.“ (CNOPF 1927:129) Es wurde nun dringend empfohlen, auch weil durch das zu starke Graswachstum der Besatz am Wachstum verhindert worden sei, ,das Gras an den Rändern des Sees mit den Wurzeln ausreißen und fortschaffen zu lassen.“ (:129), aber dies bekanntlich aus den oben genannten Gründen.

„Der eigentliche ausschlaggebende Moment des Niederganges der Teichwirtschaft“, zieht deshalb CNOPF (1927:142) das Resümee, ,ist in dem Erstarken der Landwirtschaft zu erblicken.“ (:142) Sie ließ es vorteilhaft erscheinen, „einen alten Fischteich zu cassiren, und ihn in beständiges Ackerland, Wiesen oder Weiden zu verwandeln.“ (SPRENGEL 1838:86)

Im 18. Jahrhundert setzte zudem eine stark rückläufige Bewegung ein, indem es zuerst in Hofkreisen nicht mehr für fein galt, Fische in diesem Ausmaß zu konsumieren, wie es im 16. und 17. Jahrhundert noch der Fall war. Dieser Rückgang im Fischverbrauch infolge der ,reduzierten Hoftafel“ (CNOPF 1927:137) ist bald darauf auch in Bürgerkreisen feststellbar. Und so konnte der ständig rückläufige Fischkonsum am Hofe nicht durch die Nachfrage in der Bevölkerung kompensiert werden. Die Fischpreise hielten sich infolgedessen auf niedriger Höhe (:141).

Der immer heftigere Missmut über die fortlaufend niedrigen Fischpreise erzeugte geradezu eine feindselige Stimmung gegen die Teichwirtschaft, die in dem Satz von Josef SUSTA (1898:52), Güterdirektor der berühmten Fürst-Schwarzenberg'schen Teichwirtschaft in Böhmen, gipfelte: „Es soll an keinem Ort ein Teich bestehen, wo eine Wiese, Acker oder Weide sein kann, weil der Ertrag der Fische nicht so hoch angeschlagen werden kann.“

Es sind also die Änderungen im Geschmack, in der Lebensart und in den Ernährungsgewohnheiten in den oberen Schichten zu nennen, die an einem Rückgang schuldig sind (CNOPF 1927:137). Während sich das Volk von Brot und Getreide ernährte, verlangte die barocke Lebensart, die allmählich von Frankreich herüberschwappte, für die Tafeln der Herren ausgefallenere und exotische Speisen (BARCZYK 1991). Der Bedarf an Fischen ging zurück, die Preise verfielen (KONOLD 1991:365). Demgegenüber stand die große Zahl an Karpfenteichen, die trotz der bereits zu diesem Zeitpunkt vorgenommenen Teichlegungen $\mathrm{zu}$ diesem Zeitpunkt noch bestanden und letzten Endes eine Überproduktion zur Folge haben musste.

Die Gründe dieses Rückganges mögen nicht allein in der Knappheit des Ackerlandes bei zunehmender Bevölkerung und des dadurch bedingten Landhungers liegen sowie mit den ungünstigen Erbteilungen, den Intensivierungsbestrebungen in der Landwirtschaft, einer erhöhten Viehhaltung und dem Mangel 
an Wiesen und Grasland und veränderten Ernährungsgewohnheiten zu begründen sein, sondern auch in der vorherrschenden Wirtschaftsform: die primitive Bewirtschaftung der Teiche mittels Femelbetriebes, d. h. das Halten der verschiedenen Jahrgänge in einem Teiche, die nur spärlichen Gewinn brachte (CNOPF 1927:22).

Ab Mitte des 18. Jahrhunderts traten zudem weitergehende Schwierigkeiten und Verluste auf, die den Bestand der Teichwirtschaft empfindlich schädigten: Zum einen scheinen ,auch Fischkrankheiten [...] grassiert zu haben.“(CNOPF 1927:130)

Aus dem mittelfränkischen Marktbiberter Amt des Hochstiftes Würzburg berichtet CNOPF (1927:129) aus alten Quellen zudem von „schlimmer Reiherplage“. Der Ertrag aus einem Fischteiche namens ,Hahnensee' „wird als sehr gering angegeben, weil diese ,Raubtiere' den Fischbestand dezimiert hatten." Interessant ist die Mitteilung, dass die Ansbacher und Schwarzenberger Untertanen zum großen Teil ihre Privatweiher eingehen lassen mussten, da die Reiherplage durch „die befohlene Hegung dieser schädlichen Tiere" dermaßen zugenommen hatte, dass sich eine Fischzucht nicht rentierte. „Wir können aus diesen Berichten entnehmen“, so CNOPF (:129) in seiner Analyse, „daß durch die Jagdleidenschaft der hohen Herrn nicht nur die Bauern durch unermesslichen Wildschaden aufs schwerste beeinträchtigt wurden, sondern daß auch die Teichwirte durch die Hegung der Reiher vor die Frage gestellt wurden, ob es sich überhaupt lohne, weiterhin Fischzucht zu treiben, wenn diese gefräßigen Fischräuber einen Großteil der Sangen wie Setzlinge hinwegstehlen.“ (:129)

Ab dem zweiten Drittel des 18. Jahrhundert machen sich plötzlich die Anzeichen des Verfalls in auffälliger Weise noch aus anderen umwelthistorischen Gründen bemerkbar. So scheinen strenge Winter- und Hochwasserschäden im Jahr 1784 der Teichwirtschaft im mittelfränkischen Raum schwer geschadet zu haben (CNOPF 1927:114). CNOPF (:115) spricht von „Katastrophenjahren“, in denen die Verbindung von strengen Wintern mit folgenden Überschwemmungen und heißen Sommern mit großer Trockenheit den Fischbestand dezimiert und den Niedergang beschleunigt hat $(: 115,130,142)$.

VOGEL (1898:23) schreibt für diesen Zeitraum die Zeilen: „Wir haben zur Zeit leider in Deutschland fasst noch mehr verwahrloste alte Teiche, als auf der Höhe der Teichkultur stehende neue." Zudem glaubten Wassermüller vielfach, durch eine oberhalb ihrer Mühlen angelegte Teichwirtschaft „eine Einbuße an Wasser" zu erleiden (:58). Wenn dies auch insofern mehr ein Irrtum war, da die oberhalb liegenden Teichanlagen bei Wassermangel anstelle einer Entziehung eher für eine Zuführung von Wasser sorgten, da ihre Anspannung bereits in wasserreichen Zeiten erfolgte. Und auch in der Person des „Seemeisters“ bzw. „Teichaufsehers“ liegende Gründe gaben Anlass zur Aufgabe. Tatsächlich scheint diese verantwortungsvolle Stellung von ihren Trägern nicht immer zum Wohle der Teichwirtschaft ausgenutzt worden zu sein; beispielsweise durch unklug abgefasste Pachtverträge, die zu kurzfristig abgeschlossen wurden oder die eine Fortführung des Fischteichbetriebes über den Pachtzeitraum hinaus nicht verbindlich geregelt hatten (vgl. CNOPF 1927:139).

So verschwand die Teichwirtschaft in weiten Teilen Deutschlands. Die großen Teiche wurden nach und nach aufgelassen, am meisten hat dann das 19. Jahrhundert unter ihnen aufgeräumt (KUHN 1954:154). Unter umweltökologischen Gesichtspunkten betrachtet, war diese Auflassung insofern nachteilig, als dadurch der Weg frei war „für eine dichtere Besiedlung der Niederungen“ (:154).

Wie die reliktäre, ja in manchen Teilen fast wüste Situation im Jahre 1783 in der Lausitz, einem wahren Teichintensivgebiet der wendischen Fischerbevölkerung, ausgesehen haben mag, ,urtheilte der berühmte Fischkundige Dr. Markus Gliefer Bloch ${ }^{[2] ، ~(z i t . ~ a u s: ~ F R I E D E L ~ 1884: 45): ~}$

\footnotetext{
${ }^{2}$ BLOCH, Markus Elieser [nicht Gliefer]: Mediziner ( 1723 Ansbach - $†$ 06.08.1799 Karlsbad). Bloch befasste sich mit den Studien der Anatomie, des Lateinischen, aber auch der Naturgeschichte, wurde promoviert und ließ sich in Berlin als approbierter Arzt nieder. Mit dem Oberkonstistorialrat Silberschlag verfasste er eine Beschreibung des Müggelsees. Diese erschien 1780 im Band 1 der Publikationen der 1773 gegründeten Berlinischen Gesellschaft naturforschender Freunde, deren Mitglied Bloch war. Bloch war des Weiteren Mitglied der Akademie der Wissenschaften zu Berlin und weiterer wissenschaftlicher Akademien und Gesellschaften im In- und Ausland. Er veröffentlichte 1782 in Berlin die „Abhandlung von der Erzeugung der Eingeweidewürmer und den Mitteln wider dieselben“. Diese Schrift wurde von der Königlich Dänischen Societät der Wissenschaften in Kopenhagen mit einem Preis gewürdigt. Bereits 1774 erschienen seine „Medicinischen Bemerkungen. Nebst einer Abhandlung vom Pyrmonter Augenbrunnen“ in Berlin. Doch zum Eigentlichen:
} 
„Es sind allenthalben in der Mark Spuren zu finden, daß zu der Wendenzeit die mehresten Brücher in den Heiden und Feldmarken mittelst Grabens in Verbindung gestanden haben, welche durch die Länge der Zeit verfallen sind; und wahrscheinlich sind die mehresten Brücher und Löcher Karpfen- oder andere nutzbare Fischteiche gewesen. Spuren von aneinander hängenden Teichen findet man in der Chorinschen Heide, woselbst das Kloster Chorin Karpfen- und Fischteiche gehabt, welche aber im dreißigjährigen Kriege und nach der Reformation, da es den Besitzern an der Geldvorlage zur Unterhaltung dieser Anstalten gefehlt, oder die Güter bona vacantia geworden, eingegangen sind. Es gehört also zur Landeskultur, dergleichen verfallene Teiche, welche wegen der Stagnation des Wassers nachtheilige Ausdünstungen und eine ungesunde Weide hervorbringen und daher schädlich sind, wiederum herzustellen. - Zur Wendenzeit ist das platte Land in der Mark weit besser bevölkert und kultivirt gewesen, als heut zu Tage, [...] und die zu Teichen dienlichen Oerter kaum mehr zu erkennen sind, wenigstens mit großen Kosten wiederum von neuem angeschafft werden müssen."

Von großer Tragweite für den Rückgang der Teichflächen waren in diesem Zusammenhang die fast zeitgleich durchgeführte Säkularisierung und die Mediatisierung (1803 - 1806). „An die Stelle der eher traditionsverbundenen Klosterverwaltungen und der Organe der selbstbewußten reichsfreien Stadtstaaten traten nüchterne Beamte auswärtiger Fürstenhäuser. Die neuen Herren hatten es oftmals eilig, aus ihren Besitztümern möglichst rasch und viel Kapital zu schlagen." (KONOLD 1991:365) Nach der Säkularisation wurden zahlreiche Weiher also entweder aus Rentabilitätsgründen aufgelassen und die Sperrriegel weitgehend zerstört oder sie wurden nicht gefällt, sondern zur Fischzucht weiter verpachtet (HERBST 1992:65,128). Gleichzeitig erlaubte die Säkularisation und die damit einhergehende politische Neugestaltung ,eine verstärkte Auflassung der Weiher, um die bereits eingeleiteten Meliorationsmaßnahmen in großem Umfang beschleunigen zu können." (:145) Mit der Auflassung der Fischweiher wurden aber auch umweltgeschichtlich wichtige Hochwasserspeicher aufgegeben (:65).

Die meisten Autoren begnügen sich mit dem allgemeinen Hinweis, dass die Säkularisation die Hauptursache des ersten deutlichen Niederganges der Teichwirtschaft gewesen sei. Gewiss hat diese dadurch einen empfindlichen Stoß erlitten, ,aber es ist nur sehr fraglich, ob dieser Stoß einen völlig gesunden oder schon angekränkelten Wirtschaftskörper getroffen hat" (CNOPF 1927:22). Die bäuerliche Teichwirtschaft jedenfalls war zu dieser Zeit bereits stark dezimiert und fiel als Bestandsträger aus. Des Weiteren lässt sich der einseitigen Sakulärisierungsbegründung mit folgender Position entgegentreten:

Die Fürsten setzten sich zwar in den Besitz der geistlichen Gründe, aber blieben selbstverständlich schon im eigenen Interesse bemüht, das überkommene Gut möglichst gut zu verwalten, um einen hohen Reingewinn zu erzielen. „Es erscheint nicht sehr wahrscheinlich, daß sie die Teichwirtschaft vernachlässigt hätten, wenn der materielle Erfolg ein solch bedeutender nicht gewesen wäre, wie vielfach angenommen wird. Zweifelsohne müssen hier ausschlaggebende wirtschaftliche Gründe die Veranlassung gegeben haben“ (CNOPF 1927:22). Nach Auffassung von CNOPF (:23) „kann man die Fürsten nur dafür verantwortlich machen, daß sie vielfach nicht kongeniale Nachfolger der Mönche waren, die durch ihre kluge Bewirtschaftung die zahme Fischerei zur höchsten Blüte gebracht hätten“. Wenn man also die Gründe des Zusammenbruchs in den Zusammenhang damit stellt, dass die Säkularisation den stärksten Anteil an dem Verschwinden der Teichwirtschaft gehabt zu haben, so scheint dies nur einer rein äußerlichen Betrachtung standzuhalten, „denn die Vereinigung des Kirchengutes mit dem Staatsgute und die Aufhebung der Territorialherrschaften erfolgte zu einem Zeitpunkt, als die Teichwirtschaft vielfach schon den letzten Verzweifelungskampf mit der

Der vielseitig interessierte Naturforscher publizierte seine Arbeitsergebnisse u. a. in dem Werk „Allgemeine Naturgeschichte der Fische“, das 1781/82 in 12 Teilen mit 432 farbigen Kupferstichen erschien. Es war lange Zeit das erste und umfassendste Werk über diese Tiergruppe. Seine naturkundliche und Fischsammlung wurde später durch die preußische Regierung angekauft und kam dann an das Berliner Zoologische Museum, jetzt Museum für Naturkunde (LUISE 2004). 
Landwirtschaft kämpfte.“ (:142). Dennoch lässt sich feststellen, dass die eintretende Säkularisierung den Prozess des Niederganges zumindest beschleunigte.

Doch als mit der Aufhebung der Leibeigenschaft im Jahre 1805 die Hand- und Spanndienste fortfielen, konnten auch die Güter die Pflege großer Teichländereien nicht mehr bewältigen. Viele Teiche legte man für ständig trocken, in anderen wurden in immer längerem Zyklus Getreide angebaut. Schließlich blieben vielerorts nur noch solche Teiche gestaut, die nicht vollständig ablassbar waren oder die als Viehtränke oder Tierschwemme benötigt wurden.

SCHENK (1998:248) zeigt am Beispiel der ,Steigerwaldteiche' die Folgen für die Zeit nach 1804 auf: "Die Bauern zeigten wenig Interesse, die klösterliche Teichwirtschaft fortzuführen, denn schließlich, so wurde argumentiert, hätten die Franzosen bei ihren Durchgängen die Bäche und Weiher völlig leergefischt, so daß es nun an Brut für die Weiterzucht fehle [...] und überhaupt, so meinten die Burgwindheimer Bauern [...], wäre es besser, wenn die Teiche ,meistens ausgetrocknet werden'”, da wegen der aufgehobenen Klöster die Fischerei nicht erträglich ausfallen würde. Auch HOFMANN (1937:130) weist für die zweite Hälfte des 18. Jahrhunderts im nordbayerischen Raum nach, dass die Klosterlegung und Bauernbefreiung ,frankenweit zu einem allgemeinen Auflassen von Teichen geführt hat.“

Eine ähnliche Situation lässt sich für Oberschwaben nachzeichnen: „Innerhalb von zwei Jahren, 1803 war das Kloster Weingarten säkularisiert worden und die ganzen Liegenschaften und damit auch die Weiher fielen in die Hände des Fürstenhauses Oranien-Nassau, legte man bspw. von den klösterlichweingartischen Weihern 270 ha trocken und verpachtete sie an Bauern." (KONOLD 1991:365) Die Bauern hingegen wollten vor allem die großen, bisweilen fast 20 ha umfassenden Teiche erwerben, um sie dann gemeinschaftlich kultivieren zu können. Dazu mussten die Dämme abgetragen werden und in diesem Zusammenhang verschwanden dann auch die Mönche, Holzrechen, Ablasskanäle etc. Die Teiche wurden also einer landwirtschaftlichen Nutzung zugeführt. Die Meliorationen gestalteten sich aber oftmals als sehr schwierig und so blieben dann die Weiher offen liegen, verbuschten oder man nutzte die Weiher als Streuwiese u. Ä. (:365). „In anderen Herrschaftsgebieten sah es nicht anders aus. Man könnte sagen, daß Oberschwaben damals innerhalb kurzer Zeit entwässert wurde“ (:365).

„Die weiträumige Auflassung von mittelalterlichen Weihern brachte allein im oberschwäbischen Jungmoränengebiet einen Verlust von 25 bis 30 Mio. $\mathrm{m}^{3}$ Speicherraum (HERBST 1992:146). Im Altmoränengebiet lässt sich allein für das Gewässersystem des Rotbaches ein zusätzlicher Abgang von $200.000 \mathrm{~m}^{3}$ Weiherstau feststellen (:146). Der Verlust dieses Fassungsvermögens, das auf 12 Teiche verteilt war, darunter ein im Jahre 151115 ha großer und mindestens $30.000 \mathrm{~m}^{3}$ fassender Fischweiher (,Höllweiher') südlich von Schammach (:23f.), machte sich ab dem Jahre 1817 durch eine „,deutliche Zunahme der Rotbachhochwässer im Biberacher Stadtgebiet bemerkbar“ (:36). 


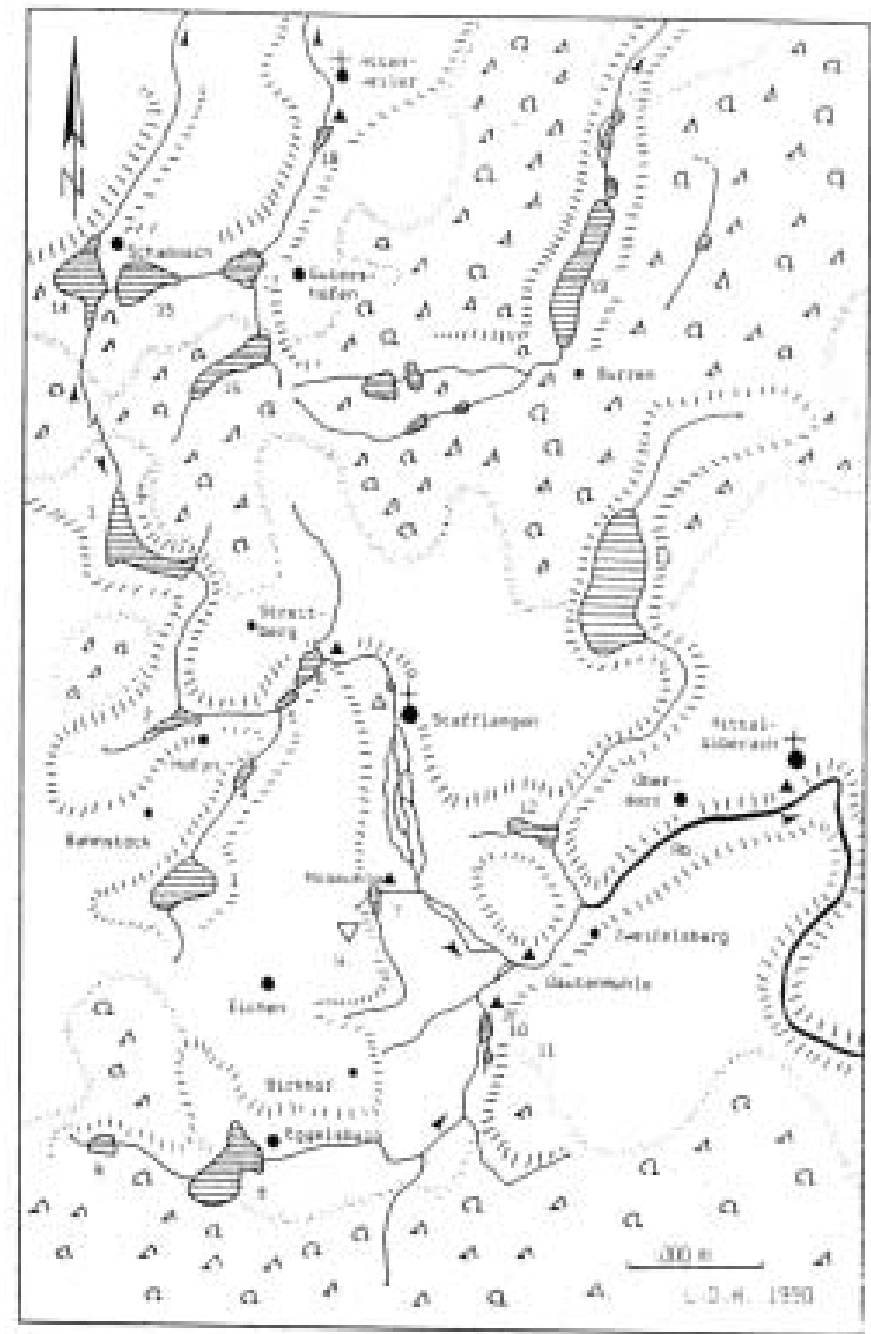

Abb. VIII-2: Das rekonstruierte ehemalige Weihergebiet im Oberlauf des Rotbaches um 1800

Die einzelnen Teiche sind durchnummeriert von $1-19$. Von den einzelnen Namensbezeichnungen sollen nur die im Text genannten wiedergegeben werden: 1: Höllweiher, 2. Tächernweiher, 6: Aiweiher (aus: HERBST 1992:22)

Weiterhin ist der im Gebiet von Hofenist vom Aibach gestaute ,Aiweiher' „als einziger der ehemals insgesamt sechs Weiher" und „einst etwa $20.000 \mathrm{cbm}$ fassenden Weihertreppe erhalten geblieben.“ (HERBST 1992:26) Und auch für den 8 ha großen, seit dem 12. Jahrhundert erwähnten ,Tächernweiher', verzeichnet die Flurkarte 1832 keinen Weiher mehr (:25).

Dass sich eine große Anzahl Weiher trotzdem so lange halten konnte, lag in den meisten Fällen in Erwägungen begründet, die eine Trockenlegung nicht ratsam erschienen ließen, wenn nicht gar unmöglich machten:

Einige Restflächen blieben zum Beispiel dort erhalten, wo administrative Beschlüsse, wie seitens der am Ende des 18. Jahrhunderts gefasste Beschluss der Hofkammer Würzburgs, Teiche durch Pachtverträge an Bauern zur Umwandlung in Äcker und Wiesen zu übergeben, mit der Auflage die Dämme einzureißen und die Löcher und Mulden auszufüllen, fehl schlugen (CNOPF 1927:136f.). Denn der Beschluss fand nicht den so durchgreifenden Erfolg. War auch der Bauer durch die gesteigerte Viehhaltung gezwungen sich nach Futterland umzusehen, so waren die Zeitpachtverträge von 6 - 12 Jahren nicht in seinem Interesse (:137). Die Gründe dafür liegen auf der Hand: „Der Bauer sollte kostspielige Meliorations- und Kultivierungsarbeiten vornehmen, sollte die großen und schweren Dämme, die sich in dieser Gegend durch besondere Wucht und Größe auszeichneten, einreißen und das Weihergelände einebnen, einen unerhört hohen Pachtzins zahlen und das umgewandelte Teichgelände vom 4. bzw. 10. Jahre der Bestandszeit an nach bestimmten Vorschriften als Wiese pflegen, um sie dann dem Hochstift im besten Kulturzustand zurückgeben zu müssen, ohne 
auch nur einen schwachen Hoffnungsschimmer zu besitzen, daß er den kultivierten Boden weiterhin in Pacht bekommen wird.“(:137)

Ebenso wurde der Umbruch in Wiesen in der mittelfränkischen Gemeinde Marktbibert nicht angestrebt: Sie wollte Ende des 18. Jahrhundert den ,Horatzsee' weiterhin als Weiher nutzen, „da sie im Falle eines Hochwassers Schutz durch den See hätten und die Erträge ihrer Wiesen in Sicherheit bringen könnten.“(CNOPF 1927:135).

Weiterhin konnten einige Restflächen dort bestehen, wo sich die Bodenbeschaffenheit nur wenig für landwirtschaftliche Nutzformen eignete (vgl. REITZENSTEIN 1881; HOFMANN 1935; KLUPP/FÄRBER 1980; REICHLE 1980; aus: HUBERT 1991:17). Wie zum Beispiel in dem „Oberlausitzer Heide- und Teichgebiet“, das durch grundwassernahe Talsande in Höhenlagen von 135 bis $150 \mathrm{~m} \mathrm{NN}$ geprägt und mit über $500 \mathrm{~m}$ breiten, nur wenige Meter tieferen Talniederungen vergesellschaftet ist (BfN 2000:A-10). Ein weiterer Grund für die Bewahrung ist in der Tradition zu sehen. Nur einzelne, und hier nur die größeren Gutsherrschaften retteten durch ,ihren Hang am Althergebrachten" (TAURKE 1927:1) die Fischzucht resp. die Karpfenzucht in die Neuzeit hinein. Nach RUST (1952:21) blieben die Güter gar nach der Umwandlung der Klöster in königliche Ämter (Reinbek 1528, Ahrensbök 1542, Cismar 1560, Reinfeld 1582) ein Jahrhundert lang ,die alleinigen Pflegestätten der Teichwirtschaft.“

Als weitere Erhaltungsgründe sind zu nennen: die Abgabe von Zehnten, wie der Heu- und Oehmzehnt auch bei nur vorübergehendem Anbau des Teichgeländes mit Getreide, der Forst- und Jagdzehnt, auch Stockzehnt genannt, bei Vorhandensein von Wasserjagdrechten, bestehende Hutungs- und Tränkrechte, Stauweiher, die für den Mühlenantrieb unentbehrlich waren, Weiher, die als Wasserreservoir für Feuergefahren unbedingt erhalten werden mussten, sowie Wasserrechte und sonstige Privilegien (CNOPF 1927:146). Trotz dieser Vielzahl an Belegen, die die Aufgabe der Teichwirtschaften bis zum 18. Jahrhundert begründen, behaupteten also einige ihre Stellung mit gutem Erfolg bis etwa 1780 (:142).

In diese Zeit des größten Tiefstandes fiel Mitte des 19. Jahrhunderts die epochemachende Erfindung der künstlichen Befruchtung der Fische durch Remy und Gehin, die vor allem durch Coste eine starke Förderung fuhr. Diese Erfindung war aber nur eine Wiederentdeckung der genialen Versuche zur künstlichen Befruchtung des deutschen Landwirtssohnes Stephan Ludwig Jakobi (1711 - 1784) in Lippe-Hohenhausen. Seine Berichte veröffentlichte er 1763 und 1765 (CNOPF 1927:147).

Veranlasst wurde die Wiederbelebung der Teichwirtschaft insbesondere durch die nachfolgenden Ergebnisse der wissenschaftlichen Teichwirtschaftslehre, die eine Intensivierung der vorhandenen Flächen durch moderne Betriebsmethoden propagierten. Vor allem Ödländereien wurden für die Fischzucht nutzbar gemacht. Dubisch und Burda hießen die großen Lehrmeister der modernen Teichwirtschaftslehre. Praktische Maßnahmen wie künstliche Düngung und Fütterung wurden aus der Landwirtschaft übernommen. Dazu ermöglichte die künstliche Fischzucht die Teichwirtschaft weiter $\mathrm{zu}$ spezialisieren und zu intensivieren. Wenn sie auch schon im 15. Jahrhundert nach einem ,planvoll durchgegliederten, arbeits- und kapitalintensiven System“ (KUHN 1954:152) erfolgte, so brachte erst das 19. Jahrhundert neue Fortschritte auf diesem Gebiet (Hauptteiche, Laichteiche, Vorwärmteiche etc.): „Diese Art der Karpfenzucht erforderte ungleich größere Teiche, als sie bis dahin üblich gewesen waren, man rechnete einen Morgen Wasserfläche auf ein Schock Karpfen“ (:153).

Für eine Reanimation sorgten begleitend auch die Central-Fischerei-Vereine, die vor allem seit den 1870er Jahren mit dem Ziel gegründet wurden, die Interessen der Binnenfischerei mit Einschluss der Teichwirtschaft als eine Art Genossenschaft zu vertreten und die Vermehrung der Fischteiche zu betreiben. Zu den Aufgabenbereichen gehörte auch die Hilfe beim Teichbau vor Ort, die Publikation von Informationen durch ein eigenes Zeitschriftenorgan u. a. m. Dem „Central-Fischerei-Verein Schleswig-Holstein“ beispielsweise wird das Verdienst zugeschrieben, mit Beginn seines Wirkens im Jahr 1877 bis 19051400 ha neue Teichflächen bewirkt zu haben (RUST 1952:38). 
Entgegen kam der wiedererstandenen Teichwirtschaft der Beginn der flächendeckenden schienengebundenen Erschließung weiter Landstriche seit Mitte des 19. Jahrhunderts mit der Möglichkeit des Fischtransportes auf Schmalspurbahnen. Eine neue Ära des Transportes von Frischfisch setzte ein, als Eisenbahn-Spezialwaggons konstruiert wurden, d. h. Güterwagen, die mit wassergefüllten Bassins ausgestattet waren und die durch Sauerstoffflaschen ein Überleben der wertvollen Fracht über größere Entfernungen gewährleisteten.

Eine Umwälzung zugunsten der Karpfenteichwirtschaft setzte erst in den Jahren nach 1880 ein. Der Preis für das wichtigste Produkt der Bauern, das Getreide, fiel durch Einfuhren aus Übersee. Tierische Erzeugnisse dagegen waren aufgrund mangelnder Transportmöglichkeiten nicht von einer Einfuhrkonkurrenz betroffen (HUBERT 1991:17). Die nun spürbar bessere Ertragslage durch das Zurückgehen der Reinerträge aus den landwirtschaftlich genutzten Flächen bewirkte, dass man mit Beginn des 20. Jahrhunderts auch den Kleinteichen wieder größere Aufmerksamkeit zuwendete (TAURKE 1927:1; ebenso WALTER 1937). An vielen Orten ist mit der Wiederherstellung ehemaliger Teiche und der Neuanlage solcher vorgegangen worden und die Teichflächen vergrößerten sich wieder (TAURKE 1927:1). Allein in der Teichwirtschaft der gräflichen-stolbergschen Domänen Veckenstedt und Stapelburg im Nordharz nahm man elf neue Forellenteiche in Betrieb (WÜSTEMANN 1982:25).

Eine weitere Ursache für die Wiederbelebung bzw. Forcierung der Teichwirtschaften, insbesondere in dem Bemühen um eine Forellenzucht, liegt in den Bereichen der Umweltveränderungen. Um 1800 wurden die Arbeiten der Flussregulierung an fast allen größeren und mittelgroßen Flüssen in Angriff genommen. Das Ziel war die Sicherstellung der Schiffwege, des Hochwasserschutzes und der Landwirtschaft. Die Flüsse wurden zwischen Dämme gezwängt, die großen Biegungen durchschnitten, die Nebenarme und toten Flussarme vom lebendigen Wasser abgeschlossen. So wurde zwar die Schifffahrt sicherer gemacht und große Gebiete für den Ackerbau gewonnen (SOLYMOS 1983:48), aber die natürlichen Lebensbedingungen für die Fische reduziert. Zugleich führte die stärker werdende Umgestaltung der kleinen bzw. kleineren Flusssysteme durch den Menschen - vor allem durch den Ausbau und die Errichtung der Hammer- und Mühlsysteme - zu einer Veränderung der natürlichen Umgebung. Die Fließgeschwindigkeit der Bäche und kleineren Fließgewässer verringerte sich durch die vielen Stauwehre, und die Temperatur des Wassers erhöhte sich. Diese neuen Bedingungen verdrängten die kälteliebenden Fische, der wärmeliebende Karpfen hingegen profitierte von dieser Entwicklung. Doch dieser konnte ohnehin besser in Weihern abwachsen.

Die Veränderung des Artenspektrums durch Urbarmachung verdeutlicht KAUP (1996:126) am Beispiel der Oder: „Viele Fische, deren Habitat eigentlich der schnell fließende Fluß ist, suchen zum Laichen flachere und strömungsärmere Bereiche, wie sie im Bereich des Bruchs zahlreich vorhanden waren, auf. [...] Infolge der Meliorationsarbeiten wurden die Überschwemmungen seltener, damit aber auch die Laichplätze vernichtet, so daß das Vorkommen des Hechts überall stark zurückgegangen war. Die Fischerei endete nicht abrupt mit der Eindeichung des Bruchs. Wie lange es noch möglich war, die angestammte Tätigkeit der Fischerei weiter auszuüben, war abhängig von der Stärke der vorgenommenen Entwässerung.“ Aber „möglicherweise ist der Rückgang der Fischer [...] durch die Zudämmung der vielen kleinen Wasserläufe im Bruch bedingt, denn dort, wo es noch viele Flußläufe gab [...], gab es auch entsprechend viele Fischer.“(:127)

Die zweifelhaften Erfolge der Flussregulierungs- und Meliorationsmaßnahmen für den Hochwasserschutz, der zuletzt wieder in den Jahren 2000 und 2002 den Beweis für seine Wirksamkeit schuldig blieb, sollen hier nicht weiter diskutiert werden, aber die Auswirkungen dieser frühen Maßnahmen für das Abflussregime in Verbindung mit einer starken Wassernutzung durch Wasserkraftwerke, führte wohl schon zu den Überlegungen einer Wasserbevorratungspolitik, die zu einem Anheben des Teichbaus beitrug. Denn gleichzeitig konnten dadurch Perioden des Wassermangels besser überstanden werden. Um diese Vorteile zu nutzen, wurden deshalb auch bauliche Veränderungen getroffen. Einen teichwirtschaftlich interessanten Aspekt verspricht deshalb die Aussage „man sollte in den Thälern ablaßbare Teiche anlegen, dadurch würde auch dem bei Dürre eintretenden Wassermangel in wirksamster Weise begegnet. Wenn das Wasser in der Zeit des Ueberflusses zur Füllung der Teiche benutzt wird, so ist dies den Triebwerken nützlich. [...] Für 
größere Bäche, welche zeitweise stark anschwellen, legt man in den Teichdamm einen geräumigen Ueberfall, der auch die größten Fluthen abzuleiten im Stande sein soll.“ (BORNE 1886:277f.) Teiche wurden demnach im Umfeld der Teichwirtschaft in Aufstauung von Fließgewässer nicht nur als Fischteiche genutzt, sondern auch als „Schwellteiche“ bzw. als „Reservoirteiche“ angelegt, um eine ausreichende bzw. ausgeglichene Wasserversorgung zu gewährleisten.

Mit dem Einsetzen der Phase der Frühindustrialisierung verschlechterten sich zudem die Gewässerqualität aufgrund der Einleitungen und damit die Bedingungen für die Flussfischerei und für die Fischzucht in Bachteichen so sehr, dass aus ländlichen und immer entfernteren Gebieten Fisch herbeigeschifft werden musste. Auch nach LIETMANN (1941:6) mag „der Niedergang der Teichwirtschaften [...] auch in Zusammenhang mit industrieller Deposition gesehen werden." In der zweiten Hälfte des 19. Jahrhunderts beschwerten sich die Fischer schon massiv über Fischmangel. Infolge der Verunreinigungen der Retorten-Verkohlungsanstalt in Rübeland (Harz) beispielsweise, die in den 1880er Jahren teerige Substanzen in die Bode ableitete, verarmte der Flusslauf allmählich so sehr, dass die Fischer ihren Lebensunterhalt nicht mehr sichern konnten und sich das Fischereigewerbe in Quedlinburg von 18 auf 4 Fischmeister verminderte (WÜSTEMANN 1982:26). Die berufsmäßige Fischerei in den kleineren Fließgewässern entwickelte sich in der zweiten Hälfte des 20. Jahrhunderts zur Liebhaberangelei. Am Ende des Jahrhunderts war sogar das „saubere“ Land Österreich auf Fischimport angewiesen (SOLYMOS 1983:48). Zunächst wurde mit örtlichen Verordnungen und später mit Fischereigesetzen versucht, die Not der Flussfischerei abzuwenden (WÜSTEMANN 1982:26). Eine weitere Art ihre Produktion zu vergrößern war, dass man sich bemühte, die Fanggeräte zu verbessern (SOLYMOS 1983:50).

Die weiteren Flussregulierungen, der zunehmende Schiffsverkehr und dann die Überhandnahme des industriellen Schmutzwassers hatten die Fischerei in den Naturgewässern so weit gefährdet, dass neben dem juristischen Schutz das Bedürfnis der künstlichen Fischvermehrung und der Verwirklichung neuer Teichwirtschaften immer dringender wurde (SOLYMOS 1983:48). Diese Forderungen wurden vor allem in den 1905-30er Jahren erhoben.

Insbesondere die ehemals „im Flachlande fast bei jedem Dorf, Gut usw. vorhandenen Kleinteiche“ (WALTER 1933:7) galt es deshalb wiederherzustellen. Zu der Karpfenaufzucht sollten „die vorhandenen Kleinteiche herangezogen werden und damit ihrerseits wieder [...] zur Hebung der heimischen Fischerei in natürlichen Gewässern beitragen." (:8) Mit der Erfindung der Ertragssteigerung durch Kalk und später durch den Einsatz von Kunstdüngung wurde der Intensivierung der Teichwirtschaft weiter Vortrieb geleistet, die mit der Zusatzfütterung von Dungund Fleischabfällen ihre nochmalige Verstärkung fand. Im gebirgigen Westen Deutschlands jedoch fehlten die Karpfenzuchten traditionell „fast gänzlich“ (:8), in dieser Gegend waren „die kleinen Teiche nur spärlich vorhanden" (:8). Der badische Landesfischereiverband beispielsweise hatte sich deshalb mit einem „Aufruf zur Anlage von Gemeindeweihern, die zugleich als Brandweiher zu dienen hätten" (:8), an die badischen Gemeinden gewandt, um auf diese Weise zumindest das Besatzmaterial an Karpfen, Schleien usw. für die Altwässer des Rheins und des Neckars aufziehen zu können.

Anders die Entwicklung bei der Forelle, die zunächst als Bachforelle in klaren und kalten Flüssen und Bächen gefangen wurde. „Ihre regelmäßige Zucht in kühleren Teichen ist erst durch die Entdeckung der künstlichen Befruchtung und Erbrütung der Eier möglich geworden “ (BENECKE 1885:IV), die im 18. Jahrhundert erfolgte und sich im Laufe der weiteren Zeit verbreitete.

Infolge dieser Entdeckung, der oben beschriebenen Schwierigkeiten der Flussfischerei und vor dem Hintergrund des zu Beginn des 20. Jahrhunderts aus verschiedenen Gründen einsetzenden Niedergangs der Mühlenwirtschaft (siehe Pkt. VIII 2.a), erfolgte die vermehrte Schaffung von Fischteichen durch Umwandlung von Mühlteichen und deren weiteren Ausbau.

1903 beispielsweise beginnt der Mühlenbesitzer Carl Büschleb von der Büschleb-Mühle in Worbis an der Wipper mit dem Aufbau der Forellenzucht. Auf dem Mühlengelände, zwischen Wehr und Beginn des steinernen Gerinnes, wurden Teiche ausgeschachtet und aus dem Mühlgraben mit Wasser versorgt. 1906 waren 24 Teiche, eine Brutanstalt und ein Eiskeller fertig. Um 1911 kamen weitere 
Teiche auf dem sog. Pfingstrasen dazu. 1912 war die gesamte Anlage fertiggestellt. „Eier und Setzlinge lieferte man bis nach Osteuropa, das Speisefischgeschäft florierte ebenfalls." (ROGGE 1993:32).

Der Vorteil der Lage der Teiche an Forellenbächen bestand darin, dass sie die Fischerei sehr erleichterte. Sie konnte man dadurch, in rationellerer Weise betreiben, wie dies bei der wilden Fischerei möglich ist." (BORNE 1886:278) Wenn auch oft schon vorher mit Besatzfischen eine kombinierte Fisch-/Mühlteichnutzung erfolgte, so verlangte die Fokussierung auf eine vollständige Teichwirtschaft aber von den Mühlen erhebliche Investitionen in eine andere bautechnische Anlage (siehe VII 2 und 3), die zugleich eine professionelle Mühlenbewirtschaftung nicht oder nur eingeschränkt möglich machte.

Der Erste Weltkrieg zerstörte die aufblühende Forellenzucht. Viele Teiche wurden entweder wieder trockengelegt oder verschiedene Betriebe stellten sich wieder auf die Karpfenhaltung um, die überall in lebensmittelarmen Zeiten an Bedeutung zu gewinnen pflegte (RUST 1956:52).

Nach dem Ersten Weltkrieg setzte die Meeresfischerei, d. h. die Küsten- und Hochseefischerei verstärkt ein (RUST 1956:65) und verschaffte der gerade wieder erneut aufstrebenden Forellenteichwirtschaft große Konkurrenz (obschon bereits im Mittelalter die Heringsfänge vor der Küste Schonens gewaltige Massen an Fisch in den Häfen der Ostseeküste anlandeten, diese salzten und somit transportfähig machten). Doch erst mit der Entwicklung der Dampfschifffahrt in der Küsten- und Hochseefischerei erwuchs der binnenländischen Teichwirtschaft eine scharfe Konkurrenz, da die Massen billiger transportiert und angeboten werden konnten und so der - im tiefen Binnenland weitgehend geschmacklich unbekannte - Seefisch den Süßwasserfisch weitgehend verdrängte.

Im 20. Jahrhundert verloren auch die herkömmlichen Nebennutzungen immer mehr an Bedeutung. Die Sömmerung fand nur noch als Teichbodenpflege (Mineralisierung der Teichschlämme) und Düngung (z. B. Hülsenfruchtanbau, Einbringen von Kompost, Lehm oder Exkrementen) statt (POHL 1924, SCHMIDT 1985). Schilf, Rohr und Binsen wurden kaum noch verwandt, so dass spezielle arbeitsintensive Entkrautungsmaßnahmen notwendig wurden. Ebenso mussten regelmäßig Entlandungen vorgenommen werden. Die dabei geborgenen Teichschlämme wurden teilweise noch auf die Äcker gebracht (BfN 2000:D-9).

Jeweils zu Notzeiten, wie sie infolge der Kriegsgeschehen während und nach dem Ersten und Zweiten Weltkrieg ausbrachen, wurde die Wiederinbetriebnahme landwirtschaftlicher Brachländer angeregt. Die periodisch ansteigende Zahl wissenschaftlicher Veröffentlichungen und praktischer Ratgeber des Reichsnährstandes aus dieser Zeit und zu diesem Thema vermitteln dieses Bild auf eindruckvolle Weise, wie die Situationsbeschreibung von LIETMANN aus den Ende der 1930er und Anfang der 1940er Jahre zeigt (die durchaus aber eine reale Vorstellung widerspiegeln könnte): „Reste alter Teichanlagen finden sich sehr oft noch im Gelände. Sie sind zum größten Teile späterhin Äcker, Wälder, Wiesen und Weiden geworden. Es liegen aber noch heute viele zur Teichwirtschaft geeignete Geländeteile brach, andere liefern der heutigen Zeit entsprechend vollkommen ungenügende Erträge oder erweisen sich zur landwirtschaftlichen oder forstwirtschaftlichen Melioration infolge unverhältnismäßig hoher Kosten als ungeeignet.“ (LIETMANN 1941:6)

In den Händen des Reichsnährstandes lag die wirtschaftliche Förderung, Beratung und Betreuung, „der diese Aufgaben durch die neugeschaffene berufsständische Vertretung, den Reichsverband der Deutschen Fischerei, mit seinen gaubezirklichen Gliederungen der Landesfischereiverbände ausführt.“ (LIETMANN 1941:6). Die Landesfischereiverbände mussten dabei solche Fachleute nachweisen „oder zur Verfügung stellen und auch sonst stets praktischen Rat erteilen.“(:8)

Nach ihrer Ansicht waren nicht nur die Karpfenteiche wieder zu beleben, auch „die Forellengewässer harren noch der intensiveren Nutzung.“ (LIETMANN 1941:6). Es wurde hier im Osten „,natürlich in erster Linie“ darum „solches Gelände zu Teichanlagen verwendet, welches man im landwirtschaftlichen Sinne als Unland oder Ödland bezeichnet.“(:6) 
Es ist jedoch eine widersinnige Politik, zum einen zur Reanimierung der Teichwirtschaft aufzurufen, zum anderen bestehende Anlagen durch Infrastrukturmaßnahmen zu vernichten. So wurden z. B. zum Bau des Autobahndammes Berlin-Prag, der die Teichgruppe Niederspree in Nord/Südrichtung teilt, einige Teiche Ende der 1930iger Jahre „über mehrere Jahre trockengelegt. Diese Maßnahme führte wieder zu einer fast vollständigen Verlandung“" (BfN 2000:D-33).

Doch nur wenige Zuchtbetriebe überdauerten in ihrer damaligen Form und Größe den Ersten und Zweiten Weltkrieg. Da während des Krieges keine Besatzfische aus dem Karpfenherkunftsland Südosteuropa importiert werden konnten, mussten viele Teiche, insbesondere die von den Besatzfischen abhängigen kleineren Teichwirtschaften, die keine vollständige Zucht betrieben, während der Kriegszeiten trockengelegt werden (RUST 1952:39). Die Ausbreitung einer verlustreichen Karpfenseuche, damals unter der Bezeichnung „Bauchwasserseuche“ geführt und erstmals 1935 in Franken aufgetreten, führte durch den Mangel an gesunden Satzfischen zu überhöhten Preisen. Zum einen war damit die Kostendeckung der Speisekarpfenerzeugung (KEIZ 1995:19), zum anderen der Absatzmarkt in Frage gestellt. Zudem erschwerten während der Kriegsund Nachkriegsjahre vernachlässigte ungepflegte Teiche den Neubeginn (:19).

Nach dem Zweiten Weltkrieg und mit dem Ende der Mangelwirtschaft begann eine erneute Periode der Intensivierung. Sie wurde durch die Preisverhältnisse der Nachkriegszeit veranlasst und wurde vor allem durch bereits nach dem Ersten Weltkrieg eingeführte Verwendung von Kalk und Kunstdünger sowie die künstliche Zufütterung gesteigert (SCHÄPERCLAUS 1961:168).

Auf der Gegenseite jedoch stellten sich im Nachkriegsdeutschland veränderte Konsum- und Essgewohnheiten ein und verschärfte die wirtschaftliche Situation in der Teichwirtschaft: Die Hauptsaison der Abfischung begann sonst im Oktober/November und erreichte ihren Höhepunkt im Dezember um Weihnachten und Neujahr. Die Nachsaison reichte bis in das Frühjahr mit Anstiegen vor Ostern. RUST (1956:64) stellte aber bereits Mitte der 1950er Jahre fest, dass der Karpfenkonsum „sich heute auf wenige Festtage“ beschränkt. „Eine Entwicklung, die ganz besonders seit Ende des letzten Krieges spürbar wurde." Die soziale Umschichtung infolge der Industrialisierung machte den Karpfen zu einem Luxusartikel, und veränderte religiöse und ernährungsmäßige Gewohnheiten trugen zu einem veränderten (zeitlichen) Konsum bei, der sich seither, ähnlich der Weihnachtsgans, auf die Festtage im Jahr beschränkt.

Ehemalige Kerngebiete der Karpfenzucht, wie z. B. Schlesien, Böhmen, Mähren, gingen des Weiteren infolge von Gebietsabtretungen nach 1945 als Produktionszentrum verloren (HUBERT 1991:17). Karpfenimporte aus den sog. Ostblockstaaten störten mit Dumpingpreisen empfindlich das heimische Marktgeschehen (KEIZ 1995:19).

Um dem Konkurrenzdruck zu begegnen wurden seit den 1950er Jahren „unterschiedliche, landschaftlich bedingte Eigenarten in der Teichwirtschaft innerhalb Deutschlands durch die moderne Technik ausgeglichen“ (RUST 1956:1). Dies gelang nur bedingt und so hat sich die berufliche Binnenfischerei in allen Bundesländern „der wirtschaftlichen Entwicklung anpassen und sich in Gebiete zurückziehen müssen, in denen aus der Fischerei bzw. aus der Fischzucht und Fischhaltung noch ein hinreichendes Einkommen erwirtschaftet werden kann.“ (SEEDORF/MEYER 1996:418)

Übten die meisten Betriebe die Fischerei in diesen „Rückzugsgebieten“ infolgedessen an den größeren Flüssen (z.B. Elbe, Weser, Aller und Ems) und an einigen Seen (z.B. Steinhuder Meer, Dümmer und Zwischenahner Meer) aus, die keiner besonderen Erfordernisse baulicher Art bedurften, und verbanden hier die Fischerei meist mit der Veredlung der gefangenen Fische, mit Gaststätten und Fremdenverkehr (vgl. SEEDORF/MEYER 1996:418), so ist aufgrund der schlechten Wasserqualität auch hier der Fang seit den 1970/80er Jahren wenig ertragreich (Bsp. Weser) oder nicht mehr möglich (Bsp. Dümmer See).

In dem anderen Sektor der beruflichen Binnenfischerei, der Teichwirtschaft, finden sich neben der herkömmlichen und über Jahrhunderte nahezu unveränderten Fischproduktion mit dem üblichen 
technischen Fortschritt in der Teichwirtschaft in Einzelfällen auch Ansätze für eine technische Weiterentwicklung zur „Aquakultur“, d. h. zur Anwendung neuer hochtechnisierter Verfahren und Anlagen der Intensivhaltung und -zucht, die erhebliche Produktionssteigerungen ermöglicht.

Nach dem Zweiten Weltkrieg wurde in Gebieten der DDR die Teichbewirtschaftung durch Gründung von VEB Binnenfischereibetrieben intensiviert, die so planmäßige Getreidezufütterung durchführten. Weitere Intensivierungen in den 1970er und 1980er Jahren wie Mischfuttereinsatz und Teichbelüftung führten zur sog. „Pelletintensivwirtschaft“. Eine ähnliche Entwicklung nahm die Fischwirtschaft im gesamten Mitteleuropa. So werden die Spitzenwerte von rund $3000 \mathrm{~kg}$ pro Hektar und Jahr gegenwärtig fast ausschließlich von tschechischen Intensivstbetrieben unter Einsatz von PelletZufütterung, massiver Kalkung und Düngung erreicht. Nach sächsischen Erfahrungen muss ein Teichwirt unter den heutigen ökonomischen Rahmenbedingungen Erträge von 800 bis $1000 \mathrm{~kg} / \mathrm{ha}$ erwirtschaften, um in der Speisefischproduktion wirtschaftlich erfolgreich zu sein (SCHULTE 2000).

Die Aufzucht und die Mast von Fischen in solchen Anlagen geht von der kontinuierlichen Wasseraufbereitung in Kreislaufanlagen aus, die ausreichen muss, um das durch die Stoffwechselausscheidungen der Fische belastete Wasser so weit zu behandeln, dass es stets wieder benutzt werden kann. Jedoch birgt jede Form der Intensivhaltung von Tieren auch beträchtliche Risiken, die Folgen für die historisch gewachsene Kulturlandschaft einmal unberücksichtigt gelassen. In diesen Intensivanlagen stehen die Fische unter erheblichem Stress und sind deshalb leicht Krankheiten ausgesetzt. In Niedersachsen wurden beispielsweise 1995 in 8 Kreislaufanlagen jährlich ca. 200 t Fische produziert.

Eine andere Form der Intensivhaltung ist die Haltung insbesondere der Regenbogenforellen in Netzgehegen. Sie wird in Niedersachsen in mindestens $10 \mathrm{~m}$ tiefen und möglichst nährstoffarmen Baggerseen betrieben. Netzgehege sind „mobile Kleinteiche“ bei denen der Aufenthaltsraum der Fische durch Netzwände und einen Netzboden abgegrenzt ist. Sie bestehen aus einem quadratischen oder rechteckigen Rahmen, in dem der Netzkörper (Tiefgang $=2,30-2,50 \mathrm{~m}$ ) befestigt ist. In Niedersachsen produzierten 19958 Betriebe mit insgesamt 88 Netzgehegen jährlich ca. 100 t Fische (SEEDORF/MEYER 1996:418).

Schließlich wird in jüngster Zeit in ehemaligen riesigen Stallungen der Schweinemastbetriebe der LPG in einzelnen Sauenställen Forellenzucht unter Dach betrieben. Im Land Thüringen wie im Land Brandenburg wird die Aquakultur neben Teichwirtschaften in technischen Anlagen wie in Netzkäfigen, in Becken-, Rinnen-, Siloanlagen durchgeführt. Und dies betrifft die Aufzucht von Satzkarpfen, Aal, Stör und Wels, die Versuchsproduktion von Streifenbarschen sowie die Erbrütung von Karpfen- und Welsbrut. Mit einem Anteil von mehr als $80 \%$ an der Gesamtabfischung von Speisefischen ist die Aquakultur wie in den Vorjahren auch im Berichtszeitraum des Jahre 2000/02 der dominierende Zweig der Binnenfischerei, wenn auch der Schwerpunkt der Aquakultur weiterhin in der Bewirtschaftung von Karpfenteichen liegt (BRANDENBURG 2003).

Die Diversifizierung der Einkommensmöglichkeiten der fischereilichen Unternehmen hat sich in den letzten Jahren fortgesetzt. Zunehmend werden Dienstleistungen im Fremdenverkehr, die Direktvermarktung und die Veredelung der Produkte erweitert. Diese Entwicklung wird durch die Landesregierungen mit Unterstützung der EU gezielt gefördert. Im Rahmen einer Marketingkooperation wurde zum Beispiel im Land Brandenburg eine Initiative zur Förderung des Absatzes von Fisch und des Tourismus im ländlichen Raum Brandenburgs unter dem Logo „Märkische Fischstraße“ gestartet, der sich 30 Unternehmen angeschlossen haben.

Dennoch waren die Abfischungsergebnisse des Berichtszeitraumes im Vergleich zu den Vorjahren in allen Produktionsbereichen rückläufig. Das gesamte Speisefischaufkommen im Land Brandenburg von $1.840 \mathrm{t}$ stellt gegenüber dem Jahr 2001 eine Verringerung um $12 \%$ dar.

Betrachtet man gar die hier in diesem Kapitel angesprochene Teichwirtschaft, so ist bei dem Karpfen sogar ein Rückgang von $20 \%$ zum Jahr 2001 und von $23 \%$ zu dem Durchschnitt der letzten fünf Vorjahre zu verzeichnen. Auch in der Forellenproduktion ist im Jahr 2002 ein Produktionsrückgang zu 
verzeichnen. Mit einem Ergebnis von 470 t Regenbogenforellen und 40 t Saiblingen wurden ca. $11 \%$ weniger Salmoniden als in den Vorjahren produziert.

Der Landesfischereiverband Brandenburg schätzt ein, „dass in der zunehmend schlechten Wasserversorgung einiger Teichwirtschaften und in der unzureichenden Satzfischgrundlage die Hauptursachen liegen“ (BRANDENBURG 2003).

Erschwerend für die Teichwirtschaft kommen Auflagen und Regelungen hinzu, so sinnvoll sie aus ökologischer Perspektive (Stoffbelastung, zusätzliche Wasserentnahme) und teichbetriebswirtschaftlichen Gründen (Wärme- und Nahrungsverlust) auch sind So fordert beispielsweise die bayerische „Teichbaurichtlinie“ grundsätzlich für bestehende und genehmigte Fischteiche Nach- und Umrüstungen: Fischteiche dürfen nicht im Hauptanschluss des Fließgewässers betrieben werden, es sind Umlaufgräben zu bauen und Karpfenteiche sollen nicht als Durchflussteiche betrieben werden, und der Mindestabfluss im Bachbett ist unter Berücksichtigung der biologischen Vielfalt für jede Anlage individuell festzusetzen. Neue Teichanlagen werden in Teichintensivgebieten wegen der Vielzahl bereits vorhandener Fischteiche als problematisch angesehen (BAYERISCHES LANDESAMT FÜR WASSERWIRTSCHAFT 1996:124)

Aber nicht nur in der Fischwirtschaft, auch in der Seen- und Flussfischerei verzeichneten die Binnenfischereibetriebe des Landes Brandenburg in 2002 aus der fischereilichen Bewirtschaftung von 61.000 ha Flüssen und Seen im Vergleich zu den Vorjahren einen Rückgang um ca. 8 \%. Dies betrifft vor allem den Aal als den „Brotfisch“ der Fluss- und Seenfischerei. Der Landesfischereiverband bezeichnet hier die „Kormoranschäden und Fischwilderei als die Hauptursachen“ (BRANDENBURG 2003).

Mit dem langsamen Verfall der Preise für Süßwasserfische gehen des Weiteren in Bayern immer mehr Teichwirte dazu über, als Alternative Satz- oder Speisekrebse zu produzieren (BOHL et al. 2001:2,30). Der Nettoertrag von bis zu $300 \mathrm{~kg} / \mathrm{ha}$ Teichfläche ist - bei einer ausschließlichen Haltung der weit größer werdenden Männchen - etwa 10mal so hoch wie in freien Gewässern (:30). Doch dieser Vergleich erübrigt sich angesichts der Tatsache, dass heimische Edelkrebse aus ihren früheren Gewässern weitgehend verschwunden sind und sich nur noch auf kleine Inselvorkommen in isolierten Gewässern und im Oberlaufbereich konzentrieren. „Obwohl sich in neuerer Zeit Wasserqualität und Struktur der Gewässer durch eine ökologisch orientierte Wasserwirtschaft wesentlich verbessert haben, konnten sich die ursprünglich vorhandenen Krebsbestände nicht wieder aufbauen.“ (:16). Dies liegt, obgleich es eine Reihe von heimischen Krankheiten und Parasitosen gibt, vor allem an den Teichwirten selbst, von denen einige Krebsliebhaber in den 60er Jahren des 20. Jahrhundert den ,Signalkrebs' (Pacifastacus leniusculus) von der Pazifikküste Nordamerikas nach Europa importierten (:12). Trotz ernster wissenschaftlicher Bedenken und Warnungen versuchte man, mit ihm den weitgehend ausgestorbenen Edelkrebs zu ersetzen. Die Folge war, dass die meisten der noch verbliebenen Restbestände des Edelkrebses vernichtet wurden, denn der Signalkrebs ist ein latenter Dauerüberträger der Krebspest und breitete sich durch leichtfertigen Besatz von Teichen ausgehend in Fließgewässer aus.

Ebenfalls wurde auch der ,Rote Amerikanische Sumpfkrebs' (Procambarus clarkii), ursprünglich im subtropischen Louisiana (Mississippidelta) beheimatet, importiert und ist gerade im Begriff, auch mitteleuropäische Gewässer zu besiedeln. Als Überträger der Krebspest vernichtet er innerhalb weniger Jahre die heimischen Krebse. Bis zu $6 \mathrm{~m}$ tief im Boden eingegraben überlebt der Krebs selbst längere Trockenperioden. Deshalb ist eine erfolgreiche Bekämpfung in der Natur so gut wie unmöglich. Wider Erwarten kann sich der Rote Sumpfkrebs auch unter den mitteleuropäischen Klimaverhältnissen fortpflanzen und ausbreiten. Obwohl nur klein und minderer Fleischqualität, findet er immer wieder Abnehmer in der Gastronomie (BOHL et al. 2001:14).

Alle gebietsfremden Arten sind durch Einschleppung oder Besatz in die Gewässer gelangt. Sie müssen „als Invasoren betrachtet werden, die fatale Folgen für die heimische Fauna und Flora mit sich bringen“" (BOHL et al. 2001:7) - ursprünglich gedacht, neue Absatzmärkte zu erschließen und eine aussterbende Art zu ersetzen. 
Über den gesamten Zeitraum der Teichwirtschaft hinweg, dies lässt sich zusammenfassend betrachten, wurden Teiche ausgehoben, aufgegeben, verlandet oder umgewidmet, andere wurden zwischenzeitlich verkleinert, während gleichzeitig oder nachfolgend in benachbarten Gebieten Teiche neu hinzukamen bzw. bestehende vergrößert wurden. Weiterhin fanden bauliche Veränderungen innerhalb der Teichgruppen wie Teichzusammenlegungen, -vertiefungen, Uferbefestigungen statt. Eine Kontinuität war somit auch in den „historischen Teichwirtschaften“ nicht gegeben, auch wenn der heutige Teichbestand mit Sicherheit einen historischen Tiefstand erreicht hat.

Die historisch-umweltgeschichtliche Entwicklung verzeichnet dennoch einen verhalten positiven Ausblick der traditionellen Teichwirtschaft als historisch-geographisches Erscheinungsbild in der Landschaft. Nach 1990 erfolgte mit der (Re-) Privatisierung der Teichwirtschaften auf dem Gebiet der ehemaligen DDR eine Extensivierung der Fischzucht, die Raum lässt für eine nachhaltige, ökologisch verträgliche und die Kulturhistorie der Teichwirtschaften berücksichtigende Wirtschaftsweise. Modellprojekte initiieren und unterstützen eine solche Entwicklung, wie zum Beispiel die vom Bundesamt für Naturschutz geförderten Naturschutzgroßprojekte „Teichgebiete NiederspreeHammerstadt" und „Waldnaab-Aue“.

\section{b Historisch-geographische Verbreitung}

Die erste Nennung von über Fischweihern („vivaria piscinum“ oder „piscinae“) finden wir in den Schilderungen des Marcus Terentius Varro (116 - 27 v. Chr.), Reichsbibliothekar und bedeutendster gelehrter Schriftsteller Roms, in seinem Alterswerk über den Landbau „Rerum rusticarum libri III“ und durch Plinius den Älteren (23/24 - 79 n. Chr.) in seinen - auf Varro aufbauenden - Schriften der Naturgeschichte (,Naturalis historia“) in Band IX c 49 und 50 seines insgesamt 37 Bände zählenden Werkes (CNOPF 1927:9; BROCKHAUS 1980, 11. Bd.: 667).

Ungeklärt ist, ob die Römer diese „piscinae“ zur Fischzucht verwendet haben oder es sich bei diesen Teichen lediglich um Hälteranlagen gehandelt hat. Es ist aber zu vermuten, dass diese Teichanlagen zur Erkenntnis der Fischzucht geführt haben, „dadurch, daß die gehegten Fische zufälliger Weise laichten und Nachwachsen von Brut zu beobachten war“, wie CNOPF (1927:9) argumentiert: „Da der Ausfang aus den Flüssen zu unbeständig gewesen sein mag, indem manchmal eine Ueberfülle von Fischen anfiel, ein andermal die Ausbeute sehr gering gewesen sein mochte, außerdem bei dem ständigen Raubbau zu befürchten stand, daß der natürliche Fischreichtum der Gewässer einmal versiege, so liegt der Gedanke nahe, daß man zunächst kleine Weiher anlegte, die als Hälteranlagen dienten, und den Ueberschuß des Ausfanges aufnahmen. So war man nicht von den Wechselfällen des Fischausfanges abhängig und konnte kluge Vorratspolitik treiben. Im Laufe der Zeit wird man sich mit dieser primitiven Methode der Abwachsteiche nicht mehr begnügt haben und zur eigentlichen Fischzucht übergegangen sein.“ „Aber irgendwelche größere Bedeutung“, resümiert CNOPF (:9), ,hat die Fischzucht bei den Römern nicht erreicht; der Hauptsache nach beschränkte man sich auf Fischhaltung, um für die üppigen Gastmähler ständig frische Fische im Vorrat zu haben.“

Wann die Teichwirtschaft in Deutschland ihren Einzug gehalten hat, wird sich nicht mit Bestimmheit feststellen lassen, „wohl aber dürfen wir annehmen, daß mit dem Vordringen des Christentums und der Verbreitung der Klöster dieser Wirtschaftszweig bei uns heimisch wurde" (CNOPF 1927:10).

$\mathrm{Ob}$ und wie weit die aus römischer Zeit her bestehenden Bistümer Basel, Konstanz, Straßburg, Mainz, Trier, Köln und Augsburg die Pflege der Fischteiche betrieben, konnte ich nicht ermitteln. Sicher aber ist, dass durch das Vordringen des Christentums dieser Wirtschaftszweig seine Verbreitung gefunden hat. Auf Grundlage der Christianisierungstätigkeit des angelsächsischen Benediktinermönches Bonifatius (672/73 - 754), die in Deutschland in die Zeit von 719 - 755 fällt, müssen die ,ersten Teichanlagen im Laufe des 8. Jahrhunderts entstanden sein“ (CNOPF 1927:11). Man kann sagen, dass die Teichwirtschaft seit etwa 1200 Jahren in Deutschland üblich ist. 
Die erste zuverlässige Kunde über Anlage von Fischteichen stammt aus dem Capitulare de Villis, die Kaiser Karl dem Großen $(768$ - 814) zugeschrieben wird, aber tatsächlich wohl von seinem Sohn Ludwig stammt $(778$ - 840). Ihr ist zu entnehmen, dass man vor dem Erlass dieser Wirtschaftsordnung die Bedeutung der Fischzucht oder, besser gesagt, Fischhaltung schon gekannt hatte und bestrebt war, die Verbreitung der Weiher in noch stärkerem Maße durchzuführen (CNOPF 1927:10; AMACHER 1996:87; LAMPEN 2000:126).

Die als Verwaltungsanleitung für die königlichen Güter in Aquitanien vermutlich in dem Jahr 794/95 erlassene Wirtschaftsverordnung, die sich nicht auf deutsche Gebiete bezieht, enthält - neben Hinweisen über die Funktion der Krongüter, über die Rechte und Pflichten der iudices und über die Abgaben und den Zehnten - detaillierte Anmerkungen zu den einzelnen Erwerbszweigen der Landwirtschaft, zu der auch die Teichwirtschaft zählt. Kapitel 21 betrifft die königlichen Fischteiche: Die iudices werden hierin aufgefordert, die bestehenden vivaria zu erhalten und - wo möglich und noch nicht vorhanden - neue Teiche anzulegen. Die Fischhaltung in künstlichen, vielleicht ursprünglich auch natürlichen Teichen war demnach zu dieser Zeit im Frankenreich bereits bekannt. Die Verwendung der Fische wird in Kapitel 44 und Kapitel 65 weiter beschrieben. Zwei Drittel des Ertrages sollten als Fastenspeise jährlich an den königlichen Hof geliefert werden. Den Rest sollten die Aufseher teilweise verkaufen, teilweise sollten die Fische jedoch im vivarium verbleiben, so dass bei Anwesenheit des Königs immer genügend Fische vorhanden seien (LAMPEN 2000:126). Kurzum: Er ordnete an, dass auf jedem Königshof Fischweiher angelegt werden sollten und die Fische verkauft werden könnten, außer wenn der Kaiser und sein Gefolge auf dem Hof zu erwarten waren (AMACHER 1996:87).

Der König hatte keine feste Residenz. Karl der Große hielt - zumindest in den ersten Jahrzehnten seiner Regierung - an der Auffassung seiner Vorgänger fest, dass der Herrscher im gesamten Reich gegenwärtig sein müsse. Es kam also nicht zur Ausbildung eines festen Hofes als dauernder Residenz, sondern zu wechselnden Schwerpunkten in den einzelnen Reichsteilen. Diesem Regierungsstil dienten die über das ganze Reich verteilten Pfalzen ${ }^{3}$ und die Königshöfe, auch Königsgüter oder Königsdörfer genannt, die eine pfalzenähnliche Stellung einnahmen, als staatliche Stützpunkte dieser Art der Königsherrschaft und Aufenthaltsorte des Königs ${ }^{4}$.

Das Wort „Königshof“ ist dabei ein umfassender Begriff; in der Regel versteht man darunter den Bau befestigter Hofanlagen, die zur militärischen Sicherung des Frankenreiches errichtet worden waren. Sie hatten eine hohe strategische Bedeutung und waren vermutlich der Schwerpunkt der lokalen Verteidigungsanlagen.

Die Königshöfe waren in den besetzten Landstrichen etwa schachbrettartig verteilt und durch Versorgungsstraßen miteinander verbunden. Systematisch wurden, entlang der Heerstraßen nach Norden zu, Klöster und befestigte Königshöfe angelegt, die als Königslehen an bewährte, verdiente Gefolgsleute verliehen wurden. Sie waren die Stationen der königlichen Wanderschaft, deren Erträge ausreichen mussten, einen hungrigen Hofstaat mit seinem riesigen Tross eine längere Zeit

\footnotetext{
${ }^{3}$ Das äußerliche Erscheinungsbild der Pfalzen differierte stark; es reichte von größeren Gutshöfen, die dem König und seinem Gefolge Unterkunft und Verpflegung boten, über starke Reichsburgen bis hin zu befestigten Städten mit ausgedehnten königlichen Palastbauten wie Goslar in Sachsen, Wimpfen in Schwaben, Frankfurt am Main, Hagenau im Elsass oder Aachen als Kaiserpfalz, die Massierung von drei Königspfalzen im Innviertel, in Ranshofen, Mattighofen und Ostermiething als waldreiches Treibjagdgebiet. Infolgedessen wird der Begriff „Pfalz“ oft synonym mit Königshof genannt. Hier hingegen soll eine Unterscheidung vorgenommen zwischen den Pfalzen, die dem, wenn auch weiterhin nur temporären, so dennoch längerfristigen Aufenthalt dienten und dementsprechend eine andere bauliche Ausstattung und Ausdehnung hatten, und den oben beschriebenen traditionellen, eher einfachen „Höfen“. So hatte der Kaiser beispielsweise eine Vorliebe für die Pfalz Aachen, wo er sich mit seinem Hof oft und lange aufhielt, ohne die Pfalz zu seiner dauernden Residenz zu machen.

${ }^{4}$ Diese Gewohnheit blieb auch unter seinen Nachfolgern bestehen, wenn sich hier auch ein differenziertes Bild bot. Nach den Reichsteilungen zeigte sich im Westfränkischen Reichs Karls des Kahlen bald eine besondere Auffassung vom Königtum, das sich an dem französischen Vorbild mit Herausbildung einer feste Königsresidenz (Paris) orientiert, im ostfränkischen Reich hingegen, das aus den Herzogtümern Franken, Sachsen, Bayern, Schwaben und Lothringen bestand und sich im 10. Jahrhundert zum Deutschen Reich entwickelte, blieb die Vorstellung von der Präsenz des Königtums im gesamten Reichsgebiet lebendig. So hatte zwar Otto der Große eine Vorliebe für die Pfalz Magdeburg, wo er 968 ein Erzbistum errichtete, hielt aber trotzdem am Prinzip der „Reiseherrschaft“ als Zeichen der Präsenz im ganzen Reich fest.
} 
unterzubringen und zu verpflegen. Königshöfe waren beispielsweise Remagen, Recklinghausen, die weniger bedeutsamen Nachbarhöfe Oer und Brünninghoff, Alff und Prüm im Moselgebiet, Ampen im Gebiet der heutigen Soester Börde; die davon nächstgelegenen waren die Königshöfe Erwitte und Westhofen, Plettenberg am Egge-Gebirge, darüber hinaus gab es Königsgüter in Lügde und Schieder, bei Brakel und Warburg und auch in Altkloster, Harsefeld und Stade zwischen Elbe und Weser entstanden befestigte fränkische Königshöfe zur Festigung der Macht.

Um sich eine Vorstellung von solcher Hofanlage zu machen und daraus den Standort von den erwähnten vivaria, den Teichen, abzuleiten, sei der „Recklinghauser Königshof" beschrieben: Er hatte eine Ausdehnung von ca. 120 x 140 Metern und war von einer einfachen Befestigungsanlage umgeben, die aus einem aus Holzpfählen errichteten Zaun auf einem Erdwall und einem Wassergraben bestand. Wie die meisten Königshöfe der Zeit bestand auch der Recklinghauser Hof aus Wohnbauten, Arbeitshäusern z. B. für das Weben, Kochen und Backen, Stätten für das Vieh, Scheunen und Speichern, vermutlich einer Mühle sowie einer königlichen Kapelle. Außerdem gab es zum Schutz gegen feindliche Überfälle Wohntürme. Man kann sich die Königshöfe dieser Zeit generell als größere, befestigte „Bauernhöfe“ vorstellen.

Der Hof bot den Truppen Karls des Großen beim Durchmarsch Schutz, Unterkunft und Verpflegung, genau genommen aber nur den Truppenführern. Die einfachen Soldaten lagerten auf dem Kamp (campus $=$ Feld). Der Kamp war durch einen Erdwall geschützt und mit schattenspendenden Obstbäumen bepflanzt. Im Schutz der königlichen Hofanlage entwickelte sich eine kleine, recht betriebsame Marktsiedlung, vorwiegend bestehend aus Handwerkern und Kaufleuten (KOSSMANN 1971; ALFF 1999; HENKE 2000; DOPSCH 2001; RECKLINGHAUSEN 2004). Dies bedeutet, dass die Teiche nicht unmittelbar vor der Stadt, sondern in etwas weiterer Umgebung, zumindest aber außerhalb des Kamps gelegen sein mussten.

Geht man von dem unmittelbaren Vollzug dieser kaiserlichen Anordnung seit Ende des 8. Jahrhundert aus, müssen zu diesem Zeitpunkt infolge der räumlichen, ,schachbrettartigen“ Verbreitung der Königshöfe zahlreiche Weiher bestanden haben bzw. im Zuge dieser Anordnung errichtet worden sein. Die mitziehenden und vorbeimarschierenden Truppen wollten versorgt werden wie natürlich auch der König mit seinem Dienstgefolge. Dabei ist davon auszugehen, dass sich höfisches Leben nicht allzu oft im Jahr abspielte und sich die Bedeutung von Fischteichen nicht allein auf die Versorgung des kaiserlichen Trosses beschränkte. Verständlich wird die Forderung nach Anlage von Teichen erst dann, wenn bekannt ist, dass finanziell das merowingisch-karolingische Königstum hauptsächlich auf den Erträgen dieser Güter ruhte, daneben auf einem größeren Anteil an der Kriegsbeute und auf freiwilligen Gaben der Untertanen. Mit Sicherheit ist also davon auszugehen, dass nicht nur die Versorgung sichergestellt werden sollte, sondern auch Handel mit den Fischen getrieben wurde. Das heißt, der Bemessungsmaßstab der Teichgrößen orientierte sich nicht allein an primären Verpflegungsaspekten, sondern auch an betriebswirtschaftlichen Kenngrößen.

Hinsichtlich der kleinräumlichen Verteilung und Größe der Teiche ist zu beachten, dass die Nachbarkönigsdörfer an einem Tage zu Fuß zu erreichen waren und dementsprechend Fischvorrat zur Deckung der Versorgungsspitzen nur für die Dauer des Aufenthalts bereitgehalten werden musste. Dabei ist bei einer vorübergehenden Lagerung von maximal einigen Tagen auszugehen; handelte es sich um grenzlägige Höfe als Standort bzw. Ausgangspunkt mehrwöchiger Belagerungen oder Schlachten, ist mit einer mehrwöchigen bzw. mehrmonatigen Versorgung zu rechnen. In die Überlegungen zur Anlage von Teichen zur Deckung des Bedarfs an Fisch, ist aber die hydrologischtopographische Lagewahl von Königshöfen nicht außer Acht zu lassen, die sämtlich an Gewässern bzw. Bachläufen lokalisiert waren. Die dortigen Wasserverhältnisse mit dem sich anbietenden Flussfischfang waren dem Anliegen der Versorgung besonders günstig.

Kaiser Karl der Große weitete um das Jahr 812 n. Chr. in seinen Capitularien die Vorschriften für die Anlage von Fischteichen aus: ,Jeder Amtmann soll auf unseren Landgütern Fischweiher halten, wo sie schon waren, ja, er soll sie mehren, wo dies möglich ist, und wo früher noch keine waren, solche aber jetzt sein können, soll er sie neu anlegen." (WUNDER 1956:5) Insofern kann davon ausgegangen 
werden, dass die zahlreichen Königsgüter, die über das ganze Land verstreut waren, eine wichtige Rolle für die Ausbreitung der Fischteiche spielten (CNOPF 1927:11).

Da die Bestimmungen des Capitulare de Villis nichts über die Aufzucht und Pflege der Fische aussagen, kann wohl davon ausgegangen werden, dass es sich in diesen Fällen nicht um kontrollierte Zucht, sondern eher um einfache Hälterungsteiche zum Frischhalten der Fische handelte, in denen die Fische aufbewahrt wurden, bevor sie als Abgabe in die Königshöfe gelangten.

Der Begriff piscina (lat.: Fischteich) wird in den Urkunden das erste Mal in einem Diplom Karls II. von 885 verwendet. Anlässlich der Bestätigung der Schutz- und Wahlprivilegien des Trierer Klosters St. Maximin wird dem Konvent ein Fischbecken unterhalb einer Trierer Brücke bestätigt. Es ist jedoch nicht deutlich, ob hier wirklich ein Fischteich gemeint ist oder nicht eher ein Aufbewahrungsbehälter für Fische, der im Fluss verankert war. Ähnliche Fischbehälter sind nämlich als Aufbewahrungs- und Transportkästen für frische Süßwasserfische z. B. in Köln belegt (LAMPEN 2000:128).

Als Hinweis auf ein ausgeklügeltes Teichsystem mit einheitlichem Besatz und getrennten Zuchtphasen können die Passagen des Capitulare de Villis und anderer Urkunden nicht gedeutet werden; trotzdem zeigen die Hinweise, dass bereits um 800 Fischteiche wichtige Bestandteile nicht nur klösterlicher Grundherrschaften waren. Diese Deutung unterstützen auch die anderen herrschaftlichen Verwaltungsvorschriften karolingischer Zeit. Auch im Brevium Exempla ad discribendas res ecclesiasticas et fiscales ${ }^{5}$, das kurze Zeit nach dem Capitulare de Villis, wahrscheinlich um oder kurz nach 800, entstanden ist, finden sich Hinweise auf frühe Fischteiche. In diesem Verzeichnis der Besitzungen werden mehrere Fischteiche nicht nur für verschiedene Königshöfe, sondern auch eines Klosters als Besitz erwähnt (DOPSCH 1916:41ff.; BERGMANN 1967:213ff.; LAMPEN 2000:127).

Aus diesen frühen schriftlichen Quellen zur künstlichen Schaffung von Fischteichen wird ersichtlich, dass nicht nur die Klöster, wie zumeist in den Vordergrund gestellt, sondern auch der Adel als Vermittler antiker Teichwirtschaften gelten kann. Die Teichwirtschaft war also vorerst nicht nur Teil der Hauswirtschaft klösterlicher, sondern auch weltlicher Großhaushalte (AMACHER 1996:87). Die Fischzucht, formuliert ERGERT (1995:12), „wurde zu einer wichtigen ,Mode' beim Adel“. Doch nicht kunstvolle Teiche, sondern Burggräben, Stadtgräben, Tränkeweiher usw. wurden zur Aufzucht von Karpfen eingesetzt, wie AMACHER (1996:88) am Beispiel der Stadt Zürich herausgefunden hat. Schon die mittelalterlichen Grundherren hatten es verstanden, in damals eigentlich nicht zu diesem Zwecke hergestellten Hohlformen oder auf infolge hohen Grundwassers wertlosen und ertragsarmen Flächen Teiche anzulegen. Auf diese Weise wurden bis dahin nicht fischwirtschaftlich nutzbare Flächen in ertragreiche Teiche umgewandelt (HUBERT 1991:17) - und dies auf mannigfache Weise.

Den zweckentfremdeten Hohlformen zur Fischzucht zur Seite gestellt wurden die eigentlichen Fischteiche. Das Gebiet des heutigen Kantons Zürich beispielsweise war am Ende des Mittelalters von einer Unzahl von Weihern bedeckt. Entlang des Zürichsees und der Flüsse, bei Burgen, Städten und Klöstern gab es zahlreiche Fischteiche, allein im Raum Andelfingen existierten nach einer Zählung von AMACHER (1996:88) 28 Weiher.

Auch im Harzgebiet waren die weltlichen Grundherren Förderer der Fischzucht. Nach Einführung des Christentums zu Anfang des 10. Jahrhundert wurde nahezu der gesamte Gebirgswald als Reichsbannforst zum Königtum geschlagen. Damit lagen Jagd- und Fischereirecht im Oberharz ausschließlich in den Händen der Könige (WÜSTEMANN 1982:23). Infolge des allmählichen Zusammenbruchs des Königtums ging die Jagd- und Fischereigerechtigkeit im ehemaligen Bannforst im Verlauf des 12. Jahrhundert auf die neuen Besitzer, kleine Grafschaften und Herrschaftsbereiche, über und blieben damit in adeliger Hand.

\footnotetext{
${ }^{5}$ Das Brevium Exempla hatte formelhaften Charakter, das heißt, es wurde in der königlichen Kanzlei als Musterinventar abgeschrieben und tradiert. Das Brevium Exempla besteht aus der Güteraufzeichnung des Hofes Staffelsee in Oberbayern, einem Verzeichnis der Lehen und Prekarien des Klosters Weißenburg und einem Inventar der Königshöfe bei Lille.
} 
Die Forschung lokalisierte hingegen weithin insbesondere die Karpfenzucht als Nebenzweig der Teichwirtschaft bisher in das Umfeld der Klöster. Das Kloster galt als Wissenshort und erster Rezipient antiker Teichkultur. Es steht jedoch nach Ansicht von LAMPEN (2000:134) hier „zu fragen, ob es sich hier nicht ebenso wie bei der Teichkultur allgemein, um einen hartnäckigen Topos der Forschung handelt." Um tradierte Fehlurteile, die die Mission und die christlichen Fastengebote als Motor für den Aufschwung des Fischhandels hervorheben.

Die Domestizierung des Karpfens in aufwendigen Teichanlagen bildete nach dieser These einen Höhepunkt klösterlichen Wissens- und Wirtschaftslebens. Das langsame Vordringen von Teichen nach Osten und Norden wurde dementsprechend durch die Mission und Klosterneugründungen in diesen Gebieten erklärt. Dieser Vorstellung widerspricht Richard Hoffmann, ,einer der besten Kenner der mittelalterlichen Teichkultur" (LAMPEN 2000:137). In seinen Arbeiten (z. B. HOFFMANN 1994) untersucht er die historischen Belege für Karpfenfische außerhalb ihres natürlichen Verbreitungsgebietes, um so Nachweise für eine entwickelte Teichkultur zu liefern. Grundlage von Hoffmanns Untersuchung ist dabei eine chronologische Kartierung der schriftlichen und archäologischen Belege über Karpfenreste. Die Analyse Hoffmanns kann somit auch Aufschlüsse über die Ausbreitung der Teichwirtschaft allgemein liefern, da Karpfenreste in einer Siedlung, einem Kloster oder in einer Stadt ein sicheres Indiz für Teichanlagen sind. Wie lange an diesen Orten bereits eine Teichkultur mit anderen Fischen gepflegt wurde, kann anhand der Karpfenreste jedoch nicht geklärt werden. Auffällig ist jedoch, dass es sich bei den frühesten Fundplätzen nicht - wie eigentlich anzunehmen ist - um Klöster handelt, sondern um Siedlungsplätze und vor allem um frühe Adelssitze (LAMPEN 2000:137). Die Verbreitungskarten belegen in einigen Gebieten, die besonders stark von klösterlichen Gemeinschaften durchdrungen waren, wie z. B. Burgund, dass sich die Karpfenzucht dort erst relativ spät etablierte, nach Hoffmann ein Argument gegen die Theorie von der Vorrangstellung der klösterlichen Teichkultur. Und auch die Verbreitung der Teichwirtschaft in England zeigt, wie unterschiedlich die Chronologie für die Teich- und Karpfenzucht verlaufen kann: Während Fischteiche in England schon für das 12. Jahrhundert belegt sind, stammen die ersten Hinweise auf Karpfenzucht in Deutschland erst aus dem späten 14. bzw. frühen 15. Jahrhundert (vgl. CURRIE 1991:101; HOFFMANN 1994a:140).

Die zweifelhafte These Hoffmanns, dass nicht die Klöster Wegbereiter der Karpfenzucht waren, sondern der Adel (HOFFMANN 1994a:146), warf für LAMPEN (2000:126) weiterhin die Frage auf, ob dieses Modell auf die Entstehung und Verbreitung der Teichwirtschaft allgemein anwendbar ist. Zur Überprüfung dieser Vermutung sammelte sie zuerst die urkundlichen Belege für die Ausbreitung der Teichkultur hinsichtlich ihres Kontextes - klösterlich oder weltlich -, um diese dann anschließend den Nachweisen Hoffmanns gegenüberzustellen. Das Ergebnis ihrer Analyse ergab, dass die wenigen früh- und hochmittelalterlichen Hinweise auf gezüchtete Karpfen nicht ausreichen, um eine von den Klöstern unabhängige Verbreitung im 9. und 10. Jahrhundert festzumachen. Eine andere Situation ist jedoch für das spätere Mittelalter festzustellen: Basierend auf den frühesten archäologischen Funden, die aus dem 12. und - mit einer größeren Dichte - aus dem 13. Jahrhundert stammen, in Verbindung mit ebenfalls aus dem 13. Jahrhundert und aufwärts vorliegenden schriftlichen Quellen, wird die Kenntnis dieser Fischart insbesondere für die weltliche Grundherrschaft belegt. Während sich also die frühe Teichkultur auf Klöster als technisch innovative Zentren gründete, kann diese Vorreiterrolle des Klosterwesens im Gegensatz zur herrschenden Forschungsmeinung für die Karpfenzucht des späteren Mittelalters nicht bestätigt werden. Stattdessen muss als ein wesentlicher Träger der Adel herausgestellt werden: „Der Adel, der sich [...] seit dem 13. Jahrhundert stark in der finanziell attraktiven Teichwirtschaft engagierte, sorgte in der gleichen Zeit für die Eingliederung dieses neuen Teichfisches, der noch schnelleres Wachstum und damit größere Gewinne versprach.“ (:137f.) Diese wirtschaftliche Effektivität der Teichzucht veranlasste seit dem 12. Jahrhundert vor allem den Adel, eigene Teiche vor allem der Fische wegen anzulegen (:140). „Von hier gingen Anregungen zur Verbesserung der Teichfischhaltung aus, hier sammelte man Erfahrungen und hielt sie schriftlich fest“, so auch KEIZ (1995:18). Nach den wenigen Beispielen aus dem 12. Jahrhundert dominieren diese im 13. Jahrhundert sogar das Fundbild, wobei die Urkunden vor allem die Vergabe der Teiche an Klöster festhalten, wie anlässlich der Überlieferungssituation bereits angesprochen. Die Führungsrolle der Klöster beginnt demnach im 13. Jahrhundert zu enden, als zunehmend auch Adelige die Einträglichkeit großer Fischteichanlagen erkannten. 
Eine völlig gegensätzliche, sicherlich überspitzte Haltung vertreten DELATOUCHE et al. (1950), die nicht die Fastengebote als Ursache für den Aufschwung nennen, sondern die Fastengebote als Folge ökonomischer und hygienischer Notwendigkeiten verstehen. Die Masse der Bevölkerung war nicht mehr allein durch Getreide und das wertvolle Fleisch zu versorgen. Fisch als Eiweißlieferant konnte hingegen eine ausreichende Ernährung gewährleisten. Nach DELATOUCHE wurden Fasttage vermehrt, um die Bevölkerung zum Fischkonsum anzuhalten. Einen ähnlichen Standpunkt vertritt auch CURRIE (1992:90ff.), der den Charakter der Fischerei und besonders der Fischzucht als Statussymbol betont.

Der hohe Bedarf der Klöster an Fischen während der Fastenzeit war demnach für die Aufwärtsentwicklung der Karpfenteichwirtschaft nicht allein verantwortlich, „der Genuß der Karpfens erfreute sich auch in weltlichen Kreisen großer Beliebtheit, nicht nur zur Fastenzeit.“ (HUBERT 1991:17) „Die starke Nachfrage führte zu einem Anstieg der Karpfenpreise, so daß sie im 15. Jahrhundert weit über den damaligen Fleischpreisen lagen. Diese unverhältmäßig hohen Karpfenpreise waren ein Anreiz zur Anlage von weiteren Teichen. So beteiligten sich an der Ausdehnung der Weiherflächen weltliche Grundherrschaften im gleichen Maße wie die Klöster.“ (:17) Allerdings lagen die Ausgaben für den Teichbau und die Unterhaltung meist dennoch über den Einnahmen aus der Teichfischerei (WÜSTEMANN 1982:24).

Wichtige Regionen für die adelige Teichwirtschaft waren vor allem Westfalen und Württemberg, vereinzelt auch der Mittelrhein und Magdeburg. Im mecklenburgischen und pommerschen Gebiet waren es hingegen - bedingt durch die dort anders gelagerten rechtlichen Gegebenheiten - vor allem die Landesherren, die Fischteiche betrieben. Adelige Besitzer tauchten hier seit dem letzten Viertel des 14. Jahrhundert auf (LAMPEN 2000:130). In Niedersachsen sind frühe Teiche aus dem Harzgebiet bekannt. Einer der ältesteten urkundlich erwähnten Teiche in der Grafschaft Wernigerode ist der im 14. Jahrhundert durch Graf Konrad angelegte ,Graf-Kurts-Teich'. Im Jahre 1384 wird auch ein ,Schreiberteich’ erwähnt (WÜSTEMANN 1982:24).

Im 13. Jahrhundert traten sogar die Städte, wenn auch in geringerem Maße als Adelige und Landesherren, als Betreiber von Fischteichen hervor. Auch sie übernahmen die damalig lukrative Teichwirtschaft und nutzten sie für die städtische Wirtschaft und zur Eigenversorgung (LAMPEN 2000:134). WÜSTEMANN (1982:25) bestätigt dies auch für die Stadt Quedlinburg. Hier entwickelte sich eine Fischerzunft, deren Fischmeister die gewerbsmäßige Fischerei in der Bode ausübten. Auch nach KUHN (1954:153) existieren „seit der Mitte des 15. Jahrhunderts eine Fülle von Urkunden“, die den Stadtbürgern die Anlage von Teichen gestatten.

Eine weitere, in Zusammenhang mit der Anlage von Teichen oftmals vergessene, Bevölkerungsgruppe sind die Bauern, die regional unterschiedlichen Einfluss bei der Verbreitung von Teichwirtschaften besaßen. In Mittelfranken beispielsweise, einer Region weitgehend ohne gutsherrlichen Einfluss, hatten die Bauern einen großen Anteil an der Vermehrung von Teichflächen und prägten durch ihren kleinteiligen „Zwergbesitz“ (CNOPF 1927:22) die Ausformung der Kulturlandschaft mit Kleinteichen entscheidend mit. Angesichts der Tatsache, dass das Kloster Heilsbronn mit ausgedehntem Grundbesitz zwischen Main und Donau zur Zeit seiner höchsten Blüte über nicht mehr als 93 Weiher verfügte; „eine verschwindend kleine Anzahl, gemessen an der Zahl von etwa 22000 Weihern“, die allein für Mittelfranken errechnet worden sind, so CNOPF (:19), „nötigen uns [...] diese wie andere Beispiele $[\ldots]$ gewissermaßen zu der bisher noch wenig beachteten Tatsache, daß ein großer Teil der Teiche sich in Händen der Bauern befunden hat. Man wird keine andere Lösung finden, um diese Vielzahl der Weiher in der damaligen Zeit erklärbar zu machen.“

Die Ausdehnung und Zahl dieser Klosterweiher kann nämlich nicht allein mit dem Verbrauch an Fischen in der Klosterküche begründet werden, vielmehr wird dieser Ansatz angesichts der wirklichen Zahl an Klostersassen, d. h. an Mönche, Konversen und mitunter auch der Übernachtungsgäste unterschiedlicher Rechts- und Berufsgruppen, und damit die notwendige Besatzdichte in den zahlreichen Weihern weit überschätzt. Gewiss, der Fischverbrauch in den Städten war ein außerordentlicher, denn auch die weniger Bemittelten nahmen an diesem Konsum reichlich Anteil. 
Zugegeben auch, dass der Verbrauch in den Klöstern, bei den Hofhaltungen wie auf den Tafeln der Grundherrn, die sämtlich ja über stattliche Teichanlagen verfügten, ein bedeutender war. Die Ausbeute aber war viel zu groß, als dass die Menge der anfallenden Fische in den Städten, Refektorien und Herrensitzen hätte verzehrt werden können. So werden wir nach Ansicht von W. CNOPF (1927:18) „unwillkürlich zu dem Schluß gedrängt, einer der Hauptkonsumenten war das platte Land, der [...] Bauer.“, so dass infolgedessen der „der Bauer auch einer der Hauptträger der Teichwirtschaft war“ (:18f.). So darf man sich nach CNOPF (:19) ,wohl die Entwicklung vorstellen, und so nur ist es erklärlich, daß das teure Fischfleisch als Nahrungsmittel bei der durch harte Steuern und Fronen bedrückten und verarmten Landbevölkerung Eingang finden konnte. Die Bauern waren nicht zu unerheblichem Prozentsatz Produzenten wie Konsumenten.“ Nichts wäre für ihn ,abwegiger, als die langsame, organische Entwicklung dieses Vollendungsprozesses leugnen zu wollen und zu behaupten, ein ,Deus ex machina' hätte, wie es vielfach dargestellt wird, im Verlauf einer verhältnismäßig kurzen Zeit eine blühende Teichwirtschaft hervorgezaubert.“(:16). Für CNOPF (:14) ist es schließlich einfach „logischer, die Entwicklung der Teichwirtschaft aus der der Landwirtschaft abzuleiten, denn sie ist ja ein Seitenprozeß derselben“.

Dennoch gibt auch er zu, dass die Klöster der „spiritus rector“ dafür waren (:20), dass die Teichwirtschaft sich zu dieser Blüte entwickeln konnte und dass dieser Entwicklungsgang nur für das Frankenland Geltung besaß, in anderen deutschen Landschaften war er oftmals ein grundverschiedener: Dort waren geistliche wie grundherrliche Kräfte nicht nur die Träger der Idee, sondern auch ,ausschließlich die Repräsentanten des gesamten Weiherbesitzes“ (:20).

Im Gegensatz dazu hatte der Landwirt im grundherrlich geprägten Holstein - bis zur Privataufteilung des Grundbesitzes und der Verkoppelung - keine eigene fischteichhistorische Wirkung. Der Bauernstand beeinflusste gewässerbezogen nur insoweit die Kulturlandschaft, als er im Dienste der kirchlichen und weltlichen Grundherrschaft wirkte: beispielsweise beim Mühlenstau, als angestellter Fischmeister oder Pächter. Während die Mönche anfänglich selbst in der Teichwirtschaft arbeiteten, gingen die Klöster im 15. Jahrhundert dazu über, fast alle Teiche zu verpachten. Es ist anzunehmen, dass die Klöster wegen der Streulage der Teiche von der Selbstbewirtschaftung zur Verpachtung übergingen (RUST 1952:28).

Doch trotz der Bedeutung der Teichwirtschaft für den Adel, des städtischene Bürgertums wie auch der Bauern, übernahmen die Klöster die Funktion der Tradierung der Teichkultur. Bei den Geistlichen und den Ordensleuten finden wir die ältesten Spuren der Teichwirtschaft und der Fischzucht. Aus dem Jahr 820 ist bekannt, dass das von dem adeligen Grundherrn und Mönch Sigfried gestiftete Benediktinerkloster Engelbrechtsmünster an der Ilm, welches er zur Dotation nach St. Emmeran in Regensburg übereignete, seinen Fischbedarf aus einem oberen und unteren Weiher bezog (FASTLINGER 1903:73). Zu berücksichtigen ist bei der frühen Anlage von Teichen im klösterlichen Umfeld auch, dass neben den Königshöfen auch die Bischöfe und teilweise die Reichsäbte zur Beherbergung und Verpflegung des Königs und seines Gefolges verpflichtet waren und dazu gehörte Erledigung des Auftrags der ausreichenden Fischversorgung. Deshalb hielten sich die deutschen Könige häufig und auch recht lange in Bischofsstädten auf, wo nicht sie selbst bzw. die Verwalter der Königspfalz, sondern der jeweilige Biachof für den Unterhalt des Königshofes zu sorgen hatte. Dieses Recht auf „Gastung“ stand dem König zu, weil die deutsche Reichskirche vor allem von den fränkischen und deutschen Königen ausgestattet worden war und deshalb der Herrscher ein „Obereigentum“ am Reichskirchengut geltend machen konnte.

Gerade die fränkische Landschaft war mit solchen Mustergütern reichlich bedacht, so vor allem Forchheim, Ampferbach, Rietfeld, Windsheim, späterhin auch Erlangen und Fürth. Dem Beispiel dieser Mustergüter, wie vor allem auch der immer größeren Verbreitung der Klöster verdankt die Teichwirtschaft in Franken die Grundlage für ihren späteren Aufstieg. Hier wären vor allem zu nennen die beiden Kulturzentren Eichstätt und Würzburg, deren Gründung bis ins 8. Jahrhundert zurückgeht. Fernerhin sei erwähnt die Pfalz Bamberg, gegründet durch Kaiser Heinrich den Heiligen 1007. Für das heutige Mittelfranken war die Gründung des Klosters Heilsbronn im Jahre 1135 durch Otto den Heiligen, Bischof von Bamberg, von großer Wichtigkeit; weiterhin das durch seine Teichzucht 
berühmte Kloster Michelsberg und auch Ebrach, obschon für Mittelfranken eine Besonderheit der teichwirtschaftlichen Ausbreitung besteht.

Die besondere Stellung der Klöster in Bezug auf die Teichwirtschaft ist sicher zum einen durch die quellenmäßige monastische Überlieferungssituation bedingt. Zum anderen aber waren es auch besonders die Mönche als die Kulturträger des beginnenden Mittelalters, die die Kenntnisse der Karpfenzucht auf ihrem Missionierungsgang zu Beginn des 8. Jahrhundert in die nördlichen Gebiete Mitteleuropas mitbrachten und ihr $\mathrm{zu}$ weiter Verbreitung verholfen haben. Sie legten überall im Einzugsgebiete ihrer Klöster Teiche an und hielten Karpfen darin. Zum Weiteren war für die Anlage von Fischteichen die Verfügungsgewalt über Grundbesitztum entscheidend und dieses wurde ihnen vom Adel übertragen.

Während beim Beispiel des Harzes der Oberharz in weltlichem Besitz war, wie wir gesehen haben, so bestanden im Unterharz und im Harzvorland andere Verhältnisse; hier war der Besitz viel stärker geteilt, und damit auch das Fischereirecht. Insbesondere erhielten Klöster und geistliche Stiftungen, die sich dort ansiedelten, Fluss- und Wasserläufe mit der gesamten Fischereigerechtigkeit und damit die Möglichkeit zur Teichanlage. Die Rechte aber wurden ihnen durch die Landesherren zugesprochen, wie zum Beispiel Kloster Drübeck durch König Otto II. im Jahre 984 und Kloster Ilsenburg durch König Otto III. (WÜSTEMANN 1982:23). Diese Situation zeigt, wie sehr sogar intraregional differenziert die Anlage von Teichen zu betrachten ist.

Um das Harzgebiet entstand seit dem 9. Jahrhundert so ein ganzer Kranz von geistlichen Einrichtungen, als eines der ältesten Klöster Wendhusen (Alt Thale), dann die erwähnten Klöster Drübeck, Ilsenburg und Michaelstein, von dem später noch die Rede sein wird. In der Grafschaft Wernigerode befanden sich auf engstem Raum nicht weniger als sechs geistliche Stiftungen (WÜSTEMANN 1982:23), die alle mit Klostergut und dementsprechend mit Fischteichen ausgestattet waren. $\mathrm{Zu}$ den Klöstern mit großer Teichfischerei gehörten Ilsenburg, Drübeck, Michaelstein und Walkenried. Zahlreiche Fakten zur Fischerei des Benediktinerklosters Ilsenburg sind überliefert. So legten die Mönche 1463 den „Groten dik“ (piscina maior), also den Großteich bei Veckenstedt, nach einer Landschenkung des Grafen Heinrich zu Stolberg-Wernigerode an. In den Urkunden von 1496 wird bereits die stattliche Anzahl von 15 Teichen und Hälterteichen genannt, die das Kloster Ilsenburg bewirtschaftete.

Den Grund für die besondere Rolle der Klöster beim Teichbau ist in dem großen Bedarf der Mönche an Fisch als Fastenspeise begründet, der aus den „strengen“ römischen Fastengeboten resultierte. Man sah in der erlaubten Fastenspeise Fisch - zu der auch Krebs und Biber als Wasserbewohner zählten eine willkommene Bereicherung des Speisezettels, und so entstanden die unzähligen Fischteiche (ERGERT 1995:12). Darüber hinaus gab es auch strenge Fastengebote, wie RUST (1956:18) von den schleswig-holsteinischen Klöstern Reinfeld und Ahrensbök berichtet, die auch außerhalb der Fastenzeit jeglichen Fleischgenuss untersagten. Um ihn decken zu können, musste See- und Süßwasserfisch entweder von weither zugekauft oder vor Ort gefangen werden. Den Klosterverwaltern war deshalb an einer zum einen sicheren und ausreichenden, zum anderen günstigen Fischversorgung gelegen. So wurden die Konvente durch die Teichzucht unabhängiger von den eingehandelten und somit teuren Fischlieferungen (LAMPEN 2000:131) und von den Wechselfällen der Fischerei in den natürlichen Gewässern. Zudem oblag gerade die Fischereigerechtigkeit in offenen Fließgewässern dem Landesherrn und somit war die Teichwirtschaft in versorgungstechnischer Hinsicht ein Ersatz für das Verbot, aus wilder Fischerei den Fischbedarf zu decken (RUST 1952:18).

Zusammenfassend lässt sich feststellen, dass - mit den Ausnahmen einiger Kleinteichwirte bäuerlichen und städtischen Besitzstandes - die Teichwirtschaft im Mittelalter vor allem eine Domäne der Klöster und des Adels blieb. Denn unabhängig von dem technischen Wissen, das die Städte schnell rezipierten, benötigte man für die Teichwirtschaft ausreichend Landbesitz, Geld und Arbeitskräfte; vor allem ersterer war in den Städten begrenzt. Während es sich hier um eine durch den Stadtraum vorgegebene räumliche Begrenztheit handelte, war bei der Landbevölkerung die oftmals nur eine Subsistenzwirtschaft ermöglichende zu kleine Hofgröße der beschränkende Faktor. Zudem 
war in der Stadt der Zugang zu der massenhaft importierten Ware Salzfisch zu leicht, als dass man ihn nicht genutzt hätte.

Eine Analyse der urkundlichen Überlieferung, die von LAMPEN (2000:128ff.) durchgeführt worden ist, und die zuvor von HUBERT (1991:17ff.), HOFFMANN (1994a:141ff.) und AMACHER (1996:89ff.) untersuchten erzählenden und statistischen Quellen in Verbindung mit den Auswertungen der ersten karolingischen Aufzeichnungen zeigen, dass die Ausbreitung der Teichkultur in mehreren Phasen vor sich ging und in unterschiedlichen geographischen Räumen schwerpunktartig verlief:

Die erste Phase ist gekennzeichnet durch den systematischen Aufbau und die Verbreitung von Teichen als Fischhälter entlang der Königshöfe und Pfalzen der Frankenkönige, die im 8. und 9 Jahrhundert beginnen.

In der zweiten Phase, zeitlich einzuordnen in das 10. und 11. Jahrhundert, treten als Besitzer von Fischteichen ausschließlich kirchliche Institutionen auf. Die älteste Erwähnung eines kirchlichen „vivarium“, das zur Aufbewahrung von Speisefischen diente, stammt aus einer Urkunde für den Bischof von Eichstätt. Die frühen Herrscherurkunden enthalten keine Hinweise über das Aussehen oder gar weiterführende Informationen, wie die Teiche angelegt und bewirtschaftet wurden. Weiterhin fehlen Hinweise auf die Zucht von Fischen. Wahrscheinlich handelte es sich in diesen Fällen - ebenso wie in den karolingischen Kapitularien - lediglich um Aufbewahrungsbecken für die Fische.

In der dritten Phase, die im 11. Jahrhundert einsetzt, breitet sich die Teichkultur, nach den Urkundenempfängern zu schließen, weiter nach Norden und Osten aus. Neue Regionen, in denen nun Fischteiche gebaut werden, sind der Mittelrhein, Westfalen und der Magdeburger Raum. Ein sehr frühes Beispiel ist für Köln belegt. Im Jahre 1128 schlichtete der Erzbischof Friedrich I. einen Streit um einen Fischteich zwischen dem Kloster St. Pantaleon und dem Apostelstift. Der Streit belegt, dass der Teich, hier ein Mühlteich, auch schon vor 1128 im Besitz des Klosters war. Auch in dieser zweiten Phase dominierten nach den genannten Urkunden die kirchlichen Institutionen als Besitzer und Empfänger von Teichen. Eine Ausnahme stellte der westfälische Raum dar, in dem bereits sehr früh adelige Grundherren, vor allem die Grafen von Tecklenburg, als Besitzer auftreten.

Im 13. Jahrhundert, der vierten Phase, erreicht die Teichzucht schließlich die nördlichen und östlichen Gebiete. Besonders verbreitet ist sie nun in den Neusiedelgebieten, in Württemberg und weiterhin im westfälischen Raum. Aus dieser Zeit stammen auch die ältesten Hinweise auf städtische Fischteiche. Für die Hansestadt Lübeck sind bereits kurz nach ihrer Gründung stadteigene Fischteiche nachweisbar: Eine Urkunde Papst Innozenz III. (1198 - 1216) von 1208 berichtet über einen Streit zwischen dem Johanniskloster und der Stadt um einen Fischteich. Bereits für das 12. Jahrhundert ist ein Fischteich „gleich einem See“ für die pfälzische Stadt Kaiserslautern belegt und im 13. Jahrhundert wird dieser anfangs wohl auch zur Befestigung benutzte Teich in eine intensive Fischereiwirtschaft mit Stauanlagen und weiteren Mühlen eingebunden. Ähnliche Teiche werden in den meisten Städten, soweit ihre topographische Situation es zuließ, in dieser Zeit erbaut worden sein. Seit dem 14. Jahrhundert gehören Karpfenknochen zu den regelmäßigen Fundresten von Siedlungen, Klosteranlagen und Adelssitzen. Im Spätmittelalter des 16. Jahrhunderts expandierte die Karpfenzucht dann weiter nach Norden und Osten: nach England, Skandinavien und in die slawischen Gebiete und erreichte dort ihren Höhepunkt.

Die Teichwirtschaft verbreitete sich vor allem als Nutzungsbestandteil der Mühlen. Die Klöster waren insoweit Keimzellen der Teichkultur, als sie die Vorreiterrolle im Mühlenbau übernahmen. Die technischen Erfindungen, die im Zuge der Mühlenausbreitung verbessert wurden, konnten auch für die Fischerei genutzt werden. Vor allem im Hochmittelalter, mit dem Aufschwung der Wassermühlen, wurden zahlreiche Mühlenweiher aufgestaut; AMACHER (1996:89) spricht gar von einem „Bauboom bei den Fischteichen“.

Die archäologischen Reste wurden überwiegend im Rheinmündungsgebiet, im mittelrheinischen Raum und in Lübeck gefunden. Diese Gebiete zählten im 13. Jahrhundert gleichzeitig zu den wirtschaftlich und technisch stark entwickelten Regionen, die auch andere technische Neuerungen wie 
zum Beispiel eben das Mühlenwesen früh aufgegriffen haben. LAMPEN (2000:137) vermutet daher, dass die Domestizierung des Karpfens hier mit der Verbreitung der Wassermühle einherging.

Der Fischertrag aus diesen Teichen stellte aber wohl anfänglich, so mutmaßt weitergehend AMACHER (1996:87ff.), ,ein nicht geplantes Nebenprodukt dar“ und so sieht er die Mühlenbauten des 15. Jahrhundert nicht in diesem Zusammenhang - im Gegenteil: Zwar wurden die Teiche nach seiner Meinung nicht selten oberhalb von Mühlen angelegt und von den Müllern als Wasserspeicher (mit-) benutzt oder es wurde auch nachträglich eine Mühle am Ausfluss eines bestehenden Weihers gebaut; die Interessen der Fischzüchter waren jedoch oft den Interessen der Müller völlig entgegengesetzt, was sich auch in zahlreichen Konflikten niederschlug. Die Fischweiher sollten nämlich immer einen genügend hohen Wasserstand aufweisen, was die Teichwirte mit einem Wehr sicherstellten, um das Wasser $\mathrm{zu}$ stauen, sowie eine Vorrichtung, um die Fische am Flussabwärtsschwimmen zu hindern (Rechen, Gitter); während die Müller für den Mühlenantrieb die Wasserkraft maximal ausnutzen wollten. Beim Wiederauffüllen des Weihers fehlte unterhalb das Wasser - und die Müller saßen auf dem Trockenen. Zudem dienten die Teiche für die Mühlen als Wasserspeicher in Trockenperioden; wurden nun die Weiher bei der Fischernte völlig abgelassen, fehlte dieses Wasser dann den Müllern. Was den Zusammenhang zwischen Mühlen- und Fischteichbau angeht, sind die Meinungen also unterschiedlich. Gesichert ist nur, dass Mühlteiche auch für die Fischhaltung und Fischteiche ebenso für den Mühlantrieb genutzt worden sind und die Klöster als Motor dieser Synergieeffekte, wie man im heutigen Sprachgebrauch sagen würde, angesehen werden. So ist die Bedeutung der Klöster für die Teichkultur auch noch in der Terminologie präsent: Der Wasserabfluss vor oder an den Teichdämmen, der den Wasserstand regelt und über längere Zeit konstant hält, wird, wie weiter oben schon ausführlich beschrieben, allgemein „Mönch“ genannt (siehe Pkt. VII 2c.2.8.3.5).

Die klösterliche Teichkultur wurde nicht zuletzt entscheidend durch die Aktivitäten der Zisterzienser gefördert, in deren wirtschaftlicher Organisation der Salzhandel und die Fischzucht eine wesentliche Position einnahmen. Einzelne Klöster wie z. B. Salem und Waldsassen spezialisierten sich sogar ausschließlich auf die Fischzucht. Die Mönche machten damals Sumpfgebiete urbar, sie errichteten breite Dämme, mit deren Hilfe sie das Wasser in Teichen aufstauten, und nutzten die benachbarten trockengelegten Gebiete landwirtschaftlich. Überall wo Klöster entstanden, widmeten sie sich auch der Karpfenzucht. In den Ostgebieten fand die Teichwirtschaft vorwiegend durch die Ordensritter Eingang (LIETMANN 1941:6).

Als „Hauptpflegestätten der Teichwirtschaft“ (RUST 1956:42) galten aber nicht nur die Klöster, wie wir bereits am Anfang gesehen haben, sondern auch die überkommenen Gutswirtschaften. Regionalgeographisch traten dabei besonders die Ländereien in Schlesien mit zum Teil sehr großen Teichwirtschaften hervor. Ebenso ließ der Aufschwung des Bergbaus zahlreiche Bergwerksteiche entstehen, davon allein im nordwestlichen Oberharz mehr als siebzig mit 255 ha Fläche. Bergbau- und Forstbeamte nutzten sie vielfach zur Produktion von Karpfen, Schleien, Forellen und Hechten (WÜSTEMANN 1982:25; siehe VIII 3).

Schließlich lässt sich eine fünfte Phase in der Ausbreitung der Teichkultur feststellen, die bislang unerwähnt blieb: die sog. „vollkommene“ Forellenteichwirtschaft. Sie beschreibt eine vollständige künstliche Forellenzucht, die erst seit dem frühen 18. Jahrhundert möglich ist. Die Entdeckung, die Vermehrung der Fische künstlich zu befördern, ist im Lippischen beheimatet und wird so erzählt:

„Die häufige Beobachtung dieses Vorganges [die natürliche Befruchtung der Eier durch Milch des Rogners; B.B.] führte einen deutschen Landwirt in Lippe-Detmold, Stephan Ludwig Jacobi aus Hohenhausen (geb. 1709, † 1784) auf den Gedanken, reifen Forellen die Geschlechtsprodukte abzustreichen, die Eier durch Vermischung mit der Milch künstlich zu befruchten und sie dann in einem von Wasser durchströmten Kasten auszubrüten. Seine ersten Versuche begannen schon im Jahre 1723 [mit 14 Jahren?; B.B.]; er machte von denselben verschiedenen Gelehrten Mitteilung, aber erst 1763 und 1765 gelangten gedruckte Nachrichten über seine Entdeckung in die Öffentlichkeit. Ungeachtet des großen Aufsehens, welches die Sache damals erregte, und obgleich 


\begin{abstract}
Jacobi und später einer seiner Söhne die künstliche Forellenzucht fortdauernd mit Erfolg betrieben, datirt doch der große Aufschwung der künstlichen Fischzucht erst von den in den 40ger Jahren unseres Jahrhunderts [1840; B.B.] unternommenen Arbeiten des verdienstvollen Embryologen Coste in Paris und von der auf seine Anregung im Jahre 1848 von Napoleon III angeordneten Anlage der Brutanstalt bei Hüningen im Elsaß." (BENECKE 1885:50).
\end{abstract}

Von hier aus also, aus dem Gebiet Lippe-Detmold, vollzog sich die geographische Ausbreitung von Forellenzuchtteichwirtschaften, die nicht nur die bereits bestehenden Teiche der Karpfen und Karpfenartige ergänzten, sondern aufgrund ihrer erweiterten Funktionalität in ihrer Anlageform besonders zahlreiche und spezielle Teiche hervorbrachten, die die bisherigen reinen Hälterteiche ergänzten. Es entstanden so - auch an Neustandorten - ganze Terrassenteichanlagen, die in manchen Landstrichen so zu einer weiteren Verwässerung und gewässerbezogenen Umgestaltung der Landschaft in erheblichem Maße beitrugen. Vor allem die für eine Karpfenteichwirtschaft ungeeigneten kühleren Bach- und Gebirgsläufe des Berglandes und der der Mittel- und Hochgebirge wurden zu den auserwählten Standorten der Forellenteichwirtschaft. Gleichzeitig, so ist zu vermuten, schwächten sie den Flussfang nach Forellen.

Große Verdienste um die Entwicklung der Forellenfischerei in Flüssen, Bächen und Teichen erwarben sich zu dieser Zeit die Forstbeamten. Bereits um 1840 führte Revierförster Meyer in Kamschlacken (Sösetal im Harz) den ersten Versuch einer künstlichen Forellenbrütung durch (WÜSTEMANN 1982:25). Verstärkt wurde die Forellenzucht durch die 1882 aus Nordamerika eingeführte Regenbogenforelle (Salmo gairdnérii).

In der Zeit seit Mitte des 19. Jahrhunderts waren es insbesondere aber die zentralen Versuchsteichanlagen, die „man möchte sagen, wie Pilze aus der Erde“ schossen (VOGELS 1898:482). Sie ließen sich nach der Säkularisation vor allem auf ehemaligem Klostergrund nieder, den sie zum Teil wieder für die Fischzucht herstellen mussten und deren weiteren Ausbau sie vornahmen.

Als erste fischereibiologische Forschungsstätte im damaligen Deutschland nahm 1896 die „Teichwirtschaftliche Versuchsstation zu Trachenberg in Schlesien" ihren Betrieb auf, um im Jahr 1906 schon wieder zu schließen (WUNDER 1956:12). Das Interesse, so die Begründung, wandte sich immer verstärkter den Fischereiinstituten in München und Berlin zu. So wurde später beispielsweise die teichwirtschaftliche Versuchsstation in Wielenbach in Oberbayern gegründet, mit „40 Teichen von je 20 a Fläche“"(:12).

Zu Anfang der 1920er Jahre schloss sich jedoch erneut eine größere Anzahl von Teichwirtschaften in dem „Teichwirtschaftlichen Versuchsring Schlesien“ zusammen, der es sich zur Aufgabe machte, eine Arbeitsbasis für Untersuchungen auf dem Gebiet der Teichforschung zu schaffen (WUNDER 1956:13). Außerdem entstand 1938 an der Universität Breslau die Forschungsstelle für Teichwirtschaft und Fischzucht (:13).

Diese Förderung und Institutionalisierung der Teichwirtschaft seit dem zweiten Drittel des 19. Jahrhunderts ist in Zusammenhang mit dem Sterben dieses wasserreichen Zweiges der Landwirtschaft zu betrachten. Deshalb erging die publizierte Aufforderung, ,die deutschen Binnengewässer müssen zu einem großen Theile neu mit Fischen bevölkert werden und dazu gehört die weiteste Verbreitung von Kenntnissen von der Kunst der Fischzüchtung.“ (BORNE 1886:Vorwort) Um diese „neue“ Inwertsetzung in die Praxis zu übertragen, fand denn auch die entsprechende Aufklärung und Ermunterung statt: „Unsere Landseen dürften alle, mit Ausnahme der hochgelegenen Alpenseen, für die Karpfenzucht geeignet sein; denn wir finden den Fisch unter anderem in folgenden Alpenseen: Bodensee, Tegern-, Schlier-, Klagenfurter-, Vierwaldstätter-, Züricher-, Comersee - und der Karpfen gedeiht ganz vortrefflich in den mit Düngertheilen geschwängerten, schlammigen Dorfpfützen sowie in dem kaffeebraunen Wasser der Torflachen.“"(:297)

Dies verstärkte jedoch auch die unfachmännische Anlage von neuen Teichen sowie die unsachgemäße Nutzung bestehender wasserbespannter Hohlformen. Sägewerkbesitzer beispielsweise, die ehemals an 
nahezu allen Gewässerläufen ansässig waren, betrieben häufig kleinere Fischzuchtbetriebe und Teichwirtschaften, wie zum Beispiel die Sägewerkbetreiber in Kleisingen bei Ellrich oder Quernheim bei Bünde, die oftmals aus stillgelegten Teichen zum Antrieb der Sägeblätter hervorgingen.

Die Vielgestaltigkeit und Häufigkeit der früheren Teichwirtschaft kann als Ausdruck der besonderen Bedeutung der Fischhaltung bewertet werden, die noch bis in die Mitte des 20. Jahrhunderts andauerte. In gewässerreichen Räumen mit seenartigem Charakter, beispielsweise der küstennahen Jungmoränenlandschaft Mittel- und Ostholsteins und auch in den ehemals torfreichen Gebieten der norddeutschen Tiefebene, ja selbst in den Marschen, wurden in den 50er Jahren ,vereinzelt Kuhlen, die durch Materialentnahme für Straßen-, Bahn- und Deichbauten entstanden sind, jährlich ausgepumpt und somit als ablaßbare Teiche genutzt“ (RUST 1956:44), wenn sie auch hier ,infolge widriger Klima- und Vorflutverhältnisse nicht verbreitet" waren (:42).

Im Zeitalter der Industrialisierung wurden sogar Fabrikteiche, wie zum Beispiel Zuckerfabrikteiche, mit Fischen besetzt. Wenn es auch hier zuweilen zu einem „Übermaß an Nährstoffen“ (WALTER 1933:11) kam, so war diese überhöhte organische Teichdüngung aber durchaus erwünscht, zeigten doch die Erträge der Dorfteiche und Hofteiche, „die unter allen Teichen die erste Stelle“ einnahmen, „wie außerordentlich der Fischzuwachs dadurch gefördert“ wurde (:65).

Der ,große nationalökonomische Wert der Fischzucht“ lag aber darin, dass es neben der Zufuhr von kostenfreien organischen Abfallprodukten in Form von Jauche, Kloake, Kompost, Stalldünger etc. (WALTER 1933:65) ermöglicht war, ,unfruchtbare, schlechte Böden, die entweder brach daliegen oder nur einen geringen Ertrag liefern, in viel höherwertiges Areal zu verwandeln. [...] Brüche, saure Wiesen, Sandflächen, kurz jedes Terrain, das der Landwirt nur mit scheelen Augen betrachtet, sollte in Form von Fischteichen nutzbar gemacht werden“"(CRONHEIM 1907:21). Die Fischzucht ermöglichte es ,gewisse Ödländereien, gewissermaßen ein Abfallsprodukt der Landwirtschaft [...] nutzbringend zu verwerten“"(:2).

Dieser Vorteil der Fischwirtschaft und die verstärkte Aufforderung zur Teichbewirtschaftung sind vor allem vor dem Hintergrund des explosiven Bevölkerungswachstums und den Schwierigkeiten einer ausreichenden Nahrungsmittelversorgung während der Industrialisierungsphase zu betrachten. Man könnte sagen, die Teichwirtschaft war in diesen Zeiten nach der Epoche der klösterlichen Anlage von Karpfenzucht- und Mühlenteichen in einer Hoch- und Verbreitungsphase, die nie wieder erreicht wurde.

\section{c Landschafts- und naturgeographische Verbreitung}

Die physiogeographischen Voraussetzungen als Anhaltspunkt für die Lage von Fischteichen zu bewerten, ist ein schwieriges Unterfangen.

Selbstverständlich war die Anlage von umfangreichen Fischteichen abhängig von den natürlichen Gegebenheiten. Vorzugsweise im durch Relief und hydrologisch begünstigten Gelände in der Nähe von Quellen, Flussläufen und Bachauen siedelten sich die Klöster als dominierende Kultivierer des Teichbaus wie auch die Höfe der Könige, des Adels, des Bürgertums und der Bauern an und ermöglichten somit eine weiträumige Aufstauung und Abzweigung von Gewässern zur Fischzucht (siehe Pkt. V 2).

Doch der Gewässerlauf bzw. der Zufluss von Frischwasser konnte so korrigiert und der Untergrund so verändert und den speziellen Bedingungen angepasst werden, dass die heutige Standortbeschaffenheit nur unter vorsichtiger Annäherung den ursprünglichen Charakter widerspiegelt. Gleichzeitig veränderten sich hydrographische Faktoren so sehr, dass heutige Trockentäler in früheren Zeiten wasserführende Gewässereinschnitte waren. Dennoch soll der Versuch unternommen werden einige „Regelhaftigkeiten“ der Lage von Teichen zusammenzustellen. 


\section{c.1 Die Bedeutung der Topographie und Pedologie für die Lage und Anlage von Teichen}

Um die große Ausbreitung der Teichwirtschaften voll zu verstehen, ist es nötig die geologischen Verhältnisse darzustellen.

„Am besten geeignet für den Bau von Fischteichen war eine natürliche Senke: möglichst ebenes Land mit leichten Geländeerhebungen an den Rändern.“ (AMACHER 1996:90) Auch TAURKE (1927:47) sieht als ein geeignetes Terrain, eine von Hügeln begrenzte Landfläche, um „durch Ziehen eines Dammes einen Teich herzustellen". Diese naturräumliche Abhängigkeit lässt sich beispielsweise für Oberschwaben nachweisen. Die oberschwäbische Glaziallandschaft ist geprägt von zahlreichen Rücken, Senken und Rinnen. Die Oberflächenstrukturen dieser Landschaft, Talwasserscheiden in alten Abzugsrinnen der Gletscher-Schmelzwässer, erlaubten es durch einen vergleichsweise geringfügigen baulichen Aufwand, Dämme aufzuschütten und damit künstliche Gewässer anzulegen (KONOLD 1991:355).

„Ebenfalls eine Voraussetzung war genügend Wasser. In idealer Weise erfüllten diese Bedingungen verlandete Seen. Tatsächlich legte man viele Weiher auf Mooren oder Riedwiesen an, die von verlandeten Seen oder Seeteilen herrührten. Beliebt waren auch sumpfige Auen entlang von Flussläufen.“ (AMACHER 1996:90) Deshalb war für den Betrieb der Fischzucht „es vorteilhaft, den Fischteich in der Nähe eines Sees zu errichten; kleine bestehende Seen bezog man in die Teichwirtschaft ein.“ (:90) So wurden beispielsweise im Zürichgebiet direkt neben dem Katzensee, Lützelsee, Türlersee und Greifensee sowie im Thurgauer Bichelsee Fischweiher angelegt. Wahrscheinlich hat man zunächst die Weiher in Mooren und verlandenden Seen gebaut oder aber bestehende Seen höher gestaut (:90). Dabei konnten die die Seen speisenden Zuflüsse um- und zugeleitet werden, wie beim Bichelsee die zufließende Lützelmurg, der Seebach und der Itaslerbach. Heute sind die Teiche wieder zum großen Teil verlandet und repräsentieren wieder den Zustand vor dem Teichbau, wie man sich das an dem heute 10 ha große Flachmoorgebiet „Allmend Katzensee“ vorstellen kann.

Für AMACHER (1996:90) ,liegt auf der Hand, dass für die Weiher nicht das fruchtbarste Land ([...] Ackerland beispielsweise) überschwemmt wurde, sondern minderwertige Grundstücke im sogenannten Saltus-Bereich ${ }^{6}$ “" Auch für WUNDER (1956:6) gehören die Karpfenteiche „,meistens [...] den ärmeren Bodenklassen an." Diese Flächen lägen so tief, dass sie bei landwirtschaftlicher Nutzung viele Monate unter stauender Nässe zu leiden hätten und keine richtigen zuverlässigen Erträge auf Jahrzehnte hinaus bringen würden. TAURKE (1927:47) hingegen ist der Meinung, dass für die Teichherstellung „selbst der beste Boden nicht zu schade ist.“ Auch ZOBEL (1992:58) sieht als „die ertragreichsten Karpfenteiche [...] jene, deren Boden aus Lehm oder Ton besteht." Dennoch ist auch er Ansicht, die Teiche seien ,zumeist [...] auf ärmeren Böden angelegt worden, da die Landwirtschaft auf Moor- und Sandböden weniger großen Wert legte.“

Kann diese Annahme auch als grundlegend für den Teichbau angesehen werden, so ging man aufgrund hoher Gewinnerwartungen ,später zunehmend daran, Äcker und Wiesen, also landwirtschaftlich wertvollere Flächen zu überstauen“(KONOLD 1991:356).

Es erklärt sich selbst, dass die Teiche zunächst in Bereichen angelegt wurden, die sich durch Böden mit einer hohen natürlichen Grundnässe auszeichnen und dadurch - im Vergleich zur kompletten Melioration zur Gewinnung von Wiesen und Weiden bzw. Ackerland - relativ geringe Eingriffe notwendig machten und eine Wasserarmut eher ausschlossen.

Je nach Präferenz jedoch, die an der wirtschaftlichen Bedeutung gemessen wurde, legte man die Teiche nicht nur in minderwertigen moorigen bzw. anmoorigen Böden an, sondern auch auf bereits meliorierten Flächen. Dass dabei Lettenböden mit einer gewissen Staunässe bevorzugt wurden, liegt

\footnotetext{
${ }^{6}$ Saltus-Bereich (lat. saltus = Sprung): lässt sich als Übergangsbereich zwischen trockenem und wässrigen Substrat deuten; der sog. amphibische bzw. feuchte Bereich.
} 
auf der Hand, mussten hier keine weiteren mühsamen Vorkehrungen zum Abdichten des Teichbodens getroffen werden und konnte auch der Aushub vorteilhaft zum Dammbau genutzt werden.

Denn es ist kein Zufall, dass gerade in Mittelfranken die Weiherwirtschaft eine so große Ausbreitung finden konnte. „Das liegt darin begründet, daß die Mehrzahl der Weihergebiete auf Keupergrund gebettet ist." (CNOPF 1927:24) Seine Schichtung besteht dabei in der Hauptzahl aus einer Reihe von Sandsteinen und Tonschichten. Der Grund also, dass auf diesen großenteils mageren, sandigen Böden die Weiher eine so große Verbreitung finden konnten, ,ist darin zu suchen, daß unterirdisch, nahe am Boden, Lettenschichten hinziehen.“(:25) „Wir können [...] fast regelmäßig, wenn wir auf solche Weiher oder stehende Gewässer wie auch Sümpfe und Moore stoßen, auf das Vorhandensein von Lettengrund schließen.“(:26)

Des Weiteren besteht geomorphologisch-hydrogeographisch betrachtet hier ein zur Rednitz als natürliche Ablaufrinne sanft geschwungenes, durch parallele Flussläufe durchzogenes Gelände, die „Fränkische Schichtstufenlandschaft". Sie breitet sich von Dinkelsbühl, Gunzenhausen, Pleinfeld über Roth, Schwabach, Ansbach, Herzogenaurach, Höchstadt a. d. Aisch bis an den Fuß der Altenburg bei Bamberg. Charakteristisch für dieses Landschaftsbild sind „die zahlreichen Weiher, die oft wie Perlen an der Schnur aneinander gereiht, sich in fast jedem Fluß- und Bachtal vorfinden." (CNOPF 1927:25)

\section{c.2 Die Bedeutung des Wassers für die Lage und Anlage von Teichen}

Topographisch und von der landschaftlichen Ausstattung betrachtet sind Teichwirtschaften also bevorzugt in wassernassen und wasserreichen Gunststandorten angelegt worden: In Feuchtauen und wiesen, an oder in der Nähe von Fließgewässern.

Vor allem die Hälterung und die intensive Salmonidenzucht in Teichen ist an - neben genügend fließendes -sauerstoffreiches und kühles Wasser gebunden (SCHÄPERCLAUS 1961:167f.). So ist ,eine rationelle Forellenwirtschaft [...] nur möglich, wenn Wasser in [...] entsprechenden Mengen zur Verfügung steht.“(CRONHEIM 1907:8).

Teiche brauchen als Ausgleich für Verdunstung und Versickerung je Hektar mindestens einen Wasserzufluss von einem Liter je Sekunde (ZOBEL 1992:57). Allgemein ausgedrückt muss eine entsprechende Versorgung „mit gutem Wasser“ derart gewährleistet sein, „daß es auch im heißen Sommer, in Perioden langanhaltender Dürre nicht an Wasser gebricht.“"(CRONHEIM 1907:8)

Die Wassermenge muss in Teichwirtschaften mit integrierter Fischzucht ferner ausreichen, um neben den Aufzuchtteichen auch die Hälter, Winterteiche und Laichteiche mit genügend ständigem Wasserdurchstrom zu versehen (SCHÄPERCLAUS 1961:151). Für moderne Forellenteiche ist gar eine zwei- bis fünfmalige Wassererneuerung am Tag anzustreben (ZOBEL 1992:58).

Auf der anderen Seite braucht man im eigentlichen Karpfenteich „nur so viel Wasser, wie nötig ist, um durch Versickerung und Verdunstung entstandene Verluste auszugleichen“ (CRONHEIM 1907:8). Die Wassermenge muss also nur insofern ausreichen, um „Karpfenteiche dauernd hinreichend unter Wasser zu halten“ (SCHÄPERCLAUS 1961:151).

Eine Wasserversorgung für Fischteiche lässt sich dabei jedoch - ähnlich der Bodenbeschaffenheit nie nach einem vorgegebenen Schema einrichten. Hinsichtlich der natürlichen Standortwahl spielt zwar das Vorhandensein einer konstanten Wasserzufuhr eine entscheidende Rolle, die Wassermenge ist jedoch dabei von untergeordneter Bedeutung bzw. gar nicht so sehr erwünscht: „Ein gar zu starker Zufluß des Wassers ist auch bey einem Teiche nicht viel nütze. Man muß einen gar kostbaren Bau an Dämmen und Fludern anwenden.“ Zudem würden „die Fische zu sehr in ihrer Ruhe gestört und bei Ausbrechen des Wassers viel Schaden und Unglück hervorgerufen." (DYHRN 1782:12)

DYHRN (1782:13) unterscheidet zwei „Arten des zu gebrauchenden Wassers“ in einer Teichwirtschaft: 
1. Quell- und Flußwasser

2. Bloßes Fluthwasser

„Gutes beständig fließendes Quell- und Flusswasser" sei dabei von beiden Wasserarten generell am besten für die Teichwirtschaft zu gebrauchen. DYHRN (1782:13) schreibt dazu als Vorteil, dass diese „,niemals austrocknend“ bzw. ,,immer bespannt bleibend“ seien. Bedingung für diese Art der Füllung von Teichen sei ein „fester Grund“ (:13), damit bei Hitze und lange ausbleibendem Regen die Fischteiche nicht zu sehr austrocknen.

Bei den sog. Strichteichen (siehe Pkt. VII 2.b.2.1.1) jedoch ist das „bloße Fluthwasser“, „dem Flußund Quellwasser noch weit vorzuziehen“ (DYHRN 1782:14), ,besonders wenn diese Fluth noch dazu von guten wohl gedüngten Aeckern, oder aus Dörfern herkommt" (:13). Dadurch bekommen die Fische „viele gute Nahrung in den Teich“ (:14). Zudem können Flutwasserteiche, wenn sie unbewässert sind, „zum Bepflanzen und Besäen besser“ benutzt werden.

In allen Gebieten, in denen qualitativ gute Quellwassermengen oder Bäche mit guten Wasserqualitäten vorhanden sind, wie zum Beispiel im Niedersächsischen Bergland und in der Lüneburger Heide, haben sich Teichwirtschaften entwickelt. Sie unterscheiden sich aber in Bezug auf die Gewässergüte und -art hinsichtlich ihrer Fischartenbesatzes. So finden sich die meisten Karpfenteichanlagen in der südlichen Lüneburger Heide, während Forellenteichanlagen vorwiegend im Bergland angelegt wurden, weil hier reichlich Quellwasser vorhanden ist (vgl. SEEDORF/MEYER 1996:417f.).

\section{c.3 Die Bedeutung des Klimas für die Lage und Anlage von Teichen}

Neben dem Wasser als primäres Kriterium, der Geländeausformung und der Beschaffenheit des Bodens spielen hinsichtlich der Lagewahl von Teichen die klimatischen Verhältnisse eine Rolle. Vor allem die Art der Verbreitung von Teichwirtschaften ist durch ein geeignetes Klima bedingt, denn dieses lässt sich nicht bzw. wenn, dann nur mikroklimatisch, beispielsweise durch eine sonnen- oder schattenexponierte Lage verändern. Für Karpfenteichwirtschaften beispielsweise sind ihr nach Norden und Osten durch die Abnahme der mittleren Jahrestemperaturen und durch Absinken der MinimumTemperaturen eine Grenze gesetzt, das sich als Band von Ostholstein bis in die östlichen Odergebiete ziehen lässt (SCHÄPERCLAUS 1961:167).

Die klimatischen Verhältnisse entscheiden demnach über die Art der betriebenen Teichwirtschaft und über deren Erfolg. So ist beispielsweise neben den hervorragenden geologischen Voraussetzungen zur Anlage von Weihern besonders die hohe durchschnittliche Jahrestemperatur von $8 \mathrm{bzw} .9^{\circ} \mathrm{C}$ der Grund für die intensive Karpfenzucht im Aischgrund und in der Lausitz. Der größte Negativfaktor im Aischgrund wie in der Lausitz ist die geringe Niederschlagsmenge. In regenarmen Jahren sind besonders die Himmelsweiher, die sich nur durch Niederschläge füllen, durchaus vom Austrocknen bedroht. Wenn sie auch trotzdem angelegt wurden und Bestandteil eines größeren Teichgebietes sind, so reihen sich lediglich die Vertreter der anderen Art der Teiche, nämlich die Bach- oder Quellweiher, zu kilometerlangen Ketten, die die Gebiete deutlich prägen.

\section{d Regional-geographische Verbreitung}

„Die wichtigsten und größten Teichwirtschaften zeichnen sich deutlich in der lokalen Häufung von Teichen ab.” (RUST 1952:43) Diese Schwerpunkträume aufzuzeigen ist Anliegen dieses Kapitels. Gleichzeitig sind sie die Gebiete der Großbetriebe und der genossenschaftlich betriebenen Teichwirtschaften. Bei der Darstellung der großräumigen Verbreitung von Teichwirtschaften ist es deshalb voraussehbar, dass die vielen kleineren (privaten) Teichanlagen in weiten Teilen unberücksichtigt bleiben werden. Damit bleibt weiterhin die Forschungslücke offen, „daß es infolge der zerstreuten Lage der einzelnen Teiche der Kleinteichwirte meist an einer Darstellung der Kleinteiche mangelt.“ (WALTER 1933:84) 
Deshalb sollen auch, um wenigstens eine kleinen Beitrag zur Schließung dieser Forschungslücke beizutragen, obschon gleichwohl der Fokus auf den Mehrteichwirtschaften liegt, dort wo Hinweise aus dem Literatur- und Quellenstudium vorliegen, auch mittlere und kleinere Teichwirtschaften in die regional-geographische Übersichtsdarstellung mit einfließen.

Doch zunächst ist zu klären, anhand welcher Kriterien sich große von kleinen Teichwirtschaften unterscheiden lassen, um aufgrund dieser Definition mögliche Schwerpunktgebiete dieser Betriebsgrößen differenziert darstellen zu können.

\section{d.1 Unterscheidung der Teichwirtschaft nach Größe und Betriebsform}

Hinsichtlich der Größe einer Teichwirtschaft wird zwischen Groß- und Kleinteichwirtschaft unterschieden. Unterscheidungskriterium ist dabei nach RUST (1956:44) die Anzahl und Funktion von Teichen:

1. Groß-bzw. Mehrteichwirtschaft

2. Klein- bzw. Einteichwirtschaft

Dieser Zweiteilung lässt sich in gleicher Weise die Unterscheidung der Teichwirtschaft nach Voll- und Nebenerwerb gegenüberstellen. WALTER (1933:7) unterscheidet:

1. berufsmäßige Teichwirtschaft

2. bäuerliche Kleinteichwirtschaft

In einer dritten Differenzierung nach SCHÄPERCLAUS (1961:168) lassen sich innerhalb der beiden Hauptzweige der Teichwirtschaft (Karpfen- und Forellenzucht) weitere zwei Betriebsformen unterscheiden:

1. intensive Betriebe

2. extensive Betriebe

Groß- und Kleinbetriebe bzw. Intensiv- und Extensivteichwirtschaften sind vergleichbar der gängigen Einteilung in der Agrar- und Viehlandwirtschaft. So unterscheiden sich die beiden letztgenannten Bewirtschaftungsformen im Wesentlichen dadurch, dass bei der extensiven Teichwirtschaft ,auf den Einzelfisch relativ wenig Teichfläche“ und in der intensiven Teichwirtschaft ,auf den einzelnen Fisch relativ viel Teichfläche entfällt" (SCHÄPERCLAUS 1961:168).

In gleicher Hinsicht sind die als Berufsteichwirtschaften geführten Teichbetriebe sowohl Erzeuger-als auch Zuchtanstalten und werden im Haupterwerb betrieben (WALTER 1933:8). Bäuerliche Kleinteichwirte hingegen versorgen ,kleine, nicht berufsmäßig bewirtschaftete Teiche“. „Der Teich ist bei ihnen nur ein Zubehör, ein wenig beachteter Nebenteil der Wirtschaft, der in althergebrachter Weise [...] bewirtschaftet wird und der befriedigt, wenn er gerade noch die für die Kirchweih erforderlichen Karpfen liefert.“ (:8)

Einzig also die Unterscheidung Mehrteich- zu Einteichwirtschaften ist eine Besonderheit der fischereiwirtschaftlichen Landwirtschaft, die aber inhaltlich wie oben dargestellt mit der Groß- und Kleinteichwirtschaft übereinstimmt und synonym verwendet werden kann: Mittlere bis große Teichbetriebe werden danach gekennzeichnet durch mehrere, verschieden große und zumeist funktionell verschiedenartige Teiche in Streulage. Eine Karpfenteichwirtschaft zum Beispiel im Vollbetrieb setzt zweierlei voraus: a. eine Mindestfläche von 20 - 30 ha und b. das Vorhandensein von Sondereinrichtungen, vor allem der verschiedenen Teicharten. Aber sogar bei einer Fläche von $20-30$ ha können die für die Bruterzeugung erforderlichen Aufwendungen nie voll ausgenutzt werden. Für die Aufzucht der Brut eines einzigen Rogeners zu Speisekarpfen würden, so ist zu lesen, mindestens 150 ha notwendig sein (vgl. SCHÄPERCLAUS 1961:235). 
Kleine teichwirtschaftliche Betriebe sind hingegen bestimmt durch Einzelteichflächen. Sie bestehen oft nur aus einem (größeren) Teich (TAURKE 1927:26; RUST 1956:44). Diese Kleinteichwirtschaften definiert RUST (:43) als „Betriebe mit Teichflächen unter 3 ha Größe“. Eine statistische Erhebung der Teichflächen im Freistaat Sachsen aus dem Jahr 1934 hat 20.133 Teiche mit einer Fläche von 9.512 ha festgestellt, also mit einer Durchschnittsgröße von nicht einmal $1 / 2$ ha je Teich (WALTER 1933:7). Und dabei fallen in diese Bemessung die großen Teichwirtschaften der Lausitz als statistische Größe. Die Mehrzahl der Teiche in Deutschland, insbesondere der in Gebirgslagen, wird also sogar noch wesentlich kleiner gewesen sein. Mengenmäßig stellen sie aber den größten Anteil an Teichen.

Die Wirtschaftsmethoden (Teichbau, Umtrieb etc.) sind dabei im Allgemeinen in der Kleinteichwirtschaft die gleichen, wie sie für den Vollbetrieb gelten (vgl. SCHÄPERCLAUS 1961:548; siehe auch Pkt. VII 2b und c). Die besondere andersartige Situation bei Kleinteichwirten ergibt sich erst hinsichtlich der Teicharten. So besitzt der Kleinteichwirt ,in den weitaus meisten Fällen keine zur Überwinterung geeigneten Winterteiche“ (WALTER 1933:29). Dem Landwirt wurde deshalb dazu geraten, ,sich die [...] Satzfische in einer derartigen Größe zu kaufen, daß er sie in einem Sommer zu Verkaufsware heranzüchten kann.“(CRONHEIM 1907:4) Für die Kleinteichwirtschaft ist also die Fischhaltung im einsömmrigen Umtrieb $^{7}$ die gegebene Wirtschaftsmethode (WALTER 1933:29; SCHÄPERCLAUS 1961:548).

Die eigentliche Zucht, d. h die Besatzfischaufzucht, kann infolgedessen nicht Aufgabe des Kleinteichwirts sein, sie scheidet bei ihr eigentlich gänzlich aus (WALTER 1933:8,46f.). Das ,Besatzmaterial' wird von speziellen Züchtern bezogen (:47). Solche Satzfischzuchten sind spezialisierte Teichwirtschaften ohne Speisefischerzeugung. Aufzuchtbetriebe sind nur in Zusammenhang mit größeren Betrieben entstanden und sind ,in Gegenden mit viel Kleinteichwirtschaft (z. B. Thüringen) entwickelt worden, wo sie helfen sollen, den Satzfischmangel zu beseitigen.“ (SCHÄPERCLAUS 1961:168) Einzig ,in Gebieten, in denen es an Berufsteichwirtschaften mangelt, kann auch der Kleinteichwirtschaft noch die Aufgabe des Besatzfischlieferanten zufallen“ (WALTER 1933:8). Die Einteichfischerei läuft dabei in der Regel als Nebenbetrieb des Landwirts und Forstmanns.

Aufgrund ihrer eingeschränkten Kapazität wird unter Kleinteichwirtschaft deshalb die Bewirtschaftung kleiner, einzeln gelegener Teiche verstanden, ,in denen nicht in wirtschaftlicher Weise Karpfen vom Ei bis zum Speisefisch gezogen werden können“ (SCHÄPERCLAUS 1961:548). Die Kleinteichwirtschaft dient also in erster Linie zur Erzeugung von Speisefischen.

Obgleich hinsichtlich der Sömmerung als Kennzeichen von Kleinteichwirtschaften auch hier die Einschränkung zutrifft: „keine Regel ohne Ausnahme“ (WALTER 1933:46). Denn es wurde in manchen Fällen nicht nur 2jähriger Saamen zu 3jährigen Tieren gesetzt, sondern auch „,die Strichkarpfen werden [...] in diejenigen Teiche mit eingesetzt. [...] Nur ganz kleine Teiche, [...] pflegt man bloß mit Karpfen zu besetzen." (DYHRN 1782:64).

In dem Fall, in dem der Einteich auch als Laichteich dient, wurde einfach eine Abtrennung der Laichstätten in einzelne Laichkammern vorgenommen. Ein Stück der „flachen Uferpartie, welches mit vorteilhaftem Pflanzenwuchs" bestanden war, wurde durch ein Drahtmaschengitter gegen den übrigen Teil des Wassers abgegrenzt. In diesem „geschlossenen Raum“ wurden die Laichfische eingesetzt. Fehlte es an Pflanzen in diesen Laichkammern, so mussten "Nadelholzzweige eingelegt werden.“ (TAURKE 1927:92)

Es ist also keine Schwierigkeit, gemessen an der Anzahl an Teichen in der Landschaft, Klein- und Großteichwirtschaften voneinander zu unterscheiden. Einzelne, weit und unregelmäßig verstreut liegende Kleinteichareale lassen sich gut differenziert von zusammenliegenden mosaikartigen

\footnotetext{
${ }^{7}$ Das heißt, Satzfische von geeignetem Alter und Stückgewicht werden im Frühjahr eingesetzt, in einem Sommer zu Speisefischen heranwachsen und im Herbst als Speisefische abgefischt und nach der Herbstabfischung sofort abgeschlagen. Der Teich wird sodann über Winter trockengelegt (WALTER 1933:29; SCHÄPERCLAUS 1961:548). Denn ,einjährige Fische zwei Jahre in demselben Teiche sitzen zu lassen, empfiehlt sich nicht [...] entbehrt ein solcher Teich der Wohltat des Trockenliegens“ (TAURKE 1927:27).
} 
Teichlandschaften beispielsweise anhand der Auswertung topographischer Karten oder Luftbilder erkennen. Die quantitative Auswertung lässt aber keine gesicherte Aussage über die „Vollständigkeit“ bzw. Betriebsform einer Teichwirtschaft zu. Mehrere Teiche können zu einer reinen Satzfischproduktion benutzt worden sein, wie dies aber auch ein Teich leisten kann; gleichwohl können mehrere Teiche wie auch nur ein Teich die Aufzucht von Fischchen bis zum Speisefisch vornehmen, wenn auch die dargelegten allgemeinen Richtlinien in den meisten Fällen für erste Variante - die reine Satzfischproduktion - Gültigkeit besitzen dürften. In historischer Sicht wichtig ist des Weiteren die Erkenntnis, dass auch dispers liegende Einteiche nicht nur einer bäuerlichen Bewirtschaftung unterlagen, sondern theoretisch durchaus $\mathrm{zu}$ einer z. B. klösterlichen großen Teichwirtschaft gehört haben können. Diese - eher Ausnahmen - sind bei einer Unterscheidung der Teichwirtschaft nach Größe und Betriebsform zwar zu berücksichtigen und unterstützen eine differenzierte Betrachtung, sind jedoch bei einer geographischen Darstellung der großräumlichen Verbreitung der Teichwirtschaften zu vernachlässigen, will man zu einem überblicksartigen Ergebnis der Schwerpunktbereiche kommen. Bei einer solchen Zielsetzung kann allein die quantitative Größe, die Anzahl von Teiche (Teichzahl) in einem bestimmten, in seinen Grenzen festgelegten Gebiet herangezogen werden.

\section{d.2 Verbreitung der Teichwirtschaft nach Größe und Betriebsform}

\section{d.2.1 Überblick}

Die größten zusammenhängenden Teichgebiete, die „Hauptzuchtgebiete von Karpfen“ (SCHÄPERCLAUS 1961:166) liegen im zentralen Mitteleuropa, wenn sie auch heute nur noch eine kleine Restfläche der ehemals weiter ausgedehnten Teichflächen darstellen, in der sächsischen und brandenburgischen Lausitz, in Thüringen, im Aischgrund in Bayern, in der Lüneburger Heide und auch in Norddeutschland, hier in Mecklenburg, Schleswig-Holstein und im Oldenburgischen Münsterland, im Weiteren in den Ländern Ostelbiens (Ostpreußen und Pommern) und Schlesien (Böhmen und Mähren).

Dass die großen Karpfenteichwirtschaften in Deutschland noch heute vor allem in den ostdeutschen Bundesländern vorkommen, ergibt sich neben der Historie unter anderem auch daraus, dass in der ehemaligen DDR der größte Teil in mehreren volkseigenen Binnenfischerei-Betrieben zusammengeschlossen war. Jeder dieser Betriebe umfasste bis zu etwa 2.000 ha Teichfläche (SCHÄPERCLAUS 1961:169). Die deutsche Kleinteichwirtschaft ist in erster Linie in Thüringen zu finden. Aber auch im Großteichgebiet Aischgrund in Bayern sind manchmal sogar ,mehrere Bauern in einem einzigen Teich fischereiberechtigt.“ (:169) Mittlere Karpfenteichwirtschaften „liegen hauptsächlich in Bayern, Schleswig-Holstein und Niedersachsen."(:169)

Forellenzucht in Deutschland, natürlicherweise gebunden an kühles, sauerstoffreiches Wasser, wird seit jeher besonders in der Nähe der Nordseeküste, in Niedersachsen, vor allem in den Mittelgebirgen, in Süddeutschland und Niederösterreich betrieben (SCHÄPERCLAUS 1961:166f.).

Das eigentliche Verbreitungsgebiet der Forellenzucht aber war und ist Süddeutschland, vor allem die Länder Württemberg, Baden und Bayern (RUST 1952:85). Innerhalb der Forellenteichwirtschaften war Bayern in den 1950er Jahren mit 100 ha das Land mit der größten Forellenteichfläche. Es folgten Niedersachsen mit 68 sowie Baden-Württemberg und Nordrhein-Westfalen mit je 52 ha (SCHÄPERCLAUS 1961:169).

Seit Ende des Zweiten Weltkrieges, mit der Zusammenlegung in Landwirtschaftliche Genossenschaften in den 1950er Jahren, entwickelte sich die Forellenzucht in der ehemaligen DDR auch besonders südwestlich der Stadt Brandenburg und in Mecklenburg, in den Bezirken Potsdam und Schwerin in der Nähe der Ostseeküste mit ihren Fischabfällen, daneben aber auch in verstärktem Maße im Erzgebirge und in Thüringen (SCHÄPERCLAUS 1961:166,169).

Aber auch vor der Gründung der LPGs gab es in Mitteldeutschland, in Brandenburg und Sachsen Forellenteichwirtschaften, vor allem Mittelbetriebe von $10-100$ ha und einige Großbetriebe von 
sogar mehr als 100 ha. In Nord- und Süddeutschland und auch in Ostpreußen hingegen betrugen die Teichflächen je Betrieb gar meist weniger als 20 ha.

Soweit als Einführung der allgemeine geographische Überblick.

\section{d.2.2 Detail}

\section{d.2.2.1 Tiefland}

Schleswig-Holstein ist in Europa das nördlichste Verbreitungsgebiet für die Karpfenteichwirtschaft. Hier, im norddeutschen Flachland, auf der schleswig-holsteinischen Geest, findet der Karpfen seine nördliche Verbreitungsgrenze (RUST 1956:1). Die Lufttemperaturen in der Abwachszeit (Mai September) reichen gerade aus, um die Teiche auf die für eine einträgliche Teichwirtschaft erforderlichen $17^{\circ}-20^{\circ} \mathrm{C}$ zu erwärmen (:89). Im Jahr 1905 besaß Schleswig-Holstein eine Teichfläche von 4.200 ha, verteilt auf rd. 5.600 Teiche. Darin enthalten sind die sog. Kleinteichwirtschaften (Einzelteiche unter je 3 ha Größe) mit ca. 800 ha Wasserfläche.

Während Schleswig-Holstein vor dem Zweiten Weltkrieg nur absolut lokale, bestenfalls regionale Bedeutung in der deutschen Teichwirtschaft hatte, wurde es nach Beendigung des Krieges durch den Ausfall der Ostgebiete und die Intensivierung der Teichwirtschaft seit den 1950er Jahren in der Bundesrepublik hinter Bayern und zusammen mit Niedersachsen flächen- und produktionsmäßig eines der wichtigsten Teichgebiete. In Schleswig-Holstein wurden 12\% der westdeutschen Karpfenmenge erzeugt (RUST 1956:86,90). Der Ausbau der Teichwirtschaft führte aber dennoch, dies sei hier angemerkt, in Niedersachsen und vor allem in Süddeutschland infolge besserer Klimabedingungen zu weit größeren Ertragsteigerungen als in Schleswig-Holstein.

Von der schleswig-holsteinischen Teichfläche entfielen auf Ostholstein ca. 80 - $85 \%$ (RUST 1956:43,89). Die Jungmoränenlandschaft Ostholsteins, vor allem der Kreis Plön, südlich Preetz, Lütjenberg, westlich Oldenburg, Fehmarn und der Raum Lübeck-Hamburg, war damit Hauptverbreitungsgebiet. Dieses erklärt sich zum einen aus den morphologischen und hydrographischen Verhältnissen (Gelände-, Boden-, Wasserbedingungen): Die Landschaftsgestaltung und das verzweigte Wassernetz ermöglichten die große Anzahl von Kleinteichen in Ostholstein (:43f.). Teichbau war hier aufgrund des reliefierten Geländes unproblematischer möglich. In ganz Ostholstein gehören ablassbare Teiche wegen ihrer großen Anzahl und Flächenhaftigkeit zu den besonderen Bestandteilen der Kulturlandschaft. Innerhalb Schleswig-Holsteins herrscht in Ostholstein dabei die Karpfenteichwirtschaft vor. 


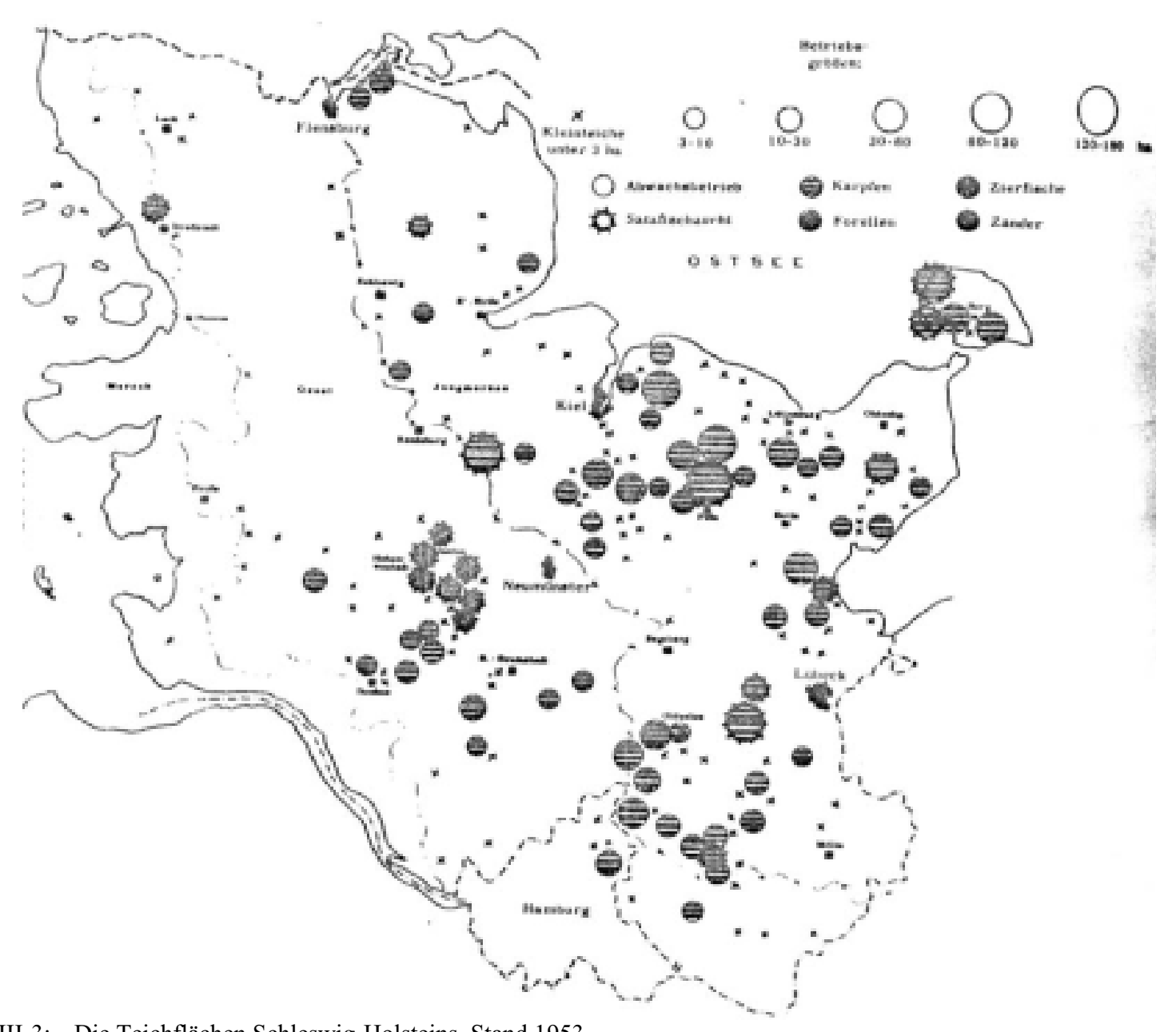

Abb. VIII-3: Die Teichflächen Schleswig-Holsteins. Stand 1953 (aus: RUST 1956:127, Abb. 3)

Zum anderen war die Verbreitung historisch bedingt. In Holstein beginnt die Teichwirtschaft im Gefolge der klösterlichen Kulturtätigkeit, zumindest lassen sie sich ab diesem Zeitpunkt nachweisen. Die Mehrzahl der holsteinischen Klostergründungen fällt in das 12. und 13. Jahrhundert: Segeberg 1136, Neumünster 1123/36, Reinfeld 1186, Preetz und Reinbek 1220, Itzehoe 1230, Ütersen 1240, Harvestehude 1242, Cismar 1245, Ahrensbök 1397. Besonders die Reinfelder Zisterziensermönche waren hervorragende Wasserbautechniker und gelten in der Überlieferung als die Begründer der holsteinischen Teichwirtschaft. Sie brachten diese Kenntnisse vom Mutterkloster Loccum (gegr. 1163) aus Niedersachsen nach Holstein (RUST 1956:17f.). Von 1327 stammt der erste urkundliche Beleg über einen Teich des Klosters Reinfeld.

Da die Klöster und Güter vor allem im südlichen und östlichen Holstein über arrondierten Großgrundbesitz verfügten, breiteten sich vor allem hier die umfangreichen Teichanlagen aus (RUST 1956:17). Die Teichwirtschaft, als Ausdruck klösterlicher Betriebsamkeit, prägte zu dieser Zeit in Holstein, so kann man sagen, die Kulturlandschaft: Die Reinfelder Mönche beispielsweise legten im Verlaufe ihres Wirkens ca. 60 Teiche an (CLASEN 1952:72, nach RUST 1956:18). Das Kloster Ahrensbök besaß etwa 50 Teiche (KUSS 1820:294). Für das Kloster Preetz hat KLOS (1950:144) 27 Teiche im Bereich der Walddörfer nachgewiesen.

Nach den Angaben von KLOS und von RUST (1956:19) umfassten diese 27 Teiche folgendes Areal:

- um 1500 ca. 500 „to Teichland“海 = ca. 260 ha

\footnotetext{
${ }^{8}$ Bei der Angabe „to“ handelt es sich wahrscheinlich um die niederdeutsche Flächenmaßangabe „Tonnen“. $1 / 2$ Tonne $=1$ Morgen $=$ ca. $25 \mathrm{Ar} ; 24$ Tonnen $=1$ Last $=$ ca. $12 \frac{1}{2}$ ha.
} 
$\begin{array}{ll}\text { - um } 1550 \text { ca. } 570 \text { „to Teichland“ } & =\text { ca. } 296 \text { ha } \\ \text { _ um } 1650 \text { ca. } 740 \text { „to Teichland“ } & =\text { ca. } 385 \text { ha }\end{array}$

Dazu kommen nach ihren Angaben 34 Flurnamen, die auf ehemals klösterliche Teiche hindeuten, aber kartographisch nicht mehr als solche dargestellt sind. G. v. BUCHWALD (1882:93) führt des Weiteren aus dem Tafelregister des Lübecker Bischofs Nicolaus von Sachow (1417 - 89, Bischof von 1439 - 49, zuvor [1437-38] Generalvikar) 17 Teiche im bischöflichen Grundbesitz zwischen Lübeck und Eutin an, aber leider ohne Größenangabe.

Nach der Säkularisierung der holsteinischen Klöster wurden die angelegten Teiche von den Gütern übernommen und vielfach weiter ausgebaut. Nur mit wenigen Ausnahmen betrieben alle holsteinischen Güter Teichwirtschaft. Vom Gut Salzau werden 178618 große und 5 kleine Teiche genannt, vom Meierhof Schalhorn im Gut Fresenburg bei Oldesloe 9 Teiche von je ca. 18 „to Land“, das sind insgesamt ca. 81 ha. Die Teichfläche umfasste damit etwa $5 \%$ vom Gesamtareal des Gutes Fresenberg (RUST 1956:20).

Dennoch waren die Teichflächen stark rückläufig und Hinweise aus dem Jahr 1847 besagen, dass die Teichwirtschaft früher in sehr viel größerem Umfang betrieben wurde (REVENTLOW-FARWE/ WARNSTEDT 1847:312f.). Das Gut Koselau (bei Oldenburg) besaß im Jahre 1841267 „to land“ = 133,5 ha Teichland. Der Anteil der Teiche am gesamten Gutsareal (ohne den See) betrug ca. $12 \%$. Das Gut Farve (Krs. Oldenburg) hatte 191033 Teiche aufgestaut. Umfangreiches Teichareal gehörte in Schleswig-Holstein außerdem zu den Gütern Bothkamp, Emkendorf, Kletkamp, Kühren, Lammershagen, Lehmkuhlen und Rixdorf. Die Teiche des Gutes Bothkamp bilden einen selbständigen teichwirtschaftlichen Pachtbetrieb; die Teiche bei Muxall gehören zum größten teichwirtschaftlichen Hauptbetrieb Schleswig-Holsteins. Die folgende Karte veranschaulicht den beträchtlichen Anteil des Teichlandes am Areal einzelner holsteinischer Güter.

Entsprechend den Geländebedingungen Ostholsteins handelt es sich aber bei allen klösterlichen Teichen, wie auch bei den gutsherrlichen Teichanlagen (siehe Abb. VIII-4), um Aufstauungen in natürlichen Hohlformen (RUST 1956:19). BRAND (1933:37) bestätigt diese Annahme durch den Hinweis, dass der Bischof von Lübeck 1143 um Eutin ,,in großer Zahl in den natürlichen Hohlformen künstliche Stauteiche anlegen ließ." Wenn sie also - und dies scheint bei der Mehrzahl der kleineren Teiche der Fall gewesen zu sein - durch teichbauliche Anlagen künstlich auf- und abgestaut wurden, so waren die Teichformen von der Geländegestaltung abhängig bzw. vorgegeben. 

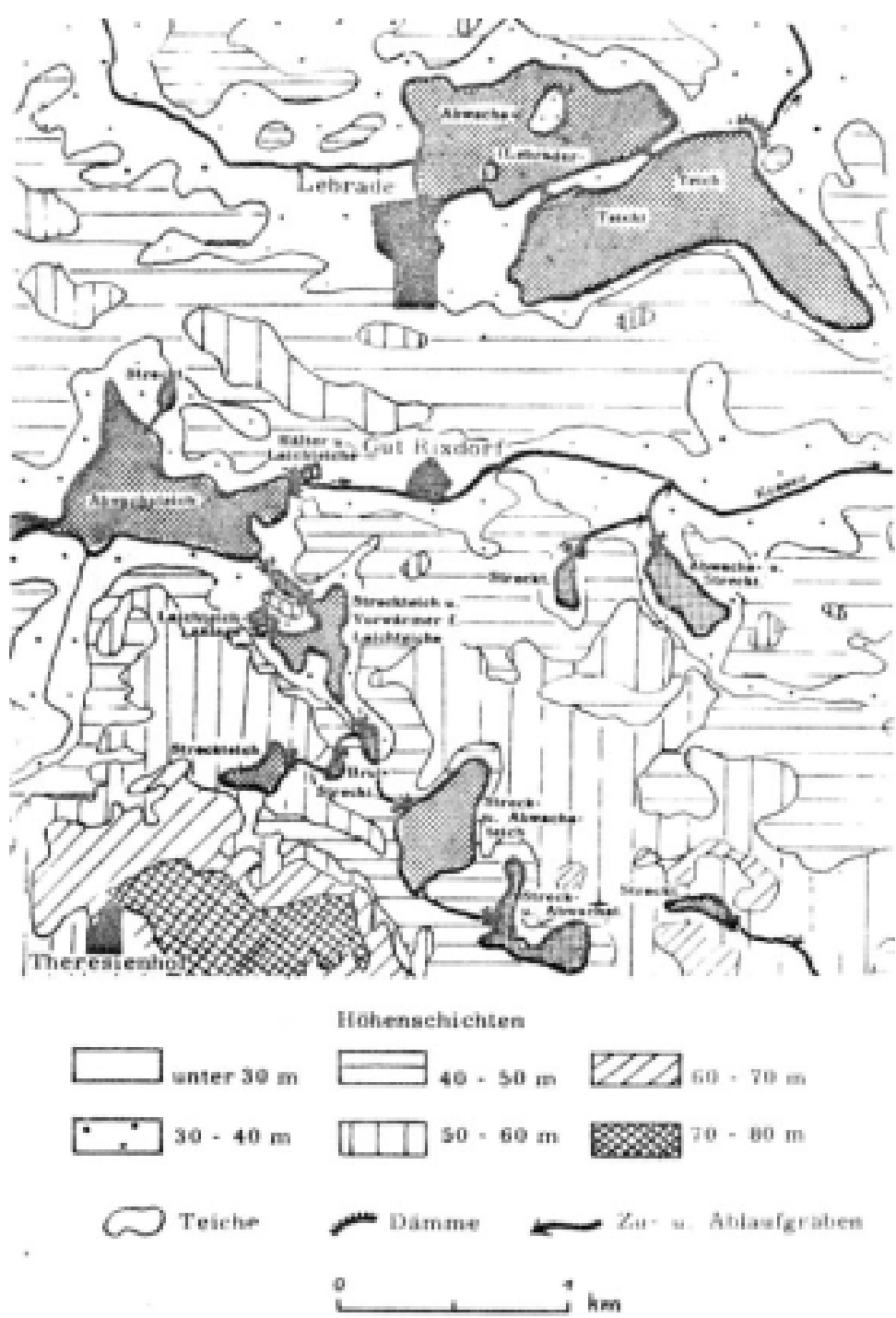

Abb. VIII-4: Die Teiche des Gutes Rixdorf in Ostholstein

Es lassen sich nicht nur die Vielzahl, Ausdehnung und Größe des Teichlandes erkennen, sondern auch die Lage der Teiche in Höhenschichten zumeist von $30-40$ m, in einigen Fällen, vor allem im südlichen Kartenausschnitt, auch in 40 - 50 m (Ausschnitt aus den Messtischblättern Plön [Nr. 1828] und Selent [Nr. 1728]) (aus RUST 1952: 125).

Die größte Teichwirtschaft Schleswig-Holsteins liegt an der Westküste Fehmarns, in Wallnau. Es handelt sich hierbei um ein relativ junges Teichgebiet, denn mit dem Bau wurde erst 1880 begonnen. Die Teichfläche Wallnaus betrug um 1910 ca. 320 ha (siehe Abb. VIII-5). Möglich wurde dies erst mit der Landgewinnung durch Eindeichung des Südwestzipfels Fehmarns mit privaten Mitteln im Jahre 1864. Der Teichbesitzer konnte die Teiche aber erst ausbauen, nachdem der Boden genügend salzfrei war. 


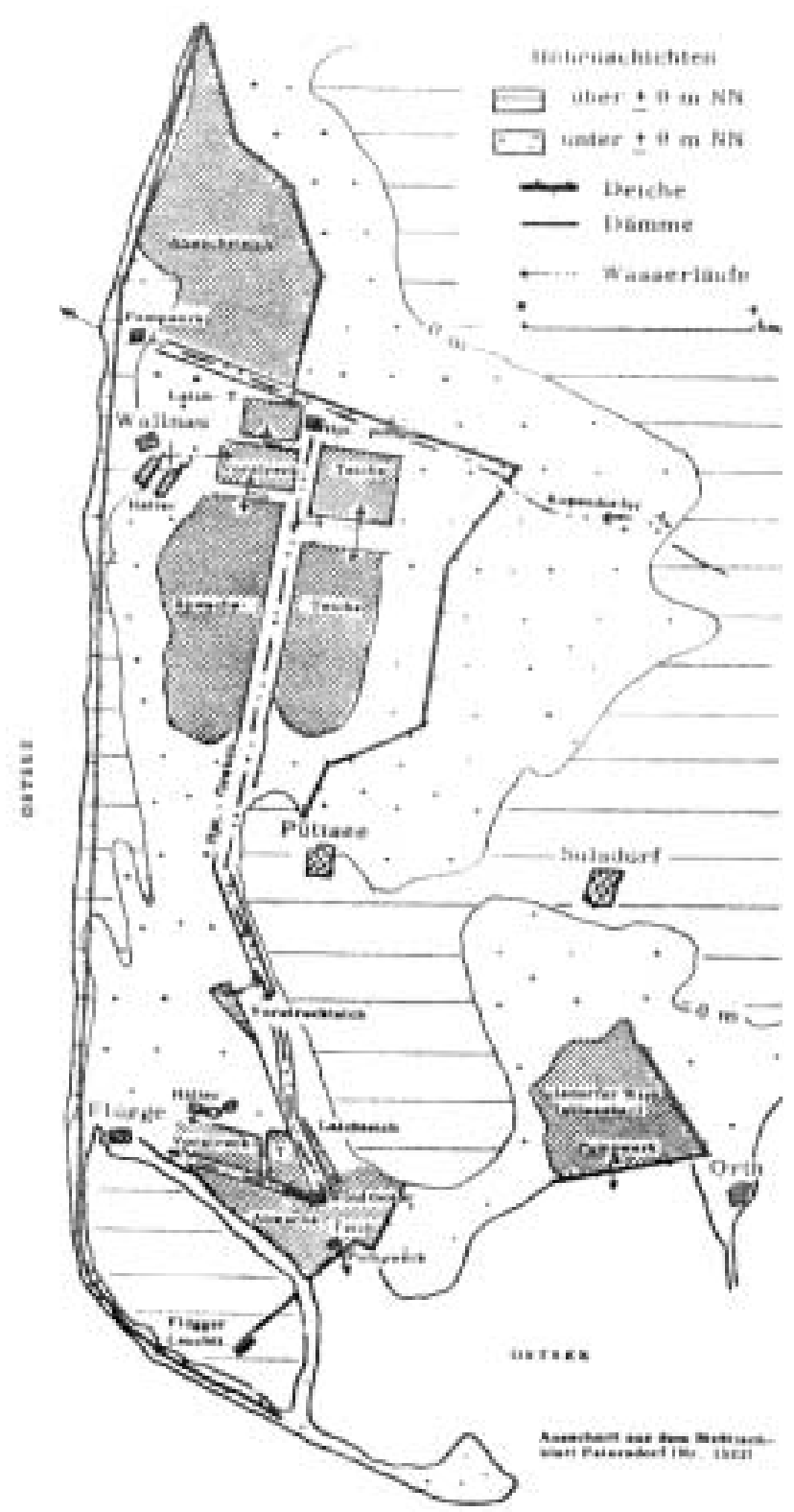

Abb. VIII-5: Die Teichwirtschaften Wallnau und Flügge auf Fehmarn

Die Teichflächen liegen hier gar sämtlich unter NN (aus RUST 1956: 132).

Der Deutsche Bund für Vogelschutz erwarb 1975 das über 300 Hektar große Teichgut Wallnau als Wasservogelreservat. Über das von der Teichwirtschaft angelegte Kanalsystem kann der Wasserstand auf Wallnau in allen Wiesen, Gräben und Teichen derartig geregelt werden, dass in bestimmten Teichflächen das Wasser je nach Jahreszeit angestaut oder abgelassen wird, und so auf engstem Raum diversifizierte Brut- und Nahrungsräume entstehen. Für die Zugvögel besteht sogar die Möglichkeit, auf einem größeren Teich Ebbe und Flut nachzuahmen.

Als weitere Beispiele späten Teichbaus seien die 1890 angelegten Teiche bei Bokelholm (Kreis Rendsburg) und bei Mühlenbarbek (Kreis Steinburg) genannt.

Viele Kleinteiche unter je 3 ha Größe, wenn auch typisch für die gesamte Jungmoränenlandschaft, konzentrieren sich im Kreis Plön und erklären sich aus den morphologischen und hydrographischen Verhältnissen (RUST 1956:43).

In Plön wird auch von einer biologischen Fischerei-Versuchsstation berichtet. Diese Versuchsanstalt wie die meisten Teiche im postglazial geformten Norddeutschland insgesamt - unterscheidet sich insofern von den anthropogen entstandenen Versuchsanstalten vor allem der Mittelgebirge, als sie in 
natürlich entstandenen Seen ihre Versuche durchführten und nicht in anthropogenen Teichwirtschaften (VOGELS 1898:482).

In Mittelholstein gibt es zwar ebenfalls viele Kleinteiche. Ihre Anzahl ist jedoch hier weit kleiner als in Ostholstein. Zum Unterschied zu den meisten Teichanlagen in Ostholstein ist die Teichwirtschaft auf der holsteinischen Geest sehr jung (RUST 1956:50). Erst seit der zweiten Hälfte des 19. Jahrhundert sind hier zahlreiche Teichanlagen gegraben worden. Hier herrschten Kleinbetriebe vor, die in „kleinen schachtelförmigen Terrassenteichanlagen“ (:50f.) hauptsächlich Forellenzucht mit Karpfen, Zander und Zierfischen als Nebenbesatz betrieben.

Die ersten Teichbetriebe der Geest entstanden auf Anregung des Central-Fischerei-Vereins für Schleswig-Holstein um die Mitte des vorigen Jahrhunderts. Seit Ende des 19. Jahrhunderts begann im Raum Itzehoe eine intensive Forellenzucht. 1908 gelang auf Gut Sarlhausen zuerst in SchleswigHolstein die Aufzucht der Regenbogenforelle. Hier wurden auf rd. 6 ha Wasserfläche auch in solchen Teichen, die sich nicht für die Forellenzucht eigneten, weiterhin Karpfen gezüchtet (RUST 1956:52).

RUST nennt vor allem den Raum Hohenwerdt-Innien, des Weiteren die Teichwirtschaften um Itzehoe, Kellinghusen und Sarlhausen. Sie bedienten den Absatzmarkt Hamburg und auch die Truppenübungsgelände, wie beispielsweise das Lockstedter Lager. Die Zuchtbetriebe um Hohenwestedt besaßen die verkehrsgünstige Lage an der Eisenbahnstrecke Heide-Neumünster (1956:50ff.).

Seit Ende des Zweiten Weltkrieges wurde die Forellenzucht jedoch nur in wenigen Betrieben beibehalten (RUST 1956:53), so dass die moderne Teichwirtschaft nur eine kurze Episode in Schleswig-Holstein darstellte. Die gesamte Kleinteichfläche Schleswig-Holsteins gibt RUST für 1956 (:44) mit rd. 200 ha an.

In der Marsch hingegen ,ist die Teichwirtschaft infolge widriger Klima- und Vorflutverhältnisse nicht verbreitet“ (RUST 1956:42). Dieses gilt jedoch nicht für die Kleinteichwirtschaft. Denn „selbst in den Marschen werden vereinzelt Kuhlen, die durch Materialentnahme für Straßen-, Bahn- und Deichbauten entstanden, jährlich ausgepumpt und somit als ablaßbare Teiche genutzt.“ (:44) Als Beispiel wird von RUST (:44) der Herrenkoog bei Niebüll mit insgesamt 6 ha genannt. Generell jedoch spielt die Teichwirtschaft ,nördlich der Linie Nord-Ostsee-Kanal - Eider kaum noch eine Rolle“ (:42) und als eine ordentliche Teichwirtschaft, geschaffen primär zum Zwecke der Fischzucht, kann eine solche nach seiner Ansicht auch nicht bezeichnet werden.

Die in den 1950er Jahren „größte deutsche Forellenzuchtanstalt“ in Schnede und besaß 15 ha Wasserfläche (SCHÄPERCLAUS 1961:166). Die Forellenzucht Dobbin in Mecklenburg umfasste 8,5 ha reine Wasserfläche (:166).

Im Oldenburger Münsterland, ca. $5 \mathrm{~km}$ nordwestlich von Ahlhorn, an der Bundesautobahn liegt die Staatliche Teichwirtschaft „Ahlhorner Fischteiche“. Sie umfasst ein System von etwa 50 fischereiwirtschaftlich genutzten Teichen in der Größe von mehreren hundert Quadratmetern bis zu 2 ha (WADEHN 1982:217). Die Wasserversorgung der nur maximal 1,5 m tiefen Teiche erfolgt durch die Lethe, deren ausgezeichnetes Wasser in drei Stauseen gespeichert und von dort durch ein offenes Zuleitersystem auf die Teiche verteilt wird (:217). 


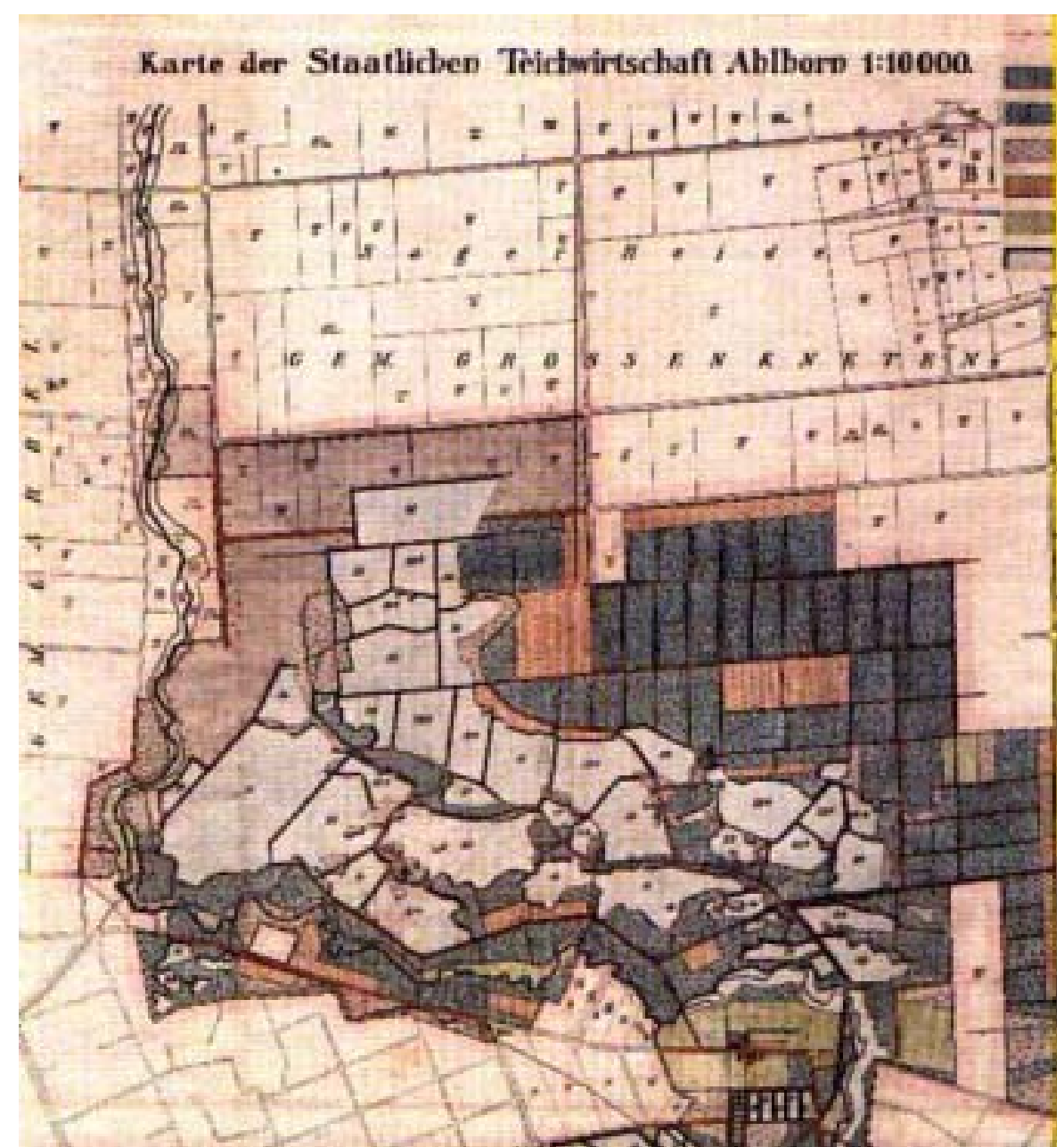

Abb. VIII-6: Karte der Staatlichen Teichwirtschaft Ahlhorn 1:10.000 (um 1930)

(aus: FENSKE 1999)

Vom Zeitpunkt der Anlage der Teiche um 1900, wobei um 1884 der ,Rüdersee' (3 ha) als erster Teiche angelegt wurde, bis heute, hatte die Teichwirtschaft mit Wassermangel zu kämpfen, da es versäumt worden war, die Böden der auf sandigem Untergrund angelegten Teiche abzudichten (WADEHN 1982:217).

Die eigentliche Anlage von Teichen und Staus geschah im „Schwarzen Moor“ und in der „Haller Mark" des Gebietes von 1901 bis 1929 durch Strafgefangene aus Vechta, um 1916 durch Kriegsgefangene und später im Rahmen des Reichsarbeitsdienstes.

Nachdem die Teichbewirtschaftung ab 1918 aus der Verwaltung des Großherzogtums Oldenburg in das Siedlungsamt Oldenburg und 1931 an die Forstverwaltung des Freistaats Oldenburg verwiesen wurde, war es nach 1945 selbständige Teichwirtschaft des Landes mit Karpfen, Schlei, Laich-Zander, Forelle. 1971 erfolgte die Eingliederung in das Staatliche Forstamt Ahlhorn.

Seit Beginn der 1970er Jahre ist jedoch die Teichwirtschaft in ihrem Bestand bedroht, da die Wasserspende der Lethe, verursacht durch Niederschlagsdefizite, halbiert wurde. Außerdem wurde im benachbarten Gebiet Baumweg die jährliche Trinkwasserförderung in Höhe von 5 Mio. $\mathrm{m}^{3}$ aufgenommen. „Durch den Wassermangel sind die Wasserstände der Fischteiche so weit abgesunken, $\mathrm{da} \beta$ einige davon erst gar nicht mehr gefüllt, sondern landwirtschaftlich genutzt wurden. In anderen haben sich durch Eutrophierung, vor allem durch abfließende oder versickernde Gülle als Immissionen aus Massentierhaltungen, Flachwasserzonen gebildet, die von vielen Lurcharten bevorzugt werden. Hinzu kommen insbesondere in den größeren Teichen ausgeprägte Schilfgürtel, die den Grünfröschen als Rückzugsraum dienen.“ (WADEHN 1982:218) Langfristig ist mit einem Absinken des 
Grundwasserspiegels zu rechnen. Ein negativer Einfluss auf die Wasserstände der Fischteiche wäre dann sehr wahrscheinlich (:217).

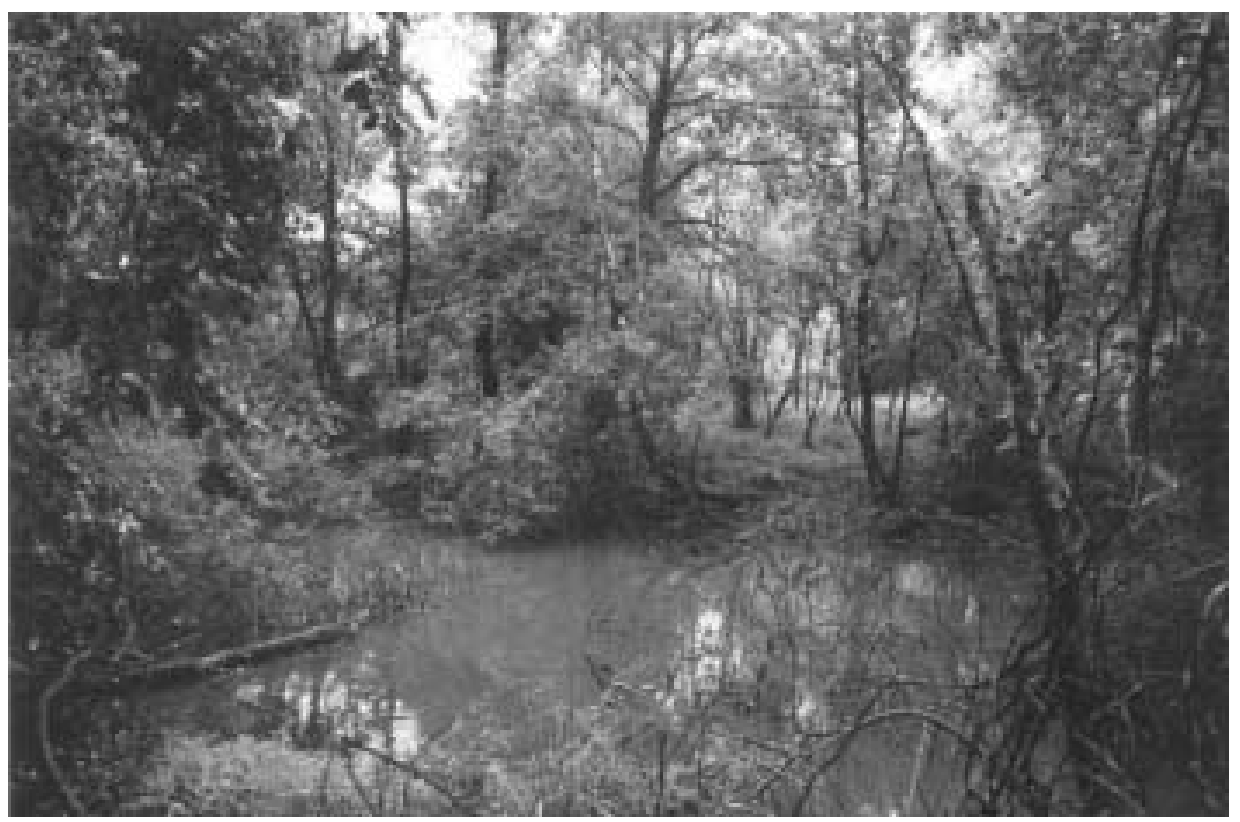

Abb. VIII-7: „Ungepflegter“, nicht mehr bewirtschafteter Teich der Teichwirtschaft Ahlhorn.

Viele solcher sich selbst überlassenen Teiche sind auf dem Areal der Staatlichen Teichwirtschaft festzustellen. Ehemalige Gräben sind zugewachsen, ein Frischwasseraustausch damit verhindert, eine beschleunigte Verlandung somit die Folge. Die Wiederaufnahme eines derartig versauerten Tümpels nimmt eine lange Zeit in Anspruch und ist mit großen Kosten verbunden (eig. Aufnahme 2003).

Im brandenburgischen Havelland, im „Ländchen Bellin“, existiert seit Ende des 19. Jahrhunderts eine große Karpfenteichwirtschaft um den Ort Linum, weshalb die Gegend auch den Namen „Teichland Linum“ trägt.

Den eigentlichen ,Grundstein' für die Teichwirtschaft legte der Torfabbau im Luch ${ }^{9}$ vor ca. 200 Jahren, denn die ersten Teiche entstanden erst nach mühsamer Errichtung von Deichen rund um die wassergefüllte tiefen Torfabbaufelder, die der Torfstich hinterlassen hatte. Nach dem Ende des großflächigen Torfabbaus bei Linum, Ende des 19. Jahrhunderts, lagen viele dieser Flächen des Luchs unter dem Wasserspiegel des Rhin und der Kanäle, so dass langsam Sümpfe und Wasserflächen entstanden, deren Bildung durch defekte Deiche noch gefördert wurde.

Der damalige Domänenpächter Linums setzte 1899 in einem Torfsee erstmals 1000 Karpfen aus, um zu prüfen, ob sich die ungenutzten Torfflächen wirtschaftlich rentabel verwerten ließen. Da die Fische gut gediehen und der Versuch ein finanzieller Erfolg war, wurde die Fläche des Teichlandes von 1900 bis 1906 auf über 71 Hektar erweitert. Den zweiten großen Ausbau erlebte die Anlage Ende der 1960er Jahre. Sie umfasst nunmehr ca. 270 ha Wasserfläche und ca. 400 ha Grundfläche. Am Anfang mussten die Teiche noch mit Pumpen be- und entwässert werden. Ab 1916 wird das Abfischen, für das man das Wasser aus dem Teich pumpt, dann über den Niveauunterschied des Wassers zwischen Altem

\footnotetext{
${ }^{9}$ Das Teichland gehört morphologisch ebenfalls zur Landschaft des Norddeutschen Tieflandes, und ist Teil des sog. Oberen Rhinluchs, das während dieser Eiszeit durch die typische glaziale Serie Urstromtal, Sander, Grundmoräne und Endmoräne gestaltet worden ist. Das Rhinluch umfasst die vom Rhin und seinem Grabensystem entwässerten Flächen und ist Teil des Eberswalder Urstromtals, dass die Schmelzwasser über die Elbe zur Nordsee leitet.

In demselben $\mathrm{Ma}$ wie sich die Landformation veränderte, gestaltete sich auch das Gewässernetz nach der Eiszeit um. Der Rhin floß nun durch die Ruppiner Seenrinne in das Luch und verzweigte sich in Richtung Untere und Obere Havel. Der Rückstau der Flüsse und ein hoher Grundwasserspiegel führten zur Vernässung und der Bildung von neuen Wasserflächen. Punktuell entstanden Verlandungsmoore. Vor ca. 8.000 - 5.000 Jahren begann dann die großflächige Vermoorung des Rhinluchs. Durch die Verlandung der Seen und flächenhafte Versumpfungen bildete sich das Niedermoor, das in den Talsenken bis zu 20 Meter mächtig war, ansonsten aber nur eine Dicke von 2-3 Metern hatte. Mit dem mittelalterlichen Landesausbau um 1200 begann dann der Eingriff des Menschen in den Wasserhaushalt des Rhinluches. Die Eindeichungen an Elbe und Havel führten zu einem Rückstau des Frühjahrshochwassers im Rhinluch und damit zu einer verstärkten Moorbildung, aus der das Linumer "Gold", der Torf, heranwuchs.
} 
Rhin und Breitem Graben gesteuert. Seit der zweiten Ausbauphase werden die Teiche über Einlaßund Auslaßbauwerke be- und entspannt.

Einen höhenmäßigen Übergangsbereich im norddeutschen Tiefland zum Berg- und Hügelland bildet der Hohe Fläming im südlichen Land Brandenburg. Die hier ansässigen zahlreichen kleineren Teichwirtschaften liegen im Buckau- und im Plane-System: Unmittelbar an der Plane bestehen Betriebe an der Werdermühle zwischen Lühnsdorf und Niemegk, an der Komturmühle zwischen Dahnsdorf und der Autobahnauffahrt Niemegk, in Locktow und an der Wühlmühle östlich von Neschholz. Einen kleinen Planezufluss nutzt eine am Hang zwischen Lütte und Dippmannsdorf gelegene Teichwirtschaft. Und am Flüsschen Buckau, zwischen den Orten Buckau und Rottstock, liegt unterhalb des Flächennaturdenkmals „Gesundbrunnen“, einem der naturnahen Quellkessel des Hohen Flämings, die „Forellenzucht Gesundbrunnen“. Wie man aus den Ortsbeschreibungen ersehen kann, handelt es sich vor allem um ehemalige Mühlenteiche, z. B. in Ragösen und Dippmannsdorf, und um die künstlichen, zur Fischzucht errichteten Stillgewässer auf der ansonsten so gewässerarmen Hochfläche des Flämings, so in Wiesenburg oder Jeserig (NATURPARK HOHER FLÄMING 2003).

Im Niederen Fläming, in Dahme, liegen die „Körbaer Teiche“. Dahmer Karmelitermönche ließen hier im Mittelalter das Schweinitzer Fließ anstauen, um in der Fastenzeit genügend Karpfen für ihre Mahlzeiten zu haben, und schufen ein 27 ha großes Teichgebiet (EBERTS 1904:8).

Die in Siehdichum, in den Neuzeller Stiftsforsten zwischen Eisenhüttenstadt und Guben gelegenen Teiche nahmen 1904 einen Flächenraum von 142 ha ein. Aufgrund ihrer durchschnittlichen Tiefe von 5,5 -9 m kann man aber auch - wie bei der Plöner Versuchsanstalt - hier nicht von einer künstlichen Anlage ausgehen (EBERTS 1904:8).

Innerhalb Norddeutschlands waren auch in der Lüneburger Heide Fischzuchten ansässig. Obschon der Teichbau durch den sandigen Boden erschwert war, haben sich hier aufgrund der Bäche mit guten Wasserqualitäten Teichwirtschaften entwickelt.

So finden sich die meisten Karpfenteichanlagen in der südlichen Lüneburger Heide (SEEDORF/MEYER 1996:417f.). Besonders im Celler Teichgebiet waren sie verbreitet, wie zum Beispiel die ehemalige Teichgutwirtschaft zu Oerrel an den ,Häßelteichen' der Häßelmühle gelegen. Nach dem Zweiten Weltkrieg entstanden aus den gleichen Beweggründen wie in Schleswig-Holstein auch in der Lüneburger Heide viele Forellenzuchten bzw. bestehende wurden intensiviert (RUST 1956:52,85).

Bei Bockel, im Übergang der südlichen Heide in das nördliche Hannoveraner Land erlaubte 1478 Herzog Friedrich d. Ältere von Braunschweig und Lüneburg dem Probst Lüder zu Isernhagen die Anlage von Teichen (BOSSE 1991:46). Wie überhaupt die hier ansässigen Klöster als Träger der Teiche angesehen werden können (neben Isenhagen, Wienhausen, Walsrode, Ebstorf, Lüne und Medingen). Nach der Reformation sind alle sechs Lüneburger Kloster zu evangelischen Damenstiften umgewidmet worden und in ihnen leben noch heute alleinstehende Frauen lutherischen Glaubens (BURGHARD 1988d:45).

Vor allem aber sind im ,Celler Teichgebiet' die ,Meißendorfer Teiche' des Gutes Sunder zu nennen. Der Ursprung von Gut Sunder lag in einem Freihof des Klosters St. Michaelis in Lüneburg. In diesem Fall war also die Kirche der Grundherr. Der Lüneburger Kanzler am Celler Hof Baltasar Klammer wurde 1548 von Abt Herbold vom Kloster St. Michaelis mit den Besitzungen des Klosters in Meißendorf belehnt. Als erstes verlegte er den Hof aus dem Ort Meißendorf an die zum Hof gehörenden Ländereien. Der Auszug aus dem Dorf wird als der Ursprung des Namens: gesondert, sonder, sunder, gedeutet. Auf das Gut wollte der Kanzler Jagdgesellschaften einladen und sich von der Arbeit im nur ca. $20 \mathrm{~km}$ entfernten Celle aufs Land zurückziehen. Im Laufe der Jahre erwarb Klammer ständig weitere Besitzungen in der Umgebung. Bis ins 19. Jahrhundert gehörten zu Gut Sunder: ein Vollhof, 2 Halbhöfe, 24 Kotstellen und eine Halbkote. Auf einem von Gräben umgebenen Platz entstand das Herrenhaus. Es war kein reines Wirtschaftsgebäude, wie die alten Bauernhäuser, sondern ein repräsentatives Wohnhaus im Stil der Celler Bürgerhäuser. Die Frau des Hermann Baltasar 
Klammer, einem Enkel des Kanzlers, Agnese von der Schulenburg, wurde nach seinem Tod Lehnsherrin von Sunder. Nachdem das Gut mehrfach den Besitzer gewechselt hatte, ging es 1752 in das Eigentum der Familie von Schrader über, in dem es bis 1977 blieb. Ernst v. Schrader ließ in der zweiten Hälfte des 19. Jahrhunderts neue Wirtschaftsgebäude bauen; unter anderem eine Wassermühle mit Sägewerk an der Meiße, die man jedoch in den siebziger Jahren des 20. Jahrhunderts abgerissen hat.

1881 machte Ernst v. Schrader erste Versuche mit der Teichwirtschaft. Im Hausteich wurden zehntausend Karpfenbruteier ausgesetzt, und nach drei Jahren konnten sie als Speisefisch nach Hannover verkauft werden. Nach Erkenntnissen, die v. Schrader in der Bewirtschaftung seiner Teichgüter in Schleswig-Holstein gesammelt hatte, wurden 51 größere und kleinere Teiche auf den Heide- und Moorflächen angelegt. Das Wasser der Meiße speiste diese und floss von einem Teich zum darunter liegenden nächsten. An den Ablassmönchen hatten sie eine Tiefe von 1-1,5 m und waren nach oben flach auslaufend. Bis auf einige Teiche, die zur Überwinterung der Fische dienten, lag der Rest im Winter trocken. Auf 250 ha des damals 480 ha großen Gutes entstanden im Lauf der Zeit ehemals etwa 80 Fischteiche. Ackerbau und Viehzucht wurden aufgegeben und lediglich Forstwirtschaft weiter betrieben. Es entstand die größte Karpfenzucht Norddeutschlands. Viele Bauern der Umgebung folgten Schraders Beispiel und legten insgesamt weitere 250 ha Teiche an.

Durch die Form der Bewirtschaftung hatte sich auch das Bild der Landschaft verändert: Dämme wurden aufgeschüttet und in den ertragsarmen Moorwiesen Fischteiche angelegt. Teilweise wurden auch Waldgebiete in Fischteiche umgewandelt. Durch Kanalisierung der Meiße konnte die Wasserversorgung der Teiche reguliert werden. 


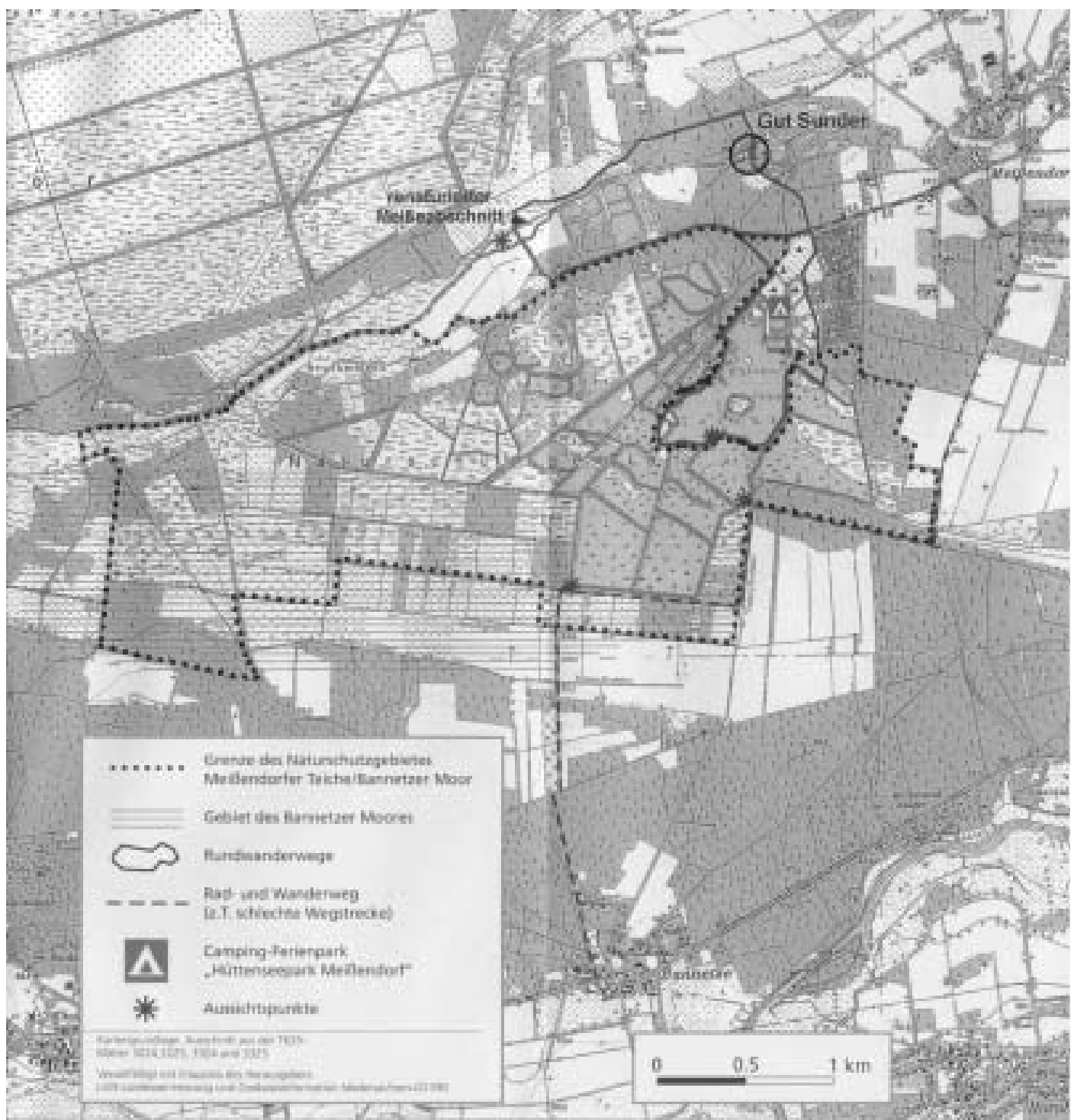

Abb. VIII-8: Karte des Meißendorfer Teichgebietes in seinen Schutzgebietsgrenzen (punktierte Linie).

Wie man erkennen kann, sind viele Teiche bereits verlandet und nur noch als Wiesenschraffur dargestellt bzw. unterliegen dieser in zunehmender Form (LANDKREIS CELLE 2003, Ausschnitt aus der TK 25, Blätter 3224, 3225,3324 und 3325).

Die Fischteiche in der Meißeniederung entwickelten sich in den folgenden Jahrzehnten zu einem ökologischen „hot spot“ von überregionaler Bedeutung. Viele Arten der Feuchtlebensräume siedelten sich an den Meißendorfer Teichen an und 1948 kam der bekannte Tier- und Naturfilmer Heinz Sielmann nach Meißendorf, um an den Teichen Aufnahmen für seinen ersten Kinofilm "Lied der Wildbahn" zu drehen. 1967 verwandelte Barthold v. Schrader einen Teil der Teichanlagen in ein Erholungsgebiet mit Badesee, Campingplatz und Wochenendhausgebiet. Es entstand der „Hüttenseepark“. Der Name hat seinen Ursprung in den Pfahlhütten über dem Wasser, in denen früher Schweine gehalten wurden. Deren Kot diente als Nahrung für Fische und Plankton.

In den 60er und 70er Jahren stellte man die extensive Fischzucht zum größten Teil ein. Um den Erhalt dieses bedeutsamen Feuchtlebensraumes zu sichern, kauften der Deutsche Bund für Vogelschutz (DBV), der heutige Naturschutzbund (NABU), und die Bundesregierung einen großen Teil des Gebietes. 1984 wurde eine etwa 850 ha große Fläche zum „Naturschutzgebiet Meißendorfer Teiche/Bannetzer Moor“" erklärt. 


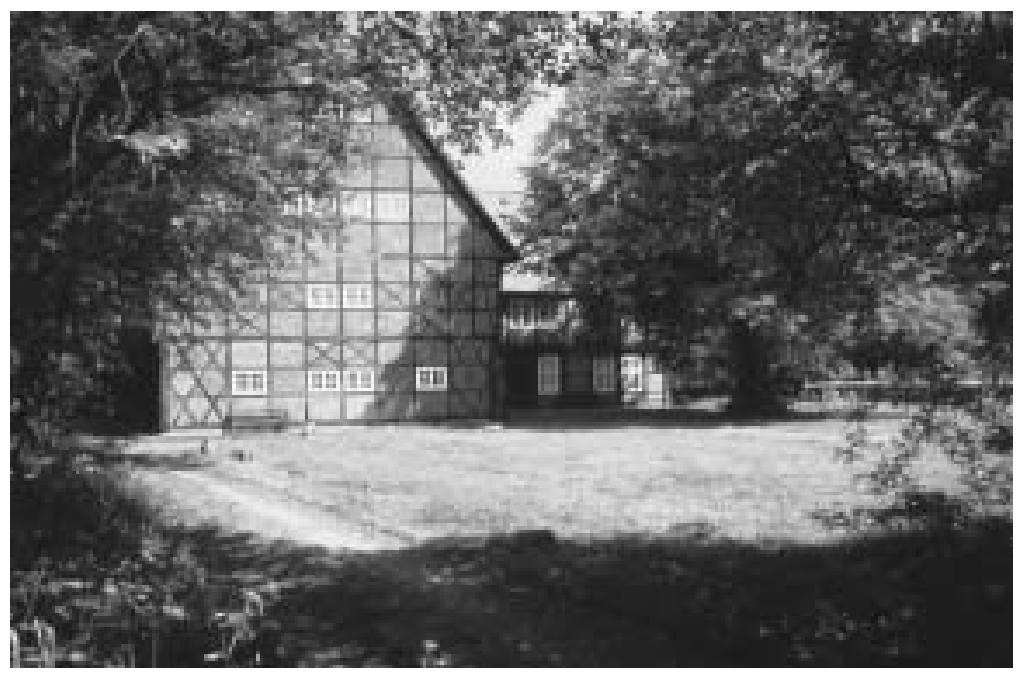

Abb. VIII-9: Herrenhaus des ,Teichgutes Sunder“.

1384 zum ersten Mal urkundlich erwähnt, wurde 1548 der Nordflügel gebaut, 1649 folgte der Bau des Ostflügels. Um 1750 wurden die beiden bis dahin separat stehenden Gebäude durch einen Zwischentrakt (Treppenhaus) verbunden.

Durch die Einführung der Fischzucht und die Entwicklung des Anwesens vom repräsentativen Landsitz im 17. und 18. Jahrhundert zum landwirtschaftlich geprägten Gut im 19. und 20. Jahrhundert wurde die Umgebung von Gut Sunder stark umgestaltet. 1729 lag das Gut auf einer künstlichen Insel. Ein Teil des damaligen Hausteiches und der Gräben ist noch erhalten. Die Gräben auf der Westseite dieser Insel existieren nicht mehr. In dem Hausteich lag eine weitere Insel mit dem „Lustgarten“, der eine barockartige kreuzförmige Aufteilung besaß. Dieser Inselgarten ist verschwunden, heute liegt hier die Landzunge, die den Hausteich vom neuen Meißebett trennt. An die bis 1902 zum Gut gehörige Mühle (Getreidemühle und Sägewerk), die in unmittelbarer Nachbarschaft am Ende des Hausteichs stand, erinnert noch ein Stauwehr. 1980 erwarb der DBV Gut Sunder, um hier eine Bildungsstätte in unmittelbarer Nähe zum Naturschutzgebiet.einzurichten. Zum 30.9.2003 stellte der NABU-Bundesverband im Zuge der Neuausrichtung und Regionalisierung seiner innerverbandlichen Bildungsarbeit den Betrieb der Akademie auf Gut Sunder ein und übergab die Liegenschaft an den NABU Niedersachsen. Zukünftig soll Gut Sunder als regionales Naturerlebniszentrum des NABU Niedersachsen fungieren. (eig. Aufnahme 2004)

Im Raum Gifhorn-Wolfsburg sind die Räderloher Teiche am Räderlohbach in Räderloh in Richtung Blickwedel zu nennen. 14 Teiche, ,wie Perlen auf einer Schnur aufgereiht“ (BURGHARD 1988a:26), verlaufen hier von Räderloh nach Marwede. Wie bei der Ahlhorner Teichwirtschaft gab es auch hier „,in der preußischen Landesaufnahme von 1899 [...] keinen dieser 14 Teiche.“ (:26) Das Teichgut bei der gleichnamigen Siedlung im Raum Gifhorn wurde 1908 von der Landwirtschaftskammer Hannover als Lehr- und Versuchsanlage für Teichwirtschaft ins Leben gerufen. Die ausgewiesene Gesamtgröße betrug 135 Hektar (BURGHARD 1988d:45). Im Jahre 1919 erwarb der aus Sumte/Elbe stammende ehemalige Molkereimeister Friedrich Nabein das Teichgut und erweiterte die Teichfläche in wenigen Jahrzehnten auf über 60 ha. In 27 ablassbaren Teichen unterschiedlicher Größe wurde hier eine vorbildliche Fischwirtschaft aufgebaut, die weithin Anerkennung fand (:45).

Das Teichgebiet Riddagshausen vor Braunschweig zwischen Nussberg und Buchhorst hingegen verdankt seine Entstehung dem Schaffen der Zisterziensermönche vor rund 900 Jahren. Im Jahre 1145 ließen sich hier vor den Toren der Stadt Zisterzienser des Konvents aus Amelungsborn nieder. Sie begründeten das Amelungsborner Tochterkloster „Marienzelle“, das kurz darauf den Namen des benachbarten Dorfes Riddagshausen („Ritdageshusen“) annahm. Die Gründung eines Klosters war seit 1143/44 durch Ludolf von Wenden vorbereitet worden, der in Personalunion Ministerialer Heinrichs des Löwen und Vogt von Braunschweig und Amelungsborn war.

Die ausgedehnte Teichlandschaft in Riddagshausen ist auf die Tätigkeit der Zisterziensermönche zurückzuführen, die die damals sehr sumpfige Gegend entwässerten und Fischteiche anlegten. 

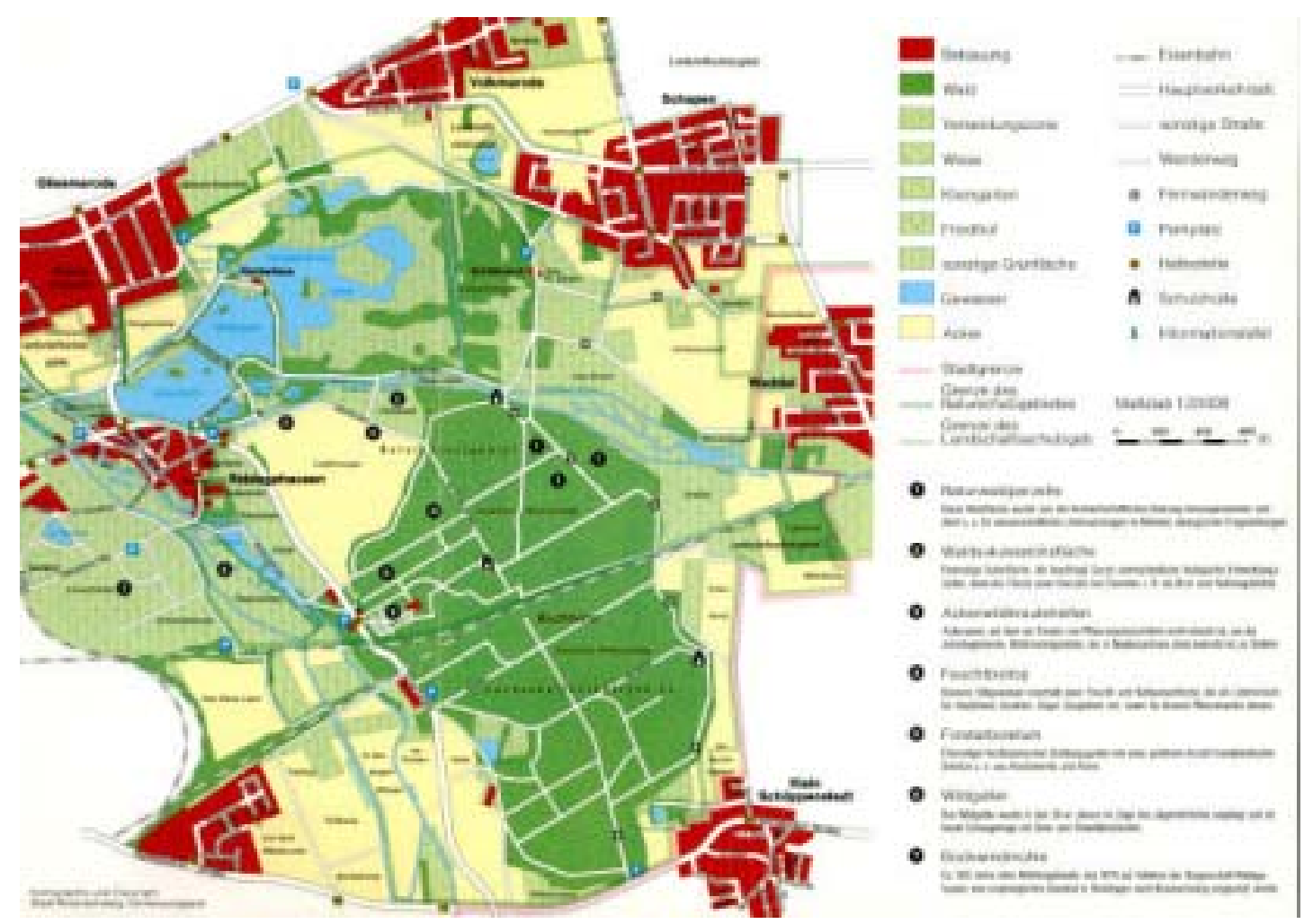

Abb. VIII-10: Die Riddagshauser Teiche (Kartographie von 1994)

Die Teiche wurden in die weite, flache Mulde, die sich ca. $3 \mathrm{~km}$ lang und $1 \mathrm{~km}$ breit im Tal von Mittelriede und Wabe von Riddagshausen bis Weddel hinzieht, angelegt. Außerhalb des Naturschutzgebietes befinden sich das östlich anschließende „Weddeler Teichgebiet“ mit dem ;Weddeler Teich', dem ,Kaulenteich' sowie die Mönchsteiche in der Buchhorst. Von den früheren, zur Zeit der Zisterzienser vorhandenen, 28 Teichen, gibt es heute nur noch 11 (SCHULZE 2004: mündl.). Die Riddagshauser Teiche werden, bis auf den ,Schaperbruchteich' noch fischereilich bewirtschaftet und erzielen jährlich ca. 9 Zentner Fisch je Hektar.

Das Weddeler Teichgebiet ist seit 1936 Naturschutzgebiet, wodurch einem weiteren Heranrücken der städtischen Bebauung Einhalt geboten werden konnte, und umfasst eine Fläche von heute 478 ha (STADT BRAUNSCHWEIG, GRÜNFLÄCHENAMT 1994, SCHULZE 2004: mündl.). 1962 wurden die Riddagshäuser Teiche in den Rang eines „Europareservates“ erhoben. Mittlerweile besteht die Gefahr, dass dieser Titel wieder aberkannt wird, da die Zahl der seltenen Vogelarten, die hier brüten oder auf ihrem Durchzug rasten, rückläufig ist.

\section{d.2.2.2 Mittelgebirge}

Zentrales Umweltproblem des Erzbergbaus war die Bildung saurer Wasser, die das Gewässernetz auf oft weite Erstreckung schwer beeinträchtigte. Das Wasser, das sich in den über Jahrhunderte hinweg entstandenen Harzer Grubenbauen sammelte und über den Abzugsstollen zum Beispiel der Gose und Oker zugeführt wurde, war so aggressiv, so wird berichtet, dass ,,Zwei Meilen flußabwärts vom Punkt der Einmündung der Gose keine Fische mehr leben konnten.“ (BARTELS 2000:41)

Womöglich sind die Gewässerverschmutzungen Gründe für die Anlage von Fischteichen oder die Nutzung der Bergbauteiche als Fischteiche gewesen, weil in den Harzer Bächen kein Fischleben mehr möglich war. Im Gegensatz zur schlechten Gewässerqualität der Fließgewässer galten die Teiche des Oberharzes aufgrund ihrer Quellwasserspeisung als vorzügliche Fischgewässer. Beispielweise liegen im Grumbach (Bockwiese/Harz) einige Becken; es sind die Fischzuchtanlagen der Teichwirtschaft. Der ehemalige „Wäschengraben“ des Bockswieser Reviers versorgt die Fischzuchtteiche mit Frischwasser aus dem Mittleren Grumbacher Teich (HAASE 1961:72). 
Des Weiteren gab es um 1670 im Kuttelbach-Tal einige Fischteiche und weiter oben im Quellgebiet des Kuttelbaches ein als „Teich“ angegebenes Vorbecken. Das ist der heutige „Karpfenteich“ von Hahnenklee (HAASE 1961:73). Diese Bezeichnung ist insofern ungewöhnlich, als dass die kühlen Harzer Wasser eigentlich nur für die Forellenzucht geeignet sind.

Generell aber waren die Teichanlagen im Oberharz zur Beaufschlagung im Bergbau und Hüttenwesen dienlich und die Teichwirtschaft stellte im besten Falle eine Nebennutzung dar. Die im nördlichen und südlichen Harzvorland ansässigen Klöster und Güter waren die Verbreitungsgebiete der Teichwirtschaften, wie die Goslarer Klöster, Kloster Walkenried bei Bad Sachsa und Michaelstein bei Blankenburg.

Bei dem zu den Goslarer Klöstern gehörenden Klostergut Riechenberg haben, schreibt BORNE (1883:42), „wenigstens 30 ha Karpfenteiche existirt, die meisten sind aber schon vor langer Zeit trocken gelegt, nur ein Teich ist noch vorhanden." Auch bei den Klostergütern Grauhof und Ohlhof sind früher einige Karpfenteiche mehr vorhanden gewesen (:42).

Bei Vienenburg existierten im zweiten Drittel des 19. Jahrhunderts noch drei oder vier von der Radau gespeiste Teiche, die früher mit Karpfen besetzt waren und heute zur Forellenzucht benutzt werden (BORNE 1883:42).

Ebenso scheint bei Wöltingerode früher Teichwirtschaft betrieben worden zu sein (BORNE 1883:42). In jüngerer Zeit entstanden hier an alter Stelle - im Klostergarten des Klostergutes Wölteringerode bei Vienenburg an der Oker - im nördlichen Harzvorland neue Teiche zur Fischaufzucht und Hälterung. Beginnend im Jahr 1981 wurden die Voraussetzungen für den Aufbau und den Betrieb einer Fischzuchtanlage auf ausschließlich wissenschaftlicher Basis unter der Obhub der Universität Göttingen geschaffen (WELTE/ZUNDEL 2000:103). Die sich in diesem Gebiet in nordöstliche Richtung erstreckende und von der Oker durchflossene Talaue wurde im Wesentlichen von dem in den 1960er Jahre beginnenden Kiesabbau geprägt. Auf dem Gebiet des Klostergutes Wölteringrode sind seither in terrassenartiger Abfolge links der Oker 11 größere Teiche unterschiedlicher Größe und Tiefe entstanden (:7). Außer den 4 Aufzuchtbecken sind in dem Garten der inneren Klostermauern noch acht rechteckige Teiche von je $40 \mathrm{~m}^{2}(8 \times 5)$ angelegt worden, um länger andauernde Hälterungsversuche durchführen zu können. Sofern sie unbesetzt waren, wurden sie auch für Quarantänezwecke in Anspruch genommen (:104).

Großen Anteil an der Harzer Teichwirtschaft hatte die „Gräflich Stolberg-Wernigerodische Teichfischerei“ (BORNE 1883:42). In räumlicher Verteilung waren im zweiten Drittel des 19. Jahrhunderts insgesamt 41 ha Teiche mit Fischen besetzt. Die Domänen, auf welchen sich die Teiche befanden und zum Teil noch befinden, sind Wernigerode mit 14 Teichen von ca. 21,7 ha, in Beckenstedt standen 6-7 Teiche mit ca. 24,7 ha und an dem sog. Kaffeeborn weitere 11 Forellenteiche mit zusammen 2 ha, in Schmatzfeld-Langeln 7 kleinere Teiche mit ca. 2,6 ha, und Ilsenburg hatte 5 Teiche mit zusammen ca. 3,6 ha, wobei diese - mit einer Ausnahme - Sammelteiche für die dortigen Hüttenwerke gewesen sind und nur bedingt fischereilich zu nutzen waren (:42f.).

Als Beispiel einer zentral um das Kloster angeordneten und noch heute bestehenden „historischen“ Teichwirtschaft des Harzes sei die Teichanlage des 1147/52 begründeten Kloster Michaelstein bei Blankenburg aufgeführt. Die Klosterteiche sind im Mittelalter von den Mönchen ursprünglich zur Karpfenzucht benutzt wurden. Dieser für Harzteiche zunächst ungewöhnlich anmutende Teichbesatz wird erklärlich, wenn man liest, dass sich das Wasser ,in den unteren Teichen im Sommer bisweilen bis $20^{\circ} \mathrm{C}^{\text {“ }}$ erwärmte (BORNE 1886:277).

Im zweiten Drittel des 19. Jahrhundert sind die Karpfenteiche zu Forellenzuchtteichen umgewandelt worden. Dies geschah vor dem Hintergrund, dass die Regierungen von Preußen, Braunschweig und Anhalt beabsichtigten, die Forellenfischerei in den Gewässern des Harzes zu verbessern, denn von den unmittelbaren Bachläufen war bekannt, dass sie „früher keine Forellen enthielten“ (BORNE 1886:277). Zu diesem Zweck wurde in Michaelstein 1882/83 eine „Central-Fischzucht-Anstalt“ 
errichtet, um eine große Zahl von Forelleneiern zu befruchten und anzubrüten. Die gewonnene Forellenbrut sollte zum Besetzen der Bäche verwendet werden. Ferner wurden an geeigneten Stellen "kleine Brutanstalten" hergestellt, welche von Michaelstein mit Eiern versorgt wurden (BORNE 1883:35).

Der Ausbau der ehemaligen Klosterfischerei Michaelstein zur Zentralfischzuchtanstalt erfolgte in dieser Zeit durch den Blankenburger Amtmann Dieckmann, der diese Aufgabe übertragen bekommen hatte. Hier erbrütete man um 1883 etwa eine Million Bachforelleneier und stellte sie für den Besatz der Harzgewässer zur Verfügung. Außerdem wurden jährlich $600 \mathrm{~kg}$ Speiseforellen gezüchtet. Mit dieser Produktion gehörte Michaelstein zu den größten Forellenzuchtanstalten Deutschlands (WÜSTEMANN 1982:25). Die Forellen wurden aber im zweiten Drittel des 19. Jahrhundert in den Teichen nicht mehr wie früher gezüchtet, um Speisefische zu erhalten, sondern nur zur Eiergewinnung benutzt (siehe zur dieser „einseitigen“ Spezialisierungsform Pkt. d1).

Es handelt sich hiermit also nicht nur um eine größenmäßig beachtenswerte neuzeitliche Fischzuchtanlage, sondern auch um eine Forellenzuchtanlage auf der Grundlage mittelalterlicher Karpfenteiche. Ein interessantes und seltenes Beispiel frühen Nutzungswandels.

Die Anlage wird von zwei Bächen gespeist, welche am Ostabhang des Harzes entspringen und in der Regel wenig Wasser führen (BORNE 1886:277). Der eine Zufluss, der Klostergrundbach, ist $6 \mathrm{~km}$ lang, entspringt im Eggeröder Brunnen $463 \mathrm{~m}$ ü. NN und hat bei Michaelstein $240 \mathrm{~m}$ und bei der Münchenmühle $225 \mathrm{~m}$ Meereshöhe. Er nimmt unterhalb von Michaelstein rechts den Silberbornbach auf, der $5 \mathrm{~km}$ oberhalb am Harzrand entspringt und den Bastgrund durchfließt. Die Quelle des Eggeröder Brunnen ,fließt zunächst durch mehrere Teiche, welche der dort wohnende Förster zur Forellenzucht benutzt. Darauf durchfließt der Bach die zur Central-Fischzucht-Anstalt gehörigen Teiche.“ (BORNE 1883:17)

Beide Bäche speisten nach dem Verzeichnis der „bei Michaelstein im Jahre 1883 vorhandenen Teiche" insgesamt 28 Teiche mit einer Gesamtgröße von 9,82 ha (siehe BORNE 1883:18; BORNE 1886:277). 1851 aber, bei Übernahme der Fischerei durch den Amtmann Dieckmann waren nur 8 Teiche bespannt: der ,Große Hafenteich', ,Große Silberteich', ,Kleine Silberteich', ,Priorteich', ,Schirrteich', ,Pferdeteich', ,Krugteich' und ,München-Mühlenteich'. 1862 wurde der ,Hafenteich' wieder instand gesetzt und auch die anderen niederliegenden Teiche (der ,Heller Nr. 1' beim Forsthaus, der, Volkmarteich').

Auch die nächste Abbildung von 1886 stellt nur einen Teil der gesamten Anlage früherer Zeit dar. Damals betrug der gesamte Bestand ca. 12.000 Forellen. Von den insgesamt früher 28 Einzelteichen enthielten nach Schilderung von BORNE (1886:277f.) 8 Teiche ca. 4000 Mutterforellen, deren Zahl in den nächsten Jahren auf 8000 vermehrt werden sollte, und in 14 Teichen waren kleine Forellen untergebracht. 


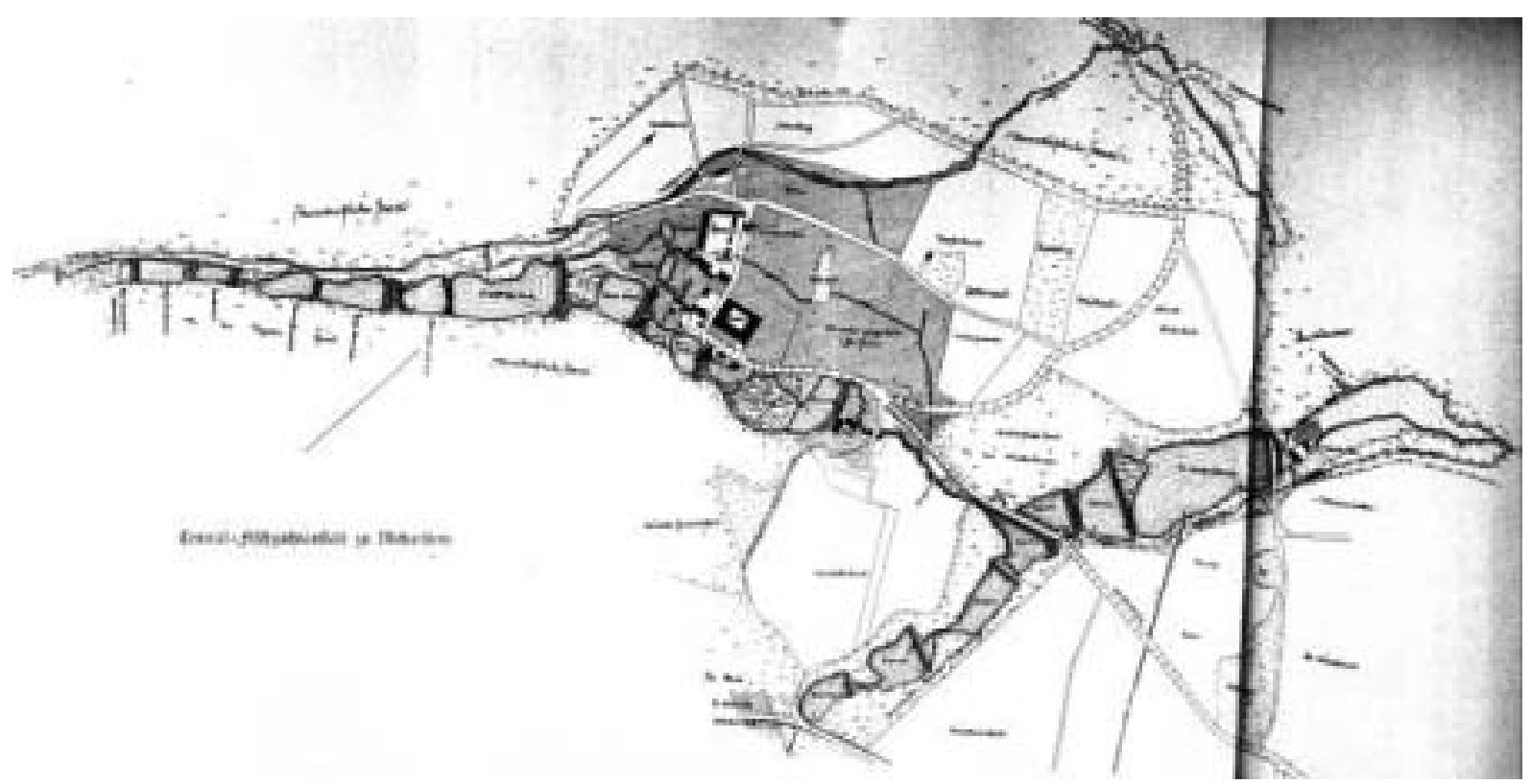

Abb. VIII-11: „Central-Fischzucht-Anstalt zu Kloster Michaelstein“ bei Blankenburg im Harz.

(aus: BORNE 1886:277, Tafel II). Die Abbildung enthält einschließlich der unteren Mühlenteiche nur 18 Teiche und somit längst nicht alle Teiche, die von der Teichwirtschaft Michaelstein etwa um Mitte des 19. Jahrhunderts bewirtschaftet wurden. Es fehlen mindestens 6 vormals als bespannt genannte Teiche, die zu diesem Zeitpunkt trocken liegen und teils als Wiese oder Angerfläche benutzt, teils mit Obstbäumen bepflanzt sind. Eingezeichnet ist ferner zwar ein Teilstück des Wildgerinnes, das ,neben den Teichen herläuft und bei Schneeschmelzen das Hochwasser an den Teichen vorbei führt“, aber nicht der „Trockenteich“, ein ehemaliges und neu angestautes Wiesengelände, von dem aus das Wildgerinne abgeleitet wird. Schließlich fehlen einige sog. „Bastteiche“, die in der Liste der Teiche zwar genannt werden, in der Abbildung aber nicht auftauchen (BORNE 1883:20). Der Vertikalstrich in der echten Bildhälfte entsteht durch die Faltung der Zeichnung im Original.

Den zentralen Bereich der Fischzuchtanstalt gibt die folgende Abbildung wieder, aus der auch die wasserbauliche Situation zu entnehmen ist.

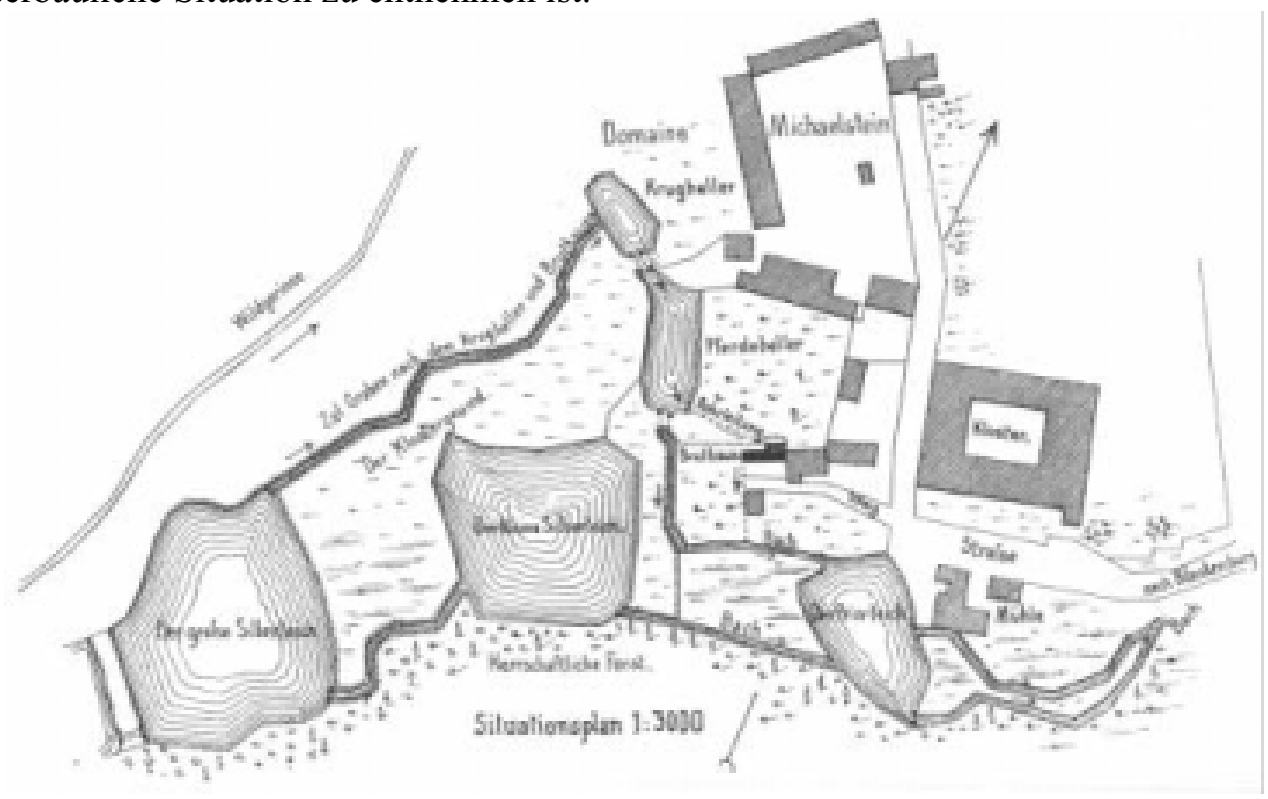

Abb. VIII-12: Zentrale Fischzuchtanstalt Kloster Michaelstein (1883)

Wasserbaulich betrachtet, erhalten die in dem „Situationsplan“ eingezeichneten Hälter ,Pferdeheller' und ,Krugheller' ihr Wasser aus dem 1 ha umfassenden ,Großen Silberteich' durch einen $152 \mathrm{~m}$ langen Graben, der wiederum aus dem Klostergrundbach sein Wasser bezieht. Aus dem ,Pferdeheller' wird das Wasser in das 1881 erbaute und 4,3 m breite und 18,5 m lange Bruthaus der ,Central-Fischzucht-Anstalt' geleitet. Der unterhalb liegende ,Priorteich' ist eigentlich der Sammelteich einer Farbenmühle und besitzt „wenig Werth“ (aus: BORNE 1883:20). 
Die so gewonnenen Forelleneier wurden von der ,Central-Anstalt zu Michaelstein' an „geeignete Personen, namentlich an Forstbeamte“ verteilt, die damit „kleine Fischzuchtanstalten“ im Harz betrieben. Diese bestanden ,zum größten Theil in einem oder mehreren Californischen Trögen, welche unter einen laufenden Wasserstrahl, oft an einen Brunnen aufgestellt wurden. Die betheiligten Regierungen haben im Harz zahlreiche solcher Apparate an vertheilt" (BORNE 1886:278; siehe zu den Bruttrögen auch Pkt. VI 7e.2).

Während der DDR-Zeit wurde Michaelstein in ein VEB-Kombinat umgewandelt. Michaelstein ging, wie auch die anderen Teiche in Wernigerode, Veckenstedt und Stiege vom entfernt gelegenen VEB Binnenfischerei Peitz nach kurzer Eigenleitung an den VEB Binnenfischerei Potsdam über und bildete bis zur Wende einen Teil des 1977 gegründeten VEB Binnenfischerei Magdeburg (WÜSTEMANN 1982:25). Seit der Wende wird sie als private Fischzucht weiterbetrieben und versorgt zum Beispiel nahelegene Restaurants, wie das Michaelsteiner Klosterrestaurant „Cellarius“ oder das Mühlenrestaurant „Zum Fischer“ mit Frischfisch.

Das Zisterzienser-Kloster Walkenried, 1129 am südlichen Harzrand nordwestlich von Nordhausen als Tochter des Mutterklosters Altenkampen am Niederrhein gegründet, entwickelte sich relativ schnell zu einem mächtigen geistlichen und wirtschaftlichen Zentrum des Deutschen Reiches (KLEßEN 2000:92). Die Zisterzienser engagierten sich erfolgreich im Bergbau und Hüttenwesen, überliefert ist die Schenkung eines Viertels der Erzausbeute des Rammelsberges bei Goslar an Walkenried durch Kaiser Friedrich Barbarossa im Jahre 1188 (KLEßEN 2000:92).

Mit großer Energie machten sich die Mönche und Konversen daran, die sumpfigen Niederungen der Wieda-, Zorge- und Helme-Aue zu entwässern und das Ödland zu kultivieren (KLEßEN 2000:92). Das Kloster dehnte seinen Grundbesitz bis nach Nordhausen und über den Kyffhäuser hinaus aus und „,industrialisierte die Fischzucht“ (KLEßEN 2000:92).

Sitz der klostereigenen Verwaltung wurde das Dorf Immedeshausen, später „Mönchehof“ und heute „Münchehof“ genannt. „Umfangreiche Wasserwirtschaftsanlagen im Pendelbachtal und ein Klosterhof (Grangie) mit 4000 Morgen Wirtschaftsfläche in Immedeshausen dienten der Versorgung des gesamten Wirtschaftskomplexes.“ (KLEßEN 2000:92) Das Kloster Walkenried und dessen Güter besaßen zu Anfang des 18. Jahrhunderts, so sagte man volksläufig, ,so viele Teiche [...] als Tage im Jahr“ (BORNE 1883:44). Im zweiten Drittel des 19. Jahrhunderts gehörten zur Domäne Walkenried 13 ablassbare Teiche, 52,5 ha groß mit 40 ha Wasserfläche (:44).

Weitere 8 Teiche mit zusammen 13,93 ha befanden sich im südlichen Harz im Gebiet der Grafschaft Stolberg-Stolberg im Tal der Selke. Sie waren zwar mit Fischen besetzt, dienten jedoch, wie den Namen (,Mühl-Teich', ,Sägemüller-Teich') zu entnehmen ist, primär den Wasserwerken (BORNE 1883:44).

Teiche des alten Klosters Ilfeld, schreibt BORNE für das Jahr 1883 (:41) „sind nicht mehr vorhanden, jedoch sind die Dämme einiger derselben noch erkennbar." Erst um 1850 seien noch zwei von ihnen niedergelegt worden.

Im Großherzogtum Hessen hebt sich hinsichtlich seiner Zahl von Teichen das Brunnthal (Erbach), das zum Besitz des Fürsten zu Löwenstein-Wertheim-Rosenberg gehörte, hervor. Neben einer Brutanstalt betrieb der Fürst hier in 10 Teichen Forellen- und Karpfenzucht mit einer Fläche von 0,25 ha. 


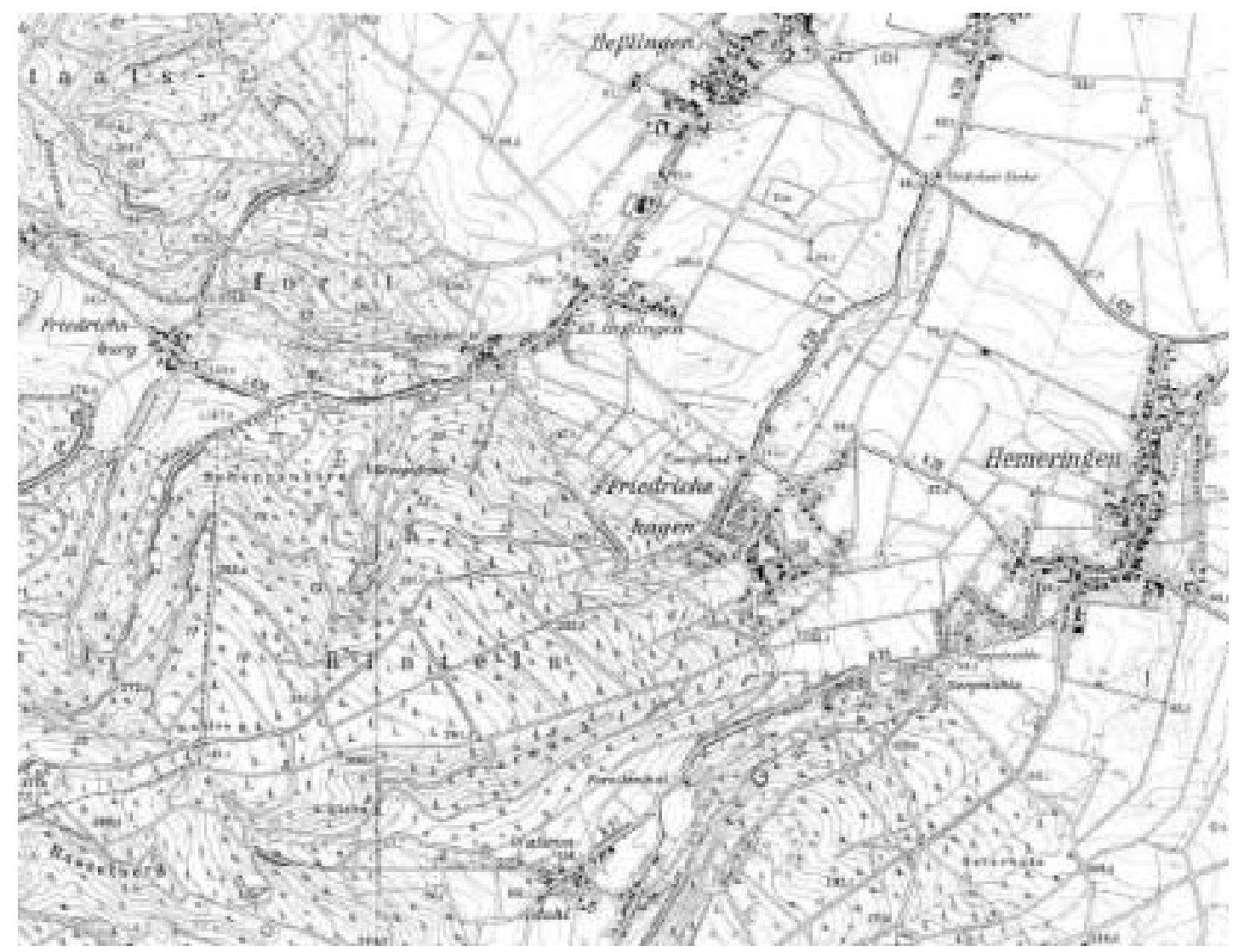

Abb. VIII-13: Ausschnitt aus der TK25 mit Darstellung von kleinen Mehrteich-Teichwirtschaften am Heßlinger und Hemeringer Bach, südl. Hessisch Oldendorf (Normalausgabe, Blatt 3280, 9. Aufl. 1995, umfassende Aktualisierung 1994)

Ein Hauptgebiet der Binnenfischerei, vor allem der Teichwirtschaft in Deutschland bildet der nordbayerische Raum. Franken besitzt Teichwirtschaftsbetriebe für Karpfen mit ca. 5.000 ha Wasserfläche. Die Karpfenteiche ziehen sich wie ein von Westen nach Osten verlaufender Gürtel über den gesamten fränkischen Raum, mit besonderer Konzentration in den Landkreisen ErlangenHöchstadt, Neustadt-Bad Windsheim und Ansbach, die in über 3.300 Teichen Deutschen Speisekarpfen produzieren (HUBERT 1991:13). Der Schwerpunkt der Karpfenteichwirtschaft in Bayern liegt dabei im fränkischen Aischgrund. Der „Aischgrund“ ist das „fränkische Kerngebiet der Karpfenhaltung" (KEIZ 1995:19) und zugleich das größte zusammenhängende Teichgebiet Westdeutschlands in seinen Grenzen bis 1990 (HUBERT 1991:13). In diesem traditionsreichen Karpfenzuchtgebiet wurde bis zu diesem Zeitpunkt in seinen mehr als 4.000 Teichen fast ein Drittel der deutschen Speisekarpfenproduktion erzeugt (vgl. HUBERT 1991:13).

Der größte Teil des Aischgrundes als Gebiet der Karpfenteichwirtschaft umfasst neben dem Haupteinzugsgebiet der Aisch auch die südlich und südöstlich der Aisch gelegenen Einzugsbereiche der kleineren Bäche wie Lindach, Mohrbach, Seebach sowie den unteren Teil der Aurach zwischen Emskirchen und Frauenaurach (vgl. HUBERT 1991:13). „Die Karpfenteiche sind hier das charakteristische Merkmal der Kulturlandschaft.“ (:13) Deshalb nennt man diesen Raum auch gerne im Volksmund die „Weiherlandschaft des Aischgrundes“. (:13) bzw. im Fachjargon das „Aischgründer Karpfenteichwirtschaftsgebiet“.

Die Karpfenzucht im Aischgrund kann aus dem Grund auf eine jahrhundertelange Tradition zurückblicken, da hier insbesondere die Klöster auf den damals infolge des hohen Grundwassers ertragsarmen Flächen begonnen haben, Teiche anzulegen. Durch die schlechte Bodenbeschaffenheit im Aischgrund und die Absatzmärkte in den Städten Erlangen, Fürth und Nürnberg blieben dort die Teiche, während sie in anderen Regionen während und nach Einbrüchen durch Kriegswirren des 16. und 17. Jahrhundert (siehe Pkt. 1a) regelrecht zusammenbrachen, zumindest weitgehend erhalten, wenn auch hier Einbußen hingenommen werden mussten. Erst um 1880, als der Getreidepreis wegen 
der Importe aus Übersee wieder sank, wuchs auch hier die Anzahl der Teiche wieder. Durch den Verlust der ehemaligen Kerngebiete der Karpfenzucht, wie z. B. Schlesien, Böhmen und Mähren, gewann der Aischgrund nach 1945 überregional an Bedeutung.

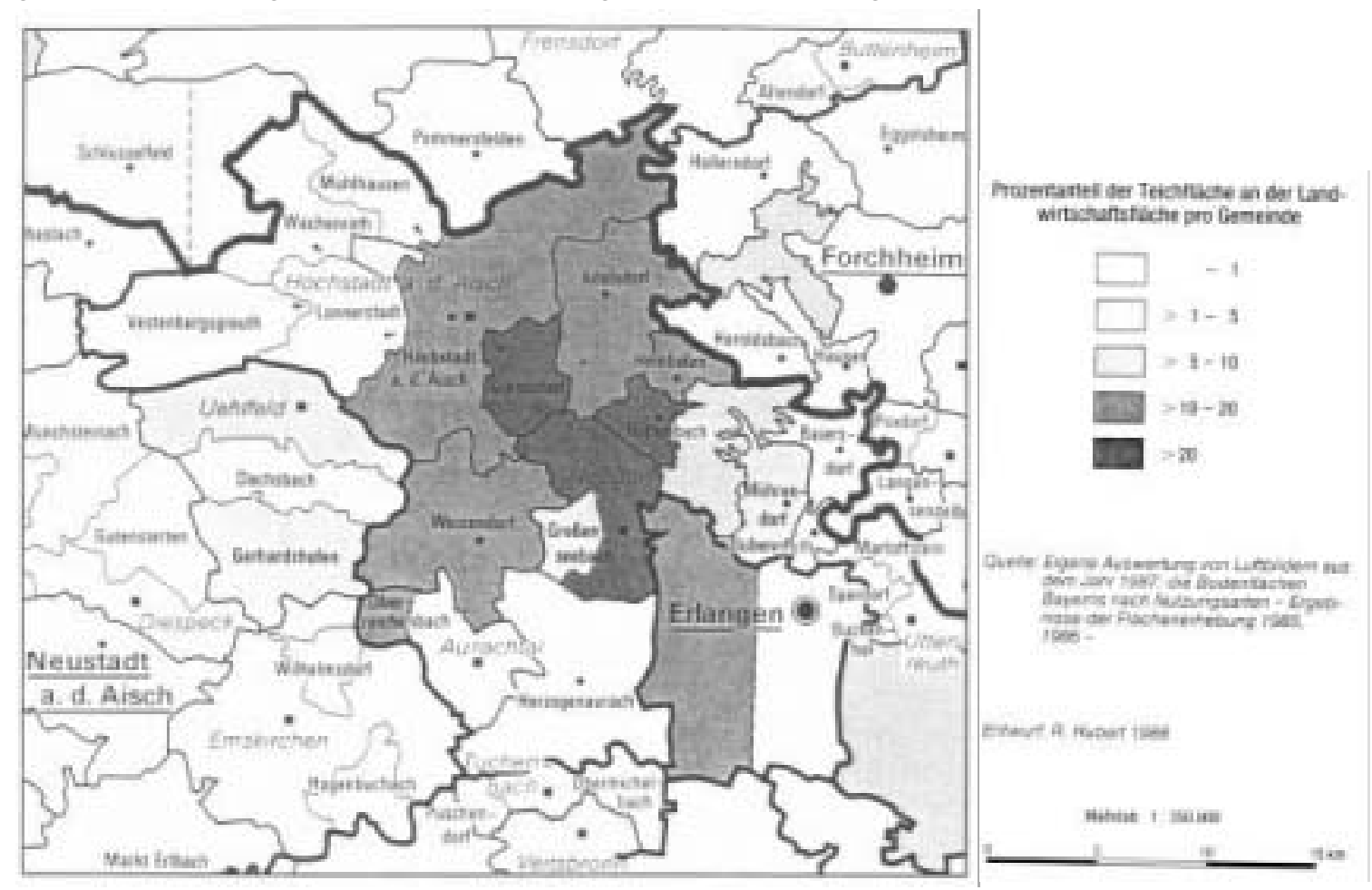

Abb. VIII-14: Räumliche Abgrenzung des Aischgründer Karpfengebietes (aus: HUBERT 1991:28, Abb. 4).

Als Kleinteichwirtschaften in Franken sind auch die seit dem Mittelalter bestehenden Teiche des Würzburger Hochstiftes zu erwähnen, die schon im 16. Jahrhundert im 2jährigen Umtrieb genutzt wurden. Zwar wurden mehrere Fischjahrgänge gemeinsam in einen Teich gesetzt, doch schon nach einem System, das an einen modernen Mischbesatz erinnert: Brut, Setzlinge und laichreife Fische wurden jährlich so rationell verteilt, dass alle Fische gleichmäßig abwuchsen und nach zwei Jahren wiederum eine bestimmte Anzahl von Brut, Setzlingen und Speisefischen abgefischt werden konnte (CNOPF 1926:126; RUST 1952:29, aus Teichbüchern des 16. Jahrhundert).

Eine besondere wirtschaftliche Bedeutung hatte die Teichwirtschaft in Mittelfranken des Weiteren durch die Teichwirtschaft des Klosters Heilsbronn, dass Mitte des 16. Jahrhundert (1554) über 93 Weiher verfügte, wovon 90 ohne Winterungen waren. Die Heilsbronner Teichwirtschaft war verteilt auf vier Ämter mit differenzierter Weiherdichte: Waizendorf, Heilsbronn bzw. Bonhof, Neuhof und Merkendorf.

Während die beiden erstgenannten Ämter eine verhältnismäßig große Zahl Weiher geringeren Umfanges aufwiesen (mit der größten Weiheranzahl in Waizendorf), zeichneten sich die beiden letzteren Ämter durch weniger, aber größere, Teichanlagen aus, so CNOPF 1927 (:30), leider ohne differenzierte Zahlenangabe.

Wie den Bestands- und Ausfanglisten von 1629 - 1632 zu entnehmen ist, waren im Klosteramtsbezirk in diesen Jahren insgesamt noch 72 Weihern vorhanden, von denen aber nur zwischen 24 und 33 Weiher besetzt waren (CNOPF 1927:57). Von 1632 an machten sich die Folgen des Dreißigjährigen Krieges in steigendem Maße bemerkbar: Insgesamt wurde 26 Weiher ,teils schwer, teils leichter beschädigt" (:57).

Nach den Verwüstungen des Dreißigjährigen Krieges waren vom Kloster Heilsbronn Mitte des 17. Jahrhundert wieder 44 Teiche mit Karpfen und Hechte besetzt worden, aber auch noch im Jahr 1665, sind - mit geringen Ausnahmen - „fast alle Weiher reparaturbedürftig, der Krieg mit seinen 
Verwüstungen hatte den Teichen $\mathrm{zu}$ stark zugesetzt und die allenfalls vorgenommenen Instandsetzungsarbeiten waren wegen Geldmangel so oberflächlich durchgeführt, daß bald wieder Schäden auftraten.“(CNOPF 1927:62).

Der Gesamtbesitz an Weihern im Markgrafentum Ansbach im angehenden 18. Jahrhundert, das neben der Heilsbronner Teichwirtschaft über weiteren, weitverzweigten Teichbesitz verfügte, war aber weitaus größer: Insgesamt waren in den einzelnen Ämtern ${ }^{10}$ herrschaftliche Weiher unterschiedlicher Größe - ohne die der jeweiligen Gemeinden gehörigen und auch nicht die zahlreichen Fischgruben und Winterungen mitgerechnet - in einer Anzahl von ca. 330 vorhanden mit einem Gesamtbesitz an Teichfläche von rd. 1700 tgw. ${ }^{11}$ (CNOPF 1927:88).

Weiterhin muss auch die Teichwirtschaft des reich begüterten Deutsch-Herren-Ordens in den Komtureien ${ }^{12}$ Ellingen und Nürnberg innerhalb der Ballei ${ }^{13}$ Franken, die ihren Ordenssitz in dem 1274 erbauten Marienburg hatten, „über sehr reichen Weiherbesitz verfügt haben“, so CNOPF (1927:91), ohne nähere Gesamtangabe. Unter ihren Vogteien, die sich durch Weiherbesitz auszeichneten, ragen besonders Dinkelsbühl und Eschenbach hervor (:91). Mitte des 17. Jahrhunderts verfügte die Vogtei Eschenbach, deren Teiche in eigener Regie geführt wurden, im Gegensatz zu den Dinkelsbühler Weihern, die bis zum 19. Jahrhundert immer in Pacht gegeben waren (:92), über 13 Teiche, die Besetzungsliste von 1683 weist sodann 17 Weiher auf (:93).

Die Teichwirtschaft der Obervogtei Dinkelsbühl weist im zweiten Drittel des 17. Jahrhunderts ca. 20 Teiche und einige Gruben auf (CNOPF 1927:103). Dies spiegelt aber nicht das wahre Erscheinungsbild wider. Nach der Kosmographie des Sebastian Münster aus dem Jahre 1550 war „das Landschaftsbild um Dinkelsbühle [...] mit Weihern übersät, von denen ein großer Teil der Reichsstadt gehörte.“(:114)

Die Teichwirtschaft der Deutsch-Ordensritter in Absberg und Ellingen, die von der Kommende Ellingen bewirtschaftet wurden, bevor der Ordensbesitz an den bayerischen König und dann zum größten Teil durch Geschenk an den Feldmarschall Karl von Wrede in dessen Privatbesitz überging, war ebenfalls eine sehr bedeutsame. 1789-1800 beträgt die Zahl der Weiher in Ellingen und Absberg 47, von denen im Folgenden einige trockengelegt, andere zu Wiesen für die Meierei umgerissen oder versteigert und von den 10 Weihern bei Besitzübernahme Mitte des 19. Jahrhunderts nur noch 3 Weiher und der Schlossgraben zur Fischnutzung genutzt wurden (CNOPF 1927:123).

Auch in Oberfranken wurde die Teichwirtschaft nachhaltig von den Klöstern beeinflusst. Die Zisterzienserklöster Ebrach und Klosterlangheim und besonders die Fürstbischöfe von Bamberg führten die Karpfenteichwirtschaft vom 13. bis 16. Jahrhundert zu einer bis heute nicht wieder erreichten Blüte. Historische Quellen aus den Jahren 1403 bis 1634 belegen, dass die Fürstbischöfe von Bamberg sog. Seemeister beschäftigten - die ersten Fischereisachverständigen im fränkischen Raum, die für die damals fast doppelt so vielen Teiche wie heute zuständig waren.

\footnotetext{
${ }^{10}$ Die Weiherzahl verteilte sich auf die Ämter: Kloster Auhausen (10), Klosteramt Bemberg (11), Burgthann (5), Cadolzburg (13), Colmberg (8), Crailsheim (20), Feuchtwangen (32), Fondorf (37), Giebelstadt (3), Mainbernheim (2), Stiftamt Ansbach (34), Hofkastenamt Ansbach (34), Röckingen (16), Schwabach (3), Stauff-Tahlmässing (11), Sulz (11), Uffenheim (2), Waizendorf (35), Wassertrüdingen (28), Wittelshofen (6), Windsbach (9) (Zusammenstellung aus CNOPF 1927:83-88).

${ }^{11}$ Tgw [Tagwerk]: Von 1809 bis 1872 war vor allem im südlichen Bayern die Maßeinheit für landwirtschaftlich genutzte Fläche das Tagwerk und kennzeichnete damit die Betriebsgröße einer Hofstelle. 1 Tagwerk [tgw.] entsprach 100 Dezimalen (200 Fuß x $200 \mathrm{Fu}$, wobei $200 \mathrm{Fu}=58,37 \mathrm{~m}$ ), die somit 3407,27 $\mathrm{m}^{2}$ ergeben (FICKERT 1989). Im nördlichen Bayern dagegen wurde der Begriff Morgen („Frankenmorgen“ = 0,213 ha) benutzt. Die früheren Flächenmaße waren zum Teil entstanden durch Umwandlung eines Zeitbegriffs. So auch das Tagwerk (bzw. die Mannsmahd), die die von einem Mann an einem Arbeitstag abzumähende Wiesenfläche bezeichnete. Diese mit der Verordnung von 1809 eingeführte Maßeinheit wurde in Bayern 1872 durch das metrische Maßsystem abgelöst.

${ }^{12}$ Komturei: Verwaltungseinheit innerhalb einer Ballei des Deutschen Ordens; wird von einem Komtur geleitet.

${ }^{13}$ Ballei: Bezeichnung für eine Provinz des Deutschen Ordens. Dieser Begriff wird seit dem 13. Jahrhundert gelegentlich und seit dem 14. Jahrhundert regelmäßig verwendet. Er ist wahrscheinlich romanischen Vorbildern, insbesonders der Verwaltungsorganisation Siziliens, nachgebildet. Die Verwaltung einer Ballei leitete der Landkomtur. Insgesamt gab es im Deutschen Orden 12 Deutsche Balleien, die dem Hoch- bzw. Deutschmeister unterstanden (DEUTSCHER ORDEN 2004).
} 
Die Teichwirtschaf im Herzogtum Coburg ist insbesondere im ab 1132/33 bei Lichtenfels entstandenen Kloster Langheim nachgewiesen, von dem aus etwa 1153 bzw. 1156 das Kloster Tarnbach gegründet wurde sowie 1135 das Kloster Michelsberg. Hinzu kam das Kloster Mönchröden (1149).

Die ersten Nachweise über die Teiche im Coburger Land wurden 1509 veröffentlicht. 1519 wurden die zwei Kernmater Seelein genau beschrieben, Lage und Beschreibung der zum Mönchrödener Kloster gehörigen Teiche. Von 1669- 1674 erschienen weitere Veröffentlichungen etwa jährlich. Nach dem Coburger Kastenamts-Erbbuch gab es in diesem näheren Bereich insgesamt sieben Fischgüter (u. a. Morschnitz, Almerswind, Mürschnitz, Wolsbach, Horbruck (Haarbrücken), Effeltrich (Effelder) und Kurttendorf (Cortendorf).

In diesen Veröffentlichungen wurden wiederum nur Karpfen als Fische erwähnt. Auch hier hat man entsprechend den bereits vorhandenen Kenntnissen unterschiedliche Teiche für die Aufzucht benutzt.

In der fränkischen Neustadter Chronik von 1905 wurden im Jahre 1865 noch 147 größere und kleinere Teiche genannt. Davon entfielen auf die Neustadter Flur 6, Eberdorfer 1, Wildenheider 22, Meilschnitzer 43, Ketschenbacher 7, Thanner 27, Haarbrücker 15, Brüxer 8, Höhner 13, Rüttmannsdorfer 5 und auf die Weimarsdorfer Flur kein Teich.

Gegenwärtig gibt es im Neustadter Gebiet noch 3 größere Teiche und einen kleinen, nämlich die 3 ,Rottenbachsteiche' und das ,Liebermannsteichlein'. Der große Neustadter Teich, auch ,Herrenteich' genannt, der sich in dem Grund bei der Herrenmühle erstreckte und im 17. Jahrhundert mit 60 Schock Karpfen besetzt wurde, besteht nicht mehr. Als das Domänengut Anfang der 1870er Jahre vereinzelt wurde, wurden auch hier fast alle Teiche trockengelegt und zu Wiesen gemacht. In der Meilschnitzer Flur ist noch der ,Paarhosenteich' vorhanden. In der Ketschenbacher Flur sind folgende Teiche vorhanden: ,Schafteich', ,Hutteich', ,Büttnersteich' und das ,Schloßteichlein'. In der Thanner Flur gibt es folgende Teiche: 2 ,Dorfteiche', 4 ,Müsteichlein', 5 ,Pechseitenteiche', den ,Fischbacherteich', 2 ,Torteiche' am Lohholz, 2 ,Räumteiche', 4 ,Kohlhutsteiche'.

In der Haarbrückener Flur gibt es noch den ,Fischersteich'. Er hieß im 17. und 18. Jahrhundert ,Schottenteich', wurde an den Kaufmann Georg Fischer verkauft, von seinem Sohn wieder gekauft und hat seitdem den Namen ,Fischersteich'. weiter liegen dort 2 ,Müsteiche', der ,Erffenteich' (der früher den Herren von Erffa gehörte), 2 Rohrteiche, das ,Bauernteichlein', das ,Dorfteichlein', der ,Hirtenteich', der ,Haiderteich', der ,Boitsteich' und ,Ehrlichersteich' (oder ,Erlesteich') in der Heide. Ein schwerer Einbruch in die Fischzucht und Fischversorgung waren die Verwüstungen im Dreißigjährigen Krieg. Ganze Dörfer mit den dazugehörigen Teichen verödeten. Michelsdorf nahe dem heutigen Rodach mit dem Heinrichsteichlein, oder Herbartsdorf bei Neida, früher 4, jetzt 1 Teich, zeugen davon ${ }^{14}$.

„In großer Zahl prägten Teiche die Steigerwaldlandschaft.” (SCHENK 1988:243, Hervorhebung im Original). Den Weiher- und Handthalergrund, oberhalb des Klosters Ebrach gelegen (Abb. VIII-15) durchzogen ganze Teichketten. Die einzelnen Teiche wurden von Dämmen und Mönche unterteilt, was die Fischernte und die Pflege der Becken erleichterte. Daneben dienten sie zugleich als Vorhalteraum für den Antrieb der Klostermühlen (:243). Die „Steigerwaldmönche“ betrieben demnach eine geregelte Teichwirtschaft (:245).

Die klösterliche und bäuerliche Teich- und Fischwirtschaft im Steigerwald hat SCHENK (1988) als Teilbereich seiner Dissertation untersucht. Danach besaß die Abtei um 1800, eine frühere Datierung ließ die Quellenlage nicht zu, etwa 333 3/4 Morgen $^{15}$ „herrschaftliche Weiher“ (siehe Tab. VIII-1).

\footnotetext{
${ }^{14} \mathrm{URL}=$ http://www.forellenzucht-lautertal.de/ltt/chronik_cbg.htm; 08.01.2004

${ }^{15}$ Dass es sich bei dieser Flächenangabe um ein älteres deutsches Feldmaß handelt, das in den Ländern unterschiedlichen Flächengrößen entspricht (in Preußen z. B. ist $1 \mathrm{M}=25,5$ a, in Bayern =34,97 und in Hannover $=26,6$ a) und sich nicht genau in ein modernes Flächenmaß umrechnen lässt, darauf ist schon früher hingewiesen worden. Doch entsprechen die Weiher - legt man hier korrekterweise das bayerische Maß zugrunde - einer Teichfläche von rund 11.670 a, umgerechnet 11.67 ha.
} 
Außer dem Schwanensee, einst auf Alitzheimer Gemarkung gelegen und 1726 von der Gemeinde Alitzheim erworben und heute verlandet, gehörten die in der Tabelle aufgeführten Vorlandweiher alle zum Besitz des Klosters.

Tab. VIII-1: „Herrschaftliche Weiher und Seen“ im Besitz des Kloster Ebrach um 1800 in Morgen (und Ruthen) (aus: SCHENK 1988:62f., Tab. 5; während SCHENK Angaben zweier, hinsichtlich der Größe teilweise divergierender Quellen auswertet (StAB und HStAM), wird hier - zur Kenntlichmachung ausreichend - nur die Quelle des StAB tabellarisch umgesetzt).

\begin{tabular}{|c|c|c|c|}
\hline Orts- und Hofnamen & Weihernamen & Flächengröße & Gesamt \\
\hline \multicolumn{4}{|l|}{ Ebrach } \\
\hline & „Großer Weihersee“ & 15 & \\
\hline & „Kleiner Weihersee“ & $43 / 4$ & \\
\hline & „Sandseelein“ & 2 & \\
\hline & „Pfisterseelein“ & 8 & \\
\hline & „Röhrenseelein“ & 2 & \\
\hline & „Ständerlein“ & $03 / 4$ & \\
\hline & „Brünnseelein“ & 1 & \\
\hline & „Fastensee“ & $21 / 2$ & \\
\hline & „Oberer Handelsee“ & 3 & \\
\hline & „Unterer Handelsee“ & 8 & \\
\hline & „Stockseelein“ & 1 & \\
\hline & „Adventsee“ & 1 & \\
\hline & „Oberer Harbachsee“ & $31 / 4$ & $521 / 4$ Morgen \\
\hline \multicolumn{4}{|l|}{ Waldschwind } \\
\hline & „Alter See“ & 5 & \\
\hline & „Neuer See“ & 6 & \\
\hline & „Hofsee“ & 6 & 17 Morgen \\
\hline \multicolumn{4}{|l|}{ Koppenwind } \\
\hline & „See Koppenwinder Hof“ & 2 & \\
\hline \multicolumn{4}{|l|}{ Winkelhof } \\
\hline & „See Winkelhof“ & 2 & \\
\hline \multicolumn{4}{|l|}{ Kappel } \\
\hline & „Heiliges Seelein“ & $21 / 4$ & \\
\hline & „Kapeller Dorfsee“ & $91 / 2$ & $113 / 4$ Morgen \\
\hline \multicolumn{4}{|l|}{ Mönchherrnsdorf } \\
\hline & „Unterer Grisselbach“ & 2 & \\
\hline & „Ständerlein“ & 1 & \\
\hline & „Kleine Wässerung“ & $01 / 4$ & \\
\hline & „Dorfsee“ („Winterung“) & $61 / 2$ & \\
\hline & „Thomassee“ & 7 & \\
\hline & „Eichelsee“ & $201 / 4$ & 37 Morgen \\
\hline \multicolumn{4}{|l|}{ Burgwindheim } \\
\hline & „Kunzensee“ & & \\
\hline & „Gemeindsee“ & & \\
\hline & „Neuer See“ & & \\
\hline & „Großer Gielensee“ & & \\
\hline & „Kleiner Gielensee“ & & \\
\hline & „Dorfsee“ & & \\
\hline & „Kleines Ziegelseelein“ & & \\
\hline & „Ständerlein“ („Amtmannseelein“) & durch & hend ohne Flächenangaben \\
\hline \multicolumn{4}{|l|}{ Sulzheim } \\
\hline & „Schwanensee“ & 20 & \\
\hline & ,Alter See“ & 60 & \\
\hline & „Amtenseelein“ & 10 & \\
\hline & „Neuer See“ & 40 & 130 Morgen \\
\hline \multicolumn{4}{|l|}{ Mönchstockheim } \\
\hline & „Dorfsee“ & 30 & \\
\hline \multicolumn{4}{|l|}{ Weyer } \\
\hline & „Altwasser“ & 5 & \\
\hline & & Insgesamt & 248 Morgen [ohne Burgwindheim] \\
\hline
\end{tabular}

Des Weiteren besaß das Kloster auf Weyrer Gemarkung, im Überschwemmungsbereich des Mains unterhalb des Dorfes, zwei sog. „,wilde Seen“, die weder zu besetzen noch zu entleeren waren. Sie wurden durch „Auslaufung des Maines“ gefüllt und vom Amtshof befischt, wie SCHENK (1998:241) aus alten Quellen zu berichten weiß.

Zu den Wirtschaftshöfen Winkelhof und Waldschwind gehörten ebenfalls umfangreiche Teichanlagen (SCHENK 1988:244). 


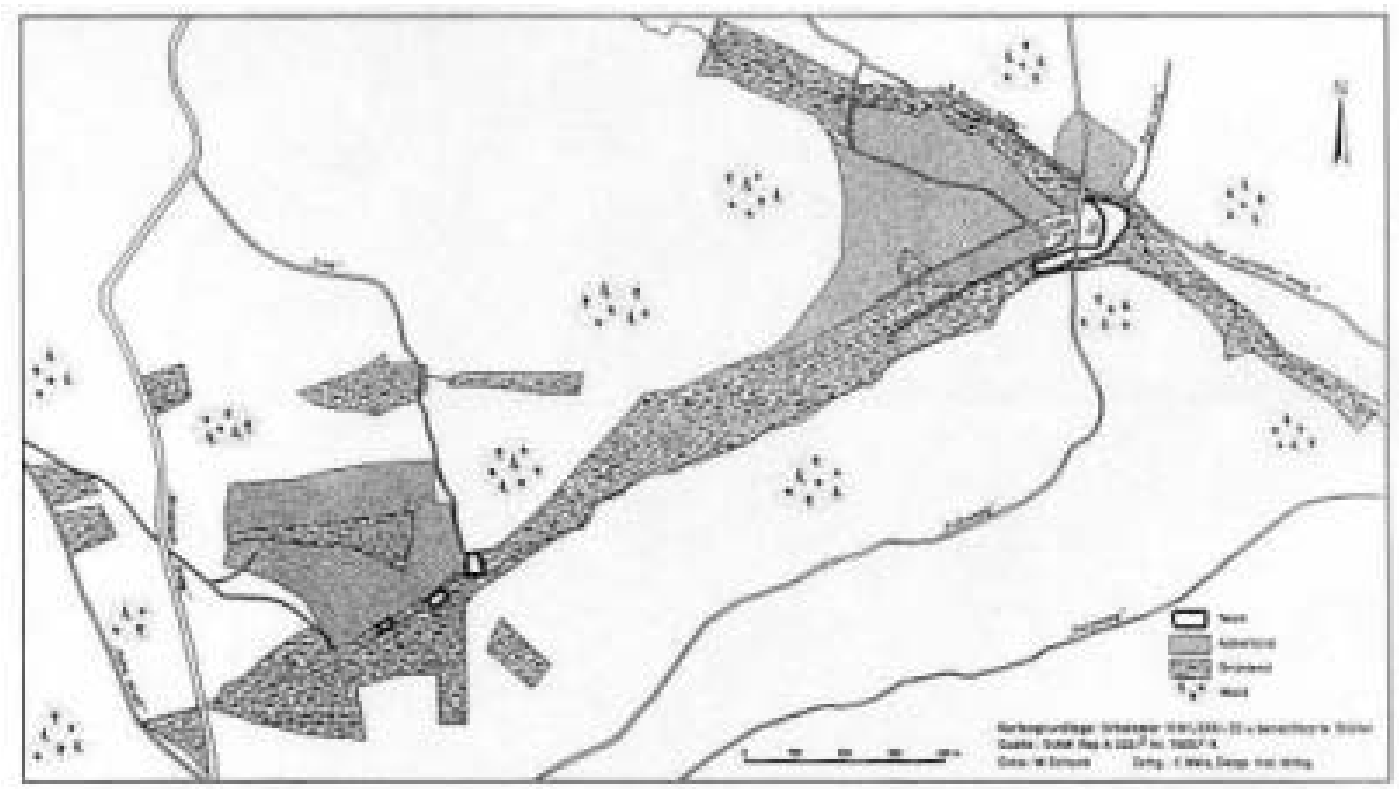

Abb. VIII-15: Bodennutzung dem zum Kloster Ebrach gehörenden „Guet Winckhel“ 1694 (aus: SCHENK 1988:186)

Dies war mit Sicherheit nur noch ein Teil des einstigen Teichbesitzes des 16. Jahrhundert, denn nach dem Schwedischen Krieg verfielen die Teiche mehr und mehr und nur ein Teil wurde nach 1670 wieder rekultiviert (SCHENK 1988:241). Die Mehrzahl der Teiche waren „schon kurz nach der Aufhebung der Abtei nicht mehr in bester Verfassung. [...] Der Kleine Weihersee im Weihergrund war 1804 schon ganz versandet und die Mauern eingefallen." (:248)

Zugleich waren die teichwirtschaftlich genutzten Wasserflächen des Steigerwaldvorlandes, die sog. Steigerwaldteiche, ,ihrem Charakter nach überwiegend Flachseen mit einem natürlichen Kern in von Bächen durchzogenen Tiefenlinien.“ (SCHENK 1988:243). Diese waren besonders von Verlandungsund Austrocknungsprozessen bedroht.

So war beispielsweise der ,Amtensee' schon zum Ende der Klosterzeit weitgehend verlandet. Von der Verlandung des im zuerst im bäuerlichen und danach im gemeindlichen Besitz befindlichen „Schwanensees' war bereits die Rede. Der ,Neusee', als letztes Glied einer Weiherkette, drohte im Sommer auszutrocknen, wenn er im Herbst nicht ausreichend gefüllt worden war. Der ,Herlheimer Mühlsee' erhielt sein Wasser durch Ableitungsrinnen aus dem Mühlbach (SCHENK 1988:243), die bekanntlich zuvorderst die Mühlräder antrieben und in wasserarmen Zeiten aufgrund der Versorgungspriorität leer fiel.

Aber nicht nur Karpfenzucht wurde in Oberfranken betrieben, sondern auch eine intensive Forellenteichwirtschaft. Vor allem die Gewässer der Fränkischen Schweiz, des Fichtelgebirges, des Frankenwaldes und des Coburger Raumes sind hierfür bekannt. Die Anfänge der oberfränkischen Forellenteichwirtschaft gehen zurück auf fischereiliche Aktivitäten des Coburger Herzogenhauses. In den damaligen Fischzuchtbetrieben der Coburger Domänenverwaltung wurden seit dem Jahre 1830 Bachforellen künstlich vermehrt. Dies geschah also bereits zu einem Zeitpunkt, an dem die Methoden der künstlichen Besamung bei Forellen noch nicht Allgemeingut waren.

Aufgrund der besonderen Bedeutung, die der Bezirk Oberfranken für die Teichwirtschaft noch heute hat, ist hier die gebietskörperschaftliche „Fachberatung für Fischerei“ (Bayreuth) ansässig mit dem angeschlossenen „Beispielbetrieb für Fischerei“'16.

\footnotetext{
16 Dieses Amt - mit Unterstützung durch das Bayerische Staatsministerium für Ernährung, Landwirtschaft und Forsten steht den Fischzüchtern und Teichwirten bei der Produktion von Fischen beratend zur Seite. Für die Teichwirte ist die Produktion gesunder, natürlich gewachsener Fische und deren erfolgreiche Vermarktung eine Existenzfrage. Die Fachberatung für Fischerei wirkt des Weiteren als Gutachter beim Vollzug der verschiedenen Gesetze mit, soweit dort fischereiliche Fragen behandelt werden, und regt fischereiliche Förderprogramme an. Sie vertritt den Artenschutz in den
} 
Östlich anschließend, zwischen Vorderem Oberpfälzer Wald, Fichtelgebirge und der Naab-WondrebSenke liegt die „Tirschenreuther Teichpfanne“, das sog. „Land der tausend Teiche“, als eines der größten zusammenhängenden Teichgebiete. Der Großteil der Teichfläche im Tirschenreuther Teichgebiet (ca. $90 \%$ ) befindet sich in dieser Senke, durch die sich die stark mäandernden Flüsse Naab und Wondreb ziehen. Aus seiner Form und Lage sowie der Konzentration von großen und kleinen Teichen leitet sich die Gebietsbezeichnung „Teichpfanne“ her.

Seit dem 12. Jahrhundert prägen Teiche die Landschaft im Landkreis Tirschenreuth, dessen Entwicklung die Zisterziensermönche des Klosters Waldsassen maßgeblich mitgetragen haben. Auf dieser Fläche verteilen sich mehr als 3.500 Teiche, mit einer Wasserfläche von etwa 2.000 ha. Die Tirschenreuther Teichpfanne ist eines der größten zusammenhängenden Teichgebiete in der Bundesrepublik Deutschland. Sie wird von den Orten Tirschenreuth, Mitterteich, Wiesau, Friedenfels und Falkenberg umgrenzt. Die größten Teiche sind der ,Paulusschwamm' mit 17 ha und der ,Rothenbürger Weiher' mit 16 ha, der ,Seeteich', der ,Rollnhöfer Weiher' und der ,Seidlersreuther Weiher' mit je etwa 15 ha Fläche.

Fischteiche sind in der Oberpfalz auch rund um die Vils/Amberg, besonders am Vilsoberlauf in Vilseck, seit dem Mittelalter fester Bestandteil der Kulturlandschaft. Derzeit gibt es in ihrem Einzugsgebiet an die 1.000 Fischteiche, die meistens im Nebenerwerb betrieben werden (WASSERWIRTSCHAFTSAMT AMBERG 1996).

Fischwirtschaft, zum Teil in großflächiger Ausdehnung, wurde jedoch auch in anderen, weniger bekannten Landschaften Deutschlands praktiziert.

Auch im Oberschwäbischen „existieren hunderte von Weiher“, von denen „allenfalls die Dämme“ noch übrig geblieben sind, „die insbesondere dann erhalten sind, wenn ein Weg oder eine Straße darüber führt." (KONOLD 1991:364)

Im Bereich Blitzenreute gab es ehemals etwa 610 ha See- und Weiherflächen. Davon sind noch etwa 84 ha übrig geblieben, und zwar fast ausschließlich die natürlichen Seen. Auf der heutigen Gemarkung Kißlegg befanden sich einstmals 327 ha größere Weiher und Seen; heute sind es noch 116 ha; und zwar auch hier ganz überwiegend in Gestalt der nicht ablassbaren Seen. Das heißt, die Verluste von etwa 211 ha gingen fast ausschließlich zu Lasten der Teiche. In der Gemeinde Achberg existiert von ehemals 11 Weihern nur noch einer, und dies in reduziertem Umfang. 98\% der Weiherflächen sind verloren gegangen (KONOLD 1991:367)

KONOLD (:355) hat die bis etwa zum Jahr 1450 zur Verfügung stehenden Unterlagen zusammengetragen, die nach eigener Angabe „mit Sicherheit bei weitem nicht vollständig sind” und kommt nur für den südlichen Teil Oberschwabens auf immerhin 120 größere Teiche.

In den oberschwäbischen Landschaften existierten häufig ganze Weiherketten, die jedoch unterschiedlichen Zwecken dienten. In fischereiwirtschaftlicher Sicht treten dabei vor allem die Benediktinerabtei Weingarten, die Fischzucht des Spitals Biberach und die Grafschaft MontfortTettnang hervor; allein in dem Adelbezirk existierten um 157926 Weiher (KONOLD 1991:356), beim Kloster Weingarten bestanden entlang des ,Stillen Baches' 26 Stauweiher (HERBST 1987b:28).

Gewässern und führt besondere Aktionen zum Schutz der Fische und der Gewässer durch, zum Beispiel die Wiederansiedlung gefährdeter Fischarten, Muscheln und Krebse in ihrem ursprünglichen Lebensbereich.

Der ,Beispielbetrieb für Fischerei' hat sich zur zentralen Anlaufstelle für alle Interessenten der Fischerei im oberfränkischen Raum entwickelt. In diesem Betrieb werden praxisbezogene Versuche durchgeführt, um den Teichwirten Kenntnisse zu vermitteln, wie Fische ökonomisch sinnvoll und ökologisch verträglich produziert werden. Weiterhin werden in diesem Betrieb drei Ausbildungsplätze für Fischwirte zur Verfügung gestellt, um dem oberfränkischen Nachwuchs eine qualifizierte Ausbildung im Bereich der Fischzucht zu ermöglichen. 
Zahlreiche Klosterteiche (Fischweiher) waren auch noch auf einer Karte von 1803 beim adeligen Frauenkloster Frauenalb im Tal der ,Ettlinger Alb' auf den „Konventwiesen“ außerhalb des engeren Klosterbezirks verzeichnet (SCHEIFELE 1993:22).

In Thüringen ist in erster Linie die Kleinteichwirtschaft zu finden. Hier „waren die Kleinbauern häufig bestrebt, in einem eigenen, sehr oft noch mit Zapfenverschluss versehenen, Teich die ,Kirmeskarpfen' selbst zu züchten.“ (SCHÄPERCLAUS 1961:169)

Doch auch auf thüringischem Boden gibt es große, zusammenhängende Teichflächen, die aber weniger bekannt sind.

Zwischen 450 und $500 \mathrm{~m}$ ü. d. M. liegt nördlich von Schleiz, im Bereich der Wasserscheide zwischen Saale und Elster, in einem Landstrich mit typisch norddeutschen Charakter auf einem Bereich von 10 km Durchmesser das „Plothener Teichgebiet“, das - wie die ,Tirschenreuther Teichpfanne” - auch als „Land der tausend Teiche“ bezeichnet wird (PASOLD 1992:7). Der Begriff ist nach Ansicht von PASOLD (:14) „keine Übertreibung, denn noch heute ist trotz Melioration und Bepflanzung diese Zahl der erstrangig der Karpfenzucht dienenden Gewässer zutreffend." Der älteste Hinweis über die von Mönchen angelegten Gewässer stammt aus dem Jahre 1074 (:46).

Die tiefgründige Verlehmung der Kulmlandschaft, geprägt durch kulmische Schiefer aus der Steinkohlenzeit, hat hier die Entstehung einer ausgedehnten Teichlandschaft ermöglicht (PASOLD 1992:7, 10). Auf diesem verlehmtem Untergrund aus Tonschiefer staute sich das Wasser der hier reichlichen Niederschläge an und wurde durch künstliche Dämme zu Fischteichen umgebildet (:46). $\mathrm{Da}$ der Niederschlagsreichtum die reichliche Wasserauffüllung bewirkte, spricht man in diesem Fall von Himmelsteichen (siehe Pkt. VII 1b). „Alle Teiche sind mit Hilfe künstlicher Dämme angelegt und ablassbar, können also jährlich durchaus geregelt abgefischt werden“"(:14). Es wird hier also seit Jahrhunderten eine geregelte Fischzucht betrieben durch Ablassen der Gewässer normalerweise im Herbst eines jeden Jahres (:46). Hauptabfluss ist der Plothenbach, der die aus Niederschlagswasser bespannten Plothenwasser bei Ziegenrück in die Saale führt (:46f.). Im größten Teich, dem ,Plothenteich' mit einer Gesamtfläche von 32 Hektar, steht ein auf 90 Pfählen errichtetes Holzhaus, weswegen der große Plothenteich auch oder noch mehr unter dem Namen ,Hausteich' bekannt ist $(: 14)$.

Eine „kleinere Anlage“ ist aus Worbis/Thüringen bekannt und verdeutlicht beispielhaft den Zusammenhang zwischen Mühlenteich und Fischteich, dessen Hauptnutzung als Mühlteich und in der Regel bezogen auf Einzelteiche intensiviert im nachfolgenden Kapitel zur Verbreitung der Mühlenteiche dargestellt wird.

Die Büschlebmühle an der Wipper jedenfalls ist ein Beispiel des sukzessiven Ausbaus einer Mühlteichanlage zu einer Mehrteichanlage der Teichwirtschaft. 1663 aus einer Pulvermühle hervorgegangen, erwarb 1828 Alois Büschleb die Mühle und bewirtschaftete sie im Nebenbetrieb. Als Landwirtschaft wurde sie neben dem Mühlgeschäft aufgebaut. Ein weiterer Erwerbszweig war die Bäckerei - dies ist so weit eine klassische Gesamtanlage einer größeren Mühlenwirtschaft.

1903 begann Carl Büschleb den Aufbau einer Forellenzucht. Auf dem Mühlengelände, zwischen Wehr und Beginn des steinernen Gerinnes, wurden Teiche ausgeschachtet und aus dem Mühlgraben mit Wasser versorgt. Auch heute noch erfolgt die Bespannung der Teiche durch das Wasser des Mühlgrabens. 1906 waren 24 Teiche, eine Brutanstalt und ein Eiskeller fertig. Um 1911 kamen die Teiche auf dem Pfingstrasen dazu. 1912 war die Anlage fertigestellt. Eier und Setzlinge lieferte man bis nach Osteuropa, das Speisefischgeschäft florierte ebenfalls (ROGGE 1993:32). 


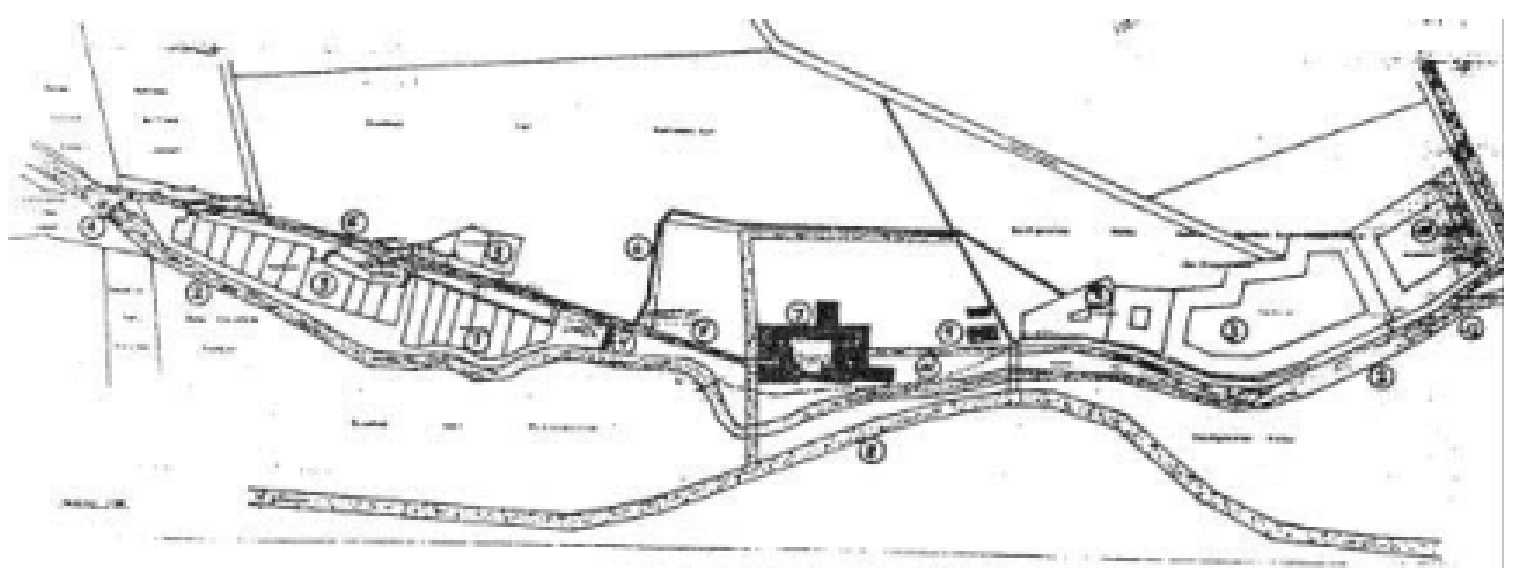

Abb. VIII-16: Teichwirtschaft der „Büschlebmühle“ an der Wipper in Worbis

1. Überlauf und Stauwehr, 2. Wipper, 3. Fischteiche, 4. Abschlagwehr, 5. Aquaedukt (Mühlgraben), 6. Wassergraben, 7. Mühle, 8. jetzige B 80, 9. Unterwasser, 10. jetziges Freibad, 11. Versorgungsleitung, 12. Wehr für Neumühle (ROGGE 1993:31).

Im Süden des Landkreises Leipziger Land, in unmittelbarer Nähe zum Land Thüringen, befindet sich eingebettet in das Landschaftsschutzgebiet Kohrener Land das Naturschutzgebiet „Eschefelder Teiche". Häufige Stauschichten im Altenburger Lößlehmgebiet führten zu Vernässungen und Quellenreichtum. Das war Anlass für die Anlegung der Teiche. Die ersten Teiche entstanden am Nord-Ost-Rand des Windischleubaer Acker-Wald-Gebietes, offenbar im Ergebnis von Teilwüstungsprozessen im 13. und 14. Jahrhundert.

Der Großteich entstand 1457 im Auftrag des Herrn von Einsiedel, Besitzer der Burg Gnandstein, zu Fischereizwecken. 1476 und 1529 erfolgten Erweiterungen und die Aufschüttung des Dammes auf der Frohburger Seite. Der Ziegelteich wurde 1551, der geteilte ,Streckteich' 1586 und der ,Kinderteich' 1610 erstmals erwähnt. 1926 wurde der ,Neuteich' als Folge von Sanierungsarbeiten am Straßenteich angelegt. Die Himmelsteiche wurden und werden hauptsächlich zur Fischzucht genutzt.

Die Wasserstände der Teiche unterlagen starken Niederschlagsschwankungen. Deshalb wurde 1936 eine Rohrverbindung zur Wyhra geschaffen, durch die bei Bedarf Wasser in die Teiche gepumpt wird. Ende der 1960er Jahre wurden die Teiche kurzzeitig zur Entenmast genutzt.

Aufgrund der Artenvielfalt der in diesem Gebiet brütenden Vögel, vor allem bestandsgefährdeter Arten, wurden die Eschefelder Teiche am 11.09.1967 als Naturschutzgebiet ausgewiesen. Das Gebäude „Teichhaus Eschefeld“ beinhaltet eine Naturschutz Station in der Trägerschaft des NABU Sachsen e.V.

In alt-wendischer Gegend, nämlich in Peitz, Kreis Cottbus, hat sich die künstliche Teichwirtschaft noch immer in einer großartigen Ausdehnung erhalten. Es ist dort die Karpfenbörse für einen nicht unbeträchtlichen Teil sogar von Norddeutschland seit Jahrhunderten verankert. Das hier ansässige „Institut der Pritzstapel“ (oder Pritzstabel) ${ }^{17}$, die als Fischereiaufseher sich von der Wendenzeit her noch bis in das 20. Jahrhundert in Köpenick, Ruppin und Spandau erhalten hatten, beweist nicht nur, dass „das Fischwesen bereits in der slavischen Vorzeit polizeilich geregelt und überwacht wurde“ (FRIEDEL 1884:45f.), sondern gibt auch Aufschluss über die Größe und Bedeutung, die die Teichwirtschaft in der Niederlausitz gehabt hat und, wenn auch mit Abschwächung, noch immer hat. Allein die Domäne Peitz bei Cottbus in der Lausitz hatte 82 Teiche von 1.176 ha Größe (BORNE 1886:262).

Teichgebiete sind vor allem „wesentliche Bestandteile sächsischer Kulturlandschaften“ (LFUG 2002:6). Die Fischerei, insbesondere die Karpfenteichwirtschaft, hat im Freistaat Sachsen eine lange historische Tradition. Die sächsischen Karpfenteiche wurden ab dem Jahre 1200 durch adlige

\footnotetext{
${ }^{17}$ Pritzstapel leitet sich vom wendischen „Pristaw“ = Vogt ab.
} 
Grundherren nach böhmischem Vorbild angelegt. Und bereits ab dem 16. Jahrhundert wurden die Karpfenzucht in getrennter Jahrgangszucht betrieben; bis ins ausgehende 19. Jahrhundert im 4- bis 5sömmrigen Umtrieb (Lausitzer Schuppenkarpfen); seit Einsatz des raschwüchsigeren galizischen Spiegelkarpfens im 3-sömmrigen Umtrieb. Um 1900 bemühte man sich um die Zucht regionaler Rassen, wie z. B. den Niederspreer Karpfen oder die Quolsdorfer Schleie. Bis Mitte des 19. Jahrhundert fand keine künstliche Zufütterung der Fische statt.

Grundlage der heutigen binnenfischereilichen Produktion in Sachsen bilden 8.410 ha Teichfläche. Davon werden über 7.500 ha haupterwerblich für die Erzeugung von Speisekarpfen genutzt. Die $51 \mathrm{im}$ Haupterwerb tätigen Teichwirtschaften erzeugen jährlich über $3.000 \mathrm{t}$ Karpfen und $300 \mathrm{t}$ andere Speisefische. Jeder vierte deutsche Speisekarpfen kommt aus Sachsen. Die Durchschnittsgröße der Haupterwerbsunternehmen liegt bei 146 ha Teichnutzungsfläche (SCHULTE 2000).

Von großer Bedeutung sind vor allem die Teichwirtschaften in der Oberlausitz, aber auch die Teichwirtschaften Wermsdorf, Moritzburg oder Torgau sind eng mit der sächsischen Geschichte verbunden (SCHULTE 2000). „In deutschlandweit einmaliger Dichte prägen im Oberlausitzer Heideund Teichgebiet und in den angrenzenden Teilen der Naturräume Königsbrück-Ruhlander Heiden und Westlausitzer Hügel- und Bergland über 5000 ha Teiche das Landschaftsbild. Weitere der insgesamt etwa 8400 ha bewirtschafteten Karpfenteiche Sachsens [...] verteilen sich auf die anderen Naturräume, wobei im Nordsächsisches Platten- und Hügelland, Leipziger Land und in der Großhainer Pflege ebenfalls großflächige Teichgebiete vorhanden sind:

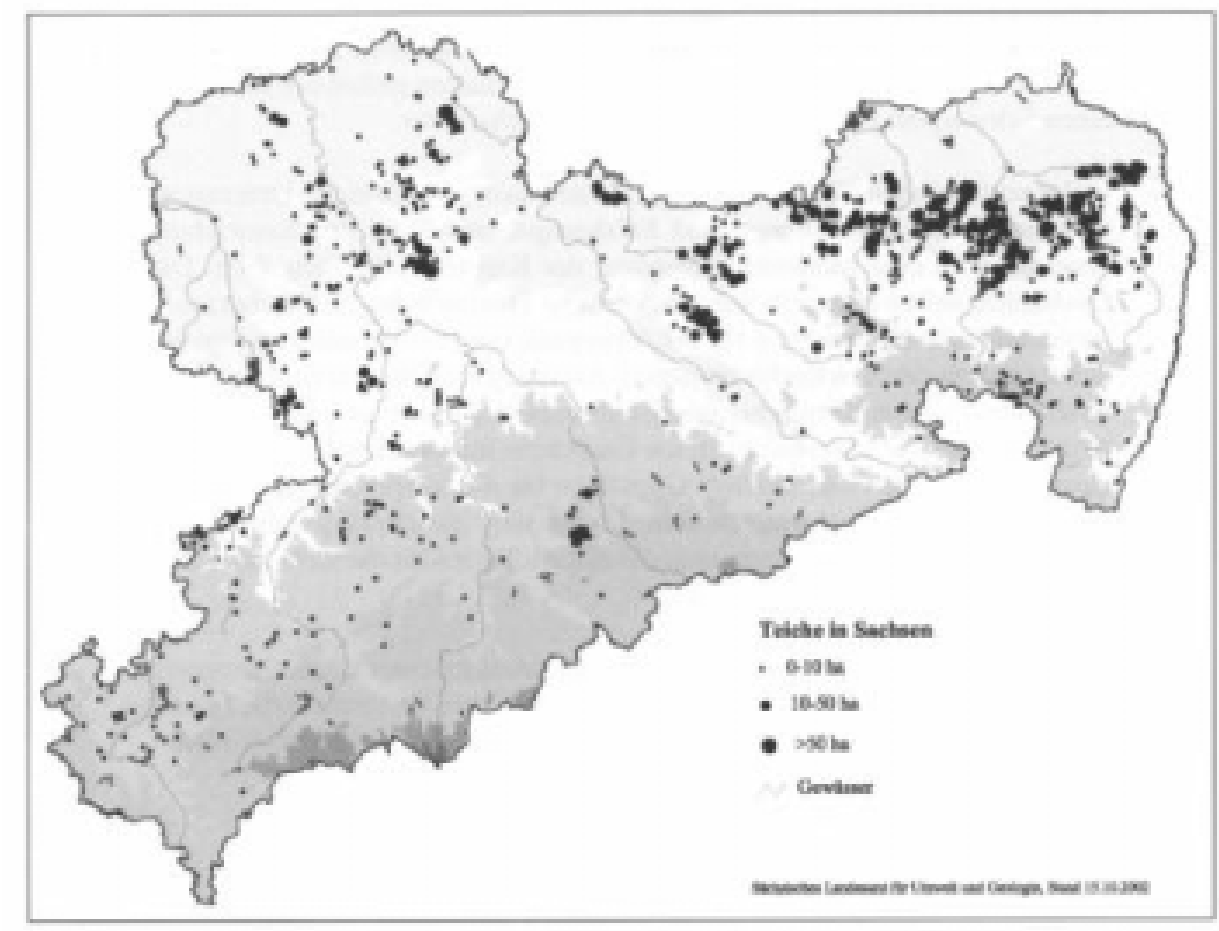

Abb. VIII-17: Teiche in Sachsen

(aus: LFUG 2002:6)

Am bekanntesten ist zumindest in Sachsen als Hort der Teichwirtschaft das sog. „Oberlausitzer Heideund Teichgebiet“, denn ,bis heute ist das Ober- und Niederlausitzer Teichgebiet die größte zusammenhängende Teichlandschaft Deutschlands“ (BfN 2000:D-10). Physiogeographische Ursache hierfür ist die naturräumliche Ausstattung mit Vergesellschaftungen grundwassernaher Talsande in Höhenlagen von 135 bis $150 \mathrm{~m}$ mit hunderten von Metern breiten, aber nur wenigen Metern eingesenkten Talniederungen. Es treten nicht nur trockenheitsanfällige und wenig fruchtbare Sandflächen auf, sondern auch Vernässungen zählen zu den bestimmenden Merkmalen dieses Naturraumes. Diese Konstellation machte den Landschaftsraum weitgehend uninteressant für Ackerbau und Großviehzucht und vermied dadurch damit einhergehende Meliorationen. „Deshalb eignete sich dieser Naturraum auch besonders für die Anlage von Teichen“"(IG 2001:7). 


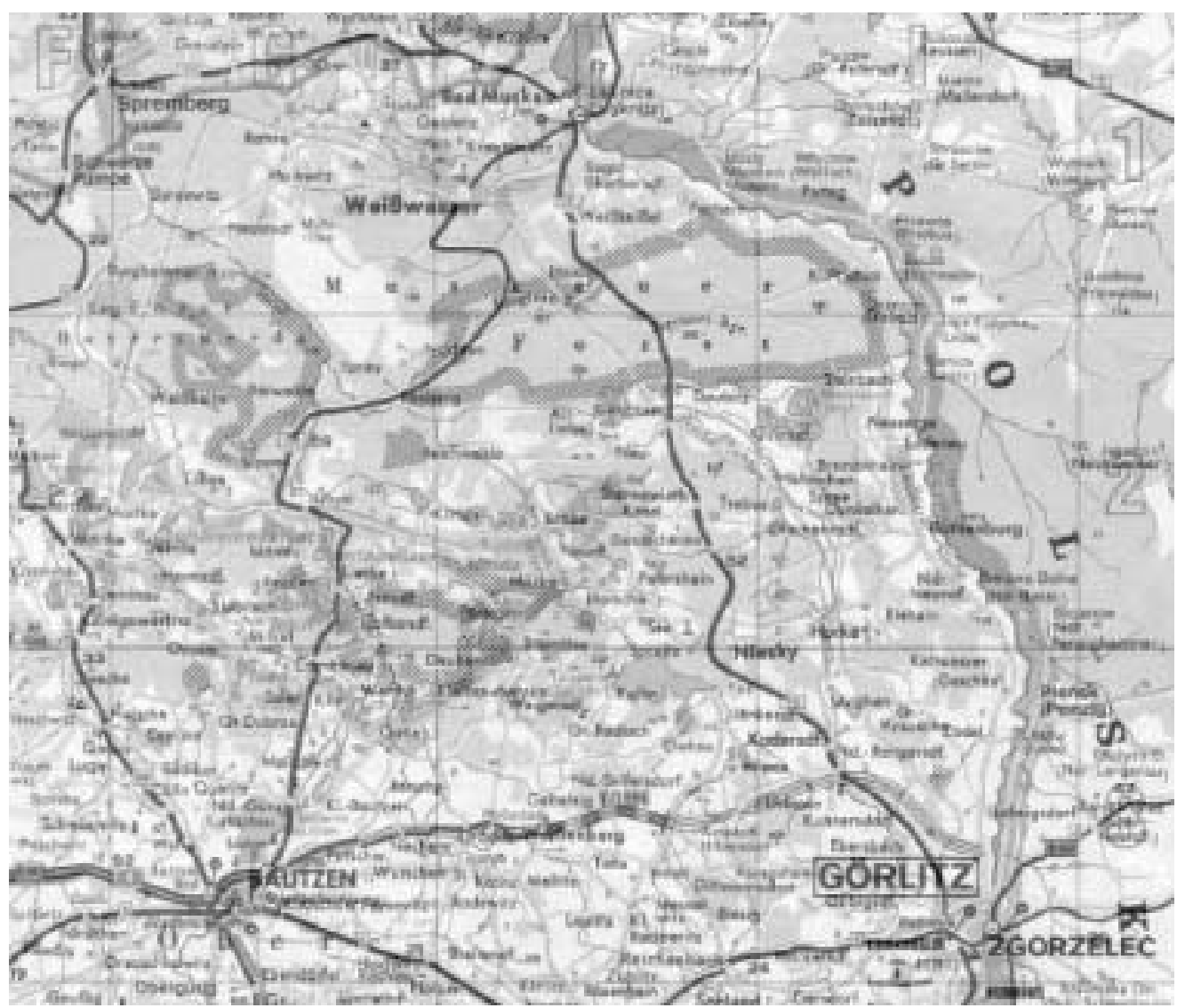

Abb. VIII-18: Übersichtskarte des „Biosphärenreservat Oberlausitzer Heide- und Teichlandschaft“ Original-Maßstab 1:400.000.

Bereits aus dem 13. und 14. Jahrhundert ist die Teichfischerei in der Oberlausitz belegt. Im 15. und 16. Jahrhundert wurden Teiche - mit den dazugehörigen Gräben - speziell für die Fischzucht angelegt (FÜLLNER 1995). Anfang des 18. Jahrhunderts dann bestanden in der sächsischen und preußischen Oberlausitz eine Reihe von großen „Teichrevieren“, beispielsweise die Teichgruppen um Rietschen und Quolsdorf.

Während im Laufe des 19. Jahrhundert teilweise auch hier - dem allgemeinen Trend entsprechend sogar alte Teiche im Lausitzer Hügelland zugunsten der ackerbaulichen Nutzung aufgegeben wurden (Melioration fruchtbarer Böden), blieb die Teichwirtschaft im Heidegebiet weiterhin eine relativ ertragreiche und sichere Einkommensquelle. Dies erklärt zum Teil die noch heute so bedeutsame Teichwirtschaft. Allerdings waren Teichtrockenlegungen in der Zeit nach der sog. „Separation“ (1860), der Umwandlung in Äcker und Wiesen, relativ häufig.

Aber auch die im Gegensatz zur dominierenden Oberlausitz vielfach unbeachtete „Westlausitz“ kann mit einem Anteil von 22\% Wasserfläche in der Region - als Teichgebiet von überörtlicher Größe bezeichnet werden. „Hunderte von stehenden Gewässern, die bereits zum größten Teil im Mittelalter künstlich angelegt wurden und im wesentlichen als Fischteiche genutzt wurden, gehören zur heutigen Naturraumausstattung. Eines der größten stehenden Gewässer ist der Großteich ,Zschorna' der Gemeinde Tauscha.“(IG 2001:8).

Das Gebiet ist dadurch gekennzeichnet, dass es von zahlreichen Fließgewässern durchflossen wird, die alle zum Einzugsgebiet der Schwarzen Elster gehören und über diese zur Elbe entwässern. Dazu zählen u. a. die Große Röder, die Pulnitz mit Hasel- und Otterbach sowie Bohraer und Zietscher Wasser, dazu Ruhlander Schwarzwasser, das Schwosdorfer Wasser und der Saleskbach (IG 2001:8).

Doch nur ein Teil der landschaftsprägenden Teiche von 17 Teichwirtschaften wird zur Zeit wirtschaftlich genutzt (IG 2001:8). 
Auch im südwestlich anschließenden Mittelsachsen präsentiert sich mit der Teichwirtschaft Moritzburg eine der traditionsreichsten in Sachsen. Die Karpfenzucht nahm im 15. Jahrhundert ihren Anfang. Heute werden in 22 Teichen mit einer Gesamtfläche von 340 ha Karpfen aller Größen, Schleie, Hechte, Zander, Aale und Forellen aufgezogen. $\mathrm{Zu}$ einem beliebten Höhepunkt, einem regelrechten Volksfest und Gaumenschmaus zugleich, ist das "Schau-Abfischen“ am letzten Oktoberwochenende jeden Jahres vor dem Moritzburger Schlossteich geworden (MEILAND 2003).

Wie auch in anderen Teichgebieten war auch hier das flachwellige fließgewässerreiche Hügelland mit seinen Vertiefungen, Mulden und Senken ausgezeichnet zur Anlage von Teichen eignet. Es wird als sicher angenommen, dass schon beim Bau des Schlosses und später unter dem sehr wirtschaftlich denkenden Kurfürsten August (1525-1586) auf die Anlage von Fischteichen Wert gelegt wurde. Zwar erwähnt selbst das sog. „Erbbuch“ von 1551 keine Teiche, doch lässt sich aus den Andeutungen erkennen, dass solche Teiche bereits damals und auch schon früher vorhanden gewesen sein müssen.

$\mathrm{Zu}$ nennen ist hier der bereits im Jahr 1502 angelegte ,Bernsdorfer Teich', wie aus einem Schreiben aus diesem Jahr, das von dem Herzog Georg dem Bärtigen unterzeichnet wurde, hervorgeht: „Item den Teich, den man itzt zu Kunnertswalde bawet, den sollen sie die Pauern und Invoner zu Bernsdorff und Kunnertswalde, auch fischen helfnenn und die Handfroner sollen die Fische aus demselben Teiche in die helder gen Bernsdorff furen“. ${ }^{18} 1651$ führte er den Namen „der neue Teich“ („,der Naw Theych im Frydewalde, der Bernsdorffer genandt“. Dann folgen die Bezeichnungen ,Großteich', ,Großer Teich', „Bernsdorfer Teich', ,Bärnsdorfer Großteich'.

Die Größe des Teiches wird 1573 mit 162 Ackern angegeben. Das sind etwa 46 ha (1 Acker = 28,5 a). Heutzutage ist er mit rund 87,5 ha vermessen. Damit übertrifft er alle anderen Moritzburger Teichgewässer, obgleich durch Verbindung kleiner nahe beieinander liegender Teiche die Teichfläche im Rahmen der Erweiterung der Teichwirtschaftsanlage allmählich vergrößert wurde. So ist zum Beispiel der ,Dippelsdorfer Teich' um die Mitte des 16. Jahrhunderts aus kleineren Teichen hervorgegangen und besitzt eine Teichfläche von 69,03 ha. Auch der Schlossteich in Moritzburg ist aus dem ,Mosebruchteich', aus dem ,Kapellenteich' und aus dem ,Kapitel'- und ,Presteich' angelegt worden, wie dies aus einer Bemerkung zu einer Karte aus dem Anfang des 18. Jahrhunderts hervorgeht.

Darüber hinaus werden folgende Teiche mit ihren Flächenangaben vermerkt: ,Frauenteich' (67,22 ha), ,Mittelteich' (56,20 ha), ,Schlossteich' (37,23 ha), ,Oberer Waldteich' (26,34 ha), Niederer Waldteich' (18,84 ha) sowie der, ,Köckeritzteich' (18,92 ha).

\section{c.2.2.3 Alpen und Alpenvorland}

Die in den glazial geformten Voralpengebieten ansässigen Klöster fanden für die Anlage von Fischteichen die gleichen idealen Bedingungen vor die Güter der eiszeitlich geformten Landschaften des Norddeutschen Tieflandes. Durch Gletscherrückzüge vorgeformte Mulden, vermoorte Niederungsgebiete und von Stromtäler und Bächen durchflossene, die den Teichbau erleichterten. Das Kloster Salem (1139) am Bodensee beispielsweise, neben Maulbronn (1139), Herrenalb (1149), Schöntal (1157) und Bebenhausen (1190), eines der Hauptklöster der Zisterzienser in Süddeutschland, besaß im 19. Jahrhundert noch 24 Teiche, die diese gegebenen Vorzüge für sich zu nutzen wussten (vgl. RÖSENER 1974:145).

Doch nicht alle heutigen Teichgebiete sind auf glazigener Vorlage entstanden und rein fischereiwirtschaftlichen Ursprung, wie das folgende Beispiel zeigt:

\footnotetext{
${ }^{18}$ Hauptstaatsarchiv Amt Moritzburg/Vol.IV Nr. 50/104
} 
Zentrum der Karpfenproduktion in Deutschland war bzw. ist neben dem Gebiete der Lausitzer Teichlandschaft und der Vielzahl der fränkischen Teichwirtschaften das „Ismaninger Teichgebiet“ bei München.

Bei diesem erst Ende der 1920er Jahre künstlich angelegten Teichgebiet im Nordosten von München östlich der Gemeinde Ismaning handelt es sich um einen großen und eine Reihe kleinerer Teiche. Die Wasserflächen umfassen 848 ha, das Gesamtareal innerhalb der Dämme 995 ha.

Die Funktion dieser Teiche war aber nicht eine rein fischwirtschaftliche. Eine Funktion des Teichgebiets war und ist das Speichern von Wasser, um den Betrieb der Kraftwerkskette der mittleren Isar zu sichern. Zugleich dienten der Speicher und die als Vorfluter fungierenden Teiche zur biologischen Klärung des Abwassers der Stadt München und damit als „Rieselfelder“ (siehe Pkt. VII 5z.2). Hierzu wurden und werden die Abwässer mit Isarwasser vermischt. Bis in die 1960er Jahre erfolgte die biologische Reinigung des Münchner Abwassers allein im Ismaninger Teichgebiet. Seit Anfang der 1970er Jahre entlastet ein Klärwerk mit moderner biologischer Reinigungsstufe das Teichgebiet. Die Wasserqualität wurde hierdurch zwar deutlich verbessert, dennoch erzeugte diese Entwicklung nicht die ungeteilte Zustimmung der Naturfreunde und Ornithologen. Ein deutlicher Rückgang der Vielfalt der vorkommenden Vogelwelt war nämlich festzustellen, weil die Massenvermehrung von Kleinstlebewesen, die im Verlauf der biologischen Reinigung der Abwässer einsetzt und von denen sich die Fische, vor allem Karpfen ernähren, ausblieb. Aber auch für die Wasservögel entfiel dieses Nahrungsangebot, aus diesem Grund erst entwickelte sich das Ismaninger Teichgebiet hinsichtlich der hier vorkommenden, brütenden oder zu Besuch weilenden Vögel zu einem der bedeutendsten Gebiete Mitteleuropas. Seit das moderne Klärwerk die Teichgruppe entlastet, werden deutlich weniger Nährstoffe eingetragen. Die Wasserqualität hat sich hierdurch verbessert, die Zahl der Vogelarten jedoch deutlich verringert.

Auch an diesem Beispiel ist die vorteilhafte Verkettung zwischen differenzierter historischer Nutzungsform und Biodiversität zu erkennen, wie im späteren Verlauf zusammenfassend beschrieben wird.

Ca. 1870 überließ der Bayernkönig Ludwig II dem Bayerischen Fischerei-Verein das „SiebenquellenAnwesen", ein bereits bestehendes 135 Tagwerk großes Karpfenteichgebiet bei Starnberg, zum Zwecke des Betriebes einer Fischzuchtanstalt. Es entstand daraufhin eine der leistungsfähigsten Fischzuchtanstalten Deutschlands, vor allem als diese erweitert und 1912 als „Königlich Bayerische Teichwirtschaftliche Versuchsstation“ weitergeführt wurde. Das vom König übereignete Anwesen ,an den sieben Quellen“ bei Starnberg wurde gleichzeitig zur Wiege der Fischereischule des Bayerischen Landesfischerei-Vereins, die in der 1952 vom Staat gegründeten „Bayerischen Landesanstalt für Fischerei“" mündete und in einem Neubau auf einem Teil dieses Grundstücks der Aus- und Fortbildung dient.

Eine andere Einrichtung in Oberbayern, die teichwirtschaftliche Versuchsstation in Wielenbach, besaß bei Gründung um 1910 ursprünglich 40 Teiche von je 20 a Fläche (WUNDER 1956:12). Das Gelände umfasst heute 84 ha mit 145 Teichen und ca. 20 ha Wasserfläche und wurde mehrfach - nach dem Ersten und Zweiten Weltkrieg und zuletzt 1978 - durch Neuanlage von Teichen erweitert und umgebaut (LIEBMANN/KEIZ 1965:7). Zu der bis 1954 rund 50 ha großen Anlage wurden in den 1960er Jahren weitere 6 ha dazu erworben bei rund 20 ha bespannte Teichfläche verteilt auf 120 Teichen. Davon wurden etwa 40 Teiche mit Quellwasserversorgung vorzugsweise zur Haltung von Forellen genützt; rund 80 Teiche dienen vorzugsweise der Karpfen- und Schleienhaltung und nehmen den größten Teil des Areals ein (:12f.). 


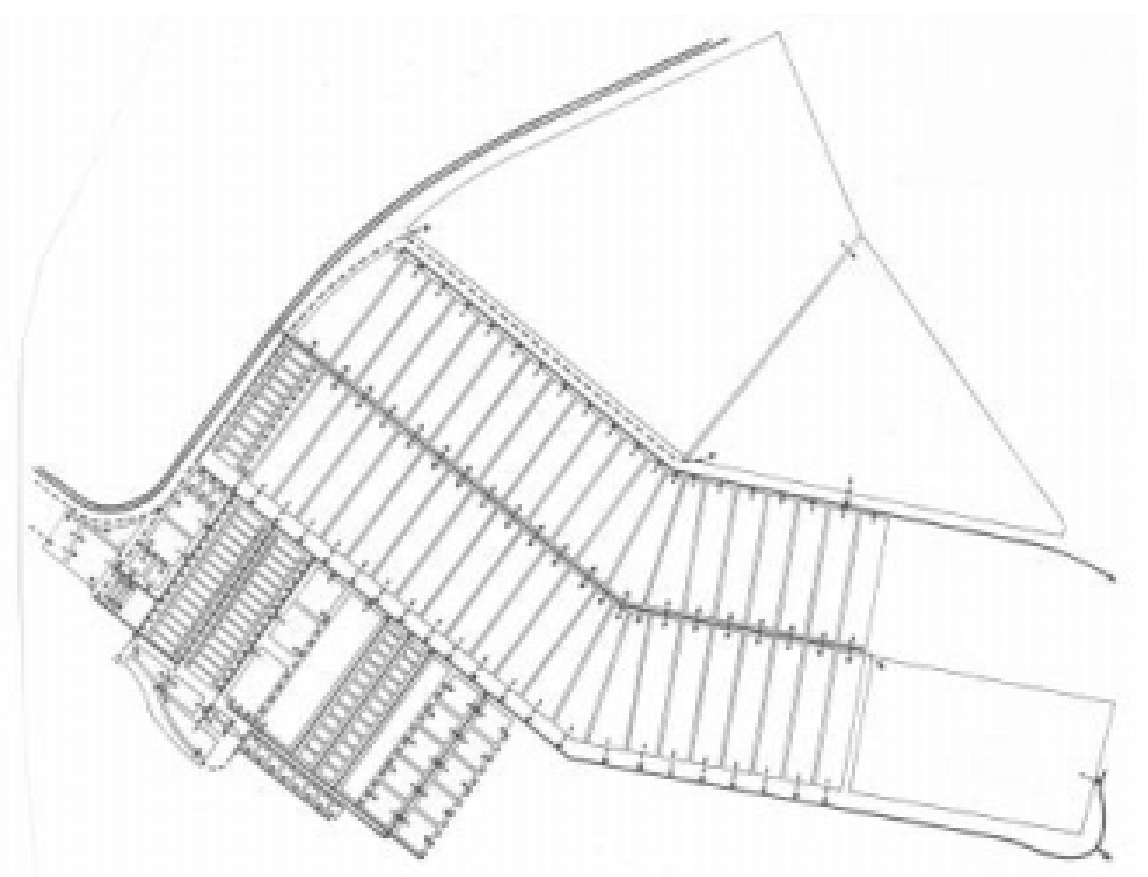

Abb. VIII-19: Übersichtsplan der Teiche in der Wielenbacher Anlage Zustand um 1960 (aus: LIEBMANN/KEIZ 1965:9)

Es war überhaupt die Zeit von ganzen Forschungsrichtungen und -einrichtungen. Schon um 1869 unternahm Richard Braungart in Weihenstephan an der Königlich Bayerischen Akademie Weihenstephan erste Versuche mit Fischlaich. 1881 wurde dort nach einem ministeriellen Erlass der Unterricht für Fischzucht und Fischereiwesen aufgenommen (KEIZ 1995:18). Damit verbunden war die Anlage einer kleinen Fischbrutanstalt zu Siebenbrunn bei Harlaching vor München.

In Österreich hat die Karpfenteichwirtschaft ihre regionalen Schwerpunkte in den niederösterreichischen und steirischen Grenzgebieten (EDER 2002:55).

Besonders hervorzuheben ist die niederösterreichische „Waldviertler Teich-, Heide- und Moorlandschaft" mit 1.600 Hektar Teichfläche (EDER 2002:58). Vor allem im nördlichen Waldviertel mit dem Teichgebiet bei Litschau im Einzugsgebiet des Reißbachs bestehen mehr als ein Dutzend Fischteiche (u. a. ,Herrenteich', ,Kufsteinteich', ,Richterteich', ,Schönauer Teich') mit ungefähr 8,79 ha Gesamtfläche (KRANZ 2000:15f.).

Weitere Forellen-Teichwirtschaften befinden sich schwerpunktmäßig in Österreich in der Steiermark, am Oberlauf der Freischütz. In der Weststeiermark liegt mit der Gemeinde Unterbergla im Bezirk Deutschlandsberg mit über hundert Teichen und ca. 400 Hektar Teichfläche der teichreichste Bezirk Österreichs (vgl. EDER 2002:58,62). Bäuerliche Teiche prägen als Teichkette die weststeierischen Riedellandschaften entlang der Landstraße zwischen Gleinstätten und Groß St. Florian (:61). Ebenfalls kann der ,Herrengraben' nördlich von St. Martin im Sulmtal als Beispiel für kettenartig in Etagen angelegt bäuerliche Teiche gelten (EDER 2002:57) und die, Waldschacher Teiche' als Beispiel einer herrschaftlichen Teichanlage (:59).

Dass gerade die Weststeiermark sich zu einem Zentrum der österreichischen Teichwirtschaft entwickelte, hat zwei Gründe: Zum einen sind hier äußerst günstige physiogeographische Standortvoraussetzungen zur Anlage von Teichen gegeben (tonig-lehmige Böden, sommerwarmes Klima, südexponierte Lage vieler Seitentäler, ausreichende Niederschläge, da viele Teiche im Riedelland Himmelsteiche sind); zum anderen gehören große Teile dieses Gebietes, hauptsächlich um Deutschlandsberg und Leibnitz, seit dem 10. Jahrhundert zum Einflussbereich der Salzburger Erzbischöfe. So war es nahe liegend, dass Mönche hier Hunderte Teiche anlegen ließen (EDER 2002:57). Allerdings wurden auch hier im 19. und 20. Jahrhundert viele Teiche aufgelassen (:58). 
In Österreich werden in heutiger Zeit (Stand: 2000/01) ca. 2.900 Hektar Teichfläche für Zwecke der Karpfenzucht genutzt. Von den 2900 Hektar entfallen ca. 1.700 Hektar (oder 58,6 \%) auf Niederösterreich und ca. 1.000 Hektar (oder 34,5 \%) auf die Steiermark. Der Rest von ca. 200 Hektar (oder 6,9\%) verteilt sich auf die Bundesländer Burgenland (ca. 85 Hektar), Kärnten, Oberösterreich und Salzburg (EDER 2002:58).

\section{c.2.2.4 Ehemalige Reichsgebiete und Protektorate}

Teichgebiete sind seit dem Mittelalter prägende Elemente europäischer Kulturlandschaften. Insbesondere in den ost- und südosteuropäischen Staaten wie Polen, Tschechien, Ungarn, Kroatien oder Bulgarien blicken viele Karpfenteichwirtschaften auf eine Tradition von mehreren hundert Jahren zurück. Die Ausdehnung der Karpfenteichgebiete differiert regional sehr stark.

Ein Hauptsitz der Teichwirtschaft in Mitteleuropa waren bin ins 19. Jahrhundert die ebenen ostmitteldeutschen Landschaften entlang der Flussniederungen: das Innere Böhmens und Mährens, die Lausitz, Schlesien und das westliche Polen.

Schlesien ist vielleicht das historische Gebiet der Fischteiche in Mitteleuropa. Es umfasst das beiderseitige Einzugsgebiet der fruchtbaren Flussebenen der Oberen und Mittleren Oder und ihrer Nebenflüsse $^{19}$. Die Nordostgrenze läuft im Wesentlichen auf der Wasserscheide zwischen Oder und Warthe-Weichsel durch die Flachhügellandschaft der osteuropäischen Ebenen. Die Nordwestgrenze verliert sich in der Lausitzer Übergangszone zur Mark Brandenburg.

Der größte Teil dieser Landschaft bildete bis 1941 die preußische Provinz Schlesien. Sie bestand aus den Regierungsbezirken Breslau, Liegnitz und Oppeln. 1945 kam Schlesien bis zur ,Oder-NeißeLinie' unter polnische Verwaltung, die Restgebiete diesseits dieser Linie an die sowjetische Verwaltung.

Für die historische Teichwirtschaft bedeutsam ist 1163 die Bildung zweier schlesischer Herzogtümer: Niederschlesien mit Breslau und Oberschlesien mit Ratibor, Beuthen und etwas später Oppeln.

Die Teichwirtschaft Schlesiens lag mitten in diesem Gebiet und genau diese geographische Mittellage erschwert eine räumlich umgrenzte Darstellung, die durch die politische Wechselhaftigkeit noch weiter verkompliziert wurde. Die politische Geschichte beginnt mit der mittelalterlichen deutschen Kolonisation und der damit verloren gegangenen Einheit des Raumes, geht über die Grenzziehung von 1742 zwischen Österreich und Ungarn, die erste Teilung Polens 1772, die Gründung „Neuschlesiens“ durch Preußen 1795 - 1807 und die Zurechnung nach 1815 zum Gebiet des Deutschen Bundes und die Aufteilung Oberschlesiens zwischen dem Deutschen Reich, der Tschechoslowakei und Polen 1920/21. Es folgten die Angliederung des „Olsagebietes“ an Polen 1938, 1939/40 der Versuch, der neuen Provinz Oberschlesien fast alle früher im Osten verlorenen Gebiete wieder anzusiedeln, und endet schließlich 1945 mit der Austreibung der Deutschen und der damit verbundenen Wiederherstellung der Grenzen von 1937. Eine solche zeitlich und politisch-geographisch differenzierte Einordnung führte aber zeitlich und inhaltlich über den Rahmen der im Folgenden zu behandelnden Entwicklung der Teichwirtschaft hinaus und beschreibt hier aber die Schwierigkeit der geographischen Zuordnung, die mit der Aufteilung zwischen Polen und Tschechien verbunden ist:

Die hydrologische Situation erleichterte zunächst die Anlage von Teichen:

In Oberschlesien bedeckten sich seit 1440 die Talböden der Gebirgsflüsse, der Oder, Ostrawitza und Olsa, der Weichsel von Skotschau bis über Zator hinaus, der Lobnitz, Bialka, Sola, Wieprzówka und Skawa mit langen Ketten von Teichen. Auch an den Flüssen der Ebene, Plesserbach, Korzyniec,

\footnotetext{
${ }^{19}$ Entwässert wurde Schlesien fast ausschließlich von der Oder und ihren Nebenflüssen. Von rechts u. a. von Ruda, Birau, Klodnitz, Malapane, Stober, Weide, Bartsch und Faule Obra; von links: Oppa, Zinna, Hotzenplotz, Glatzer Neiße, Ohle, Lohe, Weistritz, Katzbach, Bober mit Queis und Lausitzer Neiße; außerdem im Nordwesten durch Spree und Schwarze Elster zur Elbe; im südlichen Randbereich durch Weichsel und Prosna.
} 
Gostyne und Mleczna, an Summina, Ruda, Birawka, Klodnitz, Himmelwitzer Wasser und Stober zogen sie sich hin, im Sandgebiet traten sie an allen geeigneten Stellen auf. Östlich von Oppeln mussten 1534 sogar drei Dörfer der Anlage des großen Kalischteiches weichen. Ein eigenes großes Teichgebiet liegt noch heute um Falkenberg an der Steinau und unteren Neiße (KUHN 1954:153).

Auf tschechischer Seite befindet sich mit Mähren-Ostrau das ehemalige „Westschlesien“. Durch das rechtsodrige Hügelland zieht hier von Westen nach Osten ein Band von ebenen Talniederungen von der Oder und unteren Olsa zur Weichsel: „Seit dem 15. Jahrhundert entfaltete sich in den Talniederungen eine ausgedehnte gutsherrliche Teichwirtschaft. Noch heute erfüllen zusammenhängende Ketten von Fischteiche einzelne Talzüge“" (KUHN 1954:25), an anderen Stellen hingegen zeugen „oft nur noch die alten eichenbestandenen Dämme, die mitten zwischen den Bauernfeldern verlaufen [...], von der ehemaligen Ausdehnung des Teichlandes“, beschreibt KUHN (:154) die semireliktäre Situation schon für die 1950er Jahre.

Wegweisend aber in dem Wirtschaftszweig der Teichwirtschaft „,waren die Landes- und Grundherren und sie führten die größten Anlagen aus“" (KUHN 1954:153). Teiche bis zu einer Spannfläche von 6 $\mathrm{km}^{2}$ wie der ,Große Beruner' sind bezeugt (:153). In Schlesien herrschten Großbetriebe mit Teichflächen von $100-500$ ha vor, einige Betrieb verfügten gar über mehr als 1.000 ha. Aber auch die Bauern, Schulzen und Pfarrer legten hier ,,in den Auen der Waldhufendörfer [...] ein Teichlein hinter dem anderen an." (:152) Zum Beispiel gab es in Deutschweichsel 1572 nicht weniger als 65 ,Bauernteiche' (:153). Vielfach bestand eine Arbeitsteilung in der Art, dass die schlesischen Kleinfürsten und Gutsherren ,die in den kleinen Dorfteichen gezogenen Jungfische aufkauften und in ihre eigenen Hauptteiche einsetzten.“ (:153)

Die Ausmaße der Teichwirtschaft müssen, legt man die dokumentierte Ausbeute zugrunde, erstaunlich groß gewesen sein: Aus den Teichen der Auschwitzer Krongüter wurden 1522663 Schock Karpfen ausgefischt, etwa $80.000 \mathrm{~kg}$, und „die Lustration von 1564 veranschlagte sogar 1039 Schock, die dem Verbrauch der königlichen Tafel in Krakau dienten“. (KUHN 1954:153f.). Ein Mehrfaches davon betrug die Herrschaft Pleß: „Fast drei Viertel der jährlichen Einnahmen entfielen auf die Teichwirtschaft und nur ein Viertel auf die Abgaben der Bürger und Bauern, die Erträge der vier Vorwerke aus Ackerbau und Viehzucht.“(:154)

Zwei herrschaftliche Teichwirtschaften sollen im Folgenden vorgestellt werden:

Die „Bartschniederung“ war eines ,der bedeutendsten früheren Teichwirtschaftsgebiete Deutschlands” (BLEICHER 1952:176, aus: RUST 1952:43). Die Teichwirtschaft der ehemaligen Standesherrschaften Militsch bzw. Mielitisch (poln.: Milicz) und Trachenberg liegt im Einflussgebiet der Bartsch. Die hydrogeographische Lage und das Klima bestimmten die Ausrichtung der Wirtschaft in der Region, die seit dem Mittelalter vor allem mit der Fischzucht verbunden ist. Allein das Fürstentum Trachenberg in Schlesien besaß 1752 ha Karpfenteiche (BORNE 1886:262).

An der Bartsch lag auch die „die erste fischereibiologische Forschungsstätte auf deutschem Boden“ überhaupt (WUNDER 1956:12): die 1895 vom Schlesischen Fischerei-Verein gegründete teichwirtschaftliche Versuchsstation zu Trachenberg ${ }^{20}$. Sie ist gegründet worden, ,nachdem Se. Durchlaucht Fürst Hatzfeldt-Trachenberg und Excellenz Graf Fred Frankenberg-Tillowitz in hervorragender Weise für Gründung und Fortbestand derselben gesorgt hat" (VOGELS 1898:477). Es bestand also, wie bei Michaelstein schon vor der Institutionalisierung der Trachenberger Fischzuchtanstalt eine - hier - herrschaftlich geführte Teichwirtschaft. Sie hatte zur Aufgabe erhalten, „noch ungeklärte Fragen der Wasserwirthschaft aus wissenschaftlicher Grundlage zu lösen“ (:477). Darüber hinaus sollten Lehrkurse für ausgebildete Teichwirte (nicht für Laien!) abgehalten sowie praktische Versuche in besonderen Versuchsteichen angestellt werden $(: 477,480)$. Aber bereits um das Jahr 1906 ging diese große teichwirtschaftliche Versuchsstation wieder ein. Das Interesse, so

\footnotetext{
20 Emil WALTER, der schon an vielfachen Stellen zitiert worden ist, war früher Leiter der teichwirtschaftlichen Versuchsstation Trachenberg; Eugen PROBST, ausgebildet in Weihenstephan, war Nachfolger von Walter.
} 
begründet WUNDER (1956:12) den Abgang, ,wandte sich immer mehr den Fischereiinstituten in München und Berlin zu.“

Die reiche teichwirtschaftliche Tradition der Stadt und der Umgebung ist vor allem einer Familie, der Familie von Kurzbach (ca. 1500 - 1590) zu verdanken, die nach den Zisterziensern die Karpfenzucht fortführte. Die damals häufigen Fastenzeiten und andere Gründe hatten den steigenden Bedarf an Fisch zur Folge, was mittelbar die Entwicklung der Teiche in der Umgebung von Militsch beeinflusste. Die Freiherren Kurzbach haben Aussiedler aus dem Schwabenland angeworben und neue Dörfer angelegt, sie haben Wälder gerodet, Dämme und Schleusen gebaut. Zu ihren Zeiten gab es schon den größten Teich: ,Krabownitze' - mit 500 ha Fläche.

Ein weitere bekannte große Teichwirtschaft liegt am kleinen Flüsschen Mietzel, nicht weit von der ehemaligen Kreisstadt Königsberg (Chojna) entfernt, gut $10 \mathrm{~km}$ von dem Dorf Warnitz (Warnice), südlich von Pätzig (Piaseczno) und östlich von Wartenberg (Chclm Dolny). Hier, in der Neumark als östlicher Teil der Mark Brandenburg, lag das ehemalige Gut Berneuchen (Barnówko) zu dem die Teichwirtschaft gehörte.

Als nach wechselhaften Besitzverhältnissen im Jahr 1863 der Kammerherr Gustav von dem Borne seinem Sohn Max Berneuchen übergab, war das ganze Rittergut von 12.000 Morgen Land „ein gesunder, vielseitiger, sich selbst tragender Organismus, ein Vorbild für einen fruchtbaren Gutsbetrieb. Es gab eine Wasser-, Mahl- und Schneidemühle. Durch Abtragungen unzulänglicher Löcher im Erdboden sowie durch Ausrodung von Forstparzellen waren Ackerfelder um das Doppelte vermehrt worden. Wo dürftige Weiden waren oder Sandschollen ganz unbenutzt lagen, entstanden größere Flächen von Föhrenforstland. Eine Kornbrennerei wurde angelegt. Diese Durchgestaltung und Ausnutzung von Grund und Boden wurde nun von meinem Großvater fortgesetzt. Es kam die Ziegelei Bornhofen dazu. Aber das kostbarste Vermächtnis war die Fischerei: Fischzucht und Teich- und Seewirschaft", so die historische Betrachtung von Kreuzwendedich v. dem BORNE (1985:13f.), dem Sohn Max v. dem BORNEs und letzter v. dem Borne, der auf Schloss Berneuchen im Jahre 1901 geboren wurde.

Die Erwähnung der „Seewirtschaft“ ist insofern von Bedeutung, als dass bereits Mitte des 17. Jahrhunderts, als Hans Georg v. dem Borne (1589 - 1656), „Churfürstlicher Rat und Cancelern bei der Neumärkischen Regierung“, den Besitz erwarb, natürliche Seen als Mitbesitz genannt werden: Blambeck, Roßkam, Dibelsee, Darsenow (BORNE 1985:13f.).

Aber erst Max v. dem BORNE baute die „natürliche Seenwirtschaft“ des postglazial überformten Areals weiter aus. Zwei Kanäle, vom Mietzelwasser bewässert, wurden angelegt und 1867 vollendet. Diese speisten die in Rieselwiesen angelegten Teiche, die ständig vermehrt wurden. „Diese Tat wurde bald weltbekannt, sie brachte ihm den Titel und Rang eines königlichen Kammerherrn ein, besonders weil er zielbewußt die deutsche, vaterländische Fischzucht verbessern wollte und konnte." (BORNE 1985:13f.)

Die Fischzucht von von dem Borne wird sogar literarisch verarbeitet. Sie wird in Theodor FONTANEs Roman „Irrungen, Wirrungen“ erwähnt, der 1887 erschien. Da heißt es nämlich von einem Buch über künstliche Fischzucht, dass man es endlich lesen müsse,

„und zwar aus Lokalpatriotismus; denn die Neumark, unsere gemeinsame glückliche Heimat, ist seit Jahr und Tag schon die Brut- und Geburtsstätte der künstlichen Fischzucht, und wenn ich von diesem nationalökonomisch so wichtigen neuen Ernährungsfaktor nichts wüßte, so dürfte ich mich jenseits der Oder im Landsberger gar nicht mehr sehen lassen, am allerwenigstens aber in Berneuchen bei meinem Vetter Borne. “

Auch Siegfried LENZ, der 1926 in Lynck, einer kleinen Stadt im masurischen Ostpreußen, geboren wurde, nimmt in seinem 1994 erschienenen Werk „Die Auflehnung“ vermutlich die Verhältnisse der 
Berneucher Teichwirtschaft an einer Stelle auf. Dort heißt es: „Der Bruder Frank Wittmann ist Fischmeister in der ererbten Teichwirtschaft.“

Von dem Schloss Berneuchen hingegen steht nichts mehr (MOES 1985:9f.). Am 31. Januar 1945 trafen die ersten russischen Panzer in Berneuchen ein und brannten es samt Kirche Anfang Februar nieder. „Nur der Fischer Krocke“, berichtet sein Nachfahre, „mußte die Fischteiche weiter pflegen und hüten“"(BORNE 1985:13f.).

Doch dem Niedergang der Güterteichwirtschaft infolge des Zweiten Weltkreiges ging ein Aufschwung voraus: Nach dem Bruch mit der Monarchie und Ende des Ersten Weltkrieges schloss sich Anfang der 1920er Jahre eine größere Anzahl von Teichwirtschaften in dem Teichwirtschaftlichen Versuchsring Schlesien zusammen, ,der es sich zur Aufgabe machte, eine Arbeitsbasis für Untersuchungen auf dem Gebiete der Teichforschung zu schaffen." (WUNDER 1956:13). 1938 entstand daraufhin an der Universität Breslau die Forschungsstelle für Teichwirtschaft und Fischzucht (:13). Auch die Universität Königsberg besaß ein eigenes Fischerei-Institut, das sich auch mit der Binnenfischerei beschäftigte. Gegenwärtig umfasst die Teichwirtschaft in Polen ca. 45.000 ha (SCHULTE 2000).

In den ehemaligen Reichsgebieten war die Karpfenteichwirtschaft auch vor allem in der heutigen Tschechischen Republik zu Hause, wo es im 16. Jahrhundert 180.000 ha Teiche in Böhmen (tschech. Cechy) und Mähren (Morava) gab (SCHÄPERCLAUS 1961:166f.). Bis zum Jahr 1959 schrumpfte dieser Bestand in Böhmen auf nur noch 52.000 ha Teichfläche. Der größte böhmische Teich umfasste zu diesem Zeitpunkt aber immer noch 711 ha Katasterfläche (:166f.). Der ,Böhmische Karpfen’ und der ,Galizier' „standen in hohem Ansehen“ (KEIZ 1995:19). Die galizische Teichwirtschaft ist durch ihn „,besonders bekannt geworden“ (SCHÄPERCLAUS 1961:167). Schon im 13. Jahrhundert gab es in Nordböhmen eine ganze Anzahl von planmäßigen Teichwirtschaften, die ihre Besatzkarpfen selbst zogen. Im 14. Jahrhundert kann man schon „,von einer blühenden Fischwirtschaft“ sprechen (SKOWRONNEK 1904:9).

In Südböhmen hingegen wurde die Teichwirtschaft im 13. und 14. Jahrhundert noch nicht planmäßig betrieben, der gesamte Karpfenabwachs ging in ein und demselben Teich vor sich. „Erst gegen Ende des 14. Jahrhunderts finden wir Ansätze für eine Systematisierung der Fischzucht. Im Ausgang des 15. Jahrhunderts wurde die Aufzucht schon meist entsprechend den Alterstufen der Fische vorgenommen (BUCHWALD 1879:28, aus: RUST 1952:29).

Ein Grund für dieses „Aufblühen“ in den böhmischen und galizischen Erbländern Österreichs war der Kaiser Maximilian I. (1459-1519) „,dem die Jagd- und Fischwaid über alles ging.“ (SKOWRONNEK 1904:9) „Mit seinen Interessen für die Fischwaid steht Maximilian I. ganz einzig da. Ich wüsste nicht einen einzigen Fürsten bis zur neuen Zeit namhaft zu machen, der sich auch nur im geringsten um die Bewohner des Wassers so bekümmert hätte, wie um die Tiere des Waldes.“(:10).

Ein anderer Grund lag auch hier wiederum in dem natürlichen Relief begründet: Böhmen bildet ein von waldreichen Gebirgen umschlossenes Gebiet (Böhmerwald im SW, Fichtel- und Erzgebirge im NW, Sudetenwald im NO und Böhmisch-Mährische Höhe im SO), das wiederum in einzelne Erhebungen gegliedert ist, zwischen denen Becken und Senken eingefügt sind, die sich vorteilhaft für die Anlage von Großteichen anboten

Als Schwerpunktort der Teichwirtschaft in Böhmen ist die ehemalige Domäne Wittingen zu nennen. Die Siedlung Wittingau entstand im 12. Jahrhundert an einem Handelspfad und gelangte zunächst in den Besitz des Geschlechts der Wittigonen. Der tschechische Name erscheint erst im 14. Jahrhundert, als der bereits zu einer kleinen Festung erweiterte Ort in den Besitz einer der einflussreichsten Familien in den böhmischen Ländern überging. Die Rosenberger kauften 1366 Trebon samt Umgebung und gründeten gleich zu Beginn ihrer Herrschaft die Kirche des heiligen Ägidius und später auch das Augustiner-Kloster, das von 1367 an existierte bis zu der Zeit des Kaisers Josef II., der die Klöster auflöste und so auch das Kloster in Wittingau. 
Die umfangreichen Teichländer hingegen waren nicht Werk des Klosters. Durch die die Burgsiedlung umgebenden Flussläufe und Sümpfe wurde zwar Wittingau zu einer uneinnehmbaren Stadt, aber für die Wirtschaft war das Gebiet praktisch nicht nutzbar. Deshalb riefen zu Anfang des 16. Jahrhunderts die Rosenberger Stepanek Netolicky (1460-1538) in ihren Dienst. Netolicky, eigentlich ein Fischer aus Netolice, wird als der "Architekt" der Teiche bezeichnet, die beginnend im Jahr 1505 geschaffen wurden. Sein Schüler Jakub Krcin von Jelcany setzt das Werk fort und schuf bzw. beendete den Bau von großen Teichen wie den ,Velky Tisy', ,Opatovicky', ,Zabov' und den „Horusicky'. Ebenso realisierte er den von Netolicky konstruierten, der Abwasserzuführung dienenden $48 \mathrm{~km}$ langen „Goldbach” genannten Kanal. In diesem 1513 bis 1531 gebauten „Goldenen Kanal“ (Zlata Stoka) wurden die zur Karpfenmast benötigten Nährstoffe zugeführt.

Diese beiden ,pisci culturists“ schufen die ganze künstlich angelegte Kultur- und Wirtschaftsnutzung des Gebietes, indem sie das Wasser aus dem Moorgebieten in gesicherte Senken umleiteten, wodurch sich die Teiche bildeten. Das andere trockengelegte Gebiet aber konnte für die Landwirtschaft oder die Forstwirtschaft genutzt werden.

Das komplexe Teichsystem war nun nicht nur die Basis für die Fischerei, es bildete auch die Grundlage für eine Land- und Forstwirtschaft. Nach dem Dreißigjährigen Krieg übernahmen die Schwarzenberger Fürsten die Herrschaft und bauten die Teichwirtschaft weiter aus. Zu ihrem Besitz zählten im zweiten Drittel des 19. Jahrhundert 187 Teiche von 5.564 ha Inhalt (BORNE 1886:262). Die dortigen Teiche wurden vor allem durch Zuflüsse von der Braun bespannt, aber auch die Lainsitz, Luschnitz (Luznice), die südlich von Weitra entspringt und nach ca. $180 \mathrm{~km}$ in die Moldau mündet, war ebenso wichtig für die Entwässerung der Wittingauer Teiche wie der Strobnitzbach (Stropnicka), der im Grenzgebiet zwischen Niederösterreich und Gratzen entspringt und bei Strobnitz in die Moldau entwässert.

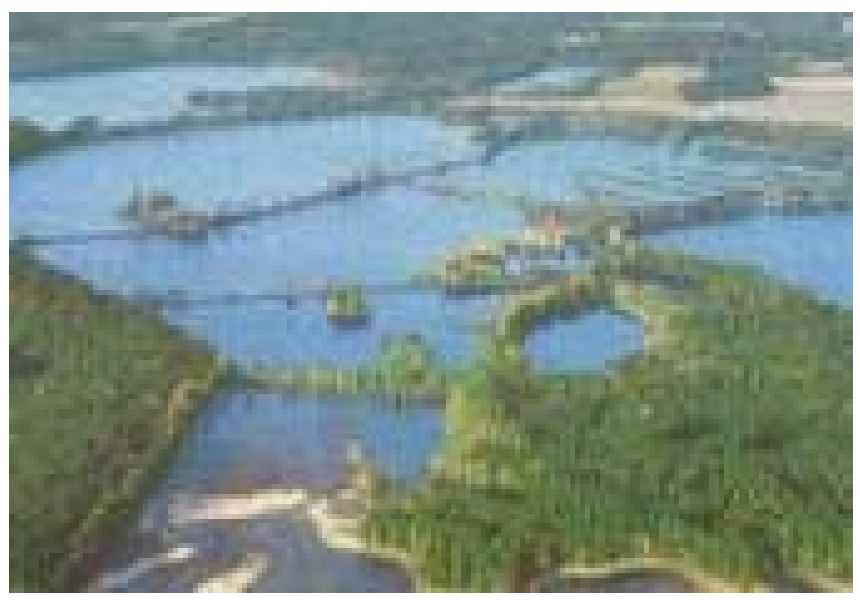

Abb. VIII-20: Teiche Wittingau

Tab. VIII-2: Einige Teiche im Wittingauer Teichgebiet

\begin{tabular}{|l|l|l|}
\hline Deutsch & Tschechisch & Beschreibung \\
\hline Hornitzer Teich & $?$ & -- \\
\hline Opatowitzer Teich & Opatovicky rybnik & Südl. Wittingau, 2 km lang, 1 km breit \\
\hline Rosenberger Teich & Rozmber, Rozmbersky rybnik & $\begin{array}{l}\text { Größter der Wittingauer Teiche, nördl. Wittingau, 3 km } \\
\text { lang 1 km breit }\end{array}$ \\
\hline Schwarzenberger Teich & Svarcenberk rybnik & $\begin{array}{l}\text { größter Teich d. östl. Wittingauer Teichplatte, bemerkens- } \\
\text { werte Form, Ost-Ufer bildet über 6 km die Grenze zu } \\
\text { Niederösterreich }\end{array}$ \\
\hline Stankauer Teich & Stankovsky rybnik & $\begin{array}{l}\text { Südwestlich Wittingau, 3 km lang, 1 km breit, wurde vor } \\
\text { über 400 Jahren vom Teichbauer Jakub Krcin konstruiert }\end{array}$ \\
\hline Welt (Teich) & Rybnik Svet, Svet \\
\hline
\end{tabular}


Als Ausläufer der südböhmischen Teichplatte befindet sich der Großteil der niederöstereichischen Teichflächen im oberen Waldviertel mit zirka 1.500 ha (PLANANSKY 1983:78). Die Entstehung der ,Waldviertler Teiche' geht nachweisbar bis in das 14. Jahrhundert zurück und Namen heutiger Teiche sind in alten Archiven schon aus der damaligen Zeit gleich geblieben (:78). Längs der österreichischtschechoslowakischen Grenze liegen die Teiche auf böhmischem Massiv in der Nähe der Orte Litschau, Eisenreich, Heidenreichstein, Gmünd und Kirchberg am Walde. Weiter von der Grenze entfernt befinden sich die Teiche bereits auf lehmigem Boden zwischen den Ortschaften Waidhofen, Geras, Altenburg (:78).

Die räumliche Trennung früher zusammenhängender Gebiete soll mit dem niederösterreichischen EUProjekt „Grenzüberschreitende Teichwirtschaft“ aufgehoben bzw. ausgeglichen werden. Es ist erkannt worden, dass die „unzähligen Karpfenteiche“ in der Region Waldviertel-Südböhmen „nicht nur ein prägendes Element der Kulturlandschaft, sie bilden auch eine wichtige Einkommensgrundlage für die Bevölkerung.“ Ziel des Projektes ist „die Stabilisierung des Marktpreises für Karpfen durch Koordinierung mit der südböhmischen Teichwirtschaft und dadurch die wirtschaftliche Absicherung der Teichwirtschaft.“ $\mathrm{Zu}$ besseren Koordinierung und Dokumentation der Bedeutung dieser „berühmten“ Region wird der Internationale Teichwirteverband seine Zentrale im Waldviertel errichten (NOEL 2003).

Obschon nicht zu den eigentlichen östlichen Reichsgebieten bzw. Protekoraten zählend, darf neben diesen Hauptgebieten der Fischzucht eine kleine, aber vielleicht die historische bedeutsamste Teichanlage nicht unerwähnt bleiben: das Mitte des 19. Jahrhunderts in Hüningen im Elsass gegründete „Etablissement de Pisciculture de Hunigue“, das 1871 an Deutschland überging (CNOPF 1927:147) und bis 1918 mit einem Teil von Lothringen das Reichsland „Elsaß-Lohtringen“ bildend.

Landwirt Stephan Ludwig Jacobi aus Hohenhausen hat, wie bereits ausgeführt, 1733 die Befruchtung des laichreifen Rogens durch die Milch bei gefangenen Fischen vorgenommen und diese Ergebnisse 1765 veröffentlicht (SKOWRONNEK 1904:12). Aber ,in die Praxis eingeführt wurde sie zuerst im Jahre 1848 durch Napoleon III., der zu Hüningen im Elsaß eine Fischzuchtanstalt gründete“, so SKOWRONNEK (:12f.). Das Gründungsjahr wird dabei nicht einheitlich wiedergegeben: Im Gegensatz zu SKOWRONNEK setzt CNOPF 1852 als Gründungsjahr fest.

Gegründet jedenfalls wurde zwar die Hüningsche Fischzuchtanstalt durch das französische Landwirtschaftsministerium, aber auf Betreiben eines Prof. Costé, der sich bei dem Fischer Remy in den Vogesen von der Wichtigkeit und dem Erfolg der Jacobi'schen Befruchtungsart überzeugt hatte. $1 \mathrm{~m}$ Jahre 1840 gelang es Remy, die für die Zucht notwendigen Techniken zu entwickeln und die leer gefischten Wildbäche und Teiche seiner Region mit Forellen wiederzubesiedeln.

Angesichts dieser Erfolge beauftragte der Staatsminister für Landwirtschaft Professor Costé, die praktischen Anwendungsmöglichkeiten der Forellenzucht zu prüfen. Wegen der Nähe zum Rhein und der Wasserqualität der Grundwasseraufstöße („Giessen“) wählte Costé 1852 das Gebiet der Petite Camargue aus, um die erste industrielle Fischzucht Europas zu errichten. Der Rhein war damals sehr fischreich und sollte die Millionen von Fischeiern liefern, die für die Wiederbesiedlung der Flussläufe Frankreichs und Europas benötigt wurden.

1860 waren die Gebäude und Teiche der Fischzucht fertiggestellt. Die Einrichtung erhielt den Namen Kaiserliche Fischzucht von Hüningen, da dies die einzige allgemein bekannte Stadt in der Umgebung war

Nach dem Französischen Krieg begann mit dem 1872 gegründeten Deutschen-Fischerei-Verein eine „letzte erfreuliche Periode der deutschen Fischereigeschichte“ (SKOWRONNEK 1904:13) und die Anlage wurde für 6 Millionen Eier ausgebaut.

Mitunter aus dieser Entwicklungsgeschichte heraus zeichnete sich ebenfalls das Keuperland Lothringen, „durch eine bedeutende Teichwirtschaft“ aus und wies in den 1920 Jahren „eine Ausdehnung von rund 4100 ha Weiherfläche" auf (CNOPF 1927:26). 
Zusammenfassend betrachtet lagen die „Hauptpflegestätten der Teichwirtschaft“ (WUNDER 1956:5) im zentralen Mitteleuropa seit dem 14. Jahrhundert in Schlesien, vor allem in der Ober- und Niederlausitz und ihren Nachbargebieten mit ihren großen Karpfenteichwirtschaften. Große Teichwirtschaften sind des Weiteren vor allem aus Böhmen mit seinem österreichischen Grenzgebiet und aus Franken (Nordbayern) bekannt. Es folgen die gutsherrlichen Teichwirtschaften in SchleswigHolstein, Mecklenburg und Ostpreußen.

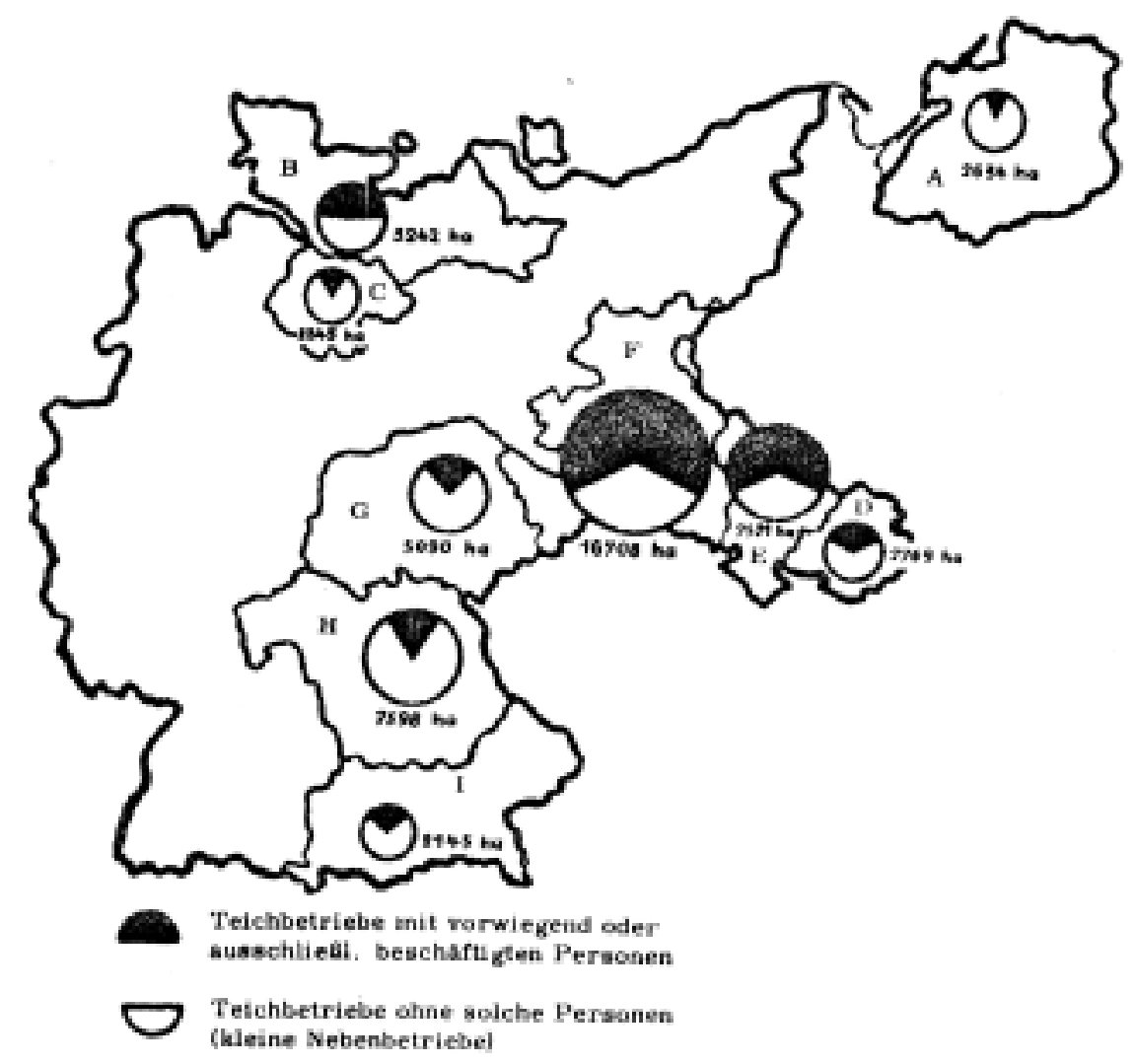

Abb. VIII-21: Die Hauptteichgebiete Deutschlands in seinen Grenzen bis 1945 (Stand 1925).

A. Ostpreußen, B. Schleswig-Holstein, Mecklenburg, C. Bezirk Lüneburg, D. Oberschlesien, E. Bezirk Breslau, F. Lausitz und Nachbargebiete, G. Mitteldeutschland (Westsachsen, Thüringen usw.), H. Nordbayern, I. Südbaden. Insgesamt besaßen diese Gebiete eine Teichfläche von 50.053 ha. Mit den sonstigen Gebieten, die über eine Teichfläche von 9.851 ha verfügten, addierte sich die Fläche an Teichland auf 59.903 ha (aus: RUST 1952:145, Karte 16, hat insges. 59.919 ha berechnet[sic]).

In all diesen Gebieten ist das Landschaftsbild charakterisiert durch miteinander verflochtene, mehrteilige und verkettete Teichanlagen, die als „Teichfluren“ bezeichnet werden können. Es handelt sich bei diesen, oft viele 100 Hektar großen mittelalterlichen und frühneuzeitlichen Teichflächen dabei zumeist um Anlagen der Karpfenzucht. 


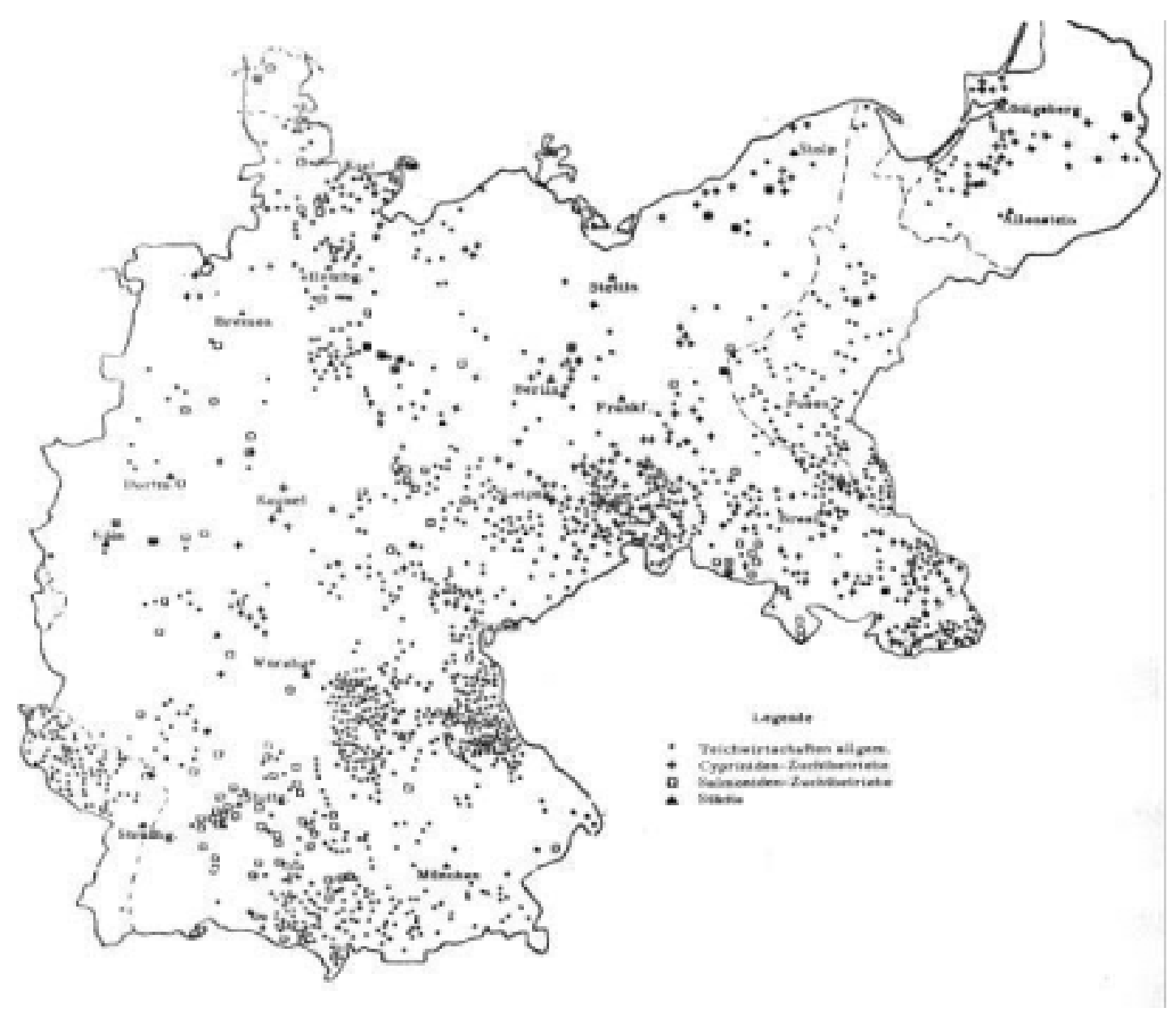

Abb. VIII-22: Die wichtigsten Teichwirtschaften Deutschlands im Jahr 1915

(nach SMOLIAN, K.: Merkbuch der Binnenfischerei, Karte II; entnommen aus: RUST 1952:143)

Aber nicht zu vergessen sind die vielen „kleineren“, zahlreichen Teichgebiete ehemaliger Güter und Klöster sowie, Ende des 19. Jahrhunderts beginnend, der Fischerei-Versuchsanstalten, die oftmals auf diesen alten Anlagen aufbauten und ein singuläres Erscheinungsbild von Teichflächen inmitten der Kulturlandschaft bieten. Überhaupt ist es die Vielzahl an kleineren Teichwirtschaften, die ein generalisiertes Aufzeigen der Verbreitung so schwierig machen.

Und schließlich die unzähligen Kleinteiche in den wasserreichen Tälern, die in ihrer dispersen, nicht zusammenhängenden, aber dennoch ubiquitären Verbreitung rein zahlenmäßig die Mehrheit der Teichanlagen gestellt haben dürften. Sie konnten nur vereinzelt Berücksichtigung finden.

Doch „da sich die Teichwirtschaft in Mitteleuropa zeitlich und räumlich gleichartig entwickelte, ist man berechtigt, aus anderen Landschaften vergleichende Rückschlüsse zu ziehen.“ (RUST 1952:29) Das Bild, das hinsichtlich ihrer räumlichen Verbreitung sowie ihres zeitgeschichtlichen Aufstrebens und ihres Niedergangs anhand von regionalen und lokalen Beispielen gezeichnet worden ist, kann insofern auf die Vielzahl der nicht genannten Teichwirtschaften übertragen werden. 


\section{Wassermühlen}

Die verlassene Mühle

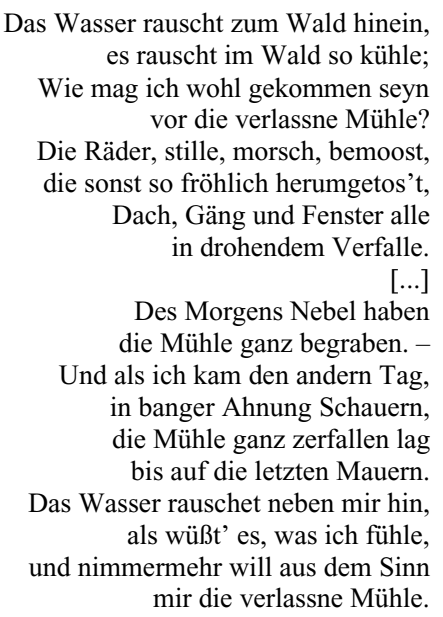

[August SCHNEZLER ${ }^{21}$ ]

\section{a Historisch-umweltgeschichtliche Entwicklung}

„....die Wassermühle mit dem Mühlrad am plätschernden Bach, angeregt durch ihre besondere Lage in einem Talbett, umgeben von alten Bäumen oder einem davorstehenden Lindenbaum; und daneben der aufgestaute Mühlteich“, dieses Idealbild, wie es BOSSE noch 1991 (:140) beschreibt und es auch in dem obigen Vers des feuchten, Morgennebel durchzogenen Mühlentales zum Ausdruck kommt, gibt es dem Gedichtauszug August SCHNEZLERs zufolge bereits in der späten ersten Hälfte des 19. Jahrhunderts nicht mehr. Doch bis dahin und in einigen Fällen noch zeitlich darüber hinaus, prägten und bestimmten die Wassermühlen über viele Jahrhunderte die Gewässerlandschaft. Die verbliebene Restbestände stellen heutzutage wertvolle „Technikzeugnisse einer historischen Kulturlandschaft” dar (ERLER/MATTHIESEN 1989:23), denn das Klappern der Mühle am rauschenden Bach ist längst verstummt...

Pflug und Wassermühle waren die bestimmende Technik, die Arbeit, Produktivität, Wirtschaft und Gesellschaft des Mittelalters in entscheidender Weise beeinflussten. Beide entstammen dem Erfindungsgeist der römischen Antike. Römische Ingenieure hatten um Christi Geburt begonnen die Kräfte des Wassers für den Antrieb der Mahlvorrichtungen zu nutzen und hatten nachfolgend die geniale Kombination vom Wasserrad, Getriebe und Mahlwerk fast bis zur Perfektion entwickelt. Bald waren diese Mühlen im gesamten römischen Einflussbereich verbreitet (DOBELMANN 1980:7; GRIES 1999:120). Die Kenntnis über ihre Technik geriet jedoch in der Völkerwanderungszeit, wie so viele antike Errungenschaften, in Vergessenheit (MÜLLER/LUDWIG 1982:122).

Den ältesten literarischen Hinweis einer wasserbetriebenen Anlage für Deutschland (lat. molina) finden wir bei dem römischen Dichter Decimus Magnus Ausonius (um 310 - 395 n. Chr.), dem ersten Moseldichter und Erzieher des Kaisers Gratian im 4. Jahrhundert in Trier in seiner Schilderung einer

\footnotetext{
${ }^{21}$ SCHNEZLER, August ( 1809 Freiburg i. Br. $-\dagger 1853$ ): studierte in Freiburg und München, lebte als Schriftsteller an verschiedenen Orten. Er übernahm vor allem Sagen in seine Gedichte, nicht nur wie im vorliegenden Fall der ,verlassenen Wassermühle“, wo Zwerge sie des Nächtens auf wundersame Weise zum Laufen bringen, sondern auch in anderen Fällen (z. B. „Der Lilienstengel“ und das vertonte Gedicht „Der Mummelsee“). Das 1846 erschienene, aber vielleicht schon viel früher verfasste Gedicht „Die verlassene Mühle“, gehört zu den 1100 wichtigsten Gedichte der deutschen Literatur aus dem Zeitraum zwischen 1730 und 1900 und belegt dort Platz 450. Diese Zusammenstellung und Platzierung basiert auf der Auswertung von 14 Gedichtanthologien, die im Projekt „Klassikerwortschatz“ der Universität Freiburg ausgewertet worden sind [siehe für weiteres http://www.klassikerwortschatz.uni-freiburg.de].
} 
Rhein-Mosel-Reise. Demnach lag die erste Wassermühle im deutschen Raum an einem Nebenfluss der Mosel - wahrscheinlich der Kyll - und dürfte um 370 errichtet worden sein (DÜRING 1977: 8; MERTES 1995:22). Funde von Mühlsteinen und Mühlanlagen in der Nähe der Kyll, bei Virneburg und Wasserspeicher an der Nitz oder bei Lösnich an der Mosel belegen nach Ansicht von MERTES (1995:22) diese Angaben in Liedform. KREINER (1996:90) spricht von vereinzelten frühen Mühlenbelegen schon ab dem 2. Jahrhundert $\mathrm{n}$. Chr. an der Ruwer, einem rechtsseitigen Nebenfluss der Mosel, ohne aber Quellen zu benennen.

Nach diesen Belegen wurden also in Eifel und Hunsrück, also beiderseits der Mosel, die ersten Wassermühlen zur Römerzeit errichtet. „Von der Mosel und Eifel aus“, so wird der weitere Expansionsvorgang beschrieben, „haben sich in der nachrömischen Zeit die Wassermühlen nach und nach über ganz Deutschland verbreitet.“ (MERTES 1995:22). Sie wurden früher auch als Fränkische Mühlen bezeichnet, denn ,die Franken haben sie von den Römern übernommen, als sie die Eifel einnahmen" (:22). Die ersten Nachweise für die anschließende fränkische (merowingische) Zeit des 6./7. Jahrhundert lassen sich folglich ebenfalls an der Mosel und ihren Nebenflüssen, sowie weiter nördlich an Neffel-Bach und Rot-Bach im Umfeld Zülpichs feststellen (DOBELMANN 1980:7; KREINER 1996:90). Das technische Prinzip der Mühle war also schon sehr alt, als die Franken dort ihre ersten Mühlen an Bächen und Flüssen errichteten.

Karl der Große richtete sie in der Nähe seiner Königshöfe ein und erließ auch bald das erste Mühlenregal. Er verfügte im Mühlenregal von 812, dass jeder Königshof mit einer Mühle auszustatten sei. Es ist anzunehmen, dass die Errichtung einer Mühle, gleichsam den Fischteichen, an jedem Fürstenhof oder Gutshof die Regel wurde, wo nur immer die Voraussetzungen gegeben waren (LANGE 1989:24; vgl. auch HOEK 1986:11). Damit ist der Auffassung KREINERs (1996:93), „der Adel dürfte in der Transferierung der Mühlentechnologie [...] wohl keine Rolle gespielt haben " und auch der Ansicht SCHRÖDERs (1978:9), die Klostermühlen wären „die frühesten Wassermühlen” gewesen, sowie der Aussage von LAMPEN (2000:132), die ersten Mühlen ließen sich ,ausschließlich im klösterlichen Umfeld nachweisen“ zu widersprechen. Wie in der Teichwirtschaft nimmt der Adel eine besondere Rolle in der Verbreitung der Wassermühle ein, zumindest in der „Startphase“. Für diese These spricht allein auch die Tatsache, dass die Abteien und Klöster die ersten Mühlen aus der Hand des Königs und des Adels übereignet erhielten.

Wie die großen Waldungen sehr bald zu Bannforsten erklärt wurden, so trat schon frühzeitig eine Änderung im Fischereirecht ein, indem die größeren Gewässer, vorzüglich schiffbare und flößbare Bannwässer erklärt wurden, ein die Fischereinutzung einschließendes Hoheitsrecht, das zunächst nur dem König zustand. Dieses wurde bald auch den Landesherren verliehen.

Im Laufe der Entwicklung und der herrschaftlichen Bestrebungen, das Nutzungsrecht auf die nicht öffentlichen (nicht schiffbaren) Gewässer auszudehnen, entwickelte sich allmählich die Auffassung eines Fischereiregals, demzufolge die Fischereiberechtigung und Nutzung auch in nicht öffentlichen Gewässern nur den Landesherren zustand.

Da jedoch die einzelnen Dynasten das ihnen zustehende Fischereinutzungsrecht nicht voll durchführen konnten, so belehnten sie die Grundherrschaften, Gemeinden und vor allem die Klöster mit dem Fischereiregal (CNOPF 1927:12f.).

Bei den Grundbesitzübereignungen (Schenkungen) an Klöster und Belehnungen an Höfen und Höfegruppen war die Formel „aquis aquarumque, molendinis, piscationibus“ (lat.: „, mit den stehenden und fließenden Gewässern, den Mühlen, den Fischereien“) im 8. und 9. Jahrhundert n. Chr. allgemein üblich (VOGT 1998:16f.). Das ist ein starkes Indiz dafür, dass Wassermühlen damals doch schon zum selbstverständlichen Bestandteil von Höfen und Höfegruppen gehört haben müssen (VOGT 1998:16f.) und insofern muss die Ordnung des Königsguts unter Karl dem Großen (Capitulare de Villis) das Bestehen von Wassermühlen offenbar vorausgesetzt haben, denn um 815 waren zu dieser Zeit die Wassermühlen im fränkischen Reich schon weit verbreitet. Von der ersten Mühle in Schwetzingen beispielsweise, die wohl mit Wasserkraft betrieben wurde, wurde 783 berichtet. Es handelte sich um eine Schenkungsurkunde an das 764 gegründete Kloster - spätere Reichsabtei - Lorsch in Schriesheim 
a. d. Bergstraße (MOSSEMANN 1971:4), in deren Besitz weitere fünf Wassermühlen genannt werden (KREINER 1996:91).

Im Gebiet des späteren deutschen Reichs tauchen Wassermühlen erstmals im bayerischen und alemannischen Gebiet auf. Untersuchungen der Salzburger, St. Galler und Freisinger Traditionsnotizen belegen die Verbreitung in diesem Gebiet für das 8. Jahrhundert (LAMPEN 2000:132). Mit dem Beginn der Anwendung der Wassermühlentechnik wird mit Wassermühlen auch für den westfälischravensbergischen Raum im 8./9. Jahrhundert gerechnet (MÖRSTEDT 1995:268).

Aber auch im nördlichen, wikingerzeitlichen Dänemark sind im 9. Jahrhundert Wassermühlen in Betrieb gewesen (SCHÖN 1995:113) und einige Autoren haben für dieses Jahrhundert Beweise für das Vorkommen der Wassermühle auch beiderseits der Unterelbe gefunden (ROSENBOHM 1956:242; KLEEBERG 1964). Bei Grabungen im Bereich des Bachbettes (Bachbettstratigraphie) von Haithabu sind 1935/36 Holzkonstruktionen freigelegt worden, die JANKUHN (1936:113) und nachfolgend auch HÜBENER (1959:187) als Rinnenleitung bzw. Aufstauungseinrichtungen und Wasserrad ableiten und als Überrest einer Wassermühle des 9. Jahrhundert deuteten. Auch nach Ausgrabungen eines Wasserlaufs, von Steinpflasterung, Holz- und Mahlsteinfunde etc., in Limburg und Brabant sollen die ersten Wassermühlen der Niederlande aus dem 8. und 9. Jahrhundert stammen (FOCKEMA 1952; aus: SCHÖN 1995:90).

Die weitere Vermittlung hingegen übernahmen die damals gegründeten Klöster als „Träger des technischen Fortschritts“. Wassermühlen entstanden in der Nähe der Klöster und wurden zum Teil von ihnen im Rahmen der Kultivierungsarbeit angelegt (SCHRÖDER 1978:7). Neben den Korn- und Walkmühlen zählten zu den klösterlichen Leistungen auf diesem Gebiet bereits im 9. Jahrhundert die Eisenhämmer, die von Mühlrädern bewegt wurden (MÜLLER/LUDWIG 1982:135). Die Wassermühlentechnologie wurde, ,also schon im Frühmittelalter auch in die relativ dünnbesiedelten Waldgebiete eingeführt.“ (KREINER 1996:91) Aus dem Odenwald ist beispielsweise bekannt, dass im Jahr 877 der Klosterbesitz um einen Adelshof in Leutershausen erweitert wurde, der weitere 3 Mühlen in Schriesheim besaß, die vom wasserreichen Kanzelbach betrieben wurden (MOSSEMANN 1971:4).

Für die Ausbreitung der Wassermühlen seit dem Frühmittelalter (nicht aber die massenhafte Verbreitung, die erst im Hochmittelalter einsetzt), 1935 von Marc Bloch als „Siegeszug“ bezeichnet, war „aber erst der beginnende demographische Aufschwung des 8. Jh. [...] die Grundlage für die explosionsartige Ausbreitung der Wassermühle in ganz Westeuropa.“ (KREINER 1996:90) Wassermühlen wurden zu einem zentralen Gegenstand der frühmittelalterlichen Wirtschaft, da sie es ermöglichten, natürliche Energiequellen für Getreideherstellung nutzbar zu machen (LAMPEN 2000:132).

Schwierigkeiten treten auch heute noch nicht nur bei der Datierung, sondern auch bei der Standortbestimmung auf. Die Meinungsverschiedenheiten gehen dahin, ob Wassermühlen an künstlichen oder natürlichen Wasserläufen angelegt worden sind. Die vergleichende Literatur aus Niedersachsen sagt aus, ,daß Mühlen in jener frühen Zeit nur an natürlichen Wasserläufen angelegt wurden." (BINTZER 1991:6) Die Ergebnisse von aus Bohrungen gezogenen Bohrkernen an heute still gefallenen Wasserläufen, an denen Wassermühlen gelegen waren, belegen, dass zum Beispiel die wilden Wasser der Werra vor Jahrhunderten nördlich des heutigen Laufes flossen. Es handelt sich dabei also nicht um künstlich angelegte Mühlgräben. Mitunter sind aber auch vorzugsweise stille Seitenarme zu „Mühlgräben“ umfunktioniert worden.

Eine weitere Schwierigkeit besteht in der Prüfung der Aussage, „,bei Errichtung des römischen Reiches im Jahre 534 gab es nur Mühlen an öffentlichen Flüssen und Kanälen, nicht aber an kleinen Bächen und Quellwasser.“ (LANGE 1989:53) „Das alte römische Recht“, argumentiert LANGE (:53), „,regelte wohl die Wasserrechte, aber hinsichtlich des Zufließens von Quellwasser hatte es eine Lücke gelassen“: das Recht auf Bäche und Bachquellen. Auch das aus dem königlichen Wasserrecht abgeleitete „Mühlenregal“ - die zentrale Staatsgewalt des 12. Jahrhunderts - verlangte lediglich die Baugenehmigung des Königs für Wassermühlen an größeren schiffbaren Flüssen mit der Bedingung, nicht die Schifffahrt zu behindern (MAGER et al. 1989:128). 
Die genehmigungsfreie Nutzung des bloßen Zufließens von Quellwassers, entschied das ergänzende deutsche Recht laut Urteil höchster deutscher Gerichte, gab dem unteren Grund- oder Mühlenbesitzer kein Recht auf dieses Wasser gegen den Quell-Eigentümer, um diesen in der Verwendung des Wassers zu beschränken (LANGE 1989:53). In karolingischer und fränkischer Zeit gründete sich das Recht zur Errichtung und zum Betrieb einer Mühle auf den Gemeingebrauch an Gewässern (Gemeindemühlen) (MOSSEMANN 1971:4). Dies hatte nicht nur weitreichende Folgen für den Mühlenbetrieb an den Unterläufen, sondern führte auch zur Anzapfung vor allem kleinster Bach- und Quellläufe, die für viele Mühlenbesitzer, vor allem der an den Quellbächen liegenden Wassermühlen, später zum Verhängnis werden sollte (LANGE 1989:53). Sie nämlich konnten mit dem normalen Wasserfluss keine Mühle antreiben.

Wann zum Ausgleich des spärlichen Wasserflusses die ersten Mühlteiche entstanden sind, weiß man nicht, weil die schriftlichen Quellen fehlen. Es ist jedoch anzunehmen, dass zunächst einfache Quellstauungen gebaut wurden, aus denen das Wasser in einem Mühlkanal zum Wasserrad geleitet wurde. „Mit den ersten Mühlennennungen“, die - wie bereits beschrieben - ab dem 6./7. Jahrhundert, aber vor allem seit dem 8. Jahrhundert auftauchen, ,können wir damit wohl auch die ältesten weiherartigen Gewässer datieren“ (KONOLD 1991:355).

Diese wurden nicht nur einseitig als Mühlenstau betrieben, sondern auch zur Fischzucht benutzt. Die enge Verbindung von Mühlen und Fischereien, wie sie auch Abtsviten ${ }^{22} \mathrm{zu}$ entnehmen sind, bestätigen, dass Mühlteiche schon früh als Fischhälterungsbecken genutzt wurden. Die Verbindung von Mühlen und Fischteichen wird darüber hinaus auch durch die urkundliche Überlieferung belegt. Bei der Vergabe von Mühlrechten ist in der Mehrzahl der Urkunden das Fischereirecht eingeschlossen. Die Mühlenteiche bildeten somit den Nährboden für die mittelalterliche Teichwirtschaft. Die aufgestauten Mühlteiche, die ein gleichbleibendes Betreiben der Mühlräder gewährleisten sollten, boten sich in idealerweise Weise als Hälterungsbecken für Fische an. Die Fischerei wurde zu einem beliebten Nebenerwerb der Mühlenbetreiber. Der Beginn der Teichwirtschaft muss demzufolge im Zusammenhang mit der Einführung der Wassermühlen im 9. Jahrhundert gesehen werden, die ebenfalls zuerst im klösterlichen Milieu auftauchten. Durch die Intensivierung des Mühlenbaus und die dort erworbenen wasserbaulichen Kenntnisse konnte sich auch die Teichwirtschaft weiter verbreiten (LAMPEN 2000:132ff.). Dies wird auch in dem Namen ,Forelle Müllerin' deutlich.

Alte Hinweise auf Mühlen verdichten sich dann ab dem 10. Jahrhundert. Die Mönche - vor allem die Benediktiner und die Zisterzienser - bauten zwischen dem 10. und 12. Jahrhundert ihre Klöster und wurden aufgrund ihrer mathematischen und physikalischen Kenntnisse „zu den tragenden Kräften der Mühlenbaukunst“ (VOGT 1998:14). Das Kloster „als Wirtschaftszentrale der von ihm beherrschten Grundherrschaft“ war „Ausgangsort entscheidender Anstöße zur Modernisierung von Arbeitsprozessen und Energiegewinnung”, wie MÜLLER/LUDWIG (1982:131) es formulieren. Es waren deshalb auch sie, die Klöster, die für die Mühlen ,im großen Stil Investitionen für die größten und teuersten mittelalterlichen Maschinen wagten“" (:131). Deshalb ist es nicht erstaunlich, dass sich Klostermühlen so rasch verbreiteten wie die Klöster (VOGT 1998:15). Die Erwähnung einer Mühle in der Inschrift des Tympanon in der Engerschen Stiftskirche beispielsweise stammt vermutlich aus dem 10. Jahrhundert und ist damit die früheste Nachricht zur reichen Mühlengeschichte im Kreis Herford überhaupt (MÖRSTEDT 1995:268).

Im gleichen Maße wie die Getreideanbauflächen wuchs der große Bedarf an Getreidemühlen exponentiell an. Aber erst mit der systematischen Rodungstätigkeit ab dem 11. Jahrhundert, der Anlage

\footnotetext{
${ }^{22}$ Die Erstellung von Abtviten bzw. Heiligenviten fällt in das Aufgabenfeld der Hagiographie. Sie umfasst sowohl die Darstellung des Lebens von Heiligen und deren Persönlichkeitsdarstellung (Abtsviten im eigentlichen Sinne), als auch die wissenschaftliche Erforschung solcher Darstellungen und der damit verbundenen Legenden. Die Hagiographie im eigentlichen Sinne will das Leben bedeutender Mitglieder der Kirche als Vorbild für die Nachwelt festhalten. Dabei treten historische Fakten oft hinter dem exemplarischen (gleichzeitig auch ideologischen) Charakter der Lebensbeschreibungen zurück.

Die Geschichte der Hagiographie beginnt im 2. Jahrhundert mit Lebensbeschreibungen von Märtyrern, Asketen und Mönchen. Im Mittelalter, der Blütezeit der Hagiographie, gibt es Lebensbeschreibungen fast aller bedeutenden Heiligen der Kirche. Im übertragenen Sinne bezeichnet der Begriff Hagiographie eine „unkritische und euphemistische Biografie, die dem Beschriebenen quasi einen ,säkularen Heiligenschein’ verleihen soll“ (WIIPEDIA - die freie Enzyklopädie 2004).
} 
größerer Ackerflächen und der neuen Anbaumethode der Dreifelderwirtschaft nahm der Bedarf an Mühlen zur Verarbeitung des Getreides zu (VOGT 1998:16f.). Zugleich verbesserten Mühlen die Mehlqualität und den Ertrag und machten so also die Versorgung großer Abteien mit dem Hauptnahrungsmittel Brot erst möglich.

Gleichwohl sind Ersterwähnungen bis zum 12. Jahrhundert selten (VOGT 1998:16f.). Dies liegt gewiss an der allgemein geringen Überlieferungsdichte aus jener Zeit. Die Zahl der Wassermühlen im 9. bis 11. Jahrhundert dürfte in Wirklichkeit wesentlich höher gelegen haben, aber die dürftige Quellenlage lässt keine besseren Angaben zu. Zudem gilt es, die schwache Besiedlungsdichte zu berücksichtigen, die grundsätzlich eine zu hohe Vorstellung der Zahl an Wassermühlen nicht erlaubt. Die nächstälteren Nachweise stammen dann aus dem 13. Jahrhundert.

Den Mühlenanlagen der Klöster folgten in Zusammenhang mit dem im 13. und 14. Jahrhundert durchgeführten Bau von Landesburgen, landesherrliche Mühlen an den Burgorten sowie nach und nach auch Mühlenanlagen in Nähe der Landsitze ritterlicher Grundherren, der Burgmannen der einzelnen Festungsorte. „Wassermühlen“, schreibt DÜRING (1977:24), „waren die ersten Wirtschaftsanlagen eines Ritterhofes". Zudem entstanden mit der Zeit Mühlenanlagen in manchen den Klosterund Burgmühlen allzu fern gelegenen Kirchspielen (SCHRÖDER 1978:9).

Die Verbreitung von Mühlteichen ist demzufolge auch gebunden an Burgstandorte, denn üblicherweise gehörte zu einer Burg ein Wirtschaftshof sowie eine oder mehrere Mühlen und dazu wiederum ein Mühlweiher. „Sie lagen ja ohnehin meistens direkt am Wasser und hatten als Wasserburgen in der Niederung einen natürlichen oder künstlichen Zulauf für ihre Burggräben.“ (VOGT 1998:16f.) Dafür spricht auch, dass das ursprüngliche Königsrecht, Mühlen an Flüssen, Bächen und Teichen anlegen und betreiben zu können, das sog. Mühlenrecht, im hohen Mittelalter immer zahlreicher auf die Landesherren überging (MAGER et al. 1989:128). Erst in nachfränkischer Zeit wurde aus dem Gemeinrecht in vielen Gegenden ein obrigkeitliches oder grundherrliches Recht zur Anlegung und zum Betrieb von Mühlen. Mit dieser neuen Rechtslage und der wachsenden Einwohnerzahl stieg auch auf deutschem Boden die Zahl der Mühlenneubauten. Zunächst errichteten die Territorialfürstentümer in ihren landesherrlichen Besitzungen - den späteren Ämtern - „die ja in der Regel an Fließgewässern lagen, eigene Wassermühlen.“ (BOSSE 1991:20; siehe auch Pkt. V 2a). Die Grundherren verpflichteten ihre Bauern, in den herrschaftlichen Mahlbetrieben mahlen zu lassen. So entstand für die einzelnen Dörfer der Mühlenbann (MOSSEMANN 1971:4). Parallel zu dieser rechtspolitischen Entwicklung stieg die Einwohnerzahl auf dem Lande, in den Burgsiedlungen und den aufblühenden Städten und damit der weitere Bedarf an neuen Mühlen. Die Wassermühlen waren für die Versorgung die wichtigsten Produktionsstätten und brachten regelmäßige und hohe Einnahmen für die Territorialherren und ihre zahlreichen Lehnleute (VOGT 1998:16f.).

Die Angabe im „Domesday-Book”,23, einer quantitativen Erfassung des englischen Wirtschaftsbestandes im 11. Jahrhundert, zählt immerhin 5.624 Wassermühlen. Statistisch kam so auf etwa 50

\footnotetext{
23 „Domesday Book“: Schriftliche Aufzeichnung einer von Wilhelm dem Eroberer 1086 angeordneten, systematischen Untersuchung über die Grundbesitzverhältnisse in England. Wilhelm der Eroberer ( 1027/28 Falaise [Frankreich, Dép. Calvados] - $\uparrow 1087$ Rouen [Frankreich, Dép. Seine Maritime]), war als Wilhelm II. ab 1035 Herzog der Normandie und ab 1066 erster normannischer König von England. Bedeutende Neuerung seiner Regierung war die Umgestaltung des englischen Lehens- und Verwaltungssystems. Er löste die großen und unter den angelsächsischen Herrschern weitgehend unabhängigen Grafschaften auf und teilte den Grundbesitz unter den normannischen Gefolgsleuten auf.

Mit dem „Domesday Book“ (Reichsgrundbuch), einer Art Grundkataster des Landes, ließ er nahezu die gesamte Besitzaufnahme (Ausnahmen siehe unten) erfassen. Die Erhebung wurde von königlichen Beamten, den legati, mittels öffentlichen Befragungen in jeder Grafschaft durchgeführt. Der Fragenkatalog, die Inquisitio Eliensis, wurde den Vertretern der Städte und Grafschaften vorgelegt; aus den Antworten wurde dann das Domesday Book kompiliert, das dann als Grundlage für die Besteuerung, die Verwaltung und die Gerichtsbarkeit in England diente. „Domesday“ ist eine Verkürzung von „Doomesday“ (engl. „Jüngstes Gericht“); das Buch wurde so benannt, weil seine Festlegungen hinsichtlich Steuern und Abgaben unwiderruflich waren.

Das Originalmanuskript bestand aus zwei Bänden. Der erste und umfangreichere, das „Great Domesday Book“, enthielt die Daten von ganz England, mit Ausnahme der drei östlichen Grafschaften (Essex, Suffolk und Norfolk), einiger Gebiete im Norden Englands, Londons (die Einträge sind nicht erhalten) und einiger anderer Städte wie Winchester. Die Erhebungen über die drei östlichen Grafschaften waren im zweiten Band, dem „Little Domesday Book“, enthalten. Die beiden Bände wurden erstmals 1783 veröffentlicht, ein Indexband 1811, und ein Zusatzband mit der Inquisitio Eliensis kam 1816 heraus.
} 
Haushalte jeweils eine Mühle (MÜLLER/LUDWIG 1982:135). In dieser Zeit begann man auch in Deutschland und anderswo in Europa, mit der Wassermühle vertrauter zu werden (:135). Der zeitliche Schwerpunkt beim Bau neuer Wassermühlen liegt aber zum Beispiel für den gesamten Niederrhein erst zwischen 1350 und 1600 (VOGT 1998:16f.). Doch nicht nur über das ganze Erftgebiet breitete „sich die Wassermühlentechnik im Hochmittelalter flächendeckend“ in diesem Zeitraum aus (KREINER 1996:94), sondern auch im gesamten Tiefland sowie in gebirgigen Gegenden. Denn während die Wassermühlen bereits im frühen Mittelalter allgemeine Verbreitung fanden, ist die Windmühle erst eine Erfindung des ausgehenden Mittelalters. In Holland erbaute man die erste Windmühle im Jahre 1439 (SCHRÖDER 1978:8).

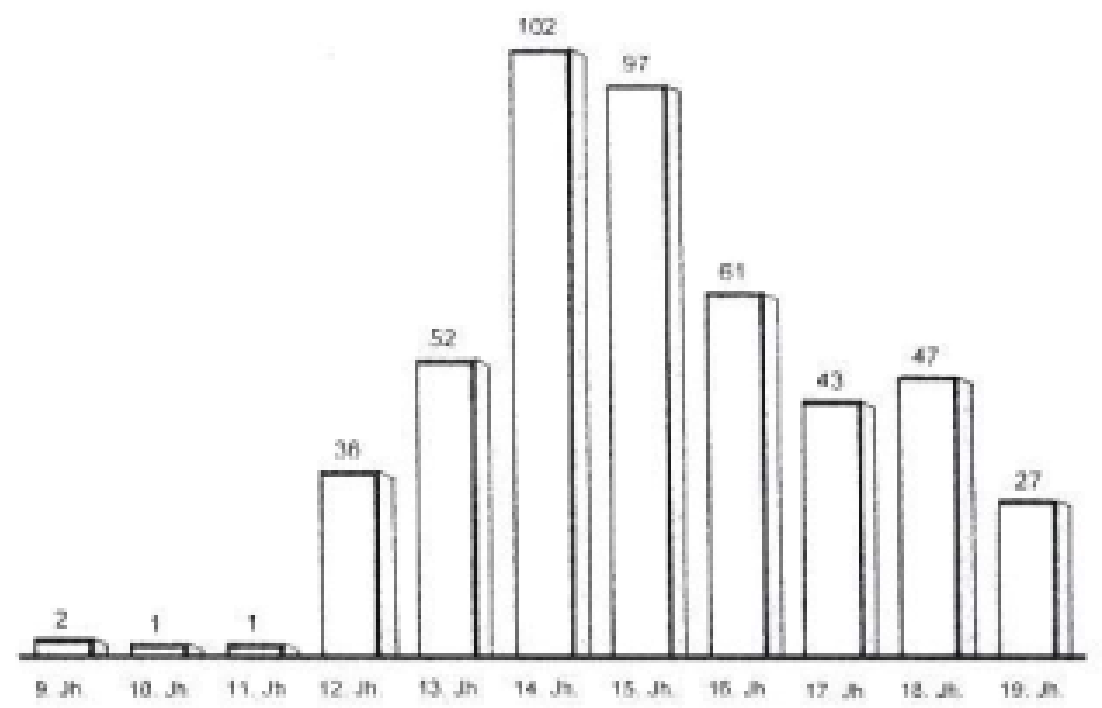

Abb. VIII-23: Die ortsfesten Wassermühlen vom 9. - 19. Jahrhundert.

Ausgewertet wurden von VOGT (1998) die Daten von 469 rheinischen Wassermühlen (aus: VOGT 1988:16).

Insgesamt setzte sich der „Siegeszug der Wassermühle“ im Laufe des Hochmittelalters fort. Um die im fortschreitenden Mittelalter gesteigerten Körnererträge zu bewältigen, nahm die Zahl der Mühlen in großem Umfang zu. Die Landesherren erteilten auch den Klöstern, Adeligen und Städten die Erlaubnis, Mühlen zu errichten und zu betreiben. Es wurden nun neben Amtsmühlen, die in den Registerverzeichnissen als herrschaftliche Mühlen bezeichnet wurden, die nicht herrschaftlichen Mühlen wie Kloster-, Rats- oder Gutsmühlen errichtet (BOSSE 1991:20): „So entstanden in allen Fluß- und Bachtälern zahlreiche Mühlen, die damals durchweg oberschächtig gebaut waren und nur einen Gang besaßen. Ihre Leistung war denkbar gering und außerdem war man gezwungen, wollte man nicht während der Trockenheit oft Monate die Mühle stillstehen lassen, Staubecken in Form von Mühlteichen anzulegen, um in der trockenen Jahreszeit die Mühle in Betrieb erhalten zu können.“ (CNOPF 1927:15) Vor allem mit der „einseitigen Bevorzugung des Körnerbaus“ (:19), „stieg die Zahl der Staubecken oder Mühlweiher ins Ungemessene." (:15) Auch der Anstieg in weiteren Produktionsbereichen war so tiefgreifend, dass an manchen Wasserläufen ganze linienhafte „Gewerbegebiete“ mit Mühlen und Gebäuden für anschließende Arbeiten entstanden. Erst jetzt beginnt die große Zeit der (spezialisierten) Mühlen: der Walkmühlen, Eisenhämmer, Papiermühlen, Sägemühlen, Flachsbrechmühlen, Zwirn- und Drahtmühlen und vieler anderer mehr, die zahlenmäßig ebenfalls eine bedeutende Rolle spielten (MÜLLER/LUDWIG 1982:135). 


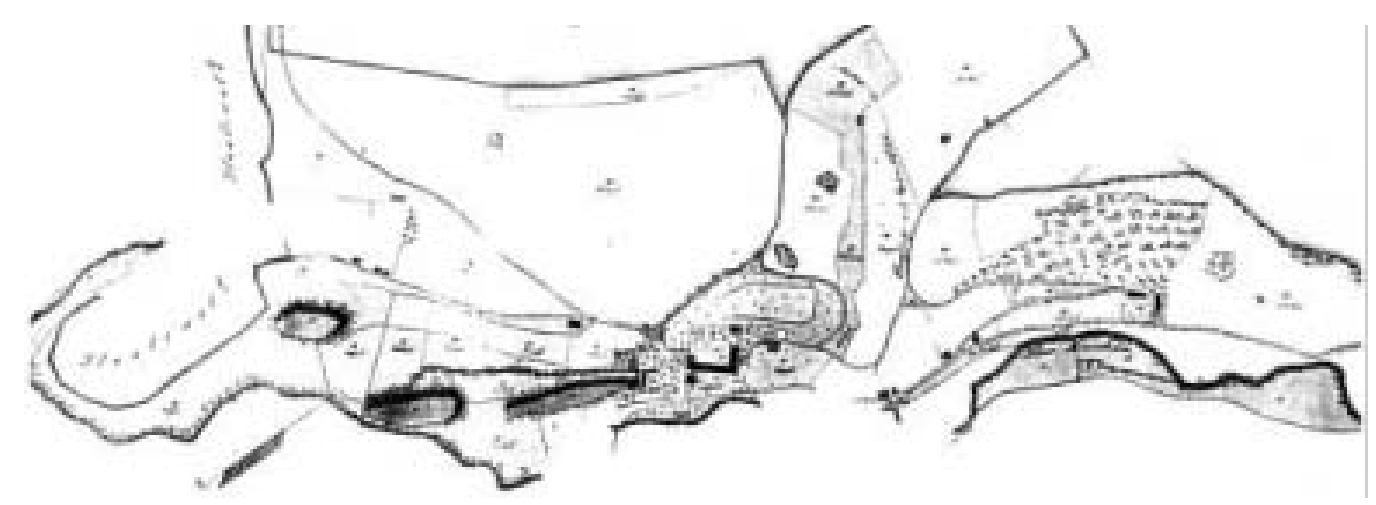

Abb. VIII-24: Karte über die zur ehemaligen Eisenhütte „Pfeilhammer“, Pöhla, gehörenden Teiche (Stand 1883), (aus: ALTMANN 1999, Abb. 128)

Die Erbauung einer Mühle im Hoch- und Spätmittelalter war juristisch aber noch immer an den Besitz von Land gebunden, so dass nur Grundherren, d. h. der Adel und der Klerus als Erbauer in Frage kamen, überdies die einzigen, die damals das erforderliche Kapital zum Bau und zur Unterhaltung einer Mühle aufbringen konnten. Klöster und Grundherrschaften unterhielten also als erste eine Mühle, die sie rechtlich als Bannmühle ausstatteten. Der Charakter einer „Domanialmühle“ oder „Landesherrliche Mühle“, wie eine zum bischöflichen respektive adeligen Tafelgut gehörende Bannmühle auch hies, bedeutete Vorrechte: Schatz- also Steuerfreiheit, bei Baumaßnahmen der kostenfreie Bezug von Steinen und Holz, Gratisanlieferung von Mühlensteinen, Inanspruchnahmemöglichkeit bäuerlicher Hand- und Spanndienste. Die Mühlengerechtigkeit (Mahlund Mühlenbann) war zwar lästig, aber auch vorteilhaft, da die Gebannten an den Grundherrn gerichtet fordern konnten, falls es der Bannmühle an Wasser fehlte, dass sie zuerst berücksichtigt würden. Damit ist hier von einem vordringlichen Mühlenteichbau zu Absicherung einer kontinuierlichen Wasserbeaufschlagung auszugehen.

Da aber die Kloster- und Standesmühlen unmöglich das Bedürfnis aller Kloster- und Gutsleute befriedigen konnten, so löste diese Überforderung mehr und mehr den Mühlenzwang. Neben der Bannmühle errichteten sie eine Anzahl kleiner Mühlen, die gegen geringen Zins Pächtern überlassen wurden und deren Verbreitung ebenfalls zu einer erhöhten Mühlendichte und damit zu einem Mühlenteichbau beigetragen haben dürfte.

Die Müller konnten die Mühle aber weder vererben noch verkaufen. Dieses Pachtverhältnis änderte sich Mitte des 16. Jahrhundert, im Übergang des Spätmittelalters zur Renaissance, als die Grundherren dazu übergingen, die Mühlen in Erbpacht zu vergeben. Nun konnten die Müller die Mühlen tauschen, vererben oder veräußern, sofern die Obereigentümer, die weiterhin den Grund und Boden besaßen, ihr Einverständnis gaben. Die Pachtabgaben der Mühlheimer Mühlen waren Ende des 16. Jahrhunderts im Vergleich zu anderen Gemeinden, die keine geistlichen Landesherren hatten, gering. Aus diesem Grund dürfte die Zeit eine wirtschaftlich besonders gute Phase der Mühlenwirtschaft gewesen sein. Darüber hinaus wurden auch hiervon Ausnahmen eingeräumt.

Bis zu Ende des 18. Jahrhunderts traten dann kontinuierlich Neubauten dem Altbestand zur Seite. So kamen beispielsweise in Mühlheim a. M. um 1720 zu den an Rodau und Bieberbach stehenden sieben vorhandenen Mühlen noch zwei weitere hinzu, getragen vor allem durch die Ausdehnung des Getreideanbaus und die drastische Absenkung des Fleischkonsums in dieser Epoche. Um 1800/1820 lag dieser Bedarf im Durchschnitt unter 20 Kilo je Person und Jahr (HELLER 2003).

Wesentliche Neuerrichtungen ergaben sich durch Veränderungen der Eigentumsverhältnisse zu Beginn des 19. Jahrhunderts, als bischöfliche und klösterliche Mühlen im Zuge der Säkularisation geistlicher Güter entschädigungslos zur staatlichen Domäne eingezogen wurden. Die Situation vor 1810 war dadurch gekennzeichnet, dass die Müller nicht Besitzer ihrer Mühle, sondern immer Angestellte eines Grund- oder Landesherrn waren (TERHALLE 1992:186). 
Im Laufe des 19. Jahrhunderts gingen sie vielfach durch Ablösung der Pachtverhältnisse auf Grund des 1831 ergangenen „Gesetzes über die Befreiung von den Grundlasten” oder durch Verkauf an Privatpersonen (z. B. Lederfabrikanten) oder Vereinigungen (z. B. Meliorations- oder Wiesenbaugenossenschaften, Tuchmacherämter) über. Weiterhin entscheidend veranlasst durch die neue zum Beispiel in Kurhessen 1834 eingeführte Gewerbefreiheit, den „civil code ${ }^{\text {‘24 }}$, der den Mühlenbann, d. h. die Verpflichtung der Mahlgäste unter Androhung von Strafe in einer bestimmten Herrschaftsmühle mahlen zu lassen beendete, fielen alle Beschränkungen für eine Mühleneinrichtung weg und es kommt dann im 19. Jahrhundert zu einem Mühlenbauboom: Beinahe ein Drittel aller Mühlen wird jetzt von Bauern, Müllern und Bürgern gegründet, so ist zu lesen (GRIMM 1988:102ff.). MÖRSTEDT (1995:268) bestätigt diese größte Vermehrung der Mühlenanzahl für das 19. Jahrhundert - mit einem Schub für die Zeit der 1840er und 1850er Jahre - für den „Mühlenkreis Herford“ mit 47 gezählten Neubauten.

Mit der Aufhebung der Feudalrechte im 19. Jahrhundert war also das Recht des Mühlenbanns und Mühlenzwangs aufgehoben. Aber welcher Müllermann, so lässt sich dem entgegnen, verfügte zu dieser Zeit schon über genügende Geldmittel, um sich selbst ein Mühle zu bauen? Für den Bau waren nicht nur die komplizierte Mühlentechnik im Innern der Mühle anzusetzen, sondern auch für den Bau eines Mühlendammes, der Errichtung der Schleusen, Wehre und der Einrichtungen der Wasserführung waren erhebliche finanzielle Mittel erforderlich, so dass zu fragen wäre, ob hier nicht wirklich nur auch nach Aufhebung der Gesetze des Banns - von den bisherigen Grundherren der verstärkte Mühlenneubau getragen worden ist und die Vermehrung der Mühlenpächter angestrebt wurde, um so einen auf mehrere Personen verteilten Pachtzins zu erhalten. Die teuren teichbaulichen Auswirkungen lassen sich so jedenfalls, vor dem Hintergrund des Grundherrn als „Bauträger“, besser erklären.

Die letzte Expansionsphase - und dies in Verbindung mit den Mühlteichen - liegt im ersten Jahrzehnt des 20. Jahrhundert, als sich einige Bauern kleine Wassertriebwerke anlegten, um die Selbstversorgung mit Futterschrot, aber auch mit elektrischem Strom zu erzielen (MÖRSTEDT 1995:268). Da sie in der Regel nur über einen schwächlichen Wasserzulauf verfügten, waren sie es, die als Träger des Kleinteichbaus bzw. des späten Mühlenteichbaus überhaupt angesprochen werden müssen.

Waren die Teichflächen zunächst auf kleinere Flächen im Kloster oder Grundbesitz beschränkt, und erhielten so schon das Prädikat „ungemessen“, so wurden sie im Laufe der Zeit durch Errichtung von weiteren bzw. Vergrößerung von vorhandenen Mühlweihern dermaßen erweitert, dass - auch vor dem

${ }^{24}$ Code civil [Code Napoleon]: ist der Name der amtlichen Originalausgabe des im Frühling 1804 erschienenen Gesetzbuches, welches die 36 grundlegenden Gesetze des französischen Zivilrechts umfasst und deshalb als „Code civil“ bezeichnet wird.

Grundlage eines solchen Verfahrens war aufklärerisches Streben nach Rechtseinheit und Rechtssicherheit sowie Vereinheitlichung der bisherigen widersprüchlichen Rechtssysteme der absolutistischen Landesherren, die uneingeschränktes Gesetzgebungsmonopol beanspruchten. Bereits 1794 wurde in Preußen ein solches kodifiziertes Recht unter dem Namen „Allgemeines Landrecht“ (ALR) verabschiedet.

Auch in Frankreich erwiesen sich die Vorarbeiten für eine landeseinheitliche Kodifikation, die den fränkisch-germanischen Rechtskreis im Nord-Osten und den des römischrechtlichen im Süden vereinheitlichen sollte, als äußerst schwierig. Bis zum Ende des Ancien régime regelten daher eine Vielzahl von ordonnances der französischen Könige einzelne Rechtsmaterien, etwa das Zivilprozess-, Handels-, Erb- und Schenkungsrecht. Weitergehende Kodifikationen hatten sich hingegen nicht durchsetzen können. Von Beginn der französischen Revolution an gehörte dann die Schaffung eines einheitlichen Zivilgesetzbuchs zu den gängigen Forderungen, die auch in der Verfassung von 1791 ihren ausdrücklichen Niederschlag fanden. Trotzdem war es erst der Aufstieg Napoleon Bonapartes, seit 1800 Erster Konsul, der für schnelle Fortschritte bei den Gesetzgebungsarbeiten sorgte, so dass diese - unter seiner intensiven persönlichen Beteiligung - ausführlich beraten und 1804 als Code civil verkündet wurden. Die am klassischen Institutionensystem orientierten und auf den Bestimmungen beider bisheriger Rechtskreise aufbauenden Artikel dieses Gesetzbuches verwirklichten mit den Mitteln des Privatrechts die revolutionären Forderungen nach Gleichheit vor dem Gesetz, Freiheit des Eigentums und Vertragsfreiheit. Anders als das preußische ALR ist der Code civil dabei nicht um die möglichst präzise Regelung jedes denkbaren Einzelfalls bemüht, sondern beschränkt sich auf knappe, abstrakte Regelungen, die sich dadurch als hinreichend flexibel erwiesen, um unbeschadet zahlreicher Reformen bis heute in Geltung bleiben zu können. Auf die Vereinheitlichung des Zivilrechts folgte in Frankreich in dichter Folge die einheitliche Regelung der übrigen Rechtsmaterien (1806 Zivilprozessordnung, 1807 HGB, 1808 StGB). Von all diesen Kodifikationen war es aber vor allem der Code civil, der als erstes modernes Gesetzbuch eines säkularisierten, ständefreien Staates international auf Anerkennung stieß. Parallel zu den militärischen Eroberungen breitete sich das Geltungsgebiet der auch als Code Napoleon bezeichneten Cinq codes innerhalb weniger Jahre - zumindest kurzfristig - in ganz Europa aus (JURA UNI-ERLANGEN 2003). 
Hintergrund der dann eintretenden Überlast - in den Landschaften des 19. Jahrhunderts nochmals eine unvorstellbar große Zahl an „Notspeichern“ hinzukam. Sie ließen in den Auen der Flussläufe, aber auch in Quellgebieten oder sogar durch Auffang von Niederschlagswasser in „Trockengebieten“ eine anthropogene „Stillgewässerlandschaft“ entstehen, die durch ihre Offenlage zur einer erhöhten Evaporation und durch ihre baulichen $\mathrm{Zu}$ - und Ablaufvorrichtungen $\mathrm{zu}$ einer veränderten Abflussdynamik geführt haben muss.

Die wirtschaftliche Folge war, dass allenthalben Wassermühlen entstanden und so den bisherigen Mühlen eine erhebliche Konkurrenz erwuchs (TERHALLE 1992:67). Mit dem Aufkommen der zahlreichen neuen Mühlen nach 1810 war selbst auf großen und bedeutenden Mühlen nicht mehr das große Geld zu verdienen. So mussten die Besitzer wie Betreiber immer wieder nach neuen Gewerbemöglichkeiten Ausschau halten. Die Anlage eines Graupenganges, der Anbau einer Lohmühle und später einer Sägemühle, wie dies die Berkel-Mühle zeigt, belegen dies. Und selbst diese Erweiterungen sicherten dem Müller gegen Ende des vorigen Jahrhunderts nicht mehr seinen Lebensunterhalt, so dass die Mühlen oftmals aufgegeben werden mussten (TERHALLE 1992:185).

Bereits aber schon zu Beginn der Neuzeit zeichnete sich eine erste Umkehr des Mühlenbooms ab. Bis zum 15. Jahrhundert war die Kost immer fleischärmer geworden und die Mahlmühlen profitierten davon. Nun brachte der Zutrieb von Lebendschlachtvieh aus Polen und Ungarn einen Gegentrend. Von Verbraucherzentren wie Frankfurt, Leipzig, Köln lagen die dortigen Aufzuchtgebiete, der vierte „Ring“ im System Thünens, 1000 bis 1500 km entfernt. Auf den Absatzmärkten des Ochsenhandels zählte man oft an die zwanzigtausend Tiere. Selbst Handwerksgesellen und Arbeiter verzehrten in dieser Ära um 1500 täglich mehrere Pfund Fleisch. Diese einseitige Eiweißnahrung in der Bevölkerung führte zu einem vielleicht ersten Einbruch in der Mühlenexpansion.

Des Weiteren beginnt im 16. und 17. Jahrhundert der Bau neuer Wassermühlen deutlich nachzulassen, weil man wohl auch die günstigsten Staumöglichkeiten bereits ausgenutzt hatte und eine Ausweitung schnell auf natürliche Grenzen stieß. So ist beispielsweise die Benredesmühle an der Este, $3 \mathrm{~km}$ westlich von Bötersheim/Landkreis Harburg 1578 aus Wassermangel eingegangen (RUMP 2001:19). Und auch die im selben Landkreis gelegene Wassermühle in Emmelsdorf musste 1603 aus gleichem Grunde aufgegeben werden und wurde abgebrochen (:30). Durch Überbesetzung waren auch die vier Mühlen am und in Wimmersbach nicht mehr existenzfähig (OPEL 1991:65f.).

Zusätzlich waren in Fehde- und Kriegszeiten Wassermühlen, bei der hohen Wertschätzung, die sie genossen, bevorzugte Plünderungsobjekte und fielen oftmals völliger oder teilweiser Zerstörung anheim (DOBELMANN 1980:20). Vor allem der Dreißigjährige Krieg ruinierte durch seine Kriegsunruhen die Mühlen. Sie gingen oftmals in Flammen auf (OPEL 1991:28), wie die Domhorster Pulvermühle im Amt Reinbek 1647 (FINK 1969:222) oder wurden einfach aus verteidigungstaktischen Gründen destruiert. So mussten infolge der Schanzarbeiten während des Dreißigjährigen Krieges in München vier Wassermühlen dem Mauerbau weichen. Bei anderen wurde in diesem Zusammenhang der Bach, an dem sie lagen, aufgelassen, wodurch das für die Errichtung eines Betriebes notwendige Gefälle verloren gegangen war (KOHL 1969:36,47).

Die noch im 17. Jahrhundert in manchen Gebieten wie in Südwestdeutschland, Hessen, Franken und Thüringen entstandene Realerbteilung führte zu immer kleineren Bauernhöfen mit immer kleineren Landflächen. Aber für einen solchen Kleinstbauern lohnte sich der Anbau von Hafer nicht mehr, da er keine Pferdegespanne mehr besaß, sondern zum „Ochsen-“ bzw. „Kuhbauern“ wurde. Als Rinderfutter aber verwendete man Gras, Heu und vor allem Rüben. Für die Müller war der Rückgang des Getreideanbaus mit dem Verlust von Arbeit und Einkommen verbunden, dem sie mit dem Aufbau einer eigenen Landwirtschaft zur Selbstversorgung zu begegnen suchten. Am Ende des 18. Jahrhundert gab es zum Beispiel in Mühlheim keinen Müller mehr, der nicht Wiese und Acker besaß (GRIES 1977).

Schließlich war es die Auflösung der alten Dreifelderwirtschaft im 18. Jahrhundert, die zu den wirtschaftlichen Schwierigkeiten der Müller beitrug. Die Einführung neuer Feldfrüchte wie Kartoffel, Klee und Luzerne führte zu einer zunehmenden Bebauung der bisherigen Brache. 
Vor allem drängte die Kartoffel die überkommende, beinahe allumfassende Getreidekost in weiten Teilen der Bevölkerung deutlich zurück (ERLER/MATTHIESEN 1989:20). Nicht nur, weil sie einen $1 \frac{1}{2}$ fachen und damit weitaus höheren Flächenertrag als Getreide lieferte, sondern weil Ausbringung und Ernte ohne besondere Werkzeuge möglich war, des Weiteren Wild und weidendes Vieh dem Kartoffelkraut keinen Schaden anzurichten pflegte und man auch auf schlechten und steinigen Böden und in steilen Hanglagen Kartoffeln anbauen konnte. Zum Schluss war auch die häusliche Zubereitung viel einfacher als beim Getreide: Kartoffeln muss man weder dreschen noch mahlen noch aus ihnen Brot backen.

Erst die Nöte des Dreißigjährigen Krieges trugen jedoch zur Verbreitung der Kartoffel bei, obgleich sie bereits im 16. Jahrhundert nach Deutschland eingeführt worden ist und erstmals durch den Botaniker Clusius im Jahre 1588 erwähnt wird. Zunächst wurde die Kartoffel wegen ihrer Blüte als Zier- und Gartenpflanze angebaut. Damen schmückten beispielsweise ihr Haar mit Kartoffelblüten. Es vergingen jedoch rund 200 Jahre, bis die unterirdischen, verdickten Sprossteile, die als Speicher für die Reservestoffe (Stärke) der Pflanze dienen, als Nahrungsmittel eingesetzt wurden.

Die frühesten Nachrichten über Kartoffelanbau auf deutschem Boden stammen 1647/48 aus Selb und Pilgramsreuth bei Rehau, Nordfranken, aus dem Fichtelgebirge und dann erst aus dem angrenzenden Vogtland und der damals bevölkerungsreichen Pfalz (HELLER 2003). In Württemberg wurden Kartoffeln 1701 nachweisbar in dem Waldenser Ort Schönenberg bei Maulbronn zu Nahrungszwecken angepflanzt und sukzessive in jedem der 15 Waldenser Orte zum weiteren Ausbau angebaut.

Die Geschichte der Kartoffel als Volksnahrungsmittel in Deutschland beginnt aber erst mit den Anordnungen des Preußenkönigs: Friedrich der Große (1712 - 1786) befahl den Kartoffelanbau in Pommern und Schlesien (BROCKHAUS 1979, Bd. 6:190). Er erkannte, dass die neue Frucht eine entscheidende Abhilfe für die immer wieder auftretenden großen Hungersnöte und zur Ernährung seiner Soldaten versprach, und traf energische Maßnahmen zur Einführung der Kartoffel in den beiden Landesteilen, die im Übrigen auch die Landschaften der Teichwirtschaft waren. 1744/45 ließ er die Kartoffel in einer großen Kampagne in ganz Preußen kostenlos verteilen. 1756 macht er den Kartoffelanbau zur Pflicht und erließ die Anordnungen, dass der „15. Teil des Bodens“ mit Kartoffeln anzupflanzen sei.

Im Siebenjährigen Krieg gelang der Kartoffel dann der Durchbruch als Grundnahrungsmittel, obgleich der Kartoffelanbau Teile Oberbayern noch um 1850/80 nicht erreicht hatte (HELLER 2003). Allgemein aber ist von einer flächenhaften Einführung der „Bauerntrüffel“ ab etwa 1770 auszugehen. Für die im Industriezeitalter schnell wachsende Bevölkerung wurde die Kartoffel gar - bei sonst zu verzeichnender Nahrungsmittelknappheit - zu einer preiswerten Nahrungsquelle ${ }^{25}$.

Die Verbreitung der Kartoffel brachte aber einschneidende Veränderungen der Essgewohnheiten in Deutschland mit sich. Abgesehen vom Brotverzehr wurde die übrige Getreidekost fast vollständig verdrängt. Wassermühlen haben mit ihren Betriebsleistungen dafür gesorgt, dass die landsässige $\mathrm{Be}-$ völkerung über Jahrhunderte hinweg hinlänglich zu essen bekam. Die Nachfrage nach Mehl aber blieb „angesichts des neuen Volksnahrungsmittel Kartoffel begrenzt.“(ERLER/MATTHIESEN 1989:88).

Auf der anderen Seite entstand durch die im Dreißigjährigen Krieg bedingten Verwüstungen ein großer Bedarf an Bauholz, um die im Krieg zerstörten Gebäude wieder zu reparieren und in Stand zu setzen (FINK 1969:223) und infolgedessen stiegen die Anträge zur Errichtung von Sägemühlen (OPEL 1991:23). Doch als die ersten Aufbauarbeiten beginnen, als der Dreißigjährige Krieg gerade vorüber ist, war „von der Vorkriegsbevölkerung [...] kaum jemand übriggeblieben.“(GRIES 1999:18) Da die Bevölkerung immens geschrumpft war, stand es um die Getreide verarbeitenden Wassermühlen mehr oder weniger schlecht. Auch wenn sie nicht zerstört waren, ,hatten sie wegen der geringen Bevölkerungszahl und der dadurch stark reduzierten Landwirtschaft nur wenig zu mahlen.” (:18) Die

\footnotetext{
${ }^{25}$ So rasant sich der Aufstieg der Kartoffel im 19. Jahrhundert vollzog, so dramatisch ist der Rückgang des Verzehrs in der 2. Hälfte des 20. Jahrhunderts. Noch 1890 wurden ca. $1 \mathrm{~kg}$ Kartoffeln pro Kopf und Tag verzehrt. Heute liegt der Pro-KopfVerbrauch bei ca. 200 g Kartoffeln. Und etwa 40\% davon sind „,veredelte“ Kartoffelerzeugnisse, wie zum Beispiel Pommes Frites, Knödelpulver und Kartoffelchips.
} 
geringe Kapazitätsauslastung führte - parallel zur Bevölkerungszunahme - nur zu einem allmählichen Wieder- bzw. Neuaufbau.

Dieser Aufbau wurde im Siebenjährigen Krieg erneut unterbrochen. So brannten die Franzosen 1757 die Holm-Mühle an der Seeve und die Gutswassermühle in Jesteburg an der Jeste bis zu den Grundmauern nieder. Nach dem Wiederaufbau zerstörten die Truppen Napoleons 1813 die Mühlen von neuem.

Bereits 1725 begannen auch die Klagen der Schwetzinger Schlossmüller über die Wasseranlagen des Schlossgartens, die ihnen das Wasser weg nahmen und die Mühle zum Stillstand brachten (OPEL 1991:11). Da Kurfürst Karl Theodor (1742 - 99) die Mühle schon längere Zeit als Störung empfunden hatte, die Lärmbelästigung durch Fuhrleute und der nicht gerade leise Gang der Mühle zudem die Schlossgäste behelligte, beschloss er den Abbruch der Mühle (:11).

Mit ihrem Lärm und dem bei der Mühle haltenden Zugvieh, das die Frucht anfuhr und auf die Mehllieferung wartete, passte die Wassermühle Oftersheim auch nicht mehr in die Umgebung des baden-württembergischen Schlosses Oftersheim (MOSSEMANN 1971:10). Im Jahr 1745 wurde die Schlossmühle deshalb abgebrochen und 1747 an einen anderen Standort verlegt und bachaufwärts oberhalb von Oftersheim neu aufgebaut. Doch nicht aufgrund von Lärmemissionen oder aus ,ästhetischen“ Gründen wurde die hier betroffene Oftersheimer Mühle schließlich später endgültig beseitigt. Durch die vom Müller durchgeführte - geringe - Erhöhung des Wasserbettes bzw. des Mühlkanals um 13 Zoll wurde der Fall des Leimbachwassers gemindert. Das wirkte sich nachteilig auf das untere Wasserwerk des Schlossgartens aus. Deshalb hat die kurfürstliche Verwaltung - wegen des ohnehin geringen Wasserfalles des Leimbaches -, die Wassermühle abreißen lassen (:18).

Aus gleichen Gründen, der Unvereinbarkeit von lärmender Mühle, zierender Gartengestaltung und des Lustwandels, wurde auch das Mühlenanwesen an der Schleme in Reinbek in Parkanlagen umgestaltet (FINK 1969:254)

Anfang des 19. Jahrhunderts verschlechterte sich die Situation für die Müller abermals. Die mit der Säkularisation verbundene Auflösung der Klöster, die ehemals Obereigentümer der meisten Mühlen waren, und die Umwidmung bzw. Einziehung des Vermögens, der Hoheitsrechte, der Besitztümer und der Ländereien von Erzbistümern, Bistümern, Abteien, Klöstern und Stiftern durch den Staat führte zur Änderung der Rechtsverhältnisse. Die Mühlengesetze wurden weitaus strenger und die Reinigung der Bachbetten, der Bau oder der Erhalt neuer Wehre und zu errichtende Eichpfähle u. Ä. waren Pflichtinvestitionen, die neben Geldsteuern die Müller finanziell belasteten.

Ungünstig wirkten sich auch die Preiserhöhungen für Gebäude und landwirtschaftliche Nutzflächen um 1800 aus, die durch steigende Bevölkerungsdichte und damit eine größere Nachfrage bedingt waren. Sie hatten zur Folge, dass bei Erbfällen der übernehmende Erbe erhebliche Schulden machen musste, um die Miterben auszahlen zu können. Aus diesem Grund wurden notwendige Verbesserungen und Investitionen oft lange hinausgeschoben oder sogar ganz unterlassen, so dass die Mühle den Anschluss an die technische Entwicklung ihrer Zeit verlor. Um 1900 arbeiteten die meisten von ihnen noch genauso wie im Mittelalter (GRIES 1977).

Wo Privilegien wie die Gewerbefreiheit eingeführt und Reglementierungen wie der Mahlzwang aufgehoben wurden, hat sich die Anzahl der Mühlen in manchen Gebieten verdoppelt. Zumindest aber bewirkten die Erleichterungen eine erhebliche Steigerung des Mühlenbestandes. Mühlen erlebten eine Blütezeit und prägten Mitte des 18. bis Mitte des 19. Jahrhunderts das Landschaftsbild wie zu keiner anderen Zeit. Es entstand dadurch aber erhebliche Konkurrenz, und die Niederlassung an Wasserläufen, die keinen ausreichenden Betrieb gewährleisteten, hatte den Niedergang dieser Mühlen zur Folge bzw. solche Neugründungen an guten Fließen führte zu einem Überbesatz und somit zu einem ähnlichen Ergebnis.

Des Weiteren führten die in der zweiten Hälfte des 19. Jahrhunderts durchgeführten Separationen und Generalteilungen zum Niederlegen zahlreicher Mühlenteiche. So hat man den ,Stöcke Teich' im 
Landkreis Soltau zwischen 1856 und 1864 entwässert und später trockengelegt (BOSSE 1991:125). Auch Mühlengebäude der Solinger Klostermühle wurden abgebrochen und die zugehörigen Klosterteiche in Wiesen umgewandelt (LUNKENHEIMER 1990:48).

Allgemein lässt sich sagen, dass durch die naturräumliche Ausstattung die Mühlenteichlegung durch Flurstückumlegungen das Mittelgebirge viel stärker als das norddeutsche Tiefland traf. So waren beispielsweise in Franken 99 \% aller im Jahre 1861 betriebenen Getreidemühlen Wassermühlen (BEDAL 1992:85) mit einem dementsprechend hohen Anteil an Wasserstauungen und -sammlungen.

Darüber hinaus bestimmten eine Vielzahl von wirtschaftlichen Faktoren gerade im 19. Jahrhundert die europäische und die deutsche Politik, deren Auswirkungen auch das Mühlengewerbe zu spüren bekam. Die Wollweber beispielsweise, die damals in Not gerieten, weil die deutsche Wirtschaft mit der europäischen, vor allem der englischen Entwicklung nicht Schritt gehalten hatte, weil diese mit dem mechanischen Webstuhl Produktionsvorteile besaß: Die englischen Stoffe und Tuche waren den deutschen schlicht qualitativ und quantitativ überlegen. Dies führte zu einem Niedergang der Walkmühlen, der sich dadurch verstärkte, dass einige Betriebe, um gegenüber der englischen Konkurrenz überleben zu können, ihre Ware „billiger” im Ausland herstellen ließen. Zudem schwächte sich die Konjunktur am Ende des 19. Jahrhunderts weiter ab. Besonders betroffen waren neben den Tuchmachern mit ihren Walkmühlen die Gerber in ihren Lohmühlen (BINTZER 1991:46).

Der zu diesem Zeitpunkt einsetzende Überseehandel schwächte auch die Farbholzmühlen, die sich anstelle des heimischen Färberwaids zur Herstellung von Farbextrakten der Verarbeitung geraspelter und gemahlener überseeischer Farbhölzer bedienten. Um 1900 gab es in Deutschland noch etwa ein Dutzend Farbholzmühlen. Sie kamen mit der Zeit fast alle zum Erliegen. 1969 gab es nur das Unternehmen Zipperling Kessler \& Co. in Schiffbek bei Reinbek, heute Hamburg, das schließlich auch durch den Gebrauch synthetischer Farbstoffe anstelle natürlicher Färbemittel verdrängt wurde (FINK 1969:257).

Auch die durch Bevölkerungswachstum eigentlich zu erwartende Existenzsicherung von Wassermühlen, deren Vermehrung ja u. a. aufgrund des demographischen Faktors erst erfolgt war, ist differenziert zu beurteilen und lässt sich nicht allein mit Überproduktion begründen. Vom ersten Drittel bis zur Hälfte des 19. Jahrhunderts vermehrt sich zwar die Ortsbevölkerung durch starken Zuzug. Aber immer mehr Menschen verdienten ihr Geld in Handwerk und Industrie und kauften ihr Brot beim Bäcker, der schon aus Kapazitätsgründen auf die Großmühlen zurückgreifen musste. In der Folge gerieten die kleinen dörflichen Mühlen langsam, aber sicher in die Verlustzone und mit ihnen die zahlreichen kleinteiligen Mühlenteiche. Im zweiten Drittel des 19. Jahrhunderts bis zu Anfang des 20. Jahrhunderts wuchs die Einwohnerzahl und ihr Bedarf an Mahl- und sonstigen Mühlenprodukten nochmals, doch konnte auch daran der kleingewerbliche Wassermüller nicht partizipieren. In der Zeit um 1910 dann befand sich das Mühlengewerbe in einer ernsthaften Überproduktionskrise. Die Großmühlen machten den kleinen Handwerksmühlen große Konkurrenz.

Vor allem die günstigen mühlenfähigen Gewässer und die an ihr liegenden leistungsfähigsten und vielseitigsten Mühlen waren zunächst die Gewinner von dieser Entwicklung, die einherging mit veränderten hydrologischen und strukturellen Bedingungen an den kleinen Bachmühlen. Kundschaft kam in Trockenperioden auch von weit her, denn wenn andernorts die kleinen Wassermühlen nicht immer mahlen konnten, verfügten die „,besseren“ Mühlen noch immer über - wenn auch nicht immer Wasserkraft für alle Gänge - zumindest aber über die nötige Energie „für ein hinlänglich Gemahl“ (MÖRSTEDT 1995:127). Die „schlechteren“ Mühlen hatten, da sie zuweilen gar nicht mahlen konnten, das Nachsehen, weil man sich nicht immer auf sie verlassen konnte. Zuerst kamen in der Regel nur die Wechselkunden, nachfolgend blieb die Kundschaft aber nicht nur bei wenigem Wasser aus. Sie hatten auch in Zeiten, wo es ihnen nicht an Wasser gebrach, das leere Nachsehen (:273). Stauteiche waren von dieser Entwicklung besonders betroffen, lagen sie zumeist an kleinen Wasserläufen.

Ausgelöst wurde die „Wasserschwäche“ von kleineren Wasserläufen auch durch die verstärkte Wassernutzung infolge der Erweiterung von Mühlen. Es entstand durch zusätzliche Mahlwerke und 
Wasserräder ein erhöhter Bedarf nach Aufschlagwasser, dem vor Erfindung der Dampfmaschine zunächst durch eine Vergrößerung des Mühlenteiches bzw. Erhöhung des Mühlenstaus begegnet wurde.

Bereits in den frühen 20er Jahren des 19. Jahrhunderts begann sich die deutsche Mühlenbauerzunft für die amerikanische Mahlmühle zu interessieren. Die erste dieser Mühlen wurde im 18. Jahrhundert in den USA erbaut. Dort hatte um 1785 der Mühlenbauer Oliver EVANS ${ }^{26}(1755$ - 1819) die erste automatisch laufende Großmühle errichtet. Diese sog. Kunstmühlen zeichnen sich durch eine durchgreifende Technisierung und Automatisierung aus, die einen reibungslosen Tag- und Nachtbetrieb ermöglichte. Personal wurde nur zur Überwachung des Produktionsablaufes wie zum Abtransport der Mehlfässer benötigt (BEDAL 1992:78). Parallel zu den verkehrstechnischen Verbesserungen, wie etwa dem Kanalbau oder der Eisenbahn, die den Handel förderten und neue Märkte erschlossen, der industrialisierten Herstellung von Eisen als Substitut des nur geringfügig haltund belastbaren Baustoffs Holz, entstand die Großmühle als Produkt einer im Wachsen begriffenen Industrie und Wirtschaft.

Die erste Kunstmühle auf deutschen Boden wurde im Jahre 1822 in Berlin errichtet, 1823 folgte eine weitere in Magdeburg (BEDAL 1992:80). In Süddeutschland wurde in der Nähe Stuttgarts im Jahre 1830/31 die erste Mühle nach amerikanischem Schema gebaut. Fast zeitgleich wurde in Bayern, in Nürnberg-Dutzendteich, die erste Kunstmühle errichtet bzw. eine alte Hütte zu einer Kunstmühle umgebaut (:81). Sie sollte jedoch aufgrund verschiedener Faktoren (schlechte verkehrstechnische Erschließung der Mühlen, d. h. fehlende große Abnehmermärkte, enorme Kosten einer Großmühle) die zunächst einzige Kunstmühle Bayerns bleiben. „In den nächsten Jahren wurden bevorzugt Großmühlen in den Hafenstädten erbaut, da die Vorteile eines günstigen und schnellen Wassertransportweges für den Mehlhandel erkannt wurden.“ (:80)

Die Situation auf dem Lande war jedoch eine andere als die der Stadt. Während hier im zweiten Drittel des 19. Jahrhunderts in größeren fränkischen Städten zu diesem Zeitpunkt die amerikanische Kunstmühle die alte deutsche Mühle abgelöst hatte, waren die überwiegende Mehrzahl der fränkischen Mühlen Kleinbetriebe mit durchschnittlich zwei Beschäftigten geblieben (BEDAL 1992:82). Aber trotz der Größenvorteile wurden antriebstechnisch ,auch die frühen Kunstmühlen in Franken [...] bei ihrer Erbauung im Jahre 1863 [...] mit Wasser betrieben.” (:84) Insofern kann davon ausgegangen werden, dass vor allem an ländlichen Mühlenstandorten und dann vor allem an kleinen, schwächer wasserführenden und bzw. oder stark mit Mühlen besetzten Fließgewässern auf Mühlenteichanlagen für den Wasserbetrieb nicht verzichtet worden ist.

Um die Jahrhundertwende erreichte die deutsche Müllerei im Gefolge der Großmühlen ihre Blütezeit. Der Wert ihrer Produktion lag zu diesem Zeitpunkt höher als der des Bergbaus und rangierte auch vor dem der chemischen Industrie. Nur die Eisen- und Textilindustrie übertraf noch die wirtschaftliche Bedeutung des deutschen Mühlenwesens.

In diesem Zeitraum stieg der Kraftbedarf durch die wachsende Integration der einzelnen Arbeitsschritte (DIX 1997:159), der dadurch zufrieden gestellt werden konnte, indem Maschinen mit einem außerordentlich hohen Wirkungsgrad entwickelt wurden. Der französische Ingenieur Claude BURDIN [Bourdin] (1790 - 1873), Professor für Mechanik an der Bergbauschule in St. Etienne, entwickelte aufbauend auf vorherigen Konstruktionen von D. BERNOULLI (1730) und L. EULER (1754) - 1824

\footnotetext{
${ }^{26}$ Evans, Oliver ( 1755 Newport/Delaware - $\dagger 1813$ Pittsburgh): Mechaniker, kam bei einem Wagner in die Lehre und konstruierte bzw. verbesserte u. a. die Details der Mahlmühlen. Für die Müllerei konstruierte er den Elevator, den Conveyer, den Mehlkühler namens „Hopper Boy“, den Aufschüttler etc. Er erfand mit seinen Brüdern die oben erwähnte erste automatische Getreidemühle und suchte 1786 die Patentierung einer Dampfmühle und eines Dampfwagens, die mit hohem Dampfhochdruck ohne Kondensation betrieben werden sollten und die er zur Fortbewegung von Wagen empfahl. Von diesen Konstruktionen sandte er 1787 und 1794 Zeichnungen nach England. Um 1800 begann er den Bau derartiger Einrichtungen, und 1804 baute er einen Dampfbagger, der durch ein von Dampfmaschinen bewegtes Schaufelrad getrieben wurde. Ewen nimmt neben Watt eine sehr hervorragende Stellung in der Geschichte der Dampfmaschine ein, aber er wurde nicht in gleichem Maße durch die Verhältnisse gefördert, und epochemachende Ideen, wie die Benutzung der Dampfmaschine zum Fortbewegen von Schiffen und Lastwagen, konnte er nicht zur Ausführung bringen, weil kein Unternehmen bzw. Geldgeber ihn unterstützte. An technischer Literatur schrieb er „The young millwright's and miller's guide“ - New York 1795 (MEYERS KONVERSATIONSLEXIKON 1888, Bd. 5:431).
} 
ein neuartiges Wasserradprinzip und sprach in diesem Zusammenhang erstmals von einer „Turbine“ (lat. turbo $=$ Kreisel oder Wirbel). $\mathrm{Zu}$ jener Zeit (1826) hatte die französische Sociétè d'Encouragement pour l'industrie Nationale in Paris einen Preis von 6000 Francs für die Konstruktion eines Wasserrades ausgesetzt, das insbesondere zur Energiegewinnung der Industrie einsetzbar sein sollte. Burdin erfüllte die Bedingungen zwar nicht, aber sein Schüler, der französische Zivilingenieur Benoit FOURNEYRON (1802 - 1867) entwickelte sie weiter und baute 1827 die erste technisch verwendbare Wasserturbine, d. h. ein horizontales Wasserrad zur Nutzung der Wasserkraft um elektrischen Strom zu erzeugen. Die Fourneyron-Wassermaschine wurde in den kommenden Jahren verfeinert: 1830 durch den Franzosen PONCELET und 1837 in Deutschland durch Karl Anton HENSCHEL/Kassel, der ein Patent auf seine Axialturbinen erhielt, von denen die erste 1841 in Holzminden zum Einsatz kam. In demselben Jahr ließ sich JONVAL eine ganz ähnliche Turbine in Frankreich patentieren und ein Jahr später, 1838, wurde die Konstruktion von dem Amerikaner Samuel B. HOWARD [Howd], den Gebrüdern THOMSON und dem Ingenieur BOYDEN weiter ausgebaut.

In jenen frühen Jahren aber war für die Betreibung der ersten auf Fourneyron aufgebauten AusflussÜberdruckturbinen ein noch größerer Wasserbedarf erforderlich, der ab der ersten Hälfte des 19. Jahrhunderts eine erhebliche Steigerung der Ausnutzung von Wasserkraft zur Folge hatte. Für die effektive Nutzung der Turbinen, um den möglichen Wirkungsgrad von 80 bis $85 \%$ zu erzielen, war dementsprechend eine weitere Erhöhung des Gefälles notwendig und damit eine entsprechende Vertiefung des Flussbettes und eine Umgestaltung der Wehre (BINTZER 1991:18f.). Ihr Nachteil bestand darin, dass die Leitschaufeln beim Verlassen des Wassers Turbulenzen erzeugten, die das Laufrad bei geringeren Fließgeschwindigkeiten des Wassers abbremsten.

Bei geringstem Gefälle bis zu einem Meter waren Wasserräder noch rentabel, während bei allen sonstigen Wasserverhältnissen aber Turbinen eindeutig überlegen waren. In der Zeitspanne von 1880 bis ca. 1925 werden jedenfalls bereits ein Großteil der Wasserräder - und wie man an den Herkunftsbzw. Schaffensländern der Konstrukteure erkennen kann, zumindest in allen frankophilen, deutschsprachigen und anglo-amerikanischen Sprachräumen - durch Turbinen ersetzt (BEDAL 1992:88). Einige ließen von Wasser betriebene Turbinen einsetzen, um die Mahlkraft zu erhöhen. Auch andere Arbeiten wie Brennholzschneiden, Häckselschneiden und auch Schroten des Viehfutters wurden mit der Turbine durchgeführt (LANGE 1989:198).

Mit der Einführung verschiedener Turbinentypen, wie der 1849 nach ihrem Erfinder James Bichemo FRANCIS (1815 - 1892) „Francis-Turbine“ genannte Wassertriebswerkskonstruktion von Propellerflügeln mit äußerer Beaufschlagung, konnten auch in wasserarmen Gegenden liegende Wassermühlen mit den Horizontalrädern ausgerüstet werden. So waren seit Mitte des 19. Jahrhunderts Turbinenmühlen auch an Flüssen mit geringem Gefälle wie der Aisch oder der Altmühl häufig anzutreffen (BEDAL 1992:88). Die Turbine befand sich weit unterhalb des Wasserspiegels in einem geschlossenen Rohrsystem, das den Wasserdruck nahezu voll und ohne „Vorbeikommen“ auf das Flügelrad wirken ließ und so einen Wirkungsgrad von 90 \% erzielte. Sie wird für Fallhöhen zwischen 10 und $700 \mathrm{~m}$ eingesetzt.

Konstruktionen wie die im Jahre 1860 vom US-amerikanischen Ingenieur Lester PELTON (1829 Ohio - 1908 Camptville/Kalifornien) entwickelte Freistrahlturbine auf den kalifornischen Goldfeldern, die als Pelton-Turbine bekannt wurde, verstärkten diese Bestrebungen nach hoher Energieleistung. Die Pelton-Turbine nutzte insbesondere die Energie aus großer Höhe fallenden Wassers. Sie stellt die typische Hochgebirgsturbine für Wasserfallhöhen von 200 bis über $2000 \mathrm{~m}$ und mehr dar.

Die aber an wirklich kleinen Bächen mit nur geringem Gefälle liegenden Wassermühlen, die die erhöhte Wasserkraft durch den Bau eines Turbinenhauses und auch durch eine Erhöhung der Stauhöhe nicht nutzen konnten und die somit eine Steigerung der Produktion nicht zuließen, scheiterten an ihrer mangelnden Wettbewerbsfähigkeit (LANGE 1989:198). Mit der fortschreitenden Technik setzte sich also der Niedergang der ,alten“ Wassermühle weiter fort und mit ihr verschwanden die Mühlenteiche, die gerade an den kleinen, nur schwach wasserführenden Bächen lagen. Als letzte Maßnahmen in dieser Periode der wechselnden Wasseraufschlagtechnik wurden sie jedoch zunächst massenhaft errichtet, wie der aus dem Jahr 1827 stammende Eichteich, Vorder- und Hinterteich sowie der 1884 
angelegte Stockteich der Gutsmühle des sächsischen Rittergutsbesitzers Baron von Rochow in sächsischen Schwepnitz vermuten lassen. Zugleich gruben die Elektrizitätswerke den traditionellen Wassermühlen an neu zu grabenden Seitenarmen das „Wasser ab“, wie obiges Beispiel zeigt, wo der Gutsbesitzer einen Abzweig in der Ortmitte bis hin zu den Teichen anlegen ließ (SCHWEPNITZ 2004).

Daran änderte auch die vom Ingenieur und Professor in Brünn Viktor KAPLAN (1876 - 1934) 1912 erfundene axiale Flügel-Wasserturbine, die später Kaplan-Turbine genannt wurde und speziell für geringe Gefällehöhen konstruiert worden ist, nichts. Er fand heraus, dass weder die Francis-Turbine noch die Pelton-Turbine für die Wasserkraftnutzung bei großer, stark wechselnder Wassermenge und niedrigem Gefälle brauchbar waren. Angesichts der sich abzeichnenden technischen Entwicklung wurden jedoch Turbinen benötigt, mit denen man große Flüsse zur Stromgewinnung nutzen konnte

Aber auch für die anderen Betriebe, die, um mit der Entwicklung der Mühlentechnik Schritt zu halten, in der Mitte des 19. Jahrhunderts die schweren und trägen Wasserräder durch die flinken Wasserturbinen ersetzt haben (LORENZ 2000:43), bedeutete die Einführung und Verbreitung der Turbine die Abkehr von der Verarbeitung und Produktion von dinglichen Waren. Denn die Umstellung auf Turbinenbetrieb bedeutete nicht, ,mehr Korn zu mahlen, sondern Wasserkraft in elektrische Energie umzuwandeln“ (TERHALLE 1992:188). So steht die Turbine für die Ausnutzung der vorhandenen Wasserkraft hauptsächlich zur Stromerzeugung, bevor die Elektrifizierung der Dörfer im Jahre 1927 erfolgte (LANGE 1989:198). Die Umstellung auf Turbinenbetrieb bedeutet also letztlich die Umwandlung in ein Elektrizitätswerk.

Schließlich konnten auch die auf Turbinenbetrieb umgestellten Wassermühlen mit den verfügbaren Wasserkräften mit der Entwicklung nicht mehr Schritt halten, wie LORENZ (2000:43) von der Nebel und vom Teuchelbach berichtet. Nach Ablösung der Wasserräder durch Turbinen waren sie selbst an der Reihe. In einer Zeitspanne, in der begonnen wurde, die alten Wassermühlen leistungssteigernd mit Turbinen auszurüsten, wurden die mit einem künstlichen Mühlenmotor ausgestatteten ersten großvolumigen, schornsteinhohen Dampfmühlen gebaut (ERLER/MATTHIESEN 1989:86; BEDAL 1992:91).

Die im Gefolge mit der Erfindung der Dampfmaschine im Jahre 1784 einsetzende industrielle Revolution - in London arbeitete zu Ende des 18. Jahrhunderts die erste dampfbetriebene Mühle, während die ersten Dampfmaschinen in Deutschland je nach Landstrich zum Beispiel in Preußen bereits 1837 und bis spätestens ca. 1885 im Vredener Land betrieben wurden (TERHALLE 1992:188) - erleichterte zwar die Arbeitsprozesse, aber mit dem Aufkommen der Dampfmaschine ging die Ausnutzung der Wasserkraft immer mehr zurück, bis sie schließlich ganz wegfiel. Die seit Ausgang des 18. Jahrhunderts in den Städten errichteten Dampfmühlen mit Walzenmahlwerk waren den alten Wassermühlen mit scheibenförmigen Mühlsteinen hinsichtlich Leistung, Kapazität, Produktivität, Qualität des gemahlenen Mehls, Unabhängigkeit des Standortes und Unabhängigkeit von natürlichen Einflüssen (Hoch-, Niedrigwasser, Eisgang) schon weit überlegen. Es setzte das unwiderrufliche „Mühlensterben“ ein (HÖLSCHER 1987:22).

Im Kreis Holzminden beispielsweise drehten sich um 1800 noch um die 100 Wasserräder, davon kamen etwa 80 auf Getreide- und Ölmühlen, der Rest verteilte sich auf Papier-, Säge-, Loh- und Steinschleifmühlen, dazu Blank- und Nagelschmieden. Um 1900 waren es nur noch 70 Mühlen aller Art, die ausschließlich die Wasserkraft nutzen und auch da waren teilweise die Wasserräder durch Turbinen ersetzt (HÖLSCHER 1987:22).

Insbesondere die kleineren Wassermühlen an Bachläufen mit eher spärlicher Wasserkraft und häufigem Wassermangel durch Trockenheit sahen sich veranlasst auf Dampfmaschinenbetrieb umzustellen. Da diese Mühlen aber zumeist gleichzeitig diejenigen Mühlentypen waren, die über einen Stauteich verfügten, verfielen diese im Zuge der Umstellung, wenn die Müller nicht aus Vorsichtsmaßnahmen im Falle zum Beispiel eines technischen Defektes den Teich weiterhin bespannt hielten.

Der Dampfkessel steht für die Erzeugung von Dampf zum Antrieb der Dampfmaschine und als Prozessdampf für Heizzwecke, er steht aber auch für die Auflösung der Standortgebundenheit: Die 
Mühle war von den Naturkräften des Wassers unabhängig geworden und damit an keinen festen Standort mehr gebunden. Da die mit Rohöl und Elektrizität zu betreibenden Anlagen witterungsunabhängig betrieben werden konnten, wurden auch die Mühlteichen zum (Ersatz-)Antrieb nicht mehr gebraucht (ERLER/MATTHIESEN 1989:20).

Trotz der Abhängigkeit vom Wasserdargebot war die Nutzung der Turbine gegenüber der Anschaffung einer stärkeren Dampfmaschine aber noch immer eine attraktive Variante, so dass das lange Festhalten an der Wasserkraft „nicht als technologische Rückständigkeit zu bewerten ist.“ (DIX 1997 :159): Hohe Anfangsinvestitionen bei der Installation einer Dampfmaschine, niedrige laufende Kosten und eine weniger störanfällige Turbine waren einige der Argumente, die für den Weiterbetrieb mit Wasser sprachen.

Auch die Dampfmaschinen verbreiteten sich nicht so schnell. So erlangte zum Beispiel die Dampfmaschine als Antriebsmotor einer fränkischen Mühle „so gut wie keine Bedeutung.“ (BEDAL 1992:82). Die Hauptursachen waren die hohen Anschaffungs- wie auch Reparaturkosten und die schwierige Beschaffung großer Mengen des Brennstoffes, denn die Dampfmaschine war ein „Kohlenfresser“ (:82), obgleich auch die vor allem aus Holz bestehenden Wasserräder sowie letztlich auch die eisernen, wenn auch verzinnten Schaufeln in Zyklen aufwendig erneuert werden mussten und die Reparaturarbeiten den Mühlengerinnen einen hohen Betrag verschlangen.

Des Weiteren kamen künstliche Antriebsquellen „meist nur dort zur Anwendung, wo die Wasserkraft unzuverlässig war.“ (BEDAL 1992:91) Erst nachdem beispielsweise „die Kraft der mehrfach aufgestauten Bomlitz nicht mehr reichte, wurde im Jahr 1873 die erste Dampfmaschine aufgestellt (ERLER/ MATTHIESEN 1989:29). Auch in Franken kam die Dampfmaschine ,zu dieser Zeit allmählich und in ganz geringem Unfang“" auf (BEDAL 1992:84). Ebenfalls in manchen oberschwäbischen Orten, wie zum Beispiel in Bieber, ,zog sich das ,Sterben' der örtlichen Mühlen zeitlich etwas länger hin als in vergleichbaren Orten" (GRIES 1999:127). Oft ließen einige Müller auch in der Art eines Mischbetriebs zusätzlich zum Wasserrad, um die Leistungsfähigkeit der Wassermühlen zu erhöhen und die wasserarmen Zeiten (Sommer, Winterfrost) zu überbrücken, einen Dieselmotor einbauen. Dennoch wurde auf die Wasserkraft nicht verzichtet: „Um Dieselöl zu sparen, wurde nachts mit Wasserkraft geschrotet.“ (BUNSE 1991:34) „Die Intensivierung der Wasserkraftnutzung und Einführung der Dampfmaschine folgten also nicht stufenweise nacheinander, sondern liefen parallel und wurden individuell an jedem Standort je nach den natürlichen und technischen Voraussetzungen auch miteinander kombiniert.“ (DIX 1997:159)

Vor allem dort, wo die verfügbare Wassermenge auch mittels Stauteich ohnehin nur sehr gering gewesen ist, erfolgte zu Ende des 19. Jahrhunderts der Einbau einer Dampfmaschine (MÖRSTEDT 1995:81).

Aber auch dort, wo eine leistungskräftige Mühle an einem eigentlich wasserreichen Gewässerlauf lag, wie beispielsweise die im 14. Jahrhundert erwähnte, in ihrer Form 1849 errichtete und 1989 stillgelegte Oberbehmer Mühle (,,Roggenmühle“) an einem separaten Wassereinlauf der Werre, dem Fluss mit der größten Wasserführung im Kreisgebiet von Herford, ,,wurde die Wasserkraft für die Mühle im Sommer doch knapp." Diese Verknappung trat hier seit Mitte des 19. Jahrhunderts verstärkt auf, so dass die Mühle spätestens im Jahr 1871 auch über eine Dampfmaschine verfügte (MÖRSTEDT 1995:123). Dieser Wassermangel korreliert jedoch auch hier nicht unbedingt mit dem schwächeren Wasserzulauf, sondern vor allem mit dem Kapazitätsausbau. Die Handwerksmühle war zu einer Industriemühle gewachsen, mit einem der Bedeutung entsprechenden Neubau der Staueinrichtungen sowie dem Ausbau der Mahlgänge. 28 Mitarbeiter belieferten größtenteils Abnehmer im Ruhrgebiet, aber auch in der heimischen Region, wie beispielsweise Oetker in Bielefeld, oder Hoffmanns Stärke in Bad Salzuflen (:145).

Des Weiteren entschlossen sich insbesondere im 19. Jahrhundert zahlreiche Müller wegen häufigen Wassermangels Windmühlen zur Ergänzung der Wassermühle zu bauen, um mögliche Ausfallzeiten durch Wassermangel zu reduzieren (SCHEFFLER 1982:45). 
Erst der steigende Bedarf an Antriebskraft für die Werkzeug- und Verarbeitungsmaschinen, der durch Wasser und Wind nicht mehr aufgebracht werden konnte, bahnte der Dampfmaschine den Weg in Gewerbe und Industrie. So war die Einführung mechanischer Webstühle an die Einführung der Dampfmaschine gekoppelt, „da die Wasserkraft für die Webstühle einen zu unregelmäßigen Antrieb lieferte.“(DIX 1997:53f.).

Nicht alle auf Dampfbetrieb umgerüsteten Wassermühlen gewannen den Wettlauf mit der Zeit. Sie lagen zwar an wasserreichen Wasserläufen, jedoch der Verkehr verlagerte sich zunehmend auf die Straße, die Schiene und auf schiffbare Flüsse. Große Mühlen, zunächst mit Dampfantrieb, dann mit Elektroantrieb, suchten sich günstigere Standorte abseits der nicht mehr notwendigen zu beaufschlagenden und bespannenden Wasserläufe. Diese allerorten aufkommende Handelsmüllerei mit anspruchsvollerer Technik und dadurch qualitativ hochwertigeren Mehlerzeugnissen ist weniger bekannt, aber kaum unbedeutender für das allmähliche Verschwinden. Der Niedergang der Mühlen bahnte sich unaufhaltsam an. Das Zeitalter der Wassermühlen neigte sich seinem Ende zu (LORENZ 2000:43).

Nach dem Siegeszug der Dampfmaschine führten am Ende des 19. Jahrhunderts die Erfindungen der Benzin- und Elektromotoren zum endgültigen Untergang der traditionellen Wassermüllerei im Land. Die Müller konnten ihre Existenz nur retten, indem sie sich selbst der neuen Energiequellen bedienten und ihre Mühlen mit Dampfkessel und Benzin- oder Benzolmotoren betrieben. Gerade für kleinere Mühlen wurde der Motor erst mit Einführung des Diesels rentabel, der kein besonderes Personal, anders als etwa die Dampfmaschine, erforderte und auch nicht so wartungsaufwendig war wie diese. Ein Dieselmotor verbrannte Gasöl, Rohöl und Teeröl gleichermaßen und hatte zudem einen kleineren Raumbedarf als eine Dampfmaschine (BEDAL 1992:91; ebenso GRIES 1977).

Im Gegenzug fiel die Landwirtschaft, die zur Fütterung geschrotetes Getreide benötigte, mit der Elektrifizierung der ländlichen Gebiete als Kunde aus; denn nun konnte jeder Bauer im Eigenbetrieb auf dem Hofe seine eigene kleine Motormühle für den täglichen Futterbedarf betreiben (TERHALLE 1992:186). Zudem buken Bauern nicht mehr Brot selbst, sie kauften es zu (ERLER/MATTHIESEN 1989:20). Gleichzeitig war mit dem Aufkommen der modernen Großmühlen das Ende fast aller Kleinmühlen gekommen (DOBELMANN 1980:8f.; TERHALLE 1992:186). Die Mühlweiher verloren ihre Funktion mit dem Ausbau der Elektrizitätswirtschaft, die auf der Verstromung fossiler Brennstoffe basierte (KONOLD 1991:366). Der Stauteich wurde im 19. Jahrhundert - zunächst zu Aushilfszwecken, später als ausschließliche Antriebskraft - durch Motorkraft ersetzt. Der Teich als Ersatzwasser für den Mühlenräderantrieb hatte ausgedient. Zudem waren keine so großen Flächen für die Wasserbevorratung und der Wasserzufuhr mehr notwendig. Bei zu Motormühlen umgebauten Wassermühlen wurde der Teich, da funktionslos geworden, in den meisten Fällen abgelassen und seiner Verlandung anheim gegeben oder zugeschüttet. Die entstehenden Großmühlen zogen Motoren vor, da sie den Vorteil der freien Standortwahl besaßen. „Die Mühle brauchte nicht mehr an Flußläufen, sondern konnte an jeder beliebigen Stelle errichtet werden.“ (BEDAL 1992:91)

Die „Unentwegten“ der Getreidemühlen gaben zuerst die Herstellung von Feinmehl auf und wollten ihre Wassermühle mit dem Herstellen von Futtermitteln am Leben erhalten, wie zum Beispiel die Stiftsmühle in Quernheim sogar bis 1991. Doch die Bauern, besaßen sie keine eigene motorbetriebene Schrotmaschine, „liefen ihnen davon und holten sich [...] aus den neuen Futtermittelfabriken ihre Fertigfuttermittel“" (ERLER/MATTHIESEN 1989:21). Geraume Zeit später dann schloss dann auch die Schroterei. Generell aber wurden die Mahlmühlen etwas länger betrieben als die Schleifmühlen und Hämmer, bisweilen bis in die 1970er und sehr vereinzelt sogar bis zu Anfang der 1990er Jahre, da sie u. a. einen geringeren Energieaufwand benötigten als die schweren Hämmer und Gussfabriken.

Viele Wassermühlen waren aber nicht nur als Getreidemühlen eingerichtet, sondern neben den Mahlgängen waren andere Werkzeuge wie Ölschlag, Kollergang, Pressen, Sägen, Stampfwerke, Dynamos etc. eingebaut. Die Wasserräder trieben also je nach wirtschaftlichem Erfordernis und Gelegenheit über angepasste Getriebe im Wechsel unterschiedliche Werkzeuge an. Quasi nebenbei wurde die Wasserkraft von Mühlenanlagen auch zum Antrieb landwirtschaftlicher Maschinen ausgenutzt, wozu Seiltransmissionen vom Mühlgebäude zum Haupthaus der Höfe angelegt wurden. Nicht 
weniger als 59 solcherart kombinierte Wassermühlen ließen sich beispielsweise im Kreis Herford nachweisen (MÖRSTEDT 1995:270).

Viele Nutzungen hingegen wurden bereits zeitlich vorher niedergelegt: Die Ölschlägerei wurde bis Ende des 19. Jahrhunderts aufgegeben und ein Großteil der Bokemühlen wurde schon einige Zeit später stillgelegt, als nach dem Niedergang des Leinengewebes auch die Maschinen zur Flachsverarbeitung nicht mehr gebraucht wurden. Gleiches widerfuhr den Lohmühleneinrichtungen und auch die letzten Zichorienmühlen wurden nach dem Zweiten Weltkrieg aufgegeben. Die Grützemühlen erfüllten zuletzt in der Zeit nach dem Ersten Weltkrieg ihren Dienst und halfen nicht unwesentlich mit, die seinerzeitige Ernährungskrise zu überstehen (MÖRSTEDT 1995:270).

Bei diesem „Totentanz vorindustrieller Technik“ (ERLER/MATTHIESEN 1989:21) kamen die Sägemühlen zuletzt dran, weil sie noch einige Zeit billig Schnittholz für den Wohnungs- und Gewerbebau sowie die für den Eisenbahnbau notwendigen Eichenschwellen herstellen konnten. Zudem wurde der Rohstoff Holz nicht in dem Maße durch synthetischen oder Importprodukte ersetzte, wie das bei Raps, Leinöl, Lohe, Leinen und Zichorienkaffee der Fall war. Die Modernisierungswelle aber erfasste nach dem Zweiten Weltkrieg auch die letzten abgelegen wasserbetriebenen Kleinmühlen. Die letzte Anwendungsform der Stromproduktion wurde in aller Regel aufgegeben, sobald die Höfe an das Stromnetz angeschlossen waren.

Bislang fast unberücksichtigt blieben in ihren Auswirkungen für den Niedergang der Wassermüllerei die klimatische Entwicklung und die durch übermäßige Wassernutzung verursachte Änderung des Wasserhaushaltes, an dem - neben anderen Einflussfaktoren - auch die Wassermühlen selbst mitgewirkt haben: Wie bereits erwähnt, hatten bereits vom 10. bis 13. Jahrhundert neben Klostermühlengründungen auch die Adelsmühlen einen ,herausragenden Anteil am systematischen Gebrauch und Nutzen der Wasserkraft“ (ERLER/MATTHIESEN 1989:12), waren seit dem Mittelalter, spätestens aber seit dem 12. Jh. in Mitteleuropa ,in allen Gegenden verbreitet“ (BEDAL 1992:31). Die Auswirkungen der Ansiedlung von Wassermühlen auf die Gewässerveränderung durch Ableitungen, Wehre, Mühlgräbenbau etc. waren erheblicher Natur. Zudem kam es durch Eingriffe des Menschen in die anderen Umwelten, durch Rodung von Wäldern, Trockenlegung von Mooren, Meliorationen, Siedlungsbau, Bergbau usw. zu Veränderungen in der Landschaft, die nicht zuletzt an den Gewässern sichtbar wurden.

Als zum Beispiel 1857 mit den Abteufarbeiten des Antonieschachtes in Bantorf/Kreis SchaumburgLippe begonnen wurde, ,führte der Radbach plötzlich wesentlich weniger Wasser. Das führte dazu, daß die beiden Wassermühlen [Piepmühle, Waltringhäuser Mühle, B.B.] ihren Betrieb einstellen mussten und in Riehe in trockenen Jahreszeiten großer Wassermangel herrschte. Hinzu kam noch, daß das Wasser des Ammerbaches zum Teil umgeleitet wurde. In extrem trockenen Sommern versiegten demzufolge die meisten Brunnen, weil Riehe auf einer etwa $10 \mathrm{~m}$ starken wasserundurchlässigen Tonschicht liegt. Nun musste das lebensnotwendige Wasser in Jauchefässern von dem Gemeindebrunnen geholt werden.“ (SCHRÖDER 1979) Der Steinkohlenbergbau erschwerte also die Nutzung der Wasserkraft und brachte das „gewachsene System der Wassernutzungsrechte aus dem Gleichgewicht“ (NEUBER 2002:213): „Mühlteiche verschlammten, Quellen und Bäche wurden trockengelegt oder das Bachwasser direkt für Betriebszwecke abgeleitet.“ (:213)

Neben die vermehrte Wassernutzung im Zuge der Wassermühlenneubauten trat die Wasserentnahme für eine zentrale Wasserversorgung der Stadtbewohner, die durch den Bau von neuzeitlichen Wasserkünsten und Laufbrunnen repräsentiert ist und sich bis in die gegenwärtige Zeit mit dem Rohrleitungsbau fortsetzt. BUNSE (1991:51) berichtet von der Boutenmühle an der Glinde, dass mit dem Bau der Wasserversorgung der nachliegenden Gemeinde in den Nachkriegsjahren durch die Wasserentnahme die Betriebskraft der Mühle wesentlich geschmälert wurde und so, bevor die Mühle aufgegeben wurde, zunächst ein Mühlenteich angelegt wurde. Der Wassermangel machte auch der im 19. Jahrhundert neu errichteten Teichmühle in Güstrow schwer zu schaffen. Der Wasserspiegel des Inselsees sank ab, und die Gleviner Mühle geriet in große Schwierigkeiten. „Schuld daran war nicht nur die große Trockenheit im Sommer des Jahres 1887“, wie LORENZ (2000:42) feststellt, sondern 
auch die zu starke Wasserentnahme. Bei Wassermangel hatte im städtischen Umfeld die Wasserkunst immer Vorrang (:42).

Die Wassermühlen konnten nicht auf andere Wasserquellen ausweichen, sie waren ausschließlich auf den Bach oder Teich als Wasserquellen angewiesen. Vermutlich waren es gerade auch die schlechten Wasserbedingungen an den Bachläufen - Zuflussschwankungen gekoppelt mit Verschmutzungen die den Betrieb der Mühlen, vor allem den der Papiermühlen so stark einschränkten, dass diese schließlich nicht mehr rentabel arbeiten konnte und aufgegeben wurden (DIX 1997:194f.). Schließung und Verkauf von Mühlenbetrieben können verschiedene Ursachen gehabt haben, aber unter anderem auch durch die Verschlechterung der Wasserqualität und Wasserknappheit des Baches ausgelöst sein $(: 64)$.

$\mathrm{Zu}$ geringe Wasserführung, vor allem bei Quellmühlen, weil zum Beispiel die Gemeinde Wasserrechte an der Quelle erkauft hatte, um Wasser aus dem Quellgebiet zu entnehmen, aus dem eigentlich auch die Mühle ihr Aufschlagwasser bezog, führte zur Aufgabe (BEDAL 1992:128) und dies bis in neueste Zeit. So versiegte 1971 der an zwei Stellen als Brunnen gefasste Käsborn in Offenbach-Bieber, „der jahrhundertlang das Wasser für Menschen und Tiere auf der Käsmühle geliefert hatte und aus dem bis dahin auch die Mühlenbewohner [...] ihr Wasser entnehmen konnten. Innerhalb eines Jahres sank der Wasserspiegel um beinahe drei Meter“ (GRIES 1999:10). Die Käsmühle ist heute ein beliebtes Ausflugslokal im nahen Frankfurter Umland.

Auch die Wasserkraft des niederelbischen Bornbaches „reichte um 1888/89 nicht mehr aus, die Mahlwerke der erst 1870 errichteten Mühle anzutreiben“, so dass der Besitzer eine Dampfmaschine aufstellen ließ (ERLER/MATTHIESEN 1989:32). Der im Wendland verlaufende Göttiener-Lübelner Mühlenbach führte an seinem oberen Lauf bei den Dörfern Maddau und Kukate (seit 1972 Ortschaften der Gemeinde Waddeweitz) den Namen „Wistruck“ (dt. „Schneller Bach“). „Doch suchen wir dort heute einen Bach vergebens. Die hier einst vorhandenen Mühlen Kukate und Zebelin „dürften vermutlich wegen zunehmenden Wassermangels eingegangen sein. [...] Das gleiche Schicksal dürften weitere Mühlen am Oberlauf einiger Bäche erlitten haben“(LANGE 1989:50).

Dem zunehmenden Wassermangel suchte man durch zweierlei Maßnahmen zu begegnen: Durch höheres Anstauen des Baches und Anlegung von Teichen. Sie sollten eine Wasserbevorratung und -aufschlagung ergeben, die eine Verwandlung der Mühlen in mittelschlächtige und - bei ausreichenden Höhenunterschieden - in oberschlächtige Mühlen ermöglichten, denn durch längeres Halten des Wassers auf den Grindeln wurde die Schwerkraft des Wassers besser ausgenutzt und die Leistungen der Mühlen wesentlich erhöht. Seit Ende des 19. Jahrhunderts wurden von einigen Müllern sogar die Teiche höher gelegt, um entweder die bis dahin noch mittelschlächtige Mühle mit einem oberschlächtigen Wasserrad versehen zu können oder um eine höhere Effektivität zu erzielen. Trotz dieser Maßnahmen: Die Wassermühlen, deren Wasserräder von einem nur gering angestauten Bach getrieben wurden und die auch nur einen Mahlgang geringen Durchmessers hatten, leisteten dementsprechend nur wenig und waren nur von kurzer Dauer. Auch wurden einige Mühlen weiter talwärts verlegt, um mehr Wasser auf das Rad zu bekommen (LANGE 1989:50ff.).

Schließlich reichte die durch zunehmende Verschlammung der Mühlenbäche und Teiche reduzierte Wasserkraft nur noch zum Antrieb von einem Wasserrad zum Ölschlagen aus, wie beispielsweise der an der Drawehner Jeetzel gelegenen Drawehner Mühle in Lüchow (LANGE 1989:124). Auch „wiederholte Regulierungen [...] führten letztlich dazu, daß nur noch mit einem Wasserrad gearbeitet werden konnte“, wie LANGE (:127) von der Dumme berichtet.

„Das Zurückgehen der Wassermühlen“, ist sich SCHEFFLER (1982:45) sicher, „hängt mit dem jeweils eintretenden Wassermangel zweifellos zusammen" und ihr landschaftlicher Begleiter ist der Stauteich. Er kann zum einen als „Zeiger“ einer auf der Suche nach Effizienz, Leistungsausbeute, Betriebssicherheit und dem Markterfordernis nach schnellerer Produktion strebenden Mühlenwirtschaft angesehen werden und zum anderen als landschaftshistorischer Ausdruck von Wasserdefizit als Folge einer veränderten Oberflächenwasserstruktur. 
Nicht aber nur wasserverarmende Veränderungen führten zum Abbruch von Wassermühlen, sondern auch ein Zuviel an Wasser durch Dammbrüche der Mühlteiche infolge von Unwettererscheinungen: LANGE (1989:95) beschreibt am Beispiel der Wassermühle Thalmühle bei Vietze/Kreis Wendland: „Am 30. August 1902 ging ein wolkenbruchartiger Gewitterregen im Höhbeck-Gebiet nieder. Die Dämme der Teiche brachen. In der zehn Meter tiefen von den Wasserfluten gerissenenen Rinne versanken ein Teil der Scheune Seitdem hat sich das Mühlrad nicht wieder gedreht. Der Bach suchte sich [...] seinen eigenen Weg zur Elbe.“ Von einer Sägemühle, die wegen starker Wasserschäden 1815 abgerissen wurde, weiß auch FINK (1969:217) zu berichten. Und bereits im Jahre 1588 wurde bei starkem Unwetter die Pulvermühle zu Altrahlstedt „durch große Wassermassen demoliert und weggerissen“(:220).

Rein spekulativ ist der hier von mir vertretene Gedanke, dass in anderen Fällen der Wasserabfluss durch zufließende Wässer aus Bergbaustollen, die in wasserreichen Zeiten nicht mehr in Staubecken haben zurückgehalten werden können, die Wasserführung immens erhöht und zur Zerstörung von Wassermühlen in bzw. unterhalb von Bergbaurevieren geführt hat. Obschon an anderen Tagen die bergbauliche Grubenwasserabführung der Wasserkraftnutzung am Bach sehr dienlich war, fiel so das Abflussverhalten durch den künstlichen Wasserzufluss im Jahresverlauf gleichmäßiger aus.

Die Nach- und Zwischenkriegszeiten im 20. Jahrhundert bedeuteten aus vielerlei Hinsicht eine Zäsur für die ländlich gelegenen Wassermühlen. Nach dem Ersten Weltkrieg, vor allem in den 1920 und 30er Jahren wurden beim Bau von Talsperren zahlreiche Mühlen abgerissen oder einfach überwässert, wie zum Beispiel die Mühle Helminghausen bei der Diemeltalsperre (BUNSE 1991:57). Damit anheim fielen selbstverständlich auch die vielen Mühlteiche, die in den größeren „Stauteichen“ aufgingen.

Vor, während und nach dem Ersten und dem Zweiten Weltkrieg mussten Wassermühlen Truppenübungsplätze weichen, insbesondere im Heidmarkgebiet des Altkreises Fallingbostel, wie in Munster, Bostel, Pröbsten. Die Wassermühle Reiningen beispielsweise gehört „zu den zahlreichen Mühlen im Landkreis Soltau-Fallingbostel, der der Ausweisung oder Erweiterung von Truppenübungsplätzen zum Opfer gefallen sind.“ (ERLER/MATTHIESEN 1989:66) Bereits 1937 war die Mühle bei der Erweiterung des Truppenübungsplatzes durch den Reichsfiskus aufgekauft worden (:66). Noch früher, 1892/93, geriet die Wassermühle Sültingen am Oberlauf der Oertze in die Einrichtung des Militärübungsplatzes Munster (:76).

Im Zweiten Weltkrieg dann wurden auch Wassermühlen Opfer des Kriegsgeschehens. Durch vorrückende britische Truppen beispielsweise wurde die Jarlinger Wassermühle im Landkreis SoltauFallingbostel mit Panzergeschützen zerstört (ERLER/MATTHIESEN 1989:53). Durch Fliegerangriffe wurde die Bockmühle an der Hahle bei Worbis vernichtet (ROGGE 1993:54) und Fliegerbomben trafen 1944 auch die „Trinns- oder Schäferskotten“ im Itter-Tal (LUNKENHEIMER 1990:63) und den wasserbetriebenen „Köllerskotten“ am Lochbach (:93).

Ein weiterer Grund für das in den Kriegsjahren niedergehende Mühlenwesen ist darin zu sehen, dass Modernisierungen mangels Werkstoffen ausbleiben mussten und im Falle der Ölmühlen die Bauern den arbeitsaufwendigen Flachsanbau auf Grund der schlechten Arbeitskräftesituation nicht mehr betreiben konnten (OLMÜHLE DÖRNTHAL 2004). Zudem wurden einige Müller bzw. deren Söhne oder Gesellen zum Kriegsdienst einberufen. Ihre Frauen bzw. Schwestern sorgten in den wirtschaftlich schwierigen Zeiten dafür, dass den Bauern der Umgebung das rationierte Korn zu nächtlicher Stunde vermahlen wurde.

Nach dem Krieg bis in die 1950er Jahre gab es noch einmal einen Aufschwung, weil in den Städten gerade die industriellen Zentren zerstört waren.

Als nach dem Zweiten Weltkrieg mit Beginn des Wirtschaftswachstums in den 1950er Jahren das Mühlensterben seinen Höhepunkt erreichte, verzichteten viele Müller gegen Entschädigungszahlungen auf ihr Stau- und Mahlrecht. So erwarb Mitte der 1950er Jahren zum Beispiel die Stadt Fallingbostel die Wasserstaurechte an den Mühlen (ERLER/MATTHIESEN 1989:45). „Hierdurch war es möglich, 
den Bach zur regulieren und den Wiesenertrag zu erhöhen.“ (LANGE 1989:54) Gleichzeitig wurde den verbleibenden Müllern durch Abgraben des Mühlenbaches das Wassers zum Mühlenbetrieb entzogen (:53). Pathetischer drückt dies ERLER/MATTHIESEN (1989:21) aus: „Den jahrhundertealten Mühlenplatz endgültig als Grabstelle auszuweisen, dafür steht als Sterbehilfe eine politische Maßnahme der Fünfziger Jahre das sog. Mühlenstillegungsprogramm. Danach bekam jeder Müller eine Geldprämie dafür, wenn er den Tod seiner Mühle auf eine Zeitdauer von dreißig Jahren beschwor." 1953 entschied das Kabinett Adenauer, die Mühlenwirtschaft den Marktkräften uneingeschränkt auszusetzen. Ein Konzentrationsprozess kam in Gang, in vielen Mühlen standen Kapazitäten ungenutzt zur Verfügung. 1959 und mehrmals in den 1960er Jahren erhielten Müller, die ihre Mühle stilllegen wollten, eine Prämie. Das Geld für diese Stilllegungsaktionen brachten die am Markt verbliebenen Mühlen als Abgabe auf jeden vermahlenen Zentner Getreide auf; über die „Mühlenstelle Bonn“ wurde die Prämienzahlung angewickelt (MÖRSTEDT 1995:271)

Während dieser als „Mühlensterben“ bekannt gewordenen Stilllegungswelle der Fünfziger und Sechziger Jahre des 20. Jahrhunderts gaben allein im Kreis Herford mindestens 20 Betriebe in jedem Dezenium auf. Betrachtet man den Zeitraum etwa genauer, so ist der Schwerpunkt der Stilllegungswelle eindeutig in der ersten Hälfte der 1960er Jahre festzustellen.

Mit dem Wirtschaftsaufschwung wurde auch dem Tourismus wieder nachgegangen. Es entstanden vielfach auf ehemaligem Mühlengelände Campingplätze, auch, um den Mühlteich als Badesee zu nutzen, wie zum Beispiel beim Mühlenteich der Hellberger Wassermühle in Kirchboitzen geschehen (ERLER/MATTHIESEN 1989:54). Auch aus der Düshorner Mühle sollte aus dem Teich und dem Mühlenanwesen ein Campingplatz mit Badesee entstehen. Von der Mühle aber ist hier ,außer dem Teich nichts mehr vorhanden.“ (:42). Ebenfalls entstand am Lingerhahner Mühlenteich auf den Hunsrückhöhen ein „Camping und Mobilheimpark“. Den ehemaliger Mühlenteich der Fischendorfer Wassermühle in Dorfmark im Landkreis Soltau-Fallingbostel, der nachfolgend zur Wassersicherung als Rückhaltebecken angelegt worden war, baute die Gemeinde Dorfmark zu einer Badeanstalt um (:40). Auch aus ehemaligen Teich der Neuenkirchener Wassermühle, die seit 1986 stillsteht, ist inzwischen eine Badeanstalt geworden (:58). Die ehemaligen ,Scheimker Mühlenteiche' nördlich Isenhagen, Kreis Gifhorn, sind heute Badeanstalt und Teile des Isenhagener Sees (BOSSE 1991:141; siehe unten). Für den Bau des Ittertales Strandbades, in das mehrere Mühlenteiche integriert worden sind, wurde um 1921 der Linderskotten niedergelegt. Bei der Erweiterung zu einer Badeanstalt musste 1944 der Zielskotten und ebenso der Kirschbaumskotten abgebrochen werden und ihre Kleinteiche wurden einbezogen (LUNKENHEIMER 1990:56ff.).

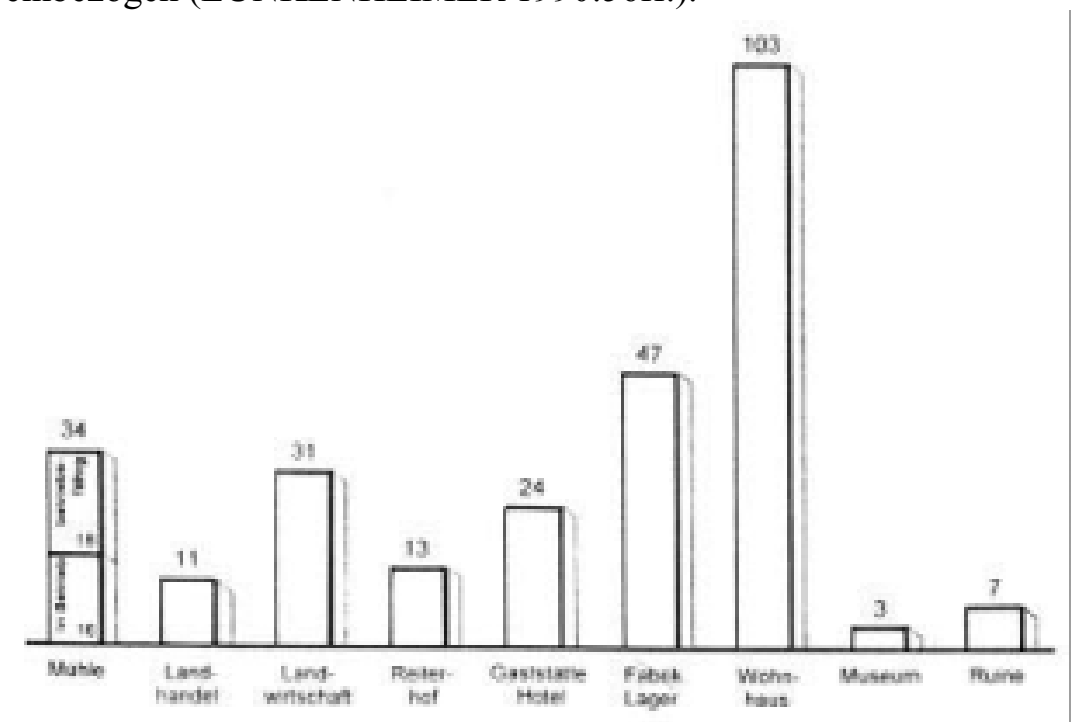

Abb. VIII-25: Die heutige Nutzung der ehemaligen Wassermühlen einschließlich ihrer Rest- oder Nachfolgegebäude (Auswertung von 273 Mühlen, aus: VOGT 1988:16)

Vor allem in touristischen Gebieten fand die Umwandlung von Wassermühlen in Gasthöfe und Pensionen statt und mit ihnen oftmals die Entwicklung eines Mühlenteiches als Boots- und Angelparadies. In der Fränkischen Schweiz zum Beispiel die Weihersmühle in Weismain und im 
Ittertal die Heidberger Mühle (siehe Abb. VI-36). Der kulturhistorische Vorteil hier besteht darin, dass sie in ihrer ursprünglichen Anlageform zumindest erhalten geblieben sind, wenn sie auch einem anderen Nutzungszweck zugeführt wurden.

Andere wiederum wurden an Originalplätzen abgebaut und fristen ihr künstliches Dasein in Freilichtmuseen oder wurden an ihrem ursprünglichen Standort als regionalgeschichtliches Heimathaus (z. B. die Wassermühle in Lassan), als besonderes Mühlenmuseum (z. B. das private Mühlenmuseum „Greener Mühle“ im Raum Bad Neuenahr-Ahrweiler an der Ahr oder das Wilhelm-Busch-Museum in Ebergötzen), als Cafestube (z. B. das Mühlencafe Bevern) oder Bürgerbegegnungsstätte (z. B. des Heimat- und Wandervereins Venne e. V. in der Linnenschmidt'schen Mühle), als Sitz eines Kunstvereins (Kunstkreis e.V. Wassermühle Lohne) oder einer Fischereivereins (z. B. die Wassermühle Fladder-Fünfhausen bei Wardenberg), als landschaftsgebundenes Umweltinformationszentrum (z. B. die Biologische Station Osterholz-Scharmbeck in der Rönn'schen Mühle, das Umweltzentrum Heerser Mühle bei Bad Salzuflen oder die Blumberger Mühle im Biosphärenreservat Schorfheide-Chorin), Verwaltungssitz (Stiftung für Natur und Denkmalpflege, Heersfelder Mühle im Regierungsbezirk Arnsberg), als Jugendhaus (Wassermühle Rössing/Nordstemmen) oder als kirchliches Ersatzzentrum zum Abhalten von Gottesdiensten (Hartingsche Wassermühle in Kleinenbremen) hergerichtet. Ihre Mühlteiche aber wurden oftmals nicht in das Ensemble historisch eingebunden. Eine Ausnahme bilden die eben gescholtenen Freilichtmuseen, die zumindest den wasserbaulichen Zusammenhang rekonstruiert haben.

Auch Umbauten zu Wohnhäusern, Landschulheimen oder Planierung von Mühlanlagen mit nachfolgender Errichtung einer modernen Wohnsiedlung mit Reihenhäusern (GRIES 1999:57; OPEL 1991:23,34), führten zu einem Wegfall von Teichen und Wasserstauungen. Umnutzungen von Mahlmühlen zu Möbelwerkstätten, Windenfabriken, Bürstenbindereien und Dampfwäschereien (OPEL 1991:24ff.) ließen vorhandene Mühlteiche funktionslos werden und wurden teilweise auch wie im Fall der Wäscherei und Lohnbügelei in Bautzen beseitigt.

Wassermühlen fielen sogar, so schizophren es klingt, der Begradigung von Bächen zum Opfer, wie die Grasbecker Papiermühle in Walsrode an der Greßbecke belegen, die 1967 der Regulierung resp. Verlegung des Mühlenbaches weichen musste und damit war auch das Ende des Mühlenteiches besiegelt. Die Grasbecker Papiermühle wurde durch einen Teich betrieben und 1608 erstmals erwähnt: Der „Teich ist mittlerweile aufgeschüttet und heute eine Wiese“ (ERLER/MATTHIESEN 1989:80f.). Das endgültige Aus für den bereits weitgehend eingestellten Mühlenbetrieb der 1423 erstmals urkundlich erwähnten Aumühle in der Gemeinde Eyb, ca. $2 \mathrm{~km}$ östlich von Ansbach, bringt auch die Verlegung der fränkischen Rezat im Jahr 1974 (BEDAL 1992:236). Das Hauptgebäude, die eigentliche Mühle, lag nördlich des von der Rezat abgezweigten, als Hauptwasser der Mühle dienenden Mühlbaches, der dadurch aber kein Wasser mehr bekam (:224f).

Sogar der Fall, dass mangels ausreichender Wasserführung anstelle einer Wassermühle eine Windmühle errichtet wurde, ist belegt. Wie zum Beispiel bei der Weyhauser Mühle, von der es nur noch den Mühlenteich gab, der aber mittlerweile auch zugeschüttet worden ist (BOSSE 1991:87). Bei dem nachträglichen Aufsatz einer Windradeinrichtung auf eine Wassermühle wie bei dem Beispiel der Hüvener Mühle nordöstlich von Haselünne im Emsland, wurden ebenfalls die ehemaligen Teiche unbrauchbar und im Zuge der Bachlaufverlegung zugeschüttet. 


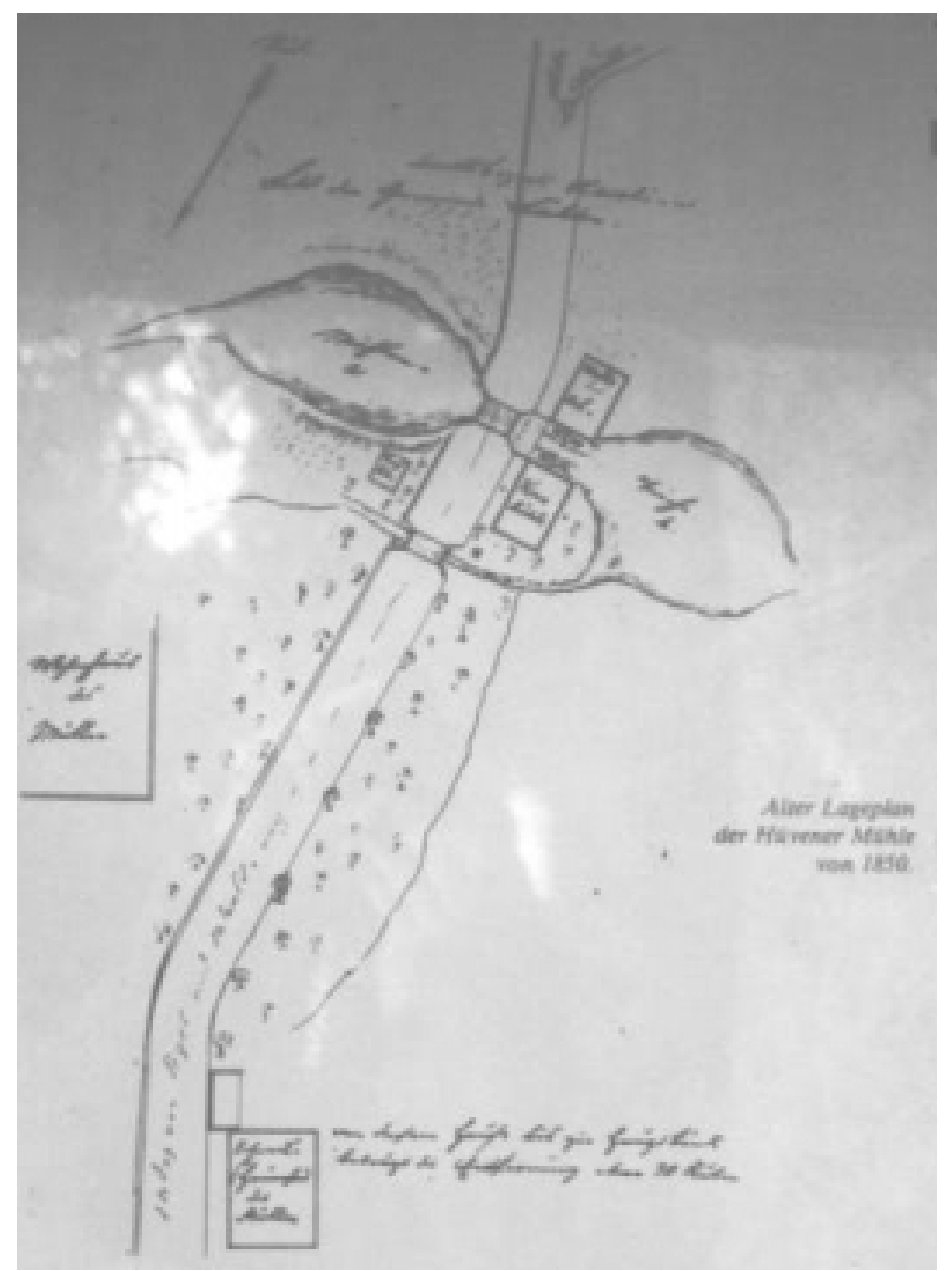

Abb. VIII-26: Ehemalige Teiche der „Hüvener Mühle“ in einem alten Lageplan von 1850

(eig. Aufnahme von der Informationstafel) Bei der anstehenden Rekonstruktion der Mühle wird leider nur Gebäudesanierung betrieben.

Vor allem im Zuge von Straßenbaumaßnahmen sind viele Mühlteiche vernichtet worden oder sind als Wassermühlenrelikte stehen geblieben. Die untere Quernheimer Mühle in der Gemeinde Kirchlengern, Kreis Herford, wurde in Zusammenhang mit dem Ausbau der Bundesstraße B 239 in der Mitte der 1970er Jahre abgerissen und der Mühlenteich zugeschüttet. Bereits über 35 Jahre vorher, im Jahr 1938 wurde unmittelbar hinter der Wassersägemühle Wense, Landkreis Soltau-Fallingbostel, die Trasse der Autobahn Hamburg-Hannover gezogen. Auch diese Mühle musste den Infrastrukturmaßnahmen weichen und wurde bis 1940 völlig abgerissen, immerhin sind „die Teiche [...] in Wense heute noch vorhanden. Sie werden vom Bundesforstamt unterhalten und dienen der Fischzucht.“ (ERLER/ MATTHIESEN 1989:66) Ebenso wirkte sich der Bau des Luppekanals ab 1934 bis 1958 für die verfügbare Wassermenge der Elstermühlen bei Leipzig negativ aus und führte zu einem vorzeitigen Einbau alternativer Betriebsaggregate (KORMANN 2003). 


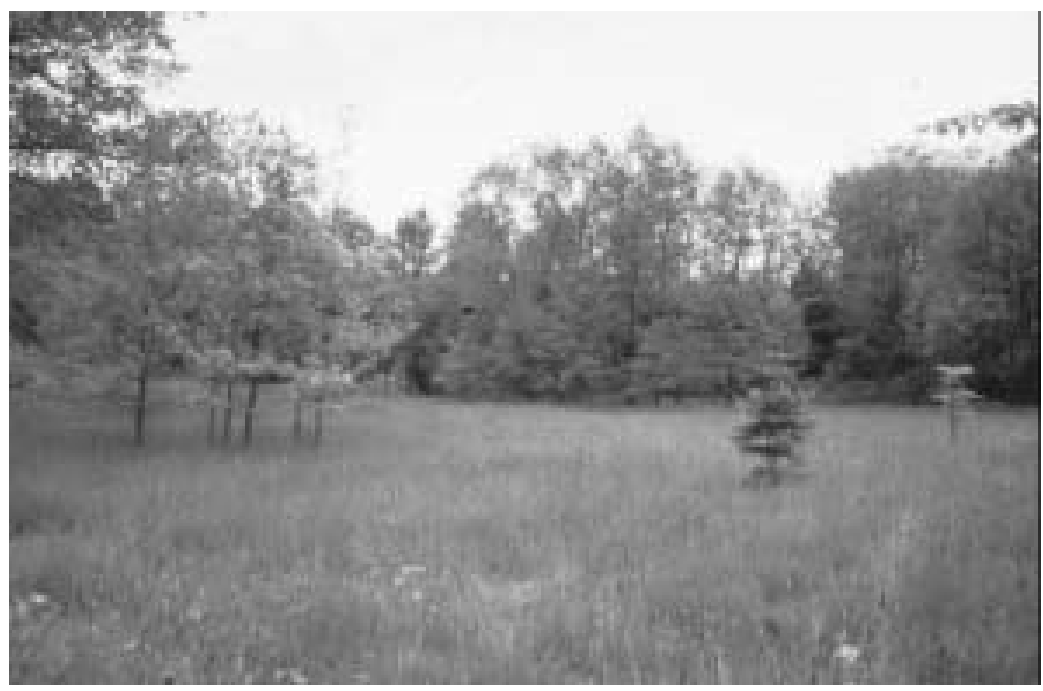

Abb. VIII-27: Ehemaliger Standort der „Unteren Quernheimer Mühle“

Im Volksmund auch „Schnittger Mühle“ genannt, eine von drei Wassermühlen am Stiftsbach. Von der Mühle und dem Mühlenteich ist, wie diese Aufnahme auch deutlich machen soll, im Gelände nichts mehr übrig geblieben. Die Geländetopographie und die historische Wegeverbindung zur Mühle wurden durch den Straßenausbau (B 239) vollständig verändert. Erdaushub aus der Geländevertiefung oberhalb wurde hier als Straßendamm wieder aufgetragen, das Mühlenareal flächig verfüllt. Im Hintergrund der Bundesstraßendamm, davor befand sich links der Mühlenteich, in der Mitte stand das zweigeschossige Mühlengebäude, rechts davon an der Pappelreihe die Stallungen. Vom Bach abgehend verlief der Mühlenkanal, wobei die Speisung des Mühlenteiches wie die Wasserbeaufschlagung durch einen Quellenzulauf verstärkt wurde. Von dieser Quellschüttung, die diesen Mühlenstandort so ideal erschienen ließen, erinnert nur noch ein in der Wiese verbauter Kanalschacht (eig. Aufnahme 2004).

Durch die Anlage von Klärwerken verschwanden in den Tälern einzelne Hämmer und Schleifkotten, wie LUNKENHEIMER am Beispiel der Solinger Bachläufe beweist: An die Stelle des Herderskotten wurde ein Klärwerk gesetzt (1990:77), ebenso verschwand der Plückerskotten im Zuge des Kläranlagenbaus (:107) und die Kottermühle am Nacker Bach stand an der Stelle, wo heute das Wärterhaus der 1914 in Betrieb genommenen Kläranlage Heidbergtal steht (:109). Mit ihnen verschwanden auch die Wasserstauteiche. Eventuell, wie leider nicht belegt ist, sind sie sogar als Klärbecken in die Kläranlage integriert worden.

Im selben Gebiet wurden in den Jahren 1966/67 der Kuckesberger Kotten an der Itter abgebrochen, an dessen Stelle ein Hochwasser-Rückhaltebecken $\left(1.200 \mathrm{~m}^{3}\right.$ ) errichtet wurde (LUNKENHEIMER 1990:77). Auch hier ist die Vermutung berechtigt, es könnte sich um einen ehemaligen Mühlenteich gehandelt haben.

Auf dem Gebiet der ehemaligen Deutschen Demokratischen Republik (DDR) verlief der Prozess etwas anders. Die Enteignung in der Sowjetischen Besatzungszone (SBZ) im Rahmen der Bodenreform $^{27}$ des Jahres 1945, das allen Grundbesitz über 100 ha betraf, ächtete auch die Gutsmühlen (ROGGE 1993:42). Dies führte dazu, dass der private Grundbesitz mit einer landwirtschaftlichen Nutzfläche von mehr als 100 ha aufhörte zu existieren und die zahlreichen leistungsfähigen Wassermühlen, die nahezu jeden Gutsbesitz kennzeichneten, ebenfalls. Davon ist zumindest auszugehen, da es keine expliziten Informationen darüber gibt, ob und inwieweit hiervon auch die Mühlen betroffen waren. Der Großgrundbesitz, besonders in dem vormaligen Land Mecklenburg und der früheren Provinz Mark Brandenburg, galt als Synonym für rückständige Wirtschaftsweise und parasitäre Lebensführung. Bereits wenige Wochen nach dem Ende der Hitlerdiktatur forderte im Osten Deutschlands in der SBZ die KPD in ihrem Aufruf vom 11. Juni 1945 u. a. die Liquidierung des Großgrundbesitzes und die Zuteilung an die durch den Krieg ruinierten und besitzlos gewordenen

\footnotetext{
${ }^{27}$ Die Bodenreformverordnung legte fest, den Grundbesitz aller Personen, die als aktive Mitglieder der NSDAP galten bzw. als Kriegsverbrecher eingestuft wurden, und die Ländereien von Guts- und Großgrundbesitzern mit mehr als 100 ha entschädigungslos zu enteignen. Neben dem Grund und Boden unterlagen der Enteignung alle Bauten, das gesamte Besitzinventar sowie die landwirtschaftlichen Vermögen des o. g. Personenkreises.
} 
Bauern (Zwangsaussiedler) und der neu aufs Land gekommenen Städter. Es galt die Losung „Junkerland in Bauernhand“". Zu den Gütern gehörende Ländereien wurden an Aufstock- und Neubauern, die Gemeinde, die Staatlichen Forstwirtschaftsbetriebe und die Länder aufgeteilt.

Realität ist aber auch, dass nicht sämtliche Güter zum Abriss kamen, sondern vielfältige Verwendung fanden: als Altersheim, Krankenhaus, SED-Schule, Erholungsheim der Sozialversicherungsanstalt sowie des Caritasverbandes und als landeseigene Betriebe. Andere wiederum dienten als Schulen, als Wirkungsstätte von Gemeindevertretungen oder nach baulichen Veränderungen als Wohnstätten von Neubauern. Schlösser bzw. Herrenhäuser wurden auch von der Roten Armee belegt, wie MAHLICH (1999:26) am Beispiel des Kreises Haldensleben aufzeigt.

Der Enteignung entgingen der Grundbesitz und das Vermögen der landwirtschaftlichen und wissenschaftlichen Forschungsinstitute, der Versuchs- und Lehranstalten, der landwirtschaftlichen Genossenschaften, der Klöster und kirchlichen Institutionen. Nicht enteignet werden sollten ferner der Boden, der Stadtverwaltungen gehörte und zur Produktion landwirtschaftlicher Erzeugnisse für die Stadtbevölkerung benötigt wurde, sowie das Gartenland.

Die Aufteilung der enteigneten Güter und Höfe wurde bereits bis Ende Oktober 1945 im Wesentlichen beendet, die gesamte Bodenverteilung im Herbst 1946 weitgehend abgeschlossen. Diese radikale Veränderung der Agrar- und Besitzstruktur, ist u. a. vor dem Hintergrund einer raschen Wiederbelebung der landwirtschaftlichen Produktion zu sehen, damit die Bauern unverzüglich mit der Herbstaussaat beginnen sollten. Auch dürfte versucht worden sein, die Mühlen in diesem Zeitraum wieder in den Produktionsprozess durch Umwandlung in Volkseigene Betriebe (VEB) zu integrieren.

So war beispielsweise die zwischen 1906 und 1936 zu einer Industriemühle umgestaltete historische Lucke-Mühle nahe der Weißen Elster-Aue in Stahmeln bis 1945 ein Familienbetrieb. Nach der Enteignung gehörten die dann volkseigenen Mühlenwerke Stahmeln zum VE-Kombinat Getreidewirtschaft Leipzig (KORMANN 2004). Auch die Ragower Mühle in Schernsdorf/Brandenburg als zum Gut Ragow zugehörige Säge- und Ölmühle, arbeitete bis zur Enteignung im Rahmen der Bodenreform. Ab dem Jahr 1968 wurde sie dann gänzlich stillgelegt und nicht weitergenutzt.

Diese Devastierung von Eigentum durch Zwangskollektivierung der Landwirtschaft im Zuge der Bodenreform 1945/46 traf auch die Mühlgräben, Mühlteiche und Mühlen in den Vertreibungsgebieten Böhmen, Mähren und Schlesien sowie im rumänischen Siebenbürgen. Beispielsweise in Bruntál (Freundenthal) im nordmährischen und Roudnice (Raudnitz) im nordböhmischen Kreis. Die Mühlen dort wurden in diesen Jahren stillgelegt, u. a. auch weil die Felder brach lagen. Nach Aufteilung und entschädigungsloser Konfiskation aller landwirtschaftlichen Güter wurden sie nachfolgend als Lagerhaus für Futtermittel benutzt.

In der SBZ Deutschlands wurde also in den Jahren 1945/46 bis 1950 eine Bodenreform durchgeführt, die als eine der ökonomisch-politischen Voraussetzungen späterer Umgestaltungen in der Landwirtschaft der DDR gelten kann und auch erhebliche Auswirkungen auf die Müllerei gehabt hat. Die sozialistische Umgestaltung der Landwirtschaft galt nämlich gleichzeitig als eine der schwierigsten, kompliziertesten Aufgaben der Übergangsperiode vom Kapitalismus zum Sozialismus.

Die Erträge auf den maximal 20 ha großen Agrarflächen blieben jedoch so weit hinter den Produktionszielen zurück, dass noch im Jahre 1950 ein Schuldenerlass von etwa 50\% für Baukredite von Neu- und Altbauern erfolgte. Die Landaufgabe von größeren bäuerlichen Betrieben erreichte derartige Ausmaße, dass sich die Versorgung der Bevölkerung mit Nahrungsmitteln aus eigener Produktion beträchtlich erschwerte. Im April 1952 lagen ca. 235.000 ha brach, etwa 4\% der landwirtschaftlichen Nutzfläche der DDR. Darunter befanden sich aber nicht nur aufgegebenes Bodenreformland, sondern gleichfalls Ländereien von Altbauern (MAHLICH 1999:46). In diesen Zeitraum wird auch eine existentiell bedrohliche Phase der Mühlenwirtschaft gefallen sein, da bei Ernteausfall auch keine größeren Mengen Getreide zum Mahlen anfielen. 
Ohne jetzt an dieser Stelle den historischen Ablauf und die Periodisierung der Entwicklung der Landwirtschaft der DDR weiter ausführen zu wollen, entstand nach Abschluss der Bodenreform eine Kollektivierung der privaten Landwirtschaftbetriebe, um diese Defizite zum Beispiel durch Zusammenlegung von Maschinenparks und Anbauflächen zu beheben. Die „sozialistische Umgestaltung“ der Landwirtschaft als Leitbild zur Reform der Landwirtschaft beinhaltete den Zusammenschluss der kleinen und mittelgroßen Betriebe $\mathrm{zu}$ zuerst losen, dann immer intensiver kooperierenden landwirtschaftlichen Produktionsgenossenschaften (LPG). Sie stellten das wichtigste Element beim Aufbau des Sozialismus auf dem Lande dar.

Die Umwälzungen in der Landwirtschaft führten zu grundsätzlichen Veränderungen in der ländlichen Sozialstruktur: die bäuerlichen Kategorien Landarbeiter, klein-, mittel- und Großbauern verschwanden im Zuge des Aufbaus des Sozialismus. Auf dem Lande bildete sich gemäß der marxistischleninistischen Idiologie eine neue Klasse, die Klasse der Genossenschaftsbauern heraus. Sie galten als der Hauptverbündete der Arbeiterklasse bei der Errichtung des Sozialismus in der DDR (MAHLICH 1999:445). Denn neben der Überführung sämtlicher Bauern in LPG vollzogen sich in diesem Zusammenhang umfassende Veränderungen auf politisch-ideologischem, sozialem und kulturellem Gebiet des ländlichen Raumes, einschließlich der Wandlung des Alltagslebens.

Spätestens nach der 2. Parteikonferenz der SED im Sommer 1952 bis zum Beginn der 1960er Jahre stand die Umgestaltung der Herrschaftsstrukturen der Gesellschaft nach den Prinzipien des Marxismus-Leninismus in der konkreten Ausformung des sowjetischen Modells im Mittelpunkt des politischen Agierens der SED-Führung.

Daraufhin setzte ein großes Mühlensterben in der damaligen DDR ein, dem 1972 ein zweites großes Mühlensterben folgte, von dem besonders kleinere Betriebe mit staatlicher Beteiligung betroffen waren, aber auch bis dahin private Mühlenbetriebe. So wurde beispielsweise die „Dresdner Mühle“ bis 1972 privat geführt und danach enteignet. Fortan war die offizielle Bezeichnung „VEB Mühlenwerke Dresden BT II“. Diese Tendenz bestimmte die weitere Entwicklung: Wenige VEB Großmühlen versorgten fortan den Markt. Kleinere Mühlenbetriebe bekamen zudem manchmal in den 1950er Jahren kein Getreide mehr und lagen damit still (GOETTLE 2003; ÖLMÜHLE DÖRNTHAL 2004; DRESDNER MÜHLE 2004). Dass von dieser Entwicklung auch besonders die Mühlteiche betroffen waren, wird allein dadurch ersichtlich, da sie ja zumeist die an schwächeren Wasserläufen liegenden kleineren Mühlen bei ihrer Arbeit unterstützten bzw. sie erst möglich machten. So wird beispielsweise die in Pkt. $2 b$ noch zu erwähnende Ziddorfer Gutsmühle nach der Enteignung im Jahr 1945 zwar für eine Interimszeit bis 1956 von einem „Volksgenossen“ bewirtschaftet und ab diesem Zeitpunkt bis 1975 von der LPG betrieben, aber der Mühlenbach wird bereits 1968 umgeleitet und der Teich trocken gelegt. Mit Elektroenergie wird bis zur endgültigen Stilllegung weiter gemahlen. Insbesondere auch die innerhalb der Demarkationslinie im Grenzgebiet zur Bundesrepublik liegenden Mühlen dürften hiervon allein aus ihrer Lagebeziehung heraus betroffen gewesen und ein Abgang einiger Wassermühlen einschließlich ihrer Stauteiche zu belegen sein.

Im Auftrag der LPG wurden aber auch zahlreiche Mühlen erfolgreich weiterbetrieben, wie zum Beispiel die Rolf's Mühle in Worbis bis zum Jahr 1987 (ROGGE 1993:9), die Nordhäuser Mühle bis 1990, die aber über eine Grundinstandsetzung nicht hinauskamen, und die Dörnthaler Ölmühle nahe Freiberg, die heute die älteste noch produzierende Ölmühle in Deutschland ist. Weitere Beispiele sind die VE Mühlenwerke Camburg an der Saale, Hildesbrandtsche Mühlenwerke Halle-Dölau, VEB Mühlenwerke Hermsdorf-Flöha, VEB Mühlenwerke Dresden. Die verbliebenen ehemaligen Mahlmühlen wurden aber auch wie die dann VEB Saalemühlen oder die VEB Wasserwirtschaft Frankfurt/Oder an Energiekombinate zur Stromgewinnung eingegliedert.

Es gab sogar Ende der 1960er Jahre - entgegen dem allgemeinen Trend - einen Aufschwung für die Mühlen, aber nur mit Schrotung. Es wurde Tierfutter geschrotet für die private Tierhaltung der umliegenden Bauern und in den 1970er Jahren dann, als überall in der DDR die großen Tierbestände aufgebaut wurden mit riesigen Schweinemastanlagen, ,so war die Mühle für eine ganze Weile wieder voll ausgefüllt“" (GOETTLE 2003). 
Nach der Wende begann 1991/92 ein drittes großes Mühlensterben; diesmal nicht durch staatliche Misswirtschaft, sondern durch mangelnde Marktfähigkeit in einem nunmehr weit geöffneten Wettbewerb.

Großflächige Lösungen und Produktionen, mit entsprechender vorhandener Logistik und Absatzmärkte waren in Westdeutschland vorhanden, denen die - trotz der Enteignungen und Zusammenlegung - noch vorhandene mehr regionale, höchstens nationale, kleinteiligere Produktionsweise, unterlegen war.

Viele Wassermühlen befanden sich in Treuhandbesitz oder wurden an Westfirmen verkauft und liegen seitdem wüst bzw. sind vollständig umgenutzt worden (ROGGE 1993:33f.). Die o. g. Mühle Stahmeln beispielsweise wurde unter Treuhandregie in eine $\mathrm{GmbH}$ umgewandelt und zum Verkauf ausgeschrieben. Die Vereinigte Kunstmühlen AG aus Hamburg erwarb den Betrieb zu günstigen Konditionen, wollte den Betrieb aber aus betriebswirtschaftlichen Gründen einige Jahre später wieder schließen, durch ein Management-Buy-Out des bisherigen Geschäftsführers.

Der tiefgreifende Wandel der wirtschaftlich-technischen und sozialen Strukturen hat aber mittlerweile fast alle Mühlenbetriebe, ob in West- oder Ostdeutschland, zur Aufgabe gezwungen und das traditionsreiche Gewerbe verdrängt. Denn letztlich führten in beiden Teilen Deutschlands verschiedenartige Wege langfristig zum gleichen Ziel, produktionsstarke und rentable Landwirtschaften nach industriellem Vorbild bei der damit verbundenen Ausschaltung der bäuerlichen Einzelbewirtschaftung zu schaffen. Anders als in den Ländern, die mit Ausrichtung auf das sozialistische Gesellschaftsmodell den Aufbau des Sozialismus in der Landwirtschaft auf direktem Wege beschritten, versuchten westeuropäische Politiker und Wirtschaftsexperten, den gleichen volkswirtschaftlichen Sicherungseffekt durch freiwillige Teilsozialisierung (Vergenossenschaftung), Anonymisierung durch Kapitalaufstockung, Konzentration und liberale konkurrierende Marktwirtschaft - also durch Wirtschaftsmaßnahmen - zu erzielen (MAHLICH 1999).

Der Abstieg mancher Mühlen ist zwar in ihren Auswirkungen radikal, aber in ihrem Verlauf subtil: sie verfallen, brennen $a b$, werden ersatzlos abgebrochen oder werden vollständig umgestaltet (BEDAL 1992:191). Daran ändert auch nichts, dass übrig gebliebene Einzelobjekte von Heimat- und Fördervereinen liebevoll gepflegt und vor dem Verfall gerettet werden, so wertvoll die Arbeit für den Einzelbestand auch sein mögen. Das Gesamtbild ehemaliger Verbreitung von Wassermühlen mit ihren vereinzelten Mühlenteichen an den Wasserläufen wird nicht mehr hergestellt. Einzig die Bemühungen des Mühlenkreises Minden-Lübbecke e.V. stellen das Bemühen dar, auf regionaler Ebene das ursprünglich weit verbreitete Mühlenwesen zu dokumentieren und zu bewahren. Mühlenteiche als Landschaftsrelikte und als Bestandteile eines früheren Wassermühlenplatzes hingegen werden nicht explizit mit einbezogen. Dabei waren sie früher von weiter Verbreitung.

\section{b Historisch-geographische Verbreitung}

„Als ich im ersten Jahr des laufenden Jahrhunderts geboren wurde, quälten sich noch ein Dutzend Mühlen im Tal des Bommersbaches, der
abschnittsweise auch Sprengerbach oder Brucherbach genannt wurde, mühsam durch die schon ,fortgeschrittenen' frühindustriellen Zeiten.
Heute kann ich meinen Enkeln nicht mehr eine einzige Mühle im Bommersbachtal vorweisen.”
[Philipp RUPP, Müller in Bous (Saar), im Juni 1980]

Die Wasserkraft spielte im Mittelalter bis zur vorindustriellen Zeit eine sehr große Rolle, wie oben dargestellt worden ist, „vergleichbar mit dem Öl in unserem Jahrhundert“ (MERTES 1995:22). Das muss man im Hintergrund bedenken, um zu verstehen, dass sich so viele Mühlen an unseren Bächen etablierten. Eine kleine Hausmühle, die, angeschlossen an einen Bauernhof, für den Eigenbedarf produzierte, benötigte nicht viel: „Ein Bächlein von $30 \mathrm{~cm}$ Breite (1 Schuh) und $7-8 \mathrm{~cm}$ Tiefe (3 Zoll) genügte, um in einem kleinen Weiher oder Sammelkasten in der Stunde etwa 730 Eimer Wasser anzusammeln.“ (:22) Diese Zuflussmenge reichte aus, um solche Eigenversorgungsmühlen „auch an kleinen Rinnsalen mit einem Mahlgang ab und zu zu betreiben." (:22) 
Aber: Wenn auch die heute sehr kümmerlichen bzw. als kümmerlich wahrgenommenen Fließgewässer zum Betrieb von Mühlen, vor allem mit Unterstützung durch den Aufstau genutzt wurden, wie zum Beispiel die kleine Erpa, der Finkelbach, der Lipper Bach, der Sothbach und der Elsbach im Erftgebiet (KREINER 1996:65), so sind die aufgrund mangelnder Zuflüsse sehr austrocknungsgefährdeten Bachläufe schon im Hochmittelalter nicht mehr genutzt worden, da sich durch die Rodungsbewegung die hydrologischen Verhältnisse der hier genannten Bördenbäche dramatisch verschlechtert hatte. Im 18. Jahrhundert konnte von diesen Fließgewässern, die KREINER (1996:66) für das Erftgebiet benennt, nur noch der Finkelbach als Mühlengewässer genutzt werden. Bedingt durch ihre natürliche Gefällearmut haben sie durch die Rodungstätigkeiten ein sehr ungleichmäßiges Abflussverhalten bekommen, was schließlich zur Aufgabe von Mühlenplätzen geführt hat. Nur dort, wo eine größere Wasservorratsspeicherung durch eine starke und gleichmäßige Quellschüttung ermöglicht werden konnte, wurden die Gewässer zu ausgedehnten Mühlenstandorten.

Die vollständige Auflistung der ehemals zahlreichen und der wenigen noch bestehenden Wassermühlenteiche würde eine Vorstellung von der bis zu einem gewissen Zeitpunkt nahezu ubiquitären Verbreitung geben und ermöglichen, eventuelle Schwerpunkte der Verbreitung herauszuarbeiten. Leider aber wird in den Mühlenbüchern bzw. historischen sowie modernen „Mühlenkatastern“'28 nicht immer erwähnt, ob auch Teiche bestanden haben. Dies ist insofern von entscheidender Bedeutung, als dass einerseits nicht automatisch künstliche Mühlenteiche Bestandteil der Anlage einer Wassermühlenanlage gewesen sind, andererseits gleichzeitig das wahre Vorkommen von Mühlteichen dadurch verschleiert wird. Nach einer von mir durchgeführten online-Abfrage aus der über 1300 Mühlen zählenden Datenbank der Deutschen Gesellschaft für Mühlenkunde und Mühlenerhaltung (DGM) e.V. waren nur 12 von insgesamt 672 Wassermühlen aus 13 Bundesländern bzw. Regionen mit einem Mühlenteich gespeichert: 8 in Niedersachsen und Bremen, 2 in SchleswigHolstein und Hamburg und 2 in Westfalen-Lippe, obschon beispielsweise Baden-Württemberg mit 196 Wassermühlen und Sachsen mit 90 Nennungen die beiden führenden „Mühlenländer“ darstellen (Stand 02/2004).

Bei den vielen Mühlengewässern ist es aber an dieser Stelle unmöglich, alle Regionen zu benennen und schwierig, Maßstäbe für einen Vergleich zu finden, d. h. Schwerpunkträume der Verteilung von Mühlenteichen zu fixieren. Zu unterschiedlich sind Breite, Wassermenge und vor allem das verfügbare Gefälle. Bei letzterem kommt noch hinzu, dass man kaum für einen längeren Wasserlauf ein für dessen ganze Länge zutreffendes Durchschnittsgefälle angeben und dazu etwa die Mühlendichte in ein hypothetisches Verhältnis setzen könnte. Mit anderen Worten: Die Mühlen standen nicht im gleichen Abstand zueinander. Die Abstände konnten sich höchstens nach einer mehr oder weniger gerechten Aufteilung des Gefälles richten, wie man das zum Beispiel bei der Niers schon früh durch die „NiersOrdnungen" geregelt hat (VOGT 1998:19): Schon 1487 wurde für den Unterlauf der Niers ab Oedt diese vertragliche Regelung getroffen, wonach jeder Mühle 111/2 Fuß $(\mathrm{rd} .65 \mathrm{~cm})$ Stauhöhe zugestanden wurde. Die zulässigen Höhen wurden an der Mühle durch amtliche Marken (Pegelbretter/Eisennägel) kenntlich gemacht. Zum Schutz besonders gefährdeter Uferbereiche gab es Uferdämme (:20).

Die Mühlendichte wurde aber auch von den bestehenden Siedlungs- und Wirtschaftsschwerpunkten beeinflusst. In diesen Räumen wurden die Gewässer mit Mühlen belegt - meistens durch Wasserbauten unterstützt -, um eine entsprechend große Zahl an Wassermühlen zu erreichen: An der Erft lagen 36, an der Düssel 12, an der Niers 60, an der Wurm 31 und an der Schwalm 24 Mühlen. Hinzu kommen noch die zahlreichen Mühlen an den $\mathrm{Zu}$ - und Nebenflüssen. Tatsächlich aber haben im

\footnotetext{
${ }^{28}$ Historische Mühlenkataster liegen vor allem aus dem 19. Jahrhundert vor. Darin wird zum Beispiel vermerkt, dass ein zweiter Mahlgang angebaut worden ist oder dass ein Mahlgang noch nicht vollendet ist und also deswegen noch nicht betrieben werden kann. Aber es werden auch solche umweltgeschichtlich bedeutsamen Hinweise gegeben, dass zum Beispiel wegen Wassermangels diese Werke nie gleichzeitig betrieben werden konnten oder nur während der nassen Herbstmonate nach der Ernte im Oktober und November zu betreiben gewesen seien. Weiterhin lassen Niederschriften in Mühlkataster derart, dass die Mühle sehr zerfallen sei und nur noch ein schwacher Betrieb verzeichnet werde, Rückschlüsse auf die Situation von Mühlen zu einem gegebenen Zeitpunkt zu.

Im Gegensatz zu dem originären Mühlenkataster beinhaltet ein modernes Mühlenkataster die Erfassung möglichst aller Mühlen in einem bestimmten Gebiet (entlang eines Flusslaufs, eines Gewässereinzugsgebietes, innerhalb eines Kreises als Verwaltungseinheit). Vorbildlich zum Beispiel Christoph MÖRSTEDT für den Kreis Herford.
} 
Einzugsgebiet Rhein/Issel von den 48 Gewässern mit stationären Mühlen nur 12 Flüsse und Bäche mehr als 5 Mühlen aufzuweisen.

Allgemein wurden anfangs die Zahl und die Abstände der Mühlen durch die Praxis bestimmt. Man wusste, dass es wenig Sinn machte, die Mühlen zu dicht aufeinander folgen zu lassen und sich so gegenseitig das Wasser „abzugraben“. Umgekehrt war man bestrebt und musste es wohl auch sein, möglichst viele Wasserantriebe anzulegen. Die Überflutungen und Versumpfungen im Uferbereich wurden in Kauf genommen. Schließlich war die Nutzung der Wasserkraft bis zum Beginn der Dampfmaschinenzeit wichtiger als die Nutzung der Ufergrundstücke (VOGT 1998:20).

Des Weiteren ließe sich versuchen die Verbreitung von Wassermühlen in Abhängigkeit vom Mühlenrecht zu berechnen. Im Wendland zum Beispiel gab es aber nur Zwangsmühlen der Landesherrschaft, dagegen keine gutsherrlichen Zwangsmühlen wie in der Altmark. In der Altmark hingegen war, wie vielen anderen Gegenden, der Mühlenbann ${ }^{29}$ wirksam. Dies bedeutete hier, dass im Umkreis einer Bannmeile keine neue Mühle errichtet werden durfte (LANGE 1989:61). In manchen Gegenden Deutschlands wurde zudem auch ein Mahlzwang auferlegt, und zwar in der Weise, dass die Bewohner eines bestimmten Bezirks ihr Getreide nur in einer für sie bestimmten Mühle mahlen lassen durften $(: 61)$.

Mathematische Hochrechnungen auf der Grundlage statistischer Auswahlbeispiele von Wasserläufen würden deshalb nur ein ungenaues Bild der Realität zeichnen und Beweise fehlen lassen, die auf die Anlage von Mühlenteiche bei einer gegebenen Mühlenzahl in einem bestimmten Abstands- und Abflussverhältnis schließen lassen.

Zum Weiteren gab es in Gebieten mit einem günstigen Bodenrelief erheblich mehr Wassermühlen. So weist die südliche Niederrheinhälfte bis einschließlich Schwalm, Raum Gladbach/Viersen sowie den Räumen Meerbusch und Düsseldorf doppelt so viele Wassermühlen auf wie am nördlichen Niederrhein (VOGT 1998:19). Waren aber die weniger begünstigten Gebiete deshalb Vorzugsräume für den Mühlenteichbau?

Bei der vorliegenden Literaturauswertung lassen sich solche spezifischen Fragen der hydrologischen und topographischen Situation nicht beantworten. Es lassen sich aber - unabhängig von einer differenzierten Betrachtung - generelle Aussagen zu den landschaftsgeographischen Standorten von Mühlenteiche machen und Vorurteile, unzulässige Vereinfachungen und Falschaussagen beseitigen.

\section{b.1 Tiefland}

HÖLSCHER (1987:11) zum Beispiel schreibt: „Während die Windmühle naturgemäß im Flachland die Verwendungsform ist - man findet sie bereits im Raum Hildesheim - ist im südlichen Niedersachsen, also im Mittelgebirge, die Wassermühle verbreitet.“ Genauso zweifelhaft ist in diesem

\footnotetext{
${ }^{29}$ Es handelt sich hier um feudale Bannrechte: Herrschaft und Einkünfte adeliger und kirchlicher Grundherrschaften gründeten sich den allgemeinen Gerichts- und Schutzrechten noch auf eine Vielzahl weiterer Einzelrechte, zu denen auch der Anspruch auf den Mahl- und Mühlenbann (banalité du moulin) zählte. Die Gemeinde musste eine Erklärung über die Anerkennung der Bannmühle abgeben und somit die Mühlengerechtigkeit des Grundherrn (Mahl- und Mühlenbann) bestätigen. Darüber hinaus gab es beispielsweise den Backbann (Ofenbann, banalité du four), den Kelterbann (banalité du pressoir) und die Biermeile.

Es ist aber bei der Mühlengerechtigkeit zwischen Mahlzwang und Mühlenbann zu unterscheiden: Der Mahlzwang bezog sich auf alle im Bann des Grundherrn ansässigen Bauern, also nicht nur auf die, dessen Ackerfläche in dem Mühlenort lag, sondern auch auf die umliegenden Dörfer, die ihr Korn in der Mühle des Grundherrn mahlen lassen mussten. Vom Mahlzwang ausgenommen waren meist der Meier und der Pfarrer. Der Mühlenbann bedeutete, dass der Grundherr das alleinige Recht besaß, eine Mahlmühle zu erbauen, es also keinem Müller erlaubt war, in dem Bereich seiner Herrschaft eine Mühle zu errichten. Sie standen somit im Dienste des Grundherrn, der ihnen zudem die Pflicht auferlegt, die im Bann Gesessenen hinsichtlich des Mahlzwanges zu überwachen.

Diese generelle Handhabung wurde aber auch unterbrochen. So konnte man durchaus Anfang des 18. Jahrhunderts durch die fürstliche oder gräfliche Regierung die Genehmigung zum Mühlenbau erhalten, ohne dass eine Bebannung ausgesprochen wurde, sondern die Mühle konnte von jedermann in Anspruch genommen werden. Als Gegenleistung für das Wasserrecht hatte der Müller in diesem Fall jährlich 1 Malter Korn Manderscheider Maß an die Kellnerei nach Manderscheid zu liefern (WIßKIRCHEN 1985).
} 
Zusammenhang die Begründung von VOGT (1998:10): „Im Rheinland ist kein einziger Beleg für eine römische Wassermühle gefunden worden, weder in schriftlichen Quellen, noch bei den vielfachen Ausgrabungen. Auch aus der fränkischen Zeit sind hierzulande keine Wassermühlen bekannt, was vielleicht an dem ungünstigen Gefälle gelegen haben mag [...]. Bei den Windmühlen war das einfacher. Denn Wind weht fast überall.“

Zum einen war die Wassermühle auch in den flachen Landschaften die zeitlich frühere Nutzungsform, erst im 18. Jahrhundert kommen Windmühlen dazu und es gab zum anderen vor den Regulierungsund Kanalisierungsmaßnahmen auch im Flachland Gewässerläufe mit einer enorm hohen Fließgeschwindigkeit (ERLER/MATTHIESEN 1989:43). Des Weiteren ist es irrige Annahme, Windmühlen seien nur im (norddeutschen) Flachland zu finden: In Deutschland wird die erste Windmühle 1222 in Köln bezeugt, in Limburg an der Lahn auf dem Stephanshügel 1331 und in Rheinbach 1370. Auch ,die weitverbreitete Meinung, es habe seit dem Mittelalter in der Eifel keine Windmühlen mehr gegeben [...] ist ein Irrtum“, wie MERTES (1995:25) feststellt. Dass es auch im Flachland, wie z. B. in Börde- und Heidelandschaften windstille bzw. windarme Gebiete gibt, beweisen zudem die oft schwierige Standortsuche moderner Windräder und die häufigen Stillstandszeiten nicht allein aus technischen Problemen.

Zulässig aber ist die Aussage, dass sich im gefälleärmeren Flachland ein ganz anderes Mühlenbild als in gefällereichen Flussstrecken bot. Die „Diversifikation der Wasserkraftnutzung“ ist hier „weniger ausgeprägt als im Mittelgebirge.“ (KREINER 1996:148) Und es ist feststehend, dass Windmühlen, die den Wind als Antriebskraft nutzten „größtenteils im Flachlande verbreitet gewesen sind” (DOBELMANN 1980:8).

Aus Nordfriesland werden im Kreis Husum drei Wassermühlen mit angeschlossenen Mühlteichen beschrieben. 1. Die Wassermühle von Goldebek, am ,Goldebeker Mühlenstrom' war mit einem mittlerweile verschwunden - Mühlteich ausgestattet. 2. Die Wassermühle zu Bredtstedt (1839 - 48), die ein oberschlächtiges Rad antrieb, wurde mit einem Staudamm für den Mühlenteich angelegt. Die zur Verfügung stehende Wassermenge des Mühlenteiches reichte aber auf Dauer nicht aus. Der Teich selbst jedoch mit den „Weiden am Mühlendamm ist auch heute noch als Landschaftsbild ansprechend" (SCHEFFLER 1982:143). 3. Die bereits im 12. Jahrhundert angelegte Wassermühle Osterhusum war mit zwei oberschlächtigen Wasserrädern ausgestattet, „gespeist durch einen riesigen, künstlich angelegten Mühlenteich“", und betrieb damit 6 Mahlgänge (:144f.). Außer diesen drei KornWassermühlen gab es im Kreis auch noch eine solche zur Ölbereitung: Die Wassermühle auf Stollberg, $1 \mathrm{~km}$ nördlich von Husum bestand aber ,wegen Wassermangels bereits in der Mitte des 19. Jahrhunderts nicht mehr" (:144). Die Mehrheit in diesem Kreis hingegen wurde durch eine große Zahl an Windmühlen, vor allem von Bockmühlen gestellt.

Im Kreis Südtondern gab es in früheren Zeiten ebenfalls mehrere Wassermühlen im Bezirk: 1. Eine Wassermühle auf dem adeligen Gut Gaarde [,Garten“] in der Leckaue, 2. zwei in Leck, ebenfalls an der Lecker Au, sowie zwei weitere Wassermühlen in Karlum und in Lexgaard, beide an der Karlum Au. Sie alle waren „mit kleinen Teichen“ ausgestattet, deren „Wasserreservoir bald erschöpft war“ (SCHEFFLER 1982:213).

Die Ausnahme von dem Vorkommen von Wassermühlen (mit Teichen) in Nordfriesland bildet der Kreis Eiderstedt: Die Halbinsel Eiderstedt ,war einst sehr reich an Windmühlen, während wir eine Wassermühle in den Marschen ihrer Köge bzw. auf dem schmalen Gardinger Geestrücken vergeblich suchen würden." (SCHEFFLER 1982:109).

Ebenso gab es Wassermühlen im Flachland des Rheiderlandes/Ostfriesland „mangels Gefälle nur selten” (HOEK 1986:11). Die hier heute als „Wassermühlen“ bezeichneten Mühlen waren windbetriebene „Wasserschöpfmühlen“, die dem Zweck dienten, die Ländereien der tiefliegenden, küstennahen Marsch leer zu pumpen. Vor allem bei heftigem Niederschlag arbeiteten sie Tag und Nacht.

Wenn diese Aussage auch generell bestätigt werden muss, so dürfen hingegen wasserbetriebene Wassermühlen nicht ausgeschlossen werden: Bei der Howieker Wassermühle von 1608 in Ocholt 
beispielsweise, in der Gemeinde Edewecht zwischen den Ortschaften Westerscheps und Apen gelegen, im zentralen Ammerland, handelt es sich um eine solche Anlage mit Mühlenteich.

Anders sieht die Situation in Kreis Eckernförde aus. Wenn heute auch das Wasserrad hier nicht mehr vorkommt (SCHEFFLER 1982:43), so gab es hier früher zahlreiche Wassermühlen, deren Antrieb durch einen Mühlenteich unterstützt wurde. Die frühesten Mühlen im Kreis Eckernförde wurden bereits urkundlich 1339 als Wassermühlen erwähnt. Im 15. Jahrhundert werden weitere genannt. Um 1650 werden die ersten Windmühlen genannt, von denen es aber erst sehr wenig gab. Der kleinen Gruppe von 5 Windmühlen standen damals mindestens 20 Wassermühlen gegenüber. Bis in das 18 . Jahrhundert waren die Wassermühlen durchaus vorherrschend gegenüber den Windmühlen. Um 1800 dann kamen in dem Gebiet auf 13 Wassermühlen bereits 19 Windmühlen, um 1850 war dann das Verhältnis schon 10:30. In den 1980er Jahren waren von den mit Wasserrädern getriebenen Mühlen noch drei vorhanden: Schnaap, Stenten und Schirnau, die alle mit einem Mühlenteich ausgestattet waren (:41). „In Schnaap und auch sonst ist der Mühlenteich nach der Stillegung des Betriebes abgelassen worden." (:45)

Von der Ornumer Mühle bei Missunde nördlich von Eckernförde in der Gemeinde Kosel gelegen, existieren nur noch Fundamentreste. Bis ins Jahr 1629 trieb die Koseler Au (Kollholmer Au) das Mühlenrad der Ornumer Wassermühle an. Sie entspringt dem Hügel Kollhüh mit einer Höhe von 48 m. Dieser Wasserlauf fließt durch die Ort Loose, Barkelsby, Gammelby und Kosel schließlich in das Ornumer Noor. Das Wasser der Koseler Au wurde an der Ornumer Wassermühle bereits von der Koseler Brücke abwärts gestaut, damit der Müller genügend Wasser für den Betrieb hatte, zusätzlich verfügte die Mühle über einen Notwasserspeicher. Da aber bei zu hohem Wasserstand die Wiesen schnell in eine Seenlandschaft umgewandelt wurden, einigte man sich über eine Maximalhöhe des aufgestauten Wasserstandes. Die Folge war, dass der Müller sehr oft nicht genug Wasser im aufgestauten Becken hatte, wenn die Niederschläge auf sich warten ließen. Der Betrieb stand dann still. Dem Müller wurde zwar für den entstandenen finanziellen Verlust eine Entschädigung gezahlt, aber als die Ornumer Mühle 1810 abbrannte, wurde sie nicht wieder aufgebaut und die Reste im Jahr 1836 verkauft (MISSUNDE 2004).

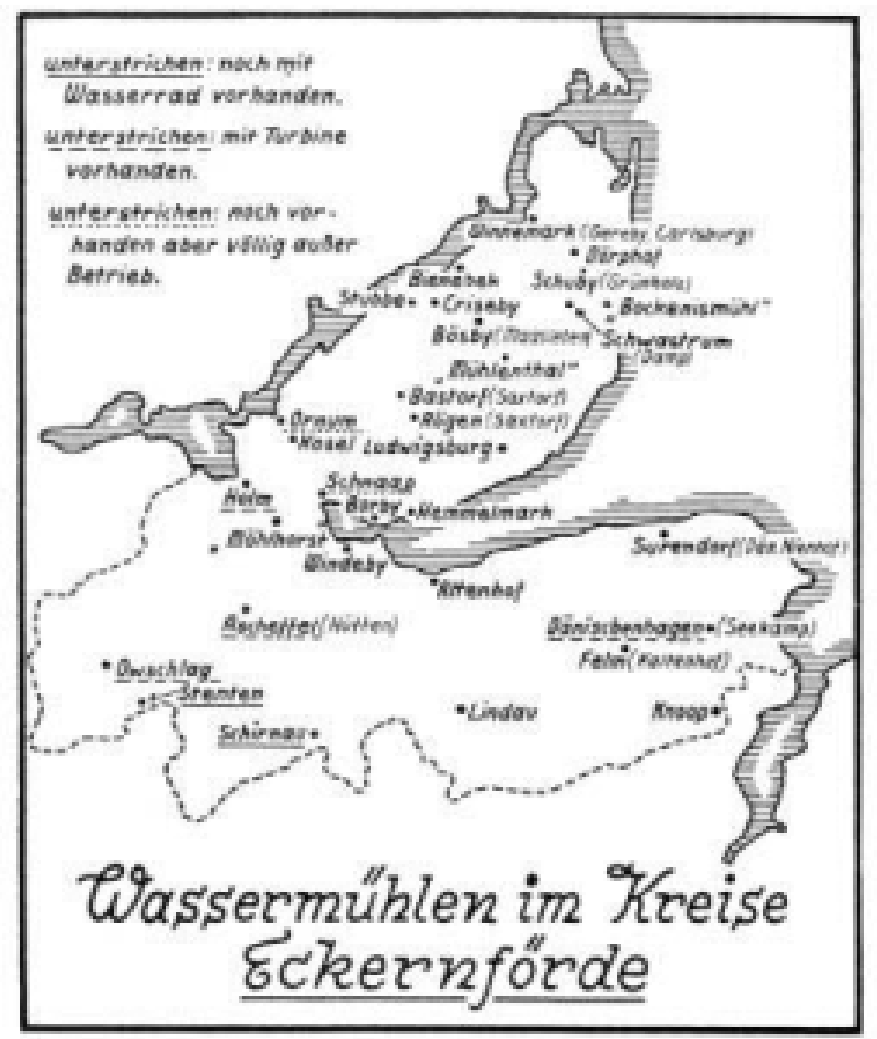

Abb. VIII-28: Wassermühlen im Kreis Eckernförde (aus: SCHEFFLER 1982:42) 
Südlich von Eckernförde, in Owschlag, liegt im heutigen Naturpark „Hüttener Berge“ die Stentenmühle am Rande der Sorge-Au. Sie besitzt noch heute eine mehrteilige Teichanlage von insgesamt 2 ha Größe, mit einem $15.000 \mathrm{~m}^{2}$ großen Mühlenteich. In den Stauteichen werden heute Edelkrebse, Karpfen und Hechte gezüchtet, aber sie werden auch als Badeteich genutzt und verfügen über eine Badestelle mit Umkleidekabine. Heute ist hier also eine fremdenverkehrliche Nutzung eingezogen, sie wird aber bereits wieder [Januar 2004] zum Verkauf angeboten (RICKERT 2004).

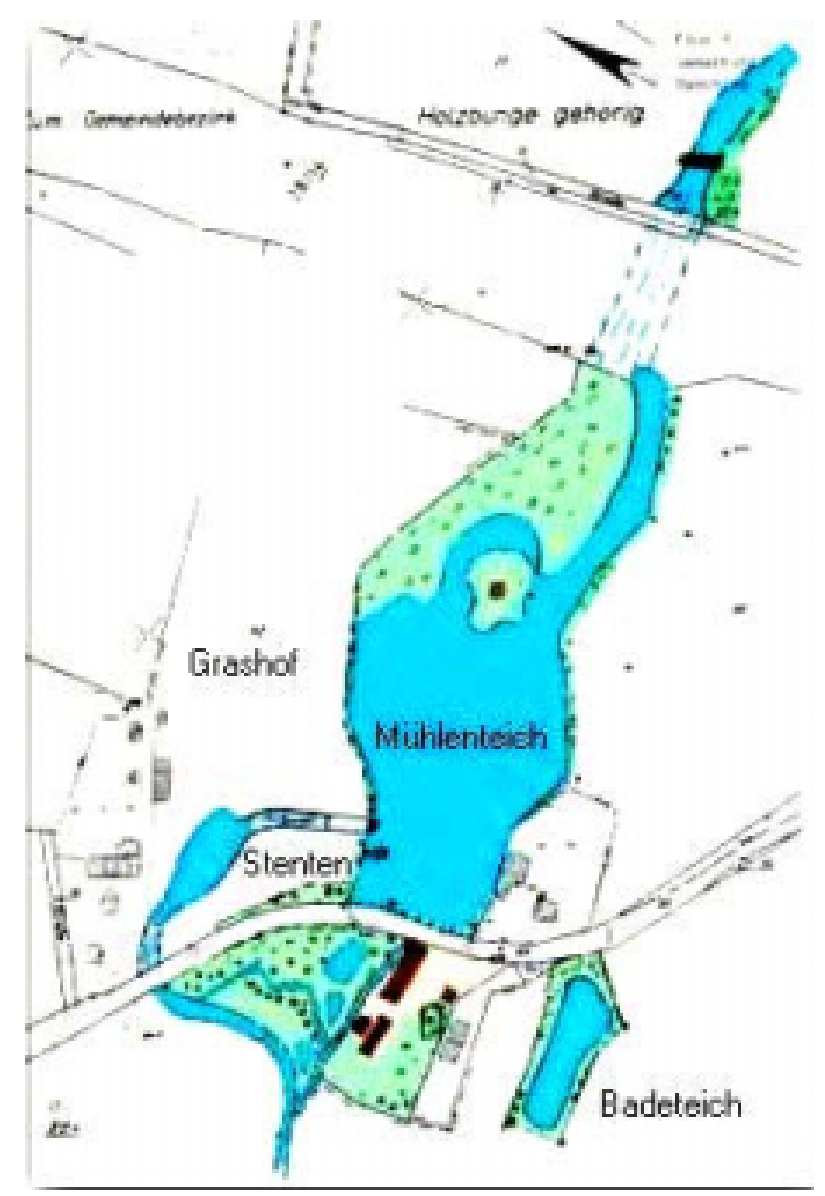

Abb. VIII-29: Lageplan der „Stentenmühle“

Weitere Wassermühlen mit Teichen befinden sich in Schleswig-Holstein beispielsweise in Kühren unterhalb von Preetz (Kührenermühle), in Grömitz beim Kloster Cismar (Klostermühle) und im nordwestlich davon gelegenen Lehnsan die Gutsmühle auf Gut Petersdorf.

Das Zurückgehen der Wassermühlen hängt mit dem jeweils eintretenden Wassermangel zweifellos zusammen (SCHEFFLER 1982:45). Es gab Gegenden, in denen die Flüsse langsam strömten, viel zu langsam, um ein Kraftwerk anzutreiben, auch wenn ein Mühlenteich als Reservoir vorhanden war. Gegen Ende des 12. Jahrhunderts tauchte daher in solchen Regionen die Windmühle auf (MÜLLER/LUDWIG 1982:136). Doch entgegen dieser Vorstellung gab sehr wohl, wie wir gesehen haben, auch in den norddeutschen Tiefländern wasserbetriebene Mühlenwerke, die alle, so hat es den Anschein, über einen Mühlenteich bedient wurden.

Im nördlichen Umland von Hamburg mehren sich die Überlieferungen bzw. Standorte von Wassermühlen. In Kaltenkirchen, im Ortsteil Kampen, befand sich eine Wassermühle, die mit dem Wasser der Schirnau betrieben wurde und über einen Mühlenteich verfügte (GEMEINDE KALTENKIRCHEN 2004).

Die in Trittau im Kreis Stormarn gelegene ehemalige Amtsmühle stammt aus dem 16. Jahrhundert und verfügt über einen Mühlenteich. Überhaupt ist der Trittauer Raum mit der Bille und ihren Nebengewässern (Corbek, Friebek, Trittauer Mühlenteich) ein mühlen- und mühlenteichreiches Gewässer. 
Neben der erwähnten Amtsmühle gab es in Trittau noch die Kornwassermühle von 1728 und eine von 1650 bis 1694 bestehende Sägemühle, eine weitere Kornmühle stand an der Bille in Bergedorf. Der Mühlenteich diente der hier 1208 erbauten Kornwassermühle als Antrieb und wurde von der aufgestauten Bille bespannt, die zugleich nicht nur dem Schloss als Wasserschutz, sondern auch zur Füllung des Stadtgrabens diente.

Der Reinbeker Mühlenteich wurde ebenfalls für den Betrieb dreier Mühlen aufgestaut: eine 1238 an das Kloster Reinbek übergebene Kornmühle, eine 1577 angelegte Säge- und Brettmühle, die 1644 zu einer Lohmühle umgebaut wurde und eine 1578 erbaute Walkmühle. 1794 wurden die Mühlen wegen Frost und Wassermangel stillgelegt und 1815 dann endgültig abgerissen.

Des Weiteren stand eine Wassermühle westlich von Hamfelde, die 1616 als Kupfermühle eingerichtet worden ist, aber bereits 1799 wurde dort der Betrieb wieder eingestellt und 1896 in ein Restaurant umgewandelt. Die Grander Mühle steht seit 1230 bis heute an der Bille gegenüber Grande in Rothenbek

Die Corbek trieb in Grönwohld, Rausdorf und Witzhave zusammen sieben Wassermühlen an. Während die in den letzten beiden Orten liegenden Wassermühlen (Kupfermühlen) durch Stauteiche unterstützt wurden, die aus dem Bach ihr Teichwasser erhielten, trieb ein Abfluss aus dem Großensee die Grönwohlder Mühlen an, die Draht, Messing, Kupfer und Papier herstellten (HAMBURG UMWELTBEHÖRDE 2004).

In der Hamburgischen Landgemeinde Groß Hansdorf-Schmalenbek legte der Besitzer Jasper Meyer des Schmalenbeker Hofes etwa in der Mitte der vierziger Jahre des 17. Jahrhunderts eine Wassermühle an, deren Triebwerk durch das Wasser aus dem durch einen Damm aufgestauten kleinen, von Hoisdorf herabfließenden Bach in Bewegung gesetzt wurde. Der Betrieb ward in de 1840er Jahren eingestellt und das Mühlengebäude abgebrochen. Die seit der Jahrhundertwende des 19. Jahrhunderts errichtete und parallel betriebene Windmühle brannte 1869 nieder.

Die beiden ehemaligen Dörfer Groß Hansdorf und Schmalenbeck liegen im Flussgebiet der Alster auf ansteigenden Höhen. Im Nordwesten Hansdorfs vereinigen sich zwei Bäche zu einem nach Ahrensburg und dann weiter nach der Alster fließenden, in diese bei Wohldorf sich ergießenden größeren Bach. Von diesen kleineren Bächen sind der von Osten nach Westen fließende Bach die Aue und der andere der Hopfenbach. Sie entspringen beide in der Niederung zwischen dem Hagener Forst und Volksdorf. Der Punkt des Zusammentreffens jener beiden Bäche liegt etwa 38 m über Meeresspiegel und verschaffte somit ein ausreichendes Gefälle, um eine oberschlächtige Mühle anzutreiben; ein Stauteich scheint dennoch notwendig gewesen zu sein: Seit 1529 wird von der Mühle in Hansdorf berichtet. Zwei Mühlenteiche werden erwähnt, ein größerer und ein kleinerer. Der Mühlenteich wurde auch zum Fischfang benutzt, Nachrichten dazu liegen, dies ist dem Werk VOIGTs zu entnehmen, aus den Jahren 1529 und 1530 vor. Am Ende des 16. Jahrhunderts war die Mühle aber bereits nicht mehr vorhanden. Um 1640 wurde auch eine Wassermühle in Schmalenbek eingerichtet, die der schon vorher bestehenden herrschaftlichen Wohldorfer Mühle Konkurrenz bereitet hat. Auch hier wird von einem Mühlenteich gesprochen (VOIGT 1906).

Oberhalb von Ahrensburg stand die Lasebekmühle, zwischen dem Gut Lasbek und Tremsbüttel. Der Mühlenteich war 7 ha groß. Zusätzlich wird noch ein 3 ha großer „Besteteich“ und außerdem ein 1/2 ha großer „Roter Teich“ verzeichnet. Die Vermutung aufgrund der Größe und Anzahl dieser Teichflächen bestätigt sich, denn in allen wurde Karpfenzucht betrieben. Das Gesamtareal der zur Mühle gehörenden Ländereien und Teiche betrug 27 ha (OLDEKOP 1908).

Weitere, noch bestehende Mühlenteiche im Randgebiet einer Metropolenregion sind die der Wohldorfer Mühle sowie der Mühlenteich der Poppenbütteler Mühle im nördlichsten Stadtgebiet von Hamburg. 


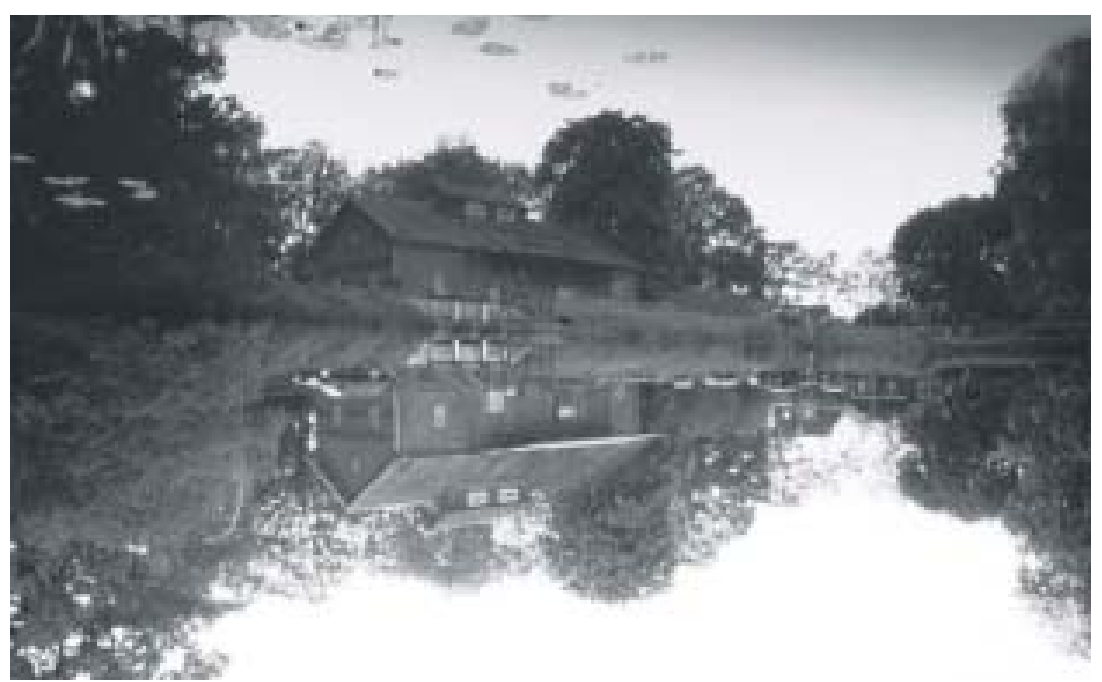

Abb. VIII-30: Mühlenteich der Wohldorfer Kornmühle

Dieser wird noch durch einen weiteren, oberhalb liegenden Stauteich ergänzt. Der Ursprung der Kornmühle geht bis in das Jahr 1471 zurück. Im Jahr 1809 wurde neben der Kornmühle noch eine Ölmühle errichtet. Beide Mühlen wurden von dem Wasser der aufgestauten Aue angetrieben. Während die Ölmühle 1860 zum Abbruch kam, wurde die Kornmühle nach einem Brand im Jahr 1863 wieder aufgebaut. Sie ist bis heute nahezu unverändert erhalten und steht seit 1997 unter Denkmalschutz. Seit 1975 wird in der Mühle kein Korn mehr gemahlen, es wird aber noch Hafer, Gerste und Mais für den benachbarten Reiterhof verarbeitet und die Wasserkraft des Mühlteiches genutzt, um Strom für das seitlich anliegende Restaurant zu produzieren (eig. Aufnahme 1999).

Im zentralen Hamburg ist ein bekanntes Beispiel für einen Mühlenteich der Binnen- und Außenalsterstau in Hamburg. Die Alster ist ein Fluss, der in seinem unteren Lauf im 12. und 13. Jahrhundert zum Betrieb von Mühlen an verschiedenen Stellen aufgestaut wurde und von dort schließlich in die Elbe mündet (RULLE 2001:171). Bis 1842 trennte ein fester Damm mit einer Mühle am Ausgang der Binnenalster (heute Jungfernstieg) die Alster von der Elbe. Man ersetzte den Damm durch eine Schleuse und senkte gleichzeitig den Wasserspiegel der Alster. Damit wurden zugleich die weiten, an der Außenalster gelegenen Gebiete von Uhlenhorst, Harvestehude und Winterhude, „die bis dahin wegen periodischer Überschwemmungen kaum nutzbar waren, in bebauungsfähiges Land umgewandelt.“ (HARMS/SCHUBERT 1989:21) Nach dem Großen Brand von 1842 wurde die Stauung an der Alster in der bisherigen Form zum Betrieb von Mühlen aufgegeben (RULLE 2001:171).

Der heutige Hamburger Stadtteil Harburg war ebenfalls durch zahlreiche Wassermühlen mit Mühlteichen gekennzeichnet (siehe Abb. VIII-31). Die Harburger Walkmühle besaß einen sog. „Walkmühlenteich". Dieser war bereits 1753 sehr verfallen, doch wurde er durch den Erlös aus dem Verkauf der Mühlenkarpfen wiederhergestellt. 1844 war der inzwischen verkleinerte Walkmühlenteich nur noch ein Zierteich. 1859 kaufte die Stadt Harburg die nunmehrige Papiermühle und schüttete den Walkmühlenteich zu. Den Wasser zu- und abführenden Mühlenbach hat die Stadt 1892 gänzlich vertunnelt (RUMP 2001:42). Ähnlich erging es der Harburger Graupenmühle mit ihrem Graupenmühlenteich, später „Hanstedter Teich“ genannt - er wurde 1908 verschüttet (:42) - wie auch der Lohmühlenteich der Harburger Lohmühle (:43) und der ehemalige Mühlenteich der Wassermühle in Moisburg, Landkreis Harburg, der heute als Papierwiese bezeichnet wird (:68). Insgesamt existierten in HarburgStadt 14 Wassermühlen, von denen außer den genannten zwar keine weiteren Berichte ausgewertet wurden, aber aufgrund der Vielzahl an anderen Wassermühltypen (Kornwassermühle, Schlossmühle, Ölmühle, Papiermühle, Seidenbändermühle etc.) die Annahme berechtigt erscheint, dass weitere Mühlteiche existierten (:380). Im angrenzenden Gebiet erscheint eine Wassermühle an der Engelbek bei Wilstorf bzw. Willersdorf, die vom Außenmühlteich gespeist wird. Bereits 1564 ließ Otto II., Herzog von Braunschweig-Harburg (1523 - 1603), den Außenmühlteich aufstauen und die Kornwassermühle anlegen (:110). 


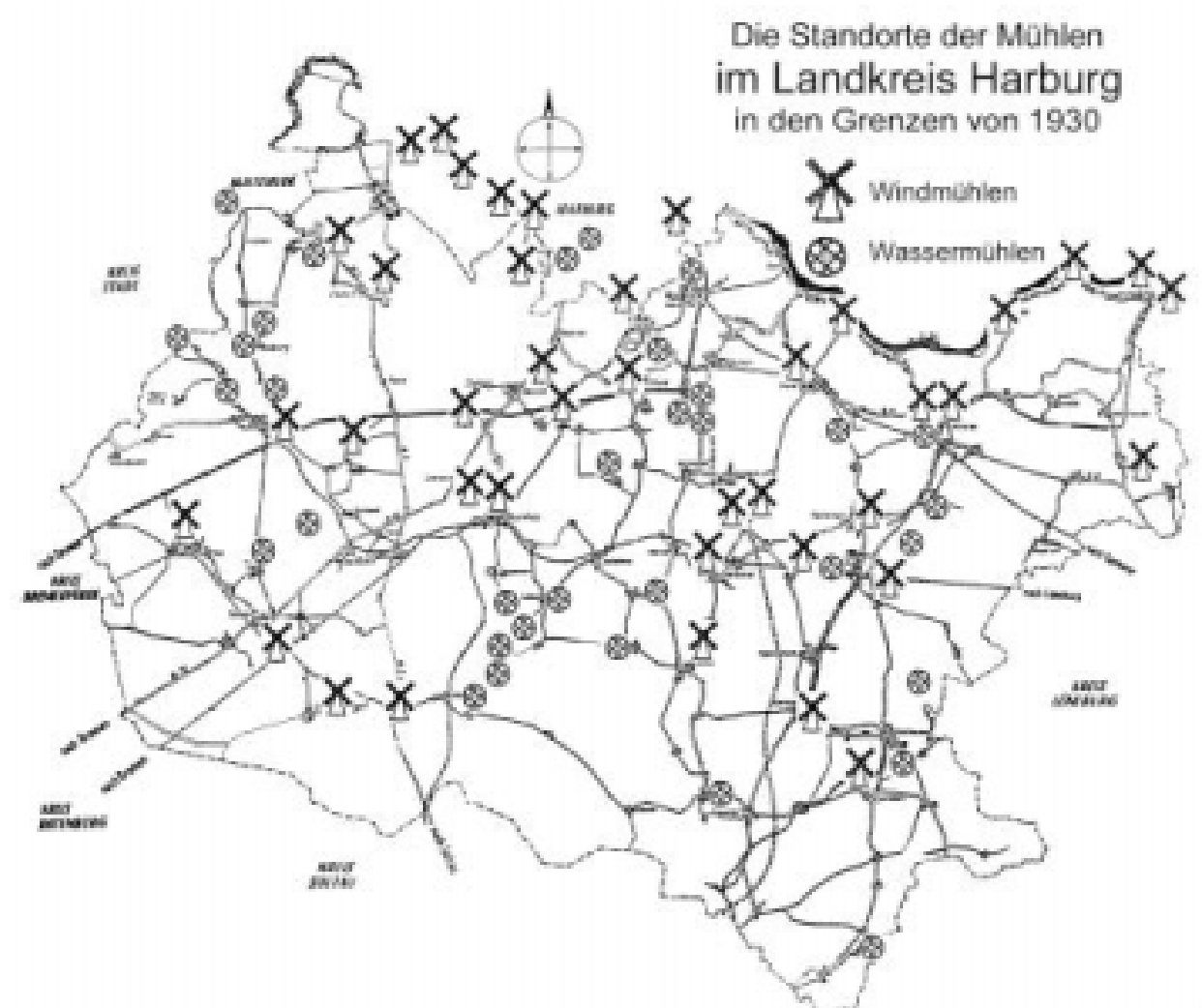

Abb. VIII-31: Die Standorte der Wasser- und Windmühlen im Landkreis Harburg

in den Grenzen von 1930. Auch noch in diesem Zeitraum, in dem die Ausbreitung der windbetriebenen Mühlen durch ihre Unabhängigkeit von den Unwägbarkeiten und Beschränkungen des Wasserdargebotes, vor allem in den küstennahen Windgunsträumen, profitierte, zeigt sich ein relativ ausgeglichenes Wasser/Windmühlenverhältnis von 34:40 (aus: RUMP 2001, Anhang).

Die im südöstlichen Hamburger Umland heute als Außenstelle des Kiekenberg-Museums betriebene Moisburger Mühle, südlich von Buxtehude, ist eine klassische Wassermühle, liegt aber an der stark wasserführigen Este und entspricht somit dem zu erwartenden Bild: Mittels eines Wehres wird die Wasserkraft direkt aus dem Flusslauf auf das Wasserrad geführt, ein Stauteich war hier nicht notwendig.

Im westlichen Hamburger Umland, dem schleswig-holsteinischen Amt Reinbek, das aus dem Besitz des ehemaligen Klosters Reinbek entstanden ist und bei Aufhebung der Ämter 1867 in den preußischen Kreis Stormarn eingegliedert worden ist und schon bei der Anlage und dem Betrieb von Teichwirtschaften eine besondere Rolle gespielt hat, sind zahlreiche Mühlenteiche bekannt (FINK 1969:5). Im 13. und Anfang des 14. Jahrhundert sind im Gebiet des ehemaligen Amtes Reinbek sieben Mühlen urkundlich nachgewiesen. All die nachfolgend gelisteten Mühlen, bis auf die Mühlen unter der Nr. 3, die durch den kleinen Schleemer Bach in Betrieb gesetzt worden sind, wurden durch die beim Dorf Stellau entspringende Glinder Au bis zu ihrer Mündung in die Bille angetrieben (:251).

1. Glinder Mühle bzw. Klostermühle (1229)

2. Hinschendorfer Mühle (1238)

3. Zwei Schiffbeker Mühlen (1256 und 1276)

4. Stemwarder Mühle (1273)

5. Oststeinbeker Mühle (1313)

6. Steinbeker Mühle (1321) 
Die Glinder Mühle, auch Klostermühle genannt, weil sie ehemals zum Kloster Hoibeke [Hoibek] gehörig war, zählt mit der erstmaligen Erwähnung 1229 zu den ältesten Mühlenstandorten in Schleswig-Holstein. Doch ob es auch bereits einen Mühlteich gab, ist nicht überliefert.

Die Mühlen 3, 5 und 6 sind im Jahr 1342 verwüstet worden, so dass von den genannten Mühlen nur noch drei vorhanden waren: Glinder Mühle, Hinschendorfer Mühle und Stemwarder Mühle (FINK 1969:1ff.).

Mitte und gegen Ende des 16. Jahrhunderts entstanden nun neue Mühlen, entweder durch Umnutzung oder wirklichen Neubau, denn die bisherigen Mühlen waren alle zu jener Zeit im Gebiet des früheren Amtes Reinbek Kornmühlen (FINK 1969:234f.). Im Zeichen wirtschaftlichen Aufschwungs in jenen Jahren haben Kaufleute bei der Holsteinischen Landesherrschaft um die Erlaubnis zur Anlegung oder Umnutzung von Wassermühlen nachgesucht und sie auch bekommen (:2). So wurden im Amt Reinbek 5 Mühlen neu erbaut: 1 . Im Jahr 1557 wurde neben der als Kornmühle betriebenen Glinder Mühle eine Sägemühle angelegt, die 1643 in eine Lohemühle umgewandelt worden ist, 2. 1587 kam die Anlage einer Walkmühle zu Reinbek hinzu, wobei einer der ursprünglich zwei Gänge der Mühle $1711 \mathrm{zu}$ einer Holzmühle umgewandelt und wie die Sägemühle 1815 abgebrochen wurde (:218) und 3. sowie die Pulvermühlen in den Orten Steinfurth (1578), Domhorst an der Glinder Au (1581) und in Altrahlstedt an der Wandse (1581) (:220ff.).

Im Laufe des 17. Jahrhunderts wurden weitere Wassermühlen angelegt: 1624 eine zusätzliche Pulverund eine Lohemühle, 1644 eine Walkmühle an der Schleeme, 1648 eine Fellmühle an der Glinder Au und 1740 die Papiermühle an einer auf dem Oher Feld entspringenden kleinen Au unweit ihrer Einmündung in die Bille. Sie war die letzte der im ehemaligen Amt Reinbek erbauten Wassermühlen. Vormals stand hier das 1229 gestiftete Maria-Magdalenen-Kloster Hoibeke, welches 1238 nach Köthel und dann nach Hinschendorf verlegt wurde (FINK 1969:221,238). Danach folgten nur noch die Errichtung einer mit Dampfkraft betriebenen Farbholzmühle in Schiffbek (1876) und der Bau von vier Windmühlen $(1792,1851,1874,1887)$, die sämtlich Kornmühlen waren (:213).

Obgleich auch bei den anderen Mühlen von einer ähnlichen Gewässersituation auszugehen ist, kann einzig bei vier Wassermühlen ein Mühlenteich nachgewiesen werden: So ist zum einen bei der Klostermühle ein Mühlteich mit Fischfangrechten beschrieben, der 1859 bestanden hat (FINK 1969:216). 1965 wird sie auf Hammerschlag umgebaut und sowohl für elektrischen als auch für Turbinenantrieb eingerichtet (:248). Von ihr ist 1969 - während der Buchaufnahme von Walter FINK, aus dessen Darstellung hier zitiert wird - überliefert, der Mahlbetrieb konnte „nur noch mit elektrischem Strom betrieben werden, da der Glinder Mühlenteich vollständig versiegt ist” (:229) und nachfolgend zum Erliegen kam.

Ebenfalls mit Mühlteichen ausgestattet war die 1321 erstmals urkundlich erwähnte Mühle zu Kirchsteinbek, oben als ,Steinbeker Mühle' bezeichnet. Sie besaß 1734 zwei „Fische Teiche” (FINK 1969:234), nachdem die ursprüngliche Korn- und Walkmühle 1635 zu einer Fellgerbermühle geändert wurde, 1656 die Fellgerbermühle wieder in eine Walkmühle für die Hamburger Kleintuchmacher umgewandelt worden ist, 1663 die Mühle zu einer Lohmühle aptiert und, da zum Aufbau einer Lohmühle die Mittel nicht ausreichten, wiederum in eine Walmühle umfunktioniert wurde, und 1681 schließlich der Wiederaufbau der Mühle zu einer „Brasilien- und Ostindischen Holzmühle” mit dem Privileg der alleinigen Berechtigung im Amt, solches Holz zu mahlen erfolgte („Brasilienholzmühle”). Auch an dieser Stelle wird deutlich, dass die Mühlteiche nicht allein dem Mühlenstau, sondern auch der Fischzucht dienten und die Bezeichnung eine eindeutige Primärfunktionszuweisung erschweren. 1970 wurden dann Kakao- und Haferschalen auf der Mühle gemahlen - motorenbetrieben (FINK1969:231ff.).

Und schließlich, was aufgrund der ungünstigen Gewässerausstattung zu erwarten war, ist ein zu Mühlenzwecken dienender Teich bei der Schleemer Mühle für das 17. Jahrhundert bekundet: Um dem Wassermangel des Schleemer Baches zu begegnen, wurde dem Müllerpächter schon 1632 der Oyendorfer Teich verpachtet, der aber 1675 wieder den Oyendorfer Eingesessenen zur Heugewinnung als Pacht gegeben wurde. 
Mit der deutschen Ostbesiedlung im hohen Mittelalter entstanden auch die ersten Wassermühlen entlang der Bille und der Delvenau im Lauenburgischen. Die Palmmühle in Lauenburg gehört zu diesen ersten Mühlenstandorten in der Region. Im Kreisgebiet gab es im Lauf der Jahrhunderte neben den Getreidemühlen auch Walk-, Lohgerber-, Papier-, Pulver- und Kupfermühlen. Für das südliche Kreisgebiet sind 26 Standorte für Wasser- und Windmühlen nachweisbar. Die Mühlen stützten sich dabei in den meisten Fällen, wie der Farchauer Mühle in Schmilau oder der Gülzower Mühle auf Gut Gülzow bei Ratzeburg, auf Stauteiche.

In mecklenburgischen Güstrow trieb die Nebel zahlreiche Wasserräder an und füllte die Mühlteiche einiger Mühlen, die wiederum auch der Fischzucht dienten (LORENZ 2000:16).

Von der 1791 als Herrschaftsmühle des Schlosses Kuchelmiß, der heute gleichnamigen Gemeinde bei Krakow, errichtete Wassermühle überlebte das Mitte des 20. Jahrhunderts abgerissene Herrschaftsgebäude nicht nur als technisches Denkmal, sondern auch mit seinen Wasserbauten. Bei der Kuchelmißer Wassermühle beispielsweise wird der vorgelagerte Mühlteich ,auch heute noch zur Fischzucht genutzt." (LORENZ 2000:16)

In der Umgebung, zwischen Waren und Teterow, lag die 1866 vom Grafen von Bassewitz errichtete Ziddorfer Wassermühle. Im vorderen Bereich befand sich der Mühlenteich, der den durch die Mühle fließenden Mühlgraben mit Wasser speiste.

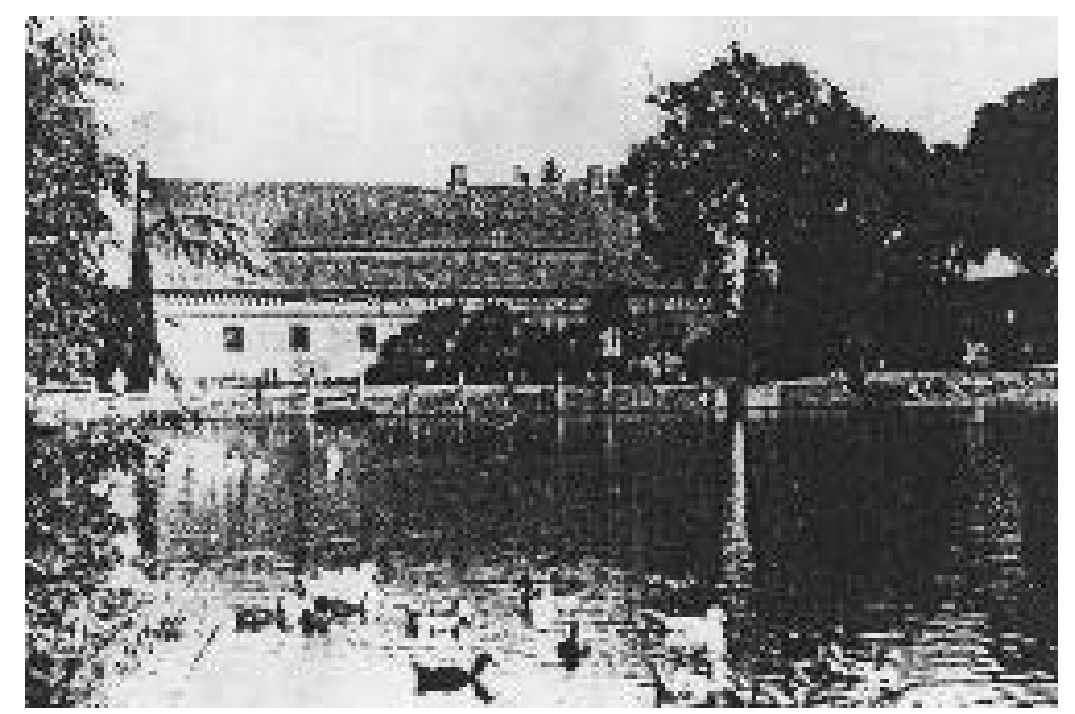

Abb. VIII-32: Ziddorfer Mühlenteich, um 1900

Wie schon bei den Fischteichen, so ist auch der Hohe Fläming im ansonsten eher flachen Bundesland Brandenburg Verbreitungsgebiet zahlreicher Mühlen gewesen, da hier Gefällewasser zur Verfügung stand. Die Kraft der Flämingbäche hat man sich schon früh zunutze gemacht. Bis ins 17. Jahrhundert reicht die Mühlentradition um Belzig. Allein am Verlorenwasserbach gab es früher acht, an der Buckau neun Mühlen. Überwiegend dienten sie zur Papier- oder Ölerzeugung. Die Mühlenteiche wurden hier oft gleichzeitig zur Fischzucht genutzt. Noch heute wird an einigen ehemaligen Mühlenstandorten die Forellenzucht betreiben, z. B. in Neschholz (Wühlmühle), Lühnsdorf (Werdermühle) oder Dahnsdorf (Komthurmühle). Da im Fläming oberirdisch Wassermangel geherrscht hat, wurden hier die zahlreichen Mühlenteiche angelegt und wahrscheinlich auch aus diesem Grund, da das Stauwasser knapp war, in zweifacher Hinsicht wirtschaftlich genutzt.

Für den Bremer Raum, dem nördlichen Landkreis Osterholz-Scharmbeck, beschreibt DÜRING (1977 :8) die Situation sehr treffend : „Da in der hiesigen Gegend weder ein allzu großes Gefälle noch eine andauernd starke Strömung vorhanden war, wurden die Mühlen meistens mit oberschlächtigen Wasserrädern versehen. Der relativ geringe Wasserzulauf verlangte, daß den Wassermühlen zudem noch Teiche als Speicherbecken für Nachtwasser und für das überschüssige Wasser aus Regenzeiten 
vorgelagert wurden. Erst hiermit konnte ein gleichmäßiger Wasserzulauf über viele Arbeitstage hinweg erreicht werden." Zeitlich betrachtet, ist der Bremer Raum ein Ort früher Wassermühlen. Bereits 788 wurde in der Diozöse Bremen ein Mulinbach (Mühlenbach) als östliche Grenze genannt (:8). Urkundlich wird 1182 erstmalig im Ritterhof von Westerbeck direkt eine Wassermühle genannt (:24). Um 1185 folgt für das Kloster Osterholz die Umleitung des Baches in das Klostergebiet und nach Gründung des Klosters Lilienthal 1233 wird ein Stau an der Wörpe angelegt und eine Wassermühle gebaut. Aber ein Mühlenteich wird zu diesem Zeitpunkt nachrichtlich erstmals für die Wassermühlen des Gutes Meyenburg erwähnt: Durch das reichlich fließende Wasser der Sprott- und Sprengbeeke, der beiden Hautquellbäche, war es zwar möglich, am Mühlengraben mehrere Wassermühlen zu errichten, aber ein Mühlenteich war trotzdem ob der Vielzahl an Mühlen notwendig (:35). Auch die Fehsenfelder Wassermühle, die letzte von ehemals 9 Wassermühlen, die am Scharmbecker Bach gestanden haben, besaß einen Mühlenteich (:69). Ebenso die Wassermühle des Rittergutes Sandbek, die sog. Rönn'sche Mühle, an der Beeke.

Im Norden der Lüneburger Heide herrschten wegen der geologischen Gegebenheiten die schlechten Böden vor. Den verarmten Heideflächen vermochten die Heidebauern nur sehr bescheidene Getreideernten abzuringen, die in den Wassermühlen ,am Rande der großen Heideregion“ vermahlen wurden, da „das Endmoränengebiet rund um den Wilseder Berg das notwendige Wasser nicht hergab.“ (ERLER/MATTHIESEN 1989:87) Wie zum Beispiel in der im 15. Jahrhundert erbauten Bahlburger Wassermühle an der Luhe deutlich wird, bei der ein Mühlenteich erwähnt wird, auf den 1930 aber schon nur noch der Flurname verweist (RUMP 2001:110).

Die zu anderen Regionen vergleichsweise geringe Anzahl der Mühlen im Mittelalter bescherten, da es aufgrund der verbesserten Anbaumethoden möglich wurde, auch in den Heidegebieten größere Mengen Getreides anzubauen, dem Altkreis Soltau einen regelrechten Windmühlenbauboom bescherten, mit einer überzogenen Anzahl von Neugründungen (ERLER/MATTHIESEN 1989:87). Sie zeigen darüber nur zu deutlich an, wie bodenkarg und menschenarm die weiträumigen Heideflächen des Nordkreises über die Jahrhunderte waren und blieben: die geringen Getreideerträge reichten schon für den Betrieb weniger Mühlen, kleinzelliger Anlagen zumeist mit nur geringer Leistung. Dementsprechend gering dürfte auch die Mühlenteichdichte gewesen sein, wenn sie auch gemessen am tatsächlichen Mühlenbestand - hoch gewesen sein mag. Schwach fließende und schnell versickernde Heidegewässer bedurften eben eines Speicherbeckens, wie es auch für das Bremer Gebiet bezeugt ist.

Mühlendicht wird es erst im Südkreisgebiet, die Bodenverhältnisse der Flusslandschaften, besonders die im weiten Urstromtal der Aller, zeigten sich hier deutlich getreideanbaufähiger und ertragreicher. Bedeutend mehr Menschen fanden hier eine dauernde Existenzgrundlage, weil mehr Mühlen mehr Korn zu mahlen bekommen hatten (ERLER/MATTHIESEN 1989:88). „Landschaftsbedingt und aus einer besonderen grundherrlich-mühlengeschichtlichen Entwicklung heraus, haben hier stets die Wassermühlen das Sagen gehabt.“"(:21)

Bei dem Landkreis Soltau-Fallingbostel handelt es sich um ein außerordentlich mühlenträchtiges Kreisgebiet mit über 30 Wassermühlenplätzen (ERLER/MATTHIESEN 1989:10,24): Der Altkreis Soltau mit ca. 15 Wassermühlen und der südwestlich anschließende Altkreis Fallingbostel mit nahezu derselben Anzahl alter Wassermühlenanlagen, ,die hier überwiegend das walsrodesche Kloster betrieb oder der landsässige Adel errichtete und besaß.“ (:24).

Die Landschaftsform hier aber ließ und lässt nur Flüsse und Bäche mit geringer Fließgeschwindigkeit zu, zumeist unzureichend als Antriebswasser für einen Wassermühlenbetrieb, der ausreichend Korn zu mahlen hatte. „Erst von Menschenhand weitflächig aufgestautes Wasser vermochte diesem Dauermangel abzuhelfen: Aufstauteiche insgesamt, die sich landschaftsprägend und zumeist nachhaltig - verschönend bis heute erhalten haben. Zumeist verschwunden sind die zugehörigen Wassermühlen“ (ERLER/MATTHIESEN 1989:24). Hier werden deshalb zahlreiche Sammelteiche in Zusammenhang mit Wassermühlen genannt: Der Wasserteich an der Wassermühle Bassel, die an der Kleinen Aue, Abel-Beke genannt, in Bassel bei Soltau liegt, der Cordinger Mühlenteich im Ortsteil Benefeld der Gemeinde Bomlitz, der Mühlenteich der Düshorner Wasser- und Windmühle, der 1644 
im Erbregister des Amtes Walsrode datierte Grasbecker Teich der Grasbecker Papiermühle in Walsrode an der Greßbecke gelegen $(: 41,80)$. Von der Cordinger Wassermühle beispielsweise ist bekannt, dass Johann von der FULDE sie 1408 an das Kloster Walsrode verkauft (:29). Entsprechend den allgemeinen Entwicklungen im Mühlenbau bauten die Müller um die Jahrhundertwende die Wasserräder aus und Turbinen übernahmen die Kraftgewinnung, ,aber die Sammelteiche hatten noch Funktion behalten“ (:51). Ob Wasser- oder Windmühle, kann bei der Düshorner Mühle nicht so ohne weiteres entschieden werden, denn von 1911 bis etwa 1922 war die Mühle ein „Zwitter": Auf das Gebäude der Wassermühle baute die Betreiberfamilie wie bei der oben erwähnten emsländischen Hüvener Mühle einen Windantrieb, um die Mühle bei Wassermangel in Betrieb halten zu können oder um zu weiter gesteigerten Leistungen zu gelangen $(: 41,86)$. Ebenso ist die Hellberger Wasser- und Windmühle in Kirchboitzen noch um einen zusätztlichen Windantrieb verstärkt worden $(: 54,86)$.

Bemerkenswert ist bei Düshorner Mühle - und dies unterscheidet sie von anderen kombinierten Wasser/Windmühlen - der $15.000 \mathrm{~m}^{2}$ große Mühlenteich, der aus Quellen gespeist wird. Einen echten Mühlenbach gibt es nicht, der Teich war daher unbedingt notwendig, weil die Quellen allein nicht für den Antrieb der Wasserräder ausreichten. Düshorn war insofern eine „Deichmühle”, d. h. „ein Landstück wurde mittels eines Deiches in einen Teich umgewandelt, mit dem eine Mühle betrieben werden konnte." (ERLER/MATTHIESEN 1989:41) In gleicher Weise, mit einem Quellteich, wurde auch die reine Wassermühle Reiningen betrieben: Gespeist wurde der Mühlenteich aus Quellen, die dem Reininger Moor entspringen und in einen Bach münden, der in die Wietze fließt (:66). Und auch bei der Wassermühle Harber, die einen $2 \frac{1}{4}$ ha große Mühlenteich besaß, wurde dieser durch mehrere Quellen gespeist und mündete anschließend im kleinen Harber-Bach (:49).

Eine „Dammmühle“ war auch die erste Wassersägemühle in Wense. Sie „stand bis 1804 auf dem Damm zwischen dem Kapellen- und dem Mühlenteich. [...] Die durch Wasserkraft angetriebene Mühle war damals sehr klein, hatte nur eine Säge“ (ERLER/MATTHIESEN 1989:66). Im Gegensatz zu der Düshorner Teichmühle aber erfolgte der Wasserzulauf aus dem Raum Grefel/Aspeloh über den Wenser Bach via einer Teichkette zur Mühle (:66).

Weitere ehemalige Mühlenteiche sind von der Wassermühle Dittmer-Hambostel und von der Wassersägemühle Mengebostel bekannt. Während der Stauteich in Hambostel heute nicht mehr vorhanden ist und lange Zeit als Fischteich Erwähnung findet (ERLER/MATTHIESEN 1989:39), dient der alte Mühlenstau der Wassermühle in Mengebostel seit der Stilllegung 1986 noch immer als Fischteich (:57). Mühlenteiche waren zugleich auch Fischteiche bei der einen Mühlteich schon etymologisch prognostizierenden sog. Weiher-Mühle in Tetendorf, benannt nach dem Bauherr Heinrich von WEIHER (:76) und bei der Eggersmühle bei Wesselohe (:81f.). Des Weiteren bestanden Mühlenteiche bei der Brochdorfer Rutenmühle, bei der Bispinger Wassermühl und der Wassermühle Lünzen an der Veerse (:55f.).

Schmaler, aber beherrschender Fluss des Kreisgebietes ist die ,Böhme'. In ihrem Einzugsgebiet siedelten sich die meisten Wassermühlen an. Weitere Wassermühlen hat es dann im Einzugsgebiet von Luhe, Oertze und Aue im Nordosten des Landkreises gegeben, im Südwesten an Lehrde und Bomlitz. ERLER/MATTHIESEN (1989:87) sprechen von einer „böhme-bezogenen sog. Wassermühlenachse“. „Zu allen Zeiten sind“ nach ihrer Meinung ,westlich und östlich dieser gedachten Achse die meisten Mühlen gebaut worden." (:88). In Erweiterung des axialen Begriffes, manifestiert sich die zentrale „Mühlenteichachse“ im Einzugsgebiet der kleinen Flüsse Luhe, Oertze, Böhme, Bomlitz, Bombach, Meiße, Lehrde, Wense und Warnau, Veerse und Fintau. An dem hier zentralen Fluss, der Böhme, wurde aber das Antriebswasser zumeist nur geringfügig durch ein Wehr aufgestaut, weil davon stets ausreichend vorhanden war (:88). Mühlteiche wurden aus diesem Grund hier nicht angelegt.

Man erkennt, dass dieses Landkreisgebiet eine Wassermühlenregion gewesen ist. Darüber hinaus zeichnen sich die beiden Altkreise Soltau und Fallingbostel durch das Kleinfließgewässer strukturierte und pedologisch bedingte Vorkommen von Mühlteichen aus. Hier waren zu allermeist Wassermühlen ansässig, „,ie über Jahrhunderte rentabel arbeiteten, denn die Flüßchen und Bäche hier führten und führen noch immer genügend Wasser und weisen zudem ausreichend Gefälle auf, weil sie enge Geesttäler durchfließen. Deren Fließgeschwindigkeit wird nicht unberechenbar schnell, und mit 
Hochwasser haben sie nur selten zu tun. Und bei kleineren Bächen vermögen zusätzliche Stauteiche die notwendigen Betriebsbedingungen zu erbringen, einen Wasserspeicher, der stets für ausreichend Wasser und den benötigten Wasserdruck sorgt." (ERLER/MATTHIESEN 1989:88) Die hochwasserträchtige und landschaftsdominierende mittlere Aller hingegen und ein kaum nennenswertes Gefälle in den Flussmarschen ließen „den Bau der sonst üblichen Wassermühlen nicht zu. [...] Deshalb kamen hier ausschließlich Windmühlen zum Zuge.“ (:88)

Sämtliche einst im an die Ostheide angrenzenden Wendland existierenden Mühlen und deren Standorte hat LANGE (1989) erfasst: Er beschreibt dabei die Mühlen des Wendlandes in den Grenzen des heutigen Landkreises Lüchow-Dannenberg, dem einstigen Siedlungsgebiet der Wenden. Geographisch bilden die Höhen des Drawehn im Westen, die Elbe im Nordosten, die Altmark im Südosten und die Niederungen der Dumme und des Landgrabens im Süden die natürliche Grenzen (:11). Westlich der Jeetzel gab es fast nur Wassermühlen, die von den aus dem Drawehn herabfließenden Bächen getrieben wurden. Östlich der Jeetzel gibt es kaum fließende Gewässer mit ausreichendem Gefälle, um Wassermühlen zu treiben, „dort war daher die Windmühle vorherrschend.“(LANGE 1989:11):

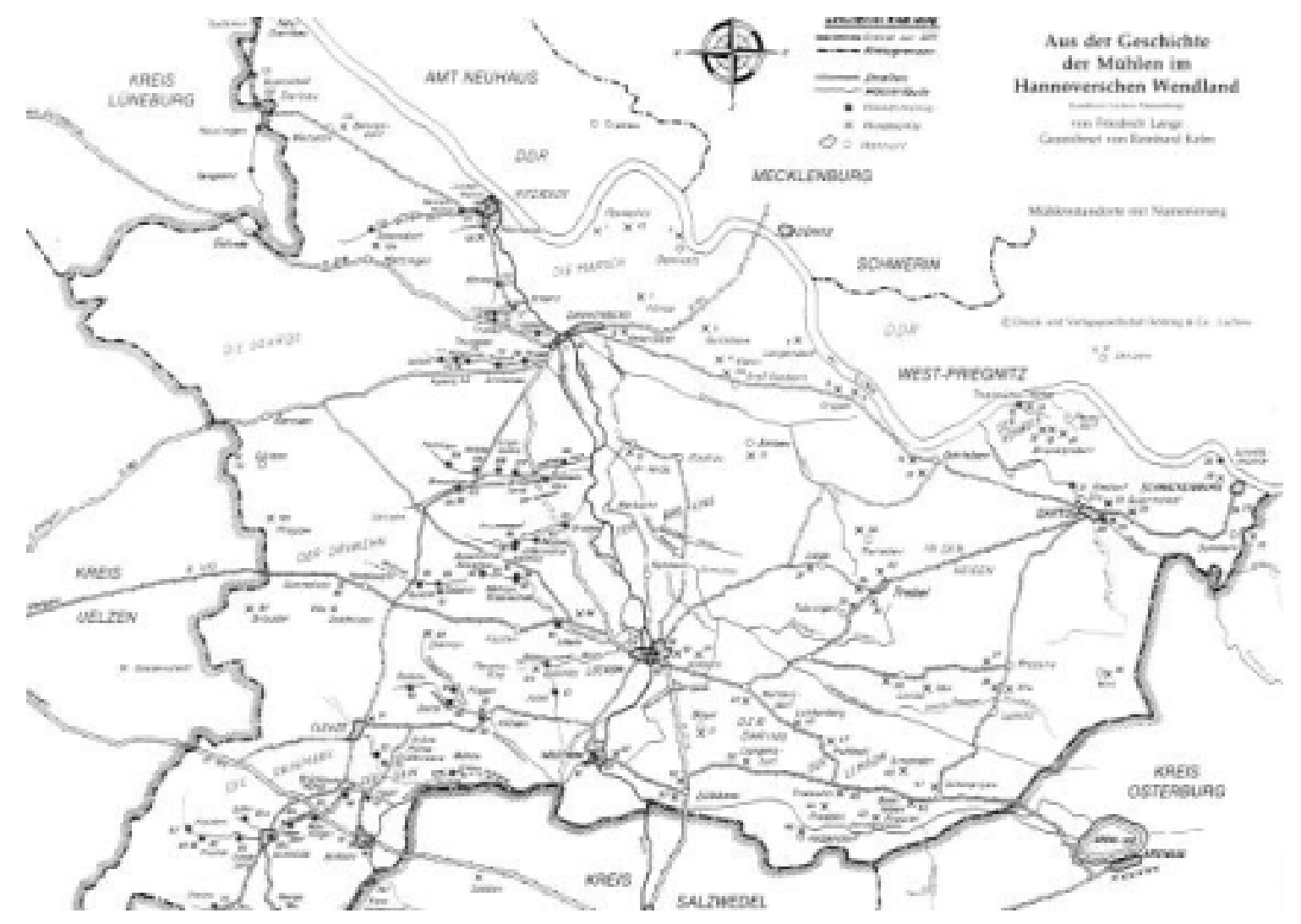

Abb. VIII-33: Wasser- und Windmühlen im Hannoverschen Wendland, einschließlich ihrer Wasserläufe (aus: LANGE 1989:Anhang)

Der gesamte Mühlenbestand des Wendlandes umfasste zur Höchstzeit im 19. Jahrhundert 132 Mühlen und verteilte sich auf etwa 60 Wasser- und 70 Windmühlen. Obschon dies ein ausgeglichenes Verhältnis ist, waren zeitlich betrachtet die ersten Mühlen des Drawehn vornehmlich Wassermühlen. Erst die wachsende Bevölkerung und abnehmende Mühlenleistung durch geringere und unregelmäßigere Wasserführung der Dumme, die hauptsächlich durch Trockenlegung von Mooren hervorgerufen wurde, führten zu Beeinträchtigungen, die durch den Bau einer Windmühle im Jahre 1822 behoben werden sollten.

Aber auch der Wassermühlenbau findet im Verhältnis zu anderen Regionen erst spät Verbreitung (LANGE 1989:64). „Zur Zeit Karls des Großen“, ist sich LANGE (:13) sicher, „gab es im Wendland mit Sicherheit noch keine Mühlen“. Die bevölkerungsmäßigen Umschichtungen waren noch längst nicht abgeschlossen, das Gebiet politisch noch instabil. Das Wendland war Grenzgebiet des karolingischen Reiches, das deutsche Rittertum hatte hier noch nicht Fuß gefasst (:13) und auch 
missionarisch wurde das wendische Land erst recht spät heimgesucht. Das durch den Grafen Hermann von Lüchow und Warpke 1160 gegründete Kloster Diesdorf in der Altmark wird 1161 durch Bischof Hermann von Verden geweiht und als Ausgangspunkt für die Missionierung der Wenden bestimmt. Die im Wesentlichen zehntfreien Orte öffnen sich aber nur zögernd dem Christentum. Im Wendland kommt es zu keiner einzigen Klostergründung und darum auch zu keiner von Mönchen in eigener Regie betriebenen Klostermühle (LANGE 1989:41; KIRCHENGESCHICHTE 2004). Im Gegensatz zu anderen Gebieten gab es im mittelalterlichen Wendland auch „keine Mühlen in städtischem Besitz. Es gab keine Mühlen, die Patriziern oder Gilden gehörten [...]. Nur einige Mühlen gab es, deren Aufkünfte Kirchen und Klöstern überschrieben worden waren.“ (LANGE 1989:24) Nach den Urkunden überträgt die Schwiegertochter Heinrich des Löwen 1243 die Mühle in Harpe dem entfernt gelegenen Kloster zu Isenhagen (:13). Verlässliche Daten über die ersten Wassermühlen gibt es also erst aus der Zeit der Welfen. In den nachfolgenden Jahren im Verlauf des 13. und 14. Jahrhunderts mehren sich die Mühlengründungen, wie die zum Beispiel in Lüchow, Dannenberg und der Schlossmühle Gartow. Weitere Standorte, von denen es Nachrichten gibt, war 1487 ein Hauptarm der Jeetzel, es folgten 1574 Wassermühlen in den Dörfern Trebel, Tobringen und Marleben (:18).

Die Anlagen bestanden hauptsächlich aus Mühlenbach und Stauteich, die von „meistens eher sumpfigem Gelände mit Holzung, dem Ellernbruch“ (LANGE 1989:38) umschlossen waren und die damaligen Acker- und Wiesenflächen bildeten. Zum Mühlenanwesen der Walk- und Baakemühle Wustrow im Wendland gehörte 1754 ,damals eine Weide für zwei Pferde und vier Kühe, der oberhalb der Mühle gelegene Bruch und die Fischerei in den beiden Mühlenteichen." (:194) Ebenso besaß die Wassermühle Darzau einen Mühlenteich, der von den Müllerfamilien nach Wegfall der Müllerei als Forellenzucht betrieben wurde. „Der Mühlenteich ist heute verschlammt und zugewachsen“, beschreibt LANGE (:198) die Situation. Mühlenteiche wurden des Weiteren noch im Jahre 1970 sichtbar an den Wassermühlen Wöhningen, Brüchau, Oldendorf, Karmitz, Kähmen und Sarchem (:59). Auch die Wassermühle Dötzingen bei Hitzacker-Dötzingen hatte einen oder mehrere Mühlteiche (:127).

Weiter südlich, im Gebiet des Knesebecker Amtsbezirkes, wird ebenfalls von Mühlteichen berichtet. Die Amtsmühle Knesebeck wird anno 1336 mit einem oberhalb gelegenen Mühlenteich erwähnt (BOSSE 1991:109). Die Problematik dieses Teiches bestand darin, dass die Wassermühle „der Verfügungsgewalt des Knesebecker Amtmannes unterstand, dessen Interessen lediglich auf eine große Fischausbeute und den daraus zu erzielenden ökonomischen Gewinn abzielten, wogegen der Amtmann zu Isenhagen bei Hankensbüttel, als Verwalter der ehemaligen Klostermühle, sich mehr um die Gewähr eines ständig fließendes Gewässers als Antriebselement für seine Mühle sorgte.“ (:125) Des Weiteren besaß die Wassermühle Krummühle zu Knesebeck 1451 einen Mühlenteich. Für dasselbe Jahr wird auch für die Baumgartenmühle und für die Stackmannsmühle bei Knesebeck ein Mühlenteich erwähnt. Ein Mühlenteich trieb auch die 1343 urkundlich genannte Lütje Mühle bei Hagen an und der ,Stöckener Teich' unterstützte die Stöckener Wassermühle. Die vom Emmer Bach angetriebene und 1341 erwähnte Emmener Mühle benötigte einen zusätzlichen Mühlenteich, dessen Zustand aber 1744 erbärmlich gewesen sein muss und der deshalb seine Funktion nicht entsprechend erfüllen konnte: „Der Teich war zugeschlammt und beangert, daher fehlte zu Sommers Zeiten das benötigte Antriebswasser“. Des Weiteren „habe sich der Kitt an der steinernen Schleuse stellenweise gelöst, und dort versuche nun das Wasser durchzudringen.” (:136).

Mühlenteiche gab es auch bei der Bottendorfer Klostermühle, auch Schweimker Gosemühle genannt, in Schweimke nördlich von Isenhagen im heutigen Kreis Gifhorn. Es ist das seltene Beispiel einer Wandlung eines Fischteiches in einen Mühlenteich: 1476 werden in einer Urkunde (Briefschaft) von Heinrich dem Frommen die Klosterteiche erstmals erwähnt (BOSSE 1991:142). Aus dem Jahre 1567 liegt ein Teich- und Fischereiverzeichnis des Klosters Isenhagen vor, das aussagt, dass das Kloster drei Teiche hinter dem Vorwerk hatte: den ,Mühlenteich', einen ,Guseteich' und einen wüsten, nicht näher bezeichneten Teich, der hier zweiter Guseteich genannt werden soll. In näherer Umgebung des Weiteren einen ,Haselbecks Teich' (,Häßelteich') und zwei auswärtige Teichlehen (:141). Aus den geschichtlichen Quellen geht weiterhin hervor, dass das Rittergeschlecht derer von Gos bei der Einkleidung ihrer Töchter im Kloster Isenhagen dem Kloster als Aussteuer zwei Teiche in der Nähe Schweimkes, im Schweimker Moor gelegen, geschenkt hat. Diese seien lange Zeit als Fischteiche 
genutzt worden, bis dort dann 1699 eine Mühle erbaut worden sei (:140ff.). Diese Teiche waren also nach der Schenkung ein „Pertinenz-Stück“ (Zubehör) des Klosters, das früher die Teiche zunächst als Fischteiche genutzt bzw. weiter benutzt hat, bevor sie - mit größter Wahrscheinlichkeit additional der Beaufschlagung einer Wassermühle dienten. Der zweite ,Guseteich' ist bereits seit ca. 1630 ein „wüster Teich“. Ein Hauptmann Dannenburg hat „,ihn abgelassen und ausgefischet, währe aber nicht wieder zugemacht und besetzet.“ (:141, nach alten Quellen) Zu diesem Zeitpunkt sei aber der Teich schon zugewachsen gewesen, nur der Mönch habe noch herausgeragt. Im weiteren Verlauf des Schwedischen Krieges seien dann beide Teiche wüst gelegen, „bis endlich der damalige Amtsschreiber [...] die Teiche wieder ausbringen, stauen lassen und mit Karpfenlaich besetzet habe.“ (:142) 17 Jahre nach dem Dreißigjährigen Krieg dann ,habe der starke Schneefall eine solche Wasserflut ausgelöst, daß der Damm im Frühjahr gebrochen sei. Seit der Zeit liege der Teich wüste.“ (:142) Die Geschichte einer Wassermühle am ,Goseteich' beginnt also erst Ende des 17. Jahrhunderts mit dem Jahr 1697, als ein Begehren eines Müllers, an einem der beiden Goseteiche eine Wassermühle anzulegen, eingeleitet wurde (:142 ). 1699 konnte der Bau beginnen.

Auch aus dem Raum Gifhorn sind aus der Literatur Hinweise für die Existenz von Mühlenteichen zu filtern. So lag die 1213 erwähnte Gifhorner Walkmühle an einem ,Gerdes-Teich', ,ein ,Springwasser', der das benötigte Wasser sowohl zum Antrieb des Mühlenrades als auch für den Walkvorgang liefern sollte.“ (BOSSE 1991:44) Ein Mühlteich wird hier des Weiteren von der 1566 beurkundeten Martinsmühle genannt, aus dem nach der Stilllegung des Mühlenbetriebs ein Karpfenteich geworden ist (:65). Aus dem 16. Jahrhundert stammt der Hinweis eines nordwestlich von Gifhorn gelegenen ,Jembker Mühlenteiches' der Jembker Wassermühle (:85). Etwas später (1619) erscheint ein Mühlenteich an der Weyhauser Mühle an der Kleinen Aller und am Kiebitzbach, einem Allerzufluss die Kiebitzmühle, deren Teich heute verlandet ist (:93f.).

Südlich von Wolfsburg wird in der Müllerkartei im Staatsarchiv Wolfenbüttel die Heiligendorfer Teichmühle aufgeführt. Vor 1692 bereits ist der Mühlenteich ausgebracht worden und dabei das Gerinne, so das Wasser auf das Mühlrad führte, um 14 Zoll erhöht worden. Damit war der zwar der Fischerei gedient gewesen, das Mahlwerk aber fast ganz zum Stillstand gebracht worden (BOSSE 1991:171). Südlichwestlich von Wolfsburg beginnt 1489 die erste Aufzeichnung der ,Ehmener Wassermühle'. Der zugehörige Mühlteich wird 1707 in den Akten genannt. Bereits 1843 aber ,legte man den etwa hundert Morgen großen Teich trocken" (:175). Nördlich von Wolfsburg findet 1366 die Wippermühle an der sog. Wipperaller ihre erstmalige Erwähnung: „Den Radantrieb der unterschlächtigen Wassermühle besorgte das Fließgewässer der Wipperaller, die aus dem einst zwischen Velstove, Eischott, Wendschott und Brechtorf gelegenen fast 700 Morgen großen Wipperteich.” (:100) Der ,Wipperteich' wurde ebenfalls als Fischteich genutzt und alle drei Jahre abgefischt. Für die Dauer der Abfischung musste der Teich abgelassen werden (:101). 1841 wurde die Trockenlegung des Wipperteiches beabsichtigt und eine Veräußerung an die benachbarten Gemeinden Velstove und Eischott angestrebt.

Der früheste Nachweis einer wasserbetriebenen Mühle für das Gebiet des Osnabrücker Nordlandes ergibt sich aus der 977 auftretenden Benennung eines Ortes Muliun (1037/52 Mulion). Der Name bekundet den Standort einer Mühle, bei der es sich nur um eine Wassermühle gehandelt haben kann. Als Lokalisierung wird ein Ort Wulften bei Badbergen genannt (DOBELMANN 1980:8). Nicht überliefert ist, ob ein Mühlteich zum Anwesen gehörte.

Die genaue Zahl der durch die Jahrhunderte im Osnabrücker Nordland vorhandenen gewesenen Wassermühlen ist nicht bekannt, doch aus der Größenangabe kann geschlossen werden, dass es sich um eine ausgesprochene Wassermühlenlandschaft handelt, in der aufgrund des hohen Mühlenbesatzes mit ebenso vielen Mühlenteichen zur Unterstützung des Mühlbetriebes gerechnet werden kann. Bis zum Ende des 19. Jahrhundert können etwa 82 Wassermühlen nachgewiesen werden. Hinzu kommen 6 Wassermühlen, bei denen die Existenz lediglich nur aufgrund von Flurnamen vermutet werden kann. Als Beispiel seien nur die im Verhältnis zur Wasserstrecke zahlreichen Mühlen an der Sültebeke bzw. „Sülte“ genannt, „der einzigen Wasserader der Bauernschaft Lonne-Vechtel“ (SCHRÖDER 1978:5). Unter „Sülte” (Sulte) versteht man hier eine wasserreiche Niederung, eine Wasseransammlung, je einen Teich mit Wassereinfluss und Wasserauslauf. Der Sültebach ist demnach der den Teich 
durchfließende Bach, die Sültemühle die an diesem Bach oder Teich gelegene Mühle (SCHRÖDER 1978:10f.). Der Sültebach besitzt nur eine Länge von ca. 1 km, erreicht aber auf dieser kurzen Strecke soviel Gefälle, dass an seinem Verlauf 3 Mühlen entstehen konnten, die aber alle durch den ,Sültemühlenteich' in ihrem Betrieb unterstützt werden mussten (OSTENDORFF 1978:17). Bereits 1408 sind Teiche in Zusammenhang mit dem Landgut Lonne, dessen Name soviel bedeutet wie wasserreiches Gelände, Waldaue, erwähnt. In der Nähe der Teiche entstanden dann nach und nach die bereits erwähnten drei zum Hause Lonne gehörigen Wassermühlen, die Sültemühlen. Der Mühlenteich einer der drei Sültemühlen, der Ölmühle in Bippen, Ortsteil Lonnerbeck bei Fürstenau, ist noch heute zu entdecken.

Die Wassermühle des Klosters Bersenbrück, das 1786 noch vor der Säkularisierungswelle zu Beginn des 19. Jahrhunderts aufgelöst wurde, befindet sich im Klosterbezirk an der Hase und wird deshalb auch Hasemühle genannt. Das Kloster ließ 1292/93 die Hase zu diesem Zweck ableiten und verlegen und einen künstlichen Arm als Wasserstau und Zufluss zur klösterlichen Hasemühle anlegen (DOBELMANN 1980:27). Die Klostermühle benötigte durch die Wasserkraft der Hase keinen Stauteich, wohl aber ein Mühlenstau.

Eine große Zahl an Mühlen lagen auch am Nordhang des Naturparks Wiehengebirge, im unmittelbaren Übergang zum norddeutschen Tiefland. Der Venner Mühlenbach zum Beispiel trieb einst vier Wassermühlen im alten Kirchdorf Venne an: die Gutsmühle Borgwedde, die Landesherrliche Mühle zu Venne (Linnenschmidt'sche Mühle), die Stüven Mühle und die Gutsmühle Streithorst. An der engsten Stelle der Mühlenbachsenke, zwischen Westhang der Hiese und dem Kalkrieser Berg, konnten Bauwerke die Anlage einer Wassermühle ermöglichen. Sowohl die hier aus Dämmen errichteten Mühlenteiche, als auch die bei den Gutsmühlen vorhandenen Mühlengräften, lenkten die zu bändigenden Mühlenbachwasser auf die oberschlächtigen Wasserräder. Noch heute werden Pflege und Instandsetzungsarbeiten an den Mühlenteichen durchgeführt.

Die allgemeine Strömung der natürlichen Wasserläufe im nördlich anschließenden Ems- und Artland war in der Ebene zu gering, um allein das Mühlrad zu betreiben. Wasser musste hier nach Auffassung von DOBELMANN (1980:27) in Reservebecken (Mühlteichen) und in den Stauanlagen (Mühlkanälen) aufgestaut werden, damit bei Bedarf Wasser für den Betrieb der Mühlen zur Verfügung stand.

Die Situation wurde hier aber nicht primär durch die Anlage von Mühlteichen gelöst, sondern vor allem durch den „einfachen“ Wasserstau des Mühlwassers. Um Stauungen entlang der flachen Ufer zu ermöglichen, wurde beispielsweise schon in der ersten Hälfte des 13. Jahrhunderts, nach Errichtung der beiden Mühlen in Quakenbrück, die Hase oberhalb Quakenbrücks eingedeicht. Ende des 15. Jahrhunderts wurde der Haselauf auf der langen Strecke von fast $10 \mathrm{~km}$ Länge begradigt und mit neuen Uferdeichen versehen, um den stärkeren Zufluss des Wassers zu den landesherrlichen Mühlen in Quakenbrück zu verbessern und die Ergießung des Hase-Stromes zu reglementieren.

Unter den Kreisen im Regierungsbezirk Münster zählte 1837 das am Südhang des Teutoburger WaldAusläufers befindliche Tecklenburg mit 76 die meisten und der Kreis Ahaus mit 23 die wenigsten Wassermühlen. Von der Wassermühle zu Ahaus ist bekannt, das sie in der Nähe des Schlosses stand und vom Wasser der Aa und der Schlossgräfte als Mühlteichersatz angetrieben wurde. Sie konnte trotzdem nicht kontinuierlich betrieben werden. „Im Winter bei Eisgang und im Sommer bei stets geringer Wasserführung der Aa lag die Mühle still.” (TERHALLE 1992:52)

Als Wassermühlenstandort des Westmünsterländer Flachlandes tritt auch die Stadt Vreden in Erscheinung. Das ehemalige adelige Familienstift und spätere Reichsabtei Vreden besaß im Mittelalter im unmittelbaren Umfeld mindestens drei Mühlen: 1. die abteiliche Wassermühle an der Berkel, als älteste Mühle der Abtei wahrscheinlich schon 1024 existent, 2. eine Ölmühle und 3. eine Papiermühle, beide am kleinen Ölbach gelegen. Vor allem die vorbeifließende Berkel bot „bei entsprechenden Wasserbaumaßnahmen eine ideale Gelegenheit, zum einen um den Stiftsgraben mit Wasser zu füllen und zugleich am Stau eine Mühle zu betreiben. Gerade hier im Flachland des Westmünsterlandes war ein Befestigungssystem am leichtesten mit einem Wassergraben zu erreichen. Es müssen im frühen 
bzw. hohen Mittelalter offensichtlich gewaltige Erdbewegungen an der Berkel in Vreden stattgefunden haben, um eine Stauhöhe von etwas über $5 \mathrm{~m}$ zu erreichen, wobei man vermutlich landschaftliche Vorgegebenheiten ausnutzen konnte, die heute nach vielen Veränderungen im Gelände nicht mehr erkennbar sind." (TERHALLE 1992:27) Im Gegensatz zur oberen Berkel aber besaß nachweislich die Ölmühle zur Striepe am Ödingbach bzw. Odingbeke, heute Ölbach genannt, mehrere Teiche (:93).

Weiter Wassermühlen des Stiftes lagen im Kirchspiel Ramsdorf (,Ramsdorfer Mühle'), in Honroden und in der Bauernschaft Ellewick. Für die Honroder Wassermühle ist eine sog. Möllenkuhle überliefert, bei der sich um einen Mühlenteich gehandelt haben könnte.

Von den im 19. Jahrhundert zahlreichen Mühlen im Vredener Land - in der ehemaligen Stadt Vreden und der ehemaligen Landgemeinde Ammeloe - „ist keine in funktionsfähigem Zustand erhalten geblieben.” (TERHALLE 1992:9).

\section{b.2 Mittelgebirge}

Große Bedeutung für die Energiegewinnung hatte die Nutzung der Wasserkraft in Mittelgebirgen (VOIGTMANN 1999:74). Vor allem in den heute strukturschwachen Mittelgebirgsregionen waren es die wasserradbetriebenen Mühlen und Hämmer, die gleichsam perlschnurartig die Bach- und Flussläufe säumten. Aus diesem Grund war es in Gebirgen nicht so sehr das mangelnde Gefälle oder die zu geringe Wasserführung, vielmehr war es die große Konkurrenz, die eine Wasserbevorratung notwendig machte. Dazu einige Beispiele.

Das ausgedehnte westfälische Wiehengebirgsvorland des heutigen Kreises Herford, das östlich an das Lippische Bergland angrenzt und im Süden an die Ausläufer des Teutoburger Waldes, besitzt „wegen seiner naturräumlichen und wirtschaftsgeschichtlichen Gegebenheiten eine auffallend dichte und vielfältige Mühlenlandschaft" (MÖRSTEDT 1995:7) und ist ein wahres Wassermühlenteichgebiet, wenngleich heute die Müllerei als Gewerbe im Kreis Herford „,nahezu ausgestorben“ ist“ (:7). Nördlich der Else erlaubten die vom Wiehen abfließenden Bäche die Anlage zahlreicher kleiner Wassermühlen, die aber einen Teich unabdingbar machten.

Aber auch hier ist eine räumlich differenzierte Betrachtung geboten, da es hier einerseits solche Schwerpunkte von Wassermühlenstandorten mit angeschlossenem Stauteich gibt, während andererseits mit Werre und Else die beiden größten Flüsse des Kreises Herford den Landstrich durchziehen, die aufgrund ihrer Wasserkraft eine Stauvorrichtung nicht notwendig erscheinen ließen. In anderen Gegenden des Kreises wiederum waren die Windmühlen proportional stark präsent, wobei sie zuweilen aus Wassermühlen hervorgegangen sind bzw. erst recht spät errichtet worden sind. Sie stammen alle aus dem 20. Jahrhundert. Aber immer sind es die Wassermühlen, die nicht nur die ältesten Mühlenplätze, sondern auch die Masse an früherer Mühlentechnik darstellen.

Im Bereich der Stadt Bünde hat es von ehemals insgesamt 27 Mühlen, in denen 9 Motormühlen eingerechnet sind, von denen einige wiederum frühere Wassermühle darstellen, 13 Wassermühlen gegeben (MÖRSTEDT 1995:16,33) Mit Ausnahme der zwei Wassermühlen an der wasserreichen Else besaßen nachweislich die meisten von ihnen, wie die Wassermühle Kreimer am Gewinghauser Bach im Ortsteil Muckum, einen Stauteich, der in diesem wie auch in den meisten anderen Fallen in den späten 1950er Jahren mit Stilllegung der Mühle zugeschüttet wurde (:33).

Im Bereich der heutigen Stadt Herford hat es insgesamt mindestens 50 Mühlen gegeben. Das „Schwergewicht liegt in Herford bei den Wassermühlen, die mit 26 Standorten die Hälfte der Gesamtmenge ausmachen. 10 dieser Mühlen sind erhalten, 16 verschwunden." (MÖRSTEDT 1995:68). „Die diversen Wasserläufe haben in der Vergangenheit das Stadtbild Herfords wesentlich mitgeprägt, und die Wasserkraftnutzung im Stadtgebiet war über viele Jahrhunderte eine wichtige Voraussetzung für das Funktionieren der Stadtökonomie. Davon ist seit der Verfüllung von Bowerre und Kleiner Werre kaum noch etwas zu spüren." (:68). Lediglich die an dem Hauptfluß ,Werre' liegenden Mühlen besaßen keinen Stauteich, obschon auch sie teilweise „ihre Wasserkraft vollständig eingebüßt" haben und $u$. a. auch aus diesen Grund verschwunden sind (:77). An den zahlreichen in sie 
einmündenden Nebenflüssen hingegen wurden zahlreiche Wasserreservoire angelegt. Zur 1224 erstmals erwähnten ,Rote Mühle’ am Putchemühlenbach gehörte „ein recht großer Stauteich, aus dem das Bachwasser zum einzigen Wasserrad der Mühle floß, das mit einer hölzernen Radstube verkleidet war.“ (:80). Auch die 1821 errichtete und mittlerweile verschwundene ,Mühle Wattenberg' am Ulenbach im Ortsteil Schwarzenmoor „leitete er Wasser aus dem Ulenbach durch seine ,Eufelkendieker Wiese' zu einem Stauteich, von wo aus es über ein oberschlächtiges Wasserrad lief.“ (:81). Der Stauteich mit einem kleinen Zufluss ist noch vorhanden. Die als Hofmühle des Bauernhofes Rührup 1870 errichtete ,Mühle Rührup' am ,Tiefentalbach' im Ortsteil Falkendiek, in der bis 1960 mittels Motorkraft der Schrot für den Bedarf des Hofes und der Nachbarn hergestellt wurde, lag aber schon seit etwa 1938 wegen Wassermangels still. „Abgesehen von der Einfassung des Stauteiches sind von der Anlage keine Reste mehr zu sehen.“ (:83).

Im Bereich der nördlich an das Herforder Stadtgebiet angrenzenden Gemeinde Hiddenhausen hat es insgesamt mind. 11 Mühlen gegeben. „Im Gegensatz zu vielen anderen Gebieten des Kreises Herford ist der Anteil der Wind- und Motormühlen an der Gesamtzahl recht hoch, was auf die geringe Zahl günstiger Wassermühlenplätze zurückzuführen ist. Lediglich an Brandbach und Werre hat es auf Hiddenhauser Gebiet insgesamt 3 Wassermühlen gegeben." (MÖRSTEDT 1995:110). Aber diese drei Wassermühlen zählen nicht nur zu den ältesten Mühlenplätzen, sondern besaßen alle auch einen Mühlenteich. Wie zum Beispiel die beiden ehemaligen Bustedter Gutsmühlen am Brandbach im Ortsteil Bustedt, die 1443 und 1536 erstmals erwähnt wurden. Bei der 1973 eingestellten Mahlmühle ist „,der früher der Mühle direkt gegenüberliegende Stauteich [...] heute verfüllt"“ (:111). Bei der Bustedter Öl- und Bokemühle hingegen ist nicht nur das Mühlengebäude, sondern auch der zugehörige Stauteich verschwunden.

Auch der Bereich der heutigen Stadt Enger, mit einer vergleichsweise großen Zahl an Windmühlen und nur einer gleich hohen Anzahl Wassermühlen, ,was erkennen läßt, daß Enger kein günstiges Wassermühlengebiet war" (MÖRSTEDT 1995:44), verzeichnet bei den nachgewiesenen Wassermühlen einen hohen Anteil an Mühlteichen. Zum Antrieb der 1556 erstmals erwähnten Glösinghauser Mühle am Baringerbach im Ortsteil Westerenger/Glösinghausen, wurde „der Baringer Bach teilweise abgezweigt und das Wasser in einem Stauteich von beträchtlicher Größe gesammelt." (:45) Auf häufigen Wassermangel lässt der Umstand schließen, dass die Maschinerie auch mittels Göpel angetrieben werden konnte. Die Mühle diente hauptsächlich dem Eigenbedarf des Hofbetriebs an Futterschrot. Stauteich und Betriebsgraben sind verfüllt, der Bachverlauf geändert (:45f.). Die ebenfalls ehemals am Baringerbach liegende und 1693 erwähnte und ebensolche Hofmühle Baringhofmühle wurde zwar im Gegensatz 1976 abgerissen. Hier aber ist der Stauteich noch vorhanden (:47). Auch bei der 1712 erstmals erwähnten Pödinghofmühle am Pödinghauser Bach im Ortsteil Pödinghausen, ist der Steuteich noch vorhanden. Das Gebäude des gegen Ende der 1950er Jahre eingestellten Betriebes wurde zu Wohnzwecken umgebaut (:49). Gleichfalls deutet auf den alten Standort der 1772 errichteten Bartlings Mühle an der Asbeke im Ortsteil Herringhausen lediglich ein „Stauteich und Reste des Gerinneeinlaufs auf den Mühlenbetrieb hin“ (:56). Sie wurde 1978 abgebaut und in $40 \mathrm{~km}$ Entfernung im Siekertal in Bad Qeynhausen im Museumshof wider aufgebaut. Ebenso prägt die Wasserkraftanlage mit Stauteich und Umlauf der 1342 erwähnten Steinbecker Mühle am Bolldammbach, im Ortsteil Belke-Steinbeck auf typische Weise die Tallandschaft (:59).

Im Bereich der heutigen Gemeinde Kirchlengern hat es insgesamt mindestens 18 Mühlenbetriebe gegeben. Sie verteilen sich nach Antriebsarten wie folgt: 9 Wassermühlen, 3 Windmühlen, 4 Motormühlen, 1 Handmühle und 1 Rossmühle. „Kirchlengern ist als typisches Wassermühlengebiet zu bezeichnen, da die Abflussverhältnisse vergleichsweise günstig waren und ausgenutzt wurden. Folgerichtig machen die Wassermühlen auch die Hälfte aller Anlagen aus.“ (MÖRSTEDT 1995:122). Mit 5 Anlagen trieb der ,Quernheimer' bzw. ,Rehmerloh-Mennighüffer Mühlenbach' mit Zufluss Osterbach über die Hälfte aller Wassermühlen Kirchlengerns an, auf Löhner Gebiet nochmals 3 (:122), wie weiter unten beschrieben wird. Die 1226 nachzuweisende ,Mittelste Mühle' in Stift Quernheim dürfte der älteste Standort im Bereich Kirchlengern sein, im Kreisgebiet gehört er ebenfalls zu den ältesten überhaupt (:122). Diese Mühle stellte zum Jahresende 1991 als letzter Mühlenbetrieb auf Kirchlengeraner Gebiet ihren Betrieb ein und lief bis zum Schluss - unterstützt bei Wassermangel durch zwei Stauteiche - mit Wasserkraft (:122). Auch bei der 1495 erstmalig erwähnten ,Niederste 
Mühle’ („Nedermolen“) half ein Mühlenteich bei der Antriebsarbeit aus. „Um die ohnehin knappe Wasserkraft besser auszunützen, vergrößerte [...] nach 1908 den Stauteich und ließ 1939 das Wasserrad durch eine Turbine ersetzen.“(:135). 1974 wurde die Wassermühle im Zuge des Ausbaus der B 239 abgerissen, der Teich verfüllt. „Von ihr sind keinerlei Reste erhalten geblieben, das Gelände ist vollständig verändert.“ (:135f.). Bei der ,Mühle Gerker', einer Wassermühle aus dem 18. Jahrhundert am ,Rehmerloh-Menninghüffer Mühlenbach' im Ortsteil Häver, ist der ehemalige Mühlenteich in mehrere Fischteiche umgewandelt worden. Auch für die 1822 am ,Osterbach' errichtete Hofmühle des Colon Böschemeyer musste, ,das Wasser des Osterbaches [...] für den Betrieb zunächst in einem größeren Teich gesammelt werden.“ (:137). Trotzdem stand die Mühle wegen Wassermangels während der Sommermonate in der Regel still. Die Kapazität dürfte daher den Eigenbedarf des Hofes und weniger Nachbarn gereicht haben (:137).

Im Bereich der heutigen Stadt Löhne mit mindestens 39 Mühlenstandorten „fällt der hohe Anteil an Wasserkraftanlagen auf, die mit 23 Standorten knapp 2/3 aller Anlagen ausmachen." (MÖRSTEDT 1995:144). Aber auch hier sind die meisten ehemals vorhandenen Mühlenteiche verschwunden. Beispielsweise ist der ursprüngliche Stauteich der Schlossmühle des adeligen Gutes Ulenburg im gleichnamigen Löhner Ortsteil verfüllt (:174), die Wasserkraft des zufließenden ,RehmerlohMenninghüffer Mühlenbach' allein reichte anscheinend zum Antrieb der Räder nicht allein aus (:149). Wie in den anderen Fällen zuvor wurden auch auf Löhner Gebiet zahlreiche kleinen Hofmühlen betrieben, die eines Stauteiches bedurften. Die zum Hof Krutemeyer gehörige ,Krutmühle' am ,Nagelsbach' im Ortsteil Bischofshagen beispielsweise wurde 1810 zum Vermahlen des Korns für den Eigenbedarf des Hofes, aber auch für eine - eingeschränkte - Kundschaft errichtet. Sie hatte zunächst nur einen Gang „und litt oft unter Wassermangel.“ (:174). Ebenso zählte zu den ältesten und größten Höfen der Umgebung, dem Hof Nagel, eine Hofmühle. Die ,Nagels Mühle' am Bramschebach im Ortseil Bischofshagen verfügte lediglich über einen Gang, ,,der zudem wegen Wassermangels oft nicht zu benutzen war.“ Die zugehörigen zwei Stauteiche, schreibt MÖRSTEDT (1995:175), verlanden.

Im nördlichen Betrachtungsgebiet des Kreises liegt die heutige Gemeinde Rödinghausen und wird als eine „typische Wassermühlenregion“ beschrieben (MÖRSTEDT 1995:180). Von insgesamt 20 Mühlen lagen 10 Wassermühlen lagen an den Bächen, die vom Südhang des Wiehengebirges zur Else hin fließen, 3 weitere lagen an ,Großer Aue' bzw. ,Mühlenbach', der in Taleinschnitten nach Norden in das norddeutsche Tiefland abfließt (:180). Bei der erst 1765 erwähnten, aber wesentlich älteren ,Neuen Mühle' am Mühlenbach im Ortsteil Schwenningdorf handelt es sich um die ehemalige Gutsmühle des Gutes Oheimb, das auch dem 13. Jahrhundert stammt. Der Mühlenteich ist auf einer Karte von 1787 noch erkennbar und trieb früher zusammen mit dem Bachwasser 2 oberschlächtige Wasserräder an. Am ,Gewinghauser Bach' im Ortsteil Bieren, lagen insgesamt mindestens 7 Wassermühlen: Die Wasserkraft muss aber im gesamten Verlauf zu allen Zeiten so spärlich gewesen sein, das Stauteiche über diesen Mangel hinweg helfen mussten. Bei der heute verschwundenen ,Buntermöllers Ölmühle' beispielsweise wurde das Wasser des Bachs und einiger Quellen in einem Teich gesammelt, „trieb zunächst eine Ölmühle an, wurde in einem zweiten, heute verfüllten Teich wieder angestaut und konnte dann über das Rad der Mahlmühle fließen.“ (MÖRSTEDT 1995:184f.). Die schon 1316 erwähnte und seinerzeit zum Stift Quernheim gehörige ,Bunte Mühle’ zeichnete sich ebenfall durch eine geringe Wasserkraft aus. Der Betriebs des Wasserrades, „das sein Wasser aus dem Stauteich jenseits des Buntemühlenweges erhielt [...] reichte an normalen Arbeitstagen für einen höchstens fünfstündigen Betrieb. Die Mühle lief aber nach Möglichkeit während des ganzen Jahres.“ (:185). Der Stauteich ist verfüllt und der Bachlauf verlegt.

Im Gebiet der heutigen Stadt Spenge haben sich insgesamt mindestens 16 Mühlen befunden: Davon 7 Wassermühlen. Wichtigstes Mühlengewässer war die ,Warmenau', die in ihrem Verlauf allein 5 Betriebe mit Wasserkraft versorgte (MÖRSTEDT 1995:200). Der andere Wasserlauf war der, Spenger Mühlenbach'. Die Wasserkraft der hier seit dem 14. Jahrhundert anliegenden, 1967 abgebrannten und dem Stift Enger zugehörigen ,Mühlenburger Mühle’ („Mulenburg“) muss eher spärlich gewesen sein. „Die Mühle benötigte für ihren Betrieb einen vergleichsweise großen Stauteich“ (:201), der auch noch vorhanden ist. Der Oberlieger am ,Spenger Mühlenbach' war die Anfang des 16. Jahrhunderts errichtete ,Werburger Mühle' und bestand aus zwei Mühlen: Die Getreidemühle bezog ihr Wasser 
dabei direkt aus dem Bach, während die separate Bokemühle mit einem eigenen oberschlächtigen Rad sein Wasser aus dem Stauteich der Mühle zuführte (:203).

Der Bereich der heutigen Stadt Vlotho nimmt mit mindestens 52 Mühlen eine besondere Stellung ein und weist damit die höchste Anzahl im Kreisgebiet auf: Von den ehemals 43 Wasserkraftanlagen, d. h. über $80 \%$ aller Standort gehörten in die Kategorie Wasserkraftnutzer, sind noch 19 erhalten. Der wesentliche Grund für die hohe Gesamtzahl besteht in dem für die Wasserkraftnutzung sehr günstigen Geländerelief. „Allein die Linnenbeeke und ihre Zuflüsse trieben zusammen 29 Anlagen. Es war in diesem Bereich möglich, mit vergleichsweise wenig aufwendigen wasserbaulichen Eingriffen in die Gewässerläufe ausreichendes Nutzgefälle zu erzielen.“ (MÖRSTEDT 1995:220) „Die Mühlenlandschaft Vlothos ist als Ganzes gesehen schon ein Phänomen“, schreibt MÖRSTEDT (:220) und begründet dies nicht nur damit, dass es eine solche technische Vielfalt an Produktionstypen (Getreidemühlen, Schmiede, Tischlerei, Papiermühle, Stromerzeugung, Öl-, Boke-, Sägemühle etc.) auf so engem Raum im übrigen Kreisgebiet nicht gab, sondern es andererseits noch im 20. Jahrhundert konventionelle Wassermühlen (1901 und 1906) neu hinzukamen, was im übrigen Kreisgebiet in dieser Zeit nur noch ein weiteres Mal stattfand (:220). Die Mühlendichte und die Größe der Gewässerläufe korrelieren dabei geradezu mit den Grundvoraussetzungen für einen Mühlenteichbau. So deuten bei der 1811 fast ausschließlich für den Eigenbedarf errichteten ,Mühle Krumme' im Ortsteil Steinbründorf „lediglich die Fischteiche [...] auf diesen Mühlenstandort noch hin.“ (:221). Auch bei der ,Mühle Niehage' an der Linnenbeeke von 1812 im Ortsteil Linnenbeeke sind Reste der wasserbaulichen Anlage auf der TK als mehrere Fischteiche verzeichnet. Ebenso sind bei der 1901 errichteten kleinen, Wassermühle Lücking' an der Linnenbeeke im Ortsteil Valdorf, die hauptsächlich für den Eigenbedarf mahlte und auch mittels Seiltransmission landwirtschaftliche Maschinen im Bansenhaus antrieb, wasserbaulichen Anlagen mit Betriebsgraben und Stauteichen erhalten und zur Fischzucht eingerichtet (:225). Sogar bei der bereits 1514 im Güterverzeichnis des Vlothoer Klosters als zum Gut zu Valdorf gehörigen ,Domteichmühle' an der ,Linnenbeeke' wird ein Teich erwähnt. Das Wasser für die Mühle kam ,,ursprünglich zum größten Teil aus dem Domteich. Daher die frühere Bezeichnung ,Domteichmühle'. Der Gutsbesitzer ließ 1813/14 am Domteich eine neue Wassermühle bauen. Sie bezog ihr Wasser in der Anfangszeit sogar nur aus dem Domteich, nicht jedoch aus der Linnenbeeke. Mit den im Jahr 1860 erfolgten Modernisierungen und Umbauten wurde auch Stauteich neu anlegt, der nunmehr sein Wasser vollständig aus der Linnenbeeke bezog - der Domteich trocknete in der Folgezeit aus. Der Teich ist nunmehr verlandet, „in seinen Umrissen aber auch heute noch [1986?] gut zu erkennen.“ (:229f.).

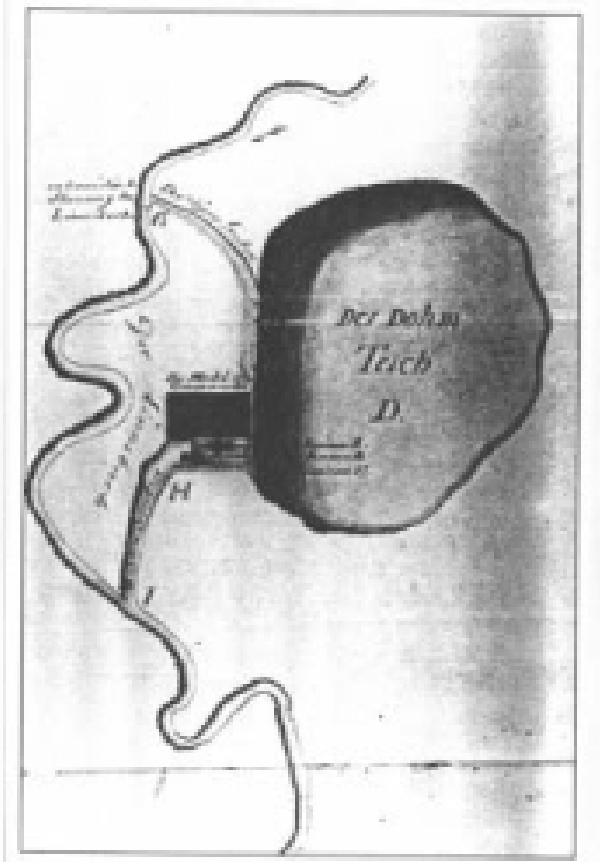

Abb. VIII-34: „Domteichmühle“ mit Stauteich in Vlotho, OT Valdorf

Links fließt die „Linnenbecke“; das Wasser aber für die Mahl- und Graupenmühle „Drewel“ kam ursprünglich zum größten Teil aus dem „Domteich“. Daher die frühere Bezeichnung „Domteichmühle“. Der Teich ist verlandet, aber in seinen Umrissen noch gut zu erkennen (Stand 1995) (aus: MÖRSTEDT 1995:229). 
Weitere Stauteiche an der Linnenbeeke existieren bzw. existierten auf der ehemaligen Hofmühle von Henrichsmeier, bei der 1840 errichteten Messerschmiede Schmieding an der Linnenbeek, OT Valdorf, dessen 2 Stauteiche heute zur Fischzucht genutzt werden (MÖRSTEDT 1995:233f.) sowie bei der 1850 errichteten ,Mühle Akemeier', dessen Gebäude im Zuge des Straßenneubaus 1969 abgerissen wurden. Erhalten geblieben sind an diesem Standort mehrere Teiche, die heute ebenfalls der Fischzucht dienen (:236). Lediglich die ,Plattenmühle', die größte und älteste Mühle an der Linnenbeeke - und die mit einer Ersterwähnung im Jahr 1556, aber einem deutlich früheren Standort auch zu den ältesten und wichtigsten Mühlenbetrieben im gesamten Kreis Herford zählt -, besaß keine Teiche, lediglich einen eigenen Betriebsgraben. Obschon sie als zeitweise Königsmühle mit Zwangsmahlgästen und von 1745 bis ins frühe 19. Jahrhundert 2 oberschlächtige Wasserräder, 1829 sogar 3 Wasserräder anzutreiben hatte. Zu Beginn des 20. Jahrhunderts dann verfügte die Mühle nur noch über 1 oberschlächtiges Rad, bis dann 1971 die Betriebseinstellung erfolgte.

Am Oberlauf des ,Exterbaches' stand die um 1900 errichtete ,Mühle Reckefuß', die als kleine Wassermühle für den Eigenbedarf des Hofes produzierte. „Schon bald musst er einsehen, daß trotz Stauteich die Wassermenge an dieser Stelle nicht ausreichend war." (MÖRSTEDT 1995:254) Die Quelle im Arnholz vermochte den Stauteich für einen befriedigenden Betrieb nicht ausreichend schnell zu füllen (:254). Bei der an einem namenlosen Bach um 1793 ebenfalls für den Eigenbedarf errichteten ,Mühle Lübke' wurde das Wasser aus einem Stauteich bezogen. Das Wasserrad trieb neben dem Mahlgang für den Eigenbedarf eine Seiltransmission an (:255).

Im sauerländischen Marsberger Raum waren sehr viele Wasserkraftanlagen und Wassermühlen vorkommend, bedingt durch das landwirtschaftliche Hinterland, das Erzvorkommen und den Waldreichtum (BUNSE 1991:5). An der Glinde beispielsweise gab es einst von der Quelle bis zur Mündung in die Diemel bei einem Höhenunterschied von $56 \mathrm{~m}$ vierzehn Wasserkraftanlagen. Einige dieser Mühlen hatten nur ein geringes Gefälle und damit eine geringe Kraft (:5). Dieser Nachteil musste durch zusätzliche Stauteiche aufgefangen werden $(: 11,12,21)$.

Auch in den Abbaugebieten großer Bergbauregionen wie dem Oberharz gab es zahlreiche dem Mühlbetrieb dienende Stauteiche: Vier alte Mühlenteiche liegen noch heute zwischen Zellerfeld und Wildemann, die den in der Nachbarschaft liegenden Unter-, Mittel- und Wegsmühlen zugeordnet waren. Die Müller aber mussten sich selbst um ausreichendes Wasser für trockene Zeiten kümmern, denn der Bergbau hatte in der Wassernutzung absoluten Vorrang. Bestehende Mühlenteiche mussten sodenn dem Bergbau helfen, wenn dieser in Not war (SCHMIDT 1997:196).

Aufgrund dieser Konkurrenzsituation waren vor allem in den Vorlanden intensiver Bergbauregionen die wasserbetriebenen Betriebsstätten ansässig. In Osterode beispielsweise gab es eine große Anzahl verschiedener Mühlbetriebe: Sägemühle, Kornmühle, Ölmühle, städtische Kalkmühle, Pulvermühle, Wollmühle und Tuchfabriken, Walkemühle, Papiermühle und Gipsmühle (MURKEN 1997:23).

Doch wurde hier eine Stauanlage nicht allein errichtet um Wasser zu bevorraten, sondern auch um Wasser zurückzuhalten. Im Sösetal zum Beispiel ließ sich die Energie der Söse hier wie auch andernorts im Harz nicht direkt gebrauchen, sondern dies war - bedingt durch den jahreszeitlichen Wechsel zwischen Niedrig- und Hochwasser mit seinen oftmals katastrophalen Auswirkungen - nur über einen Abzweig der Söse möglich, nämlich über einen Mühlgraben, dessen Wasserfluss regulierbar war (BECKER 1997:22). Ein Mühlenstau zur Wasserbevorratung war hier anscheinend nicht notwendig.

Im Oberweserbergland gab es eine Vielzahl unterschiedlicher Mühlen. Während an den Bächen mit größerem Gefälle große oberschlächtige Mühlräder in Betrieb waren, gab es an den wasserreicheren Bächen und auch an Werra und Fulda mittel- und unterschlächtige Wasserräder, die als Energieerzeuger nicht nur zur Müllerei benutzt wurden (HENCKEL 1988:71). Dabei gab es an Werra und Fulda aufgrund ihres Wasserreichtums keine Mühlenteiche, diese waren nur an den kleineren Bächen notwendig. Die größte Mühlen- und Stauteichdichte ist zwischen 1850 und 1870 anzunehmen, in dieser Zeit erreichte auch die Mühlsteinfertigung im oberen Wesertal ihren Höhepunkt (:71). Ab 1875 waren hier die ersten Turbinen in Hemeln und Vekkerhagen in Betrieb (:71). 
Vor allem das thüringische Eichsfeld des Landkreises Heiligenstadt, war ehemals, wie Erhard MÜLLER (1992) nachweist, eine wahrer „Mühlenkreis“, in dem in jedem Ort eine oder mehrere Wassermühlen standen. Aus dem Eichsfeld sind Speicherteiche an der Hahle und an der kleinen Wipper bekannt. Im Bereich der Stadt Worbis gab es insgesamt sieben Mühlen mit Mühlenteichen (ROGGE 1993:2). Eine ehemals starke Wassermühlendichte wies auch das sächsische Vogtland ${ }^{30}$ auf, die durch zahlreiche Abgänge bereits stark dezimiert wurde.

Im Erzgebirge, zwischen Olbernhau und Freiberg, nutzten 11 Mühlen in Dörnthal die Kraft des Dorfbaches. Hierbei setzten die Dörnthaler Mühlenbauer die großen Erfahrungen des nur wenige Kilometer entfernten Freiberger Silberbergbaus ein, der zum Antrieb der Maschinen die Wasserkraft ebenfalls aufspannte. Von einer, der ,Dörnthaler Ölmühle' ist bekannt, dass noch 1934 nach dem Kauf durch einen anderen Besitzer, ein Stauteich gebaut und die Mühle modernisiert wurde (ÖLMÜHLE DÖRNTHAL 2004).

Auch in der gemäßigten Hügellandschaft am Nordwestrand des sächsischen Lausitzer Berglandes, das hinsichtlich des Teichwesens durch die Fischteichbewirtschaftung bekannt ist, wurden zahlreiche Wassermühlen betrieben, die aufgrund der Wasserarmut durch künstliche Teiche ergänzt werden mussten. Der Wasserstrich beispielsweise, zwischen dem Quellort Neukirch, Gottschdorf und Schwepnitz das „Grüne Tal“ durchfließend, trieb durch einen Abzweig früher zahlreiche Mühlen an. Allein zum Antrieb der Gutsmühle wurden im 19. Jahrhundert vier Teiche angelegt, wobei auf einem von ihnen eine $30 \mathrm{~m}^{2}$ große Insel errichtet worden ist (SCHWEPNITZ 2004).

Ein gut dokumentiertes Gebiet sind die Wassermühlen und -hämmer im Bergischen Land. Um die Wasserkraft nutzen zu können, wurden die Werkstätten an die Bachläufe verlegt. Auch das hier ansässige Tuchgewerbe nutzte das Wasser als Energiequelle beim Walken der Tuche. Die erste bekannte Walkmühle entstand 1484 am Wiebach, wie WEISER (1997:84) in ihrer Untersuchung am Beispiel der Stadt Hückeswagen nachweist. Durch die Blüte des Hückeswagener Eisen- und Tuchgewerbes im 18. Jahrhundert stieg die Zahl der Wasserhämmer und -mühlen in diesem Zeitraum stark an. Während das Eisengewerbe schon Anfang des 19. Jahrhunderts eine Krise erlebte, führte die Industrialisierung und die damit verbundene Umstrukturierung des Tuchgewerbes erst im Verlauf des 19. Jahrhunderts ,zur Aufgabe der Gewerbestandorte in den engen Tälern der Bachläufe“ (:84f.). An der Wupper wurde ein Teil der Mühlen- und Hammerstandorte im Zuge der Industrialisierung aufgegeben, ein anderer Teil zu modernen Produktionsstätten zusammengefasst. Andere Standorte gingen beim Bau der Bever- und der Wuppertalsperre verloren (:85). Als Beispiele werden von WEISER bezüglich eines Mühlenensembles mit angeschlossenem Mühlteich im Bergischen Land die Purder Mühle und für ein Hammerwerk der Goldenbergshamme' genannt.

Seit Jahrhunderten wird auch die Lenne, in der Übergangszone zwischen Bergischem Land und dem Lennegebirge, sowie die anderen Flüsse in den ehemaligen Kreisen Altena, Iserlohn und Lüdenscheid zur mechanischen Energiegewinnung genutzt. Vor allen an den kleinen Flüssen der Region wurden viele Hammerteiche angelegt. Wasserräder trieben die Mühlen, Hammerwerke und Drahtwerke. Die Betriebe waren aber auf Gedeih und Verderb vom Regen abhängig. Blieb der aus, konnte nur sehr eingeschränkt produziert werden. Man schmiedete das Eisen so lange, bis der Teich leer war. Allein in Plettenberg waren zur damaligen Zeit fast 30 Anlagen in Betrieb. Ein bekanntes Beispiel war die Dunkelsche Mühle (KLAAS 2003).

Auch die Bachläufe in den Solinger Tälern, die von vielen Quellen und reichlichen Niederschlägen gespeist werden, ergaben früher eine billige ideale Kraft zum Antrieb von Hämmern, Schleifkotten und zum Bespannen von Mühlenteichen (LUNKENHEIMER 1990:10). Über drei Jahrhunderte

\footnotetext{
${ }^{30}$ Einen Überblick über die Verbreitung von Mühlteichen im Vogtland zu geben, ist aufgrund der landesspezifischen Regionalisierungen nicht leicht, da noch heute besonders die geographische Grenze zwischen sächsischem und thüringischem Teil nicht festlegbar ist und auch das bayerische Vogtland in das thüringischen Gebiet fließend übergeht. Im Mittelalter besteht eine einheitliches Vogtland erst recht nicht, es setzt sich vielmehr aus dem „Sächsischen Vogtland“, das das eigentliche vogtländische Stammland seit dem 12. Jahrhundert mit den Kreisen Plauen, Oelsnitz und Auerbach beschreibt, dem „Thüringischen Vogtland“, bestehend aus den Fürstentümern Reuß, Ronneburg, Auma, Ziegenrück und Triptis, dem „Bayerischen Vogtland“ mit Hof und dem Regnitzland sowie dem „Böhmischen Vogtland“ zusammen.
} 
hinweg nutzte mancher Hammer und Schleifkotten bzw. manche Mahlmühle die Wasserkraft. Sie begründeten gar den wirtschaftlichen Aufstieg Solingens seit dem 18. Jahrhundert. Zu Anfang des 20. Jahrhunderts wurden in den Hammerwerken Hobeleisen und Feilen geschmiedet, Blausensen verfertigt, in den Schleifkotten mit Wasserkraft Remscheider und Solinger Eisenfabrikaten (Rasiermesser, Taschenmesser) geschliffen und poliert, die teilweise zu Weltgeltung fanden. Die gewerbliche Nutzung der Bäche war vor 180 Jahren so weit fortgeschritten, dass in der Reihe der Wassertriebwerke kaum mehr eine Lücke, d. h. kein unbenutztes Gefälle mehr zu finden war (:10). Insbesondere die Itter mit ihren kleinen Nebenbächen und die Seitentäler der Wupper war bevorzugter Standort von Wassermühlen und Kotten, deren hohe Anzahl wiederum eine Wasserbevorratung notwendig machte.

Die Itter entspringt in Gräfrath im Heiligen Born, der etwas unterhalb von einer zweiten Quelle gespeist wird. In dem Wiesengrund, der von dem aus dem Heiligen Born gespeisten Bach durchflossen wird, liegen schon die ersten zwei Teiche, die die Stauteiche der Klostermühle darstellen (LUNKENHEIMER 1990:47). Etwa 100 m unterhalb des ersten wurde dieser Nebenlauf der Itter nochmals in einem Teich aufgefangen (:48):

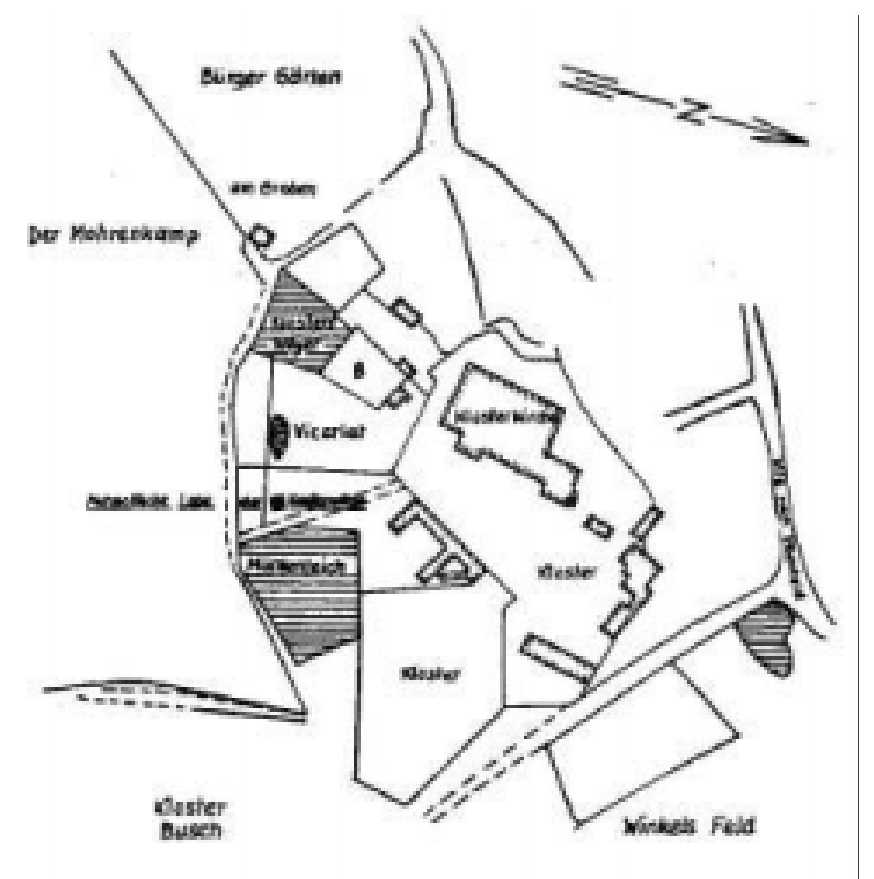

Abb. VIII-35: Lageskizze der zum ehemaligen Kloster Gräfrath gehörenden Klosterteiche

Die dadurch unterstützend angetriebenen Mühlen - bestehend jeweils aus einem kleinen Fachwerkgebäude - sind bereits auf einer Ortskarte von 1796 nicht mehr dargestellt, wohl aber zwei Teiche im vom Grünewalder Bach durchflossenen Wiesengrund. Im restaurierten Klostergebäude aus dem 17. Jahrhundert ist das Deutsche Klingenmuseum untergebracht (Umzeichnung des Lageplans von G. W. Buschmann von 1796 durch LUNKENHEIMER 1990:47, Abb. 30).

Beide Teiche sind in einer Karte von 1796 dargestellt. Der „Mühlenteich” ist der Stauteich der ersten Klostermühle. Der, wie gesagt, ca. $100 \mathrm{~m}$ unterhalb der Klostermühle befindliche zweite Stauteich wird auf der Karte von 1796 als der „Klosterweyher” bezeichnet ist. Der „Klosterweyer” diente also der einen Klostermühle, der Mühlenteich der anderen Klostermühle. Sie wurden dementsprechend und zur Unterscheidung „Klostermühle am Mühlenteich” und „Klostermühle am Klosterteich” genannt (LUNKENHEIMER 1990:47). Die Mühle am Klosterweiher hat im ersten Viertel des vorigen Jahrhunderts noch bestanden, doch nach dem Abbruch des Mühlengebäudes sind die Teiche in Wiesen- und später in Bauland umgewandelt worden (:48).

Bei der früher ebenfalls zu dem Kloster gehörigen und oberhalb der beiden Klostermühlen gelegenen Bandesmühle, waren ebenfalls zwei Stauteiche und ein Obergraben vorhanden (LUNKENHEIMER 1990:48). Die mangelnde Wasserführung des am Unterlauf des Bertramsmühler Baches stehenden „Kirchbaumkotten” wurde ebenso durch einen „Kottenteich” ausgeglichen (:24). Die beiden Luhnshämmer am Eschbach (Burger Bach) teilten sich einen Teich. Der zweite Hammer war auf das verlorene Wasser des ersten angewiesen. Vielleicht gab es deshalb die Anlage eines Teiches, der die 
Wasserversorgung des zweiten garantierte (:32). Auch der am Eschbach stehende „Kotten zum Steg” besaß einen Stauteich. Um 1800 wurde ein neuer, größerer Mühlteich angelegt auf einer 118 Ruten $^{31}$ großen Wiese. Der neue Teich sollte die besonders im Sommer misslichen Wasserverhältnisse der Mühle verbessern (:40). Durch den trockenen Sommer des Jahres 1911 jedoch führte der Eschbach so wenig Wasser, dass eine Verschlammung des Stauteiches eintrat und trotz vergrößertem Stauteich kein normaler Betrieb mehr gewährleistet war (:38). Die an der Itter kurz vor der Einmündung des Nümmener Baches gelegene Bausmühle besaß ebenfalls einen 1808 genannten Mühlenteich von 1161/2 Ruten.

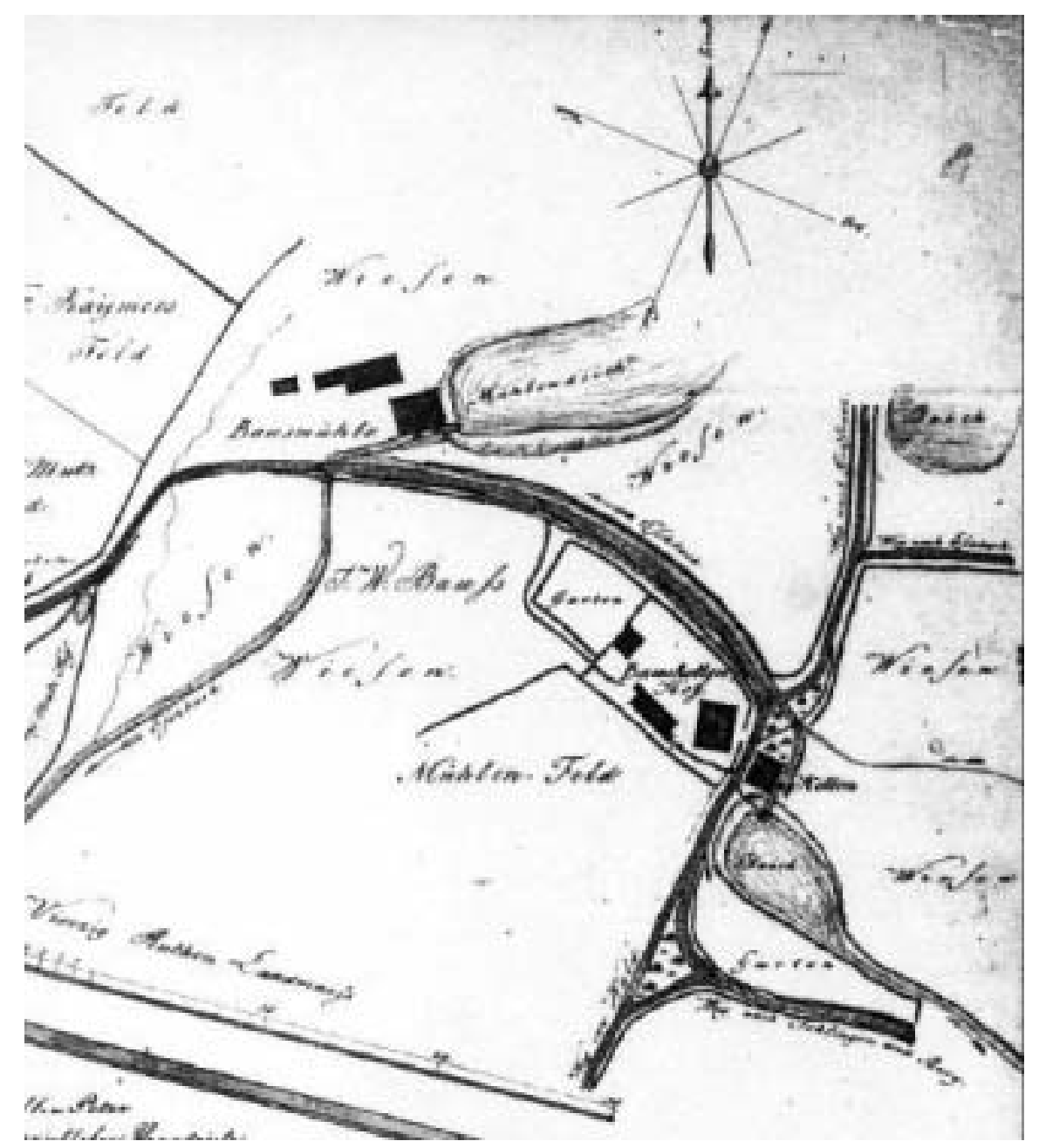

Abb. VIII-36: Ausschnitt aus einer 1790 vermessenen „Situations-Charte“ der Bausmühle

Der Lageplan zeigt den die Bausmühle speisenden und heute vollständig verlandeten „Mühlendeich“; darüber hinaus im unteren rechten Bildrand den zum Baushofkotten [?] gehörenden „Deich“ (heute verfüllt) sowie oberhalb - nur zur Hälfte dargestellt - eine weiteren „Deich“, der nach Norden hin ehemals das ganze Tal ausfüllte und unter anderen Kratzkotten antrieb. Der verbliebene Rest dient heute als Pferdeweide (Plan aus: LUNKENHEIMER 1990:53).

Mit einem Teich nebst Gerinne ausgestattet war der Zieleskotten, der etwa 100 unterhalb des Zusammenflusses von Itter, Nümmener- und Holzerbach stand (siehe Abb. VIII-37).

\footnotetext{
${ }^{31}$ Rute (Ruthe): altes deutsches Längenmaß, das regional unterschiedlich zwischen rund 3-5 m bemessen war: z. B. Anhalt 3,76 m, Baden 3,00 m, Bayern 2,90 m, Braunschweig 4,56 m, Hannover 4,67 m, Hessen 3,99 m, Preußen 3,76 m (hier 433,68 m). Das aus der Rute abgeleitete Flächenmaß ist die Quadratrute, die hier gemeint sein muss. Sie maß wiederum nach Ländern unterschiedlich zwischen rund 8,2-32,2 $\mathrm{m}^{2}$. Da 1 preußische Rute $=14,1843 \mathrm{~m}^{2}$, hat die Wiese eine Größe von $2.666,65 \mathrm{~m}^{2}$ gehabt.
} 


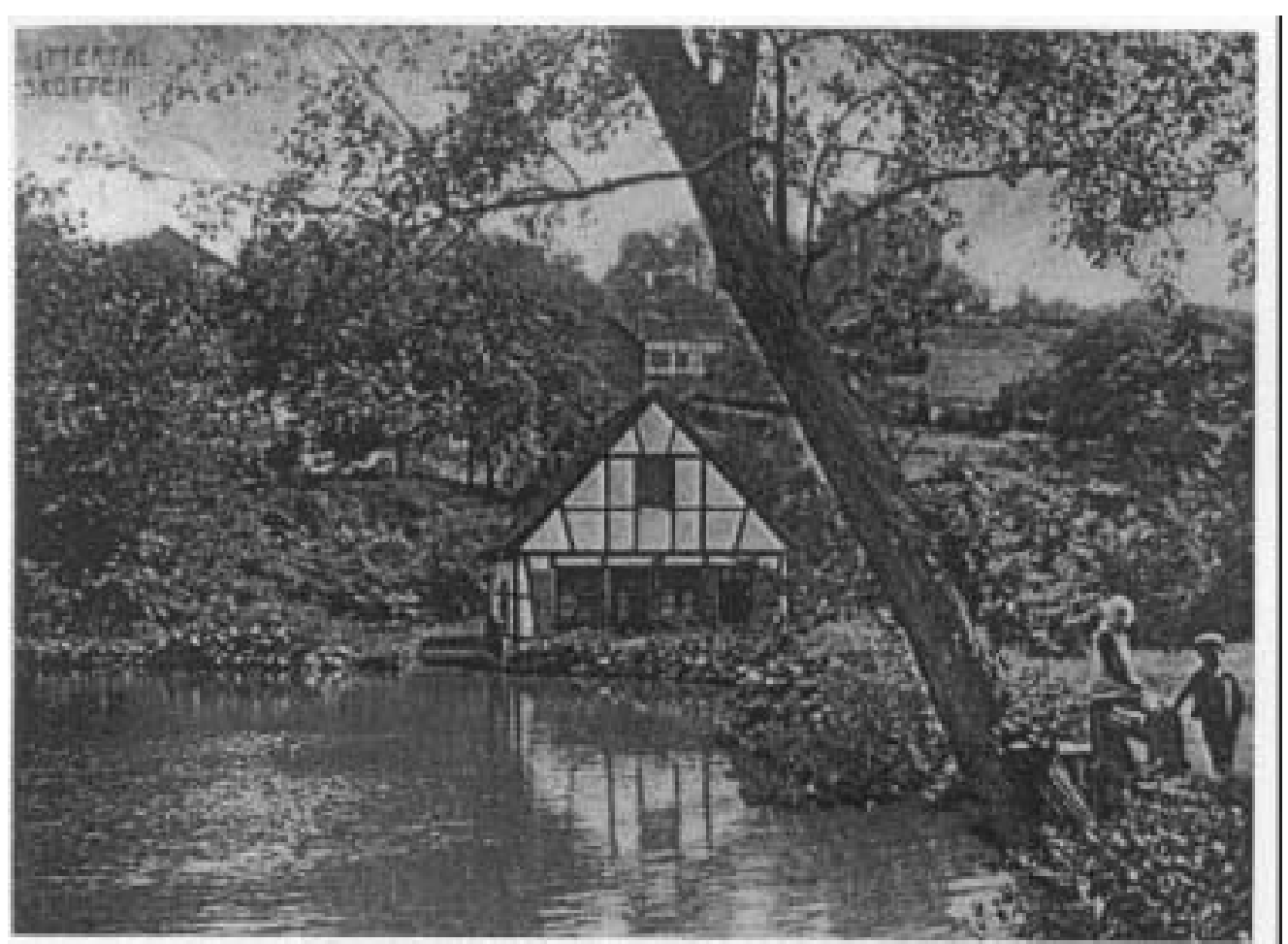

Abb. VIII-37: Zieleskotten mit Teich und Kindern am Wehr. Nach einer Postkarte um 1900

Der Zieleskotten befindet sich westlich der Bausmühle und präsentiert sich heute als modernisierter und baulich erweiterter Fachwerkständerbau. Der Teich ist nicht mehr vorhanden, eine Straße führt teilweise über ihn hinweg (Foto aus: LUNKENHEIMER 1990:55, Abb. 38).

Der Linderskotten besaß einen Teich mit Ober- und Untergraben von ca. 40 Ruten. Des Weiteren der Neuenkotten, zu dem ein ca. 60 Ruten großer Stauteich gehörte. Auch zur Heidberger Mühle gehörte ein Sammelteich mit Zulauf des Wiedenhofer Baches und einem Untergraben zum Itterbach (LUNKENHEIMER 1990:68; siehe auch Abb. VII-42). Zur Brucher Mühle gehört ein Stauteich (:73) und der Lautterjungskotten besaß zwei Sammelteiche, die vom Lochbach und dem Demmeltrather Bach gespeist wurden (:81) und die benötigte Triebkraft ergaben.

Der ehemals 5 Ar $12 \mathrm{~m}^{2}$ große Teich des Locher Kotten am Lochbach war bereits 1897 in eine große Wiese umgestaltet worden (LUNKENHEIMER 1990:92). Die Broßhauser Mühle, die heute als Antiquitätengeschäft geführt wird und durch ihre Lage an einer Straßenkreuzung die Wassergebundenheit vermissen lässt, besaß auch einen großen Teich. Die ehemalige alte Mühle stand dabei hinter dem jetzigen Mühlengebäude (:107). Und ebenso am Becher Hammer (an der „Bäch”), gleichfalls am Lochbach gelegen, wurde 1779 auf einer großen Wiese ein Stauteich errichtete (:96).

Der Ernenkotten, am Nacker Bach, gelegen, besaß um 1839 zwei Sammelteiche mit Damm und Deich, der an dem Bachlauf ansässige Kotterhammer hatte einen Teich mit einer Größe von 140 Ruten und 80 Fuß (LUNKENHEIMER 1990:111), der Nackerkotten besaß einen Teich mit Teichdamm (:112), der Schaafenmühler Kotten ebenso (:114f.). Der ,Kottenteich' des Nester Kotten hatte eine Größe von 96 Ruten und $90 \mathrm{Fuß} \mathrm{(LUNKENHEIMER} \mathrm{1990:115)} \mathrm{und} \mathrm{die} 1911$ vollständig niedergebrannte Cronemühle besaß ebenfalls einen Wassersammelteich (:118). Auch der Nöhrenkotten besaß einen sog. , Kottenteich' (:119f.).

Die letzten Hämmer wurden bis in die Mitte der 1930er Jahre betrieben: Beim Brucher Kotten an der Itter trieb noch bis zum Jahre 1945 das Wasserrad die Schleifsteine des Kottens an, dann erst trat Kraftstromantrieb an seine Stelle (LUNKENHEIMER 1990:75). Auch für den Schaafenschleifkotten lieferte die Itter trotz Stromanschluss noch bis 1946 das Wasser für den Antrieb (:72). Im Kuckesberger Kotten an der Itter waren sogar 1958 noch 8 Schleifer beschäftigt (:76). 
Zahlreiche Wassermühlen mit Mühlteichen gab es auch an den Eifelbächen: An Ahr, Alf und Brohl' ${ }^{32}$, an Elz, Endert und der Kyll, an Lieser, Nette, Nims, der Our sowie an Prüm, Salm, Uess (Üß) und all ihren Nebenbächen (MERTES 1995).

Die Eifelabtei Prüm hat eine wesentliche Rolle in der Gewässergeschichte der Eifel gespielt. Spätestens im 9. Jahrhundert waren die Wassermühlen in der Eifel weit verbreitet. Im Urbar des Klosters Prüm von 893 werden schon 35 Mühlen im klösterlichen Besitz angeführt und es waren bis in die Zeit des Mühlensterbens nach dem Zweiten Weltkrieg überwiegend Wassermühlen im Einsatz, die durch Mühlenteiche angetrieben bzw. insbesondere im Antrieb ergänzt wurden (MERTES 1995:22f.).

Das Vorkommen von Mühlenteichen folgt hier in der Eifel vor allem der jeweiligen Dynamik der Wasserführung: „Die Mühlen an den kleinen Bächen der Eifel hatten häufig einen Mühlenteich als Wasserreservoir. Dies war zum Beispiel im oberen Bereich des Elzbaches mit seinen Nebengewässern ausschließlich der Fall“, wie beispielsweise der Weiher der kleinen Salchrather Mühle im oberen Elztal, während sich die insgesamt ehemals 34 Mühlen an der Wilden Endert bei Höchstberg-Cochem a. d. Mosel von Mühlen an anderen Bächen dadurch unterschieden, dass sie ab Martental keinen großen Mühlenteich hatten. Sie bezogen ihr Wasser aufgrund es Wasserreichtums direkt vom Wassergraben (MERTES 1995:22,95,113) .

Auch am Ürsfleder Bach, einem Nebenbach der Elz in der Gemarkung Ürsfeld und Gunderath, wird ein alter Mühlenteich der Blumsmühle genannt, ebenso von der Uess bei Mosbruch/Bad Bertrich. Dort stand die oberste Mühle direkt hinter dem Weiherdamm auf der rechten Bachseite: „Der Weiher war stets als Fischweiher genutzt worden und wurde alle drei Jahre ausgefischt. Vom überlaufenden Wasser des Weihers waren die nächsten Mühlen am oberen Uessbach bis Berenbach-Furth abhängig.“ (MERTES 1995:118) Eine prekäre Situation wird sich daraus für die Unterlieger oft ergeben haben, wenn das Bachwasser nicht ausreichte, den Mühlbetrieb der Dammmühle zu gewährleisten und auf das Speicherwasser zurückgegriffen werden musste.

Als weiteres Beispiel eines Sammelbeckens an einem kleinen Eifeler Bachlauf kann die Kraulsmühle am Sammetbach, einem Nebengewässer der Alf, genannt werden. Auch diese Mühle besaß einen Mühlenteich (MERTES 1995:129). Ein Weiher am Nettehammer, einer ehemaligen, dem adeligen Frauenkloster St. Thomas zugehörigen, Mahlmühle an der Nette, ist heute noch vorhanden.

Am Utzerather Bach, einem kleinen Nebenbach der Uess, standen einst zwei Mühlen in Ulmen, „die beide ursprünglich ihr Wasser aus dem großen Weiher bezogen, der heute [...] Jungfernweiher heißt“" (MERTES 1995:121). Mitte des 19. Jahrhunderts war der Müller „,mit dem abfließenden Wasser aus dem großen Weiher nicht mehr zufrieden. Auf seine Anregung hin wurde schließlich ein Stollen zum Maarwasser getrieben, das die Ulmener Mühlen danach antrieb. [...] Das durch den Stollen abfließende Wasser erreicht als Ollen- oder Ulmener Bach (heute Nollenbach) unterhalb der erwähnten Mühle den Uessbach.“"(:122)

In ähnlicher Weise gestaltete man auch die Wasserzufuhr zu der dem Kloster Maria Laach gehörigen Laacher Klostermühle. Sie wurde nicht von einem Teich gespeist, der das Stauwasser aus einem Bach erhielt, sondern aus einem unterirdischen Abzweig aus dem aus vulkanischer Bildung hervorgegangenen Laacher See. Dieser ,Fulbert Stollen' hat seinen Namen von dem Abt FULBERT (1152 1177) der Benediktinerabtei Laach, der im südlichen Kraterwall des Sees einen ca. $825 \mathrm{~m}$ langen Stollen durchtrieben ließ. 1842 - 1844 wurde ein neuer Stollen angelegt, durch den der Seespiegel um $7 \mathrm{~m}$ gesenkt wurde. Damals errichtete man am Austritt des Seewassers aus dem neuen Stollen eine Getreidemühle, eben die heutige Laacher Mühle. Das abfließende Seewasser wird vor der Mühle in einem Mühlenteich aufgefangen und fließt danach als Laach-Graben ab. Im Mittelalter hingegen stand die alte Klostermühle innerhalb der Klostermauern und wurde von dem kleinen Gewässer angetrieben, das von den Beller Wiesen abfließt und heute noch ein paar Teiche füllt (MERTES 1995:79).

\footnotetext{
${ }^{32}$ Es gibt in der Eifel zwei Brohlbäche, einen im Kreis Ahrweiler und einen im Kreis Cochem-Zell.
} 


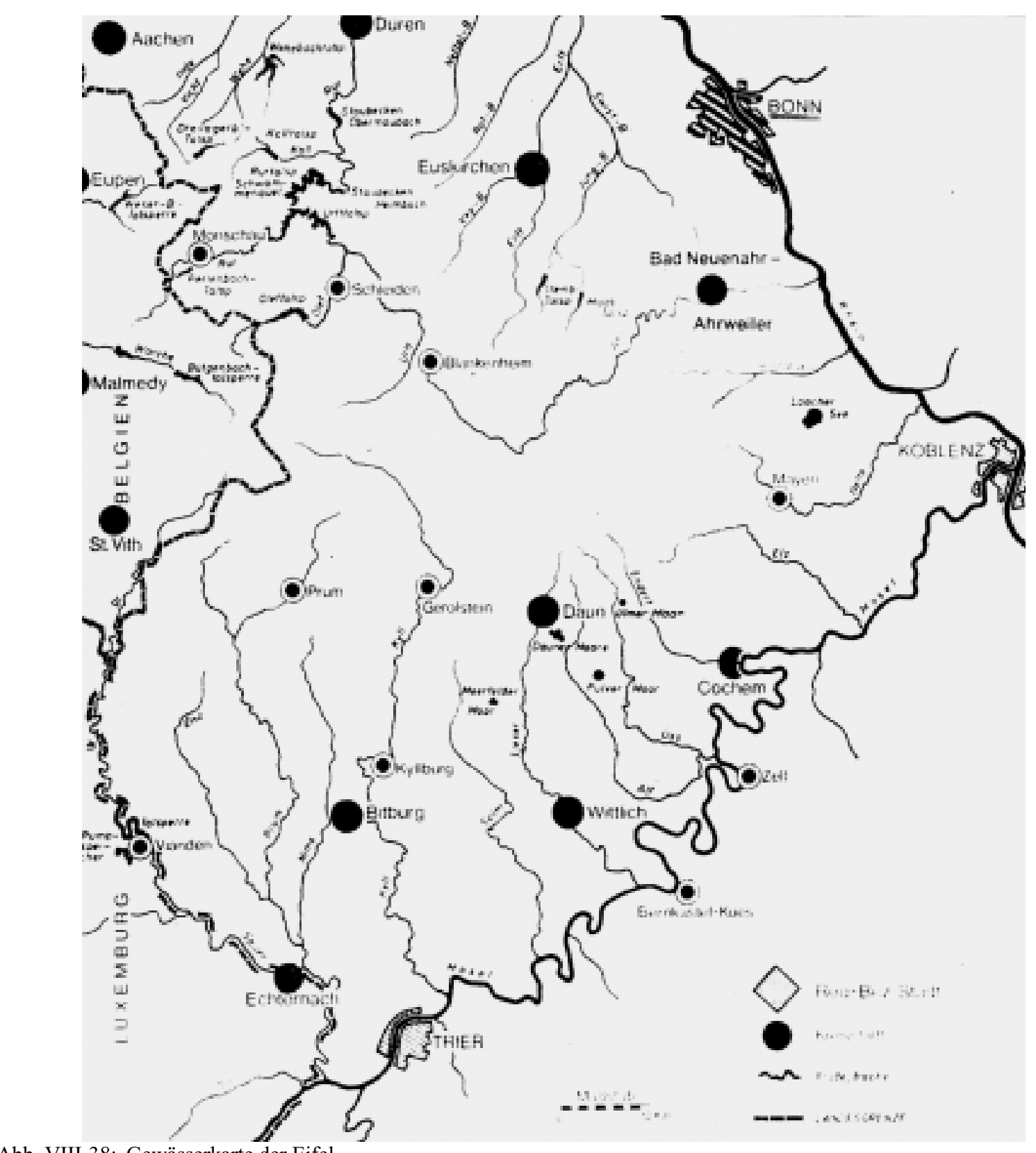

Abb. VIII-38: Gewässerkarte der Eifel

(aus: MERTES 1995:48)

Die größeren Gewässer Salm und Kyll trieben ebenfalls eine Vielzahl von Mühlrädern an. Wie zum Beispiel die Beisenmühle (Binsenmühle) an der Salm oder im „Mühlendorf Schutz“, wo durch die kleine Kyll vier Mühlen, wie beispielsweise die Heckelsmühle (Hinkelsmühle) oder die Bleckhausener Mühle angetrieben wurden (WIßKIRCHEN 1985). Doch diese Mühle wurde erst recht spät um 1800 errichtet und für sie alle war aufgrund des im Verhältnis zu den anderen Bächen starken Wasserflusses kein Stauteich notwendig. Dies wurde erst an den Nebenbächen notwendig, an denen interessanter Weise die ältesten Mühlen standen.

Die Regenmühle (Regmühle), 1238 erwähnt, und die im 14. Jahrhundert errichtete Rutschmühle lagen am Wallenborner Bach (Wallmer Bach), einem Nebengewässer der Kyll. Die Rutschmühle gar lag einige Meter höher als der Wallmerbach selbst, so dass dieser für den Antrieb der Mühle nicht in Frage kam. In dem Berghang oberhalb der Mühle gab es eine Reihe von Quellen. Das Wasser mehrerer Quellen wurde aufgefangen und gesammelt einem kleinen Staubecken oberhalb der Mühle zugeführt, so dass es anschließend über das Mühlrad in den Wallmerbach fließen konnte. Hier herrschte jedoch Wassermangel von Mai bis November (WIßKIRCHEN 1985). Das einzige, das heute 
noch an die Rutschmühle erinnert, ist ein kleiner, von der Ortsgemeinde vor einigen Jahren renovierter Weiher, der Wasserstau der Mühle.

Auch der etwas außerhalb, südöstlich der Eifel liegende Mühlheim-Kärlicher Bach beispielsweise, ein insgesamt nur kleines Gewässer zwischen Bassenheim und Rhein, weist zahlreiche Mühlenteiche aus, gab es an ihm doch an die 10 Mühlen (MERTES 1995:85).

Im gesamten Erftgebiet standen einmal mehr als 200 Wassermühlen (KREINER 1996:49), unter anderem auch bedingt dadurch, dass das Erftgebiet siedlungshistorisch seit dem Spätmittelalter dicht mit Städten besetzt war (:50). Vor allem ,entlang der Erft [...] finden sich zahlreiche Mühlenbäche, Mühlengräben oder Mühlenteiche“, so DIX (1997:135), leider ohne nähere Zahlenangabe für die Mühlteiche. Doch das Vorkommen an Mühlteichen muss angesichts der Anzahl an Wassermühlen beträchtlich gewesen sein: Allein die Erft trieb auf ihren damals $131 \mathrm{~km}$ nicht weniger als 75 Mühlen an (KREINER 1996:114). „Damit hebt sich dieses Gewässer mit seiner Mühlendichte deutlich gegenüber den anderen Bächen dieser Region heraus.“ (DIX 1997:154). In die Gesamtzahl integriert sind die Mühlen am Kuchenheimer Erftmühlenbach, einem rechten Erftarm, der schon im Frühmittelalter reguliert wurde. Hier allein konnte man am Ende des 18. Jahrhunderts - bei einer Länge von ca. $11,5 \mathrm{~km}-23$ Mühlenstandorte zählen. Dabei ist zu bedenken, dass ein zwei Kilometer langer Abschnitt wegen schlechterer Gefälleverhältnisse vor dem 19. Jahrhundert gar keine Mühle besaß. Auf weniger als $10 \mathrm{~km}$ reihten sich also die Mühlen in diesem „mühlenreichsten Gewässerabschnitt des Erftgebietes“ (KREINER 1996:63) im Abstand zwischen $230 \mathrm{~m}$ und 2,3 km. Der Erftmühlenbach bildete eine regelrechte „Mühlengasse“ (:102). „Diese Mühlendichte ist im Erftgebiet - und darüber hinaus im deutschen Flachland - einzigartig.“(:102)

Aber auch an den übrigen kleineren mühlentauglichen Erftflüssen standen zahlreiche Wassermühlen: Mitte des 19. Jahrhunderts an Veybach, Rheindorfer Bach, Mertener und Schwadorfer Bach insgesamt 28 und allein 34 am Strundener Bach, die alle durch ihre in der Eifel liegenden Quellgebiete reichhaltige Zuflüsse erhielten. Sie zeichnen sich durch ein für den Mühlenbetrieb günstiges ausgeglichenes Abflussverhalten aus.

Der hydrologischen Situation entsprechend finden wir im Erftgebiet Mühlenstauteiche „nur im Einzugsgebiet der Swist, sowie von Gill, Norf und Finkelbach, den Bächen des Erftgebietes, die ein vergleichweise unregelmäßiges Abflußverhalten aufweisen“ (KREINER 1996:116). Denn generell hatte im Erftgebiet „,die überwiegende Zahl der Mühlen keinen Kolk nötig, da ihre Gewässer über ein genügendes Mindestwasseraufkommen verfügten. Sie waren - von Zeiten extermer Trockenheit abgesehen - auch keinen durch Wassermangel bedingten Betriebseinschränkungen unterworfen.“ (:116).

Der bedeutendste Fluss des niederrheinischen Tieflandes, die Niers, galt auf ihrer - vor der Regulierung zu Beginn des 19. Jahrhunderts - 129 km langen Strecke mit 39 Mühlen als ein mühlenreiches Gewässer (KREINER 1996:113f.). Aber auch die niederrheinischen Flüsse Schwalm und Nette gelten landläufig als klassische Mühlenteichgewässer. „An den niederrheinischen Flüssen Schwalm, Niers und Nette besaßen fast alle Mühlen einen Kolk“ (:116). Doch auch das gestaute Wasser reichte bei vielen der dortigen Mühlen nur für wenige Betriebsstunden pro Tag.

Im Mühlental des Heisterbacher Tales im Siebengebirge, „gab es bereits seit dem 10. Jh. Wassermühlen.“ (BURGGRAAFF et al. 2001:6). Unter anderem wird ein Standort einer Walkmühle genannt, die ,auf einen Damm zwischen dem zweiten und dritten Fischteich nördlich des Klosters Heisterbach" gelegen war (:6). Diese Teichdammmühle wird 1202 in einer Heisterbacher Urkunde des Kölner Erzbischofs Dietrich von Heinsberg erwähnt. Auch hier wird die gleichzeitige Nutzung eines Teiches als Fisch- und Antriebswasser greifbar.

Anfang des 18. Jahrhunderts erlebte die Abtei einen Aufschwung und im Mühlental sind zu dieser Zeit mehrere Mühlen in Betrieb, „es war in dieser Zeit geradezu eine gewerblich orientierte Mühlenlandschaft.“ (BURGGRAAFF et al. 2001:9). Aus dem Urkataster von 1825 sind die Standorte 
von sechs Wassermühlen zu entnehmen, wobei bereits drei Mühlen bis dahin abgängig waren. BURGGRAAFF et al. (:26) sprechen von einer „Wassermühlenreihung Heisterbacher Mühlental“.

Für das Frankenland werden seit dem frühen 11. Jahrhundert Wassermühlen in schriftlichen Quellen erwähnt. Gar ,die meisten Mühlen in Franken dürften bereits vor 1300 entstanden sein, auch wenn sie der historischen Quellenlage entsprechend, meist erst im 14./15. Jahrhundert erstmals urkundlich erwähnt werden“(BEDAL 1992:31).

„Eine der ausgeprägtesten und romatischsten Mühlenlandschaften in Franken“ (BEDAL 1992:178) stellt der mittelfränkische Anteil des Taubertales um Rothenburg dar. Im $28 \mathrm{~km}$ langen Tal trieb „die junge wasser- und gefällreiche Tauber von der Quelle bis Tauberzell 36 Mühlen“ an. Bezieht man die Nebenbäche mit ein (Schand-Tauber, Wohnbach), so sind es sogar 47 Mühlen, die im kleinen mittelfränkischen Einzugsbereich der Tauber liegen. Im Gesamtbereich Tauber entfallen etwa 3 Mühlen auf $2 \mathrm{~km}$ Bachlauf. Ganz besonders dicht, „wie Perlen auf der Schnur aneinandergereiht“, folgen die Mühlen dem einst zur Reichsstadt gehörigen Taubertal unterhalb Rothenburgs. In diesem Streckenverlauf liegen 2 Mühlen pro km (:178).

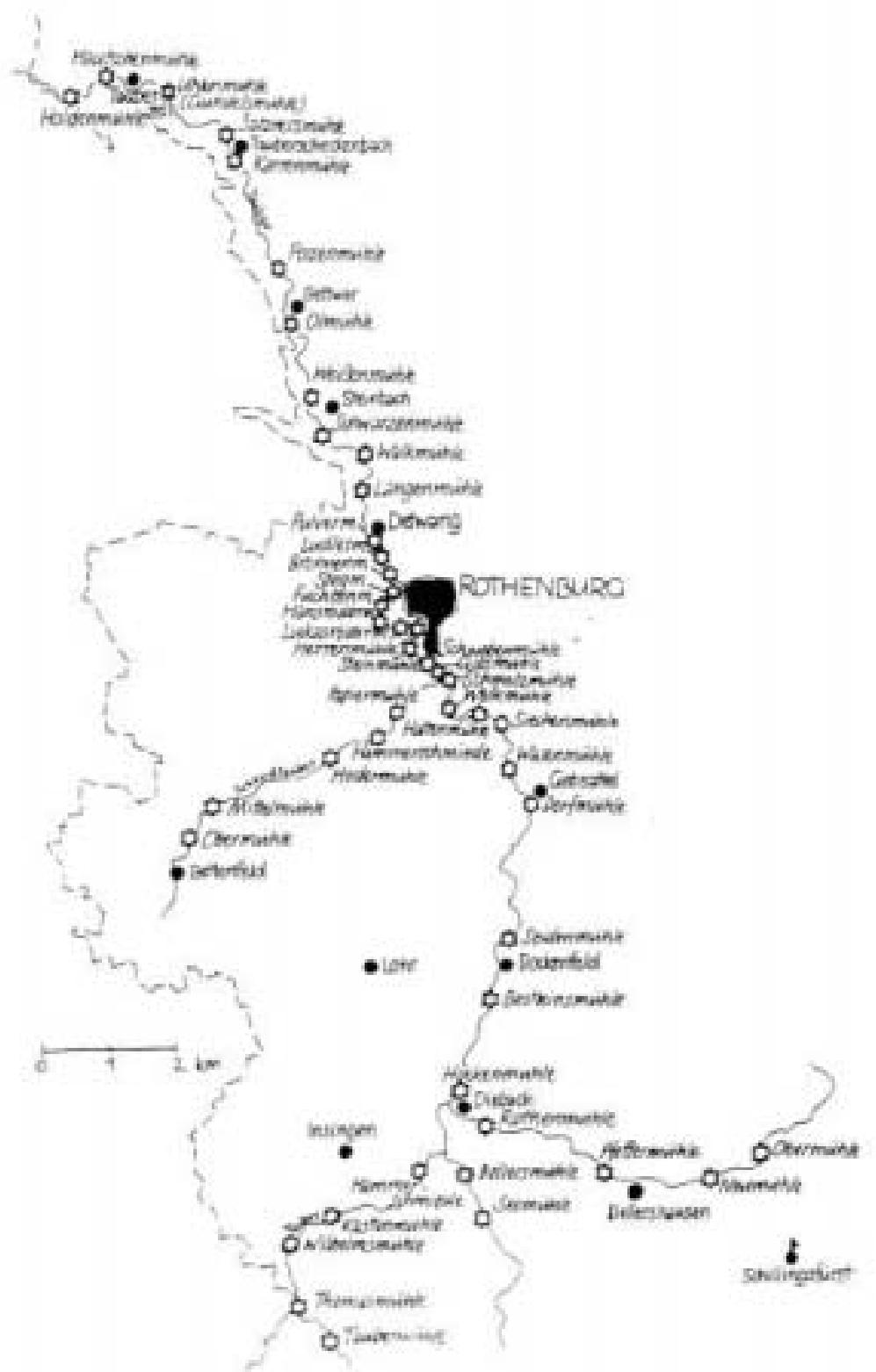

Abb. VIII-39: „Taubermühlen“: Wassermühlen im Einzugsgebiet der Tauber (aus: BEDAL 1992:178). 
Eine Vielfalt an Wassermühlanlagen lagen auch an der Aisch, zwischen Windsheim und Neustadt. 30 Mühlen sind vom „Aischloch“, d. h. der Aischquelle, bis hinter Neustadt erfasst (BEDAL 1992:181).

Nur noch eine von ehemals zahlreichen Wassermühlen ist heute als Mahlmühle in Betrieb, keine jedoch besitzt mehr ein Wasserrad (BEDAL 1992:181). Gleichwohl muss nicht darauf besonders hingewiesen werden, dass sich das Aischgebiet aufgrund der Vielzahl an Teichwirtschaften als Mühlengelände geradezu anbot.

Anders als bei den Taubermühlen oder den Mühlen an der Aisch, die dicht an einem Flusslauf aufgereiht liegen und zugleich ihre Bedeutung auch nahen Städten (Rothenburg, Windsheim, Neustadt) verdanken, liegen die Mühlen im Einzugsbereich der Bibert weit gestreut, dafür aber gleichmäßig verteilt. Keine Stadt oder sonstiges größeres Zentrum liegt in ihrem Bereich (Ansbach und Heilbronn im Süden sind nur zur Orientierung eingezeichnet), es handelt sich um ein heute fast rein landwirtschaftlich strukturiertes Gebiet inmitten des ,Naturparks Frankenhöhe' (BEDAL 1992:184). Die Bibert mit den zahlreichen Nebenflüssen, wie der Rippach, der Mettlach und der Haslach hatten nicht allzuviel Gefälle und auch keine besonders große Wassermenge. Dennoch lagen 36 Mühlen an ihren Wegen, die heute größtenteils stillgelegt sind. Wasserräder haben sich offenbar keine erhalten (:184), dafür aber einige Teiche, die aufgrund der Gewässersituation angelegt werden mussten.

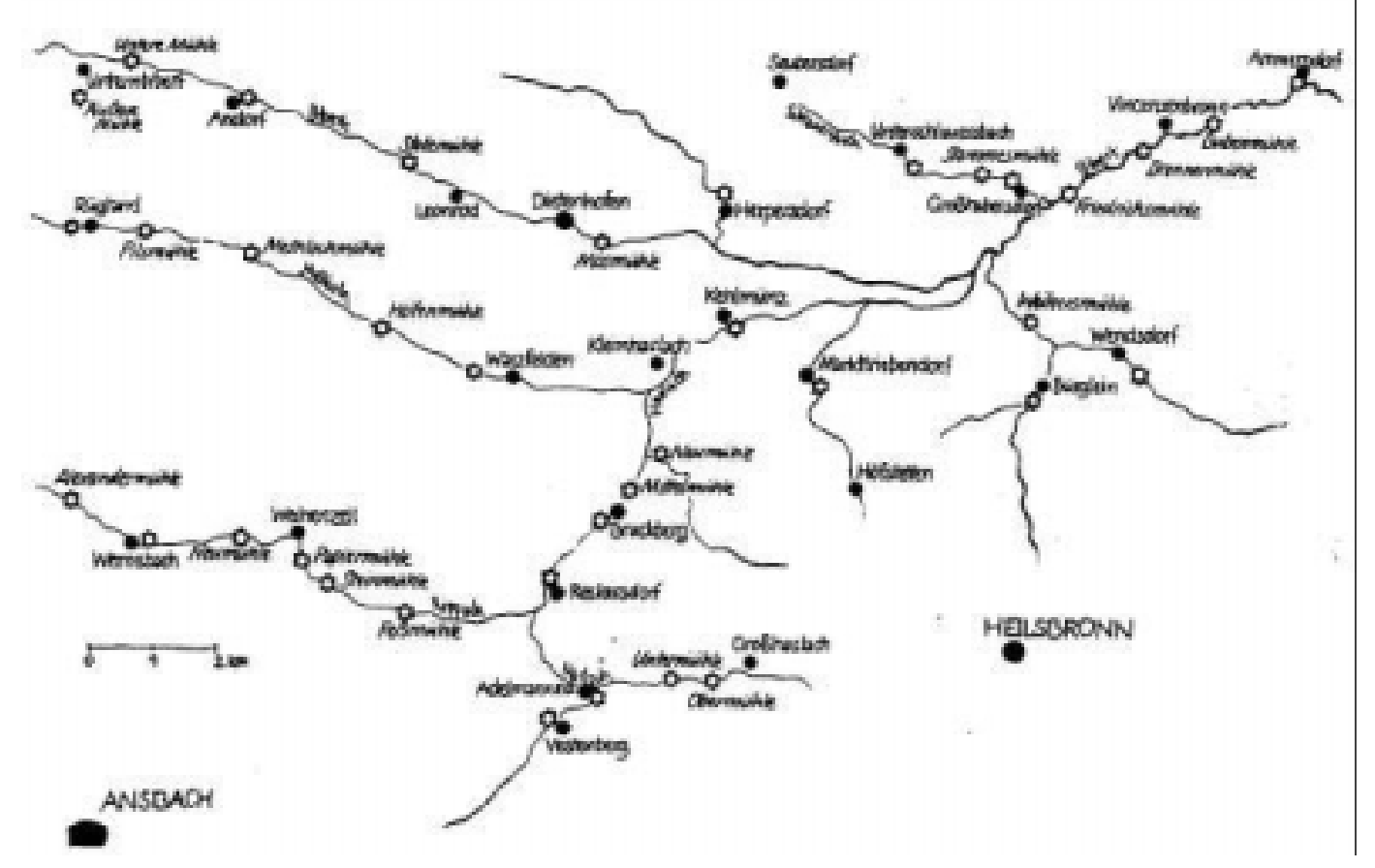

Abb. VIII-40: Kartenausschnitt der Bibert mit ihrem Einzugsbereich (aus: BEDAL 1992:184).

Ein gegenüber dem Bibertgrund gänzlich anderes Verbreitungsbild ergeben die im Einzugsbereich des Breitbaches, oberhalb von Marktbreit, gelegenen Mühlen. Es sind meist tief in den Muschelkalk eingeschnittene, enge Tälchen, „,in denen sich die Mühlen z. T. geradezu drängen, während die im Allgemeinen großen und dichten Dörfer auf den wasserarmen Höhen liegen“ (BEDAL 1992:186). Am Iffigbach von Ippesheim bis Iffigheim folgt eine Mühle dicht auf die andere, fast schon so eng wie an der Tauber bei Rothenburg. Die im Vergleich zu den Taubermühlen kleineren Ausmaße (Gebäude, weniger Mahlgänge) in Verbindung mit den von ihnen zu versorgenden großen Dörfern mit ihren guten ertragsreichen Ackerböden, dürfte die überraschend große Zahl der Mühlen in diesem sonst eher dünn besiedelten Gebiet erklären (:186).

Die Fränkische Schweiz mit der Wisent und ihren Nebenflüssen gilt in der allgemeinen Vorstellung als besondere Mühlenlandschaft - und ist es auch. Im Vergleich mit anderen Gegenden Frankens und Deutschlands erscheint aber die Fränkische Schweiz auch nicht wesentlich dichter mit Mühlen besetzt $\mathrm{zu}$ sein und ältere Mahlwerke sind auch genauso wenig erhalten wie anderswo. Mitunter lag das 
verbreitete Mühlenbild an dem hier sehr früh einsetzenden Fremdenverkehr, an den „Romantikern“, die diesen Landstrich wie kaum einen anderen Frankens bereisten.

Bedingt durch die Lage in engen felsen- und wasserreichen Tälern lassen sich um 1890 rund 150 Mühlen in der gesamten Fränkischen Schweiz noch nachweisen. 1980 existierten davon noch rund 20 als Mühlenbetriebe (BEDAL 1992:188). Inzwischen dürften es vermutlich bereits erheblich weniger sein. So sind die auf dem Kartenausschnitt erfassten 34 Mühlen im Trubachtal sowie dem Mittleren Wisenttal alle nicht mehr in Betrieb. Nur für einige Mühlen sind Mühlenteiche erwähnt.

In der Mitte des 18. Jahrhunderts lassen sich für fast alle Dörfer im Spessarter Untersuchungsgebiet von DENZER (1996:178) Wassermühlen archivalisch nachweisen. Dies sind die Dörfer Mespelbrunn, Heimbuchenthal, Wintersbach, Krausenbach, Hessenthal und Hobbach. Die Mühlen lagen „vor allem in den jeweiligen Wiesengründen“ des hier „Bayerischer Spessart“ genannten Spessartteiles.

Für den Hochspessart ist ein weitmaschiges Netz tief eingeschnittener Täler, mit meist nur kleinen Bächen, charakteristisch. Quellen treten dagegen im hohen Spessart kaum auf, da der Buntsandstein stark wasserdurchlässig ist. Quellen befinden sich erst wieder in den mittleren und unteren Teilen der Täler. Bedeutende Gewässer sind insbesondere die Elsava, die Hafenlohr, die Lohr sowie die Sinn. Der größte Teil des Vorspessarts wird über die Flusssysteme der Kahl und der Aschaff entwässert. Im Vorspessart ist der geringen Durchlässigkeit der kristallinen Gesteine entsprechend die Taldichte recht hoch und dementsprechend die Anzahl an Wassertriebwerken, die wiederum im höheren, wasserärmeren Fluss- bzw. Quellgebieten ein künstlich aufgestautes stehendes Gewässer benötigten (NATURPARK SPESSART 2004).

Aber auch Hammerwerke lassen sich für den Spessart nachweisen, die eine ganz andere Größe und demzufolge Kapazität hatten. Im oberen Elsavatal befanden sich drei Eisenhammerwerke: der Höllhammer, der Hobbacher Hammer und der Neuhammer.

Seit ihrer Anlage bis zur Aufgabe Mitte des 19. Jahrhunderts haben die Mühlen und Hämmer gemeinsam das Landschaftsbild im Spessart entscheidend mitgeprägt. Dies betrifft vor allem die aufgrund der Antriebskraft erforderlichen wasserbautechnischen Anlagen für den Antrieb der Hammerwerke, für die ebenfalls Teiche nachgewiesen sind: 


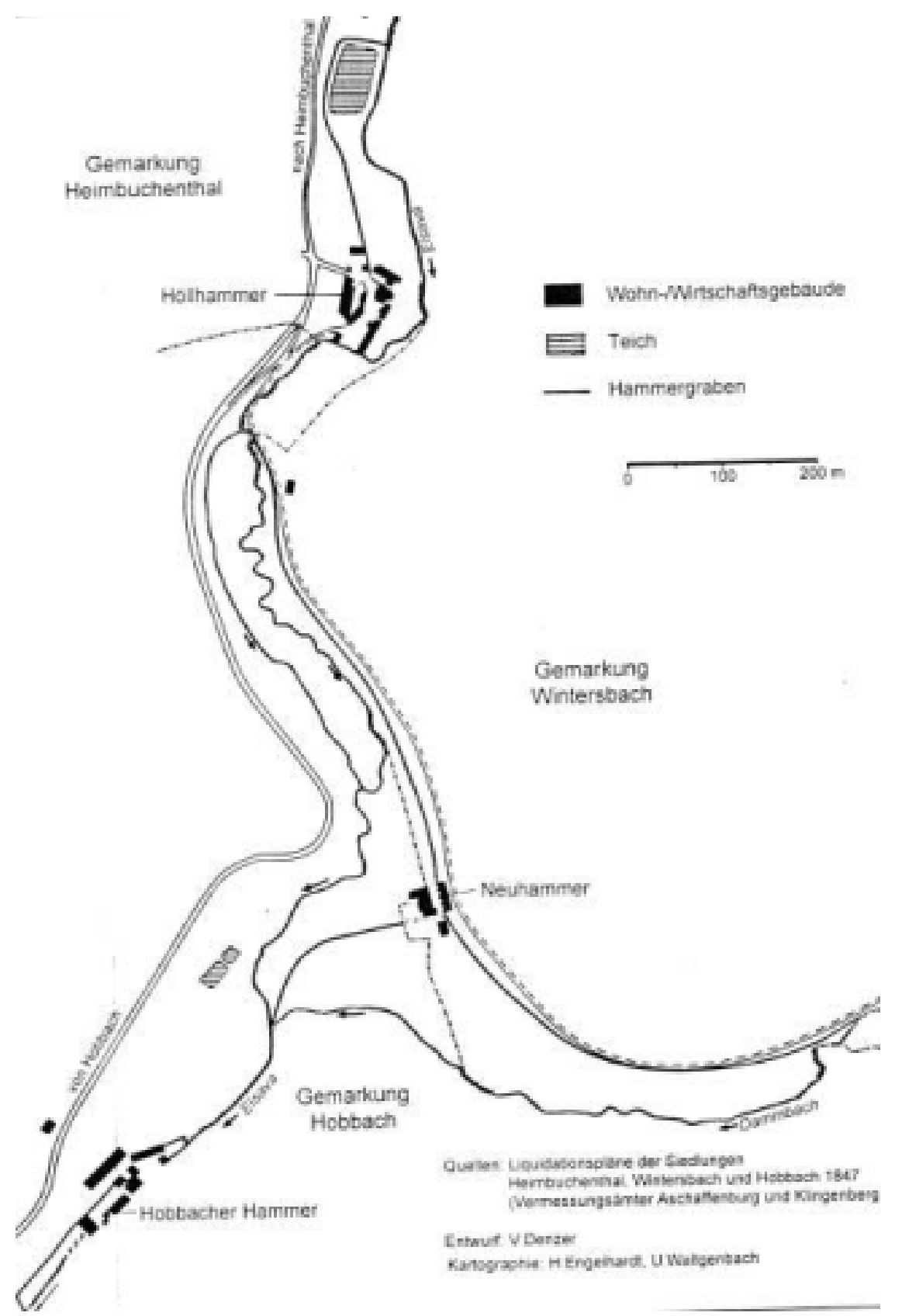

Abb. VIII-41: Teich des Höllhammers an der Elsava, Gemarkung Heimbuchenthal (aus: DENZER 1996:178)

Die Kurfürsten von Mainz sowie die Grafen von Löwen-Wertheim siedelten hier in dem wald- und wasserreichen Gebiet eine regelrechte „Hammerwerks-Industrie“ an und es entstanden zahlreiche Eisenhämmer an jedem geeigneten Wasserlauf in Winterbach, Lichtenau, Waldaschaff, Laufach und Hasloch. Allein vier Eisenhämmer wurden hiermit früher am Haselbach betrieben. Jeweils einige hundert Meter talaufwärts der Hämmer wurde ein künstlicher Wassergraben angelegt, in dem das Wasser gespeichert und den Hammertriebwerken zugeleitet wird. $3 \mathrm{~km}$ nördlich des Dorfes Hasloch am Haselbach wird der letzte verbliebene Hammer heute noch mit seiner Einrichtung aus der Gründungszeit im Jahre 1779 als „Wasserkraftwerk“ betrieben. Die Wasserkraft aus dem Haselbach, der im Spessart unterhalb von Rohrbrunn entspringt, wurde anschließend ebenfalls dazu benutzt, die hier aus dem ausgeschmiedeten Luppeeisen hergestellten Pflugschare, Hacken und Hauen in der benachbarten Barthels-Mühle zu schleifen, die dafür einen Stauteich mit dem Wasser des Haselbachs gefüllt hatte (HOCK 2004).

Bis an den Spessart und bis kurz vor Würzburg erstreckt sich das Gebiet der Grafschaft Wertheim, auf linksmainischer Seite bis ins Taubertal und ins Bauland. Den Mittelpunkt bildete die Stadt Wertheim 
mit ihrer Burg (UECKER 1999:43). Die folgende Abbildung soll die weite Verbreitung der Wasserkraft in der Grafschaft verdeutlichen (:8). Eingezeichnet sind dort die Mühlen, die heute entweder als tätige Mühle oder auch nur als Gebäude erhalten sind; diejenigen Mühlen, die heute nicht mehr existieren und bei denen nachvollziehbar ist, wo sie sich einst befunden haben, sind auch vermerkt.

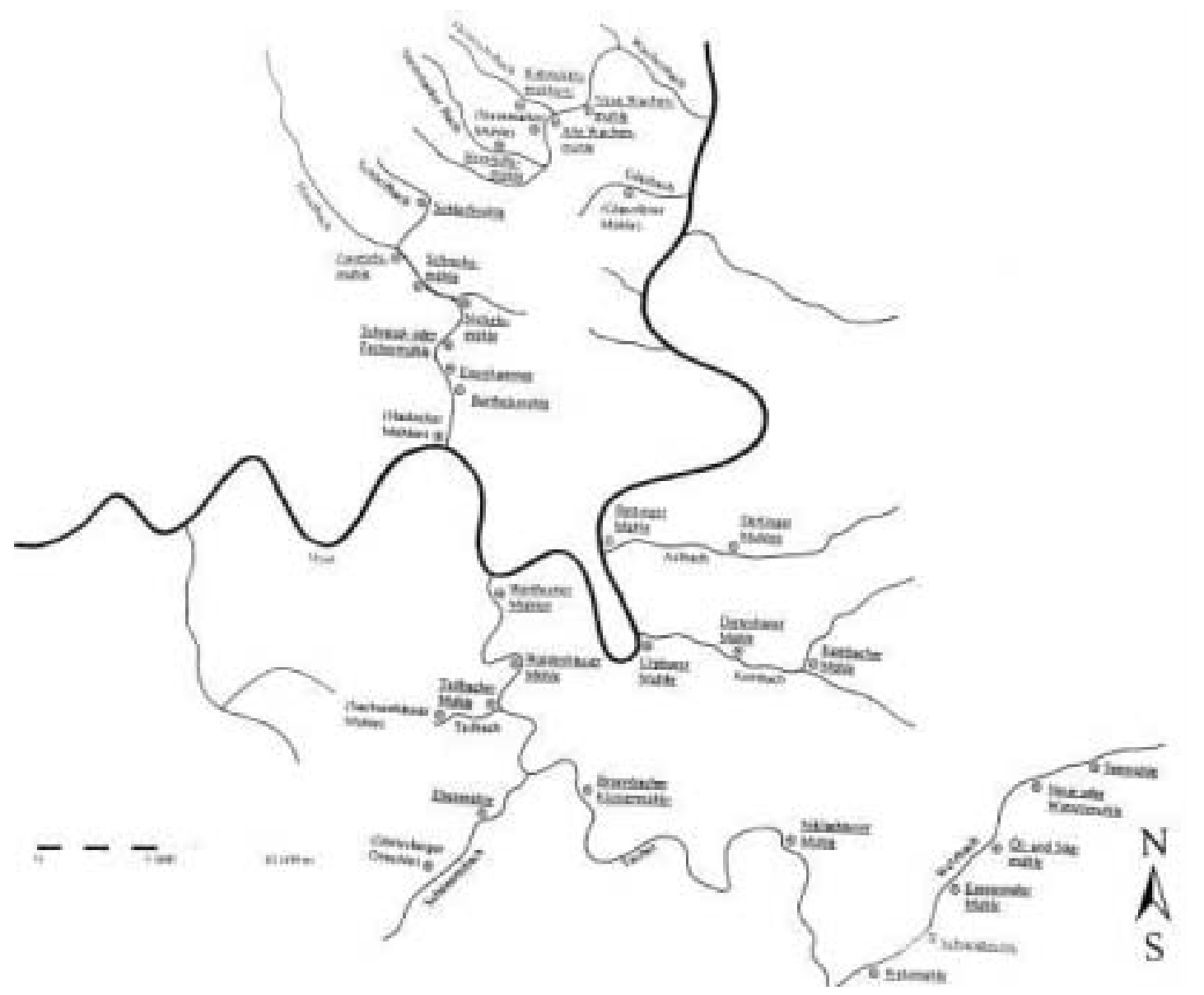

Abb. VIII-42: Mühlenkarte der Grafschaft Wertheim (aus: UECKER 1999:85)

Im Hessischen Spessart, in der Gemarkung Bieber, am Bieberbach auf eine Strecke von 2,5 km verteilten sich ehemals fünf Mühlen, von denen vier noch heute erhalten geblieben sind (GRIES 1999:9ff.). Obschon die Voraussetzungen gleich waren, ist von den ehemals fünf Mühlen die Käsmühle die einzige mit Mühlteich. GRIES (:81) beschreibt die besondere reliktäre Situation wie folgt: „Atypisch und einzigartig im Vergleich zu den anderen Bieberer Mühlen ist aber, daß ungefähr $50 \mathrm{~m}$ südlich des alten Mühlengebäudes, etwa an der Stelle, an der sich heute der Parkplatz der Gastwirtschaft befindet, ein sogenannter Mühlteich vorhanden war, der vom Mühlbach durchflossen wurde. Mit einer Größe zwischen 600 und $700 \mathrm{~m}^{2}$ konnte er seiner ursprünglichen Aufgabe gut gerecht werden, dem Müller in Zeiten schwacher Wasserführung des Bieberbachs noch eine zusätzliche Antriebsreserve zu verschaffen, was vor allem im Spätsommer ein bedeutender Vorteil gegenüber anderen Mühlen gewesen sein muß. Leider wurde dieser Mühlteich [...] in den [19]50er Jahren nach und nach mit Bauschutt und anderem Abfuhrmaterial zugeschüttet."

Das Mühlengewerbe an Rodau und Bieber in Mühlheim am Main erreichte eine solche „Industriedichte“, dass am Höhepunkt des alten Handwerks insgesamt zehn Mühlen nachzuweisen sind. Neben Mühlheim, das schon im Mittelalter mehrere Rodaumühlen hatte, brachte auch Lämmerspiel mit seiner Dorfmühle und Meilsheim mit der Melsamer Mehlmühle jeweils noch einen Mühlenbetrieb mit ein. Während die großen Rodaumühlen mit Stauwehren arbeiteten, ergänzten Mühlteiche den Wasseraufschlag an den schwächeren Zuflüssen. 
Merzig an der Saar, im Saar-Bergland im Südwesten Deutschlands gelegen, war seit dem frühen Mittelalter die Stadt der Mühlen und besaß im Jahr 185223 Mühlen, von denen einzig noch die 1767 erbaute Fellenbergmühle steht, die heute - entsprechend ihrer letzten Nutzung - ein feinmechanisches Museum beherbergt. Aber nicht an der Saar, sondern am aus dem Bergland zufließenden Seffersbach standen die Wassermühlen und hatten diesen mehrfach durch Wehre aufgestaut. Im relativ steilen Gelände wurden kleine terrassierte Stauteiche angelegt (DITTMANN 1997).

Im Gebiet links und rechts des Neckars zwischen Heidelberg und Eberbach, an den Neckarzuflüssen aus Odenwald und Kraichgau standen ebenfalls ehemals zahlreiche Wassermühlen (OPEL 1991:5). Sechs Mühlen am Rohrbach, vier am Schlierbach und die vielen Neckargemünder Mühlen an Elsenz und Hilsbach, an Pleutersbach und an der Schönau.

Die Mösmühle ist heute die einzige von ehemals acht Getreidemühlen im Rotbachsystem, die mit Wasserkraft arbeitet. Im Rotbachsystem entwässern zahlreiche Quelläste. Sowohl die aufgestauten Quellen im Randbereich des Quellgebietes als auch die zu den Bächen vereinigten Gewässerläufe lieferten bedeutende Wassermengen für den Antrieb von Wassermühlen. Einer der Quelläste, der bereits im 16. Jahrhundert zu den stärksten Quellen Oberschwabens zählende „Ahlebrunnen“, trieb die Mösmühle an. Sie kann sich nicht mehr allein auf die Quellschüttung des Ahlebrunnens verlassen, da diese seit den Jahren 1967/1970 die regionale Trinkwasserversorgung sicherstellt (HERBST 1992:29).

Es gibt hier richtige Mühlendörfer und -städte, wie sie von OPEL (1991) genannt werden: das Mühlendorf Ziegelhausen, die Mühlenstadt Eberbach. Im Mühlendorf Ziegelhausen liefen in der Nähe der Klöster Schönau und Neuburg (1130 - 1150) insgesamt vierzehn Mühlen am Steinbach (:21). In der Mühlenstadt Eberbach standen ehemals 9 Mühlen (:43ff). Die Auflösung der Klöster ab 1803 führte auch hier zu einer raschen Beseitigung der meisten Weiherbauten im Einzugsgebiet des Rotbaches, da sie dem württembergischen Staat als Rechtsnachfolger unwirtschaftlich erschienen (HERBST 1992: 36).

Im Mühlener Tal, oberhalb des Dorfes Mühlen bei Ehingen wurden an den wasserführenden Donauseitentälern künstliche Fischteiche angelegt und die Wasserführung frühzeitig kanalisiert, da ohne diese Maßnahmen die Wasserschüttung und -haltung unregelmäßig gewesen wäre und das Wasser sehr bald im karstigen Untergrund versickert wäre (BERKE/KIND 1987:355). Die Gewässer wären nicht beständig genug gewesen, um Fische zu beherbergen.

\section{b.3 Alpen und Alpenvorland}

Für die im 14. Jahrhundert auf etwa 10.000 Einwohner geschätzte Bürgerschaft der Stadt München lagen seit der zweiten Hälfte des 14. Jahrhunderts bis zum allmählichen Abgang Mitte des 19. Jahrhunderts 15 bis 20 Mühlen an den Stadtbächen Münchens (KOHL 1970:1,8,35). Die Stadtbäche Münchens können dabei in vier verschiedene Bachsysteme eingeteilt werden: Die inneren und äußeren Bäche, der Dreimühlenbach, der Triftkanal und der Auermühlenbach (:8). Sie waren Münchens Stadtbäche im eigentlichen Sinne. 


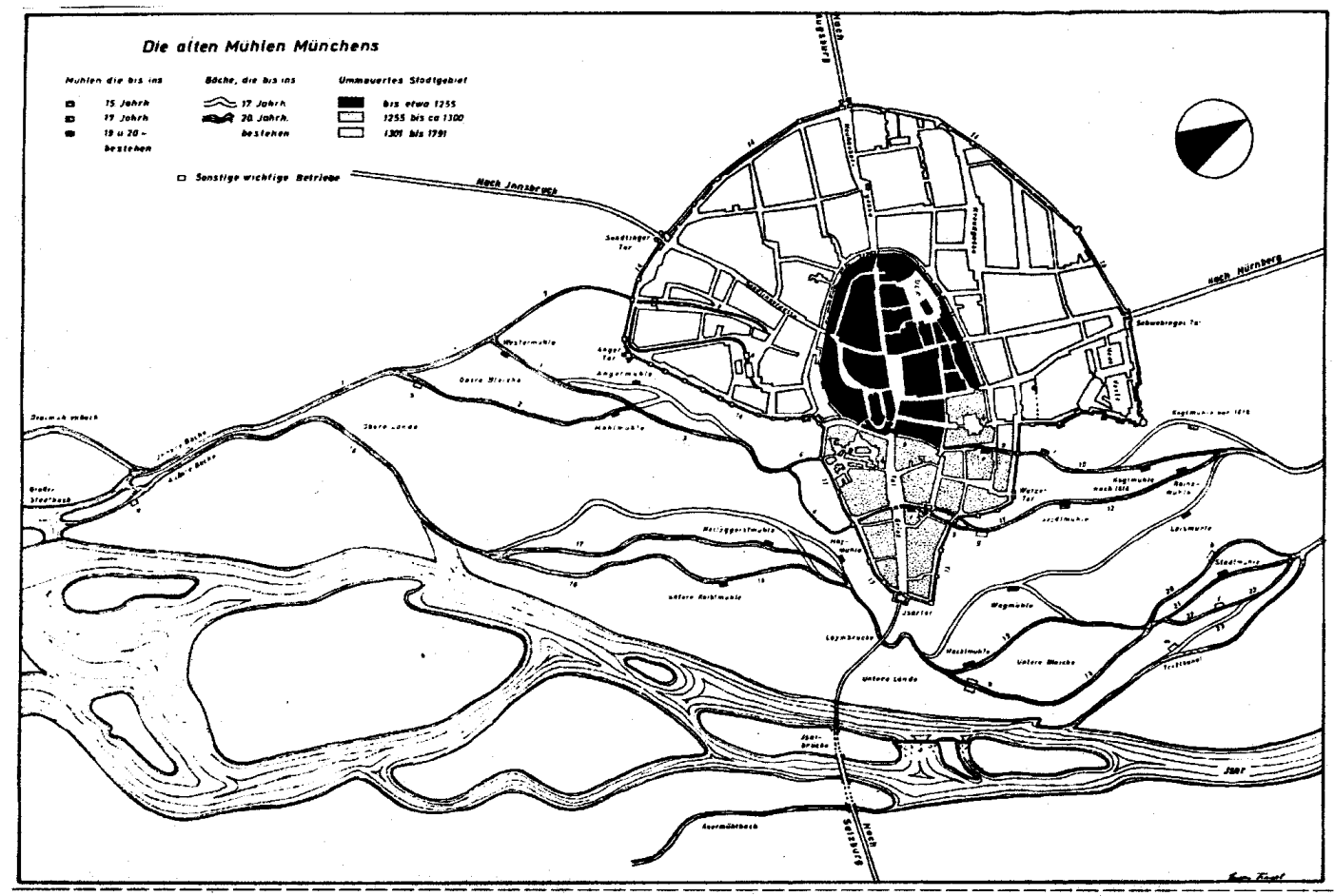

Abb. VIII-43: Die Isar und ihr verzweigtes Flusssystem in München.

Die Wassermühlen liegen an den Stadtbächen Münchens, die das umschlossene Stadtgebiet östlich umlaufen (aus. KOHL 1969: Anhang).

Die Stadtbäche waren ursprünglich natürliche Nebenarme der Isar. Vor allem die Nebenflüsse trieben die Getreidemühlen, die Walk-, Schleif- und Sägemühlen und die Hammerwerke der Stadt an, denn die Isar selbst war zur Anlage von Wasserwerken ungeeignet. Der für den Betrieb eines solchen Wasserwerkes erforderliche gleichbleibende Wasserstand konnte aber auch in den Stadtbächen durch Regulierung des Wasserzuflusses erreicht werden (KOHL 1970:8).

Die Münchner Mühlen waren sämtlich Werke „mit gespannter Wasserkraft”, d. h. das Wasser der Mühlbäche wird auf seiner ganzen Breite durch ein Wehr aufgestaut (:7). Bei den Verhältnissen in den Stadtbächen war dies „die technisch einzig mögliche Antriebsart” (KOHL 1970:7). Mühlteiche kamen aus Platzgründen nicht in Betracht.

Zusammenfassend betrachtet vollzog sich die Wassermühlengeschichte - und mit ihr die Geschichte der Mühlenteiche -in zeitlichem Wechsel des Auf- und Abschwungs, zwischen Stabilität und Instabilität und immer nur begleitet von kurzen Phasen der Kontinuität. Und bei all diesen „,interkontinentalen Novationsschüben“ ist es wichtig, die gesamtwirtschaftlichen Zusammenhänge zu sehen: „Bevölkerungsdruck und Steuervorteile, bäuerliche Eigeninitiative oder herrschaftliche Steuerung, die Revolutionierung der althergebrachten Dreifelderwirtschaft durch nunmehrige ,Besämung' der Brache.“ (HELLER 2003)

Vor diesem gesellschaftspolitischen Hintergrund lassen sich zusammenfassend für eine allgemeinräumliche Darstellung folgende Gemeinsamkeiten bzw. Grundsätze und Bedingungen für die Anlage von Mühlenteichen herausarbeiten:

An den größeren, nicht schiffbaren Flussläufen wurden Mühlen bevorzugt eingerichtet. Hier sind nach MÖRSTEDT (1995:16) die ältesten Mühlenplätze zu verzeichnen. Sie erforderten zwar eine aufwendige wasserbauliche Anlage, wegen des reichlicheren Wasserdargebots verfügten sie aber auch über größere Kapazitäten, die zudem während der Trockenperioden vergleichsweise stabil blieben. Ein im Aufbau und in der Instandhaltung teurer Mühlenteich wurde hier in der Regel nicht benötigt.

Da davon auszugehen ist, dass Mühlen an solchen dynamischen Standorten als Betriebsstandort zur gewerblichen Produktion, des Handels und der Veredlung funktionierten und über eine dementspre- 
chend umfangreiche Betriebsanlage verfügten, wäre eine solcher Mühlenteich, um eine solche Wassermasse für Notzeiten bereitzustellen, nicht nur sehr kostenaufwendig, sondern auch wahrscheinlich in seiner Ausdehnung nicht in das im 19. und 20. Jahrhundert bereits begrenzte räumliche Platzangebot integrierbar gewesen. Auch bereits in diesen Jahren waren die dafür zur Verfügung stehenden Auen - durch die Regulierung - teilweise bebaut und die Retentionsbecken bei Dammbruch zudem eine sehr große Gefahr gewesen. Zudem hätte hier ein Stauteich mit seinem relativ geringen Antriebsreservoir keinen Sinn gehabt, wenn es galt eine große Mühle mit mehreren Wasserrädern zum Antrieb von mehreren Mahlgängen zu beaufschlagen (MÖRSTEDT 1995:123).

Wassermühlen an kleineren Bachläufen hingegen benötigten zum Antrieb einen Stauteich. Obschon die Mühle hauptsächlich den Eigenbedarf des Hofbetriebs an Futterschrot diente, musste das Wasser in einem Stauteich „,von beträchtlicher Größe“ gesammelt werden (MÖRSTEDT 1995:45). Je größer der Bedarf an Aufschlagwasser und je karger bzw. unregelmäßiger der Wasserzufluss durch den Bachlauf war, desto größer musste der Teich ausfallen. In Fällen unsicherer Wasserzufuhr mussten also die meisten Müller einen Mühlteich anlegen, von dem aus das Wasser in oberirdischen Rinnen herangeführt wurde. In einem Beispiel (Laacher See) geschah dies sogar durch einen unterirdischen Stollen.

Die Gründe, die zum Bau von Mühlenteichen an kleineren Bachläufen führten, lagen wohl anscheinend darin, dass die kleinen Bäche nicht genügend Antriebsleistung für die Wassermühle hergaben. Mit einem Mühlenteich war es nun möglich, eine bessere oder in manchen Notzeiten (Sommer, Winter) überhaupt eine Wasserkraftausnutzung zu erzielen.

Doch in manchen Fällen, zum Beispiel bei unzureichenden Quellschüttungen reichte nicht einmal die Wassermenge, um es in einem Teich zu sammeln. Dies führte zur baldigen Aufgabe der Betriebe. Aber nicht alle an kleinen Bachläufen gelegenen Wassermühlen wiederum besaßen überhaupt einen Teich, um das Wasser zu stauen - aus welchen Gründen auch immer. Der Müller konnte deshalb hier nur wenige Stunden am Tage mahlen. Wiederum andere Mühlen und vor allem Hämmer vergrößerten ihren Teich oder legten gar einen zweiten Sammelteich an, um in Sommermonaten ausreichend Antriebswasser zu erhalten bzw. für einen notwendigen stärkeren Aufschlag zu sorgen.

Auch an größeren Bachläufen mit einer entsprechend dichten Reihung von Wassermühlen, schmälerte sich aufgrund der Betriebsdichte das zur Verfügung stehende Wasser oftmals im Jahr derart, dass es auch hier zur Anlage von Mühlenteichen kam, obgleich die eigentliche Wasserkraft eine zusätzliche Sammlung nicht notwendig gemacht hätte. Des Weiteren trugen wirtschaftliche und demographische Faktoren, wie Städte- und Bevölkerungswachstum zur vermehrten Anlage von Wassermühlen und damit zum Bau von Mühlteichen bei, wobei es von dieser Regelhaftigkeit natürlich auch Ausnahmen gibt.

Aber auch wenn die Mühlendichte mäßig erschien, so wurden dennoch Staubecken aufgrund der Vielzahl an Nebennutzungen benötigt oder zumindest gut geheißen: Wasserablässe zu Zwecken der Wiesenwässerung, der Eisgewinnung oder der Nebennutzung als Fischteich zum Beispiel, mögen Anlass gewesen sein, einen Mühlenteichen ohne eigentliche Dringlichkeit anzulegen. Denn auch zur Mühle gehörten nahezu immer Ackerbau und Viehzucht, oft waren Mühlen zugleich besonders große Bauernhöfe. Eine Mühle war, vom Grundbesitz her, einer bäuerlichen Hofstelle unterschiedlicher rechtlicher Qualität vergleichbar, die zusätzlich mit der „Mühlengerechtigkeit“ behaftet war. Es ist eventuell sogar berechtet, geht man von der vorrangigen Bedeutung der Mühle und ihrer Verbreitungsdichte aus, die Wassermühle als Träger der Teich- und Fischereiwirtschaft zu bezeichnen.

Gleichzeitig sollte das Antriebswasser auch beherrschbar sein, denn Hochwasser oder zu starke Strömung gefährdeten die Wasserradtechnik, so dass Mühlenteiche auch als Auffangreserve in Hochwasserzeiten angelegt wurden.

Dagegen lassen sich - anders als bei den Teichwirtschaften - Aussagen zur geographischen Verbreitung nur schwer treffen. Wassermühlenplätze gab es in der Vergangenheit so zahlreich, in jedem Bachtal waren sie in der Neuzeit anzutreffen, dass man sie als ubiquitär bezeichnen kann. 
Schwerpunkte hinsichtlich einer geographischen Zuordnung von Mühlenteichstandorte, die man als „Mühlengroßlandschaften“ bezeichnen könnte, ergeben sich aus den genannten Beispielen ebenfalls nicht eindeutig. Sowohl in flachen als auch gebirgigen Ländern wurden Wassermühlen mit angeschlossenem Mühlenteichen betrieben. Sie stellen vielmehr, im Gegensatz zu Windmühlen in Mittelgebirgen, keine Ausnahmen dar, sondern waren zu Anfang der Mühlenwirtschaft in allen Regionen sogar die nicht nur zeitlich frühere, sondern auch einzige Antriebsform in gewerblichem Maßstab. Windmühlen sind im Mittelgebirge bzw. im Berg- und Hügelland zwar nur in wenigen Fällen nachweisbar, waren aber auch in Franken neben den Wassermühlen im 16. Jahrhundert nicht unbekannt.

„Windmühlen“, schreibt ERLER/MATTHIESEN (1989:87) „,wurden erst dann errichtet, wenn in den $\mathrm{zu}$ Gebote stehenden Landstrichen aus den verschiedensten Gründen wasserangetriebene Mahlwerke nicht existieren konnten. “ Der nachträgliche Aufbau von Windrädern auf Wassermühlen vor allem zu Anfang des 19. Jahrhunderts gibt einen möglichen Hinweis darauf, dass Windmühlen nicht aufgrund der Topographie, sondern erst dann verstärkt errichtet worden sind, nachdem massive Eingriffe in den Gewässerhaushalt eine Wasserbewirtschaftung nicht oder nicht mehr ausreichend möglich machten. In Einzelfällen wurde sogar der ganze Antrieb von Wasser auf Wind umgestellt. Doch schließlich ist es auch denkbar, dass einfach notwendige Produktionssteigerungen den Ausschlag für die Erweiterung bzw. den Neubau zum Windfang gaben.

Unter besonderen landschaftlichen Voraussetzungen, zum Beispiel in der ostfriesischen Landschaft, gab es ehemals auch zahlreiche ,windgetriebene Wassermühlen” (HOEK 1986:76). Im Frühling und Herbst, sobald es länger geregnet hatte, waren sie oft tage- und nächtelang in Betrieb, um das Weideland, in dem häufig auch das Grundwasser über die Gräben stieg, von der „Watervorlast“ zu befreien. Diese Wasserschöpfmühlen dienten in den Frieslanden ,außer zur Entwässerung zum Mahlen von Weizen und Roggen [...] zum ,Schälen' von Graupen, die früher ein Hauptnahrungsmittel in Ostfriesland waren" (:12). An einen Mühlenteich wurde hier nicht gedacht, denn Wasser war ja mehr, als den Menschen lieb war, oberflächennah verfügbar und der Winddruck war ein höherer als in der gefällearmen Landschaft mit dem Wasseraufschlag zur Verfügung gestanden hätte.

Nicht verschwiegen sein soll auch der Einsatz von Zugtieren im Mühlenwesen an wasserreichen Strecken: Zusätzlich konnte sogar bei einigen Mühlen, um Ausfallzeiten bei Wassermangel aufzufangen, die Maschinerie mittels Göpel angetrieben werden (MÖRSTEDT 1995:45,184). Sogar im gewässerreichen oberen Aischgrund waren einige Rossmühlen, d. h. eine durch Zugtiere (Pferde, Ochsen, Kühe) angetriebene Mühlenart, nachweisbar (BEDAL 1992:11). Rossmühlen dürften also, wenn sie schon in solchen Wasserlandschaften eingesetzt worden waren, auch andernorts eine größere Verbreitung gehabt haben, als bisher bekannt ist. Und nur wenige erhaltene Rossmühlen müssen auf eine ehemals vermutlich sehr weite Verbreitung hindeuten.

Allgemein, aber nicht prinzipiell, sahen sich die Müller an Flüssen und Bächen der Flachlandregionen aufgrund ihres nur geringen Gefälles gezwungen, Mühlenteiche anzulegen, um nicht ausschließlich mit der Fließgeschwindigkeit der jeweiligen Wasserströmungen auskommen zu müssen. Des Weiteren wurde im Flachland seit Anfang des 14. Jahrhunderts vermehrt das leistungsfähigere, oberschlächtige Wasserrad eingesetzt. Da es sich bei der zur Verfügung stehenden Wasserkraft aber nicht um Gebirgsbäche mit starkem natürlichem Gefälle handelt und das ebene Gelände nicht die genügende Neigung aufwies, wurde ein Stauen des Mühlbaches zum Mühlenteich notwendig.

Obgleich also wasserbetriebene Mühlen und Werke in allen geographischen Räumen Deutschlands bzw. des zentralen Mitteleuropas zu beobachten sind, gibt es dennoch zumindest einige Vorzugsräume, die sich durch eine besondere Häufung von Mühlteichen auszeichnen. Wassermühlen und ihre Mühlteiche waren zum einen vor allem dort schwerpunktmäßig vertreten, wo die Gewässerläufe wegen der warmen Quellen nicht zufrieren konnten. Zum anderen und vor allem aber hatte die enge Nachbarschaft zu großen Dorf- oder Klostermühlen zur Folge, dass manche Mühlen nur über ein Gefälle von 0,5 - 0,7 m verfügten. Diese besondere Position, die die bachabwärts gelegene Mühle praktisch von der Wassernutzung der oberhalb gelegenen Mühle abhängig machte, hatte die besondere Massierung von Stauteichen zur Folge. Diese spezialisierten Mühlen waren gewöhnlich sehr klein und 
nur zu gewissen Zeiten in Betrieb, wenn etwa Pflugscharen oder ähnliche Schneidewerkzeuge zu schärfen waren. Da auch ihre Steine niemals die Größe der üblichen Steine zum Getreidemahlen erreichten, benötigten sie zum Antrieb auch weniger Energie und konnten daher mit dem Stauwasser eine Zeit lang leben.

Schwierig sind Verbreitungsaussagen schließlich deshalb, weil die Mehrzahl der morphologischen Mühlenbecken gegenüber der ursprünglichen Verbreitung verschwunden ist. Die mittelalterliche bis vorindustrielle Kulturlandschaft war geprägt, man kann auch sagen: durchsetzt, von Wassermühlen und ihren Teichen. Eine ganzheitliche Vorstellung der regionalräumlichen Verbreitung von Wassermühlen und ihrer Stauteiche, die eine technikgeschichtliche und gewässerhistorische Kulturlandschaft realiter zu porträtieren vermögen, wird jedoch mit dem Verschwinden unmöglich, wie die Darstellung von BEDAL (1992:7) glaubhaft macht:

„Mühlen sind selten geworden, auch in Franken. Dabei waren sie bis vor wenigen Jahrzehnten in großer Zahl übers Land verteilt. Oft folgten sie im Abstand von wenigen Kilometern dicht an Bach- und Flußläufen oder sie lagen verschwiegen in Seitentälern abseits der Orte; dann wieder als Dorfmühle mittendrin. Heute erinnern manchmal nur noch die Namen an ihre Existenz, der Mahlbetrieb ist längst eingestellt, Mühlbäche und Mühlweiher sind zugeschüttet. Die Gebäude selbst stehen gelegentlich noch, aber als technische Anlage hat die Mühle in den meisten Fällen längst ausgedient. Die Zeit der alten Mühlenherrlichkeit ist vorbei - und was bedeuteten die Mühlen doch einst für die Menschen, für ihr tägliches Brot! Die Erinnerung daran verblaßt mehr und mehr und wird in einer Generation kaum mehr vorhanden sein - übrig bleiben einzelne, zu Wochenendhäusern umgebaute Mühlengebäude und vielleicht romantisch geprägte Vorstellungen von klappernden Mühlen am rauschenden Bach, ohne konkreten Bezug zur einstigen Wirklichkeit, ohne Kenntnis von der elementaren Bedeutung der Mühlen für die menschliche Ernährung und für ihre Rolle bei der technischen Entwicklung seit dem Mittelalter."

\section{Bergbau}

\section{a Historisch-umweltgeschichtliche Entwicklung}

Die Geschichte der Verbreitung der Bergbauteiche ist eng verknüpft mit der kulturellen, wirtschaftlichen und technologischen Entwicklung sowie den naturräumlichen Verhältnissen in den Bergbaugebieten:

Der Prozess des Teichbaus im Bergbau folgte zwar den großen Linien allgemeiner historischer Entwicklung, wie sie auch bei den Teichwirtschaften und den Mühlteichen beschrieben worden ist, aber die Spezifik der verschiedenen Räume, der Technologien und die fast bedingungslose Ausrichtung auf eine Wirtschaftsform gaben der bergbaulichen Gewässerwirtschaft allzeit eigene Züge.

Wenn man die Wasserwirtschaft des Bergbaus betrachtet, so ergab sich dort, wo abbauwürdiges Gestein zu Tage trat bzw. vor allem unter Tage gewonnen werden musste, eine Notwendigkeit des Wassereinsatzes, die auch nur dank der gespeicherten Wasserkräfte die Jahrhunderte überdauern konnte.

Dies war jedoch nicht immer so und auch nicht in allen Abbaurevieren. Bergbau als gezielter Abbau mineralischer Rohstoffe ist seit dem Jungpaläolithikum belegt und erlebte seinen ersten Höhepunkt europaweit im Jung- und Endneolithikum, wo in beeindruckenden Anlagen bereits ausgedehnter Bergbau auf Silex, den „Stahl der Steinzeit“, betrieben wurde (JOCKENHÖVEL 1996a:8). 
In der Kupferzeit (4000 - 1500 v. Chr.) und Bronzezeit (etwas $1800-700$ v. Chr.) beginnt der Abbau von Erzen. Bunt- und Edelmetalle wurden in der Bronzezeit in teilweise komplizierten Verhüttungsprozessen gewonnen. Der Einstieg in die Eisentechnologie fand später statt, in Mitteleuropa gegen Beginn des 1. Jahrtausends v. Chr. (JOCKENHÖVEL 1996a:8). Da Eisenerze in ihren verschiedenen Ausprägungen zu den häufigsten Erzen in der Erdkruste zählen und vielerorts relativ leicht zugänglich sind, war ein Grubenbergbau mit seinen Anlagen in den Anfängen nicht notwendig; die Eingriffe in die Landschaft dürften auf die Abschürfung oberflächennaher Bereiche begrenzt gewesen sein.

Aufgrund seiner besonderen Werkstoffeigenschaften begann Eisen nach und nach alle Lebensbereiche zu durchdringen. Dieser Vorgang, kulminierend in einem weltweiten „Stahlboom“, fand erst mit der Erfindung der „Plastik-Kunststoffe“ eine starke Einschränkung (JOCKENHÖVEL 1996a:8).

Wenn auch bereits in vorchristlicher Zeit Oberharzer Eisenerze in Düna, einer Wüstung bei Osterode, verhüttet worden sein sollen, wie Befunde ergeben haben (KLAPPAUF 1996:98) und im 3. Jahrhundert n. Chr. ein intensiver Bergbau in der Harzregion betrieben wurde (SCHMIDT 1997:11) und ebenso im Schwarzwald die letzten spätantiken Hinweise auf Bergbau, genauer auf Eisengewinnung, aus dem 4./5. Jahrhundert bekannt sind, so ist von dort bis zur Karolingerzeit von einem Bergbau nicht mehr die Rede (STEUER 1999:49). Es verfielen nach dem Zusammenbruch des Römischen Reiches und in den Wirren der Völkerwanderung die Marktbeziehungen und die angewandten Technologien, und der Bergbau ging schroff zurück. Seine Wiederbelebung und gar Ausweitung war ein langwieriger Prozess und die Gründe für den Beginn eines solchen großflächigen Bergbaus vielschichtigerer Natur:

Eine Geldwirtschaft bestand weder allgemein im Merowingerreich noch im Gebiet der Alamannen. Das Gold als Münze diente als Geschenk, Sold oder Zahlung für kostbarste Güter und Waffen (STEUER 1999:49). Erst das neue Wirtschaftsgefüge der Karolinger auf Basis von Silbergeld brauchte auch neues Silber und es ist nach Auffassung von STEUER (:50) davon auszugehen, dass der Silberbergbau im 8./9. Jahrhundert wieder begonnen haben wird. Für den Kraichgau im Gebiet von Heidelberg bei Leimen beispielsweise ist neben römischem auch karolingerzeitlicher Bergbau im 9. Jahrhundert nachgewiesen. Spätestens seit ottonischer Zeit $(919$ - 1024) ist auch im Harz Bergbau auf Silber betrieben worden (WEISGERBER 1999:132). Der archäologische Nachweis karolingerzeitlichen Bergbaus ist hingegen für den südlichen Schwarzwald „noch nicht einwandfrei gelungen“ (STEUER 1999:50). Erst im ersten Drittel des 11. Jahrhunderts werden beispielsweise Kropach, Sulzburg und ebenso das Kloster St. Cyriak als Bergwerksorte genannt (STEUER 1999:50ff.; WEISGERBER 1999:132).

In weiten Teilen des deutschen Königreiches wurde erst im 12. Jahrhundert die bis dahin dominierende Naturalwirtschaft von der vordringenden Geldwirtschaft überflügelt. Es war der Bergbau, der das für die Geld- und Warenzirkulation unentbehrliche Münzmetall zu liefern hatte (CZAYA 1990:7). Die Gewinnung von silberhaltigen Erzen erhielt demnach seinen entscheidenden Stimulus aus dem Vordringen der Geldwirtschaft, die im 12. Jahrhundert die bisher vorherrschende Naturalwirtschaft überflügelte. Damit wuchs das Verlangen nach Münzmetall (:12).

Des Weiteren erhielten im 12. Jahrhundert die am nördlichen und südlichen Harzrand neu gegründeten Klöster bestimmte Regionen der damaligen „Harzer Bergwildnis“ vom Kaiser als Lehen, vor allem die vielen Täler des Südharzes und des Harzvorlandes (LIESSMANN 1997:14). Neben den Benediktinern vom Kloster Riechenberg bei Goslar (um 1125 gegründet) waren es vor allem die Zisterzienser vom Kloster Walkenried (1127 gegründet), die direkt am Bergbau beteiligt waren (:14).

Von den Mönchen ging auch ein wesentlicher Impuls bei der Erschließung des Harzinneren und der Aufnahme des Oberharzer Bergbaus aus. Um das Jahr 1200 herum entstand bei der später danach benannten Bergstadt Zellerfeld das Kloster Cella (monasterium in cellis) unweit des Zellerfelder Gangzuges. Damit begann die erste Bergbauperiode auf der unwirtlichen Hochfläche, während der es zumeist bei einer oberflächennahen Gewinnung der silberreichen Bleierze blieb (LIESSMANN 1997:14). Die auf den eigenen Zechen geförderten Erze wurden zur Verhüttung in Gebiete geschafft, 
wo der Orden die vom Kaiser verliehenen Nutzungsrechte besaß (:14), aber wo man auch in tieferen Tallagen über die nötigen Wasserkräfte verfügen konnte. Mit dem Rückgang der kaiserlichen Macht in Goslar erwuchs der Einfluss des Zisterzienser-Ordens auf das Montanwesen.

Zunächst konzentrierte sich also der Abbau auf die reichen Erze in der oberflächennahe Oxidationszone, aber die dort anzutreffenden Vorkommen erschöpften sich schnell. Man musste, um Silber zu gewinnen, zum Tiefbau übergehen und damit in den unverwitterten Bereich vordringen (CZAYA 1990:12). Dies war schon im 13. und 14. Jahrhundert der Fall. Und damit begann auch der Ausbau des komplexen montanen Wasserbewirtschaftungssystems, zu dessen wichtigen Bestandteilen der oberirdische anthropogene Wasserstau in Hohlformen zählt.

Wenn auch der Forschungsschwerpunkt zu den vorindustriellen Montanzentren beim Erzbergbau liegt (FESSNER 2000:103), so gilt diese Entwicklung gleichermaßen für den mittelalterlichen Steinkohlenbergbau.

Um 1200 bei Lüttich und im Aachener Raum ist der Beginn der Steinkohlengewinnung belegt und er entwickelte sich in der Folgezeit insbesondere bei Lüttich zu einem höchst bedeutsamen Gewerbezweig - ,wohl nicht weniger bedeutsam für die Entwicklung der mittelalterlichen Stadt Lüttich als der Erzbergbau für Goslar oder Freiberg in Sachsen." (BARTELS 2000:159) Auch hier wurde das Ausgraben von Steinkohle in kleinen Tagebau-Gruben betrieben, die man verließ, sobald sich Probleme mit dem Grundwasser ergaben (:159).

Gegen Ende des 13. Jahrhunderts wurde die Wasserhaltung zu einem Problem, dessen erfolgreiche Bewältigung auch hier im Zentrum der Entwicklung dieses Montanreviers stand. „Hinsichtlich der Grubenteufe und der Schwierigkeit der Aufgabe waren die dort zu überwindenden Probleme nicht geringer als im Erzbergbau.“ (BARTELS 2000:168) Die Steinkohle zu diesem Zeitpunkt: fand Verwendung v. a. als Heizmaterial ärmerer Bevölkerungsschichten, teils auch als Schmiedekohle.

Um sowohl im Erz- als auch im Steinkohlenbergbau den dadurch entstandenen Schwierigkeiten bei der Wasserhaltung zu begegnen, wurde damit begonnen, Stollen zur Grubenentwässerung zu bauen. Auch wurden erste Versuche mit Maschinen (Künste) zur Hebung von Grubenwasser angestellt (CZAYA 1990:12). Der wasserwirtschaftlich ausgerichtete Bergbau unter Einsatz von Mühlen- und Hebetechnik setzt zu diesem Zeitpunkt ein. Sammelteiche und Wassergräben lieferten fortan jahrhundertelang Aufschlagwasser für die Kunst- und Kehrräder, die wiederum die Energie für Fördermaßnahmen und Pumpen übertrugen (siehe Pkt. VII 4).

Die erste Blütezeit des Bergbaus dauerte etwa bis zum Jahre 1350. Sie wurde im Harz und anderswo zunächst unterbrochen, als kriegerische Auseinandersetzungen zwischen dem Staufer Friedrich I. Barbarossa und seinem Vetter, dem Welfen Heinrich d. Löwe zur Einstellung der Erzgewinnung führten. In dem seit 1176 bis 1181 folgenden Krieg wurde das Harzvorland ebenso wie weite Teile des südwestdeutschen Raumes verwüstet. Im Jahre 1180 zerstörte Heinrich die Goslarer Hüttenbetriebe, was nach der historischen Lehrmeinung die Eröffnung des Oberharzer Bergbaus zur Folge hatte, da die Hüttenleute in die sichereren Bergregionen abwanderten (KLAPPAUF 1996:96). Diese räumliche Verschiebung dürfte damit auch der Beginn der umfassenden Veränderung des Landschaftsbildes auf den Hochflächen des Oberharzes gewesen sein, mit seinen zahlreichen Wasserzuführungs- und -aufstauungssystemen, die auf der einen Seite durch Anzapfung weiter entfernt Quellgebiete hier zu einer Vertrocknung geführt hat und auf der anderen Seite durch Wasseransammlung auf vorher zumindest nur mooriger bzw. -anmooriger Fläche hier eine gesteuerte großflächige Verwässerung unter Trockenlegung der Feuchtflächen bewirkte.

$\mathrm{Ab} 1235$ unterstand der erneut aufgenommene Rammelsberger Bergbau den Herzögen von Braunschweig und die Ausbeute floss wieder reichlicher (LIESSMANN 1997:114). Der Oberharzer Bergbau aber dürfte weiterhin betrieben worden sein, denn die Ausbeute galt es auf höchstes Niveau zu fahren.

Mitte des 14. Jahrhunderts jedoch endete praktisch mit dem Einzug der Pestepidemie die mittelalterliche Betriebsperiode des Bergbaus (LIESSMANN 1997:116; SCHMIDT 1997:11). Es wird berichtet, 
dass 1347 - 1350 die Pest den Harz wie auch anderswo entvölkert und den Bergbau zum Stillstand gebracht habe (BARTELS 2000:39). Geschah es, dass durch ein exogenes Ereignis wie die Pest „eine Zeitlang den Grubenbetrieb stocken und die Baue voll Wasser laufen ließ, so konnte das einer Katastrophe gleichkommen: Wo es gerade noch gelungen war, die stetigen Wasserzuflüsse zu beherrschen, war es ein Ding der Unmöglichkeit, zusätzlich Hohlräume von oft vielen Kubikmetern Rauminhalt wieder vom Wasser zu befreien." (:40). Zudem leiteten Mitte des 14. Jahrhunderts neue kriegerische Auseinandersetzungen das Ende der mittelalterlichen Bergbauepoche ein (LIESSMANN 1997:116).

Aber die Pest war nicht der alleinige Grund einer 170jährigen Pause. Die Holzknappheit infolge der Überforderung des Waldes für Schachtausbau, Brennholz und zum Erzschmelzen tat ein Übriges (SCHMIDT 1997:11). Weiterhin hatten sich auch die Grubenverhältnisse nach 200jährigem Raubbau sehr ungünstig entwickelt: Nicht nur, dass ungenügende und vermorschte Pfeiler und Schweben das durch den Abbau instabile Gebirge nicht mehr zu stützen vermochten. Denn der Abbau in großen, hallenartigen Räumen, die in den Erzkörper getrieben und nach Auserzung nicht wieder zugesetzt wurden, führte immer wieder zu Einstürzen, zumal die Festigkeit des Berges durch seine zunehmende Durchörterung nachließ und Spalten und Klüfte entstanden (CZAYA 1990:12; KAUFHOLD 2000: 43). Vor allem kündigte sich aus weitaus schwerwiegenderen Gründen vom Ende des 13. Jahrhunderts an eine Krise des Bergbaus an, die bis gegen Ende des 14. Jahrhunderts anhielt: die Wassernot. In technischer Hinsicht wird diese Krise häufig mit Schwierigkeiten erklärt, die durch Wassereinbruch und bei der Wasserlösung auftraten (CZAYA 1990:12). Offensichtlich reichte das durch die Künste hochgepumpte Wasser auf Dauer nicht mehr aus, die nicht zuletzt durch die Zerklüftung des Berges zunehmenden Zuflüsse abzuleiten: Durch steigende Wasserzuflüsse ersoffen zahlreiche Baue, vor allem die tieferen regelrecht in den Stollen. Um sich ein Bild von dem Ausmaß dieser Entwicklung zu machen, muss man sich bewusst sein, dass das Aufgehen der Wasser stets auch die benachbarten Gruben, die keine eigenen Zeuge besaßen, in Mitleidenschaft zog, und oft einen ganzen Revierabschnitt außer Betrieb setzte. Erst so erfasst man die ganze Schwere und Tragweite solcher Ereignisse (BOGSCH 1966:95).

Die Schwierigkeiten der Wasserhebung im 14. Jahrhundert können aber auch im Klimawandel ihre Ursache haben. Hier wird die dramatische Klimaentwicklung mit einer Abkühlung und unerhört gesteigerten Regenfällen vor allem um 1320 angesprochen. STROMER (2000:151ff.) spricht in diesem Zusammenhang von einer „Klimakatastrophe“.

In den durch relativ raues Klima gekennzeichneten Mittelgebirgs- und alpinen Regionen bzw. dortigen Bergbaurevieren dürfte die ansteigende Temperatur zu Beginn des 14. Jahrhunderts, der Periode der „mittelalterlichen Warmzeit“ (ALHEIT/HAGEN 2000) - auf der Clausthaler Hochfläche beispielsweise herrschte eine im Vergleich zu heute um etwa $1,5^{\circ} \mathrm{C}$ höhere Durchschnittstemperatur, die durchaus Ackerbau zugelassen haben dürfte - besonders zu spüren gewesen sein (BARTELS 2000:167). Aber: In keinem der Reviere brachte offenkundig der ungeheure Regenfall unmittelbar den Bergbau zum Erliegen. Es mag aber sein, dass die doch „längerfristige Abkühlung die Situation dauerhaft verschlechterte und die technischen Probleme (und damit die Kosten) anwachsen ließ." $(: 166)$

In den folgenden 100 Jahren blieben alle Versuche, diese Talbaue zu entwässern, erfolglos (LIESSMANN 1997:117; KAUFHOLD 2000:43). So vergingen beispielsweise in Rammelsberg zwischen der Überflutung der tiefsten Baue um 1300 und ihrer erneuten Öffnung mehr als 280 Jahre (BARTELS 2000:40). Um 1360 scheint der Bergbau im Unterharz fast völlig geruht zu haben (KAUFHOLD 2000: 43). Aber schon ab den 1460er Jahren erfolgte die Wiederaufwältigung des Rammelsberges (:52).

Die zweite Blütezeit fiel etwa in die Periode von 1470 bis Mitte der zweiten Hälfte des 16. Jahrhunderts, die vor dem Hintergrund des allgemeinen wirtschaftlichen Aufschwungs und im Bergbau vor allem durch die Lösung des Schachtwasserproblems zu sehen ist. Ab 1455 gelang es durch den kostspieligen Einbau einer wasserkraftgetriebenen „Heinzenkunst“ die alten Baue wieder zu sümpfen. Nächster Schritt zur Verbesserung der Wasserbewältigung war die „Kunst mit dem krummen Zapfen“ die 1566, aus Meißen stammend, die alte Heinzenkunst im Bulgenschacht ersetzte 
und die endlich „die Sümpfung auch der tiefsten Baue ermöglichte.“ (LIESSMANN 1997:117) Die Methode ist jedoch erst anwendbar, wenn genügend Aufschlagwasser vorhanden ist, so dass zu diesem Zeitpunkt vermehrt Stauteiche errichtet worden sind bzw. bereits zu anderen Zwecken (Fischteiche, Mühlteiche) bestehende Teiche umgewidmet worden sein müssen.

Man erkannte bald ,wie wichtig es war, Wasser zu speichern, um auch in längeren Trockenperioden über genügend Betriebswasser verfügen zu können.“ (LIESSMANN 1997:190) Denn wegen der ungünstigen Hochlage der Bergstädte gab es in unmittelbarer Umgebung kaum nutzbare Wasser. Als Wasserreservoir für die Künste legte man deshalb beispielsweise 1561 den $25.000 \mathrm{~m}^{3}$ fassenden ,Herzberger Teich' im Tal der Abzucht oberhalb der Gruben an (:117).

In der zweiten Hälfte des 16. Jahrhunderts folgte ein Niedergang der Produktion aus makroökonomischen Gründen: Von dieser Zeit an strömte immer mehr Silber aus Mexiko und Peru nach Europa, wodurch die heimische Silberproduktion unter Druck geriet. Der Rückgang des Marienberger Erzbergbaus im Erzgebirge zum Ende des 16. Jahrhunderts aber erklärt sich nicht aus dem Rückgang des Silberwertes infolge der gesteigerten Edelmetalleinfuhr aus den spanischen Kolonien und „nicht aus dem Schmälerwerden des Erzes allein, sondern vermutlich ganz wesentlich aus der Einstellung der Menschen zum Bergbau.“ (BOGSCH 1966:84) „Den Menschen begann [...] die Baulust und der Unternehmungsgeist zu fehlen. Die Zeiten waren vorbei, wo unternehmungslustige junge Menschen von allen Seiten nach dem neuen Gebirge strömten, ihre ganze Arbeitskraft, ihr ganzes Kapital hier einzusetzen und zu wagen. Ein müder Zug geht durch alle Maßnahmen. Man war alt geworden. Alte Männer saßen im Bergamt [...], eine große Anzahl alter Männer leitete [...] die Geschicke der Gruben“(:85). Zudem: „Je stärker sich die Anzeigen mehrten, daß der reichste Segen, der mühelos gewonnen werden konnte, erschöpft war, desto mehr zogen sich die Spekulanten und Abenteurer aus der Unternehmung [...] zurück.“"(:85) Die sich daraus ergebende Verknappung des Kapitals bekamen auch andere Bergreviere zu spüren. Nicht nur die anderen sächsischen Reviere, sondern „der gesamte deutsche Bergbau liegt am Ende des Jahrhunderts darnieder“" (:87), für BOGSCH der Beweis dafür, dass es sich „nicht um eine örtliche, sondern eine allgemeine, ja eine Weltkrise handelte.“

Im Gegensatz zu dieser negativen Entwicklung im Silberbergbau erscheint der vorindustrielle Steinkohlenbergbau im Glanze. Viele Gewerbebereiche in der Grafschaft Mark zum Beispiel setzten bereits vom 16. Jahrhundert an sukzessive die Steinkohle als Brennstoff ein: die Alaun- und Vitriol ${ }^{33}$ siedereien, Salinebetriebe, Schmieden und Reckstahlhämmer, das Messing- und Drahtgewerbe, die Glashütten, die Kalk-, Ziegel-, Branntwein- und Essigbrennereien, die Brauereien und Zuckersiedereien sowie die Bleichereien (FESSNER 2000:107). Das Bleichgewerbe in der Grafschaft Mark und im Bergischen Land nahm ein nicht unbedeutendes Quantum an Steinkohlen zum Kochen der Garne ab (:107). Die Salinenbetriebe bei der westfälischen Stadt Unna stellten im Jahre 1600/01 den Siedebetrieb vom knapper werdenden Brennstoff Holz auf den reichlich vorhandenen Energieträger Steinkohle um, als die Salzproduktion auf der Basis des teueren Holzbrandes infolge des vermehrten Importes ausländischen Salzes unrentabel wurde (:107). Die Holzverknappung und die damit einher gehende Verteuerung des Holzes führten zum alternativen und zukunftsweisenden Energieträger Steinkohle bei den Unnaer Salinen (:107). Neueste Forschungsergebnisse zum Harzer und Mansfelder Montanbereich weisen aus, dass es bereits in der zweiten Hälfte des 16. Jahrhunderts auch im Hüttenwesen umfangreiche und auch erfolgreiche Versuche zur Substitution des knapper werdenden Brennstoffes Holz durch den Energieträger Steinkohle gegeben hat (:104). Des Weiteren nutzten Adelshäuser Steinkohlenriegel zur Beheizung der Wohnräume (:111).

\footnotetext{
${ }^{33}$ In der neuzeitlichen Chemie ist Vitriol eine veraltetete Bezeichnung für kristallwasserhaltige Sulfate (Schwefelsalze) der Metalle Kupfer, Eisen und Zink. Vitriolöl ist die früher aus Eisenvitriol hergestellte rauchende Schwefelsäure und wurde zum Färben benutzt. Die Bezeichnung Vitriol (lat. vitrum = Glas) soll schon Plinius als Bezeichnung für grünes, kristallines Eisensulfat verwendet haben, weil dieses eine entfernte Ähnlichkeit mit grünem Glas hat. In der Alchemie hingegen ist dieses ein Symbolwort für die Transmutation unedler in edle Metalle, besonders Blei in Gold. Hier steht Vitriol für ein Kunstwort, das aus den Anfangsbuchstaben eines alchemistischen Lehrsatzes gebildet wird, eine in geheimen Künsten gängige Art der Verschlüsselung unter Zusammenziehung der Anfangsbuchstaben des folgendes Satzes: „Visita Interiora Terrae Rectificando Invenies Occultum Lapidem (Veram Medicinam)“ („Suche das Innere der Erde auf, vervollkommene es, und du wirst finden den verborgenen (geheimen) Stein, die wahre Medizin“) (KRUMMENACHER 1994).
} 
Aufgrund dieser vermehrten Steinkohlengewinnung ist man schon im 16. Jahrhundert von dem Pingenbergbau abgekommen; es handelte sich bereits zu Zeiten der Renaissance nicht mehr nur „um eine einfache Kohlengräberei“ (BARTELS 2000:159). Als Folge dieser Expansion traten aber auch hier Wasserhaltungsprobleme auf, da man in die Tiefe hinabsteigen musste.

Da der Abbau von Steinkohle vom Produkt her betrachtet keine Konkurrenz zum Erzabbau ist, sondern vielmehr zum Holz und zur Wasserkraft als Energiespender, unter technischer Sicht hingegen ein Hauergewerbe darstellt, das nahezu die identischen Bergbaumethoden verwendet bei Einsatz von ähnlich ausgebildetem Personal. Veränderungen des Personalstocks mussten sich folglich in gleicher Weise ausgewirkt haben.

So forderte eine weitere Pestepidemie im Jahr 1625 in Andreasberg im Hochharz einige Hunderte Todesopfer und reduzierte die Einwohnerzahl auf etwa 1000 (LIESSMANN 1997:189). Daraufhin lag der Andreasberger Bergbau für 30 Jahre still (:189). Vor allem aber im Dreißigjährigen Krieg geriet das Montanwesen in einen trostlosen Zustand, „massenhaft wurden Gebäude, die ehemals dem Bergbau dienten, wie Huthäuser, Zechenhäuser, Pochwerke usw., zu landwirtschaftlicher Verwendung als Schuppen, Stall, Scheune oder auch als Wohnhaus verkauft oder vermietet.“ (BOGSCH 1966:96) Aber auch die alten Bergwerksteiche, die nach dem Eingehen der Zechen keinem funktionslos gewordenen Zeugen des früheren Bergbaus mehr Aufschlagwasser zu spenden hatten, entgingen ihrer eigentlichen Bestimmung. So verfiel im erzgebirgischen Marienberg beispielsweise der ,Rückerswalder Hauptteich' nach dem Dreißjährigen Krieg, nachdem ihn Kriegsvölker beschädigt und verwüstet hatten. Wenn auch die Zuführung zu den Teichen nur wenig gelitten hatte, so wurde sie aber von den ortsansässigen Müllern als Betriebswasser für Pochwerke und Wäschen, und den Fischteichwirten in Zeiten des Wassermangels zu ihren Zwecken abgedämmt und seitlich abgezogen. Nachdem auch die Zeuge stillstanden und verbrochen waren, ,hatte niemand Interesse an der viele Kosten verursachenden Wiederherstellung des Teiches. Auch beim Bergamt waren keine Mittel zur Reparatur des Teiches vorhanden." (:119). In anderen Fällen ging man sogar daran sie abzulassen und die Fläche landwirtschaftlich zu nutzen (:96f.). „Am Vorabend des Dreißigjährigen Krieges“, beschreibt BOGSCH (:96f.) die Situation, ,glich demnach das Marienberger Revier einem Trümmerfeld.“ Auch in der Mitte und zweiten Hälfte des 17. Jahrhunderts wurde die „Teichstatt [...] weiterhin wie bisher von den Großrückerswalder Bauern zur Hutung und Aussaat genutzt, wodurch der Teichgrund sicher nicht besser wurde.“ (:119) Das Wasser aus dem Rückerswalder Bergwerksteich wurde gar für die Stadtmühlen genutzt. Damit war aber der Tiefbau unmöglich, denn es fehlte das Aufschlagwasser für das Kunstgezeug in den Gruben, das zuvor in Bergbauteichen gespeichert war. Aufgrund der Weiternutzung der Bergbauteiche als Wasserreservoir in einigen Fällen, wenn auch für andere Zwecke, dürfte der Wegfall von Teichen in den Bergbaurevieren geringer ausgefallen sein. Auch eine zwischenzeitliche Brache mit Feldbestellung in Form einer Feld-Teich-Wechselwirtschaft dürfte einer Folgenutzung nicht geschadet haben, ebenso wenig wie ein Vertritt des Bodens durch Weidevieh mit den Folgen der Durchlüftung und der Düngung, entspricht sie sogar vielmehr in idealer Weise der Teichwirtschaftslehre (siehe Pkt. VII 4a). Eine dauerhafte Schädigung trat dann, wenn die Brache bzw. die Feldbestellung zu einem Umpflügen des Teichdammes und zu einer Beseitigung bzw. - wie im Marienberger Revier - Veränderung und Umnutzung der Teichanlagen geführt hat oder die Brache aufgrund ihrer Mehrjährigkeit ein Zuwachsen der Teichfläche zur Folge gehabt hätte.

Nach 1650 erholte sich der Bergbau nur sehr langsam. Jahrelang ruhte der Abbau, da die Hütten durch kriegerische Einwirkungen zerstört waren (LIESSMANN 1997:117). Der Bergbau brauchte „die ganze zweite Hälfte des 17. und den Anfang des 18. Jahrhunderts, um die Schäden des Dreißigjährigen Krieges einigermaßen zu überwinden." (CZAYA 1990:13). Es fehlte vor allem an Arbeitskräften. Negativ wirkte sich wiederum auch der akute Holzmangel auf die Montanwirtschaft aus (LIESSMANN 1997:117f.). Was für den Bergbau aus wirtschaftlichen Gründen und das Wasserbewirtschaftungssystem schlecht war, denn die bestehenden Teiche wurden nicht mehr gepflegt und drohten zu verlanden, kam, die sei an dieser Stelle angemerkt, den devastierten Waldbeständen zugute. Da das Nachwachsen der Holzbestände während der florierenden Bergbauperioden nicht mit dem Verbrauch an Holz Schritt halten konnte, konnte es erst nach einer längeren Ruhephase, wie sie in diesem Falle durch den Dreißigjährigen Krieg und seine Folgen im 17. Jahrhundert eintrat, wieder zu einer Erholung des Waldbestandes in den Abbaurevieren selbst, wie aber vor allem auch in den jeweiligen 
Bezugsländern bzw. -gebieten kommen. Hinzu kam aber auch die schon in der ersten Hälfte des 18 . Jahrhunderts einsetzende starke Verwendung der Steinkohle in Pottöfen, bei Bierbrauereien und Schnapsbrennereien; insbesondere in denjenigen Gegenden, die in unmittelbarer Nähe zu den Steinkohlenvorkommen lagen (FESSNER 2000:111).

Der Aufwärtstrend wurde durch den Siebenjährigen Krieg abgebrochen, der um 1760 Staat und Bergbau durch die sich rapide verschlechternde Finanzlage an den Rand des Ruins brachte (CZAYA 1990:13; LIESSMANN 1997:192). Neben der ständig zunehmenden Verschuldung der Gruben aber „behinderte zusätzlich der Mangel an Aufschlagwasser und das Fehlen von tieferen Stollen die Erschließung neuer Erzmittel“"(LIESSMANN 1997:184,189).

Die dritte Blütezeit erstreckte sich von der zweiten Hälfte des 18. Jahrhunderts bis ins zweite Drittel des 19. Jahrhunderts, wobei sich Mitte des 18. Jahrhunderts der Bergbau bereits weitgehend stabilisiert hatte. Doch als der nach dem Siebenjährigen Krieg wiederaufgenommene Bergbau in immer größere Tiefen vordrang, entwickelte sich die Versorgung der zahlreichen Kunst- und Kehrräder mit Aufschlagwasser zu einem vorrangigen Problem (LIESSMANN 1997:162). Zudem gestattete die unsystematische Abbauführung und die veralteten, seit dem 16. Jahrhundert unveränderten Förderund Wasserhaltungsmethoden keine Steigerung der Grubenproduktion (:118). In diesen Zeitraum, beginnend bereits um 1700, fällt parallel zum Bau neuer Stollen der Bau eines ausgreifenden Wasserversorgungssystems, das in den folgenden Jahrhunderten das Landschaftsbild vor allem des Harzer Intensivbergbaureviers massiv prägen sollte. Nachdem hier akuter Wassermangel in der Mitte des 17. Jahrhunderts und wiederholte katastrophale Trockenzeiten vor allem in den Jahren 1732 1734 eintraten, wurden mit einem langen Damm die weiter entfernt liegenden Gewässer und Quellläufe angezapft und der Bevorratung in Speicherbecken zugeleitet, wenn sie nicht als Aufschlagwasser zugeführt wurden (HAASE 1961:15).

Das 19. Jahrhundert mit den gewaltigen technischen und sozialökonomischen Umwälzungen der industriellen Revolution führte den Erzbergbau in Deutschland in eine tiefe Krise. Silber, Gold und Nichteisenmetalle kamen in zunehmenden Mengen aus Übersee ins Land, und zwar zu Preisen, mit denen die heimische Produktion immer weniger konkurrieren konnte, weil sich die ergiebigen Lagerstätten erschöpften und das noch vorhandene Erz nur mit steigenden Kosten zu gewinnen war. Die durch das Einströmen vor allem des amerikanischen Silbers ausgelöste Krise betraf die Lagerstätten in ganz Europa.

Zum Niedergang des Erzbergbaus aber hat eine Vielzahl weiterer Faktoren beigetragen. ALTMANN (1999:214f.) nennt für die erzgebirgischen Eisenhütten insgesamt 11 Faktoren: Von der unrentablen Produktion durch die Holzkohle fressenden Hochöfen über die falsche Zollpolitik Preußens sowie die alten landesherrlichen Verordnungen nach 1818 und unzureichende Erz- und Holzvorräte bis hin zu den Konkurrenzprodukten aus vor allem England und dem Einsatz der Steinkohle, die im Zuge der Industrialisierung zu einem der am meisten nachgefragten Produkte in der industriellen Entwicklung wurde (FESSNER 2000:103). Außerdem erwähnt er die nachteiligen Standortbedingungen in den engen Tallagen des Erzgebirges, die für Betriebserweiterungen hinderlich waren. Im Oberharz - wie auch in allen anderen Bergbaugebieten der Mittelgebirge - mögen es zudem die unzureichenden Verkehrsinfrastrukturverhältnisse gewesen sein, die die Erschließung der Tal- und Hochlagen erschwerten (LIESSMANN 1997:236). Zum Transport geeignete Gewässer, die über die Flößung von Holz hinausgingen, waren zudem mit Ausnahme einiger Flussläufe (Oker, Innerste) nicht oder nur in weiter Entfernung verfügbar (Leine, Saale). Wohingegen die Steinkohlenreviere über sie verfügten, wie das Beispiel der Grafschaft Mark mit der Ruhr, Lippe und weiterführend dem Rhein aufzuzeigen vermag (siehe VI 11b).

Für die Ausnutzung der Wasserkraft gab es ab der Mitte des 19. Jahrhunderts neben den Wasserrädern, die „an vielen Stellen den Jahrhundertwechsel überlebten“ (BALCK 1999:5), die bereits technisch vorteilhafteren Turbinen, die weniger Raum benötigten und mit höherem Gefälle arbeiten konnten (:5). Die Versorgung mittels Sammelteiche und -gräben blieb jedoch - wie bei den Wassermühlen auch bei dieser effektiveren Wasserkraftausnutzung noch für einige Zeit erhalten. 
Den Wegfall der Teichbewirtschaftung lässt sich nur durch einen Grund erklären: Seit dem letzten Viertel des 18. Jahrhunderts kam es auch im deutschen Bergbau zu einer nennenswerten Anwendung von Dampfmaschinen. Zur Aufstellung der ersten in Deutschland gebauten Dampfmaschine des Wattschen Prinzips kam es 1785 in einem Schacht bei Hettstedt im Mansfeldischen (CZAYA 1990: 45f.). In Freiberg wurden die ersten Dampfförderungsanlagen 1844 gebaut, weil die Wassermengen nun nicht mehr dem Energiebedarf genügten. Mit Hilfe der Dampfkraft ließen sich - gleichzeitig unabhängig von den Wasserverhältnissen - große Wasserpumpen antreiben, die die Gruben trockneten und Erze hoben. Aber auch in der Folgezeit - bis zum Niedergang des Bergbaus - „fiel den eingesetzten Dampfmaschinen im wesentlichen nur die Aufgabe zu, die vorhandenen Wasserräder zu ergänzen“ (:47). Ähnlich wie in der Mühlenwirtschaft hatte die Dampfmaschine zunächst nur substituierenden Charakter.

Denn während andere Regionen die Möglichkeiten der beginnenden Industrialisierung aufgrund der Transportwege der Eisenbahn schon früh nutzen konnten und teilweise aufgrund des geringen Wassergefälles auch mussten, kam diese wegen der Transportprobleme für die Kohle vergleichsweise spät in die hohen Mittelgebirge, wie den Oberharz: Erst 1878 erleichterte die Fertigstellung der Eisenbahnlinie nach Clausthal und Zellerfeld den Transport der Kohlen (BALCK 1999:113): „Im Oberharz war noch für lange Zeit die vorhandene Wasserkraftnutzung in den vielen kleineren Schachtanlagen der neuen Technik mit Kohle überlegen.“

Über mehrere Jahrhunderte wirkte die Wasserkraft, die durch Stauteiche unterstützend bereitgestellt bzw. auch aufgefangen wurden, für die Montanwirtschaft. Dann wurde sie zunächst von der Dampfkraft und später von der Elektrizität abgelöst (BALCK 1999:113). Doch ganz ausgedient hatte die anthropogen gestaltete Wasserstauung immer noch nicht. Nachdem die Anwendung elektrischer Kraft im Oberharzer Bergbau Eingang gefunden hatte, wurde auch das Wassersystem nach und nach für die Energiegewinnung genutzt. So war es nicht mehr nötig, die Wasser zur unmittelbaren Beaufschlagung der Wasserräder auf ein möglichst hohes Niveau zu bringen, sondern sie wurden zur Stromerzeugung auf mehrere Wasserkraftwerke geleitet, die sich zumeist unter Tage befanden. Hubkünste wurden erst seit 1909 abgebaut und durch Pumpstationen mit elektrisch angetriebenen Kreiselpumpen ersetzt. Dadurch aber waren die wasserzuführenden Teiche noch nicht überflüssig geworden. Im Verbund mit dem elektrischen Energienetz hatten die angeschlossenen Teiche als Pumpspeicherwerk zu dienen (NIETZEL 1983:25).

1910 kam der Bergbau in St. Andreasberg zum Erliegen, 1930 auch in Clausthal. 1913 musste die Produktion im Freiberger Revier eingestellt werden. Einzig das Erzbergwerk Grund bei Bad Grund im Harz, das seit 1930 allein die Oberharzer Gangerzlagerstätten noch abbaute, erreichte in seiner letzten Betriebsphase zwischen 1975 und 1985 sogar den Höhepunkt der Roherzförderung (BARTELS 2000:48). Heute ist der Bergbau stillgelegt, keine der drei Antriebsarten ist mehr in Betrieb (CZAYA 1990:223; BALCK 1999:4).

Zerstörungen durch Kriegseinflüsse, verheerende Seuchen, Holzmangel, die Bewegungen der Preise für Metalle, die die Rentabilität der Mühlen und der Gruben beeinflussten, und alternative Energieformen heißen zusammengefasst die Einbruchfaktoren des historischen Bergbaus. Der Bergbau entwickelte sich deshalb nicht kontinuierlich, mit gleicher Intensität. Abschnitte lebhafter Schürftätigkeit und reicher Silberausbringung wechselten mehrfach mit Stagnation, Niedergang und Verfall ab. Vor allem durchlebten alle Reviere, die im Mittelalter bestanden, unabhängig vom Abbauprodukt, ähnliche Schwierigkeiten, als der Vorstoß in größere Tiefen erforderlich wurde. Hier setzt die Bedeutung der Wasserkraft ein, die in der historischen Darstellung des Bergbaus nicht entsprechend herausgestellt wird. Trockenjahre, die die Energieversorgung lähmten, trugen ebenso zum Niedergang bzw. Stillstand bei wie Wasserüberschusszeiten. Denn trat ein Mangel an Wasser ein oder fehlte das Wasser, so ließ sich der Schacht mittels der durch Wasserkraft betriebenen Künste nicht entsumpfen. Bei trockenen Zeiten waren die Ströme der kleinen Bäche ziemlich schwach und auf diese Art noch lange nicht ausreichend, den Betrieb der Bergwerke zu erhalten. Bei Hochwasserereignissen andererseits durfte das Wasser nicht in den Bergschacht eindringen. 
Die Lösung der sich jahreszeitlich und bergbaulich veränderbaren Wasserverhältnisse führte zu den umfangreichen Teich- und Wasserkunstbauten, die schließlich zu einer vom Bergmann gestalteten Teichlandschaft in den Bergbaurevieren geführt hat. So wie heute kein Gewerbegebiet ohne eine ausreichende Energieversorgung existieren kann, so wenig konnte ein Bergbaugebiet vor einigen Jahrhunderten ohne „die einzige großmaßstäbliche Energieversorgung der Zeit, die Wasserkraft“ auskommen (SCHMIDT 1997:7). Es waren neben den Gräben und Wasserläufen die Teiche, die zur Bereitstellung von Betriebswasser errichtet wurden.

Doch nicht alle Teiche der Bergbaureviere wie die des Harzes sind ursprünglich bergmännischer Natur. Man denke nur an die Flößerteiche und an die zahlreichen Fischteiche. So hatte beispielsweise die Teiche bei der Heinrichsmühle am westlichen Teil des ,Unteren Eschenbacher Teiches' bei Clausthal-Zellerfeld das Kloster Cella zur Fischversorgung angelegt. Auch die benachbarten ,Pfauenteiche' gehen auf diesen Einfluss und der Fischzucht in Teichen zurück. Erst später wurden sie als Speicherteiche der wasserwirtschaftlichen Bergbauanlage ausgenutzt und in das Wasserbewirtschaftungssystem integriert (SCHMIDT 1997: Abb. 11 und 13; BALCK 1999:17).

Eine ähnliche Entwicklung haben als Mühlenteiche dienende Anlagen durchlebt. Der ,Untere Hahnebalzer Teich“ beispielsweise, zu dem damaligen Zeitpunkt „Mühlenteich“ genannt, trieb eine Mühle an, die nach einer Belehnungsurkunde schon 1581 vorhanden gewesen ist und das Recht besaß, Wasser von der Innerste durch einen Graben abzuleiten; jedoch nur soviel, dass das Bergwerk nicht beeinträchtigt wurde (HAASE 1961:7,50). Es gibt darüber hinaus, wie HAASE herausgefunden hat, „,noch manchen kleinen Teich im Bereich der Bergstädte“, der als Fisch- und Mühlenteich in den Urkunden erwähnt ist. Nur wenige aber ,sind dem Namen nach bekanntgeworden, bevor sie wieder eingeebnet sind. " (:52)

Des Weiteren entstanden ,in fast allen Harzer Tälern sowie an den Flußläufen des Harzvorlandes [...] seit Beginn der Neuzeit zahlreiche kleine und mittelgroße Eisenhütten“ (LIESSMANN 1997:108).

Oberhalb dieser wasserbetriebenen Hütten wurden Stauteiche errichtet, die Aufschlagwasser für das Wasserrad zum Antrieb der Hämmer bereithielten und so zu einer weiteren „Verteichung“ der Bergbaulandschaften beitrugen.

Die Teiche dienten demnach - zumindest in den Anfängen des Bergbaus - nicht der Erzgewinnung allein, sondern zuvor dem Mühlenwesen oder/und der Fischzucht und später in parallelem Betrieb sowohl dem Mühlenantrieb als auch dem Bergbau, bis dann der Bergbau im Wesentlichen allein die Bedürfnisse der Wasseransammlung bestimmte und für den wesentlichen Ausbau der bestehenden Teichanlagen wie auch für die Vergrößerung der Anzahl sorgte. Zugleich wurde in den Bergbauteichen intensive Fischnutzung betrieben, wobei aber Einschränkungen zum Beispiel beim Abfischen hinzunehmen waren; dahingehend dass ein Ablassen der Teiche, wie sonst allgemein in der Teichwirtschaft üblich, hier entweder unterbleiben musste und insofern mühsam und zeitaufwendiger mit Netz abgefischt werden musste, oder aber aufgrund von Wassermangel der Spiegel der Teiche so großen Schwankungen ausgesetzt war, dass die Fische aufs Trockene gesetzt wurden.Die Bergwerksteiche wurden „nur so weit zur Fischzucht benutzt, als sie vollständig abgelassen werden können und als ihre Zuflüsse hinreichende Nahrung für die Flüsse besitzen." (BORNE 1883:42) Sogar Karpfenzucht wurde ab dem zweiten Drittel des 19. Jahrhunderts in den kalten Bergwerksteichen betrieben. Bis in die 1870er Jahre hingegen war es nicht gelungen, in den Oberharzer Bergwerksteichen Karpfenstrich zu erzielen. Abfallende Ufer, Entfernung ,alles Gesträuch und alles Schilf“, zu niedrige Wassertemperaturen verhinderten dies zunächst. Anfang der 1870er Jahre hat man den „Wasserläuferteich" bei Clausthal, 154 Ar groß zum Streichteich eingerichtet, die Ufern mit Schilf bepflanzt, mit einigen Laichkarpfen und -schleien besetzt und Karpfenstrich geerntet. Dies war jedoch nur möglich, weil der Teich für den Bergbaubetrieb nur geringe Wichtigkeit besaß und in kalten Jahren wurde auch gar kein Strich erzielt (:39). Deshalb war die Karpfenzüchterei auf dem Oberharz zum größten Teil auf den Ankauf von Karpfenstrich aus den am nördlichen Harzvorland liegenden Teichen angewiesen (:39). Die Bedingungen zumindest für den Karpfenzuchtbetrieb waren also sehr rauhe. Als Streck- und Abwachsteiche hingegen wurden einige Oberharzer Teiche erfolgreich eingesetzt. In sieben Teichen der Bockswiese beispielsweise wurden Karpfen, Schleie und Hechte gezüchtet (:39ff.). 
Aber auch für die Forellen war der Oberharzes ein nicht unbedingt freundliches Revier: „Im Winter bilden sich in vielen Bächen des Harzes große Eismassen, die im Frühjahr starken Eisgang herbeiführen und vielen Fischen und Fischbrut den Tod bringen.“, wie BORNE (1883:36f.) berichtet. Die wasserbetriebenen Bergwerkstriebwerke schädigen die Fischerei zudem dadurch, ,daß bei niedrigem Stande alles Wasser in den Zuleitungsgraben geführt und dadurch eine Strecke des Bachbettes trocken gelegt wird.“ (:37), obschon sich hier schon weit vor den Karpfenversuchen zwischen Clausthal und St. Andreasberg eine Brutanstalt befunden hat und zahlreiche Teiche als Forellenteiche genutzt worden sind (:41).

Die Teiche der bergbaulichen Wasserwirtschaft sind auch nach Ende des Bergbaues nachgenutzt worden. Anfangs geschah dies weiterhin zur Elektrizitätserzeugung und heute noch für die zentrale Trinkwasserversorgung (SCHMIDT 1997:197). Die Beispiele zeigen, ,wie sich von der älteren Bergund Hüttenzeit her, über die Fisch- und Mühlenteiche, schließlich bis zur späteren bergbaulichen Wasserwirtschaft und der heutigen Wasserkraftnutzung hin, ein einziger langer Faden spinnt!“ (HAASE 1961:12).

\section{b Historisch-geographische Verbreitung}

Der Bergbau war lange Zeit auf die nahe erreichbaren Wasser angewiesen. Ganze Landstriche in ihrer Umgebung wandelten durch die Wasserabhängigkeit ihr Gesicht. Sie wurden sowohl zu Mondlandschaften, geprägt von Grubenbetrieben mit ihren Kauen und Scheidebänken, von hohen Göpelwerken und Halden, von rauchspeienden Schmelzhütten, schwelenden Röstplätzen und schlammigen Waschwerken, als auch zu großen künstlich angelegten Teichlandschaften, die das kostbare Betriebswasser für die Wasserräder und Waschwerke sammelten (STUHLING 1996:88).

Mit zunehmendem Bergbau, im Laufe der Zeit waren die Wasserräder schneller und mächtiger, die Zahl der zu Sätzen verbundenen Pumpen umfangreicher und damit auch der Bedarf an Aufschlagwassern größer, begann die Ausdehnung dieses Wasserhaltungssystems, eine Ausdehnung, die in der ganzen Bergbauzeit nicht aufhörte, gleich welchen Veränderungen sie unterworfen waren.

Insbesondere die Mittelgebirgsregionen, ,wiesen im Mittelalter und in der frühen Neuzeit intensive Montantätigkeit auf" (BARTELS 2000:32). Die ältesten schriftlichen Zeugnisse über mittelalterlichen Bergbau in Deutschland aber liegen für den Harz vor (:36), der deshalb hier auch einen so weiten Raum in der Darstellung einnimmt. Die Tal- oder Muldenlage in den Mittelgebirgsrevieren mit ihren Hochplateaus war zur Anlegung eines Teiches zweckmäßig, die Zuleitung von Spannwasser notwendig und die Höhelage eines Teichdammes wünschenswert. In den Revieren ,waren derartige Teiche ein Lebensnerv des Bergbaus.“ (CZAYA 1990:36).

Aber auch in den Tieflandsebenen fand sich an einigen Standorten der Bergbau ein.

\section{b.1 Tiefland}

„Ausgedehnte Raseneisenerzlagerstätten finden sich in weiten Teilen des norddeutschen Flachlandes [...], vor allem in den flachmoorigen Niederungsgebieten innerhalb der Sander- und Talsandflächen im Nahbereich der Weichselvereisung sowie in feuchten Niederungen von Bächen und Auen" (HAUKE 1966:58).

In Schleswig-Holstein konzentrieren sich die Erzlagerstätten im Bereich des schleswig-holsteinischen Mittelrückens, einem Landstrich, der durch relativ flache Altmoränenkuppen und Sanderflächen geprägt ist und sich von Flensburg bis Hamburg erstreckt (HAUKE 1966:58).

Das Erz war sehr leicht zugänglich, um es abbauen zu können, musste lediglich die darüber liegende Ackerschicht entfernt werden (HAUKE 1966:58). „In der Regel tritt das Erz hier in Mächtigkeit von 20 bis $40 \mathrm{~cm}$ und konzentriert in Linsen mit einem Durchmesser von 3 bis $10 \mathrm{~m}$ auf.“ (:58) Diese 
Erzlagerstätten bildeten die Grundlage für die vor- und frühgeschichtliche Eisenproduktion, die vor allem während der römischen Kaiserzeit, schwerpunktmäßig im jüngeren Abschnitt dieser Epoche und auch in geringerem Umfang während der Wikingerzeit und dem Mittelalter stattfand (:58). Auch in den benachbarten Regionen Mecklenburg-Vorpommern und Niedersachsens zeichnet sich eine deutliche Produktionssteigerung im 4. und 5. Jahrhundert n. Chr. ab (:58).

Leicht zu gewinnende Raseneisenerze oder Bohnerze aber sind in fast allen Landschaften vorhanden und durch alle Jahrhunderte kontinuierlich ausgebeutet worden; eine besondere Teichbewirtschaftung, die das Wasser als Aufschlagkraft zur Hebung von Erzen und Wasser aus der Tiefe bewerkstelligt, war so jedoch nicht notwendig. Erst die Gewinnung von Gangerzen über regulären Bergbau im Tage- oder Untertagebau setzte besondere Kenntnisse des montanen Wasserbewirtschaftungssystems voraus (STEUER 1999:49).

Der Steinkohlenbergbau war schon vor Beginn der Industrialisierung ein bedeutsamer Wirtschaftszweig und die Steinkohle ein gefragtes regionales und überregionales Wirtschaftsgut. Das gut dokumentierte Gebiet des niedersächsischen Steinkohlenbergbaus (NEUBER 2002) erstreckt sich mit seinen Steinkohlenrevieren im niedersächsischen Weser- und Leinebergland (Bückeberg, Rehburger Berge, Deister, Süntel, Nesselberg, Osterwald und Hils) und im Osnabrücker Hügelland (Piesberg, Bohmte und Lintorf) sowie im nördlichen Teutoburger Wald. Handelt es sich hierbei offenkundig um Kohlenvorkommen des Mittelgebirges, so streichen seine Kohlenabbaufelder in das norddeutsche Tiefland hinein, wie zum Beispiel in das Schaumburger Land und das Wiehengebirgsvorland um Sundern und Levern (RÖMHILD 1988:281).

Der Bau von umfangreichen Anlagen der Wasserhaltung kann aber im niedersächsischen Steinkohlenbergbau nicht festgestellt werden. Bis zum 19. Jahrhundert erfolgte die Förderung der Grubenwässer „praktisch ausschließlich in durch Stollen entwässerten Revieren [...], aus denen das Grubenwasser selbständig abfloß“ (NEUBER 2002:32), obschon auch hier chronische Wasserhaltungsprobleme auftraten (:44). Zudem wurde die Kohle bis dahin in oberflächennahen kleinen und zumeist geringmächtigen Stollenrevieren „mit oftmals kaum einem Dutzend Berglauten“ (:33) abgebaut. Bei zunehmender Abbautiefe und größeren Wasserzuflüssen trat bereits in vorindustrieller Zeit die Mechanisierung des Bergbaus ein (:30). So spielten in den niedersächsischen Revieren seit Mitte des 19. Jahrhunderts Dampfmaschinen bei den oberirdischen Förderanlagen, der Wasserhaltung und der Bewetterung eine zunehmende Rolle. Mit Dampfpumpen wurde hier das Wasser abgepumpt (:30f.)

Im Verlauf des 19. Jahrhunderts vollzog sich zwar in nahezu allen niedersächsischen Revieren eine wichtige Veränderung des Abbaubetriebes dahingehend, dass teils die Erschöpfung der über Entwässerungsstollen erreichbaren Kohlenfelder, teils aber auch die mit größerer Tiefe zunehmende Kohlenqualität ein Umsteigen auf den Tiefbau erforderte (NEUBER 2002:32). So wurden die unter der tiefsten Stollensohle gelegenen Gruben mit starken Pumpen vor dem - wie es in der Bergmannssprache heißt - „Absaufen“, d. h. dem Volllaufen des Schachts mit Wasser, bewahrt. Obschon zu diesem Zweck seit 1835 auf dem Schaumburger Kunstschacht I eine Wassersäulenmaschine mit Wasserkraft betrieben wurde, musste aus Mangel an Aufschlagwasser eine Dampfmaschine zu Hilfe genommen werden. „letzlich“, schreibt NEUBER (:32) für den niedersächsischen Steinkohlenbergbau, „waren daher Dampfmaschinen unabdingbar.“

Eine ähnliche Abbausituation lässt sich auch für das Abbaugebiet der Schaumburger Mulde konstatieren, wenn auch hier ungleich schwierigere Abbaubedingungen herrschten: „Lag das Flöz in den Bückebergen oft nur $10 \mathrm{~m}$ unter der Erdoberfläche, tauchte es unter der Schaumburger Mulde bis in einige hundert Meter ab"(NEUBER 2002:46). Wie es scheint, beschränkt sich der Schaumburger Steinkohlenbergbau mit seiner ersten Blüte nach 1600 aber auf die Bergländer, wie beispielsweise den Bückeberg. Die Förderung der Kohle erfolgte hier zunächst in durch Stollen entwässerten Revieren am Hang der Bückberge über eine Vielzahl zugleich den Gruben dienender Schächte. Seit 1835 wurde der Tiefbau bereits maschinell entwässert (:46f.). Von Bergwerksteichen wie beispielsweise im Oberharz ist hier nicht die Rede. Die Entwässerung der Stollenreviere muss auch in vormaschineller Zeit allein durch Stollen erfolgt sein. Ein weiterer Ausbau der Wasserkraftnutzung im Tiefbau - über die 
Leistungsfähigkeit der dampfbetriebenen Wassersäulenmaschinen hinaus - war aufgrund der naturräumlichen Ausstattung halt nicht möglich (:99).

\section{b.2 Mittelgebirge}

Oberharzgeschichte ${ }^{34}$ ist Bergbaugeschichte ist Wassergeschichte. Weil neben den reichen Silber-, Blei- und Zinkvorkommen auf dem Oberharz die Voraussetzungen für die Wasserkraft als Energielieferant ,außerordentlich günstig“ (SCHMIDT 1997:7) waren, insbesondere die Hochlagen des Oberharzes sind ein sehr niederschlagsreiches Gebiet mit - im Bereich des Brocken - Niederschlagsmengen von $1600 \mathrm{~mm} / \mathrm{Jahr}$, und die Möglichkeit bestand, durch Wasser Wasser zu heben, hat sich hier seit dem Mittelalter und insbesondere im 17. und 18. Jahrhundert eines der großen Industriegebiete der frühen Neuzeit in Europa entwickeln können. Hier entwickelte sich „die erste geschlossene Industrielandschaft Deutschlands.“ (LIESSMANN 1997:Vorwort)

Nach dem Niedergang durch den Dreißigjährigen Krieg avancierte speziell das Oberharzer Revier in der Barockzeit zum „größten Silberproduzenten Europas.“ (LIESSMANN 1997:Vorwort) Die Größe des Energiebedarfs erzwang eine weiträumige Erschließung, Heranführung und Speicherung von Wasser aus der Ferne. Es entwickelte sich hier daraufhin eine ganz besondere, eng mit dem Bergbau und seiner Technik verknüpfte Wasserbaukultur, die vielleicht einzigartig war und bis heute geblieben ist: „Das Außergewöhnliche und Herausragende auf dem Oberharz“ sind die für den Gangerzbau entstandenen umfangreichen Teichanlagen, die über Jahrhunderte Wasser erfolgreich speicherten und ableiteten. „Dieses sucht weltweit seinesgleichen.“ (SCHMIDT 1997:7)

Um 1600 gab es im Oberharz Wasserspeicher für die Montanbetriebe mit zusammen rd. 0,65 Mio. $\mathrm{m}^{3}$ Kapazität. Insbesondere zwischen 1640 und 1740 glich der Oberharzer Raum „einer gigantischen Baustelle, in der auf rd. $100 \mathrm{~km}^{2}$ Teiche bis kleine Stauseen angelegt und Verbindungsgräben durch die Landschaft gezogen wurden.“ (BARTELS 2000:45) 1632/33 fanden die ersten Pulversprengungen im Harz statt, „,und dies leitete eine explosive Entwicklung des Wasserbaus“ (:47) ein, da der Bedarf an Wasserrädern für die Pumpen und Fördermaschinen nun exponentiell anwuchs: 1640 waren es 1,15 Mio. $\mathrm{m}^{3}$ (LIESSMANN 1997:162) und ,zwischen 1640 und 1660 entstanden drei neue Stauteiche mit 0,8 Mio. $\mathrm{m}^{3}$ Volumen, 1660 bis 1680 nicht weniger als 25 Teiche mit 3,15 Mio. $\mathrm{m}^{3}$ Speicherkapazität. [...] 25 Stauteiche versorgten die Wasserräder, von denen 25 Fördermaschinen antrieben und 40 bis 50 die Pumpen in den Gruben, so daß für den Bergwerksbetrieb um die 70 Räder eingesetzt waren. Die Aufbereitungsanlagen und Hütten, Hammerwerke, Bohrmühlen und Sägegatter sind dabei noch unberücksichtigt, sie waren gut mit der gleichen Zahl, allerdings meist kleinerer Räder, ins System eingebunden.“ (BARTELS 2000:47) Das Gebiet der Wassersammlung wurde bald weit über den Rahmen des eigentlichen Bergbaureviers hinaus ausgedehnt. Um 1760 war ein Stand erreicht, bei dem alle mobilisierbaren Wasserreserven angezapft und so weit wie möglich zum Bergbaugebiet umgeleitet waren. Bis zum Ende des 18. Jahrhunderts umfasste die Anlage mehr als 120 Teiche (LIESSMANN 1997:162) mit einer Gesamtfläche von 260 ha und 10 Mio. $\mathrm{cm}^{3}$ Fassungsvermögen (CZAYA 1990:37). Ein sehr großer Teil davon, ob nun 62 (NATTERMANN 1922), 65 (LIESSMANN 1997:162), 67 (TRUNZ 2000:VI) oder 68 (CZAYA 1990:37) Teiche, sind heute noch vorhanden und funktionstüchtig. Sämtliche zwischen 1536 und 1866 angelegten Speicherbauten bilden heute ein Teil des „Kulturdenkmals Oberharzer Wasserregal“ und sie alle stehen unter Denkmalschutz (SCHMIDT 1997:12,17).

In den historischen Tabellen von DUMREICHER (1866/68) (siehe Tab. A-3 im Anhang) sind alle Teiche aufgeführt: In einer Spalte sind die Namen der Teiche, aus denen die Aufschlaggräben ihr Wasser erhalten, bezeichnet, in weiteren Spalten Flächengröße und Flächeninhalt, d. h. zum Fassungsvermögen der Teiche, dessen ursprüngliche Maßeinheiten in Hektar und Kubikmeter umgerechnet wurden. Am wichtigsten war damals die Angabe, wie viele Tage ein Wasserrad bei vollkommener Trockenheit mit diesem Wasservorrat arbeiten kann, ein 8 h-Tag vorausgesetzt.

\footnotetext{
${ }^{34}$ Das herkömmliche Gliederungsprinzip der Harzlandschaften ist die Unterscheidung nach unterschiedlichen Höhenlagen in Hoch-, Ober-, Mittel- und Unter- und Südharz. Daneben gibt es die Unterscheidung nach den Flussgebieten.
} 
Darüber hinaus gehörten zum System der Oberharzer Wasserwirtschaft rund $500 \mathrm{~km}$ bekannte Gräben (LIESSMANN 1997:162), über $100 \mathrm{~km}$ Wasserlösungsstollen (TRUNZ 2000:VI) und $30 \mathrm{~km}$ Wasserläufe (LIESSMANN 1997:162), von denen rund $70 \mathrm{~km}$ Gräben sowie $20 \mathrm{~km}$ Wasserläufe im Rahmen des Denkmalschutzes als Teil des „Kulturdenkmals Oberharzer Wasserregal“ weiterhin von der Harzwasserwerke GmbH aktiv genutzt und unterhalten werden (TRUNZ 2000:VI).

Bei der Oberharzer Teichlandschaft handelt es sich dabei um eine kleinteilige in langen Zeiträumen mühsam zusammengewachsene Gewässerstruktur. Die Teiche „entstanden ursprünglich ohne übergreifendes Konzept". Über viele Generationen optimierte man das System mit hohem Aufwand und nur schwerfällig (BALCK 1999:114). Aber nur im Zusammenhang betrachtet, wird der Umfang des gespeicherten Wassers sichtbar. Das Ensemble von Teichen ist es, die den Oberharzer Bergbau so einzigartig macht. Deshalb ist der Oberharz neben dem Erzgebirge nicht nur „eine der wohl vielgestaltigsten und eindrucksvollsten historischen Bergbaulandschaften Mitteleuropas“ (LIESSMANN 1997:Vorwort), sondern auch eine der größten Teichlandschaften und daher ein sehr lohnendes Ziel für gewässerhistorische Montanexkursionen.

Im Zellerfelder Revier entstanden im Einzugsgebiet der hier entspringenden Gewässer (Grumbach, Spiegelbach und Schalkbach) zahlreiche Stauteiche: beispielsweise der ,Obere Zechenteich', der ,Mittlere Zechenteich', der, Wasserläufer Teich' und der, Carler Teich', die das Aufschlagwasser zum Antrieb der Fördermaschinen lieferten (LIESSMANN 1997:162; BALCK 1999:39).

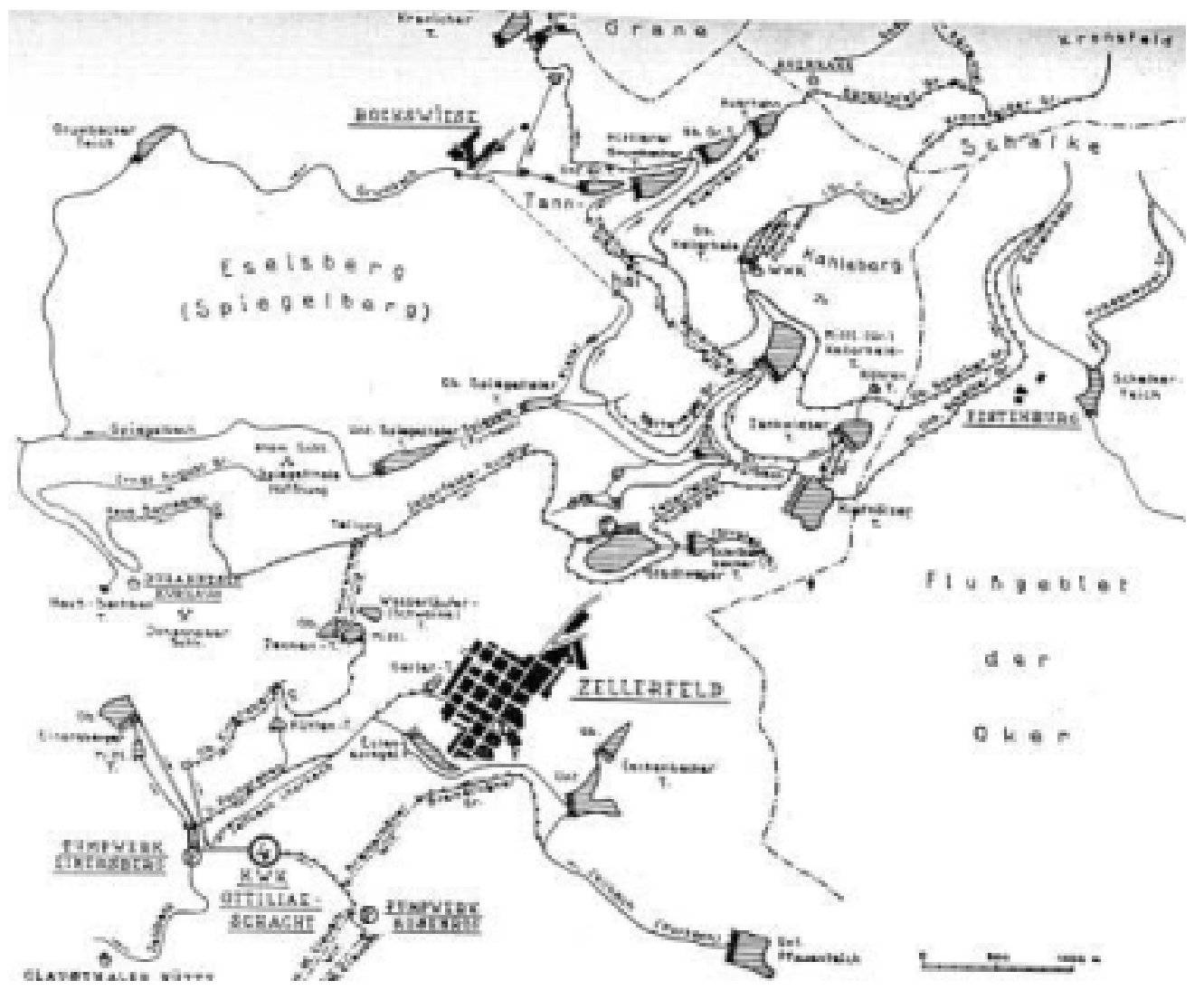

Abb. VIII-44: Teiche auf dem Zellerfelder Bergbaurevier (aus: HAASE 1961:39).

Im benachbarten Clausthaler Bergbaurevier entwickelte sich ein eigenes Wasserversorgungssystem (LIESSMANN 1997:162). Durch den Einschnitt des Zellbachtales ist die Hochharzfläche geteilt. Das ist wasserwirtschaftlich insofern von Bedeutung, als dass der südliche Teil um Clausthal (Buntenbock) und der nördliche Teil um Zellerfeld jeder für sich ein eigenes Sammel- und Versorgungsgebiet bildeten (HAASE 1961:25). 


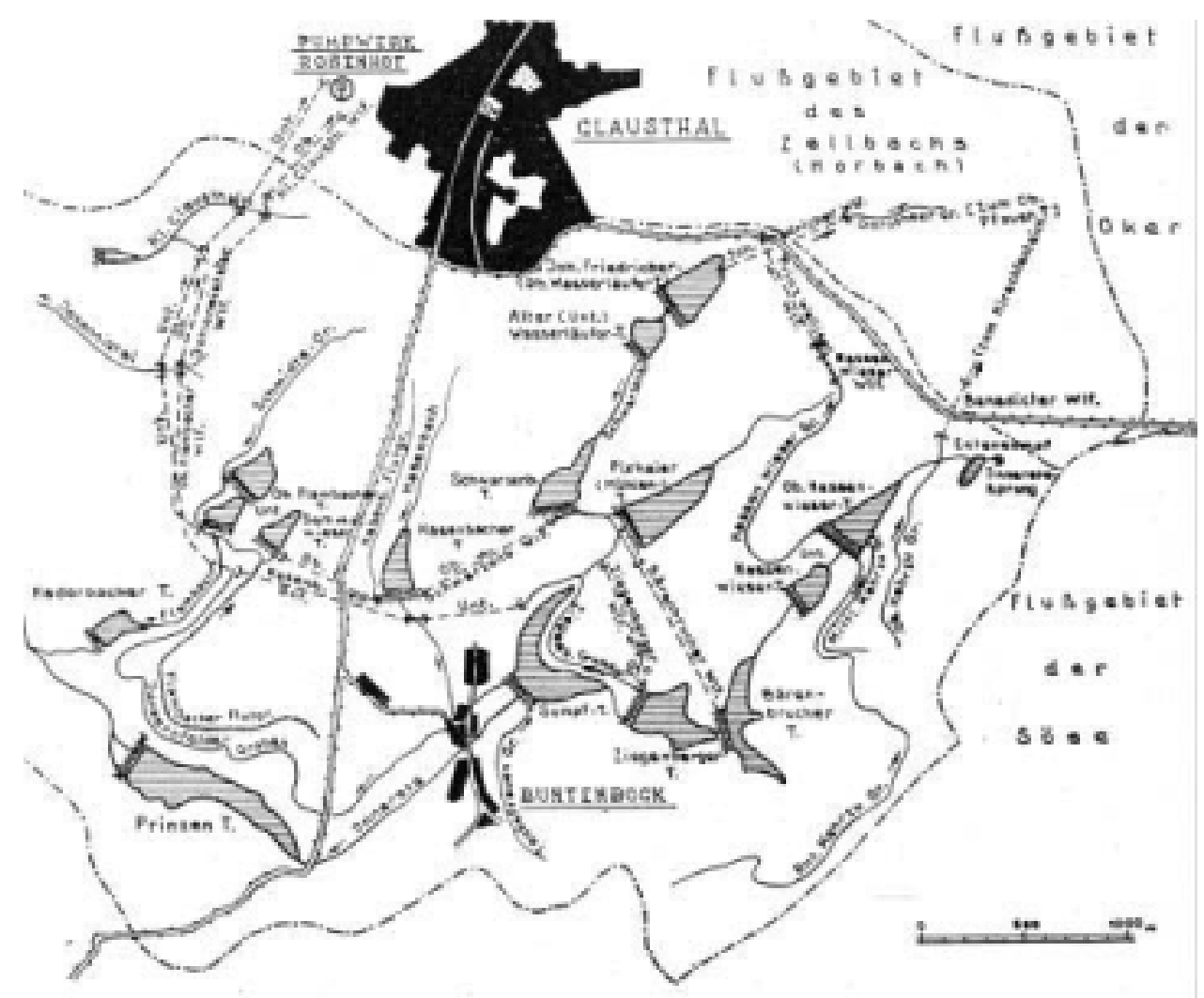

Abb. VIII-45: „Wiesenteiche“ auf der Buntenbocker Höhenfläche südlich Clausthal (aus: HAASE 1961:8)

Für die Wasserversorgung der abbaureichen, aber wasserarmen Gruben des Rosenhöfer Reviers, die kein großes eigenes Wassereinzugsgebiet hatte, orientierte man sich nach Süden, ins Quellgebiet der Innerste', die nördlich von Buntenbock entspringt. Im landwirtschaftlich genutzten Gelände rund um das Dorf entstanden 13 sog. Wiesenteiche, die ,in den Tälern der Innerste und ihrer kleineren Seitenbäche eingesenkt" lagen (HAASE 1961:49), und führte deren Wasser über lange Grabenstrecken und Wasserläufe nach Clausthal zu den Gefällen der Rosenhöfer Gruben (NIETZEL 1983:35; LIESSMANN 1997:162f.).

Die Wiesenteiche von Buntenbock haben die alten Quellen und den obersten Wasserlauf der Innerste vollständig überformt. Gleiches geschah mit den Seitentälern. Die ursprünglich flache und sumpfige Quellmulde des Horbachs (hôr = Sumpf) zum Beispiel ist heute durch den ,Hirschler Teich' und die ,Pfauenteiche' verhüllt (HAASE 1961:28f.,40). 


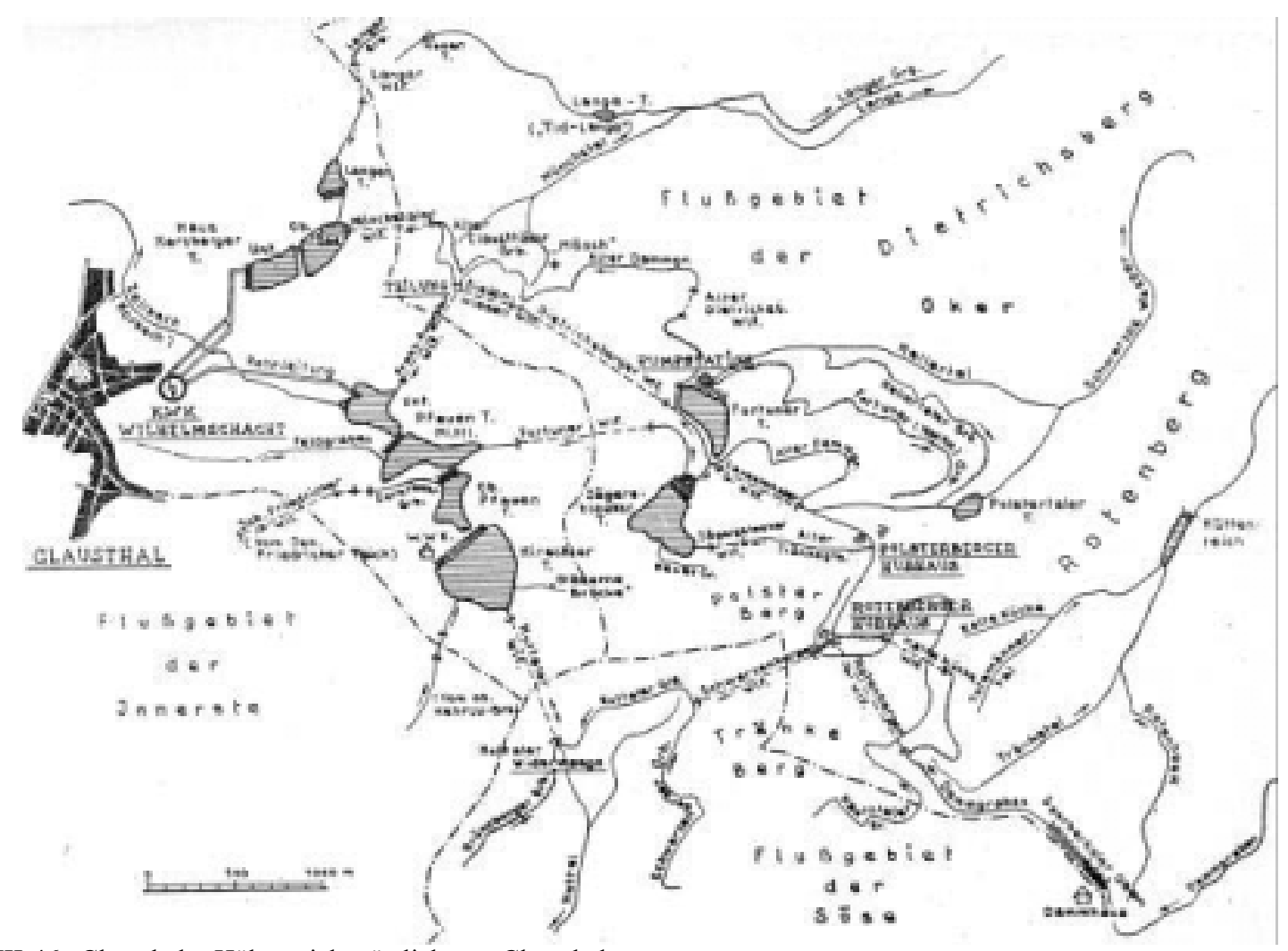

Abb. VIII-46: Clausthaler Höhenteiche, östlich von Clausthal

Der „Hirschler Teich“ befindet sich in der Bildmitte (aus: HAASE 1961:27)

Der ,Hirschler Teich' gilt als der größte der Oberharzer Teiche (HAASE 1961:28f.). Von ihm wurde das 1726 errichtete Caroliner Kunstrad beaufschlagt. Zur Verbesserung der Wasserversorgung wurde der Damm des Hirschler Teichs insgesamt 3mal erhöht, seit 1765 beträgt sein Fassungsvermögen ca. 699.000 $\mathrm{m}^{3}$ (LIESSMANN 1997:165).

Vom ,Hirschler Teich' fällt eine Stufentreppe von weiteren Teichen abwärts: der ,Obere', ,Mittlere' und ,Untere Pfauenteich', von dem all die Wasser - mitsamt den rückwärtigen Reservebecken - zum Kraftwerk im Wilhelmsschacht geführt wurden und die Kehrräder der Gruben Dorothea und Caroline antrieben (HAASE 1961:35; LIESSMANN 1997:165). Der ,Mittlere Pfauenteich' betrieb des Weiteren zusammen mit dem Zellwasser Mitte des 18. Jahrhunderts eine Schmelzhütte; ,zugleich wird er, wie andernorts auch, Fischteich gewesen sein.“(HAASE 1961:36)

Im Grunde des Tales befindet sich der ,Polstertaler Teich'. Er wurde 1728 angelegt, 1742 und 1748 erhöht und erfasst neben dem Wasser des Schwarzen Wassers als dem eigentlichen Quellfluss des Haupttales auch die herabkommenden Zuflüsse (HAASE 1961:29). Der Teich stand neben dem Bergbau, den Pochwerken im Polstertal und den Altenauer Hütten zur Verfügung (:29). Der vor dem Dammfuß des Teiches befindliche Vorteich wird als „Widerwaage“ bezeichnet und sollte die austretenden Wasser auf die Höhe des hier abgehenden Jägersbleeker Grabens anheben, um eine Verbindung des Polstertaler Teich mit dem ,Fortuner Teich' zu erhalten (:29f.). Dafür wurden vom Polstertaler Vorteich zwei Kunsträder betrieben, die über ein Feldgestänge die Kraft auf eine Pumpe übertrugen. Damit ließen sich die Wasser des Dammgrabens um $18 \mathrm{~m}$ zum Graben heben, der das Wasser zum Bespannen zum ,Jägersbleeker Teich', auch ,Neuschmieder Teich' genannt, leitete (:29). Die Wasser des ,Jägersbleeker Teiches' konnten nun auf zweifache Weise weiterverwendet werden: Erfolgte die Entnahme über den unterhalb ansetzenden Jägersbleeker Graben und den Fortuner Wasserlauf, dann erreichte das Wasser den ,Mittleren Pfauenteich'. Wurde der ,Jägersbleeker Teich' aber über den Grundstriegel entleert, ging sein Wasser wieder dem Dammgraben zu, der unterhalb des Teiches entlangzieht (:30).

Eine Gruppe von Teichen, deren Glieder inmitten der bisher geschilderten Anlagen, aber teils auch am nördlichen Rand des Wasserwirtschaftsgebietes des Oberharzes liegen, sind die sog. Kaskaden von 
Bockswiese und Hahnenklee. Ihre Wasser wurden aber nicht mehr über die Tiefstollen ausgenutzt und auch nicht aus den Herkunftstälern hinweggeführt. Hier vereinfachte sich der Wasserhaushalt, indem das Wasser im Ursprungsgebiet, nämlich in der Innerste und ihren Seitentälern, gesammelt wurde (HAASE 1961:65). Nur noch wenige „erkennbare Überbleibsel der vergangenen Zeit“ (:65) lassen den ehemaligen Umfang der Teichanlagen in diesem Gebiet um Wildemann verschwimmen.

Früher wurde vom Spiegelbach (= Kleiner Furbach), einem südlichen Quellarm des Furbachs der ,Zankwieser Teich' und der ,Kiefhölzer Teich' bespannt im linken Seitental durch den Strotebach der ,Schröterbacher Teich' und der darunter liegende ,Stadtweger Teich'. Um etliche Höheneinheiten tiefer folgt diesen Speichern eine Reihe von weiteren Teichen: So befindet sich im Strotebach gleich unter dem Damm des ,Stadtweger Teiches' der, Brinkmühlen-Teich'. Westlich davon in einer kleinen Talkerbe liegen der ,Obere und Untere Germannsteich', beide waren schon 1680 vorhanden. Von dem im gleichen Jahr entstandenen nachfolgenden ,Unteren Spiegeltaler Teich' erhielten nicht nur die Gruben, sondern auch die Pochwerke und Mahlmühlen rings um Wildemann ihr Aufschlagwasser (HAASE 1961:70), falls der Wasserbedarf des Pochwerks (heute ,Spiegeltaler Zechenhaus') durch den Pochgraben, der vom Spiegelbach abzweigte, nicht gedeckt werden konnte (:71). „Im Gegensatz zu den auf lichten Wiesenhöhen gelegenen Teichen" des Oberharzes, bietet sich hier zudem ein neues Bild der Wasserbespannung: Um bei Hochwasser den ,Oberen Spiegeltaler Teich ' nicht zu gefährden, wurden bei Höchststand die zufließenden Wasser im Oberen Spiegeltaler Flutgraben um den Teich herumgeleitet (:70). In diesem Bereich sind des Weiteren die Teiche des Kuttelbachtales zu erwähnen: ,Oberer' und ,Unterer Kranicher Teich' und der ,Kuttelbacher Teich', die alle im zweiten Drittel des 17. Jahrhunderts angelegt wurden (:73).

Zur Versorgung des Oberharzer Bergbaus mit Aufschlagwassern entstanden seit Mitte des 16. Jahrhunderts zunächst um Clausthal-Zellerfeld, im Raum Hahnenklee-Bockswiese, Altenau, Buntenbock und Wildemann an die 70 Teiche. Trotzdem reichten auf der Clausthaler Hochfläche die in den Teichen gespeicherten Wasser bald nicht mehr aus (NIETZEL 1983:9).

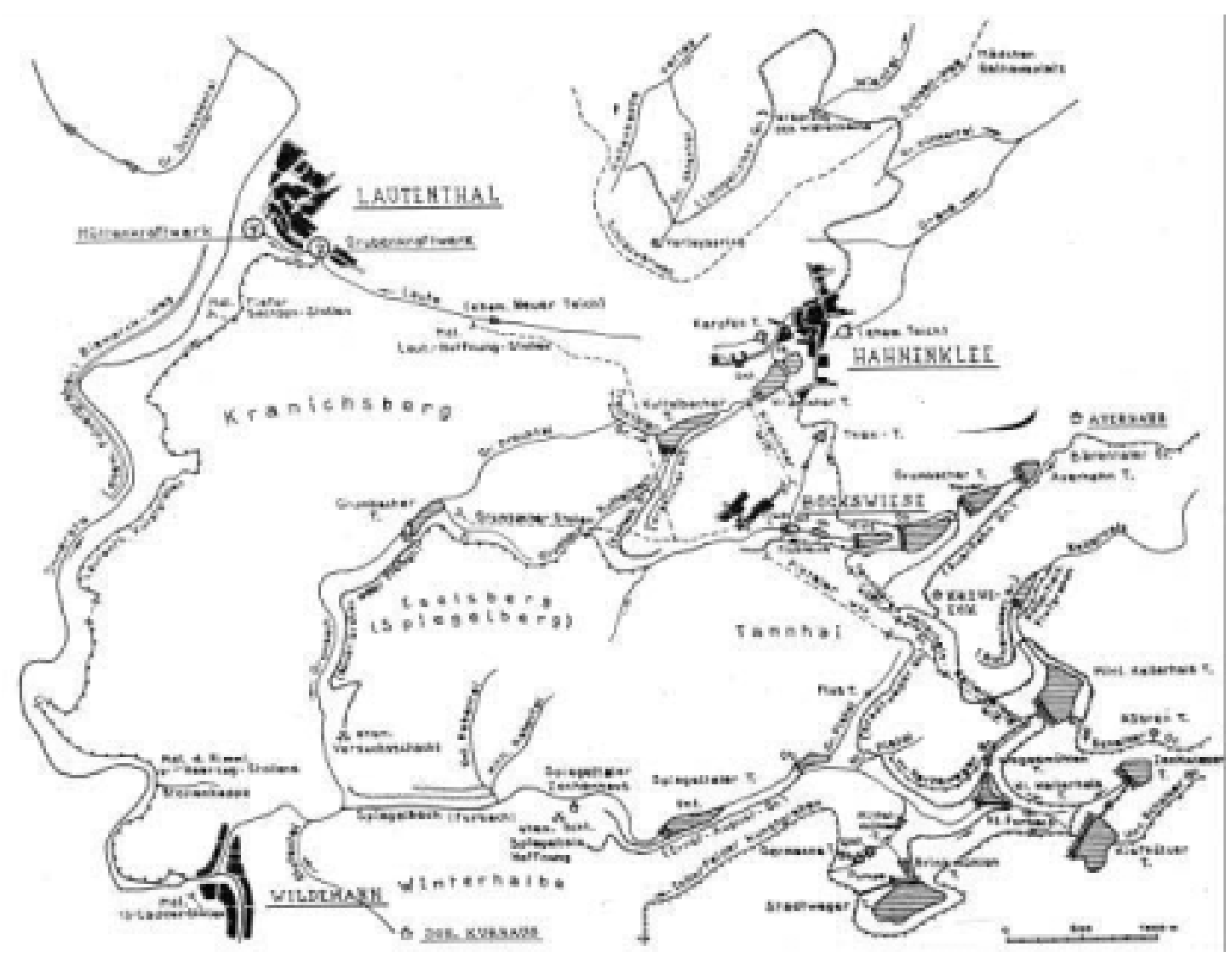

Abb. VIII-47: Bergbaulich genutzte Teiche im Gebiet um Hahnenklee-Bockswiese (aus: HAASE 1961:66) 
Die unten stehende Zeichnung zeigt die wesentlichsten Teilgebiete des Oberharzer Wassersystems: das Clausthaler, das Zellerfelder und das Buntenböcker System. Die Darstellung lässt die flächenmäßige Ausdehnung der Bergbauteiche und des gesamten bergbaulichen Wasserbewirtschaftungssystems erkennen; in West-Ost-Richtung sind es $25 \mathrm{~km}$ und in Nord-Süd-Richtung $15 \mathrm{~km}$.

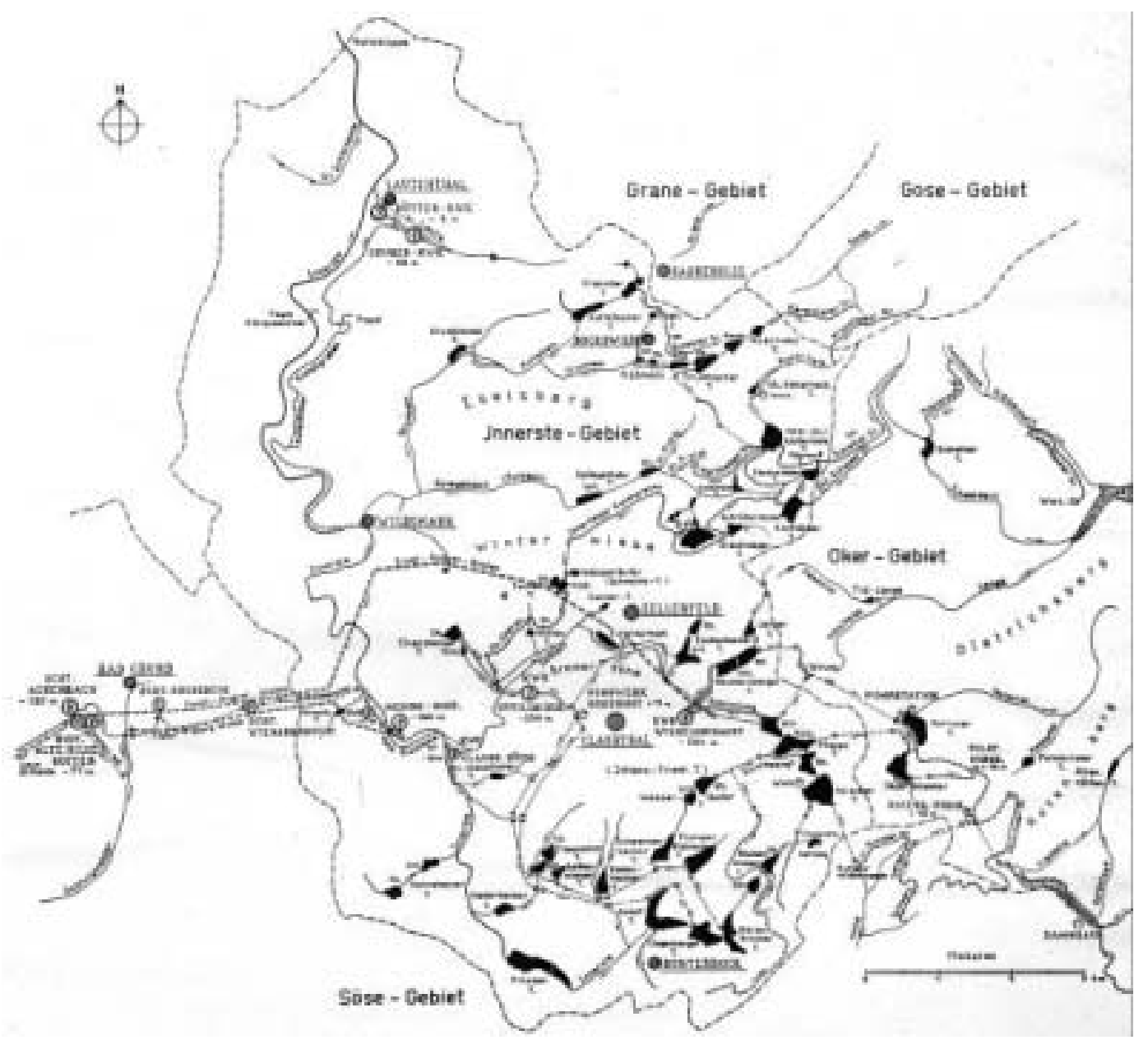

Abb. VIII-48: Übersicht über das Oberharzer Wassersystem mit seinen Teichen (aus: HAASE 1961: Innenseite).

Zur Anlage vieler kleiner Stauteiche aber war im Gegensatz zum Oberharz die Morphologie des Mittelharzes, zum Beispiel des Andreasberger Reviers, das sich am Südrand des Brockenmassivs rund um die gleichnamige Stadt befindet, nicht geeignet. Daher entschloss man sich zur Schaffung eines größeren Stausees am Oberlauf der Oder. So entstand von 1714 bis 1721 (LIESSMANN 1997:190; VOIGT 2000:22) bzw. bis 1723 (HAASE 1961:90; CZAYA 1990:37) mit einem Fassungsvermögen von 1,75 Mio. $\mathrm{m}^{3}$ der ,Oderteich', die älteste (VOIGT 2000:22) und bis zum Anfang des 20. Jahrhunderts die größte Talsperre Deutschlands (LIESSMANN 1997:190) bzw. Europas (CZAYA 1990:37). Gleichzeitig entstand mit ihr ein Wasserversorgungssystem, das trotz der ungünstigen Hochlage der Bergstadt neben der Versorgung mit Aufschlagwasser vor allem die mit Trinkwasser gewährleistete. „Der $22 \mathrm{~m}$ hohe und $184 \mathrm{~m}$ lange, aus behauenen Granitquadern gefertigte Damm hatte eine Sohlenbreite von 16 m, zur Abdichtung erhielt das Bauwerk einen Kern aus Granitgrus. Das Volumen des Oderteichs reichte aus, um auch in regenlosen Zeiten die Gruben 6 Monate lang mit Aufschlagwasser zu versorgen.“ (LIESSMANN 1997:190) Dank dieses Wasserbaus konnte der Betrieb 14 bis 16 Wochen auch ohne Regen durchgeführt werden (CZAYA 1990:37). Dies war umso wichtiger, als der Andreasberger Bergbau seinen Bekanntheitsgrad vor allem dem Vorkommen zum Teil äußerst seltener, edler Silbererze verdankte, die das Revier zum bedeutendsten Bergbaugebiet im Mittelharz machten. Der Oderteich wurde in der regenreichsten Gegend des Harzes angelegt (HAASE 1961:90) und sammelte die Wasser der Oder und der Rotenbeek und erhält Zugang mittels zweier Hanggräben aus Gewässern, die sonst erst unterhalb des Teiches zur Oder stoßen würden (:91). Die Wasserwirtschaft von St. Andreasberg - abseits der großräumigen Verbundanlagen im Clausthaler 
Bereich - bildete eine abgeschlossene Teichanlage der Oberharzer Wasserwirtschaft. Die Gruben in Sankt Andreasberg bezogen ihr Aufschlagwasser allein aus dem Oderteich über den Rehberger Graben (BALCK 1999:53).

Doch nicht überall im Harz wurde erfolgreich Bergbau betrieben: Das Odertaler Revier im Oberen Odertal beispielsweise, stellt die östliche Fortsetzung des St. Andreasberger Silbererzreviers dar. Der Bergbau hatte hier jedoch wirtschaftlich kaum eine Bedeutung. Ursache hierfür war die geringe Qualität der einheimischen Erze (VOIGT 2000:23). Aus diesem Grund, der geringen bergbaulichen Bedeutung, konnte die Quellbereiche und Bäche des Odergebietes für andere, gewinnträchtigere Bergbaureviere angezapft werden.

Einen solchen Weg beschritt man auch am „Rammelsberg“, dem früher wichtigsten Silberbergbaurevier des gesamten Harzes. Hier wurde im 13. Jahrhundert zunächst Aufschlagwasser aus dem „Bergtal“ für den Betrieb der Bulgen- und Heinzenkünste hergeleitet (HAASE 1961:81). Eine dauernde Trockenhaltung der Gruben, die im 15. Jahrhundert notwendig wurde, erhoffte man sich durch einen tieferen Wasserlösungsstollen, der jedoch nicht vollendet worden ist (:82). „Um die Betriebswasser bereitzustellen, war 1561 der einzige Wasserspeicher der Rammelsberger Wasserwirtschaft angelegt worden: Am Ausgang des Bergtals, unter dem Osthang des Herzberges, entstand der etwa $25.000 \mathrm{~m}^{3}$ große ,Herzberger Teich"“ (:82). Ein unterhalb des Teiches errichtetes Kehrrad trieb über ein $360 \mathrm{~m}$ langes Feldgestänge die Förderanlage des hangaufwärts liegenden 200 m tiefen Kanekuhler Schachts an (HAASE 1961:83; LIESSMANN 1997:118). Als Grundlage für eine langfristig kontinuierliche und steigende Erzgewinnung wurde 1768 zunächst der Damm des ,Herzberger Teichs' um 4 m erhöht, wodurch der Speicherraum auf $100.000 \mathrm{~m}^{3}$ stieg (LIESSMANN 1997:118).

Von den anderen (Oberharzer-) Revieren unterscheidet sich der Südwestharz deutlich durch das weitgehende Fehlen von Blei-, Zink- und Silbererzen. Seit dem 15. Jahrhundert wurde hier nach Kupfererzen geschürft, erst ab Mitte des 19. Jahrhunderts begann man mit der Gewinnung von Schwerspat. Der Schwerpunkt dieses Bergbaugebietes liegt zwischen St. Andreasberg, der Sieber, Bad Lauterberg und dem südlichen Harzrand.

Das sog. Lauterberger Revier, in dem bereits 1402 die Zisterziensermönche des Klosters Walkenried nach Kupfererzen schürften, war durch den Dreißigjährigen Krieg völlig am Boden. Erst 1686 wurde der Kupferbergbau wieder aufgenommen und erlebte in den ersten vier Jahrzehnten des 18. Jahrhunderts eine unvergleichlich reiche Ausbeute (LIESSMANN 1997:208). Doch nachfolgend, wie in anderen Revieren, ,ließen Probleme bei der Wasserlösung bei zunehmender Teufe nicht lange auf sich warten. So entstanden zur Versorgung des Kupferbergbaus mit Aufschlagwasser bis Mitte des 18 . Jahrhunderts 8 Stauteiche und etwa 40 km Hanggräben zur Versorgung der Gruben mit Aufschlagwasser" (LIESSMANN 1997:208; ebenso VOIGT 2000:24). Ältester und einziger aus dieser Zeit noch vorhandener Stausee ist der südöstlich der Stadt gelegener, Wiesenbeker Teich', der heute Waldschwimmbad ist, umgeben mit einem Seehotel und einem Campingplatz (LIESSMANN 1997:208). Der 1715 begonnene und 1720 - 22 in seiner heutigen Form aufgeschüttete Damm staute Wasser für das Kunstrad der „Grube Aufrichtigkeit“, das unterhalb des Teichs stand und die Kraft mittels Feldgestängen zu den beiden, oberhalb des Tals gelegenen Schächten übertrug. Ein $11 \mathrm{~km}$ langer Zulaufgraben führte zusätzlich Wasser aus der Oder heran, sein Einlauf befindet sich heute innerhalb der Odertalsperre (:210).

Gegen Ende des 18. Jahrhunderts war der Abbau jedoch so weit unter die Talsohle vorgedrungen, dass das Wasser auf den tieferen Sohlen auch mit Hilfe der Wasserkraft nicht mehr zu bewältigen war und somit die Gruben aufgelassen werden mussten (VOIGT 2000:24). Damit verloren auch die Teiche ihre Funktion.

Die Anfänge des Berg- und Hüttenwesens im Raum Wieda-Zorge-Hohegeiß gehen ebenfalls auf die Aktivitäten des 1127 gestifteten Zisterzienserklosters Walkenried zurück (LIESSMANN 1997:236). Neben dem frühen Kupferschieferabbau am Harzrand und der Gewinnung von Quecksilber in der Nähe von Wieda am Silberbach, begann der eigentliche Eisenerzbergbau um 1500 (:236). Er expandierte während der 2. Hälfte des 16. Jahrhunderts nach der Entdeckung hochwertiger Roteisenstein- 
vorkommen im Kastental, östlich von Wieda (:236). Auch in diesem Bereich wurden zahlreiche Teiche angelegt, die aber, so ist zu vermuten, zuerst der Fischwirtschaft des Klosters dienten.

Im Unterharz ist ein „nach dem Vorbild der Oberharzer Wasserwirtschaft gestaltetes System“ vorzufinden (LIESSMANN 1997:265). „Bleibende Zeugen des historischen Silberbergbaus im zentralen Unterharz sind die zahlreichen Teiche, Gräben und Wasserläufe, die in der Zeit zwischen 1703 und 1903 im Gebiet um Straßberg und Neudorf herum entstanden sind.“ (:263)

Einst gab es im gesamten Unterharz 36 Bergbauteiche mit einer Staukapazität von 2,6 Mio. $\mathrm{m}^{3}$. Räumlicher Schwerpunkt war das Selke-Einzugsgebiet mit 21 Teichen (LIESSMANN 1997:263). Heute sind noch 26 der ehemaligen Kunstteiche bespannt, d. h. sie führen Wasser (:263). Die ältesten wasserbaulichen Anlagen befinden sich im Rödelbachgebiet südwestlich von Straßberg. Schon im Jahre 1610 gab es hier den ,Gräfingründer'- und ,Unteren Kiliansteich“, „die sehr wahrscheinlich der bergbaulichen Wasserhaltung dienten." (:263) Mit der Wiederaufnahme von Gruben entstanden zunächst bis 1707 weitere 6 Kunstteiche im Rödelbach- und Glasebachtal (:264). Anschließend wurde die Anlage bis 1750 stark erweitert und die Oberharzer Dammbautechnik eingeführt. In der Mitte des 18. Jahrhunderts umfasste die Anlage 10 Kunstteiche im Rödelbach- und Glasebachtal, davon sieben im Rödelbachgebiet und drei im Tal des Glasebaches (:264). Und mit dem ,Glasebachteich' als zweitgrößtem und dem ,Frankenteich' als dem mit Abstand größten, entstanden 1716 bzw. 1724 die größten Teiche des Unterharzes (:263f.). Von den Teichen aus führten 6 in je 3 Niveaus übereinander angelegte Kunstgräben zu den Radkünsten der Straßberger Gruben sowie zu den Pochwerken (:264).

Nachdem man erkannt hatte, dass die im Einzugsgebiet der Selke vorhandenen Wasser nicht allein ausreichten, die neuen Stauteiche zu versorgen, wurden zusätzlich Sammel- und Zufuhrgräben nach Westen bis ins Ludegebiet (Stolberg) gebaut, der die Wasserscheide zwischen Thyra und Selke durch zwei Röschen querte und so zusätzlich Wasser heranführte. Das etwa $20 \mathrm{~km}$ lange Ludegrabensystem wurde 1745 fertiggestellt. Mit den Teichen verbunden war früher ein System von insgesamt 26 Gräben und Aufschlagröschen ${ }^{35}$, die zusammen eine Länge von etwa $47 \mathrm{~km}$ aufwiesen (LIESSMANN 1997:263).

Für den im anhaltinischen Unterharz liegenden Silber- und Kupfererzbergbau des Birnbaumer- und das Neudorfer Reviers standen nur die Zuflüsse aus den sehr kleinen Einzugsgebieten der Schmalen Wipper und des Birnbaumbaches zur Verfügung (LIESSMANN 1997:264).

In der Betriebsperiode um 1700 entstanden im stolbergischen Harz in den nächsten Jahren „erste Kunstteiche“ (LIESSMANN 1997:2557). Der 1699 eigentlich als Hüttenteich angelegte ,Birnbaumteich' sammelte das Aufschlagwasser für die beiden Hauptschächte im Birnbaumer Revier. Die Radkunst auf dem Pfaffenberg des Neudorfer Reviers wurde mit dem Wasser des ,Grenzteichs' an der Schmalen Wipper betrieben. Das notwendige Aufschlagwasser zum Antrieb der Pumpenkünste lieferten anfangs nur der, Grenzteich' (1723) und der ,Pfaffenberger Kunsteich' (:260).

Seit Mitte des 18. Jahrhunderts entwickelten sich die östlich von Neudorf gelegenen Grube Pfaffenberg und Grube Meiseberg zu „den bedeutendsten Erzbergwerken des ganzen Unterharzes“ (LIESSMANN 1997:260). Ein wesentlicher Ausbau der Neudorfer Wasserhaltung erfolgte 1792/93, als der ,Neudorfer Gemeindeteich', der nun auch die Meiseberger Radkunst beaufschlagte, an das erweiterte Grabensystem, mit dem auch die Lude angezapft wurde, angeschlossen wurde. Auch der für die Grube Pfaffenberg angelegte ,Neudorfer Kunstteich' erhielt jetzt zusätzlich Lude-Wasser (:264).

Aber als der Abbau auf den Hauptgruben solche tiefen Teufen erreichte, stieg der Aufschlagbedarf so rapide, dass die Speicherkapazität in Trockenperioden nicht mehr ausreichte, um die Sümpfung der Gruben zu gewährleisten. Eine unter Tage aufgestellte Dampfmaschine übernahm seit 1837 in den wasserarmen Jahreszeiten die Wasserhebung (LIESSMANN 1997:264). Die Teiche blieben aber daraufhin weiterhin als primäre wasserverwahrende Kraftspender erhalten, war die Zuverlässigkeit der

\footnotetext{
${ }^{35}$ Unter „Röschen“ versteht man im Unterharz allgemein die unter Tage verlaufenden Grabenabschnitte, im Oberharz heißen solche Wassertunnel „Wasserläufe“.
} 
frühen Dampfmaschinentechnik zu diesem Zeitpunkt noch nicht gegeben. Die bei den Mühlen als Grund für eine erst zögerliche Verwendung der Dampfkraft genannten hohen Kosten für die Anschaffung, dürfte im „reichen“ Bergbau keine vergleichbar große Rolle gespielt haben.

Nach der Einstellung des Neudorfer Bergbaus 1903 erfuhr die Unterharzer Wasserwirtschaft eine erneute Umgestaltung. Der bislang von dortigen Silberhütte genutzte ,Teufelsteich', sowie bei Bedarf der ,Fürstenteich' und der ,Silberhütter Pochwerksteich' erhielten nun die vom Lude- und Rödelbachgebiet herangeführten Wasser durch den neuangelegten Siebengründer Graben. Das insgesamt $25,5 \mathrm{~km}$ lange, jetzt „Silberhütter Kunstgraben“ genannte System hatte ein Einzugsgebiet von 11,8 $\mathrm{km}^{2}$ und versorgte 5 Teiche mit einer Speicherkapazität von 0,33 Mio. ${ }^{3}$ (LIESSMANN 1997:264).

Teile eines bergbaulichen Wassergrabensystems sind auch im Kupfenberger Revier (Landkreis Kulmbach) im Frankenwald festzustellen (SLOTTA 1983:142).

Als historische montane Wasserlandschaft, wenn auch nicht ganz so ausgeprägt wie der Harz, kann auch das mittlere und westliche Erzgebirge um die Bergstadt Freiberg betrachtet werden.

Die Landschaft des sächsischen Erzgebirges war in seinen Bergrevieren im 16. Jahrhundert mit einem komplexen Wasserwirtschaftssystem ausgestattet, das über Jahrhunderte hinweg bis in das ausgehende 19. Jahrhundert hohe Bedeutung für den Bergbau hatte und internationale Bedeutung errang: Gemeint ist das „System bergmännischer Wasserwirtschaft im Freiberger Bergrevier“ (VOIGTMANN 1999 :74). $\mathrm{Zu}$ ihm gehören neben unsichtbaren untertage verlaufenden technischen Einrichtungen wie Abflussstollen, vor allem auch solche, die oberirdisch sichtbar sind, einen Gewässerbezug aufweisen und damit für die historische Gewässergeographie besondere Bedeutung besitzen: wie Wasserscheider bzw. -teiler, Kunstgräben, Röschen und Mundlöcher, Bergwerkskanäle und eben Bergwerksteiche. Es handelt sich hierbei heute um Denkmale dieses Wasserwirtschaftssystems, der sog. „Revierwasserlaufanstalt“ (VOIGTMANN 1999:75).

Der Freiberger Bergbau umfasste gegen Ende des 13. Jahrhunderts, aber vor allem im ausgehenden 15. und zu Beginn des 16. Jahrhunderts mit Siebenlehen bei Nossen und Scharfenberg unterhalb von Meißen nicht nur die nördlicheren, sondern weiterhin die südöstlichen und auch die südwestlichen Gebiete um Freiberg mit Rochlitz, Colditz, Hohnstein, Chemnitz, Zwickau, Aue, Oberwiesenthal, Annaberg, Buchholz, Wolkenstein, Zschopau, Lauenstein, Marienberg, Altenberg und besonders in Schneeberg im oberen Erzgebirge.

Im Erzgebirge war es seit der Mitte des 15. Jahrhunderts mit seiner sehr intensiven Blütezeit im 16. Jahrhundert der Silberbergbau, der zusammen mit dem immer größere Bedeutung erlangenden Zinnbergbau zu einem stetigen und mitunter sprunghaften Zuwachs in der Wasserbewirtschaftung führte (CZAYA 1990:14; ALTMANN 1999:15). Häufig trat auch an die Stelle des Edelmetallbergbaus ein Bergbau auf unedle Metalle. Im Revier Schneeberg-Neustädtel zum Beispiel schloss sich Wismut- und vor allem Kobaltbergbau an. In anderen Revieren rückten Zink, Blei und Kupfer an die erste Stelle; Silber war dann höchstens noch anfallendes - natürlich gern gesehenes Beiprodukt (:14).

Über die allgemeinen Erfordernisse der Wasserversorgung hinausgehend, gab es für den erzgebirgischen Erzbergbau hinsichtlich des Wassers folgende zwei Aufgaben, die traditionell den Bergbaus kennzeichneten: Erstens musste man das untertägige, mitunter in großen Mengen aus dem Berg tretende Wasser abtransportieren, um die Gruben arbeitsfähig zu halten. Denn bereits im 13. Jahrhundert verhinderte auch hier die Ohnmacht gegenüber dem anfallenden Wasser oft das weitere Abteufen der Gruben. Zur Entwässerung der Gruben und Ausnutzung des Wassers als Betriebskraft, d. h. um ein jederzeit verfügbares Wasserangebot zu gewährleisten, wurden die Grabensysteme durch Stauanlagen ergänzt, die gewissermaßen als Vorratskammer für das vom Bergbau benötigte Wasser fungierten. Die Bestrebungen, die Wasserkräfte des sächsischen Obergebirges dem über einen weiten Raum verstreuten Bergbau dienstbar zu machen, hatten im Laufe der Zeit zur Anlage eines weitverzweigten Systems von Gräben und Bergwerksteichen geführt. Auf diese Weise wurden die für Betriebszwecke benötigten Aufschlagwasser gespeichert und herangeführt. Für diese Graben- und Teichwirtschaft 
waren aus landesherrlichen Kassen erhebliche Mittel zur Unterstützung der bauenden Gewerke bewilligt worden (HOFFMANN 1959:23f.).

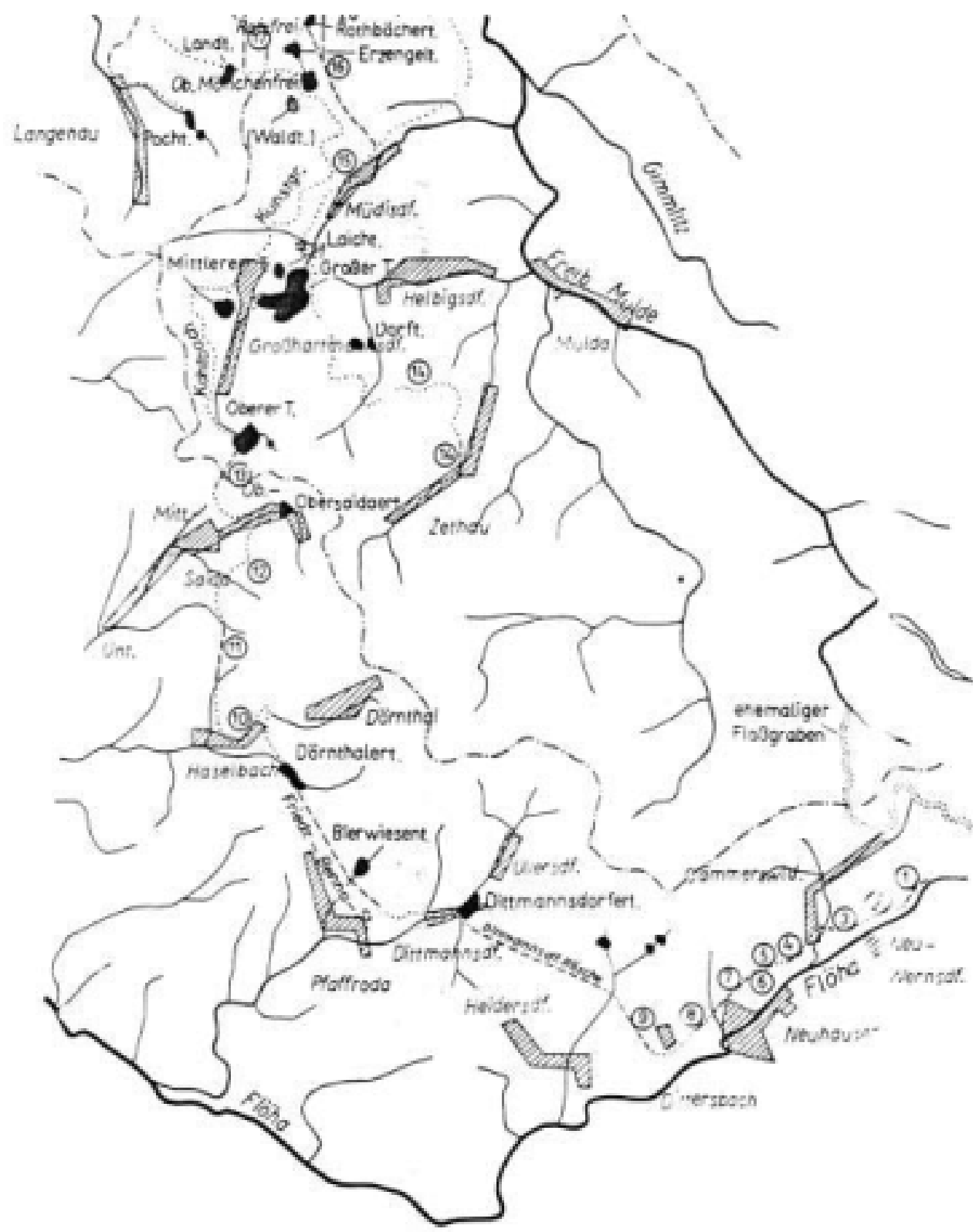

Abb. VIII-49: Bergbauteiche und andere Bestandteile der alten bergmännischen Wasserwirtschaft (1) auf dem Freiberger Bergrevier (aus: VOIGTMANN 1999:76)

In der Chronologie ihrer Entstehung ist die Ausdehnung der bergmännischen Wasserwirtschaft nach Süden, also immer weiter in das Gebirge hinauf, zu verfolgen (VOIGTMANN 1999:78). Der ,Hüttenteich' bei Berthelsdorf entstand um 1555 - 60 unmittelbar südlich von Freiberg mit einem Fassungsvolumen von $45.000 \mathrm{~m}^{3}$ Wasser, der noch heute erhaltene ,Filzteich' bei Schneeberg stammt gar aus dem Jahre 1483. Der höchstgelegene ist der ,Dittmansdorfer Teich' mit einem Fassungsvermögen von $500.000 \mathrm{~m}^{3}$, der zwischen 1826 und 1828 angelegt wurde. Die größten Teiche des Bergbaus im Freiberger Revier sind der ,Untere Großhartmannsdorfer Teich' (16. - 18. Jahrhundert) mit 1.680.000 $\mathrm{m}^{3}$ und der ,Dörnthaler Teich' (angelegt zwischen 1842 und 1844) mit $1.000 .000 \mathrm{~m}^{3}$ Stauraum. Das Anstauen erfolgte in diesen Fällen mittels vermauerter aufgeschütteter Erd- und Gerölldämme (VOIGTMANN 1999:78ff.). Im Jahr 1835 war die Wasserversorgung auf 11 Bergwerksteiche erhöht worden. Für die Zechenteiche errechnet sich für Freiberg ein Inhalt von rund 5,7 Mio. $\mathrm{m}^{3}$. Um das Jahr 1800 konnten aus den Freiberger Bergwerksteichen und -gräben bei vollem Wasserstand etwa $36 \mathrm{~m}^{3}$ pro Minute entnommen werden, womit sich 16 Räder betreiben ließen (HOFFMANN 1959:23,27; CZAYA 1990:36f.; VOIGTMANN 1999:80). 


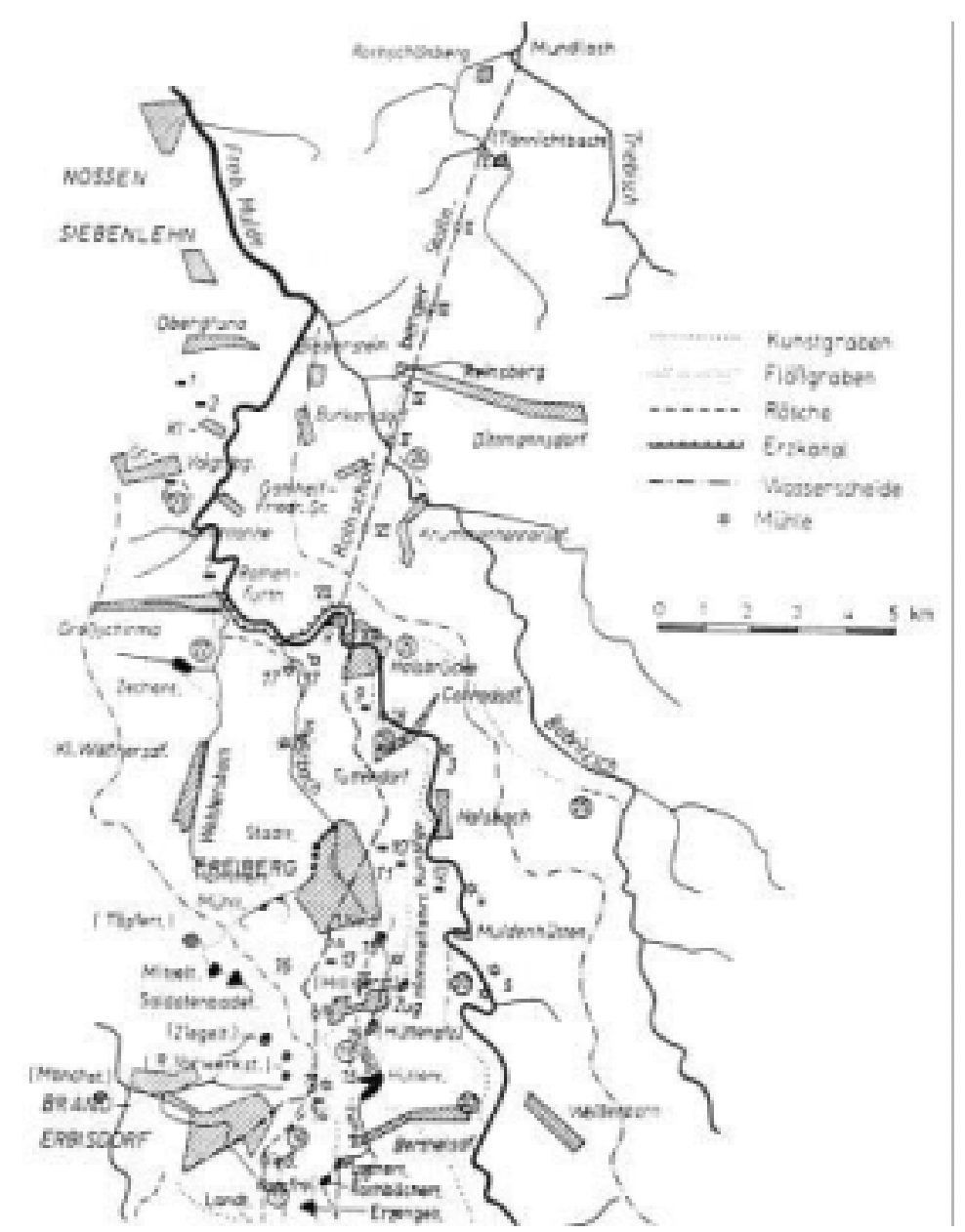

Abb. VIII-50: Bergbauteiche und andere Bestandteile der alten bergmännischen Wasserwirtschaft (2) auf dem Freiberger Bergrevier (aus: VOIGTMANN 1999:76).

Die Zuführung des Wassers musste oft auf große Entfernungen geschehen. Um der nördlich von Freiberg, zwischen Halsbrücke und Hohenfurth, rechtsseitig der Mulde, bestehenden Grube St. Anna samt Grube Altväter das Aufschlagwasser für ein dringend benötigtes Kunstrad zur Wasserhebung zu verschaffen, wurde der linksseitig der Mulde fließende Münzbach gestaut und ungefähr zwanzig Meter über dem mittleren Wasserspiegel der Mulde mit einem 188,50 m langen Aquädukt auf die andere Talseite hinübergeführt (CZAYA 1990:36). Die vom 16. bis ins 19. Jahrhundert im Freiberger Revier angelegten Kunstgräben zur Abführung der Gruben- und Herbeischaffung der Aufschlagwasser haben eine Gesamtlänge von 134 Kilometern. Weitere 29 Kilometer künstlicher Wasserläufe mussten durch den Bau von Röschen unter Geländeerhebungen hindurchgeführt werden.

Zweitens wurde das Wasser für den Bergbau als Hilfsmittel in den Erzwäschen benötigt; vor allem aber seit der Einführung des Kehrrades, später der Wasserturbine als Energiequelle. Es galt große, aber möglichst gleichbleibende Mengen von Wasser an die Gruben heranzuführen (VOIGTMANN 1999:75).

Für das Westerzgebirge um Schwarzenberg ist Eisensteinbergbau, Zinnseifen und Zinnbergbau seit dem 14. Jahrhundert bezeugt (ALTMANN 1999:25). Die Gewinnung von Eisenstein erfolgte bergmännisch im Tagebau und Untertagebau, die des Zinnsteins durch Zinnseifen im Tagebau sowie im bergmännischen Untertagebau (:26). Zwei bedeutende Eisenstein-Bergbaubereiche im Schwarzenberger Gebiet waren der Emmler bei Raschau und der Rothenberg bei Erla. Der Emmler (Emla) - eine Anhöhe zwischen Mittweida und Schwarzwasser - wurde bis 1536 unter der Klosterherrschaft von Grünhain betrieben, danach im kurfürstlichen Amt Grünhain fortgeführt (:27). Die in diesem Gebiet verlaufenen Wasserläufe Schwarzbach (Schwarzwasser), Elterleiner Wasser, Mipe und Zwickauer 
Mulde, wurden in einigen Bereichen aufgestaut, vor allem dort, wo die im 14. und 15. Jahrhundert urkundlich erwähnten Hammerhütten lagen, um die Wasserkraft zu nutzen $(: 76,77,142)$.

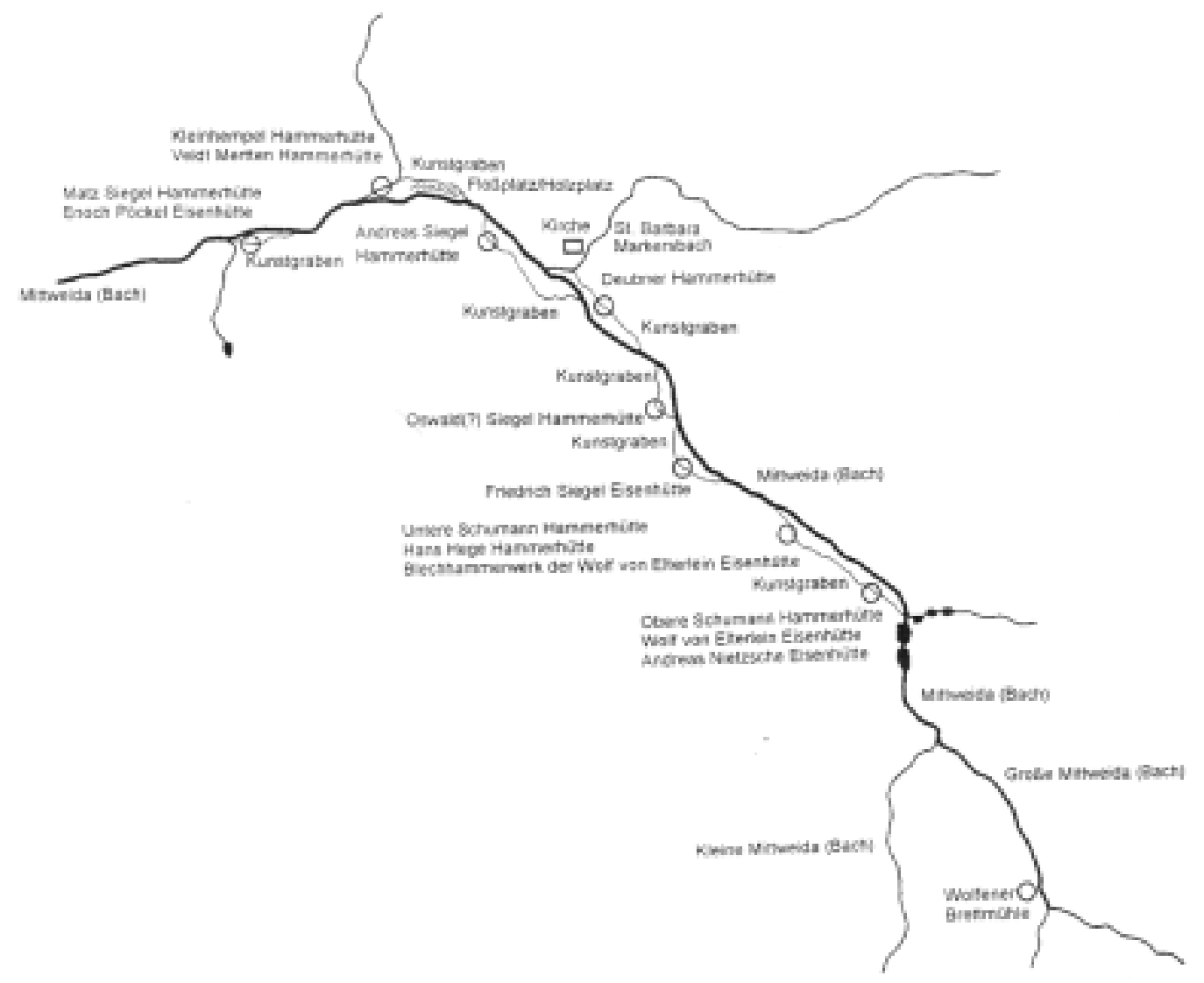

Abb. VIII-51: Hammer- und Eisenhütten des Erzgebirges und Vogtlandes 12. bis 19. Jahrhundert. Stauteiche stehen vor allem am Oberlauf des Mittweida-Baches (aus: ALTMANN 1999:220-225, Übersicht 29).

Das Gebiet um Schwarzenberg entwickelte sich seit dem 16. Jahrhundert, mit einer umfangreichen Verbreitung in der 2. Hälfte des 18. Jahrhunderts (ALTMANN 1999:80), zu einem Ballungszentrum der Eisenmetallurgie (Walzwerke, Drahthammerwerke, Sensenhammer) im Kurfürstentum Sachsen. Bedingt durch reiche Eisenerzvorkommen, umfangreiche Waldbestände und „wasserreiche Bäche und Flüsse“" $(: 36,95)$. Des Weiteren siedelte sich unter der Nutzung der Wasserkraft der Flöha und des Rungstockbaches Ende des 17. Jahrhunderts die Gewehrindustrie in Olbernhau an, die bis zur Mitte des 19. Jahrhunderts hier wirksam war (:91). Häufige Stillstandszeiten der Hammer- und Eisenhütten traten aber auch hier durch ,naturbedingte Produktionsunterbrechungen, im Winter durch Frost und Eis, im Sommer Wassermangel“ (:108) auf, trotz der angelegten Stauteiche.

Nach den ersten Funden von 1517 - 19 begann die Erschließung der Lagerstätten im Marienberger Revier. In dem Jahrzehnt von 1550 - 1560 erlangte der Marienberger Bergbau seine größte Ausdehnung und die höchste Zahl an Zechen (BOGSCH 1966:59). 58 Zechen waren in diesem Gebiet aufgeschlossen (:9).

Ausgehend vom Rosenberg östlich der Stadt und vom Wildsberg und Mönchsberg im Südosten erfasste er bald die Hänge südlich und westlich von Zöblitz (den Rabenberg, Sonneberg, Rittersberg), die Höhen ostwärts und nördlich von Marienberg (den Mardersberg, Hellberg, Stadt- und Mühlberg) und erstreckte sich schließlich von Lauta und vom Herbstgrund hier in das Kiesholz zwischen Marienberg und Wolkenstein (BOGSCH 1966:9).

An Aufschlagwasser fehlte es bereits zu dieser Zeit nicht, schon im 16. Jahrhundert war für den Tiefbau ein weitläufiges Netz von Wassergräben und Bergwerksteichen entstanden. Die wichtigste Anlage war der 1551 geschaffene sog. Reitzenhainer Kunst- und Zeuggraben, der das Reitzenhainer Grenzwasser durch den Buchwald zu einem riesigen Teich bei Großrückerswalde brachte. Aus dem 
,Großrückerswalder Bergwerksteich' wurden die Gruben im Kiesholze mit Aufschlagwasser versorgt und die ,Lautaer Teiche' wie der ,Viermaßener', der eigentliche ,Lautaer Teich', der auch mit dem Wasser des Lautenbaches aufgefüllt wurde, und der ,Heinzenteich' sowie der ,Schwarzenmohrener' aufgestaut, der übrigens noch aus dem ,St. Elias-Tagesstollen' Zufluss erhielt (BOGSCH 1966:118). Die Förderung aber dürfte in der Hauptsache durch große Pferdegöpel bewerkstelligt worden sein $(: 11)$.

Das System von Kunstteichen und Kunstgräben zur Wasserbereitstellung bilden zusammen jenes Geflecht der bergmännischen Wasserwirtschaft im Freiberger Revier, welches gemeinsam mit Halden und anderen Übertageanlagen „der Landschaft um Freiberg neue geografische Strukturen verleiht.“ (VOIGTMANN 1999:75. 81)

Weitere frühe Bergbaugebiete, die aber eher Zentren der Eisen- und Stahlverarbeitung waren, sind das Siegener Land, die Oberpfalz und Böhmen.

Die ehemalige Schwarzwälder Montanwirtschaft liegt aus wasserbauhistorischer Sicht etwas im Schatten des Freiberger und Harzer Bergbaus. Die für den dortigen Bergbau allgemein zutreffende Begründung, es läge „zum größten Teil an der äußerst spärlichen schriftlichen Überlieferung“ (HAASIS-BERNER 1999:97), greift bei Relikten der Wasserwirtschaft nur, wenn sie tatsächlich im fossilen, d. h. oberirdisch nicht oder nur sehr schwer erkennbaren Zustand vorliegen. Dafür spricht, dass der Bergbau im Schwarzwald lediglich eine Zeitspanne vom 10. Jahrhundert bis ins 16. Jahrhundert umfasst hat (STEUER 1999:54) und „nur eine kurze Blütezeit“ erlebte (CZAYA 1990:14), während er im Harz beispielsweise vereinzelt sogar noch ins 20. Jahrhundert betrieben worden ist. Die Bergwerke nördlich von Freiburg wurden gar erst nach 1500 in Betrieb genommen, wie die Bergwerke im Simonswald, für das Suggental, das Glottertal und Zähringen. Der Dreißigjährige Krieg bedeutete auch hier das Ende des Bergbaus. Die jüngeren Phasen sind nur noch „als Nachlese zu betrachten. Wirtschaftlicher Erfolg war ihnen nicht mehr beschert.“ (HAASISBERNER 1999:98) Dennoch führten Geländebegehungen im Suggental/Glottertal ,entlang der Relikte der montanen Wasserwirtschaft", die HAASIS-BERNER (:97) unternommen hat, nach seiner Ansicht „zu einer völligen Neubewertung der Bedeutung der Reviere“ und lässt die „Bedeutung der Wasserwirtschaft für den Bergbau nachvollziehen."

Nördlich von Freiburg ist mittelalterlicher Bergbau durch ein wasserbauhistorisches Relikt nachgewiesen. Im Bereich des Suggen- und des Glottertales hat sich mit einem heute „Urgraben“ genannten, $15 \mathrm{~km}$ langen Kanal ein bedeutendes Denkmal der Wasserbautechnik des 13. Jahrhunderts erhalten (STEUER 1999:54). Der bereits 1284 urkundlich bezeugte Urgraben führte Wasser von der Ostseite des Kandels auf dessen Westseite zum Erzrevier ins Suggen- und Glottertal. Hier diente das Wasser zum Betrieb einer Wasserkunst. Zumindest im Suggental lässt sich diese Anlage nachweisen. Der Verlauf des Kanals ist heute noch gut zu erkennen. An steilen und teilweise felsigen Hängen entlang wurden drei Wasserscheiden überwunden, eine davon mittels eines Tunnels (HAASIS-BERNER 1999:98f.; STEUER 1999:56).

Der Hangkanal zeigt auf, „daß Wasserbauten, wie sie im Harz für das 17./18 Jahrhundert bekannt sind, im Schwarzwald schon Jahrhunderte früher gebaut worden sind“ (HAASIS-BERNER 1999:100), und muss in seiner Art „als erste nachweisbare Anlage Europas angesehen werden“ (:101). „Zwar wurden hier nicht“, dem ist sich auch HAASIS-BERNER (:100) bewusst, „mit derselben Konsequenz wie im Harz oder auch im Erzgebirge alle verfügbaren Gewässer genutzt, dennoch sind die Bauwerke vergleichbar.“ Allein die Existenz des Urgrabes deutet seiner Auffassung nach darauf hin, „daß es sich bei diesem Revier um eines der ertragreichsten des 13. Jahrhunderts gehandelt haben muß. Für die Zährtinger und die Grafen von Freiburg war dies wohl eines ihrer wichtigsten Reviere (:100).

Weitere, wenn auch nicht so lange, Gräben gibt im Schwarzwald noch im Bollschweil-Ehrenstetter Grund, hier ist ein Stauwehr mit Hangkanal, der zu einer Radstube führt, archäologisch nachgewiesen (STEUER 1999:53,57f.), sowie in Todtnauberg, Sulzburg und Hofsgrund. 
An Infrastruktureinrichtungen kommen des Weiteren Radstuben, Mühlengebäude und andere Wasserbauten hinzu, die beweisen, dass Wasserkünste wohl schon im 13. Jahrhundert im Schwarzwald bekannt waren, um die Gruben vom Wasser zu befreien, womit Tiefen unterhalb der Talsohlen erreicht werden konnten. Im Revier Sulzburg Tal des Sulzbaches im Südschwarzwald, lassen sich im Gelände neben Bergbaurelikten wie schluchtartigen Tagebauen (Verhauen) und verstürzten Schächten (Pingen) auch kleine Plateaus für Bergschmieden beobachten (RAUSCHKOLB 1999:59).

Bergbau fand sich an anderen Stellen im Schwarzwald noch im Bereich des oberen Münstertales (Revier Schauinsland, Revier Süßenbrunn), im Möhlintal (Bergbaurevier St. Ulrich) in der Region des Elztales und seiner Zuflüsse (Revier Freiamt-Sexau) (HAASIS-BERNER 1999:97f.; STEUER 1999:53), des Weiteren in Badenweiler und Lausberg am Schwarzwaldrand und in den Tälern zwischen Badenweiler und dem Schauinsland (WEISGERBER 1999:132).

Wenn aus den „umfangreichen Abbauspuren“ (RAUSCHKOLB 1999:59) und den vereinzelt nachgewiesenen Zeugen der montanen Wasserwirtschaft auch durchaus die ehemalige Bedeutung des Schwarzwaldes als eine mittelalterliche und frühneuzeitliche Bergbaulandschaft erkennbar wird, so bleiben dennoch Formen des Teichbaus zu Zwecken der Gewinnung und Förderung von Gesteinen nicht erkennbar.

Neben dem Bau von Hangkanälen griff das Montanwesen hier allein im Zuge der Aufbereitung und Verhüttung in das Gewässersystem ein. Künstlich angelegte Wasserläufe (Mühlkanäle) führten zu den wasserkraftbetriebenen Schmelzhütten, die aber etwas außerhalb des eigentlichen Abbaureviers lagen (HAASIS-BERNER 1999:101). Als Wasserstauungen sind hier die Hammer- und Hüttenteiche sowie die zur Trift benötigten „Schwöllungen“" zu nennen.

Der Grund, warum hier keine Bergbauteiche vorkommen, ist in dem Relief der Abbaugebiete zu suchen: Die steil stehenden silberhaltigen Erzgänge sowie die auf engstem Raum lokalisierten bergbaulichen Anstrengungen verhinderten solche Anlagen. Im Gegensatz etwa zum Altenberg im Siegerland oder auch der Clausthal-Zellerfelder Hochfläche mit ihren weiten Raum einnehmenden Scharungszonen, wurden im Schwarzwald die Erzgänge in den steilen Talflanken durch Erosion aufgeschlossen und von derart unbequemen Hängen aus von verhältnismäßig wenigen Stollen bis weit in den Berg hinein abgebaut. Wasser konnte leichter abgeleitet und Wetterprobleme bei miteinander durchschlägigen Stollen auf natürliche Weise gelöst werden. Mühsamer mit Schächten erschlossene Lagerstätten sind hier selten (WEISGERBER 1999:132).

Im Spessart hat der Bergbau keine sonderliche Bedeutung erlangt. Außer für den lokalen Bergbau im Revier Bieber, im Kahlgrund und an vereinzelten anderen Stellen ,sind die Wälder des Spessarts vor allem von Glasmachern und Kalkbrennern industriell genutzt worden.“ (BACHMANN 1996:181)

Nur kleinere Vorkommen an Buntmetallen, Silber und Eisen wurden gelegentlich und mit zeitlichen Unterbrechungen abgebaut. Allein der Abbau des in der Lagerstätte von Bieber am Spessart-Nordrand während der Jahre 1741 bis 1782 gewonnenen Kupfer, Blei, Silber usw. brachte kurzzeitig den Landgrafen von Hanau Gewinn. Zeitweilig waren hier bis zu 500 Berg- und Hüttenleute. 1803 wurde der Abbau des Kupferletten-Flözes eingestellt, 1867 dann klang der Bergbau mit der Gewinnung von Kobalt- sowie begleitenden Nickel- und Wismuterzen aus. Ingesamt wurde im Spessart über einen Zeitraum von 170 Jahren (1702 - 1875) Bergbau betrieben (BACHMANN 1996:183).

Durch das tief eingeschnittene Kocher- und Brenztal wird die nordöstliche Schwäbische Alb in zwei Hälften geteilt: in das Härtsfeld (östlicher Teil) und den Albuch (westlich). Eine Besonderheit für die Schwäbische Alb ist dabei, dass der Albuch wasserstauende, kalkarme Bodentypen besitzt und es dadurch auf Verebnungen $\mathrm{zu}$ Stagnogley und an einzelnen Stellen zu geringmächtigen Flachmoorbildungen kommt. Auf heutigen „Weiherwiesen“ fand man Eisenschwarten im Untergrund, außerdem Erzabbauspuren wie zum Beispiel Eisenschlacken, die auf eine vorgeschichtliche Eisenverhüttung hindeuten. Aufgrund der Bodenverhältnisse lassen sich hier durchaus Bergbauteiche rekonstruieren. 
Am Ost- und Westrand des Rheinischen Schiefergebirges wurden direkte archäometallurgische Belege für den Erzabbau in frühkeltischer Zeit erbracht. Vor allem aber an der Grenze Hessens zu Westfalen, im nördlichen Lahn-Dill-Gebiet, ist bereits seit vorgeschichtlicher Zeit eine Eisengewinnung nachgewiesen; sie war auch jahrelang „eine der wichtigsten Eisenerzlagerstätten des Deutschen Reiches.“ (JOCKENHÖVEL 1996b:12) Die alte Kernlandschaft des nassauischen Hessen stellte mit Dillenburg jahrhundertlang die Residenzstadt der Grafschaft Siegen-Dillenburg und diese spielten sicherlich auch bei der Ausbeutung dieser einheimischen Erzvorkommen eine besondere Rolle (:12). Eine direkt bergbauliche Teichlandschaft ist hier jedoch - aus den schmalen Bachtälern - nicht überliefert.

Im 15. Jahrhundert, und damit im Vergleich mit anderen Gebieten (Sauerland, Siegerland) recht spät, wurden die ersten wasserkraftgetriebenen Hütten- und Hammerwerke an den Bächen und Flüssen der oberen Dill errichtet (JOCKENHÖVEL 1996b:15). Vor allem im Quellgebiet von Lahn und Dill, an der oberen Dill und ihren Nebenflüsschen, besonders der Diethölze, sowie die links und rechts von ihr verlaufenden Dill, Roßbach, Nanzenbach und Schelde wurde die ortsfeste Eisenverarbeitung der in enger Nachbarschaft dazu liegenden Braun- und Roteisenerzlagerstätten angesiedelt. Hier lag - in fast schon klassischer Form - eine räumliche Trennung von Bergbau (Eisengewinnung) und Verhüttung vor. Das aus 5 - $10 \mathrm{~km}$ Luftlinie entfernte Haufwerk wurde am Verhüttungsplatz zur Beschickungsgröße mit Holz als Energieträger gepocht (:23). Mit bisher 325 aufgefundenen Eisenverhüttungsplätzen avanciert das Dill-Gebiet ,zu einer dem Siegerland und Sauerland vergleichbaren mittelalterlichen ,Eisenlandschaft"“ (:20).

Auf dem Altenberg bei Müsen im Siegerland war „genügend ebene Fläche vorhanden“ (WEISGERBER 1999:134), die eine montane Wasserbewirtschaftung durch Teichbau möglich gemacht hätte, während die anderen Erzgänge der umliegenden Berge an mehr oder weniger steilen Erzgängen ,ausbissen“ (:134), d. h. in denen die Vererzungen bis unmittelbar an die Oberfläche reichten. Hier gab es zunächst auch kein Wasser zu sümpfen: Die Schächte standen in festem Gebirge und hatten bei 16 bzw. 18 m Teufe nur wenig hölzernen Ausbau. Ein weiterer Schacht war in Ton und Schiefer geteuft worden. Er wurde bis in 22,5 m Teufe ausgegraben, ohne dass der Schachtsumpf erreicht wurde (:134).

Das Ende des erst mit dem Jahr 1571 begonnenen mittelalterlichen Bergbaus auf der unwirtlichen Höhe des Altenbergs ist möglicherweise durch kriegerische Ereignisse mit beeinflusst worden. „Ausschlaggebend für die Aufgabe des Bergwerks dürfte aber gewesen sein, daß es nicht mehr möglich war, das in die Grubenbaue einsickernde Wasser ohne Anwendung des Stollenbaus zu lösen.“ (WEISGERBER 1999:135) Warum hier nicht versucht wurde, mit einem Wasserbewirtschaftungssystem für eine Lösung dieses Problems zu sorgen, konnte ich hier an dieser Stelle nicht klären, aber vielleicht war der Aufwand für den Ertrag einfach zu groß.

Der Bergbau an den steilen Flanken muss dagegen früher eingesetzt haben, denn bereits 1311 wird die erste an Wasserläufen liegende Massenhütte 1311 erwähnt, die im Weißachtal östlich Siegens lag. Diese frühen Hütten stellten wohl noch kein Roheisen her (JOCKENHÖVEL 1996b:22).

\section{b.3 Alpen und Alpenvorland}

Neben den deutschen Mittelgebirgslandschaften wurde auch im alpinen Bereich Bergbau betrieben. Bronzezeitlicher Erzabbau ist beispielsweise aus Mitterberg/Österreich mit seinen „direkten Relikten“ in Form von Bergwerken erhalten geblieben (JOCKENHÖVEL 1996:8). Zu den alten Eisenlandschaften in den Alpengebieten zählen auch die Steiermark und Kärnten (ALTMANN 1999:15).

Im Schweizer Kanton Aargau/Gemeinde Wölflinswil, ist das Gelände spätestens seit dem 12. Jahrhundert montan bearbeitet worden; das Bergwerk war im Besitz einer Genossenschaft einheimischer Bauern. Sie betrieben Bergbau im Rahmen des jahreszeitlichen Rhythmus ihrer landwirtschaftlichen Arbeiten, man könnte fast sagen: im „Nebenerwerb“, weshalb die Erzförderung 
jeweils im Winter den größten Umfang erreichte. 1520 bestand die Genossenschaft aus 86 Bergleuten (DOSWALD 1996:153).

Das Bergwerk am Gonzen bei Sargans, Kanton St. Gallen, enthält das reichste Eisen-Mangan-Erzvorkommen der Schweizer Alpen (DOSWALD 1996:155). Kontinuierlicher Bergbau ist hier seit dem 14. Jahrhundert belegt, doch könnte die Ausbeutung wie im Jura in römische oder vorrömische Zeit zurückreichen.

Das Ferratal im Kanton Graubünden ist ebenfalls ein Bergbaurevier, aber aufgrund nur kleiner, verstreuter Vorkommen wurde mit der Erschließung der Abbauvorkommen nicht vor dem 16. Jahrhundert begonnen. Die Grube „Plattas Alvas“ beispielsweise wurde während einiger kurzer Perioden vom 16. bis ins 19. Jahrhundert im Tagebau ausgebeutet.

Bis ins 19. Jahrhundert wurden die Bergwerke am Gonzen ,in oder nahe bei natürlichen Aufschlüssen in der südöstlichen Felswand des Berges angelegt; sie lagen damit auf etwa 1250-1500 m über Meereshöhe, 750-1000 m über der Talsohle des Seezetales.“ (DOSWALD 1996:156)

Noch später erscheint der Bergbau am Schmorrasgrat. Die Lagerstätten zwischen dem Rheintal und dem Engadin scheinen hier nicht vor 1818 angegangen worden zu, eine systematische Ausbeutung ist gar nur für die Jahre von 1826 bis 1847 bezeugt. Obgleich es sich um „,das beste Eisenerzvorkommen des Distrikts“ gehandelt hat (DOSWALD 1996:161). Der Grund für diese späte Erschließung liegt wahrscheinlich an der extremen Höhenlage um $2600 \mathrm{~m}$.

Damit verknüpft waren in anderen Gebieten auch die nur saisonalen Abbautätigkeiten. So waren im Ferratal aufgrund der Höhenlage von 2160 m über Meereshöhe die Arbeiten beim Bergwerk auf die Sommermonate beschränkt. Ebenso in Sargans, dessen Förderstollen auf 1250 und 1370 m.ü.M. lagen.

Die Gründe, warum sich die alpinen Bergbaureviere nicht durch eine durch Teiche charakterisierte Wasserwirtschaft auszeichnen, liegen auf der Hand. Auch wenn der Bergbau aus klimatischen Gründen nur in den Sommermonaten stattfand, hätte die langsam auftauende dicke Eisschicht in den über mehrere Monate zugefrorenen Teichen große Schäden an den Teichanlagen angerichtet, die man jedes Mal kostspielig und zeitaufwendig hätte reparieren müssen. Vielmehr aber das zu Zeiten des frühen, mittelalterlichen und frühneuzeitlichen Bergbaus nicht im großen Stil veränderbare Georelief unterband die Anlage von Teichwirtschaften. Die dafür geeigneten Hochplateaus waren dort, wo sie vorhanden waren, nur schwer zugänglich und darüber hinaus in früheren Zeiten in weitaus niedriger gelegenen Gebieten noch vergletschert. Zudem waren die Erzaufschlüsse in die Felswände angelegt und wurden von den steilen Flanken aus als horizontale Stollen eingetrieben. Eine Sümpfung wie eine wasserunterstützte Hebung von erzhaltigen Gesteinen war so im großen Stil nicht notwendig.

Eine Wasserstauung primär zu Zwecken der Holzflößerei einzurichten und sie dann für eine Wasserbeaufschlagung für die wasserbetriebenen Hämmer und Hütten mitzubenutzen, erübrigte sich ebenfalls, lagen die Hüttenwerke ,am Rand des Talbodens und profitierten in der Regel unmittelbar von den ausgedehnten Wäldern der südlichen Talflanke und von der Wasserkraft der verschiedenen Zuflüsse“ (DOSWALD 1996:156). Falls dennoch Bau- oder Brennholz aus den höhenzonalen Gebirgslandschaften gebraucht werden sollte, so wurden sie ,geschlittet“. Wobei zu bedenken ist, dass die alpine Waldgrenze, an der geschlossene Bestände von zahlreichen Baumindividuen haltmachen, bzw. dass die - zum Teil höhergelegene, aber unter bestimmten Bedingungen auch deckungsgleiche Baumgrenze, d. h. die Höhe, bis zu der freistehende, überhaupt noch holzbare Bäume ${ }^{36}$ emporsteigen, in der hochmontanen bzw. subalpinen Stufe liegt (ELLENBERG 1986:520ff.). Bei der Festlegung exakter Höhengrenzen gilt es zum einen die vom Klima und vom Menschen verursachte Veränderung der Waldgrenze seit etwa 1500 v. Chr. zu berücksichtigen. Lag die klimatische Waldgrenze in der

\footnotetext{
${ }^{36}$ Als Bäume im alpinen Bereich dürfen ,alle Holzpflanzen gelten, die an den meisten Standorten über die mittlere Schneehöhe emporwachsen und dann den Wetterunbilden des Winters frei ausgesetzt sind.“ (ELLENBERG 1986:520). Eine bestimmte Grenzhöhe lässt sich nicht angeben, doch ist es nach Auffassung von ELLENBERG (:520) berechtigt, im Hochgebirge schon einen $2 \mathrm{~m}$ hohen Stamm als „Baum“ anzusprechen.
} 
mittleren Wärmezeit (Atlanticum, ca. 3000 v. Chr.) etwa 2200 m.ü. M., sank sie seither mit Schwankungen langsam tiefer. Nach ihrem Hochstand in der Bronzezeit erreichte die natürliche Waldgrenze mehrfach wieder Höhen über 1950 m, so auch im Mittelalter. Die anthropo-zoogene Waldvernichtung bewirkte aber seit Beginn der Eisenzeit, dass die Waldgrenze durch Holzschlag und Weide bis auf unter 1600 m herabgedrückt wurde (:522). Dies bedeutet, dass eine Holztrift oberhalb der Bergabbbaureviere seit dem Hochmittelalter, also zu dem Zeitpunkt, als zumeist der Bergbau in den Alpen erst einsetzte, gar nicht mehr möglich war.

Bergbauteiche im eigentlichen Sinne existieren demnach in den Alpenländern nicht. Dies entspricht auch den Befunden in der Landschaft.

\section{Bewässerung}

Ziel des Kapitels ist es, zum einen die vielfältigen Ursachen herauszuarbeiten, die zu den Anfängen als auch zum Niedergang und schließlich zur Aufgabe der Wiesenbewässerung geführten haben. Vor allem aber sollen regionale Schwerpunkte der Wiesenbewässerungsflächen dargestellt werden, die mit ihren Wasserableitungen und Gräben überhaupt erst die Intensivierung der Futtergrasgewinnung begünstigt haben.

\section{a Historisch-umweltgeschichtliche Entwicklung}

Die Anfänge einer Wiesenbewässerung scheinen in Deutschland mindestens bis in das 12./13. Jahrhundert zurückzugehen (DENZER 1996:135). Vor allem infolge des mittelalterlichen Klimaoptimums zwischen 800 und 1300 lagen die Niederschlagsverhältnisse wesentlich unter denen der nachfolgenden nassen und kühlen Jahrhunderte und aufgrund dessen „,ist für diesen Zeitraum die Wässerung von Wiesen angebracht gewesen“, lautet die Begründung von DENZER (:135). Dabei, dies sei vorausgeschickt, war die Bewässerung ,freilich die, welche durch den Regen von oben erfolgt.“ (WEYER 1800:53) Hierbei wurde die gleichmäßige Verteilung ebenso sehr geschätzt wie die Temperatur und die kostenfreie Beregnung. Fiele der Niederschlag regelmäßig und in ausreichender Menge, „so bedürfte es der künstlichen Bewässerung nicht“, schreibt WEYER (:53). Der Wert des Heuertrages schien aber so hoch und die klimatischen Bedingungen auf lange so ungünstig, ,daß doch eine künstliche, ganz von unserer Willkühr abhängende, Bewässerung der natürlichen weit vorzuziehen ist.“ (:53) Nach KONOLD (1994:305) war die Wiesenbewässerung bereits „seit dem 8. Jahrhundert auch in Gebieten, in denen die römische Tradition abgebrochen war, ganz allgemein in Ausbreitung begriffen“. Er belegt das damit, dass die Werke des wichtigsten römischen Agrarschriftstellers COLUMELLA aus dem 1. Jahrhundert $\mathrm{n}$. Chr. in der Karolingerzeit eine Renaissance erlebt hatten und mehrfach abgeschrieben worden waren und wohl hauptsächlich von den Benediktinern als den wichtigsten Bildungsträgern weiterverbreitet worden sind. „In Columellas ,de rustica', so KONOLD (:304), „finden wir genaue Anleitungen über Wiesenbau, Wiesenpflege und Wiesenbewässerung."“

Feststehend ist zunächst einmal, dass in den mitteleuropäischen Bereichen des humiden Klimas, im Gegensatz zu den ariden Gebieten, in denen seit vorchristlicher Zeit mit weitreichenden Bewässerungsanlagen aber keine Wiesen, sondern Felder mit Wasser versorgt worden sind, Anlagen zur Wiesenbewässerung in früheren Jahren keine alltägliche Erscheinung gewesen sein können.

Während Viehweiden ${ }^{37}$ in Mitteleuropa schon sehr alt sind, entstanden Wiesen mit den zum Mähen nötigen Werkzeugen erst verhältnismäßig spät. Vielleicht hat man schon lange, bevor man Sicheln kannte, durch einfaches Rupfen einen Teil des Winterfutters für das Vieh gesichert (ELLENBERG 1986:59). Aber diese Form der Heuerwerbung hatte keinen Einfluss auf die Gewässerlandschaft zum

\footnotetext{
${ }^{37}$ Hier ist eine deutliche Abgrenzung zwischen Weide und Wiese zu ziehen. Eine „Weide“ bezeichnet Grünflächen, die überwiegend dem Weidebetrieb dienen. Die Wiese hingegen dient in erster Linie zur Gewinnung von Heu, d. h. von Winterfutter. Anzumerken ist ferner, dass „Wiese“ sprachgeschichtlich in enger Beziehung zu „Wasser“ steht und sogar in der Bedeutung als „die zu Wässernde“ interpretiert wird (GROTTIAN 2001:5).
} 
Zwecke einer Bewässerung. Erst die Mahd, d. h. der für sämtliche Arten gleichzeitig erfolgende Schnitt bedurfte einer einheitlichen und größeren Fläche und wirkte wesentlich anders als die Auslese durch Weidetiere.

Sicher waren die ersten Wiesen einschürig, d. h. „Streuewiesen“, die man erst spät im Jahr schneidet, wenn sie bereits strohig geworden sind und als Streugut verwendet. Sie lagen „meist in nassen Niederungen, die vom Weidevieh gemieden werden und keiner Einzäunung bedürfen“ (ELLENBERG 1986:59). Als erste wurden deshalb „die nährstoffreichen Erlenbrücher in die Nutzung einbezogen, und zwar dort, wo sie in dorfnahen Flußtälern vorkamen." (:62) Hier lieferten die ausschlagkräftigen Bäume willkommenes Brennholz, und nach Vernichtung des Waldes entstanden Seggengesellschaften, die eine erhebliche Bedeutung für die Entwicklung von Heuwiesen bekommen sollten.

Die Böden der Fluss- und Bachtäler litten zu der Zeit aber an stauender Nässe. In solchen bei reichlichem Niederschlägen versumpften und in langen, trockenen Sommern dagegen vollkommen ausgetrockneten Bachtälern, die durchzogen waren von einigen trockenen Bulten und Hecken, Primärgehölzen und Weidengehölzen, gediehen nur schlechte Sumpfgräser wie Seggen, Schilf, Binsen oder Riedgräser. Diese wurden von den Besitzern gemäht, getrocknet und wie beispielsweise im saarländischen Raum ,in großen Mengen als Packheu an die Mettlacher Glas- und Porzellanfabrik verkauft“ (FIEDLER 1965:59).

Aber auch das Heu (Moorgras) der wenigen, wenn auch älteren, Waldweiden im Hochwald, der Blößen, war so sauer, dass es teilweise noch nicht einmal verfüttert werden konnte, sondern lediglich als Einstreu oder ebenfalls zum Verpacken in den Fayencefabriken in Mettlach oder Fürstenberg Verwendung fand (FIEDLER 1965:51). Und „Laubheu“, getrocknetes Laub, ebenfalls reich an Nährwerten, spielte mengenmäßig lediglich als Ergänzungsfutter eine Rolle (GROTTIAN 2001:3).

In den Heidegebieten bestanden die Weidegründe zum größten Teil aus Heideflächen, die bis spät in den Herbst hinein von Kühen, Schafen und Rindern beweidet werden konnte. Zwar wurde das junge Heidekraut auch gemäht und Rindern (speziell der angepassten Rinderrasse „Heidschlag“) und sogar Pferden als Heuersatz zugefüttert und die Heide bildete so eine wesentliche Basis für die Futterversorgung des Viehs, doch von Heide allein konnte das Vieh nicht leben. Grundlage für die Versorgung der Rinder im Winter war Roggenstroh, während mit Plaggen und Streuheide eingestreut wurde. Die Strohfütterung wurde lediglich nach Bedarf durch Heidekraut ergänzt (GROTTIAN 2001:3).

Waldweide, der Weidegang auf Stoppelfeldern und Brachflächen ergänzten das aufgestallte Futterangebot an Laubheu und Heidekraut im Sommer. Die Rinder grasten in diesem Zeitraum überwiegend auf den wenigen Grünlandflächen und in den nicht allzu vernässten Bruchwaldzonen der Talniederungen. Wichtig war jedoch, dass daneben für die Zeit der Aufstallung eine ausreichende Menge an nährstoffreichem Wiesenheu verfüttert werden konnte, das aber nicht in ausreichender Menge zur Verfügung stand.

Diese prekäre Situation wurde dadurch verstärkt, dass das Hauptanliegen der Landwirtschaft die notwendige Düngung der Pflanzen auf dem Acker war. Für die Bauern galt das Sprichwort: „Die Wiese ist die Mutter des Ackers". Das Wiesenheu, als unentbehrliches Winterfutter für das Hornvieh, lieferte über den Kuhmagen den so dringend gebrauchten Stallmist als Düngungsmittel für den Roggenacker, dessen weitere Qualität von der Stallarbeit der Knechte und Mägde sowie von der Lagerung der Dunghaufen des Gutshofes abhängig war (ALTMANN 1999:111). Die Düngung der Felder bildete eine Grundlage für gute Ernten. Fiel die Wiesenmahd aus oder war das Wiesengras wegen zu langer Überstauung verdorben, gab es wenig Stallmist und einen geringen Kornertrag beim Getreide (BOSSE 1991:52). Diente das Rind früher in der Hauptsache als Zugtier, so bekam es jetzt die weitere Aufgabe, den erforderlichen Dünger zu liefern (FIEDLER 1965:51). Fehlte ,es nun an Vieh, so fehlt es auch an Duenger, und mithin auch an Ertrag der Felder, weil diese nicht genug gebessert werden koennen, und also leidet durch den Mangel an Futter die ganze Landwirtschaft.“, schreibt (SCHEYER 1795). Gleichzeitig spielte das Wiesenland zur Futtergewinnung für Pferde eine 
große Rolle. In vormotorisierter Zeit wurden Pferde zum einen als Zugtiere gehalten, beispielsweise zum Heideplaggenziehen in Norddeutschland, zum Bäumerücken und zum Felder Bestellen, obschon hier auch das Ochsengespann eingesetzt wurde. Zum anderen wurde die in früheren Jahrhunderten blühende Pferdezucht ausgeübt (HETZEL 1957:26). So erforderte die Verwendung von Pferden zu Zug- und Reitzwecken einen immens großen Heubedarf (WEBER 1971:23). Die sog. „Spann-ReiseFuhren“ zum Beispiel, weite Reisen mit pferdebespannten Wagen, verlangten an den Umspannstationen nach Heu. Pferde bekamen bei den Stationen alsdann Mahl und Futter: „Für 4 Pferde 1 Himten Habern auf Tag und Nacht zum Füttern versprochen und Hau so viel sie gebrauchen für die Pferde“ zitiert LANGE (1989:52) aus historischer Quelle.

Für deren vermehrte Haltung standen jedoch weder die Erträge des Feldfutterbaus noch Futterhackfrüchte zur Verfügung. Fütterungsgrundlage für die Rinder und Pferde konnte nur das Rauhfutter sein, das fast ausschließlich über die Wiese bzw. das Dauergründland gewonnen werden konnte. Es galt also, die Ertragfähigkeit der Wiesen zu steigern, und zwar ohne hierfür betriebseigenen Dünger zu verwenden. Dieser hatte ja ausschließlich für die Düngung der Äcker zur Verfügung zu stehen (GROTTIAN 2001:3). Somit mussten die Anbauflächen für die grünen Futterpflanzen und des Dauergrünlandes in Form der Wässerwiesenwirtschaft vergrößert werden (FIEDLER 1965:50). Dies konnte nur in der Ausnutzung der bisher vollkommen vernachlässigten, schmalen, versumpften und überschwemmungsgefährdeten Bach- und Flusstäler geschehen, die Seiten- und Nebentäler der Ströme und schiffbaren Flüsse, da der Ackerbau an den Talhängen, auf den fruchtbaren Terrassen und Plateaus vorherrschte. Darüber hinaus passierte der Ausbau von Wiesen und Anbauflächen entlang der Kanalstrecken „mittels Lichtung [Entwaldung, B.B.] der waldigen Gegenden an der ganzen Kanalstrecke“, wie REUTER (1837:16) vom Ludwigskanal berichtet.

Wiesen auf trockeneren Standorten sind dagegen jüngeren Datums. Ohne Düngung konnten sie nur im Überschwemmungsbereich der Flüsse entstehen, wo ihnen nährstoffreiche Sedimente mit dem Hochwasser zugeführt wurden. Diese natürlichen Talauen periodischer Überschwemmungsbereiche waren jedoch nur von kleinflächiger Größe. Weite Teile der Talböden konnten gar erst durch die Einführung von Bewässerungssystemen für eine landwirtschaftliche Nutzung verfügbar gemacht werden. Die einst oft überschwemmten und wenig fruchtbaren Schotter- und Sandfüllungen der natürlichen Überschwemmungslandschaft boten für die Bodennutzung zunächst keine günstige Voraussetzung. Die Talböden erhielten erst durch die regelmäßige Bewässerung eine mineral- und humusreiche Bodenschicht. Die Anlage eines geregelten Graben- und Bewässerungssystems erlaubte es, das schwebstoffreiche Flusswasser auch zur Bodenbildung - als Grundlage einer Inwertsetzung der Flächen - zu nutzen. Durch regelmäßige Wässerung wurden Geschwemmsel, Sand und Schwebstoffe flächenhaft sedimentiert. Die Verschwemmung des suspendierten Materials über die Wässerwiesen führte im Laufe der Zeit zu einer Kolmatierung, d. h. zur Bildung einer bewirtschaftbaren Bodenschicht. Der hohe Mineralgehalt des Schwebs sicherte darüber hinaus die natürliche Düngung der Wiesen (LEIBUNDGUT 1993:33).

Wiesenähnliche Täler bilden sich aber nicht von Natur aus, wie zum Beispiel angenommen wurde, als in den Flussauen durch baumzerstörerischen Eisgang solche baumfreien Flächen entstanden. Auch in der Nähe der großen Ströme und kleinerer Fließen, in den Auenbereichen, wachsen von Natur aus Wälder und Uferbegleithölze. Das bedeutet, dass zunächst die natürliche Vegetation solcher Auelehmböden, die aus einem sehr wüchsigen Laubwald besteht, zuvor durch den Menschen und sein Weidevieh vernichtet worden sein muss. Als weitere Vorbedingung muss sodann das Vieh wieder ferngehalten werden, denn nur bei reiner Mähewirtschaft entstehen eigentliche Wiesen (ELLENBERG 1986:59). „Ohne Sense und Heuernte keine Wiesenflora“, dieser schon hundert Jahr alte Satz SCHLATTERS gilt für ganz Mitteleuropa, wenn man von den Salzwiesen der Seemarschen und den alpinen Matten absieht (ELLENBERG 1986:59). Ebenso kamen Moore, auch wenn sie Bestandteile der Allmende waren, als Weideland in ihrem Naturzustand nicht in Frage. Denn sie waren wegen ihrer Nässe kaum zugänglich, und wo sie betretbar waren, boten sie schlechtes Futter, wie oben geschildert worden ist. Die Wiesenwirtschaft entwickelte sich also an den verschiedenen Talstandorten aus dem extensiven Weidebetrieb heraus. Aus „Laubwiesen“ wurden allmählich Mähwiesen (:59). 
Später dann wird auch der Verlauf der Gewässer beeinflusst worden sein, um die sich fortwährend verändernden und inselartigen Flächen zu größeren und zusammenhängenden Wiesen zu arrondieren und nach einer „,wilden“ Berieselung eine geregelte Überschwemmung durch eine Gewässerbegradigung zu erreichen: „Da auf einer Wiese - im Gegensatz zur Weide - die Grasnarbe (besonders an den Grabenrändern) nicht durch Tritt der Tiere zerstört wird, kann man hier [...] die Bewässerung durch Gräben in Betracht ziehen." (PRAGER/VENT 1954:203) Ab dem 15. Jahrhundert kommt es an zahlreichen Orten zur Einrichtung solcher „einfachen“ Bewässerungswiesen, weil mit der Bewässerung nicht nur die Befeuchtung, sondern auch eine Nährstoffzufuhr trockener Flächen, zum Beispiel von Talhängen, erreicht werden konnte, die zu diesem Zeitpunkt flächenhaft durch Rodungen entstanden waren.

Nachdem in Klosterarealen und Herrschaftsgebieten Wässerwiesen im Verlauf der folgenden Jahrhunderte beiderseits der Ufer angelegt worden waren, die auch nach etwaiger Säkularisierung im 16. Jahrhundert fortbestanden, erreichte die Landwirtschaft zur Zeit der napoleonischen Kriege ihren tiefsten Stand. Nicht aber durch die Kriegsfolgen durch Landsknechte und die Bereitstellung von Vasallen vor allem aus den verbündeten Ländern Baden, Württemberg und Bayern (Franken), die zum Teil aus der Bauernschaft rekrutiert wurden und als Arbeitskräfte verloren gingen, sondern insbesondere durch die Bedingungen in der Landwirtschaft selbst: Die in diese Zeit fallenden SteinHardenbergschen Reformen hatten zur Folge, dass sehr bedeutende Flächen der wilden Weiden und zum Teil auch der Wiesen, die bisher der Gewinnung grüner Futterpflanzen dienten, urbar gemacht und in Ackerland verwandelt wurden. Dadurch dezimierte sich der auch zu diesem Zeitpunkt noch geringe Grünflächenanteil um 15 \% (VON FINCKENSTEIN 1960:21).

Die altüberkommenen Hutungsrechte wurden abgelöst und die gemeine Mark (Allmende) in private Besitzstücke aufgeteilt oder als Gemeindeforst bewirtschaftet. Man ging dazu über, das Rindvieh sowie die Pferde und Schweine vorwiegend im Stall zu füttern. Die Trift- oder Huteweide gingen stark zurück und können nur noch als Reste einer ehemaligen Waldnutzung an einigen Stellen der Mittelgebirge und im norddeutschen Tiefland (z. B. im Oldenburger Münsterland und im Reinhardswald) erkannt werden (ELLENBERG 1986:61). Es gab aber zu diesem noch keine rationelle Viehzucht, es mangelte sogar bei dem noch immer vergleichsweise bescheidenen Wiesenwuchs an Stallfutter für die Wintermonate. Die Bauern waren gezwungen, nur das Vieh im Stall zu überwintern, das sie unbedingt als Zugvieh benötigten. Alle anderen Rinder wurden vor Beginn des Winters für den Eigenverbrauch geschlachtet und eingepökelt oder geräuchert. Das im Stall überwinternde Vieh war in einem solchen Zustand, dass es im Frühjahr kaum aus eigener Kraft auf die Weide gehen konnte und wurde deshalb als „Schwanzvieh“ bezeichnet. Der dadurch bedingte Mangel an Stalldünger machte immer wieder eine Vergrößerung der Anbauflächen notwendig, wenn die Ernteerträge gesteigert werden sollten, denn die Landwirtschaft war vor allem auf die Kräfte der vorhandenen naturgegebenen Böden angewiesen (FIEDLER 1965:50). Noch weit bis ins 19. Jahrhundert wurde an manchen Orten die alte Dreifelderwirtschaft mit meist unbebauter Brache betrieben. Der Feldfutterbau war wenig ausgedehnt. Der Mangel an Wiesen, ein ungünstiges Verhältnis der Wiesen zur Ackerlandfläche und ein häufiges Fehlschlagen der Kultur der Futterkräuter in trockenen Jahren kamen hinzu (KROLL/KONOLD 1994:400). Zählt man zu den Wiesen die Weiden und Allmenden als Futterquelle hinzu, so standen einer Flächeneinheit Wiese, Weide und Allmende immer noch durchschnittlich etwa 13 Einheiten Ackerland gegenüber. „Aus dieser Situation resultierte ein zeitweilig ausgeprägter Futtermangel.“ (:401). Daraus wiederum ergab sich ein Mangel an Wirtschaftsdüngemitteln. Eine ganzjährige Stallhaltung, die zu einer Erhöhung der Menge an gezielt einsetzbaren, tierischen Düngemitteln führte, setzte sich erst sehr spät, gegen Mitte des 19. Jahrhundert, durch (:401).

Parallel entstand im 19. Jahrhundert mit dem Übergang zur „verbesserten Dreifelderwirtschaft“ und der Einführung neuer Feldfrüchte wie Kartoffel, Klee und Luzerne (DIERCKE 1987:118f.) sowie der zunehmenden Bebauung der bisherigen Brache ein großer Bedarf an Stalldung, um die Nährstoffversorgung der Äcker- und Feldfutterbauflächen sicherzustellen.

Da die Mineralstoffdüngung zu diesem Zeitpunkt noch nicht oder nur in sehr beschränktem Maße bekannt war, musste der Landwirt daher seinen Viehbestand vergrößern. Dies war aber nur möglich, wenn genügend Futter beschafft werden konnte. Es bestand also eine Wechselwirkung zwischen 
Grünlanderträgen und Ackerbauproduktivität (FIEDLER 1965:21). Um die Ackerbauerträge zu erhöhen, war eine Steigerung der Grünlanderträge für die Futterbeschaffung deshalb von ausschlaggebender Bedeutung. Die Beschaffung des Rauhfutters erfolgte also damals fast ausschließlich über das Dauergrünland (:21). Die Ertragsfähigkeit der bäuerlichen Betriebe aber wurde durch ein ungünstiges Wiesenverhältnis im Vergleich zur landwirtschaftlichen Nutzfläche beeinträchtigt. Der größte Teil des vorhandenen Bodens war in Acker verwandelt worden (:21).

Das Grünland beschränkte sich zu diesem Zeitpunkt weiterhin auf „natürliche“ Wiesen und Weiden, das heißt auf solche Flächen, die wegen ihres schweren, tonigen Bodens, ihres hohen Grundwasserstandes oder ihrer Hanglage nicht als Ackerland genutzt werden konnten. Da der anfallende Stallmist noch nicht einmal zur Düngung der Äcker ausreichte und Kunstdung noch nicht in Betracht kam, mussten die Wiesen auf andere Weise versorgt werden. Eine gut durchdachte Bewässerung konnte dabei zur Steigerung der Erträge führen (FIEDLER 1965:21). Die Heuwiesen schufen somit die Voraussetzung vermehrter Viehhaltung. Insbesondere in Zeiten, in denen es immer wieder zu Hungersnöten kam, war die Ertragssicherheit der Wässerwiesen besonders wichtig. Der vermehrt anfallende Stalldünger wiederum bot die Voraussetzung für eine Intensivierung des Ackerbaus. Weitere Waldflächen wurden gerodet, Offenland in hochwassersicheren Lagen in Kultur genommen und zu Ackerflächen umgebrochen.

Zur Ausbreitung kam es auch, als die jahrhundertelang ausgeübte Feld-Weide-TeichWechselwirtschaft, d. h. der Wechsel zwischen Fruchtbau, Beweidung und Fischzucht, nicht mehr propagiert und praktiziert wurde. „Wie aber das Futter beschaffen, wenn der Ackerbau im Teiche aufgegeben wird? Die Wiesen liefern es; denn die Felder im Teiche sind leicht in Wiesen umzuwandeln“, beschreibt ACKERHOF (1869:94) das Problem und gibt die Lösung vor: Als Ableitungsgräben konnten die bereits im Teich befindlichen Teichbodengräben (siehe VII 2c.2.6.2) leicht benutzt werden (:95). Überhaupt bestand das ganze System von Stau- und Verteilungseinrichtungen zur Wiesenbewässerung schon: Hauptzuleitungsgräben, Rinnen, Dämme, um einen Aufstau zum Schwemmen zu bewirken etc. Einer Berasung der ehemaligen Teichfläche stand somit nicht viel im Wege; bei der Umbildung in eine Wiese verlangte vornehmlich die Melioration, d. h. die Austrocknung des Teichbodens, den höchsten Arbeitseinsatz (ACKERHOF 1869:107ff.). Zudem verschlämmte bereits beim Teichbau das in die Teichflächen gelangende Wasser „,in kurzer Zeit alle Löcher und Poren des Grundes“ (VOGEL 1898:58) und schaffte zumindest eine Wiesenfläche, die einer gesonderten Schwemmung nicht bedurfte.

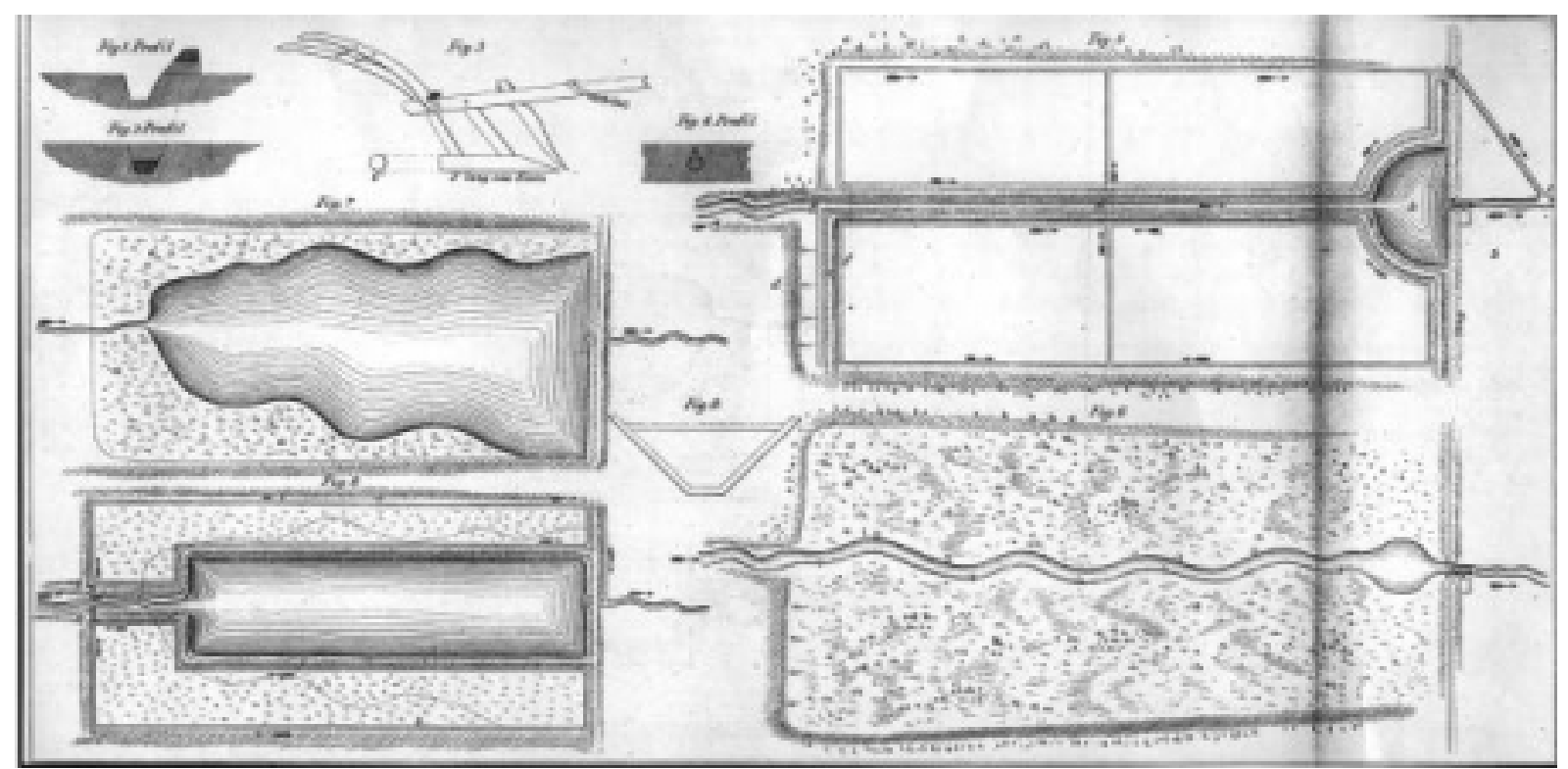

Abb. VIII-52: „Urbarmachungen und Grundverbesserungen“

Fig. 7 zeigt den Ausgangszustand: eine Teichanlage in mit einem kleinen Bachlauf durchflossenen Wiesengrund [a] mit ungeregelter Absteckung. Die zur Verfügung stehende Wiesenfläche ist schlecht zu bearbeiten, der Teich nimmt fast den gesamten Talraum ein. Fig. 8 demonstriert den Zustand nach erfolgter „Grundverbesserung“: eine schematisch-rechteckige Teichanlage mit einem umlaufenden besaeten Teichdamm und einem geformten und 
kanalisierten Bacheinlauf, dessen Zufluss durch ein Wehr [d] geregelt ist. Die Umrisse des ehemaligen Teichverlaufs [Fig. 7] sind als gestrichelte Linie noch eingezeichnet. Ein Gewinn an Wiesenwachs bzw. eine verbesserte Bearbeitung der Wiesenfläche wird somit erzielt; die nochmalige Versumpfung aufgehoben. Fig. 6 zeigt einen mäandrierenden, mit Baumbewuchs (Weiden?) bestandenen Bachlauf in einem unbearbeiteten Wiesenbruch mit Auengehölzen (die eingezeichneten Bäume (Verbuschung) mit Feuchtflächen weisen eindeutig darauf hin). Am Ende des Areals wurde durch einen Damm und eine Abflussvorrichtung ein kleiner Weiherstau erzeugt. Fig. 5 gibt ein Vorbild einer geordneten, geometrisch eingeteilten Wässerwiesenfläche mit einem gefassten Weiher und umlaufenden Wassergräben sowie einem Hauptumlaufgraben, der das Wasser hinter dem Teichdamm dem mittig durchlaufenden Bachkanal wieder zuführt. Der Teichdamm scheint verbreitert, denn er ist als „Weg“ eingezeichnet (aus: SPRENGEL 1838, Tafel II).

Zugleich fielen wegen der Begradigung und Tieferlegung von Flüssen vor allem seit Mitte des 19. Jahrhunderts zahlreiche Wiesen trocken (KONOLD/POPP 1994:392 am Beispiel der Schwarzach). Um die tiefer liegenden Grundwasserstände und die fehlenden periodischen Überschwemmungen auszugleichen, wurden daher umfangreiche und ausgefeilte Wässerwiesenanlagen notwendig.

Diese Meliorationsmaßnahmen fielen zusammen mit der Bekämpfung des sog. „Sumpffiebers“ sowie mit den zahlreichen Viehseuchen in historischer Zeit: Wie PÖRTGE (2004) ausführt, war die wirksame Bekämpfung der Ursachen von Viehseuchen und Erkrankungen der Bevölkerung am „Sumpffieber“ (Malaria) ein wichtiger Grund für umfangreiche Trockenlegungen in der Mitte des 19. Jahrhunderts. Anhand des von ihm eingesehenen Quellenmaterials aus Mitteldeutschland (Thüringen) wird deutlich, wie sehr die Bevölkerung zu leiden hatte. Als Ursache der Erkrankungen werden immer wieder feuchte Weiden/Hutungsflächen, „ungesunde Ausdünstungen“ aus Teichen und Tümpeln sowie die daraus zu Tausenden aufsteigenden Stechmücken genannt.

So hätten laut übereinstimmenden Aussagen vieler Zeitgenossen die Kühe in manchen Monaten „bis zu den Hufen“ im Schlamm gestanden und „faules Gras“ gefressen (so z. B. im Sommer 1752 sowie in den von klimageschichtlichen Untersuchungen her bekannten Hunger- und Notjahren 1770/71 und 1816). Zudem wären die Tiere auch im Stall erkrankt, da ihnen die Bauern oft nur „faules Heu“ einstreuen konnten. Hinsichtlich der Erkrankungen der Menschen am „Sumpffieber“ wird seit Beginn des 19. Jahrhunderts in vielen Unterlagen führender preußischer Behörden immer wieder bemerkt, dass man dieses Problem nur angehen kann, wenn die Brutstätten der Mücken „trocken gelegt“ bzw. „mit Erdreich verfüllt“" werden.

Einen geordneten Aufschwung nahm das Meliorationswesen dann, wie auch bei der Teichwirtschaft gesehen, durch die Gründungen landwirtschaftlicher Zentralstellen, wie beispielsweise in Württemberg mit der Gründung der „Zentralstelle für die Landwirtschaft“ im Jahr 1817. Sie waren unter anderem für die Verbreitung neuer landwirtschaftlicher Erkenntnisse sowie für die Förderung der Meliorationen verantwortlich (KONOLD/POPP 1994:380). Die königliche Landwirtschaftsgesellschaft in Celle förderte diese Anlagen schon vor 1800 durch Prämien und Zuschüsse. Preisschriften, wie die von WEYER (1800), sollten der künstlichen Wiesenbewässerung und -anlage zu weiterer Verbreitung verhelfen. Auch der 1830 gegründete „Land- und forstwirthschaftliche Provinzialverein für das Fürstentum Lüneburg“", kurz der sog. Provinzialverein, ließ ab 1845 bis 1860 alle Fluss- und Bachtäler der Gegend auf ihre Eignung zur Anlage von Rieselwiesen untersuchen (GROTTIAN 2001:21). Die Untersuchung umfasste insgesamt 54.654 Morgen Talwiesen, von denen schließlich 17.000 Morgen als sog. Sonderpläne zur Anlage von Bewässerungsflächen angefertigt wurden (:21). Es ging also um die Erhebung der schon vorhandenen Bewässerungswiesen sowie der noch ausbaufähigen Flächen, die dann einer Bewässerung zugeführt werden sollten.

Neben dieser eher wissenschaftlichen Unterstützung eines organisatorischen Überbaus bildeten sich schon recht früh, zum Beispiel im Saarland zu Ende des 18. Jahrhundert, „freiwillige Selbsthilfeorganisationen“" (FIEDLER 1965:40). Sie regelten alle Arbeiten, die für die Erhaltung und Nutzung ihrer Wiesen erforderlich waren, und hatten „die Aufgabe, Bau, Pflege und Funktion der Anlagen einer gemeinsamen Regelung zu unterwerfen und die Rechte der Mitglieder gegenüber anderen Wasserentnehmern, z. B. Triebwerksbesitzern und Müllern, wahrzunehmen.“ (:41)

$\mathrm{Zu}$ Anfang des 20. Jahrhundert wurden einige dieser Organisationen in die bedeutend straffer organisierten „Wässerungsgenossenschaften“ mit ihren strengen Satzungen überführt. Ihre Arbeit, die 
staatlich gefördert wurde, leitete „eine bedeutende Zunahme der Wässerwiesen“ ein (FIEDLER 1965 :41). Es war „die Aufgabe einer jeden Genossenschaft, eine ordentliche und erfolgreiche Bewässerung der Wiesen zu garantieren und vor allen Dingen, eine gleichmäßige Verteilung des Wassers auf alle Parzellen der Besitzer zu ermöglichen.“(:44)

Der organisierte Neu- und Ausbau wurde notwendig, da proportional zu den Anlagen von Wässerwiesen die Zahl der gehaltenen Rinder stieg. Die Ertragssteigerung in der Heu-, d. h. Winterfuttergewinnung, ermöglichte eine Aufstockung der Viehbestände, da dessen Gebrauch bzw. Einsatz einem Wandel unterworfen war. Beschränkte sich anfangs die Aufgabe der Rindviehhaltung noch auf den Gebrauch des Rindes als Zugtier und als Düngerproduzent (FIEDLER 1965:51), so bedingte der aufkommende und ansteigende Bedarf an Schlachtvieh zur Versorgung der Städte mit Fleisch und Viehprodukten und in steigendem Maße als Milchlieferant gegen Ende der 1870er Jahre eine Steigerung der Grünlandflächen. Seit etwa 1890 bis ungefähr 1906 kam es nochmals zu einer stärkeren Intensivierung der vorhandenen Wiesenflächen, d. h. zu Verbesserung der bereits vorhandenen Wiesen durch Bewässerungsanlagen. Mit der Verbesserung der Feldgraswirtschaft zu Beginn des 19. Jahrhunderts mussten auch die Bevorratungseinrichtungen erweitert werden. Der Bau von Feldscheunen war damit für die Hüttengüter notwendig geworden (ALTMANN 1999:113). Die Gewinnung von neuen großen Wiesenflächen war aber nicht mehr möglich, deshalb griffen die Genossen auf kleinere, noch ungenutzte, aber zur Berieselung geeignete, Ländereien zurück (FIEDLER 1965:53ff.)

Doch nicht überall brachte seit 1800 - 1850 die allgemeine Intensivierung der Landwirtschaft im Weidebetrieb eine tiefgreifende Umstellung dahingehend, dass umfangreiche Wässerwiesen angelegt wurden. So seien um 1800, schreibt WEYER, „nur erst an kleinen Flüssen und Bächen“ Wiesen angelegt worden. Ströme und größere Flüsse scheinen zu diesem Zeitpunkt nicht im Blick der Wiesenbauer gewesen zu sein: „darüber sind bisher bei uns noch keine Beobachtungen anzustellen gewesen“ (1800:14).

Umgekehrt bestand in den küstennahen Gegenden und im Alpenrand die Tendenz, alles Grünland mit Ausnahme sumpfiger, vernässter Areale - in ständige Weidenutzung zu nehmen und die Weideflächen durch Bodenentwässerung immer mehr zu vergrößern. Diese Betriebsform der „Standweide“ herrschte bis etwa 1960 vor: Man belässt das Rindvieh vom Beginn bis zum Ende der Vegetationsperiode, d. h. etwa von April bis Oktober, auf ein und derselben Futterfläche und stallt es nur während der ungünstigen Jahreszeit ein. Die durch Denitrifikation und Bodenauswaschung entstehenden Stoffverluste werden durch den Kot der weidenden Tiere dem Grünland wieder zugeführt (ELLENBERG 1986:61). Diese Weiden waren jedoch für eine Mahd nur schwer zu gebrauchen. Sie waren vor allem gekennzeichnet durch sog. Geilstellen, d. h. durch Rinderexkremente verunreinigte Rasenflecken, die, auch im abgemähten und mit der übrigen Mahd vermischten Zustand, von den Rindern gemieden wurden, deshalb ungestört $\mathrm{zu}$ dunkelgrünen Grasbuckeln emporwuchsen und zusätzlich eine Sensenschnitt erschwerten.

Auf der anderen Seite war eine Beweidung auf den Bewässerungswiesen zum Beispiel des Siegerlandes zu bestimmten Zeiten und Mitte des 18. Jahrhunderts erlaubt. Auch die Beweidung mit schwerem Rotvieh. Aber zu dieser Zeit war auch noch nicht der Wiesenbau zu seiner höchsten Blüte entwickelt, und so wurde das Vieh häufig noch im Mai auf die Wiesen getrieben. Dennoch entstanden auch hier Schäden, da sie den Boden auf dem noch feuchten Gelände zertrampelten und sowohl die Heu- als auch als die Grassamenernte empfindlich beeinträchtigten (JOOSTEN/JUNG 1995:25f.), was eine Regelung auch für weniger kunstvolle Wiesen notwendig machte, obgleich auf die Wiesen als Weideland nicht vollständig verzichtet werden konnte. So durften die bewässerten Talwiesen im Siegerland erst nach der Grummeternte, also dem zweiten Heuschnitt, den „letzten Schnitt“ besorgen (:25). Von der Beweidung ausgenommen blieben aber auch hier die sehr feuchten Wiesen, die vom Vieh völlig kaputt getreten worden wären.

War hier die Ausbreitung von Wiesen durch eine spezielle Betriebsform begrenzt, so waren außerdem mit Einführung auch von ausgereiften Bewässerungssystemen, Ertragssteigerungen auf den Äckern sowie der Ausdehnung der Ackerflächen auf bisher nicht beackerte Ländereien (Heide-, Torfbrandflächen) noch enge Grenzen gesetzt. Zwar verbesserte die Rieselwirtschaft die 
Futterversorgung auf den Höfen entscheidend, dennoch blieb die Ertragsfähigkeit der Äcker nach wie vor an die Erträge der Wiesenflächen gebunden. Erst die Einführung des Kunstdüngers löste diese Bindung zwischen Wiese und Acker. War über Jahrhunderte hinweg die künstliche Befeuchtung von Grünland die einzige Möglichkeit einer Ertragssteigerung, so setzte der Niedergang der Wiesenbewässerung seit dem 19. Jahrhundert mit der zunehmenden Verwendung von Kunstdünger ein. Das Aufkommen des Kunstdüngers, bei dem chemische Düngerbeigaben zur Ertragssteigerung anstelle des schwebstoffhaltigen Wassers verwendet werden, ließ die düngende Wirkung des Wassers in den Hintergrund treten.

Der Niedergang der Wässerwiesenwirtschaft wurde durch die Beseitigung der ehemaligen Wiesen verstärkt, deren Ursache in verschiedenen Prozessen liegt. So wurden beispielsweise Bewässerungswiesen mit der beginnenden Industrialisierung Mitte des 19. Jahrhunderts als Industriegebiete genutzt und in großräumige Betriebsgelände umgewandelt (HERBST 1992:66). Nach der immer wieder in ihrer Bedeutung zu erwähnenden Entsäkularisierung wurden Wässerwiesen aufgeforstet oder die Bewässerungsareale, wie beispielsweise die Wiesen des Benediktinerklosters Ochsenhausen, ab 1868 zu Truppenübungsplätzen umgewandelt (:96). Vor allem allgemein dort, wo Bewässerungswiesen als Bauerwartungsland benötigt wurden, begann Mitte des 19. Jahrhunderts eine großräumige Beseitigung sämtlicher bisheriger Wasserbauten, wurden die jahrhundertealten Wiesenbewässerungs- und entwässerungsanlagen abgeräumt und eingeebnet. Die ältesten Industriegebiete außerhalb der alten, beengten Siedlungskerne sind ,identisch mit den im Spätmittelalter besonders wichtigen siedlungsnahen Bewässerungsflächen“"(:146).

Andere Gründe waren der Entzug von Bachwasser zu gewerblichen und industriellen Zwecken anstelle der Ableitung von Bachwasser zu Bewässerungszwecken sowie die Streitigkeiten durch die Wassermühlen, da die anliegenden Wiesen durch den Rückstau überschwemmt wurden (SCHEFFLER 1982:45), was durch die damit verbundenen Versumpfungen den flussaufwärts des Staus gelegenen Wiesengräser erhebliche Schäden zugefügt hat (ERLER/MATTHIESEN 1989:53). Auf der anderen Seite erfuhren die uralten Nutzungsrechte durch ausbleibenden Wasserstauungen der oftmals jüngeren Mühlen in Bewässerungszeiten bedeutsame Einschränkungen, wenn „die Bache [...] verweigert wurde“ (DOBELMANN 1980:35). Die Müller schadeten sich, so scheint es, hierbei selbst: weniger Heu - weniger Viehfutter - weniger Dung - weniger Getreide - weniger Mahlgut, lautet eine mögliche Versorgungskette.

Es wird aber immer wieder auch die enge direkte Verzahnung zwischen der Wassermüllerei und dem Betrieb von Bewässerungswiesen beschrieben. Die Wassermühlen, insbesondere die Getreidemühlen, betrieben in der Regel auch Landwirtschaft, zumeist als Nebenerwerb bzw. zur Eigenversorgung. Zu den Agrarflächen einer Müllerei gehörten deshalb auch Wiesen, die als Rieselwiesen betrieben wurden. Die Anlage von Rieselwiesen wurde regelrecht von den Wassermüllern vorangetrieben und sie ziehen sich deshalb bevorzugt entlang von Mühlkanälen, Mühlbächen und Gewässerstauen (LANGE 1989:54). Der Bach wurde also nicht nur zum Mühlbetrieb gestaut, sondern auch, um seine Wiesen zu bewässern. Vor allem mit der Verbreitung des Kunstwiesenbaus seit 1800 gehörten die Müller zu dem tragenden Personenkreis zur Realisierung dieser Anlagen. Die Wässerung erreichte offenbar eine solche Bedeutung, dass teilweise für die Wiesenbewässerung sogar die wichtige Flößerei eingestellt werden musste. So heißt es in der Flößordnung für Werra und Schleuse von 1839 unter Punkt 14-15: „Was die Wiesenbewässerung aus der Werra insbesondere durch das Defertshäuser Wehr betrifft, so behält es bei dem bisherigen Herkommen sein Bewenden, wonach zur Heuernte 11, zur Grummeternte aber 9 Tage durch gedachtes Wehr bewässert werden kann und die Flöße während dieser Zeit eingestellt werden muß. Solange das Defertshäuser Wehr gewässert wird, darf unbeschränkt auch mit anderen Wasserwehren gewässert werden, außer den gedachten 11 resp. 9 Tagen aber nur unbeschadet der Flöße.“

Der Niedergang der traditionellen Bewässerung von Wiesen mit Bachwasser, der sich - bei weiterem Ausbau der Graslandflächen - unvermindert fortsetzte, wurde in der Zeit der Nationalsozialisten vorübergehend aufgehalten, als neue Wasser- und Bodenverbände zur Bewässerung kleiner Wiesenflächen ins Leben gerufen wurden, um die Grünfutterbasis autark zu machen und Beitritts- und Eroberungsgebiete zu kultivieren. Nur während der Weltkriege sanken die Erträge wieder auf einen 
tiefen Stand. In den Nachkriegjahren traten die bestehenden Bewässerungsanlagen noch einmal in Funktion (FIEDLER 1965:56), um dann endgültig in der Versenkung zu verschwinden.

Das endgültige Ende der landwirtschaftlichen Wiesenbewässerung im Verlauf des 20. Jahrhunderts wurde, neben der vielzitierten Wirkung des Kunstdüngers, durch verschiedene weitere Gründe verursacht: Der rasante technische, agrarstrukturelle und gesellschaftliche Wandel im 20. Jahrhundert ließ die alten Nutzungssysteme konkurrenzunfähig werden (LEIBUNDGUT 1993:13). Unter Druck geriet die Bewässerungswirtschaft vor allem durch die zunehmende Mechanisierung (GROTTIAN 2001:30): „Erst die umwälzende Rationalisierung und Mechanisierung der Landwirtschaft“, resümiert BINGELLI (1986:30) die Gründe und Folgen, „führte zur Niedergangsphase, die sich nach dem Zweiten Weltkriege beschleunigt verstärkte." So ging man bereits seit Anfang der beiden ersten Jahrzehnte des 20. Jahrhunderts dazu über, die Wiesenrücken für den Einsatz fahrbarer Mähmaschinen geeignet zu machen. Die kleinflächigen, durch zahlreiche Gräben und Rinnen durchschnittenen Wiesenflächen standen einer maschinellen Bearbeitung entgegen. Die Rücken wurden zunächst daher möglichst großflächig angelegt und erreichten eine Breite von $20 \mathrm{~m}$ und eine Länge von $200 \mathrm{~m}$ und mehr. Eine gleichmäßige, ausreichende Nährstoffversorgung war so aber nicht mehr gewährleistet. Eine effiziente Bearbeitung war zwar gewährleistet, aber zugleich ein ausreichender Ertrag verhindert.

Die Landwirtschaft wurde zunehmend weiter motorisiert und so wurden in Anpassung hieran großflächige Wiesenplanierungen durchgeführt, die auch die größeren Beetrücken verschwinden ließen. Für den Maschineneinsatz waren die Flächen zu feucht, die vielen Gräben und Wiesenreliefs bei der modernen maschinengeführten Mahd hinderlich. Die Gülle und natürlich auch die Mineraldünger waren einfacher zu handhaben und auch wirksamere Mittel als das Wässerwasser. Die arbeits- und zeitintensive Wiesenbewässerung wurde schlichtweg unzeitgemäß. Es zeigte sich aber, so FIEDLER (1965:2), „daß der Hauptgrund in einer neuen Einstellung der Besitzer zu ihren Wiesen, insbesondere zu den Wässerwiesen, liegt." Mit dieser Neubewertung zusammenhängend, aber auch für sich genommen nachteilig, sind des Weiteren die hohen Kosten für das Anlegen und die Pflege der Wiesen, für die bei komplexen und großen Wiesenanlagen extra ein Wiesenmeister oder Wiesenwart (Wässerer) $^{38}$ eingestellt werden musste. Weiterhin trug die Auflösung der Hofverbünde als Genossenschaften zur Aufgabe von Bewässerungsland bei. Große vernetzte Bewässerungswiesen können nicht singulär instand gehalten werden, dies ist nur in Gemeinschaftsarbeit möglich (:94).

Wo die individuellen bäuerlichen Eingriffe die Umwandlung von Grasland in Äcker, Tannenschonungen, Obstbaumkulturen und die Aufforstung ehemals kahler Bewässerungshänge noch nicht vollzogen hatten, trugen die zahlreichen seit den 1950er Jahren bis vor allem in die 1970er Jahre hinein durchgeführten Flurbereinigungsverfahren zur Beseitigung von Wässerwiesen bei. Die im Rahmen von Flurbereinigungen vorgenommene Begradigung der Grundstücksgrenzen und Gewässerläufe, die Grundzusammenlegungen und der Grundtausch waren es, die sich negativ auf den Fortbestand der althergebrachten Wässerwiesen ausgewirkt haben. Voraussetzungen für eine rationelle Gründlandbewirtschaftung unter modernen Gesichtspunkten wurden so geschaffen und entsprachen damit den Ansprüchen der Landwirtschaft, denn die kleinteiligen Rücken und vielzahligen Rinnen auf den Wässerwiesen störten die Bauern bei der Maschinenmahd, die zur schnellen und effizienten Heugewinnung mit dem Häckselmäher möglichst große und ebene Flächen brauchen.

Aber auch das Fehlen von entsprechenden Natur-, Umwelt- und Wassergesetzen und Streitigkeiten zwischen Landwirten und Wasserwerksbesitzern über die Benutzung des Wassers bewirkte den Niedergang der Wiesenbewässerung; galt es doch etwas Wasser von der Stauhöhe der Mühlenwehre abzuziehen, bzw. den Mühlenstau durch das Einschwemmen zu erhöhen, was wiederum für den Mühlenoberlieger zu einem Rückstau führen konnte (WEYER 1800:11). Die Auflandungen und die damit einhergehende Erhöhung des Stauwassers vor dem Wehr führten zu Rückstauungen, deren ungeregelte Überflutungen auch den Wiesenwachs selbst störten. Des Weiteren gehörten die unterhalb

\footnotetext{
38 Um eine ordnungsgemäße Bewirtschaftung und Verteilung des Bewässerungswassers zu garantieren, war jede Genossenschaft verpflichtet, einen Wiesenwärter einzustellen. Nur er allein war befugt, die Wiesen zu wässern und das Wasser so zu verteilen, dass alle Parzellen den verhältnismäßigen Anteil am Wasser erhielten. Weiterhin hatte er die Wiese zu bewachen, denn oftmals wurde Schleusen geöffnet oder die Bewässerungsanlage eigenmächtig verändert (FIEDLER 1965:32,44f.).
} 
liegenden Müller zu den größten Widersachern der Schwemm- wie Bewässerungswiesenanlagen, denn die beim Schwemmen fortgetragenen feinen Tonteilchen störten die Mahlgänge erheblich (WEYER 1800:52; SPRENGEL 1838:95). Das die Stauwerke und den Teich zusetzende Sediment musste von den Wieseninteressenten auf ihre Kosten entfernt werden; zu diesen zählten aber auch, wie oben beschrieben, die Wassermüller selbst. Die Versandung der Flussläufe und der Mühlenteiche, die in diesem Verbreitungsgebiet sehr zahlreich auftraten (siehe Pkt. VIII 2.b.1) und die man schon im ersten Drittel des 19. Jahrhunderts dem Schwemmen zuschrieb (SPRENGEL 1838:92), muss dort nicht nur in der Anfangszeit des Wiesenbaus ein ernsthaftes Problem gewesen sein und man bediente sich zu dessen Beseitigung aufwendiger Mittel: Bei den wiederkehrenden „Interimsreinigungen hat man sich gleichfalls des Flößmittels bedient, indem man für die Zeit der Reinigung den Mühlendamm durchstochen und den Sand durch solchen auf einen unterhalb demselben belegenen Raum fortgeschafft hat.“ (WEYER 1800:52f.) Der Ausbreitung von Kunstwiesen waren hier zudem räumliche Grenzen gesetzt. So kam man mit dem „untersten Wiesenstücke“ an der Lopau bei Bockum „selbst dem Mühlenteiche so nahe gerückt, daß vor demselben kein Stauwerk mehr angelegt werden konnte.“" (:51)

Vor allem seit den 1920er Jahren ging es nicht mehr um die interne Auseinandersetzung mit den Wassermühlenbesitzern und des Aufschlags von Wasser auf die Mühlräder, sondern um die zentralisierte Stromerzeugung von monopolartig strukturierten Energieversorgungsunternehmen, deren Interesse Priorität eingeräumt wurde. Die Elektrizitätswerke erhoben Einspruch gegen die Frühjahrswässerung der Wiesen, da das Wasser hierbei den Flussläufen entzogen wurde. Durch die starke Verminderung des Wasserstandes bestünde die Gefahr des Zufrierens, wodurch die Stromerzeugung gefährdet sei (KONOLD 1994:328).

Neben dem allgemeinen Wandel in der Landwirtschaft, dessen Kennzeichen unter anderem die zunehmende Motorisierung und Technisierung sowie die verstärkte Abwanderung von Arbeitskräften in den sekundären und tertiären Sektor sind, erforderte hauptsächlich auch die drastische Verschlechterung der Wasserqualität der Gewässer durch toxische Stoffe die Umstellung auf Trockenwiesen, wie KROLL/KONOLD (1994:417) für die Fehla im Fehlatal nachweisen. Dies ging sogar so weit, so beschreiben sie die historisch-ökologische Situation, „daß die Tiere nach Verzehr des mit dem belasteten Wasser bewässerten Futters erkrankten." Auch für FIEDLER (1965:63) liegt ein Hauptgrund für den Verfall , in der Verschmutzung und Unbrauchbarkeit des Rieselwassers durch das Hineinleiten von Industrieabwässern.“

Durch die weiter ausufernden Wohn- und Gewerbegebiete wurden außerdem vor allem im suburbanen Stadtrand, aber auch am Rande der Dörfer wichtige Teile der Grabensysteme bzw. die Wiesenanlage in seiner Gesamtheit zerstört (KONOLD 1994:329). Besonders nach 1950 wurden die meisten Wässerwiesen aufgelassen, zu Bauerwartungsland umgebrochen oder als Bauland versiegelt (LEIBUNDGUT 1993:13). Dabei wurden und werden die ebenerdigen Talsohlen aufgrund der besonderen Erfordernisse (An- und Ablieferung, Verkehrsanbindung, Maschinenausstattung) für den Gewerbe- und Industriebau bevorzugt, während die Eigentumsbildung vielfach auf Hanglagen - mit guter Aussicht - vorgenommen wird.

In Reihenfolge der Größe bestanden zuerst die kleinen Anlagen in den schmalen und oft stark geböschten Tälern nicht mehr und wurden bis in die Nachkriegszeit aufgegeben. Dagegen funktionierten noch die Anlagen, die an größeren Bächen mit breiter Talsohle lagen (FIEDLER 1965:77) und den Zerstörungsdruck überstanden hatten. Der Grad der Auflassung oder der Versiegelung variierte dabei von Gebiet zu Gebiet recht erheblich und vor allem im Verhältnis zum heutigen Verbreitungsbild. Noch 1957 schrieb Wolfgang HETZEL (:5) in seiner Dissertation: „Die Wiesenbewässerung nimmt in Deutschland trotz ihres Rückgangs in den letzten Jahrzehnten noch recht bedeutende Flächen ein." und beschrieb sie ferner als ,eine wesentliche Erscheinung der Kulturlandschaft" (:5). Bis 1975 zum Beispiel war die Baunacher Wiesenbewässerungsanlage in Betrieb, dann wurde sie eingestellt. Äußerer Faktor war eine „Schnakenplage“, die die Nachbardörfer belästigte, eigentlicher Grund jedoch der landwirtschaftliche Strukturwandel, der die Wässerwiesen überflüssig werden ließ (GUNZELMANN 1999:2). 
Generell ist festzuhalten, dass mit der Wirtschaftsblüte nach dem Zweiten Weltkrieg eine stetige Vernachlässigung der Wässeranlagen und -einrichtungen eintrat und der Anfang der 1950er Jahre einsetzende Verfall der Bewässerungswiesen zu einem Niedergang führte und sich nicht mehr aufhalten lässt: Die Stauschleusen zerfallen und lassen vielfach nur noch als reliktäre Reste erkennen, dass hier einst eine intensive Bewässerung betrieben wurde. Schließlich versumpft die Talsohle oder wird umgepflügt, die Hangwiesengräben und -rinnen schwemmen zu und werden nicht wieder aufgestochen und auch Steilhangwiesen werden mittlerweile in Ackerland umgebrochen. Zudem fahren die Bauern heute mit Traktoren und Anhängern auf die kombinierten Wiesen- und Weidenflächen, um sie mit Jauche zusätzlich zu düngen. Nach der Heuernte werden heutzutage die Rinder zur Weide auf die Wiesen getrieben. Früher war die Beweidung der Rieselwiesen verboten. Oder das Gras vertrocknet auf einer EU-geförderten Brache. Die Wässerwiesen als Grundlage der Viehhaltung haben ihre Bedeutung verloren. In einigen unter Schutz gestellten Gebieten verhindert die durch natürliche Überlassung einsetzende Sukzession die Offenhaltung von Wiesenland. Oder sie werden mit dem Kriterium einer „extensiven Trockenrasenfläche“ als Naturschutzgebiet geführt und jährlich durch vertragliche festgelegte Naturschutzmaßnahmen mit freiwilligen bzw. ehrenamtlichen Helfern von der einsetzenden Verbuschung befreit bzw. zur Offenhaltung mit einer Schafherde beweidet.

Heute sind fast sämtliche Wässerwiesen als historische Kulturlandschaftselemente einzustufen, deren Stadium von persistent zu reliktär wechselt und in vielen Bereichen gar als fossil zu bezeichnen ist. Entweder sie liegen also unbenutzt dar oder sie sind zum größten Teil beseitigt worden. MENARA (1994:145) stellt deshalb ernüchtert fest: „Die jahrhundertealte Berieselungsmethode mit all ihren Auswirkungen auf das Landschaftsbild, auf das Rechtswesen und auf das Leben insgesamt [...] ist erloschen.“ LEIBUNDGUT (1993:21) äußert sich zurückhaltender und schränkt ein, dass „,mit wenigen Ausnahmen [...] die Wiesenbewässerung in ganz Mitteleuropa aufgegeben worden" ist. Denn gleichwohl gibt es nach seiner Ansicht noch heute einzelne Gebiete, wie zum Beispiel im Schweizer Mittelland, ,in denen die landwirtschaftliche Nutzungsform der Wiesenbewässerung bis heute den Charakter der Kulturlandschaft prägt, obwohl die meisten Bewässerungsflächen mittlerweile aufgegeben und einem Nutzungswandel unterlegen sind.“(:13)

Doch auch in diesen Wässerwiesengebieten sind oftmals nur noch Spuren des Grabennetzes übrig geblieben. Die Bewässerungskanäle und kleinen Gräben sind verlandet, verwachsen oder aufgefüllt (BINGGELI 1986:138), die langgezogenen Geländerücken mit dem Niedergang der alten Bewässerungsmethode nahezu vollständig eingeebnet. Wenn auch partiell noch als Kulturlandschaftselemente vorhanden, so hat die Aufgabe der Bewirtschaftungsweise zu einer einschneidenden Veränderung des Landschaftsbildes geführt. Die „Wüstlegung“ der Wässerwiesen bezeichnet nach BINGGELI (:138) einen Prozess des Kulturlandschaftswandels, der der Landschaftsverarmung Vorschub leistet. Diese Bewertung trifft vor allem insbesondere deshalb zu, weil Wiesen als Wässerland in früheren Zeiten in besonderer Weise landschaftsprägend und -formend gewirkt haben.

\section{b Historisch-geographische Verbreitung}

Berichte über Wiesenbewässerung gibt es aus dem norddeutschen Tiefland (HETZEL 1957), aus vielen deutschen Mittelgebirgen (HEINEMANN 1913, SCHNUR 1982, SCHOLZ 1990, MALKMUS 1994) und aus den Alpenländern (KREUTER 1911; BINGELLI 1986). Die Arbeiten neueren Datums sind jedoch sämtlich kulturhistorische Reliktaufnahmen.

Wenn auch heutzutage zumeist nur reliktär bestehend und in wenigen Einzelfällen noch praktiziert, so besaß die Bewässerung von Wiesen in Mitteleuropa früher eine ausgedehnte Verbreitung. „Wässerwiesen“ waren einst typische Grünlandbereiche und zugleich wichtige temporäre Feuchtbiotope, ohne dass man sie unbedingt als solche bewertet hätte. Wässerwiesen waren aber vor allem eins: die ertragreichsten Heuwiesen der „Vor-Kunstdünger-Landwirtschaft“. 


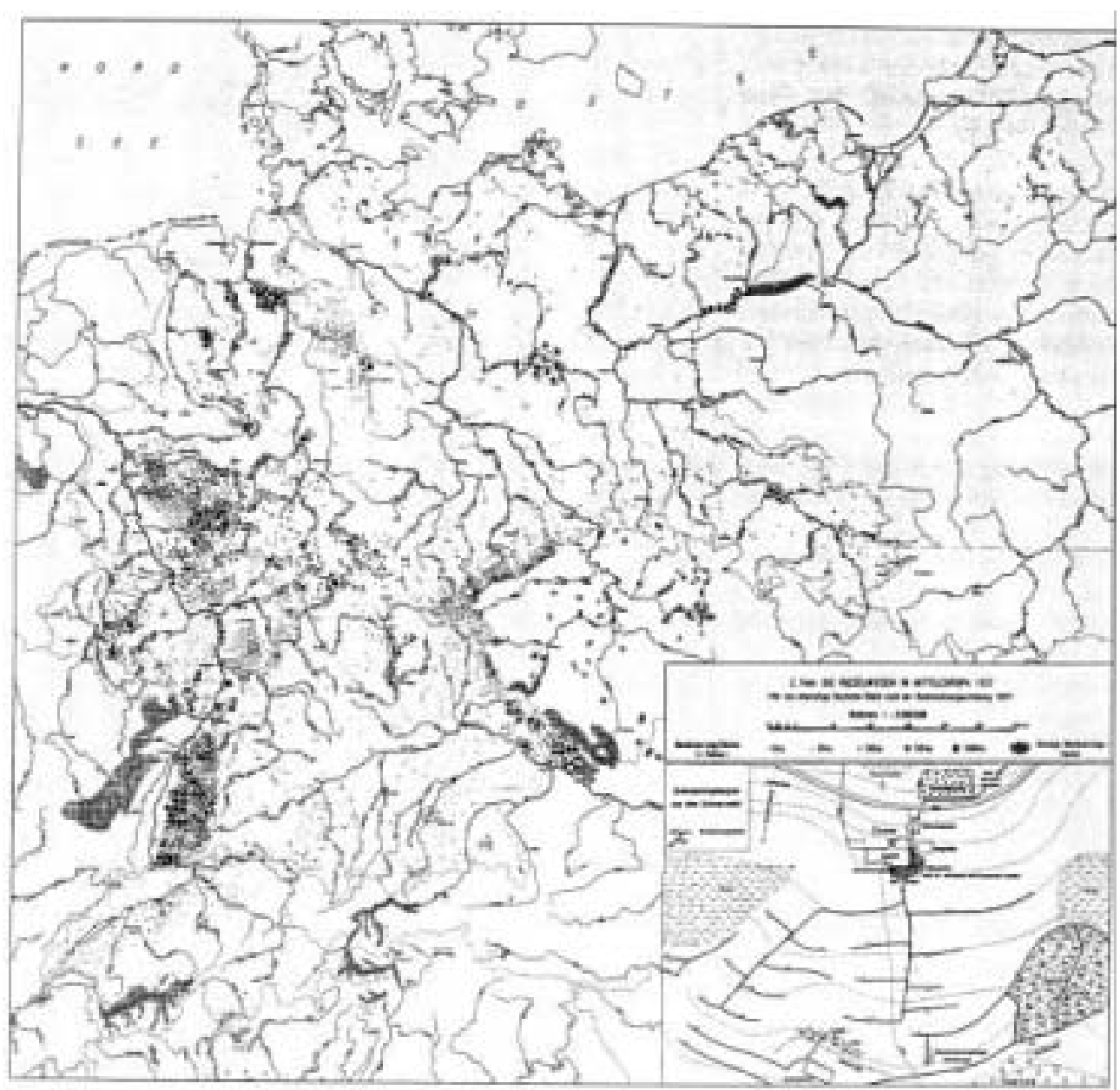

Abb. VIII-53: Rieselwiesen in Mitteleuropa für das Gebiet Deutschlands in seinen Grenzen bis 1945.

Die Karte zeigt die Verbreitung von Bewässerungswiesen in Mitteleuropa Ende der 1930er Jahre. Hauptverbreitungsgebiete entweder mit einer Vielzahl einzelner, relativ kleinflächiger Rieselwiesen oder aber vereinzelter, aber dafür umso großflächigerer Bewässerungsanlagen lagen in der Lüneburger Heide, der Wesermarsch und in Vorpommern. In den Mittelgebirgen lagen die Zentren der Wiesenbewässerung im Siegerland, im Schwarzwald, im Saarland und in der Oberpfalz. Dass zum Beispiel der Harz nahezu vollständig fehlt, lässt sich mit dem Regenreichtum, aber vor allem der Dominanz des Bergbaus erklären, dem sich alles unterzuordnen hatte. Insgesamt aber ergibt das Bild - mit Ausnahme der küstennahen und hochalpinen Bereiche - eine nahezu ubiquitäre räumliche Verbreitung (Karte von C. TROLL 1937; aus: BÖHM 1990).

Betrachtet man die geographische Verteilung der Wässerwiesen in Deutschland mitsamt den Alpen, so wird ersichtlich, dass sie in sehr unterschiedlichen Naturräumen angesiedelt und in fast allen ländlich geprägten Gegenden Deutschlands und Mitteleuropas angelegt waren, sogar in relativ kleinen Seitentälern: Die weiten Ebenen der Oberrheinebene wurden ebenso bewässert wie die steilen Hänge des Schwarzwaldes oder die Wiesentäler der Schwäbischen Alb oder entlang der Donauzuflüsse. Geologisch betrachtet wurden seit der Mitte des vergangenen Jahrhunderts vor allem ,in fast allen Wiesentälern im Buntsandsteingebiet Bewässerungsanlagen geschaffen.“ (FIEDLER 1965:58) Die Großlandschaften aus Buntsandstein mit ihren leichten und sandigen Böden des Buntsandstein eignen sich auf der einen Seite wenig zur Landwirtschaft. Auf der anderen Seite wird das Buntsandsteingebiet von vielen Bächen durchflossen, die eine große Anzahl von Tälern geschaffen haben, wie im Saargau, wo die Bäche den Muschelkalk durchschnitten und ihre Sohlen in den Hauptbuntsandstein eingesenkt haben. „In diesen Buntsandsteintälern liegen viele Bewässerungswiesen.“(:6).

Unter allgemeiner physisch-geographischer Betrachtung war „die Anlage von Bewässerungswiesen immer an das Vorhandensein von Bächen mit genügend Wasser und an Wiesentäler [...] gebunden“ (FIEDLER 1965:49). Sie wurde dabei unter so verschiedenen topographisch-geographischen Voraussetzungen und mit so unterschiedlichen technischen Mitteln gehandhabt, dass es schwer fällt, all diese Anlagen in ihren Einzelheiten und geographischen Verbreitungsräumen zu überblicken. Dieses Vorhaben wird vor allem dann ad absurdum geführt, wenn bewusst wird, dass zur Blütezeit der 
Wässerwiesen ,alle geeigneten Bäche ausgenutzt wurden“ (:77, ebenso:51). So dienen ,alle diejenigen Flüsse und Bäche [...] zum Schwemmen, welche sich durch Thäler ergiessen, oder wenigstens an der einen Seite - sey es unmittelbar am Ufer oder in gewisser Entfernung von demselben - eine Anhöhe oder einen Berg, an der entgegengesetzten Seite aber eine Sinke oder eine Ebene haben, die [...] tief genug unter der Horizontal-Linie des Stauspiegels liegt, um mittelst des neuen Zuleitungs- und Schwemmgrabens beflößt werden zu können.“ (WEYER 1800:10f.) Deshalb seien, wie bei dem ubiquitären Mühlenbetrieb, obschon hier die Schwierigkeit bestand, das Schema der Standorte von Mühlenteiche herauszufiltern, nur einige Beispiele stellvertretend für landschaftsräumliche Einheiten genannt, um einen Eindruck von dem Ausmaß ehemaliger Wässerungsflächen zu bekommen.

Sie verdeutlichen, dass man bestrebt war, jedes nur mögliche natürliche Dauergrünland zu nutzen und den Ertrag durch Bewässerung zu steigern. Vorherrschend wurden Bewässerungen auf den Tal- und Hangwiesen der benachbarten Gewässerläufe vorgenommen. Handelte es sich um Trockentäler, wie in einigen alpinen Regionen, so wurde das Wässerwasser über viele Kilometer herantransportiert. Die regenarmen Gebiete des Vinschgaus zum Beispiel konnten erst mit Hilfe der Bewässerung fruchtbar gemacht werden und die Niederschlagshäufigkeit und -verteilung kann hier als Indikator einer Schwerpunktverbreitung von Bewässerungsanlagen herangezogen werden (siehe unten). Die Niederschlagshäufigkeit und -menge als Parameter der Verteilung von Bewässerungswiesen kann hingegen für das deutsche Tiefland sowie das Berg- und Hügelland vernachlässigt werden. Auch wenn es sich um regenreiche Bachtäler, wie zum Beispiel im Schwarzwälder Hochwald, handelte, so waren auch hier - trotz der verhältnismäßig hohen Niederschläge von 800 bis $1000 \mathrm{~mm}$ pro Jahr - ,in fast allen Bachtälern Bewässerungswiesen angelegt worden“" (FIEDLER 1965:18).

Dagegen waren Wasserläufe, die Abwässer aus Berg- und Hüttenwerken und anderen industriellen Anlagen aufnahmen, für die Bewässerung nicht geeignet (FIEDLER 1965:23) und insofern auch nicht in ihrem Einflussgebiet vertreten. Auch Wasser, das auch Mooren und insbesondere aus Hochmooren stammt, ist sehr arm an Nährstoffen, besitzt einen sehr niedrigen pH-Wert und war zur Bewässerung untauglich (:22). Schlechte naturräumliche Voraussetzungen boten ebenso schmale und steilwandige Täler mit kaum vorhandener Talsohle auf schwer verwitterbaren Gesteinen wie Quarzite oder Grauwacke; solche Engtäler „sind zur Anlage von Wässerwiesen vollkommen ungeeignet“.. (:6)

Vor allem aber dort, wo der Futtermangel groß war, wie beispielsweise in den Lüneburger Heidegebieten oder in den bewaldeten, aber bodenkargen Mittelgebirgen, wurde früh „die Benutzung der Bäche zur Wiesenbewässerung“" eingeführt (THAER 1800:I).

\section{b.1 Tiefland}

Gute Voraussetzungen, mit Ausnahme der eben erwähnten Moorgebiete, herrschten für Wiesenbewässerungen im norddeutschen Flachland vor, wo zahlreiche und großflächige Bewässerungswiesen nachgewiesen sind. Im Norddeutschen Tiefland wurde hauptsächlich die Bewässerung gefällearmer Talgründe praktiziert, aber in einigen Ausnahmen - in Abhängigkeit der Topographie - auch Bewässerungen an Hängen durchgeführt.

Für Schleswig-Holstein ist die Bewässerungsanlage auf Gut Koselau, angelegt um 1795, zu nennen. Es handelte sich hierbei um eine wilde Berieselung mit einem ausgefeilten System von Zuleitungsgräben von der Koselau abgehend (siehe Abb. VIII-54). 


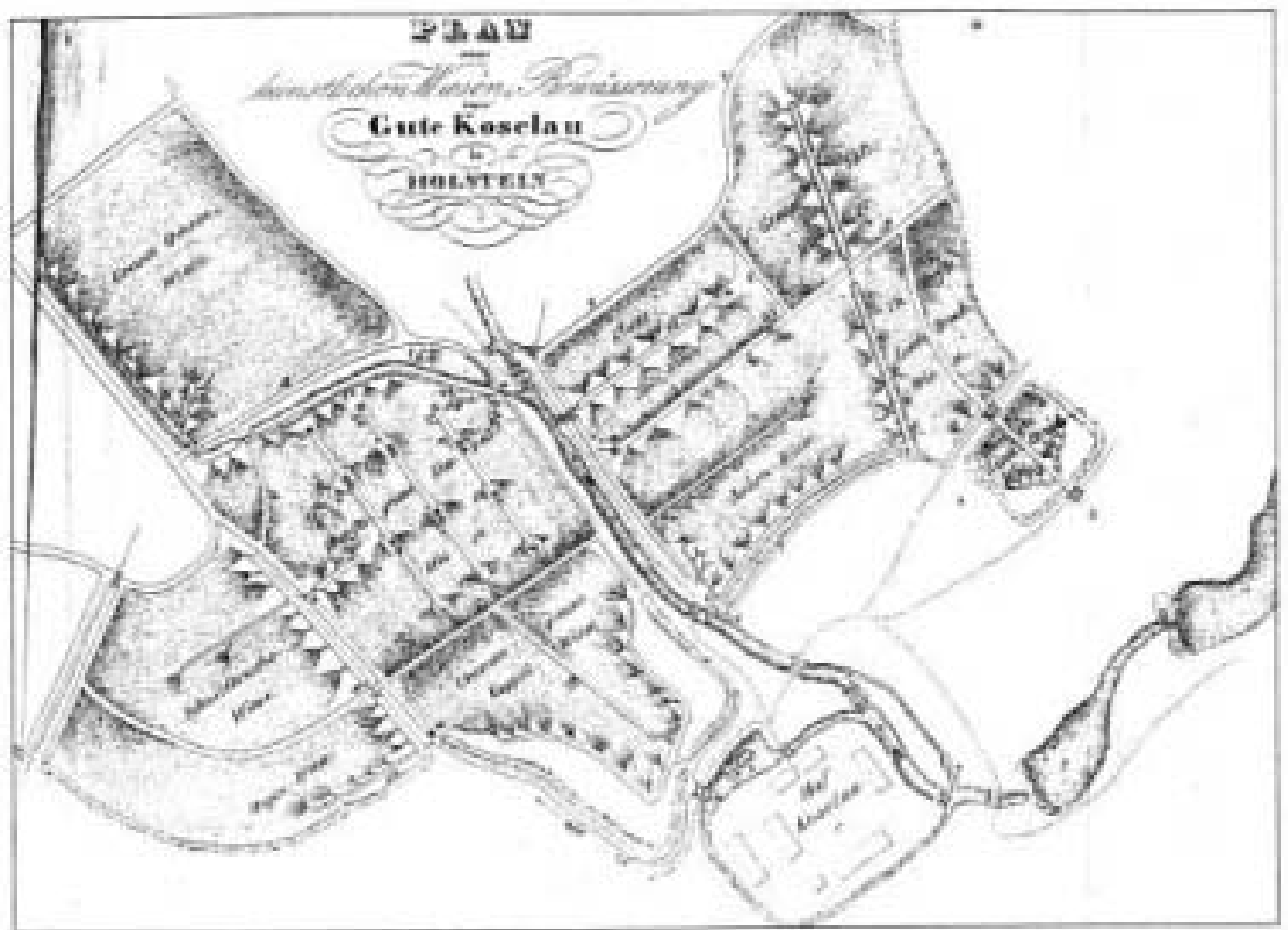

Abb. VIII-54: „Plan einer künstlichen Wiesen-Bewässerung beim Gute Koselau in Holstein“ Auffallend die streng schematische Anlage von Gräben und Kanälen zur Schwemmung und Berieselung der Wiesen (aus: LENGERKE 1836, Tab V).

In Mecklenburg-Vorpommern sind vor allem an solchen Stellen, wo feuchte Wiesengründe den Umbruch zu Ackerland, den Fruchtwechsel und die Vergrößerung der Schläge bei Gründung und nachfolgendem Ausbau der LPG im Verlauf der Übernahme und Aufsiedlungen ehemaliger Herrensitze überstanden haben, insbesondere in Grenzbezirken oder in Schutzgebieten, noch einige Wässerwiesen zu entdecken, teilweise sogar mit ihren Einrichtungen und Elementen des Wässerstaus und der Wasserleitung.

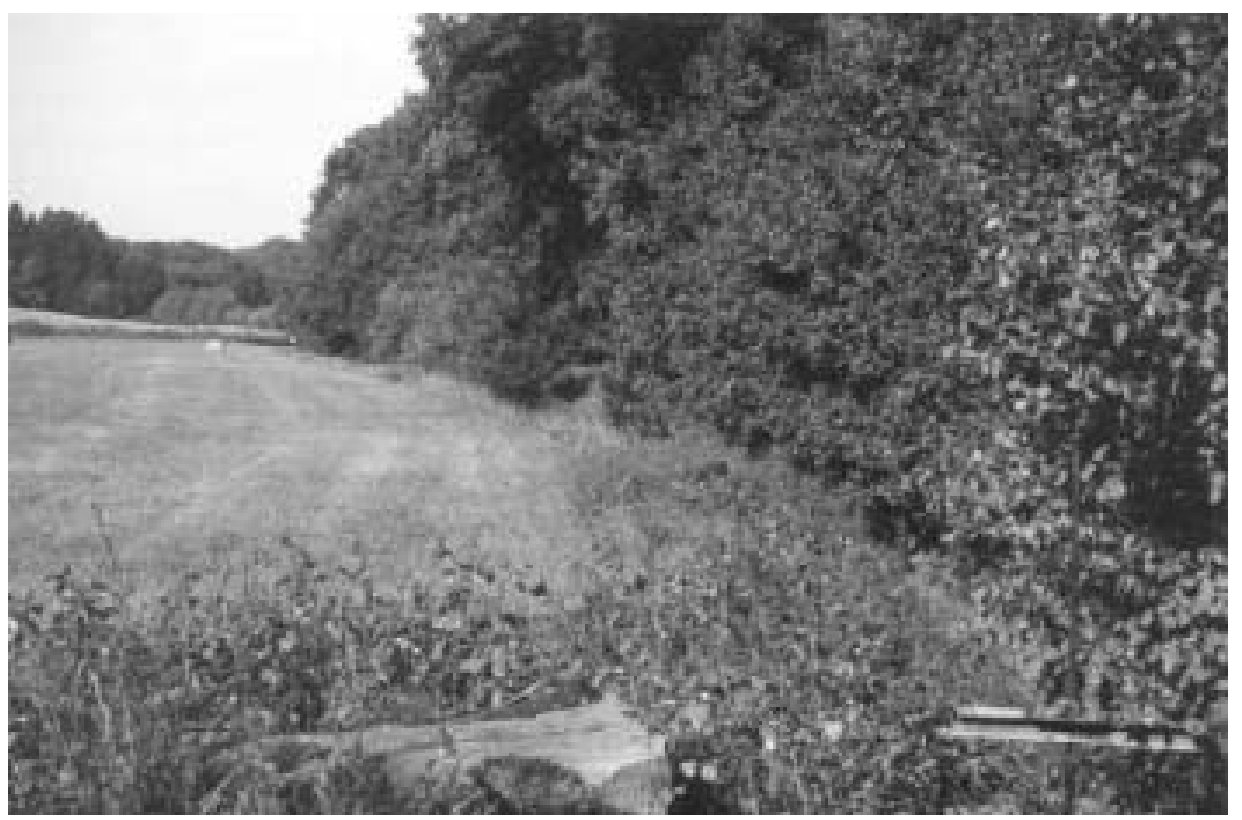

Abb. VIII-55: Wässerwiesen

Das Foto zeigt eine Schwemmwiese mit erhaltenem Stauwehr (Gewindewehr mit Staubrettern) in der Nähe des Ortes Pamitz/Ostvorpommern (eig. Aufnahme 2003). 
SPRENGEL (1838:91f.) berichtet, dass „die Bauern [...] im Bremenschen, im Verdenschen und Osnabrückschen [...] sehr häufig und schon seit langer Zeit schwemmen“. Die Provinzen seien „sehr arm an Wiesen“".

Im Bremer Land, in der Wesermarsch bei Syke, wurde zwischen 1882 und 1888 ein rund 4800 ha großes Gebiet auf diese Weise bewässerungstechnisch erschlossen (GROTTIAN 2001:10).

Im oldenburgischen Huntetal, zwischen Oldenburg und Wildeshausen, war die Wiesenbewässerung in genossenschaftlicher Ordnung weit verbreitet. Mehrere tausend Hektar Talauenwiesen wurden hier in der Form des Rückenbaus bewässert. Das gesamte Grabennetz hatte eine außerordentlich große Ausdehnung. Allein die genossenschaftlichen Gräben - also ohne die kleinen privaten Bewässerungsgräben und Grüppen - hatten eine Gesamtlänge von über $61 \mathrm{~km}$, das waren pro Hektar $217 \mathrm{~m}$ (HETZEL 1957:50). Die Bewässerung in diesem Raum war um 1840, den Zeitschnitt HETZELs vor der modernen Intensivierung wiedergebend, fast ausschließlich an die Hunte- und Letheniederung gebunden (:18). Die natürliche Ausstattung des Raumes hinsichtlich der klimatischen und hydrologischen Verhältnisse bildete die Notwendigkeit zur Bewässerung und legte gleichzeitig die zu bewässernden Räume fest. Infolge der geringen Niederschlagsmengen im Mai und Juni können nämlich die Sandböden mit tiefem Grundwasserstand leicht zu trocken werden (:14). Die Niederschlagshöhe war hier die eigentliche kritische Komponente. Eine Ausnahme bildeten die sog. Rieden (Trockentäler): „In ihnen fließt in manchen Jahren bei starken Winterregen das Wasser oberirdisch zur Hunte. Auch im Sommer bleiben sie meist so feucht, daß sie als Grünland genutzt werden können“ $(: 15)$.

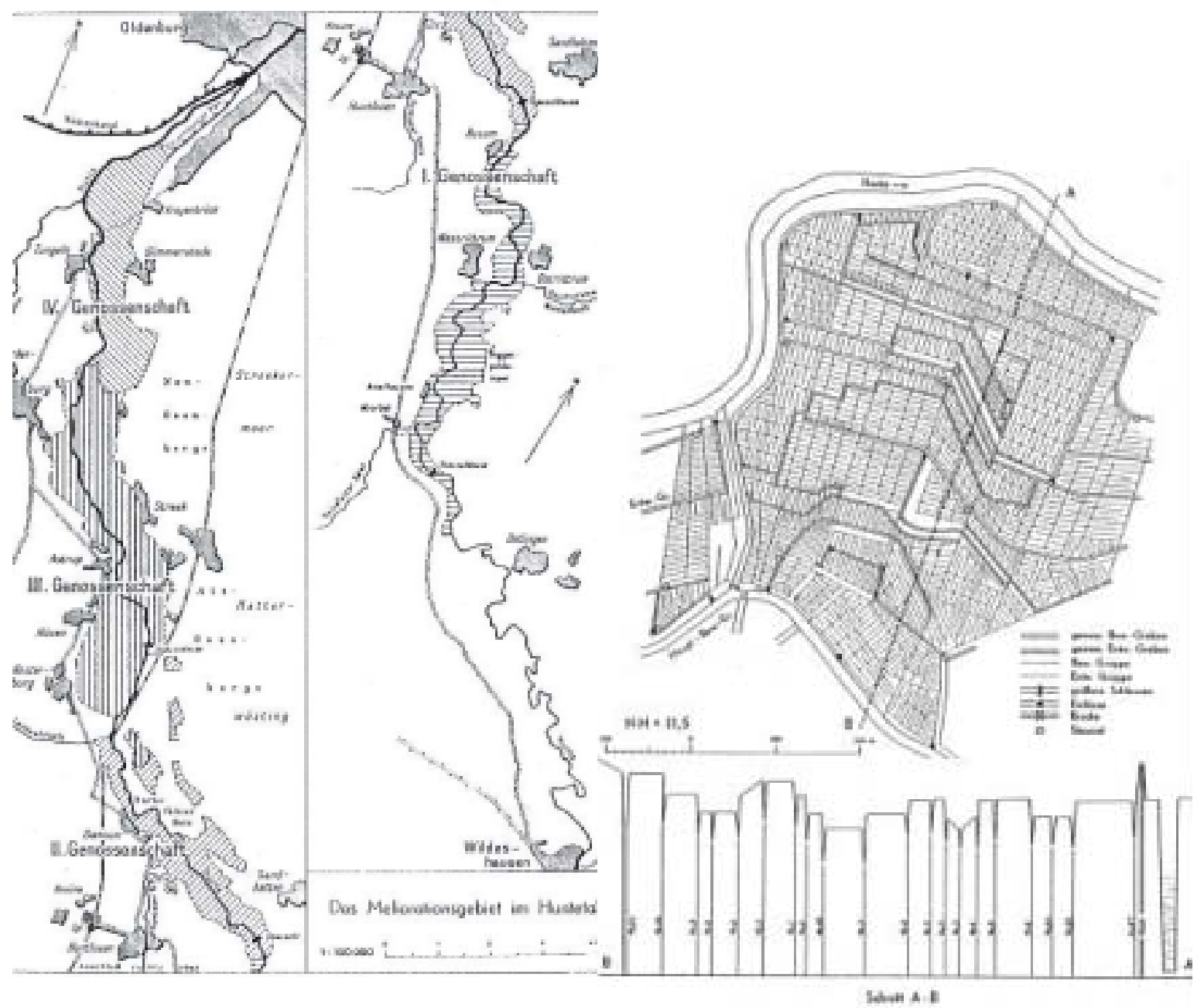

Abb. VIII-56: Das Meliorationsgebiet im Huntetal mit einem vergrößerten Ausschnitt aus dem Wässerwiesenbereich der I. Genossenschaft (aus: HETZEL 1957:48) 
Wiesenbewässerungen werden südlich der Hunte und Lethe auch vom kleineren Reitbach und vom Eickerbach in der Nähe von Quakenbrück berichtet (DOBELMANN 1980:36). Bei der Hase müssen sie eine besondere Rolle gespielt haben: Ein Stau des Wassers der Hase „war in der Zeit vom 1. Mai bis 24. August grundsätzlich nicht gestattet, da dadurch mögliche Überschwemmungen die oberhalb liegenden Heuwiesen der Quakenbrücker verderben konnten. Um Mißbrauch zu verhüten, wurden während dieser Zeit die Schütze der [...] Stauanlage in der Pfarrkirche [...] aufbewahrt.” (:35) Um den Streit um die Staurechte der Hase zu schlichten wurde in einem 1884 geschlossenen Vertrag den Bauern die Entnahme von Wasser für die Bewässerung ihrer Wiesen im Winter in den Zeiten zugestanden, wenn die Hase ,regelmäßig mehr Wasser führe als für die Triebwerke in Bramsche benötigt wird.“ (:38) Gleiches ist von anderen zahlreichen Wasserläufen des Osnabrücker Nordlandes bekannt, ,für die die Wasserläufe [...] zur Bewässerung ihrer Ländereien wesentlich waren” (:35).

TERHALLE (1992:29f.) berichtet im Vredener Land an der Berkel von einer Flur mit Namen „Mulenmersch”. Seiner Interpretation nach dürfte es sich bei dem Mulenmersch ,nicht nur um eine einfache, bei der Mühle gelegene Wiese gehandelt haben, sondern - wie im flachen Münsterland häufig - um eine Stauwiese, die vom Stauwasser einer Wassermühle zwischen Michaelis und ,Maitag' überflutet wurde." Im Sommer durften hier die meisten Wassermühlen nicht stauen, um die Äcker und Wiesen der Oberlieger nicht zu vernässen. Unter der Vredener „Mulenmersch“ ist also eine beiderseits der Berkel gelegene Mühlenweide zu verstehen.

Wenn auch Wässerwiesen in allen zur Wiesenanlage geeigneten Gebieten im zentralen Mitteleuropa vorkommen, so gibt es ,vielleicht wenig Länder in Deutschland, wo die Gelegenheit zu Anlagen dieser Art so häufig vorkommt, als in dem Fürstenthum Lüneburg.“ (WEYER 1800:1f.) Was vermögen die Ursachen dafür gewesen sein? WEYER (:2, ebenso 19) führt verschiedene Gründe für diese starke Ausprägung hier an: Zum einen nennt er ,die vielen kleinen Flüsse und Bäche, womit die Natur dasselbe so freigiebig beschenkt hat". Diese „lassen bey ihrem beträchtlichem Gefälle, unter Zuhülfenahme der Stau-Schleuse, eine solche Umleitung zu, daß damit bald größere, bald kleinere Heide-Reviere überwässert werden können.“ Des Weiteren ließen sich die sandigen, durch „richtig geleitete Kraft des Wassers“ leicht beweglichen, Heideböden mit geringen Kosten „eben zu flößen stehen“ und sich dann, ,mittelst regulärer Bewässerung, in den besten und einträglichsten Angerboden umschaffen“. Darüber hinaus bedurfte hier nur ein kleiner Teil der Schwemmung. „Bey weitem der größeste Theil ist von Natur so eben, daß man des Schwemmens überhoben seyn kann. Und dadurch werden dann die Kosten sehr vermindert.“(:120) Weiterhin war „das Misverhältniß zwischen Wiesen und Ackerlande [...] im Fürstenthume Lüneburg sehr groß.“ Die nördlichen Heidedörfer erhielten aus den fruchtbaren Marschlanden „das bedürfende Heu“; jedoch waren die Preise dafür so hoch, dass der minder wohlhabende Teil der Geestbewohner sich nur sehr kärglich damit versehen konnte. Vor allem für die im Innern der Heide gelegenen Dörfer bestand Heumangel, der auf Kosten des Ackers teuer erkauft wurde und über das der Weidemangel dadurch noch vergrößert worden ist.

Die Funktion der Viehhaltung war in den Heidegebieten ähnlich wie in anderen Gebieten; nur dass hier die Nährstoffarmut der Heideböden eine ausreichende Versorgung der Äcker mit Mist (= Dünger) zur unabdingbaren Voraussetzung für den Ackerbau überhaupt machte. Durch die Aufstallung im Winter wurde dafür besonders viel Dünger angesammelt. Doch für diese Winterstallung benötigte man viel Grünfutter, um die Kühe und Rinder die kalte Jahreszeit über zu versorgen. Angesichts der schlechten Böden in den Heidegebieten verwundert es deshalb nicht, dass in der Lüneburger Heide bereits spätestens seit dem späten Mittelalter Wiesen bewässert wurden. Der älteste urkundlich belegte Hinweis auf eine Wiesenbewässerung stammt von 1476 und bezieht sich auf eine Anlage an der Meiße in der Nähe von Meißendorf im heutigen Landkreis Celle (GROTTIAN 2001:3,10).

Im Laufe des 18. Jahrhunderts scheint sich hier die Technik des Wiesenschwemmens mehr und mehr bei der Anlage von Bewässerungswiesen durchgesetzt zu haben (GROTTIAN 2001:11). Solche „wilden“ Berieselungen waren bis um 1800 - vor der Einführung des kunstvollen Rückenbaus - in der Heide weit verbreitet (:9). Zum Beispiel bestanden solche einfachen Wässerwiesen vor $1800 \mathrm{im}$ Lopautal bei Bockum (Amt Ebstorf), die zum größten Teil zum Refardtschen Gut in Wulfsode gehörten (:15). Auch THAER (1800:VI) erwähnte schon die „,beachtlichen Wiesenanlagen des „Gutes Refarth“. „Schöne Schwemmwiesen“ waren auch auf einem „Hofe Gudehus“ zusehen (:VII). 
Aber auch bei Fallingbostel an der Böhme und im Umkreis von Suderburg: an der Hardau im Hardautal bei Hösseringen und ihren Nebentälern sowie am Oberlauf der Gerdau sollen „wilde“ Bewässerungen bestanden haben (GROTTIAN 2001:10). Überstauungswiesen sollen des Weiteren an der Oertze und ihren Nebenbächen eingerichtet gewesen sein (:10). Auch in der Amtsvogtei Soltau waren Wiesenbewässerungen gegen Ende des 18. Jahrhunderts allgemein verbreitet (:10). Weiterhin wurde in Meinersen, Gifhorn, Wieren und in Klein Hehlen bei Celle wie auch im Amt Rotenburg an der Wümme der Schwemmwiesenbau praktiziert. Hangbewässerungen dagegen gab es im 18. Jahrhundert im schmalen Tal des Hesebaches in den Gemarkungen Dreilingen bis Bargfeld, die noch bis in die 1860er Jahre existierten, und auch im Tal der oben genannten Meiße oberhalb von Bleckmar im Landkreis Celle (:11). Vor allem „,entlang der Poststraßen und Heerstraßen“, wie zum Beispiel zwischen Nienburg und Hamburg ,auf der hölländischen Straße“ habe man „an mehreren Orten [...] welche sehen“ können (THAER 1800:VIf.).

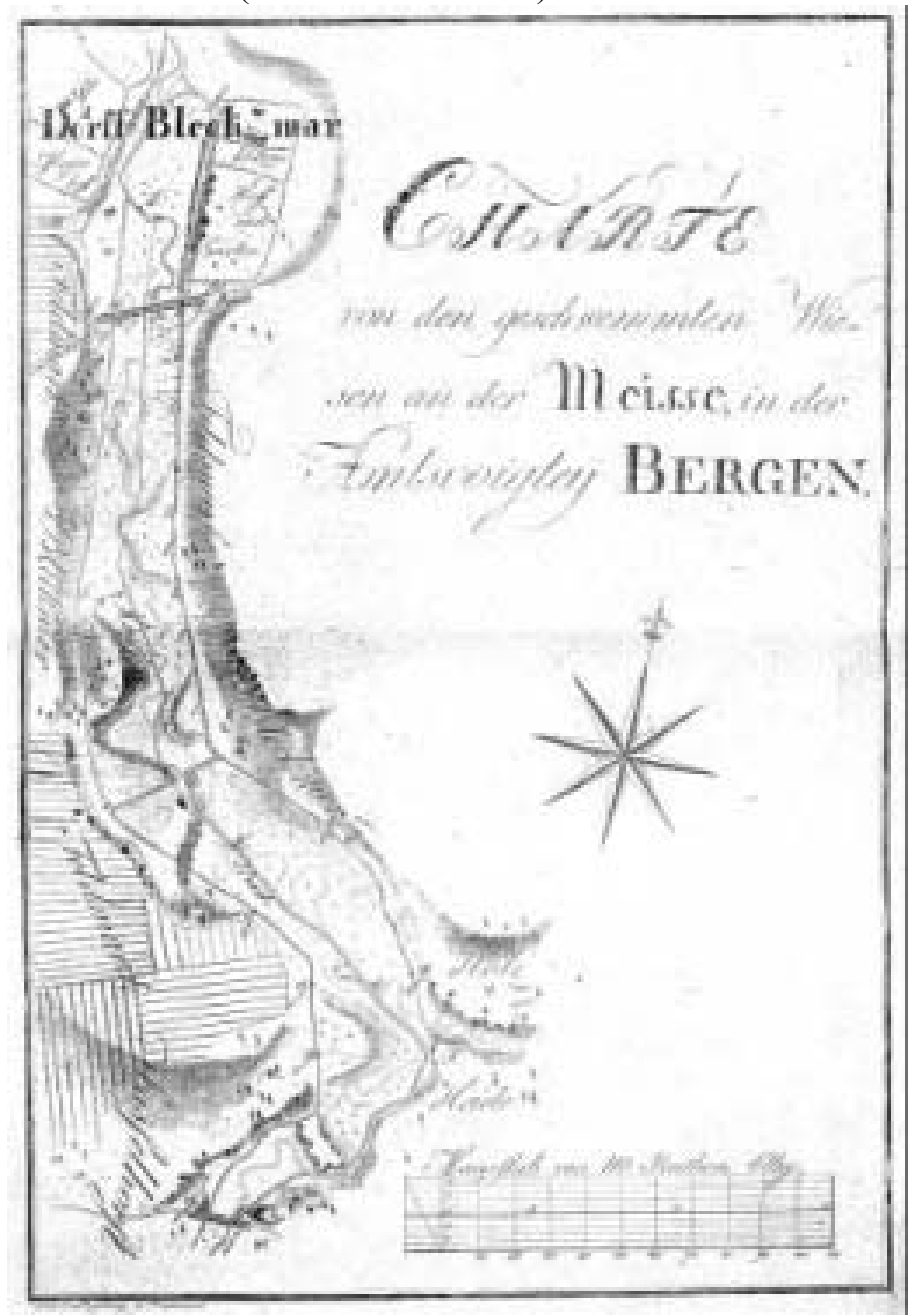

Abb. VIII-57: „Charte von den geschwemmten Wiesen an der Meisse in der Amtsvoigtey Bergen“ um 1860. Die beiderseits der Flusslaufes verlaufenden Linien markieren die Wässerwiesenflächen in diesem Bereich (aus: GROTTIAN 2001).

Dem von KIRCHNER 1844 angefertigten „Wiesen-Tableau“, einer statistischen Übersicht über die im Lüneburgischen vorhandenen Bewässerungswiesen, lässt sich entnehmen, dass es in der Lüneburger Heide jedoch auch noch zahlreiche unbewässerte potentielle Bewässerungswiesen gegeben hat. So stellte er bei dem Amt Knesebeck geeignete Flächen fest, die noch einer Beetbewässerungsanlage bedürfen: „Namentlich würden im ausgedehnten Thale des Ise-Flusses, auch der Ohra, die beträchlichsten Wiesenanlagen zu machen sein, wenn nur erst diese Wiesen entfettet und verkoppelt, sowie die Flüsse begradigt und mit den nöthigen Stauwerken versehen wären“ (1845:107ff.)

Um diese Defizite zu beseitigen, kam es am 15. November 1853 zur Eröffnung einer Wiesenbauschule in Uelzen, die aber 1865 schon wieder aufgegeben wurde (GROTTIAN 2001:36). Am 14. Januar 1854 
gründeten die Wiesenbauer in Suderburg im Amt Bodenteich ihre eigene Wiesenbauschule, wobei Suderburg bereits vorher eine Hochburg des Wiesenbaus in Lüneburg war. Sie ist nunmehr Teil der Fachhochschule Nordostniedersachsen (:2).

Anfang des 19. Jahrhunderts wurde in Suderburg eine besondere Bewässerungstechnik entwickelt, die als „Lüneburger Rückenbau“ bezeichnet wurde und mit der sich zum Teil erhebliche Ertragssteigerungen erzielen ließen (GROTTIAN 2001:1f.). Bereits THAER (1800:VII) erwähnt die berühmte Wiesenanlage bei Suderburg: „Auf der mecklenburgischen Straße liegt diesseits Uelzen zwischen Suderburg und Höfferingen eine beträchtliche [...] Strecke solcher Wiesen." In den Jahren nach 1820 - nach „Erfindung“ des Rückenbaus - und vor allem in den Jahrzehnten um 1850 entwickelte sich Suderburg zum Zentrum des Wiesenbaus in Norddeutschland (GROTTIAN 2001:16). Umfangreiche Wandertätigkeiten führten nicht nur bis ins Göttinger Land, der Erfolg des „Suderburger Rückenbaus“ (bzw. des „Lüneburger Rückenbaus“) führte durch die beauftragten Wiesenbaumeister zur Anlage von zahlreichen Wässerwiesen auch in Mecklenburg und Brandenburg, im Raum Osnabrück sowie vor allem in vielen Heidetälern im Fürstentum Lüneburg selbst (:12). Mit dem Ergebnis, dass gegen Ende des 19. Jahrhunderts „die meisten Täler der Lüneburger Heide [...] durch Rieselwiesen erschlossen waren." (:30, ebenso:2) Dennoch waren hier die Flächen begrenzt, zumal in der Lüneburger Heide mit ihren im Verhältnis zu den umliegenden Heideflächen nur schmalen Tälern nur wenig mögliches Wiesenland zur Verfügung stand (:30).

Rieselbewässerung ist auch aus dem Wendland an vielen Stellen bezeugt: Für die Dumme-Wiesen bei den Dörfern Güstrow und Luckau beispielsweise entnahmen Bauern zur Bewässerung ihrer Rieselwiesen Wasser aus der Dumme (LANGE 1989:56). Aber auch in den Bruchwiesen der Wustrower Walk- und Baakemühle wurde Bewässerungsbau betrieben (:194). Weiterhin ist belegt, dass Külitzer Bauern ihre Wiesen mit dem Wasser des Mühlenbaches bewässerten (:55).

Großflächige Stauberieselungsanlagen sind auch im Oker-Aller-Gebiet nach 1820 eingerichtet worden (GROTTIAN 2001:10). Noch 1939 waren des Weiteren Bewässerungswiesen unterhalb des Steinhuder Meeres gelegen (:30).

\section{b.2 Mittelgebirge}

Vor allem in den Mittelgebirgen lassen sich zahlreiche Wiesenbewässerungssysteme nachweisen. Ausgedehnte Ackerbauflächen waren in den waldreichen und hügeligen Gebieten wenig verbreitet, Viehhaltung als Waldweide bildete in landwirtschaftlicher Hinsicht den Schwerpunkt. Für die karge und lange Winterzeit, in der auf schneebedeckten oder gefrorenen Böden nur geringe Naturnahrung zu finden war und vor allem mit Beginn der Aufstallung im Winter wurde die Heugewinnung notwendig. Diese wurde in den Tälern im Talgrund oder auf den Hängen praktiziert.

Im Weserbergland leitete man zur Nutzung der nährstoffreichen Überschwemmungen in den Flussauen „vielerorts in den Weserauen das Flußwasser zur künstlichen Wässerung auf die Uferwiesen“ (BORGER-KEWELOH/KEWELOH 1991:55). Diese Wässerung wurde hier „auch als Flößerei bezeichnet" (:55). Die Autoren berufen sich dabei auf eine Akte im Archiv der Stadt Höxter, bei der es sich bei der Bezeichnung „um die Wässerung der Uferwiesen“ der Grube handelt. Diese Begriffsauslegung bestätigt TERHALLE (1992:30) für das Münsterland, der ebenfalls in einem Fall eine „geflößte” Wiese als bewässerte Stauwiese auslegt.

In Südniedersachsen lassen sich die Spuren der Wiesenbewässerung vor allem noch im Solling feststellen, so etwa im Tal des Rehbaches oder im Hellental (SOHNREY 1929:148ff.; REDDERSEN 1934). Des Weiteren sind kulturlandschaftliche Spuren „vom Fleuen“ noch im Derental und auf den Talwiesen der Holzminde vorhanden. Bei Letzterem sind diese sogar im Rahmen eines Wasserlehrpfades auf einer Tafel beschrieben. Eigentlich kann man sagen, dass in sämtlichen Taleinschnitten des Sollings eine Wiesenbewässerung durchgeführt wurde. Der poröse Gesteinsaufbau aus Buntsandstein machte hier, wie eingangs geschildert, eine Berieselung von Wiesengrund notwendig, die im leichten Hangbau ausgeübt wurde. 
Im südlichen Übergangsbereich vom Solling zum Brahmwald, im Raum Adelebsen, Kreis Uslar, lässt sich die Wiesenbewässerung durch schriftliche Quellen bis in das Jahr 1764 zurückverfolgen und durch alte Kartenwerke ${ }^{39}$ und Geländebefunde „bis vor 1720 wahrscheinlich machen“ (SCHRÖDER/SCHRÖDER 1997:9) Das Ehepaar SCHRÖDER hat archivalisch und geländekundlich die Schwülme und die Auschnippe unterhalb des Fleckens Adelebsen, ein Gebiet ca. 25-35 km westlich von Göttingen gelegen, untersucht. Zwei kleine Komplexe haben sich hier erhalten: im Schwülmetal ein Wiesenareal von etwa $1200 \mathrm{~m}$ Ausdehnung unterhalb der Reinshagener Kirchenruine (Flurname Behrensen) und im unteren Auschnippetal. Im Jahr 1893 wurde in Adelebsen sogar eine Genossenschaft gegründet mit Ziel durch die Bewässerung der Schwülme- und Auschnippewiesen den Ertrag zusteigern (:10). Hangbewässerungswiesen lassen sich für diesen Raum in der Gemarkung Güntersen, im Forstort Thühausen für das Jahr 1823 und im Tal des Bramker Baches, einem Nebenbach der Auschnippe, auf einer Karte von 1720 nachweisen (:12).

In Oberbehme, einem Ortsteil der heutigen Gemeinde Kirchlengern im „Mühlenkreis Herford“, wurde in den 1840er Jahren ein Überfall in der Werre gebaut, durch das es möglich wurde, Wasser zum Betrieb einer Wasserkraftanlage abzuleiten. Neben den Antrieb von 2 Rädern zum Betrieb von Mahlgängen aber, sollte ein drittes Rad eine Saugpumpe zur Wiesenberieselung antreiben. Im Januar 1851 nahm die Mühle dafür den Betrieb auf (MÖRSTEDT 1995:123). Und auch im Lippischen Bergland, in Valdorf, einem Ortsteil von Vlotho, hat es in den Wiesen der Linnenbeeke es zwei Stauwehre zum Wiesenflößen gegeben (:231).

Nicht allein die „Siegerländer Haubergswirtschaft“ ist „Kern der exemplarischen Bedeutung des Siegerlandes“" (EICHENAUER 1989:220). Im Siegerland wurde bereits sehr früh eine perfekte Wiesenbaukunst angewendet, so dass für diese Region, ,in der der Wiesenbau seit Jahrhunderten eine Hochburg hatte" (HEINRICH 1997), die urkundlichen Erwähnungen von Bewässerungswiesen bis in die 1. Hälfte des 16. Jahrhunderts zurückgehen. Und noch um 1950 waren hier Rieselwiesen „noch voll intakt, zum Teil sogar quantitativ ausgeweitet" (EICHENAUER 1989:225). Doch nur wenig später, ab 1955, zeigten sich erste Auswirkungen der Industriekonjunktur auf die Siegerländer Agrarlandschaft (MONHEIM 1959; aus: EICHENAUER 1989:236). Im Jahr 1980 dann gab es „keine einzige Bewässerungs- oder Rieselwiese mehr“ (EICHENAUER 1989:236).

Bekannt geworden ist das Siegerland als „Bewässerungsland“ aber erst mit der Gründung einer Wiesenbauschule in Siegen am 15. Oktober 1853 (HEINRICH 1997). „Mit großer Wahrscheinlichkeit breiteten sich die Kenntnisse über die Kunst des Wiesenbaus vom ,Innovationszentrum Siegen', Sitz der ältesten Wiesenbauschule in Deutschland, in andere Landesteile Deutschlands aus“, beschreibt DENZER (1996:135) den geographischen Ausbreitungsursprung. Welches Gebiet schließlich als Ausgangslandschaft einer geregelten Wiesenbewässerung gelten kann, ist schwierig zu beantworten, da die Anwärterschaft auf den ersten Platz auch andere beanspruchen (siehe Trier/Pfalz). Nach MONHEIM (1943:99) kann das Siegerland aber zumindest für sich in Anspruch nehmen, Innovationsursprung für die Wiesenbewässerung der Mittelgebirge zu sein. Hier war die Siegener Wiesenbauschule ansässig, die zur Ausbildung von Wiesenbaumeistern führte, die von anderen Wässerungsgemeinschaften, wie zum Beispiel 1844 von Besseringen/Saarland, angefordert wurden einen Lehrgang in praktischem Wiesenbau zu leiten (FIEDLER 1965:40). Es war damals in Deutschland üblich, einen Wiesenbaumeister aus dem Siegener Land zu holen. Diese Wiesenbaumeister legten in den verschiedensten Gebieten Rieselwiesen nach Siegener Art an (:41), die HETZEL (1957:48) als ,normalen Kunstbau“ bezeichnet.

Wässerwiesen im Erzgebirge wurden zum Beispiel längs der Pöhla bei Schwarzenberg in der 1. Hälfte des 19. Jahrhundert bekannt (ALTMANN 1999:110). Über die Art der Wiesenhaltung hier „kann gesagt werden, daß die Wiesen mit Gräben und Wassern gewartet wurden.“ (:111)

In dem Übergangsbereich der Nordeifel zum niederrheinischen Tiefland wurde das Wasser der Erft und ihrer Nebenbäche (z. B. Eschweiler Bach, Veybach/Kreis Euskirchen) schon zu Beginn des 19.

\footnotetext{
${ }^{39}$ SCHRÖDERs Aussagen stützen sich u. a. auf De VILLIERS „Topographische Carta des adelichen Gerichts Adelebsen“ von 1720 [Nieders. Hauptstaatsarchiv Hannover, Sign. 210/12g]
} 
Jahrhunderts zum „bewässern der Thalebene, welche fast durchgängig aus Wiesen besteht“" verwendet, wie eine Archivquelle aus dem Stadtarchiv Euskirchen aus dem Jahr 1841 belegt (zitiert nach DIX 1997:153, ebenso:169). Die gesamte im Amt Kuchenheim aus dem Erftmühlenbach bewässerte Wiesenfläche betrug ca. 177 ha (DIX 1997:171).

Ebenso wurden die an Baumschuler, Dransdorfer und Rheindorfer Bach sowie an den Mertener und Schwadorfer Bächen in den Landkreisen Bonn und Köln gelegenen Wiesen zur Bewässerung genutzt (DIX 1997:173).

Wässerwiesen, organisiert in Wiesengenossenschaften, gab es auch in den Tälern der Übergangszone zum Bergischen Land im Mydlinghover- und Stinderbachtal und dies wurde auch noch für den Juni 1932 dokumentiert $^{40}$.

Reste von Hangwässerwiesen sind des Weiteren noch heute erkennbar im Tal des Dornbaches zwischen Ronsdorf und Elberfeld, einem periurbanen Übergangsbereich zwischen Wuppertal und Remscheid.

SCHENK (1998:246) hat für den gesamten Steigerwald archivalisch Wiesenbewässerung nachgewiesen und beschreibt sie auf Basis alter Quellengrundlage wie folgt: „Wasser wurde mittels einfacher Gräben über Wiesen geleitet; ein Verfahren, das bei dem ungleichmäßigen Wasserangebot in den Möncheigen das Grasdargebot in den trockenen Sommermonaten vermehren konnte.“ Zugleich wird berichtet, dass aufgrund des wärmeren Quellwassers „,das Graß untern Eiß schon so gewachsen, daß man es frühezeitig abgrasen [hat] können“" [Satzergänzung im Original].

Eine Wiesenbewässerungsanlage im Grabenstausystem liegt im fossilen Zustand im fränkischen Baunach-Daschendorf vor, beiderseits des Ufers in den Gemarkungen Ratelsdorf, Ebing, Breitengüßbach (Oberfranken) sowie Daschendorf und Baunach (Unterfranken). Das Wasser zur Bewässerung wird seit dem späten 15. Jahrhundert von der Itz und der Baunach abgeleitet (GUNZELMANN 1987:240f.). Intensive Formen der Bewässerung entwickelten sich hier allerdings erst gegen Ende des 19. Jahrhunderts. So wurde 1869 in Baunach eine Wiesenkulturgenossenschaft gegründet. Insgesamt wurden 274 ha Ackerland in Wässerwiesen verwandelt, an denen 362 Genossen beteiligt waren $(: 241)$

Aus der Rhön werden 22 bewässerungswirtschaftliche Einzelunternehmen mit insgesamt 600 Tagwerk Fläche für die Mitte des 19. Jahrhunderts gemeldet, als die ersten Ansätze moderner Wiesenbewässerungen entstanden (GUNZELMANN 1987:241).

Auch die kleinen Wiesentälchen des Bieberbachs im Hessischen Spessart wurden bewässert, wie aus einem Vorfall, den GRIES (1999:113f.) schildert, zu entnehmen ist: Hierbei ging es um einen neu anzulegenden Mühlgraben, der die Bieber mehr als $1 \mathrm{~km}$ aus ihrem natürlichen Bett verlagern würde, so dass deshalb die Gefahr drohte, dass das Wasser zur Wiesenbewässerung nicht mehr ausreiche und die zweischürigen Wiesen zu einschürigen werden könnten - was einer Katastrophe für die Viehhaltung in Bieber gleichkäme. Wie einer Mitteilung des Schultheiß der Bieberer Landmannschaft $1717 \mathrm{zu}$ entnehmen ist, fürchteten die Bieberer Bauern bei einem Mühlenneubau um die Erträge ihrer Wiesen. Die Flächen, so ihre Argumentation, seien sehr klein und darum kostbar, doch habe man bisher durch künstliche Bewässerung jährlich zwei Heuernten erzielen können. Diese Wiesenbewässerung sei aber „über Menschengedenken“ und seit viel mehr als hundert Jahren nur infolge einer althergebrachten Absprache mit den Müllern möglich gewesen, die von Samstagabend bis Sonntagmorgen auf das Anstauen des Baches bzw. auf das Mahlen verzichteten. Damit war gemeint, dass zu den Zeiten, in denen die Wiesen bewässert werden sollten, die anliegenden Müller dafür zu sorgen hatten, dass auf dem betreffenden Abschnitt genügend Wasser im Bach war. Genauer gesagt: Der oberhalb der Wiesen gelegene Dorfmüller konnte dann theoretisch zwar mahlen, durfte den Bach aber nicht anstauen, weil sonst der unterhalb der Mühle gelegene Bachabschnitt leergeflossen wäre. HstAA Düsseldorf: Wiesengenossenschaft im Mydlinghover- und Stinderbachtal zu Erkrath: Lageplan des
Mydlinghoverbachtales v. 15. Juni 1932 
Dagegen war es erwünscht und vielleicht sogar notwendig, dass der unterhalb der Wiesen gelegene Müller die Bieber möglichst kräftig staute, damit sich der Bachspiegel zwischen den Mühlen hob und die Bewässerungsgräben in den Wiesen füllte. Mahlen durfte er jedoch keineswegs, weil dies den Bachspiegel wieder gesenkt hätte. „Daraus geht zweifelsfrei hervor, daß die Wiesenbewässerung tatsächlich nur dann funktionieren konnte, wenn Bauern und Müller in gegenseitiger Rücksichtnahme zusammenarbeiteten." (:113f.)

Im südwestlichen Spessart findet man die Wiesenbewässerung in Heimbuchenthal und Mespelbrunn für das 17. Jahrhundert erstmals erwähnt. Ihre Blütezeit mit einer ausgereiften Technik erfährt sie dann aber erst etwa zur Mitte des 19. Jahrhunderts, wie DENZER (1996:135) in ihrer Untersuchung nachgewiesen hat. Von genossenschaftlichen Bewässerungsanlagen wird des Weiteren von Schweinheim bei Aschaffenburg und Partenstein bei Lohr berichtet, mit einer Größe von insgesamt 131 Tagwerk, die im Jahr 1859 entstanden sind (GUNZELMANN 1987:241).

Heute wird der Wiesenbau im Spessart übrigens „nirgends mehr praktiziert und ist nur noch in Relikten wiederzufinden“ (DENZER 1996:135). Überreste vom Rückenbau lassen sich im Elsavatal besonders gut im Bereich der Gemeinde Heimbuchenthal erkennen (:142). Reste einer Hangbewässerung fand DENZER (:136) auch auf einem ehemaligen Wiesengelände oberhalb von Krausenbach im Forstbezirk Krausenbach im Dammbachtal. Der gesamte Wiesenkomplex befindet sich in einem Kerbsohlental und umfasst 67 Tagewerke und erstreckt sich über eine Länge von ca. $2 \mathrm{~km}$. Der Höhenunterschied beträgt nach ihrer Messung auf dieser Strecke 85,03 m.

In der Gemarkung Krausenbach gab es noch eine Reihe weiterer Anlagen für Wiesenbewässerung und -entwässerung. Sie befanden sich im Krausengrund selbst, im Gösbachgrund, im Wiesenkomplex Dorfwiese, in den Steinwiesen, in den Wiesen am Brunnfluss und am unteren Graben sowie im Seitental und im Klaffenbrunn.

Weiterhin wurde in Hobbach am Flüsschen Elsava eine intensive Wiesenberieselung bis in die Mitte des 18. Jahrhunderts durchgeführt. Und auch unterhalb von Hobbach liegen herrschaftliche Bruchwiesen, auf denen eine kombinierte Wiesen- und Weidennutzung praktiziert worden ist (DENZER 1996:142). Auf dem heute noch vereinzelt als Ackerland genutzte Talgrund sind vor Ort in regelmäßigen Abständen dunkler erscheinende, parallel zueinander ziehende Streifen zu identifizieren. Diese Streifen treffen im rechten Winkel auf die Elsava. „Die Vermutung liegt nahe, daß es sich um ehemalige Entwässerungsgräben einer früheren Rückenbewässerung handelt“"(:142).

Des Weiteren haben in den Ortschaften Lindelbach und Dietenhan im Kreis Wertheim, so erfahren wir von UECKER (1999:55) die Lindelbacher und Dietenhaner Bauern ihre Wiesen gewässert, obgleich in trockenen Zeiten die Mühle die Dietenhaner Mühle zum Mahlen zu wenig Wasser gehabt hatte.

Auch in Franken bestand eine enge Verflechtung zwischen Bauer und Müller. Der Müller war hier zumindest auf dem Land immer zugleich auch Bauer, d. h. er betrieb neben der Mühle noch eine Landwirtschaft. Dies weist damit auf ein ausgeprägtes und spezialisiertes Müllerhandwerk hin, das gleichzeitig Wiesenbau betreiben musste (BEDAL 1992:13). So gab es eine traditionelle Wiesenbewässerung zum Beispiel im Wiesental bei Kirchehrenbach im Vorland der Fränkischen Alb (KUHN 1992).

Für Baden-Württemberg weisen KROLL und KONOLD (1994) in der Schwäbischen Alb Wiesenbewässerung am Beispiel des Fehla- und Lauchtals nach.

Das untere Fehlatal liegt auf der Schwäbischen Alb zwischen Neufra und Hettingen im Landkreis Sigmaringen. Die Fehla selbst entspringt in Burladingen (Oberamt Hechingen) aus dem Weißjura der Hohenzollern Alb und gehört zu den Karstgewässern der Schwäbischen Alb. Das Tal der Fehla geht von der Mündung in die Lauchert hinauf bis zum Marktflecken Neufra und hat eine Breite von 29 bis $171 \mathrm{~m}$. Die Anlagen im unteren Fehlatal waren in Hang- oder Rückenbauweise angelegt (KROLL/ KONOLD 1994:407f.). 
$\mathrm{Zu}$ den Rieselwiesen im Oberamt Gammertingen (oder Gammeringen) gehört neben dem Fehlatal wie erwähnt auch das Lauchertal (KROLL/KONOLD 1994:402). „Die Wiesenbewässerung in diesem idyllischen Seitental der Lauchert geht mindestens bis ins 16. Jahrhundert zurück. [...] In größerem Umfang sind Unterlagen und Pläne zur Wiesenbewässerung aus dem 19. Jahrhundert erhalten.“ (:400)

FESSELER (1994:291ff.) und auch HERBST (1992:119) weisen für Oberschwaben mittelalterliche Bewässerungseinrichtungen des Benediktiner-Reichsstiftes Weingarten/Altdorf nach, die als sog. „Rungsbewässerung“ bezeichnet wird: In dem verzweigten Talgrund der Scherzach, einem ca. 8 km langer Bach, wurde das Bett künstlich in zwei Arme geteilt, in den sog. oberen Rungs und den sog. unteren Rungs (Rongs). Beide Arme umschlossen eine Bewässerungsfläche von ca. 140 ha (FESSELER 1994:293). Die Bewässerung wurde in Form einer Überrieselung der Hänge und Rücken der Wiesen durchgeführt und anschließend in den Mutterbach rückgeführt. Nach dem Klosternamen gründete sich die „Weingartner Rungsgesellschaft“, die sich aber wiederum ab Mitte des 19. Jahrhunderts allmählich auflöste (:297). Ebenso wurde Wiesenbewässerung an der Langenlachen, wie der Unterlauf des Stillen Baches genannt wurde, durchgeführt (HERBST 1987a:20f.; HERBST 1987b :28ff.). Nach Aktenlage existierten bereits vor dem 17. Jahrhundert Dammkanäle, wahrscheinlich sogar schon im 14. Jahrhundert (HERBST 1987a:21).

Auch im Einzugsbereich des Klosters Ochsenhausen im Oberschwäbischen Bergland wurde Wiesenbewässerung durchgeführt. Stadtnahe Bewässerungswiesen wurden vor den Städten Biberach am Rotbach nachgewiesen (HERBST 1992:34,50).

Hochmittelalterliche, ,suburbane“ Bewässerungslandwirtschaft wurde auch in und um Isny im Allgäu angewendet. Die Stadt Isny im Allgäu liegt ganz im Südosten des Landes Baden-Württemberg. Unmittelbar bei Isny entspringt in einem Quellgebiet die Ach (Isnyer Ach). Die Errichtung der Benediktiner-Abtei 1096 in diesem Talabschnitt wird als Kulturträger der Wiesenwässerung angesehen (KONOLD 1994:304), die das Wasser der Isine für die Wiesen benutzte und die Wassernutzungsrechte zugesprochen bekam. „Aber es ist durchaus denkbar, daß vom alten gräflichen Fronhof aus ebenfalls Wiesenbewässerung betrieben worden war" (:305). Seit 1171 wird hier von Wiesen respektive Wässerwiesen berichtet, die nicht allzu lange zuvor angelegt worden waren (:305). Die erste flächenbezogene Aussage zur Wiesenbewässerung hingegen stammt aus dem ersten Drittel des 14. Jahrhunderts und bezeichnet Flächen im Donaugebiet (:319).

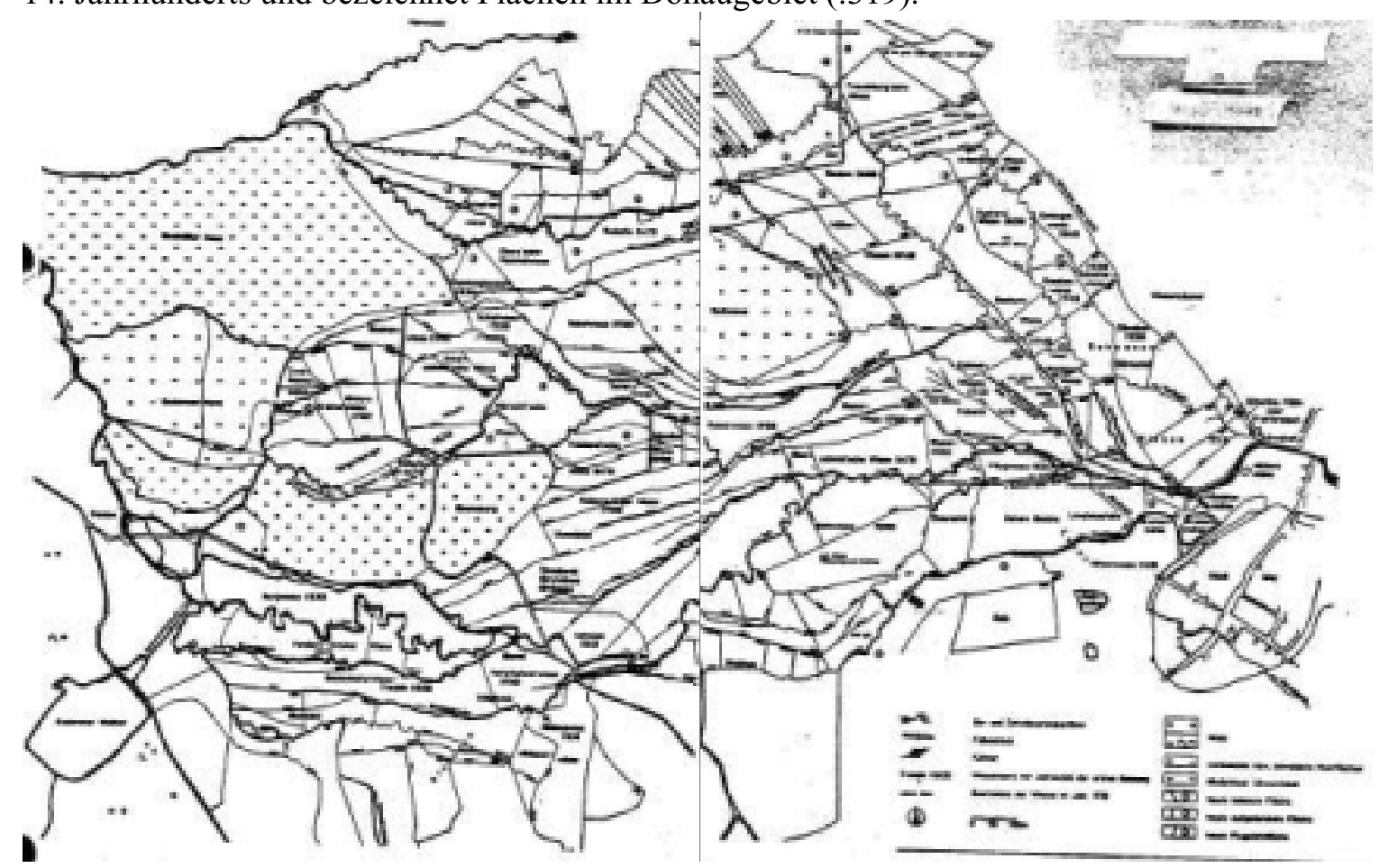

Abb. VIII-58: Die Wässerwiesen im Isnyer Moos (aus: KONOLD 1994:320) 
In Oberschwaben befanden sich insbesondere entlang der Donauzuflüsse zahlreiche bewässerte Wiesen. Im württembergischen Einzugsgebiet lagen diese vor allem im ehemaligen Donaukreis, einem der insgesamt vier Kreise, in die das damalige Königreich untergliedert war (KONOLD/POPP 1994:378f.). Ein Blick auf die nachfolgende Karte zeigt, dass an allen direkten Donauzuflüssen, nicht jedoch an der Donau selbst, Wiesen bewässert wurden. Zum Gewässerursprung hin nahm die Zahl der Wässerungen, bedingt durch die ungünstige Wassermenge und die für Bewässerungen ungünstige Geländestruktur, meist ab (:389).

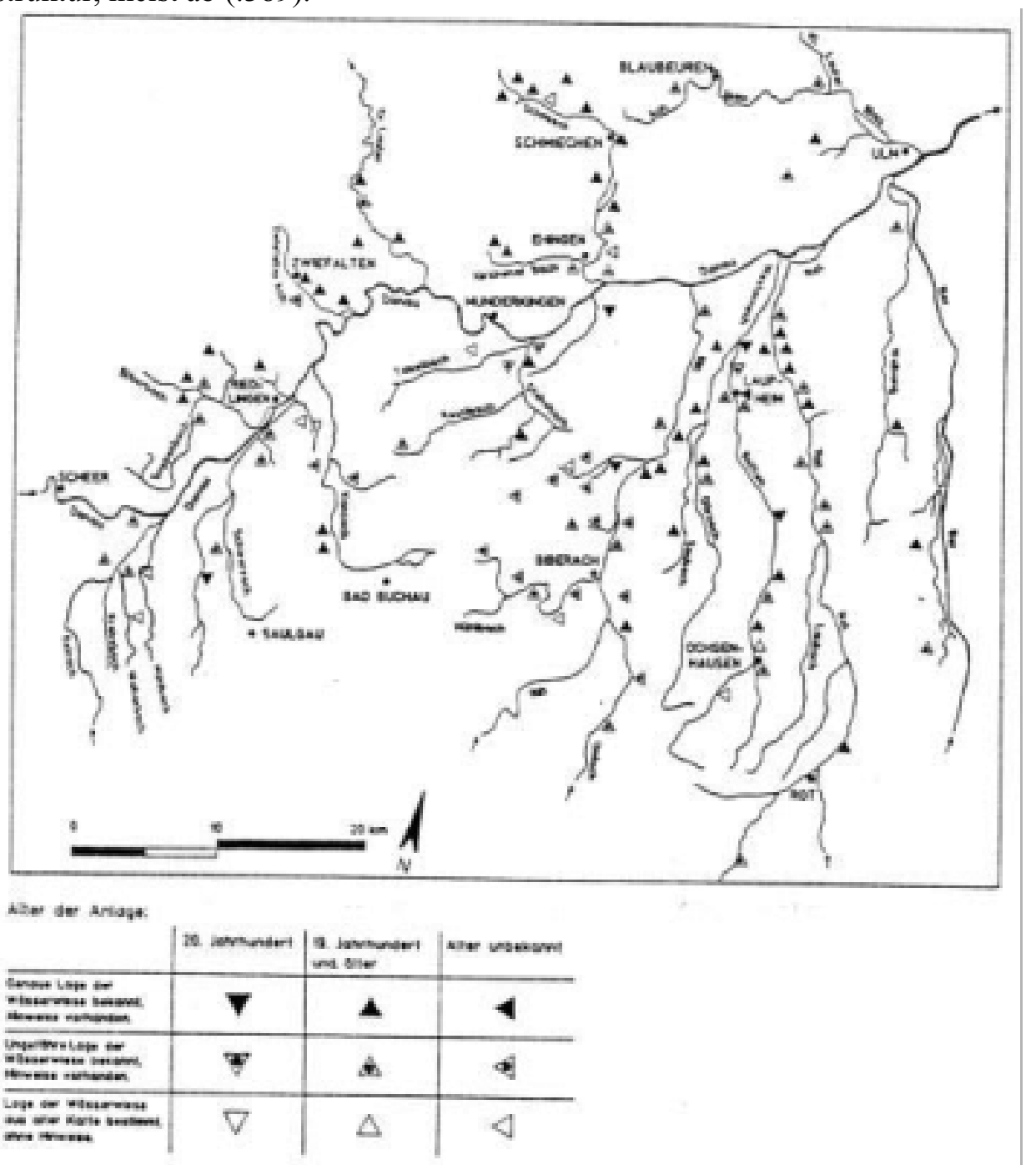

Abb. VIII-59: Ehemalige Wiesenbewässerungsanlagen im Einzugsbereich der Donau in Württemberg (aus: KONOLD/POPP 1994:390)

Im gesamten baden-württembergischen Donaukreis besaß die Wiesenbewässerung eine lange Tradition. Schon im Jahr 1322 beispielsweise existierten an der Schmiech, einem linken Donauzufluss, Bewässerungsanlagen (KONOLD/POPP 1994:379, siehe Abb....). Zahlreiche weitere Dokumente aus dem späteren 14. bis 17. Jahrhundert berichten über Bewässerungen in diesem Raum. Zum Beispiel in Herbertingen/Donauried, Ummendorf/Reichenbach, Achtal, Eggingen, Baltringen, Ehingen, Uttenweiler, Justingen, Bußmannshausen, Mittelbiberach und Reinstetten (:379.) 


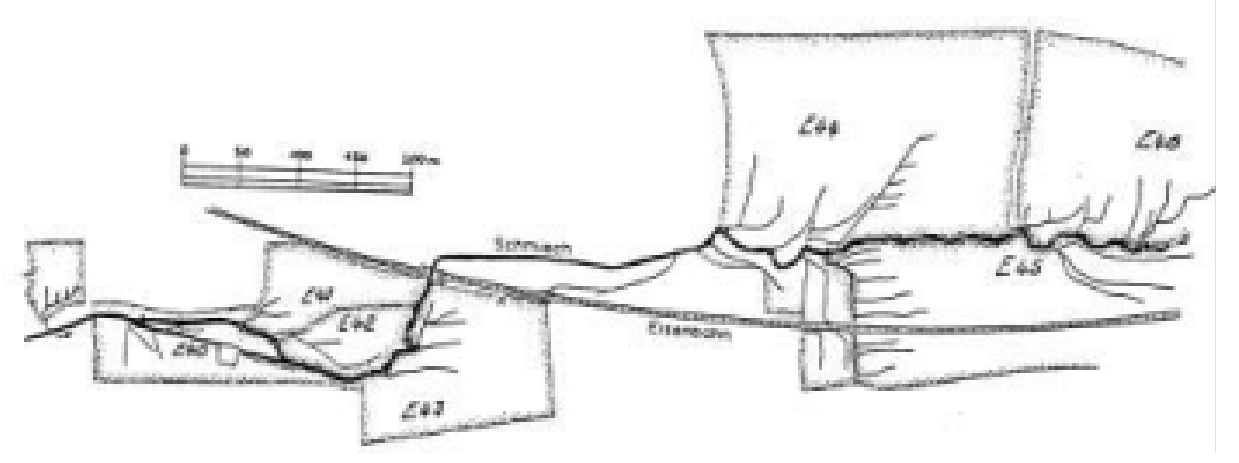

Abb. VIII-60: Verschiedene Bewässerungseinrichtungen entlang der Schmiech

in der Nähe des Dorfes Schmiechen. Die Eisenbahn unterbricht die Bewässerungsanlagen nicht (Original von 1920, aus: KONOLD/POPP 1994:394).

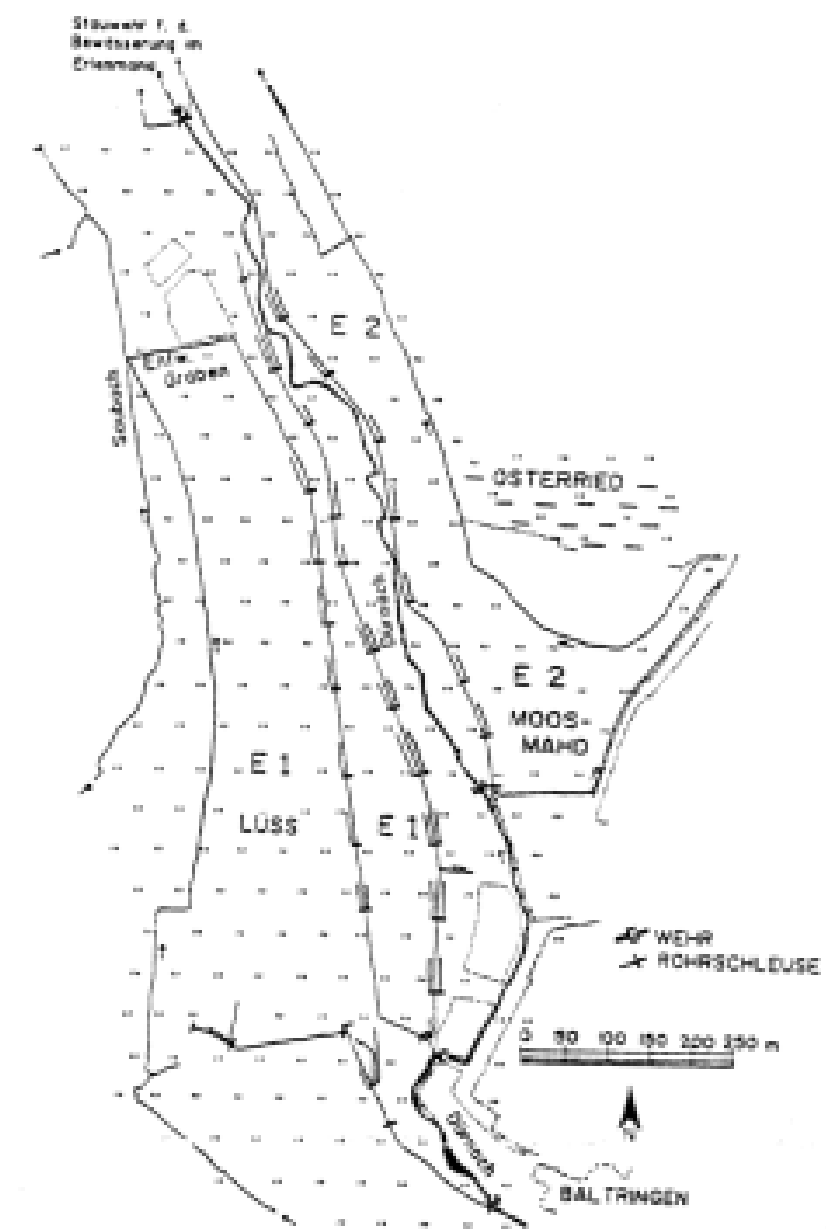

Abb. VIII-61: Bewässerungsanlage an Dürnach und Saubach bei Baltringen (aus: KONOLD/POPP 1994:392)

In dem waldreichen Mittelgebirge der pfälzischen Haardt, das von Kaiserslautern über Pirmasens bis zur französischen Grenze reicht und überwiegend aus den Schichten des Buntsandsteins aufgebaut ist, sind in den breiten, zerlappten Talweitungen und Mulden zahlreiche Wässerwiesen angelegt worden. Wie zum Beispiel am Oberlauf der Queich und an der Lauter (FIEDLER 1965:6), aber Bewässerungsanlagen bestanden auch in den Tälern der Rodalbe, der Moosalbe und vieler anderer Nebenbäche (FIEDLER 1965:6,20).

Schließlich stoßen die Haardtbäche und -flüsse in das Vorderpfälzer Tiefland vor. Die Terrassenflächen der Flüsse sind hier über ihre pleistozänen Sande und Kiese mit fruchtbarem Löß bedeckt. Während die Lößflächen hier wie anderswo für den Getreide- und Futteranbau genutzt werden, wiesen die Bachniederungen mit ihren feuchten Auen und sandigen Schwemmfächern noch bis in die 1960er 
Jahre bewässerte Wiesen auf (FIEDLER 1965:6f.,20). Vor allem hier, zwischen der Mosel im Westen und dem Ostabfall der Haardt lagen die Gebiete, ,in denen die Wiesenbewässerung bemerkenswert war" (:20).

Allein aus den noch wenigen vorhandenen Unterlagen darf angenommen werden, dass ,in der Pfalz alle geeigneten Bachtäler in Kunstwiesen umgewandelt worden waren." Nach dieser Aussage von FIEDLER (1965:15) kann die Pfalz ebenfalls als ein Stammland der Wiesenbewässerung bezeichnet werden. In der Gemeinde Schwetzingen beispielsweise wurden bereits im 18. Jahrhundert großflächig Wiesen bewässert (MOSSEMANN 1971:18). Auf den heute urbanisierten „Rohrwiesen” in Oftersheim gab es in den Jahren 1780-1791 „ausgedehnte Bewässerungswiesen“"(:18), wobei die Bewässerungsgräben mit einer Schließe versehen waren und auf einen kunstvollen Wiesenbau hindeuten (:17). Weitere Standorte der Wiesenbewässerung im östlichen Vorland des Pfälzer Waldes sind die Wiesen der Hochstadter Queich mit ihren Nebenbächen Nord- und Südqueich, Fuchsbach, Lustadterbach und der Druslach (FIEDLER 1965:77). In den breiten Wiesen der Pfalz „waren meistens die kunstvollen Rücken der Siegener Wiesenbauschule errichtet worden" (:77).

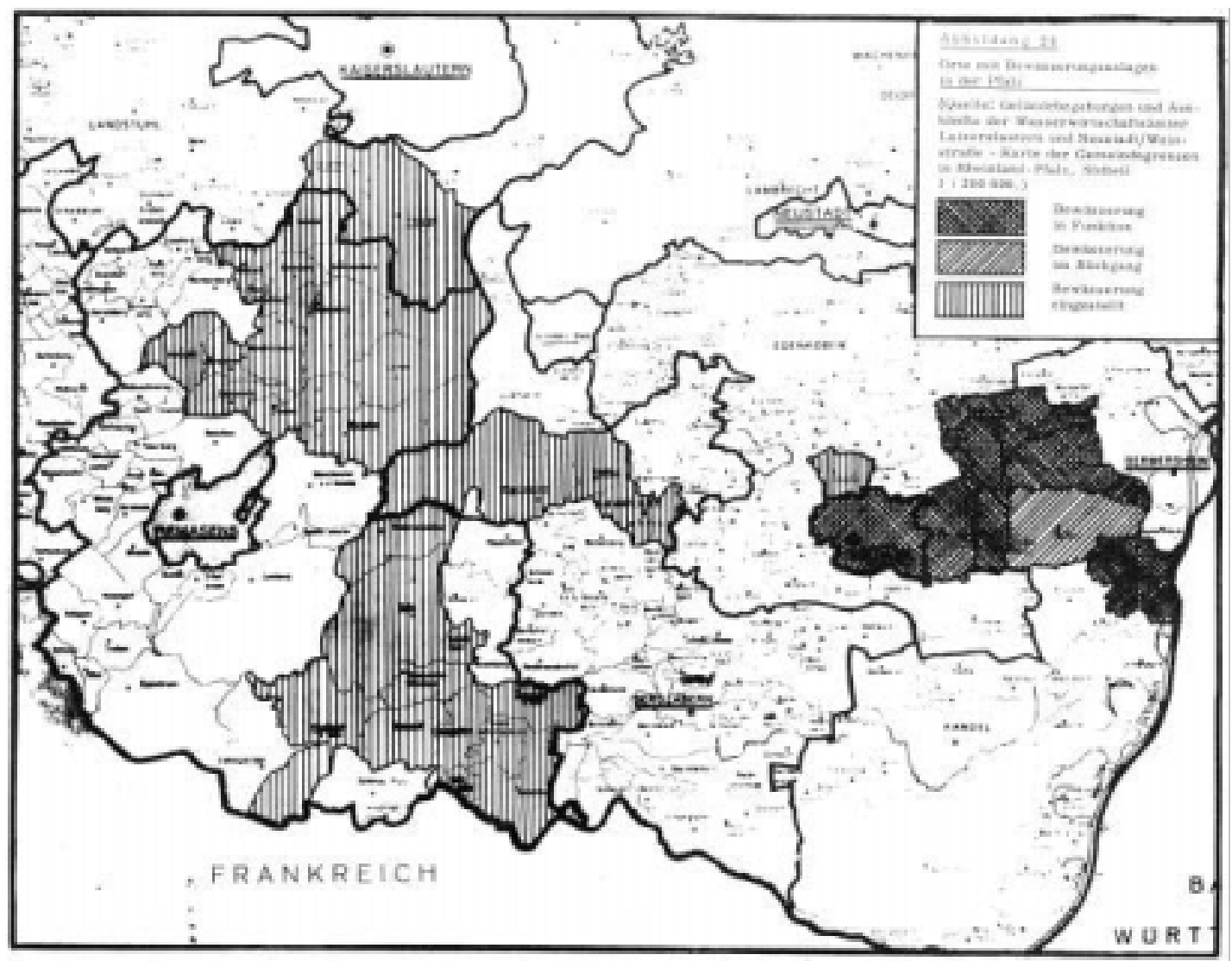

Abb. VIII-62: Orte mit Bewässerungsanlagen in der Pfalz.

Die Abbildung weist auf die ehemals weitflächige Verbreitung der Wiesenbewässerung hin. Im Jahr der Kartierung (1960er Jahre) zeigt sich - im Vergleich zu dem unten beschriebenen Saarland - für den Pfälzer Raum jedoch ein differenziertes Bild: ein Großteil der Bewässerungsanlagen wurde zwar zu diesem Zeitpunkt auch bereits eingestellt, in einem relativ großen Gebiet, im Bereich um Landau, hingegen wurde sie weiter betrieben, wenngleich auch teilweise im Rückgang begriffen (aus: FIEDLER 1965, Abb. 26).

Ebenso wurden die Wiesen der Auen des Pfälzer Waldes als Mähwiese bewirtschaftet. Spätestens seit Anfang des 19. Jahrhunderts wurden in den Tälern Bewässerungswiesen angelegt, die man hier als „Schemelwiesen“ bezeichnet, um den Ertrag zu steigern. Die Auen des Dahner Tals beispielsweise wurden ,ausschließlich als Wiesen bewirtschaftet, da eine Beweidung aufgrund der Nässe ungünstig war" (DAHN 2004). Das Vieh blieb im Stall oder weidete an den trockeneren Hängen.

Wahrscheinlich, so wird vermutet, entwickelte sich die spezielle Methode der Wiesenbewirtschaftung im Schemelbau selbständig in diesem Gebiet, und wurde nicht aus dem Siegerland Ende des 19. Jahrhunderts übernommen. Die Wiesen wurden hier in rechtwinklig zur Lauter verlaufende, 5 bis 10 
m breite Parzellen (Schemel) mit gewölbtem Querschnitt aufgeteilt. Auf dem Kamm verlief der Bewässerungsgraben, der durch einen Zulauf, der von der Lauter abzweigte und dann am Talrand verlief, mit Hilfe von Schleusen gespeist wurde. Entwässert wurden die Wiesen durch Gräben zur Lauter, die zwischen den Schemeln verliefen und durch deren (jährlichen) Aushub die Schemel entstanden.

Die letzten Schemelwiesen, die im eigentlichen Sinne im Rückenbau (siehe VII 6b.1.2) hergestellt wurden und so auch in den übrigen Tälern des südlichen Pfälzer Waldes entstanden, wiesen zuletzt einen Höhenunterschied von 0,5m zwischen Gräben und Rücken auf und wurden bis 1962 in Bobenthal genutzt, dort existiert noch heute eine Schleuse und ein funktionierender Zuleiter (DAHN 2004).

Im Jahr 1853, im gleichen Jahr wie in Siegen, kam es dann zu einer Einrichtung einer StaatsWiesenbauschule in Trier. Sie hatte neben der Ausbildung auch das Ziel, die Lehrgangsteilnehmer von der Anklammerung an das Siegener Modell zu lösen, das die Anpassung an die örtlichen Geländeformen und wirtschaftlichen Gegebenheiten nicht ausreichend berücksichtigte, weswegen die Anlagen unrentabel arbeiteten (FIEDLER 1965:41). FIEDLER (:38) sieht gar die Anfänge des kunstvollen Wiesenbaus im pfälzischen Raum. Mit einer Urkunde von 1428, in der den einzelnen Gemeinden das Recht zur Wasserentnahme aus den landesherrlichen Gewässern für Rieselzwecke zugestanden wird, wird für ihn der Beweis erbracht, dass die Wiesenbewässerung älter ist die des Siegerlandes. Insofern aber wäre nach meiner Ansicht seine Feststellung der weitverbreiteten Anwendung des Siegener Rückbaus im Saarland nicht mehr zu halten, denn dann hätte sich der Innovationsprozess von hier aus ausbreiten müssen.

Im Schwarzwälder Hochwald, im Gebiet zwischen dem Kreis Homburg und Neunkirchen (Saarland), wurde auf den dazwischen liegenden Bachtälern überall Wiesenbewässerung betrieben: „Dieses ehemalige bäuerliche Gebiet besaß ab Mitte des vergangenen Jahrhunderts die größte zusammenhängende Fläche an Wässerwiesen.“ (FIEDLER 1965:18). Nachweise einer intensiven Bewässerung liefert HERBST (1992) für die Wiesen der Benediktinerabtei St. Blasien.

Im Gegensatz zu dieser frühen Beweislage der Pfalz, lassen sich die Anfänge von Bewässerungswiesen im saarländischen Raum nur bis in das frühe 18. Jahrhundert zurückverfolgen (FIEDLER 1965:39). Die meisten im Saarland bestehenden Bewässerungsanlagen wurden gar erst etwa im Zeitraum von 1850 bis 1936 gebaut (:105). Bis dahin aber so intensiv, dass alle Landkreise des Saarlandes bewässerte Wiesenflächen aufwiesen (:15). Zunächst wurden sie durch freiwillige Selbsthilfeeinrichtungen geschaffen: in Limbach, Altstadt und Niederbexbach. Die ersten genossenschaftlichen Anlagen wurden dann im Zeitraum 1853-1868 gegründet: Otzenhausen (1853), Losheim (1856), Niederlosheim (1856), Honzrath (1857), Bachem (1857), Keßlingen (1866) und Sotzweiler (1868). Es handelt sich hierbei um eine Auswahl von Orten, die große Flächen Bewässerungswiesen anlegten. „Es darf angenommen werden, daß diese etwa $75 \%$ aller Wiesen der genannten Orte ausmachten". (:48)

In den Jahren 1872-1882 folgte im Saarland die nächste Gruppe von Wässerwiesenanlagen auf genossenschaftlicher Grundlage: Rimlingen, Wahlen, Mitlosheim, Rappweiler, Waldhölzbach und Scheiden. Sie besaßen einen reduzierten Anteil von 50 \% an den Grünflächen (FIEDLER 1965:48).

Ein dritter Gründungsabschnitt von genossenschaftlichen Wässerwiesen zeichnete sich um die Jahrhundertwende ab: in Weierweiler, Münchweiler, Nunkirchen, Büschfeld, Bardenbach, Rissenthal, Hargarten, Erbringen, Reimsbach, Düppenweiler und Haustadt mit weniger als der Hälfte der Gesamtwiesenflächen (FIEDLER 1965:49).

Lange Zeit ruhte dann die Neuanlage von Bewässerungswiesen. Ein nächster Abschnitt von Neugründungen dauerte von 1929 bis 1937. In diesem Zeitraum wurden die verbleibenden Lücken aufgefüllt: um die alten Zentren Losheim/Niederlosheim, Otzenhausen und Sotzweiler. Auch der Saargau um den alten Wässerort Keßlingen und um Homburg (Reiskirchen, Klein-Ottweiler und Jägersburg) wurde wieder von Neugründungen erfasst und dürfte nahezu $100 \%$ aller Wiesenflächen erreicht haben. 
Zu diesem Zeitpunkt hatten auch „im ganzen Kreisgebiet von Merzig-Wadern, das von der Saar bis an den Oberlauf der Prims reichte, [...] Bewässerungsgenossenschaften ihre Tätigkeit aufgenommen. Alle Wiesentäler in diesem Bereich waren in Kultur genommen und in Kunstwiesen umgewandelt worden." (FIEDLER 1965:49) Darunter fallen auch die Wiesentäler im Nordwesten des Saarlandes an der Luxemburger Grenze: im Tal des Leukbaches, in den Tälern vom Holzbach, Wahn- und Speckenbach, Wadrillbach, Lösterbach und die von der Prims bewässerten Wiesenflächen. Im Osten diente bei Hoburg der Mutterbach und besonders die Blies als Wässerwasser.

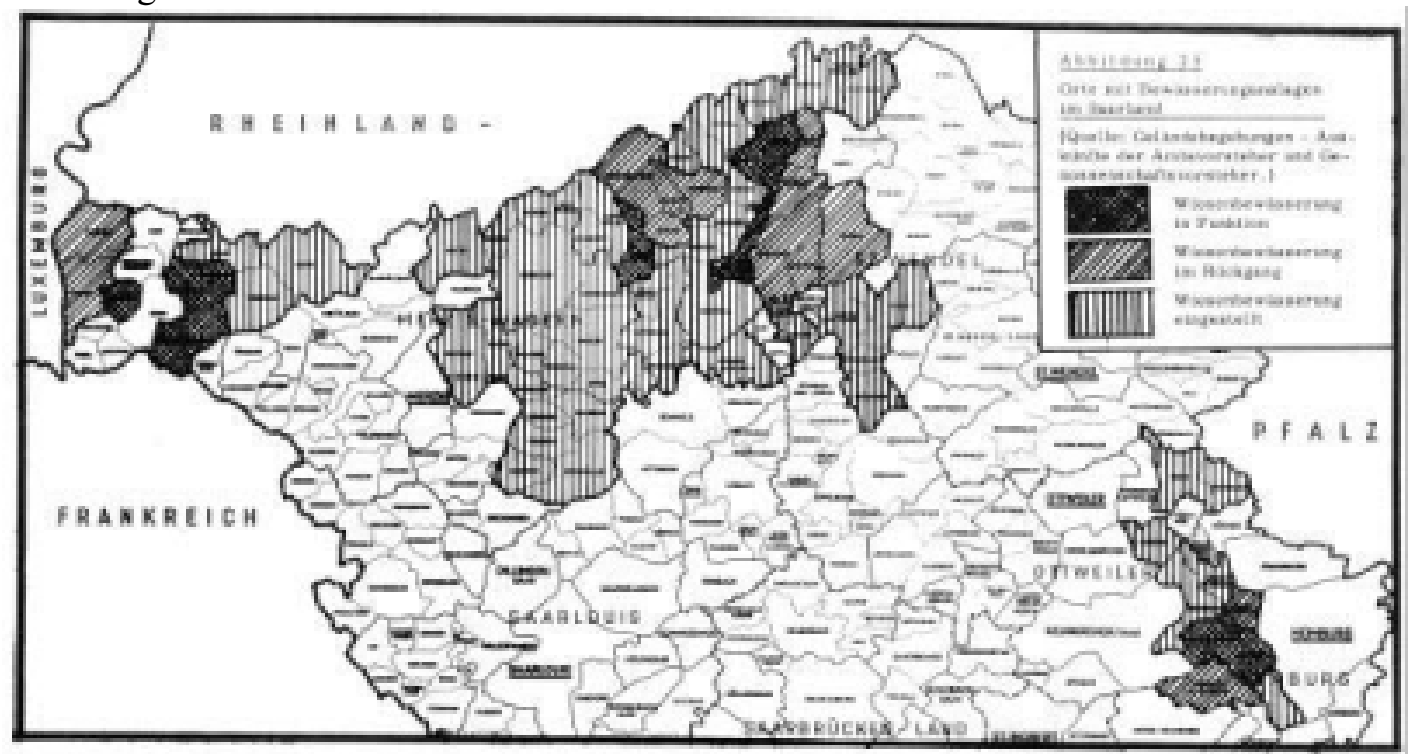

Abb. VIII-63: Orte mit Bewässerungsanlagen im Saarland

Im Jahr der Aufnahme in den 1960er Jahren zeigt sich auch hier die weitestgehende Einstellung der Wiesenbewässerung. In weiteren Bereichen wurde ein Rückgang festgestellt. Dennoch gab es noch zu diesem Zeitpunkt einige Gebiete im Saarland, in denen eine Wiesenbewässerung betrieben wurde. Im Bereich Borg, Büschdorf, Faha, zwischen Wandern und Kastel sowie zwischen Homburg und Neunkirchen. Insgesamt aber verdeutlicht diese Abbildung die ehemals weitflächige Verbreitung der Wiesenbewässerung in dem Kartierungsgebieten des Saarlandes (aus: FIEDLER 1965, Abb. 25).

Die Kunstwiesen waren nicht auf den saarländisch-pfälzischen Raum mit dem Saar-Bergland als Kernraum beschränkt. Auch im lothringischen Raum und südlich des Saarlandes, in den nördlichen Vogesen, wurden in vielen Bachtälern Bewässerungswiesen angelegt. Im Norden des Saarlandes reichten sie noch weit bis in die südliche Abdachung des Hunsrücks hinein, ,überschritten den Kamm aber nicht und fehlen daher am Moselhang vollkommen. Erst in der Eifel traten sie wieder in Erscheinung“ (FIEDLER 1965:16). Das Fehlen von Wässerungen an den Moselhängen mag mit dem hier vorherrschenden terrassierten Weinanbau und den ungünstigen und steinigen Steilhanglagen zu tun haben. An der reinen Höhenlage und den Schwierigkeiten der Wasserzuführung lag es mit Sicherheit nicht, wie die Beispiele in den Alpenländer beweisen.

\section{b.3 Alpen und Alpenvorland}

Die Bedeutung der Wässerwiesen für Wiesenkultur in allen Regionen Deutschlands gilt auch für die anschließenden alpinen Gebiete Tirols, Österreichs und der Schweiz. Zahlreiche Beispiele von Wiesenbewässerungen sind aus dem Alpenraum bekannt geworden. Man trifft die Berieselungsanlagen in allen Höhenlagen an, am Talboden ebenso wie in der Almregion. Insbesondere aber sind Bewässerungsanlagen typisch für inneralpine Trockentäler (HELLEBART 1994:186). In diesen sonnenexponierten und trockenen Tallagen und hängen konnten aufgrund der gut geschützten Lage bis über $1000 \mathrm{~m}$ über Meeresspiegel Weizen und Reben angebaut werden. Deshalb wurden hier mit dem Bewässerungswasser nicht nur Wiesenäcker, sondern auch Getreidefelder, Rebberge und Obstanlagen bewässert. Dafür aber war eine sich von Frühjahr bis zur Erntezeit im September hinziehende regelmäßige Bewässerung notwendig (NAEF 1994:24; HELLEBART 1994:186). 
Die Niederschlagsverteilung und -häufigkeit gibt allgemeine Aufschlüsse über Standorte von alpinen Bewässerungsanlagen. In den Gebieten mit hohen Niederschlagsmengen (Südalpen/Tessin, Nordalpen) finden wir keine Wiesenbewässerung. Aber schon im relativ trockenen westlichen Schweizer Mittelland und in der Nordost-Schweiz lassen sich Bewässerungssysteme nachweisen. Hauptsächlich aber die Trockeninseln, das Bündner Tal, das mittlere und untere Rhonetal sowie die südlichen Täler des Wallis sind die Regionen, in denen umfangreiche Bewässerungen durchgeführt wurden.

In dem Schweizer Kanton Graubünden, dem sog. Bündnerland, wurden in hochgelegenen, südlich exponierten Lagen zahlreiche, meistens jedoch kleinere Gebiete bewässert (SCHMID/NAEF 1994:9).

Die hochalpinen Bewässerungssysteme des Wallis sind eine „der ältesten und bedeutendsten Bewässerungsanlagen des größten Trockengebietes der Schweiz“ (SCHMID/NAEF 1994:6). Zum Teil bestehen sie noch immer und werden vor dem Verfall bewahrt, mit Sicherheit auch, weil sie die bekanntesten sind und einen touristischen Wert besitzen $(: 8)$.

Die Gründe für eine künstliche Bewässerung in einem an Wasserläufen reichen Kanton lagen im Wallis in dessen Niederschlagsarmut, die NAEF (1994:25) ,mit gewissen Gebieten Nordafrikas, des Balkans und der Pyrenäen" vergleicht. Nur durch eine ständige Bewässerung der Trockengebiete des Wallis können „sie von der Versteppung bewahrt werden.“ (:25). Da Talflusswasser in diesen Höhen nicht zur Verfügung steht, mussten und müssen die Bewohner der Berghänge durch viele und oft kühn angelegte Leitungen Wasser aus den Gletschergebieten heranzuführen. Es handelt sich bei diesen alpinen Bewässerungseinrichtungen um oft hoch über steile Felswände und zuweilen durch diese hindurch geführten offenen Bewässerungskanäle. Diese Wasserleitungen werden von den Wallisern „Suonen“ oder „Bisses“ (altgerm.: „beds“ = Bett) genannt (:24).

„Unter Anpassung an die örtlichen Gegebenheiten, vielfach auch an die Besitzverhältnisse, stellt die Bewässerung durch die Bisses ein Wasserleitungssystem dar, das in seinen Grundzügen in allen Walliser Tälern gleich ist" (NAEF 1994:25). Heute dienen sie vielfach als Touristenattraktion. Werden sie aber noch als Bewässerungseinrichtung für die Landwirtschaftspraxis gebraucht, so wird die Bewässerung weitgehend mit Hilfe von Röhren durchgeführt, welche die offenen Gräben und Leitungen nach und nach ersetzen (:24).

Als Beispiel sei der Ort Visperterminen genannt. Das Dorf liegt 1000 m höher als die Talsohle des Flussbettes der Visper. Der Boden ist sandig, locker und zerklüftet und das Wasser versickert schnell. Zusätzlich zu den klimatischen Bedingungen muss deshalb notwendigerweise Wasser zur Bewässerung befördert werden.

Als zweites Beispiel geographischer Verbreitung alpiner Bewässerungen in der Schweiz sei das Avigna-Wasser im bündnerischen Münstertal („Val Müstair“) in der östlichen Schweiz genannt. Die Nutzung des Avignabaches zu Bewässerungszwecken ist seit fast knapp 800 Jahre bekundet. Die Ursprünge der Bewässerung gehen - nach den Urbaren des Klosters von Müstair von 1322, wo auf eine heute allerdings nicht mehr auffindbare Urkunde hingewiesen wird - auf das Jahr 1211 zurück. Ein Vertrag über die Wasserrechte des Klosters von 1463 ist noch heute in Kraft (FURRER/FREUND 1994:12). In der nächstgelegenen Gemeinde Santa Maria ist ebenfalls Bewässerung betrieben worden. Hier ist die Bewässerung fast vollständig aufgegeben, in der Landschaft zeugen lediglich noch Spuren von früheren Bewässerungssystemen (:14).

Nach FURRER/FREUND (1994:15) sind Bach- und Quellnutzungen zu Bewässerungen des Weiteren in der Dauersiedlung Mariensäße, Terza, Fuldera, in der Gemeinde Zernez, in Davos, Meder/ Meierhofberg sowie in Salez nachgewiesen. Als weitere Beispiele alpiner schweizer Bewässerung sind bei HÄNNI (1994:19) die Gemeinden Strättlingen, Allmendigen und Schoren-Allmend bei Thun erwähnt.

Im zentralen Schweizer Mittelland, das Teil des nördlichen Alpenvorlandes ist, zwischen Emme und Reuss, befinden sich die Oberaargauer Wässermatten. Diese liegen an Flüsschen des nördlichen Napfgebietes zwischen Hittwil und Langenthal (Abb. 3). Die Langete stellt das Hauptgewässer im sog. 
Napfgebiet dar und tritt bei Huttwil aus der Nagelfluh ${ }^{41}$ des fluvialen Eggenlandes aus (BINGGELI 1986:127).

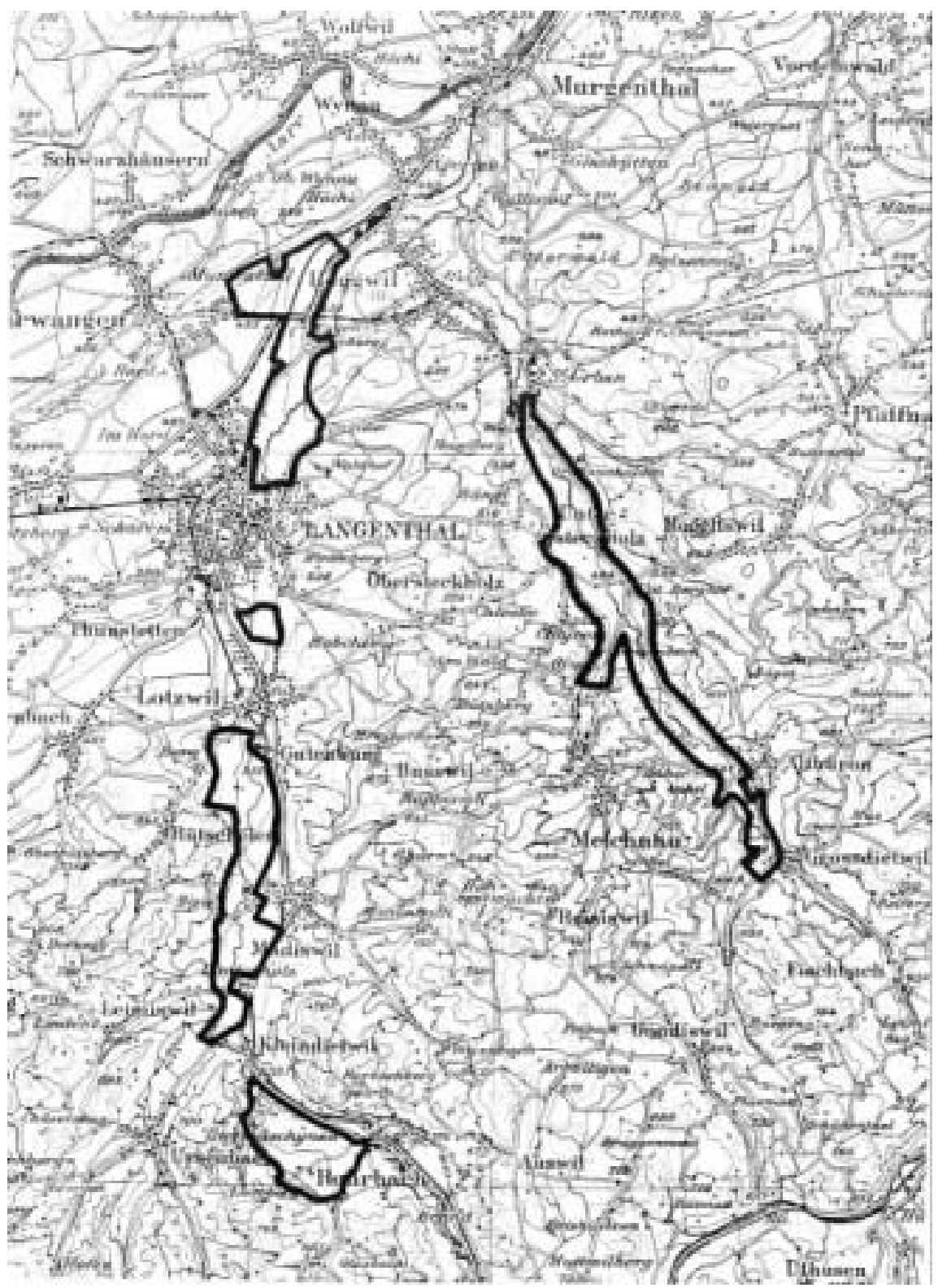

Abb. VIII-64: Wässermatten in den Tälern von Langete und Rot

Topographische Übersicht des Untersuchungsgebietes reproduziert auf Landeskarte 1:100.000 (Original-Maßstab) (aus: BINGGELI 1986:128, Abb. 3).

Zahlreiche Studien galten der Akkumulationsebene des unteren Langetentals - es wird gar von einem „Beobachtungsgebiet Langetental“ (BINGGELI 1986:136) gesprochen. Aber auch aus dem oberen Einzugsgebiet, vor allem aus dem Abschnitt Rohrbach-Kleindietwil liegen Untersuchungen zur Wiesenbewässerung vor. „Diese Wässermatten sind es, die noch heute den Landschaftscharakter der Täler im Napfvorland entscheidend prägen.“(:136)

Das Tal der Langete im Schweizerischen Mittelland ist seit rund tausend Jahren Standort der Wiesenbewässerung (LEIBUNDGUT 1993:13). Die Längsstreckung des Tales beträgt rund 22 km, der höchste Punkt liegt bei $1120 \mathrm{~m}$ über Meereshöhe, der tiefste Punkt bei $450 \mathrm{~m}$ über Meereshöhe, die

\footnotetext{
${ }^{41}$ Nagelfluh: ein betonähnliches, interglaziales und damit geologisch junges Konglomerat aus der Oberen Meeresmolasse, wobei „Molasse“ die Bezeichnung für die Sedimente der Rand- und Innensenken von Faltengebirgskomplexen, vor allem für die tertiären Schichtenserien der Alpen ist. Es handelt sich hierbei also um verfestigte Fluss- und Brandungsschotter in großen Schuttkegeln (Schuttfächer mit groben Geröllen) vor dem Alpenkörper, d. h. vor dem nördlichen Alpenrand..
} 
Laufstrecke des Talflusses beträgt $30 \mathrm{~km}$. Die Talfüllung besteht aus alluvialen Schottern. Auf Schottern liegen auch die Wässerwiesen. Die relativ unfruchtbaren, aber gut durchlässigen Schotter- und Sandflächen in der natürlichen Überschwemmungslandschaft der Langete boten für die Landwirtschaft keine günstigen Voraussetzungen. Erst durch die Bewässerung aus dem Flusswasser konnte allmählich eine Bodenbildung durch Kolmatierung erzielt und das Nährstoffangebot verbessert werden (:13).

Die Wiesenbewässerung war hier Teil eines großen Meliorationswerkes, das gemeinschaftlich von Mönchen, Bauern, Gemeinden und Wässergenossenschaften betrieben wurde (LEIBUNDGUT 1993 :13). Wie bereits erwähnt, stellt die Wiesenbewässerung im Langetental eine inzwischen über 1000jährige Einrichtung dar. Urkundliche Nachweise der Oberaargauer Bewässerung bestehen bereits für das 9. Jahrhundert. Der Beginn der systematischen Wässerwiesen-Landwirtschaft im Langetental setzt aber erst mit dem großen Meliorationswerk der Zisterziensermönche von St. Urban im 13. Jahrhundert ein. Es entstanden die ersten großen Bewässerungsanlagen (:24,33). Die „Urbarisierung“ (BINGGELI 1986:129) der wilden Langete bzw. des Langetenthals durch das Kloster begann mit einer Ableitung der Langete via Roggwil, die um 1250 zur Anlage von Wässermatten im dortigen Klosterhof diente (:129). „Die Möncharbeit wurde Vorbild für die Talbauern und im gemeinsamen Jahrhunderte langen Werk legten sie bereits die Grundzüge zum heutigen Landschaftstypus Wässermatten fest.“ (:129)

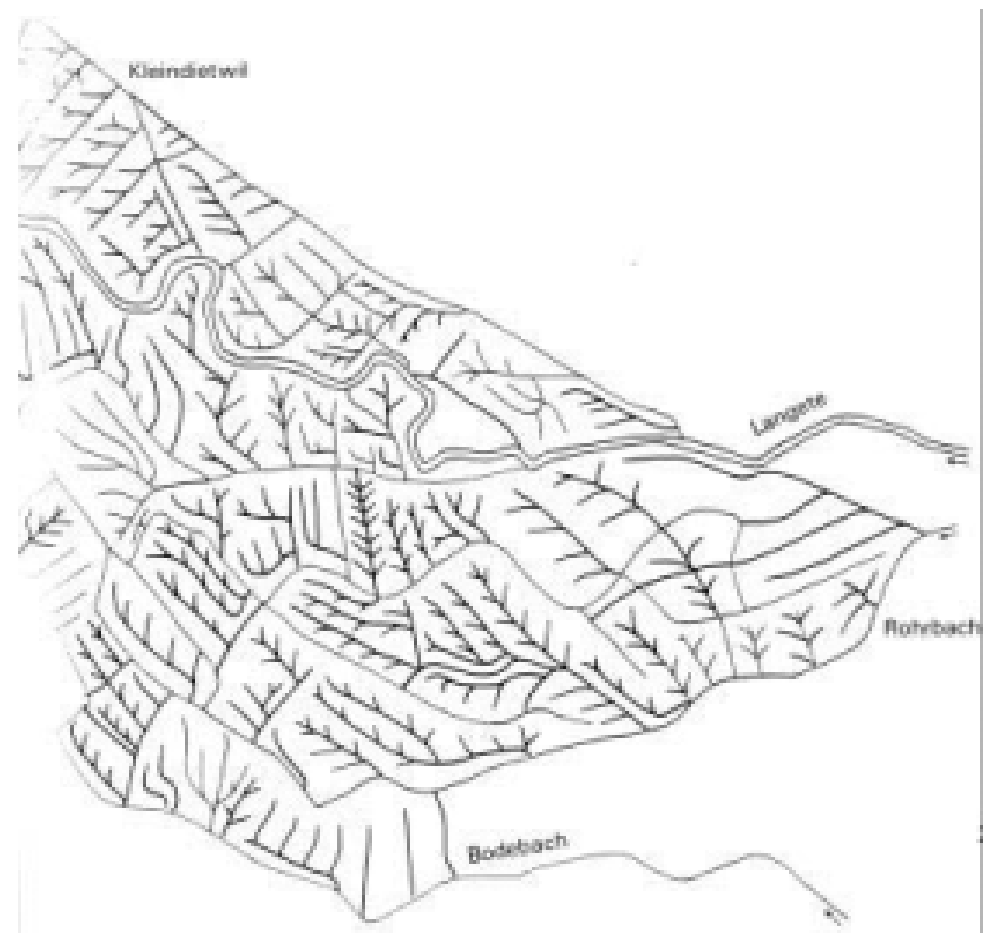

Abb. VIII-65: Vollständige Wässermattenlandschaft (Grabennetz) im Tal von Langete und Bodebach Stand 1914 (aus: BINGGELI 1986:139)

Zur Zeit der Hochblüte dieses Wirtschaftssystems prägten Wässermatten auch die Langete-Nebentäler 1. und 2. Ordnung. Die Wässerwiesen lagen hier in der Regel an steilen Hängen (LEIBUNDGUT 1993:41). Während sich die Wässermatten um die 20. Jahrhundertwende im gesamten Langetental so noch über fast 700 ha erstreckten, betrug die bewässerte Fläche 1984 nur noch 80 ha (:24). Auflösung und Verfall des traditionsreichen landwirtschaftlichen Nutzungssystems wurde durch die Landwirtschaft selbst eingeleitet. Die tiefgreifenden Strukturveränderungen in der Landwirtschaft nach 1950 ließen das arbeitsintensive Wiesenbewässerungssystem für die Landwirte unrentabel werden. Kunstdünger ersetzte auch hier die natürliche Düngung durch das Bewässerungswasser. Damit entfiel der entscheidende Vorteil für den Betrieb einer Wiesenbewässerungswirtschaft. Wässergräben und welliges Gelände standen einer Mechanisierung im Wege. Die endgültige Auflassung der Wässerung erfolgte für das Langetental im Jahre 1954 (:66). „Heute sind in den Nebentälern der Langete kaum noch bewässerte Hangwiesen zu finden." (:41).

Die Wiesenbewässerung des Langetentales kann als typisch für die landwirtschaftliche Nutzungsform im schweizerischen Mittelland gelten. Das Vorkommen von Wässermatten ist aber aus nahezu allen 
Sohlentälern des zentralen Mittellandes bekannt (LEIBUNDGUT 1993:22). Typische Wässermattenlandschaften haben neben dem Langetental auch weitere Talgebiete zwischen Emme und Suhr geprägt (:26).

Für die Schweiz hat Paul WEBER alte Formen der Wiesenbewässerung auch im Durachtal und Glattal nachgewiesen. Das Haupttal der Durach wies bis Ende des 19. Jahrhunderts eine mehr oder weniger geschlossene Wiesenfläche auf, die größtenteils bewässert wurde. Mit Sicherheit aber kann die Wiesenbewässerung bis ins 14. Jahrhundert belegt werden (1971:6). Das Untersuchungsgebiet des Durachtals unterteilt sich dabei in verschiedene Talstrecken. Dem „Hoftal“ schließt sich unterhalb von Bargen das „Merishausertal“ an, dem vom Engestieg an das felsige „Mühlental“ folgt. Die Breite der Talsohle zwischen Bargen und Merishausen beträgt 50 bis $100 \mathrm{~m}$, im Bereich Merishausen-Engestieg 200 bis $300 \mathrm{~m}$. Diese weiten Flächen eigneten sich zur Bewässerung von Wiesen ausgezeichnet (:6). Innerhalb des $85 \mathrm{~km}^{2}$ großen Einzugsgebietes zählt zu den westlichen Zuflüssen der Mühlitalbach, der Laa- oder Ladelbach, der Hohlgraben, der Dostentalbach und der Hemmertalbach. Von der östlichen Seite münden der Grätentalbach, das Bächlein von der Buchbrunnenquelle und die Fulach ein. Schienen die Zuflüsse auch reichlich, so waren die trotzdem eher geringen Gefälleverhältnisse der Duracher Talsohle aber gerade noch ausreichend, um den Wassertransport durch Kanäle zu ermöglichen. Der Vorteil des kleinen Gefälles lag jedoch darin, dass die Erosion an Kanalsohle und an Kanalwänden gering blieb (:6).

Die Bindung der Bewässerungssysteme an mediterrane Verhältnisse gilt auch insbesondere für Südtirol. MENARA (1994:145) beschreibt in eindrucksvoller Weise die besonderen klimatischen Verhältnisse des Vinschgaus, die eine Bewässerung notwendig machten:

„Im Vinschgau, einem der trockensten Alpentäler, in dem der durchschnittliche jährliche
Niederschlag nur 500 bis $700 \mathrm{~mm}$ (gegenüber 1500 bis $3000 \mathrm{~mm}$ in den meisten anderen
Alpenzonen) und in der für den landwirtschaftlichen Ertrag entscheidenden Wachstums-
periode sogar nur rund $350 \mathrm{~mm}$ beträgt, austrocknende Fallwinde und die extreme
Sonnenexposition zumindest der einen Talseite die negativen Auswirkungen der
Niederschlagsarmut noch verstärken, war und ist künstliche Bewässerung für das
Überleben der in der Landwirtschaft tätigen Bewohner unumgänglich. Von dieser
Notwendigkeit erhält man eine bessere Vorstellung, wenn man weiß, daß [...] die oben
genannten Niederschläge in manchen Jahren um bis zu 63\% unterschritten werden und
die wenigen Niederschläge meist nicht als wachstumsfördernder Nieselregen, sondern
nur als sehr kurze Starkregen fallen, so daß das Wasser in die Böden kaum eindringen
kann, sondern rasch abfließt und so zu allem Überfluß noch die Erosion fördert. [...].
Diesen klimatischen Verhältnissen, verdankte' der Vinschgau also die außerordentlich
intensive Flurbewässerung [...]. “

Das Südtiroler und insbesondere das Vinschgauer und Meraner Bewässerungswesen war bis Anfang dieses Jahrhunderts weit verbreitet. Der Ursprung der Südtiroler Waale reicht dabei - in zwar nicht genau datierbare -, aber eindeutig in prähistorische Zeiten zurück (MENARA 1994:147; siehe V 2a). Der Ausbau des Netzes an Wasserkanälen setzte hingegen wohl erst im Zuge der starken hochmittelalterlichen Rodungs- und Siedlungstätigkeit nennenswert ein und erfuhr dann eine ständige Weiterentwicklung (:146ff.). Auf Südtiroler Gebieten ist die künstliche Bewässerung durch offene Bewässerungskanäle, die sog. Waale, seit dem frühen 14. Jahrhundert urkundlich nachgewiesen (:144ff.; siehe VII 6b.2.2).

Vor allem im Vinschgau und in der Umgebung Merans zogen und ziehen sie in fast ununterbrochener Folge nicht allzu hoch über der Talsohle durch und über die Hänge. „Ihr Verbreitungsgebiet erstreckt sich bis zu den höchsten Berghöfen, weiter zu den Hochalmen, je sogar hinauf bis zur Gletscherregion." (MENARA 1994:156).

Die Auflistung von Länge und Umfang ausgewählter Südtiroler Waale geben eine Vorstellung von der Größe des ehemaligen alpinen Waalnetzes (ergänzt auf der Grundlage von MENARA 1994:148ff.): 


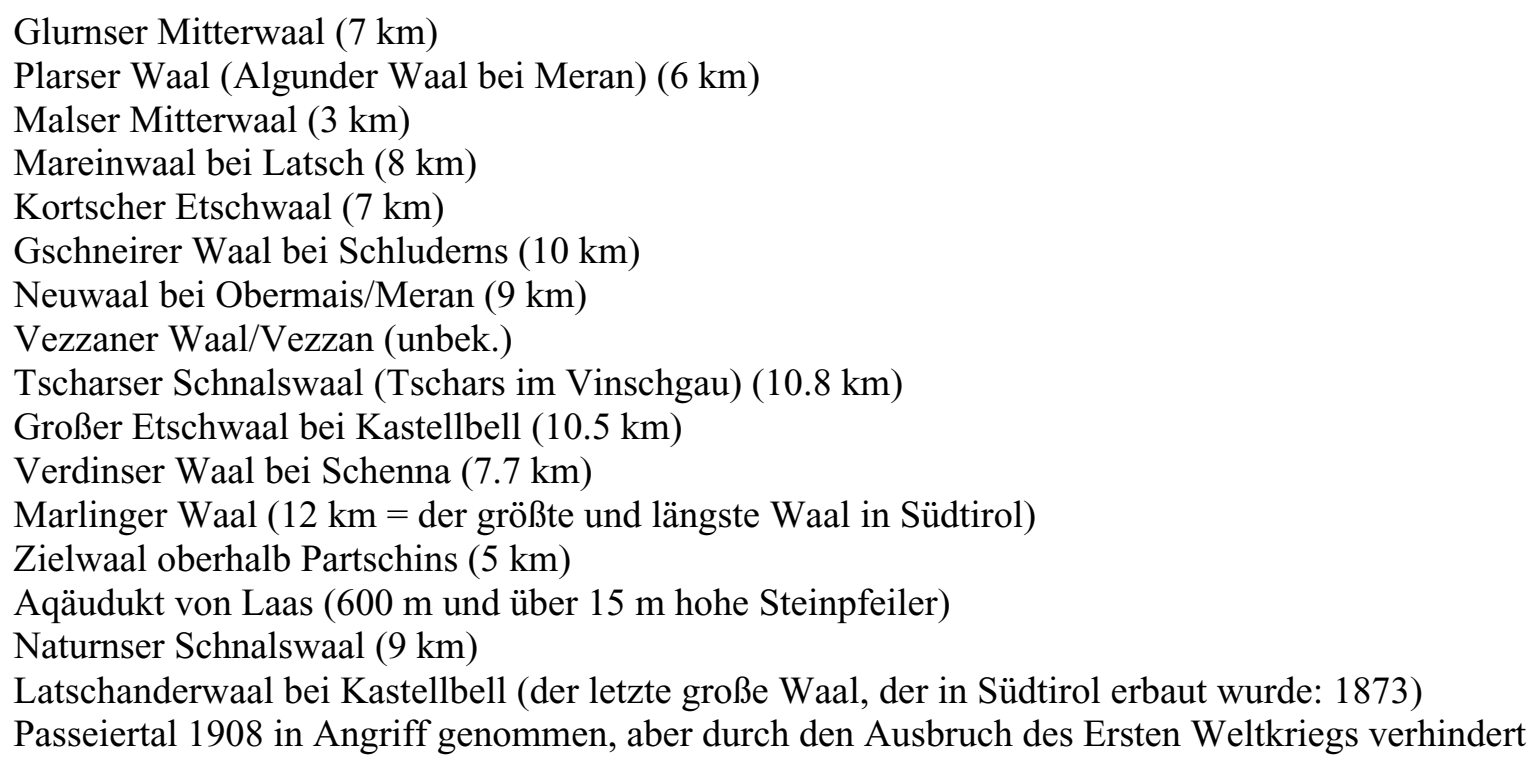

1935 gab es in den einzelnen Talschaften Südtirols folgende Bewässerungssituation:

Tab. VIII-3: Bewässerungskanäle und bewässerte Flächen in Südtirol im Jahr 1935 (aus: MENARA 1994:151)

\begin{tabular}{|l|l|l|l|}
\hline Gebiet & Zahl der Kanäle & Länge der Kanäle in km & Bewässerte Fläche in ha \\
\hline Vinschgau & 235 & 588,6 & 9.890 \\
\hline Passeiertal & 67 & 151,6 & 2.900 \\
\hline $\begin{array}{l}\text { Etschtal von Meran } \\
\text { bis Bozen }\end{array}$ & 81 & 165,4 & 3.140 \\
\hline Ingesamt & 383 & 905,6 & 15.930 \\
\hline
\end{tabular}

Hervorzuheben sind hier die Gemeinden Glurns und Laatsch und die Vinschgauer Gemeinden Burgeis, Mals und Goldrain.

In die Tabelle nicht mit aufgenommen sind das Sarntal, das Eisack- und Pustertal sowie das Südtiroler Unterland. In ihnen wies zwar die Bewässerung eine geringere Intensität auf als in den genannten erhobenen Talschaften, spielte aber dennoch auch eine gewisse Rolle (MENARA 1994:151). Diese eher unbekannten Waalorte waren es denn gerade, die von der Auflassung weitestgehend verschont geblieben sind, wenn sie auch nachfolgend nicht mehr in Betrieb genommen wurden (:153).

Um 1935, das auch den Höchst- und Endstand des althergebrachten Bewässerungsausbaus kennzeichnet, umfasste das Südtiroler Waalnetz über 400 größere und große Kanäle mit einer Gesamtlänge von über 1000 Kilometern auf einer bewässerten Fläche von 18000 ha. Die Zahl der kleinen Kanäle lässt sich nach Ansicht von MENARA (1994:152), auch nicht annähernd abschätzen, sie ging aber in die Tausende.“

1984 begann MENARA (1994:152) mit der Erkundung aller Südtiroler Bewässerungsgebiete vor Ort. Die alte Bewässerungsform der Berieselung fand er nur noch in ganz wenigen kleinen Gebieten des oberen Vinschgaus (z. B. in Planeil, in Schlinig und im Raum Stilfs-Trafoi). Um 1985 waren etwa $90 \%$ dieser Anlagen teils verschwunden, teils nur noch in Resten vorhanden. Die Gesamtlänge hatte sich um $80 \%$ verringert (:153). Nur noch ,in rund 35 bis 40 größeren und großen Südtiroler Waale fließt noch das Wasser“ (:154). „Die alte Bewässerungsform der Berieselung“, konstatiert MENARA (:153) ,ist fast gänzlich erloschen.“ Da mag auch nicht positiv stimmen, dass der Stand von 1985 im Wesentlichen auch noch für den Zeitpunkt 1991 galt.

Bewässerungssysteme sind auch für Österreich nachgewiesen. So von HELLEBART für das Oberinntal und von GÜNTSCHL (581ff.) der Bau von stadtnahen Bewässerungen am Theresienfeld der Wiener Neustadt in Niederösterreich. 
Infolge seiner allseitig hohen Bergumrandung ist das Oberinntal der trockenste Teil von Nordtirol. Insbesondere der Talkessel Ried-Putz gehört zu den abgeschlossenen Alpentälern, in denen die Regenschattenwirkung besonders hervortritt (HELLEBART 1994:186). Wie aus der Isohyetenkarte hervorgeht, nimmt die Niederschlagsmenge gegen das Alpeninnere ab. Die Austrocknung des Bodens wird zudem durch die exponierte Lage auf Sonnenterrassen besonders begünstigt (:186). Die Verhältnisse gleichen somit denen der Schweiz.

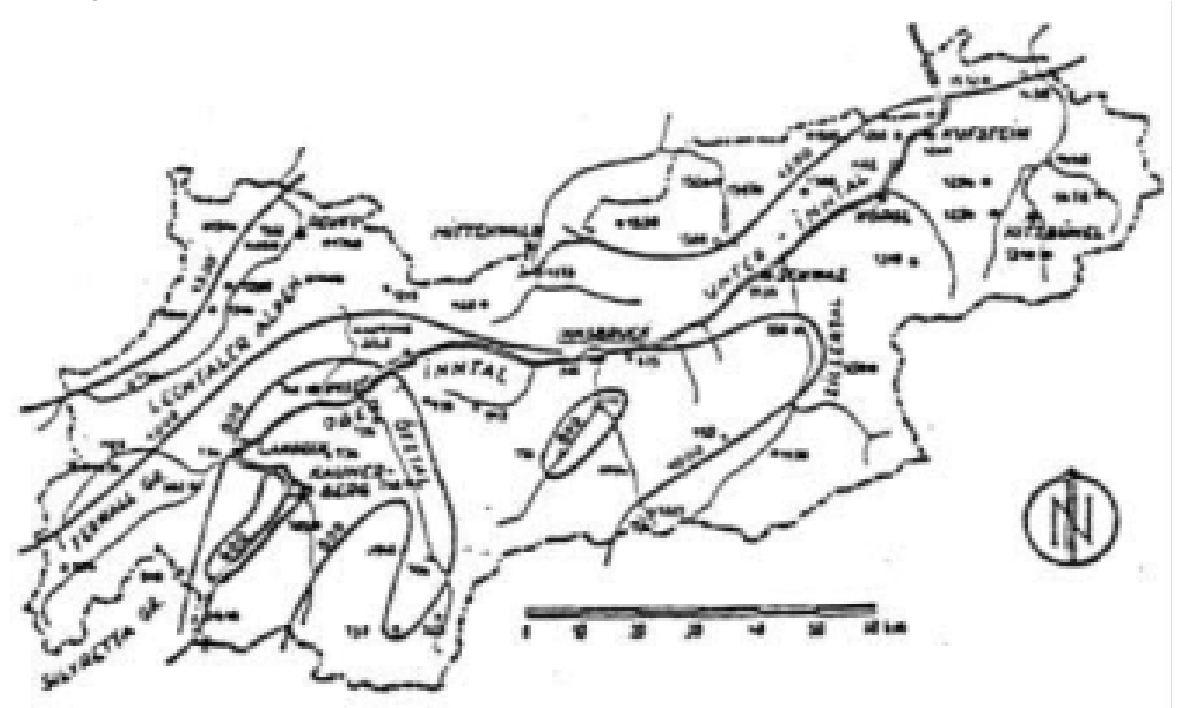

Abb. VIII-66: Isohyetenkarte von Nordtirol mit den Linien gleicher jährlicher Niederschlagsmengen in mm/Jahr (aus HELLEBART 1994:186)

Bewässerung konnte auf österreichischem Gebiet noch in den 1950er Jahren in Kematen, Imst und Obtarrenz beobachtet werden (HELLEBART 1994:192). Insbesondere die Bewässerungshänge oberhalb von Landeck seien hier erwähnt. In Stanz bei Landeck befindet sich „eines der schönsten und besterhaltenen Waalnetze im Oberinntal [...] in einer altbäuerlichen Kulturlandschaft [...] auf ca. 1000 m Meereshöhe“ (:194).

Als weiteres Bewässerungsgebiet, das durch ein umfangreiches Waalnetz gekennzeichnet ist bzw. vielmehr war, lässt sich in Nordtirol mit Nauders (1365 m ü. NN) benennen. Es stellt das ehemals größte Bewässerungsnetz Österreichs dar. Über 30 Bewässerungskanäle und 28 Bewässerungsinteressenschaften gab es hier (HELLEBART 1994:193). Schließlich sind Waale nachgewiesen in Haiming (Haiminger Hauptwaal), Ötzbruck (Ötzbruckerwaal), Mörtz (Fieberbachwaal), sowie in Pfunds, Prutz, Fließ, Landeck, wo das Wasser aus dem Inn entnommen wurde) und in Roppen (:192f.).

Zusammenfassend ist aus den vorangegangenen Ausführungen deutlich geworden ist, dass Wiesenbewässerungen nahezu überall durchgeführt worden sind. Die Beantwortung der Frage hingegen, welchen Anteil die Wässerwiesen an der Anbauflächen in den Regionen jeweils gehabt haben, um so eventuelle regionale Schwerpunkträume zu bestimmen, die auch Rückschlüsse auf die Schwere der Gewässereingriffe ermöglichen, lässt sich auf der methodischen Grundlage von Literaturauswertungen nur schwer ermitteln. Manche Räume sind gut dokumentiert und erscheinen deshalb als Hauptverbreitungsgebiete - aber sind es vielleicht gar nicht; naturräumliche Bedingungen mögen ebenfalls Anhaltspunkte für spezielle Kernräume liefern, ebenso vielleicht die Gründungen von Wiesenbauschulen mit ihrer innovativen Ausstrahlungskraft. Aber auch andere, weniger gut dokumentierte Gebiete kommen für Standorte von Bewässerungswiesen in Betracht, nur sind sie vielleicht bereits früh unerkennbar versiegelt worden, wie frühindustrialisierte und früh suburbanisierte Flächen von Ballungsräumen zum Beispiel des Ruhrgebietes und des Rheinlandes.

$\mathrm{Zu}$ widersprüchlich sind zudem die Aussagen zu den Anteilen an Wiesenland: Für den Alp-Donaukreis, haben KONOLD/POPP (1994:387) errechnet, entstanden in den Jahren 1844 bis 1849 Bewässerungswiesen auf einer Fläche von 182 Hektar. Die Erhebung der Wässerwiesen im Rahmen der Anbau- und Ernteerhebung des „Statistischen Landesamtes“ des Jahres 1904 ergab, dass der Umfang im Donaukreis auf 5305 ha gewachsen war. 1942 hingegen wurden im Donaukreis nur noch 
1561 ha Wiesen bewässert (:388). Umgerechnet auf die gesamte Wiesenfläche bedeutet dies jedoch, dass auch zur Höchstzeit des Wiesenbaus nur rund $5 \%$ aller Wiesen bewässert wurden (:387). FIEDLER (1965:15) stellt in gleicher Weise fest, dass im Saarland ,in allen Kreisen - der Stadtkreis Saarbrücken fällt naturgemäß aus - Wiesenflächen bewässert wurden, wenn auch ihre Anteile am landwirtschaftlichen Kulturboden recht gering war. Die gleiche Feststellung gilt für den Pfälzer Raum“ (FIEDLER 1965:15). Auch für HERBST (1992:137) zeigt die Entwicklung der oberschwäbischen Kulturlandschaft, „daß die zur Heugewinnung dienenden Flächen bis zum 19. Jahrhundert einen vergleichsweise geringen Anteil an der gesamten landwirtschaftlichen Produktionsfläche einer Siedlung hatten." Nichtsdestotrotz veranlasst ihn diese - leider nicht näher quantifizierte Aussage - zu der eher „wahrnehmungsgeographischen“ Ansicht, dass „Bauten zur Wiesenbewässerung seit den ersten urkundlichen Hinweisen im 8./9. Jahrhundert bis in das 20. Jahrhundert hinein das Bild der oberschwäbischen Kulturlandschaft im wesentlichen mitbestimmt" haben (:137).

Wässerungswiesen waren, dies lässt sich aus den dargestellten Aussagen zu Bewässerungsarealen und flächenmäßiger Verfügbarkeit subsumieren, zwar mit steigendem Viehbesatz in Form der Aufstallung bei Auflösung der jahrespermanenten Hutung auf nahezu jeder geeigneten Fläche in der Ebene oder am Hang geschaffen worden, aber konkurrierende Nutzungen schließt dies nicht aus: Kulturland wie Weideland, Ackerland, Brache, Torfabbau, Mühlenstaue, Teichbewirtschaftungen und Forste galt es ebenso unterzubringen wie Hof- und Siedlungsflächen, Gewerbeflächen ebenso wie Bleichwiesen und Weidenanbau. Addiert man diese gewässerbezogenen Nutzungen zu den zur Verfügung stehenden Flächen für die Wiesenbewässerung, so wird das Bild einer intensiven Landschafts- und Gewässerinanspruchnahme deutlich, die auf nur geringem Raum Platz lassen konnte für empfindliche Wässerwiesen, die einer geregelten Wasserzu- und -abfuhr bedurften und auf der sich ein Maschineneinsatz bzw. Beweiden verbat.

Aufgrund der zuvor als „kleine statistische Auswahl“ dargestellten Bewässerungsareale lässt sich diese Aussage aber als kleinster Nenner auf alle anderen mitteleuropäischen Landschaften übertragen und bestätigen. 


\section{E ANWENDUNGSBEZOGENER TEIL}

\section{Berücksichtigung gewässerhistorischer Kulturlandschaftselemente in der Praxis}

\section{Prolegomena: Renaturierung}

„Renaturierung“ heißt heute die Parole auch des technischen Wasserbaus, wie man anhand der zahlreichen Beispiele ${ }^{1}$ und Literaturtitel zu diesem Thema erkennen kann. Die Aussage von ELLENBERG aus dem Veröffentlichungsjahr 1986 (:344), in Mitteleuropa hätte ,schon längst der Wasserbauingenieur die Flüsse in Zucht genommen“, trifft für das späte 20. und beginnende 21. Jahrhundert nicht mehr vollständig zu. Vielmehr beansprucht der zunehmend ökologisch ausgerichtete Wasserbauingenieur bzw. der wasserbaulich orientierte Landschaftsplaner diesen Platz.

Im Bezug auf die Gewässer in Nordrhein-Westfalen beispielsweise wurde die „Wiederherstellung eines möglichst naturnahen Zustandes aller denaturierten Wasserläufe hinsichtlich Gewässerbett, Ufer, Aue, Wassergüte und Wassermenge“ als Ziel festgelegt (NATUR 2000 1990:6). Der Gewässerlauf soll etwas von seiner alten, verloren gegangenen, Dynamik zurückerhalten. Die Begradigungen sollen aufgehoben, Wehrverbauungen beseitigt werden. In weiten Bereichen hingegen fehlen solche Rückbauten noch immer, eine flächendeckende Renaturierung gar ist in weiter Ferne, auch wenn sie als solche betitelt wird.
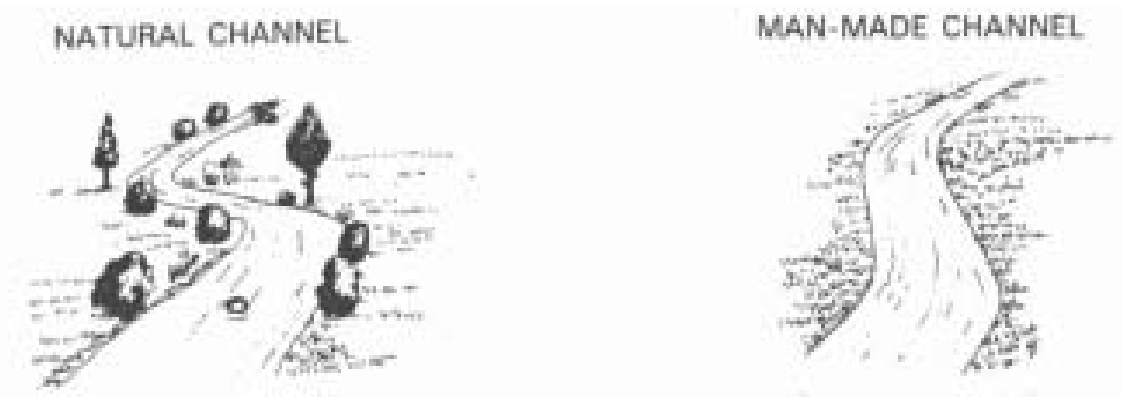

Abb. IX-1: Gegenüberstellung eines „,natürlichen“ und eines kanalisierten Bachlaufs hinsichtlich ihrer morphodynamischen Ausprägung (aus: GOUDIE 1981:150).

Ein in dieser Hinsicht beispielhaft zu nennendes Projekt aus dem urbanen Bereich ist das des im Juli 2000 begonnenen Umbaus des Wupperbettes mit dem Titel „Vom ,Industriefluss' zur ,Lebensader Wupper'“. Lebensader Wupper - das Leitbild für den Stadtfluss Wupper - ist ein Konzept, „das städtebauliche, abwassertechnische und ökologische bzw. gewässerstrukturfördernde Maßnahmen verknüpft, um ein attraktives Miteinander von Mensch, Stadt und Fluss zu erreichen.“ (KRONENBERG/JAHN 2000).

Die Umsetzung des Konzeptes „Lebensader Wupper“ - einer Initiative der Stadt Wuppertal - wird zusammen mit dem Wupperverband als Verantwortlichem für die Gewässerunterhaltung getragen und in Zusammenarbeit mit einer Gemeinnützigen Gesellschaft für Entsorgung, Sanierung und Ausbildung (GESA) umgesetzt. Die Maßnahme erfolgt im Rahmen des ökologischen Umbaus der Wupper im

\footnotetext{
${ }^{1}$ Die Beispiele von Gewässerrenaturierungen sind mittlerweile unüberschaubar, einige Beispiel dazu: Der Biesenbach nahe der Stadt Hilden wurde auf einer Teilstrecke vom Bergisch-Rheinischen Wasserverband renaturiert, die Glesse in Glesse, einem Dorf auf der Ottensteiner Hochfläche bei Hameln wurde im Rahmen der Teilnahme am Europawettbewerb „Unser Dorf soll schöner werden" vernatürlicht, in Holzminden wurde ein Abschnitt der Holzminde durch den Unterhaltungsverband „Bever-Holzminde“ freigelegt, Auslöser war ein Winterhochwasser, bei dem der Bach-Kanal verstopfte und sich das Wasser bis auf das Gelände eines Duftherstellers zurückstaute. Ab 1987 erfolgte die Offenlegung und Renaturierung des Ankerbaches, der bis zu diesem Zeitpunkt im Bereich des Forstes von Niederholtdorf bei Bonn in einem gemauerten Kanal lief. Des Weiteren wurde in Bonn der Villicher Bach entlang des Finkenweges durch einen mäandrierenden Wasserlauf mit ökologischen Feuchtzonen in neuer Trasse ersetzt und auch beim Annaberger Bach sowie seinen Zuflüssen Gieveningsbach und Klufterbach erfolgte ein naturnaher Umbau, was eine der größten zusammenhängenden Bachsanierungen in Bonn darstellt. Weiterhin wurde der Schmarler Bach in Zusammenhang mit der IGA 2003 in Rostock renaturiert (KUBITZ 2003:34; Täglicher Anzeiger Holzminden v. 9.07.2003).
} 
Stadtgebiet, hat einen klaren naturbezogenen Auftrag mit dem Ziel, die kritisch zu beurteilende historische Vergangenheit ungeschehen zu machen: „In früheren Zeiten“, so wird in der Dokumentation selbst zum Ausdruck gebracht (KRONENBERG/JAHN 2000), „stand die industrielle Nutzung der Wupper im Vordergrund: Ableitung von Abwässern aus Gewerbe, Industrie und Haushalten, Wasserkraftnutzung, gewerbliche Entnahme usw. In urbanen Bereichen - vor allem in Wuppertal - wurde die Wupper begradigt und künstlich ausgebaut. Ihre damals schlechte Wasserqualität hat sich in Zitaten und Sprichwörtern (,Schwarz wie die Wupper“ u. a.) niedergeschlagen.“

Heute hingegen, so die aktuelle Argumentation und Zielsetzung, stehen „Wasser als Element und der Fluss Wupper als ein Lebensraum mit wichtigen ökologischen Funktionen [...] im Blickpunkt. Aber auch das bloße Erleben des Flusses ist für die Menschen ein wichtiger Aspekt. Die Voraussetzungen hierfür wurden durch die Verbesserung der Wasserqualität bereits geschaffen." Doch wie sieht so eine „Umgestaltung der Wupper“ im Stadtgebiet von Wuppertal aus? Das „symbolisch erste“ Projekt „Adlerbrücke bis Loher Brücke“ mag stellvertretend die Prozesse beschreiben:

Im oberen Abschnitt wurde versucht in einem ca. 260 m langes Teilstück des Wupperufers - von der Schwebebahnstation ,Adlerbrücke' bis zur Wupperbrücke ,Wasserstraße' - die Uferstruktur dadurch $\mathrm{zu}$ verbessern, dass man ,am Rand des Gewässers abschnittsweise Steine aufgeschüttet bzw. Bepflanzungen vorgenommen“ hat. Die Möglichkeiten einer solchen „ökologischen“ Umgestaltung (Steinschüttungen und ufergerechte Bepflanzung) sind jedoch in einem eng bebauten Stadtgebiet begrenzt, wie die einschränkenden Ausführungen zeigen. So reichen auf der linken Uferseite auf ca. $160 \mathrm{~m}$ Länge Gebäudemauern bis in die Wupper hinein. Auf der rechten Uferseite gar verläuft in einer aus Natursteinen bestehenden Uferbefestigung $\left(B^{2} e^{2}\right)$, die teilweise mit Rasen, teilweise mit anderen Pflanzen bewachsen ist, ein Abwasserkanal. Dadurch kann hier der Bereich nicht verändert werden.

Auch im unteren ca. $200 \mathrm{~m}$ langen Abschnitt - zwischen den Schwebebahnhaltestellen, Wasserstraße' und ,Loher Brücke'- sollten umfangreiche Uferverbesserungen erfolgen. Aber hier begrenzten Bermen auf beiden Seiten die Wupper. Die Berme auf der rechten Seite wurde auf der gesamten Länge abgetragen. Mit dem frei werdenden Material konnte beispielsweise eine Insel und Vorschüttungen am gegenüberliegenden Ufer angelegt werden. Auf der linken Seite wurde eine Kante der Berme abgebrochen und einzelne Steine aus der mauerartigen Konstruktion entfernt. Die so entstandenen Angriffsflächen, lautet die Argumentation, ermöglichen bei höheren Wasserständen „eine Art natürliche Erosion. Die Wupper kann sich somit ihr Ufer in diesem Bereich selbst gestalten." Im gesamten Abschnitt sollen weiterhin „Störsteine im Gewässer dazu dienen, eine abwechslungsreichere Fließdynamik und einen erhöhten Sauerstoffeintrag zu erzielen.“

Das Konzept der „Lebensader Wupper“ sieht mit weiteren, darauf folgenden Maßnahmen „die Entwicklung vom Industriefluss zum erlebbaren Fluss“ vor. „Der Fluss soll sein Umfeld auch selbst mitentwickeln und so - mitten in der Stadt - naturnähere Bereiche schaffen. [...] Im Vordergrund steht die Zielsetzung, langfristig den Stadtfluss Wupper zu einem Lebens- und Erlebnisraum für die Bürgerinnen und Bürgern zu entwickeln sowie eine ökologische Verbesserung der Flusslandschaft zu erreichen.“

\footnotetext{
${ }^{2}$ Berme [franz.]: Der horizontal gehaltene Absatz einer Böschung oder Erdaufschüttung von größerer Höhe, die eine Hinabrutschen der Erde aufhalten und den Erddruck auf den Fuß der Böschung mindern soll. Eine Böschung mit steilem Hang und zwischengelegten Bermen ist - den lexikalischen Angaben des ausgehenden 19. Jh. zufolge (MEYERS KONVERSATIONSLEXIKON 1888) - widerstandsfähiger als eine Böschung mit fortlaufendem, entsprechend sanftem Hang. Zahl und Breite der Bermen (Letztere meist 0,6-1,25 m) richten sich nach der Höhe der Anschüttung und nach der Beschaffenheit des angeschütteten Bodens und des Untergrundes.

Wahrscheinlich entstammt die Berme dem (französischen?) Festungsbau [franz. auch: Lislére]. Bei Befestigungen sowohl im Feldkrieg als beim Festungsbau lässt man eine Berme zwischen äußerer (Kontreskarpe) und innerer (Eskarpe) Brustwehrböschung des Grabens, sie dient bei höheren Wällen dann auch zur Aufnahme von Hindernismitteln (Verhauen, Hecken, Palisaden etc.), damit nicht der Absatz dem Gegner das Ersteigen der Brustwehr erleichtert. - Im Deichbau ist Berme der Weg (Querweg) zwischen Damm und Ufer. - In der Archäologie werden bei Ausgrabungen ebenfalls Bermen errichtet. Nach den deutschen Unfallvorschriften müssen sie mindestens 0,60 m breit sein; Bermen, die zum Auffangen abrutschender Teile dienen, sogar mindestens $1,50 \mathrm{~m}$ breit.
} 
In der Zwischenzeit bezieht der Wasserbau dort, wo es möglich ist, d. h. zumeist im ländlichen Raum, auch die lange außer Acht gelassene Aue in die Programme und Pläne der Gewässerrenaturierungen mit ein, obschon die Beispiele von renaturierten Flusslandschaften, bei denen nicht nur das Flussbett umgestaltet, sondern auch die benachbarten, mittlerweile zu Ackerflächen umgebrochenen Auenbereiche zumindest wieder in extensives Feuchtgrünland, wenn auch nicht in Auenwälder, umgewandelt wurden, demgegenüber seltener sind. Als Beispiele dieser Art können das von der Thüringer Landesanstalt für Umwelt begleitete „Vernässungsprojekt Nesse-Aue“, der sachsen-anhaltinische Managementplan für das FFH-Gebiet „Gewässersystem der Helmeniederung“ wie auch das „Erprobungs- und Entwicklungsvorhaben Hasetal“ angesehen werden. Dieses wurde ins Leben gerufen, um das ,einzigartige Naturraumpotential des Hasetals vor Gefährdungen und negativen Entwicklungen zu bewahren, es zu erhalten, zu entwickeln und zu verbessern“. Das gesamte Projekt läuft seit 1995 und das Ziel ist neben den klassischen Aufgaben wie der Wiederherstellung der natürlichen Flussdynamik der Hase und dem Wiederanschluss von Altarmen, auenwaldtypische Biotope zu schaffen und die landwirtschaftlichen Nutzflächen in extensiv bewirtschaftete Feuchtwiesen und -wieden umzuwandeln. „Durch den ,Umbau' des Naturraums entstehen neue Weiden- und Wiesenflächen, die an interessierte Landwirte zurückverpachtet werden können“. Aber das wesentliche Leitmotiv Motto des knapp 8 Mio. $€$ teuren Renaturierungsprojektes lautet in ökologischer Einheitlichkeit: „Der Flusslauf bekommt ein Stück Natürlichkeit zurück“ (AUE-LEHRPFAD 2003).

Darunter kann auch die Lippe-Renaturierung im Gebiet „Klostermersch“ gesehen werden, die mit der naturnahen Umgestaltung der Lippe 1997 im Zuge des Lippeauenprogramms ,in Fachkreisen inzwischen als Pilotprojekt mit Vorbildfunktion“ (NUANCEN 12/2002:7) angesehen wird. Entwicklungspläne dieser Art entsprechen dem Motto: „Bringt Fluss und Aue wieder zusammen!“

Bereits 1990 rief das Ministerium für Umwelt, Raumordnung und Landwirtschaft (MURL) des Landes Nordrhein-Westfalen das Gewässerauenprogramm ins Leben, dessen Ziel es ist, Flüsse und Auen in einen naturnahen Zustand zurückzuversetzen (MURL 1990). Einer der ausgewählten Flüsse ist die 230 $\mathrm{km}$ lange Lippe, an der sukzessive Renaturierungsmaßnahmen unter Einbeziehung der Auenbereiche durchgeführt worden sind. 1996/97 wurde die Lippeaue im Naturschutzgebiet „Klostermersch“, westlich von Lippstadt, auf einer Strecke von zunächst zwei Kilometern umfassend renaturiert: Der Fluss wurde von Steinschüttungen befreit, seine Wasserfläche von 18 auf 45 Meter verbreitert, die tief eingeschnittene Sohle bis zu zwei Meter angehoben und die Verwallung entfernt oder durchbrochen. In der Aue, die nun wieder von kleineren Hochwässern überschwemmt wird, entstanden Flutrinnen, Stillgewässer und ein naturnaher Bach (Steinbach).

Die Umgestaltungsmaßnahmen stellen „,den Ausgangszustand für eine natürliche Weiterentwicklung von Fluss und Aue dar.“ Das Leitbild für die Klostermersch ist „eine naturnahe Flusslandschaft, die sich weitgehend ohne Eingriffe des Menschen entwickelt." Dafür wurden die Flächen größtenteils aus der Nutzung genommen und der Sukzession überlassen. Als nächstes ist die Renaturierung der Lippe in der Hellinghauser Mersch und bei Lippborg geplant (SCHARF 2000:34f.).

Inwieweit Naturschutzziele in einer intensiv genutzten Kulturlandschaft umsetzbar sind, war auch eine der Fragestellungen des von 1990 bis 1995 durchgeführten Erprobungs- und Entwicklungsvorhabens „Revitalisierung in der Ise-Niederung“. An der Ise - einem $42 \mathrm{~km}$ langen, in den 1960/70er Jahren stark ausgebauten Heidefließgewässer - und ihrer durch intensive landwirtschaftliche Nutzung geprägten Niederung wurde eine Entwicklung eingeleitet, die die typischen ursprünglichen Eigenschaften und Funktionen einer Flussniederung wieder hervorgehoben hat. Zum einen durch Ankauf gewässernaher Flächen und einer Extensivierung der Bewirtschaftung konnte dieses Ziel in den Auenbereichen verwirklicht werden. Zum anderen wurden hier Anpflanzungen vorgenommen und eine weitgehende Durchgängigkeit des Gewässers wiederhergestellt (BORGGRÄFE/KÖLSCH 1997).

Das in zwei Projektphasen (2002 und 2003-2004) laufende „Auenprogramm Bayern“ ist „als Beitrag zum vorbeugenden Hochwasserschutz ein wesentlicher Bestandteil des Programms „Nachhaltiger Hochwasserschutz in Bayern“. Hierbei wird ein „Konzept zum Schutz und zur Entwicklung der Auen in Bayern“ erarbeitet. Ziel ist der „,dauerhafte Schutz aller noch intakten Auen“. Darüber hinaus sollen „beeinträchtigte Auen in dem Umfang in ihrer Funktion wiederhergestellt werden, wie es mit den 
Erfordernissen einer nachhaltigen Landnutzung vereinbar ist.“ Dazu gehört aber nur „ggf.“ die „Koordination von Pilotprojekten“. Das „eigentliche Auenprogramm“ umfasst die Erarbeitung fachlicher Leitlinien für die Behandlung von Auen, einer Informations- und Kommunikationsplattform Auen sowie die Ermittlung von Schutz- und Sanierungsschwerpunkten.

Auch die Bachsanierungs- und Renaturierungsmaßnahmen beim Annaberger Bach, Villiger Bach und Ankerbach in Bonn orientieren sich an einem ,naturnahen Umbau“. Die alten Bachläufe werden durch einen mäandrierenden Wasserlauf mit ökologischen Feuchtzonen in neuer Trasse ersetzt. Aufweitung der Sohle, das Setzen von „Störsteinen“, Sohlrampen und Flutmulden sind die verwendeten Gestaltungselemente. Durch Offenlegung und Renaturierung werden „neue Biotope und Erlebnisbereiche“ geschaffen (NUA 2001).

Das gilt ebenso für die Fließgewässer des Hohen Flämings. Seit den 1990er Jahren werden in der Region ,im großen Stil““ Fließgewässer wieder durchlässig gemacht, werden Laichplätze eingerichtet und wird die ehemals vorhandene Vielfalt der Gewässer wieder zugelassen. Diese Vorhaben geschehen vor allem in Abstimmung oder mit Unterstützung des Landesanglerverbands, dem die Fischereirechte an fast allen Gewässerabschnitten im Naturpark Hoher Fläming zustehen (NATURPARK HOHER FLÄMING 2003).

Als ein ökologisch begründetes Sanierungskonzept im Bereich kleiner Fließgewässer ist ein im Flussgebiet der Vils (Oberpfalz) durchgeführtes Modellprojekt zu nennen, das aber im Rahmen eines Verbundvorhabens bundesweit sechs Gewässersysteme umfasste. Es wurden Sanierungskonzepte „,zur Regeneration, Renaturierung und Verbesserung des ökologischen Zustands kleiner Fließgewässer an ausgewählten und repräsentativen Beispielen erarbeitet" (BAYERISCHES LANDESAMT FÜR WASSERWIRTSCHAFT 1996:Vorwort). Zu der ,interdisziplinär besetzten Arbeitsgruppe“ und die „beispielhafte interdisziplinäre Zusammenarbeit“" (:Vorwort) am Bayerischen Amt für Wasserwirtschaft, der Regierung der Oberpfalz und dem Wasserwirtschaftsamt Amberg unter Beteiligung von Hochschulen, Forschungsinstituten und Planungsbüros sollten Sanierungsziele erarbeitet werden, stoffliche Belastungen und der strukturelle Zustand untersucht werden. Die historische Komponente wurde aber nicht mit behandelt, obschon eine „Analyse der Flußgeschichte der Vils“ (:113f.) vorgenommen worden ist. Aber auch hier wird hingenommen, ,daß im Zuge der natürlichen Dynamik vorhandene Altgewässer verlanden“ (:113). Im Gegenteil, es werden sogar Maßnahmen empfohlen, die die Auflassung von Teichen bzw. Weihern und die Unterbindung des Teichdurchflusses zur Folge haben (:112; siehe unten).

Die meisten Lösungsansätze der Gewässergestaltung, wie auch die vorgestellten Beispiele zeigen, orientieren sich einzig an aquatischen Lebensgemeinschaften, deren Rolle als Bioindikatoren, am Stoffhaushalt, der Landnutzung der Auen usw. Dem im ländlichen Raum stark von landwirtschaftlichen Nutzungsansprüchen geprägten und im städtischen Umfeld durch siedlungsstrukturelle Ansprüche definierten Ziel, das Gewässerbett auf engsten Flächenbedarf festzulegen, Hochwässer im Gewässerbett abzufangen und durch Deiche zu begrenzen und landwirtschaftliche wie bauliche Nutzflächen durch Grundwasserabsenkung und Verfüllung von Altwässern zu gewinnen, wird seit geraumer Zeit versucht, durch Gewässerneugestaltungen zu begegnen. Die Leitbilder hingegen für den Rückbau sind ökologischer Art (REISINGER 1992:348). Die Richtlinien für den naturnahen Ausbau und der Unterhaltung der Fließgewässer sowie die Schutzprogramme der Länder, des Bundes und der EU z. B. für Feuchtwiesen, Uferrandstreifen und Wiesenbrüter, und auch die Förderprogramme zur Umstellung von Maisäcker in Grünlandbewirtschaftung belegen dies (Thüringer Landesanstalt für Umwelt [TLU]).

So trat beispielsweise mit der Veröffentlichung im Hessischen Staatsanzeiger am 31.08.1998 die „Richtlinie zur Förderung von Maßnahmen, die der Wiederherstellung naturnaher Gewässer einschließlich ihrer Ufer und Auen dienen“ in Kraft. Die Bezeichnung lautet auch kürzer: „Landesprogramm Naturnahe Gewässer“ oder „Förderprogramm Gewässerrenaturierung“. Gefördert wird mit dem hessischen Landschaftspflegeprogramm die Umstellung von intensiver auf extensive Landwirtschaft in Bach- und Flussauen, verbunden mit einem Verzicht auf Dünge- und Pflanzenschutzmittel auf einer Uferrandstreifenbreite von mindestens $10 \mathrm{~m}$ für die Dauer von mindestens 5 
Jahren. Ebenfalls gefördert werden Ufergehölzpflanzungen. Aus Flurbereinigungsmitteln können Maßnahmen des Auen- und Gewässerschutzes, der Gewässerentwicklung und -gestaltung gefördert werden, sofern sie gleichzeitig dem Zweck der Flurneuordnung dienen. Unterstützt werden die zur Pflege und Unterhaltung verpflichteten Kommunen, Wasser- und Zweckverbände des Weiteren auch durch ein vom Land Hessen initiiertes Programm, in dem sich Gemeinden und Verbände zu „Gewässernachbarschaften" zusammenschließen (Hessisches Landesamt für Umwelt, Hessisches Ministerium für Umwelt, Energie, Jugend, Familie und Gesundheit, 1998). Das Programm dient in erster Linie der Fortbildung in den Themen Gewässerökologie und Gewässerunterhaltung (Hessisches Ministerium für Umwelt, Energie, Jugend, Familie und Gesundheit 1998b). Zudem besteht die Möglichkeit, dass von engagierten Bürgern, Vereinen, Schulklassen u. a. „Bachpatenschaften“ übernommen werden können (PATT 1998). In Kassel beispielsweise besteht eine Bachpatenschaft für einen $3 \mathrm{~km}$ langen Abschnitt des Geilebachs. Ziel der Mitglieder der „Bachpatenschaft Geilebach“ ist der naturnahe Rückbau von Streckenabschnitten, die in den vergangenen Jahrzehnten betoniert und begradigt wurden.

Grundlage der Entwicklung von Sanierungskonzepten bis hin zur „Renaturierung“ ist die Erfassung und Bewertung der unterschiedlichen Belastungssituationen: Begradigung, Vertiefung, Wasserentnahme, Fischzucht, Naherholung etc. (LUA NRW 1999a:1). Für einzelne Belastungen werden nach dem Saprobienindex, einem administrativ fest verankertem Verfahren (DIN 38419) zur Beurteilung der Auswirkungen von sauerstoffzehrenden Abwassereinleitungen, Sanierungskonzepte erarbeitet. Mit dem anderen Verfahren der "Strukturgütebewertung“ wird in erster Linie die Morphologie der Gewässer und die Nutzung der angrenzenden Umlandbereiche klassifiziert und beurteilt (LAWA 1998).

Einen anderen Weg gehen solche, sich nicht an starre Richtwerte und Indizes orientierenden Ansätze, die stattdessen in beschreibender und strukturierender Form normative Handlungsanweisungen zur Umsetzung ökologischer Zielsetzungen aufstellen. Ein solches Ziel verfolgt das Forschungsvorhaben „Typisierung und Leitbildfindung für kleine und mittelgroße Fließgewässer des Mittelgebirgsraumes NRW“ (PODRAZA et al. 1998), das eine Ergänzung des Projektes „Zielvorgaben und Handlungsanweisungen für die Renaturierung von Tieflandbächen in Nordrhein-Westfalen“ darstellt (TIMM 1999). Ziel beider Projekte ist es, das Land Nordrhein-Westfalen flächendeckend in Fließgewässerlandschaften zu gliedern und Leitbilder für sämtliche kleinere Fließgewässer zu beschreiben (LUA NRW 1999a:2).

Ebenso hat die hessische ARGE LEITBILDER (1996) im Auftrag des Hessischen Ministeriums für Umwelt, Energie, Jugend, Familie und Gesundheit für unterschiedliche Naturräume regionaltypische Leitbilder festgelegt und ökologisch definierte Referenzgewässer ausgewählt und beschrieben.

Auf gesetzlicher und nicht auf programmatischer Ebene ist ebenfalls ein ökologischer Auftrag definiert: Die am 22. Dezember 2000 rechtswirksam gewordene EU-Wasserrahmenrichtlinie (WRRL) schafft zwar einen gesamteuropäischen Ordnungsrahmen zum Schutz aller Gewässer, also der Oberflächengewässer und des Grundwassers. Aber auch hier lauten die operativen Ziele, die Erreichung eines „guten ökologischen und chemischen Zustandes“ der Oberflächengewässer (BERLINER SENATSVERWALTUNG FÜR STADTENTWICKLUNG 2002:3). Die Anforderungen der EUWasserrahmenrichtlinie sehen eine gute Wasserqualität und die Entwicklung der gesamten Flussauen vor, wobei auch die Bedürfnisse der Anwohner zu berücksichtigen sind. Bewertet wird der gesamte „ökologische Zustand eines Oberflächengewässers“. Schließlich geht es bei den Gewässerrenaturierungen auch um den Erhalt genetischer Ressourcen.

In einem anderen Fall zur Bewahrung bzw. Wiederherstellung des Zustandes von Fließgewässern geht es um eine Flächen- und Maßnahmenbevorratung in der naturschutzrechtlichen Eingriffsregelung, ,die es so bislang im deutschen Naturschutz nicht gibt" (SCHÖPS/SZARAMOWICZ 2003:36). Es soll dabei ein „Pool“ von Naturschutzmaßnahmen und/oder Flächen gebildet werden, der von Eingriffsverursachern unter bestimmten Bedingungen zu Kompensationszwecken in Anspruch genommen werden kann, denn in städtbaulichen Eingriffen in der "Grünausgleich“ mangels zur Verfügung stehender Freiflächen oftmals nicht auf städtischem Grund zu gewährleisten. Ziel ist „die Herstellung regional bedeutsamer Biotopverbundelemente oder die naturschutzfachliche Entwicklung 
von Kulturlandschaften“(:37). Es wird derzeit im Rahmen eines durch das Bundesamt für Naturschutz (Leipzig) geförderten Erprobungs- und Entwicklungsvorhabens $(\mathrm{E}+\mathrm{E})^{3}$ in Brandenburg erprobt. Das Schlüsselprojekt umfasst eine „Gebietskulisse“ von ca. $1000 \mathrm{~km}^{2}$ entlang der Havel und am Emsterkanal (Havelland) und beinhaltet zum Beispiel die Grünlandextensivierung, die Entwicklung weiterer Lebensräume sowie das Landwassermanagement in den Poldern dieses Gebietes, die zu einem Biotopverbund für die Avifauna zwischen FFH-Gebieten beitragen soll (:37ff.). Das „Poolkonzept“ für die Eingriffsregelung wird dabei übernommen durch die „Flächenagentur Kulturlandschaft Mittlere Havel GmbH (kurz: Flächenagentur KMH), einem selbständigen Poolträger, dessen Angebot allen Gebietskörperschaften und Vorhabenträgern in seinem Einzugsgebiet offen steht $(: 36)$.

Zusammenfassend lässt sich feststellen, dass Leitbilder und Renaturierungsplanungen für Fließgewässer häufig nur den heutigen Zustand berücksichtigen. „Ziel ist dann ein gedachter vermeintlich ursprünglicherer Idealzustand, der sich an Leitvorstellungen wie biologischer Vielfalt und Kleinräumigkeit orientiert.“ (DIX 1997:38) Zu den in den letzten Jahren verstärkt diskutierten Fragen zur Renaturierung und des naturnahen Wasserbaus liegt dazu seit Mitte der 1980er und Anfang der 1990er Jahre ein umfangreiches Schrifttum vor (z. B. von der DVWK oder von der ANL). Dies trug zweifellos zur Klärung wichtiger Grundsatzfragen der ökologischen Bedeutung und Bewertung von naturnahen Fließgewässern bei. Ein Defizit liegt aber bei Lösungsansätzen vor, die den kulturhistorischen Wert angemessen berücksichtigen.

Die Bäche und Flüsse nämlich, dies ist auch aus den vorherigen Ausführungen deutlich geworden, unterliegen im urbanen wie auch im ländlichen Raum einer langen historischen, bereits seit dem frühen Mittelalter bedingten Umformung. Die notwendigen kulturhistorischen Maßnahmen, die nicht dem naturnahen Ausbau dienen, sondern einen kulturhistorisch-orientierten Um- bzw. Rückbau bedeuten, werden jedoch zumeist negiert.

\footnotetext{
3 Erprobungs- und Entwicklungsvorhaben (E+E-Vorhaben): Der Fördertitel des Bundesumweltministeriums (BMU) Erprobungs- und Entwicklungsvorhaben im Bereich Naturschutz und Landschaftspflege wurde 1987 eingerichtet. Er eröffnet die Möglichkeit, die konzeptionellen Vorstellungen des Bundes zur Naturschutzpolitik beispielhaft zu demonstrieren, in der Praxis weiterzuentwickeln und so die Entscheidungsgrundlagen für die künftige Arbeit zu verbessern. Der Fördertitel wird fachlich und administrativ vom Bundesamt für Naturschutz (BfN) betreut.

Die E+E-Vorhaben sollen zur Erhaltung der biologischen Vielfalt beitragen. Von besonderer Bedeutung sind dabei Projekte, die Schutz- und Nutzaspekte zusammenführen. Als Förderprojekte des Bundes haben die E+E-Vorhaben folgende Aufgaben: 1) Umsetzung wichtiger Forschungsergebnisse in die Praxis, 2) Erprobung neuer und verbesserte Anwendung schon erprobter Methoden und 3) Aufbereitung der gewonnenen Erfahrungen (Erfolge und Misserfolge) für allgemein verwertbare Empfehlungen.

Von E+E-Vorhaben soll eine bundesweite Anstoßwirkung ausgehen. Daher steht die praktische Anwendung einer Idee oder eines Konzepts im Mittelpunkt der Vorhaben. Sie wird durch wissenschaftliche Untersuchungen begleitet.

Die Förderschwerpunkte und beispielhaften Lösungsansätze erstrecken sich auf die Bereiche: a) Artenvielfalt bewahren (Wiedereinbürgerung und Schutz hochgradig gefährdeter Tiere und Pflanzen), b) Naturschutzgerechte Regionalentwicklung vorantreiben (Umsetzung von Nutzungs- und Pflegekonzepten), c) Wertvolle Lebensräume schützen (Verfahren und Methoden zur Renaturierung von Biotopen), d) Gesellschaftliche Akzeptanz für den Naturschutz steigern (Naturschutzbildungsund Informationszentren, Partizipationsmodelle) und e) Naturschutz in die Stadtentwicklung integrieren (Ökologische Stadterneuerung).

Grundlage der Förderung sind die Richtlinien des Bundesministers für Umwelt, Naturschutz und Reaktorsicherheit zur Förderung von Erprobungs- und Entwicklungsvorhaben im Bereich Naturschutz und Landschaftspflege vom 16. Dezember 1987. Allgemein lässt sich zur den Förderkriterien sagen, dass sie vier Bedingungen erfüllen müssen: 1) Bundesinteresse: Das Vorhaben muss über seine regionale Wirkung hinaus für den Naturschutz in Deutschland von Bedeutung sein. 2) Neuartigkeit: Im Vorhaben sollen entweder neue Verfahren erprobt und weiterentwickelt oder verschiedene bekannte Verfahren neuartig kombiniert werden. Außerdem können Vorhaben, die eine Übertragung von Technologien und Verfahren aus anderen Anwendungsbereichen zum Ziel haben, gefördert werden. Das Konzept soll an den aktuellen Wissensstand anknüpfen. Neuartigkeit und Erprobungsbedarf müssen deutlich zum Ausdruck gebracht werden. 3) Modellcharakter: Das Projekt soll Modellcharakter für den Naturschutz haben. Es soll Wege aufzeigen, die zur Nachahmung anregen oder vergleichbare Vorhaben optimieren können und 4) Naturschutzzielsetzung: Naturschutz und Landschaftspflege müssen bei der Zielsetzung des Vorhabens an erster Stelle stehen.
} 


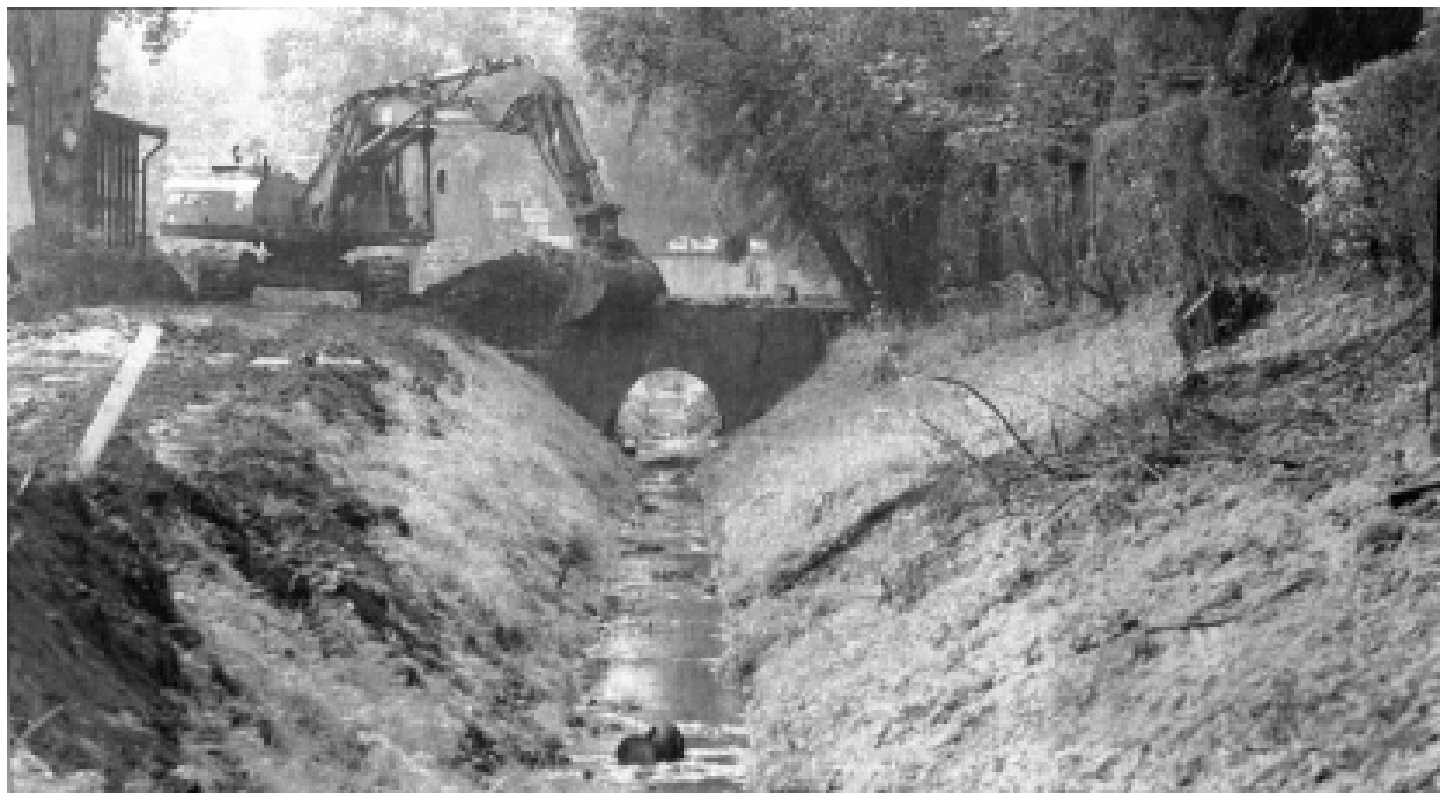

Abb. IX-2: Der Pillebach in Gerresheim b. Düsseldorf

Für das direkt am historischen Stadtkern vorbeifließende, bislang kanalisierte Flüsschen wird auf $350 \mathrm{~m}$ Länge ein „großzügiges, naturnahes Bett“ ausgehoben. Dabei „werden alte Brücken abgerissen, die nicht mehr benötigt werden“ (RHEINISCHE POST v. 23.10.2003, Nr. 246).

Aus den konzeptionellen Aussagen und planerischen Ausführungen des Projektes „Lebensader Wupper" beispielsweise lässt sich wohl das Leitbild einer ökologisch-orientierten Gewässerumgestaltung ableiten. Die kulturhistorische Ausprägung im Gewässerbau hingegen bleibt hier unberücksichtigt. Die Berme beispielsweise bestanden aus ,ehemals aus der Wupper entnommene[n] Steine[n] und Schotter" und hätten als ehemalige Nutzung des Flussbettes zu Zwecken des steinernen Fassung im Sinne eines ,erlebbaren Stadtgeschichte der Wupper“ entsprechend integriert werden können.

Im Fall der Renaturierung der Lippe wird eine „,naturnahe Flusslandschaft“ verfolgt, „Sukzession“ und „aus der Nutzung genommen“ lauten die Maßnahmen, die „halboffene Landschaft“ ist das parallele Entwicklungsziel im Auenbereich (SCHARF 2000:34f.). Dies ist umso widersprüchlicher, als dass sehr wohl erkannt wird, dass sich ohne eine Bewirtschaftung bzw. Beweidung der Ländereien eine Verbuschung eingestellt, dem mit einer extensiven Beweidung durch Heckrinder und Ponies begegnet wird.

Als Vorzug der Maßnahmen zum ökologisch-begründeten Gewässerumbau ist unbestritten zu sehen, dass ,in einzelnen Fällen [...] durch den Naturschutz einige Gewässer zunächst gerettet werden“ konnten (WEBER 1992:95). Unbestritten ist auch, dass es sich bei den wiederhergestellten natürlichen oder naturnahen Fließgewässer nicht um die „Restnaturen“ handelt, die in einsamen Bachtälern verblieben sind, vielmehr wird versucht naturnahe Gewässerstrukturen in verbrauchten bzw. ausgeräumten Agrarlandschaften wiederherzustellen, ebenso wie in städtischen und randstädtischen Bereichen, wenngleich hier der künstlich nachempfundenen Mäandrierung nur eine begrenzte Fläche eingeräumt werden kann. Umso mehr ist das kulturhistorische Erbe in solchen alten Siedlungsräumen zu berücksichtigen, um Geschichte erlebbar zu machen und gleichzeitig den zönophilen Lebensbedingungen zu entsprechen, die sich ebenfalls im Laufe der Geschichte eingestellt haben. Denn es hat sich gezeigt, dass kulturhistorische Elemente dabei weitgehend ausgespart blieben. Ehemalige Mühlengewässer beispielsweise sind durch Renaturierungsmaßnahmen wieder in einen weitgehend naturbelassenen Zustand versetzt worden oder es wurden im Rahmen von ökologisch begründeten Sanierungsvorhaben „Umgehungsbäche“ bzw. „Umgehungsgerinne“ naturnah neu angelegt, die zwar eine biologische Durchgängigkeit von Fließgewässern herstellen (BAYERISCHES LANDESAMT FÜR WASSERWIRTSCHAFT 1996:116ff.), aber dadurch die Wasserzuführung zu den alten Triebwerksanlagen schwächen. 


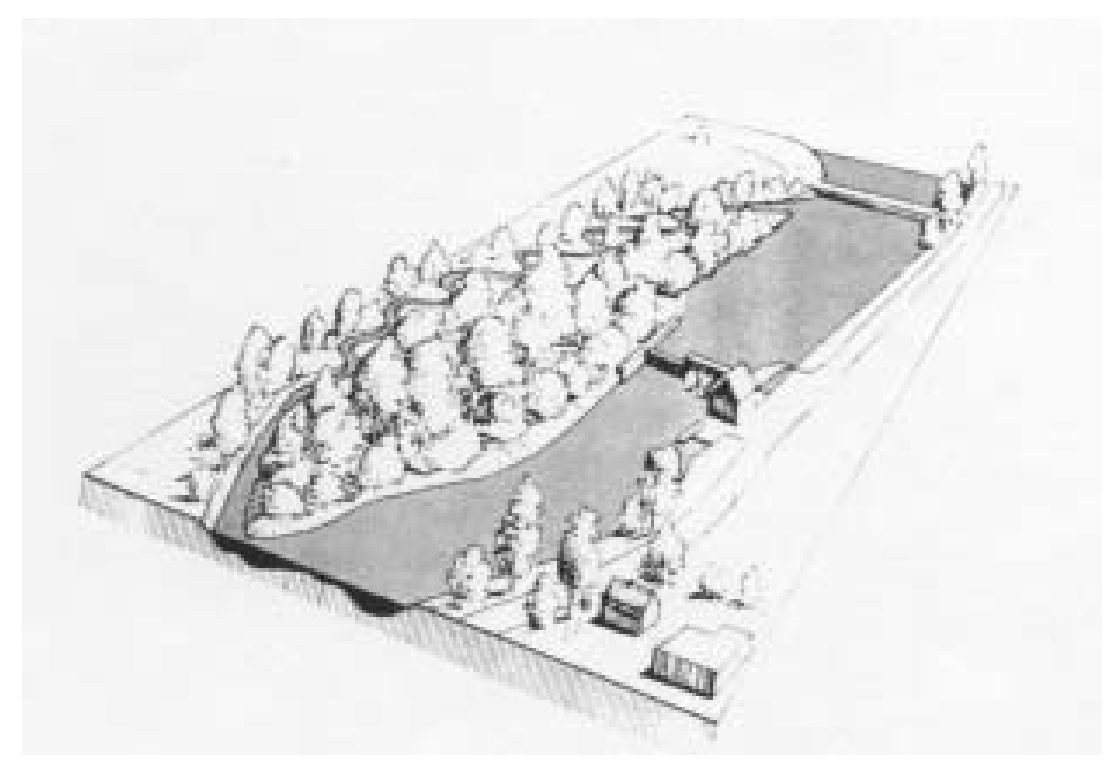

Abb. IX-3: Umgehungsbach an einem Mühlwehr (aus: BAYERISCHES LANDESAMT FÜR WASSERWIRTSCHAFT 1996:117)

Renaturierungsmaßnahmen oder nachhaltige Bewirtschaftungspläne müssen deshalb vielmehr „,zu historischen, traditionellen Bewirtschaftungen, zur Wiederherstellung und ,Restaurierung ${ }^{6}[\ldots]$ oder gar zur Rekonstruktion historischer Kulturlandschaften (Parkanlagen, Teiche oder Wiesenbewässerung)“ führen, „zu Leitbildern, die sich an historischen Landschaftszuständen orientieren, die vor den gravierenden großräumigen [...] Eingriffen und Ausräumungen die einst kleinteilige und differenzierte, vielgestaltige Kulturlandschaft prägten“ (DENECKE 2000:202). Denn traditionelle Wirtschaftslandschaften, wie z. B. Wässerwiesen und Teichanlagen, ,können zwar auch bauliche Elemente aufweisen, die jedoch weitgehend nur dann erhalten bleiben, wenn die Bewirtschaftung, die zur Entstehung geführt hat, auch weiterhin so betrieben wird“"(:206).

Vor diesem Hintergrund „stehen beim geographischen Arbeitsansatz nicht Schutz, Bewahrung oder historische Weiternutzung als Leitziel im Vordergrund, sondern eine Landschaftsentwicklung, Landschaftsplanung und Eingriffsregelung, die das gewordene Kulturlandschaftspotential als solches historisch bewußt und sorgsam zu integrieren weiß. Es geht um Interesse und Bewusstsein für kulturelle Werte in der Landschaft und ihre Lebensqualität für den Menschen, um Evolution in der Kulturlandschaft und der Entwicklungsplanung.“ (DENECKE 2000:205).

Dabei muss klar sein, dass die Möglichkeiten und Erfolge einer Kulturlandschaftspflege beschränkt sind, sie können nicht alle Landschaftseinheiten umfassen und richten sich deshalb auf „landschaftsbestimmende Elemente wie Gräben [...] oder Gewässer, die auch im Zuge von Renaturierungen eingebracht werden“" (DENECKE 2000:208).

Ein solches Beispiel nicht der „Renaturierung“ eines ländlichen, sondern der „Rekultierung“ eines urbanen und zudem noch künstlichen Gewässers ist das Projekt der Öffnung des „Pleißemühlengrabens" in Leipzig. Bis 1950 prägten die Flüsse Pleiße, Elster, Parthe und Luppe mit ihren jeweiligen Kanälen das Bild der Stadt. Vor dem Hintergrund des historischen Leipziger Städtebaus, der durch die Entwicklung dieses dichten Wassernetzes in seinem Duktus festgelegt ist, „besitzt die Öffnung des Pleißemühlengrabens einen gewissen Symbolcharakter für den aktuellen Stadtumbau, die Neuakzentuierung des Wassers in der Stadt“ (KUNZE 2001:28). „Nach 50 Jahren bestand die Chance,“ so die städtebaulich motivierte Zielsetzung, „der Stadt Leipzig mit der Öffnung des unterirdisch verlaufenden Mühlgrabens und seiner stadtgestalterischen Einbindung ein Stück Identität zurückzugeben" (:28). Es handelt sich dabei um eine insgesamt $3680 \mathrm{~m}$ lange Strecke, bei der die Uferzonen ,in fast allen Bereichen steinern gefasst mit einigen Ufertreppen, Bootsanlegestellen, Stegen an der strassenabgewandten Ostseite“ gestaltet wurden. „Wo immer es möglich war, wurden die vorhandenen Ufermauern und die alten Brückenauflager erhalten und durch feinfühlige Nachbauten gestalterisch ergänzt“"(:28). 
Ein anderes Beispiel der Berücksichtigung eines kulturlandschaftlichen Leitbildes ist aus Kanada mit dem „Heritage River“-Konzept bekannt, das mittlerweile von mehreren Ländern übernommen wurde (NAGEL/GOLDAMMER 1997:275ff.). Dort sind zur Zeit insgesamt acht „Canadian Heritage River“ unter Schutz gestellt und von der UNESCO zum Naturerbe erklärt. Der French River zum Beispiel wurde aufgrund seiner ursprünglichen Schönheit und seiner historischen Signifikanz ${ }^{4} 1986$ zu einem „Heritage River“ erklärt. Ebenso der Campbell River, das Kanadische Schild wie auch der Fluss Nahanni dazu ernannt wurden, Letztere auch zu einem Weltkulturerbe der UNESCO.

Doch nicht nur aus dem Fließgewässerbereich gibt es eine Rückbesinnung auf historischgeographische Elemente in der Planung zu konstatieren: Einen frühen Hinweis für die Beachtung dieses Ansatzes in der Landschaftsplanung liefert ein Beitrag von HEIN in der Fachzeitschrift „LandschaftsArchitekten“ aus dem Jahr 1995, in dem über die Maßnahme „Bestandsaufnahme und Erhaltung der Wiesenbewässerung Kirchehrenbach und Weilersbach" von Angelika KÜHN [erschienen in: Kulturlandschaftsforschung H. 1/2, 1992] berichtet wird.

Dieses Beispiel bildet dennoch die Ausnahme und deshalb ist die Frage zu stellen nach der Berücksichtigung umweltgeschichtlicher Elemente in der Gewässerplanung, verbunden mit der Frage nach dem Beitrag der (Historischen) Geographie zur „Renaturierung“ von Gewässern, denn diese Begriffsformel ist nach meiner Auffassung unauslöschbar.

Dies scheint umso wichtiger, als dass in den meisten Fällen eine die kulturhistorische Vergangenheit negierende Gewässersanierung betrieben wird, wie das Negativ-Beispiel der oben beschriebenen „,modellhaften Erarbeitung eines ökologisch begründeten Sanierungskonzeptes für das Fallbeispiel Vils" in der Oberpfalz belegt (WASSERWIRTSCHAFTSAMT AMBERG 1996). Hier werden auf der Basis eines ökosystemaren Leitbildes Sanierungsmöglichkeiten für das System aus Fluss, Aue und Einzugsgebiet abgeleitet und im Planungsteil die notwendigen Sanierungsmaßnahmen im Rahmen der Gewässerentwicklung aufgezeigt; die, gelangen sie zur Ausführung, den Bestand kulturhistorischer Teichanlagen gefährden, die im Teicheinzugsbereich der Vils mit Furthbach, Freihung, Gebenbach, Krumbach und Eisenbach seit dem Mittelalter hier fester Bestandteil der Kulturlandschaft sind. Die Öko-Bilanz ist jedoch in ihrer Aussage eindeutig: „Besonders der Vilsoberlauf in Vilseck und die Nebengewässer lassen negative Auswirkungen durch die Fischteiche erkennen. Schlamm und Nährstoffe, die aus den Teichen in die Gewässer gelangen, verschlechtern die Qualität der Gewässer. Manche Bäche leiden darunter, daß sie für Wasserentnahmen aufgestaut werden oder durch Fischteiche hindurchführen. Das Leitbild wäre am besten erfüllt, würde man die Anzahl der Teichanlagen, besonders am Gewässeroberlauf, verringern und die verbleibenden Teiche gemäß der Teichbaurichtlinie von 1993 nachrüsten bzw. extensivieren. Die dazu notwendigen Maßnahmen werden im Arbeitsblatt vorgestellt“".

Die Maßnahmen bestehen unter anderem darin, die Staueinrichtungen zur Wasserausleitung, die die Durchgängigkeit der Bäche beeinträchtigen, zu entfernen. „Dadurch, dass manche Bäche ihren Weg direkt durch Teiche nehmen, verlieren sie auf dieser Strecke ihren Charakter als fließendes Gewässer“", so die Begründung (WASSERWIRTSCHAFTSAMT AMBERG 1996). Des Weiteren bewirkten „Wasserentnahmen aus ohnehin wasserarmen Bächen [...], dass in den ,Restwasserstrecken' zu wenig Wasser verbleibt". In der Folge sollen Extensivierungsprogramme für die Teichwirte eingeleitet werden, die damit für ihre Ertragseinbußen finanziell entschädigt werden sollen, wie sie aus der Landwirtschaft hinlänglich bekannt sind und durch Brache zu einem „gewollten“ Offenlassen der Teiche führt. Die konkreten Ziele im Vilsgebiet lauten: 1. Auflassen der Forellenteiche bei Seugast mit besonders hohen Belastungsbeiträgen (v. a. Stickstoff), 2. Reduzierung der Karpfenteiche im Oberlauf der Seitenbäche, vor allem im Gebenbach-, Krumbach- und Eisenbachgebiet und 3. sollen Karpfenteiche am Furthbach nicht länger als Durchflussteiche betrieben werden.

\footnotetext{
${ }^{4}$ Die Indianer ebenso wie französische Entdecker fuhren zu Anfang des 17. Jahrhundertes auf ihm. Es folgten Missionare aus Neufrankreich [Quebec]; Pelzjäger und -händler in ihren riesigen Frachtkanus waren auf dem French River unterwegs und zu Ende des 19. Jahrhunderts wurde der Holzreichtum der French River Region auf dem Fluss transportiert.
} 
Anhand entsprechender Beispiele aus den Bereichen „Teichwirtschaft“ und „Mühlenteich“ wird versucht, ausgesuchte landschaftsplanerische und biologische Fachplanungen und Modellvorhaben auf ihren kulturhistorischen Gehalt zu untersuchen und Ergebnisse eigener historischer Nachforschungen und Überlegungen in denjenigen Fällen den vorliegenden Beispielen gegenüberzustellen, falls sie historisch-geographische Zielsetzungen vermissen lassen, um so den Nachweis der mangelnden Berücksichtigung historisch-geographischer Gewässerforschung zu erbringen. Anschließend werden ausgewählte gewässerhistorische Projekte skizzenartig vorgestellt, die sich auf verschiedenen Ebenen „Gewässergeschichte“ planen, rekonstruieren oder gar inszenieren.

\section{Beispiel Teichwirtschaft}

\section{a Die Klosterteiche Heisterbach}

\section{a.1 Das Projekt „Klosterlandschaft““}

In einem modellhaften Forschungsprojekt zur Klosterlandschaft Heisterbacher Tal, das der Rheinische Verein für Denkmalpflege und Landschaftsschutz e.V., die Stadt Königswinter und die Stiftung Abtei Heisterbach in Auftrag gegeben haben und mit Mitteln der Bundesstiftung Umwelt (Osnabrück) und der Stadt Königswinter finanziert worden ist, wurde die historische Kulturlandschaft der ehemaligen Abtei Heisterbach im nördlichen Teil des Siebengebirges untersucht. Die Abtei selbst wurde um 1200 anstelle einer ehemaligen Augustinererimitenklause errichtet.

Bei der Erforschung der Kulturlandschaft des Heisterbacher Tales standen zwei Fragen im Mittelpunkt: einerseits die Erforschung aller heute noch greifbaren Spuren, die die Menschen - vor allem die Mönche der Abtei - im Heisterbacher Tal hinterlassen haben. Andererseits die Frage, wie mit diesem kulturellen Erbe in der Zukunft umzugehen ist.

Ziel dieses Projektes war und ist es, Methoden und Konzepte im Umgang mit der historischen Kulturlandschaft am Beispiel der „Klosterlandschaft Heisterbach im Naturpark Siebengebirge“ zu entwickeln, um eine ,werterhaltende Nutzung und Bewahrung dieser herausragenden historischen Kulturlandschaft" (BURGGRAAFF et al. 2001:2) zu ermöglichen.

Fachgutachten verschiedener Fachdisziplinen (Archäologie, Hydrologie, Biologie, Forstwirtschaft, Historische Geographie) wurden erarbeitet und ein ,innovatives Kulturlandschafts-Management“ entwickelt, ,in dem die Interessen der Gegenwart mit der Werterhaltung und Wertschöpfung des historischen kulturellen Erbes in Verbindung gebracht werden“ (BURGGRAAFF et al. 2001:26). Dabei ging es nicht nur um den eingefriedeten Klosterbereich, sondern auch die angrenzende, unmittelbar auf das Kloster bezogene umgebende Kulturlandschaft mit den Fischteichen, die hier von besonderer Bedeutung sind.

\section{a.2 Die Klosterteiche Heisterbach}

Im Rahmen des interdisziplinären Forschungsprojektes „Modellhafte Konzeptentwicklung ,Kulturlandschaft Heisterbacher Tal'" war die Wasserversorgung und -nutzung durch das Zisterzienserkloster ein Fragenkomplex des Modellprojektes (ANDRIKOPOULOU-STRACK et al. 2002:73), um das mittelalterliche Zisterzienserkloster zu rekonstruieren. Nach meinem Kenntnisstand in bislang einmaliger Weise in Deutschland wurde versucht, nicht nur die Wasserversorgungs- und Abwassereinrichtungen des inneren Klosterareals darzulegen, sondern auch im Rahmen des Forschungsprojektes durch eine archäologische bzw. archäologisch begleitete Bestandserhebung von Klosterteichen, sein äußeres Umfeld auf die Fragestellungen der Teichwirtschaft hin zu untersuchen.

Ausgangspunkt dieser gewässerhistorischen Untersuchungen, die sich auf die Wassernutzung außerhalb der Klostermauern beziehen, war ein Plan, den der Geometer M. MINZENBACH 1804 für den Verkauf des Klosters angefertigt hat, nachdem der Konvent in Zusammenhang mit der Säkularisierung 1803 aufgehoben wurde. 


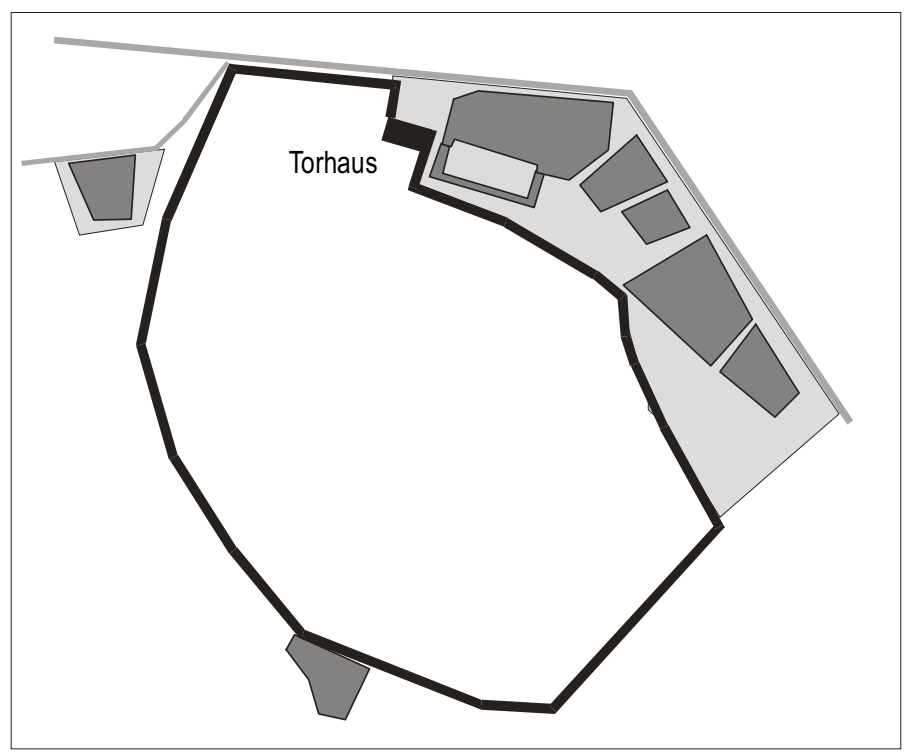

Abb. IX-4: Fischweiher am Kloster Heisterbach nach dem Lageplan von Minzenbach 1804 (nach HOITZ 1987, zur Verfügung gestellt von K.-D. KLEEFELD 2004)

In diesem Plan sind im Bereich der heutigen Wiese (,Keltersiefens') unmittelbar vor den Klostermauern insgesamt acht Teiche eingetragen, die damals offensichtlich noch existiert haben (ANDRIKOPOULOU-STRACK et al. 2002:73; WIPPERN 2003:136; BURGGRAAFF et al. 2001:9). Mehrere dieser ehemaligen Fischteiche außerhalb der Mauer, heute der Bereich des Parkplatzes in Richtung Mühlenbach vor dem Torhaus, sind wohl schon im 12. Jahrhundert vorhanden gewesen, weil, so die Argumentation, 1202 zwischen dem zweiten und dritten Fischteich eine Walkmühle erwähnt wird (BURGGRAAFF et al. 2001:7).

1820 erfolgte die Versteigerung des Klosterhofes Heisterbach und den Zuschlag erhielt Wilhelm Graf zur Lippe-Biesterfeld für die Wirtschaftsgebäude, das Klosterareal sowie die umliegenden landwirtschaftlichen Flächen. Einzig die Kirche und die sich anschließenden Konventsgebäude waren davon ausgenommen, da sie von der Regierung zuvor verkauft worden waren (ANDRIKOPOULOUSTRACK et al. 2002:53). Über eine Nutzung der Teiche nach 1803, dem Jahr der Säkularisierung, und auch, ob sie von Lippe-Biesterfeld mit übernommen und bewirtschaftet wurden, ist wenig bekannt; sie blieben jedenfalls wohl, so die Aussage von BURGGRAAFF et al. (2001:10), „zunächst noch einige Jahre wasserführend“.

Aber schon nach Ausweis der „Preußischen Uraufnahme“ von 1843 befanden sich talabwärts zwar noch mehrere (Mühl-) Teiche und auch innerhalb der Klostermauer waren drei Teiche vorhanden, aber die von MINZENBACH kartierten „Außenteiche“ waren auf topographischen Aufnahmen nicht mehr nachweisbar. Sie verlandeten ,,in der zweiten Hälfte des 19. Jh., weil sie seit der Säkularisation nicht mehr genutzt und gepflegt wurden. Sie dienten seitdem überwiegend als feuchtes Grünland“ (BURGGRAAFF et al. 2001:10). 


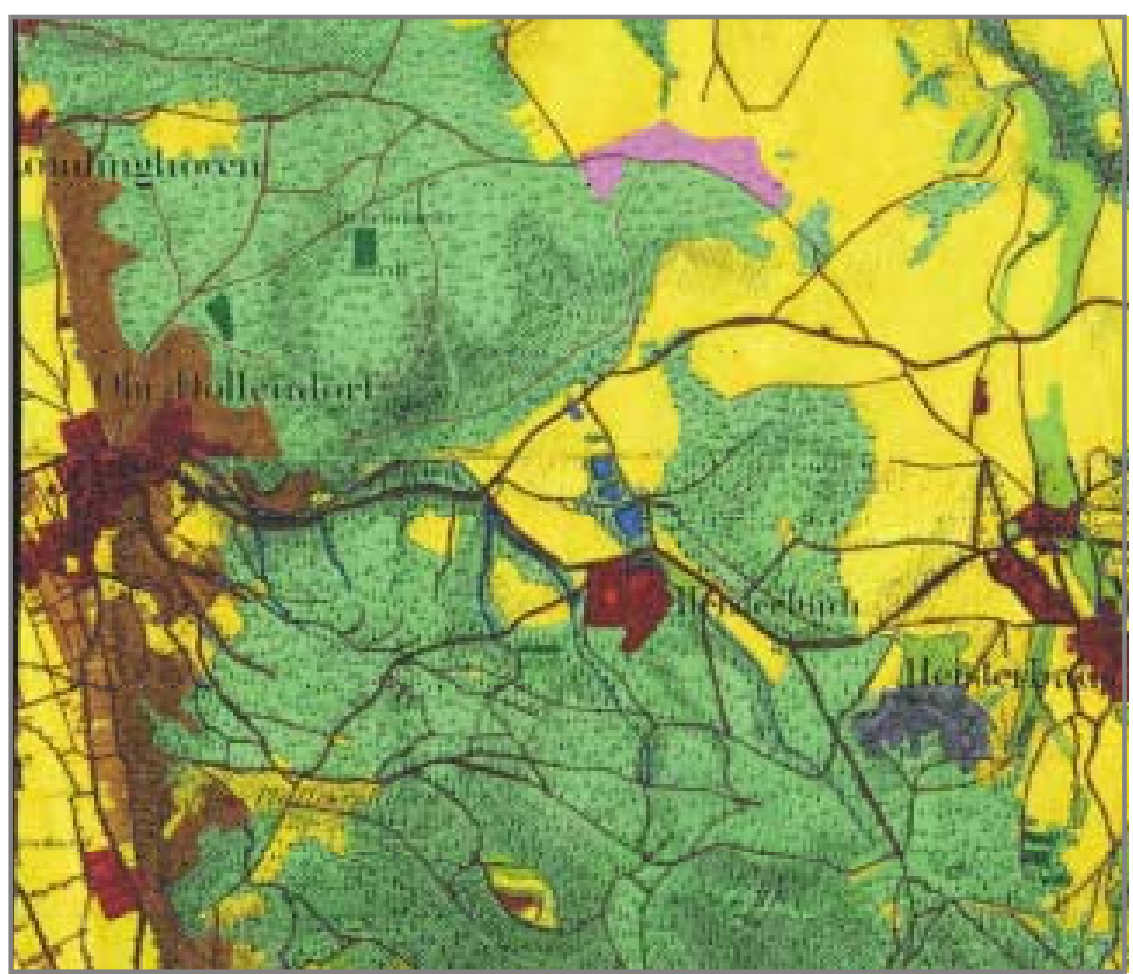

Abb. IX-5: Fischweiher im Heisterbachtal nach Preußischer Uraufnahme von 1843 (Entwurf und Kartographie P. BURGGRAAFF, K.-D. KLEEFELD)

Mittels verschiedener vermessungstechnischer, archäologischer und geophysikalischer Methoden wurde versucht, das Klosterteichareal mit den auf der Karte von Minzenbach dargestellten Teichen zu rekonstruieren und gegebenenfalls zu bestätigen:

1. Im Rahmen einer Diplomarbeit des FB Vermessungswesen an der Universität Essen wurde eine komplette Aufmessung des Klostergeländes durchgeführt. Die topographische Aufnahme wurde anschließend digital umgesetzt und dabei versucht, sie auf die georeferenzierte Altkarte von MINZENBACH zu übertragen.

2. Da zur Rekonstruktion der Klosterweiher, die auf dem Plan von 1804 eingetragen waren, die Einpassung anhand von Passpunkten in die heutige topographische Situation nicht möglich war und erhebliche Diskrepanzen auftraten, sollte versucht werden, die damaligen Weiher mittels geophysikalischer Magnetik zu lokalisieren (WIPPERN 2003:136). Mit Hilfe von Magnetometermessungen wurde 2001/2002 eine ca. 2,5 ha große Wiese, die als Klosterteichareal auf dem Minzenbach-Plan im nordöstlichen Anschluss an das Klostergelände ausgewiesen ist, untersucht (:136). Extrem morastige Bereiche mussten dabei ausgespart werden. Die Messwerte wurden mit einem Punktabstand von $0,25 \mathrm{~m}$ entlang der $0,5 \mathrm{~m}$ entfernten Profile in $40 \times 10$ m-Quadranten im Zick-Zack-Modus aufgezeichnet. Mehr als $25 \%$ der Fläche wurden ein zweites Mal mit einer orthogonalen Lage der Profile vermessen und der Offset der einzelnen Spuren durch Vergleich der beiden Datensätze ermittelt (:136).

3. Um die Substanz des Bodendenkmals zu schonen, wurde der Schwerpunkt zunächst auf Geländeaufnahme und geophysikalische Untersuchungen gelegt. Sondageschnitte sollten auf minimale Größe beschränkt bleiben (KELLER 2003:135). Mit einem sog. Suchschnitt sollte dennoch die Lage von drei Teichen sowie der Aufbau von Dämmen und Teichsohle geklärt werden, da eine Renaturierung bzw. Neuanlage im Rahmen des Projektes angedacht wird.

Im Auftrag des Rheinischen Vereins für Denkmalpflege und Landschaftsschutz wurde von der Firma W.S. van de Graaf Archäologie die Untersuchung im Dezember 2001 durchgeführt. Es wurde ein 69 m langer Schnitt auf der Wiese des Keltersiefens angelegt, der - legt man den Minzenbachplan zugrunde - drei Teiche anschneiden sollte. Die Durchführung der Prospektion gestaltete sich auf Grund des extrem feuchten Untergrundes schwierig und bereits in einem 
Meter Tiefe austretendes Grundwasser führte zum wiederholten Abrutschen der Bodenschnitte, die daher nur schematisch aufgenommen werden konnten. Eine Dokumentation des Planums wurde durch das schnell steigende Wasser verhindert.

Die Identifizierung der nach der historischen Karte zu vermutenden Dämme gelang aufgrund dessen nur an einer Stelle mit Sicherheit. Der hier etwa zwölf Meter breite Damm bestand demnach aus mehreren Lagen tonigen Materials, welches mit Bruchsteinen durchsetzt war. Holzeinbauten oder Uferbefestigungen waren in diesem Profil nicht erkennbar.

Letztlich blieb seitens des Rheinischen Amtes für Bodendenkmalpflege als zuständige Fachbehörde nur die Feststellung, dass auf Grund der schlechten Grabungsbedingungen eine genaue Klärung des Befundes nicht möglich war. Mit Sicherheit ließ sich nur feststellen, dass die Dämme nicht durch massive Steinanschüttungen oder Holzeinbauten befestigt waren.

Insgesamt gesehen sollten „mit dem integrativen Ansatz des Projektes [...] einerseits die rechtlichen Rahmenbedingungen ausgeschöpft werden, aber auch Aussagen und Handlungsempfehlungen zur Landschaftsplanung gegeben werden.“ (KLEEFELD 2003:134). Für die Teichlandschaft als ein Teil des Gesamtkomplexes Kulturlandschaft Klosterlandschaft Heisterbach Tal hingegen liegt noch keine abschließende Landschaftskonzeption vor: Wiedervernässung oder gestaltetes Grün? Oder „Imitation“ einer Nutzung wie beispielsweise bei einer Niederwaldbewirtschaftung? (KLEEFELD 2003:mündl.)

„Ein Ausheben der Verfüllung zwecks Renaturierung“, so jedenfalls die archäologische Diagnose nach der Sondage, „erscheint daher kaum möglich. Es muß eher damit gerechnet werden, dass die Teiche vollständig neu angelegt werden müssten (ANDRIKOPOULOU-STRACK et al. 2002:73,74). Damit kommt im Falle einer angedachten Wiederbelebung der Klosterteiche keine historisch wertvollere Wiederinbetriebnahme im Sinne einer Aufspannung der verbliebenen Hohlformen, sondern nur eine völlige Neueinrichtung in Frage.

Die Schwierigkeit einer solchen Rekonstruktion bei einer Klosterteichanlage besteht darin, dass, während bei der Rekonstruktion der Klosteranlage auf andere Zisterzienserklöster (z. B. Englands) oder auf die Anlage von Corbie zurückgegriffen werden kann, dies für Teiche nicht möglich ist. $\mathrm{Zu}$ unterschiedlich ist das Morphorelief, zu verschieden die Baumuster.

Aus den Offenlegungen der Kanalsysteme ist zum Beispiel hervorgegangen, dass die Fäkalien in Richtung Teich weggespült worden sind (KELLER 2003:mündl.). Des Weiteren dienten zumindest einige Teiche auch (oder hauptsächlich?) als Wasserstau dem Mühlenantrieb, wie urkundlich nachgewiesen worden ist.

\section{b Das Reiherbachtal}

\section{b.1 Das Projekt „Hutewald“}

Der Solling ist eine Landschaft, die durch zahlreiche Reste ehemaliger Hutewaldwirtschaft geprägt ist. In die lichten, meist eichenreichen Wälder sind hier noch bis vor 150 Jahren Weidetiere, insbesondere Hausschweine und rinder, aber auch Schafe und Pferde zu Tausenden hineingetrieben worden. Diese lichten Wälder als seltene Landschaftsrelikte einer alten Wirtschaftsweise bedürfen heute eines besonderen Schutzes und Pflege, soll der Reinbestand erhalten bleiben und nicht durch die flächige Ausbreitung der konkurrenzstarken Buche gefährdet werden. Gleichzeitig werden die herkömmlichen Pflegemethoden, zum Beispiel mit motorbetriebenen „Freischneidern“, dem Schutzziel nicht gerecht. Sie sind zeit- und kostenintensiv und mit hohem maschinellem Einsatz verbunden.

Seit dem 28. August 2000 weiden aus diesen Gründen - zur Pflege und Entwicklung eines ehemaligen Hutewaldes und angrenzender Flächen - in den noch lichten Eichenwäldern eines Teilbereiches des Sollings ganzjährig Heckrinder (rückgezüchtete Auerochsen) und Exmoor-Ponies. Beide Tierrassen zeichnen sich durch besondere Robustheit gegenüber Klima und Nahrung aus und haben wildtierähnliche Eigenschaften. Sie stehen stellvertretend für ursprünglich in Europa heimische Weidetiere. Im Reiherbachtal bei Amelith/Bodenfelde (Landkreis Northeim) wurde zur Durchführung des 
modellhaften Forschungsvorhabens „Hutelandschaftspflege und Artenschutz mit großen Weidetieren im Naturpark Solling-Vogler“ eine Fläche von zunächst ca. 200 ha gegattert". Nur 15 ha der Gesamtfläche bestehen aus - ehemals landwirtschaftlich genutztem - Offenland. Dieser hohe Waldanteil im Projektgebiet zeichnet das Vorhaben im internationalen und nationalen Vergleich aus. Das Besondere am Projekt im Reiherbachtal ist weiterhin, dass erstmalig die extensive Waldbeweidung auf großer Fläche erprobt wird. Es wird somit als ein Modellvorhaben von überregionaler Bedeutung für den Naturschutz angesprochen.

Die Fläche beweideten zu Beginn des Projektes sieben Exmoor-Ponys und sechs Heckrinder mit drei Kälbern. Seitdem wurden bisher 7 Kälber und 5 Fohlen im Projektgebiet geboren. Damit befinden sich derzeit (Stand 11/2003) 19 Heckrinder und 14 Exmoor-Ponies im Projektgebiet. Zusätzlich wurde eine „Erweiterungsfläche“ unterhalb des Schlosses Nienover eingerichtet, auf der 5 weitere Heckrinder und 3 Exmoor-Ponies weiden. Weiterhin befindet sich auch einwanderndes Schwarz-, Dam- und Rehwild innerhalb des Gatters, welches mit zunächst drei und vier sog. Sauklappen versehen ist, die aber vom Wild unbenutzt bleiben und das stattdessen, um in den gegatterten Bereich zu gelangen, den Wildzaun untergräbt. Der Tierbestand, dies ist das Ziel, soll sich langsam weiter selbst aufbauen, so dass eine kooperative Entwicklung der Weidetiere und der von ihnen genutzten und mitgestalteten Standorte, der Vegetation und der Fauna erreicht wird.

Im Mai 2002 wurde zudem ein „Hutewald-Erlebnispfad“ eröffnet und im Jahr 2003 ein Informationszentrum am Schloss Nienover eingerichtet. Zwei Beobachtungstürme sollen den besonderen Blick ins Innere des Gebietes vermitteln und eine ständige Beobachtungsmöglichkeit von Heckrindern und Exmoor-Ponies für die Besucher auf das Erweiterungsgehege bieten.

Das Entwicklungs- und Erprobungsvorhaben „Hutewaldprojekt“ wird unter der Trägerschaft des Bundesamtes für Naturschutz $(\mathrm{BfN})$ Bonn gefördert und von der Universität-Gesamthochschule Paderborn bzw. seiner Fachhochschulabteilung für Tierökologie in Höxter gemeinsam mit der niedersächsischen Landsforstverwaltung und der Naturparkverwaltung Solling-Vogler durchgeführt. Das Vorhaben ist zunächst für die Dauer von fünf Jahren, d. h. bis zum Jahr 2005 finanziell gesichert, ein EU-Anschlussförderung ist aber in Aussicht gestellt.

Die an den Anfang gestellte landschaftshistorische Bedeutung und Problematik des Weidewaldes soll hier noch einmal aufgegriffen werden, um daraus ein Verständnis für den Theorieansatz der hier ergriffenen bioökologischen Maßnahmen abzuleiten:

Hutelandschaften, wie die im Bereich des Sollings, waren in Deutschland und in Europa ehemals weit verbreitet, müssen heute jedoch als stark gefährdet angesehen werden. Die aus der Hutenutzung hervorgegangenen lichten Eichenwälder sind heute durch die dominantere Buche zugesetzt, aus Biotop- und Artenschutzgründen jedoch erhaltenswert, da sie den Lebensraum für weithin bedrohte Pflanzen- und Tierarten bilden. Weiterhin gelten sie als Kerngebiete der Landschaftsvielfalt und Schönheit. Daher wird hier versucht, die schutzwürdigen Wälder mit geringen Weidetierdichten weiterzuentwickeln. Der Buchenjungwuchs soll ohne die unerwünschten Folgen einer Übernutzung unterdrückt werden. Die Form der extensiven Beweidung mit großen Weidetieren begründet sich in der Annahme, dass im nacheiszeitlichen Europa noch fast überall große Pflanzenfresser, wie Auerochsen, Wisente, Rothirsche und Wildpferde, lebten. Diese wirkten durch ihren Fraß und Tritt der flächendeckenden Ausbreitung von geschlossenen Wäldern entgegen und sorgten bereits vor dem Auftreten des modernen Menschen durch ihr Wirken für reichstrukturierte, aufgelockerte Lebensräume.

Das heißt, im Vorhaben wird in diesem ungefähr 200 ha großen Wald-Offenland-Komplex eine neue „alte“ Form der Beweidung auf zukunftsweisende Art erprobt und eventuell etabliert, mit der eine

\footnotetext{
${ }^{5}$ Eine ganzjährige Beweidung mit der rückgezüchteten Rinderrasse „Auerochse“ wurde meines Wissens erstmals in Deutschland in der „Klostermersch“, einem renaturierten Auenbereich der Lippe durchgeführt. 1991 wurden die ersten Heckrinder auf eine damals 8 ha große Fläche in der Klostermersch geführt, die bis heute auf 61 ha vergrößert wurden (SCHARF 2000:36).
} 
ökologisch und historisch bedeutende Waldlandschaft erhalten und weiterentwickelt werden soll. Dieses Projekt zeichnet sich vor allem durch eine behutsame Vorgehensweise aus. In dieser Hinsicht unterscheidet es sich grundsätzlich von der ursprünglichen Hutewirtschaft - diese belastete die Landschaft alljährlich mit einem einige Wochen oder Monate dauernden Masseneinstand von Vieh, was teilweise mit heftiger Degradation der Landschaft verbunden war.

Deshalb lautet die Zielsetzung hier, eine bedeutende „Hutelandschaft“ mit ihren seltenen Tier- und Pflanzenarten zu erhalten und weiterzuentwickeln. Durch die extensive Beweidung soll zum einen ermittelt werden, ob die für Hutelandschaften typische Lebensraum- und Artenvielfalt erhalten und langfristig die bedeutende Verzahnung von Offenland und Wald gesichert werden kann. Zum anderen sollen Entwicklungslinien für eine künftige wirtschaftliche Nutzung von Wald- und Grünland in Mittelgebirgsregionen aufgezeigt werden. Der Erhalt lichter Eichenwälder und ehemaliger Hutewälder ist auch ein Ziel der Niedersächsischen Landesforstverwaltung, in deren Besitz die Waldflächen im Reiherbachtal sind. Der besondere Wert der Hutelandschaften basiert daher ebenso auf Kriterien des Naturschutzes - des Lebensraum- und Artenschutzes - wie auf einer jahrhundertelangen Kulturgeschichte. Dessen ungeachtet zeigt dieses Vorhaben nach Ansicht der Vorhabenträger, dass auch kulturgeschichtlich mitbegründete Artenvielfalt stets mit jenen Mitteln zu pflegen und zu entwickeln ist, die in der jeweiligen Zeit verankert sind.

Dennoch stellt sich in diesem Projektgebiet aufgrund der besonderen naturräumlichen Ausstattung vor allem unter dem Gesichtspunkt einer gewässerhistorisch-geographischen Betrachtung die Frage der „Ahistorizität" bzw. - als Preis des Erhalts von Waldrelikten - die des Verfalls von Teichrelikten.

\section{b.2 Die Teichanlagen des Reiherbachs}

Das Projektgebiet im Reiherbachtal liegt inmitten eines gewässerhistorischen Kleinods. Landschaftsprägend sind nicht nur die ehemaligen Hutewälder an den Hängen des Tales, sondern zahlreiche offengelassene, unbewirtschaftete, zum Teil schon „reliktäre“ Weiher liegen entlang des Gewässerlaufs Reiherbach, der das Tal namensgebend duchläuft.

Auf einer Ortskarte von 1774 gibt es dort nach WEISE (1989:54) zwei Teichstätten, als „Fisch[be]hälter eingezeichnet“, und auch auf der Landesaufnahme von 1784 seien sie erkennbar, „wenn auch offensichtlich bereits stark verlandet.“ Man findet sie, so beschreibt WEISE (:54) die Lage, „südwestlich des Mühlenteiches, unmittelbar vor dem Burgenstieg, nördlich der Zehntscheune“ des Schlosses Nienover.

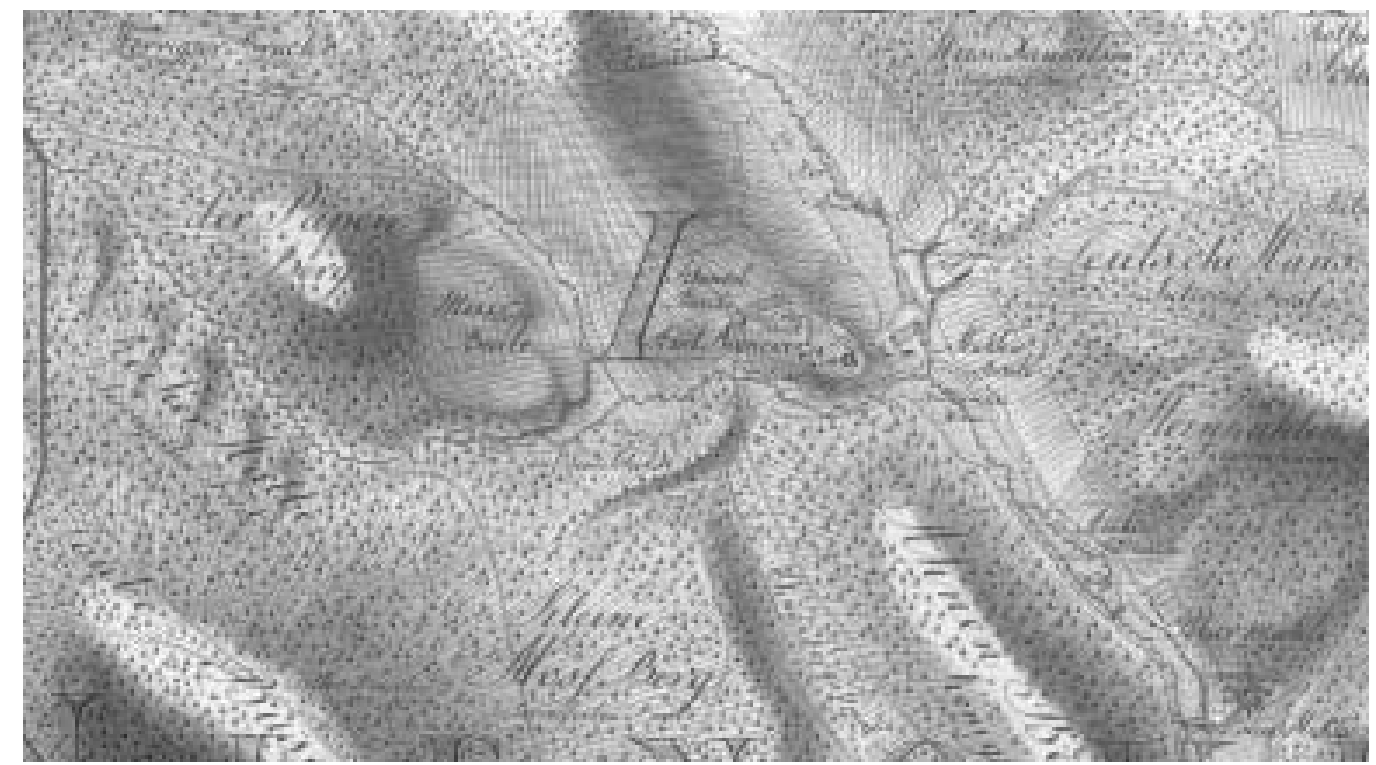

Abb. IX-6: Ausschnitt aus der Kurhannoverschen Landesaufnahme des 18. Jahrhunderts (1784)

Blatt Uslar 149. Deutlich erkennbar ist der große, oberhalb der Nienover Mühle liegende, Mühlenteich sowie zwei kleinere Teiche westlich der Mühlengebäude. Alle drei sind heute verlandet. Weiter westlich, das Reiherbachtal hinauf, ist der große ,Reiherteich' eingezeichnet. Weitere Teiche sind der Karte dem Gebiet nicht zu entnehmen 
(Reproduktion LGN [Landesvermessung und Geobasisinformation Niedersachsen], Hannover 2003, Orig.Maßstab $\left.1: 21.333^{1} / 3\right)$.

Diese Lagebeschreibung ist nach meiner Auswertung der Landesaufnahme nicht zu entnehmen, aber auf der Karte von PAPEN von 1842 ist dieses von WEISE (1989) beschriebene Teichgelände unterhalb der Mühle und Zehntscheune als verlandeter Bereich erkennbar:

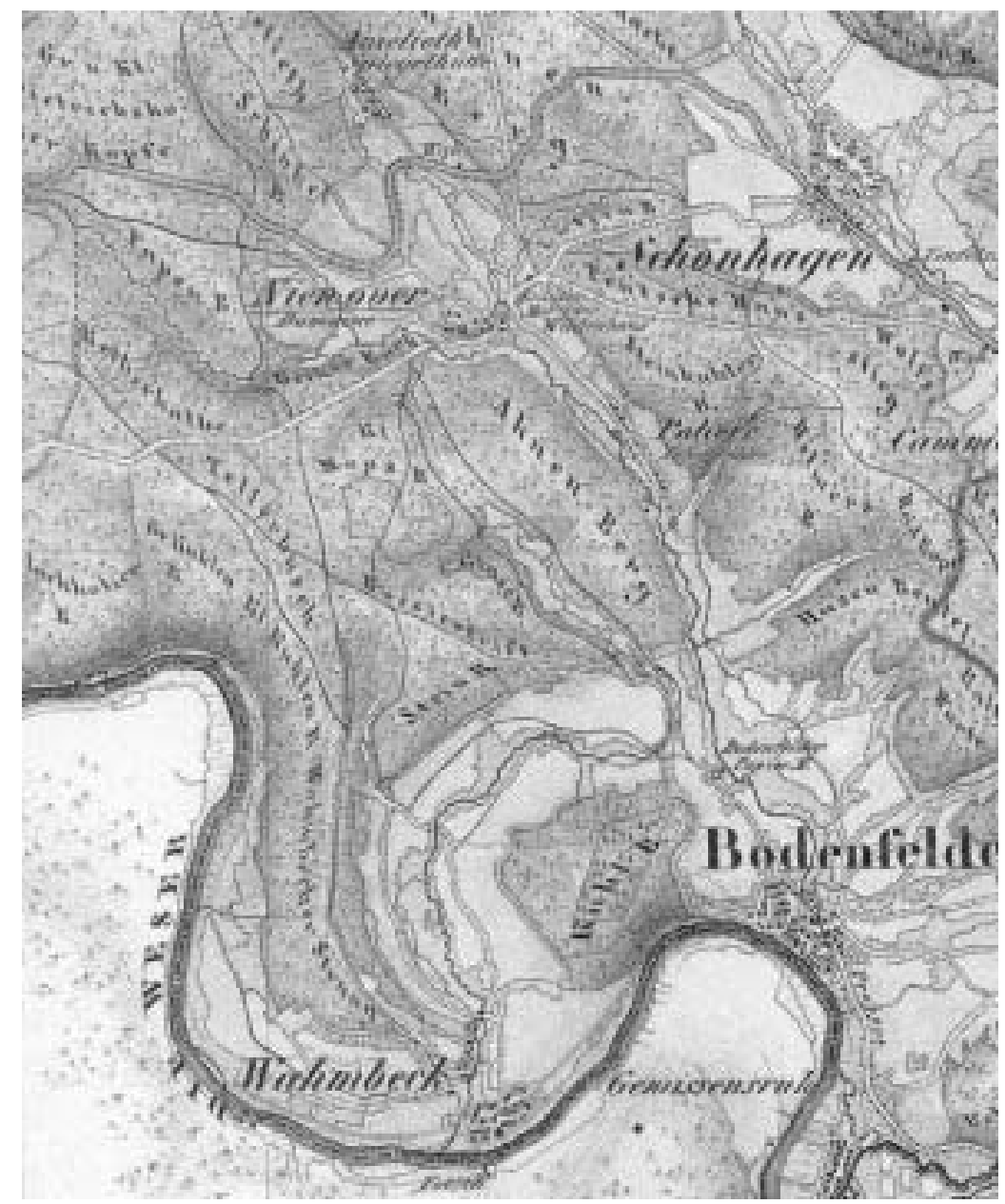

Abb. IX-7: Ausschnitt aus dem Topographischen Atlas des Königreichs Hannover und Herzogtums Braunschweig von August PAPEN (1842), Blatt 63 Göttingen. Erkennbar ist der große Teich am Mittellauf des „Reiher Bachs“, der große Mühlenteich wie aber auch ein bereits verlandeter Teich unterhalb Mühle und Zehntscheune (Reproduktion LGN [Landesvermessung und Geobasisinformation Niedersachsen], Hannover 1999, Orig.Maßstab 1:100.000).

Die Situation stellt sich nach der Landesaufnahme von 1914 wiederum gänzlich anders resp. verschlechtert dar. Der Reiherbach ist seiner Größe reduziert wiedergegeben, der große Mühlenteich gänzlich verschwunden (Wiesensignatur), der unterhalb gelegene Verlandungsteich weggefallen. 


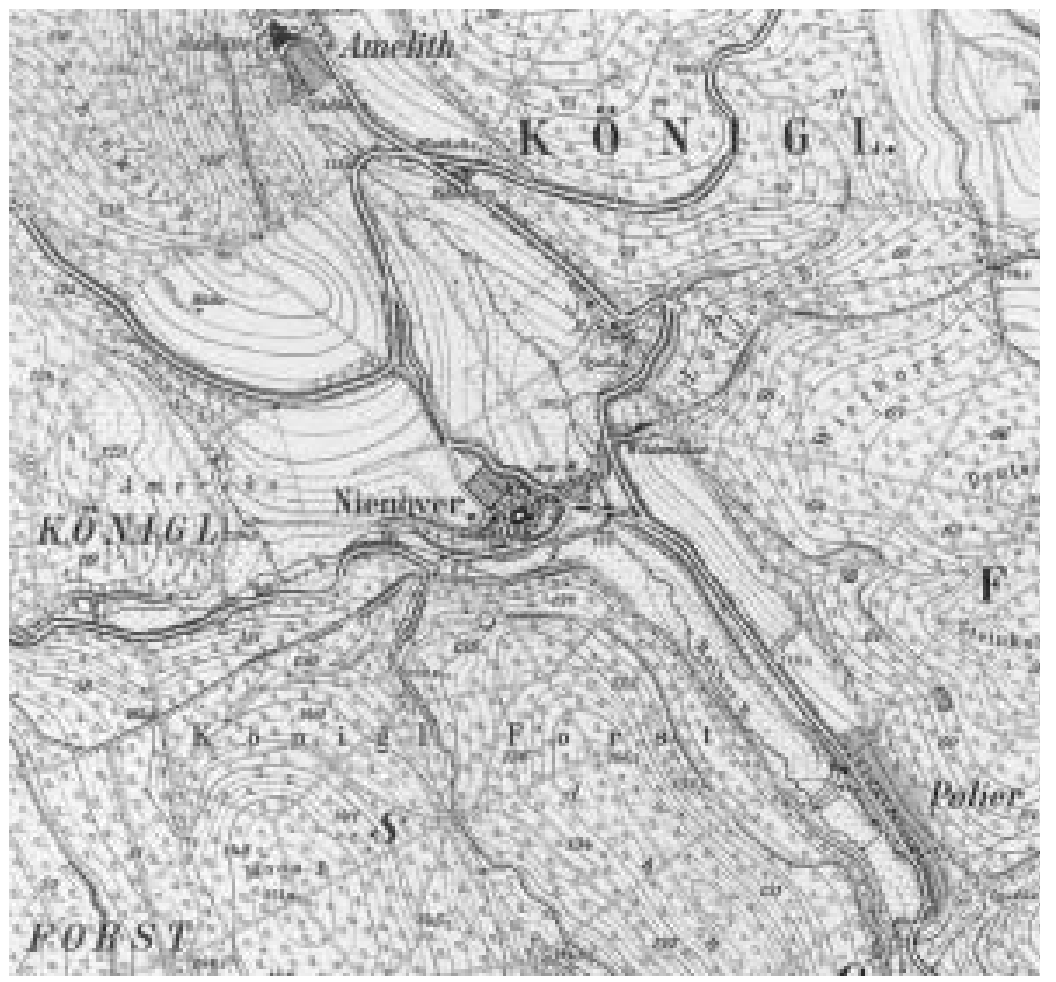

Abb. IX-8: Ausschnitt aus der Königlich-Preussischen Landesaufnahme 1896

Auflagedruck 1914, Blatt 4323 Uslar. Der Wegfall sämtlicher Teiche fällt zeitlich zusammen mit dem Niedergang der traditionellen, mit Wasserkraft betriebenen Mühlenwirtschaft und der Teichwirtschaft im Allgemeinen.

Mitte des 20. Jahrhunderts dann stellt sich die teichbezogene Situation im Vergleich zum Jahr 1914 insofern verändert dar, als dass ein unterhalb des ,Reiherteichs' gelegener Teich eingezeichnet ist.

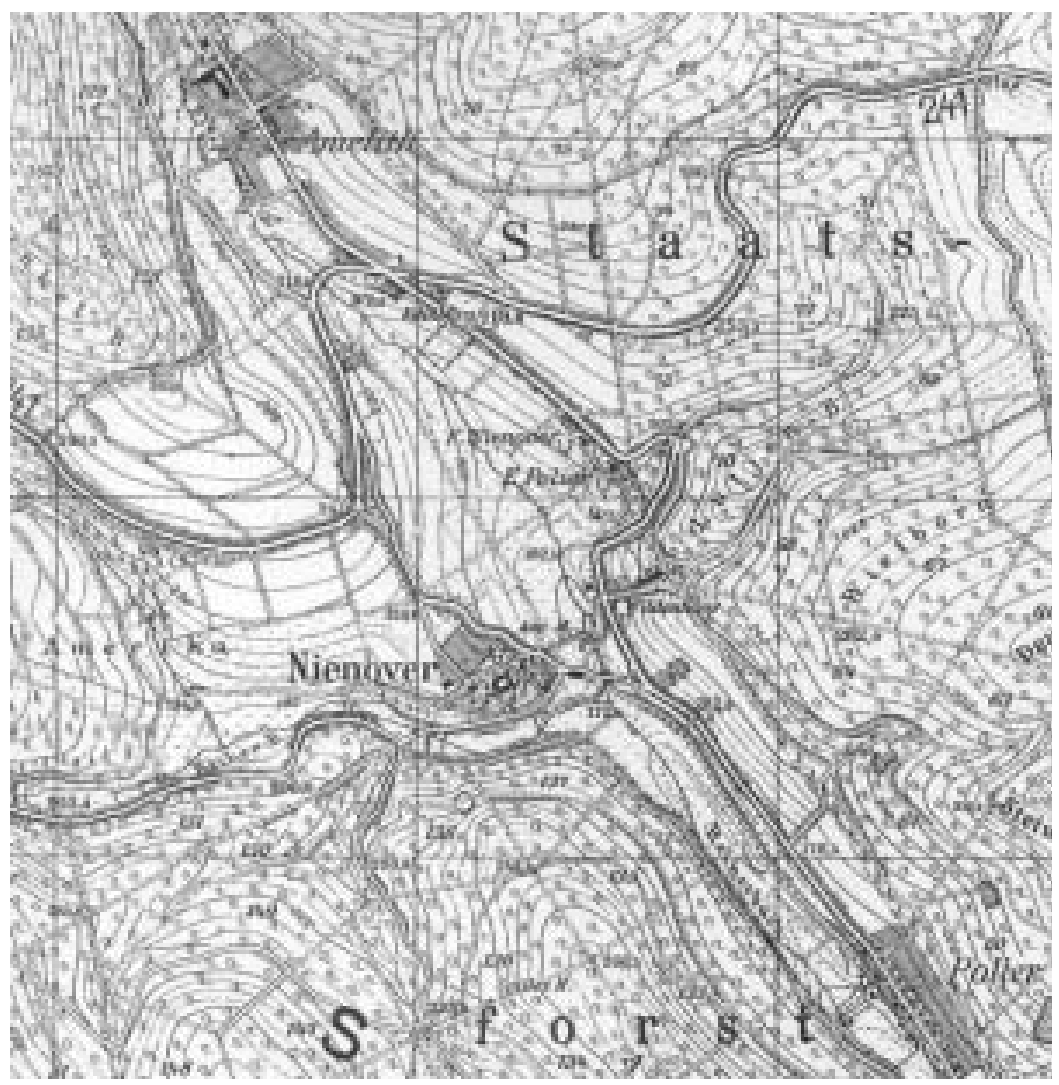

Abb. IX-9: Ausschnitt aus der Topographischen Karte 1:25.000, Blatt 4323 Uslar

Ausgabe 1956. Hier ist erstmals ein zweiter Reiherteich eingezeichnet (unmaßstäbliche Abbildung). 
Erkundet man aber das Gelände vor Ort, so zeichnet sich eine ganz andere Situation ab: Eine Vielzahl von Teichen ziehen sich vielmehr als eine kleine Weiherkette durch das Reiherbachtal. Die noch heute bespannten Teiche können ergänzt werden durch einige verlandete Teiche, deren Umrisse durch ehemalige Dämme im Feld noch gut zu erkennen sind. Sie alle liegen zwischen dem wüst gegangenen Ort Winnefeld, dessen Kircheruine noch unmittelbar an der den Solling durchquerenden Bundesstraße 241 liegt und ein von der Kirche etwas entfernt gelegenes Forstamt mit seinem Namen auf den ehemals größeren Ort hinweist, und der erwähnten Zehntscheune bzw. Nienover Mühle.

Da aber auf den Altkarten und auch auf der relativ aktuellen Topographischen Karte von 1956 nicht sämtliche Teiche eingezeichnet sind, die sich vor Ort im Geländerelief rekonstruieren lassen, so stellt sich die Frage nach dem zeitlichen Ursprung der übrigen Teiche. Über die Geschichte der Reiherbachteiche aber weiß man wenig. Die wenigen Hinweise ergeben sich im Zusammenhang mit dem oberhalb, auf einem Bergsporn liegenden Schloss Nienover:

Mitte des 16. Jahrhunderts wird vorgeschlagen, sie zu räumen und mit Fischen zu besetzen. Dann würde die Fürstin nach drei Jahren ein gutes Aufkommen haben, heißt es in einer Relation vom 26. August 1588. Dort rät ein Gutachter namens Reinhold „stehende Gewässer, die verschlammt sind, entweder ganz auszutrocknen und Wiesen daraus zu machen oder Karpfenteiche anzulegen“, denn wenn, so die Begründung, ,richtige, tiefe Teiche angelegt werden, haben diese Fischräuber das Nachsehen“" (StA Hannover, Cal. 2 XXXVIII Nr. 20; aus: WEISE 1989:81).

Die Teichwirtschaft hat wohl auch zuerst gut angeschlagen, obschon es an der Bewirtschaftung selbst Mängel gab, und aus dieser Notiz sind auch Forellenteiche bezeugt. Für das Jahr 1646/47 gibt es eine Nachricht über den Ertrag aus den Teichen in einem Handbüchlein der Herzogin: „Vom Forellenteich zu Nienover ist nichts eingekommen, da er nicht abgefischt worden ist.“ (WEISE 1989:55) Später muss es sich nicht mehr gelohnt haben, „Fische in den Nienoverschen Teichen auszusetzen, weil Ottern und Raubvögel die meisten haben" (StA Hannover 76 Aa Nr. 5, StA Wolfenbüttel 2 Alt vorl. Nr. 1713 Bd. 2:66-89; aus: WEISE 1989:55).

Die Überlieferungen sind hinsichtlich der Teichbeschreibung und des Teichbesatzes widersprüchlich, da Karpfenteiche, wie in VII 2b.2.1 dargestellt, eher flachgründig zu sein hatten. Weiterhin ist das kühl-luftfeuchte Reiherbachtal kein idealer klimatischer Ort für Karpfen, sondern eher für Forellenartige. Doch zum einen kann es sich hier auch vormals auch um wirklich sehr flache, wiesenähnliche Flachformen außerhalb des engen Tales gehandelt haben, die es für eine Karpfenhaltung zu vertiefen galt (,richtige Teiche“). Dann würde die anfängliche Karteninterpretation von Weise wieder einen Sinne ergeben, der diese Teiche in der „offener Landschaft“ bei Mühle und Zehntscheune erkennt. Zum anderen aber wurden Forellen zu der Zeit nicht in Teichen gehalten und gezüchtet schon gar nicht, sondern in den Bächen gefangen. Maximal wurden sie in Hälterteichen bis kurz vor dem unmittelbaren Verzehr aufbewahrt. Um einen solchen wird es sich auch bei den Nienover Forellenteiche gehandelt haben.

Vor allem aber der Hinweis, dass es bereits 1588 „stehende, verschlammte Gewässer“ gegeben hat, veranlasst zu der spekulativen Deutung einer bereits zeitlich früheren Teichanlage, die unterhalb der Burg bestand, aber zwischenzeitlich nicht bewirtschaftet wurde und brach lag.

Eine Interpretation geht von der Annahme aus, dass es sich bei dem bereits genannten Ort Winnefeld wie auch bei dem ehemals in der Nähe des Reiherbachtals befindlichen wüsten Ort Seefeld um Villikationen, d. h. um Meierhofsiedlungen, des 744 gegründeten Missionsklosters Fulda gehandelt hat, denen bereits sehr früh (KOKEN 1841) eine Fischerei zugesprochen wurde.

Ein anderer Zusammenhang erschließt sich über das ehemalige Kloster Hethis bei Neuhaus im Solling, das sich, bezieht man die alte Wegeverbindung über Winnefeld in die Berechnung mit ein, ca. $4-5$ $\mathrm{km}$ von dem ersten, heute im Gelände befindlichen Teich befunden hat.

Ein schließlich dritter Aspekt sieht gar keine - zumindest primär - fischereiwirtschaftliche Nutzung, sondern geht von Teichanlagen zu Zwecken der Flößerei bzw. Holztrift aus, die mit einer Schwöllung 
zur Weser getriftet werden sollten. Erst nachdem diese Pläne nicht umgesetzt worden sind bzw. nachdem die Kurzholzflößerei eingestellt wurde, wären diese wasserbespannten Hohlformen als Fischteiche genutzt worden.

\section{b.3 Kulturhistorischer Waldschutz vs. Gewässerschutz}

Wie die Darstellung des Reiherbachs in Bezug auf die Gewässerstruktur gezeigt hat, sind hier die Teiche ebenso Bestandteil der historischen Kulturlandschaft wie die Hutewälder. Die Teichflächen, ihre Nutzungsform und ihr Erhalt sind aber nicht Gegenstand des Modellprojektes. Der Fokus liegt allein auf der extensiven Waldbeweidung unter den Gesichtspunkten des Naturschutzes, der Landschaftspflege und der Forstwirtschaft. Innerhalb der bislang gegatterten Modellfläche befindet sich von den zahlreichen kleinen und mittelgroßen Teiche des Reiherbachtals zwar nur ein Teich, die anderen sind weiterhin der Öffentlichkeit zugänglich, aber an diesem Beispiel soll die Problematik einer nur eindimensional auf tier- und pflanzensoziologische Verhältnisse ausgerichteten Betrachtungsweise einer Kulturlandschaft, hier die Bewirtschaftungsform des Hutewaldes, aufgezeigt werden. Oder ist gar die Waldweide - unbeabsichtigt in diesem Projekt - die kulturhistorisch originäre, $\mathrm{d}$. $\mathrm{h}$. gewünschte duplexe Ergänzung zur Teichbewirtschaftung im Sinne etwa einer einigermaßen geregelten Teich-Wechselwirtschaft (siehe Pkt. b.4) bzw. kann sie als annähernd originalgetreuer Ausdruck einer oftmals krisenhaften, ambivalenten, weil ungesteuerten Beweidung auch von Teicharealen gesehen werden? Als letztes bliebe nur der Hinweis, dass alle diese Mutmaßungen auf der Annahme beruhen, dass es sich bei den Reiherbachteichen wirklich um diejenigen Teiche handelt, die während der Waldweidezeit bestanden haben. Der geschichtliche Nachweis dieser Verhältnisse kann an dieser Stelle aus Zeitgründen nicht erbracht werden, die Bedeutung einer historischgeographischen Betrachtungsansatzes aber wird aus der folgenden Situationsschilderung deutlich.

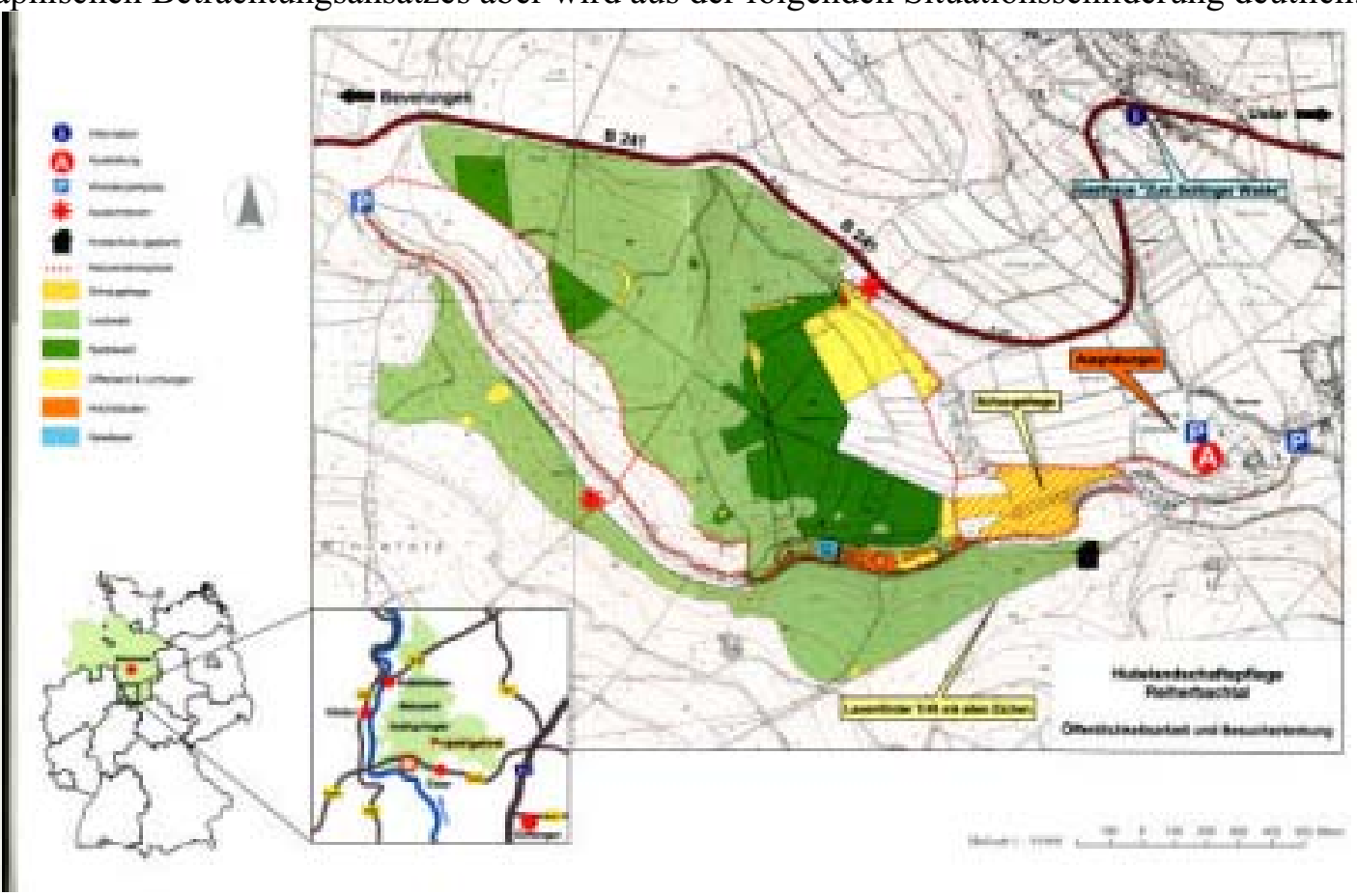

Abb. IX-10: Das Projektgebiet Hutewald im Solling

In der unteren Bildmitte ist der als ,Reiherteich' bezeichnete Teich zu erkennen. Die anderen Teiche des Reiherbachtals liegen außerhalb des Projektgeländes (aus: SONNENBURG/GERKEN 2003:20)

Durch die ähnlich wie ihre ,wildlebenden“ Vorfahren ganzjährig im Freien lebenden Rinder und Ponies und da „beide mit Zugang zum Reiherbach“ (GERKEN/MARTENSEN 2003:5) die Wasserflächen nutzen, sind auch die Teiche in ihrer Anlage und in ihrem Fortbestand potentiell betroffen: „Durch ihre Aktivitäten entstehen nicht nur triftähnliche Wege, sie legen auch zahlreiche Wühlstellen an. Mit ihren Hufen und Zähnen gestalten sie die Standorte für Vegetation und Fauna“ (BFN 2002). „Zwei Jahre nach Beginn der flächendeckenden Beweidung“, so auch die Zwischenbilanz (GERKEN/MARTENSEN 2003:7), „sind die Spuren der Weidetätigkeit im Projektgebiet in den meisten Teilbereichen nicht zu übersehen." Die bisherigen Untersuchungsergebnisse hingegen belegen 
eine Schädigung der Nassbereiche nicht: „Keine Veränderungen konnten bislang in der Vegetation von [...] Naßwäldern (Carici elongatae-Alnetum) und Wasserpflanzenbeständen (Lemnetea- u. Potametea- sowie Wassermoosgesellschaften) festgestellt werden. An diesen Orten wurde die Weidetiere bislang nur ,meteorisch' beobachtet, da hier eine für sie interessante Vegetation fehlt oder für sie unerreichbar ist (permanente Staunässe, offenes Wasser). “(:10) Diese Aussage konnte bei einer geführten Geländebegehung am 18.10.2003 nicht verifiziert werden.

Obgleich vor allem im Winter die Eichenflächen innerhalb des Gatters zur Nahrungssuche und -aufnahme aufgrund der Vollmast von den Rindern aufgesucht werden und ebenso für die einstreifenden Wildschweine von besonderer Bedeutung sind, suchen sie eben auch die ebenen, baumfreien und mit Gräsern und krautigen Pflanzen bestandenen Teichrandflächen zur Nahrungsaufnahme auf, da sie diese Flora in den eher trockenen und schneller vereisten Böden der Wälder nicht bekommen. Die Exmoor-Ponies fressen zum Beispiel sogar die Seggenbestände ab und betreten dazu die unmittelbaren Übergangsbereiche zum Teichwasser. Vor allem aber die mit dieser Maßnahme gestiegenen Schwarzwildbestände (GWN 2003) richten mit ihren Suhlen- und Wühlstellen große Schäden an den Teichrändern an, da sie ,unabhängig von den 4 eingerichteten Klappen zahlreiche Wechsel durch den Projektzaun“ nutzen, „der ihre Raumnutzung nicht spürbar beeinträchtigt“ (GERKEN/MARTENSEN 2003:15). Aber auch die Scharrstellen und Begrasungen der Rinder und Ponies verletzen mit dem Betritt den Teichdamm. Die Projektleiter müssen selbst zugestehen, dass für „die Bachaue des Reiherbaches [...], den die Weidetiere beim Wechseln der Talseite durchqueren müssen, [...] die Beweidung als zu intensiv angesehen" wird.

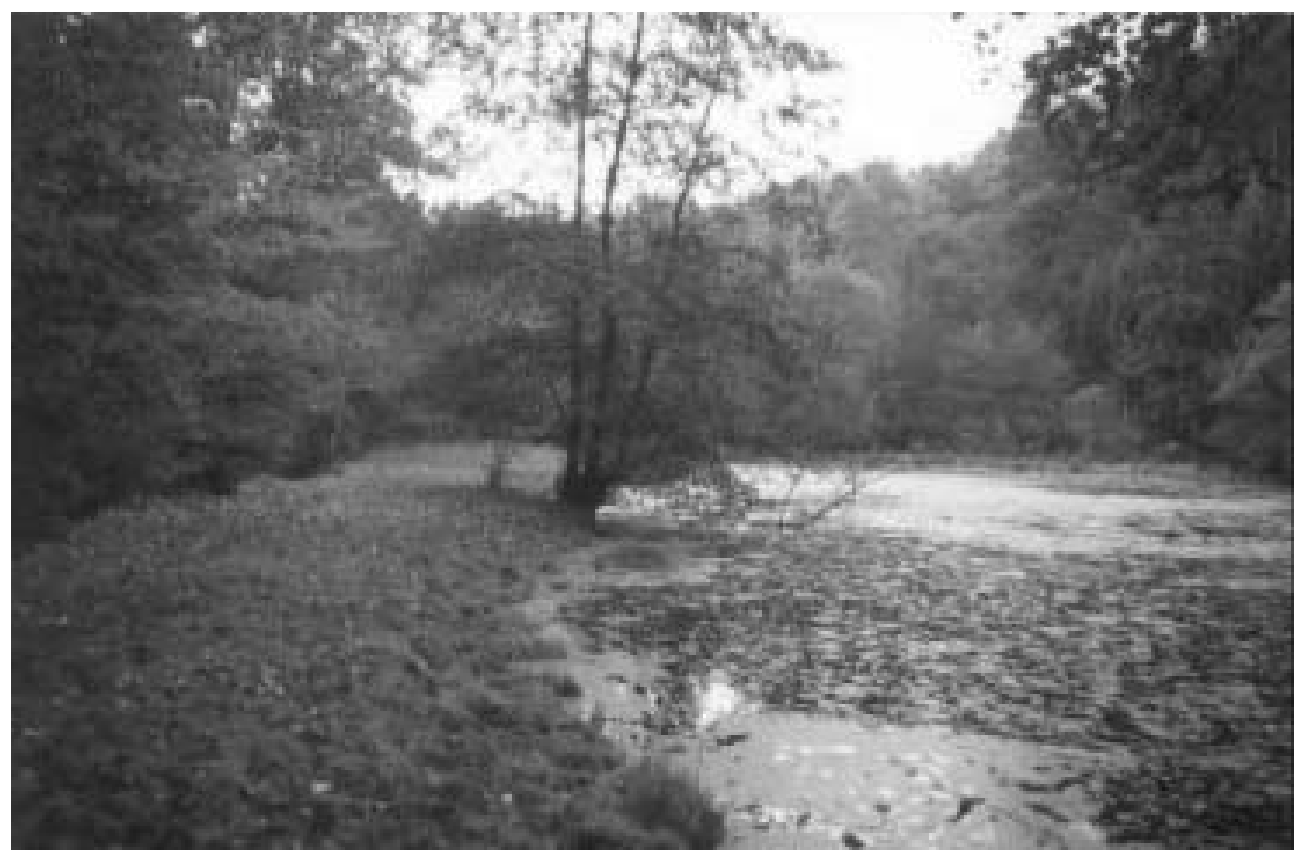

Abb. IX-11: Teichdamm des Hauptteiches im Reiherbachtal.

Durch den Viehvertritt infolge Äsung und Tränkung schwerer Weidetiere lockert sich die Dammgrasnarbe, der Teichdammrand rutscht und schiebt sich immer weiter in den offenen Wasserbereich hinein. Neben der Auflösung des eindeutigen Morphoreliefs besteht bei weiterer Durchnässung die Gefahr des Dammbruchs (eig. Aufnahme 2003).

Es bestehen jedoch in kulturhistorischer Sicht auch Vorteile: Zwar hat das Wildschweinwühlen und Beweiden eine teils massive Beschädigung der Dammrasenflächen zu Folge, führt aber auch ,in der Regel zu einer deutlichen Abnahme der Keimlings- und Sämlingszahlen“ (GERKEN/MARTENSEN 2003:6), die wiederum damit eventuell zu einer Offenhaltung der unmittelbaren Teichumgebung durch Vernichtung der Naturverjüngung beiträgt. Das Abfressen der Seggenbestände unterstützt diesen Prozess.

Nicht dokumentiert sind in den vorliegenden Berichten des Weiteren - im Gegensatz zu den Staubbadstellen im trockeneren Bereich - entsprechende Wasserbadestellen in den Teichen. Die in dem Zusammenhang mit Verbissschäden an Bäumen aufgedeckte gestiegene Rehpopulation ist hier 
insofern ebenfalls von Bedeutung, als dass sie, wie sich mit Hilfe des Fährtenbildes erkennen lässt, bestimmte Tränkestellen an dem Teich aufsuchen und dadurch ebenfalls zum Vertritt der Teichkanten beitragen. Aber nur aus Gründen des Modellprojektes wird darüber nachgedacht, die gestiegenen Wildzahlen jagdlich zu regulieren, um die Verbiss- und Scheuerschäden besser den Weidetieren zuordnen zu können; denn im Reiherbachtal sollen, wie anfangs berichtet, Erkenntnisse darüber gewonnen werden, ob sich lichte Eichenwälder mit Hilfe von großen Weidetieren schonender als mit Maschinen und vor allem kostengünstiger, weil mit weniger Aufwand verbunden, pflegen lassen.

Dabei wird zwar beachtet, dass „Hutewälder“ indirekt anthropogen gestaltete Waldlandschaften sind, aber nicht, dass in ihnen, wie der Name schon besagt, nur eine vom Hütejungen bzw. Hirten beaufsichtigte und insofern ,regulierte“ Waldweide betrieben wurde. Fischteiche galten in früherer Zeit als wertvoll und deshalb wurden die Tiere mit Sicherheit zumindest von den Dämmen ferngehalten, im Rahmen der Feld-Teich-Wechselwirtschaft hingegen aber durchaus durchgeführt worden sein (Auflockerung des Teichbodens, Dung). Bei der modernen Form der Waldweide hingegen ist nur ein „geringer Betreuungsbedarf“ (BUNDESAMT FÜR NATURSCHUTZ) vorhanden. Die Weidetiere weiden unbeaufsichtigt innerhalb ihrer weiträumigen Absperrung gelassen.

Ein weiteres, vor dem Hintergrund der Aufgabenstellung unberücksichtigtes, Problem stellt die Dungproduktion der Weidetiere dar und dessen Abfluss in die Talsenke und der damit verbundene Transport des Kotgeschwemmsels und der Harnproduktionen in die Teiche. Da es sich hier um ursprüngliche Forellenteiche handelt, ist - im Gegensatz zu den Karpfenteichen, bei denen tierische Exkremente durchaus willkommen waren - eine solche Düngerbeigabe während des Teichbetriebes unerwünscht, da sie eine spezielle „Dungfauna“ etabliert. Die „mittelfristige Prognose zur Entwicklung der Syntaxa“ bei den eutraphenten Röhrichten und Großseggenrieden fällt hingegen rückläufig bis stagnierend aus (GERKEN/MARTENSEN 2003:13).

Dass Kulturlandschaftsschutz auch Naturschutz bedeutet, ist mittlerweile unbestritten. Durch den Nichterhalt der Mehrzahl der Teichflächen konnte bei der Artenzählung im Untersuchungsjahr 2001 die noch 1999 im Reiherbachtal vorkommende Wasserfledermaus (Myotis daubentonii) nicht nachgewiesen werden: „Der fehlende Nachweis der Wasserfledermaus lässt sich durch die Absenkung der Wasserspiegel in einigen der im Untersuchungsgebiet vorhandenen Stauteiche erklären" (GERKEN/MARTENSEN 2003:16). Auch hier führt der Niedergang der anthropogenen Teichbewirtschaftung zu einer defizitären Entwicklung bei einer Tierpopulation.

Generell stellt sich abschließend die Frage, welches Schutzziel mit einer Hutebeweidung verfolgt werden soll: die Wiederherstellung einer - als verzerrtes Trugbild in die Moderne projizierte extensiv bewirtschafteten Kulturlandschaft des Waldes, die es so niemals gegeben hat, separiert von der historischen Teichlandschaft, die nachweislich zu diesen Zeiten betrieben worden ist, oder die Sicherung einer landschaftshistorische Gewässerelemente integrierenden nachhaltigen Waldnutzung in nicht zugangsbeschränkter Flur?

Allgemein ist bezüglich der Authentizität festzustellen, dass aufgrund der gestiegenen Populationszahlen das Areal zukünftig bejagt werden muss, doch dafür wurde das „Jagdschloss Nienover“ ja früher auch hauptsächlich benutzt. Ahistorisch ist hingegen die Tatsache, dass 2003 das erste Mal eine größere Offenlandfläche namens „Amerika“ zeitweilig abgesperrt werden musste, so dass die Weidegrasvegetation zum Herbst aufwachsen und die notwendige Basis für den „Winterspeck“ der Rinder bilden konnte. Vor dieser Maßnahme haben die Rinder ab Oktober ausschließlich das Offenland beweidet und seit Mitte November mit Heu zugefüttert werden müssen, da sie das Rindenschälen in der Winterzeit noch nicht beherrschen (GERKEN/MARTENSEN 2003:5). Das Projekt Hutewald ist also auf anthropogene Hilfestellungen angewiesen ${ }^{6}$.

\footnotetext{
${ }^{6}$ Eine Zufütterung mit Heu erfolgte je nach Hochwasser und Witterung auch im Projektgebiet der „Klostermersch“ zwischen Dezember und März. Eine künstliche Nachbildung ehemaliger Flussmorphologien ermöglicht auch hier das Nachstellen solcher Beweidungsflächen: „Die Weideflächen können völlig überflutet werden, die Rinder ziehen sich dann bis zu drei Wochen lang auf eigens angelegte ,Hochwasserinseln' zurück.“ (SCHARF 2000:36).
} 
Bei einer historisch-geographischen Projektbewertung wäre bei einer Fortsetzung des Hutewaldprojektes, erst recht bei einer Flächenerweiterung, die Einbeziehung von Teichflächen in das Modellvorhaben insofern zu steuern, als dass die Teiche aus der Beweidung herausgenommen werden müssten, oder der Fragenkomplex quellenmethodisch dahingehend zu erweitern, ob zu originären Hutezeiten eine Ausklammerung der Teiche erfolgt ist oder eine - eher unwahrscheinliche Einbeziehung in die Hutefläche verfolgt worden ist. Aus dem Betrachtungsansatz der Kulturlandschaftspflege wäre es beispielsweise weiterhin $\mathrm{zu}$ begrüßen, eine Feld-TeichWechselwirtschaft modellhaft zu praktizieren und in das Offenlandkonzept zu integrieren.

Des Weiteren wird durch die Absperrung des Reiherbaches eine kulturhistorische Wegeverbindung unterbrochen: Die Straße den Reiherbach hinauf, die bis in die 1960er Jahre „Reiherstraße“ genannt wurde, war „in ältester Zeit die kürzeste Landverbindung, mit der man die Weserschleifen in nordsüdlicher Richtung umgehen konnte.“ (WEISE 1989:4) Der Weg, der hier unterhalb des Schlosses entlangführte, war der von Lippoldsberg-Bodenfelde nach Neuhaus-Holzminden (:7). „Über die Höhe hinweg kam man auf der Straße bei Beverungen wieder an den Fluß“(:4).

Unabhängig von der Bewertung des modellhaften Naturschutzprojektes als Ursache für eine Schädigung der Teichdämme und -ränder ist der seit Jahren fortdauernde allmähliche Verfall der noch wasserführenden sowie der bereits verlandeten Teiche außerhalb des Untersuchungsgebietes zu beklagen. Hier wäre ein gewässerbezogenes Kulturlandschaftspflegekonzept zu erarbeiten, das zum einen die Sukzession aufhält und zum anderen eine Rekultivierung bereits reliktärer Teichflächen anstrebt.

\section{Beispiel Mühlenteich}

\section{a Die ,Mydlinghovener Mühlenteiche‘}

\section{a.1 Untersuchungsraum und -gegenstand}

Das hier zu betrachtende gewässerhistorische, von mir als „Mydlinghovener Mühlenteiche“ bezeichnete Teichensemble liegt verstreut innerhalb des Naturschutzgebietes [NSG] „Hubbelrather Bachtal“". Dieses liegt im östlichsten Stadtgebiet von Düsseldorf, in der Übergangszone des rechtsrheinischen Düsseldorfer Stadtvorlandes zum Bergischen Land des Kreises Mettmann, südlich des Ortskernes Hubbelrath und östlich der Erkrather Landstraße (K 12).

Die zu untersuchenden Mühlenteichgewässer werden resp. wurden gespeist vom Hubbelrather Bach und werden räumlich begrenzt im Süden vom Gut Höltgen, einem bis vor kurzem als Ausflugsgaststätte genutzten ehemaligen Wirtschaftsgut, und im Norden vom „Gut Mydlinghoven“" , einem ehemaligen Rittergut, das heute eine gehobene Seniorenresidenz beherbergt. Unmittelbar westlich des Untersuchungsgebietes liegt die Mitte der 1970er Jahre eingerichtete und zur Erweiterung geplante Mülldeponie Hubbelrath. Westlich einer nicht mehr existenten Mühle lag der heute in der Deponiefläche mit einbezogene „Mühlenbusch“, durch den die 1565 erwähnte „Mühlenstraße“ eine Verbindung nach Hubbelrath und zu den Höfen im benachbarten Rotthäuser Bachtal herstellte. Noch bis 1835 hieß der heutige Hubbelrather Bach „Mühlenbach“ bzw. „Mydlinghover Bach“ oder auch nach dem nahegelegenen Gut - „Höltgenbach“.

Der Mydlinghover Bach ist topographisch wie kulturlandschaftsgeschichtlich prägender Bestandteil einer heute als „Hubbelrather Bachtal“ bezeichneten Senke. Das Hubbelrather Bachtal gehört naturräumlich zu den Mettmanner Lößterrassen innerhalb des Bergisch-Sauerländischen Unterlandes und ist Teil des Bergisch-Sauerländischen Gebirges. Durch Quellen, Bäche und Erosion haben sich hier im gesamten Raum zum Teil recht steile Täler in den Lößboden eingeschnitten.

\footnotetext{
${ }^{7}$ In den Baugenehmigungsakten von 1942 wird der Name Rittergut „Mydlinghofen“ geschrieben. In den Denkmalbüchern steht Gestüt Mydlinghoven, aber auch Mühlenkoven ist zu lesen. Andere Flurbezeichnungen in unmittelbarer Nähe lauten Mühlenbusch usw. „Hubbelrather Bach“ ist eine neue Bezeichnung.
} 
Darüber hinaus hat sich - vielleicht gerade - hier, in einem kleinen, tief eingeschnittenen und bislang noch ländlich geprägten Bachtal in unmittelbarer Nähe zur Bundesautobahn A 3 Oberhausen-Köln, gelegen zwischen den zusammenwachsenden Städten Mettmann und Düsseldorf-Gerresheim, eine kleinteilige und reich strukturierte historische Kulturlandschaft mit einer Vielzahl gewässergebundener Kulturlandschaftselemente erhalten können, die das begleitende umliegende Landschaftsbild prägen. Dazu zählen vor allem eine Vielzahl von rezenten Teichen, die noch heute zum Teil fischereiwirtschaftlich betrieben werden. Dennoch ist nachzuweisen, dass es auch hier ehemals weitere Teichflächen und gewässergebundene Einrichtungen gegeben hat, die in einem nunmehr reliktären Zustand vorliegen.

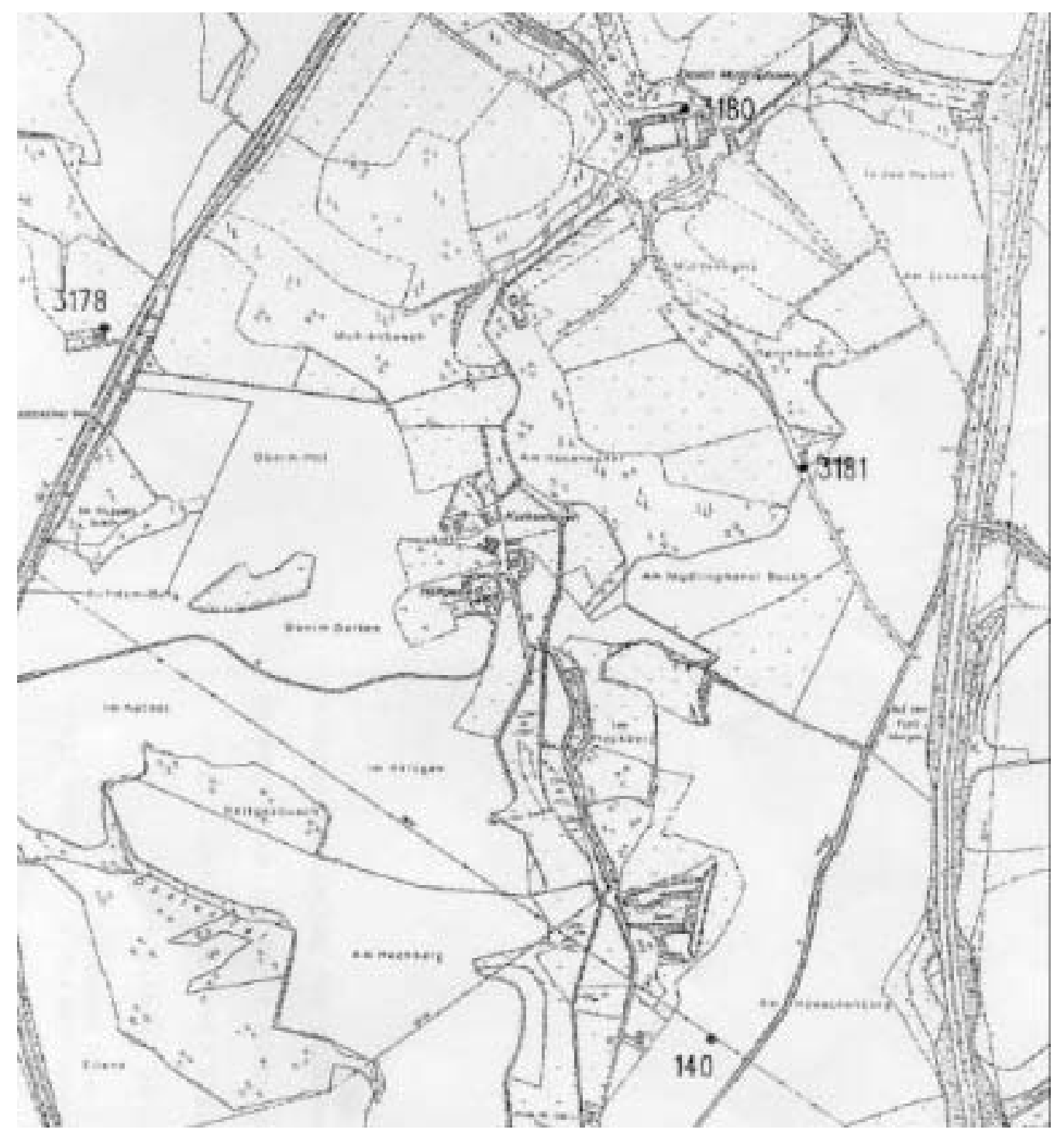

Abb. IX-12: Ausschnitt aus der DGK 5 „Hubbelrath, Dorp West“

Blatt 6278 mit dem Untersuchungsgebiet

Das Hubbelrather Bachtal ist wegen seiner abwechslungsreichen landschaftlichen Vielfalt, der kleinräumigen Strukturierung mit Laubwäldern, Feuchtbiotopen, Hochstaudenfluren, Wiesen und Äckern und der artenreichen Tier- und Pflanzengesellschaften im November 1995 auf eine Fläche von ca. 75 ha unter Naturschutz gestellt worden. Es ist als „landesplanerisch gesichertes Gebiet für den Schutz der Natur im Regierungsbezirk Düsseldorf“ unter der Gebiets-Kenn-Nr.: D_BL_142 eingetragen (MURL 1998). Die Festsetzung erfolgte insbesondere zur Erhaltung und Entwicklung der Lebensraumvielfalt und zur Sicherung und Förderung der Bestände seltener und gefährdeter Pflanzen und Tierarten wie Sumpfdotterblume und Gewöhnlicher Wundklee sowie Eisvogel, Wasseramsel und mehrerer Libellen- bzw. Amphibienarten. Bei der „Objektbeschreibung“ wird das Bachtal aus ökologi- 
scher Sicht in seiner Artenzusammensetzung und hinsichtlich seines Artenvorkommens als Bestandteil des landesweiten Biotopverbundes beschrieben. Als „kulturhistorische Besonderheiten“ werden hier nur ,alte Hohlweg-Reste auf den West-Hängen“ (d. h. die oben genannte „Mühlenstraße“) explizit aufgeführt. Hinweise auf die alten Mühlenteiche findet man nur - eingebunden in den Fließtext - an einer Stelle („Talsohlen mit Röhrichten [offengelassenen Fischteichen])“ (MURL 1998:28).

Hier wird aber die ehemalige Nutzung als Mühlenstauteich außer Acht gelassen und die gängige primäre und singuläre Nutzung als Fischteich kolportiert. Hier wird zu zeigen sein, dass die Unterschutzstellung mit der naturschutzfachlichen Perspektive der natürlichen Entwicklung schon heute zu einer Reliktsituation geführt hat und bei weiterer Sukzession die verbliebenen Elemente der historischen Kulturlandschaft gänzlich verschwunden sein werden.

Es wird weiterhin zu zeigen sein, dass der Denkmalschutz durch sein Konzept der Archivierung nicht zum Erhalt der kulturhistorischen Gewässerlandschaftselemente beiträgt und auch nicht alle ehemals zum eigentlichen „Ensemble“ Wassermühle gehörigen Mühlenteiche berücksichtigt und in denkmalpflegerischen Fragen - im Zusammenhang mit einer als Ausgleichsmaßnahme durchzuführenden Gewässerrenaturierung - ihr Augenmerk allein auf die Gebäudehistorie legt.

\section{a.2 Die Mydlinghover Mühle}

Siedlungshistorisch betrachtet handelt es sich bei der Wassermühle um eine Wüstung: Die Mühle liegt in einem fossilen Zustand vor und nur noch einige reliktäre Zeugen sind im Gelände zu entdecken, zu denen neben den Mauerfundamenten vor allem die Mühlenteiche gehören.

Die „Mydlinghover Mühle“ ist aufgrund von Vorarbeiten einer AG Archäologie ${ }^{8}$ seit 1994 als Bodendenkmal beim Rheinischen Amt für Bodendenkmalpflege, Außenstelle Overath, registriert; sowohl als Siedlung, technische Anlage und als Flurrelikt. Die bodendenkmalpflegerische Aufnahme des Bodendenkmalensembles „Mydlinghover Mühle“ umfasst Gebäudereste der Mühle, ein Stauwehr und den Mühlenteich.

1508 wird im Zehntregister der Äbtissin von Gerresheim, einem heutigen Stadtteil von Düsseldorf, der Hof „Haus im Winkel“ genannt, dem eine Mühle angeschlossen war. Die Mühle lag einige Meter nördlich des Hofes, der sich wiederum unmittelbar östlich von „Gut Höltgen“ und dem „Gut Kothenhoven“ befand. Bei den Gütern handelte es sich wahrscheinlich um ehemaliges Klostergut, das aber bereits im 15. Jahrhundert und bis ins 20. Jahrhundert hinein zum Grund und Boden der oberhalb liegenden alten Rittersitze Bruchhausen und Mydlinghoven gehörte. Der Hof Kothenhoven („Koddengut"), der bereits $1730 \mathrm{zu}$ einem unbedeutenden „Kothen“ (Kotten) geworden war und fortan als eigenständiges Nebengebäude des Gutes Höltgen galt, bestand bis in die 1970er Jahre und fiel erst der Düsseldorfer Mülldeponieanlage zum Opfer (BUSCHMANN-HÖLTGEN 1986:175). Auch das „Haus im Winkel“, im Jahr 1800 noch bewohnt, wurde später vollständig in Gut Höltgen integriert und in der ersten Hälfte des 19. Jahrhundert wegen Baufälligkeit abgerissen (:179), ist aber auf der Kartenaufnahme von MÜFFLING von 1824-25 noch verzeichnet. Die Wassermühle hingegen überstand diese frühen wirtschaftlichen Zusammenlegungen und Betriebsaufgaben weiterhin an ihrer Stelle.

\footnotetext{
${ }^{8}$ Hier konnte vor allem auf Vorarbeiten der ehrenamtlichen „Archäologischen Arbeitsgruppe Düsseldorf bei der Außenstelle Overath des Rheinischen Amtes für Bodendenkmalpflege“" (hier kurz AG Archäologie) und auf die Untersuchungen des Hobbyarchäologen Peter Schulenberg zurückgegriffen werden, der diese „Wüstung“ aufgrund seiner Ortskenntnis, der mündlichen Überlieferung und der Auswertung historischer Karten wiederentdeckte. Im Frühjahr 1994 kartierten Mitglieder der AG Archäologie die nur noch schwach im Gelände sichtbaren Reste der Mydlinghover Mühle. Insgesamt sechs erkennbare Fundstellen und Flurrelikte wurden im Zuge der Kartierung eruiert und mit dem Maßband eingetragen.

Eigene Archivforschung im nordrhein-westfälischen Hauptstaatsarchiv, die Durchsicht alter topographischer Karten (Urkataster) in Verbindung mit historisch-geographischer Geländebegehung und Reliktbestimmung stellen die weiteren Hauptuntersuchungsmethoden dar.
} 


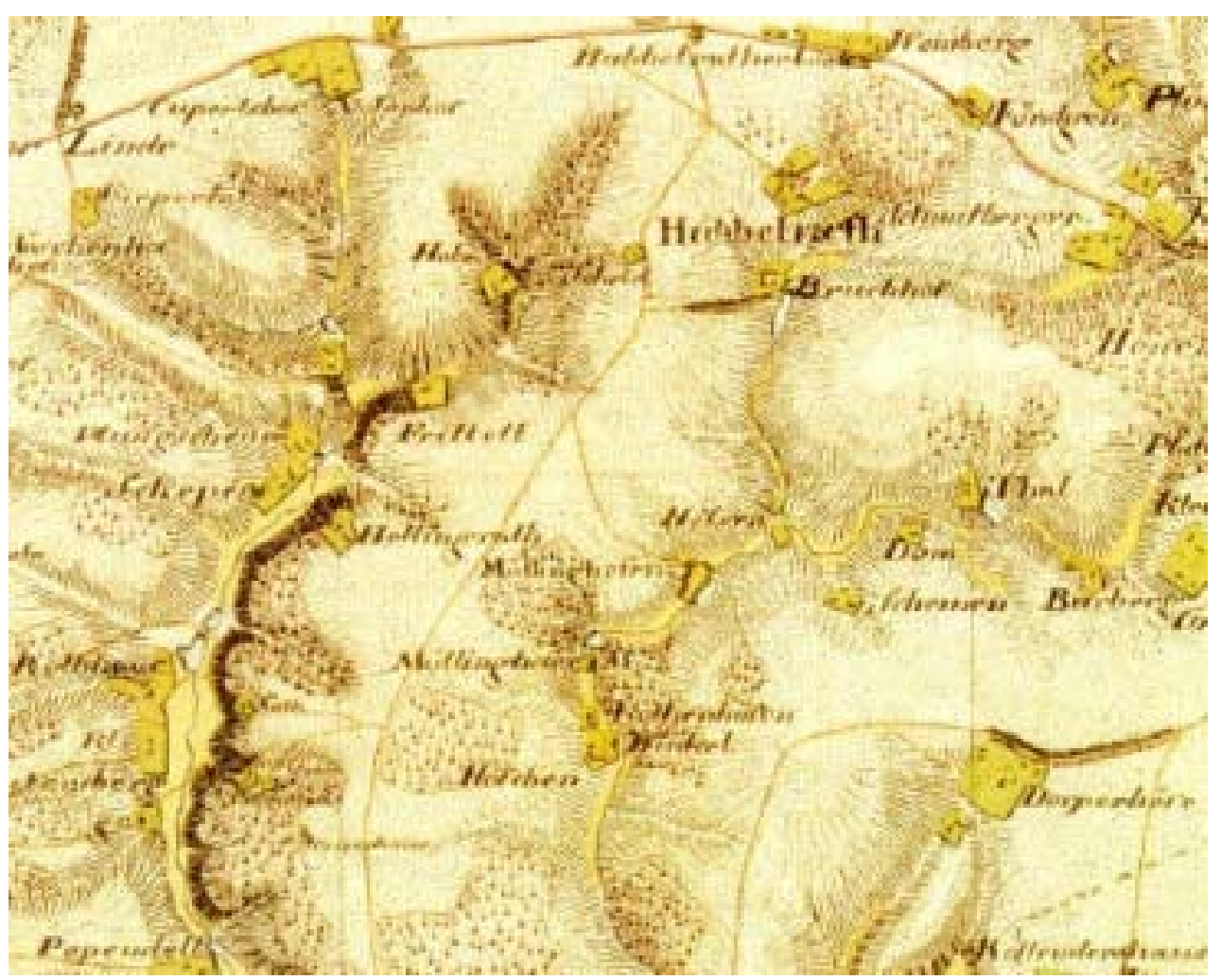

Abb. IX-13: Ausschnitt aus der topographischen Aufnahme des „Nördlichen Bergischen Landes“

Kartenaufnahme der Rheinlande von MÜFFLING 1824-1825. Das „Haus im Winkel“ erscheint hier als „Winkel“, das „Gut Höltgen“ als „Höfchen“, das „Gut Kothenhoven“ als „Kothenhöfen“, das „Gut Mydlinghoven“ als „Müllinghofen“ und die „Mydlinghovener Mühle“ als „Müllinghofer M.“.

Im Gerresheimer Kirchbuch ist von 1683 bis 1692 Wilhelm und Sybilla Neuhausen vom Winkelhof als Müller an der „Müllinghofener Meules“ erwähnt. Die Mühle, und dies ist ungewöhnlich, wenn sie einem anderen Gut, hier dem „Haus im Winkel“ zugeordnet wird, nennt sich nach dem weiter nördlich gelegenen Rittergut Mydlinghoven, das im Heberegister des Stiftes Gerresheim 1213-31 genannt und 1479 als Rittergut verzeichnet ist (BUSCHMANN-HÖLTGEN 1986:177; SCHULENBERG 1996:73). Für welche Höfe also sowie in welchem Umfang die Mühle arbeitete und wann der Betrieb eingestellt wurde, ist nicht bekannt. Den Katasterunterlagen nach wurden die Gebäude kurz vor 1928 endgültig abgerissen.

Der ehemals feuchte Talgrund ist heute teilweise aufgeschüttet und wird zeitweise als Extensivweide genutzt. Unter dieser Aufschüttung liegen die Reste von mindestens zwei Nebengebäuden und der ursprüngliche Mühlengrabenverlauf verborgen. 


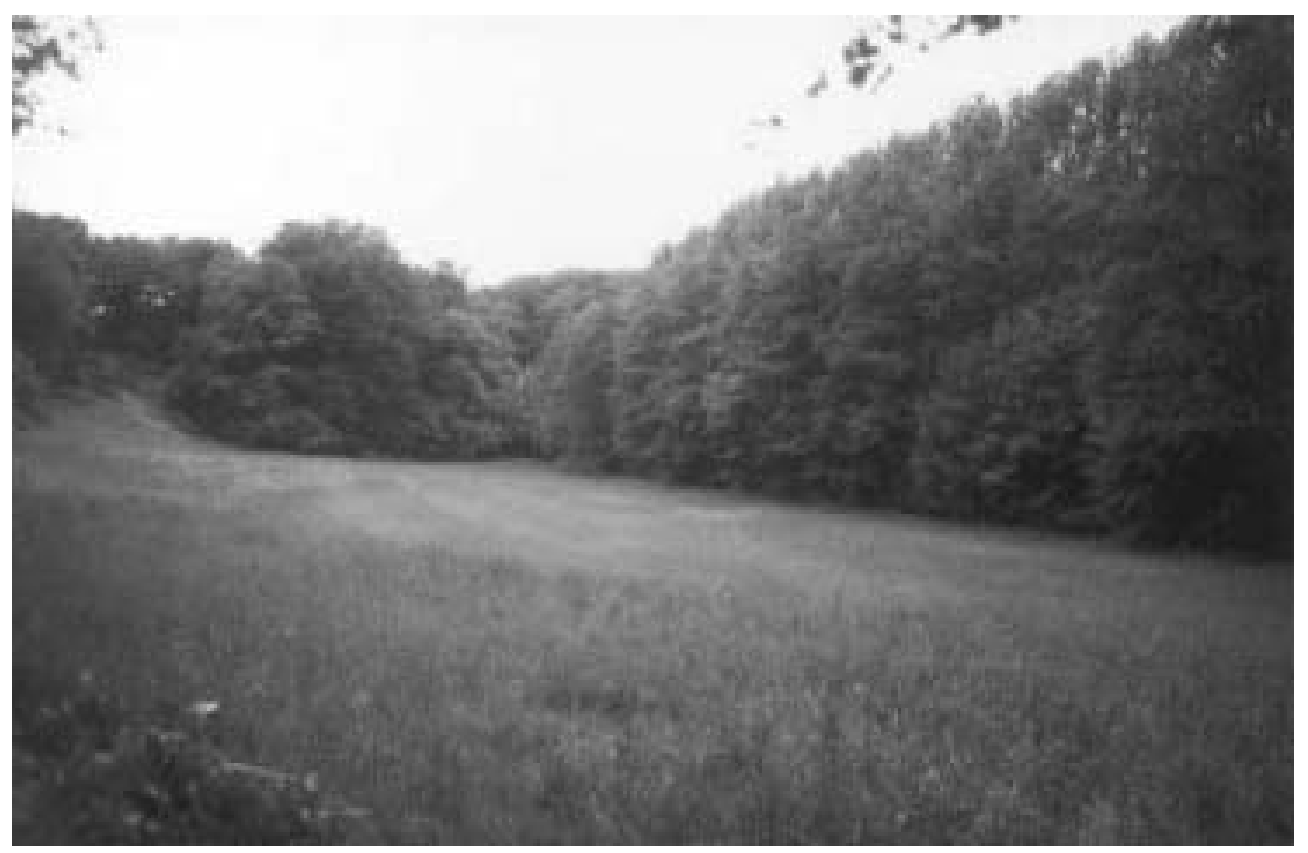

Abb. IX-14: Blick auf den ehemaligen Standort der „Mydlinghovener Wassermühle“ am hinteren Waldsaum. Von den Mühlenbauten ist unter Gras nichts mehr erkennbar (eig. Aufnahme 2002).

\section{a.2.1 Die Mühlgebäude}

65 m nördlich des Gut Höltgen befinden sich am Rand eines künstlich aufgeschütteten Dammes in einer $8 \mathrm{~m}$ breiten und etwa 5,50 m langen Mulde die stark von Brennnesseln und Moosen überwachsenen und nur wenige Zentimeter aus dem Boden ragenden restlichen Fundamente der Mydlinghover Mühle (SCHULENBERG 1996:69f.). Sie bestand ehemals aus mehreren Gebäuden: einem Haupt- und zwei Nebengebäuden, die aus Feldbrandziegeln errichtet wurden.

Die freigelegte Ziegelmauer besitzt ein $\mathrm{Ma} \beta$ von 8,50 m Länge und 0,25 m Breite. Es wurde von SCHULENBERG (1996:71f.) festgestellt, dass die Fundamente der Mühle mit devonischem Flinzschiefer verstärkt und vermörtelt waren. $150 \mathrm{~m}$ südlich der Wüstung, im Bereich der unter der Deponie verschwundenen Wüstung Kothenhofen, ist dieses Gestein in einem dichtbewachsenen Steinbruch aufgeschlossen. Es ist nach seiner Ansicht zu vermuten, dass Mauersteine für Gut Höltgen, Kothenhoven und die Mühlengebäude „mindestens seit der ersten urkundlichen Erwähnung dieser Höfe im Jahre 1508“ hier ausgebrochen worden sind (:71f.).

Der vorgefundene „,nach Süden laufende östliche“ Mauerrest ist „wahrscheinlich Teil des östlichen Mühlenhauses“ (SCHULENBERG 1996:71f.). Auf der Müffling-Karte von 1824/25 sind im untersuchten Bereich zwei Gebäude nur andeutungsweise abgebildet. Die Urkarte von 1830 zeigt demgegenüber maßstabgenau ein rechteckiges Hauptgebäude und ein etwas nach Südosten versetztes kleineres, fast quadratisches Haus. Das zweite auf der Urkatasterkarte eingezeichnete Gebäude konnte von der AG Archäologie jedoch nicht sicher lokalisiert werden (:71f.). Auf der Preußischen Uraufnahme von 1843/44 ist dann im mittleren Teil der südlichen Wiese ein drittes Gebäude quer zu den anderen verzeichnet, während in einer Karte von 1851/69 („Bürgermeisterei-Karte“) nur noch ein Gebäude verzeichnet ist. In einer sehr genauen Flurkarte von 1906 hingegen sind wiederum zwei Mühlengebäude lagegenau eingezeichnet. Auf einer Karte von 1926 sind dann die Häuser verschwunden. 


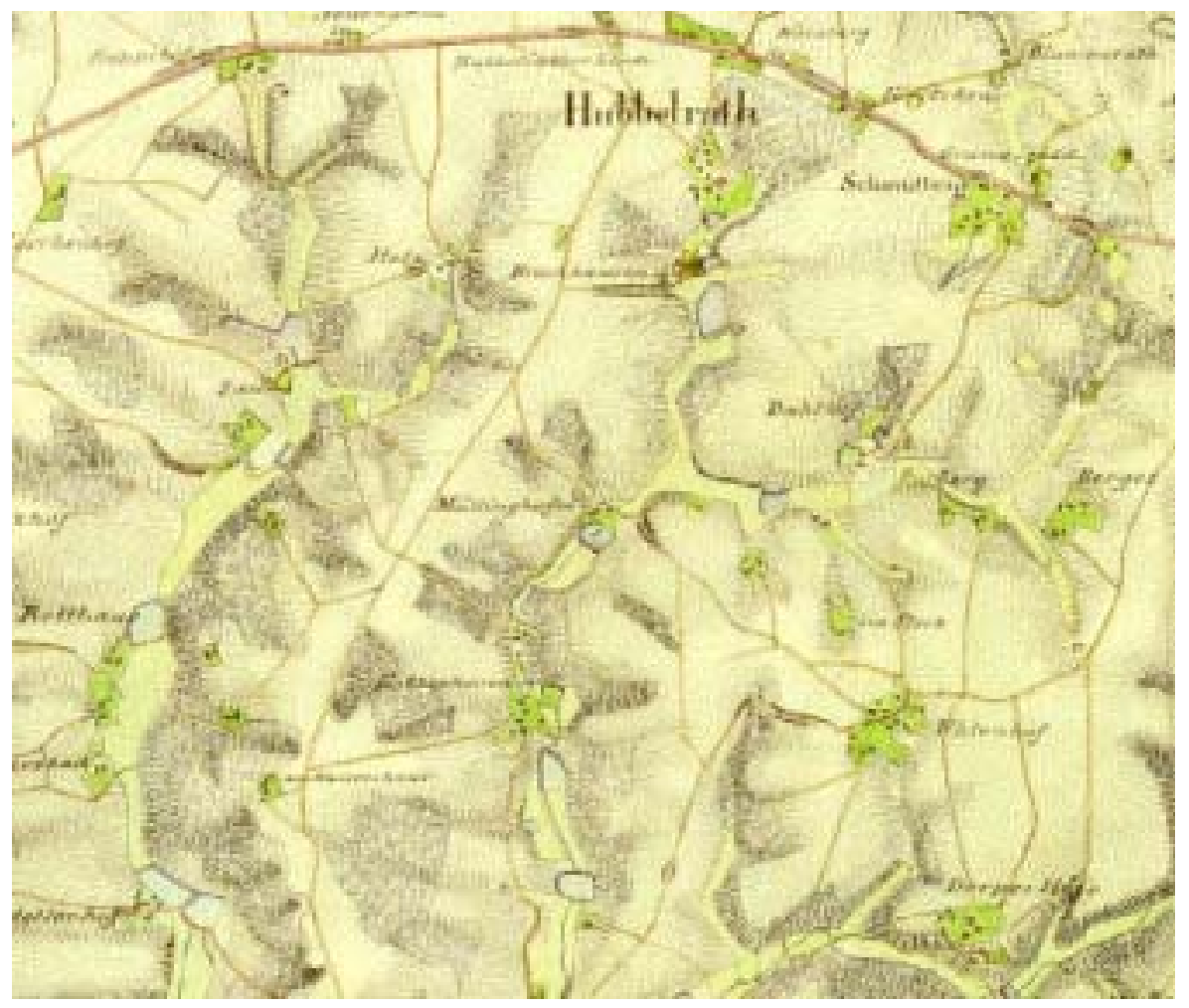

Abb. IX-15: Preußische Uraufnahme von 1843/44

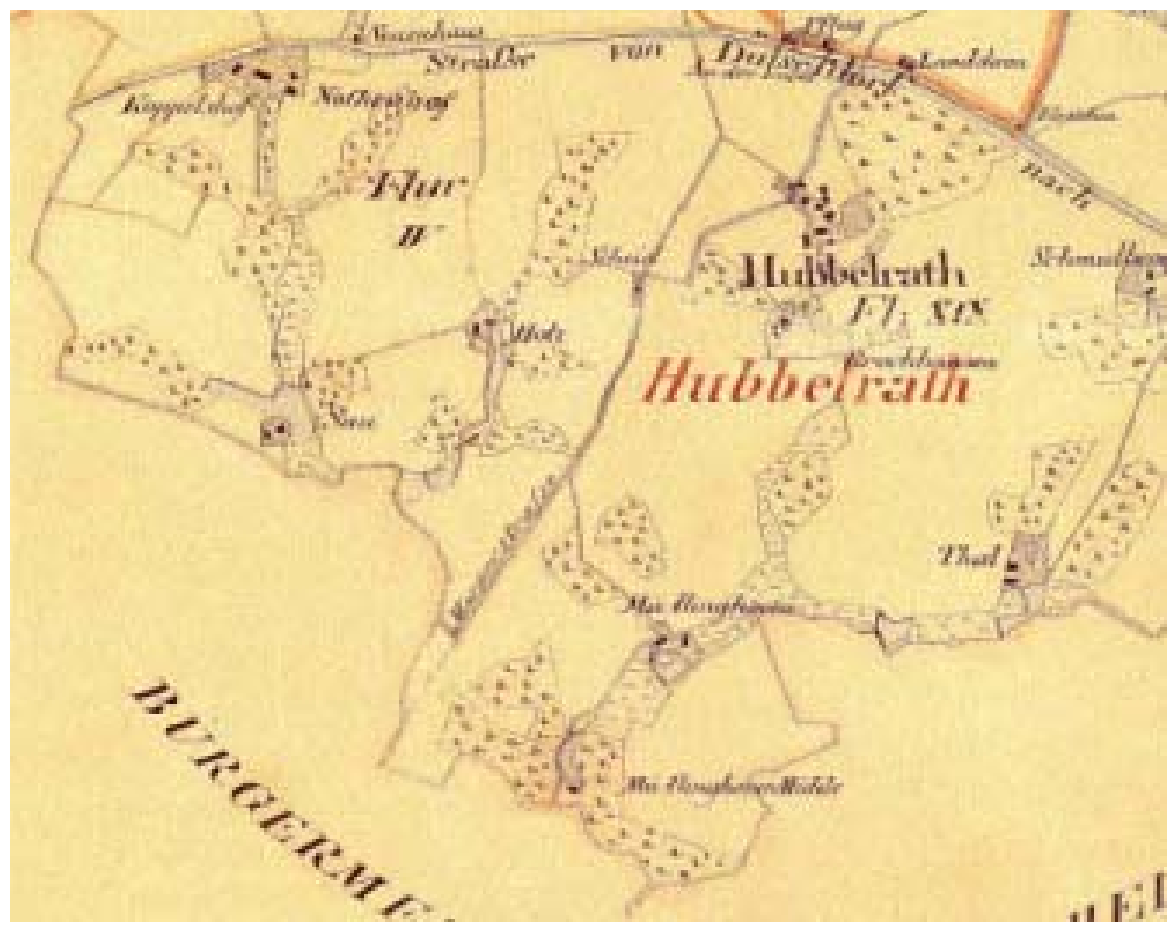

Abb. IX-16: „General-Karte der Bürgermeisterey Hubbelrath [...]“ (1851/1869)

Die Karte wurde bereits im Jahre 1851 aufgenommen, aber erst 1869 durch den Regierungsbezirk Düsseldorf bewilligt.

Endgültige Klarheit verschaffte die Einsicht von Unterlagen des Katasteramtes Düsseldorf. 1928 sind als letzte Grundstückseintragung die beiden Gebäude aus der Urkarte von 1830 mit Tinte durchgestrichen. Ein Abriss kurz vor 1928 ist also anzunehmen. Dies entspräche auch den wenigen geborgenen Fundstücken, die „um 1920“ datiert werden. Im Widerspruch dazu stehen die Topographische Karte von 1930 und ein Lageplan von 1932, die noch zwei Gebäude wiedergeben. Im 
ersten Fall scheint die lange Vorlaufzeit der Drucklegung, im zweiten die Verwendung veralteter Unterlagen der Grund zu sein.

\section{a.2.2 Der Mühlteich}

Von dem Mühlengebäude durch einen etwa $5 \mathrm{~m}$ breiten Damm getrennt, liegt nach Norden der im Gelände durch steile Damm- und Geländeränder in seiner ursprünglichen Form noch sehr gut erkennbare, jetzt verlandete Mühlenteich. Gerade der niedere und zum Teil schon recht hohe Bewuchs des Talbodens mit Schwarzerlen, Weiden und Schilfrohr gibt den Umriss des ehemaligen Teiches in der Landschaft deutlich wieder. Der Mühlenteich „füllt hier das enge, S-förmige Tal in einer Länge von $200 \mathrm{~m}$ und bis zu $60 \mathrm{~m}$ Breite aus." (SCHULENBERG 1996:71f.). Der abschließende Teichdamm hingegen ist durch dichtes Gehölzwachstum kaum noch in seiner ehemaligen Dimension wahrnehmbar.

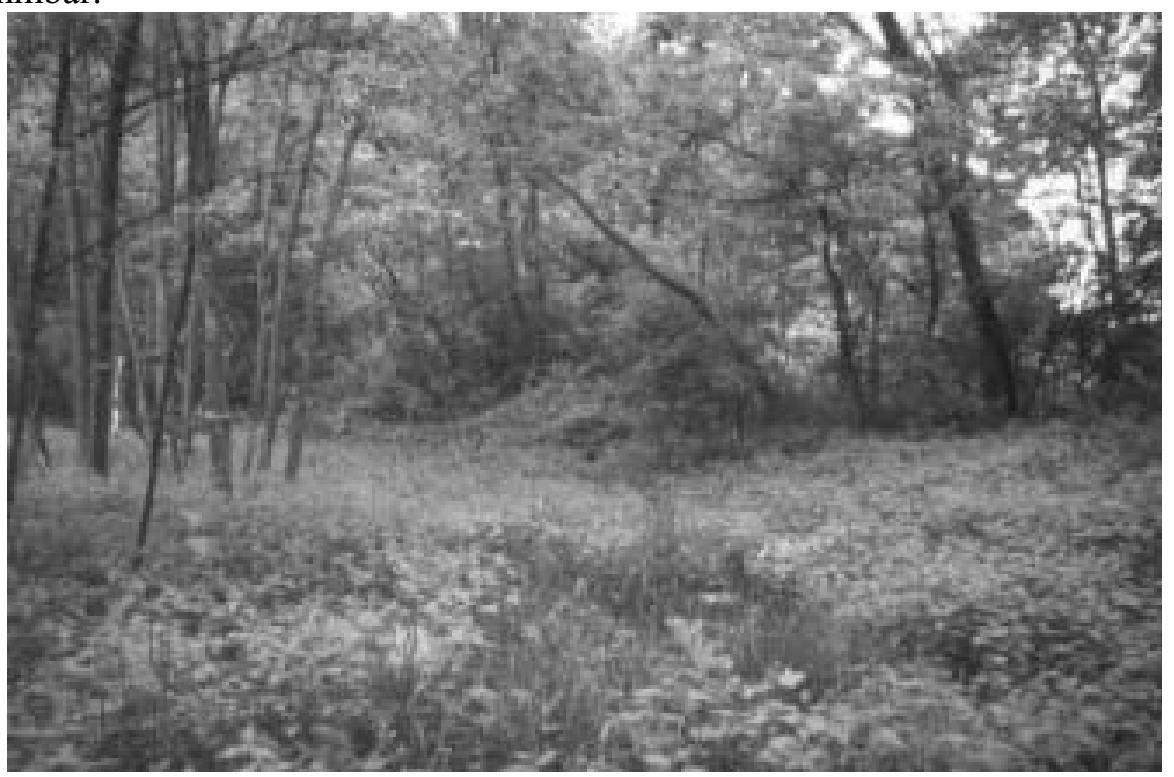

Abb. IX-17: ,Mydlinghovener Mühlenteich’ im stark reliktären Stadium

Durchgängige Verschilfung, Verbuschung mit Auengehölzen, auf trockeneren Standorten schon Koniferengehölz. Im Hintergrund der schon völlig zugewachsene ehemalige abschließende Teichdamm (eig. Aufnahme 2002).

Da ein Mühlenteich erst mit dem Betrieb einer Mühle Sinn macht, kann der Teich hier in Anlehnung an die nur anhand weniger Daten bruchstückhaft vorliegende Geschichte der Mühle rekonstruiert werden. Seit einem 1683 vorgenommenen Eintrag in das Kirchenbuch ist die Mydlinghover Wassermühle bezeugt. Aufgrund der Namensgebung, der Lage der Mühle und des Mühlenteiches, der noch heute zum Grundbesitz des Mydlinghofes zählt, kann von einem Bestand des Mühlenteiches seit dem 15. Jahrhundert, eventuell bereits seit der erstmaligen Erwähnung des Gutes Mydlinghoven im 13. Jahrhundert ausgegangen werden. Diese zeitlichen Annahmen sind entsprechend der zeitgeschichtlichen Variablen des Mühlenbaus, wie sie in ihrer Entwicklung in VIII 2a geschildert worden sind, dennoch vorsichtig $\mathrm{zu}$ betrachten. Auch muss mit einem Mühlenbau nicht zeitgleich ein Mühlenteichbau einhergehen. So können zum Beispiel erst später auftretende wechselnde, periodisch schwache Wasserstände des Baches wie auch ein vermehrter Mahlbedarf eine Wasserbespannung zum Zwecke der Wasserbevorratung notwendig gemacht haben.

Eine Auswertung der historischen Kartengrundlagen vermag aber zumindest die Lage, Form und Größe des Mühlenteiches in ihrem zeitlichen Verlauf zu klären: Auf der ältesten die „Müllinghofer Mühle“ bezeichnenden Karte, der sog. „Müffling-Karte“ von 1824/25, fehlt vom Mühlenteich die spätere nördliche Hälfte und der Teich besitzt ein eher trapezförmiges Aussehen. Auf der Preußischen Uraufnahme von 1843/44 entspricht die Lage des Teiches mit seiner länglichen, gebogenen Form der Darstellung in der „Bürgermeisterei-Karte“ von 1851/69. In der Kartenaufnahme von 1926 (Maßstab 1:10.000) ist dann der Mühlenteich als Wiese wiedergegeben. 
In der Frage nach dem Zeitpunkt der Offenlage des Mühlenteiches verschaffte erst die Einsicht von Unterlagen des Katasteramtes Düsseldorf endgültige Klarheit. 1928 ist der Teich auf der Urkarte von 1830 durch Schraffur als Wiese gekennzeichnet. Ein Verwahrlosen, Trockenfallen und nachfolgend ein Zuwachsen nach 1928 ist also anzunehmen. Im Widerspruch dazu stehen hier die Topographischen Karte von 1930 und ein Lageplan von 1932, die die Wiese noch als Teich wiedergeben. Die Begründung dafür kann die gleiche sein wie bei den Mühlengebäuden, möglicherweise aber stand der Teichbereich zu diesem Zeitpunkt noch unter Wasser.

Bei Betrachtung des Aufwuchses im Rahmen einer Geländebegehung kann eine nunmehr 60-70jährige Trockenlegung bestätigt werden. Auf dem Teichboden haben sich in einigen Bereichen bereits hochstämmige Bacherlen-Eschenwaldgesellschaften und Weidengebüsche, in anderen großflächige Schilf- und Rohrkolbenröhrichte und Großseggenriederbestände eingestellt, die auf ein etwa 60jähriges Trockenfallen hinweisen. Diese auf pflanzensoziologische Ausprägungen beruhende Annahme fände ihre Entsprechung in dem nach dem Ersten Weltkrieg noch einmal aufgenommene Teichbewirtschaftung, die aber dann der Konkurrenz der Großmühlen weichen musste. Andere Gründe können in der allgemeinen Aufgabe des Ortes, der schwierigen An- und Ablieferungswege, der Abgeschiedenheit zu den Abnehmermärkten und der Ent-Aristokratisierung liegen.

Südlich des Teiches und der ehemaligen Mühlengebäude befindet sich ein weiterer reliktärer Teich, wenngleich in seinem Verlandungsstadium noch nicht so weit fortgeschritten. Er entspricht in seinem Aufbau dem gängigen, noch heute aktuellen Teichbauschema.

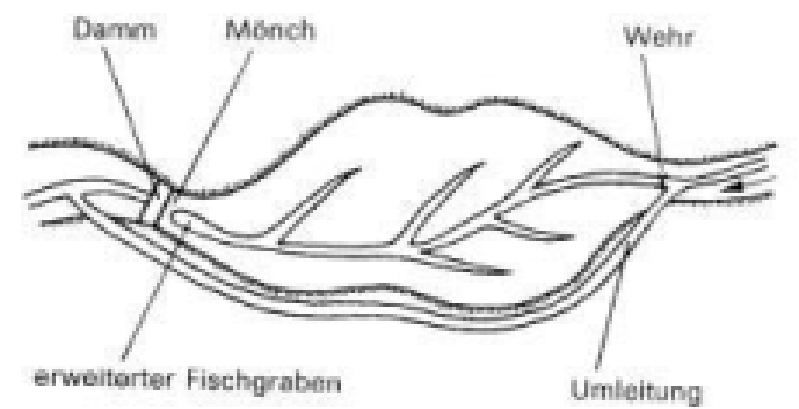

Abb. IX-18: Fischteich in Bachtal mit Fischgräben, abgeleitetem Umlauf, Teichmönch mit Teichdamm (aus: ZOBEL 1992:18)

Sämtliche $\mathrm{Zu}$ - und Ablaufvorrichtungen sind nicht mehr vorhanden, einzig ein den ehemaligen Hauptfischgraben folgender Wasserdurchlauf durch den Teichboden sowie die Stellen, an denen die Teichbauten gestanden haben, lassen sich noch im Gelände rekonstruieren. Unterhalb lässt sich der ehemals den Teich abschließende Dammrest erkennen, der jedoch das Tal nicht mehr zu schließen vermag, da er nur bis zur Hälfte erhalten geblieben ist.

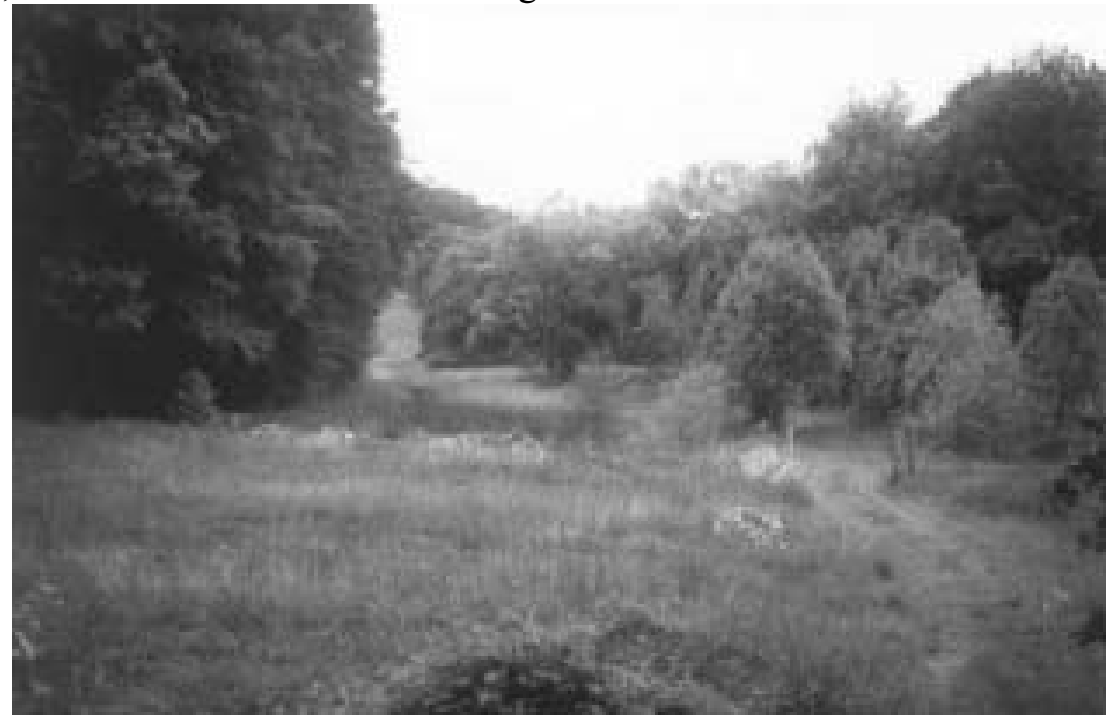

Abb. IX-19: Trockengefallener Teich südlich der ehemaligen Mydlinghovener Mühle 
Im Hintergrund der quer verlaufende ehemalige Teichdamm mit durchbrochenen einreihigen Eichenbeständen. Der Anschluss an den Talhang wird aber nicht mehr erreicht, $\mathrm{Zu}$ - und Ablaufvorrichtungen fehlen. Der Teichboden ist bereits mit Primärgehölzen bestockt (eig. Aufnahme 2002).

Aufgrund seiner unterhalb der Mühle befindlichen Lage kann jedoch kein mühlenbautechnischer Zusammenhang hergestellt werden, eine Wasserbeaufschlagung beispielsweise war aufgrund des Gefälles nicht möglich. Zu vermuten ist hier, da Quellen über eine weitere Mühle nicht vorliegen, eine fischereiwirtschaftliche Nutzung dieses Teiches.

\section{a.2.3 Der Mühlbach}

Nördlich vom Rittergut Mydlinghoven kommend, fließt die Hubbel in einem streng geradlinigen, kanalisierten Kanalbett dem Mühlenteich zu und an der Ostseite des ehemaligen Mühlenteiches als stark eingetiefter Bach zur unterliegenden ehemaligen Mühle weiter.

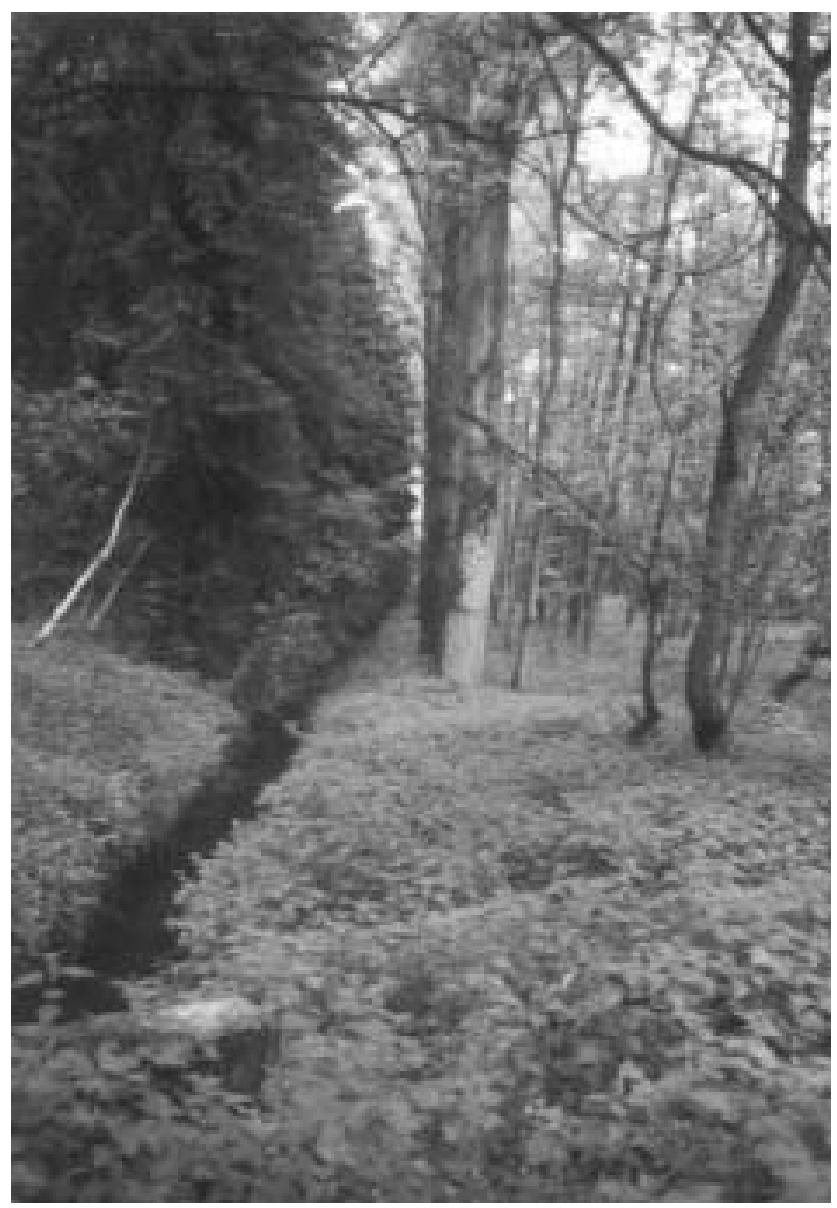

Abb. IX-20: Kanalisierter, linear verlaufender Mühlenkanal im Mydlinghovener Bachtal (eig. Aufnahme 2002)

Durch ein Raster von eingemessenen Höhenpunkten wurde von der AG Archäologie versucht, den alten Bachverlauf in einer Oberflächenreliefkarte zu lokalisieren (SCHULENBERG 1996:71f.). In Verbindung mit der Urkarte von 1830 zeigt sich folgendes Bild: Etwa $20 \mathrm{~m}$ westlich des heutigen Bachverlaufes aus dem Mühlenteich kommend durchstach der Mühlenbach den angrenzenden Damm und floss ursprünglich an der östlichen Längsseite des Hauptgebäudes der Mühle vorbei, wo auch der Standort des Mühlrades gewesen sein muss, um nach der Beaufschlagung durch die südlich vorgelagerte Wiese und dann am östlichen Hangfuß weiterzulaufen. 


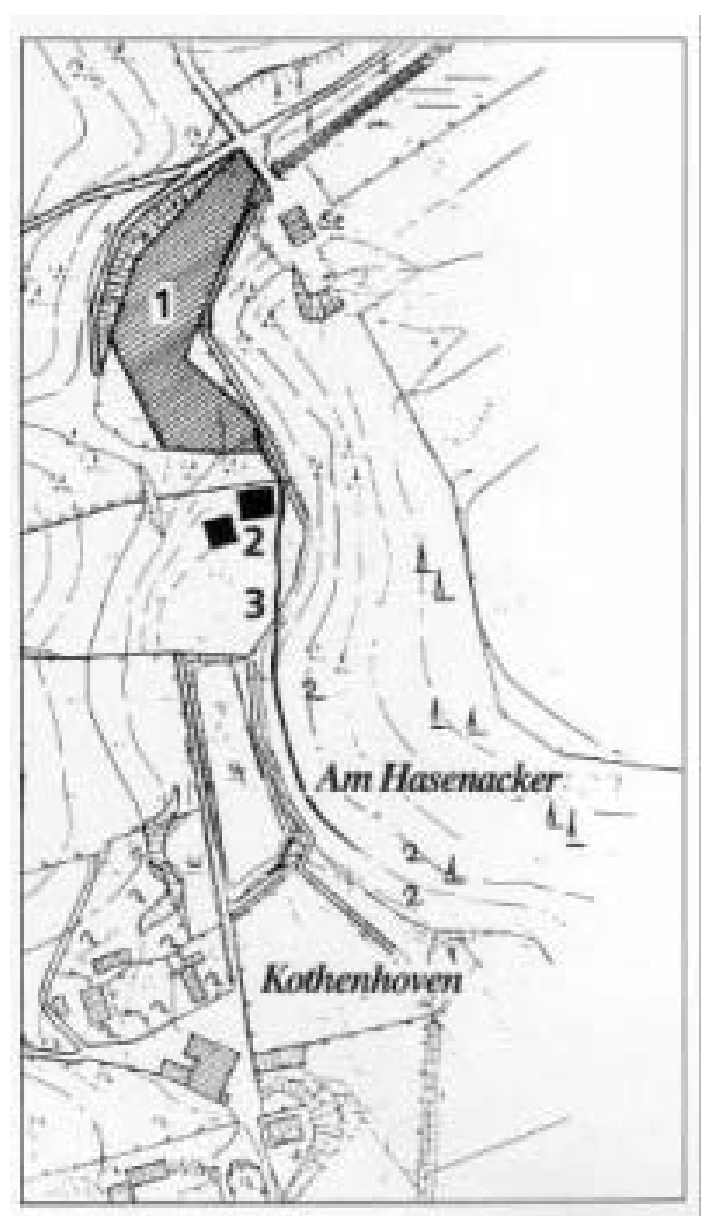

Abb. IX-21: Übertrag des Mühlenteiches [1], der Mühlengebäude [2] und des Mühlengrabens [3]

auf eine DGK 5 (aus: SCHULENBERG 1996:75). Die in der oberen Bildmitte, am nordöstlichen Teichrand zu sehende Signatur „St" steht für Stallung und beherbergte früher die Pferde des Gestütes. Sie ist im starken Verfall begriffen.

\section{a.2.4 Stauwehre}

Am nördlichen Einlauf des Mühlengrabens in den Mühlenteich ist ein in Betonausführung erneuertes „Wehr“ im Gelände zu erkennen. Das Wehr besitzt keine Stau- oder Ableitungsfunktion mehr und kann in die 1920/30er Jahre datiert werden. Der Sockel hat eine Länge von 1,30 m, eine Breite von $0,50 \mathrm{~m}$. Der Durchlass mit einer Einsparung für das ehemalige Sperrtor ist 1,85 m hoch. Es kann sich aufgrund seiner Konstruktion nicht um ein kombiniertes Stau- und Ableitungswehr handeln und ist dementsprechend in seiner ursprünglichen Funktion verändert worden. Es diente der Wasserstandsregulierung des Baches oder des ehemaligen Mühlenteiches. Dieser östliche Betonsockel ist durch Hang-Erosion fast verschüttet. 


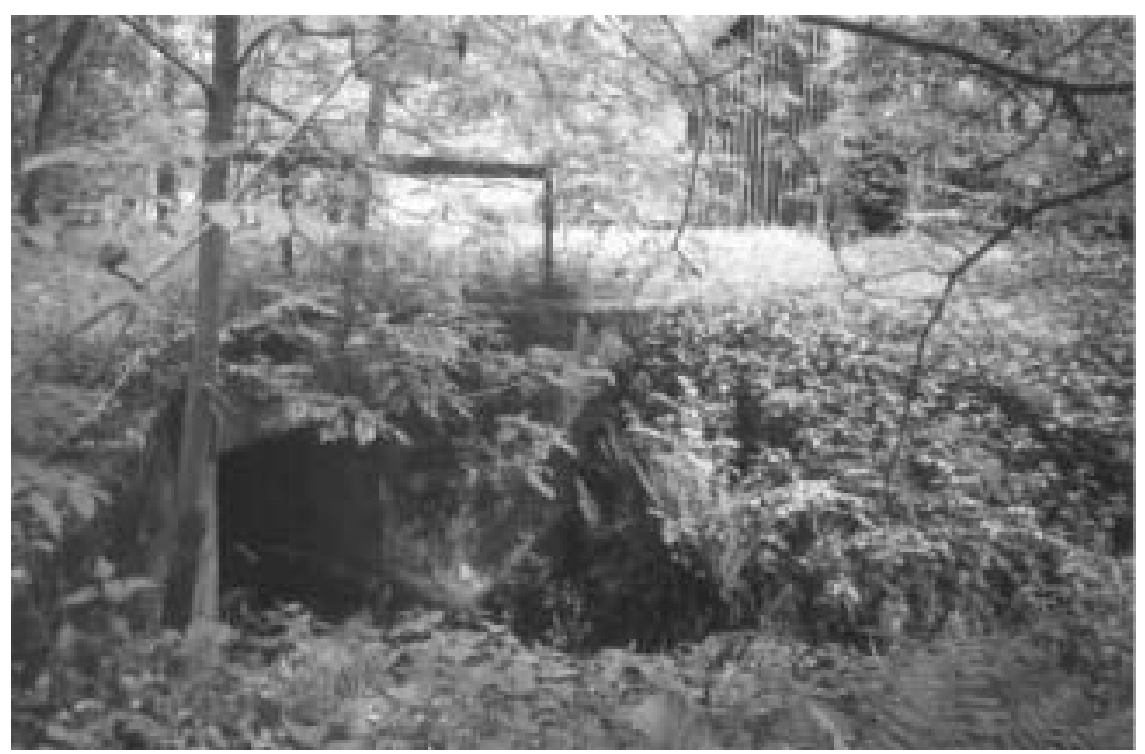

Abb. IX-22: Rest einer ehemaligen Staustufe am Ende des linearen Mühlenkanals

mit Überwegung. Im Hintergrund ist eine zum Gestüt gehörige im Verfall begriffene Stallung mit Boxen zu erkennen (eig. Aufnahme 2002).

Von den eigentlichen Ein- und Ablassvorrichtungen, die nördlich, am Teichanfang, wahrscheinlich als seitliche Einleitung, vorhanden waren, und die im südlichen Teichdamm nachgewiesene Ablassvorrichtungen des Mühlenteiches ist nichts mehr übrig geblieben. Eventuell könnten hier Fundamentgrabungen und Querschnitte Fragmente sichtbar machen.

Die Auswertung eines Lageplanes von 1906 - basierend auf dem Urkataster von 1830 - wiederum ergibt eine andere Zulaufführung, die nicht am oberen rechten Teichrand den Teichzulauf in Form einer Schütze wiedergibt, sondern am linken oberen Teichrand.

\section{a.2.5 Planungspraxis: Natur- und Denkmalschutz}

Aufgrund der in der Roten Liste NRW gefährdeten Biotoptypen Wiesentäler und Überflutungsauen, Groß- und Kleinröhrichte, seggen- und binsenreiche Feucht- und Nasswiesen, Auengebüsche und -wälder und Kleingewässer, die nach $\S 20 \mathrm{c}$ BNatSchG einem besonderen Schutz unterliegen, wurde das Hubbelrather Bachtal als Naturschutzgebiet ausgewiesen. Auf Düsseldorfer Stadtgebiet gibt es, so die naturschutzfachliche Bewertung, abgesehen von einem weiteren Bachtal, „keinen vergleichbar wertvollen Talbereich.“ (LÖLF 1988)

In der gutachterlichen Stellungnahme zur Unterschutzstellung des geplanten Naturschutzgebietes „Hubbelrather Bachtal“ der Landesanstalt für Ökologie des Landes NRW (LÖLF 1988) wird auf die gewässerkulturhistorische Bedeutung des Bachtals und insbesondere des ,Mydlinghofener Mühlenteiches' jedoch nicht differenziert eingegangen. Es werden lediglich zwei südlich von Gut Höltgen gelegene und bewirtschaftete Fischteiche genannt (die außerhalb des Untersuchungsraumes liegen und hier nicht weiter zur Betrachtung stehen) sowie „ein weiterer genutzter Fischteich“ bei Kothenhoven; hierbei dürfte es sich um den beschriebenen trockengefallenen Teich südlich der Mühlenstandortes gehandelt haben. Aber ,aus Naturschutzsicht interessanter“, so ist weiter zu lesen „sind zwei kleine, offensichtlich nicht mehr genutzte Fischteiche östlich Kothenhoven“, die hier ebenfalls nicht Gegenstand der kulturhistorischen Gewässeraufnahme sind, aber symptomatisch für die ökologischorientierte Behandlung von Kulturgewässern stehen.

Da also in diesem Gebiet ,keine Maßnahmen durchgeführt werden sollen, die zu einer Zerstörung oder sonstigen erheblichen oder nachhaltigen Beeinträchtigung führen können“, wird das Areal der natürlichen Sukzession überlassen mit der Folge, dass der erwähnte Teich bei Kothenhoven, nach meinem Befund seit Jahren ohne Frischwasserzufuhr, ein abgeschlossenes Stillgewässer im fortgeschrittenen Verlandungsstadium ist, in dem keine Fische mehr gehalten werden können. Der den 
Teich südlich abgrenzende Teichdamm schließt nicht mehr - wie beim Teichbau üblich - bis zum Talhang auf. Ein Wehr ist an der schmalsten Stelle nur noch zu vermuten. Und die genannten zwei kleinen Fischteiche im Gelände sind entgegen ihres Ursprungs in unterschiedlicher Form und Funktion auffindbar. Der eine, nordöstliche Teich dient als Sickerwasserauffangbecken der Mülldeponie, der andere östliche Kleinteich ist von einer Frischwasserzufuhr völlig abgeschlossen und besitzt Brackwassercharakter. Der „Mydlinghover Teich“ hingegen wird in dem Gutachten gar nicht angesprochen, so dass der räumlich-historische Bezug und die konkrete Kulturlandschaftselementansprache undeutlich bleiben.

Dieser zukünftigen Projektierung des Überlassens steht, so könnte man meinen, der Entwurf des Landschaftsplanes der Stadt Düsseldorf gegenüber, der folgende Aussage zum Entwicklungsziel trifft: Das Hubbelrather Bachtal soll in seiner Geländegestalt mit seinen Hang- und Schluchtwaldbereichen, einer bemerkenswerten Parkanlage mit Allee, Wiesen und Weiden (siehe unten) ,sowie dem Gewässer mit Verlandungsbereichen und Teichen erhalten bleiben“. Geeignete Pflege- und Erhaltungsmaßnahmen, die diese Zielsetzung zu realisieren vermögen, blieben jedoch bislang aus.

Erschwert wird eine durchzuführende Rekultivierung des Geländes durch die Besitzverhältnisse. Der ,Mydlinghover Teich' gehört zum 12 ha umfassenden Privatbesitz des ehemaligen Rittergutes und der heutigen Seniorenresidenz; die südlich des Teichdammes befindliche Fläche, mit dem Mühlenbodendenkmal und weiteren Teichen, befindet sich im städtischen Besitz.

Des Weiteren wurde für das in städtischem Besitz befindliche Gelände zum Ausgleich für Deponieerweiterungen der Mülldeponie Hubbelrath vor Jahren ein Renaturierungsplan diskutiert. Es sah unter anderem vor, die südliche Wiese zu bepflanzen und wieder zu vernässen. Eine Realisierung dieser Maßnahme unter kulturhistorischer Betrachtungsweise würde aber eine Wiederbespannung zur Zielsetzung haben.

Darüber hinaus kann hier von einer „Schutzgebietskonkurrenz“ gesprochen werden, die der Naturschutz für sich entschieden hat. Die vom Rheinischen Amt für Bodendenkmalpflege bestimmten Bodendenkmäler sind auch zu solchen geworden: überwachsen, beweidet, eutrophiert und kaum mehr wahrnehmbar.

Es wäre demzufolge aus kulturhistorischer Sicht wünschenswert, wenn die landschaftsprägenden historischen Gewässerrelikte nicht dem Natur- und Landschaftsschutz übergeben würde, nicht als Bodendenkmäler ihr Dasein unterirdisch fristen müssten und auch nicht dem privatem Desinteresse unterliegen würden. Eine erneute Inwertsetzung des oberen Mydlinghovener Teiches, wenn auch nicht in der Funktion als Mühlenteich, so doch als Fischteich, ist insofern nicht abwegig, als die oben erwähnten weiter südlich angrenzenden Teiche einer fortdauernden fischereiwirtschaftlichen Nutzung unterliegen.

\section{a.3 Das Rittergut Mydlinghoven}

Bislang wird in den Planungen und Gutachten nur von einem Mühlenteich und einer Mühle ausgegangen. Völlig unberücksichtigt bleibt ein von mir als ,Oberer Mühlenteich' bezeichneter ehemaliger Teich oberhalb des eigentlichen „Mydlinghover Mühlenteiches“. Auf seine Existenz kann nur vage a) methodisch mit einer kartographischen Rekonstruktion auf der Grundlage von Altkarten und b) aus der Baugeschichte des Rittergutes geschlossen werden. Weitere Rückschlüsse lassen geländetopographische Aufnahmen und die Kenntnisse allgemeiner Mühlenbauweise zu, da selten an einem Bachlauf nur eine Mühle und ein Mühlenteich zu finden ist.

\section{a.3.1 Baugeschichte}

Das ehemalige Rittergut Mydlinghoven bestand aus mehreren Gebäuden, deren Zahl, Funktion und Anordnung sich im Laufe der Zeit verändert haben. Der Hauptkomplex liegt in der Aue des Hubbelrather Bachtales (Mydlinghover Baches). 
Beim dem Rittersitz Mydlinghoven handelte es sich um ein Mannlehen der Herzöge von Berg, das freies rechtes Erbe war. Nach mehreren Pachtwechseln war Mydlinghoven Anfang des 19. Jahrhunderts noch im Besitz der Grafen von Elmendorf. Sie verkauften das Gut in der ersten Hälfte des 20. Jahrhundert an einen aus Gelsenkirchen stammenden Ernst Bischoff, der auch einige Höfe der Umgebung erworben hatte. 1912-15 errichtet dieser auf dem Rittergut Mydlinghoven eine „VollblutGestütsanlage“. Tatsächlich aber werden hier wohl Grubenpferde zum Ziehen von Kohleloren für die zahlreichen Untertagegruben und obertägigen Pferdegöpel gezüchtet und gepflegt worden sein (SCHULENBERG 2000:64). Bischoff beabsichtigte lt. Bauantrag ,die vorhandene Fachwerkscheune ...zu Pferdestallungen umzubauen und daran anschließend den Neubau eines Pferdestalles zu errichten." Die Gebäude wurden von dem Architekten Beckmann vom Bauamt des Westfälischen Bauernvereins/Abt. Bochum, für den nunmehrigen bürgerlichen Rittergutsbesitzer Bischoff errichtet.

Die Umbauzeit fällt im Wesentlichen in die Jahre 1913-1915. Bei der architektonischen Gestaltung wurde ,auf britische Vorbilder Bezug genommen“, hinsichtlich der Materialien aber ,auch auf die traditionelle Architektur des bergischen Landes Bezug genommen. Der Hauptgebäudekomplex gruppiert sich um zwei Innenhöfe. In den ersten Innenhof, der vom Hauptwohngebäude und den Stallungen/Stallflügeln umschlossen wird, gelangt man durch eine überbaute Durchfahrt zwischen Hauptwohnhaus und Nordflügel. Der Querflügel zwischen den Innenhöfen besitzt eine weitere Durchfahrt zum 1. und 2 Hof. Östlich der Doppelhofanlage ist eine Remise mit Walmdach und drei großen Toren errichtet. Da es für eine spätere Rekonstruktion von Bedeutung ist, sei hier noch erwähnt, dass das Hauptwohnhaus 1931 durch den Architekten Beckmann südlich erweitert wurde.
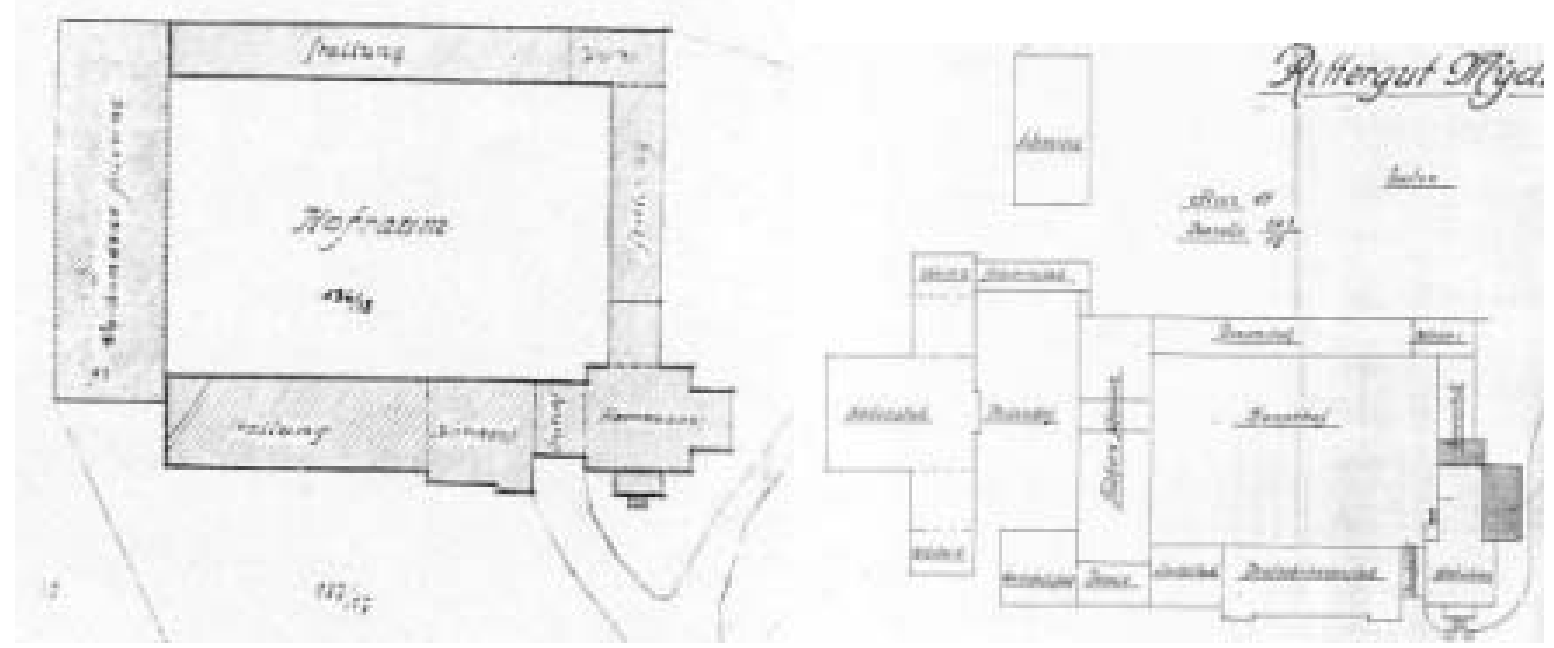

Abb. IX-23: Lagepläne: „Rittergut Mydlinghoven“ im Jahr 1912 und „Rittergut Mydlinghoven“ 1931 Beide Pläne sind Bestandteil von Bauunterlagen; der Plan von 1912 zum „Neubau einer Vollblut-Gestütsanlage auf Rittergut Mydlinghoven“ (Untere Denkmalbehörde, Stadt Düsseldorf).

Die weitere Geschichte des Gestüts bis 1970 bleibt ungeklärt. Fest steht nur, dass der Gestütsbesitzer Bischoff noch 1942 beim zuständigen Bauamt einen Antrag auf Baugenehmigung zur Erweiterung seiner Gestütsanlage stellte. Wahrscheinlich aus Kriegsgründen ist es zu diesen Erweiterungsbauten nicht mehr gekommen. Doch ob der Besitz von den Siegermächten okkupiert worden ist oder ob der Besitz ganz oder teilweise leer stand und für wie lange, lässt sich nicht zurückverfolgen. Fest steht ferner, dass ein Hengst aus der Vollblutzucht des Gestüt Mydlinghoven 1960 beim Kölner Pokal das Championat gewonnen hat, eine edle Galopperzucht somit bestanden haben muss.

Erst in Zusammenhang mit Verkaufsabsichten der Anlage in den 70er Jahren geht aus einem Schreiben hervor, dass der Rechtsanwalt Grauert und seine Frau Alice derzeitige Eigentümer des ca. 50 ha großen Besitzes waren und noch im Jahr 1984 das rechte Haus an der Zufahrt, das ehemalige Hengststallhaus bewohnten, die Familie aber aus wirtschaftlichen Gründen einen Käufer suchen musste. Die damaligen Eigentümer waren, so geht aus einer entsprechenden Akte hervor, ,angesichts [...] des umfassenden Gebäudekomplexes und der hohen [...] Kosten seit einiger Zeit nicht mehr in der 
Lage [...], Erhaltungs- oder gar Instandhaltungsinvestitionen zu finanzieren.“ Die herrschaftlichen Gebäude waren stark verwittert und standen teilweise leer.

Seit dem Jahr 1971 waren Maklerfirmen damit beauftragt, den Gestütsbereich Mydlinghoven zur Veräußerung anzubieten. Es gab in der Zeit 1971 bis Ende 1976 auch zahlreiche Interessenten, die zur Ortsbesichtigung in Mydlinghoven kamen. Es wurde aber in allen Fällen von einer abschließenden Verhandlung Abstand genommen. Für Privatleute war der Gebäudekomplex insgesamt zu groß, die Unterhaltung unmöglich.

Interessenten für Hotels, so ist zu erfahren, konnten mit dem auf Gestütsbetrieb ausgerichteten Gebäude nichts anfangen. Zwei ernsthafte Verhandlungen mit Hotelinteressenten scheiterten an den hohen Investitionskosten sowie an der Distanz zu Düsseldorf-Mitte.

Nach einer „vorläufigen Unterschutzstellung“ (gem. § 4 DSchG v. 24.6.1981) im Jahr 1981 wird das Objekt am 13.12.1984 in die Denkmalliste eingetragen, da es, so lautet die Begründung (BAUDENKMALLISTE, Blatt Nr. 3), ,ein hervorragendes Beispiel für den Typus des Gestüts im frühen 20. Jahrhundert ist. Es ist zudem eines der am besten erhaltenen Objekte dieser Art in der Region. Die Gebäude zeigen das gesamte Gestaltungsspektrum für ländliche Architektur jener Zeit, aber auch bezogen auf die Wohngebäude die Merkmale bürgerlicher Bauweise. Diese Verbindung ist charakteristisch für derartige Neubauobjekte des frühen 20. Jahrhunderts. Die Verwendung von Schiefer und Zierfachwerk verweist zu jener Zeit auf eine meist vordergründige Verbindung mit heimatlichen Gestaltungsweisen, die jedoch im Zusammenhang mit Elementen historischer Repräsentationsarchitektur bezeichnend für das Selbstverständnis der Bauherren sind. “

„Das Gestüt ist“, so die weitere Ausführung, „ein zeittypisches Beispiel aus der Zeit vor dem 1. Weltkrieg für eine der Nutzungsart nach seltene (Land-)wirtschaftliche Anlage ...". Hierin und in der architektonischen Geschlossenheit und Funktionsfähigkeit liegt die überregionale Bedeutung begründet, die ,so in Deutschland aus dieser Zeit kaum noch anzutreffen ist, zumal einige der ehemaligen Hauptzuchtgebiete für Vollblüter heute in Polen bzw. der Sowjetunion liegen“ „Mit der Unterschutzstellung unterliegt die Anlage, zu der auch ein Park gehört, dem DSchG..."

In den Jahren 1996 und 1997 schließlich wurde das Gestüt für 50 Mio. DM unter Wahrung denkmalpflegerischer Belange in eine exklusive Seniorenresidenz umgebaut, deren Eigentümerin die Hannoversche Lebensversicherung ist.

\section{a.3.2 Der Mühlteich}

Die schriftlichen Hinweise auf einen Mühlenteich mit Mühle sind spärlich: Im Jahre 1920, so ist der BAUDENKMALLISTE, Blatt Nr. 2, zu entnehmen, wurde auf der umgebauten Gutsanlage eine Scheune neu errichtet und - dies ist hier von besonderem Interesse ,ein älteres Mühlengebäude umgebaut." Weitere Hinweise dazu gibt es nicht.

Durch den Vergleich der Lagepläne von 1912 und 1931 lässt sich der Scheunenneubau („frühere Scheune“, „Scheune“) vom alten Scheunenstandort (,vorhandende Scheune“) unterscheiden. Auch auf einer Panoramaaufnahme vermutlich von 1920/30 lässt sich der Scheunenneubau gut erkennen, der sich außerhalb der geschlossenen Gestütsanlage südlich angrenzend befindet. Heute befindet sich an dieser Stelle ein Appartmentneubau. Das erwähnte ältere Mühlengebäude hingegen ist auf keinem der Abbildungen zu erkennen. 


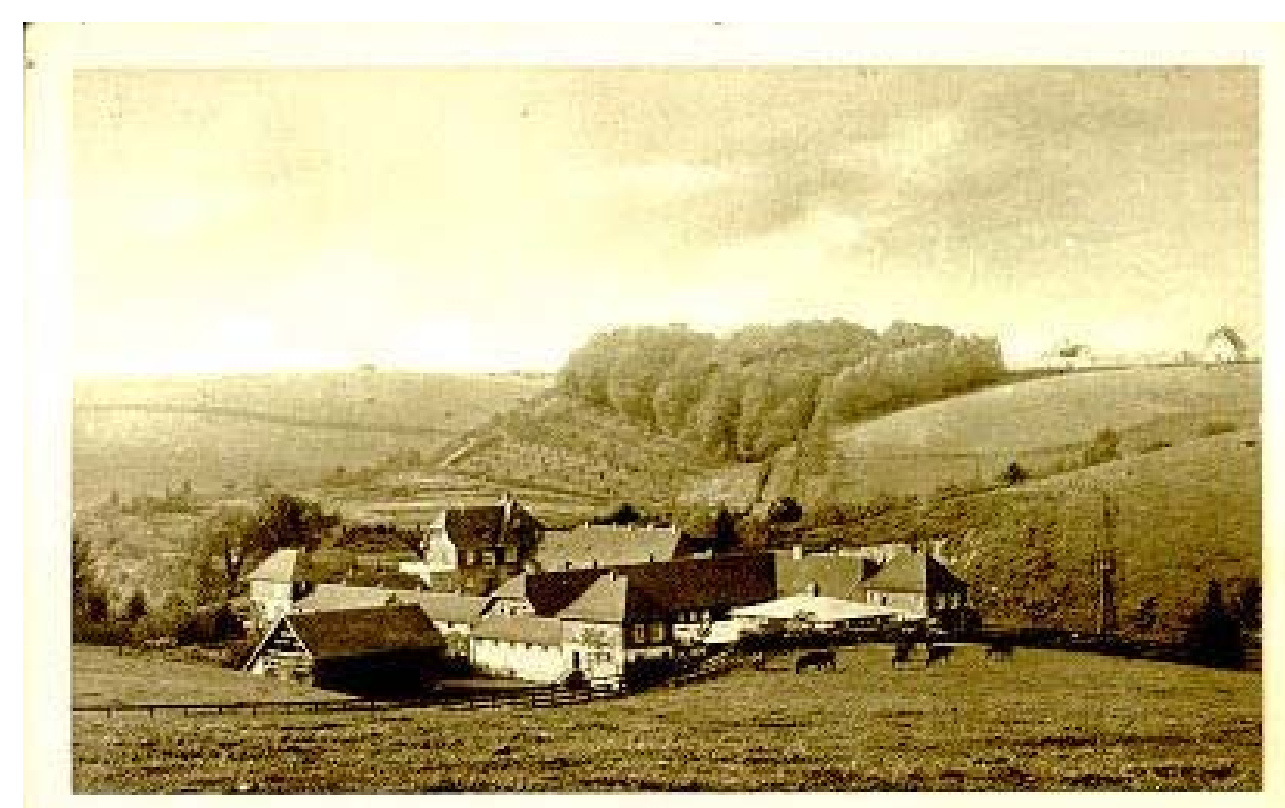

Abb. IX-24: Panoramaaufnahme des Gestüt Mydlinghoven um 1920/30.

Im Vordergrund, außerhalb des eigentlichen Vierseithofes, giebelständig nach Süden ausgerichtet, ist die „Scheune“ zu erkennen. Es ist aber zweifelhaft, ob die Scheune den Ersatzbau für die Mühle darstellt, da die Geländerreste des Mühlenteichs östlich liegen und damit Unterwasser anschließen, was absolut untypisch für einen den Wasseraufschlag fördernden bzw. unterstützenden Mühlenteich gewesen wäre (Untere Denkmalbehörde, Stadt Düsseldorf).

In einem Bericht des LANDSCHAFTSVERBANDES RHEINLAND (1996/97), der im Zusammenhang einer "sporadischen Baustellenbeobachtung“ im Rahmen der Umbaumaßnahmen zu dem Seniorenstift verfasst worden ist, wird ausgesagt, dass große Teile des 1915 errichteten Gestüts offensichtlich die historischen Reste des Gutes überdecken. „Lediglich der im Urkataster eingezeichnete Teich südlich der Gebäude war durch Gleyschichten und Erlenstrünke zu erkennen“, so stellen die Begeher fest. Noch heute deutet ein Weidenbaum und eine leichte Senke in der Wiese auf einen Teich hin.

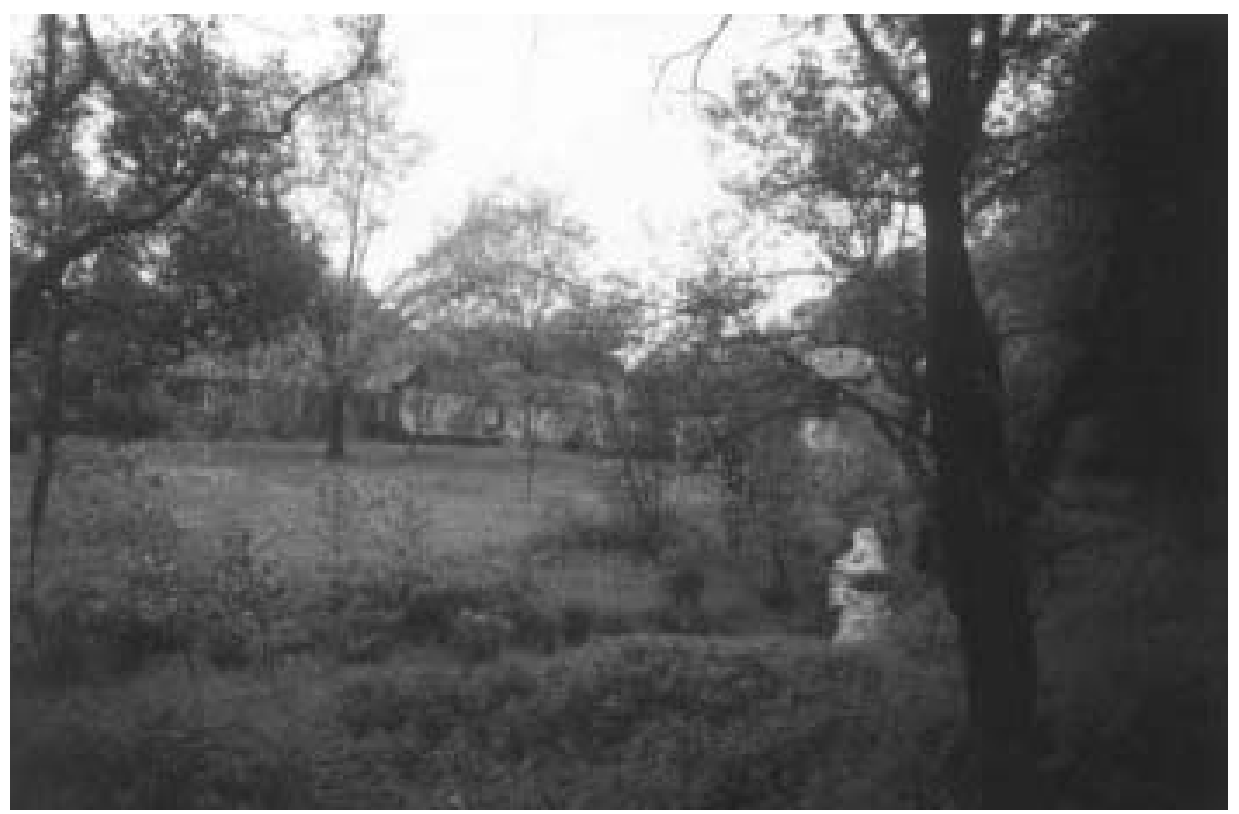

Abb. IX-25: Bodensenke vor den Gutsgebäuden, wahrscheinliche Restfläche eines ehemaligen Teiches. Rechts verläuft der renaturierte Mydlinghovener Bach (eig. Aufnahme 2003).

Bei dem Versuch einer Rekonstruktion ist den Zeichnungen aus den alten Bauakten zu entnehmen, dass das Gut durch Neubauten erheblich ergänzt und der gesamte Baukörper nach Südosten ausgedehnt worden ist. Teile des ehemaligen Mühlenteiches sind somit wahrscheinlich trockengelegt 
und mit Stallungen überbaut worden. Die ursprüngliche Teichfläche muss also erheblich größer gewesen sein.

In einem Lageplan „zum Neubau eines Einfamilienhauses auf dem Rittergut Mydlinghoven“ aus dem Jahre 1906 ist der Teich in seiner Form und Größe zu erkennen.

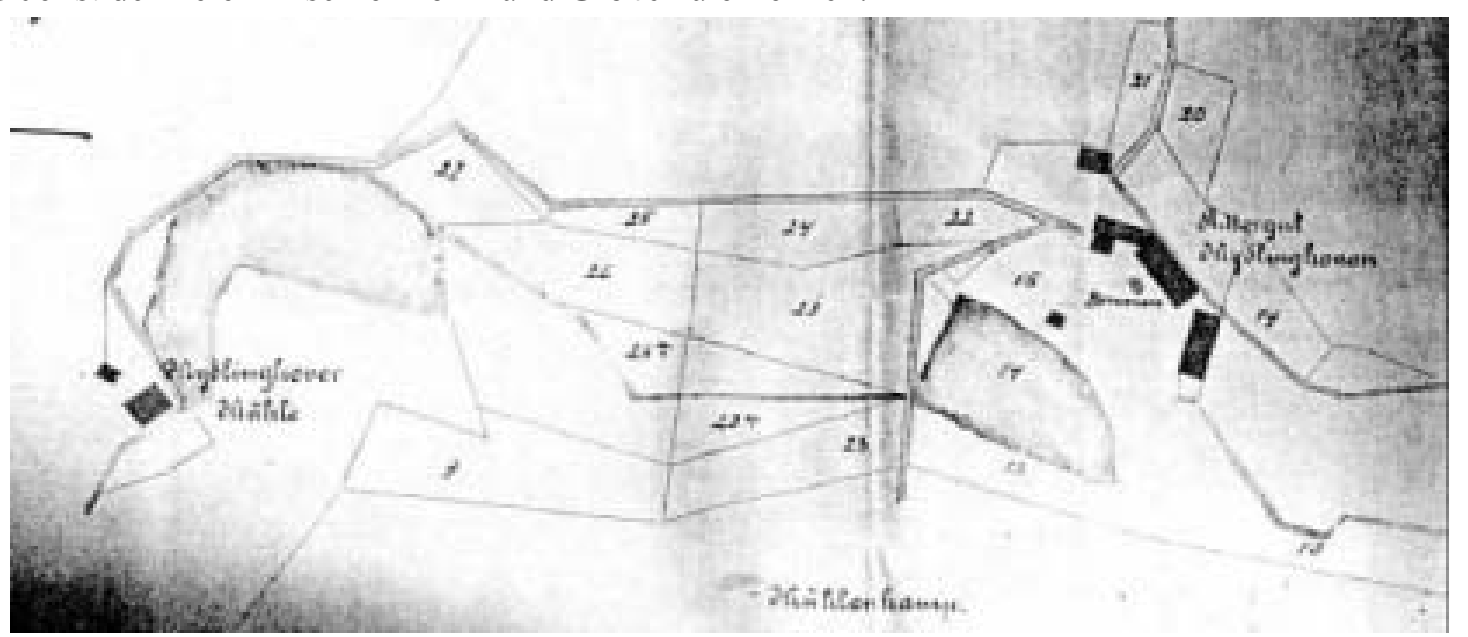

Abb. IX-26: Lageplan zum Neubau eines Einfamilienhauses auf Rittergut Mydlinghoven

bei Hubbelrath aus dem Jahr 1906. Links der ,Mydlinghovener Mühlenteich' rechts der Teich am Rittergut Mydlinghoven südlich anschließend (Untere Denkmalbehörde, Stadt Düsseldorf).

Auch auf den alten Kartenwerken von 1824/35, 1843/44 und 1851/69 ist der Teich beim Rittergut Mydlinghoven eingezeichnet. In seiner Größendarstellung übertraf er gar den ,Mydlinghovener Mühlenteich' und besaß laut der Kartendarstellung der Preußischen Uraufnahme eine größere Insel, die durch die weiße Aussparung so gedeutet werden kann. Zum Zeitpunkt der Darstellung auf dem Lageplan von 1906 unterlag er somit bereits einer Schrumpfung. Dies ist auch an dem nördlich des Teiches verzeichneten kleinen Gebäudes zu erkennen, der auf im Urkataster noch innerhalb des Teiches auf einer Insel liegt.

Wann der Mühlenteich abgelassen und trockengelegt worden ist, lässt sich nicht mehr ermitteln, es ist aber anzunehmen, dass der Mühlenteich in einer reduzierten Größe so lange erhalten geblieben ist, wie ein Gestüt betrieben worden ist, also bis in die 1960er Jahre hinein, um ihn beispielsweise als Pferdeschwemme zu nutzen. Auf einer Aufnahme aus den 1970er Jahren ist ein mit Steinen und Mauerwerk umfasstes Wasserbecken (Zierbecken, Schwimmbecken oder Springbrunnen) auf einem Stück dieser ehemaligen Teichfläche zu sehen und mitunter als Symbol einer ehemaligen Wasserbespannung an diesem Platz gedeutet worden, nachdem auch die Pferdezucht vollständig aufgegeben worden ist. 


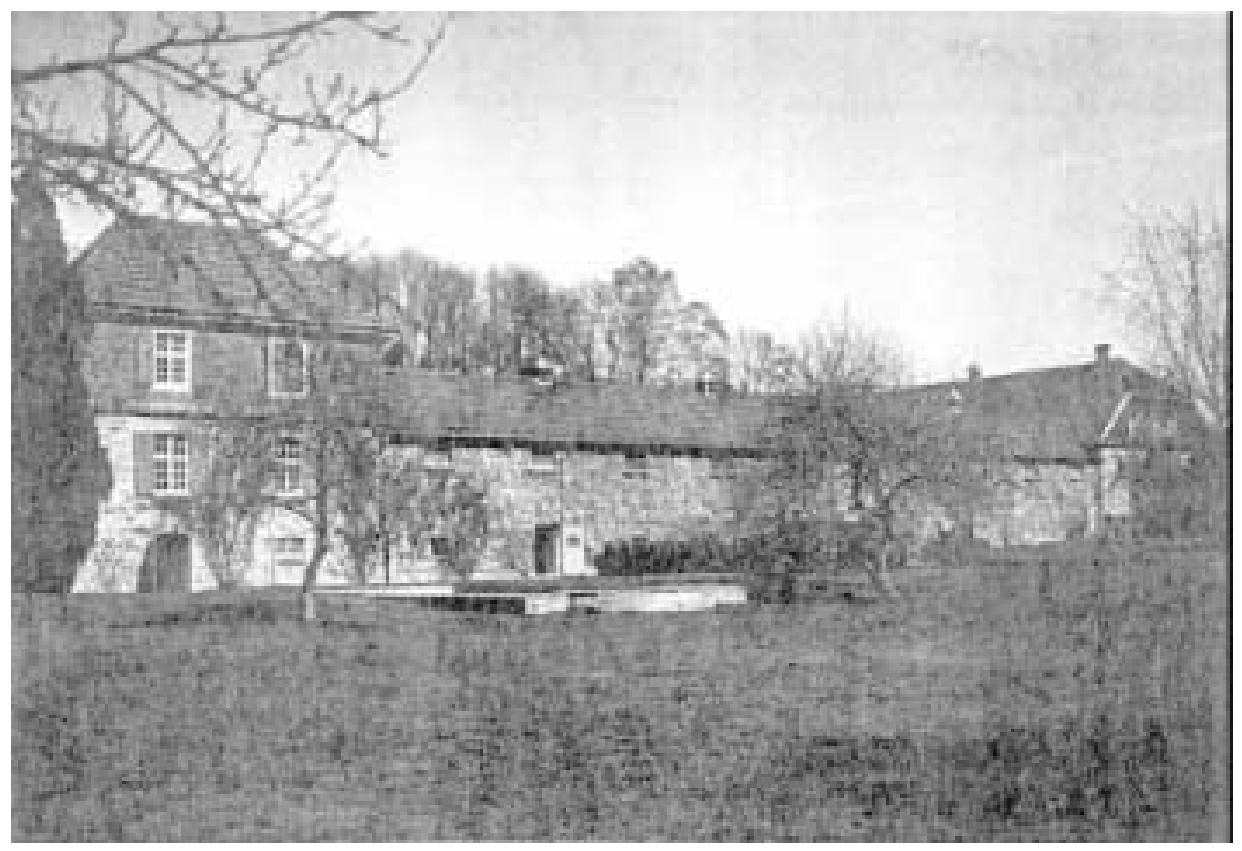

Abb. IX-27: Gestüt mit gefasstem Wasserbecken, Aufnahme aus dem Jahr 1978 (Untere Denkmalbehörde, Stadt Düsseldorf).

Ungeklärt hingegen bleibt der Standort einer Wassermühle. Da der Standort einer Mühle nie oberhalb des Mühlenteiches zu suchen ist und wenn die Scheune den Standort der ehemaligen Wassermühle präsentieren soll, so gibt es mehrfache Alternativen:

a. Die Wassermühle ist nicht identisch mit der Scheune und befand sich unterhalb des Teiches,

b. die Wassermühle ist identisch mit der Scheunenumbau, dann wären die Teiche oberhalb zu suchen oder

c. bei der Scheune handelt es sich um die ehemalige Gutswassermühle, doch lässt sich ihre Anlage in kein passendes Mühlenbauschema pressen.

Die Auswertung der zur Verfügung stehenden Altkarten führt zu interessanten Ergebnissen:

1. Auf der Müffling-Karte von $1824 / 25$ ist ein länglicher Teich eingezeichnet, der sich unmittelbar südlich dem nur in Umrissen gezeichneten Baukörper anlehnt. Ein einzelstehendes Mühlengebäude ist nicht zu erkennen.

2. Die „General Karte der Bürgermeisterey Hubbelrath“ (1:20.000), aufgenommen im Jahre 1851, zeigt zwei Baukörper des Rittergutes und einen unregelmäßig quadratischen Teich, in dem seitlich eine Wasserfläche ausgespart ist. Ein zugehöriges Mühlengebäude ist auch hier nicht auszumachen.

3. Die Preußische Kartenaufnahme (Uraufnahme) von 1843/44 zeigt zwei quer zueinander stehende, unterschiedlich große Gebäude und zwei Teiche: den großen Teich, hier auch mit einer Flächenaussparung, auf der ein Gebäude eingezeichnet ist und ein oberhalb liegender kleinerer Teich, dem ein separates Gebäude südlich vorgelagert ist. Diese Anordnung ist auch der Urkatasterkarte zu entnehmen. Eine Wassermühle in Insellage ist unwahrscheinlich, da mindestens die Hälfte des Teichwassers mit dem Gefälle ungenutzt abfließen dürfte. Eine Art Gartenhäuschen oder auch die Wohnstätte des Teichwirts ist da eher wahrscheinlich. Der Kleinteich hingegen dürfte der Größe nach aber nicht allein die nötige Wasserbeaufschlagung geliefert haben. Ebenso wenig ist ein von oben kommendes wasserführendes Fließgewässer im Gelände auszumachen. Es ist lediglich anzunehmen, dass bei Starkregen ein Trockengraben hangabfließendes Wasser aufnahm und den Teich füllte. Es konnte also als Regensammelbecken eine unterstützende Funktion in Wassermangelzeiten, d. h. wenn das Fließgewässer nicht den benötigten Aufschlag liefern konnte, ausüben. Für den Standort auch einer für den Eigenbedarf schrotenden Mühle - reichte jedenfalls der Wasservorrat nicht 
aus, ein ständiger Wasserzulauf war hier notwendig. Beachtenswert ist in diesem Zusammenhang der im Gegensatz zur heutigen Situation nördlich der Gutsgebäude umlaufende Bachlauf, der mit dieser Lagebeziehung die Rekonstruktion zu einer am Rittergut gelegenen Gutsmühle wahrscheinlich werden lässt.

4. Auf dem Lageplan von 1906 gibt wiederum eine gänzlich veränderte, kanalisierte Wasserführung eine andere Vorstellung von der damaligen Situation. Hierauf wird der Bachlauf zu einem Gebäude bzw. zu einem Gebäudeanbau geführt, bei dem sich ebenfalls durchaus um die gesuchte Mühle gehandelt haben könnte. Der unterhalb dieser Mühle liegende Rittergutsteich hätte dann keine Bedeutung für die Wasserbeaufschlagung dieser Mühle gehabt, sie wäre allein vom Fließgewässer angetrieben worden, sondern hätte als weiterer Spannteich der Mydlinghover Mühle gedient.

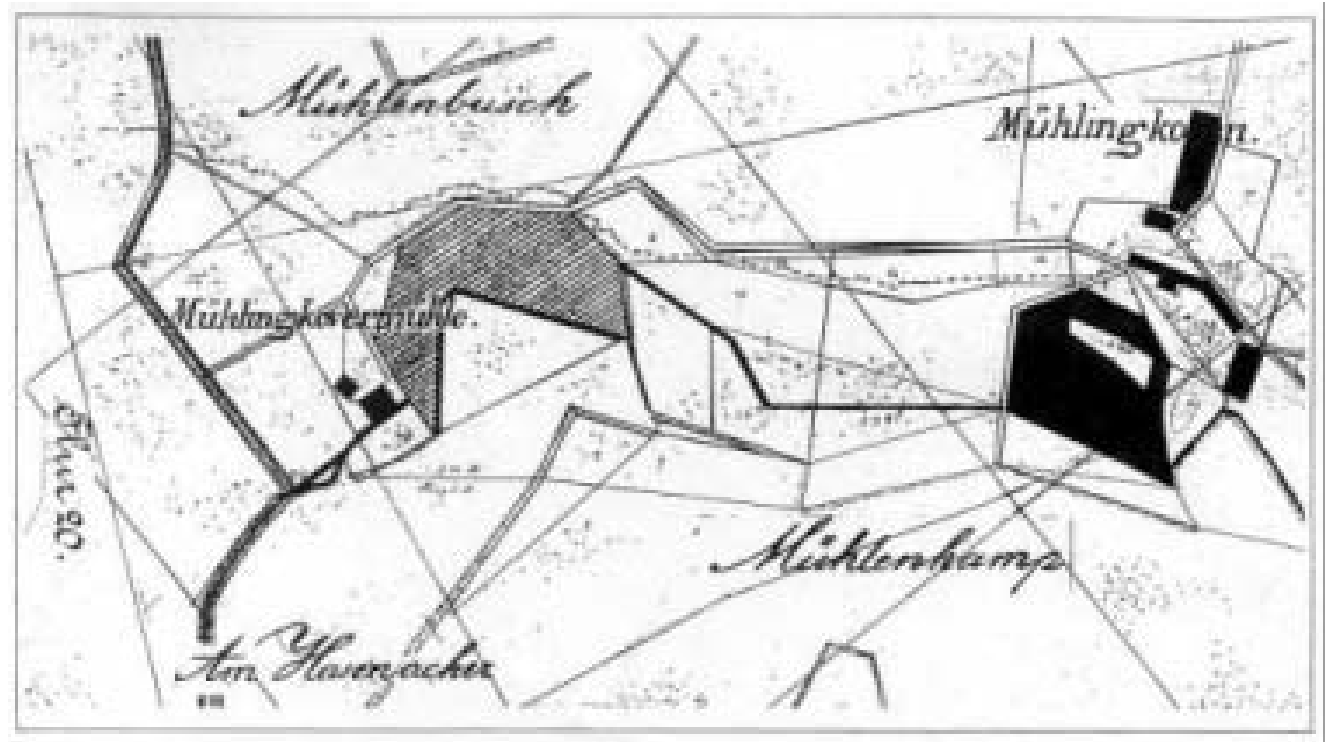

Abb. IX-28: Die Urkatasterkarte von 1830 mit der „Mühlingkovermühle“

und dem dazugehörigen Mühlenteich (schraffiert) und dem Rittergut „Mühlingkoven“ mit dem größeren Inselteich und dem oberhalb liegenden Teich mit wahrscheinlichem Mühlengebäude (ausgefüllt).

Die Auswertung der vorliegenden Kartenwerke ergibt keine eindeutige Positionsbestimmung der auf dem Gutsgelände befindlichen ehemaligen Wassermühle. Ohne Zweifel aber ist eine umfangreiche Teichanlage auszumachen. Dies bestätigt sich im Gelände, wo sich die südliche Abdachung des Teiches noch heute sehr gut im Gelände wahrnehmen lässt ist und auf dem „Teichdamm“ ein Teil des Rundweges des Residenz entlangführt. Die Existenz einer historischen Teichanlage und Nachforschungen bezüglich seiner ehemaligen Funktion blieben jedoch bei der aktuellen Gewässerplanung unberücksichtigt.

\section{a.3.3 Planungspraxis: Renaturierung}

Im Jahr 1997/98 wurde der Hubbelrather Bach, der südlich am Gestüt vorbeifloss, „renaturiert“. Anlass für die Maßnahme war die bereits erwähnte Umgestaltung des bisherigen Gestüts „Gut Mydlinghoven“ in eine Seniorenresidenz. Den Bach freizulegen diente als Ausgleichsmaßnahme für die Errichtung eines Parkhauses nördlich des Hofes und anderer baulicher Versiegelungen, die einen Eingriff in Natur und Landschaft darstellen und ausgleichspflichtig sind.

Die entscheidende Kompensationsmaßnahme für den Landschaftsraum war die Offenlegung des verrohrten Bachlaufes, „damit ein zusammenhängendes, vernetztes Ökosystem für die Bachflora und -fauna entsteht“ (PENKER 1995:10). Die Offenlegung bzw. Neuanlage des Hubbelrather Baches sollte ,die visuelle Erlebnisqualität deutlich erhöhen und eine Bereicherung des Landschaftsbildes darstellen"(:11). 
Auf einer Länge von $230 \mathrm{~m}$ wurde das Bachbett bei einer Mindestbreite von $6 \mathrm{~m}$,mit begleitenden Erlen-, Eschenbeständen (30\%) und bachbegleitenden Stauden (70\%)“ naturnah neu gestaltet. Die Uferböschung des Hubbelrather Baches wurde entsiegelt und verläuft nunmehr ,leicht geschwungen“, „mit Prall- und Gleithang“. „Zur Absicherung vor allem der Uferprallhänge“ erfolgte eine „Initialpflanzung mit Gehölzen wie zum Beispiel Schwarzerlen“ (PENKER 1995:13). Die Bepflanzung mit Eschen und Erlen „orientiert sich an der natürlichen Vegetation.“ (RHEINISCHE POST v. 3.11.1998). Am Ufersaum des Hubbelrather Baches entstand eine Sukzessionsfläche (PENKER 1995:Übersicht 2). Es wurden hier bachauetypische Bäume und Sträucher gepflanzt [...] und einige Röhrichtstauden gesetzt.“ (Amtsblatt 28.11.1998)

In den Renaturierungsplanungen wurden historisch-geographische Belange nicht berücksichtigt. Mühlenbäche weisen als Mühlengräben mitunter einen geradlinigen Verlauf auf und entsprechen in ihrem Aussehen nicht den gängigen Vorstellungen eines naturnahen Baches. „Fast 100 Jahre lang floß der Bach durch ein Rohrsystem an dem ehemaligen Gestüt Mydlinghoven vorbei“, so ist einem Zeitungsartikel zu entnehmen, der die Renaturierungsmaßnahmen als besonders gelungen hervorheben soll. Dies entspricht nicht ganz der Realität, wie der Verfasser selbst von seinen ersten Geländebegehungen vor Beginn und während der Renaturierungsmaßnahmen berichten kann: Der Hubbelbach floss zwar begradigt und anthropogen überformt, aber nicht verrohrt über das randliche Gestütsgelände.

Vor allem ein Bezug zu dem hier ehemalig bestandenen Teich wurde nicht hergestellt, entsprechende Kartenwerke bzw. archivalische Quellen nicht ausgewertet.

Das Baudenkmalamt hat zwar in seinem Bericht zur „Baustellen-Beobachtung“ auf den ehemaligen Teich hingewiesen und in der Baudenkmalliste ein Mühlengebäude erwähnt, weitere Vorgaben im Rahmen des Gestütsumbaus und der vorzunehmenden Ausgleichsregelung fehlen hingegen. Hier hätte eine denkmalpflegerische Vorgabe erfolgen müssen, zumal der Gestütsbereich mitsamt dem Park unter Denkmalschutz gestellt ist. Es ergibt sich aus diesem Beispiel der Planungspraxis ein konträres Verhältnis Natur- und Denkmalschutz vs. Kulturlandschaftsschutz.

\section{Sonstige Projekte}

\section{a REGIONALEN}

Seit dem Jahr 2000 finden im zweijährigen Turnus die REGIONALEN ${ }^{9}$, Kultur- und Naturräume in Nordrhein-Westfalen' statt, ein strategische und strukturpolitisches Instrument, „das die regionale Innovation fördert und damit einen besonderen Beitrag zur regionalisierten Strukturpolitik leistet", um so zur Profilierung einer ausgewählten Region als „Gesundheits-, Energie- und Kulturregion“ beizutragen und neue Kooperationsmodelle in der Zusammenarbeit der öffentlichen Hand und der privaten Wirtschaft zu etablieren, kurzum: die REGIONALEN sind „eine Konzeptionschance und weniger eine Förderungschance“ (REGIONALE 2001:7). Eine REGIONALE (:77) „,ist darauf ausgerichtet, über realisierte Projekte zu einem Präsentationsjahr sichtbare Erfolge der regionalen Kooperation $\mathrm{zu}$ demonstrieren. Sie verfolgt damit keinesfalls den Anspruch, die klassische Regionalplanung zu ersetzen. Mit der Ausrichtung auf ein Präsentationsjahr ist die zeitliche Befristung der REGIONALE, und damit die ihrer Aktivitäten und ihrer Organisationsstrukturen, verbunden.“

Die REGIONALEN haben in ihr Gesamtkonzept - mit mehr oder weniger starker Akzentuierung das Thema „Wassergeschichte“ in ihre drei Kernthemen: „Kunst- und Naturerlebnis“, „Kunde der Natur und Landschaft“ und „Kulturgeschichte“ mit aufgenommen (REGIONALE 2001:7). „Die konzeptionelle Auseinandersetzung mit der Entwicklung von Natur und Landschaft", so der tragende Leitgedanke, „lässt am ehesten identitätsstiftende Projekte zu“ (:76). Das Thema „Wasser“" wird dabei innerhalb des Kerninhaltes „Landschaft“ in den REGIONALEN unterschiedlich schwer thematisiert,

\footnotetext{
${ }^{9}$ Die Zitate zu diesem Thema sind sämtlich dem im Jahre 2001 erschienenen Zwischenbericht entnommen, sofern nicht anders angegeben.
} 
aber allgemein als ,,identitätsstiftende Projekte [...] zur profilierten regionalen Selbstdarstellung“ als „unverzichtbar angesehen“ (:9). „Bei allen Bewerbungen“, so heißt es in dem Zwischenbericht 2001(:21), ,ließen sich inhaltlich ähnliche Schwerpunkte wie ,Stadt am Fluß', ,Pflege der Natur- und Kulturlandschaft' [...] wieder finden, die aber von den Regionen unterschiedlich ausgearbeitet wurden“.

Die erste REGIONALE 2000 „OstWestfalenLippe“, deren Leitthemen durch die Handlungsfelder der EXPO-Initiative Ost-Westfalen-Lippes „Wir holen die Weltausstellung zu uns“ vorgegeben waren und sich an das Motto der EXPO 2000 in Hannover „Mensch, Natur und Technik“ anlehnten, realisierten in diesem Rahmen insgesamt 54 Projekte. Von diesen sollten 13 Projekte im Handlungsfeld der Kultur „zur Profilbildung und Identitätsstiftung der Region beitragen“ (REGIONALE 2001:33). So zum Beispiel unter dem Titel „Weser - Ein Fluss in Europa“, aus dem die mehrbändigen „WeserPublikationen“ hervorgegangen sind, die im Pkt. II. ,Forschungsstand' dieser Arbeit vorgestellt wurden. Die parallel veranstaltete Landesgartenschau, die „Leuchtturmcharakter“ besitzen sollte, lief unter dem Thema „AQUA Magica“ in Bad Qeynhausen und Löhne.

Ein Leitthema der REGIONALEN 2002 „EUROGA 2002plus“, das sich 2002 als „EUROpäische GArtenregion" unter Beteiligung der Region Düsseldorf/Mittlerer Niederrhein und auf niederländischer Seite der Gebiete Noord- und Midden-Limburg der Provinz Limburg präsentierte, lautete „Region der Gewässer“ (Leitthema A.) sowie „Kultur und Technik des Wassers“ (Leitthema H.) (REGIONALE 2001:43), die zusammen mit dem Projekt „Nordkanal“ zu den sog. „Leuchtturmprojekten mit eigenständiger Wirkung nach Außen“ gehörten (:44).

Die Region Düsseldorf/Mittlerer Niederrhein ist stark von ihrem Wasserreichtum geprägt. Daher hat man sich bei der Entwicklung der Routen an den Flussläufen orientiert; sie sind das Rückgrat der Routen. Jeder Flussroute lässt sich einem Thema und einem spezifischen Natur- und Landschaftserlebnis zuordnen. Im Einzelnen handelt es sich um die Rhein-Route, die Düssel- und AngerbachRoute, die Erft-Route, die Niers-Route und die Nordkanal-Route (REGIONALE 2001:45).

Die REGIONALE 2004 „Links und rechts der Ems“ zum Beispiel hat innerhalb ihrer Konzentration auf drei Themenfelder die „Kulturlandschaft und Umwelt“ als eines ihrer Kernthemen benannt. Beteiligt sind die Kommunen der Kreise Steinfurt und Warendorf und die Stadt Münster. Die REGIONALE soll hier ,als Motor der Verknüpfung von Natur- und Kulturräumen entlang der Ems genutzt werden" (:21), aber auch an anderen Gewässerläufen gänzlich anthropogenen Ursprungs. Als drei Leitprojekte wirken die Flüsse Ems und Werse sowie die Kulturbucht Münster (:24).

Die Ems soll als weit in den Raum wirkendes Band dienen, in dem sich ökologische Fragestellungen und Aspekte der Landschaftsplanung ebenso wie jene der Stadtplanung einbinden lassen. Hier soll zum Beispiel nachhaltige Landschaftsnutzung an Beispielen und Projekten präsentiert werden, aber auch ,übergeordnete Themen wie die Bedeutung von Wasser als Grundlage des Lebens aufgegriffen werden“"(REGIONALE 2001:53).

An der Werse sollen sich Fragen der Landschaftsentwicklung mit kulturellen Aspekten verbinden. „Die Werse wird ohne komplizierte wasserwirtschaftliche Korrekturen als Beispiel überformter Flusslandschaft präsentiert" (:53). Die ehemaligen Mäander sollen zu einer großen Landmarke umgestaltet werden, die Belange der Landwirtschaft, des Wassers, der Kultur etc. aufnimmt (:53).

Die REGIONALE 2006 „Spurwechsel“ im Bergischen Land umfasst die Städte Remscheid, Solingen und Wuppertal. Ihre Landschaft wird geprägt durch das Tal der Wupper und viele kleine Bäche und diese hydrologische Topologie bildet Anhaltspunkte für die inhaltliche Ausrichtung und den Rahmen. Von den insgesamt acht Leitthemen lassen sich zwei dem Thema „Wasserkultur“ zuordnen: Unter dem Leitprojekt „Grün, Wasser, Landschaft und Freiraum“ will die REGIONALE 2006 „das Element Wasser und insbesondere die wirtschaftliche, kulturelle, stadtgestalterische und ökologische Bedeutung der Wupper für die Region zu einem Thema machen“. $\mathrm{Zu}$ den Zielen gehört die Fortentwicklung der Wuppertalsperre als Freizeit- und Erholungsschwerpunkt, die Demonstration der 
Wasserkraft als Energiequelle und „die Entwicklung der Wupper mit ihren Uferbereichen zu einer auch in der Innenstadt benutzbaren und attraktiven Flusslandschaft“" (REGIONALE 2001:65).

Im Zuge der Regionale 2006 wird an schon viele Jahre bestehende Planungen der Stadt Wuppertal angeknüpft, die den Titel „Lebensader Wupper“ trägt. Die Belebung des ,einmaligen langgestreckten Stadtrückgrats", das Neben- und Miteinander von Wohnen, Arbeiten, Kultur und Grün zu stärken, ist Gegenstand der Überlegungen. Denn „wenngleich die Zeit der großen Industrie in Wuppertal vorbei ist, so schlägt das Herz der Stadt noch immer hier“. Die Industriegeschichte der Wupper wird also in den Planungen mit berücksichtigt, wie der Begründung des Stadtplanungsamtes zu entnehmen ist: „An der Wupper nahm die Entwicklung der Stadt ihren Ausgang, hier fing alles an. Insbesondere die Textilindustrie machte sich den Fluss, seine Wasserqualität und Strömung zunutze, an seinen Ufern wuchsen Industrie, Stadtteile mit Kontor- und Bürgerhäusern. Auch heute noch finden sich entlang der Wupperachse alte und neue Fabrikanlagen, einige traditionsreiche Unternehmen, neue Betriebe in alten Gebäuden, die beiden großen Stadtzentren mit ihren Einkaufszonen, Theater, Opernhaus und Stadtquartiere, in denen gewohnt und gearbeitet wird“.

Im ersten Jahr der Regionale 2006 wurde ein Leitplan zur Talachse entwickelt und verabschiedet, der sowohl einzelne Entwicklungsschwerpunkte auf der Achse entlang der Wupper ausmacht als auch in die „Zwischenräume“ schaut. In diesem Zusammenhang ist ein Konzept für die Entwicklung der Grünflächen erarbeitet worden. Unter dem Leitthema „Kultur und Licht“ sollen unter anderem verschiedene Routen entwickelt werden, ,,auf denen die industriellen, kulturellen, städtebaulichen und natürlichen Besonderheiten entlang der Wupper [...] zugänglich gemacht und inszeniert werden“" (REGIONALE 2001:65).

Neben den offiziellen REGIONALEN mit und ohne Wettbewerb gibt es auch sog. TEILREGIONALE und REGIONALE INITIATIVEN. Es handelt sich dabei um die übrigen Bewerberregionen, die aufgrund ihrer ebenfalls sehr hohen Qualität der Bewerbungen und „um diese sich etablierende Prozesse der Zusammenarbeit nicht zu bremsen“" (REGIONALE 2001:22), in die Lage versetzt wurden, „die vielversprechenden Ansätze eines integrativen, regionalen Handelns auch außerhalb einer REGIONALE weiterzuverfolgen“"(:22).

Die Bewerbung der Region „FLUSS-STADT-LAND“, an der Städte Castrop-Rauxel, Datteln, Dortmund, Lünen, Hamm, Waltrop, der Kreis Recklinghausen sowie 12 Kommunen der EmscherLippe-Region beteiligt sind, ist so eine regionale Initiative außerhalb der eigentlichen REGIONALEN. Sie „fokussiert sich auf die Kanäle und Flüsse. Die Nutzbarmachung und Inszenierung der industriell überformten Natur und die Entwicklung einer ,Natur-Kultur' durch Tourismus- und Freizeitwirtschaft ist dabei das zentrale Thema“ (REGIONALE 2001:21). Die Leitthemen heißen u.a.: „SpurensucheRoute der Wasserkultur“, „Kanale Grande - das silberne Band“, „Stadt ans Wasser“, „Brücken und Ströme - Kultur und Kulturen“ (:25). Als Alternative zur Landesgartenschau ist hier eine „Landeswasserschau“ geplant.

Auch die TEILREGIONALE „Das Ruhrtal“ thematisiert in den Leitthemen „Lebensader Ruhr“ und „Den Fluss erreichen“ das Thema Wasser aus geschichtlicher Sicht (REGIONALE 2001:25).

\section{b Gewässerentwicklungsplan Chiemsee}

Gewässerentwicklungspläne (GEP) für Seen sind ein Novum. Das ursprünglich für die Erhaltung, Entwicklung und Gestaltung von Fließgewässern aufgestellte wasserwirtschaftliche Fachkonzept erfordert für stehende Gewässer auf Grund der intensiven Wechselbeziehungen von Umweltaspekten und Nutzungsansprüchen eine wesentlich erweiterte gewässerspezifische Ausrichtung.

Im Zentrum des Chiemseeplans stand hier ein ganzheitlicher, interdisziplinärer Ansatz zur Gewässerentwicklung, der sowohl Umweltaspekte als auch die vorhandenen Nutzungen integrierend betrachtet: 
Umweltaspekte

Gewässerschutz

Gewässerökologie

Naturschutz
Nutzungen

Freizeit und Erholung

Fischerei

Landwirtschaft

Als Grundlage für die Erstellung des Gewässerentwicklungsplans Chiemsee wurden zahlreiche Fachgutachten zu Einzelthemen erstellt, die detaillierte Informationen zum Planungsprozess beisteuerten. Sie liefern darüber hinaus wesentliche Ansatzpunkte für die Entwicklung der Planungsziele und die Umsetzung der angeführten Maßnahmen.

Im Vordergrund steht die Ordnung der vielfältigen Nutzungen mit dem Ziel, nachteilige Belastungen der Seeufer und Gewässerlebensräume zu vermeiden bzw. zu verringern. Die Planungsziele orientieren sich deshalb vor allem am gewässertypischen Leitbild der Gewässerökologie (Erhaltung bzw. Sicherung bzw. Verbesserung der Wasserqualität durch Reduzierung des Nährstoffeintrags, Verbesserung der Bachauen und Biotopstruktur etc.) und an dem „Gemeingebrauch am Gewässer“, d.h. der Freizeit- und Erholungsnutzung durch Lenkungskonzepte wie die Umgestaltung und Anpassung des Wegenetzes („Uferrundweg“) sowie der Förderung des Umweltbewusstseins der Besucher (u. a. durch Infozentren).

Aber die Umsetzung des GEP erfolgt hier auch „unter Berücksichtigung der historisch gewachsenen Nutzungsansprüche“ und der Schaffung kulturhistorischer Landschaftssituationen: „Blickachsen“, als naturschutzfachlich abgestimmte Eingriffe in das Landschaftsbild, werden ,auf der Basis historischer Seeansichten zur Förderung attraktiver Seeansichten (scenic value)“ freigelegt. In die Pflegekonzepte werden „naturschutzfachlich wertvolle und kulturhistorisch geprägte Landschaftsteile“ einbezogen und eine Entlandung von Häfen und Steganlagen in die Maßnahmen mit einbezogen (ARZET o.J.:91).

\section{c Naturschutzgroßprojekte}

Naturschutzgroßprojekte (NSGP) sind Fördervorhaben des Bundes, die in Landschaften mit einer bundesweit bedeutsamen Naturausstattung durchgeführt werden. In den Projektgebieten werden Maßnahmen des Naturschutzes gefördert. Für die Vergabe zuständig ist das Bundesamt für Naturschutz (BfN).

Naturschutzgroßprojekte unterscheiden sich von anderen Naturschutzvorhaben besonders durch ihre Großflächigkeit. Die Bedeutung großflächiger Schutzgebiete liegt in der Minimierung negativer Außeneinflüsse, die sich bei kleinflächigen Schutzgebieten oft negativ auf die Schutzziele auswirken oder diese sogar ganz in Frage stellen. Über die Großflächigkeit hinaus erfolgt die Auswahl der Projekte anhand der Kriterien Repräsentanz, Naturnähe, Gefährdung und Beispielhaftigkeit.

Erklärtes Ziel des Bundesförderprogramms ist es, die Kernflächen der Projektgebiete bis zum Ende der jeweiligen Projektlaufzeit als Naturschutzgebiete zu sichern. $743 \mathrm{~km}^{2}$ der Kerngebietsflächen sind bisher als Naturschutzgebiete ausgewiesen (ohne einstweilige Sicherstellungen). Dies entspricht einem Anteil von $0,2 \%$ der Bundesfläche.

Für Naturschutzgroßprojekte übernimmt die Bundesregierung bis zu $75 \%$ der anfallenden Kosten, die Bundesländer tragen in der Regel 15\%, die Projektträger (z.B. Landkreise, Zweckverbände oder Vereine) $10 \%$ der Kosten. Die Fördermittel werden überwiegend für den Flächenankauf, daneben aber auch für langfristige Pacht, die Pflege- und Entwicklungsplanung, die Durchführung biotoplenkender Maßnahmen sowie für Personal- und Sachkosten eingesetzt.

Die erste und wichtigste Aufgabe ist die Erstellung eines Pflege- und Entwicklungsplans (PEP) für das Projekt- und Fördergebiet, in dem alle Maßnahmen für den Schutz und die Entwicklung überregional bedeutsamer Biotope und charakteristischer Pflanzen- und Tierarten aus naturkundlicher Sicht begründet und dargestellt werden. An dem hier beschrieben PEP „NSG Teichgebiete NiederspreeHammerstadt“" ist eine projektbegleitende Arbeitsgruppe beteiligt, in der Interessenvertreter der 
Region, des Freistaates Sachsen und des Bundes vertreten. Die im Pflege- und Entwicklungsplan vorgeschlagenen Maßnahmen werden mit den Grundeigentümern und Landnutzern abgestimmt. Dabei gilt der Grundsatz, dass durch keine Maßnahme die Existenz eines Nutzers gefährdet werden darf. Die Landnutzer haben die Möglichkeit, an der Umsetzung der Naturschutzmaßnahmen mitzuwirken und dafür Fördermittel zu erhalten. Dadurch werden Arbeitsplätze in diesen Bereichen erhalten und die Wirtschaft der Region gefördert. Da sich der Freistaat Sachsen und der Projektträger bereiterklärt haben, die Förderung der in diesem Gebiet eingeleiteten naturschutzrelevanten Maßnahmen langfristig sicherzustellen, ist neben einer kontinuierlichen Naturschutzarbeit auch eine zukunftsorientierte betriebswirtschaftliche Planung und der Erhalt der mit diesen Maßnahmen verbunden Arbeitsplätze möglich.

Derzeit gibt es in Deutschland nur zwei Naturschutzgroßprojekte mit dem Ziel, „eine durch eine Vielzahl von wirtschaftlich genutzten Teichgruppen geprägte Kulturlandschaft mit dem Vorkommen zahlreicher seltener, gefährdeter charakteristischer Pflanzen-, Tierarten und Biotope zu sichern und entwickeln.“ (BfN 2000:E-3) Diese sollen im Folgenden vorgestellt werden:

\section{c.1 Naturschutzgroßprojekt „Teichgebiete Niederspree-Hammerstadt“}

Das Gebiet des Naturschutzgroßprojektes „Teichgebiete Niederspree-Hammerstadt“ liegt im Niederschlesischen Oberlausitzkreis im Nordosten des Freistaates Sachsen südlich der Muskauer Heide im Naturraum „Oberlausitzer Heideland“. Innerhalb der naturräumlichen Gliederung Deutschlands liegt das Projektgebiet an der Südgrenze des Norddeutschen Tieflands, im Bereich des Oberlausitzer Heideund Teichgebietes.

Innerhalb des ca. 5.200 ha großen Projektgebietes liegt das eigentliche ca. 1.880 ha umfassende Fördergebiet, das in einem Förderzeitraum von 1997 bis 2006 mit einem Finanzvolumen von 6,49 Mio. Euro ausgestattet ist. Projektträger ist der „Zweckverband Naturschutzregion Neiße“, Projektgruppe Niederspree in Rietschen.

Das Projektgebiet wurde zur besseren individuellen Prozessbearbeitung in sog. planungsorientierte Raumeinheiten gegliedert: 1. Teichgruppen, 2. Waldflächen, 3. Landwirtschaftliche Nutzflächen, 4. Offenland, 5. Siedlungs- und Infrastrukturgebiete. Innerhalb der Raumeinheit „Teichgruppen“ wurden die Untereinheiten „Teichgruppe Daubitz“, „Niederspree“, „Oberspree“, „Hammerstadt“, „Rietschen“ und die „Teichgruppe Quolsdorf“ unterschieden.

Einige dieser Teilflächen unterliegen Sicherungen nach internationalem Recht und multilateralen Abkommen und Programmen. Das Teilgebiet Niederspree beispielsweise wurde 1993 und nachfolgend 1998 als SPA-Gebiet (,special protection area“) sowie auf einer reduzierten Fläche 1998 als FFH-Gebiet eingestuft und wurde bereits seit 1961 auf einer Fläche von 800 ha unter Naturschutz gestellt (BfN 2000:A-27-30, D-5), wobei die Grenzen sich mehrmals änderten.

Die Fördermittel fließen dabei vor allem in das sog. Kerngebiet, das den ökologisch wertvollsten Bereich des Gebietes umfasst. In dem NSGP „Teichgebiete Niederspree- Hammerstadt“ sind das die Flächen zwischen und um die Teichgruppen Oberspree, Niederspree und Daubitz. 


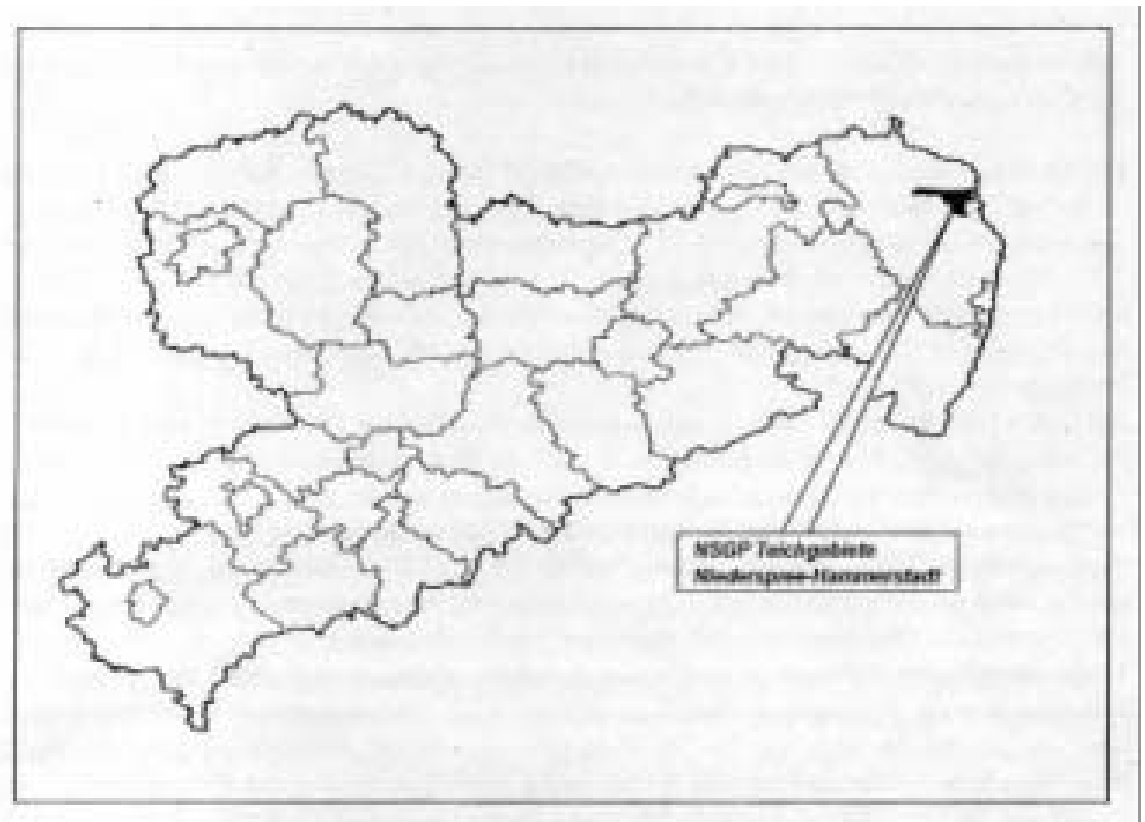

Abb. IX-29: Lage des Projektgebietes „Teichgebiete Niederspree-Hammerstadt“ (aus: BfN 2000b)

In der Projektbeschreibung heißt es: „Die seit Jahrhunderten betriebene Teichwirtschaft prägte eine naturnahe Kulturlandschaft mit großer Vielfalt an schützenswerten Lebensräumen wie extensiv genutzter Teiche mit Schilfgürteln und Großseggenrieden, Bruchwälder und Feuchtwiesen am Rande großflächiger Kiefernwälder und -forste. Wertgebend ist vor allem die Vogelwelt mit u. a. den Brutvögeln Kranich, Drosselrohrsänger, Schwarzhalstaucher, Ziegenmelker und Große Rohrdommel. Bedeutsam sind aber auch die Fledermaus-Vorkommen mit Mopsfledermaus (FFH Anhang II-Art), Grauem Langohr und Großer Bartfledermaus. Floristisch erwähnenswert ist die Teichboden- und Teichrandflora mit Zypergras, Strandling, Vielstengeliger Sumpfbinse, Sandbinse und Froschkraut (FFH Anhang II-Art). Zu den gefährdeten Amphibien und Reptilien zählen Rotbauchunke, Moorfrosch, Laubfrosch, Knoblauchkröte, Wechselkröte und Kreuzotter. Bundesweit bedeutsam ist das Gebiet auch wegen der 43 nachgewiesenen Libellenarten, darunter 21 Arten der Roten Liste Deutschlands mit u. a. Großer Moosjungfer (FFH Anhang II-Art).“

Darüber hinaus besteht eine Förderung und Handlungsbedarf, weil das Gebiet „durch eine intensiv betriebene Fisch- und Landwirtschaft gefährdet“ ist, ferner „durch Eingriffe in den Wasserhaushalt bei möglicher Fortführung des Braunkohlentagebaus“". Geplant sind die Extensivierung der Teichnutzung sowie die naturnahe Gestaltung der Teiche, die Renaturierung der Fließgewässer, Waldumbaumaßnahmen und die Ausweisung einer gar nicht mehr genutzten Waldfläche sowie die Extensivierung der landwirtschaftlichen Nutzung. Die Pflanzen- und Tierarten des Projektgebietes sollen in ihrem Bestand langfristig gesichert und ihre Lebensräume nach naturschutzfachlichen Kriterien optimiert werden. Insbesondere sollen daher die ökologisch hochwertigen Pflanzengesellschaften der Feucht- und Nassbereiche, wie Moore, Moor- und Erlenbruchwälder, Großseggenrieder, Nass- und Feuchtwiesen mit ihrem Arteninventar geschützt und entwickelt werden. Die für zahlreiche Säugetiere, Vögel, Amphibien und Insekten als Fortpflanzungs- und Nahrungsraum wichtigen Teiche mit ihren Schwimmblatt- und Röhrichtgesellschaften, ihre Zuflüsse und die als Rastund Lebensraum genutzten angrenzenden Offenlandbereiche sollen für die zu schützenden Arten erhalten bzw. in ihrer Qualität verbessert werden. Dabei soll ihre langfristige Nutzung durch den Menschen weiterhin möglich sein. Der Strukturreichtum und die Biotopfunktion der Wälder, insbesondere für störungsempfindliche Arten mit hohem Raumanspruch soll durch das Einbringen standortheimischer Laubbäume, die Förderung von Alt- und Totholz und die Anlage von Waldmänteln verbessert werden.

Das Naturschutzgroßprojekt „Teichgebiete Niederspree-Hammerstadt“ hat aber vor allem „das Ziel, eine durch eine Vielzahl von wirtschaftlich genutzten Teichgruppen geprägte Kulturlandschaft zu 
erhalten und zu entwickeln“ (BfN 2000:D-36). Dabei wird erkannt, dass, „um die Teiche mit ihrer landschaftsprägenden Funktion zu erhalten, [...] eine langfristige [...] Bewirtschaftung gesichert werden“ muss. Dies bedeutet „eine permanente Unterhaltung der Teichanlagen“ (:D-36). Darüber hinaus „soll die zukünftige Entwicklung dieses Gebietes die Naturschutzmaßnahmen im Fördergebiet unterstützen“ (:E-3). Deshalb ist eine wesentliche Zielstellung die Schaffung eines ,überregionalen Biotopverbundsystems“, die durch „eine Vernetzung der Teichgruppen Hammerstadt, Rietschen mit den Teichgruppen im Fördergebiet“ erreicht werden soll. „In diesem Zusammenhang sollte die Reklitza in den naturfernen Bereichen möglichst umfassend renaturiert [...] werden“ (:E-4).

Weiter heißt es, „der Erhalt und die langfristige Sicherung eines für diese Lebensräume günstigen Wasserhaushaltes ist daher wichtigste Grundlage und Zielstellung des Projektes“" (:E-3). Ein besonderes Problem stellen dabei die obertägigen Abbaugebieten nördlich bzw. inmitten der Teichgebiete dar. Vor dem Hintergrund der Bergbaulandschaft im Braunkohlentagebaurevier Reichwalde „hat die langfristige Sicherung der Teichgruppe Hammerstadt hinsichtlich Ausdehnung, Zustand und Wasserversorgung größte Priorität"“(:E-4).

Wenn auch die Zielsetzung eines Biotopverbundsystems den Charakter eines ökologischen Leitbildes hat, so werden im Kapitel „Leitbilder und Leitlinien“ auch Aussagen getroffen, die den kulturhistorischen Betrachtungsansatz aufnehmen: „Im Einklang mit den Forderungen des Landesentwicklungsund Regionalplanes“, so heißt es dort, „stellt der Erhalt der Kulturlandschaft in ihrer Vielfalt ein erklärtes Projektziel dar“ (:A-23). Die gesamte Entwicklung des Fördergebietes soll sich zwar ,ausschließlich an den ökologischen Ansprüchen der hier natürlich vorkommenden [...] Pflanzen- und Tierarten [...] orientieren“ (:E-4), aber es ist „eine räumliche und zeitliche Nutzungsvielfalt insbesondere in den Teichgruppen und in den landwirtschaftlich genutzten Bereichen anzustreben“" (:E-3). Und, was eine besondere Bedeutung bekommt: „Fischereiwirtschaftlich ungenutzte Teiche sollen erhalten und dauerhaft gepflegt werden“ (:E-5). Totalreservate, d. h. dauerhaft geschützte Flächen, die möglichst von jeglicher direkten menschlichen Einflussnahme abgeschirmt werden" (:E-6), sind dazu nicht geeignet:

Das Projektgebiet wird ,als Teil einer alten Kulturlandschaft“ angesehen, das „,sich im überwiegenden Bereich - insbesondere die ausgedehnten Teichgruppen [...] - als Ergebnis eines langen menschlichen Gestaltungsprozesses“ erweist. „Vor allem die wertvolleren Verlandungscoenosen bzw. auch die faunistischen Besonderheiten des Gebietes sind in der Regel mehr oder weniger direkt von Teichen und somit von einer Mindestbewirtschaftung abhängig.“ (:E-7) Dies macht „i. d. R. eine Mindestnutzung bzw. eine regelmäßige geringe anthropogene Einflussnahme geradezu erforderlich“ (:E-7). „Eine Ausweisung [...] von Teichen [...] als Totalreservat würde zwangsläufig zu einer Verringerung der Vielfalt [...] führen, ja zu vollkommen andersgestalteten Lebensräumen und in der Regel zu einem Rückgang der derzeitigen Biodiversität"“(:E-7).

Neben der Gefahr der Sukzession wird des Weiteren die Komplexität und bautechnische Ausführung der einander bedingenden Teichbauanlagen gesehen: „Sollte ein Teich mit in das Totalreservat einbezogen werden, müsste konsequenterweise die Teichbewirtschaftung vollkommen aufgegeben werden, was eine Unabhängigkeit der Wasserversorgung der anderen Teiche voraussetzt. Mit einer völligen Aufgabe des Stausystems des Teiches verbunden mit einem endgültigen Ablassen des Teiches würden Flächen frei, auf denen sich ungestört Sumpfwälder unterschiedlicher Ausbildung entwickeln könnten. In diesem Prozeß verschwinden Röhrichtgesellschaften sowie Seggenrieder, auch wertvolle Litoralcoenosen und Schwimmblattvegetation“.

Diesem Szenario der Bewirtschaftung wird die Alternative gegenübergestellt: „Eine andere Variante wäre der nicht mehr regelbare Dauerstau (endgültiger Verschluss des Ablaufbauwerkes, keine geregelte Bespannung mehr, Wasserstand je nach Grundwasserstand). Dies würde zu einer Ausbreitung der selteneren und wertvollen Wasserfeder-Erlenbrüche sowie der Entwicklung gefährdeter submerser Arten in diesem Bereich führen, bis der Teich im Laufe der Zeit letztendlich verlandet und ebenfalls wieder Sumpfwälder entstehen“" (BfN 2000:E-8). 
„Nach einer Abwägung der unterschiedlichen Zielstellungen“, kommt jedoch das BfN zu dem Entschluss, dass „,ür Totalreservate [...] dauerhaft bewirtschaftete Teiche als ganzes sowie langfristig von aktivem Wasserstandsmanagement, dauerhafter Bewirtschaftung oder Biotoppflege abhängige Lebensraumtypen [...] nicht für die Ausweisung eines Totalreservates in Betracht" kommen (:E-8). Mit der kulturhistorischen Begründung: „Da das Gebiet des Naturschutzgroßprojektes Teil einer Kulturlandschaft ist, ist der überwiegende Teil der Flächen irgendeiner Form der Flächennutzung unterzogen [...]. Um die genannten naturschutzfachlichen Zielstellungen zu erreichen und langfristig zu sichern, müssen im gesamten Projektgebiet naturverträgliche Nutzungsformen erhalten, gefördert und entwickelt werden“"(:E-26).

In die Betrachtung bezüglich der Ausweisung des Naturschutzgroßprojektes „Teichgebiete Niederspree-Hammerstadt" werden sinnvollerweise auch die fließenden Gewässer als Bestandteil der Teichanlage miteinbezogen: „Die Fließgewässer des Projektgebietes sind neben ihrer Funktion als Lebensraum für Pflanzen und Tiere notwendige Wasserzubringer für die Teiche und sorgen für die Ableitung des Wassers aus den Teichen [...]. Das Fließgewässernetz ist deshalb als ein Ver- und Entsorgungssystem der Teiche sowie als Infiltrations- und Exfiltrationselement für den Grundwasserhaushalt zu verstehen und zu erhalten“(BfN 2000:G-3).

Hinsichtlich der Bewirtschaftung der Teiche wird für eine naturschutzgerechte Teichbewirtschaftung plädoyiert, „deren Einhaltung für das gesamte Projektgebiet aus naturschutzfachlicher Sicht dringend empfohlen wird“ (:G-5). Dies bedeutet zum Beispiel die Festlegung differenzierter (Teil-) Bespannungs- und (Teil-) Ablasszeiten, die Wiederbelebung der nutzungsorientierten Pflege, die Dammpflege und -instandhaltung sowie das Bespannungsregime der fischereilich genutzten Teiche.

Dieser letzte Punkt ist - bei hoher Biodiversität als Zielstellung - insofern von besonderer Bedeutung als dass ,,in einigen teichnahen Verlandungsbereichen [...] das historische Wasserregime [...] simuliert werden muß“ (:G-6). Daraus ergibt sich „zwingend ein Management“ (:G-6) der „Historischen Simulation“, wie man es auch bezeichnen könnte.

Schließlich wird im Rahmen der Gebietsausweisung auch die betriebswirtschaftliche Ertragsfähigkeit bei Erarbeitung entsprechend berücksichtigt, „,da eine langfristig gesicherte Bewirtschaftung und damit der Erhalt der Teiche einen Mindestertrag voraussetzt, der einen wirtschaftlichen Betrieb der bestehenden Teichwirtschaften zulässt“. Es wurde, zusammengefasst ausgedrückt, „der Versuch unternommen, die naturschutzfachlichen Zielstellungen und wirtschaftlichen Interessen über das Rahmenkonzept so zu verknüpfen, daß insbesondere für den Naturschutz als auch für den Fischereibetrieb möglichst viele positive Effekte erzielt werden“ (BfN 2000:G-8).

Aus diesem Grund wurde gar „die vereinzelte Sömmerung von Teichen“ aus naturschutzfachlicher Sicht empfohlen (:G-11).

Von kulturhistorisch besonderem Interesse dürften die Veränderungen der Teichlandschaften in jüngerer Zeit sein und wie man ihnen aus heutiger ,naturschutzhistorischer“ Sicht begegnet:

Bei der letzten „Teichrekonstruktion“, die eher als eine Art „Flurbereinigung“ zu sehen ist, wurden erstens „die vom Teichboden abgeschobenen Massen einfach zu Inseln zusammengeschoben“ (BfN 2000:G-51). Zweitens kam es ,bei den letzten Teichrekonstruktionen [...] in allen Teichgruppen des Projektgebietes zu teilweise tiefgreifenden Veränderungen. Neben Entlandungen, Uferbefestigungen usw. wurden [...] mehrere kleine Teiche zu jeweils einem großflächigen Teich zusammengelegt. Einerseits wurden lediglich die Dämme aneinandergrenzender Teiche durchstochen, bei anderen wurden die Dämme teilweise oder vollständig entfernt.“ Diese „Rekonstruktionen“ werden rückgebaut, es „sollen sehr große Teiche, die in Zeiten der Pelletinintensivwirtschaft durch Zusammenlegung kleiner Teiche entstanden sind, [...] wieder in kleinere gegliedert" werden (:G-52).

Die neuere Rekonstruktion bezieht ebenso den historischen Teichdamm in die Ausführungen mit ein. Als typisch für das Gebiet der Niederspreer Teichgruppe werden nämlich die Alteichenreihen auf den Teichdämmen als typisch angesehen. Allgemein hätten Teichdammgehölze „vor allem [...] die 
Funktion der Damm- und Uferbefestigung durch ihr Wurzelwerk“. Im Rahmen des Großprojektes sollen deshalb „in allen Teichgruppen die entstandenen Lücken in den Altbaumreihen wieder mit Starkbäumen bepflanzt werden bzw. auf allen anderen Dämmen neue Baumreihen bzw. -alleen [...] oder mehrschichtige Gehölze angelegt werden“ (BfN 2000:G-53).

\section{c.2 Naturschutzgroßprojekt „Waldnaab-Aue“}

Ein weiteres in diesem thematischen Kontext anzusprechendes NSGP ist das Naturschutzgroßprojekt „Waldnaab-Aue“, wenn sich auch aus dem Projektgebietsnamen nicht unmittelbar der Zusammenhang $\mathrm{zu}$ „Teichen“ herstellen lässt.

Es handelt sich um großflächige Weiherketten in der nördlichen Oberpfalz, Landkreis Tirschenreuth, eingebettet im oberen Tal der Waldnaab des Naturraumes „Naab-Wondrebsenke“ und umgeben von Bruchwäldern und naturnahem Auen-Grünland. Die Kernfläche des Fördergebietes beträgt 1.600 Hektar in einem Förderzeitraum von 1999 bis 2008 und ist mit einem Finanzvolumen von 4,55 Mio. Euro ausgestattet. Projektträger ist der Landkreis Tirschenreuth.

„Das für den Naturschutz wesentlichste Landschaftselement“, so heißt es in der Projektbeschreibung, „ist eine Vielzahl von teilweise bereits im Mittelalter angelegten Teichen mit dem Vorkommen von entsprechender Teichbodenvegetation, Schwimmblattgesellschaften und Verlandungsmooren. Die umgebenden Wälder sind größtenteils naturferne Fichtenforste. Die Gewässer sind überwiegend naturnah und unverbaut, teilweise bestehen jedoch Probleme durch Nährstoffeintrag.“

Ziel des Projektes ,,ist die Sicherung und Optimierung der extensiv genutzten Kulturlandschaft der ,Tirschenreuther Teichpfanne', die im Bereich von Fließgewässern, in Verlandungsbereichen und im Bereich aufgegebener Teiche eine Vielzahl von bundesweit bedeutsamen Biotoptypen aufweist.“ Geplant sind unter anderem „die Renaturierung naturferner Fließgewässer, die Rückführung von Entwässerungsmaßnahmen im Auenbereich, die Extensivierung von Teichnutzungen, die Beruhigung sensibler Bereiche sowie die Überführung naturferner Fichtenbestände in standortgerechte Wälder“.

Die Zielsetzung und Planungen gehen damit in die gleiche Richtung wie bei dem ostsächsischen Vorhaben. Auch hier ist der Förderstatus gekennzeichnet vom „Natur“-Schutzgedanken aufgrund der Kennzeichnung ,durch individuenstarke Vorkommen von Kreuzotter und Moorfrosch sowie diverser bedrohter Libellenarten wie beispielsweise Große Moosjungfer, Grüne Flußjungfer und SumpfHeidelibelle. $\mathrm{Zu}$ den gefährdeten Pflanzenarten zählen u.a. die Floh-Segge, das Gras-Laichkraut, der Moorklee und der Zwerg-Igelkolben.“

Wenngleich die Zielsetzung des Projektes nicht der historisch-geographischen Perspektive in Reinform entspricht, so ist dennoch allein die Bewilligung und Durchführung von Maßnahmen in Zusammenhang mit der historischen Teichwirtschaft in dem Maße selten, das eine Erwähnung hier stattfinden musste.

Gleichzeitig muss bei der Eruierung von Informationen zu diesem Naturschutzgroßprojekt ein Defizit insofern festgestellt, dass nicht einmal die Internetpräsenz des Landkreises Tirschenreuth auf dieses Modellvorhaben hinweist. 


\section{„Historie lehrt uns, sie zu beachten, \\ uns vor ihr zu verneigen, ohne ihr nahe kommen zu können." [Gerd EDINGER, Künstler]}

\section{Ausblick: Der Beitrag der historisch-geographischen Gewässerforschung zu den drängenden Gegenwartsfragen}

Bei den vorigen Ausführungen zur Gewässergeschichte und regionalen Verbreitung historischanthropogener Gewässerformen der Wasserhaltung und der Wässerung in der mitteleuropäischen Kulturlandschaft ist die Frage berechtigt: „Handelt es sich bei alldem um eine Vorvergangenheit, die für die Gegenwart irrelevant ist?“ (RADKAU 2002:28). Oder um „vergangene Gegenwarten“ (HÖNSCH 2001) von großer gesellschaftlicher Bedeutung?

Haben die Beispiele aus der Planungspraxis und die gutachterlichen bzw. wissenschaftlichen Feldprojekte auch einige Anwendungsmöglichkeiten aufgezeigt, so soll hier der übergeordnete, visionäre oder auch philosophische Gedanke verfolgt werden. „So geht es bei einem Verständnis von und für Kulturlandschaften daher nicht alleine um den Erhalt unseres Erbes, sondern auch um Planung unserer Zukunft" (WILKIE 1988:7), die sich bereits in der Gegenwart manifestiert. In diesen Kontext wird sich auch die historisch-geographische Gewässerforschung in der nächsten Zukunft verstärkt einzubringen haben, denn ,es stellt sich die zukunftsweisende Frage, ob nun [...] wesentliche Weichen gestellt und neue Wege gewiesen werden und was an fruchtbaren grundlegenden Arbeitsrichtungen weiterführend Bestand haben wird.“ (DENECKE 2001:276)

Nach Einschätzung der Vereinten Nationen sowie verschiedener internationaler und nationaler Expertengremien wird sich das Themenfeld Wasser in den kommenden Jahren zu einem zentralen Schwerpunkt der internationalen Politik entwickeln. Die Erkenntnisse der letzten Jahrzehnte haben gezeigt, dass selbst in wasserreichen Gebieten Grenzen der Wassernutzung erkennbar sind. Auf der anderen Seite sind „die voranschreitende Industrialisierung und der mit ihr gekoppelte Lebensstandard [...] eng an die Verfügbarkeit geeigneter Wasservorkommen geknüpft" (FRIMMEL 1999:IX). Neben der Wassermenge ist dabei die Wasserqualität ,zum entscheidenden Kriterium geworden” (:IX). Beispiele, wie der Transport von Brauwasser in Tanklastzügen aus weiter entfernten Quellfassungen zum Brauort ${ }^{1}$ und auch die Beispiele aus der gewässerintensiven und zugleich unverzichtbar auf einen Anteil an Reingehaltwasser angewiesenen Papierfabrikation verdeutlichen dies.

Die, will man es verhalten ausdrücken, Verschlankung der Biodiversität lässt sich ebenfalls auf diese Negativentwicklung zurückführen. Von den ca. 70 in Bayern vorkommenden Fischarten sind 51 in der Roten Liste aufgeführt. Fische gehören mittlerweile zu den gefährdetsten Wirbeltieren Mitteleuropas. Die Äsche, die Nase, die Rutte, der Schneider und viele weitere Arten sind in den letzten 15 Jahren in weiten Teilen ihrer ursprünglichen Verbreitungsareale verschwunden (STEIN 1995:22f.).

Begründet liegt diese Entwicklung in dem Zugriff der modernen Gesellschaft, „transforming the landscape more rapidly and comprehensively than ever before" (COONES 1992:75). Die aus dieser Landschaftsveränderung resultierenden ,postmodern landscapes“ wie VOOS/MEEKES (1999:6) es ausdrücken, die „humanisierte Landschaft“, wie PFEIFER (1982:319) sie nennt, sind ,in weiten Bereichen“ charakterisiert durch „Großstrukturen und Naturferne“ (SCHENK 2000:222). Die „unity of the world", so lässt sich resümieren, ,is definitively over: man is at a distance from landscape“ (VOOS/MEEKES 1999:6). „Durch die großflächig voranschreitende Zerstörung älterer Landschaftsstrukturen sind langzeitig gewachsene und kleinstrukturierte Landschaften nur noch in wenigen Resten erhalten oder aber verändert und überformt" (DENECKE 1997:43). Damit verbunden ist der Verlust der historischen Bausubstanz, der Verlust der individuellen, historisch gewachsenen Eigenart, der Verlust ursprünglicher physiognomischer und funktionaler Vielfalt und Naturnähe, eben auch bedingt

\footnotetext{
${ }^{1}$ Die „Herforder Felsenkeller Brauerei“ lässt ihr Brauwasser, das zu Anfang aus den auf dem Firmengelände gelegenen Quellaustritten und später aus dem Uferfiltrat der nahe gelegenen Werre bezogen wurde, aus einem - nicht näher bekannten ca. $90 \mathrm{~km}$ entfernten Quellort heranbringen, da die lokalen Wasserreserven den Qualitätsansprüchen nicht mehr genügen.
} 
durch den weiträumigen Verlust von natürlich entstandenen, aber anthropogen genutzten und veränderten Quell-, Bach- und Flussläufen wie auch von rein künstlich entstandenen Kanälen, Gräben und Teichen.

Mit dem Gewässerschwund, der Gewässerverlegung und -beseitigung und dem Verlust althergebrachter gewässerbezogener Arbeitsweisen korreliert auch die Beschränkung bzw. Irreversibilität der Möglichkeiten zur Revitalisierung ehemaliger Gewässernutzungen, Bewässerungsanlagen und -einrichtungen. Gerade in Hinblick auf die Diskussion um die Aufnahme und Nutzung regenerierbarer Energien eine bislang vernachlässigte Größe. Denn: Faserpflanzen erfahren in neuerer Zeit aufgrund ihres Ölgehalts wie auch hinsichtlich ihrer Veredelungsmöglichkeiten zu Leinen eine Neubewertung. Dort bei Nutzung nachwachsender Rohstoffe, hier bei der Bekleidungswahl. Die Diskussion um die Substitution von Kunstdünger und Pflanzenschutzmitteln auf Weiden und Wiesen wird angesichts deren mindestens grundwasserbelastenden Eigenschaften ebenso geführt wie der Beitrag zur Dezentralisierung der Gewässerversorgung, d. h. der verstärkten Nutzung lokaler und oberirdischer Wasserkräfte.

Neben die Aspekte Schutz einer bedeutenden Naturressource und Erhaltung kulturaquatischer Lebensräume tritt des Weiteren zunehmend, verstärkt durch die aktuelle Klimadiskussion, auch die Bedeutung kleiner Gewässer als energetischer und ökonomischer Faktor, als regenerative Energiequellen für eine dezentralisierte Energieproduktion. Und das derzeitige Engagement dehnt sich aus auf die Wiederbelebung der alten, regenerierbaren „Energiequelle Wasser“ als Möglichkeit „schonender“ und „umweltfreundlicher" Stromerzeugung, die man nun als „alternativ“ bzw. „nachhaltig“ bezeichnet (TERHALLE 1992:188). Die alte Wassermühle, ein jahrhundertelang bewährter Energiespender, ist wieder zeitgemäß, ihr neues Leistungsangebot ist wieder gefragt. Im Landkreis Soltau-Fallingbostel beispielsweise liefern 22 kleine Wasserkraftwerke, vor allem Talsperren und Mühlen, ihren Strom an ein großes niedersächsisches Stromversorgungsunternehmen.

Ein Anfang - noch zu Beginn der 1990er Jahre lagen über 200 alte Wasserkraftanlagen, fast alles Wassermühlen, allein in Niedersachsen still, „die durchaus reparaturfähig, darauf ausgelegt sein können, ihre reaktivierte Leistung in das landesweite Stromnetz miteinzubringen“ (ERLER/MATTHIESEN 1989:123). Hinzu kommt, dass die niedersächsische Landesregierung bis $30 \%$ der Investitionskosten übernehmen will, um private Mühlenbesitzer zu veranlassen, ihre Anlagen zur Stromerzeugung wieder herzurichten (:123). Zahlreiche weitere Beispiele von Kleinwasserkraftwerken sind aus Lippoldsberg an der Schwülme und Allendorf an der Werra und aus Franken bekannt. Im westlichen Mittelfranken sind mehr als 60 solcher aus alten Mühlen entstandenen Kleinkraftwerke bisher erhalten bzw. neu installiert worden; davon speisen 21 Strom ins Netz ein, die übrigen erzeugen ihn nur für den Eigenbedarf. Das „Fränkische Überlandwerk“ in Ansbach fördert mit Zuschüssen die Neueinrichtung solcher Anlagen (BEDAL 1992:197). Mit dem Niederschlag aus dem Gebiet von Clausthal-Zellerfeld und dem Gefälle bis zum Vorharz ließen sich heute „mehrere Millionen DM pro Jahr an Stromkosten einsparen“ (BALCK 1999:21), wenn diese der Energiegewinnung dienen würden. „Einen bescheidenen Neuanfang bildet die moderne kleine Turbine im Rosenhofer Gelände“(:21).

Des Weiteren wird nicht nur vergessen, dass in der Aufgabe der kleinen Mühlen eine ungeheure Verschwendung von natürlicher, ständig erneuerbarer Energie liegt, die zudem in Jahrhunderten geschaffen wurde, sondern auch, dass durch ,unsere heutige Abhängigkeit von ,Zentral- und Großmühlen' eine Gefahr für eine sichere (weil schwerer verwundbare) Versorgung mit Mehl in Notzeiten besteht [...]. Eine gewisse Rückbesinnung tut auch hier Not.“ (BEDAL 1992:125) „Localism“ als anglo-amerikanischer Kraftausdruck bzw. die finnische „locality“-Forschung unterstreichen diese Bewegung zu einer standortbezogenen, punkthaften Interessenvertretung wie auch Nutzbarmachung nachhaltiger Ressourcen am Ort und nicht zentral in einer entfernt gelegenen Region.

Aber auch die Diskussion um die Reaktivierung alter, bisweilen heidnischer Heillehren, denen sich auch die Schulmedizin verstärkt bedient, zeigt die Modernität der Betrachtung. So findet im Gesundheitsbereich die blutreinigende Anwendung von Blutegeln wieder vermehrt statt. Mit der Zucht von Blutegeln in Teichen, die in diesen bis zu 30 Jahren alt werden können und nach einer regenerativen 
Phase wieder als „Heilmittel“ zur Verfügung stehen, verdienen in Deutschland bereits einige selbständige Zoologen ihr Einkommen. Des Weiteren können auch die anderen aus der historischen Teichwirtschaft gewonnenen Erkenntnisse einen „erheblichen Teil zur Erforschung der historischen Kulturlandschaft und zur Entwicklung ökologisch sinnvoller Zukunftsmodelle beisteuern“ (LIEPELT 1992:55).

Schließlich kann „,mit einem Minimum an Arbeit“ beispielsweise bei der Anlage von Wässerwiesen „immer noch ein beachtlicher Nutzen erreicht werden“" (FIEDLER 1965:78). Dies gelänge auch mit einem reduzierten Bewässerungssystem, wie FIEDLER (:77) es am Beispiel Neustadt a. d. Weinstraße für Mitte der 1960er Jahre aufzeigt, bei dem die Bewässerungsanlagen so stark vereinfacht wurden, dass sie weder zeit- noch kraftraubende Handarbeit erforderten (:105). Allerdings muss betont werden, dass das Rieselwasser in der Hauptsache den Boden anfeuchten soll, die früher einmal so wichtige Düngung ist nicht mehr wesentlich. Für die ausreichende Nährstoffversorgung der Wiesen wird Kunstdünger verwendet (:86). Ein ,überlagerndes Zukunftskonzept“ sieht LEIBUNDGUT (1993:27) bei der erneuten Anwendung von Wiesenbewässerungen, auch wenn es als moderne Form von Intensivnutzungen ausgeführt wird, ,,indem mehrere Extensivnutzungen [...] überlagernd durchgeführt werden." Hiermit ist die Kombination von landwirtschaftlicher Wiesenbewässerungs-Grünlandnutzung mit einer wasserwirtschaftlichen Nutzung zur Grundwasseranreicherung und der Naherholungsnutzung gemeint. Gleichzeitig könnten damit „Schutzziele des Landschaftsschutzes und Naturschutzes" erreicht werden (:27).

Aber es muss bei dieser Inwertsetzungsdiskussion Folgendes beachtet werden: 1. Durch den Abbruch von Wassermühlen und Verfüllung ihrer Mühlenteiche hat man sich der weitflächigen energetischen Grundlage beraubt. Die veränderte kulturhistorische Situation, die mit dem tausendfachen Schwund von Wasserwerken gekennzeichnet ist, macht eine Reaktivierung von wasserbetriebenen Anlagen im großen Stil unmöglich. 2. Die romantische Vorstellung einer Wassermühle projiziert auf die Moderne schlägt fehl. In dieser Situation jedoch „den Ausweg in einem weiteren Ausbau der Wasserenergienutzung und damit in einer weiteren Zerstörung der Fließgewässer zu suchen, ist falsch“ (STEIN 1995:23). Denn erstens war der Gewässerausbau schon in der Vergangenheit immens, um den Wassertriebwerken die notwendige Antriebsenergie zu geben, und würde zukünftig, um genügend Wasserenergie zu erzeugen, wahrscheinlich den neuartigen Ausbau aller möglichen Gewässerläufe bedeuten. Die Vergangenheit hat bewiesen, dass dabei auf kulturlandschaftliche Relikte keine besondere Rücksichtnahme zu erwarten ist. Zweitens ist durch die in der Einleitung angesprochene Intermittierung von Wasserläufen, deren Verrohrung und großflächige Abführung eine brutale Veränderung der hydrographischen Situation eingetreten, die eine kontinuierliche Wasserbeaufschlagung nur in wenigen Fällen ermöglicht, soll es aus den natürlichen Wasserläufen entnommen werden. Die krassen, spitz verlaufenden Niederschlagsereignisse eignen sich dafür ebenso wenig, wirken gar eher zerstörerisch. Eine Vielzahl an Faktoren negieren also eine Konversion früherer Gewässeranlagen nach historischem Vorbild. 


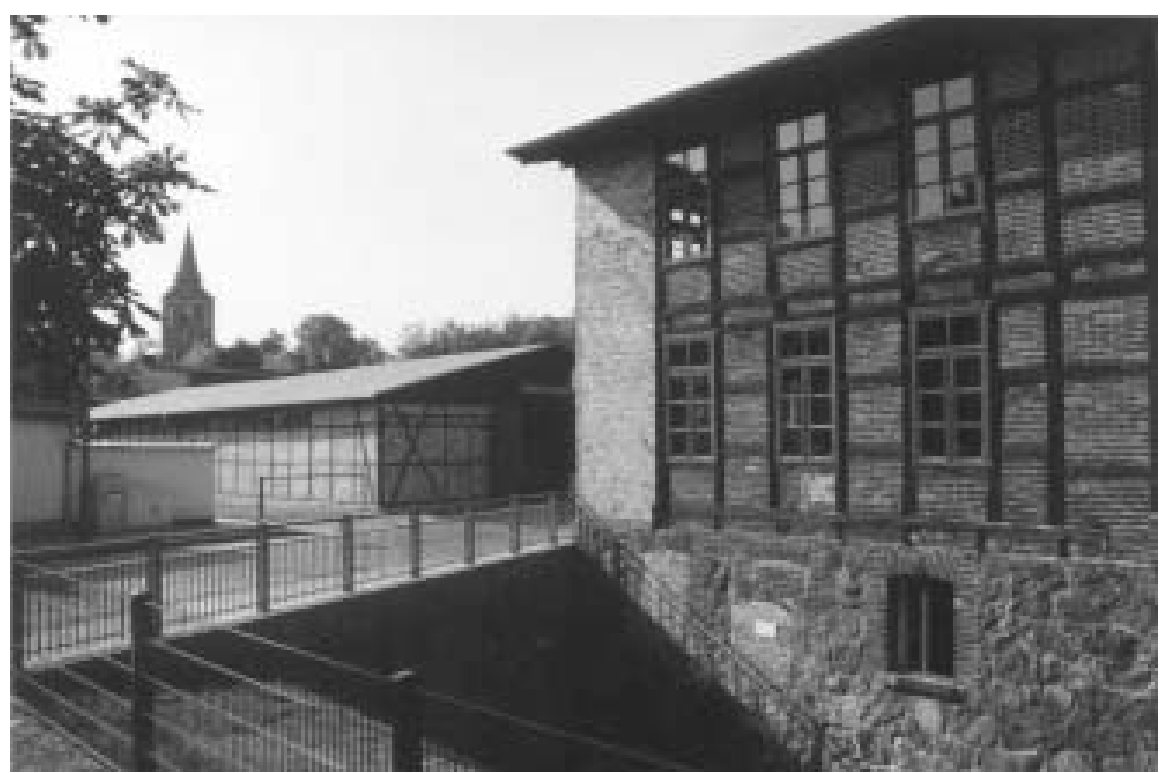

Abb. X-1: Wassermühle in Lassan, Mecklenburg-Vorpommern

Der Scheunenbau im Hintergrund des eigentlichen zweistöckigen Mühlengebäudes wurde auf dem ehemaligen Mühlenteich errichtet, der dafür verfüllt worden ist. Beide Gebäude beherbergen das heutige Museum mit Sammlungsschwerpunkt zur Agrartechnik. Das Mühleninventar ist weitgehend erhalten geblieben (eig. Aufnahme 2003).

Da die moderne Interpretation alter Techniken, wie anschaulich demonstriert, nicht unproblematisch erscheint und ein Konsens gefunden werden muss, der die Ökonomie des Wassers als effizienteste Form der Energiegewinnung und des Transportwesens und die dafür erforderlichen Umgestaltungsmaßnahmen des Flussökosystems berücksichtigt, lässt sich konklusiv festhalten, dass die in dieser Arbeit beispielhaft präsentierte und von DENECKE 1994 entwickelte ,anwendungsorientierte historisch-anthropogeographische Umweltforschung“ bei der Lösung neuzeitlicher und zukünftiger Probleme einen wesentlichen - vielfach gesellschaftlich unterbewerteten bzw. sogar unbekannten Beitrag zu leisten vermag.

Ein aktualitätsbezogener Beitrag der historisch-geographischen Gewässerforschung mag in der - im Übrigen schon seit Jahren (PAIKL/DANNINGER 1982; SAUERWEIN et al. 2000), aber zur Zeit wieder aktuell - diskutierten möglichen energiewirtschaftlichen Nutzung von kleinen Fließgewässern durch Kleinwasserkraftwerke liegen. Denn Nachdenkenswertes über umweltfreundliche historische Energiespender dahingehend, ob die alte schadstofffreie Energienutzung aus Wasser wieder neu zu besetzen sei, bedeutet in heutiger Zeit auch die Diskussion über rationellere und effizientere Wertschöpfung. Nachdem die Windkraft die potentiell günstigen und raumplanerisch möglichen Landflächen belegt hat und bereits in den Offshore-Bereich ausweichen muss, sind dies neben der Sonnen- nur die Wasserkräfte (PAIKL/DANNINGER 1982:224).

Dass eine solche Entwicklung nicht immer aber kulturlandschaftsfreundlich und zugleich effizient abläuft, beweisen die Windräder der neuen Generation. Nicht nur in den neuen Windenergieparks, sondern auch in Gebieten, die bereits über Windkraftanlagen verfügen, wird über das sog. Repowering versucht, die alten, wenig effizienten Anlagen durch neue, hoch effektive zu ersetzen mit ,in der Regel stärkeren Umweltfolgen infolge einer erheblich veränderten Dimensionierung der Anlage" (BDLA 2003:35). Mit „Der Windmühlenwahn - Vom Traum umweltfreundlicher Energie zur hoch subventionierten Landschaftszerstörung“" war die SPIEGEL Ausgabe Nr. 14 vom 29.03.2004 überschrieben und sie fakturiert, ,warum der weitere Ausbau der Windkraft der Umwelt mehr schadet als nützt“. Und ob die Gewässerneugestaltung, die - läuft sie vergleichbar wie die Substituierung von hölzernen Windmühlflügel durch Windräder mit horizontal liegender Rotorachse $a b$ - dann folgen wird, der Ausbeute und dem Landschaftsempfinden gerecht wird, mag dahingestellt sein. Schon heute ist es so, dass „wertvolle Landschaftsteile, wie zum Beispiel historisch gewachsene Kulturlandschaften, historische Landnutzungsformen, Sichtachsen zwischen prägenden Landschafts- und Bauformen, Landschaftsbereiche mit hohem Naturerlebnis- und Erholungswert, wenig vorbelastete 
Landschaftsbilder mit hoher visueller Empfindlichkeit, [...] als ,Ausschlussflächen' für die Errichtung von Windkraftanlagen zu behandeln“ sind (BDLA 2003:34f.).

Weltweit besitzt die Wasserkraft bereits heute einen höheren Anteil an der elektrischen Energieversorgung, als die bestehenden circa 500 Kernkraftwerke insgesamt. Und die Wasserkraftreserven der Erde, die vor allem noch in Asien, Afrika und Lateinamerika vorhanden sind, entsprechen der Leistung von weiteren 1000 Kernkraftwerken. Die Nutzung der Wasserkraft zur Erzeugung elektrischen Stroms stellt also heute sowohl in unserem Land, in Europa und auf weltweiter Ebene generell die wichtigste erneuerbare Energiequelle dar. Ebenso votiert der politische Wille der Bundesregierung und auch der Bundesländer für den verstärkten Einsatz der erneuerbaren Energien und damit auch für die umweltfreundliche Wasserkraft. Die Vorgabe des Erneuerbare-Energien-Gesetzes und die Vorgabe der EU, wonach aus Gründen des Umwelt- und Klimaschutzes sowie der Versorgungssicherheit der Anteil der erneuerbaren Energieträger bis zum Jahr 2010 verdoppelt werden soll, betrifft ebenfalls die Wasserkraftnutzung.

In Verbindung mit anderen regenerativen Energieformen kann zwar mit der Ausnutzung der Wasserkraft der Verbrennung fossiler Brennstoffe mit ihren klimatischen Folgen entgegen gewirkt werden, aber das bedeutet, - da die großen Wasserkraftreserven wie auch die für die Energiegewinnung in Frage kommenden großen Flüsse und die Speichermöglichkeiten in alpinen und gebirgigen Bereichen mit zum Teil gigantischen Kraftwerken (Dreischluchtenkraftwerk in China, Itaipu in Südamerika) weitestgehend ausgebaut sind und da die Anlage riesiger Stauseen wegen des Raumbedarfs, der oft die Aussiedlung von Menschen nötig macht, und aufgrund der zum Teil unvorhersehbaren ökologischen Folgeerscheinungen und technischen Risiken (Dammbruch) zur Nutzung der „weißen Energie“ umstritten ist -, dass die Energiegewinnung zukünftig in zwei entgegengesetzten Größenordnungen verbleibt: 1. als „Windräder unter Wasser“, die, gewissermaßen auf den Kopf gestellt, als Unterwasserkraftwerke Strom aus dem Meer gewinnen, indem sie die durch Ebbe und Flut entstehenden Meeresströmungen nutzen ${ }^{2}$ und 2. in der Inwertnahme vor allem der kleineren bis kleinsten Bachläufe.

So wird beispielsweise das EU-Beitrittsland Polen im Internet von einem Büro ${ }^{3}$ angepriesen als „ein Land mit großen Möglichkeiten für Investitionen im Bereich der erneuerbaren Energie und vielen verwertbaren Standorten an Flüssen“. Dieses Büro ist tätig „im Bereich der Gewinnung von Standorten und des Baus von Wasserkraftwerken auf dem Gebiet Polens" und arbeitet nach eigener Darstellung eng mit dem polnischen Umweltministerium zusammen. Dabei gehört zu den Dienstleitungen neben der „Suche nach voraussichtlichen Standorten oder bereits bestehenden Wasserkraftwerken in Polen" auch die Ausarbeitung von Angeboten und Unterlagen für langfristige Verträge mit der Polnischen Energetiknetz AG über Stromlieferungen und Systemleistungen. Momentan werden drei Wasserkraftwerke mit $100 \mathrm{~kW}, 180 \mathrm{~kW}$ und $300 \mathrm{~kW}$ Nennleistung auf dem Fluss Barycz gebaut und Planungsdokumentationen für zwei Wasserkraftwerke mit $1100 \mathrm{~kW}$ und $2200 \mathrm{~kW}$ installierter Leistung auf der Oder erarbeitet. Zur Lokalisierung und Berechnung der Wasserkraft ist das Büro ist „,im Besitz des Archivs aus der Zeit vor dem Zweiten Weltkrieg und der Nachkriegsdokumentation über die Wassergrade [sic; gemeint sind wahrscheinlich Staugrad bzw. Stauhöhe als Ausdruck der Wasserstärke, B.B.] und Orte, in denen der Bau oder der Wiederaufbau" von Wasserkraftanlagen möglich ist.

Um das bei kleinen Fließgewässern nicht genutzte, über das Wehr abfließende Wasser, das sonst für die Energiegewinnung verloren ist, zu nutzen, werden zunehmend ,schwellbetriebsfähige Laufwasserkraftwerke" eingesetzt, bei denen der Zufluss teilweise im Stauraum gespeichert werden kann. Der so zurückgehaltene Zufluss führt zwar zunächst zu einer Leistungsverminderung, allerdings ermöglicht die zusätzliche Entnahme des gespeicherten Wassers dann eine entsprechend höhere Leistung. Voraussetzung für die Nutzung der Wasserkraft durch Pumpspeicherwerke sowie je nach Fließgewäs-

\footnotetext{
${ }^{2}$ Der erste Prototyp eines Unterwasserkraftwerks dieser Art, der mit Windenergietechnik Meeresenergie erschließt, ist vor der Südküste Englands im Sommer 2003 fertig gestellt worden. Die Konstruktion wurde an der Universität Kassel entwickelt.

3 Fa. ESI-Inwest, Hr. Jacek Krzemiński [Vorstandsvorsitzender], email: biuro@esi-inwest.pl [aus: URL = http://www.wasserkraft.org/ts/df/919.html;/ 5.11.2003]
} 
sercharakteristik durch Hoch-, Mittel- und Niederdruck betriebene Laufwasseranlagen ist aber auch hier, dass eine ausreichende Menge und Fallhöhe des Wassers vorhanden ist und aufgrund eines Gefälles mit wirksamer Fließgeschwindigkeit eine Wasserturbine angetrieben werden kann. Veränderungen am Gewässerlauf zur Erhöhung des Gefälles zum Beispiel können hier schon prognostiziert werden.

Die hydrologischen und klimatischen Folgen, die sich aus dieser flächenhaften Gewässernutzung zur Stromerzeugung ergeben, wären insgesamt aber nicht absehbar, insbesondere nicht in den ariden und semiariden wie aber auch nicht in den kontinentalen Gebieten. Die ökologischen Folgen durch die Errichtung von kleinen Wasserkraftanlagen an den Fließgewässern, beispielsweise von fast 500 in Sachsen seit 1990, sind bereits heute nachweislich katastrophal. Die Ausleitungsstrecken, aus der das für die Wasserkraftanlagen notwendige Wasser entzogen wird, werden in eine künstliche Mangelsituation versetzt - sie werden vollkommen trockengelegt.

Ob dann noch die Vorzüge, die nach Ansicht des Bundesverbandes Deutscher Wasserkraftwerke e.V. ${ }^{4}$ für den „weiteren Ausbau der Wasserkraft“ sprechen, wie „hohe natürliche Stetigkeit und sehr hohe Wirkungsgrade“, „,regenerativ, unerschöpflich“, „gefahrlos und technisch erprobt und bewährt minimale Eingriffe in die Natur“, „Wasserkraft nutzt die Natur, ohne sie zu zerstören“, ,vermindert den Treibhauseffekt und reduziert die Gefahr der drohenden Klimakatastrophe“, weiterhin bestehen, ist zumindest anzuzweifeln. Der Schutz gewässerhistorischer Kulturlandschaftselemente jedenfalls ist bei der Umsetzung der Wasserkraftnutzungskonzepte zu proklamieren, sollen diese nicht der Überplanung anheim fallen. Die Historische Geographie darf hier nicht abseits stehen, da es ihr mit den ihr eigenen Methoden möglich ist, einer Schieflage in der öffentlichen Debatte und der Publizistik entgegenzuwirken: Die vorindustrielle Gewässernutzung und Gewässerwirtschaft wird nämlich zuweilen als problemloses Gegenbild im Sinne einer oberflächlich ästhetisierenden Nostalgie ausgegeben und auf die aktuellen und zukünftigen Wasserkraftnutzungsanlagen übertragen. Sie darf aber auch nicht wegschauen, wenn es um die Realdefinition des neuen Weges bei der Nutzung der Wasserkraft geht. Eine Form der Mitwirkung kann in der Sensibilisierung für die kulturgeographischen Belange und Sichtweisen bestehen.

Wenn neben Flüssen, Bachläufen und Quellen auch Teiche verschwinden oder zur Unbedeutung degradiert werden - und dies ist trotz einiger modellhafter Renaturierungen der Fall - bedeutet dies für den Menschen nicht nur existentielle Bedrohung, sondern zugleich - und zunächst - eine ungeheure seelische Verarmung und Verlust des Geschichtsbewusstseins, da von den ehemals von Weihern gesäumten Senken kein greifbarer Hinweis mehr auf die große wasserbauliche und weiherwirtschaftliche Tradition ausgeht. Die Kulturlandschaft verliert dadurch einen Teil ihrer Identität. „Es kann nicht Wunder nehmen“, so diagnostiziert PFEIFER (1982:331), „daß in unserer von dem Verlust einer Vergangenheit und einer Heimat befallenen Welt, seelische Traumata weit verbreitet sind.” „Event-Landschaften“, „Suggestive Erlebnisräume“, „Imaginationen von Geschichtlichkeit, ja von Authentizität“ (LENZ 2000:190), Landschaften als ,sauber geputzte Inszenierungen der vergangenen Arbeitswelt" in einer „fast schon klassischen postmodernen Historisierung" (:190) schaffen eine Distanzierung, Entfremdung von Natur und Alltag (MÜCKE 1988:304), die in ihrem Ausmaß für das Befinden, für ein Engagement pro Umwelt noch nicht erfasst sind. Es ist zwar „charakteristisch für Kulturlandschaften, daß sich sowohl deren Physiognomie realiter verändert als auch die Sichtweise des Begehers der Landschaft im Kontext der jeweiligen Zeit wandelt, das Abbild der Landschaft also durch kulturelle Dispositionen determiniert wird" (LENZ 2000:191), aber die Entfernung von „Landschaft", „Natur" und „Heimat" bedeutet einen großen Wahrnehmungs- und Geschichtsverlust, der über die zeitliche Kompensationsfähigkeit auch des neuzeitlichen, eher schmerzfreien Betrachters hinausgeht. Die reale „Liebe zur Natur“" erwacht eventuell zwar wieder, doch das Wissen um die Mythologie und die anthropogene Gestaltung ist zwischenzeitlich verloren gegangen. Wasser darf deshalb nicht länger nur als Sport- und Freizeitplattform, auf die chemische Formel $\mathrm{H}_{2} \mathrm{O}$ oder auf das Ökosystem „Gewässer" reduziert und damit nur als Gebrauchsmittel oder als Partner der zoologischbotanischen Werte betrachtet werden. Vielmehr gilt es, dieses einzigartige, bewegte und bewegende, Gestalt durchdringende und Gestalt formende Wesen in seiner kulturhistorischen Ganzheit zu

\footnotetext{
${ }^{4} \mathrm{URL}=$ http://www.wasserkraft.org/allgemeineinfo_seite1.htm; 5.11.2003
} 
begreifen, zu erleben und zu erfahren. Nicht auf die heutige, gefährdete Situation des Wassers konzentriert sich deshalb diese Arbeit, sondern auf dessen uralte kulturhistorische Bedeutung.

So erhält neben allen sehr aktualwissenschaftlichen Begründungen die vielgescholtene landeskundliche Deskription in Zusammenhang mit der gesellschaftlichen Bewusstseinsbildung in zunehmender Weise einen wichtigen Stellenwert hinsichtlich der Wertschätzung und Beurteilung historischer Erscheinungen im Raum. „Nur die Historische Geographie kann in interdisziplinärem Kontext und aus der Kenntnis der Vergangenheit und der Genese des Gegenwärtigen heraus Entwicklungstendenzen bewerten und ihre möglichen Einflüsse auf die Kulturlandschaft veranschaulichen“" (SCHUMACHER-GORNY 1997:313). Landschaft ist in diesem Sinne als „Archivalie“, als „Urkundenträger“ zu verstehen (SCHENK 2003). Die auf die Bewusstmachung folgende Sensibilisierung und subtilere Wahrnehmung der kulturhistorischen Elemente aufgrund der (besseren) Kenntnis der Landschaft und der Umweltgeschichte veranlasst uns oftmals erst zur Erhaltung, Pflege oder ökologisch-orientierten Unterschutzstellung eigentlich kulturhistorischer Landschaftselemente. Umwelthistorisches Verständnis also als Grundvoraussetzung von Kulturlandschaftspflege: „Landscape history is not just concerned with explaining the origins of today's landscapes. It is a source of historical information which can widen and deepen our understanding of ealier times, and of the nature and direction of historical change" (KNOWLES 1985:20). Die Eigenart einer Landschaft ist demzufolge „ohne Auseinandersetzung mit dem kulturellen Hintergrund nicht schlüssig zu begreifen und folglich nicht in ausreichendem Maß bei der Entwicklung planerischer Leitbilder zu berücksichtigen“ (RIEDEL/HASLACH 1999:179). Die kundige Beschreibung kulturbedingter Gewässertypen ist demzufolge allein damit bereits ein Beitrag zur ,Angewandten Geographie‘ im Sinne des früh planungspraktisch arbeitenden Hamburger Geographen Hans-Gottfried von ROHR (1990:8); ist aber zeitgleich auch ein Beitrag zur Gewässerökologie. Denn die „Kenntnis historischer Landschaftszustände und der Umweltgeschichte ist sowohl als Teil des Referenzsystems für eine Bewertung als auch zum generellen Verständnis der Dynamik und Ökologie von Gewässerlandschaften erforderlich“ (NIEHOFF 1996: 106).

Mit historisch-geographischen Aufarbeitungen und landschaftsgeschichtlichen Erläuterungen dieser Art werden ,sehr wirkungsvolle Beiträge geleistet für die erhaltende Landschaftspflege einerseits wie auch für die landschaftsbezogene Bildung und das historisch-genetische Landschaftserlebnis mit dem Ziel einer Erziehung zum pfleglichen Umgang mit dem Erbe der Kulturlandschaft" (DENECKE 1999:49). „Aufgabe und Anspruch einer Dokumentation und Erhaltung der Kulturlandschaft sind besonders - allerdings keineswegs allein-“, führt DENECKE (1997:40; ebenso 2001:284) weiter aus, „,in einem kulturellen Wert begründet.“

Untersuchungen und Vermittlungen über vergangene Gewässerlandschaften ermöglichen darüber hinaus auch eine gefilterte Bewertung von historischen Gewässernutzungen hinsichtlich „Umweltverträglichkeit“ bzw. „Nachhaltigkeit“, die vor allem bei der Diskussion um eine Reaktivierung ehemaliger Wirtschaftsweisen an Bedeutung gewinnt. So bleibt es beispielsweise unklar, ob (überhaupt) und inwieweit schädigende Auswirkungen von den gewässerhistorischen Nutzungsarten ausgingen. Ist die Annahme überhaupt berechtigt, dass die historischen Wirtschaftsweisen überall dort umwelt- und landschaftsschonend waren, wo sie sich in bzw. auf kleinen Gewässern abspielten und nicht auf große Seen und Flüsse bezogen waren? Oder ist das eine nostalgische Illusion?

Die Flößerei beispielsweise, so ist sich SCHUBERT (2001:31) sicher, hat nur geringe Auswirkungen auf das Flussökosystem gehabt. Zwar ging zum Beispiel der mittelalterliche bis neuzeitliche Ausbau der Fließgewässer mit Stromschnellen und die Begradigung von Gewässern auf Kosten der Ruheplätze. Generell jedoch waren die Beeinträchtigungen auf den Fluss als aquatischen Lebensraum unerheblich: Fische wurden nicht verletzt, das Flößholz schadete den Fischlaichplätzen nur in kleinem Maße und das das Aufsteigen der Fische wird - im Gegensatz zu den Mühlenwehren - nachweislich nicht behindert. Die Flößungsreste haben sogar einen positiven Einfluss auf die Fress- und Laichplätze von Fischen gehabt, da diese die Nahrungsgrundlage für Fische darstellen (:31). „Das alles beherrschende Trägheitsgesetz,“ urteilt auch RADKAU (2002:13), „,das heute oft den gedankenlosen Umgang mit der Umwelt fördert, war in Zeiten, als das Fällen und Transportieren von Bäumen sehr mühsam war, oft der beste Umweltschützer.“ 
Die früheren Flussbegradigungen führten ebenfalls zu einem positiven Nebeneffekt: Es entstanden Altwasser, Qualmgewässer und Totarme, ,die als Ökotone zwischen Wasser und Land die Strukturmannigfaltigkeit der Flußaue erhöhen" (SCHUBERT 2001:34). Aus historisch-geographischer Sicht entstand durch ehemalige anthropogene Eingriffe entsprechend ihrer Nutzungsvielfalt vielmehr eine Diversifizierung der Gewässer.

Wissenschaftliche Untersuchungen (KREY/PROFT 1980, in SCHUBERT 2001:34ff.) schreiben des Weiteren den alten Querverbauungen ,eine größtenteils positive Wirkung“ zu, aber erteilen den neueren Regulierungsaktivitäten von Querverbauungen aus naturschutzfachlicher Sicht eine Absage: Hier ist - im Gegensatz zu den alten Wehren und Schleusen - durch eine veränderte Habitatstruktur eine Abnahme der Artenzahl zu verzeichnen.

Darüber hinaus haben Untersuchungen ergeben, dass gerade Kulturlandschaften ein größeres Artenspektrum aufweisen. Thomas KAISER (1990:60ff.) hat mit dem Verschwinden von künstlich geschaffenen Fließgewässernetzen, wie sie von der Rieselwiesenwirtschaft produziert wurden, und mit der Aufgabe der Wiesenbewässerung ein Verschwinden von Amphibien festgestellt. Das künstliche Gewässersystem konnte also demnach wenigstens einen Ausgleich für vorangegangene Eingriffe in das Gewässersystem des jeweiligen natürlichen Bachlaufes geschaffen haben.

Wenn die Landwirtschaft des 19. und frühen 20. Jahrhunderts auch flächenhafte Entwässerungsmaßnahmen in den Wiesentälern und Moorgebieten durchgeführt hat, so genießt die historische Bewässerung mittlerweile doch eine allgemeine Wertschätzung (GUNZELMANN 2003:10]: In den temporär unter Wasser stehenden Entwässerungsgrippen und in den unter Staunässe ausgeprägten Randbereichen der Bewässerungswiesen hat sich ehemals ein großer Artenreichtum gebildet und gehalten. Ähnliches trifft für das Grabensystem zu. Hier konnten sich in Abhängigkeit von den vorherrschenden Wasserverhältnissen verschiedene Mikrostandort ausbilden. Trotz regelmäßiger mechanischer und handwerklicher Eingriffe zur Aufrechterhaltung ihrer Funktion konnte sich in den Gräben daher eine außerordentlich differenzierte Vegetation und Fauna halten. „Außerdem waren diese künstlichen Grabensysteme in den bewässerten Tallandschaften meist recht großräumig miteinander verbunden“ (GROTTIAN 2001:26) und erbrachten somit ihren Beitrag zum „Verbundsystem“.

Kreuzkröte und Gelbbauchunke, letztere Art ist europaweit gefährdet und unterliegt dem Schutz der FFH-Richtlinie, nutzen solche kleinen Laichgewässer, wie „rasch austrocknende Pfützen” zur Fortpflanzung. Diese beiden beispielhaft genannten amphibischen Arten sind auf diese temporären Gewässer zur Fortpflanzung und damit auf eine hohe Dynamik in der Landschaft angewiesen. Die Kreuzkröte „benötigt Kleinstgewässer mit höchstens minimalem Vegetationsaufwuchs, die sich bereits bei geringer Sonneneinstrahlung schnell und stark erhitzen.” (MERTENS 2003:25) Ähnliche Kleinbiotope entwickelten sich früher mit dem alljährlichen Hochwasser ständig neu, diese ,natürlichen" Lebensräume hingegen fehlen heute aufgrund der mangelnden Auendynamik (:25). Deren Überleben wird als fragwürdig betrachtet, nachdem diese ephemeren und zeitlich begrenzten Biotope nicht mehr neu entstehen (:25). Insofern ist Kulturlandschaftsschutz auch Naturschutz, wie auch die folgenden Beispiele zeigen:

Die zum Suhlen von Huteschweinen aufgesuchten schlammigen Tümpel inmitten der Waldweide, die es in sumpfigen Gegenden reichlich gab, und die brauchte es nicht nur zur Fellpflege (Ungezieferbeseitigung), sondern auch zum Schöpfen (waidmännisch für „Trinken“) bei Wild und Hütehund, stellen ebensolche Kleinbiotope im Verbundsystem dar.

Der zur Nutzung erforderliche Ausbau der Gewässer führte zu einem weitverzweigten Kanal- und Grabensystem, bei dem der Mensch mit ,hoher Sensibilität für morphologische, hydrologische und technische Verhältnisse [...] über Jahrtausende hinweg in den natürlichen Gewässerhaushalt [...] behutsam und nutzbringend eingegriffen hat" (HERBST 1992:126). So wirken beispielsweise auch Teiche mit ihren Zu-, Um- und Ableitungsgräben im Gelände ,regulierend in wasserwirtschaftlicher und klimatischer Hinsicht“" (LIETMANN 1941:6). 
Und die verbliebenen historischen großen Teichgebiete besitzen als oftmals letzte Raststation und Brutgebiet eine besondere biologische Bedeutung. Teichwirtschaften gelten als „Sahnestücke des internationalen Arten- und Biotopschutzes“" oder, wie Ralf SCHULTE (2000) von der NABUAkademie Gut Sunder es auch ausdrückt, als „hotspots“ der Biodiversität in der Kulturlandschaft. Zu den Gebieten von besonderer Bedeutung für den Vogelschutz (IBA, RAMSAR) zählen unter anderem die Wallnauer Fischteiche auf Fehmarn, die Meißendorfer Teiche, die Riddagshäuser Teiche, die Peitzer und Bärenbrücker Teiche sowie die Ismaninger Fischteiche. Die Anerkennung als UNESCOBiosphärenreservat tragen die Fischteiche der Blumberger Mühle in Biosphärenreservat SchorfheideChorin und die Teichgebiete der Oberlausitzer Heide- und Teichlandschaft (SCHULTE 2000). Ebenso bilden die Teichgebiete im oberfränkischen Raum, insbesondere die Karpfenteichanlagen wegen der Wasserarmut im nordbayerischen Raum mit ihren mosaikartigen Verflechtungen und Uferflächen, Wasserläufen und Flutmulden die Voraussetzungen für einen außergewöhnlichen Reichtum an Tierund Pflanzenarten. In 27 von 83 oberfränkischen Naturschutzgebieten liegen Teiche und stellen damit einen wesentlichen Bestandteil dieser Schutzgebiete dar. Daraus wird ersichtlich, welche Bedeutung insbesondere Karpfenteiche für die Artenvielfalt in Nordbayern bzw. Oberfranken haben.

Darüber hinaus wirken sie der Chemisierung der Gewässer entgegen: Nach Untersuchungen des Instituts für Binnenfischerei in Potsdam-Sacrow hält eine ordnungsgemäße Bewirtschaftung von Karpfenteichen pro Hektar Teichfläche im Mittel 5,1 kg Phosphor und 43,2 kg Stickstoff pro Hektar im Jahr durch Bindung an den Pflanzengesellschaften in den Lebenszonen (Rasenflächen) und durch Fixierung im Boden zurück. Karpfenteiche stellen also auch aus wasserwirtschaftlicher Sicht keine Belastung, sondern eindeutig eine Entlastung der Umwelt dar. Sie sind sog. Phosphat- und StickstoffFallen.

Die heutigen Teiche dienen auch als Wasserrückhaltebecken und übernehmen damit bis zu einem gewissen Grad die Bedeutung der früheren Moore, wie etwa Anreicherung des Grundwassers, Versickerung von Wasser, Niederwasseraufbereitung sowie Hochwasserrückhaltung.

Die Teichwirtschaft allein unter landschaftsökologischen Aspekten zu betrachten, hieße, ihren wichtigen Beitrag zur Ernährung unberücksichtigt zu lassen. Die Nachfrage an hochwertigem Fischfleisch ist in den vergangenen Jahren beständig gestiegen, doch die Hochseefischerei stagniert. Die Anlandungen deutscher Fangschiffe im Inland gingen von 1991 bis 2001 stetig zurück $(-51,8 \%)$ (STATISTISCHES BUNDESAMT 2002 :276). Dies hat zur Folge, dass der Bedarf an kalorienarmen, eiweißreichen Fischfleisch künftig zu einem beträchtlichen Teil von der Binnen-Teichwirtschaft übernommen werden wird. Mit extensiv erzeugten Speisefischen aus der heimischen Teichwirtschaft, wie Karpfen, Forelle, Saibling, Waller oder Zander.

Doch kann all dies nur durch eine intakte, aber gleichsam nur extensiv betriebene „BioTeichwirtschaft" gewährleistet werden, die somit zumindest in Teilen auf historischen Vorgaben aufbaut. Diese gilt es in ihrem Umfang zu erhalten und nicht die Produktion auf wenige Teichanlagen zu fokussieren, die einer Intensivhaltung gleichkommt. Der genaue Umfang der Teichwirtschaft in Deutschland in ihrem zeitlichen Verlauf ist dabei schwer zu überblicken. Das liegt daran, dass - bis auf den heutigen Tag - die Teichflächen nicht genau erfasst worden sind. In früherer Zeit hat es nur zweimal eine halbwegs brauchbare Erfassung aller Teicherträge gegeben, und zwar nach dem ersten und vor dem Zweiten Weltkrieg (SCHÄPERCLAUS 1961:168).

Nach einer Zusammenstellung auf Grund der Volks- und Betriebszählung vom 16.6.1925 waren damals in Deutschland rund 60.000 ha ablassbare Fischteiche vorhanden. Eine genauere Statistik vom 1. August 1936, die nur die wirklich bespannte Teichfläche, d. h. produktive Teichfläche erfasste, zeigte, dass nur (noch) 42.000 ha wirklich nutzbarer Teichfläche vorhanden waren. Nach der Statistik von SCHIMENZ aus den 50er Jahren entfielen auf das heutige Westdeutschland rund 20.000 ha und auf das Gebiet des heutigen Ostdeutschland rund 17.500 ha Teichfläche, also insgesamt nur noch 37.500 ha. Dies entspricht einer Dezimierung der Teichbewirtschaftungsfläche innerhalb von 20 Jahren um rund 5.000 ha. 
Zweifellos entsprechen diese Zahlen aber nicht der heute tatsächlich vorhandenen teichwirtschaftlich nutzbaren Wasserfläche. Diese sind aber leider kaum zu ermitteln: Der jährlich herausgegebene „Jahresbericht über die Deutsche Fischwirtschaft" gibt in seiner tabellarischen Darstellung derBinnenfischerei nur die ,fischereilich genutzte Fläche“ der gesamten Wasserfläche wieder (BUNDESMINISTERIUM FÜR VERBRAUCHERSCHUTZ 2003:50). Demnach existiert eine fischereilich genutzte Fläche von 505.805 ha, wobei für fünf Bundesländer keine Angaben vorliegen. Eine Differenzierung zwischen natürlicher und anthropogen geschaffener Wasserfläche ist somit nicht möglich.

Darüber hinaus gibt es die fischereistatistische Erhebung, die zum letzten Mal 1994 durchgeführt wurde $^{5}$. Diese aber wird für jedes Bundesland einzeln erfasst, eine Gesamtstatistik lässt sich so nicht „abgreifen“. Gesetzliche Grundlage dieser Statistik ist das Gesetz über Agrarstatistiken (Agrarstatistikgesetz - AgrStatG). Sie regelt in $\S \S 41-43$ die „Binnenfischereierhebung“. Dabei werden aber zum einen nur solche Betriebe erfasst, die Fluss- oder Seefischerei bzw. Fischhaltung oder Fischzucht zu Erwerbszwecken betreiben, und zum anderen nur diejenigen Betriebe der Flussfischerei „,mit einem Fischfang von jährlich mindestens zehn Dezitonnen Fisch“ und die bei der Fischhaltung oder Fischzucht „über eine Erzeugungsfläche von mindestens 100 Quadratmetern Forellen- oder 5000 Quadratmetern Karpfenteich verfügen.“ Eine umfassende, auch Kleinbetriebe der Teichwirtschaft berücksichtigende, Teichflächenstatistik liegt aber damit nicht vor. Des Weiteren sind in der Statistik der landwirtschaftlich genutzten Flächen nach Hauptnutzungsarten Fischteiche als Kulturarten nicht aufgeführt (STATISTISCHES BUNDESAMT 2003), was symbolisch dem Stellenwert dieses alten landwirtschaftlichen Kulturzweiges Ausdruck verleihen mag.

Der also natur- und ernährungswissenschaftlichen Beweisführung folgend sowie aus Gründen der ethischen Verantwortung und des nur schwierig quantifizierbaren subjektiven Ästethikempfindens kommt der Notwendigkeit zur Bewahrung der Vielgestaltigkeit der anthropogen geformten Kulturlandschaft und damit der erhaltenden, an den natürlichen Standort gebundenen Kulturlandschaftspflege eine zukunftsentscheidende Bedeutung zu. Vielfach wird bereits die großräumige Vernichtung ehemals zusammenhängender Kulturlandschaftsareale als unabwendbar angesehen und es gilt nur noch, ,Restinseln“ von Biotop- und Kulturlandschaftstypen zu erhalten, um von diesen Marginalbeständen ausgehend, die Erneuerung der Natur im Jahre X zu praktizieren (PETERS 1995:14). In Entlehnung des Begriffes der „Trittsteinbiotope“ aus dem Planungsarsenal der 1980er Jahre, die einen erster Schritt zur Biotopvernetzung darstellen sollten, bezeichnet LENZ (2000:193) beispielsweise schwimmende Gärten als „kulturelle Trittsteine“, als erste Knoten im Netz gegen eine ausschließliche „Ware Landschaft im Kopf" und sieht als solchen Trittstein zum Beispiel wassergefüllte Tagebaue.

Wenn man sich auch diesem negativen Trendszenario, diesem „düsteren Niedergangsgemälde“ (RADKAU 2002:26), nicht anzuschließen vermag, so ist durch Flächenverluste infolge von Sub- und Periurbanisierung und ruraler Wandlungsprozesse bewiesen, dass zahlreiche Landschaftselemente und -strukturen der traditionellen Wirtschaftsweisen, die das Bild der historischen Kulturlandschaft zeichneten, bereits irreversibel beseitigt, nur noch sporadisch oder nur noch reliktär und damit funktions- und zusammenhanglos innerhalb von nivellierten „Standardlandschaften“ nachweisbar sind (DENECKE 1997:45): in der Form musealer Vorführlandschaften oder als letzte Refugien der Vergangenheit. „Durch eine rücksichtslose moderne Landschaftsnutzung wird die Geschichtlichkeit und damit die Lebendigkeit ausgelöscht, wie die Auswirkungen der modernen Landwirtschaft und der Flurbereinigung bereits bewiesen haben“ (BURGGRAAFF/KLEEFELD 1997:30). Diese qualitativen und quantitativen Veränderungen und die damit eintretenden negativ zu bewertenden Folgen innerhalb der Kulturlandschaft „machen geeignete Strategien zum Schutz historischer Kulturlandschaften bzw. Kulturlandschaftselemente erforderlich, denn mit ihrer Zerstörung gehen wertvolle Bestandteile der menschlichen Umwelt verloren, bei denen es sich um nicht vermehrbare bzw. ersetzbare Güter handelt“" (RIEDEL/HASLACH 1999:169).

\footnotetext{
${ }^{5}$ Eine neue Datenerhebung wird im 1. Halbjahr 2004 durchgeführt; deren Ergebnisse aber hier nicht mehr berücksichtigt werden können.
} 
Und hier setzt nach meiner Auffassung, und ich schließe hiermit an die obige Ausführung an, der zukunftsweisende Ansatz der anwendungsorientierten historischen Umweltgeographie als Teilbereich der transdisziplinären historischen Umweltforschung an: bei der Integration von theoretischem Konzept und praktischer Anwendung im Rahmen einer das gegenwärtige Bild erklärenden wissenschaftlichen „Beschreibung und Analyse der Kulturlandschaften in ihrer historischen Entwicklung“ und der Inwertsetzung dieser Erkenntnisse bei der Lösung praktischer Aufgaben (DENECKE 1996:127, ebenso 1985:3,23f.). Es ist Zukunftsaufgabe „die Geschichte und Entwicklung unserer Kulturlandschaft wissenschaftlich $\mathrm{zu}$ erforschen und $\mathrm{zu}$ dokumentieren, um darauf aufbauend erhaltend für sie zu wirken und mit den Kenntnissen der Entwicklungsgeschichte dieser jeden Menschen umgebenden landschaftsgebundenen und im Laufe der Geschichte geschaffenen kulturellen Umwelt zur Lebensqualität und tragfähigen Zukunft unserer Gesellschaft beizutragen“ (DENECKE 2001:271). Denn ,without an accurate long-term history of the landscape and without an understanding of the processes which are guiding its evolutionary path, we are unable to envision future landscape changes“ (MARCUCCI 2000:87). Dabei gilt jedoch: „Ein effektiver Schutz des Lebensraumes ,Fischteich' ist auf Dauer nur sinnvoll und möglich, wenn die Nutzungsweisen, die zu seiner Entstehung geführt haben, bekannt sind und - wenn auch mit geringer Anpassung an die heutigen Lebensumstände - fortgeführt bzw. wiederaufgenommen werden (z. B. Art und Stärke des Fischbesatzes, Technik der Wasserstandsregulierung und des Entlandens, Methoden der Fütterung und Düngung etc.). Hinzu kommt das Wissen über eventuelle Nebennutzungen wie Ernte von Rohrkolben als ,Büttnerschilf', Zucht medizinischer Blutegel oder gar Anbau von Getreide auf dem Teichboden in Jahren der Dürre. Ein Rückbesinnen auf Kultur und Leben unserer Vorfahren kann aber keine Umkehr aus den heutigen Lebensverhältnissen in sogenannte, gute alte Zeiten' bedeuten. Vielmehr geht es darum zu begreifen, welches Handeln des Menschen in der historischen Kulturlandschaft für die Umwelt vorteilhafter war als vergleichbare Aktivitäten in der Gegenwart. Die daraus gewonnenen Erkenntnisse sind für die zukünftige Kulturlandschaft nutzbar zu machen“ (LIEPELT 1992: 54f.).

Ergebnis der beschriebenen Gewässernutzungen war ein sichtbarer Wandel des Kulturlandschaftsbildes. Eingriffe in die Fluss- und Gewässernetze führten aus der Balance und zur „kulturellen Uniformierung der Landschaft" in heutiger Zeit (RIEDEL/HASLACH 1999:169). So verbanden sich mit der Zerstörung, Auffüllung und Bebauung von Weihern, Kanälen und Grabensystemen, Flusslaufverlegungen und -begradigungen Prozesse, die die Flutmenge vergrößerten (HERBST 1992:71). Immer mehr Wiesen- und Weideland wurde zu Ackerland umgebrochen - auch in den noch überschwemmungsgefährdeten Gebieten. Bei extremen Hochwassern wurden große Teile des Ackerbodens in die Gewässerläufe fortgeschwemmt und erhöhten das Flussbett. Unter den zunehmend steigenden Bodenpreisen wurden weitere Wässerwiesen als Bauland versiegelt. Auf den flachen und dem Verkehr gut zugänglichen Talböden wurden vor allem Flächen zur Gewerbe- und Industrieansiedlung ausgewiesen (LEIBUNDGUT 1993:24). Die daraufhin eintretenden Hochwässer führten vor allem in den 1950er Jahren zu weiteren Begradigungen (HERBST 1992:39). Die ökologische Funktion der Gewässer wurde mit der zunehmenden Intensivierung der Nutzungen zunehmend eingeschränkt (LEIBUNDGUT 1986:153).

Der Grund dafür liegt unter anderem in einer - man kann sagen fast schon paranoiden - menschlichen Perspektive, wie Hoimar von DITFURTH in einem bereits 1964 verfassten und 1987 abgedruckten Beitrag erklärt: „Wie in so vielen anderen Fällen ist es auch hier wieder ein anthropozentrisches Vorurteil, das uns Wasser als ein feindliches Element erscheinen lässt. Unsere Angst vor dem Wasser ist, biologisch gesehen, nur ein Indiz für die Gründlichkeit, mit der wir uns den eigentlich abnormen Existenzbedingungen angepasst haben, denen ein lebender Organismus auf dem Festland ausgesetzt ist“ (:137). Man kann auch sagen, ,die post-industrielle Natur ist menschenfeindlich durch blinden Eifer geworden“" (EISELE 2002:148). Der Umwelthistoriker wie auch der Umweltplaner muss infolgedessen, ,in die Tiefe der Vergangenheit zurückgehen, um herauszufinden, wie unser gegenwärtiges Umweltverhalten vorprogrammiert ist“ (RADKAU 2002:28). Denn „man muß damit rechnen, daß unser gegenwärtiges Umweltverhalten teilweise sehr alten Verhaltensmustern folgt, ja unsere Wahrnehmung zu einem Teil der Problemlage früherer Zeiten entspricht" (:28). Dies gilt es bei einer historisch-orientierten Planung zu berücksichtigen, soll diese eine breite öffentliche Akzeptanz finden. 
Zugleich hinterließen Straßen- und Siedlungsbau einen weitgehend devastierten Raum. Zurück blieb eine Monotorisierung der Gewässerstruktur durch Auenverbauungen und Kanalisierungsmaßnahmen. Die umgebauten Flusstäler, Bachläufe und Regenrückhaltebecken repräsentierten einen neuen Landschaftstyp, der seit jüngster Zeit auch das Umfeld anderer Großbauwerke wie Autobahnen, Bahnschnellstrecken oder Flughäfen prägt. Es sind Ersatzlandschaften mit deutlichen Merkmalen uniformer Gestaltung. Dies haben die ausgewählten Beispiele gezeigt. So zeigen die bisherigen Erfahrungen zur naturnahen Umgestaltung ausgebauter Fließgewässer (KERN et al. 1992), dass oftmals keine genauen Kenntnisse über den kulturhistorischen Zustand der verschiedenen Fließgewässer vorhanden sind. Ohne dieses Wissen jedoch können die Zielvorstellungen und konkreten Planungsvorschläge gewässerhistorischer Elemente nicht oder nur unzureichend definiert und begründet werden. Ein schwerwiegendes Kenntnisdefizit besteht auch bei der kulturhistorischen Bewertung von Fließgewässern. Bei vielen gebräuchlichen Bewertungsverfahren dient als Basis der ehemals vermeintlich natürliche Gewässerzustand als Vergleichsbasis und Bewertungsgrundlage. Auch aus diesem Grund sind die historischen Kulturlandschaften am häufigsten durch landschaftliche Veränderungen und Umgestaltungen bedroht, die auf der Naturphilosophie aufbauen (MICHALÉK 1999:69).

Landschaftsgeschichte kann deshalb „be a valuable tool as it has the potential to improve description, prediction, and prescription in landscape planning" (MARCUCCI 2000:67). Dies gilt vor allem für die Landschaftsplanung im Sinne einer Freiraumplanung. Schwierigkeiten entstehen aber bei der Anwendung der bestehenden Leitbilder auf den urbanen und insbesondere suburbanen Raum. PABST (1998) ist sogar der Meinung, dass es für die Gewässer in der Stadt gar kein Leitbild geben kann, da der Urzustand unwiederbringlich verloren gegangen ist. Richtiger sei es, von Entwicklungszielen zu sprechen. Der kulturhistorisch-orientierte Um- bzw. Rückbau von Gewässern hingegen stellt so ein vermisstes, auf den verstädterten und vorverstädterten Raum übertragbares Leitbild dar, da hier ein ökologisch-fokussierter Gewässerumbau - allein schon aufgrund der überbauten Flächen und der kulturhistorischen, zum Teil sogar denkmalpflegerischen Elemente (Kanäle, Brücken etc.) - nur bedingt oder gar nicht realisierbar erscheint. Den entstehenden Konflikt zwischen Erhaltung und wirtschaftlicher Rentabilität kann die Historische Geographie lösen, „,wenn sie auf der Grundlage der [...] Inventarisation für beide Seiten tragbare Vorschläge zur weiteren Entwicklungsplanung macht“ (SCHUMACHER-GORNY 1997:313f.). Gleichzeitig aber ist die Einbeziehung und Freilegung ehemals verrohrter Wasserläufe unter dem Leitbild des umwelthistorischen Gewässerbaus ein Beitrag zur Verbesserung des Mikroklimas, zur Rückgewinnung von Fließdynamik und eventuell sogar zur Gewinnung von Retentionsflächen auch innerhalb bebauter Umgebungen. Angewandte kulturhistorisch-orientierte Gewässerplanung wird somit zum Träger von Natur- und Menschheitsschutz auf allen siedlungsräumlichen Ebenen.

Denn Umweltgeschichte, so haben die Überflutungen und Hochwasserkatastrophen der letzten Jahre auch gezeigt, scheint ,aufs Ganze gesehen doch weit weniger ohne die Geschichte des Menschen auskommen zu können“ (SCHUBERT 1989:31). Die „Einengung der Flußbetten durch Stromkorrekturen, die Verfüllung und Trockenlegung kleiner abflußloser Hohlformen [...] sind großräumige Veränderungen im natürlichen Landschaftshaushalt, deren Ausmaße im Verlauf der Menschheitsgeschichte noch keineswegs recht erfaßt sind“ (DENECKE 1989b:203). Diese Langzeitveränderungen und irreversiblen Störungen durch Eingriffe des Menschen in die Landschaft vermag die Historische Geographie ebenfalls aufzudecken. Entwässerungen und Flussregulierungen, Auentrockenlegung, Wiesenkultivierungen, Waldverminderung und zunehmender Ackerbau führten jedoch im Großen und Ganzen dazu, dass die mitteleuropäische Kulturlandschaft immer „dürreempfindlicher“ wurde (ELLENBERG 1986:355). Und „wo die Gefahr der Überschwemmung das Denken beherrscht, beachtet man nicht die mißlichen Folgen einer drastischen Absenkung des Grundwasserspiegels im Zuge der Flußregulierung. Ähnliche Folgen hatte die Fixierung auf die Dränage als Hauptmittel zur Steigerung der Agrarerträge“ (RADKAU. 2002:21f.). Die Erforschung der Folgewirkungen der mittelalterlichen und frühneuzeitlichen „Gewässerwüstungen“ beispielsweise ist ein klassisches historischgeographisch zu bearbeitendes, bisher jedoch noch kaum bestelltes interdisziplinäres Arbeitsfeld bei einer Kombination verschiedener Quellen, Methoden und Betrachtungsansätze (DENECKE 2001 :281). Eventuell vermag eine Beachtung historisch-geographischer Instrumentarien bei der zukünftigen Umweltplanung hier eine Lösung zu bieten. 
Für die angewandte Historische Gewässerforschung ist die Anwendung der historisch-geographischen Methodik, insbesondere der Auswertung von historischem Archivmaterial ein Anwendungsbereich, mit dem zum Beispiel eine Gewässerrekonstruktion in mitteleuropäischen Kultur-Altlandschaften ermöglicht wird, um beispielsweise eine historisch-orientierte Gewässersanierung vor dem Hintergrund einer Kulturlandschaftserhaltung durchzuführen, oder auch, um einen Betrag zur Hochwasserkatastrophendiskussion zu leisten. Derartige Angaben sind auch für die Entwicklungsländer nützlich und anwendbar; ,sofern eine der hiesigen Tradition verpflichtete Aktenüberlieferung besteht, können Versuche zur Rekonstruktion zerstörter oder veränderter Ökosysteme in ehemaligen Kolonien auf den Erfahrungen dieser Pilotstudie aufbauen“ (HERRMANN et al. 2002:55).

Des Weiteren ist eine historisch-orientierte geographische Gewässerforschung in diesem Zusammenhang mit ihrem Aktualitätsbezug darzustellen: die mitunter dramatischen Grundwasserabsenkungen und die gleichzeitige weitflächige Grundwasserbewirtschaftung seit geschichtlicher Zeit bedeuten eine irreversible Steigerung von Stoffverlusten und eine Zerstörung dieses Netzwerkes.

Zwar sieht es so aus, als würde die Historische Geographie damit „die Pose des Mahners mit dem ,erhobenen Zeigefinger' einnehmen, doch nur so kann, unter Zuhilfenahme fundierter Raum- und Geschichtskenntnis“, die wasserbezogene Kulturlandschaft, welche ja in der Vergangenheit gewachsen ist, erhalten werden. Anders gesagt, wird eine historische Wasserlandschaft „nur dann erhalten bleiben und weiterhin Teil der Kulturlandschaft sein, wenn sie auf der Grundlage der Kenntnis ihrer Genese und unter dem Vorsatz zur Erhaltung ihr eigener und sie prägender Bestandteile Gewässerpflege in der Gegenwart und für die Zukunft betreibt“" (SCHUMACHER-GORNY 1997:313).

Es gilt also das Primat, nicht eine naturgemäße, sondern kulturgemäße Umgestaltung der Flüsse und Bäche vorzunehmen und einen kulturhistorischen vernetzten Zusammenhang umzusetzen, gerade weil die unterschiedlichen Zweckbestimmungen der baulichen Anlagen zur Nutzung des Wassers dies oftmals nicht erkennen lassen: So können Teiche als Speicher zu Energiegewinnung (Mühlenantrieb), Grubenentwässerung, der Trinkwasserversorgung und der Fischaufzucht, der Bewässerung, dem Hochwasserschutz (Retentionsbecken) wie auch der Niedrigwassererhöhung (Trift) dienen, ebenso der Schiffbarmachung von Flüssen und Bächen. Die Bewertung von Bachauen und Flusstälern muss darum nicht nur unter ökologischen, sondern auch unter historischen Gesichtspunkten vorgenommen werden. Eine bloße Zurückführung in den „Urzustand“, d. h. eine auf rein ökologische Kriterien ausgerichtete Bewertungsweise wäre ohnehin ,,ahistorisch“, da sie die historischen Bedingungen, unter denen sich die intensiven Formen der Gewässernutzung (Bewässerungswirtschaft, Mühlen- und Teichwirtschaft etc.) bildeten und ausbreiteten, nicht berücksichtigt. Dieser „historische Gesichtspunkt" in der Gewässerplanung kann in der Entwicklung eines wasserwirtschaftlichen Leitbildes liegen, dessen Ziel nicht den vom Menschen unbeeinflussten (gedachten oder tatsächlich vorhandenen) Zustand eines Gewässers bezeichnet, sondern zu ihrem Sanierungsziel kulturhistorische Zielsetzungen erhebt. „Schwierigkeiten im Umgang mit der historischen Kulturlandschaft“, schreibt auch GUNZELMANN (1999a:13), ,ergeben sich vor allem deswegen, weil der Naturschutz aus fachlichen Gründen nicht den historischen oder kulturellen Gehalt der Landschaft zum Schutzzweck erheben kann, sondern immer wieder den Bezug auf den Gehalt des Artenbestandes nehmen muss oder will. Eine konsequente Auseinandersetzung mit dem Problemfeld historische Kulturlandschaft ist dann aber nicht möglich, weil sich Kulturlandschaft eben unter dem Primat der Gestaltung durch den Menschen und des kontinuierlichen Wandels definieren muss. Übrig bleibt bestenfalls eine Kulturlandschaftspflege nach den jeweils herrschenden ökologischen oder artenschützerischen Vorstellungen, die aber wenig mit der historischen Wirklichkeit der Landschaftsentwicklung zu tun hat.“

Doch welche Bedeutung können, in einer bis zur Grenze belasteten Kulturlandschaft, gewässerhistorische Kulturlandschaftselemente für die heute zu realisierenden Renaturierungsvorhaben haben und über die unbefriedigenden ,gärtnerischen“ Tätigkeiten hinausgehen? Es ist das schwierige Unterfangen der Umsetzung eines historisch-geographischen Planungsleitbildes im Gegensatz zur mittlerweile gesellschaftlich anerkannten ökologisch-orientierten Wasserwirtschaftslehre. 
Um intensiver als bisher in den Planungen historische anthropogene Gewässerveränderungen und -elemente mit berücksichtigen zu können, wären zwei Verfahrensschritte notwendig, die von der Historischen Geographie bereits entwickelt worden sind: An erster Stelle stünde die umweltgeschichtliche Analyse der historischen anthropogenen Einflüsse auf die Gewässerlandschaft und die Inventarisierung persistenter gewässerbezogener Kulturlandschaftselemente als Informationsträger, die diese Einwirkungen in Zeitschnitten kartographisch sichtbar werden lassen. Auf diese Datenbasis aufbauend müssten dann in einem zweiten Schritt Kriterien entwickelt werden, die es ermöglichen, nach dem definierten Leitbild entsprechende Elemente auszuwählen und Entwicklungskonzepte aufzustellen.

Um zu einer umfassenden Inventarisation solcher Elemente zu gelangen, d. h. um die gesamte Fülle der Elemente einer gewässerbezogenen Kulturlandschaft zu erfassen, sucht die Historische Geographie die interdisziplinäre Zusammenarbeit mit anderen Fachrichtungen wie der Archäologie, der Geschichtswissenschaft, der Physischen Geographie, der Volkskunde, der Kunstgeschichte etc.

Die Historische Geographie müsste ferner auf einem ausreichend stabilen (planungs-) rechtlichen Fundament gründen können: „Vom historisch-geographischen Standpunkt aus erscheint es von erstrangiger Bedeutung, eine neue Planungsphilosophie zu etablieren, die die Beweislast anders verteilt. Es sollte nicht mehr wie heute die Pflicht bestehen, die Bedeutung bestimmter Kulturlandschaftsbestandteile nachzuweisen, sondern umgekehrt sollte - parallel zur ökologischen Umweltverträglichkeitsprüfung - eine ,Kulturlandschaftsverträglichkeitsprüfung' verpflichtend werden“ (FEHN 1997:19). „Nach dem Fachverständnis der Angewandten Historischen Geographie müßte vor allen Eingriffen in die historische Kulturlandschaft immer abgewogen werden, in welchem Umfang historische Elemente und Strukturen durch moderne ersetzt werden dürfen. Dies impliziert einen ständigen rücksichtsvollen und sorgfältigen Umgang mit der historisch gewachsenen Kulturlandschaft“ (BURGGRAAFF/KLEEFELD 1997:30).

Ein weiteres (umwelt-)rechtliches Defizit beim historischen Kulturlandschaftserhalt stellt die Schlammbeseitigung bei dem retournierend notwendig werdenden Teichaushub in Teichwirtschaften dar, der als Sondermüll kostenintensiv beseitigt werden muss. Dieser Kostenaufwand ist gerade für Kleinteichwirte oftmals nicht trag- bzw. einsehbar und führt auf diese Weise zu einem allmählichen Verfüllen oder hat aufgrund wirtschaftlicher Überlegungen ein Auflassen zu Folge.

Ein weiteres Fundament zur stärkeren Berücksichtigung bzw. Aufnahme historischer Gewässerelemente und -zusammenhänge in der Planung könnte eine veränderte betriebs- und volkswirtschaftliche Berechnung darstellen, auch unter dem Aspekt der Zukunftssicherung. Das Wasser selbst nämlich ,hat bis heute keinen monetären Wert zugesprochen bekommen“ (SCHRAMM 1992:181). Die Wassergebühren, die der Verbraucher für das Wasser bezahlen muss, sind rein betriebswirtschaftlich zusammengesetzt: Sie ergeben sich allein aus den Kosten, die bei der Erschließung (einschließlich Bewirtschaftung der Schutzgebiete), Aufbereitung und Verteilung anfallen. „Was der Verbraucher für den Gebrauch und für die Verschmutzung des Wassers zahlt, enthält also weder Kosten für das Wasser selbst, das aus der ,Natur' extrahiert wird, noch Kosten für die bewusste Reproduktion [...] des Naturzusammenhangs, dem das Wasser abgegraben wird.“ (:181). Die konkrete Anspannung, in der sich der Wasserhaushalt in Extremsituationen (z. B. im Hochsommer) befinden kann, kommt so nicht in den Blick; eine deutliche Zunahme der Förderung von Tiefengrundwassern verhindert dies (:188). Auch nicht der Verlust der kulturhistorischen Gewässerlandschaften gelangt in das Bewusstsein, wenn beispielsweise Grundwasserstände abgesenkt werden, wie bei der Ahlhorner Teichwirtschaft sukzessive geschehend, maximal der der naturräumlichen Besonderheiten, um die es in der ökologischen Diskussion immer auch geht.

Es ist also ein anderer Bewertungsmaßstab notwendig, will man z. B. den kulturhistorischen „Wert“ des Wassers bemessen. Grundsätzlich bedeutet jede kulturhistorisch orientierte Erhaltung und Pflege zunächst einmal die Aufgabe jedweder Monetarisierung, die das Wasser aus seinem geschichtlichen Zusammenhang herauslösen würde. Zumindest in einem ersten Schritt, da sich die externen Kosten durch eine Inwertsetzung durchaus wieder amortisieren können. Deshalb wäre hier zum Beispiel ein politik-orientierter Ansatz notwendig, der die Externalisierung, d. h. die Umlegung der Kosten 
verfolgt, die bei der Bewahrung bzw. Wiederherstellung von historischen Gewässersituationen entstehen.

Schließlich ergibt sich vor dem Hintergrund einer zukünftigen Inwertsetzung die „puristische“ Forderung nach Bewahrung von mit Gewässern verbundenen historischen Kulturlandschaftselementen, denn vieles ist weiterhin bedroht. Dazu zählen Bauten und Anlagen der historischen Wasserwirtschaft wie z. B. Stau- und Bewässerungsschleusen, Stau- und Wässerungswehre, Reusen und Stellfallen, Treidelpferdeunterstellplätze, Anlagen der Flößerei, der Wasserversorgung usw. Aber auch morphodynamische Relikte wie z. B. alte Floßteiche, Floßkanäle, Dämme, Wiesenverteilungsgräben und andere alte Einrichtungen der traditionellen Bewässerungs-, Teich- und Holztransportwirtschaft. Flur- und Kulturlandschaftsrelikte sind Endformen einer Entwicklung und Ausdruck bestimmter historischer Wirtschaftsweisen, die zur Transformation der Natur in unsere Kulturlandschaft beigetragen haben.

Ein Funktionsverlust dieser Anlagen durch Flurbereinigung oder durch die ökologische Zielsetzung des Rückbaus von Fließgewässern und die Überlassung von Stillgewässern stellen ein hohes Gefahrenpotential für diese Elemente und Strukturen dar. Daher ist ein Verknüpfen des Gewässerschutz und der Gewässerplanung mit der Denkmalpflege unabdingbar. „Die Untersuchung ehemaliger Gewässernutzungen und ihrer Relikte kann aufzeigen, wo Denkmalqualität besteht und wo bspw. ein Rückbau von Querbauwerken eingehend zwischen Vertretern der Denkmalpflege und des Gewässerschutzes abgestimmt werden sollte.“(THIEM 2004)

Diese historischen Kulturlandschaftselemente können auch im Rahmen der musealen Repräsentation aufgearbeitet werden, wie vorbildhaft im Oberpfälzer Freilandmuseum Neusath-Perschen mit der Integration vorhandener Teichanlagen der Fisch- und Landwirtschaft in das Museumsgelände geschehen (LIEPELT 1992: 53f.). Es können nach DENECKE (1999:44) „Wiesenbewässerungen, Teiche [...] und vieles mehr sein, deren ehemals oft weitflächige Verbreitung landschaftsprägend gewesen sind, was zu vermitteln ist. Es sollte bei der Präsentation solcher Geländeformen und Einrichtungen jedoch keineswegs nur um funktionale ,rezente' Rekonstruktionen und Darstellungen gehen, sondern auch und gerade um die Vorstellung von Relikten dieser Kulturlandschaftselemente, wie sie sich heute noch als kulturlandschaftliche Dokumente und Denkmale im Gelände finden (,Spurensuche') und auf Geländearbeit beruhende alter Wirtschaftslandschaften ermöglichen. [...] Die Darstellung solcher Relikte in der Museumslandschaft läßt die zeitliche Dimension deutlich werden, den Vorgang des Verfalls solcher Erscheinungen ehemaliger Wirtschaftsweisen in der Landschaft, und führt sie zur Aufgabe ihrer Dokumentation und Bewahrung im Zuge einer erhaltenden Landschaftspflege wie auch zu einer Sensibilisierung, solche Relikte selbst in der Landschaft zu erkennen und zu deuten.“

Ohne diesen Verdienst der klassischen Museumseinrichtungen für die Nachwelt schmälern zu wollen, gilt es doch verstärkt der Bewahrung an den Ursprungsplätzen zu begegnen. Es kann nicht sein, dass anthropogene, historisch-geographische Gewässerelemente nur noch transloziert an musealen Freilichtstandorten erfahrbar werden. Denn nur am Originalstandort kann der vormalige Wasserbau in seiner Gesamtheit erlebbar bleiben. Es gilt, die historischen Nutzungen, wie belegte Feld-TeichWechselwirtschaften und gewässerbezogene Bewirtschaftsformen unter Beachtung der wirtschaftlichen Möglichkeiten leicht modifiziert wiederzubeleben. Dies stellt „einen neuen Tätigkeitsbereich der Angewandten Historischen Geographie“ dar (BURGGRAAFF/KLEEFELD 1997:25). Dafür gibt es mittlerweile eine Reihe von Vorbildern, vor allem bei den Wassermühlen, die, an Originalschauplätzen wieder belebt, eine museale Inszenierung - meist zu bestimmten Öffnungszeiten - betreiben.

„Noch weiter in die reale Landschaft hinein und an die in ihr lebende und wirtschaftende Bevölkerung heran führt die Konzeption des Ecomuseums.“ (DENECKE 1999:46) Es ist das „Konzept einer museal zugänglich gemachten und aufbereiteten meist peripheren traditionellen Wirtschaftslandschaft" (:46). Die Zielsetzung ist „ein großräumiger Verbund persistenter musealer Landschaftsobjekte und Reliktstandorte in einer überschaubaren Region“, die letztlich zu Landschaftsmuseen im engeren Sinne führt (:49). In diesem weitergehenden Ansatz wäre der Komplex zum Beispiel von Mühlen, Mühlteichen 
und Wiesenbewässerung im unmittelbar landschaftlichen Zusammenhang herzustellen; nicht die Präsentation vorhandener baulicher Einzelteile und singulärer Landschaftselemente für sich genommen zu verfolgen, sondern auf die wirtschaftliche Einheit an dezentralen Standorten zu insistieren. Aber die Landschaft darf nicht im Rahmen einer „Eventkultur“ zur „Inszenierung von Geschichte in der Erlebnisgesellschaft" (KÄSTNER 2003:123ff.) degradiert werden oder gar zu einer „heritage industry“ (HEWISON 1987) verkommen, die der „Sucht nach Musealisierung“ und dem Bedürfnis nach Ästhetisierung entspricht (DE JONG 2002:11).

Das den musealen Boden verlassende Konzept der „Denkmallandschaft“6 ${ }^{6}$ verfolgt nach GUNZELMANN (1999a:9) und nach SCHENK (2000:228), „eine prägende Vernetzung von Bau- und Kunstdenkmälern mit weiteren Relikten der historischen Kulturlandschaft, die gemeinsam durch eine geschichtliche Kraft geprägt wurden“; „etwa in der Weise, in der ein Zisterzienserkloster das ihm ehemals zugehörige Territorium nicht nur durch seine Bauten, sondern auch durch seine Wald-, Landund Teichwirtschaft auf eine bestimmte Weise bis heute ablesbar geprägt hat" (:228). Diese konzeptionellen Überlegungen bewegen sich in einem Übergangsbereich zwischen musealer Ansprache und denkmalpflegerischer Unterschutzstellung in angestammter Umgebung. „Sind die Elemente noch wasserwirtschaftlich genutzt, sollte das Ziel sein, nicht nur die Struktur als solche, sondern auch die Funktion zu erhalten, wie DRIESCH (1997:266) es ausdrückt. „Pflege und Erhalt wasserwirtschaftlicher Anlagen kann nicht bedeuten, eine Art Glasglocke über die Landschaft zu setzen und einen anachronistischen Konservatismus, im Sinne des Bewahrens, zu verwirklichen.“ (:266) Im Gegensatz zur konservierenden Denkmalpflege muss ein dynamisches, lebendiges System, wie es die historische Kulturlandschaft darstellt, durch gezielte rücksichtsvolle Nutzung und Bewirtschaftung geschützt werden, das sie nicht „,durch reine Konservierungsmaßnahmen und Rückführung auf einen Zeitschnitt zu einer fossilen und toten Museumslandschaft verkommt." (BURGGRAAFF/KLEEFELD 1997:30)

Das Hauptziel solcher Schutzmaßnahmen für die historisch gewachsene Kulturlandschaft ,ist die Erhaltung und die darauf orientierte Bewirtschaftung der vorhandenen historischen Strukturen und Einzelelemente sowie die Verbesserung ihrer Lesbarkeit durch Markierungsmaßnahmen“ (BURGGRAAFF/KLEEFELD 1997:29). „Die optimale Form der Erhaltung eines historischen Kulturlandschaftselements“ ist dabei dann gegeben, „wenn das Element nach wie vor die ihm ursprünglich zugedachte Funktion erfüllt, d. h. wenn die aktuelle Nutzung mit der historischen identisch ist. In diesem Falle ist nicht nur die formale Erhaltung gewährleistet, sondern auch eine inhaltlich-funktionale“ (RIEDEL/HASLACH 1999:179).

Um aber die Erhaltung von historischen Kulturlandschaftsrelikten zu erfüllen, die in formal veränderter Form vorliegen, bieten sich Vorgehensweisen an: 1) eine aktive und b) eine passive Vorgehensweise.

Von einer aktiven Erhaltung kann dann gesprochen werden, wenn die formalen Veränderungen bewusst vorgenommen und zugunsten einer unter den aktuellen Rahmenbedingungen „sinnvollen“ Nutzung gesteuert werden, „um damit die Erhaltung des historischen Kulturlandschaftselements längerfristig zu sichern“ (RIEDEL/HASLACH 1999:180). Eine Nutzung ist dabei „umso besser geeignet, je ähnlicher sie der ursprünglichen ist und je weniger sie historischen Bestand verändert (:180). Als Beispiel dafür kann die Einbindung von alten Fisch- und Flößteichen in einen geplanten neuen Gewässererlebnispfad in formal leicht veränderter Weise genannt werden (:180f.).

Im Gegensatz dazu bedeutet die passive Erhaltung, dass das „Landschaftselement weder gepflegt noch genutzt wird, und die einzige Maßnahme, die den Verlust des Landschaftselements verhindert, lediglich im Nicht-Beseitigen besteht“ (RIEDEL/HASLACH 1999:180). Ein Beispiel für ein „passiv erhaltenes Landschaftsbestandteil" (:180) können Teiche gesehen werden, die infolge Verbuschung, Verlandung oder Unter-Wald-Konservierung ,,in ihrer ursprünglichen Form nicht mehr erkennbar und in vielen Fällen nicht als Kulturlandschaftsrelikt erlebbar" sind (:180). Dies trifft ebenso für andere

\footnotetext{
6 Dort, wo die Kulturlandschaft in besonderer Weise durch geschichtliche Leistung geprägt ist, wird von „Denkmallandschaft“ gesprochen (GUNZELMANN 1999a:9).
} 
historische Gewässerelemente der Kulturlandschaft, wie das System der Kanäle, Werksgräben, Mühlenbäche und Wiesengräben, zu, wenn sie zwar nicht verändert, aber auch nicht mehr genutzt werden. „Ökowiesen“ und „Ökobäche“ kann es unter anthropogen-umwelthistorischen Gesichtspunkten nicht geben. Ein ,passiver“ Schutz, der darunter die Bewahrung der Anlagen in ihrem heutigen Zustand versteht, bedeutet eine weitere Verwahrlosung der schon heute oftmals trockenen und zum Teil stark überwachsenen Gräben, der Dämme und Böden.

Die Erhaltung eines historischen Kulturlandschaftselementes, das seine ursprüngliche Funktion bereits verloren hat, in formal unveränderter Weise ist hingegen , in der Regel nur dann möglich, wenn die historische Nutzung durch Pflege- und Unterhaltungsmaßnahmen simuliert wird“ (RIEDEL/HASLACH 1999:181). Dieser Fall tritt zum Beispiel dann ein, wenn bei dem eben beschriebenen, brach liegenden und nutzungsfreien Teich die Offenhaltung durch eine simulierte Teichbewirtschaftung (Bespannung, Ablassung, Feld-Teich-Wechselwirtschaft) betrieben wird, ansonsten treten die gleichen Folgen in der Kulturlandschaft auf, wie sie WOLF (1985:383ff.) für den Niedergang der Schäferei beschrieben hat. „Diese Art der Erhaltung von historischen Kulturlandschaftselementen entspricht damit letztlich einer musealen Erhaltung, bei der ein Teil der sich ständig in Wandel befindlichen Kulturlandschaft ,künstlich' in einem Zustand gehalten wird, wie er als Folge heutiger Lebens- und Wirtschaftsformen so nicht mehr entstehen würde" (RIEDEL/HASLACH 1999:181, Hervorhebung im Original) .

Zwischen den beschriebenen Erhaltungsmöglichkeiten - in veränderter oder unveränderter Form„gibt es zahlreiche Übergänge, und nicht in jedem Fall kann frei unter ihnen gewählt werden, denn nicht jedes Element kann in jeder Form auch tatsächlich in seinem Weiterbestehen gesichert werden“ (RIEDEL/HASLACH 1999:181). Es gibt aber historische Kulturlandschaftselemente, ,die so eng mit einer bestimmten Nutzungsweise verbunden sind, daß sie einzig und allein durch Pflege erhalten werden können, und bei weitem nicht alle historischen Kulturlandschaftselemente lassen sich als tragfähige Strukturen für aktuelle Nutzungsansprüche weiterentwickeln“ (:181). Ein Beispiel: Wenn die teichwirtschaftliche Nutzung aufgegeben wird, lassen sich die Teiche nur durch Pflege erhalten. Die passive, unveränderte Form der Erhaltung wäre in diesem Fall gleichbedeutend mit Beseitigung, denn die eintretende Sukzession ließe das kulturhistorisch bedeutsame Element Teich aus dem Landschaftsbild verschwinden. Aktive Erhaltung in veränderter Form, d. h. Suche nach einer neuen Funktion, ist in diesem Fall ebenso problematisch, weil zum Beispiel eine Forellenteichanlage hochsensibel auf jede Veränderung in der Wasserzuführung reagiert. Allein eine verfrühte Wasserzufuhr wie auch eine ungeregelte Zuleitung von Wildwasser würde zum Verlust des Fischbesatzes in gewissen Teichtypen führen.

Doch bei der häufig vorgetragenen Kritik, die gegen die Erhaltung von nicht mehr in Funktion stehenden historischen Kulturlandschaftselementen durch Pflegemaßnahmen vorgetragen wird, „daß sie den wesenhaft zur Kulturlandschaft gehörenden Wandlungsprozeß unterdrückt und stattdessen einen Zustand festschreibt, der nicht mehr der gesellschaftlichen Realität entspricht", ist Folgendes zu beachten: Dass „zur Erhaltung historisch bedeutsamer Kulturlandschaftsrelikte häufig keine andere Möglichkeit bleiben wird, als ihren Bestand auf diese Weise zu sichern." (RIEDEL/HASLACH 1999:181)

Soll jedoch die unveränderte Form gewahrt bleiben, auch in dem Bewusstsein der Erhaltungsmöglichkeit einzig durch Kulturlandschafts- rsp. Teich- oder Wiesenpflege, so bleibt ein wahrscheinlich nur politisch zu lösendes Problem: das der Finanzierbarkeit von Landschaftspflege. So steht der heutigen, zum Teil staatlich geförderten Extensivierung von Wiesenböden als Beispiel einer weitflächigen Historisierung der Landschaft die hohe Arbeitsleistung gegenüber, die auf diesen Wiesen durch Bewässerung erbracht werden müsste. Nur durch optimale Pflege und Nutzung können solche Systeme instandgehalten werden. Historische Kulturlandschaftsflächen und -elemente dulden keine Vernachlässigung durch ökologisch oder wirtschaftlich motiviertes Brachfallen oder auch - im Gegensatz dazu - durch zu starke Intensivierung. Um die Reste dieser Kulturlandschaft zu erhalten, bedarf es einer - in Anlehnung an historische Formen der Grünland- und Gewässernutzung - kenntnisreichen und erfahrenen Bewirtschaftung zum Erhalt und behutsamen Entwicklung dieser Landschaften. Eine systematische Verknüpfung der Ergebnisse aus den Bereichen der Historischen 
Gewässerforschung und dem Naturschutz hat hier leider noch nicht stattgefunden. „Sie könnte ertragreich sein, da der größte Teil der heute als naturschutzwürdig erachteten Flächen in historischer Zeit durch wirtschaftliche Aktivitäten überformt und sogar überhaupt erst geschaffen wurde" (DIX 1997:38).

Wenn diesem zukunftsorientierten Ansatz auch unter pragmatischem und förderalistischem Gesichtspunkt zugestimmt werden kann, so stellt sich aufgrund der Geschwindigkeit des Verfalls, der geringen Widerstände aufgrund weicher rechtlicher Schutzbestimmungen und einer schwachen Personaldecke die Frage, ob nicht eine „Konservierung traditioneller Kulturlandschaftselemente durch Retardation“, wie EICHENAUER (1989:225) es nennt, erreicht werden sollte. Eine solche Verlangsamung der Entwicklung ist in den wirtschaftlich schwachen ländlichen Räumen schon heute feststellbar, vorzugsweise hier bietet sich die Möglichkeit der Bewahrung.

Gleichwohl bestünde hiermit die Gefahr, wie schon bei der Musealisierung der Landschaft, dass die eh schon peripheren Gebiete als präferierte Schaulandschaften historisch-anthropogener Vergangenheitszeugen in ein „Archäologisches Reservat"“7 (Begriff nach MICHALĖK 1999:66) überführt würden. Eine Landschaft aber lebt und unterliegt stetem Wandel und deshalb lässt sich auch keine „konservierte Vergangenheit“" etablieren. Die Kulturlandschaft mit ihren jetzigen Strukturen ausschließlich als einen „Landwirtschaftspark“ (VAN DEN HÖVEL 2001:36) in „gentrifizierten ländlichen Räumen“ (BLOTEVOGEL 2003) zu konservieren ist zudem wirtschaftlich durch die dann in diesen Räumen lebenden überalterten Bewohner und Eigentümer nicht zu leisten und daher auf Dauer nicht beständig. Eine Landschaft ohne Kultur ist aber eine Kultur ohne Landschaft (VAN DEN HÖVEL 2001:36) und eine Kulturlandschaft somit erst mit den darin wirtschaftenden Menschen denkbar. Deshalb muss eine kulturphilosophische Diskussion an die Stelle der bisherigen naturphilosophischen treten.

Aber man darf nicht dem Fehler unterliegen, bei allem Respekt des hier vertretenen historischgeographischen Betrachtungsansatzes, in einen ,anthropogenistischen“ Blickwinkel zu geraten und damit - gleichwohl wie bei dem in dieser Arbeit an verschiedenen Stellen vorgetragenen „Biologismus-Vorwurf“ - mit einem „Anthropogenismus-Vorwurf“ konfrontiert zu werden: „Wer mit den Kategorien der untersten Seinsschicht allein auskommen zu können glaubt, denkt ,materialistisch', wer das Ganze aus der Schicht des Organisch-Lebendigen allein erklären will, ,biologistisch' usw.“ und, in eigener Fortführung des DITFURTH'schen (1986:413) „Algorithmus“, wer versucht, die Gegenwart mit einer Vielzahl kulturhistorischer bzw. historisierender Elemente zu überziehen, der denkt „historisch-anthropogenistisch“. Diese ideologischen Blickverengungen wären damit „die Folge einer Reduktion der Erklärungsgrundlage auf eine einzige, willkürlich aus dem Kontext der realen Welt herausgegriffene Seinskategorie“"(:413).

Aber der ökogeographisch-landschaftsökologische Gedanke wird in der historisch-anthropogeographischen Umweltforschung nicht vergessen, er bildet vielmehr die ethische Grundlage des planerischen und forschenden Handelns zur Lösung dringlicher gegenwärtiger wie zukünftiger Probleme. Um einen integralen kulturhistorischen Schutz $\mathrm{zu}$ betreiben, sind also als Entscheidungsgrundlage für die Bewertung bezüglich der Schutzwürdigkeit von Kulturlandschaften sowohl naturwissenschaftlich-ökologische, messbare Kriterien wie auch philosophisch-ethische, nicht messbare Kriterien zu verwenden sind (LEIBUNDGUT 1986:154).

Die Globalisierungsprozesse haben nämlich nicht nur städtische, sondern längst auch ländliche Randbereiche mit ihren flächenhaften Umformungen erfasst. Nur dort, wo sie bislang nicht so prägend wirken, hinterlässt die Strukturschwäche dieser Regionen kulturhistorische Brachflächen ehemaliger wirtschaftlicher Intensivgebiete. Das Problem, das vor diesem Hintergrund transparenter wird, ,stellt sich im Umfang des Wandels im Verhältnis der natürlichen Regenerierbarkeit“ (DRIESCH 1997:266).

\footnotetext{
${ }^{7}$ Ein archäologisches Reservat besteht aus einem Ensemble archäologischer Denkmäler und umgebender Landschaft mit bedeutendem Aussagewert für das Geschichts- und Kulturgeschichtsbild und von hoher Anschaulichkeit. Das archäologische Reservat muss, da es im Hinblick auf die Geschichte Erkenntnisse schaffen soll, für die gesellschaftliche Nutzung erschlossen werden. Museen und Modelle, Lehrpfade, Informationshefte, Vorträge u. a. sind Hilfsmittel für diesen Zweck“ (MICHALÈK 1999:66).
} 
Auf allen Ebenen ist deshalb die Überzeugung festzustellen, dass es wohl erlaubt sei, die Natur kunstvoll zu benutzen, dass aber unbedingt die Regenerationsfähigkeit des Gesamtsystems gewährleistet werden müsse. Und dafür müssen Lösungen, Revitalisierungsansätze gegen Verwahrlosung gefunden werden (ONGYERTH 2003: mündl.), wie die Bewahrung von Anlagen der Wasserhaltung und ein Sichtbarmachen der Anlagen in der offenen Flur. Die vorliegende Arbeit ist deshalb hoffentlich auch ein Beitrag zur kulturhistorischen Vielfalt in nicht zugangsbeschränkter Umgebung. Sie erst vermag einer Nivellierung der Landschaft entgegenzuwirken und schlussendlich eine identitätsstiftende Wirkung zu entfalten (COSGROVE et. al. 1996:549). So verdienen ,Altgewässerrelikte“, als „nahezu unbeachtete Objekte in der heimatlichen Flur“ (LIEPELT 1992), will man eine „total transformation“ (BAKER 1992:5) von Landschaften verhindern, eine entsprechende Widmung. Diese wollte ich mit vorliegender Arbeit abgeben.

So möchte ich wünschen, dass die hier vorgelegte gewässerhistorisch-geographische Arbeit nicht nur historisches und landschaftskundliches Interesse befriedigen, sondern auch bei Planungen für die Zukunft mithelfen kann. 


\section{Zusammenfassung}

Mit der vorliegenden Arbeit wird der Versuch unternommen, das große Gebiet der historischen Gewässernutzung einschließlich - bzw. vielmehr insbesondere - der sich daraus ergebenden anthropogenen Formen der Wasserhaltung und der Wässerung in einem Überblick von seinen geschichtlichen Anfängen bis hin zur Frage der Berücksichtigung kulturhistorischer Gewässerelemente in der Gegenwart und Zukunft darzustellen.

Die vorliegende gewässerhistorische Arbeit ist in ihrem Betrachtungsansatz am besten mit der Geschichte der Waldnutzung vergleichbar: der Wald als „Waldweide“, d. h zum Eintreiben von Vieh zur Eckern- und Eichelmast in den Allmendewald, als „Sammelwald“ zur Gewinnung von Waldgras, Waldhumus, Waldlaub und Waldstreu sowie zum Auflesen von Bucheckern, Eicheln und Kastanien, als „Schälwald“, in dem durch das „Bastreißen im Eichenschälwald“ die Eichenrinde als begehrter Gerbstoff und Ausgangsstoff zum Färben von Textilien gewonnen wurde, als ,Zapfwald“, in dem zur Gewinnung von „Birkenrindenöl“ die Birke angezapft wurde, um mit dem harzigen Ausfluss der Birke medizinische bzw. kosmetische Produkte oder Schmiermittel herzustellen oder in dem zur Pech- und Holzteerherstellung das Harz von Nadelhölzern aus den Wurzeln (Stubben) gewonnen wurde, um es als Dichtungsmittel beispielsweise im Boote- und Schiffsbau einzusetzen oder in der Human- und Veterinärmedizin zu verwenden, als „Niederwald“, in dem eine „Haubergwirtschaft“ mit Zwischenfruchtanbau auf den dazwischen liegenden Ackerflächen betrieben wurde, als „Köhlerwald“, in dem die Köhlerei und Pottaschebrennerei betrieben, die das Holz zu Briketts verschwelte, um dann als Brennstoff in die Städte und Dörfer gebracht zu werden oder als „Zeitlerwald“, in dem eine Waldbienenwirtschaft, auch „Zeitlerei“ oder „Beutnerei“ genannt, durch das Aushöhlen von Baumstämmen und Kappung von Baumspitzen zur Herstellung sog. „Kronenwipfel“ ideale Brut- und Honigplätze für Bienenvölker geschaffen hat. - Wenngleich auch diese historischen Waldnutzungen dem Blick entschwunden sind, ist im Gegensatz zu diesen jedoch die allgemeine Kenntnis der historischen Gewässernutzung deutlich unbekannter.

Nach meiner Kenntnis fehlt es jedoch an einer umweltgeschichtlichen und geographischen Verknüpfung bzw. wechselseitigen Betrachtung von Entwicklungen auf dem Gesamtgebiet historischer Wasser- und Gewässerwirtschaft und deren Möglichkeiten und Notwendigkeiten anwendungsbezogener Mitwirkung. Sie präsentieren sich als Teilgebiete starr nebeneinander stehend. Ihre kulturhistorische und umweltgeschichtliche Bedeutung bleibt weitgehend vergessen.

Der Historische Geograph fragt dabei - nach meiner Interpretation - nach der Genese von Landschaftsräumen in Bezug zum Gewässer, nach den Anfängen der menschlichen Umwelteingriffe und der Art anthropogen bedingter Umweltveränderungen in Gewässer. Diese sind räumlich festzumachen und zeitlich einzuordnen. Disziplinimmanente Aufgabe ist weiterhin - und der Historische Geograph geht damit über den rein „geschichtlichen“ Ansatz hinaus - die Orientierung an der Anwendbarkeit im Rahmen der Beteiligung an planungs- und politikrelevanten Prozessen.

Ziel meiner Arbeit war infolgedessen die Umsetzung dieses Betrachtungsansatzes hin zur Entwicklung einer „interdisziplinären anwendungsorientierten gewässerhistorisch-anthropogeographischen Umweltforschung“: Sie versucht nach meiner Auffassung, sowohl die kulturhistorische Entwicklungsund Nutzungsgeschichte von Fließgewässern als auch die abgeleiteten Nutzungsformen der künstlichen Wasserhaltung und Wasserführung am Beispiel von Wasserläufen ausgewählter Landschaftsausschnitte längsschnittartig von den Anfängen bis in die Gegenwart zu beschreiben, zu kartieren, zu kartographieren und hinsichtlich ihrer Schutzwürdigkeit zu evaluieren. Die kulturhistorischen Besonderheiten der Gewässer- und Flusslandschaften wie auch deren Bedeutung als Siedlungs- und Wirtschaftsraum sind dabei hervorzuheben. Zur Erfüllung dieser Aufgabenbeschreibung sind unterschiedliche historisch-interdisziplinäre Arbeitsmethoden und Quellen anzuwenden. Durch die daraus abzuleitenden historisch-geographischen Analysen werden die Möglichkeiten ihrer Inwertsetzung und Planungsbeteiligung aufgezeigt, erarbeitet und diskutiert. 
Eine solche interdisziplinäre, sowohl historisch-geographische als auch umweltgeschichtliche Aspekte und Zusammenhänge berücksichtigende Zusammenstellung wurde notwendig, sollen bei zukünftigen Planungsvorhaben, Gesetzgebungsverfahren oder bei der Übernahme und Umsetzung europarechtlicher Konventionen in Bundesrecht, wie z. B. der Wasserrahmenrichtlinie (WRRL), gewässerhistorische Belange berücksichtigt werden. Aber auch im „rechtsfreien“ Raum können durch das historische Wissen veränderte und subtilere Wahrnehmung und Empfindung zu einem rücksichtsvolleren Umgang mit Gewässern führen. Sei es bei den politischen Entscheidungsträgern, Teichwirten, Gewässeranliegern oder bei dem Wanderer. Es galt also den Ansprüchen der Fachleute hinreichend gerecht zu werden und andererseits dem Laien eine interessante Lektüre zu bieten.

Es war dabei mein Bestreben, insbesondere eine kulturhistorisch-geographische Kleingewässergeschichte $\mathrm{zu}$ beschreiben, denn kleine Fließ- und Stillgewässer blieben bislang in der Kulturlandschaftsforschung weitgehend unberücksichtigt. Anhand von exemplarischen kleinen Wasserläufen habe ich versucht, deren Wassernutzungsgeschichte zu beschreiben. Die sich aus der Gewässernutzung ergebenden morphologischen Hauptformen der Teiche standen dabei im Mittelpunkt meiner Betrachtung: Fischteiche, Mühlteiche und Bergbauteiche. Als vierte Haupeingriffsform definiere ich die Gewässernutzung zu Zwecken der Wiesenbewässerung.

Für weitere zentrale Formen der Gewässerhaltungen der ländlichen Siedlungs- und Hofformen, die nicht Bestandteil der Untersuchungsräume waren, habe ich einen Überblick geboten, um die Vielfalt der Nutzungsformen abzuschließen.

Die Einflussgrößen, die die unterschiedlichen Nutzungsformen durch verschiedenartige künstliche Eingriffe in den Wasserlauf bestimmten, habe ich versucht offenzulegen. Über die bekannten natürlichen und im Allgemeinen anthropogen verstärkten Verlandungsprozesse infolge Euthrophierung hinaus galt es die spezifischen Akteure für das Entstehen, das Verschwinden wie auch für die Persistenz der kleinräumigen historischen Wässersysteme auszumachen und in Zusammenhang mit der Umwelt- und Technikgeschichte zu stellen. Dass durch das Aufzeigen von rekultivierbaren Gewässerrelikten ein Baustein zur Biotopvernetzung gelegt werden kann, ist schließlich mehr als ein gewünschter Nebeneffekt.

Im Rahmen der hier vorgelegten Nutzungsgeschichte der Kleingewässer wurde der Beweis zur Hypothese erbracht, dass „,siedlungsunbeeinflusste“ Gewässer schon in früheren Epochen nicht mehr existierten. Sie sind entweder sämtlich anthropogenen Ursprungs, d. h. künstlich angelegt, oder aber anthropogen ge- bzw. überformt. Dieses Resultat weist den Weg zu einer holistischen Umweltforschung und -planung mit dem Leitbild einer kulturhistorischen Planungskultur. 


\section{Anhang}

\section{Abbildungen}

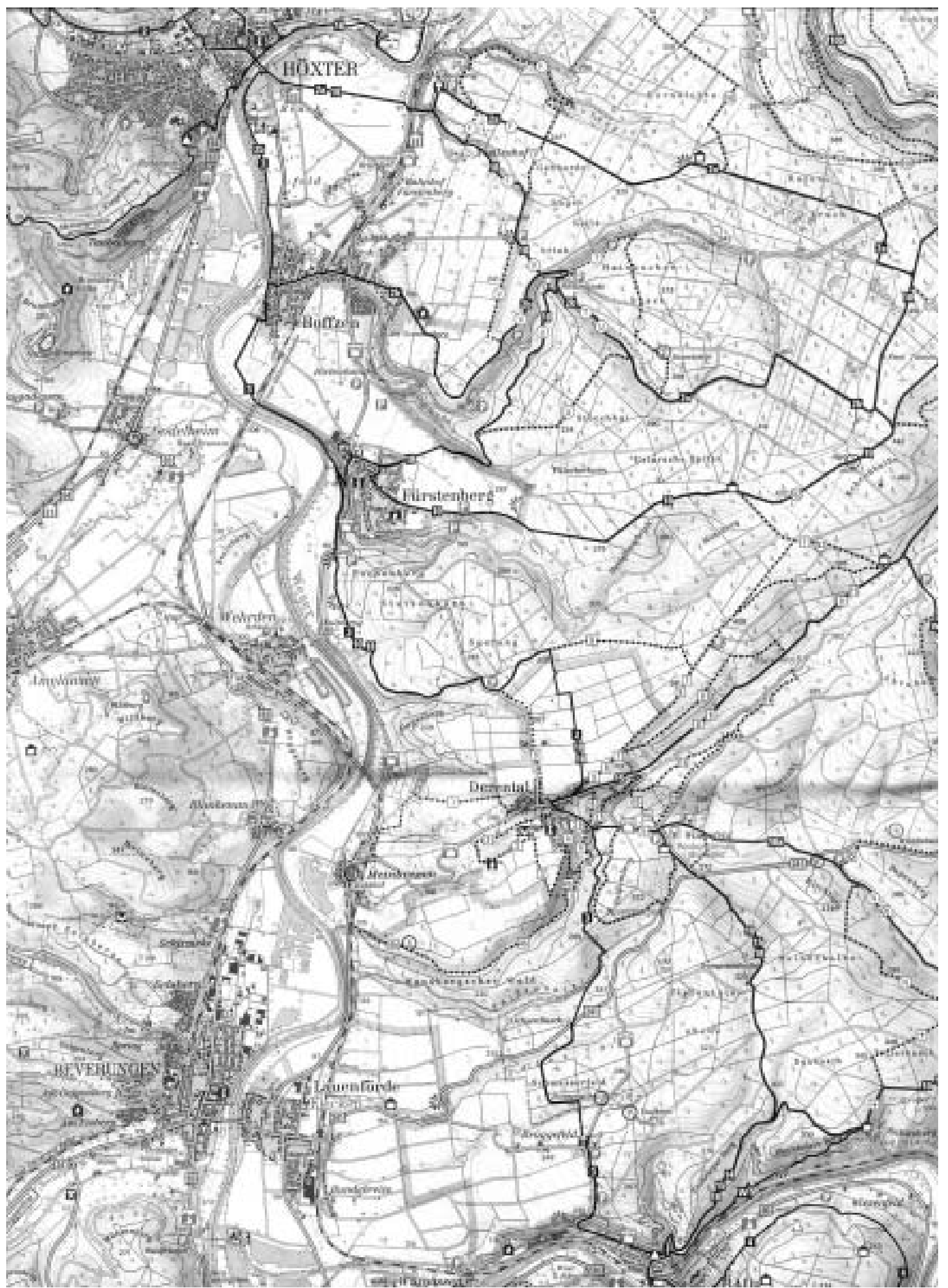

Abb. A-1: Künstliche Gewässerlandschaften durch Nassauskiesung in der Weserniederung zwischen Höxter und Bad Karlshafen (Ausschnitt aus der TK 1:50.000 Blatt „Naturpark Solling-Vogler“) 


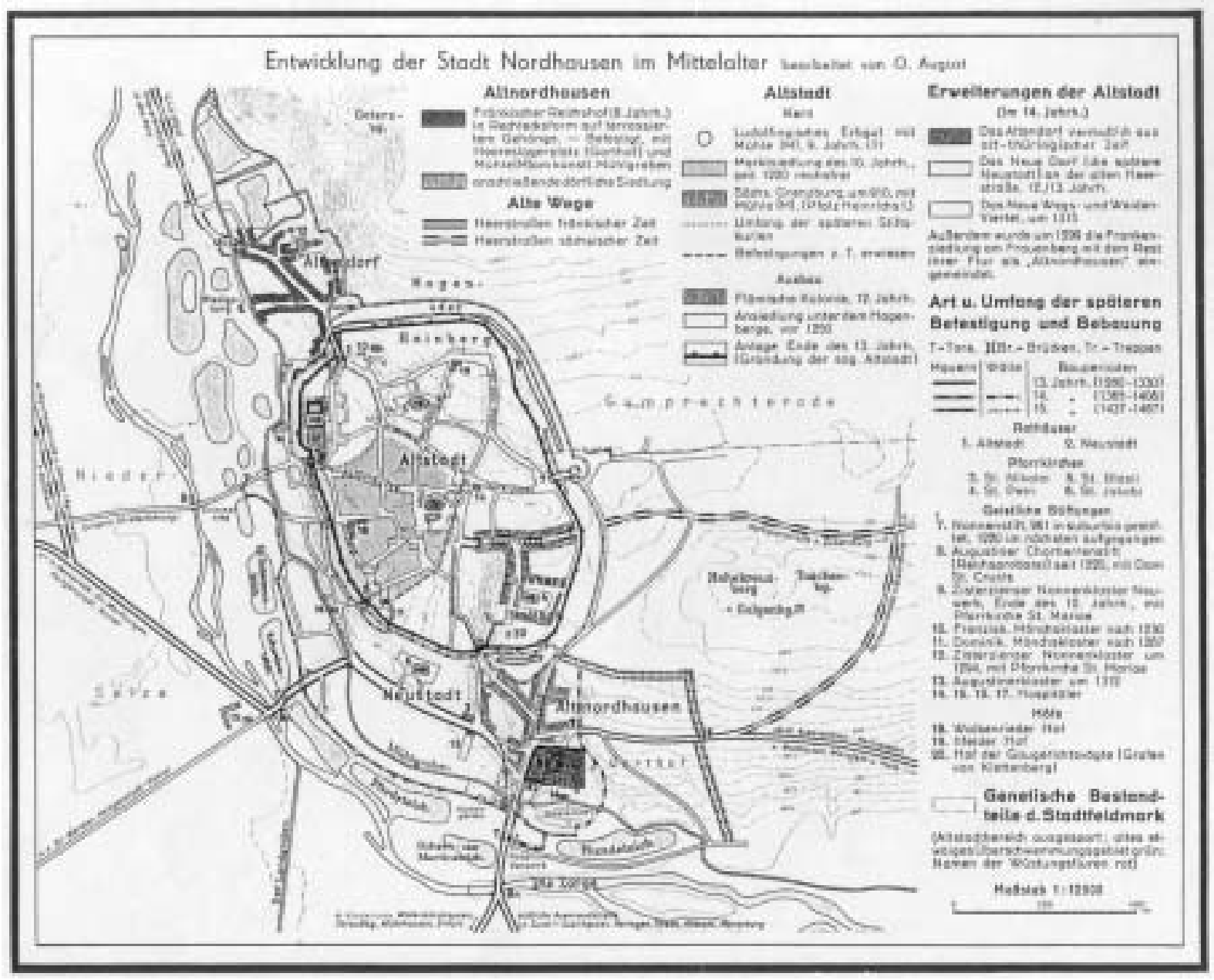

Abb. A-2: Entwicklung der Stadt Nordhausen im Mittelalter 


\section{Tabellen}

Tab. A-1: Öffentliche Wege und Gewässer im Stadtbezirk Nordhausen, Lagerbuch Bd. III (1910) (X 396) ${ }^{1}$

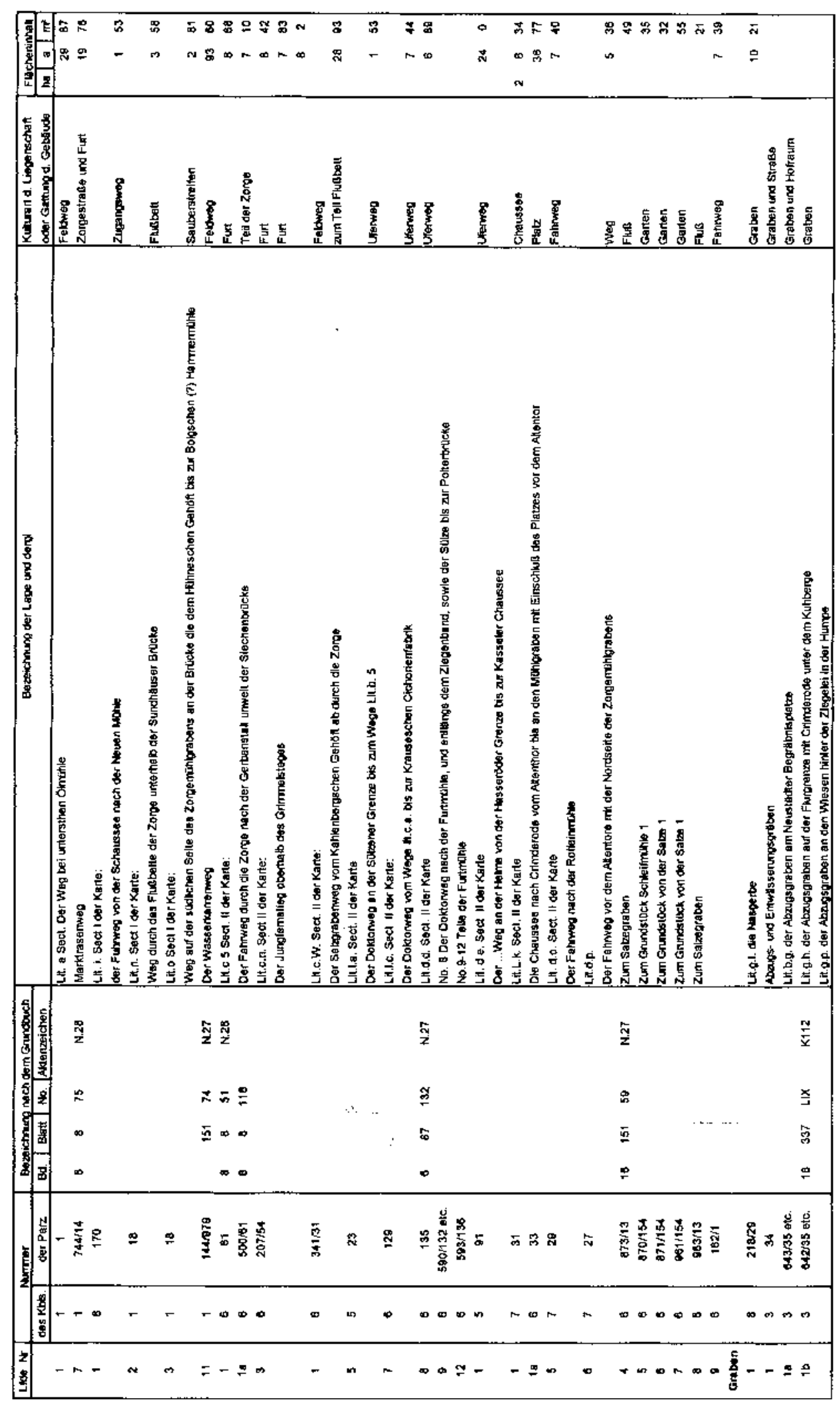

\footnotetext{
${ }^{1}$ Vermutungen zum Jahr von X396: „Im Grundbuche abgeschrieben am 19. März 1910“ (älteste Eintragung,+A261 Seite 146 : Vermerk in der Rubrik Veräußerungsart)
} 
Tab. A-1: Öffentliche Wege und Gewässer im Stadtbezirk Nordhausen (Fortsetzung)

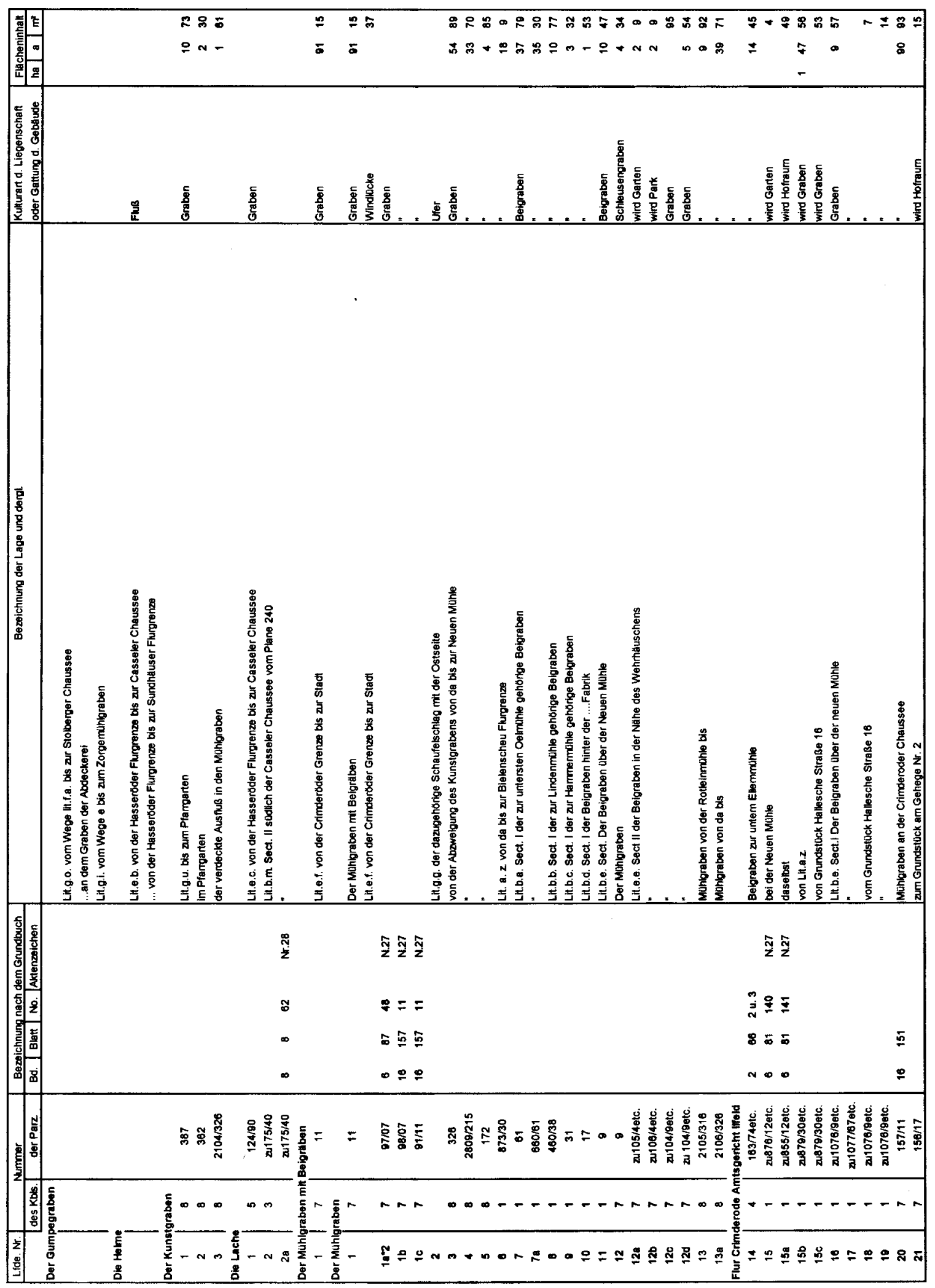


Tab. A-1: Öffentliche Wege und Gewässer im Stadtbezirk Nordhausen (Fortsetzung)

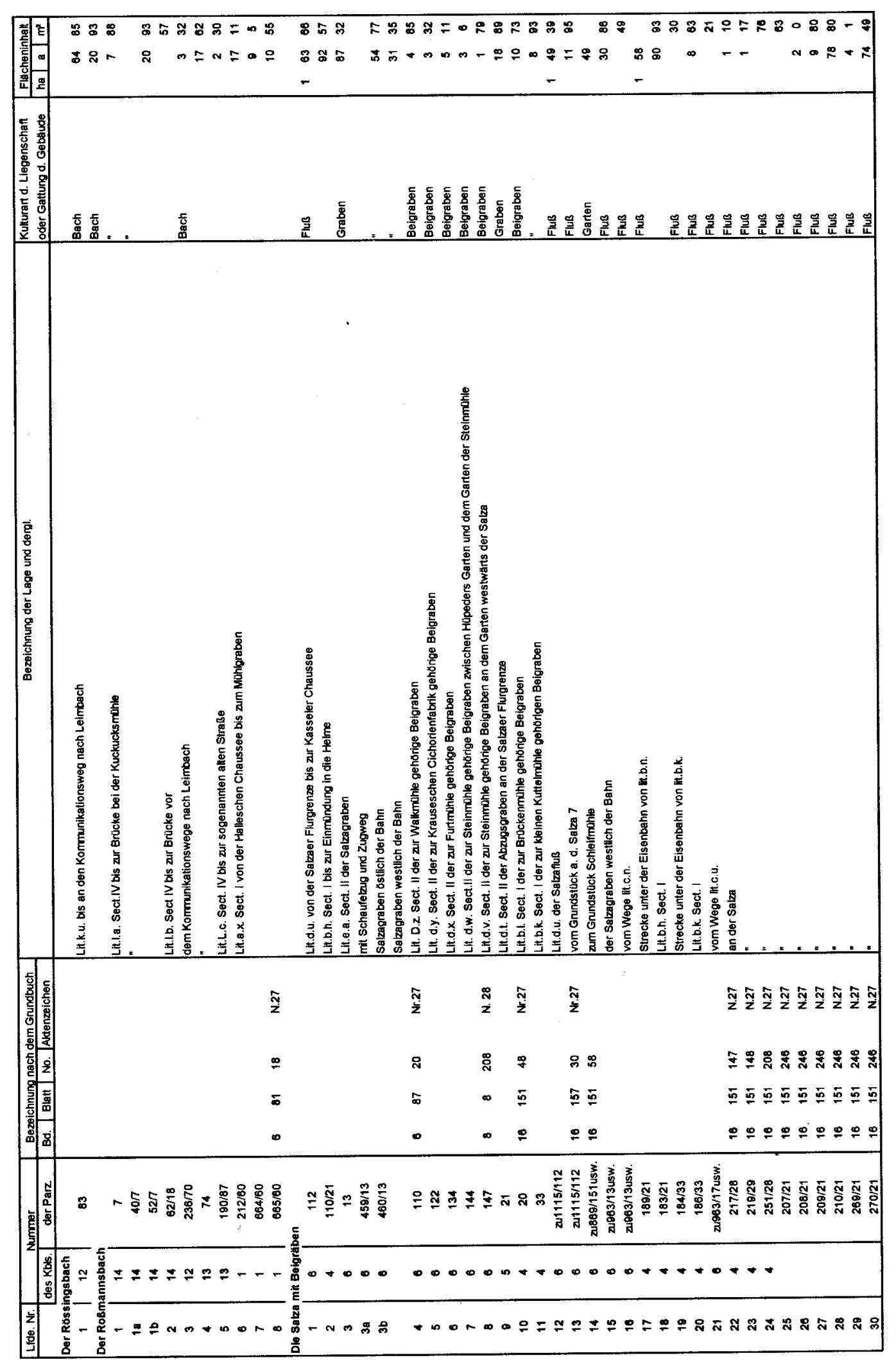


Tab. A-1: Öffentliche Wege und Gewässer im Stadtbezirk Nordhausen (Fortsetzung)

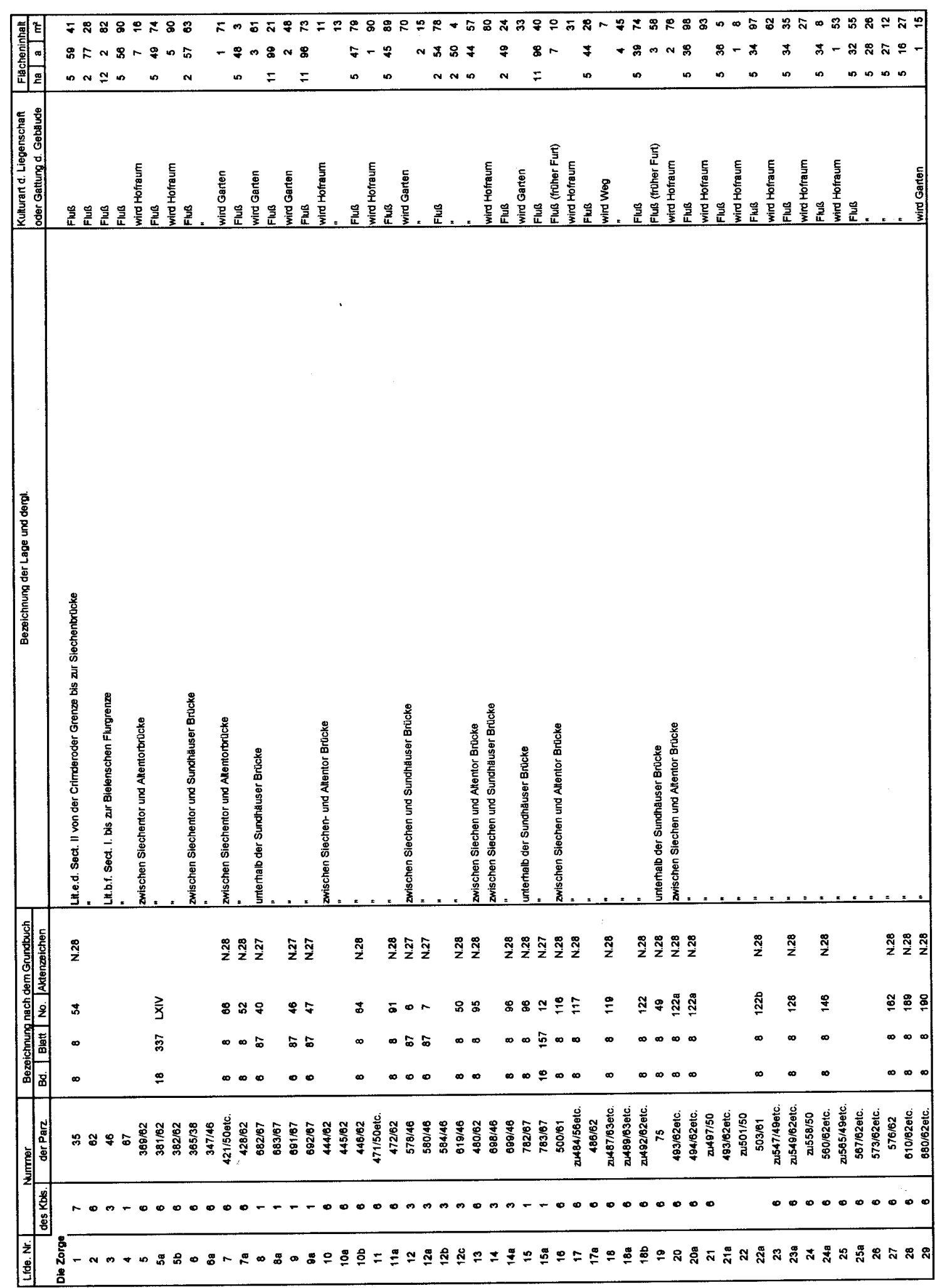


Tab. A-1: Öffentliche Wege und Gewässer im Stadtbezirk Nordhausen (Fortsetzung)

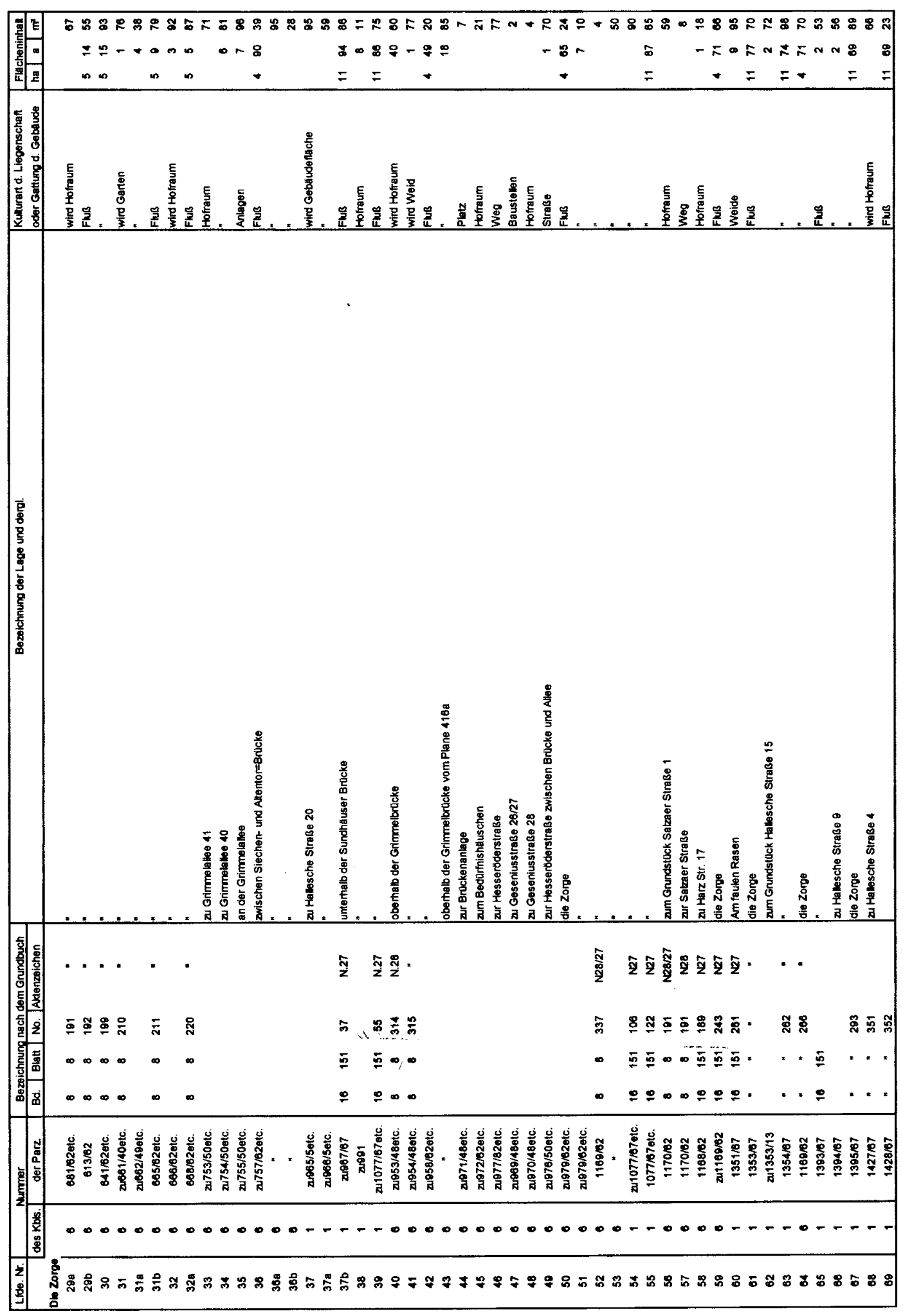


Tab. A-2: Gewässersystematik nach JUNG (1994:18)

\begin{tabular}{|c|c|c|c|c|}
\hline \multicolumn{2}{|c|}{ Haupttyp } & \multicolumn{2}{|c|}{ Intertyp } & \multirow[b]{2}{*}{ 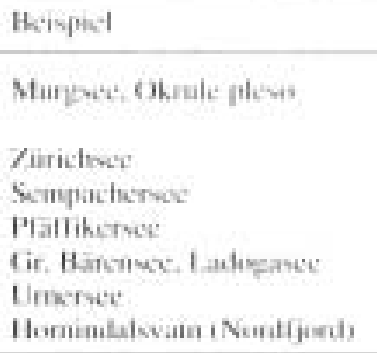 } \\
\hline GI & Gilarialumsive Sexn & $\begin{array}{l}\text { kit } \\
\text { ni } \\
\text { it } \\
\text { if } \\
\text { ij }\end{array}$ & 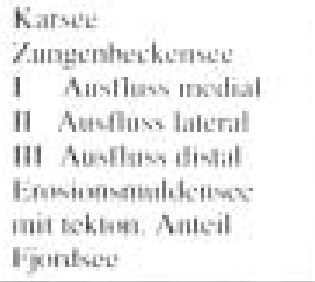 & \\
\hline Gil. & Giletshorveen & $\begin{array}{l}\mathrm{rg} \\
\text { ig } \\
\text { of } \\
\text { ug }\end{array}$ & 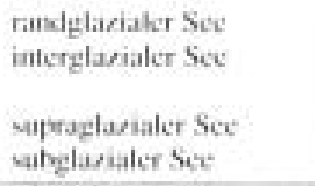 & 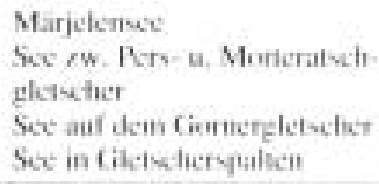 \\
\hline NS & Natarlishe Stauwen & $\begin{array}{l}\text { br } \\
\text { La } \\
\text { su } \\
\text { cs } \\
\text { cm }\end{array}$ & 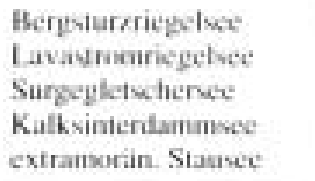 & 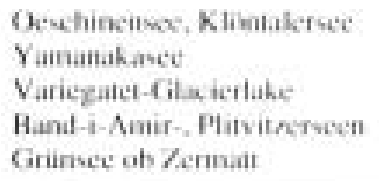 \\
\hline MA & $\begin{array}{l}\text { Muldenseen ant Akkumulations- } \\
\text { malerial }\end{array}$ & $\begin{array}{l}\text { Wrn } \\
\text { as } \\
\text { vh } \\
\text { dwe }\end{array}$ & 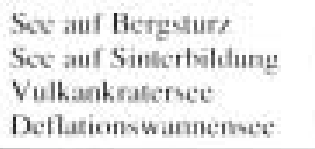 & 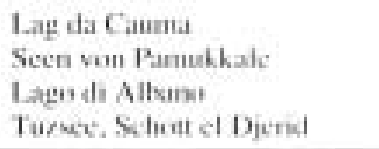 \\
\hline $\mathrm{KA}$ & Kanstiven & $\begin{array}{l}\mathrm{kh} \\
\mathrm{pos} \\
\mathrm{gl} \\
\mathrm{kr}\end{array}$ & $\begin{array}{l}\text { Karsthohlenves } \\
\text { Poljeree } \\
\text { mal Glovaleronam } \\
\text { Kryokandwe }\end{array}$ & 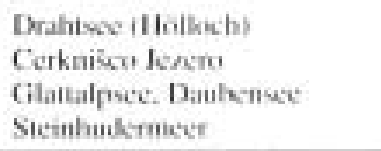 \\
\hline EK & Explosivkralerseen & $\begin{array}{l}\mathrm{ma} \\
\mathrm{ca}\end{array}$ & $\begin{array}{l}\text { Maare } \\
\text { Caldera miit See }\end{array}$ & $\begin{array}{l}\text { Pulvenmaar, I aasheres } \\
\text { Lago di Bolwena }\end{array}$ \\
\hline TE & Seen in iektuxischen Hohlformen & $\begin{array}{l}\text { gb } \\
\text { sy } \\
1 \\
\text { II } \\
\text { nit } \\
\text { cd } \\
11\end{array}$ & 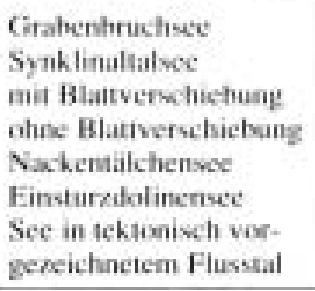 & 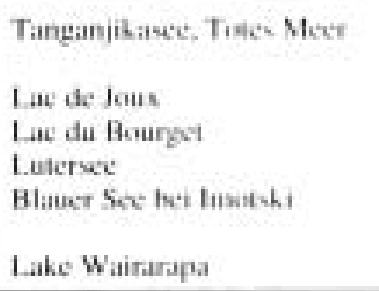 \\
\hline MS & Marine Akkumulationsseen & is & $\begin{array}{l}\text { Strandsee } \\
\text { Deltasee }\end{array}$ & $\begin{array}{l}\text { Letawes iPt.r. Burullawes } \\
\text { Elang du Vaccarics }\end{array}$ \\
\hline FS & $\begin{array}{l}\text { Seen fluvialer Entstehung } \\
\text { fluvio-glaziale Entstehung }\end{array}$ & & $\begin{array}{l}\text { Altwasser } \\
\text { Rinnenseen }\end{array}$ & $\begin{array}{l}\text { Giexsenporksec (Balkigear) } \\
\text { Scharmithelece, Teqektere }\end{array}$ \\
\hline MK & Soe in einem Meteorkrater & & & Kratervec in Quchec \\
\hline UT & See unsicherer Entstehung & & & Urmiaser \\
\hline KS & Künstlicber Stausee & & & Grianseluee \\
\hline
\end{tabular}


Tab. A-3: Verzeichnis der bergbaulich genutzten Sammelteiche in den Oberharzer Revieren

mit Umrechnung der ursprünglichen Maße und Größenangaben der Teiche in $\mathrm{m}$ und $\mathrm{m}^{3}$. (Zusammenstellung nach DUMREICHER 1866/68 [Werte in Klammern], aus: TRUNZ 2000:12ff. und HAASE 1961:12, 37,48,79,105). Es ergeben sich einige Unterschiede in beiden Auflistungen, die die Werte wie auch die Teiche an sich betreffen. Einige Teiche, die DUMREICHER noch benennt, wie der Große Prinzenteich, der Haderbacher Teich, der Obere und Untere HahnbalzTeich, der Klein-Clausthaler Teich, der Kreuzbacher Teich und der Stadtweger Teich sind bei HAASE nicht (mehr) aufgeführt. Andere wiederum, wie Wegsmühlenteich und der Neue Teich sind bei HAASE geklammert und damit als Wegfall bzw. Nichtfund gekennzeichnet. Des Weiteren ist der Obere und Untere Kranicher Teich bei DUMREICHER als ein Teich (Kranicher Teich) zusammengefasst. Die Größenbemessungen der Teiche divergieren manchmal extrem (Hirschler Teich), manchmal in angemessenem Rahmen. In 32 von 56 vergleichbaren Fällen, dort wo Vergleichszahlen gegeben sind, sind die Teiche gemessenen am Fassungsvolumen bei DUMREICHER größer als die bei HAASE, nur in 6 Fällen war dies umgekehrt.

\begin{tabular}{|c|c|c|c|c|c|c|c|}
\hline Nr. & Namen & Bauzeit & Dammhöhe [m] & $\begin{array}{l}\text { Fläche [ha] } \\
\text { [Spiegelhöhe] }\end{array}$ & Inhalt $\left[\mathrm{m}^{3}\right]$ & $\begin{array}{l}\text { Höhe ü.N.N. } \\
\text { [Teichspiegel] }\end{array}$ & $\begin{array}{l}\text { Tage, die } \\
\text { der Teich } 1 \\
\text { Rad } \\
\text { antreiben } \\
\text { kann }\end{array}$ \\
\hline \multicolumn{8}{|c|}{ A. Die Wiesenteiche von Buntenbock } \\
\hline 1 & $\begin{array}{l}\text { Oberer Nassenwieser } \\
\text { Teich }\end{array}$ & vor 1743 & $8,8[3,31]$ & $4,5[4,495]$ & $138.000[103.374]$ & 584,4 & 17 \\
\hline 2 & $\begin{array}{l}\text { Unterer Nassenwieser } \\
\text { Teich }\end{array}$ & vor 1743 & $6,0[6,88]$ & $2,4[2,61]$ & $48.000[77.867]$ & 572,2 & 11 \\
\hline 3 & Bärenbrucher Teich & 1644 & $7,5[9,169]$ & $5,6[6,1965]$ & $189.000[237.714]$ & 559,5 & 30 \\
\hline 4 & Ziegenberger Teich & $1639 / 44$ & $9,4[10,44]$ & $8,1[7,7232]$ & $324.000[337.597]$ & 553,8 & 43 \\
\hline 5 & Sumpfteich & vor 1743 & $7,5[8,16]$ & $9,0[9,0272]$ & $296.000[86.199]$ & 543,0 & 21 \\
\hline 6 & Pixhaier Teich & 1644 & $9,6[9,68]$ & $8,1[8,0508]$ & $288.000[295.149]$ & 558,0 & 14 \\
\hline 7 & $\begin{array}{l}\text { Johann-Friedricher- } \\
\text { Teich }\end{array}$ & vor 1743 & $5,9[5,09]$ & $5,8[5,7968]$ & $120.000[135.773]$ & 582,4 & 21 \\
\hline 8 & $\begin{array}{l}\text { Alter } \\
\text { Teich }\end{array}$ & vor 1565 & $6,0[6,11]$ & $2,1[2,1274]$ & $39.000[48.292]$ & 573,9 & 11 \\
\hline 9 & Schwarzenbacher Teich & $1611 / 14$ & $7,9[9,17]$ & $5,4[5,4080]$ & $184.000[207.466]$ & 558,9 & 20 \\
\hline 10 & Hasenbacher Teich & vor 1743 & $9,4[9,17]$ & $3,8[3,7284]$ & $142.000[143.031]$ & 562,6 & \\
\hline 11 & Semmelwieser Teich & vor 1743 & $7,5[8,15]$ & $1,9[1,9177]$ & $64.000[65.419]$ & 559,2 & 14 \\
\hline 12 & $\begin{array}{ll}\text { Oberer } & \text { Flambacher } \\
\text { Teich } & \\
\end{array}$ & vor 1689 & $7,2[8,15]$ & $3,5[3,4139]$ & $118.000[116.459]$ & 557,6 & 20 \\
\hline 13 & $\begin{array}{ll}\text { Unterer } & \text { Flambacher } \\
\text { Teich } & \\
\end{array}$ & 1689 & $5,3[5,35]$ & $2,2[2,0269]$ & $48.000[51.794]]$ & 551,0 & 17 \\
\hline \multicolumn{8}{|c|}{ B. Die Teiche im Dammgrabensystem } \\
\hline 14 & Jägersbleeker Teich & vor 1717 & $13,6[11,46]$ & $9,6[9,4684]$ & $405.000[420.510]$ & 586,9 & \\
\hline 15 & Fortuner Teich & $1722 / 24$ & $14,6[14,77]$ & $7,7[11,7945]$ & $345.000[436.810]$ & 569,7 & 73 \\
\hline 16 & Polstertaler Teich & 1728 & $6,4[8,15]$ & $2,1[2,1623]$ & $60.000[73.765]$ & 522,2 & 13 \\
\hline 17 & Langer Teich & vor 1606 & $7,6[8,15]$ & $1,9[1,7735]$ & $50.000[60.502]$ & 581,6 & 16 \\
\hline 18 & $\begin{array}{l}\text { Oberer Hausherzberger } \\
\text { Teich }\end{array}$ & vor 1606 & $7,4[6,62]$ & $6,4[6,3843]$ & $183.000[183.839]$ & 569,5 & 21 \\
\hline 19 & $\begin{array}{l}\text { Unterer Hausherzberger } \\
\text { Teich }\end{array}$ & $1676 / 77$ & $9,4[9,17]$ & $4,9[4,8554]$ & $220.000[220.095]$ & 569,0 & 35 \\
\hline 20 & Hirschler Teich & vor 1717 & $11,7[10,7]$ & $16,0[15,9597]$ & $699.000[3.937 .680]$ & 588,1 & 42 \\
\hline 21 & Oberer Pfauenteich & vor 1661 & $8,3[8,91]$ & $4,4[4,3367]$ & $144.000[143.020]$ & 577,7 & 21 \\
\hline 22 & Mittlerer Pfauenteich & vor 1298 & $9,4[10,18]$ & $8,5[8,3523]$ & $309.000[355.886]$ & 573,2 & 21 \\
\hline 23 & Unterer Pfauenteich & vor 1606 & $9,2[9,17]$ & $5,9[5,7269]$ & $273.000[225.821]$ & 568,5 & 35 \\
\hline \multicolumn{8}{|c|}{ C. Teiche im Okergebiet, ohne Beziehung zum Dammgrabensystem } \\
\hline 24 & Kleiner Okerteich & 1715 & $8,2[8,66]$ & $6,1[0,6138]$ & $22.000[22.235]$ & 529,4 & 4 \\
\hline 25 & Altenauer Hüttenteich & 1682 & $10,0[10,19]$ & $2,3[2,2693]$ & $148.000[95.865]$ & 479,0 & 17 \\
\hline 26 & Teich in der Lange & vor 1680 & 7,1 & $0,7[8,15]$ & $24.000[24.067]$ & 492,1 & 4,25 \\
\hline 27 & Schalker Teich & vor 1679 & $12,0[11,72]$ & $2,8[2,8722]$ & $136.000[141.204]$ & 508,5 & 24,5 \\
\hline \multicolumn{8}{|c|}{ D. Die Teiche auf dem Zellerfeld } \\
\hline 28 & Auerhahner Teich & nach 1680 & $8,1[9,17]$ & $1,6[1,185] 6$ & $62.000[62.089]$ & 610,7 & \\
\hline 29 & $\begin{array}{l}\text { Neuer } \quad \text { Grumbacher } \\
\text { Teich }\end{array}$ & nach 1680 & $9,9[10,19]$ & $2,6[2,5839]$ & $109.000[110.131]$ & 591,3 & 19,25 \\
\hline 30 & $\begin{array}{l}\text { Oberer } \quad \text { Grumbacher } \\
\text { Teich }\end{array}$ & vor 1680 & 10,7 & $4,3[4,3247]$ & $179.000[184.327]$ & 574,1 & 32 \\
\hline 31 & $\begin{array}{l}\text { Oberer } \quad \text { Kellerhalser } \\
\text { Teich }\end{array}$ & vor 1680 & $11,2[10,19]$ & $1,5[1,4416]$ & $70.000[61.442]$ & 614,0 & 10,75 \\
\hline 32 & $\begin{array}{l}\text { Mittlerer } \\
\text { Teich }\end{array}$ & $1674 / 80$ & $13,3[15,28]$ & $7,7[7,8368]$ & $474.000[500.994]$ & 580,1 & 87,3 \\
\hline 33 & Zankwieser Teich & nach 1680 & $8,4[8,15]$ & $3,9[3,9446]$ & $102.000[168.129]$ & 585,5 & 10 \\
\hline 34 & Kiefhölzer Teich & vor 1677 & $10,0[13,24]$ & $7,2[7,4699]$ & $275.000[413.724]$ & 575,5 & 70 \\
\hline 35 & Schröterbacher Teich & vor 1677 & $9,2[8,15]$ & $2,1[2,1252]$ & $72.000[72.556]$ & 574,7 & 10 \\
\hline 36 & Stadtweger Teich & nach 1680 & 9,4 & 8,5 & 293.000 & 556,3 & \\
\hline 37 & Wasserläufer Teich & nach 1680 & $5,7[5,09]$ & $1,1[1,5508]$ & $27.000[33.049]$ & 564,8 & 3 \\
\hline
\end{tabular}




\begin{tabular}{|c|c|c|c|c|c|c|c|}
\hline 38 & Oberer Zechenteich & 1565 & $6,1[6,11]$ & $1,5[1,5639]$ & $34.000[39.995]$ & 564,4 & 14 \\
\hline 39 & Mittlerer Zechenteich & 1565 & $7,4[7,13]$ & $1,6[1,6185]$ & $49.000[48.284]$ & 557,9 & 10 \\
\hline 40 & $\begin{array}{ll}\text { Oberer } & \text { Einersberger } \\
\text { Teich } & \\
\end{array}$ & vor 1680 & $9,0[8,15]$ & $3,8[3,6257]$ & $152.000[139.066]$ & 560,1 & 28 \\
\hline 41 & $\begin{array}{ll}\text { Mittlerer } & \text { Einersberger } \\
\text { Teich } & \\
\end{array}$ & vor 1680 & $4,0[5,09]$ & $0,8[10,702]$ & $16.000[22.808]$ & 543,9 & \\
\hline 42 & $\begin{array}{ll}\text { Oberer } & \text { Eschenbacher } \\
\text { Teich } & \\
\end{array}$ & 1602 & $9,5[10,19]$ & $1,6[1,6207]$ & $64.000[70.835]$ & 570,0 & 20 \\
\hline 43 & $\begin{array}{l}\text { Unterer Eschenbacher } \\
\text { Teich }\end{array}$ & 1602 & $9,0[11,47]$ & $4,7[4,5431]$ & $191.000[213.024]$ & 550,0 & 35 \\
\hline 44 & Eulenspiegler Teoch & vor 1560 & $4,8[2,80]$ & $3,5[3,2915]$ & $41.000[56.122]$ & 528,7 & 10 \\
\hline 45 & Carler Teich & vor 1563 & $5,3[5,09]$ & $0,9[0,7055]$ & $14.000[15.035]$ & 547,8 & 3 \\
\hline 46 & Hüttenteich & vor 1680 & $7,0[4,33]$ & $0,7[0,2970]$, & $13.000[5.698]$ & 537,6 & \\
\hline \multicolumn{8}{|c|}{ E. Die Teiche im Bereich des Lautenthaler Gefälles } \\
\hline 47 & Brinkmühlenteich & -- & $3,5[3,57]$ & $0,5[0,4565]$ & $6.300[6.324]$ & 547,0 & 0,25 \\
\hline 48 & Oberer Germansteich & vor 1680 & $3,5[3,31]$ & $0,6[0,5963]$ & $8.900[8.894]$ & 549,0 & 1,5 \\
\hline 49 & Unterer Germansteich & vor 1680 & $3,5[3,31]$ & $0,5[0,5198]$ & $7.200[7.201]$ & 547 & 0,3 \\
\hline 50 & Mittelmühlenteich & -- & $4,5[4,59]$ & $0,4[0,4150]$ & $5.000[7.961]$ & 528,3 & 7,25 \\
\hline 51 & [Wegsmühlenteich] & vor 1680 & $3,2[3,06]$ & $0,3[2,970]$ & $3.800[7.201]$ & 546,2 & 0,8 \\
\hline 52 & Unterer Kellerhalsteich & vor 1680 & $7,3[6,62]$ & $1,6[1,4896]$ & $54.000[41.271]$ & 541,5 & 7,25 \\
\hline 53 & $\begin{array}{ll}\begin{array}{l}\text { Oberer } \\
\text { Teich }\end{array} & \text { Spiegeltaler } \\
\end{array}$ & vor 1680 & $5,8[6,11]$ & $1,6[1,6054]$ & $53.000[41.063]$ & 501,7 & 7,2 \\
\hline 54 & $\begin{array}{ll}\text { Unterer } & \text { Spiegeltaler } \\
\text { Teich } & \\
\end{array}$ & vor 1680 & $9,6[10,19]$ & $3,5[0,36781]$ & $156.000[156.771]$ & 479,0 & 27,3 \\
\hline 55 & Than-Teich & -- & 6,7 & 0,5 & 9.000 & 574,6 & \\
\hline 56 & $\begin{array}{l}\text { Mittlerer Grumbacher } \\
\text { Teich }\end{array}$ & nach 1680 & $9,6[9,17]$ & $2,0[1,8478]$ & $76.000[70.887]$ & 561,2 & 12,32 \\
\hline 57 & $\begin{array}{l}\text { Oberer Flößteich } \\
\text { [Oberer Auguster-Teich] }\end{array}$ & vor 1680 & $4,5[4,59]$ & $0,6[0,6269]$ & $14.000[12.024]$ & 547,4 & 2 \\
\hline 58 & $\begin{array}{l}\text { Unterer Flößteich } \\
\text { [Flößteich] }\end{array}$ & vor 1680 & $6,0[4,08]$ & $0,8[0,7819]$ & $13.000[13.332]$ & 541,2 & 2,3 \\
\hline 59 & Grumbacher Teich & nach 1680 & $7,7[8,15]$ & $2,6[2,5555]$ & $82.000[87.176]$ & 479,9 & 15,25 \\
\hline 60 & Oberer Kranicher Teich & 14. Jh. & -- & 1,8 & 14.000 & 555,7 & \\
\hline \multirow[t]{2}{*}{61} & Unterer Kranicher Teich & $1674 / 78$ & 8,3 & 3,1 & 93.000 & 555,7 & \\
\hline & Kranicher Teich & & 9,17 & 4,8707 & 186.854 & & 32,5 \\
\hline 62 & Karpfenteich & vor 1680 & -- & -- & -- & 570 & \\
\hline 63 & Kuttelbacher Teich & nach 1680 & $5,3[11,21]$ & $4,1[4,0101]$ & $138.000[188.035]$ & 540,4 & 26 \\
\hline 64 & [Neuer Teich] & nach 1680 & $5,8[6,11]$ & $0,5[0,4609]$ & $11.800[11.776]$ & 423,6 & 2 \\
\hline \multicolumn{8}{|c|}{ F. Sonstige Sammelteiche im Oberharzer Revier } \\
\hline 65 & $\begin{array}{l}\text { Bährner Teich } \\
{[T \text {. vor den drei }} \\
\text { Jungfrauen] }\end{array}$ & 1667 & -- & -- & -- & 645,0 & \\
\hline 66 & Engelsburger Teich & 1662 & -- & -- & -- & 560,0 & \\
\hline 67 & Große Prinzenteich & & 9,17 & 13,3081 & 510.447 & & 49 \\
\hline 68 & Haderbacher Teich & & 10,19 & 2,4572 & 115.217 & & 28 \\
\hline 67 & Hilfe-Gottes-Teich & vor 1763 & 9,2 & 0,4 & 12.300 & 603,2 & \\
\hline 69 & Oberer Hahnbalz-Teich & & 10,19 & 2,3982 & 102.218 & & 28 \\
\hline 70 & $\begin{array}{l}\text { Unterer Hahnebalz- } \\
\text { Teich } \\
\text { [Mühlenteich] }\end{array}$ & & 8,15 & 1,6469 & 56.180 & & 28 \\
\hline 71 & Klein-Clausthaler Teich & & 8,15 & 1,0200 & & 34.796 & 14 \\
\hline 72 & Kreuzbacher Teich & & 4,33 & 3.254 & 5.896 & & 1 \\
\hline 73 & Oderberger Teich & -- & -- & -- & -- & 620,0 & \\
\hline 74 & Oderteich & $1714-1721$ & 18 & 26,8 & 1.668 .000 & 723,6 & \\
\hline 75 & Stadtweger Teich & & 11,21 & 8,8481 & 414.885 & & 72,3 \\
\hline
\end{tabular}




\section{LITERATURVERZEICHNIS}

ABBILDUNGEN DER RINDVIEH- UND ANDEREN HAUSTHIER-RACEN. Reprint nach den Originalen von 1827 - 1834. Hrsg.: Verlag Th. Schäfer - Hannover: Schäfer 1984 [Edition „libri rari“].

ABEL, C.: Preußische und Brandenburgische Staats-Geographie, in welcher der gegenwärtige Zustand, aller Reiche und Länder dieses Kgl. Chur-Hauses, [...] vorgestellet, [...]. - 1. Aufl. - Leipzig und Stendal 1711.

ABEL, F.: Das Mühlengewerbe im Nassau-Hadamar und Diez. - Stuttgart: Deutsche Verlagsgesellschaft 1910.

ABEL, W.: Die Wüstungen des ausgehenden Mittelalters. Darin: Kap. II. „Wandlungen der Bodennutzung - Spezialkulturen, Vieh- und Teichwirtschaft“. - 3. neubearb. Aufl. - Stuttgart: Fischer 1976 [Quellen und Forschungen zur Agrargeschichte; 1]: 50-53.

ABEL, W.: Geschichte der deutschen Landwirtschaft vom frühen Mittelalter bis zum 19. Jahrhundert. - 3. Aufl. - Stuttgart: Ulmer 1978.

ABELSHAUSER, W. (Hrsg.): Umweltgeschichte. Umweltverträgliches Wirtschaften in historischer Perspektive; acht Beiträge. Göttingen: Vandenhoeck und Ruprecht 1994 [Geschichte und Gesellschaft Sonderheft 15].

ABELSHAUSER, W.[b]: Einleitung. - In: ABELSHAUSER, Werner (Hrsg.): Umweltgeschichte. Umweltverträgliches Wirtschaften in historischer Perspektive; acht Beiträge. - Göttingen: Vandenhoeck \& Ruprecht 1994:7-10 [Geschichte und Gesellschaft, Sonderheft 15].

ABELSHAUSER, Werner/WENGENROTH, Ulrich: Umweltgeschichte. Umweltverträgliches Wirtschaften in historischer Perspektive. - In: Technikgeschichte 63/2 1996:188.

ACHENBACH, H.: Historische Wirtschaftskarte des östlichen Schleswig-Holsteins um 1850. - Kiel: Universität 1988 [Kieler Geographische Schriften;67].

ACHILLES, W.: Deutsche Agrargeschichte im Zeitalter der Reformen und der Industrialisierung. - Stuttgart: Ulmer 1993.

ACHTERNICH, Wolfram: Bewässerungslandbau. Agrotechnische Grundlagen der Bewässerungswirtschaft. - Stuttgart: Ulmer 1981.

ACKERHOF, A: D.: Die Nutzung der Teiche und Gewässer durch Fischzucht und Pflanzenbau. - Quedlinburg: Basse 1869.

ADAMECK, M./SCHWEEN, J.: Großräumige Kulturkontakte an der Weser in der Vor- und Frühgeschichte. Mit Überlegungen zur Weserschiffahrt und zum Landverkehr. - In: Die Weser - Ein Fluss in Europa: [eine länderübergreifende Ausstellung über 1200 Jahre Geschichte und Kultur des Weserraumes...], Bd. 1. Leuchtendes Mittelalter/Museum Hameln. Hrsg. von Norbert Humburg und Joachim Schween - Holzminden: Mitzkat 2000:8-24.

AERNI, K. et. al.: Der Mensch in der Landschaft. Festschrift Georges Grosjean. - Bern: Jahrbuch der Geographischen Gesellschaft von Bern 1985.

AERNI, K.: Das „Inventar historischer Verkehrswege der Schweiz (IVS)“. Ein Kurzbericht. - In: Siedlungsforschung 4 1986:267279.

AERNI, Klaus/GURTNER, A./MEIER, B.: Geographische Arbeitsweisen - Grundlagen zum Propädeutischen Praktikum II. Bern: Universität Bern 1989 [Geographica Bernensia;20].

AFGHANISTAN 2004 [URL = http://www.medio-afghanistan.de/nachhaltigekv-lebenselement.htm; 17.01.2004]

AGRARBERICHT 2003 [URL = http.//www.mv-regierung.de/lm/agrabericht2003/kapitel_7.htm; 08.01.2004]

AGRICOLA, G.: Vom Bergwerck: XII Bücher, darin alle Empter, Instrument, Gezeuge [...] [„,De Re Metallica Libri XII“]. Reprint nach dem Orig. d. 1. dt. Ausgabe, Basel 1557. - Hannover: Schäfer 1985.

AHLERS, Chr.: Forellenzucht: Kurze Anleitung [...]. Hrsg. v. d. Forellenzucht des Gutes Sandfort bei Osnabrück. - Osnabrück: Jaffe 1894.

AHRENS, K. (Hrsg.): Columella. Über Landwirtschaft: Ein Lehr- und Handbuch der gesamten Acker- und Viehwirtschaft aus dem 1. Jahrhundert u. Z./Columella. 2. Aufl. - Berlin: Akademie-Verl. 1972 [Schriften zu Geschichte und Kultur der Antike;4].

AHRENS, K. O.: Die Wasserwirtschaft im Lande Wursten. - Bremen: Trüjen, 1962 [Deutsche geographische Blätter;49,3/4].

AISTLEITNER, J.: Formen und Auswirkungen des bäuerlichen Nebenerwerbs: Das Mühlviertel als Beispiel. - Innsbruck 1986 [Innsbrucker Geogr. Studien;14].

AKADEMIE FÜR RAUMFORSCHUNG UND LANDESPLANUNG (Hrsg.): Großschutzgebiete: Chancen und Konflikte im Rahmen einer integrierten Regionalentwicklung - am Beispiel insbesondere auch der Flusslandschaft Elbe. - Hannover 1997 [Arbeitsmaterial der Akademie für Raumforschung und Landesplanung;239].

AKKERMANN, R.: Tümpel - Teiche - Schlatts. Hrsg. v. d. Biolog. Schutzgemeinschaft Hunte - Weser - Ems e. V. (BSH) i. V. m. d. Biolog. Arbeitskreis a. d. Univ. Osnabrück, Abt. Vechta. - Wardenburg: BSH-Verl. 1980 [Informationen zu Naturschutz und Landschaftspflege in Nordwestdeutschland;2]. 
AKKERMANN, R. (Hrsg.): Die Hunte: Porträt eines nordwestdeutschen Flusses. Hrsg. v. der Biologischen Schutzgemeinschaft Hunte-Weser-Ems e. V. in Zusammenarbeit mit dem Naturschutzverband Niedersachsen durch Remmer Ackermann. Oldenburg: Isensee 1994.

AKKERMANN, R: Kormorane im niedersächsischen Binnenland am Beispiel der Ahlhorner Fischteiche [Kurzfassung]. - In: BSH-Merkblatt 652001 [URL = http://www.bsh-natur.de/kormoran.htm; 09.10.2003].

AL NAIB, S. K.: London Docklands. Past, present and future. - 3. Aufl. - London: Thames \& Hudson 1993.

ALBERT, G. et al:: Ökologische Struktur des Landschaftsraumes Gestüt Mydlinghoven [Untersuchung zur derzeitigen ökologischen Struktur des Landschaftsraumes um das ehemalige Gestüt Mydlinghoven (Düsseldorf) - Gutachten im Auftrag der Gut Mydlinghoven GmbH \& Co.KG, Düsseldorf, September 1987.

ALBERTI, H.-J. v.: Maß und Gewicht. Geschichtliche und tabellarische Darstellungen von den Anfängen bis zur Gegenwart. Berlin: Akademie-Verl. 1957.

ALBRECHT, G./WOLLKOPF, P.: Rentierjäger und frühe Bauern. Steinzeitliche Besiedlung zwischen dem Bodensee und der Schwäbischen Alb. - Konstanz: Rosgartenmuseum, Städtische Museen 1990.

ALBRECHT, H.[a]: Bergbau. - In: SONNABEND, Holger (Hrsg.): Mensch und Landschaft in der Antike. Lexikon der historischen Geographie. - Metzler 1999:55.

ALBRECHT, H.[b]: Mühlen 1999:353) - In: SONNABEND, Holger (Hrsg.): Mensch und Landschaft in der Antike. Lexikon der historischen Geographie. - Metzler 1999:353.

ALBRECHT, H.[c]: Wasserbau. - In: SONNABEND, Holger (Hrsg.): Mensch und Landschaft in der Antike. Lexikon der historischen Geographie. - Metzler 1999:595-596.

ALFF, W.: Geschichte von Alff und Prüm 1999 [URL = http://www.geocities.com/Yosemite/Forest/5854/alff/alffgeschichte.htm; 30.01.2004].

ALHEIT, J./HAGEN, E.: Long-term climate forcing of European herring und sardine populations. - In: Fish Oceanogr 6 1997:130-139.

ALHEIT, J./HAGEN, E.: The effect of Climate Variation on Fish and Fisheries. - In: JONES, P. D./OGILVIE, A. E. J./DAVIES, T. D./BRIFFA, K. R. (Hrsg.): Climate and Climatic Impacts through the last 1000 Years. - Kluwer/Plenum 2001.

ALIMEN, M.-H./STEVE, M.-J. (Hrsg.): Vorgeschichte. - Frankfurt/Main: Fischer-Taschenbuch Verl., 1966 [FischerWeltgeschichte;1].

ALLGEMEINER ANZEIGER Nordhausen-Sondershausen v. 5.11.1997.

ALLGEMEINER ANZEIGER Nordhausen-Sondershausen: „Wie wärs mit einem Spaziergang in den Nordhäuser Stadtpark? In den Teichen tummelten sich Goldfische. Geschichtlicher Exkurs: Nach Dammbau wurde Sumpfgebiet urbar“v. 29.12.1997.

ALLGEMEINER ANZEIGER Nordhausen-Sondershausen v. 25.02.1998.

ALLGEMEINER ANZEIGER Nordhausen-Sondershausen: „Gerstensaft aus der Rolandstadt. Kühles Blondes aus dem Bürgerlichen Brauhaus“v. 13.05.1998.

ALMOND, R.: Mediaval hunting. - Stroud/Gloucestershire: Sutton 2003

ALTHÖFER-WESTENHOFF, K./WAGNER, B. J.: Geschichte im Fluß: zur Umweltgeschichte von Werre und Else im östlichen Westfalen. - Bielefeld: Verl. f. Regionalgeschichte 1997 [Herforder Forschungen;15].

ALTMANN, G.: Erzgebirgisches Eisen: Geschichte - Technik - Volkskultur. - Sächsische Landesstelle für Volkskultur, Schneeberg / Erzgebirge. - Dresden: Sächsisches Druck- und Verlagshaus 1999 [Reihe Weiss - Grün;15].

ALTNER, G.: Die Überlebenskrise in der Gegenwart: Ansätze zu Dialog mit der Natur in Naturwissenschaft und Theologie. Darmstadt: Wiss. Buchgesell. 1991.

ALTMANN, J.: Die Wachau: Perspektiven einer europäischen Flusslandschaft. Hrsg.: Arbeitskreis zum Schutz der Wachau. Krems: Malek 1995.

ALZINGER, W.: Beispiel antiker Wasserversorgungsanlagen: Epherus. - In: Die Wasserversorgung antiker Städte, Vol. 2. Mainz: Zabern 1987:180-184.

AMACHER, U.: Zürcher Fischerei im Spätmittelalter. Realienkunde, Sozial- und Wirtschaftsgeschichte der Fischerei im Zürcher Gebiet. - Zürich: Verl. Hans Rohr 1996 [Mitteilungen der Antiquarischen Gesellschaft in Zürich. Kantonaler Verein für Geschichte und Altertumskunde;63 = Neujahrsblatt 160]; Zugl.: Zürich, Univ., Diss. 1994.

AMAN, W.: Städte- und Siedlungsbau in Wien 1945-1958. - Frankfurt/Main [u.a.]: Lang 1999; Zugl.: Wien, Univ., Diss. 1988.

AMANN, Chr.: Landschaft - ein Widerspruch?. - In: HABERL, H./STROHMEIER, G.: Kulturlandschaftsforschung. - Wien, New York: Springer 1999 [iff texte;5]:31-35.

AMELUNG, U.: Einsichten aus der Geschichte der Umweltwissenschaften zum Problem des interdisziplinären Arbeitens. - In: BRANDT, E. (Hrsg.): Perspektiven der Umweltwissenschaften. - Baden-Baden: Nomos 2000 [Umweltrecht und Umweltpolitik;2]:35-47. 
AMMON, K. W.: Allgemeines Hausvieharzneibuch oder vollständiger Unterricht wie man die Krankheiten der Pferde, des Rindviehes, der Schaafe, Schweine, Hunde und des Federviehes, auf die leichteste und wohlfeilste Art heilen kann. Zum Gebrauch für angehende Thierärzte, Dekonomen und Landleute. - Ansbach: Gassert 1809.

AMT DER NÖ LANDESREGIERUNG, Abt. III/2 - Kulturabteilung [Hrsg.]: Fischerei Einst und Jetzt. Ausstellung des Landes Niederösterreich. Schloss Orth an der Donau. 15. April bis 13. November 1983 [Katalog des NÖ Landesmuseums, Neue Folge;132] - Wien: Selbstverl. 1983.

AMTSBUCH der Reichsstadt Nordhausen. 1312-1345. Liber privilegiorum et Album Civium. Hrsg. v. ROBERT, H./MÜLLER, W. - Nordhausen: Rat der Stadt Nordhausen, Stadtarchiv 1956 [Schriftenreihe heimatgeschichtlicher Forschungen d. Stadtarchivs Nordhausen/Harz;3]

ANDERMANN, K.: Das Wasserhaus zu Niederweier: ein wieder entdeckter Adelssitz des späten Mittelalters. - In: Badische Heimat 79 1999:363-368.

ANDERS, W./CREYDT, D.: Das Rittergut Denkiehausen und die Weiße Mühle. - In: Jahrbuch für den Landkreis Holzminden 22 2004:99-106.

ANDERSEN, A.: Umweltgeschichte. Forschungsstand und Perspektiven. - In: Archiv f. Sozialgeschichte 33 1991:27-54.

ANDERSEN, A.: Zum Heft Umweltgeschichte. - In: WerkstattGeschichte 31992.

ANDERSEN, A.: Umweltgeschichte. Forschungsstand und Perspektiven. Hrsg.: Friedrich-Ebert-Stiftung i. V. m. dem Inst. f. Sozialgeschichte e. V. - Braunschweig, Bonn: Dietz 1993 [Archiv für Sozialgeschichte; 33].

ANDERSEN, A.: Historische Technikfolgenabschätzung am Beispiel des Metallhüttenwesens und der Chemieindustrie 18501933. - Stuttgart: Steiner 1996.

ANDERSEN, A./BRÜGGEMEIER, F.-J./ROMMELSPACHER, T. (Hrsg.): Besiegte Natur. Geschichte der Umwelt im 19. und 20. Jahrhundert. - München: Beck 1983.

ANDERSEN, A./LENNARTZ, S. et al.: Historische Umweltforschung: wissenschaftliche Neuorientierung - aktuelle Fragestellungen; [Dokumentation einer Studienkonferenz in Zusammenarbeit mit dem Landschaftsverband Rheinland/Referat Heimatpflege]. - Bergisch Gladbach: Thomas-Morus-Akad. Bensburg 1992 [Bensberger Protokolle;71].

ANDERSEN, A./OTT, R./SCHRAMM, E.: Der Freiberger Hüttenrauch 1849-1865. Umweltauswirkungen, ihre Wahrnehmung und Verarbeitung. - In: Technikgeschichte 53 1986:169-200.

ANDERSEN, O. (B.) et al.: Transformation of Landscape in the upper mid-west, USA: The history of the lower St. Croix river valley, 1830 to present. In: Landscape and Urban Planning 35/4 1996:247-267.

ANDERSON, M.: Kulturgeschichte des „Heilen mit Wasser“. - Wiesbaden: 1993.

ANDREAE, B.: Allgemeine Agrargeographie. - New York: de Gruyter 1985 [Sammlung Göschen;2624].

ANDRES, W./SCHENK, W.: Kulturlandschaften - Archive der Vergangenheit oder Landschaftsräume der Gegenwart? - In: Geographie von heute für die Welt von morgen. - Gotha: Perthzes 2002:67-74.

ANDRIKOPOULOU-STRACK, J.-N. et al.: Archäologische Bestandserhebung im Rahmen des Projektes „Modellhafte Konzeptentwicklung Kulturlandschaft Heisterbacher Tal“. - Landschaftsverband Rheinland, Rheinisches Amt für Bodendenkmalpflege, August 2002.

ANL [Bayerische Akademie für Naturschutz und Landschaftspflege] (Hrsg.): Erhaltung und Entwicklung von Flußauen in Europa. Internationales Symposium 17. bis 20. September 1987 in Rastatt. - Laufen/Salzach: ANL 1991 [Laufener Seminarbeiträge;4].

ANL [Bayerische Akademie für Naturschutz und Landschaftspflege] (Hrsg.): Begriffe aus Ökologie, Landnutzung und Umweltschutz.. - Laufen/Salzach: ANL 1994 (Informationen ....;4].

ANL [Bayerische Akademie für Naturschutz und Landschaftspflege] (Hrsg.): Wasserkraft - mit oder gegen die Natur? Gemeinsames Seminar der Bayerischen Akademie für Naturschutz und Landschaftspflege (ANL) und der Arbeitsgemeinschaft „Wasserkraft in Bayern“ zusammen mit dem Österreichischen Verein für Ökologie und Umweltforschung und dem Schweizerischen Wasserwirtschaftsverband 7./8. September 1993 in Deggendorf. Laufen/Salzach: ANL 1994 [Laufener Seminarbeiträge;3].

ANSOHN, B. et al: Photographieren im Bergwerk um 1900: Bergwerksphotographie im Oberharz 1890-1910. Katalog zur gleichnamigen Ausstellung vom 6. November 1998 bis 7. April 1999. - Clausthal-Zellerfeld: Oberharzer Geschichts- und Museumsverein e.V. 1998.

APEL, F.: Deutscher Geist und deutsche Landschaft. Eine Topographie. - 1. Aufl. - München: Knaus 1998.

APEL, H.: Von der Saale-Flößerei: aus alten Rechnungen der Aemter Jena-Burgau von 1488 bis 1565. - In: Altes und Neues aus der Heimat. Beiträge zum Jenaer Volksblatt 41932.

ARABIEN 2004 [URL = http://www.arabien-entdecken.de/algerien.html;17.01.2004].

ARBEITSGEMEINSCHAFT ZUR REINHALTUNG DER WESER / DVWK [Deutscher Verband für Wasserwirtschaft und Kulturbau] (Hrsg.): Ökologische Gesamtplanung Weser: Grundlagen, Leitbilder und Entwicklungsziele für Weser, Werra und Fulda ; [F \& E-Vorhaben]. - Bonn: DVWK 1996. 
ARCHAEOLOGIE 2004 [URL = http://www.archaeologie-online.de/thema/2000/05/b1.php3;17.01.2004].

ARCHER-WILLS, A.: Die Kraft des Wassers: Die Kraft des Wassers, Gartendesign von der Quelle bis zum Pool. - Berlin: Nicolai'sche Verlagsbuchhandlung 1999.

ARENDS, H./FOCK, T./LIPINSKI, C.: Die Struktur der Mühlenwirtschaft in der BRD, lfd. Veröffentlichung der Wirtschaftsjahre. Hrsg.: Bundesministerium f. Ernährung, Landwirtschaft und Forsten, Abt. 2, Ref. 215. - Bonn 1991.

ARENI, K./EGLI, H.-R./FEHN, K.: Siedlungsprozesse an der Höhengrenze der Ökumene. Beispiel Alpen. 16. Tagung, Arbeitskreis für genetische Siedlungsforschung in Mitteleuropa - Univ. Bern 1991.

ARGE LEITBILDER, Hessisches Ministerium für Umwelt, Energie und Forsten (Hrsg.): Leitbilder für hessische Fließgewässer im Buntsandstein, im Schiefergebirge, im Basalt [u. a.]. - o. O. 1996.

ARING, J.: Suburbia - Postsuburbia - Zwischenstadt: die jüngere Wohnungsentwicklung im Umland der großen Städte Westdeutschlands und Folgerungen für die Regionale Planung und Steuerung. - Hannover 1999 [ARL-Arbeitsmaterial;262].

ARKADIEN AM MITTELRHEIN: Caspar und Georg Schneider; Landesmuseum Mainz, 7. Juni bis 23. August 1998. Hrsg.: Landesmuseum Mainz. - Wiesbaden: Reichert 1998.

ARL [Akademie für Raumforschung und Landesplanung] (Hrsg.): Geographische Informationssysteme in der Regionalplanung: Dokumentation des Workshops der Akademie für Raumforschung und Landesplanung und des Kommunalverbands Großraum Hannover. - Hannover: ARL 2001 [Arbeitsmaterial;284].

ARLT, H. (Hrsg.): Realität und Virtualität der Berge. - St. Ingbert: Röhrig 2002 [Österreichische und internationale Literaturprozesse;16].

ARNBERGER, E. (Hrsg.): Die Kartographie und ihre Randgebiete: Enzyklopädie. Red.: Österreichische Akademie der Wissenschaften. - Wien: Deuticke 1975 [Bd. C: Lexikon zur Geschichte der Kartographie: von den Anfängen bis zum Ersten Weltkrieg 1986].

ARNBERGER, E.: Thematische Kartographie: mit einer Kurzeinführung über EDV-unterstützte Kartographie und Quellen der Fernerkundung. - 4. Aufl. - Braunschweig: Westermann 1997 [Das geographische Seminar].

ARNIM, H. Graf v./BOELCKE, W. A.: Muskau: Standesherrschaft zwischen Spree und Neiße. - Frankfurt/Main et al.: Propyläen 1992 (Nachdr. d. Orig.-Ausg. Frankfurt/Main [et al.]: Ullstein 1978)

ARNOLD, Tim: „Wir sind mit Wupperwasser getauft ...“. Ein Beitrag zur Umweltgeschichte des Wuppertals. - Wuppertal 1987

ARORA, Surendra Kumar/FRANZEN; Josef: Eine römische Wasserleitung und eine hochmittelalterliche Wassermühle in der Elsbachniederung. - In: Archäologie im Rheinland 1988:120f.

ARZET, Klaus: Gewässerentwicklungsplan Chiemsee - Konzeption und Umsetzung. - o. O.: o. J.:91-94.

ASENSIO, Paco: Waterfront Homes. -Barcelona: Loft publications 2000.

ASHOFF, E.: Die Welt der Pferde [URL = http://www.welt-der-pferde.de;07.09.2002].

ASMUS, I.: Vermessung und kartographische Darstellung frühneuzeitlicher Güter am Beispiel der Besitzungen Carl Gustav Wrangels. - In: ASMUS, I./PORADA, H. T./SCHLEINERT, D. (Hrsg.): Geographische und historische Beiträge zur Landeskunde Pommerns. - Schwerin 1998:145-149.

ASSMANN, A.: Die Planung dezentraler, integrierter Hochwasserschutzmaßnahmen: mit dem Schwerpunkt der Standortausweisung von Retentionsarealen an der Oberen Elsenz, Kraichgau. - Hrsg.: Landesamt für Flurneuordnung und Landentwicklung Baden-Württemberg. - Kornwestheim: Landesamt für Flurneuordnung und Landentwicklung BadenWürttemberg 1999 [Schriftenreihe: Flurneuordnung und Landentwicklung in Baden-Württemberg;11]; Zugl.: Heidelberg, Univ., Diss. 1998.

ASSMANN, T./FALKE, B.: Bedeutung von Hudelandschaften aus tierökologischer und naturschutzfachlicher Sicht - In: Bundesamt für Naturschutz (Hrsg.): Alternative Konzepte des Naturschutzes für extensiv genutzte Kulturlandschaften Münster: Landwirtschaftsverl. 1997 [Schriftenreihe für Landschaftspflege und Naturschutz;54].

ASTON, M. (Hrsg.): Medieval fish, fisheries and fishponds in England. A day conference on 'Medieval fish, fishponds and water systems; Bristol 1984. - London: B.A.R. 1988 [BAR series;182].

ASTON, M.: Interpreting the landscape: landscape archaelogy in local studies. - London: Batsford 1985.

ATV-DVWK (Hrsg.): Fischschutz- und Fischabstiegsanlagen - Bemessung, Gestaltung, Funktionskontrolle. November 2002.

AUE-LEHRPFAD 2004: [http://www.aue-lehrpfad.de;04.03.2003].

AUF DEN SPUREN einer frühen Industrielandschaft: Naturraum - Mensch - Umwelt im Harz. - Hameln: Niemeyer 2000 [Arbeitshefte zur Denkmalpflege in Niedersachsen;21].

AUGUST, O.: Entwicklung der Stadt Nordhausen im Mittelalter, Maßstab 1:12500. - In: Atlas des Saale- und mittleren Elbegebietes. Hrsg. v. SCHLÜTER, O./August, O. A. - 2. völlig neubearb. Aufl. des Werkes Mitteldeutscher Heimatatlas .... - Leipzig: Verl. Enzyklopädie 1961 [Blatt 36/III; Erläuterungsheft T. 2]. 
AURIG, R. (Hrsg.): Kulturlandschaft, Museum, Identität: Protokollband zur Tagung „Aufgaben, Probleme und Möglichkeiten der Musealen Präsentation von Kulturlandschaftsrelikten“ der Arbeitsgruppe „Angewandte Historische Geographie“ vom 7.9.3.1996 in Plauen/Vogtland. - 1. Aufl. - Beucha: Sax 1999 [Schriften der Rudolf-Kötzschke-Gesellschaft;4].

AURIG, R./VOIGTMANN, J.: Kulturlandschaft - Museum - Identität. Zur Stellung der Museen bei der Bewahrung historischer Kulturlandschaft. In: AURIG, Rainer (Hrsg.): Kulturlandschaft, Museum, Identität: Protokollband zur Tagung „Aufgaben, Probleme und Möglichkeiten der Musealen Präsentation von Kulturlandschaftsrelikten“ der Arbeitsgruppe „Angewandte Historische Geographie“ vom 7.-9.3.1996 in Plauen/Vogtland. - 1. Aufl. - Beucha: Sax 1999 [Schriften der RudolfKötzschke-Gesellschaft;4]: 9-12.

AURIG, R.: Vorwort. - In: AURIG, R. (Hrsg.): Kulturlandschaft, Museum, Identität: Protokollband zur Tagung „Aufgaben, Probleme und Möglichkeiten der Musealen Präsentation von Kulturlandschaftsrelikten“ der Arbeitsgruppe „Angewandte Historische Geographie“ vom 7.-9.3.1996 in Plauen/Vogtland. - 1. Aufl. - Beucha: Sax 1999 [Schriften der RudolfKötzschke-Gesellschaft;4]:7-8.

AUWECK, F. A.: Kartierung von Kleinstrukturen in der Kulturlandschaft. - In: Natur und Landschaft 531987.

AYMANS, G.: Die handschriftliche Karte als Quelle geographischer Studien. - In: Landkarten als Geschichtsquellen. - Köln 1985 [Archivhefte der Archivberatungsstelle Rheinland;16]:21-46.

AYMANS, G.: Historische Karten und Kartenwerke aus der Sicht eines Geographen. - In: Erschließung und Auswertung historischer Landkarten. - Köln 1988 [Landschaftsverband Rheinland, Archivberatungsstelle Rheinland Archivhefte;18].

BACH; O.: Heimatgeschichte im Spiegel der Karte: alte Karten zum Gebiet des Altkreises Grafschaft Diepholz aus vier Jahrhunderten. - Diepholz: Kreissparkasse Grafschaft Diepholz 1999.

BACH, W.: Gefahr für unser Klima. Wege aus der $\mathrm{CO}_{2}$-Bedrohung durch sinnvollen Energieeinsatz. - Karlsruhe: Müller 1982.

BACH, W.: Die $\mathrm{CO}_{2}$-induzierte Klimagefahr: Möglichkeiten ihrer Abwendung. - In: Geowissenschaften in unserer Zeit 5 1984:167-175.

BACH, W.: $\mathrm{CO}_{2}$. Immer mehr Kohlendioxid in der Luft. Brennstoffe, ein Risiko für das Klima. - In: Bild der Wissenschaft 5 1985:94-105.

BACHER, Siegfried: Kulturhistorische Landschaftselemente in Brandenburg: Entwässerungssysteme am Beispiel des Oderbruchs. Darstellung der Ergebnisse des historischen Prozesses und Ableitung möglicher Entwicklungsziele. - Berlin 1999 [Akademische Abhandlungen zur Raum- und Umweltforschung].

BACHLER, G.: Salzufeln Anno dazumal: Bilder aus Großvaters Album. - 2. Aufl. - Lemgo: Wagener 1978.

BACHMANN, F.: Die alten Städtebilder: ein Verzeichnis der graphischen Ortsansichten von Schedel bis Merian. - Leipzig: Hiersemann, 1939

BACHMANN, H.-G.: Waldwirtschaft und Glashütten im Spessart. - In: JOCKENHÖVEL, A. (Hrsg.): Bergbau, Verhüttung und Waldnutzung im Mittelalter: Auswirkungen auf Mensch und Umwelt; Ergebnisse eines internationalen Workshops [Dillenburg, 11. - 15.Mai 1994, Wirtschaftshistorisches Museum „Villa Grün“]. - Stuttgart: Steiner 1996 [Vierteljahrschrift für Sozial- und Wirtschaftsgeschichte: Beihefte;121]:181-188.

BACHMANN, J. (Hrsg.): Schiffahrt, Handel, Häfen: Beiträge zur Geschichte der Schiffahrt auf Weser und Mittellandkanal. Minden: Bruns 1987.

BACKHAUS, Ch.: Von der Wasserkunst zur Wasserwirtschaft. - Bremen: Hauschild 1998.

BAD DUERKHEIM: Pollichia, Pfalzmuseum für Naturkunde. - In: Pollichia-Buch 131988.

BAD SACHSA 2003: „Damals war's ...die Ursprünge des Ortes Bad Sachsa“ [URL = http://home.eplusonline.de/fewobadsachsa/bsdamals.htm;09.01.2003].

BADER, W.: Die Verbindung von Rhein und Donau. Zur Geschichte eines bemerkenswerten Wasserstraßenprojektes. - München: Oldenbourg 1982 [Abhandlungen und Berichte des Deutschen Museums;50].

BAER, O.: Die Flußperlmuschel (Margaritifera margaritifera): Ökologie, umweltbedingte Reaktionen und Schutzproblematik einer vom Aussterben bedrohten Tierart. - Magdeburg et al: Westarp-Wiss. 1995 [Die neue Brehm-Bücherei;619].

BÄCKER, P.: Über die Entstehung tiefreichender Erdfälle und Höhlensysteme. - Blaubeuren: Mangold et al. 1982 [Abhandlungen zur Karst- und Höhlenkunde: Reihe A, Speläologie;19].

BAHLKE, J./EBERHARD, W./POLÌVKA, M. (Hrsg.): Handbuch der Historischen Stätten: Böhmen und Mähren. - Stuttgart 1998 [Kröners Taschenausgabe;329].

BAHLOW, H.: Deutschlands älteste Fluß- und Ortsnamen: erstmalig gedeutet aus verschollenem Wortgut europäischer Vorzeitvölker. - Hamburg : Selbstverl. des Verf. 1962 [Teil 1], 1963 [Teil 2].

BAHLOW, H.: Lexikon deutscher Fluß- und Ortsnamen alteuropäischer Herkunft. - Neustadt/Aisch: Degener 1981.

BAHLOW, H.: Deutschlands geographische Namenwelt. Etymologisches Lexikon der Fluß- und Ortsnamen alteuropäischer Herkunft. - 1. Aufl. - Frankfurt/Main: Suhrkamp 1985 [suhrkamp taschenbuch 1221] [Frankfurt/Main: Klostermann 1965]. 
BAHRENBERG, G. et al.: Geographie des Menschen - Dietrich Bartels zum Gedenken. Bremer Beiträge zur Geographie und Raumplanung 111987.

BAHRENBERG, G.: Über die Unmöglichkeit von Geographie als "Raumwissenschaft" - Gemeinsamkeiten in der Konstituierung von Geographie bei A. Hettner und D. Bartels. - In: BAHRENBERG, G. et al.: Geographie des Menschen - Dietrich Bartels zum Gedenken. Bremer Beiträge zur Geographie und Raumplanung 11 1987:225-239.

BAIER, K.: Streiflichter aus dem Wirken des Landesfischereiverbandes Bayern e.V. 1988 [Broschüre].

BAILES, K. E.: Critical issues in environmental history. - In: BAILES, K. E. (Hrsg.): Environmental history: Critical issues in comparative perspective. -.New York: University Press 1985:1-21.

BAILES, K. E. (Hrsg.): Environmental history: Critical issues in comparative perspective. -.New York: University Press 1985.

BAKER, A. R. H.: Introduction: on ideology and landscape. - In BAKER, A. R. H./BIGER, G. (Hrsg.): Ideology and landscape in historical perspective: essays on the meanings of some places in the past. - Cambridge: University Press 1992 [Cambridge Studies in Historical Order;18]:1-14.

BAKER, A. R. H./BIGER, G. (Hrsg.): Ideology and landscape in historical perspective: essays on the meanings of some places in the past. - Cambridge: University Press 1992 [Cambridge Studies in Historical Order;18].

BAKER, A. R. H./BILLINGE, M. (Hrsg.): Period and place: Research methods in historical geography. - Cambridge et al.: Univ. Press 1982.

BALCK, F.: Computergestützte Vermessung von Objekten in Archäologie und Denkmalpflege. - In: Ordo et Mensura III, Sachüberlieferung und Geschichte, Hrsg.: Dieter Ahrens und Rolf C. Rottländer. - St. Katharinen: Scripta Mercaturae 1995 [Siegener Abhandlungen zur Entwicklung der materiellen Kultur;15].

BALCK; F.: Thurm Rosenhof - Die Vergangenheit wird lebendig - Neue Erkenntnisse über ein altes Grubenfeld. Keimzelle des Clausthaler Bergbaus. - Clausthal-Zellerfeld: Oberharzer Geschichts- und Museumsverein e.V. 1999.

BALCK, F.: Wasserkraftmaschinen für den Bergbau im Harz: frühneuzeitliche Spuren und deren Deutung am Beispiel der Grube Thurm Rosenhof und ausgewählter Anlagen. - Clausthal-Zellerfeld: Papierflieger 1999; Zugl. Clausthal, Techn. Univ., Habil.-Schr. 1999.

BALCK, F.: Die Nutzung der Wasserkraft. - In: Auf den Spuren einer frühen Industrielandschaft. Naturraum - Mensch - Umwelt im Harz. - Hameln: Niemeyer 2000 [Arbeitshefte zur Denkmalpflege in Niedersachsen;21]:87-95.

BALCK, F./ZIEGLER, T.: Aufwältigung und Rekonstruktion eines Wasserrades im Rammelsberg. - In: Berichte zur Denkmalpflege in Niedersachsen 2 1997:111-115.

BALSIGER, P. W. (Hrsg.): Ökologie und Interdisziplinarität - eine Beziehung mit Zukunft?: Wissenschaftsforschung zur Verbesserung der fachübergreifenden Zusammenarbeit. - Basel et al.: Birkhäuser 1996 [Schwerpunktprogramm Umwelt: Themenhefte].

BANDI, H.-G.: „Pfahlbauten“ am Thunersee. - In: Der Mensch in der Landschaft. Festschrift für Georges Grosjean zum 65. Geburtstag, 17. Januar 1986. - Hrsg. v. AERNI, K. et al. - Bern: Lang 1986 [Jahrbuch der Geographischen Gesellschaft von Bern;55]:447-452.

BANIK-SCHWEITZER, R.: Die Stadt lesen wie ein Palimpsest: im Historischen Atlas von Wien. - In: Studien zur Wiener Geschichte. Jahrbuch des Vereins für Geschichte der Stadt Wien; 52/1996 53/1997:33-51.

BANK, O./KRUSCH, A.: So baut man Teiche. Eine Anleitung für den Bau von Karpfenteichen. - 2. Aufl. - Hamburg: Parey 1978.

BANSE, E.: Entwicklung und Aufgaben der Geographie: Rückblicke und Ausblicke einer universalen Wissenschaft. - Stuttgart, Wien: Humboldt 1953.

BANTELMANN, A.: Elisenhof: die Ergebnisse der Ausgrabung der frühgeschichtlichen Marschenseidlung beim Elisenhof in Eiderstedt 1957/58 und 1961/64, Teil 1: Die frühgeschichtliche Marschensiedlung beim Elisenhof in Eiderstedt: Landschaftsgeschichte und Baubefunde. - Bern: Lang 1975 [Studien zur Küstenarchäologie Schleswig-Holstein A. 1]..

BÄREN, E.: Bergseen der Alpen. - Thun: Ott 1981.

BARETT, G. F.: Lufterkundung und -bilder als Forschungsmethode bei Untersuchungen und Management von Kulturlandschaften: Ein irisches Beispiel. - In: Kulturelles Erbe. Landschaften im Spannungsfeld zwischen Zerstörung und Bewahrung. - Wittenberg 2000:157-162.

BARNER, J.: Hydrologie: Eine Einführung für Naturwissenschaftler und Ingenieure. - Heidelberg et al.: Quelle \& Meyer 1987.

BARSCH, D./KARRASCH, H. (Hrsg.): Geographie und Umwelt: Erfassen, Nutzen, Wandeln, Schonen; Tagungsbericht und wissenschaftliche Abhandlungen [48. Deutscher Geographentag Basel, 23. - 28. September 1991]. - Stuttgart: Steiner 1993.

BARTELME, N.: Geoinformatik: Modelle, Strukturen, Funktionen. - 3. erweit. u. aktualisierte Aufl. - Berlin, Heidelberg: Springer 2000.

BARTELS, C./DENZEL, M. A.: Konjunkturen im europäischen Bergbau in vorindustrieller Zeit. Festschrift für Ekkhard Westermann zum 60. Geburtstag. - Stuttgart: Steiner 2000 [Vierteljahresschrift für Sozial- und Wirtschaftsgeschichte; Beihefte 155]. 
BARTELS, C.: Das Wasserkraft-Netz des historischen Erzbergbaus im Oberharz. Seine Schaffung und Verdichtung zu großtechnischen Systemen als Voraussetzung der Industrialisierung. - In: Technikgeschichte 56 1988:177-192.

BARTELS, C.: Die Nutzung der Wasserkraft im Harzer Montanwesen im Spannungsfeld von Ökonomie, Technik und Naturwissenschaft: Einsatz, Optimierung und Resultate. - In: Naturwissenschaft und Technik im Barock 1997:51-76.

BARTELS, Christoph: Mittelalterlicher und frühneuzeitlicher Bergbau im Harz und seine Einflüsse auf die Umwelt. - In: HAUPTMEYER, Carl-Hans (Hrsg.): Mensch - Natur - Technik: Aspekte der Umweltgeschichte in Niedersachsen und angrenzende Gebieten. - Bielefeld: Verl. f. Regionalgeschichte 2000 [Materialien zur Regionalgeschichte;2]:31-51.

BARTELS, C.: Zur Bergbaukrise des Spätmittelalters. - In: BARTELS, C./DENZEL, M. A.: Konjunkturen im europäischen Bergbau in vorindustrieller Zeit. Festschrift für Ekkhard Westermann zum 60. Geburtstag. - Stuttgart: Steiner 2000 [Vierteljahresschrift für Sozial- und Wirtschaftsgeschichte; Beihefte 155]:157-172.

BARTH, E.: Die Gewässernamen im Flussgebiet von Sieg und Ruhr. - Marburg: Phil. F., Diss. 1965 [Beiträge zur deutschen Philologie;39].

BARTH, H. K./DACHNER, B. et al..: Geographie der Bewässerung. Bd. 2. (Bibliographie) - Paderborn: GHS Paderborn 1990.

BARTH, L.: Die Geschichte der Flößerei im Flußgebiet der oberen Kinzig: ein Beitrag zur Geschichte der Schwarzwälder Schifferschaften. - München, Univ., Diss. 1895.

BÄRTHEL, H.: Wasser für Berlin: die Geschichte der Wasserversorgung. Hrsg.: Berliner Wasser-Betriebe. - Berlin: Verl. für Bauwesen 1997.

BARTHEL, H.-J.: Schlittknochen oder Knochengeräte. - Weimar 1969 [Alt-Thüringen, 10. Bd. (1968/1969)].

BARTHEL, M.: Die Enkel des Archimedes. Eine etwas andere Kulturgeschichte der Hebezeuge. - Neuhaus Witten 1995.

BARTHELMEß, A.: Landschaft, Lebensraum des Menschen: Probleme von Landschaftsschutz und Landschaftspflege geschichtlich dargestellt und dokumentiert. - Freiburg et al.: Alber 1988 [Orbis academicus, Sonderband; 2,5].

BARTHOLOMÄ, W. D./DETTMER, H. (Red.): Arbeiten und Wohnen auf dem Lande: Gewässer in Oberschwaben und ihre Nutzung in früherer Zeit. - Stuttgart: W. B. Literatur 1987 [Wolfegger Blätter;3].

BÄRTSCHI, H.-P.: Der endliche Fortschritt. Unterwegs zur Zerstörung der Industriekultur. - Zürich: Orell Füssli 2002.

BARTUSCH, G./BARTUSCH, H./HERZOG, K.-H.: Die historische Entwicklung der Teichwirtschaft bis zum 30jährigen Bestehen der VEB Binnenfischerei Knau. - Knau: Binnenfischerei Knau 1988.

BÄRWINKEL, P.: Die Entwicklung der Fischerei und Fischzucht in Thüringen. - In: Thüringer Jahrbuch 1927:58-61.

BASTIAN, O. et al.: Ökosystemare Umweltbeobachtung im Biosphärenreservat „Oberlausitzer Heide- und Teichlandschaft“ (Sachsen). - In: Natur und Landschaft 77/6 2002:252ff.

BÄTZING, W.: Geographie als integrative Umweltwissenschaft? Skizze einer wissenschaftstheoretischen Standortbestimmung der Geographie in der postindustriellen Gesellschaft. - In: Geographica Helvetica 46/3 1991:105-109.

BAUDENKMALLISTE der Stadt Düsseldorf Blatt Nr. 2 und 3.

BAUER, L./HIEKEL, W./NIEMANN, F.: Historische Anlage der Wasserspeicherwirtschaft im Thüringer Wald und Schiefergebirge. Ein Beitrag zur Kulturlandschaftsforschung und praktischen Landschaftspflege in den Mittelgebirgen. - In: Zeitschrift für Landeskultur 5 1964:61-83

BAUER, M.: Vermessung und Ortung mit Satelliten : GPS und andere satellitengestützte Navigationssysteme [mit Beiträgen von Lambert Wanninger]. - 5. neu bearb. und erw. Aufl. - Heidelberg : Wichmann 2003.

BAUER, M.: Wasser, Holz und Eisenstein: Herrschaft, Gewerbe und Landwirtschaft in der Geschichte des Oberlausitzer Heideund Teichgebiets. - In: Arbeits- und Forschungsberichte zur Sächsischen Bodendenkmalpflege 39 1997:143-203.

BAUER, R.: Kulturgeographie des mittleren Saalegebietes von Saalfeld bis Orlamünde. - Jena: Inaugural-Dissertation 1944.

BAUER, R: Zur Bedeutung der Flurnamen für die Siedlungs- und Kulturlandschaftsgeschichte. Bericht über die Tagung zum Forschungsprojekt „Erfassung der Flurnamen in Bayern“ am 25. Januar 1988 in München. - In: Siedlungsforschung 6 1988:293-304.

BAUER, W./DISTER, E.: Fischteiche als Eingriffe in Tallandschaften. - In: Vogel und Umwelt. Zeitschrift für Vogelkunde und Naturschutz in Hessen 1/2 1980: 70-72.

BAUMANN, M.: Von Fährleuten, Schiffen und Fischern im Aargau: Der Fluß als Existenzgrundlage ländlicher Bevölkerung. - 2. Aufl. - Zürich: Chronos 1996 [1. Auf. 1977].

BAUMÜLLER, B./KUDER, U./ZOGLHAUER, Th. (Hrsg.): Inszenierte Natur: Landschaftskunst im 19. und 20. Jahrhundert. Stuttgart: Deutsche Verl.-Anstalt 1997.

BAUR, A.: Brunnen: Quellen des Lebens und der Freude. Technik, Geschichte, Geschichten. - München et al.: Oldenbourg 1989.

BAUR, A.: Die Yerebatan Sarayi-Zisterne in Istanbul- der versunkene Palast. - In: Frontinus-Tagung 1990 in Bochum und weitere Beiträge zur historischen Entwicklung im Bergbau. - Bergisch-Gladbach: Frontinus-Gesell. 15 1991:7-12. 
BAUR, A.: Wasserspiele für Götter, Fürsten und Volk. - München et al.: Oldenbourg 1992.

BAUSINGER, H./BEYRER, K./KORFF, G.: Reisekultur. Von der Pilgerfahrt zum modernen Tourismus. - 2. Aufl. - München: Beck 1990.

BAX; Karl: Schätze aus der Erde: Die Geschichte des Bergbaus. - Düsseldorf, Wien: Econ Verl. 1981.

BAXMANN, Mattias: Wasser für das Niederlausitzer Industriegebiet. Zum bau des ersten zentralen Wasserversorgungssystems in der Niederlausitz. - In: BAYERL, G./FUCHSLOCH, N./MEYER, T. (Hrsg.): Umweltgeschichte - Methoden, Themen, Potentiale: Tagung des Hamburger Arbeitskreises für Umweltgeschichte, Hamburg 1994. - Münster, New York: Waxmann 1996 [Cottbuser Studien zur Geschichte von Technik, Arbeit und Umwelt;1]:219-245.

BAYERISCHE AKADEMIE DER WISSENSCHAFTEN (Hrsg.): Probleme der Umweltforschung in historischer Sicht: Rundgespräch am 16. und 17. November 1992 in München. - München: Pfeil 1993 [Rundgespräche der Kommission für Ökologie; Bayerische Akademie der Wissenschaften;7].

BAYERISCHES AMT FÜR WASSERWIRTSCHAFT (Hrsg.): Geschichtliche Entwicklung der Wasserwirtschaft und des Wasserbaus in Bayern. Hrsg. v. Bayerischen Amt für Wasserwirtschaft und der Technischen Universität München. München 1981.

BAYERISCHES LANDESAMT FÜR WASSERWIRTSCHAFT (Hrsg.): Die Versuchsanlage Wielenbach. - München: Bayerisches Landesamt f. Wasserwirtschaft 2002[?] [Gewässerökologische Forschung].

BAYERISCHES LANDESAMT FÜR WASSERWIRTSCHAFT (Hrsg.): Empfehlungen für Bau und Betrieb von Fischteichen. München, Juni 2001 [Materialien;99].

BAYERISCHES LANDESAMT FÜR WASSERWIRTSCHAFT (Hrsg.): Geschichtliche Entwicklung der Wasserwirtschaft und des Wasserbaus in Bayern. 3 Bd. - München: Bayrisches Landesamt 1986.

BAYERISCHES LANDESAMT FÜR WASSERWIRTSCHAFT (Hrsg.): Grundlagen des Wasserbaus - Aktuelle Beiträge. München: Bayerisches Landesamt für Wasserwirtschaft 1989

BAYERISCHES LANDESAMT FÜR WASSERWIRTSCHAFT (Hrsg.): Hochwasser. - München 1998 [Spektrum Wasser;1].

BAYERISCHES LANDESAMT FÜR WASSERWIRTSCHAFT (Hrsg.): Ökologisch begründete Sanierungskonzepte kleiner Fließgewässer: Fallbeispiel Vils/Oberpfalz. - München: Bayerisches Landesamt für Wasserwirtschaft 1996 [Schriftenreihe des Bayerischen Landesamtes für Wasserwirtschaft;26].

BAYERISCHES LANDESAMT FÜR WASSERWIRTSCHAFT (Hrsg.): Wasserwirtschaft und Naturhaushalt-Ausleitungsbecken bei Wasserkraftanlagen. - München: Bayerisches Landesamt für Wasserwirtschaft 1989

BAYERISCHES STAATSMINISTERIUM FÜR LANDESENTWICKLUNG UND UMWELTFRAGEN (Hrsg.): Die Perlmuschel im Dreiländereck „Böhmen - Bayern - Sachsen“. Das Ökosystem der Perlmuschelgewässer und sein Schutz. München 1996.

BAYERL, G.: Zur Geschichte der Umweltproblematik. - In: Technologie und Politik 161980.

BAYERL, G.: Vorindustrielle Gewerbe und Umweltbelastung, das Beispiel der Handpapiermacherei. - In: Technikgeschichte 48/3 1981:206-238.

BAYERL, G.: Zur Erforschung der Luft- und Wasserverschmutzung in vorindustrieller Zeit. In: Siedlungsforschung 6 1988:199203.

BAYERL, G. (Hrsg.): Wind- und Wasserkraft: die Nutzung regenerierbarer Energiequellen in der Geschichte. - Düsseldorf: VDIVerl. 1989 [Technikgeschichte in Einzeldarstellungen].

BAYERL, G.: Das Umweltproblem und seine Wahrnehmung in der Geschichte. - In: CALLIEß, J./RÜSEN, J./STRIEGNIETZ, M. (Hrsg.): Mensch und Umwelt in der Geschichte. - Pfaffenweiler: Centaurus 1989:47-96.

BAYERL, G.: Die langfristige Entwicklung als Thema der Umweltgeschichte. - In: WerkstattGeschichte 3 1992:10-15.

BAYERL, G.: Prolegomenon der „Großen Industrie“. Der technisch-ökonomische Blick auf die Natur im 18. Jahrhundert. - In: ABELSHAUSER, W. (Hrsg.): Umweltgeschichte. Umweltverträgliches Wirtschaften in historischer Perspektive; acht Beiträge. - Göttingen: Vandenhoeck \& Ruprecht 1994 [Geschichte und Gesellschaft, Sonderheft 15]:29-56.

BAYERL, G.: Die Beziehungen zwischen Mensch, Technik und Natur in der Geschichte. - In: BRAUER, H. (Hrsg.): Handbuch des Umweltschutzes und der Umweltschutztechnik. Band 1: Emissionen und ihre Wirkungen. - Berlin et al. 1996:1-50.

BAYERL, G. (Hrsg.): Die Niederlausitz vom 18. Jahrhundert bis heute: eine gestörte Kulturlandschaft? - Münster ert al.: Waxmann 2002 [Cottbuser Studien zur Geschichte von Technik, Arbeit und Umwelt;19].

BAYERL, G. (Hrsg.): Die Veränderung der Kulturlandschaft: Nutzungen - Sichtweisen - Planungen. - Münster ert al.: Waxmann 2003 [Cottbuser Studien zur Geschichte von Technik, Arbeit und Umwelt;22].

BAYERL, G./FUCHSLOCH, N./MEYER, T. (Hrsg.): Umweltgeschichte - Methoden, Themen, Potentiale: Tagung des Hamburger Arbeitskreises für Umweltgeschichte, Hamburg 1994. - Münster, New York: Waxmann 1996 [Cottbuser Studien zur Geschichte von Technik, Arbeit und Umwelt;1]. 
BAYERL, G./TROITZSCH, U. (Hrsg.): Quellentexte zur Geschichte der Umwelt von der Antike bis heute. - Göttingen, Zürich: Muster-Schmidt 1998 [Quellensammlung zur Kulturgeschichte;23].

BAYERL, G./WEBER, W. (Hrsg.): Sozialgeschichte der Technik. Ulrich Troitzsch zum 60. Geburtstag. - Münster, New York: Waxmann 1998.

BAYERN 2003 [URL = www.bayern.de/wwa-bt/wassererleben/lkr_bayreuth/huellweiher.htm;12.08.2003].

BAYERTZ, K.: The Natur of morality and the morality of nature: problems of normative natural philosophy. - In: TEICH, M./PORTER, R./GUSTAFSSON, B. (Hrsg.): Nature and society in historical context. - Cambridge: University Press 1997:364-381.

BDLA [Bund Deutscher Landschaftsarchitekten]: Windenergieanlagen: Räumlich steuern, sorgfältig planen und abwägen. Handlungsempfehlungen des BDLA für Kreise, Städte und Gemeinden. - In: Stadt und Grün 7 2003:33-35.

BECHMANN, G./FREDERICHS, G.: Problemorientierte Forschung: Zwischen Politik und Wissenschaft. - In: BECHMANN, G. (Hrsg.): Praxisfelder der Technikfolgenabschätzung. Konzepte, Methoden, Optionen. - Frankfurt/Main, New York: Campus 1996 [Veröffentlichungen des Inst. f. Technikfolgenabschätzung und Systemanalyse (ITAS);3]:11-37.

BECHMANN, G./FREDERICHS, G.: Umweltforschung zwischen Erkenntnis und Organisation. - In: DASCHKEIT, A./SCHRÖDER, W. (Hrsg.): Umweltforschung quergedacht. Perspektiven integrativer Umweltforschung und -lehre. Berlin et al.: Springer 1998 [Umweltnatur- \& Umweltsozialwissenschaften]:7-29.

BECK, A.: Some Aspects of the History of Anti-Pollution Legislation in England, 1819-1954. - In: Journal of the History of Medicine and of Allied Sciences 14/4 1959:475-489.

BECK, H.: Geographie: europäische Entwicklung in Texten und Erläuterungen. - Freiburg et al.: Alber 1973 [Orbis academicus;2,16].

BECK, H.: Hermann Lautensach - führender Geograph in zwei Epochen ein Weg zur Länderkunde: Hermann Lautensach zum Gedenken. - Stuttgart: Geogr. Inst. d. Univ. 1974 [Stuttgarter geographische Studien;87].

BECK, H. et al. (Hrsg.): Reallexikon der germanischen Altertumskunde. - Berlin; New York: Springer 1978ff..

BECK, J./VOSS, R. G.: Die Alster: ein Fluss prägt die Stadt. Hrsg.: Umweltbehörde der Freien und Hansestadt Hamburg. Hamburg: Ellert und Richter 1999.

BECK, R. (Hrsg.): Streifzüge durch die Jahrhunderte. Ein historisches Lesebuch. - München: Beck 1990.

BECK, W./IMMLER, H. (Hrsg.): Vom Wert der Natur. Zur Rückkehr der Natur in die Gesellschaft. In: Protokoll Evangelische Akademie. Hofgeismar 284. - Hofgeismar 1991.

BECKER, A.: Der Siegerländer Hauberg. Vergangenheit, Gegenwart und Zukunft einer Waldwirtschaftsform. - Kreuztal: Die Wielandschmiede 1991.

BECKER, G.: Das Osteroder Mühlgraben-Verbundsystem, die davon berührten Betriebsstätten und seine Umgebung. - In: Südniedersachsen. Zs. f. Regionale Forschung und Heimatpflege 28/1 1997:22.

BECKER, B./BILlAMBOZ, A./DIECKMANN, B.: Berichte zu Ufer- und Moorandsiedlungen Südwestdeutschlands 2. Stuttgart: Theiss 1985 [Materialien zur Vor- und Frühgeschichte in Baden-Württemberg;7].

BECKER, B./FRENZEL, B.: Paläoökologische Befunde zur Geschichte postglazialer Flußauen im südlichen Mitteleuropa. - In: Frenzel, B. (Hrsg.): Jahrringforschung und nacheiszeitliches Klima in Europa. - Wiesbaden: Steiner 1977 [Erdwissenschaftliche Forschung;11]:43-61.

BECKER, B.: Dendrochronologie und Paläoökologie subfossiler Baumstämme aus Flußablagerungen - Ein Beitrag zur nacheiszeitlichen Auenentwicklung im südlichen Mitteleuropa. - Wien 1982 [Mitteilungen der Kommission für Quartärforschung der Österreichischen Akademie der Wissenschaften;5].

BECKER, B.: Postglaziale Auewaldentwicklung im mittleren und oberen Rheintal anhand dendrochronologischer Untersuchungen subfossiler Baumstammablagerungen. - In: Geologisches Jahrbuch A. 71 1983:45-59.

BECKER, E.: Gestörte Natur - Anmerkungen zur integrativen Umweltforschung aus sozial-ökologischer Sicht. - In: DASCHKEIT, A./SCHRÖDER, W. (Hrsg.): Umweltforschung quergedacht. Perspektiven integrativer Umweltforschung und -lehre. - Berlin et al.: Springer 1998 [Umweltnatur- \& Umweltsozialwissenschaften]:31-50.

BECKER, G. (Hrsg.): Stadtentwicklung im gesellschaftlichen Konfliktfeld: Naturgeschichte von Osnabrück. - Pfaffenweiler, 1991.

BECKER, H.: Die Feld-Teich-Wechselwirtschaft und ihre agrargeographischen Probleme. - In: Genetische Ansätze in der Kulturlandschaftsforschung. Festschrift für Helmut Jäger. - Würzburg 1983 [Würzburger Geographische Arbeiten;60]:171188.

BECKER, H.: 20 Jahre Historische Geographie in Bamberg: Kurzvortrag anläßlich der Eröffnung der Ausstellung „20 Jahre Historische Geographie in Bamberg“ am 13.7.2001. - In: 20 Jahre Historische Geographie in Bamberg: Festakt zum Jubiläum am 13. Juli 2001 [Bamberger Universtitätsreden; Schriftenreihe der Otto-Friedrich-Universität Bamberg;7]:6-9.

BECKER, H.: Allgemeine Historische Agrargeographie. - Stuttgart: Teubner 1998 [Teubner Studienbücher: Geographie]. 
BECKER, J: Geographie in der Postmoderne? Zur Kritik postmodernen Denkens in Stadtforschung und Geographie. - Potsdam: Selbstverl. d. Inst. f. Geographie u. Geoökologie d. Univ. Potsdam 1996 [Praxis Kultur- und Sozialgeographie;12].

BECKER, W.: Die Eigenart der Kulturlandschaft. Bedeutung und Strategien für die Landschaftsplanung. Berlin: Verl. für Wiss. und Forschung 1998 [Akad. Abh. z. Raum- und Umweltforschung].

BEDAL, K.: Die altdeutsche Mühle: Mühlentechnik der vorindustriellen Zeit in Franken. - In: BEDAL, K.: Mühlen und Müller in Franken. - 2. Aufl.. - Bad Windsheim: Verl. Fränkisches Freilichtmuseum 1992 [Schriften und Kataloge des Fränkischen Freilandmuseums;15]:28-74.

BEDAL, K.: Mühlen und Müller in Franken. - 2. Aufl. - Bad Windsheim: Verl. Fränkisches Freilichtmuseum 1992 [Schriften und Kataloge des Fränkischen Freilandmuseums;15].

BEGUSCH-PFEFFERKORN, K./SMOLINER, C.: Das Experiment Kulturlandschaftsforschung. - In: HABERL, H./STROHMEIER, G.: Kulturlandschaftsforschung. - Wien; New York: Springer 1999 [iff texte;5]:100-108.

BEHM, H.: Zur historischen Originalität des ländlichen Raumes: Methodik und Spezifika. - In: Rostocker Agrar- und Umweltwissenschaftliche Beiträge 1 1993:259-263.

BEHM, H.: Kulturlandschaftspflegerische Aspekte einer Flächennutzungsplanung in ländlichen Räumen auf kommunaler Ebene. In: SCHENK, W./FEHN, K./DENECKE, D. (Hrsg.): Kulturlandschaftspflege: Beiträge der Geographie zur räumlichen Planung. - Berlin, Stuttgart: Borntraeger 1997:87-91.

BEHM, H. (Hrsg.): Kulturelles Erbe - Landschaften im Spannungsfeld zwischen Zerstörung und Bewahrung; Beiträge zur Tagung vom 26. - 28. März 1998 in Rostock. - Wittenburg: Pro-Art-Verl. 2000.

BEHM, H.: Archäotopmanagement in ländlichen Räumen: dargestellt am Beispiel eines Schutzzonenkonzeptes. - In: TACK, Fritz (Hrsg.): Umweltgerechte Nutzung und nachhaltige Entwicklung ländlicher Räume. - Rostock 2000:305-311.

BEHM, H./SCHULZ, A.: Durch Befliegen entdeckte Strukturen: eine Herausforderung für Standortkunde und Landentwicklung. In: Landnutzung und Landentwicklung 42/1 2001:49-55.

BEHNKE, E.: Zur Geschichte der Hönkenmühle. - In: Heimatkalender für Stadt und Kreis Uelzen 1997; Archiv Landeszeitung für die Lüneburger Heide; Der Heidewanderer April 1991:56ff. [URL = www.kleiekotzer.com/page32.html; 5.11.03].

BEHRE, K.-E.: Die Umwelt prähistorischer und mittelalterlicher Siedlungen - Rekonstruktionen aus siedlungsarchäologischen und botanischen Untersuchungen im Neolithikum. - In: Siedlungsforschung 6 1988:39-55.

BEHRE, K.-E.: Ernährung und Umwelt der wikingerzeitlichen Siedlung Haithabu. -Neumünster: Wachholtz 1983.

BEHRE, K.-E.: Flussmarschlandschaft Rheiderland. - In: Archäologische Denkmäler zwischen Weser und Ems. Hrsg.: Oldenburger Landesverein für Geschichte, Natur- und Heimatkunde e. V./Staatliches Museum für Naturkunde und Vorgeschichte Oldenburg. - Oldenburg 2000:313-318.

BEHRENS, G. H. D.: „Hercynia Curiosa oder Curiöser Harz-Wald. Das ist Sonderbare Beschreibung und Verzeichnis Derer Curiösen Hölen/Seen/Brunnen/Bergen und vielen andern an- und auff dem Harz vorhandenen Denkwürdigen Sachen mit unterschiedenen Nützlichen und Ergetzlichen Medicinischen/ Physicalischen und Historischen Anmerkungen denen Liebhabern solcher Curiositäten zur Lust heraus gegeben von D. Georg Henning Behrens, Physico Ordin. Subordin. in Nordhausen. - Nordhausen: Verlegtes Carl Christian Neuenhahn/Buch-Händler 1703.

BEHRENS, H.: Die Jungsteinzeit im Mittelelbe-Saale-Gebiet. - Berlin: Verl. d. Wissenschaften 1973.

BEHRENS, H.: Brauchen wir in Deutschland mehr als 100 Archäologien? - In: Arch. Nachrichtenbl. 2 1997:22f.

BEHRENS, H./ANDERSEN, A. (Hrsg.): Wirtschaftsgeschichte und Umwelt: Hans Mottek zum Gedenken. - 1. Aufl. - Marburg: BdWi-Verl. 1996 [Forum Wissenschaftl: Studien;29; Umweltgeschichte und Umweltzukunft;3].

BEHRENS, H./AUSTER, R. (Hrsg.): Umweltgeschichte: Wissenschaft und Praxis, 2. Band von Umweltgeschichte und Umweltzukunft. - Marburg: BdWi-Verl. 1993.

BEHRENS, H./VETTER, L. (Hrsg.): Kulturlandschaftselemente - erfassen, bewerten, darstellen: Dokumentation des Ersten Neubrandenburger Symposiums vom 7. März 2001. - 1. Aufl. - Berlin: Verl. für Wiss. und Forschung 2001 [Umweltgeschichte und Umweltzukunft;9].

BEHRENS, H./VETTER, L.: Forschungen zur Kulturlandschaft an der Fachhochschule Neubrandenburg. - In: BEHRENS, H./VETTER, L. (Hrsg.): Kulturlandschaftselemente - erfassen, bewerten, darstellen: Dokumentation des ersten Neubrandenburger Symposiums vom 7. März 2001. - Berlin: Verl. für Wiss. und Forschung 2001 [Umweltgeschichte und Umweltzukunft;9]:V-X.

BEHRENS, K.: Flößerei auf Rhume und Leine. - In: Northeimer Heimatblätter 2 1951:5-12.

BEKHUIS, J. et al.: Land der lebendigen Flüsse: Die Auenlandschaft De Gelderse Poort. - Utrecht 2002.

BELIDOR, B. F. de: Architectura Hydraulica, oder die Kunst das Gewässer zu denen verschiedentlichen Nothwendigkeiten des menschlichen Lebens zu leiten; Erste Ausgabe der Version. - 2. Aufl.. - Augsburg: Klett 1764.

BELL, M.: Valley sediments as evidence of prehistoric land-use on the South-Downs. - In: Proceedings of the Prehistoric Society 49 1983:119-150. 
BELOW, G. v.: Geschichte der deutschen Landwirtschaft des Mittelalters in ihren Grundzügen. - Jena: Fischer 1937.

BENDER, O.: Angewandte Historische Geographie und Landschaftsplanung. - In: Standort. Zeitschrift für Angewandte Geographie 18/2 1994:3-12.

BENDER, O./DOREEN, J.: Ein katasterbasiertes GIS zur Erforschung und Interpretation der Landschaftentwicklung - dargestellt an drei Gemarkungen auf dem Nördlichen Frankenwald (Bayern). - In: Angewandte Geographische Informationsvearbeitung XIII. Beiträge zum AGIT-Symposium Salzburg. - Heidelberg 2001:31-36.

BENDER, R./KÖBERLE, A./SCHMIDT, M.: KLEKs - KulturLandschaftsElementeKataster. - In: BEHRENS, H./VETTER, L. (Hrsg.): Kulturlandschaftselemente - erfassen, bewerten, darstellen: Dokumentation des ersten Neubrandenburger Symposiums vom 7. März 2001. - Berlin: Verl. für Wiss. und Forschung 2001 [Umweltgeschichte und Umweltzukunft; 9]:63-88.

BENECKE, B.: Die Teichwirtschaft: Praktische Anleitung zur Anlage von Teichen und deren Ausnutzung durch Fisch- und Krebszucht. - Berlin: Parey 1885.

BENECKE, Berthold: Fische, Fischerei und Fischzucht in Ost- und Westpreussen: auf Grund eigener Anschauung gemeinfasslich dargestellt. - Königsberg/Preussen: Hartung 1881.

BENECKE, N.: Der Mensch und seine Haustiere: die Geschichte einer jahrtausendealten Beziehung. - Stuttgart: Theiss 1994.

BENECKE, N.: Frühgeschichte der Landwirtschaft in Deutschland. - Langenweissbach: Beier \& Beran 2003.

BENTHIEN, B./STRENZ, W. (Hrsg.): Beiträge zu Problemen der historischen Geographie und der geographischen Wirtschaftsgeschichte in der Deutschen Demokratischen Gesellschaft. - 1. Aufl. - Gotha et al.: Haack 1970 [Wissenschaftliche Abhandlungen der Geographischen Gesellschaft der Deutschen Demokratischen Republik;8].

BENTZIEN, H.: Damm und Deich - fruchtbar und reich. - Berlin: Westkreuz-Verl. 1997 [Reihe Märkische Miniaturen]..

BENTZIEN, U.: Bauernarbeit im Feudalismus: landwirtschaftliche Arbeitsgeräte und -verfahren in Deutschland von der Mitte des ersten Jahrtausends u. Z. bis um 1800. - Berlin: Akad.-Verl. 1980 [Veröffentlichungen zur Volkskunde und Kulturgeschichte;67].

BERCHTOLD-OGRIS, M./ENTNER, B./VERDEL, H.: Die Drau ist eine eigene Frau: ein Fluss und seine Kulturgeschichte [ Drava je svoja frava: h kulturi in zgodovini Drave]. Hrsg.: Slowenischer Kulturverband. - Klagenfurt: Zaloznik Drava 2001.

BERDOULAY, V./GINKEL, J. A. van (Hrsg.): Geography and professional practice. - Utrecht: Koninklijk Nederlands Aardrijkskundig Genootschap 1996 [Nederlandse geografische studies;206].

BERG, A. (Hrsg.): Vollständiges Adreßbuch von Nordhausen [...]. - 32. Aufl. - Nordhausen: Strenz 1824.

BERGBAU UND HÜTTENWESEN im Hammer Land: Ausstellung in Hamm. Hrsg.: Bürgergemeinschaft der Gemeinde Pracht, den Heimatfreunden aus dem Hammer Land und der Verbandsgemeindeverwaltung Hamm/Sieg. - Hamm 1985.

BERGBAU, WALDBAU, FLÖßE: Untersuchungen zur Geschichte der Flößerei im Dienste des Montanwesens und zum montanen Transportproblem. - Berlin: Akademie-Verl. 1960 [Freiberger Forschungshefte, Reihe D;28].

BERGER, D.: Duden.: geographische Namen in Deutschland: Herkunft und Bedeutung der Namen von Ländern, Städten, Bergen und Gewässern. - Mannheim, Leipzig et al.: Dudenverl. 1993 [Duden-Taschenbücher;25].

BERGMANN, A. et al.: Integrierter Zugriff auf heterogene paläoökologische Datenbestände. - In: RAUTENSTRAUCH, C./SCHENK, M. (Hrsg.): Umweltinformatik '99. Umweltinformatik zwischen Theorie und Industrieanwendung. 13. Internationales Symposium „Informatik für den Umweltschutz“ der Gesellschaft für Informatik (GI), Magdeburg 1999. Magdeburg: Metropolis-Verl. 1999: 403-416.

BERGMANN, R.: Zur Herkunft der Handschrift des „Capitulare de Viliis“ und der „Brevium Exempla“. - In: Zeitschrift für deutsches Altertum 96 1967:213-217.

BERGMANN, R.: Historische Karten als Hilfsmittel für die Wüstungsforschung dargestellt an Beispielen aus dem Astengebirge und Ostsauerland. - In: BERGMANN, R. (Hrsg): Zwischen und Pflug und Fessel. - Münster 1995:35-76.

BERGMEISTER, U./LEIPOLD-SCHNEIDER, G.: Umstritten und freudig begrüßt: 100 Jahre Fußacher Durchstich 1900-2000. Die Menschen und die Rheinregulierung. Sonderaustellung im Museum Rheinschauen ab 1. Mai 2000. - In: Montfort. Vierteljahresschrift für Geschichte und Gegenwart Vorarlbergs 52/1 2000:49-80.

BERIEF, K.-J./KOCH, W.: Die Folgenutzungsplanung beginnt mit der Historischen Recherche. - In: TerraTech 1 1996:23-27.

BERISCH, C. L. (Hrsg.): Gründliche Anweisung wie sowohl die zahme als wilde Fischerei gehörig zu betreiben, um den höchstmöglichen Ertrag hiervon zu erlangen: zur Nachricht für Landwirthe, Dorfgemeinden oder alle diejenigen, welche Fischerei haben, und die zugleich auch als Instruction für Fischerei-Aufseher und Teichwärter bei ansehnlichen Fischereien gebraucht werden kann - Leipzig: Friedrich August Leo 1794.

BERKE, H./KIND, C.-J.: Die ökologischen Verhältnisse in der Umgebung des Felsställe bei Ehingen-Mühlen (Alb-Donau-Kreis) während der Magdal'enienbesiedlung im ausgehenden Bölling-Interstadial und der mesolithischen Besiedlung im jüngeren Boreal. - In: KIND, C.-J.: Das Felsställe: eine jungpaläolithisch-frühmesolithische Abri-Station bei Ehingen-Mühlen, AlbDonau-Kreis; die Grabungen 1975-1980. Landesdenkmalamt Baden-Württemberg. - Stuttgart: Theiss 1987 [Forschungen und Berichte zur Vor- und Frühgeschichte in Baden-Württemberg;23]:355-358. 
BERKNER, A.: Die Pläne der „Gewäßer um Leipzig“ von 1748 und 1775 und der „Leipziger Wasserknoten“ im Wandel der Zeiten. - In: Leipzig im Kartenbild. - Leipzig: Leipziger Universitätsverlag 2001 [Leipziger Kalender. Sonderband;1]:63-72.

BERLINER SENATSVERWALTUNG FÜR STADTENTWICKLUNG: Zukunft Wasser - Neue Wege in der Gewässerschutzpolitik: In Europa - In Berlin 2002 [Informationsblatt zur Europäischen Wasserrahmenrichtlinie (WRRL), 1. Ausgabe].

BERNHARDT, K.-G. (Hrsg.): Revitalisierung einer Flusslandschaft; Tagungsband. Dokumentation zum Fachsymposium „Revitalisierung einer Flusslandschaft“. - Osnabrück: Zeller 1994 [Initiativen zum Umweltschutz;1].

BERTRAND, M. J.: Kunst Die Wiesen zu wässern oder vollständige Abhandlung von dem Wasser, wie solches in der LandWirthschaft und dem Feldbau zu gebrauchen, Nebst einigen Abrissen von Wasserleitungen. [Aus dem Fränzösischen übersetzt]. - Nürnberg: Schwarzkopf 1765.

BESCHOREN, B.: Über alluviale Neubildungen in historischer Zeit im Gebiet von Elbe und Oder. - In: Jahrbuch der Preußischen Geologischen Landesanstalt zu Berlin 55 1934:292-304.

BESCHORNER, H.: Historische Geographie. - In: Handbuch der geographischen Wissenschaften. Hrsg. v. v. Ende. - Wien, Berlin 1914:356.

BESTEHORN, F.: Die geschichtliche Entwicklung des märkischen Fischereiwesens. Ein Beitrag zur Kultur- und Wirtschaftsgeschichte der Mark Brandenburg. In: AfF 1 1913:1-199.

BEUSTE, J.: Kulturlandschaften un urbanen und suburbanen Räumen. - In: ARL (Hrsg.): Die Zukunft der Kulturlandschaft zwischen Verlust, Bewahrung und Gestaltung. - Hannover 2001 [Forschungs- und Sitzungsberichte der Akademie für Raumforschung und Landeskunde;215]:79-83.

BEYER, J. M.: Theatrum Machinarum Molarium, oder Schauplatz der Mühlenbaukunst. Teil 1 (Jacob Leupold, Theatrum Machinarum 9). Neudruck der Ausgabe Leipzig 1735. - Hannover 1982.

BEZIRKSREGIERUNG ARNSBERG $\quad 2004 \quad$ [URL $\quad$ http://www.bezregarnsberg.nrw.de/dieBezirksregierung/aufgaben/Aufbau/abteilungen/abteilung5/dezernat5/dezernat54/talsperren/;16.01.2004].

BEZIRKSREGIERUNG DÜSSELDORF $\quad 2004 \quad$ [URL

http://www.brd.nrw.de/BezRegDdorf/hierarchie/themen/Umwelt/Hochwasserschutz_und_Deichverbaende/Talsperren_allge meine_Informationen808.php;16.01.2004].

BfN [BUNDESAMT FÜR NATURSCHUTZ]/SMUL [SÄCHSISCHES LANDESAMT FÜR UMWELT]/ZWECKVERBAND „NATURSCHUTZREGION NEIßE“ (Projektträger): Naturschutzgroßprojekt (NSGP) „Teichgebiete NiederspreeHammerstadt“ (Niederschlesischer Oberlausitzkreis). - Pflege und Entwicklungsplan 1998-2000.

BFN [BUNDESAMT FÜR NATURSCHUTZ] (Hrsg.): Fortschritte für Naturschutz und Landschaftspflege an Wasserläufen. Bonn 1998 [Schriftenreihe für Ökologie;23].

BFN [BUNDESAMT FÜR NATURSCHUTZ] (Hrsg.): Renaturierung von Bächen, Flüssen und Strömen. Referate und Ergebnisse der Tagung vom 24.-26. November 1999 in Neuhaus im Solling, 2001 [Schriftenreihe für Ökologie;37].

BFN [BUNDESAMT FÜR NATURSCHUTZ]: Gemeinsame Pressemitteilung von Bundesamt für Naturschutz (BfN), der Universität Paderborn, Abt. Höxter und dem Naturpark Solling-Vogler, Projektgruppe Hutelandschaftspflege: Exmoorponis und Heckrinder fressen für den Naturschutz - Modellhaftes Naturschutzprojekt startet. - Bonn: Referat Presse, Öffentlichkeitsarbeit, 28. August 2000.

BFN [BUNDESAMT FÜR NATURSCHUTZ]: Lichte Wälder von besonderer Bedeutung - die Hutewälder am Reiherbach: das Wirken großer Weidetier. - Faltblatt o. J. (2002).

BIALLON, J. C.: Practische Anweisung zum Flachs- und Hanfanbau für den Landmann. - Hannover: Hahn 1794.

BIBLIOTHEK GEOGRAPHISCHER HANDBÜCHER. Hrsg.: F. Ratzel, A. Penck. Bd. 9: Handbuch der Seenkunde; allg. Limnologie 1901.

BICK, H./HANSMEYER, K.-H./OLSCHOWY, G. et al. (Hrsg.) Angewandte Ökologie: Mensch und Umwelt in 2. Bde. - Band I: Einführung - Räumliche Strukturen - Wasser - Lärm - Luft - Abfall. Stuttgart. - Band II: Landbau - Energie - Naturschutz und Landschaftspflege - Umwelt und Gesellschaft. - Stuttgart: Fischer 1984.

BICK, H.: Ökologie: Grundlagen, terrestrische und aquatische Ökosysteme, angewandte Aspekte. - 2. Aufl. - Stuttgart, New York: Fischer 1989

BICK, H.: Grundzüge der Ökologie. 3. Aufl. - Stuttgart, New York: Fischer 1993.

BIEGERT, C./Wittenborn, R.: Der große Fluß ertrinkt im Wasser. James Bay: Reise in einen sterbenden Teil der Erde. - 2. Aufl. Reinbeck: Rowohlt 1985 [Sammlung GATP].

BIERMANN, F.: Menzlin und Usedom - ein Seehandelsplatz und eine Burgstadt des frühen und hohen Mittelalters im Odermündungsgebiet. - In: Exkursionspapier zur „Exkursion der Teilnehmer der 30. Jahrestagung des Arbeitskreises für genetische Siedlungsforschung in Mitteleuropa am 20. September 2003 nach Usedom“ - Greifswald September 2003:1-7.

BIESENBACH, R.: Künstliche Fischzucht. - Leipzig 1897. 
BILDUNGSWERK BUND NATURSCHUTZ BAYERN: Tagung: „Der Fluss, die Aue, das Strömende - Strategien und Projekt zur Renaturierung von Fließgewässern“. - Bildungswerk des Bund Naturschutz in Bayern e.V., 94343 Wiesenfelden am 13.9.2003.

BILLAMBOZ, A.: Schiffbau und Waldlandschaft am Bodensee: Holzuntersuchungen an Schiffwracks und Uferkonstruktionen. In: Einbaum, Lastensegler, Dampfschiffahrt. - Stuttgart 2000:41-50.

BILUT, E.: Gewässernamen im Flussgebiet des Westlichen Bug. - Stuttgart: Steiner 1995 [Hydronymia Europaea;10].

BINDER, W.: Der Lech zwischen Landsberg und Augsburg - Umgestaltung einer süddeutschen Flusslandschaft in den letzten 100 Jahren. - In: DVWK [Deutscher Verband für Wasserwirtschaft und Kulturbau e. V.] (Hrsg.): Fluß und Lebensraum: Beiträge zur Fachtagung 1984 in Augsburg. - Hamburg; Berlin: Parey, 1984 [Schriftenreihe des Deutschen Verbandes für Wasserwirtschaft und Kulturbau e.V.;69]:25-57.

BINGGELI, V.: Kulturlandschaftswandel am Beispiel der Oberaargauer Wässermatten. Zerfall und Wiederaufbaumöglichkeiten in einem subalpinen Bewässerungssystem. - In: Der Mensch in der Landschaft. Festschrift für Georges Grosjean zum 65. Geburtstag, 17. Januar 1986. - Hrsg. v. AERNI, K. et al. - Bern: Lang 1986 [Jahrbuch d. Geogr. Gesell. von Bern;55]:123149 .

BINTZER, K. H.: Die Mühlen uffm Roste und die Herrschaftsmühle. - Eschwege: Bintzer ca. 1991.

BIOLOGISCHE STATION „Rieselfelder Münster“: Zum Biotopmanagement im Europareservat „Rieselfelder Münster“. - In: Natur und Landschaft 58/4 1983:123-128.

BIOLOGISCHE STATION „Rieselfelder Münster“: Die Rieselfelder Münster - Europareservat für Wat- und Wasservögel. Münster 1981.

BIRD, J. H.: The changing worlds of geography: A critical guide to concepts and methods. - Oxford: Clarendon Press 1989.

BIRKENHAUER, J.: Traditionslinien und Denkfiguren. Zur Ideengeschichte der sogenannten klassischen Geographie in Deutschland. Stuttgart: Steiner 2001 [Erdkundliches Wissen;133].

BIRKIGT-QUENTIN, B./BUSSE, G./SCHÄFER, W. (Hsrg.): Flachs und Leine zwischen Leine und Weser. Berichte und Bilder aus Adelebsen, Uslar und Wahlsburg. - Im Auftrag der Museen: Museum Uslar, Steinarbeiter-Museum Adelebsen, Schäferhausmuseum in Wahlsburg-Lippoldsberg. - Adelebsen et al. 1995.

BIRKS, H. et al. (Hrsg.): The cultural landscape: past, present and future. - Cambridge: Cambridge Univ. Press 1988.

BISCHOFF, W. D./DETTMER, R./WÄCHTLER, K.: Die Flussperlmuschel: Biologie und kulturelle Bedeutung einer heute vom Aussterben bedrohten Art. Ausstellung vom 27. April bis 24. August 1986. - Braunschweig: Staatl. Naturhistorisches Museum 1996 [Führer zu Ausstellungen;7].

BITTENFELD, C. H. v. et al.: Der Berliner Wasserlagenentwicklungsplan. - In: PlanerIn 2/03 2003:48-49.

BITTNER, R./SCHENK, W.: Möglichkeiten der Angewandten Historischen Geographie im Rahmen der Dorferneuerungsplanung in Thüringen.- In: Kulturlandschaft. Zeitschrift für Angewandte Geographie 4/1 1994:16-19.

BLACK, I. S./BUTLIN, R. A. (Hrsg.): Place, culture and identity: essays in historical geography in honour of Alan R. H.Baker. Québec: Les Presses de l'Université Laval 2001 [Géographie historique].

BLACK, J.: Maps and history: constructing images of the past. - New Haven, Conn. et al.: Yale Univ. Press 1997.

BLACKBOURN, D.: Besiegte Natur: Wasser und die Entstehung der modernen deutschen Landschaft. - In: Wasser. - Köln 2000:440-453

BLANCOTTE, B.: The Canal du Midi. [Engl. Ausgabe]. - Portet-sur-Garonne: Loubatières 1991 [Sammlung GATP].

BLANKE, D.: Flußkrebse in Niedersachsen. - 1. Aufl. - Hannover: Niedersächsisches Landesamt für Ökologie 1998 [Schriftenreihe: Informationsdienst Naturschutz Niedersachsen;18,6].

BLASCHKE, E.: Alte Straßen und Wege. - In: Die ur- und frühgeschichtlichen Bodendenkmale des Kreises Nordhausen. Nordhausen 1974:46.

BLASCHKE, K.: Environmental History: Some Questions for a New Subdiscipline of History. - In: BRIMBLECOMBE, P./PFISTER, C. (Hrsg.): The silent countdown. Essays in European environmental history. - Berlin et al.: Springer 1990:6872.

BLASCHKE, T.: Landschaftsanalyse und -bewertung mit GIS: methodische Untersuchungen zu Oekosystemforschung und Naturschutz am Beispiel der bayerischen Salzachauen. - Trier: Deutsche Akademie für Landeskunde 1997 [Forschungen zur deutschen Landeskunde;243]; Zugl.: Salzburg, Univ., Diss. 1995.

BLOHM, R.: Die Hagenhufendörfer in Schaumburg-Lippe. - Oldenburg i. O.: Stalling 1943 [Veröff. d. Provinzialinstituts f. Landesplanung u. niedersächsische Landes- und Volksforschung Hannover-Göttingen, Reihe A;10; Schriften d. Niedersächsischen Heimatbundes; N. F. 10]; Zugl.: Kiel, Univ., Diss. 1940.

BLOSS, O.: Die älteren Glashütten in Südniedersachsen . - Hildesheim: Lax 1977 [Veröffentlichungen des Instituts für Historische Landesforschung der Universität Göttingen;31]; Zugl.: Göttingen, Univ., Diss. 1977 
BLOTEVOGEL, H. H.: Geographische Erzählungen zwischen Moderne und Postmoderne: Thesen zur Theoriediskussion in der Geographie am Ende des 20. Jahrhunderts. - Duisburg: Institut für Geographie 1998 [Institut für Geographie: Diskussionspapier 1/1998].

BLOTEVogel, H. H.: Kernräume und Peripherien: Allgemeine Einführung in die Tagungsthematik. - Vortrag 30. Tagung des „Arbeitskreises für genetische Siedlungsforschung in Mitteleuropa“ in Greifswald vom 17. bis 20. September 2003.

BLOTEVOGEL, H. H.: „Neue Kulturgeographie“ - Entwicklung, Dimensionen, Potenziale und Risiken einer kulturalistischen Humangeographie. - Leipzig: Deutsche Akademie für Landeskunde e. V. und des Instituts für Länderkunde 2003 [Berichte zur deutschen Landeskunde; 1$]$.

BLOTNITZKI, L.: Bewässerungskanäle in den Walliser Alpen. - In: DVWK (Hrsg.): Historische Wasserwirtschaft im Alpenraum und an der Donau. Bearbeitet v. Werner Konold. - Stuttgart: Wittwer 1994:37-42.

BLÜCHEL, K. G. (Hg.): Die Jagd. - Band I und II. - Köln: Könemann 1996.

BLÜMEL, W. D./LESER, H.: „Ökologie ist geographische Umweltforschung“: Versuch eines Fazits. - In: Die Erde 126/4 1995:339-343.

BLUSCH, J.: Konrad Heresbach: Handbüchlein der Thereutik, das heisst über Jagd, Vogelfang und Fischerei. - Boppard/Rhein: Boldt 1977.

BOBEK, H.: Hauptstufen der Gesellschafts- und Wirtschaftsentwicklung in geographischer Sicht. - In: Die Erde 1959: $259-298$.

BOCK, E. (Hrsg.): Alte Berufe Niedersachsens. - Hannover: Niedersächs. Verl.-Gesell. 1926.

BOCK, H./FISCHER, P.: Die nordwestliche Altmark - eine Kulturlandschaft. - Hrsg.: Sparkasse Gifhorn-Wolfsburg. - Wittingen: Neef 1991 [Schriftenreihe zur Heimatkunde d. Sparkasse Gifhorn-Wolfsburg: Sonderbd.]

BÖCKING, Werner: Die Geschichte der Rheinschiffahrt. - Moers 1980/81.

BÖCKING, W.: Nachen und Netze: die Rheinfischerei zwischen Emmerich und Honnef. - Köln: Rheinland-Verl. 1982 [Werken und Wohnen;12].

BODINI, G.: Südtiroler Waalwege: Stille Wege am Wasser. - München: Berg 1996.

BODINI, G.: Waalwege: Wege am Wasser. Entlang den Lebensadern der Vinschgauer Bergbauern. - München: Berg 1993 [Lizenezausgabe des Tappeiner-Verlags, Lana (Südtirol)].

BOELCKE, W. A.: Bauer und Gutsherr in der Oberlausitz: ein Beitrag zur Wirtschafts-, Sozial- und Rechtsgeschichte der ostelbischen Gutsherrschaft. - Bautzen: Domowina-Verl. 1957.

BOELCKE, W. A.: Zur Problematik der frühen alemannischen Landnahme im deutschen Südwesten. - In: Wirtschaftliche und soziale Strukturen im säkulären Wandel. - Hannover 1974:23-54.

BÖLSKER-SCHLICHT, Franz: Die Hollandgängerei im Osnabrücker Land und im Emsland: ein Beitrag zur Geschichte der Arbeiterwanderung vom 17. bis zum 19. Jahrhundert. - Sögel: Verl. der Emsländischen Landschaft 1987 [Emsland/Bentheim;3]; Teilw. Zugl.: Osnabrück, Uni., Diss. 1996.

BOERLIN-BRODBECK, Y.: Vermessene Landschaft? Zur Landschaft in Zeichnung und Malerei um 1800. - In: Vermessene Landschaften 1999:113-123.

BOESCH, M.: Schweizer Geographie am Wendepunkt: Überlegungen zu einer normativen Metatheorie. - In: Geographica Helvetica 3 1986:147-154.

BOESCH, M.: Engagierte Geographie: Zur Rekonstruktion der Raumwissenschaft als politik-orientierte Geographie. - Stuttgart: Steiner 1989 [Erdkundliches Wissen;98].

BOESSNECK, J.: Zur Entwicklung vor- und frühgeschichtlicher Haus- und Wildtiere Bayerns im Rahmen der gleichzeitigen Tierwelt Mitteleuropas. - München: Kiefhaber \& Elbl in Komm. 1958 [Studien an vor- und frühgeschichtlichen Tierresten Bayerns;2]; Zugl.: München, Tierärztl. Fak., Hab.-Schr. 1957.

BOGARDI, J./BANTZ, I./GEPPERT, B.: Arbeitsberichte zum Pilotprojekt Bewirtschaftungsplan Leine: Ansätze zur Klassifizierung der Gewässernutzungen. Hrsg. im Auftrag des Umweltbundesamtes. - Karlsruhe: Institut für Siedlungswasserwirtschaft, Univ. Karlsruhe 1982 [Berichte zum Pilotprojekt Bewirtschaftungsplan Leine;7] [Texte Umweltbundesamt;13].

BOGARDI, J./BANTZ, I./GEPPERT, B.: Ansätze zur Klassifizierung der Gewässernutzungen. - Hrsg.: Niedersachsisches Ministerium für Ernährung, Landwirtschaft und Forsten. - Berlin: Umweltbundesamt 1983 [Landwirtschaft und Forsten, Hannover;7 - Schriftenreihe: Texte/Umweltbundesamt;13].

BOGSCH, Walter: Der Marienberger Bergbau seit der zweiten Hälfte des 16. Jahrhunderts: vier Studien. - Köln: Böhlau 1966 [Mitteldeutsche Forschungen;45].

BOHL, E./KELLER, M./OITDMANN, B.: Flusskrebse in Bayern: Information für Naturschutz, Wasserwirtschaft, Fischerei, Teichwirtschaft, Fisch- und Aquarienhandel, Gastronomie. - Hrsg. v. Landesfischereiverband Bayern e.V. und Bayerisches Landesamt für Wasserwirtschaft. - München: Landesfischereiverband Bayern 2001. 
BOHL, M.: 80 Jahre Wielenbacher Versuchsanlage: ein intaktes Bruthaus als Geburtstagsgeschenk. - In: Fischer und Teichwirt, Sonderdruck 43/12 1992: 444-458.

BOHL, M./RUF, M.: 75 Jahre Versuchsanlage Wielenbach. - In: Fischer und Teichwirt 71987.

BOHLE, H. W.: Limnische Systeme. - Berlin et al.: Springer 1995 [Reihe Spezielle Ökologie].

BOHLEN, Dietrich: Die Bedeutung der Fischerei für die antike Welt: ein Beitrag zur Geschichte der antiken Welt. - Hamburg, Univ., Diss 1935.

BÖHM, H./MEHMEL, A.: Das Vorgebirge. Suburbanisierung einer Gartenbaulandschaft. In: STIEHL, E. (Hrsg.): Die Stadt Bonn und ihr Umland: ein geographischer Exkursionsführer. - Bonn: Dümmler 1997 [Arbeiten zur Rheinischen Landeskunde;66]: 99-124.

BÖHM, H. (Hrsg.): Beiträge zur Geschichte der Geographie in Bonn. Herausgegeben anläßlich der Übergabe des neuen Institutsgebäudes in Bonn-Poppelsdorf. - Bonn: Institut für Geographie 1991 [Colloquium Geographicum;21].

BÖHM, H. R./DENECKE, M. (Hrsg.): Wasser: eine Einführung in die Umweltwissenschaften. - Darmstadt: Wiss. Buchges. 1992.

BÖHM, H.: Die Wiesenbewässerung in Mitteleuropa 1937. Anmerkungen zu einer Karte von C. Troll. - In: Erdkunde 44/1 1990.

BÖHME, G./BÖHME, H.: Feuer - Wasser - Erde - Luft: Eine Kulturgeschichte der Elemente. - München: Beck 1996.

BÖHME, H. (Hrsg.): Kulturgeschichte des Wassers. - Frankfurt/Main: Suhrkamp 1988 [Suhrkamp-Taschenbuch;1486].

BÖHME, H. W. (Hrsg.): Siedlungen und Landesausbau zur Salierzeit. - Sigmaringen: Thorbecke 1991.

BÖHME, K.: Illustrierte Jagdgeschichte. Vom Steinwurf des Vormenschen zum Waidwerk der Antike. - Melsungen: NeumannNeudamm 1991.

BÖHME, K.: Vom Steinwurf des Vormenschen zum Waidwerk der Antike. - Melsungen: Neumann-Neudamm 1991.

BOHNE, E. C.: Nordhäusische Chronica. Zeit- und Geschichts-Buch beschreibend der Kayserl. und des Heil. Röm. ReichsFreyen-Stadt Nordhausen. Situation, Lage und Ausgräntzung ...Frankfurt und Leipzig: Carl Christian Reuenhahn, 1701. - In: Festschrift zur 25jährigen Jubelfeier des Städtischen Museums in Nordhausen. I. Urkundliche Geschichte des Städtischen Museums (1876-1901) von Hermann Heineck. Nordhausen: C. Haacke's Buchhandlung 1901:1-85.

BONNE, G. H.: Die Klagen der deutschen Binnenfischer über die zunehmende Verunreinigung unserer Gewässer nebst den Mitteln und Wegen zur Abhilfe derselben. - Hamburg: Lüdeking in Komm. 1912 [Verhandlungen des internationalen Vereins zur Reinhaltung der Flüsse, des Bodens und der Luft;30].

BOKELMANN, K.: Wohnen am Wasser: Lagerplätze am See. - In: Archäologie in Deutschland 4 1999:26-27.

BOLDT, H. et al. (Hrsg.): Der Rhein: Mythos und Realität eines europäischen Stromes. - Köln: Rheinland-Verlag 1988.

BOLENDER, E.: Renaturierung von Fließgewässern in München: Voruntersuchungen, Maßnahmendurchführung, Konflikte. - In: Naturschutz in Ballungsräumen. - Laufen: ANL 1994 [Laufener Seminarbeiträge;2]:55-66.

BÖLSKER-SCHLICHT, F.: Die Hollandgängerei im Osnabrücker land und im Emsland. Ein Beispiel zur Geschichte der Arbeiterwanderung im 17. bis zum 19. Jahrhundert. - Sögel 1987 [Emsland/Bentheim, Beiträge zu neueren Geschichte;3].

BOOCKMANN, H. (Hrsg.): Das Mittelalter. Ein Lesebuch aus Texten und Zeugnissen vom 6. bis 16. Jahrhundert. - 2. Aufl. München: Beck 1989.

BOOCKMANN, H.: Erfahrene Umwelt. Deutschland in einem Reisebericht des 15. Jahrhunderts. - In: HERRMANN, B./BUDDE, A. (Hrsg.): Natur und Geschichte. Naturwissenschaftliche und historische Beiträge zu einer ökologischen Grundbildung. Sommerschule „Natur und Geschichte“ vom 14. bis 27. September 1989 an der Georg-August-Universität Göttingen. Hildesheim: Gerstenberg 1989 [Schriftenreihe „Expert“ des Niedersächsischen Umweltministers Hannover]:35-43.

BOOCKMANN, H.: Fürsten, Bürger, Edelleute: Lebensbilder aus dem späten Mittelalter. - München: Beck 1984.

BORCHARD, D.: Umnutzung und Wiederbelebung alter Hafen- und Uferbereiche in deutschen Städten. - Göttingen, Univ., Dipl.arbeit am Institut für Geographie, Abt. Kulturgeographie 1997.

BORGER, G. J.: Die Mittelalterliche und frühneuzeitliche Marschen- und Moorbesiedlung in den Niederlanden. - In: Siedlungsforschung 2 1984: 101-110.

BORGER-KEWELOH, N./KEWELOH, H.-W.: Flößerei im Weserraum: Leben und Arbeiten in einem alten Gewerbe. - Bremen: Hauschild 1991.

BORGGRÄFE, K./KÖLSCH, O.: Naturschutz in der Kulturlandschaft: Revitalisierung in der Ise-Niederung. - Bonn: Bundesamt f. Naturschutz 1997 [Schriftenreihe für Ökologie;12].

BORK, H.-R. et al.: Landschaftsentwicklung in Mitteleuropa: Wirkungen des Menschen auf Landschaften. - Gotha: Perthes 1998 [Perthes Geographie Kolleg].

BORK, H.-R./BORK, H./DALCHOW, C.: Landschaftsentwicklung in Mitteleuropa: Wirkungen des Menschen auf Landschaften. - Gotha et al.: Klett-Perthes 1998 [Perthes GeographieKolleg]. 
BORN, K. M.: Kulturlandschaftsbezogene Handlungsforschung - Die Erhaltung der Historischen Kulturlandschaft durch das raumwirksame Handeln von Landschaftsarchitekten und Historischen Vereinen. - Leipzig: Dt. Akad. f. Landeskde e. V. und des Instituts für Länderkunde 1997 [Berichte zur deutschen Landeskunde;1].

BORN, Martin: Arbeitsmethoden der deutschen Flurforschung. - In: BARTELS, D. (Hrsg.): Wirtschafts- und Sozialgeographie. Köln et al: Kiepenheuer \& Witsch 1970 [Neue wissenschaftliche Bibliothek;35: Wirtschaftswissenschaften]: 245-261.

BORN, M.: Geographie der ländlichen Siedlungen. - 1. Aufl. - Stuttgart: Teubner 1977 [Teubner-Studienbücher:Geographie].

BORN, M.: Die Entwicklung der deutschen Agrarlandschaft. - Darmstadt: Wiss. Buchgesell. 1989.

BORNE, K. v. dem.: Das Schloß Berneuchen und seine Geschichte. - In: Deutsches Adelsblatt. Mitteilungsblatt der Vereinigung der Deutschen Adelsverbände 24/1 1985:13 f.

BORNE, M. v. dem: Wie kann man unsere Gewässer nach den in ihnen vorkommenden Arten klassifizieren? - Circulare d. Deutschen Fischereivereins, Berlin 41881.

BORNE, M. v. dem: Fischerei und Fischzucht im Harz: mit besonderer Berücksichtig. der Forellen. - Berlin: Parey 1883.

BORNE, M. v. dem: Die Fischzucht. - 3. Aufl. - Berlin: Parey 1885.

BORNE, M. v. dem[a]: Fischzucht. - In: Handbuch der Fischzucht und Fischerei. Unter Mitwirkung von B. Benecke und E. Dallmer. Hrsg. v. Max von dem Borne. - Berlin: Parey 1886:217-329.

BORNE, M. v. dem[b]: Süßwasserfischerei. - In: Handbuch der Fischzucht und Fischerei. Unter Mitwirkung von B. Benecke und E. Dallmer. Hrsg. v. Max von dem Borne. - Berlin: Parey 1886:563-676.

BORNE, M. v. dem (Hrsg.): Handbuch der Fischzucht und Fischerei. [Unter Mitwirkung von B. BENECKE und E. DALLMER]. Berlin: Parey 1886.

BORRIES, B. v.: Didaktische Möglichkeiten und Grenzen der Umweltgeschichte. - In: BAYERL, G./FUCHSLOCH, N./MEYER, T. (Hrsg.): Umweltgeschichte - Methoden, Themen, Potentiale: Tagung des Hamburger Arbeitskreises für Umweltgeschichte, Hamburg 1994. - Münster; New York: Waxmann 1996 [Cottbuser Studien zur Geschichte von Technik, Arbeit und Umwelt;1]:309-324.

BORRIES, B. v.: Umweltgeschichte. Vergessene Einsichten und neuartige Herausforderungen.- In: CALLIEß, J./RÜSEN, J./STRIEGNIETZ, M. (Hrsg.): Mensch und Umwelt in der Geschichte. - Pfaffenweiler: Centaurus 1989:353-375.

BORRIES, Hans-Walter: Altlastenerfassung und -Erstbewertung durch multitemporale Karten- und Luftbildauswertung. Würzburg: Vogel 1992.

BORST, Otto: Alltagsleben im Mittelalter: mit zeitgenössischen Abbildungen. - 6. Aufl. - Frankfurt/Main: Insel-Verl. 1987.

BOSCH, M. et al.: Der Hochrhein. Landschaft und Alltagsleben in alten Photographien. - Karlsruhe: Braun 1997.

BOSCHERT, M./KRAMER, M.: Wässerwiesen am südlichen Oberrhein: ein Projekt zur Wiederaufnahme der Wiesenwässerung. In: Einfluß von Vernässung und Überstauung auf Wirbellose: Referate und Ergebnisse eines Workshops 1997: 297-304.

BOSSE, H.: Die Forst-, Flur- und Gewässernamen der Ueckermünder Heide. - erg. Nachdruck d. 1. Aufl. - Köln, Graz: Böhlau 1962 [1941] [Veröffentlichungen der historischen Kommission für Pommern: Reihe 5, Forschungen zur pommerschen Geschichte;2].

BOSSE, T.: Mühlen: 120 Mühlengeschichten, Kreis Gifhorn, Wolfsburg, Hasewinkel. - Hannover: Schlüter 1991.

BÖSSNECK, U.: Extensiv genutzte Fischteiche als Refugial-Lebensräume für hochgradig bestandsbedrohte Arten: der Juteteich bei Triebes (Lkr. Greiz). - In: Landschaftspflege und Naturschutz in Thüringen 38 2001:50-54.

BOSTELMANN, H.: Wasser- und Windmühlen im Kreis Dannenberg. - Lüneburg: Selbstverl. 1934.

BOSTELMANN, H.: Wasser- und Windmühlen im alten Kreise Winsen. - Lüneburg: Selbstverl. 1935.

BOSTELMANN, R./HINSENKAMP, G./KERN, K.: Naturnahe Umgestaltung von Fließgewässern. Teil 1: Leitfaden, Teil 2: Dokumentation ausgeführter Projekte. Hrsg.: Ministerium für Umwelt Baden-Württemberg. - Stuttgart 1992 [Handbuch Wasserbau;2].

BOTT, R.: Die Flußkrebse Europas (Decapoda, Astacidae). - Frankfurt/Main: Kramer 1950 [Schriftenreihe:Abhandlungen der Senckenbergischen Naturforschenden Gesellschaft;483].

BÖTTCHER, A.: Auf den Spuren der neuzeitlichen Eisenverhüttung im Mittelharz. - In: KLEßEN, R. (Hrsg.): Historischer Bergbau und Hüttenwesen im Mittelharz - Exkursionsführer. - Berlin 2000 [Geographisches Institut, Humboldt-Universität zu Berlin, Arbeitsberichte;46]:111-117.

BÖTTGER, C. H. (Hrsg.): Beschreibung der Gesundbrunnen und Bäder bey Hofgeismar. - Cassel 1772 [Reprint hrsg. von Helmut Burmeister. - Hofgeismar: Stadtmuseum 1989].

BOWLER, P. J.: Viewegs Geschichte der Umweltwissenschaften: ein Bild der Naturgeschichte unserer Erde. - Braunschweig et al.: Vieweg 1997 [Viewegs Reihe zur Geschichte der Naturwissenschaften]

BOYKE, H. J.: Darstellung der Teiche und Gräben des Burgstätter Reviers in Clausthal um 1771 nach dem Riß des Markscheiders C. A. Rausch. Hrsg.: Harzwasserwerke. - Clausthal-Zellerfeld 1996. 
BRACHMANN, H./VOGT, H.-J. (Hrsg.): Mensch und Umwelt: Studien zu Siedlungsausgriff und Landesausbau in Ur- und Frühgeschichte. - Berlin: Akademie-Verl. 1992.

BRAHMS, A.: Anfangs-Gründe der Deich- und Waßer-Baukunst [...]. - Leer: Schuster 1989 [unveränd. Nachdr. d. Ausg. Aurich 1767 u. 1773 [2 Teile].

BRAND, F.: Zur Genese der ländlich-agraren Siedlungen im Lippischen Osning-Vorland. - Münster/Westf.: Geographische Kommission 1967 [Landeskundl. Karten u. Hefte d. Geogr. Komm. f. Westfalen, Reihe: Siedlung u. Landschaft in Westfalen;6/Sonderveröff. D. Naturwissenschaftl. u. Hist. Vereins f. d. Land Lippe;17]; Zugl.: Münster, Univ., Diss. 1965.

BRAND, H. D.: Die Bäder im Oberharz, eine fremdenverkehrsgeographische Untersuchung. - Göttingen, Hannover 1987 [Schriften d. Wirtschaftswiss. Gesell. z. Stud. Nieders., R.A.; 84]

BRANDE, A. et al.: Der Gutspark Tegel in historisch-ökologischer Sicht. - In: „Der Bär von Berlin“. Jahrbuch des Vereins für die Geschichte Berlins 36 1987:197-225.

BRANDENBURG 2003 [URL = www.brandenburg.de/land/mlur/service/berichte/fisch_02.pdf;7.11.2003].

BRANDT, E. (Hrsg.): Perspektiven der Umweltwissenschaften. - 1. Aufl. - Baden-Baden: Nomos 2000 [Umweltrecht und Umweltpolitik;2].

BRANDT, E.: Interdisziplinarität in den Umweltwissenschaften. - In: BRANDT, E. (Hrsg.): Perspektiven der Umweltwissenschaften. - Baden-Baden: Nomos 2000 [Umweltrecht und Umweltpolitik;2]:49-58.

BRANDT, F. W: Fähren der Unterweser. - Oldenburg: Isensee 1993.

BRANDT, K.: Historisch-geographische Studien zur Orts- und Flurgenese in den Dammer Bergen. Göttingen 1971 [Göttinger Geographische Abhandlungen;58].

BRANDT, K.: Die Höhenlage ur- und frühgeschichtlicher Wohnniveaus in nordwestdeutschen Marschgebieten als Höhenmarken ehemaliger Wasserstände. - In: Eiszeitalter und Gegenwart 30 1980:161-170.

BRANDT, K.: Küstenhandelsplätze des frühen und hohen Mittelalters zwischen Ems und Weser. - In: Berichte zur dt. Landeskunde 52/2 1978:159-174.

BRASSEL, K./VCKOVSKI, A./SCHMITT, E.: Informatisierung der Geographie. - In: Geographica Helvetica 2 1998:43-50.

BRAUER, H.: Handbuch des Umweltschutzes und der Umweltschutztechnik. Band 1: Emissionen und ihre Wirkungen. Berlin et al.: Springer 1996.

BRAUN, B./KONOLD, W.: Kopfweiden: Kulturgeschichte und Bedeutung der Kopfweiden in Südwestdeutschland. - UbstadtWeiher: Verl. Regionalkultur 1998 [Schriftenreihe: Beihefte $\mathrm{zu}$ den Veröffentlichungen für Naturschutz und Landschaftspflege in Baden-Württemberg;89].

BRAUN, G./BUZIN, R./WINTGES, T. (Hrsg.): GIS und Kartographie im Umweltbereich. - Heidelberg: Wichmann 2001.

BRAUN, S./NEUHAUS, A.-K.: Modellhafte Erarbeitung eines ökologisch begründeten Sanierungskonzeptes für die Lahn. Hrsg.: Bundesministerium für Forschung und Technologie, Bonn. - Gießen: Regierungsbezirk, Dez. f. Wasserwirtschaft ; Univ. Gießen, GH Kassel, FB 14 Bauingenieurwesen, Inst. f. Landwirtschaftl. Betriebslehre, Abt. Projekt- und Regionalplanung 1987.

BREDERLOW, C. G. Fr.: Der Harz. - Braunschweig: S.W. Ramdohr’s Kunsthandlung 1851.

BREEST, K.: Studien zur Mittleren Steinzeit in der Elbe-Jetzel-Niederung (Landkreis Lüchow-Dannenberg). - In: Veröffentlichungen der urgeschichtlichen Sammlungen des Landesmuseums zu Hannover 47 1997:141-389.

BREHM, A. E.:: Illustrirtes Thierleben. - Vollst. Faks.-Ausg. d. 1. Aufl.. von „Brehms Thierleben“, 1863-1869. - Stuttgart: Stuttgarter Faks.-Ed. 1979.

BREHM, J./MEIJERING, M. P. D.: Fließgewässerkunde: Einführung in die Ökologie der Quellen, Bäche und Flüsse. - 3. überarb. Aufl. - Wiesbaden: Quelle und Meyer 1996 [Biologische Arbeitsbücher;36].

BREMBACH, M.: Die Trave: Ein Fluß mit vielen Gesichtern. - Bad Oldesloe: Oho Verl. 2000.

BREMER, Eckhard: Die Nutzung des Wasserweges zur Versorgung der römischen Militärlager an der Lippe. - Paderborn, Münster: Media Print 2001 [Siedlung und Landschaft in Westfalen; 31 - Schriftenr. d. Geograph. Komm. f. Westf.; zugl. Veröff. d. Altertumskomm. f. Westf.; Landschaftsverband Westfalen-Lippe;12].

BRETSCHNEIDER, H. (Hrsg.): Taschenbuch der Wasserwirtschaft. - 7.Aufl.- Hamburg et al.: Parey 1993.

BREUER, T.: Naturlandschaft, Kulturlandschaft, Denkmallandschaft. - In: Historische Kulturlandschaften. ICOMOS-Hefte des Deutschen Nationalkommitees für Denkmalschutz XI. München 1993:13-19.

BREUER, T./JÜRGENS, C. (Hrsg.): Luft- und Satellitenbildatlas Regensburg und das östliche Bayern. - München: Pfeil 1988.

BRIEM, E.: Formen und Strukturen der Fließgewässer: ein Handbuch der morphologisshen Fließgewässerkunde. Hrsg.: ATVDVWK. - Hennef: GFA 2002 [ATV-DVWK-Arbeitsbericht]. 
BRIEM, E.: Die Gewässerlandschaften der Bundesrepublik Deutschland: morphologische Merkmal der Fließgewässer und ihrer Auen - Teil 1: Fließgewässerformen - Fließgewässerstrukturen - Fließgewässertypologie. Hrsg.: Deutsche Vereinigung für Wasserwirtschaft, Abwasser und Abfall, ATV-DVWK. - Hennef: ATV-DVWK 2003 [ATV-DVWK-Arbeitsbericht].

BRIMBLECOMBE, P./PFISTER, C. (Hrsg.): The silent countdown. Essays in European environmental history. - Berlin et al.: Springer 1990.

BRIMBLECOMBE, P.: The big smoke: a history of air pollution in London since medieval times. - London et al.: Methuen 1987.

BRINKER, W.: Wasserspeicherung in Zisternen. Ein Beitrag zur Frage der Wasserversorgung früher Städte. - In: LeichtweissInstitut für Wasserbau der Technischen Universität Braunschweig 109 1990:10.

BRINKHUIZEN, Dick Constantin: Ichthyo-archaelogisch onderzoek: methoden en toepassing aan de hand van Romains vismateriaal uit Velsen; [mit englischer Zusammenfassung]. - Groningen: Rjiksuniv. 1989 [Hochschulschrift: Rjiksuniv., Diss. 1989].

BRIX, M. (Hrsg.): Main-Donau-Kanal: Ersatzlandschaft im Altmühltal. - München: Callwey 1988.

BROCKHAUS [DER GROßE BROCKHAUS], Bd. 1-12. - 18. völlig neubearb. Aufl. - Wiesbaden 1979.

BROCKHAUS-Kalender 2002.

BROEKER, W. S.: Plötzliche Klimawechsel. - In: Spektrum der Wissenschaft 1 1996:86-92.

BROERMANN, J. B. Kulturlandschaftskataster für urbane Räume: Freiflächen. Dargestellt an Beispielen aus Hamburg. Hamburg: Selbstverlag 2003 [Kulturlandschaftsforschung und Industriearchäologie;1].

BROGATIO, H.-P. (Hrsg.): Geographische Namen in ihrer Bedeutung für die landeskundliche Forschung und Darstellung: Referate des 8. Arbeitstreffens des Arbeitskreises Landeskundliche Institute und Forschungsstellen in der Deutschen Akademie für Landeskunde, Trier, 21. - 23. Mai 1988. - Trier 1999 [DL-Berichte und Dokumentationen;2].

BROGATIO, H.-P./SPERLING, W.: Der Einsatz von Karten in der landkundlichen Arbeit: zwei Beispiele aus Niederschlesien. In: Jahrbuch der Schlesischen Friedrich-Wilhelms-Universität zu Breslau 38/39 1997/98:813-830.

BROGLE, F.: Die Flößerei der oberrheinischen Gebiete Laufenburg-Basel. - Basel: Frick 1952 [Vom Jura bis zum Schwarzwald 27/1,2]; Zugl.: Basel, Univ., Diss. 1952.

BROHMER, P./EHRMANN, P./ULMER, G.: Die Tierwelt Mitteleuropas: ein Handbuch zu ihrer Bestimmung als Grundlage faunistisch-zoogeographische Arbeiten, Bd.2: Mollusca, Crustacea, Isopoda, Myriapoda. - Leipzig: Quelle \& Meyer [ca. 1962].

BROHMER, P.: Fauna von Deutschland: ein Bestimmungsbuch unserer heimischen Tierwelt. - 16. neu gestaltete u. erw. Aufl.. Heidelberg: Quelle und Meyer 1984

BROMME, E.: Oelknitz: ein Beitrag zur Siedlungsgeographie Thüringens. - Halle a. d. Saale: Klinz 1933; Zugl.: Jena, Univ., Diss. 1933.

BRONGERS, J. A.: Air photography and Celtic Fields research in the Netherlands. - Amersfoort 1976 [Nederlandse Oudheden;6].

BRÖNNIMANN, S.[a]: Die schiff- und flößbaren Gewässer in den Alpen von 1500-1800: Versuch eines Inventars. - In: Geschichtsfreund. Mitteilungen des Historischen Vereins der fünf Orte Luzern, Uri, Schwyz, Unterwalden und Zug 150 1997:119-178.

BRÖNNIMANN, S.[b]: Zum Wassertransport in den Alpen während der Frühen Neuzeit. - In: Geographica Helvetica 52/4 1997:127-128.

BROUWER, W.: Der Einfluß des Wassers auf das Gedeihen von Gräsern im Reinbestand und die Wirkung der Witterungsfaktoren auf die Wiesenerträge. - Dessau: Zirchäus 1930; Zugl. Berlin, Landw. H., Diss. 1930.

BROUWER, W./STÄHLIN, A.: Bessere Nutzung des Saaletals durch Umbruch seiner Wiesen. - Jena 1937 [Arbeiten der Thüringischen Landwirtschaftlichen Versuchsstation].

BRÜGGEMEIER, F. J./MANSK, E.-E./POULUSSEN, P.: Environmental History Newsletter 1 1989:36-68, 15-18.

BRÜGGEMEIER, F.-J.: Umweltgeschichte - warum, wozu und wie ? Überlegungen zum Stellenwert einer Disziplin. - In: Historische Umweltforschung; Wissenschaftliche Neuorientierung - aktuelle Fragestellungen. Hrsg.: Isenberg, Wolfgang Bergisch Gladbach: Thomas-Morus-Akademie Bensberg 1992:9-26 [Bensberger Protokolle; 71].

BRÜGGEMEIER, F.-J.: Das unendliche Meer der Lüfte. Luftverschmutzung, Industrialisierung und Risikodebatten im 19. Jahrhundert. - Essen: Klartext 1996.

BRÜGGEMEIER, F.-J./ROMMELSPACHER, T.: Besiegte Natur. Geschichte der Umwelt im 19. und 20. Jahrhundert. - 2. Aufl. Beck 1989 [Beck'sche Schwarze Reihe;345].

BRÜGGEMEIER, F.-J./ROMMELSPACHER, T. (Hrsg.): Blauer Himmel über der Ruhr. Geschichte der Umwelt im Ruhrgebiet 1840-1990. - Essen: Klartext 1992.

BRÜNING, K.: Alte und neue Wasserwirtschaft im Harz und ihre natürlichen Grundlagen. - In: Jahrbuch d. Geographischen Gesellschaft zu Hannover 50 1928:113-140. 
BRÜNING, K.: Der Bergbau im Harze und im Mansfeldischen. - Braunschweig 1926 [Wirtschaftswiss. Ges. z. Stud. Niedersachsens, Reihe B;1].

BRUNNACKER, K./STRAUCH, Fr.: Beiträge zur Flußgeschichte im Holozön Mitteleuropas. - In: Geolog. Blätter NordostBayern 34/35 1985:503-515.

BRUNNEN - BÜRGER - BÄDER. Ein Erinnerungsband zur 350jährigen Geschichte des „Gesundbrunnens bei Hofgeismar“. Hofgeismar: Stadtmuseum 1989 [Schriftenreihe „Die Geschichte unserer Heimat“;3].

BRÜNNER, F./SCHÖLLHORN, J.: Bewirtschaftung von Wiesen und Weiden. - 2. neubearb. Aufl. - Stuttgart: Ulmer 1972.

BRUNNER, Karl: Virtuelle und wirkliche Welt: Umweltgeschichte als Mentalitätsgeschichte. - In: SPINDLER, K. (Hrsg.): Mensch und Natur im mittelalterlichen Europa: archäologische, historische und naturwissenschafliche Befunde. - Klagenfurt: Wieser 1998 [Schriftenreihe der Akademie Friesach;4]:327-344.

BUBENDEY, J. F. (Hrsg.): Handbuch der Ingenieurswissenschaften in 5 Teilen. - Leipzig, Berlin: Engelmann 1904ff. - Bd. 1: Die Gewässerkunde 1911, Bd. 2: Stauwehre 1912, Bd. 3: Der Wasserbau 1914.

BÜCHER, J.: Von der Leinenbleiche zum „Beueler Dorf“. Gewerbliches Bleichen und Waschen in Beuel. - In: „Die Große Wäsche“: Eine Ausstellung des Landschaftsverbandes Rheinland, Rheinisches Museumsamt, Brauweiler in Zusammenarbeit mit dem Rheinischen Freilichtmuseum - Landesmuseum für Volkskunde, Mechernich-Kommern. - Köln: Rheinland-Verl., 1988 [Schriften d. Rhein. Museumsamtes;42; Zugl.: Schriften d. Rhein. Freilichtmuseums - Landesmuseum f. Volkskunde;34]:76-82.

BUCHWALD, G. v.: Schleswig-Holsteinische Fischereiverhältnisse im 15. Jahrhundert. - In: Zeitschrift der Gesellschaft für Schleswig-Holsteinische Geschichte 12/1882:73.

BUCKLAND, F.: Natural History of British Fishes: their structure, economic uses and capture by ret and rod. - London: Soc. For Promoting Christian Knowledge [1881].

BÜDDIG, C.: Die „Timmerhorner Teiche“ unterm Hammer. - In: Hamburger Abendblatt v. 25.10.2003 [URL = http://www.abendblatt.de/daten/2003/10/25/222344.html?prx=1; 26.05.2004].

BUHS, A.: Holzschleifereien und Pappenfabriken im Innerstetal: eine Episode der Wirtschaftsgeschichte im Oberharz. - In: HarzZeitschrift 48/49 1998:219-238.

BULLERMANN, H.: Wasserwege. - In: Der Speicher. Heimatbuch des Landkreises Celle 1930:332-335.

BUNZEL-DRÜKE, M./SCHARF, M.: Heckrinder in der Lippeaue. - In: Natur und Landschaftskunde 31 1995:49-54.

BUND, B.: Der Wandel der Kulturlandschaft Nordschwarzwald seit der 2. Hälfte des 19. Jahrhunderts: eine historische RaumZeit-Analyse mit Hilfe eines Geographischen Informationssystems (GIS). - Freiburg (Breisgau): Forstliche Versuchs- und Forschungsanstalt Baden-Württemberg, 1998 [Mitteilungen der Forstlichen Versuchs- und Forschungsanstalt BadenWürttemberg;204: Abteilung Betriebswirtschaft;49]; Zugl: Freiburg/Breisgau, Univ., Diss. 1998.

BUNDESMINISTERIUM FÜR BILDUNG, Wissenschaft, Forschung und Naturschutz (Hrsg.): Fluß- und Seenlandschaften. Bonn: 1996 [Berichte aus der ökologischen Forschung].

BUNDESMINISTERIUM FÜR RAUMORDNUNG, Bauwesen und Städtebau: Das Modellvorhaben Povel in Nordhorn Revitalisierung einer innerstädtischen Industriebrache. - Münster 1998 [Westf. Geogr. Schriften;48]:173-174.

BUNDESMINISTERIUM FÜR UMWELT, Naturschutz und Reaktorsicherheit (Hrsg.): Bewirtschaftungsplan in Hessen, aufgezeigt am Bewirtschaftungsplan Untermain. - Bonn 1987.

BUNDESMINISTERIUM FÜR VERBRAUCHERSCHUTZ, Ernährung und Landwirtschaft (Hrsg.): Jahresbericht über die Deutsche Fischwirtschaft. - Bonn-Berlin 2003.

BÜNGER, L.: Gewässer und historisches Fischereiwesen in Lippe. Hrsg. v. Springhorn, Rainer. - Detmold: Naturwissenschaftl. u. Hist. Verein Lippe u. Lipp. Heimatbund 1996 [Sonderveröff. d. Naturwiss. u. Hist. Vereins f. d. Land Lippe;45].

BÜNSTORF, J.: Die ostfriesische Fehnsiedlung als regionaler Siedlungsform-Typus und Träger sozial-funktionaler Berufstradition. - Göttingen: Geograph. Inst. d. Univ. 1966 [Göttinger Geogr. Abh.;37]; Zugl.: Göttingen, Univ., Diss. 1966.

BUNSE, J.: Wassermühlen im Raume Marsberg. - Marsberg: Schulte 1991.

BÜNZ, E. et al.: Fränkische Urbare. Verzeichnis der mittelalterlichen urbariellen Quellen im Bereich des Hochstifts Würzburg. Neustadt/Aisch 1998 [Veröffentlichungen der Gesellschaft für Fränkische Geschichte:Reihe 10, Quellen zur Rechts- und Wirtschaftsgeschichte Frankens;13].

BURCKHARDT, L.: Landschaft ist transitorisch. - In: TOPOS. European Landscape Magazine 6 1994:38-44.

BURDACK, J.: Die städtische Peripherie zwischen „suburbanen“ und „postsuburbanen“ Entwicklungen. - Leipzig: Dt. Akad. f. Landeskde e. V. und des Instituts für Länderkunde 2001 [Berichte zur deutschen Landeskunde;2-3].

BURGGRAAFF, P.: Die Bedeutung alter Karten im Tätigkeitsbereich der Angewandten Historischen Geographie: - In: Erschließung und Auswertung historischer Landkarten. - Köln: Rheinland-Verl. 1988 [Landschaftsverband Rheinland: Archivberatungsstelle Rheinland;18]:175-202. 
BURGGRAAFF, P.: Kulturlandschaftswandel am unteren Niederrhein seit 1150. - Köln: Rheinland-Verl. 1992 [Geschichtlicher Atlas der Rheinlande: Beiheft;4,7].

BURGGRAAFF, P.: Der Begriff „Kulturlandschaft“ und die Aufgaben der „Kulturlandschaftspflege“ aus der Sicht der Angewandten Historischen Geographie. - In: Natur- und Landschaftskunde 32 1996:10-11.

BURGgRAAFF, P.: Angewandte Historische Geographie im ländlichen Raum. Erfahrungsbericht und Perspektiven. - In: BURGGRAAFF, P./KLEEFELD, K.-D. (Hrsg.): Perspektiven der Historischen Geographie: Siedlung - Kulturlandschaft Umwelt in Mitteleuropa. - Bonn: Selbstverl. 1997:235-243.

BURGGRAAFF, P. [Red.]: Baum, Wald, Landschaft, Mensch, Kulturlandschaft - Erbe und Zukunft von und für Generationen : Symposion vom 27.10.1999 im Jugendwaldheim Obereimer/Arnsberg. - Aachen 2000 [Schriftenreihe: Kulturlandschaft;9,2].

BURGGRAAFF, P.: Fachgutachten zur Kulturlandschaftspflege in Nordrhein-Westfalen: im Auftrag des Ministeriums für Umwelt, Raumordnung und Landwirtschaft des Landes NRW. - Münster: Geograph. Komm. f. Westfalen 2000 [Siedlung und Landschaft in Westfalen;27].

BURGGRAAFF, P.: Diskussion: „Kulturlandschaften als Erbe und Verpflichtung - Projekte und ihre ,Erträge’, alte und neue Spannungsfelder, Defizite ...“ - Veranstaltung Nr. 180 „Kulturlandschaften in Deutschland - Beispiele, Projekte, Spannungsfelder“; Bildungszentrum Eichholz der Konrad-Adenauer Stiftung, vom 02.07. - 04.07.2003; Mitschrift vom 4.07.2003.

BURGGRAAFF, P. et al.: Abschlußbericht zur modellhaften Konzeptentwicklung der Kulturlandschaft Heisterbacher Tal (ungedr. Manuskript 2001).

BURGGRAAFF, P./DENECKE, D./FEHN, K.: Bibliographie zur „Siedlungsforschung. Archäologie - Geschichte - Geographie in Mitteleuropa“": Neuerscheinungen 1996/97: - In: Siedlungsforschung 15 1997:353-421.

BURGGRAAFF, P./DENECKE, D./FEHN, K.: Bibliographie zur „Siedlungsforschung. Archäologie - Geschichte - Geographie in Mitteleuropa“ - In: Siedlungsforschung 11983 - 192001.

BURGGRAAFF, P./FEHN, K.: Bibliographie zur „Siedlungsforschung. Archäologie - Geschichte - Geographie in Mitteleuropa“: Neuerscheinungen 1998/99: - In: Siedlungsforschung 17 1999:403-480.

BURGGRAAFF, P./FISCHER, E./KLEEFELD, K.-D.: Klosterlandschaft Heisterbacher Tal. - Neuss: Neusser Dr. u. Verl. 2001 [Rheinische Landschaften;49].

BURGGRAAFF, P./KLEEFELD, K.-D.: Naturschutzgebietsausweisung und Kulturlandschaftspflegmaßnahmen am Beispiel der „Bockerter Heide“ (Stadt Viersen). - In:: Rheinische Heimatpflege, N. F. 31 1994:7-22.

BURGGRAAFF, P./KLEEFELD, K.-D.: Historisch-geographische Landesaufnahme des geplanten Braunkohlenreviers Garzweiler II. - In: DIX, A. (Hrsg.): Angewandte Historische im Rheinland. - Köln: Rheinischer Verein f. Denkmalpflege und Landschaftsschutz e. V. 1997:53-70.

BURGGRAAFF, P./KLEEFELD, K.-D.: Naturschutzgebietsausweisung und Kulturlandschaftsmaßnahmen am Beispiel der „Bockerter Heide“ (Stadt Viersen). Eine neue Aufgabe der Angewandten Historischen Geographie. - In: DIX, A. (Hrsg.): Angewandte Historische im Rheinland. - Köln: Rheinischer Verein f. Denkmalpflege und Landschaftsschutz e. V. 1997:2338.

BURGGRAAFF, P./KLEEFELD, K.-D.: Historische Kulturlandschaft und Kulturlandschaftselemente. Ergebnisse aus dem F+EVorhaben 80809075 des Bundesamtes für Naturschutz. - Bonn-Bad Godesberg: Verl: Bundesamt f. Naturschutz 1998 [Angewandte Landschaftsökologie;20].

BURGGRAAFF, P./KLEEFELD, K.-D.: Kulturlandschaftserleben in der Dingdener Heide, Kreis Wesel (Nordrhein-Westfalen). In: AURIG, R. (Hrsg.): Kulturlandschaft, ... 1999:124-135.

BURGGRAAFF, P./KLEEFELD, K.-D.: Der Kulturlandschaftsbegriff in Gesetzen und Konventionen: ein Praxisbericht. - In: Petermanns Geographische Mitteilungen 146/6 2002 „Kulturlandschaftsforschung“:16-25.

BURGGRAAFF, Peter/KLEEFELD, Klaus-Dieter: Die Pilotstudie: Kulturlandschaften an der unteren Rur (Kreis Heinsberg). - In: Rheinisches Kulturlandschaftskataster 2002:21-35

BURGGRAAFF, P./KLEEFELD, K.-D.: Klosterlandschaft Heisterbacher Tal im Naturpark Siebengebirge. - In: Die Erde. Bonn 2002:535-549.

BURGHARD, H.[a]: Die Räderloher Teiche. - In: SPARKASSE GIFHORN-WOLFSBURG (Hrsg.): Reizvolle Fluß- und Seenlandschaften im Raum Gifhorn-Wolfsburg. - Peine: Schlaeer 1988 [Schriftenreihe zur Heimatkunde der Sparkasse Gifhorn-Wolfsburg;4]:25-26.

BURGHARD, H.[b]: Der Isenhagener See und das Kloster. - In: SPARKASSE GIFHORN-WOLFSBURG (Hrsg.): Reizvolle Fluß- und Seenlandschaften im Raum Gifhorn-Wolfsburg. - Peine: Schlaeer 1988 [Schriftenreihe zur Heimatkunde der Sparkasse Gifhorn-Wolfsburg;4]:27-30.

BURGHARD, H.[c]: Isebeck und Stackmanns Teiche. - In: SPARKASSE GIFHORN-WOLFSBURG (Hrsg.): Reizvolle Flußund Seenlandschaften im Raum Gifhorn-Wolfsburg. - Peine: Schlaeer 1988 [Schriftenreihe zur Heimatkunde der Sparkasse Gifhorn-Wolfsburg;4]:31-32. 
BURGHARD, H.[d]: Das Teichgut. - In: SPARKASSE GIFHORN-WOLFSBURG (Hrsg.): Reizvolle Fluß- und Seenlandschaften im Raum Gifhorn-Wolfsburg. - Peine: Schlaeer 1988 [Schriftenreihe zur Heimatkunde der Sparkasse GifhornWolfsburg;4]:45-46.

BURGHARDT, U.: Canal du Midi: ein merkantilistischer Verkehrsweg. - In: Kultur und Technik 2 1993:22-29.

BURGIS, M. J./MORRIS, P./TROUGHTON, G.: The natural history of lakes. - Cambridge et al.: Cambridge University Press, 1987.

BURGSDORF, F. A. L. v.: Forsthandbuch. Allgemeiner theoretisch-praktischer Lehrbegriff sämmtlicher Forsterwissenschaften auf Seiner königlichen Majestät von Preussen allerhöchsten Befehl [...]. - 2. Aufl. - Berlin 1790.

BURKHARDT, R. B./OTTO, A. O./HESS; C.-R.: Gewässerrenaturierung und Landwirtschaft. Hrsg.: Hess. Auswertungs- und Informationsdienst für Ernährung, Landwirtschaft und Forsten [AID] e.V. - 3. Aufl. - Bonn: AID 1997 [Schriftenreihe: AID;1111].

BURNETT, C.: Visualization and analysis of landscape in information space. - Turku: Turun Yliopisto 2002 [Turun Yliopiston julkaisuja: Sarja A;151].

BÜRO FÜR BIOTOPMANAGEMENT + NATURSCHUTZ: Entwicklungs- und Pflegeplan Naturschutzgebiet Hubbelrather Bachtal. - Gelsenkirchen 1994.

BURTON, R.: Landscape evaluation. - In: PACIONE, M. (Hrsg.): Applied heography: principles and practise. - London, New York: Routledge 1999:236-245.

BUSCH, F. W.: Vom Siegerländer Erzbergbau. - Siegen: Selbstverl. 1977.

BUSCH, F. W.: Aus der Welt der Siegerländer Berg- und Hüttenleute. - Siegen: Siegberg-Verl. 1984.

BUSCH, F. W.: Von der Waldschmiede zur Eisenindustrie. Zweieinhalb Jahrtausende Eisenerzeugung und Eisenverarbeitung im Siegerland. - Kreuztal: Verl. die Wielandschmiede 1997.

BÜSCHEFELD, J.: Flüsse und Kloaken: Umweltfragen im Zeitalter der Industrialisierung (1870-1918). - Stuttgart: Klett-Cotta 1997 [Industrielle Welt;59]; Zugl. Bielefeld, Univ., Diss. 1997.

BÜSCHEFELD, J.: Der harte Kampf um weiches Wasser: Zur Umweltgeschichte der Kaliindustrie im 19. und frühen 20. Jahrhundert. - In: HAUPTMEYER, C.-H. (Hrsg.): Mensch - Natur - Technik: Aspekte der Umweltgeschichte in Niedersachsen und angrenzende Gebieten. - Bielefeld: Verl. f. Regionalgeschichte 2000 [Materialien zur Regionalgeschichte;2]:79-109.

BUSCHMANN-HÖLTGEN: Höfe und Familien im Kirchspiel Gerresheim vor 1805. - Ratingen 1986.

BUSSANG, B.: Hexensabbat: Flammentod in Gerresheim. - In: Rheinische Post Nr. 101 v. 30.04.2004.

BUSSE, G.: Flachsanbau und Leinenherstellung. - In: BIRKIGT-QUENTIN, B./BUSSE, G./SCHÄFER, W. (Hsrg.): Flachs und Leine zwischen Leine und Weser. Berichte und Bilder aus Adelebsen, Uslar und Wahlsburg. - Im Auftrag der Museen: Museum Uslar, Steinarbeiter-Museum Adelebsen, Schäferhausmuseum in Wahlsburg-Lippoldsberg. - Adelebsen et al. 1995:4-19.

BÜSSEM, E./NEHER, M. (Hrsg.): Arbeitsbuch Geschichte: Neuzeit 1, Quellen: 16. - 18. Jh. - Tübingen: Francke [UTB;625].

BUTLIN, R. A.: Theory and Methodology in Historical Geography. - In: PACIONE, M. (Hrsg.): Historical geography: progress and prospects. - London et al.: Croom Helm 1987 [Croom Helm progress in geography series]:16-45.

BUTLIN, R. A.: Historical Geography: Through the Gates of Space and Time. - London et al.: Edward Arnold 1993.

BÜTTNER, N.: Die Erfindung der Landschaft. Kosmographie und Landschaftskunst im Zeitalter Bruegels. - Göttingen: Vandenhoeck und Ruprecht 2000 [Rekonstruktion der Künste; 1]; Zugl.: Göttingen, Univ., Diss. 1998/99.

BUTZER, K.: Early Hydraulic Civilization in Egypt. - Chicago: University of Chicago Press 1976.

BUTZER, K.: Archaeology as human ecology: method and theory for a contextual approach. - Cambridge et al.: Cambrigde Univ. Press 1982.

BUTZIN, B. et al.: Leitbilder für Landschaften - ein Tagungsbericht. - In: Berichte zur dt. Landeskunde 75 2001:5-18.

BUZIN, R.: Multimedia-Kartographie: eine Untersuchung zur Nutzer-Orientierung kartomedialer Atlanten. - Osnabrück: Der Andere Verl. 2001; Zugl.: Dresden, Techn. Univ, Diss. 2001.

CAHN, E./KAUFMANN, E. (Hrsg.): Das Recht der Binnenfischerei im deutschen Kulturgebiet von den Anfängen bis zum Ausgang des 18. Jh. - Frankfurt/Main: Klostermann 1956.

CALLIEß, J./RÜSEN, J./STRIEGNIETZ, M. (Hrsg.): Mensch und Umwelt in der Geschichte. - Pfaffenweiler: Centaurus 1989 [Der Band umfaßt die Referate der Tagung "Mensch und Umwelt in der Geschichte" vom 21. bis 23. Juni 1985 in Loccum und wurde durch weitere Beiträge ergänzt].

CALVÖR, H.: Acta Historico-Chronologico-Mechanica circa Metallurgiam in Hercynia Superiori. Oder historisch-chronologische Nachricht und theoretische und practische Beschreibung des Maschinenwesens, und der Hülfsmittel bey dem Bergbau auf dem Oberharz: darin insbesondere gehandelt wird von denen Maschinen und Hülfsmitteln, wodurch der Bergbau gefördert 
wird, als von dem Markscheiden, Schacht- und Grubenbau, von Bohren und Schiessen [...]. - Braunschweig: Verl. Fürstliche Waysenhaus-Buchhandlung, 2. Bde. 1763.

CARL HERZOG zu Braunschweig und Lüneburg: Collectio legum, privato studio facta: 1745-1749; Sammelband; Bd. 49 [Verordnung betreffend die Holz-Flößung auf dem Schunter-Fluss: Wolfenbüttel, 9.5.1747].

CARLOWITZ, H. v.: Sylvicultura oeconomica oder haußwirthliche Nachricht und Naturgemäße Anweisung zur Wilden BaumZucht [...]. - Leipzig: Braun 1713.

CAROL, H.: Zur Diskussion von Landschaft und Geographie. - In: STORKEBAUM, W. (Hrsg.): Zum Gegenstand und zur Methode der Geographie. - Darmstadt: Wissenschaftl. Buchgesell. 1967 [Wege der Forschung;58]:475-514 [ursprünglich erschienen in Geographica Helvetica 11/2 1956:111-132].

CARSON, R. L.: Silent Spring - Boston: Mifflin 1962.

CERNÁ, E.: Die hochmittelalterliche Glaserzeugung im östlichen Teil des Erzgebirges. - In: JOCKENHÖVEL, A. (Hrsg.): Bergbau, Verhüttung und Waldnutzung im Mittelalter: Auswirkungen auf Mensch und Umwelt; Ergebnisse eines internationalen Workshops (Dillenburg, 11. - 15.Mai 1994, Wirtschaftshistorisches Museum „Villa Grün“). - Stuttgart: Steiner 1996 [Vierteljahrschrift für Sozial- und Wirtschaftsgeschichte: Beihefte;121]:173-180.

CHEVALLIER, A.: Die BLV-Enzyklopädie der Heilpflanzen: über 550 Heilkräuter, ihre medizinische Wirkung und Anwendung. -2. Aufl. - München et al: blv 2000.

CHRONIK DER STADT NORDHAUSEN. Nordhausen einst und jetzt. Hrsg.: Reichsschutzbund für Handel und Gewerbe e. V., Ortsgruppe Nordhausen. - Magdeburg: Verl. F. W. Willmann o. J.

CITYPOPULATION 2004 [URL = http.//www.citypopulation.de/Algeria_d.html;17.01.2004].

CLARKE, D. L. (Hrsg.): Spatial archaeology. - London et al.: 1977.

CLARKE, R.: Wasser. die politische, wirtschaftliche und ökologische Katastrophe - und wie sie bewältigt werden kann. München: Piper 1994.

CLASSEN, A.: 100 [Hundert] Jahre Landtechnik und Wiesenwirtschaft: Auswirkungen auf Amphibien und andere Wiesentiere ; mit einem Nachschlagewerk - Zitate, Zeittafeln, Bildteil. - Singen : Institut f. Landschaftsökologie u. Naturschutz 1997 [ILNWerkstattreihe;3].

CLAVAL, P.: The cultural approach and geography - the perspective of communication. - In: Norsk Geografisk Tidsskrift 55/3 2001:126-137.

CNOPF, W.: Die Entwicklung und wirtschaftliche Bedeutung der Teichwirtschaft in Mittelfranken. - Berlin: Verl. d. Dt. FischereiVereins 1927 [Schriftenreihe: Archiv für Fischereigeschichte;11]; Zugl.: Erlangen, Univ., Diss. 1927.

COLDIZ, G.: Auen; Moore, Feuchtgebiete. Gefährdung und Schutz von Feuchtgebieten. - Basel: Birkhäuser 1995.

COLERUS, J.: Oeconomia ruralis et domestica. Das ist: Ein sehr nutzliches Hauß-Buch und kurtze Beschreibung [...]. Auch Wildund Voegelfang, Weidwerck, Fischereyen [...] - Teil 1 und 2 - Mainz: Heyl 1645.

CONRADI, A./KINDEL, M.: Die Buhnenteiche der Oberweser. - In: Höxter-Corvey 45/4 1997:5-19.

COONES, P.: Landscape Geography. - In: The Student's companion to geography. Hrsg. von Alisdair ROGERS. - Oxford: Blackwell 1992:70-76.

CORDES, A.: Holzflößerei auf der Aller. - In: Der Speicher. Heimatbuch des Landkreises Celle 1930:338-340.

CORDES; R.: Die Binnenkolonisation auf den Heidegemeinheiten zwischen Hunte und Mittelweser: (Grafschaften Hoya und Diepholz) im 18. und frühen 19. Jahrhundert. - Hildesheim: Lax 1981 [Quellen und Darstellungen zur Geschichte Niedersachsens;93]; Zugl.: Göttingen, Univ., Diss 1981.

CORNFELS, A. L. S. de: Piscinarium oder Teichordnung, warinnen von Erbauung der Teiche, derselben Tämm, Röhren, Abläße, Untersuchung deß Wassers, Außrottung des Gerörichs, von Erziegung und Verstezung der Fisch [...] gehandelt wird. - o. O.; (Druckort: Öllmütz): Selbstverl.; (Drucker: Kylian) 1680.

COSGROVE, D. (Hrsg.): Mappings. - London: Reaktion Books 1999 [Critical views].

COSGROVE, D.[a]: An elemental division: water control and engineered landscape. - In: COSGROVE, D./PETTS, G. (Hrsg.): Water, Engineering and Landscape. Water control and landscape transformation in the modern period. - London: Belhaven 1990:1-11.

COSGROVE, D.[b]: Platonism and practicality: hydrology, engineering and landscape in sixteenth-century Venice. - In: COSGROVE, D./PETTS, G. (Hrsg.): Water, Engineering and Landscape. Water control and landscape transformation in the modern period. - London: Belhaven 1990:35-53.

COSGROVE, D./DANIELS, S. (Hrsg.): The iconography of landscape: essays on the symbolic representations, design and use of past environments. - Cambridge: University Press 1988 [Cambridge studies in historical geography;9].

COSGROVE, D./PETTS, G. (Hrsg..): Water, engineering and Landscape: water control and Landscape transformation in the modern period. - London: Belhaven 1990. 
COSGROVE, D./ROSCOE, B./RYCROFT, S.: Landscape and identity at Ladybower Reservoir and Rutland Water. - In: Transactions of the Institute of British Geographers 21/3 1996:534-551.

CRAMER, L. W.: Vollständige Beschreibung des Berg-, Hütten- und Hammerwesens nebst einigen statistischen und geographischen Nachrichten von der Grafschaft Altenkirchen. - Kreuztal: Verl. die Wielandschmiede 1993.

CRANACH, P. v.: Alte Karten als Quellen. - In: Cartographica Helvetica 22 2000:31-42.

CRANG, M.: Cultural geography. - London, New York: Routledge 1998 [Routledge contemporary human geography series].

CREYDT, D.: Historien um das Hasselbach- und Nagelbachtal im Solling. - In: Jahrbuch Landkreis Holzminden 8/9 1990/91:5760.

CRONE, P.: Die vorindustrielle Gesellschaft: eine Strukturanylyse. - München: dtv 1992.

CRONHEIM, W.: Die Fischzucht. - Hannover: Jänecke 1907 [Bibliothek der gesamten Landwirtschaft;34].

CROSBY, A. W.: Ecological imperialism: the biological expansion of Europe, 900-1900. - Cambridge et al: Cambrige Univ. Press 1986 [Studies in environment and history].

CROUTIER, A. L.: Wasser. Elixier des Lebens. Mythen und Bräuche, Quellen und Bäder. - München: Heyne 1995.

CRUMLEY, C. L.[a]: Preface. - In: CRUMLEY, C. L. (Hrsg.): Historical ecology: cultural knowledge and changing landscapes. Santa Fee: School of American Research Press 1994 (Scholl of American Research advanced seminar series):XIII-XIV

CRUMLEY, C. L.[b]: Historical Ecology: A Multidimensional Ecological Orientation. - In: CRUMLEY, C. L. (Hrsg.): Historical ecology: cultural knowledge and changing landscapes. - Santa Fee: School of American Research Press 1994 [Scholl of American Research advanced seminar series]:1-16.

CRUMLEY, C. L./MARQUARDT, W. H. (Hrsg): Regional Dynamics: Burgundian Landscapes in Historical Perspective. - San Diego: Academic Press 1987.

CRUMLIN-PEDERSEN, O.: Schiffe und Seehandelsrouten im Ostseeraum 1050-1350. - In: Lübecker Schriften zur Archäologie und Kulturgeschichte 7 1983:229-237.

CRUTZEN, P.: In der Ozondebatte wirbeln Unwahrheiten durch die Welt. [Mit Paule Crutzen sprach Claudia Ehrenstein]. - In: Die Welt 27.November 1995:9.

CURDES, G.: Stadt und Landschaft - Raum und Zeit. Festschrift für Erich Kühn (Nachruf). - In: Bauwelt 72 1981: 2112.

CURRIE, C. K.: The Early History of the Carp and its Economic Significance in England. - In: Agricultural History Review 39 1991:97-101.

CURRIE, C. K.: The Role of Freshwater Fish in Medieval Society. - In: Religion and Belief. Hrsg.: GRENVILLE, J./CARVER, M./JAMES, E.. - York 1992 [Pre-Printed Papers; 6]:89-94.

CZAYA, E.: Der Silberbergbau: aus Geschichte und Brauchtum der Bergleute. - 1. Aufl. - Leipzig: Köhler und Amelang 1990.

CZAYA, S.: Der Einfluß des Menschen auf die Abflussregime der Flüsse im Oberschlesischen Industriegebiet. - In: Die Erde 128 1997:117-129.

CZERANKA, M.: GIS-basierte Entscheidungsunterstützung in der naturschutzorientierten Raumplanung: dargestellt am Beispiel der Eingriffsregelung in der Flächennutzungsplanung. - 1. Aufl. - Vechta: Vechtaer Hochschul Verl. 1997 [Studien Umweltwissenschaften Vechta;1]; Zugl.: Vechta, Hochschule, Diss 1997.

DAHL, H.-J./HULLEN, M.: Studie über die Möglichkeiten zu Entwicklung eines naturnahen Fließgewässersystems in Niedersachsen. Hannover: Niedersächsisches Landesamt für Ökologie, Sonderdruck 1989.

DAHLMANN, D.: Handelsschiffahrt auf der Polarroute: Die Suche nach einer dauerhaften Schiffsverbindung zwischen den sibirischen Flussmündungen und den europäischen Häfen von der Mitte bis zum Ende des 19. Jahrhunderts. - In: Bremer Geographische Blätter 1 2001:95-106.

DAHN 2004 [URL = http://www.naturschutz.rlp.de/dahn_lp/landschaftsgeschichte.html;26.02.2004].

DALICHOW, F.: Die Gebiete der Teichwirtschaft. - Freiburg/Breisgau, Univ., Diss. 1970.

DALLMER, E.: Seefischerei. - In: Handbuch der Fischzucht und Fischerei. [Unter Mitwirkung von B. Benecke und E. Dallmer]. Hrsg. v. Max von dem Borne. - Berlin: Verl. Paul Parey 1886:333-560.

DALLMER, E.: Fische und Fischerei in süßen Wasser: mit besonderer Berücksichtigung der Provinz Schleswig-Holstein. Segeberg 1877.

DAMROTH, M./SEEHUBER, R.: Flachs: Züchtung, Anbau und Verarbeitung. - Stuttgart: Ulmer 1988.

DANIELS, P. et al.: Geography: a discipline for the twenty-first century. - In: DANIELS, P. et al.: Human Geography. Issues for the 21st Century. - Harlow et al.: Pearson 2001:1-5.

DANIELS, Peter/BRADSHAW, Michael/SHAW, Denis/SIDAWY, James: Human Geography. Issues for the 21st Century. Harlow et al.: Pearson 2001 . 
DARBY, H. C.: The relations of history and geography: studies in England, France and the United States. [With explanatory and contextual commentary by Michael Williams ...] - 1. Aufl. - Exeter, Devon : Univ. of Exeter Press 2002.

DAS MALERISCHE UND ROMANTISCHE DEUTSCHLAND: Die Veduten des Reisewerks aus den Jahren 1836-1841. Mit einem Nachwort von Marianne Bernhard. - 5. Aufl. - Dortmund: Harenberg 1988.

DASCHKEIT, A.: Umweltforschung interdisziplinär - notwendig, aber unmöglich? - In: DASCHKEIT, A./SCHRÖDER, W. (Hrsg.): Umweltforschung quergedacht. Perspektiven integrativer Umweltforschung und -lehre. - Berlin et al.: Springer 1998 [Umweltnatur- und Umweltsozialwissenschaften]:50-73.

DASCHKEIT, A./SCHRÖDER, W. (Hrsg.): Umweltforschung quergedacht. Perspektiven integrativer Umweltforschung und lehre. - Berlin et al.: Springer 1998 [Umweltnatur- und Umweltsozialwissenschaften].

DAUM, S./DE WINKEL, T.: Aufmessung des Geländes der Klosterabtei Heisterbach. Univ. Essen, FB Vermessungswesen, Dipl.arbeiten 2002.

DAUMANN, A.: Das Mühlengewerbe in Sachsen in der Zeit vom 11. bis zum 19. Jahrhundert. - Leipzig, Univ., Diss. 1934.

DAVIER, [?] v.: Die Teichwirtschaft in der 2. Hälfte des 18. Jh. - In: Zeitschr. f. Fischerei 231925.

DBZ [Deutsche Bauzeitschrift] 51/203 2003.

DELATOUCHE, R./SAVOY, E./GRAND, R.: L'Agriculture au Moyen Age: de la fin de l'Empire Romain au XVIe siécle. Paris : Boccard 1950

DELFS, Jürgen: Die Flößerei im Stromgebiet der Weser. - Bremen-Horn: Dorn 1952 [Schriften d. Wirtschaftswiss. Gesell. z. Stud. Nieders., R. A.;34; Veröff. Nieders. Amt f. Landesplanung und Statistik;34].

DELFS, J.: Die Flößerei auf Ilse, Aller und Oertze. - Gifhorn: Landkreis 1995 [Schriftenreihe des Kreisarchivs Gifhorn;8].

DELFS, L. et al.: Flößerei auf der Elbe, Teil 1: Wege und Ziele ihrer Erforschung. - 1. Aufl. - Lauenburg: Verein zur Förderung des Lauenburger Elbschiffahrtsmuseums e. V. 1992 [Buch Nr. 01-3].

DELIUS, Adolph: Die Teichwirthschaft. - Berlin: Schotte und Voigt 1875.

DEMBISKI, M./WERDER, U. (Hrsg.): Renaturierungen von Fließgewässern und Auen. - Hamburg: VSÖ-Publikationen 1997.

DEMOLL, R./MAIER, H. N. (Hrsg.): Handbuch der Binnenfischerei Mitteleuropas, 6 Bde. - Stuttgart: Schweitzerbart 1964.

DENCKER, C.: Hengstblut der Landespferdezucht Hessen-Nassau. Warm- und Kaltbluthengste und ihre Blutlinien 1900 bis 1940. - Hrsg.: Landesverband der Pferdezüchter Hessen-Nassau. - Frankfurt/Main 1941.

DENECKE, D.: Methodische Untersuchungen zur historisch-geographischen Wegeforschung im Raum zwischen Solling und Harz: Ein Beitrag zur Rekonstruktion der mittelalterlichen Kulturlandschaft. - Göttingen: Goltze 1969 [Göttinger Geographische Abhandlungen;54]; Zugl.: Göttingen, Univ., Diss. 1967.

DENECKE, D.: Historisch-landeskundliche Exkursionskarte von Niedersachsen, Bl. Osterode [1:50000, mit Erläuterungsheft]. In: Veröffentlichungen des Instituts für historische Landesforschung der Universität Göttingen 2, Teil 2. - Hildesheim 1970 [Kapitel: „Spätmittelalterliche und frühneuzeitliche Wirtschaftsanlagen, Bergbau und Hüttenbetriebe“:95-102, Kapitel: „Altstraßen“:107-112].

DENECKE, D.: Die historisch-geographische Landesaufnahme: Aufgaben, Methoden und Ergebnisse, dargestellt am Beispiel des mittleren und südlichen Leineberglandes. - In: HÖVERMANN, J./OBERBECK, G. (Hrsg.): Festschrift Hans Poser. Göttingen 1972 [Gött. Geograph. Abhandl.;60]:401-436.

DENECKE, D.: Die Rekonstruktion wüster Orts- und Hausgrundrisse mit Hilfe des Luftbildes. Methodische Untersuchungen am Beispiel der spätmittelalterlichen Wüstung Moseborn (Gem. Holzerode, Kr. Göttingen). - In: Nachrichten aus Niedersachsens Urgeschichte 43 1974:69-84

DENECKE, D.: Historische Siedlungsgeographie und Siedlungsarchäologie des Mittelalters. Fragestellungen, Methoden und Ergebnisse unter dem Gesichtspunkt interdisziplinärer Zusammenarbeit. - In: Zeitschrift f. Archäologie d. Mittelalters 3 1975:7-36.

DENECKE, D.: Historisch-landeskundliche Exkursionskarte von Niedersachsen, B1. Moringen (1:50000, mit Erläuterungsheft). In: Veröffentlichungen des Instituts für historische Landesforschung der Universität Göttingen 2, Teil 4. - Hildesheim 1976 [Kapitel: „Naturräumliche Gliederung“: 3-6; „Ländliche Siedlungen“:32-42: „Wirtschaftsanlagen“:207-218: „Altstraßen“":219-223].

DENECKE, Dietrich: Erzgewinnung und Hüttenbetrieb des Mittelalters im Oberharz und im Harzvorland. Erläuterungen zu einer [...] Übersichtskarte (1:100000). - In: Archäologisches Korrespondenzblatt 81978 [mit Kartenbeilage: Mittelalterliche Gruben und Hüttenbetriebe im Oberharz, Mittelharz und Harzvorland]:77-85.

DENECKE, D.: Zur Terminologie ur- und frühgeschichtlicher Flurparzellierungen und Flurbegrenzungen sowie im Gelände ausgeprägter Flurrelikte. Grundzüge eines terminologischen Schemas. - In: Beck, H./Denecke, D./Jankuhn, H. (Hrsg.): Untersuchungen zur eisenzeitlichen und frühmittelalterlichen Flur in Mitteleuropa und ihrer Nutzung. - Göttingen: Abhandlungen der Akademie der Wissenschaften, Phil.-Hist. Klasse, III. Folge Nr. 115, Teil I, 1979:410-448. 
DENECKE, D.: Methoden und Ergebnisse der historisch-geographischen und archäologischen Untersuchung und Rekonstruktion mittelalterlicher Verkehrswege. - In: JANKUHN, H./WENSKUS, R. (Hrsg.): Geschichtswissenschaft und Archäologie. Sigmaringen 1979 [Vorträge und Forschungen;22]:433-483.

DENECKE, D.: Historical-geographical regional surveys. Methods, procedures and designs of cartographic recording. - In: BRANDON, P./MILLMAN, R. (Hrsg.): Recording Historic Landscapes, Principles and Practice. Polytechnic of North London, Dept. of Geography, Occasional Publication 2. - London 1980:44-49.

DENECKE, D.: Sozialtopographie und sozialräumliche Gliederung der spätmittelalterlichen Stadt. Problemstellungen, Methoden und Betrachtungsweisen der historischen Wirtschafts- und Sozialgeographie. - In: Über Bürger, Stadt und städtische Literatur im Spätmittelalter. Hrsg. v. Josef Fleckenstein und Karl Stackmann. - Göttingen 1980 [Abhandlungen der Akademie der Wissenschaften in Göttingen, Phil.-Hist. Klasse, Dritte Folge;121]:161-202.

DENECKE, D.: Erhaltung und Rekonstruktion alter Bausubstanz in ländlichen Siedlungen. Historische Siedlungsgeographie in ihrer planerischen Anwendung. - In: Berichte zur dt. Landeskunde 55 1981:343-380.

DENECKE, D.[a]: Applied historical geography and geographies of the past: historico-geographical change and regional process in history. - In: BAKER, A. R. H./BILlingE, M. (Hrsg.): Period and Place. Research Methods in Historical Geography. Cambridge Studies in Historical Geography. - Cambridge 1982:127-135 und 332-338.

DENECKE, D.[b]: Historische Geography und räumliche Planung. - In: Erdkunde 36 1982:84-90.

DENECKE, D.: Erhaltung und Rekonstruktion historischer Substanz in ländlichen Siedlungen. Bericht über die 8. Arbeitstagung des Arbeitskreises für genetische Siedlungsforschung in Mitteleuropa, Basel 1981. - In: Siedlungsforschung 1 1983:225-231.

DENECKE, D.[a]: Historisch-geographische Stadtforschung. Problemstellungen - Betrachtungsweisen - Perspektiven. - In: 44. Dt. Geographentag Münster 1983. Tagungsbericht und wissenschaftliche Abhandlungen. - Wiesbaden: Steiner 1984:136144.

DENECKE, D.[b]: Münden und Umgebung im Jahre 1785. Erläuterungen zum Blatt 160 der Kurhannoverschen Landesaufnahme des 18. Jahrhunderts, M. 1:25000. Hannover 1984 [Aufdruck auf der farbigen Ausgabe des Kartenwerkes, 8 Seiten]

DENECKE, D.[a]: Einbeck und das Einbecker Becken. Der Wandel historisch-geographischer Fragestellungen in der Entwicklung der Siedlungsforschung. - In: Einbecker Jahrbuch. Hrsg. v. Horst Hülse i. A. des Einbecker Geschichtsvereins; Bd. 36. Einbeck 1985:13-36.

DENECKE, D.[b]: Historisch-geographische Fragestellungen zur mittelalterlichen Siedlungsentwicklung im unteren Eichsfeld. In: Nachrichten aus Niedersachsens Urgeschichte. Hrsg. v. der archäologischen Komm. für Niedersachsen;54 1985:27-38.

DENECKE, D.[c]: Historische Geographie und räumliche Planung. - In: Beiträge zur Kulturlandschaftsforschung und Regionalplanung. Hrsg. v. Albert Kolb und Gerhard Oberbeck . - Hamburg 1985 [Mitteilungen d. Geogr. Gesell. Hamburg; 75]:3-55.

DENECKE, D.[d]: Wüstungsforschung als siedlungsräumliche Prozeß- und Regressionsforschung. - In: Siedlungsforschung 3 1985:9-35.

DENECKE, D.: Diskussionsbeitrag auf der 12. Tagung des AK f. genetische Siedlungsforschung,1985; zitiert in: FEHN, Klaus: Verkehrswege und ihre Bedeutung für die Kulturlandschaft. Bericht über die 12. Tagung des Arbeitskreises für genetische Siedlungsforschung in Mitteleuropa vom 25. bis 28. September 1985 in Rendsburg. - Siedlungsforschung 4 (1986):239-252 (245)

DENECKE, D.[a]: Grundlagenforschung der historischen Geographie für die Erhaltung und Gestaltung unserer Kulturlandschaft. Einführung. - In: 46. Dt. Geographentag, München, 12.-16. Oktober 1987. Tagungsbericht und wissenschaftliche Abhandlungen. - Stuttgart: Steiner 1988:153-157.

DENECKE, D.[b]: Historisch-geographische Siedlungsforschung in Großbritannien. - In: FEHN, K./BRANDT, K./DENECKE, D./IRSIGLER, F.: Genetische Siedlungsforschung in Mitteleuropa und seinen Nachbarräumen. - Bonn: Verl. Siedlungsforschung 1988.

DENECKE, D.[c]: Research in German urban historical geography. - In: DENECKE, D./SHAW, G. (Hrsg.): Urban Historical Geography. Recent Progress in Britain and Germany. - Cambridge: Cambridge Univ. Press 1988 [Cambridge Studies in historical geography;10]:24-33.

DENECKE, D.[a]: Stadtgeographie als geographische Gesamtdarstellung und komplexe geographische Analyse einer Stadt. - In: Die Alte Stadt 16/1 1989:3-23.

DENECKE, D.[b]: Eingriffe des Menschen in die naturräumliche Landschaftsentwicklung in historischer Zeit: Folgen und erhaltene Relikte. - In: HERRMANN, B./BUDDE, A. (Hrsg.): Natur und Geschichte. Naturwissenschaftliche und historische Beiträge zu einer ökologischen Grundbildung. Sommerschule „Natur und Geschichte“ vom 14. bis 27. September 1989 an der Georg-August-Universität Göttingen. - Hildesheim: Gerstenberg 1989 [Schriftenreihe „Expert“ des Nieders. Umweltministers Hannover]:199-206.

DENECKE, D.[c]: Historisch-siedlungsgeographische Forschungsansätze der Betrachtung räumlicher Prozesse, Systeme und Beziehungsgefüge. - In: DENECKE, D./FEHN, K. (Hrsg.): Geographie in der Geschichte. - Stuttgart: Steiner 1989 [Erkundliches Wissen;96]:51-71. 
DENECKE, D.: Arbeitsfelder anwendungsorientierter Historischer Geography in Forschung, Lehre und Praxis. - In: Kulturlandschaftsforschung - Zs. f. Angewandte Hist. Geographie 1/2-3 1990:69-73.

DENECKE, D.[a]: Contributions to Historical Geography. - In: DITTMANN, A./LAUX, A. D. (Hrsg.): German Research on North America. A bibliography with comments and conotations. - Bonn 1992 [Bonner Geogr. Abhandl.;84]:47-52 und 201220 .

DENECKE, D.[b]: Die Besiedlung der höheren Mittelgebirge. Bericht über die 18. Tagung des Arbeitskreises für genetische Siedlungsforschung in Mitteleuropa vom 18.-21. September 1991 in Freiburg/Breisgau. - In: Siedlungsforschung 10 (1992):281-288.

DENECKE, D.[c]: Die Besiedlung des Westharzes: ein Bericht über jüngere Forschungen zum Bergbau. - In: Siedlungsforschung 10 1992:163-171.

DENECKE, D.[e]: Historische Umwelt und Altlandschaft im Freilandmuseum. Historisch-geographische Forschungs- und Betrachtungsansätze in der Konzeption des Oberpfälzer Freilandmuseums Neusath-Perschen. In: Freilandmuseen Kulturlandschaft - Naturschutz - am Beispiel des Oberpfälzer Freilandmuseums. Seminar 29.-30. April 1991 in NeusathPerschen. Hrsg., Bayerische Akademie für Naturschutz und Landschaftspflege (ANL). - Laufen/Salzach: ANL, 1992 [Laufener Seminarbeiträge;5/92]:9-17.

DENECKE, D.[f]: Ideology in the planned order upon the land: the example of Germany. - In: BAKER, A. R. H./BIGER, G.: Ideology and landscape in historical perspective: essays on the meanings of some places in the past. - Cambrige: Univ. Press 1992 [Cambridge Studies in the historical geography;18]:303-329.

DENECKE, D.[g]: Siedlungsentwicklung und wirtschaftliche Erschließung der hohen Mittelegebirge in Deutschland. Ein historisch-geographischer Forschungsüberblick. - In: Siedlungsforschung 10 1992:9-47.

DENECKE, D.[h]: Straßen, Reiserouten und Routenbüche (Itinerare) im späten Mittelalter und in der frühen Neuzeit. - In: ERTZDORFF, X. v./NEUKIRCH, D. (Hrsg.): Reisen und Reiseliteratur im Mittelalter und in der frühen Neuzeit. Amsterdam: Cloe 1992 [Beiheft zum Daphnis,13]:227-253.

DENECKE, D.[i]: Zum Stand der Kartierung und Untersuchung von Relikten des Bergbaus und Hüttenwesens im Harz für das Mittelalter und die frühe Neuzeit. - In: Bergbau und Hüttenwesen im und am Harz. - Hannover 1992 [Veröffentlichungen der Historischen Kommission für Niedersachsen und Bremen;34]:21-29

DENECKE, D.: Entwicklungen in der deutschen Landeskunde: Helmut Jäger und die genetische Kulturlandschaftsforschung. Helmut Jäger zum 70. Geburtstag. - In: Berichte zur dt. Landeskunde 67 1993:6-43.

DENECKE, D.[a]: Die historisch-siedlungsgeographische Konzeption der Museumslandschaft und die Aufgabe eines Freilandmuseums im Rahmen einer kulturlandschaftsgenetischen und siedlungshistorischen Forschung. In: Kontroversen um die Konzeption und kulturelle Aufgabe von Freilichtmuseen - Das Beispiel: Oberpfälzer Freilandmuseum. - Nabburg 1994:74-89.

DENECKE, D.[b]: Eingriffe des Menschen in die Landschaft. Historische Entwicklung - Folgen - erhaltene Relikte. - In: Schubert, Ernst/Herrmann, Bernd (Hrsg.): Von der Angst zur Ausbeutung: Umwelterfahrung zwischen Mittelalter und Neuzeit. - Frankfurt/M. 1994:59-71.

DENECKE, D.[c]: Historische Geographie - Kulturlandschaftsgeschichte: anwendungsorientierte und angewandte Forschung: Gedanken zur Entwicklung und zum Stand der Diskussion. - Trier: Ber. z. dt. Landeskunde 68/2 1994:431-444.

DENECKE, D.[d]: Interdisziplinäre historisch-geographische Umweltforschung: Klima, Gewässer und Böden im Mittelalter und in der frühen Neuzeit. - In: Siedlungsforschung12 1994:235-263.

DENECKE, D.[e]: Wüstungsforschung als kulturlandschafts- und siedlungsgenetische Strukturforschung. - In: Siedlungsforschung 12 (1994):9-34.

DENECKE, D.[a]: Frühe Ansätze anwendungsbezogener Landes(Landschafts-)beschreibung in der deutschen Geographie (17501950). - In: Der Weg der deutschen Geographie: Rückblick und Ausblick. / 50. Deutscher Geographentag Potsdam, 2. bis 5. Oktober 1995. - Stuttgart: Steiner 1996:111-131.

DENECKE, D.[b]: „In Würdigung seiner hervorragenden Verdienste um die deutsche Landeskunde“: Verleihung der RobertGradmann-Medaille an Helmut Jäger. - Leipzig: Dt. Akad. f. Landeskde e. V. und des Instituts für Länderkunde 1996 [Berichte zur deutschen Landeskunde;1].

DENECKE, D.: Quellen, Methoden, Fragestellungen und Betrachtungsansätze der anwendungsorientierten geographischen Kulturlandschaftsforschung. - In: SCHENK, W./FEHN, K./DENECKE, D. (Hrsg.): Kulturlandschaftspflege. Beiträge der Geographie zur räumlichen Planung. - Stuttgart: Borntraeger 1997:35-49.

DENECKE, D.: Kulturlandschaftsgenese im Freiland- und Landschaftsmuseum: Konzeptionen der Dokumentation und Vermittlung. - In: AURIG, R. (Hrsg.): Kulturlandschaft [...] 1999:37-57.

DENECKE, D.: Geographische Kulturlandschaftsforschung für eine Kulturlandschaftspflege bezogen auf unterschiedliche Landschaftsräume. Ein Beitrag zur Diskussion. - In: Berichte zur deutschen Landeskunde 74/3 2000:197-219.

DENECKE, D.: 25 Jahre „Arbeitskreis für genetische Siedlungsforschung in Mitteleuropa“: Das interdisziplinäre und internationale Umfeld im Rückblick. - In: Siedlungsforschung 19 2001:271-308. 
DENECKE, D.: Vor und während der Reise. Informationen und Planungen zum Weg, zur Fahrt und zur Rast in historischer Zeit. In: Im Dienste der historischen Landeskunde 2002:459-470.

DENECKE, D.: Zentrale und periphere Räume und Standorte in der Kulturlandschaft - Der östliche Ostseeraum in historischgeographischer Perspektive. - Vortrag 30. Tagung des „Arbeitskreises für genetische Siedlungsforschung in Mitteleuropa“ in Greifswald vom 17. bis 20. September 2003.

DENECKE, Dietrich: Zur Terminologie ur- und frühgeschichtlicher Flurparzellierungen und Flurbegrenzungen sowie im Gelände ausgeprägter Flurrelikte. Grundzüge eines terminologischen Schemas. - In: BECK, H./DENECKE, D./JANKUHN, H. (Hrsg.): Untersuchungen zur eisenzeitlichen und frühmittelalterlichen Flur in Mitteleuropa und ihrer Nutzung: Bericht über die Kolloquien der Kommisssion für die Altertumskunde Mittel- und Nordeuropas in den Jahren 1975 und 1976. - Göttingen: Vandenhoeck \& Ruprecht 1979 [Abhandl. d. Akad. d. Wiss. in Gött., Phil.-Hist. Klasse, III. Folge, Nr. 115, Teil I]:410-448.

DENECKE, D./FEHN, K.: Einführung. - In: DENECKE, D./FEHN, K. (Hrsg.): Geographie in der Geschichte. - Stuttgart: Steiner 1989 [Erkundliches Wissen;96]:7-9.

DENECKE, D./FEHN, K. (Hrsg.): Geographie in der Geschichte. - Stuttgart: Steiner-Verl. Wiesbaden 1989 [Erdkundliches Wissen;96].

DENECKE, D./FEHN, K./SCHENK, W. (Hrsg.): Kulturlandschaftspflege. Beiträge der Geographie zur räumlichen Planung. Stuttgart: Borntraeger 1997.

DENERT, H.: Die Entwicklung des Oberharzer Silber-Blei-Zink-Erzbergbaus vom 16. bis zum Anfang des 20. Jh. - In: Beih. z. Geolog. Jahrbuch 118 1971:83-113.

DENKSCHRIFT 1933: „Die deutsche Binnenfischerei“. Denkschrift über ihre Lage und über die Wege zu ihrem Wiederaufbau. Hrsg.: Dt. Fischerei-Verein und Dt. Landwirtschaftsrat. - Berlin 1933.

DENZER, V.: Relikte und persistente Elemente einer ländlich geprägten Kulturlandschaft mit Vorschlägen zur Erhaltung und methodisch-didaktischen Aufbereitung am Beispiel von Waldhufensiedlungen im Südwest-Spessart. Ein Beitrag zur Angewandten Historischen Geographie.. - Mainz: Geogr. Inst. d. Johannes Gutenberg-Univ. 1996 [Mainzer Geographische Studien;43].

DENZER, V./HAASE, D.: Die Leipziger Flussauen im Wandel: Forschungsdesign eines geographischen Studienprojekts zur Erfassung und Bewertung von Nutzungspotentialen und -konflikten. - In: Koblenzer Geographisches Kolloquium 23 2001:191-199.

DENZER, V./KLEEFELD, K.-D.: Neue Informationssysteme und Angewandte Historische Geographie: einführende Überlegungen. - In: AURIG, R. (Hrsg.): Kulturlandschaft, Museum, Identität. Protokollband zur Tagung „Aufgaben, Probleme und Möglichkeiten der musealen Präsentation von Kulturlandschaftsrelikten“ der Arbeitsgruppe „Angewandte Historische Geographie“ vom 7. - 9.3.1996 in Plauen/Vogtland. - Beucha 1999 [Schriften der Rudolf-KötzschkeGesellschaft;4]:37-57.

DEPPE, A.: Flachs und Leinen. - Göttingen: Turm-Verl. 1925 [Bücher der Spinnstube. Aus dem niedersächsischen Berglande: Wirtschaftskundliche Reihe;1.]

DEPPE, A.: Holzflößerei auf der Göttinger Leine. - In: Göttinger Blätter NF 3/1 1937:59-63.

DEPPE, H. C.: Ansichten vom Fluss: Weser - Bremen - Live. - Bremen: Donath 1997.

DER ALTE BURGBEZIRK wieder hergestellt - die Ausgrabungsarbeiten an der Rothenburg. - In: Sangerhäuser Zeitung Nr. 266 v. 11.11.1938.

DER BERGBAU und Hüttenbetrieb im Lahn- und Dillgebiet und in Oberhessen. Hrsg.: Berg- und Hüttenmännischer Verein Wetzlar e.V. - Wetzlar 1932.

DER OBERKREISDIREKTOR des Kreises Steinfurt (Hrsg.): Wind- und Wasserkraftanlagen im Westmünsterland: Dokumentation des Bestandes, Überlegungen zur Erhaltung und Nutzung. - Steinfurt, Münster 1988.

DER ODERSTROM, sein Stromgebiet und seine wichtigsten Nebenflüsse. Eine hydrographische, wasserwirthschaftliche und wasserrechtliche Darstellung. Hrsg.: Bureau des Ausschusses zur Untersuchung der Wasserverhältnisse in den der Überschwemmungsgefahr besonders ausgesetzten Flussgebieten, 3. Bde. - Berlin 1898.

DER SPIEGEL: „Der Windmühlenwahn - Vom Traum umweltfreundlicher Energie zur hoch subventionierten Landschaftszerstörung“. Ausgabe Nr. 14. v. 29.03.2004:80-97.

DERCSÉNYI, B./KÉPEK, M.: Budapest. Budapest: Hungarian Pictures 1993 [Übersetzung von Gotlind B. Thurmann].

DETTEN, D. v.: Die Rheinaue Borth-Wallach. Genese einer Kulturlandschaft. - In: Das Erbenbuch der Deichschau BorthWallach. Eine Landschaftsaufnahme von 1580. - Wesel 1994:9-30.

DETTKE, B.: Die asiatische Hydra. Die Cholera von 1830/31 in Berlin und den preußischen Provinzen Posen, Preußen und Schlesien. - Berlin: de Gruyter 1995.

DEUTSCH, M.: Die Unstrutordnungen von 1607 und 1653. - In: ARATORA. Zeitschrift des Vereins für Heimatkunde, Geschichte und Schutz von Artern e.V., N.F. 8 1998:190-192. 
DEUTSCH, M.[a]: Erfassung und Bewertung historischer Hochwasserereignisse in Thüringen am Beispiel der Gera. - In: KOHLER, M./SCHÖNBEIN, F.: Symposium Naturkatastrophen in Mittelgebirgsregionen. - Karlsruhe 1999:31-33.

DEUTSCH, M.[b]: ,...so wusste auch kein Mensch allhier so ein großes Wasser...“: Nachrichten zum Hochwasser der Unstrut im Februar 1799.- In: Aratora, Zeitschrift des Vereins für Heimatkunde, Geschichte und Schutz von Artern e.V., N.F. 9 1999:6671.

DEUTSCH, M.[a]: Reconstruction of flood events in Middle Germany (1500-1900). - In: Georgiadi, A. (Hrsg.): Hydrological consequences of global climate changes. Geologic and historic analogs of future conditions.- Conference Paper and Abstracts, Fourth International Meeting on Global Continental Palaeohydrology "GLOCOPH 2000", Russian Academy of Sciences Moscow. - Moskau, 2000:79-80

DEUTSCH, M.[b]: Von Wassergeleit und Schleusengeld. Ein Beitrag zur Geschichte der Unstrut. - In: Aratora, Zeitschrift des Vereins für Heimatkunde, Geschichte und Schutz von Artern e.V., N.F. 10 2000:119-129.

DEUTSCH, M./PÖRTGE, K.-H.: Außergewöhnliche Niederschläge und Hochwässer in Thüringen - am Beispiel des Hochwassers der Unstrut vom Juli 1926 im Altkreis Mühlhausen. - Heidelberger Geographische Arbeiten 104 1996:289-299.

DEUTSCH, M./PÖRTGE, K.-H.[a]: Das Winterhochwasser der Unstrut (Thüringen) vom März 1947. - In: DEUTSCH, M./PÖRTGE, K.-H. (Hrsg.): Aktuelle und historische Hochwasserereignisse - Beiträge zur Jahrestagung des Arbeitskreises „Hydrologie“ im März 1997 in Erfurt. - Erfurt 1998 [Erfurter Geographische Studien;7]:129-161.

DEUTSCH, M./PÖRTGE, K.-H.[b]: Zur Untersuchung historischer Hochwässer der Werra (Abschnitt Eisfeld-Gerstungen) im Zeitraum von 1500 bis 1900. - In: MÄUSBACHER, R. (Hrsg.): Stofftransport, Methodik, Modellierung, Regionale Aspekte. - Jena 1998:18-19.

DEUTSCH, M./PÖRTGE, K.-H.: Hochwasser in Vergangenheit und Gegenwart. - In: Entwicklung der Umwelt seit der letzten Eiszeit. - München: Verlag Dr. F. Pfeil 2000 [Rundgespräche der Kommission für Ökologie;18]:139-153.

DEUTSCH, M./PÖRTGE, K.-H.[a]: Historical floods in Thuringia, using the example of the flood in Langensalza on the 15th June 1815. - In: Hlavinková, P. / Munzar, J. (Hrsg.): Nature and society in regional context (4th Moravian Geograpical Conference CONGEO`01 Tisnov, CR 10. - 14.09.2001). - Brno: Regiograph 2001:16-23

DEUTSCH, M./PÖRTGE, K.-H.[b]: Historische Hochwasserinformationen - Möglichkeiten und Grenzen ihrer anwendungsbezogenen Auswertung . - In: ATV-DVWK Landesverband Bayern (Hrsg.): Hochwasser - Niedrigwasser Risiken [Nürnberger Wasserwirtschaftstage Nürnberg 09. - 10.05.2001]. - München: Hirthammer 2001:23-38.

DEUTSCH, M./PÖRTGE, K.-H.[a]: Erfassung und Bewertung historischer Hochwasserereignisse in Thüringen am Beispiel der Gera. - In: Fiedler, F. / Kohler, M. / Nestmann, F. (Hrsg.): Naturkatastrophen in Mittelgebirgsregionen. - 1. Aufl. - Berlin: Verl. für Wissenschaft und Forschung GmbH 2002:185-212.

DEUTSCH, M./PÖRTGE, K.-H.[b]: Historische Hochwasser der Unstrut. -Fallbeispiel Altengottern (Unstrut-Hainich-Kreis). - In: SEDLACEK, Peter (Hrsg.): Exkursionsführer Thüringen 2002:41-43.

DEUTSCH, M./PÖRTGE, K.-H.[c]: Hochwasserereignisse in Thüringen. - Jena: Offizin Hildburghausen GmbH 2002 [Schriftenreihe der Thüringer Landesanstalt für Umwelt und Geologie;63].

DEUTSCH, M./PÖRTGE, K.-H.[d]: ,und es regnete Tag und Nacht“: Das Hochwasser von 1871 in Thüringen. - In: ATV-DVWK Landesverband Sachsen/Thüringen (Hrsg.): Von der Kläranlage zum Gewässer (ATV-DVWK Landesverbandstagung Sachsen/Thüringen am 5. Juni 2002 in Chemnitz ) 2002:187-193.

DEUTSCH, M./PÖRTGE, K.-H.[e]: Wasserwirtschaftliche Akten- und Kartenbestände (ca. 1700-1945) in den Archiven Mitteldeutschlands. Aussage- und Nutzungsmöglichkeiten für die Renaturierung von Fließgewässern. - In: FELDMANN, H. et al.: (Hrsg.): Die Elbe - neue Horizonte des Flussgebietsmanagements (10. Magdeburger Gewässerschutzseminar Spindlermühle/ CR 21. -26.10.2002). - Stuttgart et al.: Teubner 2002:395 -398.

DEUTSCH, M./PÖRTGE, K.-H./TELTSCHER, H. (Hrsg.): Beiträge zum Hochwasser/Hochwasserschutz in Vergangenheit und Gegenwart. - Erfurt 2000 [Erfurter Geographische Studien;9].

DEUTSCHE FORSCHUNGSGEMEINSCHAFT. Senatsausschuß f. Umweltforschung: Beiträge zur Umweltforschung. Von SCHOLDER, Klaus et al. - Boppard: Boldt 1976.

DEUTSCHER GEOGRAPHENTAG: Forderungen der Pflege an eine historisch-geographische Grundlagenforschung. Tagungsbericht und wissenschaftliche Abhandlungen. 46. Dt. Geographentag. 1987 in München.

DEUTSCHER GEOGRAPHENTAG: „Geographie und Umwelt“, 49. Dt. Geographentag 1991 in Basel.

DEUTSCHER ORDEN 2004 [URL = http://www.deutsch-orden.at/d/glossar.htm;24.07.2004].

DEUTSCHER VERBAND FÜR WASSERWIRTSCHAFT UND KULTURBAU e. V. (Hrsg.): Historische Talsperren. Bearbeitet von Günther Garbrecht. - Stuttgart: Wittwer Bd. 1 1987; Bd. 21991.

DICKMANN, F.: Web-Mapping und Web-GIS. - 1. Aufl. - Braunschweig: Westermann 2001.

DICKMANN, F./ZEHNER, K.: Computerkartographie und GIS. - 2. Aufl. - Braunschweig: Westermann 2001 [Schriftenreihe: Das geographische Seminar]. 
DIE ELBE IM KARTENBILD: Vermessung und Kartierung eines Stromes; Vorträge zum Symposium vom 20.-22. September 1991 an der TU Dresden. Hrsg.: TU Dresden, Inst. f. Kartographie. - Dresden 1994 [Kartographische Bausteine;9].

DIE ELBE: ein Lebenslauf. - Katalog der Ausstellung Dresden, Hamburg, Prag 1992/93. - Berlin: Nicolaische Verlagsbuchhandlung 1992.

„DIE GROßE WÄSCHE“. Eine Ausstellung des Landschaftsverbandes Rheinland, Rheinisches Freilichtmuseum - Landesmuseum für Volkskunde, Mechernich-Kommern. - Köln: Rheinland-Verl. 1988 [Schriften d. Rhein. Museumsamtes;42; zugl. Schriften d. Rhein. Freilichtmuseums - Landesmuseum f. Volkskunde;34].

DIE KANALISIERUNG DER MITTELWESER von Minden bis Bremen. Hrsg. v. Verein zur Wahrung der Weserschiffahrtsinteressen e. V. - Bremen 1950.

DIE LAHN, ein Fliessgewässerökosystem: modellhafte Erarbeitung eines ökologisch begründeten Sanierungskonzeptes für kleine Fliessgewässer am Beispiel der Lahn; Abschlußbericht. Projektleitung: Regierungspräsidium Gießen. - Gießen: Regierungspräsidium 1994.

DIE ROLLE DER GEOGRAPHIE in der Gesellschaft. Berichte und Referate zum Schweizerischen Geographentag vom 2./3. Mai in Bern. - In: Geographica Helvetica 3 1986:126-133.

DIE WASSERVERSORGUNG ANTIKER STÄDTE. Band 2: Pergamon - Recht/Verwaltung - Brunnen/Nymphäen Bauelemente. - Mainz: Zabern 1991.

DIE WASSERVERSORGUNG ANTIKER STÄDTE. Band 3: Mensch und Wasser - Mitteleuropa - Thermen - Bau/Materialien Hygiene. - Mainz: Zabern 1988.

DIE WASSERVERSORGUNG ANTIKER STÄDTE. Band 4: Die Wasserversorgung im Mittelalter. - Mainz: Zabern 1991.

DIE WESER - Ein Fluss in Europa[a]: [eine länderübergreifende Ausstellung über 1200 Jahre Geschichte und Kultur des Weserraumes ...]; Bd. 1: „Leuchtendes Mittelalter“ / Museum Hameln. Hrsg. von Norbert Humburg und Joachim Schween. - Holzminden: Mitzkat 2000.

DIE WESER - Ein Fluss in Europa[b]: [eine länderübegreifende Ausstellung über 1200 Jahre Geschichte und Kultur des Weserraumes ...]; Bd. 2: „Aufbruch in die Neuzeit“ / Weserrenaisssance-Museum Schloß Brake. Hrsg. von José Kastler und Vera Lüpkes. - Holzminden: Mitzkat 2000.

DIE WESER - Ein Fluss in Europa[c]: [eine länderübegreifende Ausstellung über 1200 Jahre Geschichte und Kultur des Weserraumes ...]; Bd. 3: „Von Baltimore nach Bünde“ / Deutsches Tabak- und Zigarrenmuseum. Heidrun Großjohann (Berab.). Hrsg. vom Kreisheimatverein Herford e.V. in Zusammenarbeit mit dem Tabak- und Zigarrenmuseum Bünde. Holzminden: Mitzkat 2000.

DIE WESER - Ein Fluss in Europa[d]: eine Flussfahrt durch die Geschichte der Weserregion. Hrsg. vom WeserresenaissanceMuseum (WRM) Schloß Brake. - Holzminden: Mitzkat 2000[?].

DIENEL, H.-L. (Hrsg.): Der Optimismus der Ingenieure: Triumph der Technik in der Krise der Moderne um 1900. - Stuttgart: Steiner 1998

DIERCKE-Wörterbuch der Allgemeinen Geographie. Bd. 1 A-M. - 3. Aufl. - Braunschweig: Westermann; München: Dt. Taschenbuch Verl. 1987.

DIERKE, M.: Die Geschichte des Gewässerschutzes in ihrem Entwicklungsgang dargestellt und dokumentiert. Freiburg/Breisgau et al.: Alber 1981 [Orbis academicus, Sonderbd. 2.4: Problemgeschichte von Naturschutz ...].

DIERKES, M./FIETKAU, H.-J.: Umweltbewußtsein, Umweltverhalten. - Metzler-Poeschel 1988 [Materialien zur Umweltforschung; 15].

DIERSCHKE,H./BRIEMLE, G.: Kulturgrasland. - Stuttgart: Ulmer 2002.

DIETZ, B./FESSNER, M./MAIER, H. (Hrsg.): „Technische Intelligenz und ,Kulturfaktor Technik‘. Kulturvorstellungen von Technikern und Ingenieuren zwischen Kaiserreich und früher Bundesrepublik Deutschland. - Münster: Waxmann Verl. 1996 [Cottbuser Studien zur Geschichte von Technik, Arbeit und Umwelt;2].

DIETZ, J.: Die Veränderungen des Rheinverlaufs zwischen Ahrmündung und Köln in historischer Zeit. - In: Rheinische Vierteljahrsblätter 31 1966/67:351-376.

DIKAU, R./SAURER, H. (Hrsg.): GIS for Earth Surface Systems. - Stuttgart: Bornträger 1999.

DINGLE, A. E.: „Das schlimmste aller Übel“: Landbesitzer, Alkalifabrikanten und Luftverschmutzung (1828-1864). - In: SIEFERLE, R. P. (Hrsg.): Fortschritte der Naturzerstörung. - Frankfurt/Main 1988:61-94.

DINNEBIER, A.: Das Sonnborner Autobahnkreuz - kulturlandschaftliches Element der Gegenwart. - In: Stadt + Grün 51/10 2002:7-12.

DINZELBACHER, P.: Heilige oder Hexen?: Schicksale auffälliger Frauen in Mittelalter und Frühneuzeit. - München et al.: Artemis \& Winkler 1995.

DIRLMEIER, U.: Umweltprobleme in deutschen Städten des Spätmittelalters. - In: Technikgeschichte 48/3 1981:191-206. 
DIRLMEIER, U.: Historische Umweltforschung aus der Sicht der mittelalterlichen Geschichte. - In: Siedlungsforschung 6 (1988):97-111.

DIRLMEIER, U.: Umweltprobleme im Mittelalter, Abwasser und Müll: Wohin damit? - In: Damals 8 1992:16-21.

DIRLMEIER, U./FOUQUET, G. (Hrsg.): Menschen, Dinge und Umwelt in der Geschichte. Neue Fragen der Geschichtswissenschaft an die Vergangenheit. - In: Siegener Abhandlungen zur Entwicklung der matriellen Kultur, Bd. 5. St. Katharinen 1989.

DITFURTH, H. v.: Unbegreifliche Realität: Reportagen, Aufsätze, Essays eines Menschen, der das Staunen nicht verlernt hat. - 1. Aufl. - Hamburg; Zürich: Rasch und Röhring 1987. (Daraus: „Auszug aus dem Wasser. Einer der geheimnisvollsten Schritte in der Geschichte irdischen Lebens“:135-141 [1964]; „Anthropologisch-psychologische Voraussetzungen einer erfolgreichen Umwelt- und Friedenserzeihung: unbewusste Grenzen unserer Friedensfähigkeit“: 135-413 [1986]).

DITTMANN, M.: Mühlen und Maschinen. In Merzig lebt die museale Technik. - In: Frankfurter Allgemeiner Zeitung Nr. 261 v. 10. November 1997.

DITTRICH, A.: Wasserwirtschaftliche Studie über die historische Entwicklung der Donau zwischen Donaueschingen und Fridingen. - In: Wasserwirtschaft. Zs. f. Wasser und Umwelt 83/6 1993:334-341.

DIX, A.: Umwelt hat noch immer Geschichte: Historische Umweltforschung: Wissenschaftliche Neuorientierung - aktuelle Fragestellungen, Studienkonferenz der Thomas-Morus-Akademie in Zusammenarbeit mit dem Landschaftsverband Rheinland, 19. - 20. März 1991. - In: Bonner Geschichtswerkstatt 4 1991:18-21.

DIX, A. (Mitarb. u. Red.): Kulturgüterschutz in der Umweltverträglichkeitsprüfung (UVP). Bericht des Arbeitskreises „Kulturelles Erbe in der UVP“. Hrsg. v. Umweltamt des Landschaftsverbandes Rheinland, Rheinischem Verein für Denkmalpflege und Landschaftsschutz u. Seminar für Historische Geographie der Universität Bonn. Köln 1994; Zugl.: Kulturlandschaft 4/2 1994 [Sonderheft].

DIX, A.[a]: Angewandte Historische Geographie im Rheinland: Planungsbezogene Forschungen zum Schutz, zur Pflege und zur substanzerhaltenden Weiterentwicklung von historischen Kulturlandschaftselementen. - Köln: Rheinischer Verein $f$. Denkmalpflege u. Landschaftsschutz 1997.

DIX, A.[b]: Bibliographie zur Angewandten Historischen Geographie und zur fächerübergreifenden Kulturlandschaftspflege. - In: DIX, A. (Hrsg.): Angewandte Geographie im Rheinland: Planungsbezogene Forschungen zum Schutz, zur Pflege und zur substanzerhaltenden Weiterentwicklung von historischen Kulturlandschaften. Mit einer Spezialbibliographie zur fächerübergreifenden Kulturlandschaftspflege. - Köln: Rheinischer Verein für Denkmalpflege und Landschaftsschutz e. V. 1997:100-212.

DIX, A.[c]: Industrialisierung und Wassernutzung: Eine historisch-geographische Umweltgeschichte der Tuchfabrik Ludwig Müller in Kuchenheim. - Köln: Rheinland-Verl. 1997 [Landschaftsverband Rheinland, Rheinisches Industriemuseum: Beiträge zur Industrie- und Sozialgeschichte; Bd. 7]; Zugl.: DIX, Andreas: Industrialisierung und Wassernutzung. Fragestellungen einer historisch-geographisch orientierten Umweltforschung an ein industrielles Relikt: Die Tuchfabrik Ludwig Müller in Kuchenheim und die Textilindustrie in Euskirchen - Bonn: Phil. Diss. Univ. Bonn 1994.

DIX, A.: Kontaminierte Landschaften - Rieselfelder in Westfalen im 19. und 20. Jahrhundert. - In: DITT, K./GUDERMANN, R./RÜßE, N. (Hrsg): Agrarmodernisierung und ökologische Folgen. Westfalen vom 18. bis zum 20. Jahrhundert. Paderborn: Schöningh 2001:261-285.

DIX, A.: Ländliche Siedlungsplanung in der SBZ und frühen DDR von 1945 bis 1955. - In: Barth, H. (Hrsg.): Zur Grammatik sozialistischer Architekturen. Lesarten historischer Städtebauforschung zur DDR. - Berlin: Reimer 2001:99-114.

DIX, A.: „Freies Land“: Siedlungsplanung im ländlichen Raum der SBZ und frühen DDR. - Köln, Weimar: Böhlau 2002.

DOBELMANN, W.: Mühlen des Osnabrücker Nordlandes: von Wasser- und Windmühlen, von Roß- und Handmühlen. Quakenbrück: Thoben 1980 [Schriftenreihe des Kreisheimatbundes Bersenbrück;16].

DÖBLER, H.: Döblers Kultur- und Sittengeschichte der Welt: Stadt - Technik - Verkehr. - München: Goldmann 1973.

DOCKTER, J./STEINMÜLLER, A.: Erläuterungen zur Geologischen Karte 1:25000 von Thüringen-Weimar, Nr. 4530: Blatt Nordhausen Süd. - 2. Aufl. - Thüringer Landesanstalt f. Bodenforschung 1993.

DODT, J.: Die Verwendung von Karten und Luftbildern bei der Ermittlung von Altlasten. Ein Leitfaden für die praktische Arbeit. - Düsseldorf 1987.

DOERTE-BECKER, B.: Vom Flachs zum Leinengarn. - Braunschweig: Landesmuseum, 1984 [Veröff. d. Braunschweiger Landesmuseums;43:Volkskunde].

DOLLEN, B. v. der: Forschungsschwerpunkte und Zukunftsaufgaben der Historischen Geographie: Städtische Siedlungen: - In: Erdkunde 36 1982:96-102.

DÖLLING, H.: Die schlesischen Teichwirtschaften, ihr gegenwärtiger Zustand und ihre Entwicklungsmöglichkeiten. - Breslau: Hochschulverl. 1924; Zugl.: Breslau, Univ., Diss. 1924.

DOLLINGER, F.: Landschaftsanalyse und Landschaftsbewertung: die Methoden der Landschaftsforschung und ihre Anwendung in Raum- und Umweltforschung, Raum- und Landschaftsplanung und in Regional- und Umweltpolitik; vorwiegend anhand 
von Beispielen im Bundesland Salzburg. - Wien: Arbeitskreis für Regionalforschung 1989 [Mitteilungen des Arbeitskreises für Regionalforschung: Sonderband,2].

DOMBROWSKY, I.: Wasserprobleme im Jordanbecken. Perspektiven einer gerechten und nachhaltigen Nutzung internationaler Ressourcen. - Frankfurt/Main: Lang 1995.

DONAT, P.: Der Königshof Helfta. Vormittelalterliche und mittelalterliche Funde. Ergebnisse der Garbungen 1977-1981. - In: Zs. f. Archäologie 22/2 1988:246.

DÖPPERT, M.: Die Entwicklung der ländlichen Kulturlandschaft in der ehemaligen Grafschaft Schlitz unter besonderer Berücksichtigung der Landnutzungsformen: von der Frühzeit bis zur Gegenwart. - Mainz: Univ. 1987 [Geogr. Studien].

DOPSCH, A.: Das Capitulare des Villis, die Brevium Exempla und der Bauplan von St. Gallen. - In: Viertelsjahrsschrift für Sozial- und Wirtschaftsgeschichte [VSWG] 13 1916:41-70.

DOPSCH, H.: Hof und Höfisches Treiben im Mittelalter. Vorlesung am 17. Oktober 2001 im Rahmen der Ringvorlesung „Der Hof als kultureller Raum im Mittelalter“. [URL = http://www.sbg.ac.at/ger/samson/samsonarchiv/dopsch2001.pdf;30.01.2004].

DORFCHRONIK: Auszug aus der Dorfchronik der Ehrenbürgerin Johanna Rippstein, Sand a. Main. Eine Dorfgeschichte. 1138 1989. - Bamberg 1988.

DÖRFLER, H.-P./ROSELT, G.: Heilpflanzen. - München: dtv 1991.

DÖRFLER, W./KLAGES, U./TURNER, H.-J.: Die Schafställe der Nordheide: eine Bestandsaufnahme unter besonderer Berücksichtigung der Grenzgebiete zwischen den ehemaligen Stiften Bremen und Verden sowie dem Fürstentum Braunschweig-Lüneburg. Hrsg. v. Nieders. Landesverwaltungsamt, Inst. f. Denkmalpflege und dem Freilichtmuseum am Kiekeberg. - Hameln: Niemeyer 1994.

DORIDER, A.: Die Entwicklung des Mühlenwesens in der ehemaligen Grafschaft Mark: Ein Beitrag zur Domänenpolitik der brandenburgisch-preußischen Herrscher im 17. und 18. Jahrhundert. - Witten/Ruhr: Pott 1911 [Jahrbuch des Vereins für Orts- und Heimatkunde in der Grafschaft Mark verbunden mit dem Märkischen Museum zu Witten/Ruhr 25 (1910/11)]; Zugl.: Münster, Univ., Phil. Diss. O. J. (1912).

DÖRING, A./GANSOHR-MEINEL: Die Große Wäsche im Rheinland . - In: „Die Große Wäsche“. Eine Ausstellung des Landschaftsverbandes Rheinland, Rheinisches Museumsamt, Brauweiler in Zusammenarbeit mit dem Rheinischen Freilichtmuseum - Landesmuseum für Volkskunde, Mechernich-Kommern. - Köln: Rheinland-Verl. 1988 [Schriften d. Rhein. Museumsamtes; 42; Zugl.: Schriften d. Rhein. Freilichtmuseums - Landesmuseum f. Volkskunde;34]:12-30.

DOSCH, Ludwig: Die Fischwasser und die Fische des Grossherzogtums Hessen mit Einschluss der Teichwirtschaft und Gesetzeskunde. - Giessen 1899.

DOSWALD, C.: „Erzwege“: Eisenerztransport in der vorindustriellen Schweiz. - In: JOCKENHÖVEL, A. (Hrsg.): Bergbau, Verhüttung und Waldnutzung im Mittelalter: Auswirkungen auf Mensch und Umwelt; Ergebnisse eines internationalen Workshops (Dillenburg, 11. - 15.Mai 1994, Wirtschaftshistorisches Museum „Villa Grün“). - Stuttgart: Steiner 1996 [Vierteljahrschrift für Sozial- und Wirtschaftsgeschichte: Beihefte;121]:151-172.

DRANSCH, D.: Computer-Animation in der Kartographie: Theorie und Praxis. - Berlin et al.: Springer 1997.

DREISEITL, H./GRAU, D./LUDWIG, K. H. C.: „Waterscapes“: Planen, Bauen und Gestalten mit Wasser. - Basel: Birkhäuser 2001.

DRESDNER MÜHLE 2004 [http://www.dresdner-muehle.de/historie.html;08.02.2004].

DRESSEL, E./DRESSEL, C.-T.: Das Vogtland: ein Verzeichnis der Orte, Wüstungen und Mühlen der sächsisch-thüringischen, der böhmischen und bayerischen Teile. - 1. Aufl. - Bad Langensalza: Rockstuhl 1998.

DREWS, R.: Kleingewässerkunde. Eine praktische Einführung in die Welt der Tümpel und Teiche. - 2. Aufl. - Heidelberg: Quelle \& Meyer 1995 [Biolog. Arbeitsbücher;41].

DREYER-EIMBCKE, E.: Alte Straßen im Herzen Europas: Könige, Kaufleute, Fahrendes Volk. - Frankfurt/Main: UmschlagVerl. 1989

DRIESCH, U. v. den: Historisch-geographische Inventarisation von persistenten Kulturlandschaftselementen des ländlichen Raumes als Beitrag zur erhaltenden Planung. - Bonn, Univ., Diss. 1988.

DRIESCH, U. v. den: Das Walchensee-Kraftwerk - ein umstrittenes Projekt macht Geschichte. - In: Praxis Geschichte 5 1993:5356.

DRIESCH, Ursula v. den: Wasserbauliche Elemente - als Denkmale schutzwürdig? - In: BURGGRAAFF, P./KLEEFELD, K.-D.: Perspektiven der Historischen Geographie 1997:265-275.

DRIESCHER, E.: Veränderungen an Gewässern in historischer Zeit. Eine Untersuchung in Teilgebieten der Bezirke Potsdam, Frankfurt und Neubrandenburg. - Berlin, Humboldt-Univ., Diss 1974.

DRÖSCHER, W.: Der Krebs: seine Pflege und sein Fang. - 2. Aufl. - Neudamm: Neumann 1906 [Schriftenreihe: J. Neumanns fischereiwirtschaftliche Büchersammlung].

DRUBE, F.: Mühlen in Schleswig-Holstein. - Hamburg: Wachholtz 1936 [Sprache und Volkstum. Arbeiten zur niederdeutschen Sprachgeschichte und Volkskunde;6]; Zugl.: Kiel, Univ., Diss. 1935. 
DUBRAVIUS, Janus: De piscinis et pisciu in eis aluntur naturis libri quinque, vt doctissimi, itá ad rem familiarem augendam utilissimi, ad illustrem uirum Antonium Fuggerum. Item Xenocratis De alimento es aquatilibus Graecé \& latiné nunc primum aeditus cum scholijs Conradi Gesneri. - Zürich [?] 1559 [(weitere Ausgaben: Leipzig 1774, Frankfurt/Main u. Leipzig 1779, Neapel 1794].

DUBRAVIUS, Johannes: Buch von den Teichen und den Fischen, welche in denselben gezüchtet werden. - Breslau 1547 [übersetzt und bearbeitet von A. Wüstner und J. Kollmann]. - Wien 1906.

DUDEN: Etymologie: Herkunftswörterbuch der deutschen Sprache. - 2. Aufl. - Mannheim et al.: Dudenverl. 1989 [Duden;7].

DUDEN: Rechtschreibung der deutschen Sprache und der Fremdwörter. - 17. Aufl. - Mannheim et al. Dudenverl. 1973 [Duden;1].

DÜFFEL, J. v.: Vom Wasser. - Köln: DuMont, 1998.

DUFT, J.: Geschichte des Klosters St. Gallen im Überblick vom 7. bis zum 12. Jahrhundert. - In: OCHSENBEIN, P. (Hrsg.): Das Kloster St. Gallen im Mittelalter: die kulturelle Blüte vom 8. bis zum 12. Jahrhundert. - Stuttgart: Theiss 1999:11-30.

DUHwelt - Zeitschrift der Deutschen Umwelthilfe 22003.

DÜLMEN, A. van (Hrsg.): Frauenleben im 18. Jahrhundert. - München: Beck 1992.

DÜLMEN, R. van: Kultur und Alltag in der frühen Neuzeit. 3. Bde. - München: Beck 1992-1995.

DÜLMEN, R. van: Historische Anthropologie: Entwicklung, Probleme, Aufgaben. - Köln et al.: Böhlau 2000 [Einführung in die junge Wissenschaft;7].

DUMA, J.: Gewässernamen im linken Zuflussgebiet der Weichsel zwischen Pilica und Brda. - Stuttgart: Steiner 1999 [Hydronymia Europaea;14].

DUMMREICHER, A.: Gesamtüberblick über die Wasserwirtschaft des nordwestlichen Oberharzes und Grundriss, Blatt II. Profilriß. - Clausthal 1866 [Vervollständigt durch O. B. A. Sandkuhl (Markscheider).

DUNIN-WASOWICZ, T.: Natural Environment and Human Settlement over the Central European Lowland in the 13.th Century. - In: BRIMBLECOMBE, P./PFISTER, C. (Hrsg.): The silent countdown. Essays in European environmental history. Berlin et al.: Springer 1990:92-105.

DÜNKELBERG, F. W.: Der Wiesenbau in seinen landwirtschaftlichen und technischen Grundzügen: für Landwirthe, Techniker und Verwaltungs-Beamte sowie für Vorlesungen. - 4. Aufl. - Braunschweig: Vieweg 1907.

DÜSTERLOH, D.: Beiträge zur Kulturgeographie des Niederbergisch-Märkischen Hügellandes: Bergbau und Verhüttung vor 1850 als Elemente der Kulturlandschaft. - Göttingen: Geogr. Inst. d. Univ. 1967 [Göttinger geographische Abhandlungen;38]; Zugl.: Göttingen, Univ., Diss. 1967.

DVWK [Deutscher Verband für Wasserwirtschaft und Kulturbau e. V.] (Hrsg.): Fluß und Lebensraum: Beiträge zur Fachtagung 1984 in Augsburg. - Hamburg; Berlin: Parey 1984 [Schriftenreihe des Deutschen Verbandes für Wasserwirtschaft und Kulturbau e.V.;69].

DVWK [Deutscher Verband für Wasserwirtschaft und Kulturbau e.V.]: Ökologische Aspekte bei Ausbau und Unterhaltung von Fließgewässern. - Bonn 1984 [DVWK-Merkblätter zu Wasserwirtschaft 204].

DVWK [Deutscher Verband für Wasserwirtschaft und Kulturbau e. V.] (Hrsg.): Historische Talsperren. Bd. 2. Bearbeitet von Günther Garbrecht. - Stuttgart: Wittwer 1991.

DVWK [Deutscher Verband für Wasserwirtschaft und Kulturbau e. V.] (Hrsg.): Gewässer - schützenswerter Lebensraum: Fachtagung des Deutschen Verbandes für Wasserwirtschaft und Kulturbau e. V. (DVWK) am 01. Oktober 1992 in Oberhof. - Hamburg [et al.]: Parey 1992 [Schriftenreihe des Deutschen Verbandes für Wasserwirtschaft und Kulturbau e. V.;102].

DVWK [Deutscher Verband für Wasserwirtschaft und Kulturbau e. V.] (Hrsg.): Historischer Küstenschutz. Deichbau, Inselschutz und Binnenentwässerung an Nord- und Ostsee. - Stuttgart: Wittwer 1992 [Bearbeitet v. Johann Kramer / Hans Rohde].

DVWK [Deutscher Verband für Wasserwirtschaft und Kulturbau e.V.], Arbeitskreis Stauraumverlandung (Hrsg.): Verlandung von Flußstauhaltungen: Morphologie, Bewirtschaftung, Umweltaspekte und Fallbeispiele. - Hamburg et al.: Parey 1993 [Schriftenreihe des Deutschen Verbandes für Wasserwirtschaft und Kulturbau e.V.;105].

DVWK [Deutscher Verband für Wasserwirtschaft und Kulturbau e. V.] (Hrsg.): Historische Wasserwirtschaft im Alpenraum und an der Donau. Bearbeitet von Werner Konold. - Stuttgart: Wittwer 1994.

DVWK [Deutscher Verband für Wasserwirtschaft und Kulturbau]: Fluss und Landschaft: Ökologische Entwicklungskonzepte. Bonn 1996 [DVWK-Merkblätter zu Wasserwirtschaft; 240].

DVWK [Deutscher Verband für Wasserwirtschaft und Kulturbau e. V.] (Hrsg.): Gewässerentwicklungsplanung: Begriffe, Ziele, Systematik, Inhalte. - Bonn 1999.

DYHRN, E. Graf v.: Kurze Anleitung zu der Teichwirtschaft. - Breslau: Johann Ernst Meyer 1782.

EAST, W. G.: The Geography behind history. - London: Nelson 1965.

EBELING, D.: Vorwort. - In: EBELING, D. (Hrsg.): Historisch-thematische Kartographie: Konzepte - Methoden Anwendungen. - Bielefeld: Verlag für Regionalgeschichte 1999:7-8. 
EBELING, W.: Begründung für die Durchführung des Mudderns. Die Gezeiten vor der ostfriesischen Küste. - In: NordwestHeimat Leuchtfeuer Beilage zur NWZ Nr. 91985.

EBERHARDT, H.: Mittelalterliche Kanalbauten im nördlichen Thüringen. - In: Zeitschrift des Vereins für Thüringische Geschichte und Altertumskunde 52 1998:65-93.

EBERSCHWEILER, B.: Die jüngsten endneolithischen Ufersiedlungen am Zürichsee: mit einem Exkurs von Eduard Gross-Klee. Glockenbecher: ihre Chronologie und ihr zeitliches Verhältnis zur Schnurkeramik aufgrund von C14-Daten. - In: Jahrbuch der Schweizerischen Gesellschaft für Ur- und Frühgeschichte 82 1999:39-44.

EBERTS, E.: Die Fischzucht in den Preussischen Staatsforsten. - Berlin: Springer 1904.

EBHARDT, G.[ötz]: Beeinträchtigung von Feuchtgebieten durch wasserwirtschaftliche Maßnahmen. - In: DVWK [Deutscher Verband für Wasserwirtschaft und Kulturbau e. V.] (Hrsg.): Gewässer - schützenswerter Lebensraum. - Hamburg; Berlin: Parey 1992 [Schriftenreihe des Deutschen Verbandes für Wasserwirtschaft und Kulturbau e.V.;102]:197-210.

ECHL, O.: Brake: Seehafenstadt an der Unterweser. Hrsg.: Stadt Brake. - Oldenburg i. O.: Stalling 1973

ECKART, K.: Agrargeographie Deutschlands: Agrarraum und Agrarwirtschaft Deutschlands im 20. Jahrhundert. - Gotha: Perthes 1998 [Perthes Geographiekolleg].

ECKART, W. U./GRADMANN, C. (Hrsg.): Ärtzelexikon. Von der Antike bis zum 20. Jahrhundert. - München: Beck 1995.

ECKHARDT, A./GÜNTHER, W./SCHAER, F.-W. et al: Brake: Geschichte einer Seehafenstadt an der Unterweser. - Oldenburg: Holzberg 1981 [Oldenburgische Monographien].

ECKOLDT, M.: Ein Lexikon der deutschen Flüsse aus der Barockzeit. - Deutsche Gewässerkundliche Mitteilungen 8 (1962):4246.

ECKOLDT, M.: Schiffahrt auf kleinen Flüssen Mitteleuropas in Römerzeit und Mittelalter. - Oldenburg: Stalling 1980 [Schriften des Deutschen Schiffahrtsmuseums;14].

ECKOLDT, M.: Zur Frage der Schiffahrt auf kleinen Flüssen der Pfalz in alter Zeit. - In: Pfälzer Heimat 4 1981:172-184.

ECKOLDT, M.: Die Geschichte der Wasserstraßen in Nordhessen, Einführung. - In: TÖNSMANN, F. (Hrsg.): Zur Geschichte der Wasserstraßen insbesondere in Nordhessen. - Kassel: Herkules Verl. 1995 [Kasseler Wasserbau-Materialien;4]:11-13.

ECKOLDT, M. (Hrsg.): Flüsse und Kanäle: die Geschichte der deutschen Wasserwege unter Einfluß von Recht, Politik, Wirtschaft, Verwaltung, Wasserbau und Schiffahrt. - Hamburg: DSV-Verl. 1998

ECKHOLDT, M./LÖBER, U./TÖNSMANN, F. (Hrsg.): Geschichte der Wasserkraftnutzung. Berichte zur Tagung „Geschichte der Wasserkraftnutzung“ am 23. und 24. April 1982 in Koblenz. - Koblenz: Selbstverl. des Landesmuseums Koblenz 1985 [Veröffentlichungen des Landesmuseums Koblenz;13].

EDER, P.: Die Karpfenteichwirtschaft in der Steiermark. - In: Institut für Geographie und Raumforschung, Universität Graz (Hrsg.): Kontinuität und Wandel in der Kultur- und Naturlandschaft. Festschrift für Herwig Wakonigg. - Graz:Universität 2002 [Grazer Schriften der Geographie und Raumforschung;38]: 55-64.

EDSON, E.: Mapping time and space: how medieval mapmakers viewed their world. - London: British Library 1997 [British Library studies in map history;1].

EDZARDS, H.: Die Entwicklung Ahlhorns im 19. Jahrhunderts: Darstellung der Wandlungsprozesse einer ländlichen Siedlung. Oldenburg: Isensee 1997.

EGER, C.: Die jüngere vorrömische Eisen- und römische Kaiserzeit im Luhetal (Lüneburger Heide). - Rahden/Westf.: Leidorf 1999 [Schriftenreihe: Internationale Archäologie;56]; Zugl.: München, Univ., Diss. 1997.

EGLI, H.-R.: Die Rückschreibung zur Rekonstruktion der Gewannflurgenese im bernischen Seeland. - In: Geographica Helvetica 1 1985:19-24.

EGLI, H.-R.: Das Wiesenbewässerungssystem im Langetental - von der wissenschaftlichen Untersuchung bis zum Landschaftsschutz. - In: Kulturlandschaft. Zeitschrift für Angewandte Historische Geographie 4/1 1994:29-34.

EGLI, H.-R.: Angewandte Historische Geographie und Geographie. Erfahrungen und Perspektiven aus Schweizer Sicht. - In: KLEEFELD, K.-D./BURGGRAAFF, P. (Hrsg.): Perspektiven der Historischen Geographie: Siedlung - Kulturlandschaft Umwelt in Mitteleuropa. - Bonn: Selbstverl. 1997:63-71.

EHLERS, E.: Die Agrarlandschaft der Bundesrepublik Deutschland und ihr Wandel seit 1949. - In: Geographische Rundschau 40 1988:30-40.

EHLERS, E.: Die Einsamkeit der deutschen Geographie - einige Anmerkungen zur deutschen Geographie im internationalen Kontext. - In: Heidelberger Geographische Arbeiten 104 1996:24-36.

EHLERS, E.[a]: Geographie als Umweltwissenschaft. - In: Die Erde 129 1998:333-349.

EHLERS, E.[b]: Globaler Umweltwandel und Mensch-Umwelt-Beziehungen. Aufgaben für geographische Forschung und Lehre. In: PREISLER, G. et al. (Hrsg): Global denken - Lokal handeln: Geographieunterricht! Regensburger Beiträge zur Didaktik der Geographie 4 1998:11-28. 
EHLERS, E.[a]: Geographie und Umweltforschung. - In: Erdkunde 53 1999:75-79.

EHLERS, E.[b]: Geosphäre-Biosphäre-Anthroposphäre: Zum Dilemma holistischer globaler Umweltforschung. - In: DITTMANN, A./WUNDERLICH, J. (Hrsg.): Geomorphologie und Paläoökologie. - Frankfurt/Main 1999 [Frankfurter Geow. ArbeitenSerie D: Physische Geographie;25]:87-104.

EHLERS, E.[c]: Environment and Geography: International Programs on Global Environmental Change. A Survey. - In: Bulletin 491999 [International Geographical Union]:5-18.

EHLERS, E. (Hrsg.): Mensch und Umwelt. Gedanken aus Sicht der Rechtswissenschaften - Ethnologie -Geographie. Laudationes und Vorträge gehalten aus Anlaß der Verabschiedung von Frau Ursula Far-Hollender, Leiterin des Fachreferats II A 5, aus dem aktiven Dienst der Deutschen Forschungsgemeinschaft am 13. November 2000 in Bonn. [Colloquium Geographicum;25].

EHLERS, E.: Umwelten und Katastrophen. Zur Anthropozentrik der Wahrnehmung und Bewertung von Naturphänomenen. - In: Die Erde 2002:309-316.

EICHENAUER, H.: Das Siegerland als Beispiel wirtschaftsgeschichtlicher und wirtschaftsgeographischer Harmonie? Überprüfung eines kulturlandschaftlichen Exempels. - In: BECKER, G./MAYR, A./TEMLITZ, K. (Hrsg.): Sauerland Siegerland - Wittgensteinerland. Jahrestagung der Geographischen Kommission in Olpe 1989. - Münster: Selbstverl. d. Geogr. Komm. f. Westfalen 1990 [Schriftenreihe der Geogr. Komm. im Provinzialinstitut f. Westf. Landes- und Volksforschung Landschaftsverband Westfalen-Lippe; zugl. Spieker - Landeskundl. Beiträge und Berichte;33]:219-242.

EICHHORN, P.: Vertiefende Erkenntnisse zum Bergbau im Rammelsberg an der Wende vom 17. zum 18. Jahrhundert. - 1. Aufl. - Clausthal-Zellerfeld: Papierflieger 1999; Zugl.: Clausthal, Techn. Univ., Diss. 1998.

EICHLER, E.: Die Orts- und Flussnamen der Kreise Delitzsch und Eilenburg: Studien zur Namenkunde und Siedlungsgeschichte im Saale-Mulde-Gebiet. - Halle (Saale): Niemeyer, 1958 [Deutsch-slawische Forschungen zur Namenkunde und Siedlungsgeschichte; 4]; Zugl.: Leipzig, Univ., Diss., 1955

EICHLER, E.: Zur Etymologie und Struktur der slawischen Orts- und Flußnamen in Nordostbayern. In: WZ 11 1962:365-395.

EICHLER, E.[a]: Alte Gewässernamen zwischen Ostsee und Erzgebirge. - In: Beiträge zur Namenforschung NF 16 1981:40-54.

EICHLER, E.[b]: Zur ältesten (vorslawischen) Schicht der Gewässernamen im altsorbischen und altpolabischen Sprachgebiet. In: Letopis Reihe A 28 1981:122-137.

EISCH, K./HAMM, M. (Hrsg.): Die Poesie des Feldes: Beiträge zur ethnografischen Kulturanalyse. - Tübingen: Tübinger Vereinigung für Volkskunde 2001 [Untersuchungen des Ludwig-Uhland-Instituts der Universität Tübingen;93].

EISEL, U.: Landschaftskunde als „materialistische Theologie“ - ein Versuch aktualistischer Geschichtsschreibung der Geographie. - In: BAHRENBERG, G. u.a.: Geographie des Menschen - Dietrich Bartels zum Gedenken. Bremer Beiträge z. Geogr. u. Raumplanung 11 1987:89-109.

EISEL, U.: Triumph des Lebens. Der Sieg christlicher Wissenschaft über den Tod in Arkadien. - In: EISEL, U./SCHULTZ, H.-D.: Geographisches Denken. - Kassel: Gesamthochschulbibliothek 1997 [Urbs et Regio, Sonderband 65]:39-160.

EISEL, U./SCHULTZ, H.-D.: Vorwort. - In: EISEL, U./SCHULTZ, H.-D.: Geographisches Denken. - Kassel: Gesamthochschulbibliothek 1997 [Urbs et Regio, Sonderband 65]:9-11.

EISELE, H.: Bergmetaphorik und Sinnbild. - In: ARLT, H. (Hrsg.): Realität und Virtualität der Berge. - St. Ingbert: Röhrig 2002 [Österreichische und internationale Literaturprozesse;16]:147-170.

EKWALL, E.: English Rivernames. - Oxford: Clarendon 1928.

ELLENBERG, H.: Versuch einer Klassifikation der Ökosysteme der Erde nach funktionalen Gesichtspunkten. - In: Ellenberg, H. (Hrsg.): Ökosystemforschung. - Berlin et al.: Springer 1973:235-265.

ELLENBERG, H.: Vegetation Mitteleuropas mit den Alpen in ökologischer Sicht. - 4. Aufl. - Stuttgart: Ulmer 1986.

ELLENBERG, H.: Bauernhaus und Landschaft in ökologischer und historischer Sicht. - Stuttgart: Ulmer 1990.

ELLMERS, D: Die Schiffe der Angelsachsen. - In: Sachsen und Angelsachsen. Ausstellung des Helms-Museums Hamburg 1978.

ELLMERS, D./FRIEDLAND, K.: Städtebund und Schiffahrt zur Hansezeit. - Herzberg et al: Zander 1981. [Schriftenreihe d. Arbeitsgemeinschaft Südniedersachsen Heimatfreunde e.V.;5].

ELLMERS, D.: Frühe Schiffahrt in West- und Nordeuropa. - In: Zur geschichtlichen Bedeutung der frühen Seefahrt. - München 1982 [Kolloquium zur Allgemeinen und Vergleichenden Archäologie;2]:163-190.

ELLMERS, D.: Warenumschlag zwischen Schiff und Wagen im Wasser. - Bremen: Ed. Temmen 1983 [Deutsches Schiffahrtsarchiv;6].

ELLMERS, D.: Frühmittelalterliche Handelsschiffahrt in Mittel- und Nordeuropa. - 2. Aufl. - Neumünster: Wachholtz 1984 [1. Aufl. 1972] [Offa-Bücher; 22 (28); zugleich: Schr. d. Dt. Schiffahrtsmuseums; 3]

ELLMERS, D.: Wege und Transport: Wasser. - In: MECKSEPER, C. (Hrsg.): Stadt im Wandel - Kunst und Kultur des Bürgertums in Norddeutschland 1150 - 1650. - Stuttgart-Bad Cannstatt 1985, Bd. 3:243-255. 
ELLMERS, D.: Die Archäologie der Binnenschiffahrt in Europa nördlich der Alpen. - In: JANKUHN, H./KIMMIG, W./EBEL, E. (Hrsg.): Untersuchungen zu Handel und Verkehr der vor- und frühgeschichtlichen Zeit in Mittel- und Nordeuropa. Göttingen: Vandenhoeck \& Ruprecht 1989 [5. Abhandlungen der Akademie d. Wissenschaften in Göttingen, Phil.-Hist. Klasse, 3. Folge; 180]:291-350.

ELMADFA, I./LEITZMANN, C.: Ernährung des Menschen. - 2. Aufl. - Stuttgart: Ulmer 1990.

ELMAN, R. (Hrsg.): Das große Buch der Jagd. Jäger, Wild und Jagd von der Steinzeit bis zur Gegenwart. - München: Orbis-Verl. 1996.

ELM-ASSE 2003 [URL = http://elm-asse-kultur.de/htmlbody_altenautal.html;27.01.2004].

ELMSHÄUSER, K.: Kanalbau und technische Wasserführung des frühen Mittelalters. - In: Technikgeschichte 59/1 1992:1-26.

ELSASSER, H./KNOEPFEL, P. (Hrsg.): Umweltbeobachtung. - Zürich: Geographisches Institut der Universität Zürich 1990 [Wirtschaftsgeographie und Raumplanung;8].

ELSASSER, H.: Angewandte Geographie - Zusammenarbeit zwischen Forschung und Praxis. - In: Geographica Helvetica 2 1984:58-70

ELSASSER, H.: Einleitung zum Thema „Die Zukunft unseres Lebensraumes - Eine Herausforderung an die Geographie“. - In: Geographica Helvetica 4 1989:163-165.

ELSNER, H./ROLFES, W.: Moor: Gesichter einer Landschaft. - Bremen: Ed. Temmen 1999

ENDERS, L.: Die Priegnitz. Geschichte einer kurmärkischen Landschaft vom 12. bis zum 18. Jahrhundert. - Potsdamm: Verl. für Berlin-Brandenburg 2000 [BWV - Berliner Veröffentlichungen des Brandenburgischen Landeshauptarchivs; 38].

ENDLICHER, W.: Klima, Wasserhaushalt, Vegetation. - Darmstadt: Wiss. Buchgesellschaft 1991.

ENDLICHER, W.: Bodengeographisch-geoökologische Umweltforschung. Boden als Mensch-Umwelt-System. - In: Die Erde 126 1995:287-302.

ENDRISS, G.: Die künstliche Bewässerung im Schwarzwald und im Wallis. - In: Petermanns Geographische Mitteilungen 7-8 1943.

ENDRISS, G.: Die künstliche Bewässerung des Schwarzwaldes und der angrenzenden Gebiete. In: Statistik in Baden 1 1950:3458.

ENDRISS, G.: Über die künstliche Bewässerung, besonders in Süddeutschland und in der Schweiz. - Bremen 1950 [Raumforschung und Raumordnung 10, H. 4].

ENDRISS, G.: Die künstliche Bewässerung des Schwarzwaldes und der angrenzenden Gebiete. - In: Berichte der Naturforschenden Gesellschaft Freiburg im Breisgau 42 1952:77-114.

ENGEL, E. : Die Schiffahrt der Saale und die Beziehungen des Klimas zu derselben. - In: Mitt. d. Geogr. Gesell. Jena 25 1907:122.

ENGEL, F.: Erläuterungen zur historischen Siedlungsformenkarte Mecklenburgs un Pommerns. - In: Zeitschrift für Ostforschung 2 1953:208-230.

ENGEL, F.: Rodungskolonisten und Vorformen der Hagenhufen im 12. Jahrhundert. - In: Mitt. d. Ver. f. Schaumburg-Lippische Geschichte 11 1961:125-147.

ENGELHARDT, D.: Auf zu alten Ufern: Die Städte bauen nahe am Wasser. - In: General-Anzeiger v. 31. Januar/1. Februar 2004:8.

ENGELHARDT, J./RUPPELT: Stadtentwicklung am Fluss: die Neiße in Görlitz / Zgorzelec. - In: PlanerIn Heft 1/03 2003:65-66.

ENGELHARDT, W.: Was lebt in Tümpel, Bach und Weiher?: Pflanzen und Tiere unserer Gewässer; eine Einführung in die Lehre vom Leben der Binnengewässer. - 14. Aufl. - Stuttgart: Franckh-Kosmos 1996 [5. Aufl. 1971].

ENGELHARDT, W. von: Die Bedeutung der Geowissenschaften in unserer Zeit. - In: Natur und Museum 111/4 1981:93-113.

ENGLUND, R. K.: Organisation und Verwaltung der Ur III-Fischerei. - Berlin: Reimer 1990 [Berliner Beiträge zum Vorderen Orient;10]; Zugl.: München, Univ., Diss. 1987.

ENNEN, E.: Frauen im Mittelalter. - 5. Aufl. - München: Beck 1994

ENNEN, E./JANSSEN, W.: Deutsche Agrargeschichte. - Wiesbaden: Steiner 1979.

ERB, Georg: Die Landschaftsdarstellung in der deutschen Druckgraphik vor Albrecht Dürer. - Frankfurt/Main [et al.] 1997 [Europäische Hochschulschriften, R. 28: Kunstgeschichte; 282]; Zugl.: Freiburg, Univ., Diss., 1992

ERDKUNDE-ONLINE 2004 [URL = http://www.erdkunde-online.de/0031.htm;17.01.2004].

ERGERT, B.: Angelgeräte im Wandel der Zeit. - In: 1855 - 1995: 140 Jahre Landesfischereiverband Bayern, Jubiläumsbeilage zu „Bayern Fischerei und Gewässer“. Hrsg.: Landesfischereiverband Bayern e.V. [LFV] - München 1995:11-14.

ERIKSEN, W. (Hrsg.): Studia Geographica: Festschrift Wilhelm Lauer zum 60. Geburtstag. - Bonn: Dümmler 1983 [Colloquium Geographicum; 16]. 
ERLER, G./MATTHIESEN, H.: Erfahrungen am Wasserlauf: dem Wind entgegen; Mühlen der alten Heide - Erbschaft und Erlebnis. - Fallingbostel: Landkreis Soltau-Fallingbostel 1989 [Arbeitsgemeinschaft der Heimat- und Museumsvereine im Landkreis Soltau-Fallingbostel].

ERNER, J.: Vom mönchischen Leben. - Frankfurt/Main: Insel Verl.

ERNI, Peter: Geschriebene Landschaft. Der Wandel von Kulturlandschaft und Güterstruktur in Basadingen nach dem Schriftgut des Klosters Sankt Katharinental (14. - 18. Jahrhundert). - Thurgau 2000 [Thurgauer Beitr. z. Gesch.;137].

ERNST, P./HAUSNER, I. et al. (Hrsg.): Ortsnamen und Siedlungsgeschichte: Akten des Symposiums in Wien vom $28 .-30$. September 2000; Symposion „Ortsnamen und Siedlungsgeschichte“. - Heidelberg: Winter 2002.

ESCHER, F.: Berlin-Cölln als Hafen- und Handelsstadt im Mittelalter und in der frühen Neuzeit. - In: Geschichtswerkstatt SpreeInsel 1998:87-98.

EVANS, R. J.: Tod in Hamburg: Stadt, Gesellschaft und Politik in den Cholera-Jahren 1830-1910. - Reinbek: Rowohlt 1990.

EVERS, W.: Grundfragen der Siedlungsgeographie und Kulturlandschaftsforschung im Hildesheimer Land. - Göttingen 1957 [Schr. d. Wirtschaftswiss. Gesell. z. Stud. Niedersachsens N. F.;64].

FABER, T. F.: Die Luftbildauswertung: eine Methode zur ökologischen Analyse von Strukturveränderungen bei Fließgewässern. Bonn-Bad Godesberg: Bundesforschungsanstalt für Naturschutz und Landschaftsökologie 1989 [Schriftenreihe für Landschaftspflege und Naturschutz;31].

FAEGRI, K.: Preface. - In: BIRKS, H. et al. (Hrsg.): The cultural landscape: past, present and future. - Cambridge: Cambridge Univ. Press 1988:1-4.

FAGAN, B.: Book review CRUMLEY, Carole (ed.): Historical Ecology: Cultural Knowledge and Changing Landscapes. - Santa Fe: School of American Research Press, 1994. - In: California History 75/1 1996:95-96.

FAHLBUSCH, O.: Die Flößerei auf der Ilme: Aus einem Erbbuch des Amtes Hunesrück. - In: Göttinger Blätter für Geschichte und Heimatkunde Südhannovers, NF 2; 34 1936: 52-55.

FAHLBUSCH, O.: Landwehren und Warten um Göttingen. - Göttingen: Vandenhoeck \& Ruprecht 1938:15-44.

FAHMÜLLER, E.: Anfänge der Textilindustrie. - In: TROIZTSCH, U./WEBER, W. (Hrsg.): Die Technik: Von den Anfängen bis zur Gegenwart. - Braunschweig: Westermann 1982:52-57.

FAHRBACH, U.: Marstall, Marstallstraße und Heuschreuer in Heidelberg. - Heidelberg: Riedl 1989 [Veröffentlichungen zur Heidelberger Altstadt; 23].

FAHRTMANN, T. et al.: Berichtspflichten in Natura-2000-Gebieten. Empfehlungen zur Erfassung der Arten des Anhangs II und Charakterisierung der Lebensraumtypen des Anhangs I der FFH-Richtlinie. - Bonn: BfN 2001 [Schriftenreihe für Ökologie;42].

FALKE, F.: Wiesen und Weiden. - Hannover: Jänecke 1908 [Bibliothek der gesamten Landwirtschaft;19].

FALKENSTEIN, F.: Über die ehemalige Vitriolsiederei bei Schwarzenbach. - In: Jahrbuch des Landkreises Waldshut; 16 Konstanz 1992:97ff.

FASSHEBER, P.: Umweltbegriff und umweltbezogene Forschungsthemen in der Sozialpsychologie. - In: HERRMANN, B/BUDDE, A. (Hrsg.): Natur und Geschichte. Naturwissenschaftliche und historische Beiträge zu einer ökologischen Grundbildung. Sommerschule „Natur und Geschichte“ vom 14. bis 27. September 1989 an der Georg-August-Universität Göttingen. - Hildesheim: Gerstenberg 1989 [Schriftenreihe „Expert“ des Nieders. Umweltministers Hannover]:258-266.

FASTLINGER, M.: Die wirtschaftliche Bedeutung der bayerischen Klöster in der Zeit der Agilulfinger. - Freiburg/Breisgau: Herder 1903 [Studien und Darstellungen aus dem Gebiet der Geschichte;2, 2/3].

FAUST, M.: Das Capri von Pommern: Geschichte der Insel Hiddensee von den Anfängen bis 1990. - 3. Aufl. - Rostock:Koch 2001.

FEHN, H.: Waldhufendörfer im hinteren Bayerischen Wald. - In: Mitteilungen und Jahresberichte der Geographischen Gesellschaft Nürnberg 6 1937:5-61.

FEHN, K.: Zum wissenschaftstheoretischen Standort der Kulturlandschaftsgeschichte. - In: Mitteilungen der Geographischen Gesellschaft München 56 1971:95-104.

FEHN, K.[a]: Aufgaben der genetischen Siedlungsforschung in Mitteleuropa. - In: Zeitschrift für Archäologie des Mittelalters 3 (1975):69-74. [Vgl. auch dessen Literaturberichte in „Geographie, Siedlungsgeschichte und archäologische Siedlungsforschung“. - In: Blätter für deutsche Landesgeschichte 113 (1977):571-592; 116 (1980):330-362; 118 (1982):406430; 122 (1986):293-343; 125 (1989):221-249].

FEHN, K[b]: Stand und Aufgaben der Historischen Geographie. - Blätter für dt. Landeskunde 111 1975:31-53.

FEHN, K.: Wirtschaftsentwicklung und Umweltbeeinflussung in Mitteleuropa aus historisch-geographischer Sicht. - In: KELLENBENZ, H. (Hrsg.): Wirtschaftsentwicklung und Umweltbeeinflussung (14.-20. Jahrhundert). - Wiesbaden: Steiner 1982:277-292. 
FEHN, K.: Geographie, historische. - In: MEYNEN, E. (Hrsg.): International Geographical Glossary (Internationales Geographisches Glossarium). - Stuttgart: Steiner 1985:378-379.

FEHN, K.[a]: „Räume der Geschichte - Geschichte des Raums“. Der 36. Deutsche Historikertag vom 8. Bis 12. Oktober 1986 in Trier aus der Sicht der genetischen Siedlungsforschung. - In: Siedlungsforschung 4 1986:253-263.

FEHN, K.[b]: Überlegungen zur Standortbestimmung der Angewandten Historischen Geographie in der Bundesrepublik Deutschland. - In: Siedlungsforschung 4 1986:215-224.

FEHN, K.: Verkehrswege und ihre Bedeutung für die Kulturlandschaft. Bericht über die 12. Arbeitstagung des AK f. genet. Siedlungsforschung v. 25.-28.09.1985 in Rendsburg. - In: Siedlungsforschung 4 1986: 239-252.

FEHN, Klaus: Historische Geographie. - In: HAUPTMEYER, C.-H. (Hrsg.): Landesgeschichte heute. - Göttingen: Vandenhoeck \& Ruprecht 1987 [Kleine Vandenhoeck-Reihe;1522]:55-76.

FEHN, K.[a]: Konzeptionen historisch-geographischer Betrachtung siedlungsräumlicher Entwicklungen. - In: DENECKE, D./FEHN, K. (Hrsg.): Geographie in der Geschichte. - Stuttgart: Steiner 1989 [Erkundliches Wissen;96]:11-22.

FEHN, K.[b]: Persistente Kulturlandschaftselemente: Wichtige Elemente für Historische Geograaphie und Geschichtswissenschaft. - In. DIRLMEIER, U./FOUQUET, Gerhard (Hrsg.): Menschen, Dinge und Umwelt in der Geschichte: Neue Fragen der Geschichtswissenschaft an die Vergangenheit. - St. Katharinen 1989 [Siegener Abhandlungen zur Entwicklung der materiellen Kultur;5]:1-26.

FEHN, K[a]: Historische Geographie. Siedlungsgeschichte und archäologische Siedlungsforschung. In: Ber. f. dt. Landesgeschichte 128 1992:299-367.

FEHN, K.[b]: Überlegungen zu den Aufgaben und Möglichkeiten der Angewandten Historischen Geographie im Bereich der Kulturlandschaftspflege am Beispiel des Raumes zwischen Bonn / Köln und Lüttich / Maastricht. - In: Bonn und das Rheinland. Festschrift für Dietrich Höroldt. - Bonn 1992 [Bonner Geschichtsblätter;42]:673-687.

FEHN, K.[a]: Die Angewandte Historische Geographie: integrierendes Bindeglied zwischen kulturhistorischer Denkmal- und ökologischer Landschaftspflege. In: Kulturlandschaft und Bodendenkmalpflege am unteren Niederrhein. - Köln 1993 [Materialien zur Bodendenkmalpflege im Rheinland;2]:130-133.

FEHN, Klaus[b]: Kulturlandschaftspflege im Rheinland. Ein Aufgabengebiet der Angewandten Historischen Geographie. - In: Rheinische Heimatpflege 30 1993:276-286.

FEHN, K.: Grundlagenforschung der Angewandten Historischen Geographie zum Kulturlandschaftspflegeprogramm von Nordrhein-Westfalen. - Leipzig: Dt. Akad. f. Landeskde e. V. und des Instituts für Länderkunde 1996 [Berichte zur deutschen Landeskunde; 2]

FEHN, K.: Das Seminar für Historische Geographie der Universität Bonn im Jahre 1997. Standortbestimmung und Ausblick auf zukünftige Aufgaben. - In: KLEEFELD, K.-D./BURGGRAAFF, P. (Hrsg.): Perspektiven der Historischen Geographie: Siedlung - Kulturlandschaft - Umwelt in Mitteleuropa. - Bonn: Selbstverl. Kleefeld und Burggraaff 1997:539-544.

FEHN, K[a]: Kulturlandschaftspflege im Rheinland. Ein Aufgabengebiet der Angewandten Historischen Geographie. - In: DIX, Andreas (Hrsg.): Angewandte Historische im Rheinland. - Köln: Rheinischer Verein für Denkmalpflege und Landschaftsschutz e. V. 1997:11-22.

FEHN, K.[b]: Maritime Kulturlandschaften am Beispiel des Ostseeraumes: Bericht über die 23. Tagung des „Arbeitskreises für genetische Siedlungsforschung in Mitteleuropa“ vom 25. bis 28. September 1996 in Kiel. - In: Siedlungsforschung 15 1997:347-352.

FEHN, K.: Der Beitrag von Hans-Jürgen Nitz zur Methodik und Forschungsgeschichte der Historisch-genetischen Siedlungsgeographie. - In: NITZ, H.-J.: Allgemeine und vergleichbare Siedlungsgeographie (Ausgewählte Arbeiten; Bd. II). - Berlin: Reimer 1998 [Kleine geografische Schriften;9]:9-25.

FEHN, Klaus[a]: Der Raum-Zeit-Vergleich in der Historischen Geographie. Bericht über die Fachtagung des Deutschen Geographentags am 6.10.1997 in Bonn. - In: Siedlungsforschung 17 1999:325-330.

FEHN, K.[a]: Historische Kulturlandschaften. - In: Das Rheintal: Schutz und Entwicklung. Die Rheintal-Konferenz des Rheinischen Vereins für Denkmalpflege und Landschaftsschutz am 6./7. November 1997 in Mainz. Eine Dokumentation. Köln: LVR 1999:249.

FEHN, K.[c]: Wasserbauliche Anlagen für die Schlossparks in den wittelbachischen Territorien Kurköln (Raum Köln-Bonn) und Kurbayern (Raum München) während des 17. und 18. Jahrhunderts. - In: ZEHNDER, F. G. (Hrsg.): Der Riss im Himmel: Clemens August und seine Epoche. Bd. 3: Eine Gesellschaft zwischen Tradition und Wandel. Alltag und Umwelt im Rheinland des 18. Jahrhunderts. - Köln: DuMont 1999:177-190.

FEHN, K.[a]: Beitragsmöglichkeiten der Geographie zur Kulturlandschaftspflege mit besonderer Berücksichtigung der Angewandten Historischen Geographie. - In: BEHM, H. (Hrsg.): Kulturelles Erbe - Landschaften im Spannungsfeld zwischen Zerstörung und Bewahrung. - Wittenberg: Pro Art Verl. 2000:17-26.

FEHN, K.[b]: Kulturlandschaftspflege als Beitrag $\mathrm{zu}$ einer nachhaltigen Regionalentwicklung in unterschiedlichen Landschaftstypen - Tagungsbericht - Leipzig: Dt. Akad. f. Landeskde e. V. und des Instituts für Länderkunde 2000 [Berichte zur deutschen Landeskunde;3]. 
FEHN, K.[a]: Historische Geographie - Partnerin der vor- und frühgeschichtlichen Archäologie im Kreise der genetischen Siedlungsforschung und der Kulturlandschaftspflege. - In: POHL, E./RECKER, U./THEUNE, C. (Hrsg.): Archäologisches Zellwerk. Beiträge zur Kulturgeschichte in Europa und Asien. Festschrift für Helmut Roth zum 60. Geburtstag. Rahden/Westfalen: Leidorf 2001 [Internationale Archäologie, Studia Honoraria]:29-35.

FEHN, K.[b]: Vom Wert gewachsener Kulturlandschaften. - In: ARL (Hrsg.): Die Zukunft der Kulturlandschaft zwischen Verlust, Bewahrung und Gestaltung. - Hannover 2001 [Forschungs- und Sitzungsberichte der Akademie für Raumforschung und Landeskunde;215]:145-151.

FEHN, K.: „Germanisch-deutsche Kulturlandschaft“ - Historische Geographie und NS-Forschung. - In: Petermanns Geographische Mitteilungen 146/6 2002:64-69.

FEHN, K.: „Ballungsräume“ und „Notstandsgebiete“: Kernräume und Peripherien in der nationalsozialistischen Raumordnung. Vortrag 30. Tagung des „Arbeitskreises für genetische Siedlungsforschung in Mitteleuropa“ in Greifswald vom 17. bis 20. September 2003.

FEHN, K./BURGGRAAFF, P.: Der Fachbeitrag der Historischen Geographie zur Kulturlandschaftspflege. - In: Kulturlandschaft 3/1 1993:8-13.

FEHN, K./OBERBECK, G.: Vorindustrielle Verkehrssiedlungen am Wasser. Bericht über die 5. Arbeitstagung des Arbeitskreises f. genetische Siedlungsforschung in Mitteleuropa in Wilhelmshafen. - In: Zs. f. Archäol. d. Mittelalters, Jg. 7:198-205.

FEHN, K./SCHENK; W.: Das historisch-geographische Kulturlandschaftskataster - eine Aufgabe der geographischen Landeskunde: Ein Vorschlag insbesondere aus der Sicht der Historischen Geographie in Nordrhein-Westfalen. - In: Berichte zur deutschen Landeskunde 67/2 1993:479-488.

FEHRING, G. P.: Archäologie und Geschichte. - In: Siedlungsforschung 4 1986:265-266.

FELDMANN, R.: Verbreitung und Ökologie der beiden Kleinmuscheln Sphaerium corneum und Musculium lacustre im Sauerland. - In: Natur und Heimat 34 1974:67-73.

FELLENBERG, G.: Umweltforschung: Einführung in die Probleme der Umweltverschmutzung. - Berlin et al.: Springer 1977 [Heidelberger Taschenbücher;194].

FELS, E.: Der wirtschaftende Mensch als Gestalter der Erde. - Stuttgart: Steiner 1954.

FELS, E.: Stauseen - Stiefkinder der Geographie. - In: Geographie heute - Einheit und Vielfalt. Ernst Plewe zu seinem 65. Geburtstag, von Freunden und Schülern gewidmet. - Wiesbaden: Steiner 1973 [Erkundliches Wissen;33]:131-140.

FENSKE, H.: Ahlhorner Fischteiche: ein Jahrhundert extensiver Teichwirtschaft, Naturschutz und Erholung im Oldenburger Land. - Oldenburg: Isensee 1999.

FESSELER, R.: Beitrag zur Geschichte der „Rungsbewässerung“ in Altdorf/Weingarten (Baden-Württemberg). - In: DVWK (Hrsg.): Historische Wasserwirtschaft im Alpenraum und an der Donau. Bearbeitet von Werner KONOLD. - Stuttgart: Wittwer 1994:291ff.

FESSNER, M.: Der Steinkohlenbergbau in der Grafschaft Mark und seine konjunkturelle Entwicklung im 17. und 18. Jahrhundert. - In: BARTELS, C./DENZEL, M. A.: Konjunkturen im europäischen Bergbau in vorindustrieller Zeit: Festschrift für Ekkhard Westermann zum 60. Geburtstag. - Stuttgart: Steiner 2000 [Vierteljahresschrift für Sozial- und Wirtschaftsgeschichte; Beihefte 155]:103-122.

FETTKOETER, Wolfgang (Hrsg.): Wert und Auftrag geographischer Bildung. - Witterschlick/Bonn: Wehle 1988.

FEUSTEL, J.: Zwischen Wassermühlen und Sumpfwäldern: ein Reise- und Erlebnisführer in das Baruther Urstromtal. - 1. Aufl. Berlin: Bäßler 1999.

FEY, Jörg M.: Die Beeinträchtigung von Fließgewässern durch Fischteiche. - In: Natur- und Landschaftskunde. Zeitschrift für Naturschutz, Umweltschutz und Umwelterziehung in Nordrhein-Westfalen 24, H. 2 (1988): 45-48

FIEDLER, K.-H.: Die Wiesenbewässerung im Saarland und in der Pfalz. - Saarbrücken: Univ., Phil. Diss. 1965.

FIEDLER-BENDLER, G.: Vorwort. - In: ARKADIEN AM MITTELRHEIN: Caspar und Georg; Landesmuseum Mainz, 7. Juni bis 23. August 1998. Hrsg.: Landesmuseum Mainz. - Wiesbaden: Reichert 1998.

FIETZ, W.: Vom Aquädukt zum Staudamm: Die Geschichte der Wasserversorgung. - Leipzig: Koehler \& Amelang 1966.

FILSER, K.: Flößerei auf Bayerns Flüssen: Zur Geschichte eines alten Handwerks. - In: Hefte zur Bayerischen Geschichte und Kultur 111991.

FINCKENSTEIN, H. W. Graf Finck v.: Die Entwicklung der Landwirtschaft in Preußen und Deutschland 1800-1930. - Würzburg: Holzner 1960 [Veröffentlichung; Göttinger Arbeitskreis;222].

FINDEISEN, H.: Die Fischerei im Leben der altsibirischen Völkerstämme. - Berlin: Springer 1929; Zugl.: Berlin, Univ. Diss. 1929.

FINK, W.: Das Amt Reinbek 1577-1800: Höfe, Mühlen, Vorwerke und ihre Besitzer. - Frankfurt/Main: Zentralstelle für Personen- und Familiengeschichte 1969 [Genealogie und Landesgeschichte;23].

FINKE, L.: LÖK. - Braunschweig: Westermann 1986 [Das geographische Seminar]. 
FIRBAS, F.: Spät- und nacheiszeitliche Waldgeschichte Mitteleuropas nördlich der Alpen. - Jena: Fischer, Bd. 1 (1952), Bd. 2 (1949).

FIRBAS, Franz: Waldgeschichte Mitteleuropas, 1. Bd.: Allgemeine Waldgeschichte. - Jena 1949.

FISCHER, F. C. J.: Geschichte des teutschen Handels, der Schiffarth, Fischerey [...]. - Hannover: Helwig 1785-1792 [mehrbd. Werk].

FISCHER, H./GRAAFEN, R. (Hrsg.): Flusslandschaften zwischen Persistenz und Überformung. - Koblenz 2001 [Koblenzer Geographisches Kolloquium 23. Jg., Jahresheft; Zugl. Kulturlandschaft 10/1 2000].

FISCHER, P.: Jagd-, Fischerei-, Wasserrecht und Flößerei. - Lobenstein: Teich 1894 [Schriftenreihe: Sammlung von Landesgesetzen für das Fürstentum Reuß jüngerer Linie;3].

FISCHER, U.: Zum Nutzungs- und Landschaftswandel des Peenetalmoores seit 300 Jahren am Beispiel der „Peenewiesen bei Gützkow“. - In: Natur und Naturschutz in Mecklenburg-Vorpommern 36 2001:71-91.

FISCHER, V./LAMPUGNANI, V./MESEURE, A. (Hrsg.): Wohnen und Arbeiten am Fluss: Perspektiven für den Frankfurter Osthafen. - München: Prestel 1992.

FISCHEREI EINST UND JETZT: Ausstellung des Landes Niederösterreich. Schloß Orth an der Donau. 15. April bis 13. November 1983. Hrsg. und Verleger: Amt der NÖ Landesregierung, Abt. III/2 - Kulturabteilung - Wien: 1983 [Katalog des NÖ Landesmuseums, Neue Folge; 132$]$.

FISCHEREIVEREIN ENNS 2004 [URL = http://www.fvenns.at/Karpfenprojekt.htm;29.01.2004].

FITZKE, J.: Praxisrelevante Ergebnisse des OpenGIS-Prozesses. - In: Offene Umweltinformationssysteme? Chancen und Möglichkeiten der OpenGIS -Entwicklung für den Umweltbereich. Hrsg. v. BOCK, M./GREVE, K./KUHN, W. - Münster 1999 [IfGi-prints;7]:185-195.

FITZKE, J./FRIEBE, T.: Kartengestützte und internetbasierte Auskunft über die geographische Verbreitung von Pflanzen und Tieren. In: Umweltbundesamt (Hg.): Umweltdatenbanken im Web, Workshopbeiträge und Ergebnisse; Workshop des Arbeitskreises Umweltdatenbanken; 10./11. Juni 1999. - Karlsruhe, Wien 1999:18-27.

FITZKE, J./GREVE, K.: Kartengestützte Auskunftsmodule von Umweltinformationssystemen im WWW. - In: Management von Umweltinformationen in vernetzten Umgebungen. 2. Workshop des Arbeitskreises "Hypermedia im Umweltschutz". 8. Workshop der Fachgruppe "Betriebliche Umweltinformationssysteme". Hrsg. v. DADE, C./SCHULZ, B. - Nürnberg 1999: 237-240.

FLACH, D.: Römische Agrargeschichte. - München: Beck 1990 [Handbuch der Altertumswissenschaft III;9].

FLACHSBART, O.: Gewässer der Goslarer Wasserwirtschaft: eine Untersuchung über Wesen und Bedeutung der Wasserwirtschaft in der deutschen Stadtgeschichte. - Goslar: Brumby 1928 [Beiträge zur Geschichte der Stadt Goslar;4]; Zugl.: Hannover, Techn. Hochsch., Diss. 1928.

FLECK, R.: Planmäßige Umgestaltung der Landschaft im Dienste großregionaler Wirtschaftsentwicklung. - In: Petermanns Geographische Mitteilungen, 96 1952:32-35.

FLEISCH, G.: Die Oberharzer Wasserwirtschaft in Vergangenheit und Gegenwart. - Clausthal-Zellerfeld: Selbstverl. 1982/83; Zugl. Clausthal-Zellerfeld, TU, Diss.: ,[Das] Oberharzer Wassersystem und seine Anpassungsfähigkeit an sich ändernde Verbraucherstandorte und Nutzungsformen sowie seine Erhaltung“ 1982.

FLEMMING, W.: Der Wandel des deutschen Naturgefühls vom 15. zum 18. Jahrhundert. - Halle/Saale: Niemeyer 1931 [Deutsche Vierteljahresschrift für Literaturwissenschaft und Geistesgeschichte;18].

FLIEDNER, D.: Die Kulturlandschaft der Hamme-Wümme-Niederung: Gestalt und Entwicklung des Siedlungsraumes nördlich von Bremen. - Göttingen: Goltze 1970 [Göttinger geographische Abhandlungen.;55].

FLIEDNER, D.: Umrisse einer Theorie des Raumes: eine Untersuchung aus historisch-geographischem Blickwinkel. Saarbrücken: Geogr. Inst. d. Univ. 1984 [Arbeiten aus dem Geographischen Institut der Universität des Saarlandes;34].

FLIEDNER, D.: Die Entwicklung des Raumverständnisses in der Anthropogeographie in denn letzten hundert Jahren. - Karlsruhe: Inst. f. Geographie u. Geoökologie II, Uni. Karlsruhe 1990 [Karlsruher Manuskripte zur mathematischen und theoretischen Wirtschaft- und Sozialgeographie;93].

FLIEDNER, D.: Über die ursprüngliche Hufengröße im Holler Kolonisationsgebiet nördlich von Bremen [Einige sachliche und methodische Bemerkungen zum Aufsatz Hendrik van der Linden: „Die Königsrute. Eine Revision der ,Cope-Untersuchung’ bezüglich der mittelalterlichen Kultivierungssystematik]. - In: Siedlungsforschung 19 2001:375-388.

FLINT, K./MORPHY, H. (Hrsg.): Culture, landscape, and the environment. - Oxford et al.: Oxford Univ. Press. 2000 [The Linacre lectures;7].

FLOHN, H.: Klimaschwankungen im Mittelalter und ihre historisch-geographische Bedeutung - In: Berichte zur dt. Landeskunde;7]:347-357.

FLOHN, H.: Klimaschwankungen in historischer Zeit. - In: RUDLOFF, H. v.: Die Schwankungen und Pendelungen des Klimas in Europa seit dem Beginn der regelmäßigen Instrumentenbeobachtungen (1670).- Braunschweig: Vieweg 1967 [Die Wissenschaft;122]. 
FLOHN, H.: Das Problem der Klimaänderungen in Vergangenheit und Zukunft. - Darmstadt: Wiss. Buchgesellschaft 1985 [Erträge der Forschung;220].

FLÖßERMUSEUM UNTERRODACH. - München/Zürich 1990 [Bayerische Museen;14].

FLÖßERMUSEUM UNTERRODACH/BAYERISCHES LANDESAMT FÜR DENKMALPFLEGE (Hrsg.): Denkmäler der Flößerei im Frankenwald. Ein Gewerbe prägt eine Kulturlandschaft. - Bamberg 1999.

FLUSSLANDSCHAFTEN im urbanen Raum: Revitalisierungen in der Basler Region. Hrsg. v. d. Geographisch-Ethnologischen Gesellschaft Basel. - Basel: Wepf 2001 [Regio Basiliensis;42,1].

FÖHL, A./HAMM, M.: Die Industriegeschichte des Wassers: Transport, Energie, Versorgung, Weltbild - Düsseldorf: VDI-Verl. 1985

FONTANE, T.: Irrungen, Wirrungen. - Stuttgart: Reclam 1988 [orig. 1887].

FOREL, F. A.: Handbuch der Seenkunde: allgemeine Limnologie. Bibliothek geographischer Handbücher. Hrsg. v. F. Ratzel, Teil 9. - Stuttgart: Engelhorn 1901.

FORELLENZUCHT-LAUTERTAL 2004: Fischerei im Coburger Land [URL = http//www.forellenzuchtlautertal.de/ltt/chronik_cbg.htm;04.08.2004].

FORMAN, Richard T. T.: Land Mosaics: The ecology of landscapes and regions. - Cambridge et al.: University Press 1995.

FORSCHUNGSGRUPPE FLIEßGEWÄSSER: Fließgewässertypologie. Ergebnisse interdisziplinärer Studien an naturnahen Fließgewässern und Auen in Baden-Württemberg mit Schwerpunkt Buntsandstein-Odenwald und Oberrheinebene. Landsberg am Lech: ecomed 1993 [Umweltforschung in Baden-Württemberg].

FÖRSTEMANN, E.: Altdeutsches Namenbuch. Zweiter Band: Orts- und sonstige geographische Namen (Völker-, Länder-, Siedlungs-, Gewässer-, Gebirgs-, Berg-, Wald-, Flurnamen und dgl.), 2 Teile, Nachdruck der 3., völlig neu bearb., um 100 Jahre (1100-1200) erweiterten Auflage, hrsg. v. Jellinghaus, Hermann. - München-Hildesheim 1967 (Repr. Nachdr. d. Ausg. Bonn 1913/16).

FÖRSTEMANN, E. G.: Urkundliche Geschichte der Geschichte der Stadt Nordhausen bis zum Jahre 1250. - Mit Steindrucktafel. Nordhausen: Herrmann Förstemann 1840

FÖRSTEMANN, E. G.: Geschichte der Stadt Nordhausen. Erste Lieferung bis zum Jahr 1220. - Nordhausen: J. G. Müller o. J.

FÖRSTEMANN, E. G.: Kleine Schriften zur Geschichte der Stadt Nordhausen. Mit einer Steindrucktafel. - Nordhausen: Verl. Ferd. Förstemann 1855.

FOYER: Neue Ufer: Leben und Arbeiten am Wasser. - Berlin 1998 [Magazin der Senatsverwaltung für Bauen, Wohnen und Verkehr Berlin;4].

FRANK, W.: Vom Wasser zum Strom. Das Wasserkraftwerk Nauroth. Hrsg.: Koblenzer Elektrizitätswerk und VerkehrsAktiengesellschaft (KEVAG). - Koblenz 1992.

FRANKE, W.: Der Landkreis Emsland: Geographie, Geschichte, Gegenwart: eine Kreisbeschreibung. - Meppen: Landkreis Emsland 2002

FRANKE, T.: Die Bedeutung von extensiv genutzten Teichen für die Pflanzenwelt - am Beispiel des fränkischen Teichgebietes. München: Bayerische Landesanstalt für Umwelt 1988 [Beiträge zum Artenschutz;7/84]:143-153.

FRANKE, W.: Nutzpflanzenkunde: nutzbare Gewächse der gemäßigten Breiten, Subtropen und Tropen. - 6. Aufl. - Stuttgart: Thieme 1997

FRANKEWITZ, S.: Burgen, Schlösser, Herrenhäuser an den Ufern der Niers. - Kleve: Boss-Dr.- und Medien 1997.

FRANZ, E. G.: Einführung in die Archivkunde. - Darmstadt: Wissenschaftl. Buchgesell. 1993 [Die Geschichtswissenschaft].

FRANZ, G.: Geschichte de deutschen Bauernstandes vom frühen Mittelalter bis zum 19. Jahrhundert. - 2. Aufl. - Stuttgart: Ulmer 1976 [Dt. Agrargeschichte;4].

FRANZ, G./JÄGER, H.: Historische Kartographie: Forschung und Bibliographie. - 3. Aufl. - Hannover: Schrödel 1980 [Veröffentlichungen der Akademie für Raumforschung und Landesplanung: Beiträge;46].

FRANZIUS, L./SONNE, E.: Der Wasserbau. - Leipzig: Engelmann 1879 [Handbuch der Ingenieurwissenschaften;3].

FRANZIUS, O.: Die Wasserwege Niedersachsens. 58 Skizzen. - Hannover 1930 [Veröff. Wirtschaftswiss. Gesell. z. Studium Niedersachsens, Reihe B, Forschungen;8].

FRANZKE, J. et al.: Räder im Fluß: Die Geschichte der Nürnberger Mühlen. - Nürnberg 1986.

FRÄNZLE, Otto: Handbuch der Umweltwissenschaften: Grundlagen und Anwendungen der Ökosystemforschung. Landsberg/Lech: ecomed 1997 [Grundwerk]; [Erg.Lfg. 1]; [Erg.-Lfg. 2].

FRECKMANN, K./SIMONS, G./GRUNSKY-PEPER, K.: Flachs im Rheinland. Anbau und Verarbeitung. - Köln, Bonn: Rheinland Verl. 1979.

FRECKMANN, W.: Wiesen und Dauerweiden. - Berlin: Parey 1932. 
FRENZEL, B.: Ökologische Konsequenzen der Entwicklung vom Wald zum Forst in Mitteleuropa. - In: Probleme der Umweltforschung in historischer Sicht: Rundgespräch am 16. und 17. November 1992 in München. Hrsg. Bayerische Akademie der Wissenschaften. - München: Pfeil 1993 [Rundgespräche der Kommission für Ökologie;7]:141-159.

FREUND, W.: Geographische und historisch-architektonische Analyse ausgewählter ländlicher Siedlungen im Kreis Querfurt. Möglichkeiten zur Erhaltung baulicher Elemente einer Kulturlandschaft. - Halle-Wittenberg, Univ., Diss. 1985.

FRIý, A.: Die künstliche Fischzucht in Böhmen: ein Bericht über die Fortschritte der Lachs- und Forellenzucht in den Jahren 1871-74; nebst einer Anleitung zur künstl. Fischzucht. - Prag: Grégr 1874.

FRIEDEL, E.: Aus der Vorzeit der Fischerei. - Berlin: Verl. von Carl Habel 1884

FRIEDRICH, H.: Die deutsche Binnenfischerei und ihre wirtschaftsgeographische Bedeutung. - Würzburg: Mayr 1933; Zugl.: Würzburg, Univ. Diss. 1933.

FRIELING, H.-D. v./GÜSSEFELDT, J./KOOPMANN, J.: Digitale Karten in GIS. - Göttingen: Geographisches Institut 1993 [Praxis Kultur- und Sozialgeographie;11].

FRIELINGHAUS, M./MÜLLER, L./KRÜGER, F.: Landschaftsveränderungen eines Flussniederungsgebietes während der letzten 200 Jahre und daraus abgeleitete Entwicklungsziele. - In: Zeitschrift für Kulturtechnik und Landentwicklung 35 1994:365373.

FRIES, C. F. E.: Lehrbuch des Wiesenbaus. - Braunschweig: Verl. Vieweg und Sohn 1866.

FRIMMEL, F. (Hrsg.): Wasser und Gewässer: ein Handbuch. - Heidelberg et al.: Spektrum, Akad. Verl. 1999 [Spektrum Umwelt].

FRITZ, G.: Die Erfassung bestehender und verschwundener Mühlen: Das Projekt eines Mühlenatlasses. - In: WürttF 72 1988:347348.

FRÖHLICH, T.: Klimaschutz in der Sackgasse. - In: Süddeutsche Zeitung Nr. 282 v. 7./8.12.91:33.

FRONTINUS 2004 [aus: htpp://www.frontinus.de/Flyer_130503-innen-2.pdf;17.01.2004].

FRTTSCH, B.: Mensch, Umwelt, Wissen: Evolutionsgeschichtliche Aspekte der Umweltproblems. - 4. Aufl. - Zürich, Stuttgart: Teubner 1994 [1. Aufl. 1990].

FRÜHAUF, Manfred et al. (Hrsg.): Geowissenschaftliche Umweltforschung im mitteldeutschen Raum: Sammelband der 3. Tagung zur Geographischen Umweltforschung in Mitteldeutschland im Rahmen der Universitätspartnerschaft Halle-JenaLeipzig an der Martin-Luther-Universität Halle-Wittenberg, 6.-7. November 1997. - Halle/Saale: UZU 1998 [UZUSchriftenreihe; N. F. 2].

FUCHSLOCH, N.: „Rauchschäden“ im Mansfelder Land. - In: EBERSBACH, W./MEINICKE, K.-P. (Hrsg.): Bergbau- und Umweltgeschichte in Mitteldeutschland. - Halle/Saale: Martin-Luther-Univ. 1996:117-123.

FUCHSLOCH, N.: Einführung in „Methodenfragen der Umweltgeschichte“. - In: BAYERL, G./FUCHSLOCH, N./MEYER, T. (Hrsg.): Umweltgeschichte - Methoden, Themen, Potentiale: Tagung des Hamburger Arbeitskreises für Umweltgeschichte, Hamburg 1994. - Münster, New York: Waxmann 1996 [Cottbuser Studien zur Geschichte von Technik, Arbeit und Umwelt;1]:1-12.

FUHRER, H.: Feldmessen und Kartographie. - 1. Aufl. - Stuttgart: Klett-Perthes 1998.

FUHRMANN, S./STREIT, U.: Aufbau eines multimedialen hydrologischen Visualisierungssystems für das Wesereinzugsgebiet. In: GIS und Kartographie im multimedialen Umfeld: Grundlagen, Anwendungen und Entwicklungstrends. Bonn: Kirschbaum 1997 [Kartographische Schriften;2]:58-66.

FULLER, P.: The geography of Mother Nature. - In: COSGROVE, D./DANIELS, S. (Hrsg.): The iconography of landscape: essays on the symbolic representations, design and use of past environments. - Cambridge: University Press 1988 [Cambridge studies in historical geography;9]:11-31.

FUMAGALLI, V.: Der lebende Stein: Stadt und Natur im Mittelalter. - Berlin: Wagenbach 1989 [Wagenbachs Taschenbücherei;164].

FUMAGALLI, V.: Landscapes of Fear: Perceptions of Nature and the City in the Middle Ages. - Oxford: Polity Press 1994

FUNK, V.: Johann Nepomuk von Schwerz‘ Praktischer Ackerbau unter Hinzufügung der Viehzucht. - Berlin 1882.

FURRER, G./FREUND, R.: Auf den Spuren der Bewässerung im Bündnerland. - In: DVWK (Hrsg.): Historische Wasserwirtschaft im Alpenraum und an der Donau.. - Stuttgart: Wittwer 1994:11-15.

FUSS, Ulrike Valeria: Matthaeus Merian der Ältere: Von der lieblichen Landschaft zum Kriegsschauplatz - Landschaften als Kulisse des 30jährigen Krieges. - Frankfurt/Main et al.: Lang 2000 [Europäische Hochschulschriften. Reihe 28: Kunstgeschichte;350].

GÄBLER, H. J.: Die Gewässer in der Kulturlandschaft. - In: Wasser und Boden 31 1979:4-7.

GAEBE, W. (Hrsg.): Methoden und Feldforschung in der Industriegeographie: [Vorträge des 42. Deutschen Geographentages vom 5.-10. Juni 1979 in Göttingen. - Mannheim: Geographisches Inst. d. Univ. 1980 [Mannheimer Geographische Arbeiten;7]. 
GÄBELER, Jürgen: Ein Beitrag zur Frühgeschichte der Sägemühlen (1200 -1600): neue Erfassungen und kritische Überlegungen zur Entstehung aus der Mühlendiversifikation. - Remagen-Oberwinter: Kessel 2002

GALLUSSER, W. A./SCHENKER, A. (Hrsg.): Die Auen am Oberrhein. - Basel: Birkhäuser 1992.

GANTHER, Christian: Am Krottenbach: vom Bach zum Bachkanal: Auf den Spuren einer historischen Landschaft. - In: Wiener Geschichtsblätter 53, Beiheft 41998.

GANZERT, C.: Die agrarstrukturellen Grundlagen der Kulturlandschaft und ihre Bedeutung für den Naturschutz. - Zeitschrift für angewandte Umweltforschung 11994.

GARBRECHT, G.[a]: Gewässerbau in der Geschichte. - In: Wasser und Boden 33 (1981):372-380.

GARBRECHT, G.[b]: The water supply system at Tuspa (Hrartu). - In: XI. Congress Proceedings, Special session on the history of irrigation, drainage and flood control. - Grenoble: ICID 1981:30-38.

GARBRECHT, Günther: Wasser: Vorrat, Bedarf und Nutzung in Geschichte und Gegenwart. - Stuttgart: Rororo-Taschenbücher 1985 [Kulturgeschichte d. Naturwissenschaften und der Technik;7724].

GARBRECHT, G.: Die Talsperren der Urarträer. In: Historische Talsperren. - Stuttgart: Wittwer 1987:139-145.

GARLEFF, K.: Untersuchungen zur vorzeitlichen Bodenerosion im Einzugsgebiet des Ellerbaches östlich von Bamberg. - In: 60. Bericht der Naturforschenden Gesellschaft Bamberg 1985 (gemeinsam mit E. M. ABRAHAM DE VAZQUEZ, F. SCHÄBITZ und G. SEEMANN):173-189.

GASPER, P. /MENZ, G.: Landschaftsmaße zur Bestimmung der räumlichen Strukturen in klassifizierten Satellitenbildern. Karlsruhe 1999 [Publikationen der Deutschen Gesellschaft für Photogrammetrie und Fernerkundung;7]:333-340.

GASSEN, R. W./HOLECZEK, B. (Hrsg.)[a]: Mythos Rhein: [Ausstellung aus Anlaß des Rheinland-Pfalz-Tages 1992 in Ludwigshafen] / [Wilhelm-Hack-Museum, Ludwigshafen am Rhein]. Teil: Ein Fluß in Kitsch und Kommerz: Stadtmuseum, Ludwigshafen am Rhein, 12. Juni bis 16. August 1992 / [Ausstellung und Katalog Peter Ruf]. - Heidelberg: Braus 1992.

GASSEN, R. W./HOLECZEK, B.(Hrsg.)[b]: Mythos Rhein: [Ausstellung aus Anlaß des Rheinland-Pfalz-Tages 1992 in Ludwigshafen] / [Wilhelm-Hack-Museum, Ludwigshafen am Rhein]. Teil: Ein Fluß im Fokus der Kamera / [Ausstellung und Katalog Barbara Auer]. - Heidelberg: Braus 1992.

GEBHARDT, G.: Die Flößerei auf der Leine und ihren Nebenflüsse. - In: Heimatland 4 1995:126-128.

GEES, A.: Analyse historischer und seltener Hochwasser in der Schweiz: Bedeutung für das Bemessungshochwasser. - Bern 1997 [Geographica Bernensia;G 53].

GEISLER, G: Farbatlas Landwirtschaftliche Kulturpflanzen. - Stuttgart: Ulmer 1991.

GELLER, W.: Die Elbe - neue Horizonte des Flussgebietsmanagements. 10. Magdeburger Gewässerschutzseminar. - Hrsg. UFZUmweltforschungszentrum Leipzig-Halle GmbH - 1. Aufl. - Stuttgart et al.: Teubner 2002.

GELLING, M./COLE, A.: The landscape of place-names. - Stamford, Lincolnshire [England]: Shaun Tyas 2000.

GEMEINDE AMMERSBEK: Chronik Ammersbek, Bünningstedt, Hoisbüttel. - Ammersbek: Gemeinde 1988.

GEMEINDE KALTENKIRCHEN 2004 [URL = http://www.kaltenkirchen-land.de/gemeinden/nuetzen;11.02.2004].

GENERAL-ANZEIGER vom 29./30. November 2003: Das Heisterbacher Tal soll aufblühen.

GENOVESE, E. D./HOCHBERG, L. (Hrsg.): Geographic perspectives in history. - Oxford: Basil Blackwell 1989.

GENS, T.: Der Vorrat an Natur geht zur Neige. -In: Frankfurter Allgemeine Zeitung, Nr. 50 v. 28.2.1991 [Reiseblatt].

„GEOTOURISMUS und Landschaftsmarketing“. Tagung vom 19.-21. April 2002 in Freiburg. Eine Regionalveranstaltung zum Jahr der Geowissenschaften. [URL $=$ http//:www.geographie.uni-freiburg.de/ipg/forschung/ap6/events/2002_Freiburg; 12.05.2003].

GERBER, B.: Waldflächenveränderungen und Hochwasserbedrohung im Einzugsgebiet der Emme. - Bern 1989 [Geographica Bernensia;33].

GERBER, R/CHUAN, G. K. (Hrsg.): Fieldwork in Geography: Reflections, Perspectives and Actions. - Dordrecht et al.: Kluwer 2000 [The GeoJournal Library;54].

GERBER, R./CHUAN, G. K.: The power of fieldwork. - In: GERBER, R./CHUAN, G. K.: Fieldwork in Geography: Reflections, Perspectives and Actions. - Dordrecht et al.: Kluwer 2000 [The GeoJournal Library;54]:3-12.

GERKEN, B./DÖRFER, K. [unter Mitwirkung von LOHR, M. und SCHUMACHER, E.]: Auenregeneration an der Oberweser. Ein Strom im Wandel: Bausteine zu einer lebendigen Aue. Ergebnisse des E+E-Vorhabens „Gestaltungs- und Pflegemaßnahmen landschaftstypischer Auenstandorte der Oberweserniederung; wissenschaftliche Begleitung" des Bundesamtes für Naturschutz. - Bonn: BfN 2002 [Schriftenreihe für Ökologie;46].

GERKEN, B./GÖRNER, M. (Hrsg.): Europäische Landschaftsentwicklung mit großen Weidetieren: Geschichte, Modelle und Perspektiven. - Höxter: Univ.-Gesamthochschule Paderborn, Abt. Höxter, Lehrgebiet Tierökologie 1999 [Natur- und Kulturlandschaft;3]. 
GERKEN, B./LOHR, M./SCHUMACHER, E.: Renaturierung von Bächen, Flüssen und Strömen. Tagungsband zur gleichnamigen internationalen Fachtagung vom 24.-26. November 1999 in Neuhaus im Solling. Hrsg.: Bundesamt für Naturschutz (BfN). Bonn - Bad Godesberg: BfN 2000 [Angewandte Landschaftsökologie;37].

GERKEN, B./MARTENSEN, P.: Bisherige Ergebnisse zusammengestellt anlässlich des Wissenschaftlichen Status-Kolloqiums und der PAG-Sitzung zum E+E-Projekt „Hutelandschaftspflege und Artenschutz mit großen Weidetieren im Naturpark Solling-Vogler" am 14. Januar 2003 in Holzminden OT Neuhaus.

GERKEN, B./SONNENBURG, H.: Landscape development and species protection in woddlands, forests and pastures using large herbivores. - In: REDECKER, B./FINCK, P. et al. (Hrsg.): Pasture Landscapes and Nature Conservation. - Berlin, Heidelberg: Springer 2002:285-301.

GERKEN, B./SONNENBURG, H.: Das Hutewaldprojekt im Solling: ein Baustein für eine neue Ära des Naturschutzes. - Höxter: Huxaria Druckerei 2003 [Natur- und Kulturlandschaft;6].

GERKING, W.: Die mittelalterlichen Siedlungen der Großgemeinde Lüdge. - Detmold: Landesmuseum 1986 [Schriften d. Lipp. Landesmuseums;2].

GERLACH, R.: Flussdynamik des Mains unter dem Einfluß des Menschen seit dem Spätmittelalter. - Trier: Zentralausschuß für dt. Landeskunde, Selbstverl. 1990 [Forschungen zur dt. Landeskunde;234].

GERLACH, R.: Landschaftsgeschichte - Der Beitrag der Physischen Geographie zur genetischen Siedlungsforschung. - In: Siedlungsforschung 18 2000:145-150.

GERSTENBERGER, H.: Von Land zu Land: aus der Geschichte Bremischer Seefahrt. - Bremen: Ed. Temmen 1991 [Beiträge zur Sozialgeschichte Bremens;14].

GERSTENBERGER, H./WELKE, U.: Vom Wind zum Dampf: Sozialgeschichte der deutschen Handelsschiffahrt im Zeitalter der Industrialisierung. - Münster: Westfälisches Dampfboot 1996.

GESKE, C./ENGEL, E./PLACHTER, H.: Typologisierung und Bewertung kleiner Fliessgewässer: ein Methodenvergleich. Wiesbaden 1997 [Umweltplanung, Arbeits- und Umweltschutz;242]; Zugl.: Marburg, Univ., Dipl.-Arbeit.

GIERLOFF-EMDEN, H. G.: Luftbild und Küstengeographie am Beispiel der deutschen Nordseeküste. - Bad Godesberg: Selbstverl. d. Inst. f. Landeskunde 1961.

GIESE, E.: Die untere Haseniederung: eine ländlich-bäuerliche Landschaft im nordwestdeutschen Tiefland. - Münster: Inst. f. Geographie und Länderkunde 1969 [Westfälische geogr. Studien;20].

GIESECKE, J.: Umweltforschung mit Schwerpunkt Wasserwirtschaft an der Universität Stuttgart. - Stuttgart: Univ.-Bibliothek 1991 [Reden und Aufsätze der Univ. Stuttgart;40].

GIETL, K.: Die Chronik. - In: 1855 -1995:140 Jahre Landesfischereiverband Bayern, Jubiläumsbeilage zu „Byern Fischerei und Gewässer“. Hrsg.: Landesfischereiverband Bayern e.V. [LFV] - München 1995:5-10.

GIGGLBERGER, B.: Eine Bewässerungsanlage aus dem 19. Jahrhundert: Die Wiesenkulturgenossenschaft Baunach, Daschendorf, Ebing, Rattelsdorf. - In: Frankenland 41 1989:102-106.

GILHAUS, U.: „Schmerzenskinder der Industrie“: Umweltverschmutzung, Umweltpolitik und sozialer Protest im Industriezeitalter in Westfalen 1845-1914. - Paderborn: Schöningh 1995.

GIRTLER, R.: Methoden der Feldforschung. - 4. Aufl. - Wien et al.: Böhlau 2001 [UTB für Wissenschaft;2257: Soziologie].

GIRSCHNER, W.: Nordhausen und Umgegend. Enthaltend: die geschichtlichen und geographischen Verhältnisse, Reiseverbindungen und Merkwürdigkeiten der Stadt Nordhausen sowie ihrer näheren und ferneren Umgebung. Ein Handbuch und Wegweiser für Einheimische und Freunde. [...] Mit einem Grundriß der Stadt Nordhausen und einer Karte der Umgegend. - 3. Aufl. - Nordhausen: Verl. Georg Wimmer’s Buch- \& Kunsthandlung 1891.

GRIMM, P.: Die vor- und frühgeschichtliche Besiedlung des Unterharzes und seines Vorlandes auf Grund der Bodenfunde. Halle/Saale: Gebauer-Schwetschke 1931 [Jahresschrift für die Vorgeschichte der sächsisch-thüringischen Länder;18]; Zugl.: Halle, Univ., Diss. 1931.

GIS UND KARTOGRAPHIE im multimedialen Umfeld: Grundlagen, Anwendungen und Entwicklungstrends. Hrsg.: Deutsche Gesellschaft für Kartographie e. V., AK Kartographie und GEO-Informationssysteme. - Bonn: Kirschbaum 1997 [Kartographische Schriften;2].

GIUS, S.: Zur Geschichte der Wildbachverbauung in Südtirol. - In: DVWK (Hrsg.): Historische Wasserwirtschaft im Alpenraum und an der Donau. - Stuttgart: Wittwer 1994:167-183.

GLASER, H./KREUTER, W.: Industriesiedlungen von den Anfängen der Industrialisierung bis zur Weltwirtschaftskrise: Eisenund Stahlwerke, Glashütten, Eisenbahn. - Saarbrücken: Stadtverband Saabrücken, Umweltamt 1989.

GLASER, H.: Industriekultur und Alltagsleben: vom Biedermeier zur Postmoderne. - Frankfurt/Main: Fischer-Taschenbuch-Verl. 1994 [Fischer-Taschenbücher;11751].

GLASER, R.: Historische Hochwässer im Maingebiet - Möglichkeiten und Perspektiven auf der Basis der Historischen Klimadatenbank Deutschland (HISKLID).- In: DEUTSCH, M./PÖRTGE, K.-H. (Hrsg.): Aktuelle und historische 
Hochwasserereignisse - Beiträge zur Jahrestagung des Arbeitskreises "Hydrologie" im März 1997 in Erfurt. - Erfurt 1998 [Erfurter Geographische Studien;7]:109-128.

GLASER, R. et al.: Hochwässer als historisches Phänomen. - München: Verlag Dr. F. Pfeil 2002 [Rundgespräche der Kommission für Ökologie;24].

GLASER, R./SAURER, H./SCHENK, W.: Abschätzung von Albedoänderungen in historischer Zeit und ihre Auswirkungen auf den Strahlungshaushalt im mainfränkischen Raum. - In: Meteorologische Rundschau 44/5 1991:152-156.

GLASER, R./SCHENK, W.: Grundzüge der Klimaentwicklung in Mitteleuropa seit dem Jahr 1000.- In: HOFRICHTER, H. (Hrsg.): Fenster und Türen in historischen Wehr- und Wohnbauten. Kolloquium des Wissenschaftlichen Beirats der Deutschen Burgenvereinigung. Marksburg/Braubach: Deutsche Burgenvereinigung. 1995 [Veröff. der Deutschen Burgenvereinigung, Reihe B, Schriften 4; zugleich Sonderheft der Zeitschrift „Burgen und Schlösser“]:13-25.

GLASER, Rüdiger: Klimageschichte Mitteleuropas: 1000 Jahre Wetter, Klima, Katastrophen. - Darmstadt: Wiss. Buchges. 2001

GLAUSER, F.: Fluß und Siedlung. - In: Geographica Helvetica 2 1991:67-70.

GLAUSER, F.: Stadt und Fluß zwischen Rhein und Alpen. - In: MASCHKE, E./SYDOW, J. (Hrsg.): Die Stadt am Fluß: 14. Arbeitstagung in Kiel 14. - 16.11.1975. - Sigmaringen: Thorbecke 1978 [Stadt in der Geschichte;4]:62-99.

GLAUSER, P.: Landschaftsbeobachtung - ein Beitrag zur integrierten, langfristigen Umweltbeobachtung in der Schweiz. - In: Geographica Helvetica 4 1993:151-158.

GLEICH, A. v.: Der wissenschaftliche Umgang mit der Natur: über die Vielfalt harter und sanfter Naturwissenschaften. Frankfurt/Main et al.: Campus 1989 [Campus Forschung;601]; Zugl.: Hannover, Univ., Diss. 1988 u. d. T. „Über den wissenschaftlichen Umgang mit der Natur“.

GLEICHMANN, H. D.: Der Füsseberg: Die große Zeit des Siegerländer Eisenerzbergbaus. - Siegen: Verl. Höpner und Göttert 1994.

GLEICHMANN, H. D.: Die Eiserne Hardt. Aus dem Bergbau des Siegerlandes. - Siegen: Höpner und Göttert 1997.

GLEICHMANN, H. D.: Die Neue Haardt: Der industrielle Umbruch im Bergbau des Siegerlandes. - Siegen: Höpner und Göttert 1999.

GLEICHMANN, H. D.: Von Wingertshardt bis Silberwiese: Der Eisenerzbergbau an mittlerer Sieg und Wied. - Siegen: Höpner u. Göttert 1997

GLEITSMANN, R. J.: Rohstoffmangel und Lösungsstrategien. Das Problem vorindustrieller Holzknappheit. - In: Technologie und Politik 16 1980:105-154.

GLODECK, T.: AENGEVELT-Sprecher . - In: WZ v. 19.06.2003:9.

GLÖER, P./MEIER-BROOK, C./OSTERMANN, O.: Süßwassermollusken: Ein Bestimmungsschlüssel für die Bundesrepublik Deutschland. Hrsg.: Deutscher Jugendbund für Naturbeobachtung - Hamburg 1992.

GLOY, K. (Hrsg.): Natur- und Technikbegriffe: historische und systematische Aspekte: von der Antike bis zur ökologischen Krise, von der Physik bis zur Ästhetik. - Bonn: Bouvier 1996 [Abhandlungen zur Philosophie, Psychologie und Pädagogik;242]

GLÜCKLER, J.: Neue Wege geographischen Denkens?: Eine Kritik gegenwärtiger Raumkonzeptionen und ihrer Forschungsprogramme in der Geographie. - Frankfurt/Main: Verl. Neue Wiss. 1999

GÖBEL, I.: Die Mühle in der Stadt: Müllerhandwerk in Göttingen, Hameln und Hildesheim vom Mittelalter bis ins 18. Jahrhundert. - Bielefeld: Verl. für Regionalgeschichte 1993 [Veröffentlichungen des Instituts für Historische Landesforschung der Universität Göttingen;31]; Zugl.: Göttingen, Univ., Diss. 1991.

GOEDE, W. C.: Super Staudämme verändern das Gesicht der Erde: Wasserkraft \& High Tech. - In: PM 6 1996:42-49.

GOETTLE, G.: TAZ-Bericht v. 26.4.2003:15-18.

GOETZ, H.-W.: Leben im Mittelalter vom 7. - 13. Jahrhundert. - 6. Aufl. - München: Beck 1996.

GOLDAMMER, G.: Angewandte historisch-geographische Wasserwegeforschung. Multimediale, computerunterstützte Animation des zwischen Lübeck und Lauenburg liegenden Stecknitz-Kanals. - In: JAKOBS, K./KLEEFELD, K.-D.: Informationssysteme für die Angewandte Historische Geographie. Beiträge des Symposiums vom 20. März 1999 am Lehrstuhl für Informatik IV der RWTH Aachen. Eine Veranstaltung der Arbeitsgruppe für Angewandte Historische Geographie im Arbeitskreis für genetische Siedlungsforschung in Mitteleuropa. [Aachener Informatik-Berichte 99-6]; Zugl. 1 1999 von „Kulturlandschaft. Zeitschrift für Angewandte Historische Geographie. - Bonn: Hartmann 1999.

GOLDAMMER, G.: Der Schaale-Kanal. Relikterforschung historischer Binnenkanäle zwischen Elbe und Ostsee. - Stuttgart: Steiner 1998 [Mitteilungen der Geographischen Gesellschaft in Hamburg;87];. Zugl.: Hamburg, Univ., Diss. 1997.

GOLDAMMER, G.: Historisch-geographische Untersuchung zur Entwicklung von Schleusen an norddeutschen Binnenkanälen. In: Zur Kulturgeographie und Industriearchäologie in Norddeutschland. Versorgung, Verteidigung, Verkehr. Hrsg.: BUDESHEIM, W./NAGEL, F. N./Pries, M. - Wentorf bei Hamburg: 1999:51-66.

GOLDAMMER; G.: Relikte fast vergessener Kanäle: die Viechelsche Fahrt in Mecklenburg. - In: industrie-kultur 1 2000:8-9. 
GOLDAMMER, G.: Vorarbeiten zu einem Kanallandschafts-Kataster: Stecknitz-Delvenau-Senke. Industriearchäologische Arbeitstechniken im Bereich einer historisch gewachsenen Wasserstraße. - In: NAGEL, F. N. (Hrsg.): Kulturlandschaftsforschung und Industriearchäologie: Ergebnisse der Fachsitzung des 52. Deutschen Geographentags Hamburg. - Stuttgart: Steiner 2001 [Mitteilungen der Geographischen Gesellschaft in Hamburg;91]:151-170.

GOLDENBERG, Gert [b]: Mittelalterliche Kupfererzverhüttung in Münstertal-Süßenbrunn. - In: Früher Bergbau im südlichen Schwarzwald: Begleitheft zur Ausstellung des Museums für Ur- und Frühgeschichte der Stadt Freiburg/Breisgau Br. vom 29. Juli bis zum 21. November 1999. Hrsg. v. Landesdenkmalamt Baden-Württemberg. - Stuttgart: Ges. für Vor- und Frühgeschichte in Württemberg und Hohenzollern, 1999 [Archäologische Informationen aus Baden-Württemberg; 41]:83-88.

GOLDENBERG, Gert[a]: Geologie und Lagerstätten. - In: Früher Bergbau im südlichen Schwarzwald: Begleitheft zur Ausstellung des Museums für Ur- und Frühgeschichte der Stadt Freiburg i. Br. vom 29. Juli bis zum 21. November 1999. Hrsg. v. Landesdenkmalamt Baden-Württemberg. - Stuttgart: Ges. für Vor- und Frühgeschichte in Württemberg und Hohenzollern 1999 [Archäologische Informationen aus Baden-Württemberg; 41]:9-14.

GOLDENBERG, G.[c]: Umweltbeeinflussung durch das frühe Montanwesen: Beispiel aus dem Schwarzwald. - In: JOCKENHÖVEL, A. (Hrsg.): Bergbau, Verhüttung und Waldnutzung im Mittelalter: Auswirkungen auf Mensch und Umwelt; Ergebnisse eines internationalen Workshops (Dillenburg, 11. - 15.Mai 1994, Wirtschaftshistorisches Museum „Villa Grün“). - Stuttgart: Steiner 1996 [Vierteljahrschrift für Sozial- und Wirtschaftsgeschichte: Beihefte;121]:230-246.

GOLDENBERG, L. A.: About the place of historical geography in the system of sciences. - In: ADAMS, W.P./HELLEINER, F. M. (Hrsg.): International Geography, Vol. 1 - Montreal: IGU 1972:420-422.

GOLDMANN, K.: Märkischer Weizen für Byzanz - zum Reisebericht Ibrahim Ibn Jakubs von 965/66. - In: Ausgrabungen in Berlin 6 1982:197-210.

GOPPEL, K.: Wasserbau aus der Sicht von Raumordnung und Landesplanung. - In: ANL [Bayerische Akademie für Naturschutz und Landschaftspflege] (Hrsg.): Wasserkraft - mit oder gegen die Natur? Gemeinsames Seminar der Bayerischen Akademie für Naturschutz und Landschaftspflege (ANL) und der Arbeitsgemeinschaft „Wasserkraft in Bayern“ zusammen mit dem Österreichischen Verein für Ökologie und Umweltforschung und dem Schweizerischen Wasserwirtschaftsverband 7./8. September 1993 in Deggendorf. - Laufen/Salzach: ANL 1994 [Laufener Seminarbeiträge;3]:23-25.

GORE, AL: Wege zum Gleichgewicht. Ein Marshallplan für die Erde. - Frankfurt/Main Amerikanische Originalausgabe: Earth in the Balance -Ecology and Human Spirit. - Boston [et al.], 1992/1994

GÖRING, H./EYDELER, I./SPIEKER, J.: Wasserqualität in Natur- und Badeteichanlagen. - In: Stadt + Grün 9 2003:42-47.

GÖSCHEL, J.: Die Orts-, Flur- und Flussnamen der Kreise Borna und Geithain: namenkundliche Untersuchungen zur Sprach- und Siedlungsgeschichte Nordwestsachsens. - Köln et al.: Böhlau 1964 [Mitteldeutsche Forschungen;31]; Zugl.: Leipzig, Univ., Diss. 1961.

GOTHEIN, E.: Entstehung und Entwicklung der Murgschifferschaft: ein Beitrag zur Geschichte des Holzhandels. - Freiburg 1889 [Zeitschrift für Geschichte des Oberrheins; N.F.;4,4].

GÖTTLICH, K.-H.: Moor- und Torfkunde. - 3. Aufl. - Stuttgart: Schweizerbart 1990.

GOTTSCHALK, R. et al.: Früher Bergbau im südlichen Schwarzwald: Begleitheft zur Ausstellung des Museums für Ur- und Frühgeschichte der Stadt Freiburg i. Br. - Stuttgart: Ges. für Vor- und Frühgeschichte in Württemberg und Hohenzollern 1999 [Archäologische Informationen aus Baden-Württemberg;41].

GOTTWALD, W.: Fischzucht und Teichwirtschaft in Schlesien. - In: Würzburger medizinhistorische Mitteilungen (WmM) 6 1988:309-314.

GOUDIE, A.: Mensch und Umwelt: eine Einführung. Aus dem Englischen übersetzt und bearbeitet von Carsten Niemitz. Heidelberg et al.: Spektrum Verl. 1994 [Orig.titel: „The Human Impact on the Natural Environment"].

GOUDIE, A.: The Human Impact on the Natural Environment. - Oxford: Blackwell 1986.

GOUDIE, A.: The Human Impact on the Waters. - In: GOUDIE, Andrew: The Human Impact: Man's Role in Environmental Change. - Oxford: Blackwell 1981:140-186.

GRAAFEN, R. : Zusammenstellung von thematischen Karten zur Siedlungsgeschichte Mitteleuropas in deutschsprachigen Monographien der Nachkriegszeit. - In: Siedlungsforschung 4 1988:286-343.

GRAAFEN, R.: Die räumlichen Auswirkungen der Rechtsvorschriften zum Siedlungswesen im Deutschen Reich, unter besonderer Berücksichtigung von Preussen, in der Zeit der Weimarer Republik. - Bonn: Dümmler 1991 [Dümmlerbuch;7632]; Zugl.: Bonn, Univ., Habil.-Schr. 1989 [Bonner Geographische Abhandlungen;82].

GRAAFEN, R./BURGRAAFF, P.: Flusslandschaften zwischen Persistenz und Überformung - Bericht über die 8. Tagung der „Arbeitsgruppe für Angewandte Historische Geographie“ im „Arbeitskreis für genetische Siedlungsforschung in Mitteleuropa“" vom 9. bis 11. März 2000 in Koblenz. - In: Siedlungsforschung 18 2000:265-267.

GRABNER, E.: Heilende Wasser in Volksmedizin und Naturheilkunde. - In: Blätter für Heimatkunde Graz 74/4 2000:154-164.

GRABNER, Elfriede: Krankheit und Heilen. Eine Kulturgeschichte der Volksmedizin in den Ostalpen. - 2. Aufl. - Wien: Verl. d. Österreich. Akad. d. Wissensschaften 1997. 
GRADMANN, R.: Das mitteleuropäische Landschaftsbild nach seiner geschichtlichen Entwicklung. - In: Geographische Zeitschrift 7/7 1901:361-447.

GRADMANN, R.: Das ländliche Siedlungswesen des Königreichs Württemberg. - Forschungen z. dt. Landes- und Volkskunde 1913:1-136.

GRADMANN, R.: Unsere Flußtäler im Urzustand. - In: Zeitschrift d. Gesellschaft f. Erdkunde z. Berlin 1/2 1932:1-17.

GRÄF, H. T./PRÖVE, R.: Wege ins Ungewisse: Reisen in der frühen Neuzeit. 1500 - 1800. - Frankfurt/Main: FischerTaschenbuch-Verl. 2001.

GRAHAM, B./NASH, C. (Hrsg.): Modern Historical Geographies. - Harlow: Longman 2000.

GRAHLE, H. O./STAESCHE, U.: Die natürlichen Seen Niedersachsens. - In: Geol. Jahrb. 81 1964: 809-838.

GRANSOW, T. 2004 [URL = http://www.thomasgransow.de/Prag/Prag_Topographie.htm;19.01.2004].

GRAUL, E. H. (Hrsg.): Mensch und Umwelt: Environtologie. - Iserlohn: Medice et al. 1974, 1986.

GREES, H./SCHENK, W.: Die Landeskunde Südwestdeutschlands am Geographischen Institut Tübingen: Tradition und Perspektiven.- In: KOHLHEPP, G./PFEFFER, K.-H. (Hrsg.): 100 Jahre Geographie an der Universität Tübingen. - Tübingen 2000 [Tübinger Geographische Studien;118]:147-160.

GREULE, A.: Gewässernamen. - Köln: Rheinland-Verl. 1992 [Geschichtlicher Atlas der Rheinlande: Beiheft 10/3; Publikationen der Gesellschaft für Rheinische Geschichtskunde; N. F., 12, Abt. 1 b].

GREULE, A.: Paderborn und Pader: zur Etymologie eines alten Orts- und Flussnamens. - Paderborn: Schoeningh 1977.

GREULE, A.: Vor- und frühgermanische Flussnamen am Oberrhein: ein Beitrag zur Gewässernamensgebung des Elsaß, der Nordschweiz und Südbadens. - Heidelberg: Winter 1973 [Beiträge zur Namenforschung: Beiheft; N. F.;10]; Zugl.: Freiburg, Univ., Diss. 1971.

GREVE, D.: Das Amt Neuhaus und seine Nachbarn: Grenzbuch aus dem Jahre 1591, Generalkarte der Rögnitz-Sude-Regulierung 1789. - Lüneburg : Landkreis Lüneburg, Der Landrat 1999 [Weiße Reihe;12].

GREVE, K./Heiß, M./Weseloh, R.: Umweltinformationssysteme als Grundlage des Umweltschutzes. In: Geo-Informationssysteme 10/1 1997:6-11.

GREWE, K. (Hrsg.): Canal d` Entreroches: Der Bau eines Schiffahrtsweges von der Nordsee bis zum Mittelmeer im 17. Jahrhundert. - Stuttgart: Wittwer 1987 [Forschungsbeiträge des Förderkreises Vermessungstechnisches Museum e. V.;1].

GREWE, K.: Die Wasserversorgung im Mittelalter. Hrsg.: Frontinus-Gesellschaft e. V.. - Mainz: Zabern 1991 [Geschichte der Wasserversorgung;4].

GREWE, K.: Frühe Schiffahrtskanäle am Rhein. - In: TÖNSMANN, F. (Hrsg.): Zur Geschichte der Wasserstraßen insbesondere in Nordhessen. - Kassel: Herkules Verl. 1995 [Kasseler Wasserbau-Materialien;4]:37-46.

GREWE, K.: Auf Römerspuren rund um Rheinbach: Wasserleitungen und Fernstraßen von der Römerzeit bis zum Mittelalter. Köln: Rheinischer Verein f. Denkmalpflege u. Landschaftsschutz e. V. 2001 [Rheinische Kunsstätten;466].

GREWE, K.: Römische Wasserleitungen nördlich der Alpen. - In: Wasserversorgung 3:43-97.

GRIEP, W./JÄGER, H.-W. (Hrsg.): Reisen und soziale Realität am Ende des 19. Jahrhunderts. - Heidelberg: Winter 1983.

GRIEP, W: „...daß einem Höhen und Sehrn vergeht“. - In: Hamburg-Berlin, Berlin-Hamburg: 400 Jahre Reisen zu Fuss, zu Wasser, auf Rädern und durch die Luft. Hrsg.: Kulturbehörde d. Hansestadt Hamburg. - 1. Aufl. - Hamburg: Dölling und Galitz 1987:8-14.

GRIES, H.: Mühlen an Rodau und Bieber. - Offenbach: Offenbacher Geschichtsverein 1999 [Offenbacher Geschichtsblätter;43] [1. Aufl. 1977].

GRIES, Hartmut: Von Mühlen und Müllern in Bieber. - Offenbach: Offenbacher Geschichtsverein 1999 [Offenbacher Geschichtsblätter;43].

GRIESE, K.: Gimte: das Fischer- und Flößerdorf an der Weser. - In: 800 Jahre Stadt Münden an Werra, Fulda und Weser. Streiflichter in seine Geschichte. - Münden 1983:109-113.

GRIMM, A.: Zur Geschichte der Mühlen in Lippoldsberg und Vernawahlshausen. - In: Äten un Drinken uppen Dörpe. Materialien zur Ausstellung über die Ernährungsgeschichte von Lippoldsberg und dem oberen Weserbergland. Hrsg.: Museum und Werkstatt im Schäferhaus e.V., Wahlsburg-Lippoldsberg. - Göttingen: Die Werkstatt 1988:102-105.

GRIMM, P.: Die ur- und frühgeschichtlichen Bodendenkmäler des Kreises Nordhausen. - Nordhausen 1974.

GRINGMUTH-DALLMER, E.: Frühmittelalterlicher Landesausbau in Thüringen und Hessen. Ein Vergleich. - In: Aspekte thüringisch-hessischer Geschichte. Hrsg. v. Michael Gockel, Hessisches Landesamt für geschichtliche Landeskunde. Marburg/Lahn 1992:67ff.

GRINGMUTH-DALLMER, E.: Landesausbau. - In: Reallexikon der Germanischen Altertumskunde 17 2000:597-602. 
GRINGMUTH-DALLMER, E.: Zur Kulturlandschaftsentwicklung in frühgeschichtlicher Zeit im germanischen Gebiet. - In: Zeitschrift für Archäologie 6 1972:64-90.

GRÖNKE, H.-J.: Ein ur- und frühgeschichtlicher Fundplatz auf dem Gebiet des „fränkischen Reichshofes“ in Nordhausen. Nordhausen 1994 [Beiträge zur Heimatkunde aus Stadt und Kreis Nordhausen;19]:3-10.

GRÖNKE, H.-J.: Eine mittelalterliche Filterzisterne aus der Bäckerstraße in Nordhausen. - Nordhausen 1996 [Beiträge zur Heimatkunde aus Stadt und Kreis Nordhausen;21]: 23-28.

GRÖNKE, H.-J.: Neue linienbandkeramische Siedlungsfunde von Schate. - Nordhausen 1986 [Beiträge zur Heimatkunde aus Stadt und Kreis Nordhausen;11].

GRÖNKE, H.-J.: Die Glashütten bei Rothesütte: ein Beitrag zur Wirtschafts- und Sozialgeschichte im 18. Jahrhundert. Nordhausen 1990 [Beiträge zur Heimatkunde aus Stadt und Kreis Nordhausen;15].

GRÖNKE, H.-J.: Siedlungsgruben mit Fundmaterial aus der Rössener Kultur in Nordhausen. - Nordhausen 1991 [Beiträge zur Heimatkunde aus Stadt und Kreis Nordhausen;16]:31-39.

GROHMANN, Olaf / HAUPTMEYER, Carl-Hans / NEUBER, Dirk: Stand und Aufgaben der umweltgeschichtlichen Forschung insbesondere in Niedersachsen. - In: HAUPTMEYER, Carl-Hans (Hrsg.): Mensch-Natur-Technik: Aspekte der Umweltgeschichte in Niedersachsen. - Bielefeld: Verl. f. Regionalgeschichte, 2000 [Materialien für Regionalgeschichte; 2]:9-16

GROHMANN, O.: Die Stadt und das Wasser. Ver- und Entsorgung Hannovers im 18. Jahrhundert. - In: HAUPTMEYER, C.-H. (Hrsg.): Mensch - Natur - Technik: Aspekte der Umweltgeschichte in Niedersachsen und angrenzende Gebieten. - Bielefeld: Verl. f. Regionalgeschichte 2000 [Materialien zur Regionalgeschichte;2]:53-60.

GROSCHHUPF, J.: Der Flußgeister nächtliches Raunen. Wie sich die Menschen seit Jahrhunderten der Hunte bedienen. - In: Die Zeit v. 30. Juni 1989:52.

GROSJEAN, G.: Geschichte der Kartographie. - Bern: Geogr. Inst. d. Univ. 1980 [Geographica Bernensia: Reihe U, Skripten für den Universitätsunterricht;8].

GROSJEAN, G./KINAUER, R.: Kartenkunst und Kartentechnik: Vom Altertum bis zum Barock. - 2. Aufl. - Bern: Kümmerly + Frey 1975.

GROSSMANN, Heinrich: Flösserei und Holzhandel aus den Schweizer Bergen bis zum Ende des 19. Jahrhunderts. - Zürich: Leemann 1972.

GROßJOHANN, H.: Die Weser. Wilder Fluß und Linienzieher. - In: Die Weser - Ein Fluss in Europa: [eine länderübergreifende Ausstellung über 1200 Jahre Geschichte und Kultur des Weserraumes...] Bd. 3. „Von Baltimore nach Bünde“ / Deutsches Tabak- und Zigarrenmuseum. Heidrun Großjohann. Hrsg. vom Kreisheimatverein Herford e.V. in Zusammenarbeit mit dem Tabak- und Zigarrenmuseum Bünde - Holzminden: Mitzkat 2000:38-49.

GROTE, K. (Hrsg.): Die Abris im südlichen Leinebergland bei Göttingen: archäologische Befunde zum Leben unter Felsschutzdächern in urgeschichtlicher Zeit. Teil 1: Archäologischer Teil. Teil 2: Naturwissenschaftlicher Teil. - Oldenburg: Isensee 1994 [Veröffentlichung der urgeschichtlichen Sammlung des Landesmuseums zu Hannover;43]; Zugl.: Hamburg, Univ., Diss. 1994.

GROTE, K.: Eiszeitliche Jäger in Südniedersachsen. - Oldenburg 1998 [Archäologie in Niedersachsen;1]:50-53.

GROTE, K.: Historische Stätten im Luftbild: ein Flug zwischen Oberweser, Fulda und Werra, Leinetal und Südharz. - Göttingen: Goltze 1998.

GROTE, K.: Vom Leben unter Felsschutzdächern. - In: BOETZKES, M. et al. (Hrsg.): „EisZeit“: das große Abenteuer der Naturbeherrschung; Begleitbuch zur Sonderausstellung „EisZeit“ des Römer-Museums Hildesheim. - Stuttgart: Thorbecke 1999: 223-239.

GROTE, K.: Wildbeuterstationen, Wüstungen, Kultplätze. Zur Archäologie der Beziehungen zwischen Mensch und Landschaft am Beispiel des Reinhäuser Waldes bei Göttingen. - In: HERRMANN, B./BUDDE, A. (Hrsg.): Natur und Geschichte. Naturwissenschaftliche und historische Beiträge zu einer ökologischen Grundbildung. Sommerschule „Natur und Geschichte“ vom 14. bis 27. September 1989 an der Georg-August-Universität Göttingen. - Hildesheim: Gerstenberg 1989 [Schriftenreihe „Expert“ des Nieders. Umweltministers Hannover]:233-239.

GROTTIAN, T.: Ökowiesen oder Landschaftszerstörung?: Bewässerungswiesen in der Lüneburger Heide. - In: Jahrbuch des Naturwissenschaftlichen Vereins für das Fürstentum Lüneburg 41 1998:59-73.

GROTTIAN, T.: Wasser, Wiesen, Wischenmaker: Von Suderburg in alle Welt: Bewässerungswiesen in der Lüneburger Heide. Hrsg.: Horst W. Löbert, Museumdorf Hösseringen, Landwirtschaftsmuseum Lüneburger Heiden e.V. (LWM). - SuderburgHösseringen: Museumdorf Hösseringen 2001 [Materialien zum Museumsbesuch;21].

GROVE, R. H.: Die Anfänge des Umweltbewusstseins. - In: Spektrum der Wissenschaft 9 1992:76-81.

GRUENHOFF, D.: GIS-gesteuerte Geoökosystemanalyse: ein Konzept zur Integration des Bodenschutzes in die Stadtplanung. - 1 . Aufl. - Aachen: Verl. d. Augustinus-Buchh. 1995 [Aachener geowissenschaftliche Beiträge;10].

GRUNDMANN, L.: Burger und Lübbenauer Spreewald: Ergebnisse der landeskundlichen Bestandsaufnahme in den Gebieten von Burg und Lübbenau. - 2. Aufl. - Weimar 1994 [Werte der Deutschen Heimat;55 - in der 1. Aufl. 1981;36]. 
GRUNDMANN, L.: Die Buchreihe ,Werte der deutschen Heimat ${ }^{\star}$ - landeskundliche Inventarisierung am Beispiel des Vogtlandes. - Zusammenfassung in: KLEEFELD, K.-D.: Sechste Tagung der Arbeitsgruppe „Angewandte Historische Geographie“. Aufgaben, Möglichkeiten und Probleme der musealen Präsentation von Kulturlandschaftsrelikten in Plauen/Vogtland vom 7.3. - 9.3.1996. In: Kulturlandschaft - Zeitschrift für Angewandte Historische Geographie 1 1996:4-8.

GRÜNEWALD, U.: Beeinflussung des Wasserdargebotes durch den Braunkohlentagebau in der Niederlausitz. - In: Archives of Nature Conservation and Landscape Research 35 1997:279-288.

GRUPPE, G./HERRMANN, B. (Hrsg.): Trace elements in Environmental History. - Berlin et al.: Springer 1988.

GUELKE, L.: Historical understanding in geography: An idealist approach. - Cambridge et al.: Cambridge Univ. Press 1982.

GUMMLICH-WAGNER, J.: Zum Verhältnis von Denkmal- und Naturschutz. - In: LANGE, H. (Hrsg.): Denkmalpflege in den Städten: Stadtbaukunst, Stadtökologie, Stadtentwicklung. - Berlin, Köln: Deutscher Städtetag 2003 [Neue Schriften des Deutschen Städtetages;83]:96-101.

GUNKEL, G. (Hrsg.): Renaturierung kleiner Fliessgewässer: ökologische und ingenieurtechnische Grundlagen. - Jena et al.: Fischer 1996 [Umweltforschung].

GUNZELMANN, T.: Möglichkeiten und Grenzen der Berücksichtigung historischer Kulturlandschaftselemente in der räumlichen Planung. - Bamberg: Dipl.arbeit a. d. Univ. Bamberg 1983.

GUNZELMANN, T.: Die Erhaltung der historischen Kulturlandschaft: Angewandte Historische Geographie des ländlichen Raumes mit Beispielen aus Franken. - Bamberg: Selbstverl. des Faches Wirtschaftsgeographie der Univ. Bamberg, 1987 [Bamberger Wirtschaftsgeographische Arbeiten;4].

GUNZELMANN, T.[a]: Das Projekt „Denkmäler und Kulturlandschaft der Flößerei im Frankenwald. - In: DenkmalschutzInformationen, 23. Jg. Sonderausgabe Europarat-Kampagne. Bonn 1999:24-30.

GUNZELMANN, T.[b]s: Naturschutz und Denkmalpflege - Partner bei der Erhaltung, Sicherung und Pflege von Kulturlandschaften. Vortrag im Rahmen der Bayerischen Naturschutztage am Dienstag, 26.10.1999 in Bamberg. Memmelsdorf: Bayerisches Landesamt für Denkmalpflege, Außenstelle Bamberg 1999.

GUNZELMANN, T.: Die Erfassung der historischen Kulturlandschaft. - In: Historische Kulturlandschaft. Hrsg.: Bayerisches Staatsministerium für Landwirtschaft und Forsten, Abteilung Ländliche Entwicklung. - München: Staatsministerium 2001 [Materialien zur Ländlichen Entwicklung;39].

GUNZELMANN, T.: Flößerei im Frankenwald: die Kulturlandschaft und die Denkmäler. - In: Denkmalpflege Informationen. Ausgabe B 123, Oktober 2002 [URL = http://home.t-online.de/home/Tom.Gunzelmann/Floesser.pdf]:24-27.

GUNZELMANN, T.: Kulturlandschaft als Heimat. Landschafts- und Denkmalpflege im Zeitalter der Globalisierung. Vortrag zum 100-jährigen Jubiläum des Bayerischen Landesvereins für Heimatpflege am 11.10.2002 in Kronach, Festung Rosenberg. Bamberg: Bayerisches Landesamt für Denkmalpflege, Außensstelle Bamberg, Manuskript 2003.

GUNZELMANN, T./VIEBROCK, J.: Anhang: Denkmalpflege und historische Kulturlandschaft: Positionspapier der Vereinigung der Landesdenkmalpfleger in der Bundesrepublik Deutschland. - In: DSI 26/3 2002:93-98.

GURJEWITSCH, A.: Mittelalterliche Volkskultur. - 2. Aufl. - München: Beck 1992.

GÜTHLER, W.: Regionen im Aufbruch: Kulturlandschaften auf dem Weg zur nachhaltigen Entwicklung. Hrsg.: Deutscher Verband für Landschaftspflege e.V. (DVL). - Ansbach: DVL [ca. 1998] [Landschaft als Lebensraum;2].

GUTSER, D./KUHN, J.: Die Buckelwiesen bei Mittenwald: Geschichte, Zustand, Erhaltung. - In: Jahrbuch des Vereins zum Schutz der Bergwelt 63 1998:185-209.

GÜTTER, A.: Der Flussname „Eger“, der Raumname „Egere“ und das frühdeutsche Namengut im Nordteil des einstigen bairischen Nordgaues. - In: Archiv für Geschichte von Oberfranken 79 1999:9-22.

HAAR, U. de/HOFFMANN, D. (Hrsg.): Wasser aus dem Wald - Wasser für den Wald. - Kirchzarten: Verl. Beitr. z. Hydrologie 1982 [Beiträge zur Hydrologie; Sonderheft 4].

HAAREN, C. v.: Eifelmaare: landschaftsökologisch-historische Betrachtung und Naturschutzplanung. - Bad Dürkheim: POLLICHIA 1998 [POLLICHIA-Buch;13]; Zugl.: Hannover, Univ., Diss., 1986.

HAARNAGEL, W.: Die Grabung Feddersen-Wierde: Methode, Hausbau, Siedlungs- und Wirtschaftsformen sowie Sozialstruktur. - Wiesbaden: Steiner 1979.

HAASE, H.: Kunstbauten alter Wasserwirtschaft im Oberharz: Hanggräben, Teiche, Stollen in Landwirtschaft, Wirtschaft und Geschichte. - Clausthal-Zellerfeld: Pieper 1961 [Bearb. u. erw. von Wolfgang Lampe. - 5. Aufl. - 1985].

HAASE, H./LAMPE, W.: Kunstbauten der alten Wasserwirtschaft im Harz. - 5. Aufl. - Clausthal-Zellerfeld: Pieper 1985.

HAASE, P.: Die Entwicklung der Landnutzung an der Unteren Havel. - In: Naturschutz und Landschaftspflege in Brandenburg 4/1 1995:4-11.

HAASIS-BERNER, A.: Der Bergbau nördlich von Freiburg und die montane Wasserwirtschaft. - In: Früher Bergbau im südlichen Schwarzwald: Begleitheft zur Ausstellung des Museums für Ur- und Frühgeschichte der Stadt Freiburg/Breisgau Br. vom 29. Juli bis zum 21. November 1999. Hrsg. v. Landesdenkmalamt Baden-Württemberg. - Stuttgart: Ges. für Vor- und Frühgeschichte in Württemberg und Hohenzollern 1999 [Archäologische Informationen aus Baden-Württemberg;41]:97-102. 
HAASIS-BERNER, A.: Wasserkünste, Hangkanäle und Staudämme im Mittelalter. Eine archäologisch-historische Untersuchung zum Wasserbau am Beispiel des Urgrabens am Kandel im mittleren Schwarzwald. - Rahden/Westf.: Leidorf 2001 (Freiburger Beiträge zur Archäologie und Geschichte des ersten Jahrtausends; Bd. 5) Zugl. Freiburg/Breisgau, Univ. Diss. 1999.

HAASIS-BERNER, A./WAGNER, H./ZETTLER, A.: Glottertal - Besiedlung, Bergbau und Wassernutzung von vorgeschichtlicher Zeit bis ins Mittelalter. - In: Archäologische Nachrichten aus Baden 60 1999:19-38.

HABBE, K. A.: Das Flurbild des Hofsiedlungsgebietes im Mittleren Schwarzwald am Ende des 18. Jahrhunderts. - Bad Godesberg: Bundesanst. für Landeskunde und Raumforschung 1960 [Forschungen zur dt. Landeskunde;118]; Zugl.: Freiburg/Breisgau, Univ., Diss. 1957.

HABER, W.: Nachhaltigkeit als Leitbild einer natur- und sozialwissenschaftlichen Umweltforschung. - In: DASCHKEIT, A./SCHRÖDER, W. (Hrsg.): Umweltforschung quergedacht. Perspektiven integrativer Umweltforschung und -lehre. Berlin et al.: Springer 1998 [Umweltnatur- und Umweltsozialwissenschaften]:127-146.

HABERL, H.: Störfaktor Landschaft. - In: HABERL, H./STROHMEIER, G.: Kulturlandschaftsforschung. - Wien et al.: Springer 1999 [iff texte;5]:41-48.

HABERMAS, J.: Erkenntnis und Interesse. - 2. Aufl. - Frankfurt/Main: Suhrkamp 1973 [1. Aufl. 1968].

HADAMCZYK, P./KAMPHERN, R./PAPE, K.: Historischer Umweltatlas Münster. - Hrsg.: Der Oberstadtdirektor der Stadt Münster, Umweltamt in Verbindung mit der Projektgruppe Stadtjubiläum.. - Münster et al.: Waxmann 1993.

HÄRDTLE, W.: Die Elbtalaue: Geschichte, Schutz und Entwicklung einer Flusslandschaft; Festschrift aus Anlaß der Emeritierung von Prof. Dr. Ulf Amelung, Universität Lüneburg. - Halle/Saale: Ampyx-Verl. 1999

HAESLOOP, U.: Bemerkenswerte Egelfunde aus Graeben eines nordwestdeutschen Flussmarschgebietes (NSG „Westliches Hollerland“", Bremen). - In: Lauterbornia. Zeitschrift für Faunistik und Floristik des Süßwassers 44 2002:29-36.

HAESE, F.: Nordhausen und Umgegend im Jahre 1848. Dazu 20 Bilder auf Tafeln. - Nordhausen: Selbstverl. des Nordhäuser Geschichts- und Altertumsvereins 1909.

HÄFENER, F.: Der Wiesenbau in seinem ganzen Umfange nebst einer Anleitung zum Nivellieren, zur Erbauung von Schleußen, Wehren, Brücken etc. - Berlin: Parey 1867.

HAGEL, J.: Sturmfluten. - Stuttgart: Franckh'sche Verl.-Buchh. 1962 [Kosmos-Bibliothek;236].

HAGEL, J.: Mensch und Wasser in der alten Stadt: Stuttgart als Beispiel und Modell. - In: Die alte Stadt. Zeitschrift für Stadtgeschichte, Stadtsoziologie und Denkmalspflege 14/2 1987:126-139.

HAGEL, J.: Aufgaben und Probleme der historisch-geographischen Umweltforschung, insbesondere im Hinblick auf Umweltprobleme der frühen Neuzeit. - In: Siedlungsforschung 6 1988:129-145.

HAGEL, J.: Die Wasserläufe im Bild historischer Karten. - In: PFIZENMAYER, H. (Hrsg.): Remsack am Neckar: Die Wasserläufe im Bild historischer Karten - Fähren und Brücken über den Neckar. - Remseck: Gemeinde Remseck am Neckar 1988 [Heimatkundliche Schriftenreihe der Gemeinde Remseck am Neckar;8]:6-21.

HAGEL, J,: Verkehrsweg-Wüstungen in der Kulturlandschaft. - In: Aufgaben und Probleme der historisch-geographischen Umweltforschung. Siedlungsforschung 61988.

HAGEL, J.: Mensch und Wasser in der Geschichte: Dokumente zu Umwelt, Technik und Alltag vom 16. bis zum 19. Jahrhundert. Ausstellung des Hauptstaatsarchivs Stuttgart. - Stuttgart 1989.

HAGEL, J.: Geographische Interpretationen topographischer Karten. - Stuttgart, Leipzig: Teubner 1998 [Teubner Studienbücher der Geographie].

HAGEMANN, E.: Teichwirtschaft: Eine Anleitung zur neuzeitlichen Bewirtschaftung von Fischteichen - Minden/Westf.: Philler 1960 [Lehrmeister-Bücherei;76].

HAGEMANN, J.: Die Entwicklung der Kulturlandschaft im Hils: historisch-geographische Untersuchungen über das Werk des Oberjägermeisters Johann-Georg- von Langen im ehemaligen braunschweigischen Weserbezirk. - Hannover, Techn. Univ., Diss. 1971/72.

HAGEN, H./TOEDTER, H.: Aus Flachs wird Leinen: Anbau und Verarbeitung von Flachs; ein altes bäuerliches Handwerk. Rotenburg/Wümme: Heimatbund Wümme 1985.

HAHN, G. v./SCHÖNFELS, H.-K. v.: Von der Heilkraft des Wassers: Eine Kulturgeschichte der Brunnen und Bäder. - Aarau: AT Verl. 1980.

HAHN, G. v./SCHÖNFELS, H.-K. v.: Wunderbares Wasser. Von der heilsamen Kraft der Brunnen und Bäder. - Aarau-Stuttgart: AT Verl. 1980.

HAHN, S./REITH, R. (Hrsg.): Umwelt-Geschichte: Arbeitsfelder, Forschungsansätze, Perspektiven. - München: Oldenbourg 2001 [Querschnitte;8].

HAHN-WEISHAUPT, A./TRÖMEL, H.: Historischer Deichbau im Oderbruch. - In: Wasser und Boden 55/6:15-18. 
HAIKAL, M.: Längs der Pleisse: Zur Geschichte einer Flusslandschaft. - In: Neue Ufer 6 2001:3-19 [URL = http://www.neueufer.de/pleisse/geschichte.htm;09.02.04].

HAKE, G. H./GRÜNREICH, D./MENG, L.: Kartographie: Visualisierung raum-zeitlicher Informationen. - 8. Aufl.. - Berlin et al.: de Gruyter 2002 [De-Gruyter-Lehrbuch].

HAKELBERG, D.: Schiffahrt auf dem Bodensee: Geschichte und Archäologie von der Spätantike bis zur Industrialisierung. - In: Einbaum, Lastensegler, Dampfschiffahrt. - Stuttgart 2000:121-146.

HALBFAß, W.: Grundzüge einer vergleichenden Seenkunde. - Berlin: Borntraeger 1923.

HALFPAP, M.: Siedlungen und Wirtschaft der holsteinischen Elbmarschen unterhalb Hamburgs unter historisch-genetischem Aspekt einschließlich der Betrachtung der heutigen Situation. - Hamburg et al.: Geogr. Gesell. 1989 [Mitteilungen der Geogr. Gesell. in Hamburg;79]; Zugl. Hamburg, Univ., Diss. 1988.

HAMANN, M./EDERBERG, E.: Die Calenberger Klöster: Barsinghausen, Marienwerder, Wennigsen, Mariensee, Wülfinghausen. - Hannover: Klosterkammer 1977.

HAMBLOCH, H.: Der Mensch als Störfaktor im Geosystem. - Opladen: Westdeutscher Verl. 1986 [Vorträge: Rhein.-Westf. Akademie d. Wissenschaften: Geisteswissenschaften;280].

HAMBLOCH, H.: Allgemeine Anthropogeographie. Eine Einführung. - 5. Aufl. - Stuttgart: Steiner 1992.

HAMBURG UMWELTBEHÖRDE 2004 [URL = http:/www.hamburg.de/Behoerden/Umweltbehörde/foje/bille/muehlen.htm; 14.02.2004].

HAMMERTON, D.: The Nile River: A Case History. - In: River Ecology and Man. Hrsg.: R. OGLESBY/C. CARLSON und J. McCANN. - New York: Academic Press 1972.

HANDBUCH angewandte Limnologie: Grundlagen, Gewässerbelastung, Restaurierung, aquatische Ökotoxikologie, Bewertung, Gewässerschutz. Steinberg, Bernhardt, Klapper. - Landsberg/Lahn: ecomed 1955 [Loseblatt-Ausgabe, mehrbd. Werk].

HANDBUCH der naturräumlichen Gliederung Deutschlands. Hrsg. v. E. Meynen et al. - Bd. I/II - Bad Godesberg: Bundesanstalt f. Landeskunde u. Raumforschung, 1953-1962.

HANDTKE, R.: Flußgeschichte Mitteleuropas. Skizzen zu einer Erd-, Vegetations- und Klimageschichte der letzten 40 Millionen Jahre. - Stuttgart: Enke 1993.

HÀNEK, P.: Tradition geodätischer Instrumente in Tschechien. [URL = http://www.geomatik.ch/Zeitschrift/VPKOL_dosgesch.htm; 07.01.2004].

HANKE, C.: Eppendorf von A-Z: Das Stadtteillexikon mit Hoheluft-Ost. - Hamburg: Medien-Verl. Schubert 2001.

HÄNNI, L.: Die Bewässerung der Allmendingen- und Schoren-Allmend bei Thun. - In: DVWK (Hrsg.): Historische Wasserwirtschaft im Alpenraum und an der Donau. - Stuttgart: Wittwer 1994:17-21.

HANNING, J.: Fotografien als historische Quelle. - In: TENFELDE, K. (Hrsg.): Bilder von Krupp: Fotografie und Geschichte im Industriezeitalter. - München: Beck 2000:269-288.

HÄNSEL, C.: Gewässer und ihre Einzugsgebiete: ökologische Ansätze zur Sanierung; ausgewählte Vorträge, gehalten auf der Klausurtagung der Sächsischen Akademie der Wissenschaften zu Leipzig, 11. bis 13. Mai 1994, Hydrologisches Laboratorium Neunzehnhain, Lengenfeld/Erzgebirge. - Berlin: Akad.-Verl. 1996 [Abhandlungen der Sächsischen Akademie der Wissenschaften zu Leipzig, Mathematisch-Naturwissenschaftliche Klasse;4/58].

HANSEN, P.-D.: Limnologie und Hydrobiologie: Was ist Limnologie? - Grundseminar „Stadtgewässer im WS 2002/2003. [URL $=\mathrm{http}: / /$ www.tu-berlin.de/ oekotox/pdf/landschaftsoekologie.pdf;16.01.2004].

HANSEN, S.: Gewässerfunde in Europas. - In: Das Altertum 46/1 2000:31-63.

HANTSCHEL, R.: Neuere Ansätze in der Anthropogeographie. - In: Geographica Helvetica 3 1984:137-143.

HARD, G.: Die „Landschaft“ der Sprache und die „Landschaft“ der Geographen: semantische und forschungslogische Studien zu einigen zentralen Denkfiguren in der deutschen geographischen Literatur. - Bonn: Dümmler [in Komm.] 1970 [Colloquium geographicum;11].

HARD, G.: Die Geographie: eine wissenschaftliche Einführung. - Berlin, New York: de Gruyter 1973.

HARD, G.: Spuren und Spurenlesen: zur Theorie und Ästhetik des Spurenlesens in der Vegetation und anderswo. - Osnabrück: Rasch 1995 [Osnabrücker Studien zur Geographie;16].

HARD, G.: Landschaft und Raum. Aufsätze zur Theorie der Geographie, Bd. 1 - Osnabrück: Universitätsverl. Rasch 2002 [Osnabrücker Studien zur Geographie;22].

HARDH, B.: See- und Flußwege in Südskandinavien aus der Sicht der Archäologie. - In: Siedlungsforschung 4 1986:45-62.

HARDTKE, W.: Sozialgeographischer Strukturwandel im Spessart. - In: Die Erde 88/3-4 1957:236-254.

HARIG, G./VOTH, C.: 360 Jahre Flachs im Grönegut. - Melle: Heimatverein 1980 [Gröneberger Heimathefte;15]. 
HÄRLE, J.: Bachregulierung und Streuwiesenentwässerung: Ein landschaftsökologisches Projekt in einem Allgäuer Bachtal. - In: Geographische Rundschau (Beiheft) 8/5 1978:206-219.

HARMS, H./SCHUBERT, D.: Wohnen in Hamburg: ein Stadtführer zu 111 ausgewählten Beispielen. - Hamburg: Christians 1989 [Stadt, Planung, Geschichte;11].

HARMS, O.: Das genossenschaftliche Be- und Entwässerungswesen auf der oldenburgischen Geest unter Berücksichtigung der geologisch-bodenkundlichen Verhältnisse. - Oldenburg i. O.: Littmann 1933; Zugl. München, Techn. Hochsch., Diss. 1933.

HARRISON, R. P.: Wälder: Ursprung und Spiegel der Kultur. - München, Wien: Hanser 1992.

HARRISON, R. P. (Hrsg.): Manual of heritage management. - Oxford et al.: Butterworth-Heinemann 1994.

HARTEISEN, U.: Die historisch-ökologische Landschaftsanalyse - ein Planungsinstrument im Naturschutz: die Gemarkung Haustenbeck in der Kulturlandschaft Senne als Beispiel. - Götingen: Cuvillier 1999; Zugl.: Göttingen, Univ., Diss. 1999.

HARTEISEN, U./SCHMIDT, A./WULF, M.. Zugl.: Kulturlandschaft. Zeitschrift für Angewandte Historische Geographie 10/2 2000 - Herdecke: GCA-Verl. 2001 [Forschen und Wissen - Landschaftsgestaltung].

HARTENSTEIN, M. A.: Neue Dorflandschaften: nationalsozialistische Siedlungsplanung in den „eingegliederten Ostgebieten 1939 bis 1944. - Berlin: Köster 1998 [Wissenschaftliche Schriftenreihe Geschichte;6]. Zugl.: Bonn, Univ., Diss. 1996.

HARTER, H.: Flößerei. - In: Spätmittelalter am Oberrhein: Alltag, Handwerk und Handel 1350-1525. Aufsatzband zur Großen Landesausstellung Baden-Württemberg. Hrsg.: LORENZ, S./ZOTZ, T. - Sigmaringen: Thorbecke 2001:215-229.

HARTIG, E. F.: Lehrbuch der Teichwirthschaft und Verwaltung in Verbindung mit der Wiesen- und Ackerverbesserung: nach den Anforderungen des rationellen Landwirthes abgefaßt. - Cassel: Krieger 1831.

HARTMANN, A.: Badereise durch fünf Jahrtausende. - Mainz: Selbstverl. 1969.

HARTMANN, H./HARTMANN, W.: Die Höhlen Niederösterreichs. - Wien 1990 [Wissenschaftliche Beihefte zur Zeitschrift „Die Höhle“;37].

HARTMANN, L.: Biologische Abwasserreinigung. - 3. Aufl. - Berlin et al.: Springer 1992.

HARTSTOCK, E.[a]: Entstehung und Entwicklung der Oberlausitzer Teichwirtschaft. - Dresden: Sächsische Landesanstalt für Landwirtschaft 2000 [Schriftenreihe der Sächsischen Landesanstalt für Landwirtschaft, Sonderheft 5].

HARTSTOCK, E. [b]: Entstehung und Entwicklung der Teichwirtschaft Moritzburg. - Dresden: Sächsische Landesanstalt für Landwirtschaft 2000 [Schriftenreihe der Sächsischen Landesanstalt für Landwirtschaft, Sonderheft 5].

HÄRTWIG, R.: Über alte Fischteichanlagen in Sachsen. - In: Archiv f. Fischereigeschichte 9 1917:55-61.

HASEDER, I. E./STINGLWAGNER, G. K. F.: Knaurs Großes Jagdlexikon. - München: Droemer Knaur Verl. 1996.

HASEL, J.: Mensch und Wasser in der alten Stadt. Stuttgart als Beispiel und Modell. - In: Die Alte Stadt 14 1987:126-139.

HASEL, K./SCHWARTZ, Ekkehard Forstgeschichte: ein Grundriß für Studium und Praxis. - 2. Aufl. - Remagen: Kessel 2002 [1. Aufl. Hamburg et al: Parey 1985]

HASPEL, J./Kirschbaum, J.: Aufgaben und Perspektiven der Hafendenkmalpflege. Hrsg.: Deutsches Nationalkomitee für Denkmalschutz. - Bonn 1989 [Schriftenreihe des Nationalkomitees;40].

HASPEL, J.: „Elektropolis“: Denkmale der Stromerzeugung in Berlin. - In: industrie-kultur 1 1999:6-8.

HASPEL, J.: Industriekultur und Arbeitswelt an der Wasserkante: Zum Umgang mit Zeugnissen der Hafen- und Schiffahrtsgeschichte. Hrsg.: Kulturbehörde Hamburg. - Hamburg 1989 [Arbeitshefte zur Denkmalpflege;11].

HASSE, D.: 100 Jahre linksemsische Kanäle. - In: Jb. d. Emsländ. Heimatbundes 32 1986:39-54.

HASSLER, D./HASSLER, M./GLASEER, K.-H. (Hrsg.): Wässerwiesen: Geschichte, Technik und Ökologie der bewässerten Wiesen, Bäche und Gräben in Kraichgau, Hardt und Bruhrain; ein Gemeinschaftsprojekt des Landesnaturschutzverbandes Baden-Württemberg. - Ubstabdt-Weiher: Verl. f. Regionalkultur 1995 [Beihefte zu den Veröff. f. Naturschutz u. Landschaftspflege in Baden-Württemberg;87].

HÄSSLER, H.-J. (Hrsg.): Ur- und Frühgeschichte in Niedersachsen. - Stuttgart: Theiss 1991

HÄUBER, C./SCHÜTZ, F. X./SPIEGEL, E. M.: Die Entwicklung des Informationssystems Digitaler Archäologischer Schichtenatlas Köln. - In: Aachener Informatik-Berichte 6/99, zugleich Heft 9/1 von „Kulturlandschaft. Zeitschrift für Angewandte Historische Geographie“. - Bonn 1999:47-60.

HAUKE, J.: Eisengewinnung im Norddeutschen Flachland. - In: Alter Bergbau in Deutschland. - Stuttgart: Theiss-Verl. 1993.

HAUPTMEYER, C.-H. (Hrsg.): Mensch - Natur - Technik : Aspekte der Umweltgeschichte in Niedersachsen und angrenzenden Gebieten ; [Vorträge der Zusammenkünfte des Arbeitskreises Wirtschafts- und Sozialgeschichte der Historischen Kommission für Niedersachsen und Bremen am 8. November 1997 und am 7. März 1998] - Bielefeld : Verl. für Regionalgeschichte 2000 [Materialien zur Regionalgeschichte;2]. 
HAUPTMEYER, C.-H./FROHNER, S.: Vorwort. - In: HAUPTMEYER, C.-H. (Hrsg.): Mensch-Natur-Technik: Aspekte der Umweltgeschichte in Niedersachsen. - Bielefeld: Verl. f. Regionalgeschichte 2000 [Materialien für Regionalgeschichte;2]:78.

HAUSER-HILDEBRANDT, B./KANDER, B.: Kulturlandschaftsgeschichtliche Zeugen in Wäldern deutscher Mittelgebirge und ihre Inwertsetzung für den Tourismus. - In: Festschrift für Erdmann-Gormsen zum 65. Geburtstag. - Mainz 1994 [Mainzer Geogr. Studien;40]:403-412.

HAVERSATH, J.-B.: Die Agrarlandschaft im römischen Deutschland der Kaiserzeit: (1.-4. Jh. n. Chr.). - Passau: PassaviaUniversitätsverl. 1984 [Passauer Schriften zur Geographie;2]; Zugl.: Würzburg, Univ., Diss 1979.

HAVERSATH, J.-B.: Die Mühle am rauschenden Bach. Auf der Suche nach dem wirtschaftlichen Hintergrund des „Mühlensterbens“ in einem Tal der Fränkischen Schweiz. - In: geographie heute 41 1986:42-46.

HAVERSATH, J.-B.: Mühlen in der Fränkischen Schweiz. - 2. Aufl. - Ebermannstadt: Fränkische Schweiz-Verein e.V. 1987 [Die Fränkische Schweiz: Landschaft und Kultur;4] [1. Aufl. 1987].

HAVERSATH, J.-B./STRUCK; Ernst: Passau und das Land der Abtei in historischen Karten und Plänen: eine annotierte Zusammenstellung. - Passau: Passavia-Universitätsverl. 1986 [Passauer Schriften zur Geographie;3].

HEBELER, W./MÜLLEROTT, H.: Denkmale des Waidanbaus in Thüringen: mit Angaben zur territorialen Zugehörigkeit um 1500. - Erfurt: Internationale Gartenbauausstellung der DDR 1989.

HEDEEN, S.: The Mill Creek: An Unnatural History of an Urban Stream. - Cincinnati, OH: Blue Heron Press 1994 [Book Review in: Landscape and Planning 36/3 1996:236-237].

HEDEEN, S.: The Mill creek: An Unnatural History of an Urban Stream. - Cincinatti, OH: Blue Heron Press 1994.

HEEGE, E. und A.: Die Häuser der Toten. Jungsteinzeitliche Kollektivgräber im Landkreis Northeim. - Hildesheim: Verl. August Lax 1989.

HEER, O.: Über den Flachs und die Flachskultur im Altertum: eine kulturhistorische Skizze. - Zürich: Zürcher und Furrer 1872 [Neujahrsblatt; hrsg. v. d. Naturforschenden Gesellschaft;74].

HEGER, J. L.: Landwirthschäfftlicher Teich- und Weyher-Lust: Oder Gründliche Information zur Edlen Fischerey, wie bey dieser so wohl die Teich und Weyher auf das beste eingericht, als auch in solche die Fisch zum grösten Nutzen der hoch-löblichen Landwirthschafft eingesetzt und erzogen werden sollen [...] - Frankfurt et al.: Lochner 1727.

HEHMEYER, I./SCHMIDT, J.: Archäologische Berichte aus dem Jemen. - Bd. 5: Antike Technologie: Die Sabäische Wasserwirtschaft von Marib. - Mainz: Zabern 1991.

HEIDEMANN, W.: Der Eiderkanal. - In: Kultur und Technik 41984.

HEIDRICH, H.: Der ganze Main war hölzern. Eine Ethnographie der Flößerei. - Bad Windsheim 1993 [Schriften und Kataloge des Fränkischen Freilandmuseums;20].

HEIDRICH, H.: Kleine Alltagsgeschichte der Kartoffel in Nordbayern. - In: OTTENJAHN, H./ZIESOW, K.-H. (Hrsg.): Die Kartoffel. Geschichte und Zukunft einer Kulturpflanze. Arbeit und Leben auf dem Lande. Hrsg.: Von den Museen des Ausstellungsverbundes. - Cloppenburg: Museumsverbund 1992 [Kulturwissenschaftliche Schriftenreihe;1]:95-126.

HEIL, G.: Schiffe auf der Weser im 18. Jahrhundert. - In: Die Weser - Ein Fluss in Europa: [eine länderübergreifende Ausstellung über 1200 Jahre Geschichte und Kultur des Weserraumes...] Bd. 2. „Aufbruch in die Neuzeit“/ Weserrenaissance-Museum Schloß Brake, Lemgo. Hrsg. von Jos’e Kastler und Vera Lüpkes. - Holzminden: Mitzkat 2000:100-113.

HEIL, K. H.: Geleitwort. - In: DVWK (Hrsg.): Historische Wasserwirtschaft im Alpenraum und an der Donau. Bearbeitet v. Werner Konold. - Stuttgart: Wittwer 1994.

HEIMBERGER, H.: Alte Wiesenwässerungsanlagen im Bauland und Odenwald. - In: Forschungen und Berichte zur Volkskunde in Baden-Württemberg 1 1973:173-184.

HEIN, G.: Die Fleuthkuhlen am Niederrhein: Untersuchung und Bewertung von Feuchtgebieten im Rahmen der Naturschutzplanung. - Gießen: Selbstverl. d. Geogr. Inst. d. Justus-Liebig-Univ. 1985 [Gießener Geogr. Schriften;59].

HEIN, M.: Bericht berichtet über die Maßnahme „Bestandsaufnahme und Erhaltung der Wiesenbewässerung Kirchehrenbach und Weilersbach“ von Angelika KÜHN [In: Kulturlandschaftsforschung 1/2 1992]. - In: „LandschaftsArchitekten“ 41995.

HEINDEL, K.: Die Umgestaltung der Isar durch den Menschen. - München: Müller 1936; Zugl.: München, Univ. Diss 1936

HEINE, H.-W.: Frühe Burgen und Pfalzen in Niedersachsen von den Anfängen bis zum Mittelalter. - Hildesheim: Lax, 1991.

HEINE, H.-W. 2002: Burgen um 1000 zwischen Mittelweser und Leine. [URL = http://www.gefao.de/images/literatur/Ai04/Ai0402.pdf;20.01.2004].

HEINE, H.: Heimatbuch für Nordhausen und die Grafschaft Hohenstein. - Nordhausen/Harz: G. Wimmer's Buchhandlung o. J. (um 1900).

HEINE, H.: Geschichte von Nordhausen und dem Kreise „Grafschaft Hohenstein“. - Hannover, Berlin: Meyer 1900 [Dt. Geschichte, B. Heimatgeschichtliche Ergänzungshefte;5]. 
HEINE, K.: Fluß- und Talgeschichte im Raum Marburg: eine geomorphologische Studie. - Bonn: Dümmler in Komm. 1970 [Bonner geographische Abhandlungen;42]; Zugl.: Bonn, Univ., Diss. 1968.

HEINEBERG, H.: Geographische Stadtforschung statt Stadtgeographie? Zur Stellung der Stadtgeographie im interdisziplinären Rahmen. In: Geographie heute. Themen, Modelle, Materialien für die Unterrichtspraxis aller Schulstufen. 13/100 1992 Stuttgart: Klett:13-20.

HEINECK, H.: Das Tausendjährige Nordhausen. Zur Jahrtausendfeier hrsg. vom Magistrat der Stadt Nordhausen. - Nordhausen: Verl. d. Magistrats 1927 [Geschichte der Stadt Nordhausen;2].

HEINECK, [?]: Thüringer Allgemeine / Nordhäuser Allgemeine (Zeitung) 2. August 1994:

HEINRICH, B.: Brückenbau. - In: SCHÜTTE, I. (Hrsg.): Technikgeschichte als Geschichte der Arbeit. - Bad Salzdetfuhrt: Franzbecker 1981.

HEINRICH, R.: Die Wiesenbauschule Siegen: 1853 - 1971; Ausbildungsstätte für Praktiker, Gründungsbaustein der Universität. Siegen: Univ.-Bibliothek 1997.

HEINRICH, R./ERMERT, O.: 150 Jahre Bauwesen in Siegen: 1853 - 2003; von der Wiesenbauschule zur Universität. - Siegen: Univ.-Verl. 2003

HEINRICH, W.: Landschaft an der Oberweser. Eine Region in Aquarellen. Katalogbuch zur Ausstellung im Kloster Corvey (1.4.1999 - 1.11.1999). - Hameln: Niemeyer 1999.

HEINRITZ, G./SCHRÖDER, F.: Geographische Visionen vom Einzelhandel in der Zukunft.- Leipzig: Dt. Akad. f. Landeskunde e. V. und des Instituts für Länderkunde 2001 [Berichte zur deutschen Landeskunde;2-3].

HEINTZE, G.: Naturnahe Gewässer: Entwicklung am Beispiel der Nidda und ihrer Zuflüsse: Perspektiven einer Gestaltung der Gewässer und ihrer Auen nach gesamträumlichen Zielsetzungen; Seminar am 21. Mai 1996 in Nidda. - Bad Karlshafen: Hess. Akad. d. Forschung und Planung 1996 [Schriften der Hessischen Akademie der Forschung und Planung im ländlichen Raum;15].

HEINY, B./POLAT, H.: „Schwimmgeschichte“. Seminararbeit in der Blockeinheit: „Theorie und Praxis des Schwimmens und des Schwimmunterrichts / Bewegen im Wasser - Schwimmen“. - Universität Bremen, Fachbereich:09 - Sportwissenschaften Wintersemester 2001/2002 [Abgabe Abgabedatum: 10.07.2002].

HEITFELD, K. H.: Talsperren. - Berlin et al.: Borntraeger 1991 [Lehrbuch der Hydrogeologie;5].

HELBLING, H.: Die Jagd: Mythos, Metapher, Motiv: eine Anthologie. - Frankfurt/Main, Leipzig: Insel Verl. 1993.

HELBRECHT, I.: Das Ende der Gestaltbarkeit? - Oldenburg: Univ. 1991 [Wahrnehmungsgeographische Studien z. Reg.entwicklung;10].

HELFER, H.: Die wirtschaftliche und kulturelle Bedeutung der Binnengewässer mit besonderer Berücksichtigung Deutschlands und angrenzender Gebiete. - Stuttgart: schweizerbaart 1949 [Die Binnengewässer;17].

HELLBERG, R: Elf Mühlen und vier Badehäuser säumten Lauf des Mühlgrabens. Nordhäuser Mühlgraben mit Stadtentstehung eng verbunden. - In: Allgemeiner Anzeiger Nordhausen/Sondershausen v. 15.04.1999.

HELLEBART, S.: Berieselungsanlagen in Tirol - Erhaltungswürdigkeit aus kulturhistorischer, ökologischer und landschaftsästhetischer Sicht; aufgezeigt am Fallbeispiel des Grundzusammenlegungsgebietes Stanz bei Landeck. - Wien: Universität für Bodenkultur; Dipl.arbeit Inst. f. Raumplanung u. Agrarische Operationen 1991.

HELLEBART, S:: Die Geschichte der Bewässerung im Oberinntal. - In: DVWK (Hrsg.): Historische Wasserwirtschaft im Alpenraum und an der Donau. Bearbeitet v. Werner Konold. - Stuttgart: Wittwer 1994.185-199.

HELLER, H.-E.: Luftbildarchäologie: multitemporale und multisensoral. - In: Archäologisches Nachrichtenblatt 4/3 1999:223232.

HELLER, H.: Gastronomie und heimische Küche: Langzeitbeobachtungen zu global-regionalen Gegenläufigkeiten [URL = http://www.orient.uni-erlangen.de/kultur/papers/heller.htm;07.02.2004].

HELLMANN, B.: Zur Bedeutung des Wassers in Jena: Ein historischer Exkurs [URL = http://www.jena.de/kultur/hellmann.htm; 24.07.2004].

HENCKEL, W.: Werkzeuge und Geräte alter Berufe im Oberwesertal. - Hannoversch-Münden 1988 [Sydekum-Schriften zur Geschichte der Stadt Münden. Hrsg. v. Heimat- und Geschichtsverein Sydekum zu Münden e.V.;17].

HENGST, K. (Hrsg.): Westfälisches Klosterbuch. Lexikon der von 1815 errichteten Stifte und Klöster von ihrer Gründung bis zur Aufhebung. - Münster 1992/94 [Veröffentl. d. Hist. Kommission f. Westf.; Quellen zur Kirchen- und Religionsgeschichte;2].

HENGST, K.: Geographische Namen und Kulturlandschaft. In: AURIG, R. (Hrsg.): Kulturlandschaft, Museum, Identität: Protokollband zur Tagung „Aufgaben, Probleme und Möglichkeiten der Musealen Präsentation von Kulturlandschaftsrelikten“ der Arbeitsgruppe „Angewandte Historische Geographie“ vom 7.-9.3.1996 in Plauen/Vogtland. 1. Aufl. - Beucha: Sax-Verl. 1999 [Schriften der Rudolf-Klötzschke-Gesellschaft;4]:27-36.

HENKE, K.-W. 2000: Die Geschichte des Dorfes Ampen [URL = http://www.ampen.de/unserdorf/geschichte;30.01.2004]. 
HENKE, U.: Hochwassermarken an der Weser und ihre historisch-umweltgeographische Interpretation. - Dipl.arbeit am Institut für Geographie, Abt. Kulturgeographie, der Universität Göttingen. - Göttingen 1997/98 [Kolloqium-Mitschrift am 23.03.1998].

HENKEL, G.: Anwendungsorientierte Geographie und Landschaftsplanung: Gedanken zu einer neuen Aufgabe. - In: LOB, R. E./WEHLING, H.-W. (Hrsg.): Geographie und Umwelt. Festschrift für Peter Schneider. - Kronberg/Taunus 1977:36-59.

HENKEL, G.: Kann die überlieferte Kulturlandschaft ein Leitbild für die Planung sein? - Leipzig: Dt. Akad. f. Landeskde e. V. und des Instituts für Länderkunde 1997 [Berichte zur deutschen Landeskunde;1].

HENN, U.: Wasser im Fluss: das Lebenselement Wasser. - Köln: Müller 1992 [Arcus;19].

HENNING, F. W.: Deutsche Agrargeschichte des Mittelalters: 9. bis 15. Jahrhundert. - Stuttgart: Ulmer 1994.

HENNING, F. W.: Landwirtschaft und ländliche Gesellschaft in Deutschland. Bd. 1: 800-1750; Bd. 2: 1750. - Paderborn: Schöningh 1996 [UTB].

HENNING, G.: Das preussische Hauptgestüt Graditz. - Bernburg: Teich 1926; Hochschulschrift: Halle, Univ., Diss. 1927.

HENTSCHEL, E./WAGNER, G.: Zoologisches Wörterbuch: Tiernamen, allgemeinbiologische, physiologische und anatomische Termini und biographische Daten. - 6. Aufl. - Stuttgart: Fischer 1996 [UTB;367].

HERBST, L. D.[a]: Als die Bauern mit dem Wasser der Scherzach düngten. - In: BARTHOLOMÄ, W. D./DETTMER, H. (Red.): Arbeiten und Wohnen auf dem Lande: Gewässer in Oberschwaben und ihre Nutzung in früherer Zeit. - Stuttgart: W. B. Literatur 1987 [Wolfegger Blätter;3]:20-27.

HERBST, L. D.[b]: Die Langelachen von Altdorf-Weingarten: Neue Erkenntnisse zur Frühzeit des Stillen Baches. - In: BARTHOLOMÄ, W. D./DETTMER, H. (Red.): Arbeiten und Wohnen auf dem Lande: Gewässer in Oberschwaben und ihre Nutzung in früherer Zeit. - Stuttgart: W. B. Literatur 1987 [Wolfegger Blätter;3]:28-38.

HERBST, L. D.: Mittelalterliche Wirtschaftskanäle im Alpen- und Voralpengebiet - Erben eines binneneuropäischen Kenntnistransfers? - In: KRESSER, W. (Hrsg.): Wasserbau und Wasserwirtschaft im Alpenraum in historischer Sicht. Wien 1988 [Wiener Mitteilungen: Wasser - Abwasser - Gewässer; Hrsg. v. Inst. f. Hydraulik, Gewässerkunde und Wasserwirtschaft der Technischen Universität Wien]:199-219.

HERBST, L. D.: Ausgebaute Fließgewässer des Mittelalters und der frühen Neuzeit in Oberschwaben als Lernfelder der historischen Geographie. - Weingarten: Phil. Diss. an der Pädagogischen Hochschule Weingarten 1992 [Weingartener Hochschulschriften;17].

HERBST, L. D.: Der Stille Bach: Einmaliges Zeugnis mittelalterlicher Wasserbautechnik in Oberschwaben. - Weingarten: 1983 [Weingartener Hochschulschriften,1].

HERBST, L. D.: Wasser für das Kloster Ochsenhausen: Ein Spaziergang durch die Geschichte des Krummbaches. Hrsg.: Stadt Ochsenhausen. - Ochsenhausen 1993.

HERBST, L. D./WINGHART, B.: Mühlen und Mühlenbäche im Landkreis Ravensburg: Ein dokumentarischer Überblick. Biberach: Eigenverl. 1986.

HERINGER, J. et al. (Hrsg.): Dorfökologie: Wasser und Gewässer. - Laufen/Salzach: ANL 1988 [Laufener Seminarbeiträge;8].

HERMAN, O.: Urgeschichtliche Spuren in den Geräthen der ungarischen volksthümlichen Fischerei. Zugleich als Katalog verfasst von Otto Hermann. - Budapest 1885 [Ungarische Landes-Ausstellung; Gruppe 4].

HERMAND, J: (Hrsg.): Mit den Bäumen sterben die Menschen: zur Kulturgeschichte der Ökologie. - Köln et al.: Böhlau 1993 [Literatur - Kultur - Geschlecht: Kleine Reihe;6].

HERMAND, J.: Umweltgeschichte wozu? - In: BAYERL, G./FUCHSLOCH, N./MEYER, T. (Hrsg.): Umweltgeschichte Methoden, Themen, Potentiale: Tagung des Hamburger Arbeitskreises für Umweltgeschichte, Hamburg 1994. - Münster, New York: Waxmann 1996 [Cottbuser Studien zur Geschichte von Technik, Arbeit und Umwelt;1]:303-308.

HERRMANN, B. (Hrsg.): Umwelt in der Geschichte: Beiträge zur Umweltgeschichte. Göttingen: Vandenhoeck und Ruprecht 1989 [kleine Vandenhoeck-Reihe;1544].

HERRMANN, B.: Umweltgeschichte. - In: HERRMANN, B./BUDDE, A. (Hrsg.): Natur und Geschichte. Naturwissenschaftliche und historische Beiträge zu einer ökologischen Grundbildung. Sommerschule „Natur und Geschichte“ vom 14 . bis 27. September 1989 an der Georg-August-Universität Göttingen. - Hildesheim: Gerstenberg 1989 [Schriftenreihe „Expert“ des Nieders. Umweltministers Hannover]:145-153.

HERRMANN, B. (Hrsg.): Mensch und Umwelt im Mittelalter. - 3. Aufl. - Stuttgart: Deutsche Verl.-Anstalt 1987.

HERRMANN, B. (Hrsg.): Geschichte in der Natur. Historische Muster, die Umwelt zu verstehen. - Frankfurt/Main: Fischer 1990.

HERRMANN, B. (Hrsg.): Archäometrie: naturwissenschaftliche Analyse von Sachüberresten; eine praktikumsbegleitende Veröffentlichung aus dem Arbeitskreis Umweltgeschichte der Georg-August-Universität Göttingen. Berlin et al.: Springer 1994.

HERRMANN, Bernd: Umweltgeschichte entdecken. - In: Jahrbuch Ökologie 1994. - München: Beck [Beck'sche Reihe;1027]:271-274. 
HERRMANN, B. [a]: „Nun blüht es von End“ zu End“ all überall“: die Eindeichung des Nieder-Oderbruchs 1747-1753; umweltgeschichtliche Materialien zum Wandel eines Naturraums. - Münster et al.: Waxmann 1997 [Cottbuser Studien zur Geschichte von Technik, Arbeit und Umwelt;4].

HERRMANN, Bernd [b]: Vorlesung zur Umweltgeschichte II, SS 1997, unveröff. Mitschrift.

HERRMANN, B.: Hunger nach Wachstum? Der Beitrag der historischen Umweltforschung zum Verständnis der Zukunft. - In: Landesmuseum für Technik und Arbeit (Hrsg.): Mannheimer Zukunftstage. Verheißung der Globalisierung, demographische und ökologische Herausforderungen. - Mannheim 2001:83-95.

HERRMANN, B.: Umweltgeschichte als Integration von Natur- und Kulturwissenschaft. - In: BAYERL, G./FUCHSLOCH, N./MEYER, T. (Hrsg.): Umweltgeschichte - Methoden, Themen, Potentiale: Tagung des Hamburger Arbeitskreises für Umweltgeschichte, Hamburg 1994. - Münster, New York: Waxmann 1996 [Cottbuser Studien zur Geschichte von Technik, Arbeit und Umwelt;1]:21-30.

HERRMANN, B./BUDDE, A. (Hrsg.): Natur und Geschichte. Naturwissenschaftliche und historische Beiträge zu einer ökologischen Grundbildung. Sommerschule „Natur und Geschichte“ vom 14. bis 27. September 1989 an der Georg-AugustUniversität Göttingen. - Hildesheim: Gerstenberg 1989 [Schriftenreihe „Expert“ des Nieders. Umweltministers Hannover].

HERRMANN, B./SCHUBERT, E. (Hrsg.): Von der Angst zur Ausbeutung. Umwelterfahrung zwischen Mittelalter und Neuzeit. Frankfurt/Main: Fischer 1994 [Fischer Taschenbuch].

HERRMANN, B./SCHUTKOWSKI, H.: Naturerfahrungsgebiete - Humanökologische Prolegomena zur Sicherung der Landschaft und zur Förderung einer natur- und landschaftsverträglichen Erholung. - In: SCHEMEL, H. J. et al.: Naturerfahrungsräume. Bonn-Bad Godesberg: Bundesamt f. Naturschutz 1998 [Angewandte Landschaftsökologie;19]:13-30.

HERRMANN, B./SPRANDEL, R. (Hrsg.): Die Bevölkerungsentwicklung des europäischen Mittelalters. Das wirtschaftsgeographische und kulturelle Umfeld. - In: Saeculum 39/2 1988.

HERRMANN, B. et al.: Alles bleibt anders: Was Göttinger Anthropologen an der Diversität finden. - In: Georgia Augusta Wissenschaftsmedizin der Georg-August-Universität Göttingen: „Leben braucht Vielfalt - Biodiversität“; Ausgabe 1/2002, Dezember 2002: Hrsg. v. Präsidenten der Universität in Zusammenarbeit mit dem Universitätsbund Göttingen:53-59.

HERRMANN, R.: Einführung in die Hydrologie. - 1. Aufl. - Stuttgart: Teubner 1977 [Teubner-Studienbücher: Geographie].

HERRMANN, W./LÖFFLER, K./WILSDORF, H.: Bergbau - Wald - Flöße: Untersuchungen zur Geschichte der Flößerei im Dienste des Montanwesens und zum montanen Transportproblem. - Berlin 1960 [Freiberger Forschungshefte, Reihe D;28].

HERTZER, O.: Die Wasserversorgung der Stadt Nordhausen. - In: Der Harz, Monatszeitschrift des Harzclubs 7 1924:369.

HERZBERG, H./RIESEBERG, H. J.: Mühlen und Müller in Berlin: Ein Beitrag zur Geschichte der Produktivkräfte. - Berlin: VEB Verl. f. Bauwesen 1986.

HERZOG, F.: Das Osnabrücker Land im 18. und 19. Jahrhundert: eine kulturgeographische Untersuchung. - Oldenburg i. O.: Stalling 1938 [Veröff. Wirtschaftswissenschaftl. Ges. zum Studium Niedersachsens: Reihe A, Beiträge;40]; Zugl.: Münster, Univ., Diss. 1938.

HERZOG, W.: Die Rieselfeldkulturen der Stadt Dortmund: Kulturgeographische Auswirkungen städtischer Abwasserwirtschaft. Bonn 1956 [Arbeiten zur Rheinischen Landeskunde;11].

HESSISCHES MINISTERIUM FÜR UMWELT UND REAKTORSICHERHEIT: Naturnahe Gewässer in Hessen, Bachpatenschaften, Renaturierungsmaßnahmen. - Wiesbaden: Referat Öffentlichkeitsarbeit o. J.

HETTCHE, H.: Planung zum Um- und Ausbau der Versuchsanlage Wielenbach. - In: Bau Intern 7 1981:110-114.

HETTNER, A.: Die Gewässer des Festlandes. - Leipzig et al.: Teubner 1934 [Vergleichende Länderkunde;3].

HETZEL, W.: Wiesenbewässerung und Agrarlandschaft des oldenburgischen Huntetals. Struktur und Wandel von Landschaft und Wirtschaft in einem Jahrhundert. - Bremen/Horn: Dorn 1957 [Veröffentlichungen des Nieders. Amtes f. Landesplanung und Statistik, Reihe A I; 39; ebenso in: Schriften der wirtschaftswissenschaftlichen Gesellschaft zum Studium Niedersachsens e. V., Neue Folge; 39].

HEUSCH-ALTENSTEIN, A.: Kulturgüterschutz an Gewässer und Auen in Denkmal- und Landschaftspflege: Landschaftsgesetz und Landschaftsplanung. - In: Fließgewässer in der Kulturlandschaft. - 1999:134-144.

HEWISON, R.: The heritage industry. Britain in a climate of decline. - London: Methuen 1987.

HEYEN, F.-J.: Mosel, Fluß und Wasserstraße, Lebensraum: Ausstellung zum Rheinland-Pfalz-Tag 1989 in Zell, (Kreissparkasse, 2. bis 7. Juni 1989) und zum 25. Jahrestag der Eröffnung der Grossschiffahrt auf der ausgebauten Mosel im Landesmuseum Trier, (Rhein. Landesmuseum Trier, 10. Juni bis 30. September 1989). - Koblenz : Landeshauptarchiv 1989.

HEYENBROCK, W.[olfgang]: Hochwasserschutz bayerischer Städte. - In: DVWK [Deutscher Verband für Wasserwirtschaft und Kulturbau e. V.] (Hrsg.): Fluß und Lebensraum: Beiträge zur Fachtagung 1984 in Augsburg. - Hamburg; Berlin: Parey 1984 [Schriftenreihe des Deutschen Verbandes für Wasserwirtschaft und Kulturbau e.V.;69]:183-207.

HEYM, W.-D.: Wasser für den Branitzer Park. - In: „Natur und Landschaft im Bezirk Cottbus“ 91987.

HEYN, E.: Geographie. Wasser, ein Problem unserer Zeit. - Aarau: Sauerländer 1981 [Studienbücher Geographie]. 
HIELSCHER, K.: Zur Geschichte der Pferdegeschirre und der Fuhrwerke. - In: Zeitschrift für Agrargeschichte und Agrarsoziologie 33 1985:164-178.

HILDEBRANDT, G.: Fernerkundung und Luftbildmessung: für Forstwirtschaft, Vegetationskartierung und Landschaftsökologie. - Heidelberg: Wichmann 1995.

HILDEBRANDT, H. (Hrsg.): Hachenburger Beiträge zur angewandten historischen Geographie: [„,Kulturlandschaftsforschung im Wald"]. - Mainz: Geographisches Institut der Univ. 1994 [Beiträge der Fachtagung der Arbeitsgruppe Angewandte Historische Geographie im Arbeitskreis für Genetische Siedlungsforschung in Mitteleuropa;3]; [Mainzer geographische Studien;39].

HILF, R.B./RÖHRIG, F.: Wald und Waidwerk in Geschichte und Gegenwart; Teil 1: Der Wald (von R. B. Hilf). - Potsdam: Akad. Verl.-Ges. Athenaion 1938.

HILGER, M.-E.: Umweltprobleme als Alltagserfahrung in der frühneuzeitlichen Stadt? Überlegungen anhand des Beispiels der Stadt Hamburg. - In: Die Alte Stadt 11/2 1984:112-138.

HILLEBRECHT, M.-L.: Die Relikte der Holzkohlenwirtschaft als Indikatoren für Waldnutzung und Waldentwicklung. Untersuchungen an Beispielen aus Südniedersachsen. - Göttingen 1982 [Göttinger Geographische Abhandlungen;79].

HILLEGEIST, H. H.: Das historische Eisenhüttenwesen im Westharz und Solling. Ein Beitrag zur Wirtschaftsgeschichte dieses Raumes. - Clausthal-Zellerfeld 1974 [Der Harz und Südniedersachsen, Sonderh. 1].

HINRICHSEN, H.: Die Bille mit ihren Hamburger Wohnvierteln: Wandlung eines alten Flussidylls. - 2. Aufl. - Hamburg: Selbstverl. 1983.

HINRICHSEN, H.: Die Bille mit Bergedorf und den Sachsenwaldgemeinde: Wahrnehmung eines alten Flußidylls. - Hamburg: Selbstverl. 1994.

HIPP, H.: Freie und Hansestadt Hamburg. Geschichte, Kultur und Stadtbaukunst an Elbe und Alster. - 2. Aufl. - Köln: DuMont 1990.

HIRSCHFELDER, G.: Das Wassertrinken: Prolegomena zu einer Kulturgeschichte. - In: Archiv für Kulturgeschichte 80 1998:325-350.

HISTORISCHE KULTURLANDSCHAFTEN: Internationale Tagung, veranstaltet vom Dt. Nationalkommitee von ICOMOS in Zusammenarbeit mit dem Europarat und dem Landschaftsverband Rheinland - Rheinisches Amt für Denkmalpflege, Abtei Brauweiler, 10.-17. Mai 1992. - München: Lipp 1993 [ICOMOS. Hefte des Dt. Nationalkommitees;11].

HISTORISCHE TALSPERREN. Hrsg.: Deutscher Verband für Wasserwirtschaft und Kulturbau e.V. Bearbeitet von Günther Garbrecht. - Stuttgart: Wittwer, Bd. 1 1987, Bd. 21991.

HITZBLECK, H.: Die Bedeutung des Fisches für die Ernährungswirtschaft Mitteleuropas in vorindustrieller Zeit unter besonderer Berücksichtigung Niedersachsens. - Göttingen, Univ., Diss. 1971.

HMU [Hessisches Ministerium für Umwelt, Landwirtschaft und Forsten]: Erläuterungsbericht Gewässerstrukturgüte in Hessen 1999. - Wiesbaden 2000.

HOCHHEIMER, A.: Die Geschichte der grossen Ströme. - Einsiedeln et al.: Denziger 1954.

HOCK, A.: Der letzte Eisenhammer im Spessart: Lebendige Vergangenheit zwischen Esse und Wasserrad [URL = http://home.tonline.de/home/robert.handel/eisenhammer.htm;12.02.2004].

HOCK, F.: Biotope erleichtern Laubfrosch die Rückkehr in die Pfalz. - In: „Die Rheinpfalz“ vom 16.12.2001.

HOEBEL-MÄVERS, M./GÄRTNER, H. (Hrsg.): Umweltforschung und Umweltbildung im Ballungsraum: der Einfluß von Natur und Gesellschaft auf ein integratives Verständnis von Umwelt. - Frankfurt/Main: Lang 1990 [Europäische Hochschulschriften: Reihe 11, Pädagogik;411].

HOEK, R. C.: Mühlen und Müller im Rheiderland: ein Beitrag zur Heimatchronik. - Weser/Ems: Risius 1986.

HOFFMANN, A.: Der Harz - Land der Teiche und Talsperren. 1. Teil: Ein Streifzug durch die Geschichte der Oberharzer Wasserwirtschaft von den Anfängen im Mittelalter über die Teichwirtschaft des Bergbaus zu den heutigen Grubenkraftwerken. - Clausthal 1972.

HOFFMANN, A.: Zwischen Arnsburg und Walkenried: Grundzüge und Merkmale früher wasserwirtschaftlicher Tätigkeit der Zisterzienser im hessisch-thüringischen Bergland. - Braunschweig 1991 [Leichtweiß-Institut für Wasserbau der Technischen Universität Braunschweig; Mitteilungen; 11]:67-107.

HOFFMANN, A.: Wasser prägt eine Landschaft. - In: WOLKERS, U. (Hrsg.): Land an Eder und Diemel. - Korbach: Verl. Bing 1992:164-172.

HOFFMANN, A.: Der Oderteich in den Reisebüchern des 18. Jahrhunderts. - In: Allgemeiner Harz-Berg-Kalender 298. Clausthal-Zellerfeld 1995:75-78.

HOFFMANN, A.: Mit Löscheimer und Feuerspritze: Wasserversorgung und Brandbekämpfung im vorindustriellen Mitteleuropa. Hrsg.: Freiwillige Feuerwehr der Universitätsstadt Marburg. - Marburg: Eigenverl. 1995. 
HOFFMANN, A. (Hrsg.): Antike und mittelalterliche Wasserversorgung in Mitteleuropa. - Kassel: Herkules Verl. 1995 [Kasseler Wasserbau-Materialien; 3].

HOFFMANN, A: Weser-Main-Kanal: Der alte Traum von einer Wasserstraße durch das hessische Bergland. - In: TÖNSMANN, F. (Hrsg.): Zur Geschichte der Wasserstraßen insbesondere in Nordhessen. - Kassel: Herkules Verl. 1995 [Kasseler Wasserbau-Materialien; 4]:83-106.

HOFFMANN, A.: Uferbau und Gewässerpflege im Kurfürstentum Hessen. - In: Jahrbuch Landkreis Kassel 1996:67-74.

HOFFMANN, A.: Wassermühlen und Laufbrunnen. Zur Wasserwirtschaft im Mittelalter am Beispiel des Klosters Caldern. - In: 750 Jahre Kloster Caldern: Ein Nonnenkloster des Zisterzienserordens. - Lahntal 1999: 222-243.

HOFFMANN, A.: Kassel an der verschmutzten Fulda. Über Gewässerverunreinigungen in der Gründerzeit. - In: Jahrbuch Landkreis Kassel 1999:62-66.

HOFFMANN, A.: Wasser fürs Bier. Nordhessens Brauwasserversorgung in vorindustrieller Zeit. - In: Jahrbuch 2000 Landkreis Kassel:39-43.

HOFFMANN, A./SCHNEIDER, H. (Hrsg): Technik und Zauber historischer Wasserkünste in Kassel: von den Kaskaden Guernicos zu den Wasserfällen Steinhöfers. - Kassel: Euregio Verl. 2000

HOFFMANN, H.-C.: Die Lüneburger Heide: Kultur, Geschichte und Landschaft im östlichen Niedersachsen zwischen Elbe und Aller. - Köln: DuMont Kunst-Reiseführer 1996.

HOFFMANN, R.: Mediaeval Cistercian Fisheries: Natural and Artificial. - Hrsg.: Ministère de l'Enseignement supérieur et de la Recherche: L'espace cistercien sous la direction de Léon Pressourye. Le colloque «l'espace cistercien » (Abbaye de Frontfroide, 24-27 mars 1993). - Paris: Comité des travaux historiques er scientifiques, 1994 [Mémoires de la section d'archéologie et d'histoire de l'art;5]: 401-414.

HOFFMANN, S.: Die gesetzliche Situation zur Wasserqualität in Schwimmteichen. - In: Stadt + Grün 9/2003:35-36.

HÖFLING, P./GEBHARD, T.: Die Chiemsee-Fischerei: Beiträge zu ihrer Geschichte. München: Inst. f. Volkskunde 1987 [Beiträge z. Volkstumsforschung;24].

HOFMANN, B.: Entwicklung und gegenwärtiger Stand der Dinkelsbühler Teichwirtschaft. - Braunschweig: Wenzel 1958 [Archiv für Fischereiwissenschaft: Beiheft 1]; Zugl.: Diss.

HOFMANN, H. H.: Kaiser Karls Kanalbau. - Sigmaringen: Thorbecke 1977.

HOFMANN, J.: Die geschichtliche Entwicklung der Teichwirtschaft in Franken. - In: Jahresbericht des Historischen Vereins für Mittelfranken 67/1931.

HOFMANN, J.: Der Teichwirt. - Berlin: Parey 1987.

HOFMEISTER, B.: Editorial. In: Die Alte Stadt. 16/1 1989.

HOFMEISTER, S.: Welche Planung braucht eine nachhaltige Entwicklung? Ein Blick zurück nach vorn. - In: BRANDT, E. (Hrsg.): Perspektiven der Umweltwissenschaften. - Baden-Baden: Nomos 2000 [Umweltrecht und Umweltpolitik;2]:83-105.

HOHENBERGER, E.: Feuchtgebiete. Quellen, Flüsse, Seen, Moore. - Ravensburg: Maier 1989 [Natur erleben].

HOHL, T.: Beiträge zur Flößerei auf der Saale in geschichtlicher und wirtschaftlicher Hinsicht. - Jena, Inaugural-Diss. 1921.

HOHMANN, J./KONOLD, W.: Renaturierung von Fließgewässern: Das Beispiel Enz in Pforzheim. - Landsberg: Ecomed 1997 [Handbuch Angewandte Limnologie;7].

HOLT, R.: The mills of mediaval England. - Oxford et al.: Blackwell 1988.

HÖNES, E.-R.[a]: Zur Schutzkategorie „historische Kulturlandschafte“. - In: Natur und Landschaft 66/2 1991:87-90.

HÖNES, E.-R.[b]: Die historische Kulturlandschaft - ein unbestimmter Rechtsbegriff wertendes Inhalts. - In: Natur und Landschaft 66/2 1991:402ff.

HÖNES, E.-R.: Zum Verhältnis von Gartendenkmalpflege- und Naturschutzrecht. - In: Natur und Recht 25/5 2003:257-265.

HÖNSCH, I.: Vergangene Gegenwarten: Facetten aus dem Archiv für Geographie. - Leipzig: Institut für Länderkunde 2001.

HÖVERMANN, J.: Die Entwicklung der Siedlungsformen in den Marschen des Elb-Weser-Winkels. - Remagen: Verl. d. Amtes f. Landeskunde 1951 [Forsch. z. dt. Landeskunde; 56].

HONSING-ERLENBURG, W./WIESER, G. (Hrsg.): Die Gurk und ihre Seitengewässer. - Klagenfurt: Verl. des Naturwissenschaftlichen Vereins für Kärnten 1997 [CARINTHIA II: Naturwissenschaftliche Beiträge zur Heimatkunde Kärntens; Mitteilungen des Naturwissenschaftlichen Vereins für Kärnten;55, Sonderheft].

HOOPS, J.: Reallexikon der germanischen Altertumskunde. Hrsg. v. H. BECK; Bd. 4: Brunnen - Chronologie. - 2. Aufl. - Berlin et al.: de Gruyter 1981 [1. Aufl. 1979].

HOPPE, A.: Die Bewässerungswiesen Nordwestdeutschlands: Geschichte, Wandel und heutige Situation. - In: Abhandlungen aus dem Westfälischen Museum für Naturkunde 64/1 2002:1-103. 
HOPPE, A.: Verbreitung und Vegetation der Bewaesserungswiesen Nordwestdeutschlands. - In: Berichte der Reinhold-TüxenGesellschaft (RTG) 13 2001:247-250.

HOPPE, C..: Die großen Flußverlagerungen des Niederrheins in den letzten zweitausend Jahren und ihre Auswirkungen auf Lage und Entwicklung der Siedlungen. - Stuttgart 1970 [Forschungen z. dt. Landeskunde;189].

HORÁK, W.: Teichwirthschaft mit besonderer Rücksicht auf das südliche Böhmen: ein populäres Handbuch für Teichwirthe, Fischereibedienstete und Freunde der Fischzucht. - Prag: Calve 1869.

HORN, A./HOOP, W.: Nebenflüsse der Elbe : Pinnau - Krückau - Stör - Ilmenau - Este - Lühe - Schwinge - Oste; mit Eider und Treene. - Hamburg : Ed. Maritim 1992 [Schriftenreihe: Deutsche Binnengewässer].

HORNSMANN, Erich: Wasser: eine Problem jeder Zeit. - München: Lehnen 1956.

HORST, K./EVERS, U./SHIERHOLD, M.: Zur Vegetation und Ökologie des Naturschutzgebietes Sager Meer im südlichen Oldenburg. - Oldenburg: Drosera 1980:71-90.

HORSTIG, C. G.: Tageblätter unserer Reise in und um den Harz: Mit 16 in Kupfer gestochenen Zeichnungen grosser Naturscenen. - Dresden: Gerlach 1803.

HÖRTER, F.: Getreidereiben und Mühlsteine aus der Eifel: Ein Beitrag zur Steinbruch- und Mühlengeschichte. - Mayen: Geschichts- und Altertumskundeverein für Mayen und Umgebung e. V. 1994.

HOSKINS, W. G.: The Making of the English Landscape. - Hammondsworth: Penguin 1985 [Geography and environmental studies]; Zugl: London et al: Hodder and Stoughton 1988.

HOSS, F. T.: Die Steinmetzindustrie im Laacher Tuffgebiet unter besonderer Berücksichtigung des Ortes Weibern. - Köln: Univ. Diss. 1922.

HOSTMANN, M./KNUTII, A.: Befreite Wasser. Entdeckungsreisen in revitalisierte Flusslandschaften der Schweiz. - Zürich: Rotpunktverl. 2002.

HÖTTECKE, D.: Die Natur der Naturwissenschaften historisch verstehen. Fachdidaktische und wissenschaftshistorische Untersuchungen. - Berlin: Logos Verl. 2001 [Studien zum Physiklernen;16]; Zugl.: Oldenburg, Univ., Diss. 2000.

HOTZ, W.: Kleine Kunstgeschichte der deutschen Burg. - Darmstadt: Wiss. Buchgesell. 1991.

HOTZ, W.: Pfalzen und Burgen der Stauferzeit. Geschichte und Gestalt. - Darmstadt: Wiss. Buchgesell. 1992.

HOTZAN, J.: dtv-Atlas zur Stadt: von den ersten Gründungen bis zur modernen Stadtplanung. - München: Dt. Taschenbuch-Verl. 1994

HÖVEL, Martin van den: Kulturlandschaft - Landeskultur: Kultur und Landschaft?: - In: PlanerIN 1/01 2001:35-36.

HUBBARD, P. et al.: Thinking Geographically: Space, Theory and Contemporary Human Geography. - London, New York: Continuum 2002.

HÜBENER, W.: Die Keramik von Haithabu. Die Ausgrabungen in Haithabu 2. - Neumünster: Wachholtz 1959.

HUBER, M. G. (Hrsg.): Umweltkrise. Eine Herausforderung an die Forschung. - Darmstadt: Wiss. Buchgesellschaft 1991.

HUBERT, R.: Die Aischgründer Karpfenteichwirtschaft (im Wandel). Eine wirtschafts- und sozialgeographische Untersuchung. Passau: Passavia Universitäts-Verl. 1991 [Passauer Schriften zur Geographie;9]; Zugl.: Passau, Univ.-Diss. 1989.

HUHN, A.: Lotterbach - Ein Bauernhof in Ostpreussen: Ein Bericht über Flucht und Vertreibung. [URL = www.braunsbergostpreussen.de; 10.12.2003].

HUHN, R.: Dessau in alten Ansichten. - 2.Aufl. - Zaltbommel/Niederlande: Europäische Bibliothek 1992.

HUMBURG, N.: Schiffahrt auf der Ober- und Mittelweser. - In: Die Weser 53/7 1979:143-146; 53/8 1979:170-172.

HUMM, A.: Aus längst vergangenen Tagen: Bergbau- und Hüttenbetriebe, frühere Berufe, Volks- und Brauchtum, Jahresfeste, Wintersport in der Vergangenheit. - Clausthal-Zellerfeld: Pieper 1979.

HUNZINGER, L. M.: Flussaufweitungen: Morphologie, Geschiebehaushalt und Grundsätze zur Bemessung. - Zürich: Versuchsanst. für Wasserbau, Hydrologie und Glaziologie 1998 [Mitteilungen der Versuchsanstalt für Wasserbau, Hydrologie und Glaziologie der Eidgenössischen Technischen Hochschule Zürich;159].

HUPKA, H. (Hrsg.): Die Oder - geliebt und unvergessen. - Leer: Rautenberg 1992.

HÜTTE, E.: Ökologie und Wasserbau: ökologische Grundlagen von Gewässerverbauung und Wasserkraftnutzung. - Berlin: Parey 2000 .

HÜTTEN, H. G.: Sagen und Erzählungen vom Oberlauf der Düssel. - In: LANDESHAUPTSTADT DÜSSELDORF (Hrsg.): Die Düssel: Geschichte und Geschichten. - Köln: Rheinland-Verl. 1988:37-44.

HUTTER, C.-P./KONOLD, W./SCHREINER, J. (Hrsg.): Quellen, Bäche, Flüsse und andere Fließgewässer: Biotope erkennen, bestimmen, schützen.- Stuttgart, Wien: Weitbrecht Verl. 1996 [Biotop-Bestimmungsbücher]. 
HÜTTEROTH, W.: Quelle und Methoden historisch-siedlungsgeographischer Forschung ausserhalb Europas mit besonderer Berücksichtigung des Nahen Ostens. - In: DENECKE, D./FEHN, K. (Hrsg.): Geographie in der Geschichte. - Stuttgart, Wiesbaden: Steiner 1989 [Erdkundliches Wissen;96]:23-37.

IBA, E. M.: Sagen und Geschichten aus Nordhessen: von Weser, Diemel und Fulda. - 7. Aufl. - Hameln: Niemeyer 1998.

IG [INTERESSENGEMEINSCHAFT] „Westlausitzer Heidebogen“: Gebietskonzept LEADER+ „Westlausitzer Heidebogen“, 2001.

IHNE, W.: Die Entwicklung der rheinischen Mühlen im 19. Jahrhundert. - Würzburg: Mayr1937; Zugl.: Köln, Univ., Diss. 1937.

ILLIES, J.: Die Lebensgemeinschaft des Bergbaches. - Wittenberg: Ziemsen 1961 [Die neue Brehm-Bücherei;289].

ILLIES, J.: Tiergeographie. - 2. Aufl. - Braunschweig: Westermann 1972 [Das geographische Seminar].

ILLIES, J.: Einführung: Umwelt und Anpassung. - In: Unsere Umwelt als Lebensraum. Grzimeks Buch der Ökologie. Hrsg. v. J. Illies und W. Klausewitz. - Zürich 1973:15ff.

IMHOF, A.: Einführung in die Historische Demographie. - München: Beck 1977 [Beck’sche Elementarbücher].

IMMEL, R.: Das Schrifttum über Forstwesen, Holzwirtschaft [...], Fischerei [...] in Hessen und [...] - Mainz: Schmidt 1958.

IRAN 2004 [URL = http://www.bboxbbs.ch/Home/sparta/iran.html;10.01.2000].

IRMES, L./ULRICH, K.: Wasserlandschaften der Schweiz. Flüsse und Seen aus der Luft. - München: Ringier 1991.

IRSIGLER, F.: Europäischer Kernraum oder Peripherie? Der Rhein-Maas-Raum im Mittelalter und in der frühen Neuzeit Vortrag 30. Tagung des „Arbeitskreises für genetische Siedlungsforschung in Mitteleuropa“ in Greifswald vom 17. bis 20. September 2003.

ISENBERG, W./MÖLICH, G.: Vorwort. - In: Historische Umweltforschung. Hrsg.: IISENBERG, W. - Bergisch Gladbach: Thomas-Morus-Akademie Bensberg 1992 [Bensberger Protokolle;71]:7.

ISENBERG; W. (Hrsg.): Historische Umweltforschung: wissenschaftliche Neurorientierung, aktuelle Fragestellungen. - Bergisch Gladbach: Thomas-Morus-Akademie Bensberg 1992 [Bensberger Protokolle;71]

IUGR [Institut für Umweltgeschichte und Regionalentwicklung e.V.] (Hg.): Umweltgeschichte und Umweltzukunft: Schwerpunkt: Umweltbewegungs- und Umweltforschungsgeschichte. - Marburg 1993.

JACOB, W.: Vom Kudamm geht's direkt zum Strand. Ein Berliner Kongreß stellt das Ideal der europäischen Wasserstädte vor. In: Frankfurter Allgemeine Zeitung Nr. 272 v. 22. November 1997:37.

JACOBS, K./KLEEFELD, K.-D. (Hrsg.): Informationssysteme für die Angewandte Historische Geographie. Beiträge des Symposiums vom 20. März 1999 am Lehrstuhl für Informatik IV der RWTH Aachen. Eine Veranstaltung der Arbeitsgruppe Historische Geographie im Arbeitskreis für genetische Siedlungsforschung in Mitteleuropa. - Bonn 1999 [Aachener Informatik Berichte; 99-6. - Kulturlandschaft 9/1 1999].

JACOMET, S./KREUZ, A.: Archäobotanik: Aufgaben, Methoden und Ergebnisse vegetations- und agrargeschichtlicher Forschung. - Stuttgart: Ulmer 1999 [UTB, Uni-Taschenbücher;8158].

JAGUSCH, G.: Schlatts. - In: AKKERMANN, R.: Tümpel - Teiche - Schlatts. Hrsg. v. d. Biolog. Schutzgemeinschaft Hunte Weser - Ems e. V. (BSH) i. V. m. d. Biolog. Arbeitskreis a. d. Univ. Osnabrück, Abt. Vechta. - Wardenburg: BSH-Verl. 1980 [Informationen zu Naturschutz und Landschaftspflege in Nordwestdeutschland;2]:11-17.

JÄGER, H.: Die Entwicklung der Kulturlandschaft im Kreise Hofgeismar. - Göttingen 1951 [Göttinger Geographische Abhandlungen; 8]

JÄGER, H.: Entwicklungsgperioden agrarischer Siedlungsgebiete im mittleren Westdeutschland seit dem frühen 13. Jahrhundert. Würzburg 1958 [Würzburger Geogr. Arbeiten;6].

JÄGER, H.: Zur Methodik der genetischen Kulturlandschaftsforschung. Zugleich ein Bericht über eine Exkursion zur Wüstung Leisenberg (Krs. Northeim). - In: Berichte zur deutschen Landeskunde 30 1963:158-196.

JÄGER, H.: Historische Geographie im Felde. - In: JÄGER, H. (Hrsg.): Methodisches Handbuch für Heimatforschung in Niedersachsen. - Hildesheim: Lax, 1965 [Veröffentlichungen des Instituts für Historische Landesforschung der Universität Göttingen;1]:409-426.

JÄGER, H.: Historische Geographie. - 2. Aufl. - Braunschweig: Westermann 1973 [Das Geographische Seminar].

JÄGER, H: Elbe: Geographisches. - In: BECK, H., H. et al. (Hrsg.): Reallexikon der Germanischen Altertumskunde, Bd. 7 - Berlin 1973:94-100.

JÄGER, H.: Zur Erforschung der mittelalterlichen Kulturlandschaft. - Münster: Selbstverl. d. Geogr. Kommission f. Westfalen, 1978 [Westfälische Geographische Studien;35]:5-24.

JÄGER, H.: Revolution oder Evolution der Historischen Geographie. - In: Erdkunde 36 1982:119-123.

JÄGER, H.: Entwicklungsprobleme europäischer Kulturlandschaften. Eine Einführung. - Darmstadt: Wiss. Buchgesell. 1987.

JÄGER, H.: Frühe Umwelten in Mitteleuropa. - In: Siedlungsforschung 6 1988:9-24. 
JÄGER, H.: Einführung in die Umweltgeschichte. - Darmstadt: Wiss. Buchgesell., 1994

JÄGER, H.: Historische Geographie gestern und heute. - In: Siedlungsforschung 15 1997:341-345.

JÄGER, K.-D./NEUHÄUSL, R.: Interactions between natural environment and Neolithic man in Central Europe - an investigation based on comparative studies on Vegetation and settlement with special emphasis on the view of natural science. - In: FREZEL, BURKHARD (Hrsg.): Evaluation of land surfaces cleared from forests by prehistoric man in Early Neolithic times and the rime of migrating Germanic tribes. - Mainz: Akademie der Wissenschaften und der Literatur 1994:75-81.

JÄGER, H./SIEGLERSCHMIDT, J.: Einführung in die Umweltgeschichte. - In: Technikgeschichte 63/2 1996:186.

JÄGERSCHMID, K. F. V.: Handbuch für Holztransport und Flosswesen zum Gebrauche für Forstmänner und Holzhändler und für solche, die es werden wollen. 3. Bde. [2. Bde. und 1 Tafelbd]. - Karlsruhe: Müller 1827-28.

JAHNKE, C.: Das Silber des Meeres: Fang und Vertrieb von Ostseehering zwischen Norwegen und Italien (12. - 16. Jahrhundert). - Köln et al.: Böhlau 2000 [Quellen und Darstellungen zur hansischen Geschichte, N. F.;49]; Zugl.: Kiel, Univ., Diss. U. d. T. „Heringsfang und -handel im Ostseeraum des Mittelalters 1998.

JAHNKUHN, H.: Die Ausgrabungen in Haithabu 1935/36. - Neumünster: Wachholtz 1936 [Offa;1]:96-140.

JAHNKUHN, H. et al. (Hrsg.): Das Handwerk in vor- und frühgeschichtlicher Zeit. - Göttingen 1981 (Teil 1), 1983 (Teil 2) [Abh. Akad. d. Wiss. Göttingen, Phil.-Hist. Klasse;122]; Hier 1981:204-266, bes. 230ff.

JAKEL, K.: Bergbauliche Wasserwirtschaft. - In: KLEßEN, R. (Hrsg.): Historischer Bergbau und Hüttenwesen im Mittelharz Exkursionsführer. - Berlin: Geogr. Inst., Humboldt-Univ. Berlin 2000 [Arbeitsberichte Geographisches Institut HumboldtUniversität Berlin;46]:28-35.

JAKOBS, K. (Hrsg.): Informationssysteme für Angewandte Historische Geographie: Beiträge des Symposions vom 20. März 1999 am Lehrstuhl für Informatik IV der RWTH Aachen; eine Veranstaltung der Arbeitsgruppe für Angewandte Historische Geographie im Arbeitskreis für genetische Siedlungsforschung in Mitteleuropa. - Aachen: Fachgruppe Informatik der RWTH 1999 [Aachener Informatik-Berichte;6/99].

JAKUBOWSKI-TIESSEN, M.: Sturmflut 1717: Die Bewältigung einer Naturkatastrophe in der Frühen Neuzeit. - München: Oldenbourg 1992 [Ancien Régime, Aufklärung und Revolution;24]; Zugl.: Kiel, Univ., Habil.-Schr. 1990.

JAKUBOWSKI-TIESSEN, M.: Kein Zurück zur Natur. Wie Romantik und Commerz die Diskussion über die Halligwelt nach der Sturmflut von 1825 prägten. - In: JAKUBOWSKI-TIESSEN, M./LORENZEN-SCHMIDT, K.-J. (Hrsg.): Dünger und Dynamit. Beiträge zur Umweltgeschichte Schleswig-Holsteins und Dänemarks. - Neumünster: Wachholtz 1999.

JAKUBOWSKI-TIESSEN, M.[a]: Kommentar zu ,Wahrnehmung und Deutung von Katastrophen'. - In: ,Erfahrung' als Kategorie der Frühneuzeitforschung. Hrsg. v. Paul Münch. - München 2001 [Historische Zeitschrift: Beiheft: N.F.;31]:261-267.

JAKUBOWSKI-TIESSEN, M.[b]: „Pestilentz macht fromm, Hungersnot macht Buben...“: Erfahrung und Deutung von Katastrophen im 16. Jahrhundert. - In: ,Gott hat noch nicht genug Wittenbergisch Bier getrunken.' Alltagsleben zur Zeit Martin Luthers. Wittenberger Sonntagsvorlesungen. Hrsg.v. Peter Freybe. - Wittenberg: Drei-Kastanien-Verl. 2001:49-67.

JAMES, P. E.: Latin America. - 3. Aufl. - London: Casell 1959 [1. Aufl. 1942].

JÄNNICHEN; H.: Zur Geschichte der Sägemühlen im Mittelalter mit Ausblicken auf die Bestockungsverhältnisse südwestdeutscher Wälder. - In: Mitt. Verh. f. Forstl. Standortskunde u. Pflanzenzüchtung 16 1967:46-51.

JANKRIFT, K. P.: In subvencionem Christi pauperum parcium transmarinarum. Kontinuität und Wandel der JohanniterKommende Lage von ihren Anfängen bis zur Reformation. Ein historischer Kurzüberblick. - In: Johanniter-Kommende Lage (1245-1995). Beiträge zur Bau- und Kunstgeschichte. - Osnabrück 1995 [Schriften zur Kulturgeschichte des Osnabrücker Landes;6]:9-15;101-102.

JANKRIFT, K. P.[a]: Brände, Stürme, Hungersnöte: Katastrophen in der mittelalterlichen Lebenswelt. - Ostfildern: Thorbecke Verl. 2003.

JANKRIFT, K. P.[b]: Krankheit und Heilkunde im Mittelalter. - Darmstadt: Wiss. Buchgesell. 2003 [Studienwissen Kompakt, Mittelalter].

JANKUHN, H.: Der fränkisch-friesische Handel zur Ostsee im frühen Mittelalter. - In: Vierteljahrschrift für Sozial- und Wirtschaftsgeschichte 40 1953:193-243.

JANKUHN, H.: Die Niederelbe im Handelsverkehr des frühen Mittelalters. - In: Stader Jahrbuch 1954:35-47.

JANKUHN, H.: Die Frühgeschichte: vom Ausgang der Völkerwanderung bis zum Ende der Wikingerzeit. - Neumünster: Wachholtz 1957 [Geschichte Schleswig-Holsteins;3].

JANKUHN, H.: Vorgeschichte und Frühgeschichte vom Neolithikum bis zur Völkerwanderungszeit. - Stuttgart: Ulmer 1969 [Dt. Agrargeschichte; 1$]$.

JANKUHN, H.:Einführung in die Siedlungsaarchäologie. - Berlin et al: de Gruyter 1977

JANKUHN, H.: Klima-Änderungen seit dem Neolithikum und ihre Bedeutung für Siedlung und Wirtschaft bis zur Wikingerzeit. In: FRENZEL et al: Klimaänderungen, Mensch und Lebensraum: Vorträge gehalten auf der Tagung der Joachim-JungiusGesellschaft der Wissenschaften Hamburg am 20. und 21. Oktober 1979. - Göttingen: Vandenhoeck \& Ruprecht 1980 [Veröff. Joachim Jungius-Gesell. Wiss. Hamburg;44]:115-139. 
JANKUHN, H.: Vorgeschichtliche Heiligtümer und Opferplätze in Mittel- und Nordeuropa. Bericht über ein Symposium in Rheinhausen bei Göttingen in der Zeit vom 14. bis 16. September 1968. - Göttingen: Vandenhoeck \& Ruprecht 1970 [Abhandlungen der Akademie der Wissenschaften Göttingen, Phil.-hist. Klasse 3;74]

JANKUHN, H.: Haithabu: Ein Handelsplatz der Wikingerzeit. - 8. neubearb. Aufl. - Neumünster: Wachholtz 1986 [3. Aufl. 1956].

JANKUHN, H./SCHIETZEL, K./REICHSTEIN, H. (Hrsg.): Handelsplätze des frühen und hohen Mittelalters. [Gesamtitel: Archäologische und naturwissenschaftliche Untersuchungen an ländlichen und frühstädtischen Siedlungen im deutschen Küstengebiet vom 5. Jahrhundert v. Chr. bis zum 11. Jahrhundert n. Chr.]. - Weinheim: Acta Humaniora 1984 [Deutsche Forschungsgemeinschaft;2].

JANSEN, D: Garzweiler II und die Folgen: Der Wasserhaushalt wird für Jahrhunderte geschädigt. - In: Wasser - der bedrohte Lebensstoff: ein Element in der Krise. - Düsseldorf: VDI Verl. 1996 [Taschenbuchreihe Fakten]:77-86.

JANSEN, F.: Ansätze zu einer quantitativen historischen Landschaftsökologie - Landschaftsbilanzen und Natürlichkeitsgrade mit Hilfe der Schwedischen Matrikelkarten Vorpommerns. - Greifswald, Univ., Diss. 2004.

JANSEN, P.: Bauen am Wasser. Planungsgrundlagen für Siedlungen und Gebäude an Binnengewässern. Unter Berücksichtigung bootssportorientierten Gewässerausbaus. - Berlin: Köster 2002.

JANSSEN, W.: Methoden und Möglichkeiten der Erforschung früher Umwelten. - In: Siedlungsforschung 6 1988:25-38.

JANSSEN, W./LOHRMANN, D. (Hrsg.): Villa - curtis - grangia. Landwirtschaft zwischen Loire und Rhein von der Römerzeit zum Hochmittelalter. - München: Artemis 1983.

JANSSEN-SCHNABEL, E.: Mühlengräben in der Ruraue. - In: Rheinische Heimatpfleger 35/3 1998:194-202.

JANßEN, D. 2000: Wasserschöpfmühlen der Krummhörn, Kloster Aland und das Loppersumer Meer. - In: Heim und Heerd; $\begin{array}{llllllll}\text { Beilage } & \text { zum } & \text { Ostfriesischen } & \text { Kurier } & 1983 & - & 85 & \text { [URL }\end{array}$ http:/www.emdermuehlenverein.de/text/krummhoerner_muehlen/krummhoerner_muehlengeschichte.pdf].

JANZWEERT, E.: Vom Leinsamen zum Leinenhemd. Hrsg.: Leinenmuseum Haiger-Seelbach 1986.

JARITZ, G./WINIWARTER, V. (Hrsg.): Umweltbewältigung: die historische Perspektive. - Bielefeld: Verl. f. Regionalkultur 1994.

JAUERNIG-HOFMANN, B./HEIDRICH, H.: Der ganze Main war hölzern: eine Ethnografie der Flößerei. - Bad Windsheim: Fränkisches Freilichtmuseum 1993 [Schriften und Kataloge des Fränkischen Freilandmuseums;20].

JAWORSKI, R.: Alte Postkarten als historische Quellen. - In: Geschichte in Wissenschaft und Unterricht 51 2000:88-102.

JAX, K.: Renaturierung kleiner Fließgewässer. Möglichkeiten und Probleme einer Einbeziehung des Konzepts der natürlichen Störungen. - In: GRÜNEWALD, U. (Hrsg.): Wasserwirtschaft und Ökologie. - Taunusstein: Blottner 1994 [Umweltwissenschaften;2].

JEDICKE, E.: Biotopverbund: Grundlagen und Maßnahmen einer neuen Naturschutzstrategie. - Stuttgart: Ulmer 1990.

JEGGLE, U. (Hrsg.): Feldforschung: qualitative Methoden in der Kulturanalyse. - 2. unveränd. Aufl. - Schloss: Tübinger Vereinigung für Volkskunde e. V. 1984 [Untersuchungen des Ludwig-Uhland-Instituts der Universität Tübingen;62].

JEHN, K.: Renaturierung von Bächen. - In: Geogr. Rundschau 51 1999:318-325.

JELECK, L.: Environmentalisierung der historischen Geographie und historisches land use. - In: Historická Geografie 30 1999:5384.

JENTSCH, C./LUKHAUP, R.: Die Holztrift im Biosphärenreservat Naturpark Pfälzer Wald als ein traditionelles Element der Kulturlandschaft. - In: ANHUF, D./JENTSCH, C (Hrsg.): Beiträge zur Landeskunde Südwestdeutschlands und angewandte Geographie. - Mannheim 1998 [Mannheimer Geographische Arbeiten;46]:33-48.

JERICHO, H.: 75 Jahre Firma W. Jericho: Crimderode. - In: Nordhäuser Nachrichten 1/1 1993.

JERICHO, H.: Die Ellermühle bei Nordhausen. - In: Nordhäuser Nachrichten 1/1 1993.

JESCHKE, H. P.: Hinweis zu Begriffen, Methoden und zur Grundlagenforschung im Zusammenhang mit der Inventarisierung von Kulturlandschaften und deren historischen Elementen bzw. Historischen Kulturlandschaften. - In: Österreichische Zeitschrift für Kunst und Denkmalpflege 50/3 1996:209-226.

JESCHKE, H. P.: Entwurf der Struktur eines Pflegewerks für Cultural Heritage Landscapes (UNESCO Schutzkategorie „fortbestehende Kulturlandschaft") in föderalistisch organisierten Staaten Europas. - In: Denkmal - Ensemble Kulturlandschaft am Beispiel Wachau. Hrsg.: Bundesdenkmalamt. - Wien-Horn: 2000:116-146.

JESSEN, O.: Über die ehemalige Verbreitung der Weiher in Württemberg. - Öhringen 1923 [Erdgeschichtliche und landeskundliche Abhandlungen aus Schwaben und Franken;9].

JOB, H.: Der Wandel der historischen Kulturlandschaft und sein Stellenwert in der Raumordnung: Eine historisch-, aktual- und prognostisch-geographische Betrachtung traditioneller Weinbau-Steillagen und ihres bestimmenden Strukturmerkmals Rebterrasse, diskutiert am Beispiel rheinland-pfälzischer Weinbaulandschaften. - Flensburg: Dt. Akademie für Landeskunde, Selbstverl. 1999 [Forschungen zur Dt. Landeskunde;248]; Zugl.: Trier, Univ., Habil.-Schr. ca 1999. 
JOB, H./LEHMANN, B./SCHMITT, J.: Visualisierte Zukunftsexploration gewachsener Kulturlandschaften: eine raum- und landschaftsplanerische Herausforderung. - In: Informationen zur Raumentwicklung 5/6 1999:361-374.

JOB, H./STIENS, G.: Erhaltung und Entwicklung gewachsener Kulturlandschaften als Auftrag der Raumordnung. - In: Erhaltung und Entwicklung gewachsener Kulturlandschaften als Auftrag der Raumordnung. Hrsg.: Bundesamt für Raumwesen und Bauordnung. - Bonn 1999:I-VI.

JOCKENHÖVEL, A. (Hrsg.): Bergbau, Verhüttung und Waldnutzung im Mittelalter: Auswirkungen auf Mensch und Umwelt; Ergebnisse eines internationalen Workshops (Dillenburg, 11. - 15.Mai 1994, Wirtschaftshistorisches Museum „Villa Grün“). - Stuttgart: Steiner 1996 [Vierteljahrschrift für Sozial- und Wirtschaftsgeschichte: Beihefte;121].

JOCKENHÖVEL, A.[a]: Einführung zur Thematik und Zielsetzung des internationalen Workshops in Dillenburg (Wirtschaftshistorisches Museum „Villa Grün“), 11. bis 15. Mai 1994. - In: JOCKENHÖVEL, A. (Hrsg.): Bergbau, Verhüttung und Waldnutzung im Mittelalter: Auswirkungen auf Mensch und Umwelt; Ergebnisse eines internationalen Workshops (Dillenburg, 11. - 15.Mai 1994, Wirtschaftshistorisches Museum „Villa Grün“). - Stuttgart: Steiner 1996 [Vierteljahrschrift für Sozial- und Wirtschaftsgeschichte: Beihefte;121]:7-11.

JOCKENHÖVEL, A.[b]: Untersuchungen zur mittelalterlichen Eisengewinnung an Lahn und Dill: Das Dietzhölztal-Projekt (DHT). - In: JOCKENHÖVEL, A. (Hrsg.): Bergbau, Verhüttung und Waldnutzung im Mittelalter: Auswirkungen auf Mensch und Umwelt; Ergebnisse eines internationalen Workshops (Dillenburg, 11. - 15.Mai 1994, Wirtschaftshistorisches Museum „Villa Grün“). - Stuttgart: Steiner 1996 [Vierteljahrschrift für Sozial- und Wirtschaftsgeschichte: Beihefte;121]:1219.

JODL, O.: Teichwirtschaft und Naturschutz - Lösungsansätze und Perspektiven aus der Sicht der Naturschutzbehörde. Laufen/Salzach: Bayerische Akademie f. Naturschutz u. Landschaftspflege 1991 [Berichte der ANL;15].

JOHANSSEN, H.: The small town in urbanized society. - Joensuu/Finnland: Univ. Joensuu, Institut of Geography and Regional Planning [Mitschrift der Vorlesungsreihe im SS 1992].

JOHnStON, R. J./GREGORY, D./SMITH, D. M. (Hrsg.): The Dictionary of Human Geography. - 2. Aufl. - Oxford: Basil Blackwell 1986.

JOIST, C.: Vom Korn zum Mehl: Eine kleine Nahrungskunde. - In: BEDAL, K.: Mühlen und Müller in Franken. - 2. Aufl. 1992 Bad Windsheim: Verl. Fränkisches Freilichtmuseum 1992 [Schriften und Kataloge des Fränkischen Freilandmuseums;15]:14-28.

JONG, Robert de: Die Kulturlandschaft von morgen ist nicht die von gestern: über die Zukunft einer UNESCO Kulturlandschaft. Vortrag auf der 7. Mittelrhein Konferenz „Rheinland-Weinland“ / „Mittelrheintal“ - Koblenz, 8. November 2002:1-15 [unveröff. Manuskript]

JÖNS, H.: Eisenproduktion und Umwelt im norddeutschen Flachland in der römischen Kaiserzeit. Überlegungen am Beispiel eines spätkaiserlichen Siedlungs- und Verhüttungsplatzes in Joldelund (Schleswig-Holstein). - In: JOCKENHÖVEL, A. (Hrsg.): Bergbau, Verhüttung und Waldnutzung im Mittelalter: Auswirkungen auf Mensch und Umwelt; Ergebnisse eines internationalen Workshops (Dillenburg, 11. - 15.Mai 1994, Wirtschaftshistorisches Museum „Villa Grün“). - Stuttgart: Steiner 1996 [Vierteljahrschrift für Sozial- und Wirtschaftsgeschichte: Beihefte;121]:58-67.

JONSCHER, R.: Kleine thüringische Geschichte: Vom Thüringer Reich bis 1945. - Jena: Jenzig-Verl Gabriele Köhler 1950:18f.

JONSSEN, W./HESSLER, A. (Hrsg.): Umwelt und Gesellschaft: eine Einführung in die sozialwissenschaftliche Umweltforschung. - Berlin: Akademie-Verl. 1995.

JOOSTEN, H.-D./JUNG, P.: Mit Hirtenstab und Hütehund: vom Hudewesen im Siegerlande. - Münster-Hiltrup: Landschaftsverl. 1995 [Westfälische Volkskunde in Bildern;6].

JOOSTEN, H.-D.: Mühlen und Müller im Siegerland: mit einem Verzeichnis der Wasserkraftanlagen dieser Region. - Münster et al.: Waxmann 1996; Zugl.: Münster, Univ., Diss 1991/92.

JORDAN, S.: Abenteuer Holzflößerei. - In: KLEßEN, R. (Hrsg.): Historischer Bergbau und Hüttenwesen im Mittelharz Exkursionsführer. - Berlin: Geogr. Inst., Humboldt-Univ. Berlin 2000 [Arbeitsberichte Geographisches Institut HumboldtUniversität Berlin;46]:124.

JUCH, K.: Nordhausen. Mit einem Grundriß der Stadt Nordhausen und einer Karte der Umgegend. - 3. Aufl. - Nordhausen: Verl. Georg Wimmer's Buch- und Kunsthandlung 1891.

JUCH, K.: Nordhausen. 1. Entwurf (II A 2); Glossar, darin: Alte Nordhäuser Straßennamen und ihre Deutung. - In: Beiträge zur Heimatkunde Nordhausen 171992.

JÜNEMANN, J.: Wo einst ein Druide stand [...]: keltische Viereckschanzen im Solling und Bramwald. - Dransfeld: Selbstverl. 1995.

JUNG, G.: Seen werden, Seen vergehen: Entstehung, Geologie, Geomorphologie, Altersfrage, Limnologie und Ökologie; eine Landschaftsgeschichte der Seen allgemein; mit ausgewählten Beispielen aus aller Welt. - 1.Aufl. - Thun/Schweiz: Ott 1990.

JUNG, G.: Seengeschichte: Entstehung, Geologie, Geomorphologie, Altersfrage, Limnologie, Ökologie. - Landsberg/Lech: ecomed 1994.

JUNGBLUTH, H./ELSNER, H.: Die Schwalm: Tal der Mühlen. - 2. Aufl. - Schwalmtal: Ecken-Verl. 1990. 
JUNGBLUTH, J. H.: Die Molluskenfauna von Hessen: Ein Beitrag zur biologisch-oekologischen Landeserforschung in Hessen. In: Philippia. Abhandlungen und Berichte aus dem Naturkundemuseum im Ottoneum zu Kassel, Serie I, 7/4 1996:287-314.

JUNGE, F.: Der Dorfteich als Lebensgemeinschaft: nebst einer Abhandlung über Ziel und Verfahren des naturgeschichtlichen Unterrichts. - Kiel, Leipzig: Lipsius \& Fischer 1907 [unveränd. Nachdruck: St. Peter-Ording: Verl. Lühr \& Dircks 1985].

JÜNGEL, K.: Die Elbe. Geschichte um einen Fluß. - Böblingen: Kuo-Tykve 1993.

JÜNGEL, K.: Schiffmühlen: Eine Flotte, die fast immer vor Anker lag. Hrsg.: Landschaftsmuseum der Dübener Heide. - Halle: Druckhaus Freiheit 1987.

JUNKER, J.-M.: Nordhäuser Adreß- und Einwohnerbücher - Fahrplan und Spiegel der Geschichte. - In: Beiträge z. Heimatkde. aus Stadt u. Kreis Nordhausen 17 1992:16-27.

JUNKER, J.-M.1: Nordhäuser Nachrichten. Südharzer Heimatblätter. Verlagssonderbeilage der Thüringer Allgemeine Nr. 3 v. 4.09.1997.

JURA UNI-ERLANGEN 2003 [URL = http://www.jura.uni-erlangen.de/Lehrstuehle/Rechtsgeschichte2/w2003/ Kodifikationen.pdf;23.08.2003].

JUSCHUS, O.: Zur Flussgeschichte der Dahme: Bericht zum Projektseminar. - Berlin : Geograph. Inst., Humboldt-Univ. 2002 [Arbeitsberichte;75].

JÜTTE, R.: Geschichte der Alternativen Medizin: Von der Volksmedizin zu den unkonventionellen Therapien von heute. München: Beck 1996.

JÜTTEMANN, H.: Wassergetriebene Bauernsägen in Mitteleuropa, insbesondere im Schwarzwald, bis etwa zum Jahre 1850. Karlsruhe, Univ., Diss. 1982.

JÜTTEMANN, H.: Alte Bauernsägen im Schwarzwald und in den Alpenländern. - Karlsruhe: Braun 1984

KAACK, H. G.: Von der Stecknitz zum Stecknitzkanal - ein Transportweg im geschichtlichen Wandel. - In: Lauenburgische Heimat 129 1991:3-50.

KACHELMANN, J. (Hrsg.): Die große Flut: unser Klima, unsere Umwelt, unsere Zukunft. - Reinbek/Hamburg: Rowohlt 2002

KAISER MAXIMILIANS I. Jagd- und Fischereibücher: Jagd u. Fischerei in den Alpenländern im 16. Jh. [Text von Franz Niederwolfsgruber]. - Innsbruck: Pinguin 1992.

KAISER, K.: Die spätpleistozäne und frühholozäne Beckenentwicklung in Mecklenburg-Vorpommern: Untersuchungen zur Stratigraphie, Geomorphologie und Geoarchäologie. - Greifswald: Ernst-Moritz-Arndt-Univ. 2001 [Greifswalder geographische Arbeiten;24]; Teilw. zugl.: Greifswald, Univ., Diss. 2001.

KAISER, K. (Hrsg.): Die jungquartäre Fluß- und Seegenese in Nordostdeutschland: Beiträge zur Tagung in Hohenzieritz (Mecklenburg) vom 26. - 28. Februar 2002. - Greifswald: Ernst-Moritz-Arndt-Univ. 2002 [Greifswalder geographische Arbeiten;26].

KAISER, T.: Rieselwiesenwirtschaft und Amphibien. - In: Natur und Landschaft 65/2 1990:68-61.

KALCKERT, G.: Aqua viva: Die Wasserversorgung in den mittelalterlichen Zisterzienserklöstern. - Königswinter 1993.

KALESSE, A.: Quellenkundliche Analyse. - In: BRANDE, A. et al.: Der Gutspark Tegel in historisch-ökologischer Sicht. - In: „Der Bär von Berlin“. Jahrbuch des Vereins für die Geschichte Berlins 36 1987:202-210.

KALESSE, A.: Diskussionsbeitrag. - Veranstaltung Nr. 180 „Kulturlandschaften in Deutschland - Beispiele, Projekte, Spannungsfelder“; Bildungszentrum Eichholz der Konrad-Adenauer Stiftung, vom 02.07. - 04.07.2003 [Mitschrift vom 4.07.2003].

KALWEIT, H./BUCK, W.: Der Rhein unter der Einwirkung des Menschen: Ausbau, Schiffahrt, Wasserwirtschaft. Hrsg.: KHRArbeitsgruppe „Anthropogene Einflüsse auf das Abflussregime“; Internationale Kommission für die Hydrologie des Rheingebietes. - 2. Aufl. - Lelystad: Secretariaat CHR 1994 [Bericht der KHR:1;11].

KAMPFMANN, G./KRIMM, S.: Verkehrsgeographie und Standorttypologie der Glashütten im Spessart. - Aschaffenburg: Geschichts- und Kunstverein Aschaffenburg 1988 [Studien z. Geschichte des Spessartglases;2/Veröff. des Geschichts- und Kunstvereins Aschaffenburg e. V.;18/2].

KANALISIERUNG MITTELWESER. Hrsg. v. Mittelweser-AG. - Bremen: Schünemann, 1960.

KAPPAS, M.: Geographische Informationssysteme. - Braunschweig: Westermann 2001 [Das Geographische Seminar].

KAPPELHOFF, B.: See- und Küstenschiffahrt zwischen Ems und Elbe im 18. und 19. Jahrhundert. - In: Niedersächsisches Jahrbuch für Landesgeschichte 70 1998:93-128.

KARRASCH, H. (Hsrg.): Prozessabläufe bei der Landschafts- und Landesentwicklung: Methoden, Ergebnisse, Anwendungen. Festschrift Wilhelm Wöhlke zum 65. Geburtstag. - Berlin: Selbstverl. d. Geomorphologischen Laboratoriums der Freien Univ. 1990 [Berliner geographische Abhandlungen;53].

KARRASCH, H. (Hrsg.): Geographie: Tradition und Fortschritt. Festschrift zum 50jährigen Bestehen der Heidelberger Geographischen Gesellschaft. - Heidelberg: Heidelberger Geographische Gesellschaft 1998 [HGG-Journal;12]. 
KARRASCH, H.: Geographie und Umwelt. - In: KARRASCH, Heinz (Hrsg.): Geographie: Tradition und Fortschritt. Festschrift zum 50jährigen Bestehen der Heidelberger Geographischen Gesellschaft. - Heidelberg: Heidelberger Geographische Gesellschaft 1998 [HGG-Journal;12]:87-105.

KARTENAUFNAHME DER RHEINLANDE durch Tranchot und von Müffling 1803-1820. Neu hrsg. v. Landesvermessungsamt Nordrhein-Westfalen 1:25 000. - Bonn, Bad Godesberg 1968 [Publikationen der Gesellschaft für rheinische Geschichtskunde XII. 2. Abt., N.F.]

KARTOFFEL - Geschichte[a] [URL = http://www.infodienst-mir/bwl.de/ernaehrung/lebensmittel/ waren/getreide/kartoffel/ geschichte.htm;07.02.2004]

KARTOFFEL - Geschichte[b] [URL = http://www.toffi.net/kartoffelgeschichte_fichtelgebirge.htm;07.02.2004].

KÄSTNER, H.-G.: Eventkultur - Ein soziologischer Exkurs zur Inszenierung von Geschichte in der Erlebnisgesellschaft. - In: LANGE, H. (Hrsg.): Denkmalpflege in den Städten: Stadtbaukunst, Stadtökologie, Stadtentwicklung. - Berlin, Köln: Deutscher Städtetag 2003 [Neue Schriften des Deutschen Städtetages;83]:123-129.

KAUDER, B./HEUSER-HILDEBRANDT, B.: Rückenbewässerung in den Mühlwiesen. - In: Der Westerwald: Kreis Altenkirchen und Westerwaldkreis. Bearb. v. Hans-Helmut Wegner. - Stuttgart 1993 [Führer zu archäologischen Denkmälern in Deutschland;26].

KAUFHOLD, K. H. (Hrsg.): Bergbau und Hüttenwesen in und am Harz. - Hannover: Hahn 1992 [Veröff. d. hist. Komm. f. Nieders. u. Bremen;34, Quelle u. Untersuchungen zur Wirtschafts- u. Sozialgeschichte Niedersachsens in der Neuzeit;14].

KAUFHOLD, K. H.: Neuere Forschungen zur Wirtschaftsgeschichte des Berg- und Hüttenwesens im westlichen Harz in der vorindustriellen Zeit: Ein Überblick unter besonderer Berücksichtigung der wirtschaftlichen Wechsellagen. - In: BARTELS, C./DENZEL, M. A.: Konjunkturen im europäischen Bergbau in vorindustrieller Zeit: Festschrift für Ekkhard Westermann zum 60. Geburtstag. - Stuttgart: Steiner 2000 [Vierteljahresschrift für Sozial- und Wirtschaftsgeschichte;Beihefte 155]:3772 .

KAUFMANN-HAYOZ, R. (Hrsg.): Umweltproblem Mensch: humanwissenschaftliche Zugänge zu umweltverantwortlichem Handeln. - Bern [et al.]: Haupt 1996.

KAUP, M.: Urbarmachung des Oderbruchs. Umwelthistorische Annäherung an ein bekanntes Thema. - In: BAYERL, G./FUCHSLOCH, N./MEYER, T. (Hrsg.): Umweltgeschichte - Methoden, Themen, Potentiale: Tagung des Hamburger Arbeitskreises für Umweltgeschichte, Hamburg 1994. - Münster, New York: Waxmann 1996 [Cottbuser Studien zur Geschichte von Technik, Arbeit und Umwelt;1]:111-133.

KAUP, M.: Melioration und Umweltveränderung vom 18. bis 20. Jahrhundert am Beispiel des Oderbruchs. - In: Kulturlandschaftsforschung und Umweltplanung: Fachtagung an der Fachhochschule Hildesheim/Holzminden/Göttingen am 9.-10. November 2000 in Göttingen. Hrsg.: HARTEISEN, U./SCHMIDT, A./WULF, M.. Zugl.: Kulturlandschaft. Zeitschrift für Angewandte Historische Geographie. 10/2 2000. - Herdecke: GCA-Verl. 2001 [Forschen und Wissen Landschaftsgestaltung].

KAUTER, D.: „Sauergras“ und „Wegbreit“?: die Entwicklung der Wiesen in Mitteleuropa zwischen 1500 und 1900. Stuttgart/Hohenheim 2002 [Berichte des Institutes für Landschafts- und Pflanzenökologie der Universität Hohenheim; Beiheft/Themenheft 14].

KEARNS, G.: The Historical Geographical Perspective. - In: The Student's Companion to geography. - Oxford: Blackwell 1992:13-18.

KEEFER, E.: Die Jungsteinzeit - alt- und mittelneolithische Kulturen. Ein Überblick. - In: PLANCK, D. (Hrsg.): Archäologie in Württemberg. Ergebnisse und Perspektiven archäologischer Forschung von der Altsteinzeit bis zur Neuzeit. - Stuttgart: Theiss 1988:71-90.

KEINER, D.: Bedeutung und Entwicklung der Westerwälder Rindviehrasse in ihren Zuchtgebieten. Gießen, Univ., Dipl.arbeit 1989.

KEIZ, G.: Von der zahmen Fischerei zur Aquakultur. - In: 1855 - 1995: 140 Jahre Landesfischereiverband Bayern, Jubiläumsbeilage zu „Bayern Fischerei und Gewässer“. Hrsg.: Landesfischereiverband Bayern e.V. [LFV] - München 1995:18-21.

KELLER, C.: Archäologische Forschungen im Kloster Heisterbach. - In: Archäologie im Rheinland 2002. Hrsg.: Landschaftsverband Rheinland, Rheinisches Amt für Bodendenkmalpflege. - Stuttgart: Theiss 2003:134-136.

KELLER, H.: Stromgebiete und Gewässer: [Gesamttitel: Weser und Ems, ihre Stromgebiete und ihre wichtigsten Nebenflüsse: eine hydrographische, wasserwirthschaftliche und wasserrechtliche Darstellung. Auf Grund des Allerhöchst. Erlasses vom 28. Februar 1892 im Auftrage des preussischen Wasser-Ausschusses hsrg. v. H. Keller; Bd. 1. - Berlin: Reimer 1901.

KELLER, R.: Gewässer und Wasserhaushalt des Festlandes: eine Einführung in die Hydrogeographie. - Berlin: Haude und Spener 1961.

KELLER, R.: Hydrologie. - Darmstadt: Wiss. Buchgesell. 1980.

KEMPER, F.-J./LAUX, H.-D./THIEME, G. (Hrsg.): Geographie als Sozialwissenschaft:Beiträge zu ausgewählten Problemen kulturgeographischer Forschung; Wolfgang Kuls zum 65. Geburtstag. - Bonn: Dümmler 1985 [Colloquium Geographicum;18]. 
KERKLOH, M.: Die Position des Hieronymus in den trinitätstheologischen Debatten des 4. Jahrhunderts. - Hauptseminararbeit an der Katholisch-Theologischen-Fakultät der Westfälischen Wilhelms-Universität Münster, Fachbereich Historische Theologie, April 2003.

KERN, K.: Grundlagen naturnaher Gewässergestaltung. Geomorphologische Entwicklung von Fließgewässern. - 1. Aufl. - Berlin et al.: Springer 1994 [Korr. Nachdruck 1995].

KETTENHOFEN, [...]: Salz. - In: SONNABEND, Holger (Hrsg.): Mensch und Landschaft in der Antike: Lexikon der historischen Geographie. - Stuttgart; Weimar: Metzler 1999:435.

KETTNER, B.-U.: Flussnamen im Stromgebiet der oberen und mittleren Leine. - Rinteln: Bösendahl 1972 [Namen und Wort;6].

KEWELOH, H.-W. (Hrsg.): Flößerei in Deutschland. - Im Auftrag des Dt. Schiffahrtsmuseums Bremerhaven - Stuttgart: Theiss 1985.

KEWELOH, H.-W.: Auf den Spuren der Flößer. Wirtschafts- und Sozialgeschichte eines Gewerbes. - Stuttgart: Theiss 1988.

KEYSER, E.: Städtegründungen und Städtebau in Nordwestdeutschland im Mittelalter. - Remagen: Selbstverl. 1958.

KEYSER, E.: Westpreußen: aus der deutschen Geschichte des Weichsellandes. - Würzburg: Holzner 1962 [Göttinger Arbeitskreis;256].

KIBY, U.: Bäder und Badekultur in Orient und Okzident: Antike bis Spätbarock. - Köln: DuMont 1995.

KIBY, U.: Clemens August und die Badekultur seiner Zeit. - In: ZEHNDER, F. G. (Hrsg.): Der Riss im Himmel: Clemens August und seine Epoche. Bd. 3: Eine Gesellschaft zwischen Tradition und Wandel. Alltag und Umwelt im Rheinland des 18. Jahrhunderts. - Köln: DuMont 1999:143-176.

KIESOW, G. et al.: Land am Strom: zwei Jahrtausende Geschichte am Mittelrhein. 75 Jahre „Mittelrheinische Gesellschaft zur Pflege der Kunst“" - Wiesbaden: Reiß Verl. 1999.

KIEßEN, R.: Historischer Bergbau und Hüttenwesen im Mittelharz: Exkursionsführer. - Berlin: Geogr. Inst., Humboldt-Univ. 2000 [Arbeitsberichte Geographisches Institut, Humboldt-Universität zu Berlin;46].

KILIAN, K.: Die Holztrift auf den Pfälzer Bächen: Facharbeit. - In: Jahrbuch des Historischen Vereins der Pfalz [Bezirksgruppe Pirmasens] 1991:163-183.

KIND, C.-J.: Das Felsställe: eine jungpaläolithisch-frühmesolithische Abri-Station bei Ehingen-Mühlen, Alb-Donau-Kreis; die Grabungen 1975-1980. Hrsg.: Landesdenkmalamt Baden-Württemberg. - Stuttgart: Theiss 1987 [Forschungen und Berichte zur Vor- und Frühgeschichte in Baden-Württemberg;23].

KINDA, A.: Some traditions and methodologies of Japanese historical geography. - In: Journal of Historical Geography 23/1 1997:62-75.

KINDT, H.: Die Entwicklung der Elbe als mitteleuropäische Binnenschiffahrtsstraße. Hrsg.: Wasser- u. Schiffahrtsdirektion Nord. - Kiel 1990.

KIRCHBAUER, S./WARDA, R.: Die Alb. Ein Fluß im Wechselspiel zwischen Mensch und Natur. - 2. Aufl. - Stuttgart: Verl. Regionalkultur Badenia 2001 [Sachbuch badenia].

KIRCHENGESCHICHTE 2004 [URL = http.//www.lueneburgerheide-kirchen.de/ostheide/html/kurze_kirchengeschichte_2.html; 08.02.2004].

KIRCHNER, [...]: Wiesentableau oder übersichtliche Nachweisung der im Verwaltungs-Bezirke der Landdrostei Lüneburg zur zeit vorhandenen Berieselungs- und resp. Bewässerungswiesen [...]. - In: Landwirthschaftliche Mittheilungen, besonders für das Fürstentum Lüneburg und Verhandlungen des landwirthschaftlichen Provinzial-Vereins zu Uelzen, 8. Lieferung, Uelzen 1845:107-139.

KIRCHNER, F.: Das Zisterzienserkloster Walkenried und seine Bedeutung für die Südharzgebiete. - In: Beiträge zur Heimatkunde aus Stadt und Kreis Nordhausen 16 1991:3-13.

KIRCHNER-HESSLER, R./LORENZ, S./KONOLD, W.: Untersuchungen der Vegetation im Commerauer Teichgebiet bei Klix (Oberlausitz) und Vorschläge für die künftige Teichbewirtschaftung. - In: Ber. Naturforsch. Ges. Oberlausitz 6 1997:31-55.

KISTEMANN, E.: Historische Geographie und ihr Beitrag zur Regionalplanung in der Bundesrepublik Deutschland - Stand und Perspektiven. - In: KLEEFELD, K.-D./BURGGRAAFF, P. (Hrsg.): Perspektiven der Historischen Geographie: Siedlung Kulturlandschaft - Umwelt in Mitteleuropa. - Bonn: Selbstverl. 1997:377-396.

KISTEMANN; E.: Gewerblich-industrielle Kulturlandschaft in Schutz- und Planungskonzepten Bergisch-Gladbach 1820-1999: Inventarisation und Inwertsetzung gewerblich-industrieller Kulturlandschaften mit einer anwendungsorientierten historischgeographischen Analyse der Stadt Bergisch-Gladbach. - Essen 2000; Zugl.: Bonn, Uni. Diss. 1999.

KLAAS 2003 [URL $=$ http://www.wasser.de; 07.11.2003].

KLAGES, Hans: Studien zur Kulturlandschaftsentwicklung um Braunlage-Oberharz im 18. Jahrhundert: eine historischgeographische Untersuchung. - Hannover 1959.

KLAPP, E. L..: Wiesen und Weiden: Behandlung, Verbesserung und Nutzung von Grünlandflächen. - 4. Aufl. - Berlin, Hamburg: Parey 1971 [1. Aufl. 1938]. 
KLAPPAUF, L.: Montanarchäologie im Harz. - In: JOCKENHÖVEL, A. (Hrsg.): Bergbau, Verhüttung und Waldnutzung im Mittelalter: Auswirkungen auf Mensch und Umwelt; Ergebnisse eines internationalen Workshops (Dillenburg, 11. - 15.Mai 1994, Wirtschaftshistorisches Museum „Villa Grün“). - Stuttgart: Steiner 1996 [Vierteljahrschrift für Sozial- und Wirtschaftsgeschichte: Beihefte;121]: 93-111.

KLAPPAUF, L.: Spuren früher Montanwirtschaft im Harz. - In: HAUPTMEYER, C.-H. (Hrsg.): Mensch-Natur-Technik: Aspekte der Umweltgeschichte in Niedersachsen. - Bielefeld: Verl. f. Regionalgeschichte 2000 [Materialien für Regionalgeschichte;2]:17-30.

KLAPPER, H.: Lebensraum stehender Gewässer. - In: FRIMMEL, F. H. (Hrsg.): Wasser und Gewässer: Ein Handbuch. Heidelberg, Berlin: Spektrum 1999:211-246.

KLAUBE, F.-R.: Die Fuldaschiffahrt in Kassel auf alten Abbildungen. - - In: TÖNSMANN, F. (Hrsg.): Zur Geschichte der Wasserstraßen insbesondere in Nordhessen. - Kassel: Herkules Verl. 1995 [Kasseler Wasserbau-Materialien;4]:111-120.

KLAUS, W.: Die Städte der DDR im Kartenbild. T.1: Pläne und Grundrisse von 1550-1850. - Berlin: Deutsche Staatsbibliothek 1972 [Kartographische Bestandverzeichnisse der Deutschen Staatsbibliothek;2.1].

KLÄUI, H.: Seen im Mittelalter. - Winterhur: Stadtbibliothek 1993 [Neujahrsblatt der Stadt Winterthur;324].

KLEEBERG, W.: Hollandgänger und Heringsfänger. Ein Stück niedersächsische Wirtschaftsgeschichte. - In: Neues Archiv f. Nieders. 5 1948:193-232.

KLEEBERG, W.: Niedersächsische Mühlengeschichte. - Detmold: Bösmann 1964

KLEEFELD, K.-D.: Die Initiative Arbeitskreis für genetische Siedlungsforschung in Mitteleuropa. - In: Ur- und Frühgeschichte. Zs. f. populäre Archäologie (Erscheinen eingestellt) 17/2 1990:16-17.

KLEEFELD, K.-D.: Historisch-geographische Landesaufnahme und Darstellung der Kulturlandschaftsgenese des zukünftigen Braunkohlenabbaugebietes Garzweiler. - Bonn, Univ., Diss. 1994.

KLEEFELD, K.-D.: Sechste Tagung der Arbeitsgruppe „Angewandte Historische Geographie“. Aufgaben, Möglichkeiten und Probleme der musealen Präsentation von Kulturlandschaftsrelikten in Plauen / Vogtland vom 7.3. - 9.3.1996. - In: Kulturlandschaft - Zeitschrift für Angewandte Historische Geographie 1 1996:4-8.

KLEEFELD, K.-D.: Perspektiven der historischen Geographie. - In: Siedlung - Kulturlandschaft - Umwelt in Mitteleuropa 1997:265-276.

KLEEFELD, K-D.: Flusslandschaften zwischen Persistenz und Überformung. - In: Kulturlandschaft. Zeitschrift für Angewandte Historische Geographie 10/10 2000; Zugl.: Koblenzer Geographisches Kolloqium 23 2001:7-17.

KLEEFELD, K.-D.: Kulturlandschaft: Eine begriffliche und inhaltliche Annäherung. - In: BUND HEIMAT UND UMWELT IN DEUTSCHLAND [BHU] (Hrsg.): Kulturlandschaft sehen und verstehen: Dokumentation der Seminarveranstaltung. - Bonn: BHU April 2003:13-16.

KLEEFELD, K.-D./BURGRAAFF, P.: In: Kulturlandschaft - Zeitschrift für Angewandte Historische Geographie 4/1 1994:36-37.

KLEEFELD, K.-D./BURGGRAAFF, P. (Hrsg.): Perspektiven der Historischen Geographie: Siedlung - Kulturlandschaft Umwelt in Mitteleuropa. - Bonn: Selbstverl. 1997.

KLEEMANN, L.: Die Wäschereidörfer Ziegelhausen und Petersthal. - Heidelberg, Univ., Diss. 1905.

KLEIN, B.: Maps and the writing of space in early modern England and Ireland. - Basingstoke et al.: Palgrave 2001.

KLEIN, K.: Leben am Fluß. Ein Streifzug durch die Lande links und rechts der Kinzig. - Ortenau: Schwarzwald-Verl. 2002.

KLEINDORFER-MARX, B. (Hrsg.): Der Regen: Kultur und Natur am Fluß. - Amberg: Buch und Kunstverl. Oberpfalz 1996 [Schriftenreihe des Kreismuseums Walderbach;11].

KLEMM: R.: Das Alte Ägypten. Steinbearbeitung und Bewässerung. - In: TROITZSCH, U./WEBER, W.: Die Technik - Von den Anfängen bis zur Gegenwart. - Braunschweig: Westermann 1982:58-77.

KLEßEN, R. (Hrsg.): Historischer Bergbau und Hüttenwesen im Mittelharz - Exkursionsführer. - Berlin: Geogr. Inst., HumboldtUniv. Berlin 2000 [Arbeitsberichte Geographisches Institut Humboldt-Universität Berlin;46].

KLETT, B.: Die Geschichte der Jagd und der Fischerei: im Gebiete der ehemaligen freien Reichsstadt Mühlhausen; mit fünf Bildtafeln und einer Karte des ehemaligen Gebietes der Freien Reichsstadt Mühlhausen. - Mühlhausen in Thüringen: Röth 1924.

KLOOS, R.: Landseen, Teiche, Parkgewässer: Beschreibung von Sanierungskonzepten. Hrsg.: Der Senator f. Stadtentwicklung und Umweltschutz Berlin, Abt. Wasserwesen. - Berlin 1985 [Veröff. des Senators für Stadtentwicklung und Umweltschutz].

KLOS, C./KROTTEN, J.: Fische und Flußkrebse des Saarlandes. - Hrsg.: Fischereiverband Saar. - 1. Aufl. - Saarbrücken: Ministerium f. Umwelt d. Saarlandes 2001 [Schriftenreihe: Atlantenreihe;1].

KLOS, H. Die Preetzer Walddörfer. - Kiel., Univ., Diss. 1950.

KLOSE, J.: Die Erfassung von Wind- und Wassermühlen in Niedersachsen. - Detmold: Der Mühlstein 101989. 
KLOTZ, H.: Zivilisation der Steinzeit: Catalhüyük, eine Stadt des siebten Jahrtausends. - In: Frankfurter Allgemeine Zeitung Nr. 251 v. 28. Oktober 1995.

KLUGE, F.: Etymologisches Wörterbuch der deutschen Sprache. - 22. Aufl. - - Berlin: de Gruyter 1989.

KLUGE, T./SCHRAMM, E.: Wassernöte. Zur Geschichte des Trinkwassers. - 2. Aufl. - Köln: Kölner Volksblatt 1988.

KNAUFT, F.-J.: Entwicklung von Methoden zur GISgestützten Visualisierung von Waldentwicklungsszenarien. Dissertation zur Erlangung des Doktorgrades der Fakultät für Forstwissenschaften und Waldökologie der Georg-August-Universität Göttingen. - Göttingen 2000 [erschienen im Internet unter: http://webdoc.sub.gwdg.de/diss $/ 2000 / \mathrm{knauft} / \mathrm{inhalt.htm}$ ].

KNAUSS, J.: Weiher und Teich: Kleingewässer in der Kulturlandschaft. - Altenburg/Blankenhain: Agrar- und Freilichtmuseum Schloß Blankenhain 1999 [Hefte zu Geographie und Geschichte der Kulturlandschaft;1].

KNAUSS, J.[a]: Deich - In: SONNABEND, H. (Hrsg.): Mensch und Landschaft in der Antike: Lexikon der historischen Geographie. - Stuttgart; Weimar: Metzler 1999:91.

KNAUSS, J. [b]: Die Flurnamen Sachens. - Blankenhain : Agrar- und Freilichtmuseum Schloß Blankenhain 2002 [Hefte zu Geographie und Geschichte der Kulturlandschaft;10].

KNAUSS, J./HEINRICH, B./KLALCYK, H.: Die Wasserbauten der Minyer in der Koipais - die älteste Flußregulierung Europas. - München: TU 1984 [Institut für Wasserbau und Wassermangelwirtschaft; Bericht 50].

KNAUSS; J./VOIGTMANN, J. (Hrsg.): Technisierung des ländlichen Raumes: Landtechnik und technische Anlagen im Freilichtmuseum. Tagungsband. - Altenburg 1998 [Mensch, Wirtschaft, Kulturlandschaft;2].

KNAUT, A.: Landschaftspflege im Kaiserreich: Die Sorge um den Schutz der Heimat. - In: Damals 8 1993:22-29.

KNEISLE, A.: Es muß nicht immer Wissenschaft sein [...]. - In: Urbs et Regio 281983.

KNIEHASE, H.-F.: Das Oderbruch. Slawische und deutsche Siedlungsgenese seit dem hohen Mittelalter. - Köln: Selbstverl. Druckerei Günther Schneider 1995 [Geostudien;15].

KNÖPFLER, A.: Goldwäschereien und Goldbergbau im kuroberpfälzischen Pflegamte Murach. - In: Das Bayernland 34/18 1924:297-300.

KNOKE, Horst: Hamelner Wasserbauwerke an der Weser: die Geschichte der Schleusen und Wehre, der Münsterbrücke und des Hafens. - Bielefeld et al.: Verl. f. Regionalgeschichte 2003 [Studien zur Hamelner Geschichte;2].

KNÖSEL, H.: Ein Beitrag zur Geschichte der Holzflößerei im niedersächsischen Berglande. - In: Niedersächsisches Jahrbuch zur Landesgeschichte 11 1934:131-152.

KNOWLES, Clive H.: Landscape History. - London: Chameleon Press 1985 [General Series;107].

KNÜBEL, H.: Die Düssel. Geographie eines Fließgewässers. - In: LANDESHAUPTSTADT DÜSSELDORF (Hrsg.): Die Düssel: Geschichte und Geschichten. - Köln: Rheinland-Verl. 1988:9-14.

KNUR, F./WOLF, H. G.: Wassermühlen. 35000 Kleinkraftwerke zum Wohnen u. Arbeiten. - Heidelberg: C. F. Müller 1988.

KOBERG, H.: Mühlen rund um Hannover: Müller, Mühlenplätze, Mühlentechnik; Geschichte und Geschichten. - Hannover: Schlütersche Verl. Anst. 1987 [1. Aufl. 1967].

KOBLENZER GEOGRAPHISCHES KOLLOQUIUM, Themenheft: Flusslandschaften zwischen Persistenz und Überformung. 23. Jg., Jahresheft, Mai 2001. Zugl.: Kulturlandschaft. Zeitschrift für Angewandte Historische Geographie 10/10 2000.

KOCH, A. (Hrsg.): Enzyklopädie der gesammten Thierheilkunde und Thierzucht mit Inbegriff aller einschlägigen Disciplinen und der speciellen Etymologie: Handwörterbuch. - Wien et al.: Perles 1890.

KOCH, H.: Das Leinengewerbe im Osnabrücker Land als „westfälischer Hausfleiß“ im bäuerlichen Leben früherer Jahrhunderte. Heimatjahrbuch Osnabrücker Land 80/8 1983.

KOCH, J.: Vorschläge zur naturnahen Gestaltung eines Feuchtbiotops am Beispiel der Groß-Lengdener Fischteiche. - Göttingen: Univ., Forstwiss. Fachber., Inst. für Wildbiologie u. Jagdkunde, Abt. Fischereikunde, Dipl. Arb. 1992.

KOCH, M.: „Spurensuche“: neue Wege der Erfassung historischer Kulturlandschaft; Einsatzmöglichkeiten der Luftbildinterpretation zur Erstellung eines Katasters historischer Kulturlandschaftselemente am Beispiel des Landkreises Gifhorn; Vertiefungsprojekt an der Universität Hannover, Fachbereich Landschaftsarchitektur und Umweltentwicklung; November 1996 bis Dezember 1997; Kurzfassung. - Gifhorn: Landkreis Gifhorn 1998 [Materialien zur Archivarbeit;1].

KOCH, W.: Die Geschichte der Binnenfischerei Mitteleuropas. Handbuch der Binnenfischerei Mitteleuropas IV, Lfg. 1. Stuttgart: Schweizerbart 1925-1945..

KOCH, W.: Zur altfränkischen Fischereigeschichte. - In: Fränkische Heimat. Zeitschrift für Heimatkunde und Wandern 1924.

KOCH, W.: Baustilkunde: Das große Standardwerk zur europäischen Baukunst von der Antike bis zur Gegenwart. - München: Orbis 1994

KOCH, W.: Fischzucht: Lehrbuch für Züchter und Teichwirte. - 3. Aufl. - Berlin, Hamburg: Parey 1960. 
KÖBLER, Gerhard: Bauer, Bauerntum. B. Bäuerliche Rechtsstellung. - In: Lexikon des Mittelalters, Bd. 1. - München, Zürich: Artemis-Verl. 1980-1998 (1980): 1571-1572.

KÖBLER, G.: Deutsche Rechtsgeschichte: ein systematischer Grundriß der geschichtlichen Grundlagen des deutschen Rechts von den Indogermanen bis zur Gegenwart. - 5. Aufl. - München: Vahlen 1996 [Vahlen-Reihe Jura].

KÖBLER, G.: Historisches Lexikon der deutschen Länder: die deutschen Territorien und reichsunmittelbaren Geschlechter vom Mittelalter bis zur Gegenwart. - 6. Aufl. - München: Beck 1999 [Beck’s historische Bibliothek].

KÖCK, H.: Chorische Logik - die Grundperspektive geographischer Wertbetrachtung. - In: BAHRENBERG, G. et al.: Geographie des Menschen - Dietrich Bartels zum Gedenken. - In: Bremer Beiträge z. Geogr. u. Raumplanung 11 1987:179194.

KOCSIS, G.: Wasser nutzen, verbrauchen oder verschwenden? Neue Wege zu einem schonenden und sparsamen Umgang mit Wasser und einer naturnahen Abwasserreinigung. - 3. Aufl. - Heidelberg: C. F. Müller 1993 [Alternative Konzepte;65].

KOEHNE, C.: Das Recht der Mühlen bis zum Ende der Karolingerzeit. Ein Beitrag zur Geschichte des deutschen Gewerberechts. - Breslau: Marcus 1904 [Untersuchungen z. dt. Staats- u. Rechtsgeschichte;71].

KOENIG-WARTHAUSEN, R. v.: Land- und Waldbau für Jäger: Geschichte, Bewirtschaftung, Wildschadesnverhütung, Teichwirtschaft. - Warthausen o. J.

KOENIGSWALD, W. v./HAHN, J.: Jagdtiere und Jäger der Eiszeit.. - Stuttgart: Theiss 1981.

KOHLER, A./RAHMANN, H.: Gefährdung und Schutz von Gewässern. Tagung über Umweltforschung an der Univ. Hohenheim im Januar 1988. - Stuttgart: Ulmer 1988.

KOHL, W.: Recht und Geschichte der alten Münchner Mühlen. - München: Stadtarchiv 1969 [Neue Schriftenreihe des Stadtarchivs München;32]; Zugl.: München, Univ., Diss. 1969.

KÖHLER, H: Martini. - In: Nordhäuser Nachrichten. Südharzer Heimatblätter. Verlagssonderbeilage der Thüringer Allgemeinen Nr. 3 v. 4.09.1997.

KÖHLER, U./KÖHLER, P./FIRSCHING, U.: Einfluss unterschiedlicher Besatzdichten von Karpfen Cyprinus carpio auf die Verteilung mausernder Wasservögel in den Fischteichen des Ismaninger Teichgebietes 1996-1999. - In: Ornithologischer Anzeiger 39/2 2000:119-134.

KOKEN, K. L.: Geschichte der Grafschaft Dassel. - In. Vaterländisches Archiv des historischen Vereins für Niedersachsen, Jg. 1840. - Hannover 1841:159.

KOLB, F.: Die Stadt im Altertum. - München: Beck 1984.

KOLB, J.: Vom Rhein zur Donau: auf den Spuren der Nibelungen. - München: Droemer Knaur 1989.

KOLB, R.: Mein Deutschland: Mensch und Landschaft. - Berlin: Büchergilde Gutenberg 1938.

KOLLING, H.: Geschichte der Mühlen in Bad Staffelstein. - Lichtenfels: Schulze 2002.

KOMAREK, A.: „Österreich mit einer Prise Salz“. Ein Mineral macht Geschichte. - Wien: Kremyer und Scheriau 1998.

KOMAROW, B.: Das große Sterben am Baikalsee. der geheime Bericht eines hohen Funktionärs über die Umweltkrise der Sowjetunion [Aus dem Russischen von Anne Herbst-Oltmanns]. - Reinbek/Hamburg: Rowohlt 1979.

KÖNIG, D. 2004: Marsch und Förde [URL = http.//www.marschundfoerde.de/artikel/sood.html;04.08.2004].

KÖNIG, F. v.: Bau von Wasserkraftanlagen. Praxisbezogene Planungsgrundlagen für die Errichtung von Waserkraftanlagen aller Größenordnungen. - Heidelberg: C. F. Müller 1985.

KÖNIG, J.: Die Verunreinigung der Gewässer, deren schädliche Folgen, sowie die Reinigung von Trink- und Schmutzwasser. - 2. Aufl. - Berlin: Springer 1899.

KÖNIG, J.: Pflege der Wiesen und Weiden. - 2. Aufl. - Berlin: Parey 1906.

KÖNIG, J./SPLITTGERBER, A.: Die Bedeutung der Fischerei für die Fleischversorgung im Deutschen Reich: Mitteilung der landwirtschaftlichen Versuchsstation in Münster i. W. - Berlin: Parey 1909 [Landwirtschaftliche Jahrbücher;38, Erg. Bd. 4].

KÖNIG, R.: Fotografische Dokumentation des Altmühltals. - In: BRIX, M. (Hrsg.): Main-Donau-Kanal: Ersatzlandschaft im Altmühltal. - München: Callwey 1988:79-107.

KÖNIGSLÖW, J. v.: Flüsse Mitteleuropas: zehn Biographien. - Stuttgart : Urachhaus1995.

KÖNNEMANN, P.: Der Sand- und Kiesabbau im Wesertal an der Porta Westfalica. - Münster: Lit 1995 [Hannov. Geogr. Arbeiten;50].

KONOLD; W.: Zur Ökologie kleiner Fließgewässer: verschiedene Ausbauarten und ihre Bewertung. - Stuttgart: Ulmer 1984 [Agrar- und Umweltforschung in Baden-Württemberg;6].

KONOLD, W.: Mönche als Fischwirte. - Frankfurt 1985 [Landspiegel;1]:4-13.

KONOLD, W.[a]: Oberschwäbische Weiher und See: Kultur: Geschichte, Vegetation, Limnologie, Naturschutz. - Karlsruhe: Landesanst. f. Umweltschutz Baden-Württemberg, Inst. f. Ökologie u. Naturschutz 1987 [Beihefte zu den 
Veröffentlichungen zu Naturschutz und Landschaftspflege Baden-Württemberg;52 (2 Teile)]; Zugl.: Hohenheim, Univ., Habil.-Schr. 1988 u. d. T.: Kulturhistorische, vegetationskundliche und limnologische Untersuchungen an oberschwäbischen Stillgewässern.

KONOLD, W.[b]: Weiher im Alltag der oberschwäbischen Bauern. - In: BARTHOLOMÄ, W. D. DETTMER, H. (Red.): Arbeiten und Wohnen auf dem Lande: Gewässer in Oberschwaben und ihre Nutzung in früherer Zeit. - Stuttgart: W. B. Literatur 1987 [Wolfegger Blätter;3]:6-19.

KONOLD, Werner[a]: Mittelalterliche Weiher und Dämme in Oberschwaben. - In: DVWK (Hrsg.): Historische Talsperren. Bearbeitet von Günther Garbrecht - Stuttgart: Wittwer, Bd. 2 1991:352-369.

KONOLD, Werner[b]: Wasser, Wiesen und Wiesenwässerung in Isny im Allgäu. Ein Beitrag zur Agrar- und Stadtgeschichte. [Schriften des Vereins f. Geschichte des Bodensees und seiner Umgebung 109 1991]:161-213

KONOLD, W.[a]: Genese und Nutzungsgeschichte von Kleingewässern in Südwestdeutschland. [Metelener Schriftenreihe für Naturschutz;4] 1993:93-102.

KONOLD, W.[b]: Der Wandel von Landschaft und Vegetation an der Donau in Württemberg. - In: Berichte des Instituts für Landschafts- und Pflanzenökologie der Universität Hohenheim 2 1993:205-220.

KONOLD, W.: Wasserbewirtschaftung und Wassernutzung in Isny im Allgäu. - In: DVWK (Hrsg.): Historische Wasserwirtschaft im Alpenraum und an der Donau. - Stuttgart 1994: 299-339 [Gekürzte Fassung des Aufsatzes „Wasser, Wiesen und Wiesenwässerung in Isny im Allgäu. Ein Beitrag zur Agrar- und Stadtgeschichte“. - Schriften des Vereins für Geschichte des Bodensees und seiner Umgebung 109 1991:161-213].

KONOLD, W.: Die Veränderung einer Flußlandschaft: das Beispiel obere Donau. - In: KONOLD, W. (Hrsg.): Naturlandschaft Kulturlandschaft: Die Veränderung der Landschaften nach der Nutzbarmachung durch den Menschen. - Landsberg: Ecomed 1996:201-228.

KONOLD, W.[a]: Genese und Wandel der Oberlausitzer Kulturlandschaft. - In: Verhandlungen d. Gesell. f. Ökologie; 27 [Jahrestagung 1996] 1997:35-44.

KONOLD, W.[b]: Wässerwiesen, Wölbäcker, Hackäcker: Geschichte und Vegetation alter Kulturlandschaftselemente in Süddeutschland. - In: Verh. Ges. Ökologie 27 1997:53-61.

KONOLD, W.: Fließgewässer in der Kulturlandschaft oder „die Natur“ von Fließgewässern und ihre Bewertung: eine kritische Betrachtung. - In: LANDSCHAFTSVERBAND RHEINLAND (Hrsg.): Fließgewässer in der Kulturlandschaft. - Köln 1999:59-79.

KONOLD, W.: Wasser und Gesellschaft. - Landsberg: ecomed 2001.

KONOLD, W./KROLL, R.: Die Geschichte der Wiesenbewässerung im unteren Fehlatal. - In: DVWK (Hrsg.): Historische Wasserwirtschaft im Alpenraum und an der Donau. - Stuttgart 1994:399-419 [zuvor erschienen als: KONOLD, W./KROLL, R.: Die Geschichte der Wiesenbewässerung im unteren Fehlatal (Kreis Sigmaringen). - [Zs. f. Hohenzollerische Geschichte; 27] 1991:53-84.

KONOLD, W./OBERMANN, S.: Die Auswirkungen wasserwirtschaftlicher Maßnahmen in historischer und vegetationskundlicher Sicht. - Zs. f. Kulturtechnik und Flurbereinigung 24 1983:117-127.

KONOLD, W./POPP, S.: Zur Geschichte der Wiesenwässerung im Bereich der Württembergischen Donau. - In: DVWK (Hrsg.): Historische Wasserwirtschaft im Alpenraum und an der Donau. - Stuttgart 1994:377-398.

KONOLD, W./SCHREINER, J.: Quellen, Bäche, Flüsse und andere Fließgewässer. Biotope erkennen, bestimmen, schützen. Stuttgart et al.: Weitbrecht Verl. 1996 [Weitbrecht Biotop-Bestimmungsbücher;5].

KONOLD, W./SCHWINEKÖPER, K./SEIFFERT, P.: Analyse und Entwicklung von Kulturlandschaften: Das Beispiel Westallgäuer Hügelland. - Landsberg: ecomed 1995 [Umweltforschung in Baden-Württemberg].

KONOLD, W./WOLF, R.: Kulturhistorische und landschaftsökologische Untersuchungen als Grundlage für die Feuchtgebietsplanung am Beispiel der Gemarkung Bad Wurzach-Seibranz (Lkrs. Ravensburg). - In: Natur und Landschaft 62/10 1987:424-429.

KOPPE, W.: Zur Geschichte der Häfen und hafenähnlichen Anlagen an der Lippe: Ein-, Aus- und Umladeplätze in der Geschichte des Gütertransportes. - In: Kreis Wesel Jahrbuch 22 2001:53-64.

KOPPE, W.: Die Lippewasserstraße: Schifffahrt auf Lippe und Lippe-Seitenkanal im Rahmen der nordwestdeutschen Binnenschifffahrtsgeschichte. - Bielefeld: Verl. f. Regionalgeschichte 2004 [Schriften der Heresbach-Stiftung Kalkar;10]; Zugl.: Dortmund, Univ., Habil.-Schr. 1995.

KÖPPEN, O.: Stadt am Wasser: Konzept zur Nutzung des Warnow-Ufers im Jahr 2010. - In: Stadt + Grün 4 2003:14-17.

KÖRBER-GROHNE, U.: Nutzpflanzen in Deutschland. Kulturgeschichte und Biologie. - Stuttgart: Theiss 1987.

KORINTH, D.[a]: Der Fluß als Naturgewalt - In: Die Weser - Ein Fluss in Europa: [eine länderübergreifende Ausstellung über 1200 Jahre Geschichte und Kultur des Weserraumes...] Bd. 2. „Aufbruch in die Neuzeit“ / Weserrenaissance-Museum Schloß Brake, Lemgo. Hrsg. von J. Kastler und V. Lüpkes. - Holzminden: Mitzkat 2000:22-55. 
KORINTH, D.[b]: Der Fluß und die Politik - In: Die Weser - Ein Fluss in Europa: [eine länderübergreifende Ausstellung über 1200 Jahre Geschichte und Kultur des Weserraumes...] Bd. 2. „Aufbruch in die Neuzeit“ / Weserrenaissance-Museum Schloß Brake, Lemgo. Hrsg. von J. Kastler und V. Lüpkes. - Holzminden: Mitzkat 2000:56-93.

KORINTH, D.[c]: Güter auf dem Fluß - In: Die Weser - Ein Fluss in Europa: [eine länderübergreifende Ausstellung über 1200 Jahre Geschichte und Kultur des Weserraumes...] Bd. 2. „Aufbruch in die Neuzeit“ / Weserrenaissance-Museum Schloß Brake, Lemgo. Hrsg. von J. Kastler und V. Lüpkes. - Holzminden: Mitzkat 2000:150-187.

KORINTH, D.[d]: Schiffe auf der Weser in der Frühen Neuzeit. - In: Die Weser - Ein Fluss in Europa: [eine länderübergreifende Ausstellung über 1200 Jahre Geschichte und Kultur des Weserraumes...] Bd. 2. „Aufbruch in die Neuzeit“ / Weserrenaissance-Museum Schloß Brake, Lemgo. Hrsg. von J. Kastler und V. Lüpkes. - Holzminden: Mitzkat 2000:96-99.

KORMANN, G.: Mühlenwerke Stahmeln GmbH [URL = http://www.luetzschena-stahmeln.de/index.htm?hauptbeamto/ auenkurier/2000/11/muehlenwerke.htm;08.02.2004].

KORTE, E. J./WILLE, I.: Zur Abwehr des Kormorans (Phalacrocorax carbo) an gewerblich genutzten Fischteichen: ein Modellversuch im Kreis Limburg-Weilburg. - In: Vogel und Umwelt. Zeitschrift für Vogelkunde und Naturschutz in Hessen 10/1 1999:39-50.

KOSSMANN, B. 1971: Remagen, ein befestigter Königshof [URL = http://www.kreis.aw-online.de/kvar/VT/hjb1971/ hjb1971.7.htm;20.01.2004].

KRAAS, F.: Von der Reisebeschreibung zum Geographischen Informationssystem (GIS): Zum Problem der Erhebung und Verarbeitung geographisch relevanter Daten. - In: Geographische Rundschau 45 1993:710-716.

KRABATH, S.: Klöster als Wirtschaftsfaktor im Oberweserraum: Hertha - Der untergegangene Vorgänger von Kloster Corvey im Hochsolling bei Neuhaus. - In: Beiträge zur Denkmalpflege in Niedersachsen 20/3 2000:145-146.

KRABBE, W. R./SCHIERK, H. F.: Das Schiffshebewerk Henrichenburg. - Hagen: von Linnepe 1985.

KRACHT, V./MORISSEY, C./SCHENK; W.: Naturschutz und historische Kulturlandschaft - zur Integration geschichtlicher Aspekte in Planung und Management von Naturschutzgebieten. - In: Natur und Landschaft 78/12 2003:527-533.

KRAHE, F.-W.: Burgen und Wohntürme des deutschen Mittelalters. - Stuttgart: Thorbecke 2002.

KRAHE, H.: Unsere ältesten Flussnamen. - Wiesbaden: Harrassowitz 1964.

KRAHE, H.: Alteuropäische Flußnamen. - In: STEGER, H. (Hrsg.): Probleme der Namenforschung im deutschsprachigen Raum. - Darmstadt: Wiss. Buchgesell. 1977:39-97.

KRAHE, J. A.: Lehrbuch der rationellen Korbweidenkultur. - 6. Aufl. - Limburg/Lahn: Steffen 1913.

KRAIER, W.: Ökologisch begründete Sanierungskonzepte kleiner Fließgewässer: Fallbeispiel Vils/Oberpfalz. - Hrsg.: Bayerisches Landesamt für Wasserwirtschaft. - München: Bayer. Landesamt für Wasserwirtschaft 1996 [Schriftenreihe des Bayerischen Landesamtes für Wasserwirtschaft;26].

KRAMARCZYK, B.: Alte Laugen- und Seifenrezepte. - In: „Die Große Wäsche“: Eine Ausstellung des Landschaftsverbandes Rheinland, Rheinisches Museumsamt, Brauweiler in Zusammenarbeit mit dem Rheinischen Freilichtmuseum Landesmuseum für Volkskunde, Mechernich-Kommern. - Köln: Rheinland-Verl. 1988 [Schriften d. Rhein. Museumsamtes;42; Zugl.: Schriften d. Rhein. Freilichtmuseums - Landesmuseum f. Volkskunde;34]:127-130.

KRÄMER, B.: Gedanken zur Baugeschichte des Schlosses Bevern. - In: Schloss Bevern 1603 bis 1612: Münchhausenresidenz, Herzogresidenz, Kulturzentrum. Hrsg.: Landkreis Holzminden 1987 [Veröffentlichungen des Landkreises Holzminden;2]:311.

KRÄMER, R.: Angewandte historische Geographie im kommunalen Bereich. Das Beispiel Wesermarsch. - In: Siedlungsforschung 8 1990:259-267.

KRANZ, A.: Zur Situation des Fischotters in Österreich: Verbreitung - Lebensraum - Schutz. Wien: Umweltbundesamt 2000 [Berichte BE-177].

KRANZ, H.: Die Kölner Rheinmühlen: Untersuchungen zum Mühlenschrein, zu den Eigentümern und zur Technik der Schiffsmühlen. Aachen 1991 [Aachener Studien zur älteren Energiegeschichte;1].

KRATZ, R. (Hrsg.): Geographische Informationssysteme im Naturschutz: Forschung, Planung, Praxis. - Magdeburg: WestarpWiss. 1997.

KRAUME, E.: Überblick über die Geschichte des Unterharzer Hüttenwesens von 1635 bis zur Neuzeit. - In: Beitr. z. Gesch. d. Stadt Goslar 24 1968:167-188.

KRAUSCH, H.-D.: Farbatlas Wasser- und Uferpflanzen. - Stuttgart: Ulmer 1995.

KRAUSE, W.: Zur Kenntnis der Wiesenbewässerung im Schwarzwald. - In: Jahresheft des Vereins für vaterländische Naturkunde in Württemberg, zugleich Jahrbuch des Staatlichen Museums für Naturkunde in Stuttgart 111, H. 2 [Hans-SchwenkelFestschrift] (1956): 484-507

KRAUSE, W.: Die keltische Urbevölkerung Deutschlands: Erklärung der Namen vieler Berge, Wälder, Flüße, Bäche und Wohnorte, besonders aus Sachsen, Thüringen, der Rhön und dem Harrl. - Leipzig: Eger 1904. 
KRAUSMANN, F./WEISZ, H.: Landschaft, Landnutzung und industrielle Modernisierung. - In: HABERL, H./STROHMEIER, G.: Kulturlandschaftsforschung. - Wien et al.: Springer 1999 [iff texte;5]:49-56.

KREFT, I.: Buchweizen in Slowenien. University of Ljubljana/Slovenia. Kongresni trg 12. - Ljubljana 2001 [URL = www.bf.unilj.si/Buchweizen/slo.html,5.11.03].

KREINER, R.[a]: Dokumentation zur historischen Hydrographie im Rheinland. - Aachen: Selbstdr. d. Hist. Inst. d. RWTH Aachen, Lehrstuhl für Mittlere Geschichte 1996.

KREINER, R.[b]: Städte und Mühlen im Rheinland: das Erftgebiet zwischen Münstereifel und Neuss vom 9. Jahrhundert bis ins 18. Jahrhundert. - 1. Aufl. - Aachen: Alano-Herodot-Verl. 1996 [Aachener Studien zur älteren Energiegeschichte;5]; Zugl.: Aachen, Techn. Hochsch., Diss. 1995.

KREISEL, W.: Siedlungsgeographische Untersuchungen zur Genese der Waldhufensiedlungen im Schweizer und Französischen Jura mit einem Ausblick auf die Bevölkerungs- und agrarische Entwicklung. - Wiesbaden 1971 [Aachener Geogr. Arbeiten;5].

KREMER, B. P.: Die Auenlandschaft der unteren Sied. - In: Natur und Landschaftskunde 22 1986:99-105.

KREMER, B. P.: Schutzwürdige Lebensräume der Kulturlandschaft: 9 Dorfteiche und andere Kleingewässer. - In: Rheinische Heimatpflege, N. F. 29 1992:28-34.

KRENZLIN, A.: Die Kulturlandschaft des hannoverschen Wendlandes. - Stuttgart: Union 1931 [Forschungen zur dt. Landes- u. Volkskunde;28,4]; Zugl.: Berlin, Univ., Diss. 1931..

KRENZLIN, A.: Beiträge zur Kulturlandschaftsgenese in Mitteleuropa. Gesammelte Aufsätze aus vier Jahrzehnten. - Wiesbaden: Steiner 1983 [Erdkundliches Wissen,63].

KRESSER, W.: Die Donau - Verkehrsweg durch die Jahrhunderte. - In: DVWK (Hrsg.): Fluß und Lebensraum: Beiträge zur Fachtagung 1984 in Augsburg. - Hamburg; Berlin: Parey 1984 [Schriftenreihe des Deutschen Verbandes für Wasserwirtschaft und Kulturbau e.V.;69]:107- 146.

KRETSCHMER, P.: Das Mühlenwesen in der Stadt Holzminden um die Mitte des 18. Jahrhunderts. - In: Jahrbuch für den Landkreis Holzminden 1985.

KRETSCHMER, I./MESSNER, R.: Katasterkarte. - In: Lexikon zur Geschichte der Kartographie: Von den Anfängen bis zum Ersten Weltkrieg: A-L (Bd. 1). - Wien: Deuticke 1986 [Die Kartographie und ihre Randgebiete;C/1]:403-407.

KRETZ, F.: Spuren auf unseren Fluren: Landschaftsgeschichte, Flur- und Gewässernamen der Gemeinde Waltenschwil. Vilmergen: Sprüngli 1992.

KREUZ, A.: Fischteiche in der Landwirtschaft, deren Bau und Bewirtschaftung: nebst Anweisung für die Aufstellung von Entwürfen zu Fischteichanlagen mit extensivem Betriebe. - Münster: Selbstverl. 1901.

KREUZ, A. M.: Die ersten Bauern Mitteleuropas: eine archäologische Untersuchung zu Umwelt und Landwirtschaft der ältesten Bandkeramik. - Leiden: Univ. of Leiden 1990 [Analecta Praehistorica Leidensia;23].

KRIEG, R.: Beiträge zur Geschichte der Stadt Ellrich a. Harz. - In: Zeitschrift des Harz-Vereins für Geschichte und Altertumskunde 241891.

KRIMM, S.: Die mittelalterlichen und frühneuzeitlichen Glashütten im Spessart. - Aschaffenburg: Geschichts- und Kunstverein Aschaffenburg 1982 [Studien z. Geschichte des Spessartglases;1; Veröff. des Geschichts- und Kunstvereins Aschaffenburg e. V.;18/1].

KRINGS, W.: Forschungsschwerpunkte und Zukunftsaufgaben der Historischen Geographie: Industrie und Landwirtschaft. - In: Erdkunde 36 1982:109-114.

KRINGS, W.: Persistente Muster in der Agrarlandschaft des Baaler Bruchs, Gemeinde Weeze. - Bonn 1980 [Arbeiten zur rheinischen Landeskunde;46]:101-116.

KRINGS, W.: Rahmenbedingungen und Zukunftsperspektiven für die Historische Geographie in der Bundesrepublik Deutschland. - In: Geplaatst in de tijd. Liber amicorum aangeboden aan Prof. Dr. M. W. HESLINGA, Amsterdam 1984 [Bijdragen tot de Sociale Geografie en Planologie;9]:211-225.

KRINGS, W.: Text und Bild als Informationsträger bei Stadtdarstellungen der Frühen Neuzeit. - In: Poesis et Pictura, Studien zum Verhältnis von Text und Bild in Handschriften und alten Drucken. Festschrift für Dieter Wuttke. Hrsg. v. FÜSSEL, S./KNAPE, J. - Baden-Baden 1989 [Saecula Spiritalia, Sonderbd.]:295-335.

KRINGS, W.[a]: Die Technikgeschichte des [Zisterzienser-] Klosters Langheim. Eine Einführung aus historisch-geographischer Sicht. - In: Klosterlangheim. Symposion veranstaltet von der Hanns-Seidel-Stiftung in Zusammenarbeit mit der OttoFriedrich-Universität Bamberg und dem Bayerischen Landesamt für Denkmalpflege. München 1994 [Bayerisches Landesamt für Denkmalpflege, Arbeitsheft 65]:78-85.

KRINGS, W.[b]: Stadt und Fluß: Zur Entwicklung innerstädtischer Wasserläufe und Uferzonen. Ein Aufgabengebiet der Historischen Geographie und das Anwendungsbeispiel Bamberg. - In: GOOSSENS, M./VAN HECKE, E. (Hrsg.): Van Brussel tot Siebenbürgen. Progress in human geography in Europe. Liber Amicorum Prof. Dr. Herman Van der Haegen, Löwen 1994 [Acta Geographica Lovaniensia;34]:439-452. 
KRINGS, W.[a]: Exkursion 8: Bamberg am Wasser. Eine Exkursion aus historisch-geographischer Sicht. - In: BENDER, O. u.a. (Hrsg.): Bamberger Extratouren. Ein geographischer Führer durch Stadt und Umgebung. Bamberg 2001:170-187.

KRINGS, W.[b]: Perspektiven für die Historische Geographie in Bamberg. In: 20 Jahre Historische Geographie in Bamberg: Festakt zum Jubiläum am 13. Juli 2001 [Bamberger Universtitätsreden, Schriftenreihe der Otto-Friedrich-Universität Bamberg;7]:44-50.

KRINGS, W.: Unternehmer, Verkehrswege, Wasserkräfte. Die Industrialisierung in Deutschland und die Gründung der ersten Bamberger Industrie-Aktiengesellschaft [Mechanische Baumwollspinnerei und Weberei A.G., später ERBA]. Vortragsmskr. u. Kurzfassung. Zusammenfassend wiedergegeben in Harzenetter, Markus: Veranstaltungen rund um die ERBA - ein Tagungsbericht. Vortragsreihe "ERBA und Industriedenkmalpflege" und Photoausstellung "ERBA 2001". In: Bayerisches Landesamt für Denkmalpflege März 2003 [Denkmalpflege Informationen;B 124]:66-69.

KRINS, H..: Brücke, Mühle und Fabrik: technische Kulturdenkmale in Baden-Württemberg. - Stuttgart: Theiss 1991 [Industriearchäologie in Baden-Württemberg;2].

KRISZUN, P.: Über den guten Ton in Ostfrieslands Industrie. Entwicklung und Stand der ostfriesischen Ziegeleien. Leer/Ostfriesland 1983 [Zs. f. Kultur, Wirtschaft u. Verkehr;3]:11-16.

KRÖHAN, H.: Ausbau der Wasserstraßen. - In: Historischer Handatlas von Brandenburg und Berlin, Lfg. 9. - Berlin: de Gruyter 1964.

KROCKOW, C. v.: Die Elbreise: Landschaften und Geschichte zwischen Böhmen und Hamburg. - 2. Aufl. - Stuttgart: Engelhorn 1996

KRÖLL, U.: „Max-Clemens-Kanal“ und „Twickelervaart“: eine unvollendete Kanalverbindung zwischen Twente und dem Münsterland im 18. Jahrhundert. - unveröffentl. Manuskript o. J.

KRONBERG, P.: Fernerkundung der Erde. Grundlagen und Methoden des Remote Sensing in der Geologie. - Stuttgart: Emke 1985.

KRONBERG, P.: Tektonische Strukturen in Luftbildern und Satellitenbildaufnahmen. - Stuttgart: Emke 1995.

KRONENBERG, U./JAHN, B.: Vom „Industriefluss“ zur „Lebensader Wupper“: Der Umbau des Wupperbettes. - Stadt Wuppertal Juli 2000.

KRUFT, H.-W.: Städte in Utopia: Die Idealstadt vom 15. bis 18. Jahrhundert zwischen Staatsutopie und Wirklichkeit - München: Beck 1989.

KRUG, A.: Heilkunst und Heilkult. Medizin in der Antike. - 2. Aufl. - München: Beck 1992 [1. Aufl. 1984].

KRÜGER, H.-P.: Die Rekonstruktion von Fischteichen im Teichgebiet von Peitz, einem Feuchtgebiet von internationaler Bedeutung, unter Berücksichtigung der Entwicklung der Lebensräume für Wasservögel. - In: Beiträge zur Vogelkunde 34/1 1988:1-20.

KRÜGER, R.: Typologie des Waldhufendorfes nach Einzelformen und deren Verbreitungsmustern. - Göttingen: Geographisches Institut d. Univ. 1967 [Göttinger geographische Abhandlungen;42]; Zugl.: Göttingen, Univ., Diss. 1968.

KRUMMERT, R./STUMM, W.: Gewässer als Ökosysteme: Grundlagen des Gewässerschutzes. - 3. Aufl. - Zürich: Verl. d. Fachvereine 1992.

KRUMMENACHER, B. 1997: Grünspan, grüner Löwe und Vitriol - Die Grundlage zum Stein der Weisen. - In: Hermes Nr. 5 [URL $=$ http://www.fk-alchemie.de/texte/05VITRIOL.html;07.08.2004].

KRÜNITZ, G. J. D.: Ökonomisch-technologische Encyklopädie, oder allgem. System der Staats-, Stadt-, Haus- und Landwirthschaft, wie auch der Erdbeschreibung, Kunst- und Naturgeschichte [...], fortges. von F. J. Flörke (73. - 123. Theil), 221 Bde., Berlin ca. 1773-1854. [Stichwort Mühle:95. - 96. Teil, Berlin 1804].

KUBITZ, E.-H.: IGA am Meer: von der Idee zur Realisierung. - In: Stadt + Grün 4 2003:32-37.

KUCKENBERG, M.: Siedlungen der Vorgeschichte in Deutschland 300.000 - 15 v. Chr. - Köln: DuMont 1993 [DuMont Taschenbücher;298: Kunst und Kultur].

KUFELD, W.: Geographisch-planungsrelevante Untersuchungen am Aubachsystem (südlich von Regensburg) als Grundlage eines Bachsanierungssystems. - Laufen/Salzach: ANL 1988 [Berichte der ANL;12].

KÜHN, A..: Bestandsaufnahme und Erhaltung der Wiesenbewässerungsanlage Kirchehrenbach und Weilersbach im Rahmen der Flurbereinigung. - In: Kulturlandschaftsforschung 1/2 1992:16-20.

KÜPPERS, C.: Antrag auf neue Einleitungswerte radioaktiver Stoffe in die Mosel durch das Kernkraftwerk Cattenom. Kurzstellungnahme im Auftrag von Mouvement Ecologique Luxemburg und Bund Umwelt und Naturschutz Saarland. Darmstadt: Öko-Institut 2003.

KUHLBRODT, P.: Die Kelle - das älteste Naturdenkmal im Kreis Nordhausen. - In: Beiträge zur Heimatkunde aus Stadt und Kreis Nordhausen 151990.

KUHLBRODT, P.: Die Stadt Ellrich im 18. Jahrhundert. - In: Beiträge zur Heimatkunde aus Stadt und Kreis Nordhausen 17 1992:28-38. 
KUHN, G.: Die Fischerei am Oberrhein: geschichtliche Entwicklung und gegenwärtiger Stand. - Stuttgart: Ulmer 1976 [Hohenheimer Arbeiten; 83]; Zugl.: Hohenheim, Univ. Diss, 1975 u. d. T.: Entwicklung und Stand der Oberrheinfischerei.

KUHN, W.: Siedlungsgeschichte Oberschlesiens. - Würzburg: Oberschlesischer Heimatverl. 1954 [Veröffentlichungen der Oberschlesischen Studienhilfe e.V.;4].

KUHN, W.: Die preußische Kolonisation unter Friedrich dem Großen. - In: Deutsche Ostsiedlung in Mittelalter und Neuzeit. Köln-Wien: Böhlau 1971 [Studien zum Deutschen Osten;8]:182-196.

KUHNE, H.: Die Bedeutung der Oste als Transportweg bis zum Niedergang der Ewerschiffahrt. - In: Jahrbuch d. Männer v. Morgenstern 65 1986:45-54.

KÜHNERT, W.: Die mittlere Saale. Ein Versuch einer morphogenetischen Entwicklungsgeschichte des mittleren Saalegebietes (Saalfeld-Großheringen). - Jena, Univ., Inaugural-Diss. 1936.

KUISLE, A.: Wasser: vom Hausbrunnen zum Wasserhahn; Ausstellung zur Geschichte der Wasserversorgung im ländlichen Oberbayern, Freilichtmuseum des Bezirks Oberbayern, Großweil. - Großweil: Freilichtmuseum des Bezirks Oberbayern 1994 [Schriftenreihe, Freundeskreis Freilichtmuseum Südbayern e. V.;12].

Kulturlandschaft - Siedlung - Bauernhaus. Beiträge zur Erforschung historischer Strukturen im ländlichen Raum. Festschrift anlässlich des 65. Geburtstages von Prof. Dr.-Ing. Hartmut Wenzel. - Weimar: Universitätsverl. 2003 [Schriften der Bauhaus-Universität Weimar;114].

Kulturlandschaft [Themenheft]. - In: Garten und Landschaft 102/ 61992.

KUMMERT, R./STUMM, W.: Gewässer als Ökosysteme. - 3. Aufl. - Stuttgart: Teubner 1992.

KUNZ, A.: Verkehrsgeschichte und Computerkartographie. - In: EBELING, D. (Hrsg.): Historisch-thematische Kartographie: Konzepte - Methoden - Anwendungen. - Bielefeld: Verl. für Regionalgeschichte 1999:48-59.

KUNZE, R.: Projekt Neue Ufer : Öffnung Pleißemühlengraben Leipzig. - In: PlanerIN 3 2001:28-29.

KÜPPERS, G./LUNDGREEN, P./WEINGART, P.: Umweltforschung - die gesteuerte Wissenschaft? Eine empirische Studie zum Verhältnis von Wissenschaftsentwicklung und Wissenschaftspolitik. - Frankfurt/Main: Suhrkamp 1978 [Suhrkamp Taschenbuch Wissenschaft;215].

KUPSCH, K.: Historisches vom Strom. - Duisburg 1997 [Beiträge zur Geschichte der Oderschiffahrt, Jahrbuch 1997].

KUR, F./Wolf, H.-G.: Wassermühlen - 35000 Kleinkraftwerke zum Wohnen und Arbeiten. - Frankfurt/Main: Eichborn-Verl. 1985.

KURLANSKY, M.: Kabeljau. Der Fisch, der die Welt veränderte. - München: List Taschenbuch Verl. 2000 [Titel der amerikanischen Originalausgabe: Cod. A Biography of the Fish that Changes the World. New York: Walker \& Company 1997].

KÜRTEN, L.: Fluß- und Seenlandschaften: Berichte aus der ökologischen Forschung. Hrsg.: Bundesministerium für Bildung, Wissenschaft, Forschung und Technologie (BMBF). - Bonn: BMBF, Referat Öffentlichkeitsarbeit 1996.

KÜRTEN, W. v.: Landschaftsstruktur und Naherholungsräume im Ruhrgebiet und seinen Randzonen. - Paderborn 1973 [Bochumer Geographische Arbeiten, Sonderreihe Bd. 1]

KURTZE UND AUSFÜHRLICHE BESCHREIBUNG des am 9. August 1731 auf dem Möniche-Mühlen-Teiche bey dem Closter Michaelstein ohnweit Blanckenburg gehaltenen Hirsch-Feist-Jagens. - o. O. (ca. 1731). - 3,1 Bl.;4.

KÜRY 2004: Über die Geschichte Russlands vor Peter dem Großen. [URL = http://www.amuseum.de/medizin/CibaZeitung/ scd48.htm;20.01.2004].

KURZMANN, G.: Kaiser Maximilian I. und das Kriegswesen der österreichischen Länder und des Reiches. - Wien: Heeresgeschichtliches Museum 1985 [Militärgeschichtliche Dissertationen österreichischer Universitäten;5].

KURZWEIL, A./TODTENHAUPT, D.: Zur Geschichte und Technik der Holzteerherstellung. - In: Jahrestagung der Arbeitskreise Archäometrie in der Fachgruppe Analytische Chemie der Gesellschaft Deutscher Chemiker und der Deutschen Mineralogischen Gesellschaft. - Mainz 1996:45-47.

KUSCHKA, E./HAHN, W.: Flussspatlagerstätten des Südwestvogtlandes: Schönbrunn, Bösenbrunn, Wiedersberg. Hrsg.: Sächsisches Landesamt für Umwelt und Geologie und Sächsisches Oberbergamt]. - Freiberg et al.: Sächsisches Oberbergamt 1996 [Bergbau in Sachsen;2].

KUSS, C.: Grundriß einer Naturbeschreibung der Herzogth. Schleswig und Holstein. - Altona: Hammerich 1817.

KÜSTER, H.: Botanische Untersuchungen zur Umweltgeschichte. - In: Universitas. Zeitschrift für interdisziplinäre Wissenschaft 39/7 1984:739-748.

KÜSTER, H.: Wo der Pfeffer wächst. Ein Lexikon zur Kulturgeschichte der Gewürze. - München: Beck 1987.

KÜSTER, H.: Der prähistorische Mensch und seine Umwelt. Festschrift für Udelgard Körber-Grohne. Stuttgart 1988 [Forschungen zur Vor- und Frühgeschichte in Baden-Württemberg;31]. 
KÜSTER, H.: Botanische Untersuchungen belegen die Existenz eines Mühlweihers bei der frühmittelalterlichen Wassermühle von Dassing. - In: Das archäologische Jahr in Bayern 1993:128f.

KÜSTER, H.: Geschichte der Landschaft in Mitteleuropa. Von der Eiszeit bis zur Gegenwart. - München: Beck, 1995

KÜSTER, H.: Pollenanalyse als Methode der Umweltgeschichte. - In: BAYERL, G./FUCHSLOCH, N./MEYER, T. (Hrsg.): Umweltgeschichte - Methoden, Themen, Potentiale: Tagung des Hamburger Arbeitskreises für Umweltgeschichte, Hamburg 1994. - Münster, New York: Waxmann 1996 [Cottbuser Studien zur Geschichte von Technik, Arbeit und Umwelt;1]:31-40.

KÜSTER, H.: Geschichte des Waldes: von der Urzeit bis zur Gegenwart. - München: Beck 1998.

KÜSTER, H.: Die Ostsee: Eine Natur- und Kulturgeschichte. - München: Beck 2002.

LACHMANN, T.: Die Gewässer und ihre Nutzung. - In: FRIEDEL, B./FRIESER, C.: Nürnberg: Archäologie und Kulturgeschichte. - Nürnberg: Verl. Dr. Faustus 1999:311-314.

LAHNER, G.: Es war einmal!: eine Illustration zur Geschichte der Fischerei in Oberösterreich vor hundertfünfzig Jahren. - Linz [1900].

LAHRING, [...]: Die Stauwiesenanlagen in Flothwell in den Landkreisen Celle und Gifhorn. - In: Festschrift zum 75jährigen Bestehen der Wiesenbauschule Suderburg.: 17. Mai 1929. Hrsg. v. d. Landwirtschaftskammer für die Provinz Hannover. Hannover 1929: 105-110.

LAMB, B. O.: Highways and Waterways: Two Episodes in California's Transportation History. - In: California History 75/1 1996:12-30.

LAMB, H. H.: Klima und Kulturgeschichte: der Einfluß des Wetters auf den Gang der Geschichte. - Reinbek/Hamburg: RowohltTaschenbuch-Verl. 1989 [Rowohlts Enzyklopädie;478: Kulturen und Ideen].

LAMPEN, A.: Fischerei und Fischhandel im Mittelalter. Wirtschafts- und sozialgeschichtliche Untersuchungen nach urkundlichen und archäologischen Quellen des 6. bis 14. Jahrhunderts im Gebiet des deutschen Reiches. - Husum: Matthiesen Verl. Ingwert Paulsen 2000 [Historische Studien; 461]; Zugl. Kassel, GH/Universität, Diss. 1997.

LAMPERT, K.: Künstliche Wiesenbewässerung im Oker-Aller-Winkel und in der Lüneburger Heide. - Bonn, Univ., Diss. 1943.

LANDAU, G.: Beiträge zur Geschichte der Jagd und Falknerei in Deutschland: Die Geschichte der Jagd und der Falknerei in beiden Hessen. - Kassel: Fischer 1849 [unveränderter Nachdruck der Ausgabe: Kassel: Hamecher 1971].

LANDAU, G./RENOUARD, C. (Hrsg.): Beiträge zur Geschichte der Fischerei in Deutschland: die Geschichte der Fischerei in beiden Hessen. - Kassel: Freyschmidt 1865 [Zeitschrift d[es] Ver[eins] f[ür] hess[ische] Geschichte, Supplementband;10].

LANDELS, J. G.: Engineering in the ancient world. - Berkeley/California et al. 1978 [dt.: Die Technik in der antiken Welt. München 1979].

LANDESAMT FÜR DENKMALPFLEGE RHEINLAND-PFALZ (Hrsg.): Das Rheintal von Bingen und Rüdesheim bis Koblenz. Eine europäische Kulturlandschaft. [Dokumentation Mittelrhein, 2 Bde.]. - 2. Aufl. - Zabern 2002.

LANDESAMT FÜR UMWELTSCHUTZ SACHSEN-ANHALT: Muster-Managementplan für das FFH-Gebiet 134 „Gewässersystem der Helmeniederung“ (Landkreis Sangerhausen) - Entwicklungsplan gem. Art. 2 Abs. 3 und Art 6 Abs. 1 FFH-RL. - Magdeburg: Landesamt für Umweltschutz Sachsen-Anhalt, Fachbehörde Naturschutz 2001-2002.

LANDESHAUPTSTADT DÜSSELDORF (Hrsg.): Die Düssel: Geschichte und Geschichten. - Köln: Rheinland-Verl. 1988.

LANDESMUSEUM KOBLENZ (Hrsg.): Vom Zauber des Rheinss ergriffen [...]: zur Entdeckung der Rheinlandschaft vom 17. bis 19. Jahrhundert; [Rhein. Landesmuseum Bonn, 11.9. - 29.11.1992; Mittelrhein-Museum Koblenz, 10.9. - 25.10.1992]. München: Klinkhardt \& Biermann 1992

LANDKREIS BERGHEIM-ERFT 2001 [URL = http://www.bergheim-erft.de/Ortsteil/Glesch/histo_glesch.htm;17.08.2001].

LANDKREIS MERSEBURG: Naturraumpotential der Flossegrabenniederung (Landkreis Merseburg-Querfurt) unter besonderer Berücksichtigung des Biotopverbundes. - Landkreis Merseburg-Querfurt, Untere Naturschutzbehörde 2001-2002.

LANDSCHAFTSVERBAND RHEINLAND, Rheinisches Amt f. Bodendenkmalpflege, Fundstellenaufnahme AS-Overath: Mydlinghover Mühle, Aktivitätsnummer OV 95/53, 12.3.1994.

LANDSCHAFTSVERBAND RHEINLAND, Rheinisches Amt f. Bodendenkmalpflege, Fundstellenaufnahme AS-Overath: Baustellen-Beobachtung Gut Mydlinghoven, Aktivitätsnr. OV 98/26, 1996 bis Sept. 1997.

LANDSCHAFTSVERBAND RHEINLAND, Umweltamt (Hrsg.): Fließgewässer in der Kulturlandschaft. Fachtagung am 24./25.09.1998 - Köln: LVR 1999.

LANDSCHULZ, M.: Die Mainzer Malerei zur Goethezeit. - In: Arkadien am Mittelrhein: Caspar und Georg Schneider; Landesmuseum Mainz, 7. Juni bis 23. August 1998. Hrsg.: Landesmuseum Mainz - Wiesbaden: Reichert 1998:19-32.

LANDWIRTSCHAFTSKAMMER Westfalen-Lippe, Gruppe Technik und Bauswesen: Nutzung der Wasserkraft im ländlichen Raum. - Münster 1988. 
LANG, W.: Spätmittelalterliche Glasproduktion im Nassachtal, Uhingen, Kreis Göppingen. - Hrsg.: Landesdenkmalamt BadenWürttemberg, Abteilung Archäologische Denkmalpflege. - Stuttgart: Theiss 2001 [Schriftenreihe: Materialhefte zur Archäologie in Baden-Württemberg;59].

LANGE, B.: Suburbaner Raum als Kulturlandschaft? - Bestandsaufnahme und Handlungsstrategien aus kulturlandschaftspflegerischer Sicht. Vortrag auf der Veranstaltung Nr. 180 „Kulturlandschaften in Deutschland - Beispiele, Projekte, Spannungsfelder“; Bildungszentrum Eichholz der Konrad-Adenauer Stiftung, vom 02.07. - 04.07.2003; Mitschrift vom 2.07.2003.

LANGE, F.: Aus der Geschichte der Mühlen im Hannoverschen Wendland. - Lüchow: Köhring 1989.

LANGE, H. (Hrsg.): Denkmalpflege in den Städten: Stadtbaukunst, Stadtökologie, Stadtentwicklung. - Berlin, Köln: Deutscher Städtetag 2003 [Neue Schriften des Deutschen Städtetages;83].

LANGE, I.: Formen und Entwicklung des Bergmannshauses von den Anfängen bis zur Gegenwart. - Göttingen: Schwarz und Co. 1967

LANGE, N. de: Geoinformatik in Theorie und Praxis. - Berlin [u.a.]: Springer 2002.

LANGE, G../LECHER, K. (Hrsg.): Gewässerregelung, Gewässerpflege: naturnaher Ausbau und Unterhaltung von Fließgewässern. -2. Aufl. - Hamburg et al.: Parey 1989.

LATTIN, G. de: Grundriß der Zoogeographie. - Stuttgart: Fischer 1967 [Hochschullehrbücher für Biologie;12]

LAUER, W. (Hrsg.): Argumenta Geographica: Festschrift Carl Troll zum 70. Geburtstag (24. Dezember 1969). - Bonn: Dümmler 1970 [Colloquium Geographicum;12].

LAUER, W.: Carl Troll - Naturforscher und Geograph. - In: Erdkunde 30/1 1976:1-9.

LAUFKÖTTER, C.: Die wirtschaftliche Lage des ehemaligen braunschweigischen Zisterzienserklosters Michaelstein von 1300 bis 1544. - In: Zeitschrift des Harzvereins für Geschichte und Altertumskunde 53 1920:1-58.

LAUTENSACK, H.: Otto Schlüters Bedeutung für die methodische Entwicklung der Geographie. Ein kritischer Querschnitt durch ein Halbjahrhundert erdkundlicher Problemstellung in Deutschland. - In: Petermanns Geographische Mitteilungen 96/4 1952:219-231.

LAUTER, M.: Antlitz und Wesen der alten Goldbergbaulandschaft von Goldkronach im Fichtelgebirge. - Erlangen, Univ., Diss. 1948.

LAUTER, W.: Anleitung zur Behandlung der Wässerwiesen nach Jahreszeiten, Monaten und Witterungsverhältnissen nebst einem Anhange. - Karlsruhe 1951.

LAUTERBACH, H.: Von Floßmeistern und Flößerbräuchen: Geschichte und religiöses Brauchtum der Isar- und Loisachflößerei. - München: Wewel 1992.

LAUTERBORN, R.: Das Rheingold. - Der Rhein. 2. Band. - Ludwigshafen 1938.

LAUX, H.-D.: Forschungsschwerpunkte und Zukunftsperspektiven der Historischen Geographie: Bevölkerung - In: Erdkunde 36 1982:103-109.

LAWA [Ländergemeinschaft Wasser] (Hrsg.); LAWA-Arbeitskreis „Qualitative Hydrologie Fliessgewässer“ [QHF] (Bearb.): Fliessgewässer der Bundesrepublik Deutschland. - 1. Aufl. - Berlin: Kulturbuchverl. 1997.

LAWA [Länderarbeitsgemeinschaft Wasser]: Gewässerstrukturgütekartierung in der Bundesrepublik Deutschland: Verfahren für kleine und mittelgroße Fließgewässer. - Berlin: Kulturbuch-Verl. 2000.

LEENDERS, K. A.: Die Brabanter Torfkanäle als fossiles Verkehrssystem aus der Zeit des Spätmittelalters und der frühen Neuzeit. - In: Siedlungsforschung 4 1986:103-125.

LEENEN, M. A.: Einsam und allein? Eremiten in Deutschland. - Leipzig: Benno-Verl. 2001.

LEBENSMITTELLEXIKON 2004: Saibling [URL = http://www.lebensmittellexikon.de/b0000730.php;04.08.2004].

LEHING, B.: Die Oberlausitzer Heide- und Teichlandschaft: Eine Landschaft zwischen Bewirtschaftung und Naturschutz. - In: Praxis Geographie 12 1996:21-23.

LEHMANN, E.: Der historische Aspekt der Umweltforschung. - In: SCHEEL, H. (Hrsg.): Gesellschaft und Umwelt: Hans Mottek zum 65. Geburtstag. - Berlin: Akad.-Verl. 1976 [Sitzungsberichte d. Akad. d. Wissenschaften der DDR: G, Gesellschaftswissenschaften;1976,2]:19-26.

LEHMANN, E.: Landschafts- und Regionskarten - eine Zukunftsaufgabe von Geographie und Kartographie (Beitrag auf dem Ladenburger Symposium über „Wissenschaft und Technik im zukünftigen Deutschland“ am 24.11.1990). - In: MAYR, A./GRUNDMANN, L. (Hrsg.): Edgar Lehmann zum Gedächtnis. Ein Leben für Geographie und Kartographie. - Leipzig: Institut für Länderkunde 2001:67-73.

LEHMANN, M.: An der Clemenskirche. Eine Motivlandschaft am Mittelrhein. - In: Arkadien am Mittelrhein: Caspar und Georg Schneider; Landesmuseum Mainz, 7. Juni bis 23. August 1998. Hrsg.: Landesmuseum Mainz. - Wiesbaden: Reichert 1998:61-72. 
LEHNERT, W.: Entsorgungsprobleme der Reichsstadt Nürnberg. - In: SYDOW, Jürgen (Hrsg.): Städtische Versorgung und Entsorgung im Wandel der Geschichte: 18. Arbeitstagung in Villingen, 3. - 5. November 1979. - Sigmaringen: Thorbecke 1981 [Stadt der Geschichte; 8]:151-163.

LEIBUNDGUT, C.: Zum Wasserhaushalt des Oberaargaus und zur hydrologischen Bedeutung des landwirtschaftlichen Wiesenbewässerungssystems im Langetental. - Bern: Kümmerly + Frey 1976 [Beiträge zur Geologie der Schweiz Hydrologie; 23]:83-103.

LEIBUNDGUT. C.: Angewandte Geographie - Grundlage zu aktuellen Problemen. - In: Geographica Helvetica 2 1984:76-79.

LEIBUNDGUT, C.: Zur Methodik der Uferschutz-Bewertung. - In: Der Mensch in der Landschaft. Festschrift für Georges Grosjean zum 65. Geburtstag, 17. Januar 1986. - Hrsg. v. AERNI, K. et al. - Bern: Lang 1986 [Jahrbuch d. Geogr. Gesell. von Bern;55]:151-171.

LEIBUNDGUT, C.: Wiesenbewässerungssysteme im Langetental. Erläuterungen zu sechs Kartenblättern. - Bern: Geograph. Inst. d. Univ. Bern 1993 [Geographica Bernensia;41].

LEIBUNDGUT, C./HIRSIG, P.: Angewandte Geographie: Grundlage zu aktuellen Problemen. - In: Geographica Helvetica 2 1984:76-79.

LEIBUNDGUT, H.: Der Wald in der Kulturlandschaft: Bedeutung, Funktion und Wirkungen des Waldes auf die Umwelt des Menschen. - Bern et al.: Haupt 1985.

LEIDEL, G./FRANZ, M. R.: Altbayerische Flusslandschaften an Donau, Lech und Isar. - In: Handgezeichnete Karten des 16. bis 18. Jahrhundert aus dem Bayer. Hauptstaatsarchiv. - Weißenhorn: Anton H. Konradverl. 1998 [Ausstellungskataloge der Staatl. Archive Bayern;37].

LEIDINGER, P.: Umweltfragen in der Geschichte. Zum Verhältnis des Menschen zur Natur in der Vergangenheit. Aspekte der Umweltpolitik der Gegenwart. - In: Geschichte, Politik und ihre Didaktik 12 1984:117-125.

LEIDINGER, P. (Hrsg.): Historische Ökologie und ökologisches Lernen im historisch-poltischen Unterricht - Paderborn: Schöningh 1986 [Geschichte, Politik und ihre Didaktik; 5]:108-120.

LEIDINGER, P.: Umwelterziehung im Geschichtsunterrricht. In: CALLIEß, R./LOB, E. (Hrsg.): Handbuch Praxis der Umweltund Friedenserziehung, Bd. 2. - Düsseldorf 1987:281-292.

LEIDINGER, Paul: Von der historischen Umweltforschung zur Historischen Ökologie. Ein Literaturbericht. - In: Westf. Forschungen. Zeitschrift des Westf. Inst. f. Regionalgeschichte des Landschaftsverbandes Westfalen-Lippe 41 1991. Münster: Aschendorff 1991:495-516.

LEIER, M./HÄGERMANN, D. (Hrsg.): Das Leben im Mittelalter. Die Welt der Bauern, Bürger, Ritter und Mönche. - München: Bertelsmann 2001.

LEMECKE, Johann Friedrich Martin: Allgemeines Adreßbuch der Stadt Nordhausen. Sondershausen 1834

LENGERICHER GESCHICHTE(N), Heimatverein für das alte Kirchspiel Lengerich e.V., Lengerich 2 1996:2-3.

LENGERKE, A. v.: Encyklopädie der Landwirthschaft auf ihrem gegenwärtigen Standpunkte. 1. Bd. [A-G.]; 2. Bd. [H -Z.] Braunschweig: Westermann 1843.

LENGERKE, A. v.: Anleitung zum praktischen Wiesenbau: mit besonderer Berücksichtigung des Zustandes und der Bedürfnisse der norddeutschen Wiesenwirthschaft. - 2. Aufl. - Prag: Calve 1844 [1. Aufl. 1836].

LENZ, G.: „Event-Landschaften“. Überlegungen zu Möglichkeiten und „Pflichten“ Historischer Umweltforschung in aktuellen Prozessen der Raumgestaltung. In: HAUPTMEYER, C.-H. (Hrsg.): Mensch - Natur - Technik: Aspekte der Umweltgeschichte in Niedersachsen und angrenzende Gebieten. - Bielefeld: Verl. f. Regionalgeschichte 2000 [Materialien zur Regionalgeschichte;2]:181-196.

LENZ, S.: Die Auflehnung. - Hamburg: Hoffman und Campe 1999 [orig. 1994].

LEOPOLD, J. G.: Riemisch-Leopoldtische Praktische Landwirthschaft in fünf Teilen: oder Leopoldts Landwirthschaftliche Grundsätze [...] - Breslau, Leipzig: Korn 1802 - T. 5 (1802): Von der Teich-, Fischerey- und Holzwirthschaft, Vorwertksgebäuden, Kauf- und Pachtanschlägen.

LERSNER, H. v.: Die ökologische Wende der Wissenschaften: Festrede anläßlich der Übergabefeier für das Zentrum für Umweltforschung am 26. April 1989 in Dudweiler. - Saarbrücken: Univ. des Saarlandes 1989 [Sonderreihe öffentliche Vorträge;20].

LERSNER, H. v./HUCKE, J.: Einrichtungen der Umweltforschungen. In: Umwelt-Handwörterbuch. Umweltmanagement in der Praxis für Führungskräfte. Hrsg. DREYHAUPT, F. J./PEINE, F. J./WITTKÄMPER, G. W. - Berlin u.a.: Walhalla 1992: 551-555.

LESER, H.: LÖK: Ansatz, Modelle, Methodik, Auswertung.. - Stuttgart 1991 [UTB;521].

LESER, H. (Hrsg.): Westermann-Lexikon Ökologie und Umwelt. - Braunschweig: Westermann 1994.

LESER, H.: Ökologie: Woher - Wohin? Perspektiven raumbezogener Ökosystemforschung. - In: Die Erde 126 1995:323-338.

LESER, H. et al.: DIERCKE-Wörterbuch der Geographie. - 3. Aufl. - Braunschweig: Westermann; München: dtv. [2. Bde.]. 
LESER, H. /SCHNEIDER-SLIWA, R.: Geographie - eine Einführung: Aufbau, Aufgaben und Ziele eines integrativ-empirischen Faches. - Braunschweig: Westermann 1999 [Das Geographische Seminar].

LESSER, F. C.: Historische Nachrichten von der Kayserl [ichen] und des Heil[igen] Röm[ischen] Reichs Freyen Stadt Nordhausen [...]. - Leipzig, Nordhausen: Johann Heinrich Groß 1740.

LEUPOLD, J.: Theatrum Machinarium Molarium oder Schau-Platz der Mühlen-Bau-Kunst. Welcher allerhand Sorten von solchen Machinen, die man Mühlen nennet, so wohl historisch als practisch, nebst ihren Grund- und Auf-Rissen vorstellet und zwar wird in selbigen gehandelt [...]. Hrsg.: Johann Matthias Beyern. - Leipzig: Derr 1735 [Reprint: Hannover: Schäfer, 1982; Edition „libri rari“"].

LEUZE, E. G.: Aus den Anfängen der Galvanotechnik. Ein Rückblick aus Anlasse des 100-jährigen Bestehens der Fachzeitschrift „Galvanotechnik“- In: Galvanotechnik 1 (2002) [URL = http.//ww.leuze-verlage.de/gt/heft/aufsatz/200201/aus-denanfaengen.pdf;11.01.2004].

LEXIKON ALTE KULTUREN. Hrsg. v. BRUNNER, H. [et al.] - 3. Bde. - Darmstadt: Wiss. Buchgesell. 1990f.

LEXIKON FRÜHER KULTUREN. - Bd. 1. - Leipzig: VEB Bibliographisches Institut 1984.

LFUG [Sächsisches Landesamt für Umwelt und Geologie] (Hrsg.): Naturschutzfachliche Grundsätze zur Bewirtschaftung von Karpfenteichen in Sachsen. - Dresden: LFUG Oktober 2002 [Materialien zu Naturschutz und Landschaftspflege 2002].

LFV [Landesfischereiverband Bayern e.V.] (Hrsg.): 1855 - 1995: 140 Jahre Landesfischereiverband Bayern, Jubiläumsbeilage zu „Bayern Fischerei und Gewässer“. - München 1995.

LICHTENAUER, A.: Die geographische Verbreitung der Wasserkräfte in Mitteleuropa. - Würzburg: Kabitzsch \& Mönnich 1926 [Mitteilungen der Geographischen Gesellschaft zu Würzburg;2]; Zugl.: Würzburg, Univ. Diss. 1927.

LICHTENBERGER, E.: Die Kartierung als kulturgeographische Arbeitsmethode. - In: Mitteilungen der Geographischen Gesellschaft Wien 109 1967:308-337.

LICHTENBERGER, E.: Zum Stand der Geographie als Universitätsdisziplin. - In: Geographica Helvetica 2 1985:55-66.

LICHTENBERGER, E.: Stadtgeographie. Bd. 1: Begriffe, Konzepte, Modelle, Prozesse. - Stuttgart: Teubner 1986 [TeubnerStudienbücher der Geographie].

LIEBHART, K.: Frau und Wasser - Wasserfrauen. - In: HABERL, H./STROHMEIER, G.: Kulturlandschaftsforschung. - Wien [u.a.]: Springer 1999 [iff texte;5]:66-69.

LIEBMANN, H.: Ein Planet wird unbewohnbar: Ein Sündenregister der Menschheit von der Antike bis zur Gegenwart. München: Pieper 1973.

LIEBMANN, H./KEIZ, G.: 50 Jahre Teichwirtschaftliche Abteilung Wielenbach der Bayerischen Biologischen Versuchsanstalt. Festschrift zum 50jährigen Bestehen der Teichwirtschaftlichen Abteilung Wielenbach der Bayerischen Biologischen Versuchsanstalt. - München 1965:5-17.

LIEDTKE, H.: Namen und Abgrenzungen von Landschaften in der Bundesrepublik Deutschland. [Mit einem Anhang von Uwe Förster: Zum grammatischen Geschlecht von Landschaftsnamen auf der amtlichen Übersichtskarte der Bundesrepublik Deutschland 1:1.000.000, Landschaften, Namen und Abgrenzungen. - Trier: Zentralausschuß f. Dt. Landeskunde 1994 [Forschungen zur deutschen Landeskunde; 239].

LIENAU, C.: Die Siedlungen des ländlichen Raumes. - 2. Aufl. - Braunschweig: Westermann 1995 [Das Geographische Seminar].

LIEPELT, S.: Der Beitrag von Freilandmuseen zum Artenschutz - Das Oberpfälzer Freilandmuseum als Beispiel. In: Freilandmuseen - Kulturlandschaft - Naturschutz - am Beispiel des Oberpfälzer Freilandmuseums -. Hrsg: Bayerische Akademie für Naturschutz und Landschaftspflege (ANL). - Laufen/Salzach 1992 [Laufener Seminarbeiträge;5]:53-61.

LIEPELT, S./SUCK, B.: Historische Ökologie, Vegetation und Nutzung der Agrarlandschaft im Freilandmuseum. - Nabburg 1994 [Heimat Nabburg;15]:90-113.

LIESSMANN, W.: Historischer Bergbau im Harz. - 2. Aufl. - Berlin et al.: Springer 1997 [1. Aufl. - Köln: Loga Verl. 1992].

LIESSMANN, W.: Kupfererzbergbau und Wasserwirtschaft: zur Montangeschichte von Bad Lauterberg/Südwestharz. Duderstadt: Mecke 2001.

LIETKE, H./MARCINEK, J. (Hrsg.): Physische Geographie Deutschlands. - Gotha: Perthes 1994.

LIETMANN, H.: Teichwirtschaft und Fischzucht im deutschen Osten. - Königsberg/Preussen: Reichsnährstand Verl.-Ges. Zweigniederlassung Ostpreussen 1941.

LINDBERG, M./TODD, D.: Brown-, green- and blue-water fleets: the influence of geography on naval warfare, 1861 to the present. - Westport/Conn. et al.: Praeger 2002.

LINDGREN, U.: In welchem Verhältnis stand mittelalterliche Technik zu Mensch und Natur? - In: SPINDLER, Konrad (Hrsg.): Mensch und Natur im mittelalterlichen Europa. Archäologische, historische und naturwissenschaftliche Befunde; Akten der Akademie Friesach „Stadt und Kultur im Mittelalter“; Friesach (Kärnten), 1. bis 5. September 1997. - Klagenfurt: Wieselar 1998 [Schriftenreihe der Akad. Friesach;4]:169-206. 
LINDNER, K. [Komment.]: Zwischen Ems und Hunte. Land am Wasser und unter dem Krummstab: ausgewählte Karten und Ansichten aus der Staatsbibliothek zu Berlin. Sonderausstellung anlässlich der Ausstellung: „Imago Germaniae - das Deutschland der Kartenmacher aus fünf Jahrhunderten“ vom 5. Mai bis 21. Juni 1998, Papenburg-Aschendorf. - Berlin 1998

LINGENER TAGESPOST vom 03.05.2003

\section{LINGENER TAGESPOST vom 20.05.1999}

LIPPERT, A. et al. [Hrsg.): Mensch und Umwelt während des Neolithikums und der Frühbronzezeit in Mitteleuropa - Ergebnisse interdisziplinärer Zusammenarbeit zwischen Archäologie, Klimatologie, Biologie und Medizin. - Rahden/Westf. 2001 [Internationale Archäologie - Arbeitsgemeinschaft, Symposium, Tagung, Kongress;2].

LOB, R. E./WEHLING, H.-W. (Hrsg.):Geographie und Umwelt: Forschung, Planung, Bewußtseinsbildung; Festschrift für Prof. Dr. Peter Schneider, Essen. - 1 Aufl. - Kronberg/Taunus: Athenaeum 1977.

LÖBE, K.: Das Weserbuch. Roman eines Flusses. - 2. Aufl. - Hameln: Verl. C. W. Niemeyer 1969 [1. Aufl. 1968].

LÖBER, U.: Geschichte der Wasserkraftnutzung. Tagungsberichte. - Koblenz: Selbstverl. d. Landesmuseums 1985.

LÖBERT, T.: Die Oberrheinkorrektion in Baden: Zur Umweltgeschichte des 19. Jahrhunderts. Hrsg.: NESTMANN, Franz: Karlsruhe 1997 [Mitteilungen des Inst. f. Wasserbau u. Kulturtechnik d. Univ. Karlsruhe (TH); 193]

LOHMEYER, T.: Beiträge zur Etymologie deutscher Flussnamen. - Göttingen: Vandenhöck und Ruprecht 1881.

LOHRMANN, D.: Energieprobleme im Mittelalter: Zur Verknappung von Wasserkraft und Holz in Westeuropa bis zum Ende des 12. Jahrhunderts. - In: Vierteljahresschrift für Sozial- und Wirtschaftsgeschichte 66/3 1978:297-316.

LOHRMANN, D.: Mühlenbau, Schiffahrt und Flußumleitungen im Süden der Grafschaft Flandern-Artois (10.-11. Jahrhundert). In: Francia. Forschungen zur westeuropäischen Geschichte 12 1985:149-192.

LÖLF [Landesanstalt für Ökologie, Landschaftsentwicklung und Forstplanung Nordrhein-Westfalen]: Gutachterliche Stellungnahme zur Unterschutzstellung zum geplanten Naturschutzgebiet „Hubbelrather Bachtal“““ in Düsseldorf. - August 1988.

LOMMATZSCH, H.: Der Oberharz im Spiegel der Jahrhunderte: vom Ende der Steinzeit bis zur Gegenwart. - 3. Aufl.- Clausthal Zellerfeld: Pieper 1972.

LOOSE, R.: Der Bergbau in der Wirtschaft der Pfalz. Historisch-geographische Aspekte der Integration montan-industrieller Unternehmungen in vor- und frühgeschichtlicher Zeit. - In: Jahrbuch. f. westdeutsche Landesgeschichte 14 1988:123.

LORENZ, F.: Wasser für Güstrow: eine Wanderung entlang der Gewässer und ein Streifzug durch die Technikgeschichte. Dülmen-Güstrow: Laumann 2000.

LORENZ, S./SCHOLKMANN, B. (Hrsg.): Von Cîteaux nach Bebenhausen: Welt und Wirken der Zisterzienser. - Tübingen: Attempo Verl. 2000.

LOREY, H.: Die Kartoffel. Von der Lustpflanze zum Mann des kleinen Mannes. - In: Samensurium 11 2000:31-33.

LOREZ, C.: Bauernarbeit im Rheinwald: Landwirtschaftliche Methoden und Geräte und ihre Terminologie in ältesten urkundlich belegten Walserkolonie Büdens. - Basel: Schweiz. Ges. f. Volkskunde 1943 [Schweiz. Gesell. f. Volkskunde;25].

LÖWENSTEIN, I. v.: Waschen im Schloßhaushalt. - In: „Die Große Wäsche“: Eine Ausstellung des Landschaftsverbandes Rheinland, Rheinisches Museumsamt, Brauweiler in Zusammenarbeit mit dem Rheinischen Freilichtmuseum Landesmuseum für Volkskunde, Mechernich-Kommern. - Köln: Rheinland-Verl. 1988 [Schriften d. Rhein. Museumsamtes;42; Zugl.: Schriften d. Rhein. Freilichtmuseums - Landesmuseum f. Volkskunde;34]:118-121.

LUA NRW [Landesumweltamt Nordrhein-Westfalen] (Hrsg.)[a]: Referenzgewässer der Fließgewässertypen NordrheinWestfalens. Teil 1: Kleine bis mittelgroße Fließgewässer. - Essen: Landesumweltamt NRW 1999 [LUA-Merkblätter;16].

LUA NRW [Landesumweltamt Nordrhein-Westfalen] (Hrsg.)[b]: Leitbilder für kleine bis mittelgroße Fließgewässer in NordrheinWestfalen: Gewässerlandschaften und Fließgewässertypen. - Essen: Landesumweltamt NRW 1999 [LUA-Merkblätter;17].

LUA-Studie [Landesumweltamt Nordrhein-Westfalen]: “Typisierung und Leitbildfindung für kleine und mittelgroße Fließgewässer des Mittelgebirgsraumes NRW” (4 Bände). Bd. 1: „Leitbilder für kleine und mittelgroße Fließgewässer des Mittelgebirgsraumes NRW“ (Textband); Bd. 2: „Beschreibung von 14 ausgewählten Modellen naturnaher Mittelgebirgsbäche in NRW“; Bd. 3 und 4: Dokumentation der Voruntersuchungsphase

LÜBBE, H./STRÖKER, E. (Hrsg.): Ökologische Probleme im kulturellen Wandel. - Paderborn: Schöningh 1986.

LUDEMANN, T./NELLE, O.: Die Wälder ins Schauinsland und ihre Nutzung durch Bergbau und Köhlerei. Hrsg.: Forstliche Versuchsanstalt Baden-Württemberg, Abt. Botanik und Standortkunde. - Freiburg (Breisgau): Forstliche Versuchs- und Forschungsanstalt Baden-Württemberg 2002 [Schriftenreihe Freiburger forstliche Forschung;15].

LUICK, R./BÖCKER, R.: Weiden in Süddeutschland. - In: Geographische Rundschau 51 1999:236-240.

LUISE 2004 [URL = http://www.luise-berlin.de/Lexikon/Mitte/b/Bloch_Markus_Elieser.htm;29.01.2004]. 
LULEY, H.: Urgeschichtlicher Hausbau in Mitteleuropa: Grundlagenforschung, Umweltbedingungen und bautechnische Rekonstruktionsmöglichkeiten. - Bonn: Habelt 1992 [Universitätsforschungen zur prähistorischen Archäologie;7]; Zugl.: Köln, Univ., Diss. 1990.

LÜNING, J.: Siedlungen der Steinzeit: Haus, Festung und Kult. - Heidelberg: Spektrum der Wissenschaften 1989

LÜNING, J.: Deutsche Agrargeschichte: Vor- und Frühgeschichte. - Stuttgart: Ulmer 1997 [Deutsche Agrargeschichte].

LUNKENHEIMER, L.: Schleifkotten, Mühlen und Hämmer an den Solinger Bächen. Hrsg.: Landschaftsverband Rheinland. Köln: Rheinland-Verl. 1990 [Arbeitsheft: Landeskonservator Rheinland;33].

LÜPKES, V. (Hrsg.): Im Fluss: Bergung, Konservierung und Präsentation der historischen Weserschiffe. - Tübingen et al.: Edition Heckenhauer 2001.

LÜPPERT, H.: Das Zisterzienserkloster Michaelstein im nördlichen Harzvorland und seine landschaftsgestaltenden Wirkungen .In: Exkursionsführer für das nördliche Harzvorland insbesondere für das Helsunger Bruch. - Berlin: Geogr. Inst., HumboldtUniv. 1998 [Arbeitsberichte;27].

LÜTGE, F.: Geschichte der deutschen Agrarverfassung vom frühen Mittelalter bis zum 19. Jahrhundert. - 2. Aufl. - Stuttgart: Ulmer 1967 [Dt. Agrargeschichte;3].

LÜTGERT, S. A.: Eiskeller und Kühlhäuser als Elemente der Kulturlandschaft in Norddeutschland: ein Forschungsprojekt zwischen Historischer Geographie und Industriearchäologie. - In: BUDESHEIM, W./NAGEL, F. N./PRIES, M. (Hrsg.): Zur Kulturgeschichte und Industriearchäologie in Norddeutschland. Versorgung, Verteidigung, Verkehr. - Wentorf bei Hamburg 1999 [Beiträge für Wissenschaft und Kultur;4]:131-141.

LÜTGERT, S. A.: Eiskeller, Eiswerke und Kühlhäuser in Schleswig-Holstein und Hamburg: ein Beitrag zur Kulturlandschaftsforschung und Industriearchäologie. - Husum: Husum Druck- u. Verlagsges. 2000; Zugl.: Hamburg, Univ., FB Geowiss., Diss. 2000.

LUTHER, G.: Die technische und wirtschaftliche Entwicklung des deutschen Mühlengewerbes im 13. Jahrhundert. Mit Berücksichtigung der früheren Entwicklung und unter Fortführung bis auf die neueste Zeit. - Leipzig: Duncker und Humblot 1909.

LUTTENBERGER, K.: Untersuchung über die Flößerei auf dem Neckar und seinen Nebenflüssen: in geschichtlicher und wirtschaftlicher Hinsicht. - Heidelberg, Univ., Diss 1904.

LUTZ, W.: Wasserflächen und Wasserflugwild. Anleitung zur Biotopgestaltung und -hege. - Berlin et al.: Paray 1996 [Schriftenreihe der Forschungsstelle für Jagdkunde und Wildschadensverhütung;9].

LYON, J. G. (Hrsg): Wetland and environmental applications of GIS. - Boca Raton et al.: Lewis Publ. 1995 [Mapping sciences series].

MAACK, W.: Dörfer und Fluren des Rintelner Beckens. - Rinteln: Niemeyer 1964 [Schaumburger Studien;5].

MC DONALD, A.: Water supply and management. - In: PACIONE, M. (Hrsg.): Applied heography: principles and practise. London, New York: Routledge 1999:137-151.

MC DONELL, J.: Inland Fischeries in Medieval Yorkshire 1066-1300. - In: Borthwick Papers 60 1981:1-42.

MÄCKEL, R.: Spät- und postglaziale Flussaktivität und Talentwicklung im Schwarzwald und Oberrheintiefland. - In: MÄCKEL, R./METZ, R. (Hrsg.): Schwarzwald und Oberrheintiefland. Eine Einführung in das Exkursionsgebiet um Freiburg i. Br. Freiburg 1992 [Freiburger Geographische Berichte;36]:82-103.

MÄCKEL, R./RÖHRIG, A.: Flussaktivität und Talentwicklung des Mittleren und Südlichen Schwarzwaldes und Oberrheintieflandes. - In: Berichte zur deutschen Landeskunde 65/2 1991:287-311.

MÄDER, C.: Geographie und Regionalplanung. - In: AERNI, K. et al. (Hrsg.): Der Mensch in der Landschaft. Festschrift für Georges Grosjean zum 65. Geburtstag, 17. Januar 1986. - Bern: Lang 1986 [Jahrbuch der Geographischen Gesellschaft von Bern;55]:413-417.

MÄDING, E.: Landespflege: Die Gestaltung der Landschaft als Hoheitsrecht und Hoheitspflicht. - Berlin: Deutsche Landbuchh. 1942.

MAGER, Johannes/JUST, Rüdiger/MEISSNER, Uwe: Salz, Gott erhalts's: Kulturgeschichte alter Salzstädte und Meisterwerke deutscher Salinentechnik. - 1. Aufl. - Halle/Saale: Technisches Halloren- und Salzmuseum, 1993 [Schriften und Quellen zur Kulturgeschichte des Salzes; 2]

MAGER, J.: Mühlenflügel und Wasserrad. Leipzig: VEB Fachbuchverl. 1990.

MAGER, J./MEIßNER, G./ORF, W.: Die Kulturgeschichte der Mühlen. - Tübingen: Wasmuth 1989.

MAGERL, C./RABE, D. (Hrsg.): Die Isar. Wildfluss in der Kulturlandschaft. - Kiebitz-Buch 1999.

MAHLICH; W.: Die Herausbildung der Landwirtschaftlichen Produktionsgenossenschaften in der DDR, dargestellt in der Entwicklung des Kreises Haldensleben, Bezirk Magdeburg (1952 bis 1960). - Berlin, Univ., Landwirtschaftlich-Gärtnerische Fak., Diss. 1999.

MAHR, H.: Mühlen im Oberasbach-Altenberger Raum. - In: Fürther Heimatblätter, N. F. 18 1968:42ff. 
MAIER, K./KEIBEL-MAIER, M.: Kloster Walkenried. - München; Berlin: Deutscher Kunstverl. 1997.

MAIER; H.: Kippenlandschaft, „Wasserkrafttaumel“ und Kahlschlag: Anspruch und Wirklichkeit nationalsozialistischer Naturschutz- und Energiepolitik. - In: BAYERL, G./FUCHSLOCH, N./MEYER, T. (Hrsg.): Umweltgeschichte - Methoden, Themen, Potentiale: Tagung des Hamburger Arbeitskreises für Umweltgeschichte, Hamburg 1994. - Münster, New York: Waxmann 1996 [Cottbuser Studien zur Geschichte von Technik, Arbeit und Umwelt;1]:247-266.

MAKOWSKI, H./BUDERATH, B.: Die Natur dem Menschen untertan: Ökologie im Spiegel der Landschaftsmalerei. - München: Kindler 1983.

MANN, D.: Die Thiershäuser Teiche im Landkrs. Göttingen: Zielvorstellungen in einem potentiellen Naturschutzgebiet. Göttingen: FH Hildesheim/Holzminden, FB Forstwirtschaft 1981; Zugl.: Dipl.arbeit 1981.

MANNEN, T.: Schiffahrt auf der Weser in der 2. Hälfte des 17. Jahrhunderts. - In: Niedersächsisches Jahrbuch für Landesgeschichte 70 1998:73-92.

MANNSFELD, K./NEUMEISTER, H. (Hrsg.): Ernst Neefs Landschaftslehre heute. - Klett-Perthes 1999 [Petermanns Geographische Mitteilungen;294].

MANTEL, K.: Das Buch vom deutschen Wald: Ein Führer zu Heimatliebe und Heimatschutz. - Hannover: Fackelträger [1954]; [Copyright 1935. - Leipzig: Georg Dollheimer].

MANTEL, K.: Wald und Forst in der Geschichte: ein Lehr- und Handbuch. - Alfeld et al: Schaper 1990.

MARBURGER, M.: 2-D morphodynamische Modellierung kleiner Flüsse. - Darmstadt: Inst. f. Wasserbau und Wasserwirtschaft 1997 [Mitteilungen;98].

MARCINEK, J.: Das Wasser des Festlandes: eine Einführung. - 3. Aufl. - Gotha et al.: Haack 1978.

MARCINEK, J. / ROSENKRANZ, E.: Das Wasser der Erde: eine geographische Meeres- und Gewässerkunde. - 2. Aufl.. - Gotha: Perthes 1996 [Perthes Geographiekolleg].

MARCUCCI, D. J.: Landscape history as a planning tool. - In: Landscape and Urban Planning 49 2000:67-81.

MARENBERG, G.: Die Rur: von der Quelle bis zur Mündung; eine Beschreibung der Rur (Roer) und der Landschaften, die sie durchfließt, mit kurzen Angaben zur Entstehung der Siedlungen entlang des Wasserlaufs. - Aachen: Meyer und Meyer 1994.

MARKL, H.: Natur als Kulturaufgabe: über die Beziehung des Menschen zur lebendigen Natur. - Stuttgart: Deutsche Verl.-Anst. 1986.

MAROTI, E.: Über die Verbreitung von Wassermühlen in Europa: Beiträge zu den zwischen der ungarischen Urgeschichte und der antiken Wirtschaftsgeschichte bestehenden Verbindungen. - In: Acta antiqua Academiae Scientarium Hungaricae 23 1975:255-280.

MARSH, G. P.: The Earth äs Modified by Human Action. A New Edition of man and Nature. - New York: Scribner, Armstrong \& Co. 1874 [Die 1. Aufl. erschien 1863 unter dem Titel: Man and Nature].

MARTHALER, R./GEBHARDT, H./LINNENBACH, M.: Gewässerversauerung. Gefahr für den Lebensraum der Bachforelle. In: Biologie in unserer Zeit 19/1 1989:22-24.

MARTI, H.: Klosterkultur und Aufklärung in der Fürstabtei St. Gallen. - St. Gallen: Verl. am Klosterhof 2003 [Monasterium Sancti Galli;2].

MARTIN, W./SCHRÖDER, E.: Bäuerliche Flachgewinnung im Landkreis Göttingen und industrielle Flachsbearbeitung in SüdNiedersachsen: Zeugnisse der Flachsgewinnung vom 18. bis 20. Jahrhundert. - In: Göttinger Jahrbuch 47 1999:83-88.

MARTINI, W. (Hrsg.): Die Jagd der Eliten in den Erinnerungskulturen von der Antike bis in die Frühe Neuzeit. - Göttingen: Göttingen: Vandenhoeck \& Ruprecht 2000 [Formen der Erinnerung;2].

MASCHKE, E.: Die Brücke im Mittelalter. - In: MASCHKE, E./SYDOW, J. (Hrsg.): Die Stadt am Fluß: 14. Arbeitstagung in Kiel 14. - 16.11.1975. - Sigmaringen: Thorbecke 1978 [Stadt in der Geschichte;4]:9-39.

MASCHKE, E./SYDOW, J. (Hrsg.): Die Stadt am Fluß: 14. Arbeitstagung in Kiel 14. - 16.11.1975. - Sigmaringen: Thorbecke, 1978 [Stadt in der Geschichte;4; Arbeitstagung Südwestdeutscher Arbeitskreis für Stadtgeschichtsforschung;14].

MASSEY, D./ALLEN, J./SARRE, P. (Hrsg.): Human Geography Today. - Cambridge: Polity Press 1999.

MASSEY, D. with the collective: Issues and Debates. - In: MASSEY, D./ALLEN, J./SARRE, P. (Hrsg.): Human Geography Today. - Cambrifge: Polity Press 1999:3-21.

MATHES, J./PlAMBECKER, G./SCHAUMBURG, J.: Das Typisierungssystem für stehende Gewässer in Deutschland mit Wasserflächen $\mathrm{ab} 0,5 \mathrm{~km}^{2}$ zur Umsetzung der Wasserrahmenrichtlinie. - In: DENECKE, R./NIXDORF, B. (Hrsg.): Implementierung der EU-Wasserrahmenrichtlinie in Deutschland: Ausgewählte Bewertungsmethoden und Defizite. [Aktuelle Reihe 5/02]:15-24.

MATTHES, M.: Textil-Fachwörterbuch. - 4. Aufl. - Berlin: Schiele \& Schön 1985.

MAURER, M. (Hrsg.): O Britannien, von Deiner Freiheit einen Hut voll. Deutsche Reiseberichte des 18. Jahrhunderts. München: Beck 1992. 
MAYER-FÖLL, R.: Gegenwart und Zukunft des GIS-Einsatzes im Umweltbereich: Dokumentation des Workshops des Bund/Länder-Arbeitskreises Umweltinformationssysteme am 22.03.2001 in Stuttgart. - Hrsg.: Ministerium für Umwelt und Verkehr Baden-Württemberg; Bundesministerium für Umwelt, Naturschutz und Reaktorsicherheit. - Ulm: Univ.-Verl. Ulm 2001

MAYER-TASCH, P. C.(Hrsg.): Kulturlandschaft in Gefahr. - Köln et al.: Heymann 1976.

MAYER-TASCH, P. C./SCHÖNHERR, H.-M. (Hrsg.): Natur denken: Texte zur Entwicklung ökologischen Denkens. - 2 Bde. Bd.1: Von der Antike bis zur Renaissance. - Frankfurt/Main: Fischer-Taschenbuch-Verl. 1991 [FischerTaschenbücher;4195]; Bd. 2: Vom Beginn der Neuzeit bis zur Gegenwart. - Frankfurt/Main: Fischer-Taschenbuch-Verl. 1992 [Fischer-Taschenbücher;4196].

MAYHEW, R. J.: The effacement of early modern geography (1600-1850). A historiographical essay. - In: Progress in Human Geography 25/3 2001:383-401.

MAYR, A./GRUNDMANN, L. (Hrsg.): Edgar Lehmann zum Gedächtnis. Ein Leben für Geographie und Kartographie. - Leipzig: Institut für Länderkunde 2001.

MAYR, M.: Das Fischereibuch Kaiser Maximilians I. - Innsbruck: Wagner 1901.

MECHLER, W.: Die Rheinbrücken Straßburg-Kehl seit 1388. - In: MASCHKE, E./SYDOW, J. (Hrsg.): Die Stadt am Fluß: 14. Arbeitstagung in Kiel 14. - 16.11.1975. - Sigmaringen: Thorbecke 1978 [Stadt in der Geschichte;4]:40-61.

MECKELEIN, U.: Diskussionsbeitrag auf dem Kieler Geographentag. - In: Verhandlungen des Deutschen Geographentages 37 1969:37.

MEGERLE, A.: Landschaftsmarketing als Baustein für einen zukunftsfähigen Albtourismus. - In: Eberhard-Karls-Universität Tübingen - Geographisches Institut, NABU (Hrsg.): Wirtschaftswunder Schwäbische Alb, Naturpotential als Chance für den ländlichen Raum, Tagung am 20.11.1998 in Tübingen. - Tübingen 1999 [NABU Hochschuldialog]:37-53.

MEGERLE, A./SPEIDEL, W.: Geopark Schwäbische Alb: Auf dem Weg zum grössten Geopark Europas?, Kurzfassung für den Tagungsband der Internationalen Tagung „Geotop 2003 - Geotope - wie schützen - Geotope wie nutzen?“ vom 19. - 24. Mai 2003 in Bad Ragaz, Schweiz 2003.

MEHL, D./THIELE, V.: Fliessgewässer- und Talraumtypen des norddeutschen Tieflandes: am Beispiel der jungglazialen Naturräume Mecklenburg-Vorpommerns. - Berlin: Parey1988.

MEHL, H./TILLMANN, D. (Hrsg.): Fischer, Boote, Netze: Geschichte der Fischerei in Schleswig-Holstein. - Heide: Westholsteinische Verl.-Anst. Boyens 1999 [Volkskundliche Sammlungen; Schleswig-Holsteinisches Landesmuseum;4].

MEIER, W.: Die Dinkelsbühler Teichwirtschaft: Eine Bestandsaufnahme. - Erlangen, Univ., Examensarbeit im Fach Volkskunde 1982.

MEILAND 2003 [URL = www.meiland.de/moritzburg/karpfen.htm;7.11.2003].

MEINBREXEN ORTSCHRONIK 2003 [URL = http//:www.meinbrexen.de;12.12.2003].

MEINECKE, F.: Gestaltung und Entwicklungsgeschichte der Landschaft um Nordhausen: - In: Festschrift zur Jahrhundertfeier des Staatl. Realgymnasiums zu Nordhausen. - Nordhausen 1935.

MEINECKE, F.: Zur Morphogenie des Harzes und seines südlichen Vorlandes. Mit 10 Abbildungen. - In: Festschrift zur 39. Hauptversammlung des Deutschen Vereins zur Förderung des mathematischen und naturwissenschaftlichen Unterrichts. Hrsg. v. Dr. Franz Meinecke. - Nordhausen: Verl. Theodor Müller 1937.

MEINECKE, K.-P.: Umweltgeschichte aus ingenieurwissenschaftlicher Perspektive. - In: BAYERL, G./FUCHSLOCH, N./MEYER, T. (Hrsg.): Umweltgeschichte - Methoden, Themen, Potentiale: Tagung des Hamburger Arbeitskreises für Umweltgeschichte, Hamburg 1994. - Münster, New York: Waxmann 1996 [Cottbuser Studien zur Geschichte von Technik, Arbeit und Umwelt;1]:285-302.

MEINERS, U.: „Histourismus“ - Probleme und Chancen des Musealisierungsprozesses. - Hannover 1993 [Mitteilungsblatt Museumsverband Nieders. Bremen;45]:27-34.

MEISE, H.: So backt der Bauer sein Brot. - Bielefeld: Ceres-Verl. Rudolf-August Oetker KG 1959.

MEISSL, G.: Hochquellenleitungen und Unratsschiffe: Zur Geschichte der Wiener Wasserver- und -entsorgung vor 1914. - In: HAHN, S./REITH, R. (Hrsg.): Umwelt-Geschichte. Arbeitsfelder, Forschungsansätze, Perspektiven. - München: Oldenbourg 2001:157-179.

MELL, A.: Abhandlungen zum historischen Atlas der österreichischen Alpenländer. 14: Bemerkungen über die Ausarbeitung einer historischen Fischwasserkarte. - In: Archiv für österreichische Geschichte 111 1930:671-690.

MELLIN, A.: Einführung in die fischereiliche Bewirtschaftung nicht gewerblich genutzter Gewässer. Hrsg.: Landesanstalt für Ökologie, Bodenordnung und Forsten/Landesamt für Agrarordnung Nordrhein-Westfalen. - Münster: Landwirtschaftsverl. [1995].

MENARA, Hanspaul: Bewässerungskanäle in Südtirol. - In: DVWK (Hrsg.): Historische Wasserwirtschaft im Alpenraum und an der Donau. - Stuttgart: Wittwer 1994:139-166. 
MENDE, M.: „Denkmäler von Adel und Kraft“: Wassermühlen und Wasserkraftwerke zwischen Nutzung und Erhalt. - In: Kultur und Technik 4 1989:216-230.

MENDE, M.: Osterode und die Söse: ein Fließgewässer und seine industrielle Nutzung seit dem späten 18. Jahrhundert. - In: LANDSCHAFTSVERBAND RHEINLAND (Hrsg.): Fließgewässer in der Kulturlandschaft. - Köln 1999:43-54.

MENG, A.: Geschichte der Hamburger Wasserversorgung. - Hamburg: Medien-Verl. Schubert 1993.

MERIAN, M. (Hrsg.): Topographia Superioris Saxoniae, Thüringiae, Misniae, Lusatiae etc [...]. - Frankfurt/Main 1650 [Faksimile der Erstausgabe von 1650. - Kassel, Basel: Bärenreiter-Verl. 1964].

MERKEL, A.: Geleitwort. - In: DASCHKEIT, A./SCHRÖDER, W. (Hrsg.): Umweltforschung quergedacht. Perspektiven integrativer Umweltforschung und -lehre. - Berlin et al.: Springer 1998 [Umweltnatur- und Umweltsozialwissenschaften]: VII-VIII.

MEROTH, P.: Ein mächtiger Strom verkommt zum Rinnsal. Der Colorado-River [...]. - In: Süddeutsche Zeitung Nr. 230 v. 6.1.1992.

MERTES, E.: Mühlen in der Eifel: Geschichte - Technik - Untergang. Bd. 1. - 2. Aufl. - Aachen: Helios-Verl. 1995 [1. Aufl. 1994].

MERTENS, S.: Die Landschaftsmalerei im Werk der Brüder Caspar und Georg Schneider. - In: Arkadien am Mittelrhein: Caspar und Georg Schneider; Landesmuseum Mainz, 7. Juni bis 23. August 1998. Hrsg.: Landesmuseum Mainz. - Wiesbaden: Reichert 1998:33-44.

MEßER, J.: Auswirkungen der Urbanisierung auf die Grundwasser-Neubildung im Ruhrgebiet unter besonderer Berücksichtigung der Castroper Hochfläche und des Stadtgebietes Herne. - Bochum: DMT 1997 [DMT-Berichte aus Forschung und Entwicklung;58].

MESSERLI, B.: Über die Bedeutung der Geschichte in der geographische-ökologischen Forschung. - In: Jahrbuch d. Geogr. Gesell. von Bern 55 1983/85:51.

MESSINGER, H.: Langenscheidts Handwörterbuch Englisch. - 23. Aufl. - Berlin et al.: Langenscheidt 1996.

MEURER, P. H.: Corpus der älteren Germania-Karten. Ein annotierter Katalog der gedruckten Gesamtkarten des deutschen Raumes von den Anfängen bis um 1650. - Alphen aan den Rijn: Uitg. Canaletto/Repro-Holland 2001.

MEURER, M.: Geoökologisch-vegetationsgeographische Umweltforschung. Die Pflanzendecke als ökologische Raumfunktionsgröße. - In: Die Erde 126 1995:303-322.

MEURER, Rolf: Wasserbau und Wasserwirtschaft in Deutschland. Vergangenheit und Gegenwart. - Berlin: Parey 2000.

MEYBEYER, W.: Siedlungskundliches über den Papenteich: die Besiedlung des alten Nordwaldes zwischen Gifhorn und Braunschweig während des frühen Mittelalters im Lichte der Ortsnamen. - Gifhorn: Landkreis Gifhorn 1994 [Schriftenreihe des Kreisarchivs Gifhorn;6].

MEYER, F. et al:: Naturschutz und Teichwirtschaft - Bewertungs- und Planungsansätze des Naturschutzgroßprojektes „Teichgebiete Niederspreewald-Hammerstadt“ (Sachsen). - In: Natur und Landschaft 11 (2003).

MEYER, F.: Geschichte und Kritik des Wiesenbaues. - Leipzig, Univ., Diss. 1876.

MEYER, J. F.: Ueber die Anlage der Schwemm-Wiesen im Lüneburgischen und der Wiesenbewässerung überhaupt. [...]. - Celle: Schulze 1800 .

MEYER, Karl: Aus Nordhausens Vorzeit. Die Anfänge Nordhausens. Festschrift zur Tausendfeier der ehemaligen Kaiserlichen Freien Reichsstadt Nordhausen. Nordhausen: Selbstverl. d. Verf. o. J. [um 1900].

MEYER, K.: Die Nordhäuser Stadtflur. - In: Städtisches Archiv Nordhausen/Harz o. O. o. J. [um 1900].

MEYER, K.: Die Wasserversorgung der Stadt Nordhausen seit alter Zeit . - Wernigerode 1901/02 [Zeitschrift d. Harzvereins f. Geschichte u. Altertumskunde;34].

MEYER, K. O. [Hrsg.]/Harms, H. [Text u. Gestaltung]: Oldenburg und das Wasser. Beiträge aus der Geschichte der Kartografie: Sonderausstellung vom 22. März bis 22. April 1990, Museum für Naturkunde und Vorgeschichte, Oldenburg; 12. Mai. bis 1. Juli 1990, Deutsches Schiffahrtsmuseum, Bremerhaven; 8. Juli bis 30. Oktober 1990, Museumsdorf Cloppenburg Niedersächsisches Freilichtmuseum; 10. November 1990 bis 13. Januar 1991, Schiffahrtsmuseum der oldenburgischen Weserhäfen. - Oldenburg: Isensee/Holzberg 1990 [Oldenburger Beiträge zur Landeskunde;1].

MEYER, T.: Standortbestimmung. Zusammenfassung der Schlußdiskussion. - In: BAYERL, G./FUCHSLOCH, N./MEYER, T. (Hrsg.): Umweltgeschichte - Methoden, Themen, Potentiale: Tagung des Hamburger Arbeitskreises für Umweltgeschichte, Hamburg 1994. - Münster, New York: Waxmann 1996 [Cottbuser Studien zur Geschichte von Technik, Arbeit und Umwelt;1]:325-328.

MEYER, W.: Burg und Herrschaft zwischen Alpen und Rhein im 12./13. Jahrhundert. - In: Zeitschrift für Archäologie 24 1990:161ff.

MEYERS ENZYKLOPÄDISCHES LEXIKON. - 9. Aufl. - Mannheim: Meyers Lexikonverl. 1979.

MEYERS GROßES KONVERSATIONSLEXIKON. 20 Bde. - 6. Aufl. - Leipzig: Meyers Lexikonverl. 1908. 
MEYERS KLEINES LEXIKON TIERE. - Mannheim et al.: Meyers Lexikonverl. 1988 [Meyers kleine Lexika].

MEYNEN, H.: Angewandte Historische Geographie in der Stadt. Kulturlandschaftsforschung am Beispiel Köln. - In: KLEEFELD, K.-D./BURGGRAAFF, P. (Hrsg.): Perspektiven der Historischen Geographie: Siedlung - Kulturlandschaft Umwelt in Mitteleuropa. - Bonn: Selbstverl. 1997:277-283.

MICHALÉK, J.: Goldwaschplätze, Grubenwerke und Goldaufbereitungsanlagen Südböhmens und Probleme des Denkmalschutzes. - In: AURIG, R. (Hrsg.): Kulturlandschaft [...] 1999:66-73.

MIGGELBRINK, J.: Der gezähmte Blick: zum Wandel des Diskurses über „Raum“ und „Region“ in humangeographischen Forschungsansätzen des ausgehenden 20. Jahrhunderts. - Leipzig : Inst. für Länderkunde 2002 [Beiträge zur Regionalen Geographie;55]; Zugl.: Leipzig, Univ., Diss. 2001.

MINKENBERG, M.: Der Aachener Reichsstrom: Wasserrecht und Wassernutzung in den Beziehungen zwischen der Reichsstadt und dem Marienstift im Hoch- und Spätmittelalter. - Frankfurt/Main et al.: Lang 1999 [Europäische Hochschulschriften, Reihe III;854].

MIOSGA, O.: Die Entfernung von Wehranlagen zur Schaffung der ökologischen Durchgängigkeit in Fliessgewässern: Biotopwertverfahren. - In: Wasserwirtschaft 92/3 2002:42-49.

MISSUNDE 2004 [URL = http://www.missunde.hhm.de/om.htm; 11.02.2004]

MITCHELL, A./WILKENSON, J.: Pareys Buch der Bäume: Nadel- und Laubbäume in Europa nördlich des Mittelmeeres. - 2. Aufl. - Hamburg, Berlin: Parey 1987.

MITCHELL, D.: Cultural geography: a critical introduction. - Oxford: Blackwell 2000.

MITCHELL, J. B.: Historical Geography. - London: Engl. Univ. Press 1954.

MIZGAJSKI, A.: Anthropogener Energieeinsatz und sein Einfluß auf die Agrarlandschaftsentwicklung seit dem 19. Jahrhundert im Altkreis Lingen/Ems. - In: Hundert Jahre Geographie an der Westfälischen Wilhelms-Universität Münster (1885-1985). Münster 1987 [Münstersche Geographische Arbeiten;26].

MOECK-SCHLÖMER, C.: Wasser für Hamburg. - Hamburg: Verein für Hamburgische Geschichte 2000.

MOES, J.-F.: Berneuchen - Barnówko. - In: Deutsches Adelsblatt. Mitteilungsblatt der Vereinigung der Deutschen Adelsverbände 24/1 1985:9f.

MOHILlA, P./MICHLMAYR, F.: Donauatlas Wien: Geschichte der Donauregulierung auf Karten und Plänen aus vier Jahrhunderten. - Hrsg.: Magistrat der Stadt Wien, MA 45, Wasserbau. - Wien: Österreichischer Kunst- und Kulturverl. 1996.

MOHR, F./STENTZEL, G.: Landkarten - Zeitbilder. Rostock und Umgebung im Wandel der Zeit. Anmerkungen zu Karten aus fünf Jahrhunderten. - Bremen: Edition Temmen 2001.

MÖLLER, J. H.: Urkundliche Geschichte des Klosters Reinhardsbrunn: Reinhardsbrunn als Amt und Lustschloß. - Gotha: Müller 1843.

MONHEIM, Felix: Die Bewässerungswiesen des Siegerlandes: Eine pflanzensoziologische und wirtschaftsgeographische Untersuchung. - Leipzig: Hirzel 1943 [Forschungen zur deutschen Landeskunde; 42].

MONTANARI, M.: Der Hunger und der Überfluß: Kulturgeschichte der Ernährung in Europa. - 2. Aufl. - München: Beck 1995.

MOOSER, J.: Ländliche Klassengesellschaft 1770-1848: Bauern und Unterschichten, Landwirtschaft und Gewerbe im östlichen Westfalen. - Göttingen: Vandenhoeck und Ruprecht 1984 [Kritische Studien z. Geschichtswissenschaft;64]; Zugl. Bielefeld, Univ., Diss.

MÖRSTEDT, Christoph: Mühlen im Kreis Herford: historisches Kataster. - Bielefeld: Verl. für Regionalgeschichte 1995 [Herforder Forschungen;13].

MORTENSEN, H.: Die „quasinatürliche“ Oberflächenformung als Forschungsproblem. - In: Wiss. Zeitschrift d. Ernst-MoritzArndt-Universität. - Halle/Saale 1954/55.

MORTENSEN, H.: Probleme der mittelalterlichen deutschen Kulturlandschaft. - Flensburg: Dt. Akad. f. Landeskunde 1958 [Berichte zur dt. Landeskunde;20/1].

MOSSERMANN, K.: Die Schwetzinger Mühlen nebst einer Genealogie der Familien der Müller. - Schwetzingen: Bürgermeisteramt 1971 [Schriften des Stadtarchivs Schwetzingen;5].

MOST, O.: Binnenschiffahrt und Kanalbau im 19. Jahrhundert. - In: Historische Raumforschung, Bd. 6, Teil 2: Raumordnung im 19. Jahrhundert. - Hannover 1967 [Forschungsberichte des Ausschusses „Historische Raumforschung“ der Akademie für Raumforschung und Landesplanung;18]:35-47.

MOZDZIOCH, S.: Usus Aquarium: der Fluß im frühmittelalterlichen Alltag Schlesiens. - In: Zivot v archeologii stredoveku. - Das Leben in der Archäologie des Mittelalters. - 1997:467-481.

MÜCK, W.: Überlegungen zum Beginn der Teichwirtschaft im Aischgrund. - In: Jahrbuch des historischen Vereins für Mittelfranken 95 1990/91):13-18. 
MÜCKE, H.: Historische Geographie als lebensweltliche Umweltanalyse: Studien zum Grenzbereich zwischen Geographie und Geschichtswissenschaften. - Frankfurt/Main et al.: Lang 1988 [Europäische Hochschulschriften: Reihe 3, Geschichte und ihre Hilfswissenschaften;369]; Zugl.: Bonn, Univ., Diss. 1988.

MÜHLEN, F.: Wasserstraßen in Westfalen. - Münster: Westfälischer Heimatbund 1980 [Technische Kulturdenkmale in Westfalen;2].

MÜHLEN, Hammerwerke und Kupferhöfe im Tal der Vicht und ihre Besitzer. - Stolberg 1998 [Beiträge zur Stolberger Geschichte;23].

MÜHLENBERG, M./SLOWIK, J.: Kulturlandschaft als Lebensraum. - Wiesbaden: Quelle und Meyer 1997 [UTB f. Wissenschaft;1947].

MÜHLHÖLZL, W.: Bayerische Landesanstalt für Wasserforschung München: 80 Jahre Versuchsanlage in Wielenbach. - In: Fischer und Teichwirt, Sonderdruck 43, 12 1992:408-415.

MÜLlER, A. v./LUDWIG, K.-H.: Die Technik des Mittelalters. - In: TROIZTSCH, U./WEBER, W. (Hrsg.): Die Technik - Von den Anfängen bis zur Gegenwart. - Braunschweig: Westermann 1982:120-147.

MÜLLER, B. G.: Stimme Seiner Kranken am Siechen-Teich: Joh. V, v. 2. 3. in unsern und vorigen Tagen. - Erschienen: [S.1.], 1760.

MÜLLER, C.: Teichwirtschaft in Mittelfranken im Wandel der letzten zwei Jahrzehnte: dargestellt an Beispielen aus dem Aischgrund. - Nürnberg, Univ., Examensarbeit 1992.

MÜLLER, C. P.: Wandel der Zeit, in Stein gehauen: Im alten Zisterzienserkloster Haydau in Nordhessen [...] - In: Frankfurter Allgemeine Zeitung Nr. 209 v. 8. September 2001:13

MÜLlER, D.: Der Rossweiherast des Maulbronner Kanalsystems. - In: Maulbronn: Zum 850jährigen Geschichte des Zisterzienserklosters. Hrsg. v. Landesdenkmalamt Baden-Württemberg - Stuttgart: Theiss 1997[Forschungen und Berichte zu Bau- und Kunstdenkmalpflege;7]:575

MÜLLER, E.: Untersuchungen über Entwicklung, Umfang und Wirtschaftlichkeit der kulturtechnischen Arbeiten in den Kreisen Marienberg, Westerburg und Dillenburg. . - Bückeburg: Prinz 1934; Zugl.: Gießen, Univ., Diss. 1934.

MÜLLER, E.: Die Mühlen im Landkreis Heiligenstadt. - Heiligenstadt: Verl. Condor 1992.

MÜLLER, F. C.: Erfassung und Kartierung archäologischer Denkmale und Funde in der Gemarkung Heinsen. - In: Jahrbuch des Landkreis Holzminden 8/9 1990/91:3-7.

MÜLLER, G. /MATSCHULLAT, J. (Hrsg.): Geowissenschaftliche Umweltforschung: Tagung am 5. und 6. November 1993 in Heidelberg. - Heidelberg: Ruprecht-Karls-Univ. 1993 [Heidelberger geowissenschaftl. Abhandlungen;67].

MÜLLER, K.: Über Wiesenbewässerung. - In: Landwirthschaftl. Wochenblatt für das Großherzogtum Baden 5 1837:236-238.

MÜLLER, K.: Die Einflüsse der Flößerei auf die Fischerei in Schwedisch-Lappland. - In: Verh. intenat. Verein f. theor. angewandte Limnologie 13 1958:533-544.

MÜLLER, L.: Kleingewässer. - In: SPARKASSE GIFHORN-WOLFSBURG (Hrsg.): Reizvolle Fluß- und Seenlandschaften im Raum Gifhorn-Wolfsburg. - Peine: Schlaeer 1988 [Schriftenreihe zur Heimatkunde der Sparkasse Gifhorn-Wolfsburg;4]:1719.

MÜLLER, R. H. W. (Hrsg.): Amtsbuch der Reichsstadt Nordhausen 1312-1345. - Nordhausen: Rat der Stadt 1956 [Schriftenreihe heimatgeschichtlicher Forschungen des Stadtarchivs Nordhausen/Harz;3].

MÜLLER, T.: Schiffahrt und Flößerei auf der Schunter im 18. Jahrhundert. - In: Forschungen zur braunschweigischen Geschichte und Sprachkunde 15 1954:135-159.

MÜLLER, T.: Schiffahrt und Flößerei auf der Oker. - Braunschweig: Waisenhaus-Buchdruck 1968 [Braunschweiger Werkstücke, Veröff. a. d. Stadtarchiv und der Stadtbibliothek, Reihe A 2;39].

MÜLLER-HEYNE, C.: Staatlich gelenkte Maßnahmen zur Erschließung und Entwicklung der ländlichen Kulturlandschaft. Stuttgart: Steiner 1993 [Mitt. d. Geogr. Gesell. Hamburg;83].

MÜLLER-HOHENSTEIN, K.: Umweltforschung ohne Geographie? Historische und aktuelle Ansätze ganzheitlich vernetzten Arbeitens in der Physischen Geographie. In: Die Erde 126 1995:271-285.

MÜLLEROTT, H.: Quellen zum Waidanbau in Thüringen: mit einem Exkurs in die anderen Waidanbaugebiete Europas und Vorderasiens; Industriearchäologie, historische Geographie, Flurnamenkunde, alte Geschichte, Siedlungs- und Territorialgeschichte, Archäobotanik, Botanik. - 2. Aufl. - Arnstadt: Thüringer Chronik-Verl. 1989.

MÜLLER-SCHEESEL, K.: Jürgen Christian Findorff und die kurhannoversche Moorkolonisation im 18. Jh. - Hildesheim: Lax 1975 [Veröff. d. Inst. f. Hist. Landesf. d. Univ. Gött.;7].

MUMMENHOFF, E.: Die Pillenreuther Weiher und die Dutzendteiche. - Nürnberg: Schrag 1911/13 [Mitteilungen des Vereins f. Geschichte der Stadt Nürnberg].

MUMMENHOFF. K. E.: Wasserburgen in Westfalen. - 4. Aufl. - München; Berlin: Deutscher Kunstverl. 1977. 
MÜNCH, P.: Lebensformen in der frühen Neuzeit 1500 bis 1800. - München: Ullstein 1996.

MÜRB, R.: Landschaftsplanerische Aspekte beim Ausbau von Fließgewässern. - In: BÖHM, H. R./DENECKE, M. (Hrsg.): Wasser: eine Einführung in die Umweltwissenschaften. - Darmstadt: Wiss. Buchges. 1992:119-136.

MURKEN, A. H.: Die lange Tradition der Badekulturen. Zur Geschichte der Mineral- und Thermalbäder. - In: Wasserquellen. Mineralquellen und Heilbäder im Rheinland $<<$. Eine Ausstellung des Landschaftsverbandes Rheinland, Rheinisches Museumsamt, Abtei Brauweiler. - Köln: Rheinland-Verl. 1991 [Schriften des Rheinischen Museumsamtes;48]:10-35.

MURKEN, G.: Das Osteroder Mühlgraben-Verbundsystem, die davon berührten Betriebsstätten und seine Umgebung. In: Südniedersachsen.. Zs f. regionale Forschung und Heimatpflege 28/ 1 1997:23.

MURL [Ministerium für Umwelt, Raumordnung und Landwirtschaft NRW]: Gewässerauenprogramm. - Düsseldorf: MURL 1990.

MURL [Ministerium für Umwelt, Raumordnung und Landwirtschaft NRW]: „Zielvorgaben und Handlungsanweisungen für die Renaturierung von Tieflandbächen in Nordrhein-Westfalen” (3 Bände). Bd. 1: „Die Leitbilder für Tieflandbäche in NRW, mit Zielvorgaben und Handlungsanweisungen“; Bd. 2: „Beschreibung von zwölf ausgewählten Modellen naturnaher Tieflandbäche in NRW“; Bd. 3: „Voruntersuchung: Kataster der Probestellen an Tieflandbächen in NRW“

MURL [Ministerium für Umwelt, Raumordnung und Landwirtschaft] (Hrsg.): Landesplanerisch gesicherte Gebiete für den Schutz der Natur, Bd. 3 - Regierungsbezirk Düsseldorf. Fachliche Bearbeitung: Landesanstalt für Ökologie, Bodenordnung und Forsten/Landesamt für Agrarordnung Nordrhein-Westfalen (LÖBF/LAfAO). - Düsseldorf, Oktober 1998.

MUSALL, H.: Die Entwicklung der Kulturlandschaft der Rheinniederung zwischen Karlsruhe und Speyer vom Ende des 16. bis zum Ende des 19. Jahrhunderts. - Heidelberg: Geographisches Institut d. Univ. 1969 [Heidelberger Geographische Arbeiten;22].

MYLLYNTAUS, T./SAIKKU, M. (Hrsg.): Encountering the past in nature: Essays in environmental history. - 2. Aufl. Athens/Ohio: Ohio University Press 2001 [Ohio University Press Series in Ecology and History].

NAEF, A.: Bewässerung von hochalpinen Trockengebieten im Wallis. - In: DVWK (Hrsg.): Historische Wasserwirtschaft im Alpenraum und an der Donau. Bearbeitet v. Werner Konold. - Stuttgart: Wittwer 1994:23-27.

NAGEL, F. N.: Konzept zur Erfassung von erhaltenswerten kulturgeographischen Elementen in ländlichen Siedlungen. - In: Berichte zur deutschen Landeskunde 53 1979:81-93.

NAGEL, F. N.: Verkehrsweg-Wüstungen in der Kulturlandschaft. Ein methodischer Beitrag zur Wüstungsforschung und zur Industriearchäologie, aufgezeigt an historischen Land- und Wasserwegen in Schleswig-Holstein. - In: Siedlungsforschung 4 1986:145-170.

NAGEL, F. N.t: Kulturlandschaftsforschung und Industriearchäologie: Inhalte, Methodik, Anwendung. - In: BUDESHEIM, W./NAGEL, F. N./PRIES, M. (Hrsg.): Zur Kulturgeschichte und Industriearchäologie in Norddeutschland. Versorgung, Verteidigung, Verkehr. - Wentorf bei Hamburg 1999 [Beiträge für Wissenschaft und Kultur;4]:9-25.

NAGEL, F. N./GOLDAMMER, G.: Wasserwege als Gegenstand der Kulturlandschaftspflege. - In: DENECKE, D./FEHN, K./SCHENK, W. (Hrsg.): Kulturlandschaftspflege. Beiträge der Geographie zur räumlichen Planung. - Stuttgart: Steiner 1997:275-285.

NAGEL, F. N./SCHENK, W.: Kulturlandschaftsforschung und Industriearchäologie - eine Standortbestimmung. - In: NAGEL, F. N. (Hrsg.): Kulturlandschaftsforschung und Industriearchäologie: Ergebnisse der Fachsitzung des 52. Deutschen Geographentags Hamburg. - Stuttgart: Steiner 2001 [Mitteilungen der Geographischen Gesellschaft in Hamburg;91]:1-20.

NAGEL, K.: Die Weiher des 'Pays des étangs' im nordöstlichen Lothringen: Geschichte ihrer Entstehung und wirtschaftlichen Nutzung. - Saarbrücken, Univ., Diss. 1981; [Erschienen 1982].

NASH, C./GRAHAM, B.: The making of modern historical geographies. - In: GRAHAM, B./NASH, C. (Hrsg.): Modern Historical Geographies. - Harlow: Longman 2000:1-9.

NATERMANN, E.: Die wasserwirtschaftlichen Anlagen des Oberharzer Bergbaues und ihre wasserwirtschaftlichen Grundlagen. München: Pflaum 1922 [Auszug aus der Dissertation]; Zugl.: Berlin, Techn. Hochsch., Diss. 1922.

NATTERMANN, A.: Geschichte der Werrraflößerei. - Wernshausen o. J. (ca. 1935).

NATUR 2000 in Nordrhein-Westfalen: Leitlinien und Leitbilder für Natur und Landschaft im Jahr 2000. - Düsseldorf 1990.

NATURNAHE GEWÄSSER-ENTWICKLUNG am Beispiel der Nidda und ihrer Zuflüsse: Perspektiven einer Gestaltung der Gewässer und ihrer Auen nach gesamträumlichen Zielsetzungen: Seminar am 21. Mai 1996 in Nidda (unter der Leitung v. Gottfried Heintze). - Bad Karlshafen: Hess. Akad. d. Forschung u. Planung 1996 [Schriften d. Hess. Akad. d. Forsch. u. Planung i. ländlichen Raum;15].

NATURPARK HOHER FLÄMING 2003 [URL = http://www.np-hoher-flaeming.de;12.10.2003].

NATURPARK SPESSART 2004 [http://www.naturpark-spessart.de/Informationen/Allgemeines/Gewasser/gewasser.html; 12.02.2004].

NEBELING, A.: Es klapperten die Mühlen ...: Auf Spurensuche in Mainz. - In: Mainz. Vierteljahresschrift für Kultur, Politik Wirtschaft, Geschichte 15/1 1995:134ff. 
NEBELUNG, W.: Die Kautabakindustrie der Stadt Nordhausen: Entwicklung und Bedeutung ihrer wirtschaftlichen und sozialen Verhältnisse. - Nordhausen: Th. Müller 1929; Zugl.: Jena, Univ., Diss. 1929.

NEEF, E.: Kulturlandschaftsforschung - ein Hauptanliegen der Umweltproblematik. - In: Beiträge zur Hochgebirgsforschung und zur Allgemeinen Geographie (Festschrift U. Uhlig Bd. 2). - Wiesbaden: Steiner 1982 [Geographische Zeitschrift, Beiheft 59]:212-221.

NEEF, E.: Der Verlust der Anschaulichkeit in der Geographie und das Problem der Kulturlandschaft. - Berlin: Akad.-Verl. 1981 [Sitzungeberichte der Sächsischen Akademie der Wissenschaften zu Leipzig, Mathematisch-Naturwiss. Klasse;155,6].

NET-LEXIKON [aus: http://www.net-lexikon.de/Oliver-Evans.html;07.02.2004].

NETZWERK INDUSTRIEKULTUR BERGISCHES LAND e.V. (Hrsg): Mit Feuer und Wasser: Stationen der Industriekultur zwischen Wupper und Sieg. - Essen: Klartext-Verl. 2000.

NEUBAUR, F.: Die Vogelwelt der Fischteiche bei Peitz (Niederlausitz). - In: Deutsche Vogelwelt 65 1940:145-155.

NEUBER, D.: Die bittere Seite des Zuckers: Zuckerfabrikabwässer Ende des 19. Jahrhunderts. - In: Niedersachsen 96 (1996):195ff.

NEUBER, D.: Das Beispiel Schaumburg im Rahmen einer energie- und umweltgeschichtlichen Untersuchung des Niedersächsischen Steinkohlebergbaus. - In: HAUPTMEYER, Carl-Hans (Hrsg.): Mensch-Natur-Technik: Aspekte der Umweltgeschichte in Niedersachsen. - Bielefeld: Verl. f. Regionalgeschichte 2000 [Materialien für Regionalgeschichte; 2]: $31-51 ; 61-78$

NEUBER, D.: Energie- und Umweltgeschichte des Niedersächsischen Steinkohlenbergbaus: von der frühen Neuzeit bis zum Ersten Weltkrieg. - Hannover: Hahn 2002 [Veröffentlichungen der Historischen Kommission für Niedersachsen und Bremen; 206]; Zugl.: Hannover, Univ., Diss. 2000 u.d.T.: „Was wolt geschehen, wenn Gott nicht die Steinkohlen geoffenbaret hette?".

NEUBER, D./HAUPTMEYER, C.-H./GROHMANN, O.: Stand und Aufgaben der umweltgeschichtlichen Forschung, insbesondere in Niedersachsen. - In: HAUPTMEYER, C.-H. (Hrsg.): Mensch - Natur - Technik: Aspekte der Umweltgeschichte in Niedersachsen und angrenzende Gebieten. - Bielefeld: Verl. f. Regionalgeschichte 2000 [Materialien zur Regionalgeschichte;2]:9-16.

NEUBERT, M.: Aralsee: "Die größte menschengemachte Umweltkatastrophe dieses Jahrhunderts". Im Todeshauch des verlorenen Meeres. - In: Süddeutsche Zeitung Nr. 215 1995:3.

NEUBURGER, A.: Die Technik des Altertums. - Leipzig: Voigtländer 1919 [Reprint der Orig.ausgabe 1991, 1995].

NEUE WESTFÄLISCHE: „Transporte über Land und Fluss“; Nr. 293 v. 16.12.2000.

NEUER, Birgit S.: Mit GIS gegen das Vergessen? Spuren in der Landschaft - zu einer Inventarisierung mit GIS-Anwendung: ein Fallbeispiel aus dem Mittleren Schwarzwald. - In: Kulturlandschaft 8/1 1998:32-36.

NEUMANN, K.: Natur als Landschaft - zu Geschichte und Zukunft des Schönen in der Natur. - In: HERRMANN, B./BUDDE, A. (Hrsg.): Natur und Geschichte. Naturwissenschaftliche und historische Beiträge zu einer ökologischen Grundbildung. Sommerschule „Natur und Geschichte“ vom 14. bis 27. September 1989 an der Georg-August-Universität Göttingen. Hildesheim: Gerstenberg 1989 [Schriftenreihe „Expert“ des Nieders. Umweltministers Hannover]:64-68.

NEUMEYER, M.: Heimat: zu Geschichte und Begriff eines Phänomens. - Kiel: Geographisches Inst. d. Univ. 1992 [Kieler Geographische Schriften;84]; Zugl.: Kiel, Univ., Diss 1991 u. d. T.: „Zwischen Idylle und Lebenswelt“.

NEUNLINGER, I.: Die künstliche Bewässerung im Oberen Inntal. - Innsbruck, Univ., Diss. 1945.

NEUSCHULZ, F./PLINZ, W./WILKENS, H.: Elbtalaue: Landschaft am großen Strom. - Gräfelfing: Naturerbe Verl. Jürgen Resch 2002.

NEWEKLOSWKY, E.: Die Schiffahrt auf der oberen Donau und ihren Nebenflüssen. - München: Oldenbourg; Düsseldorf: VDIVerl. 1958 [Abhandlungen und Berichte/Deutsches Museum;26,3].

NICOLAUS, U.: Von der Querne zum Industriebetrieb: Geschichte der Hamelner Mühlen: - In: Jahrbuch des Museumsvereins Hameln 1978/79:23-35.

NIEDERSÄCHSISCHES INNENMINISTERIUM (Hrsg.): Integration ökologischer Sachverhalte im niedersächsischen Raumordnungsprogramm: Gutachten im Auftrag des Niedersächsischen Innenministeriums erstellt von der ARSUArbeitsgruppe für regionale Struktur- und Umweltforschung GmbH. - Hannover: Niedersächsisches Innenminsterium 1989 [Schriften der Landesplanung Niedersachsen].

NIEHOFF, N.: Entwicklung eines Verfahrens zur ökologischen Bewertung von Fließgewässerlandschaften Grundlage für Renaturierungs- und Sanierungsmaßnahmen, am Beispiel der Oker (Niedersachsen). - Göttingen, Univ., Diss. 1995.

NIEHOFF, N.: Ökologische Bewertung von Fließgewässerlandschaften. Grundlage für Renaturierung und Sanierung. - Berlin et al.: Springer 1996.

NIEHOFF, N./PÖRTGE, K.-H.: Umwelteinflüsse des Harzer Bergbaus im Spiegel eines Auelehmprofils der Oker. - In: Geowissenschaftliche Umweltforschung. Hrsg.: MÜLLER, G./MATSCHULLAT, J. - Heidelberg: Ruprecht-KarlsUniversität 1993 [Heidelberger geowissenschaftliche Abhandlungen;67]:114-115. 
NIEMEIER, G.: Siedlungsgeographie. - 4. Aufl. - Braunschweig: Westermann 1977 [Das Geographische Seminar].

NIEMEYER-LÜLLWITZ, A./ZUCCHI, H.: Fließgewässerkunde: Ökologie fließender Gewässer unter besonderer Berücksichtigung wasserbaulicher Eingriffe. - 1. Aufl. - Frankfurt/Main et al.: Diesterweg; Sauerländer 1985 [Studienbücher Biologie].

NIETZEL, H.-H.: Die alte Oberharzer Wasserwirtschaft [mit einem Vorwort von Carl Heinz Kurz]. - Herzberg, Pöhlde: Zander 1983.

NIQUET, F.: Die Rössener Kultur in Mitteldeutschland. - In: Jahresschrift für die Vorgeschichte der Sächsisch-Thüringischen Länder;26].

NITZ, H.-J. (Hrsg.): Historisch-genetische Siedlungsforschung: Genese und Typen ländlicher Siedlungen und Flurformen. Darmstadt: Wiss. Buchgesell. 1974 [Wege der Forschung;300].

NITZ, H.-J.: Moorkolonien. Zum Landesausbau im 18. / 19. Jh. westlich der Weser. - Münster: Geograph. Kommission f. Westfalen 1976 [Westf. Geogr. Studien;33, Festschrift f. Wilhelm Müller-Wille]:159-180.

NITZ, H.-J.: Die mittelalterliche und frühneuzeitliche Besiedlung von Marsch und Moor zwischen Ems und Weser. Siedlungsforschung 2 1984:43-76.

NITZ, H.-J.: Hochmittelalterliche Moorsiedlung in Deutschland: Möglichkeiten und Schwierigkeiten bei der Kultivierung wasserreicher Naturlandschaften. - In: SPINDLER, K. (Hrsg.): Mensch und Natur im mittelalterlichen Europa. - Klagenfurt 1988 [Schriftenreihe der Akademie Friesach;4].

NITZ, H.-J.: Strukturen der historischen Kulturlandschaft in ökologischer Perspektive. - In: HERRMANN, B./BUDDE, A. (Hrsg.): Natur und Geschichte. Naturwissenschaftliche und historische Beiträge zu einer ökologischen Grundbildung. Sommerschule „Natur und Geschichte“ vom 14. bis 27. September 1989 an der Georg-August-Universität Göttingen. Hildesheim: Gerstenberg 1989 [Schriftenreihe „Expert“ des Nieders. Umweltministers Hannover]:189-198.

NITZ, H.-J.: Historische Geographie. [Deutsche Fassung des englischsprachigen Beitrags „Historical Geography“. - In: 40 Years After: German Geography Developments, Trends and Prospects 1952-1992. A Report to the International Geographical Union. Ed. by Eckart Ehlers. Institute for Scientific Cooperation, Tübingen 1992:145-172]. - In: Siedlungsforschung 10 1992:211-237.

NITZ, H.-J. (Hrsg.): The Early Modern World-System in Geographical Perspektive. - Stuttgart 1993 [Erkundl. Wissen;110].

NITZ, H.-J.: Frühneuzeitliche Wiederbesiedlung von Wüstungen im niedersächsischen Grenzraum (1984). - In: NITZ, H.-J.: Historische Kolonisation und Plansiedlung in Deutschland. Ausgewählte Arbeiten Band I. - Berlin: Reimer 1994 [Kleine geographische Schriften;8]:293-316.

NITZ, H.-J.: Historische Kolonisation und Plansiedlung in Deutschland. Ausgewählte Arbeiten Band I. - Berlin: Reimer 1994 [Kleine geographische Schriften;8].

NITZ, H.-J.: Allgemeine und vergleichende Siedlungsgeographie. Ausgewählte Arbeiten Band II. - Berlin: Dietrich Reimer Verl. 1998 [Kleine geographische Schriften;8].

NITZ, H.-J.: Moorkolonien. Zum Landesausbau im 18./19. Jahrhundert westlich der Weser (1976). - In: NITZ, H.-J.: Historische Kolonisation und Plansiedlung in Deutschland. Ausgewählte Arbeiten Band I. - Berlin: Reimer 1994 [Kleine geographische Schriften;8]:337-358.

NITZ, H.-J.[a]: Historische Geographie 1952-1992: Entwicklungen, Trends und Perspektiven. - In: NITZ, H.-J.: Allgemeine und vergleichende Siedlungsgeographie. Ausgewählte Arbeiten Band II. - Berlin: Reimer 1998 [Kleine Geogr. Schriften;9]:121146.

NITZ, H.-J.[b]: Historische Strukturen im Industriezeitalter - Beobachtungen, Fragen und Überlegungen zu einem aktuellen Thema. - In: NITZ, H.-J.: Allgemeine und vergleichende Siedlungsgeographie. Ausgewählte Arbeiten Band II. - Berlin: Reimer 1998 [Kleine geographische Schriften;9]:398-421.

NIXDORF, B. et al.: Dokumentation von Zustand und Entwicklung der wichtigsten Seen Deutschlands. - Abschlussbericht F \& E Vorhaben FKZ 29924274 [Umweltforschungsplan des Bundesministeriums für Umwelt, Naturschutz und Reaktorsicherheit; im Auftrag des Umweltbundesamtes]. - Cottbus: Brandenburgische Technische Universität Cottbus, Lehrstuhl Gewässerschutz 2003.

NLÖ [Niedersächsisches Landesamt für Ökologie]: Das Niedersächsische Fliessgewässerprogramm: Ziele, Inhalt, Umsetzung. Merkblatt 1995.

NOEL 2003 [URL = www.noel.gv.at/service/ru/ru2/download/anhang2_2.pdf;07.11.2003].

NÖLLE-FISCHER, K.: Die Elbe: ein literarischer Reisebegleiter von der Mündung bis zum Riesengebirge. - Stuttgart: Klett-Cotta 1999.

NORDHAUSEN in urkundlicher Darstellung. Festschrift Hermann Heineck. - Nordhausen, 1902.

NORDMEYER, H./PICARD, T. (Hrsg.): Fotos - Quellen zur Stadtgeschichte: die Arbeit der Bilddokumentation im Institut für Stadtgeschichte. - Frankfurt/Main: Institut für Stadtgeschichte 1998. 
NÖRPEL, M./LESSER, H.: Renaturierung von Fließgewässern, geht das überhaupt?: Empfehlungen zum ökologisch orientierten Rückbau der Fließgewässer. - Freiburg/Breisgau: Arbeitskreis Wasser im BBU [Bundesverband Bürgerinitiativen Umweltschutz e. V.] 1995.

NORTON, W.: Historical Analysis in Geography. - London et al: Longman 1984.

NORTON, W.: Cultural geography: themes, concepts, analysis. - Oxford: Oxford Univ. Press 2000.

NORZEL, W./WEßLING, Hartmut: Ostfriesisches Mühlenbuch. - Hannover: Schlüter 1991.

NOWAKOWA, L.: Heimatkundliche Beiträge für den Landkreis Weißwasser. - Bautzen: Lausitzer Druck und Verlagshaus 1993 [O/L;9].

NRW-Stiftung: Naturschutz, Heimat- und Kulturpflege 2001.

NUA 2001 [URL = www.nua.nrw.de/kamagne/kamp02a;23.08.2001].

NUA-Heft: Die Ems - ein Modell für die Zusammenarbeit im europäischen Naturschutz!? Nr. 132003.

NUANCEN. Forum der Natur- und Umweltschutz-Akademie NRW 5/2 2002.

NUA-Seminarberichte: Gewässer ohne Wasser? Ökologie, Management und Schutz temporärer Gewässer. - NUA-Seminarbericht Band 5. - 1. Aufl. - 2000.

NÜSSLEIN, F.: Jagdkunde: ein Lehrbuch zur Einführung in das Waidwerk mit einem Abriß über Umwelt- und Naturschutz, Landschaftsschutz und Landschaftspflege und über Fischerei. - 9. Aufl. - München et al.: BLV Verl.-Ges. 1977 [BLVJagdbuch].

O'RIORDAN, T.: Einführung: Umweltwissenschaften in der Weiterentwicklung. - In: O'RIORDAN, T. (Hrsg.): Umweltwissenschaften und Umweltmanagement. Übersetzung von Armin Stasch. - Berlin et al.: Springer 1996 [Titel d. engl. Orig.ausgabe: Einvironmental Science for Environmental Management. - Longman 1994]:1-20.

OBERBECK, G.: Die mittelalterliche Kulturlandschaft des Gebietes um Gifhorn. - Bremen-Horn: Dorn 1957 [Veröffentlichungen des Niedersächsischen Amtes für Landesplanung und Statistik: Forschungen zur Landes- und Volkskunde: Natur, Wirtschaft, Siedlung und Planung; N. F.;66].

OBERWEIS, M.: Seit 175 Jahren Einsatz von Turbinen in der Wasserkraftnutzung. [URL = http://www.aliai.lu/aliai/rt/ rt19993a/rt19993a.htm;07.02.2004].

OEHME; U.: Wasserspiele: von den Nutzbarkeiten der Leipziger Gewässer. Ausstellung vom 30. Juni bis 4. September 1994, Stadtgeschichtliches Museum Leipzig. - Leipzig: Stadtgeschichtliches Museum 1994.

OELZE, H.: Das Wirtschaftsleben der Stadt Nordhausen am Harz in den letzten zwei Jahrhunderten ihrer Reichsunmittelbarkeit (17. und 18. Jahrhundert). Ein Beitrag zur Wirtschaftsgeschichte. Anhang: Die Berufsvererbung in Nordhausen im 17. und 18. Jahrhundert. - Nordhausen: Trosse 1933; Zugl.: Leipzig, Univ., Phil. Diss. 1933.

OHLER, N.: Reisen im Mittelalter. - 2. Aufl. - München et al.: Artemis \& Winkler Verl. 1988.

OHLSHAUSEN, E.: Bericht über das 3. Historisch-geographische Kolloqium in Stuttgart. - In: Die Alte Stadt 14/ 3 1987:314-315.

OLDEKOP, H.: Topographie von Bergstedt und Umgebung. - In: OLDEKOP, H.: Topographie des Herzogtums Holstein. - 2. Band - Kiel: Verl. Walter G. Mühlau 1908.

OLMER, B.: Wasser. Historisch: zu Bedeutung und Belastung des Umweltmediums im Ruhrgebiet 1870 - 1930. - Frankfurt/Main et al.: Lang 1998 [Europäische Hochschulschriften: Reihe 3, Geschichte und ihre Hilfswissenschaften;795]; Zugl.: Essen, Univ., Diss. 1997.

ÖLMÜHLE DÖRNTHAL 2004 [URL_ = http://www.oelmuehle-doernthal.de/Geschichte_der_Muehle/ body_geschichte_der_muehle.html;08.02.2004].

ONGYERTH, G.: Landschaftsmuseum oberes Würmtal : Erfassung, Vernetzung und Visualisierung historischer Kulturlandschaftselemente als Aufgabe der Angewandten Geographie. - München, Techn. Univ., Diss. 1993.

ONGYERTH, G.[a]: Das Schleißheimer Kanalsystem. Topographie, Verfall und Revitalisierungsansatz für das gemeindeübergreifende Denkmal im Kontext von 400 Jahren Umgestaltung des Gewässernetzes im Norden von München. In: Jahrbuch der Bayerischen Denkmalpflege 49-53 (1995-1999).

ONGYERTH, G.[b]: Kulturlandschaft Würmtal: Modellversuch „Landschaftsmuseum“zur Erfassung und Erhaltung historischen Kulturlandschaftselemente im oberen Würmtal. - München: Lipp, 1995 [Arbeitshefte des Bayerischen Landesamtes für Denkmalpflege; 74].

ONGYERTH, G.: Geographische Informationssysteme in der städtebaulichen Denkmalpflege in Bayern. - In: Berichte zur deutschen Landeskunde 73/4 1999:381-406.

ONGYERTH, Gerhard: Geographische Informationssysteme und städtebauliche Denkmalpflege. Copmutergestützte Verortung und Vermittlung objekt- sowie ortsübergreifender Denkmalsubstanz. - In: Ensembleschutz und städtebauliche Entwicklung. - Stuttgart 2001 [Berichte zur Forschung und Praxis der Denkmalpflege in Deutschland;9]. 
ONGYERTH, G./BURGGRAAFF, P.: Diskussion: Kulturlandschaften als Erbe und Verpflichtung - Projekte und ihre „Erträge“, alte und neue Spannungsfelder, Defizite ... - Veranstaltung Nr. 180 „Kulturlandschaften in Deutschland - Beispiele, Projekte, Spannungsfelder“; Bildungszentrum Eichholz der Konrad-Adenauer Stiftung, vom 02.07. - 04.07.2003 [Mitschrift vom 4.07.2003].

ONGYERTH, G./SCHÜTZE, M./WEICHELT, E.: Die Würm: im Fluß der Geschichte(n). Die Würm und Würmkanäle. Streifzüge von Starnberg nach Gauting, Pasing, Schwabing und Dachau, zu den Schlössern Nymphenburg, Blutenburg, Schleißheim und ins Dachauer Moos. - 2. Aufl. - München: Buchendorfer 1997.

OPEL, R. D.: Alte Mühlen im unteren Neckarraum. Band 1: Schwetzingen: Bürgermeisteramt 1991 [Schriften des Stadtarchivs Schwetzingen;30].

OPEL, R. D.: Alte Mühlen im unteren Neckarraum. Band 3: Kraichgau. - Schwetzingen: Bürgermeisteramt 1997 [Schriften des Stadtarchivs Schwetzingen;33].

OPITZ, E.: Schleswig-Holstein: Das Land und seine Geschichte in Bildern, Texten und Dokumenten. Fotografiert von Reinhard Scheiblich. - Hamburg: Ellert und Richter 1997.

ORLAND, B.: Waschen, Spülen, Schleudern, Trocknen - vereint in einer Maschine. - In: „Die Große Wäsche“. Eine Ausstellung des Landschaftsverbandes Rheinland, Rheinisches Museumsamt, Brauweiler in Zusammenarbeit mit dem Rheinischen Freilichtmuseum - Landesmuseum für Volkskunde, Mechernich-Kommern. - Köln: Rheinland-Verl. 1988 [Schriften d. Rhein. Museumsamtes;42; Zugl.: Schriften d. Rhein. Freilichtmuseums - Landesmuseum f. Volkskunde;34]:48-59.

ORTENBURG, G.: Waffen der Landsknechte 1500 - 1650. - Bonn: Bernhard und Graefe Verlag 1984.

OSCHE, G.: Ökologie. Grundlagen-Erkenntnisse - Entwicklungen der Umweltforschung. - 7. verbesserte Auflage. - Freiburg [et al.]: Herder 1978.

OSTERMEYER, T.: Risikoabwägung - Eine Diskussion am Planungsbeispiel Hemmingen „Weisser Kamp“. - In: Stadt + Grün 9/2003:33-34.

OTREMBA, E.: Allgemeine Agrar- und Industriegeographie. - 2. Aufl. - Stuttgart: Franckh 1960.

OTREMBA, E. (Hrsg.): Atlas der deutschen Agrarlandschaft. - Wiesbaden: Steiner 1962-1971. T. 1, B1. 9/10: Ortsformen und Flurformen um 1850 im Gebiet der Bundesrepublik Deutschland.

OTT, E. (Hrsg.): Zukunft der Kulturlandschaften: Aufgaben und Konzepte nachhaltiger regionaler Entwicklungen. Frankfurt/Main: Fachhochsch.-Verl. 1997 [IKU-Reihe „Kommune und Umwelt“;5].

OTT, H.: Rheinische Wasserburgen: Geschichte, Formen, Funktionen: ein Handbuch. - Würzburg: Weidlich ca. 1984.

OTTO, A.: Beiträge zur naturnahen Umgestaltung von Fließgewässern. - Karlsruhe: Univ. Fridericiane zu Karlsruhe 1991 [Mitteilungen Inst. f. Wasserbau u. Kulturtechnik;180]:1-95.

OTTO, B. (Hrsg.): Dreihundertjähriges deutsches Kloster-Kochbuch. Reprint der. Ausg. V. 1856, 1990.

OTTO, F.: Müssen Regenrückhaltebecken an Wohngebieten gezäunt werden? Erwägungen aus juristischer und planerischer Sicht. - In: Stadt + Grün 9/2003.

OVERBECK, F.: Botanisch-geologische Moorkunde unter besonderer Berücksichtigung der Moore Nordwestdeutschlands als Quellen der Vegetations-, Klima- und Siedlungsgeschichte. - Neumünster: Wachholtz 1975.

OVERBECK, G.: Die mittelalterliche Kulturlandschaft des Gebietes um Gifhorn. - Bremen-Horn 1957 [Schriften der Wirtschaftswissenschaftlichen Gesellschaft zum Studium Niedersachsens, N. F.;66].

OVERBECK, H.: Zur Rekonstruktion der mittelalterlichen Kulturlandschaft zwischen Harz und Lüneburger Heide - In: Berichte zur deutschen Landeskunde 20/1 1958.

OVERMANN, W.: Der Hanekenkanal. - In: Technische Kulturdenkmale 18 1989:46-52.

ÖZIù, Ü.: Ancient Waterworks in Anatolien. - In: Water Resources Development 3/1 1987:55-62.

ÖZIù, Ü.: Historische Wasserbauten in Anatolien: Ein Fundstellen- und Literaturverzeichnis. - In: Frontinus-Tagung 1993 in Berlin und weitere Beiträge zu wasserwirtschaftlich historischen Anlagen. - Bergisch-Gladbach: Frontinus-Gesell.1994 [Heft 18]:89-108.

ÖZIù, Ü.: Historical Water Schemes in Turkey. - In: Water Resources Development 12/3 1996:347-383.

PACIONE, M.[a]: Preface. - In: PACIONE, M. (Hrsg.): Historical geography: progress and prospects. - London et al.: Croom Helm 1987 [Croom Helm progress in geography series]:IX-X.

PACIONE, M.[b]: Introduction . - In: PACIONE, M. (Hrsg.): Historical geography: progress and prospects. - London et al.: Croom Helm 1987 [Croom Helm progress in geography series]:1-15.

PACIONE, M.[b]: Preface. - In: PACIONE, M. (Hrsg.): Applied heography: principles and practise. - London, New York: Routledge 1999:XXVI-XXVII.

PACIONE, M. (Hrsg.): Historical geography: progress and prospects. - London et al.: Croom Helm, 1987 [Croom Helm progress in geography series]. 
PACIONE, M.: In pursuit of useful knowledge: the principles and practise of applied geography. - In: PACIONE, M. (Hrsg.): Applied heography: principles and practise. - London, New York: Routledge 1999:3-18.

PACIONE, M. (Hrsg.): Applied heography: principles and practise. - London, New York: Routledge 1999.

PAFFEN, M.: Die gewerbliche Verwendung der Wasserkraft in Aachen vom späten Mittelalter bis zum Anfang des 19. Jahrhunderts. - Köln, Univ., Diss. 1927 [1928].

PAHNCKE, W.: Schwimmen in Vergangenheit und Gegenwart. - Berlin: Sport-Verl. 1979. [Beiträge zur Geschichte der Sportarten: Schwimmen].

PAIKL, F./DANNINGER, H.-G.: Kleinwasserkraftpotentiale Kleine Ybbs. - In: KLEINWASSERKRAFTWERKE: Notwendigkeit und Bedeutung. Fluss-Studien: Schwarza, Kleine Ybbs, Saalach. - Wien: Universität für Bodenkultur, Inst. f. Wasserwirtschaft 1982 [Wiener Mitteilungen Wasser-Abwasser-Gewässer;49]:150-248.

PALlMANN, R.: Die Pfahlbauten und ihre Bewohner: eine Darstellung der Cultur und des Handels der europäischen Vorzeit. Greifswald: Akademische Buchh. 1866.

PALM, R./BRAZEL, A.: Applications of geographic concepts and methods. - In: ABLER, R./MARCUS, M./OLSSON, J. (Hrsg.): Geography’s Inner Worlds. - New Brundwick NJ: Rutgers University Press 1992:342-362.

PARTON, T..: Trinkwasserversorgung im antiken Rom. Ökologische, administrative und juristische Aspekte. - In: Anregung. Zeitschrift für Gymnasialpädagogik 31 1985:371-383.

PASEWALD, R.: Die Entwicklung des Badewesens der Stadt Wiesbaden von 1806-1914. - Mainz, Univ., Diss. 1999.

PASOLD, A.: Landschaft obere Saale: Raum Schleiz. - Aalen: Wir-Verlag Walter Weller 1992.

PATZE, H./SCHLESINGER, W. (Hrsg.): Geschichte Thüringens. 1. Bd. - 2. Aufl. - Köln,Wien: Böhlau-Verl. 1985.

PAUL, J.: Die Opferstrecken werden immer länger. Die Siegverschmutzung im 19. und 20. Jahrhundert. - In: HERRMANN, B. (Hrsg.): Umwelt in der Geschichte: Beiträge zur Umweltgeschichte. Göttingen: Vandenhoeck und Ruprecht 1989 [kleine Vandenhoeck-Reihe;1544]:55-78.

PAUL, J.: Die Abwassergeschichte der Sieg im Industriezeitalter: Bilanz eines Siegeszuges. - Siegburg: Rheinlandia Verl. Klaus Walterscheid 1992 [Ortstermine. Historische Funde und Befunde aus der deutschen Provinz;2].

PAUL, J.: Grenzen der Belastbarkeit: Die Flüsse Rur und Inde im Industriezeitalter. - In: Dürener Geschichtsblätter 83 1995:1.

PAUL, J.: Die Erft im Spannungsfeld von Bergbau und Landwirtschaft: Einwirkungen auf ein rheinisches Flußgebiet vom 17. bis ins 20. Jahrhundert. - Siegburg: Rheinlandia Verl. Klaus Walterscheid 1999 [Ortstermine. Historische Funde und Befunde aus der deutschen Provinz;10].

PAUL, J./BERG, G. (Hrsg.): Grenzen der Belastbarkeit: Die Flüsse Rur (Roer) und Inde im Industriezeitalter. - Jülich: Gesellschaft f. d. Geschichte der Stadt Jülich und des Jülicher Landes 1994.

PAULINYI, A.: Die industrielle Revolution. - In: TROITZSCH, U./WEBER, W. (Hrsg.): Die Technik - Von den Anfängen bis zur Gegenwart. - Braunschweig: Westermann 1982:232-255.

PELIKAN, B.: Gewässerbetreuungskonzept. - In: Zs. f. Kulturtechnik und Landentwicklung 38 1987:58-65.

PELIKAN, B.: Umweltbezogene Planung wasserbaulicher Maßnahmen an Fliessgewässern. - Wien: Univ. f. Bodenkultur, Inst. f. Wasserwirtschaft, Hydrologie u. konstruktiven Wasserbau 1993 [Wiener Mitteilungen;101]; zugl.: Wien, Univ. f. Bodenkultur, Habil.-Schr. 1991.

PENKER, G.: Landschaftspflegerischer Begleitplan zum Bauantrag: Altenwohnheim Gut Mydlinghoven, Düsseldorf-Hubbelrath Erläuterungsbericht. - Im Auftrag der Gut Mydlinghoven Verwaltungsgesellschaft mbH \& Co, Stuttgart 1995.

PEPER, G.: Von der Wiesenbauschule zur Fachhochschule: Eine Chronik der Suderburger Lehranstalt. - Uelzen 1971

PERELS, E.: Handbuch des landwirthschaftlichen Wasserbaus. - Berlin: Parey 1884.

PESCHKE, W.: Das Mühlenwesen in der Mark Brandenburg: Von den Anfängen der Mark bis um 1600. - Berlin, Univ., Phil. Diss. 1937.

PETERS, H.-J.: Einführung einer Umweltleitplanung durch das Umweltgesetzbuch. - In: Standort. Zeitschrift für Angewandte Geographie 20/3 1996:32-34.

PETERS, N.: Editorial. In: Seevögel - Zeitschrift des Verein Jordsand zum Schutze der Seevögel und der Natur e. V. 16/2 1995:13-14.

PETRY, D./SCHOLZ, M./LUTOSCH, I. (Hrsg.): Relevanz der EU-Wasserrahmenrichtlinie für den Naturschutz in Auen Leipzig: Umweltforschungszentrum Halle-Leipzig 2002 [UFZ-Bericht;22].

PETRY-EBERLE, A.: Adel und Landschaft: der Einfluß des englischen Adels auf die Gestaltung der Kulturlandschaft in Rutland. - Frankfurt/Main et al.: Lang 1990 [Europäische Hochschulschriften: Reihe 3, Geschichte und ihre Hilfswissenschaften;430]; Zugl. Univ., Köln, Diss. 1986.

PETTS, G.: Forested river corridors: a lost resource. - In: COSGROVE, D./PETTS, G. (Hrsg.): Water, Engineering and Landscape. Water control and landscape transformation in the modern period. - London: Belhaven 1990:12-34. 
PETTS, G./BOON, P. J./CALOW, P. [Hrsg.]: River conservation and management. - Chichester et al.: Wiley 1992.

PEYER, H. C.: Gewässer, Grenzen und Märkte in der Schweizergeschichte. - Zürich: Schultheiss 1979 [Mitteilungen der Antiquarischen Gesellschaft in Zürich;3/48; Neujahrsblatt 143].

PEYRER, U.: Wasserkraftnutzung im Hochsauerlandkreis: Möglichkeiten zur Inwertsetzung der Wasserkraftanlagen im Rahmen einer touristischen Route. - Münster et al.: Lit 1994 [Geographie;2]; Zugl.: Münster(Westfalen, Univ., Diss. 1993

PFEIFER, G.: Kulturgeographie in Methode und Lehre. Das Verhältnis zu Raum und Zeit. Gesammelte Beiträge von Gottfried Pfeifer. - Wiesbaden: Steiner 1982 [Erkundliches Wissen;60]:316-338.

PFEIFFER, G./SCHÜTTLER, A.: Die kleinräumige Kartierung landwirtschaftlicher Nutzflächen und ihre kulturgeographische Bedeutung. In: Petermanns Geographische Mitteilungen 871941.

PFEIFFER, M.: Beitrag zur Geschichte der Fischerei in der Oberlausitz am Beispiel des Rittergutes Großhennersdorf. - In: Berichte d. Naturforsch. Ges. Oberlausitz 5 1996:105-127.

PFISTER, C.: Das Klima der Schweiz 1525-1860 und seine Bedeutung in der Geschichte von Bevölkerung und Landwirtschaft. Stuttgart et al.: Haupt 1985 [Academica Helvetica;6,1]; Zugl.: Bern, Univ., Habil.-Schr. 1982.

PFISTER, C.: Ressourcen, Energiepreis und Umweltbelastung. Was die Geschichtswissenschaft zur umweltpolitischen Debatte beitragen könnte. - In: SIMON. C. (Hrsg.): Umweltgeschichte heute. - Mannheim 1993 [Environmental History Newsletter, Special Issue 1]:13-28.

PFISTER, C./HÄCKLER, S.: Überschwemmungskatastrophen im Schweizer Alpenraum seit dem Spätmittelalter: Raum-zeitliche Rekonstruktion von Schadensmustern auf der Basis historischer Quellen. - Würzburg 1991 [Würzburger Georg. Arb.;80]:127-148.

PFLANZENKLÄRANLAGEN. Bau und Betrieb von Anlagen zur Wasserreinigung und Abwasserreinigung mit Hilfe von Wasserpflanzen. Grundlagen, Verfahrensvarianten, prakt. Erfahrungen. - Bauverl. 1987.

PFLESSER, W.: Die Entwicklung des Sportschwimmens: mit dem großen statistischen Anhang. - Celle: Pohl 1980

PFRIEMER, U./BEDÜRFTIG, F.: ...daß zum Zwecke Wasser fließe: Eine Sanitärchronik. - Berlin; Leiben: ABW, Wiss.Verl.Ges. 2001.

PGM [Petermanns Geographische Mitteilungen]: Themenheft: „Kulturlandschaftsforschung“, Heft 62002.

PGM [Petermanns Geographische Mitteilungen]: Themenhaft: „Neue Kulturgeographie“, Heft 22003.

PIETRUSKY, G.: Die Fischzucht Schlesiens. - Breslau: Hochschulverl. 1922; Zugl.: Breslau, Univ., Diss. 1922.

PIETZKA, S.: Das Ziegeleigelände Bergische Landstraße / Ratinger Weg. - In: Quadenhof, Heimatzeitschrift des Bürger- und Heimatvereins Düsseldorf-Gerresheim 47/1 [Sommer 1996] und 47/2 [Winter 1996].

PILKINGTON, R.: History and Legens of the European Waterways. - Book Guild 1998.

PILZ, B.: Zum Beispiel Mega-Städte. - 1. Aufl. - Göttingen: Lamuv 2001 [Lamuv-Taschenbuch;303].

PINCKERT, F. A.: Die Wiesen-Cultur in ihrem höchsten Ertrage durch zeitgemässe Meliorationen, Düngung, Pflege und Benutzung der Rasennarbe. - Berlin: Parey 1865.

PINKWART, W. (Hrsg.): Genetische Ansätze in der Kulturlandschaftsforschung: Festschrift für Helmut Jäger. - Würzburg: Insst. f. Geographie d. Univ. 1983 [Würzburger Geographische Arbeiten;60].

PIOT, G./SCHWEIZER, B.: Arbeit- und Lebenswelt eines Flößerdorfes am Beispiel von Unterrodach. - In: KEWELOH, H.-W.: Flößerei in Deutschland. - Stuttgart: Theiss 1985:118-147.

PISTOR, R.-G./SMEETS, H.: Die Fossa Eugeniana: eine unvollendete Kanalverbindung zwischen Rhein und Maas 1628. - Köln: Rheinland-Verl. 1979 [Landeskonservator Rheinland;32].

PLANUNGSBÜRO GREBE: Landschaftsplan Altmühltal 1972. - Nürnberg-Erlangen: Grebe, 1972.

PLATHNER, G.: Ueber Umschaffung veralteter Teiche und schlechter Teichwiesen in nutzbare Wiesen [...]. - Breslau, Leipzig: Korn 1824.

PLEWE, E.: Geographie in Vergangheit und Zukunft. - Stuttgart: Steiner 1986 [Erkundl. Wissen;85].

PLINIUS d. Ält.: Naturalis Historiae, 37 Bde. und Reg.-Bd. - Tusculum; Bd. 3/4 1988.

PLÖGER, R: Die maritime Kulturlandschaft der Kieler Förde in historisch-geographischer Sicht. - In: Siedlungsforschung 15 (1997):153-191.

PLÖGER, R.: GIS-Anwendungen in der Historischen Geographie. - In: ASMUS, I./PORADA, H. T./SCHLEINERT, D. (Hrsg.): Geographische und historische Beiträge zur Landeskunde Pommerns. Eginhard Wegner zum 80. Geburtstag. - Schwerin 1998 [Greifswalder geographische Arbeiten; Sonderbd.]:195-202

PLÖGER, Rolf[a]: Anwendung Geographischer Informationssysteme (GIS) für historisch-geographische Aufgabenstellungen. In: EBELING, Dietrich (Hrsg.): Historisch-thematische Kartographie: Konzepte - Methoden - Anwendungen. - Bielefeld: Verl. für Regionalgeschichte 1999:9-23. 
PLÖGER, Rolf[b]: Anwendungen Geographischer Informationssysteme in der Angewandten Historischen Geographie. - In: Kulturlandschaft. Zeitschrift für Angewandte Historische Geographie 9/1 1999:103-111.

PLÖGER, R.: Konzeptionelle Überlegungen für ein GIS-Kulturlandschaftskataster NRW und Erläuterungen zu mit Atlas GIS durchgeführten Bearbeitungen. - In: BURGGRAAFF, P.: Fachgutachten zur Kulturlandschaftspflege in NordrheinWestfalen. - Wuppertal 2000:293-322.

PLÖGER, R.: Inventarisierung der Kulturlandschaft mit Hilfe von geographischen Informationssystemen (GIS): methodische Untersuchungen für historisch-geographische Forschungsaufgaben und fürein Kulturlandschaftskataster. - Bonn, Univ., Diss. 2003.

PODRAZA et al.: "Typisierung und Leitbildfindung für kleine und mittelgroße Fließgewässer des Mittelgebirgsraumes NRW" Düsseldorf 1998

POESTGES, D.: Die Geschichte der Oberkirchener Sandsteinbrüche. Ein wichtiges Kapitel in den Handelsbeziehungen der Stadt Bremen. - In: Bremisches Jahrbuch 60/61 1982/83:95-116.

POGT, H.: Historische Ansichten aus dem Wuppertal des 8. und 19. Jahrhunderts. - 2. Aufl. - Wuppertal 1998 [Beiträge zur Geschichte und Heimatkunde des Wuppertals; Sonderband].

PONTING, C.: A Green History of the World. - Harmondsworth: Penguin 1992.

POPP, H.: Ziele einer modernen geographischen Landeskunde als gesellschaftlsbezogene Aufgabe. - In: Der Weg der deutschen Geographie. Rückblick und Ausblick. - 50. Deutscher Geographentag Potsdam 1995, Bd. 4 - Stuttgart: Steiner Verl. 1995:142-150.

PORADA, H. T.: Historisch-geographische Aspekte der Fischerei auf dem Stettiner Haff in der Frühen Neuzeit. - In: ZÖLITZMÖLLER, R. (Hrsg.): Historische Geographie und Kulturlandschaftsforschung. Beiträge zum Gedenkkolloquium für Dr. Eginhard Wegner am 4. Mai 2001 in Greifswald. Greifswald: Geographisches Inst. d. Ernst-Moritz-Arndt-Universität 2001 [Greifswalder Geographische Arbeiten;22]:51-59.

PORADA, H. T.: Die pommerschen Klöster und Stifte als Nutznießer von Fischereiberechtigungen auf dem Stettiner Haff und seinen Nebengewässern vor und nach der Reformation. - In: HANSESTADT STRALSUND (Hrsg.): Stralsunder Beiträge zur Archäologie, Geschichte, Kunst und Volkskunde in Vorpommern. Band IV: Klöster und monastische Kultur in Hansestädten. Beiträge des 4. wissenschaftlichen Kolloquiums Stralsund 12 bis 15. Dezember 2001, Rahden/Westf.: Verl. Marie Leidorf 2003 [Wissenschaftl. Publikationsreihe des Kulturhist. Museums der Hansestadt Stralsund]:165-185.

PORADA; H. T. (Hrsg.): Die Oberlausitzer Heide- und Teichlandschaft. - Köln, Weimar; Wien: Böhlau 2004 [Landschaften in Deutschland. Werte der deutschen Heimat; 67]

PÖRTGE, K.-H.: Beschreibung von „Forschungsgegenstand und Fragestellung“ des Dissertationsthemas (B3) „Wasserbauliche Maßnahmen an Fließgewässern und ihre Folgen von Anfang des 18. bis Mitte des 20. Jahrhunderts unter besonderer Berücksichtigung des Wertewandels wasserbaulicher Maßnahmen" im Graduiertenkolleg „Interdisziplinäre Umweltgeschichte: Naturale Umwelt und gesellschaftliches Handeln in Mitteleuropa“ an der Universität Göttingen. [URL = URL = http://www.uni-goettingen.de/de/sh/1134.html;24.03.2004].

POSCHMANN, C./RIEBENSAHL, C./SCHMIDT-KALLERT, E.: Umweltplanung und -bewertung. - Gotha et al.: Klett-Perthes 1988 [Perthes Geographiekolleg].

POTT, R.: Geschichte der Hude- und Schneitelwirtschaft in Nordwestdeutschland und ihre Auswirkungen auf die Vegetation. - In: Oldenburger Jahrbuch 83 1983:357-375.

POTT, R.: „Einführung in die Vegetationskunde“. - Münster: Westfälische-Wilhelms-Universität Münster, Inst. f. Geographie [Mitschrift des Proseminars im SS 1986].

POTT, R.: The impact of early neolithic agriculture on the vegetation of Northwestern Germany. - In: Paläoklimaforschung, 8 (1992): 57-72.

POTT, R.: Biotoptypen. Schützenwerte Lebensräume Deutschlands und angrenzender Regionen. Stuttgart: Ulmer 1996.

POTT, R./HÜPPE, J.: Die Hudelandschaften Nordwestdeutschlands. - Münster 1991 [Abhandlungen aus dem Westf. Museum f. Naturkunde;53].

POTT, R./REMY, D.: Gewässer des Binnenlandes. - Stuttgart/Hohenheim: Ulmer 2000 [Ökosysteme Mitteleuropas aus geobotanischer Sicht].

POTTHAST, H.: Beispiele zum Werden einer Kulturlandschaft im Raum Hemeln - Bursfelde. Flurnamen - Alte Wege Wüstungen im Oberwesergebiet. Hrsg. v. Heimat- und Geschichtsverein Sydekum zu Münden e.V. - Hannoversch Münden 1984 [Sydekum-Schriften zur Geschichte der Stadt Münden;9].

POWELL, J. M.: Historical geographies of the environment. - In: GRAHAM, B./NASH, C. (Hrsg.): Modern Historical Geographies. - Harlow: Longman 2000:169-192.

PRAGER, W./VENT, E.: Ackerbaulehre. - 3. Aufl. - Berlin: Volk und Wissen Volkseigener Verl. 1954 [Lehr- und Fachbücher für die Berufsausbildung]. 
PREISING, E. et al.: Die Pflanzengesellschaften Niedersachsens - Bestandsentwicklung, Gefährdung und Schutzprobleme: Wasser- und Sumpfpflanzengesellschaften des Süßwassers. - In: Naturschutz Landschaftspflege Niedersachsen 20/8 1990:47-161.

PRINCE, H. C.: Progress in historical geography. - In: COOKE, R.U./JOHNSON, J.H. (Hrsg.): Trends in Geography. An Introductory Survey. - New York: Pergamon 1969:110-122.

PROBLEME DER UMWELTFORSCHUNG. - Berlin: Colloqium-Verl. 1973 [Forschung und Information;14].

PROBST, E.: Teichwirtschaft und Gefügelzucht in ihren Wechselbeziehungen. - Stuttgart: Schweizerbart 1934 [Aus: DEMOLL; Reinhard / MAIER, Hermann Nikolaus (Hrsg.): Handbuch der Binnenfischerei Mitteleuropas; 4 1964:408-482].

PUFF, A.: Die Stromveränderungen des Niederrheins zwischen Wupper- und Ruhrmündung. Naturwiss. Verein zu Krefeld. Festschrift zur Feier des 50jährigen Bestehens. - Krefeld 1908:103-124.

PUNDT, H.: Integration wissensbasierter Ansätze in ein Pen-Computer-gestütztes GIS-Werkzeug für fließgewässerökologische Planungen. - Münster, Univ. Diss. 1995.

PURKARTHOFER. H.: Die Teichwirtschaft der Herrschaft Herberstein. - In: Zeitschrift des Historischen Vereines für Steiermark 56 1965:97-106.

QUAST, A.: Alter Oberharzer Bergbau bei Hahnenklee-Bockswiese: Erste Ergebnisse einer Bestandsaufnahme und Vermessung. - In: Berichte zur Denkmalpflege in Niedersachsen 20 2000:170-175.

QUASTEN, H.: Grundsätze und Methoden der Erfassung und Bewertung kulturhistorischer Phänomene der Kulturlandschaft. - In: DENECKE, D./FEHN, K./SCHENK, W. (Hrsg.): Kulturlandschaftspflege. Beiträge der Geographie zur räumlichen Planung. - Berlin, Stuttgart: Springer 1997.

QUASTEN, H./WAGNER, J. M.: Inventarisierung und Bewertung schutzwürdiger Elemente der Kulturlandschaft - eine Modellstudie unter Anwendung eines GIS. - Leipzig: Dt. Akad. f. Landeskde e. V. und des Instituts für Länderkunde 1996 [Berichte zur deutschen Landeskunde;2].

QUASTEN, H./WAGNER, J. M.: Kulturlandschaftspflege in altindustrialisierten Räumen. - Leipzig: Dt. Akad. f. Landeskde e. V. und des Instituts für Länderkunde 2000 [Berichte zur deutschen Landeskunde;3].

QUEST, T./SCHÄFER-RICHTER, U.: Dorfleben. Die Geschichte der Dörfer Lippoldsberg und Vernawahlshausen. - Wahlsburg 1989.

QUEST, T./SCHÄFER-RICHTER, U.: „Die ansehnlichste Bleichanstalt in diesem Distrikt“. Aus der Geschichte der Leinenbleiche Vernwahlshausen“. - In: BIRKIGT-QUENTIN, B./BUSSE, G./SCHÄFER, W. (Hrsg.): Flachs und Leine zwischen Leine und Weser. Berichte und Bilder aus Adelebsen, Uslar und Wahlsburg. - Im Auftrag der Museen: Museum Uslar, Steinarbeiter-Museum Adelebsen, Schäferhausmuseum in Wahlsburg-Lippoldsberg. - Adelebsen, Uslar, Wahlsburg 1995:24-25.

RACKWITZ, R.: Nachrichten über die St.-Blasil-Bibliothek in Nordhausen und das Kloster Himmelgarten bei Nordhausen. Erster Theil: Urkunden bis zur Mitte des 14. Jahrhunderts. - Nordhausen: Koppe 1883.

RADEBURG 2004: Zur Bewirtschaftung des Großteiches [URL = http://radeburg-net.de/baernsdorf/bd_bewirtschaftung.php; 04.08.2004].

RADEKE, M.: Deutschlands Bergwerke und Hütten. Band 1: Bergwerke in Deutschland. - Düsseldorf: Verl. Polytechnik 1907.

RADEMACHER, H.: Die Beeinflussung einer Stadtplanung durch die industrielle und gewerbliche Entwicklung: eine historischgeographische Untersuchung der Planungen der Stadt Düsseldorf in den Jahren von 1854 bis 1914. - Frankfurt/Main et al.: Lang 1994 [Europäische Hochschulschriften: Reihe 4, Geographie;14]; Zugl.: Bonn, Univ., Diss. 1993.

RADEMACHER, H./LOOZ-CORSWAREM, C. v./FIMPELER-PHILIPPEN, A.: Düsseldorf und seine Häfen: Zur Verkehrsgeschichte und Wirtschaftsgeschichte der Stadt aus Anlaß des 100jährigen Hafenjubiliäums 1896 - 1996. Hrsg.: Stadtwerke Düsseldorf. - Düsseldorf: Müller \& Busmann 1996.

RADETZKI, M.: The Green Myth - Economic Growth and the Quality of the Environment. - Brentwood/Essex: Multi-Science Publishing 2001.

RADIG, W.: Die Siedlungstypen in Deutschland und ihre frühgeschichtlichen Wurzeln. - Berlin: Henschelverl. 1955 [Schriften des Forschungsinstitutes für Theorie und Geschichte der Baukunst].

RADKAU, J.: Zur angeblichen Energiekrise des 18. Jahrhunderts: Revisionistische Betrachtungen über die "Holznot". - In: Vierteljahrschrift für Sozial- und Wirtschaftsgeschichte 73/1 1986:1-37.

RADKAU, Joachim: Technik in Deutschland vom 18. Jahrhundert bis zur Gegenwart. - Frankfurt/Maina 1989

RADKAU,. J.: Technik in Deutschland: vom 18. Jh. bis zur Gegenwart. - Frankfurt/Main: Suhrkamp 1989 [Edition Suhrkamp;1535].

RADKAU. J.: Unausdiskutiertes in der Umweltgeschichte. - In: HETTLING, M. et al. (Hrsg.): Was ist Gesellschaftsgeschichte? Positionen, Themen, Analysen (Hans-Ulrich Wehler zum 60. Geburtstag). - München 1991 
RADKAU, J.: Was ist Umweltgeschichte? - In: ABELSHAUSER, W. (Hrsg.): Umweltgeschichte. Umweltverträgliches Wirtschaften in historischer Perspektive; acht Beiträge. - Göttingen: Vandenhoeck und Ruprecht 1994 [Geschichte und Gesellschaft, Sonderheft 15]:11-28.

RADKAU, J.: The wordy worship of nature and the tacit feeling for nature in the history of German forestry. - In: TEICH, M./PORTER, R./GUSTAFSSON, B. (Hrsg.): Nature and society in historical context. - Cambridge: University Press 1997:228-239.

RADKAU, J.: Natur und Macht: Eine Weltgeschichte der Umwelt. - 1. Aufl. - München: 2002 [1. Aufl. 2000].

RADKAU, J./UEKÖTTER, F. (Hrsg.): Naturschutz und Nationalsozialismus. - Frankfurt, New York: Campus Verl. 2003 [Geschichte des Natur- und Umweltschutzes,1].

RADLER, S.[a]: Vorwort. - In: KLEINWASSERKRAFTWERKE: Notwendigkeit und Bedeutung. Fluss-Studien: Schwarza, Kleine Ybbs, Saalach. - Wien: Universität für Bodenkultur, Inst. f. Wasserwirtschaft 1982 [Wiener Mitteilungen WasserAbwasser-Gewässer; 49]:1.

RADLER, S.[b]: Einführungsreferat zur Vorstellung der Fluss-Studien. - In: KLEINWASSERKRAFTWERKE: Notwendigkeit und Bedeutung. Fluss-Studien: Schwarza, Kleine Ybbs, Saalach. - Wien: Universität für Bodenkultur, Inst. f. Wasserwirtschaft 1982 [Wiener Mitteilungen Wasser-Abwasser-Gewässer;49]:5-17.

RAHMANN, H./ZINTZ, K./HOLLNAICHER, M.: Oberschwäbische Kleingewässer: limnologisch-faunistische Aspekte zur ökologischen Beurteilung. - Karlsruhe: Inst. f. Ökologie u. Naturschutz 1988 [Veröff. f. Naturschutz u. Landschaftspflege in Baden-Württemberg, Beihefte;56].

RAPP, J./SCHÖNWIESE, C.-D.: Atlas der Niederschlags- und Temperaturtrends in Deutschland 1891-1990. Hrsg. v. FB Geowissenschaften der Johann Wolfgang-Goethe Univ. Frankfurt. - 2. Aufl. - 1995 [Frankf. Geowissenschaftl. Arbeiten: Serie B;5].

RASPER, M.[a]: Gewässerstrukturgütekartierung in Niedersachsen: Detailverfahren für kleine und mittelgroße Fließgewässer. Hrsg.: NLÖ [Niedersächsisches Landesamt für Ökologie]. - Hildesheim 2001.

RASPER, M.[b]: Morphologische Fließgewässertypen in Niedersachsen: Leitbilder und Referenzgewässer. - Hrsg.: NLÖ [Niedersächsisches Landesamt für Ökologie] - 1. Aufl. - Hildesheim: NLÖ 2001.

RATHGENS, H./BRUNS, F.: Die Bau- und Kunstdenkmäler der Freien und Hansestadt Lübeck. Hrsg. v. d. Baudeputation. Bd. 1, T. 1: Stadtpläne und -ansichten, Stadtbefestigung, Wasserkünste und Mühlen. - Lübeck: Nöhring 1939.

RATHJENS, C.: Die Formung der Erdoberfläche unter dem Einfluß des Menschen: Grundzüge der Anthropogenetischen Geomorphologie. - Stuttgart: Teubner 1979 [Teubner Studienbücher der Geographie].

RATUSNY, A.: Mittelalterlicher Landesausbau im Mühlviertel / Oberösterreich: Formen, Verlauf und Träger der Besiedlung vom 12. bis zum 15. Jahrhundert. - Passau: Passavia Univ.-Verl. 1994 [Passauer Schriften zur Geographie;12].

RATZEL, F.: Anthropogeographie Teil 1: Grundzüge der Anwendung der Erdkunde auf die Geschichte. - 2. Aufl. - Stuttgart: Engelhorn 1899 [1. Aufl. 1892].

RATZEL, F.: Deutschland. Einführung in die Heimatkunde. - 5. Aufl. - Berlin, Leipzig 1921 [2. Aufl. 1899].

RATZEL, F. (Hrsg.): Bibliothek geographischer Handbücher. Bd. 9: Handbuch der Seenkunde: allgemeine Limnologie 1901 (Verfasser: F. A. FOREL). - Stuttgart: Engelhorn 1901

RAU, G./RAU, M.: Fürstliches Sol-Thermal-Bad Salzuflen. - Bad Salzuflen: MR-Verl. 1989.

RAUDNER, E./BÄTZING, W./OBERLE, M.: Die Vermarktung des Aischgründer Karpfens in der regionalen Gastronomie Möglichkeiten der Aufwertung eines Regionalproduktes. - In: LfL [Bayerische Landesanstalt für Landwirtschaft: Institut für Fischerei im Jahr 2003, Versuche und Untersuchungen:1-48.

RAUH, K.: Abriß der Geschichte des Goldbergbaus im Frankenland mit besonderer Berücksichtigung des Münchberger Gebiets. In: Archiv für Geschichte von Oberfranken 78 1998:125-144.

RAUSCHKOLB, M.: „...et in valle Sulzberc ...“- Eine frühe Bergbausiedlung im Sulzbachtal. - In: Früher Bergbau im südlichen Schwarzwald: Begleitheft zur Ausstellung des Museums für Ur- und Frühgeschichte der Stadt Freiburg i. Br. vom 29. Juli bis zum 21. November 1999. Hrsg. v. Landesdenkmalamt Baden-Württemberg. - Stuttgart: Ges. für Vor- und Frühgeschichte in Württemberg und Hohenzollern 1999 [Archäologische Informationen aus Baden-Württemberg;41]:59-62.

RECH, M.: Kloster Heisterbach bei Königswinter, Rhein-Sieg-Kreis. - In: Frontinus-Gesellschaft (Hrsg.): Die Wasserversorgung im Mittelalter. - Mainz 1991 [Geschichte d. Wasserversorgung;4]:258ff.

RECKLINGHAUSEN 2004 [URL = http://www.recklinghausen.de/historie/stadtge12.html;30.01.2004].

REDDERSEN, E.: Die Veränderungen des Landschaftsbildes im hannoverschen Solling und seinem Vorlande seit dem frühen 18. Jahrhundert. - Oldenburg 1934 [Niedersächsischer Ausschuß für Heimatschutz;5].

REDECKER, B. et al. (Hrsg.): Pasture Landscapes and Nature Conservation. - Berlin, Heidelberg 2002.

REGIONALE in Nordrhein-Westfalen: Ein strategisches Instrument zur Profilierung von Regionen: Eine Zwischenbilanz. Im Auftrag des Ministeriums für Städtebau und Wohnen, Kultur und Sport des Landes NRW. - Düsseldorf: April 2001. 
REGIONALVERBAND SÜDNIEDERSACHSEN e.V. (Hrsg.): EXPO-Themenpfad Wasser. - Göttingen 2000.

REHBEIN, E.: Zu Wasser und zu Lande: die Geschichte des Verkehrswesens von den Anfängen bis zum Ende des 19. Jahrhunderts. - München: Beck 1984

REICHEL, D.: Naturschutz und Teichwirtschaft im Spannungsfeld. - Laufen/Salzach: ANL 1991 [Berichte ANL;15].

REICHELT, G.: Anthropogene Veränderungen der Pflanzendecke und ihre Folgen an Beispielen aus Mitteleuropa. Frankfurt/Main 1996 [Der Mathematisch-Naturwissenschaftliche Unterricht;19]:61-71.

REICHHOLF, J./STEINBACH, G. (Hrsg.): Feuchtgebiete: Die Ökologie europäischer Binnengewässer, Auen und Moore. München: Mosaik-Verl. 1988 [Steinbach Biotopführer;2].

REICHHOLF, J./STEINBACH, G. (Hrsg.): Die große Enzyklopädie der Fische: Süsswasser- und Meeresfische Europas. München: Mosaik-Verl. 1992.

REICHMANN, C.: Zur Besiedlungsgeschichte des Lippemündungsgebietes während der jüngeren vorrömischen Eisenzeit und der ältesten römischen Kaiserzeit. - Wesel: Verl. d. Buchhandl. Dambeck 1979; Zugl.: Bochum, Univ., Diss. 1976.

REINBOTH, F.: Die historische Wasserversorgung des Klosters Walkenried. - In: Zwanzig Jahre Verein für Heimatgeschichte und Umgebung e. V. 1964-1984. Festschrift. - Walkenried 1984:39-50.

REINERTH, H.: Das Flederseemoor als Siedlungsland des Vorzeitmenschen. - 4. Aufl. - Augsburg: Filser 1929 [Führer zur Urgeschichte;9].

REINERTH, H.: Pfahlbauten am Bodensee. - 6. Aufl. - Überlingen: Feyel 1958 [Volkstümliche Darstellungen zur Vor- und Frühgeschichte;1].

REINHARD, E. (Hrsg.): Gemeindebeschreibungen und Ortschroniken in ihrer Bedeutung für die Landeskunde. - Stuttgart: Kohlhammer 1999 [Werkhefte der Staaatlichen Archivverwaltung Baden-Württemberg: Serie A, Landesarchivdirektion;12].

REINHARDT, A. (Hrsg.): „Die erschreckliche Wasser-Fluth“ 1634: die Flut vom 11. Oktober 1634 und ihre Folgen nach zeitgenössischen Berichten und Dokumenten; mit einer Darstellung über den Einfluss der Sturmfluten auf die historische Entwicklung des nordfriesischen Küstenraumes. Hrsg. i. A. des Nordfriesischen Vereins für Heimatkunde und Heimatliebe. Husum: Husum Druck- und Verl.-Ges. 1984 [Heimatkundliche Schriften des Nordfriesischen Vereins;9].

REININK, W.: Eiskeller: Kulturgeschichte alter Kühltechniken. - Wien: Böhlau 1995 [Kulturstudien. Sonderbände;15].

REISINGER, E.[dgar]: Gewässerneugestaltung im ländlichen Raum. - In: DVWK (Hrsg.): Gewässer - schützenswerter Lebensraum. - Hamburg; Berlin: Parey 1992 [Schriftenreihe des Deutschen Verbandes für Wasserwirtschaft und Kulturbau e.V.;102]:347-357.

REISS, M.: Gewässerentwicklungsplanung - Fachinstrument zur ökologischen Gewässerentwicklung: Kurzübersicht am Beispiel Hessen. - In: Beiträge zur Hydrogeographie 32001 [URL = http://www.hydrogeographie.de;20.01.2004].

Reissinger, E.: Die Revitalisierung der Unstrut: Modellprojekt des Freistaates Thüringen. - In: DEMBISKI, M./WERDER, U. (Hrsg.): Renaturierungen von Fließgewässern und Auen. - Hamburg: VSÖ-Publikationen 1997.

REITER, R.: Bayerische Landesanstalt für Landwirtschaft (LfL), Institut für Fischerei (IFI), Fortbildungstagung für Fischhaltung und Fischzucht. - In: Fischer \& Teichwirt 54 2003:189.

REITER, R.: Kreuzungseignung verschiedener Stämme von Bach- und Seesaiblingen hinsichtlich Verlustraten, Zuwachs, Krankheitsresistenz, Ausschlachtung und Fleischqualität. - In: LfL: Bayerische Landesanstalt für Landwirtschaft: Institut für Fischerei im Jahr 2003, Versuche und Untersuchungen:1-48.

REITH, R. (Hrsg.): Lexikon des alten Handwerks. Vom späten Mittelalter bis ins 20. Jahrhundert. 60 alte Handwerksberufe.- 2. Aufl. - München: Beck 1991 [1. Aufl. 1990].

REITH, R.: Umweltgeschichte aus der Sicht historischer Methodik. - In: BAYERL, G./FUCHSLOCH, N./MEYER, T. (Hrsg.): Umweltgeschichte - Methoden, Themen, Potentiale: Tagung des Hamburger Arbeitskreises für Umweltgeschichte, Hamburg 1994. - Münster, New York: Waxmann 1996 [Cottbuser Studien zur Geschichte von Technik, Arbeit und Umwelt;1]:13-20.

REITH, R.: Internalisierung der externen Effekte. Konzepte der Umweltgeschichte und die Wirtschaftsgeschichte. - In: BAYERL, G./WEBER, W. (Hrsg.): Sozialgeschichte der Technik - Ulrich Troitzsch zum 60. Geburtstag. - Münster et al.: Waxmann 1998 [Cottbuser Studien zur Geschichte von Technik, Arbeit und Umwelt;7]:15-24.

REITZ, Heinz: Das südhessische Mühlenbüchlein. Hrsg.: Museum Otzberg 1984 [Sammlung zur Volkskunde in Hessen].

REITZENSTEIN, H. Freiherr v.: Teich- und Weiherwirtschaft in der Oberpfalz; Vortrag gehalten in Neustadt a. W. N. 11.XI.1881

REMKE, A.: Konzeption und Realisierung eines wissensbasierten GIS-Werkzeuges zur mobilen Erfassung raumbezogener Daten unter besonderer Berücksichtigung der oekologischen Bewertung von Fließgewässern. - Münster, Univ., Diss. 1997.

REMME, J.: Güterschiffahrt auf der Saale und Unstrut. - Bonn: Marcus \& Weber 1918 [Moderne Wirtschaftsgestaltungen;5].

REMMERT, H.: Der vorindustrielle Mensch in den Ökosystemen der Erde. - In: Naturwissenschaften 72 1985:627-632.

REMMERT, H.: Naturschutzforschung und -vermittlung als Aufgabe der Universitäten. - Laufen/Salzach: ANL 1988 [Berichte der ANL; 12]. 
REMMERT, H.[a]: Natur als Kulturaufgabe. - In: Die Naturwissenschaften 79 1992:489-491.

REMMERT, H.[b]: Ökologie: ein Lehrbuch. - 5. Aufl. - Berlin et al.: Springer 1992 [Springer Lehrbuch].

REMMERT, H.: Terrestrische Systeme. - Berlin et al.: Springer 1996 [Spezielle Ökologie].

RENES, J.: Historische Landschapselementen. - Wageningen: Ponsen \& Looijen 1992 [Staringcentrum rapport;201].

RENNER, E.: Entstehung und Entwicklung der Murgflößerei bis zum Dreißigjährigen Kriege. - Freiburg/Breisgau, Uni., Diss. 1928.

RETZLAFF, H.: Die Schwalm: Kulturkunde einer alten Kulturlandschaft. - Berlin, Leipzig: Dt. Verlagshaus Bong \& Co. [1936] [Bilderwerke zur deutschen Volkskunde].

REULECKE, J.: Geschichte der Urbanisierung in Deutschland 1850-1980. - Frankfurt/Main: Suhrkamp 1985 [Ed. Suhrkamp;1249, N.F., 249: Neue historische Bibliothek].

REULECKE, J./ZIMMERMANN, C. (Hrsg]: Die Stadt als Moloch? Das Land als Kraftquell?: Wahrnehmungen und Wirkungen der Großstädte um 1900. - Basel et al.: Birkhäuser 1999 [Stadtforschung aktuell;76].

REVENTLOW-FARWE, Graf E./WARNSTEDT, A. E. v.: Beiträge zur land- und forstwirthschaftlichen Statistik der Herzogthümer Schleswig und Holstein: Festgabe für die Mitglieder der 11. Versammlung Deutscher Land- und Forstwirthe. - Altona: Köbner 1847

RHEINHEIMER, G.: Mikrobiologie der Gewässer. - 3. Aufl. - Stuttgart: Fischer 1981.

RHEINISCHE POST Nr. 75 vom 29. März 2003: „Mythos Wasser“.

RHEINISCHE POST Nr. 92 v. 19.04.2003: ,...Und der Schäfer muß still stehen“.

RHODE, M.: Die morphologische Ausprägung von Fließgewässern im niedersächsischen Bergland als Grundlage der Gewässertypisierung und Gewässerentwicklungsplanung. - Göttingen, Univ., Geogr. Inst., Dipl.arbeit 2000.

RICHTER, G.: Zur Entwicklung des Umweltschutzes in Deutschland: Sachsen im 19. und 20. Jahrhundert. - Dresden: Institut für Ökologische Raumentwicklung e.V. [IÖR] 1996 [IÖR-Schriften;18].

RICHTER, R.: Saalfische in alter Zeit. - Saalfeld: Niese 1864.

RICHTLINIE 2000/60/EG des Europäischen Parlaments und des Rates vom 23.10.2000 zu Schaffung eines Ordnungsrahmens für Maßnahmen der Gemeinschaft im Bereich der Wasserpolitik“.

RICKERT, H.: Die Stentenmühle [URL = http://www.stenten-muehle.de;11.02.2004].

RICKERT, K./RUIZ-RODRIGUEZ, E./RUWENSTROTH, G.: Fallbeispiel zur Nutzwertanalyse - Wasserwirtschaftliche Planung im Emstal. - Bonn 1993 [DVWK Mitteilungen; 23].

RIECKEN, U./BLAB, J.: Biotope der Tiere in Mitteleuropa: Verzeichnis zoologisch bedeutsamer Biotoptypen und Habitatqualitäten in Mitteleuropa einschließlich typischer Tierarten als Grundlage für den Naturschutz. - Greven: Kilda-Verl. 1989 [Naturschutz aktuell;7].

RIEDEL, B./HASLACH, H.: Kulturhistorisch-denkmalpflegerische Bedeutung von Landschaftselementen und ihre Berücksichtigung in der Landschaftsplanung. - In: AURIG, R. (Hrsg.): Kulturlandschaft [...] 1999:168-183.

RIEDEL, W.: Geographie und Heimatbewußtsein. - In: BAHRENBERG, G. et al.: Geographie des Menschen - Dietrich Bartels zum Gedenken. - Bremen 1987 [Bremer Beiträge z. Geogr. u. Raumplanung;11]:557-563.

RIEDEL-LORJE, J. C./GAUMERT, T.: 100 Jahre Elbe-Forschung. Hydrobiologische Situation und Fischbestand 1842-1943 unter dem Einfluß von Stromverbau und Sieleinleitungen. - In: Archiv Hydrobiologie, Suppl. 61, Stuttgart 1982:317-376.

RIEDENAUER, E. (Hrsg.): Die Erschließung des Alpenraumes für den Verkehr im Mittelalter und der Frühen Neuzeit. - Bozen: Verl.-Anst. Athesia 1996 [Schriftenreihe der Arbeitsgemeinschaft Alpenländer. Berichte der Historikertagungen, N. F.;7].

RIEK, M./RICKENBACHER, F.: Der Vierwaldstätter See auf alten Ansichten: 1780-1880. - Schwyz: Kulturkommission d. Kanton Schwyz 1998.

RIETHMANN, J. F.: Praktische Anweisung zum Teichbau für Förster, Oeconomen. - Leipzig 1798.

RILLMANN, Gert: Entwicklung und Bedeutung der Flößerei (Trift) für die Stadt Annweiler. - In: Südliche Weinstrasse: HeimatJahrbuch 14 1992:123-126.

RIND, M. M.: Kanalarchäologie im Altmühltal. - Buch am Erlbach: Leidorf 1988.

RIPPEL, J.-K: Die Entwicklung der Kulturlandschaft am nordwestlichen Harzrand. - Hannover: Niedersächs. Amt f. Landesplanung u. Statistik 1958 [Schriften der Wirtschaftswissenschaftlichen Gesellschaft zum Studium Niedersachsens, N. F.;69].

ROBERTSON, I./RICHARDS, P. (Hrsg.): Studying cultural landscapes. - London et al.: Arnold 2003.

RÖBER, R.: Einbaum, Lastensegler, Dampfschiff: Frühe Schiffahrt in Südwestdeutschland. - Stuttgart: Theiss 2000. 
ROSCHER, Harald: Die Wasserversorgung Thüringens vom Mittelalter bis zur Gegenwart: 130 Jahre einheitliche Wasserversorgung in Thüringen; ein Beitrag zur Technikgeschichte. - Weimar: Universitätsverl. Bauhaus-Univ. 1999

ROCHOLL, Theodor: Bild „Sababurg - Pferdeschwemme im Teich“ - Hofgeismar: Sammlung Stadtmuseum 2004

ROGGE, J.: „Es klappert die Mühle am rauschenden Bach ...“: Wassermühlen in der Stadt Worbis. Hrsg. v. Worbiser Geschichtsverein. - Worbis: Geschichtsverein 1993.

ROHDEN, J.-U. v.: Die Gewässernamen im Einzugsgebiet der Treene: ein Beitrag zur Ortsnamenforschung in SchleswigHolstein. - Neumünster: Wachholtz 1989 [Kieler Beiträge zur deutschen Sprachgeschichte;13]; Zugl.: Kiel, Univ., Diss. 1987.

ROHR, A. v.: Lauensteiner Glas 1701-1829: Ein Beitrag zur Wirtschafts- und Kulturgeschichte Niedersachsens. - Hannover: Historisches Museum Hannover 1991.

ROHR, H.-G. v.: Angewandte Geographie. - 1. Aufl. - Braunschweig: Höller und Zwick 1990.

ROHRBACH, C.: Am grünen Fluss Isar - eine Wanderung von der Quelle bis zur Mündung. - München: Frederking und Thaler 2002.

RÖHRING, M.: „Der Gesundbrunnen bey Hofgeismar“. kommentierte Kunstdruckmappe mit Nachdrucken der Kupferstiche von J. H. Tischbein. - Hofgeismar: Stadtmuseum 1989.

RÖLL, W.: Die kulturlandschaftliche Entwicklung des Fuldaer Landes seit der Frühneuzeit. - Gießen: Schmitz 1966 [Giessener Geographische Schriften;9]; Zugl.: Gießen, Univ., Diss. 1966.

ROLLE, A.: Turbulent waters. Navigation and California's Southern Central Valley. - In: California History 75/2 1996:128-137.

RÖMER, G. [Hrsg.]/BERGS, I.-A./MUSALL, H./NEUMANN, J. [Bearb.]: Der Neckar in alten Landkarten: Eine Ausstellung der Badischen Landesbibliothek: Ausstellungskatalog. - Karlsruhe 1988.

RÖMHILD, G.: Die Technischen Denkmale und Industriedenkmäler, namentlich des Bergbaus. - In: DENECKE, D./FEHN, K./SCHENK, W. (Hrsg.): Kulturlandschaftspflege. Beiträge der Geographie zur räumlichen Planung. - Stuttgart: Borntraeger 1997: 285-295.

RÖMHILD, G.: Montanindustrie an der Peripherie. Die nordwestdeutsche Wealdenkohle und der frühe Bergbau im Gesamtbergamt Obernkirchen-Barsinghausen - im Übergang von der Früh- zur Hochindustrialisierung - unter besonderer Berücksichtigung des 1961 erloschenen Schaumburger Steinkohlenbergbaus. - In: Siedlungsforschung 16 1998:279-327.

ROMMEL, W.-D.: Die Flößerei auf dem Kocher: insbesondere die Versorgung der Salinen Hall und Friedrichshall und ihre forstwirtschaftliche Auswirkung auf das Limpurger Land vom Ausgang des Mittelalters bis zur Industrialisierung. Freiburg/Breisgau, Univ., Diss. 1990

ROSCHER, H.: Die Wasserversorgung Thüringens vom Mittelalter bis zur Gegenwart: 130 Jahre einheitliche Wasserversorgung in Thüringen; ein beitrag zur Technikgeschichte. - Weimar: Universitätsverl. Bauhaus-Univ. 1999.

ROSENBERGER, K.: Die künstliche Bewässerung im oberen Etschgebiet. - Stuttgart 1936 [Forschungen zur Deutschen Landesund Volkskunde 31/4].

ROSENBOHM, R.: Zur Einführung der Mühlen in Altsachsen und Nordelbingen. - Hannover 1956 [Nieders. Jahrbuch. f. Landesgeschichte;28]:240-245.

ROSENECK, R.: Die Oberharzer Wasserwirtschaft: Entwicklung - Aufbau - Erhaltungsprobleme. - In: Berichte zur Denkmalpflege in Niedersachsen 1 1983:2-6.

ROSENWICK, Norbert: Die Begriffe der Landschaft und des Landschaftsbildes sowie ihrer Vielfalt, Eigenart und Schönheit im Naturschutzrecht: zugleich eine Untersuchung über die Einbeziehung außerrechtlicher Erkenntnisse in die Auslegung von unbestimmten Rechtsbegriffen. - Hannover, Uni., Diss. 2003

RÖSENER, W.: Die Bauern in der europäischen Geschichte. - München: Beck 1993.

RÖSENER, W. (Hrsg.): Jagd und höfische Kultur im Mittelalter. - Göttingen: Vandenhoeck \& Ruprecht 1997 [Veröff. d. MaxPlanck-Instituts f. Geschichte;135].

RÖSENER, W.: Die Geschichte der Jagd: Kultur, Gesellschaft und Jagdwesen im Wandel der Zeit. - Düsseldorf: Artemis \& Winkler 2004.

RÖSSERT, R.: Grundlagen der Wasserwirtschaft und Gewässerkunde. - 2. Aufl. - München et al.: Oldenbourg 1976 [1. Aufl. 1969].

RÖSSLER, M.d: UNESCO and Cultural Landscape Protection. - In: DROSTE ZU HÜLSHOFF, B. v./PLACHTER, H./RÖSSLER, M. (Hrsg.): Cultural Landscapes of Universal Value: Components of a Global Strategy. - Jena et al.: G. Fischer 1995:42-49.

ROTH, E.: Die planmäßig angelegten Siedlungen in Deutsch-Banater Militärgrenzbezirk 1765-1821. - München: Oldenburg 1981 [Buchreihe der südostdt. Hist. Komm.;33]; Zugl. Aachen, Univ., Diss.

ROTH, H.: Das Maintal in Mainfranken: eine kultur- und wirtschaftsgeographische Studie. - Würzburg 1935 [Mitteilungen d. Geographischen Gesellschaft zu Würzburg;8]; Zugl.: Würzburg, Univ., Diss. 1935. 
ROTHEN, H.: Mit dem Floß auf der Saale: Rückbesinnung auf ein ausgestorbenes Gewerbe. - Gotha: Perthes 1995 [Thüringen unter der Lupe].

RÖTTCHER, K.[a]: Ausbau der Werra durch die hessischen Landgrafen 1752. - In: TÖNSMANN, F. (Hrsg.): Zur Geschichte der Wasserstraßen insbesondere in Nordhessen. - Kassel: Herkules Verl. 1995 [Kasseler Wasserbau-Materialien;4]:169-184.

RÖTTCHER, K.[b]: Der Kanal des Landgrafen Karl in topographischen Karten. Hrsg.: Universität GH Kassel, Fachgebiet Wasserbau und Wasserwirtschaft. - Kassel: Herkules Verl. 1995 [Kasseler Wasserbau-Materialien;4].

RÖTTCHER, K./TONDERA, J./TÖNSMANN, F.: Der Kanal des Landgrafen Karl: Planung und Bau einer Kanalverbindung von Karlshafen über Kassel nach Marburg. - Aus: Landgraf Karl und die Gründung von Karlshafen 1699-1999. - Verl. Weber 1999.

ROTTMANN, C.: Landschaft als Geschichte. Carl Rottmann 1787-1850, Hofmaler König Ludwigs I. - Ausstellung der Kunsthalle der Hypo-Kulturstiftung und der Bayerischen Staatsgemäldesammlungen München. - München: Hirmer 1998.

RUBENSTEIN, J.: The cultural landscape: an introduction to human geography. - 6. Aufl. - New Jersey: Prentice Hall 1999 [1. Aufl. 1983].

RUBNER, H.: Technisch-industrielle Entwicklung, Waldzerstörung und Waldwirtschaft von der Aufklärung bis zur Gründung des Deutschen Reiches. - In: Technikgeschichte 51/2 1984:94-103.

RUDOLPH, H.: Vollständigstes geographisch-topographisch-statistisches Ort-Lexicon von Deutschland [...] enthaltend: alle Städte, Flecken, [...] Mühlen [...] - Leipzig: Zander 1872.

RUHLENDER, O.: Die wechselvolle Geschichte von Neuhaus im Solling: Geschichte und Geschichten. - Holzminden: Mitzkat 1998.

RUHS, P.: Alte Bewässerungsanlagen in Bayern. - In: Geschichtliche Entwicklung der Wasserwirtschaft und des Wasserbaus in Bayern. Teil 1. Hrsg. v. d. Technischen Universität München. - München 1986:69-113.

RULLE, M.: Die Entstehung und der Wandel der Kanäle Hamburgs: mit Beispielen aus den Hamburger Bezirken Eimsbüttel und Hamburg-Nord. - In: Zur Kulturgeographie und Industriearchäologie in Norddeutschland 1999:82-130.

RULLE, M.: Ein innerstädtischer Wasserweg als bedeutendes stadtgestaltendes Element: Der Isebekkanal in Hamburg. - In: NAGEL, F. N. (Hrsg.): Kulturlandschaftsforschung und Industriearchäologie: Ergebnisse der Fachsitzung des 52. Deutschen Geographentags Hamburg. - Stuttgart: Steiner 2001 [Mitteilungen der Geographischen Gesellschaft in Hamburg;91]:171178 .

RUMP, R.: Mühlen im Landkreis Harburg und angrenzenden Gebieten: A - Z. - Rosengarten-Ehestorf: Freilichtmuseum am Kiekeberg 2001 [Schriften des Freilichtmuseums am Kiekeberg;39].

RUND UM DEN QUADENHOF 1/1993: Das doppelte Gut Höltgen.

RUND, J. (Hrsg.): Historisch-landeskundliche Exkursionskarte von Niedersachsen. - Bielefeld: Verl. f. Regionalgeschichte 2000.

RUNGE, G.: Wasser als Standortfaktor für Industrie und Siedlung, dargestellt an Beispielen der Orlasenke und der Saale-ElsterSandsteinplatte (östlich der Saale). - In: Wiss. Zeitschr. Friedrich-Schiller-Universität Jena 13 1965:133-152.

RUPP, M.: Geographie und Stadtplanung. - In: AERNI, K. et al. (Hrsg.): Der Mensch in der Landschaft. Festschrift für Georges Grosjean zum 65. Geburtstag, 17. Januar 1986. - Bern: Lang 1986 [Jahrbuch der Geographischen Gesellschaft von Bern;55]:419-426.

RUPPERT, W.: Die Fabrik. Geschichte von Arbeit und Industrialisierung in Deutschland. - München: Beck 1993.

RUPPRECHT, G. (Hrsg.): Die Mainzer Römerschiffe: Berichte über Entdeckung, Ausgrabung und Bergung. - 2. Aufl. - Mainz: Krach 1982 [Archäologische Berichte aus Rheinhessen und dem Kreis Bad Kreuznach;1].

RUSINEK, B. A./ACKERMANN, V./ENGELSBRECHR, J. (Hrsg.): Einführung in die Interpretation historischer Quellen. Schwerpunkt: Neuzeit. - Paderborn: Schöningh 1992.

RUSSEL, R.: Lost canals and waterways of Britain. - Newton Abbot et al.: David [and] Charles 1982.

RUSSENBERGER, H.: Das Eschheimertal und seine Weiher. - Schaffhausen: Meili in Komm. 1982 [Schriftenreihe: Neujahrsblatt der Naturforschenden Gesellschaft Schaffhausen;34].

RUST, G.: Die Teichwirtschaft Schleswig-Holsteins. - Kiel: Selbstverl. d. Geogr. Inst. 1956 [Schriften d. Geogr. Inst. d. Univ. Kiel;15/4].

RYMUT, K.: Gewässernamen im rechten Zuflussgebiet der Weichsel zwischen Dunajec und Wislok. - Stuttgart: Steiner, 2000 [Hydronymia Europaea;15].

SAEFTEL, F.: Flößerei als Grundlage der Bauholzwirtschaft in der wikingerzeitlichen Marsch Schleswig-Holsteins. - In: Dt. Schiffahrtsarchiv 3 1980:21-26.

SALONEN, A.: Die Fischerei im alten Mesopotamien: nach sumerisch-akkadischen Quellen; eine lexikalische und kulturgeschichtliche Untersuchung. - Helsinki: Suomalainen tiedeaketemia 1970 [Suomalainen tiedeakatemian toimituksia: Ser. B. Humaniora;166]. 
SAMBRAUS, H. H.[a]: Atlas der Nutztierrassen: 250 Rassen in Wort und Bild. - 4. Aufl. - Stuttgart: Ulmer 1994

SAMBRAUS, H. H.[b]: Gefährdete Nutztierrassen: ihre Zuchtgeschichte, Nutzung und Bewahrung. - Stuttgart: Ulmer 1994

SANDEN-GUJA, W. v.: Der große Binnensee. Ein Jahreslauf. - 2. Aufl. - Stuttgart: Frank'sche Verl.buchhandlung 1960.

SANDER, A.: Landschaften. - München et al.: Schirmer/Mosel 1999.

SANDER-BERKE, A.: Spätmittelalterliche Holznutzung für den Baustoffbedarf dargestellt am Beispiel norddeutscher Städte. In: JOCKENHÖVEL, A. (Hrsg.): Bergbau, Verhüttung und Waldnutzung im Mittelalter: Auswirkungen auf Mensch und Umwelt; Ergebnisse eines internationalen Workshops (Dillenburg, 11. - 15.Mai 1994, Wirtschaftshistorisches Museum „Villa Grün“). - Stuttgart: Steiner 1996 [Vierteljahrschrift für Sozial- und Wirtschaftsgeschichte: Beihefte;121]:189-203.

SANDGRUBER, R.: Umweltgeschichte - eine neue Disziplin? - In: Historicum, Winter 1992/93:14-17.

SANT, M.: Applied Geography: Practise, Problems and Prospects. - London, New York: Longman 1982.

SANZIN, W.: Über marode Gewässer und die Möglichkeiten zu ihrer Sanierung. - In: 1855 - 1995 : 140 Jahre Landesfischereiverband Bayern, Jubiläumsbeilage zu „Bayern Fischerei und Gewässer“. Hrsg.: Landesfischereiverband Bayern e.V. [LFV] - München 1995:15-17.

SAUER, L.: Book review HEDEEN, Stanley: The Mill Creek: An Unnatural History of an Urban Stream. - Cinicinnati: Blue Heron Press 1994. - In: Landscape and Urban Planning 36/3 1996:236-237.

SAUER, [...]: Furt - In: SONNABEND, H. (Hrsg.): Mensch und Landschaft in der Antike: Lexikon der historischen Geographie. - Stuttgart; Weimar: Metzler 1999:159.

SAUERWEIN, B. / SCHÖTZ, D. / TÖNSMANN; F. / TROSDORF, F.: Reaktivierung von ehemaligen Kleinstwasserkraftanlagen an der Mahlgera in Thüringen. 2. Anwenderforum Kleinwasserkraftwerke, Passau, 28./29. Oktober 1999, Tagungsband. Passau 2000: 183-212.

SCARPINO, P. V.: Great River. An Environmental History of the Upper Mississipi, 1890-1950. - Columbia: Univ. of Missouri Press 1985.

SCHACHNTER, S.: „,...in Folge der zufließenden Fabrikwässer längst der letzte Fisch gestorben...“: Umweltbelastung durch die Papierindustrie: Ideen zur musealen Präsentation. - In: Mensch und Umwelt: Ein Thema volkskundlicher Forschung und Präsentation? - Köln 1993 [Schriften des Bergischen Freilichtmuseums;4]:59-66.

SCHACHTNER, S.: Der „Wäscheberg“ - Textilien in ländlichen Haushalten vor der Industrialisierung. . - In: „Die Große Wäsche": Eine Ausstellung des Landschaftsverbandes Rheinland, Rheinisches Museumsamt, Brauweiler in Zusammenarbeit mit dem Rheinischen Freilichtmuseum - Landesmuseum für Volkskunde, Mechernich-Kommern. - Köln: Rheinland-Verl., 1988 [Schriften d. Rhein. Museumsamtes;42; Zugl.: Schriften d. Rhein. Freilichtmuseums - Landesmuseum f. Volkskunde;34]:31-37.

SCHÄFER, A.: Biogeographie der Binnengewässer: eine Einführung in die biogeographische Areal- und Raumanalyse in limnischen Ökosystemen. - Stuttgart: Teubner 1997 [Teubner Studienbücher:Geographie].

SCHÄFER, D.: Alpine Jagd- und Ferntransporte. - In: Archäologie in Deutschland 4 1999:22-23.

SCHÄFER, D.: Forderungen und Berücksichtigungen kulturlandschaftlicher Belange bei Planung und Unterhaltung von Fließgewässern und Auen aus der Sicht der Kulturlandschaftspflege mit Anlage „Kevelaerer Apell“: Statement. - In: LANDSCHAFTSVERBAND RHEINLAND (Hrsg.): Fließgewässer in der Kulturlandschaft. - Köln 1999:177-180.

SCHÄFER, H.-P.: Forschungsschwerpunkte und Zukunftsaufgaben der Historischen Geographie: Verkehr - In: Erdkunde 36 1982:114-119.

SCHÄFFER, J./DRIESCH, A. v: Tierknochenfunde aus fünf frühmittelalterlichen Siedlungen Altbayerns. - München: Kanzler 1983 [Documenta naturae;15].

SCHÄFER, W.: Der Oberrhein, sterbende Landschaft. Teil C. - In: Natur und Museum 103 1974:297-343, 358-363.

SCHALLER, J.: Topographisches Lexikon des Königreichs Böhmen, darinnen sowohl alle Städte, Teiche, Bäche, Wälder und Berge mit ihrer vormaligen und heutigen Kreislage angezeiget sind, welches zugleich das vollständige Universalregister der ganzen Topographie ausmacht. [...] - Prag: Schönfeld-Meissner 1791.

SCHAMA, S.: Der Traum von der Wildnis: Natur als Imagination. - München: Kindler 1996.

SCHÄPERCLAUS, W.: Lehrbuch der Teichwirtschaft. - 2. Aufl. - Berlin, Hamburg: Parey 1961.

SCHÄPERCLAUS, W./LUKOWICZ, M. v.: Lehrbuch der Teichwirtschaft. - 4. Aufl. - Hamburg: Parey 1998.

SCHARF, M.: Naturentwicklungsgebiete mit Heckrindern in der Lippeaue des Kreises Soest. - In: NAU-Seminarbericht, Bd. 6 2000:34-38.

SCHAUER, R.: Alle suchen nur nach Erika. Die Lüneburger Heide - eine Landschaft zwischen poetischer Verklärung und nüchternem Nutzen. - In: Frankfurter Allgemeine Zeitung Nr. 137 v. 16. Juni 1994:R 1. 
SCHAUMBURG, J.: Zur Ökologie von Stichling Gasterosteus aculeatus L., Bitterling Rhodeus sericeus amarus Bloch (1782) und Moderlieschen Leucaspius delineatus (Heckel 1843) - drei bestandsbedrohten, einheimischen Kleinfischarten. Laufen/Salzach: ANL 1989 [Berichte der ANL;13].

SCHEDELSCHE WELTCHRONIK. - 5. Aufl. - Nachdruck der dt. Ausgabe von 1493. - Dortmund: Harenberg 1933 [Die bibliophilen Taschenbücher;64].

SCHEFFLER, W.: Mühlenkultur in Schleswig-Holstein: die Mühlen des Kreises Eckernförde und Nordfrieslands. - Neumünster: Wachholtz 1982.

SCHEFFRAN, B.: Wohnküche, Waschküche und Waschhaus. - In: „Die Große Wäsche“: Eine Ausstellung des Landschaftsverbandes Rheinland, Rheinisches Museumsamt, Brauweiler in Zusammenarbeit mit dem Rheinischen Freilichtmuseum - Landesmuseum für Volkskunde, Mechernich-Kommern. - Köln: Rheinland-Verl. 1988 [Schriften d. Rhein. Museumsamtes;42; Zugl.: Schriften d. Rhein. Freilichtmuseums - Landesmuseum f. Volkskunde;34]:60-68.

SCHEIFELE, M.: Ein Schwarzwälder Floßvertrag von 1342 - Älteste deutsche Urkunde zur Regelung der Flößerei. - In: Allg. Forst-u. Jagdzeitung 162/4 1991:65-68.

SCHEIFELE, M.: Die Flösserei auf der Ettlinger Alb: aus der Geschichte des Albtales. - Gernsbach: Katz 1993.

SCHEIFELE, M.: Als die Wälder auf Reisen gingen: Wald, Holz, Flößerei in der Wirtschaftsgeschichte des Enz-Nagold-Gebiets. Hrsg.: Ministerium für Ländlichen Raum, Ernährung, Landwirtschaft. - Karlsruhe: Braun 1996.

SCHEIFELE, M.: Die Flößerei im Schwarzwald vom Mittelalter bis ins 18. Jahrhundert: Technik und wirtschaftliche Bedeutung. In: Badische Heimat 78/2 1998:275-282.

SCHEIFELE, M.: Die Flößerei im Schwarzwald vom Mittelalter bis ins 19. Jahrhundert: Technik und wirtschaftliche Bedeutung. In: Allg. Forst- u. Jagdzeitung 170/9 1999:165-169.

SCHEIFELE, M.: Über die Flößerei in Südwestdeutschland. - In: Einbaum, Lastensegler, Dampfschiffahrt. - Stuttgart 2000:229240.

SCHEINER, J.: Die Angst der Geographie vor dem Raum. Anmerkungen zu einer verkehrswissenschaftlich-geographischen Diskussion und zur Rolle des Raumes für den Verkehr. - In: Geographische Revue 4/1 2002:19-44.

SCHELHAAS, B.: Vor 50 Jahren gegründet: der Zentralverband der Deutschen Geographen. - In: Geographische Rundschau 53/11 2001:60-61.

SCHENK, A. (Hrsg.): Europäische Kulturlandschaft Siebenbürgen: Reflexion einer wissenschaftlichen Dokumentation. München: Edition Wort und Welt 1995 [Kulturdenkmäler Siebenbürgens;3].

SCHENK, H.: Die böhmischen Länder: ihre Geschichte, Kultur und Wirtschaft. - 2. Aufl. - Köln: Verl. Wiss. u. Politik 1998 [Historische Landeskunde: Deutsche Geschichte im Osten;1].

SCHENK, K. F.: Abhandlung über den Wiesenbau, und was zu dessen Verbesserung sowohl vom Staate als von den Wieseneigenthümern geschehen müsse. - Fulda 1826

SCHENK, K. F.: Der Wiesenbau in seinem ganzen Umfange, insbesondere der Kunstwiesenbau des Siegener Landes. - Siegen, Wiesbaden 1843

SCHENK, W.: Mainfränkische Kulturlandschaft unter klösterlicher Herrschaft. Die Zisterzienserabtei Ebrach als raumwirksame Institution vom 16. Jahrhundert bis 1803. - Würzburg: Selbstverl. d. Inst. f. Geographie d. Univ. Würzburg 1988 [Würzburger Geogr. Arbeiten;71].

SCHENK, W.: Eine "Thematische Karte" aus dem 17. Jh.: die „Chorographia locorum“ aus der Abtei Ebrach als historischlandeskundliche Quelle. - In: Jahrbuch für fränkische Landesforschung 49 1989:141-157.

SCHENK, W.: Der historisch-genetische Ansatz in anwendungsorientierten Arbeitsfeldern des Geographischen Instituts der Universität Würzburg.- In: Kulturlandschaft. Zeitschrift für Angewandte Historische Geographie 1 1991:99-103.

SCHENK, W.: The Use of CAD an GIS Systems in the Reconstruction of Large-scale Historical Field Systems and Land Utilization - an Example from Southern Germany. - In: History and Computing 5 1993:25-34.

SCHENK, W. (Hrsg.): Mensch und Umwelt in Franken: Festschrift für Alfred Herold. - Würzburg: Inst. f. Geographie der Univ. 1994 [Würzburger geographische Arbeiten;89].

SCHENK, W.: Planerische Auswertung und Bewertung von Kulturlandschaften im südlichen Deutschland durch Historische Geographen im Rahmen der Denkmalpflege.- In: Berichte zur deutschen Landeskunde 68/2 1994:463-475.

SCHENK, W.: Mitteleuropa - typologische Annäherungen an einen schwierigen Begriff aus der Sicht der Geographie.- In: Europa Regional 3/4 1995:25-36.

SCHENK, W.: Salz in Franken - historische und geographische Aspekte.- In: TREML, M. et al. (Hrsg.): Salz Macht Geschichte, Aufsätze. - Augsburg: Haus der Bayerischen Geschichte 1995 [Veröffentlichungen zur Bayerischen Geschichte und Kultur;29]:267-278.

SCHENK, W.: Waldnutzung, Waldzustand und regionale Entwicklung in vorindustrieller Zeit im mittleren Deutschland: historisch-geographische Beiträge zur Erforschung von Kulturlandschaften in Mainfranken und Nordhessen. - Stuttgart: Steiner 1996 [Erdkundliches Wissen;119]; Zugl.: Würzburg, Univ., Habil.-Schr. 1992. 
SCHENK, W.: Der Blick auf die Landschaft. Die Geschichte unserer Umwelt im Spiegel von Landschaftsgemälden. - In: Praxis Geschichte 11/4 1997:40-42.

SCHENK, W.: Landschaften vom Reißbrett. Agrarlandschaftswandel - Ökonomische Hintergründe und kulturräumliche Folgen. In: Praxis Geschichte 11/4 1997:33-39.

SCHENK, W.: Möglichkeiten und Begrenzungen des Aufbaus und der Auswertung „Langer Reihen“ aus Archivalien für die Erfassung vorindustrieller Waldzustände und -entwicklungen, diskutiert an frühneuzeitlichen Rechnungsbeständen aus dem mittleren Deutschland. - In: SCHENK, W. (Hrsg.): Aufbau und Auswertung „Langer Reihen“ zur Erforschung von historischen Waldzuständen und Waldentwicklungen. Ergebnisse eines Symposiums in Blaubeuren vom 26. - 28.2.1998. Tübingen 1999 [Tübinger Geographische Studien;125]:3-22.

SCHENK, W.: Zum nachhaltigen Umgang mit räumlichen kulturhistorischen Werten in der bundesdeutschen Planung. - In: Berichte zur deutschen Landeskunde 74/3 2000:221-235.

SCHENK, W.: Auen als Siedlungs- und Wirtschaftsräume vor den ingenieurtechnischen Veränderungen des 19. Jahrhundert - das Mittelmaingebiet als Beispiel. - In: Zeitschrift für Geomorphologie, Suppl.-Bd. 124 2001:55-67.

SCHENK, W.: historisch-geographische Betrachtungsweisen. - In: LEXIKON DER GEOGRAPHIE, Bd. 2 2002:112-113.

SCHENK, W.: „Landschaft“ und „Kulturlandschaft“- „,getönte“ Leitbegriffe für aktuelle Konzepte geographischer Forschung und räumlicher Planung. - In: Petermanns Geographische Mitteilungen 146/6 2002:6-13.

SCHENK, W.[a]: Historische Geographie. Umwelthistorisches Brückenfach zwischen Geschichte und Geographie. - In: SIEMANN, W. (Hrsg.): Umweltgeschichte: Themen und Perspektiven. - München: Beck 2003 [Becksche Reihe]:129-146.

SCHENK, W.[b]: Kulturlandschaften - Zur „Karriere“ eines Begriffs. Vortrag auf der Veranstaltung Nr. 180 „Kulturlandschaften in Deutschland - Beispiele, Projekte, Spannungsfelder“; Bildungszentrum Eichholz der Konrad-Adenauer Stiftung e. V. vom 02.07. - 04.07.2003 [Mitschrift vom 2.07.2003].

SCHERER-HALL, R.: Die historische Kulturlandschaft als in der Raumplanung handhabbares Objekt. - In: Siedlungsforschung: Perspektiven der Historischen Geographie 1998:363-375.

SCHERER-HALL, R.: Kleines Lexikon der historischen Kulturlandschaft und ihrer Elemente - mit tabellarischer Übersicht zur Inventarisation von historischen Kulturlandschaftselementen. $\quad-$ Köln: Selbstverl. Büro f. Geographische Informationsverarbeitung 1996.

SCHEUER, F.: Berücksichtigung allgemeiner naturschutzrechtlicher Interessen bei der wasserwirtschaftlichen Planfeststellung von Fischteichen. - In: Natur und Landschaft 56/3 1981:95-96.

SCHEUREN, E. (Hrsg.): Flößerei auf dem Rhein: eine Ausstellung des Siebengebirgsmuseum der Stadt Königswinter im Mai 1989. - Königswinter: Heimatverein Siebengebirge e. V. 1989.

SCHEWIOR, G. (Hrsg.): Wiesenbau und Bewässerung. - Leipzig: Voigt 1941 [Leitfaden zur Bodenkunde;21].

SCHEYER, J. G.: Practisch-öconomische Wasserbaukunst zum Unterrichte für Beamte, Förster, Landwirthe, Müller und jeden Landmann. 2. Bde. Leipzig 1795.

SCHICH, W. (Hrsg.): Zisterzienser Wirtschaft und Kulturlandschaft. - Berlin: Lukas 1998 [Studien zur Geschichte, Kunst und Kultur der Zisterzienser;3]

SCHICH; W.: Klosteranlage und Wasserversorgung bei Zisterziensern. - In: RÜCKERT, P./PLANCK, Dieter (Hrsg.): Anfänge der Zisterzienser in Südwestdeutschland. Politik, Kunst und Liturgie im Umfeld des Klosters Maulbronn. - Stuttgart: Kohlhammer 1999:221-232 [25-41].

SCHICKE, H.: Neuordnung des ländlichen Raumes durch Flurbereinigung: der Wege- und Gewässerplan; Empfehlung der Arbeitsgemeinschaft für das technische Verfahren der Flurbereinigung im Bundesgebiet (AtVF). Hrsg. v. Bundesministerium für Ernährung, Landwirtschaft und Forsten. - Bonn 1972 [Schriftenreihe für Flurbereinigung; Sonderheft 4].

SCHIEMENZ, F.: Die Binnenfischerei in Niedersachsen. - In: Neues Archiv f. Niedersachsen 9/3 1957/58:193-204.

SCHIEMENZ, F.: Binnenfischerei und natürliche Landschaft (Gestein, Boden und Pflanzendecke) in Niedersachsen. - Oldenburg i. O.: Stalling 1935 [Veröff. d. Wirtschaftswiss. Gesell. z. Studium Niedersachsens e. V., Reihe A, Beiträge;25].

SCHIERBLING, S.: Gewässerkataster für eine naturnahe Gewässergestaltung. - In: MÜLLER, G./MATSCHULLAT, J. (Hrsg.): Geowissenschaftliche Umweltforschung. Tagung 5. und 6. November 1993 in Heidelberg. Zusammenfassung der Vorträge und Poster.. - Heidelberg: Ruprecht-Karls-Univ. 1993 [Heidelberger Geowissenschaftliche Abhandlungen;67]:136.

SCHIESSL, H.: Geschichtlicher Abriss, Struktur sowie aktuelle Fragen und Probleme der Teichwirtschaft in der Oberpfalz. Regensburg, 1990 [Regensburger Beiträge zur Regionalgeographie und Raumplanung; 2]: 48-98

SCHIETZEL, K.: Land- und Seewege im Bereich der Schleswiger Landenge 5-11. Jh. - Weinheim: DFG 1984.

SCHILGEN, F. v. (Hrsg.): Das Gesetz betreffend die Fischerei der Ufereigenthümer und die Koppelfischerei in der Provinz Hannover vom 26.Juni 1897. - Hamm/Westfalen 1897.

SCHILLER, K./LÜBBEN, A.: Mittelniederdeutsches Wörterbuch. Photomechanischer Neudruck der Ausgabe von 1878. Wiesbaden 1969. 
SCHINDLER, K.-H.: Die Anlage von Fischteichen. - In: Natur und Recht 3/5 1981:160-168.

SCHINKEL, E. (Red.): Das Schiffshebewerk Henrichenburg- Dortmund. - Crüwell 1900 Reprint: o. J. [um 1992]. Münster:Westfälisches Industriemuseum Dortmund 1992.

SCHIPPERGES, H.: Der Garten der Gesundheit. Medizin im Mittelalter. - München: Beck 1990.

SCHIRJAEWO 2004 [URL = http.//www.germanistik.ssu.samara.ru/stadtfuehrer/schirjaewo.htm;17.01.2004].

SCHIRMER, J. W.: Johann Wilhelm Schirmer in seiner Zeit. Landschaft im 19. Jahrhundert zwischen Ideal und Wirklichkeit. Heidelberg: Kehrer 2002.

SCHIVELSBUSCH, W.: Geschichte der Eisenbahnreise: zur Industrialisierung von Raum und Zeit im 19. Jahrhundert. Frankfurt/Main: Fischer-Taschenbuch-Verl. 1999. [Fischer-Taschenbücher;4414].

SCHLAUCH, J.: Entwicklung und Struktur der deutschen Molluskenfischerei und -kultur im trilateralen Vergleich mit Dänemark und den Niederlanden. - Bamberg: Selbstverl. des Faches Wirtschaftsgeographie der Univ. Bamberg 1999 [Bamberger Wirtschaftsgeographische Arbeiten;10].

SCHLEGEL, W.: Mensch und Umwelt: Entwurf einer geographischen Humanökologie [Vorlesungsskriptum]. - Paderborn: Univ.GH Paderborn, FB 1 Geographie 1993.

SCHLENDER, T.: Alte Mühlen in Mythen, Märchen und Erzählungen. - München: Droemer Knaur 1988 [Knaur;1607].

SCHLENKER, G./LAUBNER, J.: Die Unstrut: Porträt einer Kulturlandschaft. - Halle: Mitteldeutscher Verl. [mdv] 2002

SCHLESIER, B.: Der Weiße Fluß: seine Heilung auf einfache und naturgemäße Weise. Allen leidenden Frauen gewidmet. Lüneburg, [1890].

SCHLEUTER, M./GEIß, S.: Der Main: Fluß und Wasserstraße; Vortragsveranstaltung des Wasserstraßen-Neubauamtes Aschaffenburg am 5. und 6. Mai 1997 in Würzburg. - Hrsg.: Bundesanstalt für Gewässerkunde. - Koblenz: Bundesanstalt für Gewässerkunde 1998 [Mitteilungen: Bundesanstalt für Gewässerkunde Koblenz, Berlin;17].

SCHLICHTHERLE, H.: Bodmann-Blissenhalde: Eine neolithische Ufersiedlung unter dem Steilhang des Bodenrücks. - In: ArchNachrBad 38/39 1987:38-42.

SCHLICHTHERLE, H. (Hrsg.): Pfahlbauten rund um die Alpen. Sonderheft der Zeitschrift „Archäologie in Deutschland“ 1997. Stuttgart: Theiss 1997.

SCHLICHTHERLE, H./WAHLSTER, B.: Archäologie in Seen und Mooren: den Pfahlbauten auf der Spur. - Stuttgart: Theiss 1986.

SCHLIMPERT, G./FISCHER, R. E.: Die Gewässernamen Brandenburgs. - Weimar: Böhlau 1996 [Berliner Beiträge zur Namenforschung;11].

SCHLOTT, K.: Praktizierte Umweltgeschichte: Der Sachverständige für die „Durchführung und Beurteilung von standortbezogenen Erhebungen (historische Recherche)“. - Ein neues Berufsbild für Historiker. - In: BAYERL, G./WEBER, W. (Hrsg.): Sozialgeschichte der Technik - Ulrich Troitzsch zum 60. Geburtstag. - Münster et al.: Waxmann 1998 [Cottbuser Studien zur Geschichte von Technik, Arbeit und Umwelt;7]:25-34.

SCHLÜTER, O.: Die Stellung der Geographie des Menschen in der erdkundlichen Wissenschaft. - Berlin: Mittler 1919 [Geographische Abende im Zentralinstitut für Erziehung und Unterricht;5].

SCHLÜTER, O.: Wald, Sumpf und Siedlungsland in Altpreussen vor der Ordenszeit. - Halle/Saale: Niemeyer 1921.

SCHLÜTER, O.: Die Siedlungsräume Mitteleuropas in frühgeschichtlicher Zeit. - 1. Teil: Einführung in die Methodik der Altlandschaftsforschung. - Hamburg [et al.]: List 1952 [Forschungen zur deutschen Landeskunde;63].

SCHLÜTER, O.: Über das Verhältnis von Natur und Mensch in der Anthropogeographie. Vortrag, gehalten bei dem XVI. Geographentag in München. - In: Geographische Zeitschrift 13 1907:505-517.

SCHLÜTER, O.: Lebenslauf des ordentlichen Professors der Geographie Dr. Otto Schlüter. - In: Petermanns Geographische Mitteilungen 96/4 1952:289-293.

SCHMAL, S.: Umweltgeschichte: von der Antike bis zur Gegenwart. - 1. Aufl. - Bamberg: Buchner 2001 [Buchners Edition Geschichte;5].

SCHMALING, G. C.: Sammlung vermischter Nachrichten zur Hohensteinischen Geschichte, Erdbeschreibung und Statistik [...].Halberstadt: Delius [1791].

SCHMALZ, F./WOLFF, H.-P.: Nordhausen Fotografien von gestern und heute. - Gudensberg-Gleichen: Wartberg-Verl. 1996.

SCHMEIL, O./FITSCHEN, J.: Flora von Deutschland und seinen angrenzenden Gebieten: ein Buch zum Bestimmen der wildwachsenden und häufig kultivierten Gefäßpflanzen. - 87. Aufl. - Heidelberg: Quelle und Meyer 1982.

SCHMID, J.: Das verlorene Gleichgewicht: Eine Kulturökologie der Gegenwart. - Stuttgart et al.: Kohlhammer Verl. 1992.

SCHMID, W. A./NAEF, A.: Einleitung. - In: DVWK (Hrsg.): Historische Wasserwirtschaft im Alpenraum und an der Donau. Stuttgart: Wittwer 1994:5-9. 
SCHMIDT, A.: Beitrag der historischen Landschaftsanalyse für aktuelle Fragen des Naturschutzes: eine Untersuchung durchgeführt am Beispiel des Biopshärenreservates Schorfheide-Chorin. - Herdecke 1999 [Forschen und Wissen Landschaftsgestaltung]; Zugl.: Kiel, Univ. Diss. 1999.

SCHMIDT, A.-H.: Südböhmen, Mähren und Österreich-Schlesien: Siedlung, Ethnien und Religion. - Aigen: Voglhub 1998.

SCHMIDT, C. W.: Der Fluss: eine Morphologie fliessender Gewässer. - Leipzig: Thomas [1918].

SCHMIDT, E.: Ökosystem See. Bd. 1: Uferbereich des Sees, Bd. 2: Freiwasserraum und Tiefenzone. - 5. Aufl. - Heidelberg: Quelle \& Meyer 1997 [1. Aufl. 1974] [Biol. Arbeitsbücher;12].

SCHMIDT, Gerhard: Die Reformation in Nordhausen. - Göttingen, univ., Diss., 1924

SCHMIDT, K.-H.: Der Fluß und sein Einzugsgebiet: hydrogeographische Forschungspraxis. - Stuttgart: Steiner 1984 [Wissenschaftl. Paperback, Geographie].

SCHMIDT, K.: Erdgeschichte. - 4. Aufl. - Berlin et al.: De Gruyter 1990.

SCHMIDT, J.: Beschreibende Darstellung der älteren Bau- und Kunstdenkmäler der Stadt Nordhausen. - Halle: Otto Hendel 1887 [Beschreibende Darstellung der älteren Bau- und Kunstdenkmäler der Provinz Sachsen und angrenzender Gebiete, hrsg. von der Historischen Kommission der Provinz Sachsen;11].

SCHMIDT, L./BRAUER, A.: 75 Jahre Darmstädter Wiesendüngungsversuche: mit Ergebnissen der ältesten exakten Versuche des europäischen Festlandes. - Frankfurt/Main: Sauerländer 1979.

SCHMIDT, M.: Die Flöß-Schleusen im Radauborn. - In: Unser Harz 2 1989:25-28.

SCHMIDT, M.: Die Oberharzer Bergbauteiche. - In: DVWK (Hrsg.): Historische Talsperren. - Stuttgart: Wittwer 1987. Bearbeitet von Günther GARBRECHT; Bd. 1:327-385.

SCHMIDT, M.: Die Oberharzer Bergbauteiche. - Stuttgart: Wittwer 1988.

SCHMIDT, M.: Die Wasserwirtschaft des Oberharzer Bergbaus. - 2. Aufl. - Bergisch-Gladbach 1992 [Schriftenreihe der Frontinus-Gesellschaft e.V.;13].

SCHMIDT, M.: Wasserkraftwerke für den Westharzer Bergbau im 13. bis 19. Jahrhundert.. - Kassel: Herkules Verl. 1996 [Kasseler Wasserbau-Mitteilungen;7].

SCHMIDT, M.: WasserWanderWege. Ein Führer durch das Freilichtmuseum Kulturdenkmal Oberharzer Wasserregal. Mit landschaftsökologischen Hinweisen von Helmut R. Kessler. Hrsg. v. der Harzwasserwerke GmbH. - Clausthal-Zellerfeld: Piepersche Druckerie und Verl. 1997.

SCHMIDT, M.: Hochwasser und Hochwasserschutz in Deutschland vor 1850: Eine Auswertung alter Quellen und Karten. Hildesheim: Harzwasserwerke GmbH (Hrsg) 2000.

SCHMIDT, M.: Historische Hochwasser im deutschen Rheingebiet. - In: Wasserwirtschaft 92/4,5 2002:48-52.

SCHMIDT, M.: Chausseen, Kanäle, Eisenbahnen: Verkehr im Emsland des 19. Jahrhunderts. - In: Jahrbuch des Emsländischen Heimatbundes 44 1998:156-195.

SCHMIDT, R.: Die Kartenaufnahme der Rheinlande durch Tranchot und von Müffling 1801-1828. - Köln: Hanstein 1973 [Publikationen der Gesellschaft für rheinische Geschichtskunde;12 - Erläuterungen zum geschichtlichen Atlas der Rheinlande;10].

SCHMIDT, W.: Das Feldberger Seengebiet: Ergebnisse der landeskundlichen Bestandsaufnahme in den Gebieten Feldberg, Fürstenwerder, Thomsdorf und Boitzenburg. - Weimar: Böhlau 1997 [Werte der Deutschen Heimat;57].

SCHMIDT, W. (Hrsg.): Von “Abwasser" bis "Wandern”. Ein Wegweiser zur Umweltgeschichte. Begleitband zum Schülerwettbewerb Deutsche Geschichte um den Preis des Bundespräsidenten 1986/87. - Hrsg.: Körber Stiftung Hamburg. Hamburg: o. V. 1986.

SCHMIDTCHEN, V.: Technik im Übergang vom Mittelalter zur Neuzeit zwischen 1350 und 1600. - In: Propyläen Technikgeschichte. Hrsg. v. Wolfgang KÖNIG, Bd. 2: Metalle und Macht 1000-1600.- Berlin 1992:207-598.

SCHMIDT-EICHSTAEDT, G.: Vorwort. - In: STRAUß, C.: Amphibische Stadtentwicklung: Wasser im Lebensraum Stadt; zur Integration des Wassers des Wassers in die Stadtentwicklung. - Berlin: Leue 2002 [edition stadt und region;2].

SCHMITHÜSEN, J.: Vegetationsforschung und ökologische Standortslehre in ihrer Bedeutung für die Geographie der Kulturlandschaft. - In: Zeitschrift der Gesellschaft für Erdkunde zu Berlin 3/4 1942:113-157.

SCHMITHÜSEN, J.: Geschichte der geographischen Wissenschaft: von den ersten Anfängen bis zum Ende des 18. Jahrhunderts. Mannheim et al.: Bibliographisches Inst. 1970 [BI-Hochschultaschenbücher; 363/363a].

SCHMITZ, A.: Die Siedlungsnamen und Gewässernamen des Kreises Lüchow-Dannenberg. - Neumünster: Wachholtz 1989 [Kieler Beiträge zur deutschen Sprachgeschichte;19].

SCHMITZ, M.: Leinengewerbe und Leinenhandel in Nordwestdeutschland 1650-1850. - Köln: Wirtschaftsarchiv 1967 [Schriften z. Rhein.-Westf. Wirtschaftsgeschichte;15]. 
SCHMITZ-PORTEN, H.: Die Düssel als historischer Fluß. - In: LANDESHAUPTSTADT DÜSSELDORF (Hrsg.): Die Düssel: Geschichte und Geschichten. - Köln: Rheinland-Verl. 1988:25-35.

SCHMOTZ, K-: Die vorgeschichtliche Besiedlung im Isarmündungsgebiet. - Kallmünz: Lassleben 1989 [Materialhefte zur bayerischen Vorgeschichte: Reihe A, Fundinventare und Ausgrabungsbefunde;58]; Zugl.: München, Univ., Diss. 1983.

SCHNATH, G.: Geschichtlicher Handatlas Niedersachsens. - Berlin: Gea-Verl. 1939 [Veröffentlichungen der Historischen Kommission für Hannover, Oldenburg, Braunschweig, Schaumburg-Lippe und Bremen;20].

SCHNEEKLOTH, H. et al.: Die Moore Niedersachsens, Teil 1-8. - Göttingen et al.: Wurm 1970-1983 [Veröff. d. Niedersächs. Inst. f. Landeskunde u. Landesentwicklung a. d. Univ. Göttingen: A, Forschungen zur Landes- und Volkskunde;96, 1-8; Schr. Wirtschaftswiss. Ges. z. Studium Nieders.;96, 1-8).

SCHNEIDER, H.: Einführung in die antike Technikgeschichte. - Darmstadt: Wiss. Buchges. 1992 [Die Altertumswissenschaft].

SCHNEIDER, R.: Landschafts- und Umweltgeschichte im Einzugsgebiet der Elz. - Freiburg/Breisgau, Univ., Diss. 2000 [URL = http://webdoc.sub.gwdg.de/ebook/tm/freidok/125.pdftarget=_blank>http://web].

SCHNEIDER, S.: Luftbild und Luftbildinterpretation. - Berlin et al.: de Gruyter 1974 [Lehrbuch der allgemeinen Geographie;11].

SCHNETZ, J.: Flussnamen des bayerischen Schwabens in ihrer Bedeutung für die Namenkunde, Geschichte und Landschaftsforschung. - Augsburg: Verl. d. Schwäb. Forschungsgemeinschaft, 1950 (1953) [Veröffentlichungen der Schwäbischen Forschungsgemeinschaft bei der Kommission für Bayerische Landesgeschichte: Reihe 1, Studien zur Geschichte des Bayerischen Schwabens;1 (2)].

SCHNITTER, N.: Antike Talsperren in Anatolien. - In: Leichtweiss-Inst. f. Wasserbau, Braunschweig 1979 [Mitteilungen;64]:8ff.

SCHNITTER, N.: Geschichte des Schutzwasserbaus in der Schweiz. - In: Wasser, Energie, Luft 1/2 1991:27-42.

SCHOCH, G.: Die Technik in der künstlichen Fischzucht. - Zürich: Zürcher und Furrer 1879 [Neujahrsblatt. Hrsg. v. d. Naturforschenden Gesellschaft;82].

SCHOCH, G.: Gut Berneuchen in der Neumark. - Neujahrsblatt herausgegeben von der Naturforschenden Gesellschaft auf das Jahr 1880.

SCHOLL, G.: Die Bedeutung naturnaher Teiche für die Tierwelt. Laufen/Salzach 1991 [Berichte der ANL;15].

SCHOLL, L. U.: Als die Hexen Schiffe schleppten. Die Geschichte der Ketten- und Seilschleppschiffahrt auf dem Rhein. Hamburg: Ernst Kabel Verl. 1985.

SCHOLL-LATOUR, Peter: Afrikanische Totenklage: Der Ausverkauf des Schwarzen Kontinents. - München: Bertelsmann 2001.

SCHÖLLER, P.: Die deutschen Städte. - 2. Aufl. - Wiesbaden: Steiner 1980 [Erdkundliches Wissen;17] [1. Aufl. 1967]..

SCHÖLLER, P.: Geopolitische Versuchungen bei der Interpretation der Beziehungen zwischen Raum und Geschichte. Eine kritische Bilanz der Konzeptionen und Theorien seit Friedrich Ratzel. - In: DENECKE, D./FEHN, K. (Hrsg.): Geographie in der Geschichte. - Stuttgart: Steiner 1989 [Erkundliches Wissen;96]:73-88.

SCHOLL-LATOUR, P.: Der Fluch des neuen Jahrtausends. Eine Bilanz. - München: Bertelsmann 2002.

SCHOLZ, A.: Die Grossmusscheln (Unionidae) im Regierungsbezirk Detmold. Verbreitung, Biologie und Oekologie der ostwestfaelischen Najaden. - In: Naturschutz - Landschaftspflege im Regierungsbezirk Detmold, Sonderheft 91992.

SCHOLZ, F.: Geographische Umweltforschung - Einsichten in ein Schlüsselfach. - In: Die Erde 126 1995:269.

SCHOLZ, I.: Möglichkeiten der Intensivierung der Kleinwasserkraftnutzung im Einzugsgebiet der oberen Lippe. - Münster, Univ., Geograph. Inst. d. Westf. Wilhelms-Univ., Dipl.arbeit 1986.

SCHOLZ, T. H.-D. (Hrsg.): Wasser- und Windmühlen in Kurhessen und Waldeck-Pyrmont. - Kaufungen: Verl. Axel Eiling 1991.

SCHÖN, V.: Die Mühlsteine von Haithabu und Schleswig: ein Beitrag zur Entwicklungsgeschichte des mittelalterlichen Mühlenwesens in Nordwesteuropa. - Neumünster: Wachholt 1995 [Berichte über die Ausgrabungen in Haithabu;31]; Zugl.: Hamburg, Univ., Diss. 1991.

SCHÖN, W.: Fluß. - In: SONNABEND, H. (Hrsg.): Mensch und Landschaft in der Antike. Lexikon der historischen Geographie. - Metzler 1999.

SCHÖNBORN, W.: Fließgewässerbiologie. - Jena et al.: G. Fischer 1992.

SCHÖNEWIESE, C.-D./DIEKMANN, B.: Der Treibhauseffekt. Der Mensch verändert das Klima. - Reinbeck: Rowohlt 1989.

SCHÖNFELD, D.: Bachräumung - ein altes Arbeitsfest. - In: Das Jetzelschiff 131951.

SCHÖNFELD, G./SCHÄFER, D.: Erhaltung von Kulturlandschaften als Aufgabe des Denkmalschutzes und der Denkmalpflege. In: Denkmalschutz und Denkmalpflege. 10 Jahre Denkmalschutzgesetz Nordrhein-Westfalen. - Köln 1991:235.

SCHÖNFELD, R.: Die Donau als Faktor der wirtschaftlichen Entwicklung Regensburgs. - In: MASCHKE, E./SYDOW, J. (Hrsg.): Die Stadt am Fluß: 14. Arbeitstagung in Kiel 14. - 16.11.1975. - Sigmaringen: Thorbecke 1978 [Stadt in der Geschichte;4]:110-124. 
SCHÖNFELDER, G.: Kulturlandschaft und Karte: zur kartographischen Analyse und Darstellung von Nutzflächenänderungen als Beitrag zur Problematik des Landschaftswandels. Erfahrungen landeskundlicher Arbeit in Mitteldeutschland. - In: HAASE, G. (Hrsg.): Beiträge zur Landschaftsanalyse und Landschaftsdiagnose. - Stuttgart 1999:18-74.

SCHÖNKECHT, R./GEWIESE, A.: Auf Flüssen und Kanälen. Die Binnenschiffahrt der Welt. - Berlin: transpress VEB Verl. f. Verkehrswesen 1988.

SCHÖPS, A./SZARAMOWICZ, M.: Die Flächenagentur Kulturlandschaft Mittlere Havel: Poolträger und regionaler Akteur. - In: Stadt + Grün 7 2003:36-37.

SCHORR, A.: Mit Bach gebildete Siedlungsnamen im Saar-Mosel-Raum. - In: ERNST, P. et al. (Hrsg.): Ortsnamen und Siedlungsgeschichte. Akten des Symposiums in Wien vom 28.-30. September 2000. - Heidelberg: Winter 2002:123-136.

SCHRAMM, E.: Historische Umweltforschung und Sozialgeschichte des 19. und 20. Jahrhunderts. - In: Archiv für Sozialgeschichte [AFS] 37 1987:439-455.

SCHRAMM, E.: Die historische Umweltforschung und die heutige Ökologie-Diskussion. - In: Siedlungsforschung 6 1988:147163.

SCHRAMM, E.: Der Wasseranspruch der Natur. - In: DVWK (Hrsg.): Gewässer - schützenswerter Lebensraum. - Hamburg, Berlin: Parey 1992 [Schriftenreihe des Deutschen Verbandes für Wasserwirtschaft und Kulturbau e.V.;102]:177-195.

SCHRAMM, G.: Nordpontische Ströme: Namenphilologische Zugänge zur Frühzeit des europäischen Ostens. - Göttingen: Vandenhoeck und Ruprecht 1973.

SCHRECKENBACH, H.: Das Leinen auf der Wiese. Die Geschichte der Sohlinger Musterbleiche. - In: BIRKIGT-QUENTIN, B./BUSSE, G./SCHÄFER, W. (Hrsg.): Flachs und Leine zwischen Leine und Weser. Berichte und Bilder aus Adelebsen, Uslar und Wahlsburg. - Im Auftrag der Museen: Museum Uslar, Steinarbeiter-Museum Adelebsen, Schäferhausmuseum in Wahlsburg-Lippoldsberg. - Adelebsen, Uslar, Wahlsburg 1995:27-30.

SCHRECKENBERG, K.-P. et al.: Siedlungsstrukturen in Niedersachsen: Findorff-Siedlungen in den Mooren zwischen Weser und Elbe. - Wolfenbüttel et al.: Fischer et al. 1992.

SCHREIBER, K.-F.: Was leistet die LOK für die ökologische Planung? - In: Schriftenreihe zur ORL 34 1985:7-28.

SCHREIBER, K.-F.: Beiträge der LÖK zur Ökosystemforschung und ihre Anwendung. - In: Verhandlungen der Dt. Geogr. Gesell. 45 1987:134-145.

SCHREIBER, W./WALTER, S.: Von der Frankenwald-Flößerei. - Bayreuth: Regierung von Oberfranken 1987 [Amtl. Schulanzeiger des Regierungsbezirks Oberfranken: Heimatbeil.;132].

SCHRÖDER, A./OSTENDORFF, E.: Der Sülthof und seine Mühlen, insbesondere die alte Ölmühle. - Quakenbrück: Thoben 1978 [Schriftenreihe des Kreisheimatbundes Bersenbrück;15].

SCHRÖDER, E.: Funde und Befunde zu Siedlung und Wirtschaft der spätmittelalterlichen Wüstung Dornhagen bei Adelebsen. In: Göttinger Jahrbuch 35 1987:95-116.

SCHRÖDER, E.: Relikte der Wiesenbewässerung im Raum Flecken Adelebsen. - In: Südniedersachsen - Zeitschrift für Regionale Forschung und Heimatpflege 28/1 1997:9-13.

SCHRÖDER, G./SCHRÖDER, E.: Spätmittelalterlich-frühneuzeitliche Kulturlandschaftsrelikte im Raum Güntersen, Landkrs. Göttingen. - In: Göttinger Jahrbuch 27 1979:63-81.

SCHRÖDER, K./SCHWARZ, G.: Die ländlichen Siedlungsformen in Mitteleuropa: Grundzüge und Probleme ihrer Entwicklung. 2. Aufl. - Trier: Zentralausschuß f. deutsche Landeskunde, Selbstverl. 1978 [1. Aufl. 1970] [Forschungen zur deutschen Landeskunde; 175].

SCHRÖDER, W.: Geschichte des Dorfes Riehe, 5. - 7. Mai 1979 [URL = http://www.ralf-schroederriehe.de/geschich/entwick.htm; 09.01.2002]

SCHRÖDER, W./DASCHKEIT, A.: Einführung. - In: DASCHKEIT, A./SCHRÖDER, W. (Hrsg.): Umweltforschung quergedacht. Perspektiven integrativer Umweltforschung und -lehre. - Berlin et al.: Springer 1998 [Umweltnatur- und Umweltsozialwissenschaften]:1-5.

SCHROETER, W.: Karl Friedrich Wilhelm Wallroth. Zur Wiederkehr seines 200. Geburtstages. - In: Beiträge z. Heimatkunde aus Stadt u. Kreis Nordhausen 16 1991:89-111.

SCHUA, L./SCHUA, R.: Wasser, Lebenselement und Umwelt: die Geschichte des Gewässerschutzes in ihrem Entwicklungsgang dargestellt und dokumentiert. - Freiburg/Breisgau et al.: Alber 1981 [Orbis academicus, Sonderband;2,4: Problemgeschichte von Naturschutz, Landschaftspflege und Humanökologie].

SCHUBERT, D.: Revitalisierung von Hafen- und Uferzonen in Deutschland: Chancen für die Stadtentwicklung. - In: HANSA Schiffbau - Hafen 136/3 1999:67ff.

SCHUBERT, D. (Hrsg.): Hafen- und Uferzonen im Wandel: Analysen und Planungen zur Revitalisierung der Waterfront in Hafenstädten. - Berlin: Leue Verl. 2002 [edition stadt und region]

SCHUBERT, E. (Hrsg.): Von der Angst zur Ausbeutung: Umwelterfahrung zwischen Mittelalter und Neuzeit. - Frankfurt/Main: Fischer-Taschenbuch-Verl. 1994 [Fischer-Taschenbücher;11194]. 
SCHUBERT, E./HERRMANN, B. (Hrsg.): Von der Angst zur Ausbeutung: Umwelterfahrung zwischen Mittelalter und Neuzeit. Frankfurt: Fischer alternativ 1994.

SCHUBERT, E.: Scheu vor der Natur, Ausbeutung der Natur. Die Wandlung des Umweltbewußtseins im Mittelalter. - In: HERRMANN, B./BUDDE, A. (Hrsg.): Natur und Geschichte. Naturwissenschaftliche und historische Beiträge zu einer ökologischen Grundbildung. Sommerschule „Natur und Geschichte“ vom 14. bis 27. September 1989 an der Georg-AugustUniversität Göttingen. - Hildesheim: Gerstenberg 1989 [Schriftenreihe „Expert“ des Nieders. Umweltministers Hannover]:28-43.

SCHUBERT, Stefan: Die Saale und ihre Biologie: eine Literaturstudie über anthropogene Nutzungsformen der letzten Jahrhunderte und deren Auswirkungen auf das Fließgewässerökosystem. - Erfurt: Akad. Gemeinnütziger Wissenschaften, 2001 [Sonderschriften der Akademie Gemeinnütziger Wissenschaften zu Erfurt;35]; Zugl.: Dipl.arbeit 2000.

SCHUETZ, [...]: Baumaterial. - In: SONNABEND, H. (Hrsg.): Mensch und Landschaft in der Antike: Lexikon der historischen Geographie. - Stuttgart; Weimar: Metzler 1999:54.

SCHUHKRAFT, S.: Zustandserfassung und ökologische Bewertung von Fließgewässern mit Hilfe eines Geoinformationssystems am Beispiel der Hache (Niedersachsen). - Bremen: Univ.-Buchh. 1998 [Bremer Beiträge zur Geographie und Raumplanung;33]; Zugl.: Bremen, Univ., Diss. 1997.

SCHUHMACHER, H./THIESMEIER, B.: Urbane Gewässer. - Essen: Westarp Wissenschaften 1991.

SCHUKNECHT, F.: Der Fluß, die Furt und die Brücke. - In: Allgemeiner Bürger-Schützen-Verein Dorsten: Chronik 6 1997:252263.

SCHULENBERG, G./SCHULENBERG, P.: 1050 Jahre Hubbelrath: Geschichtliche Streiflichter von der Steinzeit bis zum Jahre 2000. - Hrsg.: „Runder Tisch“ zum Jubiläum 2000:64.

SCHULENBERG, P.: Das doppelte Gut Höltgen: Archivforschung und Archäologie lösen ein Rätsel. - In: Rund um den Quadenhof 1/1993:25-27.

SCHULENBERG, Peter: Rekonstruktion einer Landschaft. -In: Rund um den Quadenhof. 47/2 1996:69-75.

SCHÜLER DUDEN - DIE GEOGRAPHIE 1997.

SCHÜLER, M.: Weltbild - Kartenbild: Geographie und Kartographie in der frühen Neuzeit. Ausstellung aus den Beständen der Niedersächsischen Staats- und Universitätsbibliothek Göttingen. - Paulinerkirche, Historisches Gebäude der SUB vom 24. 2. - 7. 4. 2002. Hrsg. von Elmar Mittler und Inka Tappenbeck. - 2. Auf. - Göttingen: Niedersächsische Staats- und Universitätsbibliothek Göttingen 2002 [Göttinger Bibliotheksschriften;19].

SCHULTE, R.: Teichwirtschaften - Sahnestücke des internationalen Arten- und Biotopschutzes. Ergebnisse eines Seminars der NABU-Akademie Gut Sunder vom 23.10. bis 24.10.1999. - NABU 2000 [URL = http://www.nabu-akademie.de/ berichte/99teiche.htm;22.02.2004].

SCHULTE, R.: Das River-Continuum-Concept. Ergebnisse des Seminars "Zielarten für den Naturschutz an Fließgewässern - Mehr Raum für Bäche und Flüsse" vom 19.09. bis 20.09.2000. - NABU 2001 [URL = http://www.nabuakademie.de/berichte/00fluss_rcc.htm;22.02.2004].

SCHULTZ, H.-D.: Die deutschsprachige Geographie von 1800 bis1970: ein Beitrag zur Geschichte ihrer Methodologie. -Berlin: Geographisches Inst. d. FU 1980 [Abhandlungen des Geogr. Inst. Berlin, Anthropogeographie;29].

SCHUKTZ, H.-D.: Beiträge zur Geschichte der Geographie. - Berlin: Geographisches Inst. Humboldt-Univ. 2004 [Arbeitsberichte, Geographisches Inst. Humboldt-Univ. zu Berlin;91].

SCHULTZ, H.-D.: Von der Apotheose des Fortschritts zur Zivilsationskritik. Das Mensch-natur-Problem in der klassischen Geographie. - In: EISEL, U./SCHULTZ, H.-D.: Geographisches Denken. - Kassel: Gesamthochschulbibliothek 1997 [Urbs et Regio, Sonderband 65]:177-282.

SCHULTZ, J..: Blüte und Niedergang der landesherrlichen Teichwirtschaft in der ehemaligen Landgrafschaft Hessen. - Berlin 1913 [Archiv f. Fischereigeschichte].

SCHULTZE-NAUMBURG, P.: Die Gestaltung der Landschaft durch den Menschen. - 3. Aufl. - München: Callwey 1928.

SCHULZ, H. H.: Auf den Spuren der Schafe. Die Canadas, Jahrhunderte alte Viehwege, führen durch ein unbekanntes Spanien. In: Frankfurter Allgemeine Zeitung Nr. 184 v. 10. August 1995.

SCHUMACHER, H./STRAUSS, J.: Das ganze Land ein Garten (The whole land a garden): Historische Kulturlandschaften an Havel, Elbe und Themse. - Potsdam: Strauss 1998.

SCHUMACHER-GORNY, S.: Die maritime Kulturlandschaft im Wandel. Der Übergang zu einer ,pseudomaritimen Kulturlandschaft“ im Bereich der Erholungslandschaft.. - In: BURGGRAAFF, P./KLEEFELD, K.-D.: Perspektiven der Historischen Geographie 1997:307-314.

SCHUMANN, D.: An der Lena flußabwärts. - Berlin: Das Neue Berlin 2002.

SCHÜTT, C.: Die Entwicklung und wirtschaftliche Bedeutung der Binnenfischerei in Schleswig-Holstein. - Kiel: Mühlau 1927.

SCHÜTTE, S.: Mensch und Umwelt in der mittelalterlichen Stadt. - In: HERRMANN, B./BUDDE, A. (Hrsg.): Natur und Geschichte. Naturwissenschaftliche und historische Beiträge zu einer ökologischen Grundbildung. Sommerschule „Natur und 
Geschichte“ vom 14. bis 27. September 1989 an der Georg-August-Universität Göttingen. - Hildesheim: Gerstenberg 1989 [Schriftenreihe „Expert“ des Nieders. Umweltministers Hannover]:240-246.

SCHÜTTE, U.: Das Schloß als Wehranlage. Befestigte Schloßbauten der frühen Neuzeit im alten Reich . - Darmstadt: Wiss. Buchgesell. 1994.

SCHÜTZE, H.: Mit dem Floß die Oertze hinunter. - In: Der Speicher. Heimatbuch des Landkreises Celle 1930:335-337.

SCHWABE-BRAUN, A.: Die Heustadel-Wiesen im nordbadischen Murgtal: Geschichte - Vegetation - Naturschutz. - In: Veröffentlichungen für Naturschutz und Landschaftspflege in Baden-Württemberg 55/56 1982:167-237.

SCHWARTZ, J. M.: The Geography Lesson: photographs and the construction of imaginative geographies. - In: Journal of Historical Geography 22/1 1996:16-45.

SCHWARZ, A.: Alte Mühlen im südwestlichen Münsterland. Die Entwicklung der Wind- und Wassermühlen im Spiegel der Landesgeschichte. - Sythen: Heimatverein Eigenverl. 1984.

SCHWARZ, B./FAIST, H.: Historisches vom Strom: Schiffahrt auf der Saale und Unstrut. - Duisburg: Verl. Krüpfganz 1993 [Personenschiffahrt-Güterschiffahrt;8].

SCHWARZ, T.: Fischgüter an der Werra bei Heringen und am Seuligssee sowie Teiche im Seulingswald im 14.-17. Jahrhundert. In: Mein Heimatland: Zeitschrift für Geschichte, Volks- und Heimatkunde 381999.

SCHWARZE, M.: Die Erhaltung traditioneller Kulturlandschaften. - Bern: Schweizer Stiftung f. Landschaftsschutz u. Landschaftspflege 1985 [Schrift Nr. 3]

SCHWARZENBERG, J. v.: Bambergische Peinliche Halsgerichtsordnung. - Bamberg: Hans Pfeil 1507. - [7] B1., B1. 3-80 [URL $=\mathrm{http}: / /$ www.uni-mannheim.de/mateo/desbillons/bambi.html;08.01.2004].

SCHWARZ-ZANETTI, G.: Grundzüge der Klima- und Umweltgeschichte des Hoch- und Spätmittelalters in Mitteleuropa. Zürich, Univ., Diss 1998.

SCHWEINFURTH, W.: Geographie anthropogener Einflüsse - das Murgsystem im Nordschwarzwald: ein Kapitel anthropogener Geomorphologie. - Mannheim: Geographisches Inst., Univ. 1990 [Mannheimer Geographische Arbeiten;26]; Zugl.: Mannheim, Univ., Diss. 1989 u. d. T.:Räumlich-zeitliche Dimesnion der anthropogenen Eingriffe in das nordschwarzwälder Murgsystem.

SCHWEIZERISCHES LANDESMUSEUM ZÜRICH 2004: Auguste Bachelin „Pfahlbaudorf aus der Jungsteinzeit“ (1867) [URL $=$ http://www.diepfahlbauer.ch/inhalt/presse/bilder/bilder_inhalt.html;23.03.2004].

SCHWEPNITZ 2004 [URL = http://www.schwepnitz.de/geschichte/schwepnitz/landschaft.html;07.02.2004].

SCHWERDTFEGER, K.: 400 Jahre Bergbau und Eisenverhüttung in Altenbrak. - Berlin: [im Selbstverl.] o. J.

SCHWERDTFEGER, K.: Eisensteingruben, Hochofen- und Hammerhütten im Bodegebiet des Harzes. - Clausthal-Zellerfeld: Piepersche Druckerei- und Verl. 1998.

SCHWERTENLEIB, M.-H.: Die Enlach im 19. und 20. Jahrhundert. - Winterthur 1989 [Neujahrsblatt der Staatsbibliothek Winterthur;219].

SCHWIND: M.[a]: Kulturlandschaft als objektivierter Geist. - In: SCHWIND, Martin: Kulturlandschaft als geformter Geist. Drei Aufsätze über die Aufgabe der Kulturgeographie. - Darmstadt: Wissenschaftl. Buchgesell.1964 [ursprünglich in: Deutsche geographische Blätter 46/1 1951]:1-16.

SCHWIND: M.[b]: Das Verhältnis des Menschen in seiner Umwelt als geographisches Problem. Ein Beitrag zur Wissenschaftsgeschichte. - In: SCHWIND, Martin: Kulturlandschaft als geformter Geist. Drei Aufsätze über die Aufgabe der Kulturgeographie. - Darmstadt: Wissenschaftl. Buchgesell. 1964 [ursprünglich in: Veröffentlichungen der Gesellschaft für Internationale Wissenschaftsgeschichte 2/1952]:27-46.

SCHWINEKÖPER, K.: Historische Landschaftsanalyse in der Landschaftsökologie: am Beispiel des Wurzacher Riedes, des Einzugsgebietes der Wolfegger Ach und des Heidenwuhres. - Ostfildern: Heimbach 1997 [Berichte des Institutes für Landschafts- und Pflanzenökologie der Universität Hohenheim, Beiheft 2]; Zugl.: Hohenheim, Univ. Diss. 1997.

SCHWINEKÖPER, K.: Historische Analyse - - In: Handbuch Naturschutz und Landespflege: Kompendium zu Schutz und Entwicklung von Lebensräumen und Landschaften. Hrsg.: KONOLD, W. et al. - Landberg/Lech: ecomed 1. erg. Lfg. 3 2000.

SCHWINEKÖPER, K.: Wässerwiesen: Geschichte und Möglichkeiten des Erhalts eines traditionellen Kulturlandschaftselements in Südwestdeutschland. - In: Kulturlandschaftsforschung und Umweltplanung 2001:119-129.

SCHWINEKÖPER, K./SCHÜLE, E.-M./KONOLD, W.: Zur Geschichte der Wässerungsgenossenschaften am Beispiel der Stadt Freiburg. - In: Alemannisches Jahrbuch 1995/96:257-292.

SCHWINN, H.: Relationale Datenbanksysteme. - München et al.: Hansen 1992.

SCHWOERBEL, J.: Einführung in die Limnologie. - 7. Aufl. - Stuttgart: Fischer 1993 [UTB;31].

SCOTT, J.: Kartenkunst: die Geschichte der Kartographie. - Braunschweig: Westermann 1994. 
SEEDORF, H. H.: Geographische Landeskunde. Bemerkungen zur einstigen Bedeutung, zum Niedergang und zu den heutigen Aufgaben der Landeskunde in Niedersachsen. - In: Neues Archiv f. Niedersachsen 38/1 1989:15-18.

SEEDORF, H. H./MEYER, H.-H.: Landeskunde Niedersachsen: Natur- und Kulturgeschichte eines Bundeslandes. - Bd. 2. Niedersachsen als Wirtschafts- und Kulturraum: Bevölkerung, Siedlungen, Wirtschaft, Verkehr und kulturelles Leben. Neumünster: Wachholtz 1996.

SEEDORF, Hans-Heinrich: Umweltprobleme aus historischer Sicht. - In: Niedersachsen 87 1987:157-160.

SEEHASE, H.: Die Fischerei in Schleswig-Holstein: ein Beitrag zur deutschen Volkskunde und zur schleswig-holsteinischen Heimatforschung. - Hamburg: Wachholtz 1935 [Sprache und Volkstum;4]; Zugl.: Kiel, Univ., Diss. 1934.

SEEL, Martin: Eine Ästhetik der Natur. - Frankfurt/Main: Suhrkamp 1996 [Suhrkamp Taschenbücher Wissenschaft;1231].

SEELE, E.: Die Weser - Strom und Schiffahrtsweg. - Münster: Aschendorff 1968 [Westfälische Forschungen;21]:162-178.

SEELIGER, M.: Wesersandstein - Sollingplatten - Höxterstein: Die Weser als Handelsweg. - In: Jahrbuch für den Landkreis Holzminden 1987/88

SEHORZ, E. H.: Die Wiesenbewässerung im Bayerischen Wald: Eine kulturgeographische Untersuchung. - In: Mitteilungen der Geographischen Gesellschaft in München 49 1964:43-153.

SEIBT, F.: Glanz und Elend des Mittelalters. Eine endliche Geschichte. - Berlin: Siedler Verl., Sonderausgabe 1999 [Orig. 1987].

SEIDENSPINNER, Wolfgang: Das Maulbronner Wassersystem - Relikte zisterziensischer Wasserbautechnik im heutigen Landschaftsbild. - In: Denkmalpflege in Baden-Württemberg 1997. Hrsg. v. Landesdenkmalamt Baden-Württember [Forschungen und Berichte der Bau- und Kunstdenkmalpflege;7]:181-191

SEIDENSPINNER, W.: Historische Wiesenwässerung im Teinachtal: Relikte der Agrar- und Technikgeschichte zwischen Funktionsverlust und Zeugniswert.- In: Denkmalpflege in Baden-Württemberg Nachrichten des Landesdenkmalamtes 20/3 1991:136-144.

SEIDENSPINNER, W.: Weiher und Kanäle. Die Genese einer Kulturlandschaft durch die Zisterzienser am Beispiel von Maulbronn. - In: Klosterlangheim. Arbeitsheft 65 des Bayr. Landesamtes für Denkmalpflege. - München 1994:90-93.

SEILER, C. W.: Die Aller: ein Fluss verändert seinen Lauf; die historische Laufentwicklung der Aller zwischen Müden und Celle. - Hrsg. vom Winser Heimatverein e.V. und dem Landkreis Celle - Kreisarchiv. - 1. Aufl. - Celle: Landkreis Celle 2002 [Schriftenreihe: Quellen und Darstellungen zur Geschichte des Landkreises Celle;5].

SEILER, S.: Riesen, Klausen und „Holländer“. - In: Damals 10 1994:66-71.

SELBMANN, S.: Mythos Wasser: Symbolik und Kulturgeschichte. - Karlsruhe: Badenia-Verl. 1995.

SELIGO, A.: Die Fischerei in den Fliessen, Seen und Strandgewässern Mitteleuropas. - 1925 [Handbuch der Binnenfischerei Mitteleuropas; Bd. 5 Lieferung 1/2].

SELTER, B.: Forstgeschichte heute: Anmerkungen zu Aufgaben und Weiterentwicklung einer traditionellen Disziplin mit besonderer Berücksichtigung des Übergangsfeldes zur genetischen Siedlungsforschung. - In: Siedlungsforschung 18 2000:151-160.

SENATOR FÜR STADTENTWICKLUNG UND UMWELTSCHUTZ (Hrsg.): Die Kanäle nördlich der Spree. - Berlin 1985.

SENATSVERWALTUNG FÜR BAUEN, WOHNEN UND VERKEHR BERLIN (Hrsg.): Wasserstadt Berlin: Mobilisierung von Wohnungsbaustandorten an Wasserlagen [Band 1-3] - Berlin 1999.

SENATSVERWALTUNG FÜR STADTENTWICKLUNG BERLIN: Entwicklung der Berliner Wasserlagen. - Berlin 2003.

SENATSVERWALTUNG FÜR STADTENTWICKLUNG BERLIN: Planwerk Westraum Berlin. - Berlin 2000.

SENT, M.: Applied Geography. - Harlow, Essex: Longman 1982.

SETTLER, H.-D.: Moselkanalisation. Bonn, Univ., Diss. bei Prof. FEHN seit 2001 [noch nicht abgeschlossen].

SETTLER, H.-D.: Die Moselkanalisation. Kurzbeitrag zur Generaldiskussion. - In: Kulturlandschaft 10/1 2001:209-212.

SETZWEIN, B: An den Ufern der Isar: ein bayrischer Fluss und seine Geschichte. - München: Koehler und Amelang 1993.

SETZWEIN, B./MOSER, G./GRÜNER, N.: Land der tausend Teiche. Das Stiftland. - Amberg: Kunstverl. Oberpfalz 1999.

SEUSER, F.: Rheinische Namen. Orts- und Flur-, Berg- und Flussnamen. - Bonn: Röhrscheid 1944.

SEYMOUR, S.: Historical geographies of landscape. - In: GRAHAM, B./NASH, C. (Hrsg.): Modern Historical Geographies. Harlow: Longman 2000:193-217.

SHERIFF, C.: The Artificial River: the Erie canal and the paradox of progress, 1817 - 1862. - New York: Hill and Wang 1996

SHURMER-SMITH, P. (Hrsg.): Doing cultural geography. - London et al.: SAGE 2002 [Schriftenreihe: Doing human geography].

SHURMER-SMITH, P.: Postcolonial geographies. - In: SHURMER-SMITH, P. (Hrsg.): Doing Cultural Geography. - London et al.: Sage 2002.

SICK, W.-D.: Agrargeographie. - Braunschweig: Westermann 1993 [Das geographische Seminar]. 
SICKLER, J. V. (Hrsg.)/GÜNTHER, J. A. (Bearb.):Die deutsche Landwirthschaft in ihrem ganzen Umfange nach den neusten Erfahrungen bearbeitet von einer Gesellschaft praktischer Oekonomen. - Erfurt: Henningsche Buchhandlung, Bd. 8: Die Teich- und Fischerey-Wirthschaft [...] 1810.

SIDE 2004 [URL = http://www.side-tr.com/sidelim.htm;29.01.2004].

SIECKEL, J. C.: Die freie Reichsstadt Nordhausen, nach ihrem Namen, Alterthum, [...] - Leipzig 1753.

SIEDLUNGEN DER STEINZEIT - Spektrum der Wissenschaften. Heidelberg 1989.

SIEDLUNGSFORSCHUNG. Archäologie-Geschichte-Geographie. - Bd. 6, Schwerpunkthema: „Historische Umweltforschung“. - Bonn: Verl. Siedlungsforschung, 1988.

SIEDLUNGFSFORSCHUNG. Archäologie-Geschichte-Geographie. Bd. 7, Schwerpunktthema: Siedlungs- und Kulturlandschaftsforschung am Unterlauf großer Ströme am Beispiel des Rhein-Maas-Deltas. - Bonn: Verl. Siedlungsforschung 1989.

SIEFERLE, R. P.: Der unterirdische Wald. Energiekrise und industrielle Revolution. - München: Beck 1982.

SIEFERLE, R. P.: Entstehung und Zerstörung der Landschaft. - In: SMUDA, M. (Hrsg.): Landschaft. - Frankfurt/Main: Suhrkamp 1986 [Suhrkamp-Taschenbuch;2069]:238-265.

SIEFERLE, R. P. (Hrsg.): Fortschritte der Naturzerstörung. - Frankfurt/Main: Suhrkamp 1988 [Edition Surhkamp;1489].

SIEFERLE, R. P.: Perspektiven einer historischen Umweltforschung. - In: SIEFERLE, R. P. (Hrsg.): Fortschritte der Naturzerstörung. - Frankfurt/Main: Suhrkamp 1988 [Ed. Suhrkmap; 1489, N.F.489]:307-377.

SIEFERLE, R. P.: Aufgaben einer künftigen Umweltgeschichte. - In: Environmental History Newsletter 11993.

SIEFERLE, R. P.: Fortschrittsfeinde? Opposition gegen Technik und Industrie von der Romantik bis zur Gegenwart. - München: Beck 1994.

SIEFERLE, R. P.: Rückblick auf die Natur. Eine Geschichte des Menschen und seiner Umwelt. - München: Beck 1997.

SIEFERLE, R. P./BREUNINGER, H. (Hrsg.): Natur-Bilder: Wahrnehmungen von Natur und Umwelt in der Geschichte. Frankfurt/Main et al.: Campus-Verl. 1999.

SILBERBORTH, H.: Das tausendjährige Nordhausen. Zur Jahrtausendfeier hrsg. vom Magistrat der Stadt Nordhausen. 1. Teil: Geschichte der Freien Reichsstadt Nordhausen. - Nordhausen 1927.

SIMMLER, S.: Historische Kulturlandschaft erfasst und sichtbar gemacht. - In: „Schönere Heimat“: Erbe und Auftrag 93/2 2004:101-108.

SIMMONS, I. G.: Environmental history. a concise introduction. - Oxford, Cambridge: Blackwell 1993 [New perspectives on the past].

SIMON, C. (Hrsg.): Umweltgeschichte heute. - Mannheim: Landesmuseum für Technik und Arbeit 1993 [Environmental History Newsletter, Special issue;1].

SIMON, K.: Die Bleicharbeit. - In: BIRKIGT-QUENTIN, B./BUSSE, G./SCHÄFER, W. (Hrsg.): Flachs und Leine zwischen Leine und Weser. Berichte und Bilder aus Adelebsen, Uslar und Wahlsburg. - Im Auftrag der Museen: Museum Uslar, Steinarbeiter-Museum Adelebsen, Schäferhausmuseum in Wahlsburg-Lippoldsberg. - Adelebsen, Uslar, Wahlsburg $1995: 25-26$

SIMSON, J. v.: Die Flußverunreinigungsfrage im 19. Jahrhundert. - In: Vierteljahresschrift für Sozial- und Wirtschaftsgeschichte 65 1978:373-390.

SIPPEL, K.: Frühneuzeitliche Glashütten im Kaufunger Wald: Denkmäler früher Industreigeschichte im nördlichen Fulda-WerraBergland. Hrsg. v. d. Abt. f. Vor- und Frühgeschichte i. Landesamt f. Denkmalpflege Hessen. - Wiesbaden 1987 [Archäologische Denkmäler in Hessen;63].

SKOWRONNEK, F.: Die Fischwaid: Handbuch der Fischerei, Fischzucht und Angelei. - Leipzig : Schmidt 1904.

SLOTTA, R.: Technische Denkmäler in der Bundesrepublik Deutschland; Bd. 4: Der Metallerzbergbau. - Bochum: Deutsches Bergbau-Museum 1983 [Veröffentlichungen aus dem Deutschen Bergbau-Museum Bochum;26].

SMEDT, O. de: Wilhelm de Raet, Baumeister und Ingenieur (ca. 1537 - 1583). - In: Braunschweiger Jahrbuch 46 1965:147-150.

SMETS, J: Der Rhein: Deutschlands Strom, aber Frankreichs Grenze: zur Rheinmythologie in Frankreich und Deutschland vom Mittelalter bis zum 20. Jahrhunderts. - In: Jahrbuch für westdeutsche Landesgeschichte 24 1998:7-50.

SMETTAN, H.: Vorgeschichtliche Salzgewinnung und Eisenerzverhüttung im Spiegel württembergischer Pollendiagramme. - In: JOCKENHÖVEL, A. (Hrsg.): Bergbau, Verhüttung und Waldnutzung im Mittelalter: Auswirkungen auf Mensch und Umwelt; Ergebnisse eines internationalen Workshops (Dillenburg, 11. - 15.Mai 1994, Wirtschaftshistorisches Museum „Villa Grün“). - Stuttgart: Steiner 1996 [Vierteljahrschrift für Sozial- und Wirtschaftsgeschichte: Beihefte;121]:84-92.

SMITH, J.: The General Historie of Virginia, New-England, and the Summer Isles (London, 1624). - Reprint: Readox Microprint Coop. 1966. 
SMOLIAN, K.: Merkbuch der Binnenfischerei. - 2. Bde. - Berlin: Denter \& Nicolas 1920 [Karte II: Die wichtigsten Teichwirtschaften Deutschlands im Jahre 1915].

SMIT, J. G.: Neubildung deutschen Bauerntums: innere Kolonisation im Dritten Reich; Fallstudien in Schleswig-Holstein. Kassel: Gesamthochschulbibiolthek 1983 [Urbs et regio;30]. Zugl.: Njimegen, Katholieke Univ, Diss. 1983.

SNEYD, J.: Alternative Nutzpflanzen. - Stuttgart: Ulmer 1995.

SOHNREY, H.: Die Sollinger, Bd. 2: „Tchiff, tchaff, toho!: Gestalten, Sitten und Bräuche, Geschichten und Sagen aus dem Sollinger Walde. - Berlin: Dt. Landbucg 1929 [II. Teil Schilderung „Vom Fleuen“:148-153].

SOMMER, H.: Zur Kur nach Ems: ein Beitrag zur Geschichte der Badereise von 1830-1914. - Stuttgart 1999 [Geschichtliche Landeskunde;48].

SOMMER, S.: Mühlen am Niederrhein: Die Wind- und Wassermühlen des linken Niederrheins im Zeitalter der Industrialisierung (1814-1914). - Köln, Bonn, Univ., Diss. 1991.

SONNABEND, H.[a]: Bad. - In: SONNABEND, H. (Hrsg.): Mensch und Landschaft in der Antike: Lexikon der historischen Geographie. - Stuttgart; Weimar: Metzler 1999:51.

SONNABEND, H.[b]: Brunnen. - In: SONNABEND, H. (Hrsg.): Mensch und Landschaft in der Antike: Lexikon der historischen Geographie. - Stuttgart; Weimar: Metzler 1999:73.

SONNABEND, H.[c]: Kanal - In: SONNABEND, H. (Hrsg.): Mensch und Landschaft in der Antike: Lexikon der historischen Geographie. - Stuttgart; Weimar: Metzler 1999:244.

SONNABEND, H. (Hrsg.)[d]: Mensch und Landschaft in der Antike. Lexikon der historischen Geographie. - Stuttgart: Metzler 1999.

SONNENBURG, H./GERKEN, B.: Das Hutewaldprojekt im Solling: Ein Baustein für eine neue Ära des Naturschutzes. - Höxter: Huxaria 2003.

SPANG, R.: Die Gewässernamen des Saarlandes aus geographischer Sicht. - Saarbrücken: Saarbrücker Druckerei u. Verl. 1982 [Beiträge zur Sprache im Saarland;3].

SPARKASSE GIFHORN-WOLFSBURG (Hrsg.): Reizvolle Fluß- und Seenlandschaften im Raum Gifhorn-Wolfsburg. - Peine: Schlaeer 1988 [Schriftenreihe zur Heimatkunde der Sparkasse Gifhorn-Wolfsburg; 4].

SPERLING, W.: Die Stellung der Historischen Geographie in einem modernen geographischen Curriculum. - In: Erdkunde 36 1982:79-84.

SPERLING, W.: Geographische Namen als interdisziplinäres Forschungsfeld: disziplinhistorische und methodologische Aspekte. - In: BROGATIO, H.-P. (Hrsg.): Geographische Namen in ihrer Bedeutung für die landeskundliche Forschung und Darstellung: Referate des 8. Arbeitstreffens des Arbeitskreises Landeskundliche Institute und Forschungsstellen in der Deutschen Akademie für Landeskunde, Trier, 21. - 23. Mai 1988. - Trier 1999 [DL-Berichte und Dokumentationen;2]:1741.

SPERLING, W.: Kulturgeographie - geographische Kultur: über den Umgang mit geographischen Dingen - In: MANNSFELD, K./NEUMEISTER, H.: Ernst Neefs Landschaftslehre heute. - Gotha: Perthes 1999:45-63.

SPETHMANN, H.: Die großen Kanalbauten in Holland und Belgien. - Oldenburg i. O.: Stalling 1935 [Veröff. d. Wirtschaftswiss. Gesell. z. Studium Niedersachsens e. V.: Reihe A, Beiträge 30].

SPIEGEL, Freiherr v.: Schlossteiche [URL = http://www.schlossbrauerei-rheder.de/geschichte2.htm;26.05.2004].

SPINDLER, E. A.: Umweltvorsorge für ein Fluß-Ökosystem: methodische Weiterentwicklung der Projekt-UVP zur Berücksichtigung gesamtsystemarer Bewertungsmaßstäbe am Beispiel der Unterweser; [überarbeitete Beiträge der Wissenschaftlichen Fachtagung „Ökosystem Unterweser - Maßstäbe zur Umweltvorsorge“, die vom Senator für Umweltschutz und Stadtentwicklung der Freien Hansestadt Bremen am 23. und 24. Juni 1992 in Bremen veranstaltet wurde]. - Hrsg.: UVP-Förderverein. - Dortmund : Dortmunder Vertrieb für Bau- und Planungsliteratur 1993 [UVP spezial;6].

SPINDLER, T.: Fischfauna in Österreich: Ökologie - Gefährdung - Bioindikation - Fischerei - Gesetzgebung. Hrsg.: Umweltbundesamt. - 2. Aufl. - Wien 1997 [Monographien;97].

SPINDLER, K.: Der Kanalbau Karls des Großen: Seine Reflexion in den mittelalterlichen Quellen und der aktuelle archäologische Forschungsstand. - In: SPINDLER, K. (Hrsg.): Mensch und Natur im mittelalterlichen Europa. - Klagenfurt 1998:47-99.

SPINDLER, K. (Hrsg.): Mensch und Natur im mittelalterlichen Europa: archäologische, historische und naturwissenschaftliche Befunde. - Klagenfurt: Wieser 1998 [Schriftenreihe der Akademie Friesach;4].

SPITTLER, R.: Vom Fluss zum Kanal und zurück? Das Schicksal der Ems im Raum Warendorf und ihre Zukunft. - In: Jahrbuch Westfalen 1992:190-196.

SPITTLER, R.: Forderungen zur Berücksichtigung kulturlandschaftlicher Belange bei Planung und Unterhaltung von Fließgewässern und Auen aus der Sicht des Naturschutzes: Statement. - Vortrag im Rahmen der Fachtagung „Fließgewässer in der Kulturlandschaft" des Landschaftsverbandes Rheinland. - Jülich 1998.

SPOHR, E.: Wasserbau und Fortifikation, Siedlungsentwicklung und Stadthygiene bis 1809. - In: LANDESHAUPTSTADT DÜSSELDORF (Hrsg.): Die Düssel: Geschichte und Geschichten. - Köln: Rheinland-Verl. 1988:45-53. 
SPONECK, C. F. Graf v.: Handbuch des Flosswesens (Manuel du Flottage) [...]: vorzüglich für Forstmänner, Kameralisten und Floss-Beamte. - Stuttgart: Metzler 1825.

SPRENGEL, C.: Die Lehre von den Urbarmachungen und Grundverbesserungen, oder: Beschreibung und Erklärung aller Urbarmachungen und Grundverbesserungen, welche die Sümpfem Brüche, Hochmoore, Teiche, Haiden, Wüstungen, Wälder, Sandschollen, Dünen, felsigen Gründe, Äcker, Wiesen und Weiden betreffen: Mit sechs Kupfertafeln. - Leipzig: Baumgärtner 1838 .

SPRENGER, M.: Bürgerhäuser und Adelshöfe in Rinteln: bau- und sozialgeschichtliche Untersuchungen zu frühneuzeitlichen Hausformen im mittleren Weserraum. - Marburg: Jonas Verl. 1995 [Materialien zur Kunst- und Kulturgeschichte in Nordund Westdeutschland;19]; Zugl.: Münster, Univ., Diss.

SPRINGER, O.: Die Flussnamen Württembergs und Badens. - Stuttgart: Kohlhammer 1930 [Tübinger Germanistische Arbeiten;11].

STAATLICHES UMWELTAMT LIPPSTADT: Lippeauenprogramm: Die Klostermersch. 1999.

STADLER, H. (Hrsg.): Albertus Magnus De animalibus libri XXVI, Bd. 2 - Münster 1921 [Beiträge zur Geschichte der Philosophie des Mittelalters;16].

STADT BRAUNSCHWEIG, GRÜNFLÄCHENAMT (Hrsg.): Naturschutzgebiet Riddagshausen: Informationen, Wanderkarte 1:20 000. - 3. Aufl. - Braunschweig: Stadt Braunschweig 1994 [1. Aufl. 1991]

STADT DÜSSELDORF, Untere Denkmalbehörde: Bescheid über die Eintragung in die Denkmalliste „Ehemaliges Gestüt Mydlinghoven“; 12.12 .1984$.

STADT HALLE: Pflege- und Entwicklungsplan für das FND „Kleiner Angersdorfer Teich“. - Stadt Halle/Saale, Untere Naturschutzbehörde 1997.

STADT HALLE: Pflege- und. Entwicklungsplan für GLB „Amselgrund und Kreuzer Teiche“. - Stadt Halle/Saale, Untere Naturschutzbehörde 1998.

STADT HANN. MÜNDEN: EXPO-Projekt Wasserspuren. Broschüre - Hann. Münden, April 2000.

STADTENTWÄSSERUNG ZÜRICH (Hrsg.): „Bäche in der Stadt Zürich“: Konzepte, Erfahrungen und Beispiele von Bachöffnungen und Bachrenaturierungen im Stadtgebiet. - Stadt Zürich: Entsorgung und Recycling (Stadtbehörde) o. J.

STADTENTWÄSSERUNG ZÜRICH (Hrsg.): Von der Schîssgruob zur modernen Stadtentwässerung. - Zürich: Verlag Neue Zürcher Zeitung, 1992.

STADTENTWICKLUNG BERLIN 2004: Der Berliner Wasserlagenentwicklungsplan. [URL = http://www.stadtentwicklung.berlin.de/planen/stadtentwicklungsplanung/de/wasserlagen/einleitung.html;21.01.2004].

STADTGEMEINDE SAALFELDEN 2004 [URL = http://www.saalfelden.at;07.09.2003].

STADTVERWALTUNG NEUENBÜRG 2003: Informationsblatt der Stadtverwaltung Neuenbürg 2003 [URL = http://www.www.neuenbuerg.de, 11.06.2003; http://www.frischglueck.de, 11.06.2003]

STAMM, R. A.: Sozio-kulturelle und philosophische Anthropologie für die Umweltwissenschaften. - In: BRANDT, E. (Hrsg.): Perspektiven der Umweltwissenschaften. - Baden-Baden: Nomos 2000 [Umweltrecht und Umweltpolitik;2]:17-34.

STANISLAW, H.: Die Oder als Kulturlandschaft: über Geschichte und Alltag in der deutsch-polnischen Grenzregion. Begleitbuch zur gleichnamigen Ausstellung der Fachgruppe „Bau- und Bodendenkmalpflege/Museumwesen“ Polen und Brandenburg. Szczecin 1998.

STATISTISCHES BUNDESAMT (2003): Betrieb und Fläche der landwirtschaftlichen Betriebe, aktualisiert am 13. November 2003 [URL $=$ http://www.destatis.de/basis/d/forst/forsttab2.php;08.08.2004].

STATISTISCHES BUNDESAMT (2002): Datenreport 2002. - Wiesbaden 2002.

STEIDLE, L.: Die Flußperlmuschel und Perlfischerei in bayerischen Gewässern. - München 1986 [Informationsbericht des Bayerischen Landesamtes f. Wasserwirtschaft;1]:13-47.

STEIN, H.: Die Aufgaben des Landesfischereiverbandes heute und morgen. - In: 1855 - 1995: 140 Jahre Landesfischereiverband Bayern, Jubiläumsbeilage zu „Bayern Fischerei und Gewässer“. Hrsg.: Landesfischereiverband Bayern e.V. [LFV] München 1995:22-23.

STEIN, H./GÖTTLE, A.: Geleitwort. - In: BOHL, E./KELLER, M./OITDMANN, B.: Flusskrebse in Bayern: Information für Naturschutz, Wasserwirtschaft, Fischerei, Teichwirtschaft, Fisch- und Aquarienhandel, Gastronomie. - Hrsg. v. Landesfischereiverband Bayern e.V. und Bayerisches Landesamt für Wasserwirtschaft. - München: Landesfischereiverband 2001:1.

STEIN, S.: Viehhaltung, Jagd und Fischfang im „Haus Bürgel“, einem spätantiken Kastell am Niederrhein. - München: Hieronymus 2000; Zugl.: München, Univ., Diss. 2000.

STEINACKER, K.: Die Bau- und Kunstdenkmäler des Kreises Blankenburg. - Wolfenbüttel: Zwissler’s Verl. 1922.

STEINBERG, C./BERNHARDT, H./KLAPPER, H.: Handbuch Angewandte Limnologie. Limnologische Grundlagen Gewässerbelastungen - Restaurierung - Aquatische Ökotoxikologie - Gewässerschutz - Bewertung. - Loseblattwerk 1995. 
STEINBOCK, E. F. von: Die noch nie genug gepriesene Kunst der edlen und hochschätzbaren Fischerey: samt allen deren Nothwendigkeiten [...] - Nürnberg: Buggel und Seitz 1730.

STEINER, E.: Zur Kormoranproblematik an den Fischteichen des Waldviertels. - In: Österreichs Fischerei 41/2,3 1988:35-44.

STEINKE, H.: Die Einführung der Kartoffel in der Waardt 1740 - 1790: Agrarmodernisierung aus bäuerlicher Sicht. - In: Zeitschrift für Agrargeschichte und Agrarsoziologie 45/1 1997:15-39.

STEINMETZLER, J.: Die Anthropogeographie Friedrich Ratzels und ihre ideengeschichtlichen Wurzeln. - Bonn: Geographisches Inst. d. Univ. 1956 [Bonner Geographische Abhandlungen;19].

STELEANU, A.: Geschichte der Limnologie und ihrer Grundlagen. - Frankfurt/Main: Haag und Hercher 1989.

STELLMACHER, H.: Die Ems im Emsland : Fluß, Kanal und kanalisierter Fluß. - In: Jahrbuch d. Emsländ. Heimatbundes 29 1983:118-141.

STELTMANN, C.: Flößerei auf Fulda, Werra und Weser. - In: TÖNSMANN, F. (Hrsg.): Zur Geschichte der Wasserstraßen insbesondere in Nordhessen. - Kassel: Herkules Verl. 1995 [Kasseler Wasserbau-Materialien;4]:207-219.

STELTZNER, G. A.: Beschreibung der sämtlichen Teiche-, Gräben und Wasserläufe. Handschrift .

STEPHAN, H.-G.: Coppengrave: Studien zur Töpferei des 13. bis 19. Jh. in Nordwestdeutschland. - Hildesheim: Lax 1981 [Materialhefte z. Ur.- und Frühgeschichte Niedersachsens;17].

STEPHAN, H.-G.: Mittelalterliche Erzgewinnung und Metallverarbeitung im Solling mit einem Ausblick auf die Neuzeit. - In: Hammaburg. Neue Folge 12 1998:165-176.

STEPHAN, H.-G.: Schloß Nienover im Solling: von der Grafenburg zum herzoglichen Amtssitz und Jagdschloß. - In: Berichte zur Denkmalpflege in Niedersachsen 19/3 1999:126-131.

STEPHAN, H.-G.: Studien zur Siedlungsentwicklung und -struktur von Stadt und Reichskloster Corvey (800-1670): Eine Gesamtdarstellung auf der Grundlage archäologischer und historischer Quellen. - Neumünster: Wachholtz 2000 [Göttinger Schriften zur Vor- und Frühgeschichte;26,1-3].

STEUER, H.: Bergbau im frühen und hohen Mittelalter im Südschwarzwald. - In: Früher Bergbau im südlichen Schwarzwald: Begleitheft zur Ausstellung des Museums für Ur- und Frühgeschichte der Stadt Freiburg/Breisgau Br. vom 29. Juli bis zum 21. November 1999. Hrsg. v. Landesdenkmalamt Baden-Württemberg. - Stuttgart: Ges. für Vor- und Frühgeschichte in Württemberg und Hohenzollern 1999 [Archäologische Informationen aus Baden-Württemberg;41]:49-58.

STEUER, H. (Hrsg.): Alter Bergbau in Deutschland. - Stuttgart: Theiss 1993 [Archäologie in Deutschland; Sonderheft].

STEUER, H./HOEPER, M.: Eine völkerwanderungszeitliche Höhenstation am Oberrhein: der Großkopf bei Berghaupten, Ortenaukreis - Höhensiedlung, Kultplatz oder Militärlager?. - In: Germania. Anzeiger der Römisch-Germanischen Kommission des Deutschen Archäologischen Instituts 77, Halbband 1 1999:185-246.

STEUER, H./ZIMMERMANN, U. (Hrsg.): Streifzüge durch die frühen Hochkulturen. Ein historisches Lesebuch. - München: Beck 1994.

STEVENS, U.: Kulturlandschaft und Denkmalpflege. - In: Denkmalpflege im Rheinland 9 1992:145-150.

STEWIG, R.: Über das Verhältnis der Geographie zur Wirklichkeit und zu den Nachbarwissenschaften: eine Einführung. - Kiel: Geographisches Institut d. Univ. Kiel 1990 [Kieler Geogr. Schriften;76].

STIENS, G.: Geographische Prognostik aus der Sicht bestehender und möglicher Anwendungsfelder. Neue Anforderungen an eine Disziplin mit Tradition. - In: Geographica Helvetiva 4 1989:187-195.

STÖCKEL, J.-P.: Die königliche Heerfahrtpraxis der frühen Stauferzeit (1125 bis 1190): dargestellt anhand der Anteilnahme des deutschen Hochadels unter Lothar III, Konrad III. und Friedrich I. Barbarossa. Berlin, Humboldt-Univ., Phil. Diss. 1993 [Maschr.].

STOELTER, Georg Friedrich: Über die möglichst gewinnreiche Benutzung von Bächen und Teichen zur künstlichen Fortpflanzung von Fischen, so wie über die Zucht von Blutegeln in Sümpfen und sumpfigen Wiesen. - Hildesheim, 1859

STOELTER, G. F.[a]: Practische Resultate der Blutegelzucht und deren Rentabilität. Nach vieljährigen Erfahrungen und auf Grund der Geschäftsbücher in tabellarischen Übersichten dargestellt und erläutert von G. F. Stoelter. - Hildesheim 1860.

STOELTER, G. F.[b]: Weitere Mittheilungen aus der Praxis der künstlichen Fischzucht; Im Anschluss an die Abhandlung über die möglichst gewinnreiche Benutzung von Bächen und Teichen zur Piscikultur. - Hildesheim 1860

STOELTER, G. F.[c]: Weitere Mitheilungen [...] über die möglichst gewinnreiche Benutzung von Bächen und Teichen zur Piscikultur. - Hildesheim 1860.

STOLL, P.-T.: Biopiraterie oder faire Teilhabe? Schutz und Nutzung der biologischen Vielfalt als Herausforderung für das internationale Recht. - In: Georgia Augusta - Wissenschaftsmedizin der Georg-August-Universität Göttingen: „Leben braucht Vielfalt - Biodiversität“; Ausgabe 1/2002:67-70.

STOLTENBERG, M.: Ein Recht auf saubere Luft?: Umweltkonflikte am Beginn des Industriezeitalters. - Erlangen: Fischer 1994; Zugl.: München: Diss, 1994 u. d. T. „Gewerbliche Luftverschmutzung und Umweltwissenschaft in Europa 1800-1860“. 
STOLZ, G.: Der alte Eiderkanal. Der Schleswig-Holsteinische Kanal. - Heide: Westholst. Verl. Anst. 1983.

STOLZ, G.: Kleine Kanalgeschichte: Vom Stecknitzkanal zum Nord-Ostsee-Kanal. Hrsg. anlässlich des 100. Jahrestages der Eröffnung des Nord-Ostsee-Kanals am 21. Juni 1895. - Boyens Buchverl. 1995 [Kleine Schleswig-Holstein-Bücher;45].

STOLZ, O.: Geschichtskunde der Gewässer Tirols. - Innsbruck, München: Wagner 1936 [Schlern-Schriften;32].

STOOB, H. (Hrsg.): See- und Flußhäfen vom Hochmittelalter bis zur Industrialisierung. - Köln et al.: Böhlau 1986 [Städteforschung, R.A., Darstellungen;24].

STORKEBAUM, W. (Hrsg.): Zum Gegenstand und zur Methode der Geographie. - Darmstadt: Wissenschaftl. Buchgesell. 1967 [Wege der Forschung;58].

STRASSER, R.: Die Veränderungen des Rheinstromes in historischer Zeit. Bd. 1: Zwischen der Wupper- und der Düsselmündung. - Düsseldorf: Droste 1992 [Publikationen der Gesellschaft für Rheinische Geschichtsforschung;68]; Zugl.: Trier, Univ., Diss. 1989.

STRASSER, R.: Die spätmittelalterlich-neuzeitlichen Rheinlaufverlagerungen zwischen Grieth und Griethausen. - In: Kulturlandschaft und Bodendenkmalpflege. Bearb. v. Brigitte Beyer und Wolfgang Wegener. - Köln 1993 [Materialien zur Bodendenkmalpflege im Rheinland;2]:54-56.

STRASSER, W.: Ökologische Planungskriterien für Wasser- und Flussbaumassnahmen. - In: Wasserwirtschaft 91/10 2001:478482.

STRAUß, C.: Amphibische Stadtentwicklung: Wasser im Lebensraum Stadt; zur Integration des Wassers des Wassers in die Stadtentwicklung. - Berlin: Leue 2002 [edition stadt und region;2].

STRECKER, W.: Die Kultur der Wiesen, ihr Wert, ihre Verbesserung, Düngung und Pflege. - 4. Aufl. - Berlin: Parey 1923.

STREICH, G. (Hrsg.): Historisch-landeskundliche Exkursionskarte von Niedersachsen: Blatt Höxter. - Bielefeld 1996 [Veröffentlichungen des Instituts für Historische Landesforschung der Universität Göttingen; 2,13].

STREICH, G. (Hrsg.): Historisch-landeskundliche Exkursionskarte von Niedersachsen: Blatt Holzminden. - Bielefeld 1997 [Veröffentlichungen des Instituts für Historische Landesforschung der Universität Göttingen;2,15].

STREIT, B.: Umwelt-Lexikon. - Freiburg/Breisgau et al.: Herder 1992.

STREITPARTH, H.: Glück und Glas - die alten Glashütten im Südwestharz und seinem Vorland. - In: Rund um den Hausberg. Heimatbeilage des Bad Lauterberger Tageblattes 10.4.1971.

STRELL, M.: Die Abwasserfrage in ihrer geschichtlichen Entwicklung von ältesten Zeiten bis zur Gegenwart. - Leipzig 1913.

STRENZ, W.: Historisch-geographische Forschungen in der DDR. Hrsg. v. Arbeitskreis Historische Geographie der Geographischen Gesellschaft der DDR unter Leitung von Wilfried Strenz. - 1. Aufl. - Gotha: Haack 1986 [Wissenschaftliche Abhandlungen der Geographischen Gesellschaft der Deutschen Demokratischen Gesellschaft der Deutschen Demokratischen Republik;17].

STRENZ, W.: Historisch-geographische Forschungen in der DDR. - Gotha: Haak 1996 [Wiss. Abhandl. d. geographischen Ges. d. Deutschen Demokratischen Republik;17].

STRENZ, W.: Ein Stadtplan von Nordhausen - aus dem beginnenden 18. Jahrhundert. - In: Beiträge zur Heimatkunde aus Stadt und Kreis Nordhausen 17 1992:5-15.

STRENZ, W.: Der Kreis Nordhausen in einem zeitgenössischen Behördenbericht vor mehr als 130 Jahren. - In: Beiträge zur Heimatkunde aus Stadt und Kreis Nordhausen19 1994:79-93.

STRENZ, W.: Grundriss der Stadt Nordhausen am Harz - ein Stadtplan aus dem Jahr 1834. - In: Beiträge zur Heimatkunde aus Stadt und Kreis Nordhausen 21 1996:89-101.

STRIFFLER, H.: Workshop I: Landschaft: Kultur - Ökologie - Ästethik: zum Begriff Kulturlandschaft. - In: Das Rheintal: Schutz und Entwicklung. Die Rheintal-Konferenz des Rheinischen Vereins für Denkmalpflege und Landschaftsschutz am 6./7. November 1997 in Mainz. Eine Dokumentation. - Köln 1999:249

STROBEL, L.: Zur Geschichte der Schiffahrt und Flößerei auf den großen Flüssen Bayerns. - In: Geschichtliche Entwicklung der Wasserwirtschaft und des Wasserbaues in Bayern. München 1983 [Landesamt für Wasserwirtschaft, Informationsbericht;3].

STROMER, W. v.: Wassersnot und Wasserkünste im Bergbau des Mittelalters und der frühen Neuzeit. - In: KROKER, W./WESTERMANN, E. (Bearb.): Montanwirtschaft Mitteleuropas vom 12. bis 17. Jahrhundert. Stand, Wege und Aufgaben der Forschung. - Bochum 1984 [Veröffentlichungen aus dem Deutschen Bergbau-Museum Bochum;30]:24-39;50-73.

STROMER, W. v.: Die Saigerhütten-Industrie des Spätmittelalters. Entwicklung der Kupfer-Silber-Scheidekünste zur ,,ars conflatoria separantia argetum a cupro cum plumbo“. - In: Technikgeschichte 62/3 1995:187-219.

STROMER, W. v.: Konjunktur im europäischen Bergbau: Wasserkünste. - In: BARTELS, C./DENZEL, M. A.: Konjunkturen im europäischen Bergbau in vorindustrieller Zeit: Festschrift für Ekkhard Westermann zum 60. Geburtstag. - Stuttgart: Steiner 2000 [Vierteljahresschrift für Sozial- und Wirtschaftsgeschichte; Beihefte 155]:151-156. 
STROTMANN, R.: Hydrologische Auswirkungen der Siedlungsentwicklung auf den Wasserkreislauf der Stadt Krefeld (1800 bis 1995). - Krefeld: Geologisches Landesamt Nordrhein-Westfalen 1998 [Scriptum; Geolog. Landesamt NRW;3]; Zugl.: Aachen, Techn. Univ., Diss. 1998.

STRUCK, E.: Passau - die Dreiflüssestadt: von der historischen Lagegunst zum aktuellen Stadtentwicklungsproblem. - In: BREUER, T./JÜRGENS, C. (Hrsg.): Luft- und Satellitenbildatlas Regensburg und das östliche Bayern. - München: Pfeil 1988:108-113.

STUBENVOLL, W.: Die deutschen Hugenottenstädte. - Frankfurt/Main: Umschau-Verl. 1990; Zugl.: Frankfurt/Main, Univ., Diss. 1952.

STUDER-EHRENSBERGER, K.: Geschichte und Naturschutz von artenreichen Kulturwiesen in der Schweiz: eine Zusammenschau. - In: Botanica Helvetica 105/1 1995:3-16.

STUHL, K.: Friesische Bewässerungsanlagen und Siedlungen an der Alzmündung aus alter Zeit. - In: Das Bayerland 23:803-806.

STUHLING, L.: Hüttentechnik und Umwelt im 16. Jahrhundert. - In: BAYERL, G./FUCHSLOCH, N./MEYER, T. (Hrsg.): Umweltgeschichte - Methoden, Themen, Potentiale: Tagung des Hamburger Arbeitskreises für Umweltgeschichte, Hamburg 1994. - Münster, New York: Waxmann 1996 [Cottbuser Studien zur Geschichte von Technik, Arbeit und Umwelt;1]:87-102.

STÜLPNAGEL; W.: Geschichtliche Entwicklung Wirtschaft und Verkehr. - In: Statistischen Landesamt Baden-Württemberg (Hrsg.): Freiburg im Breisgau. - Bd. 1, 1. Halbbd. - Freiburg 1965.

STURM, Leonhard Christoph: Vollständige Mühlen-Baukunst [...]. - 5. Aufl. - Augsburg: Riegers; Nürnberg: Schneider und Weigel 1815 [unveränd. Nachdruck nach dem Orig. d. 5. Aufl. aus dem Jahre 1815 aus dem Bestand der Universtitätsbibliothek Hannover; Begleittext am Ende des Werkes von Prof. Dr. Michael Mende, Hannover. - Hannover: Schäfer 1991 [Edition „libri rari“].

SUCCOW, M./JOOSTEN, H.: Landschaftsökologische Moorkunde. - 2. Aufl. - Stuttgart: Schweizerbart 2001.

SUDER, H.: Vom Einbaum und Floss zum Schiff: die primitiven Wasserfahrzeuge. - Berlin: Mittler 1930 [Veröff. d. Inst. f. Meereskunde u. d. Geograph. Inst. a. d. Univ. Berlin: Reihe B, Historisch-volkswirtschaftliche Reihe;7].

SUHR, N.: Zeichnungen, Aquarelle und Gouachen Caspar und Georg Schneiders. - In: Arkadien am Mittelrhein: Caspar und Georg Schneider Landesmuseum Mainz, 7. Juni bis 23. August 1998. Hrsg.: Landesmuseum Mainz - Wiesbaden: Reichert 1998:49-60.

SÜNKEL, C.: Die Bedeutung handgezeichneter Karten für historisch-geographische Landesforschung unter besonderer Berücksichtigung der Bestände in der Staatlichen Bibliothek Ansbach. - In: Mittelfranken in alten Landkarten. Ausstellung der Staatlichen Bibliothek Ansbach. - Ansbach 1984:35-43.

SURBURG, U.: Umweltgrundlagenplanung, Naturpflegeplanung und Plan-UVP: Planungsinstrumente des Umweltgesetzbuches und europarechtliche Entwicklungen. - In: Naturschutz und Landschaftsplanung 32/12 2000:380-385.

SUSKE, W.: Kultur und Landschaft im ständigen Wandel. - In. HABERL, H./STROHMEIER, G.: Kulturlandschaftsforschung. Wien, New York: Springer 1999 [iff texte;5]:112-116.

SÜSSMUTH, H./ERBE, M. (Hrsg.): Historische Anthropologie: Der Mensch in der Geschichte. - Göttingen: Vandenhoeck \& Ruprecht 1984 [Kleine Vandenhoeck-Reihe;1499]..

SUSTA, J..: Fünf Jahrhunderte der Teichwirtschaft in Wittingau: Ein Beitrag zur Geschichte der Fischzucht mit besonderer Berücksichtigung der Gegenwart. - Stettin: Dunker-Bell-Verl. 1898.

SZECHOWYCZ, R.: Die Bewässerungsanlagen von Bruchhausen-Syke-Thedinghausen. - Hannover, T. H., Diss. 1948.

SZYMANSKI, H.: Die Anfänge der Dampfschiffahrt in Niedersachsen und in den angrenzenden Gebieten von 1817 bis $1967 .-$ Hannover: Wirtschaftswiss. Ges. zum Studium Niedersachsens 1958 [Schr. d. Wirtschaftswiss. Ges. z. Stud. Nieders., N F;67].

TACKE, E.: Die Entstehung der Fürstlich-Braunschweigischen Glas- und Spiegelfabriken im Solling, Ith und Hils. - Göttingen 1969 [Neues Archiv f. Nieders.;18,3]:221-234.

TACKE, Eberhard: Die Entwicklung der Landschaft im Solling. Ein Beitrag zur Wirtschaftsgeschichte und zur Geschichte der Siedlungsplanung in Niedersachsen. Hrsg. v. Provinzial-Inst. f. Landesplanung und Niedersächsische Landes- und Volksforschung. - Oldenburg i. O.: Stalling 1943 [Veröff. d. Provinzial-Inst. f. Landespl. U. Nieders. Landes- u. Volksf.; Reihe A I;13].

TAH [TÄGLICHER ANZEIGER HOLZMINDEN]: Große Einheit und bunte Vielfalt auch im Kleinen: Natur- und Artenschutz am Beispiel der „Hutelandschaftspflege mit großen Weidetieren“, v. 18. 01.2003:22.

TARR, L.: Karren, Kutsche, Karosse: Eine Geschichte des Wagens. - 2. Aufl. - Budapest/Berlin: Helikon Kiodó 1978.

TAUCHMANN, J.: Die beiden Seelöcher und das Moosloch - Interessante Erdfälle zwischen Kleinwechsungen und Hochstedt. In: Beiträge zur Heimatkunde aus Stadt und Kreis Nordhausen 151990.

TAUCHMANN, J.: Die größte Karstquelle Thüringens - der Salzaspring: Ein heimatgeschichtlicher Beitrag über die Entstehung, Nutzung des Gewässers und die Verwirklichung der Naherholungskonzeption. - In: Beiträge zur Heimatkunde aus Stadt und Kreis Nordhausen 17 1992:39-51. 
TAURKE, F.: Die Fischzucht und Fischhaltung. Mit einer Tabelle zum Bestimmen der deutschen Süßwasserfische nach leicht erkennbaren äußeren Merkmalen. - 2. Auflage. - Hannover: Verl. Schaper 1927 [Titel der 1. Aufl.: Die Fischzucht und Fischhaltung in Gewässern aller Art und Größe, besonders in Teichen].

TEICH, M./PORTER, R./GUSTAFSSON, B. (Hrsg.): Nature and society in historical context - Symposium, Uppsala 1993 09.0811.08. - Cambridge et al.: Cambridge University Press 1997.

TEICH, W.: Die Mühlen von Schüttenitz: ihr Weg durch 5 Jahrhunderte böhmischer Geschichte. - Sinzig: Selbstverl. 1995.

TEICHE UND TALSPERREN: 400 Jahre Harz-Wasserwirtschaft; ein Büchlein für Wanderer, Wißbegierige und Wasserwirtschaftler. - Clausthal-Zellerfeld: Pieper 1950.

TEICHLAND 2004 [URL = http://www.teichland.de/HTML/E3RHINL.HTM;24.07.2004].

TEICHWIRTSCHAFT PEITZ bei Kottbus: einige allgemeine Angaben über die Teichwirtschaft Peitz, mit Erläuterungen über die Aufzucht von Karpfen. - Berlin : Reichsfischwerbung o. J.

TERHALLE, H.: Geschichte der Wind- und Wassermühlen im Vredener Land. - Vreden: Heimatverein 1991 [Beiträge des Heimatvereins Vreden zur Landes- und Volkskunde;41].

TESCH, F. W./WEHRMANN, L.: Die Pflege der Fischbestände und -gewässer: eine Anleitung für die Praxis. - 2. Aufl. Hamburg et al.: Parey 1982.

TESDORPF, J. C.: Landschaftsverbrauch in der Bundesrepublik Deutschland: Hoffnung auf eine Trendwende. - In: Geographische Rundschau 39 1987:336-342.

TEUTEBERG, H. J. (Hrsg.): Beiträge zur Geschichte der Binnenschiffahrt, des Luft- und Kraftverkehrs. Zweites Werkstattgespräch des Arbeitskreises Verkehrsgeschichte der Deutschen Verkehrswissenschaftlichen Gesellschaft e.V. Bergisch Gladbach 1994.

THAER, A.: Vorrede. - In: WEYER, J. F.: Ueber die Anlage der Schwemmwiesen im Lüneburgischen und der Wiesenbewässerung überhaupt. Hrsg. v. Albrecht Thaer. - Zelle: Schulze 1800:I-VII.

THAER, A. (Hrsg.), Über die Anlage der Schwemm-Wiesen im Lüneburgischen und der Wiesenbewässerung überhaupt. Preisschrift Johann Friedrich Meyer. - Zelle 1800.

THEIßEN, P.: Mühlen im Münsterland: der Einsatz von Wasser- und Windmühlen im Oberstift Münster vom Ausgang des Mittelalters bis zur Säkularisation (1803). - Münster et al.: Waxmann 2001 [Beiträge zur Volkskultur in Nordwestdeutschland;101; Veröffentlichungen der Historischen Kommission für Westfalen]; Zugl.: Münster/Westfalen, Univ., Diss. 1996.

THEN, R.: Spurensuche im heiligen Land. - Zeitlarn/Regensburg 2003 [URL $=$ http://www.dr-then.de/start/reise/artikel_r/ teil5.html;22.01.2004].

THEUERKAUF, G.: Einführung in die Interpretation historischer Quellen. Schwerpunkt: Mittelalter. - 2- Aufl. - Paderborn: Schöningh 1996.

THEWS, G./SERVATIUS, C. (Hrsg.): Ökosystemforschung und Umweltforschung in Rheinland-Pfalz. - Stuttgart: Fischer 1993.

THIELCKE, G.: Lebendige Elbe. - Stadler Verl. 1999.

THIEM, A.: Naturschutzgerechte Bewirtschaftung von Fischteichen in Sachsen. - In: Naturschutzarbeit in Sachsen 40 1998:23-32.

THIEM, K. T.: „Veränderungen an Gewässern durch historische Nutzungen im Südschwarzwald - Möglichkeiten einer Rekonstruktion, Erfassung und Bewertung" (Thema: A3). - Dissertationsvorhaben an der Universität Freiburg im Graduiertenkolleg (GRK) „Gegenwartsbezogene Landschaftsgenese“, Institut für Landespflege, 2001-2004 [URL= http://www.geographie.uni-freiburg.de/ipg/gkgl/diss/kothi/Index.htm; Stand: 24.03.2004].

THIEM, Wolfgang: Die Kulturlandschaftsinventarisation der Gemarkung Klosterlangheim. - In: „Schönere Heimat“: Erbe und Auftrag 93. Jg., H. 2 2004:93-100

THIENEMANN, A.: Die Binnengewässer Mitteleuropas: eine limnologische Einführung. - Stuttgart: Schweizerbart 1925 [Die Binnengewässer;1].

THIENEMANN, A.: Die Binnengewässer in Natur und Kultur: eine Einführung in die theoretische und angewandte Limnologie. Berlin: Springer 1955 [Verständliche Wissenschaft;53].

THÖNE, F.: Hans Vredemann de Vries in Wolfenbüttel. - In: Braunschweigisches Jahrbuch 41 1960:47-68.

THÜRINGEN UND DER HARZ, mit ihren Merkwürdigkeiten, Volkssagen und Legenden. Historisch-romantische Beschreibung der in Thüringen und auf dem Harz vorhanden gewesenen und noch vorhandenen Schlösser, Burgen, Klöster [...]. 2 Bände Sondershausen: Verl. Friedrich August Enpel 1840.

THÜRINGER LANDESANSTALT FÜR UMWELT, Abt. Ökologie und Naturschutz: Vernässungsprojekt Nesse-Aue (Stadtkreis Erfurt). - Erfurt: Thüringer Landesanstalt für Umwelt, Abt. Ökologie und Naturschutz 1999.

THÜRINGER MINISTERIUM für Landwirtschaft, Naturschutz und Umwelt (Hrsg.): Fließgewässerlandschaften in Thüringen: Einführung und Richtlinien zur naturnahen Unterhaltung und zum Ausbau von Fließgewässern. - Erfurt 1996. 
TIBORSKI, K.: Kanalbauprojekte in Westfalen im 19. Jahrhundert. - Münster: Inst. f. Geograaphie d. Westf. Wilhelms-Univ. 1998 [Münstersche geographische Arbeiten;41]; Zugl.: Münster, Univ., Diss. 1998.

TICHY, F.: Die Lahn: Geographische Grundlagen einer Wasserwirtschaft. - Marburg/Lahn: Elwert 1951 [Marburger Geogr. Schriften;2].

TIEDEMANN, M.: Archivalien als Mittel zur historisch-genetischen Erkundung von Rüstungsaltlasten. - In: Altlasten-Spektrum 1 1994:5-8.

TIGGESBÄUMKER, G.: Alte Landkarten und ihre Bedeutung für die Erd- und Heimatkunde. - In: Amtlicher Schulanzeiger für den Regierungsbezirk Mittelfranken 52 1984:70-73.

TIMM et al.: "Zielvorgaben und Handlungsanweisungen für die Renaturierung von Tieflandbächen in Nordrhein-Westfalen" Hrsg.: Landesumweltamt NRW. - Essen 1994/1995 [Merkblätter Landesumweltamt Nordrhein-Westfalen].

TIMM, T.: Kleine bis mittelgroße Fließgewässer. Referenzgewässer der Fließgewässertypen Nordrhein-Westfalens; Teil 1. Hrsg.: Landesumweltamt NRW. - Essen 1999 [Merkblätter Landesumweltamt Nordrhein-Westfalen;16].

TISCHLER, W.: Historische Entwicklung der Ökologie und ihre heutige Situation. - In: Zoologischer Anzeiger 207/5,6 1981:223237.

TÖLGYESSY, J./PIATRIK, M.: Wasser. - Berlin: Verl. die Wirtschaft 1990

TÖLLE-KASTENBEIN, R.: Antike Wasserkultur. - München: Beck 1990 [Beck’s Archäologische Bibliothek].

TOMASZEWSKI, R.: Die Schiffbarmachung der Unstrut in den Jahren 1791-1795 und ihre letzten Zeugen. - In: Sächsische Heimatblätter 3 1990:133-139.

TONNER, R.: Tuchmacher am Teich: aus dem Tagebuch zweier Familien um 1830 - einer Zeit wirtschaftlichen Umbruchs [überarb. u. hrsg. von Friedrich W. Dwars]. - Neumünster: Wachholtz 1989.

TÖNNSMANN, F.: Wasserkraftanlagen in Mittelalter und Neuzeit. - In: ECKOLDT, M./LÖBER, U./TÖNSMANN, F. (Hrsg.): Geschichte der Wasserkraftnutzung: Berichte zur Tagung „Geschichte der Wasserkraftnutzung“ am 23. und 14. April 1982 in Koblenz. - Koblenz 1985 [Veröffentlichungen des Landesmuseums Koblenz. Staatliche Sammlung technischer Kulturdenkmäler. B. Einzelveröffentlichungen;13]:23-44.

TÖNSMANN, F.: Erfahrungen mit dem umweltverträglichen Wasserbau. - In: Wasser + Boden 42 1990:25-30.

TÖNSMANN, F.[a]: Zur Geschichte der Wasserstraßen insbesondere in Nordhessen. - In: TÖNSMANN, F. (Hrsg.): Zur Geschichte der Wasserstraßen insbesondere in Nordhessen. - Kassel: Herkules Verl. 1995 [Kasseler WasserbauMaterialien;4]:15-36.

TÖNSMANN, F. (Hrsg.)[b]: Zur Geschichte der Wasserstraßen insbesondere in Nordhessen. - Kassel: Herkules Verl. 1995 [Kasseler Wasserbau-Materialien;4].

TÖNSMANN, F. (Hrsg.): Sanierung und Renaturierung von Fließgewässern. Grundlagen und Praxis. - Kassel 1996 [Kasseler Wasserbau-Miteilungen;6].

TÖNSMANN, F.: Sanierung und Reaktivierung von Kleinwasserkraftanlagen an der Werra. - Technische Universität Dresden: Technische Univ., Inst. f. Wasserbau und Technische Hydromechanik. - Dresden: Eigenverl. 1997 [Dresdener Wasserbauliche Mitteilungen;10].

TOPOS - European Landscape Magazine (Hrsg.): Landschaftsarchitektur in Skandinavien: Projekte in Dänemark, Schweden, Norwegen, Finnland und Island. - Callwey Birkhäuser 2002 [Edition Topos].

TREPL, L.: Geschichte der Ökologie: vom 17. Jahrhundert bis zur Gegenwart. Zehn Vorlesungen. - Frankfurt/Main: Athenäum 1987 [Athenäum-Taschenbücher; 4070].

TREUE, W.: Geleitwort. - In: SCHOLL, L. U.: Als die Hexen Schiffe schleppten: Die Geschichte der Ketten- und Seilschleppschiffahrt auf dem Rhein. - Hamburg: Ernst Kabel Verl. 1985:7-8.

TREUE, W. (Hrsg.): Achse, Rad und Wagen: fünftausend Jahre Kultur- und Technikgeschichte. - Göttingen: Vandenhoeck \& Ruprecht 1986 [frühere Aufl. 1965].

TRIER, J.: Versuch über Flussnamen. - Köln et al.: Westdt. Verl. 1960 [Arbeitsgemeinschaft für Forschung des Landes Nordrhein-Westfalen: Geisteswissenschaften;88].

TRIMBORN, J.: Das Denkmal im Zeitalter der virtual reality: die moderne Medienwelt und ihr Einfluß auf die Inszenierung des öffentlichen Raumes. - In: Die Alte Stadt 26/2 1999:117-140.

TRÖGL, H.: Fossa Carolina - Die Geschichte eines Schiffahrtsweges vom Rehin zur Donau. - In: TÖNSMANN, F. (Hrsg.): Zur Geschichte der Wasserstraßen insbesondere in Nordhessen. - Kassel: Herkules Verl. 1995 [Kasseler WasserbauMaterialien;4]:47-65.

TROITZSCH, Ulrich: Historische Umweltforschung: Einleitende Bemerkungen über Forschungsstand und Forschungsaufgaben. In: Technikgeschichte 48/3 1981:177-190.

TROITZSCH, U.: Die technikgeschichtliche Entwicklung der Verkehrsmittel und ihr Einfluß auf die Gestaltung der Kulturlandschaft. - In: Siedlungsforschung 4 1986:127-143. 
TROITZSCH, U.: Technischer Wandel in Staat und Gesellschaft zwischen 1600 und 1750. - In: Propyläen Technikgeschichte. Hrsg. v. Wolfgang KÖNIG, Bd. 3. - Frankfurt/Main, Berlin 1991:11-267.

TROITZSCH, U./WEBER, W. (Hrsg.): Die Technik: von den Anfängen bis zur Gegenwart. - Braunschweig: Westermann 1982

TROLL, C.: Die geographische Landschaft und ihre Erforschung. - In: Studium generale 3/4,5 1950:163-181.

TROLL, C.: Madrid: die Wasserversorgung der Stadt durch Quanate im Laufe der Geschichte. - Mainz: Verl.d. Akad. d. Wiss. u. Literatur 1972 [Abhandl. d. Math.-Naturwiss. Klasse; Akad. d. Wiss. u. Lit.;5].

TROTTMANN, K. J.: Die Düssel und die Frühindustrialisierung in Düsseldorf. - In: LANDESHAUPTSTADT DÜSSELDORF (Hrsg.): Die Düssel: Geschichte und Geschichten. - Köln: Rheinland-Verl. 1988:93-100.

TRUNZ, Volkmar (Hrsg.): Dumreicher, Alfred: Gesammtüberblick über die Wasserwirthschaft des nordwestlichen Oberharzes. 1. Aufl. - Neuausgabe [des Originals von] 1868. - Clausthal-Zellerfeld: Oberharzer Geschichts- und Museumsvereins e. V. 2000 [1868] [Schriftenreihe des Oberharzer Geschichts- und Museumsvereins; Das Buch zur EXPO 2000, Mensch, Natur, Technik].

TUCHEN, B.: Das Badewesen im mittelalterlichen und frühneuzeitlichen Nürnberg. - In: FRIEDEL, B./FRIESER, C.: Nürnberg: Archäologie und Kulturgeschichte. - Nürnberg: Verl. Dr. Faustus 1999:184-189.

TUCHOLSKY, Kurt: Das Ideal. - In: Berliner Illustrierte Zeitung Nr. 31 v. 31.07.1927 [aus: Tucholsky-Gesammelte Werke, Bd. 5:269ff.].

TÜMMERS, H.-J.: Der Rhein: ein europäischer Fluss und seine Geschichte. - München: Beck 1994.

TURBA-JURCZYK, B.: Geosystemforschung: eine disziplingeschichtliche Studie zur Mensch-Umwelt-Forschung in der Geographie. - Giessen: Selbstverl. d. Geogr. Inst. d. Justus-Liebig-Universität 1990 [Giessener geographische Schriften;6].

ÜCKERMANN, E.: Kulturgut Jagd: ein Führer durch die Jagdgeschichte Nordrhein-Westfalens und zu jagdhistorischen Stätten. Münster-Hiltrup: Landwirtschaftsverl. 1994

UDOLPH, J.: Studien zu slavischen Gewässernamen und Gewässerbezeichnungen: ein Beitrag zur Frage nach der Urheimat der Slawen. - Heidelberg: Winter 1979 [Beiträge zur Namenforschung: Beiheft; N. F.;17]; Teilw. zugl.: Göttingen, Diss.

UDOLPH, J.: Zum Problem der Slavisierung alteuropäischer Gewässernamen in Franken. - In: Ortsnamenwechsel [Bamberger Symposium 1986, hrsg. v. Rudolf SCHÜTZEICHEL], Heidelberg 1986:155-166.

UDOPLH, J.: Die Stellung der Gewässernamen Polens innerhalb der alteuropäischen Hydronymie. - Heidelberg: Winter 1990 [Beiträge zur Namenforschung, N. F.; Beiheft 31].

UECKER, S.: Wasserkraft im Gebiet der ehemaligen Grafschaf Wertheim: eine Bestandsaufnahme. - Würzburg 1999 [Veröffentlichungen zur Volkskunde und Kulturgeschichte;73]; Zugl.: Würzburg, Univ., Hausarb. 1999.

UERSCHELN, G./KALUSOK, M.: Wörterbuch der eurpäischen Gartenkunst. - Stuttgart: Reclam 2003.

UEXKÜLL, J. v.: Umwelt und Innenwelt der Tiere. - 2. Auflage - Berlin: Springer 1921.

UEXKÜLL, J. v.: Streifzüge durch die Umwelten von Tieren und Menschen: ein Bilderbuch unsichtbarer Welten. - Berlin: Springer 1934 [Nachdruck: Hamburg: Rowohlt 1956].

UHLIG, H.: Wassersiedlungen in Monsun-Asien. - In: KREISEL, W. et al. (Hsrg.): Siedlungsgeographisches Studien: Festschrift für Gabriele Schwarz. - -Berlin-New York: de Gruyter 1979:273-305.

UHTHOFF, M.: Der Flachs: Anbau und Verwertung in der Landwirtschaft. - Lüneburg: Kinau 1948 [Kleine Bücherei für Landwirtschaft, Gartenbau, Siedlung, Forst und Jagd;22].

ULBRICH, B. G./KRAWULSKY, R.: NORDHAUSEN AM HARZ. - Nordhausen: Buchhandlung Gerhard Rose, Anhaltinische Verl.gesell. Dessau 1996.

ULBRICHT, E.: Das Flußgebiet der thüringischen Saale: Eine flußnamenkundliche Untersuchung. - Halle/Saale: Niemeyer 1957 [Dt.-slawische Forsch. z. Namen- und Siedlungsgeschichte;2]; Erschien zuvor als Phil. Diss. Leipzig, 1953.

UNI-SAARLAND 2004[a] [aus: http://www.uni-saarland.de/fak5/anthropo/fsv/selbstd.htm.;15.01.2004].

UNI-SAARLAND 2004[b] [aus: http://www.uni-saarland.de/de/fakultaeten/fak5/fr55; 15.01.2004].

UNI-TRIER [aus: http://www.uni-trier.de/biogeo/;15.01.2004].

UNIVERSITÄT GÖTTINGEN - Fachbereich Erziehungswissenschaften, Abteilung Geographie (Hrsg.): Vom Flachs zum Leinen. Materialien zur Flachsverarbeitung und Leinenprodukltion im Eichsfeld. - Göttingen 1994.

UNIVERSITÄT HANNOVER: Umweltforschung an der Universität Hannover: Ergebnisse einer Umfrage im Jahr 1983.

UNVERFEHRT, G.: Gemalte Landschaft. Über den Quellenwert bildlicher Darstellungen für die Umweltgeschichte. Vortrag anläßlich der Sommerschule „Natur und Geschichte“ an der Universität Göttingen 1989. [Veröffentlicht als UNVERFEHRT, G.: Umwelt wird Kunst. Zur holländischen Landschaftsmalerei im 17. Jahrhundert]. - In: HERRMANN, B./BUDDE, A. (Hrsg.): Natur und Geschichte. Naturwissenschaftliche und historische Beiträge zu einer ökologischen Grundbildung. Sommerschule „Natur und Geschichte“ vom 14. bis 27. September 1989 an der Georg-August-Universität Göttingen. Hildesheim: Gerstenberg 1989 [Schriftenreihe „Expert“ des Niedersächsischen Umweltministers Hannover]:44-58. 
UNWIN, T.: Wine and the Vine: An historical geography of viticulture and the wine trade. - London: Routledge 1990.

UPHOFF, R.: Die Deicher. - Oldenburg: Isensee 1995.

USHER, M./ERZ, W. (Hrsg.): Erfassen und Bewerten im Naturschutz. Probleme, Methoden, Beispiele. - Heidelberg; Wiesbaden: Quelle und Meyer 1994 [UTB;8072].

UTSCHICK, H.: Zum Vogelschlagproblem durch Graureiher (Ardea cinerea) bei Fischteichen im direkten Umfeld von Flugplätzen/Flughäfen. - In: Vogel und Luftverkehr 2/1 1982:50-57.

VANNOTE R.L. et al.: The River Continuum Concept. - In: Can. J. Fish. Aquat. Sci. 37 1980:130 -137.

VDG [VEREINIGUNG DEUTSCHER GEWÄSSERSCHUTZ] (Hrsg.): Hochwasser - Naturereignis oder Menschenwerk? - 2. Aufl. - Bonn: VDG 2003 [Schriftenreihe der Vereinigung Deutscher Gewässerschutz;66].

VERANZIO, F.: Machinae Novae. - Faksimile der Ausgabe Venedig 1615, München: Moos 1965.

VERDENHAUSEN, F.: Alte Meß- und Währungssysteme aus dem deutschen Sprachgebiet.- Neustadt/Aisch: Verl. Degener 1993.

VEREIN DACHAUER MOOS e.V.: Die historischen Kanäle neu in Wert setzen - eine faszinierende Zukunftsaufgabe. - Flyer des Verein Dachauer Moos e.V., Karlsfeld 1998/2000.

VEREIN DACHAUER MOOS e.V. et al: Das Kanalsystem der Schlösser Nymphenburg, Schleißheim und Dachau. - Faltblatt Mai 2000.

VERGIN, U.: Mein Name ist Hase - und ich bin ein Problem. Hrsg. v. Verein für Ökologie und Umweltbildung Osnabrück e. V. Osnabrück: Selbstverl. 1997 [Osnabrücker Hefte zur Stadtökologie].

VERGIN, U.: Woher kommt es - wohin geht es? Wasser in Osnabrück. Hrsg. v. Verein für Ökologie und Umweltbildung Osnabrück e. V. - Osnabrück: Selbstverl. 1998 [Osnabrücker Hefte zur Stadtökologie].

VERHULST, A. (Hrsg.): Anfänge des Städtewesens an Schelde, Maas und Rhein bis zum Jahre 1000. - Köln et al.: Böhlau 1996 [Städteforschung: Reihe A, Darstellungen;40].

VERVLOET, J. A. J.: Zum Stand der Angewandten Historischen Geographie in den Niederlanden. - In: Ber. z. dt. Landeskunde; 601994 [ders.: Inleiding tot de historische geografie van de Nederlandse cultuurlandschappen. - Wageningen: Pudoc 1984 (Reeks landschapsstudies;4)].

VILEISIS, A.: Discovering the Unknown Landscape. A History of America's Wetlands. - Washington, D. C. et al.: Island Press 1997.

VINCENT, L.: Wiesenbau, dessen Theorie und Praxis. - Berlin: Parey 1858.

VINCENT, L.: Bewässerung und Entwässerung der Äcker und Wiesen [bearb. v. Robert Breitenbach] - 5. Aufl. - Berlin: Parey 1926 [2. Auf. 1882].

VISCHER, D.: Schweizerische Flusskorrektionen im 18. und 19. Jahrhundert. - Zürich: ETH 1986 [Mitteilungen der Versuchsanstalt f. Wasserbau, Hydrologie und Glaziologie a.d. Eidgenöss. Techn. Hochsch. Zürich;84].

VISCHER, D./HUBER, A.: Wasserbau. Hydrologische Grundlagen, Elemente des Wasserbaus, Nutz- und Schutzbauten an Binnengewässern. - 5. Aufl. - Heidelberg: Springer 1993.

VITS, B.: Hüfner, Kötter und Beisassen. Marburg/Lahn 1991 [Hess. Forschungen z. geschichtl. Landes- und Volkskunde;25]; Zugl.: Marburg, Univ., Diss. 1992.

VOGEL, A.: Historische Talsperren in den Alpen mit speziellen Retentionsaufgaben. In: DVWK (Hrsg.): Historische Wasserwirtschaft im Alpenraum und an der Donau. Bearbeitet v. Werner Konold. - Stuttgart: Wittwer 1994:229-237.

VOGEL; P.: Ausführliches Lehrbuch der Teichwirtschaft: Ein Rathgeber für Land- und Forstwirthe, angehende und erfahrene Teichwirthe. - Bautzen: Hübner 1898 [Ergänzungsbände 1900, 1905].

VOGT, H.: Niederrheinischer Wassermühlenführer. Hrsg.: Verein Niederrhein e. V., Krefeld. - Kleve: Boss 1998.

VOGT, H.: Der Niederrhein und seine Mühlen: [das Begleitheft zur Ausstellung des Niederrheinischen Mühlenverbandes e. V. im Museum für Volkskunde und Kulturgeschichte e. V. in Kevelae]. - Kevelaer: Niederrheinisches Museum für Volkskunde und Kulturgeschichte 2000 [Führer des Niederrheinischen Museums für Volkskunde und Kulturgeschichte Kevelaer;40].

VOIGT, C.: Ausgewählte Reviere des Mittelharzes. - In: KLEßEN, R. (Hrsg.): Historischer Bergbau und Hüttenwesen im Mittelharz - Exkursionsführer. - Berlin: Geogr. Inst., Humboldt-Univ. Berlin 2000 [Arbeitsberichte Geographisches Institut Humboldt-Universität Berlin;46]:22-27.

VOIGT, G.: Geographische Grundpositionen im Widerstreit. - In: Zs. f. den Erdkundeunterricht 46/11 1994:436-440.

VOIGT, J. F.: Die Hamburgische Landgemeinde Groß Hansdorf-Schmalenbek. - Hamburg: Boysen 1906.

VOIGTMANN, J.: Geburt einer Landschaft: Die Freiberger Revierwasserlaufanstalt. - In: AURIG, R. (Hrsg.): Kulturlandschaft [...] 1999:74-83.

VOLKERT, W.: Adel bis Zunft. Ein Lexikon des Mittelalters. - München: Beck 1991. 
VÖLKSEN, G.: Die Lüneburger Heide: Entstehung und Wandel einer Kulturlandschaft. - Göttingen: Göttinger Tageblatt 1984 [Veröff. d. Nieders. Inst. f. Landeskunde und Landesentwicklung a. d. Univ. Göttingen;3, Schriften d. Wirtschaftsw. Gesell. z. Stud. Nieders.: Aktuelle Themen z. nieders. Landeskunde;3].

VOLLRATH, H./LAMMEL, B.: Die Havel. Geschichten eines Flusses. - Frankfurt/Main, Berlin: Ullstein 1993.

VORLÄNDER, F.: Die Siegenische Kunst-Wiese: Eine practische Anleitung zu deren Anleitung und Pflege. Nebst einem Anhange von der Wiesen-Ueberstauungs-Methode und von der Verhandlung der natürlichen Wiesen. - Siegen 1838.

VOTLÄNDER, J. J.: Die Waldwirthschaft im Wiehen-Gebirge: nebst Vorschlägen zu deren Verbesserung. - Minden: Volkening 1863.

VOS, W./MEEKES, H.: Trends in European cultural landscape development: perspectives for a sustainable future. - In: Landscape and Urban Planning 46 1999:3-14.

VOWINKEL, K.: Beitrag zur Historie des Kartoffelanbaus im Oberharz unter besonderer Berücksichtigung der soziologischen Verhältnisse von St. Andreasberg. - In: Unser Harz 10 1998:187-191.

WAAL, L. C. de (Hrsg.): Rehabilitation of rivers: principles and implementation. - Chichester [et al.]: Wiley 1998 [Schriftenreihe: Landscape ecology series].

WÄCHTLER, K.: Zur Biologie der Flußperlmuschel Margaritifera margaritifera (L.). - In: Naturwissenschaft 73 1986:225-233.

WADEHN, F./WADEHN, A.: Die Amphibien der Ahlhorner Fischteiche (Landkreis Oldenburg). - In: Informationen Naturschutz und Landschaftspflege 2 1980:215-224.

WAGENBRETH, O.: Mühlen: Geschichte der Getreidemühlen: technische Denkmale in Mittel- und Ostdeutschland. - 1. Aufl. Leipzig et al.: Dt. Verl. f. Grundstoffindustrie 1994.

WAGENBRETH, O./WÄCHTLER, E.: Der Freiberger Bergbau. - In: Technische Denkmale und Geschichte. - Leipzig: VEB Deutscher Verl. f. Grundstoffindustrie 1989.

WAGNER, C.: Geschichte der deutschen Gartenkunst und des deutschen Gartenschrifttums im 17. und 18. Jahrhundert unter besonderer Berücksichtigung der Phase des Überganges vom Barock- zum Landschaftsgarten. - Leipzig, Univ., Diss. 1986.

WAGNER, C.: Wasser-Cultur (Teich-Wirtschaft): nach Beobachtungen und eigenen Erfahrungen. - Bremerhaven 1881.

WAGNER, C./LAMMERHUBER, L.: Die Wachau. Natur- und Kulturlandschaft. - Wien: Brandstätter 2002.

WAGNER, G. J.: Der in der Edlen Fischerey wohl-unterrichtende und erfahrne Fischer: Mit angehängter Beschreibung allerhand Einheimisch- und Ausländischer Fische und Krebse [...] - Nürnberg 1730.

WAGNER, R.: Fließgewässer, etwas andere Ökosysteme. - Laufen/Salzach: ANL 1992 [Berichte ANL;16].

WALDHOFF, J.: Die Emmer: Landschaft - Geschichte - Volkstum. Hrsg.: Heimatverein Steinheim e.V. - 3. Aufl. 1996 [Heimatgeschichtliche und volkskundliche Schriften der Stadt Steinheim;8].

WALLBAUM; U.: Die Rübenzuckerindustrie in Hannover: zur Entstehung und Entwicklung eines landwirtschaftlich gebundenen Industriezweiges von den Anfängen bis zum Beginn des Ersten Weltkrieges. - Stuttgart: Steiner 1998 [Beiträge zur Wirtschafts- und Sozialgeschichte;83]; Zugl.: Göttingen, Univ. Diss. 1997.

WALLTHOR, A.-H. v. (rsg.): „Landschaft“ als interdisziplinäres Forschungsproblem: Vorträge und Diskussionen des Kolloquiums am 7./8. Nov. 1975 in Münster. - Münster/Westfalen: Aschendorff 1977 [Veröffentlichungen d. Provinzialinstituts f. Westfälische Landes- u. Volksforschung des Landschaftsverbandes Westfalen-Lippe: Reihe 1;21].

WALMSEY, D. J./LEWIS, G. J.: Human Geography. - Harlow, Essex: Longman 1984.

WALTER, E.: Die Fischerei als Nebenbetrieb des Landwirts und Forstmannes. - Neudamm: Neumann 1903.

WALTER, E.: Sachgemäße Bewirtschaftung kleiner Teiche. - Berlin: Reichsnährstand Verl.-Ges. 1943 [Arbeiten des Reichsnährstandes;33].

WALTER, F.: Bedrohliche und bedrohte Natur: Umweltgeschichte der Schweiz seit 1800. - Zürich: Chronos 1996 [Titel der Originalausgabe „Les Suisses et l'environment. Une histoire du rapport à la nature“. - Carouge: Zoé 1990].

WALTHER, F. L.: Grundlinien der teutschen Forstgeschichte und der Geschichte der Jagd, des Vogelfanges, der wilden Fischerei und der Waldbienenzucht. - Giessen: Müller 1816.

WAND, A.: Das Katholische Reichsstift zum Heiligen Kreuz in Nordhausen und seine Auseinandersetzung mit der evangelischen Reichsstadt: 1648 bis 1802. - Leipzig: Benno-verl.1996 [Studien zur Katholischen Bistums- und Klostergeschichte;39].

WARDENGA, U.: Geographie als Chorologie. Zur Genese und Struktur von Alfred Hettners Konstrukt der Geographie. Stuttgart: Steiner 1995.

WARDENGA, U.: Von der Landeskunde zur „Landeskunde“. - In: Der Weg der deutschen Geographie. Rückblick und Ausblick. 50. Deutscher Geographentag Potsdam 1995, Bd. 4 - Stuttgart: Steiner Verl. 1995:132-141.

WARDENGA, U.: Theorie und Praxis der länderkundlichen Forschung und Darstellung in Deutschland. - In: GRIMM, F.-D./ WARDENGA, U.: Zur Entwicklung des länderkundlichen Ansatzes. Leipzig: Institut für Länderkunde 2001 [Beiträge zur Regionalen Geographie;53]:9-35. 
WARE, M. E.: Canals and Waterways. (History in Camera). - 2. Aufl. - Ayslesbury: Shire Publicationes 1990.

WARNECKE, [...]: Schiffahrtswege. - In: SONNABEND, H. (Hrsg.): Mensch und Landschaft in der Antike. Lexikon der historischen Geographie. - Stuttgart et al. Metzler 1999:438-448.

WARNER, F.: Technische Leistungen der Griechen und Römer. - In: TROITZSCH, U./WEBER, W.: Die Technik - Von den Anfängen bis zur Gegenwart. - Braunschweig: Westermann 1982:78-118.

WASSER IM FLUß: Das Lebenselement Wasser. - Köln: Müller 1992 [arcus;19].

WASSER- UND SCHIFFAHRTSDIREKTION MITTE (Hrsg.): Die Entwicklung der Binnenschiffahrt und des Kanalbaus in Deutschland. - Hannover 1993.

WASSER- UND SCHIFFAHRTSDIREKTION MÜNSTER (Hrsg.): Die Abstiegbauwerke Henrichenburg. - Münster o.J. [um 1962].

WASSER- UND STRAßENBAUDIREKTOR (Hrsg.): Badisches Wasserkraftkataster. Kander, Möhlin mit Neumagen sowie Feuerbach, Hohlebach, Klemmbach und Sulzbach, 9/10.- Karlsruhe 1929.

WASSERFORSCHUNG IM SPANNUNGSFELD zwischen Gegenwartsbewältigung und Zukunftssicherung. Denkschrift: Deutsche Forschungsgemeinschaft, Mitglieder der Senatskommission für Wasserforschung. Hrsg.: Deutsche Forschungsgemeinschaft, Kommission für Wasserforschung. - Weinheim: Wiley-VCH 2003.

„WASSERLUST: Mineralquellen und Heilbäder im Rheinland“. Eine Ausstellung des Landschaftsverbandes Rheinland, Rheinisches Museumsamt, Abtei Brauweiler. - Köln: Rheinland-Verl. 1991 [Schriften d. Rhein. Museumsamtes; 48]

„WASSERSPIELE: von den Nutzbarkeiten der Leipziger Gewässer“. Ausstellung v. 30.06.-4.09.1994. - Stadtgeschichtliches Museum 1994.

WASSERSTADT Berlin Oberhavel GmbH (Hrsg.): Wasserstadt Berlin Oberhavel: Bilanz und Perspektiven. - Berlin 1997.

WASSERSTADT GmbH (Hrsg.): Neue Adressen am Wasser: Dokumentation des Kongresses vom 23. bis 25. Oktober 1997 Berlin 1997.

WASSERSTADT GmbH (Hrsg.): Wasser in der Stadt: Perspektiven einer neuen Urbanität. - Berlin 2000

WASSERWIRTSCHAFTSAMT AMBERG: Ökologisch begründete Sanierungskonzepte kleiner Fließgewässer, Fallbeispiel Vils/Oberpfalz. - München 1996 [Schriftenreihe des Bayer. Landesamtes f. Wasserwirtschaft, H. 26]

WATERFRONT URBAN DEVELOPMENT 2004 [URL = http://www.waterfront-urban-development.org;23.01.2004].

WATTECK, N.: Einsiedler, Inklusen, Eremiten, Klausner und Waldbrüder im Salzburgischen. - Salzburg: Verlag St. Peter 1972.

WEBER, Ernst: Leitfaden für die Bewirtschaftung der Teiche. Ein Hilfsbuch für Fischereikurse. - Stuttgart: Ulmer 1905.

WEBER, F. B.: Theoretisch-Praktisches Handbuch des gesamten Futterbaus. - Leipzig: Kummer 1815.

WEBER, F. W.: Die Geschichte der Mühlen und des Müllerhandwerks der Pfalz. Dargestellt nach gegenständlichen Befunden, archivalischen Quellen und der mündlichen Überlieferung. - Otterbach: Arbogast 1978.

WEBER, F. W.: Das Wasser als Energiequelle in vorindustrieller Zeit (um 1750). Karte 1:300.000 -Pfalzatlas 981982.

WEBER, G. 2003 [URL = http://cm.jahr-tsv.de/blinker/angeln_aktuell/news3.php;29.01.2004].

WEBER, H.: Zur Fassung und Gliederung eines allgemeinen biologischen Umweltbegriffes. - In: Die Naturwissenschaften 27 1939:633ff.

WEBER, H.: Zur neueren Entwicklung der Umweltlehre J. v. Uexkülls. - In: Die Naturwissenschaften 25 1937:97ff.

WEBER, H.: Historische Kulturlandschaften: historische Landschaftsteile, Kulturlandschaftsentwicklung; mit einer Auswahlbibliographie. Hrsg.: Bundesforschungsanstalt für Naturschutz und Landschaftsökologie. - Köln: Dt. Gemeindeverl. 1992 [Dokumentation Natur und Landschaft: Sonderheft;19; zugl. Bibliographie;65].

WEBER, M.: Antike Badekultur. - München: Beck 1996 [Beck’s Archäologische Bibliothek].

WEBER, Paul: Alte und neue Formen der Wiesenbewässerung am Beispiel des Durachtals und des unteren Glattals. InauguralDissertation zur Erlangung der philosophischen Doktorwürde, vorgelegt der Philosophischen Fakultät II der Universität Zürich. - Zürich: Jurios Druck und Verl. 1971; Zugl.: Zürich, Univ., Diss. 1971.

WEBER, H. E.: Notizen zur Verbreitung der Gattung Rubus L. im Emsland anlässlich der Regionalleiterstellen Tagung in Lathen. - In: Göttinger Floristische Rundbriefe 8/4 1974:118.

WEBER, H. E.: Zur Bedeutung historischer Karten für die Kartierung der Flora in Mitteleuropa. - In: Göttinger Floristische Rundbriefe 11/1 1977.

WEBER-KELLERMANN, I.: Landleben im 19. Jahrhundert. - 2. Aufl. - München: Beck 1988.

WEEBER, K.-W.: Smog über Attika. Umweltverhalten im Altertum. - Reinbek: Büchergilde Gutenberg 1993. 
WEGNER, R.: Furten, Fähren, Brückenschläge im Raum hann. Münden: Zur Geschichte und Technik der Fluß-Übergänge über Werra, Fulda und Weser. Hannoversch Münden: Heimat- und Geschichtsverein Sydekum zu Münden e. V. 1994 [SydekumSchriften zur Geschichte der Stadt Münden;23].

WEHRT, H. (Hrsg.): Humanökologie: Beiträge zum ganzheitlichen Verständnis unserer geschichtlichen Welt. - Basel: Birkhäuser 1996.

WEICHHARDT, P.: Raumbezogene Identität. - Wiesbaden, Stuttgart: Steiner 1990 [Erkunde Wissen;102].

WEIDINGER, U.: Mit Koggen zum Marktplatz: Bremens Hafenstruktur vom frühen Mittelalter bis zum Beginn der Industrialisierung. - Bremen: Hauschild 1997.

WEINLIG, C. G.: Gründlicher Unterricht der so genannten Hausmannischen Bleiche: wie in sehr kurzer Zeit Kattune, baumwollenes Garn, Flachs, Leinwand; Zwirn, und Hanf-Gespinnste gebleicht werden können. - Berlin: Pauli 1792.

WEIS, E./FLORIAN, A.: Die Kupfer von der Quelle bis zur Mündung. - Künzelsau: Swiridoff 2001 [Sondereinband].

WEISE, E.: Geschichte von Schloß Nienover im Solling. - Hildesheim: Lax 1989 [Veröff. d. Inst. f. Hist. Landesforschung d. Univ. Göttingen;27].

WEISER, C.: Die Talsperren in den Einzugsgebieten der Wupper und der Ruhr als funktionales Element in der Kulturlandschaft in ihrer Entwicklung bis 1945: eine historisch geographische Prozeßanalyse. - Bonn, Univ., Diss. 1991.

WEISER, C.: Die historisch-geographische Kulturlandschaftsuntersuchung Hückeswagen. Ein Beitrag der Angewandten Historischen Geographie in der Planung. - In: DIX, A. (Hrsg.): Angewandte Historische im Rheinland. - Köln: Rheinischer Verein für Denkmalpflege und Landschaftsschutz e. V. 1997:75-90.

WEISGERBER, G.: Zur Bedeutung des mittelalterlichen Schwarzwälder Silberbergbaus im überregionalen Vergleich. - In: Früher Bergbau im südlichen Schwarzwald: Begleitheft zur Ausstellung des Museums für Ur- und Frühgeschichte der Stadt Freiburg/Breisgau Br. vom 29. Juli bis zum 21. November 1999. Hrsg. v. Landesdenkmalamt Baden-Württemberg. Stuttgart: Ges. für Vor- und Frühgeschichte in Württemberg und Hohenzollern 1999 [Archäologische Informationen aus Baden-Württemberg;41]:131-140.

WEISS, V.: Müller und Müllerssöhne im sächsischen Erzgebirge und Vogtland in den Tälern und Nebentälern der Zwickauer Mulde, Zschopau und Weißen Elster (1540-1721). - Neustadt/Aisch: Degener 1996 [Schriftenreihe der Stiftung Stoye;27]:543-573.

WEITHMANN, M. W.: Die Donau. Ein europäischer Fluß und seine dreitausendjährige Geschichte. - Wien: Styria Verl. 2000.

WEIZSÄCKER, E. U. v.: Erdpolitik: Ökologische Realpolitik an der Schwelle zum Jahrhundert der Umwelt. - Darmstadt: Wiss. Buchgesell. 1989.

WELTE, A.: Morphologische Studien in Nordfranken: Ein Beitrag zur Entwicklungsgeschichte des Flußsystems der fränkischen Saale. - Würzburg 1931 [Mitteilungen der Geographischen Gesellschaft zu Würzburg;5/6]; Zugl.: Würzburg, Univ., Habil.Schr. 1929.

WELTE, E./ZUNDEL, R.: Binnengewässer in Not: Zur fischereilichen Gewässerrenaturierung und landschaftsökologischen Gestaltung des Kiesabbaugebietes in der Okertalaue Goslar-Vienenburg unter dem Einfluß schwermetallhaltiger Abwässer: Eine 20-jährige Zeitstudie zur gewässer- und landschaftsökologischen Forschung. - Göttingen: Goltze 2000.

WENDT, R.: Glashütten in Mecklenburg: Beitrag zur Sozialgeschichte und Volkskunde eines ländliches Gewerbezweiges (1. Hälfte 17. bis Ende 19. Jh.). - Berlin, Humboldt-Univ. 1968.

WENIGER, H.: Industrieplanung im Niederelbegebiet: Lebensbedingungen und Lebensmöglichkeiten der hamburgischen Seehafenindustrien. - Hamburg: Hansischer Gildenverl. 1938 [Aus hansischem Raum;4]; Zugl.: Hamburg, Univ., Diss.

WENTORF, J.: Über den Quellenwert historischer Film-, Photo- und Tonaufnahmen: eine Untersuchung am Beispiel des 17. Juni 1953. - Göttingen, Univ., Diss. 1999.

WENZEL, H.: Landschaftsentwicklung im Spiegel der Flurnamen: Arbeitsergebnisse auss der mittelschleswiger Geest. - Kiel: Geogr. Inst. 1939 [Schriften des Geographischen Instituts der Universität Kiel; 9,4].

WERKMÜLLER, D.: Über Aufkommen und Verbreitung der Weistümer: nach der Sammlung von Jacob Grimm. - Berlin: E. Schmidt 1972.

WERKMÜLLER, D.: Die Weistümer. Begriff und Forschungsauftrag. - In: HILDEBRANDT, R./KNOOP, U. (Hrsg.): Brüder Grimm Symposium zur Historischen Wortforschung. Beiträge zur Magdeburger Tagung vom 5.-8.6.1985 [Historische Wortforschung;1]:103-112.

WERLEN, B.: Cultural Turn in Humanwissenschaften und Geographie. - Leipzig: Dt. Akad. f. Landeskde e. V. und des Instituts für Länderkunde 2003 [Berichte zur deutschen Landeskunde;1].

WERNICKE, H./JÖRN, N. (Hrsg.): Beiträge zur hansischen Kultur-, Verfassungs- und Schiffahrtsgeschichte. - Weimar: Böhlau 1988 [Hansische Studien;10].

WESCHENFELDER, K./ROEBER, U. (Hrsg.): Wasser, Wolken, Licht und Steine. Die Entdeckung der Landschaft in der europäischen Malerei um 1800. Katalog zur Ausstellung im Mittelrhein-Museum Koblenz. - Edition Braus im Wachter Verl. 2002. 
WESSELS, K.: Integrierte Nutzung von Geobasisdaten und Fernerkundung für die kommunale Umweltplanung: dargestellt am Beispiel der Auswertung von Thermalscannerdaten. - Osnabrück: Univ.-Verl. Rasch 2002 [Osnabrücker Studien zur Geographie;21]; Zugl.: Osnabrück, Univ. Diss. 2001.

WEßLING, H.: Mit der Kraft von Wind und Wasser, Alte Mühlen in Niedersachsen und Bremen. - Hannover: Schlütersche 2000 [Katalog des Internationalen Wind- und Wassermühlen-Museums, Gifhorn].

WESTBELD, H.: Kleinwasserkraftwerke im Emsgebiet: Nutzung einer vernachlässigten Energiequelle. - Münster, Univ., Inst. f. Geographie, Dipl.arbeit 1985.

WESTERMANN - Lexikon der Geographie: Bd. II F - K. - 2. Aufl. - Weinheim: Zweiburgen 1973 [1. Aufl. Braunschweig: Westermann 1969].

WESTERMANN HANDKARTE Deutschland: physisch und politisch. - Braunschweig: Westermann 1966.

WESTERMANNS GROSSER ATLAS ZUR WELTGESCHICHTE. - 10. Aufl. - Braunschweig: Westermann 1978 [1. Aufl. 1965].

WESTFÄLISCHES AMT FÜR DENKMALPFLEGE: Wasserkraft in Westfalen - Bestandsaufnahme, Bd. 1: Kreis Gütersloh, Münster 1986.

WEY, K.-G.: Umweltpolitik in Deutschland. Kurze Geschichte des Umweltschutzes in Deutschland seit 1900. - Opladen 1982.

WEYER, J. F.: Ueber die Anlage der Schwemmwiesen im Lüneburgischen und der Wiesenbewässerung überhaupt. Hrsg. v. Albrecht Thaer. - Zelle: Schulze 1800.

WHG: Gesetz zur Ordnung des Wasserhaushaltes [Wasserhaushaltsgesetz]. 6. Novelle vom 12.11.1996. BGB1:1695-1711.

WHITNEY, G. G.: From Coastal Wilderness to Fruited Plain. A History of Environmental Change in Temperate North America 1500 to the Present. - Cambridge: University Press 1994.

WHYTE, I. D.: Landscape and history since 1500. - London: Reaktion Books 2002 [Schriftenreihe: Globalities].

WIEGAND, C.: Spurensuche in Niedersachsen. Der Niedersächsische Heimatbund erfasst historische Kulturlandschaftsteile. - In: Neues Archiv für Niedersachsen 2 2000:109-117.

WIEGAND, C.: Spurensuche. Der Niedersächsische Heimatbund erfasst historische Kulturlandschaftselemente mit Hilfe ehrenamtlicher Mitarbeiter. - In: BEHRENS, H./VETTER, L. (Hrsg.): Kulturlandschaftselemente - erfassen, bewerten, darstellen: Dokumentation des ersten Neubrandenburger Symposiums vom 7. März 2001. - Berlin: VWF, Verl. für Wiss. und Forschung 2001 [Umweltgeschichte und Umweltzukunft;9]:21-34.

WIEGLEB, G.: Kleingewässer - Erläuterungen und Definitionen. - Wardenburg 1980 [Inf. Natursch. Landschaftspfl.;2]:82-92.

WIELAND, G.: Keltische Fluss-Schiffahrt in Südwestdeutschland. - In: RÖBER, R. [Red.]: Einbaum, Lastensegler, Dampfschiffahrt: Frühe Schiffahrt in Südwestdeutschland. - Stuttgart 2000:77-92.

WIEMANN, M./ECKLE, F./HERRMANN, F.-R.: Vermessung im Dienste der Archäologie: topographische Aufnahme und Dokumentation vor- und frühgeschichtlicher Geländedenkmäler. Hrsg. v. d. Abteilung für Vor- und Frühgeschichte im Landesamt für Denkmalpflege Hessen, Wiesbaden, in Verbindung mit der FH Frankfurt, FB Vermessungswesen. Wiesbaden: Abteilung für Vor- und Frühgeschichte 1988 [Arch. Denkmäler i. Hessen;54].

WIEMER, K.-P.: Wassermühlen an der Düssel. - In: LANDESHAUPTSTADT DÜSSELDORF (Hrsg.): Die Düssel: Geschichte und Geschichten. - Köln: Rheinland-Verl. 1988:79-92.

WIERIES, R.: Die Namen der Berge [...], Quellen, Wasserläufe, Teiche [...] im Amtsgerichtsbezirk Harzburg nebst einem Versuch, sie zu deuten. Hrsg. v. Harzburger Altertums- und Geschichtsverein. - Breunschweig: Appelhans 1910 [Die Flurnamen des Herzogtums Braunschweig;1].

WIERLING, D.: Der Waschtag städtischer Dienstmädchen. - In: „Die Große Wäsche“: Eine Ausstellung des Landschaftsverbandes Rheinland, Rheinisches Museumsamt, Brauweiler in Zusammenarbeit mit dem Rheinischen Freilichtmuseum - Landesmuseum für Volkskunde, Mechernich-Kommern. - Köln: Rheinland-Verl. 1988 [Schriften d. Rhein. Museumsamtes;42; Zugl.: Schriften d. Rhein. Freilichtmuseums - Landesmuseum f. Volkskunde;34]:44-47.

WIESE, B.: Deutsche Kulturgeographie: Werden, Wandel und Bewahrung deutscher Kulturlandschaften. - Herford: Busse Seewald 1987.

WIESEMANN, J.: Spätmittelalterliche Steinkohlenförderung im Raum Aachen. - In: BAYERL, G./FUCHSLOCH, N./MEYER, T. (Hrsg.): Umweltgeschichte - Methoden, Themen, Potentiale: Tagung des Hamburger Arbeitskreises für Umweltgeschichte, Hamburg 1994. - Münster, New York: Waxmann 1996 [Cottbuser Studien zur Geschichte von Technik, Arbeit und Umwelt;1]:81-86.

WIESER, G.: Die Gewässer des Lavanttales. - Klagenfurt: Verl. d. Naturwissenschaftlichen Vereins für Kärnten 1996 [Carinthia: 2, Naturwissenschaftliche Beiträge zur Heimatkunde Kärtens: Sonderheft;54].

WIIPEDIA - die freie Enzyklopädie: Hagiografie [URL = http://www.wikipedia.de; 18.04.2002].

WILHEIM, J.: Inseln des Konsums in einem Meer der Armut. - In: PILZ, B.: Zum Beispiel: Mega-Städte. - Göttingen: Lamuv 2001:131-134. 
WILHELM, F.: Hydrogeographie. - Braunschweig: Westermann 1993 [Das geographische Seminar].

WILHELMY, H.: Verschollene Städte im Indusdelta. - In: Geogr. Zeitschr. 681968.

WILKIE, K.: Vorwort. - In: SCHUMACHER, H./STRAUSS, J.: Das ganze Land ein Garten (The whole land a garden): Historische Kulturlandschaften an Havel, Elbe und Themse. - Potsdam: Strauss 1998:7-8.

WILL; R. D.: Geheimnis Wasser: Von heilenden und krankmachenden Wässern. - München: Droemersche Verl.anstalt Knaur 1992.

WILLERDING, U.: Geschichte der Unkräuter. - Göttingen 1986 [Göttinger Schriften z. Ur- und Frühgeschichte; 22]

WILLERDING, U.: Relikte alter Landnutzungsformen. - In: HERRMANN, B./BUDDE, A. (Hrsg.): Natur und Geschichte. Naturwissenschaftliche und historische Beiträge $\mathrm{zu}$ einer ökologischen Grundbildung. Sommerschule „Natur und Geschichte“ vom 14. bis 27. September 1989 an der Georg-August-Universität Göttingen. - Hildesheim: Gerstenberg 1989 [Schriftenreihe „Expert“ des Nieders. Umweltministers Hannover]:207-224.

WILLERDING, U.: Klima und Vegetation der Germania nach vegetationsgeschichtlichen und paläo-ethnobotanischen Quellen. Beiträge zum Verständnis der Germania des Tacitus, Teil II. Abhandlungen der Akademie der Wissenschaften in Göttingen. - Göttingen 1992 [Philologisch -Historische Klasse. Dritte Klasse;195]:332-373.

WILLERDING, U.: Paläo-Ethnobotanik und Umweltgeschichte des Mittelalters. - In: BAYERL, G./FUCHSLOCH, N./MEYER, T. (Hrsg.): Umweltgeschichte - Methoden, Themen, Potentiale: Tagung des Hamburger Arbeitskreises für Umweltgeschichte, Hamburg 1994. - Münster, New York: Waxmann 1996 [Cottbuser Studien zur Geschichte von Technik, Arbeit und Umwelt;1]:41-65.

WILSDORF, H.: Flößer bei der Scheitertrift, der Bauholzflöße und dem Langholzfloß - montanethnographische Aspekte der Kultur und Lebensweise. - Berlin: Akademie-Verl. 1979 [Arbeitsmaterial des zentralen Fachausschusses Kulturgeschichte/Volkskunde beim Kulturbund der DDR;1].

WILSDORF, H./HERRMANN, W./LÖFFLER, K.: Bergbau, Wald, Flösse: Untersuchungen zur Geschichte der Flößerei im Dienste des Montanwesens und zum montanen Transportproblem. - Berlin: Akademie-Verl. 1960 [Freiberger Forschungshefte;28].

WILSON, E. 0.: Der Wert der Vielfalt: die Bedrohung des Artenreichtums und das Überleben des Menschen. - München et al.: Piper 1995 [Englische Orginalausgabe: The Diversity of Life. - Cambridge: The Belknap Press of Harvard University Press. 1992].

WINIWARTER, V.: Umwelten. Begrifflichkeit und Problembewußtsein. - In: JARITZ, G./WINIWARTER, V. (Hrsg.): Umweltbewältigung: die historische Perspektive. - Bielefeld: Verl. f. Regionalkultur 1994:130-159.

WINIWARTER, V.: Was ist Umweltgeschichte?: ein Überblick. - Wien: Interuniv. Inst. f. Interdisziplinäre Forschung u. Fortbildung 1998 [Schriftenreihe Soziale Ökologie;54].

WINIWARTER, V.: Umweltgeschichte: Eine Einführung. - Stuttgart: UTB 2004 [UTB S;2521].

WINIWARTER, V./WILFING, H. (Hrsg.): Historische Humanökologie: interdisziplinäre Zugänge zu Menschen und ihrer Umwelt. - Wien: Facultas-Verl. 2002

WIPPERN, J. M.: Kloster Heisterbach: die Teiche - Stuttgart: Theiss 2003 (im Druck):136ff.

WIRTH, E.: Theoretische Geographie: Grundzüge einer Theoretischen Kulturgeographie.- Stuttgart: Teubner 1979 [„„Die Bedeutung der historischen Dimension für Kulturgeographie und Theoretische Geographie“:75-100].

WIRTHS, J.: Geographie als Sozialwissenschaft!? Oder: Über Theorie. Probleme in der jüngeren deutschsprachigen Humangeographie. - Kassel: Gesamthochschulbibliothek 2001 [Urbs et Regio;72].

WISSING, F. W.: Wasserreinigung mit Pflanzen. - Stuttgart: Ulmer 1995.

WIßKIRCHEN, F.: Die Regmühle in Schutz um 1900. Der Müller Josef Weber mit Angehörigen der Familie. - In: Jahrbuch Daun 1985.

WITT, F.: Beiträge zur Kenntnis der Flussnamen Nordwestdeutschlands. - Kiel: Schmidt und Klaunig 1912; Zugl.: Kiel, Univ., Diss. 1912.

WITTVOGEL, K.: Oriental Despotism: A Comparative Study of Total Power. - New Haven, Conn.: Yale Univ. Press 1957.

WITTWER, R./MANTWILl, H. (Hrsg.) [Übers.: Jürgen Peters]: Seen und Teiche im Harz. Hrsg.: Harzwasserwerke. Hildesheim et al.: Olms 2000.

WÖBSE, H.-H.: Kulturlandschaftspflege - Theorie und Praxis eines gesetzlichen Auftrages. Symposium Kulturlandschaftspflege im Rheinland, Oktober 1990. Landschaftsverband Rheinland und Rhein. Verein für Denkmalspflege und Landschaftsschutz. - Köln: Rheinland-Verl. 1991 [Beiträge zu Landesentwicklung; 46]:18-28.

WÖBSE, H.-H.: Historische Kulturlandschaften. - In: Garten und Landschaft 102/6 1992:9-13 [ebenso in: Deutsche Kunst und Denkmalpflege 50/2 1992:158-163].

WÖBSE, H.-H.: Schutz historischer Kulturlandschaften. - Hannover: Univ., 1994 [Beiträge zur räumlichen Planung 37; Schriftenreihe des Fachbereichs Landschaftsarchitektur und Umweltentwicklung der Universität Hannover]. 
WOCHEN-CHRONIK v. 17./18. Januar 1998: „Nordhäuser Stadtpark wird Pflegeobjekt“

WÖHLKE, T.: Die Kulturlandschaft als Funktion von Veränderlichen: Überlegungen zur dynamischen Betrachtung in der Kulturgeographie. - In: Geographische Rundschau 21 1969:298-308.

WOHLRAB, B. et al.: Landschaftswasserhaushalt: Wasserkreislauf und Gewässer im ländlichen Raum; Veränderungen durch Bodennutzung, Wasserbau und Kulturtechnik. - Hamburg, Berlin: Parey 1992.

WOLF, K.: Evaluierung einer wasserbezogenen Freizeiteinrichtung im großstädtischen Verdichtungsraum am Beispiel des Schultheis-Weihers in Offenbach am Main : Teil 1: Erhebung der Nachfrage im Zielgebiet, Teil 2: Ergebnisse der Befragung der Anwohner der angrenzenden Stadtteile Bürgel, Fechenheim und Rumpenheim. - Frankfurt/Main: Inst., Univ. 1997 [Materialien/Institut für Kulturgeographie, Stadt- und Regionalforschung der J. W. Goethe-Universität Frankfurt am Main;20].

WOLF, U.: Die Düsseldorfer Wasserspielplätze. - In: Garten und Landschaft 66/11 1956:325-330.

WÖLFEL; W.: Das Wasserrad: Technik- und Kulturgeschichte. - Berlin: Parey 1987.

WÖLFEL, W.: Wasserbau in den alten Reichen. - Berli: Verl. f. Bauwesen 1990.

WOLFRAM, S./SOMMER, U.: Macht der Vergangenheit - wer macht Vergangenheit? Archäologie und Politik. - Wilkau-Haslau 1993 [Beiträge zur Ur- und Frühgeschichte Mitteleuropas;3].

WOLSCHKE-BULMAHN, J. „Übers Wasser“: Wasser in der Garten- und Parkgestaltung des 20. Jahrhunderts. - Zwischen Ästhetik, sozialem Anspruch, Ökologie und Ideologie. - Institut für Grünplanung und Gartenarchitektur, Berlin, 2002 [URL = http://www.uni-hannover.de/aktuell/veroeff/unimag/02unimag3-4/13_woischke.pdf;07.04.2004].

WOLTERUNG, U.: Historische Kulturlandschaft und Kulturlandschaftsbestandteile. Forschungsbedarf. - In: Natur- und Landschaftskunde 29 1993:10-14.

WORMUTH, R.: Mühlen: Signale niederdeutscher Kulturlandschaften. - In: Beiträge zur Denkmalpflege in Niedersachsen 20/1 2000:66-70.

WORSTER, D.: Appendix: Doing Environmental History. - In: WORSTER, D. (Hrsg.): The Ends of Earth. Perspektives on Modern Environmental History. - Cambrige 1988:289-307.

WORSTER, D.[a]: Paths across the Levee. - In: WORSTER, D.: The Wealth of Natur. Environmental History and the ecological imagination. - New York, Oxford: Oxford Univ. Press 1993:16-29.

WORSTER, D.[b]: History as Natural History. - In: WORSTER, D.: The Wealth of Natur. Environmental History and the ecological imagination. - New York, Oxford: Oxford Univ. Press 1993:30-44.

WORSTER, D.[c]: Thinking like a River. - - In: WORSTER, D.: The Wealth of Natur. Environmental History and the ecological imagination. - New York, Oxford: Oxford Univ. Press 1993:123-134.

WORSTER, D.: The Wealth of Natur. Einvironmental History and the ecological imagination. - New York, Oxford: Oxford Univ. Press 1993.

WROZ, W.: Die Mühlenwirtschaft in Niedersachsen. - Göttingen 1983 [Neues Archiv f. Nieders.;32]:86-92.

WULF, M.: Erstellung langer Zeitreihen mit Hilfe unterschiedlich alter Kartenwerke und deren Anwendung in der Forschung und im Naturschutz am Beispiel historisch alter Wälder. - In: SCHENK, W. (Hrsg.): Aufbau und Auswertung „Langer Reihen“ zur Erforschung von historischen Waldzuständen und Waldentwicklungen. Ergebnisse eines Symposiums in Blaubeuren vom 26. - 28.2.1998. - Tübingen 1999 [Tübinger Geographische Studien;125]:157-177.

WUNDER, W.: Düngung in der Teichwirtschaft. Hrsg.: Landwirtschaftliche Versuchsanstalt der Thomasphosphat-Erzeuger Essen-Bredeney. - Essen: Tellus-Verlag 1956.

WÜSTEMANN, O.: Die Fischerei im Harzgebiet. - In: Der Harz. Eine Landschaft stellt sich vor. [Schriftenreihe des Hartmuseums Wernigerode;6, 1982]:23-27.

WUTTKE, M.: Erdgeschichtlich/Paläontologische Denkmalpflege und Forschungsfreiheit: Gegensätze oder Synonyme. In: Geowissenschaftliche Umweltforschung. Hrsg.: Müller, German und Jörg Matschullat. - Heidelberg: Ruprecht-KarlsUniversität 1993 [Heidelberger geowissenschaftliche Abhandlungen;67]:171-172.

WYER, H.: Die Nutzung der Wasserkraft im Alpenraum: rechtliche Grundlagen und Perspektiven. - Zürich: Schulthess; Köln : O. Schmidt; Wien: Manz 2002.

ZACHER, I.: Schloß und Park Benrath. - 2. Aufl. - Köln: Rheinischer Verein für Denkmalpflege und Landschaftsschutz 1998 [Rheinische Kunststätten;14].

ZADERER, W.: Die Verbreitung der künstlichen Flurbewässerung im Oberinntal. - Zürich, Univ., Diss. 1950.

ZANGER, O.: Forderungen zur Berücksichtigung kulturlandschaftlicher Belange bei Planung und Unterhaltung von Fließgewässern und Auen aus der Sicht der Denkmalpfleg: Statement. - In: Fließgewässer in der Kulturlandschaft. 1999:172-176. 
ZEDELIUS, V.: Münzen aus rheinischen Heilquellen. „Wasserquellen: Mineralquellen und Heilbäder im Rheinland“. Eine Ausstellung des Landschaftsverbandes Rheinland, Rheinisches Museumsamt, Abtei Brauweiler. - Köln: Rheinland-Verl. 1991 [Schriften des Rheinischen Museumsamtes;48]:36-49.

ZEELAND, S. van: Aspekte der griechischen Kolonisation am schwarzen Meer. - Hausarbeit [Hauptseminar] an der HeinrichHeine-Universität Düsseldorf, Mai 2001 [URL = http://www.vanzeeland.de/griechische_kolonisation.php;19.01.2004].

ZELLER, C. F.: Der Wiesenbau im Großherzogthum Hessen: practische Musterblätter von Bauwerken und Maschinen für Bewässerung, Entwässerung und andere Zwecke des Wiederbau's. - Darmstadt 1846.

ZESEWITZ, S./DÜNTZSCH, H./GRÖTSCHEL, T.: Ewald Bellingrath (1838-1903): Ein Leben für die Elbschiffahrt. - Das Buch zur Sonderausstellung des Elbschiffahrtsmuseums vom 22.8.03- 31.1.2004. - 1. Aufl. - Lauenburg: Verein zur Förderung des Lauenburger Elbschiffahrtsmuseums e. V. 2003 [Buch Nr. 01-4].

ZETTLER, A.: Heilige, Mönche und Laien unterwegs. Bilder und Texte zur Schiffahrt auf dem Bodensee im frühen Mittelalter. In: Einbaum, Lastensegler, Dampfschiffahrt. Frühe Schiffahrt in Südwestdeutschland. Zusammengestellt von R. RÖBER. Stuttgart 2000 [Almanach des Archäologischen Landesmuseums Baden-Württemberg; 5/6 2000/2001]:109-120.

ZIEGLER, U.: Kreuz und Schwert: die Geschichte des Deutschen Ordens. - Köln et al.: Böhlau 2003.

ZIEMEK, H.-P.: Fließ- und Stillgewässer in Mittelhessen: Ökologie und Kulturgeschichte. - Weikersheim 1991 [Ökologie in Forschung und Anwendung;4].

ZILLENBILLER, E.: Kulturlandschaft - Erbe und Auftrag: Entwicklungsphasen von der Natur- zur Kulturlandschaft; auf den Spuren der Landschafts- und Siedlungsgeschichte - ein modellhafter Beitrag zur Heimatkunde und Landschaftsplanung. Ubstadt-Weiher: Verl. Regionalkultur 1996.

ZIMMERMANN, F. M.: Kontinuität und Wandel in der Kultur- und Naturlandschaft: Festschrift für Herwig Wakonigg. - Graz: Univ., Inst. für Geographie und Raumforschung 2002 [Schriftenreihe: Grazer Schriften der Geographie und Raumforschung;38].

ZIMMERMANN, H. W.: Stallhaltung und Auswinterung der Haustiere in ur- und frühgeschichtlicher Zeit. - In: Beiträge zur Mittelalterarchäologie in Österreich 15 1999:27-33.

ZIMMERMANN, H.: Wiederherstellung eines Teichkomplexes im NSG „Fischteiche in der Lewitz“ für den Naturschutz. - In: Naturschutzarbeit in Mecklenburg-Vorpommern 36/1 1993:33-34.

ZINK, F.: Die topographisch benennbare Flußtallandschaft von Albrecht Dürer bis Karl Rössing. - In: Jahrbuch für fränkische Landesforschung 1988:163-189.

ZINTZ, K.: Verlandungsbereiche stehender Gewässer, Hülen und Tümpel. - Karlsruhe: Landesanstalt f. Umweltschutz BadenWürttemberg 2001 [Biotope in Baden-Württemberg;10].

ZINTZ, K./RAHMANN, H. (Hrsg.): Ökologie und Managment kleinerer Stehgewässer. - Weikersheim: Margraf 1990.

ZIRNSTEIN, G.: Zur Süßwasserhydrobiologie und Limnologie namentlich in Deutschland zwischen 1892 und dem Zweiten Weltkrieg - Das erste halbe Jahrhundert in der Geschichte der Limnologie. Unter besonderer Berücksichtigung der Biologischen Anstalt Plön und der aus ihr hervorgegangenen „Hydrobiologischen Anstalt der Kaiser-Wilhelm-Gesellschaft zu Plön“. - In: Limnologia 22/4 1992:285-298.

ZIRNSTEIN, G.: Ökologie und Umwelt in der Geschichte. - 2. Aufl. - Marburg: Metropolis-Verl. 1996 [1. Aufl. 1994] [Ökologie und Wirtschaftsforschung;14].

ZITSCHER, Fritz-Ferdinand: Der Einfluß der Sturmfluten auf die historische Entwicklung des nordfriesischen Lebensraumes. In: REINHARDT, A. (Hrsg): „Die erschreckliche Wasser-Fluth“ 1634: die Flut vom 11. Oktober 1634 und ihre Folgen nach zeitgenössischen Berichten und Dokumenten; mit einer Darstellung über den Einfluss der Sturmfluten auf die historische Entwicklung des nordfriesischen Küstenraumes. Hrsg. i. A. des Nordfriesischen Vereins für Heimatkunde und Heimatliebe. Husum: Husum Druck- und Verl.-Ges. 1984 [Heimatkundliche Schriften des Nordfriesischen Vereins;9]:149-202.

ZOBEL, H.: Kleinteiche und ihre Bewirtschaftung. - 1. Aufl. - Berlin: Dt. Landwirtschaftsverl. 1992.

ZÖGNER, L.: Flüsse im Herzen Europas. Rhein, Elbe, Donau. Kartographische Mosaiksteine der mitteleuropäischen Flußlandschaft. Ausstellung der Kartenabteilung der Staatsbibliothek zu Berlin. - Wiesbaden 1993 [Staatsbibliothek Berlin, Ausstellungskataloge; N. F. 6].

ZÖLITZ-MÖLLER, R. (Hrsg.): Historische Geographie und Kulturlandschaftsforschung: Beiträge zum Gedenkkolloquium für Dr. Eginhard Wegner am 4. Mai 2001 in Greifswald. - Greifswald: Ernst-Moritz-Arndt-Univ. 2001 [Greifswalder geographische Arbeiten;22].

ZÖLITZ-MÖLLER, R.: Die schwedische Landesaufnahme von Vorpommern 1692-1709 - herausragendes Katasterwerk und Quelle für die Kulturlandschaftsforschung in einem peripheren Raum - Vortrag 30. Tagung des „Arbeitskreises für genetische Siedlungsforschung in Mitteleuropa“ in Greifswald vom 17. bis 20. September 2003; zugleich „Pommern in historischen Karten aus fünf Jahrhunderten“ - Beiblatt zur gleichnamigen Ausstellung anlässlich der Tagung.

ZORN, W.: Ansätze und Erscheinungsformen des Umweltschutzes aus sozial- und wirtschaftshistorischer Sicht. - In: SCHNEIDER, J. (Hrsg.): Wirtschaftskräfte und Wirtschaftswege. Festschrift für H. Kellenbenz; Bd. 4. - Stuttgart, 1978:707723. 
ZUR GESCHICHTE DES VERMESSUNGSWESENS: Vermessung in der Antike, historische Karten, der Geodät in der Literatur und bildenden Kunst, Biographien, Basisvermessungen, Instrumentebau, Grenzmale; die Beiträge sind Helmut Minow gewidmet, dem Mitbegründer und langjährigen Leiter des Gesprächskreises „Geschichte im Vermessungswesen“ im VDV und der späteren gleichnamigen Fachgruppe im Bildungswerk VDV. - Wiesbaden: Chmielorz 1995.

ZWAFELINK, W.: Von der Industriebrache zur attraktiven Wasserstadt. - In: Stadt und Raum 6 2002:382-387.

Archivalische Quellen

I Stadtarchiv Nordhausen

DA I/62-I/70 Ziff. IV.: Öffentliche, Wohn- und Fabrikgebäude, Mühlen, Ställe und Scheunen.

DJ II/14 „,..Verpachtung der an der Salza gelegenen, der Kämmerey gehörigen sogenannten kleinen WertherMühle.“

X 115 Actum Nordhausen den 1sten May 1776: „Inventarium über die so genandte Stein-Mühle, verfertiget den 1sten May 1776 von unterschriebenen vereydeten Amts-Deputatis“.

X 370 Städt. Wasserbucheinträge betr. Mühlgraben (u. Kunstgraben) 1913-1931.

X 975 Acta betreffend den Verkauf der untern Kohnstein belegenen Oel- und Kalkmühle. 1808 (I B/17).

X 997 Acta betreff: Regulierung des Abzuggrabens der Neuen Mühle 1885-1916.

Hier: „Erläuterungsbericht zum Entwurf für die Regulierung der Zorge.

X $1124 \quad$ Actum Nordhausen den 24ten Novembr. 1791.

X 1124 Acta betreffend die Verpachtung der der Commune Nordhausen gehörigen Klostermühle im Jahre 1809; im Jahre 1812.

X 1125 Acta über die Verpachtung der Steinmühle im Jahre 1809. im Jahre 1812. Darin: „Inventarium über die sogenannte Steinmühle verfertiget den 15ten May 1776 von unterschriebenen vereydeten amtl.Deputatis“ Actum Nordhausen den 1ten May 1776.

X 1126 Acta die Verpachtung der Steinmühle an der Salza betreffl. Registratur des Magistrats zu Nordhausen. A. 32 Mai 1818-1824 und Mai 1824-1830.

X 1184 Actum Nordhausen den 24ten November 1791 Nr. 1184 „Inventarium der Klostermühle“.

Acta betreff. Badeanstalt an der Zorge. Magistrat in Nordhausen. Eingegangen am 19. April 1891.

AUSZUG AUS DEM WASSERBUCH FÜR DIE ZORGE. - Bd. III, Abt. A, Unterabteilung I, Spalte 2: Nr. 1573 B.A.W/29; Eintrag v 15.04.1929; Zugl.: Antrag v. 15.04.1929; Eintrag am 17. Okt. 1930.

FRAGEBOGEN ZUR EINTRAGUNG IN DAS WASSERBUCH ( $§ 380,186-188$ des Wassergesetzes v. 7.04.1913). - In: Auszug aus dem Wasserbuch für die Zorge. - Bd. III, Abt. A, Unterabteilung I, Spalte 2: Nr. 1573 B.A.W/29; Eintrag v 15.04.1929; Zugl.: Antrag v. 15.04.1929; Eintrag am 17. Okt. 1930.

REGESTEN der ältesten Urkunden der beiden Cisterzienser-Nonnenklöster in Nordhausen. A. Regesten von Urkunden des Cisterzienser-Nonnenklosters (Marienkloster am Frauenberge) zu Nordhausen. B. Regesten von Urkunden des CisterzienserNonnenklosters Nikolasberg (Montis St. Nicolas) zu Bischoferode, seit 1294 des Marienklosters im Altendorfe zu Nordhausen. Aus dem Nachlasse des Prof. Dr. G. E. Förstemann. Hrsg. v. Dr. Th. Perschmann. - In: Neue Mitteilungen aus dem Gebiet historisch-antiquarischer Forschungen 13, H. 4 (1874): A.: 544-567, B.: 564.

REPETORIUM des Stadtarchivs Nordhausen „Akten der Freien Reichsstadt Nordhausen 1414-1802 - Amtsbücher, Statutenund Kopialbücher 1280-1839“. Hrsg.: R. H. Walther Müller, Stadtarchivar. - Nordhausen, 16. August 1960.

STATISTISCHE DARSTELLUNG DES KREISES NORDHAUSEN. Nach amtlichen Quellen zusammengestellt im landräthlichen Bureau. Nordhausen 1863.

\section{Hauptstaatsarchiv Düsseldorf}

215.06 Akten des Landratsamtes Düsseldorf, Reg. A. Staats- und Hoheitswesen, Nr. 2 Rittergüter, Seite 8.

215.06 Akten des Landratsamtes Düsseldorf, Reg. L. Handel- und Gewerbe, Nr. 5 Energiewirtschaft, Seite 61

215.06 Akten des Landratsamtes Düsseldorf, Reg. N. Wasserbau, Nr. 1 Wasserrechte, Seite 69, Nr. 3 Instandsetzung u. Regulierung der Bäche und Gräben, Seite 70, Nr. 4 Wasserversorgung, Seite 71, Nr. 5 Mühlen, Seite 73.

215.06 Akten des Landratsamtes Düsseldorf [215.06], Reg. P. Landwirtschaft und Forsten, Nr. 6 Fischereiwesen, Seite 81, Nr. 7 Meliorationen, Seite 81 

Meldungen über Veränderungen bei den Rittergütern im Landkrs., 1914 - 1918.

B. Verwaltung des Kreises, 4. Kreisgebiet, Vermessungswesen, Topogr. Aufnahme d. Kreises, Intus: Verzeichn. der von der königlich preußischen Landaufnahme veröffentl. Pläne u. Karten 1907 - 1927.

B. Verwaltung des Kreises, 4. Kreisgebiet, Vermessungswesen, Allg. Landesaufnahme, Generalstabs- u. Kreiskarten, Bd. $21927-1929$. Entfernungsverzeichnisse, Bd. $11898-1929$.

491

L. Handel u. Gewerbe, 5. Industrie, Energiewirtschaft, Gewerbl. Anlagen, et al. Press- u. Walzwerke, Mühlen, Wäschereien, Intus: Verzeichnisse der Getreidemühlen, Bd. 11901 - 1921.

48677

Reg. D'dorf betreffend „Wasserpolizeiliche Vorschriften für die Wasserläufe im Kreise Mettmann“; Bd. II 1912 bis 19?. Zur Registratur der Königl. Regierung zu Düsseldorf. Abteilung I, Sekt. E, Fach 106 Nr. 1.

Bauamt des Westf. Bauernvereins, Abteilg. Bochum, Schreiben v. 12. Juni 1915.

Bauamt des Westf. Bauernvereins, Abteilg. Bochum, Schreiben v. 10. Juli 1915.

Baupolizeibehörde der Bürgermeisterei Hubbelrath v. 29. Mai 1942.

Stadtverwaltung Düsseldorf: Aktennotiz Amt 65/32 v. 8.4.1981 Nr. 4582.

Stadtverwaltung Düsseldorf: Ernst Jung und Partner, Architekten, Düsseldorf: Schreiben an den Oberstadtdirektor, Planungsamt Hr. Schmidt vom 22.09.1978.

Stadtverwaltung Düsseldorf: Hausakte betr. Mydlinghoven 1977 Nr. 4, Amt 62, darin: Ernst Jung und Partner Architekten, Düsseldorf: Bauvoranfrage für das Projekt Mydlinghoven; Nutzungsänderung und Umbau des jetzigen Gestüts in das Reiterdomizil Hubbelrath v. 13.11.1978.

Stadtverwaltung Düsseldorf: Planung für das Gut Mydlinghoven; Aktenvermerk von Amt 61 an Amt 63 vom 28.7.1978, Schreiben datiert 21.8.1978.

Stadtverwaltung Düsseldorf: Planungsausschußsitzung am 17. 10.1978, Punkt NÖ 7: Beabsichtigte Nutzungsänderung „Gestüt Mydlinghoven“.

Stadtverwaltung Düsseldorf: Schreiben Kulturamt v. 15.4.1981.

Stadtverwaltung Düsseldorf: Sitzung d. Ausschusses f. Planung u. Stadtentwicklung am 12.12.1979, Punkt NÖ 12: Beabsichtigte Nutzungsänderung „Gestüt Mydlinghoven“.

Verwaltungsgericht Düsseldorf: verwaltungsgerichtliches Verfahren gg. Die Eheleute Grauert, von Maltzahn, Begründung der Klageabweisung v. 12.06.1986.

Wiesengenossenschaft im Mydlinghover- und Stinderbachtal zu Erkrath: Lageplan des Mydlinghoverbachtales. - Zum Entwurf des Preuß. Kultur-Bauamtes zu Düsseldorf vom 15. Juni 1932. 


\section{Auskünfte und Besuche}

\section{Korrespondenz}

Blankenburg

Braunschweig

Bünde

Düsseldorf

Clausthal

Dingelstädt

Hofgeismar

Nordhausen

Quakenbrück

Ratzeburg

Rheder

Rietschen

Salem

Schwülper

Stolberg

Wielenbach

Wilnsdorf

Wolfenbüttel

II Auskünfte

Ahlhorn
Beberbeck
Bremen
Düsseldorf
Hilden

Holzminden
Kirchlengern/Derental
Meinbrexen
Minden
Monheim
Rinteln
Solling
Uslar

Hr. Wegner, Museum Kleines Schloss, Blankenburg i. Harz

Hr. Walter Schulze, Zisterzienser-Museum

Fr. Petra Seidel, Stadtarchiv Bünde

Fr. Regine Zeller, Goethe Museum Düsseldorf

Hr. Rolf Budach, stud. Chem.Ing. TU Clausthal

Fr. Edith Richwien, Tourist-Information

Hr. Helmut Burmeister, Fr. Müller-Späth, Stadtmuseum Hofgeismar

Hr. Dr. Peter Kuhlbrodt, Fr. Manuela Schmidt, Stadtarchiv Nordhausen

Hr. Heinrich Böning, Stadtmuseum Quakenbrück

Hr. Volker Holm, Zentrum für Niederdeutsch, Ratzeburg

Elmar Frhr. Spiegel v.u.z. Peckelsheim, Schlossbrauerei Rheder

Fr. Ute Thielsch, Natur- und Touristinformation Erlichthofsiedlung

Fr. Doris Obermaier, Schloss Salem/Salemer Kultur und Freizeit GmbH

Hr. Richard Brüdern, Schwülper, OT Rothemühle

Hr. Mario Bolte, Stolberger Geschichts- und Traditionsverein e. V.

Hr. Dr. R. D. Negerle, Bayerisches Landesamt für Landwirtschaft, Institut für Fischerei, Versuchsanlage Wielenbach

Hr. Fritz Müller, Gemeinde Wilnsdorf/Bauamt

Fr. Dr. Silke Wagner-Fimpel, Niedersächsisches Staatsarchiv Wolfenbüttel

Dr. G. Plate, Staatliche Teichwirtschaft des Niedersächsischen Forstamtes Ahlhorn

Hr. Dr. Köhling, Domäne Beberbeck

Detlef Treis, Oberwaltungsinspektor, Senat f. Inneres, Bremen

Hr. Schulenberg, AG Archäologie, ehrenamtl. Mitarbeiter des Rhein. Landesamtes f.

Bodendenkmalpflege / Stadtwerke Düsseldorf

Hr. Dr. Antweiler, Wilhelm-Fabry-Museum/Historische Kornbrennerei und Archiv der Stadt Hilden

Hr. Flee, Hof Flee

Dr. Matthias Seeliger, Stadtmuseum Holzminden

Fr. Elfriede Hagemeyer

Hr. Lothar von Mansberg, Rittergut Meinbrexen

Hr. Westermann, Wasser- und Schiffahrtsamt Minden

Fr. Elke Löpke, Biologische Station Urdenbacher Kämpe e. V.

Hr. Stefan Meyer, Museum Rinteln „Die Eulenburg“

Hr. Hans-Georg Wagner, Hutewald-Projektgebiet, FH Lippe und Höxter

Hr. Schäfer, Museum Uslar 


\section{Lebenslauf}

Von 1985-1988 Studium der Geographie im Studiengang Landschaftsökologie und den Nebenfächern Botanik und Zoologie an der Westfälischen Wilhelms-Universität Münster. Vordiplom-Prüfung bei Prof. Dr. Karl-Friedrich Schreiber. Von 1988-1991 Fortsetzung des Studiums der Geographie im Studiengang Raumplanung und den Nebenfächern Stadtplanung und Planungsrecht an der Universität Bayreuth. Studienabschluss als Diplom-Geograph im Februar 1992.

Postgraduiertes Studium der Stadt- und Regionalplanung als Stipendiat des Deutschen Akademischen Austauschdienstes (DAAD) an der Universität Joensuu/Finnland, Institut für Geographie und Regionalplanung.

Zusatzausbildung zum Spezialisten für Geographische Informationssysteme (GISSpezialist) an der Privaten Bildungsstätte Dr. Busch, Jena.

Mehrjährige Tätigkeit als Stadtplaner, CAD/GIS-Koordinator und als Bereichsleiter Tiefbauplanung in Stadtverwaltungen und privaten Ingenieurgesellschaften.

Seit Studienbeginn intensive Beschäftigung mit der historischen Kulturlandschaft. 19941995 Gasthörer an der Universität Münster im Fach „Historische Siedlungsgeographie“. 1996-1997 Gasthörer an der Georg-August-Universität Göttingen in den Fächern Kulturgeographie, Umweltgeschichte, Umweltrecht und Finno-Ugristik. Dort 2002 offizielle Einschreibung zur Promotion im Studiengang Geographie mit den Fachgebieten Umweltgeschichte und Umweltrecht. 